\title{
Workplan/RCRA Facility Investigation/Remedial Investigation Report for the Old Radioactive Waste Burial Ground 643-E, S01-S22 - Volume I - Text and Volume II - Appendices
}

by

K. R. Conner

Westinghouse Savannah River Company

Savannah River Site

Aiken, South Carolina 29808

J. Leyba

A. Preston

This paper was prepared in connection with work done under the above contract number with the U.S. Department of Energy. By acceptance of this paper, the publisher and/or recipient acknowledges the U. S. Government's right to retain a nonexclusive, royalty-free license in and to any copyright covering this paper, along with the right to reproduce and to authorize others to reproduce all or part of the copyrighted paper. 


\title{
Workplan/RCRA Facility Investigation/Remedial Investigation Report for the Old Radioactive Waste Burial Ground 643-E, S01-S22 (U)
}

\author{
Volume I - Text
}

Westinghouse Savannah River Company

Savannah River Site

Aiken, South Carolina, 29808

Prepared for the U.S. Department of Energy Under Contract Number DE-AC09-

96SR 18500

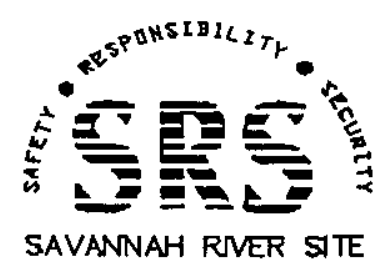

SAVANNAH RVER STE 


\section{DISCLAIMER}

This report was prepared as an account of work sponsored by an agency of the United States Government. Neither the United States Government nor any agency thereof, nor any of their employees, makes any warranty, express or implied, or assumes any legal liability or responsibility for the accuracy, completeness, or usefulness of any information, apparatus, product or process disclosed, or represents that its use would not infringe privately owned rights. Reference herein to any specific commercial product, process or service by trade name, trademark, manufacturer, or otherwise does not necessarily constitute or imply its endorsement, recommendation, or favoring by inte Uinitied States Gevernment nr any agency thereof. The views and opinions of authors expressed herein do not necessarily state or reflect those of the United States Government or any agency thereof.

This report has been reproduced directly from the best available copy.

Available for sale to the public, in paper, from: U.S. Department of Commerce, National Technical Information Service, 5285 Port Royal Road, Springfield, VA 22161

phone: $(800) 553-6847$

fax: (703) 605-6900

email: orders@ntis.fedworld.gov

online ordering: http://www.ntis.gov/ordering.htm

Avaitable-eleetronically-at-http://www.doe.gov/bridge

Available for a processing fee to U.S. Department of Energy and its contractors, in paper, from: U.S.Department of Energy, Office of Scientific and Technical Information, P.O. Box 62, Oak Ridge, TN 37831-0062 phone: (865) 576-8401

fax: (865) $576-5728$

email: reports@adonis.osti.gov

00304115.065

\section{Printed in the United States of America}

Prepared for

U.S. Department of Energy

and

Westinghouse Savannah River Company

Aiken, South Carolina 


\section{Table of Contents}

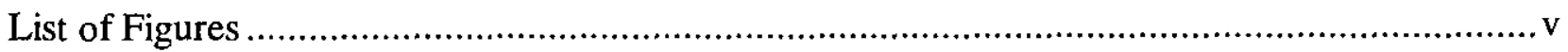

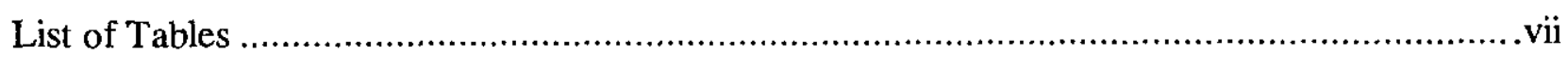

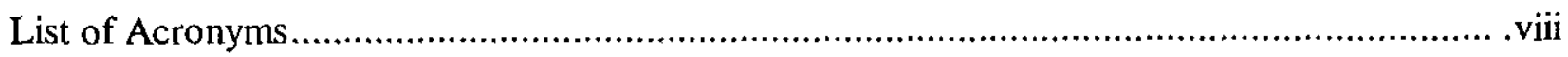

Conversion Table for Measurement Units ................................................................ xi

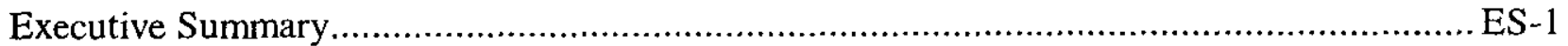

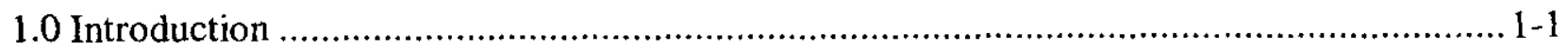

1.1 RCRA Facility Investigation/Remedial Investigation Workplan Organization............ 1-1

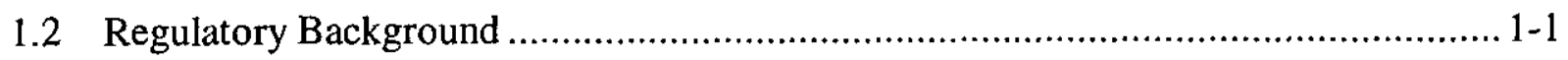

1.2.1 RCRA Facility Investigation Program............................................... 1-1

1.2.2 CERCLA Remedial Investigation Program .......................................... 1-2

1.2.3 Summary of Unit Description ...................................................... 1-3

1.2.3.1 Unit History and Characteristics............................................. 1-3

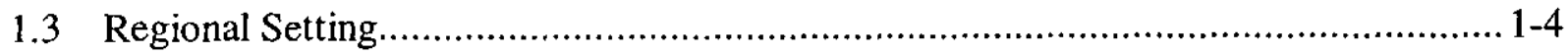

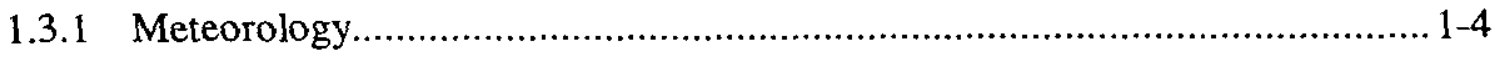

1.3.2 Physiography.......................................................................... 1-4

1.3.3 SRS Geology/Stratigraphic Sequence ............................................. 1-5

1.3.3.1 Upper Cretaceous Sediments ............................................. 1-6

1.3.3.2 Tertiary Sediments ............................................................... 1-7

1.3.3.3 SRS Hydrostratigraphy ....................................................... 1-9

1.3.3.4 General Separations Area Hydrogeology................................... 1-14

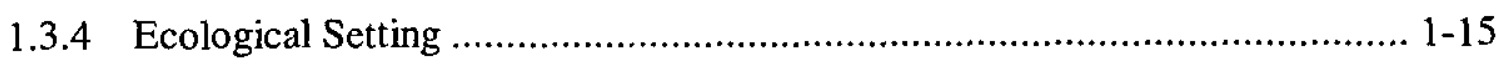

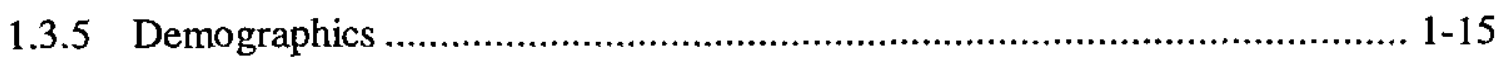

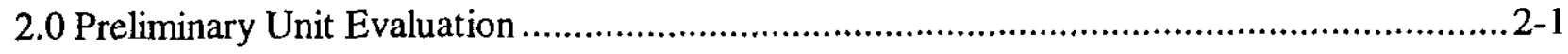

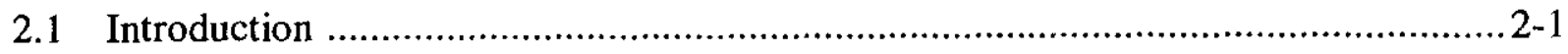

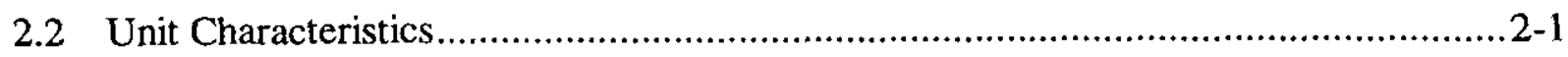

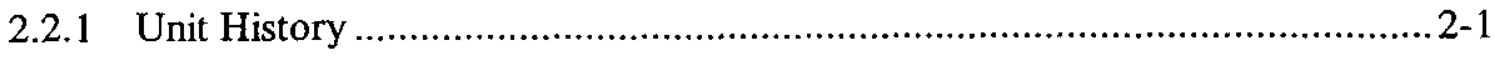

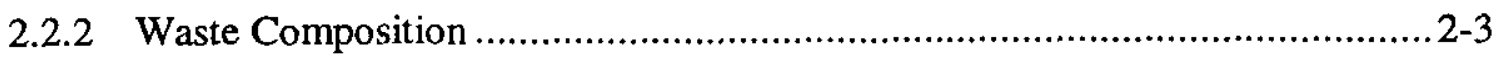

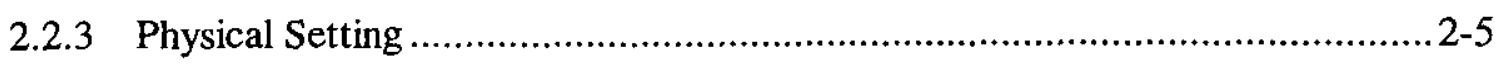

2.2.3.1 Topography and Drainage .................................................... 2-5

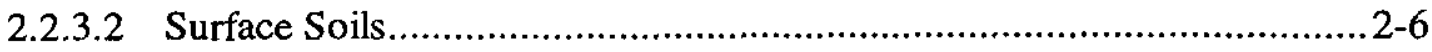

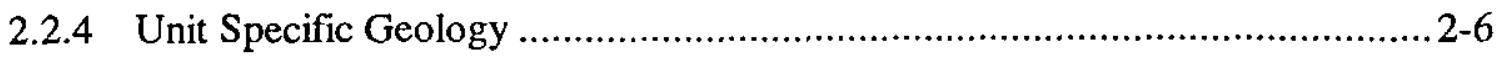

2.2.5 Unit Specific Hydrogeology ........................................................ 2-7

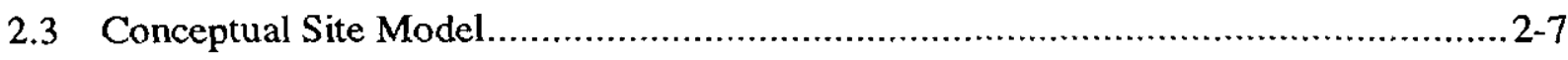




\section{Table of Contents (continued)}

2.3.1 Primary Sources of Contamination................................................... 2-7

2.3.2 Primary Release Mechanisms ......................................................... 2-9

2.3.3 Secondary Sources of Contamination ............................................ 2-10

2.3.4 Secondary Release Mechanisms .......................................................... 2-10

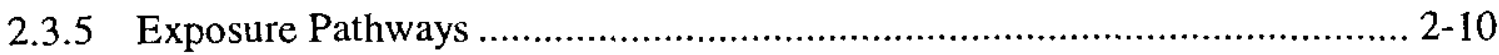

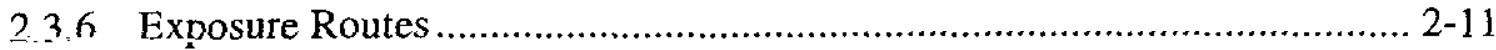

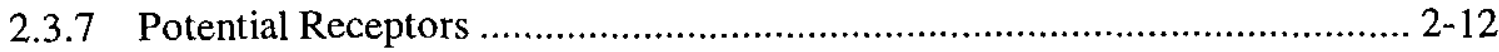

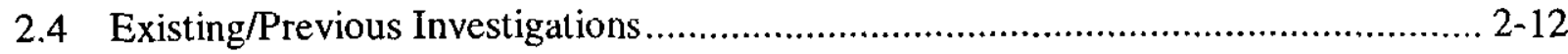

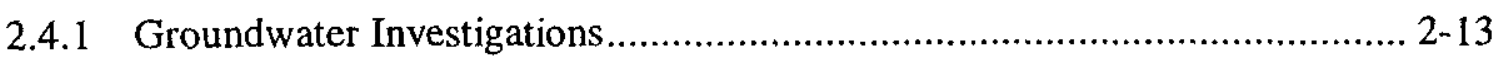

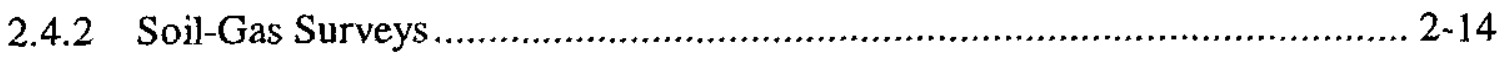

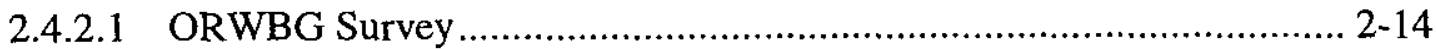

2.4.2.2 Burial Ground Railroad Survey ................................................. 2-15

2.4.2.3 Burial Ground Perimeter Survey ........................................... 2-15

2.4.3 Ambient Air Monitoring ................................................................ 2-16

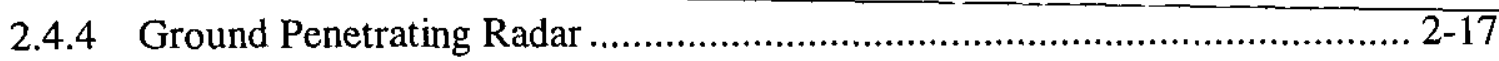

2.4.5 Volatilized Tritiated Water Vapor................................................... 2-17

2.4.6 ORWBG Field Investigation.......................................................... 2-19

2.4.7 Summary of Water Table Monitoring …........................................... 2-19

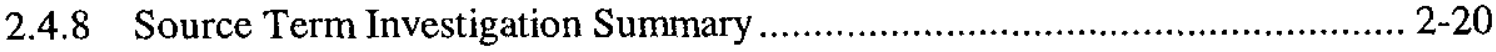

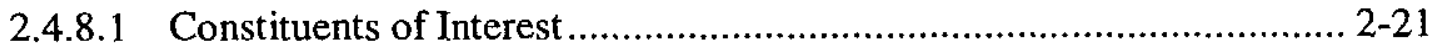

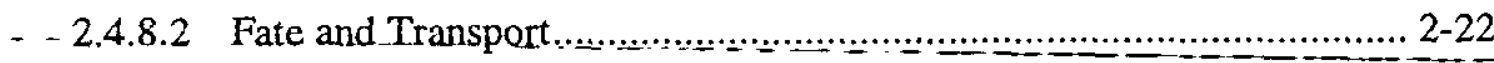

2.4.9 Hot Spot Criteria and Identification ................................................ 2-24

2.4.9.1 Inventory Analysis ............................................................ 2-24

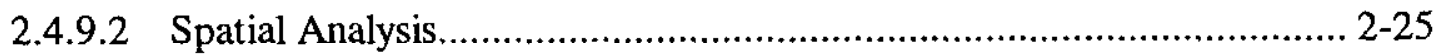

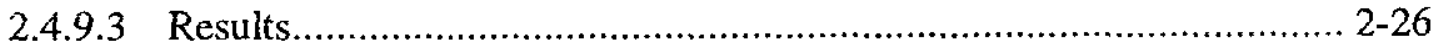

2.4.9.4 Summary of Potential "Hot Spots"............................................ 2-27

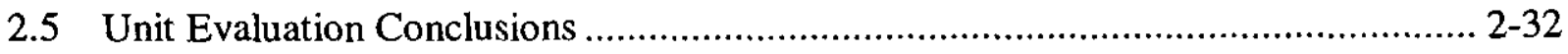

2.6 Potential ARARs and TBC Criteria ......................................................... 2-32

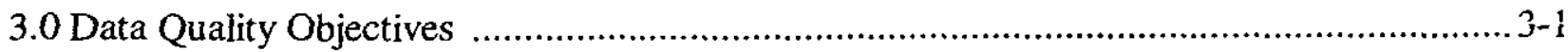

3.1 Data Quality Objective Evaluation........................................................... 3-1

3.1.1 State the Problem ............................................................................

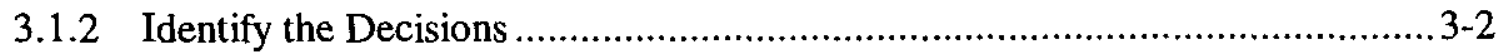

3.1.3 Identify the Inputs to the Decisions................................................ 3-2 


\section{Table of Contents (continued)}

3.1.4 Define the Boundaries of the Study................................................. 3-2

3.1.5 Develop Decision Rules................................................................. 3-2

3.1.6 Specify Tolerable Limits on Decision Errors ......................................... 3-3

3.1.7 Optimize the Design for Obtaining Data ........................................... 3-3

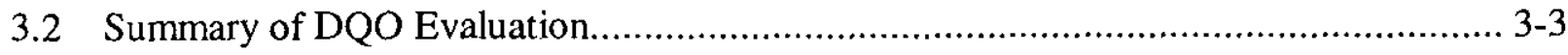

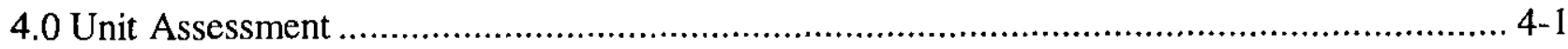

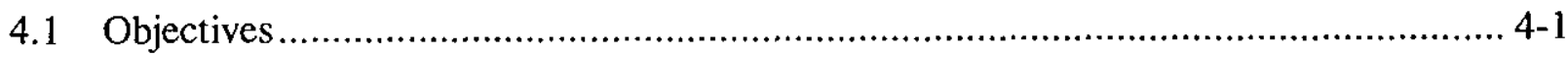

4.2 Primary Source Characterization ............................................................. 4-1

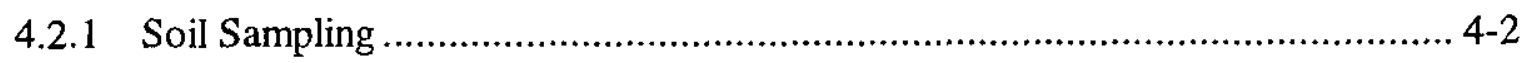

4.2.2 Background Characterization ........................................................ 4-2

4.3 Secondary Source Characterization ........................................................... 4-2

4.4 Exposure Media Characterization.......................................................... 4-2

5.0 Potential Early and/or Interim Remedial Actions ............................................... 5-1

5.1 Old Radioactive Waste Burial Ground (ORWBG) Early and/or Interim Remedial

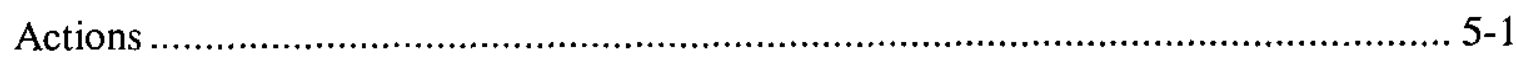

5.2 Solvent Tanks Early and/or Interim Remedial Actions .................................... 5-1

6.0 Potential Corrective Measures Study/Feasibility Study Options .................................. 6-1

6.1 Preliminary Remedial Action Objectives ................................................... 6-1

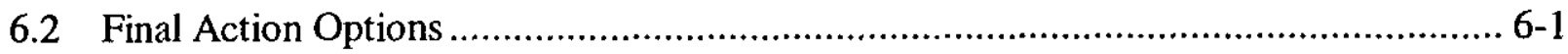

6.2.1 Standard Remedial Technologies ........................................................ 6-1

6.2.2 Innovative Remedial Technologies .................................................... 6-2

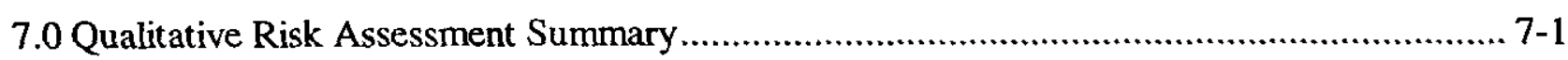

7.1 Identification of Constituents of Interest................................................... 7-1

7.2 Qualitative Risk Summary .................................................................. 7-1

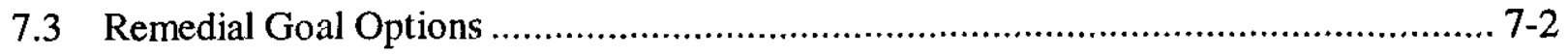

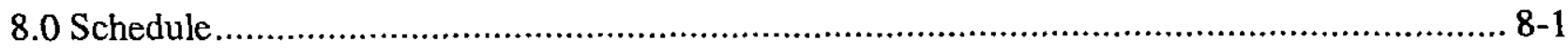

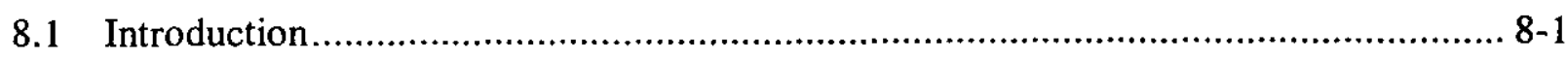

8.2 Projected Schedule for Field Activities ..................................................... 8-1

8.3 Projected Schedule for Document and Report Submittals .................................. 8-1

9.0 Safety, Health, and Emergency Response Plan ........................................................ 9-1

10.0 Quality Assurance/Quality Control Plan ...................................................... 10-1

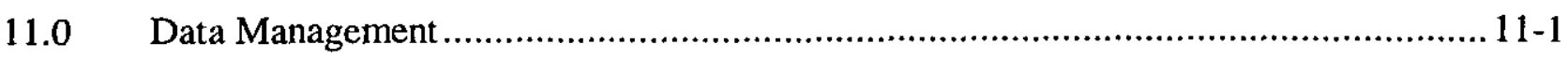

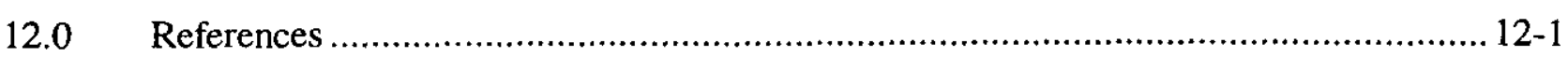


Table of Contents (continued)

\section{Appendices:}

Appendix A Source Term for the Old Radioactive Waste Burial Ground (ORWBG), Savannah River Site, WSRC-RP-97-0119, Rev. 1 Volume II

Appendix B Summary of Water Table Monitoring for the Old Radioactive Waste Burial Ground (ORWBG), WSRC-TR-97-00330, Rev. 1 Volume II

Appendix C Delineation of Potential "Hot Spots" for the Old Radioactive Waste Burial Ground (ORWBG), WSRC-TR-97-00329, Rev. 1 Volume II

Appendix D Sampling and Analysis Plan for Old Solvent Tanks S1-S22 to Address Waste Acceptance Criteria, WSRC-RP-97-00770. Volume II

Appendix E Addendum to the Workplan/RCRA Facility Investigation/Remedial Investigation Report for the Old Radioactive Waste Burial Ground 643-E, S01-S22 Volume II 


\section{List of Figures}

1-1 Location of the Burial Ground Complex at the Savannah River Site ......................... 1-17

1-2 Burial Ground Complex

1-3 General Locations of Disposal Sections in the Old Radioactive Waste Burial Ground, 1-20

1-4 Physiographic Subprovinces of the South Carolina Coastal Plain.

1-5 Map of the Savannah River Site

1-6 Lithostratigraphic Nomenclature Used at the Savannah River Site.

1-7 Generalized Correlation Between Stratigraphic and Hydrostratigraphic Units at SRS . 1-25

1-8 Regional Potentiometric Surface Map, McQueen Branch Aquifer (IA).

1-9 Regional Potentiometric Surface Map, Crouch Branch Aquifer (IB) ......................... 1-28

1-10 Regional Potentiometric Surface Map, Gordon Aquifer (IIA).

1-11 Relationship Between Hydraulic Heads of Crouch Branch (IB) and Gordon (IIA) Aquifers

2-1 Location of the Old Radioactive Waste Burial Ground within the Burial Ground Complex

2-2 Topography and Drainage Patterns in the Vicinity of the ORWBG $2-37$

2-3 ORWBG Conceptual Site Model 2-38

2-4 "Upper" Aquifer Zone ( $\left(\mathrm{IIB}_{2}\right)$ of the Upper Three Runs Aquifer (IIB) Monitoring Well Locations.

2-5 "Lower" Aquifer Zone ( $\mathrm{IIB}_{1}$ ) of the Upper Three Runs Aquifer (IIB) Monitoring Well Locations.

2-6 The Gordon Aquifer Unit (IIA) Monitoring Well Locations $2-43$

2-7 Burial Ground Complex Generalized Plume Map $2-45$

2-8 "Upper" Aquifer Zone ( IIB $\left._{2}\right)$ Tritium Activity from BGC FIP Groundwater Investigations.

2-9 "Upper" Aquifer Zone ( $\left(\mathrm{IIB}_{2}\right)$ TCE Concentration from the BGC FIP Groundwater Investigations

2-10 Background Soil Sample Locations for the Burial Ground Complex

2-11 Site Location Map of the Burial Ground Complex - Soil Gas Survey. $2-53$

2-12 Site Location Map of the Burial Ground Complex - Soil Gas Survey.

2-13 The Burial Ground Complex Ambient Air Study Sample Location Map …................. 2-57

2-14 The Burial Ground Complex Ambient Air Study Sample Location Map .................... 2-58

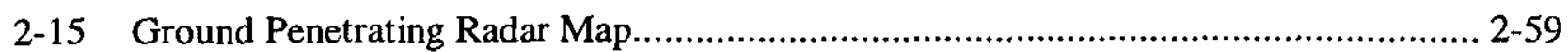

2-16 Volatilized Tritiated Water Sampling Locations 2-61 


\section{List of Figures (continued)}

2-17 Average Lead Concentrations in the Water Table, 1990 - 1995 ............................ 2-63

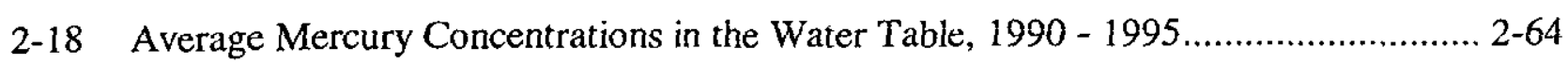

2-19 Average TCE Concentrations in the Water Table, 1990 - 1995 ............................. 2-65

2-20 Average PCE Concentrations in the Water Table, 1990 - 1995 .............................. 2-66

2-21 Average Gross Alpha Activity in the Water Table, 1990 - 1995 ......................... 2-67

2-22. Average Non-Volatile Beta Activity in the Water Table, 1990 - 1995 ..................... 2-68

2-23 Average Tritium Activity in the Water Table, 1990 - 1995 .................................. 2-69

2-24 Potential "Hot Spots" at 100 Years After Burial................................................ 2-70

2-25 Potential "Hot Spots" at 300 Years After Burial................................................ 2-71

2-26 Potential "Hot Spots" at 500 Years After Burial............................................... 2-72

8-1 ORWBG Schedule for the Submittal of Documents and Reports ............................ 8-3 


\section{List of Tables}

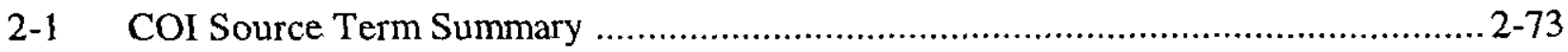

2-2 Monitoring Wells at the Burial Ground Complex........................................... 2-81

2-3 Constituents of Interest (COIs) for the Old Radioactive Waste Burial Ground (ORWBG) ........................................................................ 2-83

2-4 Qualitative Assessment of the Fate and Transport of COIs ................................ 2-84

2-5 Potential ARARs and TBC Criteria for the ORWBG ......................................2-85

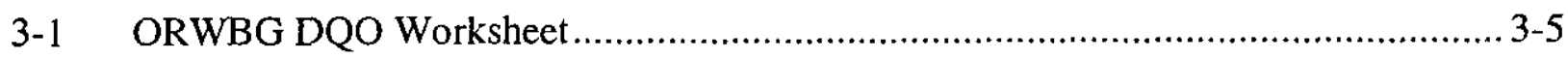

6-1 Standard Remedial Technologies............................................................. 6-3 


\section{List of Acronyms}

${ }^{\circ} \mathrm{C} \quad$ Degrees Celsius

${ }^{\circ} \mathrm{F} \quad$ Degrees Fahrenheit

$\% \quad$ Percent

AEA Atomic Energy Act of 1954

ARARs Applicable or Relevant and Appropriate Requirements

$\mathrm{Ba} \quad$ Barium

bls below land surface

BTEX Gasoline Range Aromatics (Benzene, Toluene, Eihylbenizeñe, añu Xÿlenc)

BGC Burial Ground Complex

CERCLA Comprehensive Environmental Response, Compensation and Liability Act of 1980

$\mathrm{Ci} \quad$ Curies

CIF Consolidated Incinerator Facility

Cd Cadmium

$\mathrm{cm} \quad$ centimeter

CMS/FS Corrective Measures Study/Feasibility Study

COI Constituent of Interest

COPC Constituent of Potential Concern

COBRA Computerized Radioactive-Waste-Burial-Records-Analysis

CPT Cone Penetrometer Technology

Cs Cesium

CSM Conceptual Site Model

CSV Comma-Separated Variable

CTET Carbon Tetrachloride

DOD Department of Defense

DOE Department of Energy

DQO - Data Quality Objective

EDTÄ

EMS

EPA

ESC

FFA

FIP

$\mathrm{ft}$

FY

gal

GRR

GSA

HASP

$\mathrm{Hg}$

hr

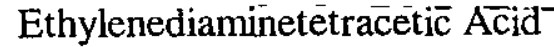

Environmental Monitoring Section

U.S. Environmental Protection Agency

Expedited Site Characterization

Federal Facility Agreement

Field Investigation Plan

feet

Fiscal Year

gallon

Ground Penetrating Radar

General Separations Area

Health and Safety Plan

Mercury

hour 


\section{List of Acronyms (continued)}

$\begin{array}{ll}\text { HSWA } & \text { Hazardous and Solid Waste Amendments } \\ \text { in } & \text { inch } \\ \text { kg } & \text { kilograms } \\ \text { km } & \text { kilometers } \\ \text { L } & \text { liter } \\ \text { lbs } & \text { pounds } \\ \text { LLRWDF } & \text { Low Level Radioactive Waste Disposal Facility } \\ \text { m } & \text { meter } \\ \text { m } & \text { cubic meter } \\ \text { MCL } & \text { Maximum Contaminant Level } \\ \text { MCLG } & \text { Maximum Contaminant Level Goals } \\ \text { mi } & \text { mile } \\ \text { ml } & \text { milliliter } \\ \text { mR/hr } & \text { milli Roentgen per hour } \\ \text { mrem } & \text { millirem } \\ \text { mCi } & \text { millicurie } \\ \text { mrad } & \text { millirad } \\ \text { msl } & \text { mean sea level } \\ \text { MWMF } & \text { Mixed Waste Management Facility } \\ \text { nCi } & \text { nano Curie } \\ \text { NEPA } & \text { National Environmental Policy Act } \\ \text { NPL } & \text { National Priorities List } \\ \text { NPR } & \text { New Production Reactor } \\ \text { ORWBG } & \text { Old Radioactive Waste Burial Ground } \\ \text { OST } & \text { Old Solvent Tank } \\ \text { Pb } & \text { Lead } \\ \text { PCE } & \text { Tetrachloroethylene } \\ \text { pcf } & \text { per cubic feet } \\ \text { pCi } & \text { pico Curie } \\ \text { PDWS } & \text { Primary Drinking Water Standards } \\ \text { PE } & \text { Polyethylene } \\ \text { POC } & \text { Point of Compliance } \\ \text { ppb } & \text { parts per billion } \\ \text { ppbv } & \text { parts per billion by volume } \\ \text { ppm } & \text { parts per million } \\ \text { ppmv } & \text { parts per million by volume } \\ \text { PVC } & \text { Polyvinyl Chloride } \\ \text { QA/QC } & \text { Quality Assurance/Quality Control } \\ \text { RAO } & \text { Remedial Action Objective } \\ \text { RCRA } & \text { Resource Conservation and Recovery Act } \\ \text { RI } & \text { Remedial Investigation } \\ & \end{array}$




\section{List of Acronyms (continued)}

RFI RCRA Facility Investigation

RFI/RI-PP RCRA Facility Investigation/Remedial Investigation Program Plan

SCDHEC South Carolina Department of Health and Environmental Control

SCHWMR South Carolina Hazardous Waste Management Regulations

$\mathrm{Sr}$

Strontium

SRS Savannah River Site (formerly the Savannah River Plant)

SRTC Savannah River Technology Center

SVOC Semi Volatile Organic Compound

SWMU Solid Waste Management Unit

TBC To Be Considered

TBP Tributylphosphate

TCE Trichloroethylene

TOC Total Organic Carbon

TOH Total Organic Halogen

TRU Transuranic

U Uranium

VOC Volatile Organic Compound

WAC Waste Acceptance Criteria

WIPP Waste Isolation Pilot Plant

WSRC Westinghouse Savannah River Company

yr Year




\section{Conversion Table for Measurement Units}

\begin{tabular}{|lll|}
\hline Metric Units & & U.S. Equivalent Units \\
\hline 1 hectare & $=$ & 2.47 acres \\
1 kilometer & $=$ & 0.6215 miles \\
1 square kilometer & $=$ & 0.39 square miles \\
1 meter & $=$ & 3.28 feet \\
1 centimeter & $=$ & 0.3987 inches \\
${ }^{\circ} \mathrm{C}$ & $=$ & $\left({ }^{\circ} \mathrm{F}-32\right) \times 5 / 9$ \\
1 liter & $=$ & 0.26 gallons \\
\hline
\end{tabular}


This page intentionally left blank. 


\section{EXECUTIVE SUMMARY}

The Old Radioactive Waste Burial Ground (ORWBG) (643-E including Solvent Tanks 650-01E to 650-22E) is located within the Savannah River Site (SRS) Burial Ground Complex (BGC). The BGC occupies approximately 75 hectares (195 acres) in the central part of SRS between F and $\mathrm{H}$ Separations Areas on a nearly flat divide between Upper Three Runs Creek to the north and Fourmile Branch to the south.

The ORWBG, including Old Solvent Tanks (S01-S22) is identified as a Resource Conservation and Recovery Act (RCRA) and a Comprehensive Environmental Response, Compensation and Liability Act (CERCLA) operable unit and is designated as Building Number 643-E. The unit is quadrilateral in shape and occupies approximately 31 hectares (76 acres) in the southern area of the BGC.

The ORWBG comprised a disposal area for solid radioactive waste produced at SRS and shipments from other Department of Energy and Department of Defense facilities. The unit received waste from 1952 to 1972; however, it was used until 1974 for small quantities of waste, primarily in retrievable form. The various levels/types of radioactive wastes were disposed in earthen trenches. The wastes included Transuranic (TRU) waste, low-level radioactive waste, and intermediate-level radioactive waste. Twenty-two underground storage tanks were used to store organic solvents for incineration in two areas of the unit. The ORWBG was also used for the storage of contaminated equipment, a sandblasting facility for equipment decontamination, and various repair facilities. There is no evidence that free liquid waste forms are buried in an "uncontained" state in the trenches at the ORWBG.

The ORWBG is relatively flat with elevations ranging from approximately 82 meters (270 feet) mean sea level along the southern perimeter to approximately 31 meters ( $300 \mathrm{feet}$ ) mean sea level adjacent to the northern boundary. The land surface generally slopes to the south, but has been locally modified by excavations and mounds of soil.

An interim action at the ORWBG has been initiated to minimize contaminant migration. The interim action places a low-permeability soil cover over the ORWBG unit with topsoil and vegetation. The role of the soil cover is to reduce stormwater infiltration through the waste layer to minimize contaminant migration to the water table. The soil cover is sloped to promote surface runoff, minimize surface erosion, and control leaching of hazardous substances from the source material. 
Previous investigations provide extensive information about the waste inventory in the ORWBG and the impact of that waste on the environment. Information concerning the waste inventory has been compiled and mapped in detail in Appendix A, "Source Term for the Old Radioactive Waste Burial Ground (ORWBG), Savannah River Site (U)." The relationship between the location of various buried waste types and the location of groundwater contamination at the ORWBG has been explored in Appendix B, "Summary of Water Table Monitoring for the Old Radioactive Waste Burial Ground (ORWBG)". Field investigations within the boundaries of the ORWBG inciude ground pentiating rauas (GPR) to verify the recorded locations of trenches of huried waste in the ORWBG, soil gas surveys, air sampling, shallow groundwater sampling, and soil sampling.

Characterization of the geology, hydrogeology, and the plumes of contamination emanating from the ORWBG has been conducted in accordance with, "A Field Investigation Plan for the Burial Ground Complex" (WSRC-RP-93-848). All groundwater associated with the burial ground complex is being addressed under the RCRA permit for the Mixed Waste Management Facility (MWMF), and complete documentation of the characterization of the plume at the ORWBG is presented in the RCRA Part B permit application for the $M W M F$. Pertinent information from the groundwater characterization is summarized in this document.

The Data Quality Objectives (DQO) evaluation and the unit assessment evaluation conclude that a single data gap remains to complete characterization of the ORWBG. This single data gap is the sampling and analysis of the remaining contents of the old solvent tanks to ensure that this material can meet the waste acceptance criteria for existing SRS disposal facilities.

This report identifies potential "hot spots" that may require special feasibility assessment in the development of a final remedy for the ORWBG. Identification of the "hot spots" is based on the following criteria:

- high concentrations or high activity levels of radioactivity;

- persistence of high radioactivity through time;

- burial type;

- waste form; and

- mobility. 


\section{0 - INTRODUCTION}

This document is a combined Workplan and Remedial Investigation Report.

\subsection{Workplan/RCRA Facility Investigation/Remedial Investigation Report Organization}

This document presents the assessment of environmental impacts resulting from releases of hazardous substances from the facilities in the Old Radioactive Waste Burial Ground (ORWBG, 643-E, including Solvent Tanks 650-01E to 650-22E, also referred to as Solvent Tanks S01-S22) at the Savannah River Site (SRS), Aiken, South Carolina.

This document is organized into twelve sections. Section 1, Introduction, outlines the regulatory framework and provides a brief description and history of the ORWBG. Section 2, Preliminary Unit Evaluation, provides detailed background information on unit characteristics and previous investigations; presents the conceptual site model (CSM); discusses general impacts on the unit and surrounding media; and provides a preliminary list of the applicable or relevant and appropriate requirements (ARARs) and "to-be-considered" (TBC) factors. Section 3, Data Quality Objectives, discusses the decision-making process for the Data Quality Objective (DQO) evaluation. Section 4, Unit Assessment, identifies the specific investigation activities (including detailed analyses of existing records) to be implemented in order to characterize the primary and secondary sources of contamination and the environmental media impacted as depicted by the CSM and as required by the DQO process needs. Early/interim remedial actions and potential Corrective Measures Study/Feasibility Study (CMS/FS) options are discussed in Sections 5 and 6, respectively. Section 7, Qualitative Risk Assessment Summary, discusses risks to human health and the environment. An estimated schedule, Health and Safety Plan (HASP), Quality Assurance/Quality Control (QA/QC) Plan, and a Data Management Plan are provided in Sections $8,9,10$, and 11 respectively. References cited in this report are listed in Section 12 .

\subsection{Regulatory Background}

\subsubsection{RCRA Facility Investigation Program}

The U.S. Department of Energy (DOE) Savannah River Operations Office, Aiken, South Carolina, manages waste materials which are regulated under the Resource Conservation and Recovery Act (RCRA) of 1976, a comprehensive law requiring stringent management of 
hazardous waste. The Hazardous and Solid Waste Amendments (HSWA) were passed in 1984 to further augment the 1976 requirements.

Certain activities conducted at the SRS require operating or post-closure permits issued in accordance with RCRA and are known as regulated units. Regulated units are those surface impoundments, landfills, and waste piles (collectively termed "land disposal units") which have received hazardous waste since November 19, 1980, and which require RCRA operating or postclosure permits. The SRS has received a RCRA permit from the South Carolina Department of Health and Environmental Control (SCDHEC). HSw' Section 3004 ( $u$ ) mandates the investigation and corrective action at non-regulated units. These non-regulated units have been termed Solid Waste Management Units (SWMUs) and may include any activity where hazardous constituents remain uncontrolled and could potentially be released to the environment. The Permit mandates that these SWMUs be further investigated to determine the actual or potential impact to human health and the environment.

\subsubsection{CERCLA Remedial Investigation Program}

On December 21, 1989, the SRS was included on the National Priorities List (NPL). A facility included on the NPL is subject to the provisions of the Comprehensive Environmental Response, Compensation, and Liability Act (CERCLA). In accordance with Section 120 of CERCLA, DOE has negotiated a Federal Facility Agreement (FFA) with the EPA and SCDHEC to coordinate cleanup activities at the SRS into one comprehensive strategy. The ORWBG, including Old Solvent Tanks (S01-S22), is identified as a RCRA/CERCLA unit under a new operable unit entitlcd "Old Radioactive Waste Burial Ground (643-E, S01-S22)."

Public participation requirements are listed in South Carolina's Hazardous Waste Management Regulation (SCHWMR) R.61-79-124 and Sections 113 and 117 of CERCLA. These requirements include the establishment of an Administrative Record file that documents the selection of cleanup alternatives and provides for review and comment by the public of those alternatives. The SRS Public Involvement Plan (DOE, 1994b) is designed to facilitate public involvement in the decision-making processes for permitting, closure, and the selection of reñedial altcrinatives. It addresses the requirements of CERCLA, RCRA, and the National Environmental Policy Act (NEPA). The Public Involvement Plan is available to the public in information repositories located in communities near the SRS. In addition to the Public Involvement Plan, the public will have access to the Administrative Record through these repositories. 
Unit-specific workplans, such as this one, will be part of the Administrative Record and will be available to the public. Information repositories have been established at DOE's Public Reading Room located at the University of South Carolina Aiken campus in Aiken, South Carolina and the Thomas Cooper Library in Columbia, South Carolina. A notice will be published in local newspapers, and announcements will be made on local radio stations, when information is being compiled regarding the investigation and cleanup of the ORWBG. Additional repositories may be added and/or locations changed to better meet the needs of the public.

The RCRA Facility Investigation Program Plan (WSRC, 1989) was developed by SRS to provide guidance and delineate standard procedures for facility investigations at SRS. The RFI Program Plan was expanded to include CERCLA hazardous substances and has been retitled the RCRA Facility Investigation/Remedial Investigation Program Plan (RFI/RI-PP, WSRC, 1993a).

\subsubsection{Summary of Unit Description}

\subsubsection{Unit History and Characteristics}

The ORWBG (643-E, including Solvent Tanks 650-01E to 650-22E) is located within the SRS Burial Ground Complex (BGC). The BGC is an area which occupies approximately 75 hectares (195 acres) in the central part of SRS between F and $\mathrm{H}$ Separation Areas, on a nearly flat divide between Upper Three Runs Creek to the north and Fourmile Branch to the south (see Figure 1-1). SRS Road E parallels the southern boundary of the ORWBG. A U.S. Government railroad and an inter-area high-level liquid waste transfer pipeline are located on the northern boundary of the ORWBG, between the ORWBG and the Mixed Waste Management Facility (MWMF)/Low-Level Radioactive Waste Disposal Facility (LLRWDF) areas (Figure 1-2). The administration building (No. 724-7E) and access road for the ORWBG are located near the southwest corner of the ORWBG, adjacent to Road E.

The ORWBG, designated Building Number 643-E, has a quadrilateral shape and occupies approximately 31 hectares (76 acres). The nearest SRS boundary is over 9.7 kilometers $(\mathrm{km})[6$ miles (mi)] to the north. The ORWBG was divided into sections to accommodate disposal of various levels/types of radioactive waste materials from 1952 until filled in 1972. These materials include transuranic (TRU) waste, low-level waste, and intermediate-level waste generated at SRS, and waste generated elsewhere. A map delineating the general locations of the disposal sections is shown on Figure 1-3. Sections 2.2.1 and 2.2.2 provide additional information on the Unit's history and waste composition. 


\subsection{Regional Setting}

\subsubsection{Meteorology}

The SRS region has a temperate climate with short, mild winters and long, humid summers. The region is subject to continental influences, but is protected from the more severe winters in the Tennessee Valley by the Appalachian Mountains to the north and northwest. It is often influenced by warm, moist maritime air masses throughout the year. Gently rolling hills, with no unusual iopogiaphic fcatures that would significantly influence the general climate, characterize the unit and the surrounding area.

The annual average temperature at $\mathrm{SRS}$ is $18^{\circ} \mathrm{C}\left(65^{\circ} \mathrm{F}\right)$. The average annual precipitation at SRS is 126 centimeters (cm) [ 49.73 inches (in)] and is distributed fairly evenly throughout the year. The greatest observed rainfall for a 24-hour period was about $50 \mathrm{~cm}$ (19.6 in) in October 1990.

Additional details concerning climatology and meteorology of SRS can be found in the Site Characteristics chapter of the Safety Analysis Report for SRS (WSRC, 1995a).

\subsubsection{Physiography}

SRS occupies an area of approximately 777 square kilometers (300 square miles) of the Aiken Plateau, as depicted on Figure 1-4. The Aiken Plateau is a subdivision of the Atlantic upper coastal plain, bounded by the Savannah River and the Congaree River on the east and west, and extends from the Fall Line in the northwest to the Orangeburg scarp in the southeast. The surface of the_Aiken Plateau is highly disected and characterized by broad interfluvial areas with narrow, steep-sided stream valleys. Local elevations can vary as much as $\overline{91}$ meters (m) [300 feet (ft)] over small distances. The plateau is usually well drained, although many poorly drained sinks and depressions exist, especially in topographically high areas [above $76 \mathrm{~m}(250 \mathrm{ft})$ mean sea level (msl)].

SRS lies wholly within the Savannah River drainage basin, with the Savannah River forming the southwestern boundary of SRS. Major tributaries to the Savannah River that flow southwestward àciosss SRS are Upper Three Runs Creek, Tinker Creek, Fourmile Branch, Pen Branch, Steel Creek, and Lower Three Runs Creek (Figure 1-5). Ground surface elevations at SRS range from approximately $21 \mathrm{~m}(70 \mathrm{ft}) \mathrm{msl}$ at the mouth of Lower Three Runs Creek to over $122 \mathrm{~m}$ (400 ft) msl on the plateau. 


\subsubsection{SRS Geology/Stratigraphic Sequence}

The age and stratigraphic correlation of geological units in the SRS area have long been controversial because of the sparseness of the fossil record and the similarity of the lithology of adjacent units. Until recently, most geologic studies used the nomenclature of Siple (1967) and Cooke and MacNeal (1952). The extensive geological and hydrological programs at the SRS have given rise to a large body of data which have greatly improved the understanding of the lithostratigraphy of the region. This explosion of data has given rise to a series of changes in the lithostratigraphic nomenclature and ranking of Price and Cook (1988). The nomenclature of Fallaw and Price (1995) is the currently approved lithostratigraphic nomenclature at the SRS. Figure 1-6 provides a general correlation between the lithostratigraphic nomenclature of these works. The nomenclature of Aadland et al. (1995) will be used in this Workplan.

SRS is underlain by a seaward thickening wedge of Cretaceous and Cenozoic fluvial, deltaic, and marine sediments. These sediments range in thickness from near zero at the fall line, $32 \mathrm{~km}(20$ miles) northwest of the SRS, to approximately $183 \mathrm{~m} \mathrm{(600} \mathrm{ft)} \mathrm{thick} \mathrm{at} \mathrm{the} \mathrm{northern} \mathrm{boundary} \mathrm{of}$ the SRS, $366 \mathrm{~m}(1,200 \mathrm{ft})$ at the southern boundary of the SRS, and more than $549 \mathrm{~m}(1,800 \mathrm{ft})$ near the Allendale-Hampton county line. Regional dip is to the southwest and averages $6.6 \mathrm{~m}$ per kilometer ( $35 \mathrm{ft}$ per mile) at the sub-Cretaceous unconformity and decreases upward through the sediment column. Over most of the study area, the Coastal Plain sequence is underlain by relatively impermeable saprolites and crystalline rocks of the Appalachian Orogen. The crystalline rocks are dominantly Paleozoic metamorphic quartzites, hornblende gneisses, and chloritehornblende schists which are intruded by slightly younger Paleozoic granitic plutons. In the southeast, the Cretaceous sediments lie on Triassic sediments of the Newark supergroup that were deposited in the Dunbarton basin. The Dunbarton basin is a Mesozoic graben formed at the time of the initial rifting of the North Atlantic basin. This basin contains as much as $1615 \mathrm{~m}$ $(5,300 \mathrm{ft})$ of terrigenous sediments which are comprised of poorly sorted fanglomerates, sandstones, siltstones, and claystones.

Rocks of the Paleozoic and Triassic have been leveled by erosion and are unconformably overlain by unconsolidated to poorly consolidated Coastal Plain sediments. The Coastal Plain sediments form a clastic wedge that thickens and dips to the southeast.

The Coastal Plain sequences near the center of the SRS consist of approximately $213 \mathrm{~m}$ (700 ft) of Late Cretaceous quartz sand, pebbly sand, and kaolinitic clays, overlain by approximately 18.3 $\mathrm{m}(60 \mathrm{ft})$ of Paleocene clayey and silty quartz sand, glauconitic sands, silts, and clays. The 
Paleocene sediments are in turn overlain by about $107 \mathrm{~m}(350 \mathrm{ft})$ of Eocene quartz sands, glauconitic quartz sands, clays, and limestones. Calcareous sediments are common in the upper parts of the downdip portion of the Eocene sediments and are commonly capped by deposits of pebbly clayey sand, conglomerates, and clays of Miocene to Oligocene age. Wide variations in lithology and thickness, both horizontally and vertically, are common in most of the Coastal Plain sediments, which were deposited during a series of marine transgressions and regressions. These variations make lithologic descriptions generalized and stratigraphic correlations difficult.

\subsubsection{Upper Cretaceous Sediments}

The Upper Cretaceous sequence consists of poorly consolidated clay-rich fine to medium grained micaceous sand, sandy clays, and gravels. The sequence is divided into the basal Cape Fear Formation and the overlying, poorly indurated Lumbee Group. The Lumbee Group is divided into the Middendorf, Black Creek, and Steel Creek Formations. The Cape Fear formation rests directly on top of the weathered and eroded surface of the basement complex.

The Cape Fear Formation consists of a moderately indurated heterogeneous sequence of sparsely fossiliferous clays, sandy clays and clayey sands which rest unconformably on 3 to $12 \mathrm{~m}$ ( 10 to $40 \mathrm{ft}$ ) of saprolites that were derived from the underlying crystalline rocks.

The Middendorf Formation unconformably overlies the Cape Fear with a distinct contact. This formation is marked by an abrupt change from the moderately indurated Cape Fear sediments to the slightly indurated micaceous sands and clayey sands, with thin lenses of kaolinitic clay, of the Middendorf. The Middendorf generally fines downdip to the southwest and has a basal zone that is commonly pebbly. The thickness of the formation ranges from $36.6 \mathrm{~m}^{-}(120-\mathrm{ft})$ in the north to $7.3 \mathrm{~m}(240 \mathrm{ft})$ in the south. The top of the Middendorf, dips to the southeast at $4.9 \mathrm{~m}$ per kilometer ( $26 \mathrm{ft}$ per mile) across the study area.

The Black Creek Formation consists of 41 to $61 \mathrm{~m} \mathrm{(150} \mathrm{to} 200 \mathrm{ft}$ ) of fluvial to upper deltaic darker colored, micaceous, comparatively well sorted, fine grained sands with a relatively high clay content. The Black Creek unconformably overlies the sediments of the Middendorf Formation. Clay lenses in this formation are commonly 6 to $12 \mathrm{~m}$ (20 to $40 \mathrm{ft}$ ) thick. The formation fines upward and is often capped by 3 to $7.6 \mathrm{~m}$ (10 to $25 \mathrm{ft}$ ) of clay.

The Steel Creek Formation (formerly the "Steel Creek Member" of the Peedee Formation) overlies the Black Creek Formation and is differentiated by a higher percentage of sand. It is characterized as yellow, tan, and gray, medium to coarse, moderately sorted sand interbedded 
with variegated clays. Pebbly zones and layers with clay clasts are common. The formation ranges in thickness from 18 to $53 \mathrm{~m}(60$ to $175 \mathrm{ft})$. The top of the Steel Creek is a 0.9 to $9 \mathrm{~m} \mathrm{(3}$ to $30 \mathrm{ft}$ ) thick clay bed of large horizontal extent. The formation dips to the southeast 20 feet per mile.

\subsubsection{Tertiary Sediments}

Tertiary sediments range from early Paleocene to Miocene in age and were deposited in fluvial to marine shelf environments. The sequence of sand, silt, and clay generally grades into highly permeable platform carbonates in the south and east. The Tertiary sequence is divided into three groups that are further subdivided into 17 formations and members. All are overlain by the unit referred to as "Upland Unit" of Price and Cook (1988) or the "Altemaha" Formation of Fallaw and Price (1995).

The Black Mingo Group consists of quartz sands, silty clays, and clays that were probably deposited in lower deltaic environments under marine influence. In the south, massive clays, often more than $15 \mathrm{~m}$ (50 ft) thick predominate. At the coast, these beds grade into limestone, anhydrite, and dolomite marine facies. The upper surface of the Black Mingo Group dips to the southeast at $3 \mathrm{~m}$ per kilometer ( $16 \mathrm{ft}$ per mile) and thickens from $18 \mathrm{~m}(60 \mathrm{ft}$ ) in the north to $52 \mathrm{~m}$ $(170 \mathrm{ft})$ in the south. The group is approximately 700 feet thick at the coastline. The Black Mingo Group consists of the Rhems Formation, and the overlying Snapp (Fallaw and Price 1995) or Williamsburg Formation (Fallaw et al 1990) and the Fourmile Formation (formerly the Fourmile Member of the Fishburn Formation).

The Rhems Formation contains five members, each representing a depositional facies. Two of these members are represented in the SRS area: the Sawdust Landing Member, an upper deltaic plain fluvial deposit that unconformably overlies the cretaceous Steel Creek/Peedee Formations, and the Lang Syne Member, a lower delta plain deposit of estuarine and littoral origin.

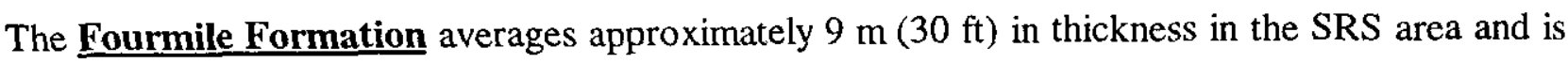
characterized as a mostly tan, yellow, orange, brown, and white moderately-to well-sorted sand with clay beds, a few feet thick, near the middle and top of the unit. It is distinguished from under lying sediments by lighter color and a lower content of silt and clay content. It is nearly indistinguishable from the overlying Congaree Formation. This formation becomes silty and clayey downdip and then grades into calcareous, glauconitic sands and fossiliferous limestones. 
The Orangeburg Group consists of the lower-middle Eocene Congaree Formation and the upper-middle Eocene Warley Hill and Tinker/Santee Formations. Over most of the SRS area, these post-Paleocene units are more marine in character than the underlying units, consisting of alternating layers of sand, limestone, marl, and clay. Sediments of this group thicken from approximately $26 \mathrm{~m}(85 \mathrm{ft})$ in the northeastern part of the SRS area to $61 \mathrm{~m}(200 \mathrm{ft})$ in the southwestern part of the area.

The Congaree Formation overlies the Fourmile Formation. It is about $9 \mathrm{~m}(30 \mathrm{ft})$ thick in the SRS area and consists of yeilow, orange, tan, gray, aliu giecen, will sorted fine to coarse quartz sand with granule and small pebble zones common. Thin clay laminae occur throughout the section. The quartz grains tend to be better rounded than those in the rest of the stratigraphic column. The Congaree grades into the platform carbonate facies of the lower Santee Limestone, beyond the sourthern border of the SRS.

The Warley Hill Formation unconformably overlies the Congaree. It consists of 3 to $6 \mathrm{~m}$ (10 to $20 \mathrm{ft}$ ) of fine-grained glauconitic sands and clayey beds commonly termed "Green Clay" in previous-SRS_reports. These sediments indicate clastic-shelf environments of deposition.

The Tinker/Santee Formations are late-middle Eocene shallow marine deposits overlying the Warley Hill Formation. These deposits consist of moderately-sorted, yellow and tan quartz sands, calcareous sand, clay, limestone, and marl. The sediments are more calcareous downdip and are sporadic in the middle of the SRS area, ranging from 0 to $21 \mathrm{~m}(0$ to $70 \mathrm{ft})$ in thickness.

The Barnwell Group are upper Eocene sediments which lie unconformably on the Tinker/Santee

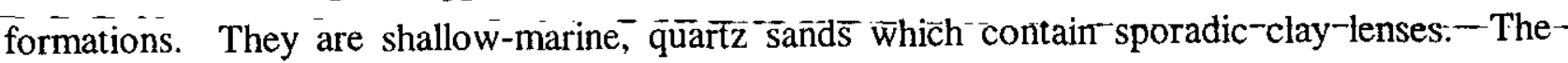
group is approximately $21 \mathrm{~m}(70 \mathrm{ft})$ thick at the northern boundary of the SRS thickening to $52 \mathrm{~m}$ $(170 \mathrm{ft})$ near its southeastern boundary. Down-dip, the Barnwell undergoes a facies change to phosphatic, clayey limestone of the lower Cooper Group. The Barnwell Group consists of the Dry Branch Formation and the Tobacco Road Formation.

The Dry Branch Formation is approximately $18 \mathrm{~m}(60 \mathrm{ft})$ thick near the center of the SRS. The formation consists of the Irwinton Sand Member, Twiggs Clay Member, and Griffins Landing Member.

The Irwinton Sand Member is a tan, yellow, and orange, moderately-sorted quartz sand with discontinuous interbedded clay layers and clay clasts. Thickness is variable, but is approximately 
$12 \mathrm{~m}(40 \mathrm{ft})$ in the north of the area. The interbedded clay layers have been referenced to the "Tan Clay" in earlier reports.

The Twiggs Clay Member is not mapable in the SRS area. It reaches a thickness of $3.7 \mathrm{~m} \mathrm{(12}$ $\mathrm{ft}$ ) in portions of the SRS, but is very discontinuous.

The Griffins Landing Member is composed of tan or green, slightly indurated quartzose calcareous micrite and sparite, calcareous quartz sand and slightly calcareous clay. Oyster beds

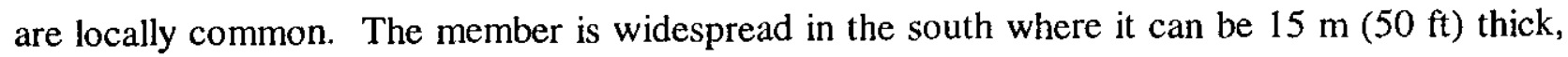
but is discontinuous in the center where it pinches out. The member seems to have formed in a shallow marine to lagoonal environment.

The Tobacco Road Formation is a Late Eocene sediment. This formation consists of moderately to poorly sorted, red, brown, tan, purple and orange, fine to coarse, clayey quartz sand. Pebble layers are common, as are clay laminae and beds. Burrow clasts are common in parts of the formation. The sands of the Tobacco Road Formation are better sorted than the overlying "Upland Unit". The lower part of the upper Eocene Cooper Group is the probable downdip equivalent of this formation.

The Cooper Group consists of marley upper Eocene/Oligocene deposits which grade horizontally into the Ocala Limestone. This Group is discontinuous in the area, having been described in only two cores in the south.

The "Upland Unit"/Hawthorn/Chandler Bridge Formations are poorly sorted, silty, clayey, pebbly sands and conglomerates which cap many of the higher elevations in the SRS area. Weathered feldspar is abundant in places and colors are variable. Changes in facies and thickness are abrupt, indicating that these may be fluvial deposits. Distinguishing characteristics include cross bedding laminations and the presence of 0.6 centimeter (cm, quarter inch) diameter white clay balls. Thickness varies and is as much as $18 \mathrm{~m}(60 \mathrm{ft})$ in some sections of the SRS area.

\subsubsection{SRS Hydrostratigraphy}

The Coastal Plain sediments underlying the SRS constitute a multi-layered hydrologic system in which water-flow retarding beds are interspersed with beds that transmit water more readily (aquifers). Groundwater flow paths and flow velocities for each of these beds are governed by the hydraulic properties and geometry of the particular bed and the distribution of recharge and discharge areas. 
In unconsolidated sediments, predominately sandy beds form aquifers. Beds containing large percentages of clay form aquatards, if thick and homogeneous, or aquapauses, if inhomogeneous or thin. Beds that form aquatards in one local area can transmit water in other areas due to lateral changes in Iithography or sporadic occurrence of the bed.

The accepted nomenclature of hydrogeologic units at SRS is that of Aadland et al. (1995). The coastal plain sequence has been divided into two Provinces: the Piedmont Hydrogeologic Province consisting of Triassic and earlier lithified sediments, metamorphic rocks, and granitic rocks, and the Southeast Coastai Plain Hydrogeologic Fıóvince, Cunsisting of unconsolidated to poorly consolidated, post-Triassic sediments. The Southeast Coastal Plain Hydrogeologic Province is divided into hydrogeologic systems as depicted in Figure 1-7. Listed from bottom to top these are designated the Appleton Confining System, the Dublin-Midville Aquifer System, the Meyers Branch Confining System, and the Floridan Aquifer System. Within these systems are individual units which are further divided into zones. Boundaries of hydrologic units do not necessarily coincide with stratigraphic boundaries, being dependent on hydrologic properties that are, in turn, more dependent on environments of deposition and post depositional history rather than time of deposition.

The following summary of the hydrostratographic nomenclature currently in use at SRS is derived from the work of Aadland et al. (1995).

The Appleton Confining System (I) correlates generally with the Cape Fear Formation and represents the bottom of the Cretaceous section at SRS. The Cape Fear Formation is an effective confining unit at SRS, because of its fine-grained character. It separates the water-bearing units of the Southeast Coastal Plain from the Paleozoic crystalline rocks and Triassic sediments of the Piedmont, which contain water of poorer quality. However, southeast and downdip from SRS, the sediments within the Cape Fear Formation become more sandy and the unit is used for groundwater withdrawal.

The Dublin-Midville Aquifer System (I) includes sediments of Cretaceous age. Over most of SRS, this system can be divided into two aquifers (the McQueen Branch [IA] and Crouch Branch [IB] aquifers) separated by the McQueen Rranch Confining Unit (IA-IB). The water-producing zones within this aquifer system constitute the major aquifers beneath and immediately surrounding SRS. Wells completed within the Dublin-Midville Aquifer System (I) are capable of producing water at a rate of thousands of gallons per minute. Subdivisions of the Dublin-Midville Aquifer System (I) are described as follows: 
The McQueen Branch Aquifer (IA) overlies the Appleton Confining System (I) and generally corresponds to the fine- to coarse-grained sands comprising the Middendorf Formation. Clay layers occur within the upper part of the Middendorf Formation, but they are only locally impervious. Sand zones in the lower third of the overlying Black Creek Formation are hydraulically connected with Middendorf Formation sands and are also considered part of the McQueen Branch Aquifer (IA). Collectively, these strata represent the water-bearing zone previously known as the "Lower Tuscaloosa Aquifer" or "Middendorf/Black Creek Aquifer."

The McQueen Branch Confining Unit (IA-IB) overlies the McQueen Branch Aquifer (IA) and consists of silty and clayey sediments within the middle third of the Black Creek Formation. The Black Creek Formation, as a whole, is more fine grained and less transmissive than the underlying and overlying formations, and contains significant clay layers that can retard vertical flow. However, these layers do not appear to be laterally continuous over large distances and are generally concentrated in the middle third of the formation. The McQueen Branch Confining Unit (IA-IB) generally corresponds to what was previously known as the "Mid Tuscaloosa Clay." Sand layers which occur in the Black Creek Formation are assigned to either the underlying McQueen Branch Aquifer (IA) or overlying Crouch Branch Aquifer (IB). However, because of its lithologic and physical character, the middle third of the Black Creek Formation can generally be considered a confining unit between the major water-producing aquifer units. This confining unit persists as a hydrogeologic barrier to vertical groundwater flow within the Dublin-Midville Aquifer (I) over most of the SRS. The McQueen Branch Confining Unit (IA-IB) thins and pinches out in the central portion of the SRS and is discontinuous in the northern areas. Within the study area, the McQueen Branch Confining Unit (IA-IB) is also referred to as the Allendale Confining System.

The Crouch Branch Aquifer (IB) is continuous throughout the SRS. It includes the sandy sediments comprising the upper third of the Black Creek Formation and the hydraulically connected sands of the overlying Steel Creek Formation. The Crouch Branch Aquifer (IB) generally corresponds to the "Upper Tuscaloosa Aquifer" or the "Black Creek/Peedee Aquifer" of previous terminology.

Overlying the Dublin-Midville Aquifer System (I) is a sequence of locally lignitic clay beds which occur within the upper part of the Steel Creek Formation (where present) and the Paleocene-age Black Mingo Group. These beds form an effective confining unit across most of SRS, separating 
groundwater in the overlying post-Paleocene Tertiary sediments from that in the underlying Cretaceous sediments. This sequence is referred to as the Meyers Branch Confining System (I-II), because of the thickness and lateral continuity of the clay beds. Both the Rhems and Snapp formations (where present) of the Black Mingo Group contain sand layers that are capable of producing significant quantities of water. However, these sands are relatively thin and discontinuous and do not constitute major aquifers. The Ellenton Member of the Rhems Formation is the principal confining unit in the ORWBG area.

The Floridan Aquifer System (II) inciudes aii of the hydirogeviugic ünitis withini the Tcritiary'age sediments overlying the Meyers Branch Confining System (I-II). Between Upper Three Runs Creek and the southern boundary of the SRS, this system is divided into two aquifer units separated by a confining unit. From bottom to top, they are designated as the Gordon Aquifer Unit (IIA), the Gordon Confining Unit (IIA-IIB), and the Upper Three Runs Aquifer Unit (IIB).

The Gordon Aquifer Unit (IIA) includes sands of the Congaree Formation and immediately overlying and underlying formations. This unit forms an aquifer that is second_in_importance only_to the aquifers within the Dublin-Midville Aquifer System (I). Wells completed within the Gordon Aquifer (IIA) are capable of producing water at a rate of hundreds of gallons per minute.

The Gordon Confining Unit (IIA-IIB) separates the Gordon Aquifer (IIA) from the overlying hydrogeologic units. This confining unit corresponds to the "Green Clay" interval found at and near the base of the McBean Member of the Santee Limestone Formation. The confining interval generally consists of one or more thin, but persistent, clay beds. The Gordon Confining Unit (IIA-IIB) is a major aquitard that is second in importance only to the clays of the McQueen Branch Confining Unit (IA-IB). Where present, especially in the central and southern part of the SRS, the unit supports significant head differences [greater than $12 \mathrm{~m} \mathrm{(40} \mathrm{ft)} \mathrm{in} \mathrm{some} \mathrm{areas]} \mathrm{between} \mathrm{wells} \mathrm{completed} \mathrm{in}$ water-bearing strata above and below the unit.

The Upper Three Runs Aquifer (IIB) groups all sediments above the Gordon Confining Unit (IIA-IIB) inte the same general unit. This unit includes the water table. Depending on the topographic and physiographic location, the Upper Three Runs Aquifer (IIB) may include, with increasing depth, one or more confined or semi-confined aquifer zones. In the area of the ORWBG, the Upper Three Runs Aquifer (IIB) can be informally subdivided into "lower" and "upper" aquifer zones $\left(\mathrm{IIB}_{1}\right.$ and $\mathrm{IIB}_{2}$, respectively), separated 
by the "Tan Clay" confining zone (IIB $\left.-\mathrm{IIB}_{2}\right)$. The "lower" aquifer zone $\left(\mathrm{IIB}_{1}\right)$ of the Upper Three Runs Aquifer (IIB) consists of fine-to coarse-grained sand between the "Tan Clay" confining zone (IIB $1-\mathrm{IIB}_{2}$ ) and the Gordon Confining Unit (IIA-IIB). These units correspond to members of the Tinker and Santee formations and lower part of the Dry Branch Formation. The "upper" aquifer zone $\left(\mathrm{IIB}_{2}\right)$ of the Upper Three Runs Aquifer (IIB) consists of the upper part of the Dry Branch Formation, the Tobacco Road Formation, and, where present, the "Upland Unit". The "Tan Clay" confining zone (IIB ${ }_{1}$ $\mathrm{IIB}_{2}$ ) corresponds to the Twiggs Clay Member of the Dry Branch Formation. Because the Twiggs Clay is only locally present, the "lower" and "upper" aquifer zones (IIB 1 and $\mathrm{IIB}_{2}$, respectively) of the Upper Three Runs Aquifer (IIB) are commonly hydraulically connected. The water table is generally found within the Barnwell Group (Tobacco Road and Dry Branch Formations). Most of the sands comprising the "Upland Unit" are unsaturated. However, perched water may occur locally above clay bodies in the Upland Unit, as has been historically reported at the ORWBG. Individual sand zones within the McBean Member may be very transmissive. However, the unit is not considered a significant aquifer at SRS, because of the overall heterogeneity of the sediments comprising the Upper Three Runs Aquifer (IIB).

Hydraulic heads of groundwater in the McQueen Branch (IA) and Crouch Branch (IB) aquifer units are controlled by recharge and discharge regions distant from the SRS. As shown on the regional potentiometric surface maps for these units (Figures 1-8 and 1-9), recharge and discharge areas are to the northeast and southwest, respectively, of SRS. The regional potentiometric surface map for groundwater in the Gordon Aquifer Unit (IIA) (Figure 1-10) indicates that recharge for that unit is to the north and east of SRS. The characteristics of the potentiometric surface contours indicate, however, that Upper Three Runs Creek and the Savannah River floodplain act as regional discharge areas for groundwater within the Gordon Aquifer Unit (IIA).

Figure 1-11 shows the regional relationships between hydraulic heads in the Crouch Branch (IB) and Gordon (IIA) aquifer units. In the northwest and east-central parts of SRS, the hydraulic head in the Gordon Aquifer Unit (IIA) is higher than the hydraulic head in the Crouch Branch Aquifer Unit (IB). Elsewhere at SRS, including the BGC/ORWBG, the hydraulic head in the Crouch Branch Aquifer Unit (IB) is higher than the hydraulic head in the Gordon Aquifer Unit (IIA). Comparisons of hydraulic heads in the McQueen Branch Aquifer (IA) with the hydraulic head in the Gordon Aquifer Unit (IIA) yield similar results. These relationships indicate that groundwater in the vicinity of the BGC/ORWBG has the potential for upward movement from underlying aquifers into the Gordon Aquifer Unit (IIA). 


\subsubsection{General Separations Area Hydrogeology}

The General Separations Area (GSA), which includes the BGC and ORWBG, is near the geographic center of the SRS and is approximately 39 square kilometers (15 square miles) in size. All runoff from the GSA moves toward the Savannah River, about 14 to $16 \mathrm{~km}$ (9 to $10 \mathrm{mi}$ ) to the southwest.

Approximately 125.3 centimeters (49.7 inches) of precipitation occurs annually at the GSA with dn esiiniatated 70 percont lost through runoff and evapotranspiration. The rest is availahle for groundwater recharge.

Hydrogeological data was obtained from observation/monitoring wells which are concentrated around and near the various facilities in the GSA, where data is more reliable. Where well density is low, the data becomes more widely separated and less reliable.

The Crouch Branch Aquifer (IB) consists of medium- to coarse-grained, micaceous sands and is considered the principal confined aquifer in the GSA. This aquifer is part of the regional groundwater flow regime and is either used as a source of drinking water at-SRS-or-is hydraulically connected to underlying aquifers used as drinking water sources from areas outside the SRS.

The Meyers Branch Confining System (I-II) is informally referred to as the "Ellenton Clay" and forms the principal confining unit between the two regional aquifer systems. The Meyers Branch (I-II) reaches a thickness of over $30 \mathrm{~m}(100 \mathrm{ft})$ in the GSA. Regional dip is to the south and southwest with local highs beneath the $\mathrm{Y} / \mathrm{Z}$-Area,-BGE, and-H-Area-Seepage-Basins.

The Floridan Aquifer System (II) is divided into the Gordon Aquifer (IIA), the Gordon Confining Unit (IIA-IIB), and the Upper Three Runs Aquifer (IIB). The Upper Three Runs Aquifer (IIB) is informally subdivided into the "upper" (IIB $)_{2}$ and "lower" (IIB 1$)$ zones of the Upper Three Runs Aquifer (IIB), separated by the "Tan Clay" confining zone (IIB $\left.1-\mathrm{IIB}_{2}\right)$.

The Gordon Aquifer Unit (IIA) ranges in thickness from 14.6 to $29.9 \mathrm{~m}$ (48 to $98 \mathrm{ft}$ ) within the GSA and consists of sands and clayey sands with small interbeds of sandy clays, clay, and calcareous sands. Clays range in thickness from 0.3 to $2.7 \mathrm{~m}$ ( 1 to $9 \mathrm{ft}$ ). Locally, calcareous sediments range in thickness from less than 1 foot near F-Area Seepage Basins to $4.6 \mathrm{~m}$ (15 ft) beneath the H-Area Seepage Basins. The Gordon Aquifer (IIA) is thickest to the west, thinning 
eastward, with the thinnest portion located under the H-Area Seepage Basins. Slight thickening occurs between the MWMF and Y/Z Areas.

The Gordon Confining Unit (IIA-IIB), informally known as the "Green Clay" Unit, dips across the GSA in a southerly direction with localized lows at the H-Area Seepage Basins and at the northern boundary of the MWMF. Carbonate sediments within this confining unit are distributed locally in approximately the same areas as the calcareous sediments in the Gordon Aquifer Unit (IIA).

The "lower" aquifer zone (IIB $)$ of the Upper Three Runs Aquifer (IIB) is irregular in thickness within the GSA with a general thinning toward the west around the F-Area Seepage Basins. It is thickest just east of the H-Area Seepage Basins. Calcareous sands and marl are variable in thickness with the thickest being adjacent to the MWMF.

The "Tan Clay" confining zone (IIB $\left.1-\mathrm{IIB}_{2}\right)$ of the Upper Three Runs Aquifer (IIB) dips southward off a high located beneath the Hazardous Waste-Mixed Waste Disposal Facility. A linear depression associated with possible faulting occurs in the vicinity of the F-Area Seepage Basins. Localized depressions are also present beneath the ORWBG and H-Area Seepage Basins.

The "upper" aquifer zone (IIB $)$ of the Upper Three Runs Aquifer (IIB) represents the "Water Table Aquifer" through most of the GSA. The depth to water varies from 1.22 to $24.38 \mathrm{~m}$ (4 to $80 \mathrm{ft})$. The saturated thickness of the "upper" zone $\left(\mathrm{IIB}_{2}\right)$ decreases over localized highs adjacent to stream valleys and to the north where the elevation of the "Tan Clay" increases over lows in the "Tan Clay" confining zone $\left(\mathrm{IIB}_{1}-\mathrm{IIB}_{2}\right)$.

\subsubsection{Ecological Setting}

The ORWBG is located within the SRS BGC, a highly industrialized area surrounded by a security fence. Within the fenced area encompassing the ORWBG, a soil cover is currently being constructed over the unit. These construction activities preclude the presence of ecological receptors at the ORWBG. Once the soil cover is completed and a vegetative cover is established for erosion control, wildlife (e.g., small mammals and birds) may become reestablished in the area.

\subsubsection{Demographics}

SRS is located approximately $40 \mathrm{~km}$ (25 mi) southeast of Augusta, Georgia, and $32 \mathrm{~km}(20 \mathrm{mi})$ south of Aiken, South Carolina. According to 1990 census data (U.S. Bureau of Census, 1991a and 1991b), the average population densities (in persons per square mile) for the surrounding 
South Carolina counties were 113 for Aiken County, 43 for Bamberg County, 37 for Barnwell County, and 29 for Allendale County; and for the surrounding Georgia Counties, 228 for Columbia County, 586 for Richmond County, 25 for Burke County, and 21 for Screven County. The population within these eight counties was 460,079 people in 1990 . The estimated population for the area in the year 2000 is projected to be 528,329 (according to projections developed by South Carolina State Budget and Control Board and Georgia Office of Planning and Budget).

Six counties provide 90 percent of the SRS work force: Aiken, Ailendale, Bamberg, and $\bar{B}$ arnweii counties in South Carolina, and Columbia and Richmond counties in Georgia (DOE, 1994a). Demographic data indicates that the population in these counties increased 13 percent from 376,000 to 425,658 between 1980 and 1990 . The population in these counties is expected to increase to 493,812 by the year 2000 . 


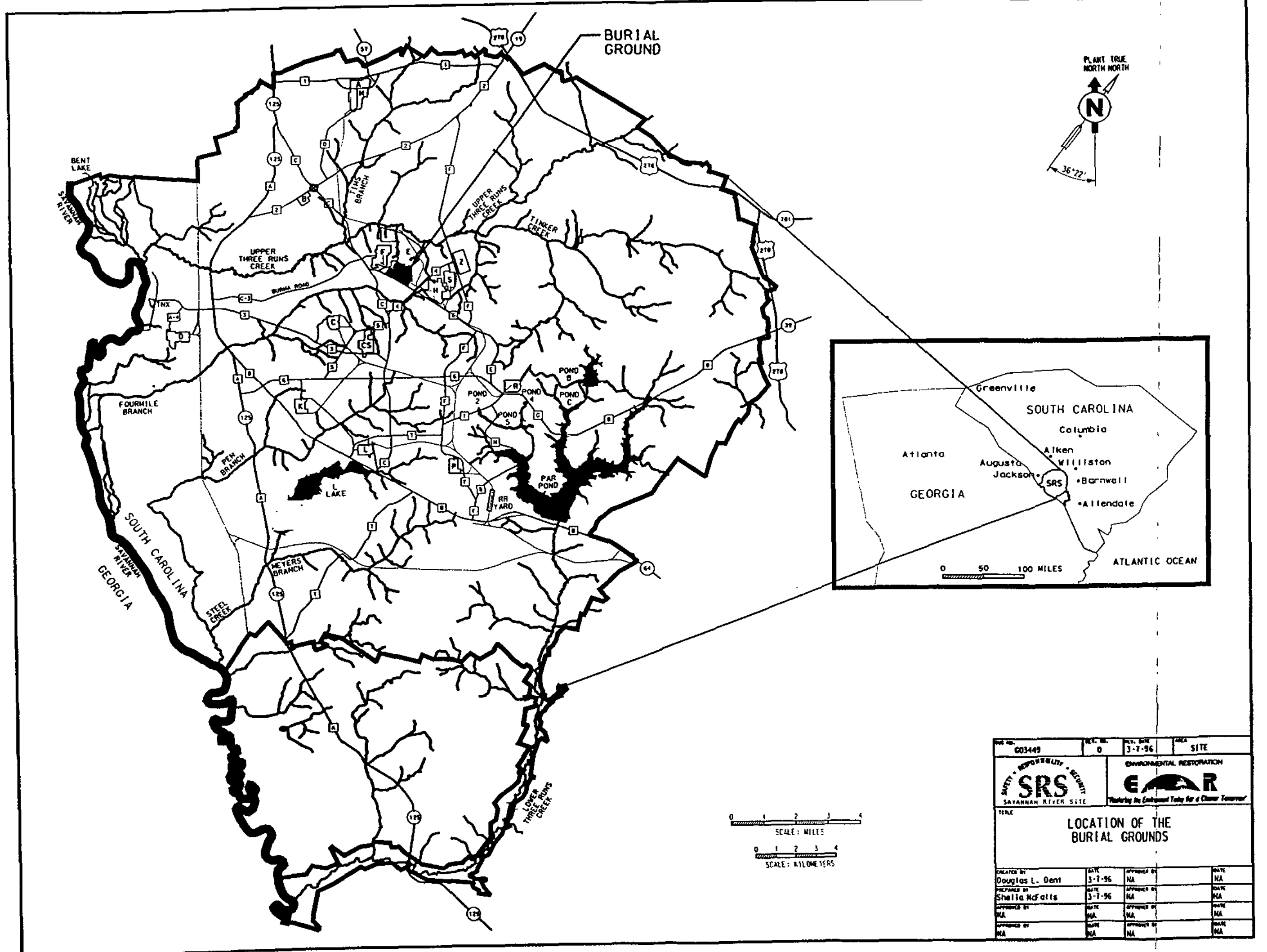

Figure 1-1. Location of the Burial Ground Complex at the Savannah River Site 


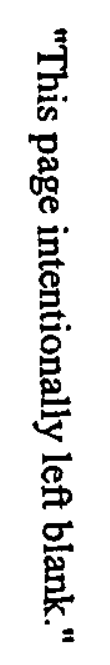

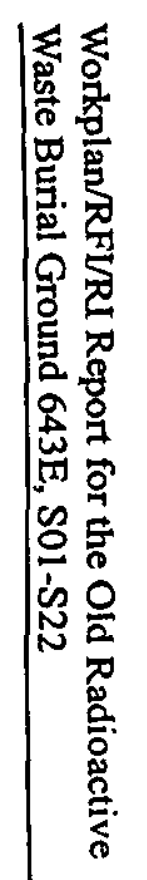

| 


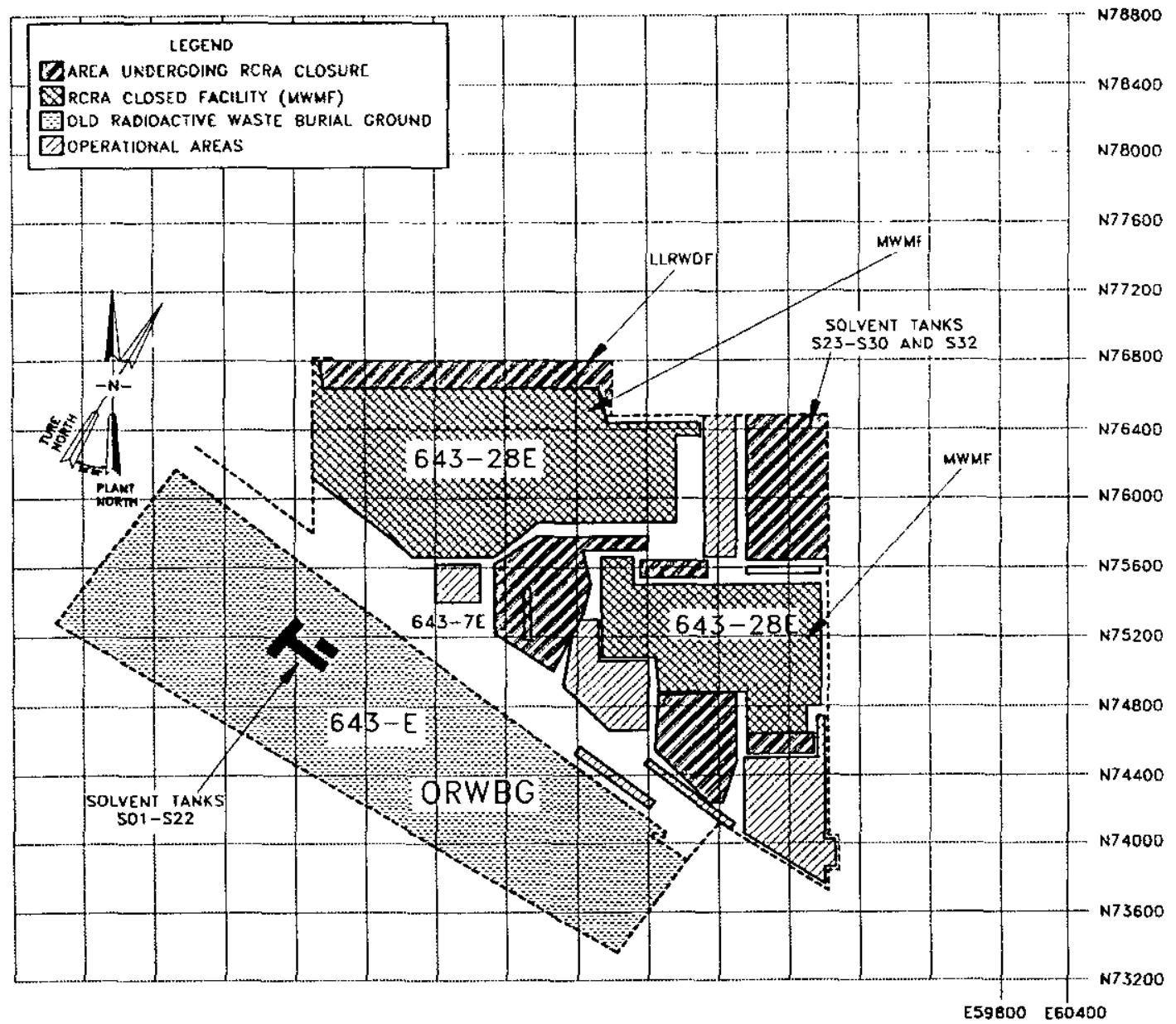

Figure 1-2. Burial Ground Complex 


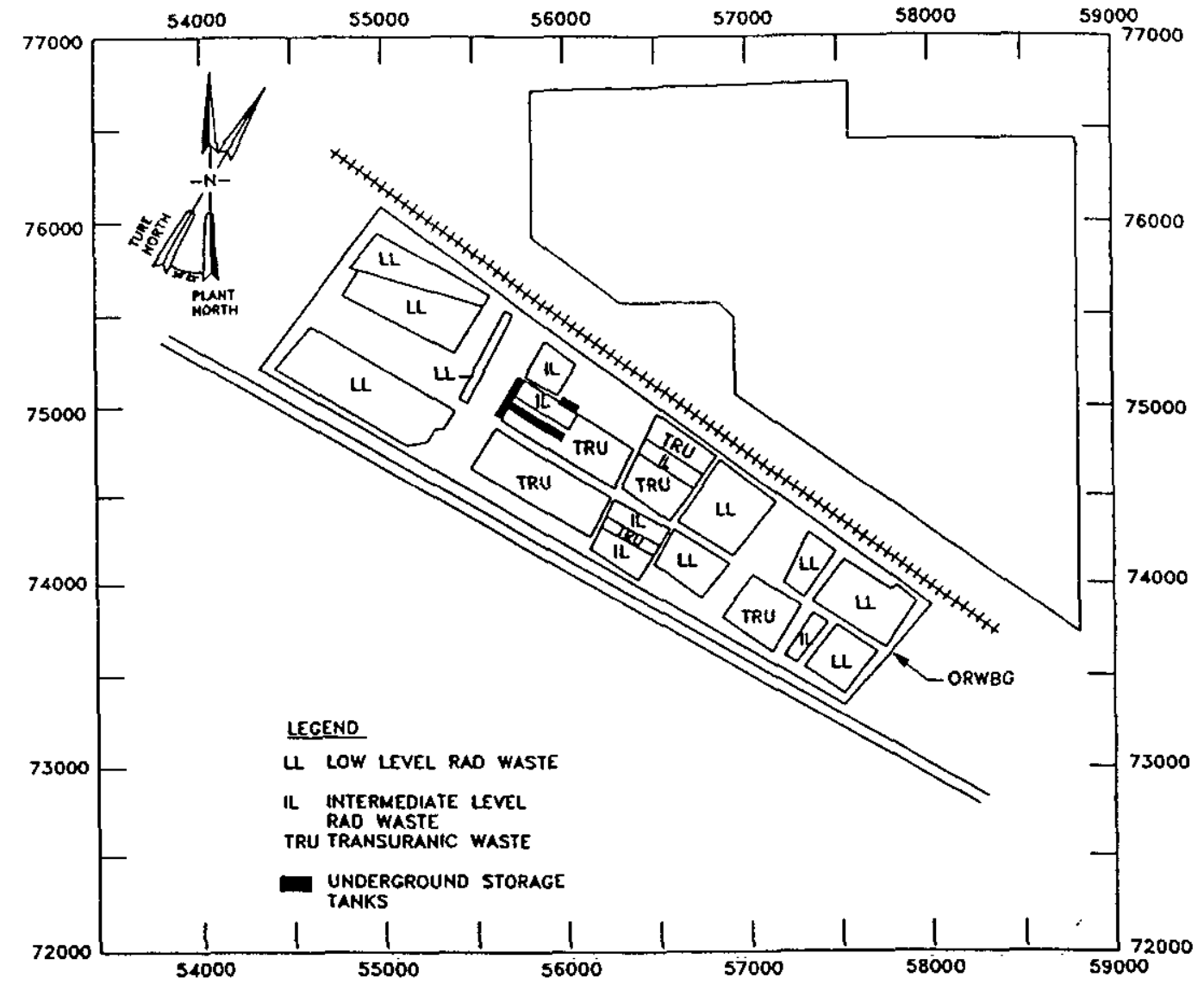

Figure 1-3. General Locations of Disposal Sections in the Old Radioactive Waste Burial Ground 


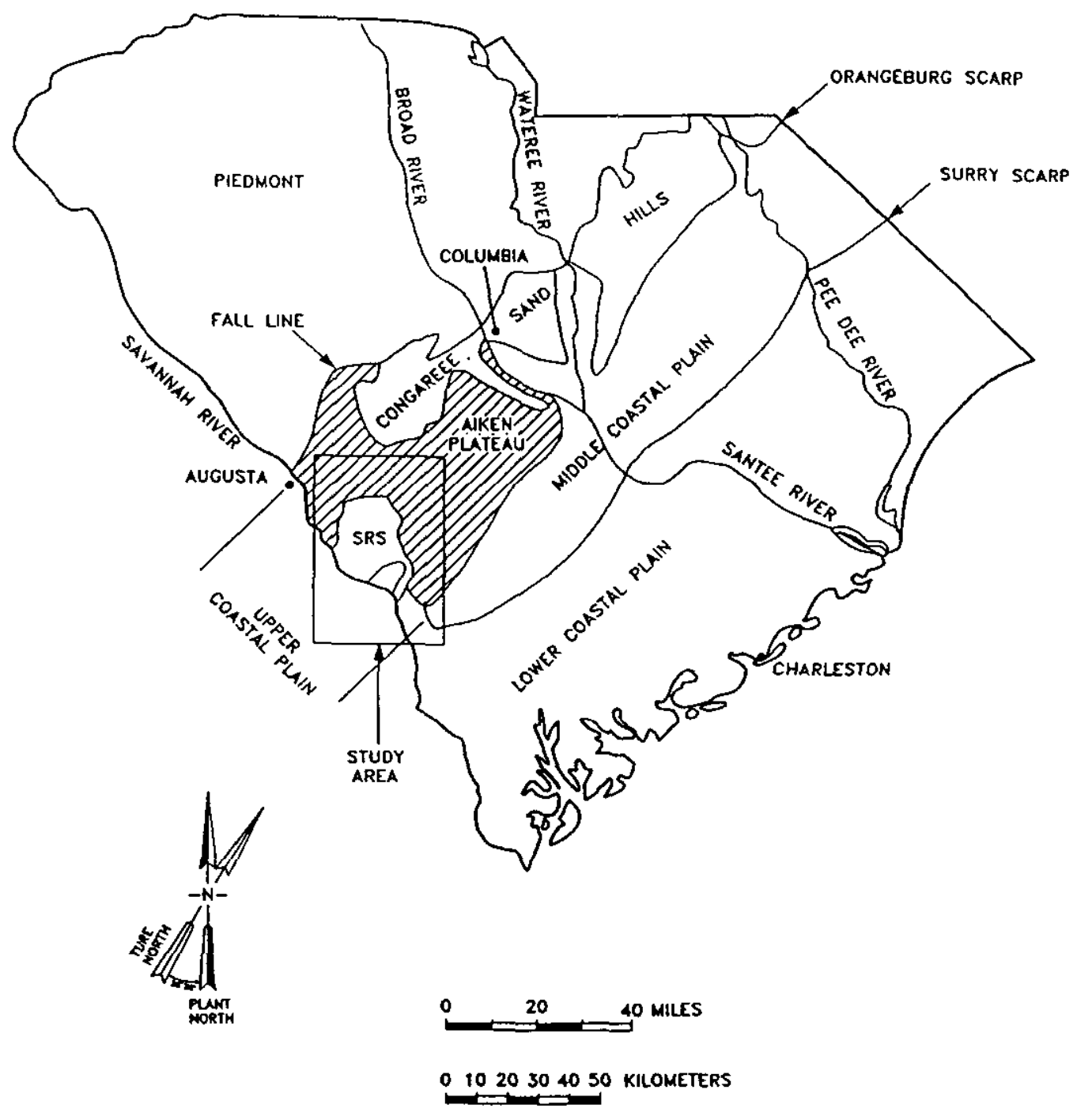

Figure 1-4. Physiographic Subprovinces of the South Carolina Coastal Plain 


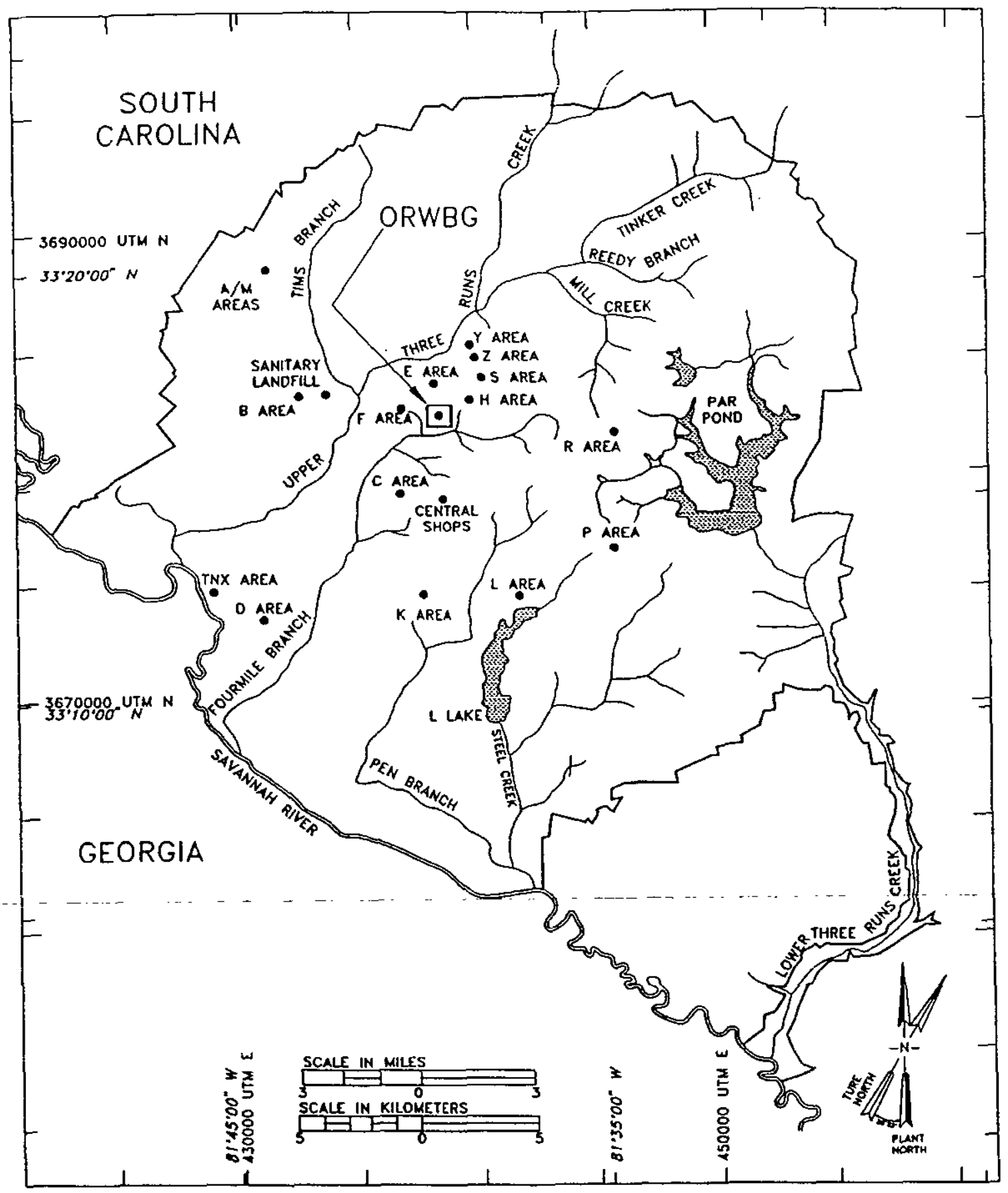

Figure 1-5. Map of the Savannah River Site 


\begin{tabular}{|c|c|c|c|c|}
\hline \multicolumn{2}{|c|}{$\begin{array}{c}\text { CHRONOSTRATIGRAPHIC } \\
\text { UNITS }\end{array}$} & \multicolumn{3}{|c|}{$\begin{array}{l}\text { LITHOSTRATIGRAPHIC UNITS } \\
\text { (Price et al.. 1888) }\end{array}$} \\
\hline System & Series & Group & \multicolumn{2}{|c|}{ Formation } \\
\hline \multicolumn{2}{|c|}{ Miocene } & \multirow{5}{*}{$\begin{array}{l}\text { Barnwell } \\
\text { Group }\end{array}$} & "Uplan & di Unit" \\
\hline \multirow{9}{*}{ Eocene } & \multirow{4}{*}{ Upper } & & Tobacco Roa & ad Formation \\
\hline & & & $\begin{array}{c}\text { Dry } \\
\text { Branch }\end{array}$ & $\begin{array}{l}\text { Ifrumbton Sand Member } \\
\text { Triggs Clay Momber }\end{array}$ \\
\hline & & & Formation & Grittions Landing Member \\
\hline & & & \multicolumn{2}{|c|}{ Clinchfield Formation } \\
\hline & \multirow{4}{*}{ Middle } & \multirow{4}{*}{$\begin{array}{l}\text { Orangeburg } \\
\text { Group }\end{array}$} & \multirow{2}{*}{$\begin{array}{c}\text { Santee } \\
\text { Formation }\end{array}$} & MeBean Mambar \\
\hline & & & & Car Car Mombar \\
\hline & & & Warley Hiil & Formation \\
\hline & & & Congaree & Formation \\
\hline & Lower & \multirow{3}{*}{$\begin{array}{l}\text { Black Mingo } \\
\text { Group }\end{array}$} & Fishburne $F_{m}$. & I Fourmile Hember \\
\hline \multirow{2}{*}{ Paleocene } & Upper & & Nilliamsburg Fon. & Snapp Member \\
\hline & Lower & & Ellenton & Formation \\
\hline \multirow{4}{*}{ Cretaceous } & \multirow{4}{*}{ Upper } & \multirow{4}{*}{$\begin{array}{l}\text { Lumbee } \\
\text { Group }\end{array}$} & Poodoo Formation & $\begin{array}{l}\text { Stool Crook Member } \\
\text { s. }\end{array}$ \\
\hline & & & Black Creet & Formation \\
\hline & & & Middendort & Formation \\
\hline & & & Cape Fear & Formation \\
\hline \multicolumn{2}{|c|}{ Triassic } & $\begin{array}{c}\text { Newark } \\
\text { Supergroup }\end{array}$ & Sedimentary Rock & (Dunbarton Basin) \\
\hline & & & Crystalline B & asement Rock \\
\hline
\end{tabular}

\begin{tabular}{|c|c|}
\hline \multicolumn{2}{|r|}{$\begin{array}{l}\text { LITHOSTRATIGRAPHIC UNITS } \\
\text { (Fallaw and Price, 1995) }\end{array}$} \\
\hline Group $=$ & Formation \\
\hline \multirow{5}{*}{$\begin{array}{c}\text { Barnwell } \\
\text { Group }\end{array}$} & Altamaha Formation \\
\hline & Tobacco Road Formation \\
\hline & \begin{tabular}{c|l} 
Dry Branch & Irwinton Sand Member \\
Formation & Irwion
\end{tabular} \\
\hline & Griffins Landilng Member \\
\hline & 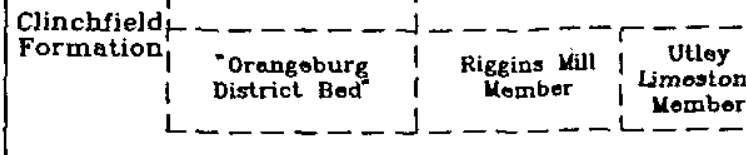 \\
\hline \multirow{3}{*}{$\begin{array}{l}\text { Orangeburg } \\
\text { Group }\end{array}$} & 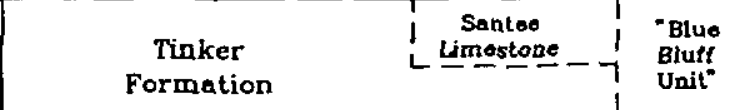 \\
\hline & Warley Hill Formation \\
\hline & Congaree Formation : \\
\hline \multirow{4}{*}{$\begin{array}{l}\text { Black Mingo } \\
\text { Group }\end{array}$} & Fourmile Branch Formation \\
\hline & Snapp Formation \\
\hline & Lang Syne Formation \\
\hline & Sardust Landing Formation \\
\hline & Steel Crook Formation \\
\hline \multicolumn{2}{|r|}{ Black Creek Group } \\
\hline \multicolumn{2}{|r|}{ Middendorf Formation } \\
\hline & Cape Fear Formation \\
\hline \multirow[t]{2}{*}{$\begin{array}{c}\text { Newark } \\
\text { Supergroup }\end{array}$} & Sedimentary Rock (Dunbarton Basin) \\
\hline & Crystalline Basement Róck \\
\hline
\end{tabular}

Figure 1-6. Lithostratigraphic Nomenclature Used at the Savannah River Site 



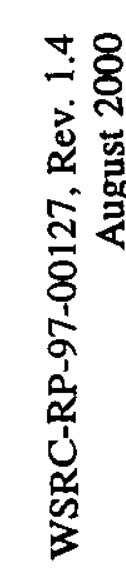

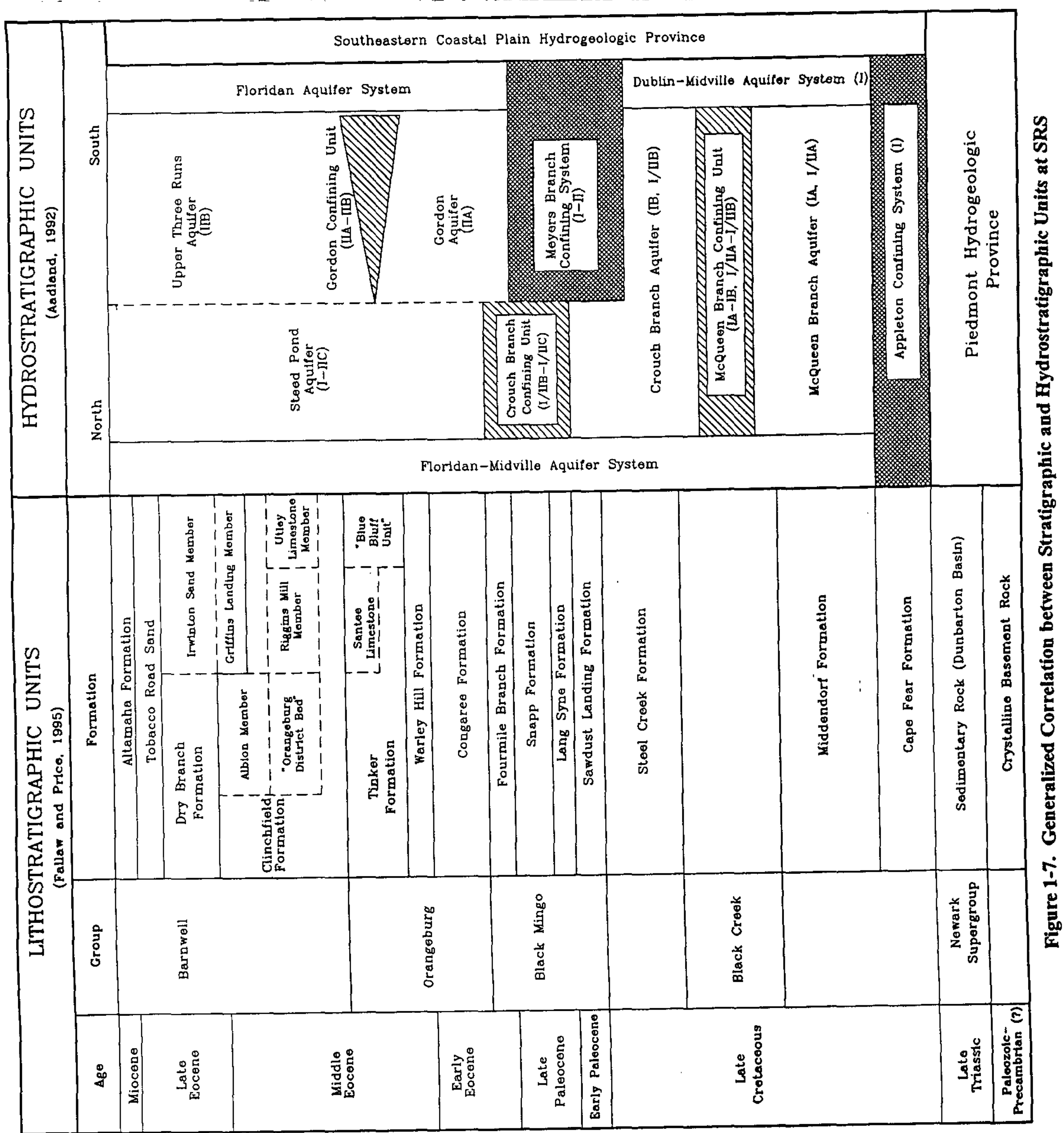





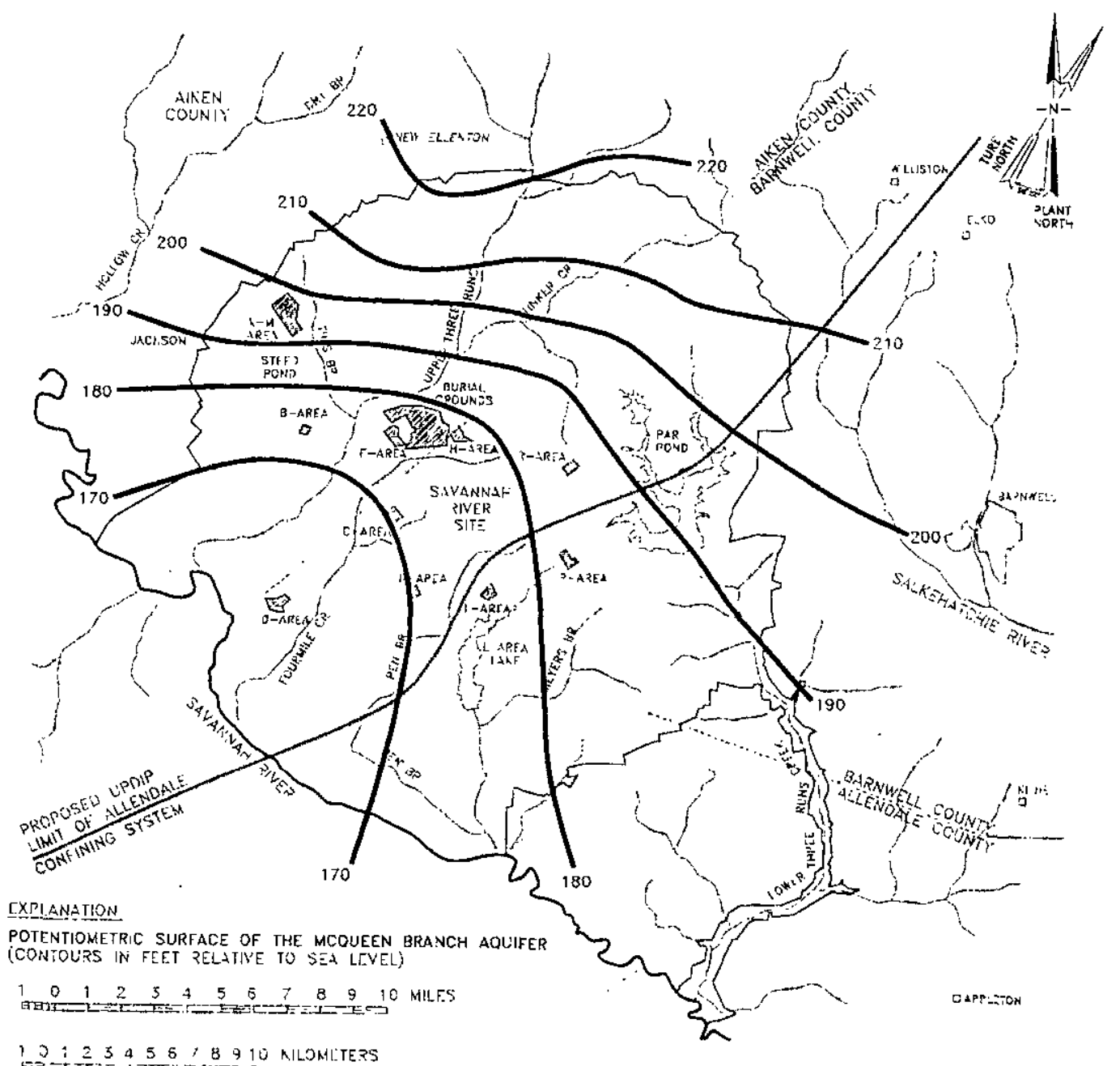

IO 12345678910 KILONILTERS 


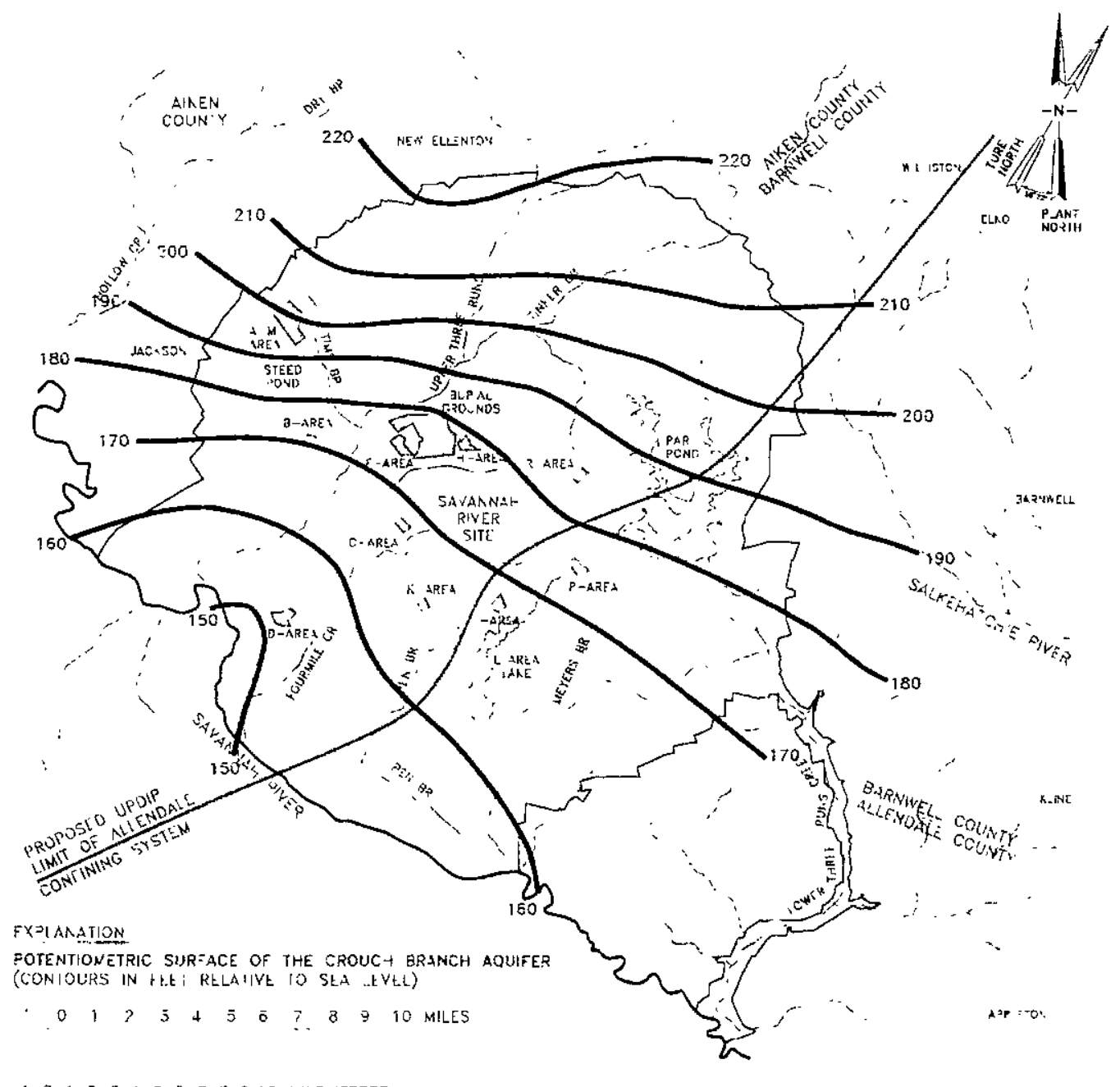

$10: 23456 \div B O 10$ KHOMETERS

Figure 1-9. Regional Potentiometric Surface Map, Crouch Branch Aquifer (IB) 


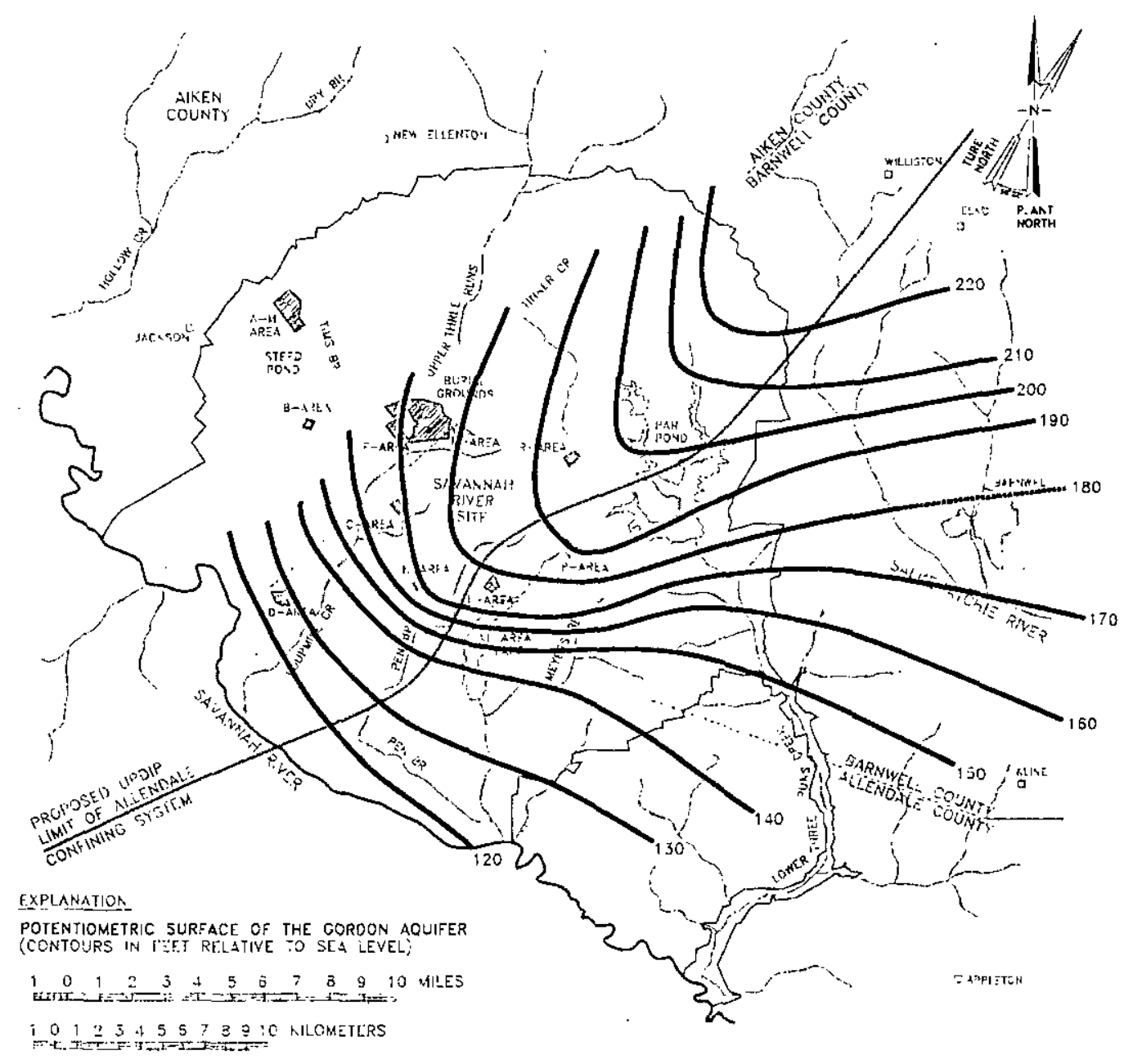

Figure 1-10. Regional Potentiometric Surface Map, 


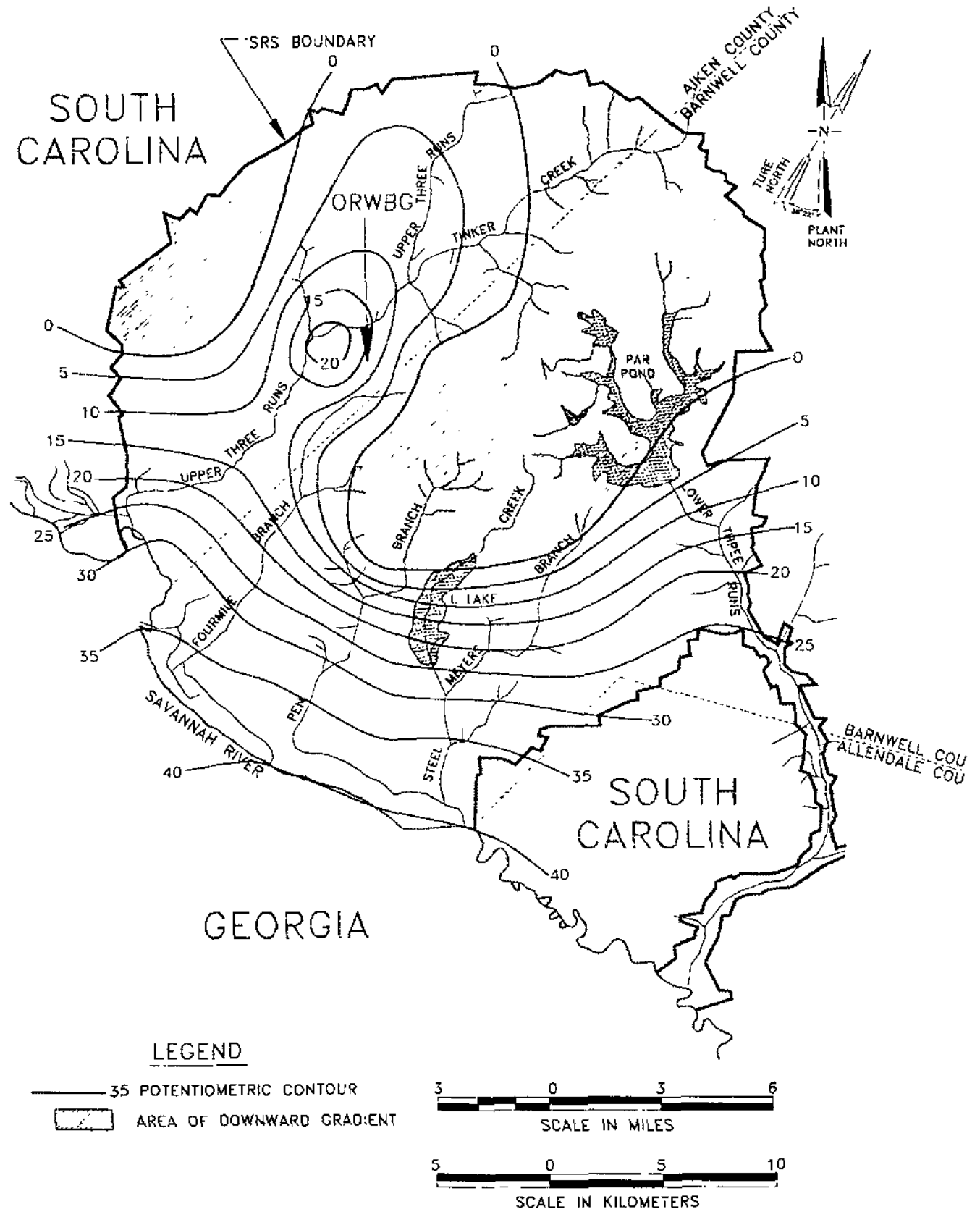

Figure 1-11. Relationship Between Hydraulic Heads of Crouch Branch (IB) and Gordon (IIA) Aquifers 


\subsection{PRELIMINARY UNIT EVALUATION}

\section{$2.1 \quad$ Introduction}

This chapter describes the results of the Preliminary Unit Evaluation of the ORWBG source operable unit located within the BGC. The evaluation is based on information determined from descriptive documents concerning the ORWBG and analysis of existing data. The literature and data reviewed address the following ORWBG Unit Evaluation categories:

- Unit Characteristics

- Conceptual Site Model

- Existing and previous investigations

- Unit Evaluation conclusions

- Potential ARARs and TBC criteria

Primary data and documents reviewed for this evaluation are referenced in Section 12.

\subsection{Unit Characteristics}

\subsubsection{Unit History}

1 The ORWBG designated as Building Number 643-E, and including Solvent Tanks S01-S22, is located in the southern area of the BGC. The ORWBG area has a quadrilateral shape approximately $1128 \mathrm{~m}(3,700 \mathrm{ft})$ long, $335 \mathrm{~m}(1,100 \mathrm{ft})$ wide on the west end, $213 \mathrm{~m}(700 \mathrm{ft})$ wide on the east end, and occupies approximately 31 hectares (76 acres, Figure 2-1). It is surrounded by an eight foot high chain link fence and is situated between Road $E$ and the F-Area railroad. A paved road leads to the entrance, and unimproved dirt roads inside the fence provide access to old burial sites. The ORWBG comprises a disposal area for solid radioactive waste produced at SRS and shipments from other Department of Energy and Department of Defense facilities.

The ORWBG began receiving waste in 1952 and was filled in 1972; however, according to the Computerized Radioactive Waste Burial Records Analysis (COBRA) database, it was used up until 1974 for small quantities of waste, primarily in retrievable form. Earthen trenches within ORWBG were excavated $6 \mathrm{~m}(20 \mathrm{ft})$ wide, $6 \mathrm{~m}(20 \mathrm{ft})$ deep, and up to $213 \mathrm{~m}(700 \mathrm{ft})$ long. These trenches were filled with various levels/types of radioactive waste materials. These materials include Transuranic (TRU) waste, low-level radioactive waste, and intermediate-level radioactive waste generated at SRS; and waste generated from other DOE and Department of 
Defense (DOD) facilities. Most of the waste in the ORWBG originated from SRS operations; relatively insignificant amounts were generated from off-SRS sources. The waste forms and burial methods of off-SRS wastes were generally similar to SRS-generated wastes. Off-SRS shipments comprise 141 burials from Mound Laboratory, Pinellas in Florida, General Electric, Sylvania Corning, Burlington in Ohio, and Miamisburg in Ohio. Off-SRS wastes total 37,978 $\mathrm{ft}^{3}$ or about $0.5 \%$ of the total inventory. Wastes from off-SRS sources contained a variety of constituents, including:

- Tritium: DOE weapons-complex facilities, primarily Mound Laboratory in Ohio and the Pinellas Plant in Florida, periodically shipped tritium-containing wastes to SRS for disposal. Additionally, certain trenches designated "Special Projects 234" include tritium burials from both on-SRS and off-SRS sources. Both of these types of burials are included in the COBRA database. Off-SRS sources contribute $\sim 1,468,300 \mathrm{Ci}$ of the source term estimate.

- Cesium-137 and Strontium-90: Relatively insignificant amounts of fission products were received from off-SRS sources.

- Plutonium-239: There are at least two special burials of Pu-239 in the ORWBG: (1) Spanish soil and (2) filtered water and airplane debris from the Greenland accident.

- Uranium: Two sources of off-SRS uranium are identified. The Mound Laboratory contributed $19 \mathrm{~kg}$ of depleted uranium and $450 \mathrm{~g}$ of enriched uranium. Area "XXX" consists of $3 \mathrm{~kg}$ of depleted uranium and $3,310 \mathrm{~g}$ of enriched uranium from an unspecified origin.

- Carbon-14: Certain fuels at offsite non-commercial facilities were shipped to SRS for reprocessing. These fuels contained varying amounts of $\mathrm{C}-14$ depending on the fuel type and irradiation history.

- Iodine-129: Certain fuels irradiated off-SRS were identified as a significant contributor to the source term inventory.

The primary uncertainties associated with off-SRS wastes are classified burials. These may include, but are not limited to, burials from the Charleston Naval Shipyard. Trenches were

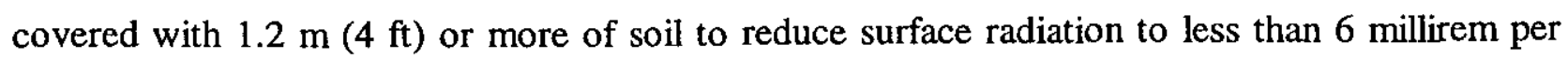
hour (mrem/hr). Twenty two underground storage tanks in the ORWBG were used to store organic solvents. There is no evidence that free liquid waste forms are buried in an "uncontained" state in the trenches of the ORWBG. 
The ORWBG area was also used for storage of contaminated equipment. In addition, the ORWBG contained several facilities and operations in the area that were not directly related to the burial of solid waste. These included two areas for the incineration of organic solvents, a sandblasting facility for decontaminating equipment, and some repair facilities (Appendix A).

It has been documented that the ORWBG Unit has contributed to localized shallow aquifer groundwater contamination. The plume of contamination from the Unit seeps into the old abandoned F-Area effluent stream channel which flows to Fourmile Branch and in turn into the Savannah River (WSRC, 1996a). Groundwater associated with the BGC is being addressed under the MWMF RCRA Part B permit. The permit application, WSRC-IM-91-53 has been submitted and is being reviewed.

An interim action at the ORWBG has been initiated to minimize contaminant migration. The objective of the interim action is to reduce stormwater infiltration through the waste layer which will minimize contaminant migration to the water table. The interim action places a lowpermeability soil cover over the Unit with topsoil and vegetation. The soil cover will be sloped to promote surface runoff, minimize surface erosion and control the leaching of hazardous substances from the source material.

\subsubsection{Waste Composition}

The ORWBG contains radioactive and hazardous waste and spent solvents generated from plant processes.

Examples of the materials disposed of at the ORWBG include the following (Appendix A):

- Incidental waste from laboratory and production operations - small equipment, spent air filters, clothes, analytical waste, decontamination residues, plastic sheeting, gloves, soil, and construction debris

- Contaminated equipment - obsolete or failed tanks, pipes, jumpers, and other process equipment from the radiochemical separations area

- Lead - lead shielding, equipment, shot, bricks, and lead sheets

- Reactor hardware - fuel components and housings not containing irradiated fuel

- Spent deionizer resins 
- Spent lithium-aluminum targets - the waste target alloy after tritium has been extracted

- Irradiated process oil from pumps in the tritium facilities and reactor areas - oil that was placed in drums containing an absorbent material and buried before bulk storage was started

- Mercury from gas pumps in tritium facilities - radioactively contaminated mercury buried before 1968 in 1-liter polyethylene (PE) bottles contained within a 0.7-cubic foot steel can

- Cadmium - associated with control rods and neutron shielding sheets

- Scintillation fluid - a mixture of organic solvents used to quantify low levels of radioactivity in environmental and bioassay samples

- Shipments from off site - for example, radioactive waste from military hardware

Known or suspected releases of hazardous substances at the ORWBG include the following (Ryan, 1983; Jaegge et al., 1987; McIntyre and Wilhite, 1987):

- Two of the 22 underground storage tanks may have leaked an estimated 1477 liters (L), (390 gallons [gals]) of tributylphosphate-kerosene extraction solvent to the groundwater in the "upper" aquifer zone of the Upper Three Runs Aquifer in 1968. This solvent contained approximately 5.6 millicuries $(\mathrm{mCi})$ of plutonium.

- In 1962 approximately $152 \mathrm{Ls}$ (40 gals) of plutonium-contaminated solvent were inadvertently pumped directly into the shallow groundwater through a test well in the north-central part of the ORWBG. The exact location and designation of the test well is not known, however, it is known that the location was near monitoring well $\mathrm{C} 17$ (MGC 17) north of the OSTs.

Ryan (1983) reports that the solvent was "pumped directly to the water table near monitoring well C17 (MGC-17), when a test well was mistaken for a solvent storage tank header (riser)." The report by Mason (1996) provides a relatively detailed analysis of potential "candidates" for the well, which received the solvent. Mason (1996) speculates that the dry wells installed at the ends of OSTs S1-S3 might have been mistaken for the tank risers, but the small volume of these wells would have 
caused them to overflow with solvent after less than ten gallons. Mason (1996) concludes that the most likely receptacle for the $\mathbf{4 0}$ gallons of solvent was one of the monitoring wells, which were installed in the immediate vicinity of the OSTs. At the time of the release, these would have included BG-1 through BG-10A. These wells were installed with carbon steel casing which was 3 inches in diameter. Well BG-8 was located closest to the OSTs, and Mason (1996) concludes that this well, or a temporary water-table well with similar construction was most likely the recipient of the 40 gallons of solvent. All of the wells that could have received the solvent have been abandoned.

- Between 1955 and 1972, 1,472,115 L (382,750 gallons) of organic solvents were burned in open pans in shallow unlined trenches located in the central part of the ORWBG.

- A decontamination station was operated in the northeast corner of the ORWBG during early operation of the facility. Complexing agents such as ethylenediaminetetracetic acid (EDTA) and phosphate detergents were used and may have been released during decontamination.

Beginning in 1962, records were kept of the contents, radiation level, and approximate storage location of each shipment of waste to the ORWBG. Later this information was retroactively recorded, from existing written burial records and from recollection of operating personnel, into the COBRA system for future reference. Many of the waste volumes and radionuclide quantities were estimated, including information on waste disposed before 1962 .

An inventory of buried waste at the ORWBG was conducted utilizing information obtained from the COBRA database, written records, and interviews with operating personnel. The results of that inventory for constituents of interest (COI) are included in Table 2-1.

\subsubsection{Physical Setting}

\subsubsection{Topography and Drainage}

The ORWBG occupies approximately 31 hectares ( 76 acres) in the central part of SRS in the BGC, between F and H Separations Areas; on a interfluvial plateau between Upper Three Runs Creek to the north and Fourmile Branch to the south (Figure 2-2). The ground surface at the ORWBG is relatively flat, with elevations ranging from approximately $82 \mathrm{~m}(270 \mathrm{ft}) \mathrm{msl}$ along the 
southern perimeter to approximately $91 \mathrm{~m}(300 \mathrm{ft}) \mathrm{msl}$ adjacent to the northern boundary. A mixture of brushland, sparse forest, and fields occupies the areas to the east, north and west of the Unit. Fourmile Branch is located less than $1.6 \mathrm{~km}(1 \mathrm{mi})$ south of the southwest corner of the ORWBG; Upper Three Runs Creek is located less than $1.3 \mathrm{~km}(0.75 \mathrm{mi}$.) north of the ORWBG. The slope is generally to the south, although the slope is locally modified by excavations and mounds of soil. Engineered ditches channel surface runoff to Fourmile Branch. The bed of Upper Three Runs Creek is about $43 \mathrm{~m}$ (140 ft) below the divide surface, while the channel of Fourmile Branch is about $27 \mathrm{~m}(90 \mathrm{ft})$ below the divide surface.

The drainage pattern in the vicinity of the ORWBG is also shown on Figure 2-2. The primary natural drainage from the ORWBG occurs by way of the old F-Area effluent stream, a tributary channel of Fourmile Branch. This tributary originates near the western boundary of the ORWBG and has a channel length of approximately one mile. Two other natural drainages originate approximately $0.5 \mathrm{~km}(0.3$ mile $)$ northwest and $0.8 \mathrm{~km}(0.5$ mile $)$ northeast of the northern boundary of the ORWBG, and transport runoff to Upper Three Runs Creek. In the southeastern part of the ORWBG, engineered ditches transport runoff to Fourmile Branch through a stormwater retention basin. These flow directions indicate the ORWBG is located on a surfacedrainage divide. The bed of Upper Three Runs Creek is about $43 \mathrm{~m}$ (140 ft) below the divide surface, while the channel of Fourmile Branch is about $27 \mathrm{~m}(90 \mathrm{ft})$ below the divide surface. The 100-year flood limits for Upper Three Runs Creek and Fourmile Branch are approximately $1.1 \mathrm{~km}$ (0.7 mile) north and $0.8 \mathrm{~km}$ (0.5 mile) south, respectively, from the ORWBG boundary.

\subsubsection{Surface Soils}

Because of the extensive excavation, construction, and fill activities that have occurred at the Unit, the soils at the surface of the ORWBG are classified as Udorthents [disturbed soils; soil group six of Looney et al., (1989)]. The physical and chemical characteristics of these soils in the Unit have not been studied quantitatively. In general, Udorthent soils have a low available water capacity and a very low content of organic matter. They are strongly to extremely acidic. Permeabilities range from moderately slow to rapid, depending on the degree of disturbance.

\subsubsection{Unit-Specific Geology}

Generalized SRS and ORWBG geology and stratigraphy are discussed in Section 1.3.3. Additional information on the ORWBG and vicinity is provided in the RCRA Part B Permit Application for the MWMF (WSRC 1995b). 


\subsubsection{Unit-Specific Hydrogeology}

The general hydrogeology and hydrostratigraphy of the SRS and of the GSA (of which the ORWBG is part) are discussed in Sections 1.3.3.3 and 1.3.3.4, respectively. Unit-specific information pertaining to hydrogeology, hydrostratigraphy, aquifer characteristics, and groundwater flow for the ORWBG is presented in Section E of the RCRA Part B Permit Application for the MWMF (WSRC 1995b).

\subsection{Conceptual Site Model}

EPA guidance for both RCRA and CERCLA remedial investigations stresses the need for and utility of a conceptual representation of the unit under consideration. Such a representation provides an objective framework around which existing information can be organized and synthesized, data gaps can be identified, and sampling programs can be designed to address critical data needs identified in accordance with the DQO process.

The CSM for the ORWBG (also known as building 643-E and includes Solvent Tanks S01 through S22), is presented in Figure 2-3. The CSM identifies the potential sources of contamination, the release mechanisms, the media of concern, and the receptors of interest. The emphasis is on pathways by which contaminants could migrate from the sources to receptors. Each of these components is described below. Data needs are also shown on the CSM and discussed in Section 3.2.

\subsubsection{Primary Sources of Contamination}

The primary sources of contamination include various levels/types of radioactive waste materials buried in the trenches and solvents stored in underground storage tanks. These materials include TRU waste, low-level waste, and intermediate-level waste. The materials were generated by various activities at SRS and received from off-site sources. Examples of the materials disposed of at the ORWBG include: waste from laboratory and production operations, contaminated equipment, reactor hardware, and various irradiated materials related to the site processes. Inorganic constituents, such as lead, mercury and cadmium were also placed in the ORWBG. Additionally, various solvents were stored in the 22 underground storage tanks including naphthalene, toluene, tributylphosphate (TBP), TBP-kerosene, trimethylbenzene, and xylene.

Known or suspected releases of hazardous substances at the ORWBG include: approximately 390 gallons of TBP-kerosene extraction solvent containing approximately $5.6 \mathrm{mCi}$ of plutonium 
leaked from two Old Solvent Tanks (OSTs), approximately 40 gallons of plutonium-contaminated solvent was pumped directly into the shallow groundwater via a test well in 1962, organic solvents were burned in open pans in unlined trenches from 1955 to 1972 , agents such as EDTA and phosphate detergents may have been released from a decontamination area in the early operation of the unit.

Beginning in 1962, records were kept of the contents, radiation level, and approximate storage location of each shipment of waste to the ORWBG. This information, along with written burial records and records based on recollection of operation personnel, was later entered into the COBRA system. Operational records were researched and a listing of radioactive/hazardous materials disposed of in the ORWBG was compiled. The results of that research is presented in Section 2.2 .2 and summarized below. The quantities are estimated, based on available records and projected quantities for time periods where no records exist. The review indicates that the ORWBG received:

$\begin{array}{ll}\text { Constituent } & \text { Estimated Ouantities } \\ \text { Mercury } & 24,195 \mathrm{lbs} \text { (buried) } \\ \text { Cadmium } & \text { Negligible (in OSTs) } \\ & 3,500 \mathrm{lbs} \text { (buried) } \\ & \text { Negligible (in OSTs) } \\ \text { Lead } & 50 \text { tons } \\ & \text { Negligible (in OSTs) } \\ \text { VOCs } & 7,100 \mathrm{~kg} \text { toluene (buried) } \\ & 7,100 \mathrm{~kg} \text { trimethylbenzene (buried) } \\ & 12,000 \mathrm{~kg} \text { xylene (buried) } \\ & 4,056 \text { gal organic phase (in OSTs) } \\ & 3,483 \text { gal aqueous phase (in OSTs) } \\ & 3,014,457 \text { Ci (buried) } \\ & 467,889 \text { Ci (decayed) } \\ \text { Tritium } & \text { Negligible (in OSTs) } \\ & 1,193 \text { grams (20,514 Ci, buried) } \\ & 16,825 \text { Ci (decayed) } \\ \text { Plutonium-238 } & 1.24 \text { grams (21.4 Ci, in OSTs) } \\ & 24,188 \text { grams (1,475 Ci, buried) } \\ & 1,474 \text { Ci (decayed) } \\ & \end{array}$




\section{Constituent}

Uranium-235

Uranium-238

Cesium-137

Strontium-90

Carbon-14

Cobalt -60

Technetium-99

Iodine-129

Neptunium-237

\section{Estimated Quantities}

1,351 grams (82.4 Ci, in OSTs)

273,185 grams $(0.6 \mathrm{Ci}$, buried)

$0.11 \mathrm{Ci}$ (in OSTs)

$44,233 \mathrm{~kg}$ (14.8 Ci, buried)

$1.1 \mathrm{Ci}$ (in OSTs)

$58,657 \mathrm{Ci}$ (buried)

26,838 Ci (decayed)

$1.30 \mathrm{Ci}$ (in OSTs)

$58,657 \mathrm{Ci}$ (buried)

$26,216 \mathrm{Ci}$ (decayed)

$1.28 \mathrm{Ci}$ (in OSTs)

$3,778 \mathrm{Ci}$ (buried)

3,767 Ci (decayed)

Negligible (in OSTs)

1,960,400 Ci (buried)

27,568 Ci (decayed)

Negligible (in OSTs)

$12 \mathrm{Ci}$ (buried)

Negligible (in OSTs)

$10.6 \mathrm{Ci}$ (buried)

Negligible (in OSTs)

$1.99 \mathrm{Ci}$ (buried)

$0.004 \mathrm{Ci}$ (ingrown)

Negligible (in OSTs)

\subsubsection{Primary Release Mechanisms}

Contaminants may be released from the primary sources by:

- Infiltration/percolation of rainwater through the waste constituent and transport to underlying soil and groundwater (leaching)

- Future excavation of trenches (potential pathway) 


\subsubsection{Secondary Sources of Contamination}

Environmental media impacted by the release of source contamination becomes a secondary source. Previous investigations have determined that ORWBG surface and subsurface soils are contaminated with hazardous and radioactive constituents from the ORWBG (643-E, including Solvent Tanks S01 through S22) and pose unacceptable risk to human health and the environment (see Section 2.4). A low-permeability cap has been constructed as an interim remedial action for source control (see Section 5). Since contaminant migration from surface and subsurface soils has been minimized, deep soil $(1: 2 \mathrm{~m}[4 \mathrm{ft}]$ to water table) and disturbed soils from future excavation of trenches are the secondary sources of contamination considered in this evaluation.

\subsubsection{Secondary Release Mechanisms}

Environmental media serve both as a reservoir via chemical bonding and biotic uptake and as a secondary release mechanism of contaminants. With the construction of the low permeable cap at the ORWBG, secondary environmental release mechanisms become minimal but may include the following:

- Leaching of contaminants from subsurface soil to groundwater

- Future excavation (direct contact)

\subsubsection{Exposure Pathways}

Contact with contaminated environmental media creates the exposure pathways for both human and ecological receptors. These pathways may include the following:

- Direct contact with sediment and surface water in and around the ORWBG (future excavation)

- Direct contact with surface and deep soils in and around the ORWBG (future excavation)

- Domestic water usage (human health only) 


\subsubsection{Exposure Routes}

Exposure routes for human and ecological receptors may include the following:

- Inhalation of contaminated emissions and airborne dust

- Ingestion of contaminated media, including soil, groundwater, surface water, produce grown by future on-unit residents, and biota

- Dermal contact with contaminated media

- Showering, which takes into account inhalation of volatiles from the shower spray and dermal contact with the water

Wind erosion of surface soil could result in the airborne dispersion of radionuclides and chemicals adsorbed to surface soil particulates (windblown dust). Exposure points also exist at the ORWBG for chemicals in air that have volatilized from surface soils. Surface soil or deep soils, if excavated in the future and redistributed onto the surface, are potential exposure points for radionuclides and chemicals present in soils.

The consumption of produce by hypothetical human receptors and vegetation by ecological receptors is a potential exposure point for contaminants present in the soil. The uptake of contaminants by living organisms and consumption by higher trophic levels also is a potential exposure point for radionuclides and chemicals present in the soil. Any future excavation of soil may result in higher radionuclide and chemical concentrations than those currently in surface soils, and potentially greater concentrations in receptor tissue.

Exposure points in groundwater may exist during future household or industrial use of groundwater. Chemicals in groundwater also may migrate to surface water and sediments where they may be contacted by potential receptors. Surface water and sediments become exposure points for chemicals in soil through erosion and transport by wind and water. Groundwater and surface water will be addressed under the MWMF RCRA Part B permit application WSRC-IM91-53. 


\subsubsection{Potential Receptors}

Human and ecological receptors are identified below. Human receptors may include the following:

- Known on-unit workers

- Hypothetical future industrial workers

- Hypothetical future on-unit residents

- Hypothetical recreational trespasser

Under the current land use designation, the known on-unit workers are considered to be individuals who periodically perform site maintenance and groundwater sample collection. Since the ORWBG is located over $10 \mathrm{~km}(6.5 \mathrm{mi})$ from the nearest SRS boundary, trespassers are not considered to be potential receptors except for the possible exposure to surface water at Fourmile Branch. Future-land use planning at SRS has designated this area as industrial and will prohibit residential development through deed restrictions. Under future industrial use, potential receptors may include industrial workers. However, if future land use is converted from industrial to residential, future receptors would include on-unit residents.

Ecological receptors may include the following:

- Terrestrial, aquatic, and semi-aquatic ecological receptors currently limited to outside the unit due to completion of the low permeability cap

- Plants and animals that may come in contact with rainwater runoff or groundwater seepage to nearby waterways

\subsection{Existing/Previous Investigations}

Existing data on extent of contamination for the ORWBG includes groundwater monitoring data, soil sampling, soil-gas sampling, coring, COBRA and written disposal records, groundpenetrating radar (GPR) surveys, air sampling, and RFI/RI BGC Field Investigation Plan (FIP) (WSRC 1994b) related sampling. Information pertaining to these investigations is presented below. 


\subsubsection{Groundwater Investigations}

Approximately 144 groundwater monitoring wells are presently located in the vicinity of the BGC (WSRC 1996b). Installation of the groundwater monitoring well network began in 1987. These wells provide groundwater quality data for groundwater assessment, monitoring, and compliance purposes. Table 2-2 lists the individual ORWBG wells and identifies the well designation (background, point of compliance (POC), or assessment) while Figures 2-4, 2-5, and 2-6 depict the groundwater monitoring wells in the appropriate screened aquifer.

Extensive groundwater investigations have been performed to delineate the horizontal and vertical extent of groundwater contamination at the ORWBG. Various sampling methodologies [i.e., Cone Penetrometer (CPT), and Hydropunch $\mathrm{II}^{\mathrm{TM}}$ well installations] were employed to assist in data gathering to characterize the horizontal and vertical extent of groundwater contamination at the ORWBG.

Hydrogeologic characterizations and review of existing groundwater data from the groundwater monitoring wells at the ORWBG indicate that there are three distinct plume areas originating from different source areas within the BGC (Figure 2-7). Groundwater data for tritium and TCE, in samples from the "upper" aquifer zone $\left(\mathrm{IIB}_{2}\right)$ of the Upper Three Runs Aquifer (IIB), were selected to represent the areal distribution of the three plume areas. Tritium and TCE were used because these constituents are the most mobile and laterally extensive (Figures 2-8 and 2-9, respectively). The three plumes also consist to varying degrees of heavy metals, radionuclides, volatile organics, and other constituents which are included within the larger TCE and tritium plumes.

Of the three plume areas, the southwest plume exhibits the highest concentrations of tritium and TCE. A majority of the groundwater contamination in this area is the result of contaminants leaching into the groundwater from buried waste at the ORWBG. The northeast plume is the largest in terms of areal extent; however, the contaminant concentrations are much lower than those in the southwest plume. The origin of the groundwater contamination in this plume area is primarily from waste disposed of at the MWMF and LLRWDF. The northwest plume is the smallest of the three, and the contaminants levels are similar to those exhibited in the northeast plume. The northwest plume results from a co-mingling of contaminants which have leached into the groundwater from both the ORWBG and the MWMF. The groundwater divide has played a continual role in the co-mingling and migrating of contaminants at this plume area (WSRC, 1996b) as depicted on Figures 2-8 and 2-9. 


\subsubsection{Soil-Gas Surveys}

Two soil-gas surveys have been conducted for the BGC. A reconnaissance soil-gas survey conducted from August 1991 to May 1992 indicated that the soils near or beneath the BGC contained volatile organic compounds (VOCs). Four separate areas within the BGC were surveyed: the ORWBG, the MWMF/LLRWDF, the Burial Ground Railroad, and the Burial Ground Perimeter. The surveys monitored the presence of hydrocarbons, normal paraffins, gasoline range aromatics (BTEX), and selected chlorinated hydrocarbons in soils at depths of 1 to 3 feet below grade. For this RFI/RI, only the soil-gas survey areas associated with the ORWBG are discussed.

A soil-gas survey was performed in 1994 as a part of implementing the BGC FIP. The 1992 soilgas survey data were evaluated and 75 additional soil-gas locations around the periphery of the ORWBG were identified along with three background locations at the New Production Reactor (NPR) site. Background locations are depicted on Figure 2-10.

\subsubsection{ORWBG Survey}

The soil-gas survey in the ORWBG consisted of 1167 samples in an irregular grid pattern designed to provide coverage over the numerous burial trenches as shown on Figures $2-11$ and 2-12.

The observations of the chlorinated solvent TCE are larger and much more widely distributed in this area than in the areas surveyed in the BGC. In contrast, observations of 1,1,1-trichloroethane are much less widely distributed as compared to observations in the MWMF/LLRWDF. This may reflect the differences in use of these solvents over the life of the BGC.

Scattered, low levels of CTET, chloroform, and trans-1,2-dichloroethylene were also observed. The most significant observations of trans-1,2-dichloroethylene are found at four sites which are easily distinguished in the central part of the area. Concentrations of trans-1,2-dichloroethylene at these sites range from 0.2 to 1 parts per million by volume (ppmv, 201 to 1,000 parts per billion by volume (ppbv)) and appear to correlate with low concentrations of TCE at three of the four sites. It is suggested that the trans-1,2-dichloroethylene may be present as the result of biological degradation of TCE.

Only a few, widely spaced observations of benzene, toulene, ethylbenzene, and xylene (BTEX). compounds were made in this area. The saturated hydrocarbons, $\mathrm{C}_{6}-\mathrm{C}_{9}$, were observed with a 
slightly greater frequency than the aromatics. In particular, hexane, heptane, and octane are well correlated with the observation of trans-1,2-dichloroethylene discussed above. No observations of decane were made. Pentane is widely distributed in low concentrations.

Levels of methane are large at selected sites. The maximum observed level exceeded 60 percent, by volume of air, and levels exceeded 5 percent at 20 other sites. These levels of methane result from the anaerobic biological degradation of buried waste. Lower levels of methane and the other light hydrocarbons may be due to the natural background in this area.

Of the 75 soil-gas locations around the periphery of the ORWBG, three were identified as duplicate background locations. These duplicate background locations are the three locations which were sampled as part of the 1992 shallow soil-gas survey. These three locations were selected for data comparison between the 1992 shallow and 1994 deep soil gas surveys. The three background soil-gas locations at the NPR site were selected due to no known groundwater or surface contamination. These locations were used for establishing soil-gas background levels. The NPR site is located approximately $3.2 \mathrm{~km}(2 \mathrm{mi})$ south of the ORWBG. The additional 78 locations sampled were used to determine the VOC contamination limits away from the ORWBG. Collection of the soil-gas samples was obtained near the water table surface.

\subsubsection{Burial Ground Railroad Survey}

The Burial Ground Railroad soil-gas survey consists of a set of 38 sites along the railroad spur adjacent to the northeastern boundary of the ORWBG area as shown on Figures 2-11 and 2-12. The purpose of the survey was to look for evidence of spills or leaks from transport over these tracks. The only observed VOC in this survey was a low level of toluene at site 10 . Levels of light hydrocarbons were low.

\subsubsection{Burial Ground Perimeter Survey}

The Burial Ground Perimeter soil-gas survey consists of a set of 298 samples collected around the perimeter of the entire ORWBG as shown on Figures 2-11 and 2-12. The purpose of the survey was to look for evidence of migration of buried contaminants outside of the ORWBG.

In general, observations of contaminants in the Burial Ground Perimeter survey are of low concentration and are isolated in occurrence. No obvious plumes of contaminants can be traced from observations inside the ORWBG across the fence to the Burial Ground perimeter. 
In two series of sites (48-52 and 85-87) along the southern perimeter of the ORWBG, the occurrence of several of the measured species including BTEX, hexane, heptane, and trans-1,2dichloroethylene are noted. At one site in each series, methane exceeded 5 percent of the soil gas. No evidence of these compounds adjacent and immediately inside the BGC was observed.

\subsubsection{Ambient Air Monitoring}

A study of the concentration of volatile species in ambient air was conducted at the ORWBG and the Burial Ground Effluent Area during November and December 1993 and January 1994. The BGC portion of the project was further divided into two parts, the ORWBG and the LLRWDF. This division resulted in a total of three areas investigated during this project. A total of 68 samples were acquired from a total of 16 locations in the combined three areas, as shown on Figures 2-13 and 2-14. Samples were collected over a time period of at least 12 hours. Each sample was analyzed using the protocols of the EPA Contract Laboratory Program following Method TO-14. Two sample sets were taken at each location, one each during periods of rising and falling barometric pressure. At each loçation during each pressure regime period, one sample was taken when the wind direction was from a 90-degree sector toward the area of interest (the "in-sector" sample) and one sample when the wind direction was from a 270-degree sector away from the area of interest (the "out-sector" sample).

Pinenes are the analytes in largest concentration which are observed in many of the samples. The pinenes are natural products related to the pine forest of the area. Several other compounds were observed in very low concentrations in most samples. Examination of the data from the laboratory method blanks reveals that levels of the target compounds acetone and propylene are present in every blank as well as acetaldehyde and benzaldehyde. Other target compounds which were occasionally observed at low levels in the blanks included 1,3-dichlorobenzene; 1,4dichlorobenzene; 1,2,4-trichlorobenzene; 2-butanone; and toluene.

Generally, the observed levels of the target compounds were low. With the exception of acetone, which is present in the laboratory method blanks (in the same range of concentrations as observed in the field samples), only one target compound observation exceeds $0.002 \mathrm{ppmv}$ ( $2 \mathrm{ppbv}$ ). That compound is acrolein, which may not be well determined because of its stability in the standard. Most observations were well below $0.001 \mathrm{ppmv}$ ( $1 \mathrm{ppbv}$ ). No effect of falling versus rising barometric pressure regime was observed. 


\subsubsection{Ground Penetrating Radar}

A ground penetrating radar (GPR) survey was executed at the ORWBG between December 1993 and February 1994. The survey was conducted to locate trenches, pits, and materials associated with the burial of wastes. The survey also helped identify discrepancies with a base map of the area. Results of the survey are summarized in Ground Penetrating Radar Interpretations at the Burial Ground Complex, Savannah River Site (Microseeps, 1994). The survey was broken into four interpretation areas (Area \#1 to \#4) which are shown on Figure 2-15.

In Area \#1 trenches were verified to run in a north-south direction. The boundaries and separation of some of the trenches were defined. Boundaries of other trenches could not be identified, particularly in areas of disturbed soil.

In Area \#2 the possibility of east-west running trenches in two blocks was identified. Previously, trenches in these blocks were thought to run in a north-south direction. The boundaries of other trenches were identified. An area previously thought to be undisturbed showed evidence of buried debris or other material.

In Area \#3 buried material exhibiting high amplitudes of diffraction were identified, suggesting the presence of metallic objects. One trench, shown on the base map, could not be located. The possible existence of a previously unidentified trench running along the south fenceline was identified.

In Area \#4 most trenches had distinct boundaries. One trench, thought to exist, could not be located. The lateral extent of several trenches was found to extend under the paved parking lot of the Administration Building.

The GPR survey confirmed the location of most trenches shown on the base map. However it was noted for future work that a survey with smaller, tighter grids would be more effective and that line positions should be accurately surveyed and marked.

\subsubsection{Volatilized Tritiated Water Vapor}

Volatilization of atmospheric tritium from a known source of tritiated water may result in a radiation dose to personnel in the immediate vicinity of the tritiated water. In order to quantify the radiation dose associated with the tritiated water, four (4) high-volume air samplers were installed at the ORWBG. 
Two sample locations at the ORWBG perimeter, BG-1 and BG-2, were marked near obvious surface-water runoff points at the eastern and western fence perimeter, Figure 2-16. Samples were collected at these perimeter locations and at the background site beginning February 28 and ending April 15, 1994. The background site was chosen in order to establish an atmospheric tritium concentration not influenced by the ORWBG. All atmospheric samples collected for 8and 24-hour duration were $1,500 \mathrm{~L}$ samples. This sample size provides adequate water vapor for ease of desorption and subsequent analysis.

Surface water samples were collected at "BG-1" and "BG-2" when available. There were times when surface-water was not evident. Surface-water samples were analyzed directly after liquid scintillation preparation. The average concentration found at " $\mathrm{BG}-1$ " was $10.96 \pm 8.04 \mathrm{pCi} / \mathrm{ml}$ and the average concentration found at "BG-2" was $27.70 \pm 28.12 \mathrm{pCi} / \mathrm{ml}$.

Atmospheric, tritiated water-vapor concentrations were monitored during the sampling period for 8- and 24-hour periods at the "BG-1" and "BG-2" perimeter locations. The "BG-1" 8-hour average was $125.32 \pm 170.99 \mathrm{pCi}$ per cubic meter $\left(\mathrm{m}^{3}\right)$ and the 24-hour average was $96 \pm 104.47$ $\mathrm{pCi} / \mathrm{m}^{3}$. The "BG-2" 8-hour average was $380.52 \pm 395.70 \mathrm{pCi} / \mathrm{m}^{3}$ and the 24 -hour average was $446.77 \pm 401.37 \mathrm{pCi} / \mathrm{m}^{3}$.

The average atmospheric, tritiated water-vapor concentrations for 24-hour samples collected at an onsite background location (BKG \#2) not influenced by the ORWBG was $854.85 \pm 979.67$ $\mathrm{pCi} / \mathrm{m}^{3}$. The 24-hour average atmospheric, tritiated water-vapor concentrations at an established sampling site near Allendale, South Carolina was $2.63 \pm 2.55 \mathrm{pCi} / \mathrm{m}^{3}$.

These atmospheric tritium concentrations are consistent with annual concentrations reported for 1992 (WSRC, 1993b). It was evident that concentration decreases for points further from $\mathrm{H}$ Area. Historic data reported in a tritium assessment document (WSRC, 1993c) also indicates a similar pattern of decreasing concentrations with distance from the center of the site. If there is any volatilized tritium water-vapor contribution to the atmospheric tritium concentrations at the ORWBG, it is obscured by nearby atmospheric tritium releases and is an extremely small contributor to dose.

Tritium concentrations found in the standing surface water were in the same range as tritium moisture concentrations in the air, suggesting the atmospheric tritium exchanged with water on the ground or that standing water was the result of rainout of tritiated atmospheric water. 
Radiation dose to workers at "BG-1" and "BG-2" was calculated using the higher of the 8- and 24-hour tritium concentrations at each location. The worker was assumed to work 8 hours per day, 250 days per year, and breathe $9.6 \mathrm{~m}^{3}$ during each 8-hour work day (Huang and Master, 1983). The DOE dose factor (DOE/EH-0071), which is based on ICRP-26 methodology, was multiplied by 1.5 to account for tritium absorption through the skin. The annual tritium dose to a worker at "BG-1", the higher concentration of the two locations is $2.9 \times 10^{-2}$ mrem, as compared to an annual natural background dose of $320 \mathrm{mrem}$ and the SRS annual radiation worker administrative control level of $700 \mathrm{mrem}$.

\subsubsection{ORWBG Field Investigation}

Groundwater associated with the entire ORWBG is being addressed under the RCRA permit for the MWMF in accordance with Settlement Agreement 87-52-SW (WSRC, 1996a). Sampling and analysis for the ORWBG has been completed in accordance with the BGC FIP.

Characterization was achieved through an aggressive program to collect hydrogeologic, groundwater, soil, and surface-water data to support all RCRA and CERCLA activities for the BGC. A variety of technologies were used in characterization. These include water sampling and geologic data collection using innovative direct-push technologies, installation of new monitoring wells, coring, geophysical logging, and wetlands sampling.

Results of the field investigation in the area of the southwest plume which originates in the ORWBG are compiled and presented in the RCRA Part B permit application for the MWMF (Revision 3).

\subsubsection{Summary of Water Table Monitoring}

Groundwater data from water-table wells (1990 through 1995) in and around the ORWBG are summarized as isoconcentration contours superimposed on burial-distribution maps for the COI inventory. Maps of lead, mercury, TCE, PCE, gross alpha, non-volatile beta, and tritium concentrations are provided as Figures 2-17 through 2-23, respectively. Burial distributions of the respective COIs are posted on each map except for lead, for which burial locations are not available.

The more mobile COIs (tritium and the VOCs) show a fairly good correspondence between burial locations and groundwater concentrations. Plumes of tritium, TCE, and PCE are located in close proximity to and down-gradient from the area within the ORWBG with the largest number of 
VOC burials. Maps of mercury, gross alpha, and non-volatile beta indicate little correspondence between burial locations associated with these constituents, and concentrations observed in the water table. The "Summary of Water Table Monitoring for the ORWBG, WSRC-TR-97-00330 Revision 0" is included as Appendix B.

\subsubsection{Source Term Investigation Summary}

The Source Term Investigation was designed to support the RFI/RI process by expanding and refining the current understanding of the ORWBG disposal history. The findings of a detailed literature review and evaluation were integrated with available aerial photographs, construction drawings, health physics burial maps, the computerized burial record analysis (COBRA) database, and interviews with SRS staff. The "Source Term for the Old Radioactive Waste Burial Ground Savannah River Site, WSRC-TR-97-0119, Revision 1" is included as Appendix A.

Significant findings regarding burial history, trench type and waste characteristics include the following:

- Approximately 7,125,000 cubic feet of waste was placed in the ORWBG from 1952 to 1974. From 1961 to 1971 , monthly waste volumes typically ranged from 25,000 to 50,000 cubic feet.

- Job control waste is the largest single waste type, representing approximately 90 percent of total ORWBG waste volume. A very high percentage of the job control waste was buried in low-level beta-gamma trenches. Irradiated scrap metal is the second largest waste type, representing about 7 percent of the total waste volume. Virtually all of the irradiated scrap metal is in high-level beta-gamma trenches. The remaining 3 percent includes a wide variety of wastes such as natural and man-made radioactive materials, equipment, and absorbed solvents and oils.

- The ORWBG is segregated into three areas: (1) the original 35-acre central portion of the ORWBG that was opened in 1952 and filled by the early 1960s; (2) a 15-acre eastern expansion that was opened around 1961 and closed in 1972; and (3) a 26-acre western expansion that was opened in 1961 and closed in 1974.

- The ORWBG disposal trenches can be grouped into several general waste categories including the following: low-level, high-level, jumpers and equipment, B-Line, scrap metal, encapsulated plutonium, storage, and special/classified burials. Solvent tanks and associated 
solvent burning pans and ash trenches define an additional category. A miscellaneous category is also established to cover those trenches and disposals that do not fit any of these categories.

- Individual trenches and/or active portions of trenches can be tracked through time, with moderately good agreement between burial locations and trench boundaries. In the eastern and western portions of the ORWBG, there are generally good correlations between the trench locations and burial locations. However, it appears that it was a common practice to list the same coordinates for all burials that took place in a specific trench area on a given day or during a given week. This often results in a high number of burials listed at one trench cell and few or no burials in the adjacent trench cells within the opened trench area. Therefore, the accuracy of individual burial locations is \pm 40 to 60 feet.

- The burial locations included in the COBRA database cover only part of the operational life of the ORWBG; no coordinate information is available prior to 1961 . The absence of burial locations in the central portion of the ORWBG suggests that, although the volumes associated with these earlier disposals are listed in COBRA, their coordinates are not. In addition, this is supported by aerial photographs, which indicated that pre-1961 burials exist in the central part of the ORWBG.

- In general, burial containers (retrievable transuranic waste) and concrete pours were well organized within the ORWBG.

- Classified waste was most commonly buried in trenches and boreholes designated as "special projects". This term generally indicates that some of the components of a burial were regarded as classified information at the time of disposal. Some aspects of these "special" burials remain classified.

\subsubsection{Constituents of Interest}

The detailed investigation was conducted to determine the inventory of COIs. COIs for the ORWBG source term characterization were determined by integrating past characterization and monitoring (soil gas, groundwater monitoring, and subsurface surveys) with the COBRA database, process history evaluation, and historical documentation. All existing data were. reviewed during this process. COIs include constituents that are mobile, hazardous, have a large inventory, and/or have a long half-life. As a result, the following COIs were identified for this study: cadmium, lead, mercury, volatile organic compounds, tritium, cesium-137, plutonioum- 
238, plutonium-249, strontium-90, uranium-235, uranium-238, carbon-14, cobalt-60, technetium99 , iodine-129 and neptunium-237. Table 2-1 provides summary information regarding inventory estimates, burial locations, waste form, and origin for each of the COIs. Table 2-3 summarizes the COIs for the ORWBG.

\subsubsection{Fate and Transport}

The fate and transport of the COI from the ORWBG depend on the leachability of COIs from their respective waste forms and their mobility in groundwater. Leachability is a function of the waste form, the chemical behavior of the COI, and the chemical composition of infiltrating water. Mobility of a constituent in groundwater is primarily a function of the chemistry of the constituent, the mineralogic composition of the aquifer, and the composition of the groundwater. Fate and transport of each COI is addressed here qualitatively. The contribution of leachability and mobility in groundwater to fate and transport is discussed for each COI in Appendix A. Here an assessment is made whether each COI is an immediate threat or potential future threat to groundwater.

The assessment of the threat of a COI to groundwater is qualitative and is meant to provide guidance for considering remedial options rather than quantitative input into remedial decisions. This assessment does not consider the effects of any remedial action. In addition, it incorporates no risk information, only the probability that concentrations of the COI may exceed current drinking water standards in the near-term and in the future. The reason for including an evaluation for the future is that fate and transport of some COIs will change with time because containers will degrade and conditions in the ORWBG will change. Table 2-4 summarizes the fate and transport of the COIs.

Leachability for each COI was estimated from expected geochemical behavior in the ORWBG environment, concentrations of the constituent in groundwater, and, where applicable, data from the Defense Waste Lysimeter Program. This program consisted of burying Defense Program waste forms in lysimeters at the ORWBG to observe the leaching rate of constituents over a several year span. The waste forms were breached to ensure infiltration of water and effluents were captured and analyzed regularly. The Defense Waste Lysimeter Program provides the best quantitative information on leachability of several COIs. Concentrations of COIs in groundwater and expected geochemical behavior are used to constrain estimates of leachability. Detailed discussions of the leachability of each COI are presented in Appendix A. 
The expected geochemical behavior of a COI is particularly important because of the unique conditions within the ORWBG. The abundance of organic matter in the form of cardboard and paper and the presence of zero valent iron in the form of drums, boxes and scrap metal causes conditions in the ORWBG to be relatively reducing. Under these conditions the plutonium isotopes, Tc-99, and Np-237 are less mobile than under the relatively oxidizing conditions that are normally common to the shallow subsurface. In contrast, the reducing environment may enhance the leachability of I- 129 by reductive dissolution of the dominant I-129 waste form, silver iodide. However, low concentrations of I-129 in groundwater suggest that this process has not been significant. It is assumed here that sometime in the future, when the source of reductants is depleted, conditions will become more oxidizing. This could enhance the leachability of the plutonium isotopes, $\mathrm{Tc}-99$, and $\mathrm{Np}-237$.

Mobility of COIs in groundwater was addressed qualitatively (Appendix A) by referring to several site specific studies of contaminant migration in groundwater associated with the ORWBG. In Table 2-4 the COIs are grouped into three categories based on their mobilities. Tritium and VOCs are highly mobile and move at or near groundwater velocity. This is reflected in the plumes of these COIs downgradient of the ORWBG. Tc-99 is also considered highly mobile, but low Tc-99 concentrations in groundwater result from its low activity in the ORWBG and possibly it's decreased leachability under reducing conditions. Most of the COIs are of medium mobility in groundwater. This category includes constituents that have estimated retardation factors of 10 to 1000. Some of these constituents, such as $\mathrm{Sr}-90, \mathrm{C}-14, \mathrm{Hg}, \mathrm{Pb}$, and $\mathrm{Cd}$ may be near-term threats to groundwater. Elevated concentrations of these constituents in groundwater from isolated grid wells have been measured. However, no coherent plumes of these constituents have been identified. The plutonium isotopes and Cs-137 are categorized as low mobility constituents with retardation factors that exceed 1000 .

Potential future threats to groundwater include all COIs other than those that will decay prior to reaching groundwater in substantial concentrations. This results because the scenario assumes all containers will eventually breach and the conditions in the ORWBG will eventually become oxidizing. Those COIs whose threat to groundwater is mitigated by decay, Co-60, Cs-137, and $\mathrm{Pu}-238$, have half-lives that are short relative to the time required for their leaching and migration to groundwater.

In summary, the immediate threats to groundwater from the ORWBG are tritium and VOCs. Evidence from groundwater beneath the ORWBG suggest that $\mathrm{Sr}-90, \mathrm{C}-14, \mathrm{Hg}, \mathrm{Cd}$, and $\mathrm{Pb}$ may be near term threats to groundwater. Future threats to groundwater include I-129, Tc-99, Np- 
237, U-235, U-238, and Pu-239. The relatively short half-lives of Co-60, Cs-137, and Pu-238 mitigate their threat to groundwater.

\subsubsection{Hot Spot Criteria and Identification}

An evaluation was performed to identify potential "hot spots" that may require a special feasibility assessment in the development of a final remedy for the ORWBG. The process for identification of the potential "hot spots" (hazardous and radioactive) is summarized below and documented in detail in the supplemental report WSRC-TR-97-00329 "Delineation of Potential 'Hot Spots' for the ORWBG" contained in Appendix C. The identification of potential "hot spots" is based on the following criteria:

- High concentrations and/or high levels of radioactivity

- Persistence of high radioactivity levels through time

- Burial type

- Waste form

- Mobility

Both radioactive and nonradioactive COIs have been considered. Table 2-3 summarizes the COIs for the ORWBG, and the rationale used to select them. Radioactive COIs have been analyzed in terms of radioactivity levels and their persistence through time. Identification of potential "hot spots" for nonradioactive COIs has been based primarily on waste form, and the density of burials at a given location.

\subsubsection{Inventory Analysis}

In this study, available inventory data (Appendix A) were compiled and analyzed for applicability to determining quantity and location of the COIs. The recent source-term study conducted by WSRC (Appendix A) estimates the inventory for each COI at the ORWBG and provides explanations for the basis of each source-term estimate. The estimated inventory is compared with available documentation in the COBRA database and other resources. Many records in COBRA refer to the same grid coordinates, and many individual burial records are associated with more than one COI. For this inventory analysis, the COBRA records for each COI were sorted and combined to create a data set containing the total quantity of each COI for each burial location. 
An accurate inventory analysis for the radioactive COIs must include a calculation of changes to the inventory due to decay. A forecast of temporal changes to the COI inventory is key to determining which radioactive constituents remain at high concentrations over long periods of time. In general, radioactive COIs with short half-lives have high activity. These COIs create the majority of the total radioactivity during a "near-term" period, but their relative contributions to the inventory will decrease over time. Analysis of temporal changes to the inventory of individual constituents determines which radioactive COIs may be considered principal contributors. To accomplish this, standard decay constants were used to calculate the percentage of each COI that remains after certain periods of time. The ORWBG received approximately 300,000 to 500,000 cubic feet of radioactive waste per year from 1951 through 1974 (Appendix A). For the purposes of this analysis, the time of burial for the entire COI inventory is set at the last year the ORWBG received waste.

\subsubsection{Spatial Analysis}

Spatial analysis combines the inventory estimates for the COIs with location information from COBRA to determine if any areas within the ORWBG exhibit pronounced levels of COI concentration or activity. In this method, spatial data for the COI inventory are derived through queries of COBRA. The data are compiled into maps to illustrate the distribution of COI burials with locations recorded in COBRA. To create the maps, COBRA data are downloaded into EXCEL spreadsheets and saved in comma-separated variable (CSV) format for loading into spatial-analysis software. The study utilized EarthVision ${ }^{\otimes}$ software to plot maps of the distribution of burials related to the COIs.

Maps of COI distribution are examined to ascertain whether any specific areas possess relatively high concentrations of COI burials. If such areas are identified, the distribution of the constituent COIs of the group are reviewed, individually if necessary, to identify which individual COIs contribute significantly to the potential "hot spot."

Areas of potential "hot spots" for the inventory of radioactive COIs are then selected, and their coordinates recorded. The coordinates of the boundaries of the potential "hot spots" are used to query the COBRA database, generating a list of burial records included within each potential "hot spot". The lists are summarized to determine the physical attributes of the potential "hot spot", such as the quantity, types, and volume of buried waste.

Because this type of analysis relies on location information, it can only be performed for those COIs that have COBRA records with grid coordinates. Because the original burial ground 
received the bulk of its contents subsequent to the implementation of COBRA, its assessment is restricted to inventory analysis only.

\subsubsection{Results}

Analyses of the potential "hot spots" fall into three categories based on the types and quantity of available data: Solvent Tanks (S1-S22), nonradioactive COIs, and radioactive COIs.

\section{Potential "Hot Spots" for Solvent Tanks S1-S22}

The estimated inventory for the OSTs is presented in Table 2-1. Volatile organic compounds contained in solvents, sludge, and their degradation products, are the primary COIs associated with the OSTs.

An operational history and data for waste form and inventory are presented in Appendix A. Solvent Tanks S1-S22 are considered a potential "hot spot" because remediation of liquid and sludge in the underground tanks could be substantially different from remediation of the waste in "landfill style" burials in the remainder of the ORWBG. Potential "hot spots" for the Solvent Tanks (S1-S22) are represented by the un-shaded polygons shown in Figures 2-24 through 2-26.

\section{Potential "Hot Spots" for Non-Radioactive COIs}

The data for burial locations of mercury and VOCs were extracted from COBRA and sorted to determine the number of individual burials recorded at each grid cell. Maps of these data were used to delineate potential "hot spots" by examining the distribution and number of burials recorded at each grid cell location.

Figures 2-24 through 2-26 indicates one area that contains a large concentration of burials associated with mercury. The potential mercury "hot spot" (HS-Hg-1) is located in the southern half of the eastern expansion area of the ORWBG. The pattern of burials within this potential "hot spot" is consistent with the reported configuration of trenches in this part of the ORWBG

\section{Potential "Hot Spots" for Radioactive COIs}

Potential radioactive "hot spots" have been identified in areas of the ORWBG where the COI activity level exceeds 60 curies within a single grid cell. The 60 curies per cell criterion represents two standard deviations above the mean of the data (total COI radioactivity in the ORWBG) at 100 years. This method essentially identifies the highest $5 \%$ of the COI activity in the ORWBG. 
An analysis of the COI inventory recorded in COBRA indicates that tritium and cobalt- 60 contribute the majority of the radioactivity during the first 100 years after burial. After that time, the principal COIs (in terms of total activity) are carbon-14, plutonium-238, and plutonium-239.

At the time of burial, COI-bearing waste contributed approximately 5.1 million curies of activity to the total COI inventory. Approximately 58\% (3,014,457 curies) of the activity is attributed to tritium and $37 \%(1,960,400$ curies $)$ is attributed to cobalt- 60 . Both of these COIs are relatively short-lived isotopes. After 100 years, the total activity will decay to less than $1 \%(36,634$ curies) of the original level.

After 500 years, the total activity will drop to $0.1 \%$ (5,440 curies) of the original level and be associated primarily with carbon-14 (3,556 curies), plutonium-238 (390 curies), and plutonium239 (1,454 curies). Of the COI activity remaining after 500 years of decay, approximately $80 \%$ (4,370 curies) will be contained within eight "hot spots" (Figure 2-26).

Spatial analysis of the burial locations and activity levels for the radioactive COIs indicates 21 potential "hot spots' after 100 years of burial (Figure 2-24). Radioactive decay reduces these to only eight potential "hot spots" 300 years after burial. These potential "hot spots" are shown in Figure 2-26. The configuration of the "hot spots" at 300 years is identical to those delineated for 500 years after burial (Figure 2-26), The potential "hot spots" identified at 300 and 500 years should be considered the "principal" potential "hot spots" because of their persistent, high activity levels. The configuration of these principal "hot spots" is due to the persistence of carbon-14, plutonium-238, and plutonium-239. The waste forms associated with these principal COIs are deionizer units that contain carbon-14, and retrievable TRU waste and concrete-encapsulated burials that contain plutonium-238 and plutonium- 239 .

\subsubsection{Summary of Potential "Hot Spots"}

Figure 2-26 provides the location of potential "hot spots". Descriptions of these "hot spots" are provided below.

\section{"Hot Spot" for the Solvent Tanks (S1-S22):}

- 7,539 gallons of VOCs in 22 individual tanks

- Radioactive COIs include:

Strontium-90

Cesium-137 
Uranium-235 and -238

Plutonium-238 and -239

\section{Hot Spot HS-Hg-I (mercury):}

- 122,500 square feet in area

- Contains an estimated 5,325 pounds of mercury in 71 recorded burials

\section{Hot Spot HS-500-1:}

- 23,000 square feet in area

- 18,339 cubic feet of waste in 754 burials

- Primary waste forms (by volume):

$\begin{array}{ll}\text { Job control waste } & 56 \% \\ \text { Capital equipment waste } & 29 \% \\ \text { Irradiated scrap metal } & 15 \%\end{array}$

- Activity (curies):

11,316 at time of burial

5,550 after 100 years

1,754 after 300 years

968 after 500 years

- Persistent COIs:

Carbon-14 in deionizer units

Plutonium-239 in retrievable TRU waste

Plutonium-238 in retrievable TRU waste

Hot Spot HS-500-2:

- 4,500 square feet in area

- 49,743 cubic feet of waste in 645 burials

- Primary waste forms (by volume):

Job control waste $98 \%$ 


$\begin{array}{ll}\text { Capital equipment waste } & 1 \% \\ \text { Irradiated scrap metal } & 1 \%\end{array}$

- Activity (curies):

$$
\begin{aligned}
16,010 & \text { at time of burial } \\
165 & \text { after } 100 \text { years } \\
107 & \text { after } 300 \text { years } \\
106 & \text { after } 500 \text { years }
\end{aligned}
$$

- Persistent COIs:

Plutonium-239 in retrievable TRU waste

\section{Hot Spot HS-500-3:}

- 4,500 square feet in area

- 33,256 cubic feet of waste in 237 burials

- Primary waste forms (by volume):

$\begin{array}{lr}\text { Job control waste } & 94 \% \\ \text { Naturally Radioactive Material } & 43 \% \\ \text { Capital equipment waste } & 1 \% \\ \text { Irridated Scrap Metal } & 1 \% \\ \text { Oil } & 1 \%\end{array}$

- Activity (curies):

571 at time of burial

77 after 100 years

74 after 300 years

72 after 500 years

- Persistent COIs:

Carbon 14 in deionizer units

\section{Hot Spot HS-500-4:}

- 13,700 square feet in area

- 33,702 cubic feet of waste in 685 burials 
- Primary waste forms (by volume):

Job control waste

Naturally Radioactive Material

- Activity (curies):

5,761 at time of burial

2,805 after 100 years

872 after 300 years

474 after 500 years

- Persistent COIs:

Plutonium-238 in retrievable TRU waste

Plutonium-239 in retrievable TRU waste

Hot Spot HS-500-5:

- 23,000 square feet in area

- 35,019 cubic feet of waste in 880 burials

- Primary waste forms (by volume):

Irradiated Scrap Metal $75 \%$

Job control waste $22 \%$

Capital equipment waste $\quad 3 \%$

- Activity (curies):

$$
\begin{aligned}
140,862 & \text { at time of burial } \\
1,102 & \text { after } 100 \text { years } \\
649 & \text { after } 300 \text { years } \\
630 & \text { after } 500 \text { years }
\end{aligned}
$$

- Persistent COIs:

Carbon-14 in deionizer units

\section{Hot Spot HS-500-6:}

- 65,000 square feet in area

- 196,226 cubic feet of waste in 3,629 burials 
- Primary waste forms (by volume):

Irradiated Scrap Metal $\quad 50 \%$

Job control waste $\quad 40 \%$

Capital equipment waste $\quad 9 \%$

Naturally Radioactive Material $\quad 1 \%$

- Activity (curies):

$\begin{aligned} 511,437 & \text { at time of burial } \\ 4,148 & \text { after } 100 \text { years } \\ 1,868 & \text { after } 300 \text { years } \\ 1,707 & \text { after } 500 \text { years }\end{aligned}$

- Persistent COIs:

Carbon-14 in deionizer units

Hot Spot HS-500-7:

- 4,500 square feet in area

- 14,230 cubic feet of waste in 516 burials

- Primary waste forms (by volume):

$\begin{array}{ll}\text { Irradiated Scrap Metal } & 81 \% \\ \text { Job control waste } & 19 \%\end{array}$

- Activity (curies):

99,660 at time of burial

664 after 100 years

428 after 300 years

417 after 500 years

- Persistent COI:

Carbon-14 in deionizer units

Hot Spot HS-500-8:

- 22,000 square feet in area

- 21,406 cubic feet of waste in 767 burials

- Primary waste forms (by volume):

Irradiated Scrap Metal $\quad 90 \%$ 
Job Control waste $\quad 10 \%$

- Activity (curies):

$\begin{aligned} 154,581 & \text { at time of burial } \\ 536 & \text { after } 100 \text { years } \\ 105 & \text { after } 300 \text { years } \\ 96 & \text { after } 500 \text { years }\end{aligned}$

- Persistent COI

Carbon-14 in deionizer units

Plutonium-238 in job control waste.

\subsection{Unit Evaluation Conclusions}

Based on the history of ORWBG operations and previous investigations (Section 2.4), it is concluded that hazardous and radioactive constituents are present in the ORWBG and surrounding soil and groundwater media. These constituents include VOCs, metals, and radionuclides.

Characterization of the ORWBG groundwater contamination has been completed through implementation of the BGC FIP. The groundwater contamination associated with the ORWBG as well as the entire BGC will be addressed under RCRA. Groundwater assessment and remediation activities are discussed in detail in the RCRA Part B permit application for the MWMF.

An Interim Record of Decision has been submitted and approved by the regulators for the installation of a low-permeability soil cover over the ORWBG. The goal of the interim action is a reduction of stormwater infiltration through the waste layer which will minimize contamination migration to the water table.

\subsection{Potential ARARs and TBC Criteria}

A preliminary list of potential applicable or relevant and appropriate requirements (ARARs) and "to be considered" (TBC) criteria for the ORWBG is presented in Table 2-5. Identification of ARARs and TBCs is performed iteratively throughout the RCRA/CERCLA process. Thus, this list of potential ARARs is expected to be modified and refined as the assessment and corrective action process at the ORWBG proceeds. ARARs may be location-specific, chemical-specific, or action-specific. 
Certain potential ARARs can be identified as inappropriate based on the unit characterization, the primary source of contamination, and other existing information available for the ORWBG. No critical habitats for endangered species have been identified at the ORWBG; therefore, the Endangered Species Act will not be included as an ARAR. No national historic landmarks or archaeological sites have been identified within the ORWBG. Thus, it is not anticipated that the National Historic Preservation Act will be included as an ARAR.

Because groundwater monitoring data indicate impacts to groundwater from the unit, the EPA aquifer classification and the South Carolina Water Classification Standards are potential ARARs. Certain other requirements may be applicable depending on specific remedial actions implemented at the ORWBG. RCRA and the SCHWMR may be considered ARARs if removal of waste material from the unit is conducted. Since radioactive materials are confirmed to be present at the ORWBG, the Atomic Energy Act (AEA) is applicable. If groundwater extraction wells are required for remedial action at the ORWBG, then the South Carolina Well Standards would be considered an action-specific ARAR. 
This page intentionally left blank. 


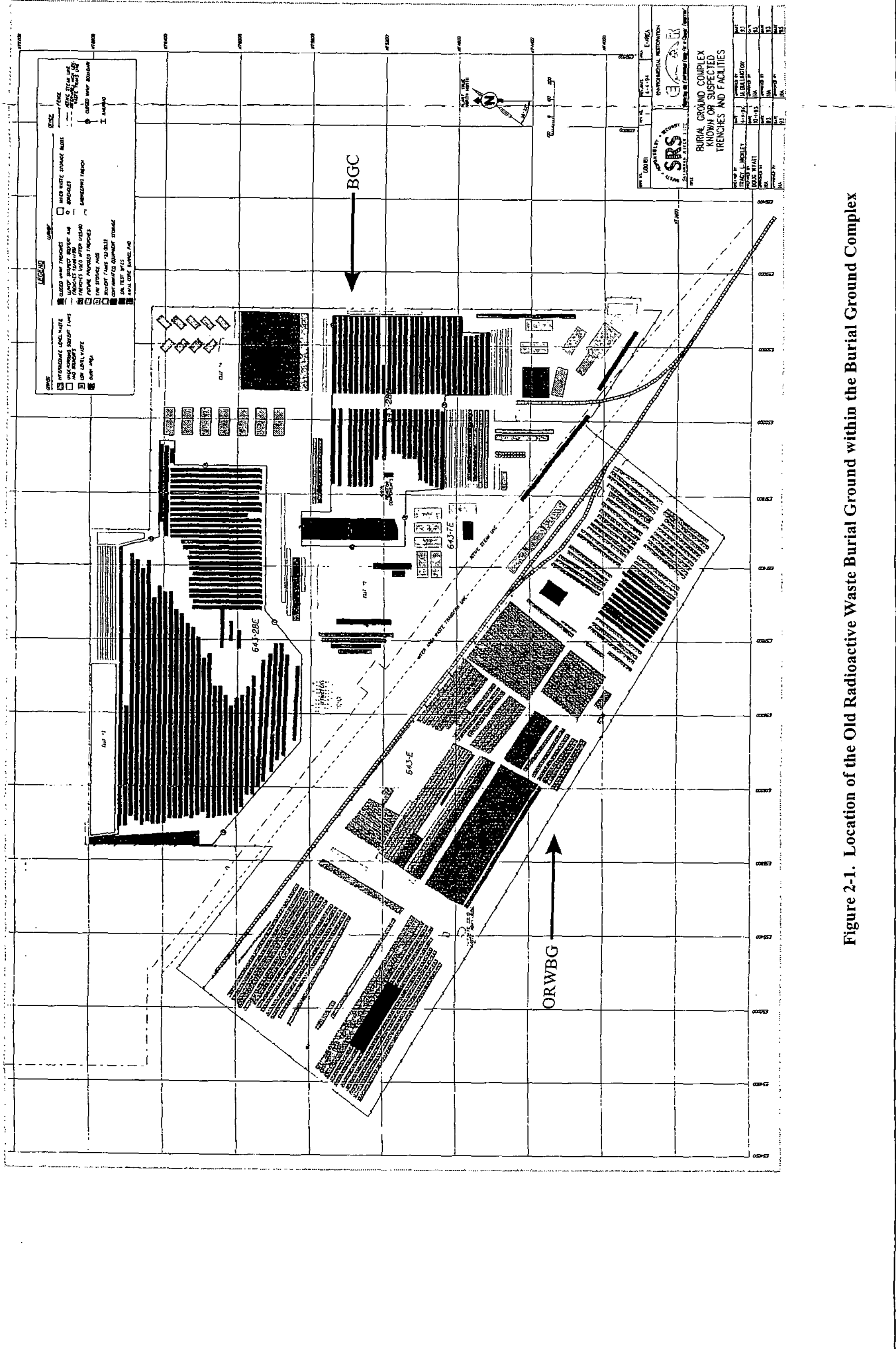





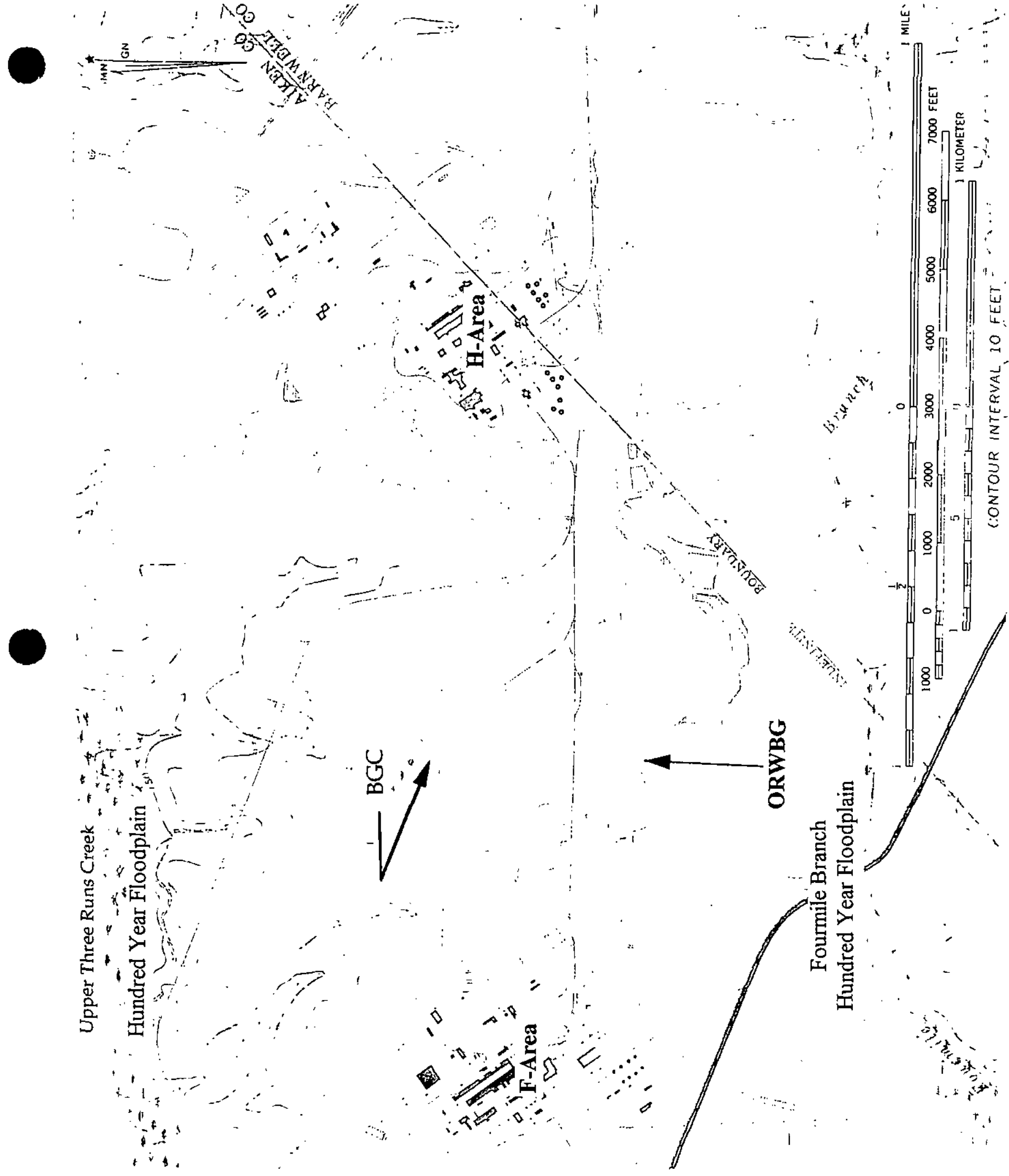

Figure 2-2. Topography and Drainage Patterns in the Vicinity of the BGC 

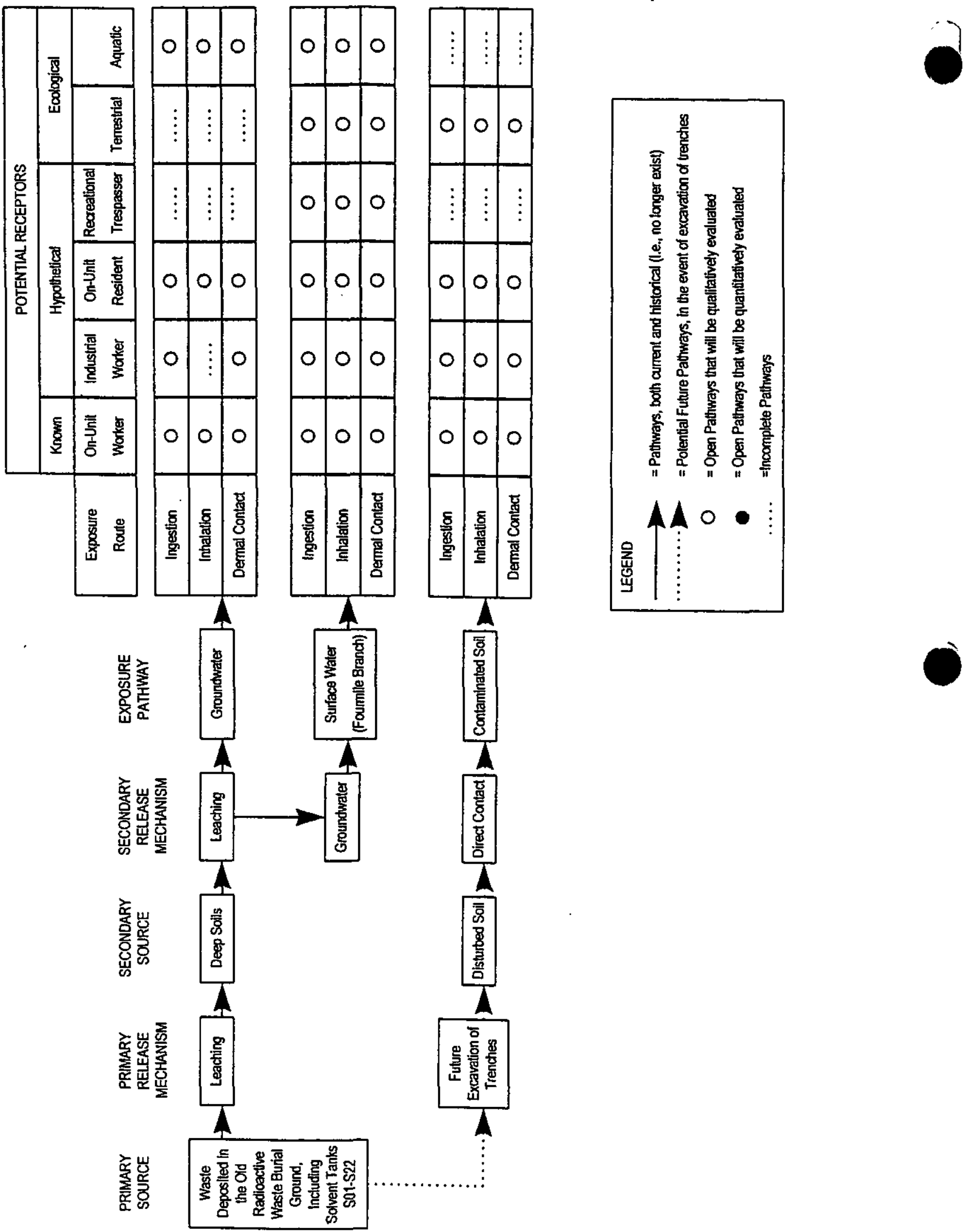

Figure 2-3. ORWBG Conceptual Site Model 


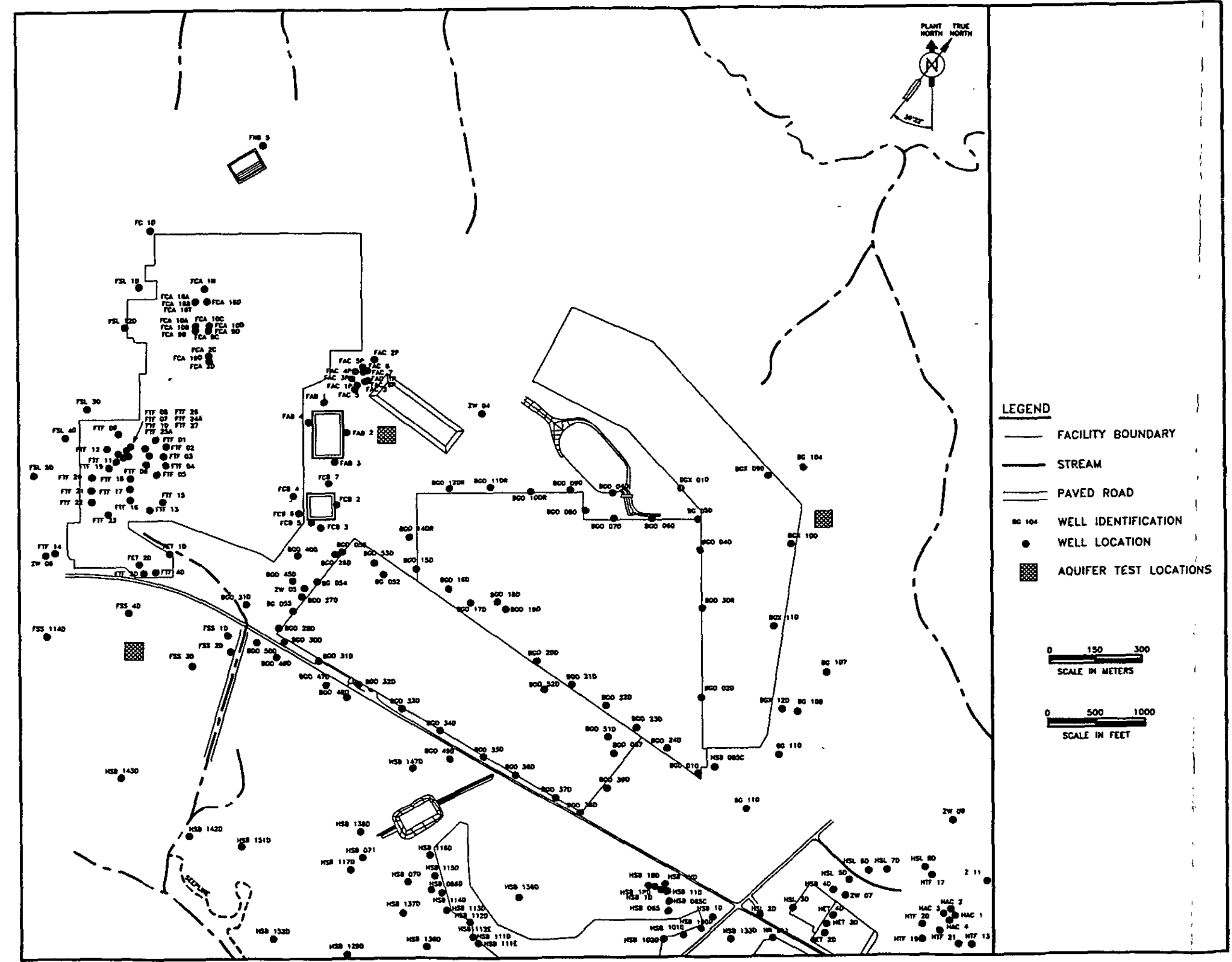

Figure 2-4. "Upper" Aquifer Zone IIB $_{2}$ of the Three Runs Aquifer (IIB) Monitoring Well Locations 



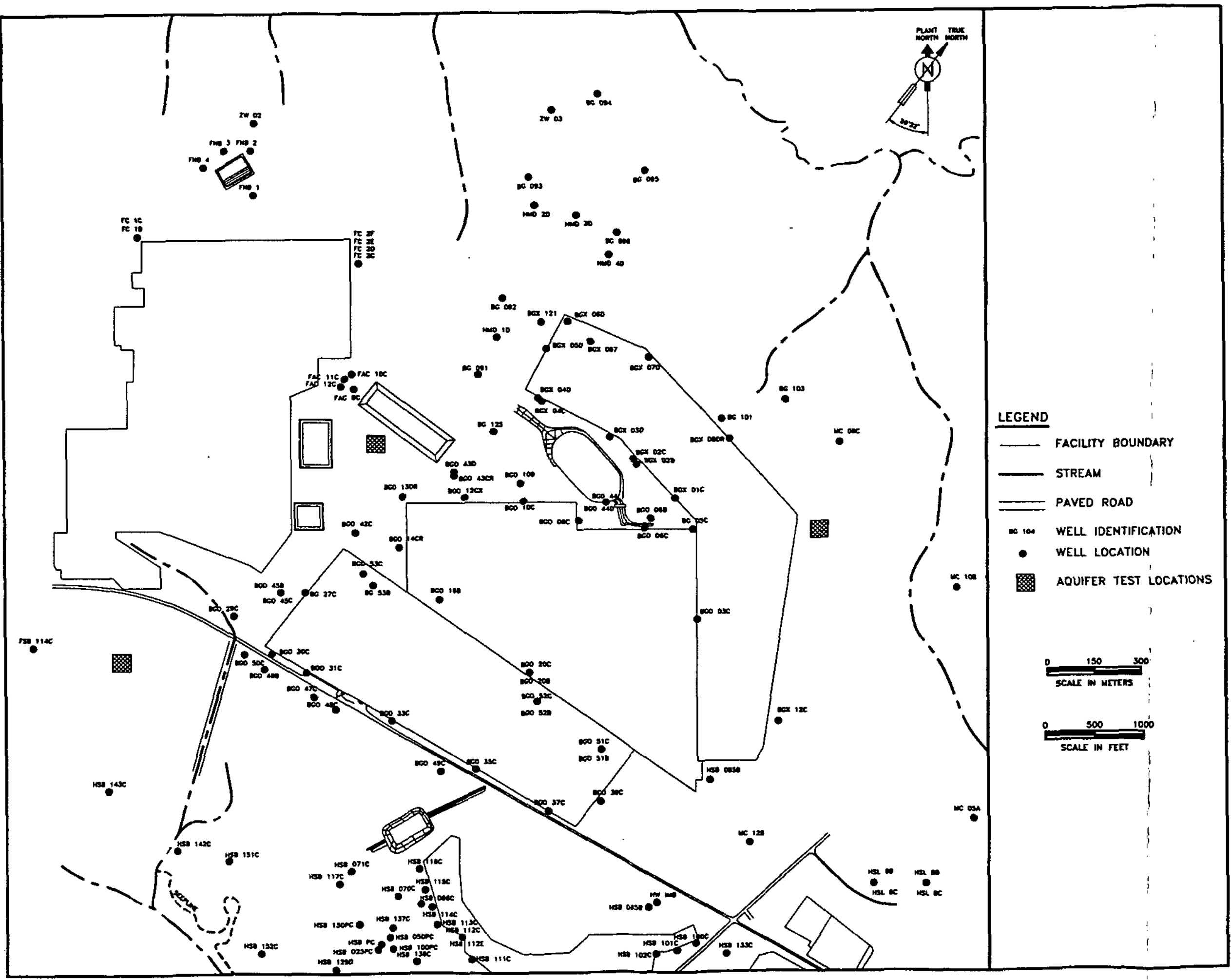

Figure 2-5. "Lower" Aquifer Zone (IIB $)$ of the Upper Three Runs Aquifer (IIB) Monitoring Well Locations 


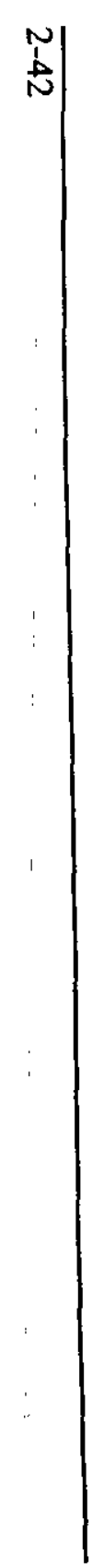

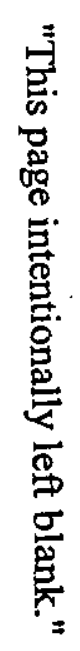

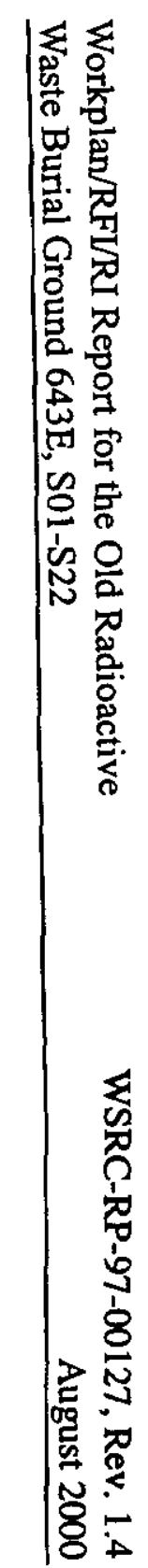




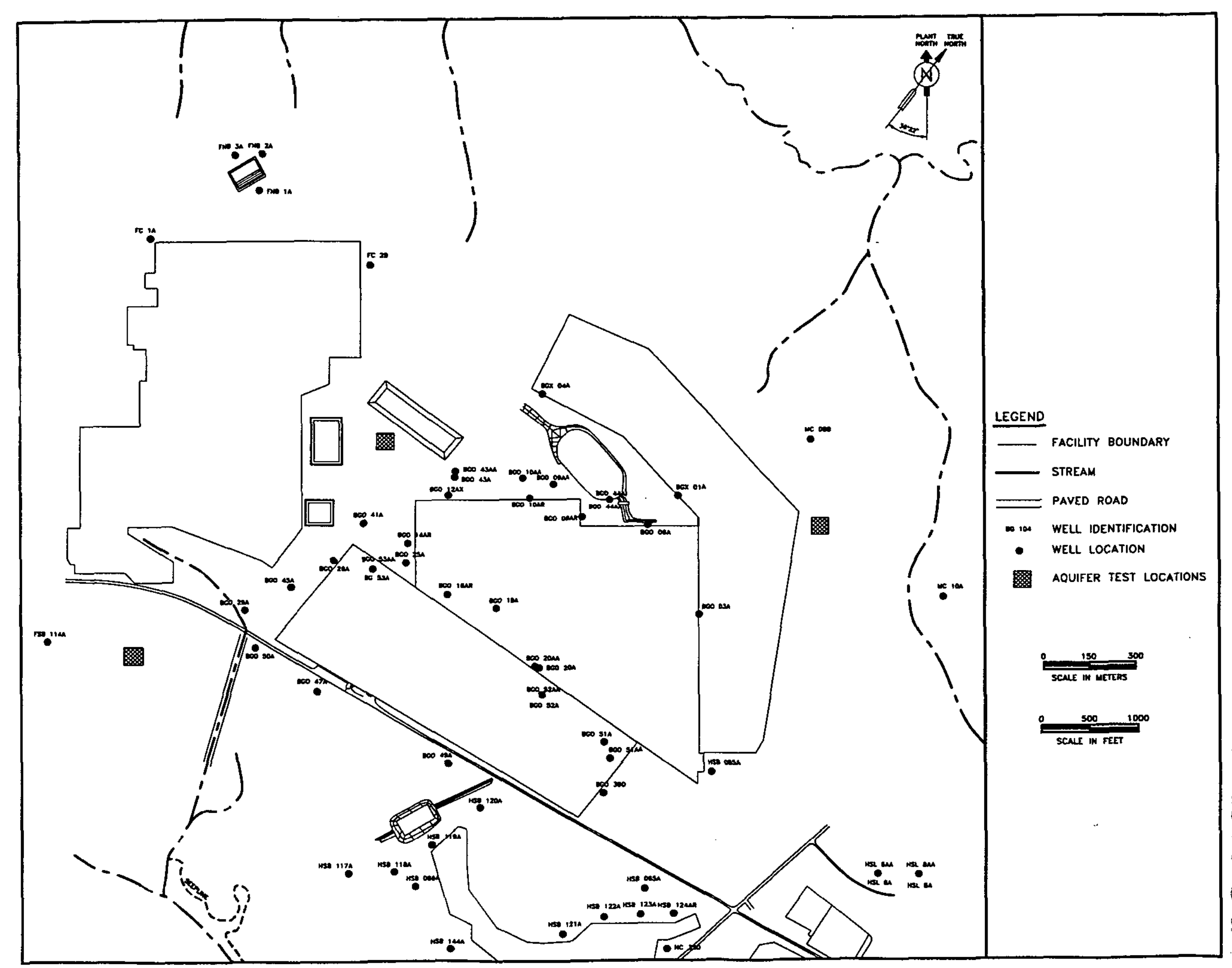

Figure 2-6. The Gordon Aquifer Unit (IIA) Monitoring Well Locations 


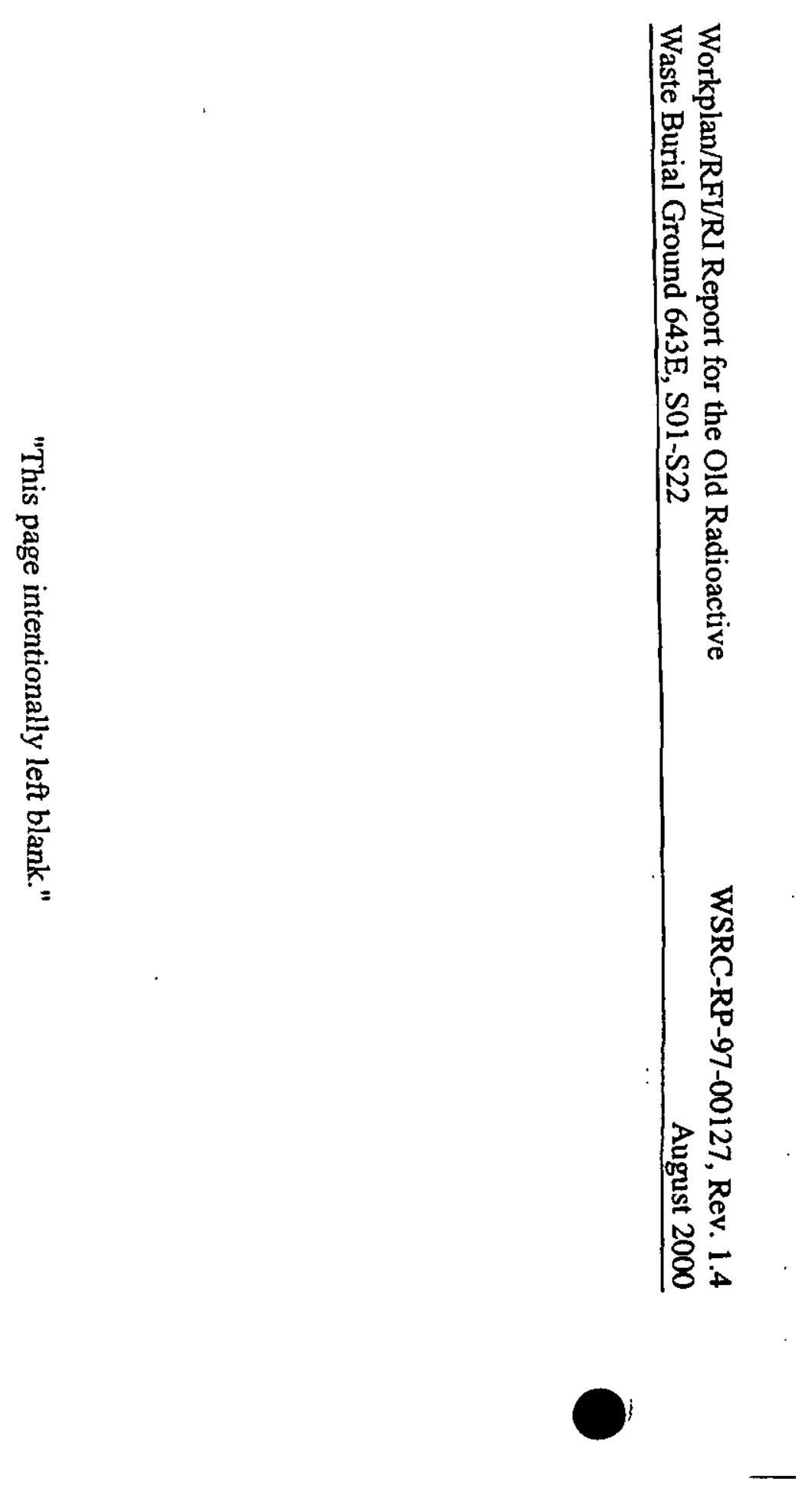




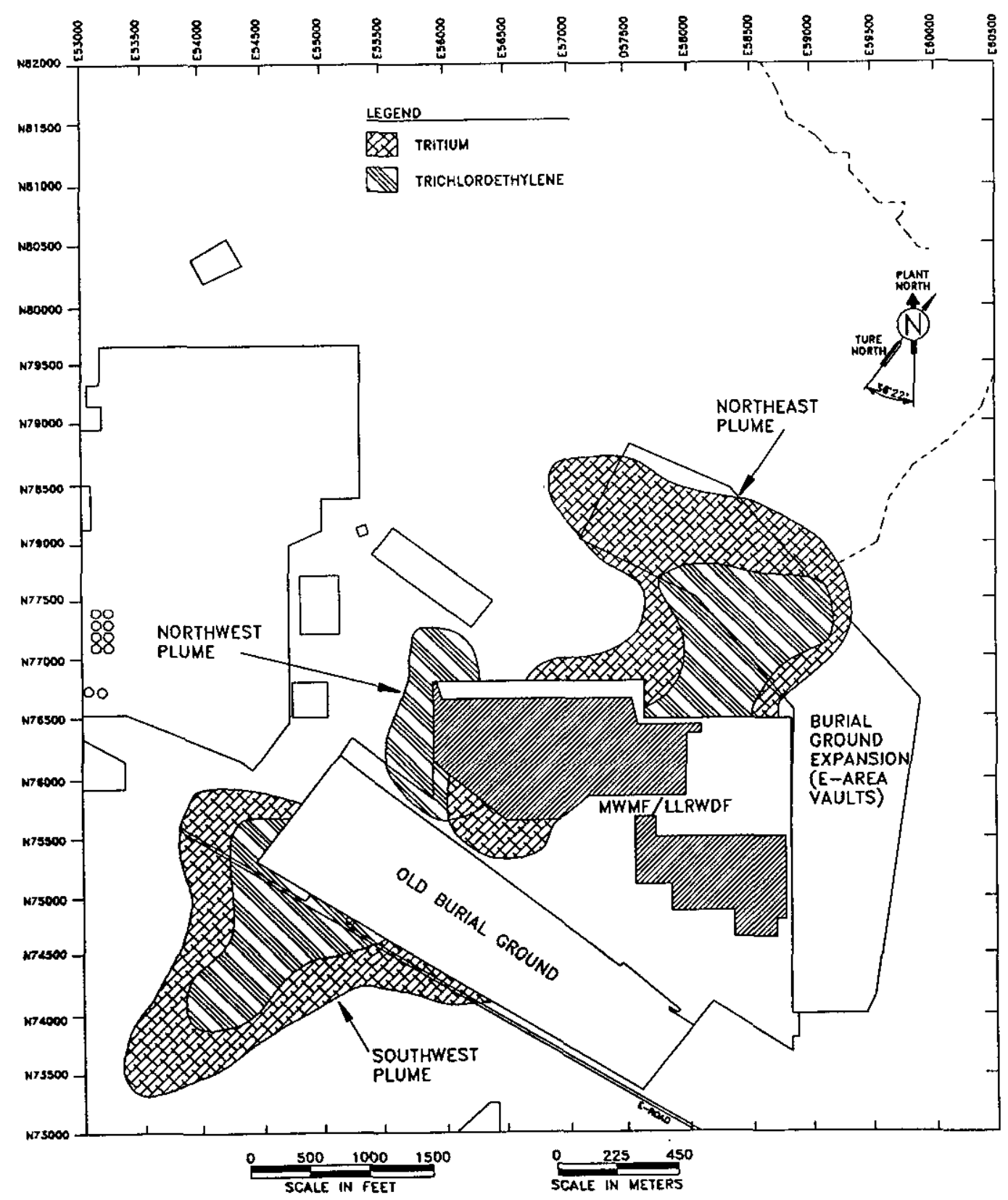

Figure 2-7. Burial Ground Complex Generalized Plume Map 
This page intentionally left blank. 


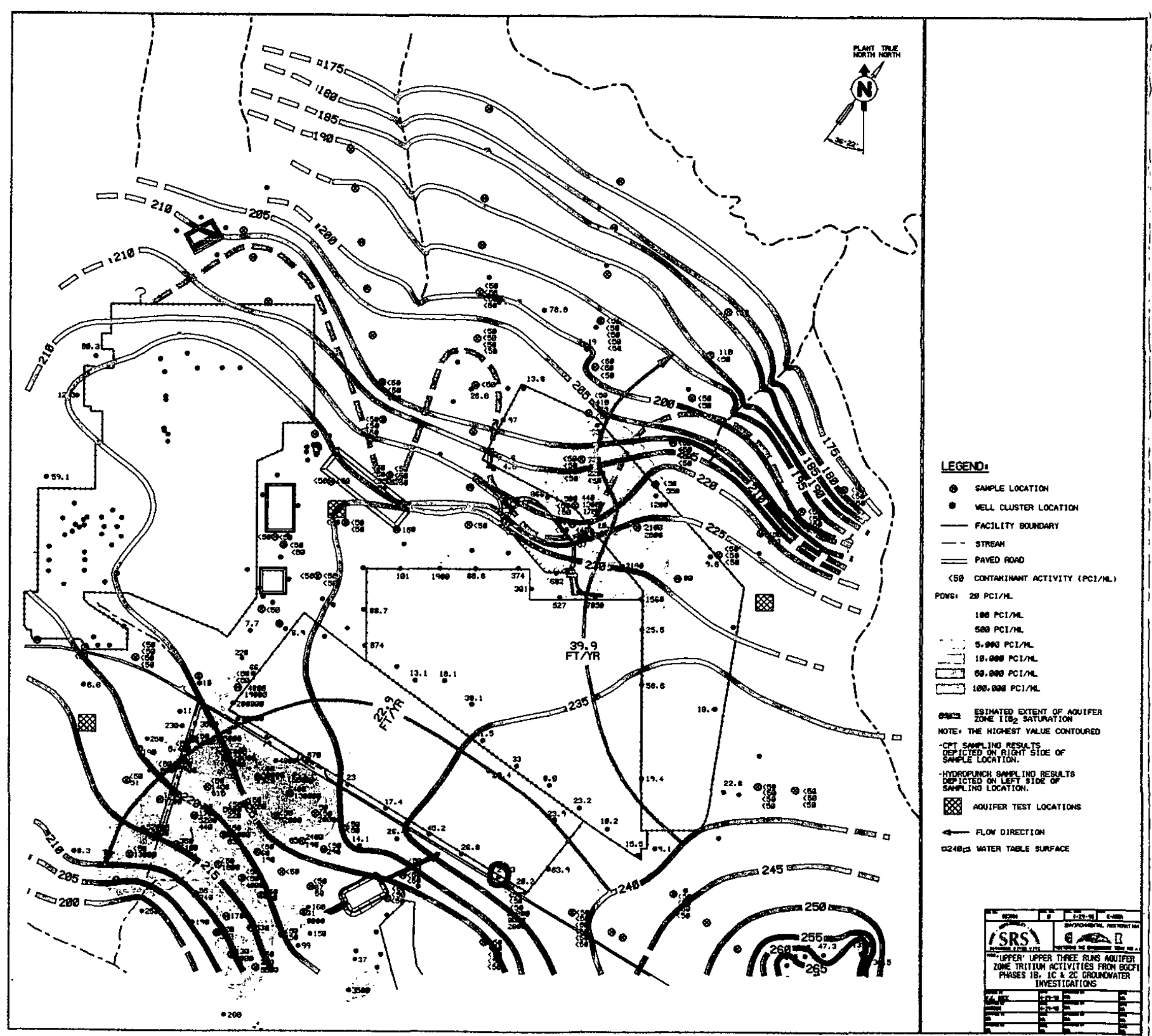

Figure 2-8. "Upper” Aquifer Zone (IIB ${ }_{2}$ ) Tritium Activity from BGC FIP Groundwater Investigations 


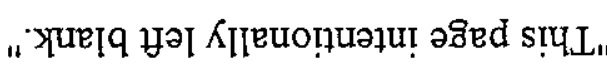




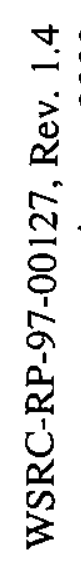

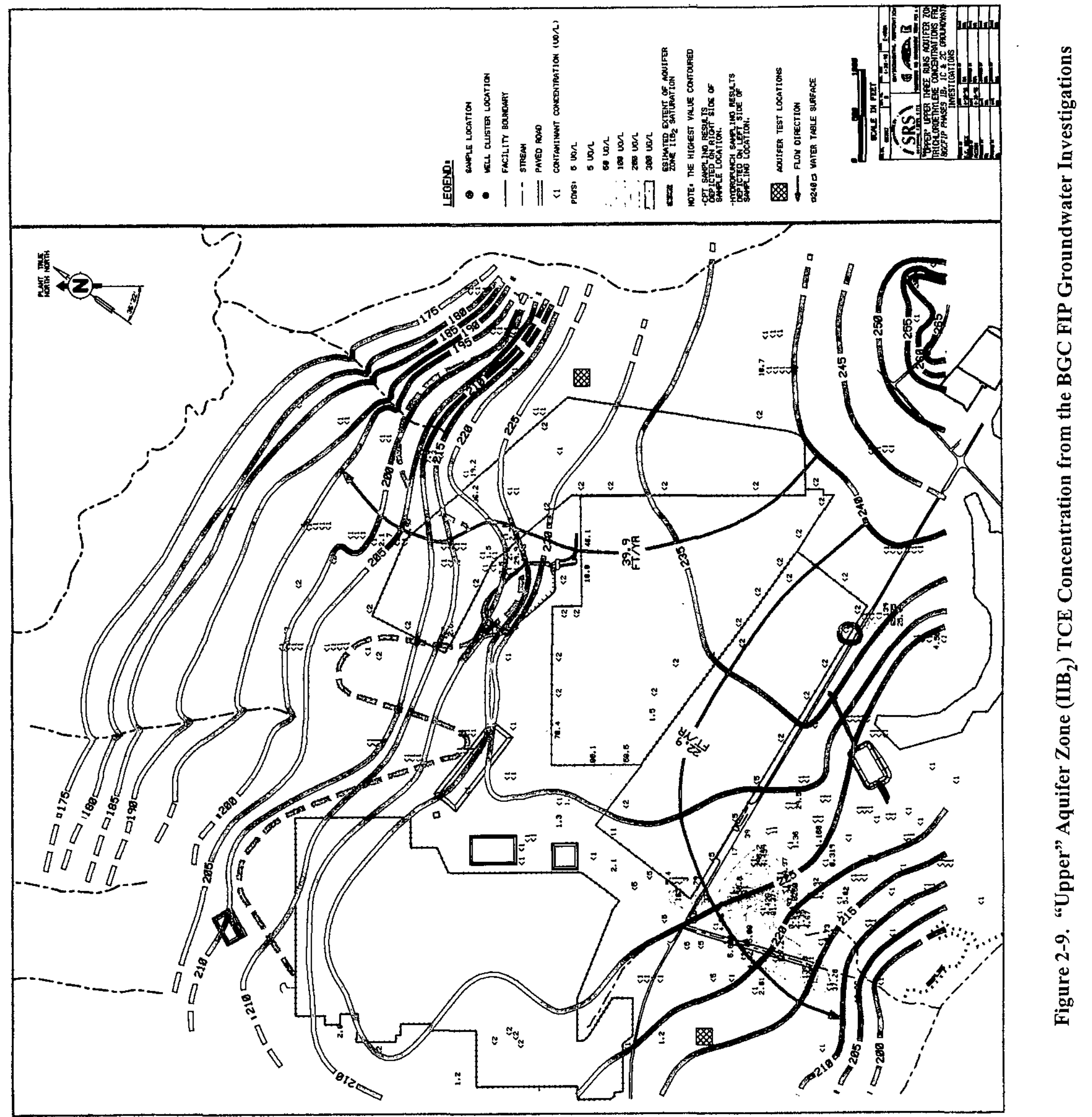

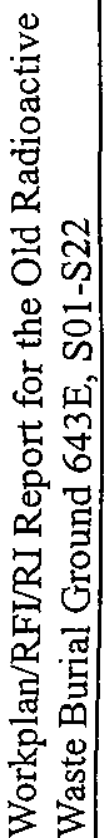




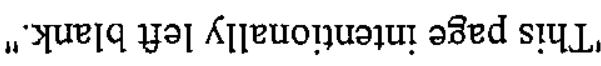




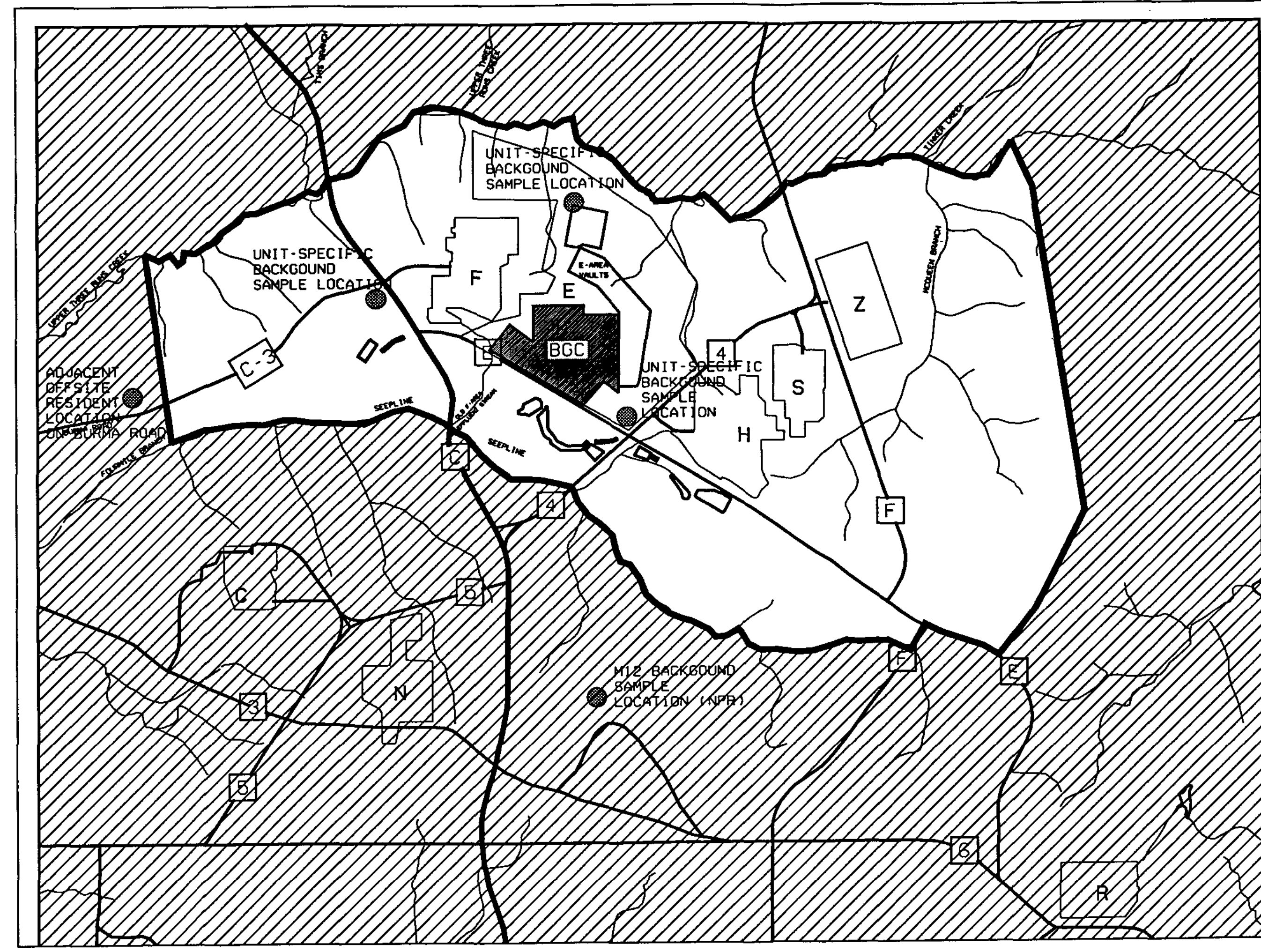

MI2-BACKGOUND SOIL GAS

SAMPLE LOCATION REACTOR,

SCALE $1: 48$ D00 MILES

3000 FEET

ELCHED KLOMETES

ETHEम

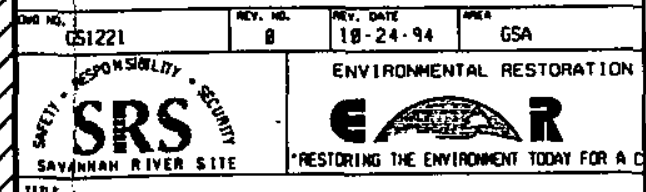

Figure 2-10. Background Soil Sample Locations for the Burial Ground Complex 



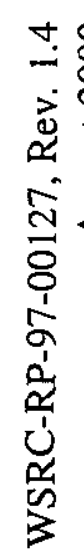

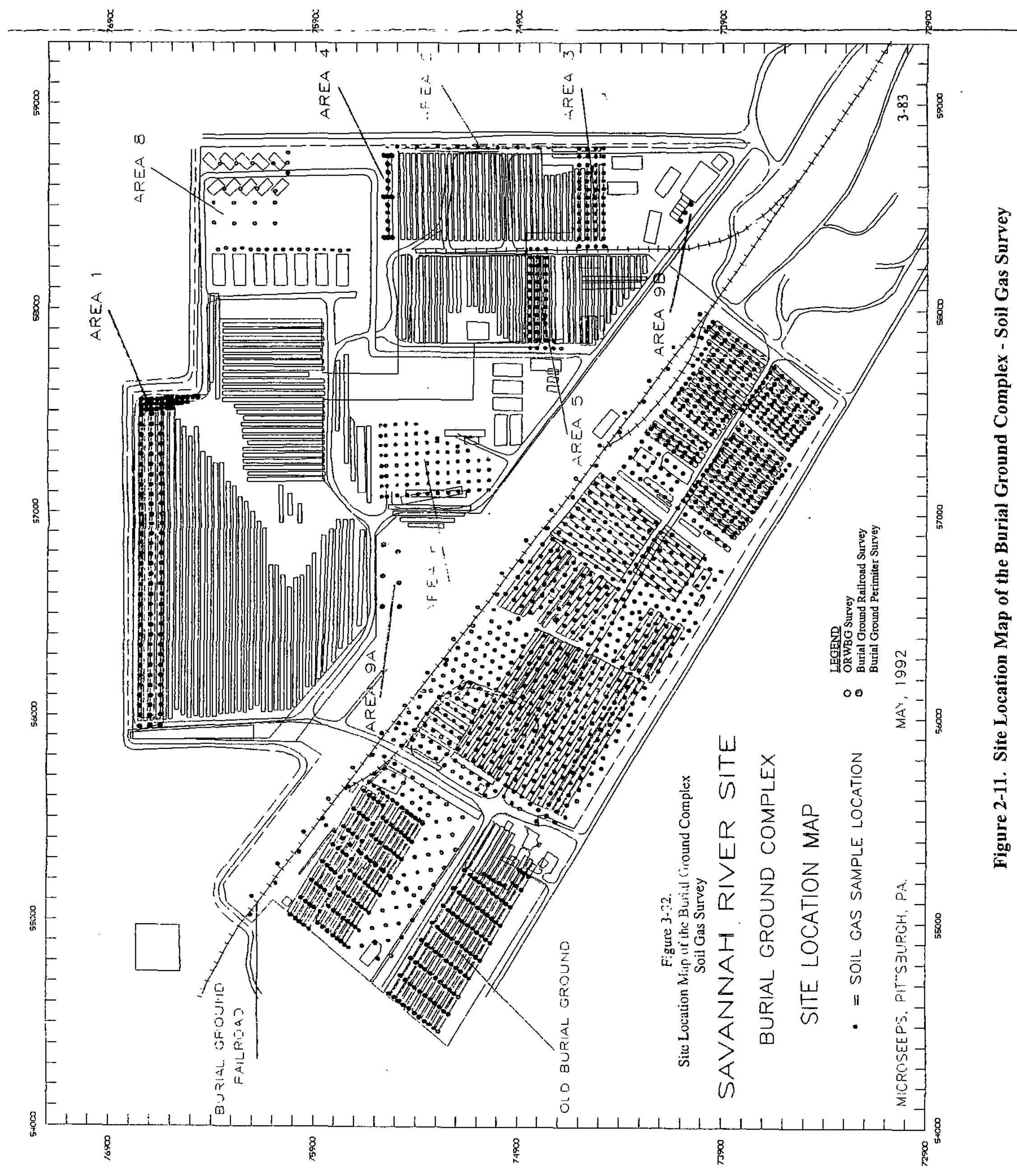

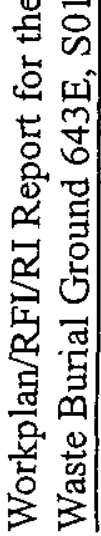





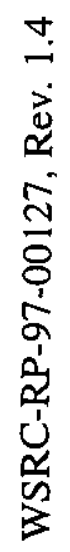

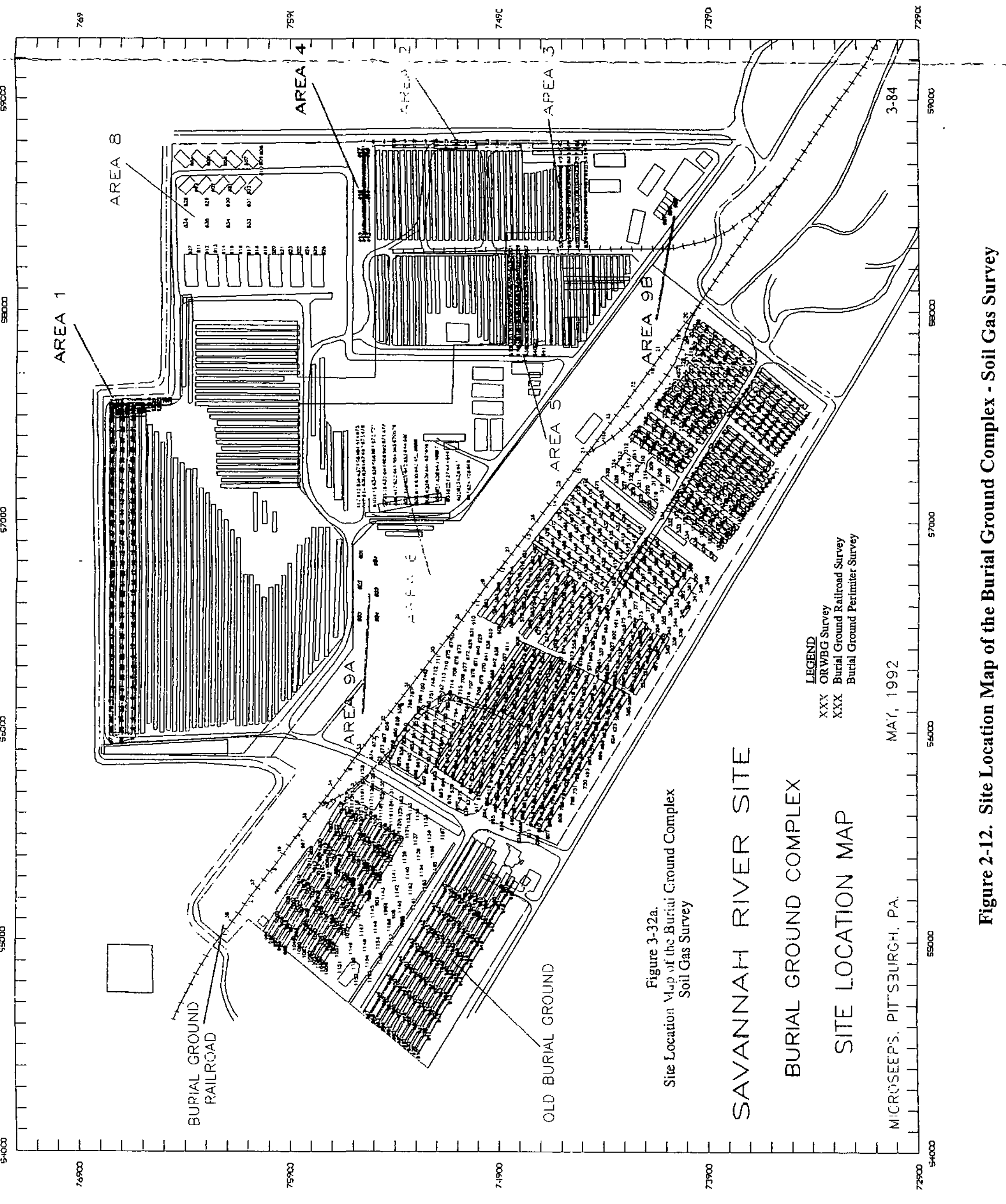

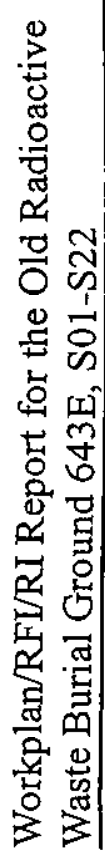




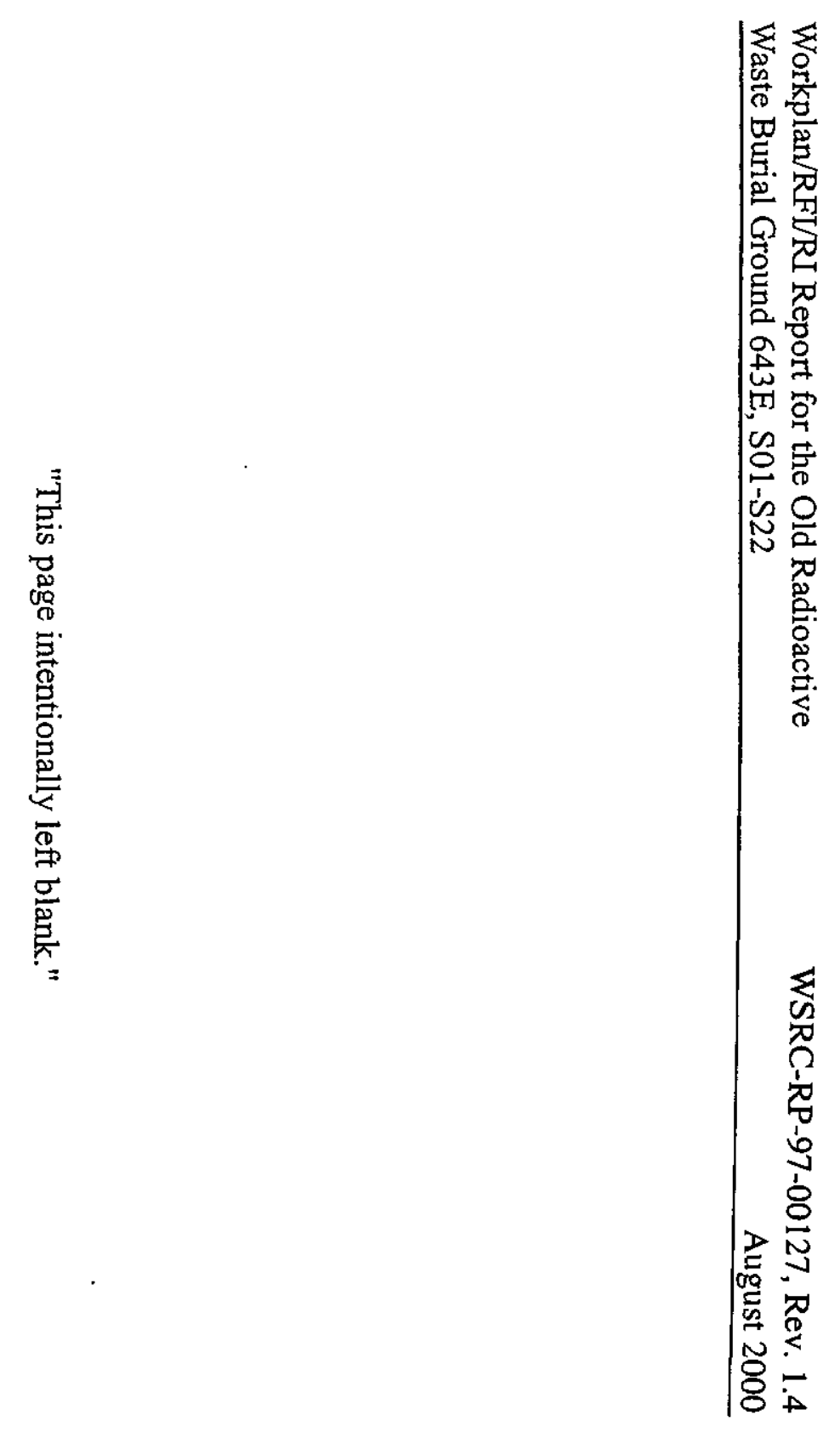



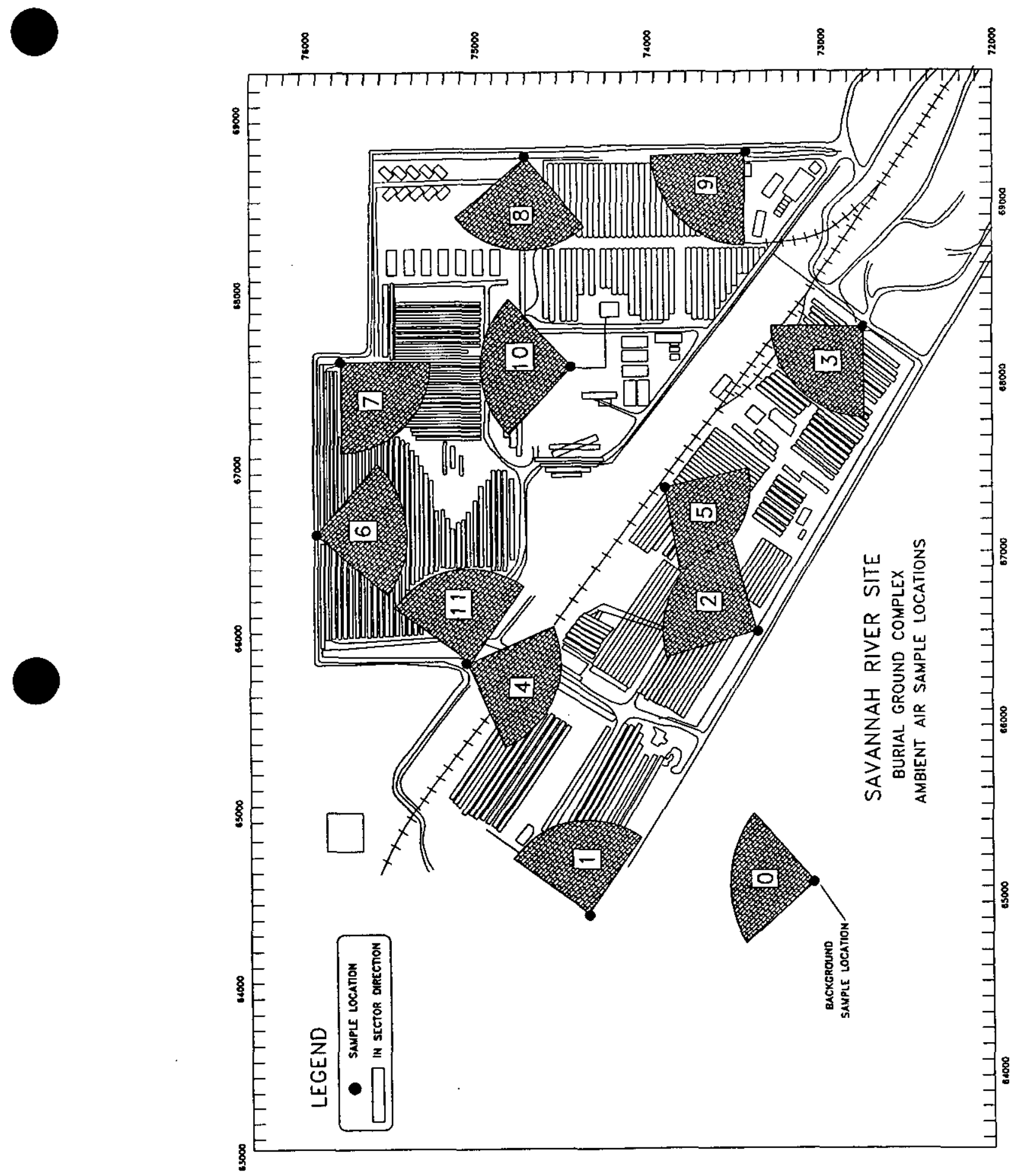

Figure 2-13. The Burial Ground Complex Ambient Air Study Sample Location Map 


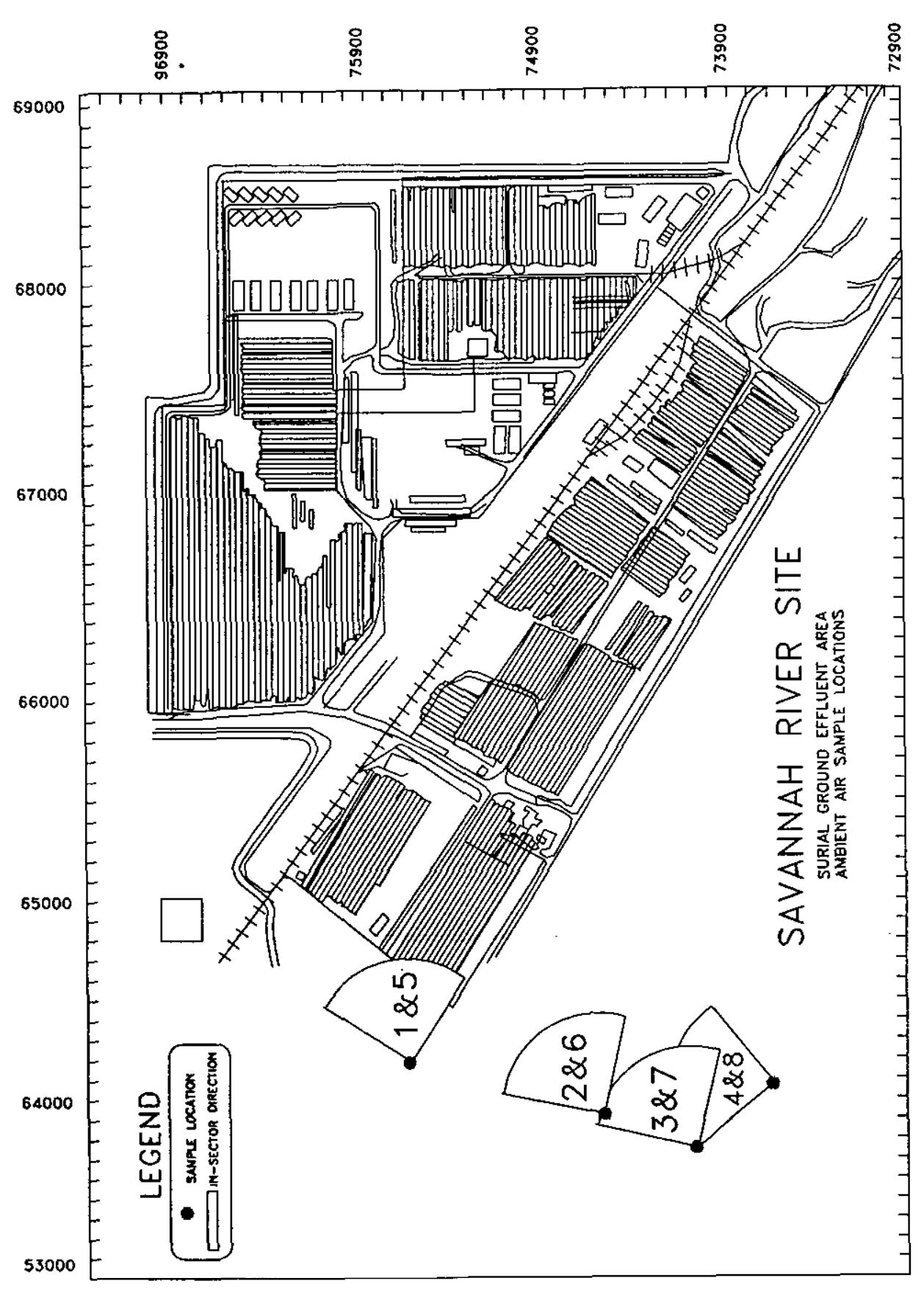

Figure 2-14. The Burial Ground Complex Ambient Air Study Sample Location Map 


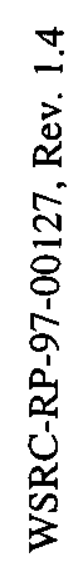

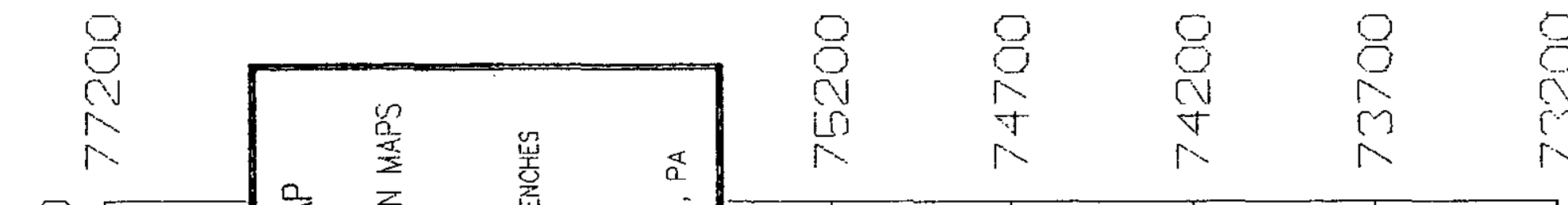

8

$Q$

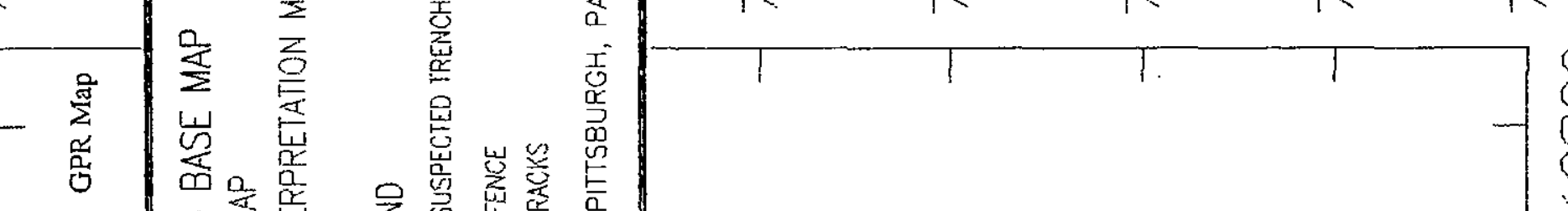

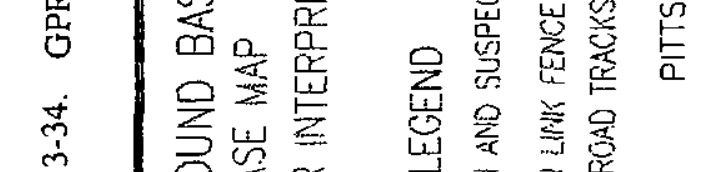

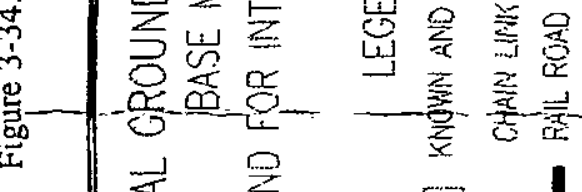

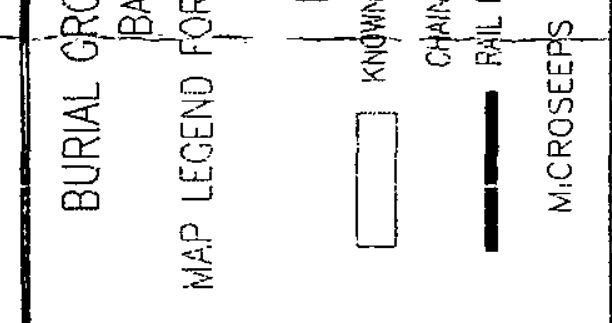
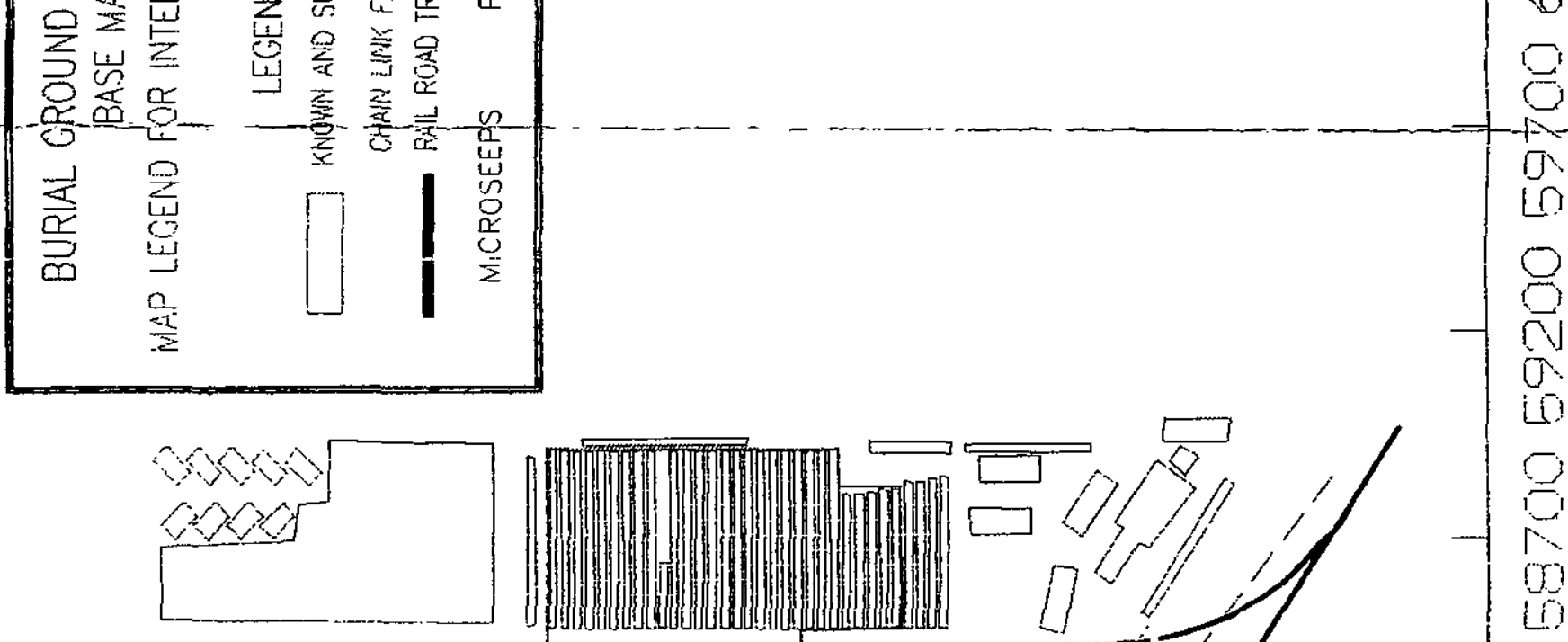

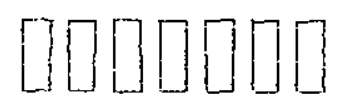

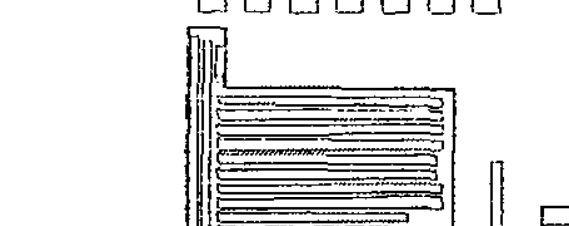

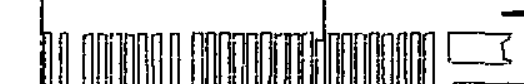

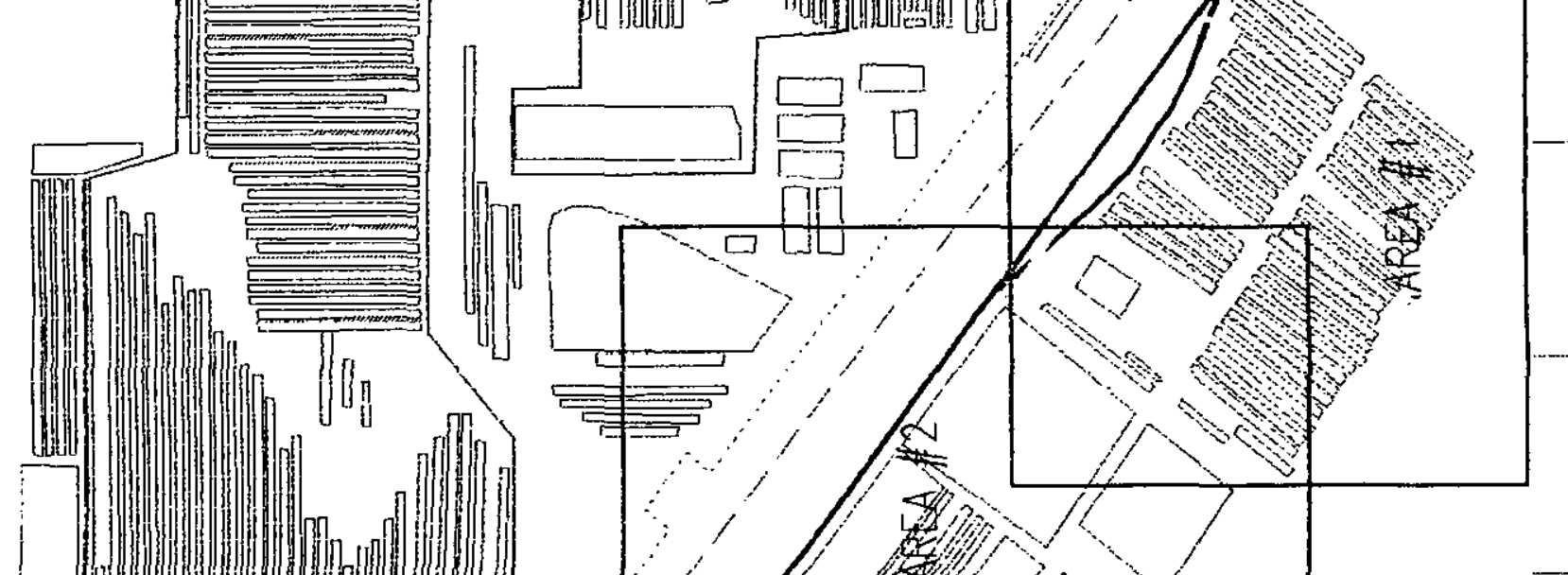

4

3

0

(5)

Q

v

10

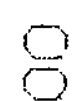

9

is

9

3

0

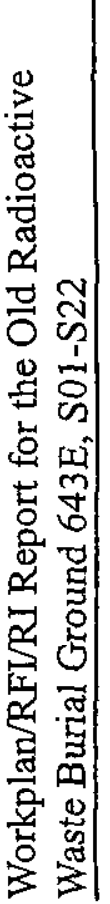

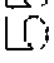

9
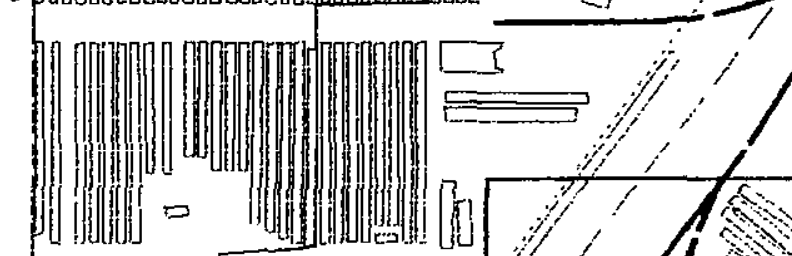

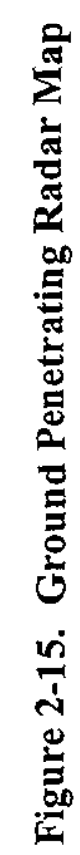
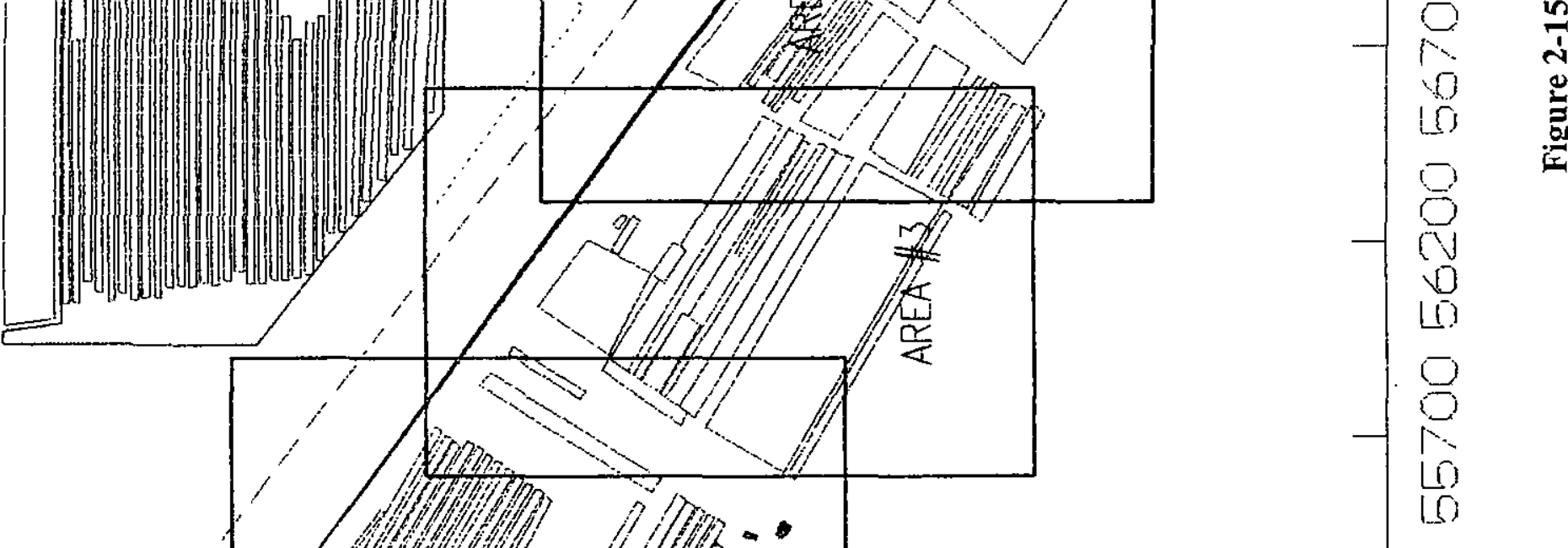

$-9$
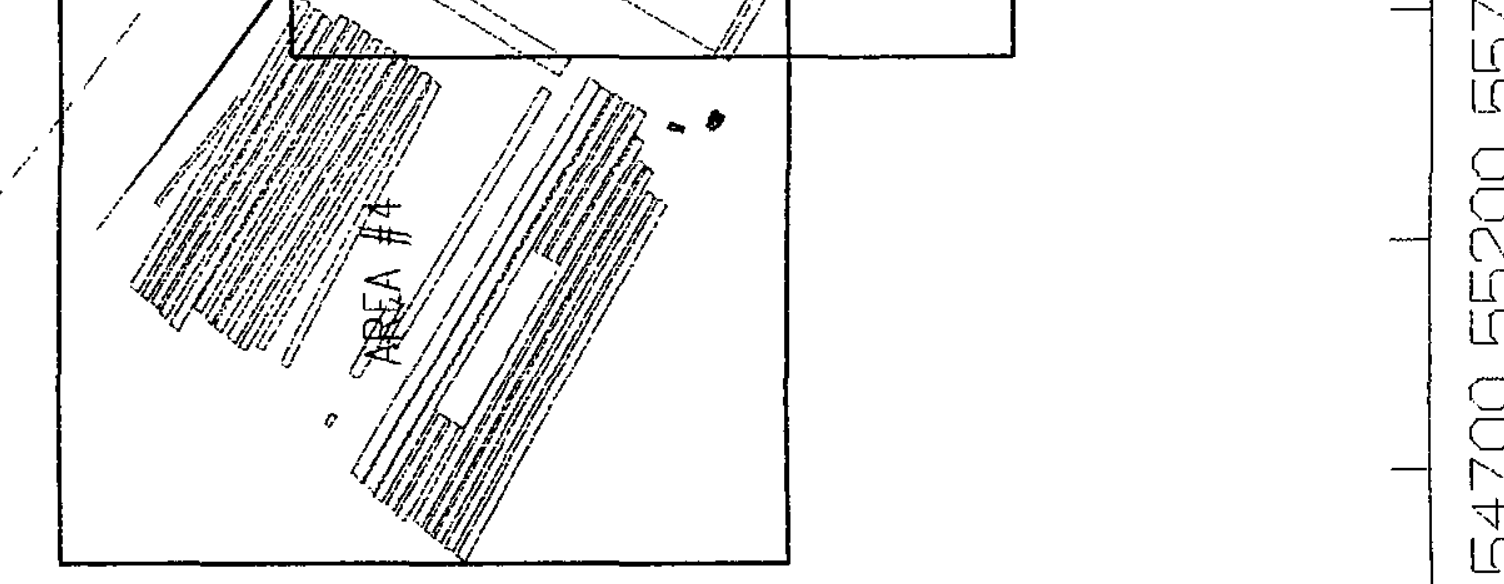

9

$-0$

0

$-8$

i

8

की

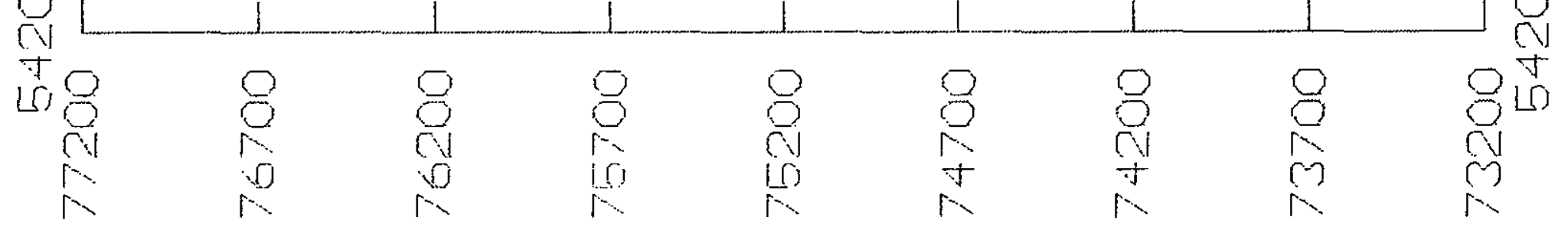


r

p

$0=0$
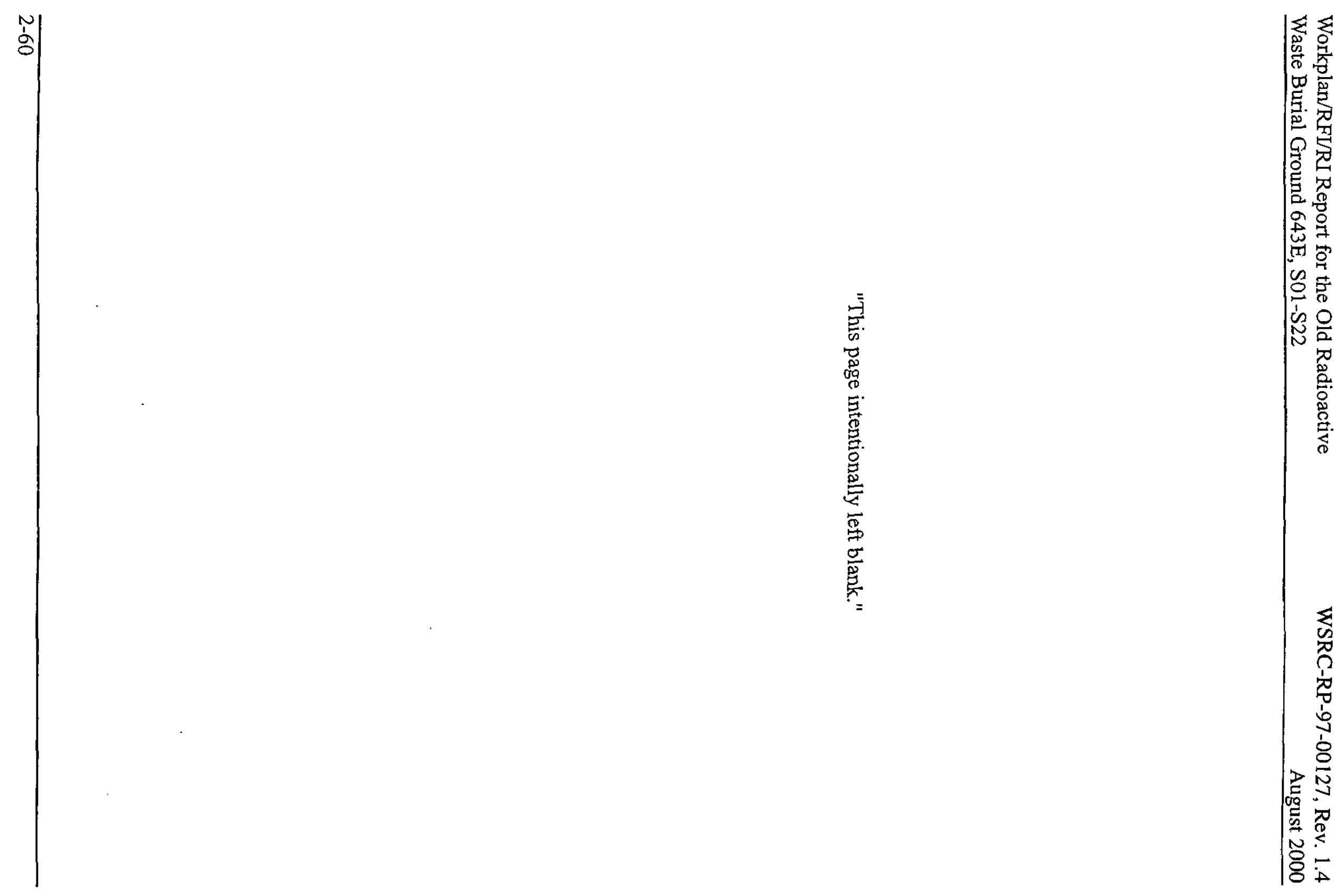

O

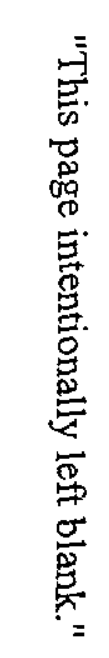

1.0

1 


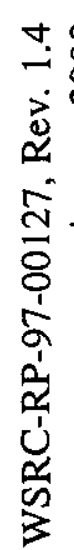



Average Lead Concentrations in the Water Table, 1990-1995

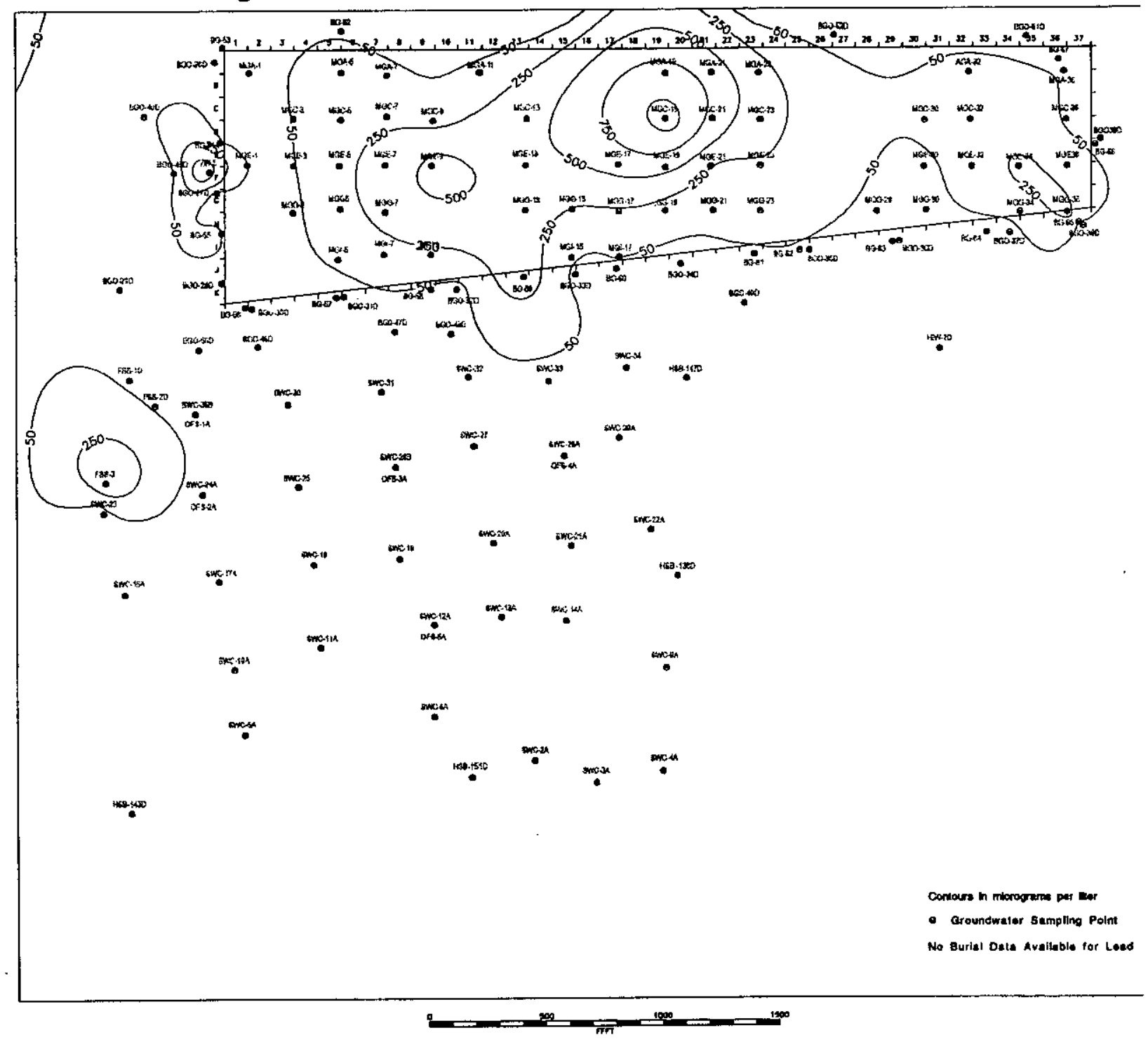

Figure 2-17. Average Lead Concentrations in the Water Table, 1990 - 1995 
Average Mercury Concentrations in the Water Table, 1990-1995

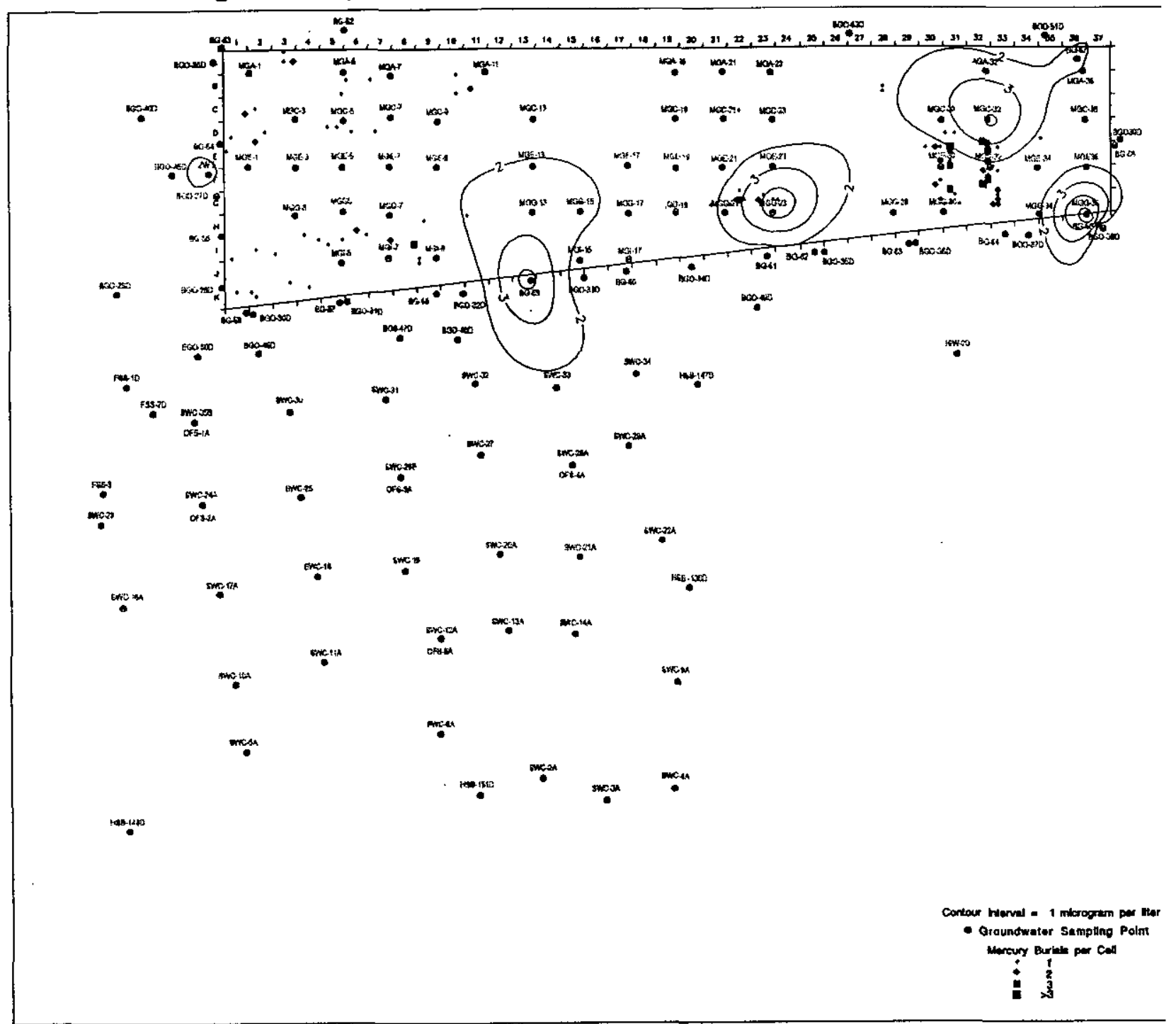

:

Figure 2-18. Average Mercury Concentrations in the Water Table, 1990 - 1995 
Average TCE Concentrations in the Water Table, 1990-1995

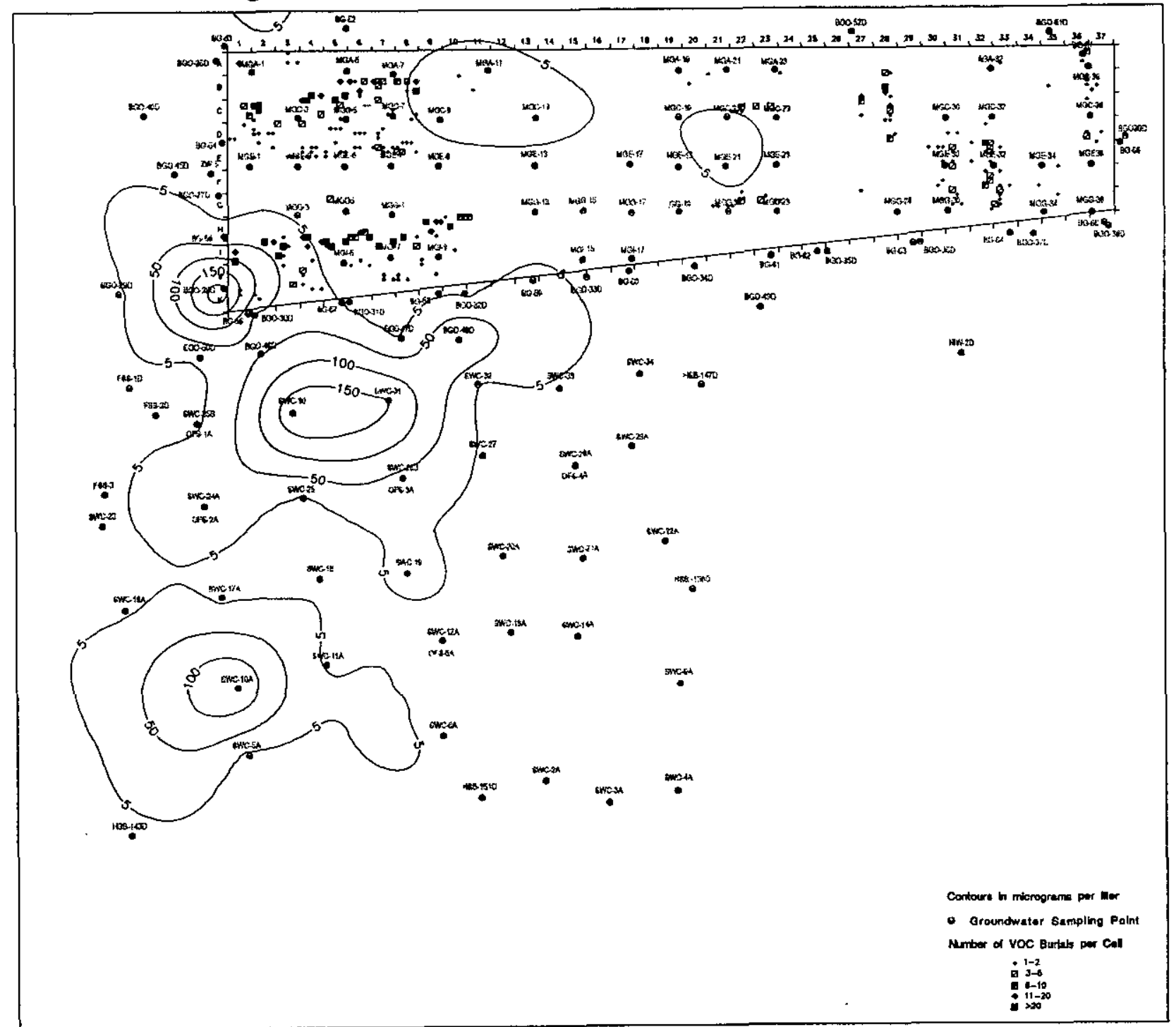

1000 1000 1000

Figure 2-19. Average TCE Concentrations in the Water Table, 1990 - 1995 
Average PCE Concentrations in the Water Table, 1990-1995
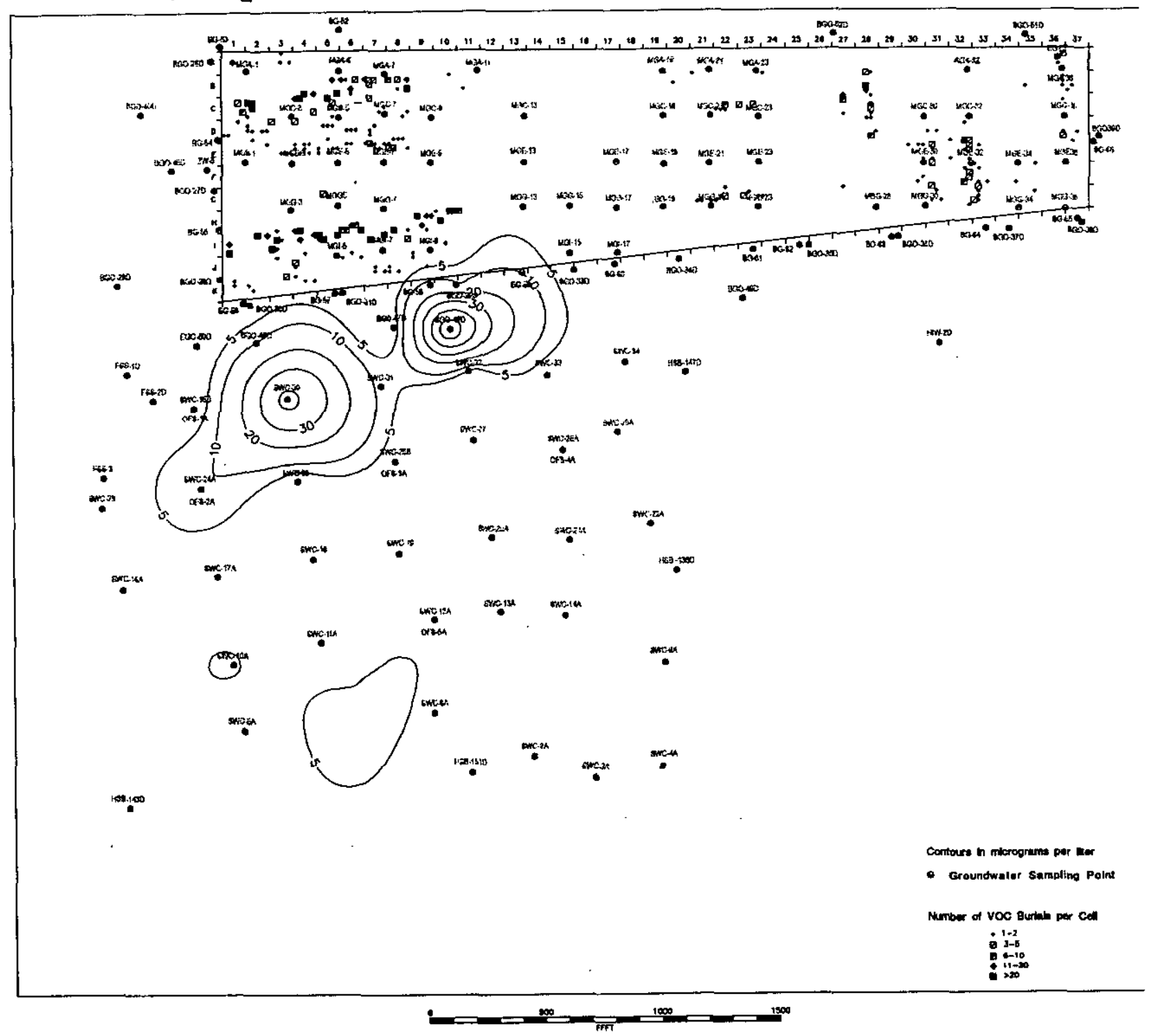

Figure 2-20. Average PCE Concentrations in the Water Table, 1990 - 1995 
Average Gross Alpha Activity in the Water Table, 1990-1995

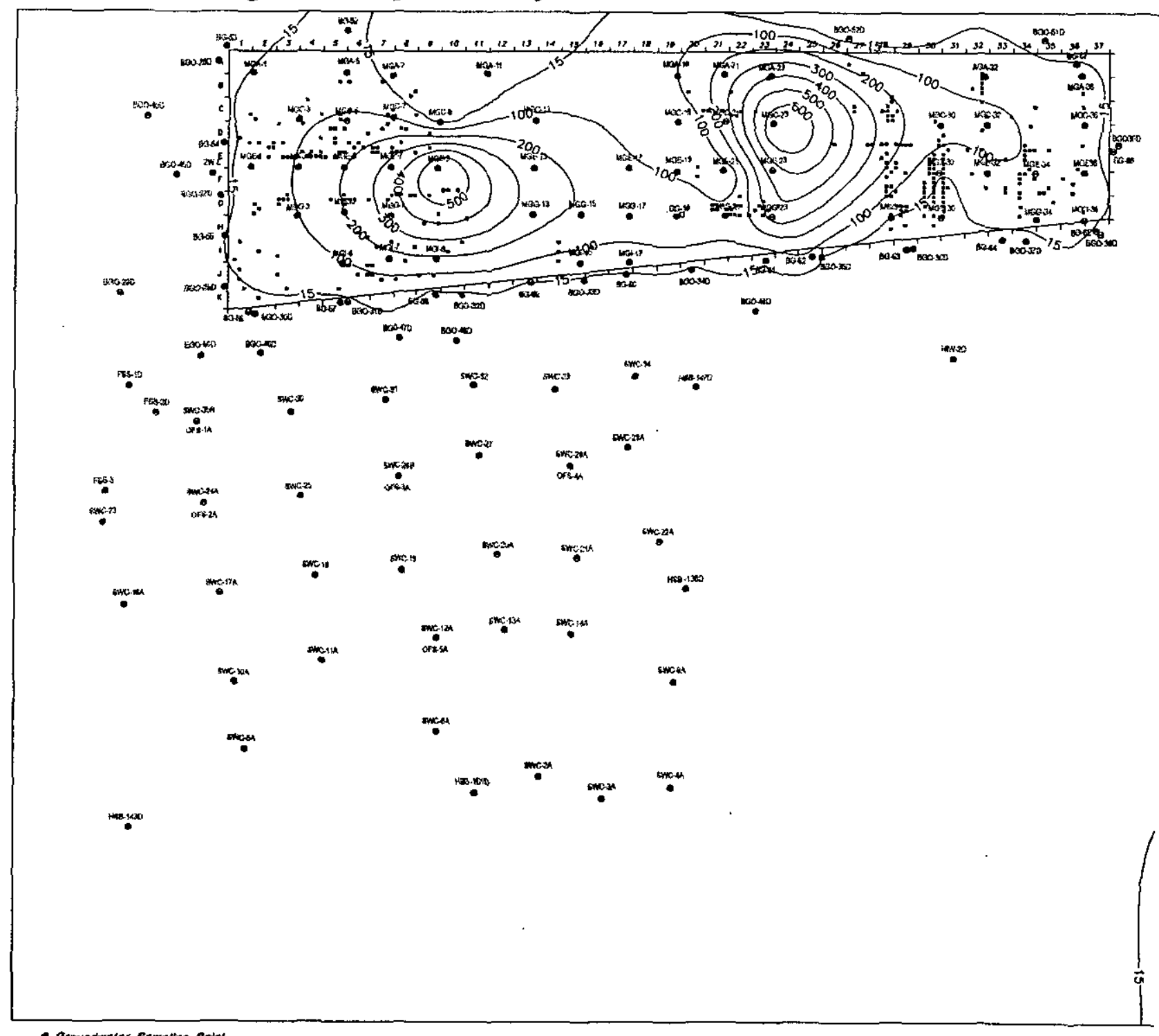

- Aroundwater sanpling Point

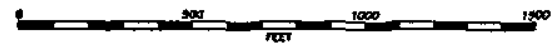

Cordocrs in porl

Figure 2-21. Average Gross Alpha Activity in the Water Table, 1990 - 1995 
Average Non-Volatile Beta Activity in the Water Table, 1990-1995

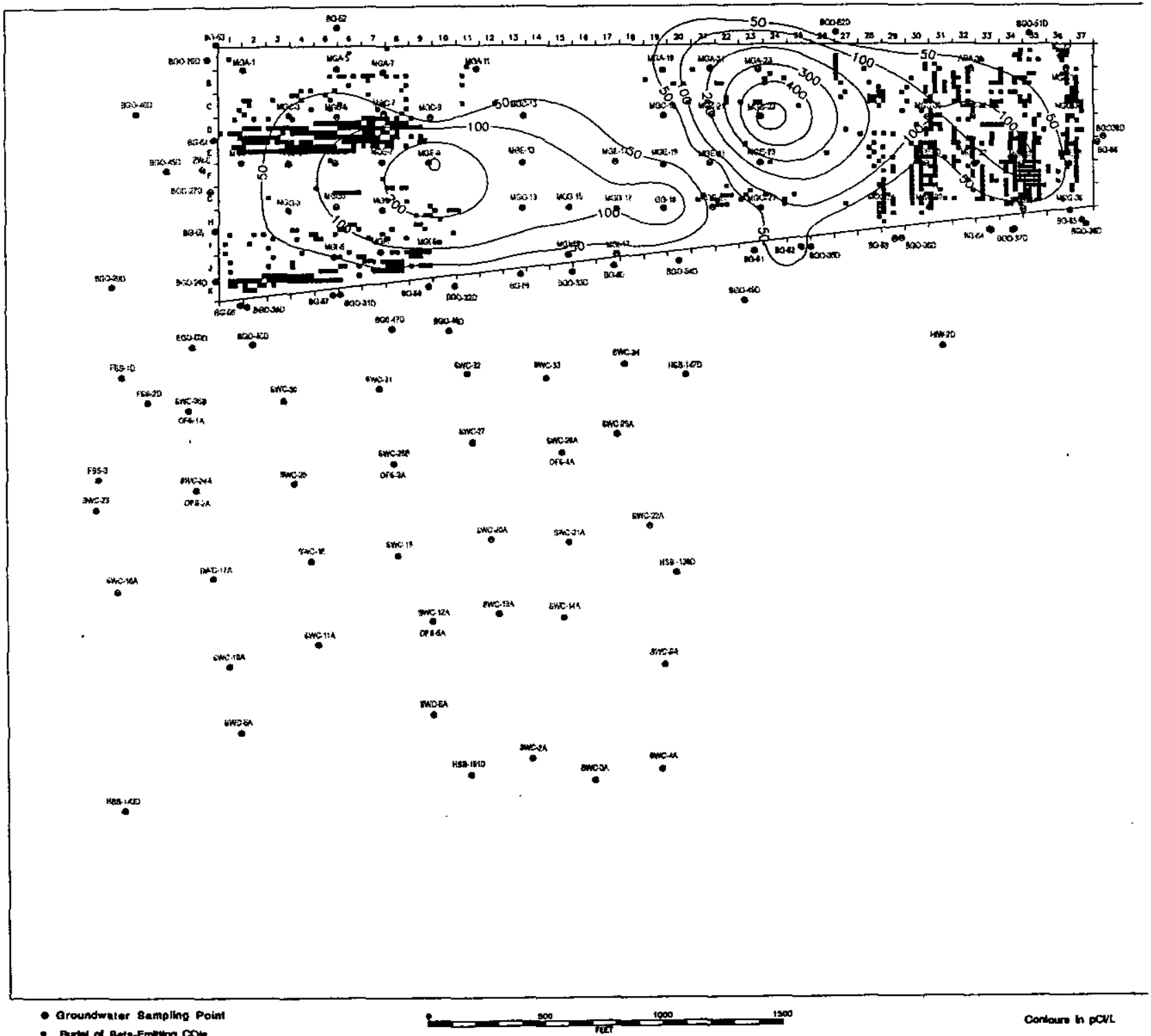

Figure 2-22. Average Non-Volatile Beta Activity in the Water Table, 1990 - 1995 
Average Tritium Activity in the Water Table, 1990-1995

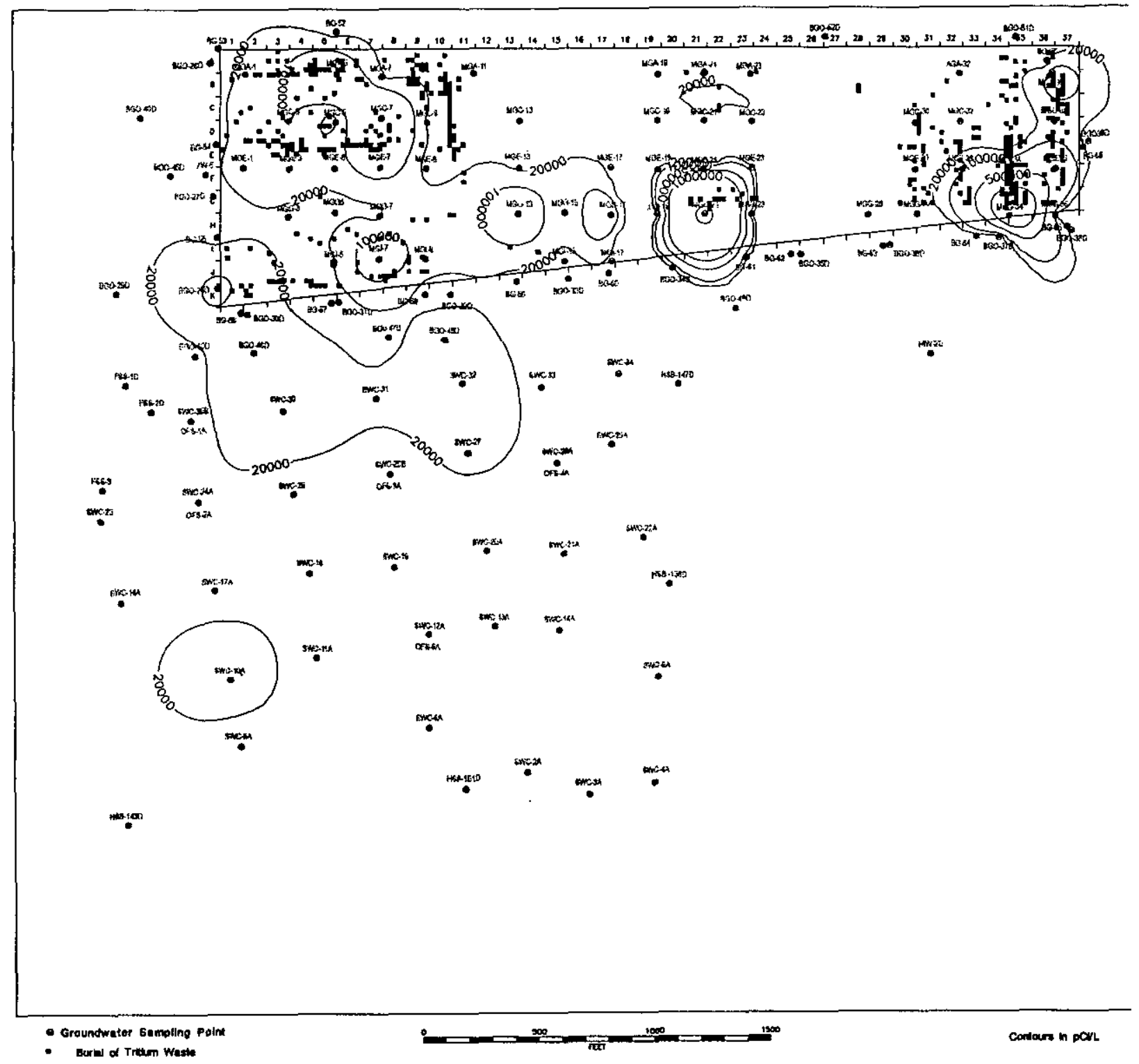

Figure 2-23. Average Tritium Activity in the Water Table, 1990 - 1995 


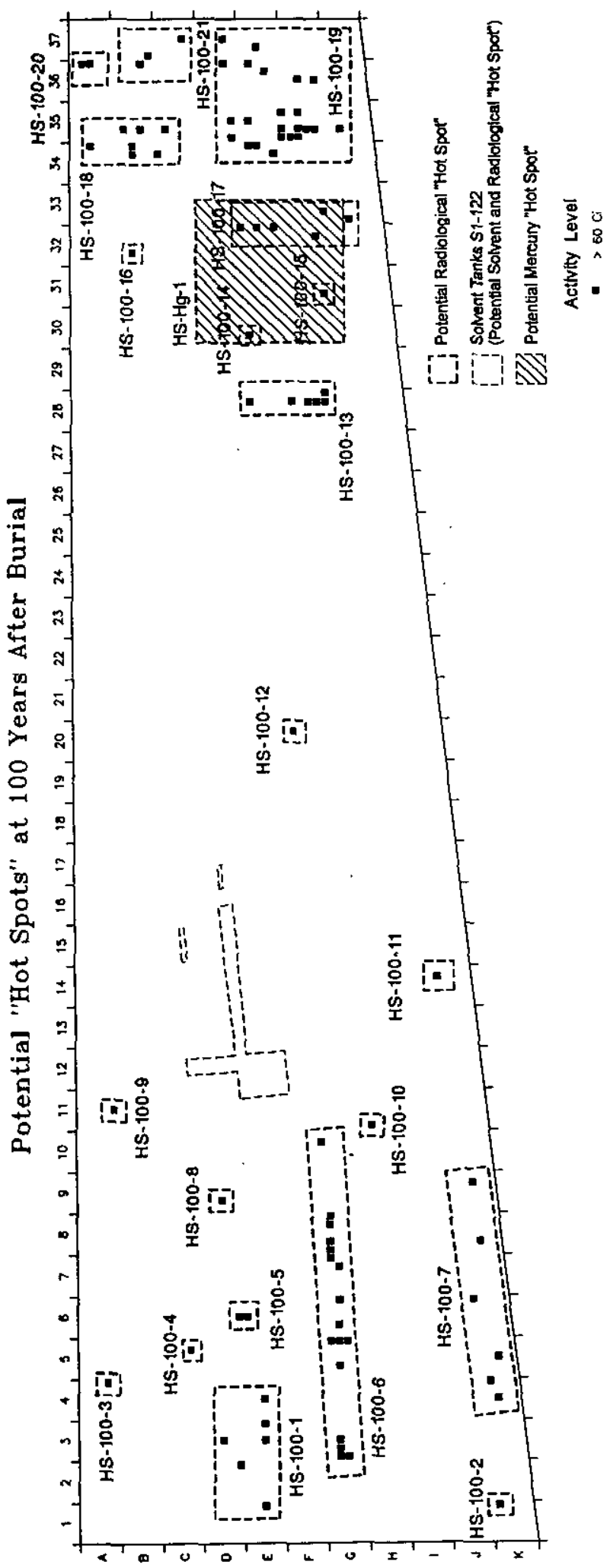

Figure 2-24. Potential "Hot Spots" at 100 Years After Burial 


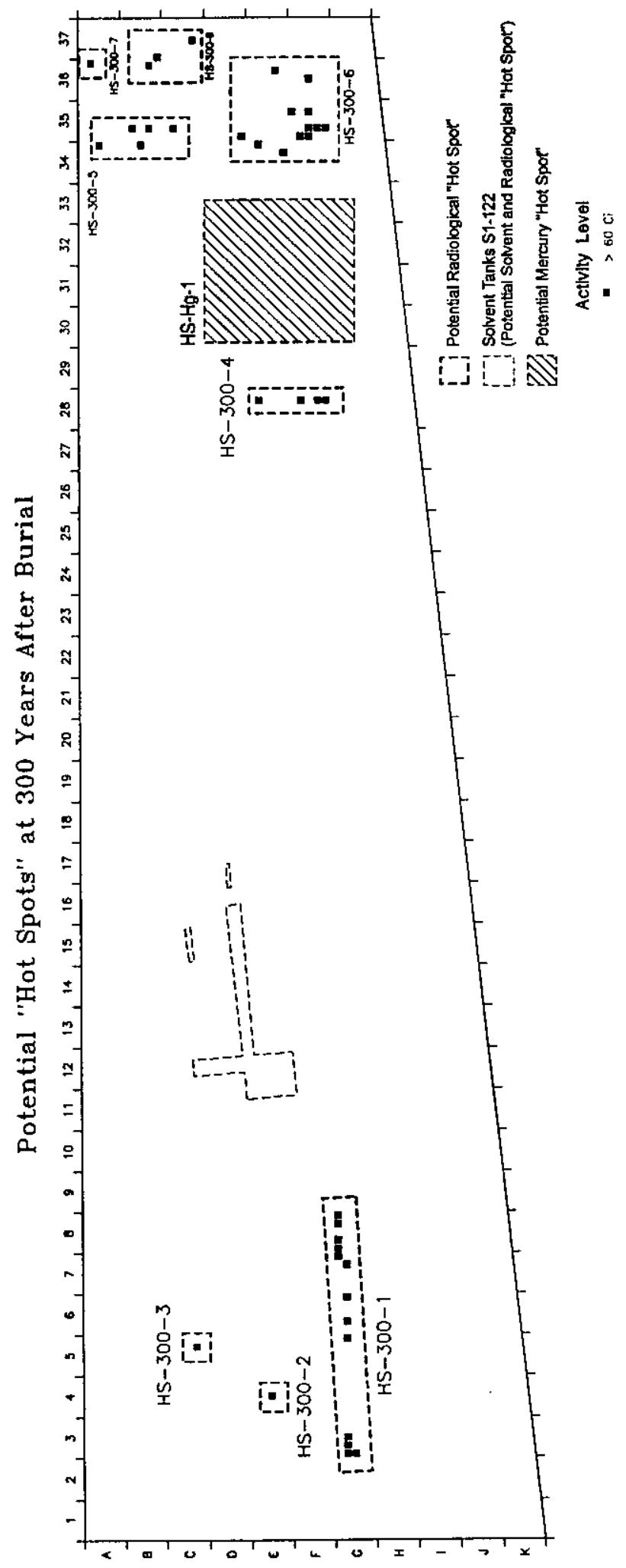

Figure 2-25. Potential "Hot Spots" at 300 Years After Burial 


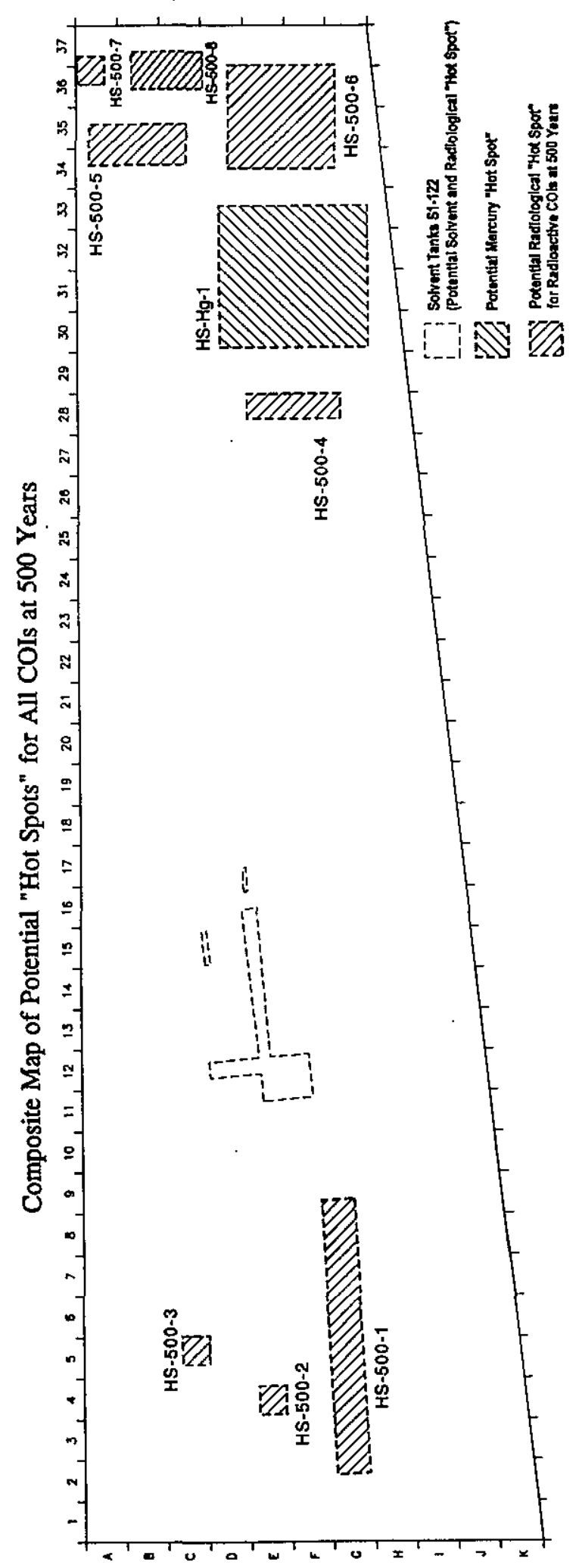

Figure 2-26. Potential "Hot Spots" at 500 Years After Burial 
Table 2-1. COI Source Term Summary (WSRC, 1997)

\begin{tabular}{|c|c|c|c|c|c|}
\hline $\mathrm{COI}$ & INVENTORY & UNCERTAINTIES & FORM & ORIGIN & NOTES \\
\hline Cadmium & $\begin{array}{l}\text { best estimate } \\
\text { buried in trenches: } \\
3,500 \mathrm{lb} \text { : } \\
2,000 \mathrm{lb} \text { from } \\
\text { control rods } \\
+ \\
75 \mathrm{lb} / \text { year of } \mathrm{Cd} \\
\text { sheet consumed } \\
\text { over } 20 \text { years } \\
(1,500 \mathrm{lb}) \\
\text { OSTs: negligible }\end{array}$ & $\begin{array}{l}\text { accuracy: } \pm 20 \% \text {. } \\
\text { Amount from L and } \\
\text { R Reactors is } \\
\text { accurate within } \\
10 \% \text {. } \\
\text { Cd sheet } \\
\text { consumption } \\
\text { accurate within } \\
30 \% \text {. }\end{array}$ & $\begin{array}{l}\text { control rods } \\
\text { safety rods } \\
\text { Cd sheets }\end{array}$ & $\begin{array}{l}\text { 2 large } \\
\text { shipments of } \\
\text { control rods } \\
\text { from } R(1964) \\
\text { and } L(1970) \\
\text { Reactors }(2,000 \\
\text { lb). } \\
\text { Cd sheet }(1,000 \\
\text { to } 2,000 \mathrm{lb}) \text {. }\end{array}$ & $\begin{array}{l}\text { Scrap metal and rods were put into disassembly basins } \\
\text { for decay of short-lived isotopes, then cut into pieces } \\
\text { and placed in casks. } \\
\text { Induced activity waste. } \\
\text { COBRA does not keep track of Cd, and no records in } \\
\text { COBRA could be identified as control rods, safety rods, } \\
\text { and neutron shielding sheets. All estimates for the } \\
\text { cadmium source term are based on process knowledge. } \\
\text { The two large shipments of control rods were buried in } \\
\text { the areas of the burial ground that were active in } 1964 \\
\text { and } 1970 \text { (during the shutdowns of } R \text { and L reactors). }\end{array}$ \\
\hline Lead & $\begin{array}{l}\text { best estimate } \\
\text { buried in trenches: } \\
50 \text { tons } \\
\text { Separations } \\
\text { disposed } 1.5 \\
\text { tons/year over } 20 \\
\text { years. } \\
\text { Also from reactors } \\
\text { and to shield } \\
\text { offsite waste. } \\
\text { OSTs: negligible }\end{array}$ & $\begin{array}{l}\text { accuracy: } \pm 30 \% \text {. } \\
\text { Amount from } \\
\text { reactors and to } \\
\text { shield offsite waste } \\
\text { is unknown. }\end{array}$ & $\begin{array}{l}\text { shielding } \\
\text { equipment (e.g. } \\
\text { junior caves) } \\
\text { shot } \\
\text { bricks } \\
\text { sheets } \\
\text { in OSTs }\end{array}$ & $\begin{array}{l}\text { Mainly } \\
\text { Separations. } \\
\text { Smaller amounts } \\
\text { from reactors } \\
\text { and to shield } \\
\text { offsite waste. }\end{array}$ & $\begin{array}{l}\text { Buried either because it was contaminated and required } \\
\text { disposal or it was used to shield buried rad waste. } \\
\text { COBRA has less than } 12 \text { references to } \mathrm{Pb} \text {. } \\
\text { Because of the use of lead to shield certain high-level } \\
\text { waste burials, the primary location for buried lead } \\
\text { would be in the high-level waste trenches. }\end{array}$ \\
\hline Mercury & $\begin{array}{l}\text { best estimate } \\
\text { buried in trenches: } \\
24,195 \mathrm{lb} \\
\text { OSTs: negligible }\end{array}$ & $\begin{array}{l}\text { accuracy: } \\
\quad+25 \% \text { to }-10 \% \\
\text { Possible mechanical } \\
\text { rupture of the } \\
\text { containers. } \\
\text { Hg is also in ash of } \\
\text { burned solvent. }\end{array}$ & \begin{tabular}{|l|}
2 or 3 one-liter \\
polyethylene \\
bottles wrapped in \\
two PE bags and \\
placed in 5 -gallon \\
steel lard cans. \\
Over 100 \\
shipments of 2 \\
cans each \\
\end{tabular} & $\begin{array}{l}\text { Tritium } \\
\text { facilities: } \\
232-\mathrm{H} \\
234-\mathrm{H} \\
232-\mathrm{F} \\
\text { Separations: } \\
221-\mathrm{H} \\
221-\mathrm{F}\end{array}$ & $\begin{array}{l}\mathrm{Hg} \text { was stored after } 1968 \text { and not sent to ORWBG. } \\
\mathrm{Hg} \text { was tritiated. } \\
\text { Used as a sealant in pumps, as a catalyst for dissolving } \\
\mathrm{Pu} \text {-Al in Separations operations, and as a component of } \\
\text { laboratory operations } \\
\text { COBRA shows burial locations of mercury. }\end{array}$ \\
\hline
\end{tabular}




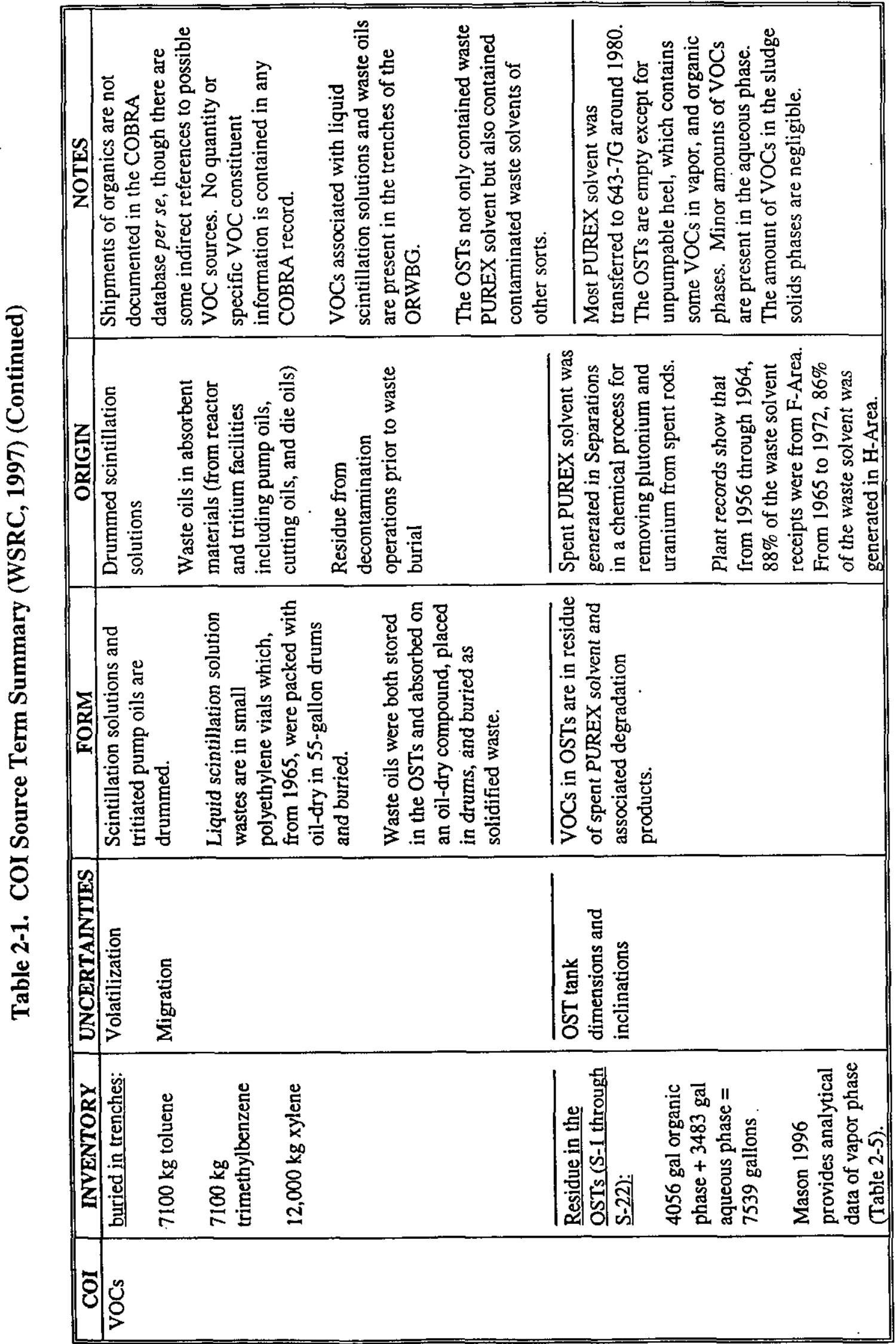


Table 2-1. COI Source Term Summary (WSRC, 1997) (Continued)

\begin{tabular}{|c|c|c|c|c|c|}
\hline $\mathrm{COI}$ & INVENTORY & UNCERTAINTIES & FORM & ORIGIN & NOTES \\
\hline Tritium & $\begin{array}{l}\text { best estimate } \\
\text { buried in trenches: } \\
3,014,457 \mathrm{Ci} \\
\text { decayed to } 1997 \\
\text { (in trenches): } \\
467,889 \mathrm{Ci} \\
\text { OSTs: negligible }\end{array}$ & $\begin{array}{l}\text { Tritium content } \\
\text { estimates in waste } \\
\text { forms (assumed } \\
\text { constant quantities } \\
\text { of tritium in a given } \\
\text { waste form). } \\
\text { Migration (there is } \\
\text { no correction for } \\
\text { such unknown loss). }\end{array}$ & $\begin{array}{l}\text { Job control waste } \\
\text { Waste oils and Hg } \\
\text { Used equipment \& } \\
\text { components } \\
\text { Spent melts } \\
\text { Reactive beds }\end{array}$ & $\begin{array}{l}232-\mathrm{H} \\
234-\mathrm{H} \\
238-\mathrm{H} \\
232-\mathrm{F} \\
\text { The bulk of tritium was } \\
\text { processed in the three H- } \\
\text { Area buildings; } 232-\mathrm{F} \\
\text { Operated only briefly in } \\
\text { the late } 1950 \text { s. }\end{array}$ & $\begin{array}{l}\text { half-life: } 12.3 \text { years } \\
\text { COBRA provides both quantity } \\
\text { and location estimates. }\end{array}$ \\
\hline Cesium-137 & $\begin{array}{l}\text { best estimate } \\
\text { buried in trenches: } \\
58,657 \mathrm{Ci} \\
\text { decayed to } 1997 \\
\text { (in trenches): } \\
26,838 \mathrm{Ci} \\
\text { OSTs: } 1.30 \mathrm{Ci}\end{array}$ & $\begin{array}{l}\text { Original estimates of } \\
\text { fission products } \\
\text { amounts (based on } \\
\text { external dose rates). } \\
\text { Variations in } \\
\text { isotopic } \\
\text { distributions. } \\
\text { Use of fixed ages in } \\
\text { decay calculations. }\end{array}$ & $\begin{array}{l}\text { This waste was buried in } \\
\text { cardboard boxes, plastic } \\
\text { bags, and metal containers. } \\
\text { The fission product-bearing } \\
\text { waste was buried in low- } \\
\text { level and high-level } \\
\text { trenches, depending on the } \\
\text { dose rate from the package. }\end{array}$ & $\begin{array}{l}\text { Byproduct of reactors } \\
\text { Fission products are a } \\
\text { component of job control } \\
\text { waste and other waste } \\
\text { streams from spent } \\
\text { reactor fuel and targets or } \\
\text { high-level liquid wastes. } \\
\text { These include reactors, } \\
\text { Separations (F- and H- } \\
\text { Areas), and associated } \\
\text { tank farms, and process } \\
\text { control and experimental } \\
\text { laboratories. }\end{array}$ & $\begin{array}{l}\text { half-life: } 30 \text { years } \\
\text { COBRA recorded "fission } \\
\text { products", not Cs- } 137 \text { per se. } \\
<50 \mathrm{mR} / \mathrm{hr} \text { wastes were buried in } \\
\text { low activity beta-gamma trenches. } \\
>50 \mathrm{mR} / \mathrm{hr} \text { wastes were buried in } \\
\text { intermediate level (aka high level) } \\
\text { trenches. }\end{array}$ \\
\hline
\end{tabular}


Table 2-1. COI Source Term Summary (WSRC, 1997) (Continued)

\begin{tabular}{|c|c|c|c|c|c|}
\hline $\mathrm{COI}$ & INVENTORY & UNCERTAINTIES & FORM & ORIGIN & NOTES \\
\hline Plutonium-238 & $\begin{array}{l}\text { best estimate } \\
\text { buried in } \\
\text { trenches: } \\
1192.7 \mathrm{grams} \\
(20,514 \mathrm{Ci}) \\
\\
\text { decayed to } 1997 \\
\text { (in trenches): } \\
16,825 \mathrm{Ci} \\
\\
\text { OSTs: } 1.24 \\
\text { grams (21.4 Ci) }\end{array}$ & $\begin{array}{l}\text { validity of COBRA } \\
\text { estimates }\end{array}$ & $\begin{array}{l}\text { Uncontainerized in } \\
\text { plastic bags and } \\
\text { cardboard boxes } \\
\text { Concrete culverts } \\
\text { containing drummed or } \\
\text { boxed waste } \\
\text { Encapsulated waste }\end{array}$ & $\begin{array}{l}\text { Thermionic heat sources for } \\
\text { power generation } \\
\text { Separations, reactor areas, and } \\
\text { research facilities like SRTC }\end{array}$ & $\begin{array}{l}\text { half-life: } 87.4 \text { years } \\
\text { Inventory estimate based on } \\
\text { COBRA, pre-COBRA burial } \\
\text { records and burned solvent } \\
\text { residues. } \\
\text { COBRA shows burial } \\
\text { locations of plutonium-238. } \\
\text {. }\end{array}$ \\
\hline Plutonium-239 & $\begin{array}{l}\text { best estimate } \\
\text { buried in } \\
\text { trenches: } \\
24,188 \text { grams } \\
(1,475 \mathrm{Ci} \text { ) } \\
\text { decayed to } 1997 \\
\text { (in trenches): } \\
1,474 \mathrm{Ci} \\
\text { OSTs:1351 } \mathrm{g} \\
\text { (82.4 Ci) }\end{array}$ & $\begin{array}{l}\text { validity of COBRA } \\
\text { estimates } \\
\text {. }\end{array}$ & $\begin{array}{l}\text { Uncontainerized in } \\
\text { plastic bags and } \\
\text { cardboard boxes } \\
\text { Concrete culverts } \\
\text { containing drummed or } \\
\text { boxed waste } \\
\text { Encapsulated waste }\end{array}$ & $\begin{array}{l}\text { Special nuclear material } \\
\text { Separations, reactor areas, and } \\
\text { research facilities like SRTC }\end{array}$ & $\begin{array}{l}\text { half-life: } 24,360 \text { years } \\
\text { Inventory estimate based on } \\
\text { COBRA database total, } \\
\text { which includes plutonium- } \\
239 \text { in special burials, pre- } \\
\text { COBRA burial records, and } \\
\text { burned solvent residues. } \\
\text { Cobra shows burial locations } \\
\text { of plutonium- } 239 \text {. }\end{array}$ \\
\hline Strontium-90 & $\begin{array}{l}\text { best estimate } \\
\text { buried in } \\
\text { trenches: } 58,657 \\
\mathrm{Ci} \\
\text { best estimate: } \\
\text { decayed to } 1997 \\
\text { (in trenches): } \\
26,216 \mathrm{Ci} \\
\text { OSTs: } 1.28 \mathrm{Ci}\end{array}$ & $\begin{array}{l}\text { Original estimates } \\
\text { of fission products } \\
\text { amounts (based on } \\
\text { external dose rates } \\
\text { and assumed } \\
\text { isotopic } \\
\text { distribution). } \\
\text { Use of fixed ages in } \\
\text { decay calculations. }\end{array}$ & $\begin{array}{l}\text { This waste was buried in } \\
\text { cardboard boxes, plastic } \\
\text { bags, and metal } \\
\text { containers. } \\
\text { The fission product- } \\
\text { bearing waste was buried } \\
\text { in low-level and high- } \\
\text { level trenches, depending } \\
\text { on the dose rate from the } \\
\text { package. }\end{array}$ & $\begin{array}{l}\text { Byproduct of reactors } \\
\text { Fission products are a } \\
\text { component of job control waste } \\
\text { and other waste streams from } \\
\text { spent reactor fuel and targets or } \\
\text { high-level liquid wastes. These } \\
\text { include reactors, Separations (F- } \\
\text { and H-Areas), and associated } \\
\text { tank farms, and process control } \\
\text { and experimental laboratories. }\end{array}$ & $\begin{array}{l}\text { half-life: } 29.12 \text { years } \\
\text { COBRA recorded "fission } \\
\text { products", not } \mathrm{Sr}-90 \text { per se. } \\
<50 \mathrm{mR} / \mathrm{hr} \text { wastes were } \\
\text { buried in low activity beta- } \\
\text { gamma trenches. } \\
>50 \mathrm{mR} / \mathrm{hr} \text { wastes were } \\
\text { buried in intermediate level } \\
\text { (aka high level) trenches. }\end{array}$ \\
\hline
\end{tabular}




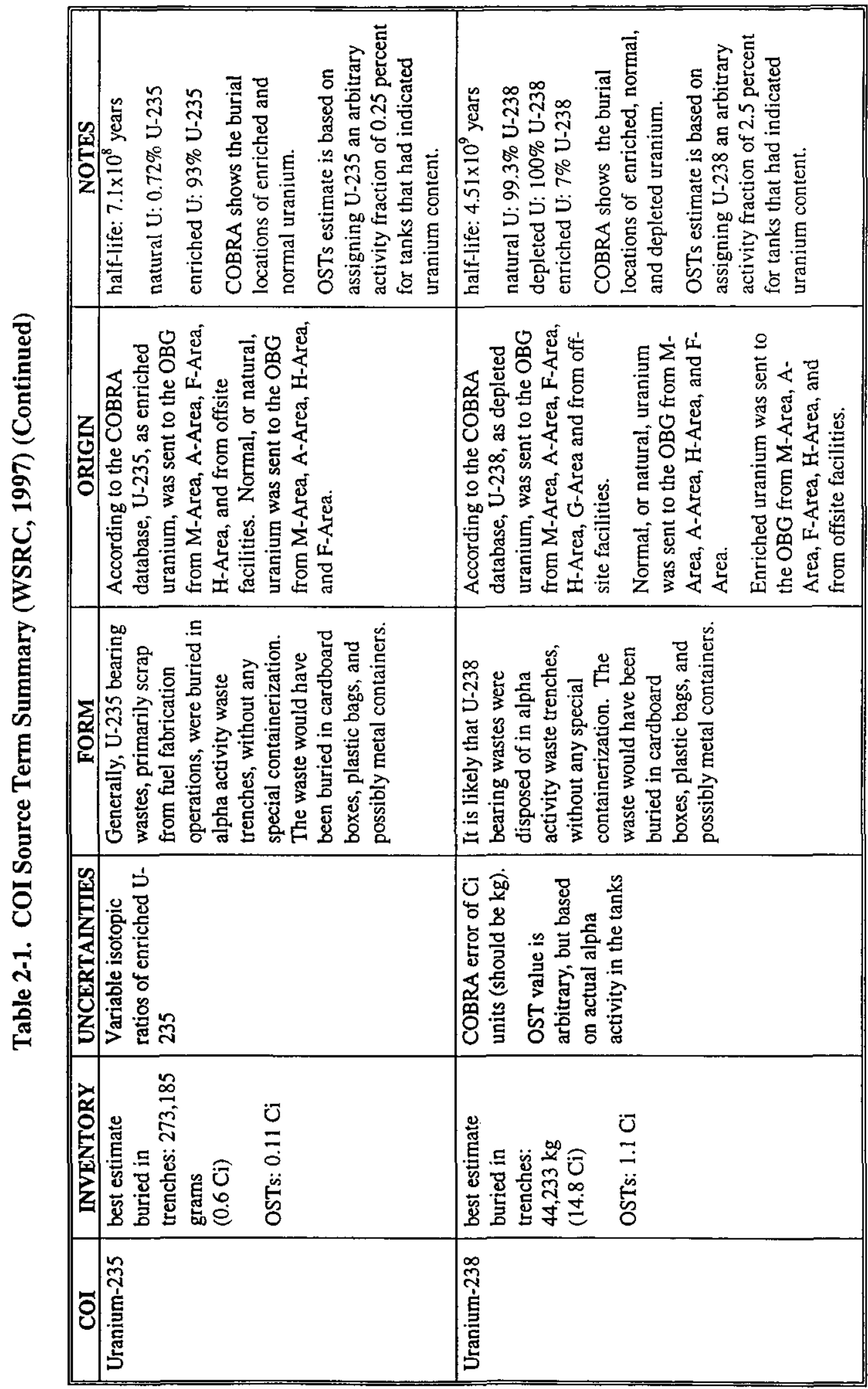




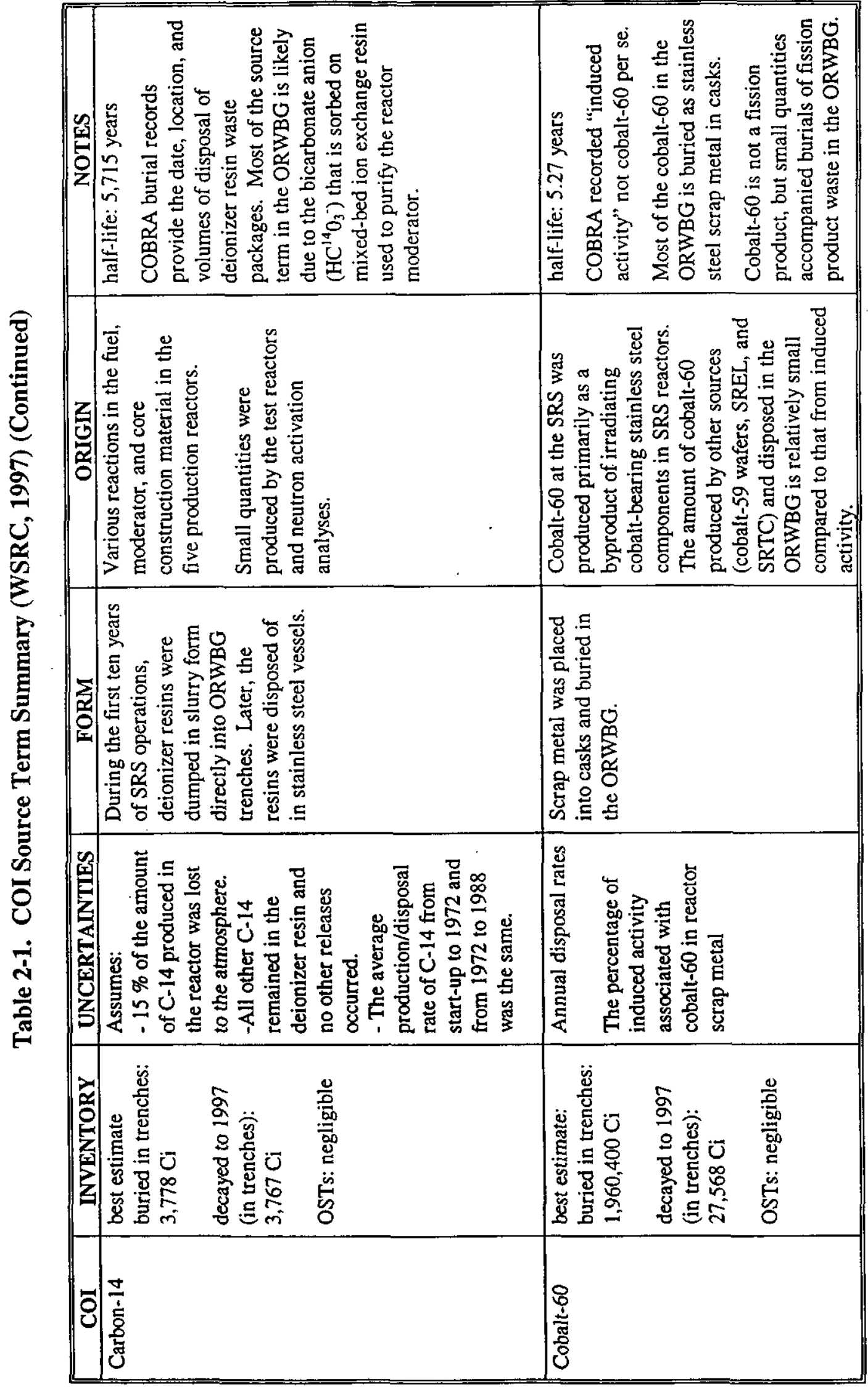


Table 2-1. COI Source Term Summary (WSRC, 1997) (Continued)

\begin{tabular}{|c|c|c|c|c|c|}
\hline $\mathrm{COI}$ & INVENTORY & UNCERTAINTIES & FORM & ORIGIN & NOTES \\
\hline Technetium-99 & $\begin{array}{l}\text { best estimate } \\
\text { buried in trenches: } \\
12 \mathrm{Ci} \\
\text { OSTs: negligible }\end{array}$ & $\begin{array}{l}\text { Five-year-old } \\
\text { in-tank waste } \\
\text { contains 5.53E-04 } \\
\text { curies of } \\
\text { technetium-99 per } \\
\text { gallon, which } \\
\text { assumes an isotopic } \\
\text { distribution of } \\
\text { fission products. } \\
\end{array}$ & $\begin{array}{l}\text { Most of the technetium-99 } \\
\text { in the ORWBG is in } \\
\text { burials of fission product } \\
\text { waste. } \\
\text { The most likely state of } \\
\text { technetium-99 in SRS } \\
\text { waste streams and solid } \\
\text { waste is } \mathrm{TcO}_{4}^{-} \text {. }\end{array}$ & $\begin{array}{l}\text { Technetium- } 99 \text { is a fission } \\
\text { product produced by the } \\
\text { fission of uranium- } 235 \text { and } \\
\text { plutonium- } 239 \text {. }\end{array}$ & $\begin{array}{l}\text { half-life: } 213,000 \text { years } \\
\text { Shipments of technetium- } 99 \\
\text { are not documented in the } \\
\text { COBRA database. } \\
\text { Technetium- } 99 \text { is assumed to } \\
\text { have been disposed with } \\
\text { other fission product waste. }\end{array}$ \\
\hline Iodine-129 & $\begin{array}{l}\text { best estimate } \\
\text { buried in trenches: } \\
10.6 \mathrm{Ci} \\
\text { OSTs: negligible }\end{array}$ & $\begin{array}{l}\text { Assumes: } \\
\text { - } 39 \text { Ci of iodine- } \\
129 \text { was } \\
\text { produced at } \\
\text { SRS from } \\
\text { startup to } 1974 \\
30 \text { percent of } \\
\text { this amount was } \\
\text { buried in the } \\
\text { ORWBG. }\end{array}$ & $\begin{array}{l}\text { spent ceramic chips coated } \\
\text { with silver nitrate (Berl } \\
\text { saddles) }\end{array}$ & $\begin{array}{l}\text { Radioiodine is a fission } \\
\text { product at the SRS that } \\
\text { originated predominantly in } \\
\text { the fuel and target materials. } \\
\text { Berl saddles were used to } \\
\text { sorb radioiodine (principally } \\
\text { I- } 129 \text { and I-131) during the } \\
\text { dissolution of fuel and targets } \\
\text { in F and H Areas. }\end{array}$ & $\begin{array}{l}\text { half-life: } 1.57 \times 10^{7} \text { years } \\
\text { In the COBRA database } \\
\text { there are no references to } \\
\text { Berl saddles, nor is there any } \\
\text { specific iodine- } 129 \\
\text { constituent information. } \\
\text { The number of spent charges } \\
\text { in the ORWBG, assuming a } \\
\text { constant disposal rate, is } \\
\text { estimated to be } 34 \text {. Each } \\
\text { container held approximately } \\
20 \text { cu ft of Berl saddles. } \\
\text { Essentially all of the iodine- } \\
129 \text { in the burial grounds } \\
\text { from Berl saddles used in the } \\
\text { process air filters. Other } \\
\text { sources contributed smaller } \\
\text { amounts to the inventory. }\end{array}$ \\
\hline
\end{tabular}




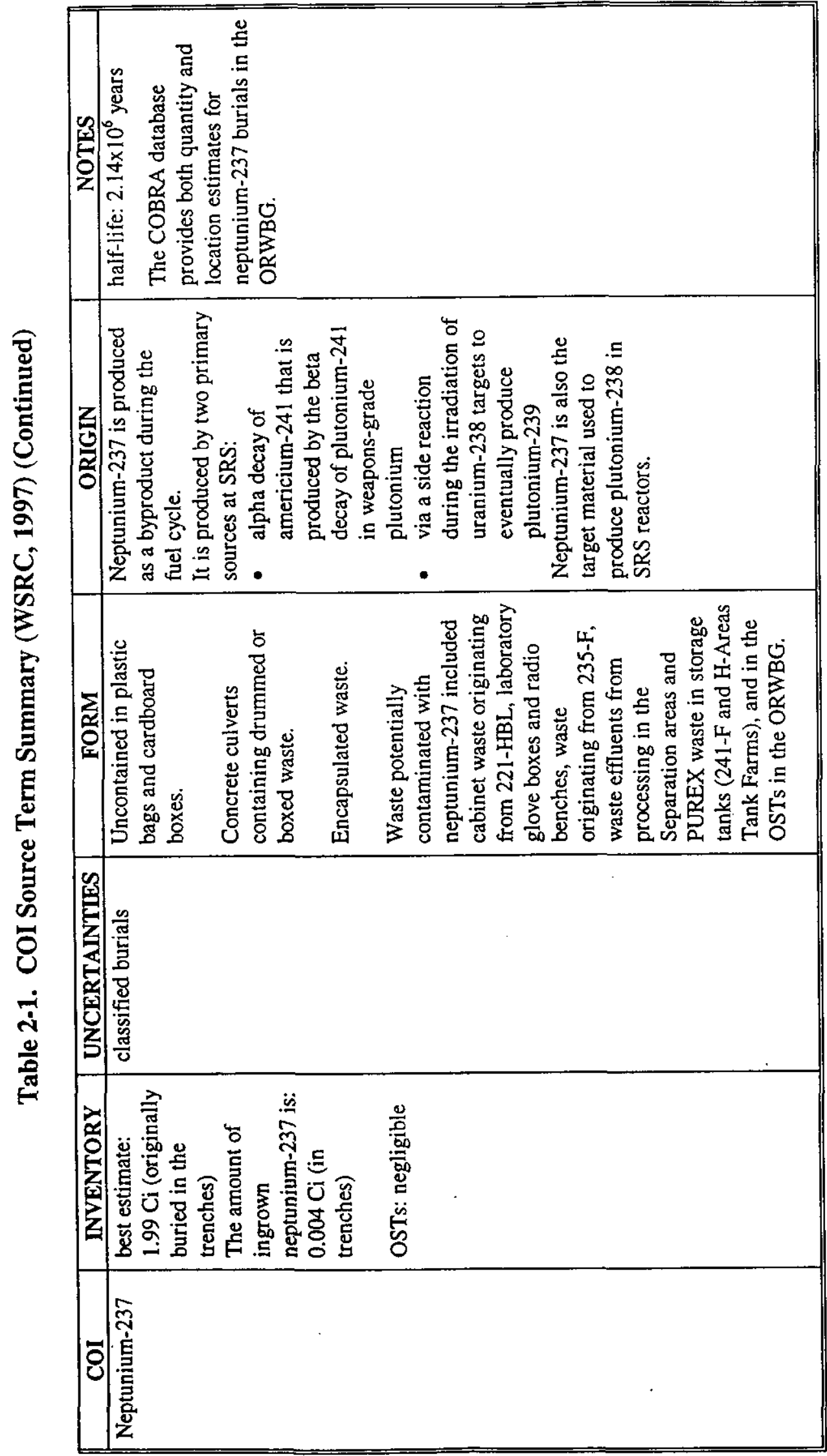


Table 2-2

Monitoring Wells at the Burial Ground Complex

\begin{tabular}{|c|c|c|c|c|c|}
\hline $\begin{array}{c}\text { Background } \\
\text { Wells } \\
\end{array}$ & \multicolumn{2}{|c|}{$\begin{array}{c}\text { Point of Compliance } \\
\text { Wells }\end{array}$} & \multicolumn{3}{|c|}{ Assessment Wells } \\
\hline BGO ID & BGO 3A & BGO 13(R)* & BGO 9AA & BGO 43AA & $\mathrm{BGO} 52 \mathrm{AA}$ \\
\hline BGO 2D & BGO 3C & BGO 14A(R) & BGO 10AA & BGO 43A & BGO 52A \\
\hline HSB 85A & BGO 3D(R) & BGO 14C(R) & BGO 10B & BGO 43C & $\mathrm{BGO} 52 \mathrm{~B}$ \\
\hline HSB 85B & BGO 4D & BGO 14D(R) & BGO 25A & BGO 43D* & BGO 52C \\
\hline \multirow[t]{25}{*}{ HSB 85C } & BGO $5 \mathrm{C}$ & BGO 15D & BGO 26A & $\mathrm{BGO} 44 \mathrm{AA}$ & BGO 52D \\
\hline & BGO 5D & BGO 16A(R) & BGO 26D & $\mathrm{BGO} 44 \mathrm{~A}$ & BGO 53AA \\
\hline & $\mathrm{BGO} 6 \mathrm{~A}$ & BGO 16B & BGO 27C & BGO 44B & BGO 53A \\
\hline & BGO 6B & BGO 16D & BGO 27D & BGO 44C & BGO 53B \\
\hline & BGO 6C & BGO $17 \mathrm{D}(\mathrm{R})$ & BGO 28D & BGO 44D & BGO 53C \\
\hline & BGO 6D & BGO 18A & BGO 29A & $\mathrm{BGO} 45 \mathrm{~A}$ & BGO 53D \\
\hline & BGO 7D & BGO 18D & BGO 29C & BGO 45B & $\mathrm{BGX} 1 \mathrm{~A}$ \\
\hline & BGO 8A(R) & BGO 19D(R) & BGO 29D & $\mathrm{BGO} 45 \mathrm{C}$ & BGX IC \\
\hline & BGO $8 \mathrm{C}$ & BGO 20AA & BGO $30 \mathrm{C}$ & BGO 45D & BGX 1D \\
\hline & BGO 8D & BGO $20 \mathrm{~A}$ & BGO 30D & BGO 46B & BGX 2B \\
\hline & BGO 9D & BGO 20B & BGO 31C & BGO 46C & BGX 2D* \\
\hline & BGO 10A(R) & BGO $20 \mathrm{C}$ & BGO 31D & BGO 46D & BGX 3D* \\
\hline & BGO $10 \mathrm{C}$ & BGO 20D & BGO 32D & $\mathrm{BGO} 47 \mathrm{~A}$ & BGX 4A \\
\hline & BGO 10D(R) & BGO 21D & BGO 33C & BGO 47C & BGX 4C \\
\hline & BGO 11D(R0 & BGO 22D(R) & BGO 33D & BGO 47D & BGX 4D* \\
\hline & BGO $12 \mathrm{~A}(\mathrm{X})$ & BGO 23D & BGO 35C & $\mathrm{BGO} 48 \mathrm{C}$ & BGX 5D* \\
\hline & BGO 12C(X) & BGO 24D & BGO 35D & BGO 48D & BGX 6D* \\
\hline & BGO 12D(R) & & BGO 34D & BGO 49A & BGX 7D* \\
\hline & & & BGO 36D & $\mathrm{BGO} 49 \mathrm{C}$ & BGX 8D* \\
\hline & & & BGO 37C & BGO 49D & BGX 9D \\
\hline & & & BGO 37D & BGO 50A & BGX 10D \\
\hline & & & BGO 38D & BGO $50 \mathrm{C}$ & BGX $11 \mathrm{D}$ \\
\hline & & & BGO 39A & BGO 50D & BGX $12 \mathrm{C}$ \\
\hline & & & BGO 39C & $\mathrm{BGO} 51 \mathrm{AA}$ & $\mathrm{BGX} 12 \mathrm{D}$ \\
\hline & & & BGO 39D & BGO 51A & HMD001D8 \\
\hline
\end{tabular}




\section{Table 2-2}

\section{Monitoring Wells at the Burial Ground Complex (Continued)}

\begin{tabular}{l|l|lll}
\hline \multicolumn{1}{c}{$\begin{array}{c}\text { Background } \\
\text { Wells }\end{array}$} & \multicolumn{3}{c}{$\begin{array}{l}\text { Point of Compliance } \\
\text { Wells }\end{array}$} & Assessment Wells \\
\hline & & BGO 40D & BGO 51B & HMD 002D* \\
& & BGO 41A & BGO 51C & HMD 003D* \\
& & BGO 42C & BGO 51D & HMD 004D* \\
\hline
\end{tabular}

NOTE:

(R) indicates replacement well

(X) indicates a replacement well of a replacement well

* well screened in the upper section of the "lower" Upper Three Runs Aquifer Unit

(WSRC, 1996) 
Table 2-3. Constituents of Interest (COIs) for the Old Radioactive Waste Burial Ground (ORWBG)

\section{Nonradioactive}

1. Cadmium

2. Lead

3. Mercury

4. Volatile Organic Compounds

\section{Radioactive}

5. Tritium

6. Carbon-14

7. Cobalt -60

8. Strontium-90

9. Technetium-99

10. Iodine-129

11. Cesium-137

12. Neptunium-237

13. Uranium-235

14. Uranium-238

15. Plutonium-238

16. Plutonium-239
(Cd)

$(\mathrm{Pb})$

( $\mathrm{Hg})$

(VOCs)

Long-

Hazardous High Lived Large

Material Mobility ( $>25 \mathrm{yr}$ ) Inventory

\begin{tabular}{|c|c|c|c|}
\hline 0 & & & 0 \\
\hline 0 & & & 0 \\
\hline 0 & & & 0 \\
\hline 0 & 0 & & \\
\hline
\end{tabular}

(H-3)

(C-14)

(Co-60)

(Sr-90)

(Tc-99)

(I-129)

(Cs-137)

(Np-237)

(U-235)

(U-238)

(Pu-238)

(Pu-239)

\begin{tabular}{|l|l|l|l|}
\hline & 0 & & 0 \\
\hline & 0 & 0 & 0 \\
\hline & & & 0 \\
\hline & & 0 & 0 \\
\hline & 0 & 0 & \\
\hline & 0 & 0 & \\
\hline & & 0 & 0 \\
\hline & & 0 & \\
\hline & & 0 & \\
\hline & & 0 & \\
\hline & & 0 & 0 \\
\hline & & 0 & 0 \\
\hline
\end{tabular}


Table 2-4

Qualitative Assessment of the Fate and Transport of COIs

\begin{tabular}{|llllc|}
\hline COI & Leachability & $\begin{array}{l}\text { Mobility in } \\
\text { Groundwater }\end{array}$ & $\begin{array}{c}\text { Immediate Threat } \\
\text { to Groundwater }\end{array}$ & $\begin{array}{c}\text { Potential Future } \\
\text { Threat to } \\
\text { Groundwater }\end{array}$ \\
\hline \hline Tritium & High & High & Yes & Yes \\
VOCs & High & High & Yes & Yes \\
Sr-90 & Medium & Medium & No & Yes \\
I-129 & Low & Medium & No & Yes \\
Tc-99 & Medium & High & No & Yes \\
$\mathrm{Cs}-137$ & Low & Low & No & No \\
$\mathrm{C}-14$ & High & Medium & No & Yes \\
$\mathrm{Co}-60$ & Medium & Medium & No & No \\
$\mathrm{Np}-237$ & Medium & Medium & No & Yes \\
$\mathrm{U}-235$ & Medium & Medium & No & Yes \\
$\mathrm{U}-238$ & Medium & Medium & No & Yes \\
$\mathrm{Pu}-238$ & Low & Low & No & No \\
$\mathrm{Pu}-239$ & Low & Low & No & Yes \\
$\mathrm{Hg}$ & Medium & Medium & No & Yes \\
$\mathrm{Pb}$ & Medium & Medium & No & Yes \\
$\mathrm{Cd}$ & Medium & Medium & No & Yes \\
\hline
\end{tabular}


Table 2-5. Potential ARARs and TBC Criteria for the ORWBG

\begin{tabular}{|c|c|c|}
\hline $\begin{array}{r}\text { Federal } \\
\text { Atomic Energy Act } \\
\end{array}$ & $\begin{array}{c}\text { Type } \\
\text { Action-/chemical-specific }\end{array}$ & $\begin{array}{l}\text { Applicability } \\
\text { Radioactive waste }\end{array}$ \\
\hline $\begin{array}{l}\text { National Environmental } \\
\text { Policy Act }\end{array}$ & Action-specific & Hazardous waste \\
\hline $\begin{array}{l}\text { Resource Conservation and } \\
\text { Recovery Act }\end{array}$ & Action-/chemical-specific & $\begin{array}{l}\text { Treatment, storage and disposal of } \\
\text { hazardous waste }\end{array}$ \\
\hline Clean Air Act & Action-/chemical-specific & Potential releases to air from units \\
\hline Safe Drinking Water Act & Chemical-specific & MCLs, MCLGs* \\
\hline Clean Water Act & Action-/chemical-specific & Discharge limitations \\
\hline Toxic Substances Control Act & Action-/chemical-specific & $\begin{array}{l}\text { Potentially applicable if specific } \\
\text { constituents determined to be } \\
\text { present }\end{array}$ \\
\hline EPA Water Classification & Location-specific & Aquifer classification \\
\hline $\begin{array}{l}\text { DOE Orders } \\
\qquad \text { State } \\
\text { S.C. Pollution Control Act }\end{array}$ & $\begin{array}{l}\text { Action-specific } \\
\text { Type } \\
\text { Action-specific }\end{array}$ & $\begin{array}{l}\text { Treatment, storage and disposal of } \\
\text { hazardous and radioactive wastes } \\
\qquad \text { Applicability } \\
\text { Potential releases to surface water, } \\
\text { groundwater, air or soil }\end{array}$ \\
\hline S.C. Wastewater Regulations & Chemical-specific & Discharge limitations \\
\hline $\begin{array}{l}\text { S.C. Drinking Water } \\
\text { Regulations }\end{array}$ & Chemical-specific & MCLs, MCLGs* \\
\hline $\begin{array}{l}\text { S.C. Hazardous Waste } \\
\text { Management Regulations }\end{array}$ & Action-specific & $\begin{array}{l}\text { Treatment, storage and disposal of } \\
\text { hazardous waste }\end{array}$ \\
\hline $\begin{array}{l}\text { S.C. Air Pollution Control } \\
\text { Regulations }\end{array}$ & Action-specific & Potential releases to air \\
\hline $\begin{array}{l}\text { S.C. Water Classification } \\
\text { Standards }\end{array}$ & $\begin{array}{l}\text { Chemical-/location- } \\
\text { specific }\end{array}$ & Surface water and groundwater \\
\hline $\begin{array}{l}\text { S.C. Well Standards and } \\
\text { Regulations }\end{array}$ & Action-specific & Well Construction requirements \\
\hline
\end{tabular}

${ }^{*} \mathrm{MCL}=$ Maximum Contaminant Level

*MCLG = Maximum Contaminant Level Goal 
This page intentionally left blank. 


\subsection{DATA QUALITY OBJECTIVES}

The Expedited Site Characterization (ESC) concept incorporates the DQO process developed by the EPA as guidance for data collection activities (EPA, 1994). The DQOs are developed using an interactive and iterative approach to decision making based on seven steps detailed in the EPA guidance.

DQOs are useful in identifying data gaps and in developing sampling and analytical plans that describe the procedures for collecting sufficient data of known and defensible quality. These data are to be used to define the extent and magnitude of contamination and to define human and ecological risks. In turn, these findings will assist decision makers in arriving at appropriate and sound decisions concerning remedial response activities. DQOs also assist in determining appropriate detection limits, analytical methods, and sampling and handling procedures/requirements.

\subsection{Data Quality Objective Evaluation}

\subsubsection{State the Problem}

The initial step in the DQO process is to clearly define the problem so that the focus of the investigation will be unambiguous. To do this, the existing information regarding the type and extent of contamination present at the ORWBG is evaluated and probable exposure pathways are identified.

The existing data are summarized and evaluated in Sections 2.4 and 2.5. These data were utilized to develop the CSM. The existing data are adequate for unit screening purposes and define the COIs in the soils and groundwater. Characterization objectives have been completely addressed in all areas of the ORWBG and no additional intrusive investigation is required. The ORWBG, source characterization of subsurface soils, data regarding unit-specific hydrostratigraphy and the presence of contamination in the groundwater have been characterized and are adequate for the evaluation of risk.

The SRS is now implementing an interim remedial action which involves placing a low permeability soil cover over the ORWBG. This interim action will minimize future leaching of contaminants from buried waste and soil. By placing clean soil over the unit, the action will also eliminate those pathways associated with surface soil within the ORWBG and reduce future risks for other pathways for which surface soil was the primary source. Another planned action to 
minimize future release from the ORWBG source area is removal of liquid wastes from the OSTs. Data are required to characterize the contents of the OSTs (S01 - S22) for waste disposal. This characterization is discussed below.

\subsubsection{Identify the Decisions}

The purpose of this DQO step is to identify the decisions that must be supported with the collected data. This helps define the objectives of the field investigation.

The decisions to be made are those concerning removal, management, and disposal of the waste material. These decisions relate principally to worker health and safety and to management/disposal of the waste such that there is compliance with applicable regulations and permits. Data collected as part of this investigation will include both screening-level and definitive-level analytical data.

\subsubsection{Identify the Inputs to the Decisions}

The purpose of this step is to identify the information needed to support the decisions presented in Section 3.1.2. Existing unit characterizations have identified the nature and extent of contamination at the ORWBG and will provide information for input into the qualitative risk assessment and remedial design. Sampling and analysis of the solvent and radiological contaminated liquids and sludge inside the solvent tanks (S01-S22) is necessary to determine the disposal path for the material in the tanks and the most viable closure technology for the tanks.

\subsubsection{Define the Boundaries of the Study}

The purpose of this step is to identify the spatial limits of the affected media and to determine the discrete area affected by the decision(s). This step also identifies the human and ecological populations at risk and investigates the impact of present and future land-use on these populations. Another goal of this step is to determine if the time of sample collection will affect the representativeness of the characterization data. For this particular investigation, the site boundaries are the ORWBG and the OSTs within the disposal area.

\subsubsection{Develop Decision Rules}

The purpose of this step is to integrate output from the previous steps of the DQO process into a statement that defines the conditions that would cause the decision makers to choose among alternative actions. The decisions will utilize the ESC concept which requires frequent team 
reviews and possible modification of field activities based on real-time data obtained during sampling. Baseline decisions are presented below. The decision rules for the ORWBG OST sampling and analysis relate primarily to management of the wastes and the Waste Acceptance Criteria (WAC) of potential SRS waste disposal facilities. The WAC provide much of the basis for sampling and analysis of the waste and defining the waste management decisions.

\subsubsection{Specify Tolerable Limits on Decision Errors}

Due to inherent uncertainty introduced by heterogeneity and error in sampling, storing, transporting, and analyzing environmental media, it is important to specify the acceptable decision error rates. Potential errors resulting from field sampling modifications implemented under the ESC program will be minimized by utilization of the decision rules outlined in Section 3.1.5. The WACs provides the basis for the acceptable levels of uncertainty.

\subsubsection{Optimize the Design for Obtaining Data}

The final step in the DQO process is development of a sampling plan that takes into account the problems, key decisions, environmental variables, and how the spatial and temporal boundaries of the contamination and populations at risk will be identified. An integral part of the ESC process is a dynamic workplan that is viewed as a guide, subject to modification, rather than an absolute, unchangeable document. As such, decisions will be made throughout the characterization regarding how uncertainty and tolerance for uncertainty will be identified.

Section 4.0 discusses the sampling and analysis plan for the ORWBG solvent tanks (S01 - S22). The plan addresses sampling protocols, procedures (including chain-of-custody), sample preservation techniques, and shipping, handling, and holding requirements as required. The types and frequency of samples are discussed, and the analytical methods are clearly defined. Precision, accuracy, and completeness of the data and documentation of the sampling and analysis are specified in the Quality Assurance/Quality Control Plan (Section 10.0) and the Data Management Plan (Section 11.0). The safety, health and emergency response requirements of the proposed field activities are included in Section 9.0.

\subsection{Summary of DQO Evaluation}

The data needs developed under the DQO process are summarized in Table 3-1. Relationships to the CSM and evaluation of potential CMS/FS options are included in the table. Methods of obtaining these data are summarized on the table and addressed in Section 4.0. 
The primary sources of contamination in ORWBG are contaminants from the radiological and chemical waste disposed at the unit. Previous sampling activities have provided adequate data to qualitatively evaluate potential risk and leachability from the primary sources.

Liquid and sludge samples from the solvent tanks will be analyzed for definitive level data. Analytical parameters will be in accordance with the WAC established by the potential receiving facilities. 
Table 3-1. ORWBG DQO Worksheet

\begin{tabular}{|c|c|c|c|c|c|c|}
\hline $\begin{array}{c}\text { Primary } \\
\text { Source Material }\end{array}$ & $\begin{array}{l}\text { Probable } \\
\text { Conditions }\end{array}$ & $\begin{array}{c}\text { Exposure } \\
\text { Pathways } \\
\text { and/or Release } \\
\text { Mechanism } \\
\end{array}$ & $\begin{array}{l}\text { Data Needs and DQOs } \\
\text { Including } \\
\text { Engineering/Physical } \\
\text { Processes }\end{array}$ & $\begin{array}{l}\text { Sampling and Field } \\
\text { Activities Including } \\
\text { Removal and } \\
\text { Characterization }\end{array}$ & Parameters & $\begin{array}{l}\text { Potential Remedial } \\
\text { Action Alternatives }\end{array}$ \\
\hline $\begin{array}{l}\text { Radioactive Waste } \\
\text { and soil in } 20 \text { feet } \\
\text { deep by } 20 \text { feet wide } \\
\text { and up to } 700 \text { feet } \\
\text { long earthen trenches. }\end{array}$ & $\begin{array}{l}\text { Radioactive Waste and } \\
\text { soil covered with } 4 \text { feet } \\
\text { of fill and graded. } \\
\text { Waste and soil present in } \\
\text { a heterogeneous mixture } \\
\text { below fill to the base of } \\
\text { the trench. } \\
\text { Potential leaching of } \\
\text { contaminants. }\end{array}$ & $\begin{array}{l}\text { Contaminants from the } \\
\text { waste and soil have the } \\
\text { potential for leaching or } \\
\text { percolating into the } \\
\text { groundwater. }\end{array}$ & $\begin{array}{l}\text { Composition of primary source } \\
\text { material has been adequately } \\
\text { characterized to determine that } \\
\text { a response action is necessary. } \\
\text { There is no further analytical } \\
\text { data required. }\end{array}$ & No further sampling. & $\begin{array}{l}\text { No chemical/physical } \\
\text { parameters are } \\
\text { necessary. }\end{array}$ & $\begin{array}{l}\text { Alternatives include } \\
\text { capping, excavation, in-situ } \\
\text { stabilization, and ex-situ } \\
\text { stabilization. }\end{array}$ \\
\hline $\begin{array}{l}\text { Solvent Tanks (1-22) } \\
\text { Sludge and solvents in } \\
\text { the underground } \\
\text { solvent tanks. }\end{array}$ & $\begin{array}{l}\text { Solvents and rad } \\
\text { contaminated sludge are } \\
\text { held in the tanks. } \\
\text { Surface spills while } \\
\text { filling tanks. }\end{array}$ & $\begin{array}{l}\text { Ingestion of and dermal } \\
\text { contact with solvents } \\
\text { and sludge during the } \\
\text { removal of material and } \\
\text { grouting of the tanks. }\end{array}$ & $\begin{array}{l}\text { Waste Acceptance Criteria } \\
\text { (WAC) sampling and analysis } \\
\text { data for potential receiving } \\
\text { facilities. }\end{array}$ & $\begin{array}{l}\text { WAC sampling for } \\
\text { potential receiving } \\
\text { facilities. }\end{array}$ & $\begin{array}{l}\text { Potential receiving } \\
\text { facility WAC } \\
\text { parameters. }\end{array}$ & $\begin{array}{l}\text { Dispose of tank waste } \\
\text { residuals in existing SRS } \\
\text { waste treatment facilities } \\
\text { and grout tanks in place. }\end{array}$ \\
\hline $\begin{array}{l}\text { Concrete encapsulated } \\
\text { TRU waste. }\end{array}$ & $\begin{array}{l}\text { TRU waste is } \\
\text { encapsulated in concrete. } \\
\text { Potential degradation of } \\
\text { concrete due to } \\
\text { infiltration. }\end{array}$ & $\begin{array}{l}\text { Ingestion of and dermal } \\
\text { contact during the } \\
\text { removal of material. }\end{array}$ & $\begin{array}{l}\text { Sufficient information exists to } \\
\text { determine if TRU wastes } \\
\text { requires a response action. } \\
\text { Sufficient information exists to } \\
\text { evaluate potential remedial } \\
\text { action objectives. } \\
\text { No further characterization is } \\
\text { required. }\end{array}$ & No further sampling. & N/A & $\begin{array}{l}\text { Excavation and temporary } \\
\text { storage or cap. }\end{array}$ \\
\hline
\end{tabular}


This page intentionally left blank 


\subsection{UNIT ASSESSMENT}

The unit assessment for the ORWBG is designed to supplement and expand the existing data base developed from the historical data, soil gas surveys, groundwater monitoring data, and the BGC FIP investigation. These data have been used to streamline characterization efforts, eliminate unnecessary sampling, and provide sufficient data required to help make decisions at various points in the environmental assessment process. The combined data will be used to support fate and transport analysis, evaluate remedial action objectives (RAOs), and support human health and ecological evaluations to satisfy RCRA and CERCLA requirements for the ORWBG.

\subsection{Objectives}

This section provides a discussion of the unit characterization objectives as they address the CSM and meet the DQO process needs. Based on the DQOs developed in Section 3, the following data need is identified (Table 3-1):

- Sampling and analysis of aqueous and sludge solvent and radiological constituents of solvent tanks (S01 - S22). The sampling is scheduled to be performed according to the schedule provided in Section 8 and is addressed in a site-specific sampling plan (see Appendix D). Analysis will be performed to meet the WAC of existing SRS waste treatment facilities. Results of these characterization efforts are provided as Appendix E.

\subsection{Primary Source Characterization}

The primary source (radiological and chemical waste) was addressed directly through compilation records of burials and through GPR and soil gas surveys. The results of these investigations are detailed in Section 2.4. In addition, extensive field characterization of soil and groundwater contamination was completed.

Investigations and sampling of the ORWBG are complete with the exception of ongoing sampling of the contents of the OSTs. Analytical data have been used to identify the nature of the primary source material and to derive a list of constituents of interest. No additional intrusive characterization will be required. Sampling and analysis of the solvent tank contents will be performed to determine waste disposal and tank closure alternatives. 


\subsubsection{Soil Sampling}

Soil sampling for chemical and radiological analysis of the primary source and sufficient data collection were performed to support fate and transport analysis.

\subsubsection{Background Characterization}

Unit-specific background borings were advanced and sampled during the field characterization. Analytical results from these samples were used to establish unit-specific background values for the ORWBG.

\subsection{Secondary Source Characterization}

Soil, groundwater monitoring data and the BGC FIP characterization results indicate that the ORWBG is a source of contamination, and secondary sources exist. The COIs for the secondary sources are considered the same as the primary sources listed in Table 2-3 of Section 2. As depicted in the CSM the secondary sources are deep soils and disturbed soils from the future excavation of source materials. Secondary source characterization has included soil sampling and soil gas surveys under the BGC FIP (WSRC 1994b) and through compilation records of burials (Appendix A). Characterization of the secondary sources has been completed as part of the BGC FIP (WSRC 1994b) and the Source Term for the ORWBG (Appendix A).

Data indicates that there has been impact to the soils beneath the ORWBG. Concentrations in subsurface soils are generally lower than those present within the primary source material (see Section 2). No additional characterization of secondary sources will be required.

\subsection{Exposure Media Characterization}

The CSM identifies pathways potentially impacted by previous activities at the ORWBG. These pathways include: air, surface soil, subsurface soil, biota, surface water and groundwater. Historical groundwater monitoring indicate the groundwater pathway has been impacted by the ORWBG. Groundwater is being addressed under RCRA and details of the groundwater assessment at the ORWBG are included in the RCRA Part B permit for the MWMF. Air sampling conducted as part of the characterization efforts is discussed in Section 2. Surface soil sampling results can be used to estimate volatilization of organics, concentrations of contaminants in fugitive dust, and potential uptake by biota, as necessary. 
As part of the continued monitoring plan, regular rounds of groundwater sampling are planned for the existing monitoring wells. These samples will be analyzed for the Environmental Monitoring Section (EMS) groundwater quality suite, which may include VOCs, semivolatile (SVOCs), pesticides/herbicides, metals, chloride, fluoride, nitrate-nitrite as nitrogen, $\mathrm{pH}$, specific conductance, sulfate, total dissolved solids, total organic carbon (TOC), total organic halogens (TOH), and total phosphate. Data from these wells will continue to indicate to what extent contaminants have migrated from the ORWBG through the vadose zone and into the groundwater. Data from the wells will be used to support fate and transport analyses and to select RAOs. 
This page intentionally left blank. 


\subsection{POTENTIAL EARLY AND/OR INTERIM REMEDIAL ACTIONS}

Potential early or interim actions were recommended to achieve near-term environmental results at the ORWBG. The overall goal of this process was to control or abate threats to human health and/or the environment from releases and/or to prevent or minimize the further spread of contamination while long-term remedies are pursued. Although intended to be implemented more quickly than traditional remedial measures, potential early or interim remedial actions may be short-term or long-term.

\subsection{Old Radioactive Waste Burial Grounds (ORWBG) Early and/or Interim Remedial Actions}

A low-permeability soil cover was selected and has been installed as an interim remedial action at the ORWBG. The soil cover provides a reduction in stormwater infiltration through the waste layer, which will minimize contaminant migration to the water table. Topsoil with a vegetative cover is also a part of the interim action. The soil cover is sloped to promote surface runoff, minimize surface erosion, and control the leaching of hazardous substances from the source material. Construction of the soil cover is presently underway.

Existing institutional controls, environmental monitoring, and site maintenance are also components of this interim action. Visual inspection of the soil cover will be performed by trained individuals at regular intervals and after significant rainstorms. Any observed damage, erosion, or subsidence will be repaired to conform with the original soil cover contours.

This interim action addresses source control at the ORWBG in advance of the final remedial action. The soil cover is consistent with the overall site strategy because it provides for a reduction in contaminant migration without hindering characterization efforts and without precluding any final remedial action developed during the FFA process.

\subsection{Solvent Tanks Early and/or Interim Remedial Actions}

Characterization of the old solvent tanks' contents will be performed to verify that the contents of the tanks meet the WAC established by the potential receiving facilities. In an effort to support the characterization of the solvent tanks, camera surveys are being conducted to determine the contents and structural integrity of the tanks. A potential interim remedial action for the solvent tanks will be considered. Potential early actions include waste removal and tank stabilization. 
Further details regarding the solvent tanks sampling and analysis activities are included in Appendix D, "Sampling and Analysis Plan for Old Solvent Tanks S1 - S22 to Address Waste Acceptance Criteria," WSRC-RP-97-00770.

The final remedial measure for the solvent tanks will be determined by the final ORWBG action. 


\subsection{POTENTIAL CORRECTIVE MEASURES STUDY/FEASIBILITY STUDY OPTIONS}

\subsection{Preliminary Remedial Action Objectives}

The overall preliminary RAOs for the ORWBG are as follows:

- Minimize the risk to workers associated with contaminants in the soil due to external exposure, indirect contact, inhalation, or ingestion

- Prevent or mitigate migration (via leaching) of contaminants to groundwater and thereby minimize future contaminant discharges to the receptor point (nearby streams)

- Minimize erosion and runoff of contaminants from the waste unit to the surrounding areas

- Prevent or mitigate intrusion into the ORWBG via intruder access controls

- Stabilize the surface of the ORWBG to prevent collapse due to compromised structural stability of waste components

\subsection{Final Action Options}

At this time, it is confirmed that hazardous and radiological substances have been released from the ORWBG. All possible remedial alternatives will be evaluated to determine the proper course of action to effect remediation at the unit.

\subsubsection{Standard Remedial Technologies}

Remedial alternatives are identified as part of the RFI/RI process. Based on the data available for the ORWBG, the areas that may require remediation are the source area (trenches and solvent tanks), leachate, and soil. From available unit information, the constituents of potential concern (COPCs) include mercury, cadmium, lead, VOCs, and radionuclides. The groundwater, as agreed upon by the regulators and WSRC, will be addressed under separate SCDHEC RCRA closure/post-closure activities. Table 6-1 lists the potential remedial technologies that may be applied to the ORWBG source area, leachate, and soil.

The final disposition of any TRU waste that may be identified for limited "hot spot" excavation would be to place the removed TRU culverts on above ground storage pads in the Burial Ground Complex until shipment to the Waste Isolation Pilot Plant (WIPP) is approved. The storage of the TRU culverts on the pads would require approval from the Solid Waste Division. 
Some areas in the ORWBG may also be identified for limited "hot spot" grouting/stabilization.

\subsubsection{Innovative Remedial Technologies}

At this time, no innovative remedial technologies have been identified. Several factors, including radioactivity and the size of the ORWBG, make it unlikely that an innovative technology will be identified. However, literature searches will continue and any new technologies identified will be considered 
Table 6-1.

Standard Remedial Technologies

\begin{tabular}{|c|c|}
\hline Institutional and Source Controls & $\begin{array}{l}\text { - } \text { Excavation } \\
\text { - Soil Covers } \\
\text { - } \text { Capping } \\
\text { - } \text { Grout Curtain } \\
\text { - } \text { Fencing } \\
\text { - Posting Signs } \\
\text { - Limiting Access } \\
\text { - In-Situ Vitrification } \\
\text { - In-Situ Solidification/Stabilization } \\
\text { - Ex-Situ Stabilization }\end{array}$ \\
\hline Leachate Controls & $\begin{array}{l}\text { - } \text { Capping } \\
\text { - Subsurface Collection Drains } \\
\text { - In-Situ Biological Treatment } \\
\text { - In-Situ Vitrification } \\
\text { - In-Situ Solidification/Stabilization } \\
\text { - Ex-Situ Stabilization }\end{array}$ \\
\hline Soil Controls & $\begin{array}{l}\text { - Excavation } \\
\text { - In-Situ Biological Treatment } \\
\text { - Capping } \\
\text { - In-Situ Vitrification } \\
\text { - In-Situ Solidification/Stabilization } \\
\text { - Ex-Situ Stabilization } \\
\end{array}$ \\
\hline Air Pollution and Gas Migration Controls & $\begin{array}{l}\text { - } \text { Capping } \\
\text { - } \text { Dust Control } \\
\text { - Vapor Collection and Treatment (e.g., } \\
\text { carbon adsorption) } \\
\text { - Thermal Oxidation } \\
\end{array}$ \\
\hline
\end{tabular}


This page intentionally left blank. 


\subsection{QUALITATIVE RISK ASSESSMENT SUMMARY}

\subsection{Identification of Constituents of Interest}

This Qualitative Risk Assessment (QRA) for the Old Radioactive Waste Burial Ground (643-E, S01-S22) presents information on contaminated media identified in the document: Source Term for the Old Radioactive Waste Burial Ground, Samannah River Site (U) [WSRC-RP-97-0119]. This report defined the nature of contaminants at the ORWBG which are referred to as Constituents of Interest (COIs). A detailed investigation was conducted to determine the origin, inventory, location and waste form of COIs (WSRC, 1997a). COIs were defined based on previous sampling (soil and groundwater), review of COBRA records, process history, and previous regulatory and historical documentation. As a result, the following COIs were identified for this unit: cadmium, lead, mercury, volatile organic compounds (VOCs), tritium, cesium-137, plutonium-238, plutonium-239, strontium-90, uranium-235, uranium-238, carbon-14, cobalt-60, technetium-99, iodine-129, and neptunium-237. Table 2-1 provides summary information regarding inventory estimates, burial locations, waste form, and origin for each of the COIs. Table 2-3 presents the relative toxicity, mobility, and volume of each of the COIs. Table 2-4 presents a qualitative assessment of the fate and transport of the COIs.

\subsection{Qualitative Risk Summary}

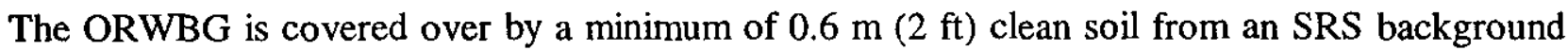
borrow area, with the exception of the Old Solvent Tanks (OSTs), and therefore, surface soil ( 0 to $0.3 \mathrm{~m}$ [0 to $1 \mathrm{ft}$ ]) and subsurface soil ( 0.3 to $1.2 \mathrm{~m}$ [1 to $4 \mathrm{ft}])$ pathways of exposure have been eliminated. Closure of the OSTs is pending and they will be covered with the same interim soil cover upon completion of closure. Although the placement of the clean interim soil cover has mitigated the exposures and risks associated with surface and subsurface soils, given the known chemical and radiological inventory, unit history, and waste-unit conditions at the ORWBG, significant unacceptable human health and ecological risk may still be posed by releases of waste to groundwater in the ORWBG. In addition, the presence of the OSTs and a significant source term at depth within the unit warrants special consideration. Therefore, the justification that unacceptable risk exists is acknowledged without the development of a quantitative risk assessment for the unit.

It is further stated that: 
- No soil characterization activities have been performed at the OST area. However, surface monitoring has been performed as a part of ongoing OST work activities using portable radiation and contamination probes. Also, the OST area is surveyed monthly as a part of routine surveillance and monmitoring activities. Surface contamination has not been detected to date during these activities although Burial Ground records indicate that spills may have occurred at the tanks during past solvent transfer operations.

- To mitigate the current risk to onsite workers from potential exposure to contaminants at the OST area associated with the vent/riser pipes of the OSTs, the OST area is currently posted as a Contamination Area (CA). These pipes are covered and sealed with 8-mil plastic containment sleeves equipped with HEPA filter cartridges. The OST CA itself is completely contained within a larger Radiological Buffer Area (RBA) that is designed to control personnel and material entry into and exit from the OST CA. Further, the RBA is completely contained within the Controlled Area of the Burial Ground Complex that has other personnel and material access controls. The cumulative effect of limiting radioactive contamination to the tanks and within the OST CA, implementing administrative controls and engineered controls to keep occupational exposure low, and continuously monitoring for environmental releases is the very low risk of exposure to the radioactivity associated with the OSTs.

- These controls mitigate the current risk to onsite workers from potential exposure to contaminants at the OST area. To mitigate risk to future workers and to miniminze migration of contaminants from potential spills, all OST remedial alternatives identified in the Correcive Measures Study/Feasibility Study (CMS/FS) will include a low permeability soil cover and/or an engineered cap consistent with the final action selected for the remaining area of the ORWBG.

\subsection{Remedial Goal Options}

Remedial goal options (RGOs) are risk-based chemical and radiological concentration ranges that are used as target cleanup criteria for consideration in the CMS/FS process during development and selection of remedial action alternatives. RGOs address the specific constituents of interest, media of concern, and potential exposure pathways associated with the unit (EPA, 1991). Remedial action objectives (RAOs) are based on the nature and extent of contamination, threatened resources, and the potential for human and environmental exposure to constituents of interest. RAOs are used to develop and assess potential remedial technologies that are protective of human helath and the environment. For example, an RAO may include the reduction of 
contaminant concentrations in impacted soils to levels that are protective of human health and the environment or they may simply eliminate the direct exposure pathways for human and ecological receptors.

In developing risk-based human health RGOs, target risk levels are established for carcinogens and target hazard quotients are established for noncarcinogens. These levels are then used in conjunction with toxicity data and exposure equations to calculate RGOs. One of the goals of the NCP is to manage total risks at the unit such that the sum of all risks for each receptor does not exceed a carcinogenic risk of $1 \times 10^{-4}$ nor a noncarcinogenic hazard exceeding unity. The EPA recommends the use of an individual target risk level of $1 \times 10^{-6}$ for permanent remedial action to provide confidence that cumulative risks do not exceed $1 \times 10^{-4}$. RGOs developed from a quantitative analysis of risk to human health and the environment are used to develop RAOs.

For the ORWBG, a streamlined approach to the risk assessment for the unit was selected, thereby eliminating the need for a quantitative analysis and the development of RGOs. Instead, the unit specific conditions and the type of source term data available rather than RGOs are used to develop RAOs. The information used for characterizing the ORWBG source term, COIs, media, and potential transport pathways will be used when developing RAOs. 
This page intentionally left blank. 


\subsection{SCHEDULE}

\subsection{Introduction}

This section provides the proposed schedule of field activities, document and report submittals for the ORWBG source unit. This schedule is subject to regulatory review timetables. Groundwater associated with the BGC is being addressed under the RCRA permit for the MWMF, therefore groundwater characterization activities are not included as part of this schedule.

\subsection{Projected Schedule for Field Activities}

EPA, DHEC and DOE have determined that no further intrusive characterization is required at the ORWBG. However, sampling of the residuals in the solvent tanks is ongoing. This information will be used to determine waste disposition alternatives. These sampling activities are projected to be completed in the second quarter of FY98.

\subsection{Projected Schedule for Document and Report Submittals}

The schedule for the submittal of documents and reports associated with the ORWBG is depicted in Figure 8-1. The signed Record of Decision is scheduled for submittal in June 2000. 
This page intentionally left blank. 


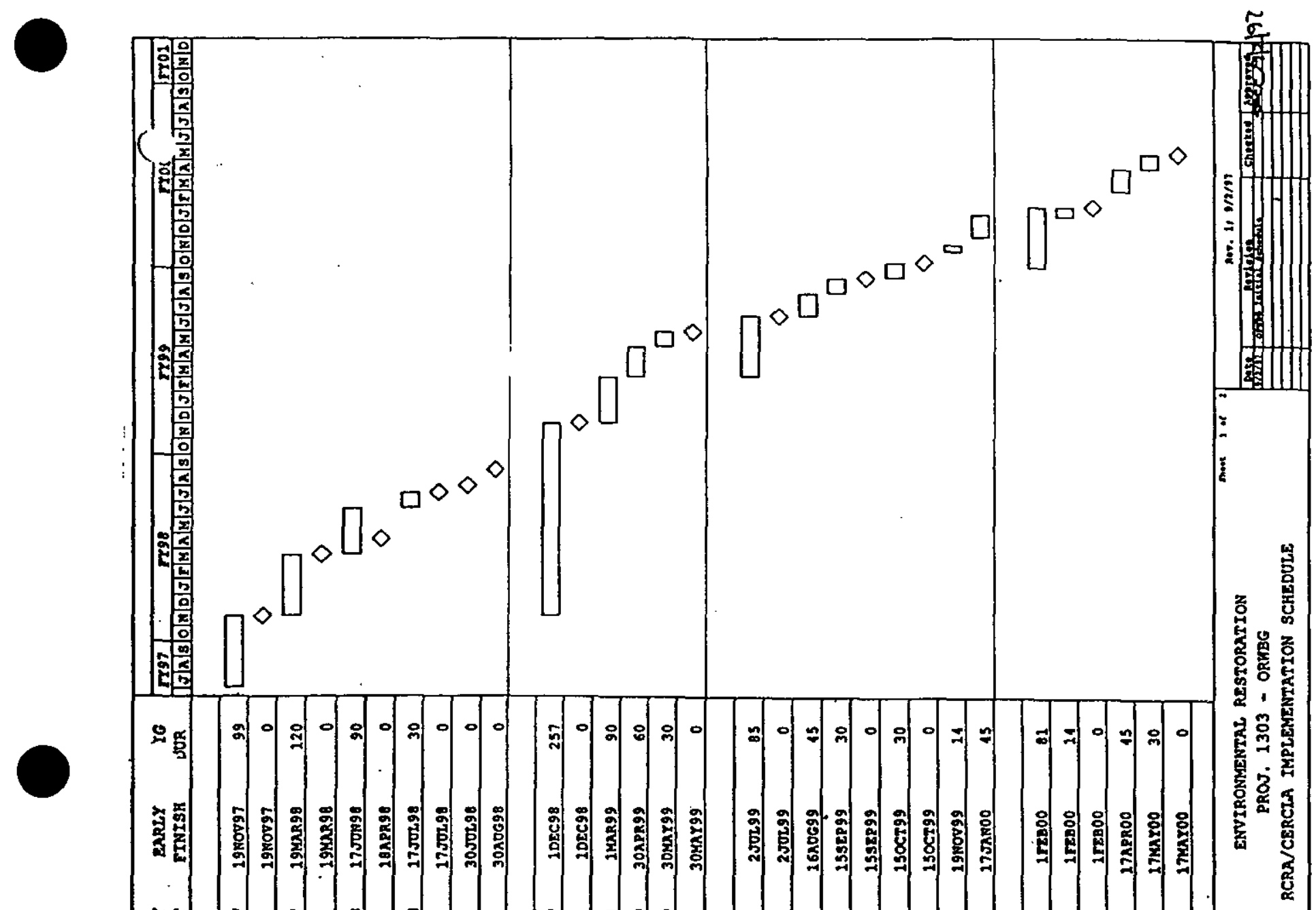

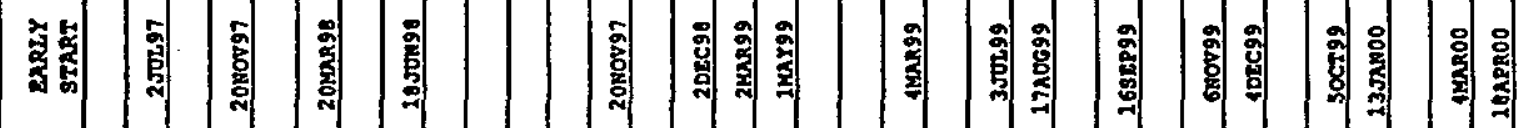

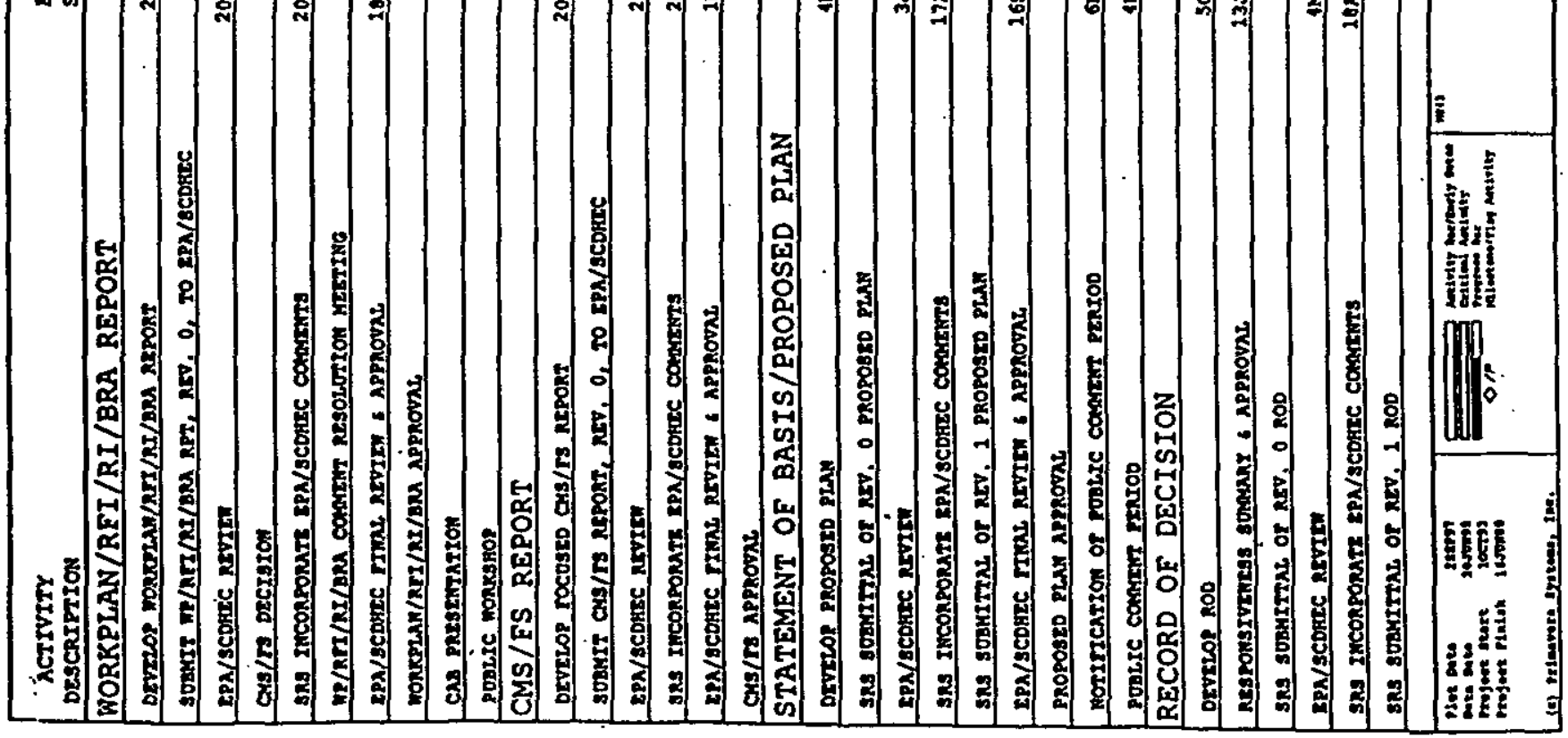




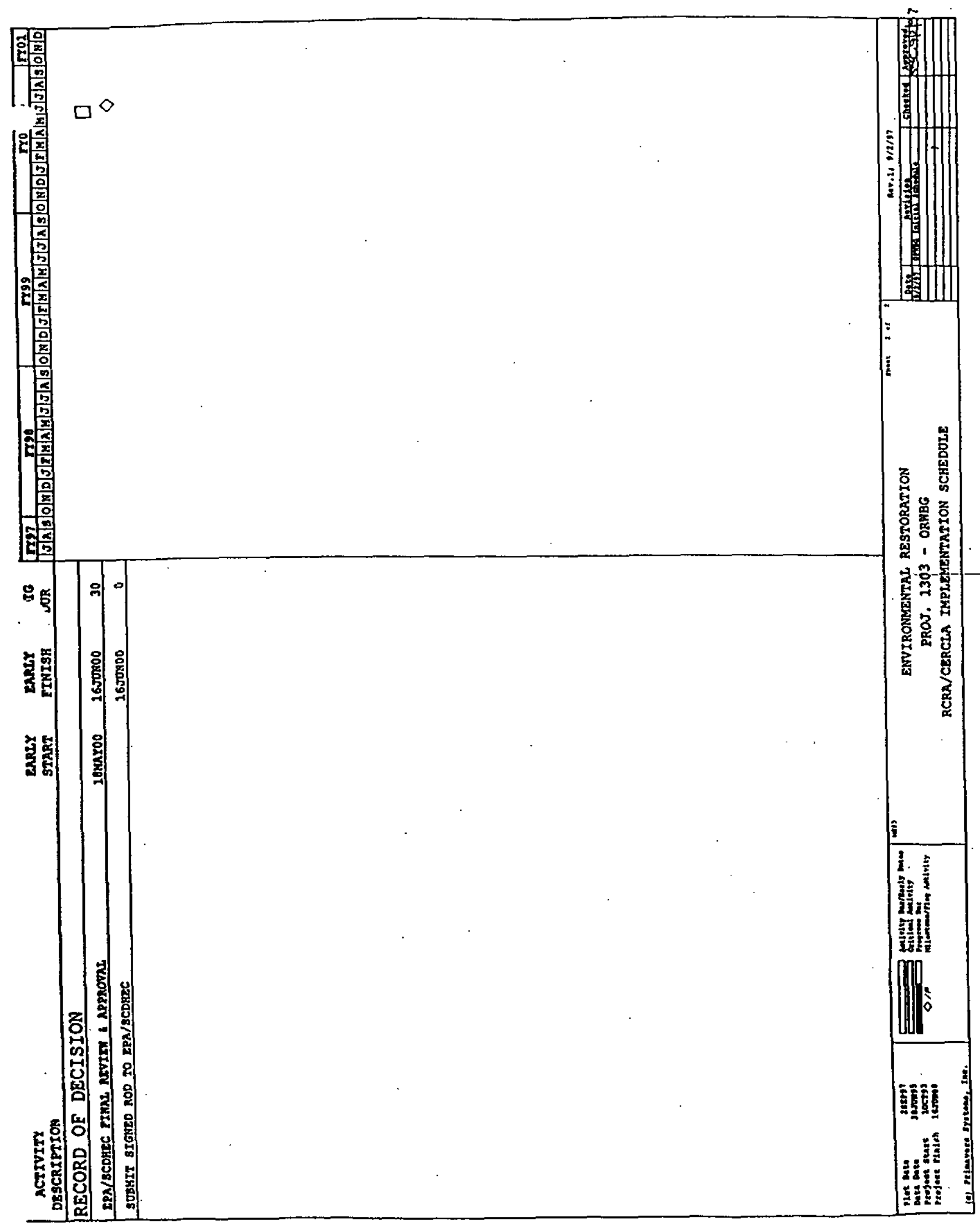




\subsection{SAFETY, HEALTH, AND EMERGENCY RESPONSE PLAN}

A site-specific Health and Safety Plan (HASP) will be prepared in accordance with 29 Code of Federal Regulations 1910.120 and approved prior to starting any field investigations. This plan will meet Occupational Safety and Heaith Administration requirements. All personnel involved in the performance of the work shall be familiar with the provisions of the HASP. 
This page intentionally left blank. 


\subsection{QUALITY ASSURANCE/QUALITY CONTROL PLAN}

This section describes the Quality Assurance and Quality Control (QA/QC) procedures that were used for the completed characterization activities for the Old Radioactive Waste Burial Ground. The purpose of the QAVQC Plan is to ensure that all analytical data collected or generated are scientifically valid, defensible, of known and acceptable accuracy, and consistent with SRS and DOE quality assurance programs.

QA sections outline the system to provide assurance, through proper record keeping and management, that monitoring of quality related activities has occurred. QC sections contain instructions and procedures to be followed in order to ensure consistency of data gathered.

QA/QC programs and procedures are based on those described in WSRC 1Q Quality Assurance Manual (U) (WSRC, 1994c). Data Quality Objectives (DQOs) relate to the concept that different data uses may require different data quality. DQOs are defined in Chapter 3 of this Workplan.

The Solvent Tank sampling and analysis activities will be performed in accordance with a Project Specific Quality Assurance Plan developed in accordance with WSRC 1Q Quality Assurance Procedure 2-1.

The Sampling and Analysis Plan found in Appendix D has been developed in accordance with WSRC 1Q Quality Assurance Procedure 21-1 QA Requirements for the Collection and Evaluation of Environmental Data.

Precision, accuracy, completeness, representativeness, comparability, and documentation of the solvent tanks sampling and analysis are specified in the site-level quality assurance procedures listed below.

- WSRC Manual 1Q, Quality Assurance Manual (U) (WSRC, 1994c)

- ESH-EMS-95-0076, Environmental Monitoring Section Environmental Geochemistry Group Program Overview (WSRC, 1995c) 
This page intentionally left blank. 


\subsection{DATA MANAGEMENT}

Data management will be performed in accordance with the WSRC Sampling and Analysis Plan for Old Solvent Tanks S1-S22 to Address Waste Acceptance Criteria (Appendix D) and the Environmental Monitoring Section Environmental Geochemistry Group Program Overview (WSRC, 1995c). 
This page intentionally left blank. 


\subsection{REFERENCES}

Aadland, R.K., and Beldsoe, H.W., 1990. Classification of Hydrostratigraphic Units at Savannah River Site, South Carolina. Savannah River Laboratory, WSRC-RP-90-987, Westinghouse Savannah River Company, Savannah River Site, Aiken, SC.

Aadland, R.K., Gellici, J.A., and Thayer, P.A., 1995. Hydrogeologic Framework of West-Central South Carolina, Water Resource Division, Report 5. State of South Carolina, Department of Natural Resources.

Bledsoe, H.W., Aadland, R.K., and Sargent, K.S., 1990. SRS Baseline Hydrogeologic Investigations Summary Report. Savannah River Laboratory, WSRC-RP-90-1010, Westinghouse Savannah River Company, Savannah River Site, Aiken, SC.

Christensen, E.J., and Gordon, D.E., 1983. Technical Summary of Groundwater Quality Protection Program at Savannah River Plant. Volume 1 - Site Geohydrology and Solid and Hazardous Wastes. DPST-83-829, E.I. du Pont de Nemours and Company, Savannah River Laboratories, Aiken, SC.

Cooke, C.W., MacNeil, F.S., 1952. Tertiary Stratigraphy of South Carolina: U.S. Geological Survey. Professional Paper 243-B, p. 19-29,

DOE, 1994a. Programmatic Spent Nuclear Fuel Management and Idaho National Engineering Laboratory Environmental Restoration and Waste Management Programs Environmental Impact Statement. Volume 1, Appendix C. U.S. Department of Energy, Office of Environmental Restoration and Waste Management, DOE Idaho Operations Office.

DOE, 1994b. Public Involvement, A Plan for Savannah River Site. Savannah River Operations Office, Aiken, SC.

Duffield, G.M., Buss, D.R., Root, R.W., Jr., Hughes, S.S., and Mercer, J.W., 1986. Characterization of Groundwater Flow and Transport in the General Seperations Areas, Savannah River Plant: Flow Model Refinement and Particle-Tracking Analysis Report. CORR86-0031, E. I. du Pont de Nemours and Company, Savannah River Laboratory, Aiken, SC.

EPA, 1994. Guidance for the Data Quality Objective Process. EPA QA/G-4 United States Environmental Protection Agency, Quality Assurance Management Staff, Washington, DC.

Fallaw, W.C., and Price, W., 1995. "Stratigraphy of the Savannah River Site and Vicinity." Southern Geology, 35(1):21-58.

Fallaw, W.C., and Price, V., and Thayer, P.A., 1990. Stratigraphy of the Savannah River Site, South Carolina: Proceedings of the Second Bald Head Island Conference on Coastal Plains Geology. November 6-11, 1990, Addendum, p. 1-4. 
Flach, G.P., Hamm, L.L., Harris, M.K., Thayer, P.A., Haselow, J.S., and Smits, A.D., 1996. Groundwater Flow and Tritium Migration from the SRS Old Burial Ground to Fourmile Branch. WSRC-TR-96-0037, Westinghouse Savannah River Company, Aiken, SC, April 1996.

Flach, G.P., and Harris, M.K., 1996. Corrective Measures Study Modeling Results for the Southwest Plume - Burial Ground Complex/Mixed Waste Management Facility (U). SRT-ESS96-435, Westinghouse Savannah River Company, Aiken, SC, 7 November 1996.

Hoeffner, S.L., Denham, E.L., and Oblath, S.B., 1985. Analysis of Organics in 643-G Groundwaters by GC/MS. DPST-85-783, E.I. du Pont de Nemours and Company, Savannah River Laboratory, Aiken, SC.

Huang, J.C., and Master, W., 1983. Recommended Breathing Rates for SAR Accident Dose Calculations. DPST-83-930, E.I. du Pont de Nemours and Co., Aiken, SC.

Jaegge, W.J., Kolb, N.L., Looney, B.B., Marine, I.W., Towler, O.A., and Cook, J.R., 1987. Environmental Information Document Radioactive Waste Burial Grounds. DPST-85-694, E.I. du Pont de Nemours and Company, Savannah River Laboratory, Aiken, SC.

Looney, B.B., Ramdeen, M., Pickett, J., Rogers, V., Shirley, P.A., and Scott, M.T., 1990. Geochemical and Physical Properties of Soils and Shallow Sediments at the Savannah River Site. WSRC-RP-90-1031, Westinghouse Savannah River Company, Savannah River Site, Aiken, $\mathrm{SC}$.

McIntyre, P.F., Wilhite, E.L., 1987. Effect of Organics on Radionuclide Mobility in the SRP Burial Ground. DPST-87-762, E.I. du Pont de Nemours and Company, Savannah River Laboratory, Aiken, SC.

Microseeps, 1994. Ground Penetrating Radar Interpretations at the Burial Ground Complex. University of Pittsburgh Applied Research Center, Pittsburgh, PA.

Oblah, S.B., 1985a. 1984 Monitoring of Mercury in the Groundwater at 643-G and 643-7G. DPST-85-407, E.I. du Pont de Nemours and Company, Savannah River Laboratory, Aiken, SC.

Oblah, S.B., 1985b. Lead and Cadmium Measurements of Groundwater Beneath the Low Level Waste Burial Grounds. DPST-85-969, E.I. du Pont de Nemours and Company, Savannah River Laboratory, Aiken, SC.

Parizek, R.R., and Root, R.W., Jr., 1986. Development of Groundwater Velocity Model for the Radioactive Waste Management Facility, Savannah River Plant, South Carolina - Final Report on Aquifer Testing and Geostatistical Modeling. U.S. Department of Energy Report, DPST-86658.

Price, V., and Cook, J.R., 1988. Mercury in Shallow Savannah River Plant Soil. DPST-86-314, E.I. du Pont de Nemours and Company, Savannah River Laboratory, Aiken, SC. 
Ryan, J.P., 1983. Groundwater Monitoring in the Savannah River Plant Low Level Waste Burial Ground. A Summary and Interpretation of the Analytical Data: DPST-83-209, E.I. du Pont de Nemours and Company, Savannah River Laboratory, Aiken, SC.

Siple, B.E., 1967. Geology and Groundwater of the Savannah River Plant and Vicinity, South Carolina: U.S. Geological Survey Water Supply. Page 1841.

U.S. Bureau of Census, 1991a. 1990 Census of Population and Housing, Summary Population and Housing Characteristics: Georgia. U.S. Bureau of Census, Washington, D.C.

U.S. Bureau of Census, 1991b. 1990 Census of Population and Housing, Summary Population and Housing Characteristics: South Carolina. U.S. Bureau of Census, Washington, D.C.

WSRC, 1989. RCRA Facility Investigation Program Plan. WSRC-RP-89-994, Westinghouse Savannah River Company, Savannah River Site, Aiken, SC.

WSRC, 1993a. RCRA Facility Investigation/Remedial Investigation Program Plan. WSRC-RP89-994, Revision 1, Westinghouse Savannah River Company, Savannah River Site, Aiken, SC.

WSRC, 1993b. Savannah River Site Environmental Data for 1992. WSRC-TR-93-077, Westinghouse Savannah River Company, Aiken, SC.

WSRC, 1993c. Assessment of Tritium in the Savannah River Site Environment. WSRC-TR-93214, Westinghouse Savannah River Company, Aiken, SC.

WSRC, 1994a. Mixed Waste Management Facility Groundwater Monitoring Report. WSRC-TR94-0345, Westinghouse Savannah River Company, Aiken, SC.

WSRC, 1994b. A Field Investigation Plan for the Burial Ground Complex (U). WSRC-RP-93848, Rev 1.0, Westinghouse Savannah River Company, Aiken, SC.

WSRC, 1994c. Quality Assurance Manual (U). WSRC Manual 1Q, Westinghouse Savannah River Company, Aiken, SC.

WSRC, 1995a. Safety Analysis Report Savannah River Site. WSRC-SR-19, Rev. 1, Westinghouse Savannah River Company, Savannah River Site, Aiken, SC.

WSRC, 1995b. Part B permit renewal application (U), WSRC-IM-91-53, v. 7, Mixed Waste Management Facility (MWMF) postclosure, 530 p. + appendices.

WSRC, 1995c. Environmental Monitoring Section Environmental Geochemistry Group Program Overview. ESH-EMS-95-0076, Westinghouse Savannah River Company, Savannah River Site, Aiken, SC.

WSRC, 1996a. Interim Record of Decision Remedial Alternative Selection Old Radioactive Waste Burial Ground (643-E) Savannah River Site. WSRC-RP-96-102, Westinghouse Savannah River Company, Aiken, SC. 
WSRC, 1996b. Burial Ground Complex Aquifer Test Plan. WSRC-RP-96-302, Rev.0, Westinghouse Savannah River Company, Aiken, SC. 


\section{Workplan/RCRA Facility Investigation/Remedial Investigation Report for the Old Radioactive Waste Burial Ground 643-E, S01-S22 - Volume I - Text and Volume II - Appendices}

by

K. R. Conner

RECORDS ADMINISTRATION

Westinghouse Savannah River Company

Savannah River Site

Aiken, South Carolina 29808

J. Leyba

A. Preston

This paper was prepared in connection with work done under the above contract number with the U. S. Department of Energy. By acceptance of this paper, the publisher and/or recipient acknowledges the U. S. Government's right to retain a nonexclusive, royalty-free license in and to any copyright covering this paper, along with the right to reproduce and to authorize others to reproduce all or part of the copyrighted paper. 
WSRC-RP-97-00127, Revision 1.4

August 2000

\section{Workplan/RCRA Facility Investigation/Remedial Investigation Report for the Old Radioactive Waste Burial Ground 643-E, S01-S22 (U)}

\section{Volume II - Appendices}

Westinghouse Savannah River Company

Savannah River Site

Aiken, South Carolina, 29808

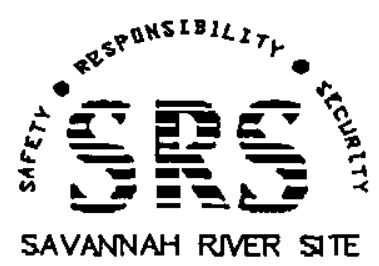

Prepared for the U.S. Department of Energy Under Contract Number DE-AC09- 


\section{DISCLAIMER}

This report was prepared as an account of work sponsored by an agency of the United States Government. Neither the United States Government nor any agency thereof, nor any of their employees, makes any warranty, express or implied, or assumes any legal liability or responsibility for the accuracy, completeness, or usefulness of any information, apparatus, product or process disclosed, or represents that its use would not infringe privately owned rights. Reference herein to any specific commercial product, process or service by trade name, trademark, manufacturer, or otherwise does not necessarily constitute or imply its endorsement, recommendation, or favoring by the United States Government or any agency thereof. The views and opinions of authors expressed herein do not necessarily state or reflect those of the United States Government or any agency thereof.

This report has been reproduced directly from the best available copy.

Available for sale to the public, in paper, from: U.S. Department of Commerce, National Technical Information Service, 5285 Port Royal Road, Springfield, VA 22161

phone: (800) 553-6847

fax: (703) 605-6900

email: orders@ntis.fedworld.gov

online ordering: http:/www.ntis.gov/ordering.htm

Available electronically at http://www.doe.gov/bridge

Available for a processing fee-to-USS-Department of Energy and its contractors, in paper, from: U.S. Department of Energy, Office of Scientific and Technical Information, P.O. Box 62, Oak Ridge, TN $37831-0062$ phone: (865) 576-8401

fax: (865) 576-5728

email: reports@adonis.osti.gov

$00 J 04115 . \mathrm{p} 65$

Printed in the United States of America

Prepared for

U.S. Department of Energy

and

Westinghouse Savannah River Company

Aiken, South Carolina 
APPENDIX A

Source Term for the Old Radioactive Waste Burial Ground (ORWBG), Savannah River Site, WSRC-RP-97-0119, Rev. 1 
This page intentionally left blank. 
SOURCE TERM FOR THE

OLD RADIOACTIVE WASTE BURIAL GROUND (ORWBG), SAVANNAH RIVER SITE (U)

May 2000

Westinghouse Savannah River Company

Savannah River Site

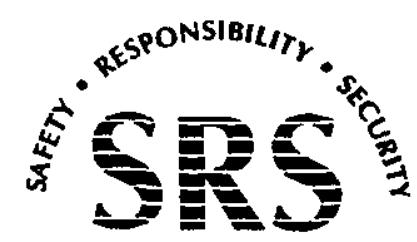

Aiken, S.C. 29808 


\section{DISCLAIMER}

This report was prepared by Westinghouse Savannah River Company (WSRC) for the United States Department of Energy under Contract No-DE-AC09-96SR-18500_and_is_an_account_of_work_performed under that contract. Neither the United States Department of Energy, nor WSRC, nor any of their employees makes any warranty, expressed or implied, or assumes any legal liability of responsibility for accuracy, completeness, or usefulness, on any information, apparatus, or product or process disclosed herein or represents that its use will not infringe privately owned rights, Reference herein to any specific commercial product, process, or services by trademark, name, manufacturer or otherwise does not necessarily constitute or imply endorsement, recommendation, or favoring of same by WSRC or by the United States Government or any agency thereof. 


\section{TABLE OF CONTENTS}

EXECUTIVE SUMMARY

ES-1

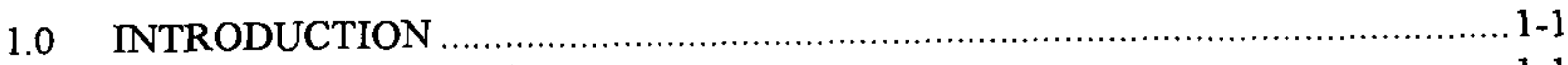

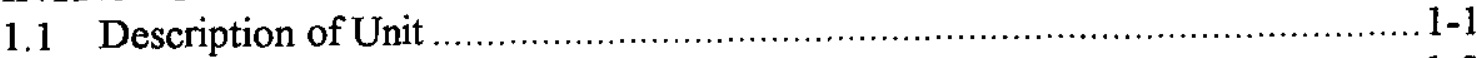

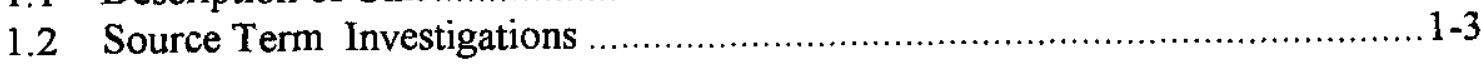

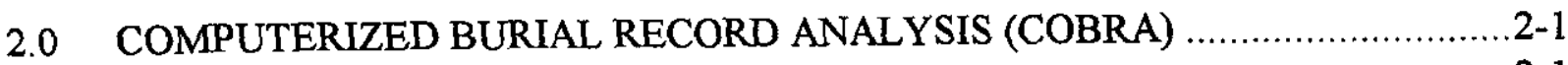

2.1 Waste Volume and Origin ............................................................

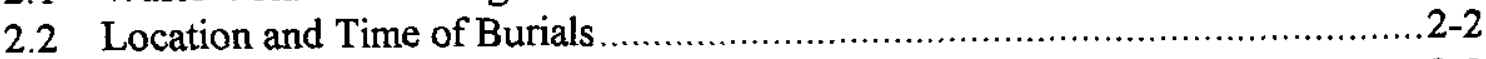

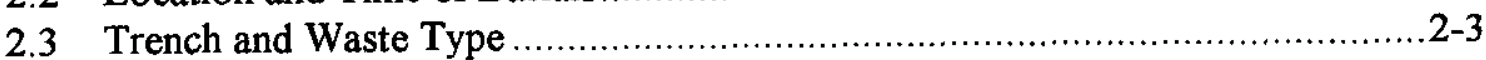

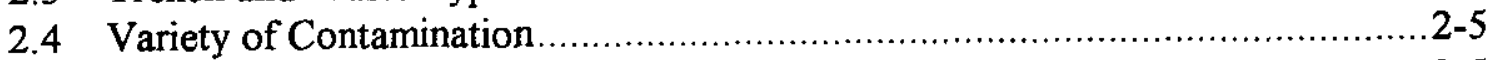

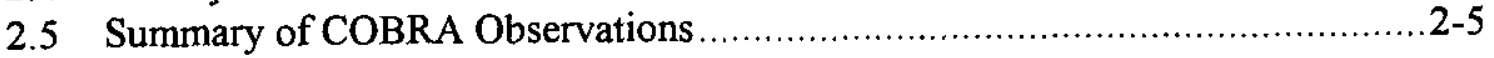

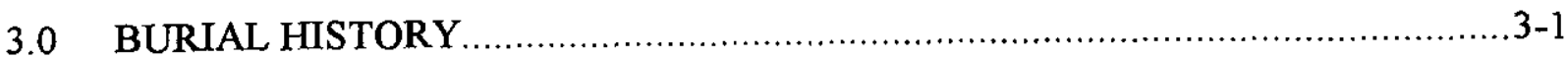

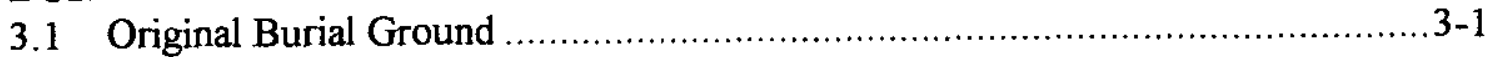

3.2 Eastern Expansion of the ORWBG .................................................. 3-4

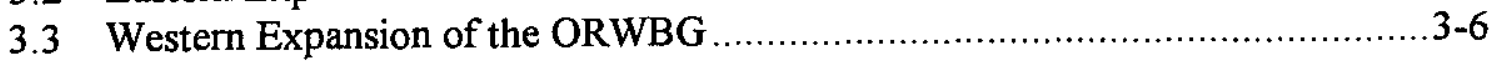

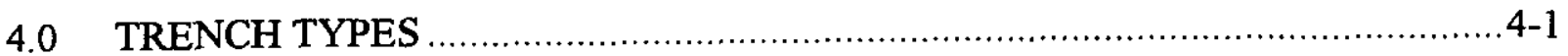

4.1 Low Level Trenches ..................................................................

4.2 High Level Trenches................................................................ 4-2

4.3 Jumpers and Equipment Trenches ................................................ 4-2

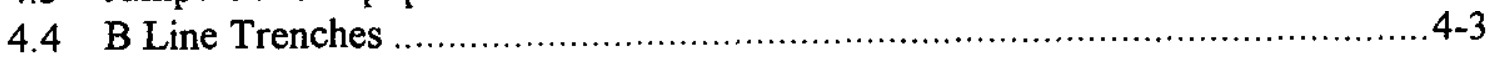

4.5 Scrap Metal Trenches ............................................................... 4-4

4.6 Encapsulated Plutonium........................................................... 4-4

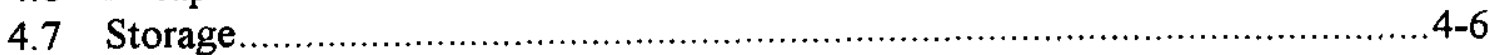

4.8 Special/Classified Projects................................................................

4.9 Solvent Tanks/Solvent Burning Pans................................................ 4-8

4.10 Miscellaneous Category ..........................................................

5.0 SUMMARY OF CONSTITUENTS OF INTEREST INVENTORY ...................5-1

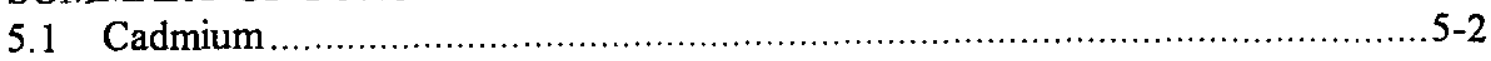

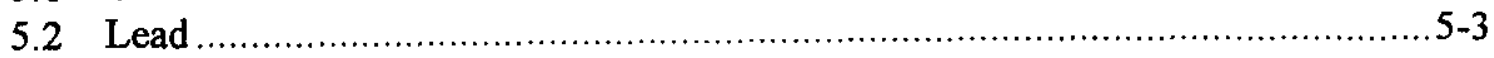

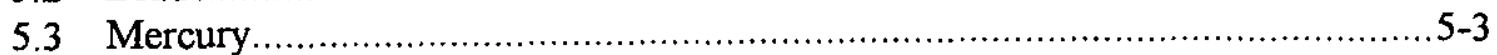

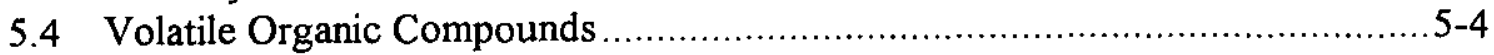

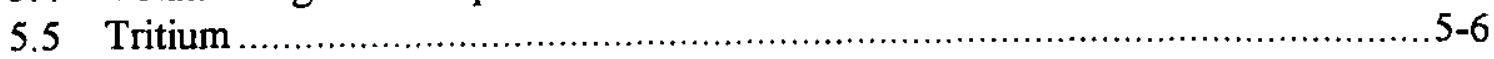

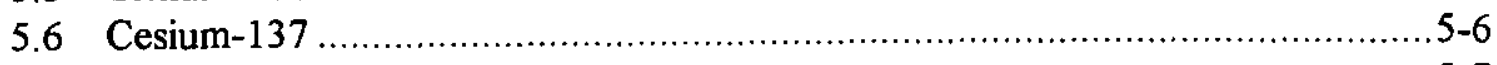

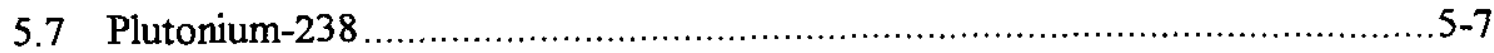

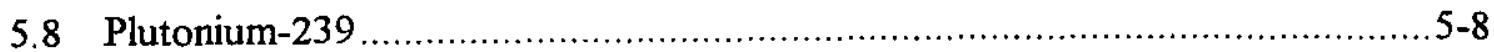

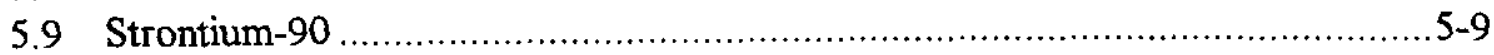




\section{TABLE OF CONTENTS (Continued)}

5.10 Uranium-235

$5-9$

5.11 Uranium-238

5.12 Carbon- 14 $5-10$

5.13 Cobalt- 60

5.14 Technetium-99

$5-12$

5.15 Iodine -129

$5-13$

5,16 Neptunium-237

6.0 REFERENCES. 


\section{LIST OF APPENDICES}

$\begin{array}{ll}\text { Appendix A } & \text { Cadmium } \\ \text { Appendix B } & \text { Lead } \\ \text { Appendix C } & \text { Mercury } \\ \text { Appendix D } & \text { Volatile Organic Compounds } \\ \text { Appendix E } & \text { Tritium } \\ \text { Appendix F } & \text { Cesium-137 } \\ \text { Appendix G } & \text { Plutonium-238 } \\ \text { Appendix H } & \text { Plutonium-239 } \\ \text { Appendix I } & \text { Strontium-90 } \\ \text { Appendix J } & \text { Uranium-235 } \\ \text { Appendix K } & \text { Uranium-238 } \\ \text { Appendix L } & \text { Carbon-14 } \\ \text { Appendix M } & \text { Cobalt-60 } \\ \text { Appendix N } & \text { Technetium-99 } \\ \text { Appendix O } & \text { Iodine-129 } \\ \text { Appendix P } & \text { Neptunium-237 }\end{array}$




\section{LIST OF FIGURES}

1-1. Location Map for Burial Ground Complex, Including Old Radioactive Waste Burial Ground South of the Railroad Spur, and the Low Level Radioactive Waste Disposal Facility on the Northern Side.

2-1. Cubic Feet of Waste Placed in ORWBG by Month, Year, and

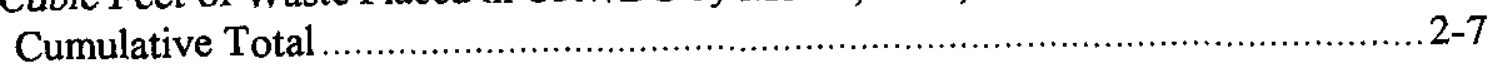

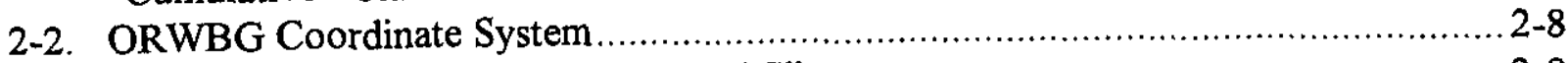

2-3. X, Y Locations for All COBRA Burial Slips ............................................... 2-9

2-4. X, Y Locations for All COBRA Burial Slips by Year .................................... 2-11

2-5. Corrected X, Y Locations for COBRA Records that Originally Plotted Outside of ORWBG Fence

2-6. X, Y Locations for COBRA Burial Codes (Left) and Type Codes (Right)

2-7. ORWBG $20 \mathrm{ft} \times 20 \mathrm{ft}$ Cell Locations Showing Number of Trench

Types (Burial Codes) Listed in COBRA for Burials Contained within

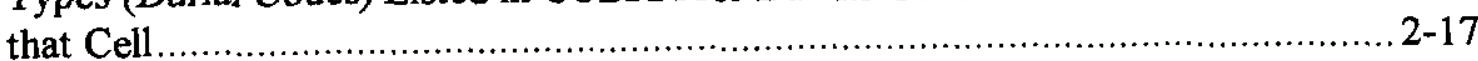

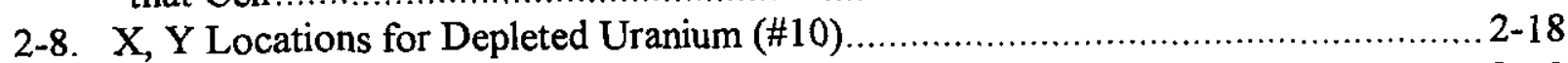

2-9. X, Y Locations for Enriched Uranium .................................................. 2-19

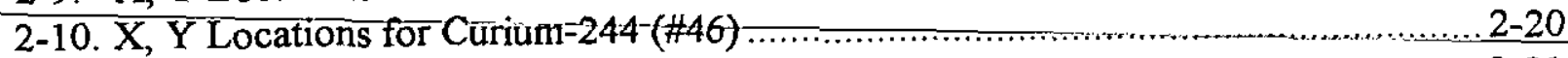

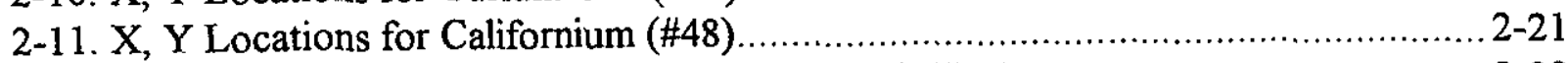

2-12. X, Y Locations for Plutonium (Weapons Grade) (\#50) ................................ 2-22

2-13. X, Y Locations for Uranium-233 (\#70) ............................................ 2-23

2-14. X, Y Locations for Normal Uranium (\#81) ............................................... 2-24

2-15. X, Y Locations for Neptunium-237 (\#82) .............................................. 2-25

2-16. X, Y Locations for Plutonium-238 (\#83) ................................................ 2-26

2-17. X, Y Locations for Deuterium (\#86) .................................................. 2-27

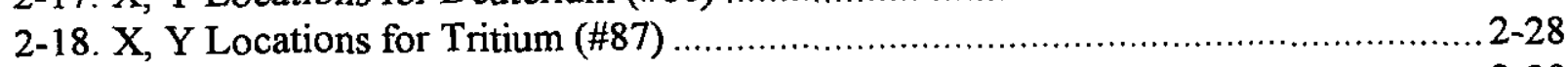

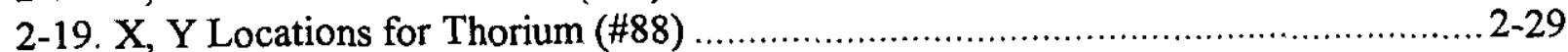

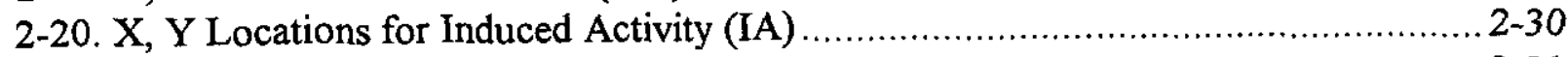

2-21. X, Y Locations for Fission Products (FP) ….......................................... 2-31

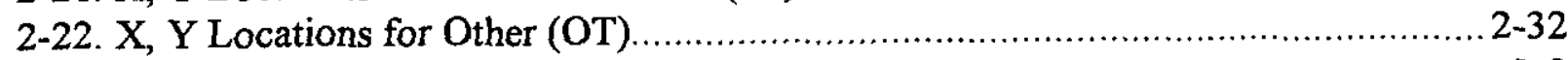

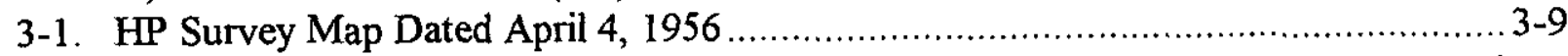

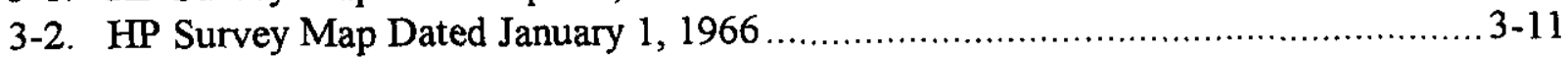

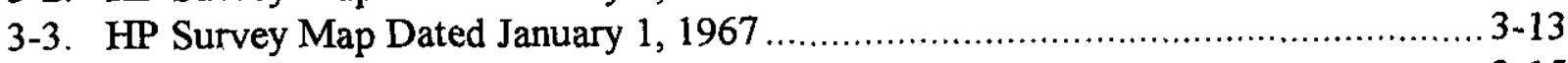

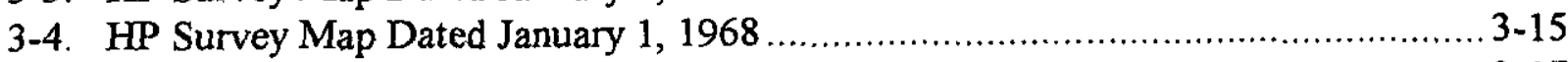

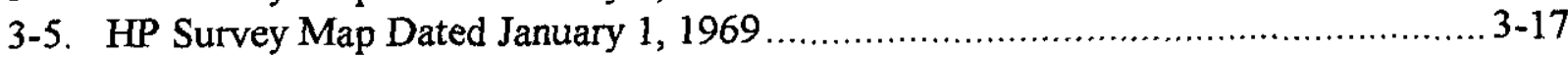

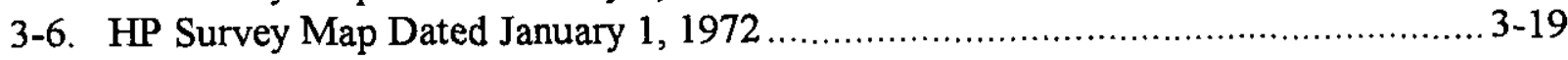




\section{LIST OF FIGURES (Continued)}

4-1. Examples of Active Low Level Radioactive Waste Trenches at the ORWBG

4-2. Burial of Contaminated Equipment

4-3. Transport Box for "Jumpers" (Canyon Piping), whose Contents Would be Dumped Via Crane into a Trench ....

4-4. H-Canyon "Frame" Being Packaged in Burial Box for Shipment and Disposal in ORWBG, Likely in an Equipment Trench

4-5. Equipment, Likely Contaminated, Awaiting Disposal.

4-6. Burial of Concrete Culverts Probably Containing TRU Waste

4-7. Worker Placing Mastic Onto Concrete Culvert that Contains FB-Line $\mathrm{Pu}$ Metal Production Waste, with Drums Containing 10-20 gram Quantities of Pu-239

4-8. Pouring Concrete Over/Around Drums Containing Pu TRU Waste

4-9. Stacked Drums of Soil from the Spanish Accident Being Placed into Trench

4-10. Arrival of Contaminated Waste Water from Greenland Accident at ORWBG

4-11. X, Y Locations for Offsite Burials (Building Code = "999")

4-12. Placing Boxed (Wooden) Mound Waste (Probably Containing Tritium) into Concrete Culvert.

4-13. Burial of Offsite(?) Waste Packaged in a Variety of Containers 


\section{LIST OF TABLES}

ES-1. COI Summary

ES-4

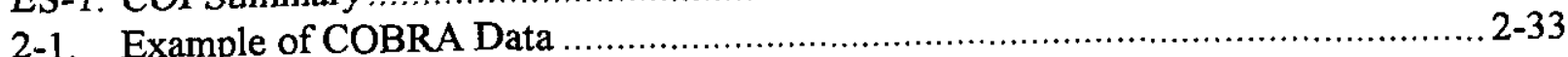

2-2. Summary Statistics for ORWBG Burial and Type Codes ..................................... 2-34

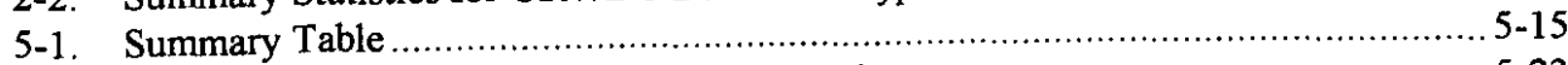

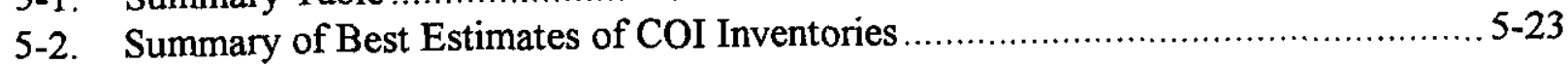




\section{LIST OF ACRONYMS}

\begin{tabular}{|c|c|}
\hline AEC & Atomic Energy Commission \\
\hline $\mathrm{BGC}$ & Burial Ground Complex \\
\hline BTEX & Benzene, Toluene, Ethyl Benzene, and the Xylenes \\
\hline $\mathrm{C}$ & Carbon \\
\hline $\mathrm{c} / \mathrm{m} / \mathrm{g}$ & Counts per minute per gram \\
\hline $\mathrm{Cd}$ & Cadmium \\
\hline CERCLA & $\begin{array}{l}\text { Comprehensive Environmental Response, Compensation, and Liability } \\
\text { Act of } 1980\end{array}$ \\
\hline $\mathrm{Ci}$ & Curies \\
\hline $\mathrm{cm}$ & Centimeters \\
\hline COBRA & Computerized Burial Record Analysis \\
\hline COI & Constituent of Interest \\
\hline Co & Cobalt \\
\hline Cs & Cesium \\
\hline DOD & Department of Defense \\
\hline DOE & Department of Energy \\
\hline DPSOP & duPont Standard Operating Procedure (adopted by WSRC) \\
\hline DTPA & Diethylene Triamine Pentaacetic Acid \\
\hline DWPF & Defense Waste Processing Facility \\
\hline EDTA & Ethylene Diaminetetraacetic Acid \\
\hline $\mathrm{ft}$ & Feet \\
\hline $\mathrm{g}$ & Grams \\
\hline GIMS & Geochemical Information Management System \\
\hline GPR & Ground Penetrating Radar \\
\hline $\mathrm{H}-3$ & Tritium \\
\hline HEPA & High Efficiency Particulate Air \\
\hline $\mathrm{Hg}$ & Mercury \\
\hline $\mathrm{HM}$ & H Modified Purex \\
\hline $\mathrm{HNu}$ & Trace Gas Analyzer \\
\hline HP & Health Physics \\
\hline${ }^{1} \mathrm{H}$ & Hydrogen \\
\hline${ }^{2} \mathrm{H}$ & Deuterium \\
\hline $\mathbf{I}$ & Iodine \\
\hline ICRP & International Commission on Radiation Protection \\
\hline $\mathrm{kg}$ & Kilogram \\
\hline $\mathrm{m}$ & Meters \\
\hline $\mathrm{mR} / \mathrm{hr}$ & Millirem/hour \\
\hline $\mathrm{Np}$ & Neptunium \\
\hline OBG & Old Burial Ground \\
\hline ORWBG & Old Radioactive Waste Burial Ground \\
\hline
\end{tabular}




\section{LIST OF ACRONYMS (Continued)}

\begin{tabular}{ll} 
OST & Old Solvent Tank \\
Pb & Lead \\
PCE & Perchloroethene (tetrachloroethylene) \\
ppb & Parts Per Billion \\
ppbv & Parts Per Billion by Volume \\
ppm & Parts Per Million \\
PUREX & Plutonium-Uranium Extraction \\
Pu & Plutonium \\
RCRA & Resource Conservation and Recovery Act \\
RFI/RI & RCRA Facility Investigation/Remedial Investigation \\
SAIC & Science Applications International Corporation \\
Sr & Strontium \\
SRS & Savannah River Site \\
SRTC & Savannah River Technology Center \\
SWDF & Solid Waste Disposal Facility \\
TBP & Tri-n-butyl phosphate \\
TCE & Trichloroethylene \\
TCLP & Toxicity Characteristic Leaching Procedure \\
Tc & Technetium- \\
TRU & Transuranic \\
ug/L & $\quad$ Micrograms per liter - \\
U & Uranium \\
VOC & Volatile Organic Compound \\
WSRC & Westinghouse Savannah River Company \\
Yr & Year \\
\hline
\end{tabular}




\section{EXECUTIVE SUMMARY}

\section{Background}

The Old Radioactive Waste Burial Ground (ORWBG) (643-E) occupies approximately 76 acres and is located within the General Separations Area in the central portion of the Savannah River Site (SRS). The ORWBG comprises a disposal area for solid radioactive waste produced at SRS, as well as shipments from other U.S. Department of Energy and Department of Defense facilities such as Charleston Naval Shipyard, Mound Laboratory, Miamisburg, Ohio, and General Electric Pinellas Plant in Pinellas Florida. Most of the wastes in the ORWBG originated from SRS operations; wastes from off-SRS sources contribute only about 0.5 percent of the total inventory by volume. Most wastes disposed in the ORWBG were placed in earthen trenches.

Waste was disposed at the ORWBG from 1952 until 1972, when the majority of waste disposal operations were moved to an adjacent area. During 1973 and 1974, small quantities of waste (primarily in retrievable form) were placed in the ORWBG. The ORWBG area was also used for storage of contaminated equipment. The ORWBG contained several related facilities and operations, including the following: 22 underground solvent storage tanks, two areas for the incineration of organic solvents, and a sandblasting facility for decontaminating equipment. The sandblasting facility was located near the north-central perimeter of the ORWBG and appears on HP maps dated from 1966 through 1972. The maps indicate a "sand blast pad" adjacent to a "sand blast basin", which probably received run-off from the facility. Photographs of the sandblasting facility in operation exist, but additional details about the procedures and practices or disposition of waste generated by this facility are not available.

\section{Source Term Investigation}

This study is designed to support the Resource Conservation and Recovery Act Facility Investigation/Remedial Investigation process by expanding and refining the current understanding of the ORWBG disposal history. The findings of a detailed literature review and evaluation were integrated with available aerial photographs, construction drawings, health physics burial maps, the computerized burial record analysis (COBRA) database, and interviews with SRS staff. 
Significant findings regarding burial history, trench type and waste characteristics include the following:

- Approximately 7,125,000 cubic feet of waste was placed in the ORWBG from 1952 to 1974. From 1961 to 1971 , monthly waste volumes typically ranged from 25,000 to 50,000 cubic feet.

- Job control waste is the largest single waste type, representing approximately 90 percent of total ORWBG waste volume. A very high percentage of the job control waste was buried in low-level beta-gamma trenches. Irradiated scrap metal is the second largest waste type, representing about 7 percent of the total waste volume. Virtually all of the irradiated scrap metal is in high-level beta-gamma trenches. The remaining 3 percent includes a wide variety of wastes such as natural and man-made radioactive materials, capital equipment, and absorbed solvents and oils.

- The ORWBG is segregated into three areas: (1) the original 35-acre central portion of the ORWBG that was opened in 1952 and filled by the early 1960s; (2) a 15-acre eastern expansion that was opened around 1961 and closed in 1972; and (3) a 26-acre western expansion that was opened in 1961 and closed in 1974.

- The ORWBG disposal trenches can be grouped into several general waste categories including the following: low-level, high-level, jumpers and equipment, B-Line, scrap metal, encapsulated plutonium, storage, and special/classified burials. Solvent tanks and associated solvent burning pans and ash trenches define an additional category. A miscellaneous category is also established to cover those trenches and disposals that do not fit any of these categories.

- Individual trenches and/or active portions of trenches can be tracked through time, with moderately good agreement between burial locations and trench boundaries. In the eastern and western portions of the ORWBG, there are generally good correlations between the trench locations and burial locations. However, it appears that it was a common practice to list the same coordinates for all burials that took place in a specific trench area on a given day or during a given week. This often results in a high number of burials listed at one trench cell and few or no burials in the adjacent trench cells within the opened trench area. Therefore, the accuracy of individual burial locations is \pm 40 to 60 feet. 
- The burial locations included in the COBRA database cover only part of the operational life of the ORWBG; no coordinate information is available prior to 1961 . The absence of burial locations in the central portion of the ORWBG suggests that, although the volumes associated with these earlier disposals are listed in COBRA, their coordinates are not. In addition, this is supported by aerial photographs, which indicated that pre-1961 burials exist in the central part of the ORWBG.

- In general, burial containers (retrievable transuranic waste) and concrete pours were well organized within the ORWBG.

- Classified waste was most commonly buried in trenches and boreholes designated as "special projects". This term generally indicates that some of the components of a burial were regarded as classified information at the time of disposal. Some aspects of these "special" burials remain classified.

\section{Constituents of Interest}

Detailed studies were conducted to determine the inventory of Constituents of Interest (COIs). COIs were defined on the basis of previous sampling (soil and groundwater), review of COBRA, process history, and previous regulatory and historical documentation. As a result, the following COIs were identified for this study: cadmium, lead, mercury, volatile organic compounds, tritium, cesium-137, plutonium-238, plutonium-239, strontium-90, uranium-235, uranium-238, carbon-14, cobalt-60, technetium-99, iodine-129 and neptunium237. Table ES-1 provides summary information regarding inventory estimates, burial locations, waste form, and origin for each of the COIs. 
Table ES-1. COI Summary

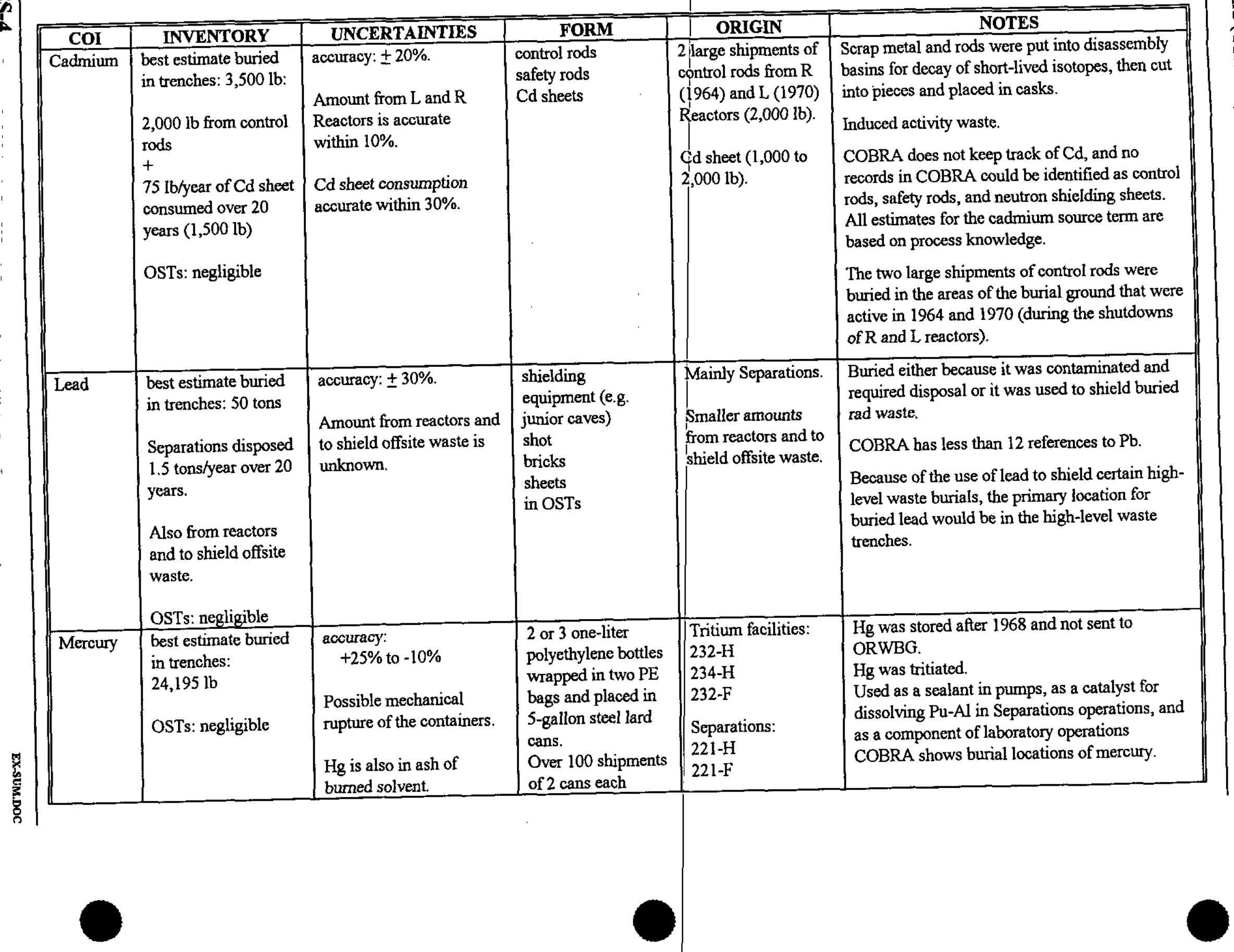


Table ES-1. COI Summary (Continued)

\begin{tabular}{|c|c|c|c|c|c|}
\hline $\mathrm{COI}$ & INVENTORY & UNCERTAINTIES & FORM & ORIGIN & NOTES \\
\hline VOCs & $\begin{array}{l}\text { buried in trenches: } \\
7100 \mathrm{~kg} \text { toluene } \\
7100 \mathrm{~kg} \\
\text { trimethylbenzene } \\
12,000 \mathrm{~kg} \text { xylene }\end{array}$ & $\begin{array}{l}\text { Volatilization } \\
\text { Migration }\end{array}$ & $\begin{array}{l}\text { Scintillation solutions } \\
\text { and tritiated pump oils } \\
\text { are drummed. } \\
\text { Liquid scintillation } \\
\text { solution wastes are in } \\
\text { small polyethylene vials } \\
\text { which, from 1965, were } \\
\text { packed with oil-dry in } \\
55 \text {-gallon drums and } \\
\text { buried. } \\
\text { Waste oils were both } \\
\text { stored in the OSTs and } \\
\text { absorbed on an oil-dry } \\
\text { compound, placed in } \\
\text { drums, and buried as } \\
\text { solidified waste. }\end{array}$ & $\begin{array}{l}\text { Drummed scintillation } \\
\text { solutions } \\
\text { Waste oils in absorbent } \\
\text { materials (from reactor and } \\
\text { tritium facilities including } \\
\text { pump oils, cutting oils, and } \\
\text { die oils) } \\
\text { Residue from } \\
\text { decontamination operations } \\
\text { prior to waste burial }\end{array}$ & $\begin{array}{l}\text { Shipments of organics are not documented in } \\
\text { the COBRA database per se, though there } \\
\text { are some indirect references to possible VOC } \\
\text { sources. No quantity or specific VOC } \\
\text { constituent information is contained in any } \\
\text { COBRA record. } \\
\text { VOCs associated with liquid scintillation } \\
\text { solutions and waste oils are present in the } \\
\text { trenches of the ORWBG. } \\
\text { The OSTs not only contained waste PUREX } \\
\text { solvent but also contained contaminated } \\
\text { waste solvents of other sorts. }\end{array}$ \\
\hline & $\begin{array}{l}\text { Residue in the OSTs } \\
\text { (S-1 through S-22): } \\
4056 \text { gal organic } \\
\text { phase }+3483 \mathrm{gal} \\
\text { aqueous phase = } \\
7539 \text { gallons } \\
\text { Mason } 1996 \\
\text { provides analytical } \\
\text { data of vapor phase } \\
\text { (Table 2-5). }\end{array}$ & $\begin{array}{l}\text { OST tank dimensions } \\
\text { and inclinations }\end{array}$ & $\begin{array}{l}\text { VOCs in OSTs are in } \\
\text { residue of spent } \\
\text { PUREX solvent and } \\
\text { associated degradation } \\
\text { products. }\end{array}$ & $\begin{array}{l}\text { Spent PUREX solvent was } \\
\text { generated in Separations in a } \\
\text { chemical process for } \\
\text { removing plutonium and } \\
\text { uranium from spent rods. } \\
\text { Plant records show that from } \\
1956 \text { through } 1964,88 \% \text { of } \\
\text { the waste solvent receipts } \\
\text { were from F-Area. From } \\
1965 \text { to } 1972,86 \% \text { of the } \\
\text { waste solvent was generated } \\
\text { in H-Area. }\end{array}$ & $\begin{array}{l}\text { Most PUREX solvent was transferred to } 643- \\
7 \mathrm{G} \text { around } 1980 \text {. The OSTs are empty except } \\
\text { for unpumpable heel, which contains some } \\
\text { VOCs in vapor, and organic phases. Minor } \\
\text { amounts of VOCs are present in the aqueous } \\
\text { phase. The amount of VOCs in the sludge } \\
\text { solids phases are negligible. }\end{array}$ \\
\hline
\end{tabular}




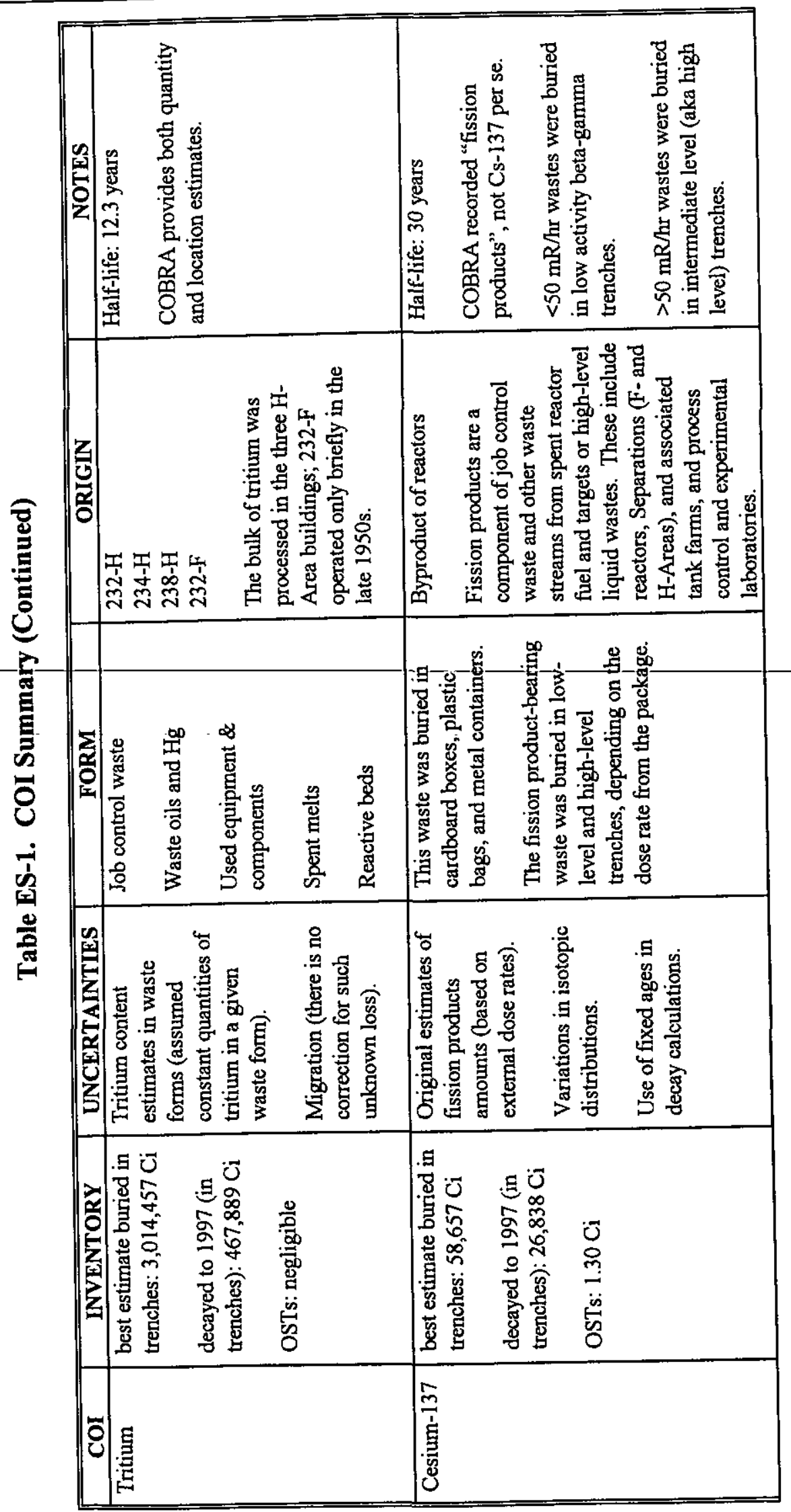




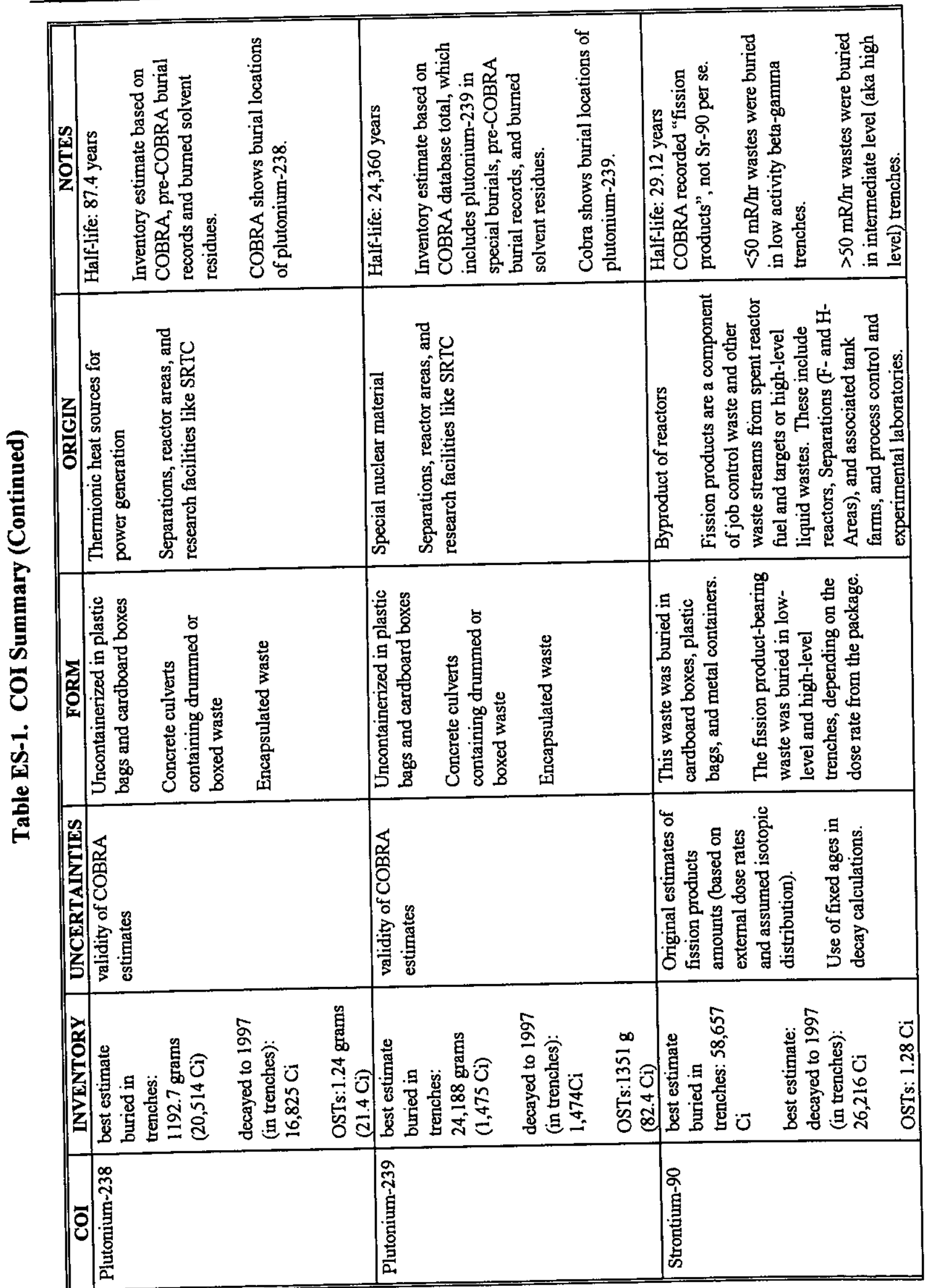


Table ES-1. COI Summary (Continued)

\begin{tabular}{|c|c|c|c|c|c|}
\hline $\mathrm{COI}$ & INVENTORY & UNCERTAINTIES & FORM & ORIGIN & NOTES \\
\hline Uranium-235 & $\begin{array}{l}\text { best estimate } \\
\text { buried in } \\
\text { trenches: } 273,185 \\
\text { grams } \\
(0.6 \mathrm{Ci}) \\
\text { OSTs: } 0.11 \mathrm{Ci}\end{array}$ & $\begin{array}{l}\text { Variable isotopic } \\
\text { ratios of enriched U- } \\
235\end{array}$ & $\begin{array}{l}\text { Generally, U-235 bearing } \\
\text { wastes, primarily scrap } \\
\text { from fuel fabrication } \\
\text { operations, were buried in } \\
\text { alpha activity waste } \\
\text { trenches, without any } \\
\text { special containerization. } \\
\text { The waste would have been } \\
\text { buried in cardboard boxes, } \\
\text { plastic bags, and possibly } \\
\text { metal containers. }\end{array}$ & $\begin{array}{l}\text { According to the COBRA } \\
\text { database, U-235, as enriched } \\
\text { uranium, was sent to the OBG } \\
\text { from M-Area, A-Area, F-Area, } \\
\text { H-Area, and from offsite } \\
\text { facilities. Normal, or natural, } \\
\text { uranium was sent to the OBG } \\
\text { from M-Area, A-Area, H-Area, } \\
\text { and F-Area. }\end{array}$ & $\begin{array}{l}\text { Half-life: } 7.1 \times 10^{8} \text { years } \\
\text { natural U: } 0.72 \% \text { U-235 } \\
\text { enriched U: } 93 \% \text { U-235 } \\
\text { COBRA shows the burial } \\
\text { locations of enriched and normal } \\
\text { uranium. } \\
\text { OSTs estimate is based on } \\
\text { assigning U-235 an arbitrary } \\
\text { activity fraction of } 0.25 \text { percent } \\
\text { for tanks that had indicated } \\
\text { uranium content. }\end{array}$ \\
\hline Uranium-238 & $\begin{array}{l}\text { best estimate } \\
\text { buried in } \\
\text { trenches: } \\
44,233 \mathrm{~kg} \\
(14.8 \mathrm{Ci}) \\
\text { OSTs: } 1.1 \mathrm{Ci}\end{array}$ & $\begin{array}{l}\text { COBRA error of } \mathrm{Ci} \\
\text { units (should be } \mathrm{kg} \text { ). } \\
\text { OST value is } \\
\text { arbitrary, but based } \\
\text { on actual alpha } \\
\text { activity in the tanks }\end{array}$ & $\begin{array}{l}\text { It is likely that U- } 238 \\
\text { bearing wastes were } \\
\text { disposed of in alpha } \\
\text { activity waste trenches, } \\
\text { without any special } \\
\text { containerization. The } \\
\text { waste would have been } \\
\text { buried in cardboard boxes, } \\
\text { plastic bags, and possibly } \\
\text { metal containers. }\end{array}$ & $\begin{array}{l}\text { According to the COBRA } \\
\text { database, U-238, as depleted } \\
\text { uranium, was sent to the OBG } \\
\text { from M-Area, A-Area, F-Area, } \\
\text { H-Area, G-Area and from off-site } \\
\text { facilities. } \\
\text { Normal, or natural, uranium was } \\
\text { sent to the OBG from M-Area, } \\
\text { A-Area, H-Area, and F-Area. } \\
\text { Enriched uranium was sent to the } \\
\text { OBG from M-Area, A-Area, F- } \\
\text { Area, H-Area, and from offsite } \\
\text { facilities. }\end{array}$ & $\begin{array}{l}\text { Half-life: } 4.51 \times 10^{9} \text { years } \\
\text { natural U: } 99.3 \% \text { U-238 } \\
\text { depleted U: } 100 \% \text { U-238 } \\
\text { enriched U: } 7 \% \text { U-238 } \\
\text { COBRA shows the burial } \\
\text { locations of enriched, normal, } \\
\text { and depleted uranium. } \\
\text { OSTs estimate is based on } \\
\text { assigning U-238 an arbitrary } \\
\text { activity fraction of } 2.5 \text { percent } \\
\text { for tanks that had indicated } \\
\text { uranium content. }\end{array}$ \\
\hline
\end{tabular}




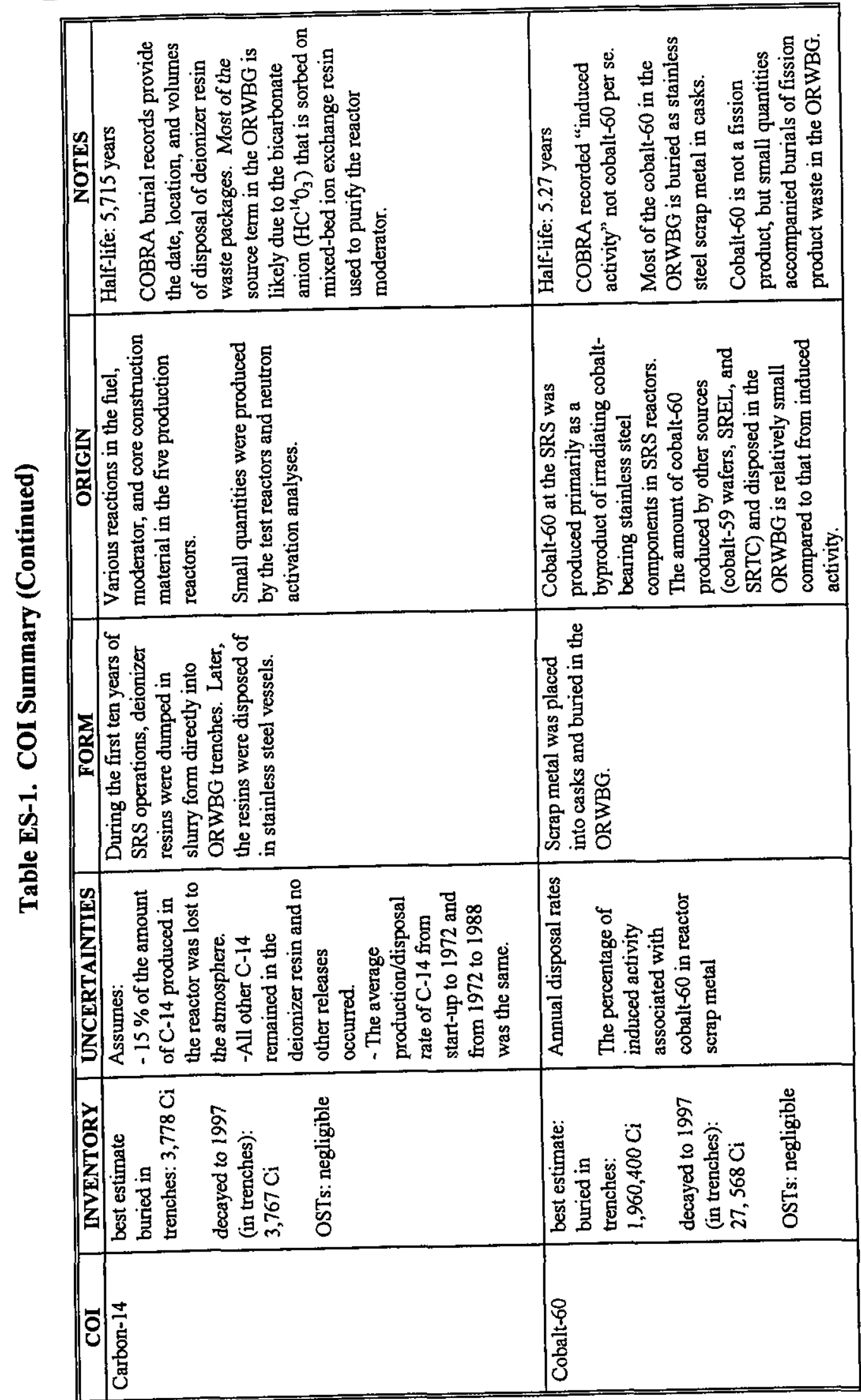




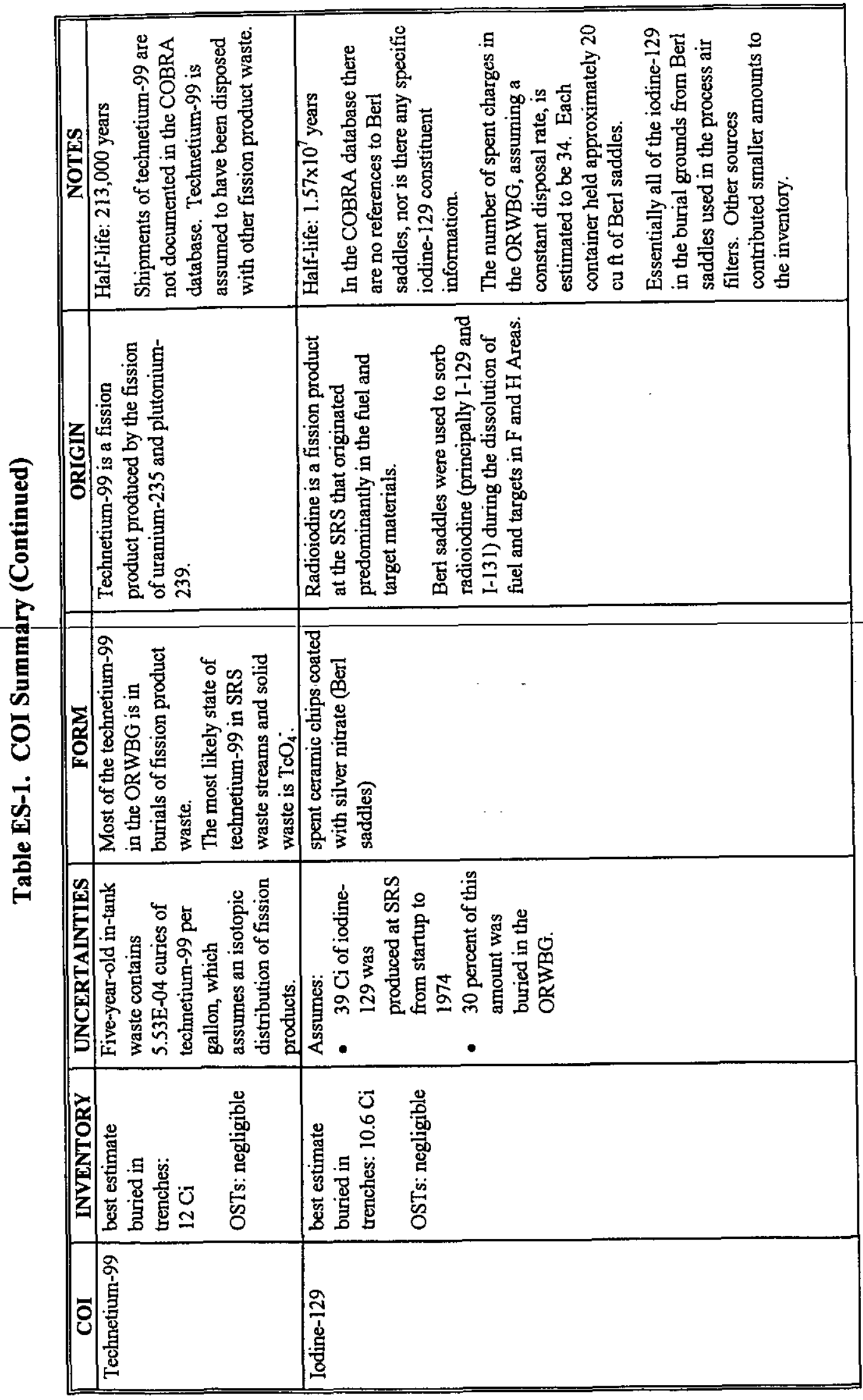


Table ES-1. COI Summary (Continued)

\begin{tabular}{|c|c|c|c|c|c|}
\hline COI & INVENTORY & UNCERTAINTIES & FORM & ORIGIN & NOTES \\
\hline Neptunium-237 & $\begin{array}{l}\text { best estimate: } \\
1.99 \mathrm{Ci} \text { (originally } \\
\text { buried in the trenches) } \\
\text { The amount of } \\
\text { ingrown neptunium- } \\
237 \text { is: } \\
0.004 \mathrm{Ci} \text { (in trenches) } \\
\text { OSTs: negligible }\end{array}$ & classified burials & $\begin{array}{l}\text { Uncontained in plastic } \\
\text { bags and cardboard boxes. } \\
\text { Concrete culverts } \\
\text { containing drummed or } \\
\text { boxed waste. } \\
\text { Encapsulated waste. } \\
\text { Waste potentially } \\
\text { contaminated with } \\
\text { neptunium-237 included } \\
\text { cabinet waste originating } \\
\text { from } 221-H B L, \text { laboratory } \\
\text { glove boxes and radio } \\
\text { benches, waste originating } \\
\text { from } 235-F, \text { waste } \\
\text { effluents from processing } \\
\text { in the Separation areas } \\
\text { and PUREX waste in } \\
\text { storage tanks ( } 241-F \text { and } \\
\text { H-Areas Tank Farms), } \\
\text { and in the OSTs in the } \\
\text { ORWBG. }\end{array}$ & $\begin{array}{l}\text { Neptunium-237 is produced } \\
\text { as a byproduct during the fuel } \\
\text { cycle. } \\
\text { It is produced by two primary } \\
\text { sources at SRS: } \\
\text { - alpha decay of } \\
\text { americium-24l that is } \\
\text { produced by the beta } \\
\text { decay of plutonium- } 241 \\
\text { in weapons-grade } \\
\text { plutonium } \\
\text { via a side reaction during } \\
\text { the irradiation of } \\
\text { uranium- } 238 \text { targets to } \\
\text { eventually produce } \\
\text { plutonium-239 } \\
\text { Neptunium-237 is also the } \\
\text { target material used to } \\
\text { produce plutonium-238 in } \\
\text { SRS reactors. }\end{array}$ & $\begin{array}{l}\text { Half-life: } 2.14 \times 10^{6} \text { years } \\
\text { The COBRA database provides } \\
\text { both quantity and location } \\
\text { estimates for neptunium-237 } \\
\text { burials in the ORWBG. }\end{array}$ \\
\hline
\end{tabular}


(This page intentionally left blank) 


\subsection{INTRODUCTION}

The Old Radioactive Waste Burial Ground (ORWBG) (643-E) occupies approximately 76 acres and is located within the General Separations Area in the central portion of the Savannah River Site (SRS) (Figure 1-1). It is part of the Burial Ground Complex, which includes the ORWBG and other operable units such as the Mixed Waste Management Facility, the Low Level Radioactive Waste Disposal Facility, Solvent Tanks S1-S22, Solvent Tanks S23-S30, and Solvent Tank 32.

\subsection{Description of Unit}

The ORWBG is a disposal area approximately 3,700 feet long, 1,100 feet wide on the west end and 700 feet wide on the east end. It is surrounded by an 8-foot-high cyclone fence and is situated between Road E and the F-Area railroad. A paved road leads to the entrance, and unimproved dirt roads inside the fence provide access to old burial sites. As part of an interim action, a soil cover is presently being placed over much of the ORWBG to reduce infiltration to the groundwater.

The ORWBG is designated as $643-\mathrm{E}$. The facility was formerly designated $643-\mathrm{G}$ when $\mathrm{G}$ was the suffix for outside facilities. The facility numbers are used interchangeably in the literature.

Waste was disposed at the ORWBG from 1952 until 1972, when the site was essentially filled and the majority of waste disposal operations shifted to the New Burial Ground (6437E). The New Burial Ground (643-7E, formerly 643-7G) is an adjacent area to the north. During 1973 and 1974, small quantities of waste (primarily in retrievable form) were placed in the ORWBG. Twenty-two underground storage tanks in the ORWBG facility were used to store organic solvents.

The ORWBG area was also used for storage of contaminated equipment. In addition, the ORWBG contained several facilities and operations in the area that were not directly related to the burial of solid waste. These included two areas for the incineration of organic solvents, a sandblasting facility for decontaminating equipment, and some repair facilities.

The ORWBG comprised a disposal area for solid radioactive waste produced at SRS, as well as shipments from other U.S. Department of Energy (DOE) and Department of Defense (DOD) facilities. It was divided into sections to accommodate disposal of various levels and types of radioactive waste materials. These materials included transuranic (TRU) waste, 
low-level waste, and intermediate-level waste generated at SRS and waste generated elsewhere. Examples of the materials disposed of at the ORWBG include the following:

- Incidental waste from laboratory and production operations, including small equipment, spent air filters, clothes, analytical waste, decontamination residues, plastic sheeting, gloves, soil, and construction debris

- Contaminated waste including obsolete or failed tanks, pipes, jumpers, and other process equipment from Separations; lead, as shielding, equipment, shot, bricks, and lead sheets; reactor hardware fuel components and housings not containing irradiated fuel; and spent deionizer resins

- Spent lithium-aluminum targets (the target alloy waste remaining after tritium has been extracted)

- Contaminated process oil from pumps in the tritium facilities and reactor areas (before bulk_storage was started, the oil was placed in drums containing an absorbent material and buried)

- Mercury from gas pumps in the tritium facilities (before 1968, radioactively contaminated mercury was buried in 1-liter polyethylene bottles placed inside two polyethylene bags that were placed in a 0.7 -cubic foot steel can)

- Cadmium (associated with control and safety rods and neutron shielding sheets)

- Scintillation fluid (a mixture of organic solvents used to quantify beta and/or alpha emitters in environmental and bioassay samples)

- Shipments from offsite, such as radioactive waste from military hardware

- Spent Plutonium-Uranium Extraction (PUREX) solvent, waste oils, and associated degradation products in the 22 Old Solvent Tanks (OSTs)

- Waste oils in absorbent materials

- Residue from decontamination operations at the ORWBG prior to waste burial 
Most wastes were placed directly in earthen trenches. The trenches within the ORWBG were generally excavated 20 feet wide, 20 feet deep, and up to 700 feet long. The trenches were filled with the waste materials, which were then covered with 4 feet or more of soil to reduce surface radiation to less than $6 \mathrm{mR} / \mathrm{hr}$.

\subsection{Source Term Investigations}

This study is designed to support the Resource Conservation and Recovery Act (RCRA) Facility Investigation/Remedial Investigation process by expanding and refining the current understanding of the ORWBG. As a first step, a detailed evaluation of over 300 key ORWBG documents was completed through an exhaustive literature search. These findings were integrated with available aerial photographs, construction drawings, burial maps prepared by Health Physics staff, the Computerized Burial Record analysis (COBRA) database, and interviews with current and previous SRS staff to refine information regarding the following: (1) waste volumes and their sources, (2) the location and time of burials, (3) waste type, form and leachability, (4) trench type and disposal characteristics, and (5) the variety of contamination. The COBRA database is described in Section 2. In addition, special emphasis was placed on reconstructing the ORWBG burial history (Section 3), identifying trench types (Section 4), and developing inventory estimates and leachability information for the 16 Constituents of Interest (COIs) (Section 5 and Appendices A-P).

COIs for the ORWBG source term characterization were determined by integrating past characterization and monitoring (soil gas, groundwater monitoring, and subsurface surveys) with the COBRA database, process history evaluation, and historical documentation. All existing data were reviewed during this process. COIs include constituents that are mobile, hazardous, have a large inventory, and/or have a long half-life. The COIs at the ORWBG are cadmium, lead, mercury, volatile organic compounds (VOCs), tritium, cesium-137, plutonium-238, plutonium-239, strontium-90, uranium-235, uranium-238, carbon-14, cobalt60 , technetium-99, iodine-129 and neptunium-237.

Appendixes A-P present detailed discussions regarding each of the COIs, including background information, estimates and assumptions used to develop inventory, distribution, waste form and leachability evaluation. The appendices present a detailed review of background information about each COI, including previously cited inventory estimates. It should be noted, however, that presentation of results of previous studies has resulted in some apparent discrepancies in historical details or the way inventories are calculated. For example, different reports cite slightly different operational lifetimes of the ORWBG. This is 
due to the fact that the disposal rate increased slowly in the early years of SRS operations, and the rate decreased in the late 1960 s to early 1970 s as the adjacent $643-7 \mathrm{G}$ facility opened. The inventory estimates in this report are based on a 20-year operational lifetime (1953-1972, inclusive), unless stated otherwise. Although SRS opened in 1952, the first production-related reactor did not reach criticality until 1953, and therefore, significant amounts of radionuclides were not buried before this time. 


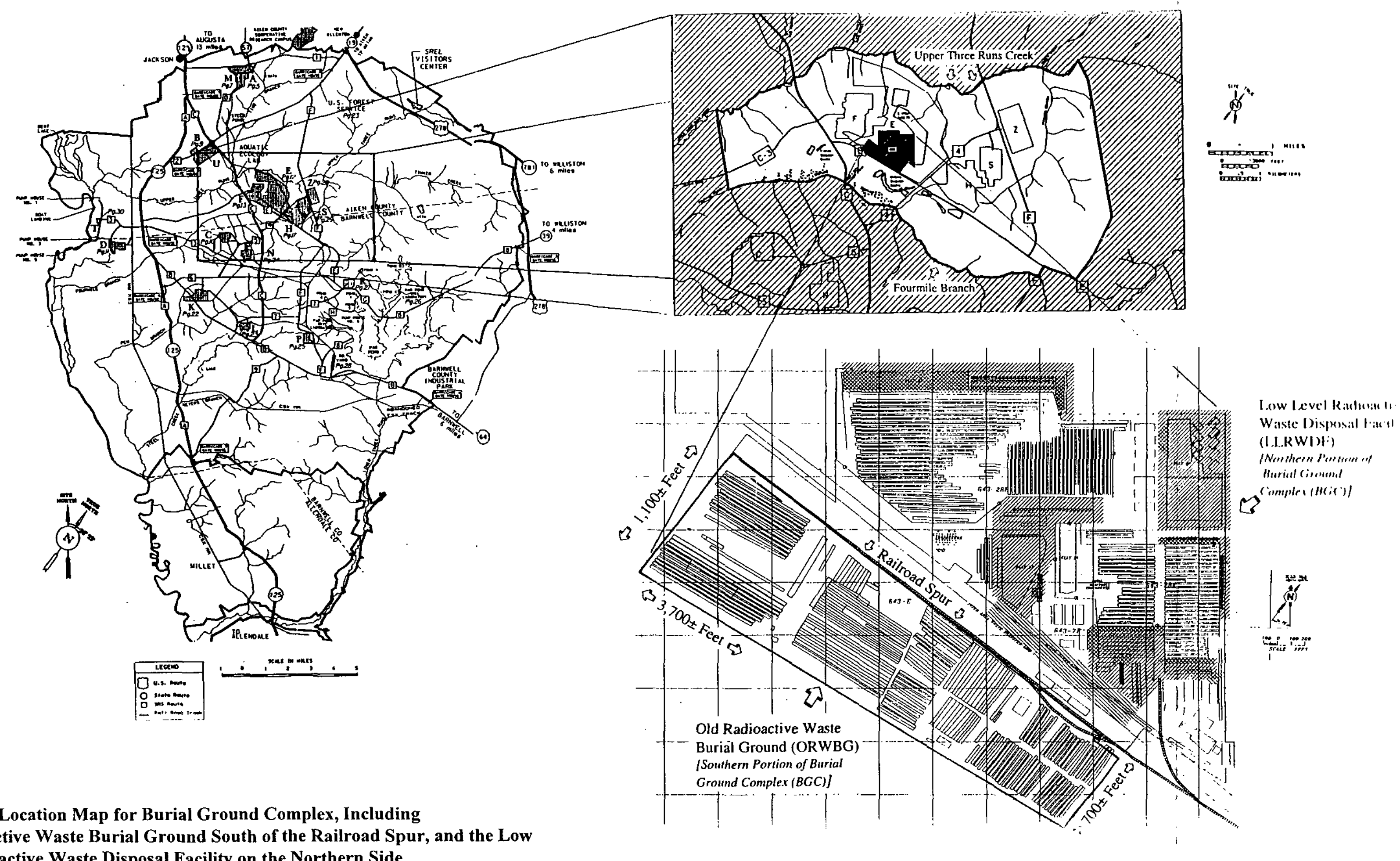

Figure 1-1. Location Map for Burial Ground Complex, Including
Old Radioactive Waste Burial Ground South of the Railroad Spur,

Old Radioactive Waste Burial Ground South of the Railroad Spur, and the Low

Level Radioactive Waste Disposal Facility on the Northern Side 


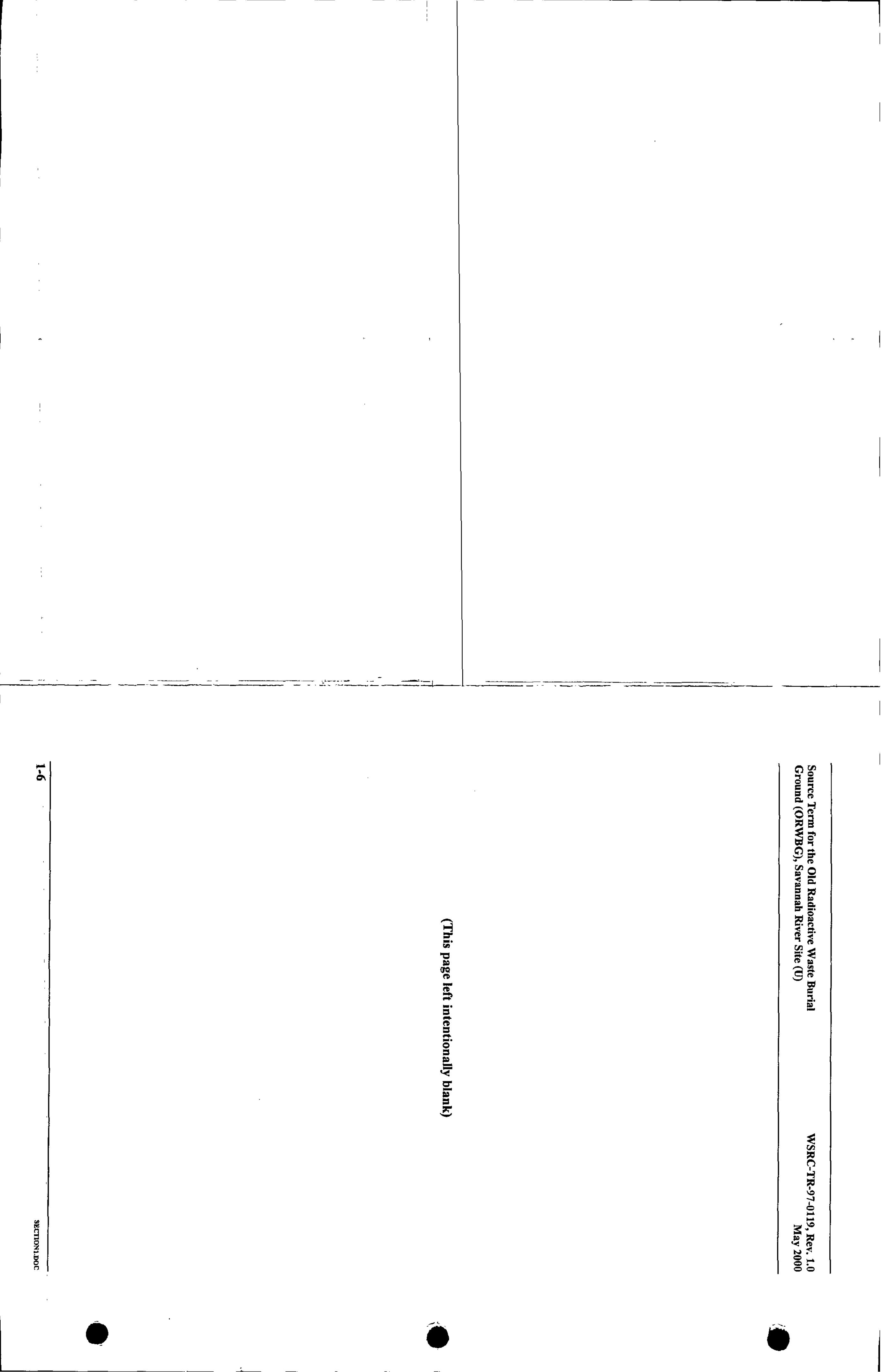




\subsection{COMPUTERIZED BURIAL RECORD ANALYSIS (COBRA)}

The most extensive source of information on the ORWBG is the COBRA database, which contains records of waste disposed from 1952 through 1974. It was compiled beginning in the first quarter of 1961, with historical data entered for the years from startup to 1960.

The COBRA database is based on information contained on "Radioactive Solid Waste Burial Ground Record" forms, also referred to as burial slips, that were filled out for each waste shipment. The database contains only information from these forms. It should be emphasized that radiological waste was the primary focus of information entered on the burial slips. Other materials that may now be of concern (e.g., nonradiological metals such as mercury or cadmium, or volatile compounds) were not generally listed on the burial slips and occur in COBRA as incidental comments.

This study used COBRA to provide information regarding the following: (1) waste volumes and their source of origin, (2) the location and time of burials, (3) waste type and form, (4) trench type and disposal characteristics, and (6) the variety of contamination. Using process knowledge as a guide, searches and sorts were performed on the COBRA database to develop insights on the general characteristics of the ORWBG and on the 16 COIs that are summarized in Section 5 and discussed in detail in Appendices A-P. A general overview of COBRA and representative plots and tables are provided below. Figure $1-1$ in the $R F I / R I$ Work Plan for the Burial Ground Complex (WSRC, 1994) was developed primarily from construction drawings of the ORWBG. With slight modifications, it serves as the underlying base for the plots presented in Section 2 and Appendices A-P of this study.

\subsection{Waste Volume and Origin}

All waste shipments to the ORWBG contained a volume estimate given in COBRA as cubic feet per burial/record (Table 2-1). COBRA records show that a total of $7,125,111$ cubic feet of waste was accepted at the ORWBG from 1952 to 1974 . Approximately 80 percent of the waste is reported to be combustible wastes. A plot showing waste volume by month, year, and cumulative total is presented in Figure 2-1. Most of the COBRA records that predate 1961 have "history correction" / "estimated data" given in the COBRA comment fields.

These records contain estimates of waste volume and waste type for many buildings/facilities that were active during this early period at SRS. The volume estimates per building/facility are typically the same from year to year, with an arbitrary assigned burial date of June 30 of 
each year. This accounts for the spikes in the monthly data curve for the years prior to 1961 (Figure 2-1).

The COBRA burial slips contain a numeric code (up to 3 digits) that indicates which building was the source of each individual waste shipment. These were used extensively in the detailed evaluation of COIs. There are a total of 270 unique building codes listed in COBRA. Nearly all of the building codes reflect the actual number of an SRS building (i.e., $773,221,105$, etc.). During the evaluation of COIs, SRS building identification codes were used in conjunction with SRS area codes to uniquely identify a given location as the waste source. These were then evaluated with respect to the process associated with the building/area to verify COI content and volume.

In addition to SRS wastes, the ORWBG also includes some offsite wastes. The building code "999" was assigned to these shipments. These offsite shipments comprise 141 burials which include waste from Mound Laboratory; Pinellas, Florida; General Electric; Sylvania Corning; Burlington, Iowa; and Miamisburg, Ohio. Offsite wastes total 37,978 cubic feet, about 0.5 percent of the total.

\subsection{Location and Time of Burials}

COBRA records are tied to a unique alpha-numeric grid system for locating each burial; the grid layout is presented in Figure 2-2. The ORWBG coordinate system consists of a series of 100 by 100 foot alpha-numeric cells, with the origin point $(0,0)$ in the upper left/northwest corner of the burial ground. Station numbers are used to identify locations within the grid. The 100 foot cell designations increase from west to east by whole number increments, and in a north to south direction with letter designations from " $\mathrm{A}$ " (at the origin) to row "K" (closest to E-Road). Each 100 foot cell has been subdivided into five 20 foot subcells using the following convention: $0.10=0$ feet, $0.20=20$ feet, $0.30=40$ feet, $0.40=60$ feet, and $0.50=80$ feet. In the east-west direction the maximum station value corresponds to 3,700 feet at the eastern fence line (station 38.10). It should be noted that each ORWBG coordinate pair corresponds with the upper left (northwest) corner of a 20 foot $\mathrm{x} 20$ foot subcell, which is the ultimate resolution of any burial location in the ORWBG (the actual resolution will be significantly poorer in most cases). For the purposes of plotting data in this report, the center of each 20 foot $\mathrm{x} 20$ foot subcell is used rather than the corner.

Figure 2-3 presents the-locations of all COBRA records (total number $=40,494$ ) for which coordinates are available. In the eastern and western portions of the ORWBG there is 
generally a good correlation between the trench locations and burial locations. Visually, it appears that there are fewer than 40,000 data points; however, this is due to the fact that often as many as 400 burials have the same given coordinate. Based on review of burial slips, it appears that it was a common practice to list the same coordinates for all the burials that took place in a specific trench area on a given day or during a given week. This often results in a high number of burials listed at one trench cell and little or none in the adjacent trench cells. Therefore, the location accuracy of individual burials is often \pm 40 to 60 feet. This uncertainty should be kept in mind when considering the location accuracy of individual burials.

Figure 2-4 presents burial locations by year for all COBRA records, and lists the number of records with and without valid coordinates. It should be stressed that burial coordinates were only available for waste placed after mid-to-late 1961. The absence of burial locations in the central portion of the ORWBG suggests that this portion of the ORWBG had already been filled by the early 1960s and was not active in later years.

A total of 53 records have coordinates that plot outside of the ORWBG fence. Review of burial slips found virtually all of these were associated with typographical errors (i.e., transposition of numbers resulting in coordinates plotting away from the ORWBG). Based on this review, a revised set of coordinates was determined for each of the 53 records. Figure 2-5 presents the revised locations and provides a listing of the associated burial slip numbers. During this investigation, no evidence was found to indicate that any radioactive burials took place outside of the existing boundaries of the ORWBG.

\subsection{Trench and Waste Type}

The COBRA database dedicated two codes to tracking: (1) the type of trench in which each waste shipment was buried, and (2) the broad waste type category for each shipment. These two codes are called "burial code" for trench type, and "type code" for waste category. Table 2-2 presents summary statistics in matrix form for each burial code and type code combination, including number of records, total waste volume, average burial volume and associated standard deviation, and maximum/minimum shipment volume. Figure 2-6 presents burial locations for COBRA trench types (left column of plots) and waste types (right column of plots). Figure 2-4 also presents burial locations at the ORWBG through time, with $x, y$ locations shown for all years for which there are data. 
As shown on Table 2-2, type code 1 (job control waste) is the largest single contributor to the ORWBG, representing approximately 90 percent of the total ORWBG waste volume. A large percentage of job control waste ( 86.5 percent) was buried in low-level beta-gamma trenches, which translates into 77.5 percent of the entire ORWBG waste volume. Of the remaining job control waste, 12.2 percent was placed in low-level alpha trenches, 0.72 percent in high-level beta-gamma trenches, 0.34 percent in potentially retrievable burial containers, and 0.21 percent in concrete pour locations.

Type code 2 (oil) is a somewhat misleading waste type category. Most of the waste in this category is not raw liquid oil, but is adsorbed oil in drums, oily rags, oil associated with tritium production, etc. The 42,083 cubic feet of waste in this category is approximately 0.6 percent of the total volume listed in COBRA for the entire ORWBG. Nearly all (99.6 percent) of this material was buried in low level beta gamma trenches, with the remainder (180 cubic feet) placed into low level alpha trenches.

Type code 3 (irradiated metal scrap) is the second largest contributor to the ORWBG, representing 6.8 percent of its total waste volume. Virtually all of the irradiated metal scrap is indicated in COBRA to have been sent to high-level beta-gamma trenches ( 99.2 percent).

The remaining metal scrap was separated by activity and buried in low-level beta-gamma trenches $(0.78$ percent), low-level alpha trenches ( 0.05 percent), or in potentially retrievable burial containers $(0.003$ percent).

Type code 4 (naturally radioactive materials) represents 2.2 percent volumetrically (153,765 cubic feet) of all waste buried at the ORWBG. COBRA records indicate that most (97.6 percent) type code 4 shipments were placed in low level beta gamma trenches. Subsidiary amounts were buried in low level alpha trenches ( 2.4 percent) and high-level beta-gamma trenches (0.006 percent).

COBRA records for type code 5 (capital equipment) indicate that 58,722 cubic feet of this type of waste was buried at the ORWBG, which is 0.8 percent of all ORWBG wastes. Most of the type code 5 waste was divided between low-level beta-gamma and high-level betagamma trenches, receiving 53.3 percent and 39.9 percent, respectively. Much smaller quantities of capital equipment were placed in low-level alpha trenches (6.6 percent) and concrete pours ( 0.2 percent). 
No COBRA records are listed for type code 6 (resin); nonetheless, a few records have the word "resin" in the description field \#1. For whatever reason, this category of waste was established, but never used.

A minute amount of waste in COBRA was placed into type code 7 (other). Only 12 records fall into this category, and all of them are listed as "history correction". They are mostly weapons grade plutonium wastes from F and A Areas; however, two of the records are the last given in COBRA (year $=1974$ ) and are offsite shipments from unspecified facilities. They total 12 cubic feet of waste.

COBRA records indicate that burials with different trench types (burial codes) were frequently placed closely together, often at the same 20 foot $\times 20$ foot grid coordinate. Figure 2-7 presents a plot showing each 20 foot $x 20$ foot grid location given in COBRA, and the number of trench types (burial codes) listed for that cell. The color scheme in this figure indicates the relative "purity" of trenches at the ORWBG, and the squares are drawn approximately to scale (i.e., each represents a 400 square foot area). As shown, only about 42 percent of the grid cell locations contain burials that were all assigned to the same trench type (i.e., only low-level beta-gamma waste, only high-level beta-gamma waste, only lowlevel alpha waste, etc.). Most (approximately 58 percent) of the 20 foot $\mathrm{x} 20$ foot grid locations in COBRA have burials that were assigned to more than one different trench type. This suggests that idealized trenches, such as low-level beta-gamma trenches, are few in number at the ORWBG.

\subsection{Variety of Contamination}

COBRA burial slips provide the opportunity to list the expected primary radiological contaminant, which appears as a two-digit alpha/numeric code in the database. A secondary contaminant type can also be given. Figures $2-8$ to $2-22$ show the burial locations at the ORWBG for each variety of contamination.

\subsection{Summary of COBRA Observations}

The COBRA database is a valuable aid in determining the operational history of the ORWBG and developing reasonably accurate source term calculations for the radiological contaminants. It is also valuable in locating waste from specific buildings, especially after 1961. Several additional observations can be made: 
(1) From 1961 to 1971 , monthly waste volumes typically ranged from 25,000 to 50,000 cubic feet. Yearly waste volumes were fairly uniform, averaging about 300,000 to 500,000 cubic feet.

(2) The burial locations included in the COBRA database cover only part of the operational life of the ORWBG, since no detailed location information is available for burials prior to 1961. The absence of burial locations in the central portion of the ORWBG suggests that, although the volumes associated with these earlier disposals are in COBRA, their coordinates are not.

(3) It appears that there is a significant component of overlap in trench type and waste type both intra-trench and across trench groups. This means, according to COBRA, that an individual trench often had burials assigned to multiple trench types (i.e., has several different burial codes) and likely contains a variety of different waste types. For example, a single trench may, over short distances (or even within a single 20 foot $\times 20$ foot location cell), be a low-level beta-gamma trench, low-level alpha trench, high-level betagamma trench, or a combination of the five burial codes that are actually used in COBRA (note: COBRA actually has seven different burial codes, but "above ground storage" and "other" are not used). In addition, idealized grouping of trenches into waste areas, such as a low-level beta-gamma cluster of trenches, should be viewed with caution.

(4) In general, burial containers (potentially retrievable TRU) and concrete pours appear to have a relatively high degree of organization within the ORWBG, and their plotted locations (Figure 2-6) tend to be limited to certain trenches. However, COBRA locations within the ORWBG are not "survey grade", and in most cases are probably only good to within 20-60 feet of actual burial locations. In fact, certain retrieval operations of large pieces of buried equipment have shown that the actual burials can be several feet away from the indicated site.

(5) Observing burial locations by year (Figure 2-4) helps to reduce the clutter that plots of the entire data set present (e.g., Figure 2-7). Individual trenches and/or active portions of trenches can be tracked through time, with moderately good agreement between burial locations and trench boundaries. Operations personnel often approximated the rectilinear ORWBG grid coordinates on trenches or sets of trenches that have long axes slightly skewed to the grid system (particularly in the western portions of the burial ground). In east-west aligned trenches, this results in sets of burials that stair-step from one $y$-axis cell row to the next, which can be located in a different trench. 


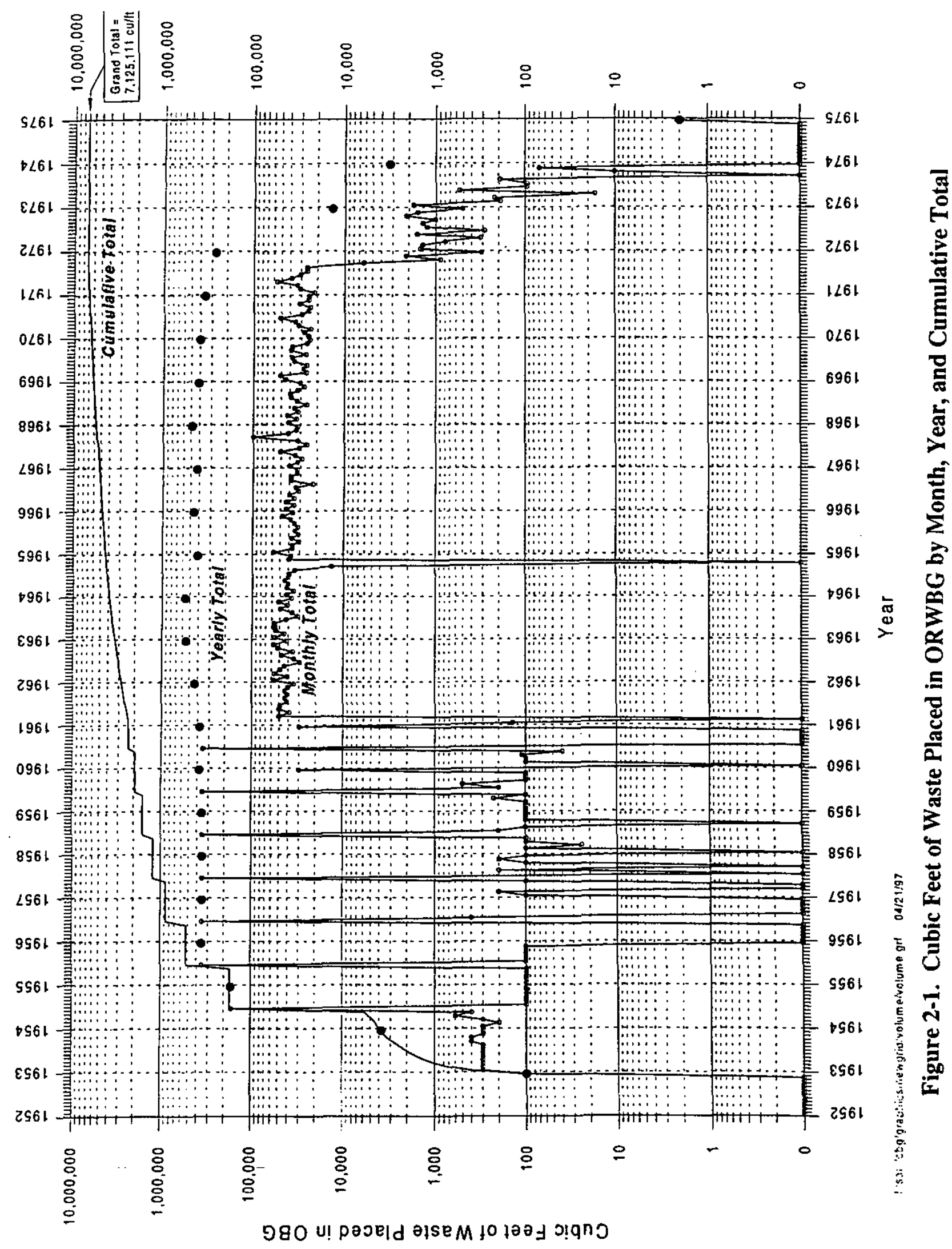


OBG "North Coordinate" (somewhat of a misnomer)

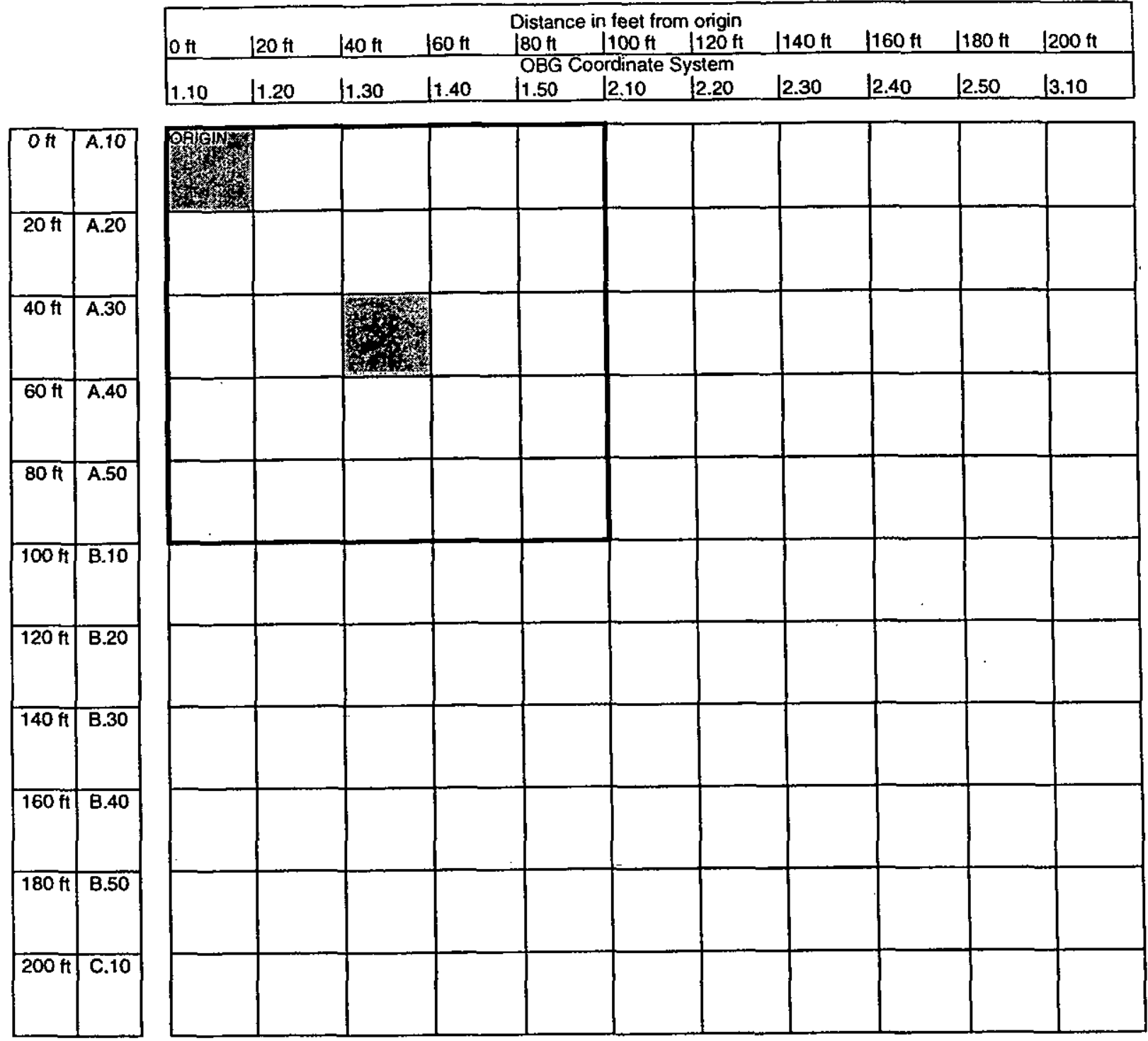

OBG "East

Coordinate"

Figure 2-2. ORWBG Coordinate System. The ORWBG coordinate system consists of a 100 foot square alpha-numeric grid, with the origin $(0,0)$ in the upper left corner of the burial ground. The $100 \mathrm{ft}$ cells increase in an east-west direction in whole number increments, and in a north-south direction with letter designations from " $A$ " (at the origin) to row " $K$ " (closest to E-Road). Each 100 foot cell has been subdivided into five $20 \mathrm{ft}$ subsections using the following convention: $.10=0 \mathrm{ft}, .20=20 \mathrm{ft}, .30=40 \mathrm{ft}, .40=60 \mathrm{ft}$, and $.50=80 \mathrm{ft}$. For example, the two shaded cells above would have the following ORWBG coordinates: 1.10 , A. 10 and 1.30 , A.30, corresponding to 0,0 and 40,40 feet, respectively, from the origin. In the east-west direction the maximum station should correspond to 3,700 feet at the eastern fence line (station 38.10). The grid origin corresponds to SRS coordinates: N76151 and E55081. 


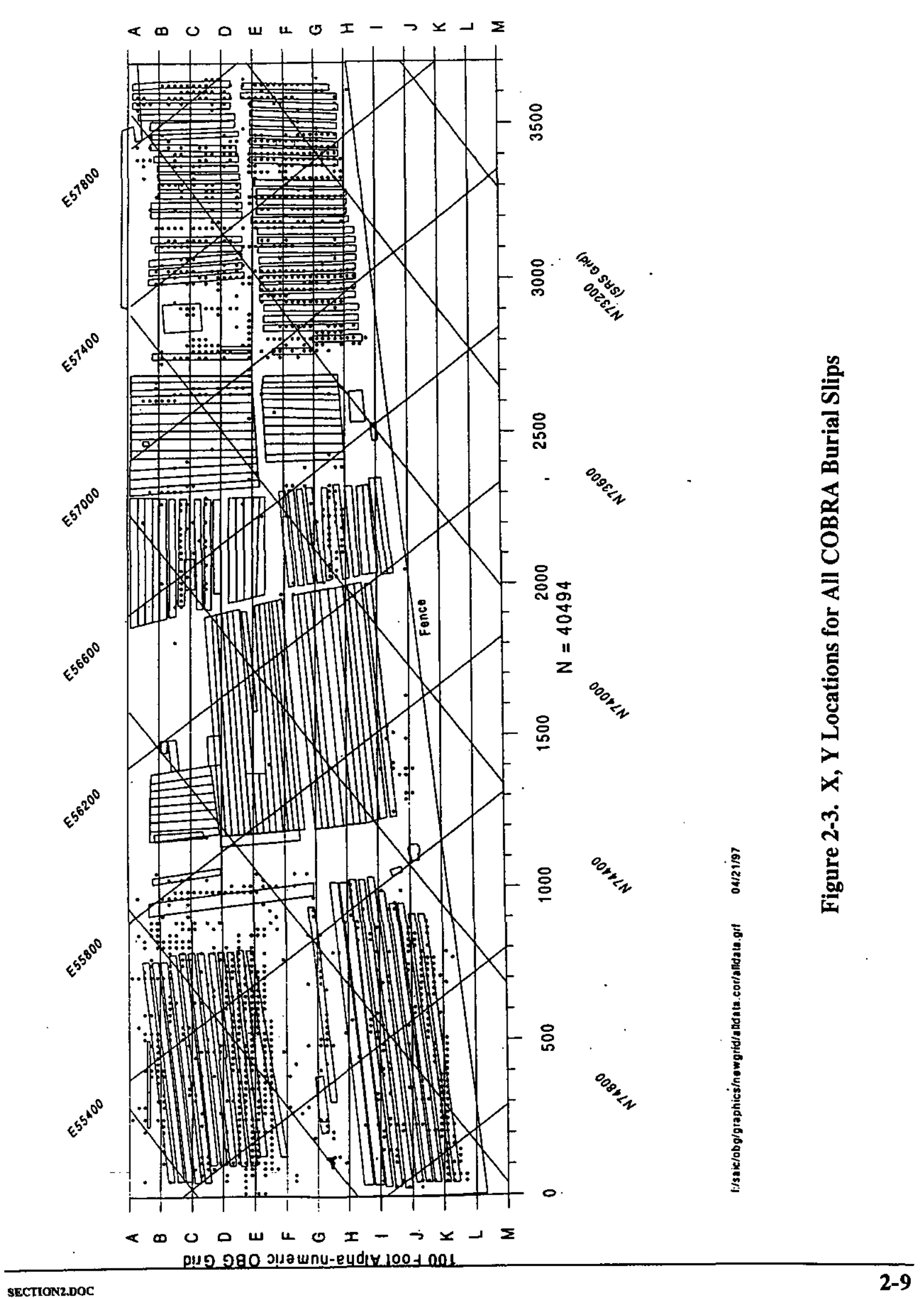


(This page left intentionally blank) 


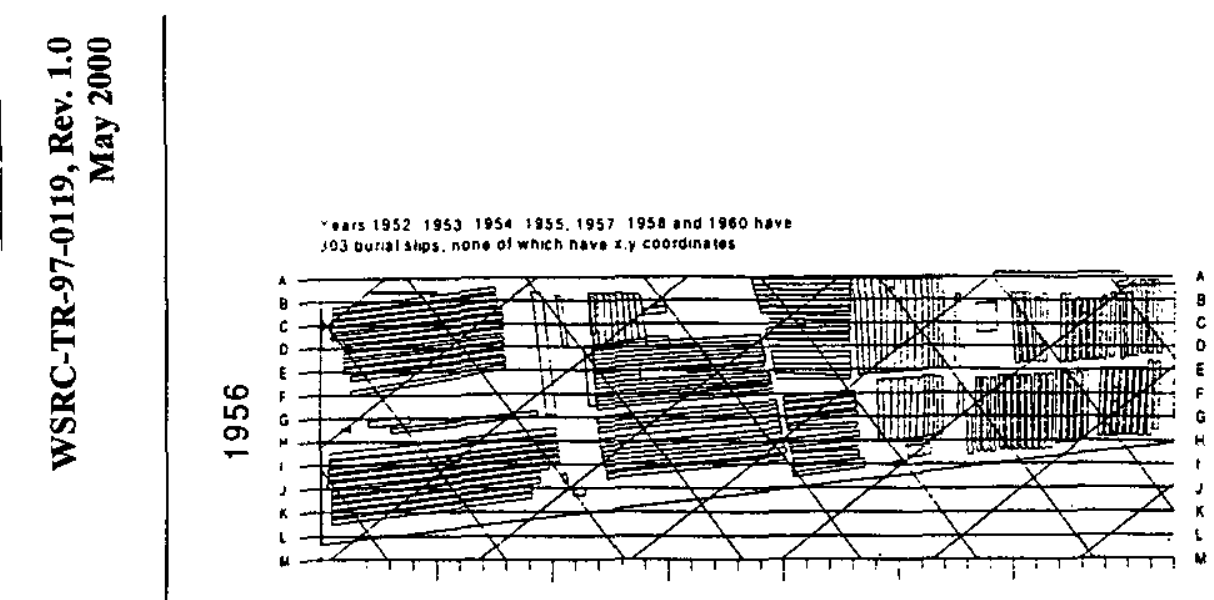

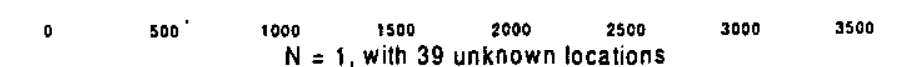
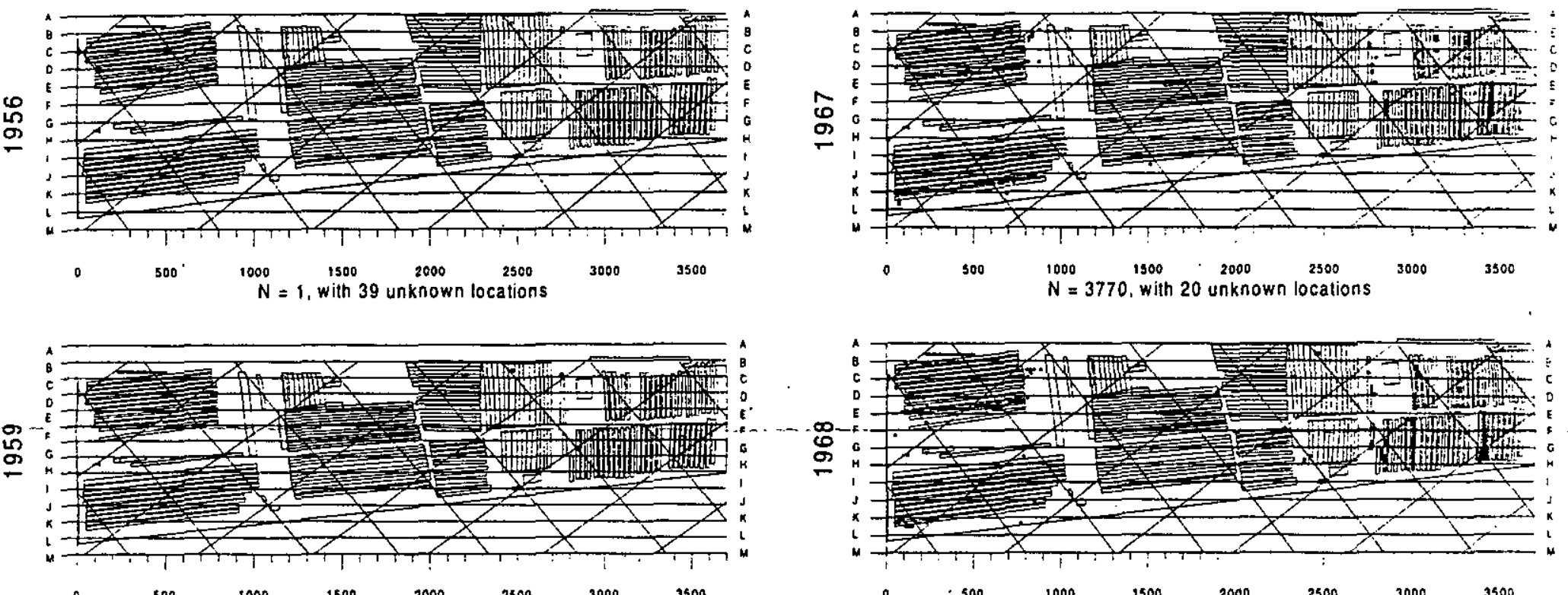

$0 \quad 300 \quad 1000 \quad 1300 \quad 2000 \quad 2500$
$N=3770$, with 20 unknown locations

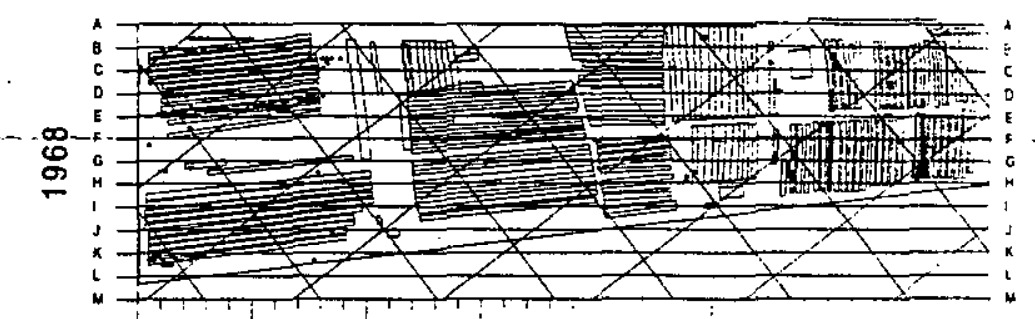

$300 \quad \stackrel{1000}{N}=1,{ }^{1500}$ with 57 unknown locations $3000 \quad 3000 \quad .3500$
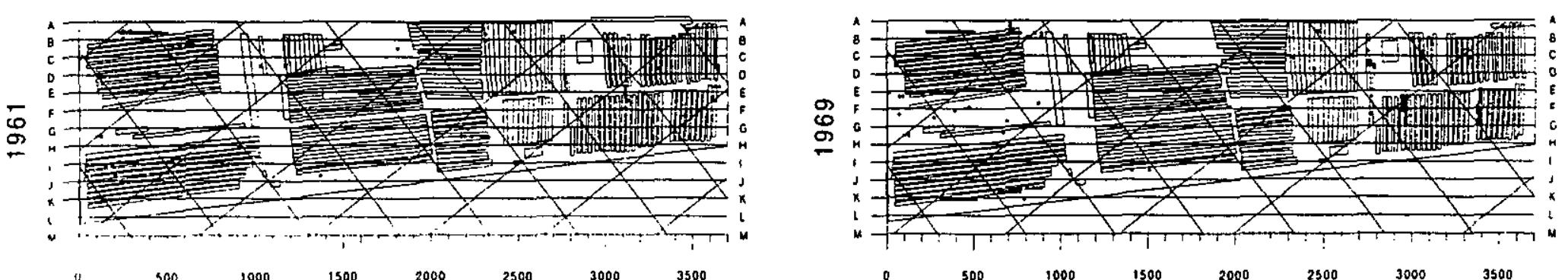

$300 \quad \begin{aligned} & 1000 \\ & \quad N=2455,\end{aligned}$
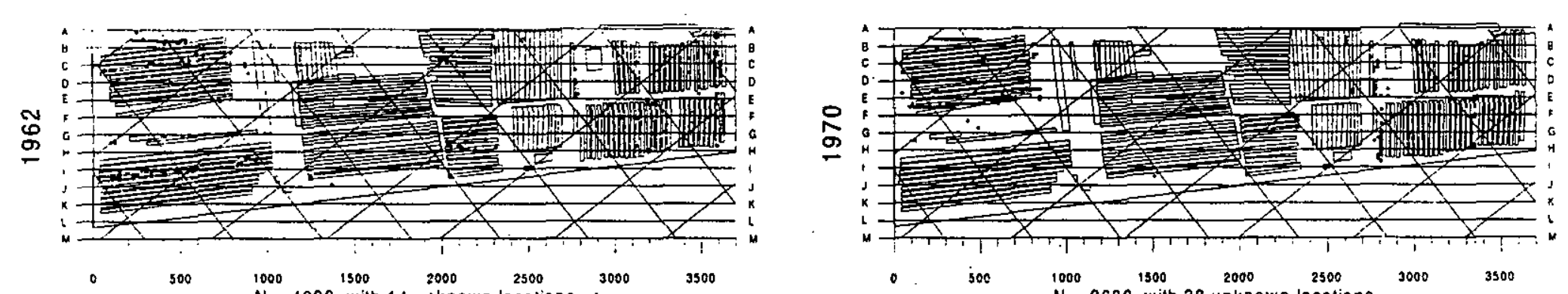

$500 \quad N=4990$, with 14 unknown locations 3000
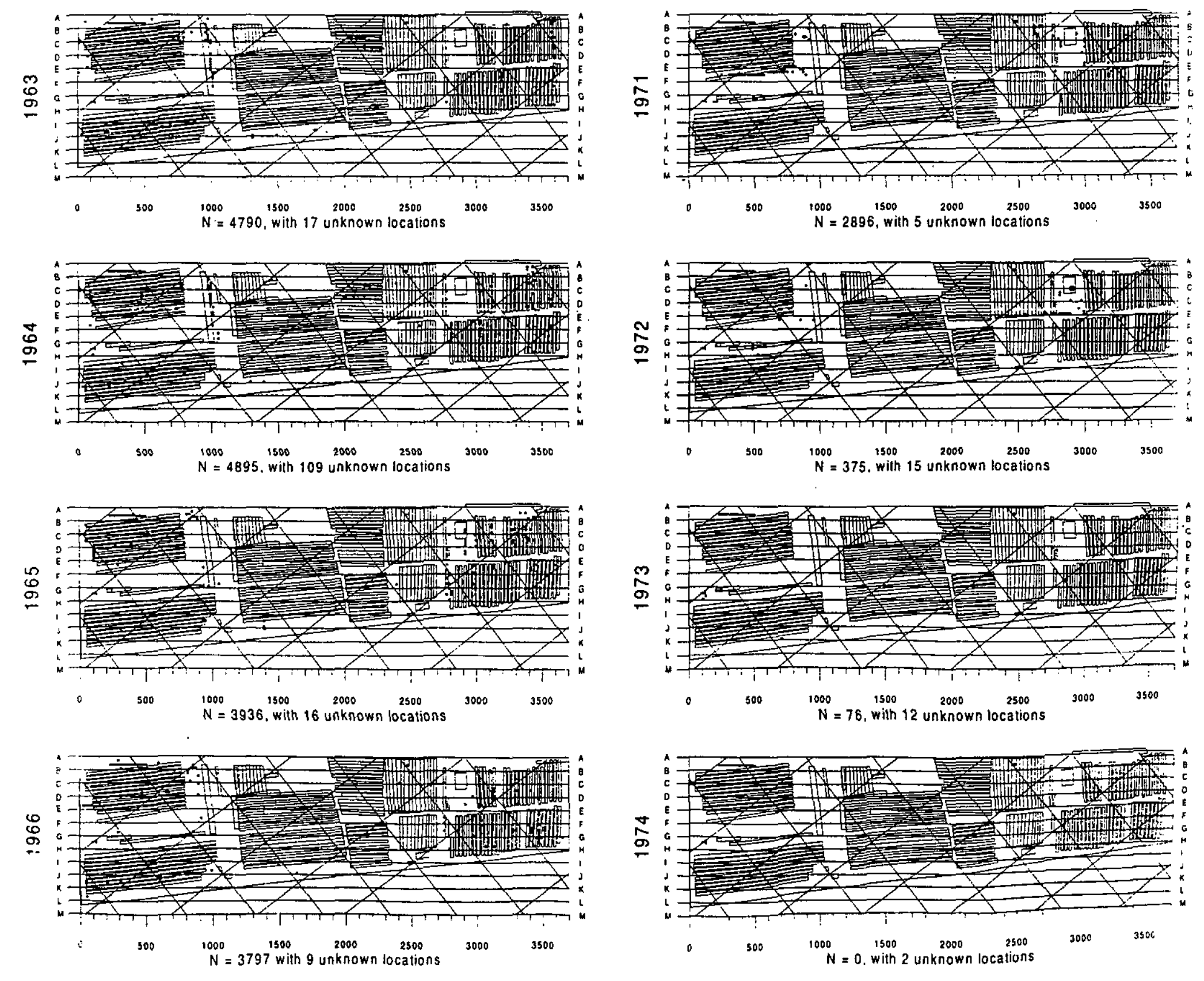

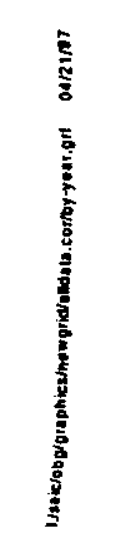


|

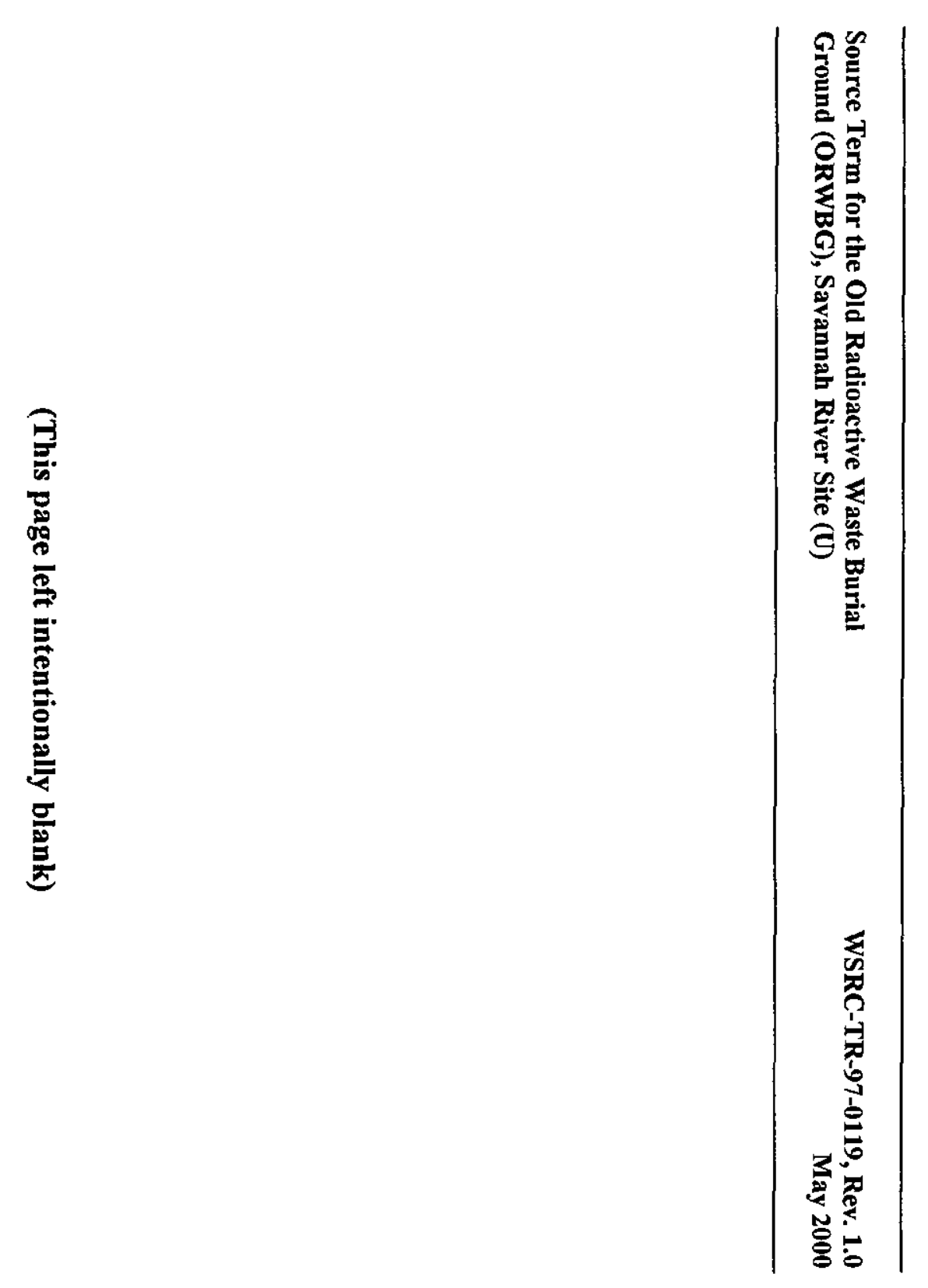

9 

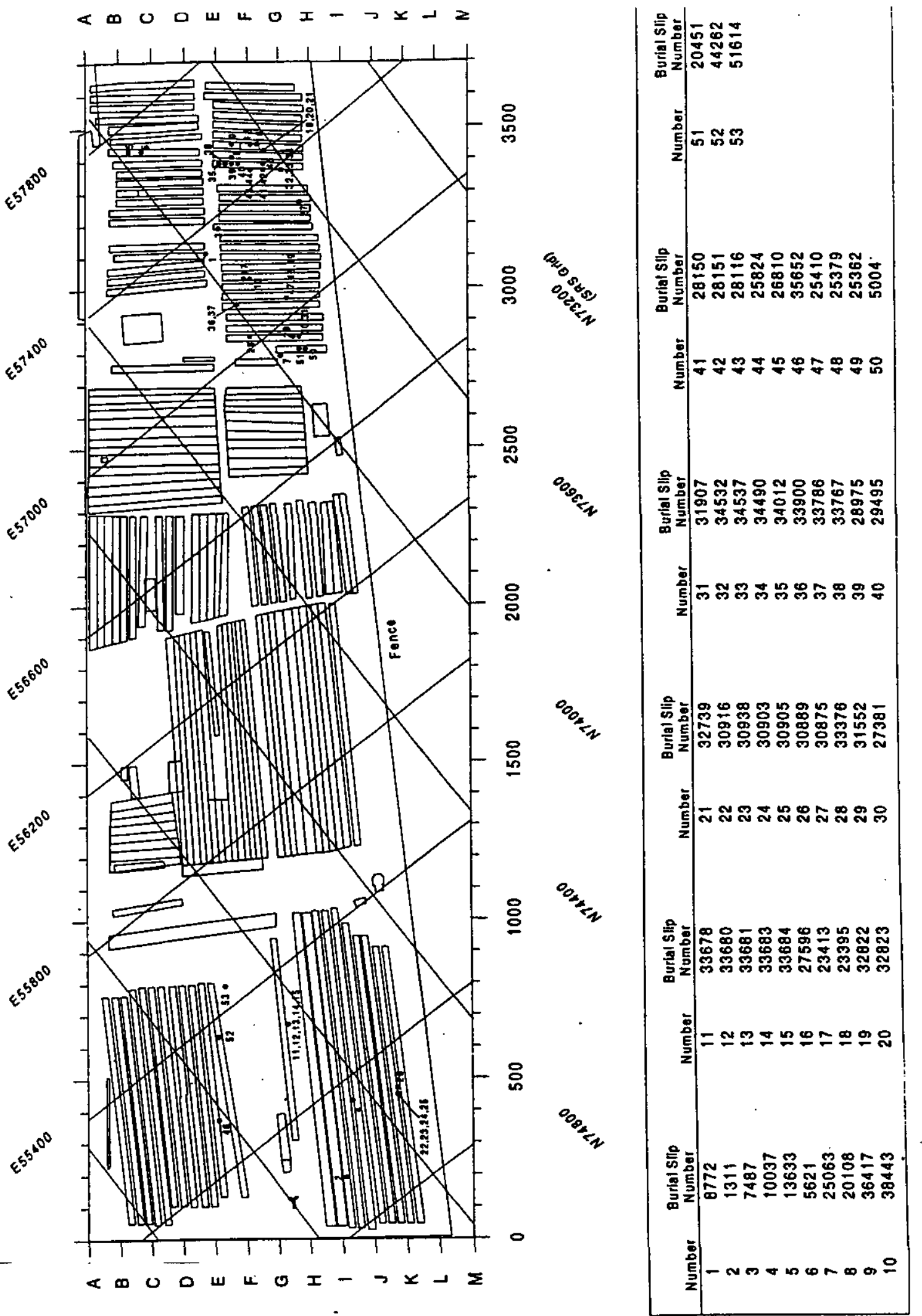

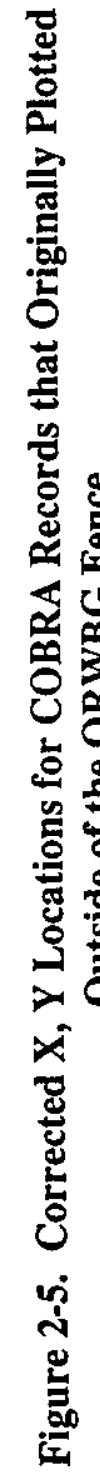

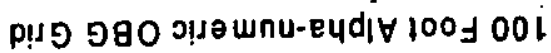


(This page left intentionally blank) 


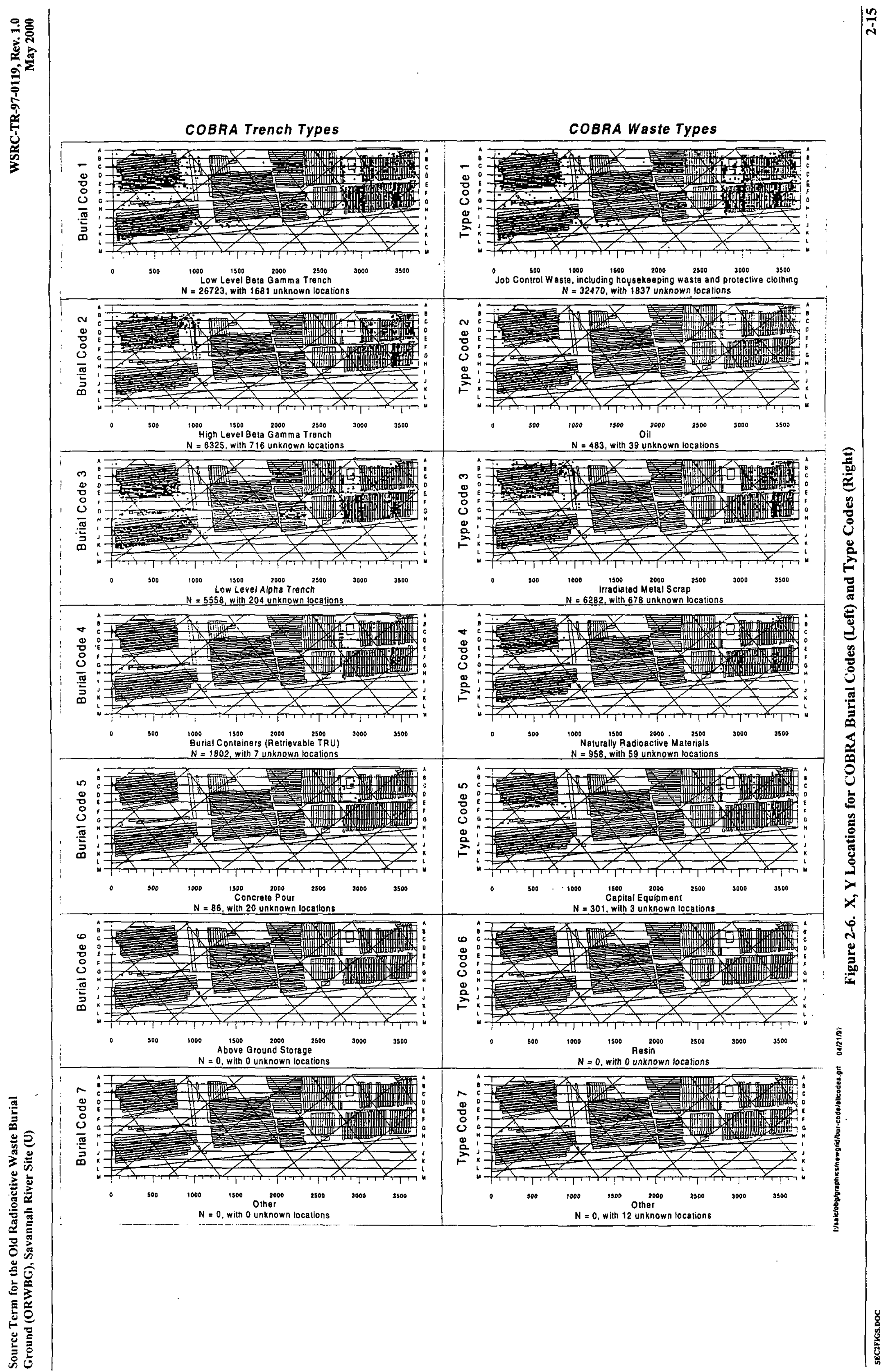




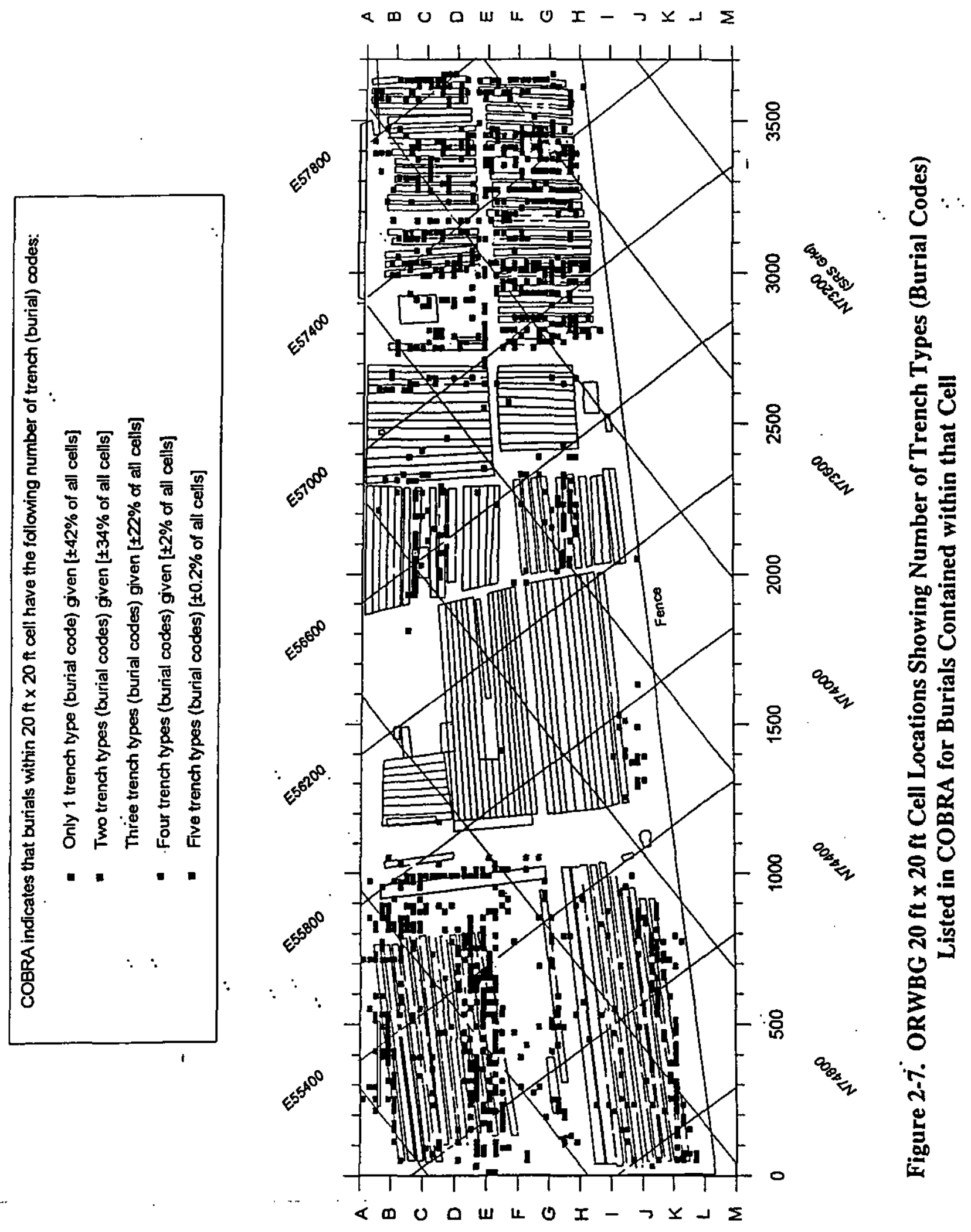

pụ 580 ग! 


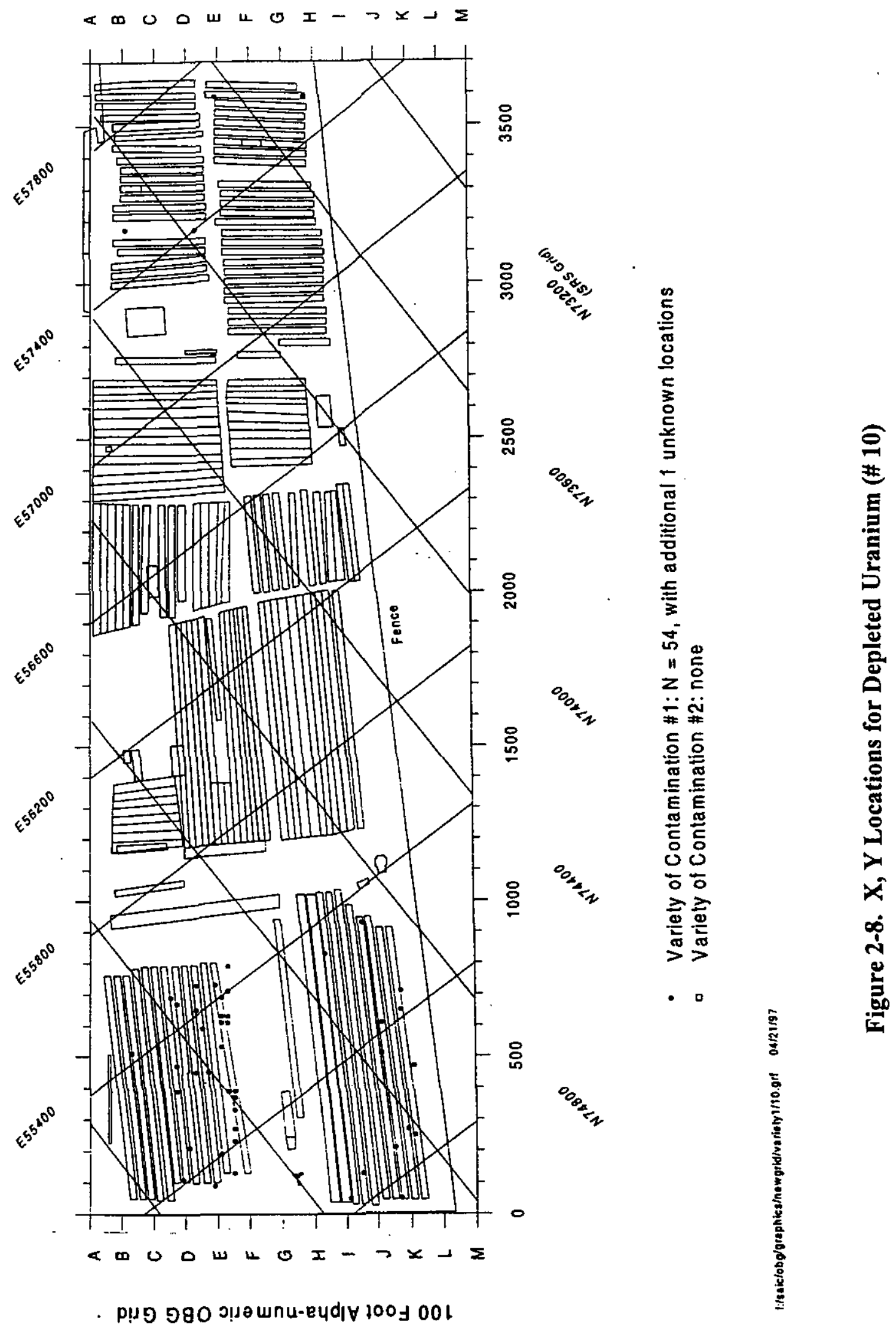

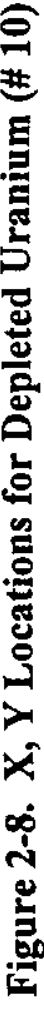

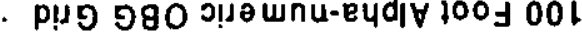




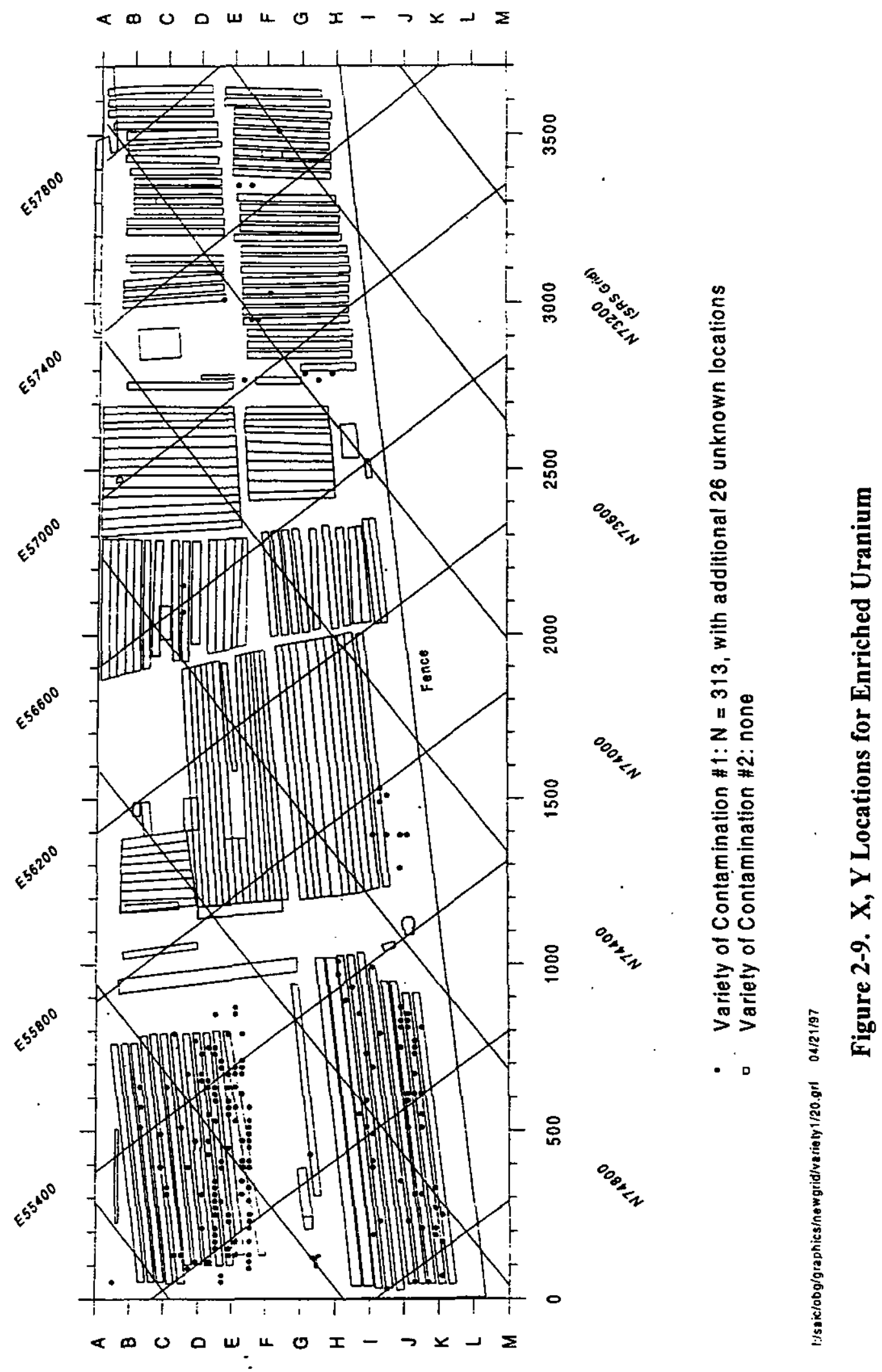

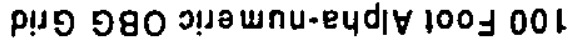




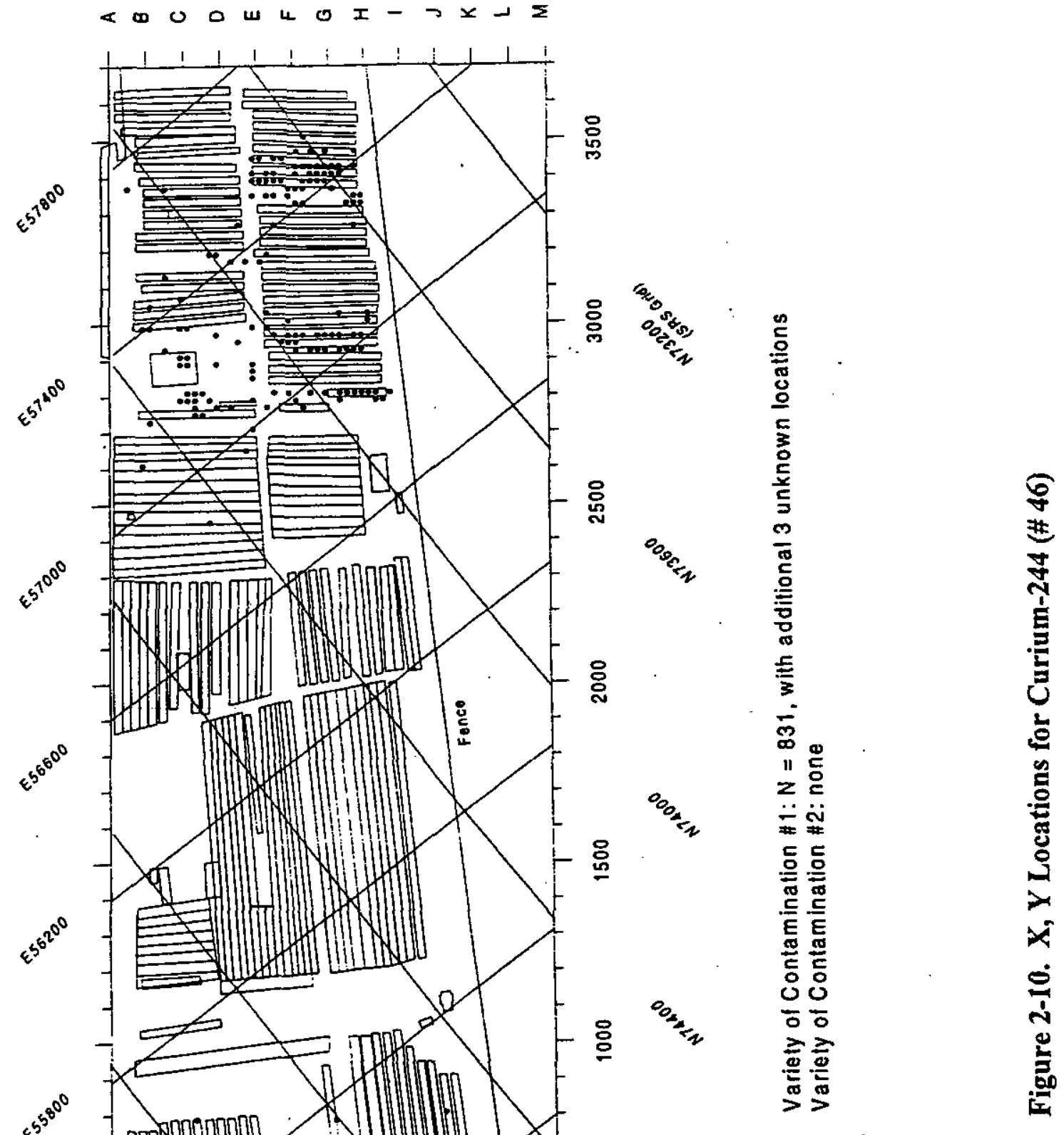




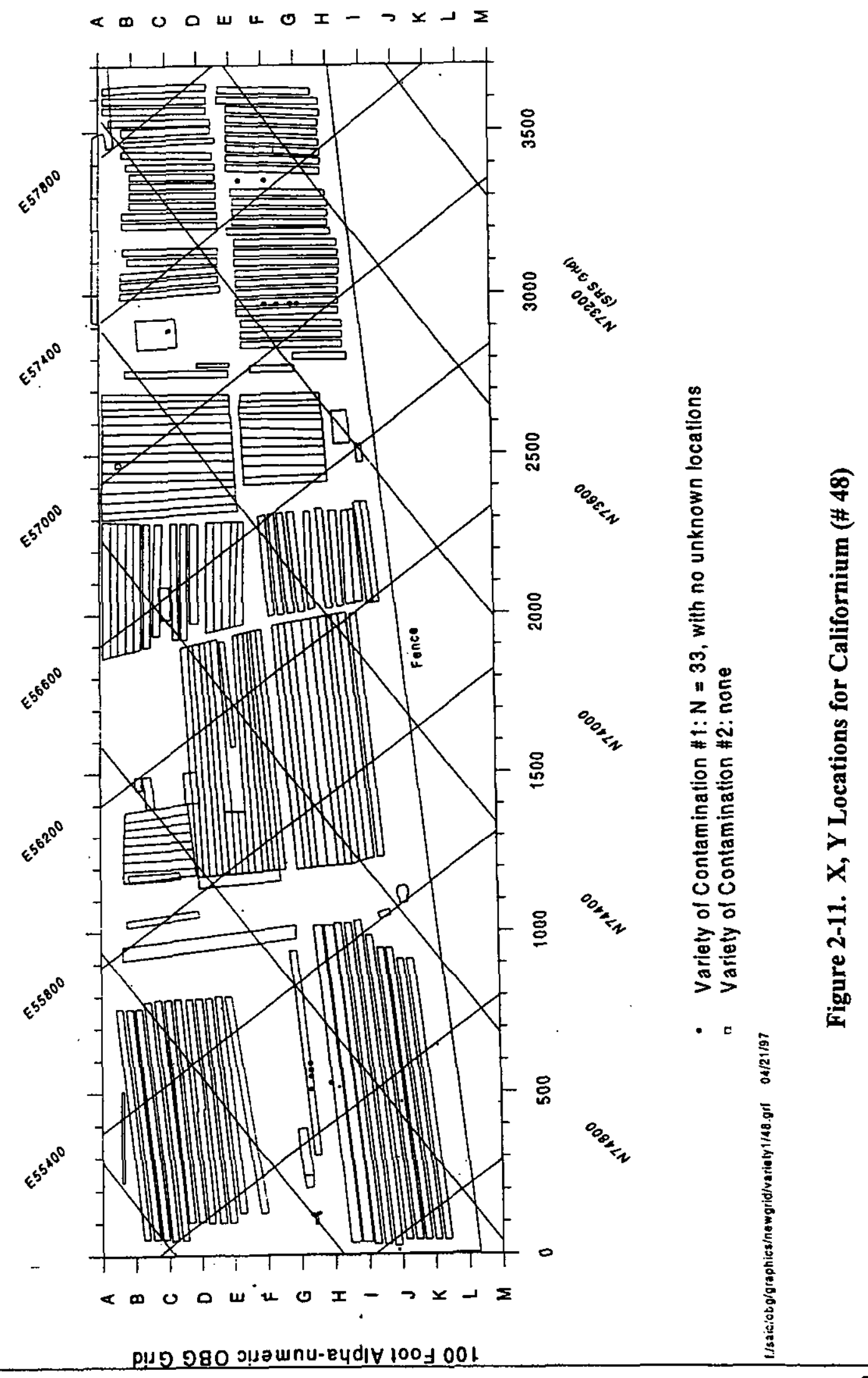




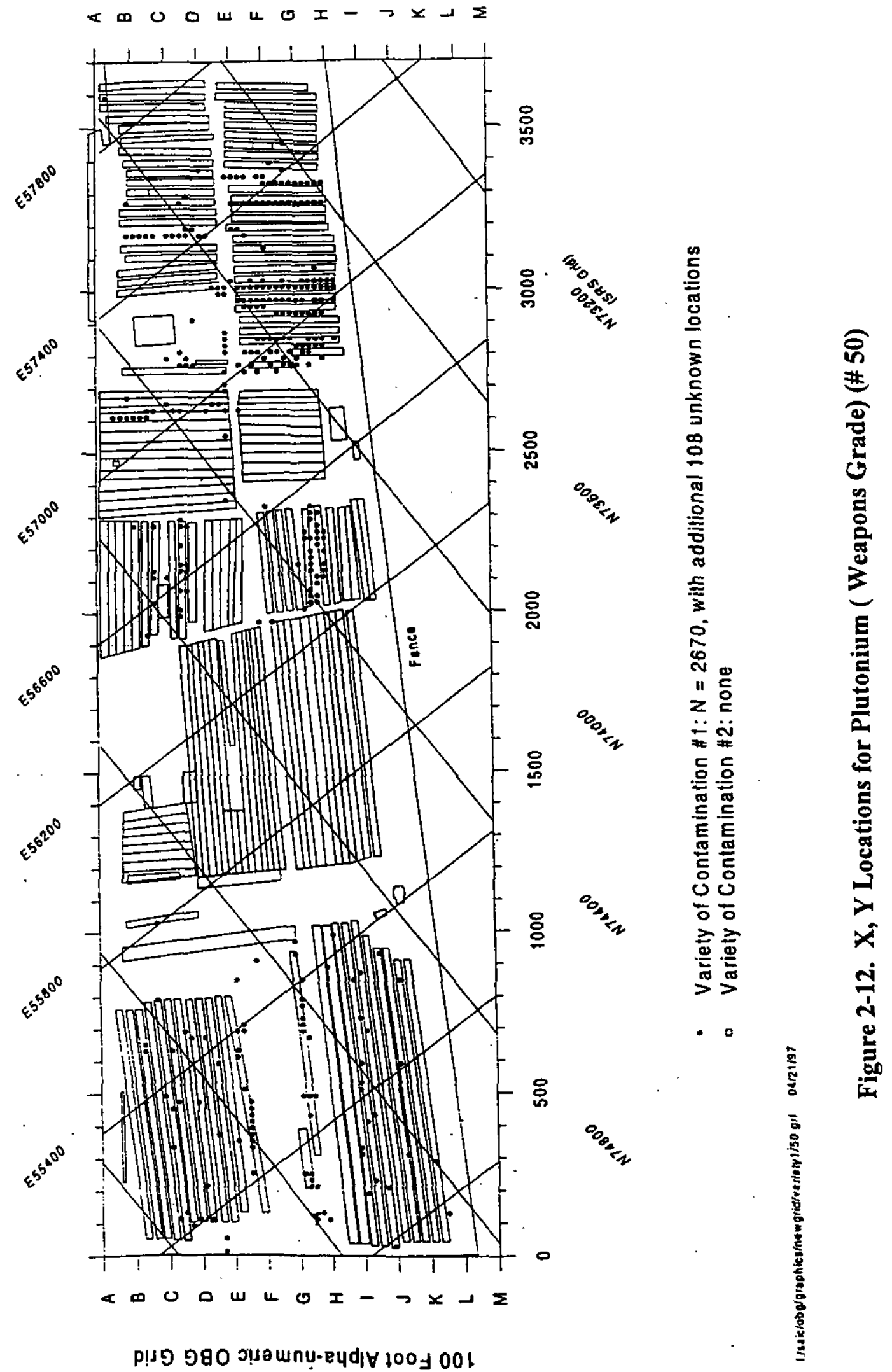




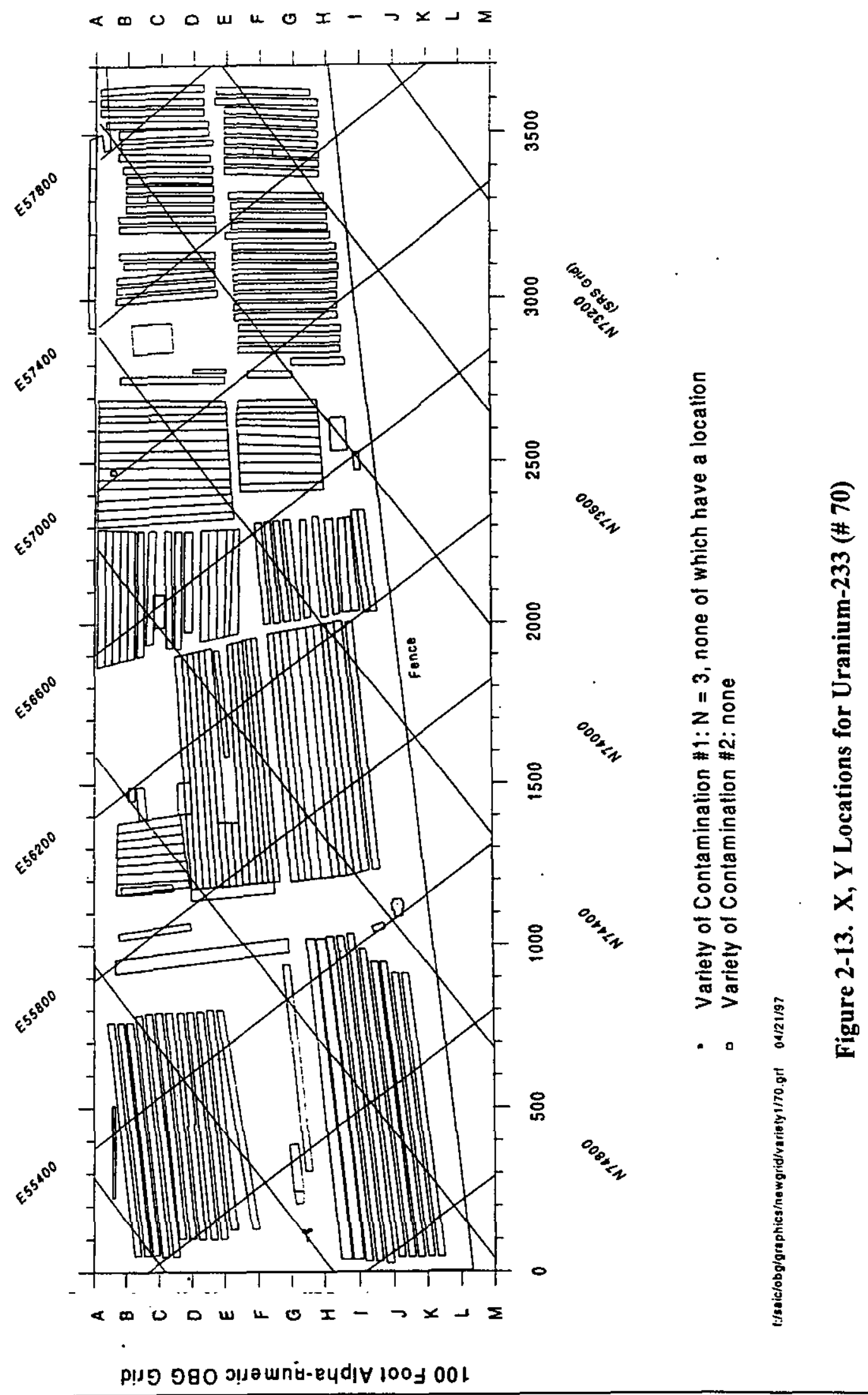




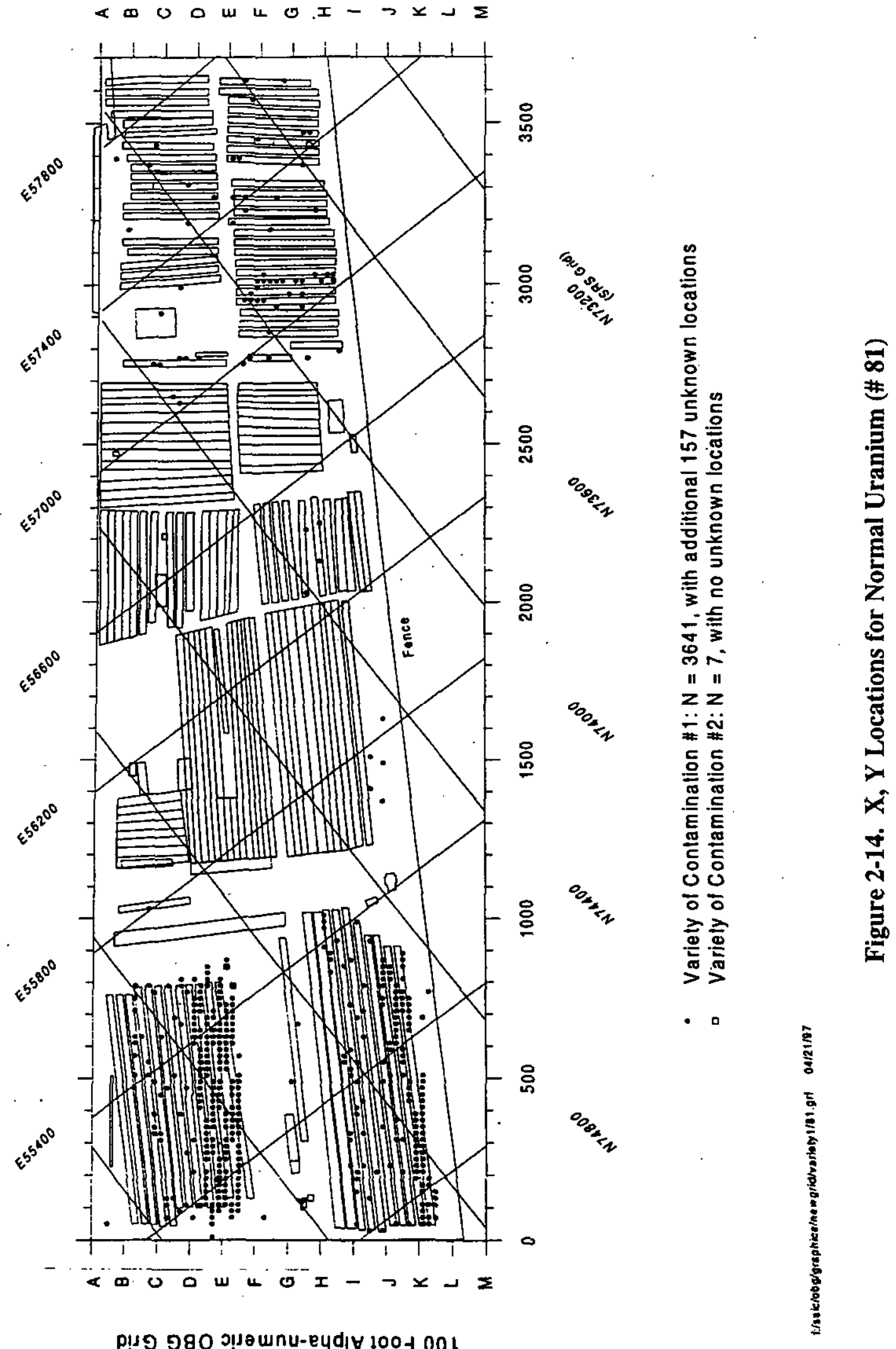




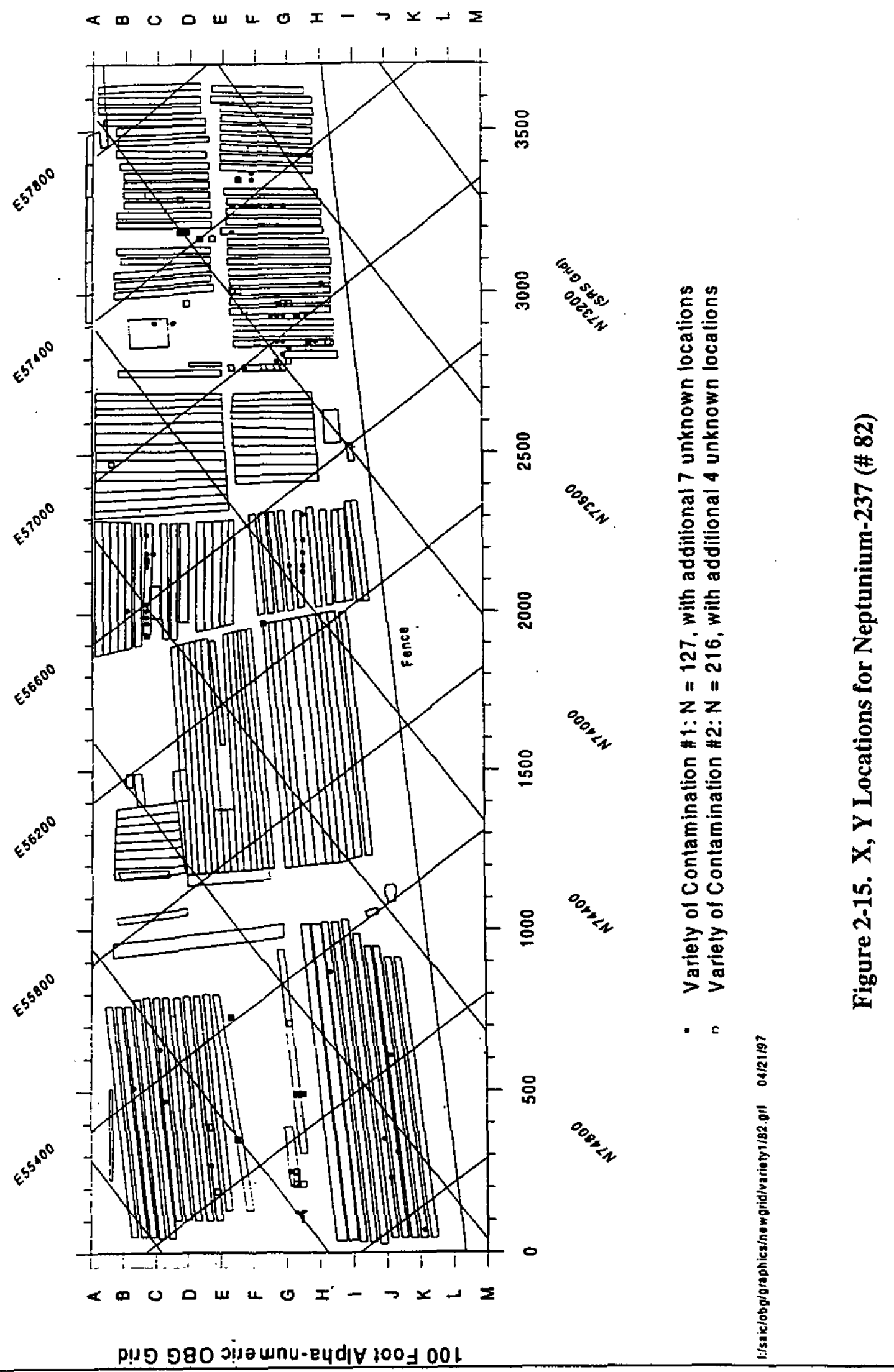




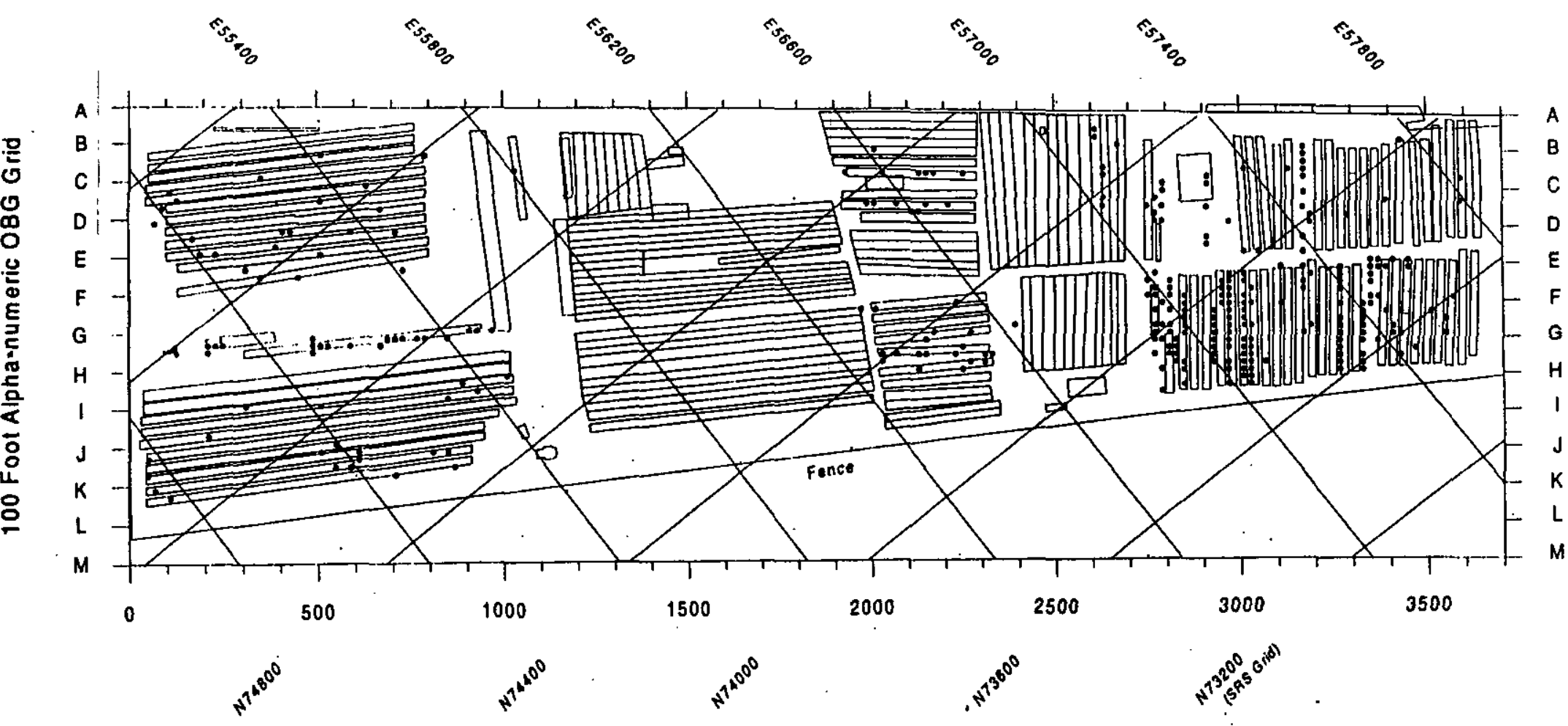

- Variety of Contamination \#1: $N=1422$, with additional 43 unknown locations

- Variely of Contamination \#2: none

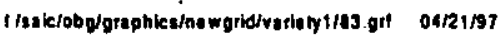

Figure 2-16. X, Y Locations for Plutonium-238 (\# 83) 


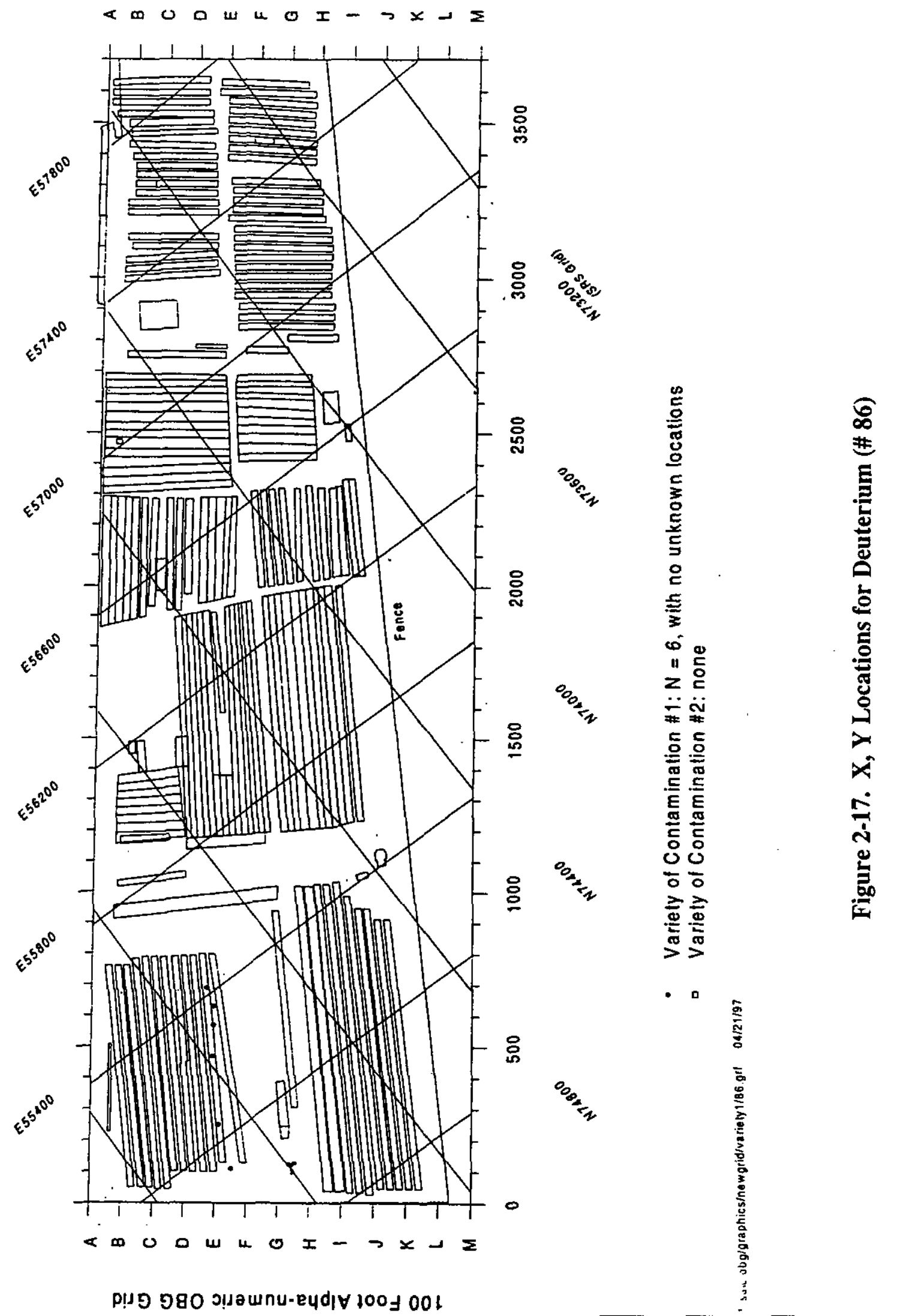




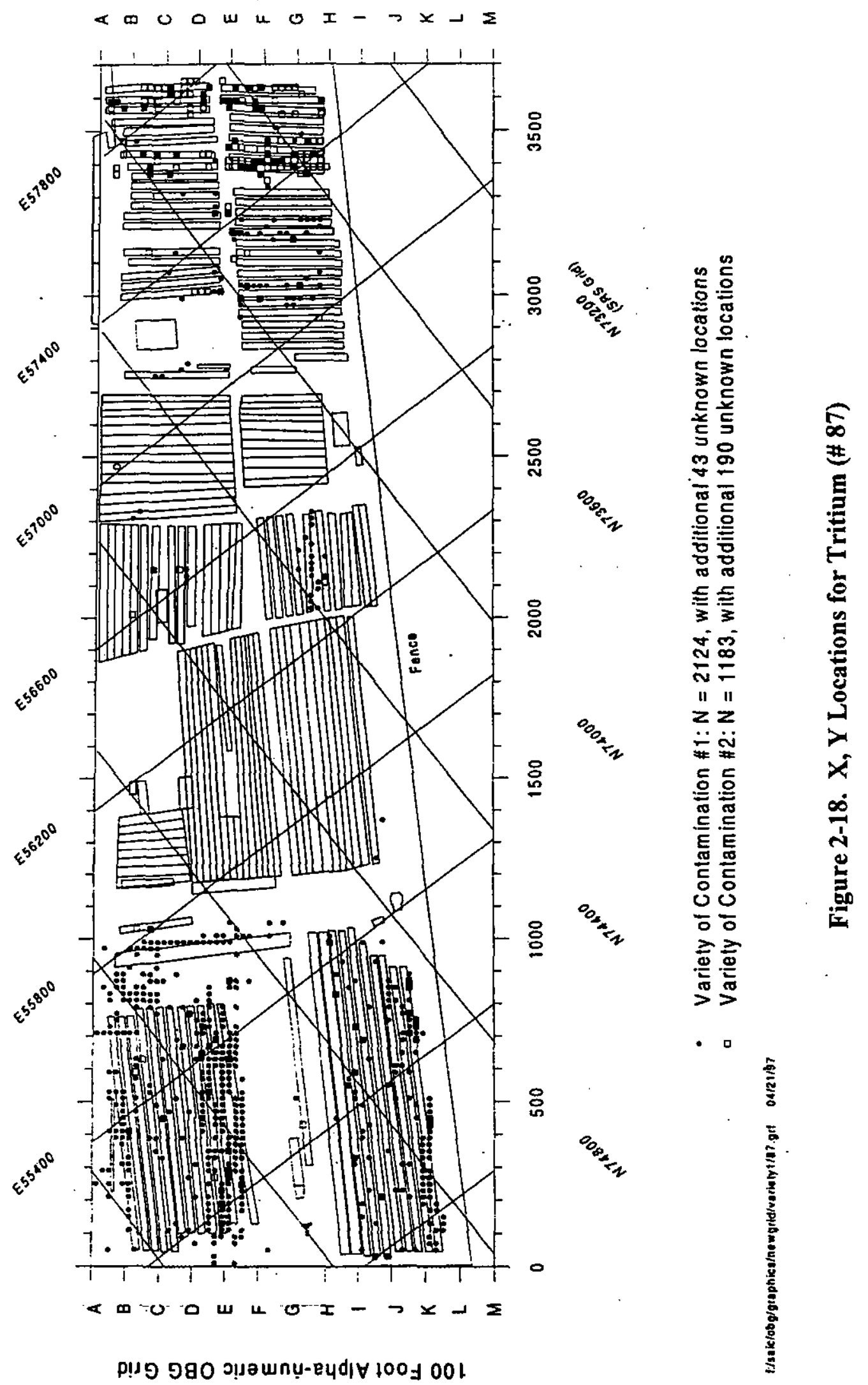




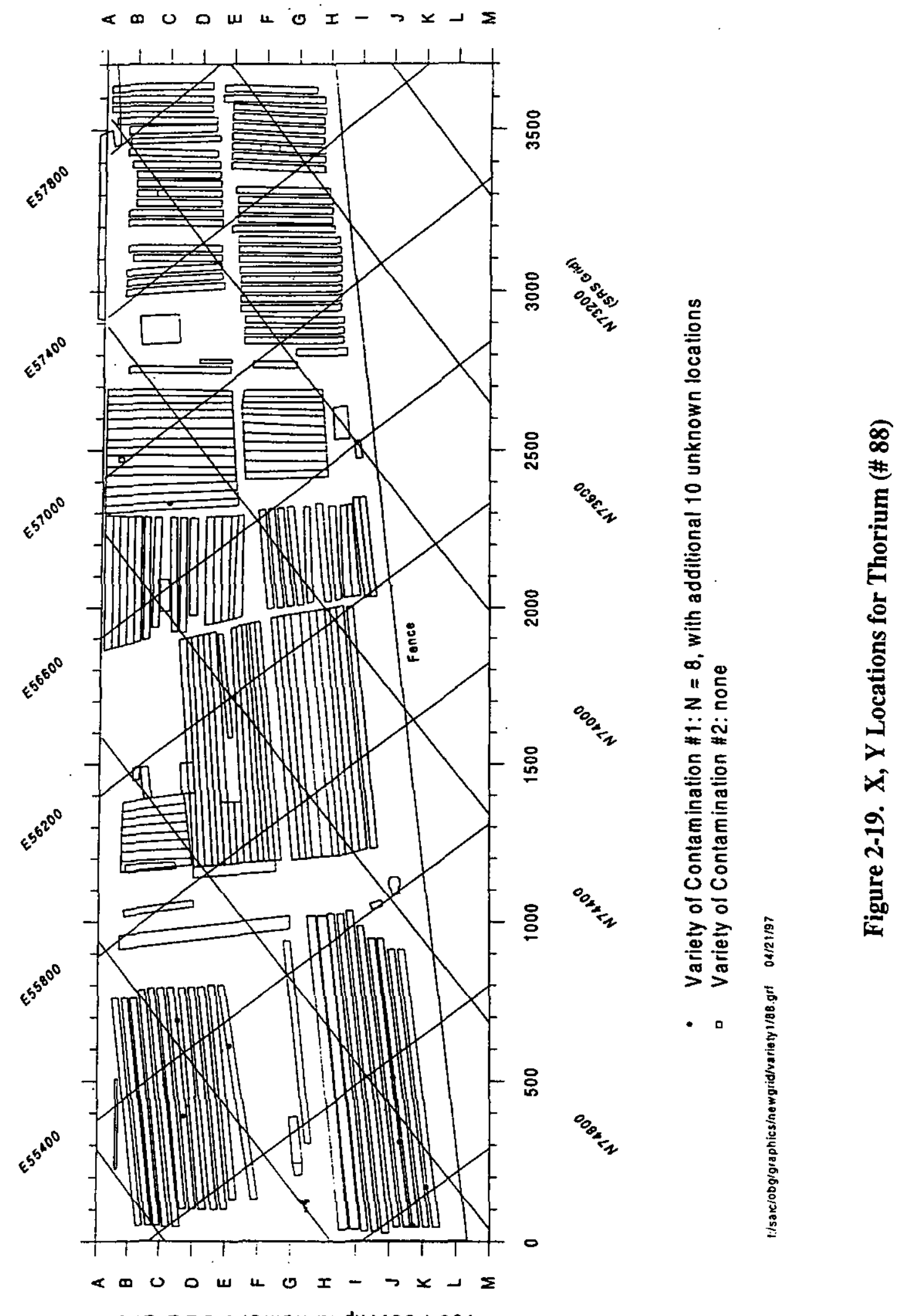

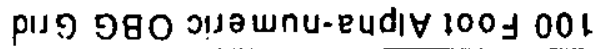




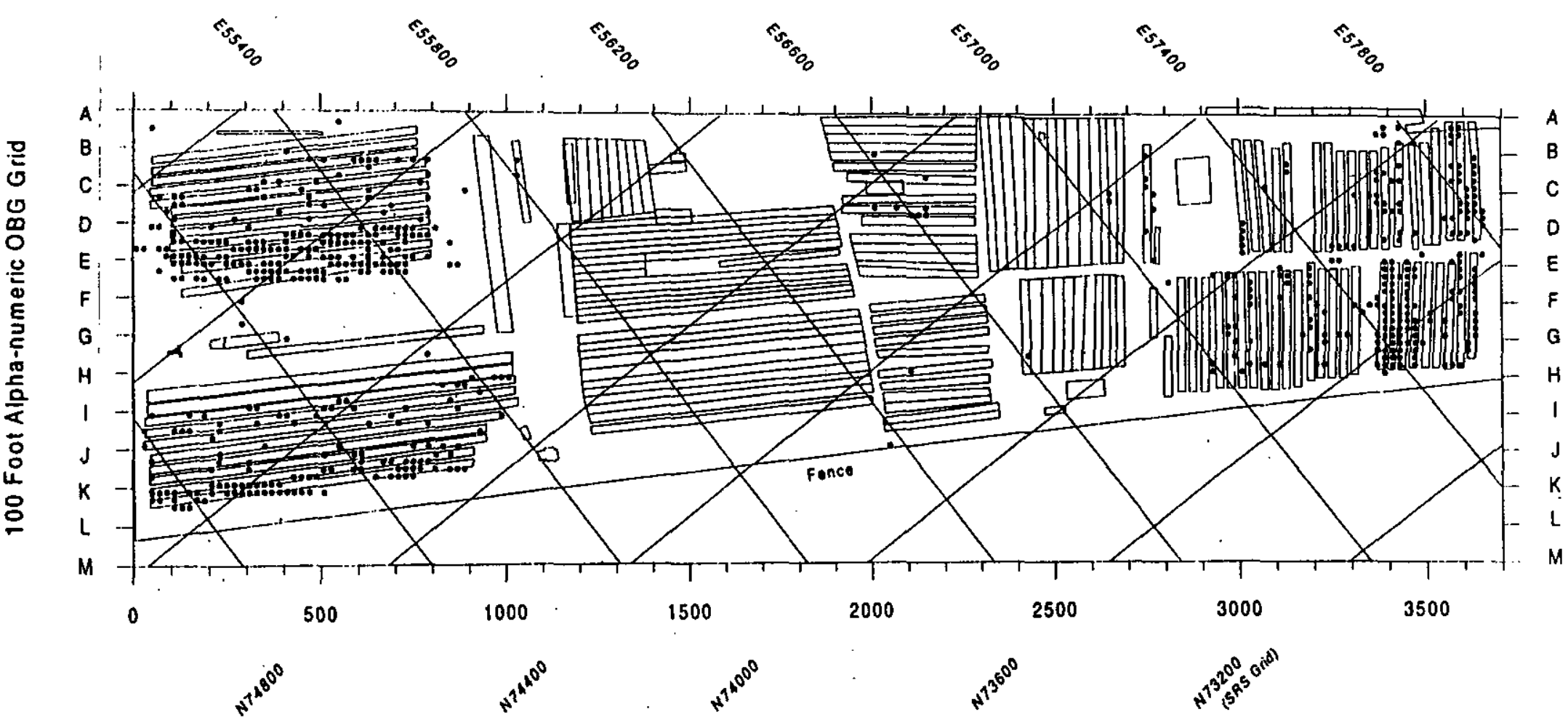

- Variety of Contamination $\# 1: N=7292$, with additional 646 unknown locations

1 Variety of Contamination $\# 2$ : none

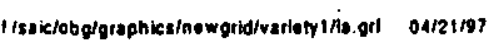

Figure 2-20. X, Y Locations for Induced Activity (IA) 


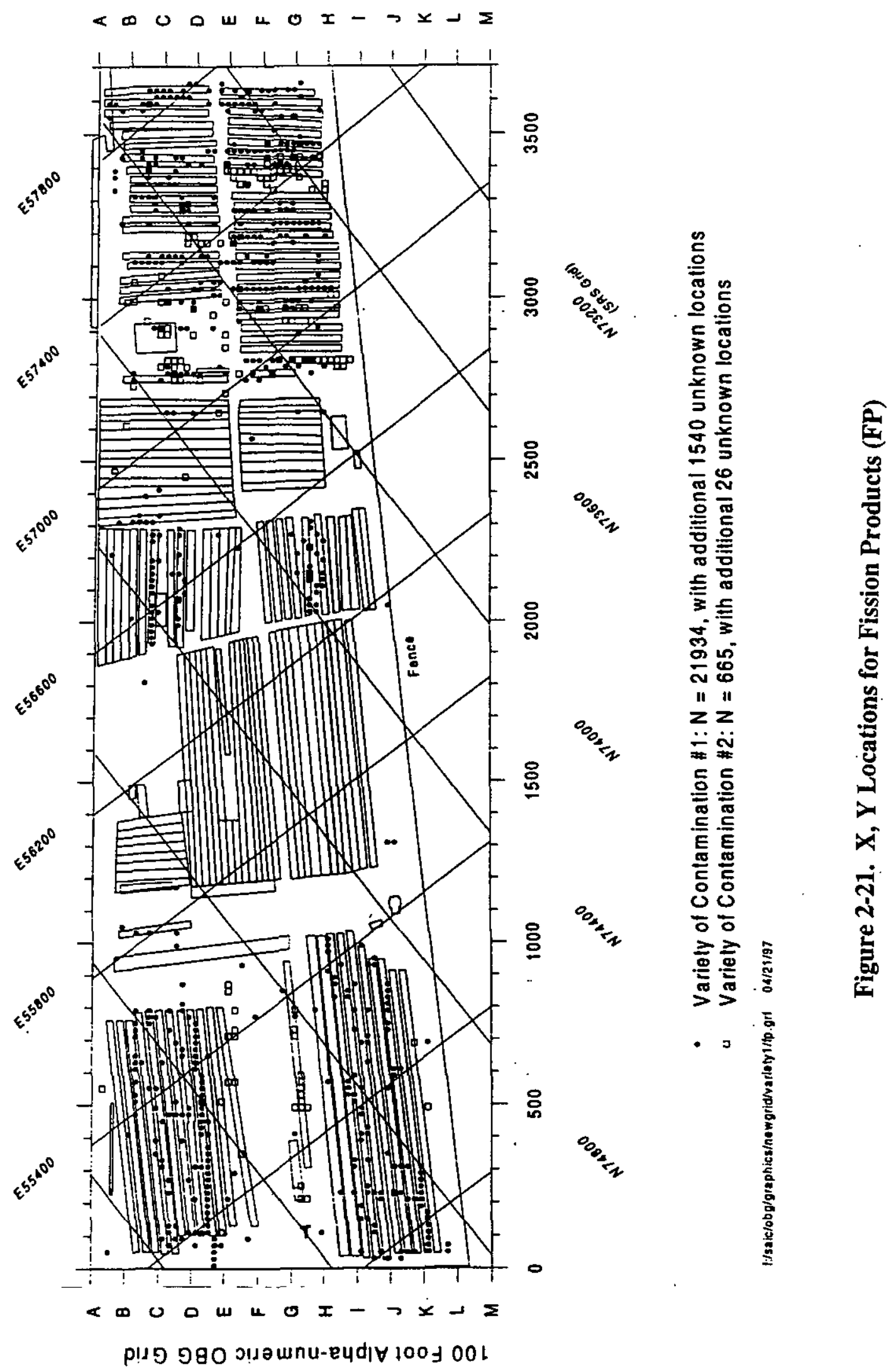



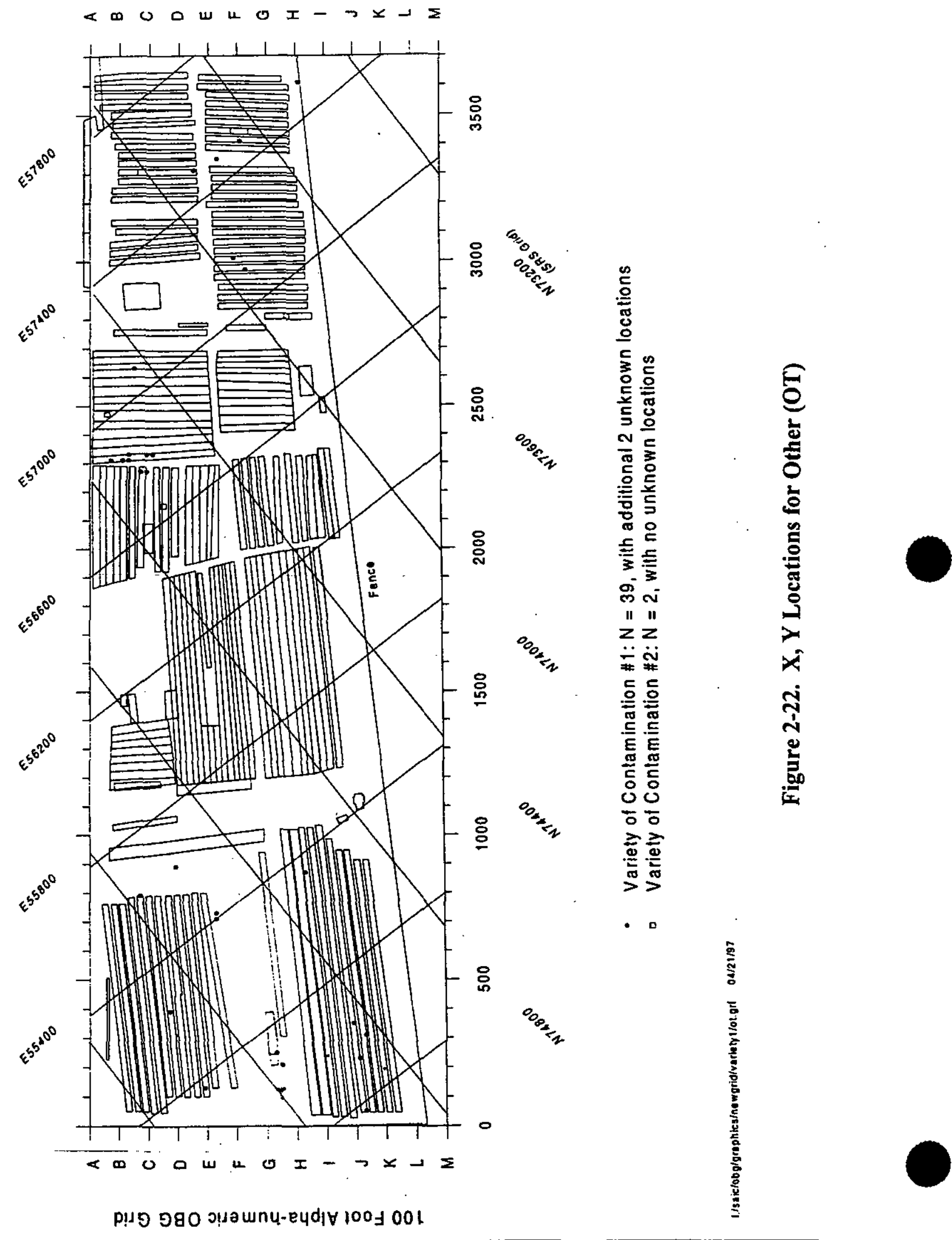
Table 2-1. Example of COBRA Data. Shown are 38 representative burial slip records. Asterisks and numbers along the top and bottom are to facilitate column/field width determination. Note that the last 7 spaces (150-157) have been truncated to fit on this page. Explanation of record fields is given in text.

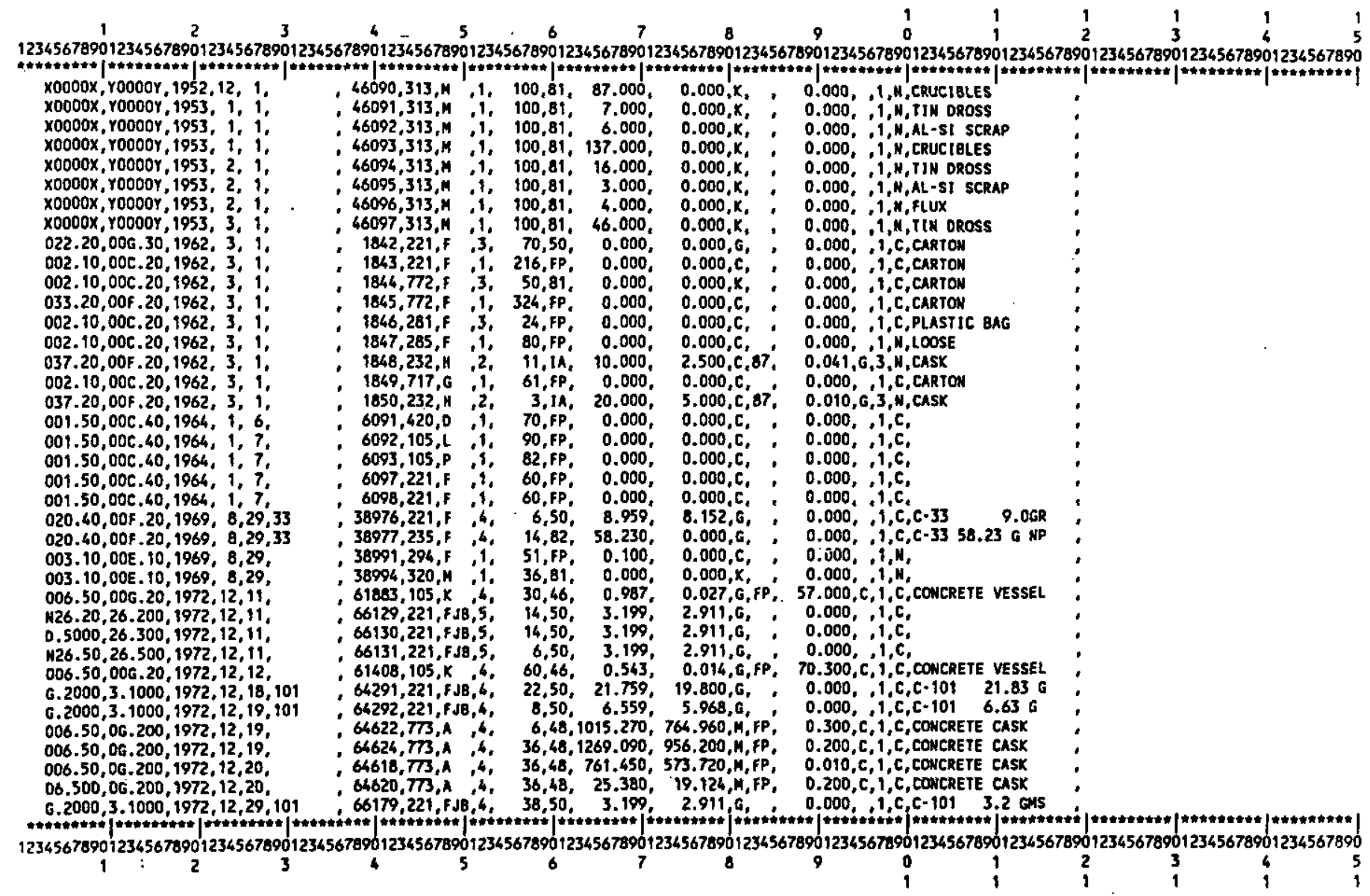




\section{Table 2-2. Summary Statistics for ORWBG Burial and Type Codes}

\begin{tabular}{|c|c|c|c|c|c|c|c|c|c|c|c|}
\hline \multirow[t]{2}{*}{ 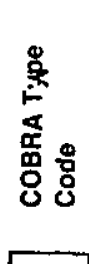 } & & & 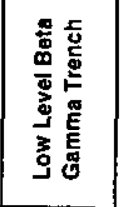 & 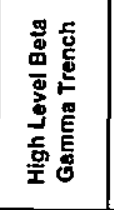 & 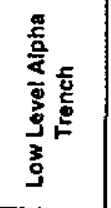 & 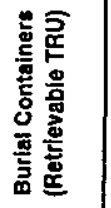 & 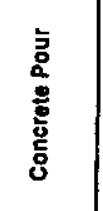 & 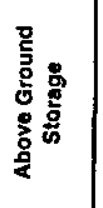 & 站 & \multirow[t]{2}{*}{ 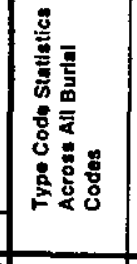 } & \multirow[t]{2}{*}{ 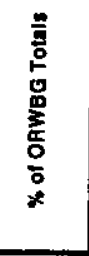 } \\
\hline & & COBRA Burial Code: & 1 & 2 & 3 & 4 & 5 & 6 & 7 & & \\
\hline \multirow{6}{*}{1} & \multirow{6}{*}{$\begin{array}{l}\text { Job Control Waste } \\
\text { lncluding houser } \\
\text { keeping wasto and } \\
\text { protective clothing }\end{array}$} & Number of Records & 26,655 & 48, & 5,695 & 1,807 & 102 & 0 & o & 34,307 & 79.6 \\
\hline & & Total Waste Volume (aint) & $5,525,781$ & 46,249 & 782,362 & 21,828 & 13,335 & - & - & $6,369,555$ & 89.7 \\
\hline & & Average Burial Volume (avit) & 207 & 964 & 137 & 12 & 131 & $\cdot$ & - & 186 & $\mathrm{n} / \mathrm{a}$ \\
\hline & & Standard Deviation & 1,520 & 1,825 & 677 & 19 & 236 & - & - & 1371 & $\mathrm{Na}$ \\
\hline & & Maximum Burial Volume (avit) & 58,199 & 5,551 & 30,000 & 432 & 1,600 & - & $\cdot$ & 58199 & $\mathrm{na}$ \\
\hline & & Minimum Burial Votume (aum) & a & 9 & 0 & of & 1 & - & $\cdot$ & of & $\mathrm{Na}$ \\
\hline \multirow{6}{*}{2} & \multirow{6}{*}{ oll } & Number of Reconds & 5213 & of & 1 & of & 의 & of & 요 & 522 & 1.2 \\
\hline & & Total Waste Volume (cu/ti) & 41,903 & $\therefore$ & 180 & - & - & - & $\cdot$ & 42,083 & 0.6 \\
\hline & & Average Burial Volume (culit) & 80 & - & $\therefore$ & $\cdot$ & - & $\cdot$ & $\cdot$ & 81 & $\mathrm{~N} / \mathrm{a}$ \\
\hline & & Standard Deviation & 88 & - & $\therefore$ & - & $\cdot$ & $\therefore$ & 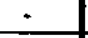 & 88 & $\mathrm{n} / \mathrm{a}$ \\
\hline & & Maximum Burial Volume (autit) & 1,036 & - & $\therefore$ & - & - & $\therefore$ & - & 1.036 & $\mathrm{~N} / \mathrm{a}$ \\
\hline & & Minimum Burial Volume (cu/t) & of & 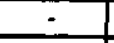 & 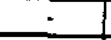 & - & - & - & $\therefore$ & of & $\mathrm{Na}$ \\
\hline \multirow{6}{*}{3} & \multirow{6}{*}{$\begin{array}{l}\text { Irediatod Motal } \\
\text { Scrap }\end{array}$} & Number of Records & 46 & 6,907 & 5. & 2 & - & 의 & of & 6,960 & 16.1 \\
\hline & & Total Waste Volume (cu/n) & 3,732 & 477009 & 253 & 13 & $\cdot$ & - & $\dot{.}$ & 481,007 & 6.8) \\
\hline & & Average Burial Volume (awn) & 81 & 69 & 51 & 7 & - & - & - & 69 & Na \\
\hline & & Stanctard Deviation & 81 & 349 & 44 & 8 & - & - & - & 347 & $\mathrm{Na}$ \\
\hline & & Maxdmum Burial Volume (aum) & 405 & 7,000 & 120 & 12 & - & - & - & 7,000 & $\mathrm{Na}$ \\
\hline & & Minimum Burial Volume (aunt) & .1 & 의 & 3 & 1 & - & - & $=$ & 0 & $\mathrm{n} / \mathrm{a}$ \\
\hline \multirow{6}{*}{4} & \multirow{6}{*}{$\begin{array}{l}\text { Naturally } \\
\text { Radloactive } \\
\text { Materials }\end{array}$} & Number of Fecords & 996 & 2 & 19 & of & of & 0 & 의 & 1,017 & 2.4 \\
\hline & & Total Waste Volume (cu/ft) & 150,106 & 9 & 3,650 & $\therefore$ & - & + & - & 153,765 & 2.2. \\
\hline & & Average Burial Volume (cu/th) & 151 & 5 & 192 & $\therefore$ & - & - & $=$ & 151 & Na \\
\hline & & Standard Deviation & 183 & 5 & 19 & - & - & - & - & 181 & na \\
\hline & & Maximum Burial Volume (cu/t) & 5,460 & 8 & 200 & - & $=$ & $\therefore$ & 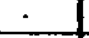 & 5,460 & na \\
\hline & & Minimum Burial Volume (cu/t) & 0] & 1 & 150 & - & - & - & $\therefore$ & o] & $\mathrm{n} / \mathrm{a}$ \\
\hline \multirow{6}{*}{5} & \multirow{6}{*}{$\begin{array}{l}\text { Caphtal Equipment, must } \\
\text { be sccompanlod by a } \\
\text { Plant Equipment } \\
\text { Transfor (PET) }\end{array}$} & Number of Records & 174 & 84 & 42 & of & 4 & of & 9 & 304 & 0.7 \\
\hline & & Total Waste Volume (cu/t) & 31,273 & 23,436 & 3,899 & $\cdot$ & 114 & - & - & 58,722 & 0.8 \\
\hline & & Average Burial Volume (ann) & 180 & 279 & 93 & $\cdot$ & 29 & - & - & 193 & 均 \\
\hline & & Standard Deviation & 446 & 1.787 & 169 & - & 20 & $=$ & $=$ & 998 & $\mathrm{Na}$ \\
\hline & & Maximum Burlad Vohme (aunt) & 3,600 & 16,000 & 1,060 & - & 48. & - & $\cdot$ & 16,000 & Na \\
\hline & & Minimum Burial Volume (aum) & 1 & 1] & 요 & - & 11 & - & 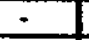 & of & $\mathrm{n} / \mathrm{a}$ \\
\hline \multirow{6}{*}{6} & \multirow{6}{*}{ Rosin } & Number of Records & 요 & 요 & ㅇ. & 0 & 0 & 요. & of & 0 & 0.0 \\
\hline & & Total Waste Volume (cu/t) & $\therefore$ & 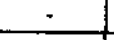 & $\therefore$ & - & $\dot{-}$ & - & - & - & $\therefore$ \\
\hline & & Average Burial Volume (cu/ti) & 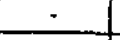 & - & $\therefore$ & - & $\therefore$ & - & - & 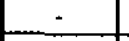 & - \\
\hline & & Standard Deviation & - & $\therefore$ & $\therefore$ & - & - & - & $\therefore$ & - & $\therefore$ \\
\hline & & Maximum Burial Volume (cu/t) & - & $\therefore$ & $\therefore$ & $\dot{-}$ & - & - & 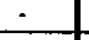 & $\therefore$ & - \\
\hline & & Minimum Burial Volume (cu/tit) & - & $=$ & $\therefore$ & - & - & - & $\therefore$ & - & - \\
\hline \multirow{6}{*}{7} & \multirow{6}{*}{ Other } & Number of Records & 12 & 의 & of & 요 & 의 & o. & of & 12 & 0.0278 \\
\hline & & Total Waste Volume (au/t) & 12 & - & 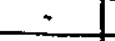 & - & $\cdot$ & - & - & 12 & 0.0000 \\
\hline & & Average Burial Volume (aum) & 1 & - & $\therefore$ & : & - & - & $\cdot$ & 1 & $n / a$ \\
\hline & & Standard Deviation & 요 & - & $\therefore$ & - & $\cdot$ & - & - & 0 & $\mathrm{na}$ \\
\hline & & Maximun Burial Volume (avit) & 1) & $\cdot$ & $\therefore$ & - & - & - & $\cdot$ & 1 & $n / a$ \\
\hline & & Minimum Burial Volume (auft) & 1 & - & $=$ & - & - & - & - & 1 & $\mathrm{Na}$ \\
\hline \multirow{4}{*}{\multicolumn{2}{|c|}{ Totals Across All 7 Type Codes }} & Number of Records & 28,404 & 7,041 & 5.762 & 1.809 & 106 & 0 & 0 & 43,122 & \\
\hline & & $\%$ of ORWBG Totals & 65.9 & 16.3 & 13.4. & 4.2 & 0.2 & 0.0 & 0.0 & 100.0 & \\
\hline & & Total Waste Volume (cutt) & $5,752,807$ & 546,703 & 790,344 & 21,841 & 13,449 & of & 역 & $7,125,144$ & \\
\hline & & $\%$ of ORWBG Totals & 80.7 & 7.7. & 11.1 & 0.3 & 0.2 & 0.0 & 0.0 & 100.0 & \\
\hline
\end{tabular}




\subsection{BURIAL HISTORY}

There is little detailed information available to reconstruct a history of burials at the ORWBG prior to 1956. After that time, several historical aerial photographs are available. These include photographs from 1956, 1966, 1972, and 1974. In addition, some of the burial maps prepared by the Health Physics (HP) staff during burial operations are available. These include burial maps from 1956, 1966, 1967, 1968, 1969, and 1972, presented here as Figures $3-1,3-2,3-3,3-4,3-5$ and 3-6, respectively.

The HP maps are especially useful because they present information from the opening of the burial ground through their date of preparation. The maps are also useful because notations on these maps identify what general type of waste went into each trench. They also include notations that indicate which trenches were only used for temporary storage. A series of memos and notes present in the SRS archives is also available. These provide additional useful information on burial histories.

The integration of these data sources, the COBRA data files discussed in Section 2, construction drawings, and discussions with site personnel all help to clarify the burial history of the ORWBG. Collectively, these sources indicate that the ORWBG can be viewed as three burial grounds: (1) the original 35-acre central portion of the ORWBG that was opened in 1952 and filled by the early 1960s; (2) a 15-acre eastern expansion that was opened around 1961 and closed in 1972; and (3) a 26-acre western expansion that was opened in 1961 and closed in 1974. Figure 3-6 presents the approximate boundaries of the three portions of the ORWBG. It should be noted that the lines delineating the three sections of the ORWBG are drawn somewhat arbitrarily, with burials taking place in both the old section and east/west expansion areas as the central burial ground was filled up and phased out.

\subsection{Original Burial Ground}

The central portion of the present ORWBG covers approximately 35 acres. In subsequent discussions this portion of the ORWBG is simply referred to as the original burial ground. Most of the waste disposal in the original burial ground predates the detailed records of the COBRA database, and only general volume estimates are available. HP maps provide the best information on the locations and types of disposals. Approximately 85 trenches are present in the original burial ground. 
According to HP survey maps and construction drawings, the 24 north-south trending trenches located in the eastern portion of the original burial ground are predominately lowlevel disposal sites. Ten of these were filled between 1952 and 1956. Most of the rest were filled between 1956 and 1961, with COBRA data indicating limited burial activity in the northernmost of these trenches until 1972. A single zirconium trench is located adjacent to the northern group of low-level trenches, and was active sometime between 1956 and 1961.

HP survey maps indicate that east-west trending trenches are located in the central and southwestern portions of the original burial ground. These include 19 high-level trenches, 22 B-Line trenches, a scrap metal trench, a graphite trench, two "AlSi" trenches, and two "old ingot" trenches.

Seven of the high level trenches were filled between 1952 and 1956. The rest were active between 1956 and 1961. Many of these may also include scrap metal. Only a few of the B-Line trenches in the original burial ground were in place by 1956 . The rest were filled between 1956 and 1961. The graphite trench was active sometime between 1956 and 1962. Graphite was used as the moderator in the 305-M Test Reactor as well as crucibles for special pours in target and fuel fabrication processes.

The two "AlSi" trenches located in the southern portion of the original burial ground were excavated in the mid to late 1950s and used for temporary storage of aluminum-silicon casting alloy (AlSi). Notations on later HP maps indicate that the barrels containing AlSi were reclaimed and removed from these trenches prior to 1966. AlSi was used in tests of this alloy as a candidate for cladding reactor elements. Most of the AISi waste would have come from M-Area.

To the east of the AlSi trenches are two smaller "old ingot" trenches. These may have contained lead bricks. They were placed between 1956 and 1961. HP maps indicate that the ingots were reclaimed prior to 1966 .

The large north-south trending trench located along the western boundary of the original burial ground is a disposal trench for equipment and jumpers (contaminated laboratory and process equipment and piping). It was used in the late 1950s and early 1960s (COBRA indicates that numerous burials took place in this trench in 1963 and 1964, see Figure 2-4). Site records noted that equipment and jumpers were placed in this trench and provide the coordinates of some pre $=1961^{-}$disposals, independently confirming its designation on HP 
maps. Several smaller equipment and jumper trenches are also present in the northwestern portion of the original burial ground.

A series of north-south trending storage trenches are present in the northwestern portion of the original burial ground. They were opened after 1956 and may have been used as temporary storage areas for equipment. Their use may have continued after disposal stopped in the original burial ground in 1961. No COBRA records correspond to burials in this group of trenches (Figure 2-4).

Just to the east of the storage trenches, HP maps indicate the presence of a sandblast pad. It was not noted on 1956 maps but is present on 1966 drawings. This area was used as a decontamination area and may be related to the decontamination of the equipment that was placed in the adjacent storage trenches. Runoff from the sandblast pad flowed to the east into a small sandblast drainage basin.

One special project trench (SP-235) is in the northeastern portion of the original burial ground. Waste in this trench originated in Building 235-F. The designation "special projects" generally indicates that some of the components buried in the trench were classified at the time of disposal. This trench was active for a period between 1956 and 1963 (COBRA records suggest several additional burials took place in this trench during 1964, Figure 2-4). Approximately 35 COBRA records exist for burials in the vicinity of this trench, with fission product, plutonium-238, and neptunium-237 listed as the radiological contaminants. No contaminant quantity or descriptive information is provided for these burials.

A single small plutonium disposal area is located in the southeastern corner, and another small plutonium disposal location is in the northeastern portion of the original burial ground. The northern location was active in a period between 1952 and 1956. The southern location is not present on 1956 maps and is not detailed in the COBRA database, which began in the first quarter of 1961. It is, therefore, most likely associated with the time period 1956 to 1961.

Twenty-two buried OSTs were installed between 1955 and 1968 near the center of the original burial ground (WSRC, 1994). Some of these tanks were utilized as fuel storage tanks at SRS and other federal facilities prior to their emplacement in the ORWBG (WSRC, 1994). All 22 tanks were constructed of thin-walled (0.75 inch) milled steel (WSRC, 1994). Hundreds of thousands-of-gallons of spent PUREX solvent from Separations facilities and smaller amounts of tritiated pump oil were stored in tanks prior to the 1980s. The PUREX 
solvent, consisting primarily of 30 percent tri-n-butyl phosphate (TBP) dissolved in kerosene, was used to extract plutonium and uranium from a nitric acid dissolver solution. The solvents were aged for about six months, during which most of the short-lived gamma-emitting fission products decayed and the heavy alpha emitters settled out of the solvent. The volume in the tanks was periodically reduced by drawing off the organic phase and then burning it in shallow open pans in trenches near the center of the ORWBG. The volatile combustion products dispersed to the atmosphere (Tharin, 1965). Hoeffner (1984) suggested that about 370,000 gallons of contaminated solvent were burned from 1956 to 1972 . Wilhite (1976) estimated the volume of solvent burned was 418,000 gallons. The residue was emptied from the pans into earthen trenches. After their useful lifetime, the pans were also buried unencapsulated in an earthen trench (Wilhite, 1976; Tharin, 1965). The residue/pan burials took place in a trench located just to the east of the solvent tanks. A second area where solvents were burned is located just south of the SP-235 trench. Open pan burning was suspended in February 1972 (Mason, 1996) and is no longer permitted (Hoeffner, 1984).

The contents of the OSTs, except for "unpumpable heel", were transferred to new tanks in the New Burial Ground (643-7E) in the late 1970s and early 1980s. The residual "unpumpable heel" in the OSTs separated into vapor, organic, aqueous, and sludge solid phases. VOCs from the spent solvent and associated degradation products are primarily concentrated in the vapor and organic phases. The concentrations of VOCs in the vapor phase are known from a recent vapor phase survey, and the amount of the organic phase is approximately 4,056 gallons.

Reviews of HP maps also indicate that the contaminated equipment and vessels were temporarily stored on the surface at several locations within the original burial ground.

\subsection{Eastern Expansion of the ORWBG}

The eastern portion of the present ORWBG covers approximately 16 acres. In subsequent discussions, this portion of the ORWBG is referred to the eastern expansion. It was opened as the original burial ground was filled and received wastes from 1961 until 1972. Most of the burials in the eastern expansion are contained in the COBRA database. HP maps, construction drawings, and SRS correspondence provide additional information.

Approximately 53 north-south trending trenches are present in the eastern expansion. According to HP survey maps, these include eight high-level trenches, seven B-Line trenches, 
trenches, a waste oil drum trench, and five plutonium disposal areas. Portions of two trenches contain contaminated dirt removed during a cleanup at 241-H. An old bulk solvent burning area is also present. Although HP survey maps show no low-level trenches in the eastern expansion, COBRA data clearly indicate that thousands of burials with burial codes 1 (low-level beta-gamma) and 3 (low level alpha) exist in the eastern expansion (Figure 2-5).

The five plutonium disposal areas are located in the western portion of the eastern expansion. Two small trenches are located south of the east-west access road. Both HP maps and the COBRA database indicate that these include encapsulated plutonium placed between 1966 and 1972. Information on the three plutonium trenches located north of the access road also indicates encapsulated plutonium was emplaced between 1966 and 1972.

A single oil drum trench is present in the northwestern portion of the eastern expansion. HP records suggest that this trench was open during most of the period between 1961 and 1972 (see oil drum trench on several of the HP survey maps, Figures 3-1 to 3-6). Burials in and around the oil drum trench can be seen on a yearly basis on Figure 2-4. The COBRA type code \#2 is a general category for "oil" wastes. Type code \#2 burial locations across all of the ORWBG, including the vicinity of the oil drum trench, are presented on Figure 2-5.

Five B-Line trenches are located in the southwestern portion of the eastern expansion. Three were filled between 1961 and 1966. The others were filled between 1966 and 1972. Two additional B-Line trenches are located in the south-central portion of the eastern expansion. One was filled between 1966 and 1969. The second was filled between 1969 and 1972.

Eight high-level trenches are located in the south central portion of the eastern expansion. Most wastes in these trenches were placed between 1961 and 1966, and the rest were completed between 1966 and 1969.

Two special project trenches are located in the south-central eastern expansion. A collision in 1966 between a bomber carrying nuclear weapons and a refueling aircraft contaminated the ground in Palomares, Spain (southern coast of Spain) with plutonium. Cleanup of the site produced 4,827 55-gallon sealed steel drums of topsoil and vegetation (tomato vines) (Horton and Corey, 1976 in Cook and Helton, 1989). The drums were placed in these two special project trenches having a cumulative length of 600 linear feet. The drums were buried 10 feet below the ground surface as a precaution against local infestation with plant and soil diseases from Spain (Corey, et al., 1970). 
below the ground surface as a precaution against local infestation with plant and soil diseases from Spain (Corey, et al., 1970).

All recoverable plutonium was removed from the soil in Spain before the soil was placed in drums. After the drums were filled, the lids were welded on. The drums were placed in a standard burial ground trench, 20 feet deep and 20 feet wide at the bottom. The drums were placed in the trench in rows of 10 drums each, across the width of the trench. Drums were double-tiered and then covered with a minimum of 10 feet of soil. Some of the details of this disposal remain classified.

A single special project trench is in the north-central eastern expansion. This trench is thought to contain some of the debris brought to SRS from Greenland following an in-flight accident. In 1968, a bomber carrying nuclear weapons crashed in Greenland, producing large quantities of contaminated ice and aircraft parts (Horton and Corey, 1976 in Cook and Helton, 1989). Recovery activities required 535 containers with a total volume of approximately 120,000 cubic feet for aircraft parts, and tanks for 630,000 gallons of water potentially contaminated with plutonium-239 (Cook and Helton, 1989). Once it arrived at SRS, the water was filtered, monitored, and sent to a seepage basin, except for a small fraction that evaporated and its concentrates, which were stored in the high-level waste tanks (Horton and Corey, 1976). The water was processed, and the empty tanks and aircraft parts were buried. Very low levels of TRU contamination were detected on this material. Some details of this disposal remain classified.

Scrap metal trenches are in the eastern portion of the eastern expansion. They fall into two groups, nine south of the east-west trending access road and six north. Review of HP maps and the COBRA database show that burials occurred concurrently in both the northern and southern groups throughout most of the operation of the eastern expansion. Within each group, the easternmost trenches were generally filled first and the western trenches filled last.

Review of HP maps also indicates that contaminated equipment and vessels were temporarily stored on the surface at several locations within the eastern expansion.

\subsection{Western Expansion of the ORWBG}

The western portion of the present ORWBG covers approximately 26 acres. In subsequent discussions, this-portion-of the ORWBG is referred to as the western expansion. It was opened as the original burial ground reached capacity and received wastes from 1961 until 
HP maps, construction drawings, and SRS comespondence and documents provide additional information.

Approximately 32 trenches are present in the western expansion. These include 23 low-level trenches, five 234-H special project disposal areas, Charleston Navy Shipyard disposals, a bunker with failed equipment from F-Area, and encapsulated plutonium and uranium disposal areas.

The low-level trenches in the western expansion fall into two groups, 12 east-west trending trenches north of the access road and 11 east-west trending trenches on the south. Review of HP survey maps (Figures 3-1 to 3-6) and the COBRA database show that burials occurred concurrently in both the northern and southern groups throughout most of the operation of the western expansion. Within each group, the northernmost trenches were filled first and the southern trenches filled last.

Several special project trenches (SP-234) are in the north and northeastern portion of the western expansion. These include a narrow slit trench in the extreme northern portion of the western expansion, an adjacent east-west trending trench, and a series of smaller disposals that include boreholes where wastes were grouted into place. The two trenches and one of the other SP-234 disposal areas were filled between 1961 and 1966 . The two other 234-H special project burials were filled between 1966 and 1972 . Waste in the special project trenches and borehole originated in $234-\mathrm{H}$, a tritium production facility. While most of these burials are in the COBRA database, the designation "special projects" generally indicates that some of the components disposed of in the trench were classified at the time of disposal. The observation that some of the wastes were placed into boreholes and grouted in place is also consistent with how some classified waste forms were buried.

Several disposals from the Charleston Naval Shipyard are near the SP-234 boreholes. Four items from the Charleston Naval Shipyard were buried in this portion of the ORWBG (Report of Conference, 1966). A burial pipe assembly was installed vertically and grouted prior to shipment of the thermocouples and sources. The first shipment was received in February 1966; the second, in March 1966. These disposals are in the COBRA database; however, some aspects are classified. This waste was placed in auger holes and grouted into place.

Some of the special burials from 234-H may also include neutron generators that were reported to have been buried in auger holes. The burial technique consisted of (1) having a 
Some of the special burials from 234-H may also include neutron generators that were reported to have been buried in auger holes. The burial technique consisted of (1) having a power line crew drill a hole 20 feet deep and 5 feet in diameter; (2) dropping boxes of neutron generators into the hole, (3) backfilling with several feet of dirt; and (4) pouring a 2-3 foot thick cement plug to seal the hole (Johnson, 1972). However, no specific burial technique was required, even though the generators were handled as classified shipments. Johnson (1972) suggested that neutron generators should be buried in a scrap metal trench similar to other classified shipments, resulting in an annual cost savings. He noted that written approval from the Atomic Energy Commission, a predecessor to the DOE, and Security should be obtained prior to changing the burial procedure. Only two COBRA records could positively be identified as neutron generators from Building 234-H.

Most HP maps of the western expansion show a "bunker" in the west-central western expansion. Verbal accounts report it to contain a piece of failed equipment removed from $F$ Area. No detailed records have been found regarding this disposal.

East of the bunker and between the northern and southern groups of low-level trenches are two other trenches. These contain encapsulated burials that are included in the COBRA database. Burials took place between 1966 and 1974. Although shown as a long trench, the southern disposals include discrete burials that contain drummed plutonium-238, plutonium239, uranium-235, uranium-238 and neptunium-237. The drums are either stacked in concrete culverts or encapsulated in concrete. In addition, a concentrated cluster of buried concrete culverts is also present at the western end of the second trench. Most of these were placed in 1973 and represent the last of the western expansion disposals. The rest of the second trench includes filter sands removed from the sand filters in the air exhaust systems in the Separations areas.

The northwestern portion of the western expansion was used as a decontamination area during the operation of the original burial ground. Review of HP maps indicates that contaminated equipment and vessels were temporarily stored on the surface at several locations within the western expansion. 


\section{Legend}

A- 643-G Office and Change Station (also known as 643-E

. 221-F Hot Canyon Jumpers

C. Outside Latrine
D. B-Line Waste

F. Solvent Tanks and Filter System

G- 100 Area Scrap Metal

H-Newly Excavated Barrel Trench

300M ALSI and Barel Buri
7773 Laboratory Waste

K-Pu Wast

- Low Level Wast

M- Scrap Metal

O-Above Ground Storage

P. Drainage Ditch

Q- Step Off Pad

S- Solvent Buming Pa

$X$-Marks Trenches Filled or Partially Filled
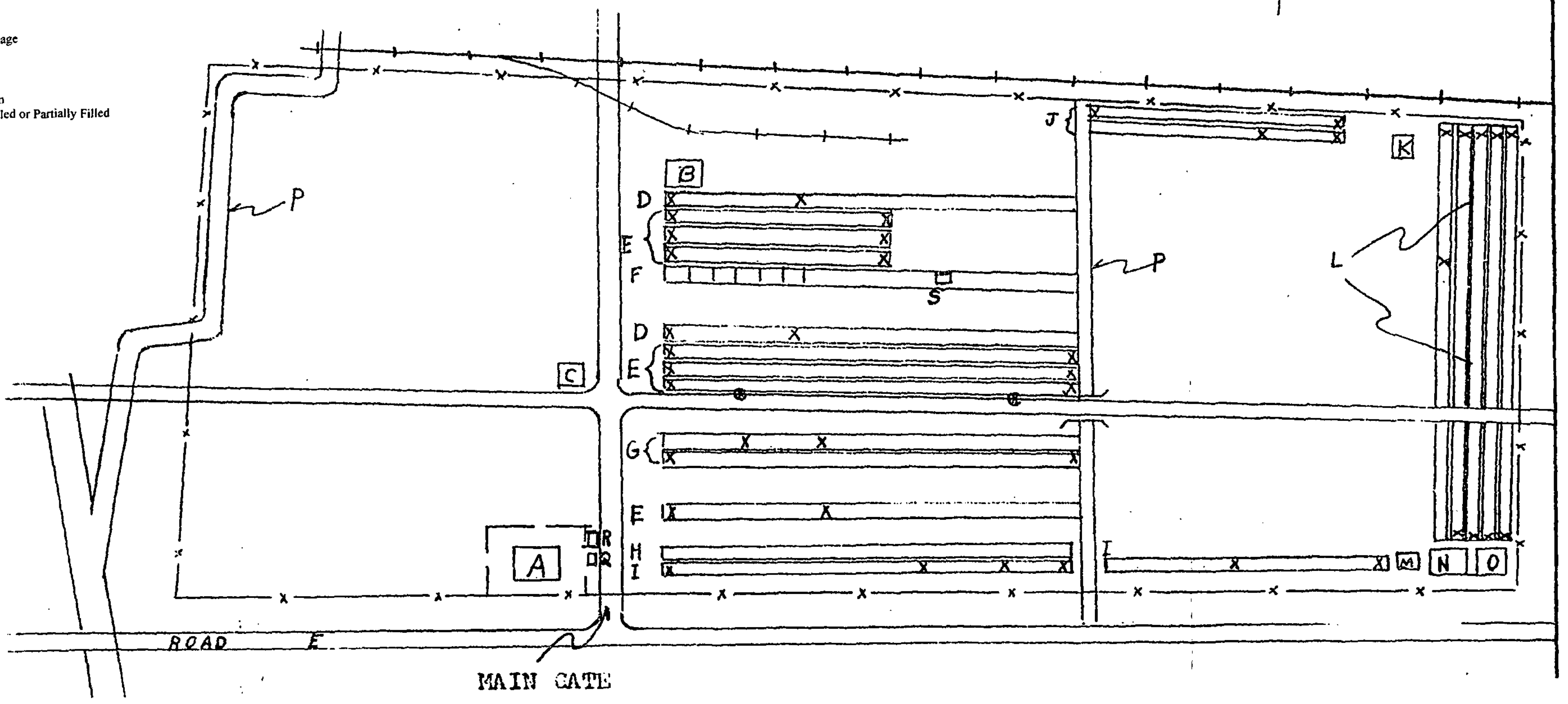

B

$D \frac{X}{X=1}$

$\left\{\begin{array}{r}x+1 \\ x\end{array}\right.$

(1)

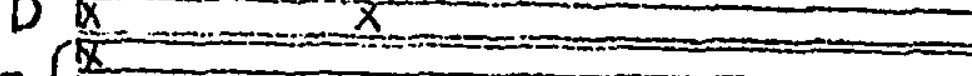

[c]
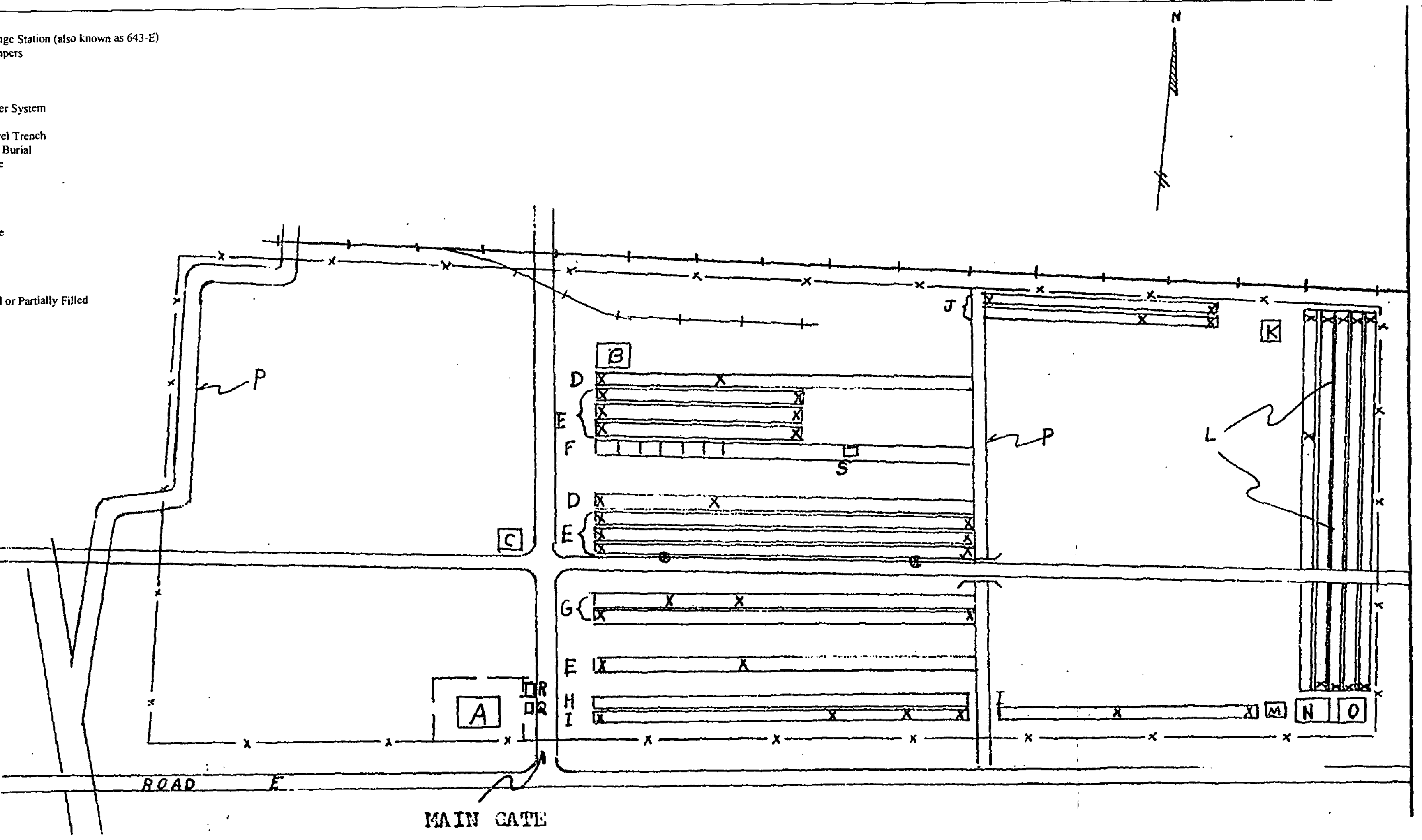

Figure 3-1. HP Survey Map Dated April 4, 1956 

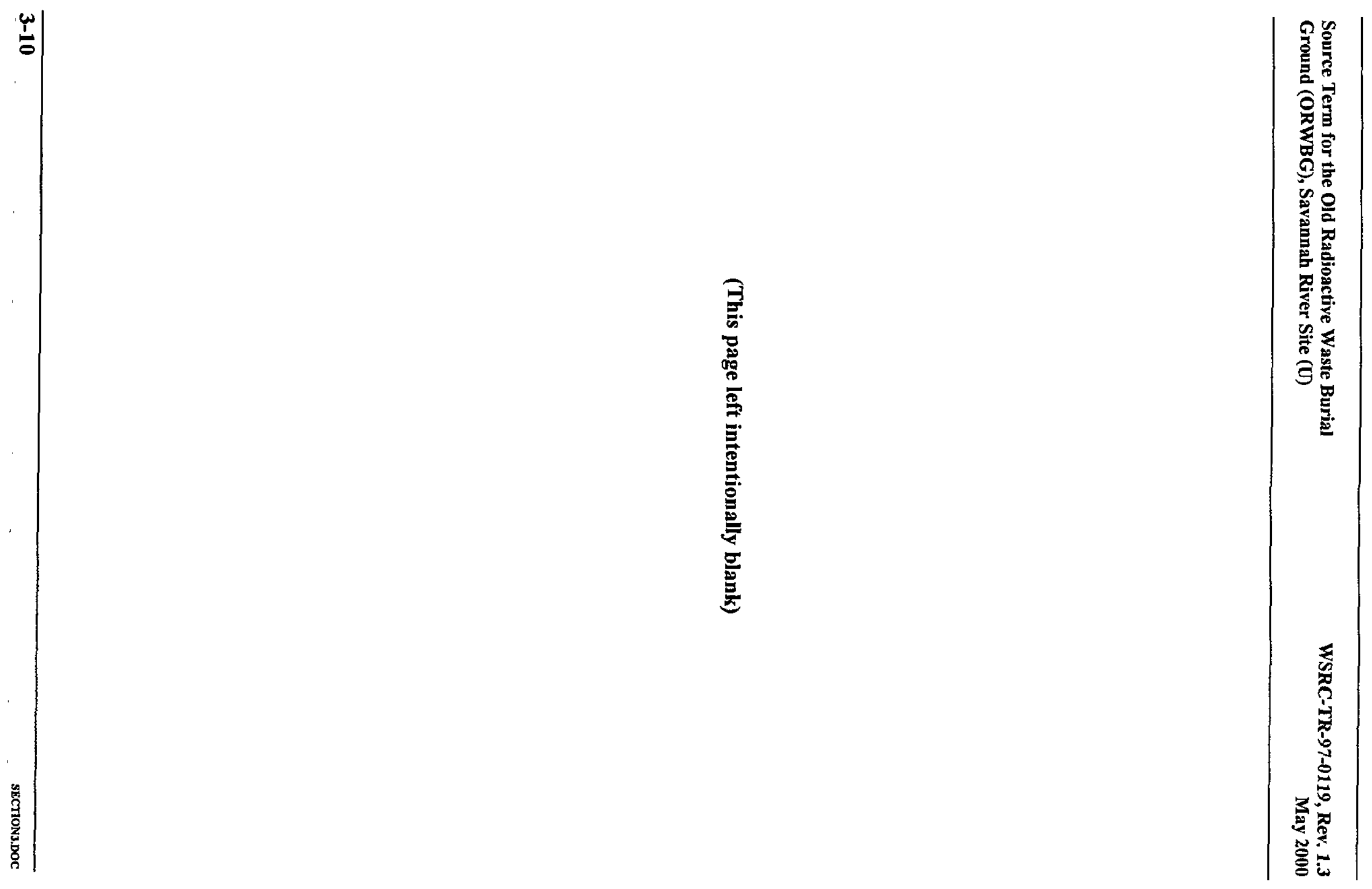


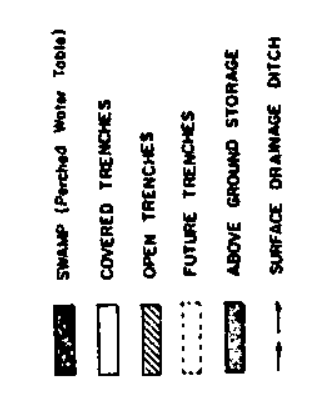

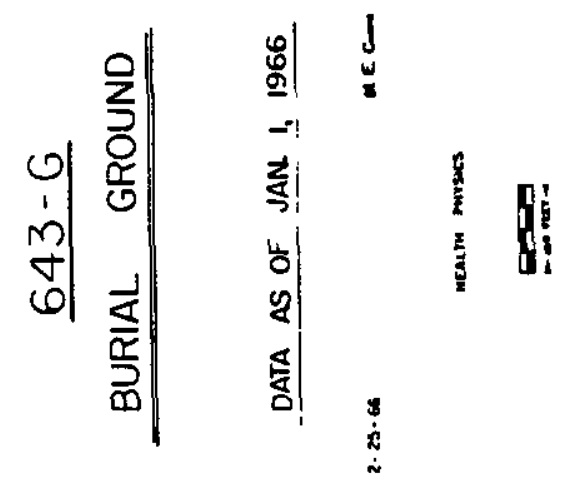
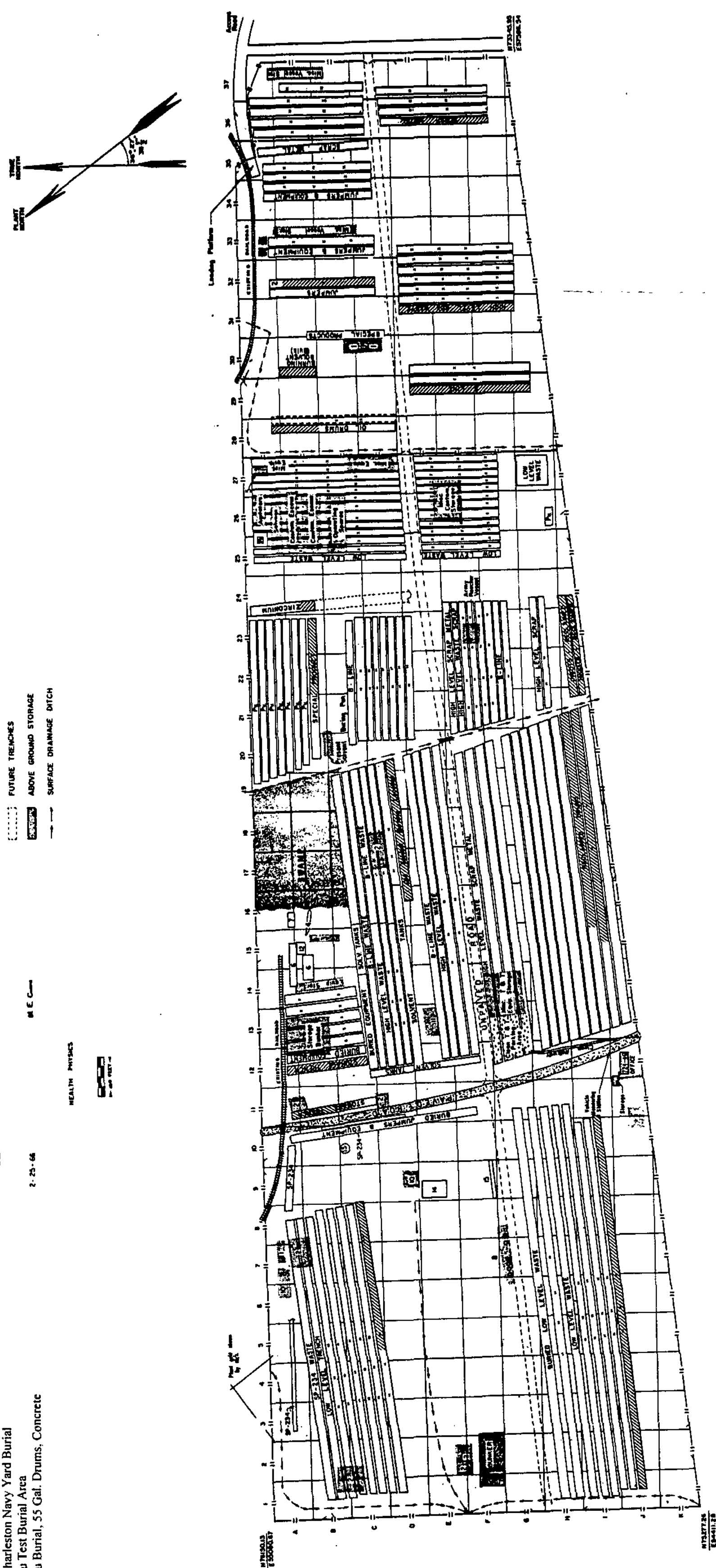


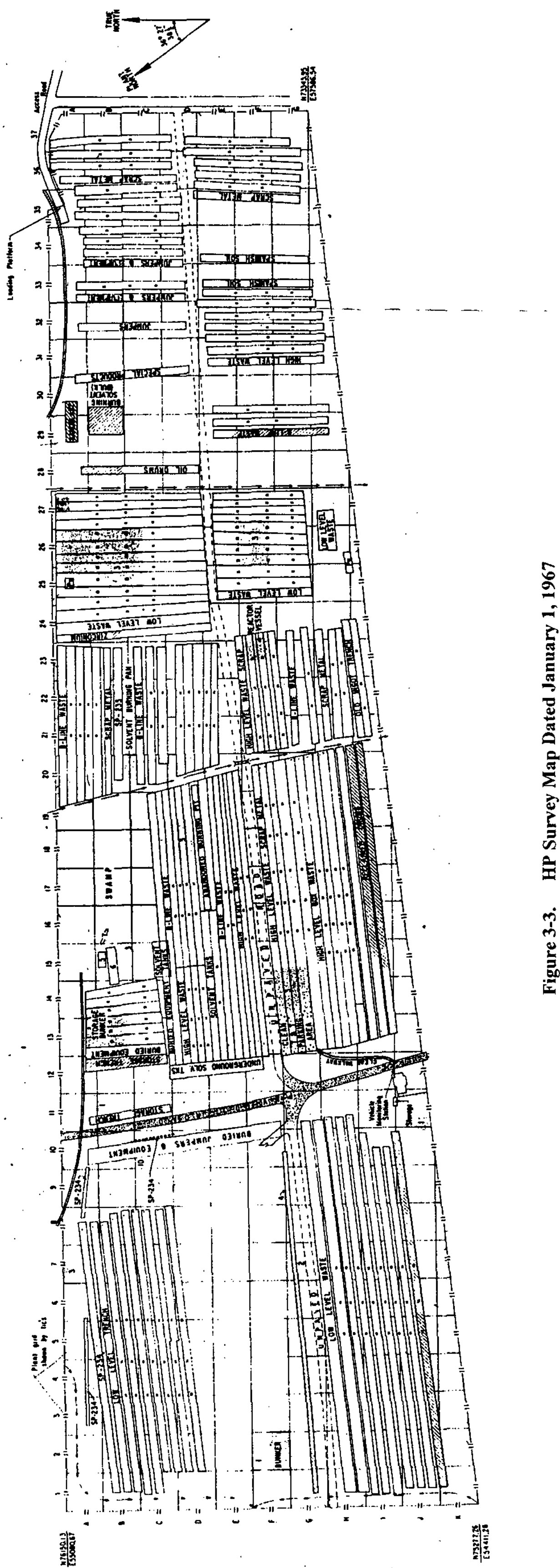


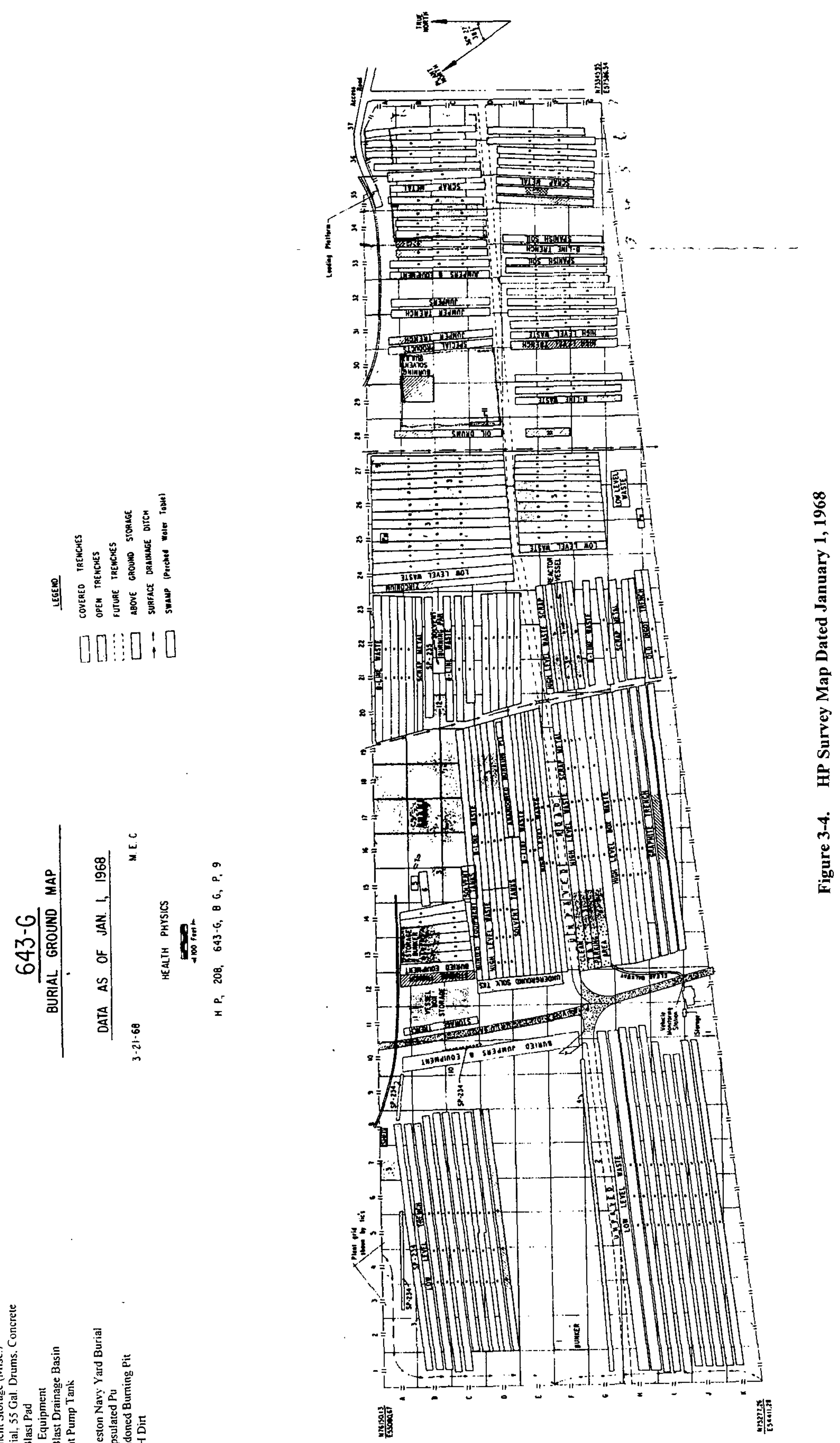

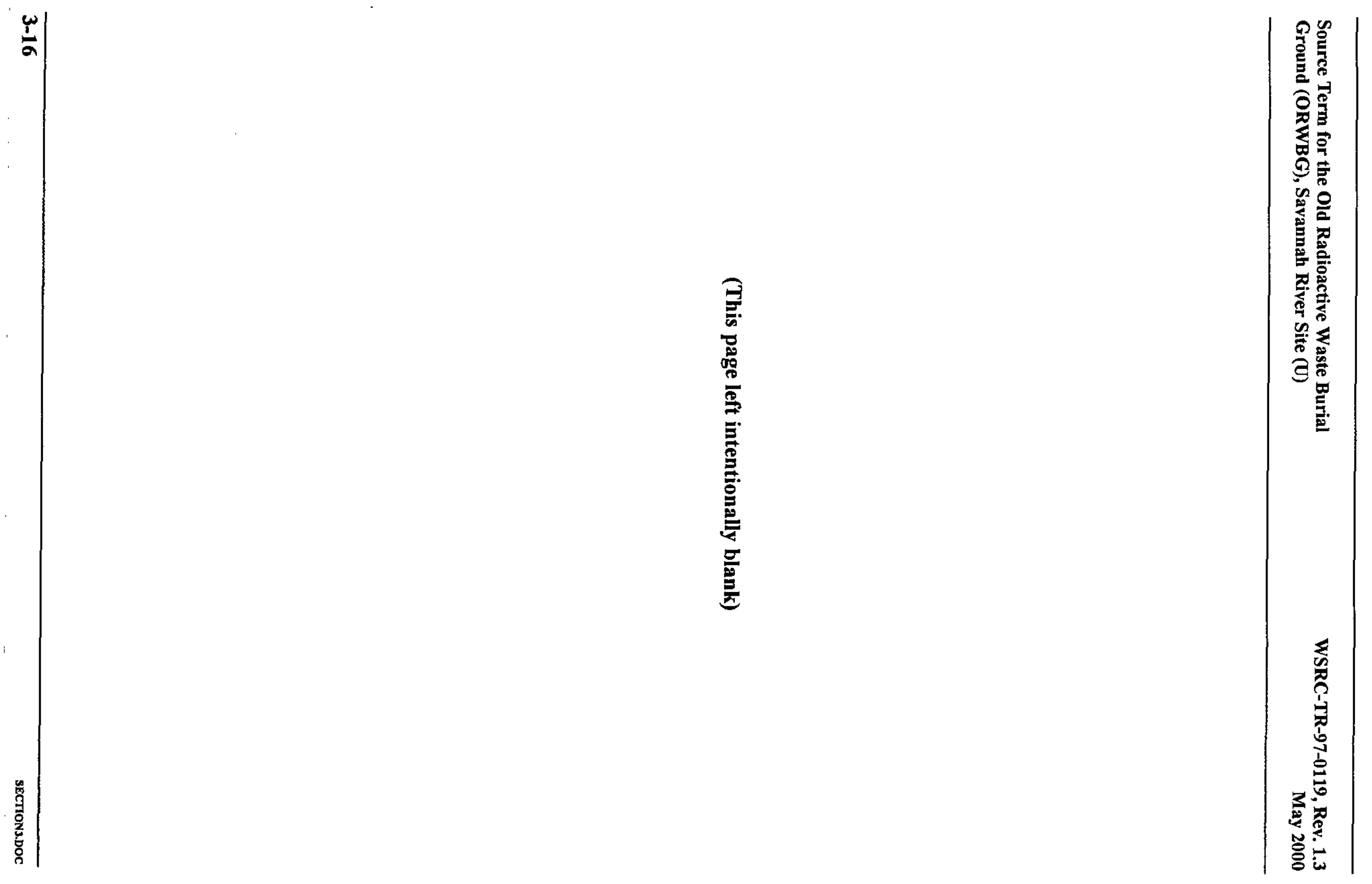
Legend

1. Vessel Storage

2. Pu Burial Containers

3. Equipment Storage (Misc.)
4. Pu Burial, 55 Gal. Drums. Concrete

5. Sand Blass Pad

7. Sand Blast Drainage Basin

8. Solvent Pump Tan

9. Lead Charleston Navy Yard Burial

11. Encapsulated Pu

13. 241 -H Dirt
14. Crested Ice, Temporary Above Ground Storage

$643-G$

BURIAL GROUND MAP

DATA AS OF JAN 1, 1969

3-3-69

M.

EALTH PHYS

50

H. P, 208, 643-G, B. G, P, 10

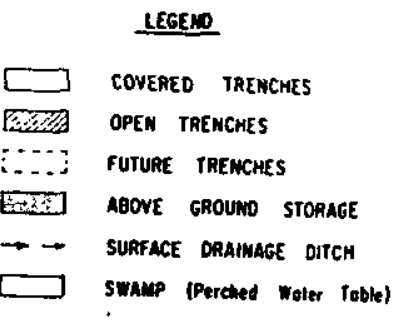

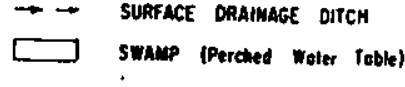

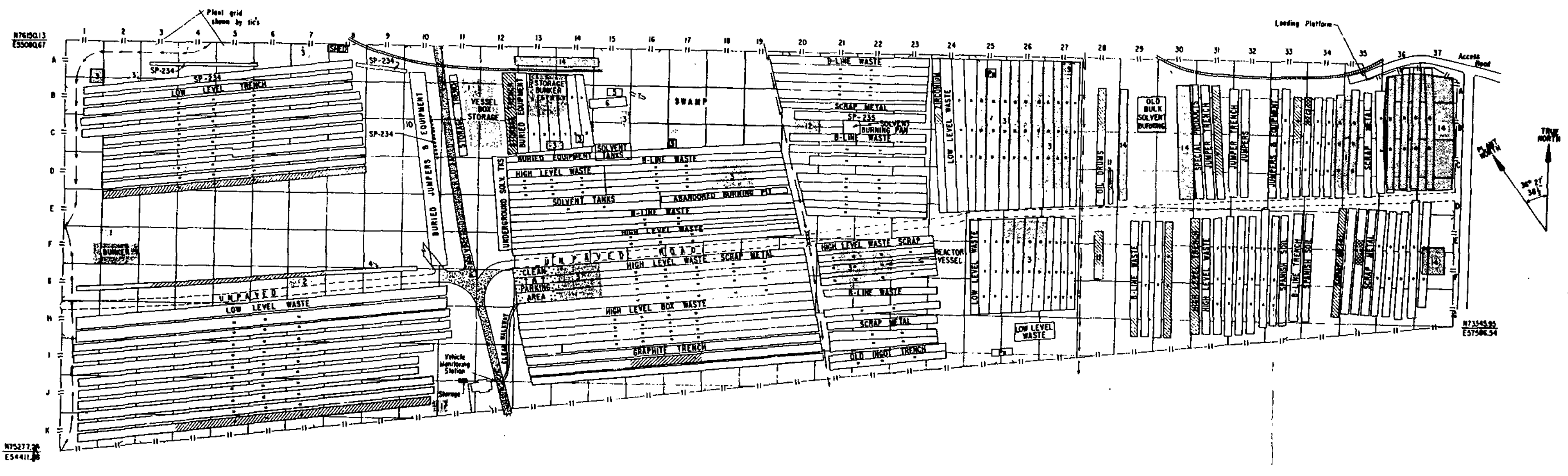

Figure 3-5. HP Survey Map Dated January 1, 1969 


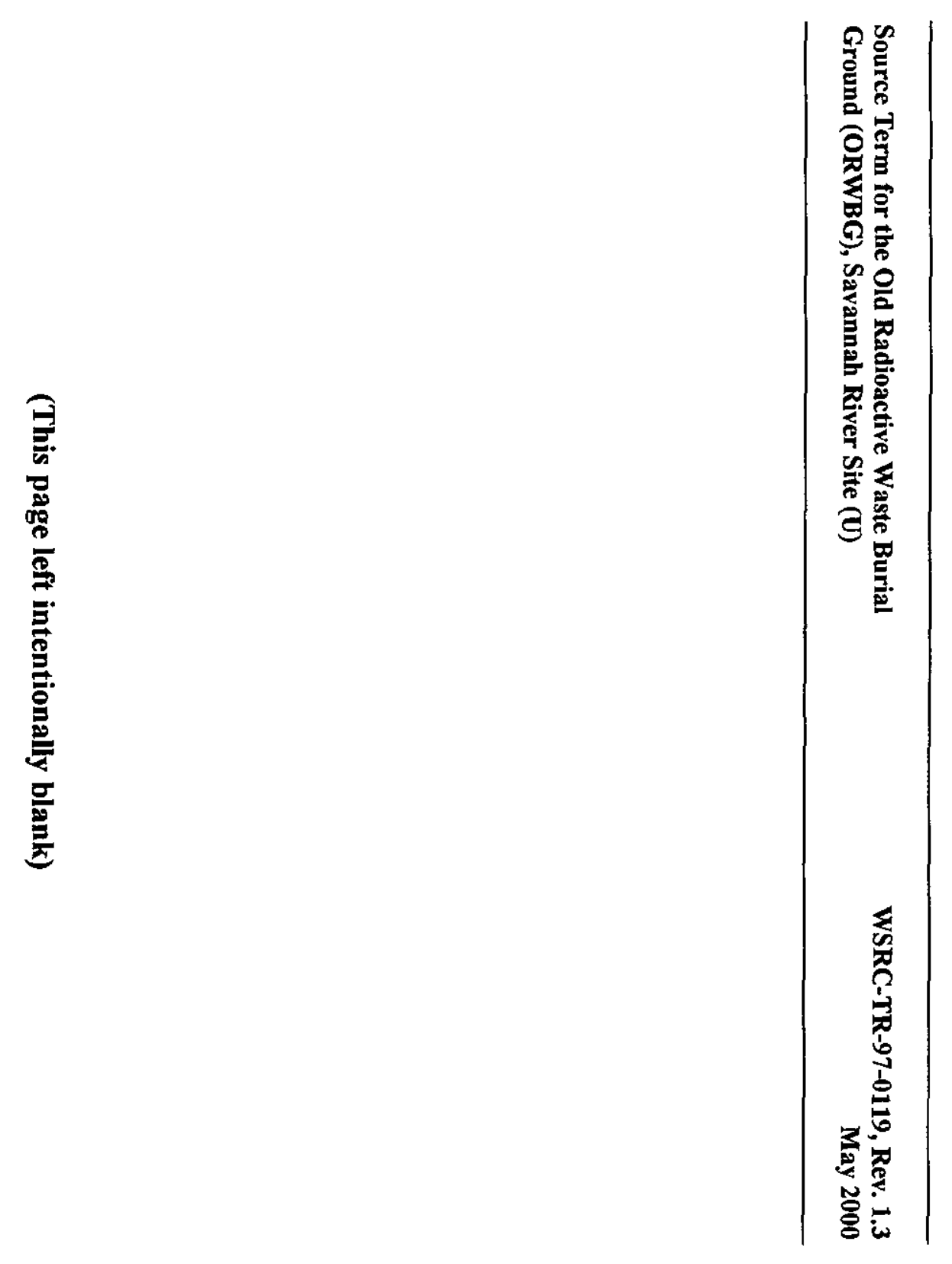



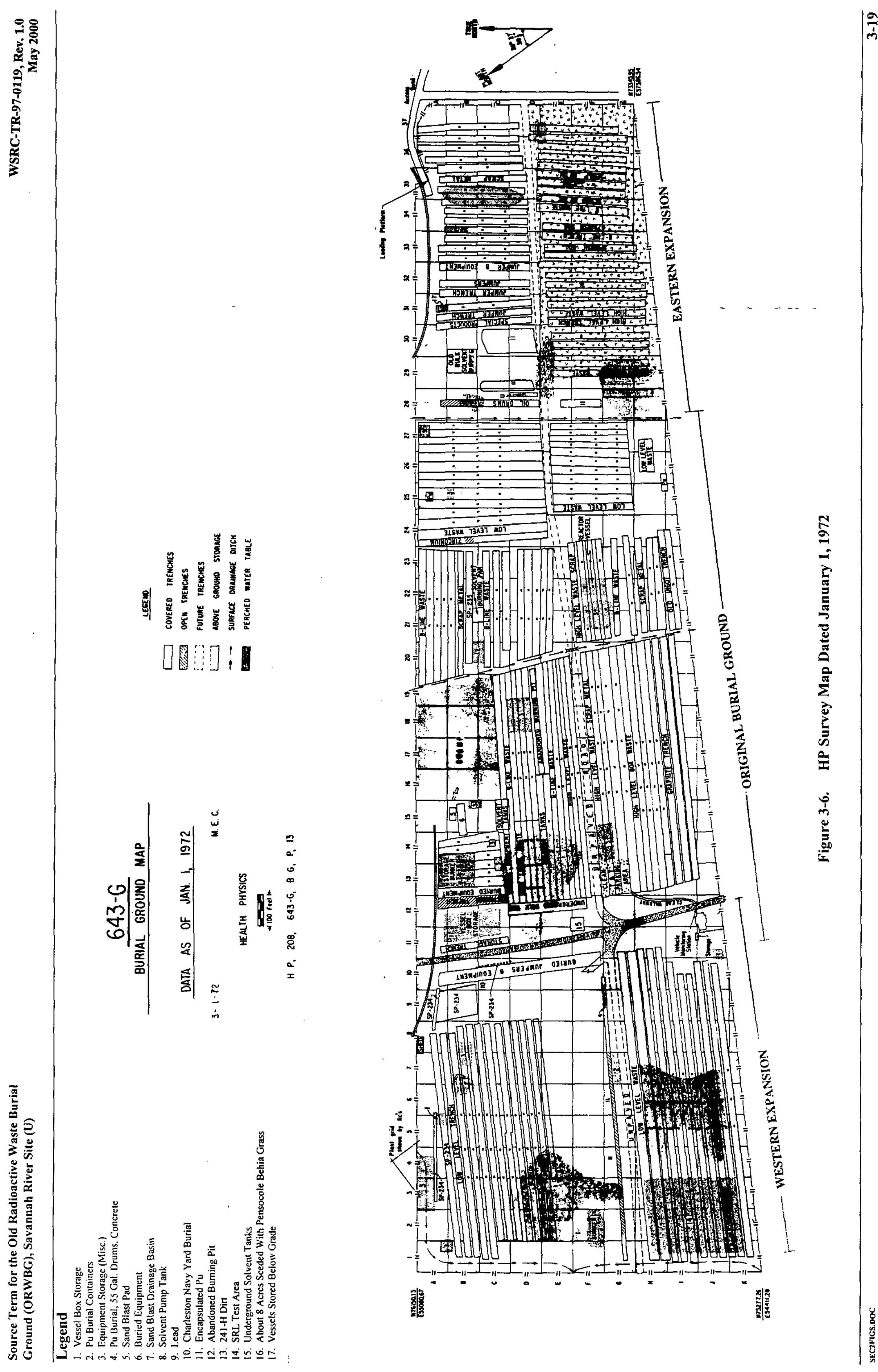


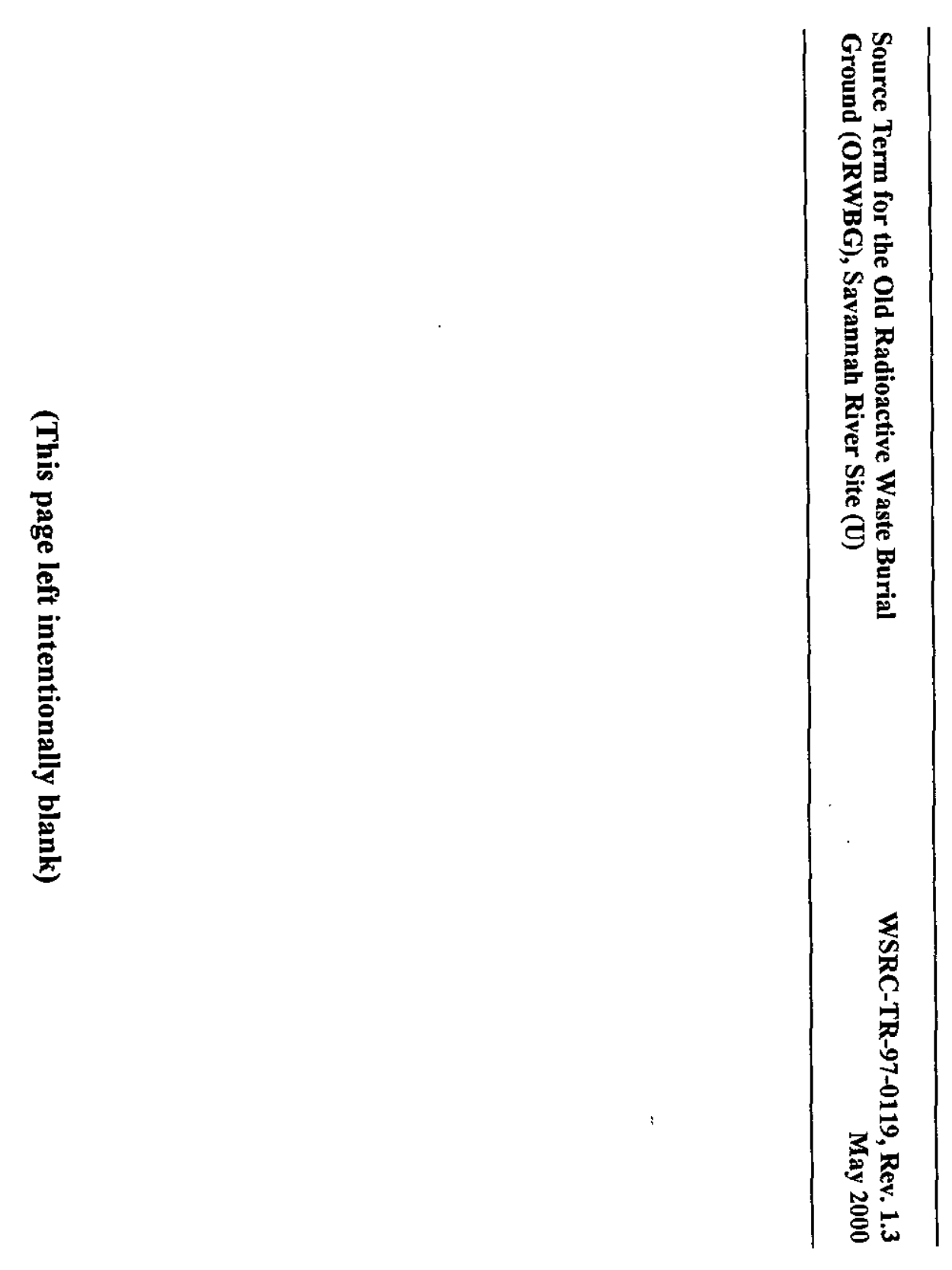




\subsection{TRENCH TYPES}

Based on review of the HP maps in Section 3.0 and construction drawings, the ORWBG disposal trenches can be grouped into several basic categories. These include low-level, high-level, jumpers and equipment, B-Line, scrap metal, encapsulated plutonium, storage, and special/classified projects. Solvent tanks and associated solvent burning pans and ash trench define an additional category. A miscellaneous category is also established to cover those trenches and disposals that do not conveniently fit any of these categories. As discussed in Section 2.3, COBRA records indicate that these generalized trench types may be oversimplifications. Further, it should be noted that even these general classifications can and often do overlap. For example, irradiated metal may be characterized as high-level waste or scrap metal depending on the readings that the HP staff observed prior to burial. It is important to view the subsequent discussion and associated maps of the ORWBG with these limitations in mind. Each of these ten trench categories is discussed below.

\subsection{Low-Level Trenches}

According to HP survey maps, about 30 percent of the trenches located in the ORWBG are low-level. According to COBRA about 5,752,807 cubic feet of low-level waste was disposed of in the ORWBG, which represents about 81 percent of its total waste volume (Table 2-2). Job control waste represents the bulk of these materials (96 percent), and other materials (irradiated metal scrap, naturally radioactive materials, oil, etc.) the remainder. According to COBRA descriptions, typical low-level waste includes a wide variety of job control waste (including housekeeping waste and protective clothing) such as paper, coveralls, a television set, dumpsters, cardboard boxes, casks, crucibles, glove boxes, grinder sludge, concrete, deionizers, drums, and complete vehicles (such as 27 dump trucks and 81 trucks). Most low-level waste consisted of relatively small items that were placed in cardboard boxes (cartons) and end-dumped into trenches. Other low-level waste includes offsite shipments from other DOE/DOD facilities.

Figure 4-1 presents examples of low-level trenches at the ORWBG. As shown on all three photographs, cardboard cartons filled with job control waste were an extremely common component of material placed into these trenches. The waste materials were end-dumped from hauling trucks into the active trench. Typically the wastes were covered with 1 to 2 feet of soil on a daily basis to help reduce the potential for trench fires. Note how the haul-truck pictured in Figure 4-1 is parked on top of a very recently placed soil cover on earlier burials.

Figures 3-1 to $3-\overline{6}$ show the distribution of low-level trenches in the ORWBG according to HP survey maps. They are concentrated in two areas, 24 in the eastern portion of the original burial ground and 
23 in western expansion. Although the HP survey maps show no low-level trenches in the eastern expansion, COBRA (Figure 2-5, upper right and left hand plots) clearly shows significant numbers of low-level trenches and job control waste burials in the eastern expansion.

\subsection{High-Level Trenches}

According to HP survey maps, about 15 percent of the trenches located in the ORWBG are high-level. COBRA indicates that high-level beta-gamma waste by volume accounted for 7.7 percent $(546,703$ cubic feet) of all ORWBG materials. The term "high-level" was used by the HP staff to denote waste that could not be directly handled due to the dose rate. This type of waste was usually off-loaded into the trench by crane or remotely dumped from a transport container. Typical "high-level" waste includes items such as varied process equipment, cartons, scrap metal, casks, fuel hangers, flow tubes, deionizers, filter cake, sand filter screen, spent melts, pumps, etc. Thorium and zirconium chips were also commonly placed in these trenches.

An example of a piece of contaminated equipment being buried in a high-level trench is given in Figure 4-2. The shielded crane cab suggests that the item being buried is probably producing a relatively high dose rate. Figures 3-1 to 3-6 show the distribution of "high-level" trenches in the ORWBG on the basis of HP survey maps. They are concentrated in two areas of the ORWBG, 16 in the central portion of the original burial ground and 8 in the eastern expansion. On the HP maps no high-level trenches are located in the western expansion. However, COBRA indicates that many shipments with burial code $=2$ (high level beta-gamma trench) were placed in western expansion trenches (see Figure 2-5, left column of plots, second from top).

\subsection{Jumpers and Equipment Trenches}

HP survey maps indicate that there are four jumper trenches, nine equipment trenches, and ten jumper and equipment trenches at the ORWBG. The term "jumper" refers to piping connecting various pieces of process equipment that operated in the separations facilities, generally in the canyons. The broad category of jumpers includes various types of piping arranged in a wide variety of configurations from straight sections of tubing to complicated custom welded headers and valve assemblies. There is no obvious category equivalent to jumper in COBRA. The database has only six records, all from $F$ and $\mathrm{H}$ areas, that can be positively identified as jumpers (phrase is given in the description field \#1). These records cut across COBRA trench and waste type categories, and include burial in low-level betagamma, high-level beta-gamma, and low-level alpha trenches, and identification as job control waste, irradiated metal scrap, and capital equipment waste categories. Because there is no characteristic code or means of identification for jumpers in COBRA, the database offers very limited help in 
understanding this waste form. COBRA has a type code category called capital equipment, in which 304 burials are identified (see Figure 2-5, right column of plots, fifth from top). However, this waste category may include only equipment that required accountability from an inventory tracking standpoint. Other equipment may have been identified using other type codes. In general, there is not a good correlation between locations of equipment trenches on the HP survey maps and burials identified as capital equipment in COBRA.

Figure 4-3 presents a photograph of a large transport box for jumpers. The transport box would be hoisted into position over an open section of trench, and then the contents would be dumped and the transport box reused. Figure 4-4 presents a large H-Canyon "Frame" being packaged in a burial box for shipment and disposal in an equipment trench at the ORWBG. Figure 4-5 pictures a variety of equipment and piping, likely contaminated, that awaits disposal in ORWBG equipment trenches. Note the polywrapped item on the left hand side of the picture; it likely was placed with the plastic sheeting intact into an equipment trench.

Figures 3-1 to 3-6 show the distribution of the equipment and jumper trenches in the ORWBG. The largest is the north-south trending trench located along the western boundary of the original burial ground. Thirteen additional jumper and equipment trenches are located in the eastern expansion. HP survey maps indicate that no jumper or equipment trenches are located in the western expansion.

\subsection{B-Line Trenches}

Twenty-five B Line trenches are in the ORWBG. This term is used to describe waste originating in B Lines operated in the canyons. The FB-Line in Building 221-F (located in F Area near the center of the SRS is adjacent to the canyon portion of the monolithic structure. Historically it converted plutonium nitrate (in solution), purified in F Canyon PUREX processing, to plutonium metal for use in defense programs. Most of this metal was "weapons-grade" plutonium, which isotopically consisted of 93 percent, or better, plutonium-239. The facility also recycled plutonium scrap generated during facility operations and from offsite sources to purify and concentrate this material to a product form.

In subsequent operations in FB-Line, the plutonium is precipitated from solution, filtered, dried and finally reduced to metal form. Processing equipment is enclosed in gloveboxes so that employees and operating areas are not exposed to the radioactive and highly toxic material. Some operations are automated. FB Line wastes would include job control waste and process equipment contaminated with plutonium.

Figures 3-1 to 3-6 show the distribution of B-Line trenches in the ORWBG. According to HP survey maps (Figures 3-1 to 3-6) they are concentrated in two areas of the ORWBG, 18 in the original burial 
ground and 7 in the eastern expansion. No B-Line trenches are located in the western expansion. COBRA has a large number of records for $F$ Area, including Building 221-F (6,164 records with a waste volume totaling 1,065,040 cubic feet), 221-FJB (294 records with a waste volume totaling 8,949 cubic feet), 221-FAL (33 records with a waste volume totaling 0 cubic feet), and 221-FBL (1 record with a waste volume of 50 cubic feet). However, COBRA does not appear to distinguish FB Line waste from other processes in F-Canyon Building 221-F, and no volume specific estimate of FB Line waste can be determined from the database. In general, there is a reasonable correlation between $\mathrm{B}$ Line wastes shown on HP survey maps and the location of Building 221-F wastes given in COBRA.

\subsection{Scrap Metal Trenches}

HP survey maps indicate about twenty scrap metal trenches are in the ORWBG. This includes irradiated metal and spent melts from the tritium process. COBRA has a good match for this trench type called irradiated metal scrap (COBRA type code =\#3). COBRA indicates that 481,007 cubic feet of irradiated metal scrap was buried at the ORWBG, which is about 6.8 percent of the total burial volume at the ORWBG (Table 2-2). COBRA descriptions for irradiated metal scrap include packaged items such as cans, cartons, drums and many casks. Other miscellaneous items given in COBRA description field \#1 for irradiated scrap metal include crucibles, deionizers, fuel hangers, cans, jumpers, low concentration slugs, metal doors, rod extensions, steel tanks, tin cans, tubes, thorium, spent melts, whirley pumps, zirconium chips, etc.

Figures 3-1 to 3-6 show the distribution of scrap metal trenches in the ORWBG. These trenches are concentrated in the eastern expansion. However, many of the high-level trenches located in the original burial ground also include "high level scrap metal". HP survey maps indicate that no scrap metal trenches are located in the western expansion. COBRA data (Figure 2-5, right column of plots, third from top) shows scrap metal burials occurred in many portions of both the eastern and western expansion.

\subsection{Encapsulated Plutonium}

Until 1965, TRU waste packaged within plastic bags and cardboard boxes was buried in unlined trenches designated specifically for this waste. Between 1965 and 1972, TRU waste was segregated according to TRU content. Waste containing less than $0.1 \mathrm{Ci}$ per package was buried unencapsulated in trenches. Waste containing greater than $0.1 \mathrm{Ci}$ per package was buried in potentially retrievable concrete containers 6 feet in diameter and 6.6 feet high. Waste that did not fit into the prefabricated concrete containers was encapsulated in place. in concrete. 
Figure 4-6 presents a photograph showing potentially retrievable concrete culverts being placed in trenches. The numbers listed on the sides of the containers $(99,111$ and 112) may correspond to the container number field given in COBRA. This type of trench is appreciably shallower (approximately 12 feet deep) than the commonly cited figure of ORWBG trenches being 20 feet wide by 20 feet deep.

Figure 4-7 presents a photograph showing six 55-gallon drums and one smaller drum containing 10-20 gram quantities of plutonium-239 inside a concrete culvert. As can be seen on the tops of the drums, these wastes were derived from the FB Line.

Figure 4-8 shows concrete being poured around 55-gallon drums containing plutonium TRU waste. Note the plywood shoring used on both ends of the active pour, and the exposed concrete face of a previous pour in the background. Note again that these trenches are significantly smaller in dimension than the idealized 20 feet wide by 20 feet deep ORWBG burial trench.

The HP survey maps (Figures 3-1 to 3-6) show plutonium disposal areas in the ORWBG as follows:

- Original burial ground: Two small plutonium disposal areas are shown located in the southeastern and northeastern portion of the original burial ground. The northern location was active in a period between 1952 and 1956. The southern location is not present on 1956 maps and is not detailed in the COBRA database, which began in 1961. It is, therefore, most likely associated with the time period 1956 to 1961.

- Eastern expansion: Five plutonium disposal areas are located in the western portion of the eastern expansion. Two small encapsulated plutonium trenches are located south of the east-west access road, and were active between 1966 and 1972. Information on the three plutonium trenches located north of the access road also indicates encapsulated plutonium was placed between 1966 and 1972.

- Western expansion: In the central-southern portion of the western expansion there are two trenches where encapsulated plutonium burials took place between 1966 and 1974. These burials are included in the COBRA database. Although shown as a long trench, the southern disposals include discrete burials that contain drummed plutonium-238, plutonium-239, uranium-235, and uranium-238. The drums are either stacked in concrete culverts or encapsulated in concrete. In addition, a concentrated cluster of buried concrete culverts is also present at the western end of the second trench. Most of these were placed in 1973 and represent the last of the western expansion disposals. The rest of the second trench includes filter sands.

COBRA has two burial code categories which fall into the potentially retrievable TRU category: (1) burial containers (potentially retrievable TRU), which is burial code \#4, and (2) concrete pours, which is burial code \#5. COBRA contains 1,809 records for potentially retrievable TRU burial containers, which have a total waste volume of 21,841 cubic feet. COBRA contains 106 concrete pour records, which have a total waste volume of 13,449 cubic feet. Only two types of waste are indicated to have 
been placed into the potentially retrievable TRU burial containers, including job control waste and irradiated metal scrap. Concrete pours entombed job control waste and capital equipment. COBRA locations for potentially retrievable TRU burial containers and concrete pours are given on Figure 2-5 (left column of plots, fourth and fifth plots from the top).

Although there is general agreement for some of the potentially retrievable plutonium locations between the HP survey maps and COBRA, COBRA shows large numbers of potentially retrievable TRU burial containers in the southeastern portion of the eastern expansion as well as scattered isolated burials. The commonality for burials in the southeastern potentially retrievable TRU cluster is that COBRA does not have any container numbers for these records. It should be noted that of the 1,809 burial container (potentially retrievable TRU) records in COBRA, 495 have $\mathrm{x}, \mathrm{y}$ coordinates that have been corrected, with 7 locations that are incorrect.

\subsection{Storage}

Notations on the HP survey maps (Figures 3-1 to 3-6) indicate that certain areas and trenches at the ORWBG were used for temporary storage. The two "AlSi" trenches located in the southern portion of the original burial ground were excavated in the mid to late 1950s and used for temporary storage. Notations on later HP maps indicate that the barrels containing AlSi were reclaimed and removed from these trenches prior to 1966 .

A series of north-south trending storage trenches are present in the northwestern portion of the original burial ground. They were opened after 1956 and may have been used as temporary storage areas for equipment contaminated with short-lived isotopes. Their use may have continued after disposal stopped in the original burial ground in 1961. No COBRA records correspond to burials in this group of trenches (Figure 2-4).

Just to the east of the storage trenches, HP maps indicate the presence of a sandblast pad. It was not noted on 1956 maps but is present on 1966 drawings. This area was used as a decontamination area and may be related to the decontamination of the equipment that was placed in the adjacent storage trenches. Runoff from the sandblast pad flowed to the east into a small sandblast drainage basin.

Numerous areas, both large and small (shown on the January 1969 HP survey map) were used for temporary vessel storage, temporary equipment storage, and temporary above ground storage for containers of the waste associated with the Greenland Accident (discussed in the following section). Similar demarcations are indicated on the other HP survey maps. 
The COBRA database does not track any temporary waste storage, only final burial locations, and therefore provides no information on areas used for temporary storage.

\subsection{Special/Classified Projects}

The designation "special projects" generally indicates that some of the aspects of a burial were classified at the time of disposal. Typically the form of the waste requires the burial to be classified, and not the quantity or type of radiological contamination. There were two methods of disposing of classified waste in trenches at the ORWBG, depending on whether the waste was buried separately or along with other waste. In either case, the waste was buried at least 6 feet below final grade in pits excavated for the specific purpose of receiving classified waste. Waste that was buried separately was covered with soil on the day of burial and a 4-inch thick concrete slab was poured. The slab extended at least 2 feet beyond the edges of the trench. If a pit was used, it was acceptable to use a concrete plug at least two feet thick that did not extend beyond the pit edge. Upon hardening, the concrete slab or plug was covered by approximately 1 foot of soil. Waste that was buried along with other waste was placed in the very bottom of a high-level waste trench and covered with at least 2 feet of either dirt or high-level waste on the day of burial. The trench was then backfilled in the normal manner (Du Pont, 1964). Some classified burials took place in 30 inch diameter auger holes.

Two special burials at the ORWBG include plutonium-contaminated waste from two accidents involving aircraft carrying nuclear weapons. Large quantities of plane debris and contaminated surface materials were drummed and shipped to the ORWBG for disposal. Figure 4-9 presents a photograph of soil filled drums from the Spanish Accident being lowered and stacked in a trench at the ORWBG. Figure 4-10 presents a photograph of large tanks containing waste water from the Greenland Accident arriving at the ORWBG via rail car. The Greenland Accident is in reference to a bomber carrying nuclear weapons that crashed onto the ice in Greenland on January 21, 1968. The crash site was surveyed and cleared of aircraft debris and ice potentially contaminated with plutonium. The recovered debris was put in drums and the ice was placed into storage tanks. Approximately 680,000 gallons of melt water from the ice arrived at the ORWBG in 535 containers with a total storage volume of 120,000 cubic feet. The water was filtered, monitored, and sent to a seepage basin, except for a small fraction that was evaporated and its concentrates stored in the high-level waste tanks. The drummed aircraft debris and empty storage tanks (shown on Figure 4-10) were buried in three separate trenches within the ORWBG (Corey and Horton, 1971). Some specifics of these two incidents remain classified. 


\subsection{Solvent Tanks/Solvent Burning Pans}

Twenty-two buried solvent tanks were installed between 1955 and 1968 near the center of the original burial ground (WSRC, 1994). All 22 tanks were constructed of thin-walled (0.75 inch) milled steel (WSRC, 1994). Some of these tanks served as fuel storage tanks at SRS and other federal facilities prior to their emplacement in the ORWBG between 1955 and 1968 (WSRC, 1994 and 1996). Hundreds of thousands of gallons of spent PUREX solvent from Separations facilities and smaller amounts of tritiated pump oil were stored in tanks prior to the 1980s. The solvents were aged for about six months, during which most of the short-lived gamma-emitting fission products decayed and the heavy alpha emitters settled out of the solvent. The volume in the tanks was periodically reduced by drawing off the organic phase and burning it in shallow open pans in trenches. Solvent was pumped from the storage tanks to a 1,400-gallon above-ground feed tank. The solvent moved via gravity feed through a device to prevent flash-back and into the burning pans. A line valve was used to regulate the solvent flow to yield a slow, continuous flow to the burning pan (Tharin, 1965).

Burning pans varied in design and composition. The earliest configurations were 6 to 12 inches in depth and made from mild steel and stainless steel, the former material being the most common. The pan design eventually took the form of the longitudinal half of 400-gallon, mild steel cylindrical tanks. The pans rested at the bottom of trenches excavated to widths and depths of 20 feet (Figure 2 in Tharin, 1965). The solvent-burning process left a thick, tar-like residue in the pan. When the pan became approximately half-filled with residue (approximately 100 gallons in the later pan designs), it was emptied by crane into the ditch bottom and covered with a layer of soil. The practice of covering the dumped residue with an "umbrella" layer of bentonite was developed in 1961-62. When the pan reached the end of its serviceable life, it was buried in the ditch with the residue (Tharin, 1965).

More than 380,000 gallons of solvent were burned on a virtually continual basis from February 1956 up until the practice was suspended by Executive Order 11507 in February 1972 (WSRC, 1996). The contents of the OSTs, except for "unpumpable heel", were transferred to new storage tanks in the New Burial Ground (643-7E) in the late 1970s and early 1980s (WSRC, 1996).

All but the earliest HP survey maps show the location of the solvent tanks in the eastern-central portion of the original burial ground. The residue/pan burials took place in a trench located just to the east of the solvent tanks (also shown on Figures 3-2 to 3-6). Other solvent burning areas include the original burial ground just south of the SP-235 trench (two solvent burning pan areas), and in the northwest corner of the eastern expansion. The procedure of burying solvent residue and spent pans resulted in râdioactive contamination of the soil (Hoeffner, 1984). 


\subsection{Miscellaneous Category}

One trench, approximately 100 feet long and located in the east-central part of the ORWBG, was used for disposal of an unknown quantity of empty oil drums. The location of this trench is in the northwest quadrant of the eastern expansion, which is shown on all but the earliest of the HP survey maps (Figures 3-2 to 3-6).

The facilities at the ORWBG included a sandblasting facility for the decontamination of equipment (Corey and Horton, 1971). One sandblasting pad operated in the northern central portion of the original burial ground. Surface drainage from this pad was towards the swampy area located immediately to the east of this area. The location of this pad is shown on all but the earliest of the HP survey maps (Figures 3-2 to 3-6). A second sandblast area is identified on the January 1967 survey map (Figure 3-3). It is located in the extreme northwest corner of the eastern expansion, just north of the bulk solvent burning area. HP maps dated from 1966 through 1972 (Figures 3-2 through 3-6) indicate a "sand blast pad" adjacent to a "sand blast basin", which probably received run-off from the facility. Two photographs of the sandblasting facility in operation appear as Figures $4 \mathrm{a}$ and $4 \mathrm{~b}$ in Corey and Horton (1971), but additional details about the procedures and practices or disposition of waste generated by this facility are not available.

COBRA indicates that 141 offsite shipments to the ORWBG took place during 1961 to 1974 . The total volume of waste for these burials is 37,978 cubic feet, and includes material from known DOE/DOD facilities and from unknown offsite sources. Most of these burials (126) went into lowlevel beta-gamma trenches, with five placed in high level beta-gamma trenches, six in low-level alpha trenches, three in burial containers (potentially retrievable TRU), and one in a concrete pour. Other offsite shipments (those that are classified) do not appear in COBRA. Offsite shipments are scattered across the ORWBG and were not placed in specially excavated trenches. A plot showing the location of offsite shipments is provided in Figure 4-11. Figure 4-12 presents a photograph of Mound Waste (probably containing tritium) being placed in a concrete culvert. Figure 4-13 shows waste materials packaged in a variety of containers, some of which may be from offsite locations. 

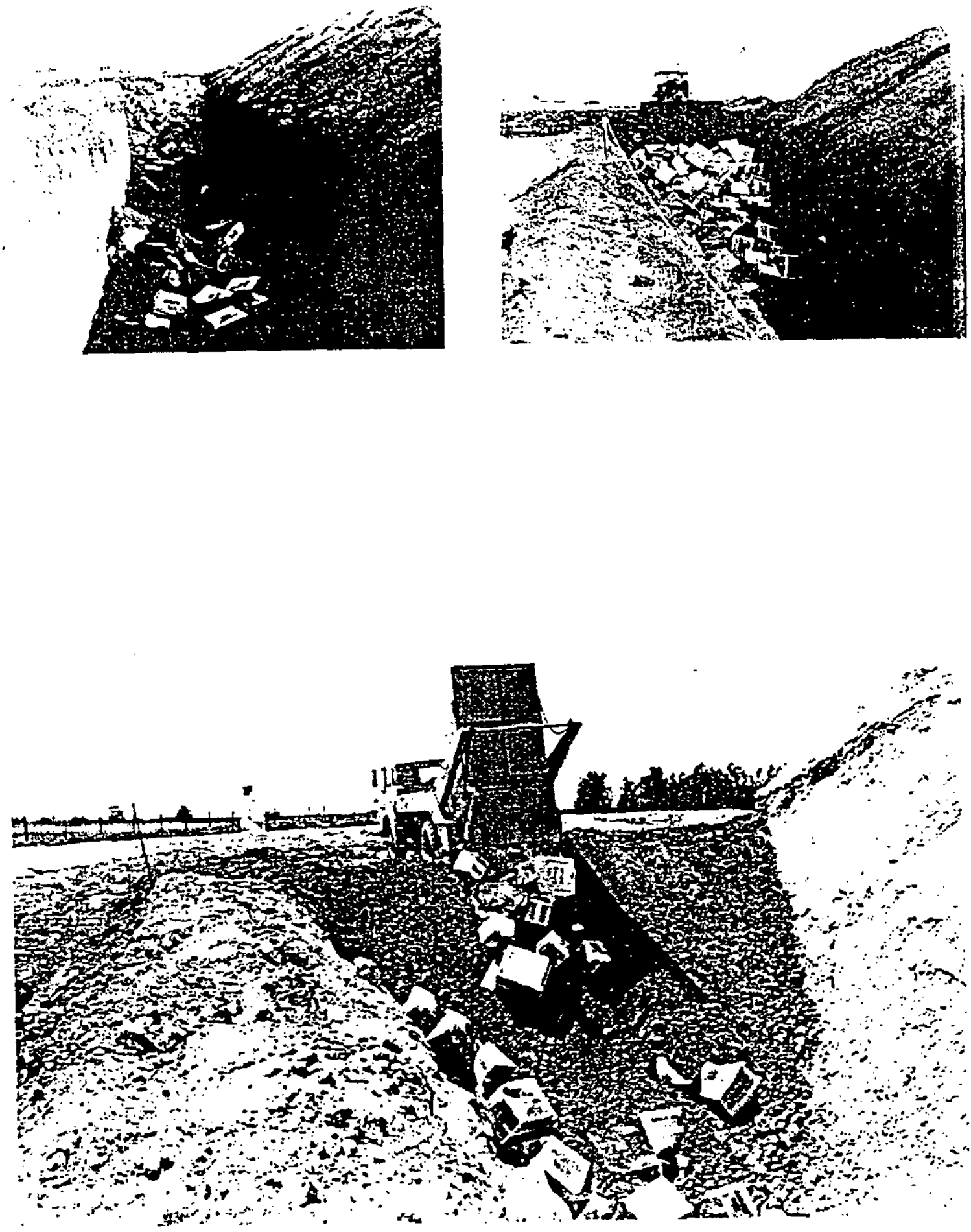

Figure 4-1. Examples of Active Low Level Radioactive Waste Trenches at the ORWBC: 


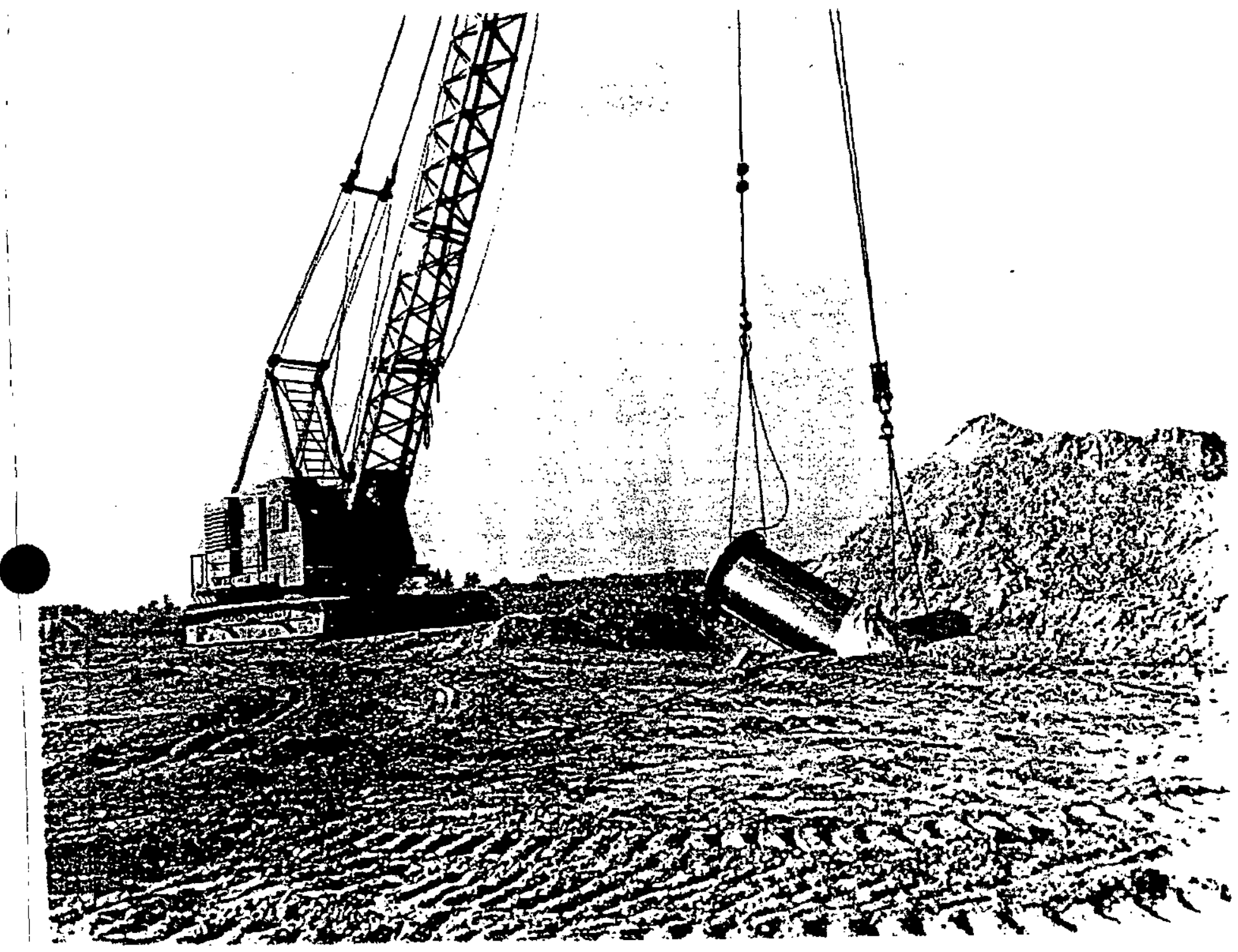

Figure 4-2. Burial of Contaminated Equipment 
Source Term for the Old Radioactive Waste Burial Ground (ORWBG), Savannah River Site (U)
WSRC-TR-97-0119, Rev, 1.0

May 2000

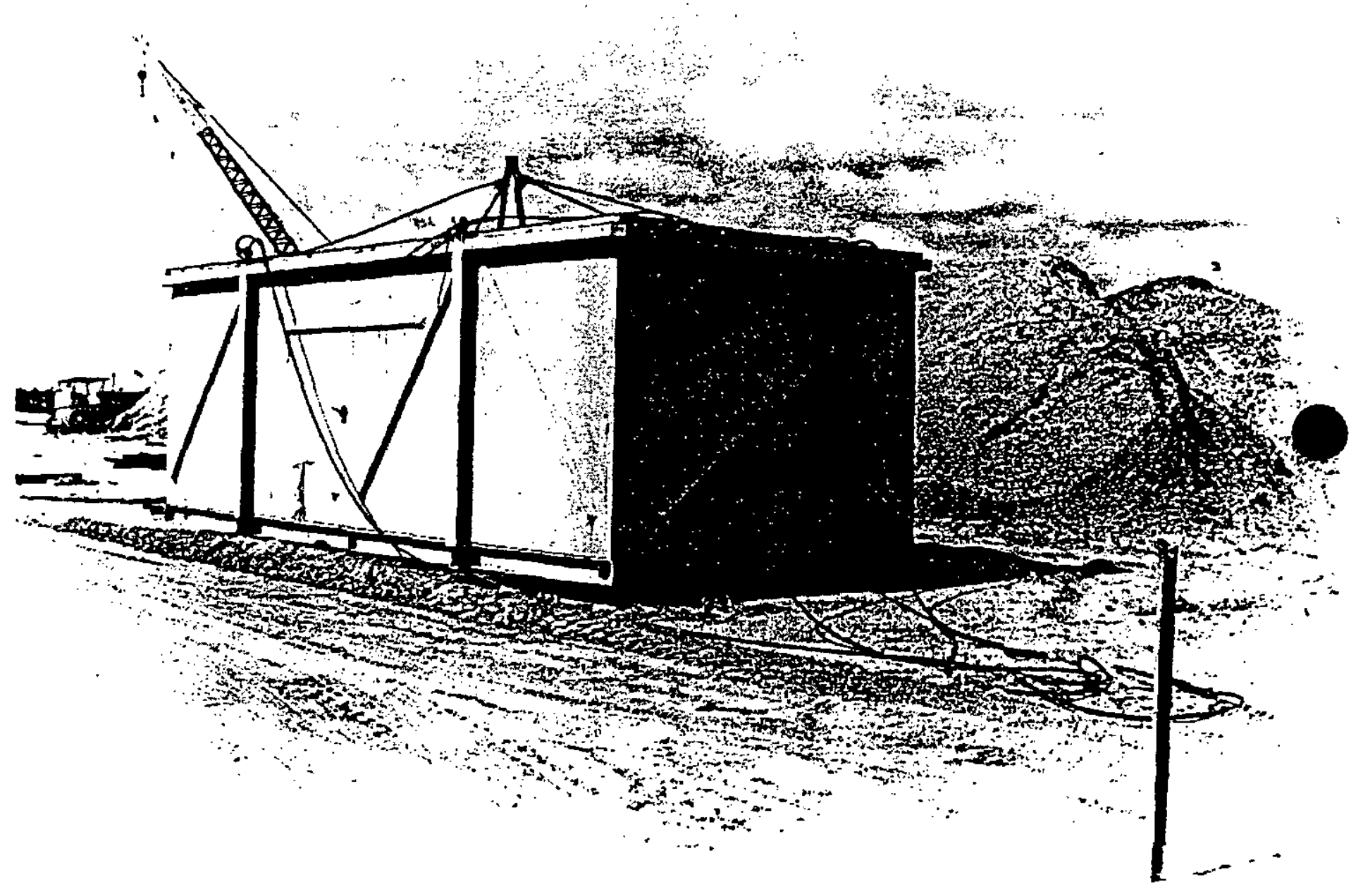

Figure 4-3. Transport Box for "Jumpers" (Canyon Piping), whose Contents Would be Dumped Via Crane into a Trench 


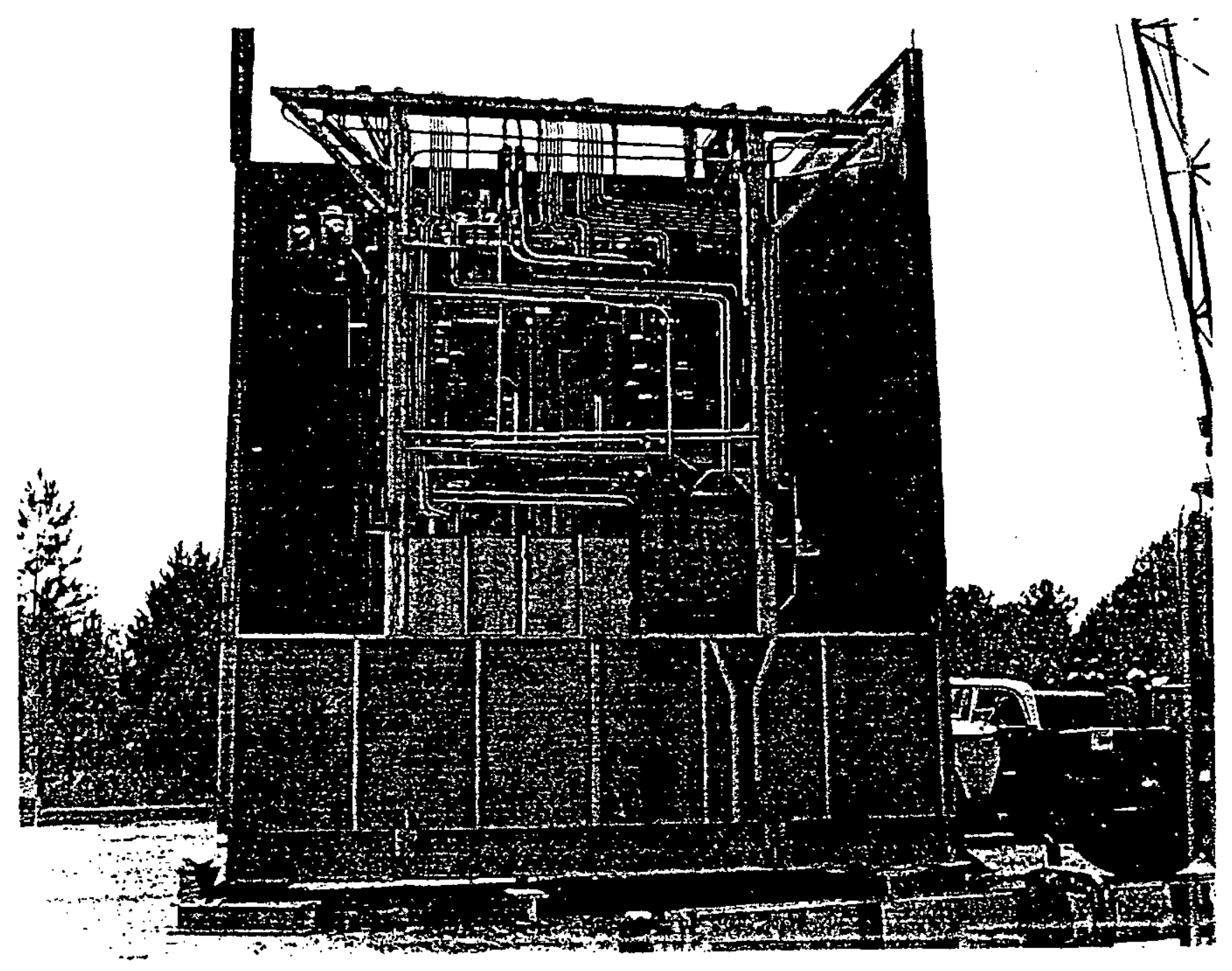

Figure 4-4. H-Canyon "Frame" Bcing Packaged in Burial Box for Shipment and Disposal in ORWBC, Likely in an Equipment Trench 


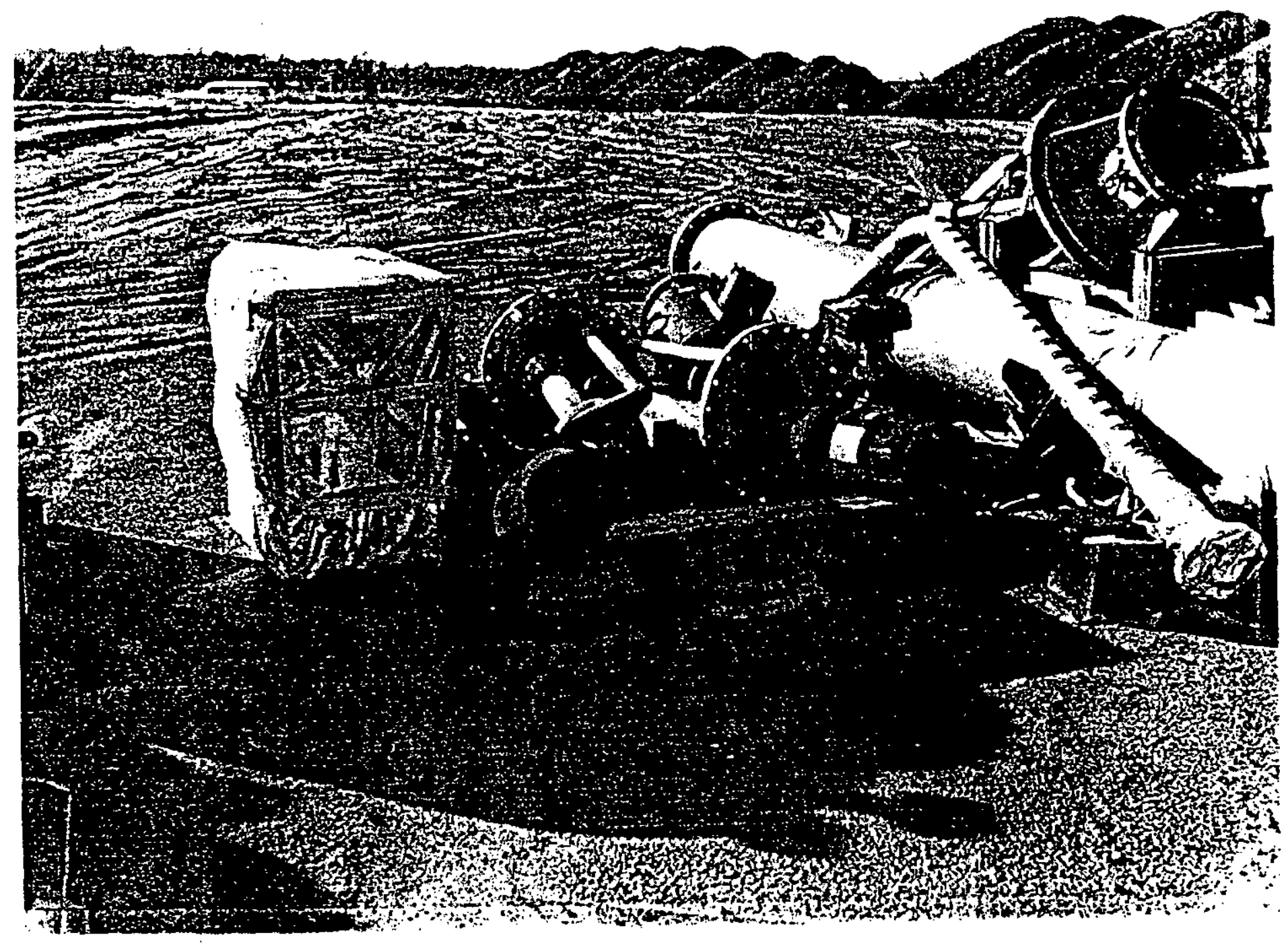

Figure 4-5. Equipment, Likely Contaminated, Awaiting Disposal 


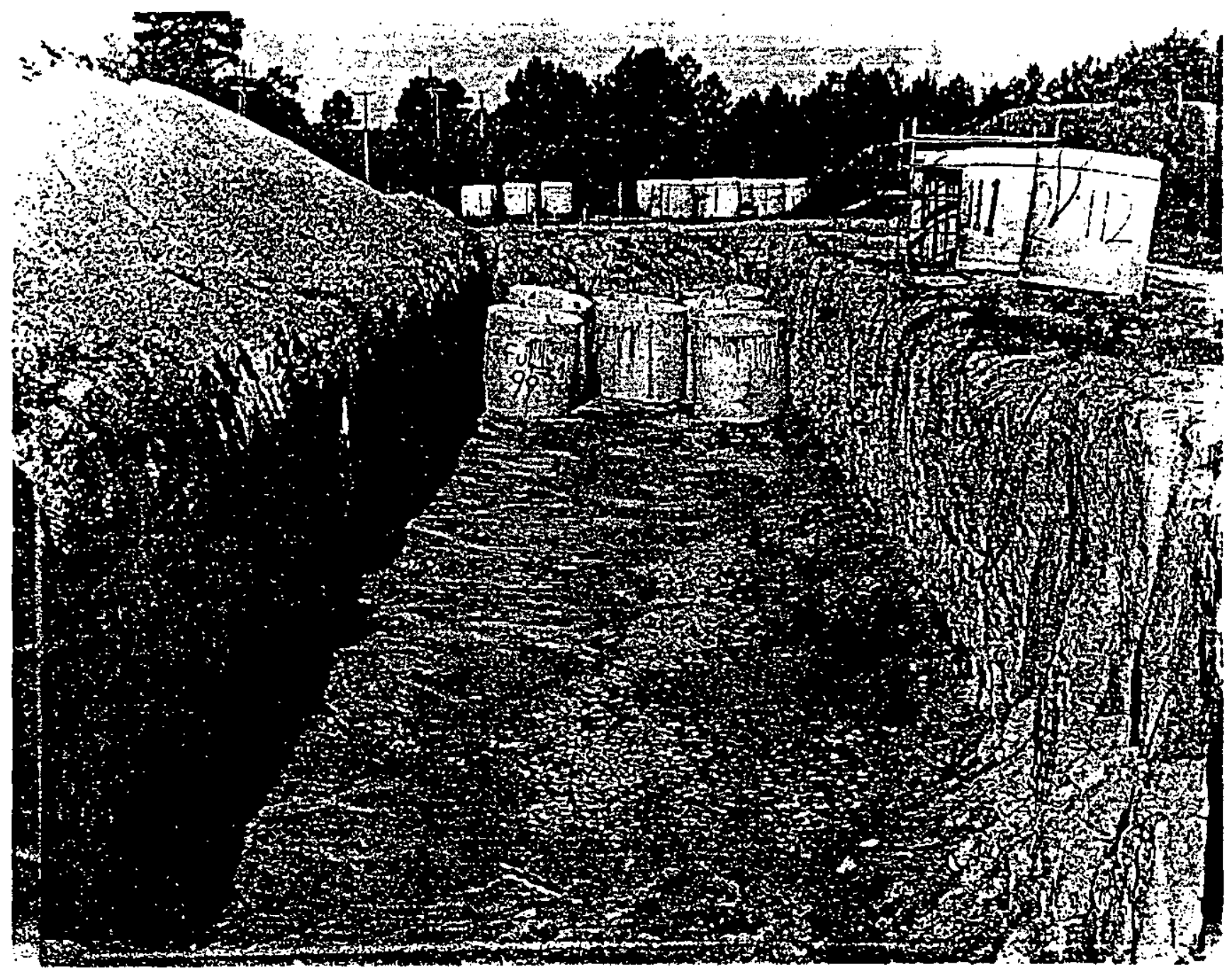

Figure 4=6. .-_Burial_of_Concrete Culverts Probably Containing TRU Waste 


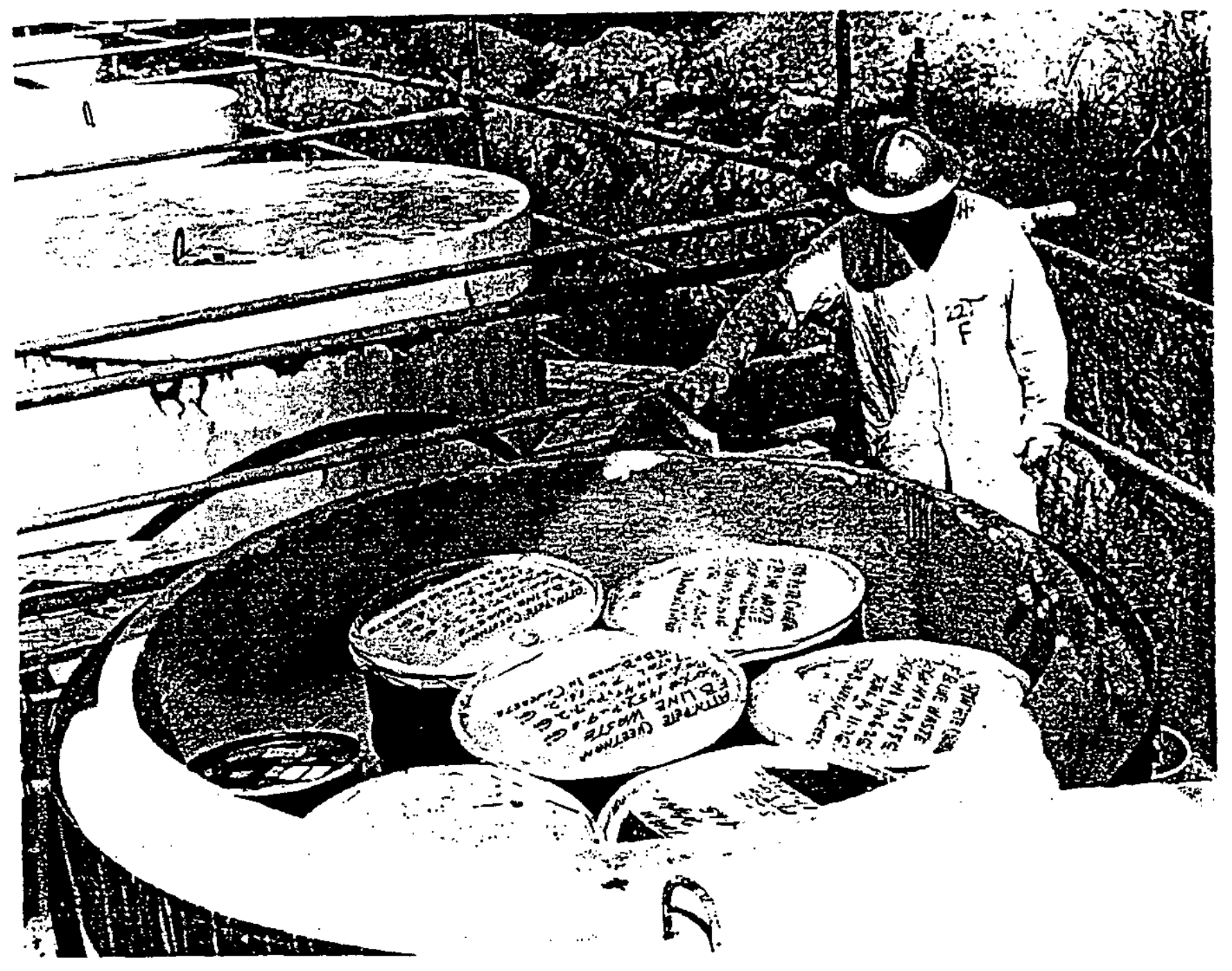

Figure 4-7. Worker Placing Mastic Onto Concrete Culvert that Contains FB-Line Pu Metal Production Waste, with Drums Containing 10-20 gram Quantities of Pu-239 
Source Term for the Old Radioactive Waste Burial Ground (ORWBG), Savannah River Site (U)
WSRC-TR-97-0119, Rev. 1.0

May 2000

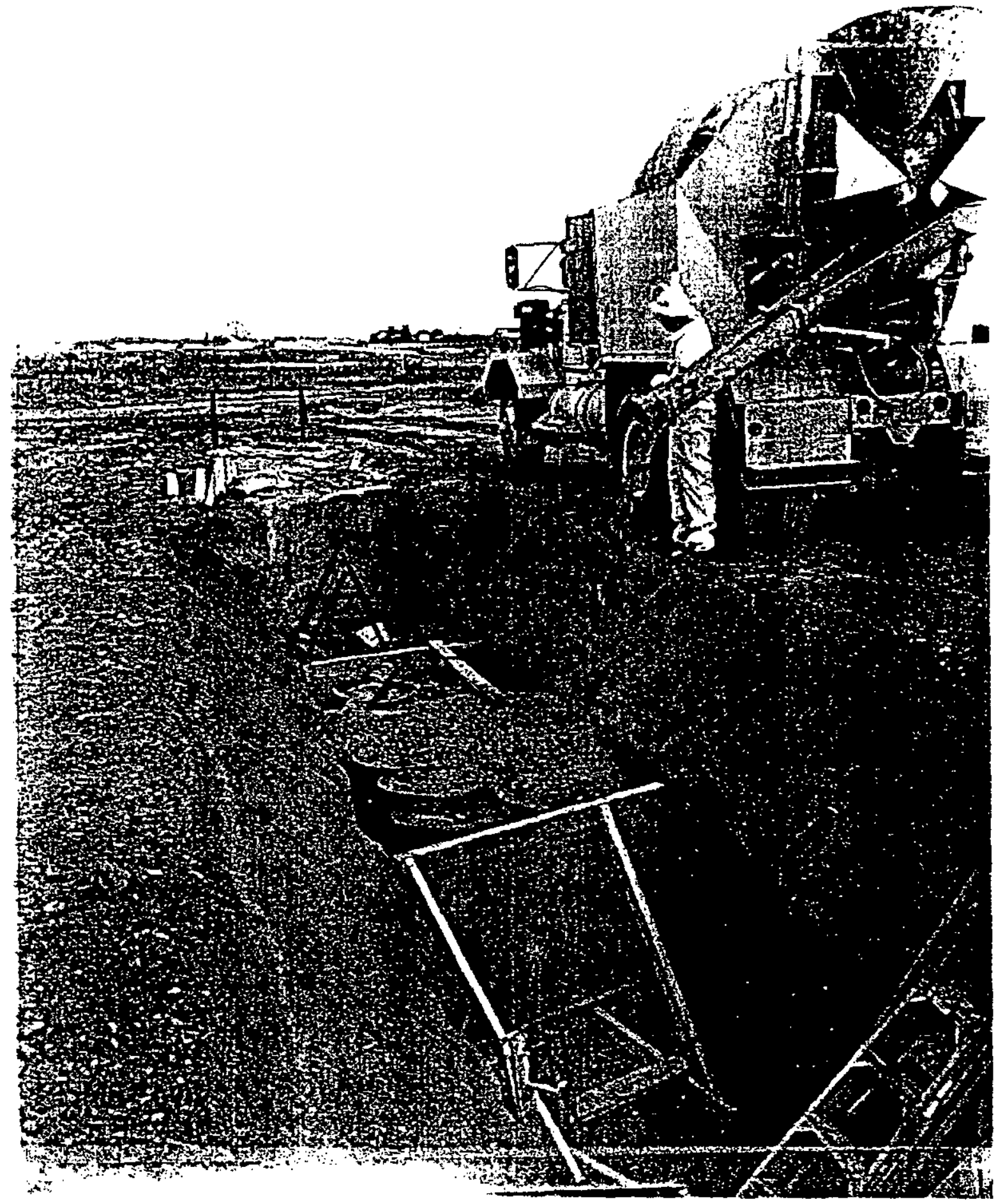

Figure 4-8. Pouring Concrete Over/Around Drums Containing Pu TRU Waste 


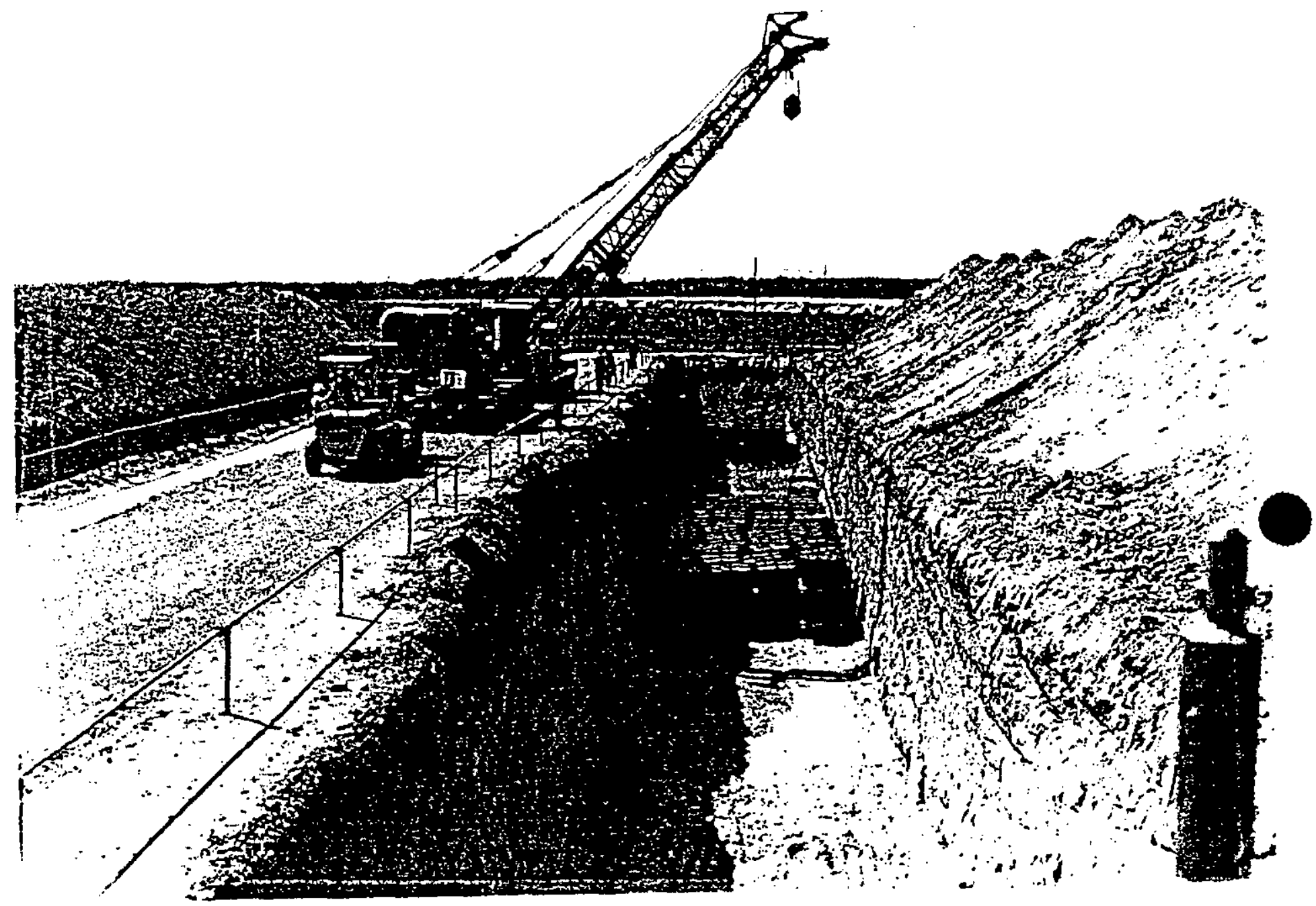

Figure 4-9. Stacked Drums of Soil from the Spanish Accident Being Placed-into-Trench- 
Source Term for the Old Radioactive Waste Burial

WSRC-TR-97-0119, Rev. 1.0

Ground (ORWBG), Savannah River Site (U)

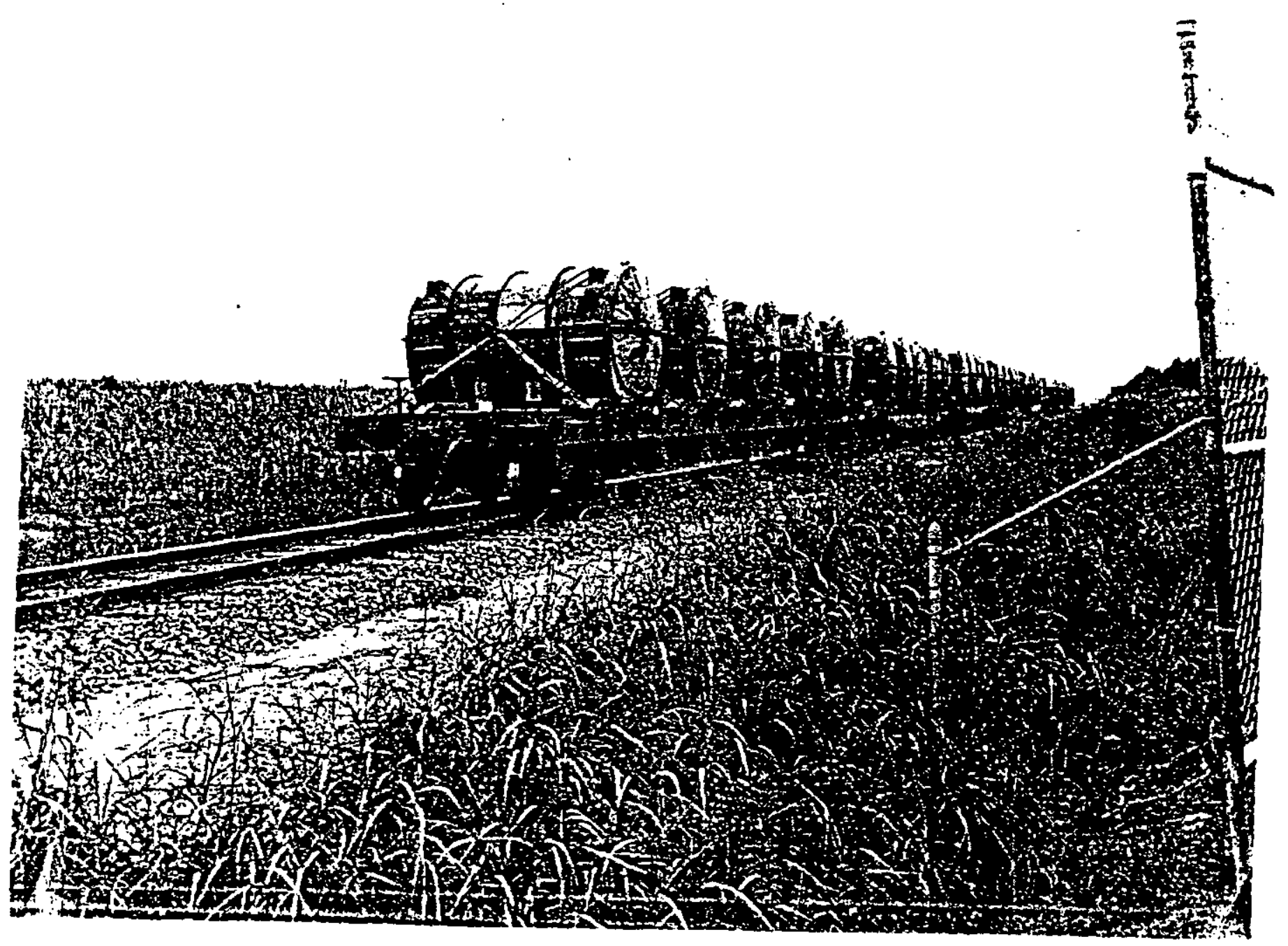

Figure 4-10. Arrival of Contaminated Waste Water from Greenland Accident at ORWBG 


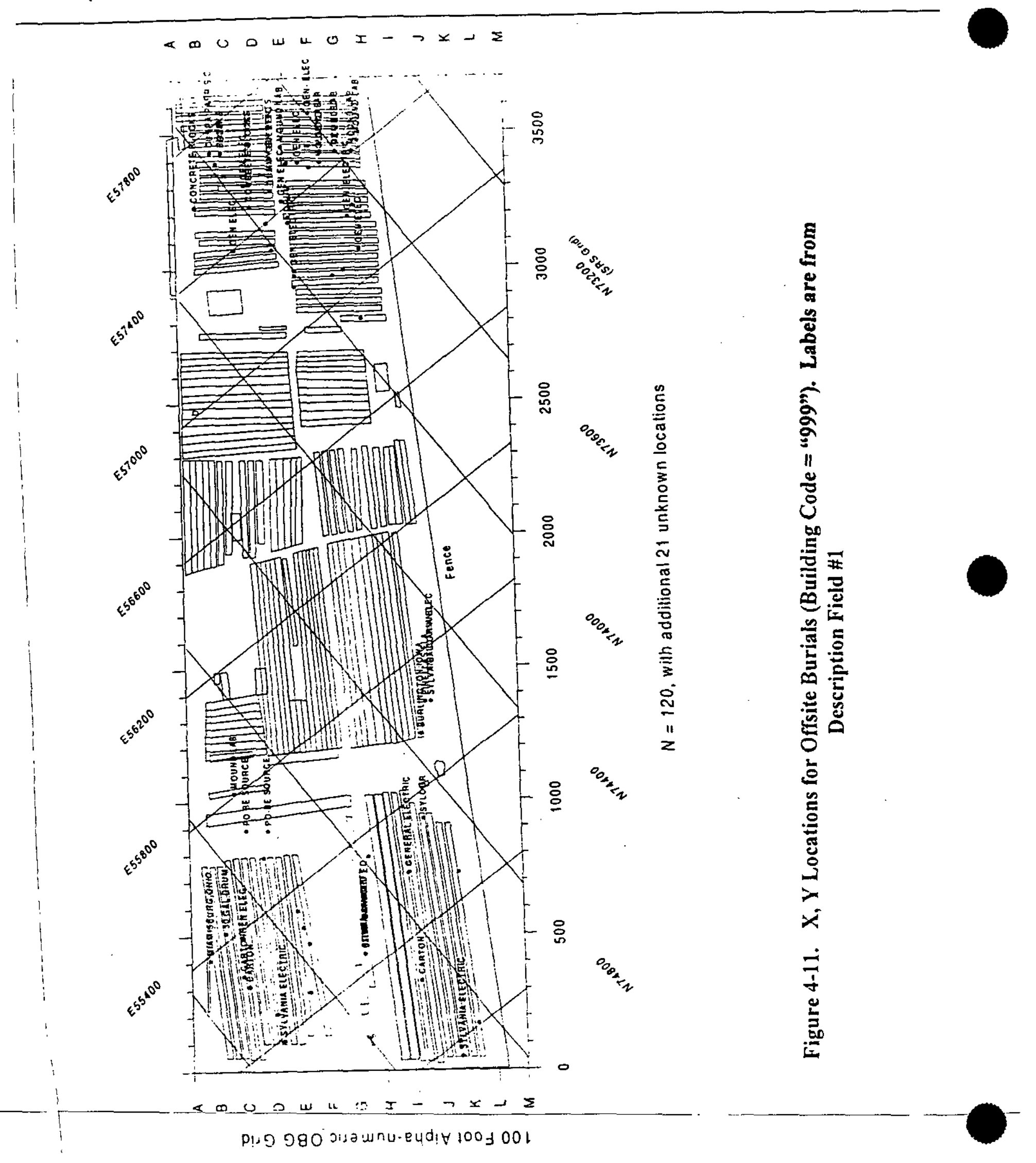




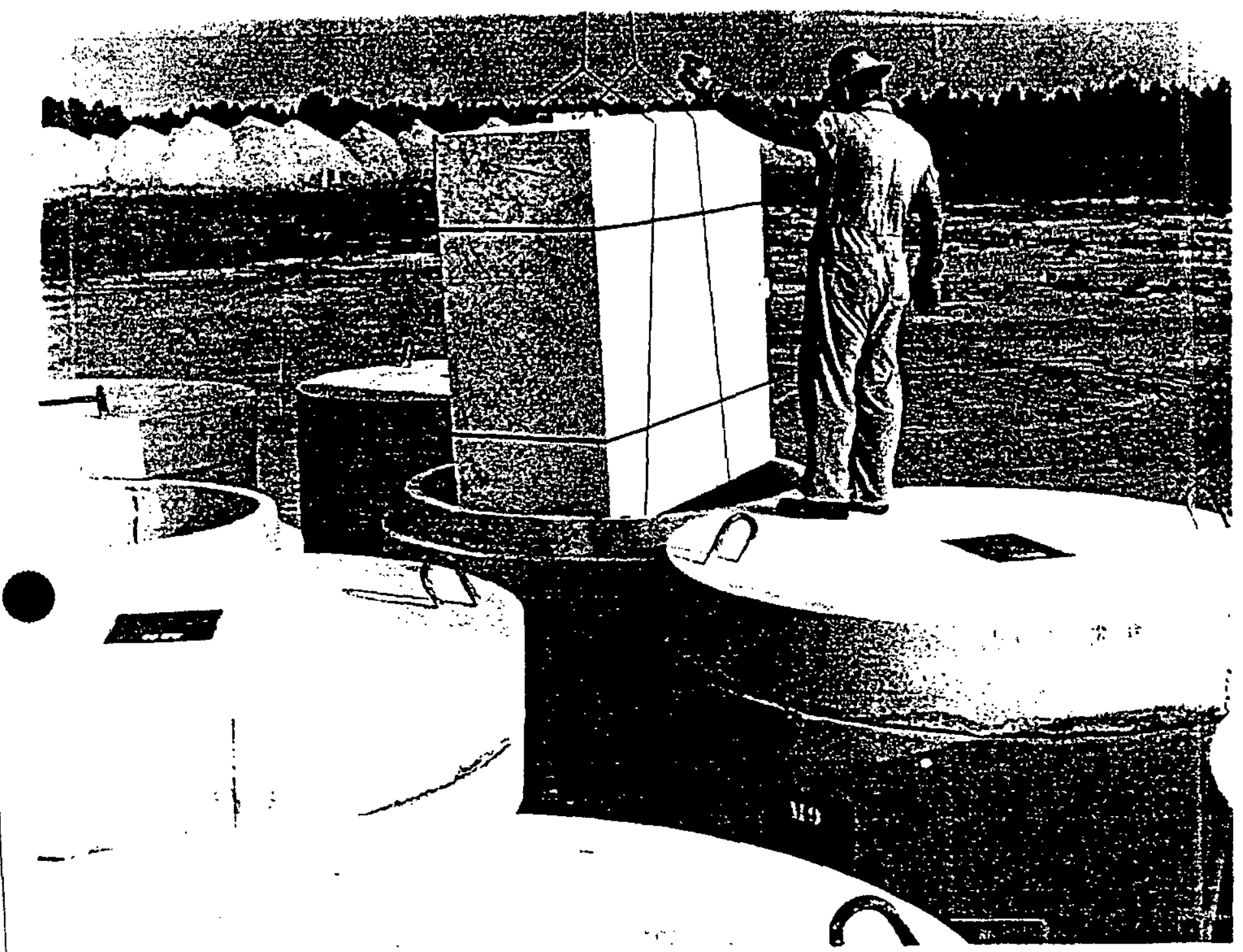

Figure 4-12. Placing Boxed (Wooden) Mound Waste (Probably Containing Tritium) into Concrete Culvert 
Source Term for the Old Radioactive Waste Burial

WSRC-TR-97-0119, Rev. 1.3

Ground (ORWBG), Savannah River Site (U)

September 1999

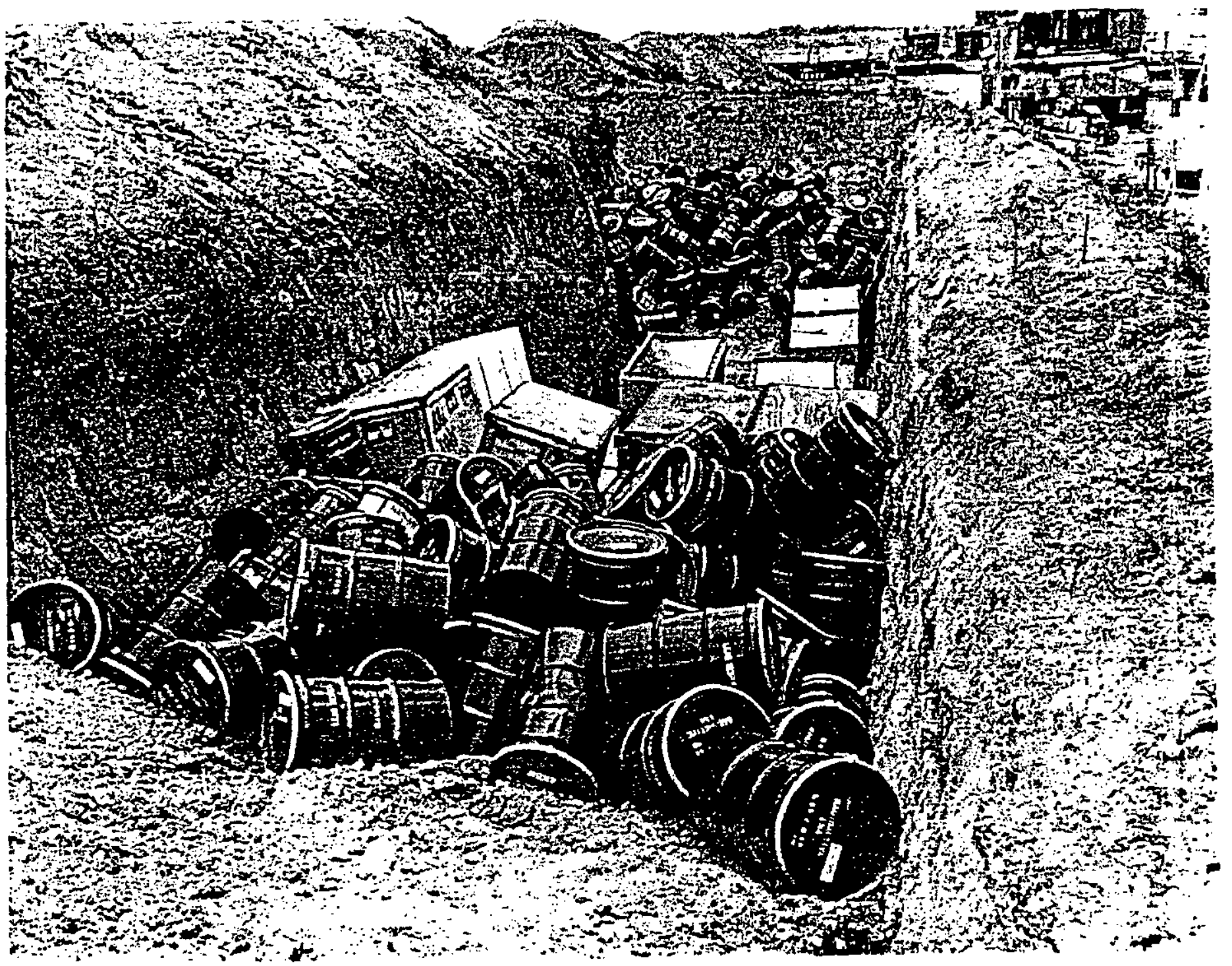

Figure 4-13 Burial of Offsite(?) Waste Packaged in a Variety of Containers 


\subsection{SUMMARY OF CONSTITUENTS OF INTEREST INVENTORY}

COIs for the ORWBG source term characterization were determined by integrating past characterization and monitoring (soil gas, groundwater monitoring, and subsurface surveys) with the COBRA database, process history evaluation, and historical documentation. All existing data were reviewed during this process. COIs include constituents that are mobile, hazardous, have a large inventory, and/or have a long half-life. The COIs at the ORWBG are cadmium, lead, mercury, VOCs, tritium, cesium-137, plutonium-238, plutonium-239, strontium-90, uranium-235, uranium-238, carbon-14, cobalt-60, technetium-99, iodine-129 and neptunium-237.

The process used to determine the range of inventory estimates, the burial method, the burial locations, the waste form and the leachability for each of the COIs is described in detail in appendices $A$ through $P$. In general, all available SRS documents related to the COIs were reviewed, additional information was obtained from personal interviews, and a process knowledge was developed from these information sources. Then, the COBRA database was used to determine the inventory and exact burial locations of each constituent. The inventory was also estimated independently of the COBRA database, and the present form of the waste was ascertained. The basic approach to determining leachability is discussed below.

The resources used to estimate leachability of the $16 \mathrm{COIs}$ include results from the defense waste lysimeter program, the ORWBG groundwater database, and knowledge of the geochemical behavior of constituents. As part of the defense waste lysimeter program, 45 defense waste lysimeters were installed between 1978 and 1980 to estimate the leaching rate of radionuclides from a variety of waste forms. The waste forms were placed in the lysimeters and then cut open to ensure leachate had access to the contaminants. Leachate was collected from the bottom of the lysimeters monthly and annual fractional release rates were calculated. These release rates provide the best estimates of plutonium, strontium, and cesium leachability.

The groundwater database for the ORWBG is an invaluable resource for understanding the leachability of contaminants. Information from three sets of wells was used in the leachability estimates presented here: (1) perimeter wells which surround the ORWBG and allow assessment of the constituents migrating beyond the ORWBG boundary, (2) data from a network of 67 grid wells placed within the ORWBG that screen the water table, and (3) data from a network of 24 wells screened at the bottom of burial trenches. The latter set of wells 
sampled water that collected or "perched" at the bottom of trenches and probably provides the most representative picture of the chemistry of water infiltrating through ORWBG trenches.

Estimates of the geochemical constraints on a constituent's leachability were used to verify that the leachability was consistent with groundwater data and results from the defense waste lysimeter program. A leaching rate was then estimated using groundwater data (mercury, cadmium, and lead) or data from the defense waste lysimeter program (plutonium, strontium, cesium). Uranium leachability was calculated from a conservative estimate of the solubility of the uranium in the ORWBG. A leachability rate was not calculated for tritium or VOCs. All estimated leaching rates are based on conservative assumptions, including using the highest concentrations of constituents in groundwater and the highest release rates from lysimeters. Waste container integrity was assumed to be zero.

Results for each COI are presented below. Sections 5.1 to 5.16 summarize the results of the literature review, interviews, process knowledge, and analysis of COBRA records. Appendices A through $P$ present detailed information about the use, inventory estimates, burial locations, waste form, and leachability for each COI. Table 5-1 provides summary information regarding inventory estimates, burial locations, waste form, and origin for each of the COIs. Table 5-2 lists the best estimate of the current inventory of each COI.

\subsection{Cadmium}

Cadmium was used at SRS as neutron absorbing material. Its primary use was in reactors as control rods, safety rods, and neutron shielding sheets (WSRC, 1994). When reactors were shut down, the rods and shielding sheets were disposed of in the ORWBG. Cadmium is also present in low concentrations in the sludge in the 22 OSTs located at the ORWBG.

There are no detailed records on cadmium burials in the ORWBG. The source term can be estimated from process knowledge and records of annual cadmium purchases and subsequent disposal.

The total inventory of cadmium placed in the ORWBG is estimated at 3,500 pounds. Most of the inventory (approximately 2,000 pounds) originated from two burials of control rods that were removed from the $R$ and L Reactors when they were shut down in 1964 and 1970, respectively (Oblath, 1985). These were the only reactors shut down during the operational history of the ORWBG. An additional 1,000 to 2,000 pounds of cadmium sheet that was used at SRS may have been disposed of in the ORWBG (Oblath, 1985). 
No specific COBRA record (or records) from Buildings $105-\mathrm{R}$ or $105-\mathrm{L}$ (the $\mathrm{R}$ and $\mathrm{L}$ Reactor buildings) could be associated with control rods. The only basis for determining the burial locations of control rods is that they are in the areas of ORWBG that were active in 1964 and 1970 (during the shutdowns of the reactors).

Based on process knowledge, cadmium would have been buried as scrap metal and induced activity waste. Control rods were put into disassembly basins for decay of short-lived isotopes and then cut with an underwater saw. The resulting cadmium pieces were placed in a cask, shipped to the ORWBG, and buried as scrap metal.

\subsection{Lead}

Lead was used at the SRS for its radiation-shielding properties. It was used primarily in separations operations; smaller amounts originated from reactors and shielding of offsite waste. Its principal use was to shield personnel from high levels of beta-gamma radiation associated with fission products.

Lead was placed in the ORWBG for two reasons: either it was contaminated and required disposal, or it was used to shield buried radioactive waste (WSRC, 1994). It is present in the burial ground as lead shielding, equipment, shot, bricks, lead sheets (WSRC, 1994) and in the OSTs (Mason, 1996).

Detailed records on lead disposals were not kept because lead was not considered hazardous during the operational history of the ORWBG. COBRA contains no detailed records on burials of lead. All estimates for the lead source term are based on process knowledge.

The total inventory of lead placed in the ORWBG is estimated at 50 tons. This estimate is thought to be accurate to within \pm 30 percent. Previous estimates of total lead in the ORWBG are $\geq 42$ tons (Oblath, 1985) and 60.6 tons (Cook, 1987). Trace amounts of lead and other toxic metals may have been concentrated to levels above regulatory limits in the sludge phase of the OSTs, although the amount of lead in the tanks is minimal relative to the other sources (Mason, 1996).

\subsection{Mercury}

Mercury was used as a sealant in pumps that handled tritium gas, as a catalyst in separations operations,-and as a -component of laboratory operations. In the pumps, the mercury sealant 
became contaminated with tritium and deteriorated due to oxidation. It was changed routinely, and the waste was disposed of in the ORWBG as low-level radioactive waste.

The estimated total inventory of mercury, principally the elemental liquid, placed in the ORWBG is 24,195 pounds. This estimate is thought to be accurate to within +25 percent and -10 percent. Previous SRS estimates for mercury vary from 20,000 to 22,000 pounds.

Approximately 20,520 pounds of the mercury inventory originated from Tritium Facilities and was buried between 1956 and 1968. After 1968, mercury was stored in the Tritium Facilities and not sent to the ORWBG. Other discarded equipment from Tritium Facilities and wastes from separations and other SRS laboratories contributed an additional 3,600 pounds to the mercury inventory.

The mercury sent from Tritium Facilities was in the elemental form. The spent mercury was placed into 1-liter polyethylene bottles. The bottles were wrapped in plastic bags, and two or three bottles were placed into 5-gallon metal cans for shipment to the ORWBG. It is estimated that slightly over 100 of these shipments of mercury were sent from Tritium Facilities.

The evaluation of the COBRA database performed during this study identified 62 locations as probable mercury burials. This represents a high percentage of the 1961-1968 mercury burials. Detailed records are not available for disposals before 1960. However, it is known that these earlier mercury disposals were in low-level beta-gamma trenches that were open at the time.

\subsection{Volatile Organic Compounds}

At the SRS, VOCs were present in PUREX solvent, liquid scintillation solutions, pump oils, cutting oils, die oils, and material used in decontamination operations. Sources of VOCs in the ORWBG include the following:

- Residual vapor and organic phases of spent PUREX solvent, waste oils, and associated degradation products in the OSTs

- Drummed scintillation solutions

- Waste oils in absorbent materials

- Residue from decontamination operations at the ORWBG prior to waste burial 
There are no detailed records on burials of organics in the ORWBG. All estimates for the source term of VOCs are based on process knowledge. Burials of organics are not documented in the COBRA database.

VOCs are present in residue in the 22 OSTs. Large amounts of spent solvent and smaller amounts of tritiated pump oil were stored in the tanks prior to the 1980s. Most of the solvent was relocated to Building $643-7 \mathrm{G}$ in the late $1970 \mathrm{~s}$ and early 1980s. The material that remains is vapor, organic, aqueous, and sludge residue that was unpumpable during the solvent relocation program, VOCs from the spent solvent and associated degradation products are primarily concentrated in the vapor and organic phases. The concentrations of VOCs in the vapor phase are known from a recent vapor phase survey, and the amount of the organic phase is approximately 4,056 gallons.

The best estimate for the total residue in the OSTs is 7,539 gallons $(4,056$ gallons organic phase and 3,483 gallons aqueous phase). The best estimate for organics that were buried in trenches is based on Cook (1987). Approximately 7,100 kilograms of toluene, 7,100 kilograms of trimethylbenzene, and 12,000 kilograms of xylene from liquid scintillation solutions are buried in trenches. The amount of residual VOCs from decontamination operations is not known.

VOCs associated with scintillation solutions and waste oils are present in the trenches of the ORWBG. Estimates of the amount of liquid scintillation wastes range from 10,000 to 11,000 gallons. These wastes are in small polyethylene vials which, beginning in 1965, were packed with "oil-dry" in 55-gallon drums and buried. Waste oils were either stored in the OSTs, or absorbed on an "oil-dry" compound, placed in drums, and buried as solidified waste.

An additional source of VOCs is residue from decontamination operations conducted in the ORWBG. Decontamination included the use of ethylene diaminetetraacetic acid (EDTA, a chelating compound) and phosphate detergents that can enhance the mobility of radionuclides like plutonium and strontium (WSRC, 1992). There are no records indicating the amounts of decontamination solutions that may have been disposed of in this area of the ORWBG, nor is it clear how or whether these chemical solutions came into contact with buried wastes. However, because VOCs are highly mobile and volatile, and because more than 40 years have elapsed since decontamination activities ceased, the amount of VOCs remaining from this source may be limited. 


\subsection{Tritium}

The production of tritium, a key component of nuclear weapons, has been a primary mission at the SRS since the mid-1950s. SRS also produced tritium for research and commercial applications. The majority of the tritium disposed in the ORWBG originated from Tritium Facilities in H-Area at SRS (Buildings 232-H, 234-H, and 238-H). Additional quantities were shipped to SRS for disposal in the ORWBG from other DOE weapons-complex facilities. The tritium was sent to the ORWBG as bulk waste (job control waste, waste oils and mercury, and used equipment and components), spent melts, and reactive beds (the latter two are byproducts of the tritium production process).

Based on Health Protection and COBRA data, it is estimated that the quantity of tritium disposed in the ORWBG was 3,014,457 curies. Accounting for radioactive decay to 1997 , the current inventory would be 467,889 curies. The OSTs are assumed to contain no tritium.

The COBRA database provides both quantity and location estimates for tritium burials in the ORWBG. Prior to 1961, tritium was likely disposed of in low-activity beta-gamma trenches. Bulk tritium buried as such is assumed to be readily available for transport downward and/or outward by intrusive water. The majority of the tritium in spent melts is inaccessible to water.

\subsection{Cesium-137}

Fission products, such as cesium-137, were a byproduct of the processes used in the five onsite production reactors at SRS. They are a component of job control waste and other waste streams that were disposed at the ORWBG.

Burial records indicate activities of fission products as a group sent to the ORWBG but do not record the amount of cesium-137 per se. The amount of cesium-137 in fission products can be estimated using process knowledge and reported isotopic ratios. The isotopic ratios depend somewhat on the age of the waste, since longer-lived radionuclides such as cesium137 become an increasingly larger fraction as the waste ages.

The cesium-137 inventory in the ORWBG is estimated at 58,657 curies $(26,838$ curies, corrected for decay to 1997). For the OSTs, the cesium-137 inventory estimate is 1.30 curie. This conservative estimate is based on the most recent total activity measurements available and the fraction of cesium-137 in each tank (Mason, 1996). 
Uncertainty in the cesium-137 inventory lies in the original estimates of fission products. These estimates were based on the external dose rate from a waste package and an assumed isotopic distribution in the waste. Variations in the isotopic distribution of the waste and unique shielding aspects of a waste package could result in errors in the fission product estimate.

COBRA provides information on the spatial distribution of fission products in the ORWBG. Waste with a dose rate less than $50 \mathrm{mR}$ per hour was buried in low-activity beta-gamma trenches. Waste with dose rates of $50 \mathrm{mR}$ per hour or greater was buried in intermediate level (also known as high-level) trenches (Cook, 1987).

No special containerization requirements existed. The waste was buried in cardboard boxes, plastic bags, and metal containers in low-level and high-level trenches, depending on the dose rate from the package.

\subsection{Plutonium-238}

A primary operation at the SRS was the production of plutonium-238, a special nuclear material, which was used in thermionic heat sources for power generation. Plutonium-238 oxide produced at SRS was shipped offsite to other facilities in the DOE weapons complex. Waste containing plutonium-238 buried at the ORWBG originated primarily in separations areas, reactor areas, and research facilities like the Savannah River Technology Center (SRTC). Spent solvent contaminated with plutonium-238 was also sent to the OSTs from Separations for storage prior to burning. Inventory estimates for plutonium238 are based on data contained in COBRA and burial records predating COBRA.

The plutonium-238 inventory originally buried in the ORWBG is estimated at 1192.7 grams (20,514 curies). This estimate is the sum of two sources: the COBRA database total and a very small quantity associated with spent solvent residues. Based on alpha activity in the OSTs, the best estimate of the plutonium-238 inventory in the OSTs is 1.24 grams (21.4 curies). The major uncertainty with the inventory of buried plutonium-238 lies in classified burials that are not fully described in COBRA. However, COBRA does contain the quantities in curies of most of these special burials.

Plutonium-238 and other alpha-bearing solid waste were managed in one of three ways: disposed of in plastic bags and cardboard boxes in trenches designated for alpha-bearing waste, disposed of in drums placed in concrete culverts in trenches, or encapsulated in 
concrete in trenches. Generally, encapsulated waste was drummed and placed in slit trenches that were then back-filled with concrete. Canyon equipment and other bulky wastes were placed directly into trenches, which were then filled with concrete (Cook, 1987). Starting in 1965 , packages with greater than 0.1 curies of TRU radionuclides were placed in concrete culverts. When full, these culverts were placed in shallow subgrade trenches for potential retrieval and processing at a future date. Such TRU waste originating during the transition period from below-ground disposal to above-ground storage is currently housed in two separate trenches in the ORWBG. The practice of subgrade storage was discontinued in 1974, when storage at-grade on concrete pads was adopted for SRS-generated waste (Cook and Helton, 1989).

\subsection{Plutonium-239}

The production of plutonium-239 for use in nuclear weapons was a primary operation at the SRS. Plutonium-239 produced at SRS was shipped offsite to other facilities in the DOE weapons complex. Wastes containing plutonium-239 in the ORWBG originated primarily in separations areas, reactor areas, and research facilities such as SRTC. Spent solvent contaminated with plutonium-239 was also sent to the OSTs from Separations for storage prior to burning. Inventory estimates for plutonium-239 are based on data contained in COBRA and records predating COBRA.

The best estimate for the plutonium- 239 inventory originally buried in the ORWBG is 24,188 grams $(1,475$ curies). This estimate is the sum of the COBRA database total for plutonium239 (22,303 grams), and the estimate in burned solvent residues (1,885 grams). The amount in the OSTs is estimated to be 82.4 curies (1351 grams). The major uncertainty related to the quantity of buried plutonium-239 is the classified special burials. However, COBRA does contain the quantities in curies of most of these special burials.

The COBRA database provides information on the spatial distribution of plutonium in the ORWBG. The disposal date and total activity of the waste package affected how the waste was handled at the ORWBG. Plutonium-239 and other alpha-bearing solid wastes were managed in one of three ways: disposed of in plastic bags and cardboard boxes in trenches designated for alpha-bearing waste, disposed of in drums placed in concrete culverts in trenches, or encapsulated in concrete in trenches. Generally, encapsulated waste was drummed and placed in slit trenches that were then filled with concrete. Canyon equipment and other bulky wastes were placed directly into the trenches, which were then filled with 
concrete (Cook, 1987). Starting in 1965, packages with greater than 0.1 curies of TRU were placed in concrete culverts. When full, these culverts were placed in shallow sub-grade trenches for retrieval and processing at a future date. Approximately 165 of these culverts have been filled; they are currently being stored in two separate trenches in the ORWBG. The practice of sub-grade storage was discontinued in 1974, when storage at-grade on concrete pads was adopted for SRS-generated waste (Cook and Helton, 1989).

\subsection{Strontium-90}

Fission products, such as strontium-90, were a byproduct of the processes used in the five onsite production reactors at SRS. They are a component of job control waste and other waste streams that were disposed of at the ORWBG. Burial records indicate activities of fission products as a group sent to the ORWBG but do not record the amount of strontium-90 per se. The fraction of the fission products that is strontium-90 is determined using reported isotopic ratios and process knowledge.

The best estimate for the strontium-90 inventory at the ORWBG is 58,657 curies $(26,216$ curies decayed to 1997). A relatively small amount of strontium-90 is also present in the OSTs. For the OSTs, the strontium-90 inventory estimate is 1.28 curie.

Waste containing the fission products from which strontium-90 activities are estimated was buried in low-level and high-level trenches, depending on the dose rate from the package. Waste with a dose rate less than $50 \mathrm{mR}$ per hour was buried in low-activity beta-gamma trenches. Waste with dose rates of $50 \mathrm{mR}$ per hour or greater was buried in intermediate level (also known as high-level) trenches (Cook, 1987). No special containerization requirements existed. The waste was buried in cardboard boxes, plastic bags, and metal containers.

\subsection{Uranium-235}

The SRS operated five production reactors, which used fuel rods containing enriched uranium-235. Other facilities at SRS manufactured fuel elements for the reactors and extracted uranium-235 from spent fuel elements.

The best estimate for the uranium-235 inventory in the trenches at the ORWBG is 273,185 grams ( 0.6 curie). For the OSTs, the best estimate of the uranium-235 inventory is 0.11 curie based on assigning the uranium-235 as 0.25 percent of the total uranium activity in tanks containing it. 
Variations in the actual uranium-235 enrichment of individual burials could result in errors in the uranium-235 inventory. The value used to convert enriched uranium inventory to uranium-235 inventory was 93 percent, which represents an upper-bound estimate for the enrichment.

The COBRA database provides information on the spatial distribution of uranium burials. Waste containing uranium was buried in alpha activity trenches without special containers. The waste was buried in cardboard boxes, plastic bags, and possibly, metal containers.

\subsection{Uranium-238}

The SRS reactors were fueled by highly-enriched uranium fuel rods. Uranium-238 slugs (depleted or natural uranium) were used as targets to produce plutonium-239. The depleted uranium used in SRS reactors as target material to produce plutonium-239 was 99.5 percent, or more, uranium-238.

Inventory estimates for uranium-238 are based on data contained in the COBRA database and records indicating burials prior to COBRA records. COBRA includes the burials of enriched uranium, normal uranium, and depleted uranium. Therefore, estimates can be extrapolated to a uranium-238 inventory assuming that uranium-238 is 100 percent of the depleted uranium, 99.274 percent of the normal uranium, and 7 percent of enriched uranium.

The COBRA estimate for the uranium-238 inventory in the trenches in the ORWBG is 44,233 kilograms (14.8 curies). It has been assumed that the COBRA database captures all of the Health Protection data related to uranium.

In the OSTs, the best estimate of the uranium-238 inventory is 1.1 curies based on assigning the uranium- 238 as 2.5 percent of the total uranium activity in tanks containing it.

The COBRA database provides information on the spatial distribution of uranium in the ORWBG. The uranium-bearing waste was buried in alpha activity trenches without special containers. The waste was buried in cardboard boxes, plastic bags, and possibly, metal containers.

\subsection{Carbon-14}

Carbon-14 at SRS was produced primarily in the moderator in the five production reactors. To maintain moderator purity, carbon-14 was removed in ion exchange resins in demineralizer 
units. When a demineralizer unit was exhausted, the ion exchange resin was buried (Carlton et al., 1993). Most of the source term in the ORWBG is likely due to the bicarbonate anion $\left(\mathrm{HC}^{14} \mathrm{O}_{3}{ }^{-}\right)$that is sorbed on mixed-bed ion exchange resin used to purify the reactor moderator. Negligible quantities of carbon-14 were produced at SRS by the test reactors and neutron activation analyses. The activity levels of radiocarbon from these sources are insignificant when compared to the activity levels in irradiated nuclear fuel, targets, and moderators (Carlton et al., 1993).

Based on process knowledge, the best estimate for the carbon-14 inventory at the ORWBG is 3,778 curies. During the first ten years of SRS operations, deionizer resins were dumped in slurry form directly into ORWBG trenches (Towler, Jr., 1989 in WSRC, 1992). Later, the resins were disposed of in stainless steel vessels. The normal practice was to displace the heavy water with light water, seal the stainless steel columns with blank flanges, and bury the whole unit in trenches.

Several uncertainties are associated with the carbon-14 inventory estimate. The buried amount is based on process knowledge, which makes several assumptions, including the following:

- percent of the amount of carbon-14 produced in the reactor moderator was lost to the atmosphere.

- All other carbon-14 remained in the deionizer resin and no other releases occurred.

- The average production/disposal rate of carbon-14 from start-up to 1972 and from 1972 to 1988 was the same.

COBRA burial records provide the date, location, and volumes of disposals of deionizer resin waste packages. From COBRA records, approximately 4,377 cubic feet of spent resin is present in the ORWBG. The best guess for the activity of individual burials is the volume of the resin, in cubic feet, multiplied by $0.86 \mathrm{Ci} / \mathrm{ft}^{3}$.

\subsection{Cobalt -60}

Cobalt-60 at the SRS was produced primarily as a byproduct of irradiating cobalt-bearing stainless steel components in SRS reactors. Irradiation of the cobalt in the stainless steel components formed cobalt-60. Operations at the disassembly basins generated excess stainless steel components, which were disposed of as scrap metal. The scrap metal was placed into casks and buried in the ORWBG (Holcomb, 1997). 
The amount of cobalt- 60 produced by other sources (cobalt-59 wafers, Savannah River Ecology Laboratory, and SRTC) and disposed in the ORWBG is relatively small compared to that from induced activity.

The best estimate of the original amount (undecayed) of cobalt- 60 buried in the ORWBG is $1,960,400$ curies. This is based on an average disposal rate of 98,020 curies annually from startup to 1972. The best estimate for the amount of cobalt-60 in the ORWBG in 1997, considering radioactive decay, is 27,568 curies.

Uncertainty associated with this estimate lies primarily with cited annual disposal rates. Another uncertainty is the percentage of induced activity associated with cobalt- 60 in reactor scrap metal.

The COBRA database was used to identify burials of cobalt- 60 by keyword searching for terms associated with induced activity. The best estimate of the cobalt- 60 activity associated with any particular burial of "induced activity" can be determined by multiplying activity of the specific burial of induced activity (from COBRA database) by 0.85 .

Most of the cobalt-60 in the ORWBG is buried as stainless steel scrap metal in casks. A small amount of cobalt- 60 debris resulting from capsule development may have been disposed of by SRTC Laboratory Operations using normal high activity solid waste disposal procedures, such as earth burial inside concrete.

\subsection{Technetium-99}

Technetium-99 is a fission product produced by the fission of uranium- 235 and plutonium-239 (Cook, 1989). Most of the technetium-99 in the ORWBG is in burials of fission product waste.

The best estimate of the amount of technetium-99 in the ORWBG is 12 curies. This value is derived using an annual disposal rate of 0.6 curies multiplied by the number of operational years of the ORWBG (20 years). Uncertainty associated with the best estimate lies primarily with an estimate that five-year-old in-tank waste contains 5.53E-04 curies of technetium-99 per gallon, which assumes an isotopic distribution of fission products. The accuracy of this value is unknown. Underlying uncertainties with the best estimate stem from the generally poor documentation of the radionuclide. No technical reports exist that provide production details, waste stream characteristics, or disposal information. 
Shipments of technetium- 99 are not documented in the COBRA database. Technetium-99 is assumed to have been disposed with other fission product waste, and to have been identified in the COBRA database as "fission products".

The most likely state of technetium-99 in SRS waste streams and solid waste is $\mathrm{TcO}_{4}{ }^{-}$ resulting from dissolution of fission-product-containing target and fuel elements in nitric acid $\left(\mathrm{HNO}_{3}\right)$. Technetium can also exist as the oxide, $\mathrm{TcO}_{2}$. Even it were buried in that form, there is evidence that the conversion to $\mathrm{TcO}_{4}{ }^{-}$would have been rapid (Bondietti and Francis, 1979 , in Oblath, 1982).

\subsection{Iodine-129}

Radioiodine is a fission product that originated at SRS predominantly in the fuel and targets that were irradiated in the nuclear materials production reactors. The predominant radioiodine-containing material buried at the Solid Waste Disposal Facility (SWDF) is spent ceramic chips coated with silver nitrate (Berl saddles) that were used to adsorb radioiodine (principally iodine-129 and iodine-131) during the dissolution of fuel and targets in $\mathrm{F}$ and $\mathrm{H}$ Areas. Essentially all of the iodine-129 in the burial ground is from Berl saddles used in the process air filters. Other sources such as SRS test reactors, spontaneous fission sources, neutron activation analysis, commercially purchased radioiodine, and global fallout contributed smaller amounts to the inventory of radioiodine at SRS.

The best estimate of the amount of iodine-129 in the ORWBG is determined by multiplying a scaled amount of 35.45 curies produced during the operational history of the ORWBG by the fraction of the total that was sent to the burial ground ( 30 percent). This yields 10.6 curies (60 kilograms). Uncertainty in the iodine-129 inventory lies in the assumptions that 39 curies of iodine-129 were produced at SRS from startup to 1974 and that 30 percent of this amount was buried in the ORWBG. The number of spent charges in the ORWBG, assuming a constant disposal rate, is estimated to be 34 . Each container held approximately 20 cubic feet of Berl saddles.

In the COBRA database, there are no references to Berl saddles, nor is there any specific iodine-129 constituent information. Because Berl saddles are not identified in the COBRA database, the precise locations of the iodine- 129 burials cannot be determined. Their locations are randomly distributed among the intermediate-level beta-gamma waste trenches (Stone et 
al., 1983). The Berl saddles were buried without containment or encapsulation in earthen trenches.

\subsection{Neptunium-237}

Neptunium-237 is produced as a byproduct during the nuclear fuel cycle. It is produced by two primary sources at SRS. One is from alpha decay of americium-241 that is produced by the beta decay of plutonium-241 in weapons-grade plutonium. The other mode of neptunium-237 production is via a side reaction during the irradiation of uranium-238 targets to eventually produce plutonium-239. Neptunium-237 is also the target material used to produce plutonium-238 in SRS reactors.

Waste potentially contaminated with neptunium-237 included cabinet waste originating from $221-\mathrm{HBL}$, laboratory glove boxes and radiobenches from the 772-F laboratory, wastes originating from 235-F, waste effluents from processing in the Separations areas, and PUREX waste in storage tanks in the 241-F and H-Area Tank Farms and in the OSTs in the ORWBG.

The best estimate of the amount of neptunium-237 originally buried in the ORWBG is 1.99 curies. The amount of ingrown neptunium-237 is conservatively calculated as 0.004 curies. The amount lost to radioactive decay is negligible due to the long half-life of the radionuclide. The major contributor to the uncertainty related to the quantity of neptunium-237 buried is any classified burials that are not described in the open literature and in unclassified databases such as COBRA.

The COBRA database provides both quantity and location estimates for neptunium-237 burials in the ORWBG.

The primary waste form of neptunium-237 in the ORWBG is very similar to that for plutonium-238. Neptunium-237 contaminated waste was buried uncontainerized in plastic bags and cardboard boxes, in concrete culverts containing drummed or boxed neptunium-237-bearing waste, and in drums and other waste forms (equipment, waste in wooden boxes, etc.) encapsulated by concrete on all sides. 


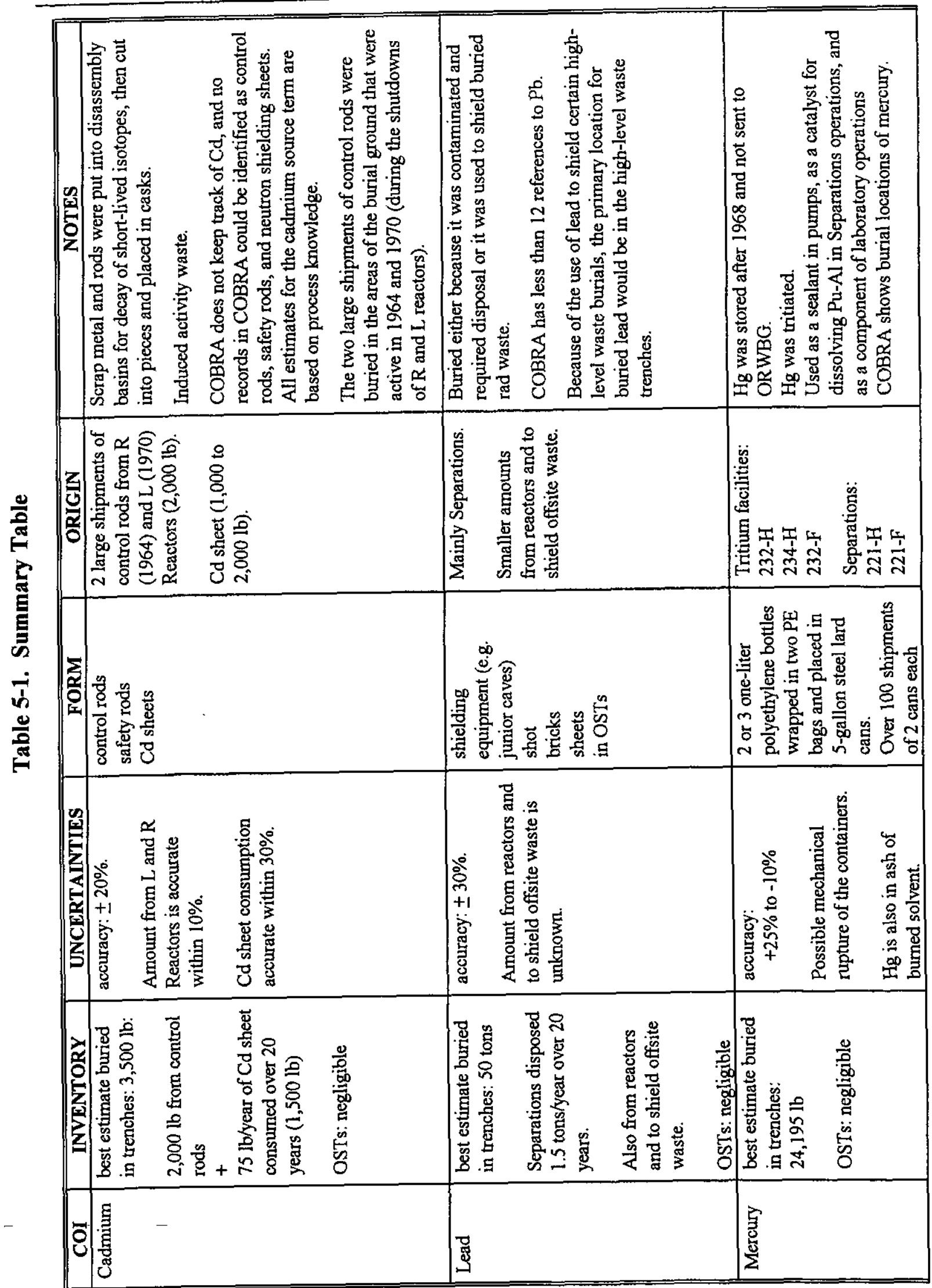


Table 5-1. Summary Table (Continued)

\begin{tabular}{|c|c|c|c|c|c|}
\hline $\mathrm{COI}$ & INVENTORY & UNCERTAINTIES & FORM & ORIGIN & NOTES \\
\hline VOCs & $\begin{array}{l}\text { buried in trenches: } \\
7100 \mathrm{~kg} \text { toluene } \\
7100 \mathrm{~kg} \\
\text { trimethylbenzene } \\
12,000 \mathrm{~kg} \text { xylene }\end{array}$ & $\begin{array}{l}\text { Volatilization } \\
\text { Migration }\end{array}$ & $\begin{array}{l}\text { Scintillation solutions } \\
\text { and tritiated pump oils } \\
\text { are drummed. } \\
\text { Liquid scintillation } \\
\text { solution wastes are in } \\
\text { small polyethylene vials } \\
\text { which, from } 1965 \text {, were } \\
\text { packed with oil-dry in } \\
55 \text {-gallon drums and } \\
\text { buried. } \\
\text { Waste oils were both } \\
\text { stored in the OSTs and } \\
\text { absorbed on an oil-dry } \\
\text { compound, placed in } \\
\text { drums, and buried as } \\
\text { solidified waste. }\end{array}$ & $\begin{array}{l}\text { Drummed scintillation } \\
\text { solutions } \\
\text { Waste oils in absorbent } \\
\text { materials (from reactor and } \\
\text { tritium facilities including } \\
\text { pump oils, cutting oils, and } \\
\text { die oils) } \\
\text { Residue from } \\
\text { decontamination operations } \\
\text { prior to waste burial }\end{array}$ & $\begin{array}{l}\text { Shipments of organics are not documented in } \\
\text { the COBRA database per se, though there } \\
\text { are some indirect references to possible VOC } \\
\text { sources. No quantity or specific VOC } \\
\text { constituent information is contained in any } \\
\text { COBRA record. } \\
\text { VOCs associated with liquid scintillation } \\
\text { solutions and waste oils are present in the } \\
\text { trenches of the ORWBG. } \\
\text { The OSTs not only contained waste PUREX } \\
\text { solvent but also contained contaminated } \\
\text { waste solvents of other sorts. }\end{array}$ \\
\hline & $\begin{array}{l}\text { Residue in the OSTs } \\
\text { (S-1 through S-22): } \\
4056 \text { gal organic } \\
\text { phase }+3483 \mathrm{gal} \\
\text { aqueous phase = } \\
7539 \text { gallons } \\
\text { Mason } 1996 \\
\text { provides analytical } \\
\text { data of vapor phase } \\
\text { (Table 2-5). }\end{array}$ & $\begin{array}{l}\text { OST tank dimensions } \\
\text { and inclinations }\end{array}$ & $\begin{array}{l}\text { VOCs in OSTs are in } \\
\text { residue of spent } \\
\text { PUREX solvent and } \\
\text { associated degradation } \\
\text { products. }\end{array}$ & $\begin{array}{l}\text { Spent PUREX solvent was } \\
\text { generated in Separations in a } \\
\text { chemical process for } \\
\text { removing plutonium and } \\
\text { uranium from spent rods. } \\
\text { Plant records show that from } \\
1956 \text { through } 1964,88 \% \text { of } \\
\text { the waste solvent receipts } \\
\text { were from F-Area. From } \\
1965 \text { to } 1972,86 \% \text { of the } \\
\text { waste solvent was generated } \\
\text { in H-Area. }\end{array}$ & $\begin{array}{l}\text { Most PUREX solvent was transferred to } 643- \\
7 \mathrm{G} \text { around } 1980 \text {. The OSTs are empty except } \\
\text { for unpumpable heel, which contains some } \\
\text { VOCs in vapor, and organic phases. Minor } \\
\text { amounts of VOCs are present in the aqueous } \\
\text { phase. The amount of VOCs in the sludge } \\
\text { solids phases are negligible. }\end{array}$ \\
\hline
\end{tabular}




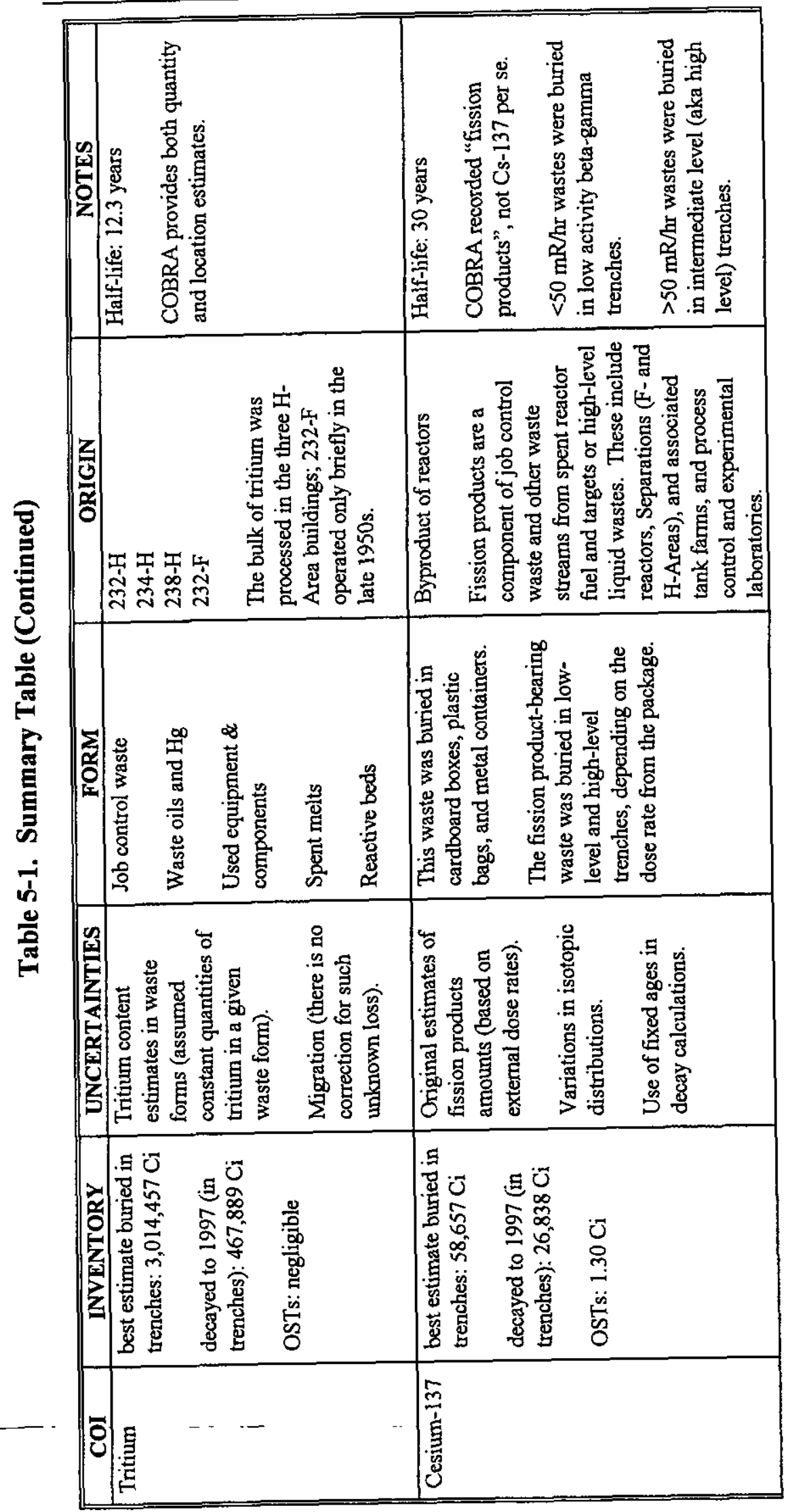


Table 5-1. Summary Table (Continued)

\begin{tabular}{|c|c|c|c|c|c|}
\hline $\mathrm{COI}$ & INVENTORY & UNCERTAINTIES & FORM & ORIGIN & NOTES \\
\hline Plutonium-238 & $\begin{array}{l}\text { best estimate } \\
\text { buried in } \\
\text { trenches: } \\
1192.7 \text { grams } \\
(20,514 \mathrm{Ci}) \\
\text { decayed to } 1997 \\
\text { (in trenches): } \\
16,825 \mathrm{Ci} \\
\text { OSTs: } 1.24 \text { grams } \\
(21.4 \mathrm{Ci} \text { ) }\end{array}$ & $\begin{array}{l}\text { validity of COBRA } \\
\text { estimates }\end{array}$ & $\begin{array}{l}\text { Uncontainerized in plastic } \\
\text { bags and cardboard boxes } \\
\text { Concrete culverts } \\
\text { containing drummed or } \\
\text { boxed waste } \\
\text { Encapsulated waste }\end{array}$ & $\begin{array}{l}\text { Thermionic heat sources for } \\
\text { power generation } \\
\text { Separations, reactor areas, and } \\
\text { research facilities like SRTC }\end{array}$ & $\begin{array}{l}\text { Half-life: } 87.4 \text { years } \\
\text { Inventory estimate based on } \\
\text { COBRA, pre-COBRA burial } \\
\text { records and burned solvent } \\
\text { residues. } \\
\text { COBRA shows burial locations } \\
\text { of plutonium- } 238 \text {. }\end{array}$ \\
\hline Plutonium-239 & $\begin{array}{l}\text { best estimate } \\
\text { buried in } \\
\text { trenches: } \\
24,188 \text { grams } \\
(1,475 \mathrm{Ci}) \\
\text { decayed to } 1997 \\
\text { (in trenches): } \\
1,474 \mathrm{Ci} \\
\text { OSTs: } 1351 \mathrm{~g} \\
(82.4 \mathrm{Ci})\end{array}$ & $\begin{array}{l}\text { validity of COBRA } \\
\text { estimates }\end{array}$ & $\begin{array}{l}\text { Uncontainerized in plastic } \\
\text { bags and cardboard boxes } \\
\text { Concrete culverts } \\
\text { containing drummed or } \\
\text { boxed waste } \\
\text { Encapsulated waste }\end{array}$ & $\begin{array}{l}\text { Special nuclear material } \\
\text { Separations, reactor areas, and } \\
\text { research facilities like SRTC }\end{array}$ & $\begin{array}{l}\text { Half-life: } 24,360 \text { years } \\
\text { Inventory estimate based on } \\
\text { COBRA database total, which } \\
\text { includes plutonium- } 239 \text { in } \\
\text { special burials, pre-COBRA } \\
\text { burial records, and burned } \\
\text { solvent residues. } \\
\text { Cobra shows burial locations of } \\
\text { plutonium-239. }\end{array}$ \\
\hline Strontium-90 & $\begin{array}{l}\text { best estimate } \\
\text { buried in } \\
\text { trenches: } 58,657 \\
\mathrm{Ci} \\
\text { best estimate: } \\
\text { decayed to } 1997 \\
\text { (in trenches): } \\
26,216 \mathrm{Ci} \\
\text { OSTs: } 1.28 \mathrm{Ci}\end{array}$ & $\begin{array}{l}\text { Original estimates of } \\
\text { fission products } \\
\text { amounts (based on } \\
\text { external dose rates } \\
\text { and assumed isotopic } \\
\text { distribution). } \\
\text { Use of fixed ages in } \\
\text { decay calculations. }\end{array}$ & $\begin{array}{l}\text { This waste was buried in } \\
\text { cardboard boxes, plastic } \\
\text { bags, and metal containers. } \\
\text { The fission product-bearing } \\
\text { waste was buried in low- } \\
\text { level and high-level } \\
\text { trenches, depending on the } \\
\text { dose rate from the package. }\end{array}$ & $\begin{array}{l}\text { Byproduct of reactors } \\
\text { Fission products are a component } \\
\text { of job control waste and other } \\
\text { waste streams from spent reactor } \\
\text { fuel and targets or high-level } \\
\text { liquid wastes. These include } \\
\text { reactors, Separations (F-and H- } \\
\text { Areas), and associated tank } \\
\text { farms, and process control and } \\
\text { experimental laboratories. }\end{array}$ & $\begin{array}{l}\text { Half-life: } 29.12 \text { years } \\
\text { COBRA recorded "fission } \\
\text { products", not Sr-90 per se. } \\
\\
<50 \mathrm{mR} / \mathrm{hr} \text { wastes were buried } \\
\text { in low activity beta-gamma } \\
\text { trenches. } \\
>50 \mathrm{mR} / \mathrm{hr} \text { wastes were buried } \\
\text { in intermediate level (aka high } \\
\text { level) trenches. }\end{array}$ \\
\hline
\end{tabular}




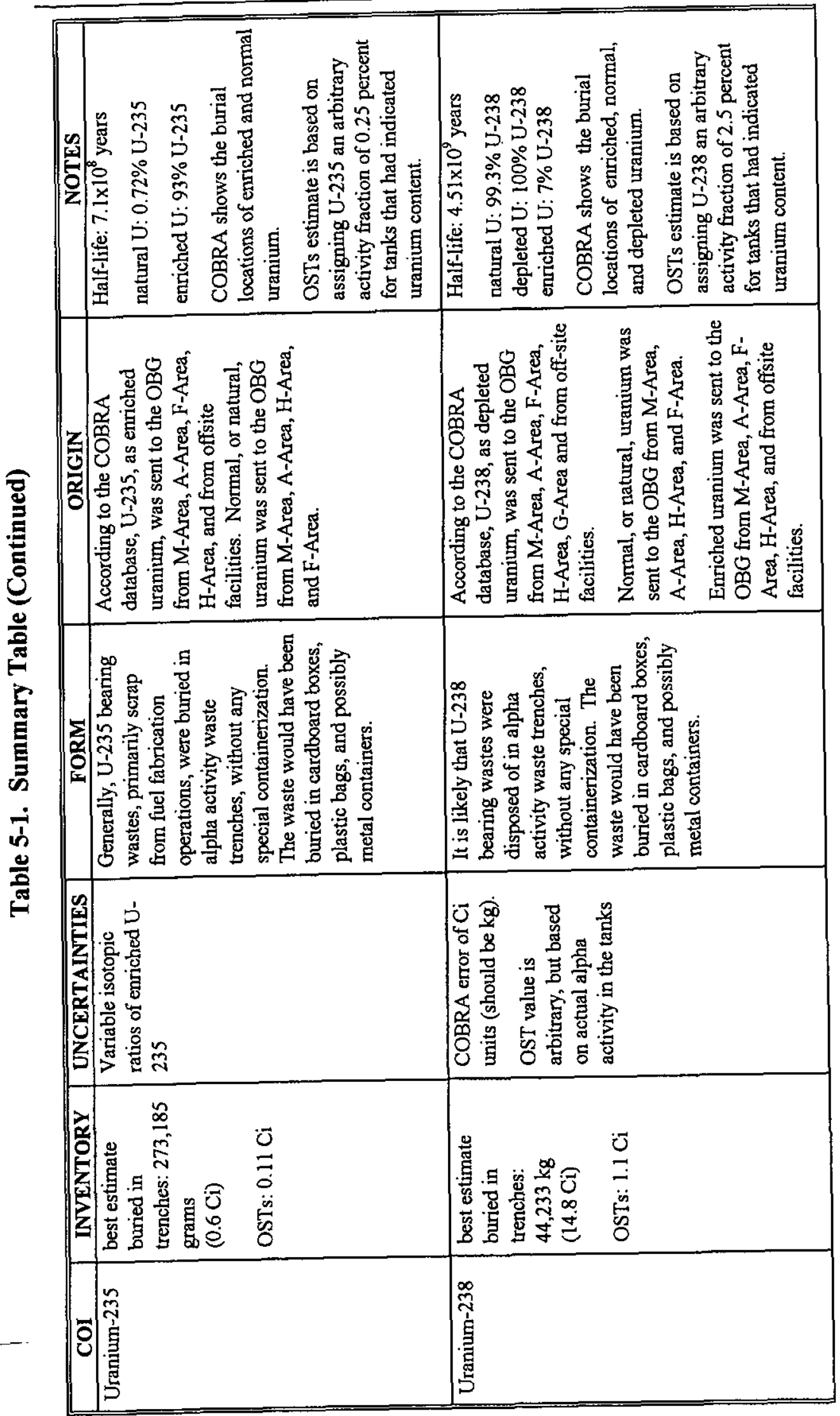




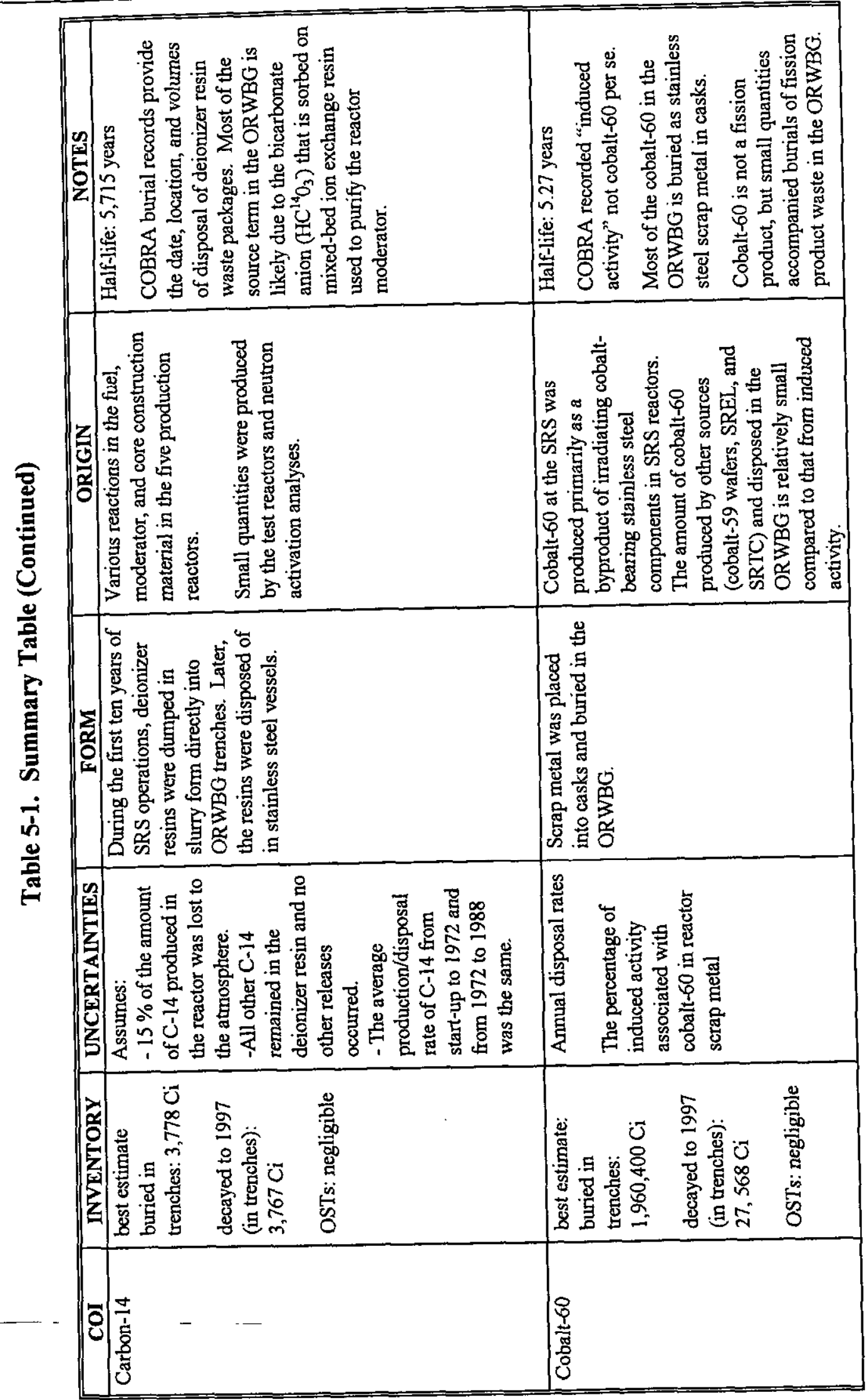




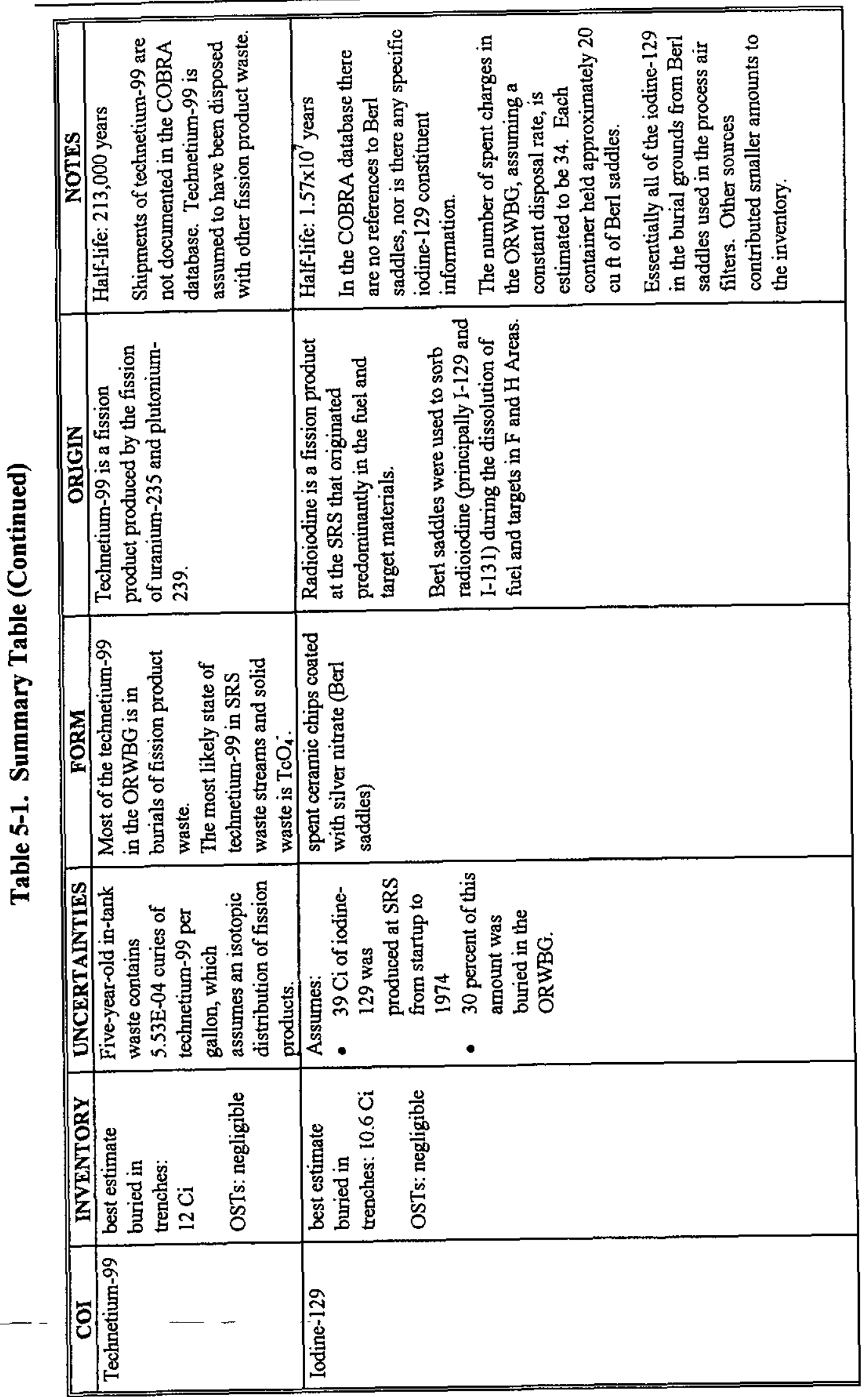




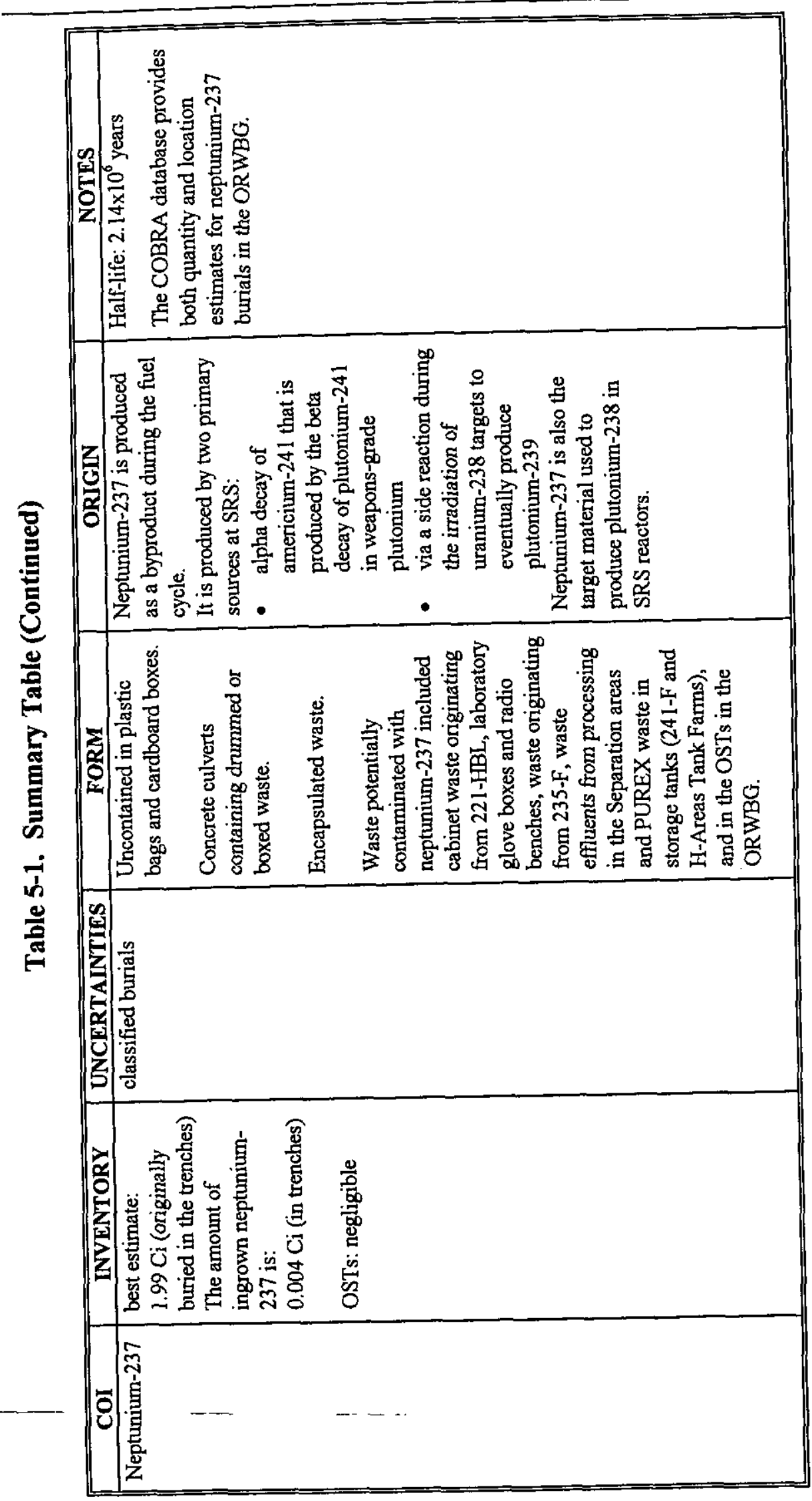


Table 5-2. Summary of Best Estimates of COI Inventories

\begin{tabular}{|c|c|c|c|}
\hline COI & $\begin{array}{l}\text { AMOUNT BURIED IN } \\
\text { TRENCHES (through 1972) }\end{array}$ & $\begin{array}{l}\text { CURRENT } \\
\text { INVENTORY IN } \\
\text { TRENCHES (1997) }\end{array}$ & $\begin{array}{l}\text { CURRENT } \\
\text { INVENTORY IN } \\
\text { OSTs (1997) }\end{array}$ \\
\hline $\mathrm{Cd}$ & $3,500 \mathrm{lb}$ & $3,500 \mathrm{lb}$ & negligible \\
\hline $\mathrm{Pb}$ & 50 tons & 50 tons & negligible \\
\hline $\mathrm{Hg}$ & $24,195 \mathrm{lb}$ & $24,195 \mathrm{lb}$ & negligible \\
\hline VOCs & $\begin{array}{c}7,100 \mathrm{~kg} \text { toluene } \\
7,100 \mathrm{~kg} \text { trimethylbenzene } \\
12,000 \mathrm{~kg} \text { xylene }\end{array}$ & $\begin{array}{c}7,100 \mathrm{~kg} \text { toluene } \\
7,100 \mathrm{~kg} \text { trimethylberizene } \\
12,000 \mathrm{~kg} \text { xylene }\end{array}$ & $7,539 \mathrm{gal}$ \\
\hline $\mathrm{H}-3$ & $3,014,457 \mathrm{Ci}$ & 467,889 & negligible \\
\hline Cs-137 & $58,657 \mathrm{Ci}$ & $26,838 \mathrm{Ci}$ & $1.30 \mathrm{Ci}$ \\
\hline $\mathrm{Pu}-238$ & $20,514 \mathrm{Ci}$ & $16,825 \mathrm{Ci}$ & $21.4 \mathrm{Ci}$ \\
\hline $\mathrm{Pu}-239$ & $1,475 \mathrm{Ci}$ & $1,474 \mathrm{Ci}$ & $82.4 \mathrm{Ci}$ \\
\hline Sr-90 & $58,657 \mathrm{Ci}$ & $26,216 \mathrm{Ci}$ & $1.28 \mathrm{Ci}$ \\
\hline $\mathrm{U}-235$ & $0.6 \mathrm{Ci}$ & $0.6 \mathrm{Ci}$ & $0.11 \mathrm{Ci}$ \\
\hline $\mathrm{U}-238$ & $14.8 \mathrm{Ci}$ & $14.8 \mathrm{Ci}$ & $1.1 \mathrm{Ci}$ \\
\hline C-14 & $3,778 \mathrm{Ci}$ & $3,767 \mathrm{Ci}$ & negligible \\
\hline $\mathrm{Co}-60$ & $1,960,400 \mathrm{Ci}$ & $27,568 \mathrm{Ci}$ & negligible \\
\hline Tc-99 & $12 \mathrm{Ci}$ & $12 \mathrm{Ci}$ & negligible \\
\hline $1-129$ & $10.6 \mathrm{Ci}$ & $10.6 \mathrm{Ci}$ & negligible \\
\hline $\mathrm{Np}-237$ & $1.99 \mathrm{Ci}$ & $1.994 \mathrm{Ci}$ & negligible \\
\hline
\end{tabular}

Due to their long half-lives, the current inventories for U-235, U-238, Tc-99, I-129 and Np-237 are assumed to be the same as the original amounts buried. Because the annual disposal amounts of H-3, Cs-137, Sr-90 and $\mathrm{Co}-60$ are known, the current inventories for these COIs account for radioactive decay during the operational history of the ORWBG. The current inventories for the other COIs assume no radioactive decay prior to December 31, 1972. The amount buried in trenches for U-235, U-238, Pu-238, Pu-239, and Np-237 include some burials in 1973 and/or 1974. 
(This page intentionally left blank) 


\subsection{REFERENCES}

Bondietti, E.A., and Francis, C.W., 1979. "Geologic Migration Potentials of Technetium-99 and Neptunium-237', Science, 203: 1337-1340.

Carlton, W.H., et al., 1993. Assessment of Radiocarbon in the Savannah River Site Environment (U), WSRC-TR-93-215, Westinghouse Savannah River Company, Savannah River Technology Center, Aiken, SC 29808, March 1993.

Cook, 1987. Plan for Closure of the 643-G Burial Ground, Technical Data Summary, DPSTD-87-2, August 1987.

Cook, J.R., 1989. Assessment of Long-Lived Radionuclides in the Savannah River Plant Radioactive Waste Burial Grounds, DPST-89-315, Memorandum to Sturm, H.F., Jr., Technical Division Savannah River Laboratory, February 23, 1989.

Cook, J.R. and Helton, B.D., 1989. An Assessment of Buried Waste Containing Transuranium Isotopes in the Savannah River Site Radioactive Waste Burial Ground, memorandum to B.G. Kitchen, August 23, 1989.

Corey, J.C., Horton, J.H., and Proctor, J.F. 1970. Storing of Solid Waste at SRP, Savannah River Site, Aiken, SC.

Du Pont, 1964. Burial of Classified Waste, DPSP-63-2048, E.I. DuPont de Nemours, Aiken, S.C., May 26, 1964.

Hoeffner, S.L., 1984. Organics in the 643-G Burial Ground, DPST-84-738, Letter to G.T. Wright.

Holcomb, H. Perry, 1997. Deriving Source Terms of Carbon-14, Cobalt-60, Technetium-99, Iodine-129, and Neptunium-237 in the Old Radioactive Waste Burial Ground, RadChemCo-97-013, Memorandum to Smits, A.D., SAIC, RadChemCo, Inc., July 26, 1997.

Horton, J.H. and Corey, J.C., 1976. Storing Solid Radioactive Wastes at the Savannah River Plant, DP-1366, E.I. du Pont de Nemours \& Co., Aiken, SC.

Jaegge, W.J., et al., 1987. Environmental Information Document, Radioactive Waste Burial Grounds, DPST-85-694, E. I. du Pont de Nemours \& Co., Savannah River Laboratory, Aiken, SC 29808, March 1987. 
Johnson, J.S., 1972. Neutron Generator Burial At 643-G. Handwritten letter from Johnson, J.S., to Barab, A.S., December 20, 1972.

Mason, 1996. Information Document on the Old Solvent Tanks SI-S22 in the Old Radioactive Waste Burial Ground 643-E (U), WSRC-RP-96-00144, Rev. 0, Westinghouse Savannah River Company, Savannah River Site, Aiken, SC, June 24, 1996.

Oblath, S.B., 1982. Migration of $\mathrm{TcO}_{4}{ }_{4}$ in SRP Soils, DPST-82-815, Memorandum to Wiley, J.R., Technical Division Savannah River Laboratory, August 27, 1982.

Oblath, S.B., 1985. Lead and Cadmium Measurements of Groundwater Beneath the LowLevel Waste Burial Ground, DPST-85-969, memorandum to H.F. Sturm, Jr., Technical Division, Savannah River Laboratory, Aiken, SC.

Report of Conference, 1966. Code 2304:Bn. Meeting date: 12/7/65. Report date: 1/11/66.

Stone, J.A, Oblath, S.B., Hawkins, R.H., Emslie, R.H., Ryan, J.P. Jr., and King, C.M., 1983. Migration Studies at the Savannah River Plant Shallow Land Burial Site, DP-MS-83-89, E. I. du Pont de Nemours \& Co., Savannah River Laboratory, Aiken, South Carolina, August 30 - September 1, 1983.

Tharin, D.W., Jr., 1965. Burning of Radioactive Process Solvent, AEC Research and Development Report, DP-942, E.I. du Pont De Nemours \& Co., Savannah River Laboratory, Aiken, SC, February 1965.

Towler, Jr. Oscar A., 1989. Integrated Report on Radionuclide Migration at the Savannah River Shallow Land Burial Site, DP-1778, E. I. du Pont de Nemours \& Co., Savannah River Laboratory Technical Division, Aiken, SC 29808, March, 1989.

Wilhite, E.L., 1976. Estimate of TRU Nuclides in Solvent Residues at the Burial Ground, memorandum to M.D. Boersma, Technical Division, Savannah River Laboratory, April 30, 1976.

WSRC, 1992. Old Radioactive Waste Burial Ground, Revised Draft, August 1992.

WSRC, 1994. RFI/RI Work Plan For the Burial Ground Complex, WSRC-RP-90-1140, Westinghouse Savannah River Company, Savannah River Site, Aiken, SC, December 1994. 
APPENDIX A

\section{CONSTITUENT OF INTEREST:}

CADMIUM 
(This page intentionally left blank) 


\section{TABLE OF CONTENTS}

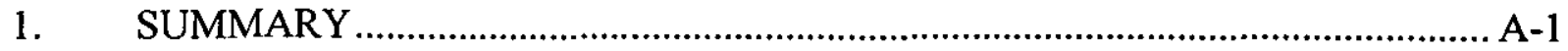

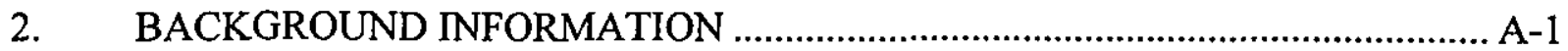

2.1 Cadmium from $L$ and $R$ Reactor Shutdowns......................................... A-1

2.2 Cadmium in the Old Solvent Tanks......................................................... A-1

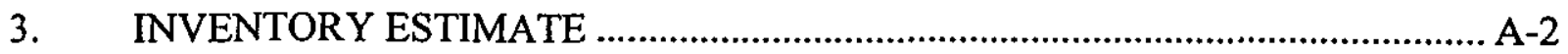

3.1 Range of Inventory Estimates ............................................................... A-2

3.2 Best Estimate for Old Radioactive Waste Burial Ground............................... A-2

3.3 Uncertainties Associated with Best Estimate …………………………...... A-3

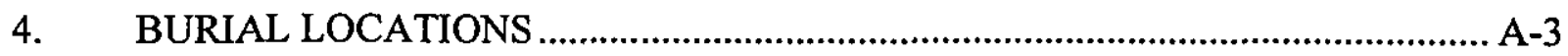

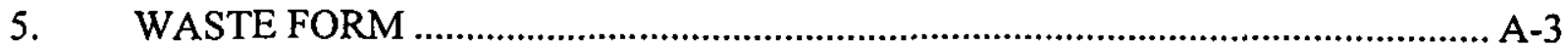

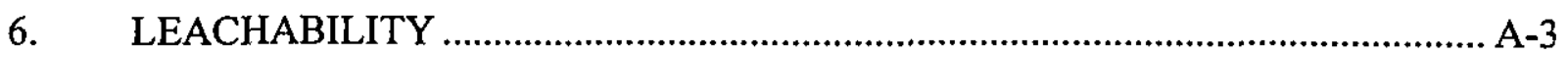

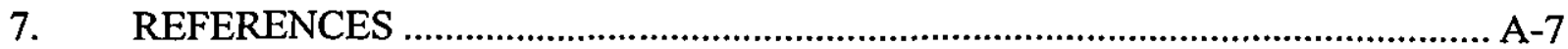




\section{LIST OF FIGURES}

Figure 1-1. Inventory Estimate Process Flow Diagram............................................. A-9

Figure 4-1. Cadmium Burial Location Process Flow Diagram ..................................... A-10

Figure 6-1. Log of Total Aluminum Concentration vs. $\mathrm{pH}$ of Groundwater

Sampled From Grid Wells in 1993 and 1994 ........................................... A-11

\section{LIST OF TABLES}

Table 3-1. The Sources of Inventory Estimates for Cadmium in the ORWBG A-12 


\section{CONSTITUENT OF INTEREST - CADMIUM}

\section{SUMMARY}

Cadmium was used at the Savannah River Site (SRS) for its neutron-absorbing properties. Its primary use was in control rods, safety rods, and neutron shielding sheets (WSRC, 1994). Based on this study, the total inventory of cadmium placed in the Old Radioactive Waste Burial Ground (ORWBG) is estimated at 3,500 pounds:

Much of the inventory originated from control rods that were in reactors when they were shut down (Oblath, 1985). During the operational history of the ORWBG, two reactors were shut down. R Reactor was shut down in 1964, and L Reactor was shut down for the first time in 1970. Approximately 1 ton (2,000 pounds) of the cadmium in the ORWBG originated from shutdown operations at $L$ and $R$ Reactors.

An additional 1,000 to 2,000 pounds of cadmium sheet was disposed in trenches in the burial ground (Oblath, 1985). This term is based on records of annual cadmium purchases and subsequent disposal.

Figure 1-1 presents the process used to develop inventory and burial locations. The Computerized Burial Record Analysis (COBRA) database does not keep track of cadmium. The inventory estimate was made based on process knowledge and interviews.

\section{BACKGROUND INFORMATION}

\subsection{Cadmium from $\mathrm{L}$ and $\mathrm{R}$ Reactor Shutdowns}

Cadmium is an effective neutron absorbing material. It was used at the SRS in reactors as control rods and safety rods to control the reaction rate. It was also used in neutron șhielding sheets to control reactivity (WSRC, 1994).

\subsection{Cadmium in the Old Solvent Tanks}

Cadmium is present in the sludge in the 22 Old Solvent Tanks located at the ORWBG. Cadmium and other toxic metals in the sludge phase may have been concentrated to levels above regulatory limits. Minor quantities of cadmium may be present in any residual aqueous phase. Little is expected in any residual organic phase (WSRC, 1996). 


\section{INVENTORY ESTIMATE}

There are no detailed quantitative records on shipments of cadmium to the ORWBG. All estimates for the cadmium source term are based on process knowledge.

\subsection{Range of Inventory Estimates}

During the operational history of the ORWBG, two reactors were shut down (R Reactor in 1964 and L Reactor in 1970). These shutdowns resulted in two large shipments of cadmium control rods to the burial ground (Oblath, 1985). These two shipments amount to about 1 ton (2,000 pounds) of cadmium (B.B. Looney, pers. comm. in Oblath, 1985).

Cadmium sheet is a stock item in stores. It is likely that most of the cadmium sheet used was disposed of in the burial ground. Purchases in the early 1980s were between 50 and 100 pounds per year (Oblath, 1985). Assuming a similar rate of purchase and burial during the 20-year operational history of the ORWBG, this could add 1,000 to 2,000 pounds to the source term.

The sum of the two shipments of control rods (2,000 pounds) and the amount of cadmium sheet (1,000 to 2,000 pounds) yields a the range of source term estimates from Oblath (1985) of 3,000 to 4,000 pounds.

Cook (1987) reported a source term of $1,200 \mathrm{~kg}$ (2,646 pounds). This estimate is approximately one-half of the above estimate (Table 3-1), and probably represents a minimum. Table 3-1 summarizes the sources of inventory estimates for cadmium in the ORWBG.

\subsection{Best Estimate for Old Radioactive Waste Burial Ground}

The "best estimate" for total cadmium in trenches in the ORWBG is 3,500 pounds. The basis for this estimate is the sum of the following:

- The ORWBG received two shipments of control rods from $\mathrm{L}$ and $\mathrm{R}$ Reactors that totalled 2,000 pounds

- An average annual rate of 75 pounds of cadmium sheet was consumed over the 20-year lifetime of the ORWBG, for a total of 1,500 pounds.

Compared to the 3,500 pounds of cadmium estimated to be in the ORWBG, the small quantity in the Old Solvent Tanks is considered negligible. 


\subsection{Uncertainties Associated with Best Estimate}

The best estimate for cadmium inventory is thought to be accurate to within $\pm 20 \%$. The estimate of 2,000 pounds of cadmium from $L$ and $R$ Reactors is thought to be accurate to within $\pm 10 \%$. The amount of cadmium sheet consumed over the 20 -year operational history is thought to be accurate to within $\pm 30 \%$.

\section{BURIAL LOCATIONS}

COBRA does not record shipments of cadmium per se, and it would be nearly impossible to locate the metal in the burial ground (Oblath, 1985). Figure 4-1 outlines the steps taken to manipulate the database to locate cadmium burials. Sorts on COBRA primarily consisted of keyword searches in description field \#1 for items such as "cadmium", "control rods", "safety rods", "rods", "sheets", and "neutron shielding". All records from L and R Reactors (Buildings 105-L and 105-R) were reviewed for any likely reference or relationship to the disposed control rods. In particular, records in the two years following each reactor shutdown were scrutinized.

No individual record (or records) from Buildings $105-\mathrm{L}$ or $105-\mathrm{R}$ could be associated as relating to control rods. The only basis for determination of burial location for the two large shipments of control rods is that they were buried in the areas of the ORWBG that were active in 1964 and 1970 (during the shutdowns of R and L Reactors).

\section{WASTE FORM}

Cadmium metal is present in the ORWBG as control rods, safety rods, and cadmium sheet buried as scrap metal and induced activity waste. There is no specific information available on the method of disposal. Control rods were put into disassembly basins for decay of shortlived isotopes and then cut with an underwater saw. The cadmium pieces were placed in a cask, shipped to the ORWBG, and buried as scrap metal.

\section{LEACHABILITY}

Cadmium leachability is controlled mainly by adsorption to the soil matrix. At $\mathrm{pH}<7$ the solubility of most common cadmium phases will not constrain cadmium concentrations to below ppm levels. In the reducing environment of the ORWBG, conditions may develop that favor the reduction of sulfate to sulfide by bacteria. If this occurs cadmium concentrations would be constrained to very low values by the precipitation of cadmium sulfide. 
Adsorption of cadmium to the soil matrix is moderate because the $\mathrm{pH}$ of the adsorption edge is higher than the $\mathrm{pH}$ of water from the trench wells and grid wells. The adsorption edge for cadmium adsorption to iron oxyhydroxides and clays is generally greater than a $\mathrm{pH}$ of 6.5 (Kinniburgh et al., 1976; Benjamin and Leckie, 1981; Elliot et al., 1986; and Schulthess and Huang, 1990). Thus, it is expected that cadmium will be more mobile than lead. Looney et al. (1987) recommend a $\mathrm{K}_{\mathrm{d}}$ value of $6 \mathrm{ml} / \mathrm{g}$ for cadmium in SRS soils. Though cadmium is mobile relative to some other metals, its transport is significantly retarded by adsorption. A $\mathrm{K}_{\mathrm{d}}$ value of $6 \mathrm{ml} / \mathrm{g}$ equates to a retardation factor of about 50 (Looney et al., 1987).

The presence of dissolved organic matter in the leachate may increase the mobility of cadmium. Oblath (1985) suggested that organic complexing may explain the presence of cadmium in groundwater sampled by the grid wells. Dissolved cadmium does not exist as a single species, but rather as a dominant species with a fraction of the total dissolved cadmium being distributed among other species. If these minor species are more mobile than the dominant species, then they will travel to the groundwater faster than the dominant species. Thus, the bulk of the cadmium may be retarded in its transport while a small fraction, perhaps organically complexed, has already reached the water table.

Cadmium concentrations in groundwater beneath the ORWBG are low, but have regularly exceeded the primary drinking water standard of $5 \mathrm{ug} / \mathrm{l}$. Oblath (1985) reported cadmium concentrations in the grid wells that ranged from 2 to $365 \mathrm{ug} / \mathrm{l}$ with an average concentration of $45 \mathrm{ug} / \mathrm{l}$ and a median of $32 \mathrm{ug} / \mathrm{l}$. The cadmium concentrations were less in samples obtained from the grid wells in 1993 and 1994. The range of cadmium concentrations in these samples was 2 to $166 \mathrm{ug} / \mathrm{l}$ and the average and median concentrations were 25 and 14 $\mathrm{ug} / \mathrm{l}$, respectively. It is unclear whether this decrease in cadmium concentration is real or a sampling artifact. Oblath (1985) reported samples from all 67 of the grid wells, but in the more recent sampling events only 13 wells had sufficient water to sample.

Because the analyses are more complete, the recent samples provide the opportunity to assess the elevated cadmium concentrations. Closer inspection of these analyses indicates that much of the cadmium may be associated with suspended sediments dispersed during bailing of the wells. The turbidities of most of the samples are high and the iron and aluminum concentrations are elevated in many of the samples. Samples with suspended sediments contain elevated iron and aluminum concentrations because the fine grained fraction of typical SRS sediments is composed of iron oxyhydroxides and clay minerals. The elevated iron concentrations ${ }^{-}$can $^{-}$only-serve-as'a-qualitative-indicator-of-suspended-sediments-becausethe redox information required to determine expected dissolved iron concentrations is not 
available. However, the elevated concentrations of aluminum can be addressed quantitatively. Figure 6-1 shows the $\log$ of the total aluminum concentrations plotted versus $\mathrm{pH}$. The solid line is the saturation curve for amorphous aluminum hydroxide. In sediment free samples the aluminum concentrations should plot near or below the aluminum hydroxide saturation curve. Most of the grid well samples plot above the saturation curve indicating that their aluminum concentrations are predominantly the result of suspended sediments rather than dissolved aluminum.

The suspended sediment in the samples results in cadmium concentrations that are misleading. Much of the cadmium in these samples is background cadmium and cadmium sequestered by the sediments from groundwater over a long period of time. This cadmium is not readily mobile and is not representative of leachate from the ORWBG. When only those analyses are used that have aluminum concentrations falling on or below the amorphous aluminum hydroxide saturation curve, the range of cadmium concentrations becomes more reasonable. They range from 2 to $46 \mathrm{ug} / \mathrm{l}$ with an average of $14 \mathrm{ug} / \mathrm{l}$ and a median of $10 \mathrm{ug} / \mathrm{l}$.

The effect of suspended sediments on cadmium concentrations in groundwater from the grid wells was addressed by Cantrell (1990). The results show that samples bailed from these wells that are filtered prior to being acidified for analysis have significantly lower cadmium concentrations than unfiltered samples. This indicates that much of the cadmium is associated with the suspended sediments.

Based on the work of Looney and Cook (1987), cadmium leachability can be estimated from the cadmium concentrations in groundwater beneath the ORWBG. Looney and Cook (1987) estimated the "worst case" lead and cadmium fluxes from the Mixed Waste Management Facility (MWMF). They point out that their estimates are worst case because well construction and sampling protocols were not consistent with site or regulatory protocols. As with the grid wells in the ORWBG, the wells within the MWMF were sampled by bailing and were constructed with components that contain lead and cadmium. These factors contribute to elevated lead and cadmium concentrations. However, for the purposes of their estimates Looney and Cook (1987) assumed that the concentrations of lead and cadmium in groundwater from these wells were representative of pure leachate from the MWMF. From the concentrations in groundwater, the flux of infiltrating water, and the background concentrations in groundwater, they estimated fluxes of lead and cadmium.

Applying this technique to the ORWBG coupled with a conservative estimate of the area of cadmium exposed to infiltrating water results in an estimate of $7.8 \mathrm{~g} / \mathrm{yr}$ of cadmium leached. 
This assumes the cadmium concentration of $46 \mathrm{ug} / \mathrm{l}$ is representative of pure leachate and that the background cadmium concentration is negligible. The water infiltration rate calculated by Orebaugh and Hale (1976), $2.36 \mathrm{~m} / \mathrm{yr}$, was used in this estimate. In the absence of information on the dimensions of disposed cadmium waste forms, it was assumed that all cadmium was in the form of $0.25 \mathrm{~cm}$ thick sheets. This is an overestimation of the area of cadmium exposed to infiltrating water. Of the 3500 pounds of cadmium disposed, 2000 pounds were in the form of control rods. These rods were cut to facilitate their disposal, but it is not known what the dimensions of the pieces were. Thus, to be conservative it was assumed that all cadmium was in the form of thin sheets. This and the fact that most cadmium concentrations in groundwater are less than $46 \mathrm{ug} / \mathrm{l}$ suggest that a leachability estimate of $7.8 \mathrm{~g} / \mathrm{yr}$ is conservative. 


\section{REFERENCES}

Benjamin, M.M. and J.O. Leckie, 1981. Multiple-Site Adsorption of $\mathrm{Cd}, \mathrm{Cu}, \mathrm{Zn}$, and $\mathrm{Pb}$ on Amorphous Iron Oxyhydroxide, Journal of Colloid and Interface Science, v. 79, p. 209221.

Cantrell, K.J., 1990. Results of the Special Well Sampling Study for the Burial Ground, memorandum to W.E. Stevens, March 28, 1990, WSRC-RP-90-364, Westinghouse Savannah River Co, Aiken, SC.

Cook, J.R., 1987. Technical Data Summary, Plan for Closure of the 643-G Burial Ground, DPSTD-87-2, E.I. du Pont de Nemours and Company, Savannah River Laboratory, Aiken, SC, August 1987.

Elliot, H.A., M.R. Liberati, and C.P. Huang, 1986. Competitive Adsorption of Heavy Metals by Soils, Journal of Environmental Quality, v. 15, p. 214-219.

Hoeffner, S.L., 1985. Radionuclide Sorption on Savannah River Plant Burial Ground Soil -A Summary and Interpretation of Laboratory Data: DP-1702, E.I. duPont de Nemours and Company, Savannah River Laboratory, Aiken, SC.

Kinniburgh, D.G., M.L. Jackson, and J.K. Syers, 1976. Adsorption of Alkaline Earth, Transition, and Heavy Metal Cations by Hydrous Oxide Gels of Iron and Aluminum, Journal of the Soil Science Society of America, v. 40, p. 796-799.

Looney, B.B. and J.R.Cook, 1987. Estimation of "Worst Case" Lead and Cadmium Fluxes for the Mixed Waste Management Facility (643-28G), memorandum March 31, 1987, DPST-87-335, E.I. du Pont de Nemours \& Co., Savannah River Laboratory, Aiken, SC.

Looney, B.B., M.W. Grant and C.M. King, 1987. Estimation of Geochemical Parameters for Assessing Subsurface Transport at the Savannah River Plant: DPST-86-710, E.I. duPont de Nemours and Company, Savannah River Laboratory, Aiken, SC.

Oblath, S.B., 1985. Lead and Cadmium Measurements of Groundwater Beneath the Lowlevel Waste Burial Grounds, memorandum dated December 11, 1985 to H.F. Sturm, Jr. DPST-85-969, E.I. du Pont de Nemours \& Co., Savannah River Laboratory, Aiken, SC.

Orebaugh, E.G. and W.H. Hale, Jr., 1976. Dispersion Study of Buried Elemental Mercury, DP-1401, E.I. du Pont de Nemours \& Co., Savannah River Laboratory, Aiken, SC.

Schulthess, C.P. and C.P. Huang, 1990. Adsorption of Heavy Metals by Silicon and Aluminum Oxide Surfaces on Clay Minerals, Soil Science Society of America Journal, v. 54, p. 679-688.

WSRC, 1994. RFI/RI Work Plan for the Burial Ground Complex (U), WSRC-RP-90-1140, Rev. 2, Savannah River Site, Aiken, SC, December 1994. 
WSRC, 1996. Information Document on the Old Solvent Tanks S1-S22 in the Old Radioactive Waste Burial Ground 643-E (U), WSRC-RP-96-00144, Rev. 0, Westinghouse Savannah River Company, Savannah River Site, Aiken, SC, 


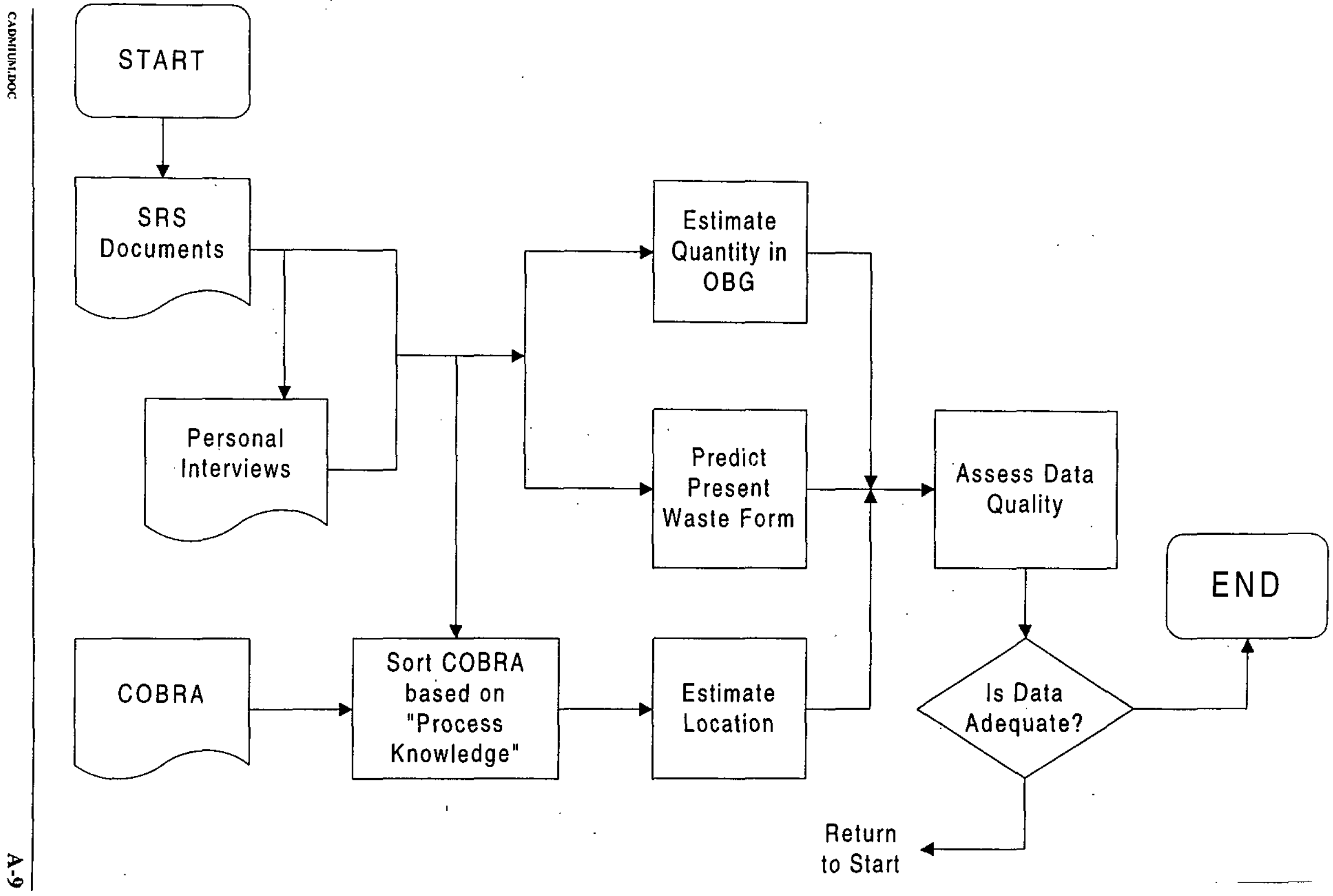

Figure 1-1. Inventory Estimate Process Flow Diagram 


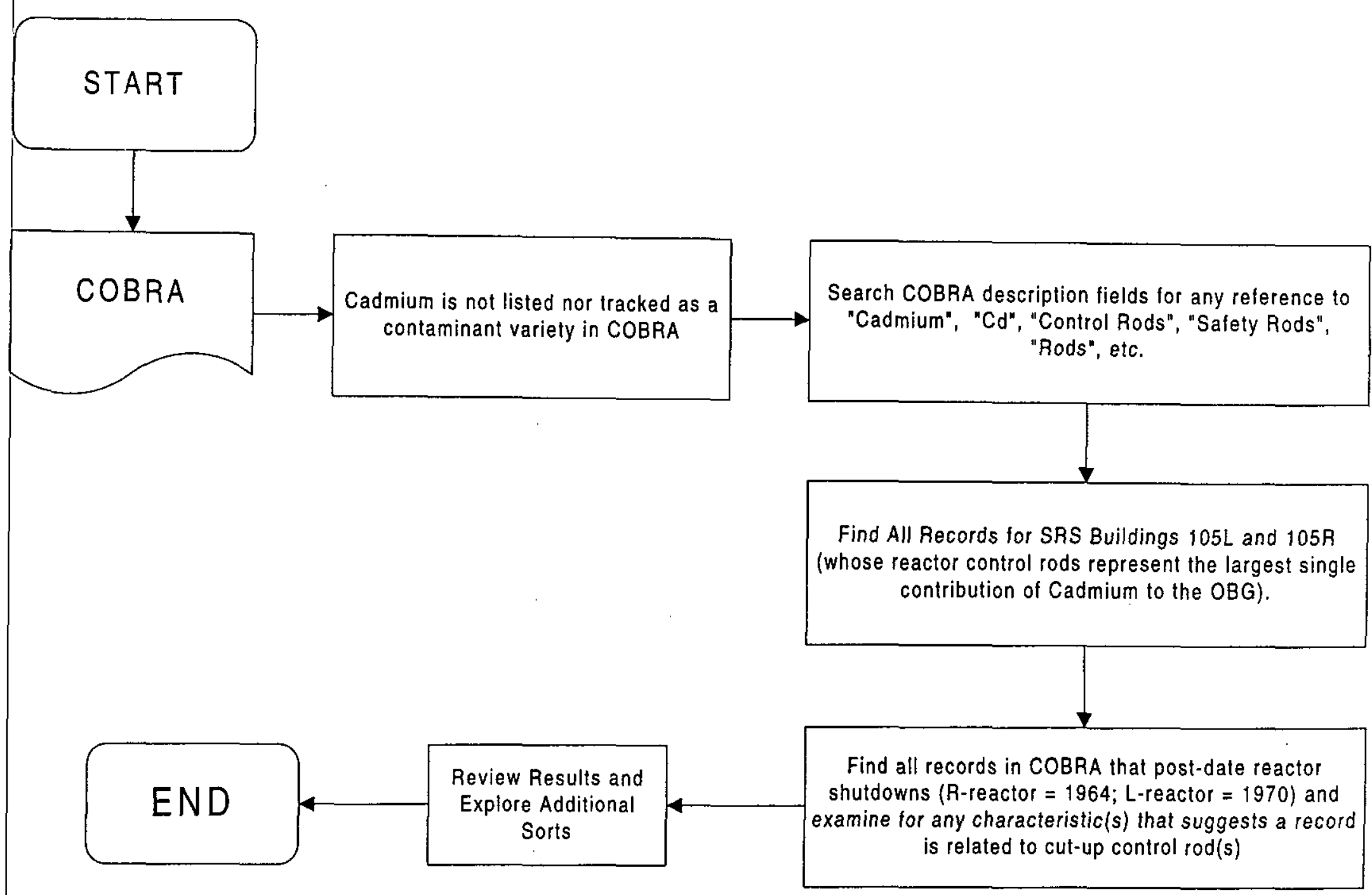

Figure 4-1. Cadmium Burial Location Process Flow Diagram 


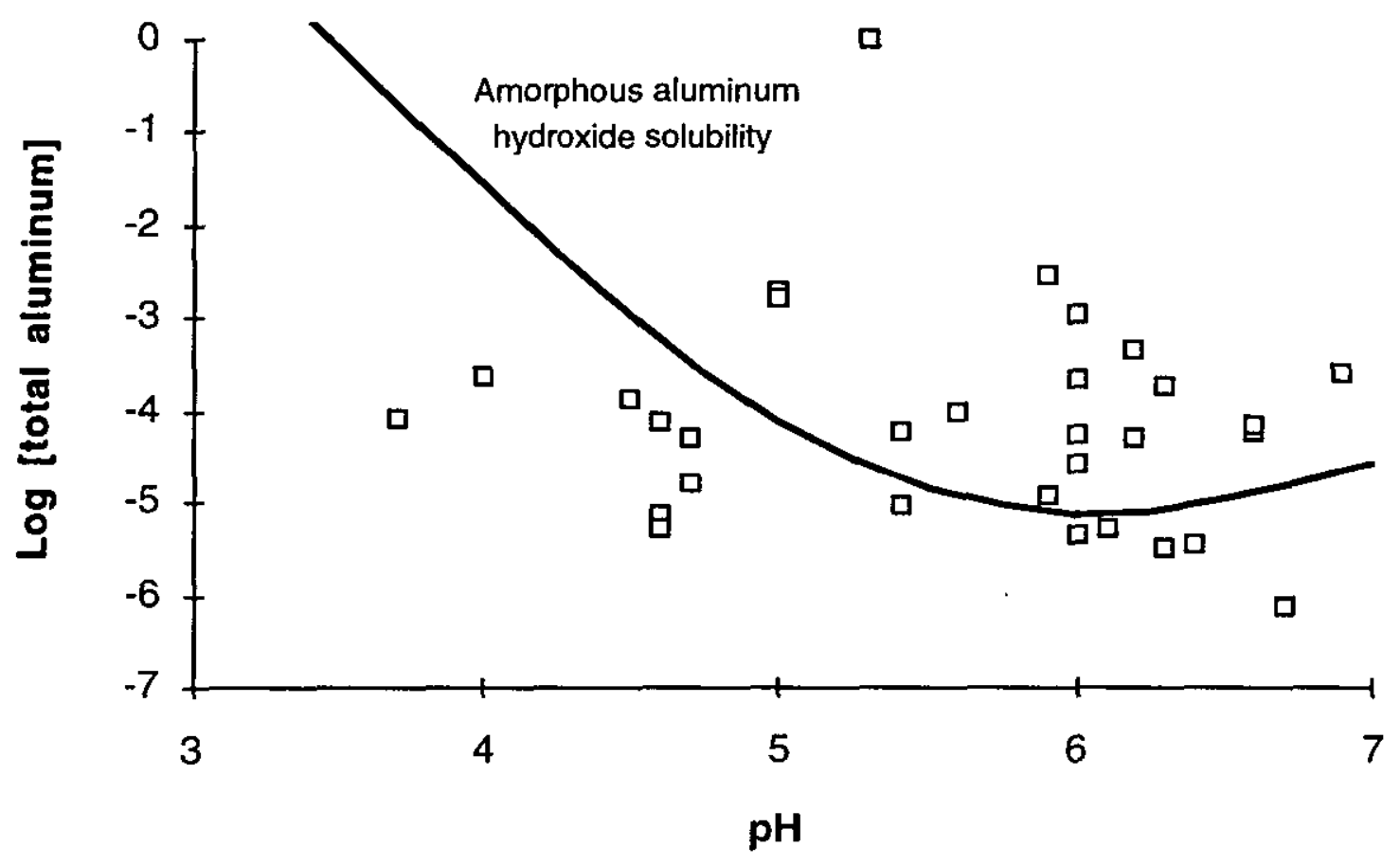

Figure 6-1. Log of Total Aluminum Concentration vs. pH of Groundwater Sampled From Grid Wells in 1993 and 1994. Saturation Curve for Amorphous Aluminum Hydroxide is Shown 
Table 3-1. The Sources of Inventory Estimates for Cadmium in the ORWBG

\begin{tabular}{|c|c|c|c|c|}
\hline Reference & Amount of Cd & $\begin{array}{l}\text { ORWBG } \\
\text { Lifetime }\end{array}$ & Cd form & Notes \\
\hline WSRC, 1994 & NA & $1952-1972$ & $\begin{array}{l}\text { control rods } \\
\text { - neutron } \\
\text { shielding } \\
\text { sheets } \\
\text { - safety rods }\end{array}$ & NA \\
\hline Cook, J.R., 1987 & $\begin{array}{c}1,200 \mathrm{~kg} \\
(2,646 \text { pounds) } \\
\\
\text { (does not reference a } \\
\text { previous article) }\end{array}$ & $1952-1974$ & $\begin{array}{ll}\text { - } & \text { control rods } \\
\text { - } & \text { neutron } \\
\text { shielding } \\
\text { sheets }\end{array}$ & NA \\
\hline Oblath, S.B., 1985 & $\begin{array}{l}-1 \text { ton }(2,000 \\
\text { pounds) came from } \\
\text { two large shipments } \\
\text { of cadmium control } \\
\text { rods }{ }^{b^{*}} \\
\text { - } 1,000 \text { to } 2,000 \\
\text { pounds came from } \\
\text { cadmium sheets }{ }^{b^{* *}}\end{array}$ & $1954-1972$ & $\begin{array}{l}\text { - cadmium } \\
\text { control rods } \\
\text { - } \\
\text { cadmium } \\
\text { sheets }\end{array}$ & $\begin{array}{l}\text { There were two large } \\
\text { shipments of cadmium } \\
\text { control rods to the burial } \\
\text { ground when } L \text { and } R \\
\text { reactors were shut down. } \\
\text { Cadmium sheet is also a } \\
\text { stock item in stores; most of } \\
\text { what is used is likely to have } \\
\text { ended up in the burial } \\
\text { ground. }\end{array}$ \\
\hline
\end{tabular}

Notes:

$\begin{array}{ll}\text { a } & \text { No discussion of basis for inventory } \\ \text { b } & \text { Inventory discussed in detail } \\ \text { NA } & \text { not addressed in article } \\ \text { * } & \text { Oblath, 1985 references B.B. Looney, Personal Communication, I1/13/85 } \\ \text { ** } & \text { Oblath, 1985 references B. Goodwin, Personal Communication, 1 1/21/85 }\end{array}$ 


\section{APPENDIX B}

\section{CONSTITUENT OF INTEREST:}

LEAD 
(This page intentionally left blank) 


\section{TABLE OF CONTENTS}

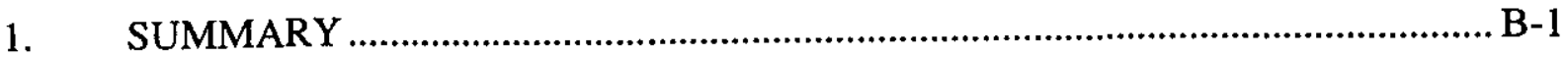

2. BACKGROUND INFORMATION .................................................................... B-1

2.1 Lead Associated with Separations, Reactors and Offsite Waste.................... B-1

2.2 Lead in the Old Solvent Tanks ........................................................................ B-2

3. INVENTORY ESTIMATE …….......................................................................

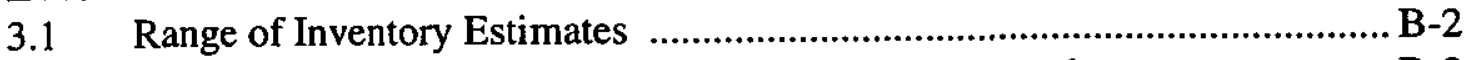

3.2 Best Estimate for Old Radioactive Waste Burial Ground ............................... B-2

3.3 Uncertainties Associated with Best Estimate .................................................. B-3

4. BURIAL LOCATIONS..................................................................................... B-3

5. WASTE FORM ............................................................................................

6. LEACHABILITY ......................................................................................... B-3

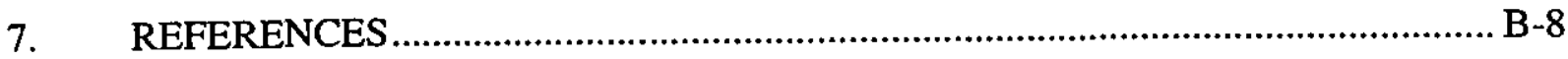




\section{LIST OF FIGURES}

Figure 1-1. Inventory Estimate Process Flow Diagram ............................................. B-10

Figure 4-1. Lead Burial Location Process Flow Diagram............................................... B-11

Figure 6-1. Log of Total Aluminum Concentration vs. pH of Groundwater Sampled From

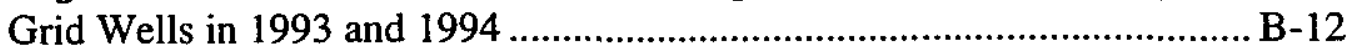

\section{LIST OF TABLES}

Table 3-1. The Sources of Inventory Estimates for Lead in the ORWBG B-13 


\section{CONSTITUENT OF INTEREST - LEAD}

\section{SUMMARY}

Lead was used at the Savannah River Site (SRS) primarily for its radiation-shielding properties. Based on this study, the total inventory of lead placed in the Old Radioactive Waste Burial Ground (ORWBG) is estimated at 50 tons.

At SRS, lead was used in Separations, reactors, and to shield offsite waste. Trace amounts of lead and other toxic metals may have been concentrated to levels above regulatory limits in the Old Solvent Tanks (WSRC, 1996).

Lead was placed in the burial ground for two reasons: either it was contaminated with radioactivity and required disposal or it was used to shield other buried radioactive waste (WSRC, 1994). It is present in the burial ground as lead shielding, equipment, shot, bricks, lead sheets (WSRC, 1994) and in the Old Solvent Tanks (WSRC, 1996).

Figure 1-1 presents the process used to develop inventory and burial locations. The Computerized Burial Record Analysis (COBRA) database does not keep track of lead. The inventory estimate was made based on SRS documents, process knowledge and interviews.

\section{BACKGROUND INFORMATION}

Lead was used primarily in Separations. Smaller amounts of lead originated from reactors and shielding of offsite waste. Minor amounts of lead are present in the Old Solvent Tanks.

Detailed records on lead disposed in the ORWBG were not kept because at that time lead was not considered hazardous. As recently as the spring of 1984 , several meetings were held to discuss whether lead qualified as a mixed (or hazardous) waste (Tom and Tallman, 1984 in Oblath, 1985).

\subsection{Lead Associated with Separations, Reactors and Offsite Waste}

Lead was used in Separations and reactors principally to shield personnel from high levels of beta-gamma radiation associated with fission products. Shielding materials used during construction activities have also added to the lead inventory in the burial ground, but the quantities are not known. Lead shot was used as shielding in the annular space of double walled vessels in the burial ground. Lead was also used to shield offsite waste (Oblath, 1985). 


\subsection{Lead in the Old Solvent Tanks}

Lead is present in the sludge in the 22 Old Solvent Tanks. Lead and other toxic metals in the sludge phase may have been concentrated to levels above regulatory limits. Minor quantities of lead may be present in any residual aqueous phase; little is expected in any residual organic phase (WSRC, 1996).

\section{INVENTORY ESTIMATE}

There are no detailed quantitative records on shipments of lead to the ORWBG nor are they widely documented in COBRA. All estimates for the lead source term are based on process knowledge. COBRA contains less than a dozen direct references to lead shipments.

\subsection{Range of Inventory Estimates}

There are two literature estimates of the total lead in the ORWBG: $\geq 42$ tons and 60.6 tons. Oblath (1985) estimated the source term in the ORWBG as a minimum of 42 tons, although the origin of the estimate is unclear. Oblath (1985) states the source term was calculated as follows: "Separation Technology Department has estimated that in an average year the separations facilities dispose 1.5 tons. If this amount was representative over the 1954-1972 lifetime of the burial ground, this would represent 42 tons of lead." However, assuming a 19year operational history: 19 years x 1.5 tons/year $=28.5$ tons. Additional problems with Oblath's (1985) estimate are that the lead used in reactors and shielding of offsite waste was not factored into the source term estimate.

Cook (1987) reported a source term estimate of $55,000 \mathrm{~kg}$ (60.6 tons). This estimate is considerably higher than that cited in Oblath (1985). Table 3-1 summarizes the sources of inventory estimates for lead in the ORWBG.

\subsection{Best Estimate for Old Radioactive Waste Burial Ground}

The "best estimate" for total lead in the ORWBG is 50 tons. The basis for this estimate is:

- Separations disposed an average 1.5 tons/year for the 20-year history of the ORWBG (30 tons).

- Additional lead from reactors and shielding offsite waste was placed in the ORWBG. 
Compared to the 50 tons of lead estimated in the ORWBG from onsite and offsite sources, the small quantity in the Old Solvent Tanks is considered negligible.

\subsection{Uncertainties Associated with Best Estimate}

The best estimate for lead inventory is thought to be accurate to within $\pm 30 \%$. The estimate of 30 tons of lead from Separations is thought to be accurate to within $\pm 20 \%$. The amount of lead from reactors and that used for shielding of offsite waste is unknown, but the total lead in the ORWBG is not believed to exceed 65 tons.

\section{BURIAL LOCATIONS}

COBRA records do not specifically track shipments of lead, and it would be nearly impossible to locate the metal in the burial ground (Oblath, 1985). Figure 4-1 outlines the steps taken to manipulate the database to locate lead burials. As noted in Section 3, less than a dozen references to lead were found. However, it is unnecessary to use lead to shield lowlevel waste because of the low dose rates emanating from it. Therefore, lead is not expected to be a major contaminant in the low-level waste trenches. Because lead was used to shield certain high-level waste burials, the primary location for buried lead would be in the highlevel waste trenches.

\section{WASTE FORM}

Lead is present in the ORWBG as lead metal shielding, in the form of shot, bricks, and lead sheets (WSRC, 1994). It was also part of the structure of certain pieces of equipment, such as "junior caves", that were buried without disassembly.

\section{LEACHABILITY}

The leachability of lead is controlled predominantly by the solubility of lead phases, adsorption of lead by the soil matrix, and redox conditons in the ORWBG. For lead to be mobile, the metallic lead that was buried must be oxidized to $\mathrm{Pb}(\mathrm{II})$ forms. Once oxidized, the solubility of $\mathrm{Pb}$ (II) is constrained by reaction with constituents in the leachate and with minerals in the soil matrix. The mobility of dissolved $\mathrm{Pb}(\mathrm{II})$ is controlled by adsorption to the soil matrix.

The prevailing reducing conditions of the ORWBG may influence the oxidation of metallic lead. The degradation of zero valent iron (scrap metal, drums, etc.) and organic material (paper and cardboard) will perpetuate reducing conditions that may hinder the oxidation of 
metallic lead. For example, the concentration of dissolved lead may be limited in some areas by the equilibrium:

$\mathrm{Fe}^{+2}+\mathrm{Pb}^{\circ}=\mathrm{Pb}^{+2}+\mathrm{Fe}^{\circ}$

For conditions in the 7 trench wells reported by Hoeffner (1985), the equilibrium lead concentration would range from less than $0.1 \mathrm{ug} / \mathrm{l}$ to $330 \mathrm{ug} / \mathrm{l}$. Though this equilibrium is not expected to control dissolved lead concentrations throughout the ORWBG, it will be significant in areas where lead is buried with metallic iron or steel.

The solubility of lead is also controlled by precipitation of relatively insoluble phases. In particular, lead may precipitate as insoluble phosphate phases. Small concentrations of phosphate in the leachate may limit the solubility of lead by precipitation of phases such as hydroxypyromorphite $\left(\mathrm{Pb}_{5}\left(\mathrm{PO}_{4}\right)_{3} \mathrm{OH}\right)$, and plumbogummite $\left(\mathrm{PbAl}_{3}\left(\mathrm{PO}_{4}\right)_{2}(\mathrm{OH})_{5} \cdot \mathrm{H}_{2} \mathrm{O}\right)$ (Nriagu, 1974). In addition, as leachate migrates through the soil lead may react with naturally occurring phosphate minerals that are common in SRS soils such as apatite, crandallite, and monazite. These reactions may be exchange reactions of lead for the dominant cation in these minerals or may result in precipitation of less soluble lead phosphate phases. In the reducing environment of the ORWBG, conditions may develop that favor the reduction of sulfate to sulfide by bacteria. If this occurs lead concentrations would be constrained to very low values by the precipitation of lead sulfide.

Kinetic factors may control the precipitation of lead phases, and thus, it is difficult to predict which phases control solubility. A conservative assumption would be that hydroxypyromorphite controls lead solubility. Additional conservative assumptions that trench waters have a $\mathrm{pH}$ of 5.8 (the minimum reported by Hoeffner, 1985) and a phosphate concentration of $1 \mathrm{ug} / \mathrm{l}$ (background concentration in SRS groundwater; Looney et al., 1987a) yield a solubility of $3600 \mathrm{ug} / \mathrm{l}$ for hydroxypyromorphite. In reality, solubility controls probably constrain lead concentrations to lower values. For example, under the same conservative assumptions about trench water chemistry and a chloride concentration of 1 $\mathrm{mg} / \mathrm{l}$, the solubility of chloropyromorphite is $78 \mathrm{ug} /$.

As dissolved lead migrates away from the lead source, adsorption will decrease the dissolved concentration. The adsorption edge for lead adsorption onto iron oxyhydroxides and clays is generally at a pH less than 6 (Kinniburgh et al., 1976;Benjamin and Leckie, 1981; Elliot et al., 1986;-'and-Schulthess-and-Huang,-1990).--Thus,-within-the_ORWBG_the_adsorption_of 
lead by soil matrix will be strong. Looney et al. (1987b) recommend a $\mathrm{K}_{d}$ value of $100 \mathrm{ml} / \mathrm{g}$ for lead adsorption to SRS soils.

The presence of dissolved organic matter in the leachate may increase the solubility and enhance the mobility of lead. Oblath (1985) suggested that organic complexing may explain the presence of lead in groundwater sampled by the grid wells. Dissolved lead does not exist as a single species, but rather as a dominant species with a fraction of the total dissolved lead being distributed among other species. If these minor species are more mobile than the dominart species, then they will travel to the groundwater faster than the dominant species. Thus, the bulk of the lead may be relatively immobile while a small fraction, perhaps organically complexed, has reached the water table.

The concentration of lead in groundwater beneath the ORWBG is generally low, but does exceed the drinking water standard of $50 \mathrm{ug} / \mathrm{l}$ in some wells. Oblath (1985) reports lead concentrations in groundwater obtained in 1984 from the 67 grid wells within the ORWBG. The lead concentrations ranged from 5 to $398 \mathrm{ug} / \mathrm{l}$ with an average of $46 \mathrm{ug} / \mathrm{l}$. Lead concentrations in 19 of the wells exceeded the drinking water standard. In 1993 and 1994 several of the grid wells were sampled and lead concentrations were generally higher than those in 1984. The lead concentrations ranged from 4 to $1420 \mathrm{ug} / \mathrm{l}$ with an average of 264 ug/l.

Because the analyses are more complete, the recent samples provide the opportunity to assess the elevated lead concentrations. Closer inspection of these analyses indicates that much of the lead may be associated with suspended sediments dispersed during bailing of the wells. The turbidities of most of the samples are high and the iron and aluminum concentrations are elevated in many of the samples. Samples with suspended sediments contain elevated iron and aluminum concentrations because the fine grained fraction of typical SRS sediments is composed of iron oxyhydroxides and clay minerals. The elevated iron concentrations can only serve as a qualitative indicator of suspended sediments because the redox information required to determine expected dissolved iron concentrations is not available. However, the elevated concentrations of aluminum can be addressed quantitatively. Figure 6-1 shows the $\log$ of the total aluminum concentrations plotted versus $\mathrm{pH}$. The solid line is the saturation curve for amorphous aluminum hydroxide. In sediment free samples the aluminum concentrations should plot near or below the aluminum hydroxide saturation curve. Most of the grid well samples plot above the saturation curve indicating that their aluminum concentrations are predominantly the result of suspended sediments rather than dissolved aluminum. 
The suspended sediment in the samples results in lead concentrations that are misleading. Much of the lead in these samples is ambient background lead and lead sequestered by the sediments from groundwater over a long period of time. This lead is not readily mobile and is not representative of leachate from the ORWBG. When only those analyses are used that have aluminum concentrations falling on or below the amorphous aluminum hydroxide saturation curve, the range of lead concentrations becomes more reasonable. They range from 4 to $392 \mathrm{ug} / \mathrm{l}$ with an average of $96 \mathrm{ug} / \mathrm{l}$ and a median of $38 \mathrm{ug} / \mathrm{l}$.

The effect of suspended sediments on lead concentrations in groundwater from the grid wells was addressed by Cantrell (1990). The results show that samples bailed from these wells that are filtered prior to being acidified for analysis have significantly lower lead concentrations than unfiltered samples. This indicates that much of the lead is associated with the suspended sediments.

Based on the work of Looney and Cook (1987), lead leachability can be estimated from the lead concentrations in groundwater beneath the ORWBG. Looney and Cook (1987) estimated the 'worst case" lead and cadmium fluxes from the Mixed Waste Management Facility (MWMF). They point out that their estimates are worst case because well construction and sampling protocols were not consistent with site or regulatory protocols. As with the grid wells in the ORWBG, the wells within the MWMF were sampled by bailing and were constructed with components that contain lead and cadmium. These factors contribute to elevated lead and cadmium concentrations. However, for the purposes of their estimates Looney and Cook (1987) assumed that the concentrations of lead and cadmium in groundwater from these wells were representative of pure leachate from the MWMF. From the concentrations in groundwater, the flux of infiltrating water, and the background concentrations in groundwater, they estimated fluxes of lead and cadmium.

Applying this technique to the ORWBG coupled with conservative estimates of the area of lead exposed to infiltrating water results in an estimate of $722 \mathrm{~g} / \mathrm{yr}$ of lead leached. This assumes the lead concentration of $392 \mathrm{ug} / \mathrm{l}$ is representative of pure leachate and that the background lead concentration is $10 \mathrm{ug} / 1$ (Looney et al., 1987a). The water infiltration rate calculated by Orebaugh and Hale (1976), $2.36 \mathrm{~m} / \mathrm{yr}$, was used in this estimate. In the absence of information on the dimensions of disposed lead waste forms, it was assumed that all lead was in the form of $0.5 \mathrm{~cm}$ thick sheets. This is an overestimation of the area of lead exposed to infiltrating water. Some of the disposed lead was in the form of bricks and pieces of equipment that would have considerably smaller surface areas. In addition, a portion of the lead disposed was as lead shot added to containers for shielding. Much of this would not be 
directly exposed to infiltrating water until the containers are breached. This and the fact that most lead concentrations in groundwater are less than $392 \mathrm{ug} / \mathrm{l}$ suggest that a leachability estimate of $722 \mathrm{~g} / \mathrm{yr}$ is conservative. 


\section{REFERENCES}

Benjamin, M.M. and J.O. Leckie, 1981. Multiple-Site Adsorption of $\mathrm{Cd}, \mathrm{Cu}, \mathrm{Zn}$, and $\mathrm{Pb}$ on Amorphous Iron Oxyhydroxide, Journal of Colloid and Interface Science, v. 79, p. 209221.

Cantrell, K.J., 1990. Results of the Special Well Sampling Study for the Burial Ground, memorandum to W.E. Stevens, March 28, 1990, WSRC-RP-90-364, Westinghouse Savannah River Co., Aiken, SC.

Cook, J.R., 1987. Technical Data Summary, Plan for Closure of the 643-G Burial Ground, DPSTD-87-2, E.I. du Pont de Nemours and Company, Savannah River Laboratory, Aiken, SC, August 1987.

Elliot, H.A., M.R. Liberati, and C.P. Huang, 1986. Competitive Adsorption of Heavy Metals by Soils, Journal of Environmental Quality, v. 15, p. 214-219.

Hoeffner, S.L., 1985. Radionuclide Sorption on Savannah River Plant Burial Ground Soil -A Summary and Interpretation of Laboratory Data: DP-1702, E.I. duPont de Nemours and Company, Savannah River Laboratory, Aiken, SC.

Kinniburgh, D.G., M.L. Jackson, and J.K. Syers, 1976. Adsorption of Alkaline Earth, Transition, and Heavy Metal Cations by Hydrous Oxide Gels of Iron and Aluminum, Journal of the Soil Science Society of America, v. 40, p. 796-799.

Looney, B.B. and J.R.Cook, 1987. Estimation of "Worst Case" Lead and Cadmium Fluxes for the Mixed Waste Management Facility (643-28G), memorandum to D.E. Gordon, March 31, 1987, DPST-87-335, E.I. du Pont de Nemours \& Co., Savannah River Laboratory, Aiken, SC.

Looney, B.B., J.B. Pickett, C.M. King, W.G. Holmes, W.F. Johnson, and J.A. Smith, 1987a. Selection of Chemical Constituents and Estimation of Inventories for Environmental Analysis of Savannah River Plant Waste Sites, DPST-86-291, E.I. du Pont de Nemours \& Co., Savannah River Laboratory, Aiken, SC.

Looney, B.B., M.W. Grant and C.M. King, 1987b. Estimation of Geochemical Parameters for Assessing Subsurface Transport at the Savannah River Plant: DPST-86-710, E.I. duPont de Nemours and Company, Savannah River Laboratory, Aiken, SC.

Nriagu, J.O., 1974. Lead Orthophosphates - IV. Formation and Stability in the Environment, Geochimica et Cosmochimica Acta, v. 38, p. 887-898.

Oblath, S.B., 1985. Lead and Cadmium Measurements of Groundwater Beneath the Lowlevel Waste Burial Grounds, memorandum dated December 11, 1985 to H.F. Sturm, Jr. DPST-85-969, E.I. du Pont de Nemours \& Co., Savannah River Laboratory, Aiken, SC. 
Orebaugh, E.G. and W.H. Hale, Jr., 1976. Dispersion Study of Buried Elemental Mercury, DP-1401, E.I. du Pont de Nemours \& Co., Savannah River Laboratory, Aiken, SC.

Schulthess, C.P. and C.P. Huang, 1990. Adsorption of Heavy Metals by Silicon and Aluminum Oxide Surfaces on Clay Minerals, Soil Science Society of America Journal, v. 54, p. $679-688$

WSRC, 1994. RFI/RI Work Plan for the Burial Ground Complex (U), WSRC-RP-90-1140, Rev. 2, Savannah River Site, Aiken, SC, December 1994.

WSRC, 1996. Information Document on the Old Solvent Tanks S1-S22 in the Old Radioactive Waste Burial Ground 643-E (U), WSRC-RP-96-00144, Rev. 0, Westinghouse Savannah River Company, Savannah River Site, Aiken, SC, June 24, 1996. 


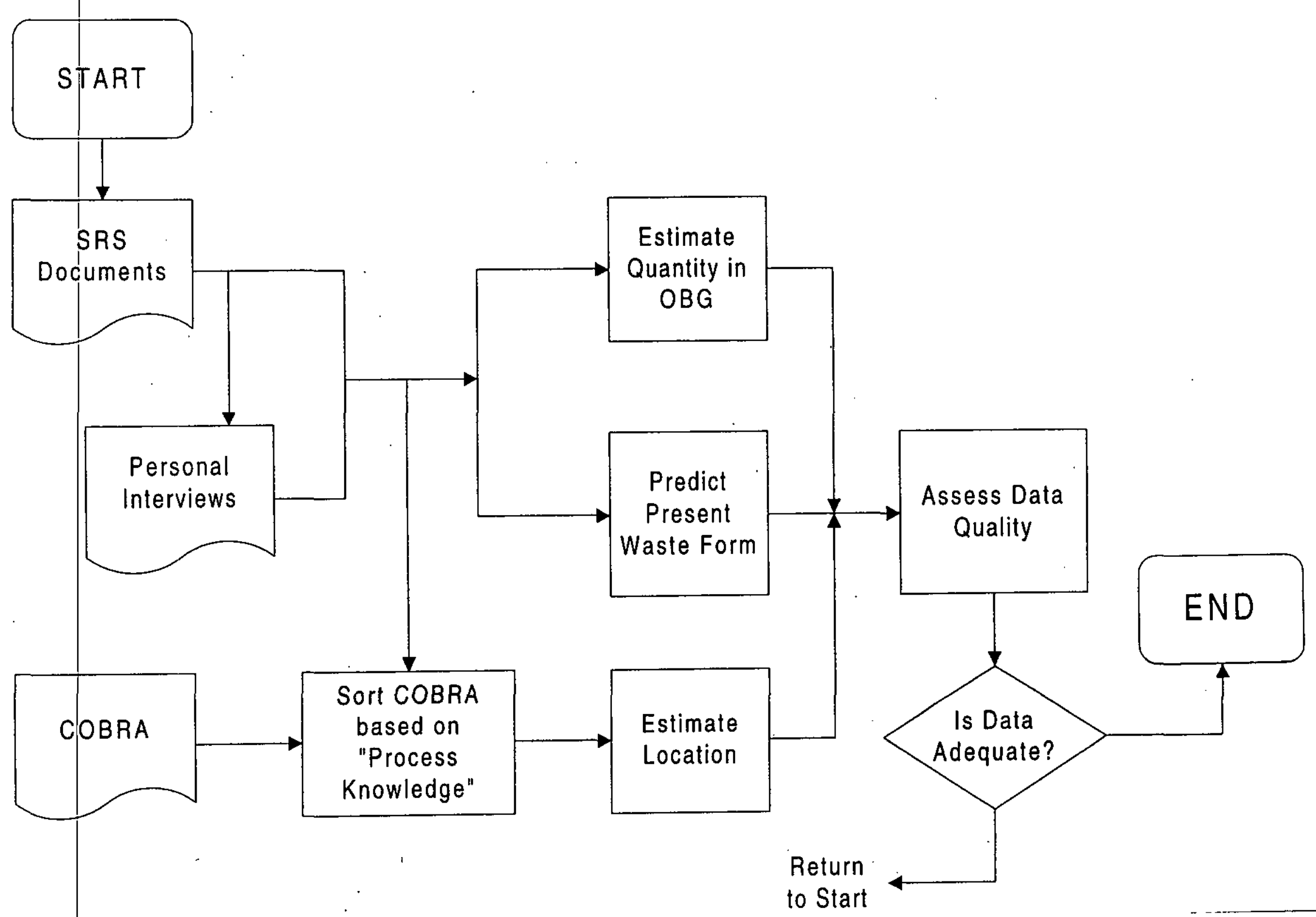

Figure 1-1. Inventory Estimate Process Flow Diagram 


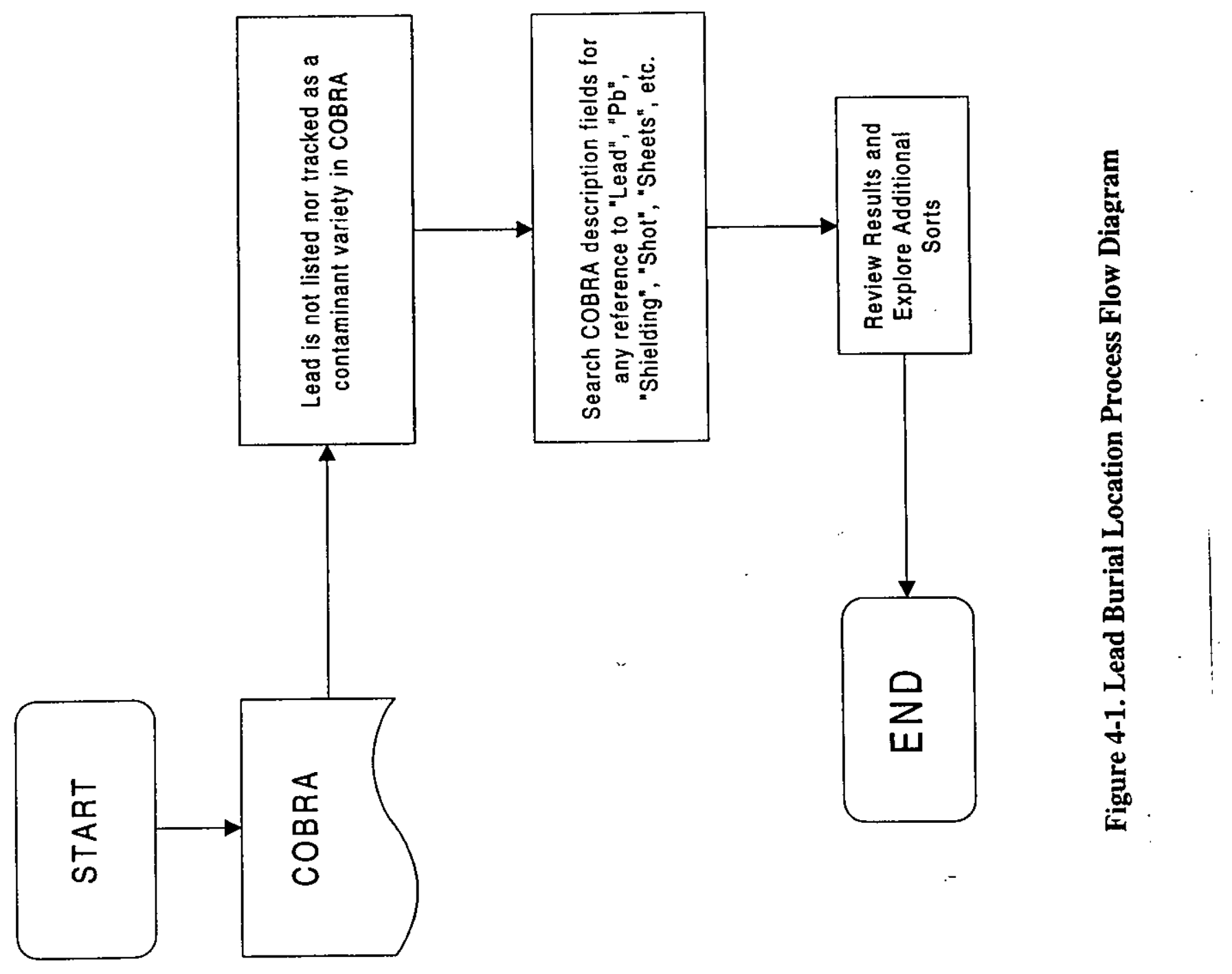




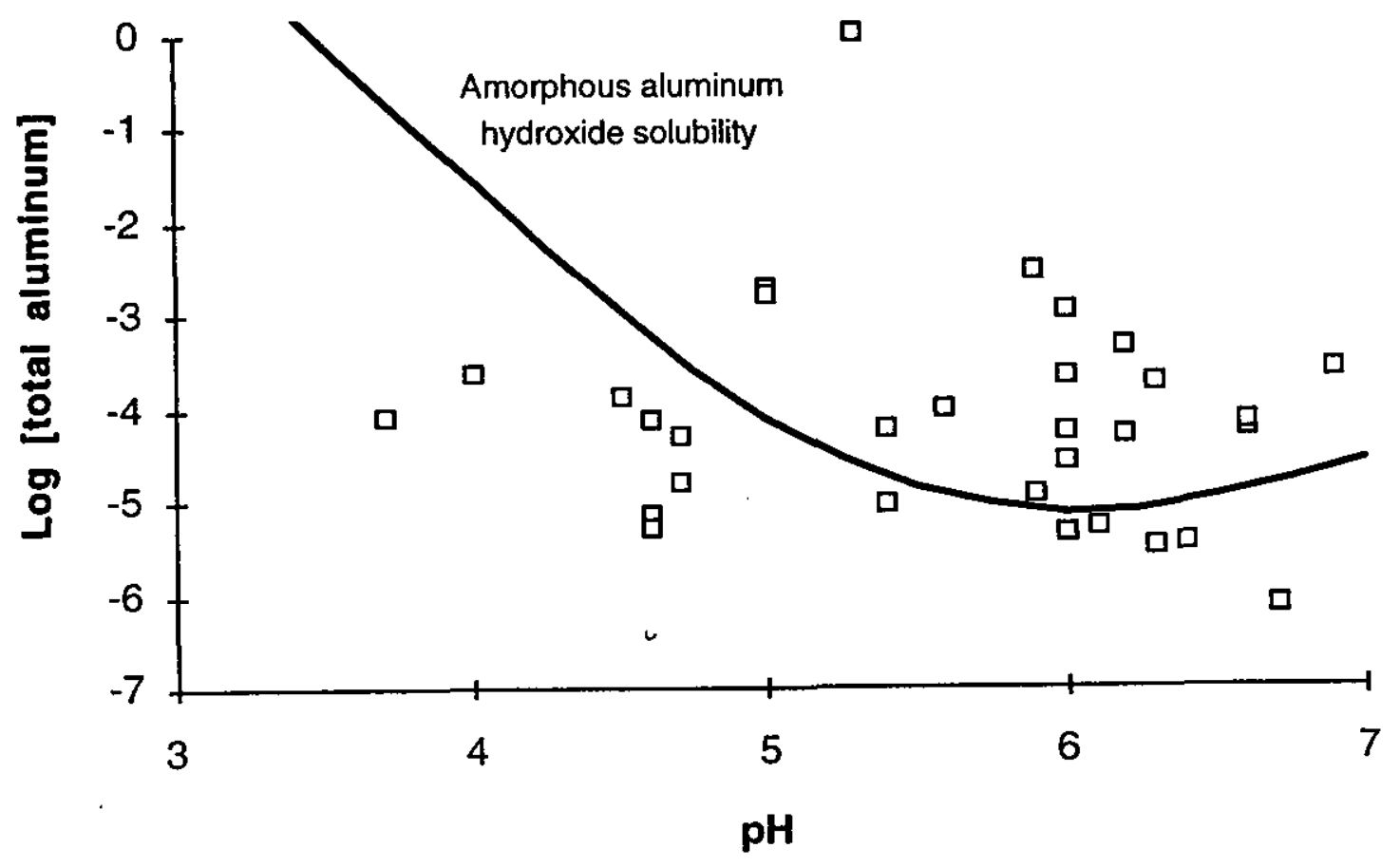

Figure 6-1. Log of Total Aluminum Concentration vs. pH of Groundwater Sampled From Grid Wells in 1993 and 1994. Saturation Curve for Amorphous Aluminum Hydroxide is Shown 
Table 3-1. The Sources of Inventory Estimates for Lead in the ORWBG

\begin{tabular}{|c|c|c|c|c|}
\hline Reference & Amount of $\mathrm{Pb}$ & $\begin{array}{l}\text { ORWBG } \\
\text { Lifetime } \\
\end{array}$ & $\mathbf{P b}$ form & Notes \\
\hline WSRC, 1994 & NA & $1952-1972$ & $\begin{array}{ll}\text { - } & \text { lead shielding } \\
\text { - } & \text { shot } \\
\text { - } & \text { bricks } \\
\text { - } & \text { lead sheets } \\
\end{array}$ & $\begin{array}{l}\text { Lead was used to shield } \\
\text { a variety of waste forms } \\
\text { or discarded due to high } \\
\text { contamination levels. }\end{array}$ \\
\hline Cook, J.R., 1987 & $\begin{array}{l}5.5 \times 10^{4} \mathrm{~kg}^{\mathrm{a}} \\
\text { (does not reference a } \\
\text { previous article) }\end{array}$ & $1952-1974$ & NA & $5.5 \times 10^{4} \mathrm{~kg}=60.6$ tons \\
\hline Oblath, S.B., 1985 & $\begin{array}{l}\mathrm{Pb} \text { source term from } \\
\text { Separations } \sim 42 \text { tons } \\
\text { (does not reference a } \\
\text { previous article) }\end{array}$ & $1954-1972$ & $\begin{array}{ll}\text { - } & \text { bricks } \\
\text { - } & \text { sheet } \\
\text { - } & \text { shot }\end{array}$ & $\begin{array}{l}42 \text { ton estimate does not } \\
\text { include Pb from sources } \\
\text { other than Separations } \\
\text { Separations facilities } \\
\text { disposed } 1.5 \text { tons in an } \\
\text { average year. } \\
\text { A source term of } 40 \text { tons } \\
\text { is probably best } \\
\text { considered a low } \\
\text { estimate. } \\
\end{array}$ \\
\hline
\end{tabular}

Notes:

a No discussion of basis for inventory

b Inventory discussed in detail

NA not addressed in article 
(This page intentionally left blank) 
APPENDIX C

CONSTITUENT OF INTEREST:

MERCURY 


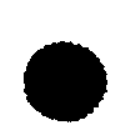

(This page intentionally left blank) 


\section{TABLE OF CONTENTS}

1. SUMMARY. C-1

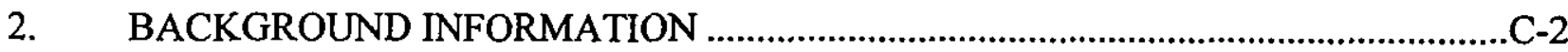

2.1 Tritium Facility Operations Involving Mercury ………….......................................

2.2 Separation Facilities Operations Involving Mercury ............................................ -3

2.3 Other Operations Involving Mercury ................................................................

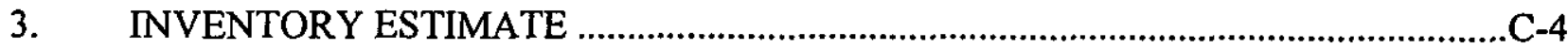

3.1 Range of Inventory Estimates .........................................................................

3.2 Best Estimate for Old Radioactive Waste Burial Ground Inventory ......................-4

3.3 Uncertainties Associated with the Best Estimate...................................................... -5

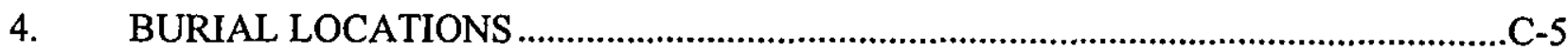

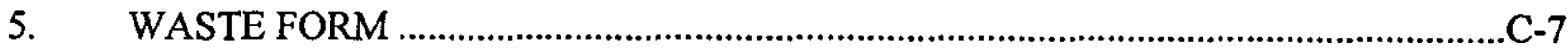

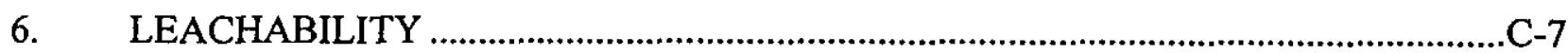

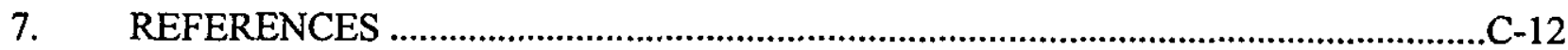




\section{LIST OF FIGURES}

Figure 1-1. Inventory Estimate Process Flow Diagram......................................................

Figure 4-1. Mercury Burial Location Estimate Process Flow Diagram ................................-15

Figure 4-2. X, Y Locations for Mercury and Potential Mercury Burials in ORWBG

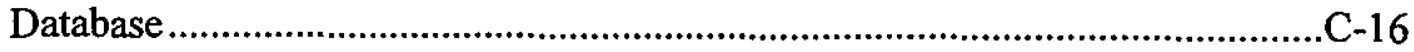

Figure 4-3. X, Y Locations for Mercury and Potential Mercury Burials in ORWBG Database.

Figure 6-1. Mercury Leachability Curve from ORWBG Assuming a Leach Rate of $59 \mathrm{~g} / \mathrm{yr}$ and Assuming the Leachable Area is Maintained at $940 \mathrm{~m}^{2}$ Throughout Leaching C-18

\section{LIST OF TABLES}

Table 2-1. Mercury Generated by Tritium Facilities. C-19

Table 3-1. The Sources of Inventory Estimates for Mercury in the ORWBG .....................-20

Table 4-1. All Description Field - 1's in COBRA with "Mercury" in Text. C- 22

Table 4-2. All COBRA Records for Buildings 232-F, 232- $\mathrm{H}$ and 234-H that have: TypeCode = "2", Variety-Code-1 = "87" (tritium), and fall between 1961-1968 .....C-23

Table 4-3. All COBRA Records for Buildings 232-F, 232-H and 234-H that have: Type Code $=$ "1", Variety Code-1 = "87" (tritium), Description Field-1 is "Cans" or "Bottles", and Fall Between 1961-1968 


\section{CONSTITUENT OF INTEREST - MERCURY}

\section{SUMMARY}

At the Savannah River Site (SRS), mercury in various forms was used as a sealant in pumps that handled tritium gas, as a catalyst in Separations operations, and as a component of laboratory operations. Based on this study, the total inventory of mercury, principally the elemental liquid, placed in the Old Radioactive Waste Burial Ground (ORWBG) is estimated at 24,195 pounds.

The majority of the inventory, approximately 20,520 pounds, was disposed from Tritium Facilities between 1956 and 1968. After 1968, mercury was stored in the Tritium Facilities and not sent to the ORWBG. Discarded equipment from Tritium Facilities, and wastes from Separations and other SRS laboratories, contributed an additional 3,600 pounds of the mercury inventory.

The mercury sent from Tritium Facilities was in the elemental form. The spent mercury was placed into 1-liter polyethylene bottles. The bottles were wrapped in plastic bags, and two or three bottles were placed into 5-gallon metal lard cans for shipment to the ORWBG. It is estimated that slightly over 100 of these shipments of mercury were sent from Tritium Facilities. The evaluation of the Computerized Burial Record Analysis (COBRA) database performed during this study identified 62 locations as probable mercury burials. This represents a high percentage of the 1961-1968 burials. Detailed records are not available for pre-1960 disposals. However, based on process knowledge, mercury was produced at about the same rate during these years. These earlier mercury disposals were in low-level betagamma trenches that were open at the time.

Figure 1-1 presents the process used to develop inventory and burial locations. First, SRS documents were reviewed. Additional information from personal interviews was received. From these information sources, a process knowledge for generating mercury at the SRS was developed. The COBRA database was used to the extent practical to determine the exact location of burials of mercury. 


\section{BACKGROUND INFORMATION}

Mercury was used in three principal areas at the SRS: (1) as sealant/lubricant in pumps used in the Tritium Facilities' gas handling system, (2) as a processing aid in aluminum dissolution and chloride precipitation in the Separations facilities; and (3) as a part of miscellaneous laboratory operations and process support efforts (Kvartek et al., 1994).

\subsection{Tritium Facility Operations Involving Mercury}

In the Tritium Facilities at SRS (232-H, 234-H, and 232-F), mercury was used in mechanical and diffusion pumps (e.g., Sprenged pumps, Edwards mercury diffusion pumps, and CEC mercury booster ejector pumps) involved in handling tritium gas (Horton, 1973). Mercury was used, rather than water or an organic oil, to prevent the tritium from exchanging with the hydrogen atoms in the water or oil. Mason (1996) reports that the mercury inventoiy per pump varied from 6 to 230 pounds ( 1 liter of mercury weighs 30 pounds).

The mercury in the pumps deteriorated from oxidation and was changed routinely. If possible, the mercury was reconditioned. The mercury also became contaminated with tritium during gas handling $(0.1 \mathrm{Ci} / \mathrm{liter})$. When the mercury could no longer be reconditioned and reintroduced to the pumps, it was disposed of at the ORWBG as low-level radioactive waste. After 1968, mercury was stored, and the practice of disposing of the mercury used in the pumps at Tritium Facilities was stopped.

Kvartek et al. (1994) state that all mercury drained from pump maintenance and replacement in the Tritium Facilities gas handling system between the years of 1958 and 1968 was buried as waste. Horton (1973) states that the mercury was produced at the average rates presented in Table 2-1 and buried at the ORWBG starting in 1956. Conservatively, a disposal start date of 1956 was assumed. These authors also suggest that as much as 2,200 pounds of mercury may have been disposed of between 1968 and 1972 as mercuric solids (from oxidized elemental mercury) in discarded equipment.

From 1956 to 1968, the spent mercury was packaged in 1 liter polyethylene bottles. The bottles were then put in plastic bags, and two or three bottles were placed in 5-gallon cans. The cans were then shipped to the ORWBG. A shipment usually included two cans and there were probably more than 100 shipments (Horton and Rusche, 1973). Table 2-1 presents the quantities of mercury, in pounds, generated by the Tritium Facilities from 1956 through 1972. The-values-from_1.960_through_1.968_are_from_Horton_and_Rusche_(1973);_whereas the values 
for 1966 and 1967 were estimated from use in 1965 and 1968. The yearly values for 1956 through 1959 were assigned the average yearly use for the years 1960 through 1968.

\subsection{Separation Facilities Operations Involving Mercury}

Mercury was used as a processing aid in the Separations facilities as a catalyst for dissolving aluminum cladding and as a precipitating agent for removing chlorides. Mercury was used in Building 221- $\mathrm{H}$ beginning in 1959 as part of the process to recover enriched uranium from aluminum clad reactor fuel. Mercury was introduced in Building 221-F in 1965 to dissolve plutonium-aluminum targets and scrap. Mercury was used to remove chlorides to prevent corrosion of the stainless steel processing equipment (Kvartek et al., 1994).

As a component of the high-level liquid waste stream generated in the Separations facilities, mercury waste would be stored in the high-level waste tanks in the tank farms. Only very small quantities of mercury associated with the off-gas cleanup systems for the Separations facilities would have been sent to the ORWBG. These quantities would be negligible.

Spent PUREX solvent from Separation facility operations was sent to the Old Solvent Tanks (OSTs), adjacent to the ORWBG. The spent PUREX solvent was put in long-term storage in the OSTs from 1955 through 1982 (Hoeffner and Oblath, 1984). During the aging period, generally about six months, most of the short-lived, high-gamma fission products decayed, and the heavy alpha emitters settled out of the solvent. During storage, the solvent separated into four phases (Mason, 1996; WSRC, 1994): vapor, organic, aqueous and sludge. After the solvent separated into phases, the volume was reduced by periodically burning the organic and aqueous phases. It was drawn out of the tanks and burned in shallow open pans in trenches (Mason, 1996; WSRC, 1992). The residue was emptied from the pans into earthen trenches. Tests show that the spent solvent sent to the OSTs contained very small amounts of mercury. These quantities are also negligible.

\subsection{Other Operations Involving Mercury}

Mercury was used as a chemical reagent or equipment component (mercury diffusion pumps, thermometers, etc.) in virtually every laboratory at SRS. Other than purchasing records for essential materials, there was no tracking system for mercury prior to 1986 . Little is known about the use of mercury at SRS in facilities other than Tritium and Separations.

For calendar year 1993, 1,100 pounds of mercury were stored at facilities other than $232-\mathrm{H}$ (Tritium) and $221-\mathrm{H}$ (Separations). Of these 1,100 pounds, 126 pounds were for process 
control at 772-D, 772-F, and 322-M; 12 pounds were used for calibration in Building 736-A; and 961 pounds were used in research in Buildings 305-A and 773-A (Mason, 1996). Kvartek et al. (1994) report that mercury has been used recently for researching its compatibility with the Defense Waste Processing Facility waste form. This research could account for the bulk of the inventory at 773-A and 305-A.

\section{INVENTORY ESTIMATE}

There are no detailed nor quantitative records on shipments of mercury to the ORWBG for the years 1956 to 1961. All estimates for the mercury in the trenches were based on process knowledge and notations in the COBRA records. After 1961, estimates are based on the information contained in the COBRA records.

\subsection{Range of Inventory Estimates}

Literature estimates for mercury vary from 20,000 to 22,000 pounds (Kvartek et al., 1994; Horton, 1973). Over 1004 - to 6-liter shipments (2 cans with 2 or 3 bottles each) were expected from Tritium Facilities (20,000 pounds are the equivalent of 667 liters). Table 3-1 summarizes the sources of inventory estimates for mercury in the ORWBG. As discussed in Section 2, the bulk of the mercury was from the Tritium Facilities.

The COBRA database contains information from burials at the ORWBG; detailed data begins in 1961. Of the records with descriptor fields from 232-H or 234-H (Tritium), 31 contain "Mercury" and an additional 17 contain either "Plastic", "Bottles", or "Plastic Bottles". The waste volumes for these 48 records greatly exceed the volume of 22,000 pounds of mercury, indicating that the volume of mercury was only a fraction of the total waste volume for many of these shipments.

The spent solvent sent to the OSTs contained minor amounts of mercury. After aging, the solvent was burned at the ORWBG, and the ash was buried in trenches. Using conservative estimates for concentration and assuming no volatilization occurred during burning, there is less than 75 pounds of mercury in the ash buried in the ORWBG.

\subsection{Best Estimate for Old Radioactive Waste Burial Ground Inventory}

The best estimate for the total mercury inventory at the ORWBG is 24,195 pounds. The basis for this inventory estimate is: 
- Table 2-1 estimates that Tritium Facilities could have used 20,520 pounds from 1956, when $232-F$ operated, to 1968 , when mercury recycling began.

- Table 2-1 estimates that as much as 2,200 pounds of additional mercury may have been disposed of between 1968 and 1972 as mercuric solids in discarded equipment.

- Based on 1993 data, approximately 140 pounds of mercury was used for non-research purposes outside of Tritium and Separations facilities. If it is assumed that similar quantities were used annually from 1952 (exclusive) through 1972, and one-half of this mercury entered the low-level waste stream, then another 1,400 pounds could be buried in the ORWBG.

- The conservative estimate for mercury in ash resulting from burning of solvents taken from the OSTs is 75 pounds.

\subsection{Uncertainties Associated with the Best Estimate}

The best estimate for mercury inventory developed in this study is thought to be accurate to within plus 25 percent and minus 10 percent. There were records of mercury generated at the Tritium Facilities, and these facilities contributed most of the mercury to the burial grounds. Other SRS facilities, in comparison, contributed only a small portion of the ORWBG inventory. In addition, based on review of records and process knowledge, classified burials that are not included in COBRA would not contain significant amounts of additional mercury. Finally, the OSTs mercury inventory represents an upper-bound estimate for mercury that might be in the ash recovered following the burning of solvents. The ash was subsequently buried in the ORWBG trenches. These factors have all been considered in developing the uncertainty estimate presented.

\section{BURIAL LOCATIONS}

As discussed in Section 3, the COBRA database contains information from burials at the ORWBG. Input of detailed burial information into the COBRA database began in 1961 . Figure 4-1 outlines the steps taken to manipulate the database to locate mercury burials from Tritium Facilities.

Of the 16,162 records with descriptors, 31 contained "Mercury" in the descriptor field. Note that all but one record are for burials prior to 1969 (the single 1969 burial was associated with contaminated hardware). These records are listed in Table 4-1.

Another search was performed using a set of search criteria developed from the 31 records found in the first search. This set included: 
- Building: 232- $\mathrm{H}$ and 234-H

- Variety Contamination \#1: 87 (tritium)

- Type Code: 2

- Year: before $1 / 1 / 69$.

These search criteria and terminology are described in the keys on Tables 4-1 and 4-2. This sort yielded 111 records and is presented as Table 4-2. All COBRA records for Buildings 232-F, 232-H and 234-H that have a Type Code of 2 (oil), Variety Code 1 of 87 (tritium) and fall between 1961 and 1968. Of the 111 records, 20 contain either "Plastic", "Bottles", or "Plastic Bottles". Three other records contain the term "Can". Additionally, three other burials (burial slips 14878,4720 , and 26282) are small volume, low activity burials made at the same times as a mercury burial and are thought to be mercury. Finally, an additional sort on Type Code $=1$ was done for descriptors similar to plastic bottles and metal cans. Table 43 shows the results of that sort. These additional eight records are likely to be mercury burials.

Figure 4-2 is a plot of these data. The black dots represent records with "Mercury" in the COBRA descriptor. The gray dots represent other records that are very likely to be mercury, that is, the descriptor contained "Plastic Bottle", or "Can". The open dots represent other possible mercury locations from $232-\mathrm{H}$ and $234-\mathrm{H}$, that is, the other records from the sort. Figure 4-3 presents the same records. In this plot, the relative size of the black and gray dots shows the volume associated with the disposal. It can be seen that the mercury disposals (typically 1 to 2 cubic feet) were included with other Tritium Facility disposals.

For comparison, Figure 4-2 presents a plot from Hyder (1994) of mercury burial locations in the ORWBG. These locations are identified with a square on the figure. This plot agrees with the black dots (records with "mercury" in the descriptor) in the figure.

Mercury-containing waste was disposed of in low-level beta-gamma trenches. The locations indicated in the figure are for 1961 through 1968. It can be assumed that prior to 1961 , the mercury was disposed of in the low-level beta-gamma trenches open during that time period. It can also be inferred from these figures that the mercury is not in trenches used for highlevel (activity) waste, transuranic waste, or special burials.

Although each individual burial cannot be pinpointed, the mercury location estimates can be classified as good for the period 1961 through 1968 and poor to fair for the earlier and later periods-Based-on-this-study-the-approximate-burial-locations-of-about-50-percent-of-the 
mercury are known.

\section{WASTE FORM}

The majority of the mercury in the ORWBG originated in the Tritium Facilities. As such, it is expected that most of this mercury source was packaged for shipment and burial as previously described in Section 2.1. These waste containers are expected to retain their integrity for several decades. This estimate of life-expectancy for the packages does not include the possibility of mechanical rupture of the containers.

Based on the results of environmental sampling surrounding the ORWBG, it appears that some containers have failed. Hale and Porter (1973) indicated that the mercury would remain in the elemental form. Mercury is not expected to flow through the soil. It would be available for other physical and chemical changes. Horton (1973) states that the mercury could exist as mercuric (oxidation state +2 ), mercurous (oxidation state +1 ), and as organic compounds. The solubility of mercury in water depends on a variety of conditions including the chemical form of the mercury and the $\mathrm{pH}$ (and other parameters) of the solvent water.

\section{LEACHABILITY}

Estimation of the leaching rate of mercury is complicated by the multiple valence states and multiple physical states in which mercury can occur naturally. Elemental mercury is subject to oxidation to $\mathrm{Hg}$ (I) or $\mathrm{Hg}$ (II), each of which behave differently in the subsurface. Elemental mercury itself can occur in three co-existing physical phases: as a dissolved species, as a nonaqueous liquid metal, and as mercury vapor. Further complicating mercury behavior are bacterially mediated reactions that produce organo-mercury compounds that are toxic and mobile in the environment. Thus, where possible, models of mercury leaching must be constrained by observed groundwater concentrations.

A large network of groundwater monitoring wells within and surrounding the ORWBG has existed since operations ceased at this facility. The 67 "grid" wells were installed between 1972 and 1976 within the ORWBG to monitor contaminants leaching into groundwater. These wells were sampled regularly until 1995 when they were abandoned. Beginning in 1976 several generations of monitoring wells were installed around the perimeter of the ORWBG to detect migration of contaminants outside the boundary of the facility. This network of wells provides excellent coverage of the groundwater that passes through and beneath the ORWBG and hence, provides a means for constraining the leaching rate of mercury. 
The Geochemical Information Management System (GIMS) groundwater chemistry database was searched for all pertinent wells over the past 5 years that had mercury concentrations that exceeded $0.33 \mathrm{ug} / 1$ the upper detection limit for quarterly monitoring). In addition, several documents that reported mercury concentrations in the grid wells were reviewed. In most of the wells along the perimeter of the ORWBG the mercury concentrations have been consistently below the detection limit. The highest concentration reported from any of these wells was $12.7 \mathrm{ug} / 1$ (well BG-59), but this is an anomalous measurement. The average of the previous 9 quarters was $0.96 \mathrm{ug} / \mathrm{l}$ and in the quarter preceding the high measurement the mercury concentration was $0.26 \mathrm{ug} / \mathrm{l}$. The grid wells within the ORWBG have been sampled regularly since their installation and mercury concentrations have generally been low. For example, in 1986 , of the 53 wells sampled only 12 had mercury concentrations that exceeded the reported detection limit of $0.1 \mathrm{ug} / \mathrm{l}$ and only one well exceeded the drinking water standard of $2 \mathrm{ug} / 1$ (McIntyre and Wilhite, 1987). This one well accounts for the highest mercury concentration, $26.5 \mathrm{ug} /$, recorded in groundwater associated with the ORWBG.

Elevated mercury measurements in the grid wells and in some of the perimeter wells (including BG-59) must be viewed cautiously because these wells are sampled by bailing rather than by dedicated pumps. Evidence suggests that bailing of wells is more likely to disperse sediment from the bottom of the well that may contaminate the sample (Cantrell, 1990). These samples are not filtered and thus, the mercury concentrations represent both mercury in the groundwater and mercury that is associated with the sediments at the bottom of a well. Mercury associated with the sediment is natural mercury plus mercury accumulated by sorption or precipitation from groundwater that has passed through the well since installation.

Orebaugh and Hale (1976) modeled the leaching rate of mercury from the ORWBG by considering the geochemistry of the soils and groundwater associated with this facility, as well as experiments on mercury mobility conducted in their laboratory. Their model assumed that all mercury containers were breached and all mercury was released to the soil. A more recent study shows that some containers are breached. Price and Cook (1988) found elevated mercury concentrations in shallow (to a depth of $30 \mathrm{~cm}$ ) soil within the ORWBG that correlate reasonably well with suspected mercury burial locations. This suggests that some containers are breached allowing mercury vapor to migrate to the surface.

From the chemistry of the groundwater and the soils Orebaugh and Hale (1976) concluded that_mercury_would_remain_predominantly in the elemental form. This is consistent with the reducing environment expected in the trenches caused by the presence of zero valent iron 
(scrap metal, carbon steel drums, etc.) and organic material (paper, cardboard, etc.). Based on surface tension of mercury and typical SRS soil pore sizes it was concluded that liquid mercury would not migrate appreciable distances. They estimated the maximum area over which liquid mercury from one crushed can could disperse to be $3.14 \mathrm{~m}^{2}$. Other researchers have found that in the absence of fractures, liquid mercury does not migrate vertically more than about $50 \mathrm{~cm}$ through soil (Henke et al., 1993). Eichholz et al. (1988) found that liquid mercury migrated only 3-4 cm into dry South Carolina Coastal Plain soil columns under a 1 $\mathrm{mm}$ mercury head. Therefore, significant migration of liquid mercury from the trenches is improbable.

Orebaugh and Hale (1976) concluded that mercury would be removed from the trenches by three mechanisms: vapor diffusion, dissolution of elemental mercury, and transport of elemental mercury by colloidal particles of silica and iron hydroxides. From: monthly measurements of water saturation zone depths in a test well within a trench, Orebaugh and Hale (1976) calculated the average flux of water through the trenches to be $2.36 \mathrm{~m} / \mathrm{yr}$. To calculate the vapor flux and the dissolved mercury leaching rate they assumed that mercury dispersed from each buried can to a leachable area of $3.14 \mathrm{~m}^{2}$. Thus the total leachable area for 300 cans would be $942 \mathrm{~m}^{2}$. They measured the diffusivity of mercury vapor through ORWBG soil and calculated a total diffusive flux of about $44 \mathrm{~g} / \mathrm{yr}$ of mercury vapor that reaches the surface of the ORWBG. From their measured solubility of elemental mercury (56 ug/l) they calculated the total flux as dissolved mercury into the soils beneath the trenches to be $114 \mathrm{~g} / \mathrm{yr}$.

During solubility measurements Orebaugh and Hale (1976) found that substantial amounts of mercury could be mobilized by colloidal particles. Their experiments investigating this indicated that mercury associated with silica and iron hydroxide colloids could pass through soil columns unimpeded. To estimate the flux of mercury associated with these colloids they assumed that mercury dispersed into spheres and that colloidal particles that contacted these spheres would sequester mercury. They assumed the minimal dispersion (minimal contact area) would be into spheres with a $1 \mathrm{~cm}$ radius and the maximal dispersion (maximal contact area) would be into spheres with a radius of $1 \mathrm{~mm}$. Orebaugh and Hale (1976) then assumed that $95 \%$ of the mercury would be minimally dispersed and $5 \%$ would be maximally dispersed. From this they estimated that $1805 \mathrm{~g} / \mathrm{yr}$ of mercury would be leached from the trenches by colloidal particles to migrate to the water table.

With 20 years of additional groundwater and soil data the estimates of Orebaugh and Hale (1976) can be evaluated. The work of Price and Cook (1988) showed that there is a flux of 
mercury vapor reaching the surface of the ORWBG. However, the estimate of Orebaugh and Hale (1976) should be considered the maximum mercury vapor flux to the surface. They used the maximum diffusivity coefficient measured in their experiments and did not consider mercury vapor adsorption to the soils. The Orebaugh and Hale (1976) estimate of the flux of dissolved mercury out of the trenches is reasonable given the assumptions used. However, the groundwater data indicate that a considerably smaller flux is actually reaching the water table. Groundwater mercury concentrations are far below the $56 \mathrm{ug} / \mathrm{l}$ solubility of elemental mercury. This suggests that there are additional controls on the leaching of mercury from the ORWBG or that there is significant attenuation of mercury in the vadose zone.

The groundwater data do not support the prediction by Orebaugh and Hale (1976) that significant amounts of mercury are mobilized by colloidal particles. Using their model of colloidal mobilization of mercury it can be calculated that groundwater concentrations on the order of $117 \mathrm{ug} / 1$ would leave the trenches and migrate relatively unimpeded to the water table. The low concentrations of mercury in the groundwater suggest that either colloidal particles are not transporting significant amounts of mercury or they are immobilized by filtration within or beneath the trenches. This is consistent with the results of Eichholz et al. (1988). They attempted to mobilize elemental mercury on kaolinite particles, but found that no transport occurred through their sediment filled columns.

Looney and Cook (1987) estimated "worst case" lead and cadmium fluxes for the Mixed Waste Management Facility by back calculating the leach rates required to produce observed groundwater concentrations. Their approach assumed that elevated groundwater concentrations of a constituent reflect real groundwater conditions rather than analytical or sampling problems and that concentrations in the groundwater represent pure infiltrating leachate. To calculate a similar estimate of mercury leaching at the ORWBG the first assumption is conservative because the highest concentrations occur in bailed wells that are subject to sampling errors. The second assumption may be less conservative for mercury because the discrete nature of the mercury burials can be considered using the assumptions of Orebaugh and Hale (1976). It is possible that discrete plumes produced by these burials may not intersect a monitoring well. However, given the large number of cans of mercury buried and the number of monitoring wells in the plumes path, this seems unlikely. If the assumptions of Orebaugh and Hale (1976) on the total area of leachable mercury $\left(940 \mathrm{~m}^{2}\right)$ and the average water flux through the trenches $(2.36 \mathrm{~m} / \mathrm{yr})$ are used, and it is assumed that the highest mercury concentration observed $(26.5 \mathrm{ug} / \mathrm{l})$ reflects the leachate concentration,

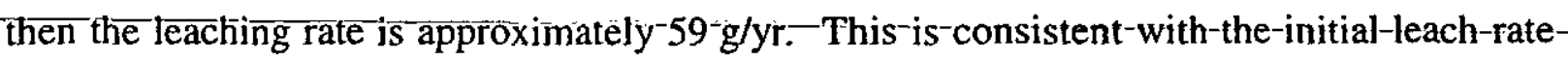


for mercury (47 g/yr) recommended by Looney et al. (1987) using the model of Baes and Sharp (1983). Because $59 \mathrm{~g} / \mathrm{yr}$ is consistent with the highest observed groundwater concentration and with an independently calculated leach rate based on the model of Baes and Sharp (1983), this leach rate is used to calculate the leachability curve in Figure 6-1.

Regardless of the details of the model used, mercury in the ORWBG is relatively immobile. Evidence indicates that some of the buried cans have ruptured, but groundwater concentrations are less than would be predicted by the colloidal transport model of Orebaugh and Hale (1976). However, even at the leach rate estimated by Orebaugh and Hale (1976) less than $2 \%$ of the mercury inventory will be leached from the ORWBG in the next 100 years. If container integrity is considered, the amount of mercury leached will be significantly less than $2 \%$. 


\section{REFERENCES}

Baes, C.F. III and R.D. Sharp, 1983. A proposal for estimation of soil leaching and leaching constants for use in assessment models, Journal of Environmental Quality, v. 12, p. 17-28.

Cantrell, K.J., 1990. Results of the Special Well Sampling Study for the Burial Ground, memorandum to W.E. Stevens, WSRC-RP-90-364, Westinghouse Savannah River Co., Aiken, SC, March 28, 1990.

Cook, J.R., 1987. Plan For Closure of the 643-G Burial Ground. DPSTD-87-2.76, E.I., du Pont de Nemours and Company, Savannah River Site, Aiken S.C, August 17, 1987.

Eichholz, G.G., M.F. Petelka, and R.L. Kury, 1988. Migration of Elemental Mercury Through Soil From Simulated Burial Sites, Water Research, v. 22, p. 15-20.

Hale, W.H., 1973. Letter to Porter, J.A., Fate of Mercury in the Burial Ground, DPST-73457.

Henke, K.R., V. Kühnel, D.P. Stepan, R.H. Fraley, C.M. Robinson, D.S. Charlton, H.M. Gust, and N.S. Bloom, 1993. Critical Review of Mercury Contamination Issues Relevant to Manometers at Natural Gas Industry Sites, Topical Report GRI-93/0117, Gas Research Institute, Chicago, IL.

Hoeffner, S.L., and Oblath, S.B., 1984. Scoping Study of Organics in Well Waters of the SRP Low-Level Waste Burial Ground, DPST-84-796, November 14, 1984

Holcomb, H. Perry, 1992. Transcription of a Presentation by Dr. E.L. Albenesius, SRS Burial Ground Operation From an Historical Perspective (U), WSRC-RP-92-349, Environmental Restoration Department, Westinghouse Savannah River Company, Savannah River Site, Aiken, SC 29808 (February 14).

Horton, J.H., 1973. Mercury in the 643-G Burial Ground, DPST-73-480, Technical Division Savannah River Laboratory, December 6, 1973.

Horton, J.H., 1978. Possible Recovery of Mercury in 643-G Burial Ground, DPST-78-256, Technical Division Savannah River Laboratory, February 21, 1978.

Hyder, L., 1994. Known Mercury Locations, memorandum to T. Gaughn, dated June 15, 1994.

Kvartek et al., 1994. Assessment of Mercury in the Savannah River Site Environment, Chapter 2.

Looney, B.B. and J.R.Cook, 1987. Estimation of "Worst Case" Lead and Cadmium Fluxes for the Mixed Waste Management Facility (643-28G), memorandum to D.E. Gordon, DPST-87-335, E.I. du Pont de Nemours \& Co., Savannah River Laboratory, Aiken, SC, March 31, 1987. 
Looney, B.B., M.W. Grant, and C.M. King, 1987. Estimation of Geochemical Parameters for Assessing Subsurface Transport at the Savannah River Plant. DPST-85-904, E.I., du Pont de Nemours \& Co., Savannah River Laboratory, Aiken, SC.

Mason, J.T., 1996. Information Document on the Old Solvent Tanks S1-S22 in the Old Radioactive Waste Burial Ground 643-E(U), WSRC-RP-96-00144, Westinghouse Savannah River Co., Aiken, SC.

McIntyre, P.F. and E.L. Wilhite, 1987. 1986 Monitoring of Mercury in the Groundwater at 643-G and 643-7G, memorandum to H.F. Sturm, Jr., December 18, 1987, DPST-87-849, E.I., du Pont de Nemours \& Co., Savannah River Laboratory, Aiken, SC.

Oblath, S.B., 1985. Lead and Cadmium Measurements of Groundwater Beneath the LowLevel Waste Burial Grounds, DPST-85-969, Technical Division Savannah River Laboratory, December 11, 1985.

Orebaugh, E.G. and Hale, W.H., Jr., 1976. Dispersion Study of Buried Elemental Mercury, DP-1401 UC-41, E.I., du Pont de Nemours \& Co., Savannah River Laboratory, Aiken, $\mathrm{SC}$.

Price, V., and J.R. Cook, 1988. Mercury In Shallow Savannah River Plant Soil, DPST-86314, E.I., du Pont de Nemours \& Co., Savannah River Laboratory, Aiken, SC.

WSRC, 1992. Old Radioactive Waste Burial Ground, Revised Draft, August, 1992.

WSRC, 1994, RFI/RI Work Plan For the Burial Ground Complex, WSRC-RP-90-1140, December 1994.RFI/RI Work Plan, 1994. 


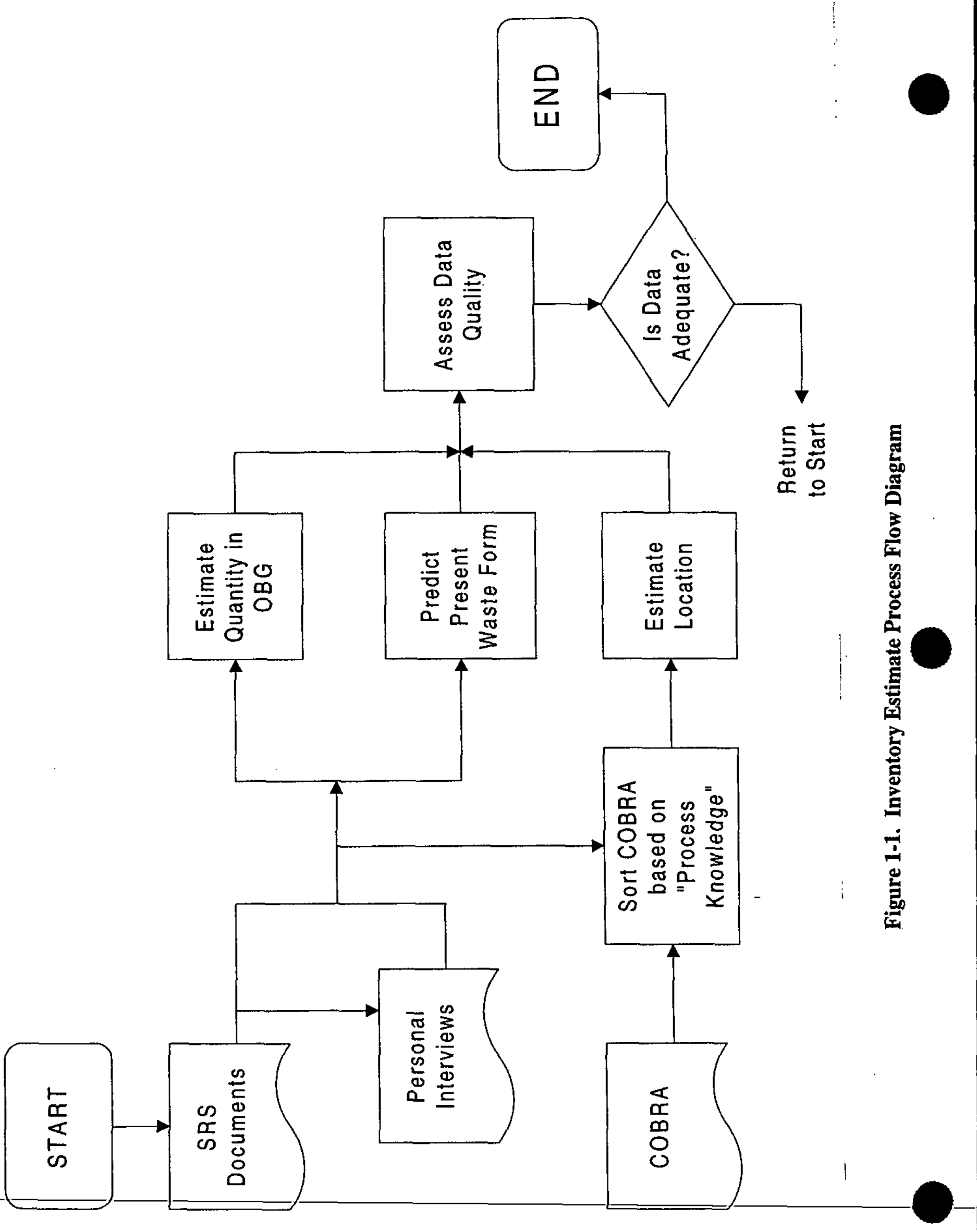




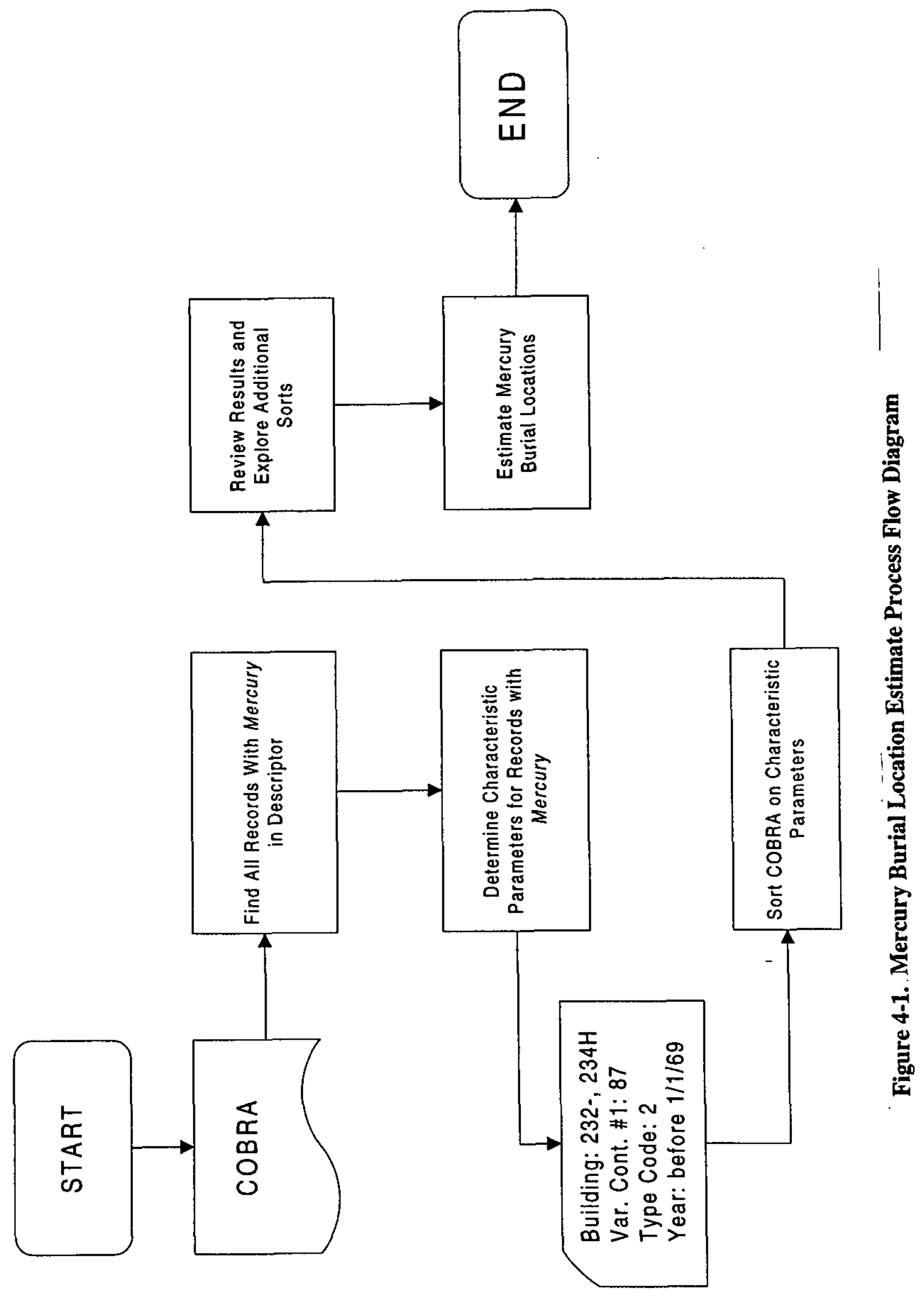




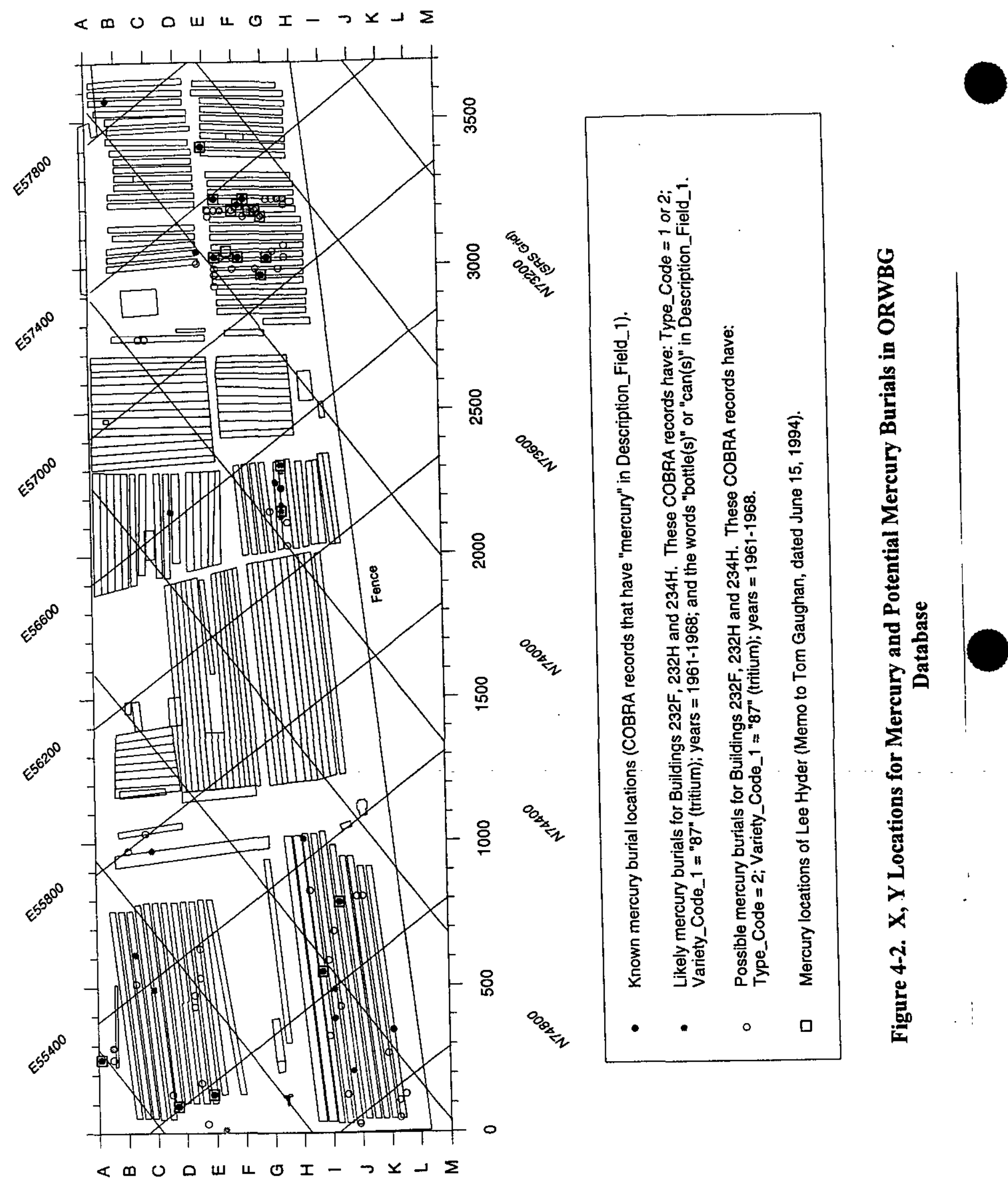

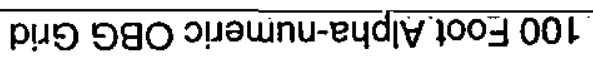



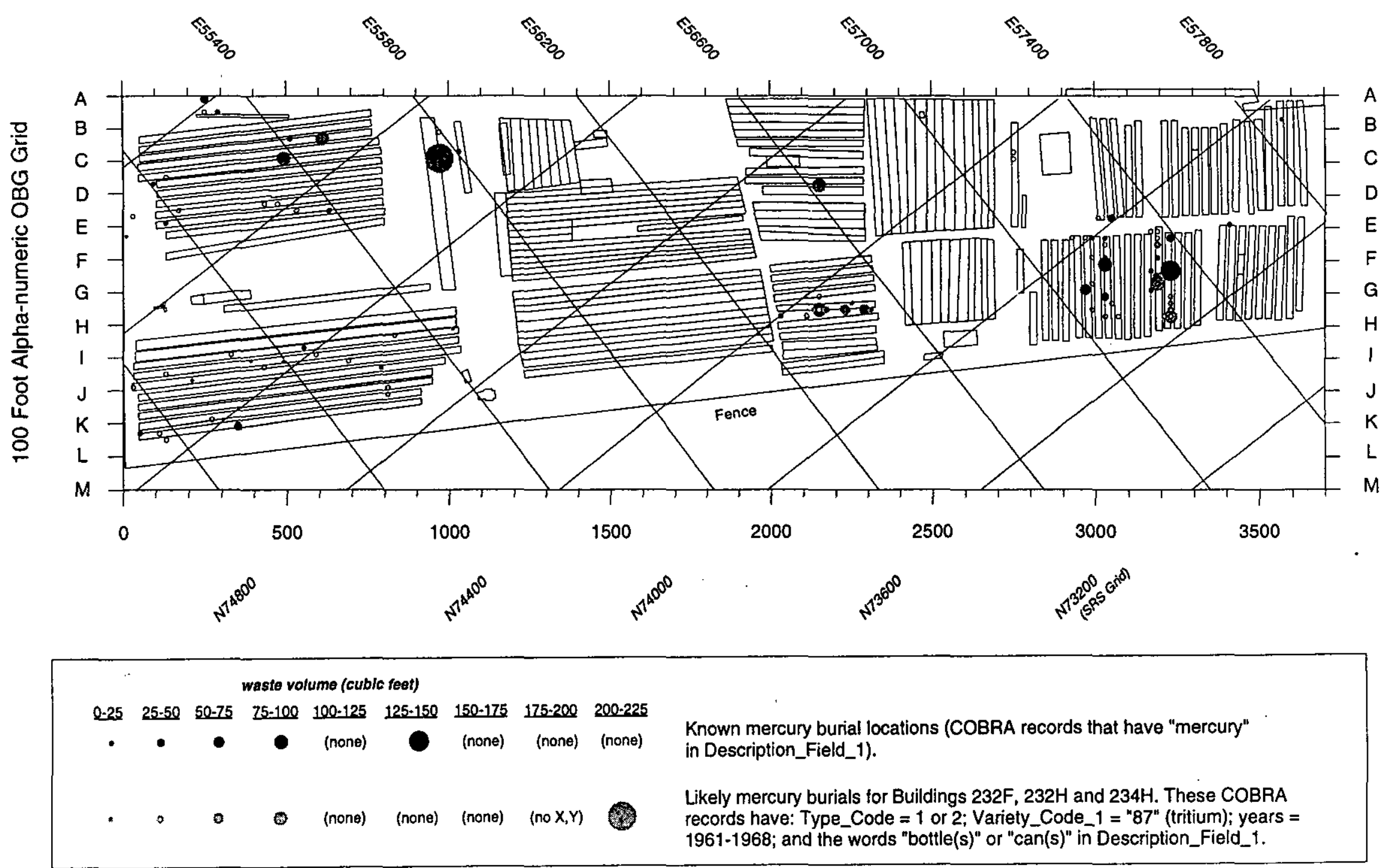

Possible mercury burials for Buildings $232 \mathrm{~F}, 232 \mathrm{H}$ and $234 \mathrm{H}$.

These COBRA records have: Type_Code $=2$; Variety_Code_ 1

$=$ " 87 " (tritium); years $=1961-1968$.

Figure 4-3. X, Y Locations for Mercury and Potential Mercury Burials in ORWBG

Database 


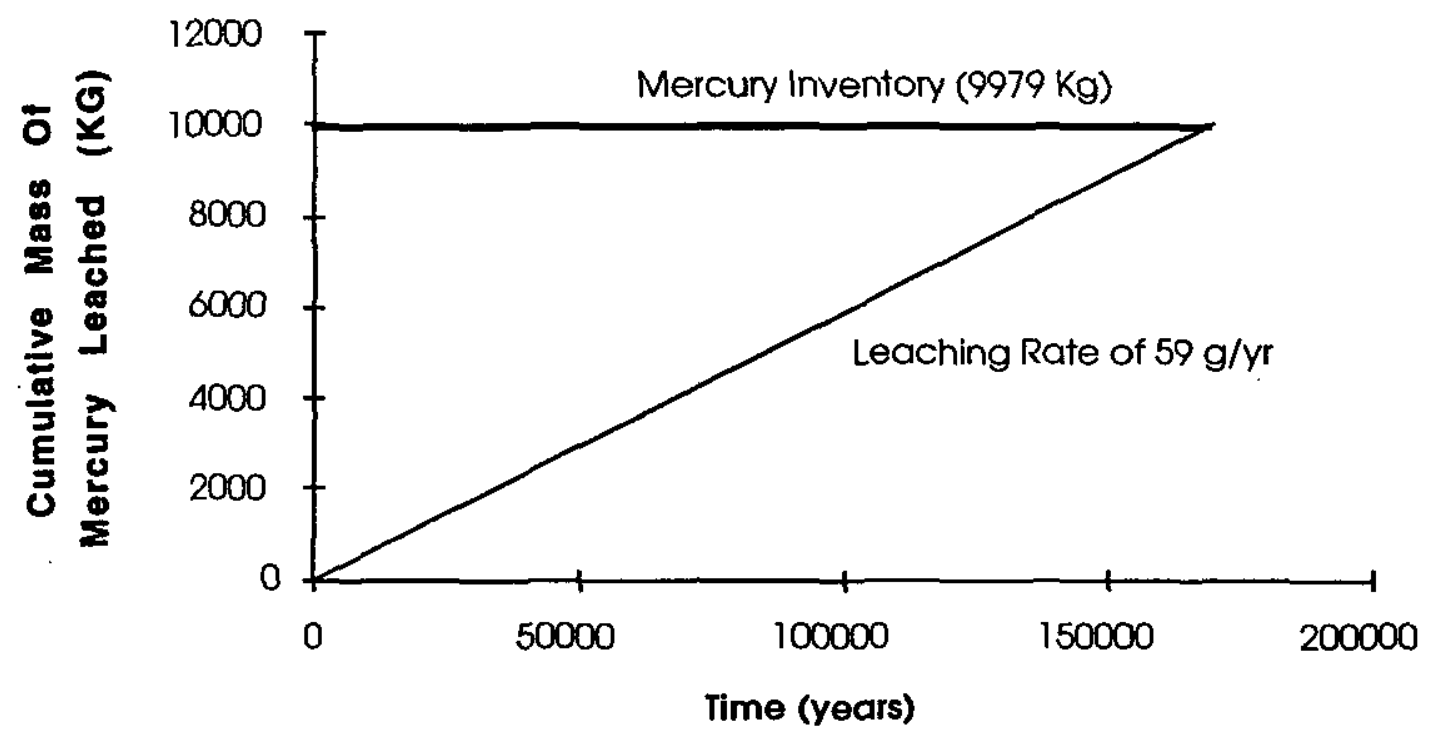

Figure 6-1. Mercury Leachability Curve from ORWBG Assuming a Leach Rate of 59 $\mathrm{g} / \mathrm{yr}$ and Assuming the Leachable Area is Maintained at $940 \mathrm{~m}^{2}$ Throughout Leaching 
Table 2-1. Mercury Generated by Tritium Facilities

\begin{tabular}{llll}
\hline Year & Mercury (lbs) & Year & Mercury (lbs) \\
\hline 1956 & 1580 & 1964 & 1600 \\
1957 & 1580 & 1965 & 1155 \\
1958 & 1580 & 1966 & 1105 \\
1959 & 1580 & 1967 & 1105 \\
1960 & 1330 & 1968 & 1055 \\
1961 & 1970 & $1969-1972$ & 2200 \\
1962 & 2110 & & \\
1963 & 2770 & Total & $\mathbf{2 2 , 7 2 0}$ \\
\hline
\end{tabular}

Source: Horton (1973) (Years 1960 - 1968). Estimates for 1969-1972 are associated with mercuric solids present in discarded equipment. 
Table 3-1. The Sources of Inventory Estimates for Mercury in the ORWBG

\begin{tabular}{|c|c|c|c|c|}
\hline Reference & Amount $\mathrm{Hg}$ (location) & $\begin{array}{l}\text { Years of } \\
\text { Disposal }\end{array}$ & $\begin{array}{l}\text { Container } \\
\text { Information }\end{array}$ & Notes \\
\hline Kvartck and others, 1994 & $\begin{array}{l}22,000 \mathrm{lbs}(643-7 \mathrm{E})^{\mathrm{a}} \\
\text { (doses nol relerence a } \\
\text { previous article.) }\end{array}$ & $1958-1972$ & $\begin{array}{l}\text { Two or three } \\
\text { 1-liter polyethylene } \\
\text { bottles placed into } \\
\text { metal cans }\end{array}$ & $\begin{array}{l}\text { - } 20,000 \mathrm{lb} \text { from } 1958-1968 \\
\text { - Little or none }(643-7 \mathrm{E}) \sim 1972 \\
\text { to present } \\
\text { - Small amount added after } 1968 \\
\text { Majority is from pumps in } \\
\text { Tritium Facilities } \\
\text { - Soil samples along Road E are } \\
\text { three times background } \\
\text { Soil samples along southern } \\
\text { area @ background } \\
\end{array}$ \\
\hline Hyder L., 1994 & NA & NA & $\mathrm{NA}$ & $\begin{array}{l}\text { Known Hg locations (22) } \\
\text { disposed from } 1961 \text { - } 1968 \text { with } \\
\text { coordinates on a map }\end{array}$ \\
\hline Holcomb, H. Perry, 1992 & $\begin{array}{l}10 \text { tons }^{\mathrm{h}} \\
\text { (does not reference a } \\
\text { previous article.) }\end{array}$ & 1968 & $\begin{array}{l}\text { Numerous very small } \\
\text { containers }\end{array}$ & $\begin{array}{l}\text { Slightly contaminated with } \\
\text { tritium } \\
\text { - Not much in upper burial tract- } \\
\text { most is in the } 76 \text { acre ORWBG }\end{array}$ \\
\hline WSRC, 1992 & $\begin{array}{l}\text { 10,000 kg (II lons) } \\
\text { (ORWBG trenches)" } \\
\text { References DP-1778 p.3-3 } \\
\text { (Intcgrated Report on } \\
\text { Radionuclide Migration at } \\
\text { the Savannah River } \\
\text { Shallow Land Burial Site) }\end{array}$ & $\overline{N A}$ & $\mathrm{NA}$ & $\begin{array}{l}\text { Beforc } 1968 \text { mercury from gas } \\
\text { pumps at the SRS tritium } \\
\text { facility was not recycled. } \\
\text { Contaminated Hg in PE bottles } \\
\text { was buricd in ORWBG } \\
\text { trenches along with other waste. }\end{array}$ \\
\hline
\end{tabular}




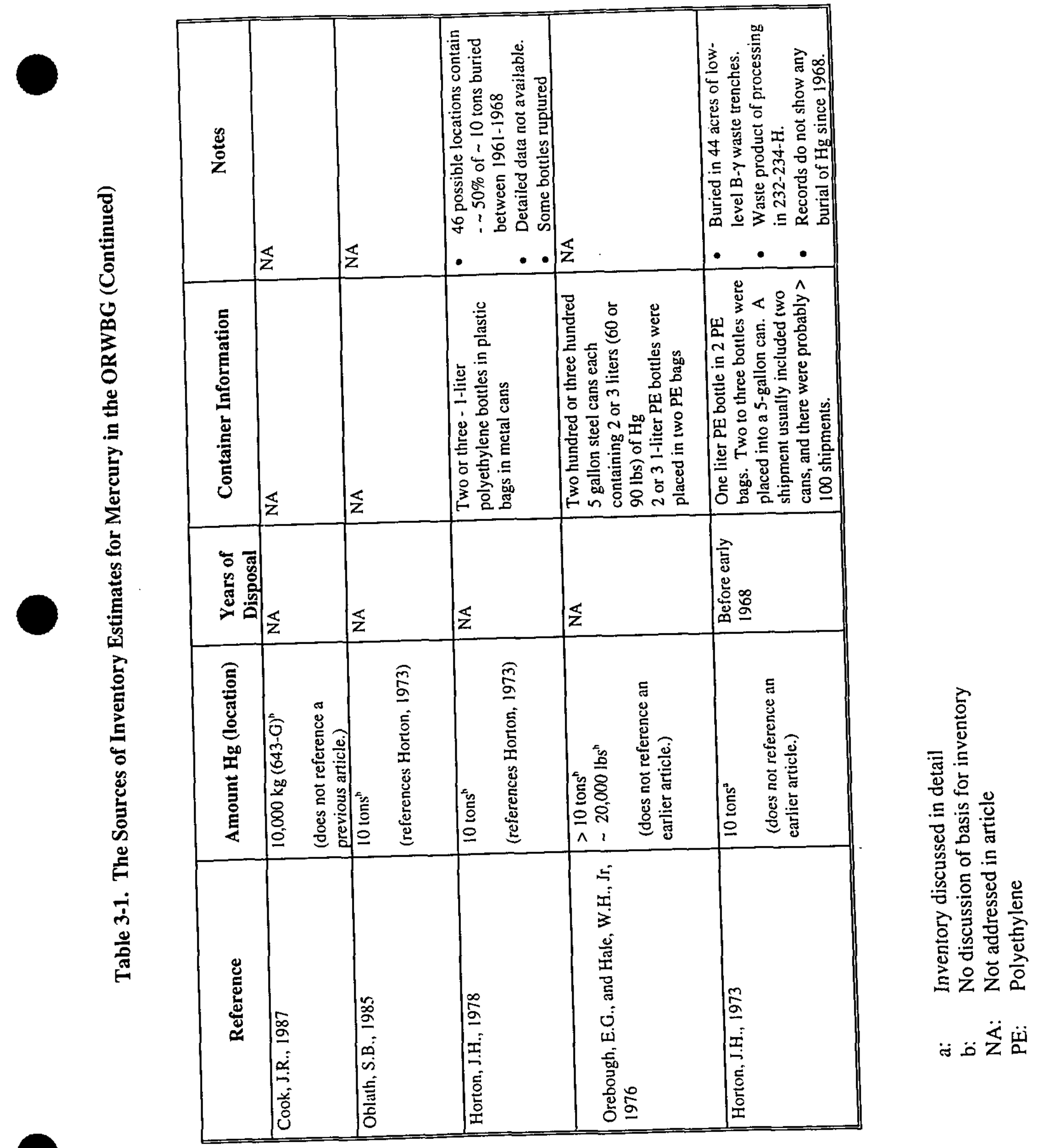



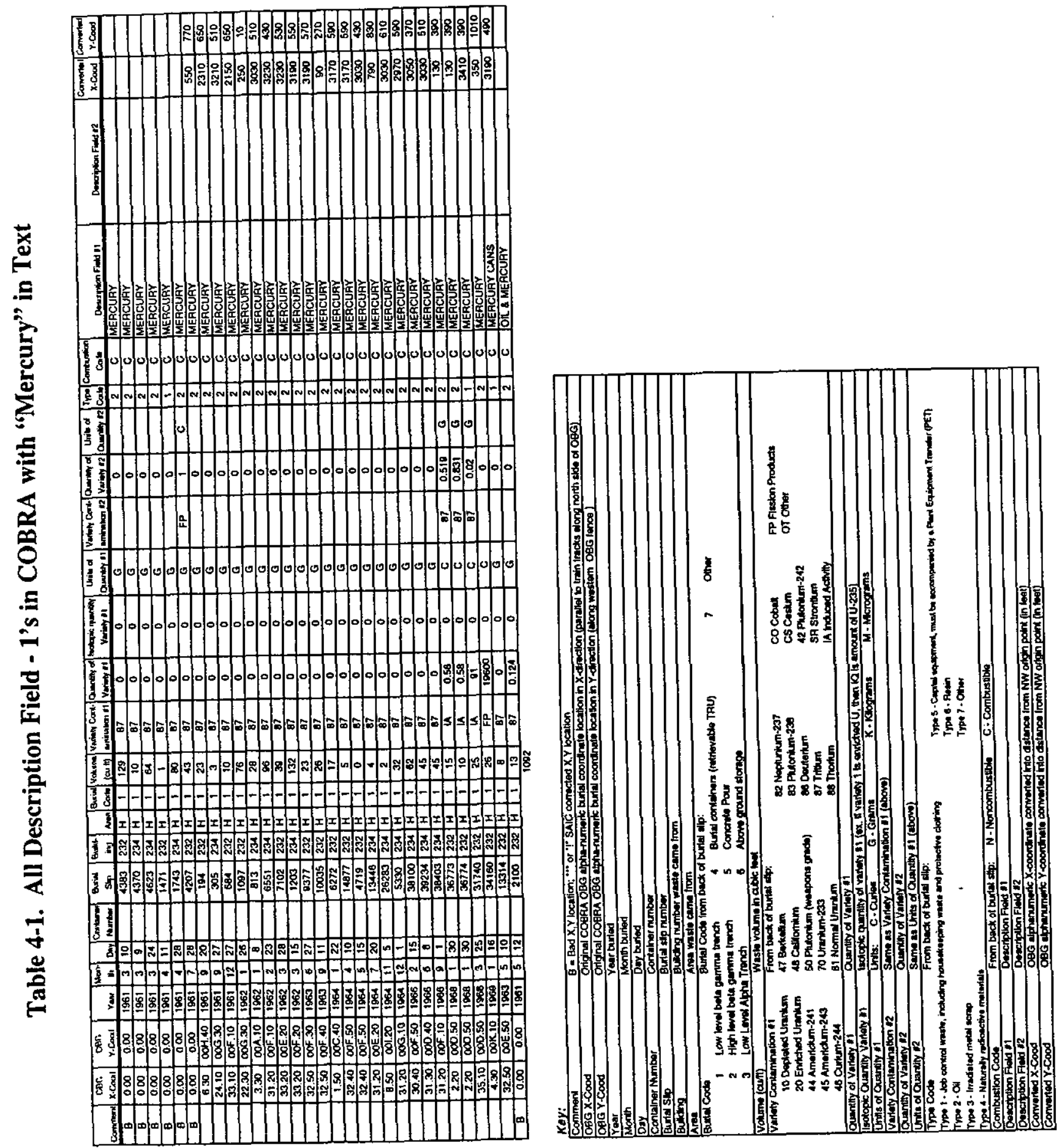


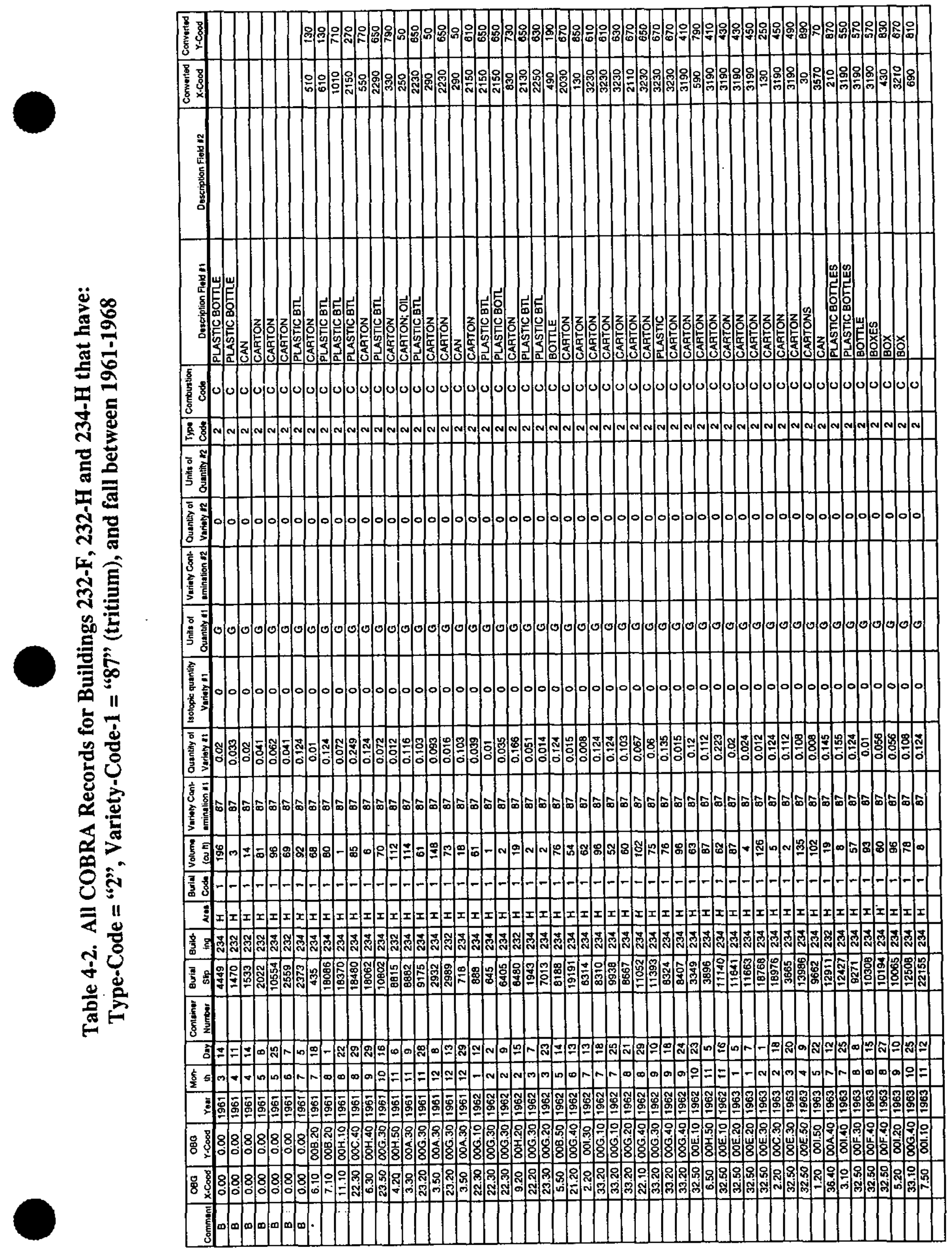




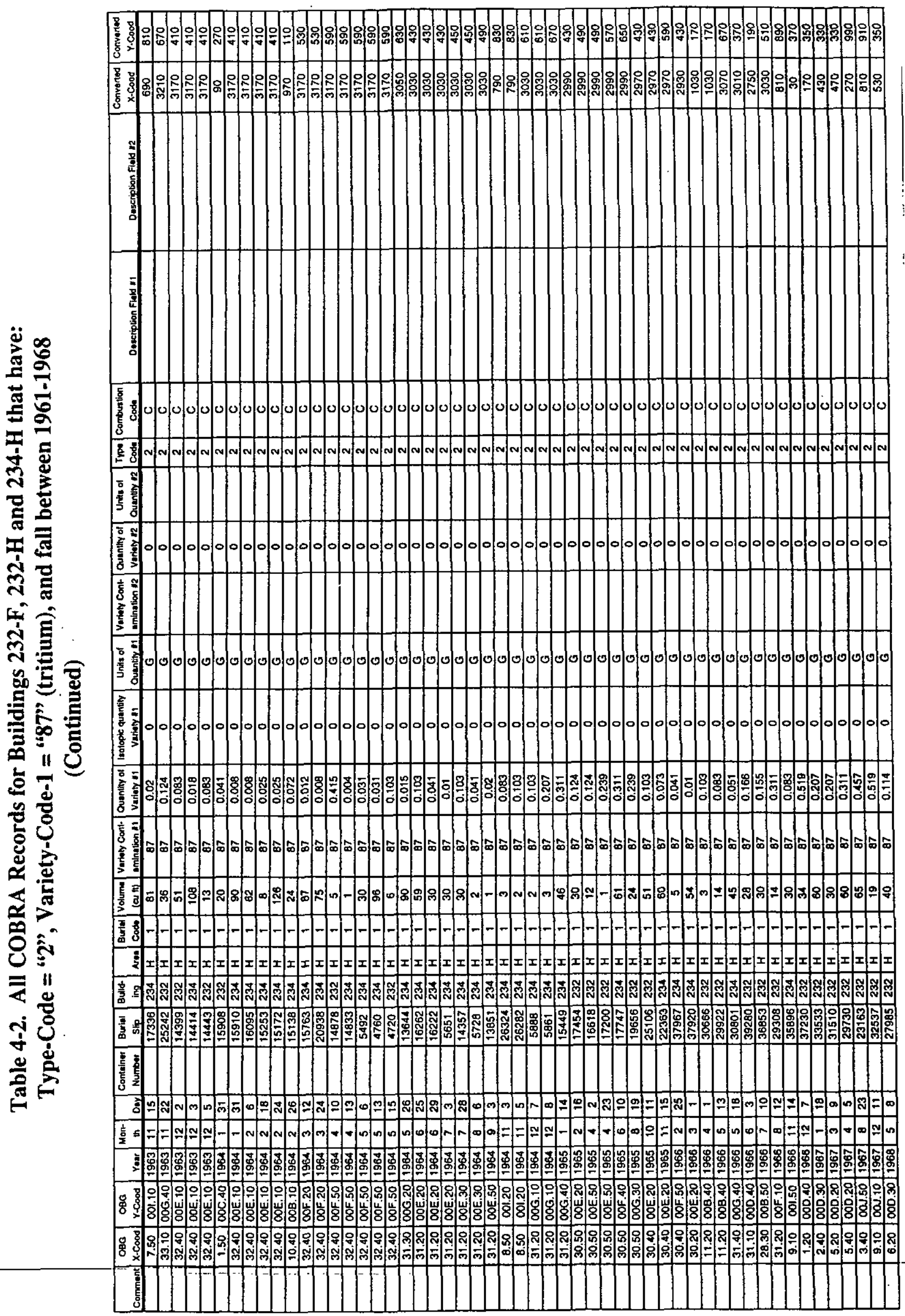


Table 4-2. All COBRA Records for Buildings 232-F, 232-H and 234-H that have:

Type-Code = “2", Variety-Code-1 = "87" (tritium), and fall between 1961-1968

(Continued)

\begin{tabular}{|c|c|c|c|c|c|c|c|c|c|c|c|c|c|c|c|c|c|c|c|c|c|c|c|c|}
\hline Commen & \begin{tabular}{|c|}
$O B G$ \\
$X \cdot C o o d$
\end{tabular} & 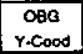 & rear & $\begin{array}{c}\text { Mom- } \\
\text { in }\end{array}$ & Doy & \begin{tabular}{|l|} 
Containat \\
Number
\end{tabular} & \begin{tabular}{|c|} 
Burisy \\
Stip
\end{tabular} & \begin{tabular}{|c|} 
Builds. \\
Inge
\end{tabular} & Area? & \begin{tabular}{|l|} 
Burias \\
coses
\end{tabular} & $\begin{array}{l}\begin{array}{l}\text { Voluming } \\
\text { cear iti }\end{array} \\
\end{array}$ & \begin{tabular}{|l|} 
Verieity Cont \\
amination en \\
\end{tabular} & $\begin{array}{l}\text { Ouantity of } \\
\text { Veriaty in }\end{array}$ & $\begin{array}{c}\text { Isotopic quantivy } \\
\text { Varlesy :11 }\end{array}$ & $\begin{array}{l}\text { Units of } \\
\text { Qunntipy in }\end{array}$ & \begin{tabular}{|l|} 
Veriaty Cont \\
eminubion in
\end{tabular} & $\begin{array}{l}\text { Ovanily of } \\
\text { variary ete }\end{array}$ & $\begin{array}{l}\text { Unths of } \\
\text { oumentition }\end{array}$ & \begin{tabular}{|l|} 
Typo \\
Coded
\end{tabular} & $\begin{array}{c}\text { Combustion } \\
\text { Code }\end{array}$ & 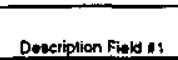 & Desctipion Fieks *2 & $\begin{array}{l}\text { Converied } \\
x \text {-Cood }\end{array}$ & $\begin{array}{l}\text { Converiod } \\
\text { r.cood }\end{array}$ \\
\hline & 7.20 & 000.30 & 1968 & 6 & 27 & & 31188 & 232 & $\mathrm{H}$ & 1 & 13 & 87 & 0.114 & 0 & $G$ & & 0 & & 2 & C & & & 630 & 350 \\
\hline & 1.30 & $00 K .20$ & 1968 & 9 & 17 & & 23726 & 232 & $\mathrm{H}$ & 1 & 45 & 87 & 0.207 & 0 & G & & 0 & & 2 & $\mathrm{C}$ & & & 50 & 1030 \\
\hline & 2.10 & DoK. 20 & 1968 & 10 & 17 & & 22849 & 232 & 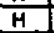 & 1 & 20 & 87 & 0.291 & 0 & $\mathbf{G}$ & & 0 & & 2 & C & & & 110 & 1030 \\
\hline & 28.30 & $00 B .40$ & 1968 & 10 & 25 & & 22744 & 232 & H & 9 & 12 & 87 & 0.332 & 0 & 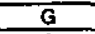 & & 0 & & 2 & C & & & 2750 & 170 \\
\hline & 2.20 & $00 \mathrm{~K} .30$ & 1968 & 11 & 5 & & 24001 & 232 & $\mathrm{H}$ & 1 & 8 & 87 & 0.228 & 0 & $\mathbf{G}$ & & 0 & & 2 & c & & & 130 & 1050 \\
\hline
\end{tabular}

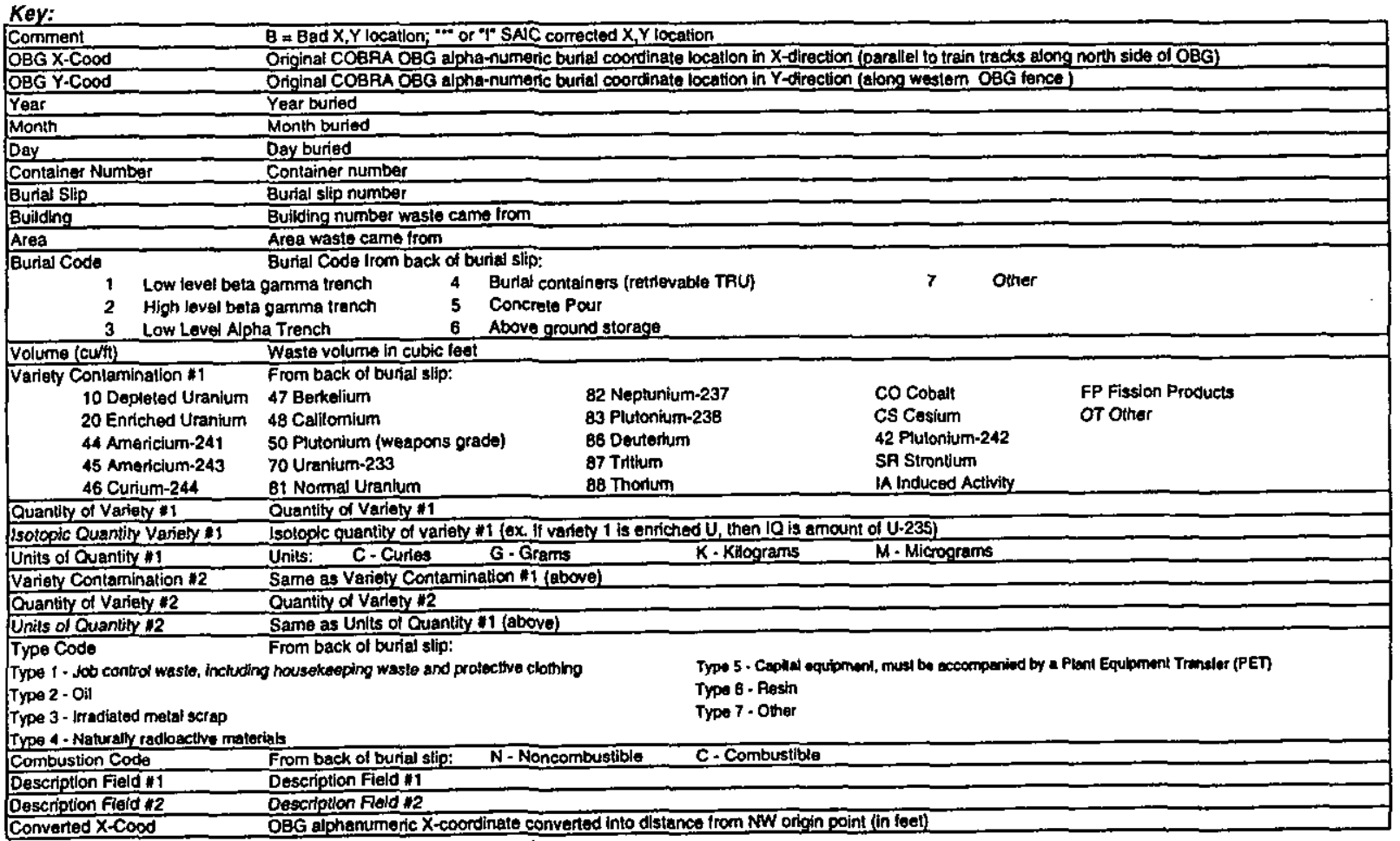



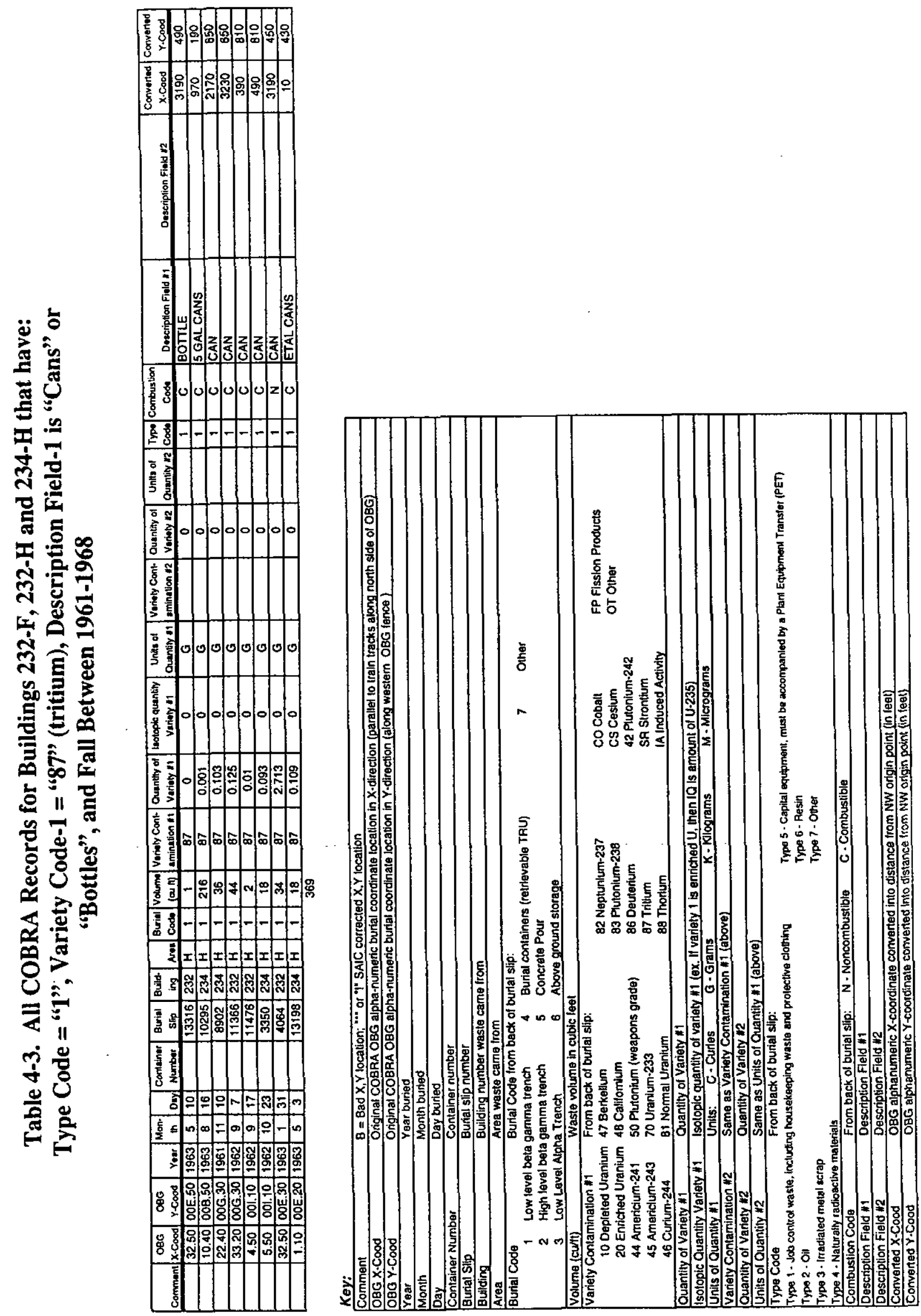
APPENDIX D

CONSTITUENT OF INTEREST:

VOLATILE ORGANIC COMPOUNDS 
(This page intentionally left blank) 


\section{TABLE OF CONTENTS}

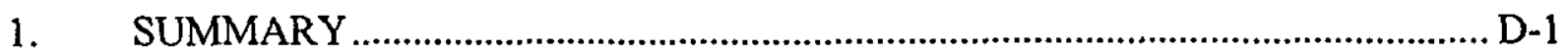

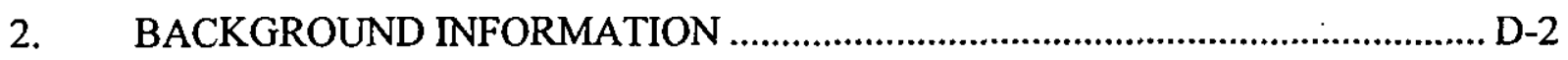

$2.1 \quad$ Spent PUREX Solvent ......................................................................... D-2

2.1.1 PUREX Solvent Composition and Degradation Products ................. D-3

2.1.2 Storage of PUREX Solvent in the Old Solvent Tanks..................... D-3

2.1.3 PUREX Solvent Burning ………………....................................... D-4

2.1.4 Volume of Solvent Stored in OSTs ............................................. D-4

2.1.5 Leaks/Spills from the Old Solvent Tanks ....................................... D-5

2.1.6 Removal of Solvent from Storage in Old Solvent Tanks ................. D-5

2.1.7 Residual Volatile Organic Compounds in the Old Solvent Tanks ... D-6 2.1.7.1 Vapor Phase ................................................................ D-6

2.1.7.2 Organic Phase .............................................................. D-7

2.1.7.3 Aqueous Phase ............................................................. D-7

2.1.7.4 Sludge Phase.............................................................. D-8

$2.2 \quad$ Liquid Scintillation Solutions ................................................................. D-8

2.3 Pump Oils, Cutting Oils, Die Oils ............................................................ D-9

2.4 Decontamination Operations .................................................................. D-9

2.5 Other Sources......................................................................................... D-9

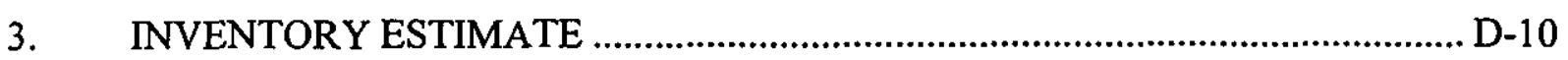

3.1 Range of Inventory Estimates ................................................................ D-10

3.1.1 Range of Inventory Estimates of Residue in the Old Solvent Tanks........................................................................................ D-10

3.1.1.1 Inventory of Organic, Aqueous, and Sludge Solid Phases ........................................................................ D-10

3.1.1.2 Concentration of VOCs in Vapor Phase........................ D-12

3.1.2 Range of Inventory Estimates of Organics in Burial Ground

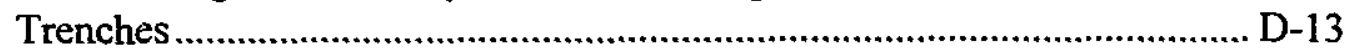

3.2 Best Estimate for Old Radioactive Waste Burial Ground........................... D-14

3.3 Uncertainties Associated with the Best Estimate........................................ D-14

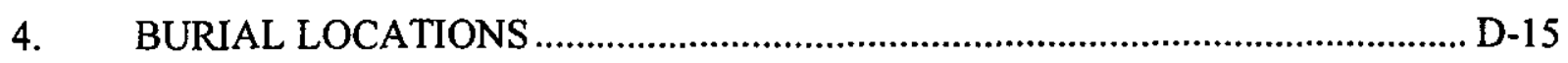

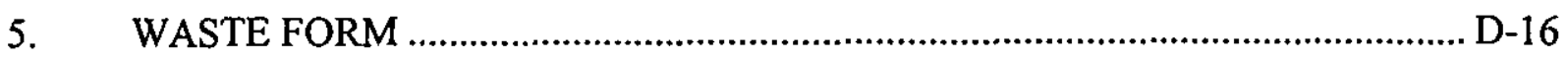

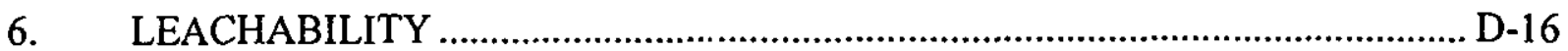

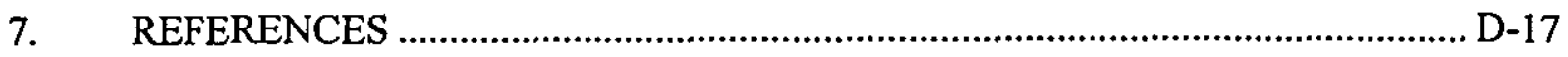




\section{LIST OF FIGURES}

Figure 1-1. Inventory Estimate Process Flow Diagram............................................. D-19

Figure 4-1. Volatiles Burial Location Process Flow Diagram .................................... D-20

Figure 4-2. X, Y Locations for Potential VOC Sources in ORWBG Database ............ D-21

\section{LIST OF TABLES}

Table 2-1. Organics Buried or Stored in the 643-G Burial Ground ............................. D-22

Table 2-2. Possible Degradation Products (Hoeffner, 1984) ...................................... D-23

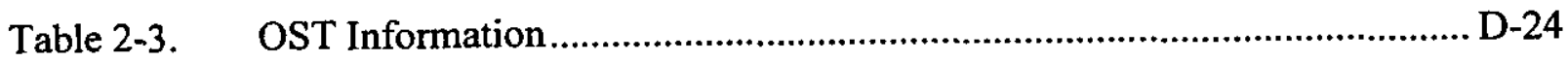

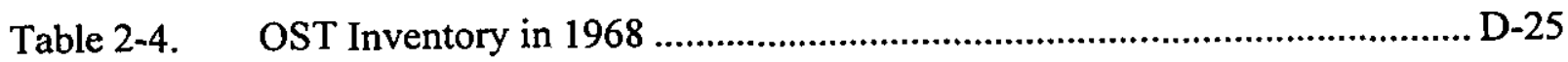

Table 2-5. Vapor Phase VOC Analytical Results (ppbv) from Solvent Tanks S1-S22 in ORWBG (Crump 1-27-95 in Mason, 1996) ............................................ D-26

Table 2-6. VOC TCLP Chemical Analyses for Organic and Aqueous Samples from Tanks S23-S30 and the Waste Trailer (Young 1992; in Mason, 1996)...... D-27

Table 3-1. The Sources of Inventory Estimates for VOCs in the ORWBG................ D-28

Table 3-2. Comparison of Historical Inventories Reported by Johnson (1978), Ryan and Johnson (1981), and Mentrup (1987) with the "folding rule" inventory (Mason, 1995), Using Corrected Tank Dimensions and Volumes ............. D-32

Table 3-3. Comparison of Inventories by Mentrup (1987) with Mason's "Folding Rule" Inventory (Mason, 1996)

Table 3-4. Maximum Total Volume, Aqueous Volume, and Organic Volume from Inventories Reported by Ryan and Johnson (1981), Mentrup (1987), and Mason's (1996) "folding rule" inventory D-34 


\section{CONSTITUENT OF INTEREST - VOLATILE ORGANIC COMPOUNDS}

\section{SUMMARY}

At the Savannah River Site (SRS), volatile organic compounds (VOCs) were present in plutonium-uranium extraction (PUREX) solvent, liquid scintillation solutions, pump oils, cutting oils, die oils, and material used in decontamination operations. Based on this study, the sources of VOCs in the Old Radioactive Waste Burial Ground (ORWBG) include:

- Residual vapor and organic phases of spent PUREX solvent, waste oils, and associated degradation products in the Old Solvent Tanks (OSTs)

- Drummed scintillation solutions

- Waste oils in absorbent materials

- Residue from decontamination operations at the ORWBG prior to waste burial

VOCs are present in residue in the 22 OSTs. Large amounts of spent solvent and smaller amounts of tritiated pump oil were stored in tanks prior to the 1980s. The contents of the OSTs, except for "unpumpable heel", were transferred to new tanks in the New Burial Ground (643-7E) in the late 1970s and early 1980s. Residual "unpumpable heel" in the OSTs is present in vapor, organic, aqueous, and sludge solid phases. VOCs from the spent solvent and associated degradation products are primarily concentrated in the vapor and organic phases. The concentrations of VOCs in the vapor phase are known from a recent vapor phase survey, and the amount of the organic phase is approximately 4,056 gallons.

VOCs associated with liquid scintillation solutions and waste oils are present in the trenches of the ORWBG. Estimates of the amount of liquid scintillation wastes range from 10,000 to 11,000 gallons. These wastes are in small polyethylene vials which beginning in 1965, were packed with oil-dry in 55-gallon drums and buried. Waste oils were stored both in the OSTs, and absorbed on an oil-dry compound, placed in drums, and buried as solidified waste.

An additional source of organic species is residue from decontamination operations that occurred in an area of the ORWBG before waste disposal activities began in that portion of the facility. Oblath (1986) states that a decontamination station was set up in the northwest corner of the ORWBG, but Towler (1989; in WSRC, 1992) states that it was in the northeast corner. It is not known whether there is an error in one of these documents, or if there were two decontamination stations. Decontamination was accomplished by use of ethylene diaminetetraacetic acid (EDTA, a chelating compound) and phosphate detergents that can 
enhance the mobility of radionuclides like plutonium and strontium (WSRC, 1992). Apparently, there are no records on the amounts of decontamination solutions that may have been disposed in this area of the ORWBG, nor is it clear how or whether these chemical solutions came into contact with buried wastes. However, because VOCs are highly mobile and volatile, and because more than 40 years have elapsed since decontamination activities ceased, the amount of VOCs remaining from this source is considered to be negligible.

Figure 1-1 presents the process used to develop the inventory and burial locations. The COBRA database does not track VOCs. However, COBRA "Type Codes" are general categories of waste, and "Type Code $=2$ " indicates radioactive waste that is associated with oil or oily material(s) (see Section 4 ).

\section{BACKGROUND INFORMATION}

Many organics have been stored and disposed in the ORWBG (Table 2-1). Their origins can be traced to four sources:

- Spent PUREX solvent and associated degradation products in the OSTs

- Liquid scintillation solutions in environmental and bioassay samples

- Waste oils from reactor and tritium facilities including pump oils, cutting oils, and die oils

- Decontamination operations at the ORWBG prior to waste burial

Relevant background information on these four sources is discussed in the following sections.

\subsection{Spent PUREX Solvent}

Hundreds of thousands of gallons of waste solvent were generated in Separations facilities at SRS in a chemical process for removing plutonium and uranium from spent fuel rods (WSRC, 1994). The PUREX solvent, consisting primarily of 30 percent tri-n-butyl phosphate (TBP) dissolved in kerosene, was used to extract plutonium and uranium from a nitric acid dissolver solution (Mason, 1996; Tharin, 1965). The spent solvent waste generated from this process was acidic and highly radioactive (WSRC, 1994). It was neutralized with caustic compounds and stored for aging in underground storage tanks in the ORWBG beginning in 1955 (Hoeffner, 1984). 


\subsubsection{PUREX Solvent Composition and Degradation Products}

Various compounds were stored in the tanks including TBP, naphthalene, toluene, trimethylbenzene, xylene, and a diluent such as n-paraffin hydrocarbon(s) (kerosene, ultrasene [a purified kerosene]) (WSRC, 1994; Hoeffner and Oblath, 1984; Hoeffner, 1984). The purpose of the kerosene was to act as a diluent, extending the TBP and reducing the viscosity of the TBP (Mason, 1996). Kerosene, mid-continent crude fifth distillation fraction (kerosene), is dominantly alkanes (C10 to $\mathrm{C} 16)$ with minor aromatic constituents (Mason, 1996). The aromatic hydrocarbons include benzene, toluene, ethyl benzene, and the xylenes (BTEX) (Mason, 1996).

Solvents and TBP degrade to a variety of organic species (Hoeffner, 1984). There are minor amounts of many TBP and diluent degradation products in the OSTs (Hoeffner and Oblath, 1984). The major TBP degradation products include monobutyl phosphoric acid, dibutyl phosphoric acid, butyl nitrate, butyl alcohol, phosphoric acid, peroxides, unsaturated compounds, organic nitrites and nitrates, and carbonyl compounds. Other possible degradation products of the PUREX solvent are alcohols ( $\mathrm{C} 12$ through $\mathrm{C} 15$ ), nitro alcohols, nitro alkanes, ketones, carboxylic acids, butyl esters, hydrozamic acids, nitrate esters, nitroso compounds, alkenes, and polymeric carboxylic acids. The degradation products of TBP and PUREX solvent are summarized in Table 2-2.

All solvent received through 1959 was 30 percent TBP, although by 1965 , the enriched uranium process produced some quantities of 3.5 percent and 7.5 percent TBP-kerosene solutions (Tharin, 1965). SRS records show that from 1956 through 1964, 88 percent of the waste solvent receipts were from F-Area (Wilhite, 1976). From 1965 to 1972, 86 percent of the waste solvent was generated in H-Area (Wilhite, 1976).

\subsubsection{Storage of PUREX Solvent in the Old Solvent Tanks}

The spent PUREX solvent was placed in long-term storage in the OSTs from 1955 through 1982 (Hoeffner and Oblath, 1984). The OSTs comprise 22 tanks designated S1 through S22 (Table 2-3). They were installed in the ORWBG between 1955 and 1968 (WSRC, 1994). Some of these tanks were utilized as fuel storage tanks at SRS and other federal facilities prior to their emplacement in the ORWBG (WSRC, 1994). All 22 tanks were constructed of thinwalled (0.75 inch) milled steel (WSRC, 1994). 
During the aging period, generally about six months, most of the short-lived gamma-emitting fission products decayed and the heavy alpha emitters settled out of the solvent. During storage, the solvent separated into four phases (Mason, 1996; WSRC, 1994):

- Vapor

- Organic

- Aqueous

- Sludge solids

\subsubsection{PUREX Solvent Burning}

After the solvent separated into phases, the volume was reduced by periodically burning the organic phase. It was drawn out of the tanks and burned in shallow open pans in trenches near the center of the ORWBG (Mason, 1996; WSRC, 1992). The volatile combustion products dispersed to the atmosphere (Tharin, 1965). Hoeffner (1984) suggested that about 370,000 gallons of contaminated solvent were burned from 1956 to 1972 . Wilhite (1976) estimated the volume of solvent burned was 418,000 gallons. The residue was emptied from the pans into earthen trenches. Some drawings suggest that the residue was encapsulated in bentonite. After their useful lifetime, the pans were also buried unencapsulated in an earthen trench (Wilhite, 1976; Tharin, 1965). The procedure of burying solvent residue and spent pans resulted in radioactive contamination of the soil (Hoeffner, 1984). Open pan burning was suspended in February 1972 (Mason, 1996) and is no longer permitted (Hoeffner, 1984).

\subsubsection{Volume of Solvent Stored in OSTs}

The amount of solvent in storage in the OSTs varied with time. Significant factors that changed the volume in storage include the rate of solvent consumption, the timing of periodic burnings, and the eventual removal of solvent from the ORWBG in the late 1970s and early 1980 s. The rate of solvent consumption changed over time with the rate of production of nuclear materials at SRS, and with improvements in the diluents that lessened the rate of solvent degradation.

Wilhite (1975; in Mason, 1996) reported that receipts of spent solvent as of 1975 totaled about 520,000 gallons. At that time (1975), there were approximately 150,000 gallons in storage in 20 storage tanks (Mason, 1996). Denard (1975; in Mason, 1996) reported an inventory of 175,185 gallons (148,935 gallons of organic plus 26,240 gallons of aqueous phase) (Tâble 2-4).-This unsigned-undated-inventory-was-believed_to_have_been_generated in 
1968 (Mason, 1996). The inventory corresponds closely to the "approximately 175,000 gallons" reported by McNatt (4-7-75; in Mason, 1996). The total amount of solvent discarded through February 1962 was reported to be 225,000 gallons, with 150,000 gallons in storage and 75,000 gallons burned (Mason, 1996).

For this study, further discussion of the volume of solvent stored is unwarranted because most of the solvent was burned or transferred to tanks in the New Burial Ground. Additional details on historical solvent storage are included in Mason (1996).

\subsubsection{Leaks/Spills from the Old Solvent Tanks}

There are 12 reported instances when solvent spills, overflows, and other accidents resulted in releases to the ground (Reference 9 in WSRC, 1992). An estimated 1.5 cubic meters of spent solvent has been released to the burial ground environment from leaks in tanks and solvent spills (Reference 1 in Oblath, 1986). Occasional solvent spills and leaks amounting to about 600 gallons occurred in the ORWBG (Hoeffner and Oblath, 1984; Hoeffner, 1984). Tank S8 was suspended from service in March 1967 after having leaked an estimated 200 gallons (Mason, 1996). Tank S17 was suspended from service in 1968 as a suspected leaker of 150 gallons (Mason, 1996). However, the leak from S17 is suspect; an inventory shortfall may have been due to an incorrect reported capacity of the tank (Mason, 1996).

In 1962 approximately 40 gallons of plutonium-contaminated solvent were inadvertently pumped directly into the shallow groundwater through a test well in the north-central part of the ORWBG (Ryan, 1983; Jaegge et al., 1987; McIntyre and Hawkins, 1987; in WSRC, 1994). The exact location and designation of the test well is not known, however, it is known that the location was near the location of monitoring well C17 (MGC 17) north of the OSTs.

Ryan (1983) reports that the solvent was "pumped directly to the water table near monitoring well C17 (MGC-17), when a test well was mistaken for a solvent storage tank header (riser)." Ryan (1983) uses well C17 as a point of reference only, this well did not yet exist in 1962. The report by Mason (1996) provides a relatively detailed analysis of potential "candidates" for the well, which received the solvent. Mason (1996) speculates that the dry wells installed at the ends of OSTs S1-S3 might have been mistaken for the tank risers, but the small volume of these wells would have caused them to overflow with solvent after less than ten gallons. Mason (1996) concludes that the most likely receptacle for the 40 gallons of solvent was one of the monitoring wells, which were installed in the immediate vicinity of the OSTs. At the time of the release, these would have included $\mathrm{BG}-1$ through $\mathrm{BG}-10 \mathrm{~A}$. These wells were 
installed with carbon steel casing which was 3 inches in diameter. Well BG-8 was located closest to the OSTs, and Mason (1996) concludes that this well, or a temporary water-table well with similar construction was most likely the recipient of the 40 gallons of solvent. All of the wells that could have received the solvent have been abandoned.

\subsubsection{Removal of Solvent from Storage in Old Solvent Tanks}

A solvent relocation program was carried out in the late 1970 s and early 1980s. Tanks S1S18 were pumped to "unpumpable heel" between March 1977 and May 1978 into Tanks S19S22 (Mason, 1996). Between November 1980 and January 1981, the solvent was transferred from Tanks S19-S22 into new, double-walled, corrosion-resistant tanks in the 643-7G burial ground (Hoeffner, 1984; WSRC, 1994; Mason, 1996). No additional waste was placed in Tanks S1-S22 after January 1981 (Mason, 1996).

\subsubsection{Residual Volatile Organic Compounds in the Old Solvent Tanks}

Presently, the 22 OSTs are empty except for residual vapor, organic, aqueous, and sludge phases of PUREX solvent (DOE/SR-WM-39-1 in WSRC, 1992). The material that remains is residue that was unpumpable during the solvent relocation program in the late 1970s and early 1980s. In addition to the various PUREX solvent compounds, there are minor amounts of many TBP and diluent degradation products (Hoeffner and Oblath, 1984). Some of these compounds are VOCs and may have hazardous characteristics. The degradation products of TBP and PUREX solvent are summarized in Table 2-2.

\subsubsection{Vapor Phase}

The vapor phase consisted primarily of the more volatile constituents of the organic phase. Degradation of the organic phase would have contributed volatiles to the vapor phase, and the vapor phase would have been in equilibrium with the organic phase. The vapor phase was released from the tanks by atmospheric exchange and by displacement during addition of new solvent. The composition of the vapor phase may have evolved gradually as the VOCs in the organic phase were depleted, and the volatiles were released from the tanks (Mason, 1996).

Tank custodians have been aware of the potential for the development of an explosive atmosphere within the tanks. In April and May 1994, the air quality at each riser was checked with an Hnu Photoionization meter and an MSA 261 combustible gas/oxygen (explosimeter) instrument. The instruments were held a few inches above the opening of the riser pipe; they were not lowered into the riser, which might have resulted in contamination - of the 
instruments. Volatile gases, capable of being ionized by the Hnu's photoionization lamp, were not detected. The explosimeter did not detect explosive gases, and the oxygen content of the air at the opening of all risers was found to be 20.8 percent, which is consistent with normal atmospheric conditions (Mason, 1996).

Between December 19, 1994 and March 13, 1995, vapor phase samples were collected from the OSTs. A tube was lowered through the riser pipe to mid-tank depth and samples were collected by passing 100 liters of the headspace gas through a silica gel cartridge (Supelco, $\mathrm{P} / \mathrm{N}$ 2-0229). The samples were transported to the Savannah River Technology Center (SRTC) for analysis by a gas chromatograph/mass spectrometer (GC/MS) semivolatiles, and radionuclide screening (Crump 1995a, 1995b). Tanks S15 and S19 contain the highest concentrations of VOCs and the greatest number of analytes. The flange covers on Tank S15 riser and vent pipe were wedged open with bolts, rather than rotated aside as they were on most of the other riser and vent pipes. Tank S19 has a high-efficiency particulate air (HEPA) filter on the vent pipe, and the riser was wrapped in black canvas and duct tape because of several personnel contamination incidents in the 1980s. These conditions would have restricted atmospheric exchange (Mason, 1996). Table 2-5 presents the results of the vapor phase analyses.

\subsubsection{Organic Phase}

The organic phase of the PUREX solvent typically consists of 30 percent tri-n-butyl phosphate dissolved in an $n$-paraffin hydrocarbon (kerosene, Ultracene ${ }^{T M}$, or Adakane ${ }^{\top M}$ ) (Mason, 1996).

The presence of both benzene and nitrate ions (from the nitric acid) caused concern that nitroaromatics might have been generated within the tanks (Mason, 1996). Nitroaromatics are shock sensitive and highly toxic (Mason, 1996). Nitroaromatics were not detected in vapor phase sampling conducted between December 1994 and March 1995, although benzene was present (Crump, 1995a and 1995b; in Mason, 1996; Mason, 1996). Because of the low vapor pressure of nitroaromatics, they may not have been detected in the vapor phase samples but may be present in the liquid organic phase (Mason, 1996). Vapor phase samples collected from each tank from January to March 1995 indicated that none of the tanks had an explosive atmosphere, and that nitroaromatics were not present in the vapor phase within the OSTs (Mason, 1996). 
Blankenhorn and Wolfe (1991; in Mason, 1996) and Young (1992; in Mason, 1996) reported VOCs, metals Toxicity Characteristic Leaching Procedure (TCLP), and VOC TCLP analyses (Table 2-6) on the organic and aqueous phases in Tanks S23-S30 (Mason, 1996). While these data are not directly applicable to the waste in Tanks S1-S22, they provide a general idea of the TCLP character of the organic and aqueous phases of typical PUREX solvent (Mason, 1996). The VOCs would be expected to remain in the organic phase (Mason, 1996). Benzene was the only TCLP constituent to exceed regulatory limits in the organic phase of Tanks S23-S30 (Mason, 1996).

\subsubsection{Aqueous Phase}

Water may have entered the tanks by (1) becoming entrained when solvent was discharged from the process, (2) condensing from steam jetting of solvent from process vessels, (3) being used in the burial ground to prime the solvent pump, and (4) being added as caustic solutions to keep the water alkaline (Tharin, 1965). The water formed an aqueous layer at the bottom of each tank. The volume of water in each tank varies from 100 to 1000 gallons; solvent volumes reported are actually total liquid volumes including water (Tharin, 1965). No VOCs exceeded TCLP limits in the aqueous phase from one or more of the tanks (Mason, 1996).

Minor amounts of VOCs may be present in the aqueous phase in the OSTs, as indicated by analytical results of the aqueous phase in Tanks S23-S30 in the New Burial Ground (Table 2-6).

\subsubsection{Sludge Phase}

Most or all of the tanks contain unpumpable sludge heels (WSRC, 1994). The sludge solids phase is depleted in VOCs, but has high levels of metals and radioactivity. Reported volumes of sludge heels in each tank vary from 0 to 1,700 gallons. No attempt has been made to recover samples of the sludge solids to determine the level of radioactivity, the isotopic constituents, the specific gravity, or the physical character of the sludge (Mason, 1996).

\subsection{Liquid Scintillation Solutions}

Scintillation fluid is a mixture of organic solvents used to quantify low levels of radioactivity in environmental and bioassay samples (WSRC, 1994). It is used in process control, bioassay, and research and development laboratories at SRS. 
Small quantities of scintillation fluid wastes and used oils from reactor and tritium facilities were disposed of in absorbent materials in the ORWBG and buried as solidified waste (Hoeffner, 1984; Hoeffner and Oblath, 1984). The liquid scintillation wastes are in small polyethylene vials which, from 1965 to 1982, were packed with oil-dry in 55-gallon drums and buried in either 643-G or 643-7G (Hoeffner, 1984). After 1982, these drums were no longer buried; they are stored on a concrete pad or, if the liquid scintillation solution has been separated from the polyethylene vials, the solution is stored in a spare solvent tank (Tiffany, 1976; in Hoeffner, 1984).

In the mid-1980s, about 60 gallons of liquid scintillation waste were generated each month (Hoeffner, 1984). Estimates of the amount of scintillation waste in the ORWBG include 11,000 gallons (Hoeffner and Oblath, 1984) and 10,000 gallons (Hoeffner, 1984).

\subsection{Pump Oils, Cutting Oils, Die Oils}

At SRS, 3,300 gallons of pump oils are consumed per year (Hoeffner and Oblath, 1984, Hoeffner, 1984). Tritiated pump oils from reactor and tritium facilities were stored in the OSTs (WSRC, 1994). Waste oils from equipment used in regulated areas formerly were adsorbed on an oil-dry compound and buried as solidified waste (Hoeffner, 1984; Hoeffner and Oblath, 1984). Before bulk storage was started, contaminated process oil from pumps in the tritium facilities and reactor areas was placed in drums containing an absorbent material and buried.

Small quantities of used oils from reactor and tritium facilities were disposed of in absorbent materials in the ORWBG (Oblath, 1986).

\subsection{Decontamination Operations}

An additional source of organic species was decontamination solvents used on large pieces of equipment during the early years of the SRS (Hoeffiner and Oblath, 1984). Decontamination operations occurred in an area of the ORWBG before waste disposal began in that portion of the facility (Hoeffner and Oblath, 1984). Oblath (1986) states that a decontamination station was set up in the northwest corner of the ORWBG, but Towler (1989; in WSRC, 1992) states that it was in the northeast corner. It is not known whether there is an error in one of these documents, or if there were two decontamination stations. The decontamination operations used soluble complexing agents, including EDTA and phosphate detergents (Hoeffner, 1984; Reference 1 in Oblath, 1986), and may have been released during decontamination. Oxalate 
ion and DTPA (diethylene triamine pentaacetic acid) are also expected to be present in the burial ground (Hoeffner, 1984).

\section{$2.5 \quad$ Other Sources}

In addition to process solvent from SRS operations, 36,000 gallons of 35 percent TBP with small amounts of natural uranium ( 5 grams/liter, maximum), but no fission products, were received from National Lead Co., Ferndale, Ohio, an offsite contractor (Tharin, 1965). This solvent was piped directly to four 1,500-gallon semi-cylindrical pans from the tank cars in which it was received (Tharin, 1965). Batches of up to 6,000 gallons each were burned; this produced large quantities of black smoke, but very little residue (Tharin, 1965).

\section{INVENTORY ESTIMATE}

There are no detailed quantitative records on shipments of organics to the ORWBG. All estimates for the source term of VOCs are based on process knowledge. Shipments of organics are not documented in the COBRA database.

\subsection{Range of Inventory Estimates}

At present, VOCs in the ORWBG include:

- Residue in the OSTs

- Organics that were buried in trenches

Table 3-1 summarizes the sources of inventory estimates for VOCs in the ORWBG.

\subsubsection{Range of Inventory Estimates of Residue in the Old Solvent Tanks}

The following discussion of inventory is restricted to the residual amounts of organics left in the OSTs after the solvent was transferred to the New Burial Ground.

\subsubsection{Inventory of Organic, Aqueous, and Sludge Solid Phases}

Five inventories have been performed since the bulk of the waste was removed from the OSTs in 1977 and 1978: Johnson (1978), Ryan and Johnson (1981), Mentrup (1987), Mason (1996), and a video survey in 1997. Two of these (Johnson, 1978; Ryan and Johnson, 1981) were performed after the solvent was transferred into Tanks S19 through S22 but before it was moved into the New Burial Ground (643-7E). Tables 3-2 and 3-3 summarize the inventories. 
The first available "retired" inventory for Tanks S1 through S18 was a hand-written document (Johnson, 1978). It reported that tanks S1 through S18 contained a total of 3,034 gallons of residual organic, aqueous, and sludge solid heels. The inventory of individual tanks ranged from "0" in Tanks S8, S17, and S18 to 736 gallons in Tank S15.

Ryan and Johnson (1981) continued Johnson's (1978) study, and reported the same volumes. The organic phase was estimated to be 20 percent of the total volume, which is 606 gallons.

Mentrup (1987) reported that the total inventory of all residue in the OSTs was 5,323.4 gallons. Tanks S19-S22 contained a total of 3,232 gallons, slightly more than the 3,034 gallon volume previously reported for Tanks S1-S18 (Johnson, 1978; Ryan and Johnson, 1981; in Mason, 1996). Mentrup's inventory for Tanks S1-S18 was 2,091.4 gallons with "0" volume in Tanks S9, S12, S13, S16, S17, and S18. These "empty" tanks contained 1,042 gallons in the Johnson (1978) and Ryan and Johnson (1981) inventories.

Mason (1996) recalculated Mentrup's (1987) inventory using the revised tank dimensions, assuming that an organic phase was present in each tank containing waste, the reported level was the top of the organic phase, and that all tanks were horizontal (which has been shown to be an incorrect assumption). Mason's total volume inventory based on these assumptions is 5,331.4 gallons, which is 8.0 gallons more than Mentrup's (1987) inventory. The organic and aqueous volumes calculated under Mason's (1996) assumptions are 3,270.9 gallons of organic and 2,052.5 gallons of aqueous. He states that tanks for which no aqueous level is reported may contain no organic phase (i.e., the waste level may also be the aqueous level). If this is the case, the volume of the organic phase may only be about $2,155.5$ gallons, and the aqueous phase volume may be $3,175.9$ gallons.

Mason (1996) obtained new measurements of the height of the sludge in the OSTs in November 1995. This inventory is referred to as the "folding rule" inventory because of the method of using folding carpenter's rulers to obtain the measurements. Total waste volume of sludge was calculated to be 7,539 gallons. The organic fraction was estimated to be 53.8 percent, or 4,056 gallons.

The total volume of the maximum values from all of the inventories (Table 3-4) indicates that as much as 9,541 gallons of total waste may still be present in Tanks S1-S22, comprised of 4,629 gallons of aqueous phase and 4,912 gallons of organic phase. The general ratio for the aqueous and organic phases for all tanks except S8 and S18 is 49 percent aqueous and 51 
percent organic. The largest heel is 2,543 gallons in Tank S20. This represents about 10 percent of the capacity of the tank.

According to the latest complete inventories (Mentrup, 1987; Mason, 1995), Tanks S5, S6, S7, S8, S15, S18, S19, S20, S21, and S22 contain over 60 percent of the total waste remaining in the Old Solvent Tanks (Shappell, 1989; in Mason, 1996). In terms of volume, the aqueous phase is the predominant waste phase remaining in most of the OSTs, the exceptions being Tanks S18, S19, S20, and S22, in which the volume of organic phase exceeds the volume of the aqueous phase.

A video survey was conducted in March 1997 in five of the Old Solvent Tanks. A video camera was lowered into the tanks and the estimated heel volumes are as follows:

\begin{tabular}{|c|c|c|c|}
\hline Tank & $\begin{array}{c}11 / 9 / 95 \\
\text { folding rule } \\
\text { inventory }\end{array}$ & $\begin{array}{c}\text { DPSOP 138-6 } \\
\text { (gal) }\end{array}$ & $\begin{array}{c}1997 \text { Video Survey } \\
\text { (gal) }\end{array}$ \\
\hline S9 & $1^{\prime \prime}$ not water & 13 & 5 \\
\hline S10 & $2.5^{\prime \prime}$ water & 53 & 20 \\
\hline S14 & $0^{\prime \prime}$ & & 437 \\
\hline S16 & $0.75^{\prime \prime}$ & 15 & 10 \\
\hline S17 & $0^{\prime \prime}$ & 0 & dry \\
\hline S18 & $3^{\prime \prime}$ & 60 & 15 \\
\hline Total & & 141 & 50 \\
\hline
\end{tabular}

Each of the tanks surveyed were inclined toward the riser end, where the 11/9/95 inventory (and previous inventories) were measured. This results in a parabolic outline for the heel and a considerable reduction from the volume calculated by the DPSOP 138-6 tables which assumed a horizontal tank.

The video survey indicated that the vent (south) end of the tank is lower than the riser end. McNatt (4/7/75) performed stratigraphic sampling through both the riser and vent pipes of Tank S14 to determine lateral and vertical homogeity within the organic and aqueous phases. The data of McNatt (4/7/75) indicate that the vent end of Tank S14 is about six (6) inches lower than the riser end. The folding rule invevtory 11/9/95 found no liquid at the vent end. The video survey found liquid in the riser end of the tanks and a number of pipes and other pieces of junk in that end of the tank. The folding rule may have encountered one of these obstructions before reaching the liquid heel. Mentrup (5/19/87) reported 2.8 inches in an inventory_conducted through the riser end. Rounding to 3 inches and adding 6 inches for tank 
inclination would yield an average liquid level of 6 inches. DPSOP 138-6 tables calculate a volume of 437 gallons for a horizontal tank with 6 inches of liquid.

White crystalline solid material (possibly hydroxides and carbonates) has observed just above the liquid level on the tank ends. Mentrup did not report an aqueous level, possibly indicating at least 3 inches of organic phase over an aqueous heel, which is confined to the lower end of the tank.

\subsubsection{Concentration of VOCs in Vapor Phase}

The concentrations of VOCs in the vapor phase are determined by recent vapor phase analyses. Table 2-5 summarizes the results of these analyses (Crump, 1995a; and 1995b; in Mason, 1996).

No VOCs were detected in Tanks S1, S7, S8, and S11. Tanks S3, S4, and S6 yielded only alkyl hydrocarbons. Tanks S15 and S19 had the highest concentrations of VOCs and the greatest variety of analytes. Acetone was detected in Tanks S5, S13, S15, S19, S20, and S21 and may be the result of organic degradation. Maximum recorded concentration of acetone was 1500 ppbv in Tank 19. Benzene was detected in Tanks S2, S5, S10, S15, S16, S17, and S18. Maximum recorded concentration of benzene was 200 ppbv in Tanks S2 and S17. Xylenes were only detected in Tank S18. The recorded concentration of xylenes was 14 ppbv. Nitroaromatics were not detected in any of the tanks. Perchloroethene (PCE) was detected in 10 of the tanks. PCE was not specifically used in the PUREX process but was widely used as a solvent and degreaser onsite (Mason, 1996). Maximum recorded concentration of PCE was $6.6 \mathrm{ppbv}$ in Tanks S2 and S17. Methyl ethyl ketone was detected in seven of the tanks. Maximum recorded concentration of methyl ethyl ketone was 2,100 ppbv in Tank S19. Methyl butyl ketone was detected in four of the tanks. Maximum recorded concentration of methyl butyl ketone was 470 ppbv in Tank S19.

During a video survey conducted in Tank S14 on March 22, 1997, an MSA, an important real-time vapor phase survey tool, recorded $6-8 \%$ of the lower explosive limit. An effort was made to reduce the "light time" as much as possible during the survey. The presence of this level of volatile organics in the tank atmosphere was unexpected because vapor phase sampling conducted in early 1995 found only 36.6 ppbv volatiles in Tank S14. 


\subsubsection{Range of Inventory Estimates of Organics in Burial Ground Trenches}

Cook (1987) cites the following masses of hazardous materials buried in 643-G:

$\begin{array}{ll}\text { Toluene } & 7,100 \mathrm{~kg} \\ \text { Tributylphosphate (TBP) } & 720 \mathrm{~kg} \\ \text { Trimethylbenzene } & 7,100 \mathrm{~kg} \\ \text { Xylene } & 12,000 \mathrm{~kg}\end{array}$

It is not clearly stated if these numbers include the inventories in both the trenches and in the OSTs. However, the primary source of toluene, trimethylbenzene, and xylene is liquid scintillation solutions, which are known to have been buried in trenches. Therefore, most or all of these inventories for these constituents are probably buried in trenches. In contrast, the primary source of TBP is spent solvent, which was stored in the OSTs. Therefore, the cited 720 kilograms is likely to be residue in the OSTs.

Four inventories of the OSTs were performed after the Solvent Relocation Program. Tables 3-2 and 3-3 summarize the results of these inventories. Estimates of the total volume range from 3,034 to 7,539 gallons. Estimates of the organic phase range from 606 to 4,056 gallons.

It is reported in Old Radioactive Waste Burial Ground (WSRC, 1992) that several hundred gallons of organic-based liquid scintillation fluids, including xylene, toluene, and trimethylbenzene, were disposed of annually beginning in 1965.

\subsection{Best Estimate for Old Radioactive Waste Burial Ground}

The best estimate for residue in the OSTs is the "folding rule" inventory by Mason (1995). It used the revised, most probable tank dimensions to calculate volume (Table 2-3). By this inventory, the total residue is 7,539 gallons $(4,056$ gallons organic phase and 3,483 gallons aqueous phase).

The best estimate of vapor phase concentrations is the recent analytical data by Mason (1996). These data are presented in Table 2-5. However, a 1997 MSA survey in Tank S14 suggests that vapor concentrations may be significantly higher.

The best estimate for organics that were buried in trenches is based on Cook (1987). Approximately 7,100 kilograms of toluene, 7,100 kilograms of trimethylbenzene, and 12,000 
kilograms of xylene from liquid scintillation solutions are buried in trenches. The amount of residual VOCs from decontamination operations is not known.

\subsection{Uncertainties Associated with the Best Estimate}

VOCs, by definition, are highly mobile and volatile. The cited inventories of VOCs in the ORWBG do not account for volitilization of VOCs to the atmosphere or migration downward with infiltration of rainwater. Unencapsulated waste and waste in broken/unsealed containers are subject to volatilization or migration from the ORWBG. Considering that waste in the ORWBG has been buried for a minimum of 25 years, the actual amount of VOCs left in ORWBG trenches may be considerably less than the disposal estimates.

No attempt has been made to adjust any of the inventories in the OSTs (including the folding rule inventory) for tank inclination. It should be recognized that inclination of the larger tanks could make a substantial difference in the waste volume. The following is an example for two of the tanks based on inclination (Mason, 1996):

\begin{tabular}{ccccccc} 
Tank & $\begin{array}{c}\text { Waste } \\
\text { level }\end{array}$ & $\begin{array}{c}\text { Riser } \\
\text { Location }\end{array}$ & $\begin{array}{c}\text { Assumed } \\
\text { Horizontal }\end{array}$ & Inclination & $\begin{array}{c}\text { Adjusted } \\
\text { Volume }\end{array}$ & Increase \\
\hline S5 & 5 inches & mid-tank & $330 \mathrm{gal}$ & $0.8 \mathrm{ft}$ to east & $461 \mathrm{gal}$ & $40 \%$ \\
S22 & 2 inches & east end & $84 \mathrm{gal}$ & 0.48 to west & $373 \mathrm{gal}$ & $344 \%$
\end{tabular}

Ground Penetrating Radar (GPR) and surface elevation data indicate that all of the tanks except S4, S6, S9, S11, and S12 are inclined to some extent. Several are inclined more than 6 inches (Mason, 1996).

There is some uncertainty about the actual size of some of the OSTs. Different documents record slightly different dimensions. The calculated amounts of residue depend on the dimensions of the tanks.

\section{BURIAL LOCATIONS}

Shipments of organics are not documented in the COBRA database. Figure 4-1 outlines the steps taken to manipulate the database to locate VOCs. In the COBRA database there are no references to "scintillation fluid", "PUREX", "oil-dry", "TCE", "degreaser", "alcohol", "xylene", "hydrocarbon", "diesel", "gas", "gasoline", etc. However, COBRA "Type Code 2" 
is a general waste category for radiological contaminants that are associated with oil or oily waste(s). No quantity information in COBRA is available for "oil" (Type Code 2) records, but their locations are shown on Figure 4-2. Indirect references to possible VOC sources (for records with type codes other than 2) include COBRA description fields containing the following words or phrases: "55 gallon drum" or "drum" (190 records), "sludge" (12 records), "skip pan" or "pan" (1161 records), and "oil" (4 records). The burial locations for these records are also shown on Figure 4-2. In general, these references are poor indicators of the presence of VOCs because items such as "drums" and "skip pans" were used for the disposal of many waste types. In addition, no quantity or specific VOC constituent information is contained in any COBRA record.

The 22 OSTs are located in a "T"-shaped block near the center of the ORWBG, about 400 feet northeast of the Burial Ground Administrative Building 724-7E and 500 feet north of Road E. The top of the "T" is about 240 feet long, and the staff of the "T", which trends east-west, is about 570 feet long. The "T"-shaped block comprises approximately 0.56 acres (Mason, 1996). The OSTs are flanked by unlined trenches that received radioactive waste in cardboard and wooden boxes, plastic bags, and metal containers. The trench on the south side is about 30 feet from the tank crowns. The trench on the north side of the tanks is about 20 feet from the crowns (Mason, 1996).

Decontamination operations were performed in the northwest corner of the ORWBG before waste was buried in that portion of the facility (Oblath, 1986; Hoeffner, 1984).

\section{WASTE FORM}

VOCs in the OSTs are primarily in the vapor and organic phases. Minor amounts may be present in the aqueous phase. The amount of VOCs in the sludge phase is negligible.

Liquid scintillation wastes are in small polyethylene vials which, from 1965 to 1982, were packed with oil-dry in 55-gallon drums and buried in either 643-G or 643-7G (Hoeffner, 1984). These drums were not buried in the ORWBG after 1972. Since 1982, they are stored on a concrete pad or, if the liquid scintillation solution has been separated from the polyethylene vials, the solution is stored in a spare solvent tank (Tiffany, 1976; in Hoeffner, 1984).

Waste oils from equipment used in regulated areas formerly were adsorbed on an oil-dry compound,_placed in drums, and buried as solidified waste (Hoeffner, 1984; Hoeffner and Oblath, 1984). 


\section{LEACHABILITY}

The geochemical controls on the leachability of volatile organic contaminants (VOCs) are minimal. Association with organic matter in soils may retard the migration of VOCs, but the generally low organic content of Savannah River Site soils minimizes retardation. The dominant controls on VOC leachability are waste packaging and infiltration rate of water through the trenches. The large plume of VOCs south of the ORWBG suggest that much of the VOC inventory may have already leached from the burial trenches. No current leaching rate is estimated here. 


\section{REFERENCES}

Blankenhorn, J. A. and Wolfe, K.H., 1991. Reported Chemical Analyses (10/7/96) (Tanks S23-S30 and the waste trailer), October 7, 1991.

Cook, 1987. Plan for Closure of the 643-G Burial Ground, Technical Data Summary, DPSTD-87-2, August 1987.

Crump, S.L. 1995a. Letter to J.T. Mason, Solvent Waste Tank Vapor Phase Characterization - Data Report (Tanks S1, S3, S4, S6, S7, S8 and S11), January 27, 1995.

Crump, S.L. 1995b. Letter to J.T. Mason, Solvent Waste Tank Vapor Phase Characterization - Data Report (Tanks S2, S5, S9, S10, S12, S13, S14, S15, S16, S17, S18, S19, S20, S21 and S22), April 26, 1995.

Denard, C.D., 1975. Burial Ground Waste Solvent Samples (Tanks S1-S7, S9-S22), June 30, 1975.

DuPont, 1975. Movement of Organically-Bound Plutonium in Soil, DPST-75-377, Savannah River Laboratory, 9/23/75, Table 2.

Hoeffner, S.L., 1984. Letter to G.T. Wright, Organics in the 643-G Burial Ground, DPST84-738.

Hoeffner, S.L., and Oblath, S.B., 1984. Scoping Study of Organics in Well Waters of the SRP Low-Level Waste Burial Ground, DPST-84-796, November 14, 1984

Jaegge et al., 1987. (in Mason, 1996)

Johnson, D.R., 1978. Monthly Summary, 6, Solvent Storage (Hazard Assessment of Sludge), December 11,1978 .

McIntyre, P.F. and Hawkins, R.H., 1987. 1987 Monitoring Report of Special Wasteform. Lysimeters - Humid Site, DPST-87-648, Savannah River Laboratory, A

McNatt, F.G., 4-7-75. Letter to R.G. Garvin, Sampling Waste Solvent in Tank 14.

Mason, J. T. to R. Frye-O'Bryant, 1995. Visual Inspections and New Inventories on Solvent Tanks S1-S22, November 27,1995

Mason, 1996. Information Document on the Old Solvent Tanks S1-S22 in the Old Radioactive Waste Burial Ground 643-E (U), WSRC-RP-96-00144, Rev. 0, June 24, 1996.

Mentrup, S.J., 1987. Weekly Solvent Inventory - Solvent Tanks S1-S22, May 19, 1987, (attached to Mentrup, August 4, 1987).

Oblath, S.B., 1986. Organic Compounds at the SRP Old Burial Ground for Low-Level Radioactive Waste, DP-MS-86-138, E.I. duPont de Nemours and Company, Savannah River Laboratory, Aiken, South Carolina.

Ryan, J.P. and D.R. Johnson, 1991., Migration and Leaching Studies of Spent Solvent Sludges,-memorandum-to-O.M.Morris January_26,1981 
E.I. duPont de Nemours and Company, Inc., Aiken, SC.

Shappell, J.R., 1989. Letter to M.A. Ebra, 5-24-89, Assessment of Fissile Material in Spent Solvent Tanks SI thru S22 Located within the Savannah River Site.

Tharin, D.W., Jr., 1965. Burning of Radioactive Process Solvent, AEC Research and Development Report, DP-942, E.I. du Pont De Nemours \& Company, Savannah River Laboratory, Aiken, SC, February 1965.

Tiffany, B., 1976. Organic Contaminants of BG-21, A Shallow Burial Ground Well, April 14, 1976.

Towler, O.A., Jr., 1989. DP-1778, Integrated Report on Radionuclide Migration at the Savannah River Shallow Land Burial Site, Savannah River Laboratory, March 1989, p. 33.

Wilhite, E.L., 1975. Movement of Organically-Bound Plutonium in Soil, DPST-75-377, September 23, 1975

Wilhite, E.L., 1976. Estimate of TRU Nuclides in Solvent Residues at the Burial Ground, Memorandum to M.D. Boersma from E.L. Wilhite, Technical Division, Savannah River Laboratory, April 30, 1976.

WSRC, 1990. WSRC-IM-90-60. Volume Volume 2. Table D-58. See wells BGO and 26A).
2. Table 6-79 and WSRC-IM-91-28. $27 \mathrm{C}$, 27D, 28D,30C,30D,31D,32D,33C,35D,37C,

WSRC, 1992. Old Radioactive Waste Burial Ground, Revised Draft 8/92.

WSRC, 1994. RFI/RI Work Plan For the Burial Ground Complex, WSRC-RP-90-1140, December 1994.

Young, J.E., 1992. Letter to K.E. Wolfe, 1-2-92, Analytical Data for Waste Classification of Burial Ground Solvent Waste Tanks. 


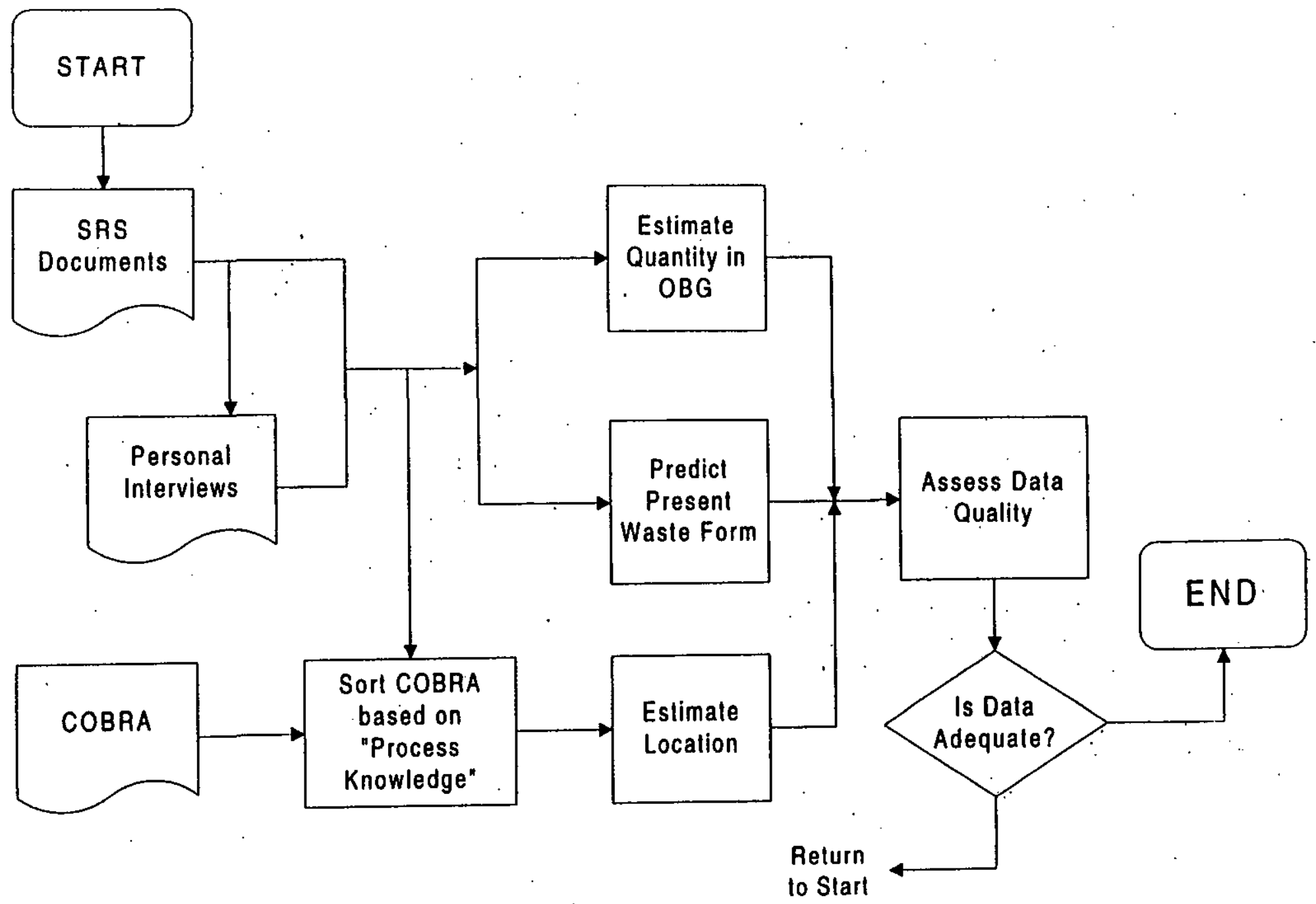

Figure 1-1. Inventory Estimate Process Flow Diagram 

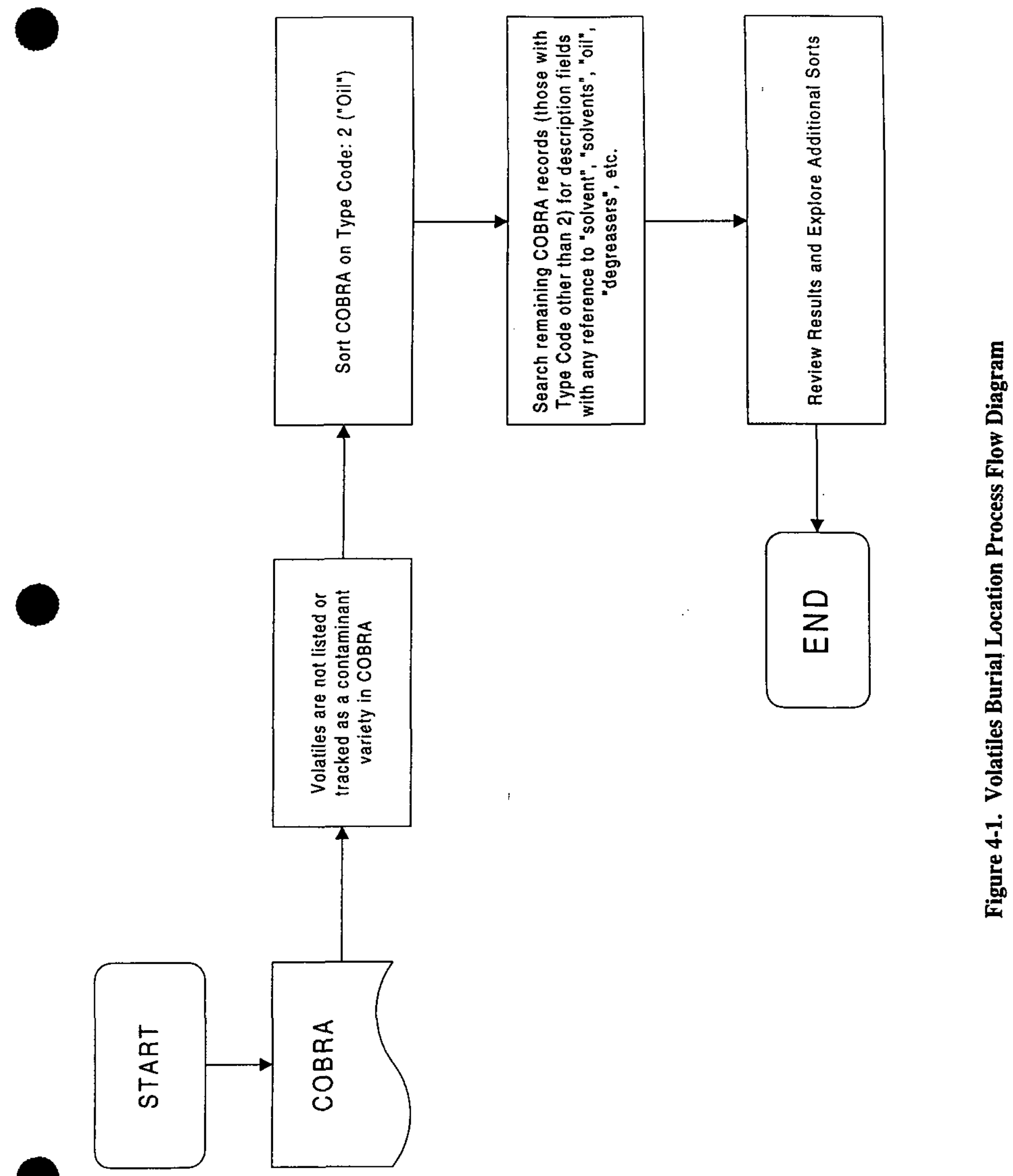


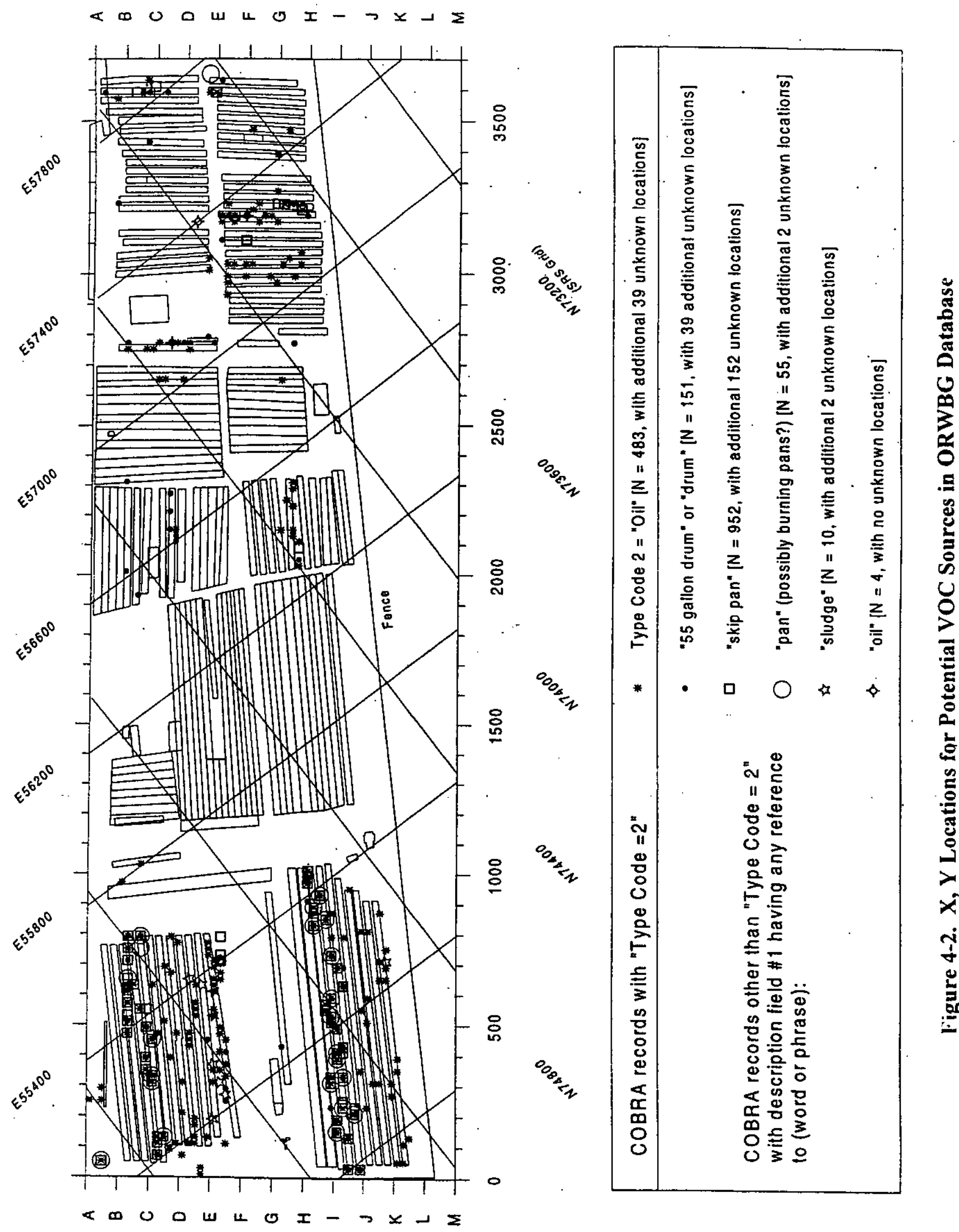

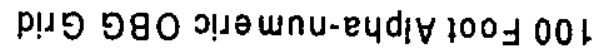


Table 2-1. Organics Buried or Stored in the 643-G Burial Ground (Sources: Hoeffner, 1984; Hoeffner and Oblath, 1984)

\begin{tabular}{|c|c|c|}
\hline SOURCE & SPECIFIC ORGANICS PRESENT & $\begin{array}{l}\text { ESTIMATED } \\
\text { INVENTORY IN 643-G } \\
\text { (GALLONS) }\end{array}$ \\
\hline Spent solvent ${ }^{*}$ & $\begin{array}{l}\text { Kerosene, n-paraffin, ultrasene, tri-n- } \\
\text { butyl phosphate }\end{array}$ & 150,000 (now in $643-7 \mathrm{G}$ ) \\
\hline $\begin{array}{l}\text { Liquid scintillation } \\
\text { solutions }\end{array}$ & $\begin{array}{l}\text { Photo-fluoric compounds, surfactants, } \\
\text { and solvents such as trimethylbenzene, } \\
\text { xylene, toluene, benzene, and dioxane. } \\
\text { Prior to } 1978 \text {, the solvent was } 10 \% \\
\text { naphthalene and } 89 \% \text { dioxane. }\end{array}$ & $\begin{array}{l}\text { 10,000 (September 18, } \\
\text { 1984, DPST-84-738, } \\
\text { Hoeffner, 1984) } \\
\text { 11,000 (November 14, } \\
\text { 1984, DPST-84-796, } \\
\text { Hoeffner and Oblath, } \\
\text { 1984) }\end{array}$ \\
\hline $\begin{array}{l}\text { Pump oils, cutting } \\
\text { oils, die oils }\end{array}$ & Branched hydrocarbons (e.g. C-34) & $3,300 \mathrm{gal} / \mathrm{yr}$ \\
\hline $\begin{array}{l}\text { Decontamination } \\
\text { operations }\end{array}$ & $\begin{array}{l}\text { EDTA, phosphate detergents, oxalic } \\
\text { acid }\end{array}$ & unknown \\
\hline
\end{tabular}

* 150,000 gallons will be burned in the beta-gamma incinerator. About 600 gallons have been inadvertently released from the $643-\mathrm{G}$ solvent storage tanks to the soil. 
Table 2-2. Possible Degradation Products (Hoeffner, 1984)

Possible TBP Degradation Products:

\author{
Major \\ Dibutyl phosphoric acid \\ Monobutyl phosphoric acid \\ Butyl alcohol \\ Nitrobutane \\ Minor \\ Phosphoric acid \\ Peroxides \\ Unsaturated compounds \\ Organic nitrites and nitrates \\ Carbonyl compounds
}

Possible Solvent Degradation Products:
Alcohols, C-12 through C-15
Unsaturated alcohols, C-12 through C-14
Nitro alcohols
Nitro alkanes
Ketones
Carboxylic acids
Butyl esters
Hydroxamic acids
Nitrate esters
Nitroso compounds
Alkenes
Polymeric carboxylic acids 
Table 2-3. OST Information. Different historical documents record slightly different tank dimensions. Mason (1996) used a photogrammetric survey to resolve several of these inconsistencies. (Sources:WSRC, 1994 and Mason, 1996)

\begin{tabular}{||c|r|r|r|c||}
\hline \multirow{2}{*}{ Tank } & \multicolumn{2}{|c|}{ Dimensions (ft) } & \multicolumn{1}{c|}{} \\
\cline { 2 - 3 } & Diameter & Length & Capacity (gal) & Year installed \\
\hline 1 & 8.0 & 26.75 & $10,059.0$ & 1955 \\
\hline 2 & 8.0 & 26.75 & $10,059.0$ & 1955 \\
\hline 3 & 8.0 & 26.75 & $10,059.0$ & 1955 \\
\hline 4 & 8.0 & 14.0 & $5,264.5$ & 1955 \\
\hline 5 & 10.5 & 38.5 & $24,939.6$ & 1955 \\
\hline 6 & 10.5 & 38.5 & $24,939.6$ & 1956 \\
\hline 7 & 8.5 & 18.0 & $7,641.2$ & 1956 \\
\hline 8 & 8.5 & 18.0 & $7,641.2$ & 1956 \\
\hline 9 & 8.0 & 20.0 & $7,520.7$ & 1959 \\
\hline 10 & 8.0 & 20.0 & $7,520.7$ & 1959 \\
\hline 11 & 8.0 & 20.0 & $7,520.7$ & 1959 \\
\hline 12 & 8.0 & 20.0 & $7,520.7$ & 1959 \\
\hline 13 & 10.0 & 23.0 & $13,513.8$ & 1960 \\
\hline 14 & 11.0 & 38.0 & $27,015.8$ & 1960 \\
\hline 15 & 7.5 & 32.0 & $10,576.0$ & 1961 \\
\hline 16 & 7.5 & 32.0 & $10,576.0$ & 1961 \\
\hline 17 & 8.0 & 18.0 & $6,768.7$ & 1962 \\
\hline 18 & 8.0 & 18.0 & $6,768.7$ & 1962 \\
\hline 19 & 10.5 & 38.5 & $24,939.6$ & 1968 \\
\hline 20 & 10.5 & 38.5 & $24,939.6$ & 1968 \\
\hline 21 & 10.5 & 38.5 & $24,939.6$ & 1968 \\
\hline 22 & 10.5 & 38.5 & $24,939.6$ & 1968 \\
\hline
\end{tabular}


Table 2-4. OST Inventory in 1968. This unsigned, undated inventory was originally believed to have been generated in 1968, based on the presence of 350 gallons of waste in Tank 17, which was retired as a "leaker" in October 1968. Most of this solvent was burned or relocated in the New Burial Ground (Denard 1975; in Mason, 1996)

\begin{tabular}{||c|c|c||}
\hline \multirow{2}{*}{ TANK } & \multicolumn{2}{|c|}{ VOLUME STORED IN 1968 (GAL) } \\
\cline { 2 - 3 } & ORGANIC & AQUEOUS \\
\hline 1 & & $\mathbf{1 , 8 0 0}$ \\
\hline 2 & $\mathbf{6 , 1 0 0}$ & 800 \\
\hline 3 & $\mathbf{8 , 0 2 5}$ & 900 \\
\hline 4 & $\mathbf{8 , 4 0 0}$ & $\mathbf{2 7 5}$ \\
\hline 5 & $\mathbf{2 7 5}$ & $\mathbf{1 , 2 2 0}$ \\
\hline 6 & $\mathbf{9 , 7 8 0}$ & 3,550 \\
\hline 7 & $\mathbf{1 9 , 3 5 0}$ & 375 \\
\hline 8 & $\mathbf{2 , 0 7 5}$ & \multicolumn{2}{|c||}{ Contains no liquid } \\
\hline 9 & $\mathbf{4 , 1 3 5}$ & 1,490 \\
\hline 10 & $\mathbf{1 , 3 6 5}$ & 215 \\
\hline 11 & $\mathbf{6 , 1 9 0}$ & 850 \\
\hline 12 & $\mathbf{5 , 0 2 5}$ & 465 \\
\hline 13 & $\mathbf{1 1 , 5 0 0}$ & 800 \\
\hline 14 & $\mathbf{2 2 , 7 0 0}$ & $\mathbf{1 , 7 0 0}$ \\
\hline 15 & $\mathbf{7 , 5 5 0}$ & 1,500 \\
\hline 16 & $\mathbf{2 , 0 0 0}$ & 2,900 \\
\hline 17 & $\mathbf{1 0 0}$ & 250 \\
\hline 18 & $\mathbf{9 6 5}$ & 100 \\
\hline 19 & $\mathbf{1 9 , 5 0 0}$ & 3,050 \\
\hline 20 & $\mathbf{7 , 9 0 0}$ & 2,750 \\
\hline 21 & $\mathbf{3 , 1 0 0}$ & 450 \\
\hline 22 & $\mathbf{2 , 9 0 0}$ & 200 \\
\hline Total & $\mathbf{1 4 8 , 9 3 5}$ & 26,240 \\
\hline & & \\
\hline
\end{tabular}


Table 2-5. Vapor Phase VOC Analytical Results (ppbv) from Solvent Tanks S1-S22 in ORWBG (Crump 1-27-95 in Mason, 1996)

\begin{tabular}{|c|c|c|c|c|c|c|c|}
\hline Tank & Acetone & Benzene & MEK & MBK & PCE & Other & Other Constituents \\
\hline S1 & - & - & $\overrightarrow{--}$ & $\overline{--}$ & - & -- & \\
\hline S2 & -- & 200 & 37 & -- & 6.6 & 31 & other alkyl oxygenates \\
\hline S3 & -- & - & -- & -- & - & 15 & alkyl hydrocarbons \\
\hline S4 & - & - & -- & - & -- & 8.5 & alkyl hydrocarbons \\
\hline S5 & 6.6 & 8.8 & - & -- & 4.4 & -- & \\
\hline S6 & - & - & - & -- & -- & 34 & alkyl hydrocarbons \\
\hline S7 & -- & -- & -- & -- & -- & - & \\
\hline S8 & -- & - & -- & -- & - & -- & \\
\hline S9 & -- & - & 35 & -- & 4.4 & -- & \\
\hline S10 & -- & 110 & - & -- & 6.4 & -- & \\
\hline S11 & - & - & -- & -- & -- & -- & \\
\hline $\mathrm{S} 12$ & -- & - & -- & -- & 4.4 & - & \\
\hline $\mathrm{S} 13$ & 140 & 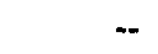 & 9.5 & -- & 4.4 & 16 & other alkyl oxygenates \\
\hline S14 & -- & - & - & -- & 4.4 & 32 & alkyl hydrocarbons \\
\hline \multirow[t]{7}{*}{ S15 } & 1100 & 4.4 & -- & 140 & 4.4 & 140 & butanol \\
\hline & & & & & & $\begin{array}{l}43 \\
23\end{array}$ & $\begin{array}{l}\text { 3-methyl-2-butanone } \\
\text { cyclopentanol }\end{array}$ \\
\hline & & & & & & 25 & 5-methyl-2-heptanone \\
\hline & & & & & & 68 & undecane \\
\hline & & & & & & 63 & 3-methyl-undecane \\
\hline & & & & & & 98 & tetradecane \\
\hline & & & & & & 23 & alkyl hydrocarbons \\
\hline S16 & -- & 18 & - & - & 4.4 & 82 & alkyl hydrocarbons \\
\hline$\$ 17$ & -- & 200 & 32 & 6.6 & 6.6 & 13 & other alkyl oxygenates \\
\hline S18 & - & 84 & 51 & 6.6 & -- & $\begin{array}{l}14 \\
88\end{array}$ & $\begin{array}{l}\text { xylenes } \\
\text { alkyl hydrocarbons }\end{array}$ \\
\hline \multirow[t]{10}{*}{ S19 } & 1500 & - & 2100 & 470 & -- & 79 & butanal \\
\hline & & & & & & 55 & 3-methyl-2,5-pentanediol \\
\hline & & & & & & 95 & 2-pentanone \\
\hline & & & & & & 30 & cyclopentanol \\
\hline & & & & & & 48 & 4-hydrocy-5-methyl-3-propyl-2-hexanone \\
\hline & & & & & & 26 & hexanal \\
\hline & & & & & & 29 & di-n-butylether \\
\hline & & & & & & 38 & 2-heptanone \\
\hline & & & & & & 31 & 3-methyl-2-heptanone \\
\hline & & & & & & 35 & undecane \\
\hline \multirow[t]{3}{*}{$\mathbf{S} 20$} & 51 & - & -- & -- & - & 24 & n-butanol \\
\hline & & & & & & 90 & tetradecane \\
\hline & & & & & & 112 & alkyl hydrocarbons \\
\hline S21 & 62 & - & - & - & -- & 52 & alkyl hydrocarbons \\
\hline S22 & - & - & 73 & - & - & 140 & alkyl hydrocarbons \\
\hline$\overline{\mathrm{MBI}}$ & tec & & & & & $\begin{array}{l}\text { met } \\
\text { erch }\end{array}$ & $\begin{array}{l}\text { hyl ethyl ketone (2-buta } \\
\text { loroethene (tetrachloroe }\end{array}$ \\
\hline
\end{tabular}


Table 2-6. VOC TCLP Chemical Analyses for Organic and Aqueous Samples from Tanks S23-S30 and the Waste Trailer (Young 1992; in Mason, 1996). The solvents stored in these tanks are similar to the solvents stored in the OSTs.

\begin{tabular}{|l|r|r|r|r|r|r|r|r|r|}
\hline \multicolumn{1}{|c|}{ Constituent } & $\begin{array}{r}\text { Reg. } \\
\text { limits }\end{array}$ & Units & Trailer & S-23 & S-26 & S-27 & S-28 & S-29 & S-30 \\
\hline Benzene & 500 & $\mathrm{ppb}$ & $<$ TCLP & $<50$ & $<5$ & 1,300 & 7 & 280 & $<5$ \\
\hline $\begin{array}{l}\text { Carbon } \\
\text { tetrachloride }\end{array}$ & 500 & $\mathrm{ppb}$ & $<50$ & $<50$ & $<5$ & $<50$ & $<5$ & $<25$ & $<5$ \\
\hline Chlorobenzene & 100,000 & $\mathrm{ppb}$ & $<50$ & $<50$ & $<5$ & $<50$ & $<5$ & $<25$ & $<5$ \\
\hline Chloroform & 6,000 & $\mathrm{ppb}$ & $42^{\mathrm{j}}$ & $<50$ & $<5$ & 510 & $<5$ & 60 & $<5$ \\
\hline 1,2-Dichloroethane & 500 & $\mathrm{ppb}$ & $<50$ & $<50$ & $<5$ & $<50$ & $<5$ & $<25$ & $<5$ \\
\hline 1,1-Dichloroethene & 700 & $\mathrm{ppb}$ & $<50$ & $<50$ & $<5$ & $<50$ & $<5$ & $<25$ & $<5$ \\
\hline MEK & 200,000 & $\mathrm{ppb}$ & 16,350 & $<500$ & 3,445 & 11,000 & 9,300 & 250 & $<100$ \\
\hline PCE & 700 & $\mathrm{ppb}$ & $<50$ & 475 & $<5$ & $<50$ & $<5$ & $<25$ & $<5$ \\
\hline TCE & 500 & $\mathrm{ppb}$ & $<50$ & 650 & $<5$ & $<50$ & $<5$ & $<25$ & $<5$ \\
\hline Vinyl chloride & 200 & $\mathrm{ppb}$ & $<50$ & $<50$ & $<5$ & $<50$ & $<5$ & $<25$ & $<5$ \\
\hline
\end{tabular}

\begin{tabular}{|l|r|r|r|r|r|r|r|r|r|}
\hline \multicolumn{10}{|c|}{ Aqueous Phase } \\
\hline Constituent & $\begin{array}{r}\text { Reg. } \\
\text { limits }\end{array}$ & Units & Trailer & S-23 & S-26 & S-27 & S-28 & S-29 & S-30 \\
\hline Benzene & 500 & $\mathrm{ppb}$ & -- & 34 & & & & & \\
\hline Carbon tetrachloride & 500 & $\mathrm{ppb}$ & $<50$ & $<5$ & & & & & \\
\hline Chlorobenzene & 100,000 & $\mathrm{ppb}$ & $<50$ & $<5$ & & & & & \\
\hline Chloroform & 6,000 & $\mathrm{ppb}$ & $<50$ & $<5$ & & & & & \\
\hline 1,2-Dichloroethane & 500 & $\mathrm{ppb}$ & $<50$ & $<5$ & & & & & \\
\hline 1,1 -Dichloroethene & 700 & $\mathrm{ppb}$ & $<50$ & $<5$ & & & & & \\
\hline MEK & 200,000 & $\mathrm{ppb}$ & 9,300 & 9,700 & & & & & \\
\hline PCE & 700 & $\mathrm{ppb}$ & $<50$ & 50 & & & & & \\
\hline TCE & 500 & $\mathrm{ppb}$ & $<50$ & 77 & & & & & \\
\hline Vinyl chloride & 200 & $\mathrm{ppb}$ & $<50$ & $<5$ & & & & & \\
\hline
\end{tabular}

j sample below reporting limit, but detected at level indicated 


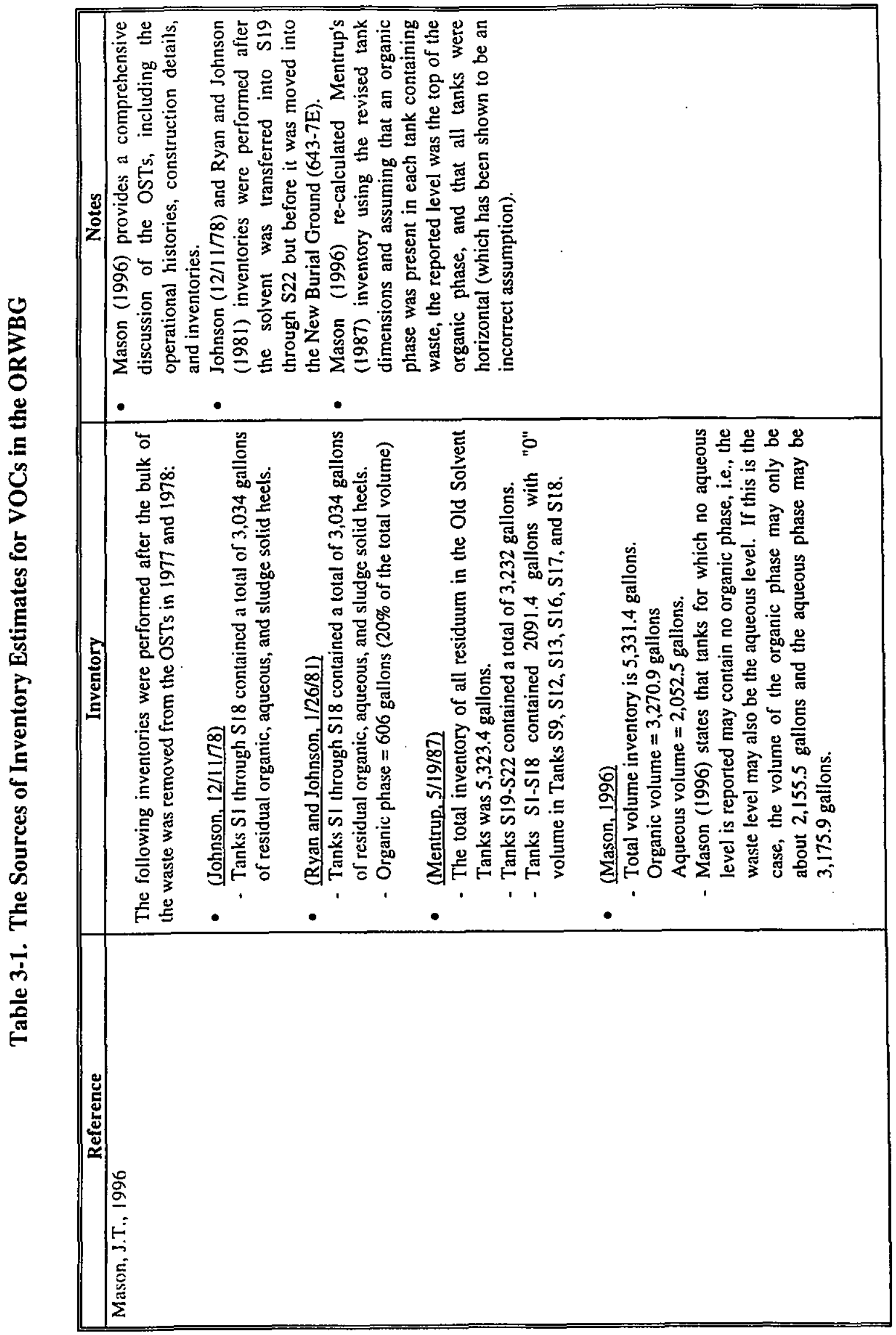




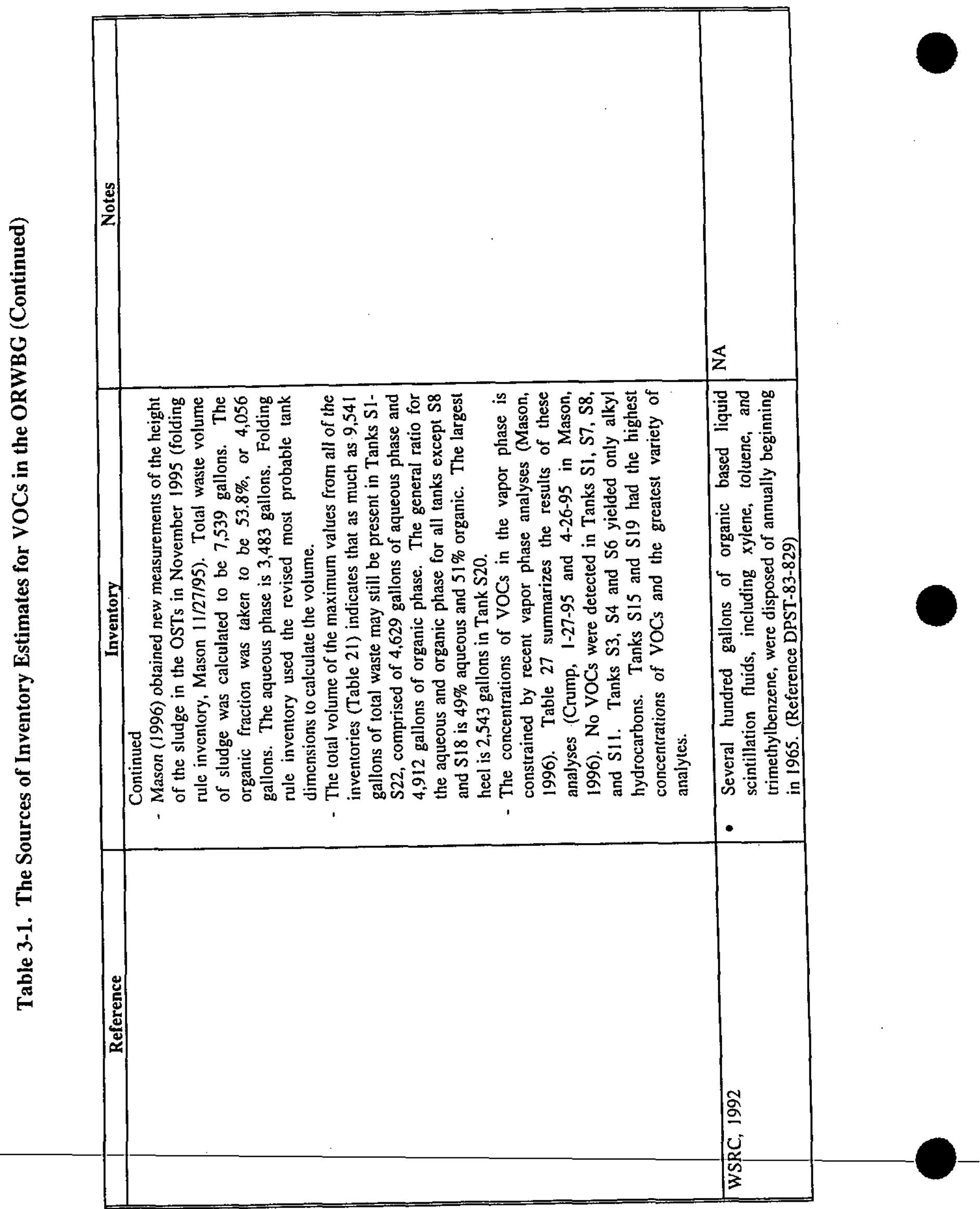




\section{Table 3-1. The Sources of Inventory Estimates for VOCs in the ORWBG (Continued)}

\begin{tabular}{|c|c|c|}
\hline Reference & Inventory & Notes \\
\hline Hoeffner, S.L. and Oblath S.B., 1984 & $\begin{array}{l}\text { Organics buried or stored in the 643-G Burial Ground } \\
\text { are shown on a table (see Table 2-1 in text). } \\
\text { (References Christensen and Gordon, (eds.) 1983). }\end{array}$ & $\begin{array}{l}\text { Most of this organic waste is spent solvent and } \\
\text { liquid scintillation waste. Other possible } \\
\text { sources are waste oils and equipment } \\
\text { decontamination solvents. The spent solvent } \\
\text { consists of TBP, a diluent such as n-paraffin, } \\
\text { and minor amounts of many TBP and diluent } \\
\text { degradation products. Spent solvent was stored } \\
\text { in underground tanks at the } 643-\mathrm{G} \text { burial } \\
\text { ground from } 1955 \text { through } 1982 \text {. Occasional } \\
\text { solvent spills and leaks amounting to about } 600 \\
\text { gallons occurred during this time (Reference } \\
\text { Wilhite, 1975). }\end{array}$ \\
\hline Hoefiner, S.L., 1984 & $\begin{array}{l}\text { Organics Buried or stored in the 643-G Burial Ground } \\
\text { is shown on a table (see Table } 2-1 \text { in text). } \\
\text { (References Christensen and Gordon, 1983). }\end{array}$ & $\begin{array}{l}\text { The majority of the organic waste is spent } \\
\text { solvent and liquid scintillation waste. Spent } \\
\text { solvent was stored in underground tanks at the } \\
643-G \text { burial ground beginning in } 1955 \text {. From } \\
1956 \text { to } 1972 \text {, about } 370,000 \text { gallons of this } \\
\text { spent solvent were burned in a large open pan. } \\
\text { The pan and resulting waste residue were } \\
\text { buried after the pan's useful lifetime, resulting } \\
\text { in contamination of the burial ground soil } \\
\text { (References DP-942). The soil is also known } \\
\text { to be contaminated with about } 600 \text { gallons of } \\
\text { organics from spent solvent spills and leaks } \\
\text { from the underground storage tanks (Reference } \\
\text { DPST-75-377). }\end{array}$ \\
\hline Cook, James R, 1987 & $\begin{array}{l}\text { Cook (1987) cites the following mass of hazardous } \\
\text { materials buried in } 643-\mathrm{G} \text { : } \\
\text { Toluene } 7,100 \mathrm{~kg} \\
\text { Tributylphosphate (TBP) } 720 \mathrm{~kg} \\
\text { Trimethylbenzene } 7,100 \mathrm{~kg} \\
\text { Xylene } 12,000 \mathrm{~kg} \\
\text { (does not reference an earlier article) }\end{array}$ & $\mathrm{NA}$ \\
\hline
\end{tabular}


Table 3-1. The Sources of Inventory Estimates for VOCs in the ORWBG (Continued)

\begin{tabular}{|c|c|c|}
\hline Reference & Inventory & Notes \\
\hline Thatin, D.W. Jr., 1965 & $\begin{array}{l}\text { - Spent solvent from radiochemical separations processes } \\
\text { is accumulated and burned in burial ground facilities. } \\
\text { Between mid-1955 and February 1964,290,000 gallons } \\
\text { were stored or burned with negligible release of } \\
\text { radionuclides. } \\
\text { (does not reference an earlier article.) }\end{array}$ & NA \\
\hline
\end{tabular}

: Inventory discussed in detail

b: No discussion of basis for inventory

NA: Not addressed in article 
Table 3-2. Comparison of Historical Inventories Reported by Johnson (1978), Ryan and Johnson (1981), and Mentrup (1987) with the "folding rule" inventory (Mason, 1995), Using Corrected Tank Dimensions and Volumes

\begin{tabular}{|c|c|c|c|c|c|c|c|c|c|}
\hline \multirow[b]{3}{*}{ TANK } & \multirow{3}{*}{$\begin{array}{c}\text { Johnson } \\
12 / 11 / 78 \\
\\
\text { Total } \\
\text { volume } \\
\text { (gal) } \\
\end{array}$} & \multirow{2}{*}{\multicolumn{2}{|c|}{$\begin{array}{c}\text { Ryan \& Johnson } \\
1 / 26 / 81\end{array}$}} & \multirow{2}{*}{\multicolumn{2}{|c|}{ Mentrup 5/19/87 }} & \multicolumn{4}{|c|}{ Mason (1996) } \\
\hline & & & & & & \multicolumn{2}{|c|}{$\begin{array}{c}\text { Revised Mentrup } \\
5 / 19 / 87 \\
\end{array}$} & \multicolumn{2}{|c|}{$\begin{array}{c}\text { "folding rule" } \\
\text { inventory }\end{array}$} \\
\hline & & $\begin{array}{c}\begin{array}{c}\text { Total } \\
\text { volume } \\
\text { (gal) }\end{array} \\
\end{array}$ & $\begin{array}{l}\text { Aqueous } \\
\text { (gal) }\end{array}$ & $\begin{array}{l}\text { Total } \\
\text { (gal) }\end{array}$ & $\begin{array}{l}\text { Aqueous } \\
\text { (gal) }\end{array}$ & $\begin{array}{l}\text { Calcd } \\
\text { DPSOP } \\
138-6 \\
\text { (gal) } \\
\end{array}$ & $\begin{array}{l}\text { Calc } \\
\text { Organic by } \\
\text { difference } \\
\text { (gal) } \\
\end{array}$ & $\begin{array}{c}\text { Total } \\
\text { Waste } \\
\text { Volume } \\
\text { (gal) }\end{array}$ & $\begin{array}{l}\text { Aqueous } \\
\text { Volume } \\
\text { (gal) }\end{array}$ \\
\hline 1 & 19 & 19 & 14 & 77 & & 85.5 & 77 & 51 & 51 \\
\hline 2 & 28 & 28 & 27 & 67 & & 67.5 & 67 & 143 & 143 \\
\hline 3 & 76 & 76 & 65 & 152 & 99 & 152.0 & 53 & 328 & 328 \\
\hline 4 & 146 & 146 & 124 & 217 & & 217.0 & 217 & 137 & 0 \\
\hline 5 & 118 & 118 & 112 & 139 & & 139.2 & 139 & 330 & 330 \\
\hline 6 & 489 & 489 & 416 & 557 & 545 & 556.8 & 12 & 923 & 923 \\
\hline 7 & 204 & 204 & 173 & 267 & 181 & 267.2 & 86 & 444 & 444 \\
\hline 8 & "0" & \begin{tabular}{r|} 
suspended \\
$3 / 67$ \\
\end{tabular} & $\begin{array}{r}\text { suspended } \\
3 / 67 \\
\end{array}$ & 71 & & 71.0 & 71 & 181 & 181 \\
\hline 9 & 88 & 88 & 64 & 0 & & 0 & 0 & 13 & 0 \\
\hline 10 & 54 & 54 & 39 & 13 & & 13 & 13 & 53 & 53 \\
\hline 11 & 38 & 38 & 36 & 10.4 & & 10.4 & 10.4 & 6 & 0 \\
\hline 12 & 88 & 88 & 64 & 0 & & 0 & 0 & 6 & 0 \\
\hline 13 & 317 & 317 & 230 & 0 & & 0 & 0 & 89 & 89 \\
\hline 14 & 84 & 84 & 61 & 141 & & 140.8 & 141 & 0 & 0 \\
\hline 15 & 736 & 736 & 536 & 380 & & 380.0 & 380 & 231 & 0 \\
\hline 16 & 549 & 549 & 467 & 0 & & 0 & 0 & 15 & 15 \\
\hline 17 & "0" & $\begin{array}{r}\text { suspended } \\
2 / 68 \\
\end{array}$ & $\begin{array}{r}\text { suspended } \\
2 / 68 \\
\end{array}$ & 0 & & 0 & 0 & 0 & 0 \\
\hline 18 & "0" & - & - & 0 & & 0 & 0 & 60 & 60 \\
\hline 19 & & & & 856 & 726 & 856.0 & 130 & 1,357 & 237 \\
\hline 20 & & & & 1757 & 283.5 & 1756.5 & 1473.5 & 2,543 & 0 \\
\hline 21 & & & & 237 & 161.5 & 237 & 75.5 & 545 & 545 \\
\hline 22 & & & & 382 & 56.5 & 381.5 & 325.5 & 84 & 84 \\
\hline Total & 3,034 & 3,034 & 2,428 & 5323.4 & $2,052.5$ & $5,331.4$ & $3,270.9$ & 7,539 & 3,483 \\
\hline & & \multicolumn{2}{|c|}{$\begin{array}{c}80 \% \text { aqueous } \\
\text { organic: } 606 \mathrm{gal}\end{array}$} & \multicolumn{4}{|c|}{$\begin{array}{c}38.6 \% \text { aqueous } \\
\text { organic: } 3,270.9 \text { gal }\end{array}$} & \multicolumn{2}{|c|}{$\begin{array}{c}46.2 \% \text { Aqueous } \\
\text { organic: } 4,056 \mathrm{gal}\end{array}$} \\
\hline
\end{tabular}


Table 3-3. Comparison of Inventories by Mentrup (1987) with Mason's "Folding Rule" Inventory (Mason, 1996)

\begin{tabular}{|c|c|c|c|c|c|c|}
\hline \multirow[b]{2}{*}{ Tank } & \multicolumn{3}{|c|}{ Mentrup 5/19/87 } & \multicolumn{3}{|c|}{ Mason (1996) "Folding Rule" } \\
\hline & $\begin{array}{l}\text { Sludge Level } \\
\text { (inches) }\end{array}$ & $\begin{array}{l}\text { Aqueous } \\
\text { Level } \\
\text { (inches) }\end{array}$ & $\begin{array}{l}\text { Total Waste } \\
\text { (gal) }\end{array}$ & $\begin{array}{l}\text { Sludge Level } \\
\text { (inches) }\end{array}$ & $\begin{array}{l}\text { Aqueous } \\
\text { volume (gal) }\end{array}$ & $\begin{array}{l}\text { Total } \\
\text { Waste } \\
\text { (gal) } \\
\end{array}$ \\
\hline 1 & 2.7 & $\mathrm{nr}$ & 77 & 2 & 51 & 51 \\
\hline 2 & 2.3 & $\mathrm{nr}$ & 67 & 4 & 143 & 143 \\
\hline 3 & 4.0 & 3.0 & 152 & 7 & 328 & 328 \\
\hline 4 & 8.2 & $\mathrm{nr}$ & 217 & 6 & 0 & 137 \\
\hline 5 & 2.8 & $\mathrm{nr}$ & 139 & 5 & 330 & 330 \\
\hline 6 & 7.1 & 7.0 & 557 & 10 & 923 & 923 \\
\hline 7 & 7.8 & 6.0 & 267 & 11 & 444 & 444 \\
\hline 8 & 3.2 & $\mathrm{nr}$ & 71 & 6 & 181 & 181 \\
\hline 9 & 0 & 0 & 0 & 1 & 0 & 13 \\
\hline 10 & 1.0 & $\mathrm{nr}$ & 13 & 2.5 & 53 & 53 \\
\hline 11 & 0.8 & $\mathrm{nr}$ & 10.4 & 0.5 & 0 & 6 \\
\hline 12 & 0 & 0 & 0 & 0.5 & 0 & 6 \\
\hline 13 & 0 & 0 & 0 & 3 & 89 & 89 \\
\hline 14 & 2.8 & $\mathrm{nr}$ & 141 & 0 & 0 & 0 \\
\hline 15 & 7.0 & $\mathrm{nr}$ & 380 & 5 & 0 & 231 \\
\hline 16 & 0 & 0 & 0 & 0.75 & 15 & 15 \\
\hline 17 & 0 & 0 & 0 & 0 & 0 & 0 \\
\hline 18 & 0 & 0 & 0 & 3 & 60 & 60 \\
\hline 19 & 9.5 & 8.5 & 856 & 13 & 237 & 1357 \\
\hline 20 & 15.5 & 4.5 & 1,757 & 20 & 0 & 2543 \\
\hline 21 & 4.0 & 3.1 & 237 & 7 & 545 & 545 \\
\hline 22 & 5.5 & 1.5 & 382 & 2 & 84 & 84 \\
\hline Total & & & $5,323.4$ & & 3,483 & 7539 \\
\hline
\end{tabular}

$38.6 \%$ Aqueous

Organic 3,270.9 gal 
Table 3-4. Maximum Total Volume, Aqueous Volume, and Organic Volume from Inventories Reported by Ryan and Johnson (1981), Mentrup (1987), and Mason's (1996) "folding rule" inventory. In some cases that aqueous and organic volumes are calculated from the ratio of the 1-26-81 inventory. The aqueous-organic ratio for Tanks S8 and $S 18$ are based on the general ratio from the other tanks ( $49 \%$ aqueous- $51 \%$ organic)

\begin{tabular}{|c|c|c|c|c|}
\hline TANK & $\begin{array}{l}\text { INVENTORY DATE } \\
\text { OF MAXIMUM } \\
\text { VALUE }\end{array}$ & $\begin{array}{c}\text { MAXIMUM } \\
\text { TOTAL (GAL) }\end{array}$ & $\begin{array}{l}\text { MAXIMUM } \\
\text { AQUEOUS } \\
\text { (GAL) }\end{array}$ & $\begin{array}{l}\text { MAXIMUM } \\
\text { ORGANIC } \\
\text { (GAL) }\end{array}$ \\
\hline 1 & $5-19-87$ & 77 & 57 & 20 \\
\hline 2 & $11-27-95$ & 143 & 138 & 5 \\
\hline 3 & $11-27-95$ & 328 & 280 & 48 \\
\hline 4 & $5-19-87$ & 217 & 184 & 33 \\
\hline 5 & $11-27-95$ & 330 & 313 & 17 \\
\hline 6 & $11-27-95$ & 923 & 785 & 138 \\
\hline 7 & $11-27-95$ & 444 & 377 & 67 \\
\hline 8 & $11-27-95$ & 181 & 89 & 92 \\
\hline 9 & $1-26-81$ & 88 & 64 & 24 \\
\hline 10 & $1-26-81$ & 54 & 39 & 15 \\
\hline 11 & $1-26-81$ & 38 & 36 & 2 \\
\hline 12 & $1-26-81$ & 88 & 64 & 24 \\
\hline 13 & $1-26-81$ & 317 & 230 & 87 \\
\hline 14 & $5-19-87$ & 141 & 102 & 39 \\
\hline 15 & $1-26-81$ & 736 & 536 & 200 \\
\hline 16 & $1-26-81$ & 549 & 467 & 82 \\
\hline 17 & $11-27-95$ & 0 & 0 & 0 \\
\hline 18 & $11-27-95$ & 60 & 29 & 31 \\
\hline 19 & $11-27-95$ & 1,357 & 237 & 1,120 \\
\hline 20 & $11-27-95$ & 2,543 & 0 & 2,543 \\
\hline 21 & $11-27-95$ & 545 & 545 & 0 \\
\hline 22 & $5-19-87$ & 382 & 57 & 325 \\
\hline \multicolumn{2}{|c|}{ Maximum in OSTs } & 9,541 & 4,629 & 4,912 \\
\hline
\end{tabular}


(This page intentionally left blank) 
APPENDIX E

CONSTITUENT OF INTEREST:

TRITIUM 
(This page intentionally left blank) 


\section{TABLE OF CONTENTS}

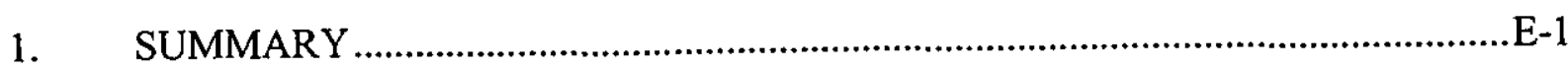

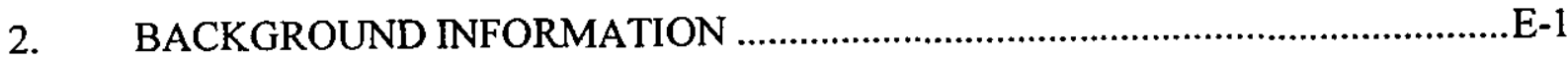

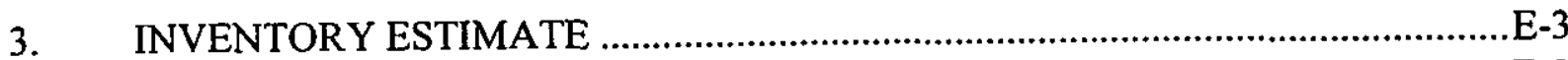

3.1 Range of Inventory Estimates ….............................................................

3.2 Best Estimate for Old Radioactive Waste Burial Ground Inventory .............E-4

3.3 Uncertainties Associated with the Best Estimate............................................

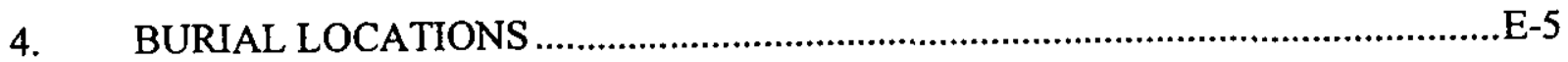

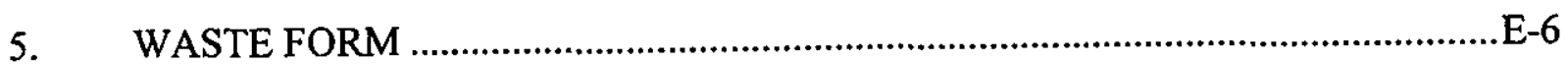

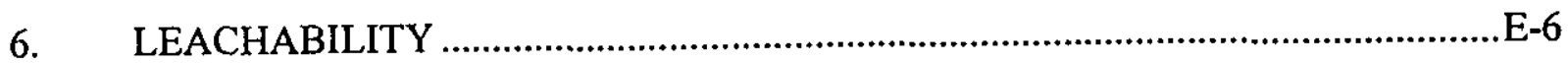

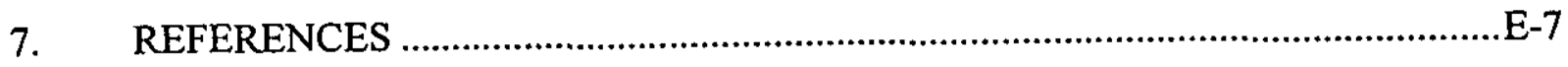




\section{LIST OF FIGURES}

Figure 1-1. Inventory Estimate Process Flow Diagram................................................

Figure 4-1. Tritium Burial Location Process Flow Diagram............................................ E-9

Figure 4-2. X, Y Locations for All ORWBG Tritium Burials [COBRA Variety of Contamination Code = 87] ....................................................................

Figure 4-3. X, Y Locations for All Offsite ORWBG Tritium Burials [COBRA Variety of Contamination Code = 87] ..................................................................

Figure 4-4. Known Spent Melt and Possible Spent Melt Locations in the ORWBG.....E-12

Figure 4-5. Pre-1967 Burials for Building 234-H .......................................................

\section{LIST OF TABLES}

Table 2-1. Revised Tritium Content Estimates ............................................................E-14

Table 3-1. The Sources of Inventory Estimates for Tritium in the ORWBG.................E-15

Table 3-2. Health Protection and COBRA Data - Tritium in the ORWBG ..................E-20

Table 3-3. Best Estimate of Tritium in ORWBG...................................................... 


\section{CONSTITUENT OF INTEREST - TRITIUM}

\section{SUMMARY}

The production of tritium has represented a primary mission at the Savannah River Site (SRS) since the mid-1950's. Tritium is a key component in nuclear weapons. Additionally, tritium used for research and commercial applications is produced at SRS.

It is estimated that the undecayed quantity of tritium disposed in the Old Radioactive Waste Burial Ground (ORWBG) is $3,014,457$ curies. The quantity decayed is 467,889 curies. This reflects radioactive decay to 1997 . The majority of the tritium originated from Tritium Facilities in H-Area at SRS (Buildings 232-H, 234-H, and 238-H). Additional quantities were shipped to SRS for disposal in the ORWBG from other Department of Energy (DOE) weapons-complex facilities.

The tritium was sent to the ORWBG in bulk waste (job control waste, waste oils and mercury, and used equipment and components), spent melts, and reactive beds (the latter two are byproducts of the tritium production process).

Figure 1-1 presents the process used to develop inventory and burial locations. The Computerized Burial Records Analysis (COBRA) database was used to determine the location of burials of tritium.

\section{BACKGROUND INFORMATION}

Tritium was produced in the five reactors at SRS. Lithium-aluminum targets were bombarded with neutrons in the reactor. The resulting reaction generated tritium. Since the mid-1950's, tritium has been processed in four buildings: $232-\mathrm{F}, 232-\mathrm{H}, 234-\mathrm{H}$, and $238-\mathrm{H}$ (Hyder, 1993). The bulk of the tritium was processed in the three H-Area buildings; 232-F operated only briefly in the late 1950's (Hyder, 1993). The individual building missions were:

232-F and 232-H: Recover tritium from irradiated targets

234-H: $\quad$ Purify, concentrate, and load tritium for offsite shipment

238-H: $\quad$ Recycle tritium

Tritium was sent to the ORWBG primarily in three forms: in bulk waste, as tritium in "spent melts", and in magnesium and other reactive beds. Bulk tritium waste shipments to the 
ORWBG included job control waste, waste oil, and discarded hardware, all contaminated with tritium.

The term "spent melts" refers to the lithium-aluminum alloy that remains after heating (melting) to remove most of the tritium. The alloy is processed in stainless steel crucibles. Not all of the tritium could be removed from the spent melts. Tritium remaining in the spent melts was shipped to the ORWBG. Processing techniques improved over time, so that less residual tritium remained in the spent melts. For many years, the crucibles containing spent melts were not packaged further. Subsequently, the crucibles were filled with an epoxy resin (Hyder, 1993).

Magnesium and other reactive beds were used to convert tritiated water to elemental tritium and to concentrate tritium.

Tritium produced at SRS was sent to other DOE weapons-complex facilities for incorporation into nuclear weapons. Periodically, these other facilities (primarily Mound Laboratory in Ohio and the Pinellas Plant in Florida) would ship tritium-containing wastes to SRS for disposal. These offsite waste shipments furnished a portion of the ORWBG source term. They are included in the COBRA database.

Certain trenches in the ORWBG are designated as "Special Projects 234". These trenches include tritium burials, from both onsite and offsite sources.

Tritium occurs in at least three other SRS waste streams:

- Waste streams from laboratories using tritium in research.

- Waste streams from reactor facilities. Tritium is produced in two ways in SRS reactors other than through bombarding lithium-aluminum targets. One way is the activation (absorbing of a neutron) of deuterium. SRS reactors are moderated with heavy water, water that has deuterium atoms $\left({ }^{2} \mathrm{H}\right)$ instead of hydrogen $\left({ }^{1} \mathrm{H}\right)$. When deuterium absorbs a neutron, it becomes tritium. However, relatively small quantities of tritium are produced in this manner because of the low cross-section and, therefore, the low probability for the neutron capture by deuterium. Contamination of the moderator by tritium also occurred by leaking target and fuel elements. The second way is as a fission product. Generally, when uranium fissions, two fragments are formed. Occasionally, three fission fragments are produced. This tertiary fission product is often tritium.

- Waste streams from separations. Tritium as a tertiary fission product can enter the separations waste stream. 
The quantity of tritium from these three sources, with the exception of some laboratory waste streams, represents a very small fraction of the tritium at the ORWBG. Virtually all of the tritium sent to the ORWBG is from tritium processing and offsite shipments.

In general, the estimated tritium quantities in waste sent to the ORWBG are from two sources: Health Protection (HP) data for the ORWBG for the years 1953 through 1964 and the COBRA database for the years $1961^{*}$ through 1972 . The differences in the two databases are discussed in Section 3.1, below. The estimates in these two databases are based on assumed tritium quantities in specific waste forms. These quantities were determined by analysis of waste form samples. Table 2-1 presents the quantity estimates used for the waste types.

The information document for the Old Solvent Tanks (OSTs) suggest that tritium is not a major constituent in the waste sludge in the tanks (Mason, 1996). Tritium is not reported as a radioactive constituent in the sludge (Mason, 1996).

\section{INVENTORY ESTIMATE}

\subsection{Range of Inventory Estimates}

The range of tritium estimates are consistent throughout the SRS technical literature. These estimates are based on the two previously mentioned information sources: HP data and COBRA. Table 3-1 presents the SRS literature reviewed to estimate the tritium quantities in the ORWBG.

The HP and COBRA databases used different bases for estimating tritium in specific waste forms. The HP estimates are based on a set of analyses in 1960. From the late 1960's to early 1970's, the tritium content in each waste type was re-examined. In all but one case, the new tritium quantity estimates are lower than or equal to the HP data. The revised results based on these series of analyses were incorporated into COBRA. All of the COBRA data were revised to reflect the newer estimates (Earle and Jacober, 1973).

Table 3-2 presents the HP and revised COBRA data. Note that the HP data shows the total disposed of in the 50's was 2,000,000 curies (Ashley, 1960). There are only two COBRA records listing tritium as a contaminant from the start of operations through 1960 (one record in 1957 and one in 1958, totaling 17,745 curies). These two entries are considered to

- COBRA contains few records prior to 1961. Input of quantitative data into COBRA began then. 
represent a small fraction of the total tritium input to ORWBG for these years, and more representative yearly estimates will be used for the COBRA source term estimation.

\subsection{Best Estimate for Old Radioactive Waste Burial Ground Inventory}

The best estimate for tritium quantities in the ORWBG is based on the revised estimates for tritium quantities in each waste form. The following steps were taken to determine the best estimate for the tritium in the ORWBG:

1. Distribute evenly the $2,000,000$ curies estimated by the HP data for "through 1959 " for the years 1953 to 1959 . In other words, for each of these seven years, it is assumed that 285,714 curies was disposed.

2. Determine the ratio of HP estimate to COBRA estimate for years $1961,1962,1963$, and 1964. For these four years, the ratios are $2.35,2.28,2.28$, and 2.88 , respectively. The average ratio is 2.45 .

3. Divide the HP estimate by 2.45 and assign this value as a "COBRA" value for years 1953 through 1960, when there is no COBRA data.

4. Decay-correct the COBRA tritium estimates to 1997.

The values for the HP and COBRA estimates are in Table 3-3. The sum of the decaycorrected values, which are based on the actual (1961-1972) and derived (1953-1960) COBRA data, represents the best estimate for tritium quantities in the ORWBG.

The OSTs are assumed to contain no tritium. Solvent stored was used in separating uranium and plutonium from fission products. Most of the tertiary fission product tritium encountered by the spent solvent in processing would remain in the aqueous phase. Very little would distribute into the organic solvent.

\subsection{Uncertainties Associated with the Best Estimate}

One major uncertainty associated with the tritium estimate is produced by assuming constant quantities of tritium in a given waste form (Table 2-1 values). Variation in these quantities, which is certain to have occurred, would result in an error in the estimate. However, it is assumed that the number and magnitude of positive errors is essentially equal to those of the negative errors, that is, the distribution is gaussian around a mean value.

A second major uncertainty arises from tritium migration from the ORWBG. Since there is no correction for such unknown loss, the best estimate is a conservative approximation of the tritium source term in the ORWBG today. 


\section{BURIAL LOCATIONS}

The COBRA database provides both quantity and location estimates for tritium burials in the ORWBG. Figure 4-1 outlines the steps taken to manipulate the database to locate tritium burials.

Figure 4-2 presents the spatial distribution of all tritium burials in the ORWBG.

The data presented in Figure 4-2 have been divided into two sets. Burial locations indicated with circles are for those burials where tritium was "Variety of Contamination 1". Burial locations indicated with squares are for those burials where tritium was "Variety of Contamination 2". COBRA includes two fields for contamination, variety 1 and variety 2 . Variety of contamination 1 is the main source of contamination; the waste generator could indicate a second type of contamination as variety 2 . There is no significance to assigning the tritium variety 1 versus variety 2 .

The data in Figure 4-2 also indicate the relative quantity of each burial. The larger the symbol, the larger the curie content of the burial.

Figure 4-3 presents the burial locations of offsite shipments received at the ORWBG. Figure 4-4 shows the locations of spent melt burials. These locations are in good agreement with comparable published burial locations (Hyder, 1993). These data are a subset of Figure 4-2 (i.e., the offsite and spent melt data shown in Figure 4-3 and in Figure 4-4, respectively, are also included in Figure 4-2).

Figure 4-5 shows the locations of tritium burials prior to 1967. This figure confirms that the burials in the "Special Projects 234 trenches" are included in the COBRA database (the "Special Projects 234 trenches" include the first long trench oriented left to right on the figure in the upper left of the figure and the furthest left trench oriented top to bottom on the figure).

Prior to 1961, tritium was likely disposed in low-activity beta-gamma trenches. One specific trench containing pre-1961 spent melts may be the trench indicated as "ingots". 


\section{WASTE FORM}

As discussed in Section 2, tritium was sent to the ORWBG as a variety of waste forms. The tritium sent as bulk tritium is assumed to be readily available for transport downward and outward by intrusive water.

One waste form that might inhibit tritium migration in water is spent melt. The majority of the tritium in spent melt is inaccessible to water. The melt essentially encapsulates the tritium in aluminum (Hyder, 1993). Tests have shown that the portion of tritium located within the bulk of the spent melt only slowly diffuses outward. Therefore, it is less available to infiltrating water than tritium that is located on the surface or near-surface of the spent melt. Since its availability for migration is reduced, decay of this innermost source term will remove a significant quantity of tritium that could otherwise migrate to groundwater.

\section{LEACHABILITY}

There are no geochemical controls on the leachability of tritium. Waste form, waste packaging, and rate of water infiltration control the rate at which tritium is released from the ORWBG. Tritium disposed in bulk waste was very susceptible to leaching and, for the most part, has been released to infiltrating waters. Tritium that is bound in waste forms (e.g., some tritium in spent melts) will probably decay within those forms with a minimum of leaching. In 1985, Stone et al. (1985) suggested that most of the tritium in ORWBG had already leached and continued leaching of tritium from waste forms should be negligible. Therefore, a leaching rate for tritium is not calculated here. 


\section{REFERENCES}

Ashley, C., 1960. SRP Radioactive Waste Release, Startup through 1959, DPSP-60-25-25, E.I. du Pont de Nemours and Company, Aiken, SC, September 1960.

Ashley, C., 1962a. 1960 Audit of SRP Radioactive Waste, DPSP-62-25-1, E.I. du Pont de Nemours and Company, Aiken, SC, February 1962.

Ashley, C., 1962b. 1961 Audit of SRP Radioactive Waste, DPSP-62-25-5, E.I. du Pont de Nemours and Company, Aiken, SC, September 1962.

Ashley, C., 1963. 1962 Audit of SRP Radioactive Waste, DPSP-63-25-1, E.I. du Pont de Nemours and Company, Aiken, SC, May 1963.

Ashley, C., 1964. 1963 Audit of SRP Radioactive Waste, DPSP-64-25-1, E.I. du Pont de Nemours and Company, Aiken, SC, May 1964.

Ashley, C., 1965. 1964 Audit of SRP Radioactive Waste, DPSP-65-25-1, E.I. du Pont de Nemours and Company, Aiken, SC, April 1965.

DuPont, 1975. Storage of Solid Radioactive Waste, DPSTS-BG-0.01 Technical Standard, SRL, January 23, 1975.

Earle, G.W. and Jacober, W.J., 1973. Tritium Burial Records, memorandum to A.S. Barab, December 26, 1973.

Hyder, M.L., 1992. Approaches to the Burial Ground Inventory Problem, memorandum to H.P. Holcomb, SRT-SAE-920518, Westinghouse Savannah River Company, Aiken, SC, Sept. 11, 1992.

Hyder, M.L., 1993. Tritium in the Burial Ground of the Savannah River Site (U), WSRCTR-93-316, Westinghouse Savannah River Company, Aiken, SC.

Mason, J.T., 1996. Information Document on the Old Solvent Tanks SI-S22 in the Old Radioactive Waste Burial Ground 643-E (U), WSRP-RP-96-00144, Westinghouse Savannah River Company, Aiken, SC.

Stone, J.A., Oblath, S.B., Hawkins, R.H., M.W. Grant, S.L. Hoeffner, C.M. King, 1985. Waste Migration Studies at the Savannah River Plant Burial Ground, a paper proposed for presentation at the DOE Low-level Waste Management Program, Las Vegas, NV. DP-MS85-86, E.I du Pont de Nemours and Company, Savannah River Laboratory, Aiken, SC.

Stone, J.A. and Weimorts, P.M., 1985. Subsurface Monitoring of Groundwater at the SRP Burial Ground: 1994 Summary of Grid Well Assays, DPST-85-353.

WSRC, 1992. Old Radioactive Waste Burial Ground,Revised Draft, August, 1992. 


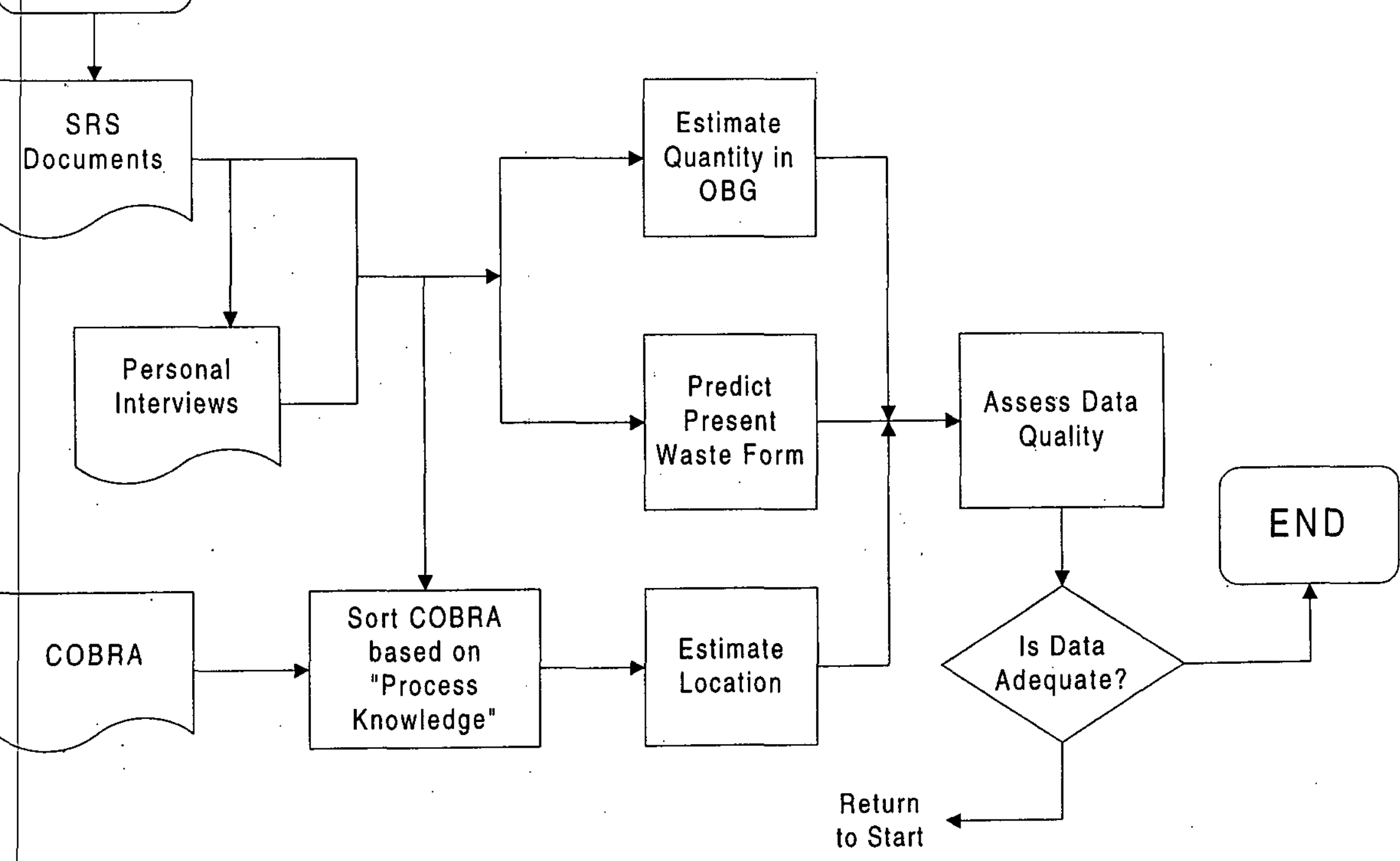

Figure 1-1. Inventory Estimate Process Flow Diagram 


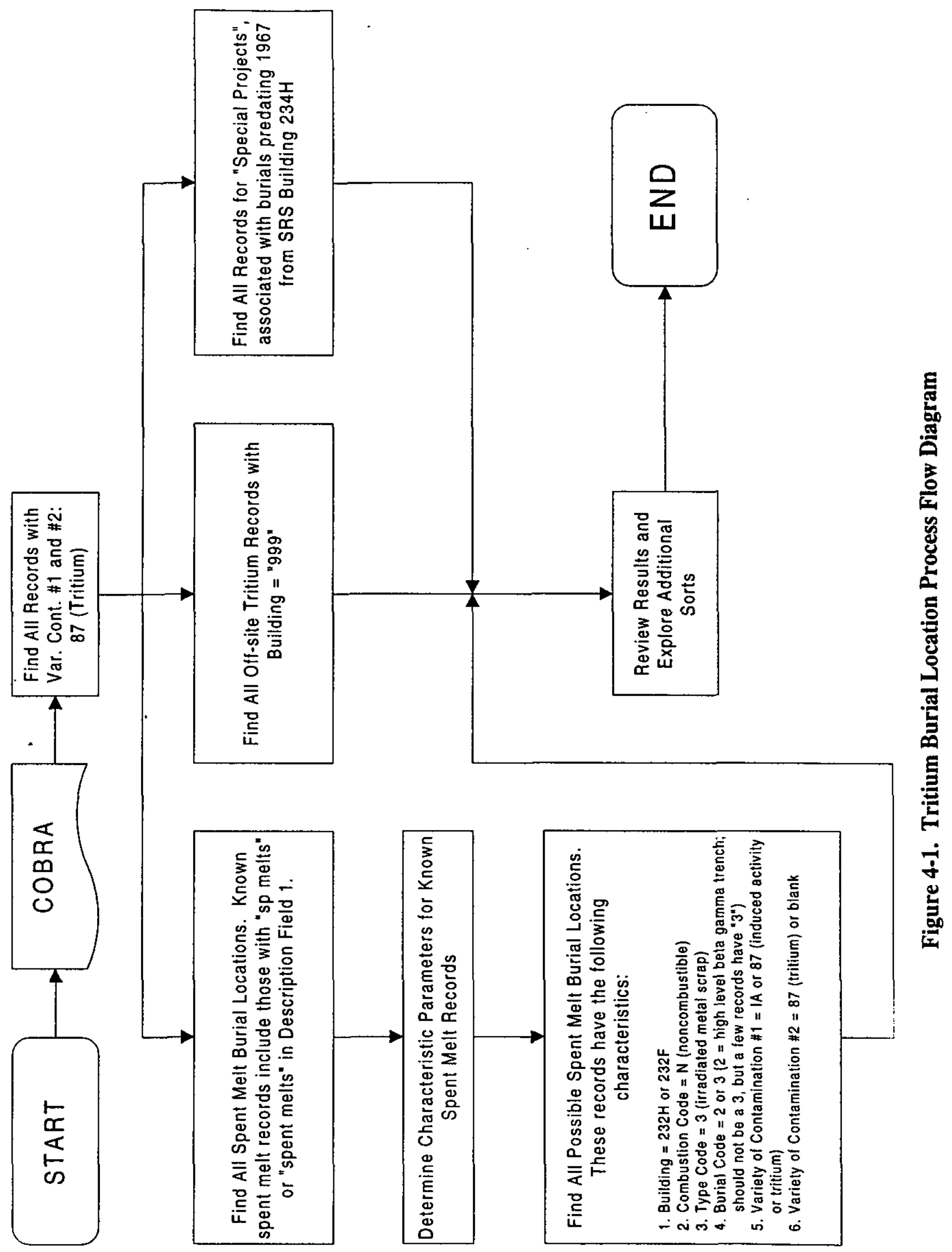



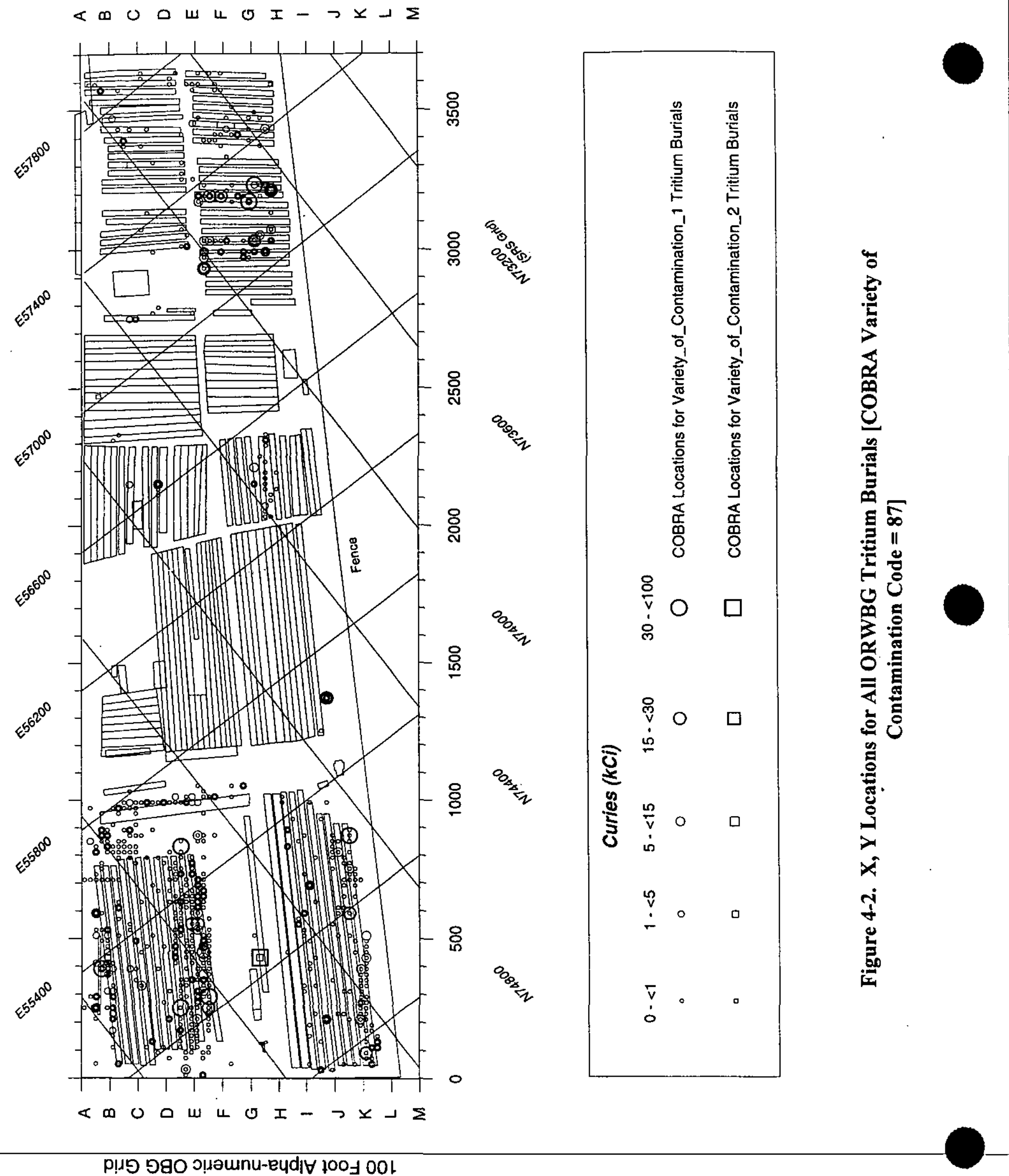

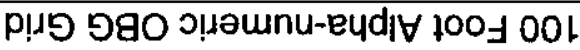



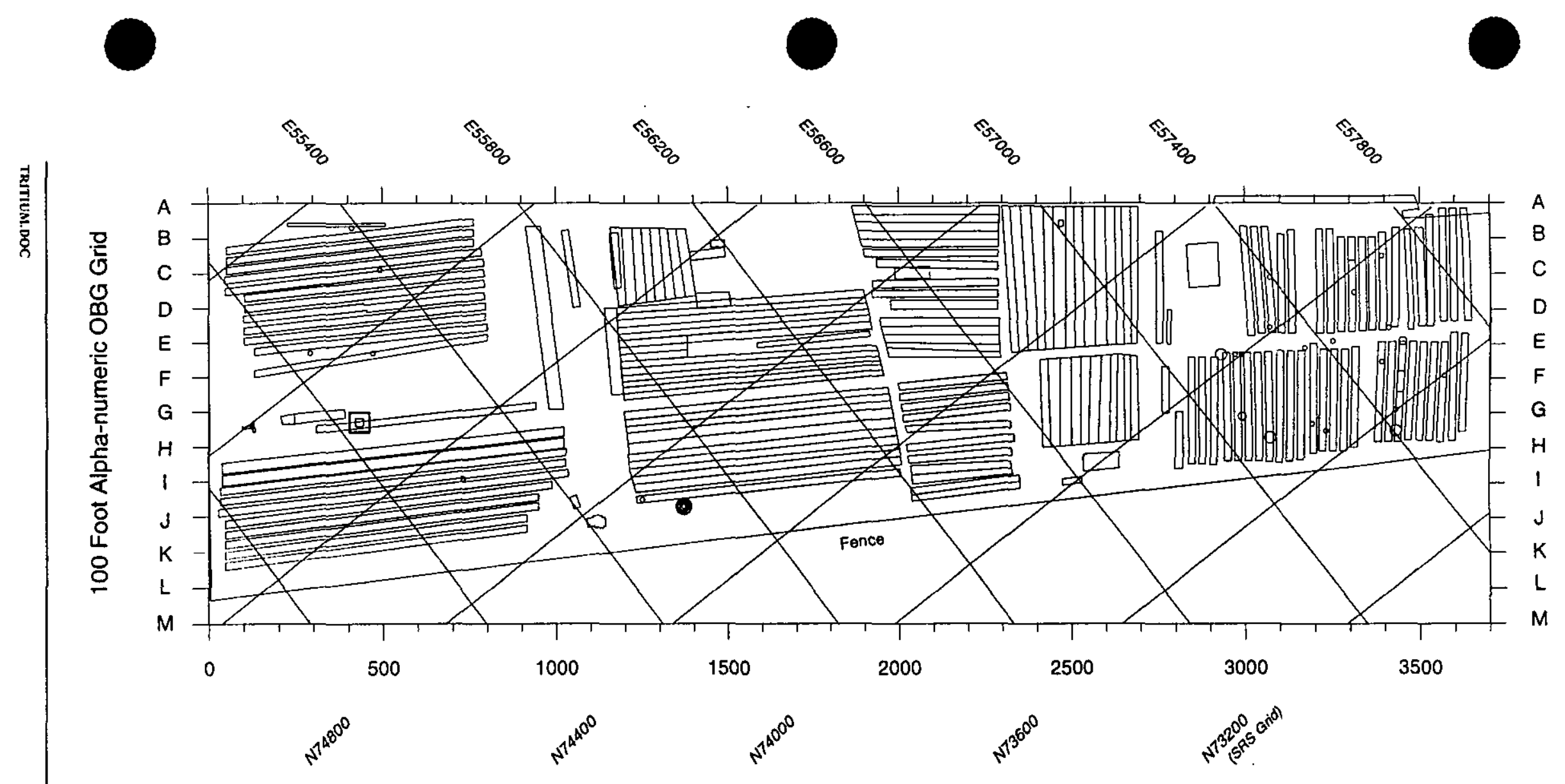

\begin{tabular}{ccccccc}
\multicolumn{7}{c}{ Curies $(\mathrm{kCi})$} \\
$0-<1$ & $1 \cdot<5$ & $5 \cdot<15$ & $15-<30$ & $30-<100$ \\
$\circ$ & 0 & 0 & 0 & 0 & COBRA Locations for Variety_of_Contamination_1 Tritium Burials \\
0 & $\square$ & $\square$ & $\square$ & $\square$ & COBRA Locations for Variety_of_Contamination_2 Tritium Burials
\end{tabular}



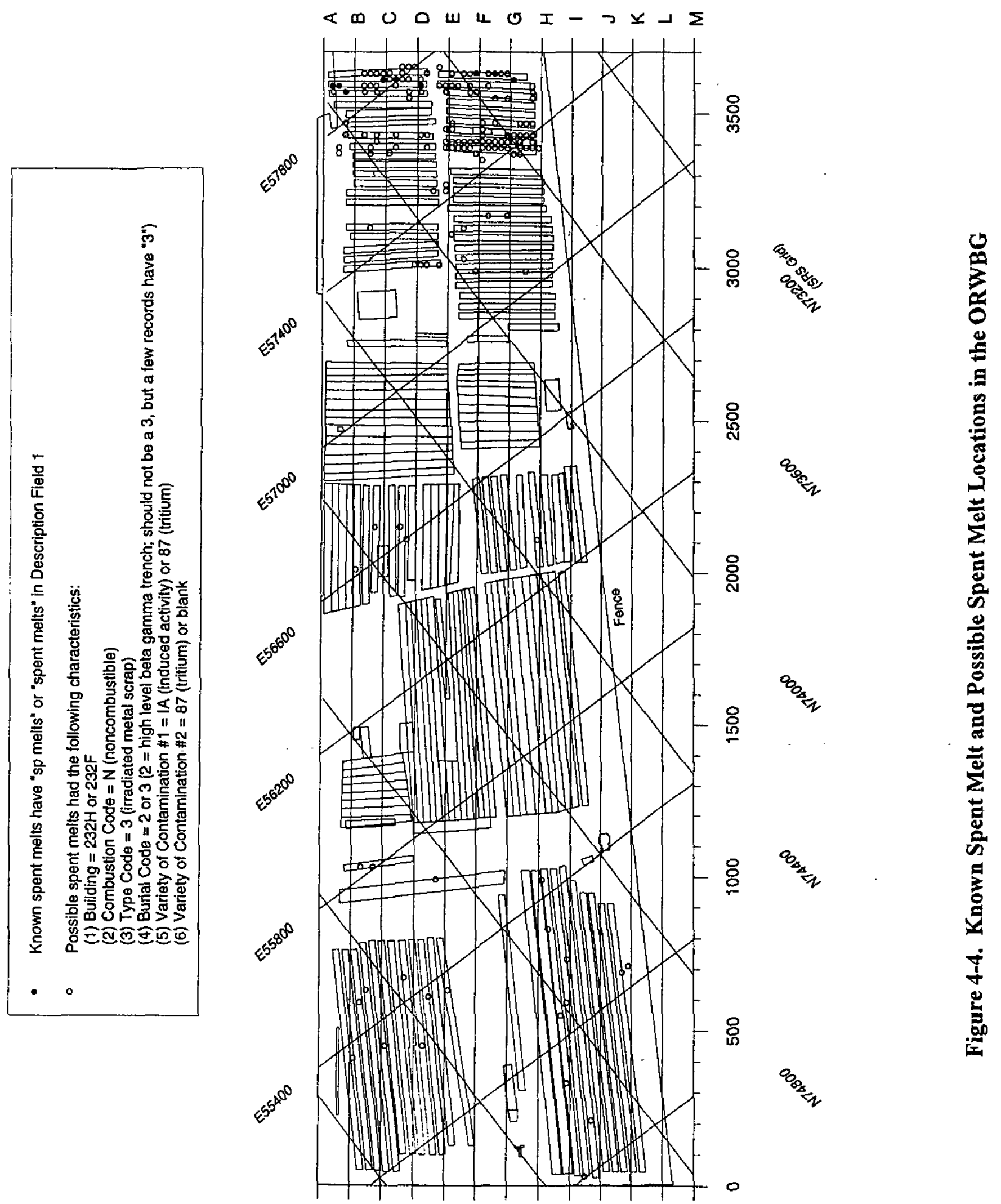

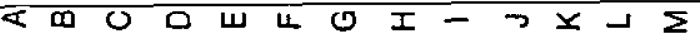

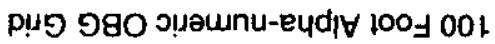




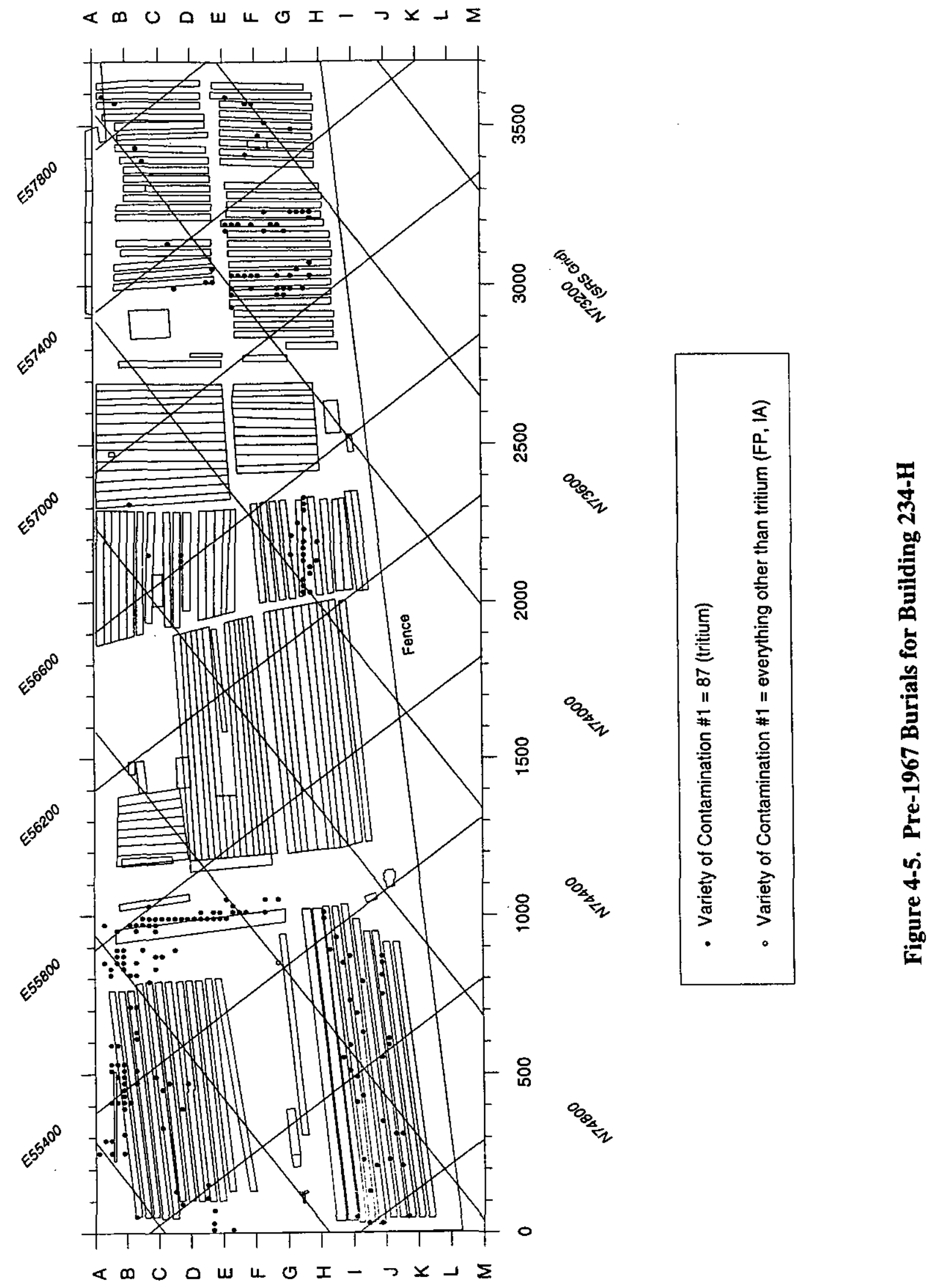

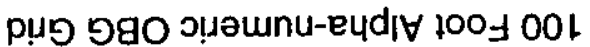


Table 2-1. Revised Tritium Content Estimates

\begin{tabular}{lll}
\hline Waste Form & Previous (HP) Estimate, $\mathrm{Ci}$ & Revised (COBRA) Estimate, $\mathrm{Ci}$ \\
\hline
\end{tabular}

Spent Melts:

\begin{tabular}{|lcc|}
\hline SRP LiAl & $400-500$ & 100 \\
\hline Hanford LiAl & 200 & 100 \\
\hline Hanford LiAlO & 500 & 1000 \\
\hline Crucible, Single Melt & 500 & 100 \\
\hline Crucible, Double Melt & 1000 & 200 \\
\hline
\end{tabular}

Scrap Casks:

\begin{tabular}{|lcc|}
\hline Control Rods J & 100 & 100 \\
\hline 6,8, Hanford LiAl & 65 & 65 \\
\hline
\end{tabular}

Bulk Waste:

\begin{tabular}{|lcc|}
\hline Waste Dumpsters & 0.1 & $0.1^{+}$ \\
\hline Vacuum Pump Oil & 1600 & 40 \\
\hline Mercury & 1600 & 0.1 \\
\hline
\end{tabular}

Reactive Beds:

\begin{tabular}{|lcc|}
\hline Mg and Z Beds & 500 & 500 \\
\hline$U$ and Hopscalite Beds & - & 500 \\
\hline
\end{tabular}

+ Usually $0.1 \mathrm{Ci}$, but determined on an individual basis.

Source: Earle and Jacober, 1973 
Table 3-1. The Sources of Inventory Estimates for Tritium in the ORWBG

\begin{tabular}{|c|c|c|c|}
\hline Reference & Tritium Inventory & Form and Container Information & Notes \\
\hline $\begin{array}{l}\text { Hyder, M.L., } \\
1993\end{array}$ & $\begin{array}{l}\text { Tritium buried (HP estimates) } \\
\text { (kCi): } \\
\text { through 1959: } 1,201 \\
\text { 1960: } 159 \\
\text { 1961: } 615 \\
\text { 1962: } 531 \\
\text { 1963: } 531 \\
\text { 1964: } 559 \\
\text { 1,800,000 Cia buried from startup } \\
\text { 10 1961 (HP estimates) } \\
\text {-900,000 Ci" (93g) (best guess for } \\
\text { the unrecorded tritium burials) } \\
\text { estimated based on } 1 / 2 \text { HP data } \\
\text { (the above do not reference earlier } \\
\text { articles) } \\
\text { The total quantity of buried tritium, } \\
\text { uncorrected for decay, was reported } \\
\text { by Cook in 1991 "Radionuclide } \\
\text { Inventory of E-Area, WSRC-RP- } \\
91-709 \text { ) as being } 172 \mathrm{~g} \text { (1,670,000 } \\
\text { Ci) in the ORWBG. This is based } \\
\text { on COBRA records, which give } \\
\text { lower values than HP. COBRA } \\
\text { records also do not include material } \\
\text { placed in the ORWBG prior to } \\
\text { 1961. }\end{array}$ & $\begin{array}{l}\text { Discarded hardware was } \\
\text { wrapped in plastic and boxed. } \\
\text { Many of the largest amounts of } \\
\text { tritium were buried in this } \\
\text { "carton" fashion. } \\
\text { - Tritium contaminated waste } \\
\text { material from offsite was put in } \\
\text { steel drums. The nature of the } \\
\text { waste material, and its internal } \\
\text { packaging, are generally not } \\
\text { known. } \\
\text { - Spent melts were discarded in } \\
\text { stainless steel crucibles in which } \\
\text { they were melted to recover the } \\
\text { tritium. For many years they } \\
\text { were discarded without } \\
\text { packaging. Later, an epoxy resin } \\
\text { was poured into the crucibles } \\
\text { containing the melts. } \\
\text { Pump oils were in sealed jars. } \\
\text { - Magnesium beds }\end{array}$ & $\begin{array}{l}\text { - There are virtually no records of specific tritium } \\
\text { burials before } 1961 \text {. The COBRA records begin in } \\
\text { 1961. The HP estimates after } 1961 \text { are about twice } \\
\text { the values recorded in individual burial records. } \\
\text { HP estimates give gross information on } \\
\text { radioisotope burials. It is reasonable to accept the } \\
\text { HP values as upper limits on the amount of tritium } \\
\text { discarded. The documented COBRA data is more } \\
\text { likely to be close to the true value. } \\
\text { COBRA shows that } 1,410,000 \mathrm{Ci} \text { (about } 84 \% \text { ) of } \\
\text { the tritium in the ORWBG was in the largest } \\
\text { burials (>1,000 Ci per item), which were } \\
\text { associated with discarded equipment and other } \\
\text { process material from H-Area and offsite. Spent } \\
\text { melts, Mg beds, and other small, routine items are } \\
\text { in the remainder. }\end{array}$ \\
\hline
\end{tabular}


Table 3-1. The Sources of Inventory Estimates for Tritium in the ORWBG (Continued)

\begin{tabular}{|c|c|c|c|c|}
\hline Reference & Tritium Inventory & $\begin{array}{l}\text { Form and Container } \\
\text { Information }\end{array}$ & & Notes \\
\hline M.L. Hyder, 1992 & NA & $\begin{array}{l}\text { Crucibles } \\
\text { contaning melted } \\
\text { targets } \\
\text { Discarded } \\
\text { equipment from } \\
\text { 244-H (and } \\
\text { perhaps } 242-\mathrm{H}), \\
\text { traps, beds, } \\
\text { pumps, vessels, } \\
\text { mercury and oils, } \\
\text { other }\end{array}$ & NA & \\
\hline WSRC, 1992 & $\begin{array}{l}\begin{array}{c}\text { ORWBG } \rightarrow \text { A) } 3,540,000^{\mathrm{NR}}-146,000^{\mathrm{R}^{*}} \\
\text { B) } 2,600,000^{\mathrm{f}}\end{array} \\
\text { ORWBG }+7 \mathrm{G} \rightarrow \text { C) } 4,090,000^{\mathrm{r}} \\
\text { D) } 1,746,156 \text { E) } 1,830,000 \\
\text { A) Waste Management Operations, Savannah River } \\
\text { Plant, Final Environmental Impact Statement, } 1975 \\
\text { B) Waste Management Program Technical Progress } \\
\text { Report, } 1987 \\
\text { C) Selection of Chemical Constituents and Estimation } \\
\text { of Inventories for Environmental Analysis of } \\
\text { Savannah River Plant Waste Sites, 1986 } \\
\text { D) Savannah River Waste Management Operations } \\
\text { Program Plan, 1989 } \\
\text { E) Integrated Rerort on Radionuciide Migration at the } \\
\text { Savannah River Shallow Land Burial Site, 1989 } \\
\end{array}$ & $\mathrm{NA}$ & $\begin{array}{l}\text { R } \\
\text { NR } \\
* \\
\text { @ } \\
\text { f }\end{array}$ & $\begin{array}{l}\text { Retrievable waste } \\
\text { Nonretrievable waste } \\
\text { Inventory estimated through } 1975 \text {, includes } \\
\text { first four years inventory at } 643-7 \mathrm{G} \text {. } \\
\text { Includes all forms of transuranic waste } \\
\text { including TRU fraction of low-level waste. } \\
\text { Does not account for radioactive decay since } \\
\text { time of burial }\end{array}$ \\
\hline
\end{tabular}

a Inventory discussed in detail.

b No discussion of basis for inventory.

NA Not addressed in article.

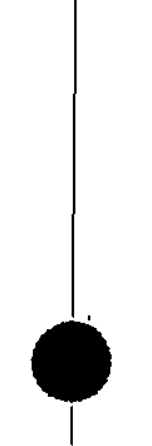


Table 3-1. The Sources of Inventory Estimates for Tritium in the ORWBG (Continued)

\begin{tabular}{|c|c|c|c|}
\hline Reference & Tritium Inventory & Form and Container Information & Notes \\
\hline $\begin{array}{l}\text { Stone, J.A. and } \\
\text { Weimorts, P.M., } \\
1985\end{array}$ & $\begin{array}{l}\text { - } 47 \text { of } 67 \text { water table wells had } \\
\text { tritium concentraions of }>0.1 \mu \mathrm{Ci} / \mathrm{L} \\
\text { in } 1984^{\mathrm{a}} \\
\text { Total amount of tritium in the } \\
\text { groundwater beneath the ORWBG is } \\
38,600 \mathrm{Ci} \text { in } 1984^{\mathrm{a}} \text {. } \\
\text { (does not reference an carlier article) }\end{array}$ & NA & $\begin{array}{l}\text { - Tritium is present as a plume under the ORWBG. } \\
\text { - A soil coring study in the vicinity of well G-21 } \\
\text { found that } 90 \% \text { of the tritium was deeper than the } \\
\text { well screen. Well G-21 is one of the oldest burial } \\
\text { areas in the ORWBG, and thus the maximum } \\
\text { plume dip is expected there. }\end{array}$ \\
\hline DuPont, 1975 & $\begin{array}{l}4 \times 10^{5} \mathrm{Ci} \text { emplaced each year at the Solid } \\
\text { Radioactive Waste Storage Site } \\
\text { (does not reference an earlier article) }\end{array}$ & NA & $\begin{array}{l}\text { Earthen trench storage (dirt trenches) is satisfactory } \\
\text { even without protection from water-saturated soil } \\
\text { (1975). }\end{array}$ \\
\hline
\end{tabular}

Inventory discussed in detail.

b No discussion of basis for inventory.

NA Not addressed in article. 


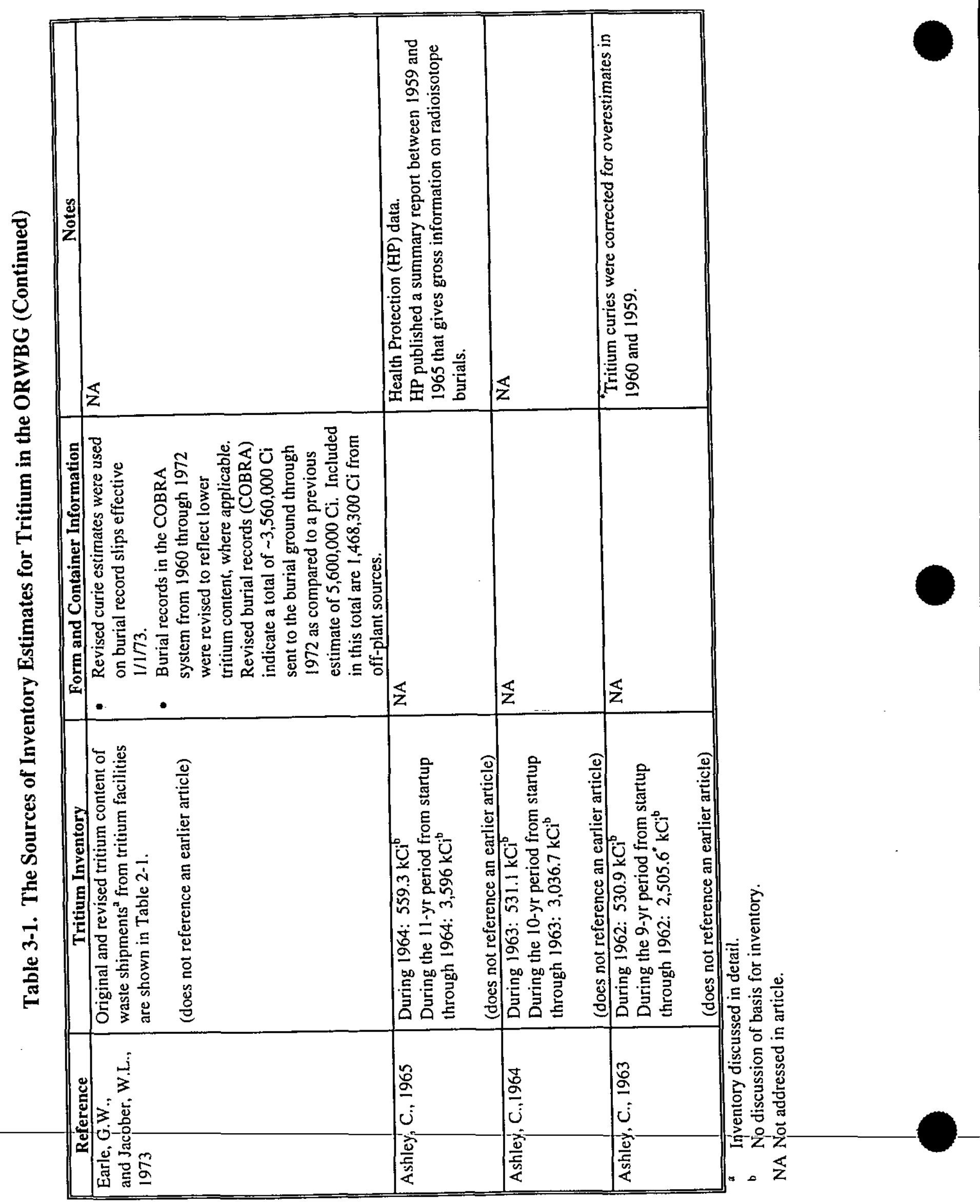




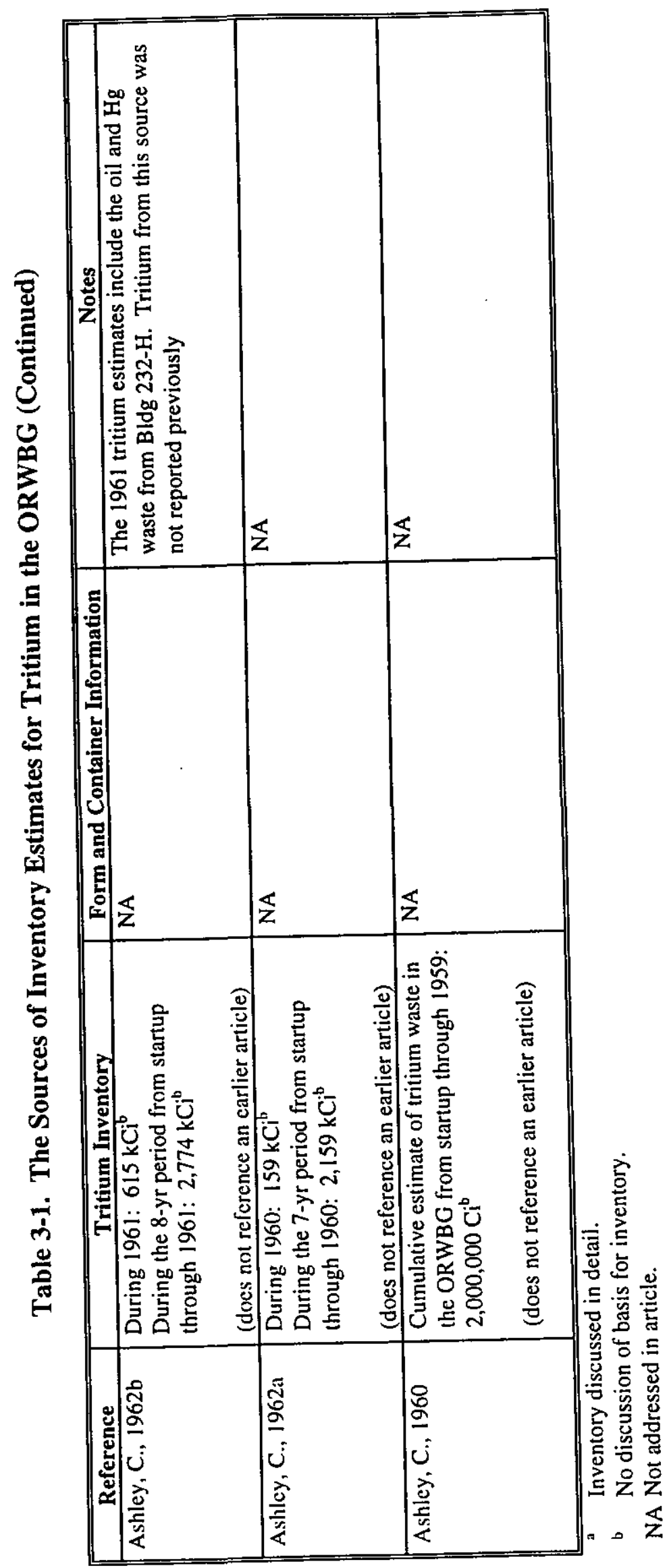


Table 3-2. Health Protection and COBRA Data - Tritium in the ORWBG

\begin{tabular}{|ccc|}
\hline Year & Health Protection Data, Ci & COBRA Data, Ci \\
\hline to 1959 & $2,000,000$ & $17,745^{*}$ \\
\hline 1960 & 159,000 & No Data \\
\hline 1961 & 615,000 & 261,806 \\
\hline 1962 & 530,900 & 232,716 \\
\hline 1963 & 531,100 & 232,716 \\
\hline 1964 & 559,300 & 193,930 \\
\hline 1965 & No Data & 106,662 \\
\hline 1966 & No Data & 116,358 \\
\hline 1967 & No Data & 145,448 \\
\hline 1968 & No Data & 145,448 \\
\hline 1969 & No Data & 223,020 \\
\hline 1970 & No Data & 310,288 \\
\hline 1971 & No Data & 19,393 \\
\hline 1972 & No Data & 145,448 \\
\hline
\end{tabular}

Source: Ashley, 1960, 1962a, 1962b, 1963,1964,1965

* Two records in COBRA (one each in 1957 and 1958) list tritium as a contaminant. Due to the paucity of pre1961 records an estimate of tritium will be used in the source term calculation.

Original COBRA data given in grams; converted to $\mathrm{Ci}$ using an specific activity of $9696.5 \mathrm{Ci} / \mathrm{g}$. 
Table 3-3. Best Estimate of Tritium in ORWBG

\begin{tabular}{|cccc|}
\hline Year & $\begin{array}{c}\text { Health Protection Data } \\
\text { (Ci) }\end{array}$ & $\begin{array}{c}\text { Adjusted HP and COBRA } \\
\text { Data } \\
\text { (Ci) }\end{array}$ & $\begin{array}{c}\text { Decay-Corrected } \\
\text { COBRA Data (Ci) } \\
\text { Best Estimate }\end{array}$ \\
\hline 1953 & 285,714 & 116,618 & 9,775 \\
\hline 1954 & 285,714 & 116,618 & 10,342 \\
\hline 1955 & 285,714 & 116,618 & 10,941 \\
\hline 1956 & 285,714 & 116,618 & 11,576 \\
\hline 1957 & 285,714 & 116,618 & 12,247 \\
\hline 1958 & 285,714 & 116,618 & 12,956 \\
\hline 1959 & 285,714 & 116,618 & 13,707 \\
\hline 1960 & 159,000 & 64,898 & 8,070 \\
\hline 1961 & 615,000 & 261,806 & 34,443 \\
\hline 1962 & 530,900 & 232,716 & 32,391 \\
\hline 1963 & 531,100 & 232,716 & 34,268 \\
\hline 1964 & 559,300 & 193,930 & 30,212 \\
\hline 1965 & No Data & 106,662 & 17,580 \\
\hline 1966 & No Data & 116,358 & 20,289 \\
\hline 1967 & No Data & 145,448 & 26,831 \\
\hline 1968 & No Data & 145,448 & 28,387 \\
\hline 1969 & No Data & 223,020 & 46,049 \\
\hline 1970 & No Data & 310,288 & 67,781 \\
\hline 1971 & No Data & 19,393 & 4,482 \\
\hline 1972 & No Data & 145,448 & $\mathbf{4 6 7 , 8 8 9}$ \\
\hline Total & & $3,014,457$ & \\
\hline
\end{tabular}


(This page intentionally left blank) 
APPENDIX F

CONSTITUENT OF INTEREST:

CESIUM-137 
(This page intentionally left blank) 


\section{TABLE OF CONTENTS}

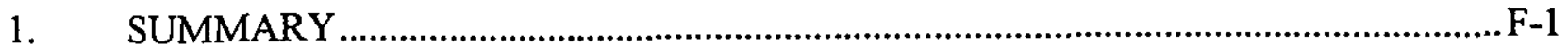

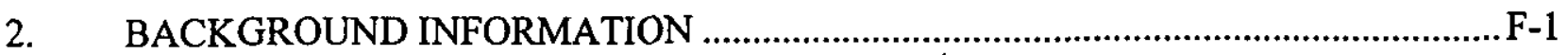

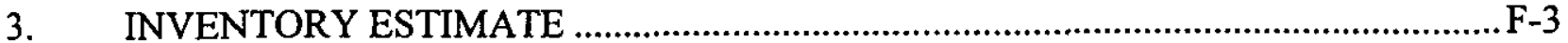

$3.1 \quad$ Range of Inventory Estimates .......................................................................F-3

3.2 Best Estimate of Cesium-137 in Burial Grounds.................................................F-5

3.3 Uncertainties Associated with Cesium-137 Inventory Estimate.............................F-5

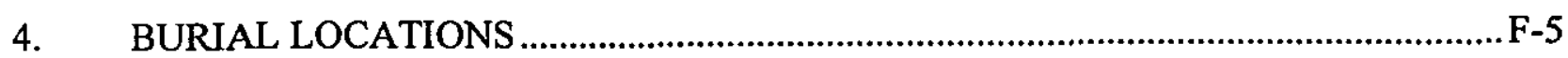

5. WASTE FORM

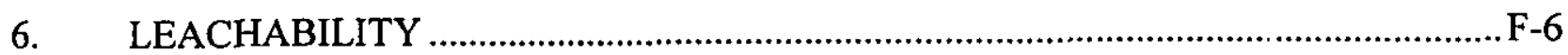

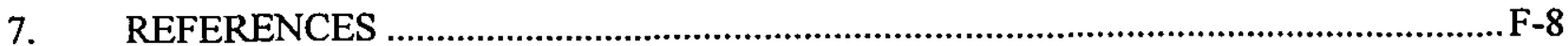




\section{LIST OF FIGURES}

Figure 1-1. Inventory Estimate Process Flow Diagram......................................................F-11

Figure 4-1. Cesium-137 Burial Location Process Flow Diagram .........................................F-12

Figure 4-2. X, Y Locations of All Fission Product Burials in ORWBG Database (Variety of Contamination \#1 and \#2 = "FP")

\section{LIST OF TABLES}

Table 2-1. Major Gamma Radionuclides in Organic and Aqueous Phases of OSTs..........F-14 Table 2-2. Summary of the Most Recent Gamma Activity Data for Tanks S1-S22 (Source: Mason, 1996) .......................................................................................

Table 3-1. Cesium-137 Estimates for the ORWBG ..........................................................16

Table 3-3. The Sources of Inventory Estimates for Cs-137 in the ORWBG ......................F-17

Table 3-4. The Sources of Inventory Estimates for Fission Products in the ORWBG ........F-19 


\section{CONSTITUENT OF INTEREST - CESIUM-137}

\section{SUMMARY}

To accomplish its national defense and space missions, the Savannah River Site (SRS) employed five nuclear fission reactors: $\mathrm{R}, \mathrm{C}, \mathrm{L}, \mathrm{P}$, and $\mathrm{K}$ Reactors. Fission products, such as cesium-137, were a byproduct of the processes used in these reactors.

The best estimate for the original cesium-137 inventory buried in trenches in the Old Radioactive Waste Burial Ground (ORWBG) is 58,657 curies (26,838 curies, corrected for decay to 1997). At present, there is $1.30 \mathrm{Ci}$ of cesium-137 in the Old Solvent Tanks (OSTs).

Waste containing fission products, from which cesium-137 inventories are estimated, was buried in low-level and high-level trenches, depending on the dose rate from the package. The waste was buried in cardboard boxes, plastic bags, and metal containers. As this packaging deteriorates, the fission product waste and the associated cesium-137 will be exposed to contact with infiltrating water.

Figure 1-1 presents the process used to develop the inventory and burial locations. The Computerized Burial Record Analysis (COBRA) database was used to determine the locations of fission product burials, from which the cesium-137 quantity estimates were made.

\section{BACKGROUND INFORMATION}

SRS operated five onsite production reactors: C, K, L, P, and R Reactors. Uranium-235 fuel was burned in the reactors. After their useful lifetime, the fuel elements were discharged from the reactor and cooled in reactor disassembly basins. The cooling period allowed fission products with very short half-lives to decay to more stable isotopes. Cesium-137, with a 30.0 year half-life (ICRP, 1983), was one of the fission products with significant activity following the cooling period.

After cooling, the spent fuel was transferred to H-Area, one of two chemical separations facilities at SRS. H-Canyon recovered uranium-235 from irradiated fuel elements from onsite and offsite reactors (DOE, 1995). In the chemical separations process, the fission products were concentrated in a liquid waste stream. The waste stream was sent to the HArea Tank Farm, a system of underground tanks used to store the liquid waste. 
Smaller amounts of fission products were produced in target slugs used in reactors for producing plutonium-239. These slugs were processed in the canyon facility in F-Area.

The first production-related fission products were produced on December 28, 1953 when RReactor, the first production reactor, went critical. The zero-power test reactor in 305-M went critical over one year earlier (September 16, 1952), but it did not produce significant amounts of fission products. Waste containing significant quantities of fission products was not produced and buried until 1954.

Fission products are a component of job control waste and other waste streams sent to the ORWBG. These streams originated from most areas of SRS that handled either spent reactor fuel and targets or managed high-level liquid waste. These include the reactors, Separations (F- and H-Areas) and associated tank farms, and process control and experimental laboratories.

Over 300 radionuclides have been observed as primary products of fission. These radionuclides are produced at different rates, or yields. The distribution of fission yield from uranium-235 fission to mass number of the fission product has a characteristic double hump shape. The two peaks on this curve, which equate to the mass numbers for the radionuclides with the greatest yields, occur between mass numbers 90 and 101, and between mass numbers 133 and 144. Cesium-137, with a mass number of 137, has a relatively high yield (6.15 percent). Also, the half-life of cesium-137 (30 years) is relatively long for a fission product. Consequently, the fraction of fission product activity associated with cesium-137 increases with the age of the fission product-bearing waste (i.e., the length of time since the fuel associated with the fission products was discharged from the reactor) (Benedict et al., 1981).

Generally, waste containing fission products was segregated according to the dose rate generated by the waste package. Waste with a dose rate less than $50 \mathrm{mR}$ per hour was buried in low-activity beta-gamma trenches. Waste with dose rates of $50 \mathrm{mR}$ per hour or greater was buried in intermediate level (also known as high-level) trenches (Cook, 1987). No special containerization requirements existed.

Spent solvent from Separations was sent to the OSTs for storage, where it separated into vapor, organic, aqueous, and sludge phases. This solvent was contaminated with fission products, including cesium-137, nuthenium-106, antimony-125 and other gamma emitters (Mason, 1996). Table 2-1 lists the radionuclides that comprised the greatest fraction of the activities-in-each-tank-in-1975--In-the-early-1980s,-the_contents_of_the_OSTs,_except_for 
"unpumpable heel", were transferred to new tanks in the New Burial Ground (643-7E) under the Solvent Relocation Program. Table 2-2 presents the most recent gamma-emitting radionuclide inventory for each of the 22 tanks in the ORWBG. The gamma activities for Tanks S8 and S17 through S22 reflect measurements taken before the Solvent Relocation Program. The activities for Tanks S1 through S7 and Tanks S9 through S16 were measured after the solvent tanks were pumped to "unpumpable heel".

To reduce the volume in the OSTs, the organic phase was periodically drawn off and burned in open pans. The burn residue and pans were buried unencapsulated in earthen trenches (Wilhite, 1976; Tharin, 1965). Mason (1996) reports no data on the amount of fission products buried with burn residues.

\section{INVENTORY ESTIMATE}

Burial records indicate quantities of fission products sent to the ORWBG, but do not record the amounts of cesium-137 per se. The amount of cesium-137 in fission products can be estimated using process knowledge and reported isotopic ratios. The isotopic ratios depend on the age of the waste, since longer-lived radionuclides such as cesium-137 become an increasingly larger fraction as the waste ages.

\subsection{Range of Inventory Estimates}

The COBRA database indicates that $621,626 \mathrm{Ci}$ of fission products were buried in the ORWBG. This estimate is comparable with Cook's (1991) estimate of 601,208 Ci. Health Protection data (Ashley, 1960, 1962a, 1962b, 1963, 1964, and 1965) indicate that 241,390 Ci of fission products were buried between ORWBG start-up and 1964. Assuming a similar rate of disposal from 1965 to 1972 , this estimate is in reasonable accord with the COBRA database and Cook's (1991) estimate.

Other references include inventory estimates specifically for cesium-137. Cook (1987) estimated the cesium-137 inventory to be $110,000 \mathrm{Ci}$, although he provides no supporting information. However, in a subsequent document, Cook presents a rigorous method to determine the cesium-137 inventory in the ORWBG (Cook, 1990). The method assumes the following:

1. COBRA estimates of fission product inventory are accurate.

2. The curie estimates in the burial records are based on gamma ray measurements of ruthenium-106, cesium-137, and cerium-144 only. 
3. Wastes from reactors, Separations, 772-F laboratories, and offsite sources contain fission products 1 year out of reactor.

4. Wastes from the F- and H-Area tank farms are 5 years out of reactor.

5. Cesium-137 comprises 8 percent of the activity for 1 -year-old waste and 71 percent of the activity for 5-year-old waste.

Table 3-1 summarizes Cook's (1990) estimate of the cesium-137 inventory. The "Original" column represents the activity when buried. Cook (1990) cites data for the years 1954 to 1972. The "Decayed to 1997" column presents the current activity corrected for decay to 1997. The total buried during the 19 years that production-related fission products were produced and that the ORWBG operated (1954 through 1972) is $56,949 \mathrm{Ci}$. Corrected for decay to 1997 , this amount is $26,058 \mathrm{Ci}$.

Minor amounts of cesium-137 are present in the OSTs. Not much cesium-137 is expected to be in the OST residual material. Cesium is present in the separations process as $\mathrm{Cs}^{+}$, a monovalent cation that does not form complexes with the solvent as ruthenium, zirconium, and other multivalent cations do. Cesium-137 has a high distribution coefficient $\left(\mathrm{K}_{\mathrm{d}}\right)$ for the aqueous phase during separations processing; most of the cesium-137 going to the aqueous waste from first cycle PUREX. A maximum concentration of cesium-137 in the OSTs can be estimated based on the data in Table 2-2 and using the following assumptions:

1. The ratio of radioisotopes in the tanks did not change after the Solvent Relocation Program.

2. For those tanks in Table 2-1 with a cesium-137 activity fraction, that fraction is used to determine the contribution of activity from cesium- 137 by multiplying it by the total activity for each tank given in Table 2-2.

3. For those tanks without a cesium-137 fraction, the remainder of the activity is assigned to cesium-137 and is multiplied by the total activity for each tank given in Table 2-2.

Based on the above assumptions, the cesium-137 activity in the 22 OSTs is $1.30 \mathrm{Ci}$. This value represents a maximum because it assumes all unattributable activity is due to cesium137. In actuality, many other radionuclides, most with shorter half-lives than cesium-137, were present. Furthermore, the activities of Tanks S8 and S17 through S22 were determined before the bulk of the solvent was removed from the tanks. The present activity in these tanks is considerably less than that shown on Table 2-2.

Table 3-3 lists the sources of the inventory estimates for cesium-137 in the ORWBG, and Fable-3-4 - lists-the-sources-of-the inventory-estimates for fission products. 


\subsection{Best Estimate of Cesium-137 in Burial Grounds}

The best estimate for the cesium-137 inventory in the ORWBG is $26,838 \mathrm{Ci}$, corrected for decay to 1997. This estimate was modified slightly from Cook (1990). Data from Cook (1990) yield an estimate of $26,058 \mathrm{Ci}$ of cesium-137, decayed to 1997. Cook (1991) uses a fission product inventory of 601,208 Ci. Although Cook (1990) does not state what value was used for total inventory, it can be assumed that it is the $601,208 \mathrm{Ci}$ value. The total fission product inventory in COBRA is $621,626 \mathrm{Ci}$, which is 3 percent greater than Cook (1991). Therefore, the cesium-137 values from Cook (1990) have been increased by 3 percent to arrive at the best estimate of $26,838 \mathrm{Ci}$.

For the OSTs, the cesium-137 inventory is $1.30 \mathrm{Ci}$ (Section 3.1). This conservative estimate is based on the most recent total activities available and the fraction of cesium-137 in each tank (Mason, 1996).

\subsection{Uncertainties Associated with Cesium-137 Inventory Estimate}

The main sources of uncertainty in the cesium-137 data are the original estimates of fission products. These estimates were based on the external dose rate from a package and an assumed isotopic distribution in the waste. Variations in the isotopic distribution of the waste and unique shielding aspects of a waste package could result in errors in the fission product estimate.

A second source of uncertainty is the method used by Cook (1990) to estimate the cesium137 inventory. The Cook (1990) method assumes two fixed ages for the waste, although the waste would have had a wide variety of ages. Also, gamma emitters other than the three radionuclides assumed in Cook (1990) could have contributed to the measured activity.

\section{BURIAL LOCATIONS}

The COBRA database provides information on the spatial distribution of fission products in the ORWBG. Figure 4-1 outlines the steps taken to manipulate the database to locate cesium137 burials. Figure 4-2 presents the burial locations for fission products. Generally, waste containing fission products was segregated by the dose rate generated by the waste package. Waste with a dose rate less than $50 \mathrm{mR}$ per hour was buried in low-activity beta-gamma trenches. Waste with dose rates of $50 \mathrm{mR}$ per hour or greater was buried in intermediate level (also known as high-level) trenches (Cook, 1987). No special containerization requirements existed. 


\section{WASTE FORM}

The waste was buried in cardboard boxes, plastic bags, and metal containers in low-level and high-level trenches, depending on the dose rate from the package. As this packaging deteriorates, the fission product waste and the associated cesium-137 will be exposed to contact with infiltrating water.

\section{LEACHABILITY}

The leachability of ${ }^{137} \mathrm{Cs}$ is controlled by adsorption to the soil matrix and ion exchange with clays and micas within the soil. Solubility does not exert significant controls on the leachability of ${ }^{137} \mathrm{Cs}$.

The retardation of ${ }^{137} \mathrm{Cs}$ by adsorption depends strongly on the chemical composition of the water in which the ${ }^{137} \mathrm{Cs}$ is migrating. Oblath (1983) found that $\mathrm{K}_{\mathrm{d}}$ values for adsorption onto ORWBG soils in distilled water were on the order of $3200 \mathrm{ml} / \mathrm{g}$. In untreated groundwater, the $\mathrm{K}_{\mathrm{d}}$ value was $410 \mathrm{ml} / \mathrm{g}$. However, addition of other cations to the groundwater lowered the $\mathrm{K}_{\mathrm{d}}$ value. The adsorption of ${ }^{137} \mathrm{Cs}$ was particularly sensitive to the concentration of potassium. At a potassium concentration of $25 \mathrm{ppm}$ (the groundwater contained $3 \mathrm{ppm}$ potassium) the $\mathrm{K}_{\mathrm{d}}$ value decreased to $170 \mathrm{~m} / \mathrm{g}$. Oblath (1983) concluded that potassium competes for adsorption sites with ${ }^{137} \mathrm{Cs}$ because of their similar chemical properties. Stone et al. (1985) reported that in trench waters the $\mathrm{K}_{\mathrm{d}}$ of ${ }^{137} \mathrm{Cs}$ was approximately $300 \mathrm{ml} / \mathrm{g}$. Thus, ${ }^{137} \mathrm{Cs}$ is rendered relatively immobile in ORWBG soils by adsorption.

This effect was seen in the soils of the Defense Waste Lysimeters. Oblath (1986) calculated the annual fractional release rate of ${ }^{137} \mathrm{Cs}$ from concentrations in the soil around a waste form in a Defense Waste Lysimeter. The release rate was several orders of magnitude greater than that calculated from the lysimeter effluent. Oblath (1986) concluded the ${ }^{137} \mathrm{Cs}$ was leaching from the waste form but was immediately immobilized by sorption to the soil.

A fraction of ${ }^{137} \mathrm{Cs}$ sequestered by soils remains irreversibly bound to the soil. Poe et al. (1974) discuss the process of cesium "fixation" by SRS soils. Cation exchange reactions can occur at the weathered edges of mica minerals in which ${ }^{137} \mathrm{Cs}$ replaces other cations. After ${ }^{137} \mathrm{Cs}$ enters the structure of these minerals it can become irreversibly "trapped" by the contraction of the crystal lattice caused by exchange of other cations. Similarly, Ohnuki and Kozai_(1994)_found_that $137 \mathrm{Cs}$ can adsorb irreversibly to smectitic clays. Thus, the mineralogy of the soils can play a major role in removing ${ }^{137} \mathrm{Cs}$ from groundwater. 
Concentrations of ${ }^{137} \mathrm{Cs}$ in groundwater beneath the ORWBG are low. Samples of groundwater from 20 grid wells were analyzed for ${ }^{137} \mathrm{Cs}$ in 1980 (Ryan, 1983). Only 3 of the samples contained concentrations that exceeded the detection limit of $8 \mathrm{pCi} / 1$. The highest of these concentrations, $16 \mathrm{pCi} /$, occurred in well G-21. In his study of sampling techniques, Cantrell (1990) analyzed samples from 7 grid wells and found only 1 contained ${ }^{137} \mathrm{Cs}$ at concentrations above detection limits. Groundwater from this well, sampled on 3 separate occasions had ${ }^{137} \mathrm{Cs}$ concentrations of $9.9,<14$, and $16.6 \mathrm{pCi} / \mathrm{l}$.

Well G-21 has an anomalous chemistry (Ryan, 1983) that may not be representative of concentrations in groundwater. McIntyre and Wilhite (1988) and Towler (1989) report that well G-21 was one of 15 wells installed through waste trenches at the ORWBG to monitor the water table. Samples from well G-21 have shown consistently high concentrations of radionuclides that should not be at the water table by migration from the trenches (Ryan, 1983). The anomalously high radionuclide concentrations (particularly Sr-90) in this well have been correlated with high, and similarly anomalous concentration of iron found in the same samples (Ryan, 1983). Possible explanations for the elevated iron concentrations include:

- a natural anomaly in the aquifer of high concentrations of organic matter or pyrite,

- contaminated water leaking from the trench down the well annulus, or

- waste debris smeared down the hole during installation of the well.

Natural iron anomalies in the water table aquifer at SRS have not been observed. Relatively immobile radionuclides (like cesium and plutonium) in water leaking down the well annulus would likely be sorbed to surfaces along the annulus and not occur in significant concentrations at the screen. Small amounts of waste debris smeared during well installation could explain the anomalous chemistry of the samples taken from this well. Monitoring well G-21 was abandoned in 1995, in accordance with accepted abandonment procedures.

Contamination from releases of liquid solvent offers an alternative explanation for the anomalous radionuclide concentrations in well G-21. Several reports discuss a 1962 incident in which 40 gallons of spent PUREX solvent, which consisted of up to $30 \%$ tri-butlyphosphate (TBP) and contained plutonium, were accidentally pumped down an unidentified test well located near the solvent tanks (Wilhite, 1975; Ryan, 1983; McIntyre and Wilhite, 1987; Mason, 1996). McIntyre and Wilhite (1987) report that in 1987, G-21 was the only 
well that showed a concentration of TBP $(0.16 \mathrm{mg} / \mathrm{l})$ above the detection limit of $(0.05 \mathrm{mg} / \mathrm{l})$. These results suggest that G-21 may have been affected by the solvent pumping incident.

The best estimate for the leachability of ${ }^{137} \mathrm{Cs}$ comes from the Defense Waste Lysimeter program. The leachability from these waste forms is measured as the annual fractional release rate. This is the cumulative activity of a constituent measured in the effluent of the lysimeter over one year divided by the known source term in the waste form buried in the lysimeter. In 1985, Stone et al. (1985) reported the annual fractional release rate of ${ }^{137} \mathrm{Cs}$ to be $10^{-7}$. McIntyre (1987) reported a similar release rate of $3 \times 10^{-7}$ for the year spanning July 1985 to June 1986. Applying this annual fractional release rate to the current ${ }^{137} \mathrm{Cs}$ inventory in the ORWBG $(27,171 \mathrm{Ci})$ gives a current leaching rate of $8 \times 10^{-3} \mathrm{Ci} / \mathrm{yr}$. 


\section{REFERENCES}

Ashley, C., 1960. SRP Radioactive Waste Release, Startup through 1959, DPSP-60-25-25, E.I. du Pont de Nemours and Company, Aiken, SC, September 1960.

Ashley, C., 1962a. 1960 Audit of SRP Radioactive Waste, DPSP-62-25-1, E.I. du Pont de Nemours and Company, Aiken, SC, February 1962.

Ashley, C., 1962b. 1961 Audit of SRP Radioactive Waste, DPSP-62-25-5, E.I. du Pont de Nemours and Company, Aiken, SC, September 1962.

Ashley, C., 1963. 1962 Audit of SRP Radioactive Waste, DPSP-63-25-1, E.I. du Pont de Nemours and Company, Aiken, SC, May 1963.

Ashley, C., 1964. 1963 Audit of SRP Radioactive Waste, DPSP-64-25-1, E.I. du Pont de Nemours and Company, Aiken, SC, May 1964.

Ashley, C., 1965. 1964 Audit of SRP Radioactive Waste, DPSP-65-25-1, E.I. du Pont de Nemours and Company, Aiken, SC, April 1965.

Benedict, M., T. Pigford, and H. Levi, 1981. Nuclear Chemical Engineering, McGraw-Hill, New York, NY.

Cantrell, K.J., 1990. Results of the Special Well Sampling Study for the Burial Ground, memorandum to W.E. Stevens, March 28, 1990, WSRC-RP-90-364, Westinghouse Savannah River Co., Aiken, SC.

Cook, J.R., 1987. Technical Data Summary: Plan for Closure of the 643-G Burial Ground, DPSTD-87-2, E.I. du Pont de Nemours and Company, Aiken, SC.

Cook, J.R., 1990. Estimation of Burial Ground Radionuclide Inventory Due to Mixed Fission Products, memorandum to W.E. Stevens, WSRC-RP-90-0495, May 29, 1990.

Cook, J.R., 1991. Radionuclide Inventory of E-Area, memorandum to W.E. Stevens, WSRC-RP-91-709, June 27, 1991.

Corey, J.C., and Horton, J.H., 1971. Savannah River Plant Burial Ground Practices, DPST70-460, March, 1971.

Department of Energy (DOE), 1995. Fact Sheet, "H Canyon", Savannah River Operations Office, Aiken, SC.

Horton, J.H. and Corey, J.C., 1976. Storing Solid Radioactive Wastes at the Savannah River Plant, DP-1366, E.I. du Pont de Nemours and Company, Aiken, SC.

International Commission of Radiation Protection (ICRP), 1983. Radionuclide Transformation: Energy and Intensity of Emission, Annals of the ICRP, ICRP-38, Pergamon Press, Oxford, England. 
Mason, J.T., 1996. Information Document on the Old Solvent Tanks S1-S22 in the Old Radioactive Waste Burial Ground 643-E (U), WSRC-RP-96-00144, Westinghouse Savannah River Company, Aiken, SC.

McIntyre, P.F., 1987. 1987 Monitoring Report for the Defense Waste Lysimeters, memorandum of August 10, 1987, to H.F. Sturm, Jr.: DPST-87-568, E.I. duPont de Nemours and Company, Savannah River Laboratory, Aiken, SC.

Oblath, S.B., 1983. Specific Factors Influencing Cesium Sorption by SRP Soils, memorandum dated May 13, 1983 to J.R. Wiley. DPST-83-490, E.I. duPont de Nemours and Company, Savannah River Laboratory, Aiken, SC.

Oblath, S.B., 1986. Radionuclide Release from Low-Level Waste in Field Lysimeters, a paper proposed for presentation at the: American Nuclear Society Meeting -- Spectrum '86. DP-MS-85-160, E.I. duPont de Nemours and Company, Savannah River Laboratory, Aiken, SC.

Ohnuki, T. and N. Kozai, 1994. Sorption characteristics of Radioactive Cesium and Strontium on Smectite, Radiochimica Acta, v. 66/67, p. 327-331.

Poe, W.L., J.W. Fenimore, J.H. Horton, I.W. Marine, and W.E. Prout, 1974. Leakage from Waste Tank 16 -- Amount, Fate, and Impact: DP-1358, E.I. duPont de Nemours and Company, Savannah River Laboratory, Aiken, SC.

Ryan, J.P., 1983. Groundwater Monitoring in the Savannah River Site Low Level Radioactive Waste Burial Ground, A Summary and Interpretation of the Analytical Data: DPST-83-209, E.I. duPont de Nemours and Company, Savannah River Laboratory, Aiken, SC.

Stone, J.A., S.B. Oblath, R.H. Hawkins, M.W. Grant, S.L. Hoeffner, and C.M. King, 1985. Waste Migration Studies at the Savannah River Plant Burial Ground, a paper proposed for presentation at the: DOE Low-level Waste Management Program, Las Vegas, NV. DP-MS-85-86, E.I. duPont de Nemours and Company, Savannah River Laboratory, Aiken, SC.

Tharin, D.W., Jr., 1965. Burning of Radioactive Process Solvent, DP-942, February 1965.

Towler, O.A. Jr., 1989. Integrated Report on Radionuclide Migration at the Savannah River Shallow Land Burial Site: $D P-1778$, E.I. duPont de Nemours and Company, Savannah River Laboratory, Aiken, SC.

Wilhite, E.L. Letter to M.D. Boersma, 1976. Estimate of TRU Nuclides in Solvent Residues at the Burial Ground, April 30,1976.

WSRC, 1992. Old Radioactive Waste Burial Ground,Revised Draft, August 


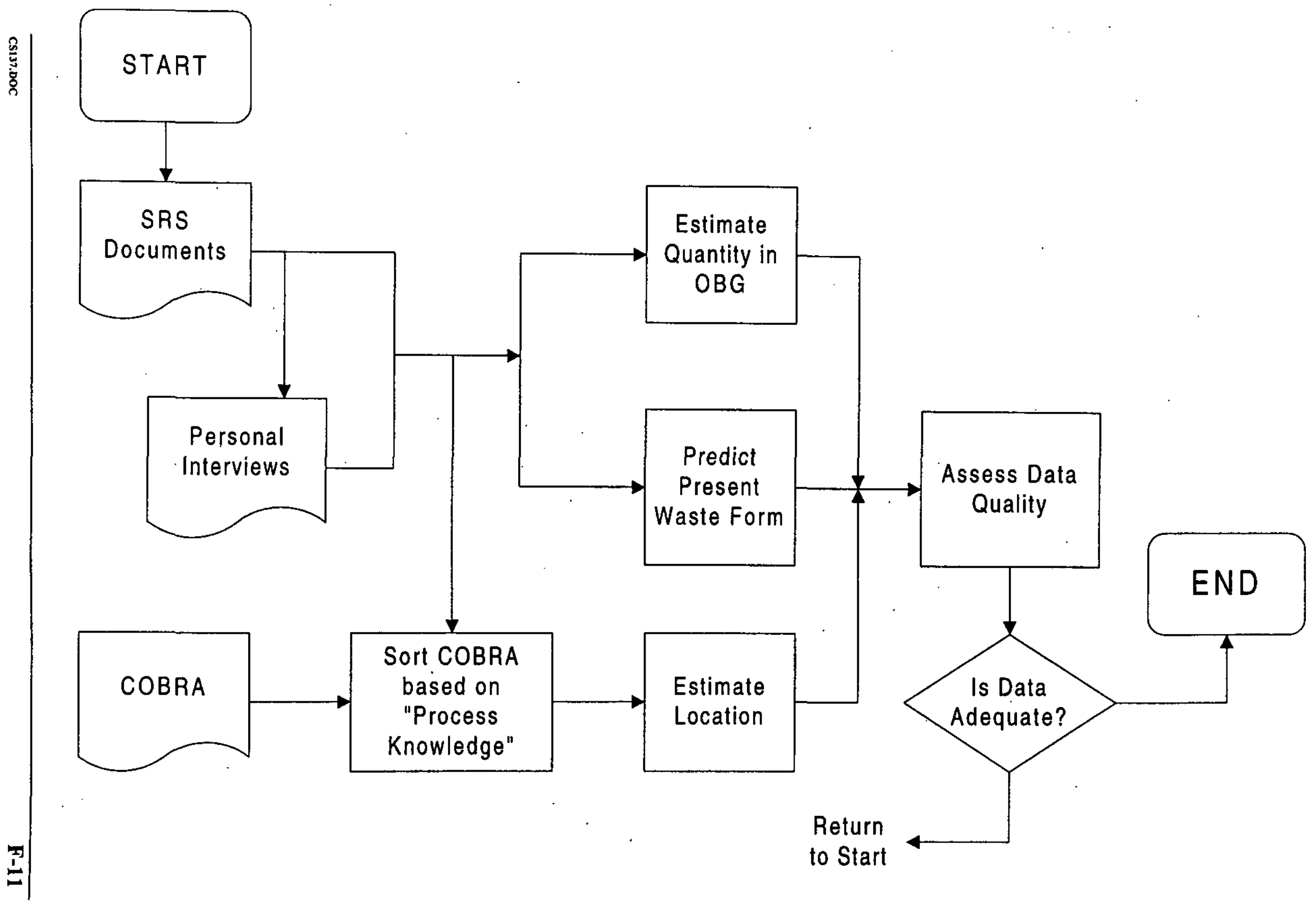

Figure 1-1. Inventory Estimate Process Flow Diagram 


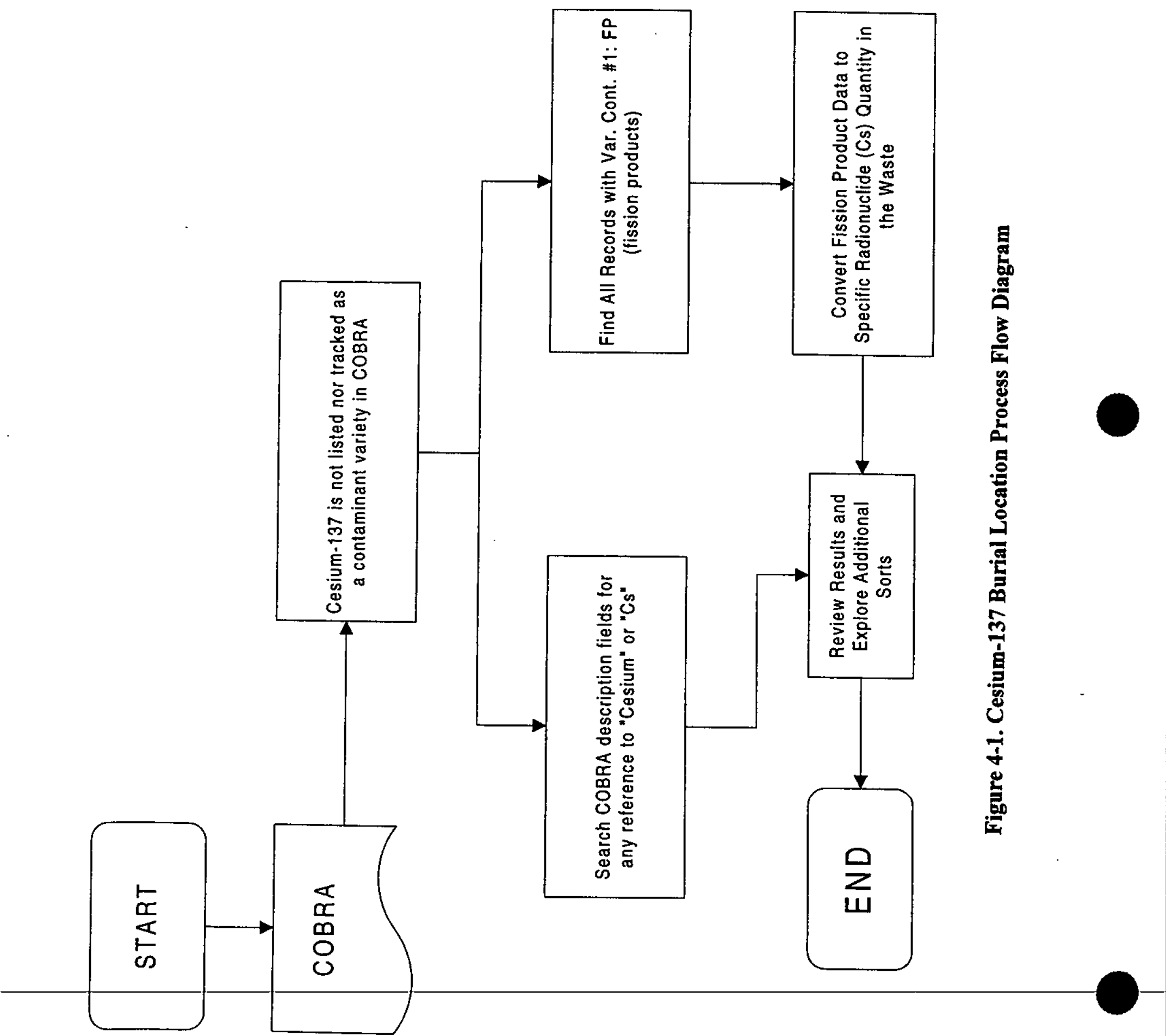



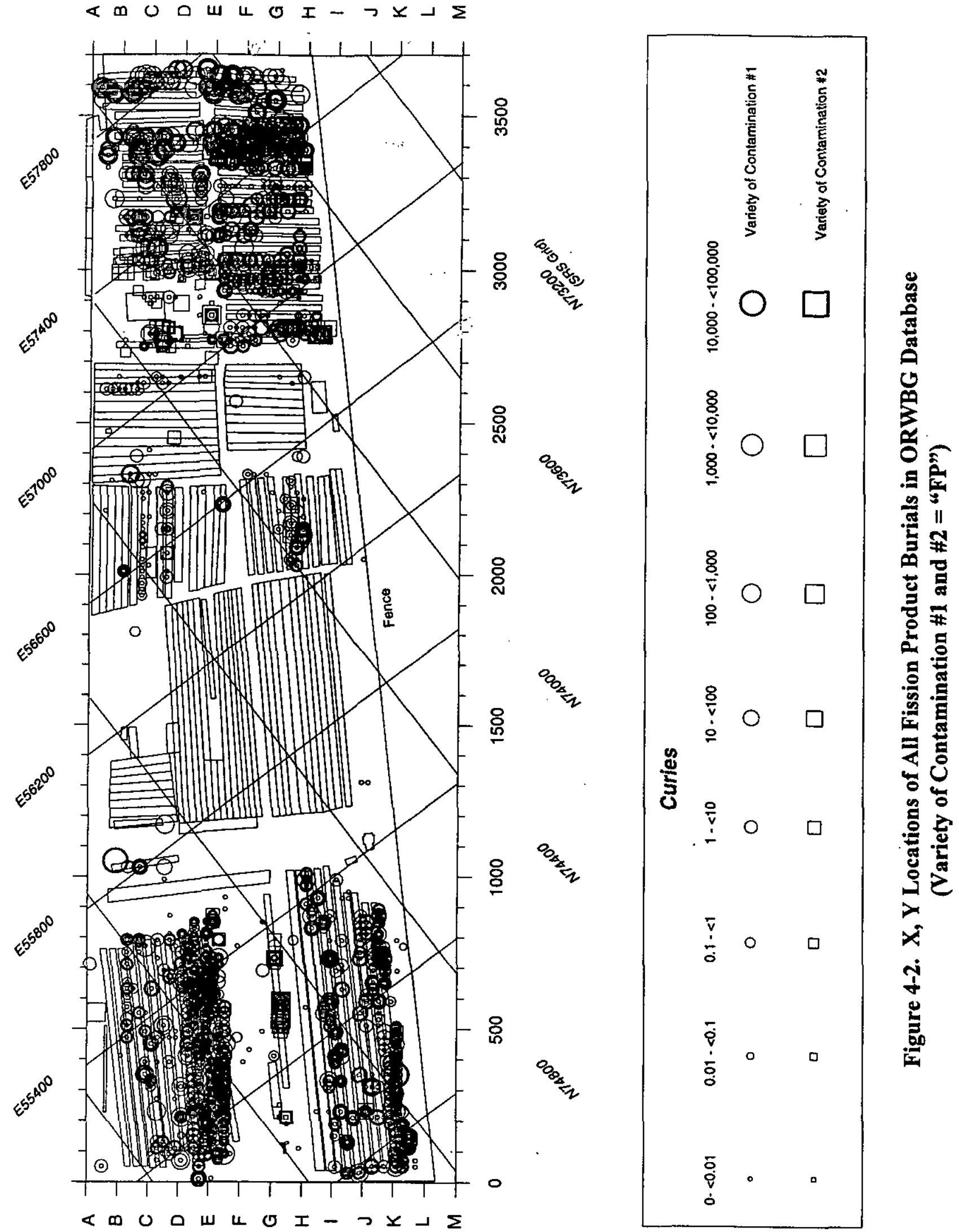

pụ פgo ง!̣əunu-eydi $\forall 100 \mathrm{~J}$ 00L 
Table 2-1. Major Gamma Radionuclides in Organic and Aqueous Phases of OSTs. These data were reported in 1975, prior to the Solvent Relocation Program.

\begin{tabular}{||l|l|l|}
\hline Tank & Organic & Aqueous \\
\hline $\mathbf{1}$ & $\mathrm{Ru}-106,97 \%$ & $\mathrm{Ru}-106,98 \%$ \\
\hline $\mathbf{2}$ & Eu-154, 49\%, Ce-144, 29\% & $\mathrm{Ru}-106,71 \%$ \\
\hline $\mathbf{3}$ & $\mathrm{Ru}-106,81 \%$ & $\mathrm{Cs}-137,68 \%$ \\
\hline $\mathbf{4}$ & $\mathrm{Ru}-106,53 \%, \mathrm{Sb}-125,38 \%$ & $\mathrm{Cs}-137,96 \%$ \\
\hline $\mathbf{5}$ & $\mathrm{Ru}-106,95 \%$ & $\mathrm{Ru}-106,97 \%$ \\
\hline $\mathbf{6}$ & $\begin{array}{l}\text { Sb-125-43\%, Cs-137, 24\% } \\
\text { Ru-106, 23\% }\end{array}$ & Cs-137, 80\% \\
\hline $\mathbf{7}$ & Sb-125, 89\% & Sb-125, 52\%; Cs-137, 45\% \\
\hline $\mathbf{8}$ & No Data & No Data \\
\hline $\mathbf{9}$ & $\mathrm{Ru}-106,99 \%$ & $\mathrm{Ru}-106,98 \%$ \\
\hline $\mathbf{1 0}$ & $\mathrm{Ru}-106,98 \%$ & $\mathrm{Ru}-106,93 \%$ \\
\hline $\mathbf{1 1}$ & $\mathrm{Ce}-144,53 \%, \mathrm{Ru}-106,32 \%$ & $\mathrm{Ru}-106,72 \%$ \\
\hline $\mathbf{1 2}$ & $\mathrm{Ru}-106,74 \%$ & $\mathrm{Ru}-106,99 \%$ \\
\hline $\mathbf{1 3}$ & $\mathrm{Ru}-106,95 \%$ & $\mathrm{Ru}-106,66 \%$ \\
\hline $\mathbf{1 4}$ & $\mathrm{Ru}-106,88 \%$ & $\mathrm{Ru}-106,57 \% ; \mathrm{Cs}-137,42 \%$ \\
\hline $\mathbf{1 5}$ & $\mathrm{Ru}-106,52 \%$, Sb-125, 48\% & $\mathrm{Ru}-106,95 \%$ \\
\hline $\mathbf{1 6}$ & $\mathrm{Ru}-106,97 \%$ & $\mathrm{Cs}-137,91 \%$ \\
\hline $\mathbf{1 7}$ & $\mathrm{Ru}-106,99 \%$ & $\mathrm{Ru}-106,95 \%$ \\
\hline $\mathbf{1 8}$ & $\mathrm{Ru}-106,99 \%$ & $\mathrm{Ru}-106,100 \%$ \\
\hline $\mathbf{1 9}$ & $\mathrm{Ru}-106,100 \%$ & $\mathrm{Ru}-106,95 \%$ \\
\hline $\mathbf{2 0}$ & $\mathrm{Ru}-106,100 \%$ & $\mathrm{Ru}-106,86 \%$ \\
\hline $\mathbf{2 1}$ & $\mathrm{Ru}-106,88 \%$ & $\mathrm{Ru}-106,100 \%$ \\
\hline $\mathbf{2 2}$ & $\mathrm{Ru}-106,99 \%$ & $\mathrm{Ru}-106,98 \%$ \\
\hline
\end{tabular}

Source: Denard (6-30-75) in Mason (1996) 
Table 2-2. Summary of Most Recent Gamma Activity Data for Tanks S1-S22 (Source: Mason, 1996). The present activity in these tanks is considerably less than these values

Beponed by Ryan and Johnson (1-26-81).

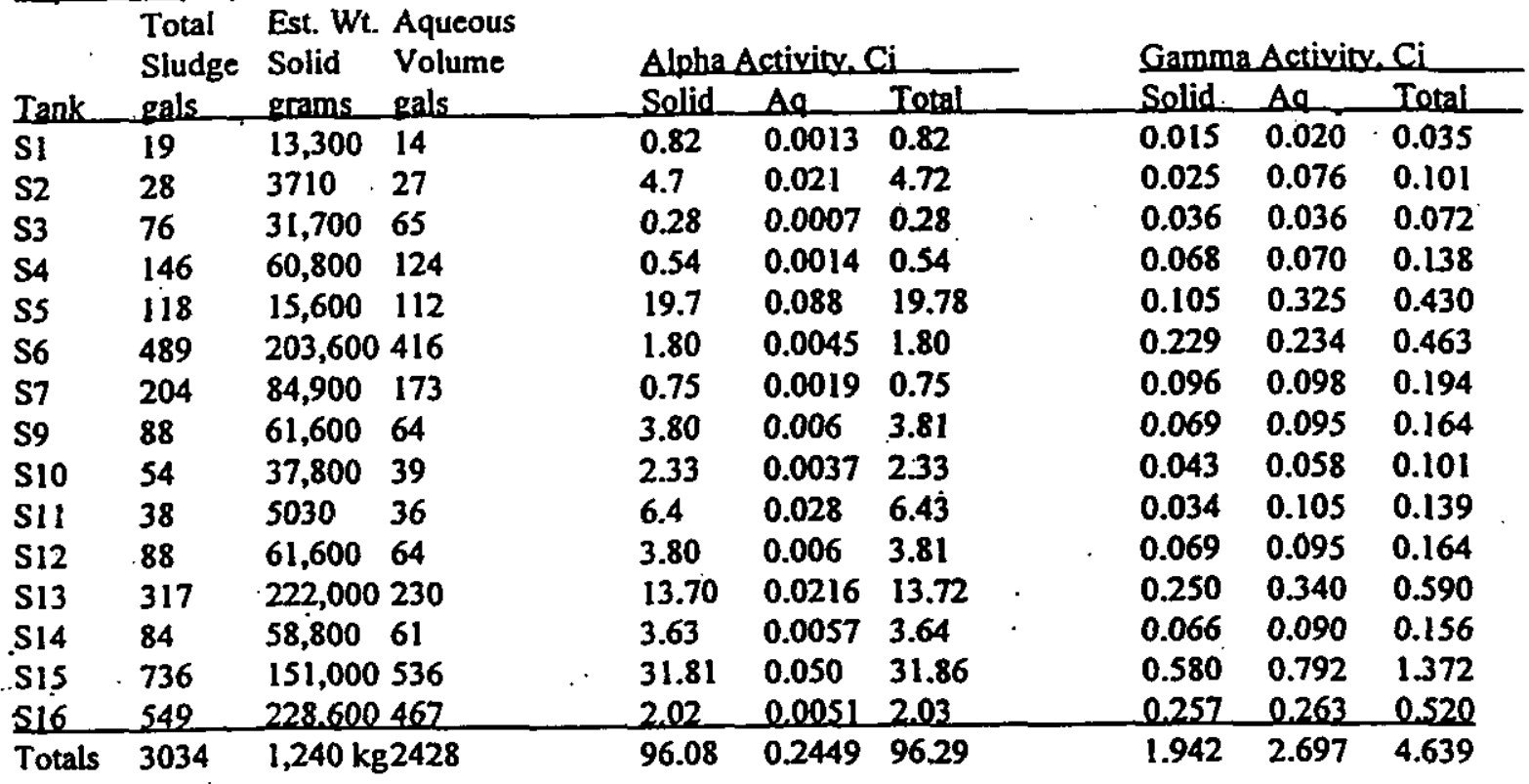

Reported by Tharin (2-65) Probably only considered organic phase.

$\begin{array}{llllll}\text { Tank } & \text { gals } & \text { Alpha } d / \mathrm{m} / \mathrm{ml} & \text { Beta } / \mathrm{m} / \mathrm{ml} & \text { Gämma } / \mathrm{m} / \mathrm{ml} & \text { Date Analyzed } \\ \text { S8 } & 6700 & 1.5 \times 10 \mathrm{E} 4 & 8.5 \times 10 \mathrm{E} 3 & 2.5 \times 10 \mathrm{E} 3 & 12 / 5 / 63 \\ & & 0.17 \mathrm{Ci} & & & \end{array}$

Reported by Denard (6-30-75). * Alpha spectrum could not be resolved.

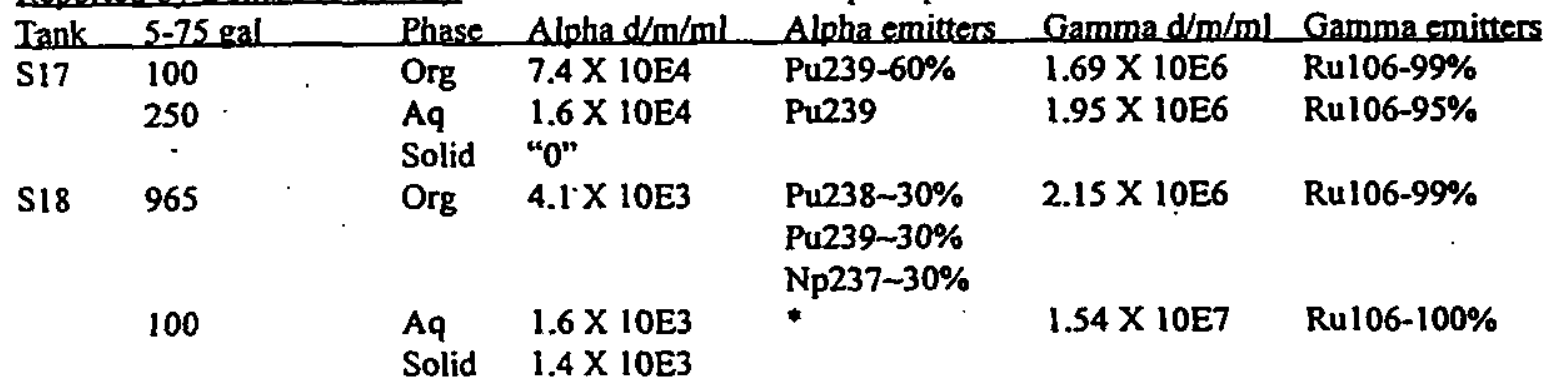

Reported by Epting (11-24-80).

$\begin{array}{lllll}\text { Tank } & \text { gal } & \text { Phase } & \text { AlphaCi } & \text { GammaCi } \\ \text { S19 } & 823 & \text { Aq } & 10.19 & 5.33 \\ \text { S20 } & 1509 & \text { Org } & 0.014 & 0.019 \\ & 330 & \text { Aq } & 0.001 & 0.292 \\ \text { S21 } & 21,582 & \text { Org } & 0.286 & 0.0035 \\ & 789 & \text { Aq } & 0.001 & 0.002 \\ \text { S22 } & 21,461 & \text { Org } & 0.032 & 0.016 \\ & 663 & \text { Aq } & 0.001 & 0.001\end{array}$


Table 3-1. Cesium-137 Estimates for the ORWBG

Data are from Cook (1990). The best estimate is determined by increasing these amounts by $3 \%$. (see Section 3.2)

\begin{tabular}{|c|c|c|}
\hline Year ${ }^{*}$ & Original Cs-137 Activity, $\mathbf{C i}^{*}$ & Cs-137 Activity, Decayed to 1997, Ci \\
\hline 1954 & 1551 & 574 \\
\hline 1955 & 3103 & 1176 \\
\hline 1956 & 3103 & 1204 \\
\hline 1957 & 3103 & 1232 \\
\hline 1958 & 3103 & 1260 \\
\hline 1959 & 3103 & 1290 \\
\hline 1960 & 3103 & 1320 \\
\hline 1961 & 4251 & 1851 \\
\hline 1962 & 3712 & 1654 \\
\hline 1963 & 1796 & 819 \\
\hline 1964 & 3156 & 1473 \\
\hline 1965 & 5055 & 2414 \\
\hline 1966 & 873 & 427 \\
\hline 1967 & 5370 & 2685 \\
\hline 1968 & 1875 & 960 \\
\hline 1969 & 3847 & 2015 \\
\hline 1970 & 4659 & 2497 \\
\hline 1971 & 1568 & 860 \\
\hline 1972 & 618 & 347 \\
\hline Total: & $\mathbf{5 6 , 9 4 9}$ & $\mathbf{2 6 , 0 5 8}$ \\
\hline
\end{tabular}

Source: Cook (1990).

No waste with significant amounts of fission products was produced before 12/28/53. 
Table 3-3. The Sources of Inventory Estimates for Cs-137 in the ORWBG

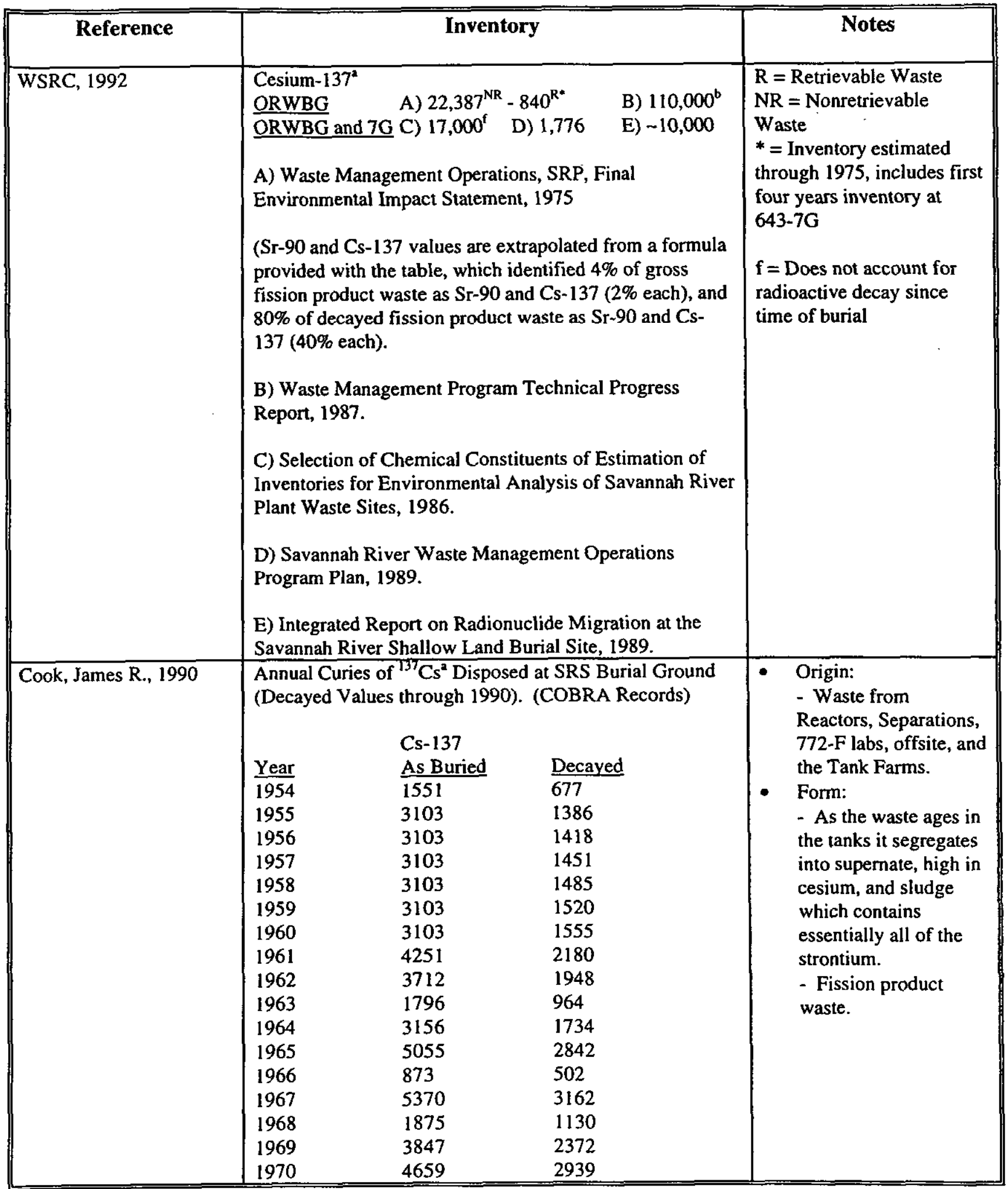


Table 3-3. The Sources of Inventory Estimates for Cs-137 in the ORWBG (Continued)

\begin{tabular}{|c|c|c|}
\hline Reference & Inventory & Notes \\
\hline & $\begin{array}{l}\text { Continued: } \\
\text { 1971 } \quad 1568 \\
1972 \quad 618 \quad 4012 \\
\text { The production program used to calculate decayed curies } \\
\text { of fission products. [Reference: Member K1206000, Data } \\
\text { Set SRL. PROD. SOURCE] was examined, and the } \\
\text { algorithm assumes that fission product distribution is } 2 \% \\
{ }^{90} \mathrm{Sr}, 2 \%{ }^{137} \mathrm{Cs}, 95.9 \% \text { isotopes with half-lives less than ten } \\
\text { years and } 0.1 \% \text { isotopes with half-lives greater than ten } \\
\text { years. }\end{array}$ & - \\
\hline Cook, James R., 1987 & $\begin{array}{l}{ }^{37} \mathrm{Cs}: 110,000 \mathrm{Ci}^{\mathrm{b}} \\
\text { (does not reference an earlier article). }\end{array}$ & $\begin{array}{l}\text { ORWBG lifetime: } 1952 \text { to } \\
1974\end{array}$ \\
\hline $\begin{array}{l}\text { Horton, J.H. and } \\
\text { Corey, J.C., } 1976\end{array}$ & $\begin{array}{l}{ }^{37} \mathrm{Cs}: 500 \mathrm{Ci}^{6} \text { emplaced each year at the Solid } \\
\text { Radioactive Waste Storage Site. } \\
\text { (does not reference an earlier article). }\end{array}$ & NA \\
\hline $\begin{array}{l}\text { Corey, J.C. and Horton, } \\
\text { J.H, } 1971\end{array}$ & $\begin{array}{l}\underset{\text { Fission Products: } 387,000^{\mathrm{b}}}{\text { Ci Remaining }} \\
{ }^{137} \mathrm{Cs}: 4,000^{\mathrm{b}} \\
\text { (does not reference an earlier article). }\end{array}$ & $\begin{array}{l}\text { Equipment Discards } \\
\text { - Slug Fragments } \\
\text { - Vessels and Jumpers } \\
\text { - Radioactive Waste } \\
\text { Burials through } 1969 \\
\text { - Residue Recoverable } \\
\end{array}$ \\
\hline
\end{tabular}
a: Inventory discussed in detail
b: No discussion of basis for inventory
NA: Not addressed in article 
Table 3-4. The Sources of Inventory Estimates for Fission Products in the ORWBG Although "fission products" currently are composed primarily of Cs-137 and Sr-90, the isotopic distribution was considerably different at the time of production.

\begin{tabular}{|c|c|c|}
\hline Reference & Inventory (Burial Ground) & Notes \\
\hline Cook, J R., 1991 & $\begin{array}{l}\text { Fission Products }{ }^{b} \\
\text { As Variety } 1: 561,063 \mathrm{Ci} \\
\text { As Variety } 2: 40,145 \mathrm{Ci} \\
\text { Total: } 601,208 \mathrm{Ci} \\
\text { (does not reference an earlier article). }\end{array}$ & $\begin{array}{l}\text { The results presented here utilize } \\
\text { COBRA database records through } \\
\text { June } 25,1991 \text {. }\end{array}$ \\
\hline Ashley C., 1965 & $\begin{array}{l}\text { Gamma, kilocuries } \quad \frac{1964}{20.61} \frac{\text { Total Since }}{\text { Plant Startup }} \\
\qquad \text { Fission } \\
\text { (b) }\end{array}$ & $\begin{array}{l}\text { Health Protection (HP) data. } \\
\text { HP published a summary report } \\
\text { between } 1959 \text { and } 1965 \text { that } \\
\text { gives gross information on } \\
\text { radioisotope burials. }\end{array}$ \\
\hline Ashley, C., 1964 & $\begin{array}{l}\text { Gamma, kilocuries } \quad \frac{1963}{19.22} \frac{\text { Total Since }}{\text { Plant Startup }} \\
\qquad \text { Fission }^{(b)} \quad 120.78 \\
\text { (does not reference an earlier article). } \\
\text { Estimated quantities of fission products in } \\
\text { underground waste storage tanks, as of December } \\
\text { 20, 1963, totaled } 397 \text { megacuries in F Area and } 407 \\
\text { megacuries in H Area (data provided by } \\
\text { Separations Technology Section). }\end{array}$ & Th o \\
\hline Ashley C., 1963 & $\begin{array}{lll}\text { Gamma, kilocuries } & \frac{1962}{21.15} & \begin{array}{l}\text { Total Since } \\
\text { Plant Startup }\end{array} \\
\text { Fission }^{(b)} & 201.56^{*}\end{array}$ & $\begin{array}{l}\text { * Gamma curies were corrected } \\
\text { for overestimates in } 1960 \text { and } \\
1959 .\end{array}$ \\
\hline Ashley C., 1962b & $\begin{array}{ll}1961 & \text { Total Since } \\
204^{*} & \frac{\text { Plant Startup }}{777}\end{array}$ & $\begin{array}{l}\text { * Includes } 52 \text { kilocuries of } \\
\text { fission products. }\end{array}$ \\
\hline Ashley C., 1962a & $\begin{array}{cc}1960 & \begin{array}{l}\text { Total Since } \\
\text { Plant Startup }\end{array} \\
573\end{array}$ & $\begin{array}{l}* \text { Includes } 232 \text { kilocuries of } \\
\text { fission products. }\end{array}$ \\
\hline Ashley, C., 1960 & $\frac{\text { From Startup through } 1959}{216,000 \text { curies }}$ & NA \\
\hline
\end{tabular}

a: Inventory discussed in detail

b: No discussion of basis for inventory

NA: Not addressed in article 
(This page intentionally left blank) 


\section{APPENDLX G}

\section{CONSTITUENT OF INTEREST:}

PLUTONIUM-238 
(This page intentionally left blank) 
TABLE OF CONTENTS

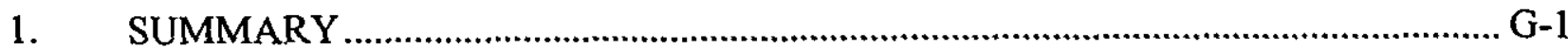

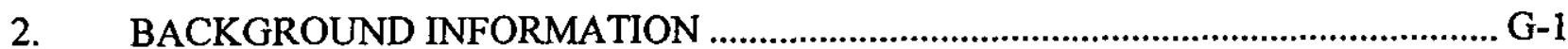

$2.1 \quad$ Plutonium-238 in Waste Streams...................................................................... G-2

2.2 Plutonium-238 Management at the Old Radioactive Waste Burial Grounds ..... G-2

2.2.1 Culverts ............................................................................................. G-3

2.2.2 Concrete Encapsulated Waste .................................................................... G-3

2.2.3 Non-Retrievable Alpha-Bearing Waste .................................................. G-3

2.2.4 Spent Solvent ...................................................................................... G-4

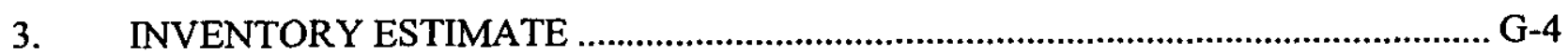

3.1 Range of Inventory Estimates ......................................................................... G-4

3.2 Best Estimate of Plutonium-238 in Burial Grounds ........................................... G-5

3.3 Uncertainties Associated with Plutonium-238 Inventory Estimate ..................... G-6

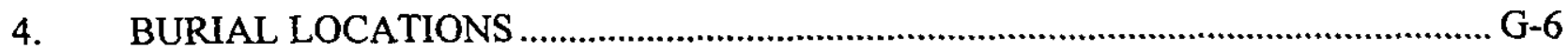

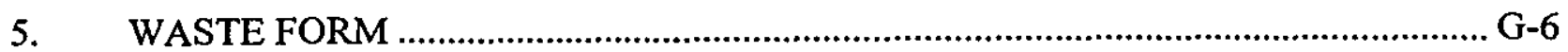

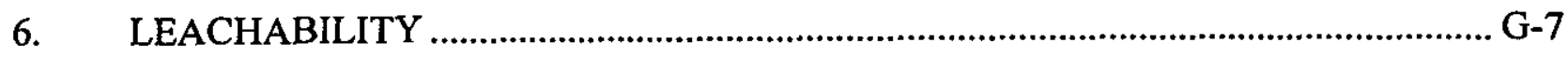

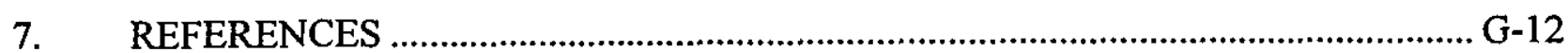




\section{LIST OF FIGURES}

Figure 1-1. Inventory Estimate Process Flow Diagram ........................................................14

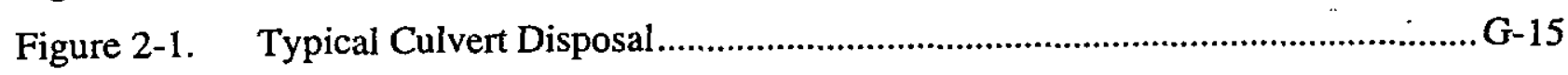

Figure 2-2. Typical Encapsulation Burial ......................................................................16

Figure 3-1. Comparison of Plutonium-238 Estimates in the ORWBG …............................ G-17

Figure 3-2. Health Protection Data Total Plutonium to Burial Ground through 1964 ........G-18

Figure 4-1. Plutonium-238 Burial Location Process Flow Diagram ................................... G-19

Figure 4-2. Shown are COBRA Plutonium-238 Locations for: (a) Non-retrievable and

(b) Concrete Pours...................................................................................... G-20

Figure 4-3. Shown are COBRA Plutonium-238 Locations for: (a) Retrievable TRU "Culverts" and (b) Retrievable TRU Other than "Culverts".............................. G-21

Figure 6-1. Eh-pH Diagram for Plutonium Species, $\mathrm{pCO}_{2}=0.01 \mathrm{~atm} . . . \ldots \ldots \ldots \ldots \ldots \ldots . . . . . . . . . . . . \mathrm{G}-22$

\section{LIST OF TABLES}

Table 2-1. COBRA Plutonium-238 Records With "Burial Code $=5$ " (Concrete Pour) .... G-23

Table 2-2. COBRA Plutonium-238 Records from 1965-1974 which have Burial Code other than 4 (Burial Container [Retrievable TRU]) or 5 (Concrete Pour) and Quantity of Plutonium-238 > 0.1 Curies per Record.............................................................

Table 3-1. The Sources of Inventory Estimates for Plutonium-238 in the ORWBG ..........G-27

Table 3-2. The Sources of Inventory Estimates for Total Plutonium in the ORWBG .......G-29

Table 3-3. Buried TRU Culverts Summary ……...............................................................30 


\section{CONSTITUENT OF INTEREST - PLUTONIUM-238}

\section{SUMMARY}

The production of plutonium-238 for use in thermionic heat sources for power generation was a primary operation at the Savannah River Site (SRS). Plutonium-238 oxide produced at SRS was shipped offsite to other facilities in the U.S. Department of Energy weapons complex. Wastes containing plutonium-238 buried at the Old Radioactive Waste Burial Ground (ORWBG) originated primarily in separations areas, reactor areas, and research facilities like the Savannah River Technology Center (SRTC).

The best estimate for the original amount of plutonium-238 inventory at the ORWBG is 1192.7 grams (20,514 curies). This estimate is the sum of two sources: the Computerized Burial Record Analysis (COBRA) database total and a relatively insignificant quantity estimated to be in burned solvent residues.

The date disposed and total alpha activity of the waste package affected how waste was handled at ORWBG. According to Cook (1987), alpha-bearing waste, which included plutonium-238, was buried in plastic bags and cardboard boxes in earthen trenches designated for alpha-bearing wastes from the beginning of operations at the ORWBG until 1965. Between 1965 and 1974, alpha-bearing waste was segregated based on its activity. Waste containing less than 0.1 curies per package was buried unencapsulated in alpha trenches. Waste containing greater than 0.1 curies per package was buried in retrievable concrete containers (Cook, 1987).

Figure 1-1 presents the process used to develop the inventory and burial locations. A process knowledge for generating plutonium-238 at the SRS was developed. The COBRA database was used to determine the location of burials of plutonium-238.

\section{BACKGROUND INFORMATION}

Plutonium-238 entered waste streams from many operations at SRS, including reactors, separations, and waste management. At ORWBG, handling methods for alpha-bearing wastes such as plutonium-238, depended on the year of disposal and the alpha activity of the waste.

Plutonium-238 has a half-life of 87.4 years and a specific activity of 17.2 curies per gram. Plutonium-238 comprises 80 to 83 percent of heat source plutonium (Cook and Helton, 
1989). Weapons-grade plutonium, isotopically primarily plutonium-239, contains only 0.007 weight percent plutonium-238.

\subsection{Plutonium-238 in Waste Streams}

Plutonium-238 was a constituent of alpha-bearing wastes originating from both separations areas: F-Area and H-Area. These wastes comprise the bulk of the plutonium-238 sent to the ORWBG.

Following irradiation in SRS reactors, chemical separation of plutonium-238 from its target parent, neptunium-237, occurred in H-Canyon. Production of plutonium-238 oxide powder took place in HB-Line. The oxide powder was formed into cylindrical pellets in Building 235-F. The pellets were shipped offsite.

Spent solvent from the separations areas was sent to the Old Solvent Tanks (OSTs), located in the ORWBG, to be stored prior to burning. This solvent was contaminated with plutonium-238.

Plutonium-238 was also a constituent of radioactive waste from other areas at SRS. These areas included the reactor areas, the F- and H-Area tank farms, and site laboratories. Generally, plutonium-238 would be a minor contaminant in job control waste.

\subsection{Plutonium-238 Management at the Old Radioactive Waste Burial Grounds}

Plutonium-238 and other alpha-bearing solid waste was managed in one of three ways: disposed of in plastic bags and cardboard boxes in trenches designated for alpha-bearing waste, disposed of in drums placed in concrete culverts in trenches, or encapsulated in concrete in trenches. Generally, encapsulated waste was drummed and placed in slit trenches that were filled with concrete. Canyon equipment and other bulky wastes were placed directly into trenches, which were then filled with concrete (Cook, 1987). Starting in 1965, packages with greater than 0.1 curies of transuranium (TRU) were placed in concrete culverts. When full, these culverts were placed in shallow subgrade trenches for retrieval and processing at a future date. They are currently being stored in two separate trenches in the burial ground. The practice of subgrade storage was discontinued in 1974, and storage atgrade on concrete pads was adopted for SRS generated waste (Cook and Helton, 1989). 


\subsubsection{Culverts}

From 1965 through 1974, alpha-bearing waste with alpha activities greater than 0.1 curies was buried in a retrievable configuration. One such configuration was a prefabricated concrete container, or culvert. Ninety-five concrete culverts containing plutonium- 238 were disposed of in the ORWBG. These culverts are 7 feet in diameter and 7.5 feet high (Cook, 1987). [Note: Horton and Corey (1976) state that the culverts were 6 feet in diameter and 6.5 feet high.] The culverts were typically filled with drums, cans, and boxes. Figure 2-1 shows a typical culvert. Such culverts were used to house high activity alpha-bearing waste containing plutonium-238 and/or plutonium-239.

\subsubsection{Concrete Encapsulated Waste}

Alpha-bearing waste with activities greater than 0.1 curies that did not fit in the prefabricated concrete containers was placed in slit trenches and encapsulated in concrete. Table 2-1 presents the six COBRA records which have a burial code of 5 ("concrete pour"). Figure 2-2 shows a photograph of a typical encapsulation burial. Encapsulated burials are also considered retrievable (Horton and Corey, 1976).

\subsubsection{Non-Retrievable Alpha-Bearing Waste}

Prior to 1965 , alpha-bearing waste, which included plutonium-238, was buried in plastic bags and cardboard boxes in earthen trenches designated for alpha-bearing wastes. From 1965 to 1974, alpha-bearing waste with alpha activities less than 0.1 curies per package was buried unencapsulated in alpha trenches (Cook, 1987). COBRA records indicate that there were 58 cases where waste containing plutonium-238 in concentrations greater than 0.1 curies per package was disposed of in trenches without encapsulation. These 58 instances were identified from COBRA records meeting the following criteria:

(1) Variety of contamination \#1 = 83 (plutonium-238)

(2) Burial code other than 4 (burial code $4=$ "burial containers [retrievable TRU]") or 5 (concrete pour)

(3) Quantity of variety \#1 exceeds 0.1 curies per record

The 58 records matching the above criteria are presented on Table 2-2. 


\subsubsection{Spent Solvent}

Plutonium-238 was a constituent of spent solvent sent from separations facilities to the OSTs. The organic phase of the solvent was pumped from the OSTs and burned. Plutonium in the organic phase of the solvent remained in the residue and was buried in trenches in the ORWBG (Mason, 1996). Plutonium-238 is a component of the liquid and solid phases remaining in the OST.

\section{INVENTORY ESTIMATE}

Inventory estimates for plutonium-238 are based on data contained in the COBRA database and burial records predating COBRA, which was first used in 1961. The COBRA database indicates that burials of Pu-238 occurred in the ORWBG as recently as 1973.

\subsection{Range of Inventory Estimates}

Table 3-1 presents the references reviewed related to plutonium-238 inventory. Table 3-2 presents the references reviewed related to total plutonium inventory. The table includes the reference, the inventory estimates provided by the reference, and any special notes associated with the inventory. Figures 3-1 and 3-2 graphically compare the inventory estimates in Table 3-1 and Table 3-2.

A comparison of plutonium-238 estimates in the ORWBG is shown in Figure 3-1. The Horton and Corey (1971) and Cook (1991) estimates shown in Figure 3-1 are through 1969. Cook (1987) provides an estimate for plutonium-238 in the ORWBG, but does not give much detail. Cook and Helton (1989) provide greater detail on the burials of plutonium-238 in the ORWBG.

Cook and Helton (1989) provides the following details on plutonium-238 burials:

- 330 curies (19.2 grams) of plutonium-238 were double-bagged and placed in a container in trenches from ORWBG start-up until May 1964.

- 2,794 curies (162.4 grams) of plutonium-238 were double-bagged and placed in a container in trenches from May 1964 through 1973.

- 9,680 curies (563 grams) and 3,531 curies (205 grams) of plutonium-238 were buried in two separate areas in retrievable concrete culverts.

- 35 curies ( 2 grams) of plutonium-238 were encapsulated in concrete.

- 1,119 curies (65 grams) were buried in a single concrete cask from Building 773-A. 
The amounts of total plutonium buried from startup through 1964 are shown in Figure 3-2. Health Protection data (Ashley, 1960, 1962a, 1962b, 1963, 1964, and 1965) indicate that from ORWBG start-up through June 1964, 3,614 grams of plutonium were buried. Cook and Helton (1989) indicate that the sum of the plutonium-238 and plutonium-239 burials from start-up through May of 1964 was 4,609 grams. The COBRA database describes all plutonium burials, through 1962 as weapons-grade plutonium, which contains only 0.007 percent plutonium-238.

The COBRA database indicates that 1,191 grams of plutonium-238 have been buried. The first burial record for plutonium-238 is March 2, 1961, and the last record is for August 9, 1993. The summary of the contribution by area is:

- A-Area (e.g., 773-A) - 112 grams

- F-Area - 319 grams

- H-Area, excluding HB-Line - 493 grams

- HB-Line - 255 grams

- K-Area - 12 grams

Table 3-3 summarizes the culvert burials. The table indicates the burial ground coordinates of each culvert, the plutonium-238 (bolded), plutonium-239, and neptunium-237 content of each culvert, and the numbers of drums, cans, boxes, and casks in the culvert.

Another source listed in Table 3-1 (Wilhite, 1976) lists additional plutonium-238 contributed by solvent residues. This residue, containing an estimated 1.7 grams of plutonium-238, was left in the burning pan after the solvent was burned.

Mason (1996) indicates that the solids remaining in the OSTs (Tanks 1 through 22) contain approximately 107 curies of alpha activity. If the same activity ratio that was found in the solvent residues (77\% Pu-239, 20\% Pu-238, and 3\% Cm-244) and reported in Wilhite (1976) is applied to this activity, then the OST inventory for plutonium- 238 would be 21.4 curies or 1.24 grams.

\subsection{Best Estimate of Plutonium-238 in Burial Grounds}

The best estimate for the original plutonium-238 inventory in trenches in the ORWBG is 1192.7 grams (20,514 curies) $(16,825$ curies decayed to 1997). The estimate is the sum of the inventory in COBRA and the plutonium-238 from the solvent residue after burning. 
For the OSTs, the best estimate of the plutonium-238 inventory is 1.24 grams (21.4 curies) (see Section 3.1).

\subsection{Uncertainties Associated with Plutonium-238 Inventory Estimate}

Plutonium-238, classified as a special nuclear material, was carefully monitored at the SRS. The location and quantity of plutonium-238 were under continuous scrutiny because it was a valuable resource. The major contributor to the uncertainty related to the quantity of plutonium-238 buried is any classified burials that are not described in the open literature and in unclassified databases such as COBRA.

\section{BURIAL LOCATIONS}

The COBRA database provides information on the spatial distribution of plutonium in the ORWBG. Figure 4-1 outlines the steps taken to manipulate the database to locate plutonium238 burials. Figure 4-2(a) presents the burial locations for non-retrievable plutonium-238. This waste was buried without special containment. Figure 4-2(b) presents the burial locations for plutonium-238 "concrete pours" (COBRA records with burial code $=5$ ). These encapsulated or grouted burials may or may not be retrievable. The figures indicate the relative size, in grams, of each burial.

Figure 4-3 shows the locations for retrievable plutonium-238 burials. Burial records having culvert (container) numbers are given on Figure 4-3(a), whereas records with no container numbers are shown on Figure 4-3(b). The exact form of the retrievable TRU burials that have no container number is uncertain. It is considered likely that these burials consist of 55gallon drums encapsulated in concrete and/or oversized equipment placed in a trench and backfilled with concrete. These burials are similar to "concrete pours", and the recovery of these plutonium-238 source terms is subject to question. Another less likely scenario for the unnumbered retrievable TRU burials is that they are unnumbered "culverts". Note that in many of these retrievable burials, plutonium-239 is also included in the waste.

The locations indicated in Figures 4-2 and 4-3 are consistent with the schematic indications of burial location given in Cook and Helton (1989). 


\section{WASTE FORM}

Pu-238 contaminated waste was buried in three ways:

- Uncontainerized waste in plastic bags and cardboard boxes. This type of containment would be the most susceptible to infiltrating water.

- Concrete culverts containing drummed or boxed plutonium-238-bearing waste. Although it provides additional barriers, this containment does not preclude the infiltration of water into the culvert. One excavated culvert was found to contain water.

- Encapsulated waste where drums and other waste forms (equipment, waste in wooden boxes, etc.) were surrounded by concrete on all sides, top, and bottom. Such waste forms would be more impermeable to water infiltration.

\section{LEACHABILITY}

The leachability of plutonium from the ORWBG is a function of the prevailing redox conditions, $\mathrm{pH}$ and chemistry of the water flowing through the trenches, as well as container integrity and waste form. For estimation of plutonium leachability the geochemical constraints will be considered in light of groundwater plutonium concentrations and plutonium leachability from the Defense Waste Lysimeters installed within the ORWBG.

Plutonium migrates in dissolved forms and is associated with colloidal particles. Solubility and adsorption control the dissolved forms and strongly influence colloidal plutonium migration. These mechanisms are complicated by the multiple oxidation states of plutonium (III, IV, V, and VI) and the tendency of plutonium to complex with a variety of anions and dissolved organic materials.

Adsorption of plutonium is strongly influenced by plutonium speciation. Prout (1958) measured soil/water distribution coefficient (Kd) values for $\mathrm{Pu}(\mathrm{III}), \mathrm{Pu}(\mathrm{IV})$, and $\mathrm{Pu}(\mathrm{VI})$ on SRS soils. Between $\mathrm{pH} 2$ and 7 the $\mathrm{K}_{\mathrm{d}}$ value for $\mathrm{Pu}(\mathrm{III})$ was 1 to 3 orders of magnitude greater than the $\mathrm{K}_{d}$ value for $\mathrm{Pu}(\mathrm{VI})$, with the difference increasing as $\mathrm{pH}$ increased. The $\mathrm{K}_{\mathrm{d}}$ value for $\mathrm{Pu}(\mathrm{IV})$ was consistently 1 order of magnitude greater than that for $\mathrm{Pu}(\mathrm{VI})$. Thus, where adsorption dominates retardation, transport of the reduced forms of plutonium is retarded, at a minimum, about 10 times that of $\mathrm{Pu}(\mathrm{VI})$ and may be significantly higher.

Within the ORWBG, plutonium is expected to exist predominantly as $\mathrm{Pu}(\mathrm{III})$ and $\mathrm{Pu}(\mathrm{IV})$. Figure 6-1 shows data from the grid wells (Ryan, 1983) plotted within an redox potential (Eh) vs. pH diagram for dissolved plutonium species. Half of the grid well data plot within 
the fields of dominance of $\mathrm{Pu}$ (III) and $\mathrm{Pu}$ (IV) species. The remaining data plot within the field of dominance of the pentavalent species $\mathrm{PuO}_{2}^{+}$, but near boundaries of the reduced species. It is uncertain which redox couples influence these Eh measurements and thus, Eh is only a general indicator of redox conditions within the ORWBG. However, these measurements do show that the presence of $\mathrm{Pu}(\mathrm{VI})$ species is unlikely. Furthermore, considering the widespread presence of organic material (paper, cardboard, wood, etc.) and zero valent iron (steel drums, scrap metal, etc.), $\mathrm{Pu}(\mathrm{III})$ and $\mathrm{Pu}(\mathrm{IV})$ are probably the dominant forms of plutonium in solution. For example, as scrap metal and drums corrode, the following plutonium reduction reactions are favorable:

$$
\begin{array}{ll}
\mathrm{PuO}_{2}{ }^{+}+1 / 3 \mathrm{Fe}^{\circ}+3 \mathrm{H}_{2} \mathrm{O}=\mathrm{Pu}(\mathrm{OH})_{4}^{\circ}+1 / 3 \mathrm{Fe}(\mathrm{OH})_{3(\mathrm{am})}+\mathrm{H}^{+} & \operatorname{logK}=7.19 \\
\mathrm{Pu}(\mathrm{OH}) 4^{\circ}+1 / 3 \mathrm{Fe}^{\circ}+3 \mathrm{H}^{+}=1 / 3 \mathrm{Fe}(\mathrm{OH}) 3(\mathrm{am})+\mathrm{Pu}^{+3}+3 \mathrm{H}_{2} \mathrm{O} & \operatorname{logK}=26.27
\end{array}
$$

Water collected from the bottom of burial trenches is more reducing than groundwater from the grid wells (Ryan, 1983). This further supports the viability of plutonium reducing reactions in the ORWBG. Hence, $\mathrm{Pu}$ (III) and $\mathrm{Pu}(\mathrm{IV})$ forms are likely to dominate the speciation of plutonium in the ORWBG.

This is in contrast to the measurements of plutonium speciation in ground water from grid well C-17 made by Wilhite (1978). The distribution of plutonium forms in this groundwater was $43 \% \mathrm{Pu}(\mathrm{VI}), 25 \% \mathrm{Pu}(\mathrm{IV}), 30 \% \mathrm{Pu}(\mathrm{III})$, and less than $2 \%$ in organic forms. Though the reduced forms dominated, the concentration of $\mathrm{Pu}(\mathrm{VI})$ was significant. However, water from this well has had anomalously high concentrations of plutonium compared to all other ORWBG wells (Towler, 1989). This is consistent with the presence of Pu(VI), because this form is more mobile than the reduced forms of plutonium. In contrast, most of the other grid wells have much lower concentrations of plutonium because the plutonium is present as $\mathrm{Pu}(\mathrm{III})$ and $\mathrm{Pu}(\mathrm{IV})$ and is strongly partitioned to the soils. Thus, the presence of $\mathrm{Pu}(\mathrm{VI})$ in well $\mathrm{C}-17$ is not indicative of the speciation of plutonium throughout the ORWBG, but is more likely related to a condition specific to this well. This may be its proximity to the solvent burning trench or the fact that multiple spills of plutonium-bearing solvent have occurred at this well (McIntyre and Wilhite, 1987).

In the absence of strong complexing or colloidal migration, plutonium in the ORWBG will remain immobilized by strong sorption of the dominant $\mathrm{Pu}(\mathrm{III})$ and $\mathrm{Pu}(\mathrm{IV})$ forms. Over the $\mathrm{pH}$ range of the trench wells (5.8-7.0), Prout (1958) measured $K_{d}$ values for $P u(I V)$ from $3000^{-}$to $8000^{-} \mathrm{mil} / \mathrm{g}^{-}$and $\mathrm{K}^{-} \mathrm{d}^{-}$values that-exceeded-10,000_ml/g_for_Pu(III)._This_suggests a 
range of retardation factors for the dominant forms of plutonium of about 24,000 to in excess of 80,000 .

Enhanced mobility of plutonium by organic complexing has not been observed at the ORWBG. The presence of abundant organic material in the ORWBG raised the concern that the degradation of this material could release organic components that would enhance the mobility of radionuclides. McIntyre and Wilhite (1987) addressed this concern by comparing the concentrations of several radionuclides with concentrations of dissolved organic components in water from the grid wells. Approximately $40 \%$ of the dissolved organics were high molecular weight components, suggesting they originated from the decay of organic material in the ORWBG. However, there was no correlation between the concentration of plutonium (or any other radionuclide measured) and the concentration of dissolved organic components. McIntyre and Wilhite (1987) concluded that either the radionuclides measured (including plutonium) do not form strong complexes with these organic components or the concentration of the organic components is not high enough to significantly affect the mobility of the radionuclides.

Though colloidal migration of plutonium may occur, the evidence suggests that it does not significantly enhance leachability. Plutonium may migrate colloidally as discrete plutonium phases or adsorbed to other metal oxide phases (Silva and Nitsche, 1995). The discrete phases tend to be polymerized $\mathrm{Pu}(\mathrm{OH}) 4$ and are called intrinsic colloids. Rai and Serne (1979) found that intrinsic colloids could only form if the concentration of plutonium was above the solubility of $\mathrm{Pu}(\mathrm{OH}) 4(\mathrm{am})$. The concentration of plutonium in groundwater beneath the ORWBG is several orders of magnitude less than this threshold value. Thus, migration of plutonium as intrinsic colloids is not occurring. From the available data it is not possible to determine the fraction of migrating plutonium that is adsorbed to colloidal particles of non-plutonium phases. However, Kaplan et al. (1994) did find that a minor amount of ${ }^{239} \mathrm{Pu}$ was migrating in association with colloidal particles from a General Separations Area seepage basin. Nevertheless, they concluded that this was only a small fraction of the plutonium released and that the transport behavior of plutonium was dominated by sorption to the aquifer matrix.

Concentrations of ${ }^{238} \mathrm{Pu}$ and ${ }^{239} \mathrm{Pu}$ in groundwater beneath the ORWBG are low. Ryan (1983) reported analyses performed in 1980 of groundwater from 12 grid wells. The highest concentrations of ${ }^{238} \mathrm{Pu}$ and ${ }^{239} \mathrm{Pu}$ were $17 \mathrm{pCi} / 1$ and $4 \mathrm{pCi} / 1$, respectively and occurred in well G-21. 
Well G-21 has an anomalous chemistry (Ryan, 1983) that may not be representative of concentrations in groundwater. McIntyre and Wilhite (1988) and Towler (1989) report that well G-21 was one of 15 wells installed through waste trenches at the ORWBG to monitor the water table. Samples from well G-21 have shown consistently high concentrations of radionuclides that should not be at the water table by migration from the trenches (Ryan, 1983). The anomalously high radionuclide concentrations (particularly Sr-90) in this well have been correlated with high, and similarly anomalous concentration of iron found in the same samples (Ryan, 1983). Possible explanations for the elevated iron concentrations include:

- a natural anomaly in the aquifer of high concentrations of organic matter or pyrite,

- contaminated water leaking from the trench down the well annulus, or

- waste debris smeared down the hole during installation of the well.

Natural iron anomalies in the water table aquifer at SRS have not been observed. Relatively immobile radionuclides (like cesium and plutonium) in water leaking down the well annulus would likely be sorbed to surfaces along the annulus and not occur in significant concentrations at the screen. Small amounts of waste debris smeared during well installation could explain the anomalous chemistry of the samples taken from this well. Monitoring well G-21 was abandoned in 1995, in accordance with accepted abandonment procedures.

Contamination from releases of liquid solvent offers an alternative explanation for the anomalous radionuclide concentrations in well G-21. Several reports discuss a 1962 incident in which 40 gallons of spent PUREX solvent, which consisted of up to $30 \%$ tri-butlyphosphate (TBP) and contained plutonium, were accidentally pumped down an unidentified test well located near the solvent tanks (Wilhite, 1975; Ryan, 1983; McIntyre and Wilhite, 1987; Mason, 1996). McIntyre and Wilhite (1987) report that in 1987, G-21 was the only well that showed a concentration of TBP $(0.16 \mathrm{mg} / \mathrm{l})$ above the detection limit of $(0.05 \mathrm{mg} / \mathrm{l})$. These results suggest that G-21 may have been affected by the solvent pumping incident.

Two other grid wells, C-15 and C-17, have consistently had elevated plutonium concentrations. These two wells were associated with the solvent spill where plutonium containing solvent was mistakenly pumped down a well head (See Section 2.1.5 of Appendix D). These anomalous wells are the only grid wells that have shown consistently elevated gross alpha-measurements-sinee-1976-Well-I-13-has-shown_slightly_elevated_gross alpha 
measurements over several years, but the ${ }^{238} \mathrm{Pu}$ and ${ }^{239} \mathrm{Pu}$ concentrations remain low. For example, in 1987 the gross alpha measurement was $5 \mathrm{pCi} / 1$ (Towler, 1989), but the ${ }^{238} \mathrm{Pu}$ and $239 \mathrm{Pu}$ concentrations were $0.5 \mathrm{pCi} / 1$ and $0.17 \mathrm{pCi} / 1$ (McIntyre and Wilhite, 1987), respectively. Of 64 grid wells measured in 1987, the average gross alpha was $4.1 \mathrm{pCi} / \mathrm{l}$ and the median was $1 \mathrm{pCi} / 1$ (the average is skewed by the measurement of $155 \mathrm{pCi} / 1$ in well G-21 -- the next highest measurement was $5 \mathrm{pCi} / 1$ ). Thus, the groundwater data show that plutonium concentrations are elevated in 3 wells that have anomalous chemistries, but throughout the ORWBG as a whole plutonium concentrations remain low.

The low concentrations of plutonium in the groundwater are consistent with the facilitated transport (Looney et al., 1987) of a small fraction of plutonium. This fraction exists associated with colloids or as a trace species that is relatively unretarded by sorption. The bulk of the plutonium leached from buried waste is subject to the high retardation factors caused by sorption to trench soil and possibly solubility of unidentified plutonium phases. The lack of thermodynamic data for these phases makes geochemical modeling of plutonium transport tenuous. Nevertheless, at a retardation factor of 24,000 the dominant fraction of $238 \mathrm{Pu}$ that is not subject to facilitated transport will decay to negligible levels prior to reaching the water table. The less mobile fraction of $239 \mathrm{Pu}$ will decay through several halflives prior to reaching the water table.

The predicted immobility of plutonium is consistent with leachability of plutonium-bearing waste in the Defense Waste Lysimeters. Data from these lysimeters provide the best basis for estimating the leaching rate of plutonium from the ORWBG. The annual fractional release rates of ${ }^{238} \mathrm{Pu}$ and ${ }^{239} \mathrm{Pu}$ from the waste form lysimeters are defined as the ratio of the annual leaching rates to the inventories of the isotopes in the wastes buried in the lysimeters (Oblath, 1983). From 1983 through 1986 the annual fractional release rates for ${ }^{238} \mathrm{Pu}$ and ${ }^{239} \mathrm{Pu}$ from the Defense Waste Lysimeters ranged from $1 \times 10^{-12}$ to $8 \times 10^{-8} \mathrm{yr}^{-}$ 1. The highest fractional release rate came from Canyon pipe jumpers waste (McIntyre, 1987). In general, waste from the High Level Caves and Actinide Materials Facility have higher fractional release rates than Separations and job control waste (McIntyre, 1987). The conditions in the Defense Waste Lysimeters may be less reducing than those in waste trenches in the ORWBG because the column of degrading waste at any point in a trench is longer than that in the lysimeters. Thus, $\mathrm{Pu}(\mathrm{V})$ and possibly $\mathrm{Pu}(\mathrm{VI})$ may occur in the lysimeters causing plutonium to be more mobile than in burial trenches.

Using the highest annual fractional release rate from the lysimeters $\left(8 \times 10^{-8} \mathrm{yr}^{-1}\right)$, the estimated initial leaching rates of unencapsulated ${ }^{238} \mathrm{Pu}$ and ${ }^{239} \mathrm{Pu}$ are $2.5 \times 10^{-4} \mathrm{Ci} / \mathrm{yr}$ and 
$2.9 \times 10^{-5} \mathrm{Ci} / \mathrm{yr}$ respectively. It is assumed here that the leaching rate of plutonium encapsulated in cement or in removable TRU containers will be significantly lower than that of plutonium disposed in plastic bags within cardboard boxes. Based on the geochemical behavior of plutonium in the conditions of the ORWBG, plutonium concentrations in groundwater, and the Defense Waste Lysimeter experiments, the leaching rate of plutonium is low. Leaching rates estimated from the maximum annual fractional release rate $\left(8 \times 10^{-8}\right.$ $\mathrm{yr}^{-1}$ ) of plutonium from the Defense Waste Lysimeters are $2.5 \times 10^{-4} \mathrm{Ci} / \mathrm{yr}$ for $238 \mathrm{Pu}$ and $2.9 \times 10^{-5} \mathrm{Ci} / \mathrm{yr}$ for ${ }^{239} \mathrm{Pu}$. It is assumed that the leaching rate of plutonium encapsulated in cement or removable TRU containers will be significantly lower than that of plutonium disposed in plastic bags within cardboard boxes. The expected dominance of reduced forms of plutonium suggests that adsorption is the major process controlling leaching. A small fraction of plutonium is leached from trenches and is relatively unaffected by adsorption or other retarding processes. This is reflected in the low plutonium concentrations in groundwater. Complexing by inorganic or organic components and colloidal migration may have facilitated the transport of this small fraction, but this is unclear from the groundwater data. This fraction, and hence the leaching rate, are expected to remain low because dramatic changes in the chemistry of water in the ORWBG trenches are unlikely. 


\section{REFERENCES}

Ashley, C., 1960. SRP Radioactive Waste Release, Startup through 1959, DPSP-60-25-25, E.I. du Pont de Nemours and Company, Aiken, SC, September 1960.

Ashley, C., 1962a. 1960 Audit of SRP Radioactive Waste, DPSP-62-25-1, E.I. du Pont de Nemours and Company, Aiken, SC, February 1962.

Ashley, C., 1962b. 1961 Audit of SRP Radioactive Waste, DPSP-62-25-5, E.I. du Pont de Nemours and Company, Aiken, SC, September 1962.

Ashley, C., 1963. 1962 Audit of SRP Radioactive Waste, DPSP-63-25-1, E.I. du Pont de Nemours and Company, Aiken, SC, May 1963.

Ashley, C., 1964. 1963 Audit of SRP Radioactive Waste, DPSP-64-25-1, E.I. du Pont de Nemours and Company, Aiken, SC, May 1964.

Ashley, C., 1965. 1964 Audit of SRP Radioactive Waste, DPSP-65-25-1, E.I. du Pont de Nemours and Company, Aiken, SC, April 1965.

Cook, J.R., 1987. Technical Data Summary: Plan for Closure of the 643-G Burial Ground, DPSTD-87-2, E.I. du Pont de Nemours and Company, Aiken, SC.

Cook, J.R. and Helton, B.D., 1989. An Assessment of Buried Waste Containing Transuranium Isotopes in the Savannah River Site Radioactive Waste Burial Ground, memorandum to B.G. Kitchen, August 23, 1989.

Cook, J.R., 1991. Radionuclide Inventory of E-Area, memorandum to W.E. Stevens, WSRC-RP-91-709, June 27, 1991.

Corey, J.C. and Horton, J.H., 1971. Savannah River Plant Burial Ground Practices, DPST70-460, E.I. du Pont de Nemours and Company, Aiken, SC, March 1971.

Department of Energy (DOE), 1995a. Fact Sheet, "F Canyon", Savannah River Operations Office, Aiken, SC.

Department of Energy (DOE), 1995b. Fact Sheet, "H Canyon", Savannah River Operations Office, Aiken, SC.

Hoeffner, S.L., 1985. Radionuclide Sorption on Savannah River Plant Burial Ground Soil -A Summary and Interpretation of Laboratory Data: DP-1702, E.I. duPont de Nemours and Company, Savannah River Laboratory, Aiken, SC.

Holcomb, H. Perry, 1992. Transcription of a Presentation by Dr. E.L.Albenesius, SRP Burial Ground Operation from an Historical Perspective (U), WSRC-RP-92-349, Environmental Restoration Department, Westinghouse Savannah River Company, Savannah River Site, Aiken, SC, February 14.

Horton, J.H. and Corey, J.C., 1976. Storing Solid Radioactive Wastes at the Savannah River Plant, DP-1366, E.I. du Pont de Nemours and Company, Aiken, SC.

Kaplan, D.I., P.M. Bertsch, D.C. Adriano, and K.A. Orlandini, 1994. Actinide Association with Groundwater Colloids in a Coastal Plain Aquifer: Radiochimica Acta, v. 66/67, p. 181-187. 
Looney, B.B., M.W. Grant and C.M. King, 1987. Estimation of Geochemical Parameters for Assessing Subsurface Transport at the Savannah River Plant: DPST-86-710, E.I. duPont de Nemours and Company, Savannah River Laboratory, Aiken, SC.

Mason, J.T., 1996. Information Document on the Old Solvent Tanks S1-S22 in the Old Radioactive Waste Burial Ground 643-E" (U), WSRC-RP-96-00144, Westinghouse Savannah River Company, Aiken, SC.

McIntyre, P.F. and E.L. Wilhite, 1987. Effect of Organics on Radionuclide Mobility in the SRP Burial Ground: DPST-87-762, E.I. duPont de Nemours and Company, Savannah River Laboratory, Aiken, SC.

McIntyre, P.F., 1987. 1987 Monitoring Report for the Defense Waste Lysimeters, memorandum of August 10, 1987, to H.F. Sturm, Jr.: DPST-87-568, E.I. duPont de Nemours and Company, Savannah River Laboratory, Aiken, SC.

Oblath, S.B., 1983. Defense Waste Lysimeters: 1983-1984 Monitoring Report: DPST-84859, E.I. duPont de Nemours and Company, Savannah River Laboratory, Aiken, SC.

Prout, W.E., 1958. Adsorption of Radioactive Wastes by Savannah River Plant Soil: Soil Science, v. 86, p. 13.

Rai, D. and R.J. Seme, 1979. Solution Species of Pu-239 in Oxidizing Environments: 1. Polymeric Pu(IV), PNL Rpt.-SA-6994, Pacific Northwest Laboratory, Hanford, WA, pp. 1-9.

Ryan, J.P., 1983. Groundwater Monitoring in the Savannah River Site Low Level Radioactive Waste Burial Ground, A Summary and Interpretation of the Analytical Data: DPST-83-209, E.I. duPont de Nemours and Company, Savannah River Laboratory, Aiken, SC.

Silva, R.J. and H. Nitsche, 1995. Actinide Environmental Chemistry: Radiochimica Acta, v. 70/71, p. 377-396.

Towler, O.A. Jr., 1989. Integrated Report on Radionuclide Migration at the Savannah River Shallow Land Burial Site: DP-1778, E.I. duPont de Nemours and Company, Savannah River Laboratory, Aiken, SC.

Wilhite, E.L., 1976. Estimate of TRU Nuclides in Solvent Residues at the Burial Ground, memorandum to M.D. Boersma, April 30, 1976.

Wilhite, E.L., 1978. Chemical Speciation of Plutonium in the Radioactive Waste Burial Ground at the Savannah River Plant: DP-1511, E.I. duPont de Nemours and Company, Savannah River Laboratory, Aiken, SC.

WSRC, 1992. Old Radioactive Waste Burial Ground,Revised Draft, August, 1992.

Westinghouse Savannah River Company (WSRC), 1993. External Dosimetry Technical Plant, DP-1366, E.I. du Pont de Nemours and Company, Aiken, SC.

Kaplan, D.I., P.M. Bertsch, D.C. Adriano, and K.A. Orlandini, 1994. Actinide Association with Groundwater Colloids in a Coastal Plain Aquifer: Radiochimica Acta, v. 66/67, p. 181-187. 


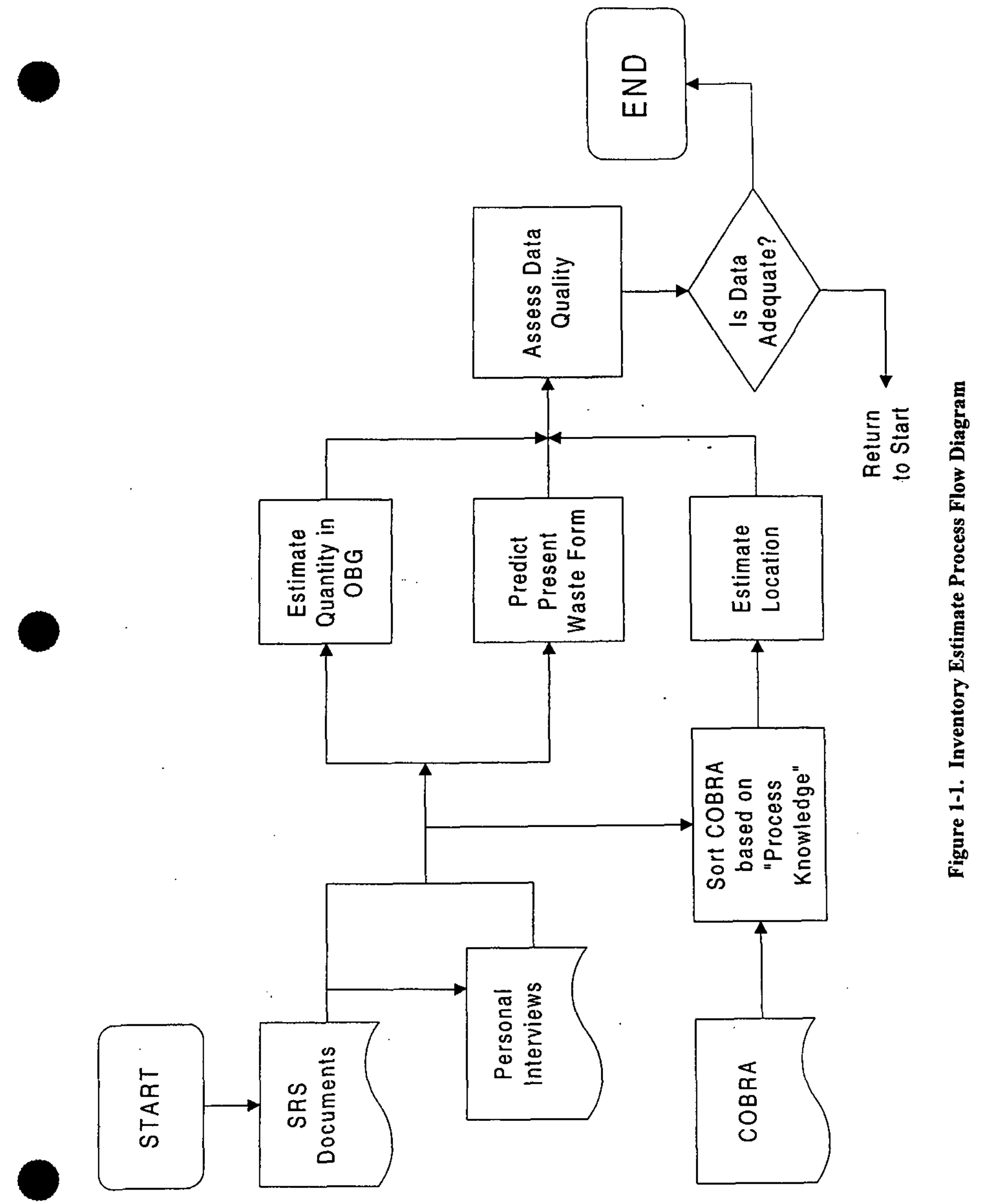




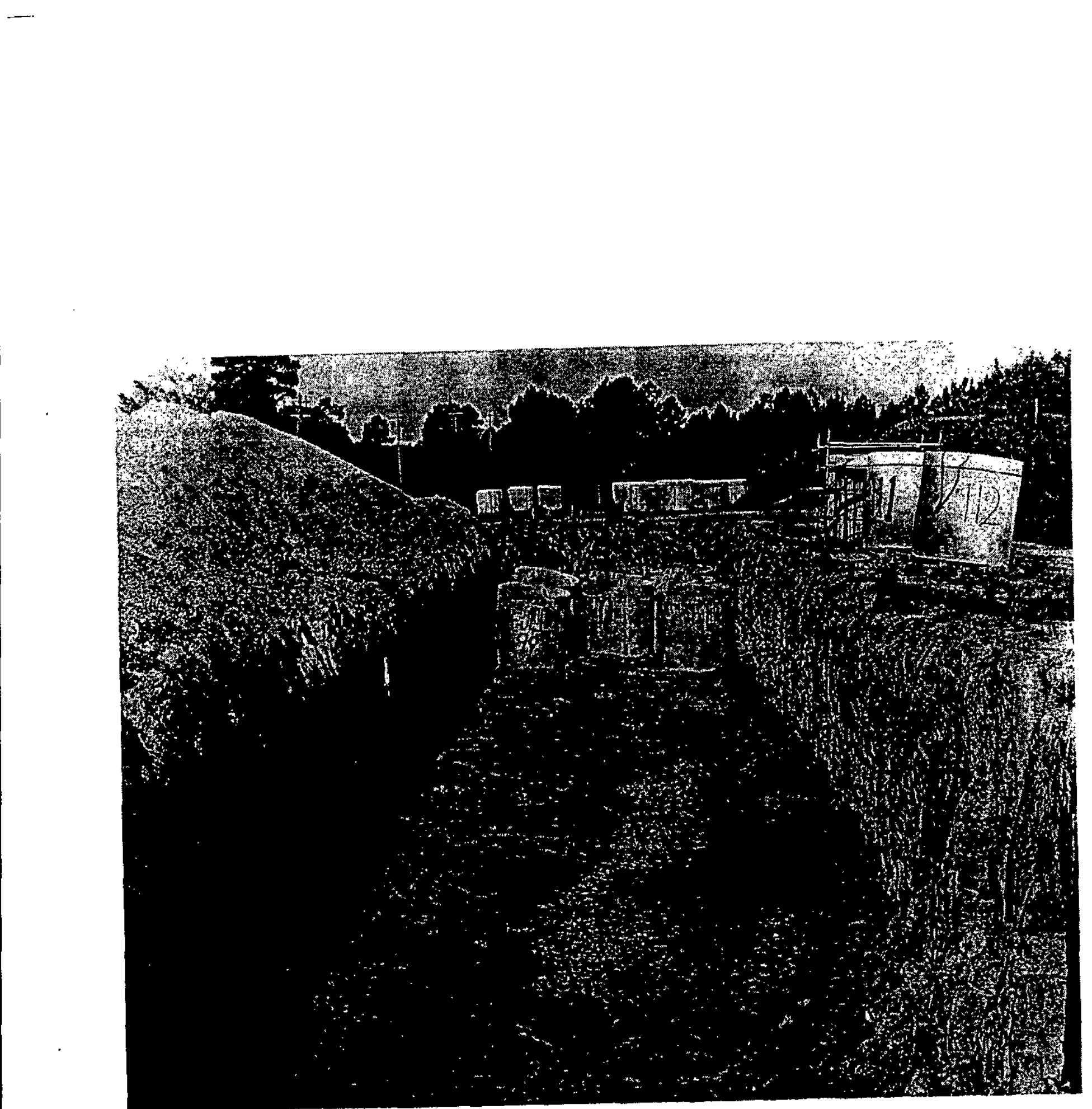

Figure 2-1. Typical Culvert Disposal 


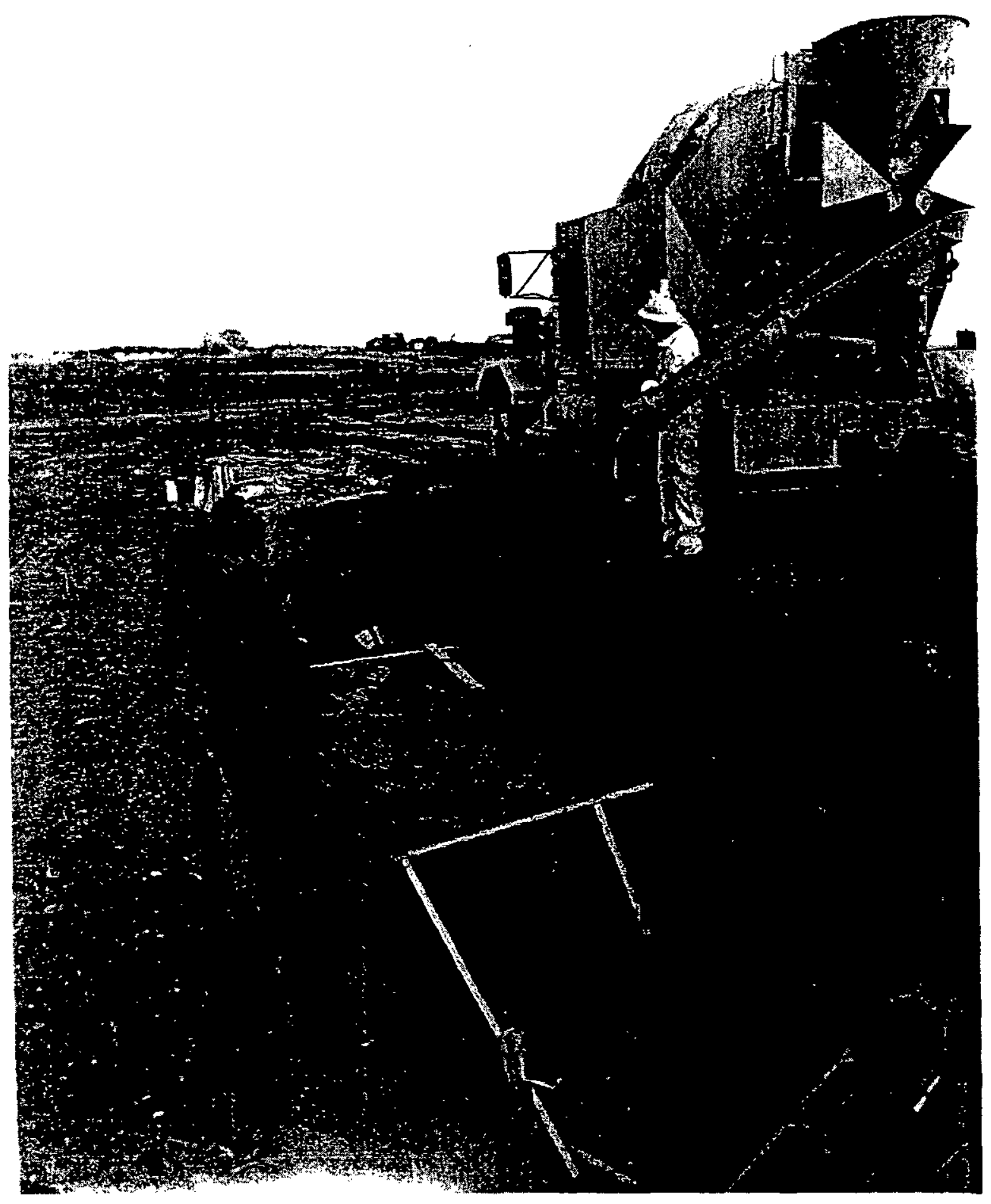

Figure 2-2. Typical Encapsulation Burial 


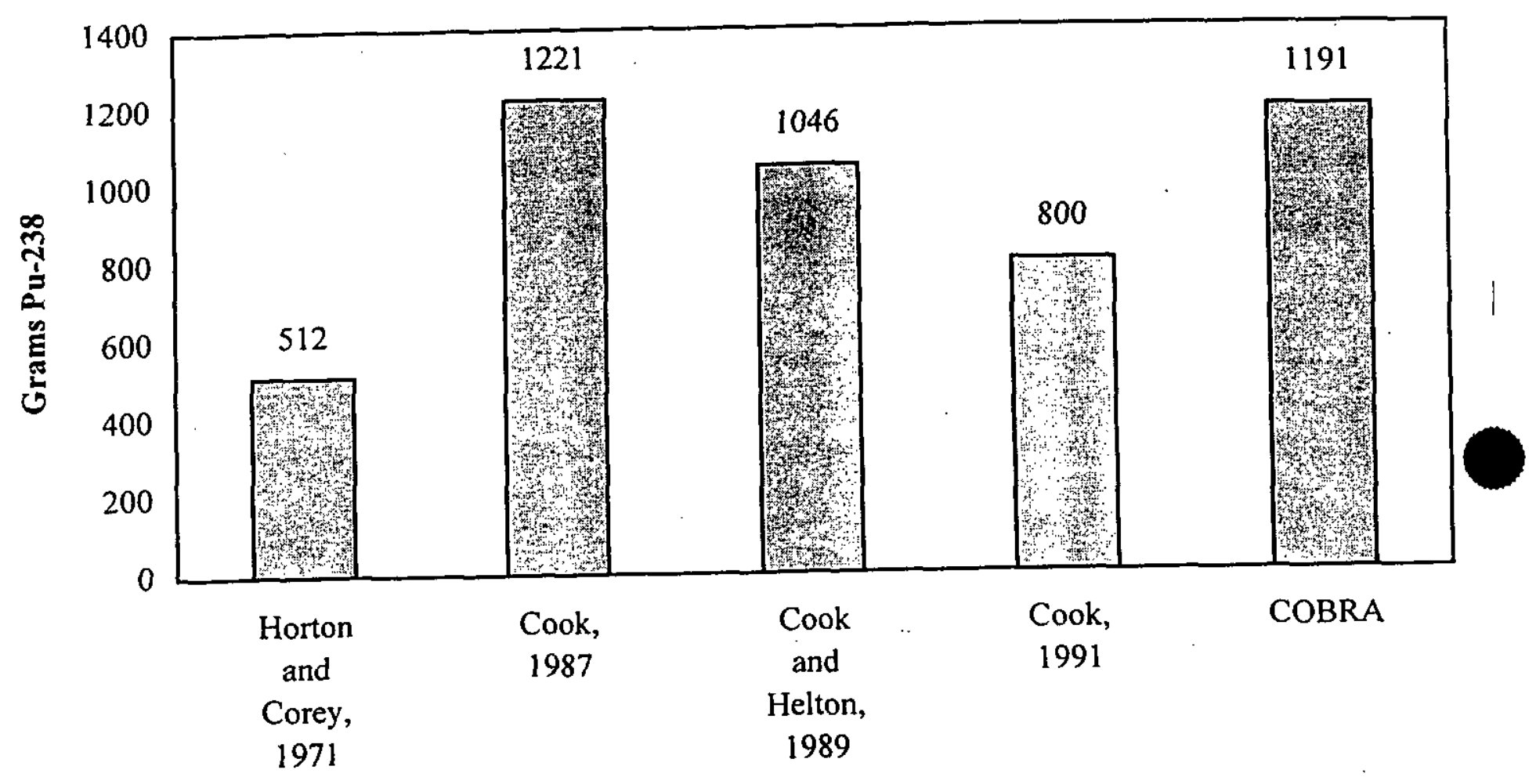

Figure 3-1. Comparison of Plutonium-238 Estimates in the ORWBG 


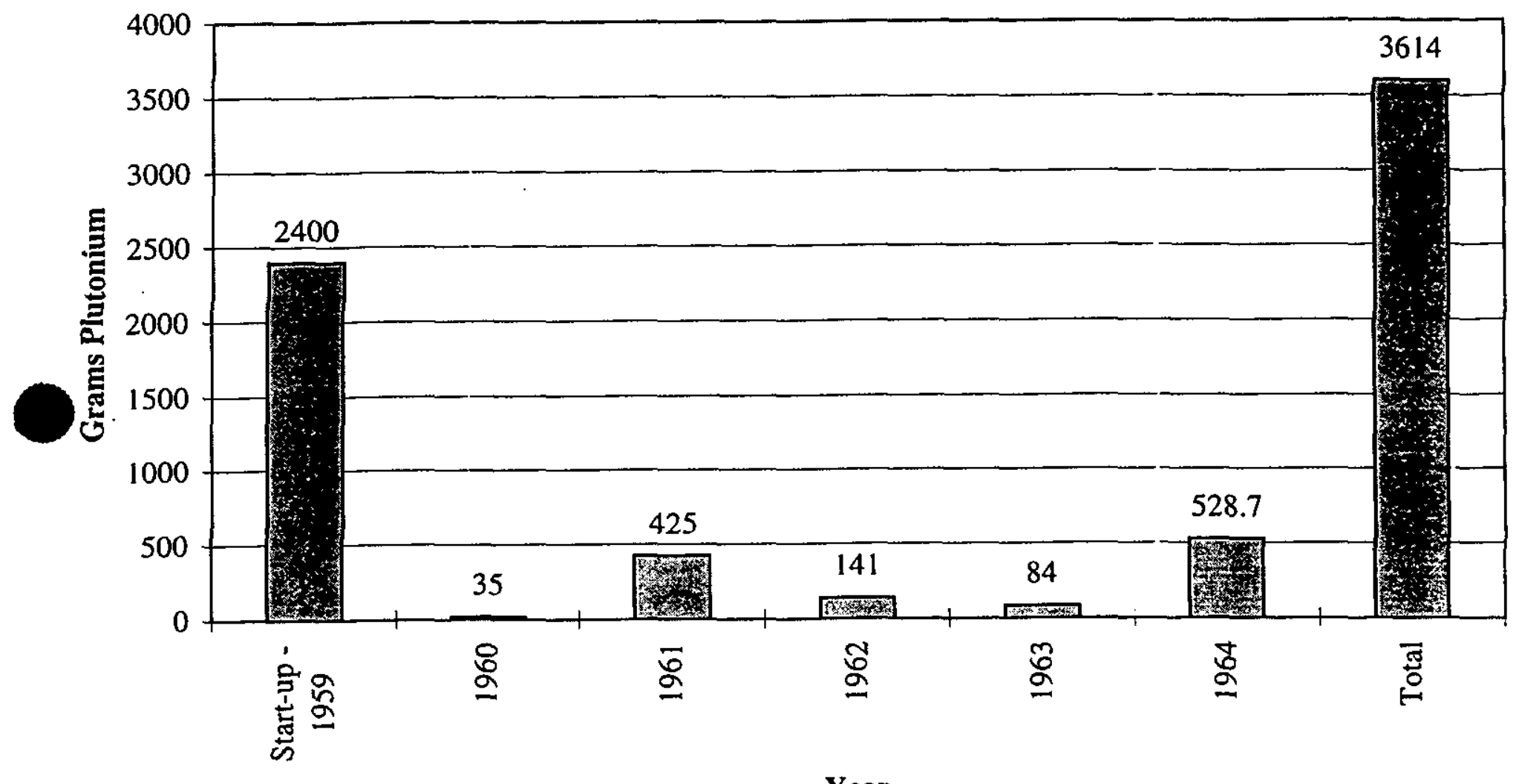

Year

Figure 3-2. Health Protection Data Total Plutonium to Burial Ground through 1964 


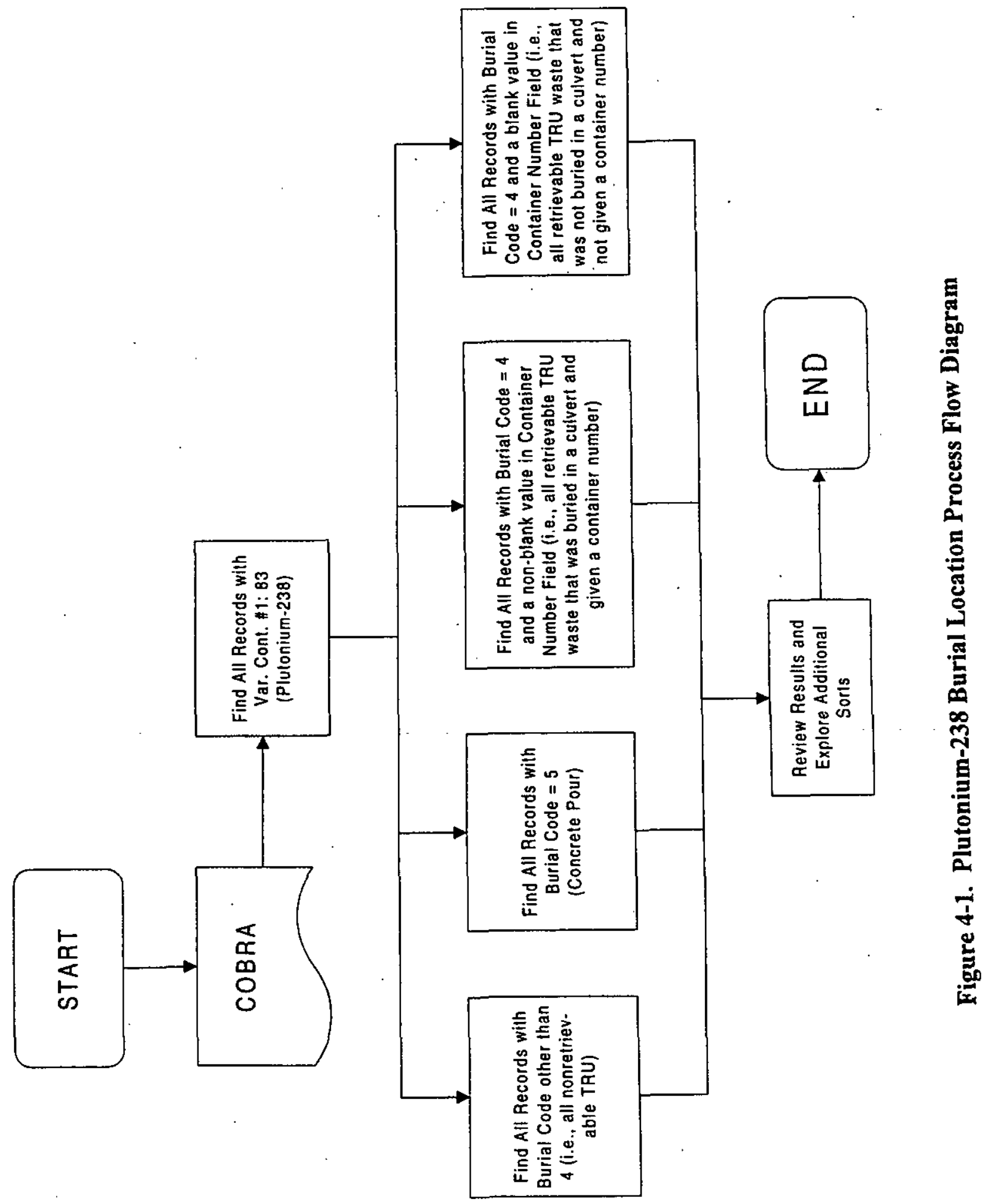


(a)

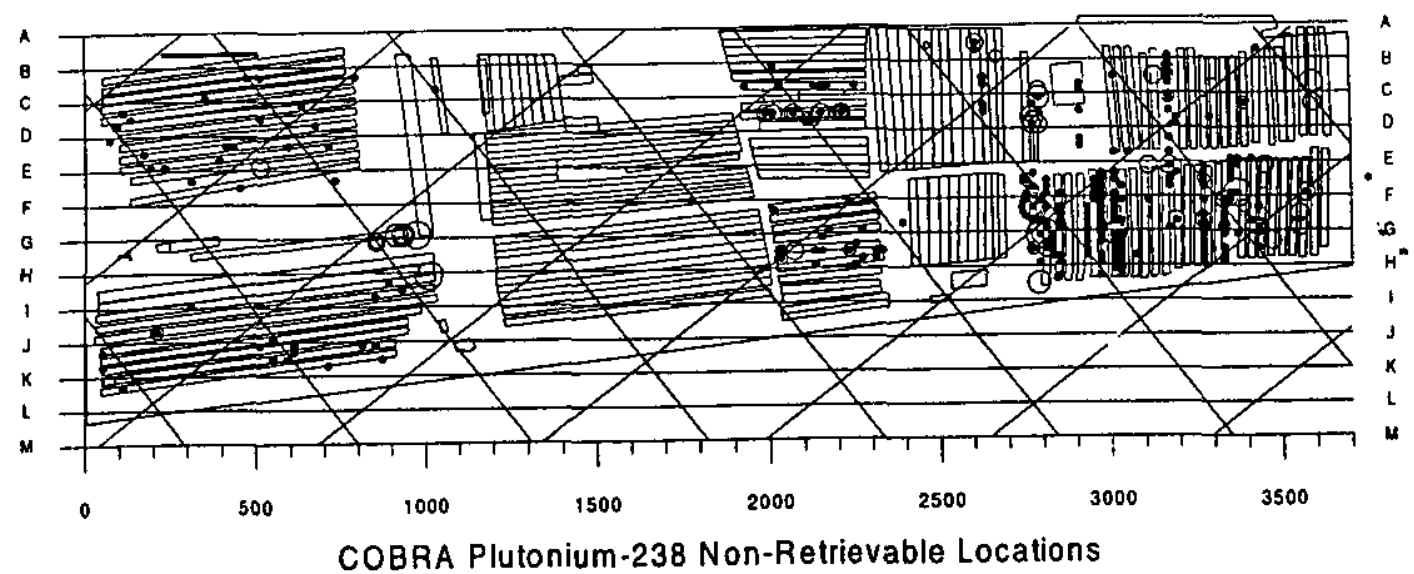

(b)

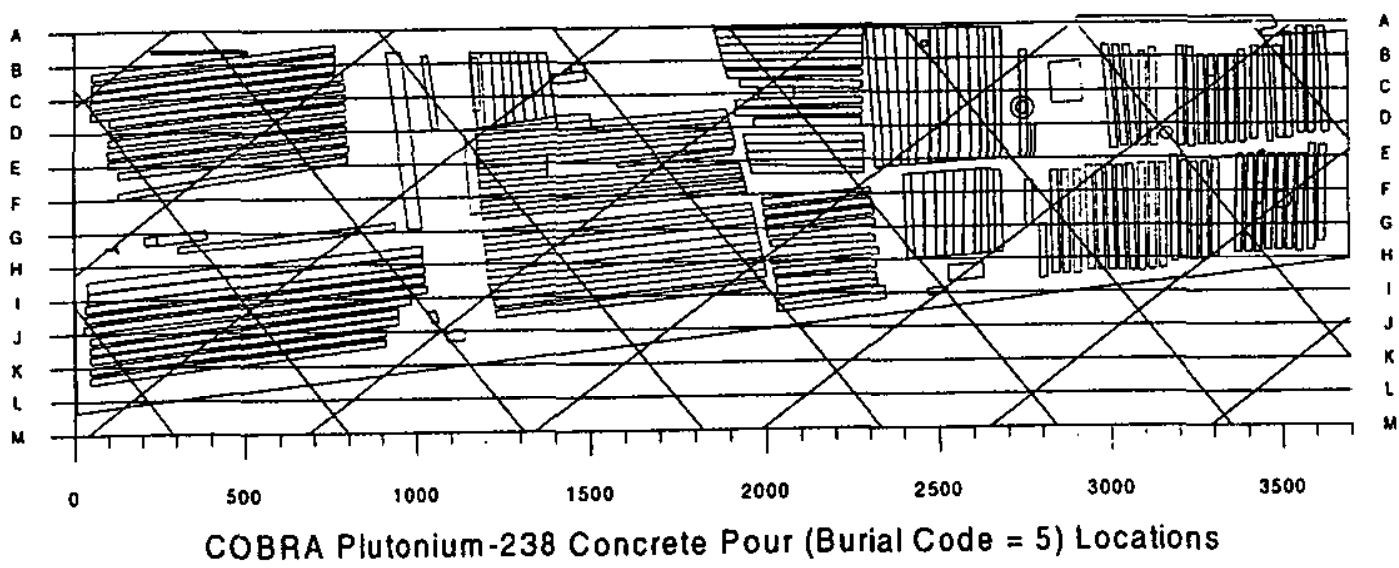

\begin{tabular}{|c|c|c|c|c|c|c|}
\hline & - & 0 & 0 & 0 & 0 & \\
\hline Grams & $0-<0.01$ & $0.01-<0.1$ & $0.1-<1$ & $1-<10$ & $10-<100$ & $100 \cdot<1000$ \\
\hline
\end{tabular}

Figure 4-2. Shown are COBRA Plutonium-238 Locations for: (a) Non-retrievable and (b) Concrete Pours 
(a)

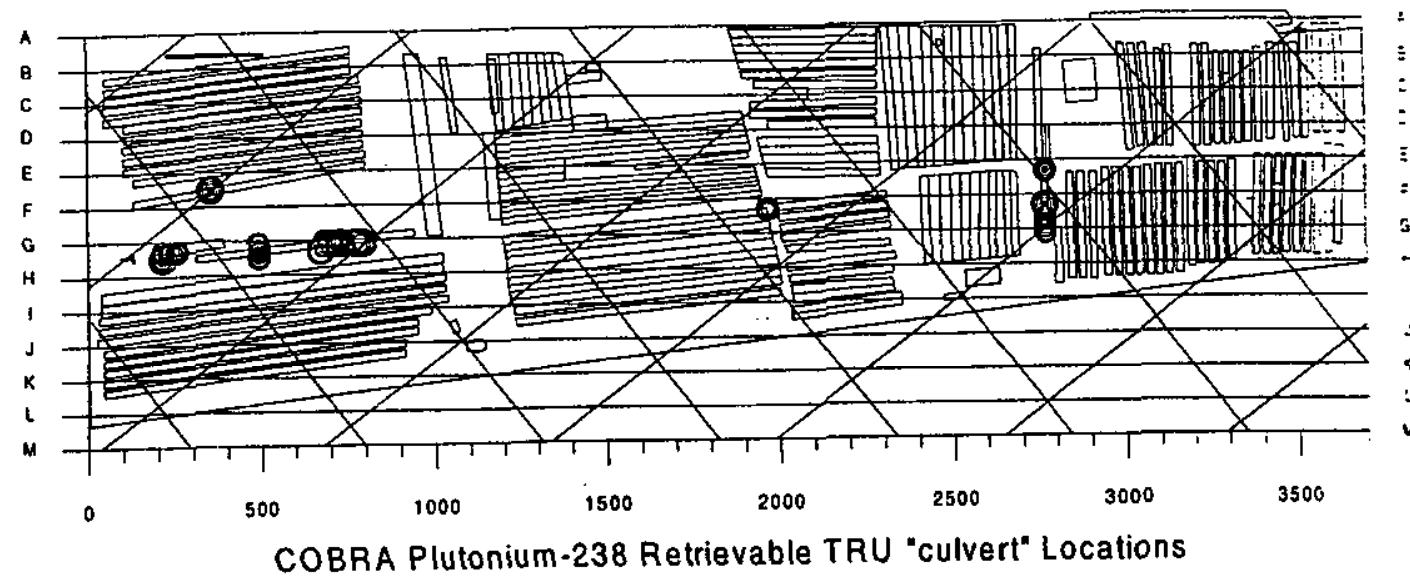

(b)

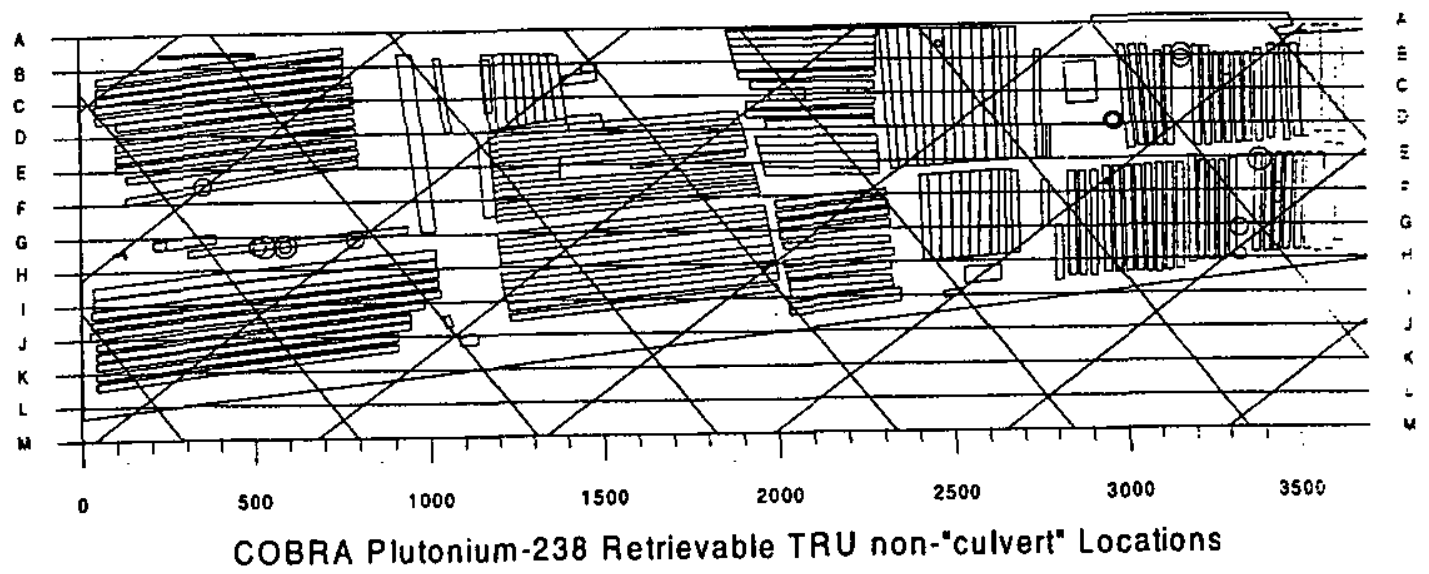

\begin{tabular}{ccccccc}
\hline Grams & 0 & 0 & 0 & 0 & 0 & 0 \\
& $0-<0.01$ & $0.01 \cdot<0.1$ & $0.1-<1$ & $1-<10$ & $10-<100$ & $100 \cdot<1000$ \\
\hline
\end{tabular}

Figure-4-3.-Shown-are-EOBRA-Plutonium-238-Locations-for:-(a)-Retrievable-TRU "Culverts" and (b) Retrievable TRU Other than "Culverts" 


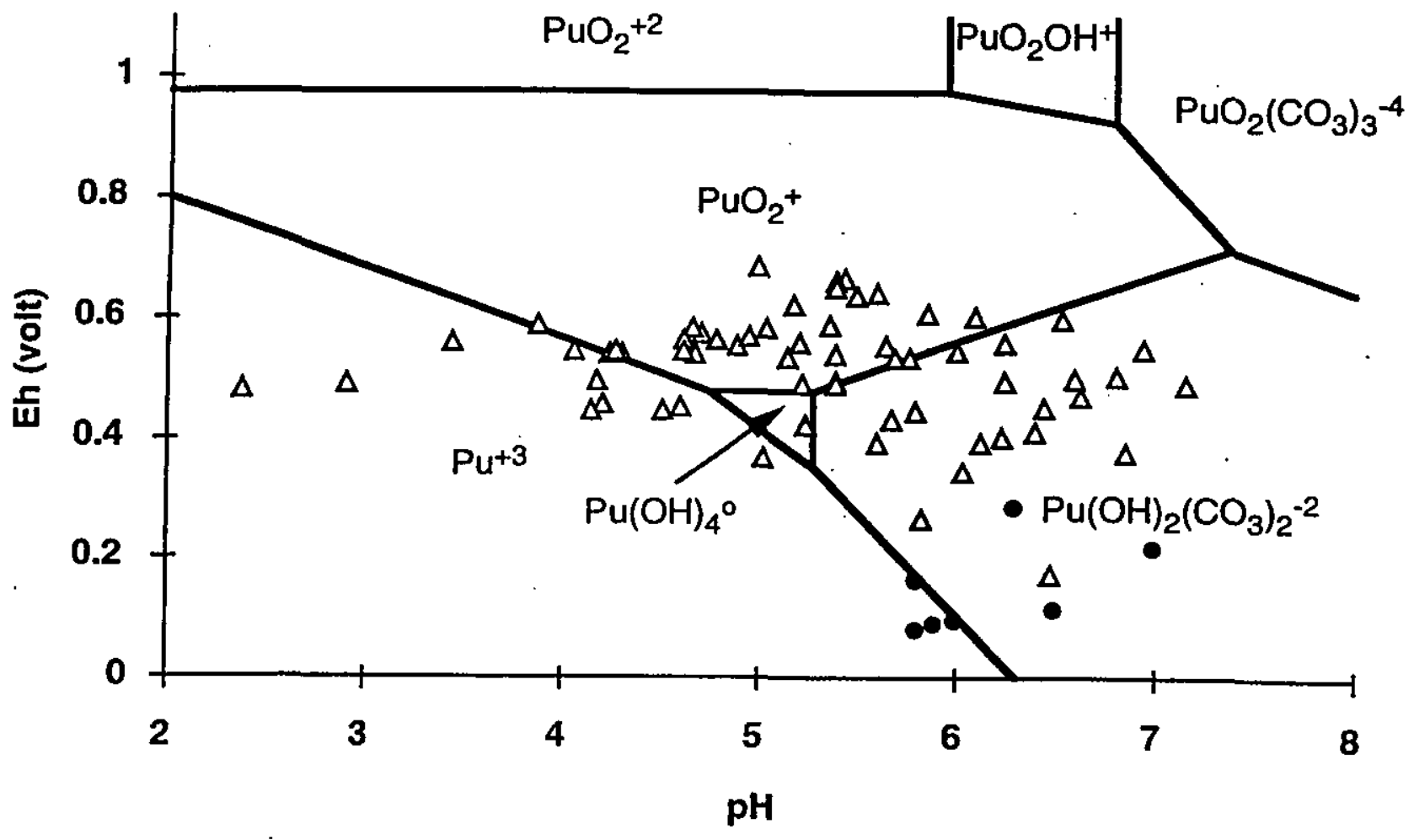

Figure 6-1. Eh-pH Diagram for Plutonium Species, $\mathrm{pCO}_{2}=0.01 \mathrm{~atm}$. Analyses of water from grid wells (Ryan, 1983) are shown as triangles, analyses of water from trench wells (Hoeffner, 1985) are shown as filled circles 
Table 2-1. COBRA Plutonium-238 Records With "Burial Code = 5" (Concrete Pour)

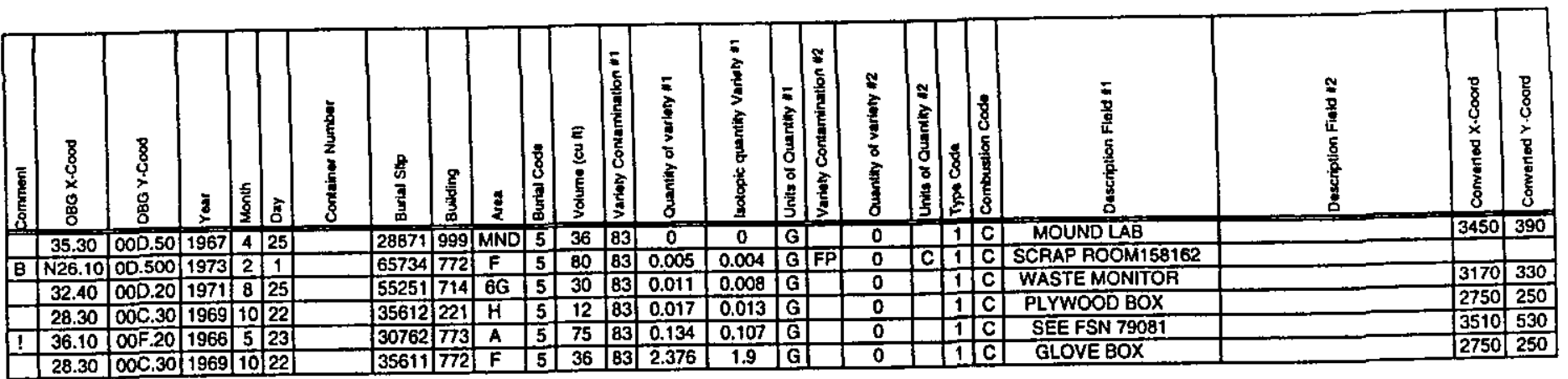

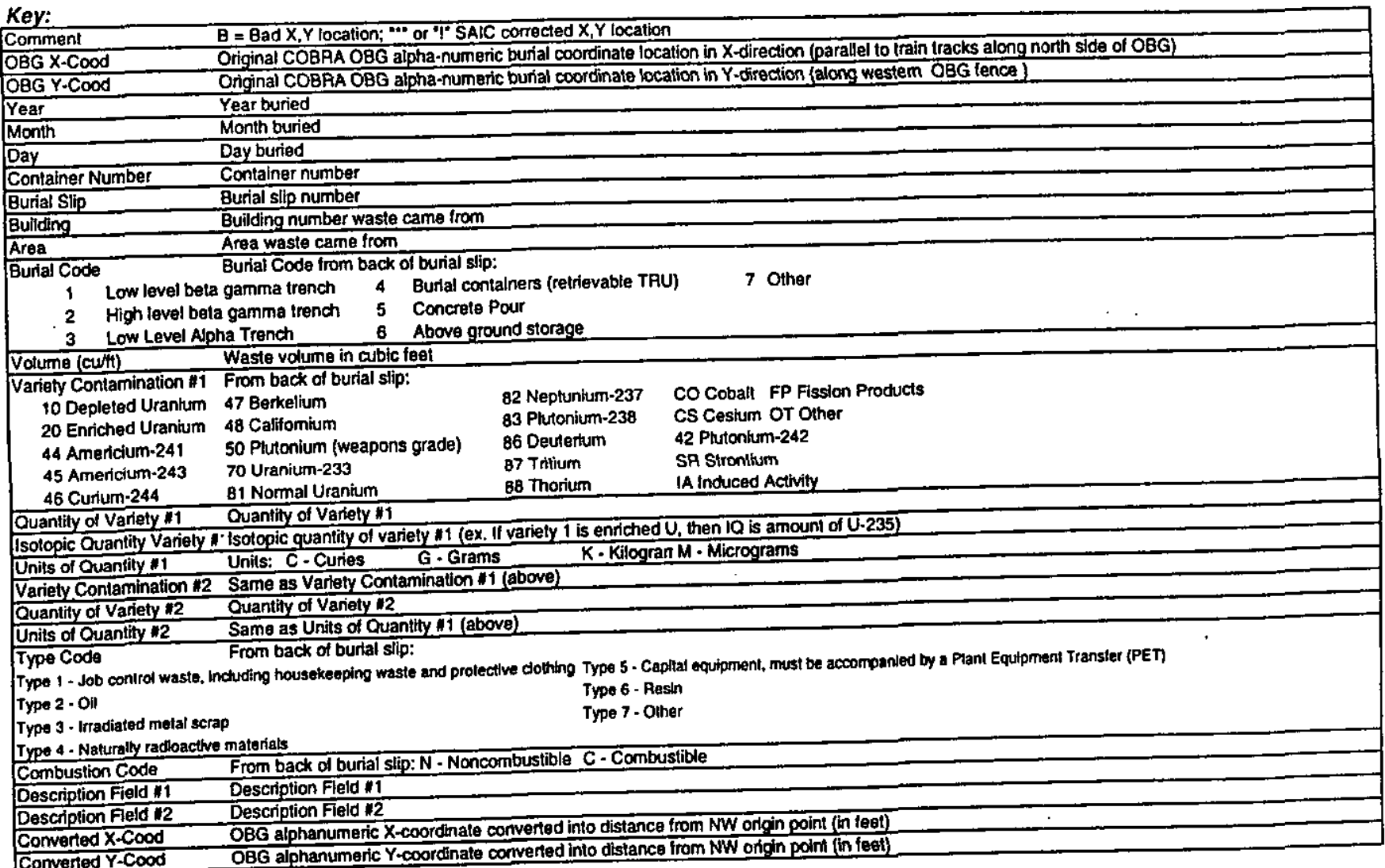




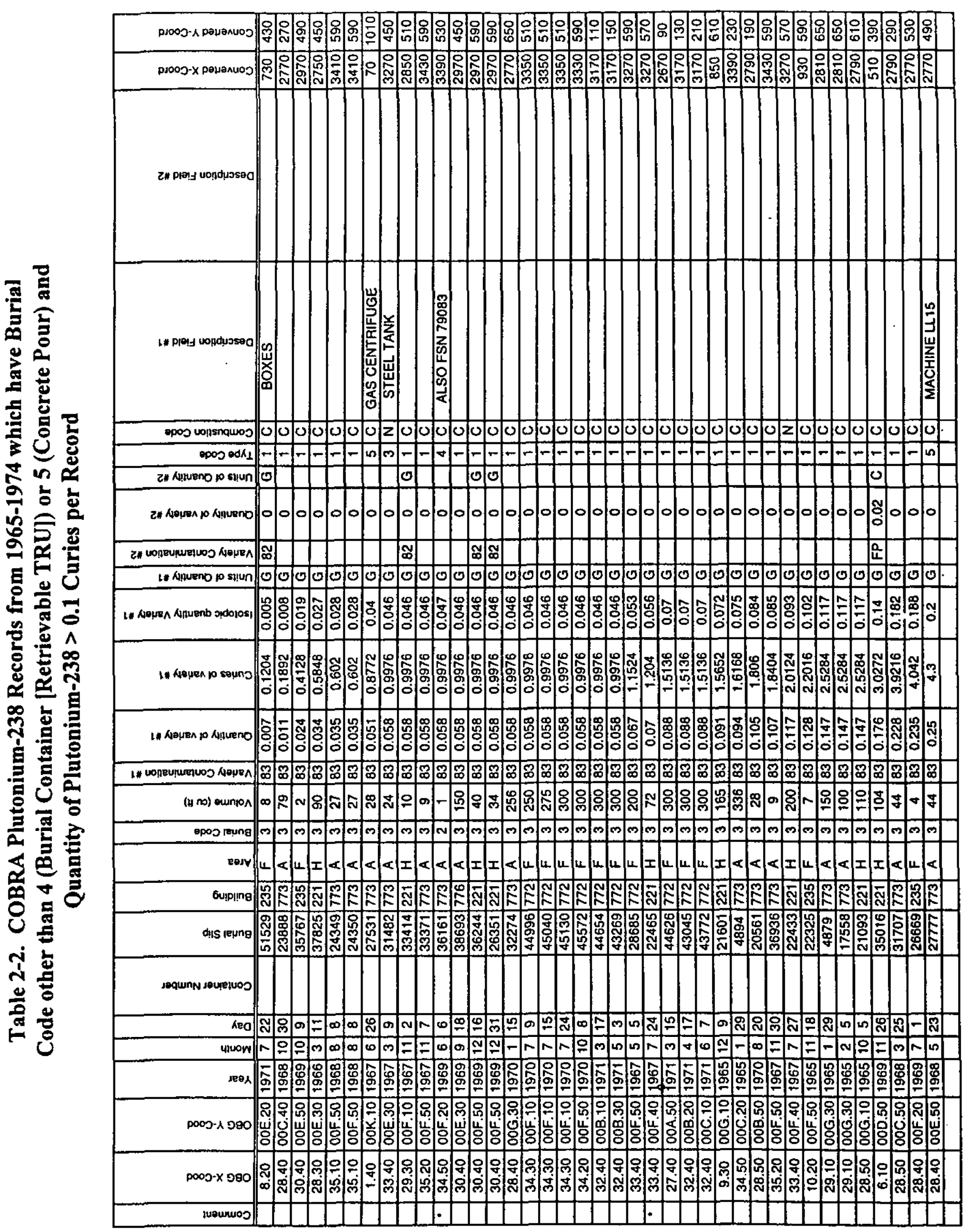



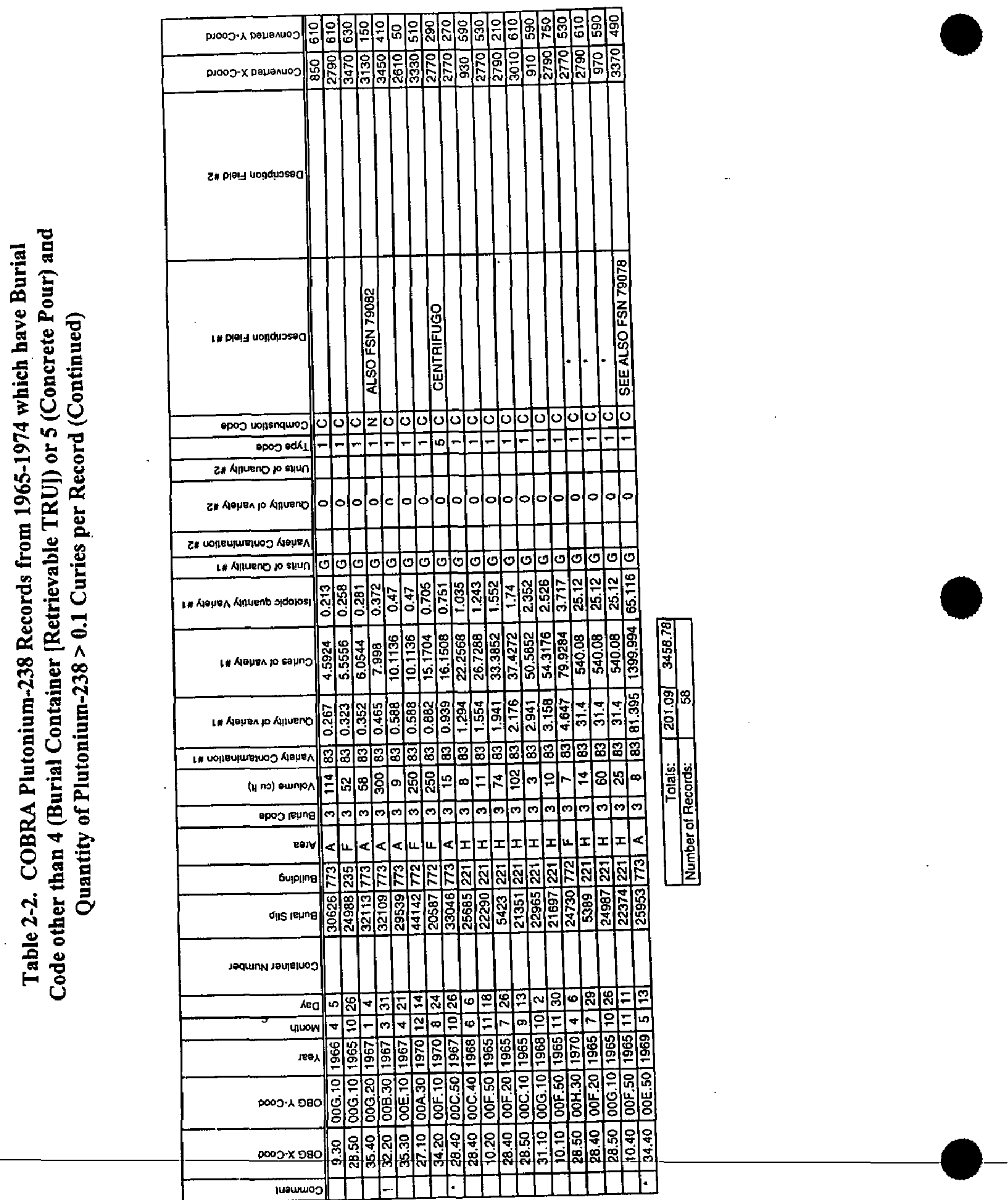
Table 2-2. COBRA Plutonium-238 Records from 1965-1974 which bave Burial

Code other than 4 (Burial Container [Retrievable TRU]) or 5 (Concrete Pour) and

Quantity of Plutonium-238 $>0.1$ Curies per Record (Continued)

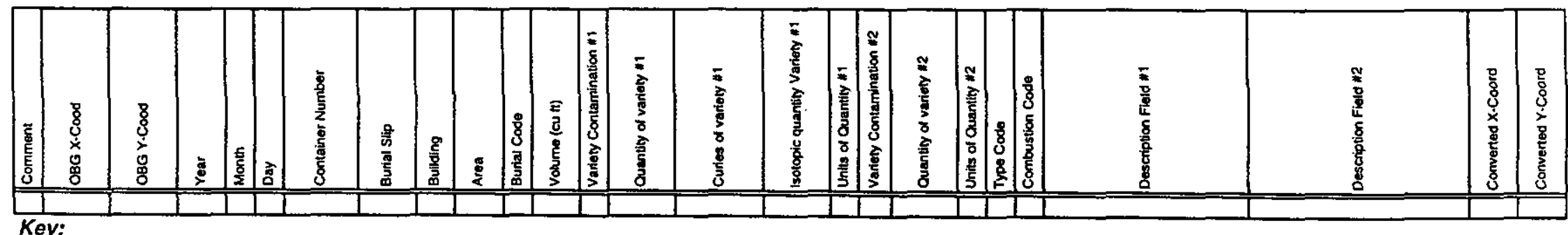

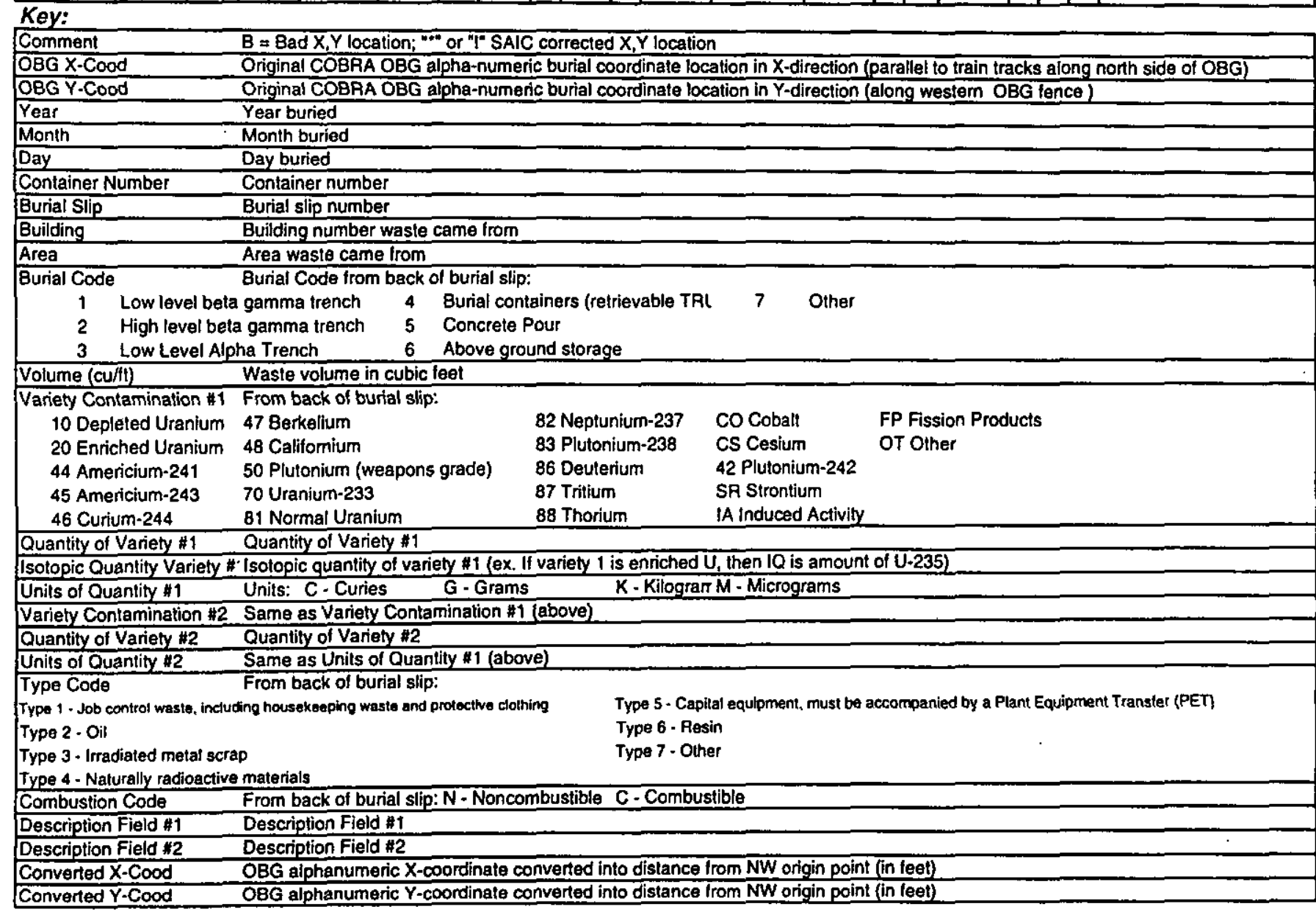


Table 3-1. The Sources of Inventory Estimates for Plutonium-238 in the ORWBG

\begin{tabular}{|c|c|c|}
\hline Reference & ${ }^{238} \mathrm{Pu}$ Inventory & Notes \\
\hline WSRC, 1992 & $\begin{array}{l}\begin{array}{l}{ }^{238} \mathrm{Pu}(\mathrm{Ci})^{\mathrm{a}} \\
\mathrm{OBG} \rightarrow \mathrm{A}) 3,380^{\mathrm{NR}}-257,000^{\mathrm{R}^{*}} \\
\text { B) } 21,000^{f(}\end{array} \\
\begin{array}{l}\mathrm{OBG}+7 \mathrm{G} \rightarrow \mathrm{C}) 5,300^{\mathrm{NRf}} \\
\text { D) } 481,582^{\oplus}\end{array} \\
\text { A) Waste Management Operations, } \\
\text { Savannah River Plant, Final } \\
\text { Environmental Impact Statement, 1975 } \\
\text { B) Waste Management Program Technical } \\
\text { Progress Report, 1987 } \\
\text { C) Selection of Chemical Constituents and } \\
\text { Estimation of Inventories for } \\
\text { Environmental Analysis of Savannah } \\
\text { River Plant Waste Sites, 1986 } \\
\text { D) Savannah River Waste Management } \\
\text { Operations Program Plan, 1989 }\end{array}$ & \begin{tabular}{ll|} 
R & Retrievable waste \\
NR & Nonretrievable waste \\
$*$ & Inventory estimated \\
& through 1975, includes \\
& first four years inventory at \\
& $643-7 \mathrm{G}$ \\
@ & Includes all forms of \\
& transuranic waste including \\
TRU fraction of low-level waste \\
f & $\begin{array}{l}\text { Does not account for } \\
\text { radioactive decay since } \\
\text { time of burial }\end{array}$ \\
&
\end{tabular} \\
\hline Holcomb, H. Perry, 1992 & NA & $\begin{array}{l}\text { The total plutonium waste at SRS is } \\
3 / 4 \text { million curies } \\
\text { (does not reference an earlier article) }\end{array}$ \\
\hline Cook, J R., 1991 & $\begin{array}{l}\text { 643-E Inventory } \\
\text { Pu-238: } 800 \text { grams }^{b}(13,760 \mathrm{Ci}) \\
\text { (does not reference an earlier article) }\end{array}$ & NA \\
\hline Cook, J.R. and Helton, B.D., 1989 & $\begin{array}{l}\text { Retrievable culverts: } 13,211 \mathrm{Ci}^{\mathrm{a}} \\
\text { (As generated) } \\
\text { Encapsulated in concrete: } 35 \mathrm{Ci}^{\mathrm{a}} \\
\text { (As generated) } \\
\text { Uncontained in trenches: } 3623 \mathrm{Ci}^{2} \text { (As } \\
\text { generated from COBRA database) } \\
\text { (does not reference an earlier article) }\end{array}$ & $\begin{array}{l}\text { Retrievable culverts }>0.1 \mathrm{Ci} \\
\text { per package (in shallow land } \\
\text { burial (SLB) trenches) } \\
\text { Encapsulated in concrete } \\
\text { (monoliths)-Waste }>0.1 \mathrm{Ci} \text { per } \\
\text { package but too large to fit into } \\
\text { the culverts } \\
\text { Uncontained in trenches-Waste } \\
<0.1 \mathrm{Ci} \text { per package } \\
\text { Spanish accident (Jan. 17, } \\
\text { 1966) }\end{array}$ \\
\hline Cook, J.R., 1987 & $\begin{array}{l}\text { Pu-238: } 21,000 \mathrm{Ci}^{b} \\
\text { (does not reference an earlier article) }\end{array}$ & NA \\
\hline $\begin{array}{l}\text { Inventory discussed in detail. } \\
\text { No discussion of basis for inventory. } \\
\text { - A-Not-addressed in article. }\end{array}$ & 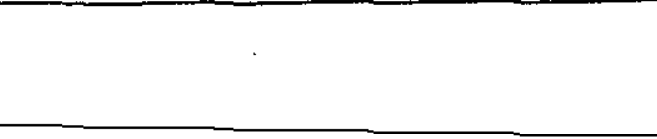 & \\
\hline
\end{tabular}


Table 3-1. The Sources of Inventory Estimates for Plutonium-238 in the ORWBG

(Continued)

\begin{tabular}{|c|c|c|}
\hline Reference & ${ }^{238}$ Pu Inventory & Notes \\
\hline Wilhite, E.L., 1976 & $\begin{array}{l}\text { (From solvent residues) } \\
\text { Pu-238: } 30 \mathrm{Ci}^{\mathrm{b}} \text { (Separations Dept.) } \\
\text { (does not reference an earlier article) }\end{array}$ & $\begin{array}{l}\text { The estimated total quantity of TRU } \\
\text { nuclides in solvent residues at the } \\
\text { OBG is } 150 \mathrm{Ci} \text {; this quantity of TRU } \\
\text { is not presently included in COBRA }\end{array}$ \\
\hline Corey, J.C. and Horton, J.H., 1971 & $\begin{array}{c}\text { Ci Buried } \\
{ }^{238} \mathrm{Pu}: 8,800 \mathrm{Ci}^{\mathrm{b}}(0.5 \mathrm{~kg}) \\
{ }^{\mathrm{Ci} \text { Remaining }} \\
{ }^{238} \mathrm{Pu}: 8,800 \mathrm{Ci}^{\mathrm{b}}(0.5 \mathrm{~kg}) \\
\text { (does not reference an earlier article) }\end{array}$ & $\begin{array}{ll} & \text { Cabinet waste } \\
\text { - } & \text { Radioactive waste burials } \\
\text { through } 1969 \\
\text { - } & \text { Residue recoverable }\end{array}$ \\
\hline
\end{tabular}

Inventory discussed in detail.

b No discussion of basis for inventory.

NA Not addressed in article. 
Table 3-2. The Sources of Inventory Estimates for Total Plutonium in the ORWBG

\begin{tabular}{|c|c|c|}
\hline Reference & Total Plutonium Inventory in the OBG (grams) $^{b}$ & Notes \\
\hline Ashley C., 1965 & $\begin{array}{l}\frac{1964}{528.7} \frac{\text { Total since plant startup (1953) }}{3614} \\
\text { (does not reference an earlier article) }\end{array}$ & $\begin{array}{l}\text { Health Protection (HP) data. } \\
\text { HP published a summary report between } \\
1959 \text { and } 1965 \text { that gives gross information } \\
\text { on radioisotope burials }\end{array}$ \\
\hline Ashley, C., 1964 & $\begin{array}{l}\frac{1963}{84} \quad \frac{\text { Total since plant startup }}{3085} \\
\text { (does not reference an earlier article) }\end{array}$ & \\
\hline Ashley C., 1963 & $\begin{array}{l}\frac{1962}{141} \frac{\text { Total since plant startup }}{3001} \\
\text { (does not reference an earlier article) }\end{array}$ & \\
\hline \begin{tabular}{|l|l|} 
Ashley C., $1962 \mathrm{~b}$ \\
\end{tabular} & $\begin{array}{l}\frac{1961}{425} \frac{\text { Total since plant startup }}{2860} \\
\text { (does not reference an earlier article) }\end{array}$ & \\
\hline Ashley C., 1962a & $\begin{array}{l}\frac{1960}{35} \frac{\text { Total since plant startup }}{2433} \\
\text { (does not reference an earlier article) }\end{array}$ & \\
\hline Ashley, C., 1960 & $\begin{array}{l}\text { Startup through } 1959 \\
\text { plutonium: } 2400 \text { grams } \\
\text { (does not reference an earlier article) }\end{array}$ & \\
\hline
\end{tabular}

- Inventory discussed in detail.

b No discussion of basis for inventory.

NA Not addressed in article. 
Table 3-3. Buried TRU Culverts Summary

\begin{tabular}{|c|c|c|c|c|c|c|c|c|c|}
\hline NORTH & EAST & culvert no. & Pu-238 & Pu-239 & $\mathrm{Np}-238$ & drums & cans & boxes & casks \\
\hline 008.50 & $00 G .10$ & 1 & 31.53 & 96.97 & 0.00 & 14 & & & \\
\hline 008.50 & $00 G .10$ & 2 & 5.43 & 143.01 & 0.00 & 11 & & 1 & \\
\hline 008.50 & $00 G .10$ & 3 & 7.76 & 101.33 & 0.00 & 14 & & & \\
\hline 008.50 & $00 G .10$ & 4 & 6.85 & 233.83 & 0.00 & 14 & & & \\
\hline 008.50 & $00 G .10$ & 5 & 15.86 & 366.03 & 0.00 & 16 & & 1 & \\
\hline 008.40 & OOG.10 & 6 & 15.21 & 325.85 & 0.00 & 15 & & 5 & \\
\hline 008.40 & $00 \mathrm{G} .10$ & 7 & 9.32 & 179.38 & 0.00 & 16 & & 1 & \\
\hline 008.20 & $00 G .10$ & 8 & 12.56 & 277.07 & 0.00 & 9 & & 19 & \\
\hline 008.20 & $00 \mathrm{G} .10$ & 9 & 39.27 & 360.19 & 0.00 & 2 & & 57 & \\
\hline 008.10 & $00 \mathrm{G} .10$ & 10 & 31.97 & 353.08 & 15.00 & 9 & & 8 & \\
\hline 008.10 & $00 G .10$ & 11 & 51.72 & 307.36 & 0.00 & & 2 & 45 & \\
\hline 007.50 & $00 G .10$ & 12 & 25.97 & 233.68 & 0.00 & 3 & & 55 & \\
\hline 007.40 & $00 G .20$ & 13 & 2.92 & 329.64 & 0.00 & 1 & & 42 & \\
\hline 028.40 & O0F.50 & 14 & 17.06 & 155.06 & 0.00 & 9 & 3 & 21 & \\
\hline 007.40 & $00 G .10$ & 15 & 17.71 & 336.04 & 0.00 & & & 60 & \\
\hline 007.40 & 00G.20 & 16 & 11.06 & 251.89 & 0.00 & & & 57 & \\
\hline excavated & & 17 & & & & & & & \\
\hline 028.40 & $00 \mathrm{F50}$ & 18 & 22.39 & 318.13 & 0.00 & & & 48 & \\
\hline 028.40 & $00 F 50$ & 19 & 8.43 & 202.96 & 0.00 & & & 28 & \\
\hline 028.40 & $00 \mathrm{G} .10$ & 20 & 14.52 & 267.89 & 0.00 & & 4 & 45 & \\
\hline NR & & 21 & & & & & & & \\
\hline 028.40 & 00F.50 & 22 & 4.34 & 235.13 & 0.00 & 2 & & 47 & \\
\hline 028.40 & OOF.50 & 23 & 3.02 & 338.22 & 0.06 & 1 & & 51 & \\
\hline 028.40 & DOF.40 & 24 & 0.24 & 176.17 & 0.51 & & 7 & 46 & \\
\hline 028.40 & $00 F .50$ & 25 & 2.46 & 53.73 & 124.90 & & 3 & 18 & \\
\hline 028.40 & OOF.40 & 26 & 3.73 & 173.26 & 13.20 & & 10 & 44 & \\
\hline 028.40 & $00 \mathrm{~F} .40$ & 27 & 0.71 & 278.81 & 0.00 & & 13 & 50 & \\
\hline 028.40 & OOF.40 & 28 & 2.06 & 202.38 & 0.00 & 1 & 10 & 45 & \\
\hline 028.40 & $00 F .20$ & 29 & 12.23 & 318.27 & 0.00 & & 9 & 54 & \\
\hline 028.40 & OOF.20 & 30 & 5.19 & 202.82 & 0.00 & & 3 & 44 & \\
\hline 028.40 & 00F.20 & 31 & 6.75 & 135.69 & 266.34 & & 3 & 44 & \\
\hline 028.40 & OOF.20 & 32 & 11.14 & 221.30 & 0.02 & & 2 & 55 & \\
\hline 028.40 & $00 F .20$ & 33 & 6.90 & 83.28 & 58.29 & & 2 & 41 & \\
\hline 028.40 & OOF.20 & 34 & 14.79 & 152.43 & 57.44 & & 6 & 52 & \\
\hline 028.40 & $00 F .20$ & 35 & 3.45 & 217.95 & 174.34 & 2 & & 62 & \\
\hline 028.40 & $00 F .20$ & 36 & 18.99 & 378.98 & 67.85 & 3 & 8 & 57 & \\
\hline 028.40 & OOF.20 & 37 & 8.63 & 121.97 & 0.00 & 1 & 4 & 55 & \\
\hline 028.40 & 00F.20 & 38 & 9.55 & 160.86 & 20.31 & 1 & & 44 & \\
\hline 028.40 & OOF.20 & 39 & 8.58 & 160.44 & 36.91 & & 2 & 62 & \\
\hline 028.40 & 00E.20 & 40 & 5.04 & 166.41 & 17.28 & 3 & 2 & 47 & \\
\hline 028.40 & $00 \mathrm{E} .20$ & 41 & 1.56 & 38.29 & 26.12 & & & 9 & \\
\hline 028.40 & OOE.20 & 42 & 3.50 & 102.29 & 10.47 & & 1 & 49 & \\
\hline 028.40 & 00E.20 & 43 & 0.94 & 150.40 & 24.56 & & 4 & 59 & \\
\hline
\end{tabular}


Table 3-3. Buried TRU Culverts Summary (Continued)

\begin{tabular}{|c|c|c|c|c|c|c|c|c|c|}
\hline NORTH & EAST & culvert no. & Pu-238 & Pu-239 & $\mathrm{Np}-238$ & drums & cans & boxes & casks \\
\hline 028.40 & OOE.20 & 44 & 0.00 & 129.67 & 0.00 & & & 65 & \\
\hline 028.40 & DOE.20 & 45 & 10.84 & 166.73 & 12.13 & & 5 & 53 & \\
\hline 028.40 & $00 E .20$ & 46 & 6.84 & 114.86 & 23.84 & & 4 & 43 & \\
\hline 028.40 & 00E.20 & 47 & 1.45 & 110.06 & 61.15 & & & 50 & \\
\hline 028.40 & OOE.20 & 48 & 0,00 & 0.00 & 0.00 & & & 1 & 1 \\
\hline 028.40 & DOE.20 & 49 & 0.00 & 0.00 & 0.00 & & & 4 & \\
\hline 003.10 & $00 G .30$ & 50 & 2.05 & 96.81 & 9.11 & & 1) & 28 & \\
\hline 003.10 & $00 \mathrm{G} .30$ & 51 & 0.86 & 137.14 & 29.35 & & *11 & 43 & \\
\hline 003.10 & $00 G .30$ & 52 & 0.00 & 20.97 & 0.00 & & & 3 & \\
\hline 003.10 & $00 G .30$ & 53 & 6.12 & 172.23 & 21.84 & & 4 & 45 & \\
\hline 003.10 & $00 G .30$ & 54 & 9.76 & 99.29 & 10.83 & 2 & 2 & 24 & \\
\hline 003.10 & $00 G .30$ & 55 & 0.00 & 255.81 & 0.00 & & & 52 & \\
\hline 003.10 & $00 \mathrm{G} .30$ & 56 & 0.00 & 0.00 & 0.00 & & & 3 & . \\
\hline 003.10 & $00 \mathrm{G} .30$ & 57 & 0.00 & 8.74 & 0.00 & & & 3 & 1 \\
\hline 003.10 & $00 G .30$ & 58 & 17.77 & 268.80 & 0.00 & & 7 & 45 & \\
\hline 003.10 & $00 G .30$ & 59 & 0.16 & 179.36 & 22.02 & 3 & 2 & 25 & \\
\hline 004.30 & OOE.30 & 60 & 1.69 & 8.74 & 2.87 & & & 23 & \\
\hline 004.30 & OOE.30 & 61 & 4.69 & 125.64 & 46.61 & & & 54 & \\
\hline 004.30 & O0E.30 & 62 & 9.19 & 105.26 & 0.00 & & 16 & 31 & \\
\hline 004.30 & OOE.30 & 63 & 12.96 & 158.25 & 0.00 & 1 & 6 & 45 & \\
\hline 004.30 & OOE.30 & 64 & 8.97 & 88.52 & 1.30 & & & 47 & \\
\hline NR & & 65 & & & & & & & \\
\hline NR & & 66 & & & & & & & \\
\hline NR & & 67 & & & & & & & \\
\hline NR & & 68 & & & & & & & \\
\hline 004.30 & 00E.30 & 69 & 6.85 & 199.17 & 65.53 & & & 43 & \\
\hline 004.30 & OOE.30 & 70 & 1.60 & 160.73 & 0.00 & & & 35 & \\
\hline 004.30 & $00 \mathrm{E} .30$ & 71 & 1.41 & 93.90 & 21.37 & & & 47 & \\
\hline 004,30 & OOE.30 & 72 & 0.55 & 232.95 & 6.00 & 4 & 12 & 28 & \\
\hline 004.30 & OOE.30 & 73 & 1.51 & 31.44 & 4.63 & & & 30 & \\
\hline 004,30 & OOE.30 & 74 & 7.84 & 70.61 & 12.16 & & & 39 & \\
\hline 004.30 & O0E.30 & 75 & 5.33 & 142.67 & 31.94 & & 5 & 57 & \\
\hline 004.30 & OOE. 30 & 76 & 2.24 & 130.88 & 0.00 & & 18 & 34 & \\
\hline 004.30 & 00E.30 & 77 & 2.88 & 105.11 & 7.00 & & 1 & 43 & \\
\hline 004.30 & OOE.30 & 78 & 6.47 & 63.76 & 16.28 & & 8 & 50 & \\
\hline 005.50 & $00 G .20$ & 79 & 4.97 & 85.60 & 22.40 & & & 56 & \\
\hline 005.50 & $00 \mathrm{G} .10$ & 80 & 7.02 & 42.50 & 0.00 & 1 & & 48 & \\
\hline 005.50 & $00 G .20$ & 81 & 9.56 & 30.42 & 6.90 & & & 30 & \\
\hline 005.50 & $00 G .20$ & 82 & 2.91 & 72.35 & 19.80 & & & 38 & \\
\hline 005.50 & $00 \mathrm{G} .20$ & 83 & 18.75 & 24.75 & 38.11 & 1 & & 48 & \\
\hline 005.50 & $00 \mathrm{G} .20$ & 84 & 14.18 & 45.85 & 35.73 & & 33 & 37 & \\
\hline 005.50 & 006.20 & 85 & 4.32 & 47.89 & $62 . \overline{44}$ & & 21 & 34 & \\
\hline 005.50 & $00 G .20$ & 86 & 6.46 & 117.06 & 14.08 & & 12 & 43 & \\
\hline
\end{tabular}


Table 3-3. Buried TRU Culverts Summary (Continued)

\begin{tabular}{|c|c|c|c|c|c|c|c|c|c|}
\hline NORTH & EAST & culvert no. & Pu-238 & Pu-239 & Np-238 & drums & cans & boxes & casks \\
\hline 005.50 & $00 G .20$ & 87 & 0.00 & 49.50 & 0.00 & 7 & & 3 & - \\
\hline 005.50 & $00 G .20$ & 88 & 4.82 & 120.21 & 41.29 & & 9 & 56 & \\
\hline 005.50 & 006.20 & 89 & 7.40 & 97.25 & 29.13 & & 12 & 54 & \\
\hline 005.50 & 006.20 & 90 & 6.31 & 21.88 & 94.88 & & $\overline{16}$ & 23 & \\
\hline 005.50 & 006.20 & 91 & 0.08 & 2.91 & 25.73 & & & 5 & \\
\hline 005.50 & $00 \mathrm{G} .20$ & 92 & 0.00 & 26.20 & 0.00 & 7 & & 2 & \\
\hline 003.10 & $00 G .20$ & 93 & 1.02 & 71.63 & 0.46 & & 4 & 18 & \\
\hline 005.50 & $00 G .30$ & 94 & 0.48 & 114.72 & 37.96 & 2 & & 37 & \\
\hline 005.50 & 006.20 & 95 & 12.17 & 75.13 & 43.29 & & & 59 & \\
\hline 005.50 & 003.10 & 96 & 0.29 & 46.01 & 102.32 & & & 41 & \\
\hline 005.50 & 006.30 & 97 & 0.00 & 2.91 & 0.00 & 6 & & & \\
\hline 005.50 & O0G.30 & 98 & 4.17 & 53.87 & 150.40 & & 7 & 43 & \\
\hline \multirow[t]{2}{*}{003.10} & OOG.20 & 99 & 2.20 & 86.62 & 8.77 & & 17 & 21 & \\
\hline & on TRU pad 2 & 100 & & & & & & & \\
\hline 003.10 & $00 G .20$ & 101 & 0.00 & 28.68 & 0.00 & 11 & & & \\
\hline 003.10 & $00 G .20$ & 102 & 14.36 & 151.56 & 0.00 & 14 & & & \\
\hline 003.10 & $00 G .20$ & 103 & 7.05 & 0.00 & 0.00 & 12 & & & \\
\hline 003.20 & $00 G .20$ & 104 & 2.03 & 172.09 & 584.97 & 14 & & & \\
\hline NR & & 105 & & & & & & & \\
\hline NR & & 106 & & & & & & & \\
\hline 003.20 & O0G.20 & 107,108 & 24.70 & 278.08 & 0.00 & & 4 & 58 & \\
\hline 003.20 & $00 G .20$ & 109 & 10.94 & 128.56 & 0.00 & 14 & & & \\
\hline 003.20 & $00 G .20$ & 110 & 5.14 & 114.00 & 0.00 & 14 & & & \\
\hline 003.20 & 006.20 & 111 & 10.30 & 304.73 & 0.00 & 14 & & & \\
\hline 003.30 & $00 G .10$ & 113 & 0.00 & 5.68 & 20.93 & 1 & & 8 & \\
\hline & & totals $(\mathrm{gr})$ & 793 & 14805 & 2659.2 & 275 & 324 & 3383 & 2 \\
\hline
\end{tabular}


RECORDS ADMINISTRATION ,

\author{
APPENDIX H
}

\title{
CONSTITUENT OF INTEREST:
}

PLUTONIUM-239 
(This page intentionally left blank) 


\section{TABLE OF CONTENTS}

1. SUMMARY

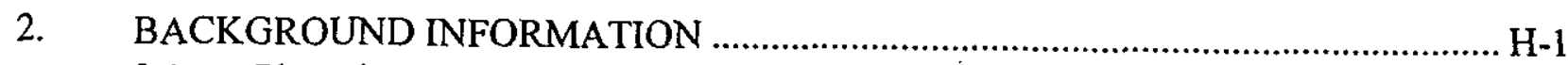

$2.1 \quad$ Plutonium-239 in Waste Streams............................................................... H-2

2.2 Plutonium-239 Management at the Old Radioactive Waste Burial Grounds ..... H-3

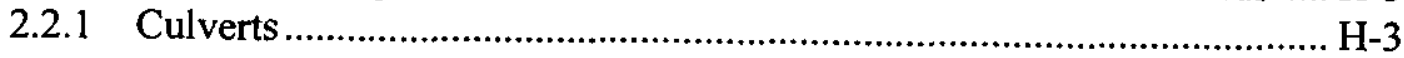

2.2.2 Concrete Encapsulated Waste ................................................................ H-3

2.2.3 Non-Retrievable Alpha-Bearing Waste .................................................. H-4

2.2.4 Special Burials of Plutonium-239................................................... H-4

2.2.5 Spent Solvent ............................................................................... $\mathrm{H}-4$

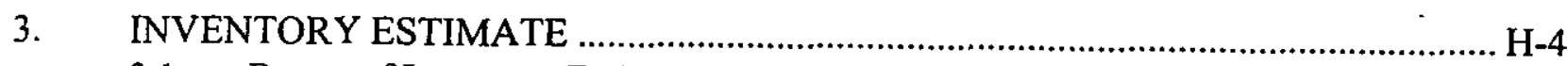

3.1 Range of Inventory Estimates .............................................................. H-4

3.2 Best Estimate of Plutonium-239 in Burial Grounds .......................................... H-6

3.3 Uncertainties Associated with Plutonium-239 Inventory Estimate ..................... H-6

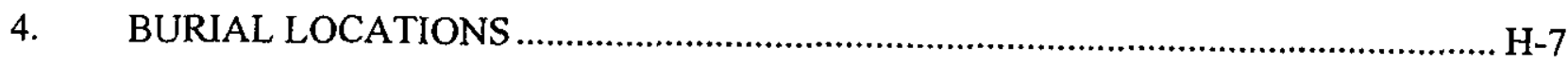

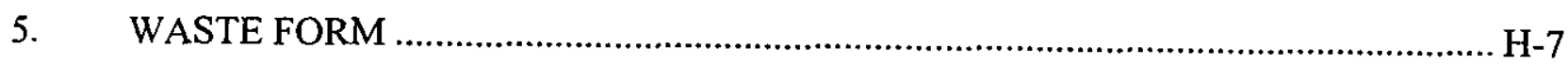

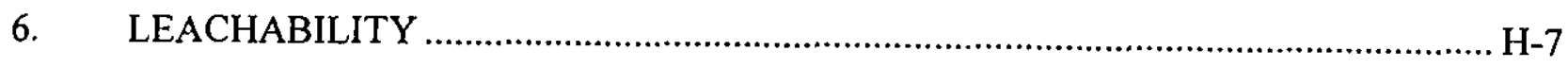

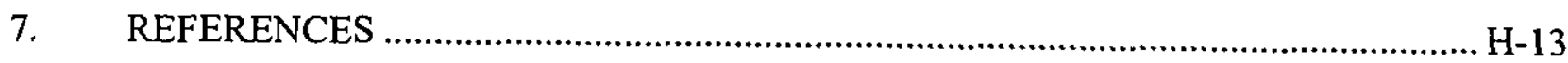




\section{LIST OF FIGURES}

Figure 1-1. Inventory Estimate Process Flow Diagram................................................ H-15

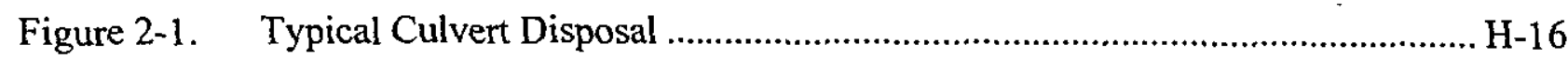

Figure 2-2. Typical Encapsulation Burial ............................................................17

Figure 3-1. Comparison of Plutonium-239 Estimates in the ORWBG …........................ H-18

Figure 3-2. Health Protection Data Total Plutonium to Burial Ground through 1964 ........ H-19

Figure 4-1. Plutonium-239 (Weapons Grade Plutonium) Burial Location Process Flow

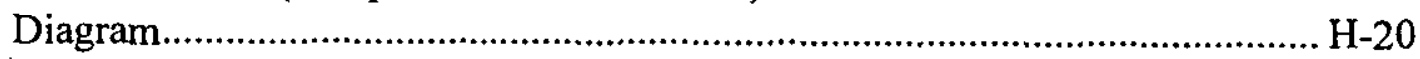

Figure 4-2. COBRA Plutonium-239 Locations for: (a) Non-retrievable and (b) Concrete

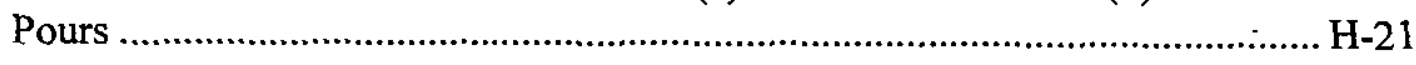

Figure 4-3. COBRA Weapons Grade Plutonium (Pu-239) Locations for: (a) Retrievable TRU "Culverts" and (b) Retrievable TRU Other than "Culverts".............................. H-22

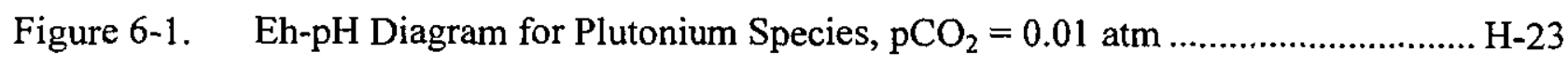

\section{LIST OF TABLES}

Table 2-1. COBRA Plutonium-239 Records With "Burial Code $=5$ " (Concrete Pour).... H-24

Table 3-1. ' The Sources of Inventory Estimates for Plutonium-239 in the ORWBG......... H-26

Table 3-2. The Sources of Inventory Estimates for Total Plutonium in the ORWBG....... H-28

Table 3-3. Buried TRU Culverts Summary.............................................................. H-29 


\section{CONSTITUENT OF INTEREST - PLUTONIUM-239}

\section{SUMMARY}

The production of plutonium-239 for use in nuclear weapons was a primary operation at the Savannah River Site (SRS). Plutonium-239 produced at SRS was shipped offsite to other facilities in the U.S.Department of Energy (DOE) weapons complex. Wastes containing plutonium-239 in the Old Radioactive Waste Burial Ground (ORWBG) originated primarly in separations areas, reactor areas, and research facilities such as the Savannah River Technology Center (SRTC).

The best estimate for the U.S. Department of Energy plutonium-239 inventory in trenches in the ORWBG is 24,188 grams (1,475 curies). This estimate is the sum of two sources: the Computerized Burial Records Analysis (COBRA) database total, which includes plutonium239 in special burials; and a relatively small quantity estimated to be in burned solvent residues. An estimated $1351 \mathrm{~g}$ (82.4 curies) is in the Old Solvent Tanks (OSTs).

The date disposed and total activity of the waste package affected how the waste was handled at the ORWBG. According to Cook (1987), alpha-bearing waste, which included plutonium239 , was buried in plastic bags and cardboard boxes in earthen trenches designated for alphabearing wastes from the beginning of operations at the ORWBG until 1965. Between 1965 and 1974, alpha-bearing waste was segregated based on its activity. Waste containing less than 0.1 curies per package was buried unencapsulated in alpha trenches. Waste containing greater than 0.1 curies per package was buried in retrievable concrete containers (Cook, 1987).

Figure 1-1 presents the process used to develop inventory and burial locations. First, SRS documents were reviewed. A process knowledge for generating plutonium-239 at the SRS was developed. The COBRA database was used to determine the location of burials of plutonium-239.

\section{BACKGROUND INFORMATION}

Plutonium-239 entered waste streams from many operations at SRS, including reactors, separations, and waste management. At the ORWBG, handling methods for alpha-bearing wastes such as plutonium-239 depended on the year of disposal and the alpha activity of the waste. 
Plutonium-239 has a half-life of 24,390 years, and a specific activity of 0.061 curies per gram. Plutonium-239 comprises 17 to 20 percent of heat-source plutonium and comprises 93 to 94 percent of weapons-grade plutonium (Cook and Helton, 1989).

\subsection{Plutonium-239 in Waste Streams}

Plutonium-239 was a constituent of alpha-bearing wastes originating from both separations areas: F-Area and H-Area. These wastes comprise the bulk of the plutonium-239 sent to the ORWBG.

F-Area houses F-Canyon, one of two canyon buildings used to separate useful radionuclides from irradiated targets and fuel. Historically, F-Canyon initiated recovery of plutonium-239 and uranium- 238 by chemically separating the contents of aluminum-clad irradiated slugs from site reactors and other test and research reactors (DOE, 1995a). In addition to the canyon building, F-Area housed facilities to convert uranyl nitrate solution into uranium trioxide powder, plutonium nitrate solution into plutonium metal or oxide, and to fabricate plutonium-238 oxide fuels for heat sources (WSRC, 1993).

H-Area contains H-Canyon, the other chemical separations building at SRS. H-Canyon recovered uranium-235 from irradiated fuel elements from onsite- and offsite reactors. Additionally, the canyon had the special capability to recover neptunium-237 and plutonium238 from neptunium-237 targets (DOE, 1995b). Other facilities in H-Area include those used to store liquid uranyl nitrate hexahydrate (enriched in uranium-235) prior to shipment to Oak Ridge, convert plutonium nitrate to plutonium oxide, and the Receiving Basin for Offsite Fuel.

Spent solvent from the separations areas was sent to the Old Solvent Tanks (OSTs), located in the ORWBG, to be stored prior to burning. This solvent was contaminated with plutonium-239.

Plutonium-239 was also a constituent of radioactive waste from other areas at SRS. These areas included the reactor areas, the F- and H-Area tank farms, and site laboratories. Generally, plutonium-239 would be a minor contaminant in job control waste. Plutonium239 was also a constituent in some waste received from offsite facilities. 


\subsection{Plutonium-239 Management at the Old Radioactive Waste Burial Grounds}

Plutonium-239 and other alpha-bearing solid waste was managed in one of three ways: disposed of in plastic bags and cardboard boxes in trenches designated for alpha-bearing waste, disposed of in drums placed in concrete culverts in trenches, or encapsulated in concrete in trenches. Generally, encapsulated waste was drummed and placed in slit trenches that were filled with concrete. Canyon equipment and other bulky wastes were placed directly into the trenches, which were then filled with concrete (Cook, 1987). Starting in 1965 , packages with greater than 0.1 curies of transuranium (TRU) were placed in concrete culverts. When full; these culverts were placed in shallow subgrade trenches for retrieval and processing at a future date. They are currently being stored in two separate trenches in the burial ground. The practice of subgrade storage was discontinued in 1974, when storage atgrade on concrete pads was adopted for SRS generated waste (Cook and Helton, 1989).

\subsubsection{Culverts}

From 1965 through 1974, alpha-bearing waste with alpha activities greater than 0.1 curies was buried in a retrievable configuration. One such configuration was a prefabricated concrete container, or culvert. Ninety-nine concrete culverts containing plutonium-239 were disposed of in the ORWBG. These culverts are 7 feet in diameter and 7.5 feet high (Cook, 1987). Note: Horton and Corey (1976) state that the culverts were 6 feet in diameter and 6.5 feet high.] The culverts were filled with a combination of drums, boxes, and cans. Figure 2-1 presents a picture of a typical culvert disposal. Such culverts were used to house high alpha activity waste containing Plutonium-239 and/or Plutonium-238.

\subsubsection{Concrete Encapsulated Waste}

Alpha-bearing waste activities with greater than 0.1 curies that did not fit in the prefabricated concrete containers was placed in slit trenches and encapsulated in concrete. Table 2-1 presents the 43 COBRA records which have a burial code of 5 ("concrete pour"). Concrete encapsulation was also used after 1965 and prior to the advent of concrete culverts for drummed and other containerized waste. Figure 2-2 is a photograph of a typical encapsulation burial. Encapsulated burials are also considered retrievable (Horton and Corey, 1976). 


\subsubsection{Non-Retrievable Alpha-Bearing Waste}

Prior to 1965 , alpha-bearing waste, which included plutonium-239, was buried in plastic bags and cardboard boxes in earthen trenches designated for alpha-bearing wastes. From 1965 to 1974 , alpha-bearing waste with alpha activities less than 0.1 curies per package was buried unencapsulated in alpha trenches (Cook, 1987).

\subsubsection{Special Burials of Plutonium-239}

There are at least two special burials of plutonium-239 in the ORWBG: soil from the Spanish accident, and filtered water and plane debris from the Greenland accident. The Spanish accident occurred in January 1966 following a collision during mid-air refueling between a bomber carrying nuclear weapons and a refueling plane. As a result, soil on the ground at Palomares, Spain, was contaminated with plutonium. 4,827 55-gallon drums of the soil were buried in two separate trenches at ORWBG. The Greenland accident occurred on January 21, 1968, when a bomber carrying nuclear weapons crashed in Greenland, contaminating ice and airplane debris. The ice was melted and the water shipped to SRS in tanks. The water was processed and the empty tanks were buried with the aircraft debris.

\subsubsection{Spent Solvent}

Plutonium-239 was a constituent of spent solvent sent from separations facilities to the OSTs. The organic phase of the solvent was pumped from the OSTs and burned. Plutonium in the organic phase of the solvent remained in the residue and was buried in trenches in the ORWBG (Mason, 1996). Plutonium-239 is a component of the liquid and solid phases remaining in the OSTs.

\section{INVENTORY ESTIMATE}

Inventory estimates for plutonium-239 are based on data contained in the COBRA database, Health Protection data, and the estimate in burned solvent residues. The COBRA database indicates that burials of weapons-grade plutonium occurred in the ORWBG as recently as 1973.

\subsection{Range of Inventory Estimates}

Table 3-1 presents the references reviewed related to plutonium-239 inventory. Table 3-2 presents the references reviewed related to total plutonium inventory. The tables list each reference, the inventory estimates provided by the reference, and any special notes associated 
with the inventory. Figures 3-1 and 3-2 graphically compare the inventory estimates in Table 3-1 and Table 3-2.

A comparison of plutonium-239 estimates in the ORWBG is shown in Figure 3-1. The Horton and Corey (1971) and Cook (1991) estimates shown in Figure 3-1 are through 1969. Cook (1987) provides an estimate for plutonium-239 in the ORWBG, but does not give much detail. Cook and Helton (1989) provide greater detail on the burials of plutonium-239 in the ORWBG. The COBRA database does not contain information on the residues from solvent burning.

Cook and Helton (1989) provides the following details on plutonium-239 burials:

- 280 curies (4,590 grams) of plutonium-239 were double-bagged and placed in a container in trenches from ORWBG start-up until May 1964.

- 88 curies (1,443 grams) of plutonium-239 were double-bagged and placed in a container in trenches from May 1964 through 1973.

- 638 curies (10,459 grams) and 434 curies (7115 grams) of plutonium-239 were buried in two separate areas in retrievable concrete culverts.

- 26.9 curies (441 grams) of plutonium-239 were encapsulated in concrete.

The amounts of total plutonium buried from startup through 1964 are shown in Figure 3-2. Health Protection data (Ashley, 1960, 1962a, 1962b, 1963, 1964, and 1965) indicate that 3,614 grams of plutonium were buried from ORWBG start-up through June 1964. Cook and Helton (1989) indicate that the sum of the plutonium-238 and plutonium-239 burials from start-up through May of 1964 was 4,609 grams. The COBRA database describes all plutonium burials, through 1962 as weapons-grade plutonium. Weapons-grade plutonium contains 93 to 94 percent plutonium-239. This isotopic conversion has been made in COBRA. After February 1962, COBRA provides data for each individual plutonium-239 burial.

The COBRA database indicates that 23,727 grams of weapons-grade plutonium have been buried. If the weapons-grade plutonium is 94 percent by weight of plutonium-239, there would be 22,303 grams ( 1,360 curies) of plutonium-239. The summary of the contribution of weapons-grade plutonium by area is:

- A-Area (e.g., 773-A) - 1,016 grams

- F-Area(F, FBL, FJB Areas) - 18,400 grams 
- An area indicated as "SRP" - (Sum of three "lumped" COBRA records labelled "startup through 1959", "1960 Data", and "January \& February 1961") 2,624 grams.

- Mound (offsite) - 120 grams

- An area indicated as "XXX" (shipment from offsite of unstated origin) - 1,568 grams

Table 3-3 summarizes the culvert burials. The table indicates the burial ground coordinates of each culvert, the plutonium-238, plutonium-239 (bolded), and neptunium-237 content of each culvert, and the numbers of drums, cans, boxes, and casks in the culvert.

Another source listed in Table 3-1 (Wilhite, 1976) lists the additional plutonium-239 contributed by solvent residues. This residue, containing an estimated 1,885 grams of plutonium-239, was left in the burning pan after the solvent was burned.

Mason (1996) indicates that the solids remaining in the OSTs (tanks 1 through 22) contain approximately 107 curies of alpha activity. If the same activity ratio that was found in the solvent residues (77\% Pu-239, 20\% Pu-238, and 3\% Cm-244) and reported in Wilhite (1976) is applied to this activity, then the OSTs inventory for plutonium-239 would be 82.4 curies or 1351 grams.

\subsection{Best Estimate of Plutonium-239 in Burial Grounds}

The best estimate for the plutonium-239 inventory in the ORWBG is 24,188 grams $(1,475$ curies). This estimate is the sum of the COBRA database total for plutonium-239 (22,303 grams), and the estimate in burned solvent residues (1,885 grams).

For the OSTs, the best estimate of the plutonium-239 inventory is 1,351 grams ( 82.4 curies) (see Section 3.1).

\subsection{Uncertainties Associated with Plutonium-239 Inventory Estimate}

Plutonium-239, classified as a special nuclear material, was carefully monitored at the SRS. The location and quantity of plutonium-239 were under continuous scrutiny, not only because it was a valuable resource, but also because of the nuclear safety requirements necessary to prevent its uncontrolled fission. The major contributor to the uncertainty related to the quantity of plutonium-239 buried is the classified special burials that are not described in the open literature and in unclassified databases such as COBRA. 


\section{BURIAL LOCATIONS}

The COBRA database provides information on the spatial distribution of plutonium in the ORWBG. Figure 4-1 outlines the steps taken to manipulate the database to locate plutonium239 burials. Figure 4-2(a) presents the burial locations for non-retrievable plutonium-239. This waste was buried without containers. Figure 4-2(b) presents the burial locations for plutonium-239 "concrete pours" (COBRA records with burial code $=5$ ). These encapsulated or grouted burials may or may not be retrievable. The figures indicate the relative size, in grams, of each burial.

Figure 4-3 shows the locations for retrievable plutonium-239 burials. Burial records having culvert (container) numbers are given on Figure 4-3(a), whereas records with no container numbers are given on Figure 4-3(b). The exact form of the retrievable TRU burials that have no container number is uncertain. It is considered likely that these burials consist of 55-gallon drums encapsulated in concrete and/or oversized equipment placed in a trench and backfilled with concrete. These burials are similar to "concrete pours", and the recovery of these plutonium-239 source terms is subject to question. Another less likely scenario for the unnumbered retrievable TRU burials is that they are unnumbered "culverts".

The locations indicated in Figures 4-2 and 4-3 are consistent with the schematic indications of burial location given in Cook and Helton (1989).

\section{WASTE FORM}

$\mathrm{Pu}-239$ contaminated waste was buried in three ways:

- Uncontainerized waste in plastic bags and cardboard boxes. This type of containment would be the most susceptible to infiltrating water.

- Concrete culverts containing drummed or boxed plutonium-239-bearing waste. Although it provides additional barriers, this containment does not preclude the infiltration of water. One excavated culvert was found to contain water.

- Encapsulated waste where drums and other waste forms (equipment, waste in wooden boxes, etc.) were surrounded by concrete on all sides, top, and bottom. Such waste forms would be more impermeable to water infiltration.

\section{LEACHABILITY}

The leachability of plutonium from the ORWBG is a function of the prevailing redox conditions, $\mathrm{pH}$ and chemistry of the water flowing through the trenches, as well as container 
integrity and waste form. For estimation of plutonium leachability the geochemical constraints will be considered in light of groundwater plutonium concentrations and plutonium leachability from the Defense Waste Lysimeters installed within the ORWBG.

Plutonium migrates in dissolved forms and is associated with colloidal particles. Solubility and adsorption control the dissolved forms and strongly influence colloidal plutonium migration. These mechanisms are complicated by the multiple oxidation states of plutonium (III, IV, V, and VI) and the tendency of plutonium to complex with a variety of anions and dissolved organic materials.

Adsorption of plutonium is strongly influenced by plutonium speciation. Prout (1958) measured soil/water distribution coefficient $\left(K_{d}\right)$ values for $\mathrm{Pu}(\mathrm{III}), \mathrm{Pu}(\mathrm{IV})$, and $\mathrm{Pu}(\mathrm{VI})$ on SRS soils. Between $\mathrm{pH} 2$ and 7 the $\mathrm{K}_{\mathrm{d}}$ value for $\mathrm{Pu}(\mathrm{III})$ was 1 to 3 orders of magnitude greater than the $\mathrm{K}_{\mathrm{d}}$ value for $\mathrm{Pu}(\mathrm{VI})$, with the difference increasing as $\mathrm{pH}$ increased. The $\mathrm{K}_{\mathrm{d}}$ value for $\mathrm{Pu}(\mathrm{IV})$ was consistently 1 order of magnitude greater than that for $\mathrm{Pu}(\mathrm{VI})$. Thus, where adsorption dominates retardation, transport of the reduced forms of plutonium is retarded, at a minimum, about 10 times that of $\mathrm{Pu}(\mathrm{VI})$ and may be significantly higher.

Within the ORWBG, plutonium is expected to exist predominantly as $\mathrm{Pu}(\mathrm{III})$ and $\mathrm{Pu}(\mathrm{IV})$. Figure 6-1 shows data from the grid wells (Ryan, 1983) plotted within an redox potential (Eh) vs. pH diagram for dissolved plutonium species. Half of the grid well data plot within the fields of dominance of $\mathrm{Pu}(\mathrm{III})$ and $\mathrm{Pu}(\mathrm{IV})$ species. The remaining data plot within the field of dominance of the pentavalent species $\mathrm{PuO}_{2}{ }^{+}$, but near boundaries of the reduced species. It is uncertain which redox couples influence these Eh measurements and thus, Eh is only a general indicator of redox conditions within the ORWBG. However, these measurements do show that the presence of $\mathrm{Pu}(\mathrm{VI})$ species is unlikely. Furthermore, considering the widespread presence of organic material (paper, cardboard, wood, etc.) and zero valent iron (steel drums, scrap metal, etc.), $\mathrm{Pu}(\mathrm{III})$ and $\mathrm{Pu}(\mathrm{IV})$ are probably the dominant forms of plutonium in solution. For example, as scrap metal and drums corrode, the following plutonium reduction reactions are favorable:

$$
\begin{array}{lc}
\mathrm{PuO}_{2}{ }^{+}+1 / 3 \mathrm{Fe}^{\circ}+3 \mathrm{H}_{2} \mathrm{O}=\mathrm{Pu}(\mathrm{OH})_{4}^{\circ}+1 / 3 \mathrm{Fe}(\mathrm{OH})_{3(\mathrm{am})}+\mathrm{H}^{+} & \operatorname{logK}=7.19 \\
\mathrm{Pu}(\mathrm{OH}) 4^{\circ}+1 / 3 \mathrm{Fe}^{\circ}+3 \mathrm{H}^{+}=1 / 3 \mathrm{Fe}(\mathrm{OH})_{3(\mathrm{am})}+\mathrm{Pu}^{+3}+3 \mathrm{H}_{2} \mathrm{O} & \operatorname{logK}=26.27
\end{array}
$$

Water collected from the bottom of burial trenches is more reducing than groundwater from the grid wells (Ryan, 1983). This further supports the viability of plutonium reducing 
reactions in the ORWBG. Hence, $\mathrm{Pu}(\mathrm{III})$ and $\mathrm{Pu}(\mathrm{IV})$ forms are likely to dominate the speciation of plutonium in the ORWBG.

This is in contrast to the measurements of plutonium speciation in ground water from grid well C-17 made by Wilhite (1978). The distribution of plutonium forms in this groundwater was $43 \% \mathrm{Pu}(\mathrm{VI}), 25 \% \mathrm{Pu}(\mathrm{IV}), 30 \% \mathrm{Pu}(\mathrm{III})$, and less than $2 \%$ in organic forms. Though the reduced forms dominated, the concentration of $\mathrm{Pu}(\mathrm{VI})$ was significant. However, water from this well has had anomalously high concentrations of plutonium compared to all other ORWBG wells (Towler, 1989). This is consistent with the presence of Pu(VI), because this form is more mobile than the reduced forms of plutonium. In contrast, most of the other grid wells have much lower concentrations of plutonium because the plutonium is present as $\mathrm{Pu}$ (III) and $\mathrm{Pu}$ (IV) and is strongly partitioned to the soils. Thus, the presence of $\mathrm{Pu}$ (VI) in well C-17 is not indicative of the speciation of plutonium throughout the ORWBG, but is more likely related to a condition specific to this well. This may be its proximity to the solvent burning trench or the fact that multiple spills of plutonium-bearing solvent have occurred at this well (McIntyre and Wilhite, 1987).

In the absence of strong complexing or colloidal migration, plutonium in the ORWBG will remain immobilized by strong sorption of the dominant $\mathrm{Pu}(\mathrm{III})$ and $\mathrm{Pu}(\mathrm{IV})$ forms. Over the $\mathrm{pH}$ range of the trench wells (5.8-7.0), Prout (1958) measured $\mathrm{K}_{\mathrm{d}}$ values for $\mathrm{Pu}(\mathrm{IV})$ from 3000 to $8000 \mathrm{ml} / \mathrm{g}$ and $\mathrm{K}_{\mathrm{d}}$ values that exceeded $10,000 \mathrm{ml} / \mathrm{g}$ for $\mathrm{Pu}$ (III). This suggests a range of retardation factors for the dominant forms of plutonium of about 24,000 to in excess of 80,000 .

Enhanced mobility of plutonium by organic complexing has not been observed at the ORWBG. The presence of abundant organic material in the ORWBG raised the concern that the degradation of this material could release organic components that would enhance the mobility of radionuclides. McIntyre and Wilhite (1987) addressed this concern by comparing the concentrations of several radionuclides with concentrations of dissolved organic components in water from the grid wells. Approximately $40 \%$ of the dissolved organics were high molecular weight components, suggesting they originated from the decay of organic material in the ORWBG. However, there was no correlation between the concentration of plutonium (or any other radionuclide measured) and the concentration of dissolved organic components. McIntyre and Wilhite (1987) concluded that either the radionuclides measured (including plutonium) do not form strong complexes with these organic components or the concentration of the organic components is not high enough to significantly affect the mobility of the radionuclides. 
Though colloidal migration of plutonium may occur, the evidence suggests that it does not significantly enhance leachability. Plutonium may migrate colloidally as discrete plutonium phases or adsorbed to other metal oxide phases (Silva and Nitsche, 1995). The discrete phases tend to be polymerized $\mathrm{Pu}(\mathrm{OH})_{4}$ and are called intrinsic colloids. Rai and Serne (1979) found that intrinsic colloids could only form if the concentration of plutonium was above the solubility of $\mathrm{Pu}(\mathrm{OH}) 4(\mathrm{am})$. The concentration of plutonium in groundwater beneath the ORWBG is several orders of magnitude less than this threshold value. Thus, migration of plutonium as intrinsic colloids is not occurring. From the available data it is not possible to determine the fraction of migrating plutonium that is adsorbed to colloidal particles of non-plutonium phases. However, Kaplan et al. (1994) did find that a minor amount of ${ }^{239} \mathrm{Pu}$ was migrating in association with colloidal particles from a General Separations Area seepage basin. Nevertheless, they concluded that this was only a small fraction of the plutonium released and that the transport behavior of plutonium was dominated by sorption to the aquifer matrix.

Concentrations of ${ }^{238} \mathrm{Pu}$ and ${ }^{239} \mathrm{Pu}$ in groundwater beneath the ORWBG are low. Ryan (1983) reported analyses performed in 1980 of groundwater from 12 grid wells. The highest concentrations of $238 \mathrm{Pu}$ and ${ }^{239} \mathrm{Pu}$ were $17 \mathrm{pCi} / \mathrm{l}$ and $4 \mathrm{pCi} / 1$, respectively and occurred in well G-21.

Well G-21 has an anomalous chemistry (Ryan, 1983) that may not be representative of concentrations in groundwater. McIntyre and Wilhite (1988) and Towler (1989) report that well G-21 was one of 15 wells installed through waste trenches at the ORWBG to monitor the water table. Samples from well G-21 have shown consistently high concentrations of radionuclides that should not be at the water table by migration from the trenches (Ryan, 1983). The anomalously high radionuclide concentrations (particularly Sr-90) in this well have been correlated with high, and similarly anomalous concentration of iron found in the same samples (Ryan, 1983). Possible explanations for the elevated iron concentrations include:

- a natural anomaly in the aquifer of high concentrations of organic matter or pyrite,

- contaminated water leaking from the trench down the well annulus, or

- waste debris smeared down the hole during installation of the well.

Natural iron anomalies in the water table aquifer at SRS have not been observed. Relatively immobile radionuclides (like cesium and plutonium) in water leaking down the well annulus would likely be sorbed to surfaces along the annulus and not occur in significant concentrations at the screen. Small amounts of waste debris smeared during well installation could explain the 
anomalous chemistry of the samples taken from this well. Monitoring well G-21 was abandoned in 1995, in accordance with accepted abandonment procedures.

Contamination from releases of liquid solvent offers an alternative explanation for the anomalous radionuclide concentrations in well G-21. Several reports discuss a 1962 incident in which 40 gallons of spent PUREX solvent, which consisted of up to $30 \%$ tri-butly-phosphate (TBP) and contained plutonium, were accidentally pumped down an unidentified test well located near the solvent tanks (Wilhite, 1975; Ryan, 1983; McIntyre and Wilhite, 1987; Mason, 1996). McIntyre and Wilhite (1987) report that in 1987, G-21 was the only well that showed a concentration of TBP $(0.16 \mathrm{mg} / \mathrm{l})$ above the detection limit of $(0.05 \mathrm{mg} / \mathrm{l})$. These results suggest that $\mathrm{G}-21$ may have been affected by the solvent pumping incident.

Two other grid wells, C-15 and C-17, have consistently had elevated plutonium concentrations. These two wells were associated with the solvent spill where plutonium containing solvent was mistakenly pumped down a well head (See Section 2.1.5 of Appendix D). These anomalous wells are the only grid wells that have shown consistently elevated gross alpha measurements since 1976. Well I-13 has shown slightly elevated gross alpha measurements over several years, but the ${ }^{238} \mathrm{Pu}$ and ${ }^{239} \mathrm{Pu}$ concentrations remain low. For example, in 1987 the gross alpha measurement was $5 \mathrm{pCi} / 1$ (Towler, 1989), but the ${ }^{238} \mathrm{Pu}$ and ${ }^{239} \mathrm{Pu}$ concentrations were $0.5 \mathrm{pCi} / 1$ and 0.17 pCi/ (McIntyre and Wilhite, 1987), respectively. Of 64 grid wells measured in 1987, the average gross alpha was $4.1 \mathrm{pCi} / \mathrm{l}$ and the median was $1 \mathrm{pCi} / \mathrm{l}$ (the average is skewed by the measurement of $155 \mathrm{pCi} / 1$ in well $\mathrm{G}-21$-- the next highest measurement was $5 \mathrm{pCi} / \mathrm{l}$ ). Thus, the groundwater data show that plutonium concentrations are elevated in 3 wells that have anomalous chemistries, but throughout the ORWBG as a whole plutonium concentrations remain low.

The low concentrations of plutonium in the groundwater are consistent with the facilitated transport (Looney et al., 1987) of a small fraction of plutonium. This fraction exists associated with colloids or as a trace species that is relatively unretarded by sorption. The bulk of the plutonium leached from buried waste is subject to the high retardation factors caused by sorption to trench soil and possibly solubility of unidentified plutonium phases. The lack of thermodynamic data for these phases makes geochemical modeling of plutonium transport tenuous. Nevertheless, at a retardation factor of 24,000 the dominant fraction of ${ }^{238} \mathrm{Pu}$ that is not subject to facilitated transport will decay to negligible levels prior to reaching the water table. The less mobile fraction of ${ }^{239} \mathrm{Pu}$ will decay through several half-lives prior to reaching the water table. 
The predicted immobility of plutonium is consistent with leachability of plutonium-bearing waste in the Defense Waste Lysimeters. Data from these lysimeters provide the best basis for estimating the leaching rate of plutonium from the ORWBG. The annual fractional release rates of $238 \mathrm{Pu}$ and ${ }^{239} \mathrm{Pu}$ from the waste form lysimeters are defined as the ratio of the annual leaching rates to the inventories of the isotopes in the wastes buried in the lysimeters (Oblath, 1983). From 1983 through 1986 the annual fractional release rates for ${ }^{238} \mathrm{Pu}$ and ${ }^{239} \mathrm{Pu}$ from the Defense Waste Lysimeters ranged from $1 \times 10^{-12}$ to $8 \times 10^{-8} \mathrm{yr}^{-1}$. The highest fractional release rate came from Canyon pipe jumpers waste (McIntyre, 1987). In general, waste from the High Level Caves and Actinide Materials Facility have higher fractional release rates than Separations and job control waste (McIntyre, 1987). The conditions in the Defense Waste Lysimeters may be less reducing than those in waste trenches in the ORWBG because the column of degrading waste at any point in a trench is longer than that in the lysimeters. Thus, $\mathrm{Pu}(\mathrm{V})$ and possibly $\mathrm{Pu}(\mathrm{VI})$ may occur in the lysimeters causing plutonium to be more mobile than in burial trenches.

Using the highest annual fractional release rate from the lysimeters $\left(8 \times 10^{-8} \mathrm{yr}^{-1}\right)$, the estimated initial leaching rates of unencapsulated ${ }^{238} \mathrm{Pu}$ and ${ }^{239} \mathrm{Pu}$ are $2.5 \times 10^{-4} \mathrm{Ci} / \mathrm{yr}$ and $2.9 \times 10^{-5} \mathrm{Ci} / \mathrm{yr}$ respectively. It is assumed here that the leaching rate of plutonium encapsulated in cement or in removable TRU containers will be significantly lower than that of plutonium disposed in plastic bags within cardboard boxes. Based on the geochemical behavior of plutonium in the conditions of the ORWBG, plutonium concentrations in groundwater, and the Defense Waste Lysimeter experiments, the leaching rate of plutonium is low. Leaching rates estimated from the maximum annual fractional release rate $\left(8 \times 10^{-8} \mathrm{yr}^{-1}\right)$ of plutonium from the Defense Waste Lysimeters are $2.5 \times 10^{-4} \mathrm{Ci} / \mathrm{yr}$ for ${ }^{238} \mathrm{Pu}$ and $2.9 \times 10^{-5} \mathrm{Ci} / \mathrm{yr}$ for ${ }^{239} \mathrm{Pu}$. It is assumed that the leaching rate of plutonium encapsulated in cement or removable TRU containers will be significantly lower than that of plutonium disposed in plastic bags within cardboard boxes. The expected dominance of reduced forms of plutonium suggests that adsorption is the major process controlling leaching. A small fraction of plutonium is leached from trenches and is relatively unaffected by adsorption or other retarding processes. This is reflected in the low plutonium concentrations in groundwater. Complexing by inorganic or organic components and colloidal migration may have facilitated the transport of this small fraction, but this is unclear from the groundwater data. This fraction, and hence the leaching rate, are expected to remain low because dramatic changes in the chemistry of water in the ORWBG trenches are unlikely. 


\section{REFERENCES}

Ashley, C., 1960. SRP Radioactive Waste Release, Startup through 1959, DPSP-60-25-25, E.I. du Pont de Nemours and Company, Aiken, SC, September 1960.

Ashley, C., 1962a. 1960 Audit of SRP Radioactive Waste, DPSP-62-25-1, E.I. du Pont de Nemours and Company, Aiken, SC, February 1962.

Ashley, C., 1962b. 1961 Audit of SRP Radioactive Waste, DPSP-62-25-5, E.I. du Pont de Nemours and Company, Aiken, SC, September 1962.

Ashley, C., 1963. 1962 Audit of SRP Radioactive Waste, DPSP-63-25-1, E.I. du Pont de Nemours and Company, Aiken, SC, May 1963.

Ashley, C., 1964. 1963 Audit of SRP Radioactive Waste, DPSP-64-25-1, E.I. du Pont de Nemours and Company, Aiken, SC, May 1964.

Ashley, C., 1965. 1964 Audit of SRP Radioactive Waste, DPSP-65-25-1, E.I. du Pont de Nemours and Company, Aiken, SC, April 1965.

Cook, J.R., 1987. Technical Data Summary: Plan for Closure of the 643-G Burial Ground, DPSTD-87-2, E.I. du Pont de Nemours and Company, Aiken, SC.

Cook, J.R. and Helton, B.D., 1989. An Assessment of Buried Waste Containing Transuranium Isotopes in the Savannah River Site Radioactive Waste Burial Ground, memorandum to B.G. Kitchen, August 23, 1989.

Cook, J.R., 1991. Radionuclide Inventory of E-Area, memorandum to W.E. Stevens, WSRCRP-91-709, June 27, 1991.

Corey, J.C. and Horton, J.H., 1971. Savannah River Plant Burial Ground Practices, DPST-70460, E.I. du Pont de Nemours and Company, Aiken, SC, March 1971.

Department of Energy (DOE), 1995a. Fact. Sheet, "F Canyon", Savannah River Operations Office, Aiken, SC.

Department of Energy (DOE), 1995b. Fact Sheet, "H Canyon", Savannah River Operations Office, Aiken, SC.

Hoeffner, S.L., 1985. Radionuclide Sorption on Savannah River Plant Burial Ground Soil -- A Summary and Interpretation of Laboratory Data: DP-1702, E.I. duPont de Nemours and Company, Savannah River Laboratory, Aiken, SC.

Holcomb, H. Perry, 1992. Transcription of a Presentation by Dr. E.L.Albenesius, SRP Burial Ground Operation from an Historical Perspective (U), WSRC-RP-92-349, Environmental Restoration Department, Westinghouse Savannah River Company, Savannah River Site, Aiken, SC, February 14.

Horton, J.H. and Corey, J.C., 1976. Storing Solid Radioactive Wastes at the Savannah River Plant, DP-1366, E.I. du Pont de Nemours and Company, Aiken, SC.

Kaplan, D.I., P.M. Bertsch, D.C. Adriano, and K.A. Orlandini, 1994. Actinide Association with Groundwater Colloids in a Coastal Plain Aquifer: Radiochimica Acta, v. 66/67, p. 181-187. 
Looney, B.B., M.W. Grant and C.M. King, 1987. Estimation of Geochemical Parameters for Assessing Subsurface Transport at the Savannah River Plant: DPST-86-710, E.I. duPont de Nemours and Company, Savannah River Laboratory, Aiken, SC.

Mason, J.T., 1996. Information Document on the Old Solvent Tanks S1-S22 in the Old Radioactive Waste Burial Ground 643-E" (U), WSRC-RP-96-00144, Westinghouse Savannah River Company, Aiken, SC.

McIntyre, P.F. and E.L. Wilhite, 1987. Effect of Organics on Radionuclide Mobility in the SRP Burial Ground: DPST-87-762, E.I. duPont de Nemours and Company, Savannah River Laboratory, Aiken, SC.

McIntyre, P.F., 1987. 1987 Monitoring Report for the Defense Waste Lysimeters, memorandum of August 10, 1987, to H.F. Sturm, Jr.: DPST-87-568, E.I. duPont de Nemours and Company, Savannah River Laboratory, Aiken, SC.

Oblath, S.B., 1983. Defense Waste Lysimeters: 1983-1984 Monitoring Report: DPST-84-859, E.I. duPont de Nemours and Company, Savannah River Laboratory, Aiken, SC.

Prout, W.E., 1958. Adsorption of Radioactive Wastes by Savannah River Plant Soil: Soil Science, v. 86, p. 13.

Rai, D. and R.J. Serne, 1979. Solution Species of Pu-239 in Oxidizing Environments: 1. Polymeric Pu(IV), PNL Rpt.-SA-6994, Pacific Northwest Laboratory, Hanford, WA, pp. 1-9.

Ryan, J.P., 1983. Groundwater Monitoring in the Savannah River Site Low Level Radioactive Waste Burial Ground, A Summary and Interpretation of the Analytical Data: DPST-83-209, E.I. duPont de Nemours and Company, Savannah River Laboratory, Aiken, SC.

Silva, R.J. and H. Nitsche, 1995. Actinide Environmental Chemistry: Radiochimica Acta, v. 70/71, p. 377-396.

Towler, O.A. Jr., 1989. Integrated Report on Radionuclide Migration at the Savannah River Shallow Land Burial Site: DP-1778, E.I. duPont de Nemours and Company, Savannah River Laboratory, Aiken, SC.

Wilhite, E.L., 1976. Estimate of TRU Nuclides in Solvent Residues at the Burial Ground, memorandum to M.D. Boersma, April 30, 1976.

Wilhite, E.L., 1978. Chemical Speciation of Plutonium in the Radioactive Waste Burial Ground at the Savannah River Plant: DP-1511, E.I. duPont de Nemours and Company, Savannah River Laboratory, Aiken, SC.

WSRC, 1992. Old Radioactive Waste Burial Ground, Revised Draft, August, 1992. 


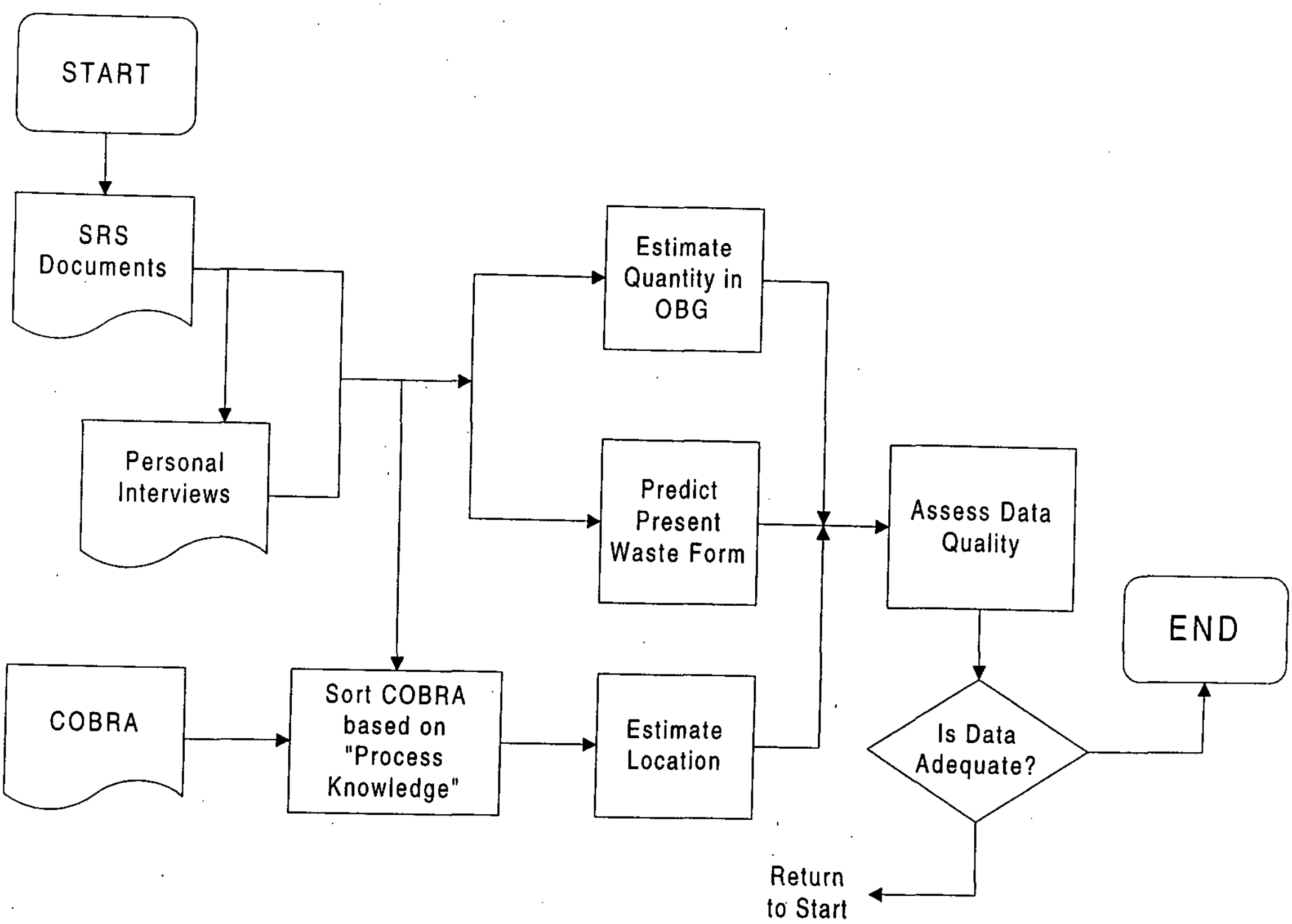

Figure 1-1. Inventory Estimate Process Flow Diagram 


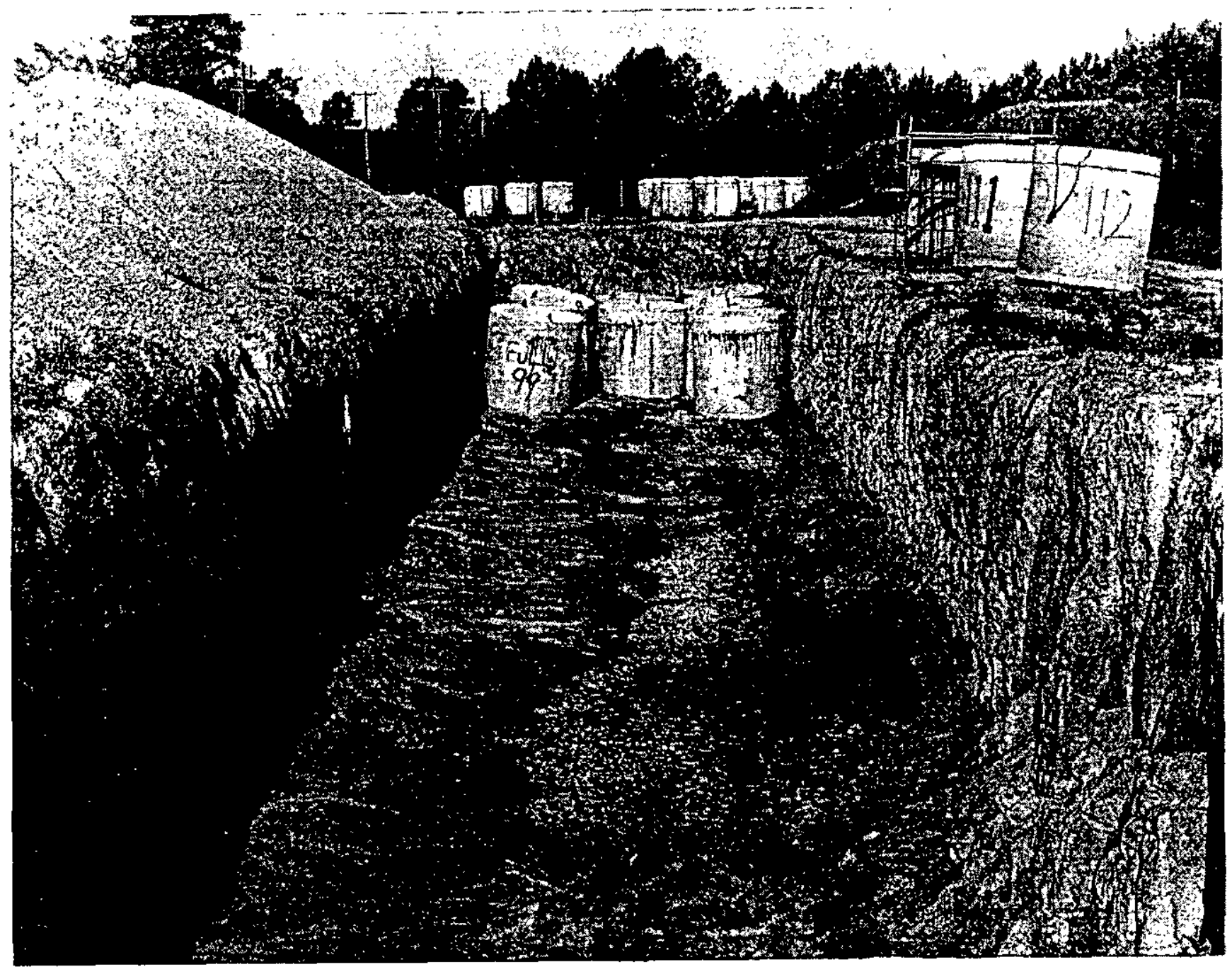

Figure 2-1. Typical Culvert Disposal 


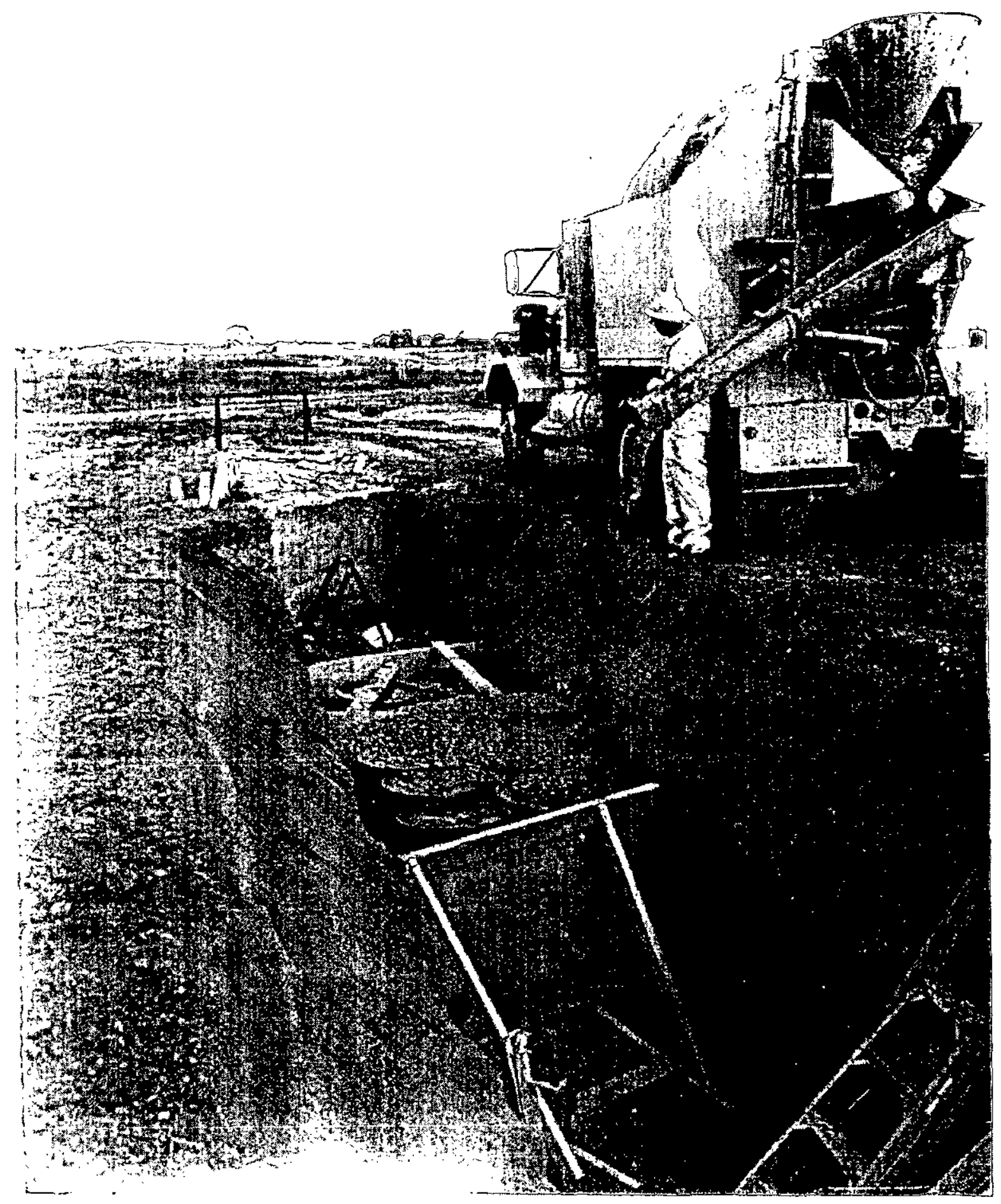

Figure 2-2. Typical Encapsenlation Burial 


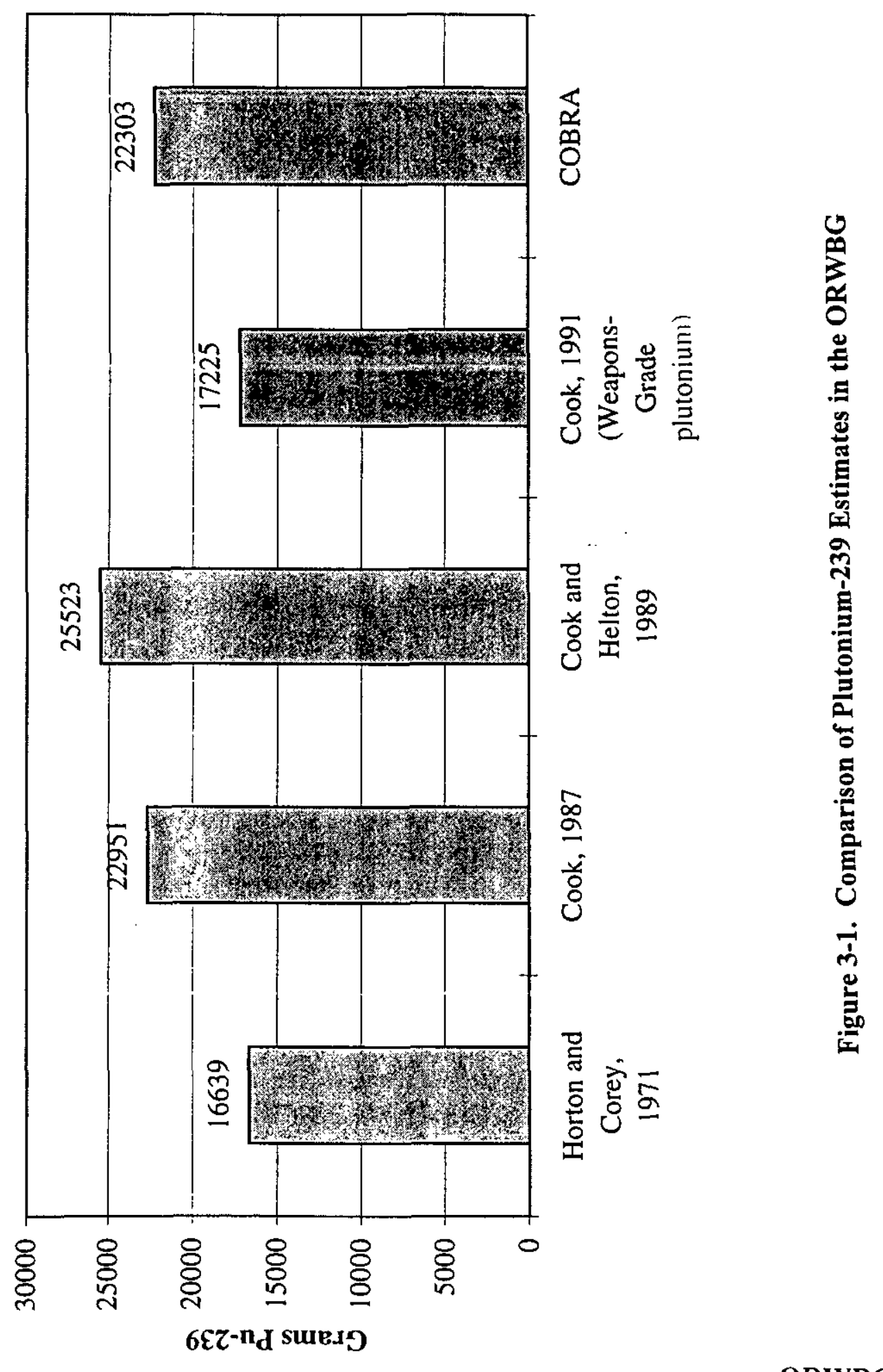

ORWBG 


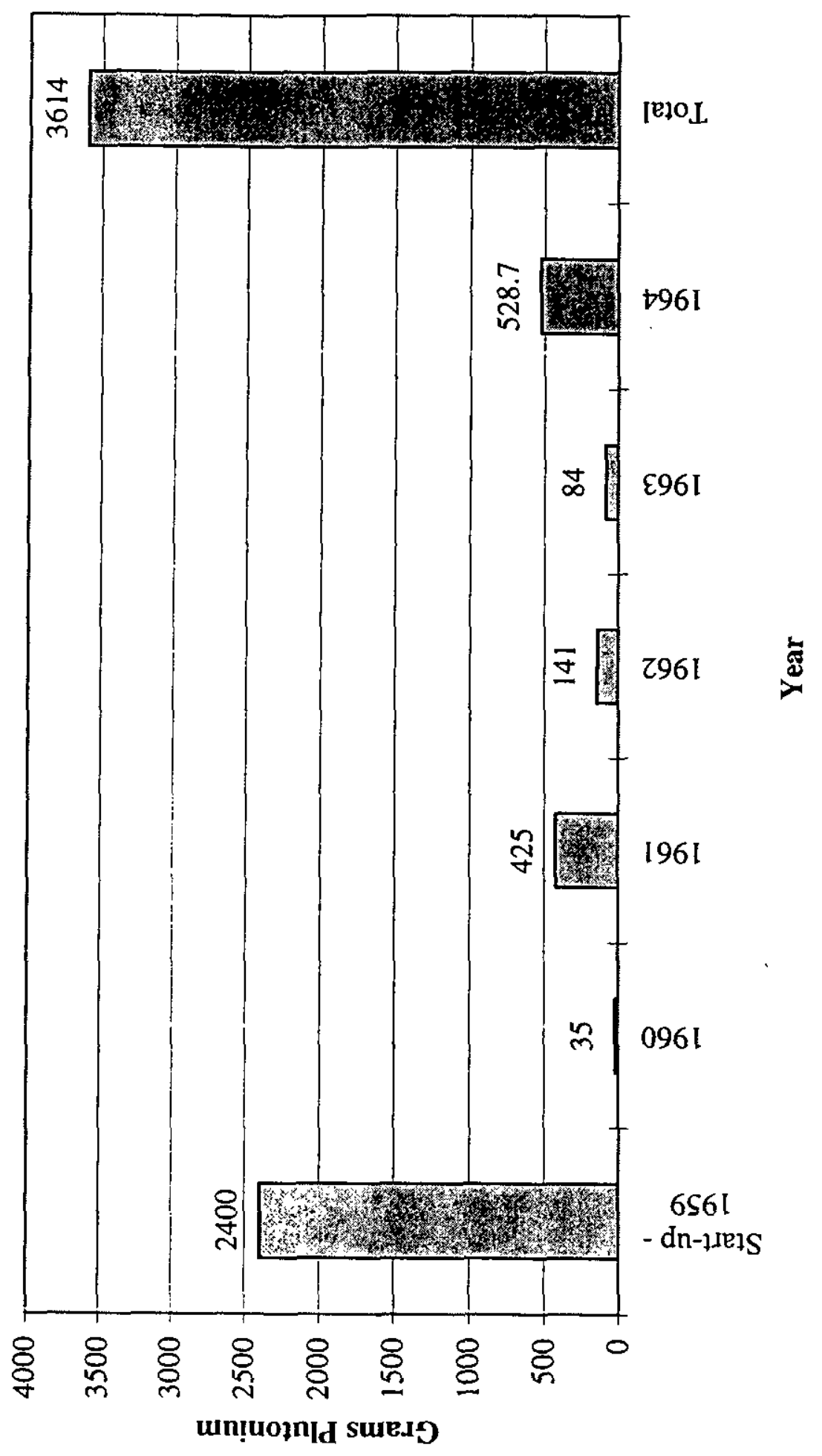

资 


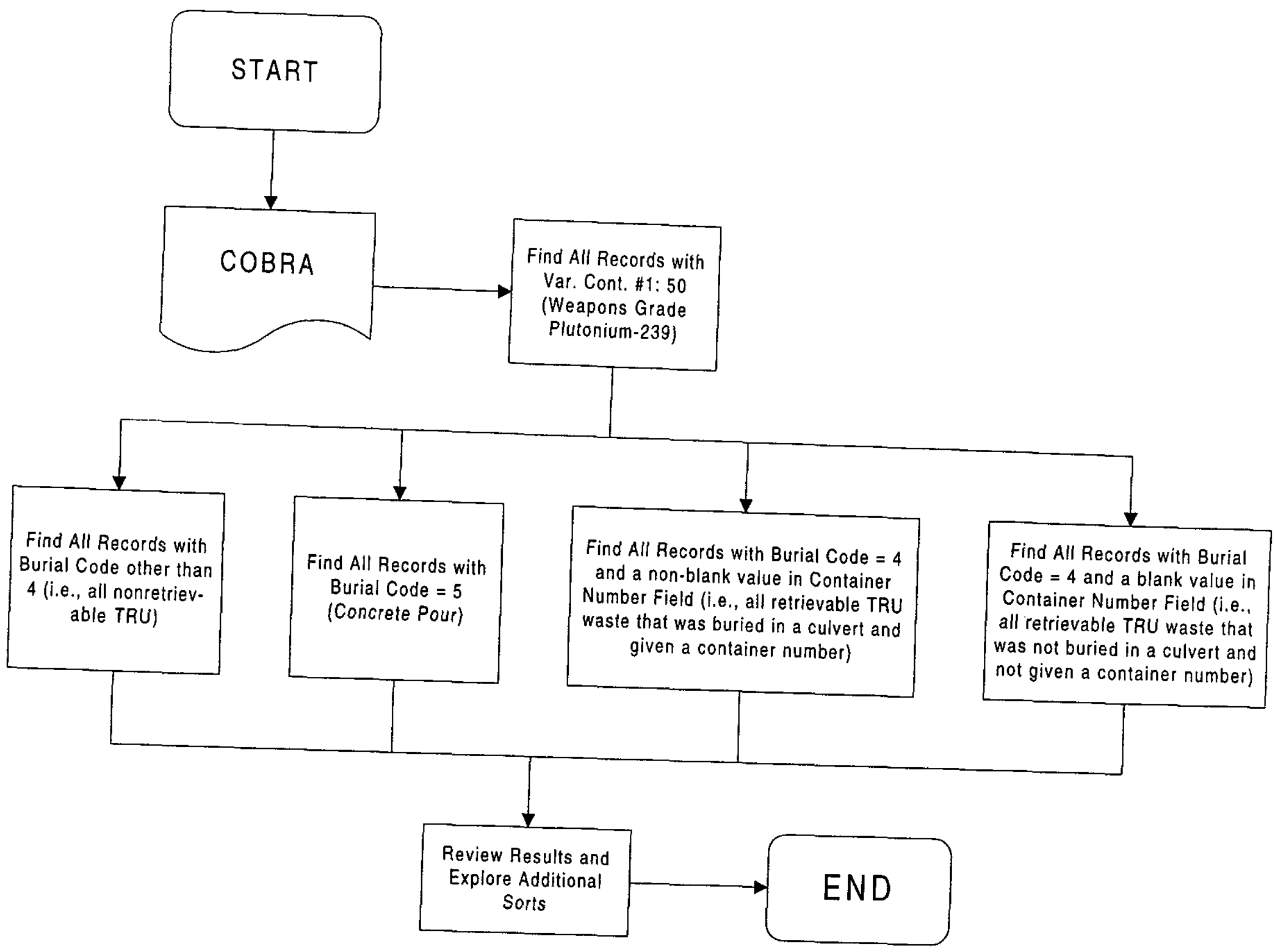

Figure 4-1. Plutonium-239 (Weapons Grade Plutonium) Burial Location Process Flow Diagram 
(a)

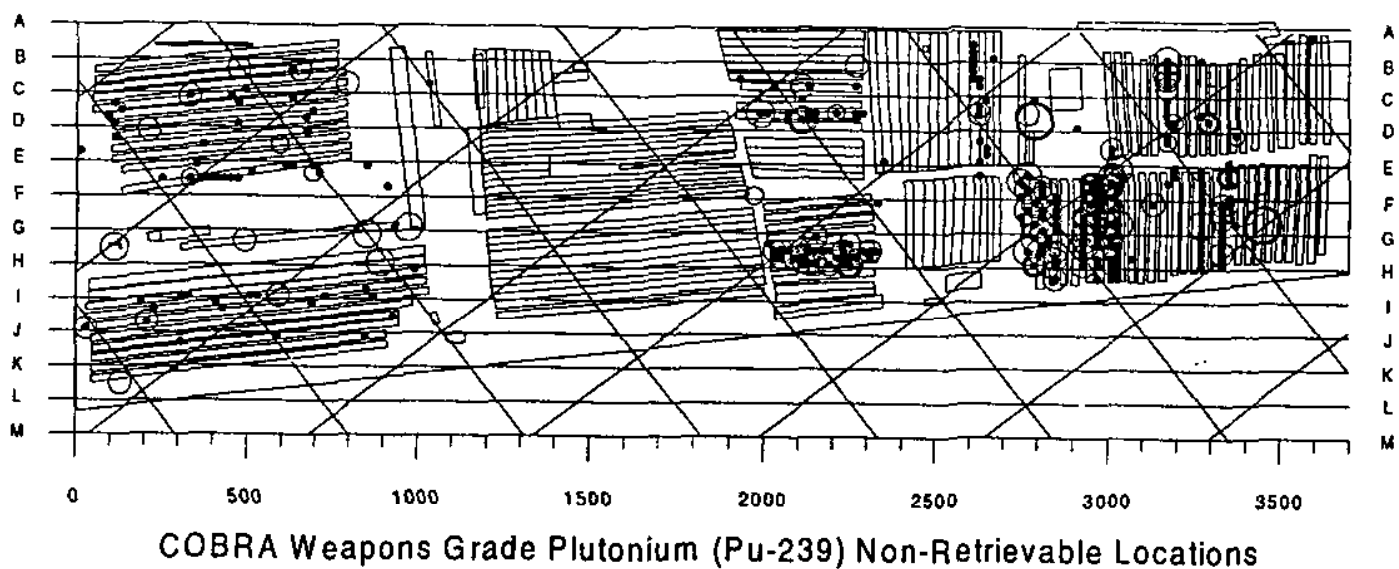

(b)

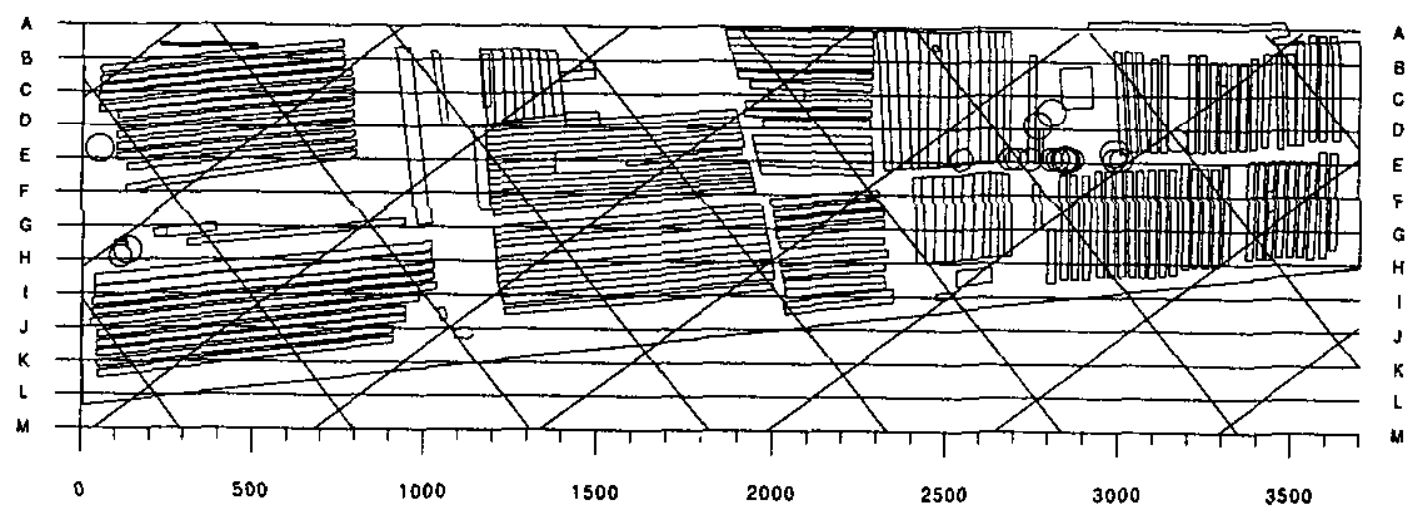

COBRA Weapons Grade Plutonium (Pu-239) Concrete Pour (Burial Code $=5$ ) Locations

\begin{tabular}{cccccccc}
\hline Grams & 0 & 0 & 0 & 0 & 0 & 0 & See Note Below \\
& $0-<0.01$ & $0.01 *<0.1$ & $0.1-<1$ & $1-<10$ & $10-<100$ & $100 \cdot<1000$ & $1000-<10000$ \\
\hline
\end{tabular}

Figure 4-2. COBRA Plutonium-239 Locations for: (a) Non-retrievable and (b) Concrete Pours.

The two largest individual listings for non-retrievable weapons-grade plutonium in COBRA have no $\mathrm{x}$, y coordinates, and include a 1,427 gram shipment from offsite and 2,184 gram "lumped" record labeled "Startup thru 1959" 
(a)

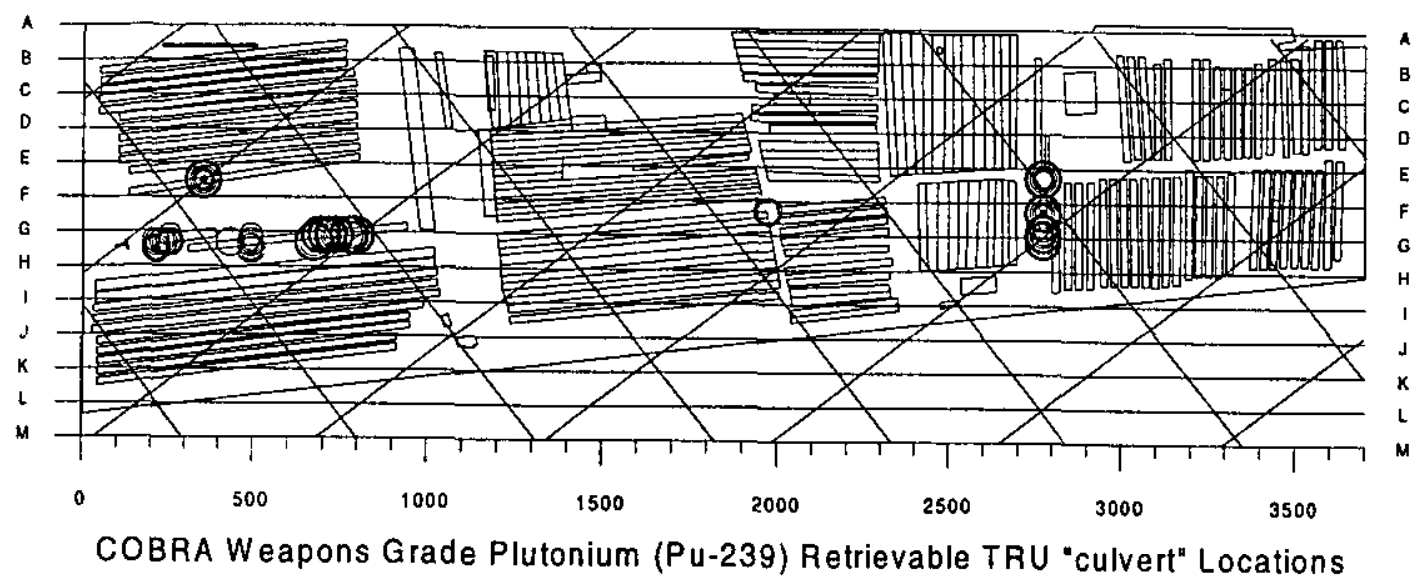

(b)

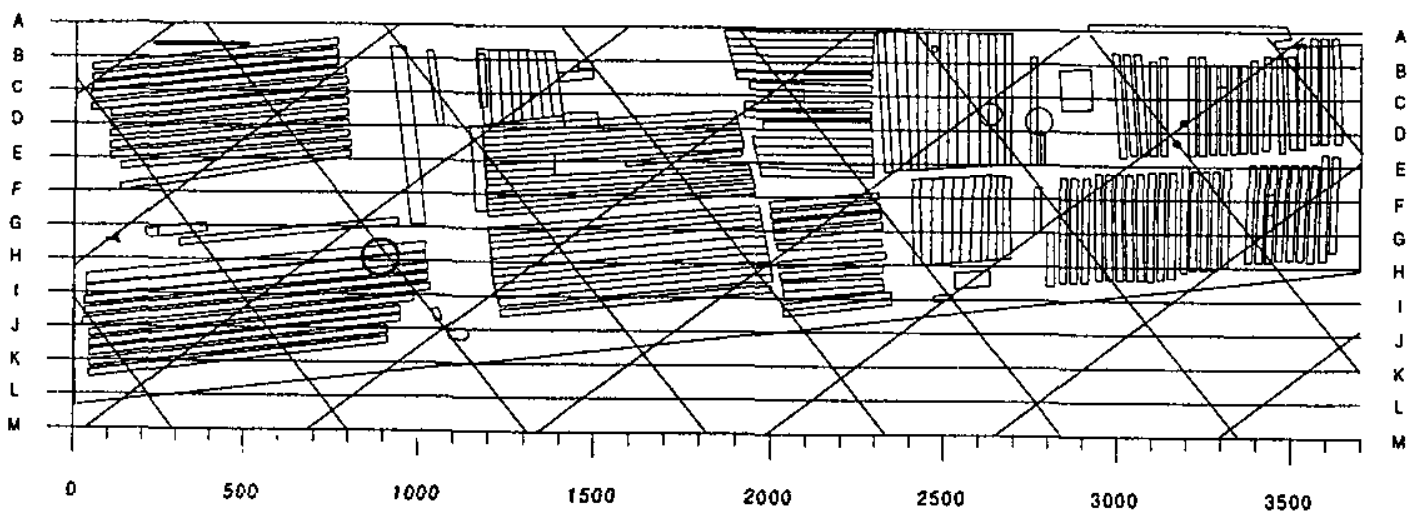

COBRA Weapons Grade Plutonium (Pu-239) Retrievable TRU non-"culvert" Locations

\begin{tabular}{|cccccccc|}
\hline Grams & 0 & 0 & 0 & 0 & 0 & $\bigcirc$ & none \\
& $0 \cdot<0.01$ & $0.01-<0.1$ & $0.1 \cdot<1$ & $1 \cdot<10$ & $10-<100$ & $100-<1000$ & $1000 \cdot<10000$ \\
\hline
\end{tabular}

Figure 4-3. COBRA Weapons Grade Plutonium (Pu-239) Locations for: (a) Retrievable TRU “Culverts" and (b) Retrievable TRU Other than "Culverts" 


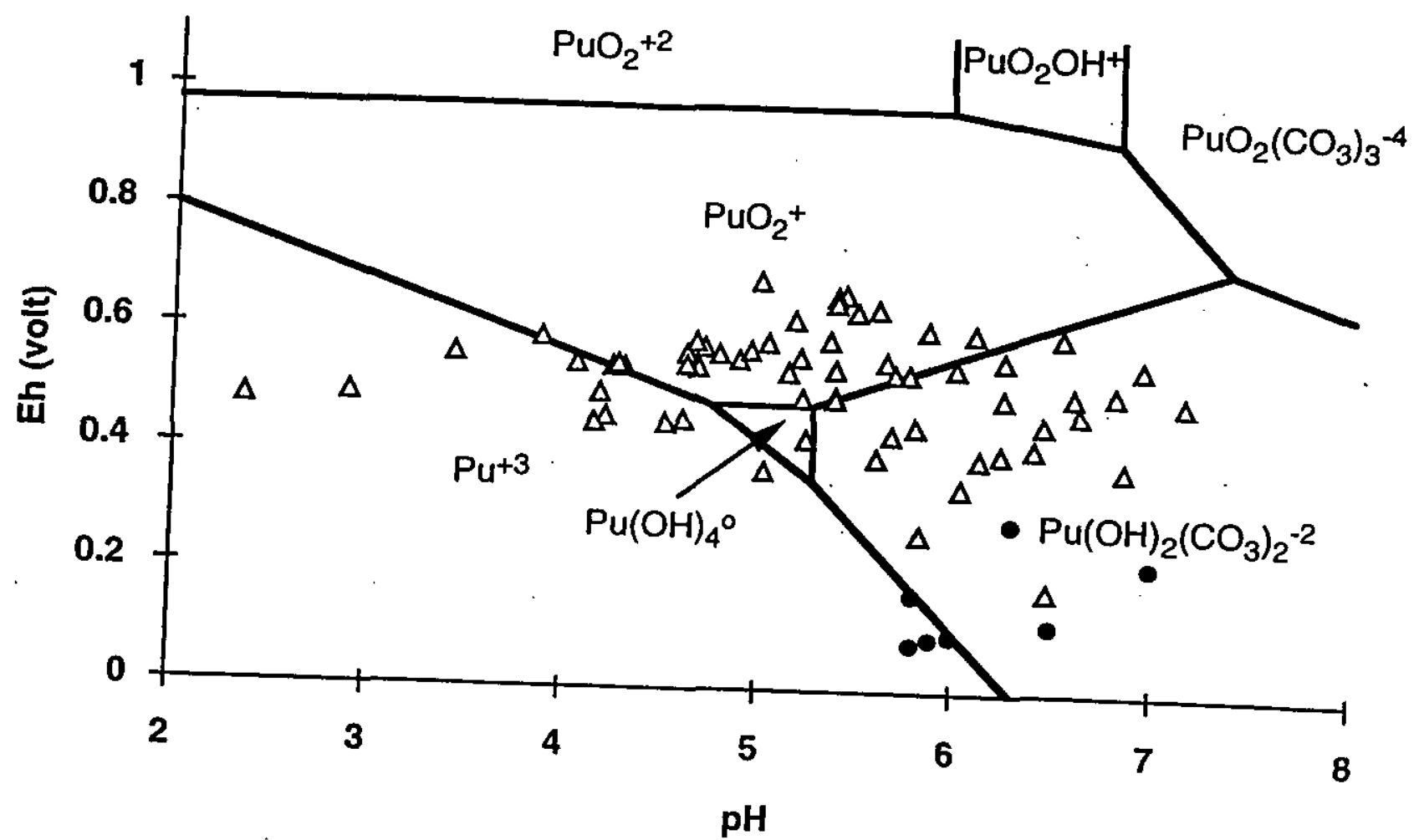

Figure 6-1. Eh-pH Diagram for Plutonium Species, $\mathrm{pCO}_{2}=0.01 \mathrm{~atm}$. Analyses of water from grid wells (Ryan, 1983) are shown as triangles, analyses of water from trench wells (Hoeffner, 1985) are shown as filled circles 
Table 2-1. COBRA Plutonium-239 Records With "Burial Code $=5$ " (Concrete

Pour)

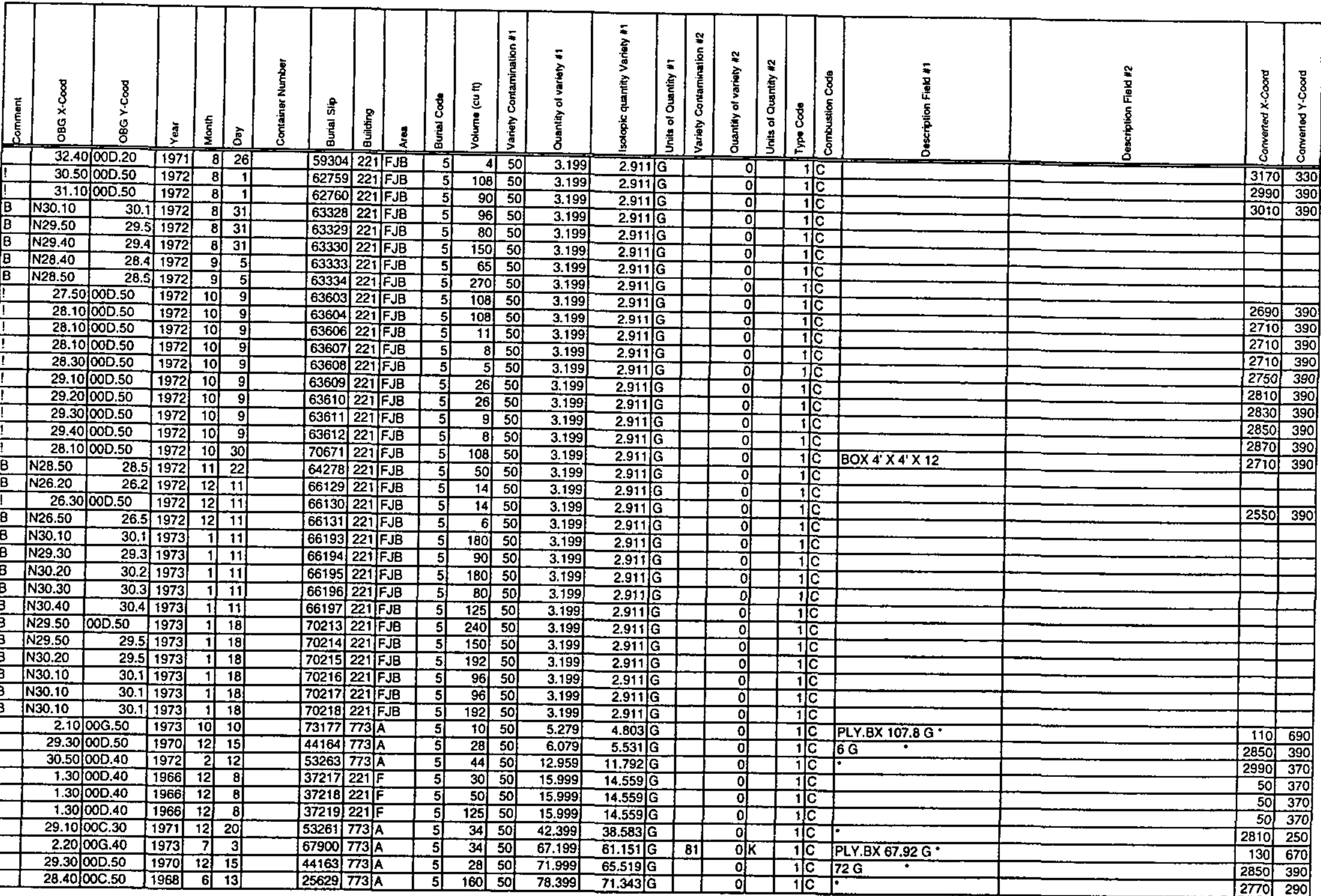


Table 2-1. COBRA Plutonium-239 Records With "Burial Code $=5$ " (Concrete Pour) (Continued)

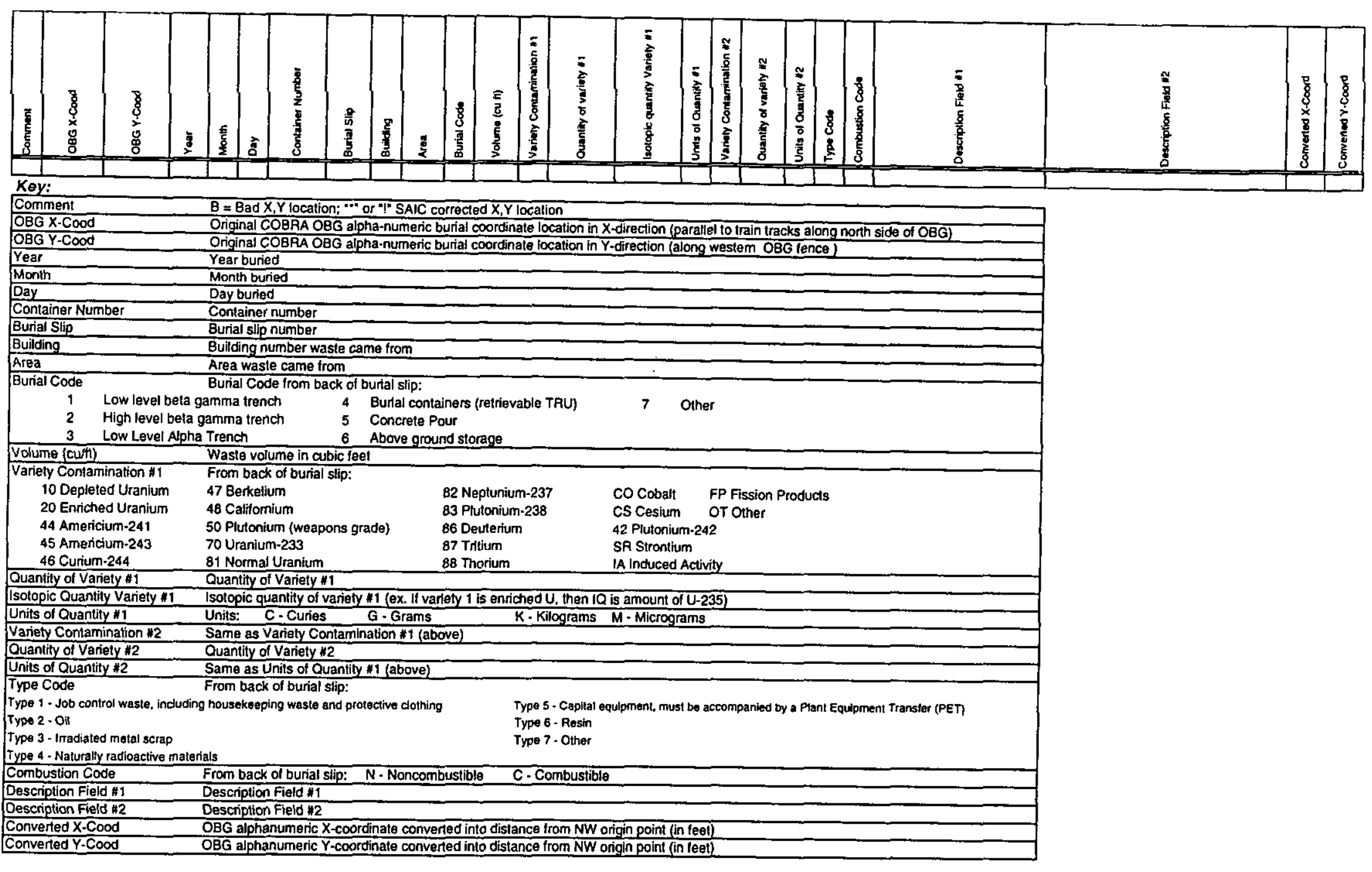


Table 3-1. The Sources of Inventory Estimates for Plutonium-239 in the ORWBG

\begin{tabular}{|c|c|c|}
\hline Reference & ${ }^{239}$ Pu Inventory & Notes \\
\hline WSRC, 1992 & 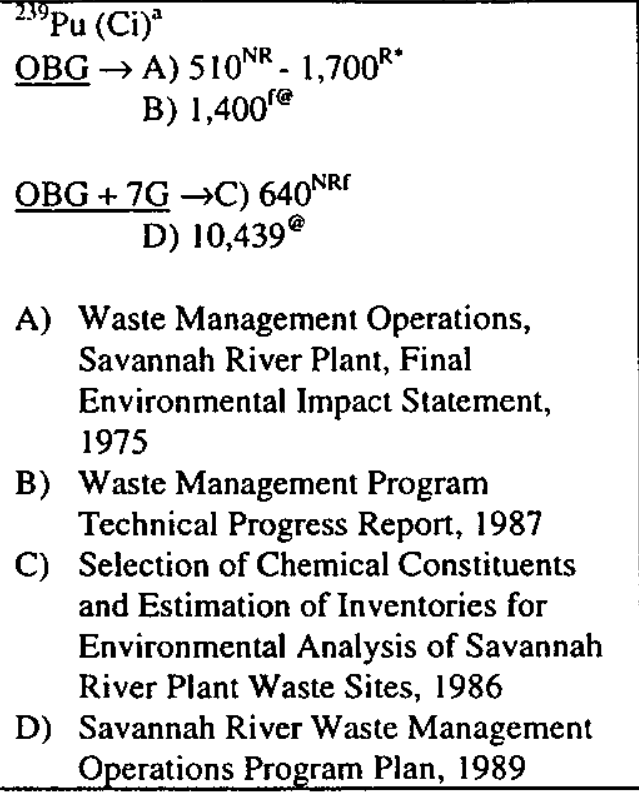 & $\begin{array}{ll}\text { R } & \text { Retrievable waste } \\
\text { NR } & \text { Nonretrievable waste } \\
* & \begin{array}{l}\text { Inventory estimated } \\
\text { through 1975, includes first } \\
\text { four years inventory at }\end{array} \\
& 643-7 \mathrm{G} \\
\text { @ } & \begin{array}{l}\text { Includes all forms of } \\
\text { transuranic waste including }\end{array} \\
\text { TRU fraction of low-level waste } \\
\text { f } \quad \begin{array}{l}\text { Does not account for } \\
\text { radioactive decay since } \\
\text { time of burial }\end{array}\end{array}$ \\
\hline Hoicomb, H. Perry, 1992 & $\mathrm{NA}$ & $\begin{array}{l}\text { The total plutonium waste at SRS is } \\
3 / 4 \text { million curies } \\
\text { (does not reference an earlier article) }\end{array}$ \\
\hline Cook, J R., 1991 & $\begin{array}{l}\text { 643-E inventory: } \\
\text { Weapons Grade Pu: } 17,225 \text { grams }^{\mathrm{b}} \\
{ }^{239} \mathrm{Pu}: 988 \mathrm{Ci} \\
\text { (does not reference an earlier article) }\end{array}$ & $\begin{array}{l}\text { Weapons Grade plutonium } \\
\text { - } 93-94 \% \text { Pu-239 } \\
\text { - } \quad 6 \% \text { Pu-240 } \\
\text { - } \quad<1 \% \text { other } \\
\end{array}$ \\
\hline Cook, J.R. and Helton, B.D., 1989 & $\begin{array}{ll}\text { - } & \text { Retrievable culverts : } 1072 \mathrm{Ci}^{\mathrm{a}} \text { (as } \\
\text { generated) } \\
\text { Encapsulated in concrete: } 26.9 \mathrm{Ci}^{\mathrm{a}} \text { (as } \\
\text { generated) } \\
\text { Uncontained in trenches: } 368 \mathrm{Ci}^{\mathrm{a}} \text { (As } \\
\text { generated; in shallow land burial } \\
\text { trenches) (As generated from COBRA } \\
\text { database) } \\
\text { (does not reference an earlier article) }\end{array}$ & $\begin{array}{ll}\text { - } & \text { Retrievable culverts }>0.1 \mathrm{Ci} \text { per } \\
\text { package (in shallow land burial } \\
\text { (SLB) trenches) } \\
\text { - Encapsulated in concrete } \\
\text { (monoliths)-Waste }>0.1 \mathrm{Ci} \text { per } \\
\text { package but too large to fit into } \\
\text { the culverts } \\
\text { - Uncontained in trenches-Waste } \\
<0.1 \text { Ci per package } \\
\text { Special Projects }\end{array}$ \\
\hline Cook, J.R., 1987 & $\begin{array}{l}\text { Pu-239: } 1400 \mathrm{Ci}^{\mathrm{b}}(22,951 \text { grams) } \\
\text { (does not reference an earlier article) }\end{array}$ & NA \\
\hline
\end{tabular}

anventory discussed in decail.

b No discussion of basis for inventory.

NA Not addressed in article. 
Table 3-1. The Sources of Inventory Estimates for Plutonium-239 in the ORWBG (Continued)

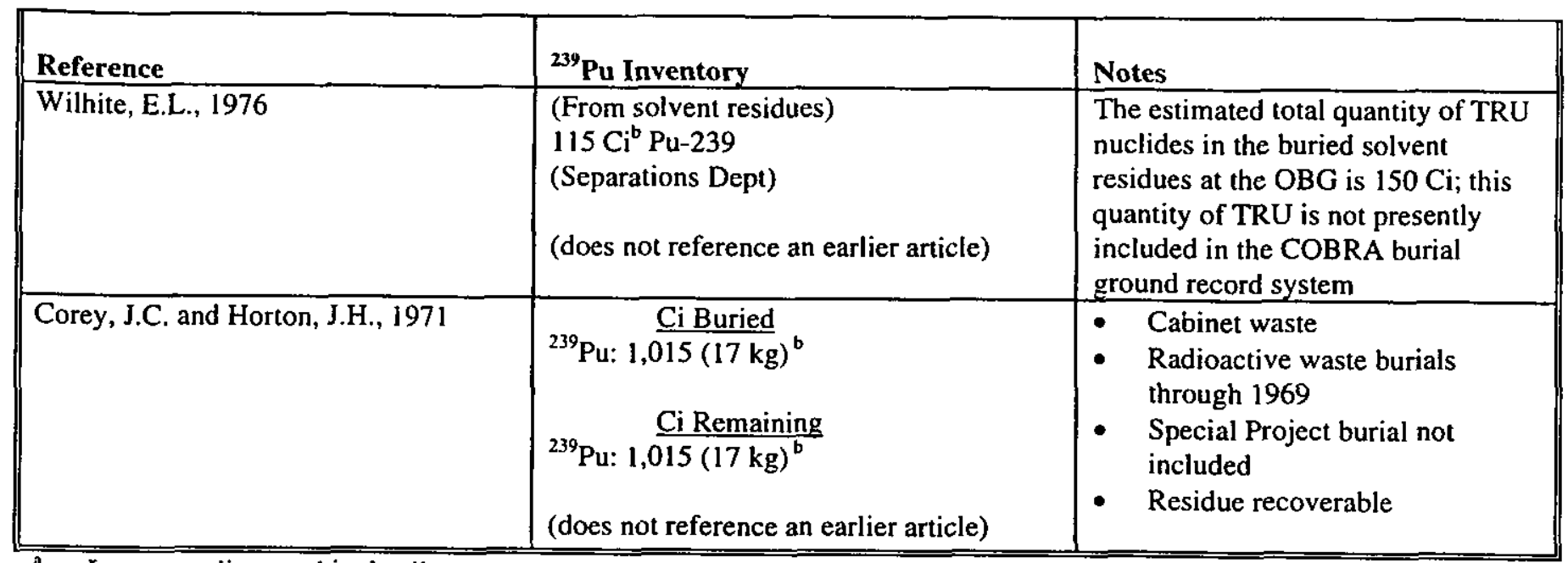

Inventory discussed in detail.

b No discussion of basis for inventory.

NA Not addressed in article. 
Table 3-2. The Sources of Inventory Estimates for Total Plutonium in the ORWBG

\begin{tabular}{|c|c|c|}
\hline Reference & Total Plutonium Inventory in the OBG (grams) ${ }^{b}$ & Notes \\
\hline Ashley C., 1965 & $\begin{array}{l}\frac{1964}{528.7} \frac{\text { Total since plant startup (1953) }}{3614} \\
\text { (does not reference an earlier article) }\end{array}$ & $\begin{array}{l}\text { Health Protection (HP) data. } \\
\text { HP published a summary report between } \\
1959 \text { and } 1965 \text { that gives gross information } \\
\text { on radioisotope burials }{ }^{\text {b }}\end{array}$ \\
\hline Ashley, C., 1964 & $\begin{array}{l}\frac{1963}{84} \quad \frac{\text { Total since plant startup }}{3085} \\
\text { (does not reference an earlier article) }\end{array}$ & \\
\hline Ashley C., 1963 & $\begin{array}{l}\frac{1962}{141} \frac{\text { Total since plant startup }}{3001} \\
\text { (does not reference an earlier article) }\end{array}$ & \\
\hline Ashley C., $1962 \mathrm{~b}$ & $\begin{array}{l}\frac{1961}{425} \frac{\text { Total since plant startup }}{2860} \\
\text { (does not reference an earlier article) }\end{array}$ & \\
\hline Ashley C., 1962a & $\begin{array}{l}\frac{1960}{35} \frac{\text { Total since plant startup }}{2433} \\
\text { (does not reference an earlier article) }\end{array}$ & \\
\hline Ashley, C., 1960 & $\begin{array}{l}\text { Startup through } 1959 \\
\text { plutonium: } 2400 \text { grams } \\
\text { (does not reference an earlier article) }\end{array}$ & \\
\hline
\end{tabular}

a Inventory discussed in detail.

b No discussion of basis for inventory.

NA Not addressed in article. 
Table 3-3. Buried TRU Culverts Summary

\begin{tabular}{|c|c|c|c|c|c|c|c|c|c|}
\hline NORTH & EAST & culvert no. & Pu-238 & Pu-239 & $\mathrm{Np}-238$ & drums & cans & boxes & casks \\
\hline 008.50 & OOG.10 & 1 & 31.53 & 96.97 & 0.00 & 14 & & & \\
\hline 008.50 & $00 G .10$ & 2 & 5.43 & 143.01 & 0.00 & 11 & & 1 & \\
\hline 008.50 & $00 G .10$ & 3 & 7.76 & 101.33 & 0.00 & 14 & & & \\
\hline 008.50 & O0G.10 & 4 & 6.85 & 233.83 & 0.00 & 14 & & & \\
\hline 008.50 & $00 \mathrm{G} .10$ & 5 & 15.86 & 366.03 & 0.00 & 16 & & 1 & \\
\hline 008.40 & $00 \mathrm{G} .10$ & 6 & 15.21 & 325.85 & 0.00 & 15 & & 5 & \\
\hline 008.40 & OOG.10 & 7 & 9.32 & 179.38 & 0.00 & 16 & & 1 & \\
\hline 008.20 & O0G.10 & 8 & 12.56 & 277.07 & 0.00 & 9 & & 19 & \\
\hline 008.20 & $00 \mathrm{G} .10$ & 9 & 39.27 & 360.19 & 0.00 & 2 & & 57 & \\
\hline 008.10 & $00 \mathrm{G} .10$ & 10 & 31.97 & 353.08 & 15.00 & 9 & & 8 & \\
\hline 008.10 & $00 \mathrm{G} .10$ & 11 & 51.72 & 307.36 & 0.00 & & 2 & 45 & \\
\hline 007.50 & $00 G .10$ & 12 & 25.97 & 233.68 & 0.00 & 3 & & 55 & \\
\hline 007.40 & $00 G .20$ & 13 & 2.92 & 329.64 & 0.00 & 1 & & 42 & \\
\hline 028.40 & OOF.50 & 14 & 17.06 & 155.06 & 0.00 & 9 & 3 & 21 & \\
\hline 007.40 & $00 \mathrm{G} .10$ & 15 & 17.71 & 336.04 & 0.00 & & & 60 & \\
\hline 007.40 & 00G.20 & 16 & 11.06 & 251.89 & 0.00 & & & 57 & \\
\hline excavated & & 17 & & & & & & & \\
\hline 028.40 & 00F50 & 18 & 22.39 & 318.13 & 0.00 & & & 48 & \\
\hline 028.40 & 00F50 & 19 & 8.43 & 202.96 & 0.00 & & & 28 & \\
\hline 028.40 & $00 G .10$ & 20 & 14.52 & 267.89 & 0.00 & & 4 & 45 & \\
\hline NR & & 21 & & & & & & & \\
\hline 028.40 & $00 \mathrm{~F} .50$ & 22 & 4.34 & 235.13 & 0.00 & 2 & & 47 & \\
\hline 028.40 & $00 F .50$ & 23 & 3.02 & 338.22 & 0.06 & 1 & & 51 & \\
\hline 028.40 & OOF.40 & 24 & 0.24 & 176.17 & 0.51 & & 7 & 46 & \\
\hline 028.40 & OOF.50 & 25 & 2.46 & 53.73 & 124.90 & & 3 & 18 & \\
\hline 028.40 & OOF.40 & 26 & 3.73 & 173.26 & 13.20 & & 10 & 44 & \\
\hline 028.40 & $00 \mathrm{~F} .40$ & 27 & 0.71 & 278.81 & 0.00 & & 43 & 50 & \\
\hline 028.40 & OOF.40 & 28 & 2.06 & 202.38 & 0.00 & 1 & 10 & 45 & \\
\hline 028.40 & $00 F .20$ & 29 & 12.23 & 318.27 & 0.00 & & 9 & 54 & \\
\hline 028.40 & 00F.20 & 30 & 5.19 & 202.82 & 0.00 & & 3 & 44 & \\
\hline 028.40 & 00F.20 & 31 & 6.75 & 135.69 & 266.34 & & 3 & 44 & \\
\hline 028.40 & OOF.20 & 32 & 11.14 & 221.30 & 0.02 & & 2 & 55 & \\
\hline 028.40 & 00F.20 & 33 & 6.90 & 83.28 & 58.29 & & 2 & 41 & \\
\hline 028.40 & 00F.20 & 34 & 14.79 & 152.43 & 57.44 & & 6 & 52 & \\
\hline 028.40 & 00F.20 & 35 & 3.45 & 217.95 & 174.34 & 2 & & 62 & \\
\hline 028.40 & OOF.20 & 36 & 18.99 & 378.98 & 67.85 & 3 & 8 & 57 & \\
\hline 028.40 & OOF. 20 & 37 & 8.63 & 121.97 & 0.00 & 1 & 4 & 55 & \\
\hline 028.40 & $00 F .20$ & 38 & 9.55 & 160.86 & 20.31 & 1 & $\rightarrow$ & 44 & \\
\hline 028.40 & $00 \mathrm{~F} .20$ & 39 & 8.58 & 160.44 & 36.91 & & 2 & 62 & \\
\hline 028.40 & $00 \mathrm{E} .20$ & 40 & 5.04 & 166.41 & 17.28 & 3 & 2 & 47 & \\
\hline 028.40 & $00 E .20$ & 41 & 1.56 & 38.29 & 26.12 & & & 9 & \\
\hline 028.40 & OOE.20 & 42 & 3.50 & 102.29 & 10.47 & & 1 & 49 & \\
\hline 028.40 & $00 E .20$ & 43 & 0.94 & 150.40 & 24.56 & & 4 & 59 & \\
\hline
\end{tabular}


Table 3-3. Buried TRU Culverts Summary (Continued)

\begin{tabular}{|c|c|c|c|c|c|c|c|c|c|}
\hline NORTH & EAST & culvert no. & Pu-238 & Pu-239 & $\mathrm{Np}-238$ & drums & cans & boxes & casks \\
\hline 028.40 & OOE.20 & 44 & 0.00 & 129.67 & 0.00 & & & 65 & \\
\hline 028.40 & 00E.20 & 45 & 10.84 & 166.73 & 12.13 & & 5 & 53 & \\
\hline 028.40 & 00E.20 & 46 & 6.84 & 114.86 & 23.84 & & 4 & 43 & \\
\hline 028.40 & 00E.20 & 47 & 1.45 & 110.06 & 61.15 & & & 50 & \\
\hline 028.40 & $00 \mathrm{E} .20$ & 48 & 0.00 & 0.00 & 0.00 & & & 1 & 1 \\
\hline 028.40 & $00 \mathrm{E} .20$ & 49 & 0.00 & 0.00 & 0.00 & & & 4 & \\
\hline 003.10 & 00G.30 & 50 & 2.05 & 96.81 & 9.11 & & 1 & 28 & \\
\hline 003.10 & O0G.30 & 51 & 0.86 & 137.14 & 29.35 & & *11 & 43 & \\
\hline 003.10 & OOG.30 & 52 & 0.00 & 20.97 & 0.00 & & & 3 & \\
\hline 003.10 & $00 \mathrm{G} .30$ & 53 & 6.12 & 172.23 & 21.84 & & 4 & 45 & \\
\hline 003.10 & O0G.30 & 54 & 9.76 & 99.29 & 10.83 & 2 & 2 & 24 & \\
\hline 003.10 & O0G.30 & 55 & 0.00 & 255.81 & 0.00 & & & 52 & \\
\hline 003.10 & $00 \mathrm{G} .30$ & 56 & 0.00 & 0.00 & 0.00 & & & 3 & \\
\hline 003.10 & 00G.30 & 57 & 0.00 & 8.74 & 0.00 & & & 3 & 1 \\
\hline 003.10 & $00 \mathrm{G} .30$ & 58 & 17.77 & 268.80 & 0.00 & & 7 & 45 & \\
\hline 003.10 & OOG.30 & 59 & 0.16 & 179.36 & 22.02 & 3 & 2 & 25 & \\
\hline 004.30 & OOE.30 & 60 & 1.69 & 8.74 & 2.87 & & & 23 & \\
\hline 004.30 & $00 \mathrm{E} .30$ & 61 & 4.69 & 125.64 & 46.61 & & & 54 & \\
\hline 004.30 & $00 E .30$ & 62 & 9.19 & 105.26 & 0.00 & & 16 & 31 & \\
\hline 004.30 & 00E. 30 & 63 & 12.96 & 158.25 & 0.00 & 1 & 6 & 45 & \\
\hline 004.30 & 00E.30 & 64 & 8.97 & 88.52 & 1.30 & & & 47 & \\
\hline NR & & 65 & & & & & & & \\
\hline NR & & 66 & & & & & & & \\
\hline NR & & 67 & & & & & & & \\
\hline NR & & 68 & & & & & & & \\
\hline 004.30 & 00E.30 & 69 & 6.85 & 199.17 & 65.53 & & & 43 & \\
\hline 004.30 & $00 \mathrm{E} .30$ & 70 & 1.60 & 160.73 & 0.00 & & & 35 & \\
\hline 004.30 & OOE.30 & 71 & 1.41 & 93.90 & 21.37 & & & 47 & \\
\hline 004.30 & OOE.30 & 72 & 0.55 & 232.95 & 6.00 & 4 & 12 & 28 & \\
\hline 004.30 & OOE. 30 & 73 & 1.51 & 31.44 & 4.63 & & & 30 & \\
\hline 004.30 & 00E.30 & 74 & 7.84 & 70.61 & 12.16 & & & 39 & \\
\hline 004.30 & OOE.30 & 75 & 5.33 & 142.67 & 31.94 & & 5 & 57 & \\
\hline 004.30 & OOE. 30 & 76 & 2.24 & 130.88 & 0.00 & & 18 & 34 & \\
\hline 004.30 & 00E.30 & 77 & 2.88 & 105.11 & 7.00 & & 1 & 43 & \\
\hline 004.30 & $00 \mathrm{E} .30$ & 78 & 6.47 & 63.76 & 16.28 & & 8 & 50 & \\
\hline 005.50 & $00 \mathrm{G} .20$ & 79 & 4.97 & 85.60 & 22.40 & & & 56 & \\
\hline 005.50 & $00 \mathrm{G} .10$ & 80 & 7.02 & 42.50 & 0.00 & 1 & & 48 & \\
\hline 005.50 & $00 G .20$ & 81 & 9.56 & 30.42 & 6.90 & & & 30 & \\
\hline 005.50 & $00 G .20$ & 82 & 2.91 & 72.35 & 19.80 & & & 38 & \\
\hline 005.50 & $00 \mathrm{G} .20$ & 83 & 18.75 & 24.75 & 38.11 & 1 & & 48 & \\
\hline 005.50 & $00 \mathrm{G} .20$ & 84 & 14.18 & 45.85 & 35.73 & & 33 & 37 & \\
\hline 005.50 & 00G.20 & 85 & 4.32 & 47.89 & 62.44 & & 21 & 34 & \\
\hline 005.50 & $00 G .20$ & 86 & 6.46 & 117.06 & 14.08 & & 12 & 43 & \\
\hline
\end{tabular}


Table 3-3. Buried TRU Culverts Summary (Continued)

\begin{tabular}{|c|c|c|c|c|c|c|c|c|c|}
\hline NORTH & EAST & culvert no. & $\mathrm{Pu}-238$ & Pu-239 & Np-238 & drums & cans & boxes & casks \\
\hline 005.50 & $00 G .20$ & 87 & 0.00 & 49.50 & 0.00 & 7 & & 3 & \\
\hline 005.50 & $00 G .20$ & 88 & 4.82 & 120.21 & 41.29 & & 9 & 56 & \\
\hline 005.50 & 00G.20 & 89 & 7.40 & 97.25 & 29.13 & & 12 & 54 & \\
\hline 005.50 & 006.20 & 90 & 6.31 & 21.88 & 94.88 & & 16 & 23 & \\
\hline 005.50 & $00 \mathrm{G} .20$ & 91 & 0.08 & 2.91 & 25.73 & & & 5 & \\
\hline 005.50 & $00 G .20$ & 92 & 0.00 & 26.20 & 0.00 & 7 & & 2 & \\
\hline 003.10 & $00 \mathrm{G} .20$ & 93 & 1.02 & 71.63 & 0.46 & & 4 & 18 & \\
\hline 005.50 & $00 \mathrm{G} .30$ & 94 & 0.48 & 114.72 & 37.96 & 2 & & 37 & \\
\hline 005.50 & $00 \mathrm{G} .20$ & 95 & 12.17 & 75.13 & 43.29 & & & 59 & \\
\hline 005.50 & 003.10 & 96 & 0.29 & 46.01 & 102.32 & & & 41 & \\
\hline 005.50 & $00 \mathrm{G} .30$ & 97 & 0.00 & 2.91 & 0.00 & 6 & & & \\
\hline 005.50 & $00 \mathrm{G} .30$ & 98 & 4.17 & 53.87 & 150.40 & & 7 & 43 & \\
\hline \multirow[t]{2}{*}{003.10} & $00 G .20$ & 99 & 2.20 & 86.62 & 8.77 & & 17 & 21 & \\
\hline & on TRU pad 2 & 100 & & & & & & & \\
\hline 003.10 & $00 G .20$ & 101 & 0.00 & 28.68 & 0.00 & 11 & & & \\
\hline 003.10 & $00 \mathrm{G} .20$ & 102 & 14.36 & 151.56 & 0.00 & 14 & & & \\
\hline 003.10 & $00 G .20$ & 103 & 7.05 & 0.00 & 0.00 & 12 & & & \\
\hline 003.20 & $00 \mathrm{G} .20$ & 104 & 2.03 & 172.09 & 584.97 & 14 & & & \\
\hline NR & & 105 & & & & & & & \\
\hline$\overline{N R}$ & & 106 & & & & & & & \\
\hline 003.20 & $00 G .20$ & 107,108 & 24.70 & 278.08 & 0.00 & & 4 & 58 & \\
\hline 003.20 & $00 G .20$ & 109 & 10.94 & 128.56 & 0.00 & 14 & & & \\
\hline 003.20 & $00 G .20$ & 110 & 5.14 & 114.00 & 0.00 & 14 & & & \\
\hline 003.20 & 006.20 & 111 & 10.30 & 304.73 & 0.00 & 14 & & & \\
\hline 003.30 & $00 \mathrm{G} .10$ & 113 & 0.00 & 5.68 & 20.93 & 1 & & 8 & \\
\hline & & totais (gr) & 793 & 14805 & 2659.2 & 275 & 324 & 3383 & 2 \\
\hline
\end{tabular}


(This page intentionally left blank) 
APPENDIX I

CONSTITUENT OF INTEREST:

STRONTIUM-90 
(This page intentionally left blank) 


\section{TABLE OF CONTENTS}

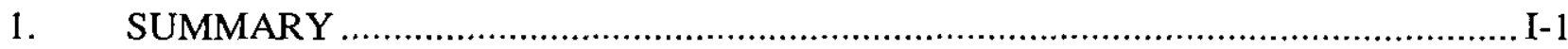

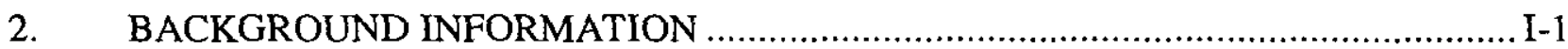

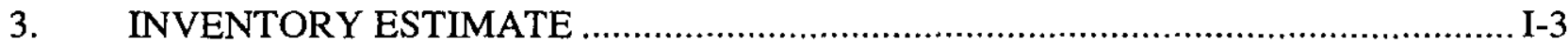

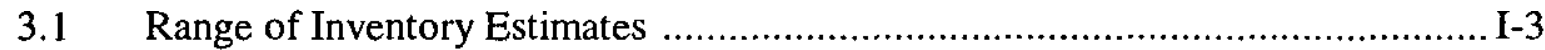

3.2 Best Estimate of Strontium-90 in Burial Grounds .......................................... I-5

3.3 Uncertainties Associated with Strontium-90 Inventory Estimate ...................... I-5

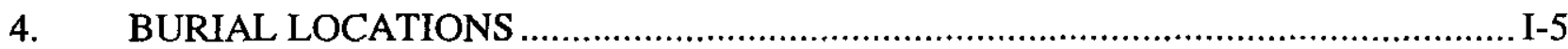

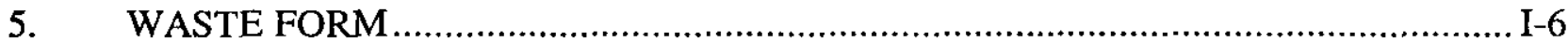

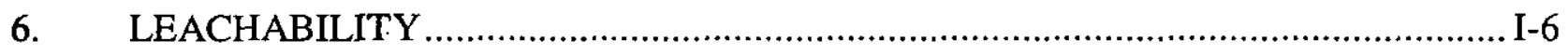

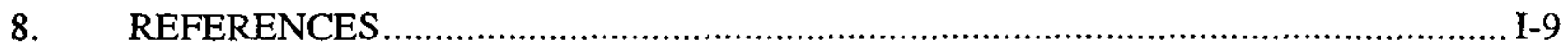




\section{LIST OF FIGURES}

Figure 1-1. Inventory Estimate Process Flow Diagram................................................. I-10

Figure 4-1. Strontium-90 Burial Location Process Flow Diagram ……............................. I-11

Figure 4-2. X, Y Locations of All Fission Product Burials in ORWBG Database (Variety of Contamination \#1 and \#2 = "FP") ........................................................... I-12

\section{LIST OF TABLES}

Table 2-1. Major Gamma Radionuclides in Organic and Aqueous Phases of OSTs

Table 2-2. Summary of the Most Recent Gamma Activity Data for Tanks S1-S22 (Source: Mason, 1996).

Table 3-1. Strontium-90 Estimates for the ORWBG................................................ 1-15

Table 3-3. The Sources of Inventory Estimates for Strontium-90 in the ORWBG.............. I-16

Table 3-4. The Sources of Inventory Estimates for Fission Products in the ORWBG ......... I-18 


\section{CONSTITUENT OF INTEREST - STRONTIUM-90}

\section{SUMMARY}

To accomplish its national defense and space missions, the Savannah River Site (SRS) employed five nuclear fission reactors: R, C, L, P, and K Reactors. Fission products, such as strontium-90, were a byproduct of the processes used in these reactors.

The best estimate for the original strontium-90 inventory in trenches in the Old Radioactive Waste Burial Ground (ORWBG) is 58,657 curies (26,216 curies decayed to 1997). A relatively small amount of strontium-90 is also present in the Old Solvent Tanks (OSTs). The amount in the tanks is estimated to be $1.28 \mathrm{Ci}$.

Waste containing fission products, from which strontium-90 activities are estimated, was buried in low-level and high-level trenches, depending on the dose rate from the package. The waste was buried in cardboard boxes, plastic bags, and metal containers. As this packaging deteriorates, the fission product waste and the associated strontium-90 will be exposed to contact with infiltrating water.

Figure 1-1 presents the process used to develop the inventory and burial locations. The Computerized Burial Record Analysis (COBRA) database was used to determine the locations of fission product burials, from which the strontium-90 activity estimates were made.

\section{BACKGROUND INFORMATION}

SRS operated five onsite production reactors: C, K, L, P, and R Reactors. Uranium-235 fuel was burned in the reactors. After their useful lifetime, the fuel elements were discharged from the reactor and cooled in reactor disassembly basins. The cooling period allowed fission products with very short half-lives to decay to more stable isotopes. Strontium-90, with a 29.12 year halflife (ICRP, 1983), was one of the fission products with significant activity following the cooling period.

After cooling, the spent fuel was transferred to H-Area, one of two chemical separations facilities at SRS. H-Canyon recovered uranium-235 from irradiated fuel elements from onsite and offsite reactors (DOE, 1995). In the chemical separations process, the fission products were concentrated in a liquid waste stream. The waste stream was sent to the H-Area Tank Farm, a system of underground tanks used to store the liquid waste. 
Smaller amounts of fission products were produced in the target slugs used in reactors for producing plutonium-239. These slugs were processed in the canyon facility in F-Area.

The first production-related fission products were produced on December 28, 1953 when RReactor, the first production reactor, went critical. The zero-power test reactor in 305-M went critical over one year earlier (September 16,1952), but it did not produce significant amounts of fission products. Waste containing significant quantities of fission products was not produced and buried until 1954.

Fission products are a component of job control waste and other waste streams sent to the ORWBG. These streams have originated from most areas of SRS that either dealt with spent reactor fuel and targets or managed high-level liquid waste. These include reactors, F- and $\mathrm{H}$ Areas and their associated tank farms, and process control and experimental laboratories.

Over 300 radionuclides have been observed as primary products of fission. These radionuclides are produced at different rates, or yields. The distribution curve of fission yield from uranium-235 fission to mass number of the fission product has a characteristic double hump shape. The two peaks on this curve, which equate to the mass numbers for the radionuclides with the greatest yields, occur between mass numbers 90 and 101, and between mass numbers 133 and 144 . Strontium-90, with a mass number of 90 , has a relatively high yield (5.77 percent). Also, the halflife of strontium-90 (29.12 years) is relatively long for a fission product. Consequently, the fraction of fission product activity associated with strontium-90 increases with the age of the fission product-bearing waste (i.e., the length of time since the fuel associated with the fission products was discharged from the reactor) (Benedict et al., 1981). Although waste containing fission products was composed of many different radionuclides at the time of production, currently it is composed primarily of strontium-90 and cesium-137.

Generally, waste containing fission products was segregated according to the dose rate generated by the waste package. Waste with a dose rate less than $50 \mathrm{mR}$ per hour was buried in lowactivity beta-gamma trenches. Waste with dose rates of $50 \mathrm{mR}$ per hour or greater was buried in intermediate level (also known as high-level) trenches (Cook, 1987). No special containerization requirements existed.

Spent solvent from Separations was sent to the OSTs for storage, where it separated into vapor, organic, aqueous, and sludge phases. This solvent was contaminated with fission products, including ruthenium-106, cesium-137, antimony-125 and other gamma emitters (Mason, 1996). Table 2-1 lists the radionuclides that comprised the greatest fraction of the activities in each tank 
in 1975. Strontium-90 was probably considered a minor component because it is a pure beta emitter, but because of its divalency, it was probably more abundant in the spent solvent than was cesium-137.

To reduce the volume in the OSTs, the organic phase was periodically drawn off and burned in open pans. The burn residue and pans were buried unencapsulated in earthen trenches (Wilhite, 1976; Tharin, 1965). Mason (1996) reports no data on the amount of fission products buried with burn residues.

In the early 1980s, the contents of the OSTs, except for unpumpable heel, were transferred to new tanks in the New Burial Ground (643-7E) under the Solvent Relocation Program (Mason, 1996).

Table 2-2 presents the latest gamma-emitting radionuclide inventory of each of the 22 tanks in the ORWBG. Although strontium-90 is not a gamma emitter, the amount of strontium-90 is approximately equal to that of cesium-137. Therefore, the table is useful in estimating the amount of strontium-90 in the tanks. The gamma activities for Tanks S8 and S17 through S22 reflect measurements taken before the Solvent Relocation Program. The activities for Tanks S1 through S7 and Tanks S9 through S16 were measured after the solvent tanks were pumped to "unpumpable heel".

\section{INVENTORY ESTIMATE}

Burial records indicate quantities of fission products sent to the ORWBG, but do not record the amounts of strontium-90 per se. The fraction of fission products that is strontium-90 is determined using reported isotopic ratios, where available, and process knowledge.

\subsection{Range of Inventory Estimates}

The COBRA database indicates that 621,626 curies of fission products were buried in the ORWBG. This estimate is comparable with Cook's (1991) estimate of 601,208 Ci. Health Protection data (Ashley, 1960, 1962a, 1962b, 1963, 1964, and 1965) indicate that 241,390 Ci of fission products were buried between ORWBG start-up and 1964. Assuming a similar rate of disposal from 1965 to 1972 , this estimate is in reasonable accord with the COBRA database and Cook's (1991) estimate.

Other references include inventory estimates specifically for strontium-90. Cook (1987) estimated the strontium-90 inventory to be 110,000 curies, although he provides no supporting information. 
However, in a subsequent document, Cook presents a rigorous method to determine the strontium-90 inventory in the ORWBG (Cook, 1990). The method assumes the following:

1. COBRA estimates of fission product inventory are accurate.

2. The curie estimates on the burial records are based on gamma ray measurements of ruthenium-106, cesium-137, and cerium-144 only.

3. Wastes from reactors, Separations, 772-F laboratories, and offsite sources contain fission products 1 year out of reactor.

4. Wastes from the $\mathrm{F}$ - and $\mathrm{H}$-Area tank farms are 5 years out of reactor

5. Cesium-137 comprises 8 percent of the activity for 1-year-old waste and 71 percent of the activity for 5-year-old waste.

6. The strontium-90 activity equals the cesium-137 activity.

Table 3-1 summarizes Cook's (1990) estimate of the strontium-90 inventory. The "Original" column represents the activity when buried (Cook, 1990). Cook (1990) cites data for the years 1954 to 1972. The "Decayed to 1997" column presents the current activity corrected for decay to 1997 . The total buried during the years that the ORWBG operated (1954 through 1972) is $56,949 \mathrm{Ci}$. Corrected for decay to 1997 , this amount is $25,453 \mathrm{Ci}$.

Minor amounts of strontium- 90 are present in the OSTs. A maximum concentration of strontium90 in the OSTs can be estimated based on the data in Table 2-2 and using the following assumptions:

1. The ratio of radioisotopes in the tanks did not change after the Solvent Relocation Program.

2. The amount of strontium-90 equals that of cesium- 137 .

3. For those tanks in Table 2-1 with a cesium-137 activity fraction, that fraction is used to determine the contribution of activity from cesium-137 (strontium-90) by multiplying it by the total activity for each tank given in Table 2-2.

4. For those tanks without a cesium-137 fraction, the remainder of the activity is assigned to cesium-137 (strontium-90) and is multiplied by the total activity for each tank as given in Table 2-2.

Based on the above assumptions, the strontium-90 activity in the 22 OSTs is $1.28 \mathrm{Ci}$. This value represents a maximum because it assumes all unattributable activity is due to strontium-90. In actuality, many other radionuclides, most of which with shorter half-lives than strontium-90, were present. Furthermore, the activities in Tanks S8 and S17 through S22 were determined before the 
bulk of the solvent was removed from the tanks. The present activity in these tanks is considerably less than that shown on Table 2-2.

Table 3-3 lists the sources of the inventory estimates for strontium-90 in the ORWBG, and Table 3-4 lists the sources of the inventory estimates for fission products.

\subsection{Best Estimate of Strontium-90 in Burial Grounds}

The best estimate for the strontium-90 inventory in trenches in the ORWBG is $26,216 \mathrm{Ci}$, corrected for decay to 1997. This estimate was modified slightly from Cook (1990). Data from Cook (1990) yield an estimate of 25,453 $\mathrm{Ci}$ of strontium-90, decayed to 1997. Cook (1991) uses a fission product inventory of $601,208 \mathrm{Ci}$. Although Cook (1990) does not state what total inventory is used, it can be assumed that it is the $601,208 \mathrm{Ci}$ value. The total fission product inventory in COBRA is $621,626 \mathrm{Ci}$, which is 3 percent greater than Cook (1991). Therefore, the values from Cook (1990) have been increased by 3 percent to arrive at the best estimate of 26,216 Ci.

Strontium-90 is not a major constituent in any of the OSTs (Mason, 1996). The inventory in the OSTs is estimated to be $1.28 \mathrm{Ci}$ (Section 3.1). This activity reflects radioactive decay to 1997 .

\subsection{Uncertainties Associated with Strontium-90 Inventory Estimate}

The main sources of uncertainty in the strontium-90 data are the original estimates of fission products. These estimates were based on the external dose rate from a package and an assumed isotopic distribution in the waste. Variations in the isotopic distribution of the waste and unique shielding aspects of a waste package could result in errors in the fission product estimate.

A second source of uncertainty is the method used by Cook (1990) method to estimate the strontium-90 inventory. The Cook (1990) method assumes two fixed ages for the waste, although the waste would have had a wide variety of ages. Also, other gamma emitters other than the three radionuclides assumed in Cook (1990) could have contributed to the measured activity.

\section{BURIAL LOCATIONS}

The COBRA database provides information on the spatial distribution of fission products in the ORWBG. Figure 4-1 outlines the steps taken to manipulate the database to locate strontium-90 burials. Figure 4-2 presents the burial locations for fission products. Generally, wastes containing fission products were segregated by the dose rate generated by the waste package. Waste with a dose rate less than $50 \mathrm{mR}$ per hour was buried in low-activity beta-gamma trenches. Waste with 
dose rates of $50 \mathrm{mR}$ per hour or greater was buried in intermediate level (also known as highlevel) trenches (Cook, 1987). No special containerization requirements existed.

\section{WASTE FORM}

The waste was buried in cardboard boxes, plastic bags, and metal containers in low-level and high-level trenches, depending on the dose rate from the package. As this packaging deteriorates, the fission product waste and the associated strontium-90 will be exposed to contact with infiltrating water.

\section{LEACHABILITY}

The leachability of ${ }^{90} \mathrm{Sr}$ is controlled mainly by adsorption onto soils. The relatively high solubility of most common strontium phases does not constrain the activity of ${ }^{90} \mathrm{Sr}$ in groundwater to below regulatory limits. Minor exchange reactions and co-precipitation of ${ }^{90} \mathrm{Sr}$ with Ca-bearing phases may occur, but these reactions exert minimal control on the mobility of ${ }^{90} \mathrm{Sr}$.

Hoeffner (1985) studied the adsorption of strontium onto ORWBG soils. In groundwater from one of the grid wells the $\mathrm{K}_{\mathrm{d}}$ values ranged from about $100 \mathrm{ml} / \mathrm{g}$ to $2000 \mathrm{ml} / \mathrm{g}$ between $\mathrm{pH} 6$ and 7. The addition of ferrous iron to the water lowered the $\mathrm{K}_{\mathrm{d}}$ value significantly. Hoeffner (1985) also measured $\mathrm{K}_{\mathrm{d}}$ values for strontium in water from the trench wells. Adsorption was less in the trench well water than in the grid well water. The $\mathrm{pH}$ of the trench wells were between 6 and 7 and the $K_{d}$ values for strontium ranged between 8 and $300 \mathrm{ml} / \mathrm{g}$. Hoeffner (1985) suggested that this was caused by the higher iron concentration or higher ionic strength in water from the trench wells. Based on this study the mobility of ${ }^{90} \mathrm{Sr}$ in ORWBG trenches may range from moderate to very low, depending on the chemistry of the infiltrating water.

Concentrations of ${ }^{90} \mathrm{Sr}$ in groundwater beneath the ORWBG are generally low. Of 12 grid wells sampled in 1980, 5 had concentrations above the $6 \mathrm{pCi} / \mathrm{l}$ detection limit (Ryan, 1983). These 5 had ${ }^{90} \mathrm{Sr}$ concentrations that ranged from 7 to $1600 \mathrm{pCi} / 1(7,18,19,30$, and $1600 \mathrm{pCi} / \mathrm{l})$. The high value occurred in well G-21. These wells were sampled again in 1987 and the average $90 \mathrm{Sr}$ concentration was $7 \mathrm{pCi} / 1$ with a high concentration of $81 \mathrm{pCi} / 1$ (Towler, 1989).

Well G-21 has an anomalous chemistry (Ryan, 1983) that may not be representative of concentrations in groundwater. McIntyre and Wilhite (1988) and Towler (1989) report that well G-21 was one of 15 wells installed through waste trenches at the ORWBG to monitor the water table. Samples from well G-21 have shown consistently high concentrations of radionuclides that 
should not be at the water table by migration from the trenches (Ryan, 1983). The anomalously high radionuclide concentrations (particularly Sr-90) in this well have been correlated with high, and similarly anomalous concentration of iron found in the same samples (Ryan, 1983). Possible explanations for the elevated iron concentrations include:

- a natural anomaly in the aquifer of high concentrations of organic matter or pyrite,

- contaminated water leaking from the trench down the well annulus, or

- waste debris smeared down the hole during installation of the well.

Natural iron anomalies in the water table aquifer at SRS have not been observed. Relatively immobile radionuclides (like cesium and plutonium) in water leaking down the well annulus would likely be sorbed to surfaces along the annulus and not occur in significant concentrations at the screen. Small amounts of waste debris smeared during well installation could explain the anomalous chemistry of the samples taken from this well. Monitoring well G-21 was abandoned in 1995, in accordance with accepted abandonment procedures.

Contamination from releases of liquid solvent offers an alternative explanation for the anomalous radionuclide concentrations in well G-21. Several reports discuss a 1962 incident in which 40 gallons of spent PUREX solvent, which consisted of up to $30 \%$ tri-butly-phosphate (TBP) and contained plutonium, were accidentally pumped down an unidentified test well located near the solvent tanks (Wilhite, 1975; Ryan, 1983; McIntyre and Wilhite, 1987; Mason, 1996). McIntyre and Wilhite (1987) report that in 1987, G-21 was the only well that showed a concentration of TBP $(0.16 \mathrm{mg} / \mathrm{l})$ above the detection limit of $(0.05 \mathrm{mg} / \mathrm{l})$. These results suggest that G-21 may have been affected by the solvent pumping incident.

The best estimate of ${ }^{90} \mathrm{Sr}$ leachability is obtained from the results of the Defense Waste Lysimeter program. The leachability from these waste forms is measured as the annual fractional release rate. This is the cumulative activity of a constituent measured in the effluent of the lysimeter over one year divided by the known source term in the waste form buried in the lysimeter. In 1985 the annual fractional release rates for ${ }^{90} \mathrm{Sr}$ containing wastes ranged from $10^{-3}$ to $10^{-7}$ (Oblath and Grant, 1985). The highest release rate was from Canyon jumpers. In 1986, the Canyon jumpers again had the highest annual fractional release rate at $4 \times 10^{-5}$ (McIntyre, 1987). When the maximum annual fractional release rate $\left(10^{-3}\right)$ is applied to the source term of the ORWBG $(26,516 \mathrm{Ci})$ the current release rate is approximately $26 \mathrm{Ci} / \mathrm{yr}$. 


\section{REFERENCES}

Ashley, C., 1960. SRP Radioactive Waste Release, Startup through 1959, DPSP-60-25-25, E.I. du Pont de Nemours and Company, Aiken, SC, September 1960.

Ashley, C., 1962a. 1960 Audit of SRP Radioactive Waste, DPSP-62-25-1, E.I. du Pont de Nemours and Company, Aiken, SC, February 1962.

Ashley, C., 1962b. 1961 Audit of SRP Radioactive Waste, DPSP-62-25-5, E.I. du Pont de Nemours and Company, Aiken, SC, September 1962.

Ashley, C., 1963. 1962 Audit of SRP Radioactive Waste, DPSP-63-25-1, E.I. du Pont de Nemours and Company, Aiken, SC, May 1963.

Ashley, C., 1964. 1963 Audit of SRP Radioactive Waste, DPSP-64-25-1, E.I. du Pont de Nemours and Company, Aiken, SC, May 1964.

Ashley, C., 1965. 1964 Audit of SRP Radioactive Waste, DPSP-65-25-1, E.I. du Pont de Nemours and Company, Aiken, SC, April 1965.

Benedict, M., T. Pigford, and H. Levi, 1981. Nuclear Chemical Engineering, McGraw-Hill, New York, NY.

Cook, J.R., 1987. Technical Data Summary: Plan for Closure of the 643-G Burial Ground, DPSTD-87-2, E.I. du Pont de Nemours and Company, Aiken, SC.

Cook, J.R., 1990. Estimation of Burial Ground Radionuclide Inventory Due to Mixed Fission Products, memorandum to W.E. Stevens, WSRC-RP-90-0495, May 29, 1990.

Cook, J.R., 1991. Radionuclide Inventory of E-Area, memorandum to W.E. Stevens, WSRCRP-91-709, June 27, 1991.

Corey, J.C., and Horton, J.H., 1971. Savannah River Plant Burial Ground Practices, DPST-70460, March, 1971.

Department of Energy (DOE), 1995. Fact Sheet, "H Canyon," Savannah River Operations Office, Aiken, SC.

Hoeffner, S.L., 1985. Radionuclide Sorption on Savannah River Plant Burial Ground Soil -- A Summary and Interpretation of Laboratory Data: DP-1702, E.I. duPont de Nemours and Company, Savannah River Laboratory, Aiken, SC.

Horton, J.H. and Corey, J.C., 1976. Storing Solid Radioactive Wastes at the Savannah River Plant, DP-1366, E.I. du Pont de Nemours and Company, Aiken, SC.

International Commission of Radiation Protection (ICRP), 1983. Radionuclide Transformation: Energy and Intensity of Emission, Annals of the ICRP, ICRP-38, Pergamon Press, Oxford, England. 
Mason, J.T., 1996. Information Document on the Old Solvent Tanks SI-S22 in the Old Radioactive Waste Burial Ground 643-E (U), WSRC-RP-96-00144, Westinghouse Savannah River Company, Aiken, SC.

McIntyre, P.F., 1987. 1987 Monitoring Report for the Defense Waste Lysimeters, memorandum of August 10, 1987, to H.F. Sturm, Jr.: DPST-87-568, E.I. duPont de Nemours and Company, Savannah River Laboratory, Aiken, SC.

Oblath, S.B. and M.W. Grant, 1985. 1985 Monitoring Report for the Defense Waste Lysimeters, memorandum dated November 4, 1985 to H.F. Sturm. DPST-85-893, E.I. duPont de Nemours and Company, Savannah River Laboratory, Aiken, SC.

Ryan, J.P., 1983. Groundwater Monitoring in the Savannah River Site Low Level Radioactive Waste Burial Ground, A Summary and Interpretation of the Analytical Data: DPST-83-209, E.I. duPont de Nemours and Company, Savannah River Laboratory, Aiken, SC.

Tharin, D.W., Jr., 1965. Burning of Radioactive Process Solvent, DP-942, Feb. 1965.

Towler, O.A. Jr., 1989. Integrated Report on Radionuclide Migration at the Savannah River Shallow Land Burial Site: DP-1778, E.I. duPont de Nemours and Company, Savannah River Laboratory, Aiken, SC.

Wilhite, E.L. to M.D. Boersma, 1976. Estimate of TRU Nuclides in Solvent Residues at the Burial Ground, April 30,1976.

WSRC, 1992. Old Radioactive Waste Burial Ground,Revised Draft, August, 1992. 


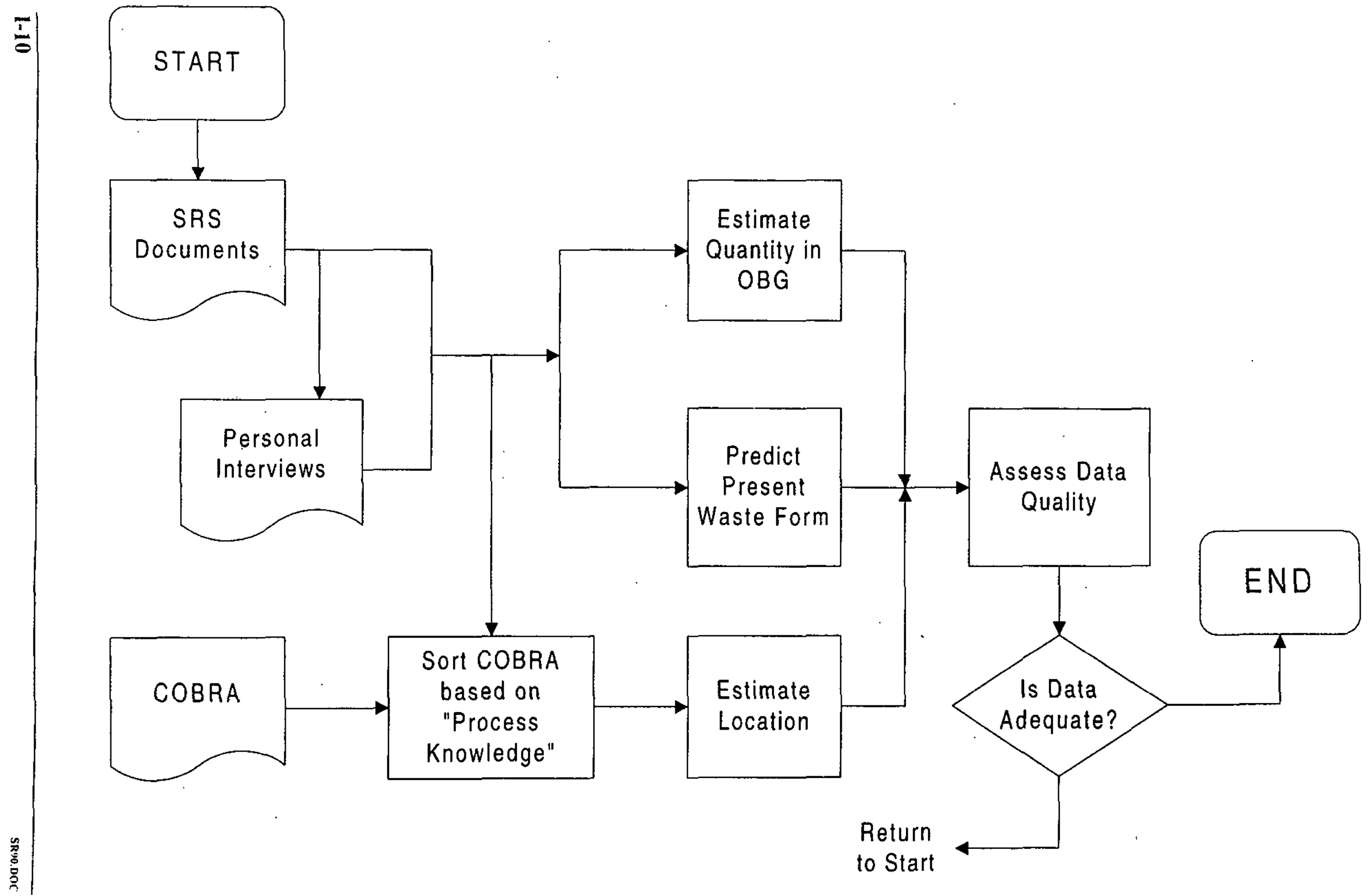

Figure 1-1. Inventory Estimate Process Flow Diagram 


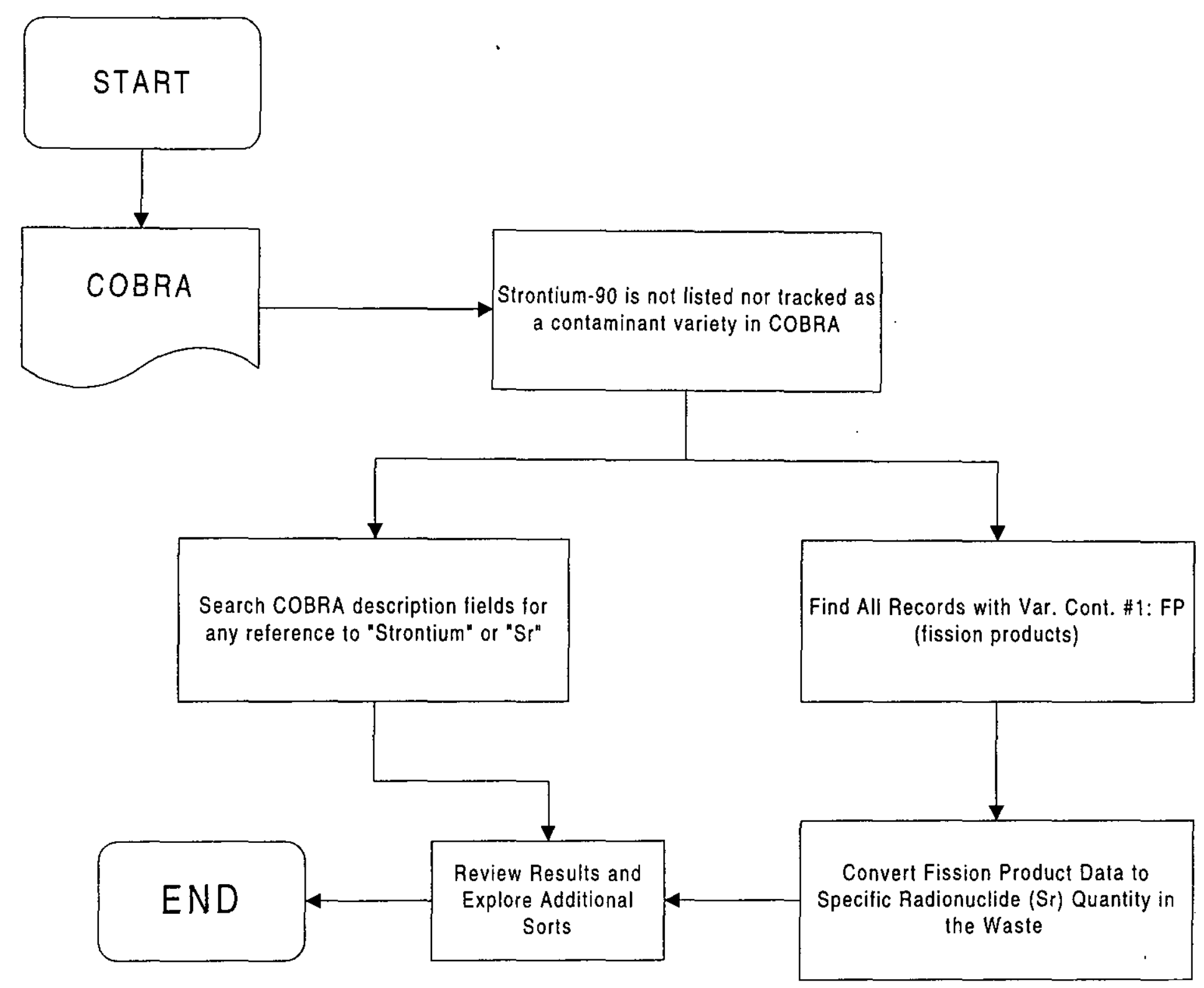

Figure 4-1. Strontium-90 Burial Location Process Flow Diagram 


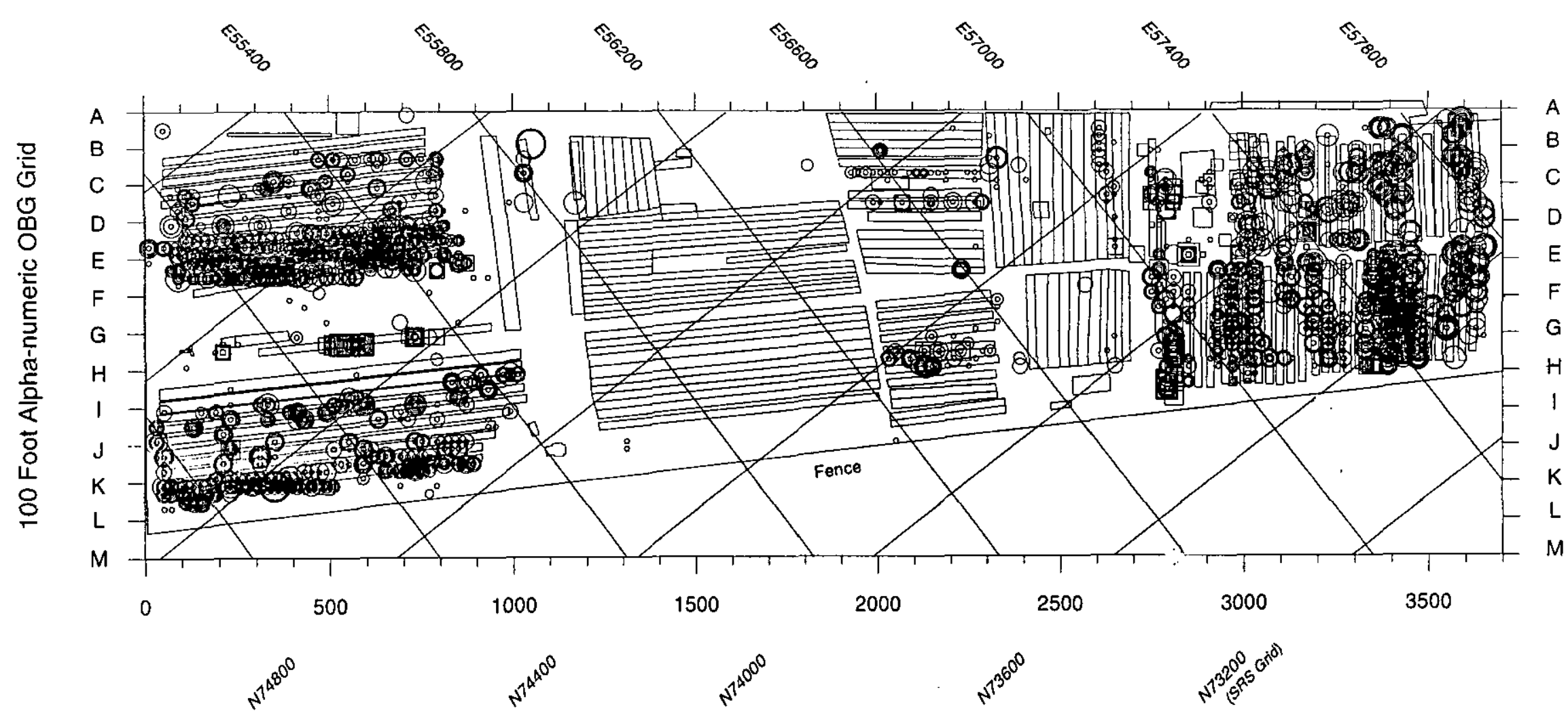

\begin{tabular}{ccccccccc}
\hline \multicolumn{7}{c}{ Curies } \\
$0 .<0.01$ & $0.01 \cdot<0.1$ & $0.1 \cdot<1$ & $1 \cdot<10$ & $10 \cdot<100$ & $100 \cdot<1,000$ & $1,000 \cdot<10,000$ & $10,000 \cdot<100,000$ \\
$\circ$ & 0 & 0 & 0 & 0 & 0 & 0 & $\bigcirc$ & Variety of Contamination \#1 \\
0 & $\square$ & $\square$ & $\square$ & $\square$ & $\square$ & $\square$ & $\square$ & $\square$ Variety of Contamination \#2 \\
\hline
\end{tabular}

Figure 4-2. X, Y Locations of All Fission Product Burials in ORWBG Database

(Variety of Contamination \#1 and \#2 = "FP") 
Table 2-1. Major Gamma Radionuclides in Organic and Aqueous Phases of OSTs. The amount of strontium-90 is assumed to be the same as the amount of cesium-137. These data were reported in 1975, prior to the Solvent Relocation Program

\begin{tabular}{|c|c|c|}
\hline$\overline{\text { Tank }}$ & Organic & Aqueous \\
\hline $\mathbf{1}$ & $\mathrm{Ru}-106,97 \%$ & $\mathrm{Ru}-106,98 \%$ \\
\hline 2 & Eu-154, 49\%, Ce-144, 29\% & $\mathrm{Ru}-106,71 \%$ \\
\hline 3 & $\mathrm{Ru}-106,81 \%$ & Cs- $137,68 \%$ \\
\hline 4 & $\mathrm{Ru}-106,53 \%, \mathrm{Sb}-125,38 \%$ & Cs $-137,96 \%$ \\
\hline 5 & $\mathrm{Ru}-106,95 \%$ & $\mathrm{Ru}-106,97 \%$ \\
\hline 6 & $\begin{array}{l}\mathrm{Sb}-125-43 \%, \mathrm{Cs}-137,24 \% \\
\mathrm{Ru}-106,23 \%\end{array}$ & Cs- $137,80 \%$ \\
\hline 7 & $\mathrm{Sb}-125,89 \%$ & Sb- $125,52 \%$; Cs- $137,45 \%$ \\
\hline 8 & No Data & No Data \\
\hline 9 & $\mathrm{Ru}-106,99 \%$ & $\mathrm{Ru}-106,98 \%$ \\
\hline 10 & $\mathrm{Ru}-106,98 \%$ & $\mathrm{Ru}-106,93 \%$ \\
\hline 11 & $\mathrm{Ce}-144,53 \%, \mathrm{Ru}-106,32 \%$ & $\mathrm{Ru}-106,72 \%$ \\
\hline 12 & $\mathrm{Ru}-106,74 \%$ & $\mathrm{Ru}-106,99 \%$ \\
\hline 13 & $\mathrm{Ru}-106,95 \%$ & $\mathrm{Ru}-106,66 \%$ \\
\hline 14 & $\mathrm{Ru}-106,88 \%$ & $\mathrm{Ru}-106,57 \% ; \mathrm{Cs}-137,42 \%$ \\
\hline 15 & $\mathrm{Ru}-106,52 \%, \mathrm{Sb}-125,48 \%$ & $\mathrm{Ru}-106,95 \%$ \\
\hline 16 & $\mathrm{Ru}-106,97 \%$ & Cs- $137,91 \%$ \\
\hline 17 & Ru-106, 99\% & $\mathrm{Ru}-106,95 \%$ \\
\hline 18 & $\mathrm{Ru}-106,99 \%$ & $\mathrm{Ru}-106,100 \%$ \\
\hline 19 & $\mathrm{Ru}-106,100 \%$ & $\mathrm{Ru}-106,95 \%$ \\
\hline 20 & Ru- $106,100 \%$ & $\mathrm{Ru}-106,86 \%$ \\
\hline 21 & Ru- $106,88 \%$ & Ru- $106,100 \%$ \\
\hline 22 & Ru-106,99\% & $\mathrm{Ru}-106,98 \%$ \\
\hline
\end{tabular}

Source: Denard (6-30-75) in Mason (1996) 
Table 2-2. Summary of the Most Recent Gamma Activity Data for Tanks S1-S22

(Source: Mason, 1996). The amount of strontium-90 is taken to be the same as that for cesium-137. The present activity in these tanks is considerably less than these values

\begin{tabular}{|c|c|c|c|c|c|c|c|c|c|}
\hline \multirow[b]{2}{*}{ Tank } & \multirow{2}{*}{$\begin{array}{l}\text { Total } \\
\text { Sludge } \\
\text { eals }\end{array}$} & \multicolumn{8}{|c|}{ Est. Wt. Aqueous } \\
\hline & & grams & gals. & Solid & Al & Total & Solid & Aa & Total \\
\hline SI & 19 & 13,300 & 14 & 0.82 & 0.0013 & 0.82 & 0.015 & 0.020 & 0.035 \\
\hline S2 & 28 & 3710 & 27 & 4.7 & 0.021 & 4.72 & 0.025 & 0.076 & 0.101 \\
\hline S3 & 76 & 31,700 & 65 & 0.28 & 0.0007 & 0.28 & 0.036 & 0.036 & 0.072 \\
\hline S4 & 146 & 60,800 & 124 & 0.54 & 0.0014 & 0.54 & 0.068 & 0.070 & 0.138 \\
\hline S5 & 118 & 15,600 & 112 & 19.7 & 0.088 & 19.78 & 0.105 & 0.325 & 0.430 \\
\hline S6 & 489 & 203,600 & 416 & 1.80 & 0.0045 & 1.80 & 0.229 & 0.234 & 0.463 \\
\hline S7 & 204 & 84,900 & 173 & 0.75 & 0.0019 & 0.75 & 0.096 & 0.098 & 0.194 \\
\hline S9 & 88 & 61,600 & 64 & 3.80 & 0.006 & 3.81 & 0.069 & 0.095 & 0.164 \\
\hline S10 & 54 & 37,800 & 39 & 2.33 & 0.0037 & 2.33 & 0.043 & 0.058 & 0.101 \\
\hline S11 & 38 & 5030 & 36 & 6.4 & 0.028 & 6.43 & 0.034 & 0.105 & 0.139 \\
\hline $\mathrm{S} 12$ & 88 & 61,600 & 64 & 3.80 & 0.006 & 3.81 & 0.069 & 0.095 & 0.164 \\
\hline $\mathrm{S} 13$ & 317 & 222,000 & 230 & 13.70 & 0.0216 & 13.72 & 0.250 & 0.340 & 0.590 \\
\hline S14 & 84 & 58,800 & 61 & 3.63 & 0.0057 & 3.64 & 0.066 & 0.090 & 0.156 \\
\hline S1S & 736 & 151,000 & 536 & 31.81 & 0.050 & 31.86 & 0.580 & 0.792 & 1.372 \\
\hline$\$ 16$ & 549 & 228,600 & 467 & 2.02 & 0.0051 & 2.03 & 0.257 & 0.263 & 0.520 \\
\hline Totals & 3034 & $1,240 \mathrm{~kg}$ & 2428 & 96.08 & 0.2449 & 96.29 & 1.942 & 2.697 & 4.639 \\
\hline
\end{tabular}

Keported by Tharin (2-65) Probably only considered organic phase.

$\begin{array}{llllll}\text { Jank } & \text { gals } & \text { Alpha } \mathrm{d} / \mathrm{m} / \mathrm{mL} & \text { Beta } \mathrm{c} / \mathrm{m} / \mathrm{mL} & \text { Gämma } \mathrm{c} / \mathrm{m} / \mathrm{mL} & \text { Date Analyzed } \\ \text { S8 } & 6700 & \begin{array}{llll}1.5 \times 10 \mathrm{E} 4 \\ 0.17 \mathrm{Ci}\end{array} & 8.5 \times 10 \mathrm{E} 3 & 2.5 \times 10 \mathrm{E} 3 & 12 / 5 / 63\end{array}$

Reported by Denard (6-30-75). * Alpha spectrum could not be resolved.

\begin{tabular}{|c|c|c|c|c|c|c|}
\hline \multirow{3}{*}{$\begin{array}{l}\text { Tank } \\
\text { S17 }\end{array}$} & $5-75 \mathrm{gal}$ & Phase & Alpha $\mathrm{d} / \mathrm{m} / \mathrm{mL}$ & Alpha emitters & Gamma $\mathrm{d} / \mathrm{m} / \mathrm{ml}$ & Gamma emitters \\
\hline & 100 & Org & $7.4 \times 10 \mathrm{E} 4$ & Pu239-60\% & $1.69 \times 10 E 6$ & Ru106-99\% \\
\hline & 250 & $\begin{array}{l}\text { Aq } \\
\text { Solid }\end{array}$ & $\begin{array}{l}1.6 \times 10 \mathrm{E} 4 \\
\text { "0" }\end{array}$ & Pu239 & $1.95 \times 10 \mathrm{E} 6$ & Rul06-95\% \\
\hline $\mathrm{S} 18$ & 965 & Org & $4.1 \times 10 \mathrm{E} 3$ & $\begin{array}{l}\text { Pu238-30\% } \\
\text { Pu239 30\% } \\
\text { Np237 30\% }\end{array}$ & $2.15 \times 10 \mathrm{E} 6$ & Ru106-99\% \\
\hline & 100 & $\begin{array}{l}\text { Aq } \\
\text { Solid }\end{array}$ & $\begin{array}{l}1.6 \times 10 E 3 \\
1.4 \times 10 E 3\end{array}$ & * & $1.54 \times 10 E 7$ & Rul06-100\% \\
\hline
\end{tabular}

Reported by Epting (1)-24-80)

$\begin{array}{lllll}\text { Tank } & \text { gal } & \text { Phase } & \text { Alpha Ci } & \text { Gamma Ci } \\ \text { S19 } & 823 & \text { Aq } & 10.19 & 5.33 \\ \text { S20 } & 1509 & \text { Org } & 0.014 & 0.019 \\ & 330 & \text { Aq } & 0.001 & 0.292 \\ \text { S21 } & 21,582 & \text { Org } & 0.286 & 0.0035 \\ & 789 & \text { Aq } & 0.001 & 0.002 \\ \text { S22 } & 21,461 & \text { Org } & 0.032 & 0.016 \\ & 663 & \text { Aq } & 0.001 & 0.001\end{array}$


Table 3-1. Strontium-90 Estimates for the ORWBG. Data are from Cook (1990). The best estimate is determined by increasing these amounts by $3 \%$ (see Section 3.2 ).

\begin{tabular}{|ccc|}
\hline Year $^{\star}$ & Original Sr-90 Activity, Ci & Sr-90 Activity Decayed to 1997, Ci \\
\hline 1954 & 1551 & 557 \\
\hline 1955 & 3103 & 1142 \\
\hline 1956 & 3103 & 1170 \\
\hline 1957 & 3103 & 1198 \\
\hline 1958 & 3103 & 1227 \\
\hline 1959 & 3103 & 1256 \\
\hline 1960 & 3103 & 1286 \\
\hline 1961 & 4251 & 1805 \\
\hline 1962 & 3712 & 1614 \\
\hline 1963 & 1796 & 800 \\
\hline 1964 & 3156 & 1439 \\
\hline 1965 & 5055 & 2360 \\
\hline 1966 & 873 & 417 \\
\hline 1967 & 5370 & 2630 \\
\hline 1968 & 1875 & 940 \\
\hline 1969 & 3847 & 1976 \\
\hline 1970 & 4659 & 2450 \\
\hline 1971 & 1568 & 845 \\
\hline 1972 & 618 & 341 \\
\hline Total: & $\mathbf{5 6 , 9 4 9}$ & $\mathbf{2 5 , 4 5 3}$ \\
\hline
\end{tabular}

Source: Cook (1990).

No waste with significant amounts of fission products was produced before $12 / 28 / 53$, when the first production reactor went critical. 
Table 3-3. The Sources of Inventory Estimates for Strontium-90 in the Old Radioactive Waste Burial Ground

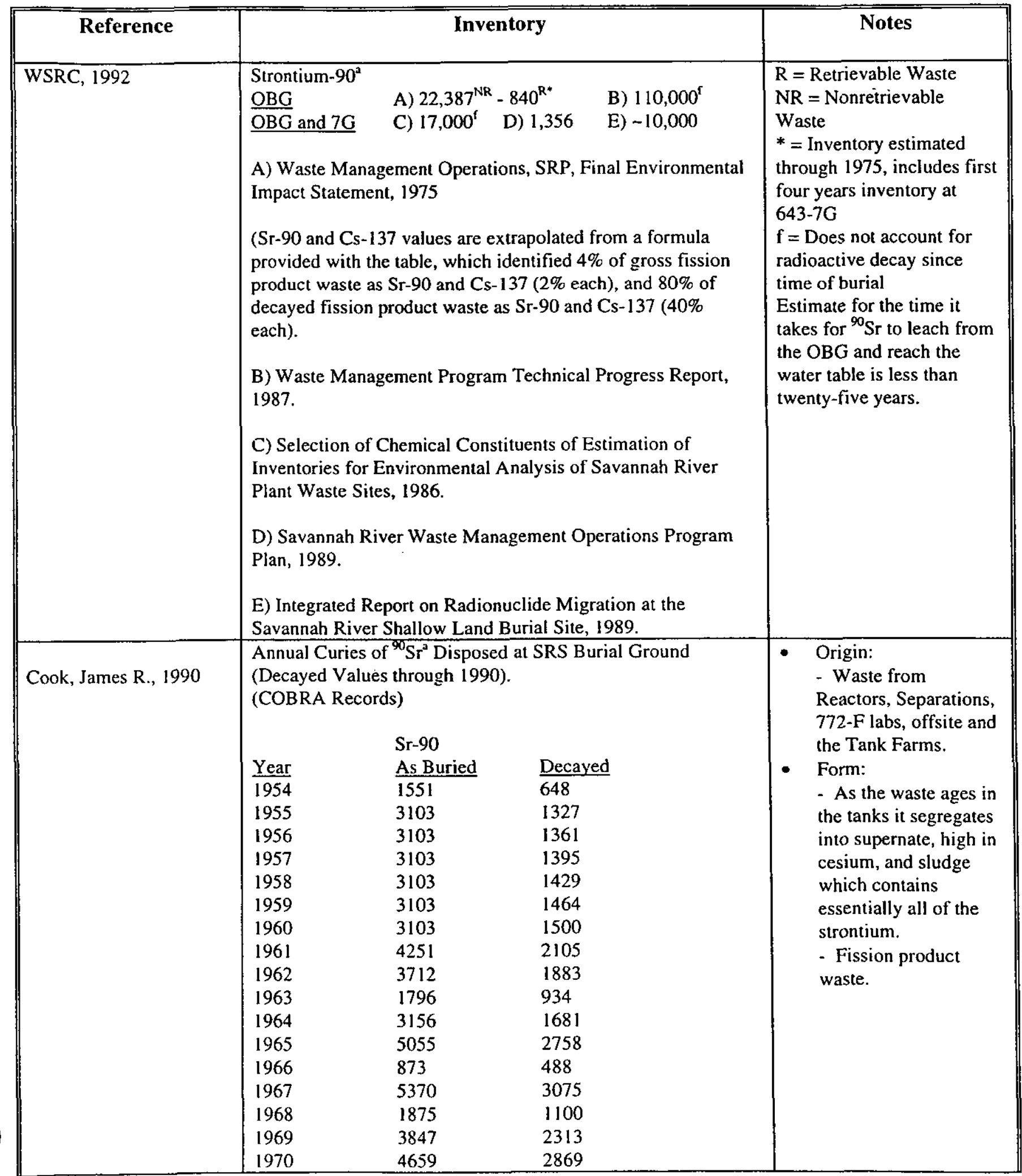




\section{Table 3-3. The Sources of Inventory Estimates for Strontium-90 in the Old Radioactive Waste Burial Ground (Continued)}

\begin{tabular}{|c|c|c|}
\hline Reference & Inventory & Notes \\
\hline & $\begin{array}{l}\text { Continued: } \\
1971 \quad 1568 \\
1972 \quad 618 \quad 489 \\
\text { The production program used to calculate decayed curies of } \\
\text { fission products. [Reference: Member K1206000, Data Set } \\
\text { SRL. PROD. SOURCE] was examined, and the algorithm } \\
\text { assumes that fission product distribution is } 2 \%{ }^{90} \mathrm{Sr}, 2 \%{ }^{137} \mathrm{Cs} \text {, } \\
95.9 \% \text { isotopes with half-lives less than ten years and } 0.1 \% \\
\text { isotopes with half-lives greater than ten years. }\end{array}$ & \\
\hline Cook, James R., 1987 & $\begin{array}{l}{ }^{90} \mathrm{Sr}: 110,000 \mathrm{Ci}^{6} \\
\text { (does not reference an earlier article). }\end{array}$ & $\begin{array}{l}\text { OBG lifetime : } 1952 \text { to } \\
1974\end{array}$ \\
\hline $\begin{array}{l}\text { Horton, J.H. and } \\
\text { Corey, J.C., } 1976\end{array}$ & $\begin{array}{l}{ }^{90} \mathrm{Sr}: 500 \mathrm{Ci}^{b} \text { emplaced each year at the Solid Radioactive } \\
\text { Waste Storage Site. } \\
\text { (does not reference an earlier article). }\end{array}$ & $\widehat{\mathrm{NA}}$ \\
\hline $\begin{array}{l}\text { Corey, J.C. and Horton, } \\
\text { J.H, } 1971\end{array}$ & $\begin{array}{ll}\text { Fission Products: } \frac{\mathrm{Ci} \text { Buried }}{387,000^{\mathrm{b}}} & \frac{\text { Ci Remaining }}{{ }^{90} \mathrm{Sr}: 4,000^{\mathrm{b}}} \\
\text { (does not reference an earlier article). } & \end{array}$ & $\begin{array}{l}\text { Equipment Discards } \\
\text { - Slug Fragments } \\
\text { - Vessels and Jumpers } \\
\text { Radioactive Waste } \\
\text { Burials through } 1969 \\
\text { - Residue Recoverable }\end{array}$ \\
\hline
\end{tabular}

a: Inventory discussed in detail

b: No discussion of basis for inventory

NA: Not addressed in article 
Table 3-4. The Sources of Inventory Estimates for Fission Products in the ORWBG

Although "fission products" currently are composed primarily of Cs-137 and Sr-90, the isotopic distribution was considerably different at the time of production.

\begin{tabular}{|c|c|c|}
\hline Reference & Inventory (Burial Ground) & Notes \\
\hline Cook, J R., 1991 & $\begin{array}{l}\text { Fission Products } \\
\text { As Variety } 1: 561,063 \mathrm{Ci} \\
\text { As Variety } 2: 40,145 \mathrm{Ci} \\
\text { Total: } 601,208 \mathrm{Ci} \\
\text { (does not reference an earlier article). }\end{array}$ & $\begin{array}{l}\text { The results presented here utilize } \\
\text { COBRA database records through } \\
\text { June } 25,1991 \text {. }\end{array}$ \\
\hline Ashley C., 1965 & $\begin{array}{l}\text { Gamma, kilocuries } \quad \frac{1964}{20.61} \frac{\text { Total Since }}{\text { Plant Startup }} \\
\qquad \text { Fission } \\
241.39\end{array}$ & $\begin{array}{l}\text { Health Protection (HP) data. } \\
\text { HP published a summary report } \\
\text { between } 1959 \text { and } 1965 \text { that } \\
\text { gives gross information on } \\
\text { radioisotope burials. }\end{array}$ \\
\hline Ashley, C., 1964 & $\begin{array}{l}\text { Gamma, kilocuries } \quad \frac{1963}{19.22} \frac{\text { Total Since }}{220.78} \\
\qquad \text { Fission }^{(\mathrm{b})}\end{array} \quad \begin{array}{l}\text { Plant Startup } \\
\text { (does not reference an earlier article): } \\
\text { Estimated quantities of fission products in } \\
\text { underground waste storage tanks, as of December } \\
\text { 20, 1963, totaled } 397 \text { megacuries in F Area and } 407 \\
\text { megacuries in H Area (data provided by } \\
\text { Separations Technology Section). }\end{array}$ & NA \\
\hline Ashley C., 1963 & $\begin{array}{lll}\text { Gamma, kilocuries } & \frac{1962}{21.15} & \begin{array}{l}\text { Total Since } \\
\text { Plant Startup }\end{array} \\
\text { Fission }^{(b)} & 201.56^{*}\end{array}$ & $\begin{array}{l}\text { * Gamma curies were corrected } \\
\text { for overestimates in } 1960 \text { and } \\
1959 .\end{array}$ \\
\hline Ashley C., $1962 \mathrm{~b}$ & $\begin{array}{lll}\text { Gamma emitting } & \text { Total Since } \\
\text { radionuclides } & (\mathrm{b}) . \\
\text { kilocuries } & \underline{1961} & \frac{\text { Plant Startup }}{777}\end{array}$ & $\begin{array}{l}* \text { Includes } 52 \text { kilocuries of } \\
\text { fission products. }\end{array}$ \\
\hline Ashley C., $1962 \mathrm{a}$ & $\begin{array}{lcc}\begin{array}{l}\text { Gamma emitting } \\
\text { radionuclides } \\
\text { kilocuries. }\end{array} & \frac{1960}{357^{*}} & \frac{\begin{array}{l}\text { Total Since } \\
\text { Plant Startup }\end{array}}{573} \\
& & \end{array}$ & $\begin{array}{l}* \text { Includes } 232 \text { kilocuries of } \\
\text { fission products. }\end{array}$ \\
\hline Ashley, C., 1960 & $\frac{\text { From Startup through } 1959}{216,000 \text { curies }}$ & NA \\
\hline
\end{tabular}

a: Inventory discussed in detail

b: No discussion of basis for inventory

NA: Not addressed in article 
APPENDIX J

CONSTITUENT OF INTEREST:

URANIUM-235 
(This page intentionally left blank) 


\section{TABLE OF CONTENTS}

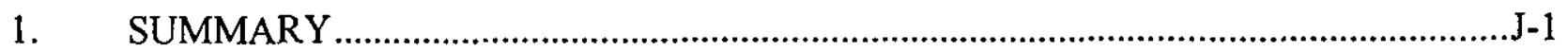

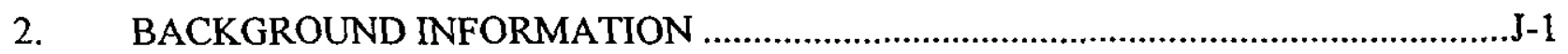

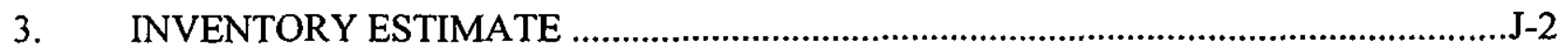

3.1 Range of Inventory Estimates …………….........................................................

3.2 Best Estimate of Uranium-235 in Burial Grounds................................................

3.3 Uncertainties Associated with Uranium-235 Inventory Estimate........................... -4

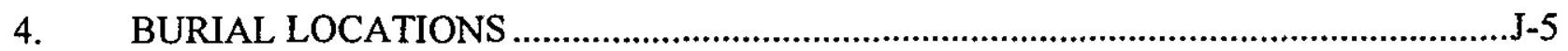

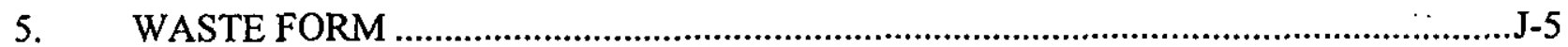

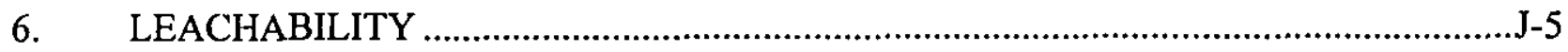

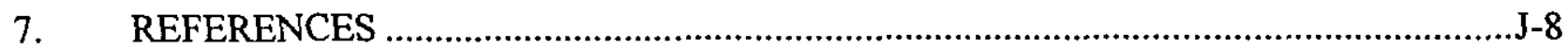




\section{LIST OF FIGURES}

Figure 1-1. Inventory Estimate Process Flow Diagram......................................................... J-10

Figure 3-1. Range of Uranium-235 Estimates in the ORWBG ..............................................

Figure 3-2. Health Protection Data Uranium to Burial Ground through 1964 .......................J-12

Figure 4-1. Uranium-235 Burial Location Process Flow Diagram .......................................

Figure 4-2. X, Y Locations of Enriched Uranium Burials in ORWBG Database (Variety of Contamination \#1 = "20") ................................................................................

Figure 4-3. X, Y Locations for Normal Uranium Burials in ORWBG Database (Variety of Contamination \#1 and \#2 = "81").....................................................................

Figure 6-1. Eh-pH Diagram Showing Fields of Dominance of Aqueous Species of Uranium $\mathrm{J}-16$

Figure 6-2. Solubility Curve for Schoepite $\left(\mathrm{UO}_{2}(\mathrm{OH})_{2} \cdot \mathrm{H}_{2} \mathrm{O}\right)$ with $\mathrm{pH}$ and Varying

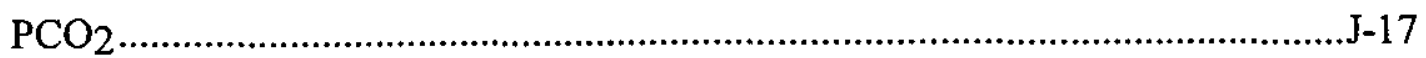

Figure 6-3. Solubility of Uraninite $\left(\mathrm{UO}_{2}\right)$ Compared to That of Schoepite $\left(\mathrm{UO}_{2}(\mathrm{OH})_{2} \cdot \mathrm{H}_{2} \mathrm{O}\right)$ $\mathrm{J}-18$

\section{LIST OF TABLES}

Table 2-1. Alpha Inventory in OSTs ........................................................................... J-19

Table 3-1. The Sources of Inventory Estimates for Uranium in the ORWBG......................J-20

Table 3-2. Reported Uranium Inventories Converted to Grams of Uranium-235 and Uranium-238 


\section{CONSTITUENT OF INTEREST - URANIUM-235}

\section{SUMMARY}

To accomplish its national defense and space missions, the Savannah River Site (SRS) has employed five production reactors: $\mathrm{R}, \mathrm{C}, \mathrm{L}, \mathrm{P}$, and $\mathrm{K}$ reactors. These reactors were powered by burning fuel rods that contained enriched uranium-235. Other facilities at SRS manufactured fuel elements for the reactors and extracted uranium-235 from spent fuel elements.

Uranium-235 is found in naturally-occurring uranium. Natural uranium is 0.72 percent uranium-235 (99.274 percent uranium-238 and 0.005 percent uranium-234). Uranium with naturally-occurring isotopic abundances was used in early reactor operations at SRS. Highlyenriched uranium fuel was used in later operations. Highly-enriched uranium is uranium with greater than 20 percent uranium-235. Depleted uranium was used in SRS reactors as target material to produce plutonium-239; it was at least 99.5 percent uranium-238.

The best estimate for the uranium-235 inventory in the trenches at the Old Radioactive Waste Burial Ground (ORWBG) is 273,185 grams (0.6 Ci). In the Old Solvent Tanks (OSTs), the best estimate of the uranium-235 inventory is $0.11 \mathrm{Ci}$.

Wastes containing uranium was buried in alpha activity trenches without special containers. The waste was buried in cardboard boxes, plastic bags, and possibly, metal containers.

Figure 1-1 presents the process used to develop inventory and burial locations. The Computerized Burial Record Analysis (COBRA) database was used to determine the location of burials of uranium-235.

\section{BACKGROUND INFORMATION}

Highly-enriched uranium was sent to SRS from other facilities in the Department of Energy's weapons complex. It was used by facilities in M-Area at SRS to manufacture aluminum-clad fuel elements for the five onsite reactors: $C, K, L, P$, and $R$. The fuel elements were burned in the reactors. After their useful lifetime, the spent fuel elements were discharged from the reactors and cooled in the reactor disassembly basins.

After cooling, the spent fuel was transferred to H-Area. Spent fuel elements from some offsite reactors were sent to the Receiving Basin for Offsite Fuel, also in H-Area. H-Area 
contains H-Canyon, one of two chemical separations facilities at SRS. H-Canyon recovered uranium-235 from irradiated fuel elements from onsite and offsite reactors. Other facilities in $\mathrm{H}$-Area include those used to store liquid uranyl nitrate hexahydrate prior to shipment to Oak Ridge, where it is processed for future use as highly-enriched uranium (DOE, 1995).

Research activities using uranium-235 took place primarily at the Savannah River Laboratory (now the Savannah River Technology Center), which is located in A-Area (773-A).

According to the COBRA database, uranium-235, as enriched uranium, was sent to the ORWBG from M-Area, A-Area, F-Area, H-Area, and from offsite facilities. Normal, or natural, uranium was sent to the ORWBG from M-Area, A-Area, H-Area, and F-Area.

Waste containing uranium-235 was primarily scrap from fuel fabrication operations. It was disposed of in the ORWBG in alpha waste trenches, with no special containerization (Horton and Corey, 1976).

Spent solvent from the separations areas was sent to the OSTs to be stored prior to burning. This solvent was likely contaminated with uranium-238 and minor amounts of uranium-235. Table 2-1 lists the alpha inventory and major constituents, by tank, in the OSTs. This information is used to estimate the amount of uranium-235 in the tanks (see Section 3.0).

\section{INVENTORY ESTIMATE}

Inventory estimates for uranium-235 are based on data contained in the COBRA database and records indicating burials prior to COBRA records. Nuclear criticality safety issues in the various processing facilities and during storage required maintaining inventory records of uranium-235. The COBRA database indicates that burials of enriched uranium occurred in the ORWBG as recently as 1974 .

\subsection{Range of Inventory Estimates}

Table 3-1 presents the sources of the uranium inventory. The table includes the reference, the inventory estimates provided by the reference, and any special notes associated with the inventory. Figure 3-1 shows the range of uranium-235 estimates in the ORWBG.

Cook (1987) presents inventory estimates, in curies, for individual uranium isotopes (e.g., U233, U-234, U-235, and U-238). For Figure 3-1, the curie estimate for uranium-235 has been converted to grams using the specific activity for uranium-235, $4.65 \times 10^{5}$ grams per curie. Cook (1991), presents the inventory for enriched uranium (in grams), normal uranium (in 
kilograms), and depleted uranium (in kilograms). These estimates have been converted to a uranium-235 inventory by assuming that uranium-235 is 93 percent of the enriched uranium (fully enriched), 0.72 percent of the normal uranium, and is not present in depleted uranium. The reported uranium inventories were converted to grams of uranium-235 and uranium-238 and are presented in Table 3-2.

The COBRA database includes burials of enriched uranium, normal uranium, and depleted uranium. The COBRA database estimates have been converted to a uranium-235 inventory by assuming that uranium- 235 is 93 percent of the enriched uranium, 0.7 percent of the normal uranium, and is not present in depleted uranium.

The sources of the enriched and normal uranium waste burial, according to COBRA, are as follows:

- A-Area: 80,663 grams of enriched uranium and 1,957 kilograms of normal uranium

- F-Area: 6,360 grams of enriched uranium and 6 kilograms of normal uranium

- H-Area: 24 grams of enriched uranium and 123 kilograms of normal uranium

- M-Area: 137,103 grams of enriched uranium and 6,418 kilograms of normal uranium

- Mound (offsite): 450 grams of enriched uranium

- Area "XXX" (offsite shipment of unspecified origin): 3,310 grams of enriched uranium

Figure 3-2 shows the enriched, normal and total uranium inventories through 1964 . Health Protection data (Ashley, 1960, 1962a, 1962b, 1963, 1964, and 1965) indicate that from ORWBG start-up through 1964, 145 grams of enriched uranium and 5,359,000 grams of natural (normal) uranium were buried in the ORWBG. These data are inconsistent with the data in COBRA. COBRA indicates that 644 grams of enriched uranium and 7,382,000 grams (7,382 kilograms) of normal uranium were buried in the ORWBG from start-up through 1964. Note that all of the uranium data in COBRA reflect discrete waste shipments that were detailed on corresponding burial slips. Some of these slips are dated as early as December 1952. This is unlike data for some radionuclides, e.g. plutonium, that were adjusted by "lumping" records in COBRA.

Data are very limited for uranium-235 associated with spent solvents sent to the OSTs. There are no estimates of uranium-235 in solvent residues. This residue was buried in the ORWBG. 
Mason (1996) includes some uranium data from investigations of the OSTs, but plutonium238, plutonium-239, and curium-244 are the primary alpha-emitting radionuclides documented. Table 13 in Mason (1996) includes uranium-235 as a radionuclide found in Tanks $6,7,9,12$, and 15 , but no concentration data are presented.

To estimate the uranium-235 content in the tanks, an arbitrary fraction (e.g., 0.25 percent) of the alpha activity can be assigned to the uranium-235 activity. This can be done for Tanks 6 , $7,9,12$, and 15 , in which uranium was detected. This method yields the following estimates:

- Tank 6: $0.25 \%$ of $1.8 \mathrm{Ci}$ of alpha $=0.0045 \mathrm{Ci}$ of U-235

- Tank 7: $0.25 \%$ of $0.75 \mathrm{Ci}$ of alpha $=0.0019 \mathrm{Ci}$ of U-235

- Tank 9: $0.25 \%$ of $3.81 \mathrm{Ci}$ of alpha $=0.0095 \mathrm{Ci}$ of U-235

- Tank 12: $0.25 \%$ of $3.81 \mathrm{Ci}$ of alpha $=0.0095 \mathrm{Ci}$ of $\mathrm{U}-235$

- Tank 15: $0.25 \%$ of $31.86 \mathrm{Ci}$ of alpha $=0.07965 \mathrm{Ci}$ of U-235

\subsection{Best Estimate of Uranium-235 in Burial Grounds}

The best estimate for the uranium-235 inventory in the trenches in the ORWBG is 273,185 grams $(0.6 \mathrm{Ci})$. This estimate is from COBRA. It has been assumed that the COBRA database captures all of the Health Protection data related to uranium and has not been adjusted. The uranium-235 total is based on the following calculation:

1. Multiply the total quantity of "Enriched Uranium", in grams, by 0.93 (i.e., 93 percent U-235) to determine grams of uranium-235 in enriched uranium (211,956 grams).

2. Multiply the total quantity of "Normal Uranium", in kilograms, by 0.00722 (i.e., 0.72 percent U-235) to determine kilograms of uranium-235 in normal uranium $(61.23$ kilograms). Convert to grams (61,229 grams).

3. Sum items 1 and 2 above: 273,185 grams.

For the OSTs, the best estimate of the uranium-235 inventory is $0.11 \mathrm{Ci}$. This estimate is based on assigning uranium-235 an arbitrary activity fraction of 0.25 percent for tanks with uranium content (Section 3.1).

\subsection{Uncertainties Associated with Uranium-235 Inventory Estimate}

The uranium-235 estimates are based on an assumed enrichment of "enriched uranium". Variations in the actual uranium-235 enrichment of individual burials could result in errors in the uranium-235 inventory. Note, however, that the value used to convert enriched uranium 
inventory to uranium-235 inventory was 93 percent, which represents an upper-bound estimate for the enrichment.

Uranium-235 is not a major alpha emitting radionuclide in the OSTs, nor is it a significant component of those tanks with relatively large uranium inventories in the tank sludge. The estimate is based on approximated amounts of total uranium and an assumed isotopic ratio.

\section{BURIAL LOCATIONS}

The COBRA database provides information on the spatial distribution of uranium in the ORWBG. Figure 4-1 outlines the steps taken to manipulate the database to locate uranium235 burials. Figure 4-2 presents the burial locations for enriched uranium (variety of contamination $\# 1=20$ ). This waste was uncontainerized and would have been buried in cardboard boxes, plastic bags, and possibly, metal containers. The figure indicates the relative size, in grams, of each burial.

Figure 4-3 presents the locations for normal (natural) uranium burials (variety of contamination \#1 and \#2 = 81). Similarly, this waste was uncontainerized and would have been buried in cardboard boxes, plastic bags, and possibly, metal containers. The figure indicates the relative size, in grams, of each burial.

\section{WASTE FORM}

As discussed above, the uranium-bearing waste was buried in alpha activity trenches with no special containers. The waste was buried in cardboard boxes, plastic bags, and possibly, metal containers. As this packaging deteriorates, the waste and the associated uranium and other contaminants will be exposed to contact with infiltrating water.

\section{LEACHABILITY}

The leachability of uranium is controlled by the solubility of uranium phases, the chemistry of infiltrating water, the redox conditions within the ORWBG and adsorption of uranium onto the soil matrix. Another consideration when evaluating the leachability of uranium is that $238 \mathrm{U}$ and $235_{\mathrm{U}}$ occur naturally and are relatively abundant in the Savannah River Site environment. Isotopic ratios in groundwater and soil can be used to identify anthropogenic uranium, but quantitative assessments are difficult. They must account for isotopic exchange, precipitation, and dissolution of natural minerals. 
Redox conditions in the ORWBG are important to understanding leachability of uranium in the ORWBG. As dissolved species, uranium can occur in oxidation states, U(IV), U(V), and U(VI). In solid phases uranium occurs as either U(IV) or U(VI). Generally, uranium is much less soluble and therefore less mobile under reducing conditions. Figure 6-1 shows the dominant aqueous species of uranium in Eh-pH space. The circles represent grid well analyses reported by Ryan (1983) and the squares represent trench well analyses reported by Hoeffner (1985). These analyses indicate that $U(V I)$ is the dominant form of leached uranium in the ORWBG.

Figure 6-1 also demonstrates the importance of the carbonate system in the leachability of uranium. The figure assumes a partial pressure of $\mathrm{CO}_{2}\left(\mathrm{PCO}_{2}\right)$ of $10^{-2}$ atmospheres which is consistent with the total inorganic carbon analyses of groundwater from grid wells reported by Ryan (1983). At this $\mathrm{PCO}_{2}$ and $\mathrm{pH}>5, \mathrm{UO}_{2}\left(\mathrm{CO}_{3}\right)^{\circ}$ and $\mathrm{UO}_{2}\left(\mathrm{CO}_{3}\right)_{2}{ }^{-2}$ are the dominant species of uranium. This has significant implications for the adsorption and solubility of uranium.

The competition for uranium between surface sites and dissolved carbonate species may severely limit uranium adsorption in the presence of carbonate. Both Hsi and Langmuir (1985) and Waite et al. (1994) found that at $\mathrm{pH}>6$ the presence of carbonate in solution limited the adsorption of uranium onto iron oxyhydroxides. The adsorption edge for uranium is generally between a pH of 4 and 5 . Thus, from $\mathrm{pH} 4$ to 6 , uranium may adsorb strongly to soils showing a positive correlation with $\mathrm{pH}$. At $\mathrm{pH}>6$, uranium adsorption will decrease with increasing $\mathrm{pH}$. This suggests that the mobility of dissolved uranium may vary widely throughout the ORWBG depending on local conditions.

Conservative estimates of uranium solubility constrain uranium concentrations in groundwater to ppm levels. If conditions are right, precipitation of uranium phases can limit uranium concentrations to much lower levels. However, the $\mathrm{PCO}_{2}$ plays a major role in the solubility of all uranium phases. For example, Figure 6-2 shows solubility curves for the mineral schoepite $\left(\mathrm{UO}_{2}(\mathrm{OH})_{2} \cdot \mathrm{H}_{2} \mathrm{O}\right)$ at 3 different $\mathrm{PCO}_{2}$ values. The solubility of schoepite is at a minimum at $\mathrm{pH}$ values between 6 and 6.5 , but varies widely depending on the $\mathrm{PCO}_{2}$. At the minimum schoepite solubility for $\mathrm{PCO}_{2}=10^{-2}$ atm the concentration of uranium is about $5 \mathrm{mg} / \mathrm{l}$. Schoepite is a common phase and is often assumed to be the dominant control on uranium leachability from nuclear fuel (Finch et al., 1992). However, uranyl silicates and phosphates may limit the solubility to ppb levels. These phases have been found in weathering studies of Uraninite ( $\mathrm{UO}_{2}$ ) (Finch and Ewing, 1992; and Wronkiewicz et al., 1992). Wronkiewicz et al. (1992) found that dripping water onto $\mathrm{UO}_{2}$ at $90^{\circ} \mathrm{C}$ resulted in a 
two stage uranium release. In the initial stage uranium solubility appeared to be controlled by schoepite. After 2 years the released rates decreased and the solubility appeared to be controlled by uranyl silicates.

In the ORWBG, uranium concentrations in groundwater can be constrained to the ppm level by schoepite solubility, but it is uncertain whether further constraints by uranyl phosphates and silicates are applicable. Uraninite $\left(\mathrm{UO}_{2}\right)$ has been considered as a natural analogue of nuclear fuel (Finch and Ewing, 1992), and thus, its solubility may more truly represent the initial leachability of uranium in the ORWBG. Figure 6-3 shows the solubility curve of uraninite compared to that of schoepite at a $\mathrm{PCO}_{2}=10^{-2}$ atm and an $\mathrm{Eh}=0.2$ volts. If a $\mathrm{pH}$ of 6 is chosen to represent conditions in the ORWBG, the solubility of uraninite is about 1.5 $\mathrm{mg} / \mathrm{l}$. Cantrell (1990) reported uranium analyses of groundwater from 7 of the grid wells. The concentrations ranged from $<0.02 \mathrm{mg} / \mathrm{l}$ to $0.74 \mathrm{mg} / \mathrm{l}$. Thus, assuming a concentration of $1.5 \mathrm{mg} / \mathrm{l}$ for uranium leaching in the ORWBG may be reasonable.

To calculate the leaching rate of uranium, assumptions must be made on the dimensions of uranium waste forms in the ORWBG. The assumptions here are based on generic information on the dimensions of uranium fuel pellets (Lamarsh, 1983). Site specific information on the dimensions of waste forms would decrease uncertainty in these estimates. It is assumed here that all of the uranium is in cylinders $2 \mathrm{~cm}$ long with a diameter $1 \mathrm{~cm}$. Furthermore, it is assumed that the leachable area of the cylinders is equal to the lengthwise cross-sectional area $-2 \mathrm{~cm}^{2}$. Using these dimensions, the infiltration rate of water into the trenches of $2.36 \mathrm{~m} / \mathrm{yr}$ (Orebaugh and Hale, 1976) and the solubility of uraninite yields leaching rates for ${ }^{238} \mathrm{U}$ and ${ }^{235} \mathrm{U}$ of $217 \mathrm{~g} / \mathrm{yr}$. and $11 \mathrm{~g} / \mathrm{yr}$. respectively. 


\section{REFERENCES}

Ashley, C., 1960. SRP Radioactive Waste Release, Startup through 1959, DPSP-60-25-25, E.I. du Pont de Nemours and Company, September 1960.

Ashley, C., 1962a. 1960 Audit of SRP Radioactive Waste, DPSP-62-25-1, E.I. du Pont de Nemours and Company, February 1962.

Ashley, C., 1962b. 1961 Audit of SRP Radioactive Waste, DPSP-62-25-5, E.I. du Pont de Nemours and Company, September 1962.

Ashley, C., 1963. 1962 Audit of SRP Radioactive Waste, DPSP-63-25-1, E.I. du Pont de Nemours and Company, May 1963.

Ashley, C., 1964. 1963 Audit of SRP Radioactive Waste, DPSP-64-25-1, E.I. du Pont de Nemours and Company, May 1964.

Ashley, C., 1965. 1964 Audit of SRP Radioactive Waste, DPSP-65-25-1, E.I. du Pont de Nemours and Company, April 1965.

Cantrell, K.J., 1990. Results of the Special Well Sampling Study for the Burial Ground, memorandum to W.E. Stevens, March 28, 1990, WSRC-RP-90-364, Westinghouse Savannah River Co., Aiken, SC.

Cook, J.R., 1987. Technical Data Summary: Plan for Closure of the 643-G Burial Ground, DPSTD-87-2, E.I. du Pont de Nemours and Company, Aiken, SC.

Cook, J.R., 1991. Radionuclide Inventory of E-Area, memorandum to W.E. Stevens, WSRC-RP-91-709, June 271991.

Cook, J.R. and Helton, B.D., 1989. An Assessment of Buried Waste Containing Transuranium Isotopes in the Savannah River Site Radioactive Waste Burial Ground, draft memorandum to B.G. Kitchen, August 231989.

Department of Energy (DOE), 1995. Fact Sheet, "H Canyon", Savannah River Operations Office, Aiken, SC.

Finch, R.J. and R.C. Ewing, 1992. The Corrosion of Uraninite Under Oxidizing Conditions, Journal of Nuclear Materials, v. 190, p. 133-156.

Finch, R.J., M.L. Miller, and R.C. Ewing, 1992. Weathering of Natural Uranyl Oxide Hydrates: Schoepite Polytypes and Dehydration Effects, Radiochimica Acta, v. 58/59, p. 433-443.

Hoeffner, S.L., 1985. Radionuclide Sorption on Savannah River Plant Burial Ground Soil -A Summary and Interpretation of Laboratory Data: DP-1702, E.I. duPont de Nemours and Company, Savannah River Laboratory, Aiken, SC. 
Horton, J.H. and J.C. Corey, 1976. Storing Solid Radioactive Wastes at the Savannah River Plant, DP-1366, E.I. du Pont de Nemours and Company, Aiken, SC.

Hsi, C.D. and D. Langmuir, 1985. Adsorption of Uranyl onto Ferric Oxyhydroxides: Applications of the Surface Complexation Site-Binding Model, Geochimica et Cosmochimica Acta, v. 49, p. 1931-1941.

Lamarsh, J.R., 1983. Introduction to Nuclear Engineering, Addison-Wesley Publishing Company, Reading, MA, 689 pp.

Langmuir, D., 1978. Uranium Solution-Mineral Equilibria at Low Temperatures with Applications to Sedimentary Ore Deposits, Geochimica et Cosmochimica Acta, v. 42, p. 547-569.

Mason, J.T., 1996. Information Document on the Old Solvent Tanks S1-S22 in the Old Radioactive Waste Burial Ground 643-E (U), WSRC-RP-96-00144, Westinghouse Savannah River Company, Aiken, SC.

Orebaugh, E.G. and W.H. Hale, Jr., 1976. Dispersion Study of Buried Elemental Mercury, DP-1401, E.I. du Pont de Nemours \& Co., Savannah River Laboratory, Aiken, SC.

Ryan, J.P., 1983. Groundwater Monitoring in the Savannah River Site Low Level Radioactive Waste Burial Ground, A Summary and Interpretation of the Analytical Data: DPST-83-209, E.I. duPont de Nemours and Company, Savannah River Laboratory, Aiken, SC.

Waite, T.D., J.A. Davis, T.E. Payne, G.A. Waychunas, and N. Xu, 1994. Uranium (VI) Adsorption to Ferrihydrite: Application of a Surface Complexation Model, Geochimica et Cosmochimica Acta, v. 58, p. 5465-5478.

Wronkiewicz, D.J., J.K. Bates, T.J. Gerding, E. Veleckis, and B.S. Tani, 1992. Uranium Release and Secondary Phase Formation During Unsaturated Testing of UO2 at $90^{\circ} \mathrm{C}$, Journal of Nuclear Materials, v. 190, p. 107-127. 


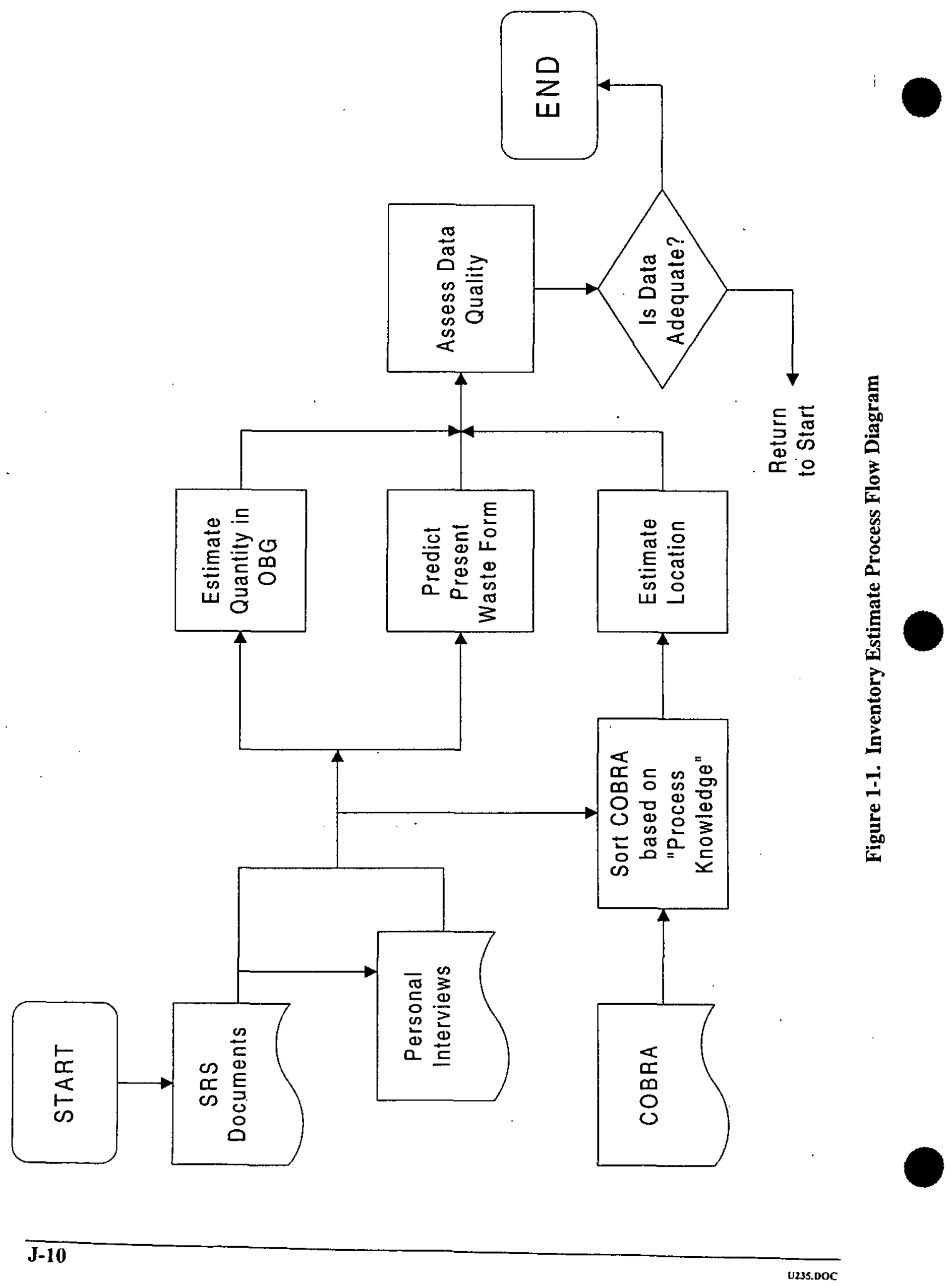




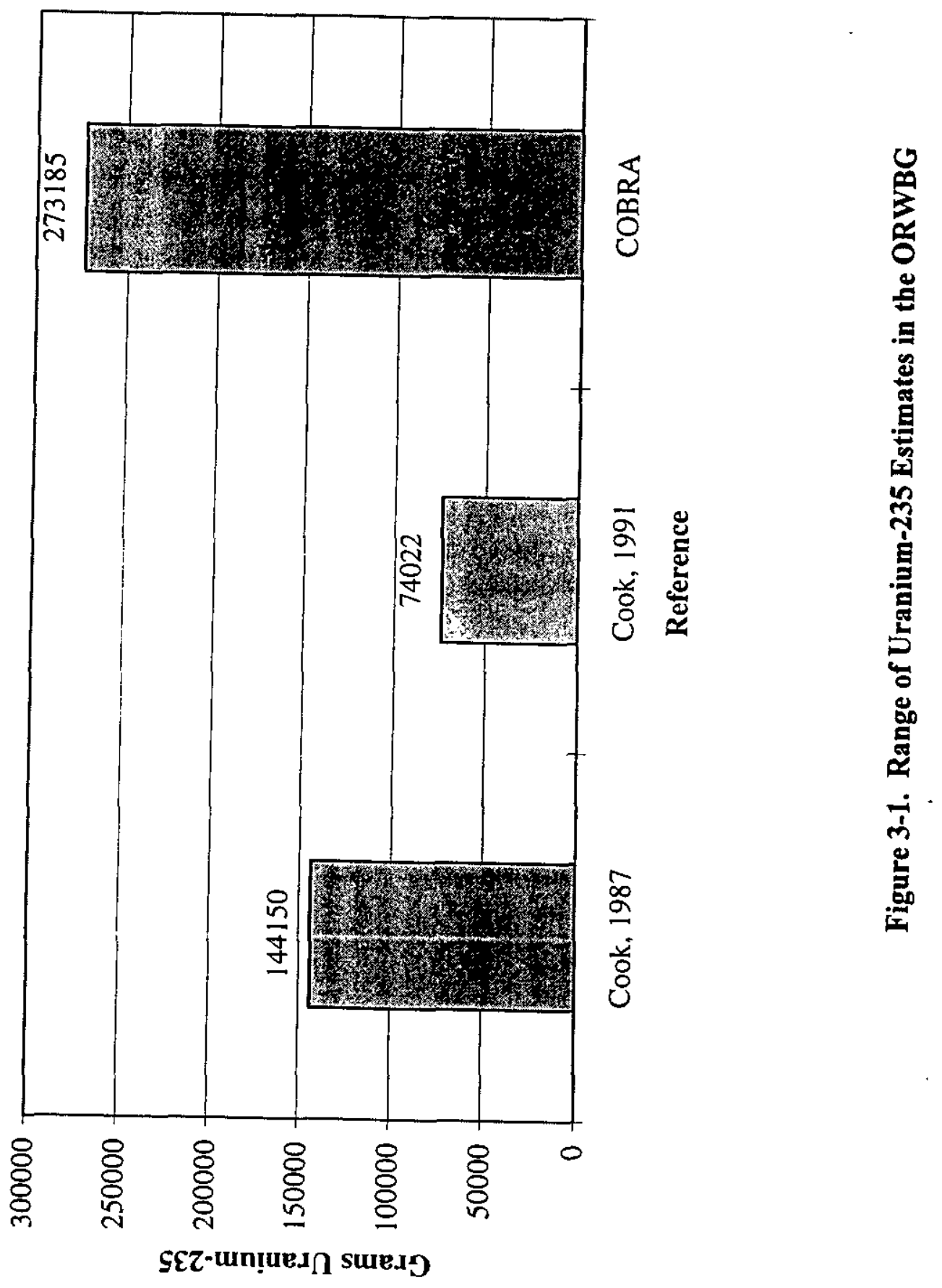




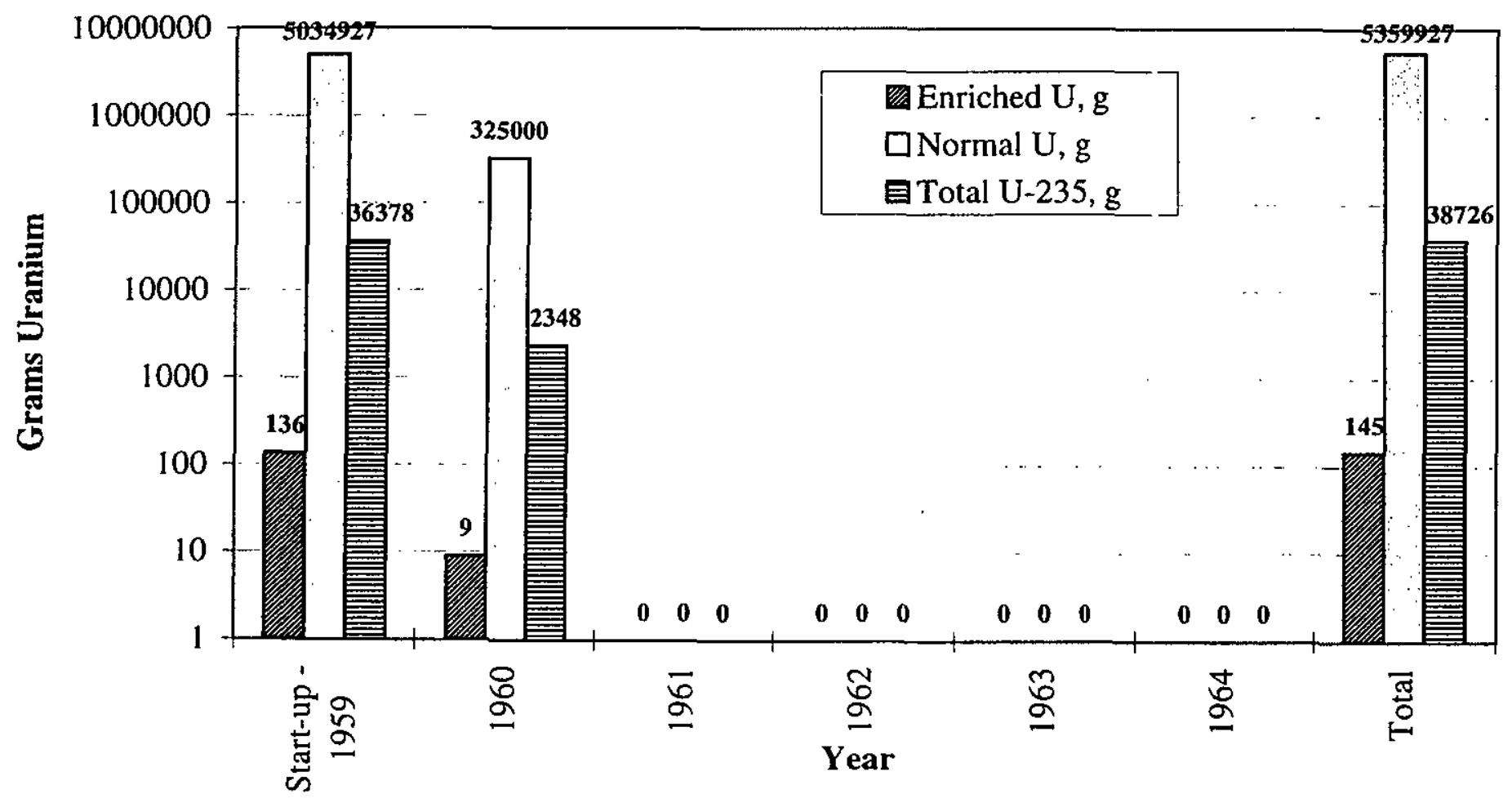

Figure 3-2. Health Protection Data Uranium to Burial Ground through 1964 


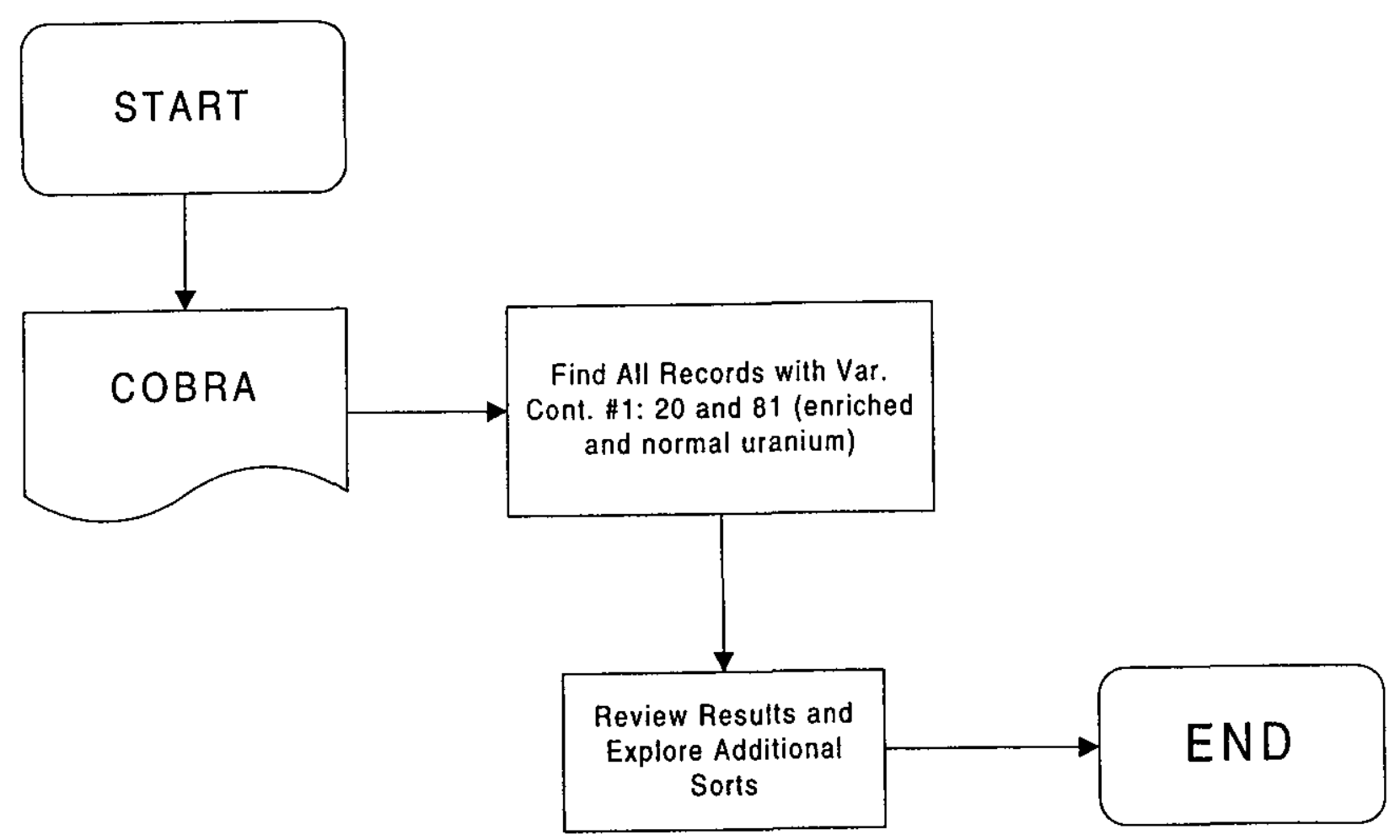

Figure 4-1. Uranium-235 Burial Location Process Flow Diagram 

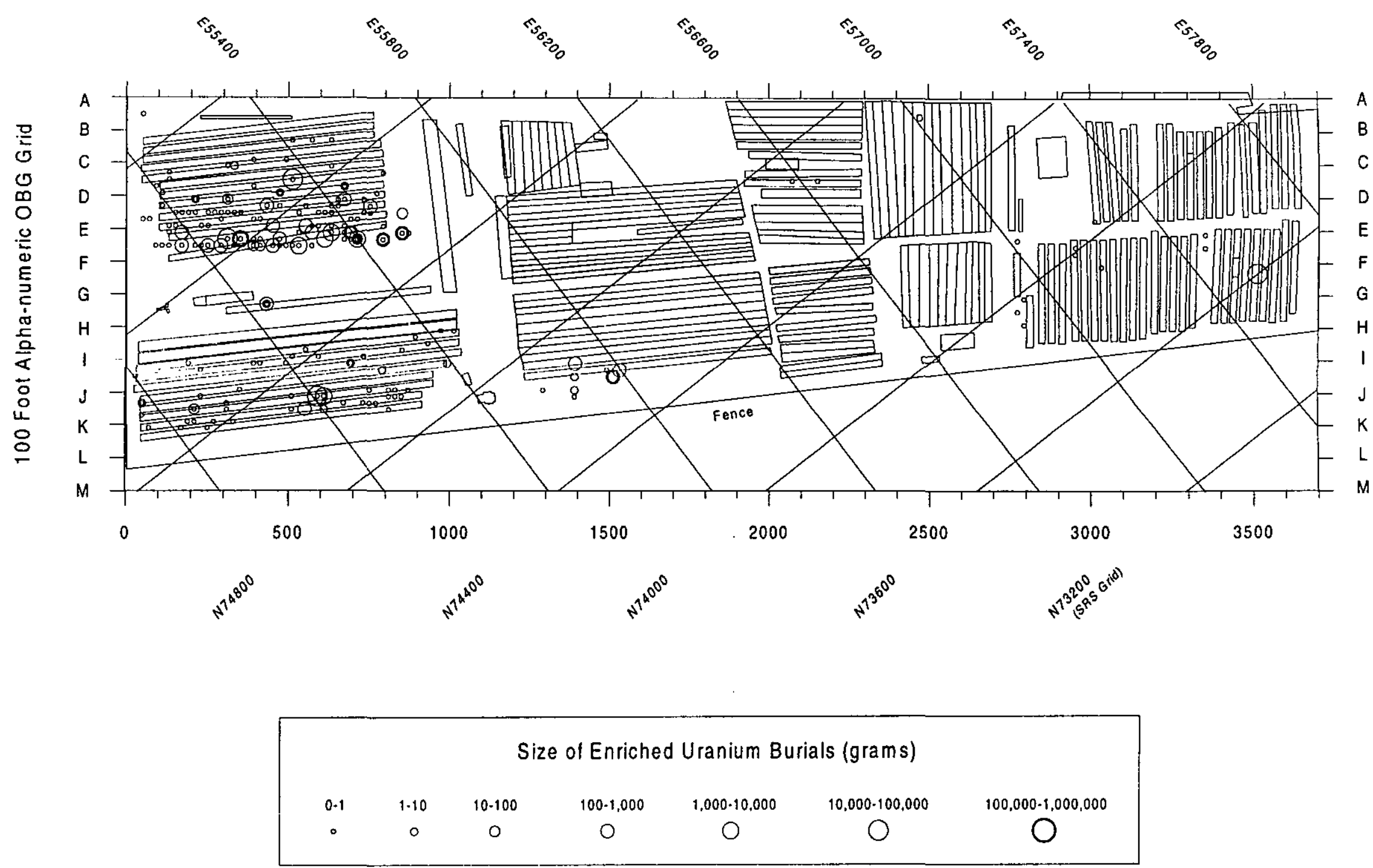

Figure 4-2. $X, Y$ Locations of Enriched Uranium Burials in ORWBG Database

(Variety of Contamination \#1 = "20") 


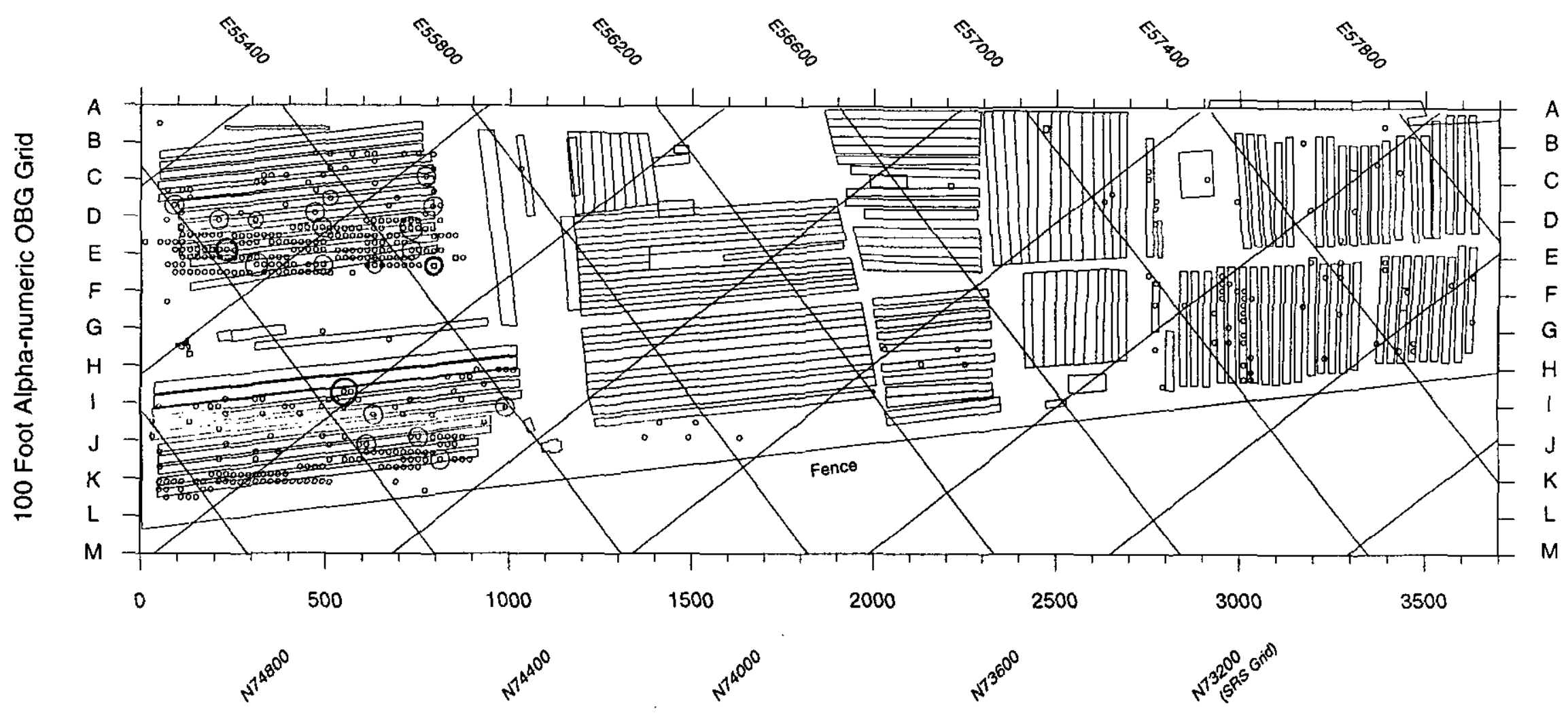

Size of Normal Uranium Burials (grams)

$\begin{array}{cccccccc}0.1 & 1-10 & 10-100 & 100-1,000 & 1,000-10,000 & 10,000-100,000 & 100,000-1,000,000 & \\ 0 & 0 & 0 & 0 & 0 & O & \bigcirc & \text { Variety of Contamination \#1 } \\ 0 & \text { (none) } & \text { (none) } & \text { (none) } & \text { (none) } & \text { (none) } & \text { (none) } & \text { Variety of Contamination \#2 }\end{array}$

Figure 4-3. X, Y Locations for Normal Uranium Burials in ORWBG Database (Variety of Contamination \#1 and \#2 = "81") 


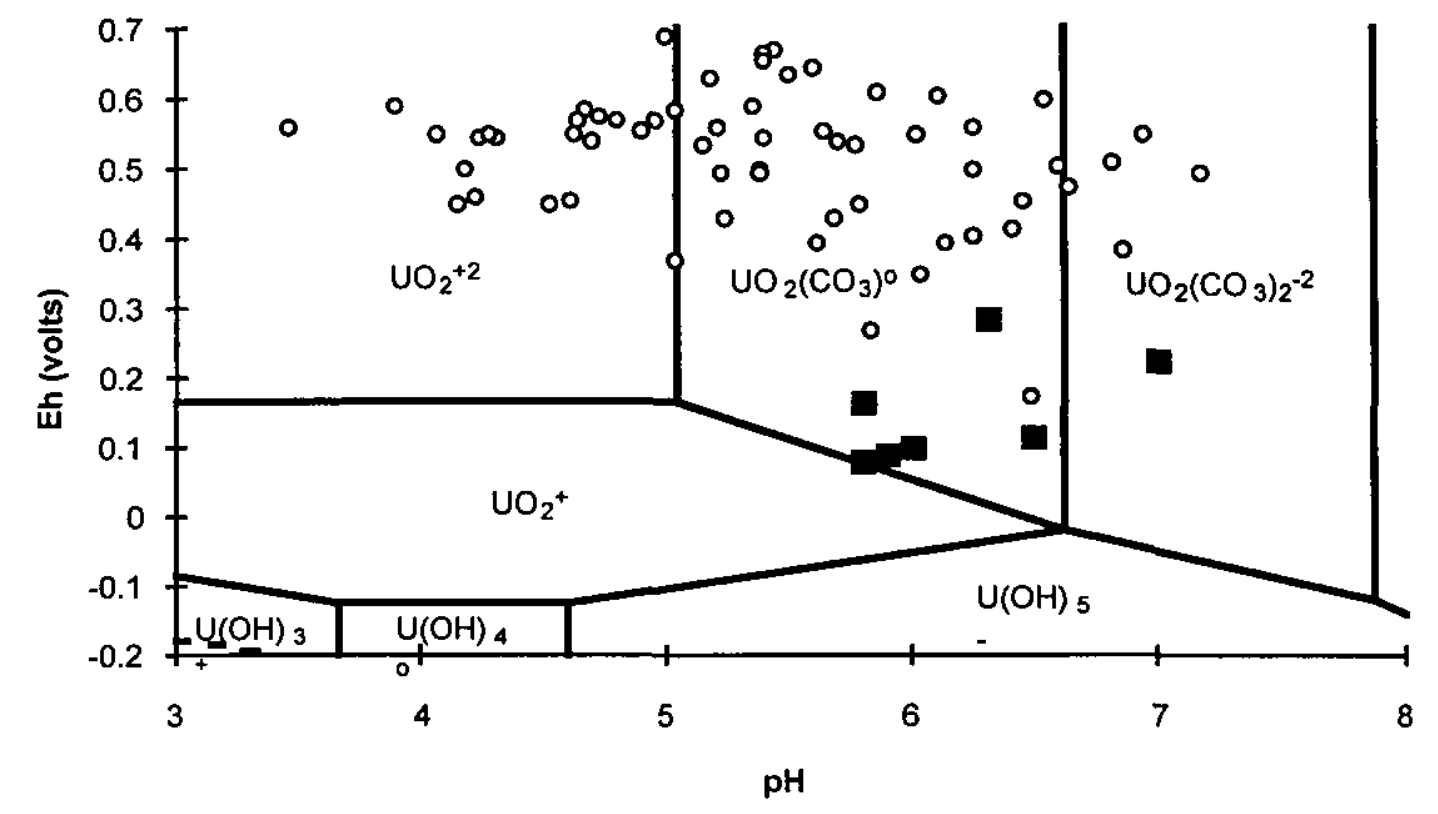

Figure 6-1: Eh-pH Diagram Showing Fields of Dominance of Aqueous Species of

Uranium. Circles represent analyses of grid well groundwater (Ryan, 1983) and squares represent analyses of trench wells (Hoeffner, 1985). Data for diagram construction from Langmuir (1978). $\mathrm{P}^{\mathrm{CO} 2}=10^{-2} \mathrm{~atm}$ 


\section{Schoepite Solubility}

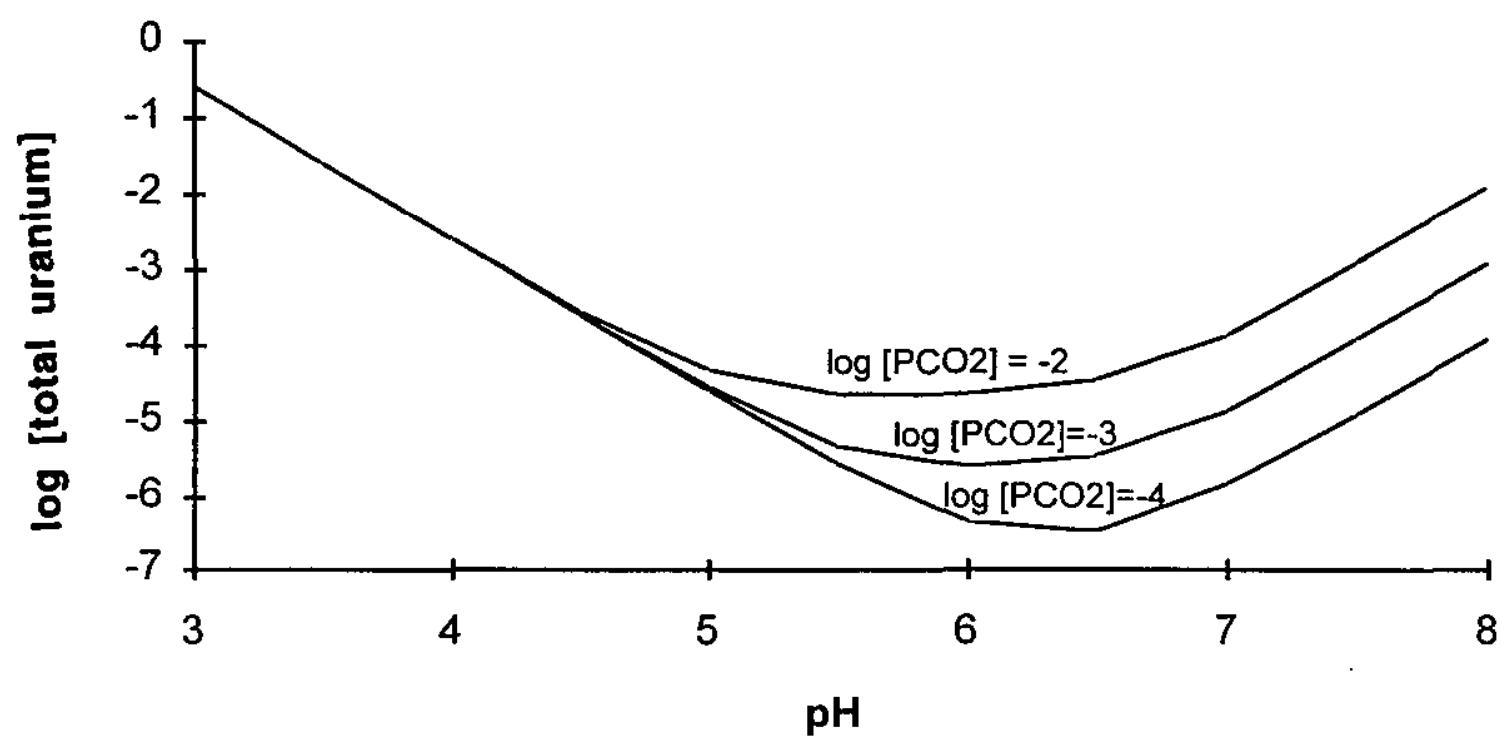

Figure 6-2. Solubility Curve for Schoepite ( $\left.\mathrm{UO}_{2}(\mathrm{OH})_{2} \cdot \mathrm{H}_{2} \mathrm{O}\right)$ with $\mathrm{pH}$ and Varying $\mathrm{PCO}_{2}$. Data for curve construction from Langmuir (1978) 


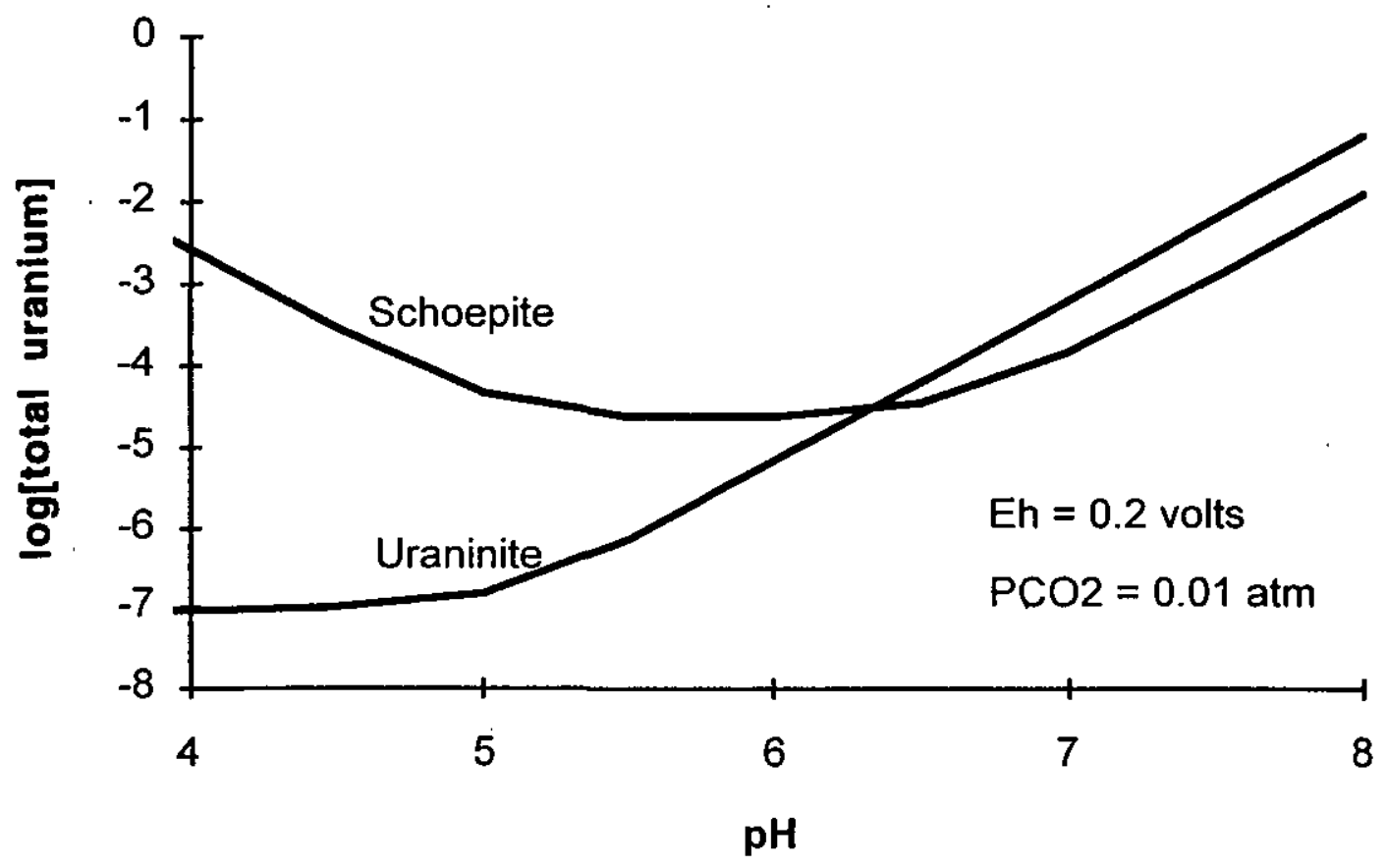

Figure 6-3. Solubility of Uraninite ( $\left.\mathrm{UO}_{2}\right)$ Compared to That of Schoepite $\left(\mathrm{UO}_{2}(\mathrm{OH})_{2} \cdot \mathrm{H}_{2} \mathrm{O}\right)$. Data for diagram construction from Langmuir (1978) 
Table 2-1. Alpha Inventory in OSTs

Uranium is not listed as a predominant radionuclide in any of the tanks, but small amounts are present in Tanks 6, 7, 9, 12, and 15 (see Section 3.0).

\begin{tabular}{|ccl|}
\hline Tank \# & Alpha Inventory, Ci & Predominant Radionuclides \\
\hline 1 & 0.82 & Cm-224,66\% \\
\hline 2 & 4.72 & Pu-238, 88\% \\
\hline 3 & 0.28 & $\mathrm{Pu}-238,70 \%$ \\
\hline 4 & 0.54 & $\mathrm{Pu}-238,67 \%$ \\
\hline 5 & 19.78 & $\mathrm{Cm}-244,93 \%$ \\
\hline 6 & 1.80 & $\mathrm{Cm}-244,80 \%$ \\
\hline 7 & 0.75 & $\mathrm{Pu}-238,77 \%$ \\
\hline 8 & 0.17 & No Data \\
\hline 9 & 3.81 & $\mathrm{Cm}-244,30 \% ; \mathrm{Pu}-239,30 \%$ \\
\hline 10 & 2.33 & $\mathrm{Pu}-238,50 \%$ \\
\hline 11 & 6.43 & $\mathrm{Cm}-244,56 \%$ \\
\hline 12 & 3.81 & $\mathrm{Pu}-238,63 \%$ \\
\hline 13 & 13.72 & $\mathrm{Pu}-238,97 \%$ \\
\hline 14 & 3.64 & $\mathrm{Pu}-238,98 \%$ \\
\hline 15 & 31.86 & $\mathrm{Cm}-244,63 \%$ \\
\hline 16 & 2.03 & No Data \\
\hline 17 & 24.55 & $\mathrm{Pu}-239,60 \%$ \\
\hline 18 & 1.84 & $\mathrm{Pu}-238,30 \% ; \mathrm{Pu}-239,30 \% ; \mathrm{Np}-237,30 \%$ \\
\hline 19 & 10.19 & $\mathrm{Cm}-244,65 \%$ \\
\hline 20 & 0.001 & $\mathrm{Pu}-238,70 \%$ \\
\hline 21 & 0.001 & No Data \\
\hline 22 & 0.001 & $\mathrm{Cm}-244,70 \%$ \\
\hline
\end{tabular}

Source: Mason (1996), Tables 23 and 26 
Table 3-1. The Sources of Inventory Estimates for Uranium in the Old Burial Ground

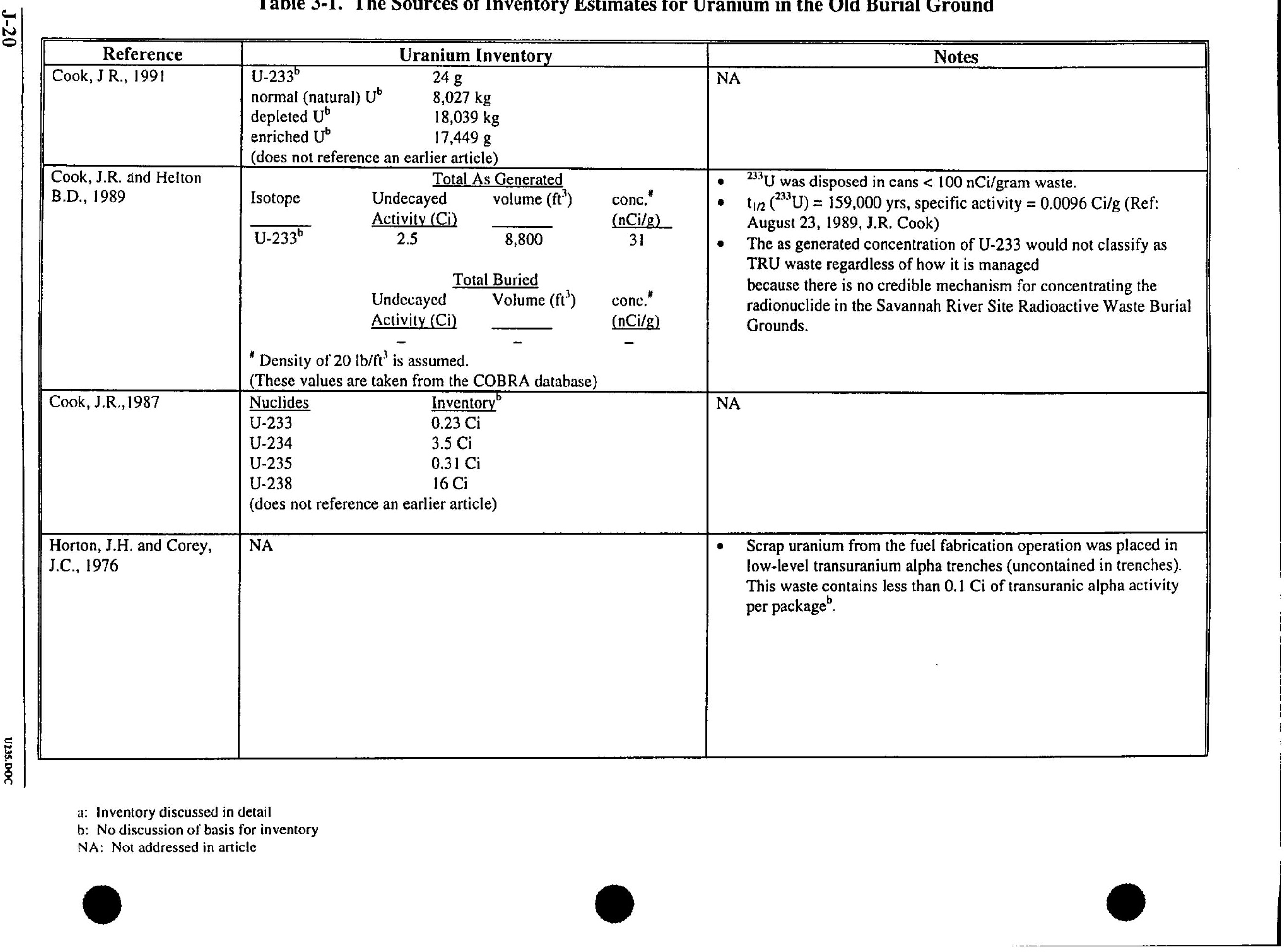


Table 3-1. The Sources of Inventory Estimates for Uranium in the Old Burial Ground (Continued)

\begin{tabular}{|c|c|c|c|c|}
\hline Reference & \multicolumn{3}{|c|}{ Uranium Inventory } & Notes \\
\hline Ashlcy C., 1965 & $\begin{array}{ll}\begin{array}{l}\text { During } 1964 \text { and during the } \\
\text { eleven year period from }\end{array} & \text { Uranium }^{b} \text {, (grams) } \\
\text { plant startup through } 1964 & \text { Natural } \\
\text { (does not reference an earlier article) }\end{array}$ & $\begin{array}{l}\frac{1964}{-} \\
-\end{array}$ & $\begin{array}{c}\text { Total Since Plant Startup } \\
\begin{array}{c}145 \\
53.59 \times 10^{5}\end{array}\end{array}$ & $\begin{array}{l}\text { Health Protection (HP) data. HP } \\
\text { published a summary report } \\
\text { between } 1959 \text { and } 1965 \text { that gives } \\
\text { gross information on radioisotope } \\
\text { burials. }\end{array}$ \\
\hline Ashley, C., 1964 & $\begin{array}{ll}\text { During } 1963 \text { and during the } & \text { Uranium }^{\mathrm{b}} \text {, (grams) } \\
\text { ten-year period from plant } & \text { Enriched } \\
\text { startup through } 1963 & \text { Natural } \\
\text { (does not reference an earlier article) }\end{array}$ & $\frac{1963}{-}$ & $\begin{array}{c}\text { Total Since Plant Startup } \\
145 \\
53.59 \times 10^{5}\end{array}$ & Health Protection (HP) data. \\
\hline Ashley C., 1963 & $\begin{array}{ll}\text { During } 1962 \text { and during the } & \text { Uranium }^{b} \text {, (grams) } \\
\text { nine-year period from plant } & \text { Enriched } \\
\text { startup through } 1962 & \text { Natural } \\
\text { (does not reference an earlier article) }\end{array}$ & $\begin{array}{l}1962 \\
-\end{array}$ & $\begin{array}{c}\text { Total Since Plant Startup } \\
\begin{array}{c}145 \\
53.59 \times 10^{5}\end{array}\end{array}$ & Health Protection (HP) data. \\
\hline Ashley C., $1962 \mathrm{~b}$ & $\begin{array}{ll}\text { During } 1961 \text { and during the } & \text { Uranium }^{b} \text {, (grams) } \\
\text { cight-year period from plant } & \text { Enriched } \\
\text { startup through 1961 } & \text { Natural } \\
\text { (Does not reference an earlier article) }\end{array}$ & $\frac{1961}{-}$ & $\begin{array}{c}\text { Total Since Plant Startup } \\
\begin{array}{c}145 \\
53.59 \times 10^{5}\end{array}\end{array}$ & Health Protection (HP) data. \\
\hline Ashley C., 1962a & $\begin{array}{ll}\begin{array}{l}\text { During } 1960 \text { and startup } \\
\text { through } 1960\end{array} & \begin{array}{l}\text { Uranium } \\
\text { Enriched }\end{array} \\
\text { Natural } & \text { (grams) } \\
\text { (does not reference an earlier article) }\end{array}$ & $\begin{array}{l}\frac{1960}{9} \\
3.25 \times 10^{5}\end{array}$ & $\begin{array}{c}\text { Total Since Plant Startup } \\
\begin{array}{c}145 \\
53.59 \times 10^{5}\end{array}\end{array}$ & Health Protection (HP) data. \\
\hline Ashley, C., 1960 & 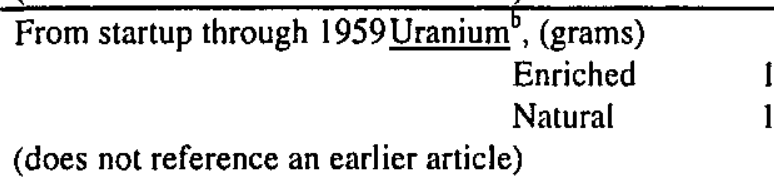 & $\begin{array}{l}\text { rams } \\
0 \text { pounds }\end{array}$ & & Health Protection (HP) data. \\
\hline
\end{tabular}

a: Inventory discussed in detail

b: No discussion of basis for inventory

NA: Not addressed in article 
Table 3-2. Reported Uranium Inventories Converted to Grams of Uranium-235 and Uranium-238

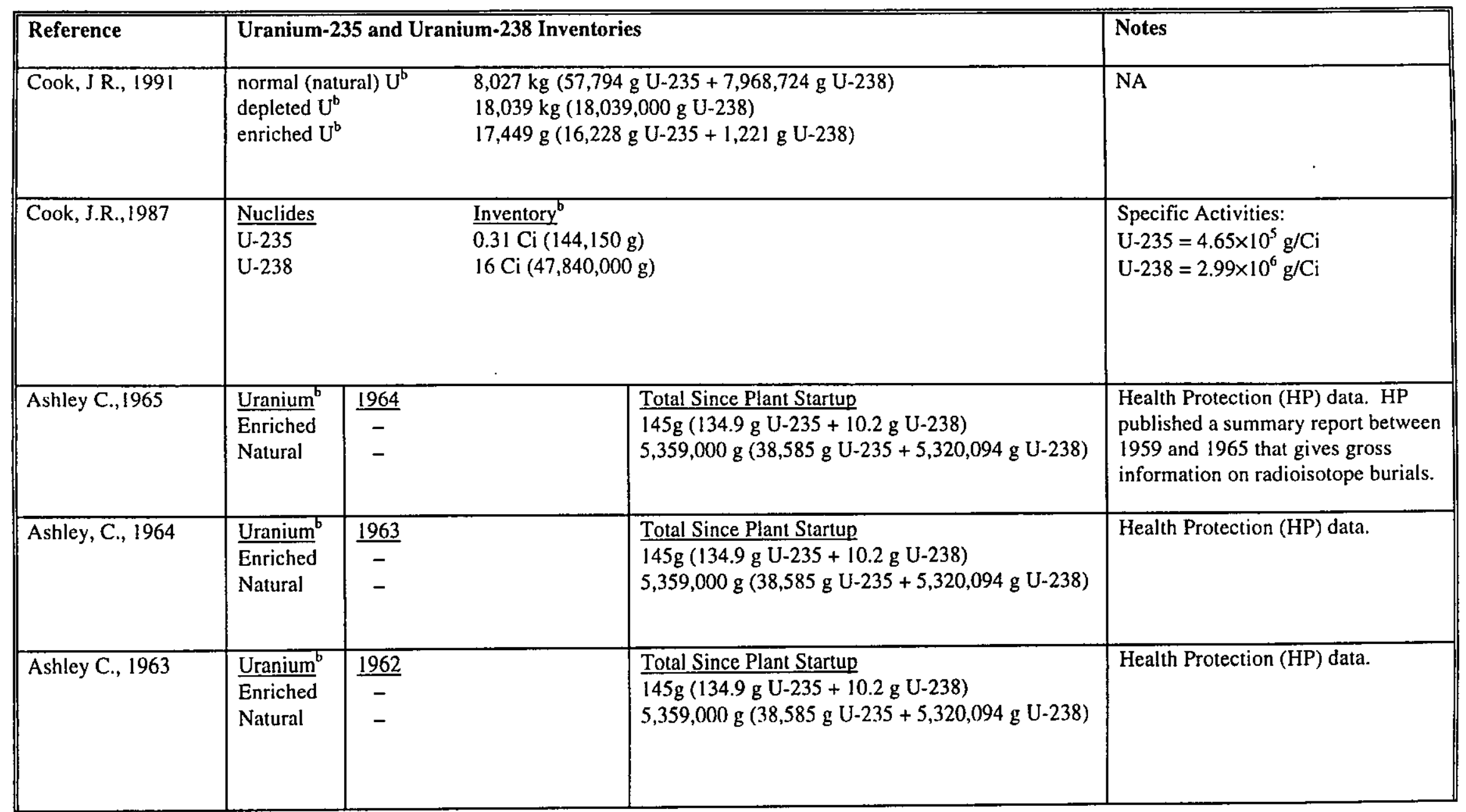

a: Inventory discussed in detail

b: No discussion of basis for inventory

NA: Not addressed in article

Natural (normal) uranium is $99.274 \% \mathrm{U}-238,0.72 \% \mathrm{U}-235$, and $0.005 \% \mathrm{U}-234$.

Depleted is $100 \% \mathrm{U}-238$.

Enriched uranium is $93 \% \mathrm{U}-235$ and $7 \% \mathrm{U}-238$. 

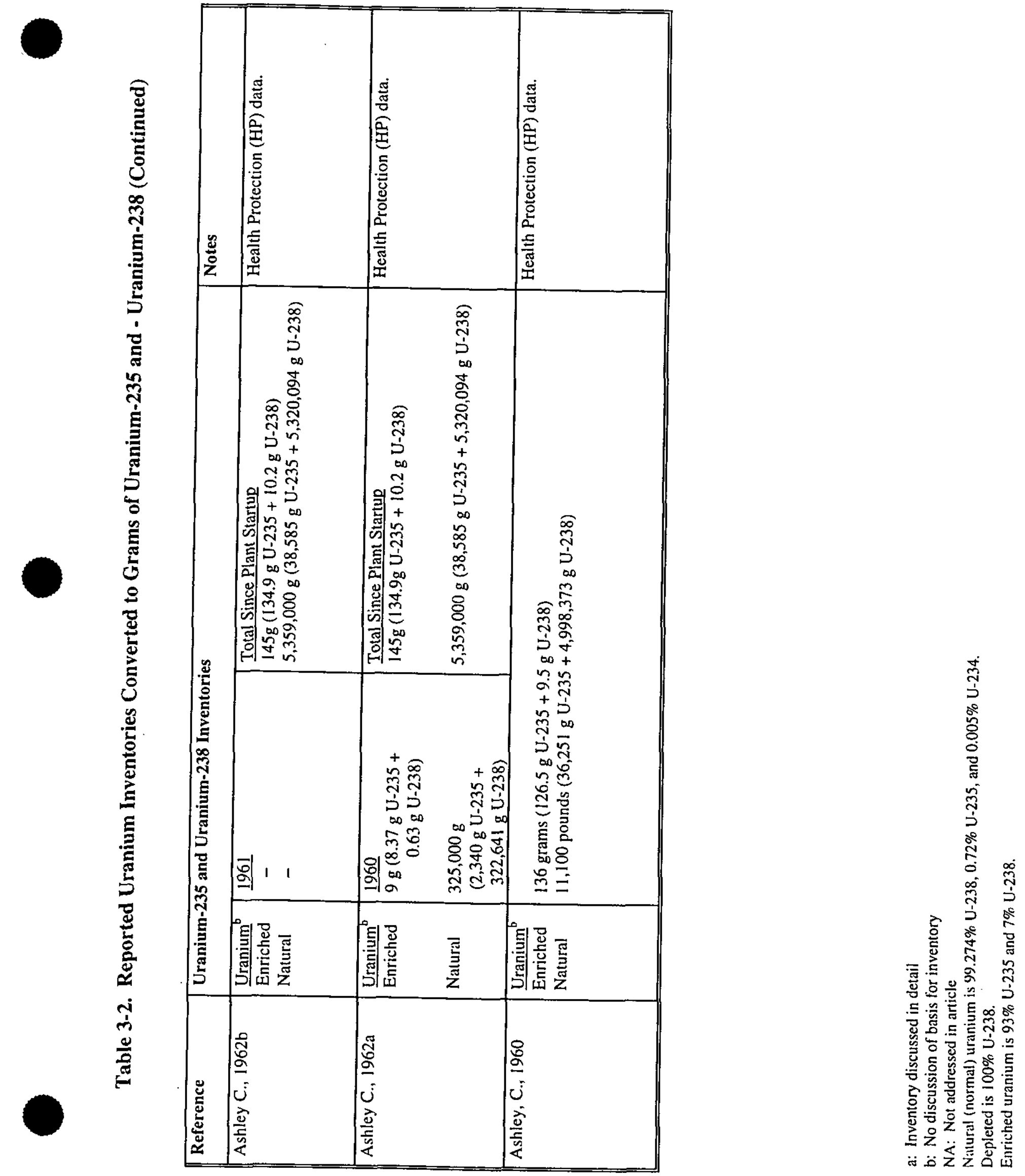
(This page left intentionally blank) 
APPENDIX K

CONSTITUENT OF INTEREST:

URANIUM-238 
(This page intentionally left blank) 


\section{TABLE OF CONTENTS}

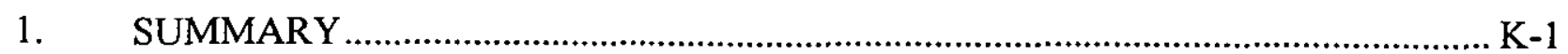

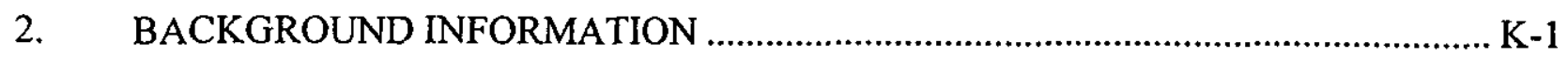

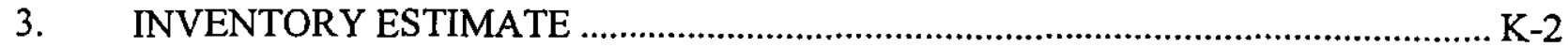

3.1 Range of Inventory Estimates .................................................................. K-3

3.2 Best Estimate Uranium-238 in Burial Grounds ............................................. K-5

3.3 Uncertainties Associated with Uranium-238 Inventory Estimate........................ K-5

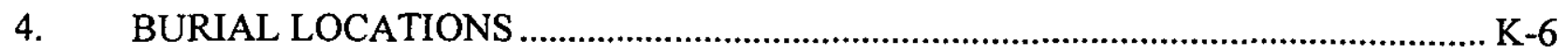

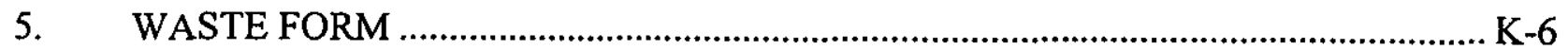

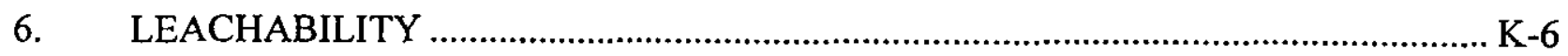

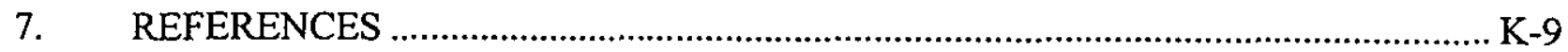




\section{LIST OF FIGURES}

Figure 1-1. Inventory Estimate Process Flow Diagram.................................................... K-11

Figure 3-1. Health Protection Data Uranium to Burial Ground through 1964 ..................... K-12

Figure 4-1. Uranium-238 Burial Location Process Flow Diagram .................................. K-13

Figure 4-2. X, Y Locations for Depleted Uranium Burials in ORWBG Database (Variety of Contamination \#1 = "10")................................................................... K-14

Figure 4-3. X, Y Locations for Normal Uranium Burials in ORWBG Database (Variety of Contamination \#1 and \#2 = "81")

Figure 4-4. X, Y Locations for Enriched Uranium Burials in ORWBG Database (Variety of Contamination \#1 = "20"). $\mathrm{K}-16$

Figure 6-1. Eh-pH Diagram Showing Fields of Dominance of Aqueous Species of Uranium

Figure 6-2. Solubility Curve for Schoepite $\left(\mathrm{UO}_{2}(\mathrm{OH})_{2} \cdot \mathrm{H}_{2} \mathrm{O}\right)$ with $\mathrm{pH}$ and Varying

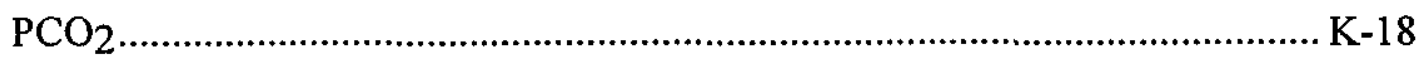

Figure 6-3. Solubility of Uraninite $\left(\mathrm{UO}_{2}\right)$ Compared to That of Schoepite $\left(\mathrm{UO}_{2}(\mathrm{OH})_{2} \cdot \mathrm{H}_{2} \mathrm{O}\right)$ $\mathrm{K}-19$

\section{LIST OF TABLES}

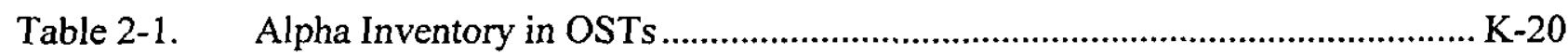

Table 3-1. The Sources of Inventory Estimates for Uranium in the ORWBG................... K-21

Table 3-2. Reported Uranium Inventories Converted to Grams of Uranium-235 and Uranium-238 


\section{CONSTITUENT OF INTEREST - URANIUM-238}

\section{SUMMARY}

To accomplish its national defense and space missions, the Savannah River Site (SRS) has employed five production reactors: $\mathrm{R}, \mathrm{C}, \mathrm{L}, \mathrm{P}$, and $\mathrm{K}$ Reactors. These reactors are fueled by highly-enriched uranium fuel rods. Highly-enriched uranium is uranium with greater than 20 percent uranium-235. Other important isotopes of uranium present are uranium-234 and uranium-238. Targets comprised of uranium-238 slugs (depleted or natural uranium) were used to produce plutonium-239.

Uranium-238 is also found in naturally-occurring uranium. Natural uranium is 99.274 percent uranium-238 ( 0.72 percent uranium-235 and 0.005 percent uranium-234). Uranium with naturally-occurring isotopic abundances was used in early reactor operations at SRS. The depleted uranium used in SRS reactors as target material to produce plutonium-239 was 99.5 percent, or more, uranium-238.

The best estimate for the uranium-238 inventory in the trenches at the Old Radioactive Waste Burial Ground (ORWBG) is 44,233 kilograms (14.8 Ci). In the Old Solvent Tanks (OSTs), the best estimate of the uranium-238 inventory is $1.1 \mathrm{Ci}$.

Wastes containing uranium was buried in alpha activity trenches with no special containers. The waste was buried in cardboard boxes, plastic bags, and possibly, metal containers.

Figure 1-1 presents the process used to develop inventory and burial locations. The COBRA database was used to determine the location of burials of uranium-238.

\section{BACKGROUND INFORMATION}

The uranium material used to produce fuel elements and targets was sent to SRS from other facilities in the Department of Energy's weapons complex or recycled from SRS operations. Facilities in M-Area at SRS manufactured aluminum-clad fuel elements and targets for the five onsite reactors: $\mathrm{C}, \mathrm{K}, \mathrm{L}, \mathrm{P}$, and $\mathrm{R}$ Reactors. The targets were irradiated in the reactors. After a prescribed exposure or useful lifetime in the reactor, the targets and fuel elements were discharged from the reactor and cooled in the reactor disassembly basins.

After cooling in the basins, the targets were taken to F-Area. F-Area houses F-Canyon, one of two canyon buildings used to separate useful radionuclides from the fission products and 
other components of the irradiated target slugs or fuel elements. Historically, F-Canyon initiated recovery of plutonium-239 and uranium-238 by chemically separating these isotopes, which were contained in the aluminum-clad irradiated target slugs from site reactors and other test and research reactors (DOE, 1995a). In addition to the canyon building, FArea housed facilities to convert uranyl nitrate solution into uranium trioxide powder (WSRC, 1993).

After cooling, the spent fuel was transferred to H-Area. Fuel elements from certain offsite reactors were sent to the Receiving Basin for Offsite Fuel, also in H-Area. H-Area contains H-Canyon, the other chemical separations facility at SRS. H-Canyon recovered uranium-235 from irradiated fuel elements from onsite and offsite reactors. Other facilities in H-Area include those used to store liquid uranyl nitrate hexahydrate prior to shipment to Oak Ridge, where it is processed for future use as highly-enriched uranium (DOE, 1995b).

Research activities using uranium-238 took place primarily at the Savannah River Laboratory (now the Savannah River Technology Center), which is located in A-Area (773-A).

According to the COBRA database, uranium-238, as depleted uranium, was sent to the ORWBG from M-Area, A-Area, F-Area, H-Area, G-Area, and from offsite facilities. Normal, or natural, uranium was sent to the ORWBG from M-Area, A-Area, H-Area, and FArea. Enriched uranium was sent to the ORWBG from M-Area, A-Area, F-Area, H-Area, and from offsite facilities.

It is likely that waste containing uranium-238 was disposed of in the ORWBG in alpha waste trenches, without any special containerization.

Spent solvent from the separations areas was sent to the OSTs (Tanks 1-22) to be stored prior to burning. This solvent was likely contaminated with uranium-238. Table 2-1 lists the alpha inventory and major constituents, by tank, in the OSTs. This information is used to estimate the amount of uranium-238 in the tanks (see Section 3.0).

\section{INVENTORY ESTIMATE}

Inventory estimates for uranium-238 are based on data contained in the COBRA database and records indicating burials prior to COBRA records. The COBRA database indicates that burials of enriched and depleted uranium occurred in the ORWBG as recently as 1974. 


\subsection{Range of Inventory Estimates}

Table 3-1 presents the references reviewed related to the uranium inventory. The table includes the reference, the inventory estimates provided by the reference, and any special notes associated with the inventory.

Cook (1987) presents the inventory estimates, in curies, for individual uranium isotopes (e.g., $\mathrm{U}-233, \mathrm{U}-234, \mathrm{U}-235$, and U-238). To convert the curie values in Table 3-1 to mass, the uranium-238 specific activity must be used: $2.99 \times 10^{6}$ grams per curie. Cook (1991) presents the inventory for enriched uranium (in grams), normal uranium (in kilograms), and depleted uranium (in kilograms). These estimates can be converted to a uranium-238 inventory assuming that uranium-238 is 100 percent of the depleted uranium, 99.274 percent of the normal uranium, and 7 percent of enriched uranium. The reported uranium inventories were converted to grams of uranium-235 and uranium-238 and are presented in Table 3-2.

The COBRA database includes the burials of enriched uranium, normal uranium, and depleted uranium. The COBRA database estimates can be converted to a uranium-238 inventory assuming that uranium-238 is 100 percent of the depleted uranium, 99.274 percent of the normal uranium, and 7 percent of enriched uranium.

The sources of the depleted, enriched, and normal uranium waste buried, according to COBRA, are as follows:

- A-Area: 599 kilograms and 58 "curies" of depleted uranium, 80,663 grams enriched uranium and 1,957 kilograms of normal uranium

- F-Area: 241.5 kilograms of depleted uranium, 6,360 grams enriched uranium and 6 kilograms of normal uranium

- H-Area: 473 "curies" of depleted uranium, 24 grams enriched uranium and 123 kilograms of normal uranium

- M-Area: 33,782 kilograms of depleted uranium, 137,103 grams enriched uranium and 6418 kilograms of normal uranium

- G-Area: 600 kilograms of depleted uranium

- Mound (offsite): 19 kilograms of depleted uranium, 450 grams enriched uranium

- Area "XXX" (offsite shipment from unspecified origin): 3 kilograms of depleted uranium, 3,310 grams enriched uranium

Note that the unit curies appears in quotations above. Two records with curies of depleted uranium appear in the COBRA database (burial slips 17909 and 3390) but are suspect here 
(see Sections 3.2 and 3.3). Given its very low specific activity, 1 curie of uranium-238 equals approximately 3,000 kilograms. It is considered likely that these two records are data entry errors, and " $C$ " for curies was typed instead of " $G$ " for grams or " $K$ " for kilograms.

Figure 3-1 shows the enriched, normal and totai uranium inventories through 1964. Health Protection data (Ashley, 1960, 1962a, 1962b, 1963, 1964, and 1965) indicate that from ORWBG start-up through 1964, 145 grams of enriched uranium and 5,359,000 grams $(5,359$ kilograms) of natural (normal) uranium were buried in the ORWBG. These data are inconsistent with the data in COBRA. COBRA indicates that 644 grams of enriched uranium and 7,382,000 grams (7,382 kilograms) of normal (natural) uranium were buried in the ORWBG from start-up through 1964. Note that all of the uranium data in COBRA reflect discrete waste shipments that were detailed on corresponding burial slips. Some of these slips are dated as early as December 1952. This is unlike data for some radionuclides, e.g. plutonium, that were adjusted by "lumping" records in COBRA.

Data are very limited regarding uranium-238 associated with spent solvents sent to the OSTs. There should be little activity due to uranium-238 in the OSTs. Most of the solvent in these tanks had been processed in the canyon washing system before it was sent to the OSTs. One of these washes is with sodium carbonate solution. Uranyl ion $\left(\mathrm{UO}_{2}^{+2}\right)$, the state of the uranium in the separations processes, forms a very stable complex with carbonate ion and would, therefore, tend to be removed from the solvent via this mechanism, since the carbonate complex has a very low soil/water distribution coefficient $\left(\mathrm{K}_{d}\right)$ in the organic solvent. However, if any of the uranium-bearing carbonate wash solution accompanied the solvent, uranium could be present in the OSTs sludge. Since uranium has a very low specific activity compared with those for plutonium-238, plutonium-239, and curium-244, a large amount of uranium would be required to produce significant activities. There are no estimates of uranium-238 in solvent residues. This residue was buried in the ORWBG.

Mason (1996) reports some uranium data from investigations of the OSTs, but plutonium238, plutonium-239, and curium-244 are the primary alpha-emitting radionuclides documented. Table 13 in Mason (1996) presents uranium-238 as a radionuclide found in Tanks $6,7,9,12$, and 15, but no concentration data are presented.

To estimate the uranium-238 content in the tanks, an arbitrary fraction (e.g., 2.5 percent) of the total alpha activity is assigned to the uranium-238 activity. This can be done for Tanks 6 , $7,9,12$, and 15 , where uranium is present. This method yields the following estimates: 
- Tank 6: $2.5 \%$ of $1.8 \mathrm{Ci}$ of alpha $=0.045 \mathrm{Ci}$ of U-238

- Tank 7: $2.5 \%$ of $0.75 \mathrm{Ci}$ of alpha $=0.01875 \mathrm{Ci}$ of U-238

- Tank 9: $2.5 \%$ of $3.81 \mathrm{Ci}$ of alpha $=0.09525 \mathrm{Ci}$ of U-238

- Tank 12: $2.5 \%$ of $3.81 \mathrm{Ci}$ of alpha $=0.09525 \mathrm{Ci}$ of U-238

- Tank 15: $2.5 \%$ of $31.86 \mathrm{Ci}$ of alpha $=0.7965 \mathrm{Ci}$ of U-238

\subsection{Best Estimate of Uranium-238 in Burial Grounds}

The best estimate for the uranium-238 inventory in the trenches in the ORWBG is 44,233 kilograms $(14.8 \mathrm{Ci})$. This estimate is from COBRA. It has been assumed that the COBRA database captures all of the Health Protection data related to uranium and has not been adjusted. The uranium-238 total is based on the following calculation:

1. Multiply the total quantity of "Enriched Uranium", in grams, by 0.07 (i.e., 7 percent U-238) to determine grams of uranium-238 in enriched uranium. Convert to kilograms (16 kilograms).

2. Multiply the total quantity of "Normal Uranium", in kilograms, by 0.99274 (i.e., 99.274 percent $U-238$ ) to determine kilograms of uranium-238 in normal uranium (8,442 kilograms).

3. Assume that the 531 curies indicated in the COBRA database are actually kilograms (see Section 3.3 below). Convert COBRA records in grams to kilograms (2.471 kilograms). Add these quantities to the depleted uranium total (35,242 kilograms) for a total of 35,775 kilograms of depleted uranium.

4. Sum items 1,2, and 3 above: 44,233 kilograms.

For the OSTs, the best estimate of the uranium-238 inventory is $1.1 \mathrm{Ci}$. This estimate is based on assigning uranium-238 an arbitrary activity fraction of 2.5 percent for tanks with uranium content (Section 3.1).

\subsection{Uncertainties Associated with Uranium-238 Inventory Estimate}

COBRA records indicate that $531 \mathrm{Ci}$ of depleted uranium was buried in the ORWBG. This activity equals $1,587,690$ kilograms. It has been assumed that these entries are in error, since kilograms, rather than curies, are the conventional units for depleted uranium. By assigning these values as kilograms, the uranium-238 estimate of 44,233 kilograms is more similar to those of 47,840 kilograms in Cook (1987) and 26,009 kilograms in Cook (1991).

For the inventory in the OSTs, the value is arbitrary, but it is based on actual alpha activity in the tanks. 


\section{BURIAL LOCATIONS}

The COBRA database provides information on the spatial distribution of uranium in the ORWBG. Figure 4-1 outlines the steps taken to manipulate the database to locate uranium238 burials. Figure 4-2 presents the burial locations for depleted uranium (variety of contamination $\# 1=10$ ). Figure 4-3 presents the locations for normal uranium burials (variety of contamination $\# 1$ and $\# 2=81$ ). Figure 4-4 presents the locations for enriched uranium burials (variety of contamination $\# 1=20$ ). All of these wastes were uncontainerized and would have been buried in cardboard boxes, plastic bags, and possibly, metal containers. The figures indicate the relative size, in grams, of each burial.

\section{WASTE FORM}

As discussed above, the uranium-bearing waste was buried in alpha activity trenches without special containers. The waste was buried in cardboard boxes, plastic bags, and possibly, metal containers. As this packaging deteriorates, the uranium and any other contaminant will be exposed to contact with infiltrating water.

\section{LEACHABILITY}

The leachability of uranium is controlled by the solubility of uranium phases, the chemistry of infiltrating water, the redox conditions within the ORWBG and adsorption of uranium onto the soil matrix. Another consideration when evaluating the leachability of uranium is that ${ }^{238} \mathrm{U}$ and $235 \mathrm{U}$ occur naturally and are relatively abundant in the Savannah River Site environment. Isotopic ratios in groundwater and soil can be used to identify anthropogenic uranium, but quantitative assessments are difficult. They must account for isotopic exchange, precipitation, and dissolution of natural minerals.

Redox conditions in the ORWBG are important to understanding leachability of uranium in the ORWBG. As dissolved species, uranium can occur in oxidation states, U(IV), U(V), and U(VI). In solid phases uranium occurs as either U(IV) or U(VI). Generally, uranium is much less soluble and therefore less mobile under reducing conditions. Figure 6-1 shows the dominant aqueous species of uranium in Eh-pH space. The circles represent grid well analyses reported by Ryan (1983) and the squares represent trench well analyses reported by Hoeffner (1985). These analyses indicate that U(VI) is the dominant form of leached uranium in the ORWBG. 
Figure 6-1 also demonstrates the importance of the carbonate system in the leachability of uranium. The figure assumes a partial pressure of $\mathrm{CO}_{2}\left(\mathrm{PCO}_{2}\right)$ of $10^{-2}$ atmospheres which is consistent with the total inorganic carbon analyses of groundwater from grid wells reported by Ryan (1983). At this $\mathrm{PCO}_{2}$ and $\mathrm{pH}>5, \mathrm{UO}_{2}\left(\mathrm{CO}_{3}\right)^{\circ}$ and $\mathrm{UO}_{2}\left(\mathrm{CO}_{3}\right)_{2}-2$ are the dominant species of uranium. This has significant implications for the adsorption and solubility of uranium.

The competition for uranium between surface sites and dissolved carbonate species may severely limit uranium adsorption in the presence of carbonate. Both Hsi and Langmuir (1985) and Waite et al. (1994) found that at $\mathrm{pH}>6$ the presence of carbonate in solution limited the adsorption of uranium onto iron oxyhydroxides. The adsorption edge for uranium is generally between a pH of 4 and 5 . Thus, from $\mathrm{pH} 4$ to 6 , uranium may adsorb strongly to soils showing a positive correlation with $\mathrm{pH}$. At $\mathrm{pH}>6$, uranium adsorption will decrease with increasing $\mathrm{pH}$. This suggests that the mobility of dissolved uranium may vary widely throughout the ORWBG depending on local conditions.

Conservative estimates of uranium solubility constrain uranium concentrations in groundwater to $\mathrm{ppm}$ levels. If conditions are right, precipitation of uranium phases can limit uranium concentrations to much lower levels. However, the $\mathrm{PCO}_{2}$ plays a major role in the solubility of all uranium phases. For example, Figure 6-2 shows solubility curves for the mineral schoepite $\left(\mathrm{UO}_{2}(\mathrm{OH})_{2} \cdot \mathrm{H}_{2} \mathrm{O}\right)$ at 3 different $\mathrm{PCO}_{2}$ values. The solubility of schoepite is at a minimum at $\mathrm{pH}$ values between 6 and 6.5 , but varies widely depending on the $\mathrm{PCO}_{2}$. At the minimum schoepite solubility for $\mathrm{PCO}_{2}=10^{-2}$ atm the concentration of uranium is about $5 \mathrm{mg} / \mathrm{l}$. Schoepite is a common phase and is often assumed to be the dominant control on uranium leachability from nuclear fuel (Finch et al., 1992). However, uranyl silicates and phosphates may limit the solubility to ppb levels. These phases have been found in weathering studies of Uraninite $\left(\mathrm{UO}_{2}\right)$ (Finch and Ewing, 1992; and Wronkiewicz et al., 1992). Wronkiewicz et al. (1992) found that dripping water onto $\mathrm{UO}_{2}$ at $90^{\circ} \mathrm{C}$ resulted in a two stage uranium release. In the initial stage uranium solubility appeared to be controlled by schoepite. After 2 years the released rates decreased and the solubility appeared to be controlled by uranyl silicates.

In the ORWBG, uranium concentrations in groundwater can be constrained to the ppm level by schoepite solubility, but it is uncertain whether further constraints by uranyl phosphates and silicates are applicable. Uraninite $\left(\mathrm{UO}_{2}\right)$ has been considered as a natural analogue of nuclear fuel (Finch and Ewing, 1992), and thus, its solubility may more truly represent the initial leachability of uranium in the ORWBG. Figure 6-3 shows the solubility curve of 
uraninite compared to that of schoepite at a $\mathrm{PCO}_{2}=10^{-2}$ atm and an $\mathrm{Eh}=0.2$ volts. If a $\mathrm{pH}$ of 6 is chosen to represent conditions in the ORWBG, the solubility of uraninite is about 1.5 $\mathrm{mg} / \mathrm{l}$. Cantrell (1990) reported uranium analyses of groundwater from 7 of the grid wells. The concentrations ranged from $<0.02 \mathrm{mg} / \mathrm{l}$ to $0.74 \mathrm{mg} / \mathrm{l}$. Thus, assuming a concentration of $1.5 \mathrm{mg} / \mathrm{l}$ for uranium leaching in the ORWBG may be reasonable.

To calculate the leaching rate of uranium, assumptions must be made on the dimensions of uranium waste forms in the ORWBG. The assumptions here are based on generic information on the dimensions of uranium fuel pellets (Lamarsh, 1983). Site specific information on the dimensions of waste forms would decrease uncertainty in these estimates. It is assumed here that all of the uranium is in cylinders $2 \mathrm{~cm}$ long with a diameter of $1 \mathrm{~cm}$. Furthermore, it is assumed that the leachable area of the cylinders is equal to the lengthwise cross-sectional area $-2 \mathrm{~cm}^{2}$. Using these dimensions, the infiltration rate of water into the trenches of $2.36 \mathrm{~m} / \mathrm{yr}$ (Orebaugh and Hale, 1976) and the solubility of uraninite yields leaching rates for $238 \mathrm{U}$ and $235 \mathrm{U}$ of $217 \mathrm{~g} / \mathrm{yr}$. and $11 \mathrm{~g} / \mathrm{yr}$. respectively. 


\section{REFERENCES}

Ashley, C., 1960. SRP Radioactive Waste Release, Startup through 1959, DPSP-60-25-25, E.I. du Pont de Nemours and Company, Aiken, SC, September 1960.

Ashley, C., 1962a. 1960 Audit of SRP Radioactive Waste, DPSP-62-25-1, E.I. du Pont de Nemours and Company, Aiken, SC, February 1962.

Ashley, C., 1962b. 1961 Audit of SRP Radioactive Waste, DPSP-62-25-5, E.I. du Pont de Nemours and Company, Aiken, SC, September 1962.

Ashley, C., 1963. 1962 Audit of SRP Radioactive Waste, DPSP-63-25-1, E.I. du Pont de Nemours and Company, Aiken, SC, May 1963.

Ashley, C., 1964. 1963 Audit of SRP Radioactive Waste, DPSP-64-25-1, E.I. du Pont de Nemours and Company, Aiken, SC, May 1964.

Ashley, C., 1965. 1964 Audit of SRP Radioactive Waste, DPSP-65-25-1, E.I. du Pont de Nemours and Company, Aiken, SC, April 1965.

Cantrell, K.J., 1990. Results of the Special Well Sampling Study for the Burial Ground, memorandum to W.E. Stevens, March 28, 1990, WSRC-RP-90-364, Westinghouse Savannah River Co., Aiken, SC.

Cook, J.R, 1987. Technical Data Summary: Plan for Closure of the 643-G Burial Ground, DPSTD-87-2, E.I. du Pont de Nemours and Company, Aiken, SC.

Cook, J.R. and Helton, B.D., 1989. An Assessment of Buried Waste Containing Transuranium Isotopes in the Savannah River Site Radioactive Waste Burial Ground, draft memorandum to B.G. Kitchen, August 23, 1989.

Cook, J.R., 1991.. Radionuclide Inventory of E-Area, memorandum to W.E. Stevens, WSRC-RP-91-709, June 271991.

Department of Energy (DOE), 1995a. Fact Sheet, "F Canyon," Savannah River Operations Office, Aiken, SC.

Department of Energy (DOE), 1995b. Fact Sheet, "H Camyon", Savannah River Operations Office, Aiken, SC.

Finch, R.J. and R.C. Ewing, 1992. The Corrosion of Uraninite Under Oxidizing Conditions, Journal of Nuclear Materials, v. 190, p. 133-156.

Finch, R.J., M.L. Miller, and R.C. Ewing, 1992. Weathering of Natural Uranyl Oxide Hydrates: Schoepite Polytypes and Dehydration Effects, Radiochimica Acta, v. 58/59, p. 433-443. 
Hoeffner, S.L., 1985. Radionuclide Sorption on Savannah River Plant Burial Ground Soil -A Summary and Interpretation of Laboratory Data: DP -1702, E.I. duPont de Nemours and Company, Savannah River Laboratory, Aiken, SC.

Horton, J.H. and J.C. Corey, 1976. Storing Solid Radioactive Wastes at the Savannah River Plant, DP-1366, E.I. du Pont de Nemours and Company, Aiken, SC.

Hsi, C.D. and D. Langmuir, 1985. Adsorption of Uranyl onto Ferric Oxyhydroxides: Applications of the Surface Complexation Site-Binding Model, Geochimica et Cosmochimica Acta, v. 49, p. 1931-1941.

Lamarsh, J.R., 1983. Introduction to Nuclear Engineering, Addison-Wesley Publishing Company, Reading, MA, 689 pp.

Langmuir, D., 1978. Uranium Solution-Mineral Equilibria at Low Temperatures With Applications to Sedimentary Ore Deposits, Geochimica et Cosmochimica Acta, v. 42, p. 547-569.

Mason, J.T., 1996. Information Document on the Old Solvent Tanks S1-S22 in the Old Radioactive Waste Burial Ground 643-E (U), WSRC-RP-96-00144, Westinghouse Savannah River Company, Aiken, SC.

Orebaugh, E.G. and W.H. Hale, Jr., 1976. Dispersion Study of Buried Elemental Mercury, DP-1401, E.I. du Pont de Nemours \& Co., Savannah River Laboratory, Aiken, SC.

Ryan, J.P., 1983. Groundwater Monitoring in the Savannah River Site Low Level Radioactive Waste Burial Ground, A Summary and Interpretation of the Analytical Data: DPST-83-209, E.I. duPont de Nemours and Company, Savannah River Laboratory, Aiken, SC.

Waite, T.D., J.A. Davis, T.E. Payne, G.A. Waychunas, and N. Xu, 1994. Uranium (VI) Adsorption to Ferrihydrite: Application of a Surface Complexation Model, Geochimica et Cosmochimica Acta, v. 58, p. 5465-5478.

Westinghouse Savannah River Company (WSRC), 1993. External Dosimetry Technical Basis Manual, WSRC-IM-92-101, Westinghouse Savannah River Company, Aiken, SC.

Wronkiewicz, D.J., J.K. Bates, T.J. Gerding, E. Veleckis, and B.S. Tani, 1992. Uranium Release and Secondary Phase Formation During Unsaturated Testing of UO2 at $90^{\circ} \mathrm{C}$, Journal of Nuclear Materials, v. 190, p. 107-127. 


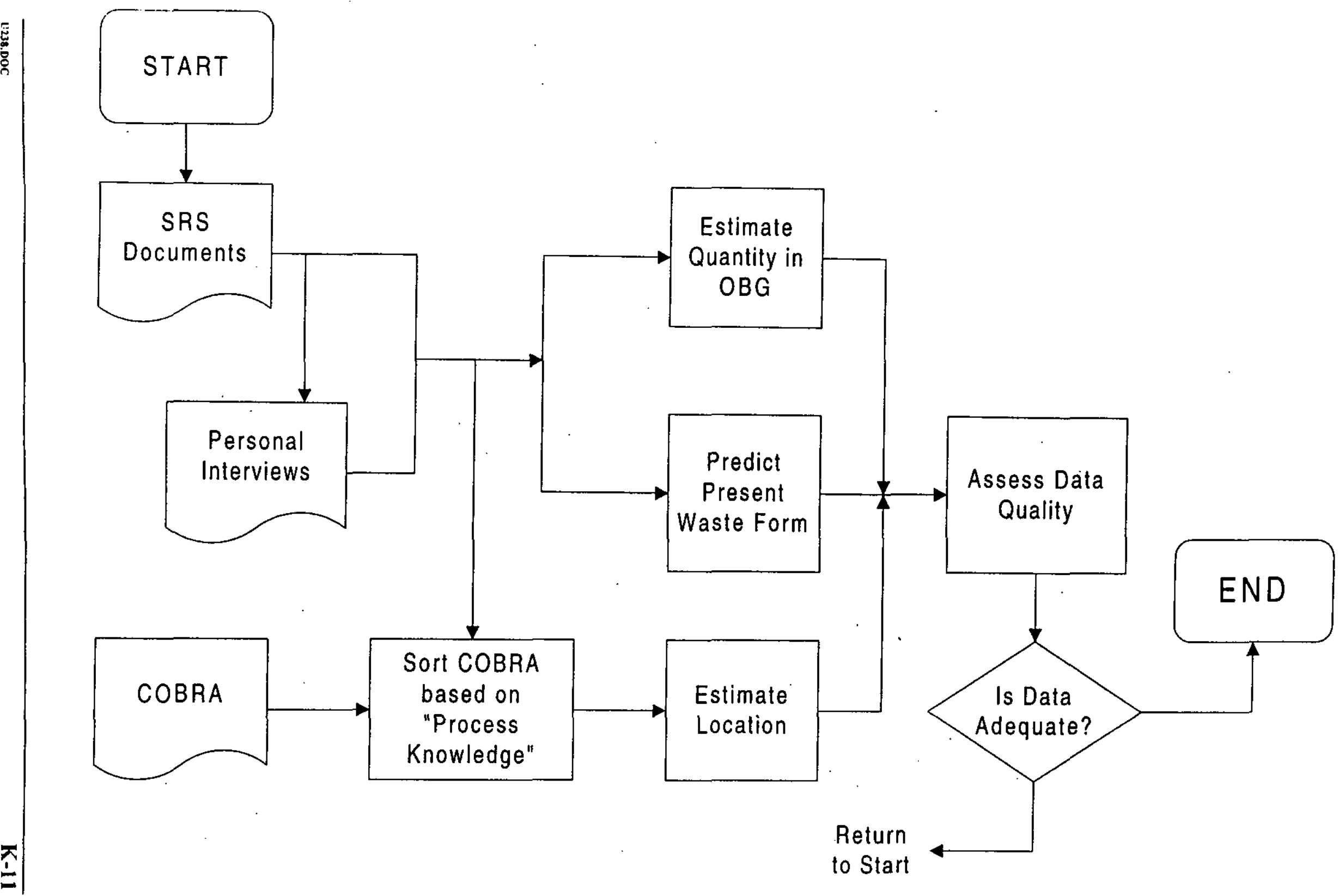

Figure 1-1. Inventory Estimate Process Flow Diagram 


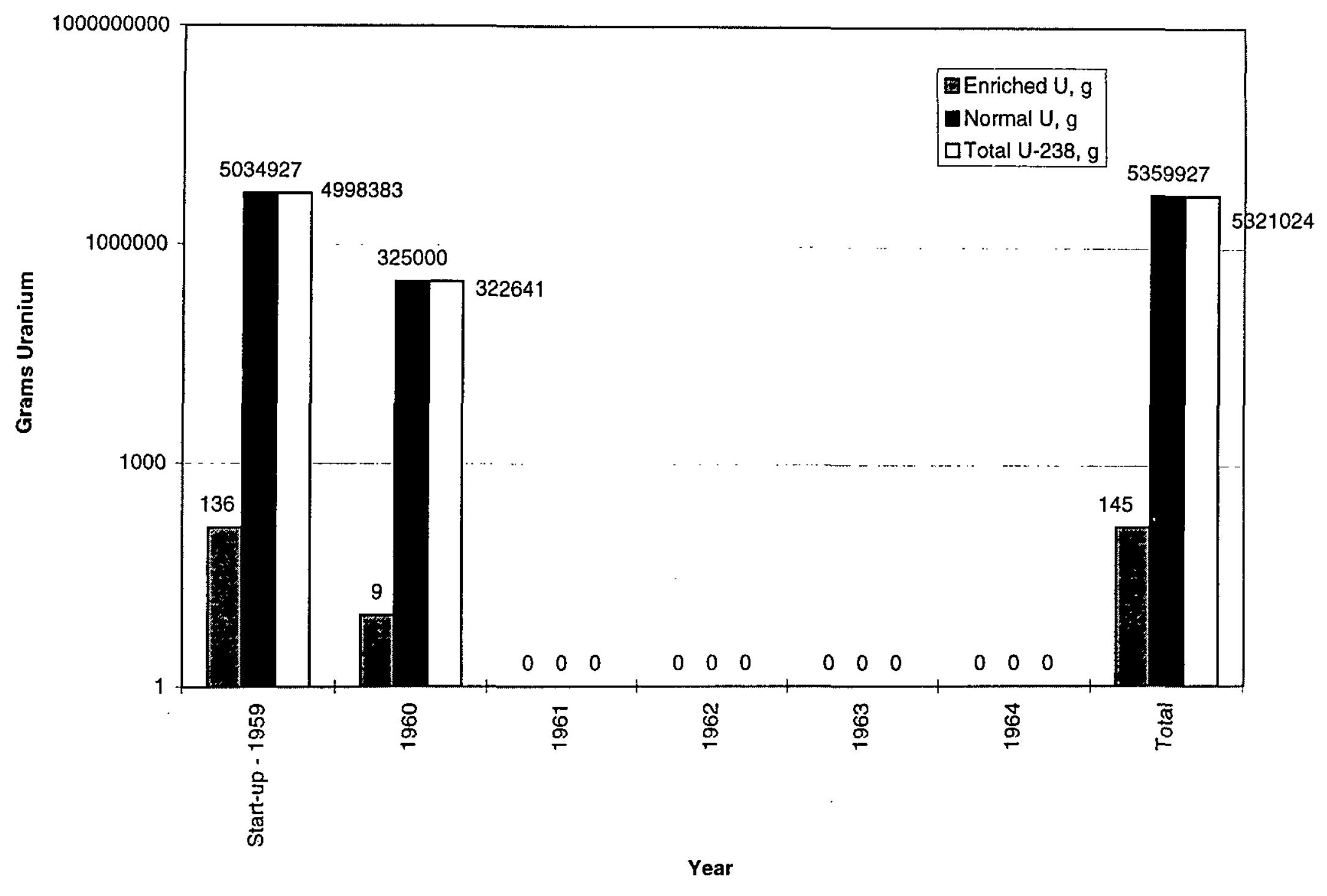

Figure 3-1. Health Protection Data Uranium to Burial Ground through 1964 


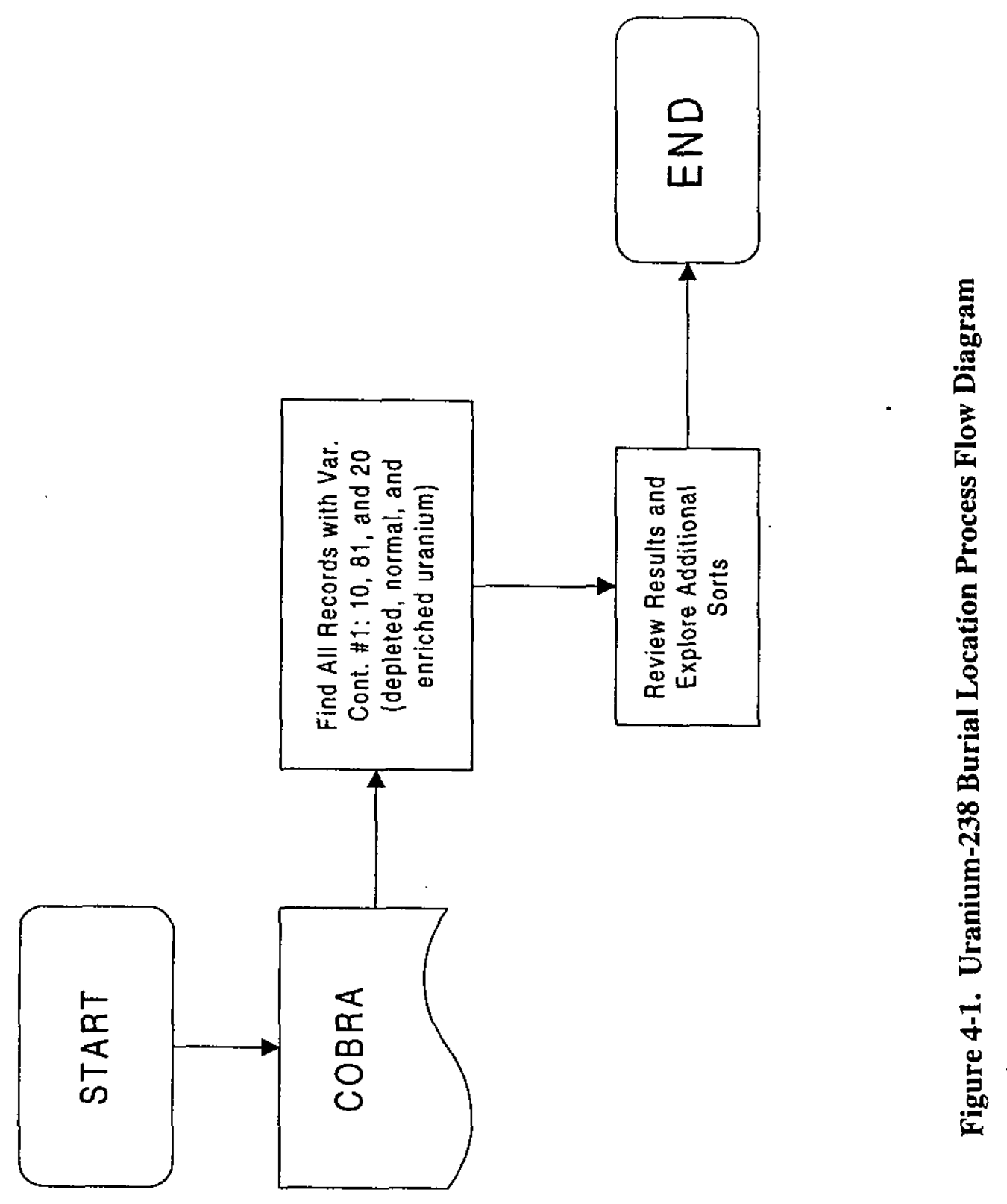




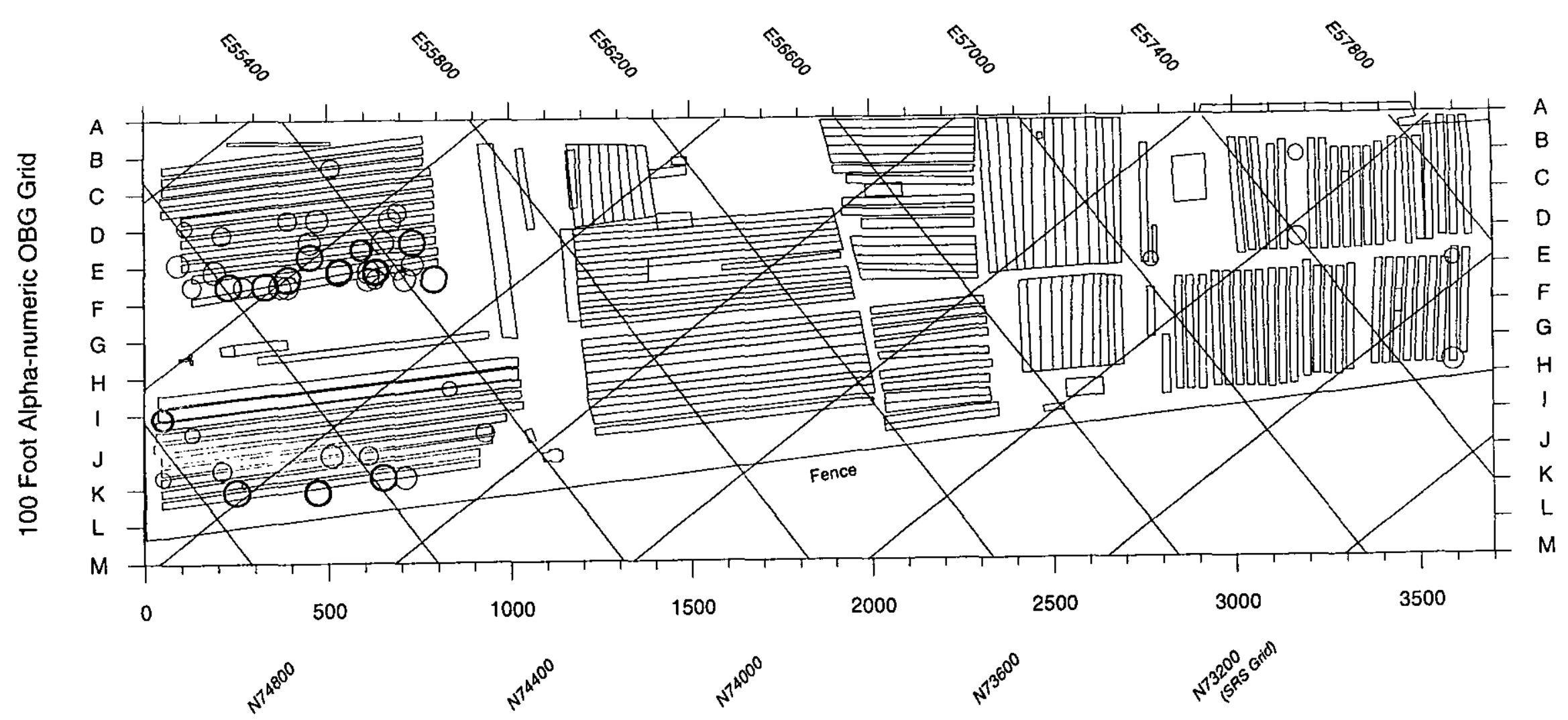

Figure 4-2. X, Y Locations for Depleted Uranium Burials in ORWBG Database (Variety of Contamination \#1 = "10") 


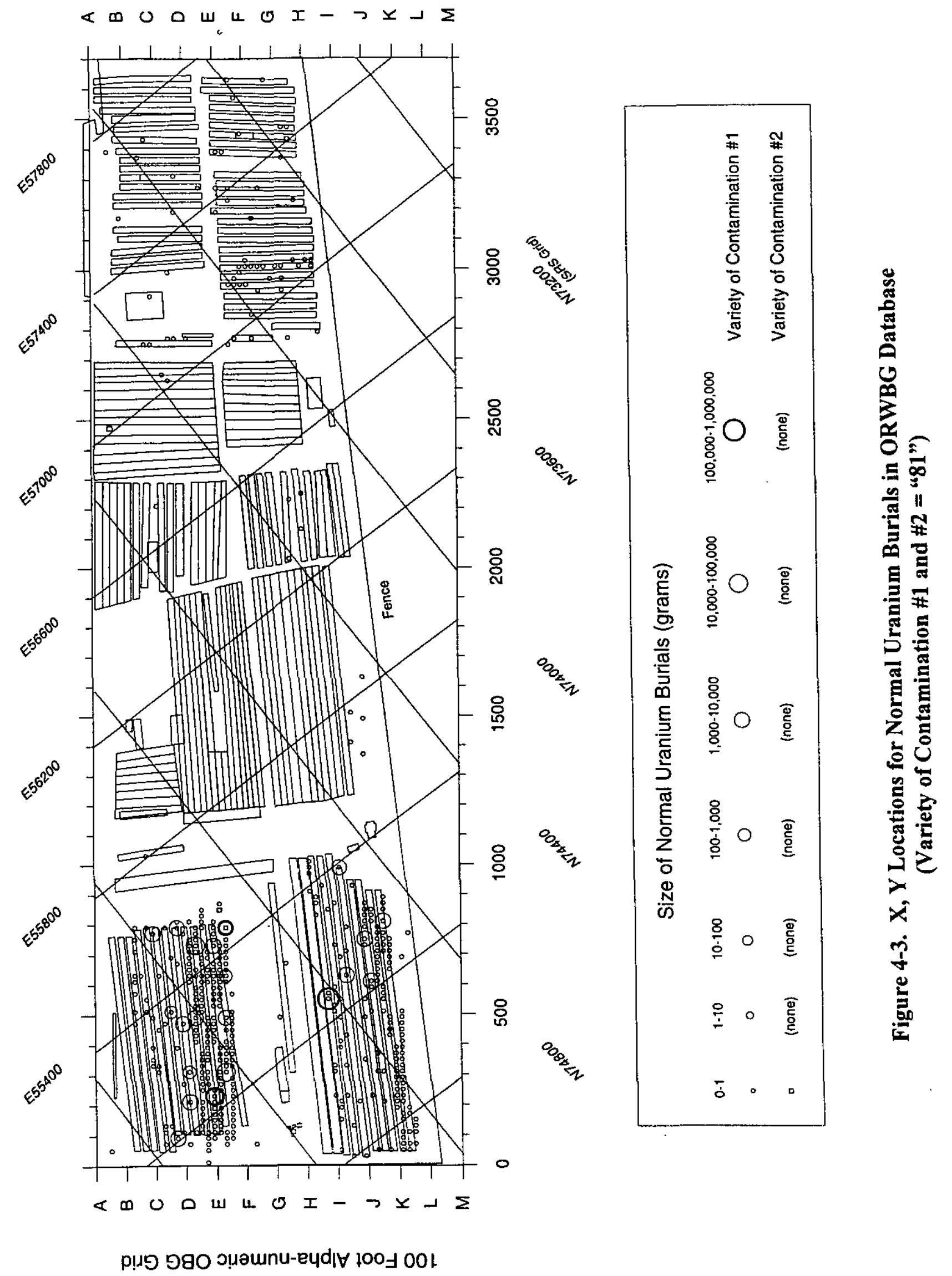



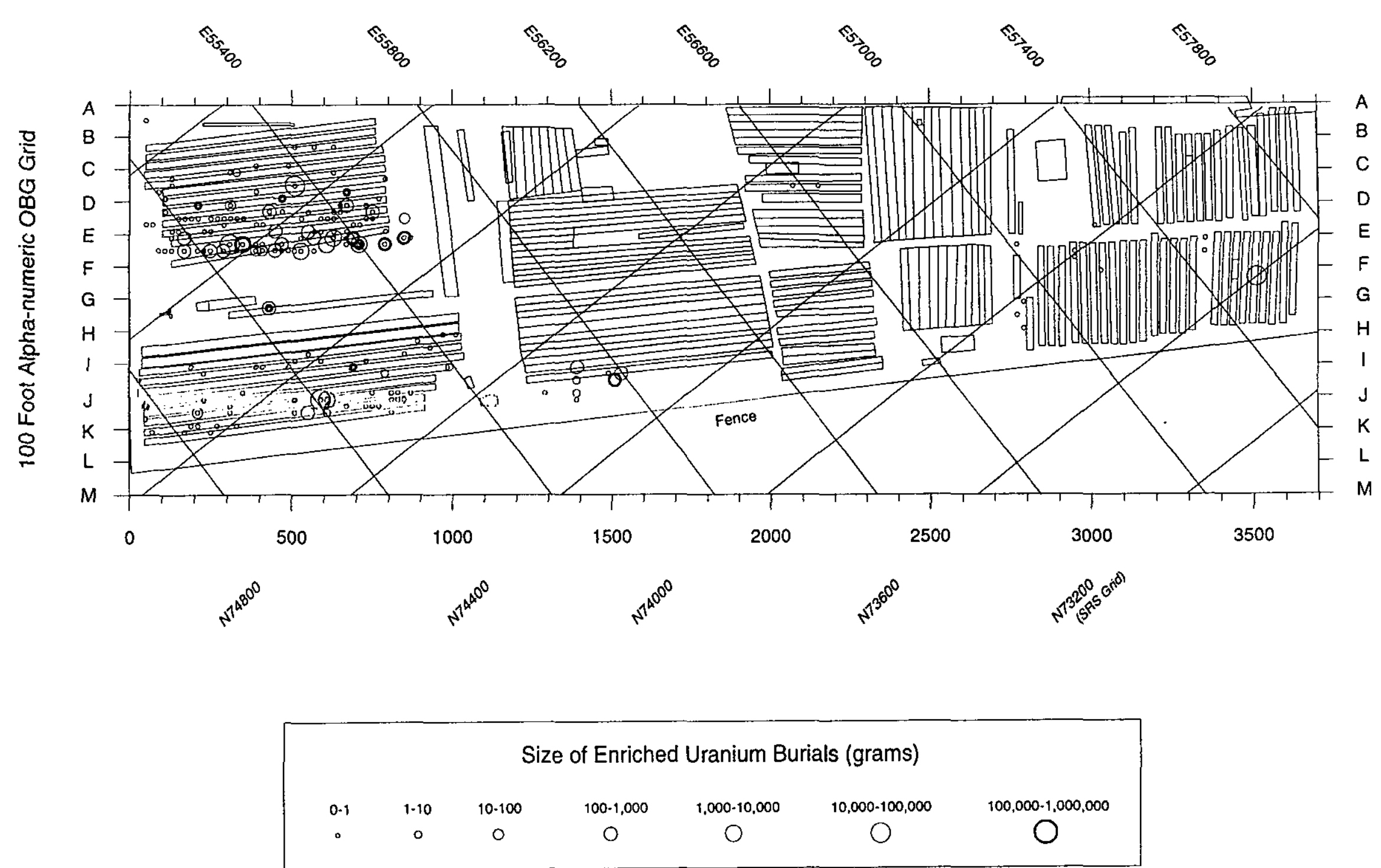

Figure 4-4. X, Y Locations for Enriched Uranium Burials in ORWBG Database (Variety of Contamination \#1 = "20") 


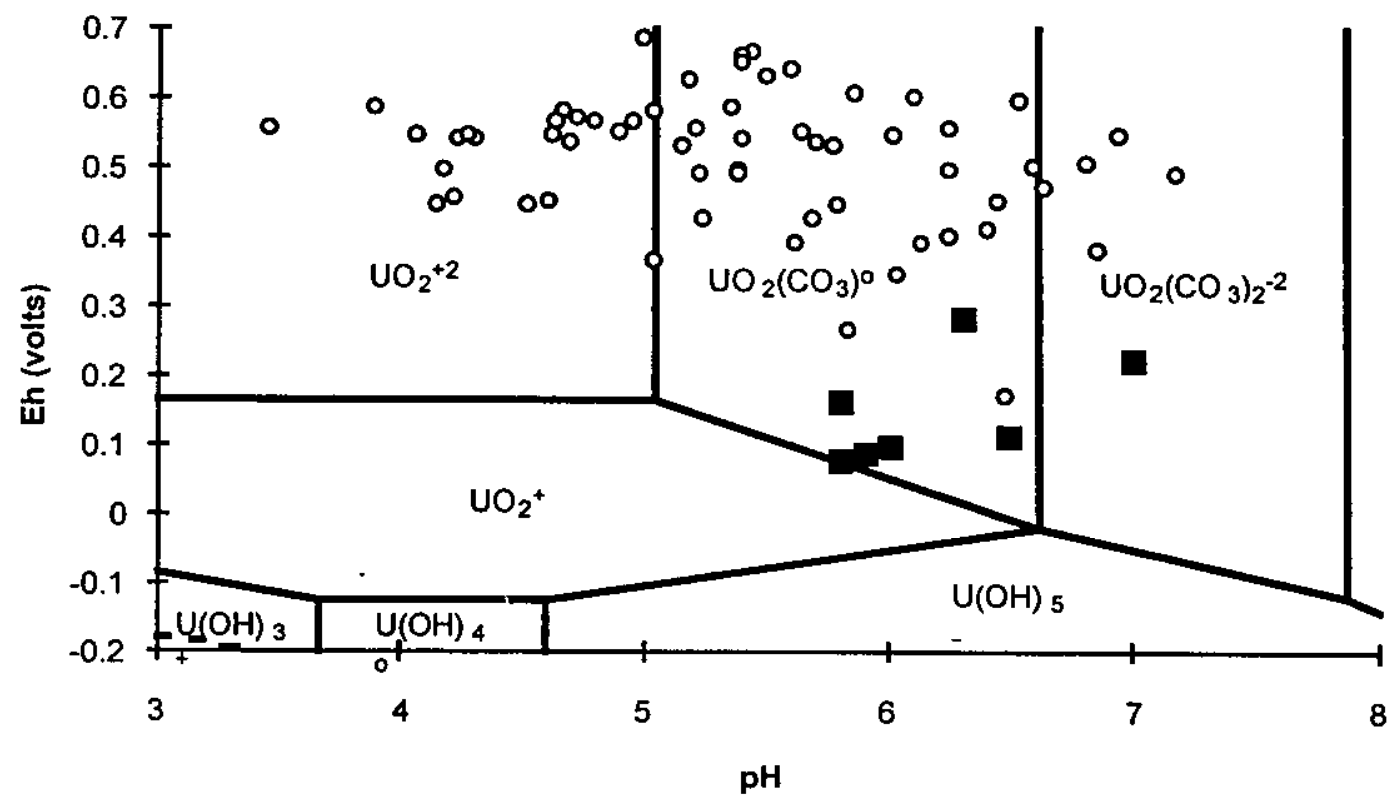

Figure 6-1: Eh-pH Diagram Showing Fields of Dominance of Aqueous Species of Uranium. Circles represent analyses of grid well groundwater (Ryan, 1983) and squares represent analyses of trench wells (Hoeffner, 1985). Data for diagram construction from Langmuir (1978). $\mathrm{P}^{\mathrm{CO} 2}=10^{-2} \mathrm{~atm}$ 


\section{Schoepite Solubility}

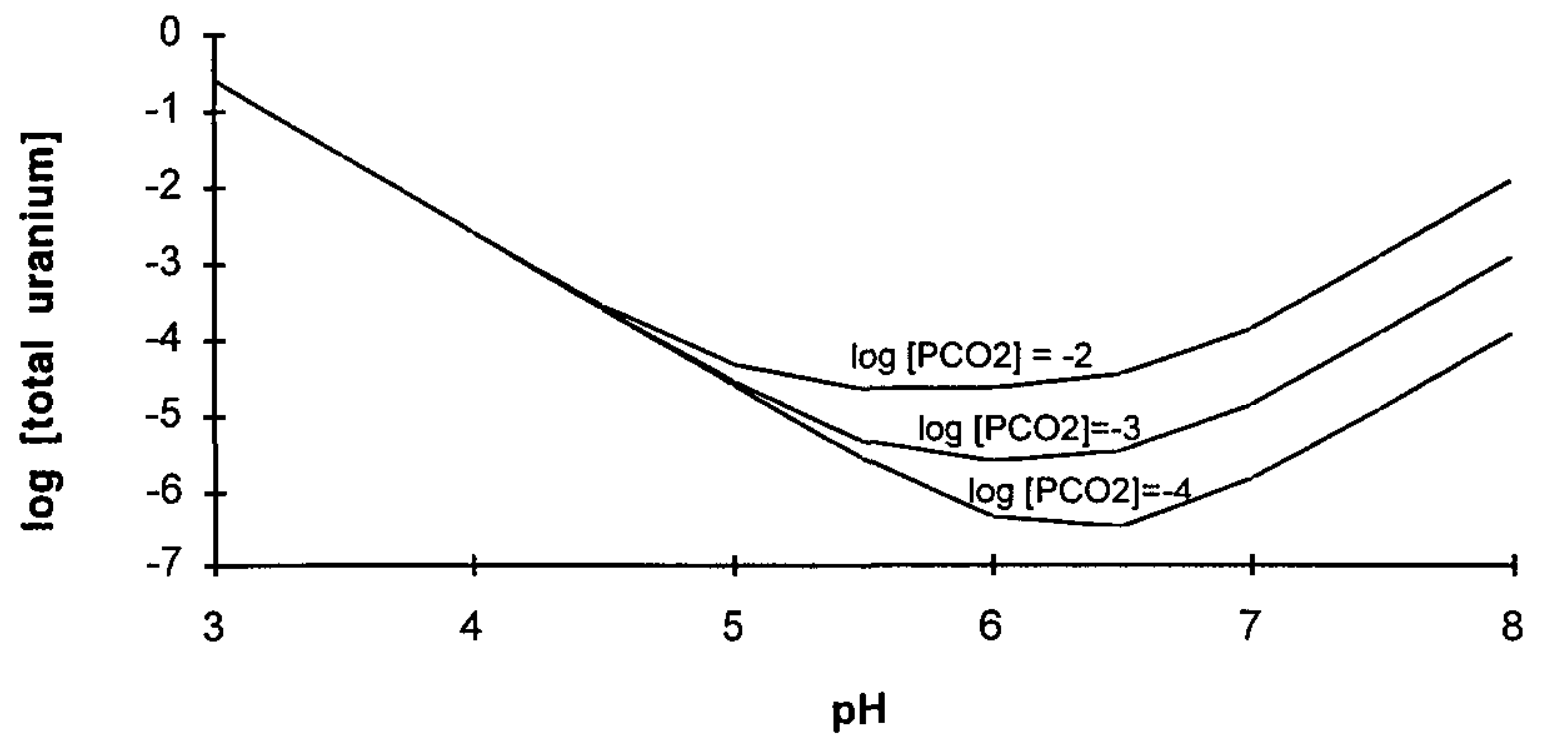

Figure 6-2. Solubility Curve for Schoepite $\left(\mathrm{UO}_{2}(\mathrm{OH})_{2} \cdot \mathrm{H}_{2} \mathrm{O}\right)$ with $\mathrm{pH}$ and Varying $\mathrm{PCO}_{2}$. Data for curve construction from Langmuir (1978) 


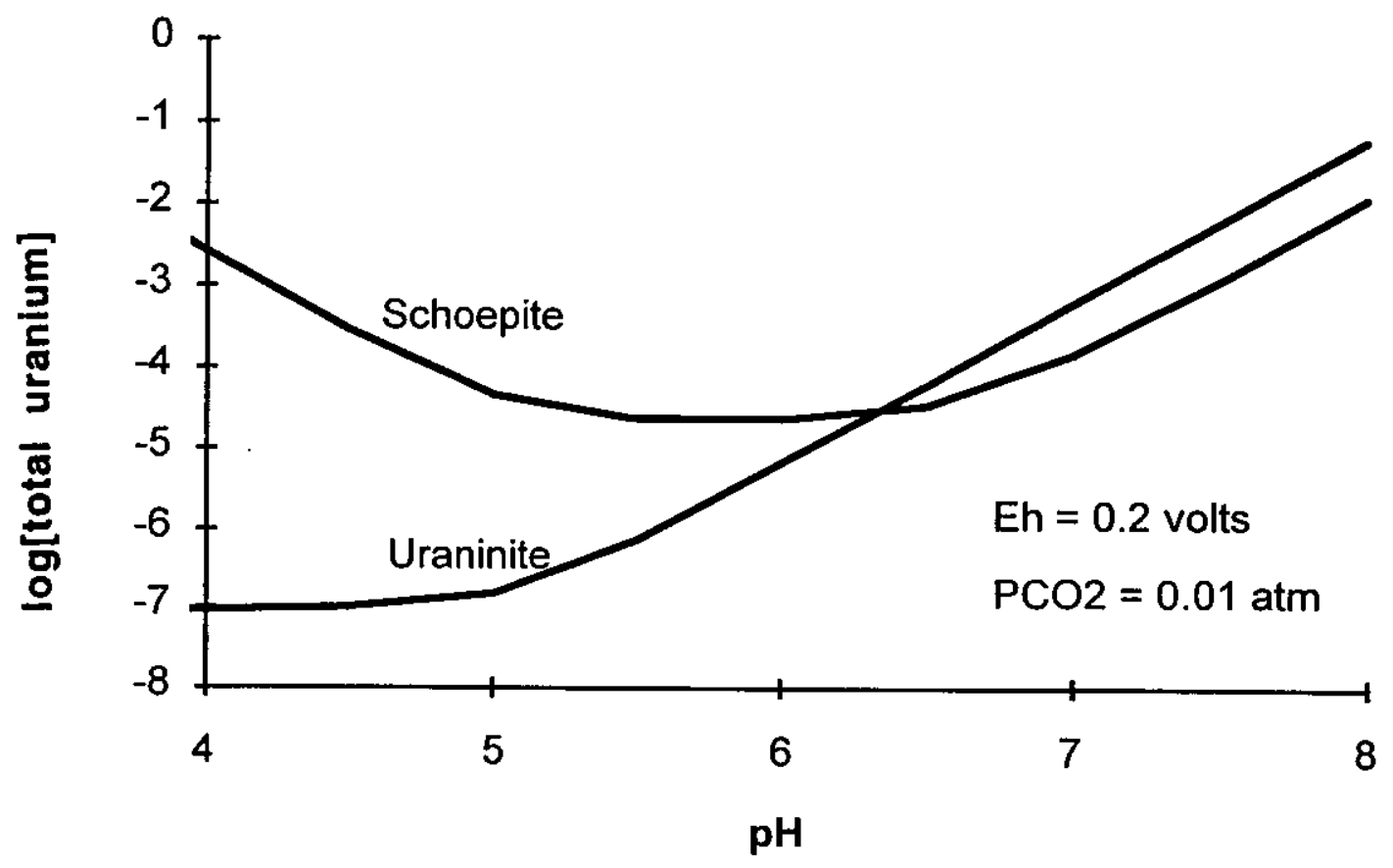

Figure 6-3. Solubility of Uraninite $\left(\mathrm{UO}_{2}\right)$ Compared to That of Schoepite $\left(\mathrm{UO}_{2}(\mathrm{OH})_{2} \cdot \mathrm{H}_{2} \mathrm{O}\right)$. Data for diagram construction from Langmuir (1978) 
Table 2-1. Alpha Inventory in OSTs

Uranium-238 is not listed as a predominant radionuclide in any of the tanks, but small amounts are present in Tanks 6, 7, 9, 12, and 15 (see Section 3.0)

\begin{tabular}{|ccl|}
\hline Tank \# & Alpha Inventory, Ci & Predominant Radionuclides \\
\hline 1 & 0.82 & $\mathrm{Cm}-224,66 \%$ \\
\hline 2 & 4.72 & $\mathrm{Pu}-238,88 \%$ \\
\hline 3 & 0.28 & $\mathrm{Pu}-238,70 \%$ \\
\hline 4 & 0.54 & $\mathrm{Pu}-238,67 \%$ \\
\hline 5 & 19.78 & $\mathrm{Cm}-244,93 \%$ \\
\hline 6 & 1.80 & $\mathrm{Cm}-244,80 \%$ \\
\hline 7 & 0.75 & $\mathrm{Pu}-238,77 \%$ \\
\hline 8 & 0.17 & No Data \\
\hline 9 & 3.81 & $\mathrm{Cm}-244,30 \% ; \mathrm{Pu}-239,30 \%$ \\
\hline 10 & 2.33 & $\mathrm{Pu}-238,50 \%$ \\
\hline 11 & 6.43 & $\mathrm{Cm}-244,56 \%$ \\
\hline 12 & 3.81 & $\mathrm{Pu}-238,63 \%$ \\
\hline 13 & 13.72 & $\mathrm{Pu}-238,97 \%$ \\
\hline 14 & 3.64 & $\mathrm{Pu}-238,98 \%$ \\
\hline 15 & 31.86 & $\mathrm{Cm}-244,63 \%$ \\
\hline 16 & 2.03 & $\mathrm{No} \mathrm{Data}$ \\
\hline 17 & 24.55 & $\mathrm{Pu}-239,60 \%$ \\
\hline 18 & 1.84 & $\mathrm{Pu}-238,30 \% ; \mathrm{Pu}-239,30 \% ; \mathrm{Np}-237,30 \%$ \\
\hline 19 & 10.19 & $\mathrm{Cm}-244,65 \%$ \\
\hline 20 & 0.001 & $\mathrm{Pu}-238,70 \%$ \\
\hline 21 & 0.001 & $\mathrm{No} \mathrm{Data}$ \\
\hline 22 & 0.001 & $\mathrm{Cm}-244,70 \%$ \\
\hline
\end{tabular}

Source: Mason (1996), Tables 23 and 26 
Table 3-1. The Sources of Inventory Estimates for Uranium in the Old Burial Ground

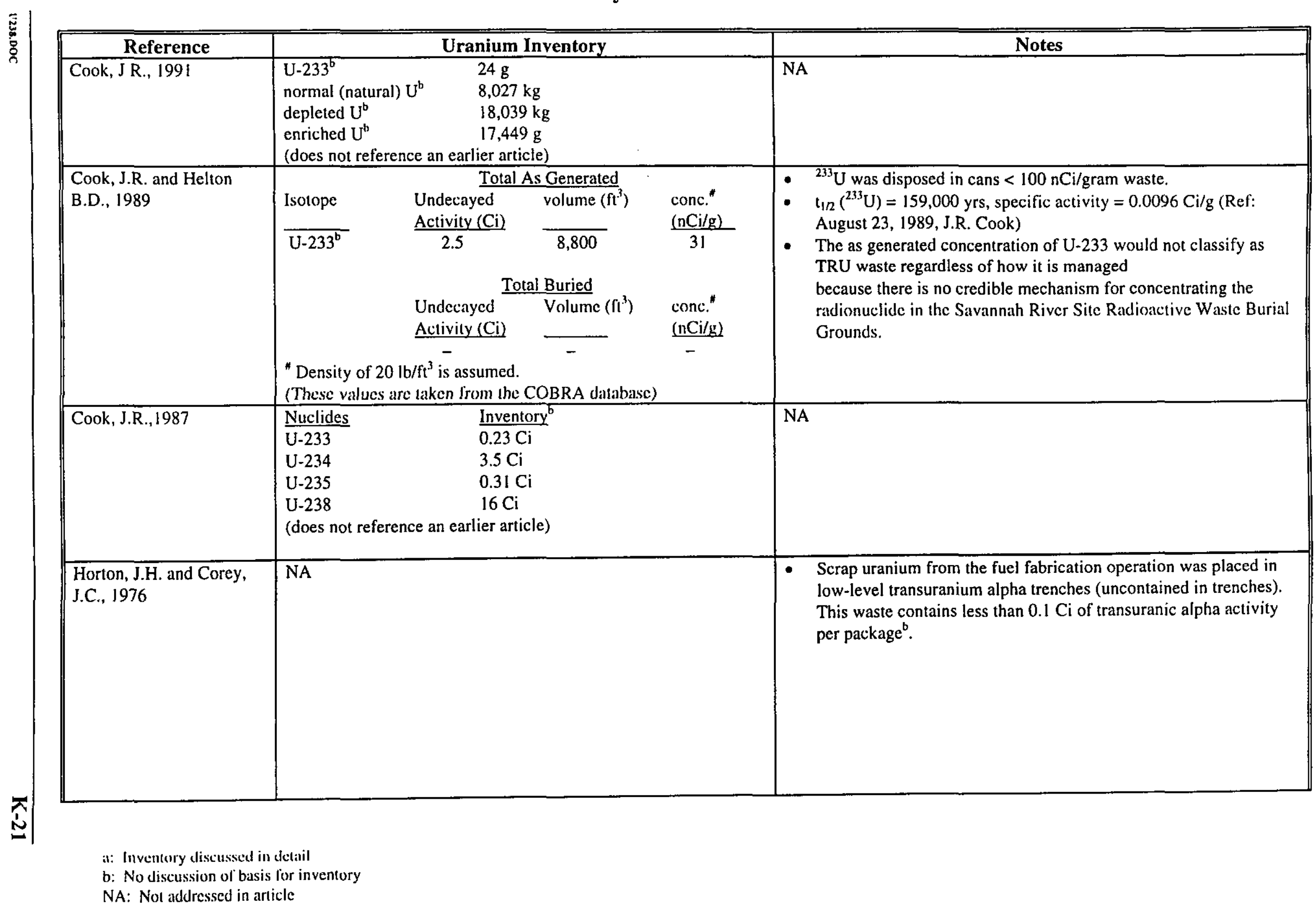



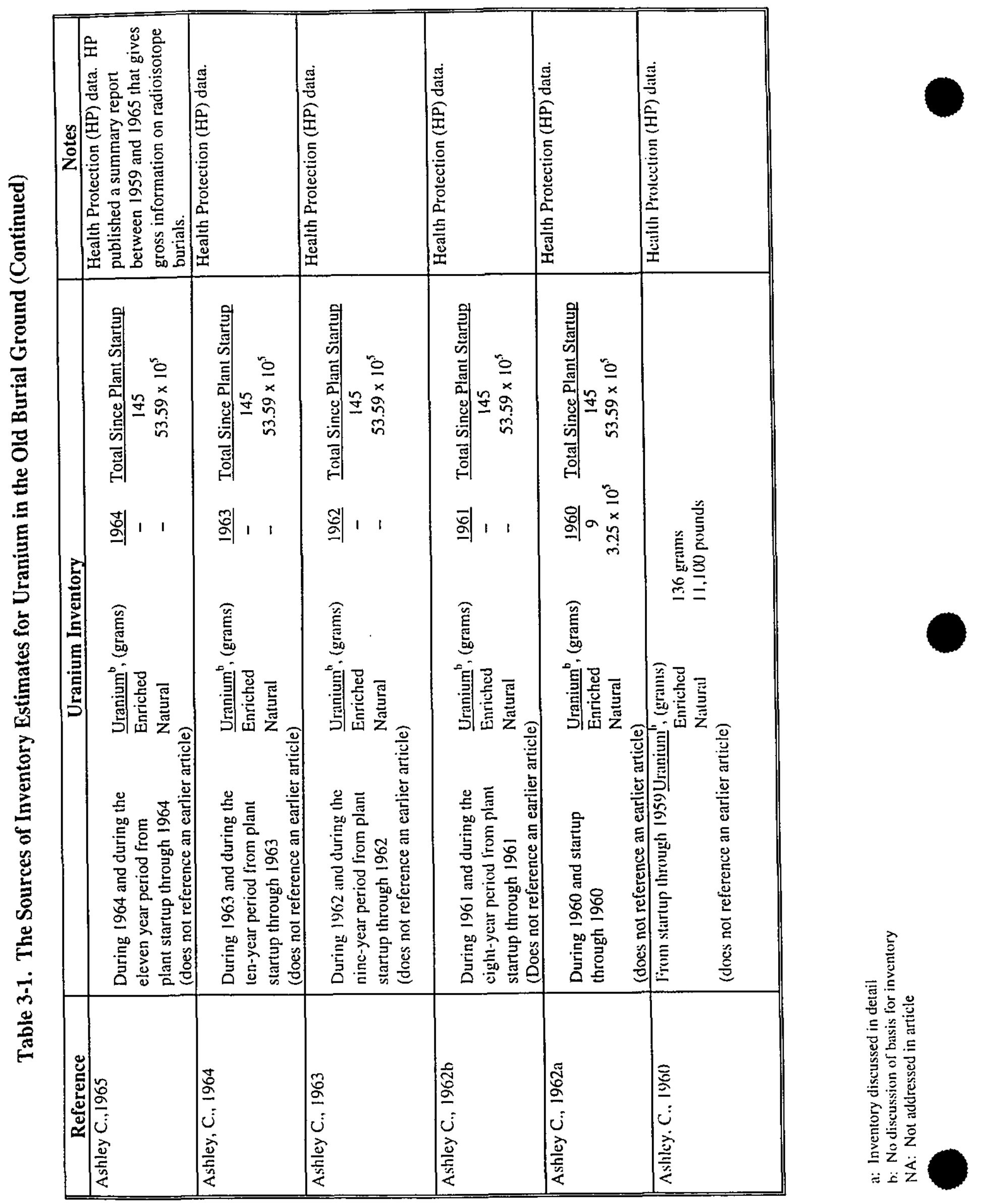

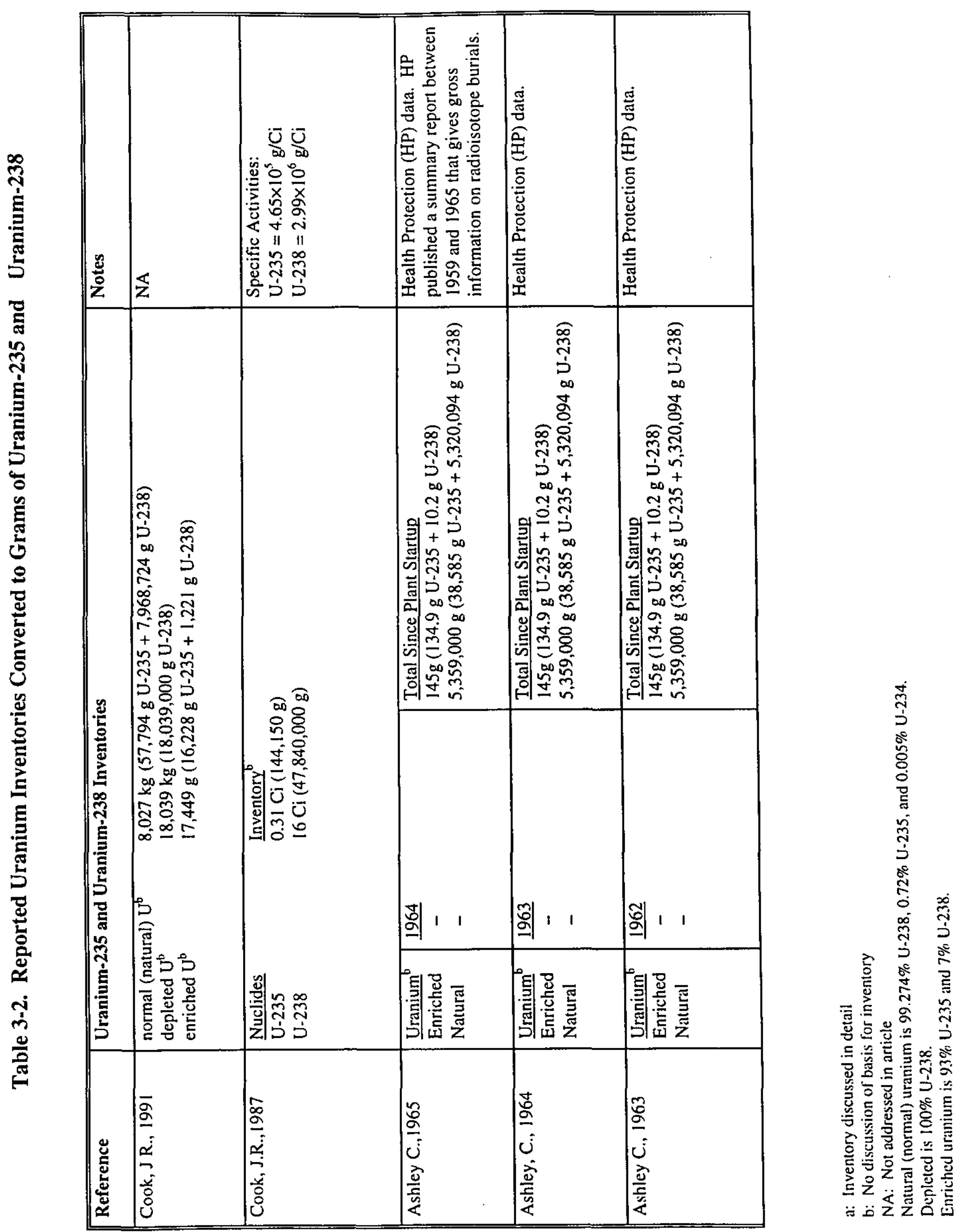
Table 3-2. Reported Uranium Inventories Converted to Grams of Uranium-235 and - Uranium-238 (Continued)

\begin{tabular}{|c|c|c|c|c|}
\hline Reference & Uranium-2 & 5 and Uranium-238 & & Notes \\
\hline Ashley C., 1962b & $\begin{array}{l}\text { Uranium }^{b} \\
\text { Enriched } \\
\text { Natural }\end{array}$ & $\begin{array}{l}\frac{1961}{-} \\
-\end{array}$ & $\begin{array}{l}\text { Total Since Plant Startup } \\
145 \mathrm{~g}(134.9 \mathrm{~g} \mathrm{U}-235+10.2 \mathrm{~g} \mathrm{U}-238) \\
5,359,000 \mathrm{~g}(38,585 \mathrm{~g} \mathrm{U}-235+5,320,094 \mathrm{~g} \mathrm{U}-238)\end{array}$ & Health Protection (HP) data. \\
\hline Ashley C., 1962a & $\begin{array}{l}\frac{\text { Uranium }}{\text { Enriched }} \\
\text { Natural }\end{array}$ & $\begin{array}{l}\frac{1960}{9 \mathrm{~g}(8.37 \mathrm{~g} \mathrm{U}-235+} \\
\quad 0.63 \mathrm{~g} \mathrm{U}-238) \\
325,000 \mathrm{~g} \\
(2,340 \mathrm{~g} \mathrm{U}-235+ \\
322,641 \mathrm{~g} \mathrm{U}-238)\end{array}$ & $\begin{array}{l}\frac{\text { Total Since Plant Startup }}{145 \mathrm{~g}(134.9 \mathrm{~g} \mathrm{U}-235+10.2 \mathrm{~g} \mathrm{U}-238)} \\
5,359,000 \mathrm{~g}(38,585 \mathrm{~g} \mathrm{U}-235+5,320,094 \mathrm{~g} \text { U-238) }\end{array}$ & Health Protection (HP) data. \\
\hline Ashley, C., 1960 & $\begin{array}{l}\text { Uranium }^{6} \\
\text { Enriched } \\
\text { Natural }\end{array}$ & $\begin{array}{l}136 \text { grams }(126.5 \mathrm{~g} \\
11,100 \text { pounds }(36,25\end{array}$ & $\begin{array}{l}5 \mathrm{~g} \mathrm{U}-238) \\
5+4,998,373 \mathrm{~g} \mathrm{U}-238)\end{array}$ & Health Protection (HP) data. \\
\hline
\end{tabular}

a: Inventory discussed in detail

b: No discussion of basis for inventory

NA: Not addressed in article

Natural (normal) uranium is $99.274 \% \mathrm{U}-238,0.72 \% \mathrm{U}-235$, and $0.005 \% \mathrm{U}-234$

Depleted is $100 \%$ U-238.

Enriched uranium is $93 \%$ U-235 and $7 \%$ U-238. 
APPENDIX L

CONSTITUENT OF INTEREST:

CARBON-14

CIATOC.DOC 
(This page intentionally left blank) 


\section{TABLE OF CONTENTS}

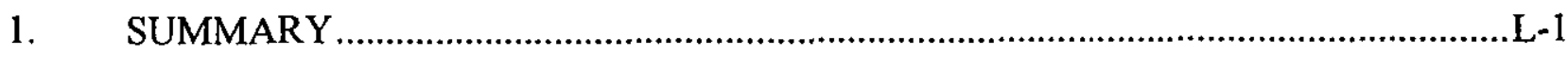

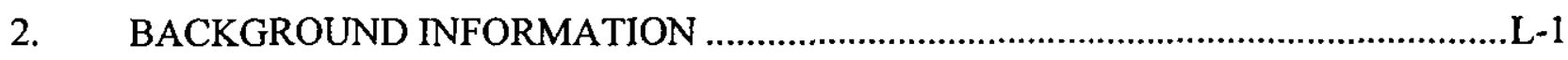

$2.1 \quad$ Origin of Carbon-14 at SRS..............................................................................

2.2 Carbon-14 from Spent Deionizer Resins ............................................................

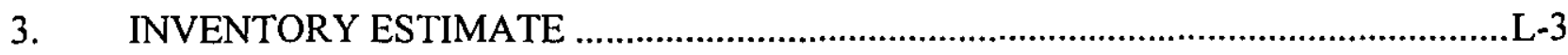

3.1 Range of Inventory Estimates ....................................................................

3.1.1 Trenches ..........................................................................................

3.1.2 Carbon-14 in the Old Solvent Tanks ....................................................-5

3.2 Best Estimate of Carbon-14 in Burial Grounds ...................................................-5

3.3 Uncertainties Associated with Carbon-14 Inventory Estimate .............................. -6

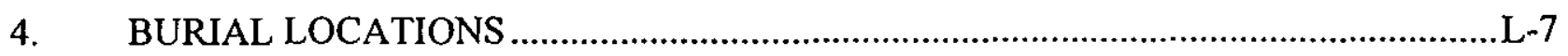

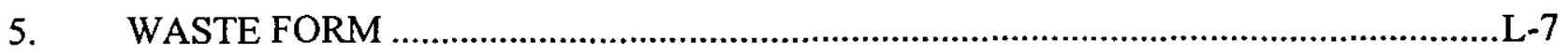

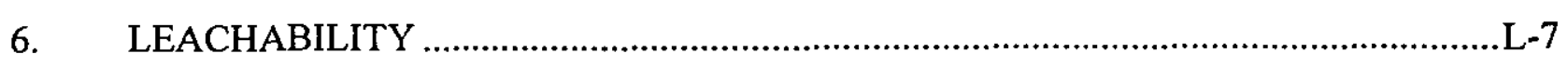

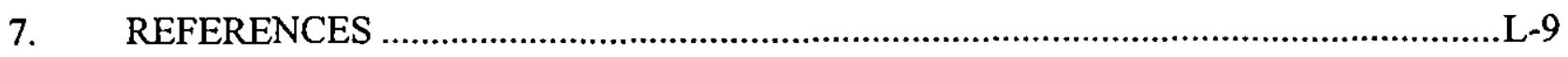




\section{LIST OF FIGURES}

Figure 1-1. Inventory Estimate Process Flow Diagram..................................................... L-11

Figure 3-1. Range of Carbon-14 Estimates in the ORWBG .................................................12

Figure 4-1. Carbon-14 Burial Location Process Flow Diagram ...............................................13

Figure 4-2. $\quad \mathrm{X}, \mathrm{Y}$ Locations for all Carbon-14 Locations in the ORWBG Database ............... L-14

\section{LIST OF TABLES}

Table 3-1. The Sources of Inventory Estimates for Carbon-14 in the ORWBG.................L-15

Table 3-2. Records for all Carbon-14 Burials in ORWBG ..................................................18 


\section{CONSTITUENT OF INTEREST - CARBON-14}

\section{SUMMARY}

Carbon-14 was generated at the Savannah River Site (SRS) primarily by the $\mathrm{O}^{17}(\mathrm{n}, \alpha) \mathrm{C}^{14}$ reaction in reactor moderators. Some of the carbon- 14 escaped as ${ }^{14} \mathrm{CO}$ and ${ }^{14} \mathrm{CO}_{2}$ to the blanket gas and was vented to the stack, but most remained in solution. To maintain moderator purity, carbon-14 was removed in ion exchange resins in demineralizer units. When a demineralizer unit was exhausted, the ion exchange resin was sent to the Solid Waste Disposal Facility (SWDF) for burial (Carlton et al., 1993).

Carbon-14 is considered to be a possible constituent of interest because it is a mobile, long-lived, beta-emitting radionuclide that was present in wastes sent to the SRS burial grounds. Most of the source term in the Old Radioactive Waste Burial Ground (ORWBG) is likely due to the bicarbonate anion $\left(\mathrm{HC}^{14} \mathrm{O}_{3}{ }^{-}\right)$that is sorbed on mixed-bed ion exchange resin used to purify the reactor moderator. During the first ten years of SRS operations, the resin was disposed of directly into trenches in a slurry form. Later, the resin was sealed and disposed of inside the stainless steel vessels used to support the resin column during the purification operation. In the early 1970 s, a limited amount of resin was removed from the support shell and buried in concrete casks.

The best estimate for the carbon-14 inventory at the ORWBG is 3,778 curies (Ci).

Figure 1-1 presents the process used to develop the inventory and burial locations. The Computerized Burial Record Analysis (COBRA) database was used to determine the locations and quantity estimates of carbon-14 burials.

\section{BACKGROUND INFORMATION}

\subsection{Origin of Carbon-14 at SRS}

The SRS produced carbon-14 by various reactions in the fuel, moderator, and core construction material in the five production reactors. The mechanisms include neutron-induced reactions $[(n, p) ;(n, \alpha)$; and $(n, \gamma)]$ and ternary fission (Hayes and MacMurdo, $1977)$. The (n,p) reaction produces carbon-14 by reaction of neutrons with nitrogen- 14 . Nitrogen occurs as an impurity in the fuel, as dissolved gas, as nitric acid, as ammonium hydroxide (used for $\mathrm{pH}$ control purposes in the moderator), and as an impurity in the core material. Small quantities of carbon-14 are also produced by the (n,p) reaction with nitrogen 
in the air in the annular cavity outside the reactor tank. The $(n, \alpha)$ reaction occurs primarily with oxygen- 17 in the moderator. The $(n, \gamma)$ reaction with carbon- 13 produces a negligible amount of carbon-14 in SRS reactors. It is more significant in graphite-moderated reactors (Carlton et al., 1993).

Small quantities of carbon-14 were also produced at SRS by the test reactors and neutron activation analyses. The activity levels of radiocarbon from these sources are insignificant when compared to the activity levels in irradiated nuclear fuel, targets, and moderators (Carlton et al., 1993). Radiocarbon is a collective term for radioactive isotopes of the element carbon. However, carbon-14 is by far the most important of these since its 5,715-year half-life is the longest.

Certain fuels irradiated at offsite noncommercial facilities were shipped to the SRS for reprocessing. These fuels contained varying amounts of carbon-14, depending on the fuel type and irradiation history (Carlton et al., 1993).

Lesser quantities of radiocarbon have been purchased from offsite vendors to use as standards for calibration of analytical instruments, to determine chemical yield in analytical chemical procedures, and as tracers in research studies at the Savannah River Ecology Laboratory (Carlton et al., 1993).

\subsection{Carbon-14 from Spent Deionizer Resins}

The main source of carbon-14 was spent deionizers used to maintain reactor moderator purity (Cook, 1989). The moderator and primary coolant in SRS reactors is heavy water, which is circulated around the fuel and target elements in the reactor core. The moderator decreases the kinetic energy (slows the speed) of neutrons emitted by the fission process. Slow neutrons have a greater probability for interaction with fuel and target materials than fast neutrons. The moderator functions as the primary coolant to remove heat from fuel and target elements. The heat is then transferred from the moderator to the secondary coolant by heat exchangers. SRS reactors used either river or pond water as the secondary coolant in the heat exchangers.

Some of the carbon-14 formed in the moderator escaped as ${ }^{14} \mathrm{CO}$ and ${ }^{14} \mathrm{CO}_{2}$ to the blanket gas and was vented to the stack. Most of the radiocarbon remained in solution and was removed from the moderator by ion exchange resins in demineralizer units used to maintain moderator purity. Measurements in 1972-1973 indicated that about $85 \%$ of the carbon-14 generated in the moderator reached the deionizer resin and about $15 \%$ was released to the 
atmosphere from the reactor stack (Holmes, W.G., 1988). When a demineralizer unit was exhausted, the ion exchange resin was sent to the SWDF for burial (Carlton et al., 1993).

During the first ten years of SRS operations, deionizer resins were dumped in slurry form directly into ORWBG trenches (Towler, Jr., 1989 in WSRC, 1992). Later, the resins were disposed of in stainless steel vessels. The normal practice was to displace the heavy water with light water, seal the stainless steel columns with blank flanges, and bury the whole unit in trenches in the radioactive waste burial grounds.

In the early 1970s, during a campaign by the Reactor Department to recycle deionizer shells, some resin was removed from the stainless steel shells and repackaged in concrete casks for burial. An unknown number of concrete casks containing "loose" resin were shipped to the burial grounds. However, in 1973, removal and repackaging the resin was discontinued and the former practice of burial in stainless steel shells resumed. In more recent years, concern about the potential release of carbon-14 to groundwater from buried resin has led to above-ground storage of the sealed demineralizer columns in H-Area (Carlton et al., 1993).

\section{INVENTORY ESTIMATE}

\subsection{Range of Inventory Estimates}

\subsubsection{Trenches}

Early estimates of the amounts of carbon-14 disposed in trenches at the SRS did not include radiocarbon in spent deionizer resins. As this is the primary source of carbon-14, the amounts were underestimated (Cook, 1989). Cook's (1987) initial estimate for the amount of carbon-14 buried in 643-G was 5.4E-03 Ci; Jaegge et al. (1987) presented a similar estimate of $6.6 \mathrm{E}-03 \mathrm{Ci}$ in the Radioactive Waste Burial Grounds. Subsequent estimates that did consider the contribution of spent deionizer resins are approximately six orders of magnitude higher.

Several inventories of carbon-14 have been developed from the amount of spent resin either produced or buried. Because burial ground records do not tabulate data for carbon-14 disposal, the carbon-14 inventory has been estimated from the amount of resin using a factor of $0.35 \mathrm{Ci}$ of carbon-14 per cubic foot of waste resin (Cook, 1989; attachment I, memorandum from W.G. Holmes to J.L. Steele dated June 28, 1988). Hayes (pers. comm., in Baumann, 1991) however, reported that $0.47 \mathrm{Ci}$ of carbon-14 is in one cubic foot of waste 
resin. Both these factors were determined from laboratory analyses of reactor moderator resin.

Holmes (1988) employed two methods to estimate the amount of carbon-14 shipped to the burial grounds (643-E and 643-7E/28E) in moderator deionizers. In the first method, COBRA burial records were reviewed to identify shipments of spent deionizers to the burial grounds between $1 / 1 / 53$ and $12 / 31 / 87$. The number of shipments obtained from COBRA records yielded an estimated $2,900 \mathrm{Ci}$ of carbon-14, assuming that the waste contained 0.35 $\mathrm{Ci}$ of carbon-14 per cubic foot of resin (Holmes, W.G., 1988).

In Holmes' (1988) second method, the generation of carbon-14 in the moderator of all SRS reactors via the $(n, \alpha)$ reaction with oxygen-17 was calculated to be about $8,000 \mathrm{Ci}$ (since startup). Of this amount, $6,800 \mathrm{Ci}$ were estimated to have been shipped to the burial grounds (643-E and 643-7E/28E) in spent deionizer resin (15\% of the amount generated was assumed to be released to the atmosphere). An estimated $5,100 \mathrm{Ci}$ of carbon-14 are believed to be buried in 643-G, assuming that carbon-14 picked up by the deionizers prior to 1972 ended up in the ORWBG. The remainder $(1,700 \mathrm{Ci})$ is believed to be buried in $643-7 \mathrm{G} / 28 \mathrm{G}$.

Holmes' (1988) review of COBRA records identified 19 potential shipments of "loose" resin (i.e., resins removed from the stainless steel shells and disposed of in concrete casks) between $9 / 72$ and $10 / 73$. Of these shipments, ten were buried in $643-\mathrm{G}$ and the remainder in 643-7G/28G (Holmes, W.G., 1988).

Corey (1988) reported two estimates of the amount of carbon-14 in the SRS radioactive burial grounds based on the results of a preliminary investigation by the Environmental Sciences Division. The first, a review of COBRA records by Jaegge and Chen (1988) yielded $2,900 \mathrm{Ci}$. The second, an assessment by Savannah River Laboratory personnel of the amount of carbon-14 generated in the moderator of SRS reactors and of the amount subsequently captured by the moderator deionizers, was estimated to be $6,800 \mathrm{Ci}$ (Cook, 1989; attachment I, memorandum from J. C. Corey to O.M. Morris dated August 2, 1988).

Cook (1989) revised his initial 1987 estimate to include spent deionizer resins. Using both reactor calculations and burial records, his revised estimate was $6,800 \mathrm{Ci}$ (Cook, 1989).

McIntyre and Wilhite (1988) estimate that 2,800 Ci of carbon-14 was disposed of at the ORWBG. The document does not compare the amount in vessels to the amount in soils. 
Dr. E.L. Albenesius, who formerly served as a research manager of SRL's Environmental Effects and Solid Waste Management Technology Divisions, reported in a 1992 discussion that the carbon- 14 inventory is $10,000 \mathrm{Ci}$ (Holcomb, 1992).

Flach et al. (1996) used a similar method to that used by Holmes (1988), calculating the carbon-14 inventory from the total volume of deionizer waste. Multiplying COBRA burials denoted by "DEION" or "RESIN" by $0.35 \mathrm{Ci} / \mathrm{ft}^{3}$ yielded $1,374 \mathrm{Ci}$. Flach et al. (1996) also cites the estimate of $5,100 \mathrm{Ci}$, which was derived by Holmes (1988) using Graves (1988). This figure was determined by estimating the amount of carbon-14 produced in reactor moderator via the $(n, \alpha)$ reaction with oxygen-17 $(8,000 \mathrm{Ci})$, and estimating the fraction that was buried in the ORWBG $(5,100 \mathrm{Ci})$. His best estimate is generated by multiplying "DEION" or "RESIN" volumes by $0.35 \mathrm{Ci} / \mathrm{ft}^{3}$ x $5,100 \mathrm{Ci} / 1,374 \mathrm{Ci}$.

Table 3-1 lists the sources of the inventory estimates for carbon-14 in the ORWBG. Figure 3-1 shows the range of carbon-14 estimates in the ORWBG.

\subsubsection{Carbon-14 in the Old Solvent Tanks}

Kolb (1978) reported concentrations of several constituents, including carbon, in the Old Solvent Tanks (OSTs). Sludge samples from Tanks S6 and S7 were analyzed by an unknown method. Carbon was among the list of detected analytes in both tanks. It was reported as 9 weight percent in Tank S6, and 15 weight percent in Tank S7. The form and activity, if any, of the carbon are unknown (see Table 36 in Mason, 1996). The amount of radiocarbon is thought to be negligible.

\subsection{Best Estimate of Carbon-14 in Burial Grounds}

In this investigation, a similar method to that used by Holmes (1988) and Flach et al. (1996) was used to calculate the best estimate of the carbon-14 inventory in the ORWBG. From process history, the amount of carbon-14 produced in a reactor moderator from startup to 1988 via the $(n, \alpha)$ reaction with oxygen- 17 is approximately $8,000 \mathrm{Ci}$. Assuming $15 \%$ of this amount was lost to the atmosphere during reactor operations, and no other releases occurred, the amount in the spent deionizer resin was $6,800 \mathrm{Ci}$. This represents the amount of carbon-14 in resin that was produced and buried over 36 years (startup to 1988). Because disposal operations at the ORWBG ceased in 1972 (after 20 years), the inventory of carbon-14 in the ORWBG is 56 percent of this amount. This amount, $3,778 \mathrm{Ci}$, represents the best estimate. This calculation assumes a similar average production/disposal rate of carbon-14 from start-up to 1972 and from 1972 to 1988 . 
The best estimate for individual burials is calculated from COBRA data, the total inventory amount $(3,778 \mathrm{Ci})$, and a modified activity of carbon-14 in spent deionizer resin. Individual burials of resin were identified by searching the COBRA database for "DEION", "DEION SHELL", "DEION VESSEL", "DE-IONIZER", "DEIONIZER CASK", "DEIONIZER CELL", "DEIONIZER RESIN", "DEIONIZER SHIELD", "SPENT RESIN", and "RESIN". This yielded 148 records. One of these records was interpreted as an error because the volume recorded $\left(16,000 \mathrm{ft}^{3}\right)$ was about three orders of magnitude greater than the other burial amounts. Omitting this suspected error yields a volume of $4,377 \mathrm{ft}^{3}$ of spent resin (147 records) (Table 3-2). If it is assumed that the activity of carbon-14 is $0.35 \mathrm{Ci}$ per cubic foot of spent resin (Hooker and Root, 1981), the amount of carbon-14 in the ORWBG would be $1,532 \mathrm{Ci}$. If it is assumed that the activity of carbon-14 is $0.47 \mathrm{Ci}$ per cubic foot of spent resin (Hayes in Baumann, 1991), the amount of carbon-14 in the ORWBG would be 2,057 $\mathrm{Ci}$. However, both these values are significantly less than the total inventory known from process knowledge $(3,778 \mathrm{Ci})$, and therefore, the estimate of carbon-14 in spent deionizer resin was modified. Assuming that the inventory of $3,778 \mathrm{Ci}$ is correct, and using the volume of spent deionizer resin in the ORWBG from COBRA records $\left(4377 \mathrm{ft}^{3}\right)$, the modified activity of carbon- 14 in spent deionizer resin is $3,778 \mathrm{Ci} / 4377 \mathrm{ft}^{3}$, or $0.86 \mathrm{Ci} / \mathrm{ft}^{3}$. The best estimate for the activity of individual burials is the volume of the resin, in $\mathrm{ft}^{3}$, multiplied by $0.86 \mathrm{Ci} / \mathrm{ft}^{3}$.

\subsection{Uncertainties Associated with Carbon-14 Inventory Estimate}

Several uncertainties are associated with the carbon-14 inventory estimate. The buried amount is based on process knowledge, which makes several assumptions, including the following:

- $15 \%$ of the amount of carbon-14 produced in the reactor moderator was lost to the atmosphere.

- All other carbon-14 remained in the deionizer resin and no other releases occurred.

- The average production/disposal rate of carbon-14 from start-up to 1972 and from 1972 to 1988 was the same.

- All errors in COBRA records have been identified, and records are complete. 


\section{BURIAL LOCATIONS}

COBRA burial records provide the date, location, and volumes of disposals of deionizer resin waste packages. Figure 4-1 outlines the steps taken to manipulate the database to locate the burials, and Figure 4-2 presents the burial locations. The activity of carbon-14 in each deionizer resin waste package was calculated using $0.86 \mathrm{Ci} / \mathrm{ft}^{3}$, as developed in Section 3.2.

\section{WASTE FORM}

During the first ten years of SRS operations, the resin was disposed of directly into trenches in a slurry form. This period was half of the lifetime of the ORWBG. For most of the second half of the operational history of the ORWBG, the resin was sealed and disposed of inside the stainless steel vessels used to support the resin column during the purification operation. For a brief time in the early 1970s, the resin was removed from the support shell and buried in concrete casks. Holmes (1988) identified 19 potential shipments of "loose" resin (i.e., resins removed from the stainless steel shells and disposed of in concrete casks) between $9 / 72$ and 10/73. Of these shipments, ten were buried in $643-\mathrm{G}$ and the remainder in $643-7 \mathrm{G} / 28 \mathrm{G}$ (Holmes, W.G., 1988).

Studies indicate that radiocarbon is present in the resin primarily as the bicarbonate ion $\left(\mathrm{HCO}_{3}\right)$.

\section{LEACHABILITY}

The leachability of Carbon-14 in the ORWBG is dependent on waste form. Demineralizing resins are the predominant waste form contributing carbon-14 to the ORWBG source term. For the first half of burial history these resins were disposed of uncontained. In the remainder of the ORWBG burial history, they were sealed in stainless steel containers and buried. If carbon-14 is easily leached from these waste forms, it's relative mobility and long half-life make carbon-14 a probable threat to groundwater under present conditions.

Carbon-14 occurs predominantly in the dissolved bicarbonate species $\left(\mathrm{HCO}_{3}{ }^{-}\right)$which is relatively mobile in groundwater. Mclntyre (1988) recommends using a $K_{d}$ value of $2 \mathrm{ml} / \mathrm{g}$ for modeling carbon-14 migration at the Mixed Waste Management Facility. This suggests that retardation of carbon-14 during migration from burial trenches to the water table will not be significant relative to the half life of carbon-14. Thus retardation coupled with decay will not significantly constrain concentrations of carbon-14 in groundwater beneath the ORWBG. 
Lysimeter experiments in the ORWBG suggest that carbon-14 is leachable from the uncontained resins. Eight years after installation of lysimeters containing demineralizing resin with carbon-14 source terms of $0.35 \mathrm{Ci}$, carbon- 14 concentrations in the leachate ranged from 0.06 to $0.89 \mu \mathrm{Ci} / \mathrm{l}$ (McIntyre, 1987). This represents a relatively high leaching rate of carbon-14.

Concentrations of carbon-14 in groundwater associated with the ORWBG are elevated. McIntyre and Wilhite (1988) analyzed for carbon-14 in 10 grid wells and observed concentrations that ranged from below detection to $580 \mathrm{pCi} /$. These are elevated, but not above the primary drinking water standard of $2000 \mathrm{pCi} / \mathrm{l}$. In addition, several of the downgradient perimeter wells of the BGO series have had elevated concentrations of carbon14 in recent years. Only one measurement at $2270 \mathrm{pCi} / \mathrm{l}$ has exceeded the drinking water standard.

Current concentrations of carbon-14 in groundwater, the leachability observed in lysimeter experiments, and the expected mobility of carbon-14 indicate that this contaminant of interest will threaten groundwater if current ORWBG conditions are maintained. 


\section{REFERENCES}

Baumann, E.W., 1991, Carbon-14 Removal for Disposal of Reactor Deionizer Resins (U), WSRC-TR-91-566, Westinghouse Savannah River Company, Savannah River Technology Center, Aiken, SC 29808, October 31, 1991.

Carlton, W.H., et al., 1993. Assessment of Radiocarbon in the Savannah River Site Environment (U), WSRC-TR-93-215, Westinghouse Savannah River Company, Savannah River Technology Center, Aiken, SC 29808, March 1993.

Cook, J.R., 1987. Technical Data Summary: Plan for Closure of the 643-G Burial Ground, DPSTD-87-2, E.I. du Pont de Nemours and Company, Aiken, SC.

Cook, J.R., 1989. Site-Specific Performance Assessment of Carbon-14 from Spent Deionizers in SRP Radioactive Waste Disposal Facilities, DPST-89-231, Technical Division Savannah River Laboratory, January 11, 1989.

Corey, J.C., 1988. Preliminary Findings of Carbon-14 in the Burial Grounds, Memo: J. C. Corey to O. M. Morris, August 2, 1988.

Flach, G.P., Lee, S.Y., Yu, A.D., 1996. Old Burial Ground COC Transport Modeling Progress Report, SRT-ESS-96-366, Memo Flach, G.P., et al, to Malanowski, R.W., Barradale, E.K., Lewis, C.M., August 12, 1996.

Graves, W.E., 1988. ${ }^{14}$ C Production in Moderator of SRP Charges, DPST-88-578, E. I. du Pont de Nemours \& Co., Savannah River Laboratory, Aiken, SC 29808.

Hayes, D.W. and K.W. MacMurdo, 1977. Carbon-14 Production by the Nuclear Industry, Health Physics, 32: 215-219.

Holcomb, H. Perry, 1992. Transcription of a Presentation by Dr. E.L. Albenesius, SRS Burial Ground Operation from an Historical Perspective (U), WSRC-RP-92-349, Environmental Restoration Department, Westinghouse Savannah River Company, Savannah River Site, Aiken, SC 29808 (February 14).

Holmes, W.G., 1988. Preliminary Results of Carbon-14 Investigation, Revision 2, Memo: W. G. Holmes to J. L. Steele, June 28, 1988. 
Hooker, R.L., and Root, R.W., Jr., 1981. Lysimeter Tests of SRP Waste Forms, US DOE Report DP-1591, E. I. du Pont de Nemours \& Co., Savannah River Laboratory, Aiken, SC 29808.

Jaegge, W.J., et al., 1987. Environmental Information Document, Radioactive Waste Burial Grounds, DPST-85-694, E. I. du Pont de Nemours \& Co., Savannah River Laboratory, Aiken, SC 29808, March 1987.

Jaegge, W.J. and J.N. Chen, 1988. Estimate of Carbon-14 Disposal in the 643-G and 643-7G Burial Grounds, Memorandum to G.H. Street, April 15, 1988.

Kolb, N.L., 1978. Request for Hazard Assessment of Sludge Remaining in 643-G Solvent Tanks, Memorandum to E.L. Albenesius, June 6, 1978.

Looney, B.B., J.B. Pickett, C.M. King, W.G. Holmes, W.F. Johnson, and J.A. Smith, 1987. Selection of Chemical Constituents and Estimation of Inventories for Environmental Analysis of Savannah River Plant Waste Sites, DPST-86-291, E.I. du Pont de Nemours and Company, Savannah River Laboratory, Aiken, SC,

McIntyre, P.F., 1987. 1987 Monitoring Report for the Defense Waste Lysimeters, DPST-87568, E.I. du Pont de Nemours \& Company, Aiken, SC.

McIntyre, P.F., 1988. Sorption Properties of Carbon-14 on Savannah River Plant Soil, DPST-88-900, E.I. du Pont de Nemours \& Company, Aiken, SC.

McIntyre, P.F. and E.L. Wilhite, 1988. Radionuclide Analyses of Burial Ground Well Water, DPST-88-375, E.I. du Pont de Nemours \& Company, Aiken, SC.

Mason, J.T., 1996. Information Document on the Old Solvent Tanks S1-S22 in the Old Radioactive Waste Burial Ground 643-E (U), WSRC-RP-96-00144, Westinghouse Savannah River Company, Aiken, SC.

Towler, Jr., Oscar A., 1989. Integrated Report on Radionuclide Migration at the Savannah River Shallow Land Burial Site, DP-1778, E. I. du Pont de Nemours \& Co., Savannah River Laboratory Technical Division, Aiken, SC 29808, March, 1989.

WSRC, 1992. Old Radioactive Waste Burial Ground, Revised Draft, August, 1992 


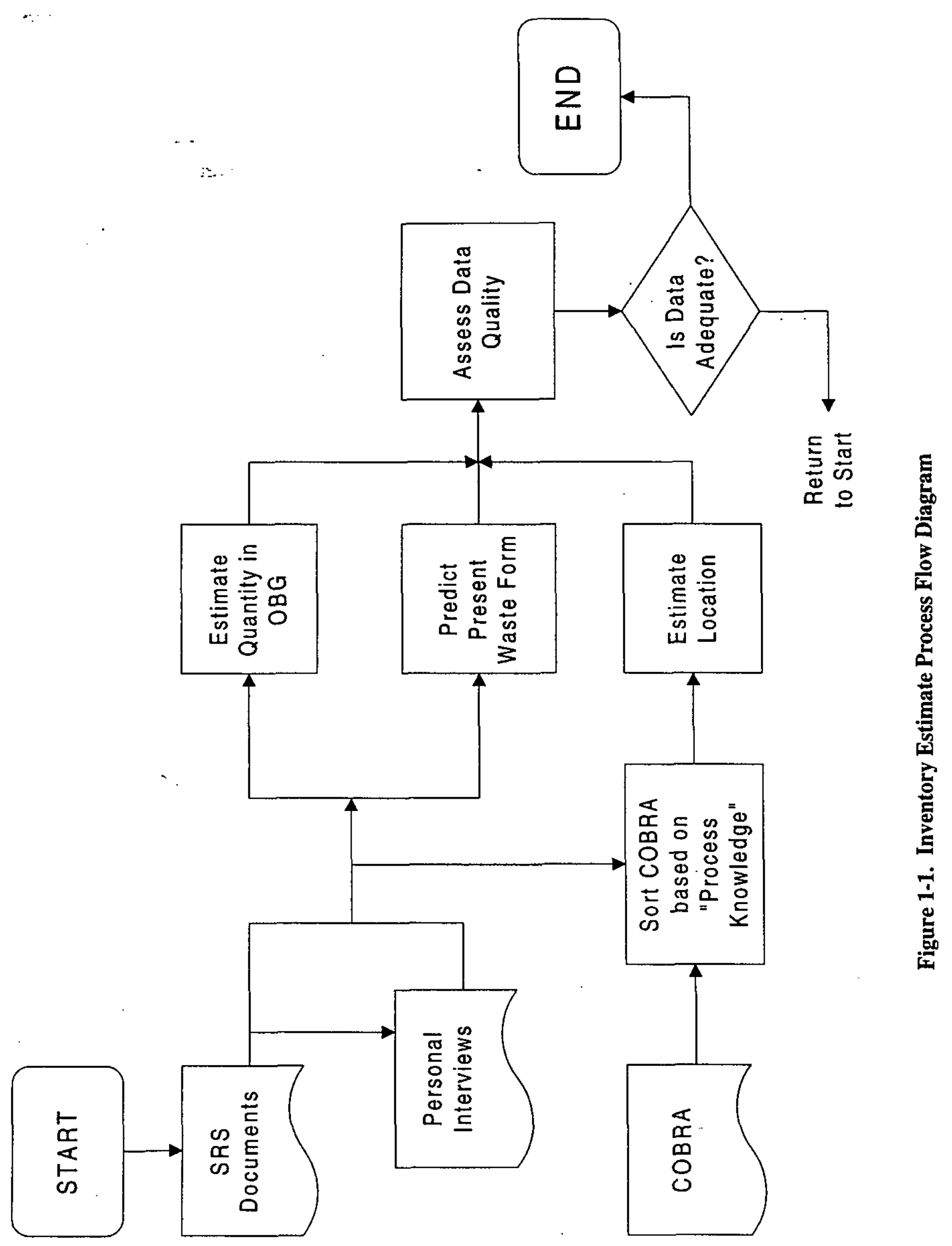




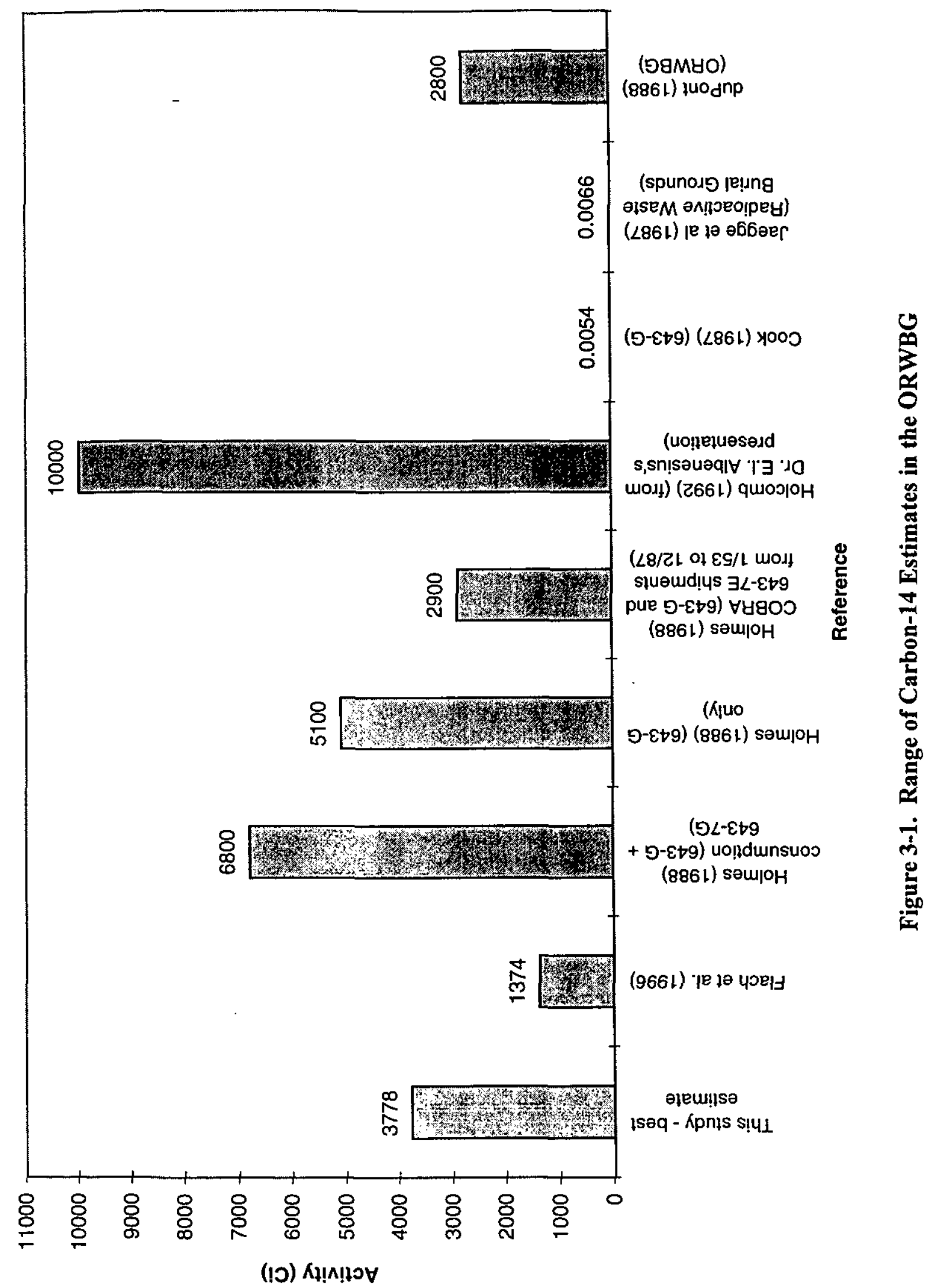




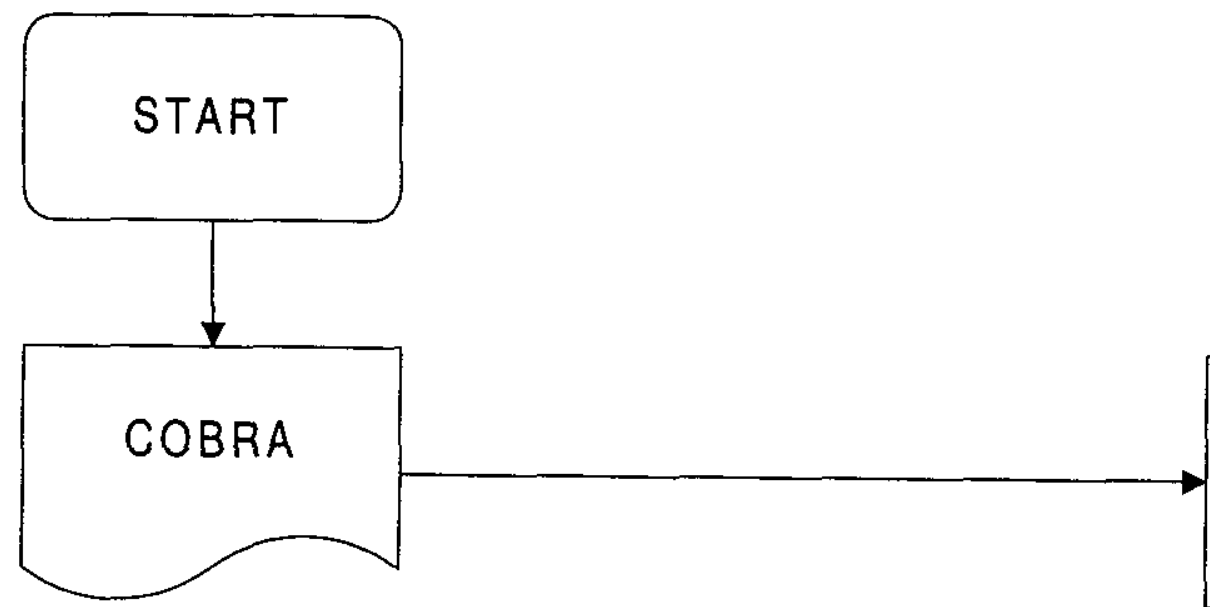

Carbon-14 is not listed nor tracked as a contaminant variety in COBRA

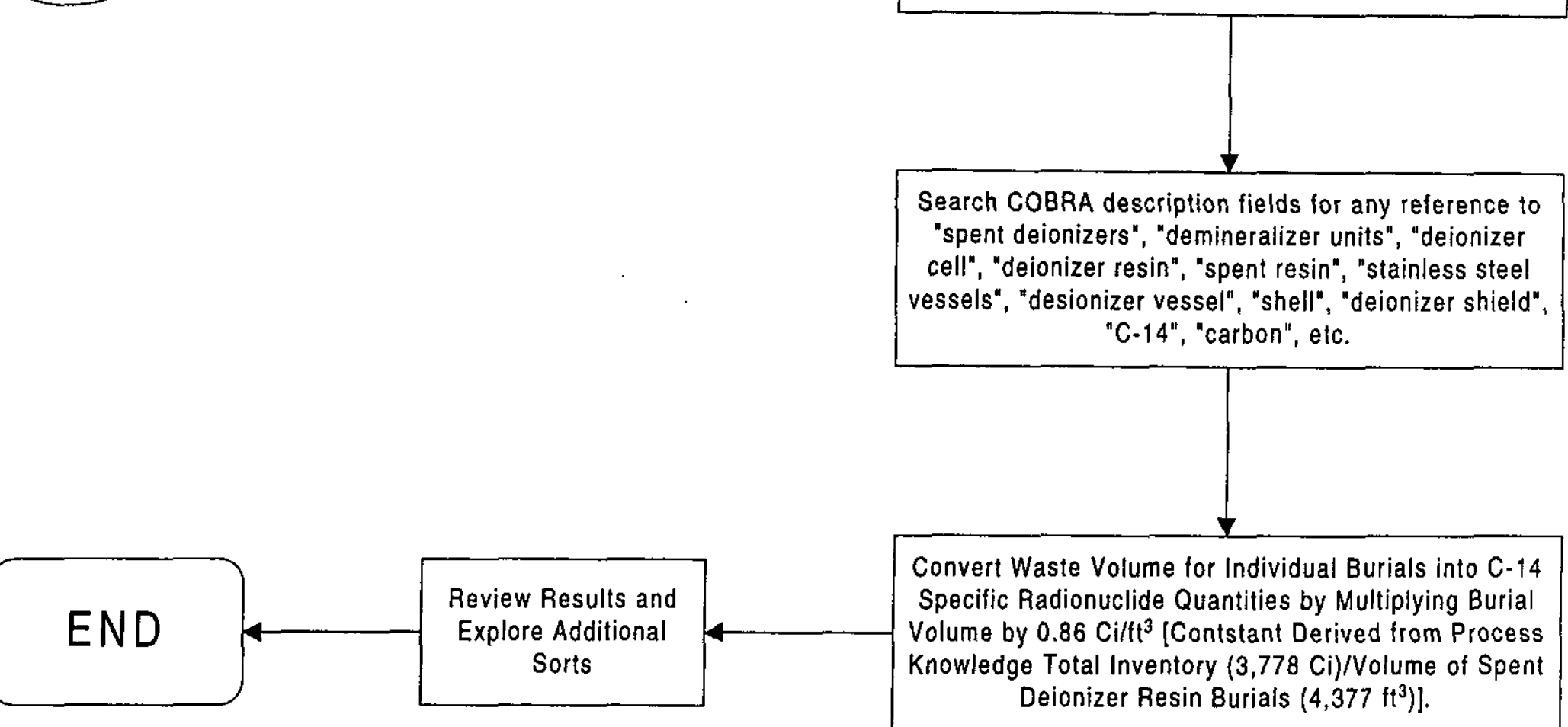

Figure 4-1. Carbon-14 Burial Location Process Flow Diagram 

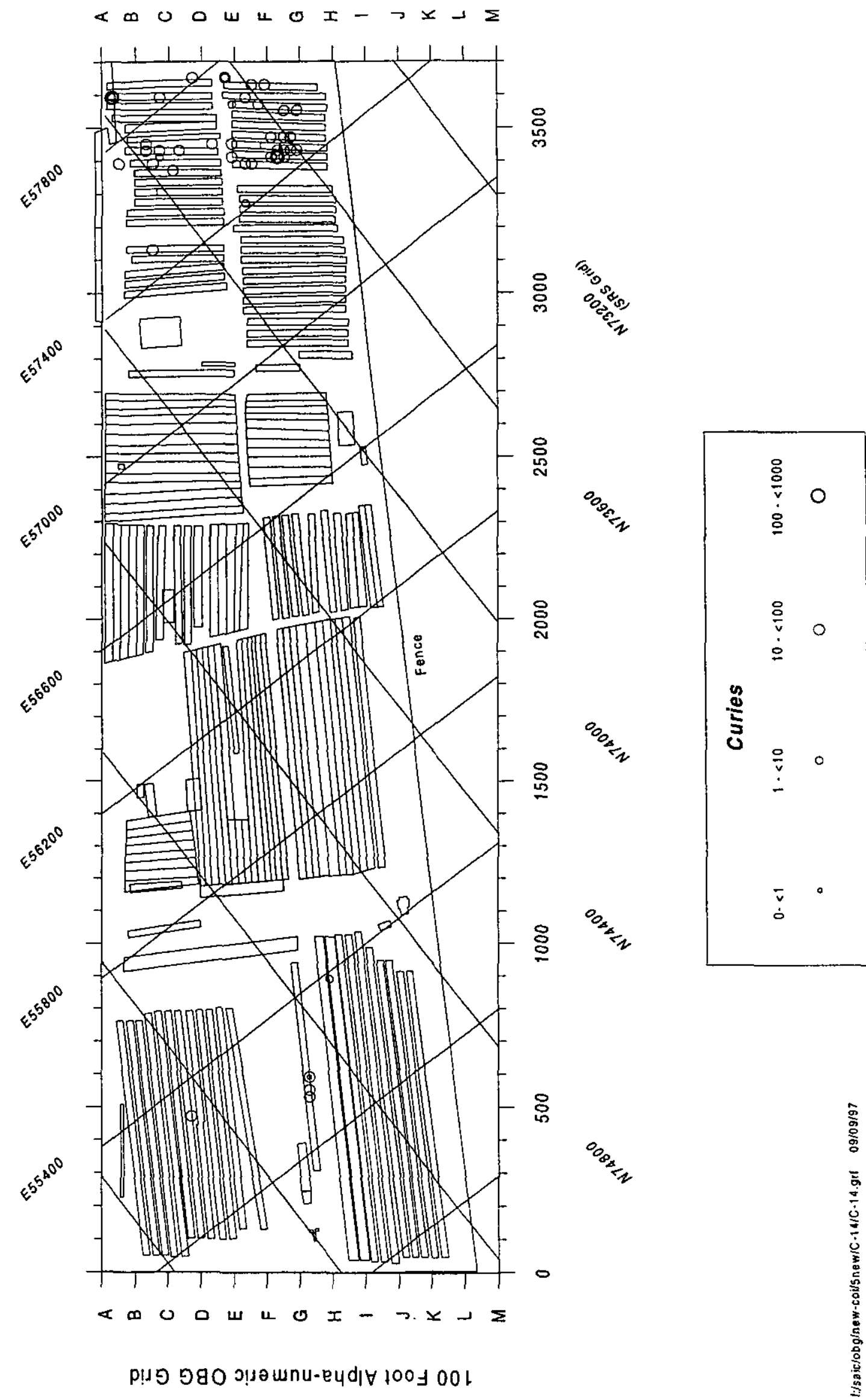

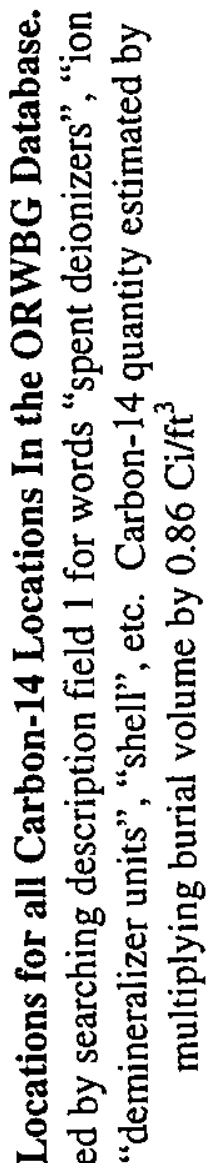

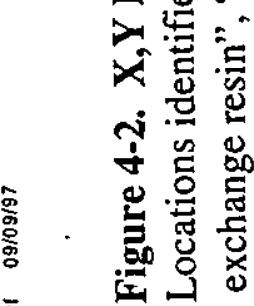

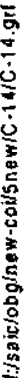

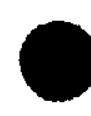


Table 3-1. The Sources of Inventory Estimates for Carbon-14 in the ORWBG

\begin{tabular}{|c|c|c|}
\hline Reference & Inventory & Notes \\
\hline $\begin{array}{l}\text { Flach, G.P., Lee, S.Y. and Yu, A.D., } \\
1996\end{array}$ & $\begin{array}{l}\text { - } 1374^{2} \mathrm{Ci} \text { (Estimated from the total } \\
\text { volume of deionizer waste by } \\
\text { multiplying COBRA burials denoted } \\
\text { by "DEION" or "RESIN" by } 0.35 \\
\mathrm{Ci} / \mathrm{ft}^{3} \text {.) } \\
8000^{\mathrm{a}} \mathrm{Ci} \text { (total produced) (Estimated } \\
\text { from the generation of carbon-14 in } \\
\text { reactor moderator via the ( }, \propto) \\
\text { reaction with oxygen-17). } \\
5100^{\mathrm{a}} \mathrm{Ci} \text { (buried in the ORWBG). } \\
\text { (Holmes, 1988 used Graves, } 1988 \text { to } \\
\text { calculate the amount produced and } \\
\text { were buried in the ORWBG). } \\
\text { (references an earlier article) }\end{array}$ & $\begin{array}{l}\text { The main source of C-14 is } \\
\text { spent deionizers used to } \\
\text { maintain reactor moderator } \\
\text { purity (Cook, 1989). } \\
\text { Deionizers contain an estimated } \\
\text { C-14 content of } 0.35 \text { Ci per } \\
\text { cubic foot of resin. (Cook, } 1989 \text {, } \\
\text { attachment I, Memorandum } \\
\text { from W.G. Holmes to J.L. } \\
\text { Steele dated June 28, 1988). }\end{array}$ \\
\hline Mason, J.T., 1996 & $\begin{array}{l}\text { Analysis of sludge samples from Tanks S6 } \\
\text { and S7 (Kolb, 6-6-78). } \\
\begin{array}{ccc}\text { Analyte }^{b} & \text { Weight } * & \\
$\cline { 2 - 3 } & \text {$Tank S6 } & \text { Tank S7 } \\
\text { C } & 9 & 15\end{array}\end{array}$ & $\begin{array}{l}\text { Kolb (1978) reported concentrations } \\
\text { of several constituents, including } \\
\text { carbon. }\end{array}$ \\
\hline Carlton, W.H., et al., 1993 & $\begin{array}{l}\text { An estimated total of } 6,800^{\circ} \mathrm{Ci} \text { of } \\
\text { radiocarbon in ion-exchange resin has } \\
\text { been buried at the SWDF (Cook, 1989). } \\
\text { (References an earlier article) }\end{array}$ & $\begin{array}{l}\text { Most of the resin is contained } \\
\text { inside the stainless steel vessels. } \\
\text { A limited amount of resin was } \\
\text { removed from the support shell } \\
\text { and buried in concrete casks. } \\
\text { Most of the }{ }^{14} \mathrm{C} \text { produced is } \\
\text { trapped on demineralizers and } \\
\text { buried in the SWDF. }\end{array}$ \\
\hline Holcomb, Perry H., 1992 & $\begin{array}{l}1{\mathrm{E} 04^{\mathrm{b}} \mathrm{Ci}} \\
\text { (Does not reference an earlier article) }\end{array}$ & $\begin{array}{l}\text { C-14 is a component of spent } \\
\text { resin from the reactor areas } \\
\text { buried in the old burial ground. } \\
\text { Most of the resin is buried in } \\
\text { stainless steel vessels except for } \\
\text { one period when the resin was } \\
\text { placed directly in trenches. }\end{array}$ \\
\hline WSRC, 1992 & $\begin{array}{l}2,800^{\mathrm{b}} \mathrm{Ci}(\mathrm{ORWBG}) \\
\text { (References an earlier article) }\end{array}$ & $\begin{array}{l}\text { Deionizer resins used to capture } \\
\text { long-lived carbon-14 from } \\
\text { heavy water coolant in SRS } \\
\text { reactors were dumped in slurry } \\
\text { form directly into ORWBG } \\
\text { trenches during the first ten } \\
\text { years of operations. Later, the } \\
\text { resins were disposed of in } \\
\text { stainless steel vessels. }\end{array}$ \\
\hline
\end{tabular}


Table 3-1. The Sources of Inventory Estimates for Carbon-14 in the ORWBG (Continued)

\begin{tabular}{|c|c|c|}
\hline Reference & Inventory & Notes \\
\hline Cook, James R., 1989 & $\begin{array}{l}\text { Estimated inventory of C-14: } 6.8 \times 10^{3} \\
{ }^{2} \mathrm{Ci} \text { in the Burial Grounds } \\
\text { (References an earlier article) }\end{array}$ & $\begin{array}{l}\text { Origin: Spent deionizers from the } \\
\text { reactor areas. (Used to purify the } \\
\text { moderator of SRP reactors) }\end{array}$ \\
\hline Holmes, W.G., 1988 & $\begin{array}{l}\text { Two estimates of the amount of } \\
\text { C-14 shipped to the burial } \\
\text { grounds in moderator deionizers: } \\
2,900^{\mathrm{a}} \mathrm{Ci} \text { of C-14, based on } \\
\text { COBRA records between } 1 / 1 / 53 \\
\text { and } 12 / 31 / 87, \text { assuming that resin } \\
\text { contained } 0.35 \text { curies of } \mathrm{C}-14 \mathrm{per} \\
\text { cubic foot. } \\
6,800^{2} \mathrm{Ci} \text {, assuming the } \\
\text { generation of carbon-14 in the } \\
\text { moderator of all SRP reactors via } \\
\text { the (n, } \propto \text { ) reaction with oxygen- } 17 \\
\text { was } 8,000 \text { Ci. Of this amount, } \\
6,800 \text { Ci were estimated to have } \\
\text { been shipped to the burial grounds } \\
\text { in spent deionizer resin (15\% of } \\
\text { the amount generated was } \\
\text { assumed to be released to the } \\
\text { atmosphere). } \\
\text { An estimated } 5,100^{\mathrm{a}} \mathrm{Ci} \text { of C-14 } \\
\text { are believed to be buried in } 643- \\
\text { G, assuming that C-14 picked } \\
\text { up by the deionizers prior to } \\
1972 \text { ended up in the ORWBG. } \\
\text { The remainder (1700 Ci) is } \\
\text { believed to be buried in } 643- \\
7 \mathrm{G} / 28 \mathrm{G} \text {. } \\
\text { The C-14 inventory in the } \\
\text { Radioactive Waste Burial } \\
\text { Grounds may be about one } \\
\text { million times larger than } \\
\text { assumed in the Environmental } \\
\text { Information Document (DPST- } \\
85-694 \text { ). (References an earlier } \\
\text { article) }\end{array}$ & $\begin{array}{l}\text { Form: C-14 was shipped to the } \\
\text { radioactive waste burial grounds } \\
\text { in spent deionizers, which were } \\
\text { used to maintain moderator purity } \\
\text { during reactor operations. } \\
\text { - deionizer vessel } \\
\text { - deionizer shells } \\
\quad \text { - loose resin } \\
\text { - The sealed vessels were } \\
\text { shipped to the radioactive } \\
\text { waste burial grounds for } \\
\text { disposal in trenches. } \\
\text { However, in the early } 1970 \text { 's } \\
\text { an undetermined number of } \\
\text { concrete casks containing } \\
\text { "loose" resin were shipped to } \\
\text { the burial grounds. } \\
\text { COBRA records identified } \\
19 \text { potential shipments of } \\
\text { "loose" resin between } 09 / 72 \\
\text { and 10/73. Of these, ten } \\
\text { were buried in } 643-G . \\
\text { Uncertainities with this estimate } \\
\text { are: } \\
\text { 1. Possibility of incomplete or } \\
\text { erroneously recorded } \\
\text { COBRA records } \\
\text { 2. The assumption that all } \\
\text { deionizer shipments } \\
\text { contained } 0.35 \text { curies of C- } \\
14 \text { per cubic feet of waste }\end{array}$ \\
\hline
\end{tabular}


Table 3-1. The Sources of Inventory Estimates for Carbon-14 in the ORWBG (Continued)

\begin{tabular}{|c|c|c|}
\hline Reference & Inventory & Notes \\
\hline Corey, J.C., 1988 & $\begin{array}{l}\text { Environmental Sciences Division } \\
\text { investigation results for the amount of } \\
\mathrm{C}-14 \text { shipped to the radioactive waste } \\
\text { burial grounds: } \\
\text { - } 2900^{6} \mathrm{Ci} \text { based on a review of } \\
\mathrm{COBRA} \text { records by W.J. Jaegge } \\
\text { and J.N. Chen } \\
6800^{6} \mathrm{Ci} \text { based on an assessment } \\
\text { by SRL personnel of the amount } \\
\text { of carbon-14 generated in the } \\
\text { moderator of SRP reactors and of } \\
\text { the amount subsequently captured } \\
\text { by the moderator deionizers. } \\
\text { (References an earlier article) }\end{array}$ & NA \\
\hline
\end{tabular}

a: Inventory discussed in detail

b: No discussion of basis for inventory

NA: Not addressed in article 
Table 3-2. Records for All Carbon-14 Burials in ORWBG. Records Identified by

Searching Description Field 1 for "Spent Deionizers", "Ion Exchange Resins",

"Demineralizer Units", "Shell", etc.

\begin{tabular}{|c|c|c|c|c|c|c|c|c|c|c|c|c|c|c|c|c|c|c|c|c|c|c|c|c|}
\hline $\begin{array}{l}\overline{\mathbf{D}} \\
\text { E్ } \\
\text { हुํ. } \\
\mathcal{S} \\
\end{array}$ & $\begin{array}{r} \\
0 \\
0 \\
x \\
0 \\
0 \\
0 \\
\end{array}$ & 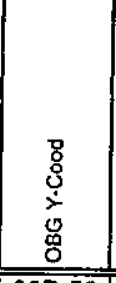 & 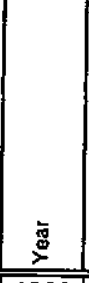 & $\begin{array}{l}\mathbf{c} \\
\text { 言 } \\
\underline{\Sigma}\end{array}$ & $\begin{array}{c}\text { 至 } \\
\end{array}$ & 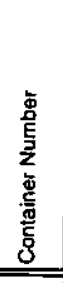 & 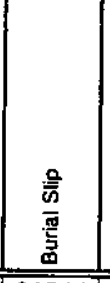 & 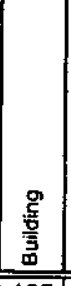 & 嵒 & 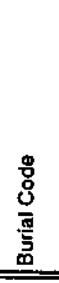 & 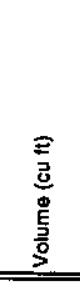 & 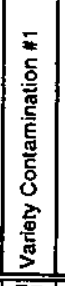 & 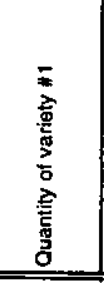 & 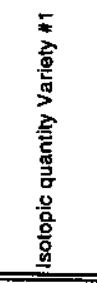 & 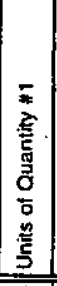 & 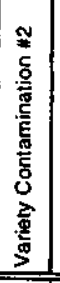 & 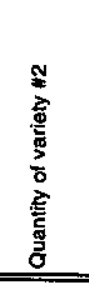 & 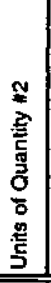 & 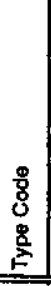 & 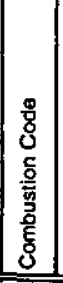 & 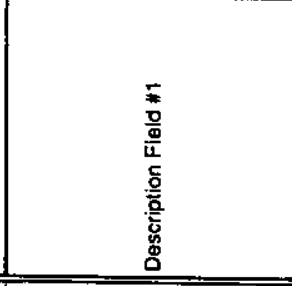 & 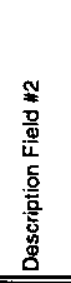 & 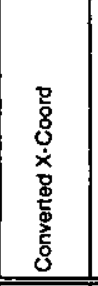 & 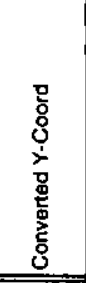 \\
\hline & 35.10 & 000.50 & 1968 & 3 & 15 & & 31844 & 105 & $\bar{C}$ & 2 & 30 & FP & 80 & 0 & $\mathrm{C}$ & & 0 & & 5 & C & DEION SHELL N134 & & 3410 & 390 \\
\hline & 35.10 & 000.50 & 1968 & 3 & 15 & & 31843 & 105 & C & 2 & 30 & $\overline{\mathrm{FP}}$ & 480 & 0 & C & & 0 & & 5 & C & DEION SHELL N145 & & 3410 & 390 \\
\hline & $35 . \overline{40}$ & $00 \mathrm{~F} .10$ & 1966 & 10 & 11 & & $30441 \mid$ & 105 & $\bar{c}$ & 2 & 25 & IA & 49 & 0 & $\mathrm{C}$ & & 0 & & 5 & C & DEION, N6143-12 & & \begin{tabular}{|l|}
3470 \\
\end{tabular} & 510 \\
\hline & 37.30 & 000.40 & 1961 & 10 & 10 & & \begin{tabular}{|l|}
10719 \\
\end{tabular} & 105 & $\bar{P}$ & 1 & 2 & FP & 10 & 0 & $\mathrm{C}$ & & 0 & & 1 & c & DEION. VESSEL & & 3650 & 370 \\
\hline & 6.50 & $00 \mathrm{G} .20$ & 1972 & 10 & 18 & & 61879 & 105 & $\mathrm{~K}$ & 4 & 30 & 83 & 4.941 & 3.952 & $\mathrm{G}$ & FP & 89.9 & $\mathrm{C}$ & 1 & c & DEION N-350 RESI & & 590 & 630 \\
\hline & 36.30 & OOF.30 & 1964 & 3 & 20 & & 21024 & 105 & $\bar{c}$ & 1 & 20 & FP & 14.2 & 0 & C & & 0 & & 1 & c & DE-IONIZER & & 3550 & 550 \\
\hline & 36.30 & OOF.30 & 1964 & 3 & 23 & & 20977 & 105 & $\bar{c}$ & 1 & 36 & $\mathrm{FP}$ & 1.24 & 0 & $\mathrm{c}$ & & 0 & & 1 & C & DE-1ONIZER & & \begin{tabular}{|l|}
3550 \\
\end{tabular} & 550 \\
\hline$B$ & 0.00 & 0 & 1961 & 4 & 4 & & 3025 & 105 & $R$ & 1 & 19 & FP & 0.2 & 0 & C & & 0 & & 1 & C & DEIONIZER & & & \\
\hline B & 0.00 & 0 & 1961 & 4 & 12 & & 1498 & $6 \overline{8}$ & $\mathrm{G}$ & 1 & 81 & $\overline{\mathrm{FP}}$ & 0 & 0 & C & & 0 & & 4 & $\mathrm{C}$ & DEIONIZER & & & \\
\hline $\bar{B}$ & 0.00 & 0 & 1961 & 5 & 17 & & \begin{tabular}{|l|}
10376 \\
\end{tabular} & \begin{tabular}{|l|}
105 \\
\end{tabular} & C & 2 & 19 & $\mathrm{FP}$ & 53.2 & 0 & c & & 0 & & 3 & $\mathrm{~N}$ & DEIONIZER & & & \\
\hline & 37.30 & 000.40 & 1961 & 11 & 10 & & 8891 & 105 & $\mathrm{R}$ & 2 & 19 & $\mathrm{AA}$ & 16 & 15.68 & C & & 0 & & 3 & $\mathrm{~N}$ & DEIONIZER & & 3650 & 370 \\
\hline & 37.20 & OOE.30 & 1961 & 12 & 8 & & 2925 & 105 & A & 2 & 19 & IA & 4.5 & 4.41 & C & & 0 & & 3 & $\bar{N}$ & DEIONIZER & & \begin{tabular}{|l|}
3630 \\
\end{tabular} & 450 \\
\hline & 37.20 & $00 \mathrm{E} .30$ & 1962 & 1 & 23 & & 1016 & 105 & $R$ & 1 & 20 & IA & 0.8 & 0 & $\mathrm{C}$ & & 0 & & 1 & C: & DEIONIZER & & 3630 & 450 \\
\hline & 37.20 & $00 E .50$ & \begin{tabular}{|l|}
1962 \\
\end{tabular} & 2 & 6 & & 667 & 105 & C & 2 & 19 & FP & 23.7 & 0 & $\mathrm{C}$ & & 0 & & 3 & $\mathrm{~N}$ & DEIONIZER & & \begin{tabular}{|l|}
3630 \\
\end{tabular} & 490 \\
\hline & 37.20 & $00 \mathrm{E} .50$ & 1962 & 2 & 7 & & 6348 & 105 & c & 2 & 19 & FP & 23.7 & 0 & C & & 0 & & 3 & $N$ & DEIONIZER & & \begin{tabular}{|l|}
3630 \\
\end{tabular} & 490 \\
\hline & 36.50 & 00A.20 & 1962 & 3 & \begin{tabular}{|l|}
19 \\
\end{tabular} & & 6926 & 100 & $\mathrm{k}$ & 1 & 385 & IA & 70.4 & 0 & C & & 0 & & 1 & c| & DEIONIZER & & 3590 & 30 \\
\hline & 36.50 & $00 A .20$ & 1962 & 3 & 26 & & 7025 & 105 & $\mathrm{c}$ & 1 & 19 & FP & 2.7 & 0 & $\mathrm{C}$ & & 0 & & 1 & C & DEIONIZER & & \begin{tabular}{|l|}
3590 \\
\end{tabular} & 30 \\
\hline & 36.50 & $00 A .20$ & 1962 & 3 & \begin{tabular}{|l|}
27 \\
\end{tabular} & & 7051 & 100 & $C$ & 1 & 19 & FP & 20 & 0 & C & & 0 & & 1 & \begin{tabular}{|c|}
$c$ \\
\end{tabular} & DEIONIZER & & 3590 & 30 \\
\hline & \begin{tabular}{|l|}
36.50 \\
\end{tabular} & \begin{tabular}{|l|} 
OOA.20 \\
\end{tabular} & 1962 & 3 & 27 & & 7052 & 105 & C & 1 & 19 & FP & 14.96 & 0 & $\mathrm{C}$ & & 0 & & 1 & c & DEIONIZER & & 3590 & 30 \\
\hline & 36.50 & $00 A .20$ & \begin{tabular}{|l|}
1962 \\
\end{tabular} & 3 & \begin{tabular}{|l|}
27 \\
\end{tabular} & & 7053 & 105 & C & 1 & 19 & FP & 26.6 & 0 & $\begin{array}{ll}\text { C } \\
\end{array}$ & & 0 & & 1 & C & DEIONIZER & & 3590 & 30 \\
\hline & 36.50 & $00 E .20$ & 1963 & 1 & \begin{tabular}{|l|}
18 \\
\end{tabular} & & 11829 & 105 & C & 1 & 19 & $\mid \mathrm{A}$ & 49.6 & 0 & $\mathrm{C}$ & & 0 & & 1 & C & DEIONIZER & & \begin{tabular}{|l|}
3590 \\
\end{tabular} & 430 \\
\hline & \begin{tabular}{|l|}
36.50 \\
\end{tabular} & OOE.20 & \begin{tabular}{|l|}
1963 \\
\end{tabular} & 1 & \begin{tabular}{|l|}
18 \\
\end{tabular} & & 11830 & 105 & C & 1 & 19 & IA & 8 & 0 & $\mathrm{C}$ & & 0 & & 1 & $\begin{array}{ll}c \\
c\end{array}$ & DEIONIZER & & 3590 & 430 \\
\hline & 36.50 & O0A.20 & 1963 & 6 & 5 & & 12354 & 105 & C & 1 & 19 & $\mathrm{FP}$ & 17 & 0 & c & & 0 & & 1 & $\mathbf{N}$ & IDEIONIZER & & 3590 & 30 \\
\hline & 36.50 & $00 \mathrm{~B} .40$ & 1963 & 10 & 11 & & 12707 & 105 & $\mathbf{R}$ & 1 & 60 & IA & 16 & 0 & $\mathrm{C}$ & & 0 & & 1 & C & DEIONIZER & & \begin{tabular}{|l|}
3590 \\
\end{tabular} & 170 \\
\hline & 36.40 & 000.50 & 1963 & 11 & 5 & & 5214 & 770 & U & 1 & 2 & FP & 26.4 & 0 & $\mathrm{C}$ & & 0 & & 1 & C & DEIONIZER & & \begin{tabular}{|l|}
3570 \\
\end{tabular} & 390 \\
\hline & 36.40 & OOE.40 & 1964 & 2 & 5 & & 16135 & 105 & c & 1 & 19 & 87 & 0 & 0 & $\mathrm{G}$ & & 0 & & 1 & C & DEIONIZER & & 3570 & 470 \\
\hline & 36.40 & OOE.40 & 1964 & 2 & 6 & & 16087 & 105 & C & 1 & 25 & IA & 21 & 0 & C & & 0 & & 1 & c & DEIONIZER & & \begin{tabular}{|l|}
3570 \\
\end{tabular} & 470 \\
\hline & 36.40 & $00 E .40$ & 1964 & 2 & 7 & & 16100 & 105 & $\mathrm{C}$ & 1 & 20 & FP & 15 & 0 & $\mathrm{C}$ & & 0 & & 1 & C & DEIONIZER & & \begin{tabular}{|l|}
3570 \\
\end{tabular} & 470 \\
\hline & 36.40 & OOE.40 & \begin{tabular}{|l|}
1964 \\
\end{tabular} & 2 & 11 & & 16030 & \begin{tabular}{|l|}
105 \\
\end{tabular} & C & 1 & 19 & FP & 49 & 0 & $c$ & & 0 & & 1 & $\begin{array}{ll}\mathrm{C} \\
\end{array}$ & DEIONIZER & & \begin{tabular}{|l|}
3570 \\
\end{tabular} & 470 \\
\hline & 36.40 & OOE.40 & 1964 & 2 & 11 & & 16035 & 105 & C & 1 & 19 & $\mathrm{FP}$ & 32 & 0 & C & & 0 & & 1 & C & DEIONIZER & & 3570 & 470 \\
\hline & 36.40 & OOE.40 & 1964 & 2 & 12 & & 16010 & 105 & c. & 1 & 25 & FP & 29.6 & 0 & $c$ & & 0 & & 1 & C I & DEIONIZER & & 3570 & 470 \\
\hline & 36.30 & 00F.30 & 1964 & 3 & 3 & & 15056 & 105 & $\mathrm{C}$ & 1 & 25 & FP & 34.6 & 0 & $c$ & & 0 & & 1 & $\mathrm{C}$ & DEIONIZER & & 3550 & 550 \\
\hline & 36.30 & O0F.30 & 1964 & 3 & 3 & & 15058 & 105 & C & 1 & 19 & IA & 105 & 0 & c & & 0 & & 1 & $\mathrm{C}$ & DEIONIZER & & 3550 & 550 \\
\hline & 36.30 & OOF.30 & 1964 & 3 & 5 & & 15899 & 105 & $\mathrm{C}$ & 1 & 19 & IA & 148 & 0 & $C$ & & 0 & & 1 & $\mathrm{C} \quad \mathrm{C}$ & DEIONIZER & & 3550 & 550 \\
\hline & 5.40 & $00 \mathrm{C} .40$ & \begin{tabular}{|l|}
1964 \\
\end{tabular} & 3 & 6 & & 15867 & 100 & $L$ & 1 & 88 & FP & 0 & 0 & C & & 0 & & 1 & C: & DEIONIZER & & 470 & 270 \\
\hline & 35.30 & 00B.20 & 1964 & 5 & 29 & & 13551 & 105 & C & 1 & 25 & FP & 7.02 & 0 & C & & 0 & & 1 & C I & DEIONIZER & & 3450 & 130 \\
\hline & 35.20 & 008.20 & 1964 & 5 & 29 & & 13554 & \begin{tabular}{|l|}
105 \\
\end{tabular} & C & 1 & 25 & FP & 15.7 & 0 & c & & 0 & & 1 & C I & DEIONIZER & & 3430 & 130 \\
\hline & 35.20 & 00B.20 & \begin{tabular}{|l|}
1964 \\
\end{tabular} & 6 & 2 & & 16487 & 105 & C & 1 & 25 & FP & 9.5 & 0 & C & & 0 & & 1 & C & DEIONIZER & & 3430 & 130 \\
\hline & 34.50 & $00 B .30$ & 1964 & 11 & 10 & & 26213 & 105 & $\bar{P}$ & 1 & 100 & IA & 0 & 0 & C & & 0 & & 1 & $C$ & DEIONIZER & & 3390 & 150 \\
\hline & \begin{tabular}{|l|}
34.40 \\
\end{tabular} & $00 \mathrm{C} .10$ & .1965 & 10 & 11 & & 25149 & 105 & $P$ & 1 & 25 & FP & 8.75 & 0 & C & & 0 & & 1 & C 10 & DEIONIZER & & 3370 & 210 \\
\hline
\end{tabular}


Table 3-2. Records for All Carbon-14 Burials in ORWBG. Records Identified by

Searching Description Field 1 for "Spent Deionizers", "Ion Exchange Resins",

"Demineralizer Units", "Shell", etc. (Continued)

\begin{tabular}{|c|c|c|c|c|c|c|c|c|c|c|c|c|c|c|c|c|c|c|c|c|c|c|c|c|}
\hline $\bar{\Phi}$ & 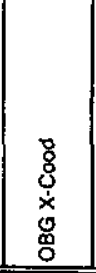 & 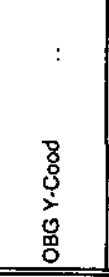 & 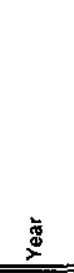 & 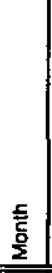 & 嘼 & 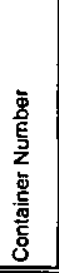 & 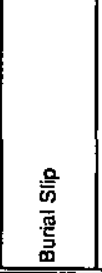 & 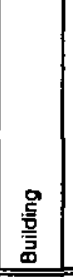 & 焉 & 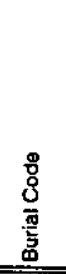 & 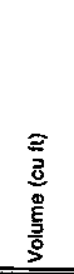 & 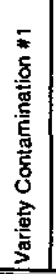 & 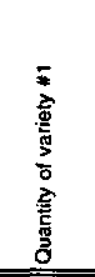 & 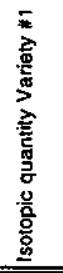 & 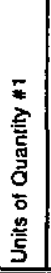 & 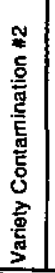 & 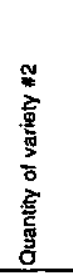 & 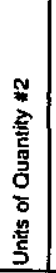 & $\begin{array}{l}0 \\
8 \\
0 \\
0 \\
0 \\
2\end{array}$ & 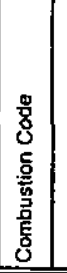 & 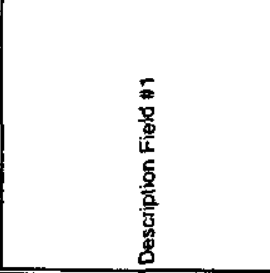 & 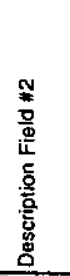 & 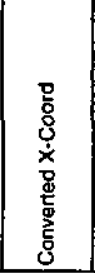 & 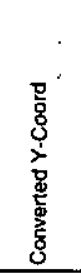 \\
\hline & 35.10 & $00 \mathrm{~F} .30$ & 1966 & 2 & 2 & & 36430 & 105 & c & 2 & 25 & $\mathrm{FP}$ & 0 & 0 & $\mathrm{c}$ & & 0 & & 5 & & DEIONIZEF & & 3410 & 0 \\
\hline & 32.20 & OOB.30 & 1967 & 3 & 27 & & 31346 & 105 & \begin{tabular}{l|l} 
C \\
\end{tabular} & 1 & 25 & IA & 51 & 0 & $\mathrm{C}$ & & 0 & & 1 & & DEIONIZER & & 3130 & 150 \\
\hline & 35.20 & 00F.30 & 1967 & 9 & 28 & & 32691 & 105 & C & 2 & 25 & FP & 186 & 0 & C & & 0 & & 5 & & DEIONIZER & & 3430 & 550 \\
\hline & 35.20 & $00 F .30$ & 1967 & 9 & 28 & & 32692 & 105 & C & 2 & 30 & $\mathrm{FP}$ & 225 & 0 & C & & 0 & & 5 & $\begin{array}{lll} & 0 \\
\end{array}$ & DEIONIZER & & 3430 & 550 \\
\hline & 35.20 & OOF.30 & 1967 & 10 & 12 & & 33225 & 105 & C & 2 & 25 & $\mathrm{FP}$ & 23.7 & 0 & c & & 0 & & 5 & $\bar{c} 0$ & DEIONIZER & & 3430 & 550 \\
\hline & 35.20 & O0F.30 & 1967 & 10 & 16 & & 33182 & 105 & $\mathrm{c}$ & 2 & 25 & FP & 756.8 & 0 & c & & 0 & & 5 & \begin{tabular}{l|l}
$C$ & $D$ \\
\end{tabular} & DEIONIZER & & 3430 & 550 \\
\hline & 35.20 & $00 \mathrm{~F} .50$ & 1967 & 11 & 7 & & 33362 & 105 & C & 2 & 30 & $F P$ & 968 & 0 & C & & 0 & & 5 & C & DEIONIZER & & 3430 & 590 \\
\hline & 34.50 & $00 E .20$ & 1969 & 2 & 5 & & 33914 & 105 & K. & 2 & 30 & IA & 481 & 0 & C & & 0 & & 5 & $c \mid 0$ & DEIO & & 3390 & 430 \\
\hline & 34.50 & $00 E .20$ & 1969 & 2 & 6 & & 33884 & 105 & K & 2 & 27 & IA & 445 & $\overline{0}$ & $c$ & & 0 & & 5 & $\mathrm{C}$ & DEIONIZER & & 3390 & 430 \\
\hline & 34.50 & OOE.20 & 1969 & 2 & 6 & & 33886 & 105 & $\mathbf{K}$ & 1 & 30 & IA & 961 & 0 & C & & 0 & & 1 & $C \mid D$ & DEIONIZEA & & 3390 & 430 \\
\hline & 34.50 & OOE.20 & 1969 & 2 & 12 & & 33825 & 105 & $\mathrm{~K}$ & 2 & 30 & $\mathbf{I A}$ & 710 & 0 & c- & & $\pi$ & & 5 & C $1 \bar{D}$ & DEIONIZER & & 3390 & 430 \\
\hline & 34.50 & $00 E .20$ & 1969 & 2 & 13 & & 33803 & 105 & $\mathrm{~K}$ & 2 & 30 & $\mid \mathbf{A}$ & 171 & 0 & c & & $v$ & & 5 & $c \mid c$ & DEIONIZER & & 3390 & 430 \\
\hline & 34.50 & OOE.20 & 1969 & 2 & 14 & & 33820 & 105 & $\mathrm{~K}$ & 2 & 30 & $\mathbb{A}$ & 210 & 0 & c & & 0 & & 5 & \begin{tabular}{c|c}
$c$ & 0 \\
$c$
\end{tabular} & DEIONIZER & & 3390 & 430 \\
\hline & 34.50 & O0E.20 & 1969 & 2 & 20 & & 29119 & 105 & $\mathrm{~K}$ & 2 & 30 & IA & 230 & 0 & c & & 0 & & 5 & \begin{tabular}{l|l}
$\mathrm{C}$ & $\mathrm{C}$ \\
\end{tabular} & DEIONIZER & & 3390 & 430 \\
\hline & 34.50 & OOE.20 & 1969 & 2 & 20 & & 29120 & 105 & $\bar{k}$ & 2 & 30 & FP & 115 & 0 & c & & 0 & & 5 & C 10 & DEIONIZER & & 3390 & 430 \\
\hline & 34.50 & 00 OE.30 & 1969 & 2 & 21 & & 29071 & 105 & $\mathrm{~K}$ & 2 & 30 & $\mathrm{IA}$ & 633 & 0 & c & & 0 & & 5 & \begin{tabular}{c|c}
$c$ & 0 \\
$c$
\end{tabular} & DEIONIZER & & 3390 & 450 \\
\hline & 34.50 & $00 E .30$ & 1969 & 2 & 24 & & 29072 & 105 & $\mathrm{~K}$ & 2 & 30 & A A & 355 & 0 & c & & 0 & & 5 & & DEIONIZER & & 3390 & 450 \\
\hline & 35.10 & $00 \mathrm{~F} .30$ & 1966 & 1 & 31 & & 36479 & 105 & C & 2 & 25 & IA & 0 & 0 & c & & 0 & & \begin{tabular}{l|l}
5 \\
\end{tabular} & c $\}$ & DEIONIZER 4310 & & 3410 & 550 \\
\hline & 35.10 & $00 F .30$ & 1966 & 1 & 31 & & 36478 & 105 & C & 2 & 20 & FP & 0 & 0 & c & & 0 & & 5 & & DEIONIZER 4311 & & 3410 & 550 \\
\hline & 35.10 & $00 F .30$ & 1966 & 2 & 1 & & 36447 & 105 & C & 2 & 25 & $F P$ & 9 & 0 & c & & 0 & & 5 & & DEIONIZER 8814 & & 3410 & 550 \\
\hline & 35.10 & 000.50 & 1968 & 3 & 13 & & 31879 & 105 & C & 2 & 30 & $\mathrm{FP}$ & 112 & 0 & C & & 0 & & 5 & & DEIONIZER N0161 & & 3410 & 390 \\
\hline & 35.10 & 000.50 & 1968 & 3 & 11 & & 31880 & 105 & $\bar{c}$ & 2 & 30 & $\mathrm{FP}$ & 24 & 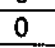 & $c$ & & 0 & & 5 & & \begin{tabular}{|l} 
DEIONIZER N0162 \\
\end{tabular} & & 3410 & 390 \\
\hline & 35.10 & $00 F .10$ & 1968 & 5 & 13 & & 27953 & 105 & C & 2 & 30 & IA & 550 & 0 & C & & 0 & & 5 & & DEIONIZER 157 & & 3410 & 510 \\
\hline & 35.10 & 00F.10 & 1968 & 5 & 9 & & 27969 & 105 & $\bar{c}$ & 2 & 25 & $\mid \bar{A}$ & 825 & 0 & C & & 0 & & 5 & & DEIONIZER 158 & & 3410 & 510 \\
\hline & 34.50 & $00 A .30$ & 1964 & 11 & 4 & & 26294 & 105 & C & 2 & 25 & $\mathrm{FP}$ & 47 & 0 & C & & 0 & & 5 & & DEIONIZER $2822-\uparrow$ & & 3390 & 50 \\
\hline & 34.50 & OOB.30 & 1964 & 11 & 18 & & 26123 & 105 & c & 1 & 19 & FP & 2.3 & 0 & c & & 0 & & 1 & & DEIONIZEA 2822.3 & & 3390 & 150 \\
\hline & 34.50 & \begin{tabular}{|l|}
$00 A .30$ \\
\end{tabular} & 1964 & 11 & 2 & & 26330 & 105 & $\mathrm{C}$ & 2 & 19 & $F P$ & 30 & 0 & c & & 0 & & 5 & & DEIONIZEA 2822-7 & & 3390 & 50 \\
\hline & 34.50 & $00 A .30$ & 1964 & 11 & 2 & & 26331 & 105 & $\bar{c}$ & 2 & 19 & FP & 13.4 & 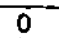 & C & & 5 & & 5 & $\mathrm{C} D$ & DEIONIZER $2822-8$ & & 3390 & 50 \\
\hline & 34.50 & \begin{tabular}{|l}
$0 O B .30$ \\
\end{tabular} & 1964 & 11 & 16 & & 26157 & 105 & C & 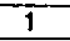 & 19 & FP & 7.7 & 0 & c & & 0 & & $\frac{1}{1}$ & & ER 3696-4 & & 3390 & 150 \\
\hline & 32.20 & 008.30 & 1967 & 3 & 2 & & 27444 & 105 & C & 2 & 25 & FP & 25.9 & 0 & c & & 0 & & 5 & & DEIONIZER 4184 & & 3130 & 150 \\
\hline & 35.10 & OOB.40 & 1965 & 1 & 4 & & 15591 & 770 & U & 1 & 5 & FP & 0 & 0 & c & & 0 & & 1 & C. D & DEIONIZER 44-1 & & 3410 & 170 \\
\hline & 35.40 & OOF.30 & 1966 & 10 & 31 & & 30182 & 105 & $\mathrm{c}$ & 2 & 25 & FP & 41.4 & 0 & C & & 0 & & 5 & $c \mid 0$ & DEIONIZER 4881 & & 3470 & 550 \\
\hline & 35.40 & OOF.10 & 1966 & 10 & 19 & & 30301 & 105 & c & 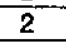 & 48 & $\mathrm{FP}$ & 12 & 0 & c & & 0 & & 5 & & DEIONIZER 4885 & & 3470 & 510 \\
\hline & 36.30 & OOF.50 & 1964 & 4 & 1 & & 13570 & 100 & $\bar{c}$ & 1 & 20 & FP & 17.8 & 0 & $c$ & & 0 & & 1 & $c \mid 0$ & \begin{tabular}{|l} 
DEIONIZER $7165 C$ \\
\end{tabular} & & -3550 & 590 \\
\hline & 35.20 & 008.40 & 1964 & 6 & 26 & & 16230 & 105 & $\bar{c}$ & 1 & 100 & FP & 66 & 0 & 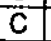 & & 0 & & 1 & $\begin{array}{c}\bar{C} \mathrm{D} \\
\end{array}$ & DEIONIZER 7636-8 & & 3430 & 170 \\
\hline & 34.50 & 008.30 & 1964 & 11 & 18 & & 26120 & 105 & $\bar{c}$ & 2 & 25 & FP & 68 & v & C & & 0 & & 5 & & DEIONIZER 7936 & & 3390 & 150 \\
\hline & 34.50 & 00 B.30 & 1964 & 11 & 10 & & 26248 & 105 & $\bar{c}$ & 2 & 20 & FP & 13.4 & 0 & c & & 0 & & 5 & $\mathrm{C} D \mathrm{D}$ & DEIONIZER $7971-1$ & & 3390 & 150 \\
\hline & 34.50 & 008.30 & 1964 & 11 & 17 & & 26140 & 105 & $\bar{c}$ & 1 & 25 & FP & 77 & 0 & $a t$ & & 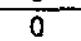 & & 1 & & OEIONIZER 7971 & & 3390 & 150 \\
\hline & 34.50 & 00.30 & 1964 & 11 & 4 & & 26292 & 105 & $\bar{c}$ & 2 & 19 & FP & 7.7 & 0 & c & & 0 & & 5 & & DEIONIZER 7971-5 & & 3390 & 50 \\
\hline & 35.20 & $00 B .20$ & 1964 & \begin{tabular}{l|l}
6 & \\
\end{tabular} & 2 & & 16525 & 105 & $c$ & a & 25 & $\mathrm{FP}$ & 7.2 & 0 & c. & & 0 & & 1 & $C D$ & DEIONIZER $7971-6$ & & 3430 & 130 \\
\hline
\end{tabular}


Table 3-2. Records for All Carbon-14 Burials in ORWBG. Records Identified by Searching Description Field 1 for "Spent Deionizers", "Ion Exchange Resins",

"Demineralizer Units", "Shell”, etc. (Continued)

\begin{tabular}{|c|c|c|c|c|c|c|c|c|c|c|c|c|c|c|c|c|c|c|c|c|c|c|c|c|}
\hline & 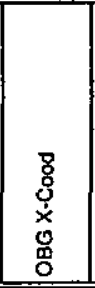 & 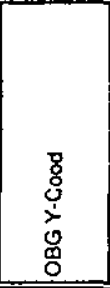 & 离 & $\begin{array}{l}\text { 訔 } \\
\text { 产 }\end{array}$ & 离 & 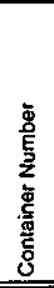 & 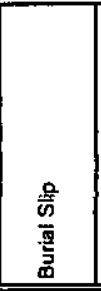 & 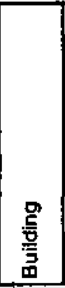 & $\frac{\mathbb{g}}{2}$ & 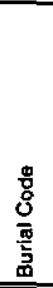 & 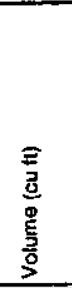 & 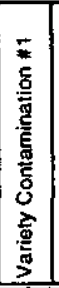 & 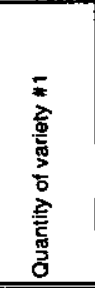 & 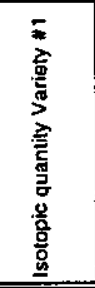 & 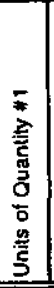 & 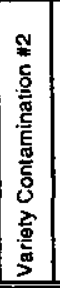 & 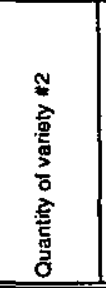 & 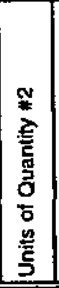 & $\begin{array}{l}8 \\
8 \\
0 \\
8 \\
8 \\
\end{array}$ & 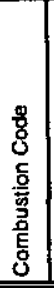 & 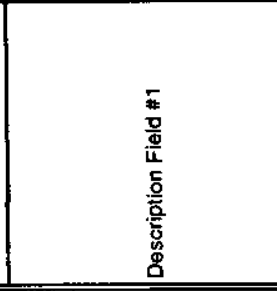 & 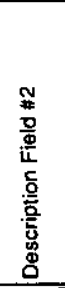 & 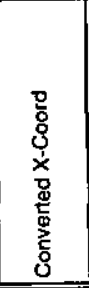 & 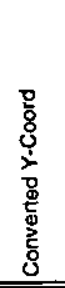 \\
\hline & 34.50 & $00 \mathrm{~B} .30$ & 1964 & 11 & 17 & & 26139 & 105 & $\mathrm{C}$ & 1 & 25 & $\mathrm{FP}$ & 28 & 0 & C & & 0 & & 1 & c & DEIONIZER 7971.7 & & 3390 & 150 \\
\hline & 35.20 & $00 \mathrm{C} .20$ & 1964 & 7 & 20 & & 13438 & 105 & C & 1 & 25 & $\mathrm{FP}$ & 80 & 0 & $\mathrm{C}$ & & 0 & & 1 & $\mathrm{C}$ & DEIONIZER 7971-9 & & 3430 & 230 \\
\hline & 35.40 & 00F.10 & 1966 & 10 & 13 & & 30413 & 105 & $\mathrm{C}$ & 1 & 25 & IA & 21.3 & 0 & C & & 0 & & 1 & C & DEIONIZER 9611 & & 3470 & 510 \\
\hline & 6.20 & $00 \mathrm{G} .20$ & 1972 & 10 & 2 & & 61877 & 105 & $\mathrm{~K}$ & 4 & 100 & \begin{tabular}{|l|}
46 \\
\end{tabular} & 0.003 & 0 & $G$ & FP & 0.8 & C & $i$ & C & DEIONIZER CASK & & 530 & 630 \\
\hline B & 0.00 & 0 & 1961 & 4 & 3 & & 2995 & 105 & $\mathrm{C}$ & 2 & 19 & FP & 48 & 0 & $\bar{c}$ & & 0 & & 3 & $\mathrm{~N}$ & DEIONIZER CELL & & & \\
\hline$B$ & 0.00 & 0 & 1961 & 4 & 4 & & 3013 & 105 & $\mathrm{C}$ & 1 & 30 & $\mathrm{FP}$ & 56 & 0 & $\mathrm{c}$ & & 0 & & 1 & C & DEIONIZER CELL & & & \\
\hline $\mathrm{B}$ & 0.00 & 0 & 1961 & 4 & 5 & & 3040 & 105 & $\mathrm{C}$ & 1 & 19 & $\mathrm{FP}$ & 7.2 & 0 & C & & 0 & & 1 & $\mathrm{C}$ & DEIONIZEA CELL & & & \\
\hline & 37.30 & $00 \mathrm{C} .40$ & 1961 & 9 & 19 & & 155 & 105 & C & 1 & 19 & IA & 178 & 0 & $\mathrm{C}$ & & 0 & & 1 & $\mathrm{C}$ & DEIONIZEA CELL & & 3650 & 270 \\
\hline & 37.30 & 000.40 & 1961 & 9 & 20 & & 176 & 105 & $\bar{c}$ & 1 & 19 & FP & 73.4 & 0 & $c$ & & 0 & & 1 & C & DEIONIZER CELL & & 3650 & 270 \\
\hline & 37.30 & $00 \mathrm{C} .40$ & 1961 & 9 & 20 & & 177 & 105 & $\mathrm{C}$ & 1 & 19 & FP & 28 & 0 & $\mathrm{C}$ & & 0 & & 1 & C & DEIONIZER CELL & & 3650 & 270 \\
\hline & 36.50 & $00 A .20$ & 1962 & 3 & 26 & & 7028 & 105 & C & 2 & 19 & \begin{tabular}{|l|}
$F P$ \\
\end{tabular} & 7.04 & 0 & $\mathrm{C}$ & & 0 & & 3 & $\bar{N}$ & DEIONIZER CELL & & 3590 & 30 \\
\hline & 36.30 & $00 F .50$ & 1964 & 4 & 2 & & 13586 & 100 & $\mathrm{C}$ & 1 & 20 & FP & 18.9 & 0 & $\mathrm{C}$ & & 0 & & 1 & C & OEIONIZER CELL & & 3550 & 590 \\
\hline & 35.20 & $00 \mathrm{~B} .20$ & 1964 & 5 & 18 & & 13730 & 100 & C & 1 & 20 & FP & 11.6 & 0 & C & & 0 & & 1 & $\mathrm{C}$ & DEIONIZER CELL & & 3430 & 130 \\
\hline & 35.10 & 000.50 & 1968 & 3 & 18 & & 31822 & 105 & C & 2 & 30 & IA & 275 & 0 & C & & 0 & & 5 & $C$ & DEIONIZER N0135 & & 3410 & 390 \\
\hline & 35.10 & 000.50 & 1968 & 3 & 7 & & 31924 & 105 & $\mathrm{C}$ & 2 & 30 & $\mathrm{FP}$ & 330 & 0 & C & & 0 & & 5 & C & DEIONIZER N0136 & & 3410 & 390 \\
\hline & 35.10 & 000.50 & 1968 & 3 & 12 & & 31866 & 105 & $\vec{c}$ & 2 & 30 & $\mathrm{FP}$ & 40 & 0 & C & & 0 & & 5 & $\mathrm{C}$ & DEIONIZER N0137 & & 3410 & 390 \\
\hline & 35.10 & 000.50 & 1968 & 3 & 15 & & 31842 & 105 & C & 1 & 30 & FP & 400 & 0 & C & & 0 & & 5 & C & DEIONIZER N0141 & & 3410 & 390 \\
\hline & 35.10 & 000.50 & 1968 & 3 & 11 & & 31882 & 105 & C & 2 & 25 & $\mathrm{FP}$ & 248 & 0 & $\mathrm{C}$ & & 0 & & 5 & $\mathrm{C}$ & DEIONIZER N01436 & & 3410 & 390 \\
\hline & 35.10 & 000.50 & 1968 & 3 & 11 & & 31884 & 105 & $\bar{c}$ & 2 & 30 & FP & 140 & 0 & $\mathrm{C}$ & & 0 & & 5 & $c$ & DEIONIZER N0159 & & 3410 & 390 \\
\hline & 35.10 & OOF.20 & 1968 & 5 & 20 & & 27857 & 105 & C & 2 & 30 & $\mathrm{FP}$ & 550 & 0 & C & & 0 & & 5 & C & DEIONIZER N0164 & & 3410 & 530 \\
\hline & 35.10 & OOD.50 & 1968 & 3 & 11 & & 31883 & 105 & C & 2 & 25 & FP & 350 & 0 & C & & 0 & & 5 & C & DEIONIZER N04183 & & 3410 & 390 \\
\hline & 35.40 & OOF.30 & 1966 & 10 & 24 & & 30251 & 105 & $D$ & 4 & 25 & FP & 19.54 & 0 & C & & 0 & & 1 & $\bar{C}$ & DEIONIZER N1433 & & 3470 & 550 \\
\hline & 35.40 & OOF.30 & 1966 & 10 & 28 & & 30204 & 105 & C & 1 & 25 & FP & 56 & 0 & C & & 0 & & 1 & C & DEIONIZER N1433 & & 3470 & 550 \\
\hline & 35.40 & $00 \mathrm{~F} .40$ & 1966 & 11 & 15 & & 35880 & 105 & C & 2 & 25 & FP & 47 & 0 & $\mathrm{C}$ & & 0 & & 5 & \begin{tabular}{|c|}
$c$ \\
\end{tabular} & DEIONIZER N-1437 & & 3470 & 570 \\
\hline & 35.20 & $00 F .30$ & 1967 & 9 & 18 & & 32851 & 105 & C & 2 & 25 & FP & 77 & 0 & C & & 0 & & 5 & $\mathrm{C}$ & DEIONIZER N1438 & & 3430 & 550 \\
\hline & 35.30 & 000.20 & 1967 & 4 & 3 & & 29732 & 105 & $\mathrm{C}$ & 2 & 25 & FP & 228 & 0 & $c$ & & 0 & & 5 & $c$ & DEIONIZER N1439 & & 3450 & 330 \\
\hline & 35.10 & $00 F .20$ & 1968 & 5 & 16 & & 27924 & 105 & $\bar{C}$ & 2 & 200 & IA & 1375 & 0 & C & & 0 & & 5 & C & DEIONIZER N160 & & 3410 & 530 \\
\hline & 35.20 & $00 F .40$ & \begin{tabular}{|l|}
1967 \\
\end{tabular} & 9 & 6 & & 32962 & 105 & C & 2 & 25 & FP & 243 & 0 & C & & 0 & & 5 & C & DEIONIZER N1810 & & 3430 & 570 \\
\hline$!$ & 6.50 & OOG.20 & 1972 & 8 & \begin{tabular}{|l|}
11 \\
\end{tabular} & & 61856 & 105 & $\mathrm{~K}$ & 4 & 0 & 46 & 0.191 & 0.005 & $G$ & FP & 84.42 & C & 1 & C & DEIONIZER N-224 & & 590 & 630 \\
\hline & 6.50 & $00 G .20$ & 1972 & 8 & 14 & & 61857 & 105 & $\mathrm{~K}$ & 4 & 30 & 46 & 0.827 & 0.022 & $G$ & FP & 42.18 & C & 1 & C & DEIONIZER N-319 & & 590 & 630 \\
\hline 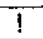 & 6.50 & $00 G .20$ & 1972 & 8 & 16 & & 61859 & 105 & $\mathrm{~K}$ & 4 & 30 & 46 & 0.765 & 0.021 & $G$ & FP & 84 & C & 1 & C & DEIONIZER N-321 & & 590 & 630 \\
\hline & 6.30 & $00 G .20$ & 1972 & 8 & 7 & & 61851 & 105 & $\mathrm{~K}$ & 3 & 30 & 46 & 1.448 & 0.039 & $\mathrm{G}$ & FP & 190.19 & $\bar{C}$ & 1 & $\vec{C}$ & DEIONIZER N322 & & 550 & 630 \\
\hline & 6.30 & $00 G .20$ & 1972 & 8 & 8 & & 61853 & 105 & $K$ & 3 & 30 & 46 & 0.003 & 0 & $\mathrm{G}$ & $\mathrm{FP}$ & 50.5 & $\mathrm{C}$ & 1 & C & DEIONIZEA $\mathrm{N}-323$ & & 550 & 630 \\
\hline & 35.40 & $00 F .30$ & 1966 & 10 & 24 & & 30250 & 105 & C & 4 & 25 & FP & 40 & 0 & C & & 0 & & 1 & $\mathrm{C}$ & DEIONIZER N4317 & & 3470 & 550 \\
\hline & 35.40 & OOF.10 & 1966 & 10 & 14 & & 30390 & 105 & C & 1 & 25 & FP & 32 & 0 & $\begin{array}{ll}\mathrm{C} \\
\end{array}$ & & 0 & & 5 & C & DEIONIZER N4887 & & 3470 & 510 \\
\hline & 6.50 & $00 G .20$ & 1972 & 11 & 7 & & 61402 & 105 & $\mathrm{~K}$ & 4 & 30 & 46 & 0.987 & 0.027 & $G$ & FP & 703 & $\mathrm{C}$ & 1 & C & DEIONIZER RESIN & & 590 & 630 \\
\hline & 37.20 & $00 E .30$ & 1961 & 12 & 21 & & 1285 & 105 & C & 1 & 20 & FP & 73.4 & 0 & C & & 0 & & 1 & C & DEIONIZER SHELL & & 3630 & 450 \\
\hline & 35.30 & 000.20 & 1967 & 4 & 19 & & 29570 & 105 & C & 1 & 25 & FP & 44 & 0 & c & & 0 & & 5 & $\mathrm{C}$ & DEIONIZER SHELL & & 3450 & 330 \\
\hline & 35.20 & $00 F .40$ & 1967 & 9 & 5 & & 32980 & 105 & C & 1 & 25 & FP & 107 & 0 & C & & 0 & & 5 & C & DEIONIZER SHELL & & 3430 & 570 \\
\hline & 35.20 & $00 F .30$ & \begin{tabular}{|l|}
1967 \\
\end{tabular} & 9 & $\frac{5}{12}$ & & \begin{tabular}{|l|}
32909 \\
\end{tabular} & 105 & C & 2 & 25 & AA & 5 & 0 & $\mathrm{C}$ & & 0 & & 5 & $\mathrm{C}$ & DEIONIZER SHELL & & 3430 & 550 \\
\hline
\end{tabular}
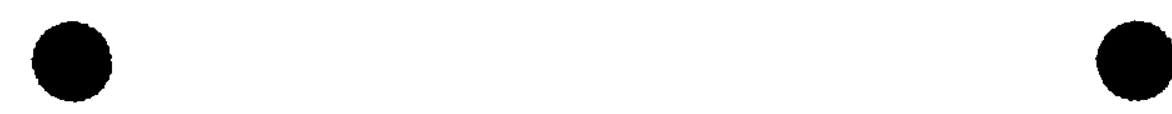
Table 3-2. Records for All Carbon-14 Burials in ORWBG. Records Identified by

Searching Description Field 1 for "Spent Deionizers", "Ion Exchange Resins",

"Demineralizer Units", "Shell", etc. (Continued)

\begin{tabular}{|c|c|c|c|c|c|c|c|c|c|c|c|c|c|c|c|c|c|c|c|c|c|c|c|c|}
\hline 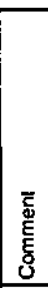 & 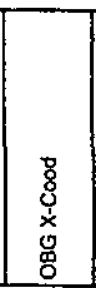 & 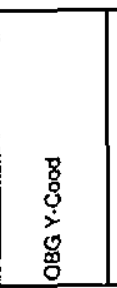 & 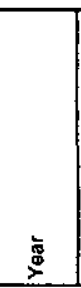 & $\begin{array}{l}\underline{5} \\
\underline{\Sigma}\end{array}$ & 겸 & 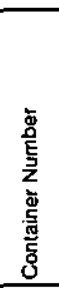 & 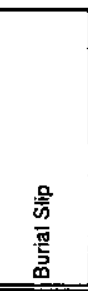 & 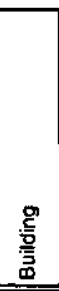 & 兽 & 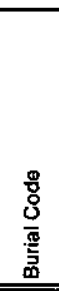 & 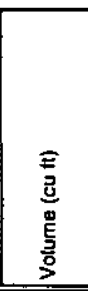 & 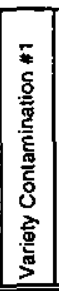 & 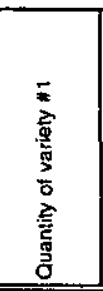 & 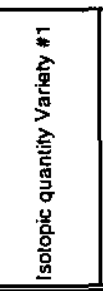 & 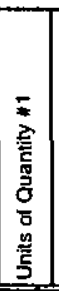 & 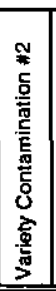 & 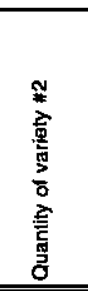 & 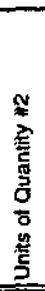 & 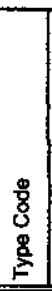 & 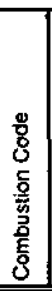 & 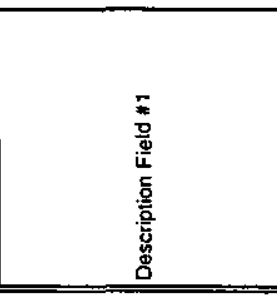 & 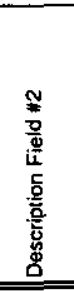 & 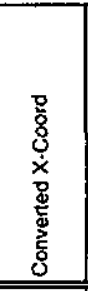 & 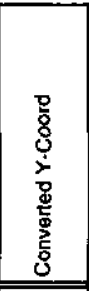 \\
\hline & 35.20 & OOF. 40 & 1967 & 9 & 19 & & 32826 & 105 & $\overline{\bar{c}}$ & 2 & 25 & FP & 31 & 0 & C & & 0 & & 5 & $\mathrm{c}$ & DEIONIZER SHELL & & 3430 & 570 \\
\hline & 35.20 & \begin{tabular}{|l|}
$00 F .20$ \\
\end{tabular} & 1967 & $\frac{10}{10}$ & 3 & & 30935 & 105 & c & 2 & 25 & FP & 296 & $\frac{0}{0}$ & \begin{tabular}{l|l}
$\mathrm{c}$ \\
\end{tabular} & & $\frac{0}{0}$ & & 5 & $\mathrm{c}$ & DEIONIZER SHELL & & 3430 & 530 \\
\hline & 35.20 & \begin{tabular}{|l|}
$00 F .50$ \\
\end{tabular} & 1967 & 11 & 7 & & 33361 & 100 & c & 2 & 25 & IA & 255 & 0 & c & & 0 & & 5 & $\mathrm{C}$ & DEIONIZER SHELL & & 3430 & 590 \\
\hline & \begin{tabular}{|l|}
35.20 \\
\end{tabular} & \begin{tabular}{|l|}
$00 F .50$ \\
0.0
\end{tabular} & 1967 & 11 & 8 & & 33372 & 105 & c & 2 & $\frac{25}{25}$ & $\mid \frac{1}{\mid A}$ & 299 & 0 & \begin{tabular}{|c|}
$c$ \\
\end{tabular} & & $\frac{\pi}{0}$ & & 5 & $\mathrm{c}$ & DEIONIZER SHELL & & 3430 & 590 \\
\hline & 35.10 & \begin{tabular}{|l|}
000.50 \\
\end{tabular} & 1968 & 3 & 20 & & 31760 & 105 & 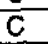 & 2 & 30 & IA & 400 & 0 & c & & 0 & & 5 & $\mathrm{C}$ & DEIONIZER SHELL & & 3410 & 390 \\
\hline & 35.10 & 000.50 & 1968 & 3 & 22 & & 31751 & 105 & $\mathrm{C}$ & 2 & 30 & IA & 330 & 0 & c & & 0 & & 5 & c & DEIONIZER SHELL & & 3410 & 390 \\
\hline & 35.30 & 000.50 & 1967 & 4 & 13 & & 29654 & 105 & $\mathrm{c}$ & 1 & 25 & FP & 148 & 0 & c & & 0 & & 5 & $c$ & DEIONIZER SHIELD & & 3450 & 390 \\
\hline & 36.50 & \begin{tabular}{|l|}
$00 A .20$ \\
\end{tabular} & 1963 & 5 & 16 & & 9581 & 770 & $\mathrm{U}$ & 1 & 5 & FP & 2.5 & 0 & C & & 0 & & 1 & $a t$ & DEIONIZER VESSEL & & 3590 & 30 \\
\hline & 35.20 & 000.20 & 1964 & 8 & 19 & & 20837 & 105 & $\mathrm{c}$ & 1 & 20 & $F P$ & 45.1 & 0 & c & & 0 & & 1 & $\mathrm{c}$ & DE-IONIZER3696-7 & & 3430 & 230 \\
\hline & 37.30 & 000.40 & 1961 & 11 & 7 & & 8827 & 105 & $\mathrm{c}$ & 2 & 19 & FP & 16 & 0 & c & & 0 & & 3 & $\mathrm{~N}$ & DEIONIZER54439-R & & 3650 & 370 \\
\hline & 35.20 & 000.20 & 1964 & 8 & 19 & & 20836 & 105 & $\bar{c}$ & 1 & 20 & FP & 43.2 & 0 & C & & 0 & & $\frac{1}{1}$ & $c$ & DE-IONIZER7 636-3 & & 3430 & 230 \\
\hline & 35.20 & 008.20 & 1964 & 5 & 29 & & 13552 & 105 & U U & $\frac{1}{1}$ & 19 & FP & 47.5 & 0 & \begin{tabular}{|l|l}
$c$ \\
\end{tabular} & & 0 & & 1 & $\mathrm{c}$ & DEIONIZERD7971-1 & & 3430 & 130 \\
\hline & 36.50 & OOA.20 & 1963 & \begin{tabular}{l|l}
6 \\
\end{tabular} & 10 & & 12273 & 232 & $\mathrm{H}$ & 2 & 11 & IA & 10 & 2.5 & c & 87 & 0.041 & $\mathbf{G}$ & 3 & $\mathrm{~N}$ & DEIONIZERT3328-3 & & 3590 & 30 \\
\hline & 36.30 & OOF.50 & 1964 & 4 & 1 & & 13571 & 105 & C & 1 & 19 & FP & 10.4 & 0 & C & & 0 & & $\frac{1}{1}$ & $\overline{\mathrm{C}}$ & DEIONIZERV7165-A & & 3550 & 590 \\
\hline & 35.20 & $00 B .40$ & 1964 & 7 & 17 & & 13459 & 105 & c & 1 & 20 & FP & 95 & 0 & \begin{tabular}{|l|l|}
$c$ \\
\end{tabular} & & 0 & & 1 & $\mathrm{c}$ & DEIONIZEERV7971-8 & & 3430 & 170 \\
\hline & 35.20 & 00C.20 & 1964 & 7 & 30 & & 14309 & 105 & C & $\because$ & 25 & FP & 76 & 0 & $\begin{array}{ll}\mathrm{C} \\
\end{array}$ & & 0 & & 1 & $c$ & DEIONIZERW2822-1 & & 3430 & 230 \\
\hline & 35.20 & OOB.40 & 1964 & 7 & 17 & & 13460 & 105 & c & 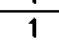 & 20 & FP & 70 & 0 & c & & 0 & & 1 & $\mathrm{c}$ & DEIONIZERW282212 & & 3430 & 170 \\
\hline & \begin{tabular}{|l|}
35.20 \\
30
\end{tabular} & 00C.20 & 1964 & 7 & $\frac{12}{29}$ & & 14324 & 105 & c & 1 & 19 & FP & 73.8 & 0 & c & & 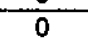 & & 1 & $c$ & DEIONIZERW2822-2 & & 3430 & 230 \\
\hline & 35.20 & $00 B .20$ & 1964 & 6 & \begin{tabular}{|l|l|}
2 & \\
\end{tabular} & & 16524 & 100 & c & 1 & 20 & $F P$ & 26.95 & 0 & c & & 0 & & 1 & $\mathrm{c}$ & DEIONIZERW2822.5 & & 3430 & 130 \\
\hline & \begin{tabular}{|l|}
35.20 \\
\end{tabular} & 000.20 & 1964 & 7 & 30 & & 14308 & 105 & c & 1 & 25 & $F$ & 77 & 0 & c & & 0 & & 1 & $\mathrm{C}$ & DEIONIZERW3696-8 & & 3430 & 230 \\
\hline & 35.30 & 000.50 & 1964 & 9 & 14 & & 13747 & 105 & \begin{tabular}{|l}
$\mathrm{C}$ \\
$\mathrm{C}$
\end{tabular} & 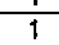 & 20 & $F P$ & 114.4 & 0 & c & & 0 & & 1 & $\mathrm{C}$ & DEIONIZERW3696-9 & & 3450 & 390 \\
\hline & $\mid \frac{35.30}{36.30}$ & \begin{tabular}{|l|}
$00 \mathrm{D} .30$ \\
0.30
\end{tabular} & 1964 & $\frac{5}{3}$ & $\mid \frac{14}{24}$ & & 20961 & 105 & C & 1 & 25 & IA & 14.1 & 0 & \begin{tabular}{|l|l|l|l|l}
$c$ \\
\end{tabular} & & 0 & & 1 & C & DE-JONIZER 39029 & & 3550 & 550 \\
\hline & \begin{tabular}{|l|}
5.20 \\
6.20 \\
\end{tabular} & $\mid 00 \mathrm{G} .20$ & 1972 & 10 & 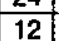 & & 61878 & 105 & $\mathrm{~K}$ & 4 & 50 & \begin{tabular}{|l|}
46 \\
\end{tabular} & 2.753 & 0.075 & $G$ & FP & 76 & c & 1 & c & DENONIZER 345 & & 530 & 630 \\
\hline & 9.50 & 006.50 & & 1 & 12 & & 33607 & 221 & $F$ & 3 & 4 & 50 & 15.999 & 14.559 & $\bar{G}$ & & 0 & & 1 & c & RESIN & & 890 & 690 \\
\hline & \begin{tabular}{|l|}
33.50 \\
330 \\
\end{tabular} & \begin{tabular}{|l|} 
OOD. \\
00.20 \\
\end{tabular} & 1967 & 3 & 3 & & 29192 & $\frac{211}{221}$ & $\mathrm{H}$ & $\frac{5}{3}$ & $\frac{7}{6}$ & 83 & 0 & 0 & $\bar{G}$ & & 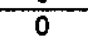 & & 1 & $\mathrm{C}$ & RESIN & & 3270 & 430 \\
\hline & $\mid 0.40$ & 000.20 & $\frac{1507}{1972}$ & 10 & 16 & & 61872 & $\frac{221}{105}$ & $\frac{\pi}{k}$ & 4 & 30 & 83 & 7.211 & 5.768 & $G$ & $F \bar{P}$ & 150 & $\bar{c}$ & 1 & c & RESIN FROM N350 & & 530 & 630 \\
\hline & 6.50 & $00 \mathrm{G} .20$ & 1972 & 9 & 12 & & 61874 & 105 & $\overline{\mathrm{K}}$ & 4 & 30 & 83 & 0.017 & 0.013 & $G$ & $F P$ & 26 & C & 1 & $\mathrm{C}$ & SPENTRESININVALT & & 590 & 630 \\
\hline & & & & & & & & & & & & Cubi & cFeet & & & & & & & & & & & \\
\hline & & & & & & & & & & & 3764.2 & Curi & sक 0. & cubic ff & & & & & & & & & & \\
\hline & & & & & & & & & & & (Note: & xeluc & es 16,00 & cubic ft & recor & & & & & & & & & \\
\hline & & & & & & & & & & & & & & & & & & & & & & & & \\
\hline & & & & & & & & & & & & $\mid s x y$ & $96 \%$ & 4190 & & & & & & & & & & \\
\hline & & & & & & & & & & & & $10 x y$ & $4 \%$ & 187 & & & & & & & & & & \\
\hline & & & & & & & & & & & & & ume & 437 & & & & & & & & & & \\
\hline
\end{tabular}


This page intentionally left blank 
APPENDIX M

CONSTITUENT OF INTEREST:

COBALT-60 
(This page intentionally left blank) 


\section{TABLE OF CONTENTS}

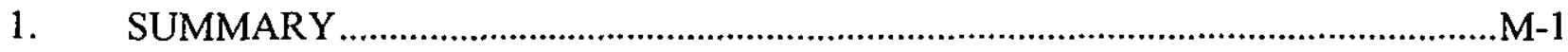

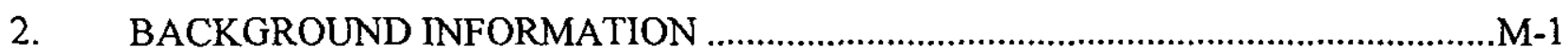

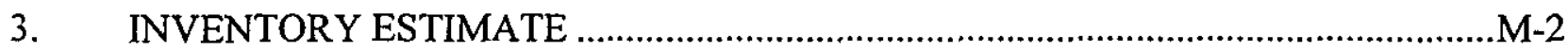

3.1 Range of Inventory Estimates ...................................................................

3.2 Best Estimate of Cobalt-60 in Burial Grounds .....................................................

3.3 Uncertainties Associated with Cobalt-60 Inventory Estimate ................................-4

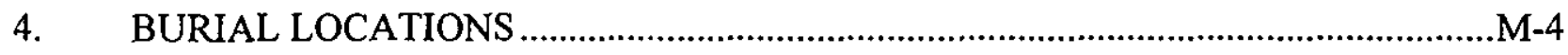

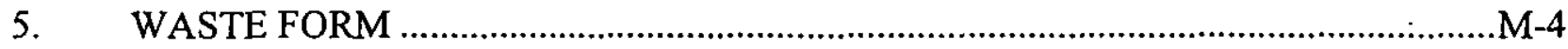

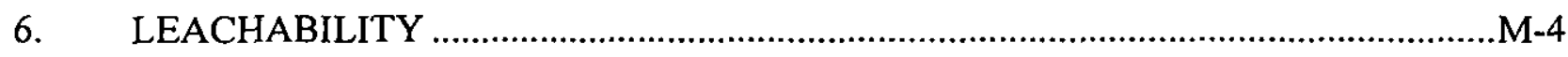

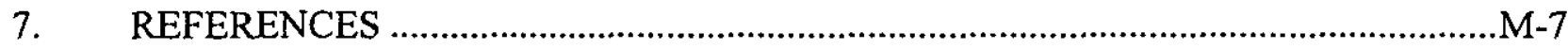




\section{LIST OF FIGURES}

Figure 1-1. Inventory Estimate Process Flow Diagram......................................................9

Figure 4-1. Cobalt-60 Burial Location Process Flow Diagram ...........................................10

Figure 4-2. X,Y Locations for all Cobalt-60 Burials in ORWBG.......................................11

Figure 6-1. Curve Showing the log of the Co-60 Concentration (pCi/l) Released from a Trench that would Decay to $100 \mathrm{pCi} / \mathrm{l}$ (Y-axis) by the Time It Reached the Water Table for a Given Kd Value (X-axis).

\section{LIST OF TABLES}

Table 3-1. The Sources of Inventory Estimates for Cobalt-60 in the ORWBG M-13

Table 3-2. Best Estimates for Cobalt-60 in the ORWBG, Corrected for Radioactive Decay M-15 


\section{CONSTITUENT OF INTEREST - COBALT-60}

\section{SUMMARY}

The cobalt-60 in the Old Radioactive Waste Burial Ground (ORWBG) was produced by irradiating stainless steel in SRS reactors. Operations at the disassembly basins generated excess stainless steel components, which were disposed of as scrap metal. The scrap metal contained cobalt- 60 , and was placed into casks and buried in the ORWBG.

The best estimate of the original amount (undecayed) of cobalt-60 buried in the ORWBG is $1,960,400 \mathrm{Ci}$, based on an average disposal rate of $98,020 \mathrm{Ci}$ annually from startup to 1972 . The best estimate for the amount of cobalt-60 in the ORWBG in 1997, considering radioactive decay, is $27,568 \mathrm{Ci}$.

Figure 1-1 presents the process used to develop the inventory and burial locations. The Computerized Burial Record Analysis (COBRA) database was used to determine the locations and quantity estimates of cobalt- 60 burials.

\section{BACKGROUND INFORMATION}

Cobalt -60 was produced in SRS reactors by the cobalt- 59 (n, $\gamma$ ) cobalt- 60 reaction (Holcomb, 1997). It has a half-life of 5.27 years (KAPL, 1996). The element cobalt has only one stable isotope, cobalt-59.

Most of the cobalt- 60 in the ORWBG was produced by irradiating stainless steel components in SRS reactors. Stainless steel contains cobalt, primarily as an impurity. Irradiation of the cobalt in the stainless steel components formed cobalt-60. Operations at the disassembly basins generated excess stainless steel components, which were disposed of as scrap metal. The scrap metal containing cobalt-60 was placed into casks and buried in the ORWBG (Holcomb, 1997).

Cobalt-60 was also produced at SRS by the irradiation of cobalt-59 wafer targets in the reactors. The resulting cobalt- 60 was shipped offsite to government and private industry customers for use as high energy gamma sources. The wafer targets were not chemically processed at SRS; therefore, little cobalt-60 from this actual production mode is expected to be in the ORWBG (Holcomb, 1997). 
The Savannah River Ecology Laboratory used a small cobalt-60 radiation source for irradiation studies on vegetation and small mammals in the early 1960s. This source (originally $180 \mathrm{Ci}$ ) decayed to unusable levels after two years of operation and was declared excess material. The Department of Energy requested that the source (then $8.3 \mathrm{Ci}$ ) be disposed of in the ORWBG (Reese, 1982 and Smith, 1982 in Tom, 1984).

Cobalt-60 debris such as chips, powder, and metallography specimens resulting from capsule development at the Savannah River Technology Center (SRTC) were disposed of by SRTC Laboratory Operations by normal high-activity solid waste procedures, probably earth burial inside concrete (King, 1966). Only a small fraction of this debris was buried in the ORWBG, and the cobalt- 60 activity from this source is believed to be negligible.

Cobalt-60 was also present in the Old Solvent Tanks. Wilhite (1975 in Mason, 1996) documented that the inventory was 100,000 counts per minute per gram $(\mathrm{c} / \mathrm{m} / \mathrm{g})$ in Tank $\mathrm{S} 6$, $1,300,000 \mathrm{c} / \mathrm{m} / \mathrm{g}$ in Tank $\mathrm{S} 9$, and $750,000 \mathrm{c} / \mathrm{m} / \mathrm{g}$ in Tank $\mathrm{S} 12$.

Cobalt-60 is not a fission product, but small quantities accompanied burials of fission product waste in the ORWBG. The activity in these burials is relatively small compared to that from induced activity.

\section{INVENTORY ESTIMATE}

\subsection{Range of Inventory Estimates}

Although several investigators have reported inventory estimates, most did not include detailed discussions of how the estimates were determined. Hoeffner (1984 and 1985a) cites the estimate by Stone and Christensen (1983) that about $540,000 \mathrm{Ci}$ were buried in the burial ground trenches as of 1982. This estimate pertains to the cumulative undecayed amount in both the ORWBG and 643-7G. Cook (1987) lists the inventory of cobalt-60 in the ORWBG as $1,300,000 \mathrm{Ci}$. Jaegge et al. (1987) report that $4,920 \mathrm{~m}^{3}$ of waste containing cobalt-60, originally $1,110,000 \mathrm{Ci}$, were buried in SRS burial grounds from 1952 to 1985 . These data were based upon COBRA records. For modeling purposes, however, Jaegge et al. (1987) use an undecayed inventory of $3,300,000 \mathrm{Ci}$, as cited in Looney et al. (1987a).

Looney et al. (1987a) state that 98,020 Ci were disposed of annually in the burial grounds. The estimate is the sum of reported inventory of cobalt- 60 , the amount from induced activity, and the amount from fission products: 


\begin{tabular}{lr} 
"Reported Inventory" & 34,000 \\
Induced Activity & 64,000 \\
Fission Product Inventory & 20 \\
\cline { 2 - 2 } TOTAL: & 98,020 \\
\end{tabular}

The reported inventory is given as $34,000 \mathrm{Ci}$ annually, which is determined by dividing the cumulative amount of cobalt-60 buried through $1985(1,110,000 \mathrm{Ci}$, as cited in Jaegge et al., 1987 ) by the number of operation years of the SRS to that time ( 33 years). The induced activity is reported to be $64,000 \mathrm{Ci}$ annually, and is based on an assumption that 62 percent (Looney et al., 1987a) of induced activity in reactor scrap metal is associated with cobalt-60. As determined by Towler and Cook (1985), the amount of cobalt-60 that accompanied fission product wastes is given as $20 \mathrm{Ci}$ annually, a relatively small quantity compared to that from induced activity.

WSRC (1992) cites an estimated 300,000 to $400,000 \mathrm{Ci}$ have been buried in the ORWBG and $643-7 \mathrm{G}$, as of 1982 .

Table 3-1 lists the sources of the inventory estimates for cobalt-60 in the ORWBG.

\subsection{Best Estimate of Cobalt-60 in Burial Grounds}

The best estimate of the original amount of cobalt- 60 disposed in the ORWBG is determined by multiplying the annual disposal rate of $98,020 \mathrm{Ci}$ (Looney et al., 1987a) by the number of years that the ORWBG was in operation (20 years). The result is $1,960,400 \mathrm{Ci}$.

Because of the relatively short half-life of cobalt-60 (5.27 years), the best estimate of the present amount in the ORWBG must account for radioactive decay. From Table 3-2, the best estimate for the amount of cobalt-60 in the ORWBG in 1997 is $27,568 \mathrm{Ci}$.

To determine the cobalt- 60 activity in individual burials in the ORWBG, three assumptions must be made: (1) because the activity associated with fission products is very small $(20 \mathrm{Ci}$ per year), and because the fraction of activity in fission products associated with cobalt-60 is negligible, the activity of cobalt- 60 in burials of fission products is assumed to be negligible and is not addressed herein; (2) based on process knowledge, all of the annual inventory reported by Looney et al. (1987a), except fission products, is assumed to be associated with induced activity $(98,000 \mathrm{Ci} / \mathrm{yr})$; and (3) a certain percentage of induced activity in reactor scrap metal is associated with cobalt -60 . This percentage can be determined by either of two 
methods. Either the value of $0.62(62 \%)$ can be used (Looney et al., 1987a), or it can be calculated by dividing the total activity of cobalt- 60 in the ORWBG $(1,960,000 \mathrm{Ci})$ by the total activity of "induced activity" burials in COBRA $(2,312,029 \mathrm{Ci})$. This value is 0.85 $(85 \%)$. Because the value of 0.62 (Looney et al., 1987a) pertains only to induced activity in reactor scrap metal, the value of 0.85 is used herein. The $0.85(85 \%)$ value is more conservative. The best estimate of the cobalt-60 activity associated with any particular burial of "induced activity" can be determined by multiplying activity of the specific burial of induced activity (from the COBRA database) by 0.85 .

\subsection{Uncertainties Associated with Cobalt-60 Inventory Estimate}

The best estimate is based solely on the assumption that, on average, $98,020 \mathrm{Ci}$ of cobalt- 60 were disposed of annually from startup to 1972 . The assumptions used to determine the cobalt-60 activity associated with any particular burial of "induced activity" are outlined in Section 3.2 .

\section{BURIAL LOCATIONS}

The COBRA database was used to identify burials of cobalt-60 by keyword searching for terms associated with induced activity. Specifically, the database was searched for "scrap metal" (Type Code = 3), "stainless steel", and "IA" (Induced Activity) from Reactor Buildings (105 and 100). The database was also searched for "cobalt-60 debris", "debris", "chips", "powder", and "metallography specimens" (originating in the High-Level Caves Experimental Encapsulation Facility, 773-A) resulting from capsule development in laboratory operations. Figure 4-1 outlines the steps taken to manipulate the database to locate the burials, and Figure 4-2 presents the burial locations.

\section{WASTE FORM}

Most of the cobalt- 60 in the ORWBG is buried as stainless steel scrap metal in casks. A small amount of cobalt- 60 debris resulting from capsule development may have been disposed of by SRTC Laboratory Operations using normal high-activity solid waste procedures, probably earth burial inside concrete.

\section{LEACHABILITY}

The dominant controls on the leachability of cobalt-60 from the ORWBG are the short halflife of cobalt -60 (5.27 years) and the waste form in which most of this radionuclide occurs. 
Most of the cobalt- 60 in the ORWBG was produced by irradiation of stainless steel reactor components. Leachability of cobalt- 60 from this waste form is relatively low because of the resistance of stainless steel to corrosion and because much of the cobalt-60 is embedded beneath the surface of the components. This, coupled with the short half-life of cobalt- 60 , ensures that a large fraction of the activity will decay in place rather than leach into infiltrating water. Furthermore, the short half-life constrains cobalt-60 to short migration distances if any significant retardation by adsorption to soil occurs.

Significant retardation of cobalt- 60 would be expected in the soils of the ORWBG. Hoeffner (1985b) measured $K_{d}$ values for cobalt-60 from batch experiments with ORWBG soils. In groundwater with a composition typical of that associated with the ORWBG and a $\mathrm{pH}$ of 4.7 , the measured $\mathrm{K}_{\mathrm{d}}$ value was $10 \mathrm{ml} / \mathrm{g}$. In water from the trench wells, the measured $\mathrm{K}_{d}$ values ranged from 30 to $100 \mathrm{ml} / \mathrm{g}$. The retardation factor $\left(\mathrm{R}_{\mathrm{f}}\right)$ can be calculated from the equation, $R_{f}=1+\frac{\rho_{b} K_{d}}{\theta}$

where $r_{b}$ is the bulk density of the soil and $q$ is the volume fraction of water in the soil. For a bulk density of $1.6 \mathrm{~g} / \mathrm{cm}^{3}$ (Looney et al., 1987b) and a volume fraction of water of 0.3 (Looney et al., 1987b), a $\mathrm{K}_{\mathrm{d}}$ value of $10 \mathrm{ml} / \mathrm{g}$ translates to a retardation factor of 54.3. If the groundwater travel time from the base of a trench to the water table is 3.8 years (based on a vertical velocity of $6.6 \mathrm{ft} / \mathrm{yr}$ from Jaegge et al., 1987 and a distance of $25 \mathrm{feet}$ ), then approximately 39 half-lives would pass before the center of gravity of a cobalt- 60 plume reached the water table. Using the same parameters for bulk density, volume fraction of water, and groundwater travel time, Figure 6-1 shows for a given $K_{d}$ value, the log of the initial concentration of cobalt- 60 that would decay to the primary drinking water standard of $100 \mathrm{pCi} / 1$ in the contaminant travel time dictated by the given $\mathrm{K}_{\mathrm{d}}$ value. In a dramatic albeit hypothetical illustration, consider the entire ORWBG at burial inventory of cobalt-60 (1.96 x $10^{6} \mathrm{Ci}$ ) dissolved in 1 liter of water and released at the base of a trench. If the $\mathrm{K}_{\mathrm{d}}$ value were greater than $15 \mathrm{ml} / \mathrm{g}$, then the concentration of cobalt- 60 would decay to below $100 \mathrm{pCi} / \mathrm{l}$ by the time the plume reached the water table. Hence, unless large fractions of cobalt- 60 are subject to facilitated transport, dissolved concentrations of cobalt-60 released from trenches must be very high to threaten groundwater.

The low leachability of cobalt-60 is reflected in waste form lysimeter experiments conducted at the ORWBG (McIntyre, 1987). The two waste forms that had significant source terms for cobalt-60 used in the waste form lysimeter experiments were reactor resin and reactor scrap metal. The annual fractional release (the activity released to lysimeter effluent per year 
divided by the source term) of cobalt- 60 from the reactor resin waste ranged from $8 \times 10^{-9}$ to $3 \times 10^{-7}$ over the time period of 1983 through 1986. The annual fractional release from the reactor scrap metal waste ranged from $3 \times 10^{-8}$ to $6 \times 10^{-7}$ over the same time period. The highest cobalt -60 concentration reported in effluent from these lysimeters was $92 \mathrm{pCi} / 1$.

The effect of retardation and decay on concentrations of cobalt-60 in groundwater is reflected in the low concentrations of cobalt-60 measured in groundwater beneath and downgradient from the ORWBG. In all of the measurements of cobalt-60 in groundwater from the grid wells, only 1 was above detection limits at $13 \mathrm{pCi} / \mathrm{l}$ (McIntyre and Wilhite, 1988). This was measured in well E-17 in a study reported by Ryan (1983) that sampled 20 of the grid wells. McIntyre and Wilhite (1988) analyzed groundwater from 18 grid wells for cobalt-60 and found that no samples exceeded the detection limits $(3.0$ to $15.3 \mathrm{pCi} / \mathrm{l})$. Likewise, Cantrell (1990) analyzed for cobalt-60 in groundwater from 7 grid wells and found no concentrations above detection limits ( 7 to $24 \mathrm{pCi} / 1$ ).

The speciation and the low concentrations of cobalt-60 in groundwater suggest that facilitated transport of cobalt- 60 is minor. Calculations of speciation using the geochemical speciation and modeling program MINTEQA2 indicate the dominant species of $\mathrm{Co}$ (II) expected in trench waters is a hydrolyzed species. By analogy to other metals, this cationic hydrolyzed species of cobalt -60 would be expected to adsorb to soil minerals. If colloidal transport of cobalt-60 were significant, travel time to the water table would be less than 1 half-life, and concentrations approaching those observed in the lysimeter experiments would be expected. The evidence suggests that facilitated transport of cobalt-60 is minor, and thus retardation coupled with decay will significantly decrease cobalt- 60 concentrations during migration from the trenches to the water table.

Evidence from the lysimeter experiments and groundwater measurements indicate that cobalt- 60 from the ORWBG is not currently a threat to groundwater, nor will it be a threat in the future. The low leachability from the dominant waste forms and the short half-life of cobalt-60 suggest that concentrations in groundwater will not exceed the current drinking water standard of $100 \mathrm{pCi} / \mathrm{l}$ in the future. 


\section{REFERENCES}

Cantrell, K.J., 1990. Results of the Special Well Sampling Study for the Burial Ground (U), WSRC-RP-90-364, Westinghouse Savannah River Company, Aiken, SC 29808.

Cook, J.R., 1987. Technical Data Summary: Plan for Closure of the 643-G Burial Ground, DPSTD-87-2, E.I. du Pont de Nemours and Company, Aiken, SC.

Hoeffner, S.L., 1984. Cobalt Sorption onto SRP Soils, DPST-84-670, E. I. du Pont de Nemours \& Co., Savannah River Laboratory, Aiken, SC 29808, August 30, 1984.

Hoeffner, S.L., 1985a. Cobalt Sorption onto Savannah River Plant Soils, DP-1703, E. I. du Pont de Nemours \& Co., Savannah River Laboratory, Aiken, SC 29808, June 1985.

Hoeffner, S.L., 1985b. Radionuclide Sorption on Savannah River Plant Burial Ground Soil - A Summary and Interpretation of Laboratory Data, DP-1702, E.I. du Pont de Nemours \& Co., Aiken, SC 29808.

Holcomb, H. Perry, 1997. Deriving Source Terms of Carbon-14, Cobalt-60, Technetium-99, Iodine-129, and Neptunium-237 in the Old Radioactive Waste Burial Ground, RadChemCo-97-013, Memorandum to Smits, A.D., SAIC, RadChemCo, Inc., July 26, 1997.

Jaegge, W.J., et al., 1987. Environmental Information Document, Radioactive Waste Burial Grounds, DPST-85-694, E. I. du Pont de Nemours \& Co., Savannah River Laboratory, Aiken, SC 29808, March 1987.

KAPL, 1996. Chart of the Nuclides, 15th edition, Knolls Atomic Power Laboratory, Naval Reactors, U.S. Department of Energy, revised to 1996.

King, F.D., 1966. Cobalt-60 Storage and Disposal, Memorandum to Ross, C.P., DPST-66-513, E. I. du Pont de Nemours \& Co., Savannah River Laboratory, Aiken, SC 29808, September 15, 1966.

Looney, B.B., Pickett, J.B. King, C.M. Holmes, W.G. Johnson, W.F. and J.A. Smith, 1987a. Selection of Chemical Constituents and Estimation of Inventories for Environmental Analysis of Savannah River Plant Waste Sites, DPST-86-291, E.I. du Pont de Nemours and Company, Savannah River Laboratory, Aiken, SC.

Looney, B.B., M.W. Grant, and C.M. King, 1987b. Estimation of Geochemical Parameters for Assessing Subsurface Transport at the Savannah River Plant, DPST-85-904, E.I. du Pont de Nemours \& Co., Aiken, SC 29808. 
McIntyre, P.F., 1987. 1987 Monitoring Report for the Defense Waste Lysimeters, DPST-87568, E.I. du Pont de Nemours \& Co., Aiken, SC 29808.

McIntyre, P.F, and E.L. Wilhite, 1988. Radionuclide Analyses of Burial Ground Well Water, DPST-88-375, E.I. du Pont de Nemours \& Co., Aiken SC 29808.

Mason, J.T., 1996. Information Document on the Old Solvent Tanks S1-S22 in the Old Radioactive Waste Burial Ground 643-E (U), WSRC-RP-96-00144, Westinghouse Savannah River Company, Aiken, SC.

Reese, W.A., 1982. Disposal of Excess Co-60 Irradiation Source, Letter to M.H. Smith, March 26, 1982.

Ryan, J.P., 1983. Groundwater Monitoring in the Savannah River Plant Low Level Waste Burial Ground: A Summary and Interpretation of the Analytical Data, DPST-83-209, E.I. du Pont de Nemours \& Co., Aiken, SC 29808.

Smith, M.H., 1982. Request for Assistance in the Disposal of a Co-60 Radiation Source, Letter to R. Maher, April 19, 1982.

Stone, J.A., and Christensen, E.J., 1983. Technical Summary of Groundwater Quality Protection Program at Savannah River Plant, Volume II - Radioactive Waste, DPST-83-829, E. I. du Pont de Nemours \& Co., Savannah River Laboratory, Aiken, SC, 1983.

Tom, S.M., 1984. Burial of SREL'S 8.3 Curie Co-60 Source, DPSOX-9752, E. I. du Pont de Nemours \& Co., Savannah River Laboratory, Aiken, South Carolina, July 2, 1984.

Towler, O.A., and Cook, J.R., 1985. Radionuclide Distribution in Fission Product and Induced Activity Solid Waste Streams, DPST-87-398, E. I. du Pont de Nemours \& Co., Savannah River Laboratory, Aiken, South Carolina, September 26, 1985.

Wilhite, E.L., 1975. Movement of Organically-Bound Plutonium in Soil, DPST-75-377, E. I. du Pont de Nemours \& Co., Savannah River Laboratory, Aiken, South Carolina, September 23, 1975 .

WSRC, 1992. Old Radioactive Waste Burial Ground, Revised Draft, August, 1992. 


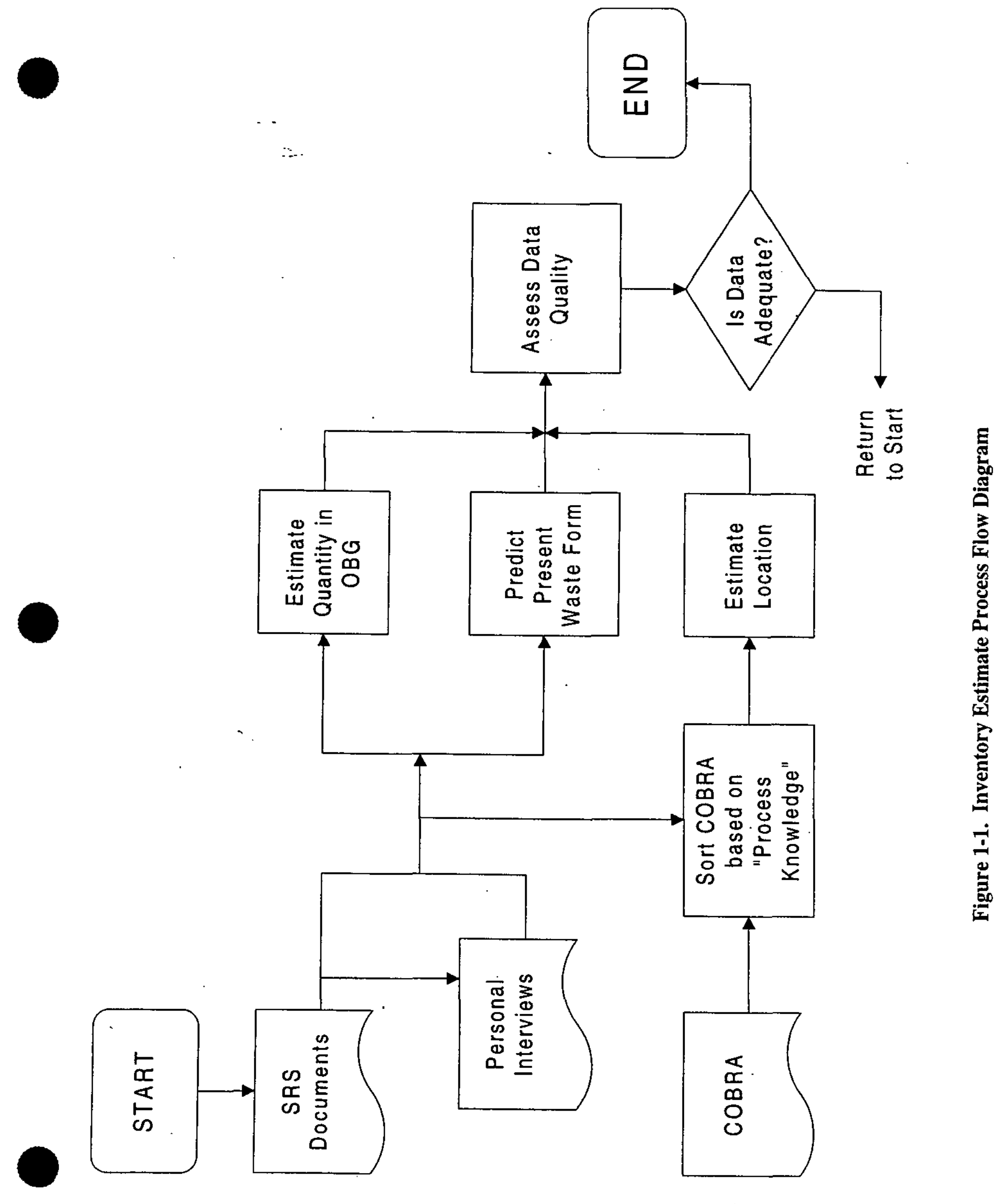




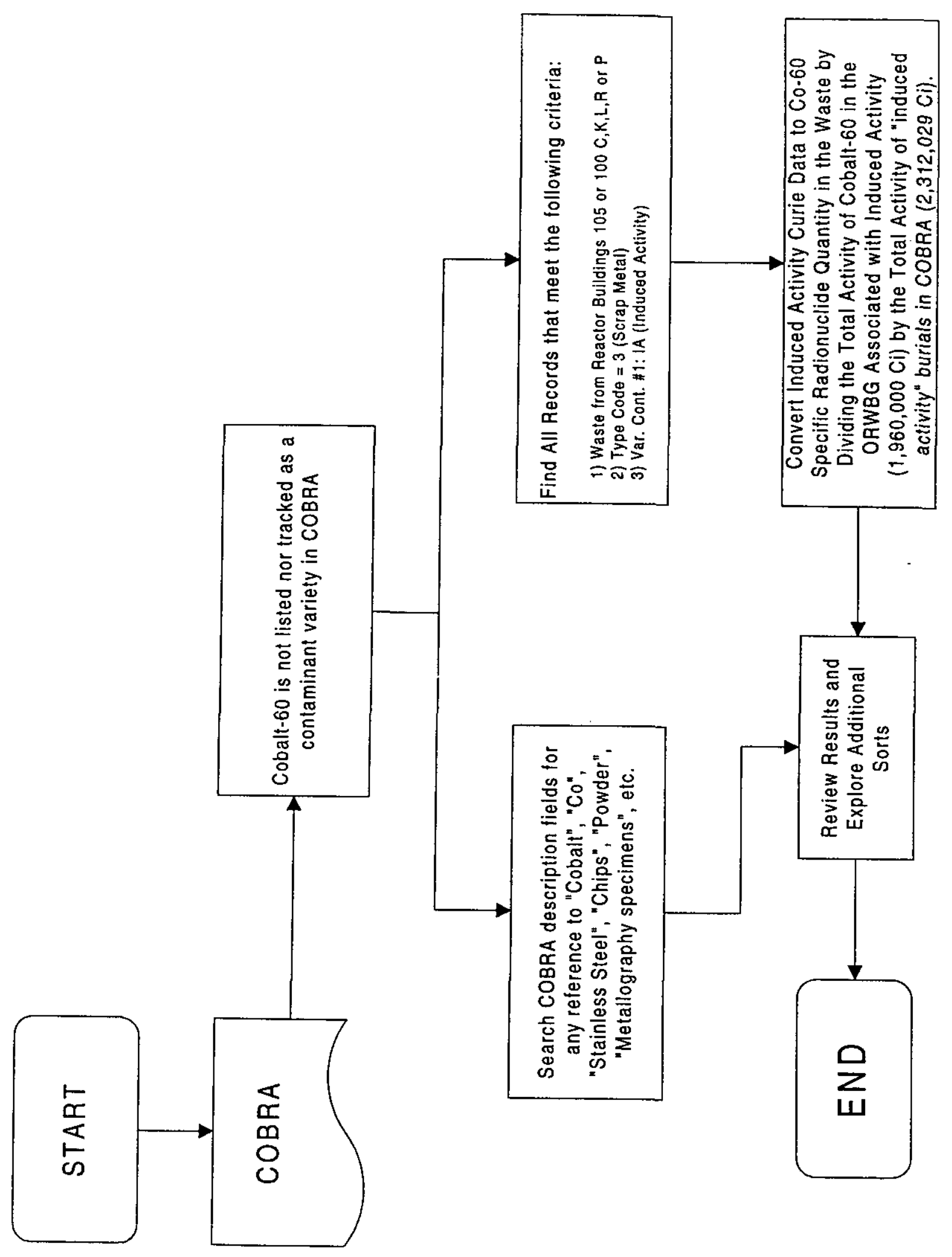



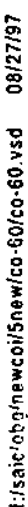




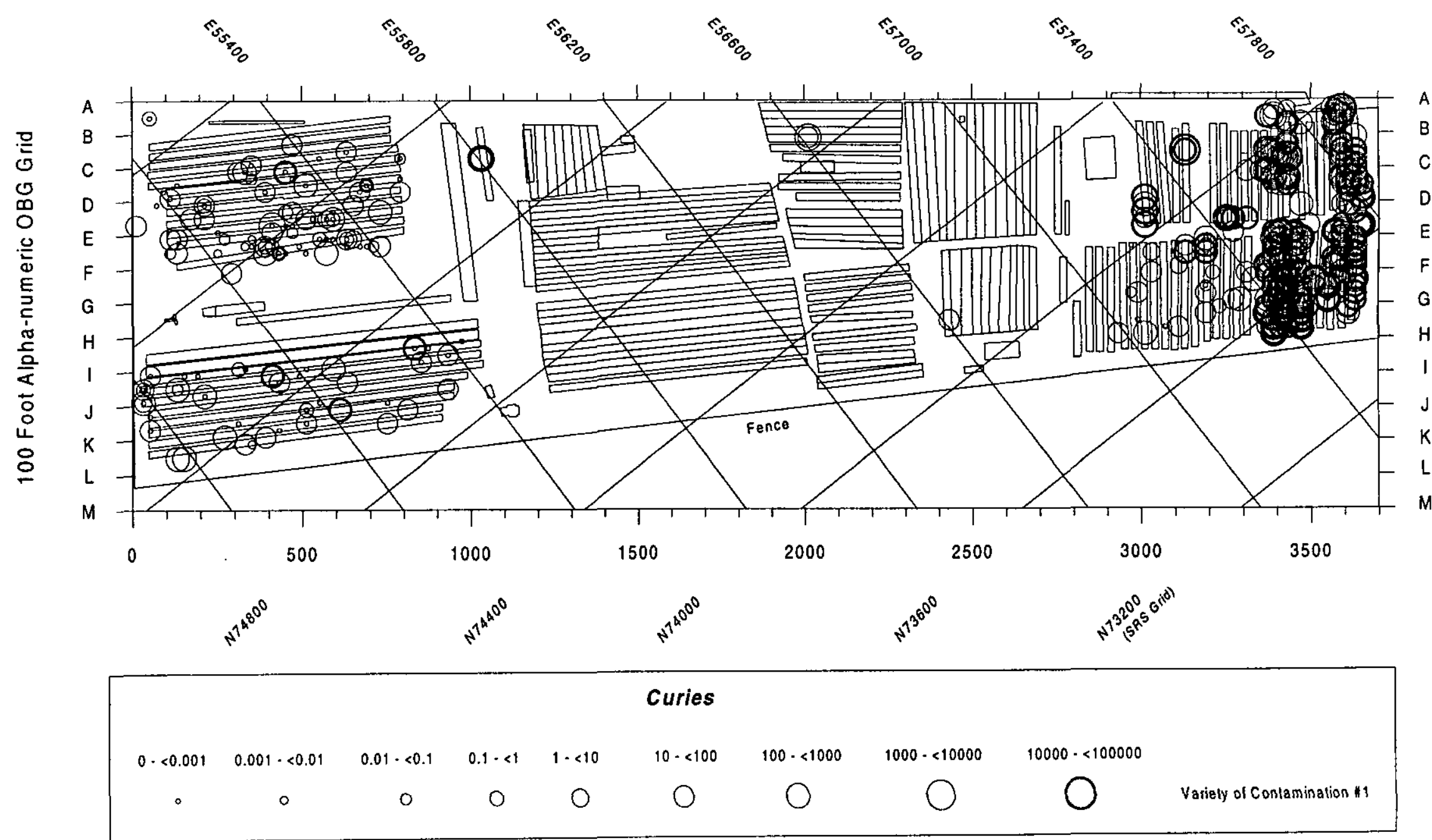

Note: Only $51 \%$ of the 0.60 burials $(824,911$ curies) have $x, y$ coordinates, $49 \%(778,683$ curies) have no location information.

Figure 4-2. $X, Y$ Locations for all Cobalt-60 Burials in ORWBG. Note that these locations were derived by multiplying a constant 0.85 (discussed in report) by the curie content of each COBRA record meeting the following screening criteria:

(1) Burial from Reactor Buildings 100 or $105 \mathrm{C}, \mathrm{K}, \mathrm{L}, \mathrm{R}$ or $\mathrm{P}$

(2) Type Code $=3$ (Scrap Metal)

(3) Variety of Contamination \#1 = IA (Induced Activity) 


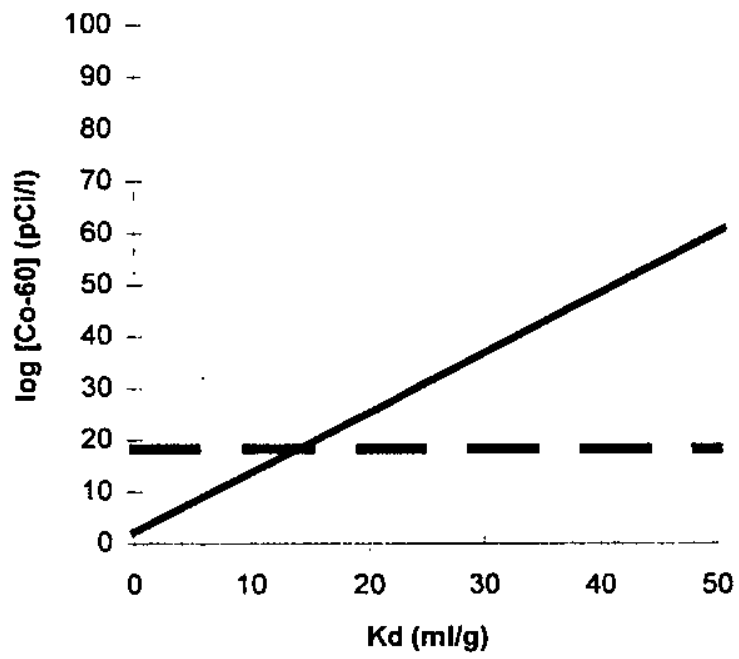

Figure 6-1. Curve Showing the log of the Co-60 Concentration (pCi/l) Released from a Trench that would Decay to $100 \mathrm{pCi} / \mathrm{l}$ (Y-axis) by the Time It Reached the Water Table for a Given Kd Value (X-axis). Dashed line shows the hypothetical concentration achieved by dissolving the entire at burial inventory of Co-60 in 1 liter of water. 
Table 3-1. The Sources of Inventory Estimates for Cobalt-60 in the ORWBG

\begin{tabular}{|c|c|c|}
\hline Reference & Inventory & Notes \\
\hline WSRC, 1992 & $\begin{array}{l}\text { An estimated } 300,000 \text { to } 400,000 \mathrm{Ci} \text { of Co-60 } \\
\text { have been buried in the ORWBG and } 643-7 \mathrm{G} \text {. } \\
\text { (Does not reference an earlier article) } \\
\text { Cobalt-60 (Ci) } \\
\text { ORWBG } \\
\text { (A) Unrecorded } \\
\text { (B) } 1,300,000^{\mathrm{F}} \\
\text { ORWBG \& 7G } \\
\text { (C) } 3,300,000^{\mathrm{F}} \\
\text { (D) } 350,680 \\
\text { (E) } 413,000 \\
\text { (References earlier articles) }\end{array}$ & $\begin{array}{l}\text { (A) Waste Management Operations, } \\
\text { Savannah River Plant, Final Environmental } \\
\text { Impact Statement, } 1975 \text {. } \\
\text { (B) Waste Management Program Technical } \\
\text { Progress Report, 1987. } \\
\text { (C) Selection of Chemical Constituents and } \\
\text { Estimation of Inventories for Environmental } \\
\text { Analysis of Savannah River Plant Waste } \\
\text { Sites, } 1986 . \\
\text { (D) Savannah River Waste Management } \\
\text { Operations Program Plan, } 1989 \\
\text { (E) Integrated Report on Radionuclide } \\
\text { Migration at the Savannah River Shallow } \\
\text { Land Burial Site, 1989. } \\
\text { (F) Does not account for radioactive decay } \\
\text { since time of burial. }\end{array}$ \\
\hline $\begin{array}{l}\text { Looney, B.B., Pickett, J.B. } \\
\text { King, C.M. Holmes, W.G. } \\
\text { Johnson, W.F. and J.A. } \\
\text { Smith, } 1987\end{array}$ & 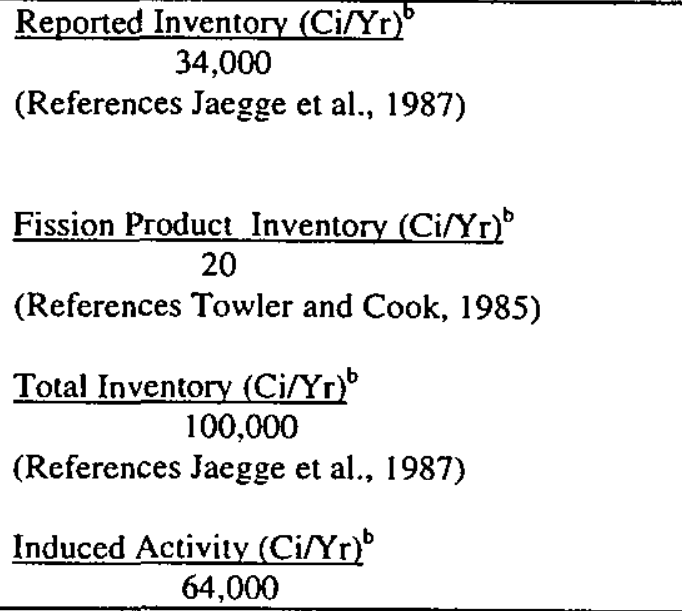 & $\begin{array}{l}\text { - Induced activity in reactor scrap metal: } \\
\frac{\text { Radionuclide }}{\mathrm{C} / 2, \mathrm{yr}} \frac{\text { Percentage of }}{\frac{\text { Activity }}{62}} \\
\text { - } 6.3 \\
\text { Total inventory to the Burial Ground in } \\
\text { Ci/Yr as sum of reported inventory plus } \\
\text { fission product waste plus induced } \\
\text { activity to one or two significant } \\
\text { figures. }\end{array}$ \\
\hline Jaegge, W.J., et al., 1987 & 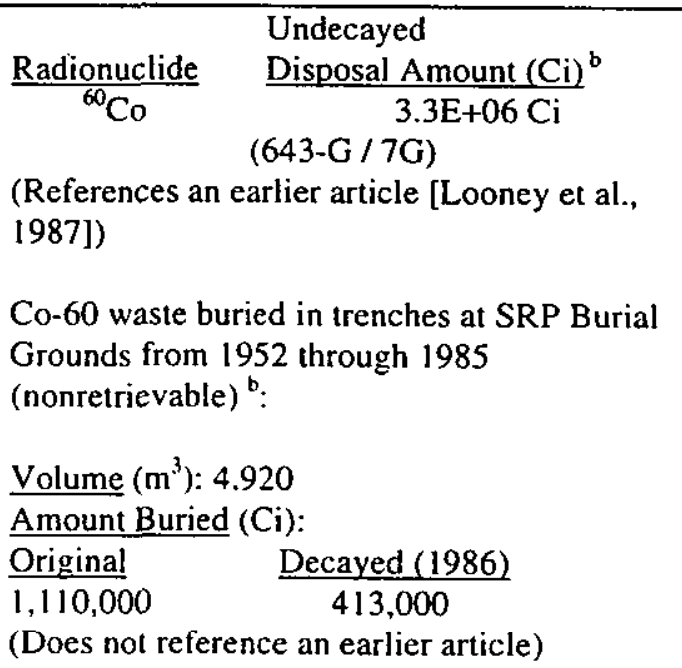 & NA \\
\hline
\end{tabular}


Table 3-1. The Sources of Inventory Estimates for Cobalt-60 in the ORWBG (Continued)

\begin{tabular}{|c|c|c|}
\hline Reference & Inventory & Notes \\
\hline Cook, James R., 1987 & $\begin{array}{lc}\text { Nuclides } & \frac{\text { Inventory }(\mathrm{Ci})}{1.3 \times 10^{6}} \\
\mathrm{Co}^{6}-60^{\mathrm{b}} & (643-\mathrm{G} \text { Site) } \\
& (\text { Does not reference an earlier article) }\end{array}$ & $\mathrm{NA}$ \\
\hline Hoeffner, S.L., 1985 & $\begin{array}{l}\text { As of } 1982 \text { about } 540,000 \mathrm{Ci} \text { of cobalt- } 60 \\
\text { were buried in the trenches. } \\
\text { (References Stone and Christensen, 1983) }\end{array}$ & $\mathrm{NA}$ \\
\hline $\begin{array}{l}\text { Towler, O.A., and Cook, J.R., } \\
1985\end{array}$ & $\begin{array}{l}\text { Radionuclide Content of } 5 \text {-year-old In-tank } \\
\text { Waste: } \\
\text { Isotope } \quad \text { Ci/Gal } \\
\begin{array}{l}\text { Co-60 } 1.93 \mathrm{E}-02 \\
\text { (Does not reference an earlier article) }\end{array}\end{array}$ & $\begin{array}{l}\text { - The "five years" means five years out } \\
\text { of the reactor. }\end{array}$ \\
\hline Hoeffner, S.L., 1984 & $\begin{array}{l}\text { As of } 1982 \text { about } 540,000 \mathrm{Ci} \text { of cobalt- } 60 \\
\text { were buried in the trenches. } \\
\text { (References Stone and Christensen, 1983) }\end{array}$ & NA \\
\hline
\end{tabular}

a: Inventory discussed in detail

b: No discussion of basis for inventory

NA: Not addressed in article 
Table 3-2. Best Estimate for Cobalt-60 in the ORWBG, Corrected for Radioactive Decay

\begin{tabular}{|c|c|c|c|}
\hline Year & $\begin{array}{c}\text { Elapsed Time to } \\
1997 \text { (years) }\end{array}$ & $\begin{array}{c}\text { Annual Inventory, Original } \\
\text { Activity (Ci) }\end{array}$ & $\begin{array}{c}\text { Annual Inventory Decayed } \\
\text { to 1997 (Ci) }\end{array}$ \\
\hline 1953 & 44 & 98,020 & 301 \\
\hline 1954 & 43 & 98,020 & 343 \\
\hline 1955 & 42 & 98,020 & 391 \\
\hline 1956 & 41 & 98,020 & 447 \\
\hline 1957 & 40 & 98,020 & 509 \\
\hline 1958 & 39 & 98,020 & 581 \\
\hline 1959 & 38 & 98,020 & 662 \\
\hline 1960 & 37 & 98,020 & 756 \\
\hline 1961 & 36 & 98,020 & 862 \\
\hline 1962 & 35 & 98,020 & 983 \\
\hline 1963 & 34 & 98,020 & 1121 \\
\hline 1964 & 33 & 98,020 & 1279 \\
\hline 1965 & 32 & 98,020 & 1458 \\
\hline 1966 & 31 & 98,020 & 1663 \\
\hline 1967 & 30 & 98,020 & 1897 \\
\hline 1968 & 29 & 98,020 & 2163 \\
\hline 1969 & 28 & 98,020 & 2467 \\
\hline 1970 & 27 & 98,020 & 2814 \\
\hline 1971 & 26 & 98,020 & 3210 \\
\hline 1972 & 25 & 98,020 & 3661 \\
\hline & & & \\
\hline
\end{tabular}


(This page intentionally left blank) 
APPENDIX N

CONSTITUENT OF INTEREST:

TECHNETIUM-99 
(This page intentionally left blank) 


\section{TABLE OF CONTENTS}

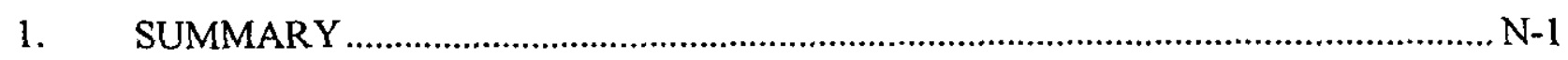

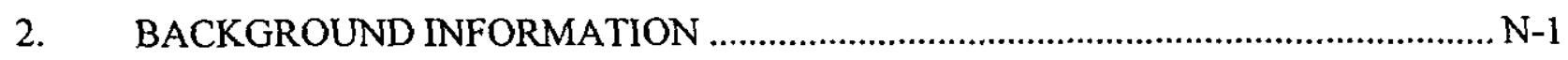

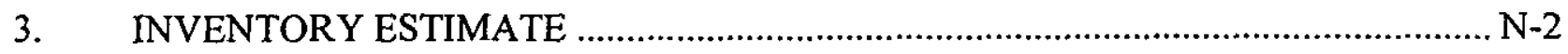

3.1 Range of Inventory Estimates .............................................................. $\mathrm{N}-2$

3.2 Best Estimate of Technetium-99 in Burial Grounds.......................................... N-3

3.3 Uncertainties Associated with Technetium-99 Inventory Estimate.................... N-3

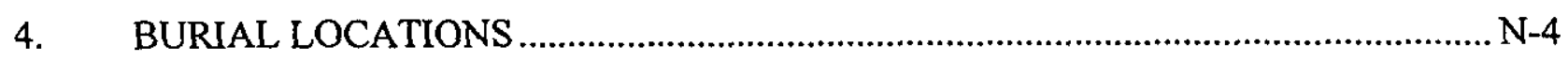

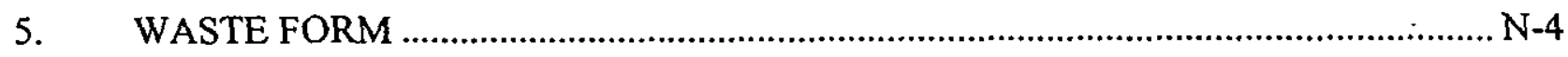

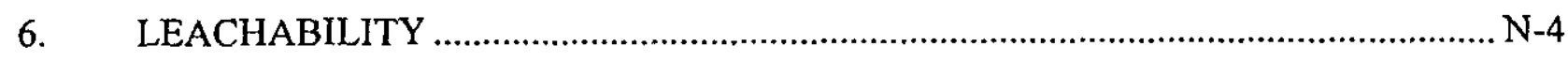

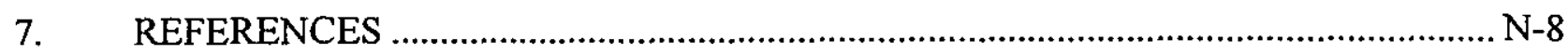




\section{LIST OF FIGURES}

Figure 1-1. Inventory Estimate Process Flow Diagram............................................ N-11

Figure 4-1. Technetium-99 Burial Location Process Flow Diagram.............................. N-12

Figure 4-2. X,Y Locations for all Technetium-99 Burials in ORWBG .......................... N-13

Figure 6-1. Speciation of Technetium Dissolved in Water of Eh=0.1 Volt ..................... N-14

Figure 6-2. Time Series Plot of Nonvolatile Beta Measurements (pCi/l) in Groundwater from Seven Grid Wells that are Located in Areas of High Burial Concentrations of Tc-99

Figure 6-3. Minimum Concentrations of Tc-99 in Grid Wells Predicted from the Leaching Model of Baes and Sharp (1983) N-16

\section{LIST OF TABLES}

Table 3-1. The Sources of Inventory Estimates for Technetium-99 in the ORWBG N-17 


\section{CONSTITUENT OF INTEREST - TECHNETIUM-99}

\section{SUMMARY}

The technetium-99 in the Old Radioactive Waste Burial Ground (ORWBG) is present due to the disposal of mixed fission product waste (Oblath, 1986). Technetium is the major radionuclide remaining in Savannah River Site (SRS) soluble waste after in-tank removal of cesium and strontium (Bibler and Wallace, 1984).

The best estimate of the amount of technetium-99 in the ORWBG is $12 \mathrm{Ci}$. This value is derived using an annual disposal rate of $0.6 \mathrm{Ci}$ multiplied by the number of operational years of the ORWBG (20 years).

Figure 1-1 presents the process used to develop the inventory and burial locations. The Computerized Burial Record Analysis (COBRA) database was used to determine the locations and quantity estimates of technetium- 99 burials.

\section{BACKGROUND INFORMATION}

Technetium-99 is a weak beta-emitting radionuclide with a half-life of 213,000 years and a specific activity of $56 \mathrm{~g} / \mathrm{Ci}$ (Cook, 1989). None of the isotopes of technetium are stable. Consequently, technetium does not occur in nature and its chemistry has not been studied extensively except at nuclear sites (Fowler et al., 1984). Its use in ionic solution as a corrosion inhibitor and in metallic form as a chemical catalyst has been discussed (Bibler and Wallace, 1984).

Technetium has been the object of environmental concern with regard to underground disposal of radioactive waste because it does not seem to be strongly sorbed on geologic material (Neretnieks, 1971, in Cook, 1989). It tends to accumulate in plants (Wildung et al., 1977, in Cook, 1989), and it concentrates in some parts of the human body (McAffee et al,, 1964, in Cook, 1989). The combination of long half-life and low retentivity (high mobility) result in a of a high potential for the release of technetium to groundwater and movement into the accessible biosphere (Cook, 1989). The primary solution form of technetium is the pertechnetate ion, $\mathrm{TcO}_{4}^{-}$, a relatively mobile anion.

Technetium-99 is a fission product produced by the fission of uranium-235 and plutonium-239 (Cook, 1989). It is generally found in all wastes resulting from nuclear fuel reprocessing. It is present in spent fuel and targets from both SRS and offsite reactors (Bibler and Jurgenson, 1986; 
Fowler et al., 1984). Most of the technetium-99 in the ORWBG is in burials of fission product waste.

Because of its high solubility and its chemistry in the SRS Separations processes, the source of most technetium-99 at SRS was in the high-level radioactive liquid waste and not in mixed fission product waste sent to the Solid Waste Management Facilities. The waste was transferred to the waste tanks for processing at the Saltstone Facility in Z Area, which opened in 1988 (Bibler and Wallace, 1984). Fowler et al. (1984) estimated the technetium-99 inventory in sludge and soluble waste was $31,050 \mathrm{Ci}$. At the Saltstone Facility, the waste was mixed with fly ash and cement to make a solid concrete-like waste known as saltstone. The saltstone was not buried in the ORWBG.

Fission products are present in the Old Solvent Tanks in the ORWBG. Technetium-99 may exist in minor quantities, but it has not been reported as a significant constituent in any of the tanks (Mason, 1996).

\section{INVENTORY ESTIMATE}

\subsection{Range of Inventory Estimates}

Although several investigators have reported inventory estimates, most did not include detailed discussions of how the estimates were determined. Oblath (1982), assuming the relative amounts of cesium, strontium, and technetium are determined solely by fission yields, estimated that between 1 and $100 \mathrm{Ci}$ of technetium have been disposed in 643-G. Jaegge et al. (1987) presented an estimate of $20 \mathrm{Ci}$ (undecayed disposal amount) in the Radioactive Waste Burial Grounds (Looney et al., 1987a in Jaegge et al., 1987). Cook (1987) estimated that $17 \mathrm{Ci}$ have been buried in 643-G, and about $20 \mathrm{Ci}$ have been buried in the burial grounds (Cook, 1989). Wilhite et al. (1989) also cited that about $20 \mathrm{Ci}$ of technetium-99 have been buried in the burial ground.

Dr. E.L. Albenesius, who formerly served as a research manager of the Savannah River Laboratory's (now the Savannah River Technology Center) Environmental Effects and Solid Waste Management Technology Divisions, reported in a 1992 discussion that there is much more technetium in the saltstone than there is in the burial ground (Holcomb, 1992).

Looney et al. (1987a) cited that $0.6 \mathrm{Ci}$ of technetium-99 was disposed of annually in the burial ground. This was based on an isotopic distribution of fission products presented in Towler and Cook (1985), which cites that five-year-old in-tank waste contains 5.53E-04 Ci technetium-99 per gallon. 
The amount of technetium-99 in the burial ground has been calculated by Holcomb (1997) using fission product activity ratios in Webb (1994) as well as the assumption that no separation of the individual fission products had occurred during processing. Using a cesium-137 source term of $26,943 \mathrm{Ci}$ (WSRC, 1997) and a technetium-99/cesium-137 maximum activity ratio of 2.26E-04, Holcomb calculated a maximum activity of $6.09 \mathrm{E}+00 \mathrm{Ci}$ of technetium-99 in the ORWBG. Similarly, using a strontium-90 source term of 26,516 Ci (WSRC, 1997) and a technetium-99/strontium-90 activity ratio of $2.94 \mathrm{E}-04$, Holcomb calculated a maximum technetium-99 activity of $7.80 \mathrm{E}+00 \mathrm{Ci}$. These inventory estimates are similar to the unsubstantiated estimates in previous reports; however, these estimates are subject to uncertainty about whether or not there has been preferential separation/concentration of the isotopes by chemical or physical processes. Due to the nature of chemical operations at Separations facilities, the activity ratios of fission products in unprocessed fuel or targets from SRS reactors as calculated by Webb (1994) are expected to be different from the ratios in fission product contaminated waste from separations. However, the ratios of technetium-99 to cesium-137 or to strontium-90 would not differ greatly because their relatively similar solution chemistries in separations make most of these three radionuclides divert to the aqueous waste stream from the 1 st cycle of PUREX solvent extraction (the 1AW stream).

Table 3-1 lists the sources of the inventory estimates for technetium-99 in the ORWBG.

\subsection{Best Estimate of Technetium-99 in Burial Grounds}

The best estimate of technetium-99 in the ORWBG is derived using the annual disposal rate of 0.6 $\mathrm{Ci}$ cited in Looney et al. (1987a). This value is multiplied by the number of operational years of the ORWBG (20 years). This yields $12 \mathrm{Ci}$. This estimate is in reasonable accord with other estimates by Oblath (1982), Jaegge et al. (1987), Cook (1987), Cook (1989), and Wilhite et al. (1989), and the values calculated by Holcomb (1997).

\subsection{Uncertainties Associated with Technetium-99 Inventory Estimate}

An obvious uncertainty with the best estimate is that it is based on an isotopic distribution of fission products presented in Towler and Cook (1985), which cites that five-year-old in-tank waste contains 5.53E-04 Ci technetium- 99 per gallon. The accuracy of this value is unknown.

Underlying uncertainties with the best estimate stem from the generally poor documentation of the radionuclide. No technical reports exist that provide production details, wastestream characteristics, or disposal information. 


\section{BURIAL LOCATIONS}

Shipments of technetium-99 are not documented in the COBRA database. Figure 4-1 outlines the steps taken to manipulate the database to locate the burials. In the COBRA database there are no references to "decontaminated filtrate", "saltstone", "salt solution", etc. In addition, no quantity or specific technetium-99 constituent information is contained in any COBRA record.

Technetium-99 is assumed to have been disposed with other fission product waste, and to have been identified in the COBRA database as "fission products". The total fission product activity from COBRA records is $621,626 \mathrm{Ci}$. Assuming the technetium-99 inventory of $12 \mathrm{Ci}$ was distributed throughout the $621,626 \mathrm{Ci}$ of "fission product" burials, the amount of technetium-99 in each burial is determined by multiplying the individual burials of fission products (in $\mathrm{Ci}$ ) by 12 $\mathrm{Ci}$ and dividing by $621,626 \mathrm{Ci}$. Figure $4-2$ presents the burial locations.

\section{WASTE FORM}

The most likely state of technetium-99 in SRS waste streams and solid waste is $\mathrm{TcO}_{4}^{-}$resulting from dissolution of fission-product-containing target and fuel elements in nitric acid $\left(\mathrm{HNO}_{3}\right)$. Technetium can also exist as the oxide, $\mathrm{TcO}_{2}$. Even if it were buried in that form, there is evidence that the conversion to $\mathrm{TcO}_{4}^{-}$would have been rapid (Bondietti and Francis, 1979 in Oblath, 1982). Pertechnetate, $\mathrm{TcO}_{4}^{-}$, is expected to be the stable form of technetium-99 in both the saturated zone beneath the burial ground and in the burial trenches (Oblath, 1982).

\section{LEACHABHLITY}

The leachability of technetium is controlled by redox conditions and $\mathrm{pH}$. Similar in chemistry to manganese, technetium occurs in a range of oxidation states from +3 to +7 . Under mildly oxidizing conditions (typical of near surface groundwater at the SRS) the TC(VII) form is stable. The dominant species of this form in most groundwater is the mobile $\mathrm{TcO}_{4}^{-}$Hoeffner (1985) reports experimental results that indicate that this species moves at $13 \%$ to $90 \%$ of groundwater velocities in groundwater associated with the ORWBG. However, under moderately reducing conditions Tc(IV) species may dominate the speciation of technetium, greatly reducing its mobility. Figure 6-1 shows the change in speciation of technetium with $\mathrm{pH}$ at $\mathrm{Eh}=0.1$ volts. At $\mathrm{pH}<6.2$, the $\mathrm{Tc}(\mathrm{IV})$ species $\mathrm{TcO}(\mathrm{OH})_{2}$ is dominant. By analogy to other metals, the cationic hydrolized species of technetium would be expected to adsorb more strongly to soil minerals than the anionic species $\mathrm{TcO}_{4}^{\circ}$. Thus, under reducing conditions the mobility of technetium is decreased. 
The concentration technetium-99 in groundwater associated with the ORWBG is relatively low. In 1982 , technetium-99 was measured at concentrations of 4.4 and $2.7 \mathrm{pCi} / 1$ in groundwater from Grid Wells E-17 and G-21 and at a concentration of $1.5 \mathrm{pCi} / 1$ in groundwater from a well approximately 600 feet downgradient from the ORWBG (Oblath, 1986). McIntyre and Wilhite (1987) analyzed for technetium-99 in groundwater from ten grid wells and three downgradient wells. The technetium-99 concentration was below detection limits in groundwater from all wells except grid well I-7, which contained $13 \mathrm{pCi} / 1$. For comparison the, EPA primary drinking water standard for technetium- 99 is $900 \mathrm{pCi} / \mathrm{l}$.

Measurements of nonvolatile beta emission in groundwater associated with the ORWBG are also generally low. Though nonvolatile beta is only a semi-quantitative measurement and is not directly correlated to technetium-99 concentration, it is expected that high concentrations of technetium-99 would be reflected in elevated nonvolatile beta measurements. Groundwater from the grid wells was monitored regularly for nonvolatile beta from 1976 through 1986 . The highest yearly median measurement was $30 \mathrm{pCi} / \mathrm{l}$ in 1976 . For that year, the current primary drinking water standard of $50 \mathrm{pCi} / 1$ was exceeded in only 7 of 66 grid wells. Figure 6-2 shows a time series plot of average yearly nonvolatile beta measurements of groundwater from seven grid wells that monitored groundwater in close proximity to locations where large quantities of fission products were buried. The highest concentrations of technetium-99 beneath the ORWBG should be in these wells. Yet, with the exception of three elevated measurements, nonvolatile beta has remained relatively low in these wells, and there is no trend toward higher values with time. In addition, nonvolatile beta measurements of groundwater from downgradient perimeter water table wells (BGO series) have remained relatively low.

The low nonvolatile beta measurements and technetium-99 concentrations in groundwater associated with the ORWBG suggest that conditions in the ORWBG are not conducive to the formation of the mobile species, $\mathrm{TcO}_{4}^{-}$. The presence of technetium-99 in groundwater beneath and downgradient of the ORWBG at concentrations that are low, but significantly above background, suggests that a fraction of the technetium-99 in the ORWBG is migrating as $\mathrm{TcO}_{4}{ }^{\circ}$. However, concentrations are much lower than would be expected were this the dominant species. Figure 6-3 shows the concentrations expected over time based on the leaching model of Baes and Sharp (1983). The model here assumes a $\mathrm{K}_{d}$ value for $\mathrm{TcO}_{4}{ }^{-}$of $0.33 \mathrm{ml} / \mathrm{g}$ (Hoeffner, 1985), a soil bulk density and porosity of $1.6 \mathrm{~g} / \mathrm{cm}^{3}$ and 0.2 respectively (Looney et al., 1987b), a layer of waste 5 meters thick (Looney et al., 1987b), and a groundwater travel time of 5 years from the base of a trench to the water table. Infiltration rates of $2.36 \mathrm{~m} / \mathrm{yr}$ (Orebaugh and Hale, 1976) and $0.38 \mathrm{~m} / \mathrm{yr}$ (Looney et al, 1987b; for typical SRS soil) are shown. Based on the burial location 
map it was assumed that the $8 \mathrm{Ci}$ of technetium-99 was distributed evenly over $1 / 3$ of the area of the ORWBG. Though it is not a comprehensive model, this estimate of concentrations suggests that, from 1980 through 1986, concentrations of technetium- 99 should have been on the order of 100 to several thousand $\mathrm{pCi} / \mathrm{l}$. Yet, concentrations of technetium-99 of this magnitude were not seen in grid well samples analyzed for technetium-99. Of four grid wells located in areas of high burial concentrations of technetium-99 and sampled in 1986, one had a concentration of $13 \mathrm{pCi} / \mathrm{l}$, the other three had technetium- 99 concentrations below detection. Furthermore, nonvolatile beta measurements of the grid wells and BGO series wells do not indicate high concentrations of technetium-99. Therefore, it is likely that the dominant species of technetium-99 in the ORWBG is the reduced and less mobile species $\mathrm{TcO}(\mathrm{OH})_{2}$.

Conditions in the ORWBG are reducing and trench well samples reported by Hoeffner (1985) suggest that $\mathrm{TcO}(\mathrm{OH})_{2}$ may be the dominant technetium-99 species in much of the ORWBG. Figure 6-1 indicates that at $\mathrm{Eh}=0.1$ volt and $\mathrm{pH}<6.2, \mathrm{TcO}(\mathrm{OH})_{2}$ is the dominant species. Water from three of the seven trench wells reported by Hoeffner (1985) meet these conditions. For water with $\mathrm{Eh}=0.1$ volt and $\mathrm{pH}$ between 5.6 and 6.2 , a measurable fraction of technetium-99 would co-exist as the species $\mathrm{TcO}_{4}{ }^{-}$. This is consistent with the low concentrations of technetium99 in groundwater beneath and downgradient from the ORWBG.

The reducing conditions in the ORWBG are caused by the oxidation of organic matter (paper, cardboard, etc.), iron, steel, and other metals. Reducing conditions will persist until the supply of these materials is depleted. Reduction of infiltration by capping would cause conditions to become more reducing and increase the time that conditions remain reducing. However, when the cap is no longer an effective barrier to infiltration conditions will eventually become more oxidizing, causing the remaining technetium-99 to become more leachable.

Thus, technetium-99 from the ORWBG is not an immediate threat to groundwater, but may become a threat in the future. 


\section{REFERENCES}

Baes, C.F., III and R.D. Sharp, 1983. "A Proposal for Estimating Soil Leaching and Leaching Constants for Use in Asessment Models", Journal of Environmental Quality, v. 12, p. 17-28.

Bibler, N.E., and Jurgensen, A.R., 1986. Leaching Tc-99 from DWPF Glass in Simulated Geologic Repository Groundwaters, Memorandum to Albenesius, E.L., Coffey, C.E., Technical Division Savannah River Laboratory, September 30, 1986.

Bibler, N.E., and Wallace, R.M., 1984. Extended Ion Exchange Process for Removal and Recovery of Technetium from Soluble Waste, DPST-84-507, Memorandum to Ebra, M.A., Technical Division Savannah River Laboratory, May 22, 1984.

Bondietti, E.A., and Francis, C.W., 1979. "Geologic Migration Potentials of Technetium-99 and Neptunium-237", Science, 203: 1337-1340.

Cook, J.R., 1987. Technical Data Summary: Plan for Closure of the 643-G Burial Ground, DPSTD-87-2, E.I. du Pont de Nemours and Company, Aiken, SC.

Cook, J.R., 1989. Assessment of Long-Lived Radionuclides in the Savannah River Plant Radioactive Waste Burial Grounds, DPST-89-315, Memorandum to Sturm, H.F., Jr., Technical Division Savannah River Laboratory, February 23, 1989.

Fowler, J.R., Hamm, B.A., and Cook, J.R., 1984. Technetium-99 in SRP High-Level Waste and Saltstone, DPST-84-334, Memorandum to Wilds, and G.W., Albenesius, E.L., Technical Division Savannah River Laboratory, February 24, 1984.

Hoeffner, S.L., 1985. Radionuclide Sorption on Savannah River Plant Burial Ground Soil - A Summary and Interpretation of Laboratory Data, DP-1702, E.I. du Pont de Nemours \& Co., Aiken, SC 29808.

Holcomb, H. Perry, 1992. Transcription of a Presentation by Dr. E.L. Albenesius, SRS Burial Ground Operation from an Historical Perspective (U), WSRC-RP-92-349, Environmental Restoration Department, Westinghouse Savannah River Company, Savannah River Site, Aiken, SC, February 14, 1992.

Holcomb, H. Perry, 1997. Deriving Source Terms of Carbon-14, Cobalt-60, Technetium-99, Iodine-129, and Neptunium-237 in the Old Radioactive Waste Burial Ground, RadChemCo-97-013, Memorandum to Smits, A.D., SAIC, RadChemCo, Inc., July 26, 1997. 
Jaegge, W.J., et al., 1987. Environmental Information Document, Radioactive Waste Burial Grounds, DPST-85-694, E. I. du Pont de Nemours \& Co., Savannah River Laboratory, Aiken, SC 29808, March 1987.

Looney, B.B., Pickett, J.B. King, C.M. Holmes, W.G. Johnson, W.F. and J.A. Smith, 1987a. Selection of Chemical Constituents and Estimation of Inventories for Environmental Analysis of Savannah River Plant Waste Sites, DPST-86-291, E.I. du Pont de Nemours and Company, Savannah River Laboratory, Aiken, SC.

Looney, B.B., M.W. Grant, and C.M. King, 1987b. Estimation of Geochemical Parameters for Assessing Subsurface Transport at the Savannah River Plant, DPST-85-904, E.I. du Pont de Nemours \& Co., Aiken, SC 29808.

McAffee, J.G., Fueger, C.F., Stern, H.S., Wagner, H.N., and Migita, T. Jr., 1964. "Technetium-99 Pertechnetate for Brain Scanning", J. Nucl. Med. 5, 811.

McIntyre, P.F. and E.L. Wilhite, 1988. Radionuclide Analyses of Burial Ground Well Water, DPST-88-375, E.I. du Pont de Nemours \& Co., Aiken, SC 29808.

Mason, J.T., 1996. Information Document on the Old Solvent Tanks S1-S22 in the Old Radioactive Waste Burial Ground 643-E (U), WSRC-RP-96-00144, Westinghouse Savannah River Company, Aiken, SC.

Neretnieks, I. 1977. Retardation of Escaping Nuclides from a Final Repository, Royal Institute of Technology Report KBS-0030.

Oblath, S.B., 1982. Migration of $\mathrm{TcO}_{4}$ in SRP Soils, DPST-82-815, Memorandum to Wiley, J.R., Technical Division Savannah River Laboratory, August 27, 1982.

Oblath, S.B., 1986. Technetium-99 and Iodine-129 in the Burial Ground Plume Summary, DPST-86-278, Memorandum to Sturm, H.F., Jr., Technical Division Savannah River Laboratory, February 6, 1986.

Orebaugh, E.G. and W.H. Hale, Jr., 1976. Dispersion Study of Buried Elemental Mercury, DP1401 UC-41, E.I. du Pont de Nemours \& Co., Aiken, SC 29808.

Stone, J.A., Fenimore, J.W., Hawkins, R.H., Oblath, S.B., and Ryan, J.P. Jr., 1983. Shallow Land Burial of Solid Low-Level Radioactive Wastes - 30 Years of Experience at the Savannah 
River Plant, DP-MS-82-61, E. I. du Pont de Nemours \& Co., Savannah River Laboratory, Aiken, South Carolina, May 16-20, 1983.

Towler, O.A., and Cook, J.R., 1985. Radionuclide Distribution in Fission Product and Indced Activity Solid Waste Streams, DPST-87-398, E. I. du Pont de Nemours \& Co., Savannah River Laboratory, Aiken, South Carolina, September 26, 1985.

Webb, R.L., 1994. Production Limits for Fission Product Ratios (U), EPD-CTG-94-0006, Safety Engineering Department, Westinghouse Savannah River Company, Savannah River Site, Aiken, SC, June 15, 1994.

Wildung R.E., Garland, T.R., and Cataldo, D.A., 1977. "Accumulation of Technetium by Plants", Health Phys. 32, 314.

Wilhite, E.L., Cook, J.R., and McDonell, W.R., 1989. Program for Low Level Radioactive Waste Disposal at the Savannah River Site, U.S. Nuclear Materials Production Facility, DP-MS-88-160, Rev. 1, Westinghouse Savannah River Company, Savannah River Site, Aiken, SC, October 1989.

WSRC, 1997. Source Term for the Old Radioactive Waste Burial Ground (ORWBG), Savannah River Site $(U)$, WSRC-RP-97-0119, Draft, Westinghouse Savannah River Company, Savannah River Site, Aiken, SC, April 1997. 


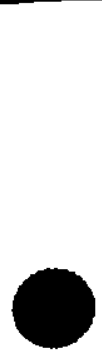

N-10 


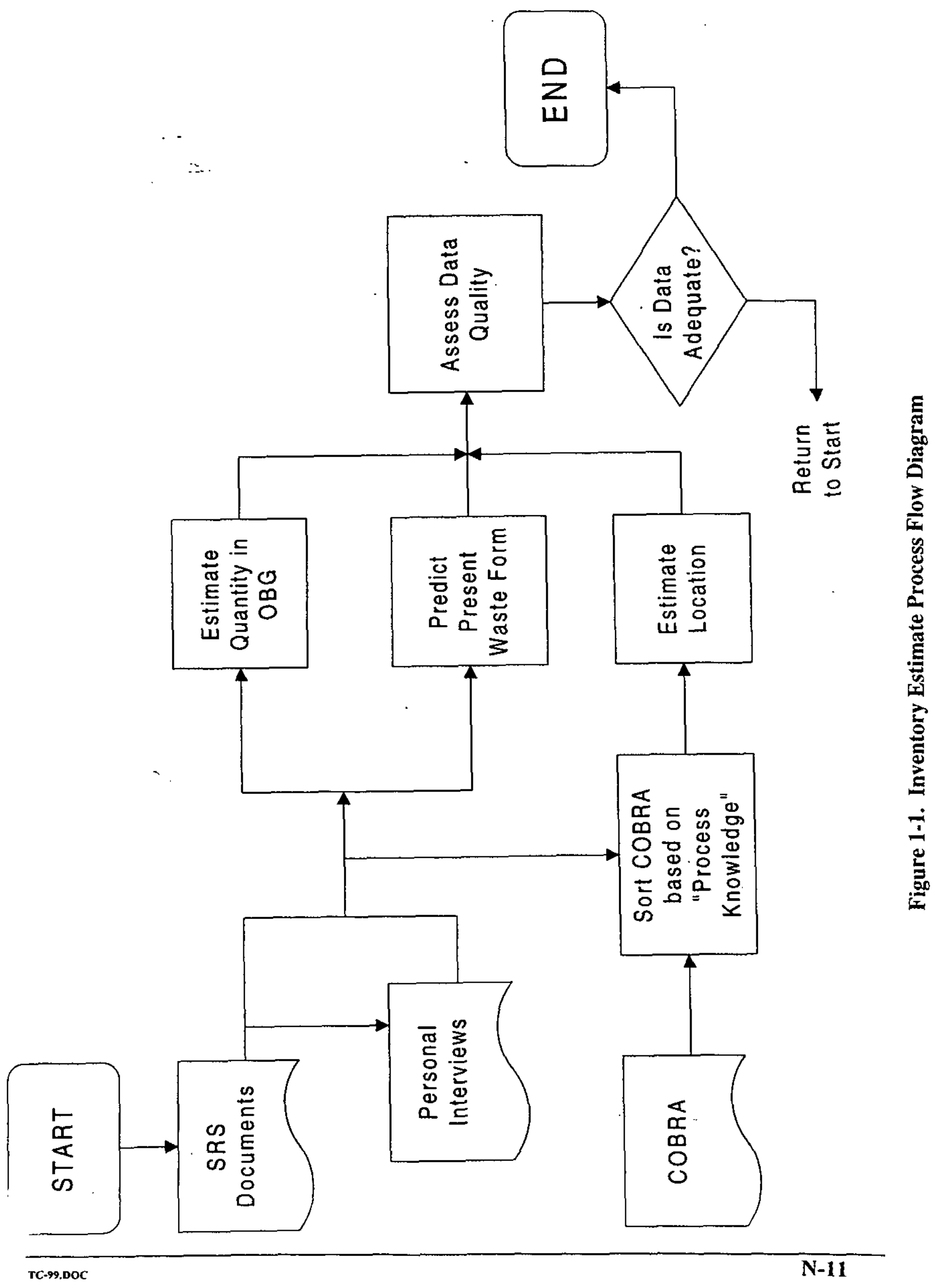




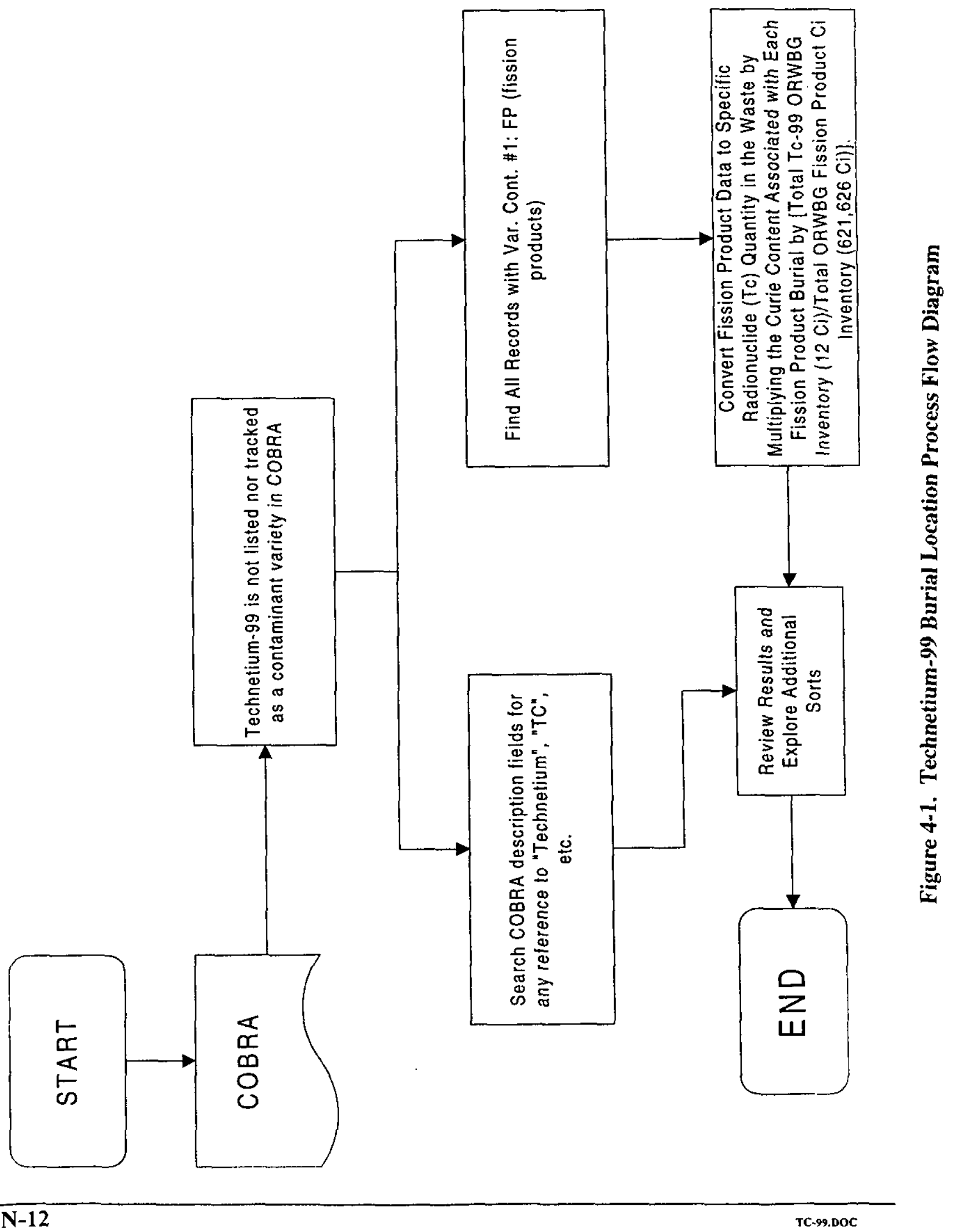




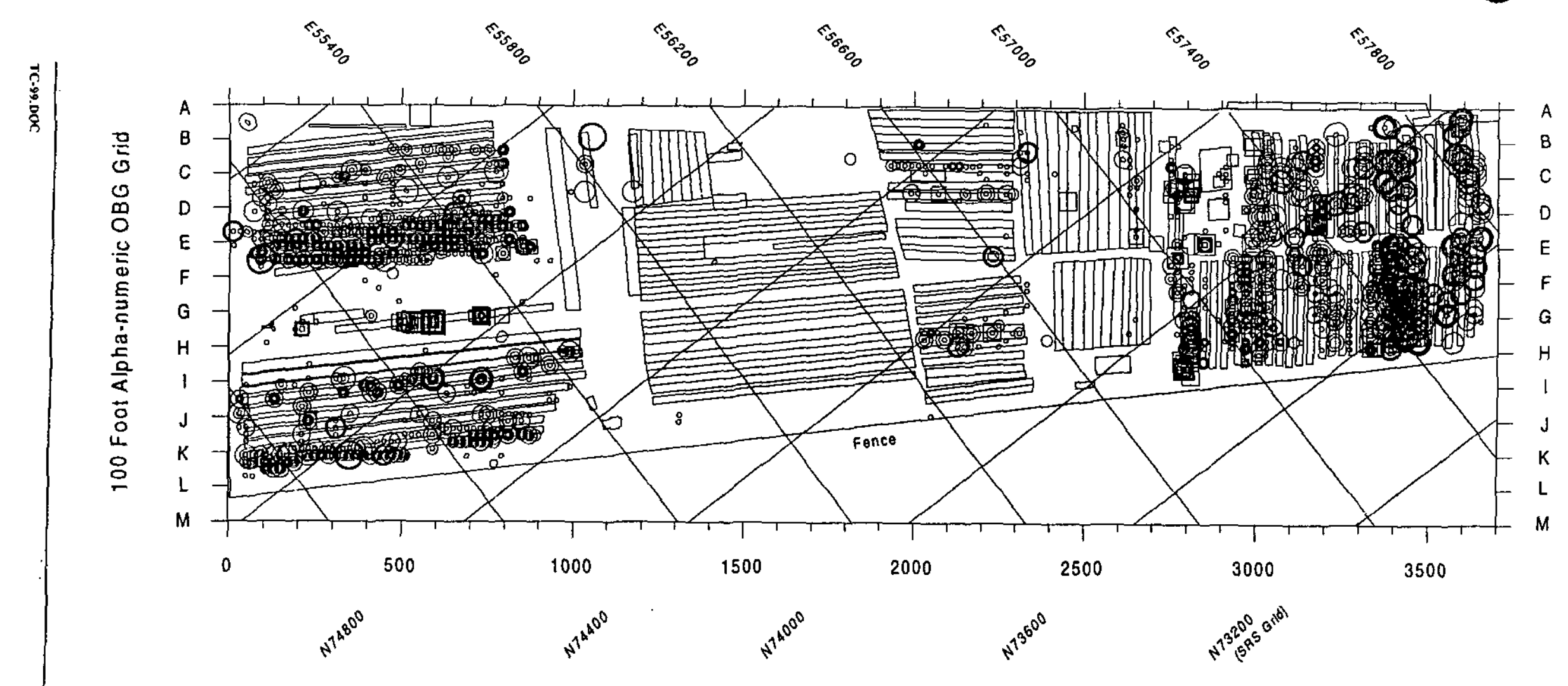

\begin{tabular}{|c|c|c|c|c|c|c|c|c|}
\hline & & & Curies & & & & & \\
\hline $0 .<0.0000001$ & $0.0000001 \cdot<0.000001$ & $0.000001 \cdot<0.00001$ & $0.00001 \cdot<0.0001$ & $0.0001 \cdot<0.001$ & $0.001 \cdot<0.01$ & $0.01 \cdot<0.1$ & $0.1 \cdot<1.0$ & \\
\hline$\circ$ & $\circ$ & 0 & 0 & $\mathrm{O}$ & 0 & & & Variety of Contamination 1 \\
\hline 0 & $\square$ & $\square$ & $\square$ & $\square$ & $\square$ & & & Variely of Contamination 2 \\
\hline
\end{tabular}

$\frac{z}{\omega}$

Figure 4-2. X,Y Locations for all Technetium-99 Burials in ORWBG. Note that these locations are based on fission yields from COBRA database fission product burials (Variety of Contamination \#1 and \#2 = "FP") 
Speciation of Technetium at Eh=0.1 volt

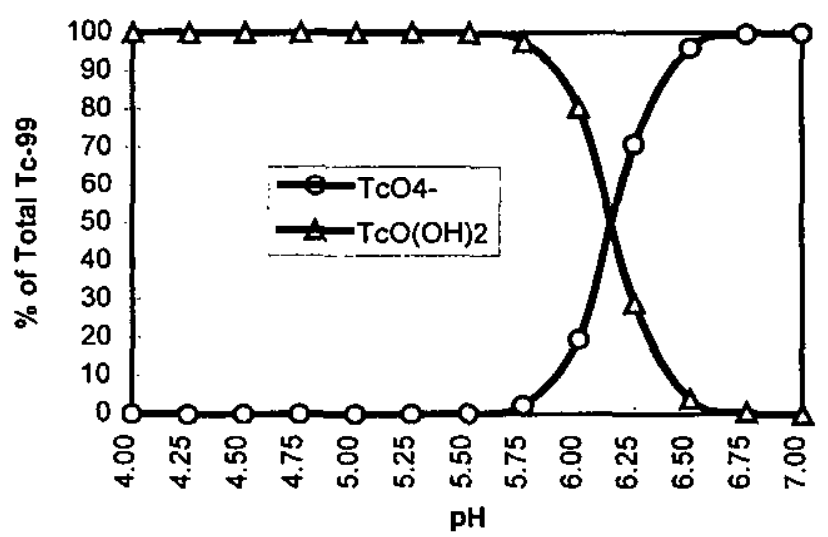

Figure 6-1. Speciation of Technetium Dissolved in Water of $\mathbf{E h}=0.1$ volt. Triangles Show $\%$ of $\mathrm{TcO}(\mathrm{OH})_{2}$, Circles Show \% of $\mathrm{TcO}_{4}{ }^{-}$ 
Nonvolatile Beta in Groundwater from Grid Wells

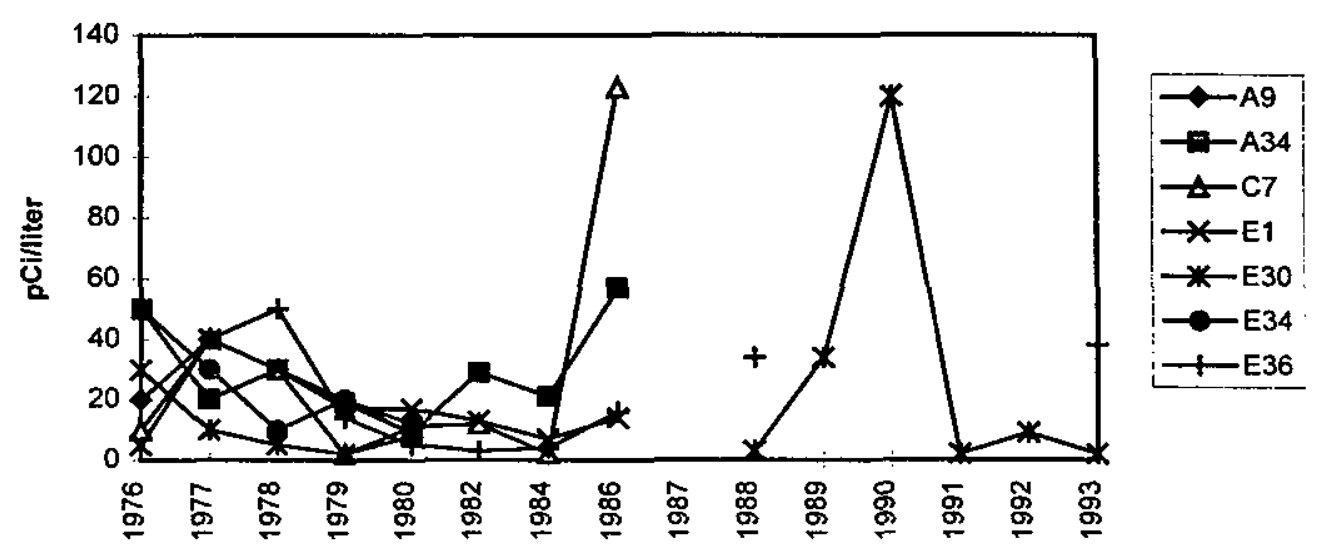

Figure 6-2. Time Series Plot of Nonvolatile Beta Measurements (pCi/l) in Groundwater from Seven Grid Wells that are Located in Areas of High Burial Concentrations of Te-99. 


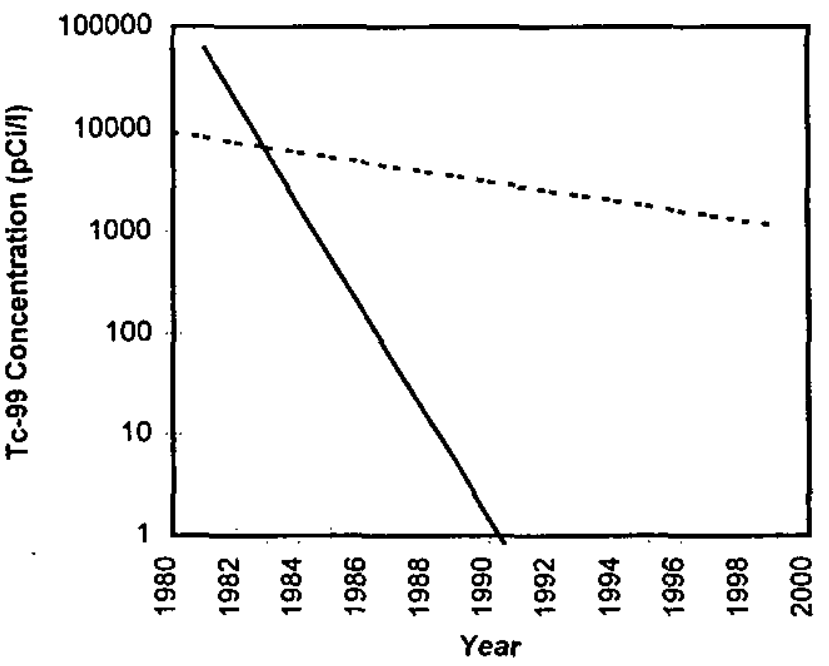

Figure 6-3. Minimum Concentrations of Tc-99 in Grid Wells Predicted from the Leaching Model of Baes and Sharp (1983). Solid line represents an infiltration rate of $2.36 \mathrm{~m} / \mathrm{yr}$ (Orebaugh and Hale, 1976) and the dashed line represents an infiltration rate of $0.38 \mathrm{~m} / \mathrm{yr}$ (typical SRS soil; Looney et al., $1987 \mathrm{~b}$ ). Other parameters used are: $\mathrm{Kd}=0.33 \mathrm{ml} / \mathrm{g}$ (Hoeffner, 1985), bulk density $=1.6 \mathrm{~g} / \mathrm{cm}^{3}$ (Looney et al., $1987 \mathrm{~b}$ ), porosity $=0.2$ (Looney et al., 1987b), a layer of waste 5 meters thick (Looney et al., 1987b), and a groundwater travel time from base of trench to water table of 5 years. 
Table 3-1. The Sources of Inventory Estimates for Technetium-99 in the ORWBG

\begin{tabular}{|c|c|c|}
\hline Reference & Inventory & Notes \\
\hline Holcomb, H. Perry, 1997 & $\begin{array}{c}6.09 \mathrm{Ci}^{\mathrm{a}} \text { from } \mathrm{Cs}-137 \\
\text { and } \\
7.80 \mathrm{Ci}^{\mathrm{a}} \text { from } \mathrm{Sr}-90 \\
\text { (References an earlier article) }\end{array}$ & $\begin{array}{l}\text { Based on activity ratios of } \mathrm{Tc} / \mathrm{Sr} \text { and } \mathrm{Tc} / \mathrm{Cs} \\
\text { and source terms of } \mathrm{Cs} \text { and } \mathrm{Sr} \text {. } \\
\text { Assumes that there has been no preferential } \\
\text { separation/concentration of the isotopes by } \\
\text { chemical or physical processes since } \\
\text { generation }\end{array}$ \\
\hline Holcomb, Perry H., 1992 & NA & $\begin{array}{l}\text { There is much more technetium in the } \\
\text { saltstone than there is in the burial ground. }\end{array}$ \\
\hline Cook, James R., 1989 & $\begin{array}{l}\text { about } 20 \mathrm{Ci} \text { was buried in the burial } \\
\text { grounds } \mathrm{s}^{\mathrm{b}} \text {. } \\
\text { (Does not reference an earlier article) }\end{array}$ & $\begin{array}{l}\text { Tc- } 99 \text { is a weak beta-emitting radionuclide } \\
\text { with a half life of } 213,000 \text { years and a } \\
\text { specific activity of } 56 \mathrm{~g} / \mathrm{Ci} \text {. } \\
\text { Technetium- } 99 \text { is a fission product produced } \\
\text { by the fission of uranium-235 and plutonium- } \\
239 \text {. } \\
\text { Technetium in waste may occur in a myriad } \\
\text { of valence states and chemical forms. } \\
\text { However, its most likely state will be as } \\
\text { pertechnetate ion }\left(\mathrm{TcO}_{4}^{-}\right) \text {which is highly } \\
\text { mobile in surface soils. }\end{array}$ \\
\hline $\begin{array}{l}\text { Wilhite, E.L., Cook, J.R., and } \\
\text { McDonell, W.R., } 1989\end{array}$ & $\begin{array}{l}\text { about } 20 \mathrm{Ci} \text { in the burial ground } \\
\text { (Does not reference an earlier article) }\end{array}$ & (2) \\
\hline $\begin{array}{l}\text { Mclntyre, P.F., and Wilhite, } \\
\text { E.L., } 1988\end{array}$ & NA & $\begin{array}{l}\text { Tc-99 is present as the mobile pertechnetate } \\
\text { anion }\left(\mathrm{TcO}_{4}\right) \text { which is transported through } \\
\text { the soil at a rate comparable to nitrate. }\end{array}$ \\
\hline
\end{tabular}


Table 3-1. The Sources of Inventory Estimates for Technetium-99 in the ORWBG (Continued)

\begin{tabular}{|c|c|c|}
\hline Reference & Inventory & Notes \\
\hline $\begin{array}{l}\text { Looney, B.B., Pickett, J.B. King, } \\
\text { C.M. Holmes, W.G. Johnson, } \\
\text { W.F. and J.A. Smith, } 1987\end{array}$ & $\begin{array}{l}\frac{\text { Fission Product Inventory }(\mathrm{Ci} / \mathrm{Yr})^{\mathrm{b}}}{0.6} \\
\text { (References Towler and Cook, } \\
\text { 1985) } \\
\frac{\text { Total Inventory }(\mathrm{Ci} / \mathrm{Yr})^{\mathrm{b}}}{0.6} \\
\text { (References Jaegge et al., 1987) }\end{array}$ & NA \\
\hline Jaegge, W.J., et al., 1987 & 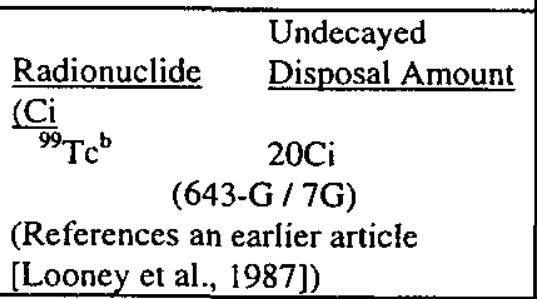 & NA \\
\hline Cook, James R., 1987 & $\begin{array}{lc}\frac{\text { Nuclides }}{\text { Tc-99 }} & \frac{\text { Inventory }(\mathrm{C})}{17} \\
& (643-\mathrm{G} \text { Site) } \\
\text { (Does not reference an earlier } \\
\text { article) }\end{array}$ & NA \\
\hline Oblath, S.B., 1986 & NA & $\begin{array}{l}\text { - The technetium- } 99 \text { in the burial ground is } \\
\text { present due to the disposal of mixed fission } \\
\text { product waste. } \\
\text { - As anionic species, } \mathrm{Tc}-99 \text { (as } \mathrm{TcO}_{4}{ }^{-} \text {), is } \\
\text { expected to be mobile in the soils beneath the } \\
\text { burial ground. }\end{array}$ \\
\hline $\begin{array}{l}\text { Bibler, N.E., Jurgensen, A.R., } \\
1986\end{array}$ & NA & $\begin{array}{l}\text { Tc-99 is a beta-emitting fission product in the } \\
\text { high level radioactive waste stored at SRS. }\end{array}$ \\
\hline
\end{tabular}




\section{Table 3-1. The Sources of Inventory Estimates for Technetium-99 in the ORWBG (Continued)}

\begin{tabular}{|c|c|c|}
\hline Reference & Inventory & Notes \\
\hline $\begin{array}{l}\text { Towler, O.A., and Cook, J.R., } \\
1985\end{array}$ & $\begin{array}{l}\text { Radionuclide Content of 5-year-old } \\
\text { In-tank Waste: } \\
\text { Isotope } \underline{\mathrm{Ci} / \mathrm{Gal}^{\mathrm{a}}} \\
\text { Tc-99 } 5.53 \mathrm{E}-04 \\
\begin{array}{l}\text { (Does not reference an earlier } \\
\text { article) }\end{array}\end{array}$ & $\begin{array}{l}\text { - The "five years" means five years out of the } \\
\text { reactor. }\end{array}$ \\
\hline $\begin{array}{l}\text { Stone, J.A., Fenimore, J.W., } \\
\text { Hawkins, R.H., Oblath, S.B., } \\
\text { Ryan, J.P. Jr., } 1983\end{array}$ & NA & $\begin{array}{l}\text { - Tc-99 is expected to migrate as the } \mathrm{TcO}_{4}^{-} \\
\text {anion, which has little soil adherence. }\end{array}$ \\
\hline Oblath, S.B., 1982 & $\begin{array}{l}\text { Between } 1 \text { and } 100 \mathrm{Ci}^{6} \text { of } \mathrm{Tc} \text { have } \\
\text { been disposed in } 643-\mathrm{G} \text {, based on } \\
\text { fission yields. } \\
\text { (Does not reference an earlier } \\
\text { article) }\end{array}$ & $\begin{array}{l}\text { - Pertechnetate } \mathrm{TcO}_{4}^{-} \text {is expected to be the } \\
\text { stable form of } \mathrm{Tc}-99 \text { in both the saturated } \\
\text { zone beneath the burial ground and the burial } \\
\text { trenches. Only when } \mathrm{TcO}_{4}^{-} \text {is present at } \\
\text { greater than } 1 \mathrm{mCi} / \mathrm{L}^{-} \text {concentration is there } \\
\text { any likelihood that } \mathrm{TcO}_{2} \text { would form, and then } \\
\text { only in the burial trenches (Oblath, 1982). } \\
\mathrm{Tc} \mathrm{should} \mathrm{be} \mathrm{present} \mathrm{in} \mathrm{SRS} \mathrm{waste} \mathrm{streams} \mathrm{as}_{\mathrm{TcO}_{4}^{-} \text {due to the dissolution of the target }} \\
\text { elements in } \mathrm{HNO}_{3} \text {, and enter the burial ground } \\
\text { in that form. Even if it is buried as } \mathrm{TcO}_{2}, \\
\text { there is evidence that the conversion to } \mathrm{TcO}_{4} \\
\text { would be rapid (Bondietti and Francis, } 1979 \text { in } \\
\text { Oblath, 1982). }\end{array}$ \\
\hline
\end{tabular}

a: Inventory discussed in detail

b: No discussion of basis for inventory

NA: Not addressed in article 
(This page intentionally left blank) 
APPENDIX O

\section{CONSTITUENT OF INTEREST:}

IODINE-129 
(This page intentionally left blank) 


\section{TABLE OF CONTENTS}

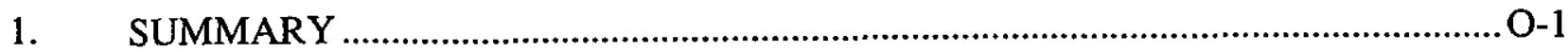

2. BACKGROUND INFORMATION ……….............................................................. O-1

$2.1 \quad$ Major Sources of Iodine-129 at SRS.................................................................. O-1

2.2 Minor Sources of Iodine-129 at SRS ..............................................................

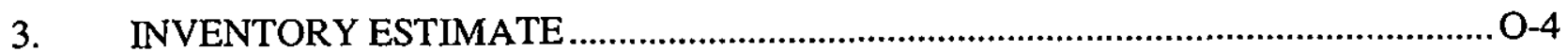

3.1 Range of Inventory Estimates ...............................................................................

3.2 Best Estimate of Iodine-129 in Burial Grounds ..................................................

3.3 Uncertainties Associated with Iodine-129 Inventory Estimate ............................. O-6

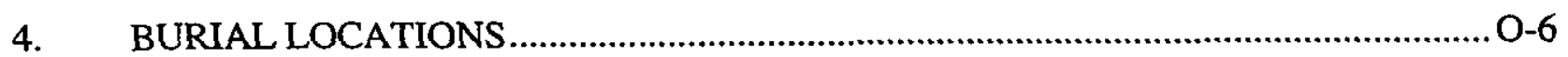

5. WASTE FORM

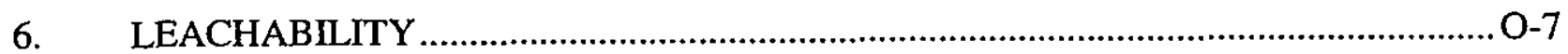

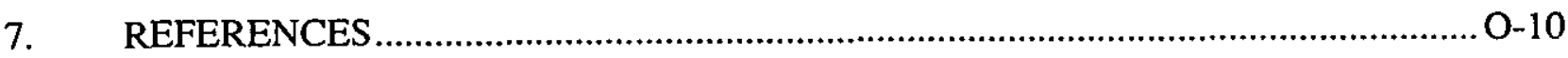




\section{LIST OF FIGURES}

Figure 1-1. Inventory Estimate Process Flow Diagram ………............................................

Figure 4-1. Iodine-129 Burial Location Process Flow Diagram .......................................... O-14

Figure 4-2. $\quad \mathrm{X}, \mathrm{Y}$ Locations for all COBRA Burial Slips ......................................................

\section{LIST OF TABLES}

Table 3-1. The Sources of Inventory Estimates for Iodine-129 in the ORWBG

O-16 


\section{CONSTITUENT OF INTEREST - IODINE-129}

\section{SUMMARY}

Radioiodine is a fission product at the Savannah River Site (SRS) that originated predominantly in the fuel and targets that were irradiated in the nuclear materials production reactors. The predominant radioiodine-containing material buried at the Solid Waste Disposal Facility (SWDF) is spent ceramic chips coated with silver nitrate (Berl saddles) that were used to sorb radioiodine (principally iodine-129 and iodine-131) during the dissolution of fuel and targets in F and $\mathrm{H}$ Areas. Other SRS operations and offsite sources contribute smaller amounts to the inventory of radioiodine at SRS.

The best estimate of the amount of iodine-129 in the ORWBG is determined by multiplying a scaled production amount of $35.45 \mathrm{Ci}$ during the operational history of the ORWBG by the fraction of the total that was sent to the burial ground ( 30 percent). This yields $10.6 \mathrm{Ci}$ (60 $\mathrm{kg})$.

Figure 1-1 presents the process used to develop the inventory and burial locations. The Computerized Burial Record Analysis (COBRA) database was used to determine the locations and quantity estimates of iodine- 129 burials.

\section{BACKGROUND INFORMATION}

Iodine-129 is a beta-emitter with a half-life of $15,700,000$ years (KAPL, 1996). It is a mobile, multivalent radionuclide that is known to have been present in wastes sent to the SRS burial grounds. Although iodine- 129 occurs in nature, the principle sources of environmental iodine-129 are effluents from nuclear fuel processing and fallout from nuclear weapons tests (Cornman, 1974).

\subsection{Major Sources of Iodine-129 at SRS}

Radioiodine is a collective term for radioactive isotopes of the element iodine. The major sources of radioiodine at SRS are fuel and targets irradiated in production reactors and certain fuels irradiated offsite. Numerous radioactive isotopes of iodine are formed as by-products during the irradiation of fuel and targets. The principal mechanism for production of radioiodine is neutron-induced fission. When a reactor is operating, neutron-induced fission reactions occur in the uranium-235 fuel of the reactor core. The reactions form a variety of 
fission products, which include iodine isotopes, principally long-lived iodine-129 and short-lived iodine-131.

The fission yield of iodine- 129 has been estimated at 0.54 percent for uranium-235 fission (England and Rider, 1994). The total inventory of radioiodine in the core of an operating production reactor is approximately $1 \mathrm{E}+09 \mathrm{Ci}$. The radioiodine inventory comprises approximately 6 percent of the total fission-product inventory during reactor operation. Radioiodine activity levels decrease quickly after reactor shutdown. For example, only 26 percent of the inventory remains 24 hours after the end of irradiation (Kantelo et al., 1993). Most of the isotopes are short-lived and decay to insignificant activity levels between the end of irradiation and the beginning of reprocessing. Except for iodine-129 (half-life = $15,700,000$ years), all radioactive isotopes of iodine generated at SRS by normal operations have half-lives less than or equal to 8 days, and therefore decay to insignificant levels after a period of months.

Under ideal conditions, radioiodine was contained within the cladding of fuel and target elements during irradiation and cooling. However, traces of radioiodine escaped to the environment through small defects in the cladding. Air and water at reactors were monitored for such releases. After the cooling period, fuel and target elements were treated in the chemical separation areas to recover the desired products from the waste products.

Because of the nature of separations processes at SRS, radioiodine is found primarily in aqueous wastes at the chemical separations facilities. Liquid waste that potentially contains radioiodine has been stored at the SWDF, which was previously known as the burial grounds. Degraded solvent from the separations areas was burned in open pans at the SWDF in the early years of operation. Since 1975, the waste has been stored in steel tanks at the SWDF pending combustion in an incinerator for radioactive waste. Given the propensity of iodine to react with organic compounds, the degraded solvent may contain iodine-129, even though the solvent has been scrubbed with caustic. No iodine-129 analyses of the spent solvent have been performed (Kantelo et al., 1993).

The primary emission control for iodine removal from dissolver off-gas was an iodine reactor that contained a bed of ceramic chips coated with silver nitrate. These chips were known as Berl saddles. The radioiodine that passed through the Berl saddles reacted with silver nitrate to form solid silver iodide (Kantelo et al., 1993). 
During PUREX processing in F-Area, an estimated 50 percent of the iodine-129 from the irradiated targets was absorbed on silver nitrate reactors during dissolution, about 20 percent went through the process vessel vent system during solvent extraction and washing, about 15 percent was sent to waste storage, and about 15 percent reached the seepage basin. During operation of the HM and frame processes in H-Area, an estimated 95 percent of the iodine-129 was sent to waste storage, and about 1-2 percent was distributed in each of the other three process pathways (Cornman, 1974).

Spent Berl saddles containing iodine-129 were routinely removed from the silver nitrate reactors (Cornman, 1974). When a spent charge of Berl saddles is first removed from service, radioiodine isotopes other than iodine-129 predominate. Practice has been to store the spent charges in closed metal drums at the separations facilities for 12 months or longer. This allows decay of the shorter-lived radionuclides and reduces radiation exposure to personnel in handling (Hawkins, 1983).

In early years of operations, spent chips were sent to the Oak Ridge National Laboratory for iodine-129 recovery. The spent chips were washed and reused, and the wash solutions were processed and stored in underground tanks for radioactive waste (Cornman, 1974).

In later years, spent chips were buried in the SWDF (Cornman, 1974). The Berl saddles were buried without containment or encapsulation in earthen trenches designated for intermediate-level beta-gamma waste (Hawkins, 1983). Essentially all of the iodine-129 in the burial ground is from Berl saddles used in the process air filters. Each container contained approximately $20 \mathrm{cu} \mathrm{ft}$ of Berl saddles. At least 48 spent charges of Berl saddles had been buried through 1980 (Chostner, 1980, and Pickett, 1980, in Hawkins, 1983) with an average iodine-129 content of approximately $275 \mathrm{mCi} /$ charge (Hawkins, 1983). The practice of burying Berl saddles was terminated in the early 1980s. Since that time, they have been stored at the SWDF (Kantelo et al., 1993).

\subsection{Minor Sources of Iodine-129 at SRS}

Minor sources of radioiodine at SRS include solid waste from material irradiated in SRS test reactors, spontaneous fission sources (such as californium-252), neutron activation analysis, commercially purchased radioiodine, and global fallout. The isotopes iodine-125, iodine-129, and iodine-131 were purchased from commercial vendors typically in quantities less than $1 \mathrm{E}-03 \mathrm{Ci}$. The isotopes were used for experimental purposes, primarily at the Savannah River Technology Center (Kantelo et al., 1993). SRS has received global fallout of man-made 
radioiodine since the 1940s. Most global fallout has occurred because of atmospheric weapons tests (Kantelo et al., 1993). The contribution to present background levels from atmospheric weapons testing fallout is calculated to be about $1 \mathrm{E}-06 \mathrm{pCi} / \mathrm{g}$ in soil, based on the uniform deposition of $8.4 \mathrm{Ci}$ of iodine-129 $(40 \mathrm{uCi} / \mathrm{kt} \times 2.1 \mathrm{E}+05)$ over land and water in the northern hemisphere (Hochel, 1976). The activity levels of radioiodine from these minor sources are insignificant when compared to the activity levels in irradiated nuclear fuel and targets.

Iodine-129 may exist in minor quantities in the Old Solvent Tanks in the ORWBG, but it has not been reported as a significant constituent in any of the tanks (Mason, 1996).

\section{INVENTORY ESTIMATE}

\subsection{Range of Inventory Estimates}

Cornman (1974) estimated that $39 \mathrm{Ci}$ of iodine-129 was produced between plant startup and 1974. This value was estimated from total cesium-137 fission-product inventory corrected for decay assuming nuclear yields of 6.2 and 1.0 percent respectively for cesium-137 and iodine-129. Fission yields of iodine-129 of 0.9 percent for uranium-235 fission and 1.4 percent for plutonium-239 fission were assumed. Burnup of iodine-129 was not considered. The disposition of long-lived iodine- 129 produced during the first 20 years of chemical separations processing is estimated to be 40 percent stored in waste tanks, 30 percent buried in the SWDF $(11.7 \mathrm{Ci}), 20$ percent released to the atmosphere $(7.8 \mathrm{Ci})$, and 10 percent released to seepage basins.

Hawkins (1983) noted that the annual amount of iodine-129 sent to the SRS burial ground had not been reported, but the annual SRS releases to the atmosphere were recorded. Atmospheric releases of iodine-129 at SRS for the period 1975-1982 were 1.24 Ci (DuPont, 1975 through 1982, in Hawkins, 1983). Hawkins (1983) assumed that the earlier distribution between burial ground and atmospheric releases was valid and used Cornman's (1974) data and subsequent production data to determine that $1.86 \mathrm{Ci}$ of iodine- 129 were stored at the burial ground during the period $1975-1982$ and a total of $11.7+1.9$ or $13.6 \mathrm{Ci}$ of iodine-129 were estimated to have been stored at the burial grounds through 1982 (Hawkins, 1983). Hawkins (1983) reported that most iodine-129 in the burial ground is on spent Berl saddles, and that the average volume of this waste was approximately $40 \mathrm{cu} \mathrm{ft} / \mathrm{year}$.

Several other articles published after Cornman (1974) and Hawkins (1983) cite similar inventories. Kantelo et al. (1993) report the buried inventory of iodine-129, as of 1982, is 14 
Ci. Oblath (1986) reports $12 \mathrm{Ci}$ in the burial ground. Jaegge et al. (1987) present an estimate of $14 \mathrm{Ci}$ (undecayed disposal amount) in the Radioactive Waste Burial Grounds (Looney et al., 1987, in Jaegge et al., 1987). McIntyre and Wilhite (1988) cite approximately $12 \mathrm{Ci}$ of iodine-129 in 643-G. Dr. E.L. Albenesius, who formerly served as a research manager of the Savannah River Laboratory's (now Savannah River Technology Center) Environmental Effects and Solid Waste Management Technology Divisions, reported in a 1992 discussion that the iodine-129 inventory is 10 curies (Holcomb, 1992). The documents include no explanation of these estimates; they may be derived directly from Cornman (1974) and Hawkins (1983).

Looney et al. (1987), using Hawkins (1983), stated that $0.4 \mathrm{Ci}$ was buried annually in the burial ground as Berl saddles. He also reported that an additional $1 \mathrm{E}-03 \mathrm{Ci}$ was disposed annually as fission products. The amount in fission products was based on an isotopic distribution of fission products presented in Towler and Cook (1985) that cites that five-year-old in-tank waste contains $9.42 \mathrm{E}-07 \mathrm{Ci}$ iodine-129 per gallon.

Cook (1987) estimated that $2.9 \mathrm{E}-02 \mathrm{Ci}$ were buried in $643-\mathrm{G}$. Two years later, he referenced Cornman (1974) and Hawkins (1983) and cited $13.6 \mathrm{Ci}$ as the amount buried in the burial grounds (Cook, 1989).

Holcomb (1997) used a different approach than that of Cornman (1974) and Hawkins (1983). He calculated the amount of iodine- 129 from information about other fission products. Assuming that there had been no separation of iodine-129 from strontium-90 or cesium-137 since the reactor operations that produced them ceased, Holcomb calculated the iodine-129 activity in mixed fission product waste using fission product ratios from Webb (1994) and already-stated best estimates for the activities of the primary fission products, cesium- 137 and strontium-90. Holcomb's estimate does not include the iodine- 129 associated with the Berl saddles. Using a cesium-137 source term of $26,943 \mathrm{Ci}$ (WSRC, 1997) and maximum iodine-129/cesium- 137 activity ratio of $4.50 \mathrm{E}-07$, he calculated a maximum activity of $1.21 \mathrm{E}-02 \mathrm{Ci}$ of iodine-129 in the ORWBG. Similarly, using a strontium-90 source term of $26,516 \mathrm{Ci}$ (WSRC, 1997) and a maximum iodine-129/strontium-90 activity ratio of 6.03E-07, Holcomb calculated a maximum iodine- 129 activity of $1.60 \mathrm{E}-02 \mathrm{Ci}$. These values are several orders of magnitude lower than those calculated from process knowledge (Cornman, 1974; Hawkins, 1983), which may be due to preferential separation/concentration of the isotopes by chemical or physical processes.

Table 3-1 lists the sources of the inventory estimates for iodine-129 in the ORWBG. 


\subsection{Best Estimate of Iodine-129 in Burial Grounds}

The best estimate of iodine-129 is calculated from Cornman's (1974) report, which states that $39 \mathrm{Ci}$ of iodine-129 was produced at SRS from startup until 1974, and that the fraction that was sent to the burial ground was 30 percent of the total. Because the ORWBG was closed in 1972 , the inventory of $39 \mathrm{Ci}$ includes at least two years of radioiodine was sent to 643-7G. To compensate for this, the inventory of $39 \mathrm{Ci}$ is multiplied by $20 / 22$ years, which is $35.45 \mathrm{Ci}$. This assumes that the rate of iodine production from startup to 1972 was similar to that from 1972 to 1974. This estimate is the amount produced at SRS from startup to 1972. The best estimate for the burial grounds is obtained by multiplying this amount $(35.45 \mathrm{Ci})$ by the fraction that was buried in the ORWBG (30 percent), to arrive at $10.6 \mathrm{Ci}$. Using a specific activity of $1.766 \mathrm{E}-04 \mathrm{Ci} / \mathrm{g}$ for iodine-129 (DuPont, 1979), the mass of iodine-129 in the ORWBG is estimated at $60 \mathrm{~kg}$.

\subsection{Uncertainties Associated with Iodine-129 Inventory Estimate}

Several assumptions are evident in the calculation of the best estimate. First, it is assumed that $39 \mathrm{Ci}$ of iodine-129 was produced at SRS from startup to 1974. This value is derived from process knowledge. Second, it is assumed that 30 percent of the iodine that was produced ended up as solid waste and was buried. Third, the estimate assumes that the rate of iodine production from startup to 1972 was similar to that from 1972 to 1974 .

Less evident uncertainties associated with the estimate include the assumption that Berl saddles are the primary source of iodine-129, and that other significant sources have not been overlooked. Other solid wastes may have been contaminated with iodine-129 (e.g., spent reactor deionizers). No analyses of these materials for iodine-129 content have been performed (Kantelo et al., 1993). Additionally, degraded solvent from the separations areas was burned in open pans at the SWDF in the early years of operation. The contribution of iodine-129 from this source is thought to be negligible, though no iodine-129 analyses of the spent solvent have been performed (Kantelo et al., 1993).

\section{BURIAL LOCATIONS}

At least 48 spent charges of Berl saddles had been buried in the burial grounds through 1980 (Chostner, 1980; and Pickett, 1980, in Hawkins, 1983) with an average iodine-129 content of approximately $275 \mathrm{mCi} /$ charge (Hawkins, 1983). Some of these were buried in the ORWBG and some in $643-7 \mathrm{G}$. The number in the ORWBG can be estimated by multiplying 48 by the number of operational years of the ORWBG (20) and dividing by the total number of years 
that the 48 spent charges were disposed of ( 28 years). The number of spent charges in the ORWBG, assuming a constant disposal rate, is estimated to be 34 .

Each container held approximately $20 \mathrm{cu} \mathrm{ft}$ of Berl saddles. Their locations are randomly distributed among the intermediate level burial trenches (Stone et al., 1983a).

Figure 4-1 outlines the steps taken to manipulate the database to locate the burials.

In the COBRA database there are no references to "Berl saddles", "Beryl saddles", "spent ceramic chips", "silver nitrate", "spent charges", "process air filters", "air filters", "iodine", "iodine reactors", "radioiodine", "silver iodide", etc. In addition, no quantity or specific iodine-129 constituent information is contained in any COBRA record.

Because Berl saddles are not identified in the COBRA database, the precise locations of the iodine-129 burials cannot be determined. Their locations cannot be deduced from "fission products" because most burials of "fission products" contained negligible amounts of iodine-129; the vast majority of iodine-129 is contained in an estimated 34 burials.

An HP survey map, dated 1/1/66 (see Figure 3-2 in Chapter 3), shows a location of Berl saddles in the southwest corner of A-16. The quantity of Berl saddles at this location is unknown. There are no burial slips for any burials in this vicinity (Figure 4-2). It is also questionable that the location was ever an active burial site because of the presence of known perched water in this area.

\section{WASTE FORM}

The chemical form of iodine- 129 on the Berl saddles was not determined. The saddles carry a coating of silver nitrate when they begin air filter service; off-gas radioiodine in process air is believed to react with the silver nitrate and to be retained as silver iodide. Therefore, iodine-129 on the buried Berl saddles probably occurs as silver iodide (Stone et al., 1983b; Hawkins, 1983). Equilibrium chemistry indicates that iodine should be present as iodide (I) or iodate $\left(\mathrm{IO}_{3}{ }^{-}\right)$, depending on the $\mathrm{pH}$ of the water (Hoeffner, 1984 (4a), in Oblath, 1986).

\section{LEACHABILITY}

The leachability of iodine- 129 from the ORWBG is complicated by the predominant iodine129 waste form. iodine-129 typically migrates as the anion iodide ( $\mathrm{I}^{\circ}$ ) and is only weakly attenuated in the acidic SRS soils. From batch experiments with ORWBG soils, Hoeffner (1985) reported $K_{d}$ values ranging from 3 to $10 \mathrm{ml} / \mathrm{g}$ that varied inversely with the 
concentration of stable iodine-127 (the most abundant natural iodine isotope). In natural groundwater conditions there are no solubility controls on the migration of iodine- 129 . However, most iodine-129 in the ORWBG occurs in a form that was designed to remove iodine-129 from waste emissions as silver iodide (AgI). These filters were effective because of the very low solubility of AgI. The leachability of this waste form is controlled by the natural iodide concentration in infiltrating water and by the redox behavior of silver. Under oxidizing conditions the solubility of AgI is low, and is controlled mainly by the iodide concentration of infiltrating water. Under reducing conditions the solubility is potentially increased by the reduction of $\mathrm{Ag}^{+1}$ to metallic silver.

The reaction that dictates the behavior of AgI under reducing conditions is:

$\mathrm{AgI}+\mathrm{e}^{-}=\mathrm{Ag}_{(\mathrm{m})}+\mathrm{I}^{-} \quad \log \mathrm{K}=-2.56$

Thus, $\mathrm{p} \varepsilon=-2.56-\log \left[\mathrm{I}^{-}\right]$or $\mathrm{Eh}=-0.151-0.059 \log \left[\mathrm{I}^{-}\right]$. The Eh at which metallic silver and AgI coexist at equilibrium is controlled by the iodide concentration in groundwater. Oblath (1986) reports iodide concentrations that range up to $1.19 \mathrm{mg} / \mathrm{l}$ downgradient of the ORWBG. However, in a study of the trench wells, McIntyre and Wilhite (1988) found no iodide concentrations that exceeded the detection limit of $0.05 \mathrm{mg} / \mathrm{l}$ (as I-127). If $0.05 \mathrm{mg} / \mathrm{l}$ is used as the background concentration of iodide, then from the equation above, the Eh at which metallic silver is in equilibrium with $\mathrm{AgI}$ is 0.227 volts. More reducing Eh values have been reported in water from the trench wells (Hoeffner, 1985), suggesting that reductive dissolution of AgI may occur, releasing iodine-129. However, the equilibrium between $\mathrm{AgNO}_{3}$ and $\mathrm{AgI}$ requires that virtually all of the $\mathrm{AgNO}_{3}$ in the Berl saddles be consumed by reductive dissolution prior to the dissolution of any AgI. This may delay and decrease the rate at which iodine-129 can be released by reductive dissolution of AgI.

The few analyses of groundwater beneath the ORWBG for iodine-129 show relatively low concentrations. Oblath (1986) reported analyses of groundwater done in 1982 and 1983 that found a maximum concentration of $12 \mathrm{pCi} / \mathrm{l}$ in a well 600 feet downgradient of the ORWBG. Two perimeter wells had iodine- 129 concentrations of 0.033 and $0.92 \mathrm{pCi} / 1$ and the one groundwater sample from a grid well had a concentration of $0.006 \mathrm{pCi} / \mathrm{l}$. McIntyre and Wilhite (1988) analyzed for iodine-129 in groundwater from 10 grid wells, as well as the 2 perimeter wells and the downgradient well reported by Oblath (1986). They found no concentrations exceeding the detection limits that ranged from 6 to $9 \mathrm{pCi} / 1$. However, the current primary drinking water standard for iodine- 129 is $1 \mathrm{pCi} / 1$. Though iodine-129 
concentrations remain relatively low in groundwater beneath the ORWBG, they may exceed the drinking water standard.

The iodine-129 concentrations in groundwater are consistent with those reported from an iodine-129 waste form lysimeter experiment (Stone et al., 1983). In this experiment, concentrations of iodine- 129 in the leachate ranged from 0.5 to $5.0 \mathrm{pCi} / 1$. These concentrations are consistent with the solubility of $\mathrm{AgI}$ in oxidizing conditions. At a background iodide concentration of $0.05 \mathrm{mg} / \mathrm{l}$ and a background $\mathrm{Ag}^{+}$concentration of $0 \mathrm{mg} / \mathrm{l}$, the solubility of AgI is $2.2 \times 10^{-10}$ moles/liter. Thus, at these conditions in oxidizing groundwater the maximum iodine- 129 concentration would be $4.9 \mathrm{pCi} / \mathrm{l}$.

The evidence is unclear whether iodine-129 in the ORWBG is a current threat to groundwater. Based on the solubility of AgI in oxidizing conditions the maximum concentrations in groundwater could exceed the primary drinking water standard of $1 \mathrm{pCi} / \mathrm{I}$. In the future, as conditions in the ORWBG become more reducing from the oxidation of organic material and metals, reductive dissolution of AgI could result in higher concentrations of iodine-129 in groundwater. 


\section{REFERENCES}

Chostner, D.F., 1980. Personal Communication, Separations Technology Department, Savannah River Plant, Aiken, SC.

Cook, J.R., 1987. Technical Data Summary: Plan for Closure of the 643-G Burial Ground, DPSTD-87-2, E.I. du Pont de Nemours and Company, Aiken, SC, August 1987.

Cook, J.R., 1989. Assessment of Long-Lived Radionuclides in the Savannah River Plant Radioactive Waste Burial Grounds, DPST-89-315, Memorandum to Sturm, H.F., Jr., Technical Division Savannah River Laboratory, February 23, 1989.

Cornman, W.R., 1974. Estimation of Iodine-129 Distribution in SRP Separations Processes, DPST-74-533, Memorandum to E.L. Albenesius, Technical Division Savannah River Laboratory, November 21, 1974.

DuPont, 1975 through 1982. Environmental Monitoring in the Vicinity of the Savannah River Plant, Annual Reports for Years 1975 through 1980, Reports DPSPU 75-30-1 through DPSPU 82-30-1, Savannah River Plant, Aiken, SC.

DuPont, 1979. Accountability Manual, DPSOP 23-11, Rev. 11/79, E.I. du Pont de Nemours \& Co., Savannah River Plant, Aiken, SC.

ERDA-1537. Final Environmental Impact Statement Waste Management Operations, Savannah River Plant, September 1977.

England, T.R. and Rider, B.F., 1994. Evaluation and Compilation of Fission Product Yields: 1993, LA-UR-94-3106 (ENDF-349), Los Alamos National Laboratory, Los Alamos, NM, October.

Hawkins, R.H., 1983. Mobility of 1-129 in Buried Waste, DPST-83-590, Memorandum to Wiley, J.R., Technical Division Savannah River Laboratory, June 15, 1983.

Hochel, R.C., 1976. Preliminary lodine-129 Measurements in the SRP Environs, DPST-76-221, Memorandum to Boni, A.L., Technical Division Savannah River Laboratory, January 23, 1976.

Hoeffner, S.L., 1984. Additional Laboratory Studies on Radionuclide Sorption at the SRP Burial Ground, DPST-84-797, October 31, 1984. 
Hoeffner, S.L., 1985. Radionuclide Sorption on Savannah River Plant Burial Ground SoilA Summary and Interpretation of Laboratory Data, DP-1702, E.I. du Pont de Nemours \& Co., Aiken, SC.

Holcomb, H. Perry, 1992. Transcription of a Presentation by Dr. E.L. Albenesius, SRS Burial Ground Operation from an Historical Perspective (U), WSRC-RP-92-349, Environmental Restoration Department, Westinghouse Savannah River Company, Savannah River Site, Aiken, SC February 14, 1992.

Holcomb, H. Perry, 1997. Deriving Source Terms of Carbon-14, Cobalt-60, Technetium-99, Iodine-129, and Neptunium-237 in the Old Radioactive Waste Burial Ground, RadChemCo-97-013, Memorandum to Smits, A.D., SAIC, RadChemCo, Inc., July 26, 1997.

Jaegge, W.J., et al., 1987. Environmental Information Document, Radioactive Waste Burial Grounds, DPST-85-694, E.I. du Pont de Nemours \& Co., Savannah River Laboratory, Aiken, SC, March 1987.

Kantelo, M.V., Bauer, L.R., Marter, W.L., Murphy, C.E., Jr., and Ziegler, C.C., 1993. Radioiodine in the Savannah River Site Environment (U), WSRC-RP-90-424-2, Westinghouse Savannah River Company, Savannah River Site, Aiken, SC, January 15, 1993.

KAPL, 1996. Chart of the Nuclides, 15th edition, Knolls Atomic Power Laboratory, Naval Reactors, U.S. Department of Energy, revised to 1996.

Looney, B.B., J.B. Pickett, C.M. King, W.G. Holmes, W.F. Johnson, and J.A. Smith, 1987. Selection of Chemical Constituents and Estimation of Inventories for Environmental Analysis of Savannah River Plant Waste Sites, DPST-86-291, E.I. du Pont de Nemours and Company, Savannah River Laboratory, Aiken, SC.

McIntyre, P.F. and Wilhite, E.L., 1988. Radionuclide Analyses of Burial Ground Well Water, DPST-88-375, E.I. du Pont de Nemours \& Co., Savannah River Laboratory Technical Division, Aiken, SC 29808, June 3, 1988.

Mason, J.T., 1996. Information Document on the Old Solvent Tanks S1-S22 in the Old Radioactive Waste Burial Ground 643-E (U), WSRC-RP-96-00144, Westinghouse Savannah River Company, Aiken, SC. 
Oblath, S.B., 1986. Technetium-99 and Iodine-129 in the Burial Ground Plume Summary, DPST-86-278, Memorandum to Sturm, H.F., Jr., Technical Division Savannah River Laboratory, February 6, 1986.

Pickett, C.E., 1980. Personnel Communication, Separations Technology Department, Savannah River Plant, Aiken, SC, 1980.

Stone, J.A, Oblath, S.B., Hawkins, R.H., Emslie, R.H., Ryan, J.P. Jr., and King, C.M., 1983a, Migration Studies at the Savannah River Plant Shallow Land Burial Site, DP-MS-83-89, E. I. du Pont de Nemours \& Co., Savannah River Laboratory, Aiken, South Carolina, August 30 - September 1, 1983.

Stone, J.A., Fenimore, J.W., Hawkins, R.H., Oblath, S.B., and Ryan, J.P. Jr., 1983b. Shallow Land Burial of Solid Low-Level Radioactive Wastes - 30 Years of Experience at the Savannah River Plant, DP-MS-82-61, E. I. du Pont de Nemours \& Co., Savannah River Laboratory, Aiken, South Carolina, May 16-20, 1983.

Towler, O.A., and Cook, J.R., 1985. Radionuclide Distribution in Fission Product and Indced Activity Solid Waste Streams, DPST-87-398, E. I. du Pont de Nemours \& Co., Savannah River Laboratory, Aiken, South Carolina, September 26, 1985.

Towler, O.A., 1989. Integrated Report on Radionuclide Migration at the Savannah River Shallow Land Burial Site, Savannah River Laboratory, March 1989.

Webb, R.L., 1994. Production Limits for Fission Product Ratios (U), EPD-CTG-94-0006, Safety Engineering Department, Westinghouse Savannah River Company, Savannah River Site, Aiken, SC, June 15, 1994.

WSRC, 1992. Old Radioactive Waste Burial Ground, Revised Draft, August 1992.

WSRC, 1997. Source Term for the Old Radioactive Waste Burial Ground (ORWBG), Savannah River Site (U), WSRC-RP-97-0119, Draft, Westinghouse Savannah River Company, Savannah River Site, Aiken, SC, April 1997. 


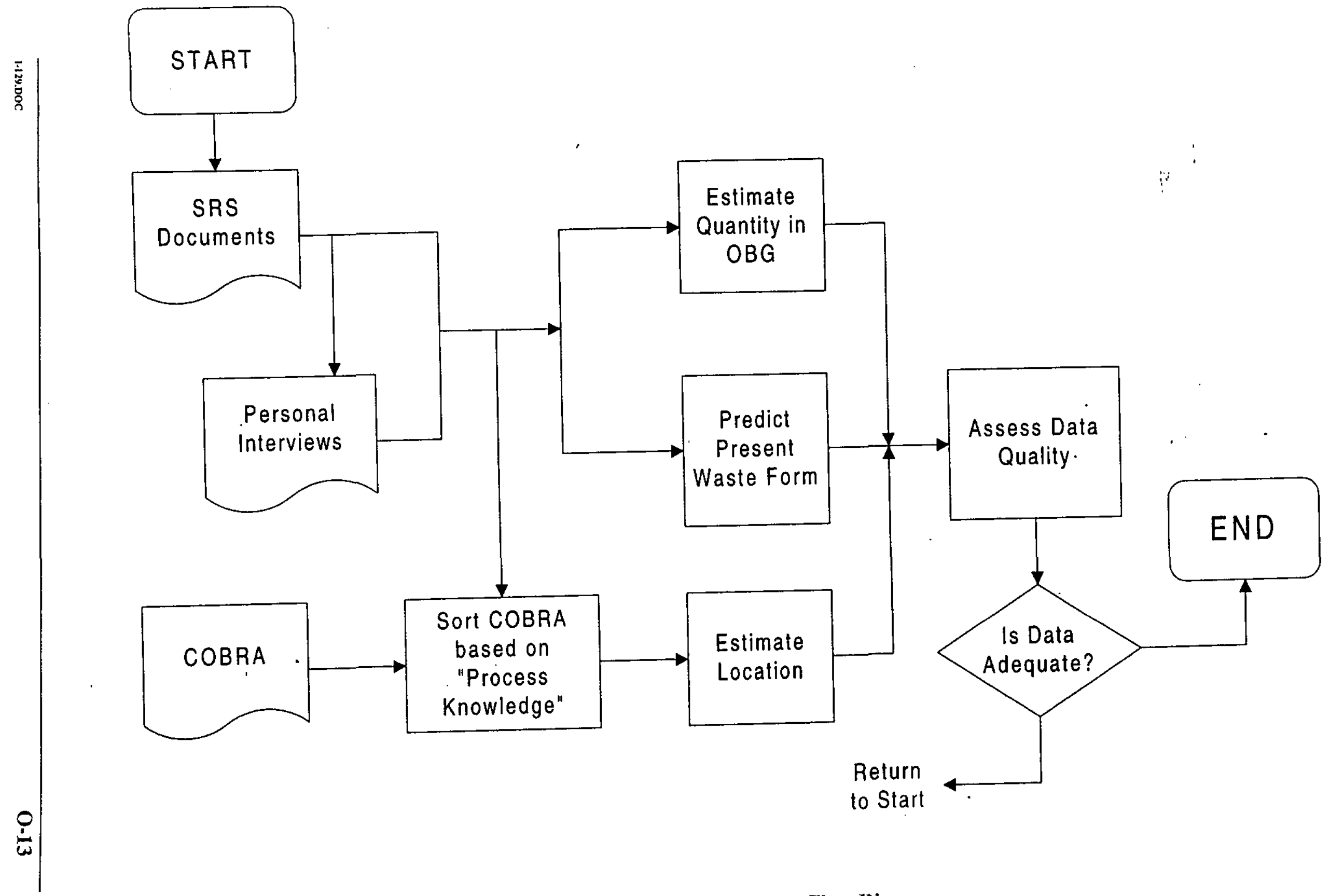

Figure 1-1. Inventory Estimate Process Flow Diagran 


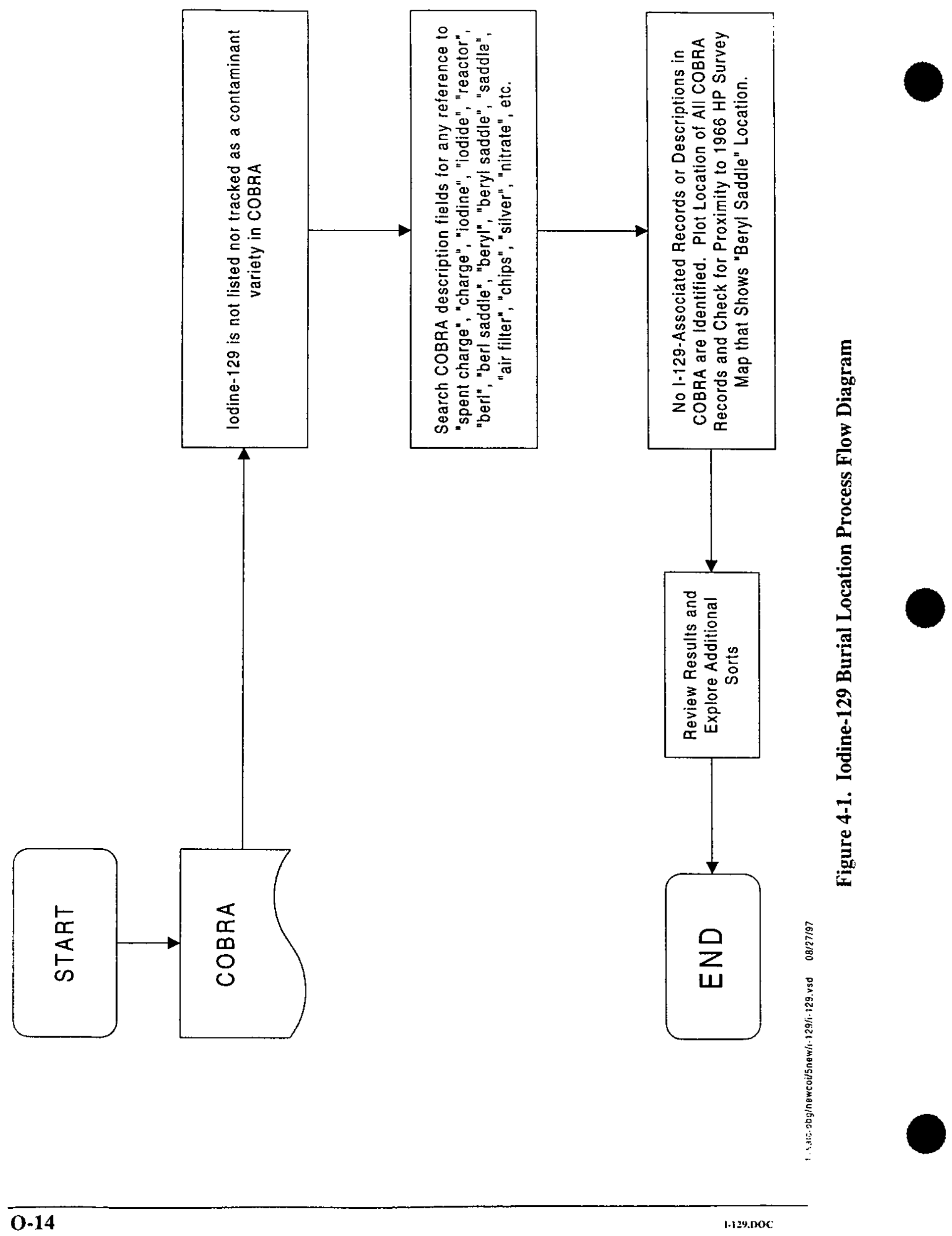




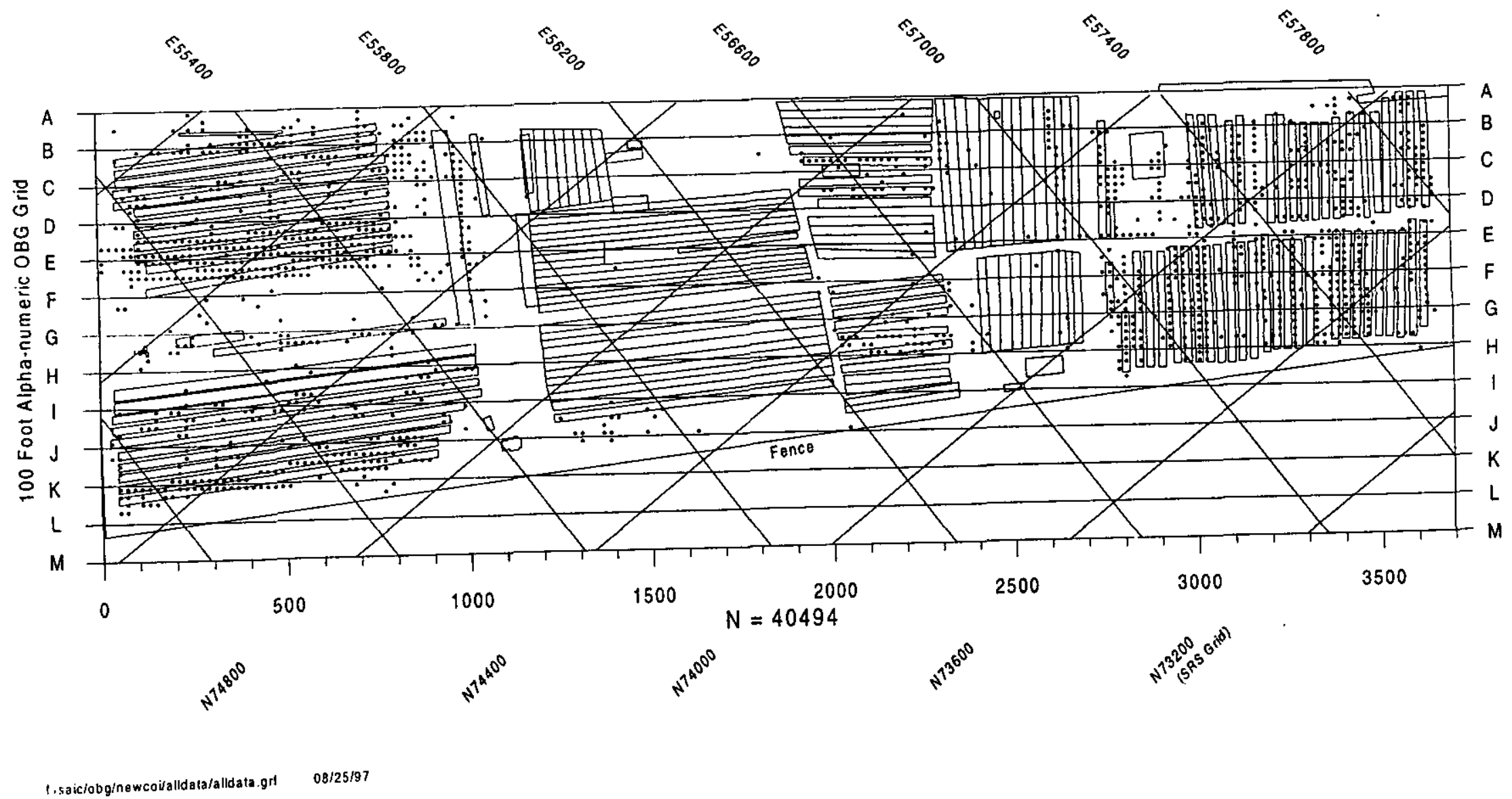

Figure 4-2. X,Y Locations for all COBRA Burial Slips 
Table 3-1. The Sources of Inventory Estimates for Iodine-129 in the ORWBG

\begin{tabular}{|c|c|c|}
\hline Reference & Inventory & Notes \\
\hline Holcomb, H. Perry, 1997 & $\begin{array}{c}1.21 \mathrm{E}-02 \mathrm{Ci}^{\mathrm{a}} \text { from } \mathrm{Cs}-137 \\
\text { and } \\
1.6 \mathrm{E}-02 \mathrm{Ci}^{\mathrm{a}} \text { from } \mathrm{Sr}-90 \\
\text { (References an earlier article) }\end{array}$ & $\begin{array}{l}\text { Based on activity ratios of } \mathrm{V} / \mathrm{Sr} \text { and } \mathrm{I} / \mathrm{Cs} \\
\text { and source terms of } \mathrm{Cs} \text { and } \mathrm{Sr} \text {. } \\
\text { Assumes that there has been no } \\
\text { preferential separation/concentration of } \\
\text { the isotopes by chemical or physical } \\
\text { processes since generation }\end{array}$ \\
\hline Kantelo, M.V., et al., 1993 & $\begin{array}{l}\text { The buried inventory of I-129, as of } 1982 \text {, is } \\
\text { estimated to be } 14 \text { curies }{ }^{\mathrm{b}} \text { (Hawkins, 1983). } \\
\text { The predominant radioiodine containing } \\
\text { material buried at SWDF is the spent ceramic } \\
\text { chips coated with silver nitrate. } \\
\text { (References an earlier article [Hawkins, } \\
\text { 1983]) }\end{array}$ & $\begin{array}{l}\text { The sources of radioiodine are } \\
\text { categorized as follows: } \\
\text { Major Sources: } \\
\text { * fuel and targets irradiated in production } \\
\text { reactors. } \\
\text { * certain fuels irradiated offsite } \\
\text { Minor Sources: } \\
\text { * fuel and targets irradiated in SRS test } \\
\text { reactors } \\
* \text { spontaneous fission } \\
* \text { neutron activation samples } \\
* \text { commercially purchased radioiodine } \\
* \text { global fallout }\end{array}$ \\
\hline WSRC, 1992 & $\begin{array}{l}\text { While short-lived radioactive iodine probably } \\
\text { decayed before burial, the saddles are } \\
\text { estimated to have contained a total of } 12 \\
\text { curies }^{b} \text { of iodine-129 (McIntyre, P.F. and } \\
\text { Wilhite, E.L., 1988). } \\
\text { (References an earlier article) }\end{array}$ & $\begin{array}{l}\text { The berl saddles are filtration devices } \\
\text { coated with silver nitrate that were used } \\
\text { to capture radioiodine in off-gases from } \\
\text { the dissolving of irradiated fuel. When } \\
\text { disposed of, they were buried in contact } \\
\text { with the soil in OBG trenches (ERDA- } \\
1537 \text { and Towler, 1989). }\end{array}$ \\
\hline Holcomb, Рerry H., 1992 & $\begin{array}{l}10 \mathrm{Ci}^{\mathrm{b}} \\
\text { (Does not reference an earlier article) }\end{array}$ & NA \\
\hline $\begin{array}{l}\text { McIntyre, P.F., Wilhite, } \\
\text { E.L., } 1988\end{array}$ & $\begin{array}{l}\text { Silver iodide coated berl saddles account for } \\
\text { approximately } 12 \mathrm{Ci}^{\mathrm{b}} \text { of } \mathrm{I}-129 \text { and is the } \\
\text { major source in } 643-\mathrm{G} \text {. } \\
\text { (References an earlier article [Hawkins, } \\
\text { 1983]) }\end{array}$ & NA \\
\hline
\end{tabular}


Table 3-1. The Sources of Inventory Estimates for Iodine-129 in the ORWBG (Continued)

\begin{tabular}{|c|c|c|}
\hline Reference & Inventory & Notes \\
\hline $\begin{array}{l}\text { Looney, B.B., Pickett, J.B. } \\
\text { King, C.M. Holmes, W.G. } \\
\text { Johnson, W.F. and J.A. } \\
\text { Smith, } 1987\end{array}$ & $\begin{array}{l}\frac{\text { Reported Inventory }\left(\mathrm{Ci} / \mathrm{Yr}^{\mathrm{b}}\right.}{0.4 *} \\
\text { (References Jaegge et al., 1987) } \\
\frac{\text { Fission Product Inventory }(\mathrm{Ci} / \mathrm{Yr})^{\mathrm{b}}}{0.001} \\
\text { (References Towler and Cook, 1985) } \\
\frac{\text { Total Inventory (Ci/Yr) }}{0.4} \\
\text { (References Jaegge et al., 1987) }\end{array}$ & $\begin{array}{l}\text { *Based upon I- } 129 \text { on Berl/Silver Nitrate } \\
\text { saddles to the Burial Ground as } \\
\text { summarized in Hawkins, } 1983 \text {. }\end{array}$ \\
\hline Jaegge, W.J., et al., 1987 & $\begin{array}{ll}\frac{\text { Radionuclide }}{{ }^{129} \mathrm{I}^{\mathrm{b}}} & \begin{array}{l}\text { Undecayed } \\
\text { Disposal Amount (Ci) }\end{array} \\
& 14 \mathrm{Ci} \\
\text { (References an earlier article [Looney et al., } \\
\text { 1987]) }\end{array}$ & NA \\
\hline Cook, James R., 1987 & $\begin{array}{|lc|}\text { Nuclides } & \frac{\text { Inventory }(\mathrm{Ci})}{2.9 \times 10^{-2}} \\
\mathrm{I}-129^{\mathrm{b}} & (643-\mathrm{G} \text { Site) } \\
& \text { (Does not reference an earlier article) }\end{array}$ & NA \\
\hline Oblath, S.B., 1986 & $\begin{array}{l}\text { I-129 in the Burial Ground: } 12 \mathrm{Ci}^{b} \\
\text { (References Hawkins, 1983) }\end{array}$ & $\begin{array}{l}\text { The silver iodide coated Berl saddles } \\
\text { have contributed about } 12 \text { Ci of I-129 } \\
\text { to the burial ground, and are probably } \\
\text { the major source of I-129 in the burial } \\
\text { ground. } \\
\text { The I-129 waste is a compact source } \\
\text { which is already segregated from other } \\
\text { waste. }\end{array}$ \\
\hline $\begin{array}{l}\text { Towler, O.A., and Cook, } \\
\text { J.R., } 1985\end{array}$ & $\begin{array}{l}\text { Radionuclide Content of } 5 \text {-year-old In-tank } \\
\text { Waste: } \\
\text { Isotope } \quad \frac{\mathrm{Ci} /\left.\mathrm{Gal}\right|^{\mathrm{a}}}{\mathrm{I}-129} \quad 9.42 \mathrm{E}-07 \\
\text { (Does not reference an earlier article) }\end{array}$ & $\begin{array}{l}\text { The "five years" means five years out } \\
\text { of the reactor. }\end{array}$ \\
\hline
\end{tabular}


Table 3-1. The Sources of Inventory Estimates for Iodine-129 in the ORWBG (Continued)

\begin{tabular}{|c|c|c|}
\hline Reference & Inventory & Notes \\
\hline Hawkins, R.H., 1983 & $\begin{array}{l}\text { 39 Ci of I-129 had been produced at SRP } \\
\text { through } 1974 \text {, of which } 20 \%(7.8 \mathrm{Ci}) \text { was } \\
\text { released to the atmosphere and } 30 \%(11.7 \\
\text { Ci) was stored as solid waste at the burial } \\
\text { ground (Cornman, 1974). } \\
13.6 \mathrm{Ci}^{\mathrm{a}} \text { of } \mathrm{I}-129 \text { are estimated to have } \\
\text { been stored at the burial ground through } \\
1982 \text {. }\end{array}$ & $\begin{array}{l}\text { - Nuclear fuel processing at the two SRP } \\
\text { chemical separations areas is the } \\
\text { principal source of I-129. } \\
\text { Most I-129 in the burial ground is on } \\
\text { spent Berl saddles. The total volume } \\
\text { of this waste is approximately } 40 \mathrm{cu} \\
\text { ft/year, and it comes from the } \\
\text { separations areas packaged in drums } \\
\text { and segregated from other waste. } \\
\text { I-129 on the buried Berl saddles } \\
\text { probably occurs as silver iodide. } \\
\text { At the burial ground, the Berl saddles } \\
\text { are buried, without containment or } \\
\text { encapsulation, in waste trenches } \\
\text { designated for intermediate-level beta- } \\
\text { gamma waste. At least } 48 \text { spent } \\
\text { charges of Berl saddles had been } \\
\text { buried trough } 1980 \text { with an average I- } \\
129 \text { content of approximately } 275 \\
\text { mCi/charge. }\end{array}$ \\
\hline Cornman, W.R., 1974 & $\begin{array}{l}\text { An estimated } 39 \mathrm{Ci}^{2} \text { of } \mathrm{I}-129 \text { has } \\
\text { been produced since plant startup: } \\
40 \% \text { waste tanks } \\
30 \% \text { burial ground } \\
20 \% \text { atmosphere } \\
10 \% \text { seepage basins } \\
\text { (Does not reference an earlier article) }\end{array}$ & $\begin{array}{l}\text { Estimated from total }{ }^{137} \mathrm{Ce} \text { fission- } \\
\text { product inventory corrected for decay } \\
\text { assumes nuclear yields of } 6.2 \text { and } 1.0 \% \\
\text { respectively for Ce-137 and I- } 129 . \\
\text { Fission yields of } \mathrm{I}-129 \text { of } 0.9 \% \text { for } \mathrm{U}- \\
235 \text { and } 1.4 \% \text { for } \mathrm{Pu}-239 \text { were } \\
\text { assumed. Burnup of } \mathrm{I}-129 \text { was } \\
\text { neglected. } \\
\text { Some Berl saddles were sent to ORNL } \\
\text { for I- } 129 \text { recovery during the early } \\
\text { years of operation. }\end{array}$ \\
\hline
\end{tabular}

a Inventory discussed in detail

b No discussion of basis for inventory

NA Not addressed in article 


\section{APPENDIX P}

\section{CONSTITUENT OF INTEREST:}

NEPTUNIUM-237 
(This page intentionally left blank) 


\section{TABLE OF CONTENTS}

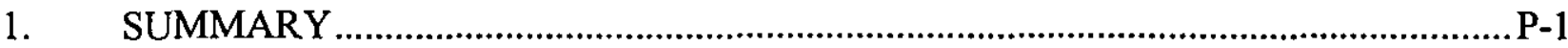

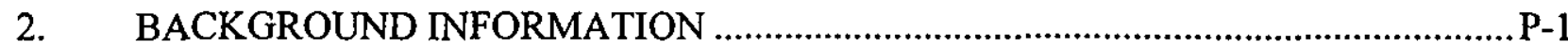

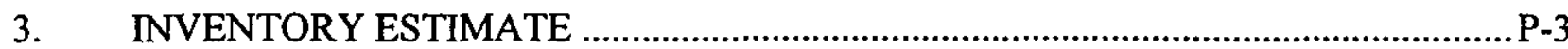

3.1 Range of Inventory Estimates .........................................................................

3.2 Best Estimate of Neptunium-237 in Burial Grounds..............................................

3.3 Uncertainties Associated with Neptunium-237 Inventory Estimate....................... -6

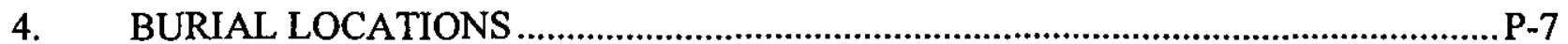

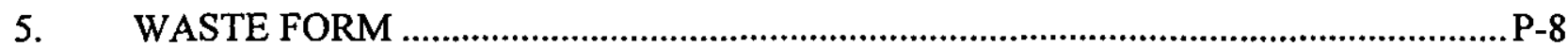

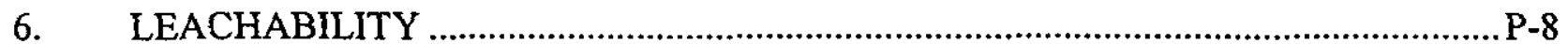

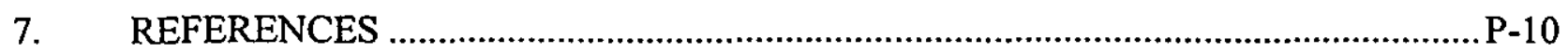




\section{LIST OF FIGURES}

Figure 1-1. Inventory Estimate Process Flow Diagram.................................................P-13

Figure 4-1. Neptunium-237 Burial Location Process Flow Diagram..................................P-14

Figure 4-2. X, X Locations for all Neptunium-237 Burials in ORWBG Database (Variety of Contamination \#1 and \#2 = "82") ......................................................

Figure 4-3. $\quad \mathrm{X}, \mathrm{Y}$ Locations for all Pu-238 Burials from Buildings 235-F and $221-\mathrm{H}$ in ORWBG Database (Variety of Contamination \#1= "83").................................16

\section{LIST OF TABLES}

Table 3-1. The Sources of Inventory Estimates for Neptunium-237 in the ORWBG $\mathrm{P}-17$ 


\section{CONSTITUENT OF INTEREST - NEPTUNIUM-237}

\section{SUMMARY}

Neptunium is a byproduct of nuclear materials production for the national defense program. Processing these materials has resulted in radioactive waste that contains neptunium.

The best estimate of the amount of neptunium-237 originally buried in the Old Radioactive Waste Burial Ground (ORWBG) is $1.99 \mathrm{Ci}$. The amount of ingrown neptunium-237 is conservatively calculated as $0.004 \mathrm{Ci}$. The amount lost to radioactive decay is negligible due to the long half life of the radionuclide.

Figure 1-1 presents the process used to develop the inventory and burial locations. The Computerized Burial Record Analysis (COBRA) database was used to determine the locations and quantity estimates of neptunium-237 burials.

\section{BACKGROUND INFORMATION}

Neptunium-237 is a long-lived radionuclide with a half life of $2.14 \times 10^{6}$ years (Anderson, 1971 in McIntyre et al., 1988). Neptunium-237 is produced during the nuclear fuel cycle. by two primary sources at SRS. One source is alpha decay of americium-241 that is produced by the beta decay of plutonium-241 in weapons-grade plutonium. The other mode of neptunium-237 production is via a side reaction during the irradiation of uranium-238 targets to eventually produce plutonium-239. The overall side reaction, as broken down into its individual components, is:

$$
\begin{aligned}
& { }_{92} \mathrm{U}^{235}+{ }_{0} \mathrm{n}^{1}={ }_{92} \mathrm{U}^{236}+\gamma \\
& { }_{92} \mathrm{U}^{236}+{ }_{0} \mathrm{n}^{1}={ }_{92} \mathrm{U}^{237}+\gamma \\
& \text { or } \quad{ }_{92} \mathrm{U}^{238}+{ }_{0} \mathrm{n}^{1}={ }_{92} \mathrm{U}^{237}+2{ }_{0} n^{1}
\end{aligned}
$$

Since uranium-237 has a relatively short half-life ( 6.75 days), it beta decays rapidly to yield the long-lived daughter, neptunium-237:

$$
{ }_{92} \mathrm{U}^{237}={ }_{93} \mathrm{~Np}^{237}+{ }_{-1} \beta^{0}
$$

Neptunium-237 is the target material used to produce plutonium-238 in SRS reactors. Much of the oxide preparation for the neptunium-237 targets was done in HB-Line. The oxide was 
encapsulated in Building 235-F. Therefore, solid waste from these two facilities could have contained neptunium-237. However, the primary activity from these would be from plutonium-238. Neptunium-237 has such a long half-life that 1 gram of neptunium-237 contains only $7 \mathrm{E}-04 \mathrm{Ci}$, and 1 kilogram of neptunium-237 contains only $0.7 \mathrm{Ci}$ (Holcomb, 1997).

The two chemical separation facilities ( $\mathrm{F}$ and $\mathrm{H}$ ) were used to reprocess irradiated fuel and targets in canyon buildings (22I-F and 221-H). Irradiated materials were dissolved, and the products of interest were chemically separated and purified from waste fission and activation products. In 1963, a modification in $\mathrm{H}$ Area allowed the recovery of neptunium-237 from the fuel. The H Modified PUREX (HM) process, was used for the chemical extraction and purification of enriched uranium and for recovery of the neptunium-237 byproduct. Also in $\mathrm{H}$ Area, the Frames process was used occasionally to recover plutonium-238 and neptunium-237 from special target elements. This process used ion exchange for separation and purification (Carlton et al., 1993).

Waste potentially contaminated with neptunium-237 included, but was not limited to the following:

- Cabinet waste originating from H-Area B-Line (221-HBL, neptunium-237 and plutonium-238 oxide powder production). This included both the normal neptunium line and the plutonium-238 oxide line (Fenninger and Tyson, 1968). Waste from the hot pressing and finishing cabinets was not monitored because of the low probability that it contained significant neptunium. In the 4-month period of slug fabrication from July through October, pulse height analysis indicated 43.8 grams of neptunium was removed from the oxide handling cabinet in waste boxes (Holcomb, 1997; Fenninger and Tyson, 1968).

- Laboratory glove boxes and radiobenches from the 772-F laboratory. These were used to handle plutonium-238 or neptunium-237 (Fenninger and Tyson, 1968).

- Wastes originating from 235-F (neptunium-237/plutonium-238 Metallurgical Facility and process lines) (Holcomb, 1997; Fenninger and Tyson, 1968).

- Waste effluents from processing in the Separations areas. These contained low levels of neptunium that were discharged to seepage basins (McIntyre et al., 1988). Such liquid waste effluents as these would have a minimal impact on the activity of neptunium sent to the Solid Waste Storage Facility (i.e., ORWBG). 
- PUREX waste in storage tanks in the 241-F and H-Area Tank Farms and in the Old Solvent Tanks (OSTs) in the ORWBG. Practically all of the neptunium in the $241 \mathrm{~F}$ and $\mathrm{H}$ Area Tank Farms was in the sludge (Daking, 1960; Prout and Fernandez, 1960). At one time, neptunium-237 comprised 30 percent of the alpha emitters in the organic phase in Tank S18 (see Table 15 in Mason, 1996), and was probably present in smaller quantities in the other tanks. The OSTs have been emptied. Most of the materials in the OSTs were removed in the late 1970 s to early 1980 s; only unpumpable heel remains in the tanks at present.

The amount of neptunium-237 activity in SRS waste should be relatively small, since the activity of neptunium produced was small compared with that for plutonium-238 and plutonium-239. However, due to the very low specific activity of neptunium-237, a relatively small activity represents a rather sizeable mass. Beginning in the 1960s, most of the neptunium-237 formed in SRS reactors was recovered to make targets for plutonium-238 production (Karraker, 1994).

\section{INVENTORY ESTIMATE}

\subsection{Range of Inventory Estimates}

The inventory of neptunium-237 at the SRS burial grounds is not known with great precision, though many estimates have been proposed. Neptunium-237 is a difficult radionuclide to detect, especially in the presence of other alpha emitters that are usually much more active. Therefore, differences in the estimates could be due to errors in various analyses for neptunium-237.

The 1977 environmental impact statement on SRS waste management reported an estimate of $0.2 \mathrm{Ci}$ of neptunium-237 in waste buried in earthen trenches at the burial grounds through 1975 (ERDA, 1977 in WSRC, 1992). Because the ORWBG closed in 1972, most of this activity would be in the ORWBG.

Cook $(1987 \mathrm{a}, \mathrm{b})$ cites an estimate of $2 \mathrm{Ci}$ of neptunium-237 in the ORWBG based on records from the COBRA database. His estimate is the sum of $5.0 \times 10^{-2} \mathrm{Ci}\left(7.20 \times 10^{3} \mathrm{ft}^{3}\right)$ as trench disposal (includes concrete pours) and $1.9 \times 10^{0} \mathrm{Ci}\left(1.40 \times 10^{3} \mathrm{ft}^{3}\right)$ in retrievable storage (in trenches). Several years later, he reported an estimate of 910 grams of neptunium-237 in the ORWBG based on the records from the COBRA database (Cook, 1991). Using a specific activity of $7.05 \mathrm{E}-4 \mathrm{Ci} / \mathrm{g}$, this is $0.64 \mathrm{Ci}$. 
Jaegge et al. (1987), based upon COBRA records documenting its placement, estimated that $54,200 \mathrm{~m}^{3}$ of "other alpha emitters", originally containing $93.3 \mathrm{Ci}$, were buried in SRS burial grounds from 1952 through 1985. He also cites that the composition percentage of neptunium-237 by activity is 0.17 percent (0.0017). Using these data, the amount of neptunium-237 from "other alpha emitters" is:

$$
(93.3 \mathrm{Ci}) \times(0.0017)=0.16 \mathrm{Ci}
$$

This activity is assumed to be a product in waste primarily from HB-Line and 235-F. This estimate includes burials through 1985, 11 years after the ORWBG closed. For modeling purposes, Jaegge et al. (1987) used an undecayed inventory estimate of $0.13 \mathrm{Ci}$, as cited in Looney et al. (1987).

A 1987 Savannah River Laboratory (now Savannah River Technology Center) study on closure for the ORWBG listed an estimated 1.1 Ci of neptunium-237 in the ORWBG (DuPont, 1987 in WSRC, 1992). A 1988 Savannah River Laboratory analysis was based on an inventory of 0.13 Ci neptunium-237 for both SRS burial grounds (Cook and King, 1988 in WSRC, 1992).

Table 3-1 lists the sources of the inventory estimates for neptunium-237 in the ORWBG.

\subsection{Best Estimate of Neptunium-237 in Burial Grounds}

The best estimate for the amount of neptunium-237 originally buried in trenches in the ORWBG is 2,829 grams $(1.99 \mathrm{Ci})$ based upon COBRA records. The COBRA database indicates that burials of neptunium-237 occurred in the ORWBG as recently as 1973. Because the half-life of neptunium-237 is very long $\left(2.14 \times 10^{6}\right.$ years $)$, the amount that has decayed since burial is negligible.

An additional factor must be considered when calculating the inventory of neptunium-237 in the future. The inventory of this radionuclide will actually increase, for a limited period of time, because the rate of radioactive decay is less than the rate of ingrowth of neptunium-237 by alpha decay of americium-241 that is produced by the beta decay of plutonium-241 in weapons-grade plutonium. Due to the relatively long half-lives of neptunium-237 (2.14E+06 years) and plutonium-239 (2.41E+04 years), there will be minimal change in their activity ratio over the next 500 years. The half-life of plutonium-241 is relatively short (14.4 years); the half-life of americium-241 is 432.7 years (KAPL, 1996). 
The best estimate of plutonium-239 in the ORWBG is 24,188 grams ( 24.2 kilograms), as calculated in Appendix $\mathrm{H}$ of this document. The great majority of plutonium produced at SRS was weapons-grade with the plutonium-240 concent being 6 percent or less. The plutonium-241 content of weapons-grade plutonium was 0.70 weight percent (Holcomb, 1994). Therefore, assuming no decay of plutonium-241, there would be $0.17 \mathrm{~kg}$ of plutonium-241 associated with the $24.2 \mathrm{~kg}$ of plutonium-239:

$(24.2 \mathrm{~kg}$ plutonium-239) $\times(0.0070)=0.17 \mathrm{~kg}$ plutonium-241 originally buried in ORWBG

Since almost two half lives of plutonium-24l have passed since closure of the ORWBG, the amount of plutonium-241 remaining at present (in 1997) is $0.05 \mathrm{~kg}$, as determined by the decay equation:

$$
A_{t}=\left(A_{0}\right)\left(e^{[-0.693 t /]}\right)
$$

where:

$A_{t}=$ plutonium -241 mass in 1997

$A_{0}=$ original mass of plutonium-241 in $1972(0.17 \mathrm{~kg})$

$\mathrm{t}=$ elapsed time since ORWBG closed $(1997-1972=25$ years $)$

$\mathrm{T}=$ half-life of plutonium-241 (14.4 years)

Assuming identical atomic weights of plutonium-241 and americium-241, the amount of ingrown americium-241 daughter is:

$(0.17 \mathrm{~kg}$ plutonium-241 in 1972$)-(0.05 \mathrm{~kg}$ plutonium-241 in 1997$)=0.12 \mathrm{~kg}$ americium -241 in 1997

The amount of neptunium-237 from the decay of ingrown americium-241 is calculated using the decay equation. To simplify the mathematics, and to calculate a conservative value, it is assumed that the entire $0.12 \mathrm{~kg}$ of americium-241 existed in 1972 . The amount of americium-241 remaining in 1997 is:

$$
A_{1}=\left(A_{0}\right)\left(e^{[-0.693 \mathrm{t} / T]}\right)
$$

where: 
$A_{t}=$ americium-241 mass in 1997

$A_{o}=$ original mass of americium-241 in $1972(0.12 \mathrm{~kg})$

$\mathrm{t}=$ elapsed time since ORWBG closed $(1997-1972=25$ years $)$

$\mathrm{T}=$ half-life of americium-241 (432.7 years)

The amount of americium-241 remaining in 1997 is $0.115 \mathrm{~kg}$. The amount of ingrown Americium-241 daughter is:

$(0.12 \mathrm{~kg}$ americium-241 in 1972$)-(0.115 \mathrm{~kg}$ americium-241 in 1997$)=0.005 \mathrm{~kg}$ americium241 ingrown

The amount of ingrown neptunium-237 from the decay of $0.005 \mathrm{~kg}$ americium-241 is determined by multiplying the mass of americium-241 by the ratio of the atomic weight of the daughter isotope to the atomic weight of the parent isotope:

$(0.005 \mathrm{~kg}$ americium-241) $\times(237 \mathrm{~kg}$ neptunium $-237 \div 241 \mathrm{~kg}$ americium-241 $)=0.005 \mathrm{~kg}$ Neptunium-237 ingrown

The mass of $0.005 \mathrm{~kg}$ is converted to curies by multiplying it by the specific activity:

$$
(0.005 \mathrm{~kg}) \times(0.000705 \mathrm{Ci} / \mathrm{g}) \times(1000 \mathrm{~g} / \mathrm{kg})=0.004 \mathrm{Ci} \text { neptunium-237 }
$$

This is the activity of ingrown neptunium-237 in 1997 from alpha decay of americium-241 that is produced by the beta decay of plutonium-241 in weapons-grade plutonium. The best estimate of the inventory of neptunium-237 in the ORWBG is the sum of this value and the original disposal amount $(1.99 \mathrm{Ci})$ :

$(0.004 \mathrm{Ci}$ ingrown $)+(1.99 \mathrm{Ci}$ buried $)=1.994 \mathrm{Ci}$ total neptunium-237 in ORWBG in 1997

\subsection{Uncertainties Associated with Neptunium-237 Inventory Estimate}

The major contributor to uncertainty related to the quantity of neptunium-237 buried is any classified burials that are not described in the open literature and in unclassified databases such as COBRA. 


\section{BURIAL LOCATIONS}

The COBRA database provides both quantity and location estimates for neptunium-237 burials in the ORWBG. Figure 4-1 outlines the steps taken to manipulate the database to locate neptunium-237 burials, and Figure 4-2 presents the spatial distribution of all neptunium-237 burials (Variety of Contamination \#1 and \#2 = "82") in the ORWBG. COBRA includes two fields for contamination, variety 1 and variety 2 . Variety of contamination 1 is the main source of contamination; the waste generator could indicate a second type of contamination as variety 2. There is no significance to assigning the neptunium-237 variety 1 versus variety 2 . The data presented in Figure 4-2 have been divided into two sets. Burial locations indicated with circles are for those burials where neptunium-237 was "Variety of Contamination 1" Burial locations indicated with squares are for those burials where neptunium-237 was "Variety of Contamination 2".

The data in Figure 4-2 also indicate the relative quantity of each burial. The larger the symbol, the larger the curie content of the burial.

Figure 4-3 presents the burial locations for all plutonium-238 burials (Variety of Contamination $\# 1=$ " 83 ") from Buildings $235-\mathrm{F}$ and $221-\mathrm{H}$ in ORWBG. These burials are not specifically identified as containing neptunium- 237 as a contaminant. However, these burials are likely to contain small amounts of neptunium-237.

The ratio of neptunium-237 to plutonium-238 in the burials from $235-\mathrm{F}$ and $221-\mathrm{H}$ is unknown and would vary depending on where in the process the waste originated. However, since plutonium-238 has such a high specific activity, it will be the dominant constituent of interest at these burial locations for at least 10 half-lives of plutonium-238, or for at least some 880 years. To illustrate the dominance of the plutonium-238 activity over that of neptunim-237, if equal masses of plutonium-238 and neptunium-237 were buried today, the activity ratio of plutonium-238/neptunium-237 would be $2.4 \mathrm{E}+04$; in 500 years it would be $4.6 \mathrm{E}+02$; in 1000 years it would be 8.9 , and in 5000 years it would be $1.7 \mathrm{E}-13$. Therefore, for at least 500 years, the activity of plutonium- 238 in these mixed burials will predominate.

As previously discussed, ingrown neptunium-237 is derived from alpha decay of americium-241, which is in turn produced by beta decay of plutonium- 241 in weapons-grade plutonium. Thus, as demonstrated in Section 3.2, relatively small activities of neptunium-237 will be associated with the weapons-grade plutonium burials. The activity of neptunium-237 that will ingrow from decay of the plutonium-241 component in the weapons-grade plutonium 
will only amount to approximately 4 percent of what is currently buried in the ORWBG as a result of the plutonium-238 program at SRS.

\section{WASTE FORM}

The primary waste form of neptunium-237 in the ORWBG is very similar to that for plutonium-238. Neptunium-237 contaminated waste was buried in three ways:

- Uncontainerized waste in plastic bags and cardboard boxes. This type of containment would be the most susceptible to infiltrating water.

- Concrete culverts containing drummed or boxed neptunium-237-bearing waste. Although it provides additional barriers, this containment does not preclude the infiltration of water into the culvert. One excavated culvert was found to contain water.

- Encapsulated waste where drums and other waste forms (equipment, waste in wooden boxes, etc.) were surrounded by concrete on all sides, top, and bottom. Such waste forms would be more impermeable to water infiltration.

\section{LEACHABILITY}

The leachability of neptunium-237 depends on $\mathrm{pH}$, redox conditions, and waste form. neptunium-237 can exist in oxidation states ranging from ${ }^{+} 3$ to ${ }^{+} 6$, but the ${ }^{+} 4$ and ${ }^{+} 5$ states are dominant under most environmental conditions. The speciation of $\mathrm{Np}(\mathrm{IV})$ is dominated by hydrolysis products that vary with $\mathrm{pH}$. The speciation of $\mathrm{Np}(\mathrm{V})$ is dominated by the oxycation $\mathrm{NpO}_{2}{ }^{+}$. Solubility and adsorption controls on mobility depend strongly on which oxidation state is dominant. The only reasonable phase with a solubility low enough to constrain neptunium-237 concentrations to below $7 \mathrm{pCi} / 1$ (the primary drinking water standard) is $\mathrm{NpO}_{2}$. The solubility of this phase is at a minimum when $\mathrm{Np}$ (IV) is the dominant oxidation state. Likewise, mobility of neptunium-237 is minimized when $N p(I V)$ is the dominant oxidation state because the hydrolized $\mathrm{Np}(\mathrm{IV})$ species are more strongly adsorbed by soils than $\mathrm{NpO}_{2}{ }^{+}$ (Silvan and Nitsche, 1995).

Reducing conditions in the ORWBG may result in $\mathrm{Np}(\mathrm{IV})$ being the dominant oxidation state, thereby limiting the leachability of neptunium-237. Bondietti and Francis (1979) observed the reduction of dissolved $\mathrm{Np}(\mathrm{V})$ to $\mathrm{Np}(\mathrm{IV})$ when reacted with several rock types isolated from atmospheric oxygen. The rocks used in these experiments would have less of a reducing effect 
than reaction with the large amounts of zero valent iron and organic material disposed of in the ORWBG. Thus, Np(IV) may be the dominant form of neptunium-237 in the ORWBG.

Analyses of groundwater and leachate from lysimeter experiments suggest that neptunium-237 is not highly leachable in the ORWBG. Groundwater from 10 monitoring wells downgradient from the ORWBG (the BGO well series) were analyzed for neptunium-237 in 1990 and 1992 and all concentrations were below detection limits. In 1986, leachates from 4 defense waste lysimeters were analyzed for neptunium-237 (McIntyre, 1987). Though the neptunium-237 in the waste forms was already in solution, concentrations of neptunium-237 in the leachate were very low. Leachate from 3 of the lysimeters contained less than $0.002 \mathrm{pCi} / 1$, while leachate from the fourth contained $0.27 \mathrm{pCi} / 1$ neptunium- 237 .

The low source term for neptunium-237 and the containment of much of the source term in culvert or encapsulated burials, the reducing conditions of the ORWBG, and the low concentrations of neptunium-237 in groundwater and lysimeter experiments suggest that this contaminant of interest is not currently a threat to groundwater, nor is it likely to be a threat to groundwater in the future. 


\section{REFERENCES}

Anderson, L.G., 1971. Standard Values for Specific Activities, Savannah River Laboratory, Aiken, SC, 1971.

Bondietti, E.A. and C.W. Francis, 1979. Geologic Migration Potential of Technetium-99 and Neptunium-237, Science, v. 203, p.1337-1340.

Carlton, W.H., et al., 1993. Assessment of Radiocarbon in the Savannah River Site Environment (U), WSRC-TR-93-215, Westinghouse Savannah River Company, Savannah River Technology Center, Aiken, SC 29808, March 1993.

Cook, J.R., 1987a. Inventories of Selected Nuclides in 643-7/28G and 643-G, DPST-87-399, Memorandum to C.M. King, E.I. du Pont de Nemours and Company, Aiken, SC, March 20, 1987.

Cook, J.R., 1987b. Technical Data Summary: Plan for Closure of the 643-G Burial Ground, DPSTD-87-2, E.I. du Pont de Nemours and Company, Aiken, SC, August 17, 1987.

Cook, J.R., and King, C.M., 1988. Some Special Considerations in Evaluating the Impacts of Long-Lived Radionuclides in LLW, E.I. du Pont de Nemours \& Co., Savannah River Laboratory, Aiken, SC 29808, 1988.

Cook, J.R., 1991. Radionuclide Inventory of E Area (U), WSRC-RP-91-709, Memorandum to W.E. Stevens, Westinghouse Savannah River Company, Savannah River Technology Center, Aiken, SC 29808, June 27, 1991.

Daking, A.E., 1960. Special Product Program - Savannah River Plant Recovery of Neptunium from Stored Wastes, DPW-60-275, E. I. du Pont de Nemours \& Co., Savannah River Laboratory, Aiken, SC 29808, October 11, 1960.

DuPont, 1987. Waste Management Program Technical Progress Report, DP-87-125-1/2, Savannah River Laboratory (Closure Alternatives for the 643-G Site), January-June 1987.

ERDA-1977. Final Environmental Impact Statement Waste Management Operations Savannah River Plant, ERDA, 1537, P.A-11, September 1977.

Fenninger, R.B., and Tyson, W.R., 1968. Monitoring Waste for Neptunium-237 and Plutonium-238, Westinghouse Savannah River Company, Savannah River Technology Center, Aiken, SC, February $20,1968$. 
Holcomb, H. Perry, 1994. Defining Weapons-Grade Plutonium, Its Isotopic Mass and Alpha Activity Distributions, and Effects of Decay on These Parameters (U), EPD-SGS-94-0139, Westinghouse Savannah River Company, Savannah River Site, Aiken, SC 29808, May 26, 1994.

Holcomb, H. Perry, 1997. Deriving Source Terms of Carbon-14, Cobalt-60, Technetium-99, Iodine-129, and Neptunium-237 in the Old Radioactive Waste Burial Ground, RadChemCo-97-013, Memorandum to Smits, A.D., SAIC, RadChemCo, Inc., July 26, 1997.

Jaegge, W.J., et al., 1987. Environmental Information Document, Radioactive Waste Burial Grounds, DPST-85-694, E. I. du Pont de Nemours \& Co., Savannah River Laboratory, Aiken, SC 29808, March 1987.

Karraker, 1994. Solubility of Neptunium in Alkaline High Level Waste, WSRC-TR-94-0526, Chemical Process Technology Department, Chemical \& Hydrogen Technology Section, Westinghouse Savannah River Company, Savannah River Site, Aiken, SC 29808, 1994.

KAPL, 1996. Chart of the Nuclides, 15th edition, Knolls Atomic Power Laboratory, Naval Reactors, U.S. Department of Energy, revised to 1996.

Looney, B.B., J.B. Pickett, C.M. King, W.G. Holmes, W.F. Johnson, and J.A. Smith, 1987. Selection of Chemical Constituents and Estimation of Inventories for Environmental Analysis of Savannah River Plant Waste Sites, DPST-86-291, E.I. du Pont de Nemours and Company, Savannah River Laboratory, Aiken, SC.

McIntyre, P.F., 1987. 1987 Monitoring Report for the Defense Waste Lysimeters, DPST-87-568, E.I. du Pont de Nemours \& Co., Aiken SC 29808.

McIntyre, P.C., Orebaugh, E.G., and King, C.M., 1988. Neptunium Sorption and Co-Precipitation of Strontium in Simulated DWPF Salt Solution (U), DPST-88-947, Westinghouse Savannah River Company, Savannah River Site, Aiken, SC 29808, November 30, 1988.

Mason, J.T., 1996. Information Document on the Old Solvent Tanks S1-S22 in the Old Radioactive Waste Burial Ground 643-E (U), WSRC-RP-96-00144, Westinghouse Savannah River Company, Aiken, SC

Prout, W.E., Fernandez, L.P., 1960. Recovery of Neptunium from PUREX Waste by an Agitated Bed of Anion Exchange Resin, DP-453, E.I. du Pont de Nemours and Company, Savannah River Laboratory, Aiken, SC, February 1960. 


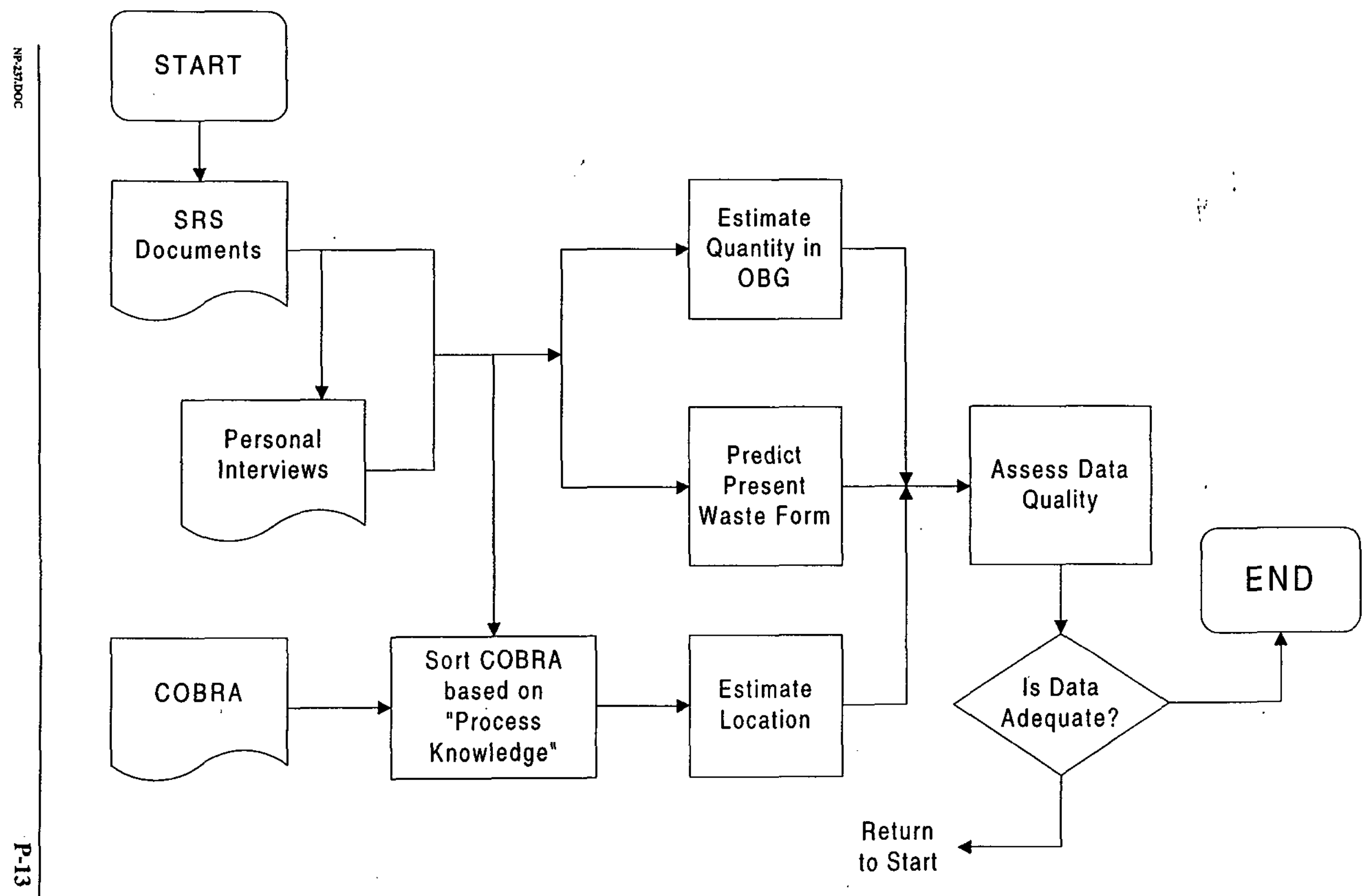

Figure 1-1. Inventory Estimate Process Flow Diagram 


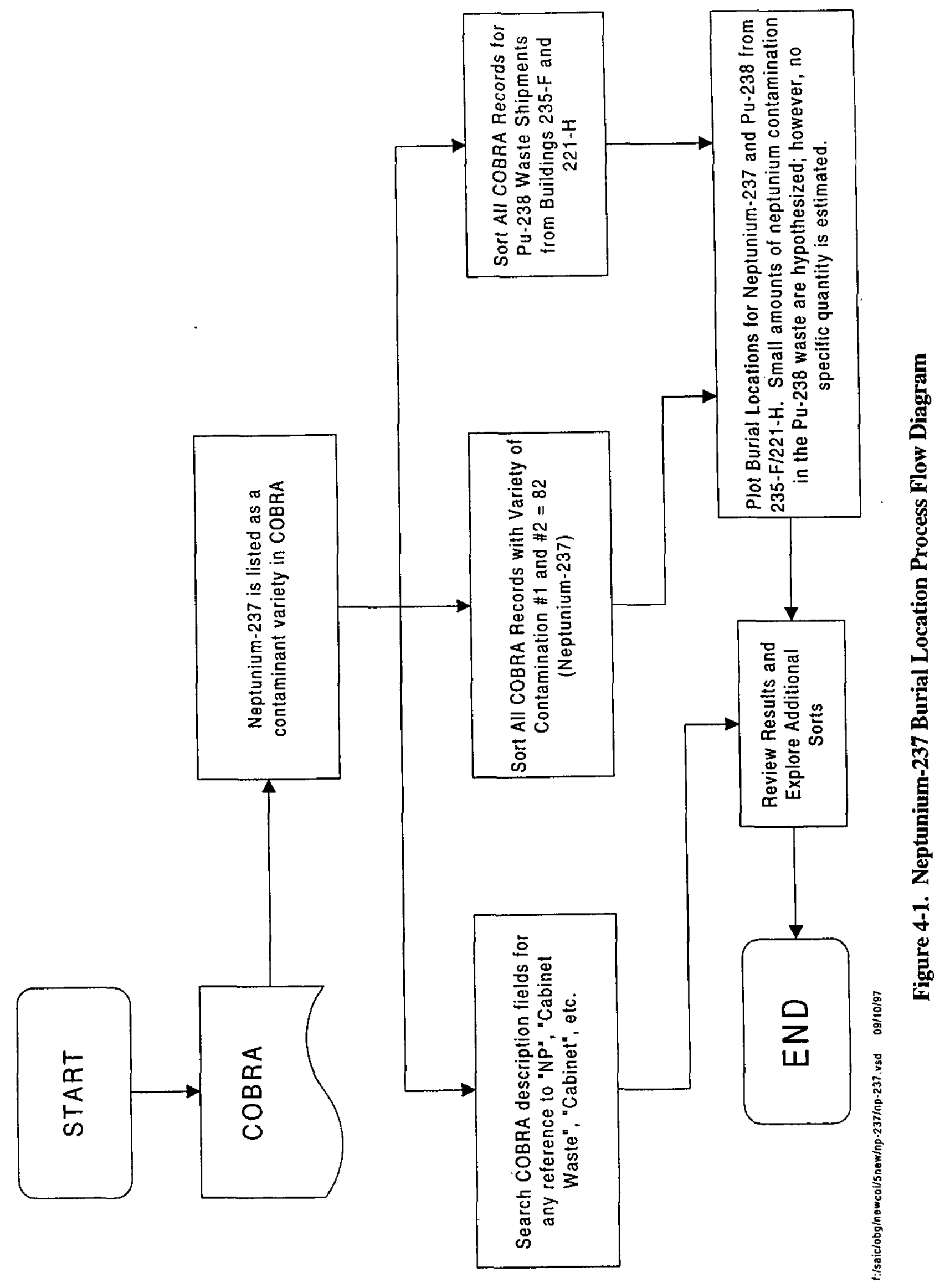




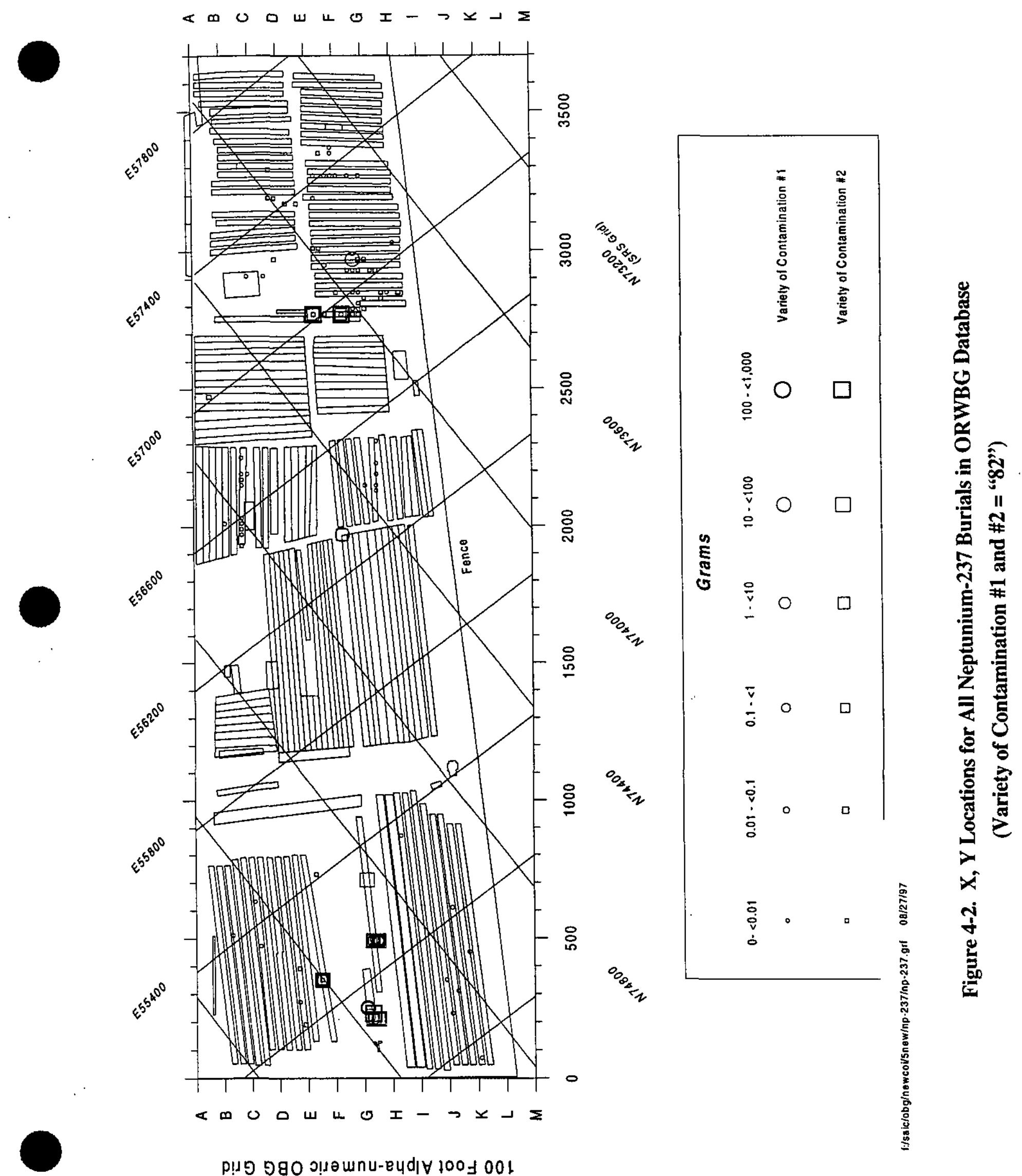




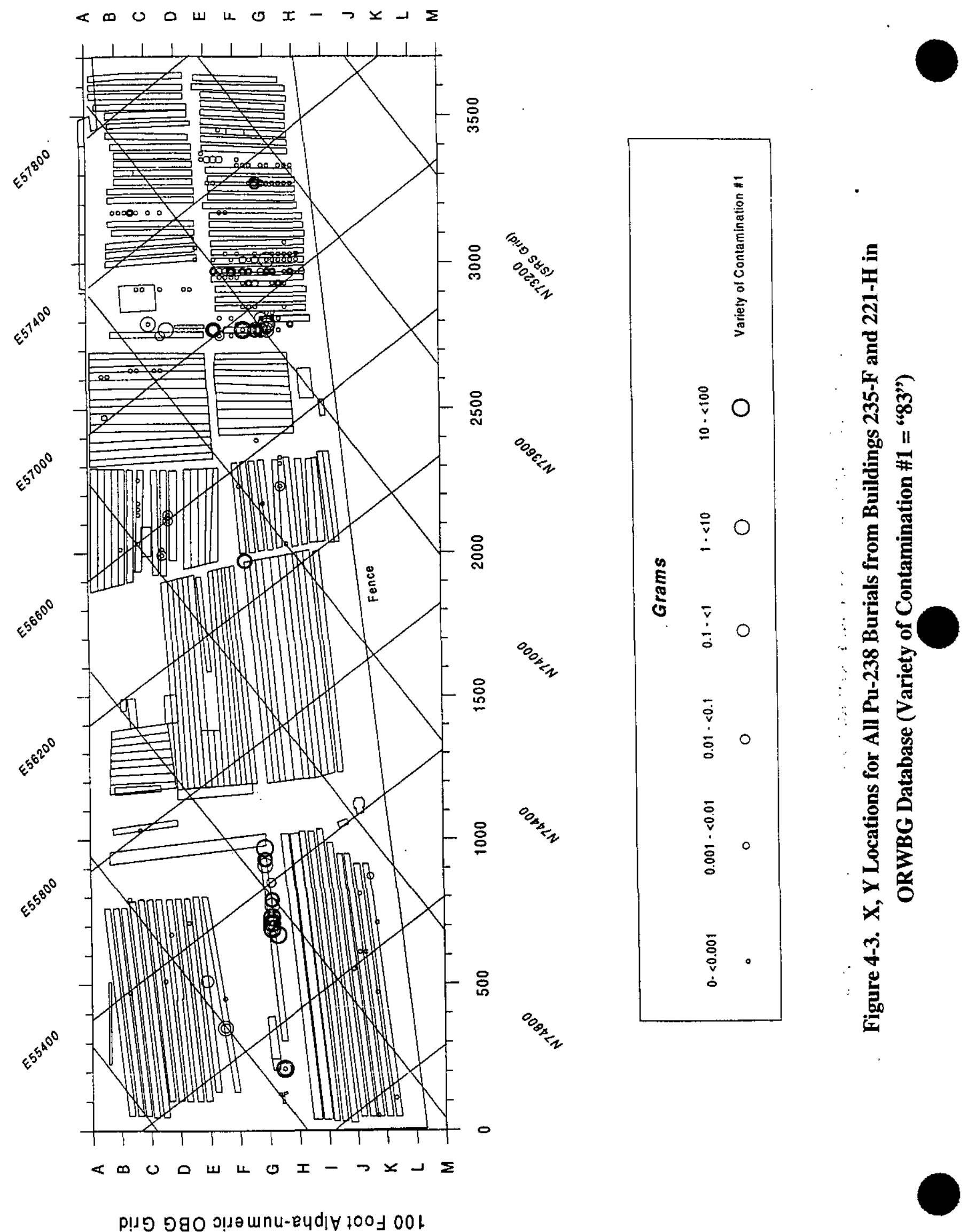


Table 3-1. The Sources of Inventory Estimates for Neptunium-237 in the ORWBG

\begin{tabular}{|c|c|c|}
\hline Reference & Inventory & Notes \\
\hline WSRC, 1992 & $\begin{array}{l}\text { - } 0.2 \text { Ci of neptunium-237 in waste } \\
\text { buried in earthen trenches at the burial } \\
\text { grounds through } 1975 \text { (ERDA, } 1977 \text { in } \\
\text { WSRC, 1992) } \\
\text { A } 1987 \text { Savannah River Laboratories } \\
\text { study on closure for the ORWBG listed } \\
\text { an estimated } 1.1 \text { Ci of neptunium-237 } \\
\text { in the ORWBG (DuPont, } 1987 \text { in } \\
\text { WSRC, 1992) } \\
\text { A } 1988 \text { Savannah River Laboratory } \\
\text { analysis was based on a 0.13 Ci } \\
\text { neptunium-237 inventory for both SRS } \\
\text { burial grounds (Cook and King, } 1988 \\
\text { in WSRC, 1992) } \\
\text { (References earlier articles) }\end{array}$ & NA \\
\hline Cook, J.R., 1991 & $\begin{array}{l}910 \text { grams of neptunium- } 237 \text { in the } \\
\text { ORWBG based on the records from the } \\
\text { COBRA database }{ }^{b} \text { Using a specific } \\
\text { activity of } 7.05 \mathrm{E}-4 \mathrm{Ci} / \mathrm{g} \text {, this is } 0.64 \mathrm{Ci} \text {. } \\
\text { (Does not reference an earlier article) }\end{array}$ & NA \\
\hline $\begin{array}{l}\text { Looney, B.B., Pickett, J.B. King, C.M. } \\
\text { Holmes, W.G. Johnson, W.F. and } \\
\text { J.A. Smith, } 1987\end{array}$ & $\begin{array}{l}\frac{\text { Total Inventory }\left(\mathrm{Ci} / \mathrm{Yr}_{\mathrm{r}}^{\mathrm{b}}\right.}{0.13} \\
\text { (Does not reference an earlier article) }\end{array}$ & 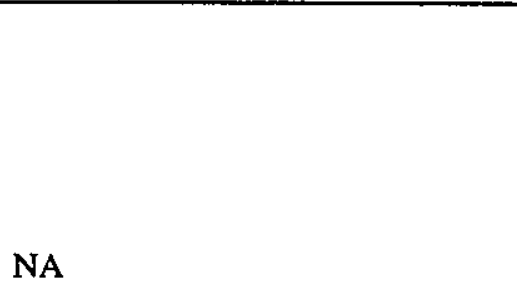 \\
\hline Jaegge, W.J., et al., 1987 & $\begin{array}{l}\text { Undecayed } \\
\frac{\text { Radionuclide }}{{ }^{237} \mathrm{~Np}} \quad \text { Disposal Amount }(\mathrm{Ci})^{\mathrm{b}} \\
\text { (643-G / 7G) } \\
\text { (References an earlier article [Looney et al., } \\
\quad \text { 1987)) } \\
\text { "Other Alpha Emitters" waste buried in } \\
\text { trenches at SRP Burial Grounds from } \\
\quad 1952 \text { through } 1985 \text { (nonretrievable) }^{\mathrm{b}} \text { : } \\
\frac{\text { Volume }\left(\mathrm{m}^{3}\right): 54,200 \mathrm{~m}^{3}}{} \\
\frac{\text { Amount Buried (Ci): }}{\text { Original }} \\
\text { 93.3 } \\
\text { (Does not reference an earlier article) }\end{array}$ & $\begin{array}{l}\text { The composition of neptunium-237 } \\
\text { from other alpha emitters is } \\
0.17 \text { percent }(0.0017) \text {. }\end{array}$ \\
\hline
\end{tabular}


Table 3-1. The Sources of Inventory Estimates for Neptunium-237 in the ORWBG

\begin{tabular}{|c|c|c|}
\hline Reference & Inventory & Notes \\
\hline Cook, J.R., 1987a & $\begin{array}{l}\text { ORWBG } \\
5.0 \times 10^{-2} \mathrm{Ci}\left(7.20 \times 10^{3} \mathrm{ft}^{3}\right) \text { as trench disposal } \\
\quad \text { (includes concrete pours) and } 1.9 \times 10^{0} \\
\mathrm{Ci}\left(1.40 \times 10^{3} \mathrm{ft}^{3}\right) \text { in retrievable storage } \\
\text { (in trenches). } \\
\text { (Does not reference an earlier article) }\end{array}$ & $\begin{array}{l}\text { This estimate was based on records } \\
\text { from the COBRA database. }\end{array}$ \\
\hline Cook, James R., 1987b & $\begin{array}{l}\frac{\text { Nuclides }}{\mathrm{Np}-237^{\mathrm{b}}} \quad \frac{\text { Inventory }(\mathrm{Ci})}{2} \\
\quad(643-\mathrm{G} \text { Site) } \\
\text { (Does not reference an earlier article) }\end{array}$ & NA \\
\hline
\end{tabular}

a: Inventory discussed in detail

b: No discussion of basis for inventory

NA: Not addressed in article 


\section{APPENDIX B}

Summary of Water Table Monitoring for the Old Radioactive Waste Burial Ground (ORWBG), WSRC-TR-97-00330, Rev.1 
This page intentionally left blank. 
WSRC-TR-97-00330, Rev. 1.0

\section{SUMMARY OF WATER TABLE MONITORING FOR THE OLD RADIOACTIVE WASTE BURIAL GROUND (ORWBG)}

MAY 2000

Westinghouse Savannah River Company Savannah River Site Aiken, S.C. 29808

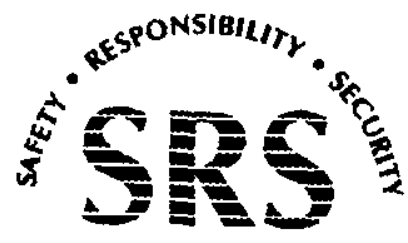




\section{DISCLAIMER}

This report was prepared by Westinghouse Savannah River Company (WSRC) for the United States Department of Energy under Contract No. DE-AC09-96SR-18500 and is an account of work performed under that contract. Neither the United States Department of Energy, nor WSRC, nor any of their employees makes any warranty, expressed or implied, or assumes any legal liability of responsibility for accuracy, completeness, or usefulness, on any information, apparatus, or product or process disclosed herein or represents that its use will not infringe privately owned rights. Reference herein to any specific commercial product, process, or services by trademark, name, manufacturer or otherwise does not necessarily constitute or imply endorsement, recommendation, or favoring of same by WSRC or by the United States Government or any agency thereof. 


\section{EXECUTIVE SUMMARY}

The Old Radioactive Waste Burial Ground (ORWBG) (643-E) occupies approximately 76 acres within the General Separations Area in the central Savannah River Site (SRS). The ORWBG served as a disposal area for solid radioactive waste produced at SRS and waste shipped from other U.S. Department of Energy and Department of Defense facilities. Most of the waste disposed in the ORWBG was placed in earthen trenches.

The ORWBG received waste from 1952 until 1972, when the majority of waste disposal operations moved to an adjacent area. The ORWBG received small quantities of waste (primarily in retrievable form) during 1973 and 1974.

Analytical data from water table wells in and around the ORWBG are summarized as isoconcentration contours superimposed on burial distribution maps for the ORWBG inventory of Constituents of Interest (COIs). Maps of lead, mercury, trichloroethylene (TCE), perchloroethene (PCE), gross alpha, non-volatile beta, and tritium are presented. Burial distributions of the COIs are posted on each map except for lead, for which burial locations are not available.

The more mobile COIs (tritium and the volatile organic compounds [VOCs]) show a fairly good correspondence between burial locations and groundwater concentrations. Plumes of tritium, TCE, and PCE are located in close proximity to and downgradient from the area within the ORWBG with the largest number of VOC burials. Maps of mercury, gross alpha, and non-volatile beta indicate little correspondence between burial locations associated with these constituents and concentrations observed in the water table. Burial locations are not available for lead. 
(This page intentionally left blank.) 


\section{TABLE OF CONTENTS}

EXECUTIVE SUMMARY

ES-1

LIST OF FIGURES

LIST OF TABLES iii

LIST OF APPENDICES

iv

LIST OF ACRONYMS

1.0 INTRODUCTION.

1

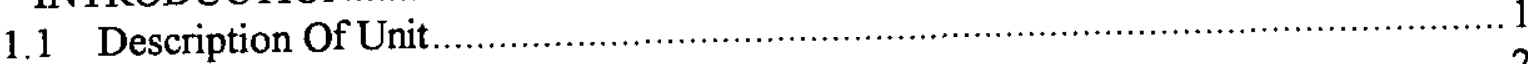

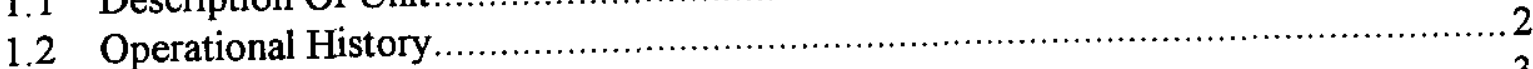

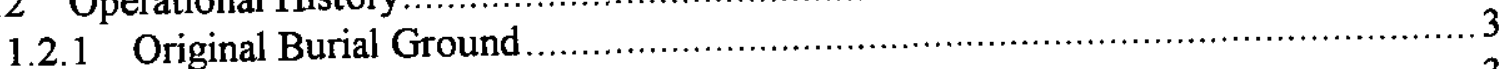

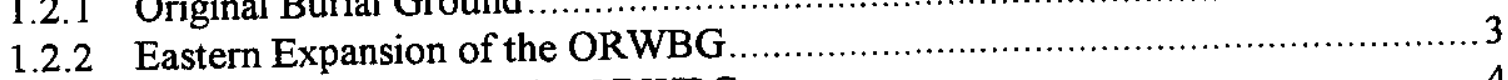

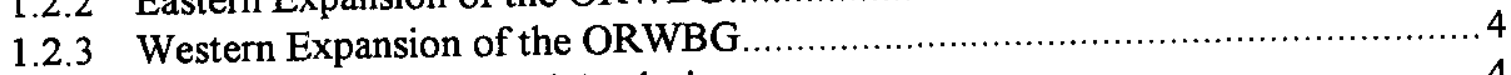

1.3 Computerized Burial Record Analysis ..................................................... 4

1.4 Constituents of Interest and Recent Source Term Investigations......................6

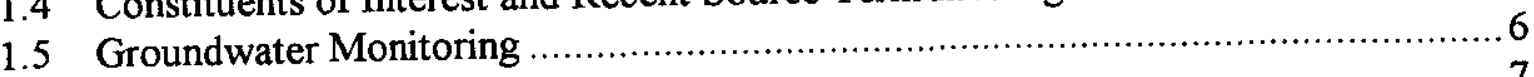

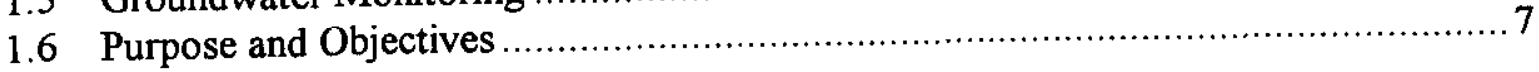

2.0 METHODS

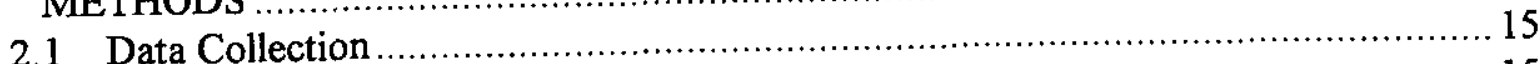

2.1.1 Computerized Burial Record Analysis Data ........................................ 15

2.1.2 Geochemical Information Management System Data ............................... 15

2.1.3 Data from Savannah River Site Documents ...................................... 15

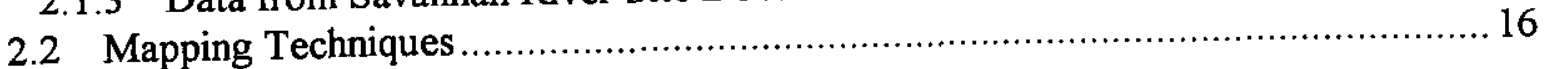

3.0 RESULTS

3.1 Nonradioactive Constituents of Interest................................................. 35

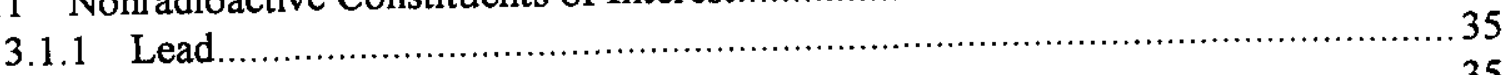

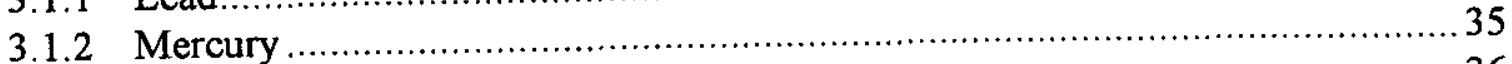

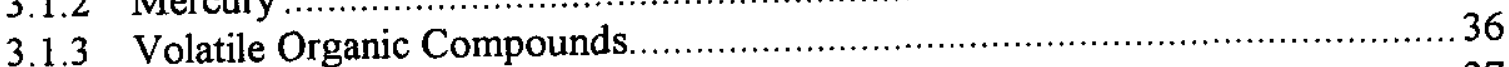

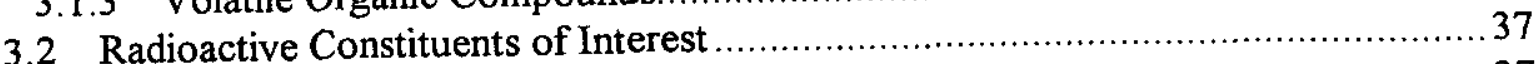

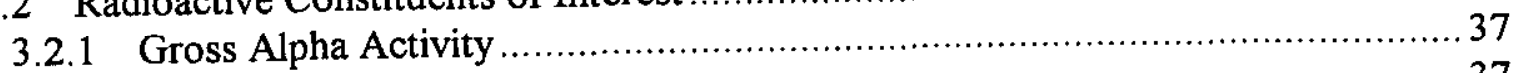

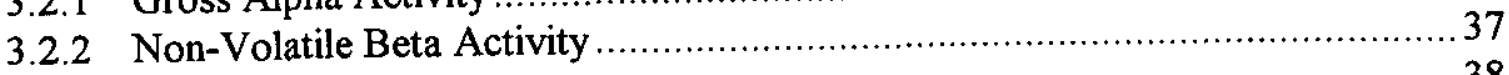

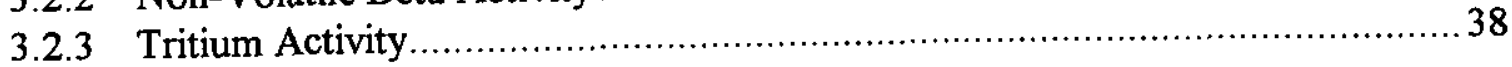

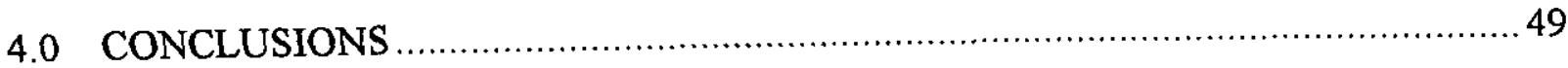

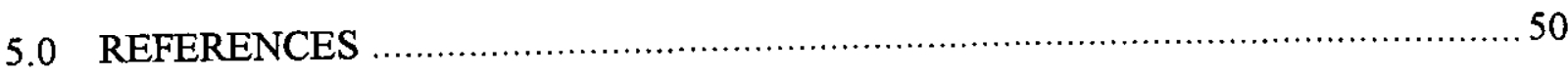




\section{LIST OF FIGURES}

1-1 Location Map for the Burial Ground Complex ........................................ 9

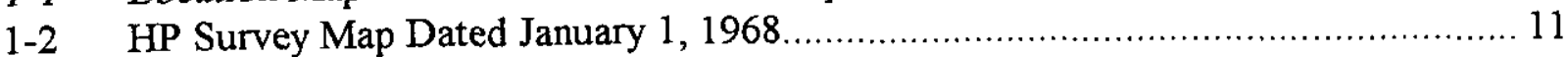

2-1 Groundwater Sample Locations and Grid Control Points ................................. 19

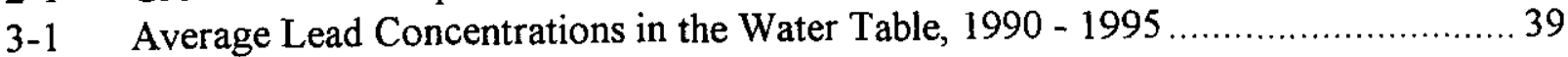

3-2 Average Mercury Concentrations in the Water Table, $1990-1995 \ldots \ldots \ldots \ldots \ldots \ldots \ldots \ldots . . \ldots 40$

3-3 Average PCE Concentrations in the Water Table, $1990-1995 \ldots \ldots \ldots \ldots \ldots \ldots \ldots \ldots \ldots . \ldots \ldots 1$

3-4 Average TCE Concentrations in the Water Table, $1990-1995$.......................... 42

3-5 Average Gross Alpha Activity in the Water Table, 1990 - 1995 ....................... 43

3-6 Average Non-Volatile Beta Activity in the Water Table, $1990-1995 \ldots \ldots \ldots \ldots \ldots \ldots \ldots . . \ldots 4$

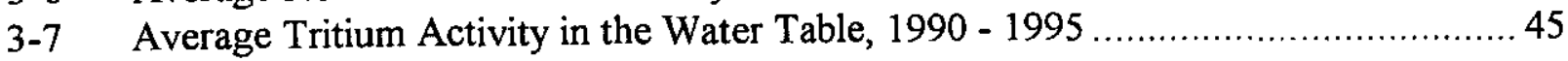




\section{LIST OF TABLES}

1-1 Constituents of Interest (COIs) for the Old Radioactive Waste Burial Ground (ORWBG)

2-1 Well Construction Details for Groundwater Sampling Points in the Vicinity of the Old Radioactive Waste Burial Ground

2-2 Average Concentrations of Metals and VOCs in Groundwater Samples from the Water Table During the Period 1990-1995

2-3 Average Concentrations of Radioactive Constituents in Groundwater Samples from the Water Table During the Period 1990-1995.

3-1 Summary of COBRA Inventory Data for Nonradioactive COIs

3-2 Summary of COBRA Inventory Data for Radioactive COIs 47 


\section{LIST OF APPENDICES}

A Summary of Source Term

Gw-tocrol.doc 


\section{LIST OF ACRONYMS}

2-D Two-Dimensional

COBRA Computerized Burial Record Analysis (Database)

COI Constituent of Interest

EDTA Ethylenediaminetetraacetic Acid

GIMS Geochemical Information Management System

HP Health Physics

ORWBG Old Radioactive Waste Burial Ground

OST

PCE Perchloroethene

PUREX Plutonium-Uranium Extraction

RCRA Resource Conservation and Recovery Act

RFI/RI RCRA Facility Investigation/Remedial Investigation

SRS Savannah River Site

TCE Trichloroethylene

TRU Transuranic

VOC Volatile Organic Compound

WSRC Westinghouse Savannah River Company 
(This page intentionally left blank.) 


\subsection{INTRODUCTION}

The Old Radioactive Waste Burial Ground (ORWBG) (643-E) occupies approximately 76 acres within the General Separations Area in the central Savannah River Site (SRS) (Figure 1-1). It is part of the Burial Ground Complex, which includes the ORWBG and other operable units such as the Mixed Waste Management Facility, the Low Level Radioactive Waste Disposal Facility, Solvent Tanks S1-S22, Solvent Tanks S23-S30, and Solvent Tank 32 (WSRC, 1997).

\subsection{Description of Unit}

The ORWBG encompasses an area approximately 3,700 feet in length that is 1,100 feet wide at its west end and 700 feet wide at its east end. The area lies between Road E and the F-Area railroad (Figure 1-1). An 8-foot-high cyclone fence surrounds the area. A paved road leads to the entrance of the facility, and unimproved dirt roads inside the fenced area provide access to burial sites (Figure 1-2).

The ORWBG received waste on a regular basis from 1952 until 1972, when the site was essentially filled and the majority of waste disposal operations shifted to the adjacent area 6437E (Figure 1-1). The ORWBG received small quantities of waste (primarily in retrievable form) during 1973 and 1974. The ORWBG area was also used for storage of contaminated equipment. The area included several related facilities and operations, including underground solvent storage tanks, areas used to incinerate organic solvents, and a sandblasting facility for decontamination of equipment.

The ORWBG contains solid radioactive waste produced at SRS, and waste shipments from other U.S. Department of Energy and Department of Defense facilities. The operational configuration of the ORWBG included different areas to accommodate various levels and types of radioactive waste. The ORWBG inventory consists of transuranic (TRU), low-level, and intermediate-level waste including the following:

- Incidental waste from laboratory and production operations, including small equipment, used air filters, clothes, analytical waste, decontamination residue, plastic sheeting, gloves, soil, and construction debris

- Contaminated waste including obsolete or failed tanks, pipes, jumpers, and other process equipment from the separations facilities 
- Lead, as shielding, equipment, shot, bricks, and lead sheets

- Reactor hardware, fuel components and housings not containing irradiated fuel; and spent deionizer resins

- Spent lithium-aluminum targets (the target alloy waste remaining after tritium has been extracted)

- Contaminated process oil from pumps in the tritium facilities and reactor areas (in bulk storage and in buried drums containing an absorbent material)

- Mercury from gas pumps in the tritium facilities (in 1-liter polyethylene bottles, double-bagged and buried in a 0.7 cubic-foot steel can)

- Cadmium associated with reactor control and safety rods and as neutron-shielding sheets

- Scintillation fluid (a mixture of organic solvents used to quantify beta and/or alpha emitters in environmental and bioassay samples)

- Offsite waste including radioactive waste from military hardware

- Spent Plutonium-Uranium Extraction (PUREX) solvent, waste oil, and degradation products contained in 22 underground solvent tanks

- Waste oil in absorbent materials

- Decontamination residue from decontamination operations at the ORWBG

Most waste was placed directly in earthen trenches. Trenches were generally excavated to 20 feet in width and depth, for lengths of up to 700 feet. Trenches were filled with the waste materials, which were covered with 4 feet or more of soil to reduce surface radiation to less than $6 \mathrm{mR} / \mathrm{hr}$ (WSRC, 1997).

\subsection{Operational History}

Detailed information is sparse for reconstruction of a history of burial at the ORWBG prior to 1956. Aerial photographs of the ORWBG taken in 1956, 1966, 1972, and 1974 are available. 
In addition, some of the annual burial maps prepared by the Health Physics (HP) staff during burial operations are available. Copies of these maps appear in WSRC (1997). This report includes the HP map from 1968 as Figure 1-2.

\subsubsection{Original Burial Ground}

The original burial area in the center of the ORWBG covers approximately 35 acres (Figure 12). In the following discussions, this part of the ORWBG is simply referred to as the original burial ground. The original burial ground contains approximately 85 trenches (WSRC, 1997). Most of the waste buried in the original burial ground predates the detailed records of the Computerized Burial Record Analysis (COBRA) database, and only general estimates of waste volume are available. HP maps provide the most useful information on the locations and types of disposals in this part of the ORWBG (WSRC, 1997).

HP maps indicate the presence of a sandblast pad east of the storage trenches (Figure 1-2). It was not noted on 1956 aerial photographs but is present on 1966 drawings (WSRC, 1997). This area was used for decontamination and may be related to the decontamination of the equipment that was placed in adjacent storage trenches. Runoff from the sandblast pad flowed to the east into a small sandblast drainage basin.

Twenty-two old underground solvent tanks (OSTs) are located near the center of the original burial ground (Figure 1-2) (WSRC, 1996a). Some of these were utilized as fuel storage tanks at SRS and other federal facilities prior to their emplacement in the ORWBG between 1955 and 1968 (WSRC, 1996a). Prior to 1980, the OSTs held hundreds of thousands of gallons of spent PUREX solvent from F and H Areas, and smaller amounts of tritiated pump oil (WSRC, 1996a). The solvent was periodically drawn from the tanks and burned in shallow, open pans. The unburned residue and used pans were buried in a trench located east of the OSTs (Figure 1-2) (Tharin, 1965). The contents of the OSTs, except for "unpumpable heel", were transferred to new storage tanks in the New Burial Ground (643-7E) in the late 1970s and early 1980s. WSRC (1996a) provides a detailed history and inventory of the OSTs.

HP maps indicate that contaminated equipment and vessels were temporarily stored on the surface at several locations within the original burial ground (Figure 1-2) (WSRC, 1997).

\subsubsection{Eastern Expansion of the ORWBG}

The eastern expansion area of the present ORWBG covers 16 acres and contains approximately 48 trenches (Figures $1-1,1-2$ ). In the following discussions, this part of the 
ORWBG is referred to as the eastern expansion area. It was opened as the original burial ground was filled, and received waste from 1961 until 1972. The COBRA database records contain most of the burials in the eastern expansion (WSRC, 1997). The eastern expansion includes trenches designated for oil drums and encapsulated plutonium buriais (Figure 1-2). Review of HP maps also indicates that contaminated equipment and vessels were temporarily stored on the surface at several locations within the eastern expansion (Figure 1-2) (WSRC, 1997).

\subsubsection{Western Expansion of the ORWBG}

The western expansion area of the present ORWBG covers 26 acres and contains approximately 32 trenches (Figures 1-1 and 1-2) (WSRC, 1997). In the following discussions, this part of the ORWBG is referred to as the western expansion. It was opened as the original burial ground reached capacity, and received waste on a regular basis from 1961 until 1972. Encapsulated plutonium waste was placed in the western expansion until 1974. The COBRA database records most of the waste in the western expansion (WSRC, 1997).

Several notable disposals occurred in the western expansions: five $234-\mathrm{H}$ special project disposal areas, Charleston Navy Shipyard disposals, a "bunker" with failed equipment from FArea, and disposal areas for plutonium (Figure 1-2). Discussions of these burials may be found in WSRC (1997).

The northwest corner of the western expansion was used as a decontamination area during operation of the original burial ground (Ryan, 1983; WSRC, 1997). HP maps indicate that contaminated equipment and vessels were temporarily stored on the surface at several locations within the western expansion (WSRC, 1997).

\subsection{Computerized Burial Record Analysis}

The most extensive source of information on the ORWBG is the COBRA database, which contains records of waste disposed from 1952 through 1974. The COBRA system was started in the first quarter of 1961, and historical data were entered for the years from startup to 1960 (WSRC, 1997).

The COBRA database is based on information contained on "Radioactive Solid Waste Burial Ground Record" forms, also referred to as "burial slips". The forms were completed for each waste shipment. The database only contains information from these forms. It should be 
emphasized that radiological waste is the primary focus of COBRA and the information entered on the burial slips does not generally list other material that may now be of concern, such as mercury, cadmium, or volatile organic compounds (VOCs). Nonradioactive materials appear as incidental comments in COBRA, if they appear at all.

The COBRA database is a valuable aid in determining the operational history of the ORWBG and developing reasonably accurate source term calculations for the radiological contaminants. It is useful for listing waste received from specific buildings, especially after 1961. WSRC (1997) describes and discusses the database in detail and draws the following conclusions regarding use of COBRA:

(1) From 1961 to 1971 , monthly waste volumes typically ranged from 25,000 to 50,000 cubic feet. Yearly waste volumes were fairly uniform, averaging about 300,000 to 500,000 cubic feet (WSRC, 1997).

(2) Many COBRA records do not include the coordinates of the burial location. The burial locations which appear in the COBRA database cover only a part of the operational life of the ORWBG. Location information is not available from COBRA for burials prior to 1961 (WSRC, 1997).

(3) COBRA indicates significant overlap of trench type and waste type both within individual trenches and across trench groups. Individual trenches appear to contain burials assigned to multiple trench types (different COBRA burial codes). For example, a single trench may, over a short distance (or even within a single 20 foot $x$ 20 foot location cell), contain burials listed in COBRA as low-level beta gamma trench, low-level alpha trench, high-level beta-gamma trench, or a combination of the five burial codes that are actually used in COBRA. Most trenches likely contain a variety of waste types. Idealized grouping of trenches into waste areas, such as a cluster of low-level, beta-gamma trenches, should be viewed with caution (WSRC, 1997).

(4) The ORWBG coordinates recorded in COBRA are not "survey grade", and in most cases are probably only accurate to within 20-60 feet of actual burial locations (WSRC, 1997). However, burial containers (potentially retrievable TRU) and concrete pours appear to have a relatively high degree of organization within the ORWBG, and their plotted locations tend to be limited to certain trenches (WSRC, 1997). 
(5) Individual trenches and/or active portions of trenches can be tracked through time, with moderately good agreement between burial locations and trench boundaries. Operations personnel at the ORWBG often approximated coordinates of burial locations, especially in trenches with long axes oblique to the rectilinear grid system. This is particularly common in the western expansion (Figure 1-2) (WSRC, 1997).

\subsection{Constituents of Interest and Recent Source-Term Investigations}

Constituents of Interest (COIs) for the ORWBG have been identified through evaluation of previous characterization and monitoring data, the COBRA database, process history, and historical documentation (WSRC, 1997). The COI list includes the constituents considered to be the most mobile, those considered to have a large inventory, long-lived radionuclides, and hazardous material known to be buried in the ORWBG (Table 1-1).

Results of a recent source-term investigation for the ORWBG are presented in WSRC (1997). This study supports the Resource Conservation and Recovery Act (RCRA) Facility Investigation/Remedial Investigation (RFI/RI) of the ORWBG by expanding the understanding of the facility and its contents, and represents a detailed review of over 300 key documents. The report integrates the literature review with aerial photographs, construction drawings, burial maps prepared by HP staff, the COBRA database, and interviews with current and former SRS staff to refine information regarding waste volumes and their source; the location and time of burials; waste type, form and leachability; trench type and disposal characteristics; and the variety of contamination. WSRC (1997) includes a summary of burial history, inventory estimate, and leachability evaluation for each of the $16 \mathrm{COIs}$ identified for the ORWBG RFI/RI.

Appendices A-P of WSRC (1997) present source terms for each of the COIs. The source terms include estimates and assumptions used to evaluate the inventory, distribution, waste form, and leachability for each COI. The COI inventory presented in WSRC (1997) combines data contained in COBRA with estimates made independently using process knowledge. A summary of source terms for the COIs as reported in WSRC (1997) is presented in Appendix A to this report.

\subsection{Groundwater Monitoring}

This report summarizes results from monitoring of the water table in the vicinity of the ORWBG during the period from 1990 through 1995. The primary source of groundwater samples analyzed during this period is the network of monitoring wells installed in and around 
the ORWBG. Most of the groundwater data used in this report originates from these wells. Additional data include analyses of samples taken using cone penetrometer and Hydropunch ${ }^{(2}$ technology. These data are the result of recent field investigations conducted in the vicinity of the ORWBG (WSRC, 1995; WSRC 1996b).

\subsection{Purpose and Objectives}

This report is a data summary designed to support the RFI/RI process by expanding and refining the current understanding of the ORWBG inventory. This report is an extension of a part of the detailed tritium transport model presented in Flach et al. (1996a) and basic contaminant mapping presented in Flach et al. (1996b).

This report presents available groundwater data in the context of the inventory estimates and burial distributions generated by the recent source-term investigation (WSRC, 1997). This report compares results from analyses of groundwater samples taken from the water table with maps of burial locations from COBRA inventory records for the $16 \mathrm{COIs}$. The groundwater data are processed into two-dimensional (2-D) grids and contoured to illustrate the relative distribution of COI detections in the water table beneath the ORWBG. The contours are superimposed over the burial distributions to attempt initial correlations between the COI inventory and observed groundwater contamination. Preliminary correlations will serve as an aid in determining how the buried inventory at the ORWBG has affected the underlying water table.

The objective of this data summary is to compare two vastly different sets of concentration data and attempt a rough correlation between their distributions. The two data sets are each based on unique assumptions, measurement techniques, and methods of validation and qualification. Identification of discrete, individual point sources for the contaminants based on this depiction is conjectural at best. 
(This page intentionally left blank.) 


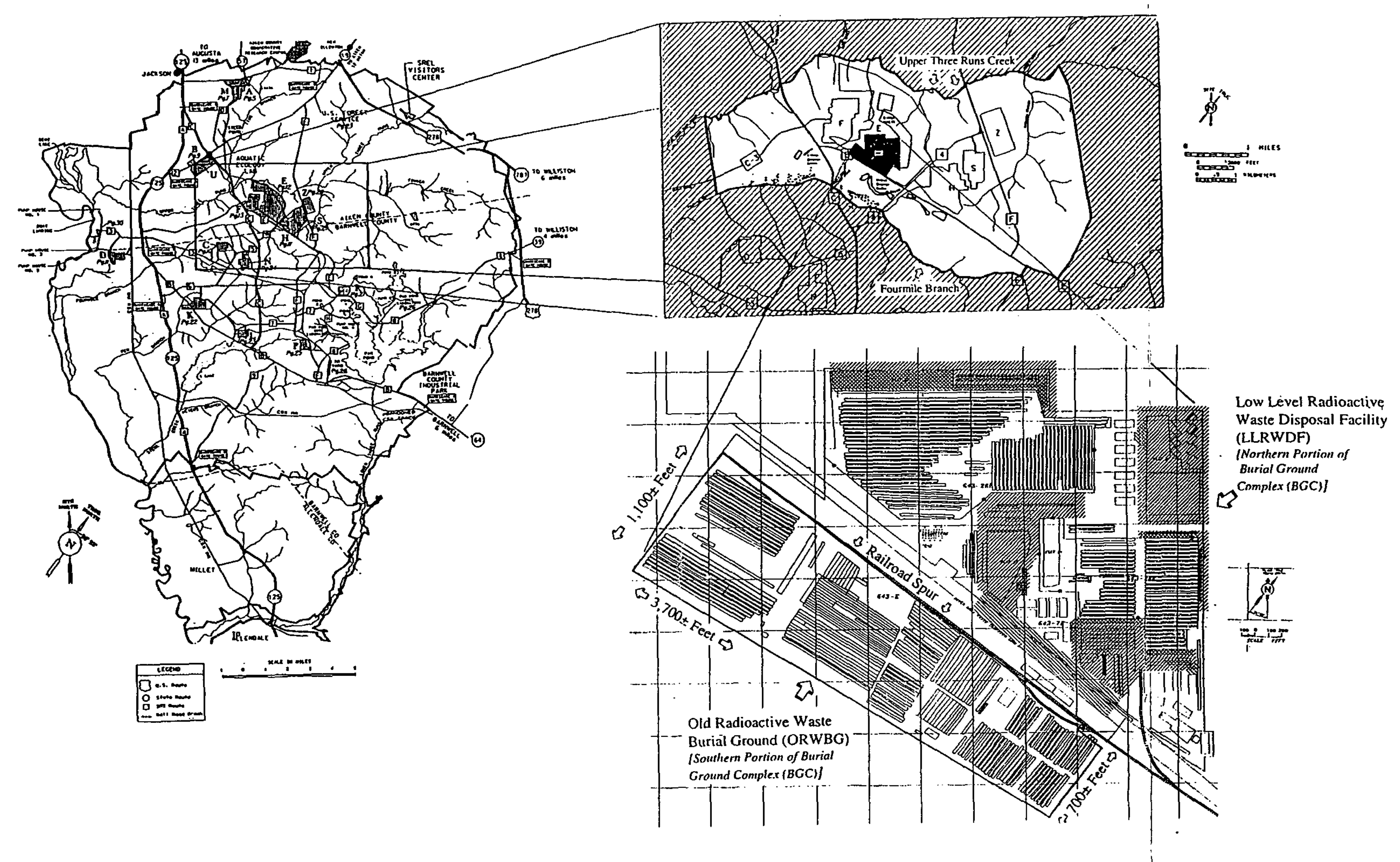

Figure 1-1. Location Map for the Burial Ground Complex 

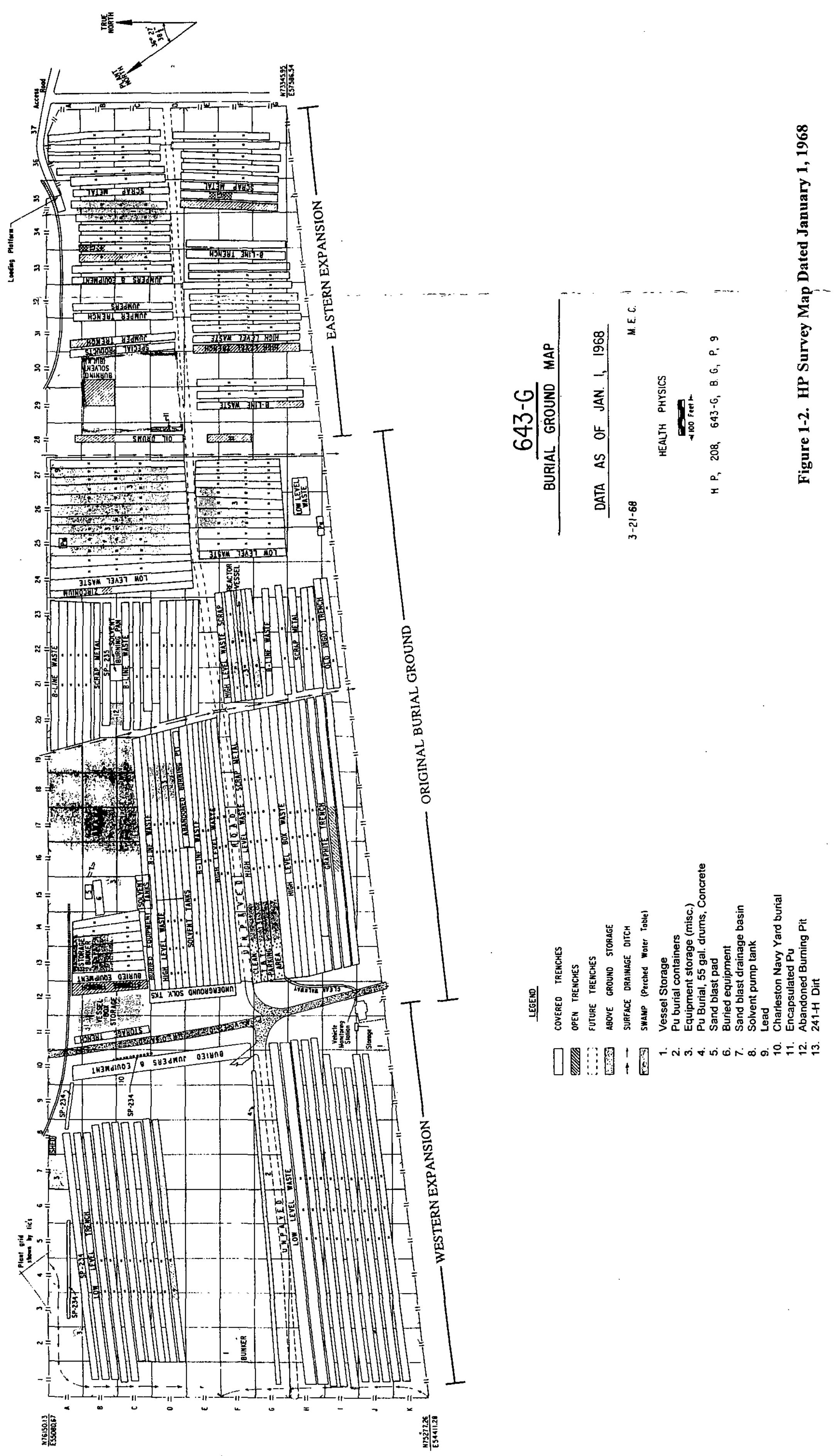
(This page intentionally left blank) 
Table 1-1. Constituents of Interest (COIs) for the Old Radioactive Waste Burial Ground (ORWBG)

\begin{tabular}{|c|c|c|c|c|c|c|}
\hline \multicolumn{3}{|c|}{ Nonradioactive } & $\begin{array}{c}\text { Hazardous } \\
\text { Material }\end{array}$ & $\begin{array}{c}\text { High } \\
\text { Mobility }\end{array}$ & $\begin{array}{c}\text { Long- } \\
\text { Lived } \\
(>25 \text { yr) } \\
\end{array}$ & $\begin{array}{c}\text { Large } \\
\text { Inventory }\end{array}$ \\
\hline 1. & Cadmium & (Cd) & & & & \\
\hline 2. & Lead & $(\mathrm{Pb})$ & & & & \\
\hline 3. & Mercury & $(\mathrm{Hg})$ & & & & \\
\hline 4. & Volatile Organic Compounds & (VOCs) & & & & \\
\hline
\end{tabular}

\section{Radioactive}
5. Tritium
6. Carbon-14
7. Cobalt- 60
8. Strontium-90
9. Technetium-99
10. Iodine-129
11. Cesium-137
12. Neptunium-237
13. Uranium-235
14. Uranium-238
15. Plutonium-238
16. Plutonium-239

(Co-60)

(Sr-90)

(Cs-137)

(Np-237)

(U-235)

(U-238)

(Pu-238)

(Pu-239)

\begin{tabular}{|l|l|l|l|}
\hline & 0 & & 0 \\
\hline & 0 & 0 & 0 \\
\hline & & & 0 \\
\hline & & 0 & 0 \\
\hline & 0 & 0 & \\
\hline & 0 & 0 & \\
\hline & & 0 & 0 \\
\hline & & 0 & \\
\hline & & 0 & \\
\hline & & 0 & \\
\hline & & 0 & 0 \\
\hline & & 0 & 0 \\
\hline
\end{tabular}


(This page intentionally left blank.) 


\subsection{METHODS}

\subsection{Data Collection}

Data used in this report include burial locations for waste disposals recorded in the COBRA database and concentrations of COIs measured in groundwater samples taken from the water table in the vicinity of the ORWBG. Data collection involved queries of electronic databases and reviewing recent SRS technical documents for pertinent tables of monitoring results. Data utilized includes the Geochemical Information Management System (GIMS), which contains SRS monitoring well data. Data from recent site characterization activities were used to supplement the well data.

\subsubsection{Computerized Burial Record Analysis Data}

Recorded and estimated concentrations of the COIs were searched and summed at each burial location in the COBRA database. The querying operation followed the same assumptions used in determining the source term as described in Appendices A through P of WSRC (1997). For each COI, the query generated a list of every burial location and the total activity associated with the COI at each location. If COBRA does not record any waste associated with the COI, an activity level of " 0 " was posted at that burial location. These results were downloaded as spreadsheet files for loading into spatial-analysis software.

\subsubsection{Geochemical Information Management System Data}

Well locations and as-built details were downloaded from GIMS on the basis of the proximity of the wells to the ORWBG. Results from groundwater analyses in these ORWBG wells were downloaded from GIMS. The data were annually averaged to dampen transient fluctuations in concentrations (Flach et al.,1996a).

Table 2-1 presents construction details for all monitoring wells used in this report. The table incorporates data from the SRS GIMS database of monitoring well construction information.

\subsubsection{Data from Savannah River Site Documents}

Additional groundwater data are available from recent field investigations (WSRC, 1995; WSRC, 1996b) The reports were reviewed for pertinent results of groundwater analyses from ORWBG wells, cone penetrometer samples, and Hydropunch ${ }^{\otimes}$ samples. Sampling locations are listed in Table 2-1. 
Data from tables in the field reports were entered into Excel spreadsheets. The spreadsheets were reviewed to identify typographical errors and ensure accurate reproduction of the original tables from the documents. The spreadsheets were used to normalize the reported concentrations of radionuclides to picocuries per liter $(\mathrm{pCi} / \mathrm{L})$ and reported concentrations of nonradioactive constituents to micrograms per liter (ug/L). Tables 2-2 and 2-3 summarize the analytical data used in this report.

\subsection{Mapping Techniques}

EarthVision ${ }^{\otimes}$ was used to create burial distribution maps for the COI inventory from the data extracted from COBRA. The location data derived by the process described in Section 2.1.1 were compiled into maps to illustrate the areal distribution of waste burials associated with each COI.

EarthVision ${ }^{\circledast}$ was used to calculate 2-D grids of the COI concentration in sampling points in the water table. The gridding algorithm produces 2-D surfaces (2-D grids), which represent a best fit of $x, y, z$ data points. In this case, $x$ and $y$ are the grid coordinates and $z$ is the concentration of the $\mathrm{COI}$ at that location. The 2-D grids for groundwater data were calculated as best fits of all data within the five-year data set for lead, mercury, perchloroethane (PCE), trichloroethylene (TCE), gross alpha, non-volatile beta, and tritium. The 2-D grids represent a best fit of all annual-averaged concentrations from each location over a period of five years. The average value for each sample location is given in Tables 2-2 and 2-3. These tables provide summary statistics for the range and average values for each COI. The grids may be viewed as contour maps to delineate areas of high COI concentrations, and to indicate trends in the concentrations of COIs within the water table.

The presentation model created in EarthVision for the groundwater data uses a clipping polygon to isolate detected concentrations originating in the ORWBG from detection in wells adjacent to nearby seepage basins (Figure 2-1). The clipping polygon uses non-detect values posted along its edge as gridding control points to minimize errors due to model extrapolation. Flach et al. (1996a) set these control points to non-detection levels of $1 \mathrm{ug} / \mathrm{L}$ for nonradioactive constituents and $0.001 \mathrm{pCi} / \mathrm{L}(1 \mathrm{pCi} / \mathrm{mL})$ for radioactive constituents. Presentations in this report follow this convention for the grid control points. Actual nondetect levels for the analyses vary considerably from sample to sample.

All contour maps of $\mathrm{COI}$ burial distribution and groundwater concentrations were automatically created using EarthVision ${ }^{\oplus}$ and do not reflect any additional interpretation or 
insights from conceptual modeling. The contours that appear on the maps are not intended to be quantitative illustrations of COI activity or concentrations in the water table. The maps illustrate relative changes in concentration between data points and should not be considered predictions of spatial distribution of contaminants. 
(This page intentionally left blank.) 


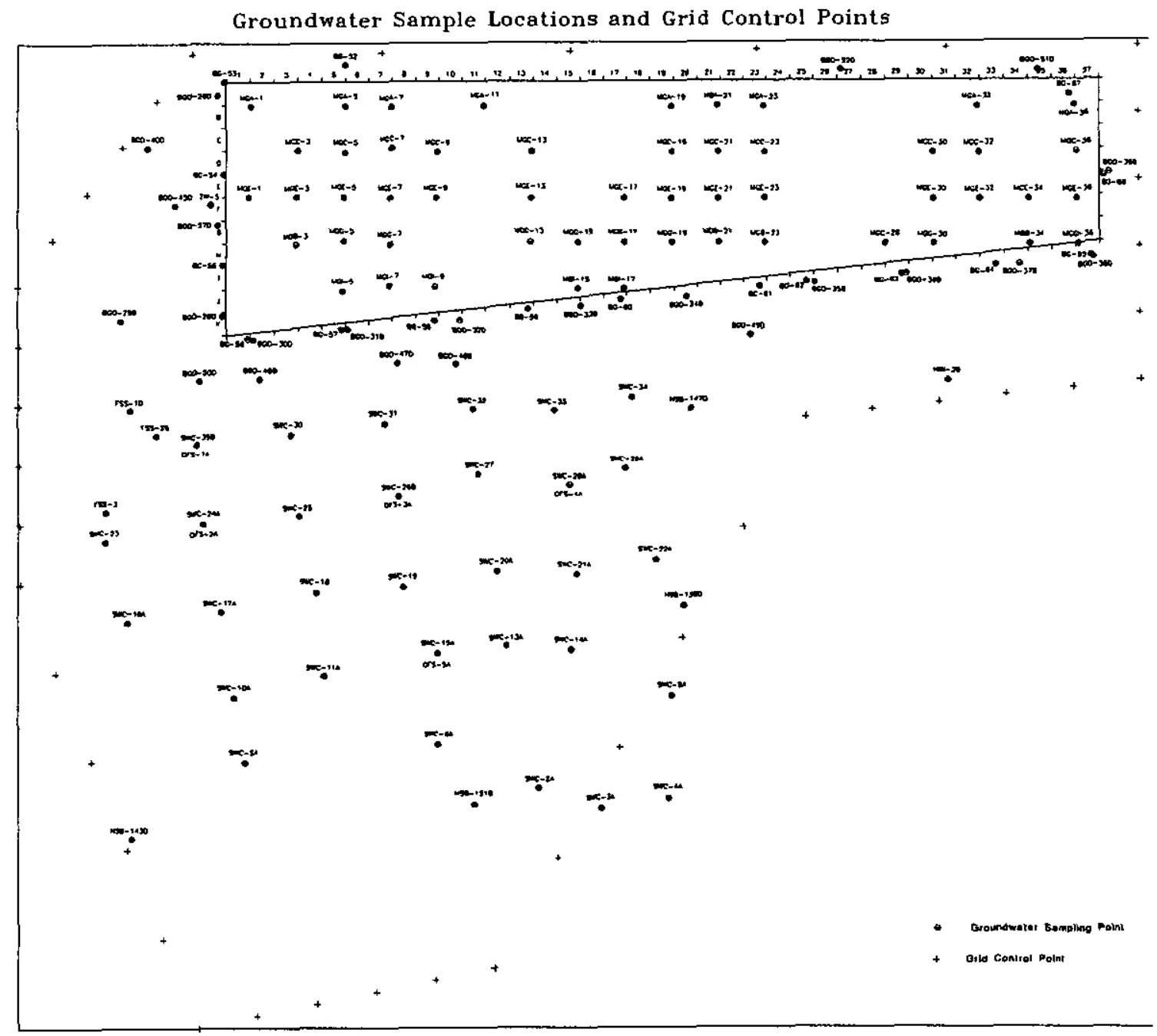

Figure 2-1. Groundwater Sample Locations and Grid Control Points 
Table 2-1. Well Construction Details for Groundwater Sampling Points in the Vicinity of the Old Radioactive Waste Burial Ground

\begin{tabular}{|c|c|c|c|c|c|c|}
\hline Well Name & $\begin{array}{c}\text { SRS } \\
\text { Northing (ft) }\end{array}$ & $\begin{array}{c}\text { SRS Easting } \\
\text { (ft) }\end{array}$ & $\begin{array}{c}\text { Ground } \\
\text { Surface } \\
\text { (ft msl) }\end{array}$ & $\begin{array}{c}\text { Top of } \\
\text { Casing (ft } \\
\text { msl) }\end{array}$ & $\begin{array}{c}\text { Top of Well } \\
\text { Screen } \\
\text { (ft msl) } \\
\end{array}$ & $\begin{array}{c}\text { Bottom of } \\
\text { Well Screen } \\
\text { (ft msl) }\end{array}$ \\
\hline \multicolumn{7}{|c|}{ Burial Ground Grid Wells } \\
\hline MGA-1 & 76003.60 & 55100.10 & 280.50 & 282.50 & 242.50 & 222.50 \\
\hline MGA-5 & 75766.80 & 55417.00 & 284.30 & 286.30 & 244.30 & 224.30 \\
\hline MGA-7 & 75644.00 & 55571.90 & 283.60 & 285.60 & 243.60 & 223.60 \\
\hline MGA-11 & 75409.90 & 55891.20 & 294.40 & 296.40 & 244.40 & 224.40 \\
\hline MGA-19 & 74927.00 & 56527.00 & 282.20 & 284.20 & 248.20 & 228.20 \\
\hline MGA-21 & 74811.50 & 56687.20 & 286.20 & 288.20 & 249.20 & 229.20 \\
\hline MGA-23 & 74688.60 & 56844.50 & 283.70 & 285.70 & 247.70 & 227.70 \\
\hline MGA-32 & 74144.80 & 57565.00 & 284.60 & 286.60 & 250.60 & 230.60 \\
\hline MGA-36 & 73904.00 & 57891.50 & 296.20 & 298.30 & 254.20 & 234.20 \\
\hline MGC-3 & 75733.00 & 55139.70 & 279.40 & 281.70 & 240.70 & 220.70 \\
\hline MGC-5 & 75606.60 & 55293.00 & 281.50 & 284.00 & 242.00 & 222.00 \\
\hline $\mathrm{MGC}-7$ & 75502.40 & 55465.00 & 282.40 & 284.60 & 242.60 & 222.60 \\
\hline MGC-9 & 75372.10 & 55610.70 & 282.30 & 284.10 & 237.30 & 217.30 \\
\hline MGC-13 & 75132.70 & 55931.40 & 290.50 & 292.50 & 245.50 & 225.50 \\
\hline MGC-19 & 74770.10 & 56408.70 & 284.60 & 286.60 & 234.60 & 230.60 \\
\hline MGC-21 & 74649.90 & 56566.50 & 285.40 & 287.40 & 248.40 & 228.40 \\
\hline MGC-23 & 74528.30 & 56726.60 & 283.90 & 287.70 & 247.90 & 227.90 \\
\hline MGC-30 & 74099.30 & 57292.30 & 280.70 & 282.70 & 249.70 & 229.70 \\
\hline MGC-32 & 73982.10 & 57448.80 & 287.00 & 298.00 & 252.00 & 232.00 \\
\hline$M G C-36$ & 73738.90 & 57776.00 & 294.40 & 296.60 & 254.40 & 234.40 \\
\hline MGE-1 & 75695.10 & 54857.40 & 272.70 & 274.70 & 234.70 & 214.70 \\
\hline MGE-3 & 75573.90 & 55015.90 & 275.90 & 277.90 & 235.90 & 215.90 \\
\hline MGE-5 & 75453.80 & 55174.70 & 279.80 & 282.70 & 240.70 & 220.70 \\
\hline MGE-7 & 75333.00 & 55331.30 & 279.50 & 282.10 & 240.10 & 220.10 \\
\hline MGE-9 & 75215.10 & 55489.40 & 281.10 & 283.60 & 238.10 & 218.10 \\
\hline MGE-13 & 74971.00 & 55809.90 & 286.40 & 288.40 & 241.40 & 221.40 \\
\hline MGE-17 & 74731.60 & 56127.30 & 284.10 & 286.10 & 244.10 & 224.10 \\
\hline MGE-19 & 74608.50 & 56287.60 & 281.90 & 283.90 & 244.90 & 224.90 \\
\hline MGE-21 & 74487.80 & 56446.20 & 282.90 & 285.00 & 247.90 & 227.90 \\
\hline MGE-23 & 74369.30 & 56609.20 & 280.40 & 282.40 & 247.40 & 227.40 \\
\hline MGE-30 & 73935.80 & 57175.40 & 280.30 & 282.20 & 249.30 & 229.30 \\
\hline MGE-32 & 73819.00 & 57332.60 & 285.80 & 287.80 & 252.80 & 232.80 \\
\hline MGE-34 & 73695.00 & 57495.10 & 292.20 & 294.40 & 257.20 & 237.20 \\
\hline MGE-36 & 73573.00 & 57657.30 & 293.70 & 295.70 & 254.70 & 234.70 \\
\hline MGG-3 & 75410.00 & 54888.30 & 286.80 & 288.80 & 246.80 & 226.80 \\
\hline MGG-5 & 75303.00 & 55058.60 & 281.50 & 283.80 & 241.80 & 221.80 \\
\hline MGG-7 & 75172,00 & 55208.50 & 279.20 & 280.40 & 238.40 & 218.40 \\
\hline MGG-13 & 74821.00 & 55690.90 & 284.30 & 286.30 & 243.30 & 223.30 \\
\hline MGG-15 & 74699.00 & 55851.50 & 282.30 & 284.00 & 243.30 & 223.30 \\
\hline MGG-17 & 74578.00 & 56011.70 & 280.10 & 282.10 & 246.10 & 226.10 \\
\hline MGG-19 & 74456.00 & 56174.30 & 278.00 & 280.00 & 246.00 & 226.00 \\
\hline
\end{tabular}


Table 2-1. Well Construction Details for Groundwater Sampling Points in the Vicinity of the Old Radioactive Waste Burial Ground (Continued)

\begin{tabular}{|c|c|c|c|c|c|c|}
\hline Well Name & $\begin{array}{c}\text { SRS } \\
\text { Northing (ft) }\end{array}$ & $\begin{array}{c}\text { SRS E asting } \\
\text { (ft) }\end{array}$ & $\begin{array}{l}\text { Ground } \\
\text { Surface } \\
\text { (ft msl) }\end{array}$ & $\begin{array}{c}\text { Top of } \\
\text { Casing (ft } \\
\text { msl) }\end{array}$ & $\begin{array}{c}\text { Top of Well } \\
\text { Screen } \\
\text { (ft msl) }\end{array}$ & $\begin{array}{c}\text { Bottom of } \\
\text { Well Screen } \\
\text { (ft msl) }\end{array}$ \\
\hline \multicolumn{7}{|c|}{ Burial Ground Grid Wells (continued) } \\
\hline MGG-21 & 74334.00 & 56333.10 & 277.60 & 279.60 & 246.60 & 226.60 \\
\hline MGG-21A & 74334.00 & 56333.10 & - & - & - & $\cdot$ \\
\hline MGG-21B & 74334.00 & 56333.10 & - & - & - & - \\
\hline MGG-21P & 74334.00 & 56333.10 & - & $\cdot$ & - & - \\
\hline MGG-23 & 74214.00 & 56491.80 & 276.10 & 277.80 & 247.10 & 227.10 \\
\hline MGG-28 & 73905.00 & 56895.40 & 274.30 & 276.50 & 250.30 & 230.30 \\
\hline MGG-30 & 73781.00 & 57059.50 & 278.00 & 280.00 & 253.00 & 233.00 \\
\hline MGG-34 & 73536.00 & 57379.70 & 288.60 & 290.60 & 253.60 & 233.60 \\
\hline MGG-36 & 73413.00 & 57541.70 & 290.50 & 291.20 & 252.50 & 232.50 \\
\hline MGI-5 & 75131.00 & 54924.80 & 276.50 & 278.40 & 240.40 & 220.40 \\
\hline MGI-7 & 75030.00 & 55099.10 & 276.10 & 278.10 & 242.10 & 222.10 \\
\hline MGI-9 & 74908.00 & 55252.40 & 278.70 & 280.70 & 241.70 & 221.70 \\
\hline MGI-15 & 74538.00 & 55730.70 & 277.50 & 279.50 & 222.50 & 218.50 \\
\hline MGI-17 & 74417.00 & 55890.30 & 275.50 & 277.50 & 241.50 & 221.50 \\
\hline \multicolumn{7}{|c|}{ Wells Just Outside the Burial Ground Fence } \\
\hline BG-52 & 75910.40 & 55524.30 & 287.60 & 289.80 & 243.80 & 223.80 \\
\hline BG-53 & 76157.30 & 55073.90 & 283.80 & 285.70 & 234.70 & 214.70 \\
\hline BG-54 & 75837.90 & 54830.30 & 275.30 & 277.20 & 235.20 & 215.20 \\
\hline BG-55 & 75525.30 & 54590.50 & 274.80 & 276.90 & 234.90 & 214.90 \\
\hline BG-56 & 75206.50 & 54481.90 & 272.60 & 274.90 & 230.90 & 210.90 \\
\hline BG-57 & 75000.40 & 54820.00 & 270.90 & 272.60 & 234.60 & 214.60 \\
\hline BG-58 & 74790.90 & 55162.30 & 276.10 & 278.20 & 238.20 & 218.20 \\
\hline BG-59 & 74593.40 & 55508.30 & 280.90 & 282.70 & 237.70 & 217.70 \\
\hline BG-60 & 74386.30 & 55850.30 & 273.60 & 275.50 & 235.50 & 215.50 \\
\hline BG-61 & 74075.40 & 56360.80 & 272.50 & 275.00 & 245.00 & 225.00 \\
\hline BG-62 & 73971.60 & 56530.90 & 270.50 & 272.50 & 242.50 & 222.50 \\
\hline BG-63 & 73754.50 & 56870.50 & 272.40 & 274.20 & 244.20 & 224.20 \\
\hline BG-64 & 73547.20 & 57212.40 & 283.30 & 285.30 & 247.30 & 227.30 \\
\hline BG-65 & 73340.60 & 57552.70 & 289.10 & 290.90 & 250.90 & 230.90 \\
\hline BG-66 & 73585.00 & 57805.00 & 294.30 & 296.00 & 251.00 & 231.00 \\
\hline BG-67 & 73954.10 & 57902.60 & 292.80 & 294.70 & 244.70 & 224.70 \\
\hline \multicolumn{7}{|c|}{ Burial Ground Perimeter Wells } \\
\hline BGO-26D & 76128.00 & 55015.20 & 283.50 & 285.50 & 233.50 & 213.40 \\
\hline BGO-27D & 75677.30 & 54680.20 & 274.30 & 276.30 & 229.30 & 209.30 \\
\hline BGO-28D & 75348.30 & 54457.90 & 275.10 & 277.40 & 230.10 & 210.10 \\
\hline BGO-29D & 75592.50 & 54099.40 & 263.50 & 265.50 & 228.50 & 208.50 \\
\hline BGO-30D & 75187.70 & 54499.20 & 272.80 & 274.80 & 227.80 & 207.80 \\
\hline BGO-3ID & 74985.30 & 54841.70 & 271.60 & 273.70 & 231.10 & 211.10 \\
\hline BGO-32D & 74727.00 & 55250.20 & 279.50 & 281.70 & 234.50 & 214.50 \\
\hline
\end{tabular}


Table 2-1. Well Construction Details for Groundwater Sampling Points in the Vicinity of the Old Radioactive Waste Burial Ground (Continued)

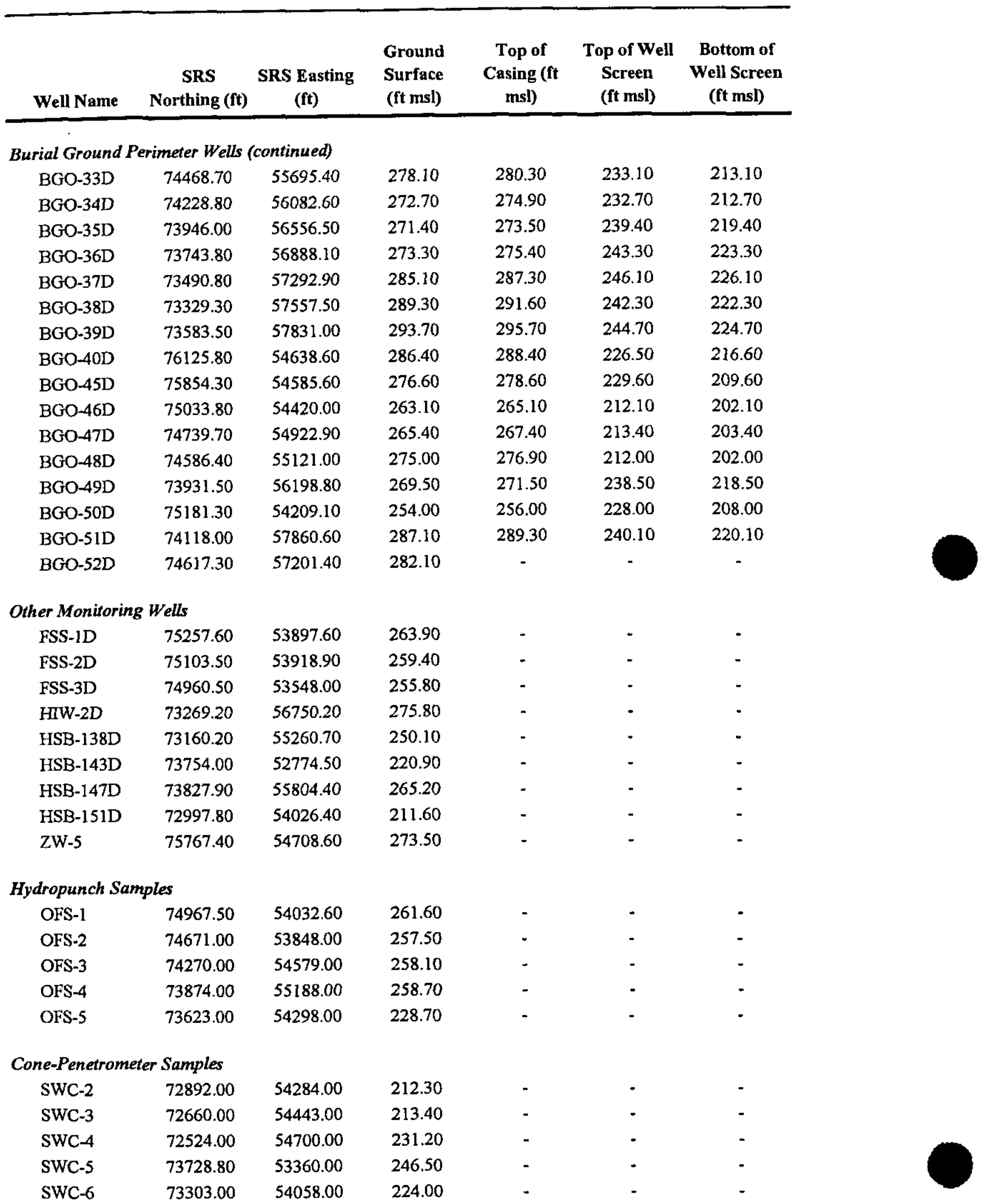


Table 2-1. Well Construction Details for Groundwater Sampling Points in the Vicinity of the Old Radioactive Waste Burial Ground (Continued)

\begin{tabular}{|c|c|c|c|c|c|c|}
\hline Well Name & $\begin{array}{c}\text { SRS } \\
\text { Northing (ft) }\end{array}$ & $\begin{array}{l}\text { SRS Easting } \\
\text { (ft) }\end{array}$ & $\begin{array}{l}\text { Ground } \\
\text { Surface } \\
\text { (ft msl) }\end{array}$ & $\begin{array}{c}\text { Top of } \\
\text { Casing (ft } \\
\text { msl) }\end{array}$ & $\begin{array}{l}\text { Top of Well } \\
\text { Screen } \\
\text { (ft msl) }\end{array}$ & $\begin{array}{c}\text { Bottom of } \\
\text { Well Screen } \\
\text { (ft msl) }\end{array}$ \\
\hline \multicolumn{7}{|c|}{ Cone-Penetrometer Samples (continued) } \\
\hline SWC-9 & 72875.00 & 54982.00 & 236.20 & - & - & - \\
\hline SWC-10 & 73984.00 & 53497.00 & 251.90 & - & - & - \\
\hline SWC-11 & 73835.30 & 53853.20 & 248.30 & - & - & - \\
\hline SWC-12 & 73623.00 & 54298.00 & 228.70 & $\cdot$ & - & - \\
\hline SWC-13 & 73477.50 & 54549.80 & 245.40 & - & - & - \\
\hline SWC-14 & 73296.00 & 54758.00 & 243.30 & - & - & - \\
\hline SWC-16 & 74521.50 & 53331.00 & 249.40 & - & - & - \\
\hline SWC-17 & 74318.50 & 53679.20 & 255.20 & - & - & - \\
\hline SWC-18 & 74144.50 & 54046.80 & 225.50 & - & - & - \\
\hline SWC-19 & 73941.50 & 54356.40 & 249.60 & - & - & - \\
\hline SWC-20 & 73757.80 & 54714.30 & 249.40 & - & - & - \\
\hline SWC-21 & 73545.10 & 54975.50 & 251.90 & - & - & - \\
\hline SWC-22 & 73390.50 & 55285.00 & 254.90 & . & - & - \\
\hline SWC-23 & 74859.90 & 53466.40 & 251.30 & - & - & - \\
\hline SWC-24 & 74671.00 & 53848.00 & 257.50 & - & - & - \\
\hline SWC-25 & 74453.80 & 54191.90 & 242.90 & - & - & - \\
\hline SWC-26 & 74270.20 & 54578.80 & 258.10 & - & - & - \\
\hline SWC-27 & 74144.50 & 54907.70 & 266.90 & - & - & - \\
\hline SwC-28 & 73873.80 & 55188.30 & 258.70 & - & - & - \\
\hline SWC-29 & 73788.00 & 55423.00 & 259.60 & - & - & - \\
\hline SWC-30 & 74763.20 & 54375.70 & 242.80 & - & - & - \\
\hline SWC-31 & 74560.20 & 54723.90 & 253.20 & - & - & - \\
\hline SWC-32 & 74386.20 & 55062.50 & 276.40 & - & - & - \\
\hline swC-33 & 74173.50 & 55333.40 & 271.00 & - & - & - \\
\hline SWC-34 & 74018.80 & 55633.30 & 266.30 & - & - & - \\
\hline SWC-35 & 74967.50 & 54032.60 & 261.60 & - & - & - \\
\hline
\end{tabular}

Notes

- no data/not applicable 
Table 2-2. Average Concentrations of Metals and VOCs in Groundwater Samples from the Water Table During the Period 1990-1995

\begin{tabular}{|c|c|c|c|c|c|c|c|c|}
\hline \multirow[b]{2}{*}{ Well Name } & \multicolumn{2}{|c|}{ Lead } & \multicolumn{2}{|c|}{ Mercury } & \multicolumn{2}{|c|}{ PCE } & \multicolumn{2}{|c|}{$\underline{\text { TCE }}$} \\
\hline & $\begin{array}{c}\text { Average } \\
\text { Conc. (ug/L) }\end{array}$ & $\begin{array}{l}\text { Number of } \\
\text { Analyses }\end{array}$ & $\begin{array}{c}\text { Average } \\
\text { Conc. }(u g / L)\end{array}$ & $\begin{array}{l}\text { Number of } \\
\text { Analyses }\end{array}$ & $\begin{array}{c}\text { Average } \\
\text { Conc. (ug/L) }\end{array}$ & $\begin{array}{l}\text { Number of } \\
\text { Analyses }\end{array}$ & $\begin{array}{c}\text { Average } \\
\text { Conc. (ug/L) }\end{array}$ & $\begin{array}{c}\text { Number of } \\
\text { Analyses }\end{array}$ \\
\hline
\end{tabular}

$\begin{array}{lrrrr}\text { Burial Ground Grid Wells } & & & \\ \text { MGA-1 } & - & - & - & - \\ \text { MGA-5 } & - & - & - & - \\ \text { MGA-7 } & - & - & - & - \\ \text { MGA-11 } & - & - & - & - \\ \text { MGA-19 } & - & - & - & - \\ \text { MGA-21 } & - & - & - & - \\ \text { MGA-23 } & - & - & - & - \\ \text { MGA-32 } & - & - & - & - \\ \text { MGA-36 } & 41.275 & 2 & 1 & 1 \\ \text { MGC-3 } & - & - & - & - \\ \text { MGC-5 } & - & - & - & - \\ \text { MGC-7 } & - & - & - & - \\ \text { MGC-9 } & 169.883333 & 3 & 1 & 1 \\ \text { MGC-13 } & - & - & - & - \\ \text { MGC-19 } & 1063.66667 & 3 & 1.00333333 & 2 \\ \text { MGC-21 } & - & - & - & - \\ \text { MGC-23 } & 355.2 & 2 & 1.115 & 2 \\ \text { MGC-30 } & - & - & - & - \\ \text { MGC-32 } & 156.18 & 3 & 4.08666667 & 3 \\ \text { MGC-36 } & 28.9133333 & 3 & 1 & 1 \\ \text { MGE-1 } & - & - & - & - \\ \text { MGE-3 } & - & - & - & - \\ \text { MGE-5 } & - & - & - & - \\ \text { MGE-7 } & - & - & - & - \\ \text { MGE-9 } & 550.59 & 3 & 1.72333333 & 3 \\ \text { MGE-13 } & - & - & - & - \\ \text { MGE-17 } & - & - & - & - \\ \text { MGE-19 } & - & - & - & - \\ \text { MGE-21 } & 240.35 & 3 & 1.61333333 & 3 \\ \text { MGE-23 } & - & - & - & - \\ \text { MGE-30 } & 24.61 & 3 & 1 & 1 \\ \text { MGE-32 } & - & - & - & - \\ \text { MGE-34 } & 274.25 & 2 & - & - \\ \text { MGE-36 } & - & - & - \\ \text { MGG-3 } & - & & - \\ & & - & -\end{array}$


Table 2-2. Average Concentrations of Metals and VOCs in Groundwater Samples from the Water Table During the Period 1990-1995 (Continued)

\begin{tabular}{|c|c|c|c|c|c|c|c|c|}
\hline \multirow[b]{2}{*}{ Well Name } & \multicolumn{2}{|c|}{ Lead } & \multicolumn{2}{|c|}{$\underline{\text { Mercury }}$} & \multicolumn{2}{|c|}{$\underline{\text { PCE }}$} & \multicolumn{2}{|c|}{$\underline{\text { TCE }}$} \\
\hline & $\begin{array}{c}\text { Average } \\
\text { Conc. (ug/L) }\end{array}$ & $\begin{array}{c}\text { Number of } \\
\text { Analyses }\end{array}$ & $\begin{array}{c}\text { Average } \\
\text { Conc. (ug/L) }\end{array}$ & $\begin{array}{c}\text { Number of } \\
\text { Analyses }\end{array}$ & $\begin{array}{c}\text { Average } \\
\text { Conc. }(u g / L)\end{array}$ & $\begin{array}{l}\text { Number of } \\
\text { Analyses }\end{array}$ & $\begin{array}{c}\text { Average } \\
\text { Conc. }(u g / L)\end{array}$ & $\begin{array}{c}\text { Number of } \\
\text { Analyses }\end{array}$ \\
\hline \multicolumn{9}{|c|}{ Burial Ground Grid Wells (continued) } \\
\hline MGG-5 & - & - & - & - & - & $\cdot$ & $\cdot$ & - \\
\hline MGG-7 & - & - & - & - & - & - & $\cdot$ & - \\
\hline MGG-13 & - & - & - & - & - & - & $\cdot$ & - \\
\hline MGG-15 & 240.35 & 2 & 2.32 & 2 & - & - & - & - \\
\hline MGG-17 & - & - & - & - & - & - & $\cdot$ & - \\
\hline MGG-19 & 171.666667 & 3 & 1.14333333 & 2 & 1 & 1 & 1 & 1 \\
\hline MGG-21 & - & - & - & - & - & - & - & - \\
\hline MGG-21A & - & - & - & $=$ & - & - & - & - \\
\hline MGG-21B & - & - & - & - & - & - & - & - \\
\hline MGG-21P & - & - & - & - & - & - & - & - \\
\hline MGG-23 & 228.75 & 2 & 4.46 & 2 & 1 & 1 & 1 & 1 \\
\hline MGG-28 & - & - & - & - & - & - & - & - \\
\hline MGG-30 & - & - & - & - & - & - & - & - \\
\hline MGG-34 & - & - & - & - & - & - & - & - \\
\hline MGG-36 & 282.783333 & 3 & 5.6 & 3 & - & - & - & - \\
\hline MGI-5 & - & - & - & - & - & $\cdot$ & - & - \\
\hline MGI-7 & - & - & - & - & - & - & - & - \\
\hline MGI-9 & - & - & - & - & - & - & - & - \\
\hline MGI-15 & - & - & - & - & - & - & - & - \\
\hline MGI-17 & - & - & - & - & - & - & - & - \\
\hline \multicolumn{9}{|c|}{ Wells Just Outside the Burial Ground Fence } \\
\hline BG-52 & 43.6275 & 4 & 1.546 & 3 & - & - & $\cdot$ & - \\
\hline BG-53 & - & - & - & - & - & - & - & - \\
\hline BG-54 & 60.34 & 4 & 1 & 1 & 1 & 1 & 1 & 1 \\
\hline BG-55 & 62.045 & 4 & 1.43 & 4 & 1 & 1 & 27.6 & 1 \\
\hline BG-56 & - & - & - & - & - & - & - & - \\
\hline BG-57 & - & - & - & - & - & - & - & - \\
\hline BG-58 & - & - & - & - & - & - & - & - \\
\hline BG-59 & 350.333333 & 3 & 4.1925 & 3 & - & - & - & . \\
\hline BG-60 & 34.5 & 3 & 1.0625 & 2 & - & $\cdot$ & - & - \\
\hline BG-61 & 19.07 & 3 & 1.34 & 2 & - & - & - & - \\
\hline BG-62 & - & - & - & - & - & - & - & - \\
\hline BG-63 & - & - & - & - & - & - & - & - \\
\hline BG-64 & - & - & - & - & - & - & - & - \\
\hline BG-65 & - & - & - & - & - & - & - & - \\
\hline
\end{tabular}


Table 2-2. Average Concentrations of Metals and VOCs in Groundwater Samples from the Water Table During the Period 1990-1995 (Continued)

\begin{tabular}{|c|c|c|c|c|c|c|c|c|}
\hline \multirow[b]{2}{*}{ Well Name } & \multicolumn{2}{|c|}{ Lead } & \multicolumn{2}{|c|}{ Mercury } & \multicolumn{2}{|c|}{$\underline{\text { PCE }}$} & \multicolumn{2}{|c|}{$\underline{\text { TCE }}$} \\
\hline & $\begin{array}{c}\text { Average } \\
\text { Conc. (ug/L) }\end{array}$ & $\begin{array}{c}\text { Number of } \\
\text { Analyses }\end{array}$ & $\begin{array}{c}\text { Average } \\
\text { Conc. (ug/L) }\end{array}$ & $\begin{array}{c}\text { Number of } \\
\text { Analyses }\end{array}$ & $\begin{array}{c}\text { Average } \\
\text { Conc. (ug/L) }\end{array}$ & $\begin{array}{c}\text { Number of } \\
\text { Analyses }\end{array}$ & $\begin{array}{c}\text { Average } \\
\text { Conc. (ug/L) }\end{array}$ & $\begin{array}{c}\text { Number of } \\
\text { Analyses }\end{array}$ \\
\hline \multicolumn{9}{|c|}{ Wells Just Outside the Burial Ground Fence (continued) } \\
\hline BG-66 & - & - & - & - & - & - & - & - \\
\hline BG-67 & 31.6675 & 4 & 2.248 & 5 & - & - & - & - \\
\hline \multicolumn{9}{|c|}{ Burial Ground Perimeter Wells } \\
\hline $\mathrm{BGO}-26 \mathrm{D}$ & 16.0014286 & 7 & 1 & 1 & 1.11 & 4 & 5.145 & 4 \\
\hline BGO-27D & 15.4633333 & 6 & 1 & 1 & 1 & 1 & 1 & 1 \\
\hline BGO-28D & 14.5166667 & 6 & 1 & 1 & 2.255 & 6 & 201.958333 & 6 \\
\hline BGO-29D & 4.194 & 5 & 1 & 1 & 1 & 1 & 1 & 1 \\
\hline BGO-30D & 22.3366667 & 6 & 1 & 1 & 2.46666667 & 6 & 53.31 & 6 \\
\hline$B G O-31 D$ & 5.15166667 & 6 & 1 & 1 & 1.23 & 3 & 1.02833333 & 2 \\
\hline $\mathrm{BGO}-32 \mathrm{D}$ & 22.7833333 & 6 & 1 & 1 & 10.0766667 & 6 & 4.58666667 & 6 \\
\hline BGO-33D & 9.37 & 6 & 1 & 1 & 1.33333333 & 2 & 1.00666667 & 2 \\
\hline BGO-34D & 8.81 & 6 & 1 & 1 & 1.18 & 3 & 1 & 1 \\
\hline BGO-35D & 11.485 & 6 & 1 & 1 & 1.26333333 & 3 & 1 & 1 \\
\hline BGO-36D & 17.2383333 & 6 & 1 & 1 & 1.03333333 & 2 & 1 & 1 \\
\hline BGO-37D & 6.88166667 & 6 & 1 & 1 & 1.04166667 & 2 & 1 & 1 \\
\hline BGO-38D & 4.06333333 & 6 & 1 & 1 & 1.01666667 & 2 & 1.02833333 & 2 \\
\hline BGO-39D & 1.84 & 5 & 1 & 1 & 1.045 & 3 & 1 & 1 \\
\hline$B G O-40 D$ & 25.63 & 5 & 1 & 1 & 2.06 & 2 & 1.94 & 5 \\
\hline BGO-45D & 1.066 & 2 & 1 & 1 & 1 & 1 & 1.008 & 2 \\
\hline $\mathrm{BGO}-46 \mathrm{D}$ & 1.192 & 3 & 1 & 1 & 9.842 & 5 & 53.434 & 5 \\
\hline BGO-47D & 1.194 & 2 & 1 & 1 & 1.142 & 3 & 10.444 & 5 \\
\hline $\mathrm{BGO}-48 \mathrm{D}$ & 1.598 & 3 & 1 & 1 & 49.996 & 5 & 98.016 & 5 \\
\hline BGO-49D & 2.86 & 5 & 1 & 1 & 1 & 1 & 1 & 1 \\
\hline BGO-50D & 1.134 & 2 & 1 & 1 & 1.116 & 4 & 11.732 & 5 \\
\hline BGO-51D & 1.21 & 2 & 1 & 1 & 1 & 1 & 1 & 1 \\
\hline BGO-52D & 1 & 1 & 1 & 1 & 1 & 1 & 1 & 1 \\
\hline \multicolumn{9}{|c|}{ Other Monitoring Wells } \\
\hline FSS-1D & 32.395 & 6 & 1 & 1 & 1 & 1 & 1 & 1 \\
\hline FSS-2D & 27.4383333 & 6 & 1.16166667 & 2 & 1 & 1 & 1 & 1 \\
\hline FSS-3D & 286.731667 & 6 & 1 & 1 & 1 & 1 & 1 & 1 \\
\hline HIW-2D & 1 & 1 & 1 & 1 & 1 & 1 & 1 & 1 \\
\hline HSB-138D & 13.7114286 & 7 & 1 & 1 & 1 & 1 & 1 & 1 \\
\hline HSB-143D & 1.26666667 & 2 & 1 & 1 & 1.25666667 & 2 & 1.01 & 2 \\
\hline HSB-147D & 8.16166667 & 6 & 1 & 1 & 1 & 1 & 1.00333333 & 2 \\
\hline
\end{tabular}


Table 2-2. Average Concentrations of Metals and VOCs in Groundwater Samples from the Water Table During the Period 1990-1995 (Continued)

\begin{tabular}{|c|c|c|c|c|c|c|c|c|}
\hline \multirow[b]{2}{*}{ Well Name } & \multicolumn{2}{|c|}{ Lead } & \multicolumn{2}{|c|}{ Mercury } & \multicolumn{2}{|c|}{ PCE } & \multicolumn{2}{|c|}{ TCE } \\
\hline & $\begin{array}{c}\text { Average } \\
\text { Conc. (ug/L) }\end{array}$ & $\begin{array}{c}\text { Number of } \\
\text { Analyses }\end{array}$ & $\begin{array}{c}\text { Average } \\
\text { Conc. (ug/L) }\end{array}$ & $\begin{array}{c}\text { Number of } \\
\text { Analyses }\end{array}$ & $\begin{array}{c}\text { Average } \\
\text { Conc. }(u g / L)\end{array}$ & $\begin{array}{c}\text { Number of } \\
\text { Analyses }\end{array}$ & $\begin{array}{c}\text { Average } \\
\text { Conc. (ug/L) }\end{array}$ & $\begin{array}{c}\text { Number of } \\
\text { Analyses }\end{array}$ \\
\hline \multicolumn{9}{|c|}{ Other Monitoring Wells (continued) } \\
\hline HSB-15ID & 6.13333333 & 3 & 1 & 1 & 1.09166667 & 2 & 1.01833333 & 2 \\
\hline ZW-5 & 683.276667 & 3 & 2.64333333 & 3 & . & - & - & - \\
\hline
\end{tabular}

\section{Hydropunch Samples}

OFS-1A

OFS-1B

OFS- $2 A$

OFS-2B

OFS-3A

OFS-3B

OFS-4A

OFS-5A

$\begin{array}{rr}2.68 & 1 \\ 1 & 1 \\ 23.27 & 1 \\ 4.88 & 1 \\ 2 & 1 \\ 4.45 & 1 \\ 1 & 1 \\ 6.29 & 1\end{array}$

$\begin{array}{rr}1 & 1 \\ 5.6 & 1 \\ 1 & 1 \\ 94.32 & 1 \\ 1 & 1 \\ 93.29 & 1 \\ 1.17 & 1 \\ 1 & 1\end{array}$

\section{Cone-Penetrometer Samples}

$\begin{array}{lll}\text { SWC-2A } & 1 & 1 \\ \text { SWC-3A } & 1 & 1 \\ \text { SWC-4A } & 1 & 1 \\ \text { SWC-5A } & 1 & 1 \\ \text { SWC-6A } & 1 & 1 \\ \text { SWC-9A } & 1 & 1 \\ \text { SWC-10A } & 1 & 1 \\ \text { SWC-11A } & 1 & 1 \\ \text { SWC-12A } & 1 & 1 \\ \text { SWC-13A } & 1 & 1 \\ \text { SWC-14A } & 1 & 1 \\ \text { SWC-16A } & 1 & 1 \\ \text { SWC-17A } & 7 & 1 \\ \text { SWC-18A } & 1 & 1 \\ \text { SWC-18B } & 1 & 1 \\ \text { SWC-19A } & 1 & 1 \\ \text { SWC-19B } & 1 & 1 \\ \text { SWC-20A } & 1 & 1 \\ \text { SWC-21A } & 1 & 1 \\ \text { SWC-22A } & 1 & 1 \\ \text { SWC-23A } & 1 & 1 \\ \text { SWC-23B } & 1 & 1\end{array}$


Table 2-2. Average Concentrations of Metals and VOCs in Groundwater Samples from the Water Table During the Period 1990-1995 (Continued)

\begin{tabular}{|c|c|c|c|c|c|c|c|c|}
\hline \multirow[b]{2}{*}{ Well Name } & \multicolumn{2}{|c|}{ Lead } & \multicolumn{2}{|c|}{ Mercury } & \multicolumn{2}{|c|}{$\underline{\mathrm{PCE}}$} & \multicolumn{2}{|c|}{$\underline{\text { TCE }}$} \\
\hline & $\begin{array}{c}\text { Average } \\
\text { Conc. }(\mathrm{ug} / \mathrm{L}) \\
\end{array}$ & $\begin{array}{c}\text { Number of } \\
\text { Analyses }\end{array}$ & $\begin{array}{c}\begin{array}{c}\text { Average } \\
\text { Conc. (ug/L) }\end{array} \\
\end{array}$ & $\begin{array}{c}\text { Number of } \\
\text { Analyses }\end{array}$ & $\begin{array}{c}\text { Average } \\
\text { Conc. (ug/L) }\end{array}$ & $\begin{array}{l}\text { Number of } \\
\text { Analyses }\end{array}$ & $\begin{array}{c}\text { Average } \\
\text { Conc. }(u g / L)\end{array}$ & $\begin{array}{l}\text { Number of } \\
\text { Analyses }\end{array}$ \\
\hline \multicolumn{9}{|c|}{ Cone-Penetrometer Samples (continued) } \\
\hline SWC-24A & 5 & 1 & - & . & 1 & 1 & 1 & 1 \\
\hline SWC-25A & 1 & 1 & - & - & 1 & 1 & 1 & 1 \\
\hline SWC-25B & 1 & 1 & - & - & 1 & 1 & 4.43 & 1 \\
\hline SWC-26A & 1 & 1 & - & - & 1 & 1 & 1 & 1 \\
\hline SWC-26B & 1 & 1 & - & - & 1.45 & 1 & 49.37 & 1 \\
\hline SWC-27A & 1 & I & - & - & 1 & 1 & 1 & 1 \\
\hline SWC-27B & 1 & 1 & - & - & 1 & 1 & 1.36 & 1 \\
\hline SWC-28A & 1 & 1 & - & - & I & 1 & 1 & 1 \\
\hline SWC-29A & 1 & 1 & - & - & 1 & 1 & 1 & 1 \\
\hline SWC-30A & 1 & 1 & - & - & 1 & 1 & 1 & 1 \\
\hline SWC-30B & 1 & 1 & - & - & 84.07 & 1 & 356.8 & 1 \\
\hline SWC-31A & 1 & 1 & - & - & 1 & 1 & 1 & 1 \\
\hline SWC-31B & 1 & 1 & - & - & 15.98 & 1 & 296.2 & 1 \\
\hline SWC-32A & 1 & 1 & - & - & 1 & 1 & 1 & 1 \\
\hline SWC-32B & 1 & 1 & - & - & 2.09 & 1 & 11 & 1 \\
\hline SWC-33A & 5 & 1 & - & - & 1 & 1 & 1 & ] \\
\hline SWC-33B & 1 & 1 & - & - & 1 & 1 & 1 & 1 \\
\hline SWC-34A & 1 & 1 & - & - & 1 & 1 & 1 & 1 \\
\hline SWC-34B & $l$ & 1 & - & - & 1 & 1 & 1 & 1 \\
\hline SWC-35A & 1 & 1 & - & - & 1 & 1 & 1 & 1 \\
\hline SWC-35B & 1 & 1 & - & $\therefore$ & 1 & 1 & 4.95 & 1 \\
\hline$\overline{\text { Maximum }}$ & 1063.66667 & 7 & 5.6 & 5 & 84.07 & 6 & 356.8 & 6 \\
\hline Minimum & 1 & 1 & 1 & 1 & 1 & 1 & 1 & 1 \\
\hline Average & 55.31 & 2.51 & 1.41 & 1.55 & 3.47 & 1.52 & 18.42 & 1.51 \\
\hline Count & 104 & 104 & 53 & 53 & 88 & 88 & 88 & 88 \\
\hline
\end{tabular}


Table 2-3. Average Concentrations of Radioactive Constituents in Groundwater Samples from the Water Table During the Period 1990-1995

\begin{tabular}{|c|c|c|c|c|c|c|}
\hline \multirow[b]{2}{*}{ Well Name } & \multicolumn{2}{|c|}{ Alpha } & \multicolumn{2}{|c|}{ Beta } & \multicolumn{2}{|c|}{$\underline{\text { Tritium }}$} \\
\hline & $\begin{array}{l}\text { Average } \\
\text { Conc. } \\
(\mathrm{pCi} / \mathrm{L})\end{array}$ & $\begin{array}{l}\text { Number of } \\
\text { Analyses }\end{array}$ & $\begin{array}{l}\text { Average } \\
\text { Conc. } \\
\text { (pCi/L) }\end{array}$ & $\begin{array}{l}\text { Number of } \\
\text { Analyses }\end{array}$ & $\begin{array}{l}\text { Average Conc. } \\
\quad(\mathrm{pCi} / \mathrm{L})\end{array}$ & $\begin{array}{r}\text { Number } 0 \\
\text { Analyses }\end{array}$ \\
\hline \multicolumn{7}{|c|}{ Burial Ground Grid Wells } \\
\hline MGA-1 & - & - & - & - & 29275 & 2 \\
\hline MGA-5 & - & - & - & - & 227850 & 1 \\
\hline MGA-7 & - & - & - & - & 19812.5 & 2 \\
\hline MGA-11 & - & - & - & - & 120 & 2 \\
\hline MGA-19 & - & - & - & - & 107 & 2 \\
\hline MGA-21 & - & - & - & - & 249 & 2 \\
\hline MGA-23 & - & - & - & - & 955.5 & 2 \\
\hline MGA-32 & - & - & - & - & 157 & 2 \\
\hline MGA-36 & 21.56 & 2 & 22.055 & 2 & 148605.75 & 2 \\
\hline MGC-3 & - & $\cdot$ & - & - & 102475 & 2 \\
\hline MGC-5 & - & - & - & - & 8300 & 1 \\
\hline MGC-7 & $\cdot$ & - & - & - & 318500 & 1 \\
\hline MGC-9 & 12.4375 & 6 & 20.1091667 & 6 & 16871.29167 & 6 \\
\hline MGC-13 & - & - & - & - & 3389.5 & 2 \\
\hline MGC-19 & 61.707 & 6 & 17.6193333 & 6 & 25.55666667 & 6 \\
\hline MGC-21 & - & - & - & - & 2840 & 2 \\
\hline MGC-23 & 670.25 & 2 & 524 & 2 & 5228.895 & 2 \\
\hline MGC-30 & - & - & - & - & 13297 & 2 \\
\hline MGC-32 & 94.524 & 6 & 93.1813333 & 6 & 7798.7495 & 6 \\
\hline MGC-36 & 23.15 & 5 & 19.2294 & 5 & 41020.27783 & 6 \\
\hline MGE-1 & - & - & - & - & 58105 & 2 \\
\hline MGE-3 & - & - & - & - & 79745 & 2 \\
\hline MGE-5 & - & - & - & - & 59027.5 & 2 \\
\hline MGE-7 & - & - & - & - & 161551 & 2 \\
\hline MGE-9 & 536.5266 & 5 & 278.18 & 5 & 16.213 & 5 \\
\hline MGE-13 & - & - & - & - & 206.5 & 2 \\
\hline MGE-17 & - & - & - & - & 174 & 1 \\
\hline MGE-19 & - & - & - & - & 219.5 & 2 \\
\hline MGE-21 & 43.2505 & 2 & 33.05 & 2 & 8813.5 & 3 \\
\hline MGE-23 & - & - & - & - & 285.5 & 2 \\
\hline MGE-30 & 86.8308333 & 6 & 67.1231667 & 6 & 138.8525 & 6 \\
\hline MGE-32 & - & $\cdot$ & - & - & 71645.5 & 2 \\
\hline MGE-34 & 83.25 & 2 & 112.025 & 2 & 171459.3333 & 3 \\
\hline MGE-36 & - & - & - & - & 305217.5 & 2 \\
\hline MGG-3 & - & - & - & - & 9060 & 2 \\
\hline MGG-5 & - & - & - & - & 715 & 1 \\
\hline
\end{tabular}


Table 2-3. Average Concentrations of Radioactive Constituents in Groundwater Samples from the Water Table During the Period 1990-1995 (Continued)

\begin{tabular}{|c|c|c|c|c|c|c|}
\hline \multirow[b]{2}{*}{ Well Name } & \multicolumn{2}{|c|}{ Alpha } & \multicolumn{2}{|c|}{ Beta } & \multicolumn{2}{|c|}{ Tritium } \\
\hline & $\begin{array}{l}\text { Average } \\
\text { Conc. } \\
(\mathrm{pCi} / \mathrm{L})\end{array}$ & $\begin{array}{c}\text { Number of } \\
\text { Analyses }\end{array}$ & $\begin{array}{l}\text { Average } \\
\text { Conc. } \\
(\mathrm{pCi} / \mathrm{L})\end{array}$ & $\begin{array}{c}\text { Number of } \\
\text { Analyses }\end{array}$ & $\begin{array}{l}\text { Average Conc. } \\
(\mathrm{pCi} / \mathrm{L})\end{array}$ & $\begin{array}{l}\text { Number of } \\
\text { Analyses }\end{array}$ \\
\hline \multicolumn{7}{|c|}{ Burial Ground Grid Wells (continued) } \\
\hline MGG-7 & - & - & - & - & 11722.5 & 2 \\
\hline MGG-13 & - & - & - & - & 211784 & 2 \\
\hline MGG-15 & 178.378333 & 3 & 120.835 & 3 & 955.97 & 3 \\
\hline MGG-17 & - & - & - & - & 218507.5 & 2 \\
\hline MGG-19 & 200.80075 & 4 & 138.17825 & 4 & 90.6525 & 4 \\
\hline MGG-21 & - & - & - & - & 15496.5 & 2 \\
\hline MGG-21A & - & - & - & - & 12125 & 2 \\
\hline MGG-21B & - & - & - & - & 519005 & 2 \\
\hline MGG-21P & - & - & - & - & 11175012 & 2 \\
\hline MGG-23 & 326.61775 & 4 & 51.78525 & 4 & 125.298 & 5 \\
\hline MGG-28 & 3.095 & 2 & 5.065 & 2 & 96.8 & 2 \\
\hline MGG-30 & - & - & - & - & 677.5 & 2 \\
\hline MGG-34 & - & - & - & - & 1934525 & 2 \\
\hline MGG-36 & 87.2256667 & 6 & 60.8375 & 6 & 90659.39667 & 6 \\
\hline MGI-5 & - & - & - & - & 18374 & 2 \\
\hline MGI-7 & - & - & - & - & 180439 & 2 \\
\hline MGI-9 & - & - & - & - & 65104.5 & 2 \\
\hline MGI-15 & - & - & - & - & 236 & 2 \\
\hline MGI-17 & - & - & - & - & 136 & 2 \\
\hline \multicolumn{7}{|c|}{ Wells Just Outside the Burial Ground Fence } \\
\hline BG-52 & 20.6266667 & 6 & 15.7111667 & 6 & 152.125 & 6 \\
\hline BG-53 & 1.28 & 1 & 2.22 & 1 & 14.8 & 1 \\
\hline BG-54 & 23.847 & 6 & 34.455 & 6 & 27.24283333 & 6 \\
\hline BG-55 & 18.9058333 & 6 & 52.8943333 & 6 & 3794.833333 & 6 \\
\hline BG-56 & 4.81 & 1 & 6.08 & 1 & 49944 & 1 \\
\hline BG-57 & 0.63 & 1 & 0.98 & 1 & 69.3 & 1 \\
\hline$B G-58$ & 1.07 & 1 & 1.36 & 1 & 14.9 & 1 \\
\hline BG-59 & 21.7036 & 5 & 15.478 & 5 & 16.3316 & 5 \\
\hline$B G-60$ & 10.5278 & 5 & 9.9182 & 5 & 16.7758 & 5 \\
\hline$B G-61$ & 20.3446 & 5 & 28.6214 & 5 & 25.1406 & 5 \\
\hline$B G-62$ & 70.944 & 1 & 83.148 & 1 & 20.067 & 1 \\
\hline BG-63 & 0.31 & 1 & 0.56 & 1 & 26.9 & 1 \\
\hline BG-64 & 1.03 & 1 & 0.42 & 1 & 23.2 & 1 \\
\hline$B G-65$ & 0.25 & 1 & 0.62 & 1 & 24.8 & 1 \\
\hline BG-66 & 0.5 & 1 & 0.71 & 1 & 32.4 & 1 \\
\hline BG-67 & 20.0335 & 6 & 21.0503333 & 6 & 3865.795333 & 6 \\
\hline
\end{tabular}


Table 2-3. Average Concentrations of Radioactive Constituents in Groundwater Samples from the Water Table During the Period 1990-1995 (Continued)

\begin{tabular}{|c|c|c|c|c|c|c|}
\hline \multirow[b]{2}{*}{ Well Name } & \multicolumn{2}{|c|}{ Alpha } & \multicolumn{2}{|c|}{ Beta } & \multicolumn{2}{|c|}{$\underline{\text { Tritium }}$} \\
\hline & $\begin{array}{l}\text { Average } \\
\text { Conc. } \\
\text { (pCi/L) }\end{array}$ & $\begin{array}{c}\text { Number of } \\
\text { Analyses }\end{array}$ & $\begin{array}{c}\text { Average } \\
\text { Conc. } \\
(\mathrm{pCi} / \mathrm{L}) \\
\end{array}$ & $\begin{array}{c}\text { Number of } \\
\text { Analyses }\end{array}$ & $\begin{array}{l}\text { Average Conc. } \\
(\mathrm{pCi} / \mathrm{L})\end{array}$ & $\begin{array}{c}\text { Number of } \\
\text { Analyses }\end{array}$ \\
\hline \multicolumn{7}{|c|}{ Burial Ground Perimeter Wells } \\
\hline BGO-26D & 1.07733333 & 4 & 1.519 & 6 & 10.58316667 & 6 \\
\hline BGO-27D & 1.35366667 & 5 & 2.20633333 & 6 & 670.2933333 & 6 \\
\hline BGO-28D & 6.828 & 6 & 5.37216667 & 6 & 137071.3685 & 6 \\
\hline BGO-29D & 4.7306 & 5 & 3.7042 & 5 & 12.1636 & 5 \\
\hline BGO-30D & 8.095 & 6 & 7.07116667 & 6 & 35504.02917 & 6 \\
\hline BGO-31D & 2.427 & 6 & 2.05333333 & 6 & 229.4733333 & 6 \\
\hline BGO-32D & 7.78583333 & 6 & 6.136 & 6 & 2656.752833 & 6 \\
\hline BGO-33D & 3.68283333 & 6 & 4.93916667 & 6 & 63.94416667 & 5 \\
\hline BGO-34D & 1.25283333 & 6 & 2.43133333 & 6 & 27.3 & 5 \\
\hline BGO-35D & 1.38733333 & 6 & 1.753 & 6 & 214.2883333 & 6 \\
\hline BGO-36D & 1.67616667 & 6 & 2.00533333 & 6 & 28.645 & 6 \\
\hline BGO-37D & 0.87385714 & 4 & 0.506 & 5 & 29.3825 & 6 \\
\hline BGO-38D & 2.141 & 6 & 2.39066667 & 6 & 30.1425 & 6 \\
\hline BGO-39D & 2.16166667 & 6 & 2.46733333 & 6 & 36.89333333 & 6 \\
\hline BGO-40D & 1.8918 & 5 & 26.3644 & 5 & 5.6642 & 5 \\
\hline BGO-45D & 0.4526 & 3 & 0.2794 & 3 & 179.318 & 5 \\
\hline BGO-46D & 1.877 & 5 & 1.2196 & 5 & 77050.1554 & 5 \\
\hline BGO-47D & 2.4632 & 5 & 0.9796 & 5 & 1790.35 & 5 \\
\hline BGO-48D & 11.365 & 5 & 6.8224 & 5 & 74952.429 & 5 \\
\hline BGO-49D & 0.1476 & 3 & 0.1354 & 3 & 22.5936 & 5 \\
\hline BGO-50D & 3.0024 & 5 & 2.468 & 5 & 3534.95 & 5 \\
\hline BGO-51D & 0.4785 & 2 & 0.4785 & 2 & 24.9 & 1 \\
\hline BGO-52D & 0.001 & 1 & 0.001 & 1 & 20.4 & 1 \\
\hline \multicolumn{7}{|c|}{ Other Monitoring Wells } \\
\hline FSS-1D & 1.61616667 & 6 & 2.4856 & 5 & 10.41283333 & 6 \\
\hline FSS-2D & 2.6045 & 6 & 3.5122 & 5 & 149.3706667 & 6 \\
\hline FSS-3D & 2.21583333 & 6 & 3.2418 & 5 & 96.662 & 6 \\
\hline HIW-2D & 1.2 & 1 & 1.1 & 1 & 22.075 & 1 \\
\hline HSB-138D & 0.02214286 & 2 & 6.17828571 & 6 & 579.0088333 & 6 \\
\hline HSB-143D & 0.8555 & 6 & 0.39 & 4 & 11.5956 & 5 \\
\hline HSB-147D & 0.91133333 & 4 & 0.68283333 & 4 & 17.598 & 5 \\
\hline HSB-151D & 0.24766667 & 4 & 1.60666667 & 6 & 248.0516 & 5 \\
\hline ZW-5 & 4.07466667 & 6 & 4.6152 & 4 & 39.54166667 & 6 \\
\hline
\end{tabular}


Table 2-3. Average Concentrations of Radioactive Constituents in Groundwater Samples from the Water Table During the Period 1990-1995 (Continued)

\section{Alpha}

Average

Conc.

Well Name $(\mathrm{pCi} / \mathrm{L})$
Beta

Average

Conc. Number of
Number of

Analyses
Tritium

Hydropunch Samples

OFS-1A

OFS-1B

OFS-2A

OFS-2B

OFS-3A

OFS-3B

OFS-4A

OFS-5A

\section{Average Conc. Number of} $(\mathrm{pCi} / \mathrm{L})$ Analyses

Cone-Penetrometer Samples

SWC-2A

SWC-3A

SWC-4A

SWC-5A

SWC-6A

SWC-9A

SWC-10A

SWC-11A

SWC-12A

SWC-13A

SWC-14A

SWC-16A

SWC-17A

SWC-18A

SWC-18B

SWC-19A

SWC-19B

SWC-20A

SWC-21A

SWC-22A

SWC-23A

SWC-23B

SWC-24A

SWC-25A

SWC-25B

SWC-26A

SWC-26B

$\begin{array}{rl}100 & 1 \\ 5400 & 1 \\ 100 & 1 \\ 42000 & 1 \\ 100 & 1 \\ 5800 & 1 \\ 100 & 1 \\ 100 & 1\end{array}$

$\begin{array}{rr}820 & 1 \\ 130 & 1 \\ 100 & 1 \\ 100 & 1 \\ 100 & 1 \\ 100 & 1 \\ 52000 & 1 \\ 350 & 1 \\ 100 & 1 \\ 100 & 1 \\ 100 & 1 \\ 100 & 1 \\ 1300 & 1 \\ 110 & 1 \\ 170 & 1 \\ 100 & 1 \\ 27000 & 1 \\ 100 & 1 \\ 100 & 1 \\ 100 & 1 \\ 190 & 1 \\ 100 & 1 \\ 100 & 1 \\ 100 & 1 \\ 1400 & 1 \\ 100 & 1 \\ 3200 & 1\end{array}$


Table 2-3. Average Concentrations of Radioactive Constituents in Groundwater Samples from the Water Table During the Period 1990-1995 (Continued)

\begin{tabular}{|c|c|c|c|c|c|c|}
\hline \multirow[b]{2}{*}{ Well Name } & \multicolumn{2}{|c|}{ Alpha } & \multicolumn{2}{|c|}{ Beta } & \multicolumn{2}{|c|}{ Tritium } \\
\hline & $\begin{array}{c}\text { Average } \\
\text { Conc. } \\
\text { (pCi } / L) \\
\end{array}$ & $\begin{array}{c}\text { Number of } \\
\text { Analyses }\end{array}$ & $\begin{array}{c}\text { Average } \\
\text { Conc. } \\
\text { (pCi/L) }\end{array}$ & $\begin{array}{c}\text { Number of } \\
\text { Analyses }\end{array}$ & $\begin{array}{l}\text { Average Conc. } \\
(\mathrm{pCi} / \mathrm{L})\end{array}$ & $\begin{array}{c}\text { Number of } \\
\text { Analyses }\end{array}$ \\
\hline \multicolumn{7}{|c|}{ Cone-Penetrometer Samples (continued) } \\
\hline SWC-27A & - & - & - & - & 100 & 1 \\
\hline SWC-27B & - & - & - & - & 62000 & 1 \\
\hline SWC-28A & - & - & - & - & 2400 & 1 \\
\hline SWC-29A & - & - & - & - & 100 & 1 \\
\hline SWC-30A & - & - & - & - & 6000 & 1 \\
\hline SWC-30B & - & - & - & - & 120000 & 1 \\
\hline SWC-31A & - & - & - & $\cdot$ & 100 & 1 \\
\hline SWC-31B & - & - & - & - & 56000 & 1 \\
\hline SWC-32A & - & - & - & - & 480 & 1 \\
\hline SWC-32B & - & - & - & - & 130000 & 1 \\
\hline SWC-33A & - & - & - & - & 100 & 1 \\
\hline SWC-33B & - & - & - & - & 100 & 1 \\
\hline SWC-34A & - & - & - & - & 100 & 1 \\
\hline SWC-34B & - & - & - & $\cdot$ & 100 & 1 \\
\hline SWC-35A & - & - & - & - & 100 & 1 \\
\hline SWC-35B & - & - & - & - & 4400 & 1 \\
\hline Maximum & 670.25 & 6 & 524 & 6 & 11175012 & $\overline{6}$ \\
\hline Minimum & 0.001 & 1 & 0.001 & 1 & 5.6642 & 1 \\
\hline Average & 43.29 & 4.16 & 30.87 & 4.21 & 111985.65 & 2.62 \\
\hline Count & 63 & 63 & 63 & 63 & 154 & 154 \\
\hline
\end{tabular}

Notes

Non-detections are noted as $0.001 \mathrm{pCi} / \mathrm{L}$

- no sample 
(This page intentionally left blank.)

Gndwater. $01 . d 00$ 


\subsection{RESULTS}

\subsection{Nonradioactive Constituents of Interest}

Table 3-1 presents the results of an assessment of inventory data available for the nonradioactive COIs. COBRA does not specifically track the nonradioactive COIs, but some burial records can be associated with mercury and VOCs (WSRC, 1997). These records do not indicate the quantity of the nonradioactive COIs, but can be compiled as location maps to provide an idea of burial location.

\subsubsection{Lead}

COBRA does not contain records of burials containing lead (Table 3-1). Detailed records on lead disposal were not kept because lead was not considered hazardous during the period when the ORWBG was in operation. The estimated source term for lead is based on process knowledge (WSRC, 1997). WSRC (1997) estimates the total inventory of lead placed in the ORWBG between 1952 and 1972 at 100,000 pounds. This estimate is thought to be accurate to within \pm 30 percent (WSRC, 1997). Trace amounts of lead and other toxic metals may have been concentrated to levels above regulatory limits in the sludge phase of the OSTs, although the amount of lead in the tanks is minimal relative to the other sources (WSRC, 1996a).

Relatively high levels of lead are present in the water table beneath the ORWBG (Figure 3-1). Figure 3-1 shows higher levels to the south and west of the ORWBG, but the samples taken during this period do not include samples from wells within the ORWBG. Figure 3-1 indicates that the highest levels detected during 1990-1995 are in the grid wells located in the oldest parts (original burial ground area) of the ORWBG.

\subsubsection{Mercury}

The estimated inventory of mercury, principally the elemental liquid, buried in the ORWBG from 1952 to 1972 is 24,195 pounds (Table 3-1). This estimate is thought to be accurate to within +25 percent and -10 percent (WSRC, 1997).

The evaluation of the COBRA database presented in WSRC (1997) identifies 150 records as probable mercury burials; 136 of these have location data (Table 3-1). Specific quantities of mercury for these burials are not available. Figure 3-2 illustrates the locations listed in these COBRA records and indicates the volume of waste recorded at each location. Known mercury burials are widespread, but cluster in the eastern expansion area of the ORWBG 
(Figure 3-2). Measurements of elevated levels of mercury from the 1990-1995 period are also concentrated in the eastern expansion area of the ORWBG (Figure 3-2); however, wells in the immediate vicinity of the cluster of mercury burials in the eastern expansion show concentrations below $2 \mathrm{ug} / \mathrm{L}$ (Figure 3-2). A direct correlation between burials of mercurybearing waste and concentrations of mercury in the water table is not evident from Figure 3-2.

\subsubsection{Volatile Organic Compounds}

Detailed records do not exist for burials of organic compounds in the ORWBG, and burials of VOCs are not specifically documented in the COBRA database. WSRC (1997) estimates the source term for VOCs based on process knowledge and identifies 1,889 records in COBRA as potential VOC burials (Table 3-1). Sources of VOCs in the ORWBG include the following:

- Drummed scintillation solutions

- Waste oil in absorbent materials

- Residual vapor and organic phases of spent PUREX solvent, waste oils, and associated degradation products in the OSTs

An additional source of VOCs is residue from decontamination operations conducted in the ORWBG. Decontamination included the use of ethylenediaminetetraacetic acid (EDTA, a chelating compound) and phosphate detergents (Ryan, 1983). There are no records indicating the amounts of decontamination solutions that may have been disposed of in this area of the ORWBG, nor is it clear how or whether these chemical solutions came into contact with buried wastes. However, because VOCs are highly mobile and volatile, and because more than 40 years have elapsed since decontamination activities ceased, the amount of VOCs remaining from this source may be limited (WSRC, 1997).

COBRA records associated with possible VOC burials plot in all parts of the ORWBG, but are concentrated in the western expansion area (Figures 3-3 and 3-4) (WSRC, 1997). Actual quantities of VOCs cannot be ascribed to any of these records (WSRC, 1997). Concentrations of PCE are restricted to samples taken outside of the ORWBG perimeter (Figure 3-3). There are only four locations inside the fence where samples were collected for VOCs. These locations are grid wells MGC-9, MGE-21, MGG-21, and MGG-23 (Table 2-2). Each of these wells yielded one sample during the period from 1990 through 1995. Of these four samples from inside the ORWBG perimeter, one detected PCE, and two 
detected TCE. Well MGC-9 contained detectable levels of both PCE and TCE, and well MGE-21 detected 6.32 ug/L TCE (Table 2-2). The patterns of theTCE and PCE contours are similar. However, TCE is more widespread and is present in higher concentrations than PCE at the same location (Figures 3-3 and 3-4). The shape of the contours suggests the VOCs in the water table are currently concentrated in a plume southwest of the ORWBG. The overall configuration of the contours in Figures 3-3 and 3-4 is consistent with the shapes of plumes for TCE and PCE interpreted from data collected during recent field investigations in this area (WSRC, 1995; WSRC, 1996b). The plumes are likely due to the release of VOCs from the burials concentrated in the southern half of the western expansion (Figures 3-3 and 3-4).

\subsection{Radioactive Constituents of Interest}

Table 3-2 presents the results of an inventory analysis for the radioactive COIs. The COBRA database provides location data for 57 percent of the estimated source term for the COIs. There are no documented burial locations for iodine-129 in the ORWBG (WSRC, 1997).

Because the groundwater monitoring data provide activity levels for tritium, gross alpha, and non-volatile beta, the radioactive COIs are grouped as alpha-emitters, beta-emitters and tritium in this report.

\subsubsection{Gross Alpha Activity}

Figure 3-5 illustrates the distribution of burials of waste containing the COIs plutonium-238, plutonium-239, uranium-235, uranium-238, and neptunium-237. The total inventory for the alpha-emitting COIs is estimated at 22,006 curies (Table 3-2). Contours of gross alpha activity in the water table are superimposed on the burial map. The higher levels of gross alpha activity generally coincide with areas that contain trenches designated "B-Line Waste" on the HP maps (Figure 1-2). The higher levels tend to be located in wells in the original burial ground area. The contours do not exhibit a pattern which clearly indicates the association between burials of alpha-emitting COIs and the activity levels in the water table (Figure 3-5).

\subsubsection{Non-Volatile Beta Activity}

Figure 3-6 illustrates locations of buried waste containing the COIs carbon-14, cobalt-60, cesium-137, strontium-90, technetium-99, and iodine-129. The total inventory for the betaemitting COIs is estimated at 2,081,515 curies (Table 3-2). Contours of non-volatile beta activity in the water table are superimposed over the burials of the beta-emitting COIs. 
Contour patterns in the east expansion suggest that some activity may correspond with betaemitting waste buried in the same area (Figure 3-6). For the most part, the non-volatile beta activity is concentrated in wells located in the original burial ground area in the central ORWBG (Figures 1-2, 3-6). Drawing correlations between the contour patterns and burial locations is difficult because of the small number of data points within the ORWBG perimeter. The general pattern does suggest that the highest activity levels for non-volatile beta are concentrated in the eastern expansion area (Figure 3-6).

\subsubsection{Tritium Activity}

Tritium was sent to the ORWBG as bulk waste (job control waste, waste oils and mercury, and used equipment and components), spent melts, and reactive beds (the latter two are byproducts of the tritium production process). The OSTs are assumed to contain no tritium, based on Health Protection and COBRA data. The COBRA database provides both quantity and location estimates for tritium burials in the ORWBG and locates 67 percent of the estimated inventory (Table 3-2).

The distribution of tritium activity according to the COBRA inventory is illustrated in Figure 3-7. WSRC (1997) estimates 3,014,457 curies of tritium are contained in the ORWBG (Table 3-2). Waste burials with locations recorded in COBRA are spread across the entire facility, but are concentrated in the eastern and western expansion areas. Tritium activity in the water table is depicted in Figure 3-7. Locations of higher activity levels in the water table generally correspond to large numbers of tritium burials. The relatively high values in the southern half of the original burial ground area coincide with trenches labeled as "High Level Box Waste" and "Graphite Trench" on the HP maps (Figures 1-2 and 3-7). The maximum average tritium activity is from a well located in the southeast corner of the original burial ground (Figure 3-7). The well is situated within a block of trenches labeled "High Level Waste Scrap" and "B-Line Waste" on the HP maps (Figures 1-2 and 3-7). These observations do not necessarily indicate that these areas are the only sources of the tritium. Tritium is highly mobile, and activity measured in the water table may originate from areas other than those in which the wells are located. 


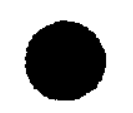

Average Lead Concentrations in the Water Table, 1990-1995

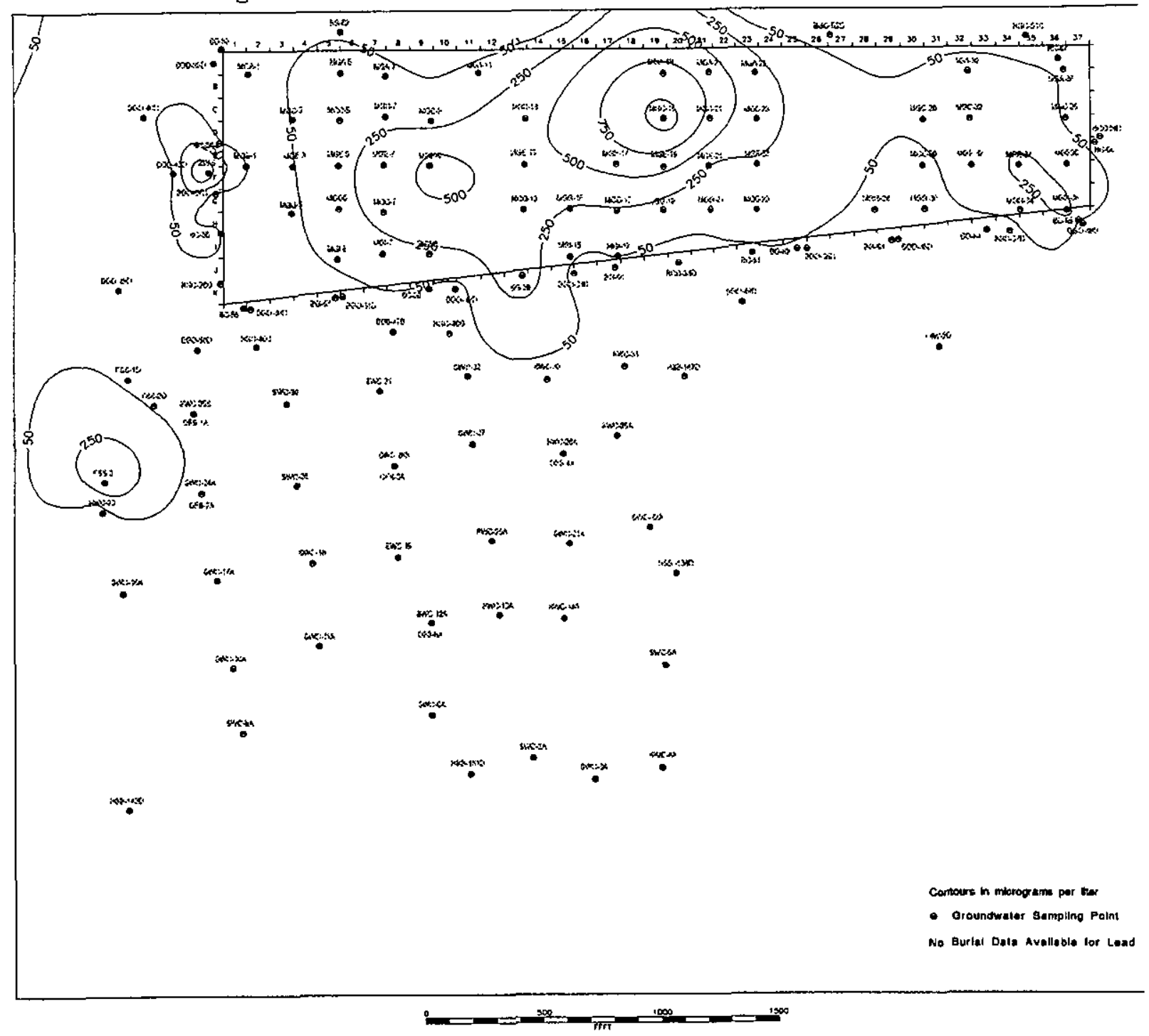

Figure 3-1. Average Lead Concentrations in the Water Table, 1990 - 1995 
Average Mercury Concentrations in the Water Table, 1990-1995

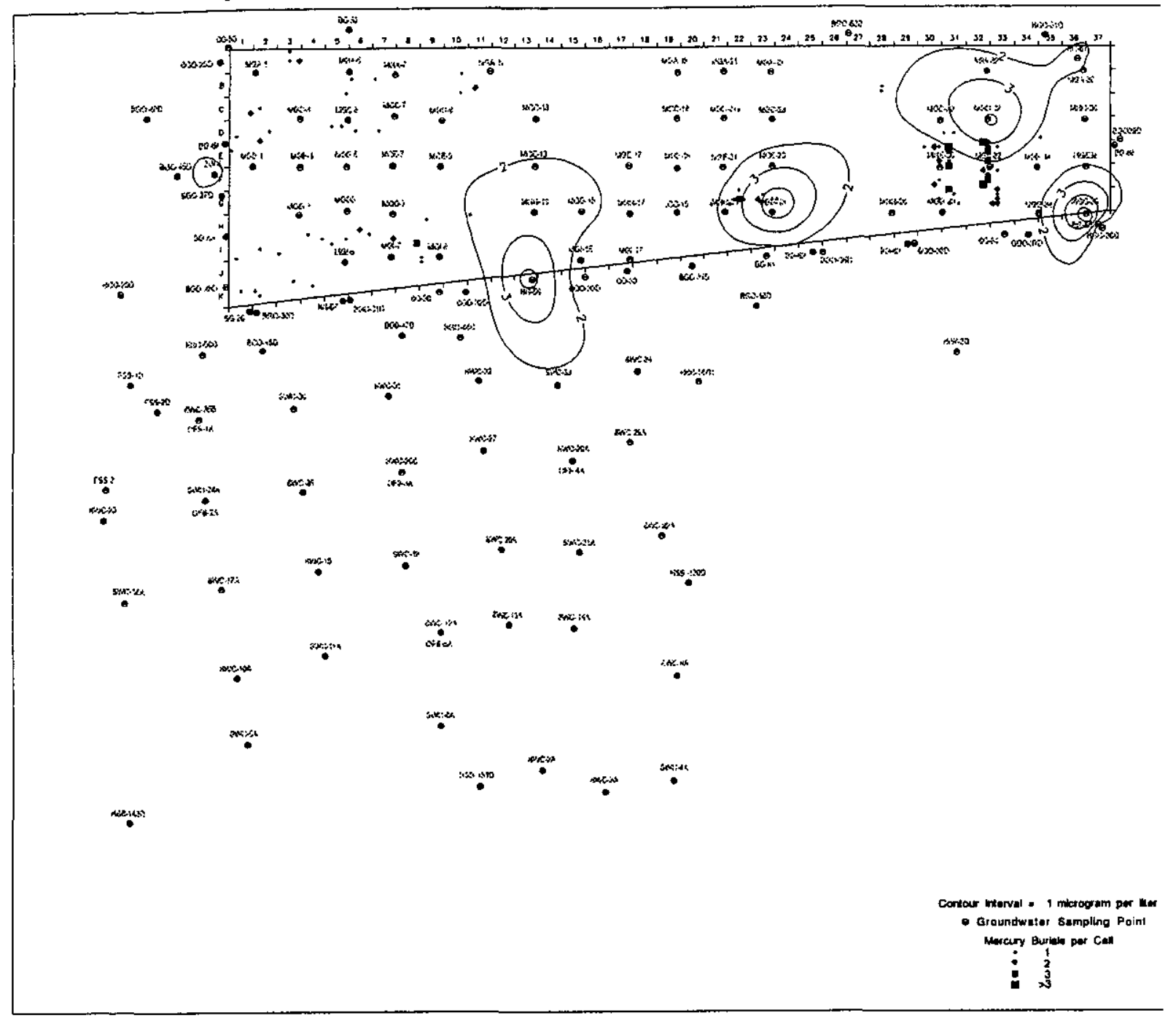

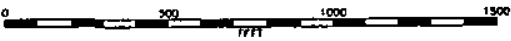

Figure 3-2. Average Mercury Concentrations in the Water Table, 1990 - 1995 
Average PCE Concentrations in the Water Table, 1990-1995

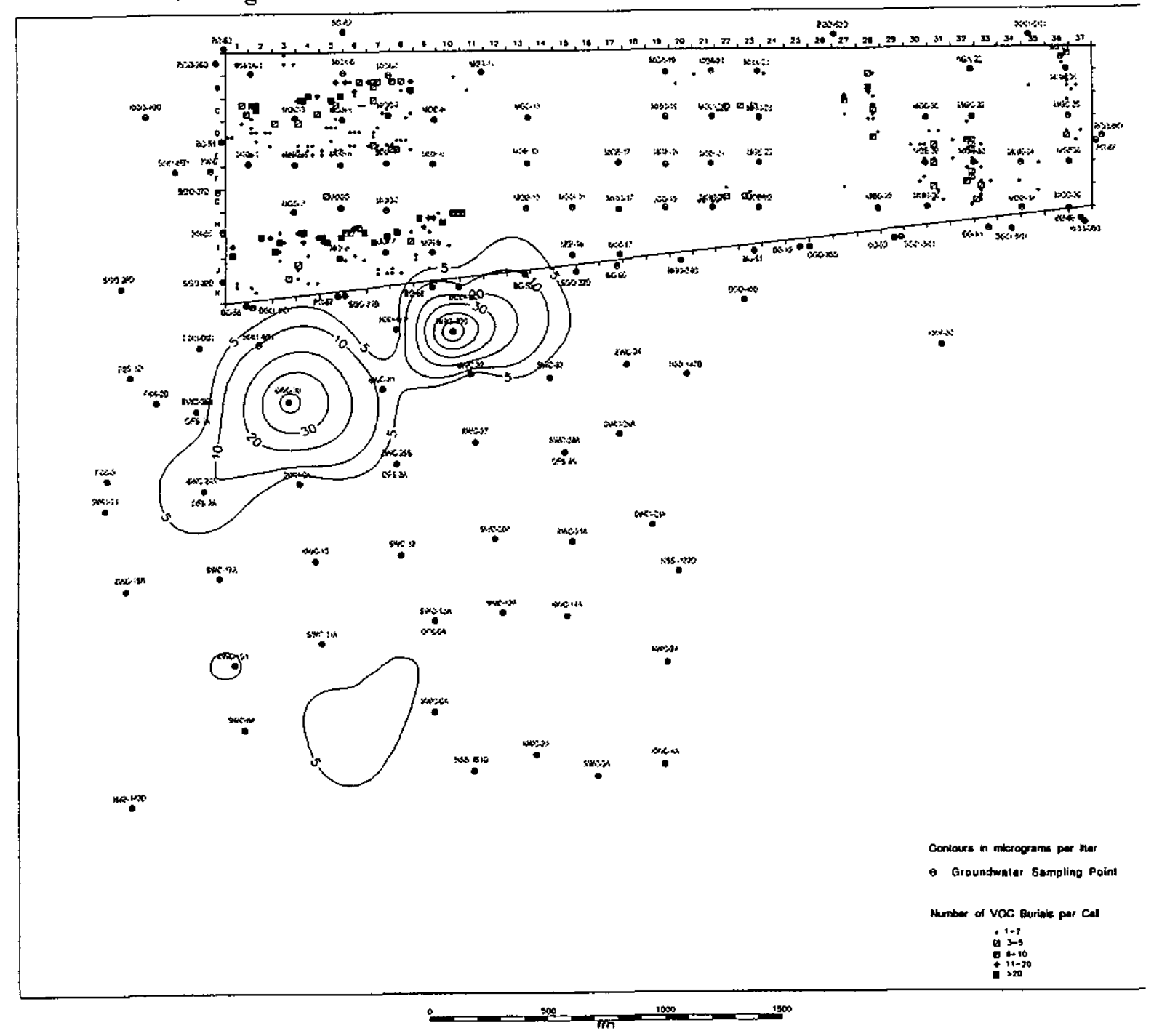

Figure 3-3. Average PCE Concentrations in the Water Table, 1990 - 1995 
Average TCE Concentrations in the Water Table, 1990-1995

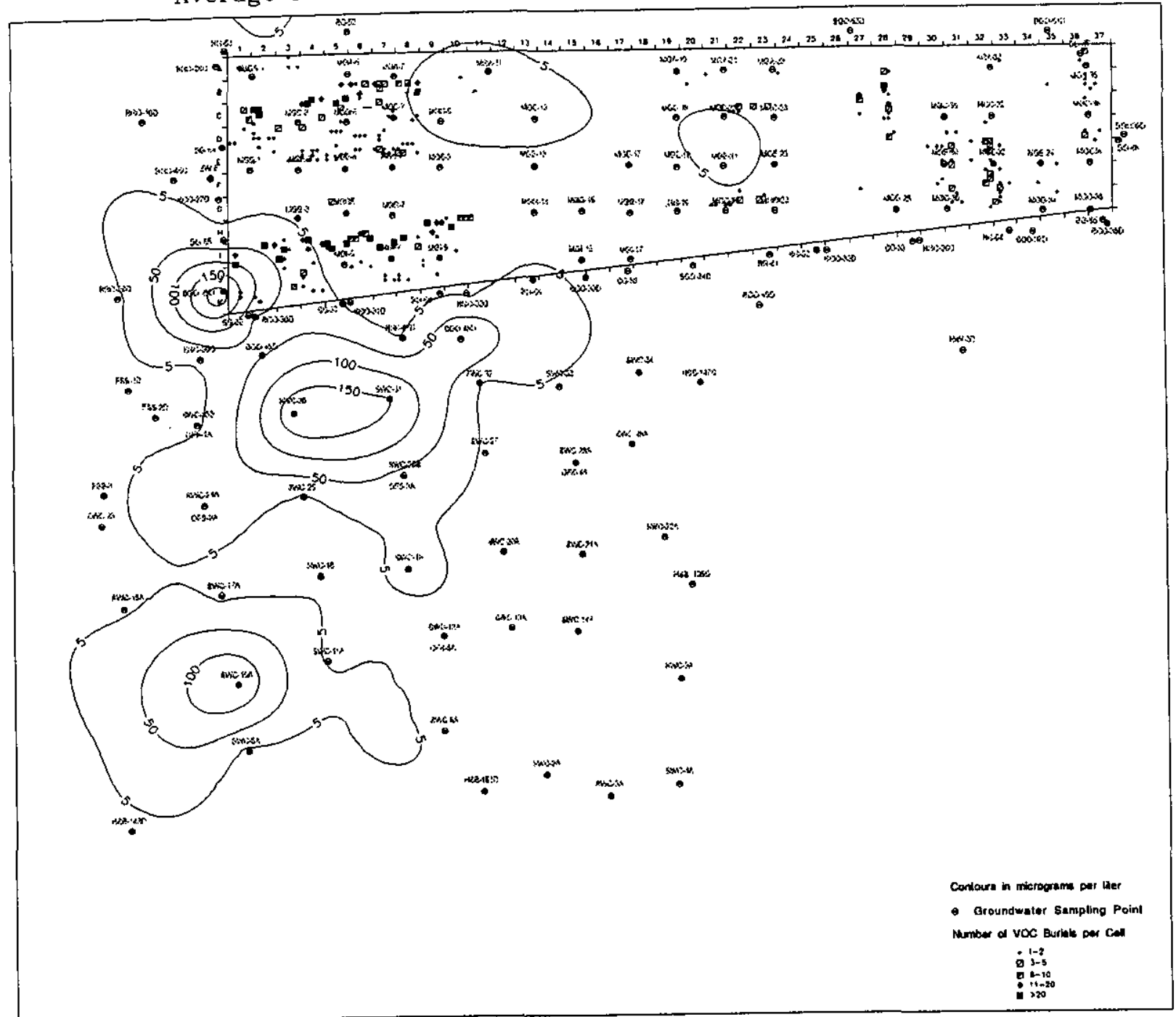

Figure 3-4. Average TCE Concentrations in the Water Table, 1990 - 1995 


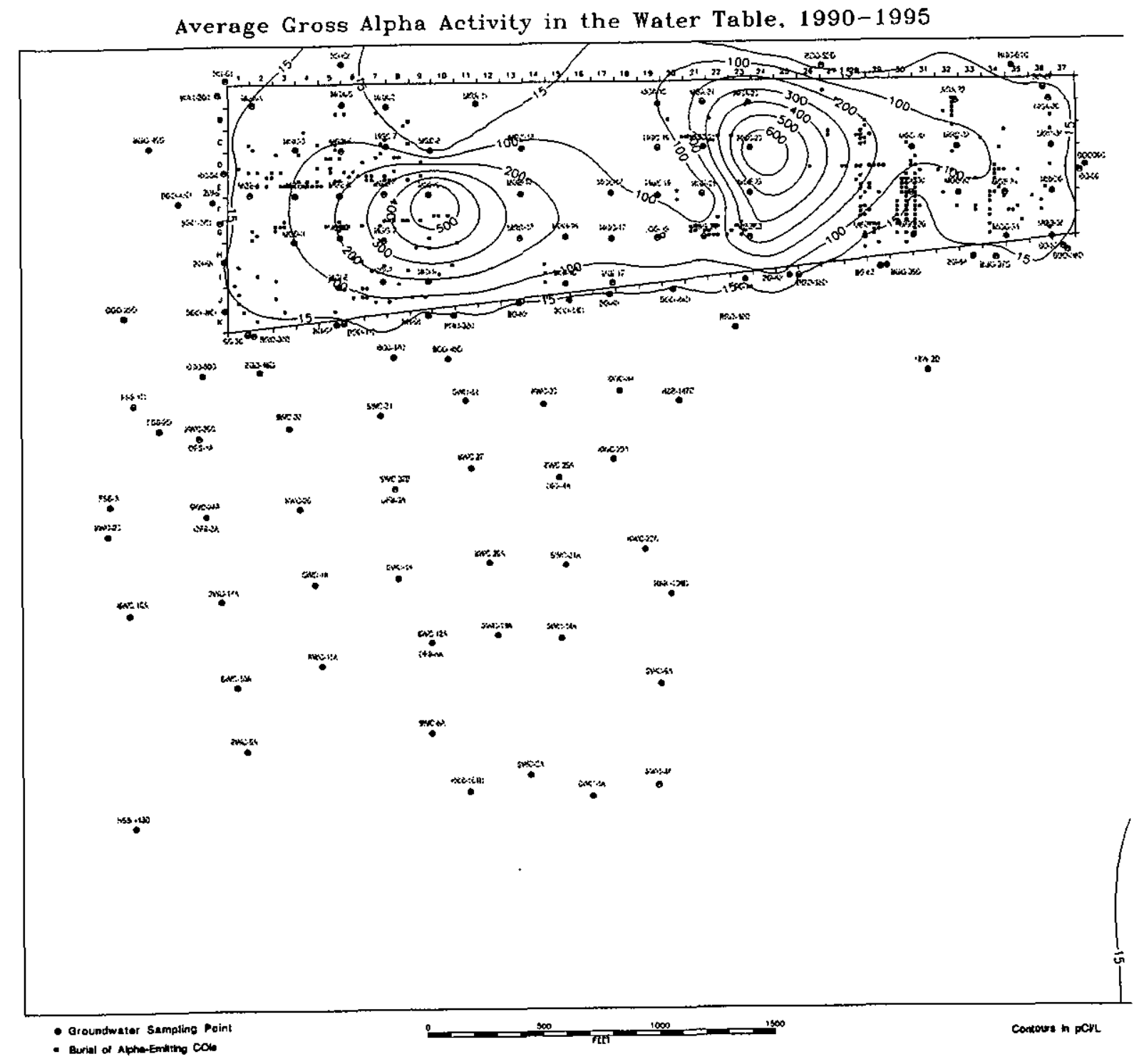

Figure 3-5. Average Gross Alpha Activity in the Water Table, 1990 - 1995 
Average Non-Volatile Beta Activity in the Water Table, 1990-1995

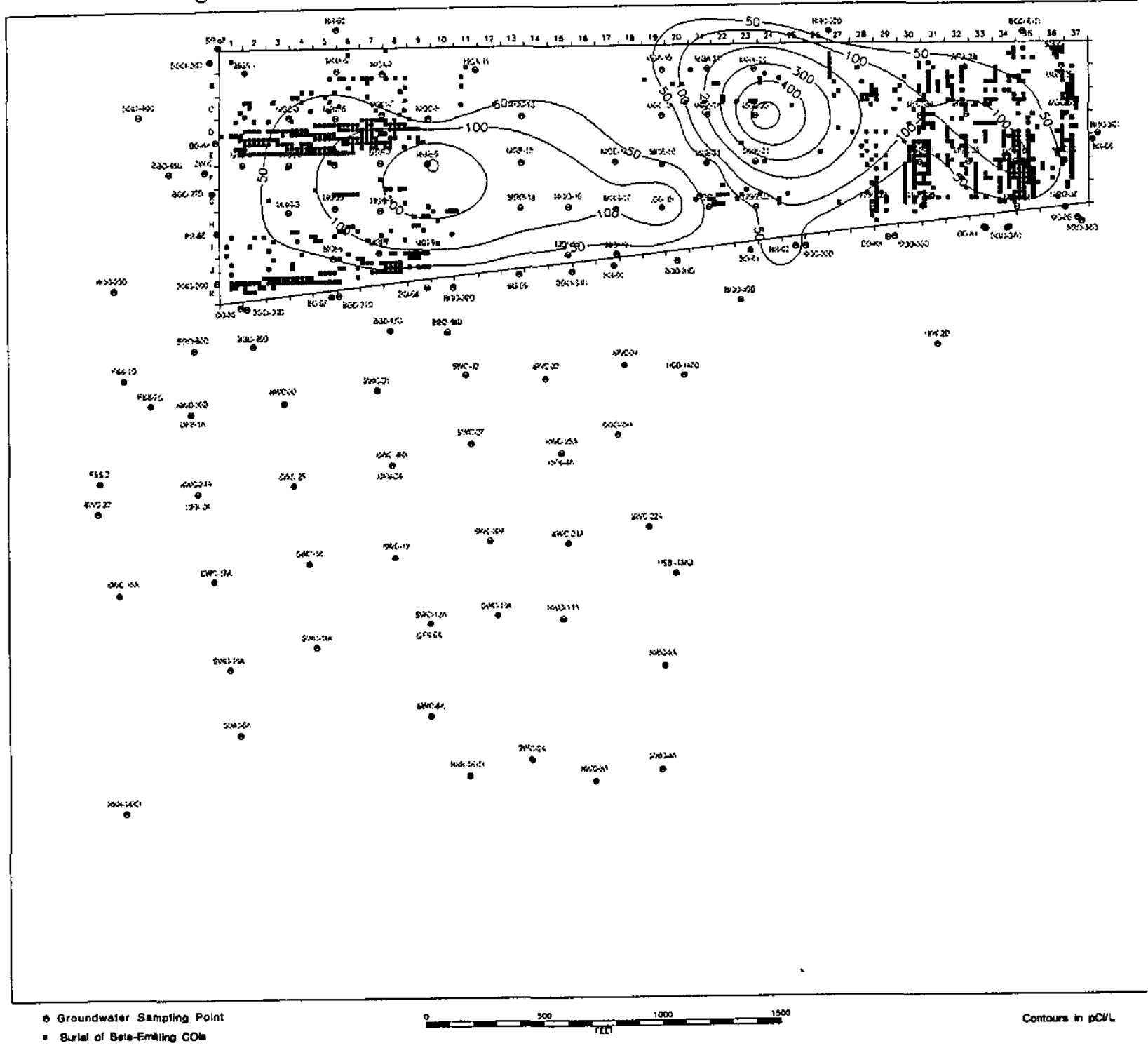

Figure 3-6. Average Non-Volatile Beta Activity in the Water Table, 1990 -1995 
Average Tritium Activity in the Water Table, 1990-1995

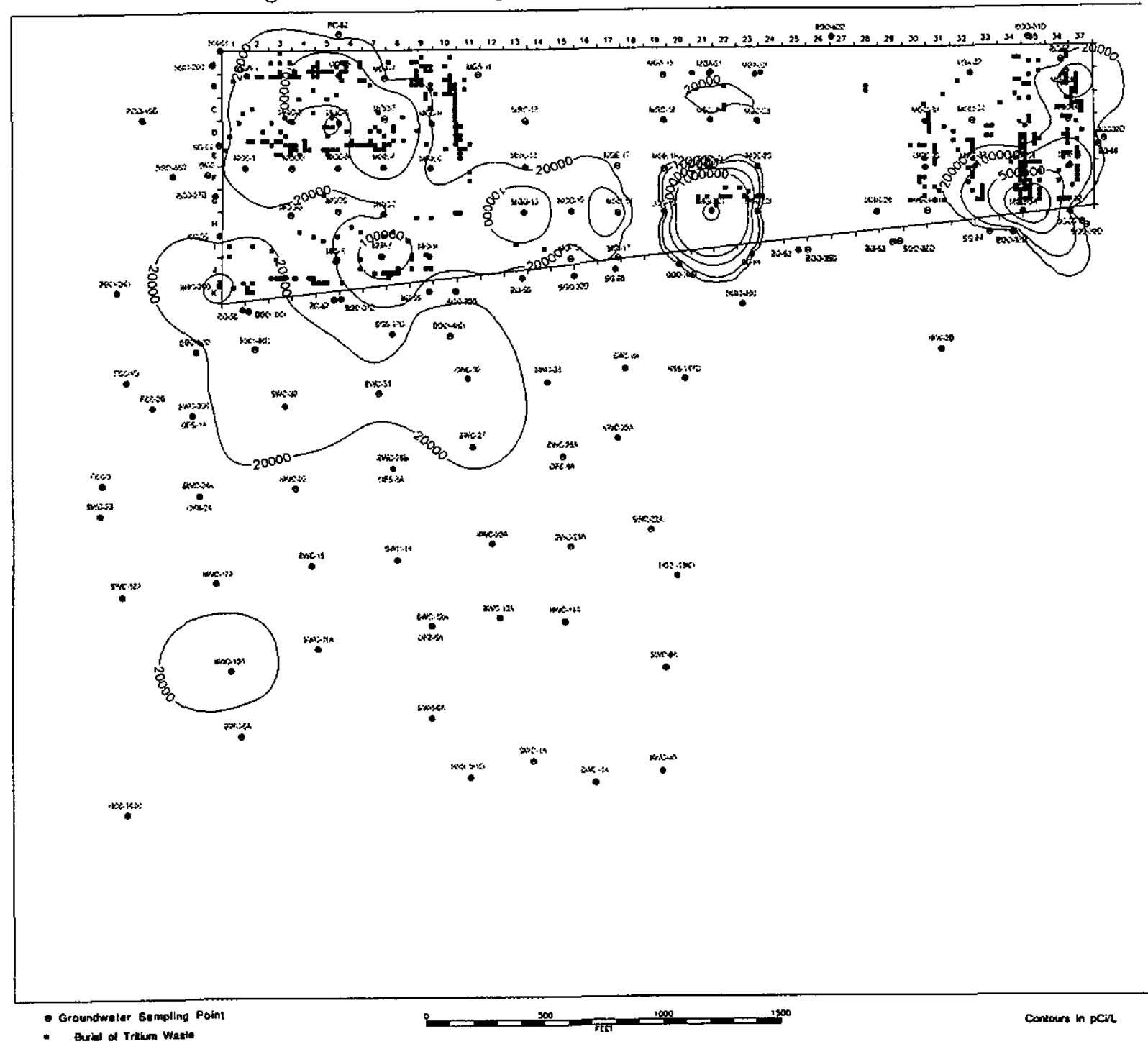

Figure 3-7. Average Tritium Activity in the Water Table, 1990 - 1995 


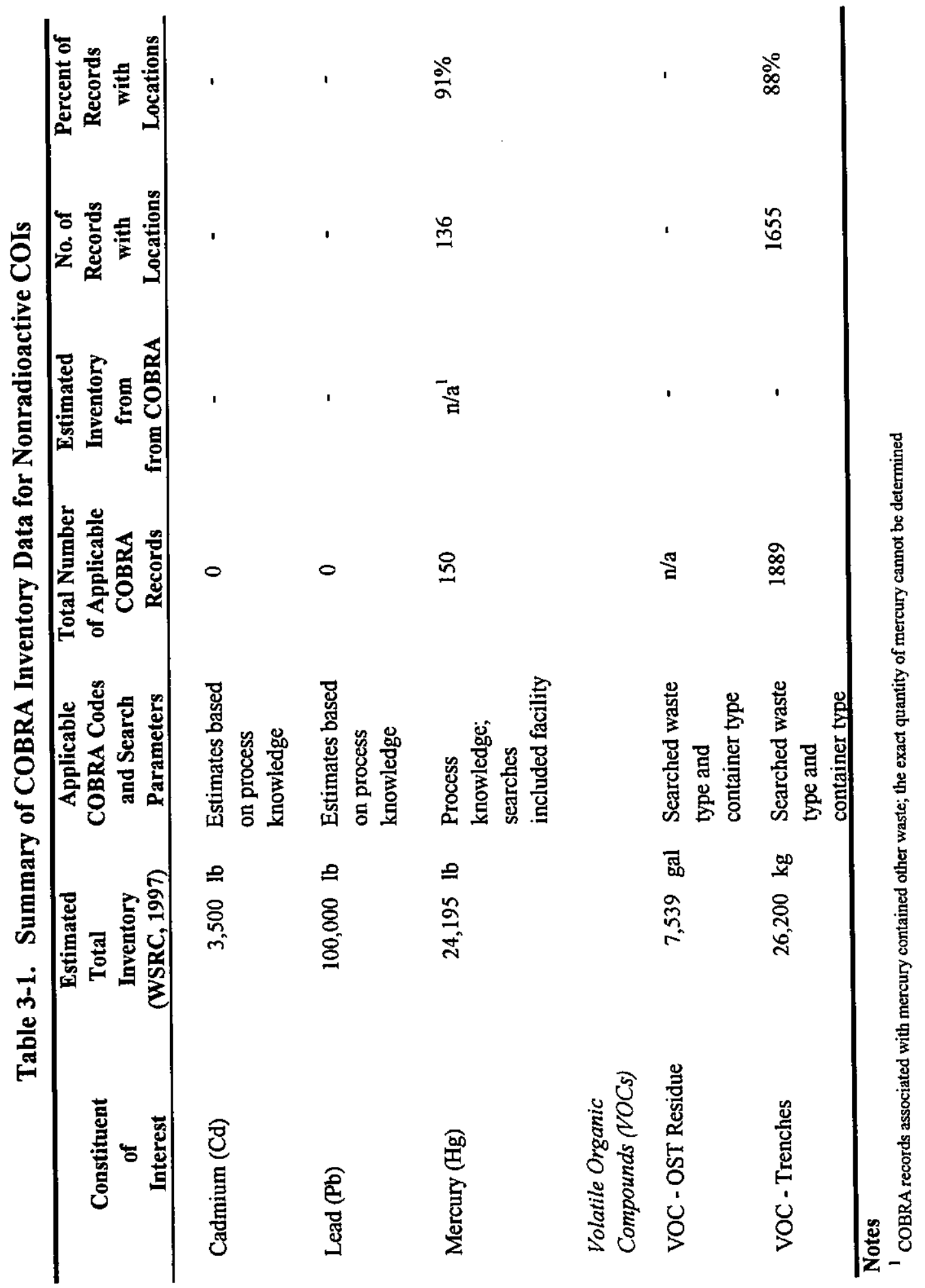


Table 3-2. Summary of COBRA Inventory Data for Radioactive COIs

\begin{tabular}{|c|c|c|c|c|c|c|c|}
\hline Constituent of Interest & $\begin{array}{c}\text { Estimated } \\
\text { Total } \\
\text { Inventory }(\mathrm{Ci})^{\prime} \\
\end{array}$ & $\begin{array}{c}\text { Applicable COBRA } \\
\text { Codes and Search } \\
\text { Parameters } \\
\end{array}$ & $\begin{array}{c}\text { Total Number of } \\
\text { Applicable } \\
\text { COBRA Records }\end{array}$ & $\begin{array}{c}\text { No. of } \\
\text { Records with } \\
\text { Locations } \\
\end{array}$ & $\begin{array}{c}\text { Percent of } \\
\text { Records with } \\
\text { Locations } \\
\end{array}$ & $\begin{array}{c}\text { Located } \\
\text { Inventory } \\
\text { (Ci) } \\
\end{array}$ & $\begin{array}{c}\text { Located } \% \\
\text { of Best } \\
\text { Estimate } \\
\end{array}$ \\
\hline Tritium $(\mathrm{H}-3)$ & $3,014,457.0$ & Variety code "87" & 3,579 & 3,307 & $92.4 \%$ & $2,023,601.4$ & $67.1 \%$ \\
\hline \multicolumn{8}{|l|}{ Beta-Emitters: } \\
\hline Carbon-14 (C-14) & $3,778.0$ & $\begin{array}{l}\text { Searched keywords related } \\
\text { to deionizers }\end{array}$ & 147 & 141 & $95.9 \%$ & $3,603.4$ & $95.4 \%$ \\
\hline Cobalt $-60(\mathrm{Co}-60)$ & $1,960,400.0$ & $\begin{array}{l}\text { Searched for "induced } \\
\text { activity"; type code "3" }\end{array}$ & 4,449 & 4,133 & $92.9 \%$ & $824,910.6$ & $42.1 \%$ \\
\hline Strontium-90 (Sr-90) & $58,657.0$ & Variety code "FP" & $24,165^{2}$ & 22,599 & $93.5 \%$ & $17,471.0$ & $29.8 \%$ \\
\hline Technetium-99 (Tc-99) & 12.0 & Variety code "FP" & $24,165^{2}$ & 22,599 & $93.5 \%$ & 5.8 & $48.7 \%$ \\
\hline Iodine-129 (I-129) & 10.6 & Process knowledge & $\mathrm{n} / \mathrm{a}$ & - & - & - & - \\
\hline Cesium-137 (Cs-137) & $58,657.0$ & $\begin{array}{l}\text { Process knowledge; } \\
\text { searched variety "FP" }\end{array}$ & $24,165^{2}$ & 22,599 & $93.5 \%$ & $18,621.7$ & $31.7 \%$ \\
\hline $\begin{array}{l}\text { Alpha Emitters: } \\
\qquad \text { Neptunium-237 (Np-237) }\end{array}$ & 1.99 & Variety codes "82" & 354 & 343 & $96.9 \%$ & 1.96 & $98.3 \%$ \\
\hline Uranium-235 (U-235) & 0.6 & Variety codes " 10 " and & 394 & 368 & $93.4 \%$ & 0.3 & $54.3 \%$ \\
\hline Uranium-238 (U-238) & 14.8 & $\begin{array}{l}\text { Variety codes "10", "20", } \\
\text { and " } 81 \text { " }\end{array}$ & 4,199 & 4,016 & $95.6 \%$ & 12.8 & $86.6 \%$ \\
\hline Plutonium-238(Pu-238) ${ }^{3}$ & $20,514.0$ & Variety code "83" & 1,465 & 1,422 & $97.1 \%$ & $20,434.9$ & $99.6 \%$ \\
\hline \multirow[t]{2}{*}{ Plutonium-239 (Pu-239) } & $1,475.0$ & Variety code "50" & 2,778 & 2,670 & $96.1 \%$ & $1,051.0$ & $71.3 \%$ \\
\hline & $5,117,978.0$ & & $41,530^{2}$ & 38,999 & $93.9 \%$ & $2,909,715.0$ & $56.9 \%$ \\
\hline
\end{tabular}

Notes:

${ }^{1}$ Estimated inventory from (WSRC, 1997)

${ }^{2}$ Source-term calculation for these COIs used same records from COBRA

${ }^{3}$ Probably less than this quantity 
(This page intentionally left blank.)

Gndwater.501.doc 


\subsection{CONCLUSIONS}

The more mobile COIs (tritium and the VOCs) demonstrate reasonably good correspondence between burial locations and groundwater concentrations. Plumes of TCE, and PCE are located in close proximity to and downgradient from the area within the ORWBG with the largest number of burials associated with these analytes. The gross geometry of these plumes is consistent with interpretations of recent field investigations. The plumes of PCE and TCE may emanate from the large volume of waste believed to contain VOCs, which is concentrated in the southwest corner of the ORWBG.

Local maxima of tritium activity in the water table generally correspond with areas containing large quantities of tritium-bearing waste. The contour pattern suggests that waste buried in the southeast corner of the ORWBG is releasing tritium to groundwater.

Maps of mercury, gross alpha, and non-volatile beta fail to demonstrate clear correspondence between burial locations associated with these constituents, and concentrations observed in the water table. Correlating concentrations of lead in the water table with specific areas of the ORWBG is problematic due to the absence of burial location data for this COI.

This report uses data from groundwater analyses of various levels of quality that were collected using a variety of sampling methods. The data for a five-year period were averaged before processing with EarthVision ${ }^{\otimes}$. For this reason, the results and conclusions should be considered qualitative. This report presents general correlations between the buried COI inventory at the ORWBG and key constituents detected in the water table beneath the facility. Specific contaminant sources, if they exist in the ORWBG, cannot be identified without the application of flow and transport analysis. Future modeling work could provide a clearer understanding of how the waste buried in the ORWBG may contribute to the presence of these analytes in the groundwater. 


\subsection{REFERENCES}

Flach, G.P., S.Y Lee, and A.D. Yu, 1996a. Old Burial Ground COC Transport Modeling Progress Report, Memorandum to R.W. Malanowski, E.K. Baradale, and C.M. Lewis, SRT-ESS-96-366, Westinghouse Savannah River Company, Savannah River Site, Aiken, $\mathrm{SC}$.

Flach, G.P., L.L Hamm, M.K. Harris, P.A. Thayer, J.S. Haselow, and A.D. Smits, 1996 b. Groundwater Flow and Tritium Migration from the SRS Old Burial Ground to Fourmile Branch (U), WSRC-TR-96-0037, Westinghouse Savannah River Company, Savannah River Site, Aiken SC.

Ryan, J.P., 1983. Groundwater Monitoring in the Savannah River Plant Low Level Waste Burial Ground: A Summary and Interpretation of the Analytical Data, DPST-83-209, Savannah River Laboratory, Aiken, SC, February 20, 1983.

Tharin, D.W., 1965. Burning of Radioactive Process Solvent, DP-942, E.I. du Pont de Nemours and Company, Savannah River Laboratory, Aiken, SC, February, 1965.

WSRC, 1995. Burial Ground Complex Field Investigation Preliminary Data Report Number One (U), WSRC-RP-94-1286, Westinghouse Savannah River Company, Savannah River Site, Aiken, SC, January 1995.

WSRC, 1996a. Information Document on the Old Solvent Tanks SI-S22 in the Old Radioactive Waste Burial Ground 643-E (U), WSRC-RP-96-00144, Rev. 0, Westinghouse Savannah River Company, Savannah River Site, Aiken, SC, June 24, 1996.

WSRC, 1996b. Burial Ground Complex Field Investigation Preliminary Data Report Number Two (U), WSRC-RP-96-060, Rev. 0, Westinghouse Savannah River Company, Savannah River Site, Aiken, SC.

WSRC, 1997. Source Term For The Old Radioactive Waste Burial Ground (ORWBG), Savannah River Site (U), WSRC-97-0119, Rev. 0, Westinghouse Savannah River Company, Savannah River Site, Aiken, SC. 
APPENDIX A

SUMMARY OF SOURCE TERM 
(This page intentionally left blank) 
Appendix A. Summary of Source Term for COIs at the ORWBG

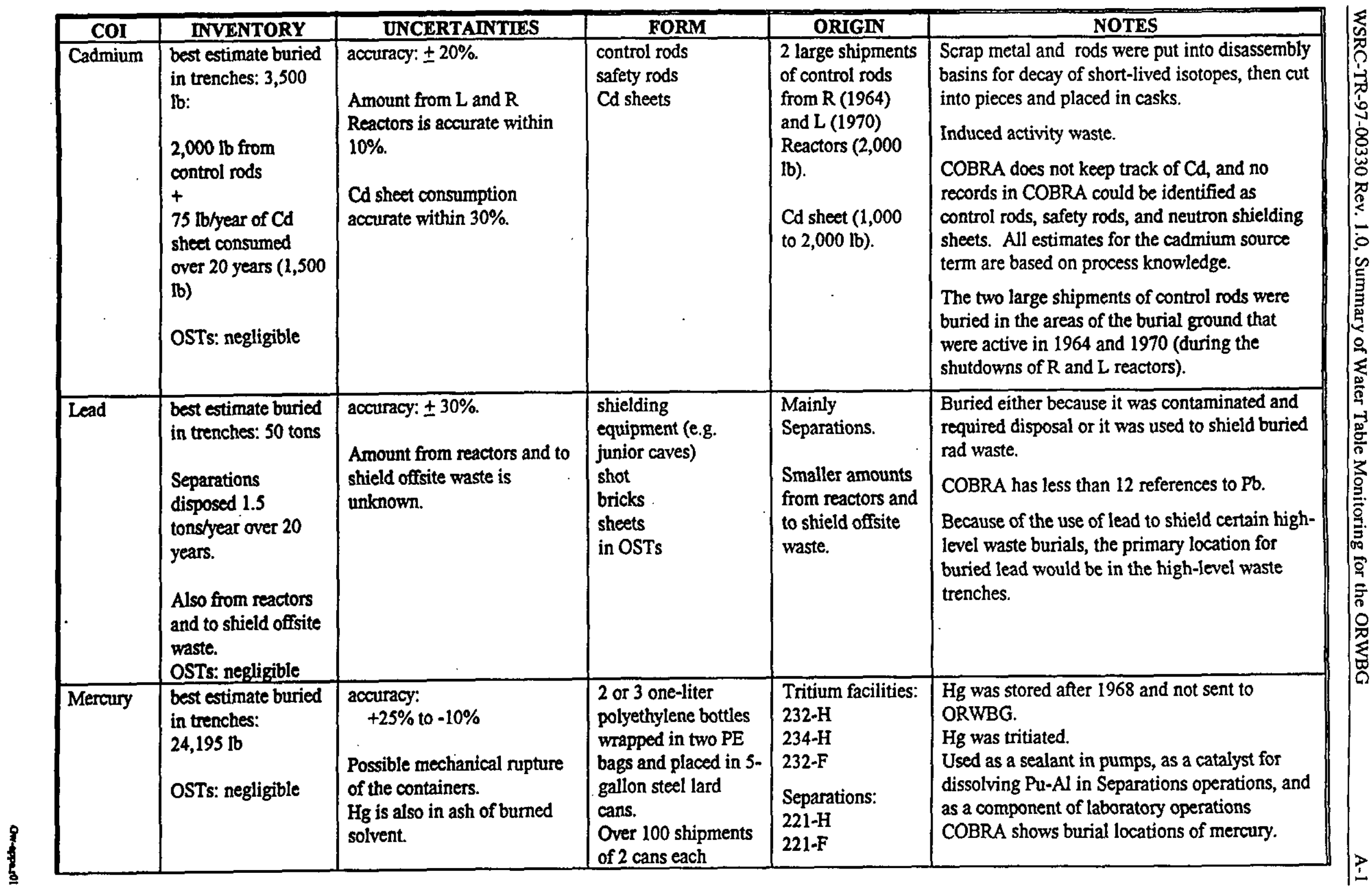


Appendix A. Summary of Source Term for COIs at the ORWBG (Continued)

\begin{tabular}{|c|c|c|c|c|c|}
\hline $\mathrm{COI}$ & INVENTORY & UNCERTAINTIES & FORM & ORIGIN & NOTES \\
\hline VOCs & $\begin{array}{l}\text { buried in trenches: } \\
7100 \mathrm{~kg} \text { toluene } \\
7100 \mathrm{~kg} \\
\text { trimethylbenzene } \\
12,000 \mathrm{~kg} \text { xylene }\end{array}$ & $\begin{array}{l}\text { Volatilization } \\
\text { Migration }\end{array}$ & $\begin{array}{l}\text { Scintillation solutions and } \\
\text { tritiated pump oils are } \\
\text { drummed. } \\
\text { Liquid scintillation solution } \\
\text { wastes are in small } \\
\text { polyethylene vials which, } \\
\text { from } 1965 \text {, were packed } \\
\text { with oil-dry in 55-gallon } \\
\text { drums and buried. } \\
\text { Waste oils were both stored } \\
\text { in the OSTs and absorbed } \\
\text { on an oil-dry compound, } \\
\text { placed in drums, and buried } \\
\text { as solidified waste. }\end{array}$ & $\begin{array}{l}\text { Drummed scintillation } \\
\text { solutions } \\
\text { Waste oils in absorbent } \\
\text { materials (from reactor and } \\
\text { tritium facilities including } \\
\text { pump oils, cutting oils, and } \\
\text { die oils) } \\
\text { Residue from } \\
\text { decontamination operations } \\
\text { prior to waste burial }\end{array}$ & $\begin{array}{l}\text { Shipments of organics are not } \\
\text { documented in the COBRA database } \\
\text { per se, though there are some } \\
\text { indirect references to possible VOC } \\
\text { sources. No quantity or specific } \\
\text { VOC constituent information is } \\
\text { contained in any COBRA record. } \\
\text { VOCs associated with liquid } \\
\text { scintillation solutions and waste oils } \\
\text { are present in the trenches of the } \\
\text { ORWBG. } \\
\text { The OSTs not only contained waste } \\
\text { PUREX solvent but also contained } \\
\text { contaminated waste solvents of other } \\
\text { sorts. }\end{array}$ \\
\hline & $\begin{array}{l}\text { Residue in the OSTs } \\
\text { (S-1 through S-22): } \\
4056 \text { gal organic phase } \\
+3483 \text { gal aqueous } \\
\text { phase }= \\
7539 \text { gallons } \\
\text { Mason } 1996 \text { provides } \\
\text { analytical data of vapor } \\
\text { phase (Table } 2-5 \text { ). }\end{array}$ & $\begin{array}{l}\text { OST tank } \\
\text { dimensions and } \\
\text { inclinations }\end{array}$ & $\begin{array}{l}\text { VOCs in OSTs are in } \\
\text { residue of spent PUREX } \\
\text { solvent and associated } \\
\text { degradation products. }\end{array}$ & $\begin{array}{l}\text { Spent PUREX solvent was } \\
\text { generated in Separations in } \\
\text { a chemical process for } \\
\text { removing plutonium and } \\
\text { uranium from spent rods. } \\
\text { Plant records show that } \\
\text { from } 1956 \text { through } 1964 \text {, } \\
88 \% \text { of the waste solvent } \\
\text { receipts were from F-Area. } \\
\text { From } 1965 \text { to } 1972,86 \% \text { of } \\
\text { the waste solvent was } \\
\text { generated in H-Area. }\end{array}$ & $\begin{array}{l}\text { Most PUREX solvent was } \\
\text { transferred to } 643-7 G \text { around } 1980 . \\
\text { The OSTs are empty except for } \\
\text { unpumpable heel, which contains } \\
\text { some VOCs in vapor, and organic } \\
\text { phases. Minor amounts of VOCs } \\
\text { are present in the aqueous phase. } \\
\text { The amount of VOCs in the sludge } \\
\text { solids phases are negligible. }\end{array}$ \\
\hline
\end{tabular}


Appendix A. Summary of Source Term for COIs at the ORWBG (Continued)

\begin{tabular}{|c|c|c|c|c|c|}
\hline $\mathrm{COI}$ & INVENTORY & UNCERTAINTIES & FORM & ORIGIN & NOTES \\
\hline Tritium & $\begin{array}{l}\text { best estimate buried in } \\
\text { trenches: } 3,014,457 \mathrm{Ci} \\
\text { decayed to } 1997 \text { (in } \\
\text { trenches): } 467,889 \mathrm{Ci} \\
\text { OSTs: negligible }\end{array}$ & $\begin{array}{l}\text { Tritium content } \\
\text { estimates in waste } \\
\text { forms (assumed } \\
\text { constant quantities of } \\
\text { tritium in a given } \\
\text { waste form). } \\
\text { Migration (there is } \\
\text { no correction for such } \\
\text { unknown loss). }\end{array}$ & $\begin{array}{l}\text { Job control waste } \\
\text { Waste oils and } \mathrm{Hg} \\
\text { Used equipment \& } \\
\text { components } \\
\text { Spent melts } \\
\text { Reactive beds }\end{array}$ & $\begin{array}{l}232-\mathrm{H} \\
234-\mathrm{H} \\
238-\mathrm{H} \\
232-\mathrm{F} \\
\text { The bulk of tritium was } \\
\text { processed in the three H- } \\
\text { Area buildings; } 232-\mathrm{F} \\
\text { operated only briefly in the } \\
\text { late } 1950 \text { s. }\end{array}$ & $\begin{array}{l}\text { Half-life: } 12.3 \text { years } \\
\text { COBRA provides both quantity } \\
\text { and location estimates. }\end{array}$ \\
\hline Cesium-137 & $\begin{array}{l}\text { best estimate buried in } \\
\text { trenches: } 58,657 \mathrm{Ci} \\
\text { decayed to } 1997 \text { (in } \\
\text { trenches): } 26,838 \mathrm{Ci} \\
\text { OSTs: } 1.30 \mathrm{Ci}\end{array}$ & $\begin{array}{l}\text { Original estimates of } \\
\text { fission products } \\
\text { amounts (based on } \\
\text { external dose rates). } \\
\text { Variations in isotopic } \\
\text { distributions. } \\
\text { Use of fixed ages in } \\
\text { decay calculations. }\end{array}$ & $\begin{array}{l}\text { This waste was buried in } \\
\text { cardboard boxes, plastic } \\
\text { bags, and metal } \\
\text { containers. } \\
\text { The fission product- } \\
\text { bearing waste was buried } \\
\text { in low-level and high- } \\
\text { level trenches, depending } \\
\text { on the dose rate from the } \\
\text { package. }\end{array}$ & $\begin{array}{l}\text { Byproduct of reactors } \\
\text { Fission products are a } \\
\text { component of job control } \\
\text { waste and other waste } \\
\text { streams from spent reactor } \\
\text { fuel and targets or high- } \\
\text { level liquid wastes. These } \\
\text { include reactors, } \\
\text { Separations (F- and H- } \\
\text { Areas), and associated tank } \\
\text { farms, and process control } \\
\text { and experimental } \\
\text { laboratories. }\end{array}$ & $\begin{array}{l}\text { Half-life: } 30 \text { years } \\
\text { COBRA recorded "fission } \\
\text { products", not Cs-137 per se. } \\
<50 \mathrm{mR} / \mathrm{hr} \text { wastes were buried } \\
\text { in low activity beta-gamma } \\
\text { trenches. } \\
>50 \mathrm{mR} / \mathrm{hr} \text { wastes were buried } \\
\text { in intermediate level (aka high } \\
\text { level) trenches. }\end{array}$ \\
\hline
\end{tabular}




\begin{tabular}{|c|c|c|c|c|c|}
\hline COI & INVENTORY & UNCERTAINTIES & FORM & ORIGIN & NOTES \\
\hline Plutonium-238 & $\begin{array}{l}\text { best estimate } \\
\text { buried in } \\
\text { trenches: } \\
1192.7 \text { grams } \\
(20,514 \mathrm{Ci}) \\
\\
\text { decayed to } 1997 \\
\text { (in trenches): } \\
16,825 \mathrm{Ci} \\
\\
\text { OSTs: } 1.24 \\
\text { grams (21.4 Ci) }\end{array}$ & $\begin{array}{l}\text { validity of COBRA } \\
\text { estimates }\end{array}$ & $\begin{array}{l}\text { Uncontainerized in } \\
\text { plastic bags and } \\
\text { cardboard boxes } \\
\text { Concrete culverts } \\
\text { containing drummed or } \\
\text { boxed waste } \\
\text { Encapsulated waste }\end{array}$ & $\begin{array}{l}\text { Thermionic heat sources for } \\
\text { power generation } \\
\text { Separations, reactor areas, and } \\
\text { research facilities like SRTC }\end{array}$ & $\begin{array}{l}\text { Half-life: } 87.4 \text { years } \\
\text { Inventory estimate based on } \\
\text { COBRA, pre-COBRA burial } \\
\text { records and burned solvent } \\
\text { residues. } \\
\text { COBRA shows burial locations } \\
\text { of plutonium-238. }\end{array}$ \\
\hline Plutonium-239 & $\begin{array}{l}\text { best estimate } \\
\text { buried in } \\
\text { trenches: } \\
24,188 \text { grams } \\
(1,475 \mathrm{Ci}) ; \\
\text { Decayed to } 1997 \\
\text { (in trenches): } \\
1,474 \mathrm{Ci} \\
\\
\text { OSTs: } 1351 \mathrm{~g} \\
(82.4 \mathrm{Ci}) \\
\end{array}$ & $\begin{array}{l}\text { validity of COBRA } \\
\text { estimates }\end{array}$ & $\begin{array}{l}\text { Uncontainerized in } \\
\text { plastic bags and } \\
\text { cardboard boxes } \\
\text { Concrete culverts } \\
\text { containing drummed or } \\
\text { boxed waste } \\
\text { Encapsulated waste }\end{array}$ & $\begin{array}{l}\text { Special nuclear material } \\
\text { Separations, reactor areas, and } \\
\text { research facilities like SRTC }\end{array}$ & $\begin{array}{l}\text { Half-life: } 24,360 \text { years } \\
\text { Inventory estimate based on } \\
\text { COBRA database total, which } \\
\text { includes plutonium- } 239 \text { in } \\
\text { special burials, pre-COBRA } \\
\text { burial records, and burned } \\
\text { solvent residues. } \\
\text { Cobra shows burial locations of } \\
\text { plutonium- } 239 \text {. }\end{array}$ \\
\hline Strontium-90 & $\begin{array}{l}\text { best estimate } \\
\text { buried in } \\
\text { trenches: } 58,657 \\
\text { Ci } \\
\text { Best estimate: } \\
\text { decayed to } 1997 \\
\text { (in trenches): } \\
26,216 \mathrm{Ci} \\
\text { OSTs: } 1.28 \mathrm{Ci}\end{array}$ & $\begin{array}{l}\text { Original estimates } \\
\text { of fission products } \\
\text { amounts (based on } \\
\text { external dose rates } \\
\text { and assumed } \\
\text { isotopic } \\
\text { distribution). } \\
\text { Use of fixed ages in } \\
\text { decay calculations. }\end{array}$ & $\begin{array}{l}\text { This waste was buried in } \\
\text { cardboard boxes, plastic } \\
\text { bags, and metal } \\
\text { containers. } \\
\text { The fission product- } \\
\text { bearing waste was buried } \\
\text { in low-level and high- } \\
\text { level trenches, depending } \\
\text { on the dose rate from the } \\
\text { package. }\end{array}$ & $\begin{array}{l}\text { Byproduct of reactors } \\
\text { Fission products are a } \\
\text { component of job control waste } \\
\text { and other waste streams from } \\
\text { spent reactor fuel and targets or } \\
\text { high-level liquid wastes. These } \\
\text { include reactors, Separations (F- } \\
\text { and H-Areas), and associated } \\
\text { tank farms, and process control } \\
\text { and experimental laboratories. }\end{array}$ & $\begin{array}{l}\text { Half-life: } 29.12 \text { years } \\
\text { COBRA recorded "fission } \\
\text { products", not Sr-90 per se. } \\
<50 \mathrm{mR} / \mathrm{hr} \text { wastes were buried } \\
\text { in low activity beta-gamma } \\
\text { trenches. } \\
>50 \mathrm{mR} / \mathrm{hr} \text { wastes were buried } \\
\text { in intermediate level (aka high } \\
\text { level) trenches. }\end{array}$ \\
\hline
\end{tabular}


Appendix A. Summary of Source Term for COIs at the ORWBG (Continued)

\begin{tabular}{|c|c|c|c|c|c|}
\hline $\mathrm{COI}$ & INVENTORY & UNCERTAINTIES & FORM & ORIGIN & NOTES \\
\hline Uranium-235 & $\begin{array}{l}\text { best estimate } \\
\text { buried in } \\
\text { trenches: } 273,185 \\
\text { grams } \\
(0.6 \mathrm{Ci}) \\
\text { OSTs: } 0.11 \mathrm{Ci}\end{array}$ & $\begin{array}{l}\text { Variable isotopic } \\
\text { ratios of enriched U- } \\
235\end{array}$ & $\begin{array}{l}\text { Generally, U-235 bearing } \\
\text { wastes, primarily scrap } \\
\text { from fuel fabrication } \\
\text { operations, were buried in } \\
\text { alpha activity waste } \\
\text { trenches, without any } \\
\text { special containerization. } \\
\text { The waste would have } \\
\text { been buried in cardboard } \\
\text { boxes, plastic bags, and } \\
\text { possibly metal containers. }\end{array}$ & $\begin{array}{l}\text { According to the COBRA } \\
\text { database, U-235, as enriched } \\
\text { uranium, was sent to the OBG } \\
\text { from M-Area, A-Area, F-Area, } \\
\text { H-Area, and from offsite } \\
\text { facilities. Normal, or natural, } \\
\text { uranium was sent to the OBG } \\
\text { from M-Area, A-Area, H-Area, } \\
\text { and F-Area. }\end{array}$ & $\begin{array}{l}\text { Half-life: } 7.1 \times 10^{8} \text { years } \\
\text { natural U: } 0.72 \% \text { U-235 } \\
\text { enriched U: } 93 \% \text { U-235 } \\
\text { COBRA shows the burial } \\
\text { locations of enriched and normal } \\
\text { uranium. } \\
\text { OSTs estimate is based on } \\
\text { assigning U-235 an arbitrary } \\
\text { activity fraction of } 0.25 \text { percent } \\
\text { for tanks that had indicated } \\
\text { uranium content. }\end{array}$ \\
\hline Uranium-238 & $\begin{array}{l}\text { best estimate } \\
\text { buried in } \\
\text { trenches: } \\
44,233 \mathrm{~kg} \\
(14.8 \mathrm{Ci}) \\
\text { OSTs: } 1.1 \mathrm{Ci}\end{array}$ & $\begin{array}{l}\text { COBRA error of } \mathrm{Ci} \\
\text { units (should be } \mathrm{kg} \text { ). } \\
\text { OST value is } \\
\text { arbitrary, but based } \\
\text { on actual alpha } \\
\text { activity in the tanks }\end{array}$ & $\begin{array}{l}\text { It is likely that U-238 } \\
\text { bearing wastes were } \\
\text { disposed of in alpha } \\
\text { activity waste trenches, } \\
\text { without any special } \\
\text { containerization. The } \\
\text { waste would have been } \\
\text { buried in cardboard } \\
\text { boxes, plastic bags, and } \\
\text { possibly metal containers. }\end{array}$ & $\begin{array}{l}\text { According to the COBRA } \\
\text { database, U-238, as depleted } \\
\text { uranium, was sent to the OBG } \\
\text { from M-Area, A-Area, F-Area, } \\
\text { H-Area, G-Area and from off- } \\
\text { site facilities. } \\
\text { Normal, or natural, uranium } \\
\text { was sent to the OBG from M- } \\
\text { Area, A-Area, H-Area, and F- } \\
\text { Area. } \\
\text { Enriched uranium was sent to } \\
\text { the OBG from M-Area, A- } \\
\text { Area, F-Area, H-Area, and } \\
\text { from offsite facilities: }\end{array}$ & $\begin{array}{l}\text { Half-life: } 4.51 \times 10^{9} \text { years } \\
\text { natural U: } 99.3 \% \text { U-238 } \\
\text { depleted U: } 100 \% \text { U-238 } \\
\text { enriched U: } 7 \% \text { U-238 } \\
\text { COBRA shows the burial } \\
\text { locations of enriched, normal, } \\
\text { and depleted uranium. } \\
\text { OSTs estimate is based on } \\
\text { assigning U-238 an arbitrary } \\
\text { activity fraction of } 2.5 \text { percent for } \\
\text { tanks that had indicated uranium } \\
\text { content. }\end{array}$ \\
\hline
\end{tabular}




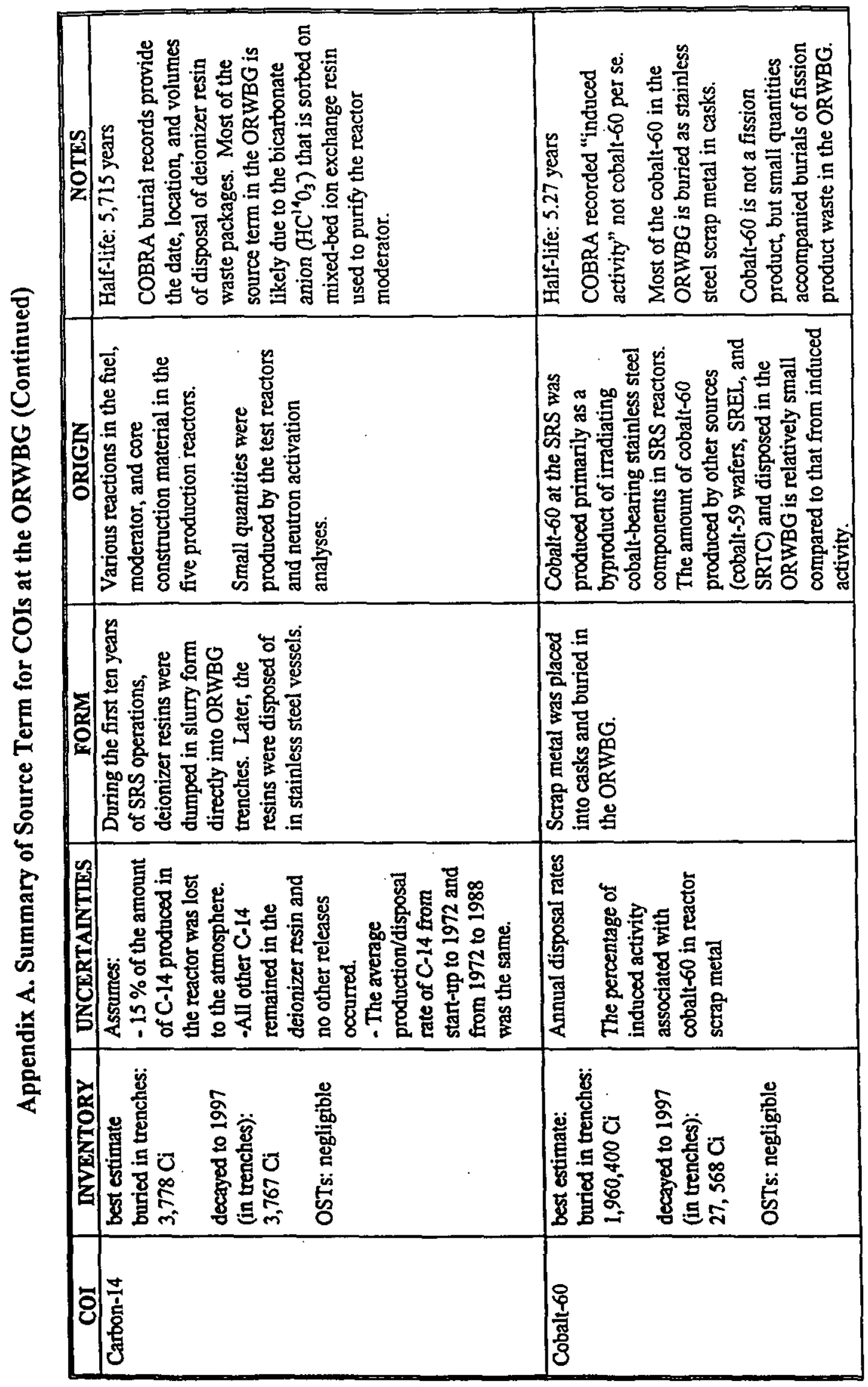




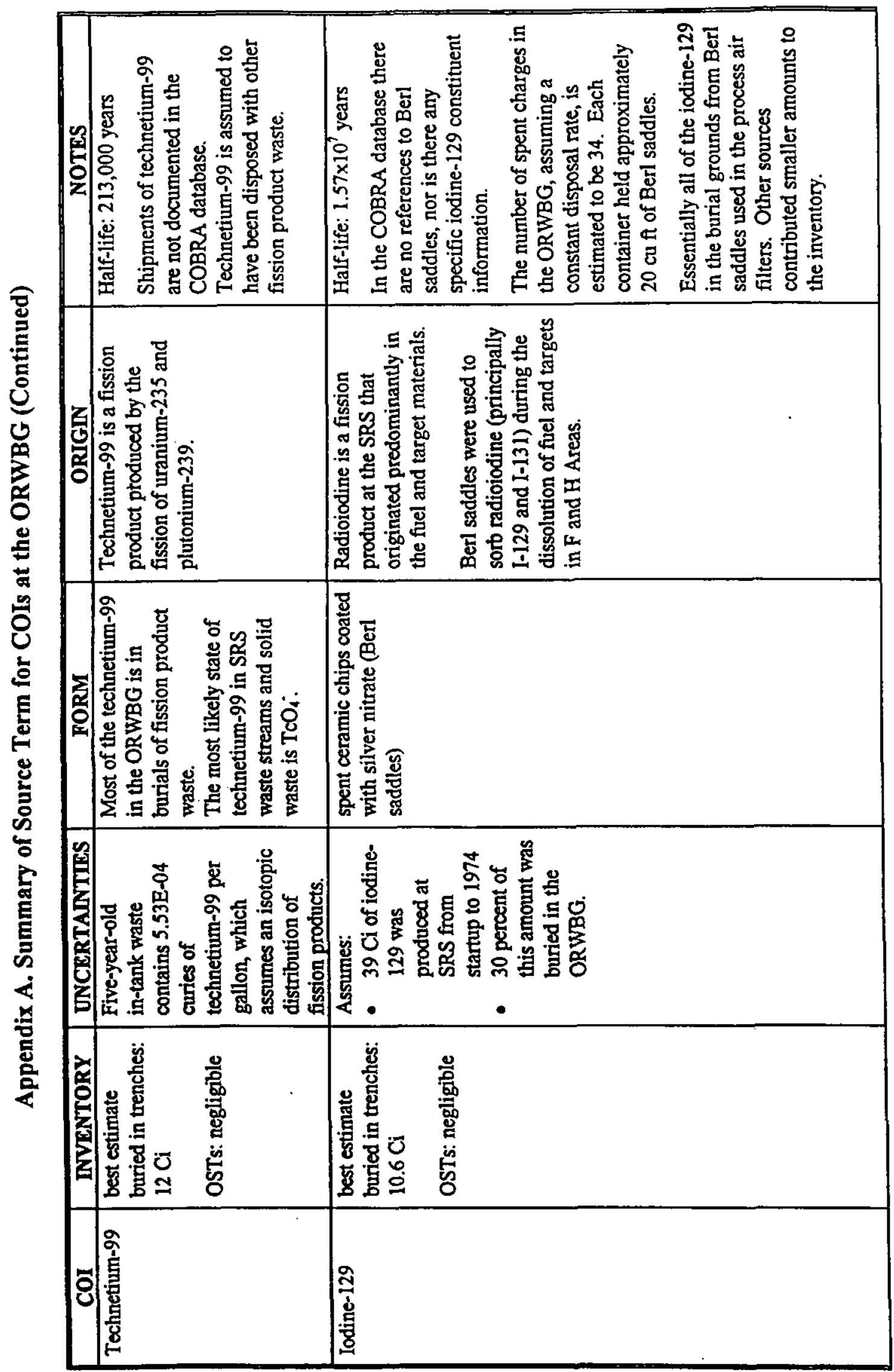


Appendix A. Summary of Source Term for COIs at the ORWBG (Continued)

\begin{tabular}{|c|c|c|c|c|c|}
\hline COI & INVENTORY & UNCERTAINTIES & FORM & ORIGIN & \\
\hline Neptunium-237 & $\begin{array}{l}\text { best estimate: } \\
1.99 \mathrm{Ci} \text { (originally } \\
\text { buried in the } \\
\text { trenches) } \\
\text { The amount of } \\
\text { ingrown } \\
\text { neptunium-237 is: } \\
0.004 \mathrm{Ci} \text { (in } \\
\text { trenches) } \\
\text { OSTs: negligible }\end{array}$ & classified burials & $\begin{array}{l}\text { Uncontained in plastic } \\
\text { bags and cardboard } \\
\text { boxes. } \\
\text { Concrete culverts } \\
\text { containing drummed or } \\
\text { boxed waste. } \\
\text { Encapsulated waste. } \\
\text { Waste potentially } \\
\text { contaminated with } \\
\text { neptunium-237 included } \\
\text { cabinet waste originating } \\
\text { from } 221-H B L, \text { laboratory } \\
\text { glove boxes and radio } \\
\text { benches, waste } \\
\text { originating from } 235-F \text {, } \\
\text { waste effluents from } \\
\text { processing in the } \\
\text { Separation areas and } \\
\text { PUREX waste in storage } \\
\text { tanks ( } 241-F \text { and H-Areas } \\
\text { Tank Farms), and in the } \\
\text { OSTs in the ORWBG. }\end{array}$ & $\begin{array}{l}\text { Neptunium-237 is produced } \\
\text { as a byproduct during the } \\
\text { fuel cycle. } \\
\text { It is produced by two primary } \\
\text { sources at SRS: } \\
\text { alpha decay of } \\
\text { americium-241 that is } \\
\text { produced by the beta } \\
\text { decay of plutonium-241 } \\
\text { in weapons-grade } \\
\text { plutonium } \\
\text { via a side reaction } \\
\text { during the irradiation of } \\
\text { uranium-238 targets to } \\
\text { eventually produce } \\
\text { plutonium-239 } \\
\text { Neptunium- } 237 \text { is also the } \\
\text { target material used to } \\
\text { produce plutonium- } 238 \text { in } \\
\text { SRS reactors. }\end{array}$ & $\begin{array}{l}\text { Half-life: } 2.14 \times 10^{6} \text { years } \\
\text { The COBRA database provides } \\
\text { both quantity and location } \\
\text { estimates for neptunium- } 237 \\
\text { burials in the ORWBG. }\end{array}$ \\
\hline
\end{tabular}




$$
\begin{gathered}
\text { WSRC-RP-97-00127 } \\
\text { Rev. } 1.4 \\
V_{01.2} P_{+.3}
\end{gathered}
$$

RECORDS ADMINISTRATION

\section{APPENDIX C}

Delineation of Potential "Hot Spots" for the Old Radioactive Waste Burial Ground (ORWBG), WSRC-TR-97-00329, Rev. 1 
This page intentionally left blank. 
WSRC-TR-97-00329, Rev. 1.0

\section{DELINEATION OF POTENTIAL "HOT SPOTS" FOR THE OLD RADIOACTIVE WASTE BURIAL GROUND (ORWBG)}

MAY 2000

Westinghouse Savannah River Company Savannah River Site Aiken, S.C. 29808

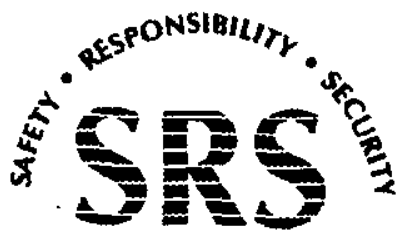




\section{DISCLAIMER}

This report was prepared by Westinghouse Savannah River Company (WSRC) for the United States Department of Energy under Contract No. DE-AC09-96SR-18500 and is an account of work performed under that contract. Neither the United States Department of Energy, nor WSRC, nor any of their employees makes any warranty, expressed or implied, or assumes any legal liability of responsibility for accuracy, completeness, or usefulness, on any information, apparatus, or product or process disclosed herein or represents that its use will not infringe privately owned rights. Reference herein to any specific commercial product, process, or services by trademark, name, manufacturer or otherwise does not necessarily constitute or imply endorsement, recommendation, or favoring of same by WSRC or by the United States Government or any agency thereof. 


\section{TABLE OF CONTENTS}

EXECUTIVE SUMMARY

ES-1

LIST OF FIGURES iiii

LIST OF TABLES iv

LIST OF APPENDICES LIST OF ACRONYMS vii

1.0

INTRODUCTION

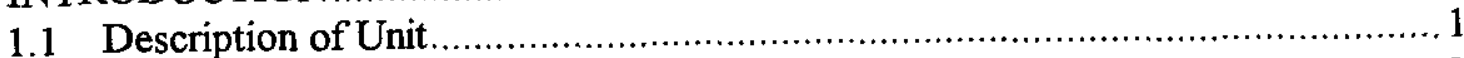

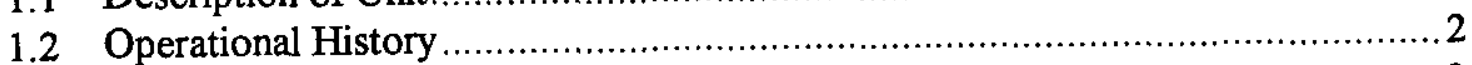

1.2.1 Original Burial Ground ........................................................... 3

1.2.2 Solvent Tanks S1-S22 ........................................................ 3

1.2.3 Expansion Areas of the Old Radioactive Waste Burial Ground ............. 4

1.3 Computerized Burial Record Analysis ............................................... 5

1.4 Constituents of Interest and Recent Source Term Investigations ..................6

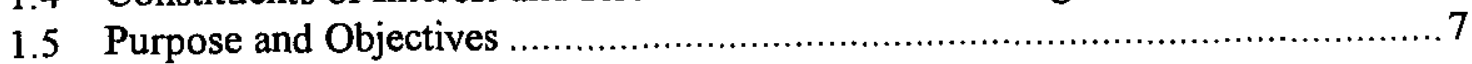

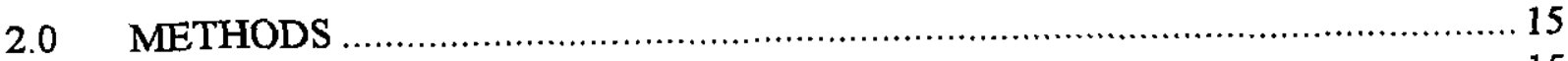

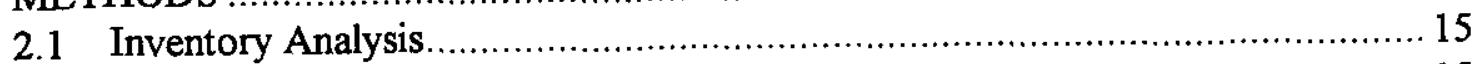

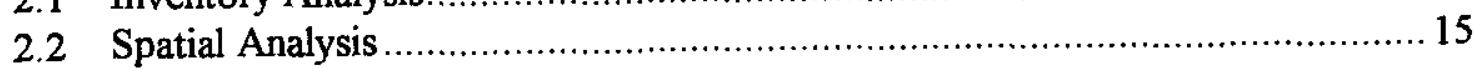

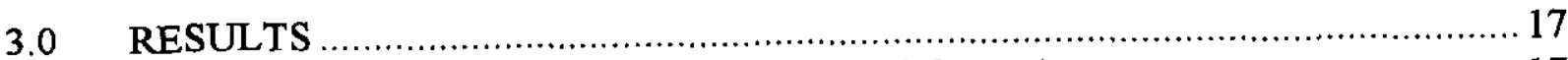

3.1 Inventory Analysis for the Original Burial Ground …........................... 17

3.2 Potential "Hot Spots" for Solvent Tanks S1-S22 .................................. 19

3.3 Inventory Analysis and Potential "Hot Spots" for Nonradioactive

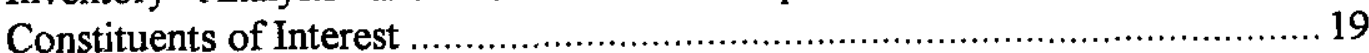

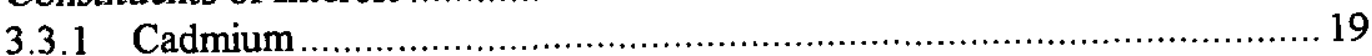

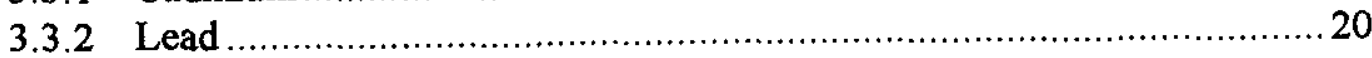

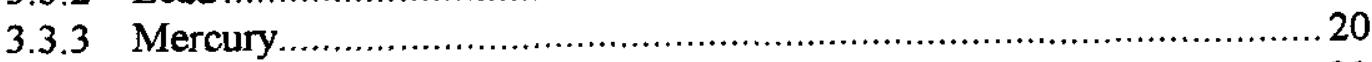

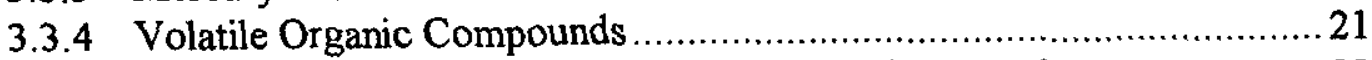

3.4 Analysis of COBRA Inventory of Radioactive Constituents of Interest ...........23

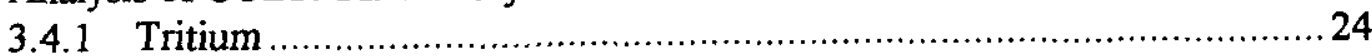

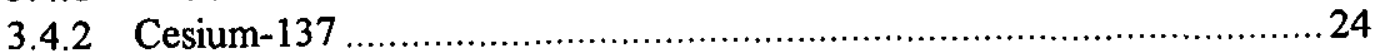

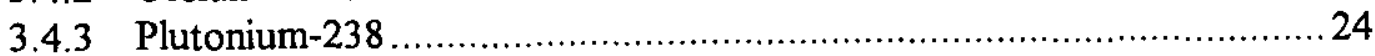

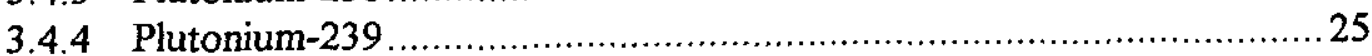

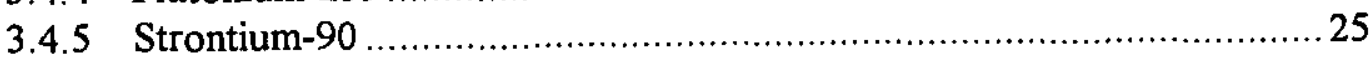

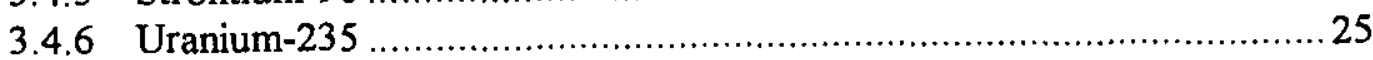

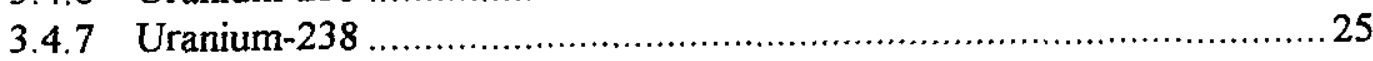

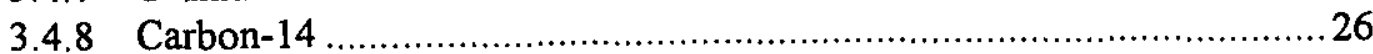

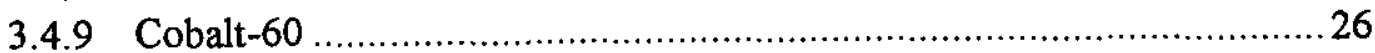

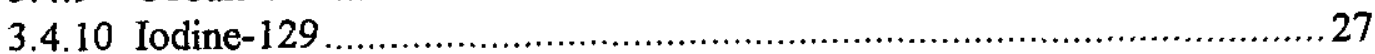

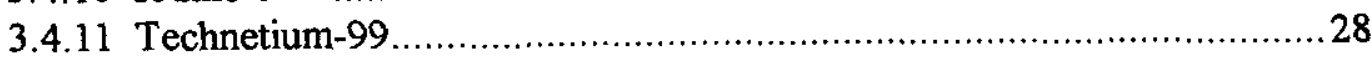

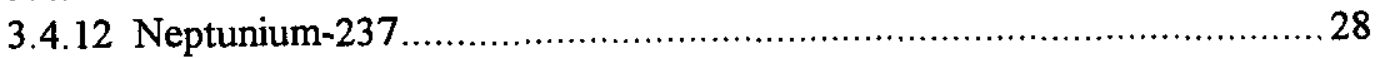




\section{TABLE OF CONTENTS (Continued)}

3.5 Potential "Hot Spots" for Radioactive Constituents of Interest .................... 29

3.5.1 Potential "Hot Spots" 100 at Years After Burial ............................. 31

3.5.1.1 Potential "Hot Spot" 1 ............................................. 31

3.5.1.2 Potential "Hot Spot" 2 …....................................... 32

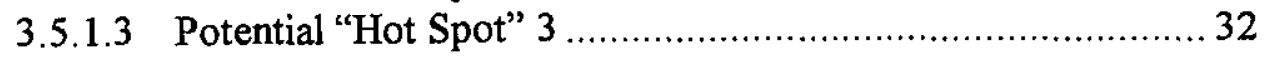

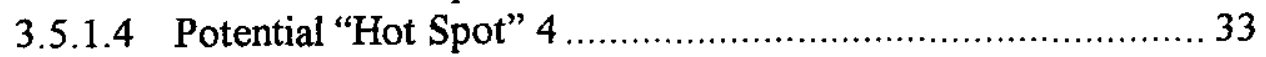

3.5.1.5 Potential "Hot Spot" 5 .................................................. 33

3.5.1.6 Potential "Hot Spot" 6 ................................................... 34

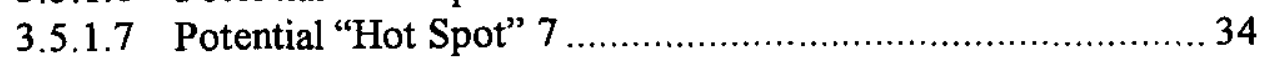

3.5.1.8 Potential "Hot Spot" 8 ............................................. 35

3.5.1.9 Potential "Hot Spot" 9 ................................................ 35

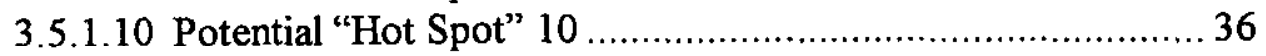

3.5.1.11 Potential "Hot Spot" 11 ................................................... 36

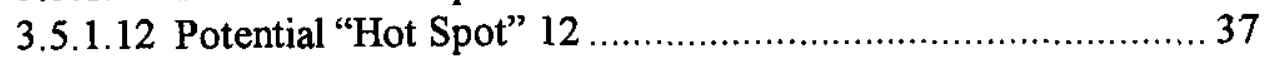

3.5.1.13 Potential "Hot Spot" 13 .................................................. 37

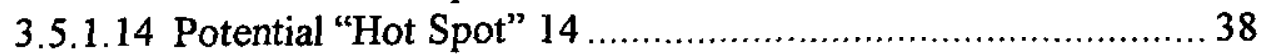

3.5.1.15 Potential "Hot Spot" 15 ........................................... 38

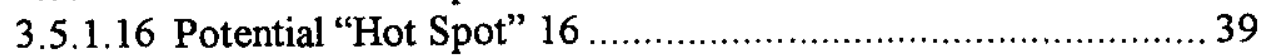

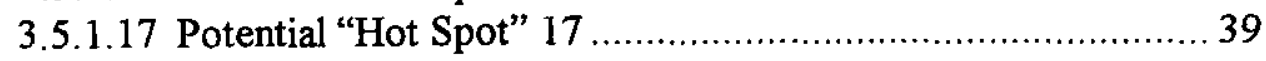

3.5.1.18 Potential "Hot Spot" 18 ................................................. 40

3.5.1.19 Potential "Hot Spot" 19 .............................................. 40

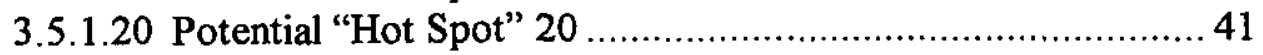

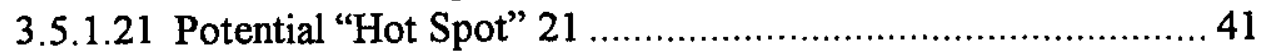

3.5.2 Potential "Hot Spots" at 300 and 500 Years After Burial ................... 42

3.5.2.1 Potential "Hot Spot" 1 ........................................... 42

3.5.2.2 Potential "Hot Spot" 2 .............................................. 42

3.5.2.3 Potential "Hot Spot" 3 ............................................... 43

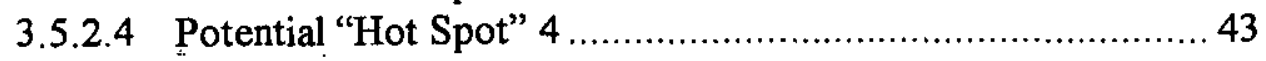

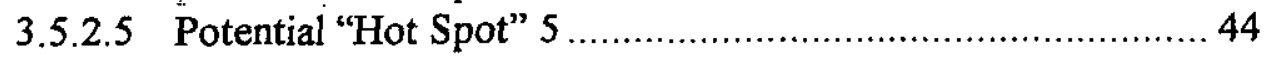

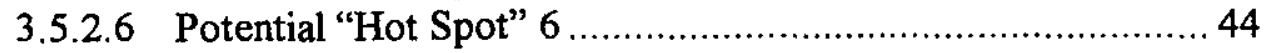

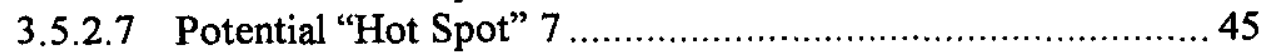

3.5.2.8 Potential "Hot Spot" 8 ......................................... 45

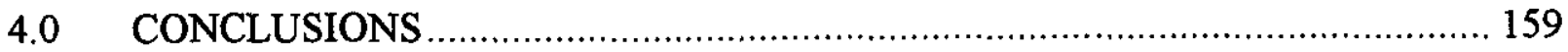

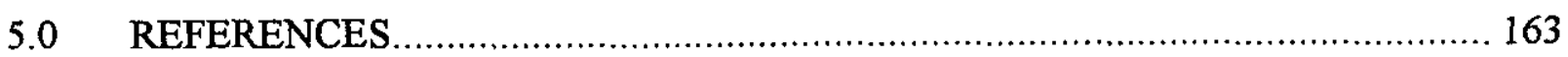




\section{LIST OF FIGURES}

ES-1 Potential "Hot Spots" at 100 Years After Burial............................................ ES-11

ES-2 Composite Map of Potential "Hot Spots" for All COIs ................................ ES-12

1-1 Location Map for the Burial Ground Complex .......................................... 9

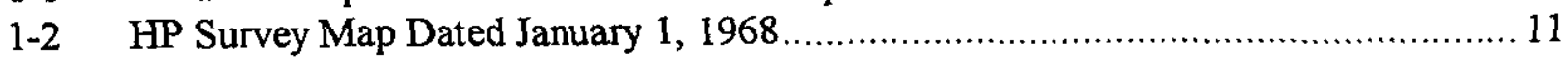

1-3 Locations of Solvent Tanks S1-S22 and Solvent Burning Trenches ....................... 13

3-1 Potential "Hot Spots" for Solvent Tanks S1-S22 ......................................... 47

3-2 Distribution of Mercury Burials.......................................................... 48

3-3 Distribution of VOC Burials ................................................................ 49

3-4 Decay Forecast for COBRA Inventory of Radioactive COIs............................50

3-5 Summary of COBRA Inventory for Radioactive COIs at Time of Burial................. 51

3-6 Summary of COBRA Inventory for Radioactive COIs at 25 Years After Burial....... 52

3-7 Summary of COBRA Inventory for Radioactive COIs at 50 Years After Burial.......53

3-8 Summary of COBRA Inventory for Radioactive COIs at 100 Years After Burial ......54

3-9 Summary of COBRA Inventory for Radioactive COIs at 300 Years After Burial...... 55

3-10 Summary of COBRA Inventory for Radioactive COIs at 500 Years After Burial ..... 56

3-11 Summary of COBRA Inventory for Radioactive COIs at 1,000 Years After Burial ... 57

3-12 Summary of COBRA Inventory for Radioactive COIs at 5,000 Years After Burial ... 58

3-13 Summary of COBRA Inventory for Radioactive COIs

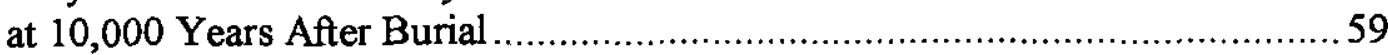

3-14 Potential "Hot Spots" at 100 Years After Burial ...............................................60

3-15 Potential "Hot Spots" at 300 Years After Burial.................................................61

3-16 Potential "Hot Spots" at 500 Years After Burial...........................................62

4-1 Composite Map of Potential "Hot Spots" for all COIs ................................. 161 


\section{LIST OF TABLES}

ES-1 Constituents of Interest (COIs) for the Old Radioactive Waste

Burial Ground (ORWBG)

ES-13

1-1 Constituents of Interest (COIs) for the Old Radioactive Waste

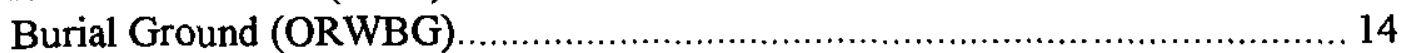

3-1 Summary of COBRA Inventory Data for Nonradioactive COIs .......................6 63

3-2 Summary of COBRA Inventory Data for Radioactive COIs .............................6 64

3-3 Summary of Location Data in COBRA by Data of Burial Slip ............................. 65

3-4 Summary of Estimated COI Inventories for the Original Burial Ground

and Solvent Tanks S1-S22 ...........................................................6. 66

3-5 Radioactive Decay of COIs to 10,000 Years After Burial ..................................67 67

3-6 Decay Forecast for Inventory of Radioactive COIs in the Original Burial Ground ..... 68

3-7 Summary of Distribution of Burial Locations for Mercury and VOCs .....................6.69

3-8 Decay Forecast for Total Inventory of Radioactive COIs in the ORWBG .............. 70

3-9 COI Activity in the ORWBG at 500 and 10,000 Years After Burial ...................... 71

3-10 Summary Statistics for COBRA Inventory of Potential "Hot Spot" HS-100-1 ......... 72

3-11 Decay Forecast for COBRA Inventory for Potential "Hot Spot" HS-100-1 ............ 73

3-12 Summary Statistics for COBRA Inventory of Potential "Hot Spot" HS-100-2 ......... 75

3-13 Decay Forecast for COBRA Inventory for Potential "Hot Spot" HS-100-2 ............ 76

3-14 Summary Statistics for COBRA Inventory of Potential "Hot Spot" HS-100-3 .......... 78

3-15 Decay Forecast for COBRA Inventory for Potential "Hot Spot" HS-100-3 ............ 79

3-16 Summary Statistics for COBRA Inventory of Potential "Hot Spot" HS-100-4 ......... 81

3-17 Decay Forecast for COBRA Inventory for Potential "Hot Spot" HS-100-4 ............ 82

3-18 Summary Statistics for COBRA Inventory of Potential "Hot Spot" HS-100-5 ......... 84

3-19 Decay Forecast for COBRA Inventory for Potential "Hot Spot" HS-100-5 ............ 85

3-20 Summary Statistics for COBRA Inventory of Potential "Hot Spot" HS-100-6 ......... 87

3-21 Decay Forecast for COBRA Inventory for Potential "Hot Spot" HS-100-6 ............ 88

3-22 Summary Statistics for COBRA Inventory of Potential "Hot Spot" HS-100-7 ......... 90

3-23 Decay Forecast for COBRA Inventory for Potential "Hot Spot" HS-100-7 ............. 91

3-24 Summary Statistics for COBRA Inventory of Potential "Hot Spot" HS-100-8 .......... 93

3-25 Decay Forecast for COBRA Inventory for Potential "Hot Spot" HS-100-8 ............ 94

3-26 Summary Statistics for COBRA Inventory of Potential "Hot Spot" HS-100-9 .......... 96

3-27 Decay Forecast for COBRA Inventory for Potential "Hot Spot" HS-100-9 ............. 97

3-28 Summary Statistics for COBRA Inventory of Potential "Hot Spot" HS-100-10 ........99

3-29 Decay Forecast for COBRA Inventory for Potential "Hot Spot" HS-100-10 ......... 100

3-30 Summary Statistics for COBRA Inventory of Potential "Hot Spot" HS-100-11 ...... 102

3-31 Decay Forecast for COBRA Inventory for Potential "Hot Spot" HS-100-11 ......... 103

3-32 Summary Statistics for COBRA Inventory of Potential "Hot Spot" HS-100-12 ...... 105

3-33 Decay Forecast for COBRA Inventory for Potential "Hot Spot" HS-100-12 .......... 106

3-34 Summary Statistics for COBRA Inventory of Potential "Hot Spot" HS-100-13 ...... 108

3-35 Decay Forecast for COBRA Inventory for Potential "Hot Spot" HS-100-13 .......... 109

3-36 Summary Statistics for COBRA Inventory of Potential "Hot Spot" HS-100-14 ...... 111

3-37 Decay Forecast for COBRA Inventory for Potential "Hot Spot" HS-100-14 .......... 112

3-38 Summary Statistics for COBRA Inventory of Potential "Hot Spot" HS-100-15 ...... 114 


\section{LIST OF TABLES (Continued)}

3-39 Decay Forecast for COBRA Inventory for Potential "Hot Spot" HS-100-15 _......... 115

3-40 Summary Statistics for COBRA Inventory of Potential "Hot Spot" HS-100-16 ...... 117

3-41 Decay Forecast for COBRA Inventory for Potential "Hot Spot" HS-100-16 .......... 118

3-42 Summary Statistics for COBRA Inventory of Potential "Hot Spot" HS-100-17 ...... 120

3-43 Decay Forecast for COBRA Inventory for Potential "Hot Spot" HS-100-17 ......... 121

3-44 Summary Statistics for COBRA Inventory of Potential "Hot Spot" HS-100-18 ...... 123

3-45 Decay Forecast for COBRA Inventory for Potential "Hot Spot" HS-100-18 .......... 124

3-46 Summary Statistics for COBRA Inventory of Potential "Hot Spot" HS-100-19 ...... 126

3-47 Decay Forecast for COBRA Inventory for Potential "Hot Spot" HS-100-19 ........... 127

3-48 Summary Statistics for COBRA Inventory of Potential "Hot Spot" HS-100-20 ...... 129

3-49 Decay Forecast for COBRA Inventory for Potential "Hot Spot" HS-100-20 .......... 130

3-50 Summary Statistics for COBRA Inventory of Potential "Hot Spot" HS-100-21 ...... 132

3-51 Decay Forecast for COBRA Inventory for Potential "Hot Spot" HS-100-21 ........... 133

3-52 Summary Statistics for COBRA Inventory of Potential "Hot Spots"

HS-300-1 and HS-500-1 ....................................................... 135

3-53 Decay Forecast for COBRA Inventory of Potential "Hot Spots"
HS-300-1 and HS-500-1

3-54 Summary Statistics for COBRA Inventory of Potential "Hot Spots"

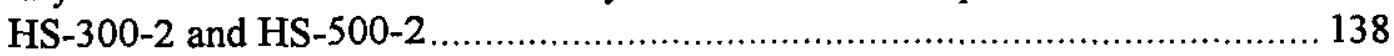

3-55 Decay Forecast for COBRA Inventory of Potential "Hot Spots"

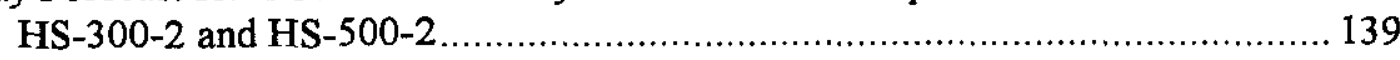

3-56 Summary Statistics for COBRA Inventory of Potential "Hot Spots"

HS-300-3 and HS-500-3 ................................................................. 141

3-57 Decay Forecast for COBRA Inventory of Potential "Hot Spots"

HS-300-3 and HS-500-3 ......................................................... 142

3-58 Summary Statistics for COBRA Inventory of Potential "Hot Spots"

HS-300-4 and HS-500-4 ............................................................. 144

3-59 Decay Forecast for COBRA Inventory of Potential "Hot Spots"

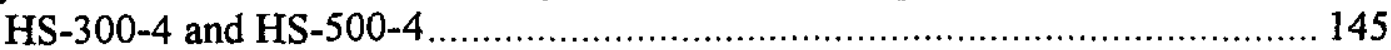

3-60 Summary Statistics for COBRA Inventory of Potential "Hot Spots"

HS-300-5 and HS-500-5 .............................................................. 147

3-61 Decay Forecast for COBRA Inventory of Potential "Hot Spots"
HS-300-5 and HS-500-5 $\ldots \ldots \ldots \ldots \ldots \ldots \ldots \ldots \ldots \ldots \ldots \ldots \ldots \ldots \ldots \ldots \ldots \ldots \ldots \ldots \ldots \ldots \ldots \ldots \ldots \ldots \ldots \ldots \ldots \ldots \ldots \ldots \ldots \ldots \ldots \ldots \ldots \ldots$

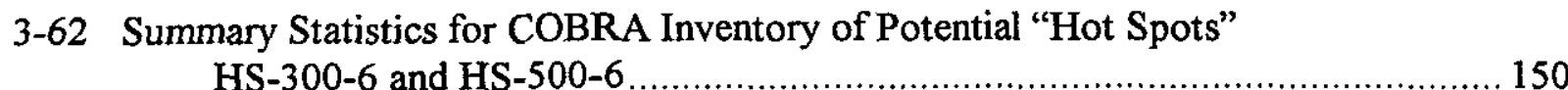

3-63 Decay Forecast for COBRA Inventory of Potential "Hot Spots"

3-64 Summary Statistics for COBRA Inventory of Potential "Hot Spots"

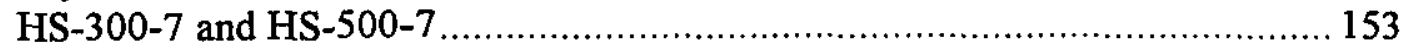

3-65 Decay Forecast for COBRA Inventory of Potential "Hot Spots"

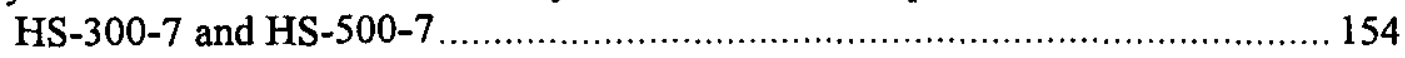




\section{LIST OF TABLES (Continued)}

3-66 Summary Statistics for COBRA Inventory of Potential "Hot Spots"

HS-300-8 and HS-500-8.

3-67 Decay Forecast for COBRA Inventory of Potential "Hot Spots"

HS-300-8 and HS-500-8.

4-1 Summary of Estimated COI Inventory for the Original Burial Ground,

Solvent Tanks (S1-S22) and Potential "Hot Spots". 


\section{LIST OF APPENDICES}

A Summary of Source Term 


\section{LIST OF ACRONYMS}

COBRA

COI

CSV

EDTA

HP

ORWBG

OST

PUREX

RCRA

RFI/RI

SRS

SRTC

TRU

VOC

WSRC
Computerized Burial Record Analysis (Database)

Constituent of Interest

Comma-Separated Variable

Ethylenediaminetetraacetic Acid

Health Physics

Old Radioactive Waste Burial Ground

Old Solvent Tank

Plutonium-Uranium Extraction

Resource Conservation and Recovery Act

RCRA Facility Investigation/Remedial Investigation

Savannah River Site

Savannah River Technology Center

Transuranic

Volatile Organic Compounds

Westinghouse Savannah River Company 


\section{EXECUTIVE SUMMARY}

\section{Purpose and Objectives}

This report identifies potential "hot spots" that may require special feasibility assessment in the development of a final remedy for the Old Radioactive Waste Burial Ground (ORWBG). The identification of potential "hot spots" is based on the following criteria:

- High concentrations and/or high levels of radioactivity

- Persistence of high radioactivity levels through time

- Burial type

- Waste form

- Mobility

Both radioactive and nonradioactive Constituents of Interest (COIs) have been considered. Table ES-1 summarizes the COIs for the ORWBG, and the rationale used to select them. Radioactive COIs have been analyzed in terms of radioactivity levels and their persistence through time. Identification of potential "hot spots" for nonradioactive COIs has been based primarily on waste form, and the density of burials at a given location.

\section{Methods}

\section{Inventory Analysis}

In this study, available inventory data (WSRC, 1997) were compiled and analyzed for applicability to determining quantity and location of the COIs. The recent source-term study conducted by WSRC (1997) estimates the inventory for each COI at the ORWBG. Appendices A-P of WSRC (1997) provide explanations for the basis of each source-term estimate. The estimated inventory is compared with available documentation in the Computerized Burial Record Analysis (COBRA) database and other resources. Many records in COBRA refer to the same grid coordinates, and many individual burial records are associated with more than one COI. For this inventory analysis, the COBRA records for each COI were sorted and combined to create a data set containing the total quantity of each COI for each burial location. 
An accurate inventory analysis for the radioactive COIs must include a calculation of changes to the inventory due to decay. A forecast of temporal changes to the $\mathrm{COI}$ inventory is key to determining which radioactive constituents remain at high concentrations over long periods of time. In general, radioactive COIs with short half-lives have high activity. These COIs create the majority of the total radioactivity during a "near-term" period, but their relative contributions to the inventory will decrease over time. Analysis of temporal changes to the inventory of individual constituents determines which radioactive COIs may be considered principal contributors. To accomplish this, standard decay constants were used to calculate the percentage of each COI that remains after certain periods of time. The ORWBG received approximately 300,000 to 500,000 cubic feet of radioactive waste per year from 1951 through 1973 (WSRC, 1997). For the purposes of this analysis, the time of burial for the entire COI inventory is set at 1973, the last year the ORWBG received waste.

\section{Spatial Analysis}

Spatial analysis combines the inventory estimates for the COIs with location information from COBRA to determine if any areas within the ORWBG exhibit pronounced levels of COI concentration or activity. In this method, spatial data for the COI inventory are derived through queries of COBRA. The data are compiled into maps to illustrate the distribution of COI burials with locations recorded in COBRA. To create the maps, COBRA data are downloaded into Excel spreadsheets and saved in comma-separated variable (CSV) format for loading into spatial-analysis software. The study utilized EarthVision software to plot maps of the distribution of burials related to the COIs.

Maps of COI distribution were examined to ascertain whether any specific areas possess relatively high concentrations of COI burials. In such areas, the distribution of the constituent COIs of the group were reviewed, individually if necessary, to identify which individual COIs contributed significantly to the potential "hot spot."

Potential "hot spots" for the inventory of radioactive COIs areas were then selected, and their coordinates recorded. The coordinates of the boundaries of the potential "hot spots" were used to query the COBRA database, generating a list of burial records included within each potential "hot spot". The lists are summarized to determine the physical attributes of the potential "hot spot", such as the quantity, types, and volume of buried waste.

Because this type of analysis relies on location information, it can only be performed for those COIs that have COBRA records with grid coordinates. Because the original burial ground 
received the bulk of its contents prior to the implementation of COBRA, its assessment is restricted to inventory analysis only.

\section{Results}

Potential "hot spots" were analyzed in three categories based on the types and quantity of available data: Old Solvent Tanks (S1-S22) (OSTs), nonradioactive COIs and radioactive COIs. Figures ES-1 and ES-2 illustrate the locations and areal extent of the "hot spot" areas.

\section{Potential "Hot Spots" for Radioactive Constituents of Interest}

Potential radioactive "hot spots" have been identified in areas of the ORWBG where the COI activity level exceeds 60 curies within a single grid cell. The 60 curies per cell criterion represents two standard deviations above the mean of the data (total COI radioactivity in the ORWBG) at 100 years. This method essentially identifies the highest 5 percent of the COI activity in the ORWBG.

At the time of burial, COI-bearing waste contributed approximately 5.1 million curies of activity to the total COI inventory. Approximately $58 \%(3,014,457$ curies) of the activity is attributed to tritium and $37 \%(1,960,400$ curies $)$ is attributed to cobalt- 60 . Both of these COIs are relatively short-lived isotopes. After 100 years, the total activity will decay to less than $1 \%(36,634$ curies $)$ of the original level.

After 500 years, the total activity will drop to $0.1 \%$ (5,440 curies) of the original level and be associated primarily with carbon-14 (3,556 curies), plutonium-238 (390 curies), and plutonium-239 (1,454 curies)(Table 3-8). Of the COI activity remaining after 500 years of decay, approximately $80 \%$ (4,370 curies) will be contained within eight "hot spots" (Figure ES-2).

Spatial analysis of the burial locations and activity levels for the radioactive COIs indicates 21 potential "hot spots" after 100 years of burial (Figure ES-1). Radioactive decay reduces these to only eight potential "hot spots" after 300 years of burial. These potential "hot spots" are shown in Figure ES-2. The configuration of the hot spots at 300 years is identical to those delineated for 500 years after burial (Figure ES-2). The potential "hot spots" identified at 300 and 500 years should be considered the "principal" potential "hot spots" because of their persistent, high activity_levels. The configuration of these principal "hot spots" is due to the 
persistence of carbon-14, plutonium-238, and plutonium-239. The waste forms associated with these principal COIs are deionizer units that contain carbon-14, and retrievable TRU waste and concrete-encapsulated burials that contain plutonium-238 and plutonium-239.

\section{Potential "Hot Spots" for Old Solvent Tanks S1-S22}

Volatile organic compounds (VOCs) are the primary COI associated with the OSTs and are contained in solvents, sludge, and their degradation products.

An operational history and data for waste form and inventory of the OSTs are presented in WSRC (1996) and WSRC (1997). Solvent Tanks S1-S22 are considered a potential "hot spot" because remediation of liquid and sludge in the underground tanks could be substantially different from remediation of the waste in the "landfill style" burials in the remainder of the ORWBG. Potential "hot spots" for the OSTs are represented by unshaded polygons in Figure ES-2.

\section{Potential "Hot Spots" for Nonradioactive Constituents of Interest}

The data for burial locations of mercury and VOCs were extracted from COBRA and sorted to determine the number of individual burials recorded at each grid cell. Maps of these data were used to delineate potential "hot spots" by examining the distribution and number of burials recorded at each grid cell location.

Figure ES-2 indicates one area that contains a large concentration of burials associated with mercury. The potential mercury "hot spot" (HS-Hg-1) is located in the southern half of the eastern expansion area of the ORWBG. The pattern of burials within this potential "hot spot" is consistent with the reported configuration of trenches in this part of the ORWBG 


\section{Summary of Potential "Hot Spots"}

"Hot Spot" for the Old Solvent Tanks (S1-S22):

- 7,539 gallons of VOCs in 22 individual tanks

- Radioactive COIs include:

Strontium-90

Cesium-137

Uranium-235 and -238

Plutonium-238 and -239

\section{Hot Spot HS-Hg-1 (mercury):}

- 122,500 square feet in area

- Contains an estimated 5,325 pounds of mercury in 71 recorded burials

Hot Spot HS-500-1:

- 23,000 square feet in area

- 18,339 cubic feet of waste in 754 burials

- Primary waste forms (by volume):

$\begin{array}{ll}\text { Job control waste } & 56 \% \\ \text { Capital equipment waste } & 29 \% \\ \text { Irradiated scrap metal } & 15 \%\end{array}$

- Activity (curies):

11,316 at time of burial

5,550 after 100 years

1,754 after 300 years

968 after 500 years

- Persistent COIs:

Carbon-14 in deionizer units

Plutonium-239 in retrievable TRU waste

Plutonium-238 in retrievable TRU waste 
Hot Spot HS-500-2:

- 4,500 square feet in area

- 49,743 cubic feet of waste in 645 burials

- Primary waste forms (by volume):

Job control waste $98 \%$

Capital equipment waste $1 \%$

Irradiated scrap metal $1 \%$

- Activity (curies):

$\begin{aligned} 16,010 & \text { at time of burial } \\ 165 & \text { after } 100 \text { years } \\ 107 & \text { after } 300 \text { years } \\ 106 & \text { after } 500 \text { years }\end{aligned}$

- Persistent COIs:

Plutonium-239 in retrievable TRU waste

Hot Spot HS-500-3:

- 4,500 square feet in area

- 33,256 cubic feet of waste in 237 burials

- Primary waste forms (by volume):

$\begin{array}{lr}\text { Job control waste } & 94 \% \\ \text { Naturally Radioactive Material } & 3 \% \\ \text { Capital equipment waste } & 1 \% \\ \text { Irradiated Scrap Metal } & 1 \% \\ \text { Oil } & 1 \%\end{array}$

- Activity (curies):

571 at time of burial

77 after 100 years

74 after 300 years

72 after 500 years

- Persistent COIs:

Carbon-14 in deionizer units 


\section{Hot Spot HS-500-4:}

- 13,700 square feet in area

- 33,702 cubic feet of waste in 685 burials

- Primary waste forms (by volume):

Job control waste $\quad 97 \%$

Naturally Radioactive Material $\quad 3 \%$

- Activity (curies):

5,761 at time of burial

2,805 after 100 years

872 after 300 years

474 after 500 years

- Persistent COIs:

Plutonium-238 in retrievable TRU waste

Plutonium-239 in retrievable TRU waste

\section{Hot Spot HS-500-5:}

- 23,000 square feet in area

- 35,019 cubic feet of waste in 880 burials

- Primary waste forms (by volume):

Irradiated Scrap Metal $\quad 75 \%$

Job control waste $\quad 22 \%$

Capital equipment waste $\quad 3 \%$

- Activity (curies):

140,862 at time of burial

1,102 after 100 years

649 after 300 years

630 after 500 years

- Persistent COIs:

Carbon-14 in deionizer units

Hot Spot HS-500-6:

- 65,000 square feet in area

- 196,226 cubic feet of waste in 3,629 burials 
- Primary waste forms (by volume):

$\begin{array}{lr}\text { Irradiated Scrap Metal } & 50 \% \\ \text { Job control waste } & 40 \% \\ \text { Capital equipment waste } & 9 \% \\ \text { Naturally Radioactive Material } & 1 \%\end{array}$

- Activity (curies):

$\begin{aligned} 511,437 & \text { at time of burial } \\ 4,148 & \text { after } 100 \text { years } \\ 1,868 & \text { after } 300 \text { years } \\ 1,707 & \text { after } 500 \text { years }\end{aligned}$

- Persistent COIs:

Carbon-14 in deionizer units

Hot Spot HS-500-7:

- 4,500 square feet in area

- 14,230 cubic feet of waste in 516 burials

- Primary waste forms (by volume):

Irradiated Scrap Metal

$81 \%$

Job control waste

$19 \%$

- Activity (curies):

99,660 at time of burial

664 after 100 years

428 after 300 years

417 after 500 years

- Persistent COI:

Carbon-14 in deionizer units

Hot Spot HS-500-8:

- 22,000 square feet in area

- 21,406 cubic feet of waste in 767 burials

- Primary waste forms (by volume):

Irradiated Scrap Metal $\quad 90 \%$

Job control waste $\quad 10 \%$

- Activity (curies): 


$$
\begin{aligned}
154,581 & \text { at time of burial } \\
536 & \text { after } 100 \text { years } \\
105 & \text { after } 300 \text { years } \\
96 & \text { after } 500 \text { years }
\end{aligned}
$$

- Persistent COI:

Carbon- 14 in deionizer units

Plutonium-238 in job control waste 
(This page intentionally left blank) 


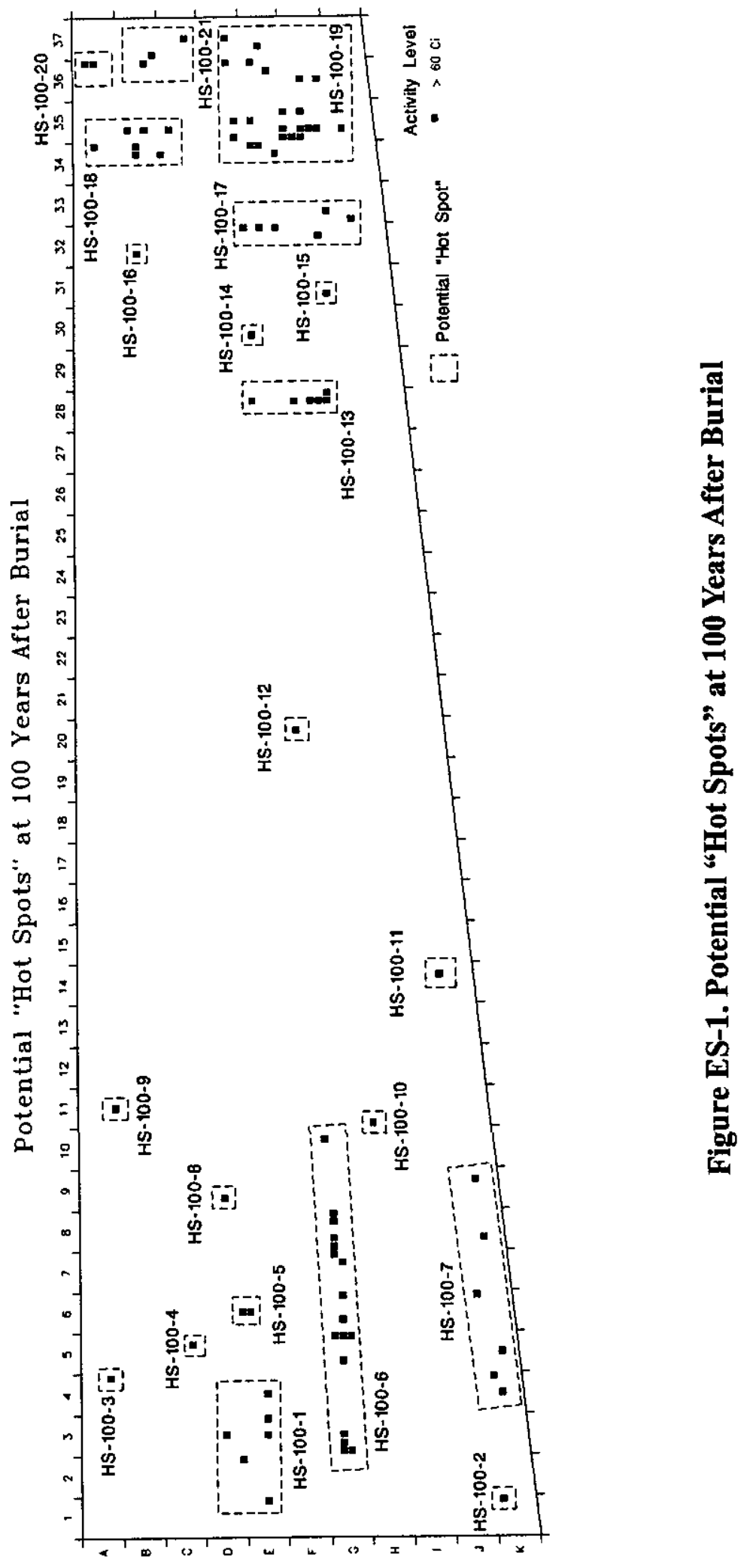




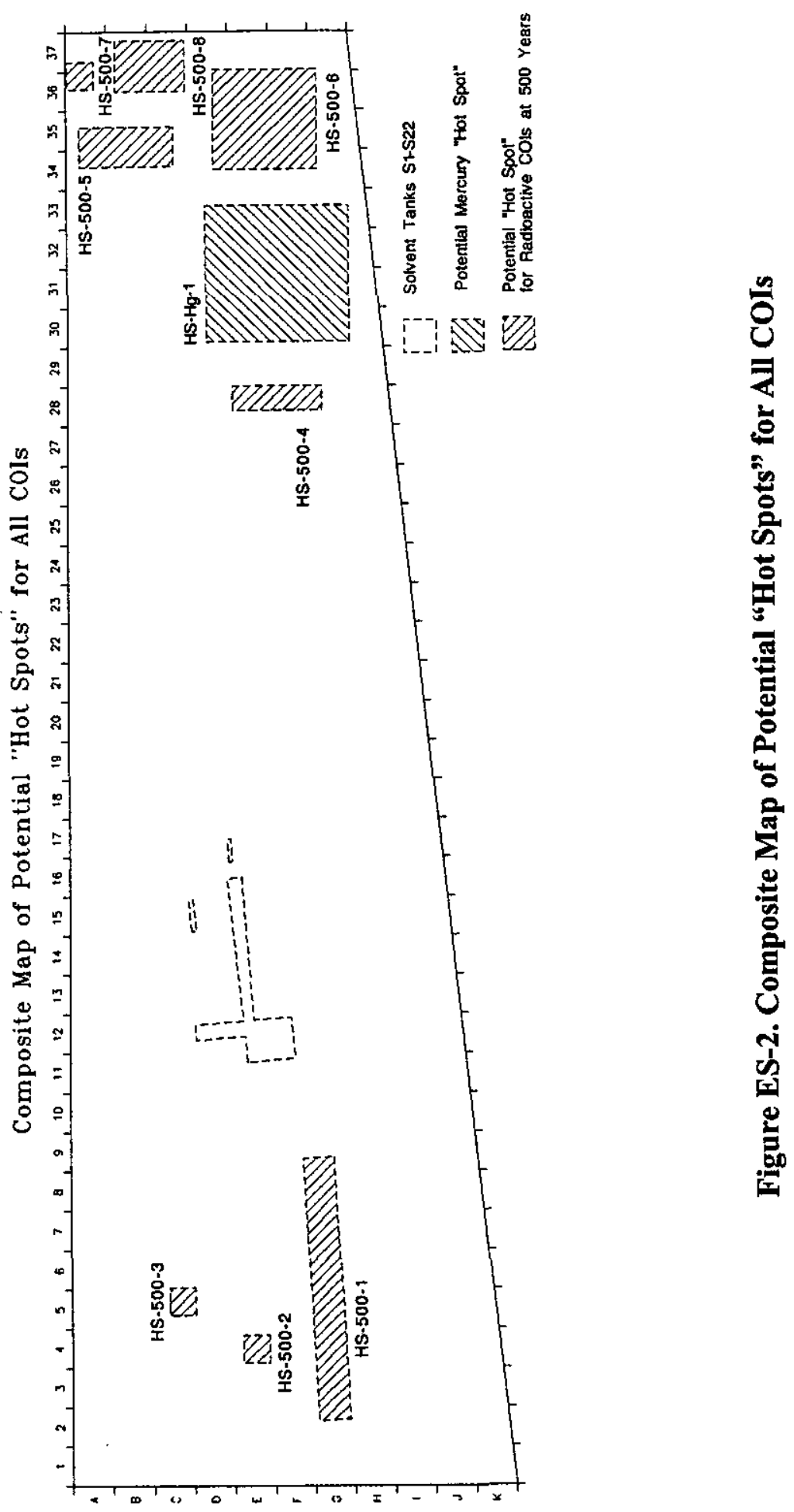


Table ES-1. Constituents of Interest (COIs) for the Old Radioactive Waste Burial Ground (ORWBG)

\begin{tabular}{|c|c|c|c|c|c|c|}
\hline \multicolumn{3}{|c|}{ Nonradioactive } & $\begin{array}{c}\text { Hazardous } \\
\text { Material } \\
\end{array}$ & $\begin{array}{c}\text { High } \\
\text { Mobility }\end{array}$ & $\begin{array}{c}\text { Long- } \\
\text { Lived } \\
\text { (> 25 yr) }\end{array}$ & $\begin{array}{c}\text { Large } \\
\text { Inventory }\end{array}$ \\
\hline 1. & Cadmium & (Cd) & & & & \\
\hline 2. & Lead & $(\mathrm{Pb})$ & & & & \\
\hline 3. & Mercury & $(\mathrm{Hg})$ & & & & \\
\hline 4. & Volatile Organic Compounds & (VOCs) & & & & \\
\hline
\end{tabular}

\section{Radioactive}
5. Tritium
6. Carbon-14
7. Cobalt -60
8. Strontium-90
9. Technetium-99
10. Iodine-129
11. Cesium-137
12. Neptunium-237
13. Uranium-235
14. Uranium-238
15. Plutonium-238
16. Plutonium-239

(Cs-137)

(Np-237)

(Pu-238)

(Pu-239)

\begin{tabular}{|l|l|l|l|}
\hline & 0 & & 0 \\
\hline & 0 & 0 & 0 \\
\hline & & & 0 \\
\hline & & 0 & 0 \\
\hline & 0 & 0 & \\
\hline & 0 & 0 & \\
\hline & & 0 & 0 \\
\hline & & 0 & \\
\hline & & 0 & \\
\hline & & 0 & \\
\hline & & 0 & 0 \\
\hline & & 0 & 0 \\
\hline
\end{tabular}


(This page intentionally left blank) 


\subsection{INTRODUCTION}

The Old Radioactive Waste Burial Ground (ORWBG) (643-E) occupies approximately 76 acres within the General Separations Area in the central Savannah River Site (SRS) (Figure 1-1). It is part of the Burial Ground Complex, which includes the ORWBG and other operable units such as the Mixed Waste Management Facility, the Low Level Radioactive Waste Disposal Facility, Solvent Tanks S1-S22, Solvent Tanks S23-S30, and Solvent Tank 32 (Westinghouse Savannah River Company [WSRC], 1997).

\subsection{Description of Unit}

The ORWBG encompasses an area approximately 3,700 feet in length that is 1,100 feet wide at its west end, and 700 feet wide at its east end. The area lies between Road $E$ and the F-Area railroad (Figure 1-1). An 8-foot-high cyclone fence surrounds the area. A paved road leads to the entrance of the facility and unimproved dirt roads inside the fenced area provide access to burial sites (Figure 1-2).

The ORWBG received waste on a regular basis from 1952 until 1972, when the site was essentially filled and the primary disposal operations shifted to the adjacent site, 643-7E (Figure 1-1). The ORWBG received small quantities of waste (primarily in retrievable form) during 1973 and 1974. The ORWBG area was also used for storage of contaminated equipment. The area included several related facilities and operations, including underground solvent storage tanks, areas used to incinerate organic solvents, and a sandblasting facility for decontamination of equipment.

The ORWBG contains solid radioactive waste produced at SRS, and waste shipments from other United States Department of Energy and Department of Defense facilities. The operational configuration of the ORWBG included different areas to accommodate various levels and types of radioactive waste. The ORWBG inventory consists of transuranic (TRU), low-level, and intermediate-level radioactive waste including the following:

- Incidental waste from laboratory and production operations, including small equipment, used air filters, clothes, analytical waste, decontamination residue, plastic sheeting, gloves, soil, and construction debris

- Contaminated waste including obsolete or failed tanks, pipes, jumpers, and other process equipment from separations facilities in $\mathrm{F}$ and $\mathrm{H}$ Areas

- Lead, as protective shielding, in equipment, lead shot, bricks, and lead sheets 
The recent source term investigation (WSRC, 1997) analyzes the HP maps, construction drawings, and aerial photographs to clarify the burial history of the ORWBG. These data indicate the ORWBG can be subdivided into three burial grounds (WSRC, 1997): (1) the original burial area of the ORWBG that was opened in 1952 and filled by the early 1960s; (2) a 15-acre eastern expansion that was opened around 1961 and closed in 1972; and (3) a 26-acre western expansion that was opened in 1961 and closed in 1974. Figure 1-2 illustrates the approximate boundaries between the three areas. Delineation of the sections is somewhat arbitrary, because burial records indicate that waste was buried concurrently in the original burial ground and in the east and west expansion areas as the central area was filled and phased out of service (WSRC, 1997).

\subsubsection{Original Burial Ground}

The original burial area in the central ORWBG covers approximately 35 acres (Figure 1-2). In the following discussions, this part of the ORWBG is simply referred to as the original burial ground. The original burial ground contains 22 old underground solvent storage tanks (OSTs) and approximately 85 trenches (WSRC, 1997). The original burial ground received waste throughout the period from 1955 through 1973, but was phased out of service when the eastern and western expansion areas opened in 1961 (WSRC, 1997). Most of the waste buried in the original burial ground predates the detailed records of the Computerized Burial Record Analysis (COBRA) database, and only general estimates of waste volume are available. HP maps provide the most useful information on the locations and types of disposals in this part of the ORWBG (WSRC, 1997).

\subsubsection{Solvent Tanks S1-S22}

The 22 OSTs lie within three areas in the central part of the original burial ground (Figure 1-3). Some of these tanks served as fuel storage tanks at SRS and other federal facilities prior to their emplacement in the ORWBG between 1955 and 1968 (WSRC, 1994 and 1996). Prior to 1980, these tanks held hundreds of thousands of gallons of spent PUREX solvent from Separations facilities and smaller amounts of tritiated pump oil. Solvent was allowed to "age" for six months whereupon it was pumped from the tanks and burned in shallow, open pans.

Solvent was pumped from the storage tanks to a 1,400-gallon above-ground feed tank. The solvent moved via gravity feed through a device to prevent flash-back and into the burning 
pans. A line valve was used to regulate the solvent flow to yield a slow, continuous flow to the burning pan (Tharin, 1965).

Burning pans varied in design and composition. The earliest configurations were 6 to 12 inches in depth and made from mild steel and stainless steel, the former material being the most common. The pan design eventually took the form of the longitudinal half of 400gallon, mild steel cylindrical tanks. The pans rested at the bottom of trenches excavated to widths and depths of 20 feet (Figure 2 in Tharin, 1965). The solvent-burning process left a thick, tar-like residue in the pan. When the pan became approximately half-filled with residue (approximately 100 gallons in the later pan designs), it was emptied by crane into the ditch bottom and covered with a layer of soil. The practice of covering the dumped residue with an "umbrella" layer of bentonite was developed in 1961-62. When the pan reached the end of its serviceable life, it was buried in the ditch with the residue (Tharin, 1965).

The burning of solvent and burial of the residue took place within trenches and pits east of the OSTs within the original burial ground (Figure 1-3). More than 380,000 gallons of solvent were burned on a virtually continual basis from February 1956 up until the practice was suspended by Executive Order 11507 in February 1972 (WSRC, 1996). The contents of the OSTs, except for "unpumpable heel", were transferred to new storage tanks in the New Burial Ground (643-7E) in the late 1970s and early 1980s (WSRC, 1996).

\subsubsection{Expansion Areas of the Old Radioactive Waste Burial Ground}

The eastern expansion area of the present ORWBG covers 16 acres and contains approximately 48 trenches (Figures 1-1 and 1-2). It was phased into service as the original burial ground was filled, and received waste from 1961 until 1973. The COBRA database records contain most of the burials in the eastern expansion (WSRC, 1997). Review of HP maps indicates that contaminated equipment and vessels were temporarily stored on the surface at several locations within the eastern expansion (WSRC, 1997). The eastern expansion area included several notable features which are indicated on the HP maps (Figure 1-2). Among these are trenches designated for encapsulated plutonium and an oil drum trench.

The western expansion area of the present ORWBG covers 26 acres and contains approximately 32 trenches (Figures 1-1 and 1-2) (WSRC, 1997). It was opened as the original burial ground reached capacity, and received waste on a regular basis from 1961 until 1973. 
Encapsulated plutonium waste was placed in the western expansion until 1974. The COBRA database records most of the waste in the western expansion (WSRC, 1997).

The western expansion contains several notable disposals: five $234-\mathrm{H}$ special project disposal areas, Charleston Navy Shipyard disposals, a "bunker" with failed equipment from F-Area, and encapsulated plutonium and uranium disposal areas. These burials are discussed in WSRC (1997). HP maps indicate that contaminated equipment and vessels were temporarily stored on the surface at several locations within the western expansion (WSRC, 1997).

\subsection{Computerized Burial Record Analysis}

The most extensive source of information on the ORWBG is the COBRA database, which contains records of waste disposed from 1952 through 1974. The database started in the first quarter of 1961, and historical data were entered for the years from startup through 1960 .

COBRA is based on information contained on "Radioactive Solid Waste Burial Ground Record" forms (OSR 7-375), also referred to as "burial slips". The forms were required for shipments of radioactive waste sent to the ORWBG. COBRA only contains information from these forms. It should be emphasized that radiological waste is the primary focus of COBRA. Information entered on the burial slips did not generally list other material that may now be of concern, such as lead, cadmium, mercury, or volatile organic compounds (VOCs). Where references to nonradioactive materials appear in COBRA, they are incidental comments.

The COBRA database is a valuable aid in determining the operational history of the ORWBG and developing reasonably accurate source term calculations for the radiological contaminants. COBRA is useful for identifying shipments of waste originating from specific buildings, especially after 1961. WSRC (1997) describes and discusses COBRA in detail and draws the following conclusions regarding use of the data:

(1) From 1961 to 1971 , monthly waste volumes typically ranged from 25,000 to 50,000 cubic feet. Yearly waste volumes were fairly uniform, averaging about 300,000 to 500,000 cubic feet (WSRC, 1997).

(2) Many COBRA records do not include the coordinates of the burial location. The burial locations which appears in the COBRA database cover only a part of the operational life of the ORWBG. Location information is generally not available from COBRA for burials prior to 1961 (WSRC, 1997). 
(3) COBRA indicates significant overlap of trench type and waste type both within individual trenches and across trench groups. Individual trenches appear to contain waste assigned to multiple trench types (different COBRA burial codes). For example, a single trench may, over a short distance (or even within a single 20 foot $\times 20$ foot grid cell), contain burials recorded in COBRA as low-level beta-gamma trench, low-level alpha trench, high-level beta-gamma trench, or a combination of the five burial codes that are actually used in COBRA. Most trenches likely contain a variety of waste types. Idealized "grouping" of trenches into "waste areas", such as clusters of low-level, beta-gamma trenches, should be viewed with caution (WSRC, 1997). The trench designations recorded on HP maps are only a general description of the material buried within these areas.

(4) The ORWBG coordinates recorded in COBRA are not "survey grade", and in most cases are probably only accurate to within 20-60 feet of actual burial locations (WSRC, 1997). Burial containers (potentially retrievable TRU) and concrete pours have a relatively high degree of organization within the ORWBG, and their plotted locations are limited to certain trenches (WSRC, 1997).

(5) Individual trenches and/or active parts of trenches can be tracked through time, with moderately good agreement between burial locations and trench boundaries (WSRC, 1997). Operations personnel often approximated the rectilinear ORWBG grid coordinates for burials in trenches with long axes which were oblique to the grid system (Figure 1-2). This is common, particularly in the western part of the burial ground (WSRC, 1997).

\subsection{Constituents of Interest and Recent Source Term Investigations}

Constituents of Interest (COIs) are drawn from the list of hazardous substances known to exist within waste contained in the ORWBG. The COIs for the ORWBG were identified through evaluation of previous characterization and monitoring data, the COBRA database, process history, and historical documentation (WSRC, 1997). The list of COIs includes those radioactive and hazardous substances considered to be the most mobile, those considered to have a large inventory, long-lived radioactive isotopes, and other hazardous material either recorded in COBRA or known to be buried in the ORWBG (Table 1-1).

WSRC (1997) presents the results of a recent source term investigation for the ORWBG. The source term investigation supports the Resource Conservation and Recovery Act (RCRA) 
Facility Investigation/Remedial Investigation (RFI/RI) of the ORWBG by expanding the understanding of the facility and its contents, and represents a detailed evaluation of over 300 key documents. WSRC (1997) integrates the literature review with aerial photographs, construction drawings, burial maps prepared by HP staff, the COBRA database, and interviews with current and former SRS staff to refine information regarding waste volumes and their source; the location and time of burials; waste type, form and leachability; trench type and disposal characteristics; and the variety of contamination. COBRA data were used to determine the inventory and burial locations of each COI. The waste inventory was also estimated independently of the COBRA database, and the present form of the waste was ascertained. Appendices A through P of WSRC (1997) include a summary of burial history, inventory estimate, leachability evaluation, and assumptions used to develop source terms for each of the 16 COIs identified for the ORWBG RFI/RI. A summary of source terms for the COIs as reported in WSRC (1997) appears in Appendix A to this document.

\subsection{Purpose and Objectives}

This report presents an inventory analysis of the concentration of COIs and a spatial analysis of their distribution in the ORWBG in order to identify potential "hot spots" for discussion in the RFI/RI work plan/report. This study uses COBRA data to provide information regarding the location and concentration of $16 \mathrm{COIs}$ in waste materials recorded by the database. This report identifies areas containing relatively high concentrations of COIs that are persistent over an extended time span as potential "hot spots". The study compiles activity levels at the time of burial (ca. 1973), at present (ca. 1997), and at intervals in the future to forecast the temporal changes in radioactivity associated with the COIs in the ORWBG.

The locations of potential "hot spots" for radioactive COIs are used to extract COBRA records for burials located within the areas. These data are sorted and analyzed to characterize the attributes of the waste buried within each potential "hot spot". This spatialanalysis approach to identification of potential "hot spots" applies only to the eastern and western expansion areas because there is virtually no burial location information for the original burial ground. 
(This page intentionally Jeft blank) 


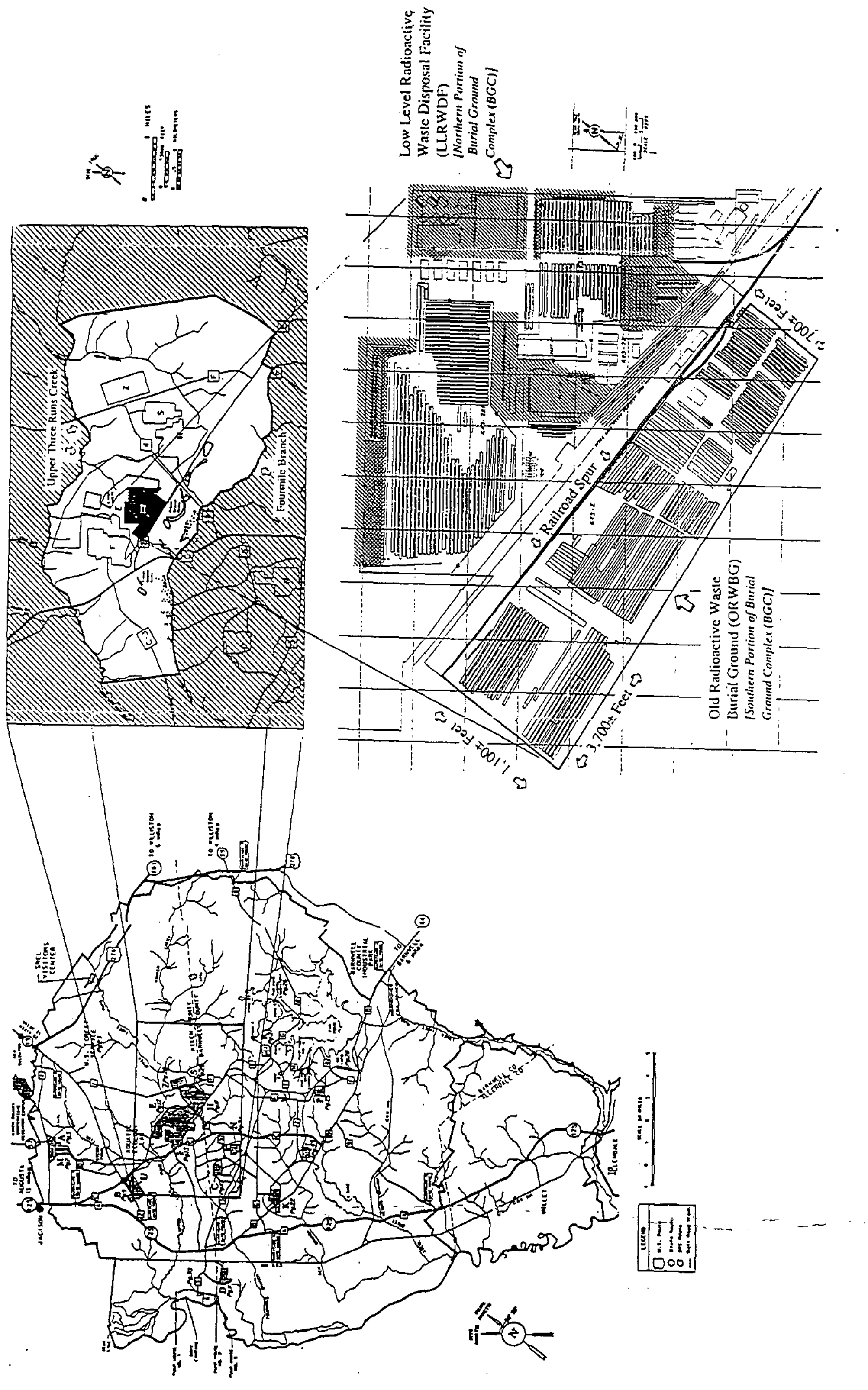

ن⿺辶一 


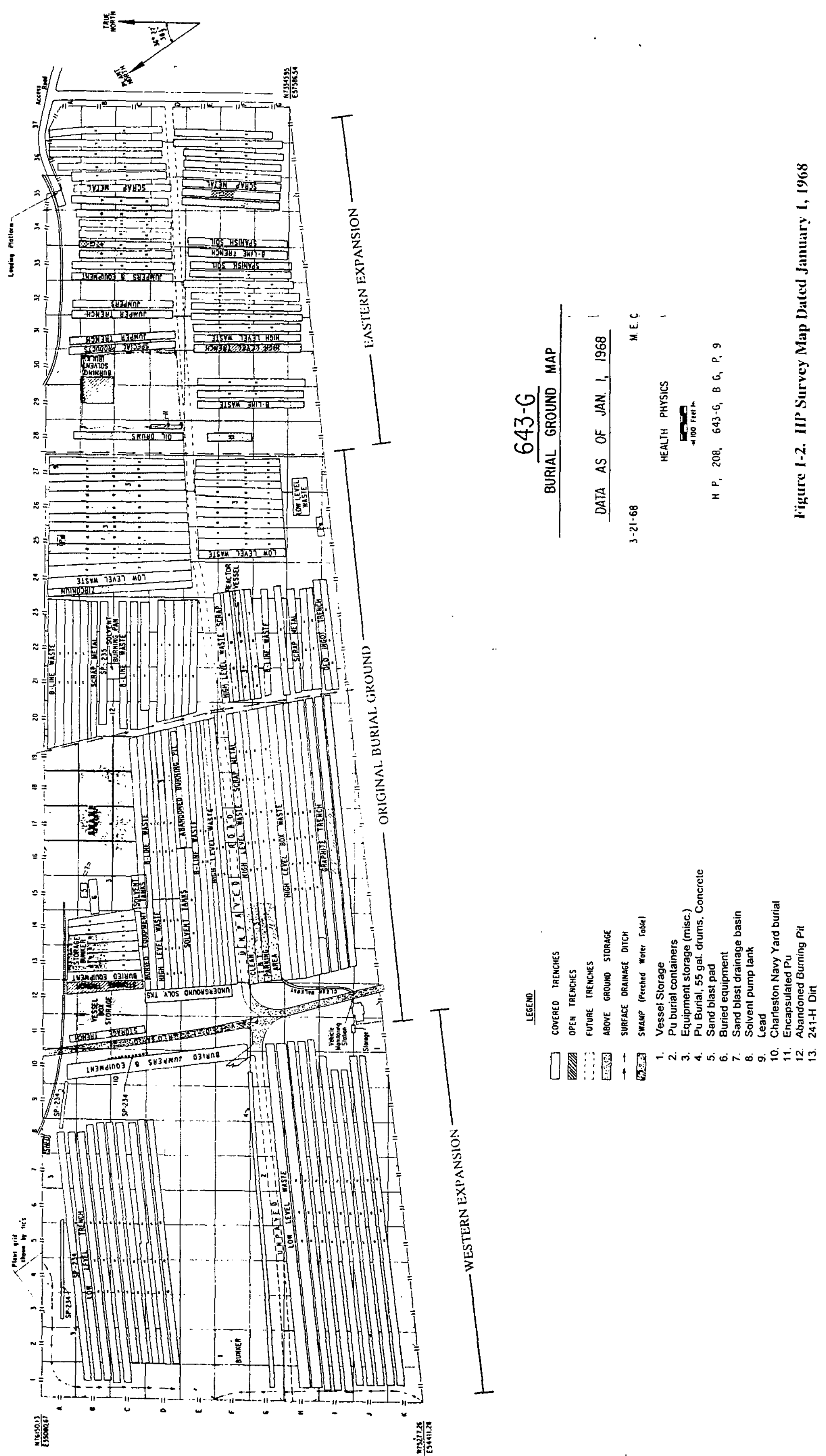

Locations of Solvent Tanks S1-S22 and Solvent Burning Trenches

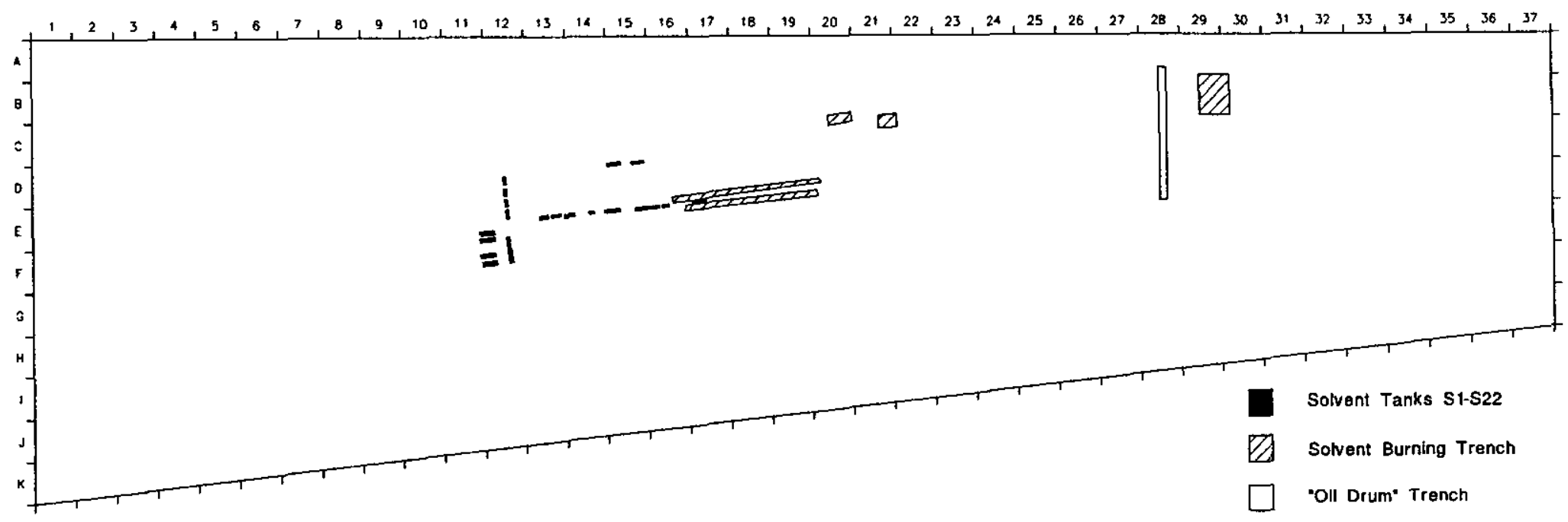

Figure 1-3. Locations of Solvent Tanks S1-S22 and Solvent Burning Trenches 
Table 1-1. Constituents of Interest (COIs) for the Old Radioactive Waste Burial Ground (ORWBG)

\begin{tabular}{|c|c|c|c|c|c|c|}
\hline \multicolumn{3}{|c|}{ Nonradioactive } & $\begin{array}{c}\text { Hazardous } \\
\text { Material }\end{array}$ & $\begin{array}{c}\text { High } \\
\text { Mobility }\end{array}$ & $\begin{array}{c}\text { Long- } \\
\text { Lived } \\
\text { (> 25 yr) }\end{array}$ & $\begin{array}{c}\text { Large } \\
\text { Inventory }\end{array}$ \\
\hline 1. & Cadmium & (Cd) & & & & \\
\hline 2. & Lead & $(\mathrm{Pb})$ & & & & \\
\hline 3. & Mercury & (Hg) & & & & \\
\hline 4. & Volatile Organic Compounds & (VOCs) & & & & \\
\hline \multicolumn{7}{|c|}{ Radioactive } \\
\hline 5. & Tritium & $(\mathrm{H}-3)$ & & & & \\
\hline 6. & Carbon-14 & $(\mathrm{C}-14)$ & & & & \\
\hline 7. & Cobalt -60 & $(\mathrm{Co}-60)$ & & & & \\
\hline 8. & Strontium-90 & $(\mathrm{Sr}-90)$ & & & & \\
\hline 9. & Technetium-99 & (Tc-99) & & & & \\
\hline 10. & Iodine-129 & $(1-129)$ & & & & \\
\hline 11. & Cesium-137 & $(\mathrm{Cs}-137)$ & & & & \\
\hline 12. & Neptunium-237 & $(\mathrm{Np}-237)$ & & & & \\
\hline 13. & Uranium-235 & (U-235) & & & & \\
\hline 14. & Uranium-238 & $(\mathrm{U}-238)$ & & & & \\
\hline 15. & Plutonium-238 & $(\mathrm{Pu}-238)$ & & & & \\
\hline 16. & Plutonium-239 & $(\mathrm{Pu}-239)$ & & & & \\
\hline
\end{tabular}




\subsection{METHODS}

\subsection{Inventory Analysis}

The inventory analysis consisted of evaluating available inventory data (WSRC, 1997) to determine the quantity and location of the COIs, then calculating the changes due to radioactive decay. The recent source-term study conducted by WSRC (1997) estimates the inventory for each COI at the ORWBG. Appendices A through P of WSRC (1997) provide explanations for the basis of each source term estimate. The estimated inventory is compared with available documentation in the COBRA database and other resources. Many records in COBRA refer to the same grid coordinates, and many individual burial records are associated with more than one COI. For this inventory analysis, the COBRA records for each COI were sorted and combined to create a data set containing the total quantity of each COI for each burial location.

An accurate inventory analysis for the radioactive COIs must include a calculation of changes to the inventory due to decay. A forecast of temporal changes to the COI inventory is key to determining which radioactive constituents remain at high concentrations over long periods of time. In general, radioactive COIs with short half-lives have high activity. These COIs create the majority of the total radioactivity during a "near-term" period, but their relative contributions to the inventory will decrease over time. Analysis of temporal changes to the inventory of individual constituents determines which radioactive COIs may be considered principal contributors. Understanding changes in the total radioactivity is useful when assessing potential "hot spot" areas.

To accomplish this, standard decay constants were used to calculate the percentage of each COI that remains after certain periods of time. For this analysis, the time of burial for the entire COI inventory was set at 1973, the last year the ORWBG received waste. The ORWBG received approximately 300,000 to 500,000 cubic feet of radioactive waste per year from 1951 through 1973 (WSRC, 1997). The COI activity levels derived from this analysis should therefore be considered conservative estimates.

\subsection{Spatial Analysis}

The spatial analysis combined the inventory estimates for the COIs with location information from COBRA to determine if any areas within the ORWBG exhibit pronounced levels of COI concentration or activity. Using this method, spatial data for the COI inventory were derived 
through queries of COBRA. The data were compiled into maps to illustrate the distribution of COI burials with locations recorded in COBRA. To create the maps, COBRA data were downloaded into Excel spreadsheets and saved in comma-separated variable (CSV) format for loading into spatial analysis software. The study utilized EarthVision software to plot maps of the distribution of burials related to the COIs.

Maps of COI distribution were examined to ascertain whether any specific areas possess relatively high concentrations of $\mathrm{COI}$ burials. The distribution of the constituent COIs in these areas were reviewed, individually if necessary, to identify which individual COIs contribute significantly to the potential "hot spot." It is possible that a potential "hot spot" may result from a cumulative effect if many relatively small quantities of COIs are buried within a small area.

Potential "hot spots" for the inventory of radioactive COIs areas were selected, and their coordinates recorded. The coordinates of the boundaries of the potential "hot spots" were used to query the COBRA database, generating a list of burial records included within each potential "hot spot". The lists were summarized to determine the physical attributes of the potential "hot spot", such as the quantity, types, and volume of buried waste.

Because this type of analysis relies on location information, it can only be performed for COIs that have COBRA records with grid coordinates. Because the original burial ground received the bulk of its contents prior to the implementation of COBRA, it was assessed using inventory analysis only. 


\subsection{RESULTS}

Analyses of the potential "hot spots" fall into three categories based on the types and quantity of available data: (1) the original burial ground; (2) the OSTs; and (3) the remainder of the ORWBG. The original burial ground was analyzed separately (Section 3.1) because this part of the ORWBG pre-dates COBRA, available data are general, and burial location data are virtually non-existent (WSRC, 1997). The OSTs were considered separately (Section 3.2) because their physical characteristics and operational history set them apart from the rest of the complex. The remainder of the ORWBG was analyzed (Sections 3.3,3.4, and 3.5) using results of the source term investigation (WSRC, 1997) and the data available from COBRA.

Tables 3-1 and 3-2 present estimates of the COI inventory for the original burial ground and the entire ORWBG. The COI inventory for the original burial ground was estimated using assumptions about production rates and process knowledge, as well as the pre-1961 data contained in COBRA. The estimated COI inventory for the entire ORWBG is taken from the source terms calculated in WSRC (1997). Tables 3-1 and 3-2 summarize search criteria and key words used in querying COBRA for burial records associated with each COI, and lists the total number of burial records found for each. Because COBRA does not specifically track all of the COIs, many records were located "manually" by searching on key words and by association with waste types. This methodology, as applied to individual COIs, is described in detail in the appendices to WSRC (1997). Tables 3-1 and 3-2 also compare the estimated source terms from WSRC (1997) with the inventory recorded in the COBRA database.

\subsection{Inventory Analysis for the Original Burial Ground}

The original burial ground within the ORWBG received waste on a regular basis until 1961, when the eastern and western expansion areas opened (WSRC, 1997). COBRA began systematically recording burial data during the first quarter of 1961 (WSRC, 1997). At that time, historical data for waste buried before 1960 were also entered into COBRA (WSRC, 1997). WSRC (1997) indicates that only $54.7 \%$ percent of COBRA records with dates from 1961 include grid coordinates and that the majority of those plot within the eastern and western expansion areas (Figure 2-4 in WSRC, 1997). Table 3-3 summarizes this data in terms of the percentage of COBRA records with grid coordinates for each year of operation for the ORWBG. The dates for opening of the eastern and western expansion areas, initiation of COBRA, and the opening of the new Burial Ground expansion (643-7G) are indicated for reference. 
Table 3-3 indicates that COBRA burial records dated from 1961 are "poorly located" when compared with the same information for subsequent years. For each year after 1961, up through the opening of $643-7 \mathrm{G}$, the located percentage for ORWBG burials exceeded $99 \%$, and did not drop below $90 \%$ until the facility was closed to routine burials in 1973 (Table 3-3). This is probably because the COBRA system requires the use of burial slips, thus encouraging recording of grid coordinates in the process. The very small percentage of nonlocated burials in the years following the implementation of COBRA supports this argument. The trend indicated by Table 3-3 suggests that burial records dated from 1961 that do not have grid coordinates represent waste buried in the original burial ground prior to 1961 and the start-up of COBRA.

The majority of the COBRA records that date from 1961 and lack burial locations are probably not the result of poor record-keeping or clerical enrors, but are likely data for waste buried prior to 1961 . The inventory analysis of the original burial ground presented in this report assumes that the records from 1961 that do not have coordinates represent waste buried in the original burial ground prior to 1961. These records were used in calculating the $\mathrm{COI}$ inventory for the original burial ground. The inventory assumes that all waste received prior to 1961 was buried in the original burial ground.

Most of the burials in the original burial ground that are recorded in COBRA do not have grid coordinates; therefore, the contribution of COIs buried in this area cannot be used in spatial analysis for delineating potential "hot spots". In order to estimate the relative contribution of the original burial ground, separate inventories were calculated for each COI. The results of this estimate and a summary of the assumptions used in the process are presented in Table 3-4. Tables 3-1 and 3-2 compare the estimated inventory for the original burial ground with the total ORWBG inventory.

Table 3-5 presents a summary of the effects of radioactive decay to the radioactive COIs. The table shows what percentage of the original quantity of the COIs will remain after the indicated time intervals. Table 3-6 summarizes the result from applying the percentages in Table 3-5 to the estimated inventory of radioactive COIs in the original burial ground given in Table 3-4. The estimated inventory of radioactive COIs in the original burial ground decays from over one million curies at burial to approximately 9,000 curies after 100 years, and decreases to only 1,800 curies after 300 years (Table $3-6$ ). 


\subsection{Potential "Hot Spots" for Solvent Tanks S1-S22}

The estimated inventory for the OSTs is presented in Table 3-4. Volatile organic compounds contained in the solvents, sludge and their degradation products are the primary COI associated with the OSTs (Table 3-4).

Locations of individual solvent tanks are presented in Figure 1-3. These locations are taken directly from the survey results presented in WSRC (1996). An operational history and data for waste form and inventory are presented in WSRC (1996) and WSRC (1997). Solvent Tanks S1-S22 are considered a potential "hot spot" for the purposes of this report by virtue of the specific information about waste form and inventory, and the well-documented locations of the individual tanks. The polygons (dashed line) in Figure 3-1 represent potential "hot spots" for the OSTs within the ORWBG.

\subsection{Inventory Analysis and Potential "Hot Spots" for Nonradioactive Constituents of Interest}

Table 3-1 presents results of an assessment of inventory data available for the nonradioactive COIs. Although COBRA does not specifically track the nonradioactive COIs, some burial records can be associated with mercury and volatile organic compounds (WSRC, 1997).

\subsubsection{Cadmium}

Cadmium was used at SRS as neutron absorbing material. Its primary use was in reactors as control rods, safety rods, and neutron-shielding sheets (WSRC, 1994). When a reactor was shut down, the control rods and shielding sheets were disposed of in the ORWBG. Control rods were put into disassembly basins for decay of short-lived isotopes and then cut into pieces with an underwater saw. The pieces were placed in a cask, shipped to the ORWBG, and buried in trenches designated for scrap metal (WSRC, 1997).

The total inventory of buried cadmium in the ORWBG is estimated at 3,500 pounds (Table 3-1) (WSRC, 1997). This estimate is based on process knowledge and records of annual cadmium purchases. Most of the inventory (approximately 2,000 pounds) originated from two burials of control rods that were removed from the $\mathrm{R}$ and $\mathrm{L}$ Reactors when they were shut down in 1964 and 1970, respectively (Oblath, 1985). An additional 1,000 to 2,000 pounds can be attributed to cadmium sheet that was used at SRS and may have been disposed of in trenches in the ORWBG (Oblath, 1985). 
There are no detailed records on cadmium burials in the ORWBG. Cadmium would have been buried as scrap metal and induced activity waste (WSRC, 1997). No specific COBRA records from Buildings $105-\mathrm{R}$ or $105-\mathrm{L}$ (the $\mathrm{R}$ and $\mathrm{L}$ Reactor buildings) can be associated with control rods (WSRC, 1997). The buried control rods are probably in areas of the ORWBG that were active in 1964 and 1970 (after shutdowns of the reactors) (WSRC, 1997).

\subsubsection{Lead}

Lead was primarily used for its radiation-shielding properties in separations operations at the SRS. Its principal use was to shield personnel from high levels of beta-gamma radiation associated with fission products. Small amounts of lead in the ORWBG probably originate from reactors and shielding used during burial of off-site waste (WSRC, 1997).

WSRC (1997) estimates the total inventory of buried lead in the ORWBG at 100,000 pounds (Table 3-1). This estimate is thought to be accurate to within \pm 30 percent (WSRC, 1997). Detailed records were not kept on lead disposal because lead was not considered hazardous during the operational history of the ORWBG. The estimated source term for lead is based on process knowledge (WSRC, 1997). COBRA does not contain detailed records for lead; therefore locations for lead-related burials are not available (Table 3-1).

\subsubsection{Mercury}

The inventory of mercury, principally the elemental liquid, buried in the ORWBG is estimated at 24,195 pounds (Table $3-1$ ) (WSRC, 1997).

Detailed disposal records do not exist for mercury and burials of mercury are not specifically documented in the COBRA database. WSRC (1997) estimates of the source term for mercury are based on process knowledge. WSRC (1997) identified 150 COBRA records that can be associated with burials of mercury at the ORWBG. Of these, 136 include grid coordinates (Table 3-1). These records do not indicate the quantity of the nonradioactive COIs, but can be compiled in maps to illustrate the distribution and number of burials at a given location.

The data for burial locations of mercury were extracted from COBRA and sorted to determine the number of individual burials recorded at each grid cell (Table 3-7). This information was used to determine how to plot the data. Symbols were chosen to represent the number of burials within each grid cell. Maps of these data were used to delineate potential "hot spots" by examining the distribution and relative concentrations of the number of recorded burials. 
Areas in the ORWBG with relatively large numbers of burials that plot close to one another are defined as potential "hot spots". Figure 3-2 illustrates the locations from these COBRA records and the number of burials recorded at each grid location. Specific quantities of mercury for these burials are not available (WSRC, 1997). Figure 3-2 illustrates the locations of COBRA records that may be associated with buried mercury (WSRC, 1997).

Figure 3-2 indicates one area that contains a large concentration of burials associated with mercury. The potential mercury "hot spot" (HS-Hg-1) is located in the southern half of the eastern expansion area of the ORWBG. The pattern of burials within this potential "hot spot" is consistent with the reported configuration of trenches in this part of the ORWBG (Figure 12). This potential "hot spot" includes several trenches, which are aligned in a north to south direction and labeled as "High-Level Waste" on the HP maps (Figure 1-2).

\subsubsection{Volatile Organic Compounds}

Sources of VOCs in the ORWBG include the following:

- Drummed scintillation solutions

- Waste oils in absorbent materials

- Residual vapor and organic phases of spent PUREX solvent, waste oils, and associated degradation products in the OSTs

- Residue from decontamination operations at the ORWBG prior to waste burial

VOCs associated with scintillation solution and waste oil are present in the ORWBG. Estimates of the amount of liquid scintillation waste range from 10,000 to 11,000 gallons (WSRC, 1997). This waste is primarily contained in small polyethylene vials which, beginning in 1965, were packed with "oil-dry" in 55-gallon drums and buried. Waste oil was either stored in the OSTs, or absorbed on an "oil-dry" compound, placed in drums, and buried as solidified waste (WSRC, 1997).

VOCs are present in residue in the 22 OSTs (Figure 1-3). Large amounts of spent solvent and smaller amounts of tritiated pump oil were stored in 22 OSTs prior to the 1980s. Most of the solvent was pumped from the OSTs and relocated to Building 643-7G in the late 1970s and early 1980s (WSRC, 1996). Residual "unpumpable heel" in the OSTs is present in vapor, organic, aqueous, and sludge solid phases. The remaining material is vapor, organic, aqueous, and "sludge residue that was unpumpable. VOCs from the spent solvent and associated 
degradation products are primarily concentrated in the vapor and organic phases. The concentrations of VOCs in the vapor phase are known from a recent vapor phase survey; the amount of the organic phase is approximately 4,056 gallons (WSRC, 1997).

The best estimate for the total residue in the OSTs is 7,539 gallons $(4,056$ gallons organic phase and 3,483 gallons aqueous phase). The best estimate for organic compounds that were buried in trenches is based on Cook (1987). Approximately 7,100 kilograms of toluene, 7,100 kilograms of trimethylbenzene, and 12,000 kilograms of xylene from liquid scintillation solutions are buried in trenches (WSRC, 1997). The amount of VOCs present in residue from decontamination operations is not known (WSRC, 1997).

VOCs are present in residue from decontamination operations conducted in the northwest corner of the western expansion area of ORWBG prior to its use for trench burial. Decontamination included the use of ethylenediaminetetraacetic acid (EDTA, a leachating compound) and phosphate detergents (Ryan, 1983). There are no records indicating the amounts of decontamination solutions that may have been disposed of in this area of the ORWBG, nor is it clear how or whether these chemical solutions came into contact with buried wastes. However, because VOCs are highly mobile and volatile, and because more than 40 years have elapsed since decontamination activities ceased, the amount of VOCs remaining from this source is probably limited (WSRC, 1997).

Detailed records do not exist for burials of organic compounds in the ORWBG, and burials of VOCs are not specifically documented in the COBRA database. WSRC (1997) estimates of the source term for VOCs are based on process knowledge. WSRC (1997) identified 1,889 COBRA records that can be associated with burials of VOCs at the ORWBG. Of these, 1,655 include grid coordinates (Table 3-1). These records do not indicate the quantity of the nonradioactive COIs, but can be compiled in maps which provide a rough idea of the distribution of the burials and the number of burials per grid cell.

The data for burial locations of VOCs were extracted from COBRA and sorted to determine the number of individual burials recorded at each grid cell location (Table 3-7). This information was used to determine how to plot the data. Symbols were chosen to represent the number of burials located within each grid cell. Figure 3-3 illustrates the locations of COBRA records that may be associated with buried VOCs (WSRC, 1997).

COBRA records associated with possible VOC burials plot in all parts of the ORWBG, but most are concentrated in the western expansion area. Actual quantities of VOCs cannot be 
ascribed to any of these records (WSRC, 1997). Flach et al. (1996) presented preliminary results of transport simulations for tetrachloroethylene and trichloroethylene at the ORWBG. Their results corroborate a concentration of potential VOC burials in the western expansion area as shown in Figure 3-3.

\subsection{Analysis of COBRA Inventory for Radioactive Constituents of Interest}

Table 3-2 presents the results of the inventory analysis for the radioactive COIs. The COBRA database provides location data for 57 percent of the estimated source term for the COIs. There are no documented burial locations for iodine-129 in the ORWBG (WSRC, 1997). Table 3-2 indicates that higher percentages of located inventory are associated with COIs having specific COBRA codes and relatively few burial records (e.g., plutonium, uranium238).

Application of radioactive decay to the estimated total inventory of COIs is summarized by constituent in Table 3-8 and illustrated in Figure 3-4. Figures 3-5 through 3-13 present summaries of the COBRA inventory of radioactive COIs at the time of burial, and at 25, 50, $100,300,500,1,000,5,000$, and 10,000 years after burial. After 300 years, tritium and cobalt-60 have decayed to essentially zero (Figure 3-9) and the total activity decreases from greater than 5,000,000 curies to approximately 7,000 curies (Figures 3-4 and 3-9). After 500 years, strontium-90 and cesium-137 have decayed to zero, and the total activity falls to 5,440 curies, approximately 0.1 percent of the total COI activity at the time of burial (Figures 3-4 and 3-13).

For the purposes of this "hot spot" analysis, principal COIs are considered to be those which, at any given time, together constitute greater than 99 percent of the total activity within an area. As radioactive decay causes highly radioactive, short-lived COIs, such as tritium and cobalt -60 , to diminish, the longer-lived COIs increase in terms of their relative abundance. In this manner, constituents which are considered principal COIs at burial may decay to low levels after a relatively short period of time, and the constituents which contribute a small percentage of the activity at burial may constitute a majority of the activity and be considered principal COIs only after a period of decay.

A summary of the activity in the COI inventory at 500 years after burial indicates that greater than 99 percent of the activity at 500 years can be attributed to carbon-14, plutonium-238, and plutonium-239 (Table 3-9). These three constituents are considered the principal COIs for the entire ORWBG inventory at 500 years after burial. After 10,000 years, the plutonium- 
238 has decayed to zero, and the principal COIs include carbon-14, plutonium-239, uranium238, and technetium-99 (Table 3-9).

\subsubsection{Tritium}

Tritium was sent to the ORWBG as bulk waste (job control waste, tritiated waste oils and tritiated mercury, and used equipment and components), spent melts, and reactive beds (the latter two are byproducts of the tritium production process). Based on Health Protection and COBRA data, WSRC (1997) estimates 3,014,457 curies of tritium are contained in the ORWBG (Table 3-2). The OSTs are assumed to contain no tritium. The COBRA database provides both quantity and location estimates for tritium burials in the ORWBG and locates 67 percent of the estimated inventory (Table 3-2).

\subsubsection{Cesium-137}

The best estimate for the original cesium-137 inventory buried in trenches in the ORWBG is 58,657 curies (Table 3-2). These estimates were based on the external dose rate from a waste package and an assumed isotopic distribution in the waste (WSRC, 1997).

Fission product waste with a dose rate less than $50 \mathrm{mR}$ per hour was buried in low-activity beta-gamma trenches. Fission product waste with dose rates of $50 \mathrm{mR}$ per hour or greater was buried in intermediate level (also known as high-level) trenches (Cook, 1987). No special containerization requirements existed. The waste was buried in cardboard boxes, plastic bags, and metal containers in low-level and high-level trenches, depending on the dose rate from the package (WSRC, 1997). COBRA locates 32 percent of the estimated source term for cesium137.

\subsubsection{Plutonium-238}

Waste containing plutonium-238 originated primarily in the separations areas, reactor areas, and research facilities like the Savannah River Technology Center (SRTC). Inventory estimates for plutonium-238 are based on data contained in COBRA and burial records predating COBRA.

WSRC (1997) estimates the plutonium-238 inventory at the ORWBG at 20,514 curies (Table 3-2). This estimate is the sum of two sources: the COBRA database total and a very small quantity associated with spent solvent residues. COBRA locates virtually 100 percent of the estimated source-term for plutonium-238 (Table 3-2). 


\subsubsection{Plutonium-239}

Waste containing plutonium-239 in the ORWBG originated primarily in SRS separations areas, reactor areas, and research facilities. The best estimate for the plutonium-239 inventory in the ORWBG is 1,475 curies (Table 3-2) (WSRC, 1997). The inventory estimate for plutonium-239 uses data contained in COBRA and records predating COBRA (WSRC, 1997). The COBRA database records locations for 71 percent of the plutonium-239 source term (Table 3-2).

\subsubsection{Strontium-90}

The process used in the five SRS reactors generated fission products, such as strontium-90, as byproducts. These byproducts became a component of job control waste and other waste streams that were disposed at the ORWBG (WSRC, 1997). Burial records report activity levels of fission products as a group sent to the ORWBG but do not specifically record the amount of strontium-90. The fraction of the fission products that can be strontium-90 is determined using reported isotopic ratios and process knowledge. WSRC (1997) estimates the strontium-90 inventory at the ORWBG to be 58,657 curies (Table 3-2).

\subsubsection{Uranium-235}

The SRS operated five production reactors, which used fuel rods containing enriched uranium-235. Other facilities at SRS manufactured fuel elements for the reactors and extracted uranium-235 from spent fuel elements.

Waste containing uranium was buried in alpha activity trenches without special containers. The waste was buried in cardboard boxes, plastic bags, and possibly, metal containers. WSRC (1997) places the total estimated inventory of uranium-235 at 0.6 curies (Table 3-2). The COBRA database contains locations for 56 percent of the uranium-235 inventory (Table 3-2).

\subsubsection{Uranium-238}

The SRS reactors were fueled by highly-enriched uranium fuel rods. Uranium-238 slugs (depleted or natural uranium) were used as targets to produce plutonium-239. The depleted uranium used in SRS reactors as target material to produce plutonium-239 consisted of at least 99.5 percent uranium-238 (WSRC, 1997). 
Uranium-bearing waste was buried in alpha activity trenches without special containers. The waste was buried in cardboard boxes, plastic bags, and possibly, metal containers. Inventory estimates for uranium-238 are based on data contained in the COBRA database and records indicating burials prior to COBRA records. COBRA includes the burials of enriched uranium, normal uranium, and depleted uranium. Therefore, estimates can be extrapolated to a uranium-238 inventory assuming that uranium-238 is 100 percent of the depleted uranium, 99.274 percent of the normal uranium, and 7 percent of enriched uranium.

The COBRA estimate for the uranium-238 inventory in the trenches in the ORWBG is 14.8 curies. It is assumed that the COBRA database captures all of the Health Protection data related to uranium (WSRC, 1997). The COBRA database provides locations for 87 percent of the uranium-238 buried in the ORWBG (Table 3-2).

\subsubsection{Carbon-14}

Carbon-14 was produced at SRS primarily in moderators in the five production reactors. To maintain moderator purity, carbon-14 was removed using ion-exchange resins in demineralizing units. When a demineralizing unit was exhausted, the resin was removed and buried (WSRC, 1997). During the first ten years of operations, deionizer resins were dumped in slurry form directly into ORWBG trenches (WSRC, 1997). Later, the resins were disposed in stainless steel vessels. The normal practice was to displace the heavy water with light water, seal the stainless steel columns with blank flanges, and bury the whole unit in trenches (WSRC, 1997).

The best estimate for the total carbon-14 inventory at the ORWBG is 3,778 curies (WSRC, 1997). COBRA burial records provide the date, location, and volume of disposals of deionizer resin waste packages. From COBRA records, approximately 4,377 cubic feet of spent resin is present in the ORWBG. The best estimate for the activity of carbon-14 in spent resin is the volume of the resin, in cubic feet, multiplied by 0.86 cubic feet (yielding $3,764.2$ curies). COBRA records locate more than 95 percent of the burials of carbon-14 (Table 3-2).

\subsubsection{Cobalt-60}

Cobalt-60 at the SRS was produced primarily as a byproduct of irradiating cobalt-bearing stainless-steel components in SRS reactors. Irradiation of cobalt in stainless-steel components formed cobalt-60. Operations at the reactor disassembly basins generated excess stainless 
steel components which were disposed as scrap metal. The scrap metal was placed into casks and buried in the ORWBG (WSRC, 1997). The amount of cobalt-60 produced by other sources (cobalt-59 wafers, Savannah River Ecology Laboratory, and SRTC) and disposed in the ORWBG is relatively small compared to that from the induced activity (WSRC, 1997). The best estimate of the activity from buried cobalt-60 in the ORWBG is $1,960,400$ curies (Table 3-2). This estimate assumes an average disposal rate of 98,020 curies per year of cobalt-60 from startup of the original burial ground through 1972 (WSRC, 1997).

The COBRA database was used to identify burials of cobalt- 60 by searching the description fields for terms associated with induced activity. This process is described in Appendix $M$ of WSRC (1997). The best estimate of the activity due to cobalt-60 associated with any particular burial of "induced activity" waste can be determined by multiplying the recorded activity of the burial (from COBRA) by 0.85 . COBRA includes locations for more than 42 percent of the burial records which are presumed to contain cobalt-60 (Table 3-2).

\subsubsection{Iodine-129}

Radioiodine is a fission product that originated predominantly in the fuel and targets that were irradiated in the nuclear materials production reactors at SRS. The predominant radioiodine-containing material buried in the ORWBG is spent ceramic chips coated with silver nitrate ("Berl saddles"). the saddles were used to adsorb radioiodine (principally iodine-129 and iodine-131) during the dissolution of fuel and targets in $\mathbf{F}$ and $\mathrm{H}$ Areas. Essentially all of the iodine-129 in the burial ground is from Berl saddles used in the process air filters (WSRC, 1997).

The best estimate of the amount of iodine-129 in the ORWBG is determined by multiplying a scaled production amount of 35.45 curies produced during the operational history of the ORWBG by the fraction of the total that was sent to the burial ground ( 30 percent). This yields 10.6 curies (Table 3-2) (WSRC, 1997). The estimate assumes that 39 curies of iodine-129 was produced at SRS from startup to 1974 and that 30 percent of this amount was buried in the ORWBG. The number of spent charges of Berl saddles in the ORWBG, assuming a constant disposal rate, is estimated to be 34 (WSRC, 1997). Each container held approximately 20 cubic feet of Berl saddles.

There are no references to Berl saddles in the COBRA database, nor is there any specific iodine-129 constituent information. Because Berl saddles are not identified in the COBRA database, the locations of the iodine- 129 burials cannot be determined. The Berl saddles were 
buried without containment or encapsulation in earthen trenches. Their locations are probably distributed randomly among the intermediate-level beta-gamma waste trenches (WSRC, 1997).

\subsubsection{Technetium-99}

Technetium-99 is a fission product produced by the fission of uranium-235 and plutonium-239 (Cook and Helton, 1989). Most of the technetium-99 in the ORWBG is present in burials of fission product waste.

The best estimate of the amount of technetium-99 in the ORWBG is 12 curies (Table 3-2). Shipments of technetium-99 are not documented in the COBRA database. Technetium-99 is assumed to have been disposed with other fission product waste, and to have been identified in the COBRA database as "fission products". COBRA records locate approximately 50 percent of the estimated source term (Table 3-2).

\subsubsection{Neptunium-237}

Neptunium-237 is produced as a byproduct during the nuclear fuel cycle. It is produced by two primary sources at SRS. One source is alpha decay of americium-241; the americium-241 is produced by the beta decay of plutonium-241 in weapons-grade plutonium. The other source is via a side reaction during the irradiation of uranium-238 targets to eventually produce plutonium-239. Neptunium-237 is also the target material used to produce plutonium-238 in SRS reactors.

The primary waste form of neptunium-237 in the ORWBG is very similar to that for plutonium-238. Neptunium-237 contaminated waste was buried in plastic bags and cardboard boxes, in concrete culverts containing drummed or boxed neptunium-237-bearing waste, and in drums and other waste forms (equipment, waste in wooden boxes, etc.) encapsulated by concrete on all sides, top, and bottom.

The best estimate of the amount of neptunium-237 originally buried in the ORWBG is 1.99 curies (Table 3-2). The amount of ingrown neptunium-237 is conservatively calculated as 0.004 curies. The amount lost to radioactive decay is negligible due to the long half-life of the constituent (WSRC, 1997). The COBRA database provides both quantity and location estimates for neptunium-237 burials in the ORWBG. COBRA records locate approximately 98 percent of the estimated inventory (Table 3-2). 


\subsection{Potential "Hot Spots" for Radioactive Constituents of Interest}

Delineation of potential "hot spots" for the inventory of radioactive COIs combined results of the inventory forecast with burial locations available from COBRA. The COBRA data were compiled into maps to ascertain the spatial distribution and concentration of radioactivity for the COI inventory. Selection of potential "hot spots" for the radioactive COIs requires more than knowledge of the location and number of burials. The selection process must also consider the levels of activity associated with the burials, and how those levels will change over time. The process by which this was accomplished is outlined below. The results are depicted on maps representing the $\mathrm{COI}$ inventory at 100,300 , and 500 years after the time of burial.

- Step 1

Activity levels for each COI were extracted from COBRA and saved to individual data files. Each COI data file contains all burial locations (grid cell coordinates) which appear in COBRA and the total activity of the COI (in curies) in each grid cell. The local burial ground grid system was used for the grid cell coordinates in the data sets. Data from multiple COBRA burial records having the same grid coordinate were summed in this process. Grid cells without applicable burial records were posted with " 0 " activity.

The appropriate decay percentages are applied to the COI inventory data to create files which represent the levels of activity within each burial cell at 100,300, and 500 years after burial. This is accomplished by multiplying the initial activity at each grid cell by the percentage of the COI which will be remaining at the end of the decay interval. Table 3-3 includes the decay percentages used in these calculations.

Data files were uploaded into EarthVision ${ }^{\otimes}$ spatial-analysis software and the EarthVision data file was created from each of the COI data files.

- Step 2

A composite data file was created for each time interval. The "interval" composite data file is the sum of the activities contributed by each COI at each grid cell. The result is a data file where each record consists of an $\mathrm{x}, \mathrm{y}$ grid coordinate, and the total number of curies created by the COI inventory at the coordinate. The statistics of these interval data sets were revjewed to establish a "threshold" value which would 
identify grid cells with relatively high levels of radioactivity. Statistics for the interval data files are presented below.

\begin{tabular}{cccccc}
$\begin{array}{c}\text { Decay } \\
\text { Interval } \\
\text { (years) }\end{array}$ & $\begin{array}{c}\text { Number } \\
\text { of Grid } \\
\text { Cells }\end{array}$ & $\begin{array}{c}\text { Average } \\
(\text { Ci/cell) }\end{array}$ & $\begin{array}{c}\text { Minimum } \\
(\text { Ci/cell) }\end{array}$ & $\begin{array}{c}\text { Maximum } \\
(\text { Ci/cell) }\end{array}$ & $\begin{array}{c}\text { Standard } \\
\text { Deviation }\end{array}$ \\
\hline 100 & 9883 & 2.49 & 0 & 1065.90 & 28.91 \\
300 & 9883 & 0.65 & 0 & 427.88 & 10.31 \\
500 & 9883 & 0.49 & 0 & 416.98 & 8.18
\end{tabular}

The 100-year decay interval approximates the end of institutional control of the SRS and the ORWBG. A value of 60 curies (approximately twice the standard deviation of the data) was selected as the "threshold" value based on the 100-year interval. This threshold was used to identify grid cells with relatively high levels of COI activity after the end of institutional control and at 300 and 500 years after burial.

\section{- Step 3}

The interval composite data are plotted to illustrate the spatial distribution of the burial locations which contain activity levels exceeding the "threshold" value of 60 curies. Symbols were chosen to identify burial locations which fall above and below the threshold value of 60 curies. Maps were compiled to illustrate the distribution of COIs exceeding the threshold value at 100,300 and 500 years after burial. Areas on the maps containing burials in excess of the threshold value were delineated as potential "hot spot" areas. The EarthVision Graphic Editor was used to draw polygons around these potential "hot spots." The maps showing the burial distribution and potential "hot spots" are presented as Figures 3-14 through 3-16. The grid coordinates of the vertices of the polygons were downloaded from EarthVision as text files.

- Step 4

The grid coordinates from polygon files were used to query COBRA for burial records located inside of the potential "hot spot." Data from the COBRA records were compiled in tabular form to summarize the physical attributes of waste buried within each potential "hot spot." Attributes of the waste in the four potential "hot spots" are discussed below. This knowledge of the attributes of waste in potential "hot spots" 
will be useful when determining available options for remediation of the potential "hot spots" and the ORWBG in general.

The polygon coordinates were used as query criteria on the individual COI data files generated in Step 1 of the process. The activity level at each grid cell within the potential "hot spot" polygon was extracted from each COI data file. These data were aggregated to create a composite data file of the total COI inventory for the potential "hot spot". This file is similar to those created in Step 2, but specific to each potential "hot spot". An inventory analysis was then performed on each potential "hot spot" composite file in a manner similar to that performed for the entire COI inventory of the ORWBG. The inventory was examined in terms of how the levels of COI activity within each potential "hot spot" change over time.

The activity-distribution maps of the principal COIs at 300 and 500 years after burial indicate eight areas that could be considered potential "hot spots" (Figures 3-15 and 3-16). Tables 3-10 through 3-67 summarize the potential "hot spots" by presenting summary statistics and a decay forecast for the COBRA inventory of each potential "hot spot." The inventory analyses present the effects of radioactive decay to the COI inventory in each potential "hot spot."

\subsubsection{Potential "Hot Spots" at 100 Years After Burial}

\subsubsection{Potential "Hot Spot"1}

Potential "hot spot" number HS-100-1 encompasses an area of approximately 50,000 square feet in the western part of the ORWBG (Figure 3-14). Table 3-10 presents summary statistics for all COBRA records located within the potential "hot spot." Table 3-11 summarizes the COI inventory within this area and forecasts the effects of radioactive decay up to 10,000 years after time of burial.

COBRA lists a total volume of 358,581 cubic feet of waste as 3,099 individual burials in this area. The burials within this area average 116 cubic feet in volume. COBRA indicates that the majority of burials contain job control waste, with subordinate amounts of naturally radioactive materials.

The potential "hot spot" contains a COI inventory which contributes approximately 231,252 curies of radioactivity at the time of burial. The principal COIs include tritium, cesium-137, plutonium-238, and strontium-90 at the time of burial. The total activity decays 
to 1,758 curies after 100 years of burial, and drops to 255 curies after 300 years. This potential "hot spot" shrinks in area to become potential "hot spot" 2 on the 300 and 500 year maps.

\subsubsection{Potential "Hot Spot" 2}

Potential "hot spot" number HS-100-2 encompasses an area of approximately 3,000 square feet in the southwestern part of the ORWBG (Figure 3-14). Table 3-12 presents summary statistics for all COBRA records located within the potential "hot spot." Table 3-13 summarizes the $\mathrm{COI}$ inventory within this area and forecasts the effects of radioactive decay up to 10,000 years after time of burial.

COBRA lists a total volume of 42,961 cubic feet of waste as 317 individual burials in this area. The burials within this area average 136 cubic feet in volume. COBRA indicates that the majority of burials contain job control waste, with subordinate amounts of naturally radioactive materials.

The potential "hot spot" contains a COI inventory which contributes approximately 32,350 curies of radioactivity at the time of burial. The principal COI is tritium at the time of burial. The total activity decays to 118 curies after 100 years of burial, and drops to 0.09 curies after 300 years. The potential "hot spot" is not persistent and drops from the 300 and 500 year maps (Figures 3-15 and 3-16).

\subsubsection{Potential "Hot Spot" 3}

Potential "hot spot" number HS-100-3 encompasses an area of approximately 3,000 square feet in the northwestern part of the ORWBG (Figure 3-14). Table 3-14 presents summary statistics for all COBRA records located within the potential "hot spot." Table 3-15 summarizes the COI inventory within this area and forecasts the effects of radioactive decay up to 10,000 years after time of burial.

COBRA lists a total volume of 879 cubic feet of waste as 23 individual burials in this area. The burials within this area average 38 cubic feet in volume. COBRA indicates that the majority of burials contain irradiated metal scrap waste, with subordinate amounts of job control waste.

The potential "hot spot" contains a COI inventory which contributes approximately 57,480 curies of radioactivity at the time of burial. The principal COI is tritium at the time of 
burial. The total activity decays to 207 curies after 100 years of burial, and drops to 0 curies after 300 years. The potential "hot spot" is not persistent and drops from the 300 and 500 year maps (Figures 3-12 and 3-13).

\subsubsection{Potential "Hot Spot" 4}

Potential "hot spot" number HS-100-4 is an area of approximately 2,400 square feet in the western part of the ORWBG (Figure 3-14). Table 3-16 presents summary statistics for all COBRA records located within the potential "hot spot." Table 3-17 summarizes the COI inventory within this area and forecasts the effects of radioactive decay up to 10,000 years after time of burial.

COBRA lists a total volume of 33,256 cubic feet of waste as 237 individual burials in this area. The burials within this area average 140 cubic feet in volume. COBRA indicates that the majority of burials contain job control waste with subordinate amounts of naturally radioactive materials and capital equipment.

The potential "hot spot" contains a COI inventory which contributes approximately 570 curies of radioactivity at the time of burial. The principal COIs include tritium and carbon-14 at the time of burial. The total activity decays to 76 curies after 100 years of burial, and drops to 73 curies after 300 years. The potential "hot spot" is persistent and appears as potential "hot spot" number 3 on the 300 and 500 year maps (Figures 3-12 and 3-13). The persistence of this potential "hot spot" is due to carbon-14, which accounts for essentially all of the radioactivity after 300 years.

\subsubsection{Potential "Hot Spot" 5}

Potential "hot spot" number HS-100-5 encompasses an area of approximately 4,500 square feet in the central western part of the ORWBG (Figure 3-14). Table 3-18 presents summary statistics for all COBRA records located within the potential "hot spot." Table 3-19 summarizes the COI inventory within this area and forecasts the effects of radioactive decay up to 10,000 years after time of burial.

COBRA lists a total volume of 35,858 cubic feet of waste as 298 individual burials in this area. The burials within this area average 120 cubic feet in volume. COBRA indicates that the majority of burials contain job control waste, with subordinate amounts of irradiated metal scrap and capital equipment. 
The potential "hot spot" contains a COI inventory which contributes approximately 59,243 curies of radioactivity at the time of burial. The principal COI include tritium at the time of burial. The total activity decays to 214 curies after 100 years of burial, and drops to 0.87 curies after 300 years. The potential "hot spot" is not persistent and drops from the 300 and 500 year maps (Figures 3-12 and 3-13).

\subsubsection{Potential "Hot Spot" 6}

Potential "hot spot" number HS-100-6 encompasses an area of approximately 36,000 square feet in the central western part of the ORWBG (Figure 3-14). Table 3-20 presents summary statistics for all COBRA records located within the potential "hot spot." Table 3-21 summarizes the COI inventory within this area and forecasts the effects of radioactive decay up to 10,000 years after time of burial.

COBRA lists a total volume of 18,708 cubic feet of waste as 762 individual burials in this area. The burials within this area average 25 cubic feet in volume. COBRA indicates that the majority of burials contain job control waste, with subordinate amounts of capital equipment.

The potential "hot spot" contains a COI inventory which contributes approximately 157,649 curies of radioactivity at the time of burial. The principal COIs include tritium, plutonium-238 and plutonium-239 at the time of burial. The total activity decays to 6,384 curies after 100 years of burial, and drops to 1,813 curies after 300 years. The potential "hot spot" is persistent and appears as potential "hot spot" number 1 on the 300 and 500 year maps (Figures 3-15 and 3-16).

\subsubsection{Potential "Hot Spot" 7}

Potential "hot spot" number HS-100-7 encompasses an area of approximately 39,000 square feet in the southwestern part of the ORWBG (Figure 3-14). Table 3-22 presents summary statistics for all COBRA records located within the potential "hot spot." Table 3-23 summarizes the $\mathrm{COI}$ inventory within this area and forecasts the effects of radioactive decay up to 10,000 years after time of burial.

COBRA lists a total volume of 311,364 cubic feet of waste as 2,183 individual burials in this area. The burials within this area average 143 cubic feet in volume. COBRA indicates that the majority of burials contain job control waste, with subordinate amounts of naturally radioactive materials. 
The potential "hot spot" contains a COI inventory which contributes approximately 181,206 curies of radioactivity at the time of burial. The principal COIs include tritium, cesium-137, and strontium- 90 at the time of burial. The total activity decays to 919 curies after 100 years of burial, and drops to 5 curies after 300 years. The potential "hot spot" is not persistent and drops from the 300 and 500 year maps (Figures 3-15 and 3-16).

\subsubsection{Potential "Hot Spot" 8}

Potential "hot spot" number HS-100-8 encompasses an area of approximately 3,000 square feet in the western part of the ORWBG (Figure 3-14). Table 3-24 presents summary statistics for all COBRA records located within the potential "hot spot." Table 3-25 summarizes the COI inventory within this area and forecasts the effects of radioactive decay up to 10,000 years after time of burial.

COBRA lists a total volume of 5,228 cubic feet of waste as 35 individual burials in this area. The burials within this area average 149 cubic feet in volume. COBRA indicates that 100 percent of the burials contain job control waste.

The potential "hot spot" contains a COI inventory which contributes approximately 58,053 curies of radioactivity at the time of burial. The principal COI is tritium at the time of burial. The total activity decays to 209 curies after 100 years of burial, and drops to 0 curies after 300 years. The potential "hot spot" is not persistent and drops from the 300 and 500 year maps (Figures 3-15 and 3-16).

\subsubsection{Potential "Hot Spot" 9}

Potential "hot spot" number HS-100-9 encompasses an area of approximately 3,100 square feet in the northern part of the ORWBG (Figure 3-14). Table 3-26 presents summary statistics for all COBRA records located within the potential "hot spot." Table 3-27 summarizes the COI inventory within this area and forecasts the effects of radioactive decay up to 10,000 years after time of burial.

COBRA lists a total volume of 3,880 cubic feet of waste as 1 individual burial in this area. The burials within this area average 3,880 cubic feet in volume. COBRA indicates that the burial contains capital equipment waste.

The potential "hot spot" contains a COI inventory which contributes approximately 1,788 curies of radioactivity at the time of burial. The principal COIs include cesium-137 and 
strontium-90 at the time of burial. The total activity decays to 172 curies after 100 years of burial, and drops to 2 curies after 300 years. The potential "hot spot" is not persistent and drops from the 300 and 500 year maps (Figures 3-15 and 3-16).

\subsubsection{Potential "Hot Spot"10}

Potential "hot spot" number HS-100-10 encompasses an area of approximately 3,000 square feet in the southern part of the ORWBG (Figure 3-14). Table 3-28 presents summary statistics for all COBRA records located within the potential "hot spot." Table 3-29 summarizes the COI inventory within this area and forecasts the effects of radioactive decay up to 10,000 years after time of burial.

COBRA lists a total volume of 13,786 cubic feet of waste as 123 individual burials in this area. The burials within this area average 112 cubic feet in volume. COBRA indicates that 96 percent of the burials contain job control waste. The remaining 4 percent of the burials contain oil, irradiated metal scrap, and naturally radioactive materials.

The potential "hot spot" contains a COI inventory which contributes approximately 2,441 curies of radioactivity at the time of burial. The principal COIs include tritium and plutonium-238 at the time of burial. The total activity decays to 112 curies after 100 years of burial, and drops to 20 curies after 300 years. The potential "hot spot" is not persistent and drops from the 300 and 500 year maps (Figures 3-15 and 3-16).

\subsubsection{Potential "Hot Spot" 11}

Potential "hot spot" number HS-100-11 encompasses an area of approximately 5,000 square feet in the southern part of the ORWBG (Figure 3-14). Table 3-30 presents summary statistics for all COBRA records located within the potential "hot spot." Table 3-31 summarizes the COI inventory within this area and forecasts the effects of radioactive decay up to 10,000 years after time of burial.

COBRA lists a total volume of 2,388 cubic feet of waste as 25 individual burials in this area. The burials within this area average 95 cubic feet in volume. COBRA indicates that approximately 100 percent of the burials contain job control waste.

The potential "hot spot" contains a COI inventory which contributes approximately 53,864 curies of radioactivity at the time of burial. The principal COI is tritium at the time of burial. The total activity decays to 194 curies after 100 years of burial, and drops to 0 curies 
after 300 years. The potential "hot spot" is not persistent and drops from the 300 and 500 year maps (Figures 3-15 and 3-16).

\subsubsection{Potential "Hot Spot" 12}

Potential "hot spot" number HS-100-12 is an area of approximately 2,800 square feet in the central part of the ORWBG (Figure 3-14). Table 3-32 presents summary statistics for all COBRA records located within the potential "hot spot." Table 3-33 summarizes the COI inventory within this area and forecasts the effects of radioactive decay up to 10,000 years after time of burial.

COBRA lists a total volume of 104 cubic feet of waste as 10 individual burials in this area. The burials within this area average 10 cubic feet in volume. COBRA indicates that 100 percent of the burials contain job control waste.

The potential "hot spot" contains a COI inventory which contributes approximately 154 curies of radioactivity at the time of burial. The principal COIs include plutonium-238 and plutonium-239 at the time of burial. The total activity decays to 72 curies after 100 years of burial, and drops to 19 curies after 300 years. The potential "hot spot" is not persistent and drops from the 300 and 500 year maps (Figures 3-15 and 3-16).

\subsubsection{Potential "Hot Spot"13}

Potential "hot spot" number HS-100-13 encompasses an area of approximately 18,000 square feet in the eastern part of the ORWBG (Figure 3-14). Table 3-34 presents summary statistics for all COBRA records located within the potential "hot spot." Table 3-35 summarizes the COI inventory within this area and forecasts the effects of radioactive decay up to 10,000 years after time of burial.

COBRA lists a total volume of 54,498 cubic feet of waste as 885 individual burials in this area. The burials within this area average 62 cubic feet in volume. COBRA indicates that 98 percent of the burials contain job control waste and the remaining 2 percent contains naturally radioactive materials and capital equipment.

The potential "hot spot" contains a COI inventory which contributes approximately 5,957 curies of radioactivity at the time of burial. The principal COIs include plutonium-238 and plutonium-239 at the time of burial. The total activity decays to 2,835 curies after 100 years of burial, and drops to 876 curies after 300 years. The potential "hot spot" is 
persistent and appears as potential "hot spot" number 4 on the 300 and 500 year maps (Figures 3-15 and 3-16).

\subsubsection{Potential "Hot Spot" 14}

Potential "hot spot" number HS-100-14 is an area of approximately 2,400 square feet in the eastern part of the ORWBG (Figure 3-14). Table 3-36 presents summary statistics for all COBRA records located within the potential "hot spot." Table 3-37 summarizes the COI inventory within this area and forecasts the effects of radioactive decay up to 10,000 years after time of burial.

COBRA lists a total volume of 7,654 cubic feet of waste as 63 individual burials in this area. The burials within this area average 121 cubic feet in volume. COBRA indicates that the majority of burials contain job control waste, with subordinate amounts of oil and naturally radioactive materials.

The potential "hot spot" contains a COI inventory which contributes approximately 46,873 curies of radioactivity at the time of burial. The principal COIs include tritium at the time of burial. The total activity decays to 170 curies after 100 years of burial, and drops to 0.15 curies after 300 years. The potential "hot spot" is not persistent and drops from the 300 and 500 year maps (Figures 3-15 and 3-16).

\subsubsection{Potential "Hot Spot" 15}

Potential "hot spot" number HS-100-15 an area of approximately 2,400 square feet in the southeastern part of the ORWBG (Figure 3-14). Table 3-38 presents summary statistics for all COBRA records located within the potential "hot spot." Table 3-39 summarizes the COI inventory within this area and forecasts the effects of radioactive decay up to 10,000 years after time of burial.

COBRA lists a total volume of 18,079 cubic feet of waste as 147 individual burials in this area. The burials within this area average 123 cubic feet in volume. COBRA indicates that the majority of burials contain job control waste, with subordinate amounts of naturally radioactive materials.

The potential "hot spot" contains a COI inventory which contributes approximately 41,484 curies of radioactivity at the time of burial. The principal COI is tritium at the time of burial. The total activity decays to 174 curies after 100 years of burial, and drops to 5 curies 
after 300 years. The potential "hot spot" is not persistent and drops from the 300 and 500 year maps (Figures 3-15 and 3-16).

\subsubsection{Potential "Hot Spot" 16}

Potential "hot spot" number HS-100-16 an area of approximately 2,100 square feet in the northeastern part of the ORWBG (Figure 3-14). Table 3-40 presents summary statistics for all COBRA records located within the potential "hot spot." Table 3-41 summarizes the COI inventory within this area and forecasts the effects of radioactive decay up to 10,000 years after time of burial.

COBRA lists a total volume of 5,416 cubic feet of waste as 51 individual burials in this area. The burials within this area average 106 cubic feet in volume. COBRA indicates that the majority of burials contain job control waste, with subordinate amounts of irradiated metal scrap.

The potential "hot spot" contains a COI inventory which contributes approximately 38,522 curies of radioactivity at the time of burial. The principal COIs include cobalt-60 and tritium at the time of burial. The total activity decays to 77 curies after 100 years of burial, and drops to 42 curies after 300 years. The potential "hot spot" is not persistent and drops from the 300 and 500 year maps (Figures 3-15 and 3-16).

\subsubsection{Potential "Hot Spot" 17}

Potential "hot spot" number HS-100-17 an area of approximately 32,000 square feet in the eastern part of the ORWBG (Figure 3-14). Table 3-42 presents summary statistics for all COBRA records located within the potential "hot spot." Table 3-43 summarizes the COI inventory within this area and forecasts the effects of radioactive decay up to 10,000 years after time of burial.

COBRA lists a total volume of 72,181 cubic feet of waste as 519 individual burials in this area. The burials within this area average 139 cubic feet in volume. COBRA indicates that the majority of burials contain job control waste, with subordinate amounts of oil irradiated metal scrap.

The potential "hot spot" contains a COI inventory which contributes approximately 275,839 curies of radioactivity at the time of burial. The principal COI is tritium at the time of burial. The total activity decays to 1,030 curies after 100 years of burial, and drops to 1 curie 
after 300 years. The potential "hot spot" is not persistent and drops from the 300 and 500 year maps (Figures 3-15 and 3-16).

\subsubsection{Potential "Hot Spot" 18}

Potential "hot spot" number HS-100-18 is an area of approximately 26,000 square feet in the northeastern part of the ORWBG (Figure 3-14). Table 3-44 presents summary statistics for all COBRA records located within the potential "hot spot." Table 3-45 summarizes the COI inventory within this area and forecasts the effects of radioactive decay up to 10,000 years after time of burial.

COBRA lists a total volume of 35,054 cubic feet of waste as 881 individual burials in this area. The burials within this area average 40 cubic feet in volume. COBRA indicates that the majority of burials contain irradiated metal scrap waste, with subordinate amounts of job control waste and capital equipment.

The potential "hot spot" contains a COI inventory which contributes approximately 140,908 curies of radioactivity at the time of burial. The principal COIs include cobalt-60 and tritium at the time of burial. The total activity decays to 1,102 curies after 100 years of burial, and drops to 649 curies after 300 years. The potential "hot spot" is persistent and appears as potential "hot spot" number 5 on the 300 and 500 year maps (Figures 3-15 and 3-16).

\subsubsection{Potential "Hot Spot" 19}

Potential "hot spot" number HS-100-19 encompasses an area of approximately 100,000 square feet in the eastern part of the ORWBG (Figure 3-14). Table 3-46 presents summary statistics for all COBRA records located within the potential "hot spot." Table 3-47 summarizes the COI inventory within this area and forecasts the effects of radioactive decay up to 10,000 years after time of burial.

COBRA lists a total volume of 199,271 cubic feet of waste as 4,302 individual burials in this area. The burials within this area average 46 cubic feet in volume. COBRA indicates that the majority of burials contain irradiated metal scrap waste, with subordinate amounts of job control waste and capital equipment.

The potential "hot spot" contains a COI inventory which contributes approximately 644,238 curies of radioactivity at the time of burial. The principal COIs include cobalt- 60 and tritium at the time of burial. The total activity decays to 4,871 curies after 100 years of burial, 
and drops to 1,986 curies after 300 years. The potential "hot spot" is persistent and appears as potential "hot spot" number 6 on the 300 and 500 year maps (Figures 3-15 and 3-16). After 300 years of burial, cobalt-60 and tritium have decayed to almost zero, and carbon- 14 accounts for more than $90 \%$ of the activity.

\subsubsection{Potential "Hot Spot" 20}

Potential "hot spot" number HS-100-20 encompasses an area of approximately 6,800 square feet in the northeastern part of the ORWBG (Figure 3-14). Table 3-48 presents summary statistics for all COBRA records located within the potential "hot spot." Table 3-49 summarizes the COI inventory within this area and forecasts the effects of radioactive decay up to 10,000 years after time of burial.

COBRA lists a total volume of 17,089 cubic feet of waste as 620 individual burials in this area. The burials within this area average 27 cubic feet in volume. COBRA indicates that the majority of burials contain irradiated metal scrap waste, with subordinate amounts of job control waste.

The potential "hot spot" contains a COI inventory which contributes approximately 121,175 curies of radioactivity at the time of burial. The principal COIs include cobalt-60 and tritium at the time of burial. The total activity decays to 698 curies after 100 years of burial, and drops to 428 curies after 300 years. The potential "hot spot" is persistent and appears as potential "hot spot" number 7 on the 300 and 500 year maps (Figures 3-15 and 3-16).

\subsubsection{Potential "Hot Spot" 21}

Potential "hot spot" number HS-100-21 is an area of approximately 22,000 square feet in the eastern part of the ORWBG (Figure 3-14). Table 3-50 presents summary statistics for all COBRA records located within the potential "hot spot." Table 3-51 summarizes the COI inventory within this area and forecasts the effects of radioactive decay up to 10,000 years after time of burial.

COBRA lists a total volume of 21,406 cubic feet of waste as 767 individual burials in this area. The burials within this area average 28 cubic feet in volume. COBRA indicates that the majority of burials contain irradiated metal scrap waste, with subordinate amounts of job control waste. 
The potential "hot spot" contains a COI inventory which contributes approximately 154,581 curies of radioactivity at the time of burial. The principal COIs include cobalt- 60 and tritium at the time of burial. The total activity decays to 536 curies after 100 years of burial, and drops to 105 curies after 300 years. The potential "hot spot" is persistent and appears as potential "hot spot" number 8 on the 300 and 500 year maps (Figures 3-15 and 3-16).

\subsubsection{Potential "Hot Spots" at 300 and 500 Years After Burial}

\subsubsection{Potential "Hot Spot" 1}

Potential "hot spot" 1 on the 300 and 500 year maps encompasses an area of approximately 23,000 square feet in the western part of the ORWBG (Figures 3-15 and 3-16). Table 3-52 presents summary statistics for all COBRA records located within the potential "hot spot." Table 3-53 summarizes the COI inventory within this area and forecasts the effects of radioactive decay up to 10,000 years after time of burial.

COBRA lists a total volume of 18,339 cubic feet of waste as 754 individual burials in this area. The burials within this area average 24 cubic feet in volume. COBRA indicates that the majority of burials contain job control waste, with subordinate amounts of capital equipment and irradiated metal scrap. The burials of job control waste include "deionizers", "concrete casks", and "concrete vessels". Ninety-six percent of the waste is contained in TRU waste. COBRA records indicate that 10 of the burials are "deionizers".

Potential "hot spot" 1 contains a COI inventory which contributes approximately 11,316 curies of radioactivity at the time of burial. The principal COIs include plutonium238, plutonium-239, and carbon- 14 at the time of burial. The total activity decays to 1,754 curies after 300 years of burial, and drops to 968 curies after 500 years. Principal COIs after 300 years include plutonium-238, plutonium-239, and carbon-14.

\subsubsection{Potential "Hot Spot" 2}

Potential "hot spot" 2 on the 300 and 500 year maps encompasses an area of approximately 4,500 square feet in the western part of the ORWBG (Figures 3-15 and 3-16). Table 3-54 presents summary statistics for all COBRA records located within the potential "hot spot." Table 3-55 summarizes the COI inventory within this area and forecasts the effects of radioactive decay up to 10,000 years after time of burial. 
COBRA lists a total volume of 49,743 cubic feet of waste as 645 individual burials in this area. The burials within this area average 77 cubic feet in volume. COBRA indicates that the majority of burials contain job control waste and 215 of the burials are listed as TRU waste.

Potential "hot spot" 2 contains a COI inventory which contributes approximately 16,010 curies of radioactivity at the time of burial. The principal COIs include tritium and plutonium-239 at the time of burial. The total activity decays to 107 curies after 300 years of burial, and drops to 106 curies after 500 years. Principal COIs after 300 years include plutonium-239.

\subsubsection{Potential "Hot Spot" 3}

Potential "hot spot" 3 on the 300 and 500 year maps encompasses an area of approximately 4,500 square feet in the western part of the ORWBG (Figures 3-15 and 3-16). Table 3-56 presents summary statistics for all COBRA records located within the potential "hot spot." Table 3-57 summarizes the COI inventory within this area and forecasts the effects of radioactive decay up to 10,000 years after time of burial.

COBRA lists a total volume of 33,256 cubic feet of waste as 237 individual burials in this area. The burials within this area average 140 cubic feet in volume. COBRA indicates that the majority of burials contain job control waste, with subordinate amounts of naturally radioactive materials, capital equipment, oil, and irradiated metal scrap.

Potential "hot spot" 3 contains a COI inventory which contributes approximately 571 curies of radioactivity at the time of burial. The principal COIs include tritium and carbon-14 at the time of burial. The total activity decays to 74 curies after 300 years of burial, and drops to 72 curies after 500 years. Carbon- 14 contributes over 99 percent of the total activity after 300 years (Table $3-57$ ). The carbon- 14 is contained in "deionizers".

\subsubsection{Potential "Hot Spot" 4}

Potential "hot spot" 4 on the 300 and 500 year maps encompasses an area of approximately 13,700 square feet in the central part of the ORWBG (Figures 3-15 and 3-16). Table 3-58 presents summary statistics for all COBRA records located within the potential "hot spot." Table 3-59 summarizes the COI inventory within this area and forecasts the effects of radioactive decay up to 10,000 years after time of burial. 
COBRA lists a total volume of 33,702 cubic feet of waste as 685 individual burials in this area. The burials within this area average 49 cubic feet in volume. COBRA indicates that the majority of burials contain job control waste, with subordinate amounts of naturally radioactive materials and capital equipment. COBRA indicates 410 burials are contained in retrievable TRU waste.

Potential "hot spot" 4 contains a COI inventory which contributes approximately 5,761 curies of radioactivity at the time of burial. The principal COIs include plutonium-238 and plutonium-239 at the time of burial. The total activity decays to 872 curies after 300 years of burial, and drops to 474 curies after 500 years. Principal COIs after 300 years include plutonium-238 and plutonium-239.

\subsubsection{Potential "Hot Spot" 5}

Potential "hot spot" 5 on the 300 and 500 year maps encompasses an area of approximately 23,000 square feet in the eastern part of the ORWBG (Figures 3-15 and 3-16). Table 3-60 presents summary statistics for all COBRA records located within the potential "hot spot." Table 3-61 summarizes the COI inventory within this area and forecasts the effects of radioactive decay up to 10,000 years after time of burial.

COBRA lists a total volume of 35,019 cubic feet of waste as 880 individual burials in this area. The burials within this area average 40 cubic feet in volume. COBRA indicates that the majority of buriais contain irradiated metal scrap waste, with subordinate amounts of job control waste and capital equipment. COBRA records indicate that 29 of the burials are "deionizers".

Potential "hot spot" 5 contains a COI inventory which contributes approximately 140,862 curies of radioactivity at the time of burial. The principal COIs include cobalt-60 and tritium at the time of burial. The total activity decays to 649 curies after 300 years of burial, and drops to 630 curies after 500 years. The principal COI after 300 years is carbon- 14 .

\subsubsection{Potential "Hot Spot" 6}

Potential "hot spot" 6 on the 300 and 500 year maps encompasses an area of approximately 65,000 square feet in the southeastern part of the ORWBG (Figures 3-15 and 3-16). Table 3-62 presents summary statistics for all COBRA records located within the potential "hot spot." Table 3-63 summarizes the COI inventory within this area and forecasts the effects of radioactive decay up to 10,000 years after time of burial. 
COBRA lists a total volume of 196,226 cubic feet of waste as 3,629 individual burials in this area. The burials within this area average 54 cubic feet in volume. COBRA indicates that the majority of burials contain irradiated metal scrap waste, with subordinate amounts of job control waste and capital equipment. COBRA records that 74 burials are "deionizers" and 206 burials are TRU waste.

Potential "hot spot" 6 contains a COI inventory which contributes approximately 511,437 curies of radioactivity at the time of burial. The principal COIs include cobalt-60 and tritium at the time of burial. The total activity decays to 1,868 curies after 300 years of burial, and drops to 1,707 curies after 500 years. The principal COI after 300 years is carbon- 14 .

\subsubsection{Potential "Hot Spot" 7}

Potential "hot spot" 7 on the 300 and 500 year maps encompasses an area of approximately 4,500 square feet in the northeastern part of the ORWBG (Figures 3-15 and 3-16). Table 3-64 presents summary statistics for all COBRA records located within the potential "hot spot." Table 3-65 summarizes the COI inventory within this area and forecasts the effects of radioactive decay up to 10,000 years after time of burial.

COBRA lists a total volume of 14,230 cubic feet of waste as 516 individual burials in this area. The burials within this area average 28 cubic feet in volume. COBRA indicates that the majority of burials contain irradiated metal scrap waste, with subordinate amounts of job control waste. COBRA records indicate that nine of the burials are "deionizers".

Potential "hot spot" 7 contains a COI inventory which contributes approximately 99,660 curies of radioactivity at the time of burial. The principal COIs include cobalt-60 and tritium at the time of burial. The total activity decays to 428 curies after 300 years of burial, and drops to 417 curies after 500 years. The principal COI after 300 years is carbon- 14 .

\subsubsection{Potential "Hot Spot" 8}

Potential "hot spot" 8 on the 300 and 500 year maps encompasses an area of approximately 22,000 square feet in the eastern part of the ORWBG (Figures 3-15 and 3-16). Table 3-66 presents summary statistics for all COBRA records located within the potential "hot spot". Table 3-67 summarizes the COI inventory within this area and forecasts the effect of radioactive decay up to 10,000 years after burial. 
COBRA lists a total volume of 21,406 cubic feet of waste as 767 individual burials in this area. The burials within this area average 28 cubic feet in volume. COBRA indicates that the majority of burials contain irradiated metal scrap waste, with subordinate amounts of job control waste. COBRA records indicate four of the burials are "deionizers".

Potential "hot spot" 8 contains a COI inventory which contributes approximately 154,581 curies of radioactivity at the time of burial (Table 3-67). The principal COIs include cobalt-60 and tritium at the time of burial. The total activity decays to 105 curies after 300 years, and drops to 30 curies after 10,000 years. Principal COIs after 300 years include carbon-14, plutonium-238, cesium-137, and strontium-90. Carbon-14 and technetium-99 are the only COIs remaining after 10,000 years (Table 3-67). 


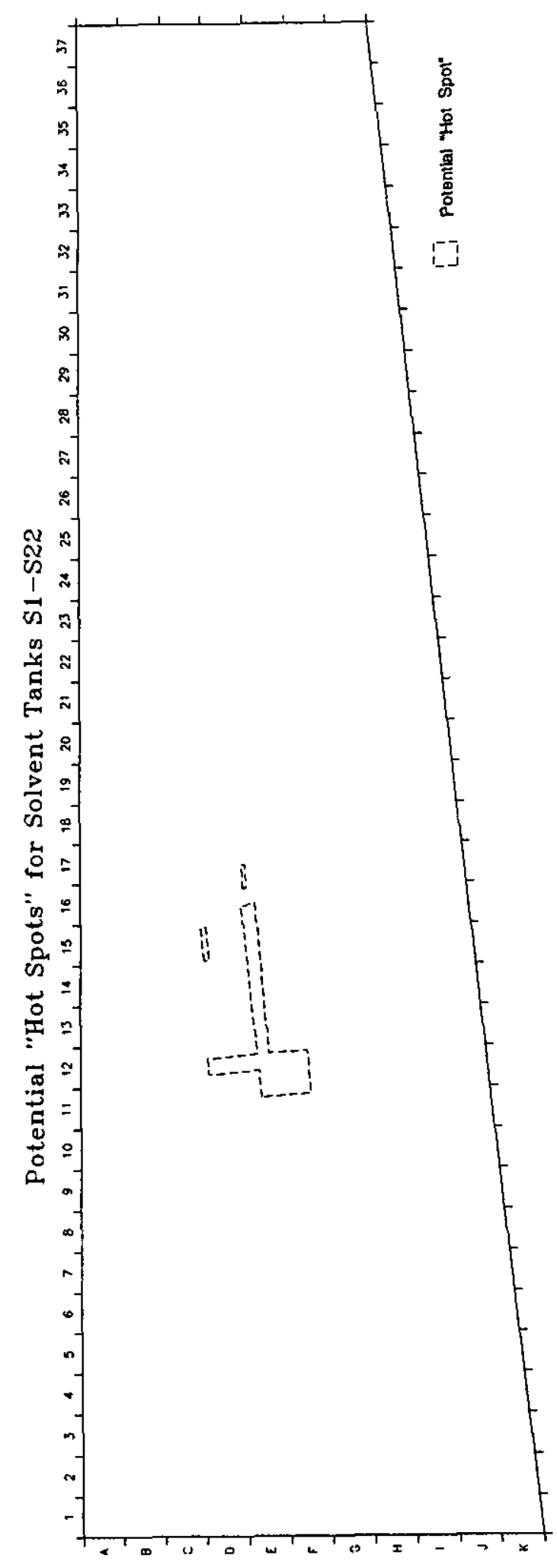

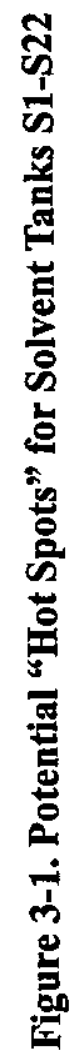


Distribution of Mercury Burials

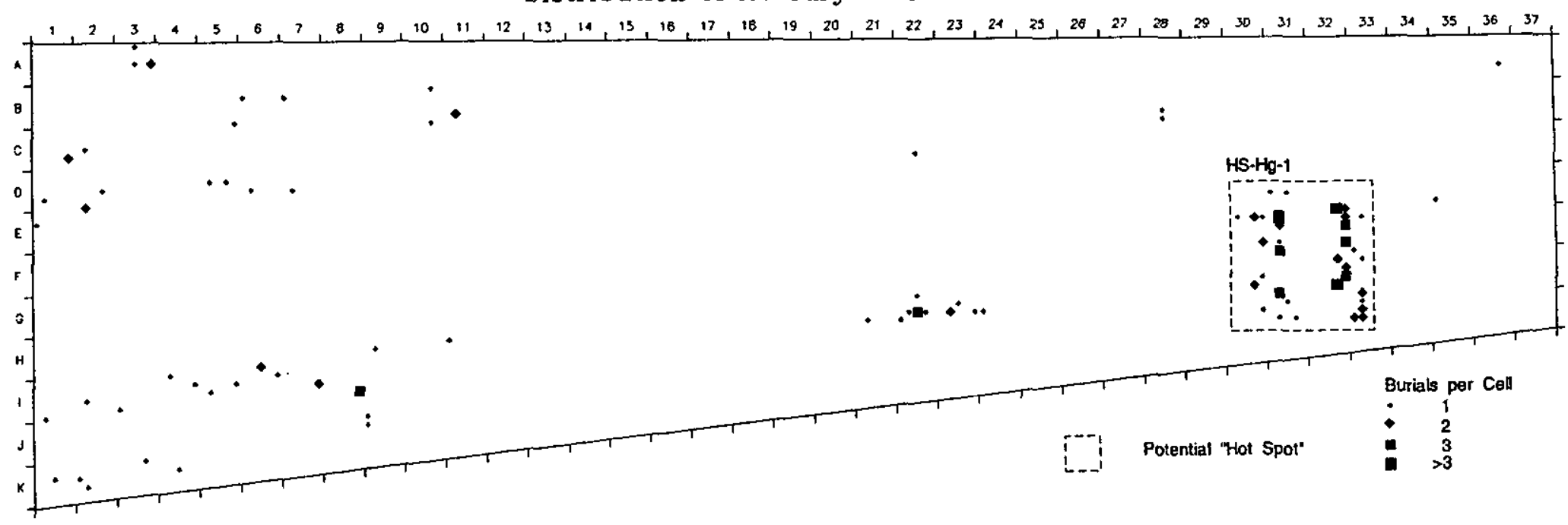

Figure 3-2. Distribution of Mercury Burials 
WSRC-TR-97-00329 Rev. 1.0, Delineation of Potential "Hot Spots" for the ORWBG

49

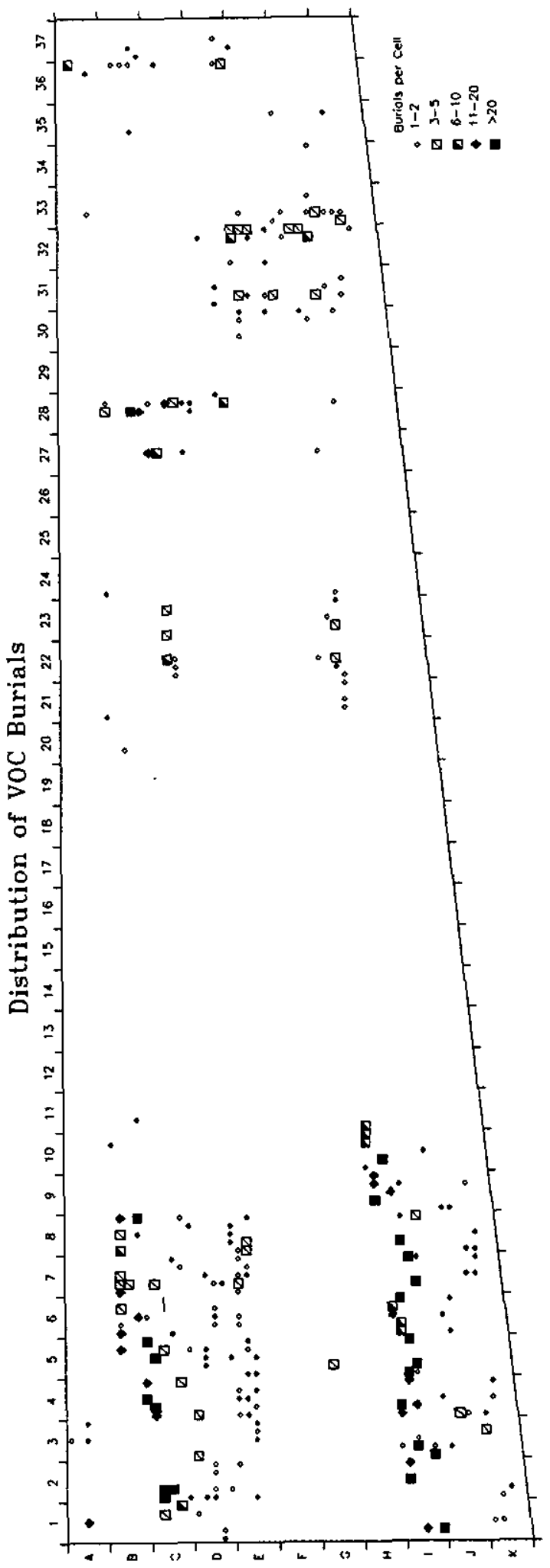

电

hotspot.r1.0.doc 


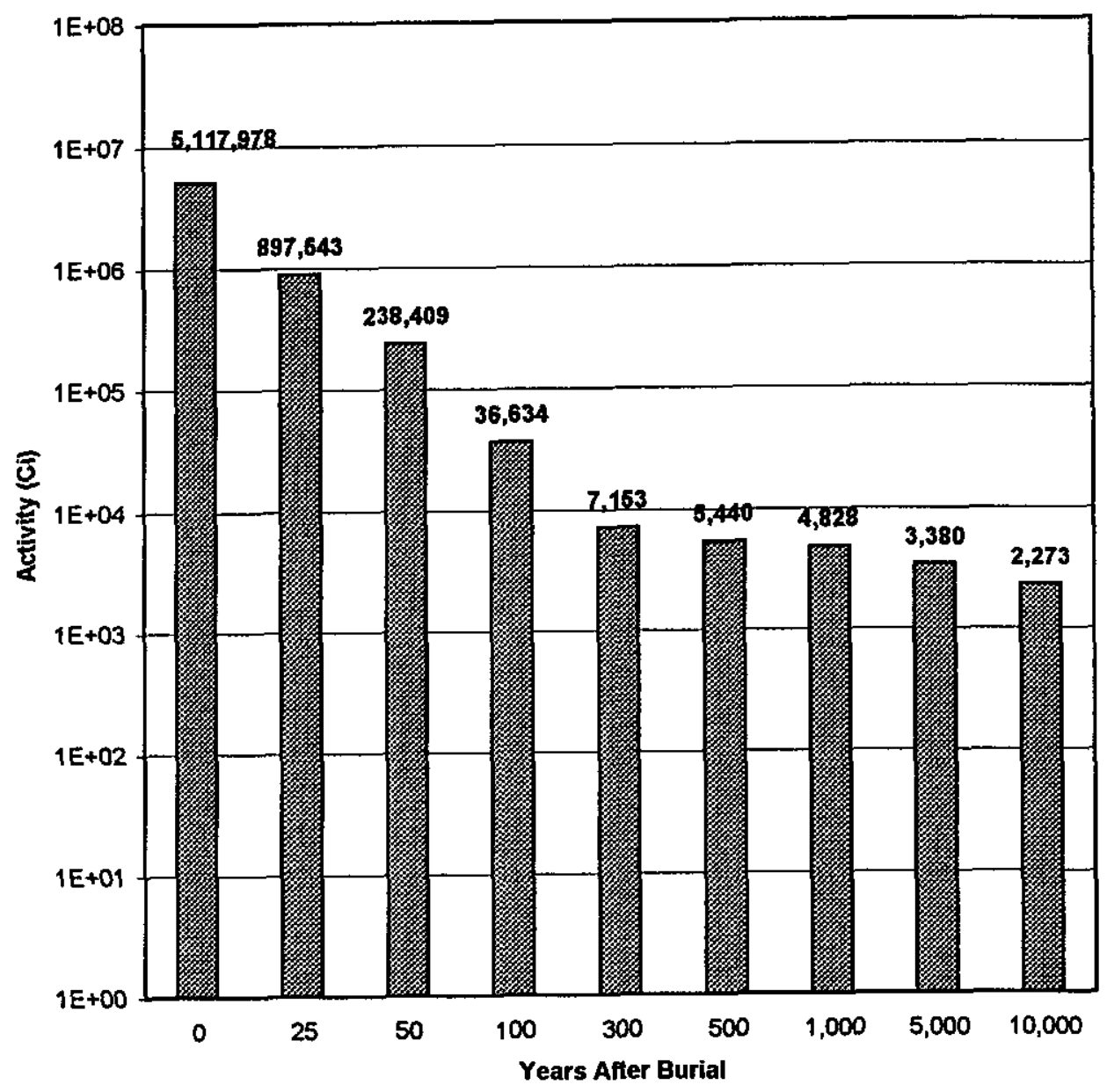

Figure 3-4. Decay Forecast for Inventory of Radioactive COIs 


\begin{tabular}{|c|c|c|c|c|c|}
\hline $\mathrm{COI}$ & Mass (g) & $\%$ Total Mass & Activity (Ci) & Activity (pCi) & $\%$ Total Activity \\
\hline Tritium & 311 & $0.00 \%$ & $3.0 \mathrm{E}+6$ & $3.0 \mathrm{E}+18$ & $58.90 \%$ \\
\hline Carbon-14 & 845 & $0.00 \%$ & $3.8 \mathrm{E}+3$ & $3.8 \mathrm{E}+15$ & $0.07 \%$ \\
\hline Cobalt-60 & 1,732 & $0.00 \%$ & $2.0 \mathrm{E}+6$ & $2.0 \mathrm{E}+18$ & $38.30 \%$ \\
\hline Strontium-90 & 430 & $0.00 \%$ & $58.7 \mathrm{E}+3$ & $58.7 \mathrm{E}+15$ & $1.15 \%$ \\
\hline Technetium-99 & 707 & $0.00 \%$ & $12.0 \mathrm{E}+0$ & $12.0 \mathrm{E}+12$ & $0.00 \%$ \\
\hline Iodine-129 & 60,023 & $0.13 \%$ & $10.6 \mathrm{E}+0$ & $10.6 \mathrm{E}+12$ & $0.00 \%$ \\
\hline Cesium-137 & 674 & $0.00 \%$ & $58.7 \mathrm{E}+3$ & $58.7 \mathrm{E}+15$ & $1.15 \%$ \\
\hline Neptunium-237 & 2,823 & $0.01 \%$ & $2.0 \mathrm{E}+0$ & $2.0 \mathrm{E}+12$ & $0.00 \%$ \\
\hline Uranium-235 & 269,767 & $0.60 \%$ & $580.0 \mathrm{E}-3$ & $580.0 \mathrm{E}+9$ & $0.00 \%$ \\
\hline Uranium-238 & $44,311,377$ & $99.19 \%$ & $14.8 \mathrm{E}+0$ & $14.8 \mathrm{E}+12$ & $0.00 \%$ \\
\hline Plutonium-238 & 1,193 & $0.00 \%$ & $20.5 \mathrm{E}+3$ & $20.5 \mathrm{E}+15$ & $0.40 \%$ \\
\hline Plutonium-239 & 24,180 & $0.05 \%$ & $1.5 \mathrm{E}+3$ & $1.5 \mathrm{E}+15$ & $0.03 \%$ \\
\hline Totals & $44,674,062$ & $100 \%$ & $5,117,978$ & $5.1 E+18$ & $100 \%$ \\
\hline
\end{tabular}
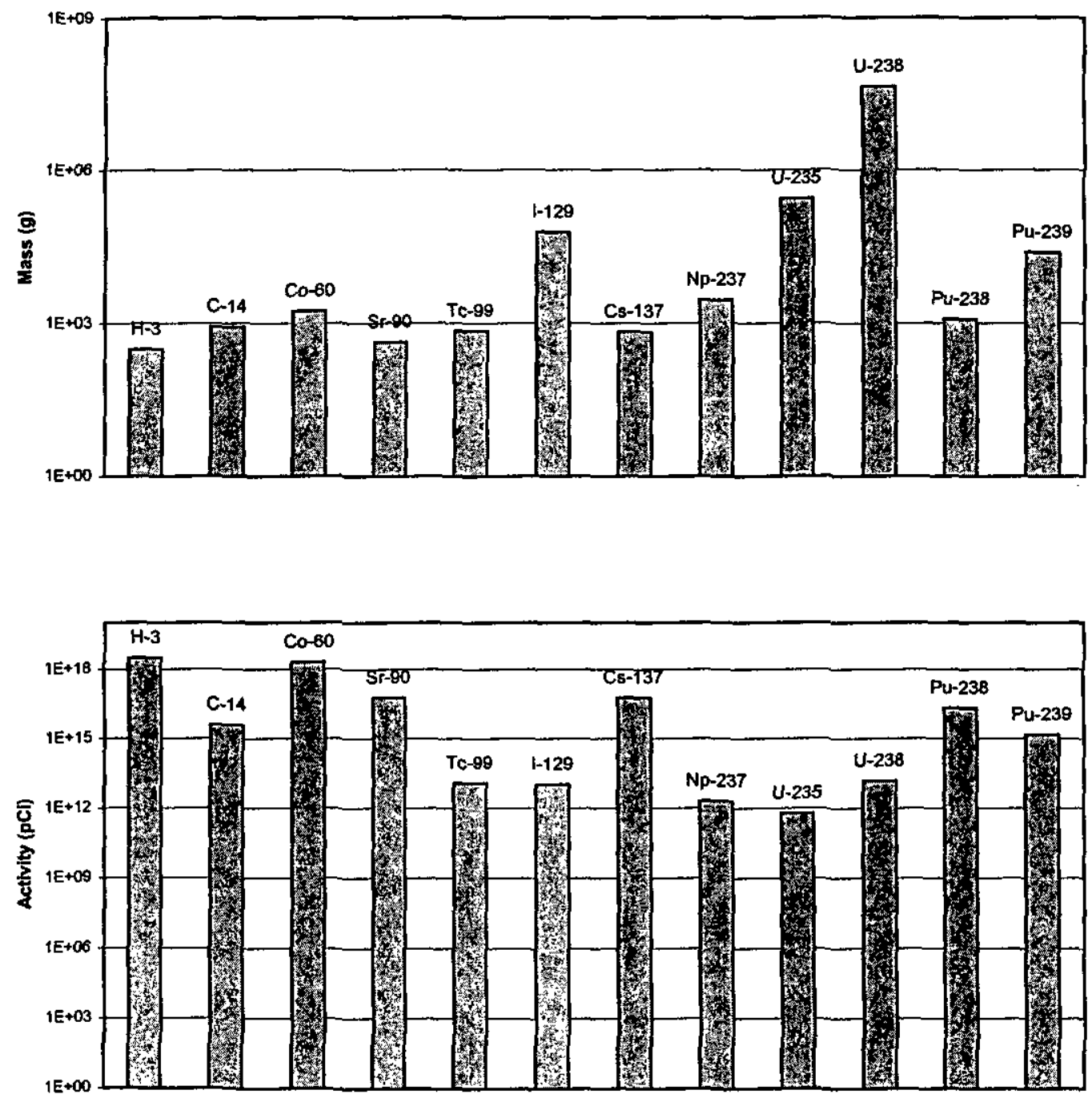

Figure 3-5. Summary of COBRA Inventory for Radioactive COIs at Time of Burial 


\begin{tabular}{|c|c|c|c|c|c|}
\hline $\mathrm{COI}$ & Mass (g) & $\%$ Total Mass & Activity (Ci) & Activity (pCi) & $\%$ Total Activity \\
\hline Tritium & 76 & $0.00 \%$ & $737.0 \mathrm{E}+3$ & $737.0 \mathrm{E}+15$ & $82.12 \%$ \\
\hline Carbon-14 & 843 & $0.00 \%$ & $3.8 \mathrm{E}+3$ & $3.8 \mathrm{E}+15$ & $0.42 \%$ \\
\hline Cobalt-60 & 65 & $0.00 \%$ & $73.1 E+3$ & $73.1 E+15$ & $8.15 \%$ \\
\hline Strontium-90 & 237 & $0.00 \%$ & $32.4 \mathrm{E}+3$ & $32.4 \mathrm{E}+15$ & $3.60 \%$ \\
\hline Technetium-99 & 707 & $0.00 \%$ & $12.0 \mathrm{E}+0$ & $12.0 \mathrm{E}+12$ & $0.00 \%$ \\
\hline lodine-129 & 60,023 & $0.13 \%$ & $10.6 \mathrm{E}+0$ & $10.6 \mathrm{E}+12$ & $0.00 \%$ \\
\hline Cesium-137 & 378 & $0.00 \%$ & $32.9 \mathrm{E}+3$ & $32.9 \mathrm{E}+15$ & $3.67 \%$ \\
\hline Neptunium-237 & 2,829 & $0.01 \%$ & $2.0 \mathrm{E}+0$ & $2.0 \mathrm{E}+12$ & $0.00 \%$ \\
\hline Uranium-235 & 269,767 & $0.60 \%$ & $580.0 \mathrm{E}-3$ & $580.0 \mathrm{E}+9$ & $0.00 \%$ \\
\hline Uranium-238 & $44,311,377$ & $99.19 \%$ & $14.8 \mathrm{E}+0$ & $14.8 \mathrm{E}+12$ & $0.00 \%$ \\
\hline Plutonium-238 & 978 & $0.00 \%$ & $16.8 \mathrm{E}+3$ & $16.8 \mathrm{E}+15$ & $1.87 \%$ \\
\hline Plutonium-239 & 24,163 & $0.05 \%$ & $1.5 \mathrm{E}+3$ & $1.5 \mathrm{E}+15$ & $0.16 \%$ \\
\hline Totals & $44,671,444$ & $100 \%$ & 897,543 & $897.5 E+15$ & $100 \%$ \\
\hline
\end{tabular}
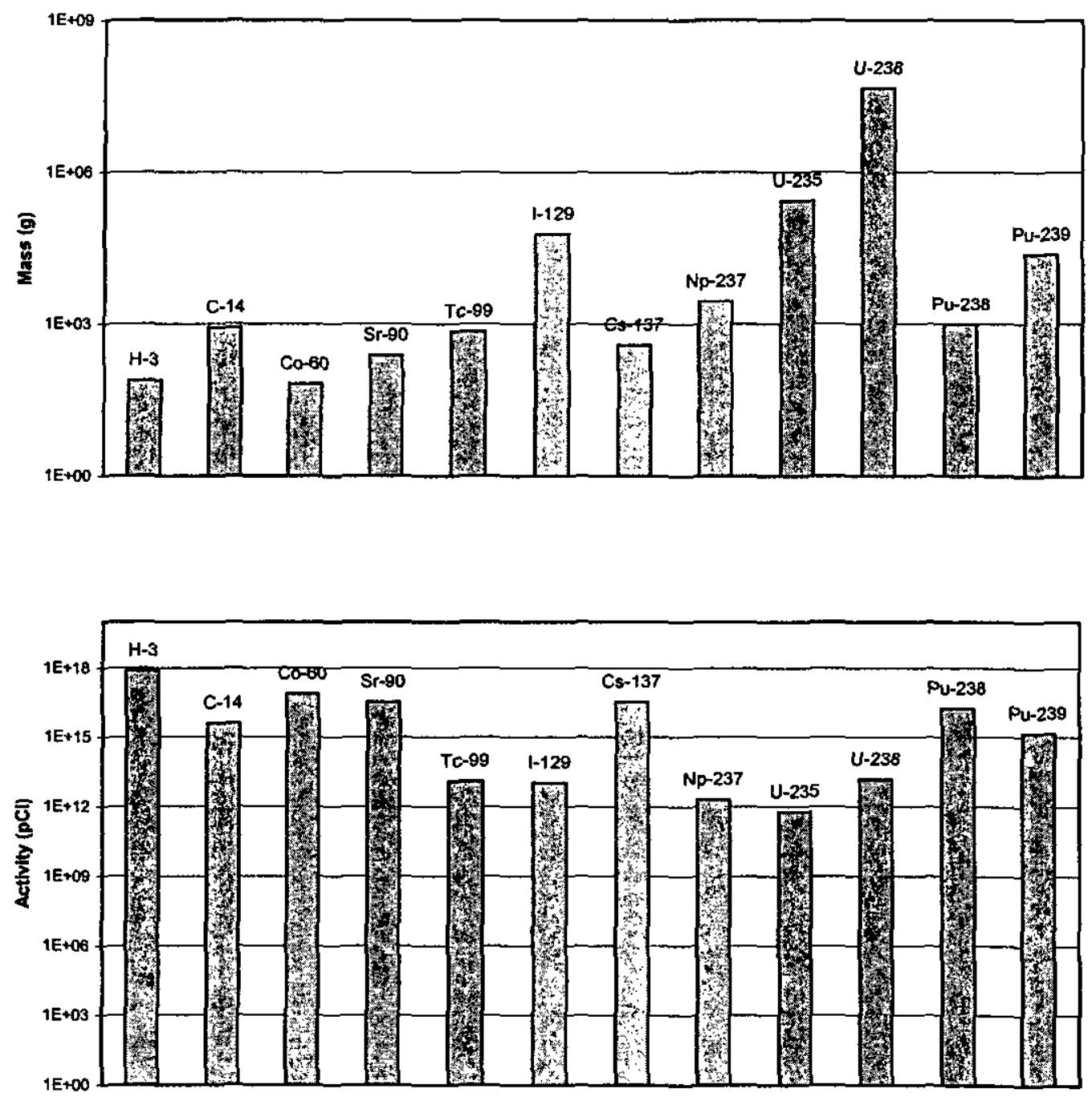

Figure 3-6. Summary of COBRA Inventory for Radioactive COIs at 25 Years After Burial 


\begin{tabular}{|c|c|c|c|c|c|}
\hline $\mathrm{COI}$ & Mass (g) & $\%$ Total Mass & Activity (Ci) & Activity (pCi) & $\%$ Total Activity \\
\hline Tritium & 19 & $0.00 \%$ & $180.3 E+3$ & $180.3 \mathrm{E}+15$ & $75.61 \%$ \\
\hline Carbon-14 & 840 & $0.00 \%$ & $3.8 \mathrm{E}+3$ & $3.8 \mathrm{E}+15$ & $1.58 \%$ \\
\hline Cobalt- 60 & 2 & $0.00 \%$ & $2.7 \mathrm{E}+3$ & $2.7 \mathrm{E}+15$ & $1.15 \%$ \\
\hline Strontium-90 & 131 & $0.00 \%$ & $17.8 \mathrm{E}+3$ & $17.8 \mathrm{E}+15$ & $7.49 \%$ \\
\hline Technetium-99 & 707 & $0.00 \%$ & $12.0 \mathrm{E}+0$ & $12.0 \mathrm{E}+12$ & $0.01 \%$ \\
\hline Iodine-129 & 60,023 & $0.13 \%$ & $10.6 \mathrm{E}+0$ & $10.6 \varepsilon+12$ & $0.00 \%$ \\
\hline Cesium-137 & 212 & $0.00 \%$ & $18.5 \mathrm{E}+3$ & $18.5 \mathrm{E}+15$ & $7.75 \%$ \\
\hline Neptunium-237 & 2,835 & $0.01 \%$ & $2.0 \mathrm{E}+0$ & $2.0 \mathrm{E}+12$ & $0.00 \%$ \\
\hline Uranium-235 & 269,767 & $0.60 \%$ & $580.0 \mathrm{E}-3$ & $580.0 \mathrm{E}+9$ & $0.00 \%$ \\
\hline Uranium-238 & $44,311,377$ & $99.20 \%$ & $14.8 \mathrm{E}+0$ & $14.8 \mathrm{E}+12$ & $0.01 \%$ \\
\hline Plutonium-238 & 802 & $0.00 \%$ & $13.8 E+3$ & $13.8 \mathrm{E}+15$ & $5.79 \%$ \\
\hline Plutonium-239 & 24,146 & $0.05 \%$ & $1.5 \mathrm{E}+3$ & $1.5 \mathrm{E}+15$ & $0.62 \%$ \\
\hline Totals & $44,670,863$ & $100 \%$ & 238,409 & $238.4 E+15$ & $100 \%$ \\
\hline
\end{tabular}
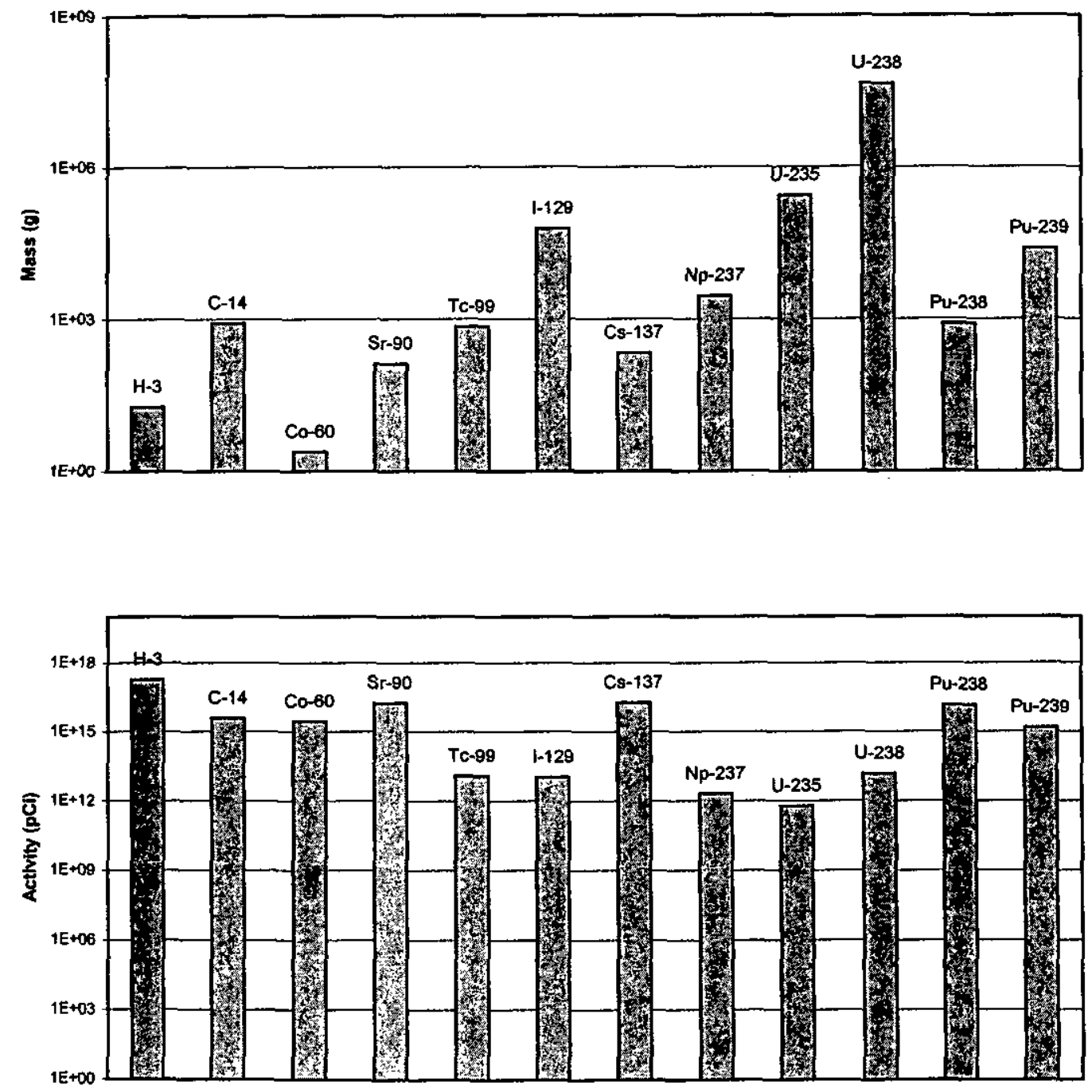

Figure 3-7. Summary of COBRA Inventory for Radioactive COIs at 50 Years After Burial 


\begin{tabular}{|c|c|c|c|c|c|}
\hline $\mathrm{COI}$ & Mass (g) & $\%$ Total Mass & Activity (Ci) & Activity $(\mathrm{pCi})$ & $\%$ Total Activity \\
\hline Tritium & 1 & $0.00 \%$ & $10.9 E+3$ & $10.9 E+15$ & $29.62 \%$ \\
\hline Carbon-14 & 835 & $0.00 \%$ & $3.7 E+3$ & $3.7 E+15$ & $10.19 \%$ \\
\hline Cobalt- 60 & 0 & $0.00 \%$ & $000.0 \mathrm{E}+0$ & $000.0 \mathrm{E}+0$ & $0.00 \%$ \\
\hline Strontium-90 & 40 & $0.00 \%$ & $5.4 \mathrm{E}+3$ & $5.4 \mathrm{E}+15$ & $14.83 \%$ \\
\hline Technetium-99 & 707 & $0.00 \%$ & $12.0 E+0$ & $12.0 \mathrm{E}+12$ & $0.03 \%$ \\
\hline lodine- 129 & 60,023 & $0.13 \%$ & $10.6 E+0$ & $10.6 \mathrm{E}+12$ & $0.03 \%$ \\
\hline Cesium- 137 & 67 & $0.00 \%$ & $5.8 \mathrm{E}+3$ & $5.8 \mathrm{E}+15$ & $15.90 \%$ \\
\hline Neptunium-237 & 2,847 & $0.01 \%$ & $2.0 \mathrm{E}+0$ & $2.0 E+12$ & $0.01 \%$ \\
\hline Uranium-235 & 269,767 & $0.60 \%$ & $580.0 \mathrm{E}-3$ & $580.0 \mathrm{E}+9$ & $0.00 \%$ \\
\hline Uranium-238 & $44,311,377$ & $99.20 \%$ & $14.8 \mathrm{E}+0$ & $14.8 \mathrm{E}+12$ & $0.04 \%$ \\
\hline Plutonium-238 & 540 & $0.00 \%$ & $9.3 E+3$ & $9.3 E+15$ & $25.34 \%$ \\
\hline Plutonium-239 & 24,113 & $0.05 \%$ & $1.5 \mathrm{E}+3$ & $1.5 \mathrm{E}+15$ & $4.02 \%$ \\
\hline Totals & $44,670,316$ & $100 \%$ & 36,634 & $36.6 \mathrm{E}+15$ & $100 \%$ \\
\hline
\end{tabular}
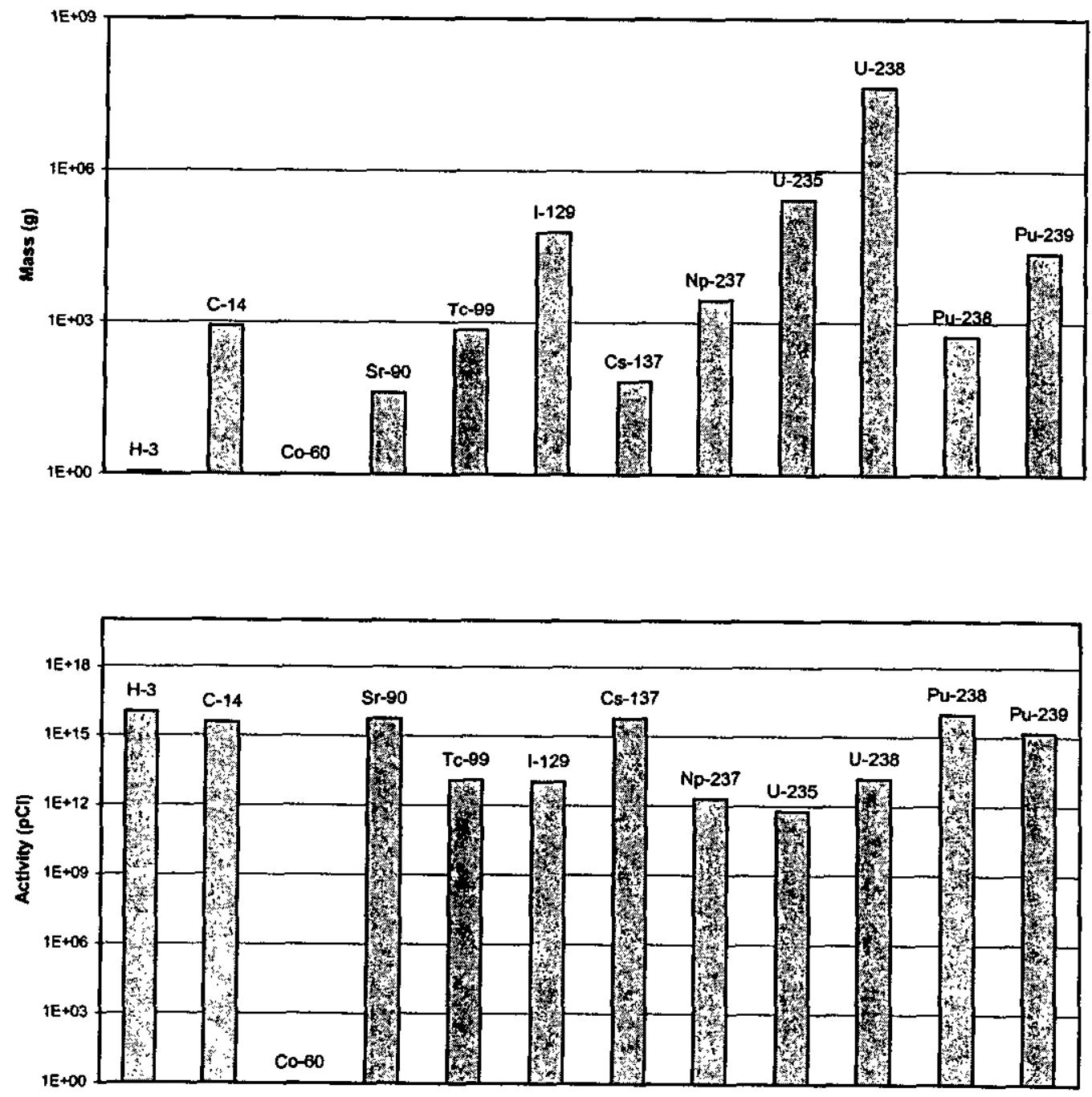

Figure 3-8. Summary of COBRA Inventory for Radioactive COIs at 100 Years After Burial 


\begin{tabular}{|c|c|c|c|c|c|}
\hline $\mathrm{COI}$ & Mass (g) & $\%$ Total Mass & Activity (Ci) & Activity (pCi) & $\%$ Total Activity \\
\hline Tritium & 0 & $0.00 \%$ & $000.0 \mathrm{E}+0$ & $000.0 \mathrm{E}+0$ & $0.00 \%$ \\
\hline Carbon-14 & 815 & $0.00 \%$ & $3.6 \mathrm{E}+3$ & $3.6 \mathrm{E}+15$ & $50.93 \%$ \\
\hline Cobalt- 60 & 0 & $0.00 \%$ & $000.0 \mathrm{E}+0$ & $000.0 \mathrm{E}+0$ & $0.00 \%$ \\
\hline Strontium-90 & $<1$ & $0.00 \%$ & $46.9 E+0$ & $46.9 \mathrm{E}+12$ & $0.66 \%$ \\
\hline Technetium-99 & 707 & $0.00 \%$ & $12.0 \mathrm{E}+0$ & $12.0 \mathrm{E}+12$ & $0.17 \%$ \\
\hline lodine-129 & 60,023 & $0.13 \%$ & $10.6 \mathrm{E}+0$ & $10.6 \mathrm{E}+12$ & $0.15 \%$ \\
\hline Cesium-137 & $<1$ & $0.00 \%$ & $58.7 \mathrm{E}+0$ & $58.7 \mathrm{E}+12$ & $0.82 \%$ \\
\hline Neptunium-237 & 2,885 & $0.01 \%$ & $2.0 E+0$ & $2.0 \mathrm{E}+12$ & $0.03 \%$ \\
\hline Uranium-235 & 269,767 & $0.60 \%$ & $580.0 \mathrm{E}-3$ & $580.0 \mathrm{E}+9$ & $0.01 \%$ \\
\hline Uranium-238 & $44,311,377$ & $99.20 \%$ & $14.8 \mathrm{E}+0$ & $14.8 \mathrm{E}+12$ & $0.21 \%$ \\
\hline Plutonium-238 & 111 & $0.00 \%$ & $1.9 \mathrm{E}+3$ & $1.9 \mathrm{E}+15$ & $26.59 \%$ \\
\hline Plutonium-239 & 23,975 & $0.05 \%$ & $1.5 \mathrm{E}+3$ & $1.5 \mathrm{E}+15$ & $20.45 \%$ \\
\hline Totals & $44,669,659$ & $100 \%$ & 7,153 & $7.2 \mathrm{E}+15$ & $100 \%$ \\
\hline
\end{tabular}
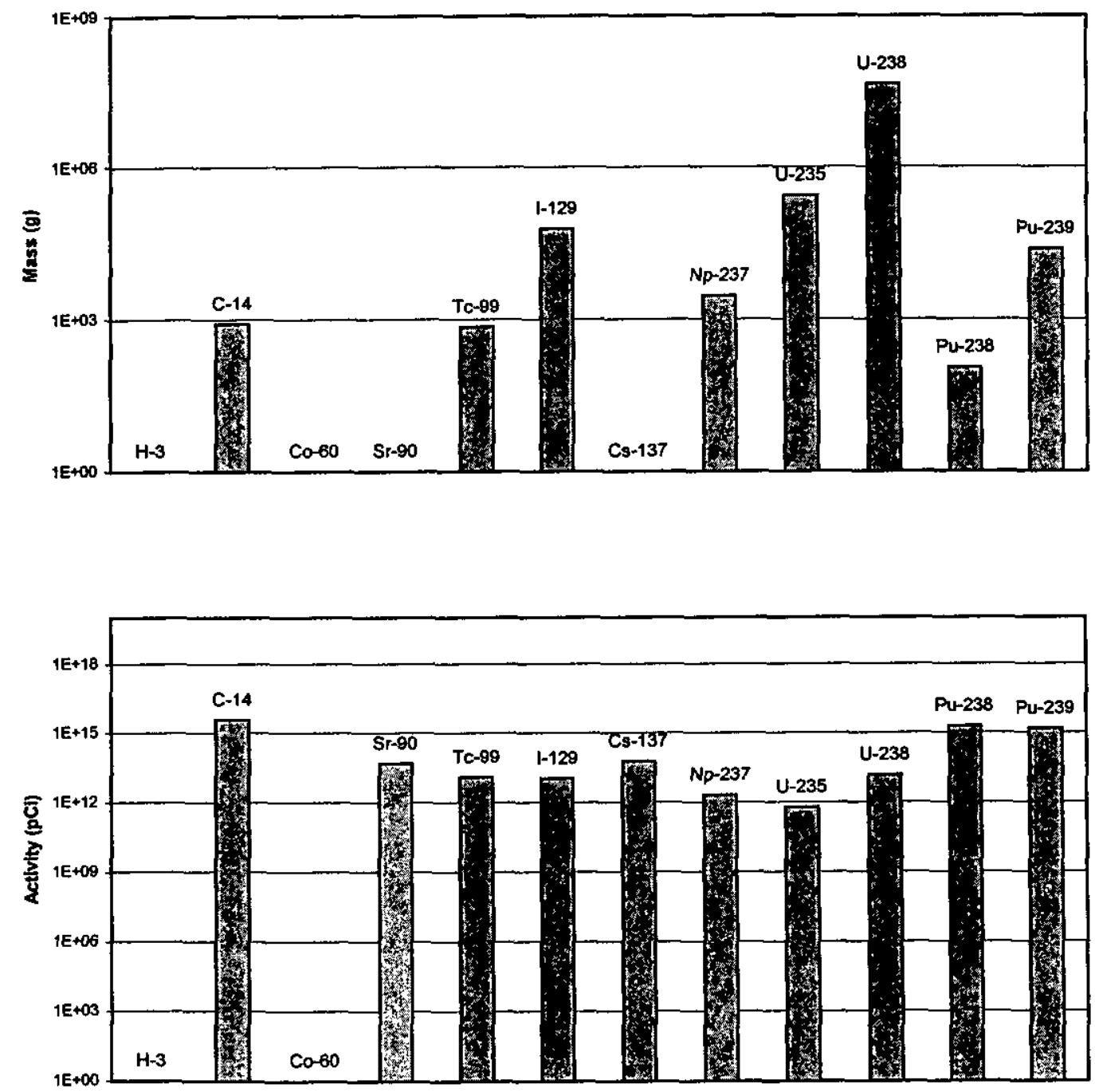

Figure 3-9. Summary of COBRA Inventory for Radioactive COIs at 300 Years After Burial 


\begin{tabular}{|c|c|c|c|c|c|}
\hline COI & Mass (g) & $\%$ Total Mass & Activity (Ci) & Activity (pCi) & $\%$ Total Activity \\
\hline Tritium & 0 & $0.00 \%$ & $000.0 \mathrm{E}+0$ & $000.0 \mathrm{E}+0$ & $0.00 \%$ \\
\hline Carbon-14 & 795 & $0.00 \%$ & $3.6 \mathrm{E}+3$ & $3.6 \mathrm{E}+15$ & $65.37 \%$ \\
\hline Cobalt-60 & 0 & $0.00 \%$ & $000.0 \mathrm{E}+0$ & $000.0 \mathrm{E}+0$ & $0.00 \%$ \\
\hline Strontium-90 & 0 & $0.00 \%$ & $000.0 \mathrm{E}+0$ & $000.0 \mathrm{E}+0$ & $0.00 \%$ \\
\hline Technetium-99 & 706 & $0.00 \%$ & $12.0 \mathrm{E}+0$ & $12.0 \mathrm{E}+12$ & $0.22 \%$ \\
\hline lodine-129 & 60,023 & $0.13 \%$ & $10.6 \mathrm{E}+0$ & $10.6 \mathrm{E}+12$ & $0.19 \%$ \\
\hline Cesium-137 & 0 & $0.00 \%$ & $000.0 \mathrm{E}+0$ & $000.0 \mathrm{E}+0$ & $0.00 \%$ \\
\hline Neptunium-237 & 2,913 & $0.01 \%$ & $2.1 \mathrm{E}+0$ & $2.1 \mathrm{E}+12$ & $0.04 \%$ \\
\hline Uranium-235 & 269,767 & $0.60 \%$ & $580.0 \mathrm{E}-3$ & $580.0 \mathrm{E}+9$ & $0.01 \%$ \\
\hline Uranium-238 & $44,311,377$ & $99.20 \%$ & $14.8 E+0$ & $14.8 \mathrm{E}+12$ & $0.27 \%$ \\
\hline Plutonium-238 & 23 & $0.00 \%$ & $389.8 \mathrm{E}+0$ & $389.8 \mathrm{E}+12$ & $7.17 \%$ \\
\hline Plutonium-239 & 23,839 & $0.05 \%$ & $1.5 \mathrm{E}+3$ & $1.5 \mathrm{E}+15$ & $26.73 \%$ \\
\hline Totals & $44,669,444$ & $100 \%$ & 5,440 & $5.4 E+15$ & $100 \%$ \\
\hline
\end{tabular}
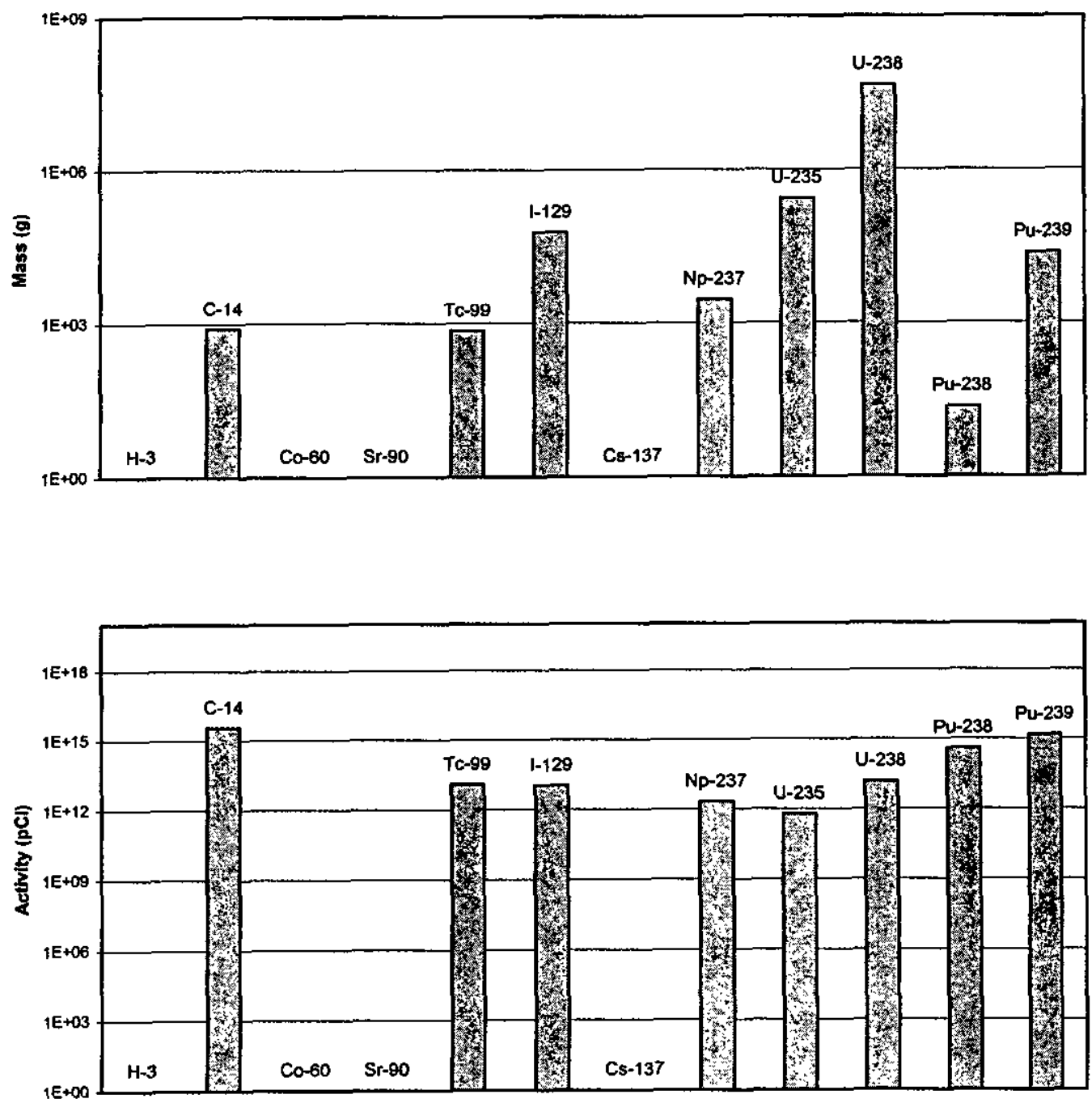

Figure 3-10. Summary of COBRA Inventory for Radioactive COIs at 500 Years After Burial 


\begin{tabular}{|c|c|c|c|c|c|}
\hline Constituent of Interest & Mass (g) & $\%$ Total Mass & Activity (Ci) & Activity (pCi) & $\%$ Total Activity \\
\hline Tritium & 0 & $0.00 \%$ & $000.0 \mathrm{E}+0$ & $000.0 \mathrm{E}+0$ & $0.00 \%$ \\
\hline Carbon-14 & 749 & $0.00 \%$ & $3.3 \mathrm{E}+3$ & $3.3 \mathrm{E}+15$ & $69.31 \%$ \\
\hline Cobalt -60 & 0 & $0.00 \%$ & $000.0 \mathrm{E}+0$ & $000.0 \mathrm{E}+0$ & $0.00 \%$ \\
\hline Strontium-90 & 0 & $0.00 \%$ & $000.0 E+0$ & $000.0 \mathrm{E}+0$ & $0.00 \%$ \\
\hline Technetium-99 & 705 & $0.00 \%$ & $12.0 \mathrm{E}+0$ & $12.0 \mathrm{E}+12$ & $0.25 \%$ \\
\hline Iodine-129 & 60,023 & $0.13 \%$ & $10.6 \mathrm{E}+0$ & $10.6 \mathrm{E}+12$ & $0.22 \%$ \\
\hline Cesium-137 & 0 & $0.00 \%$ & $000.0 \mathrm{E}+0$ & $000.0 \mathrm{E}+0$ & $0.00 \%$ \\
\hline Neptunium-237 & 2,953 & $0.01 \%$ & $2.1 \mathrm{E}+0$ & $2.1 \mathrm{E}+12$ & $0.04 \%$ \\
\hline Uranium-235 & 269,767 & $0.60 \%$ & $580.0 \mathrm{E}-3$ & $580.0 \mathrm{E}+9$ & $0.01 \%$ \\
\hline Uranium-238 & $44,311,377$ & $99.20 \%$ & $14.8 \mathrm{E}+0$ & $14.8 E+12$ & $0.31 \%$ \\
\hline Plutonium-238 & $<1$ & $0.00 \%$ & $8.2 \mathrm{E}+0$ & $8.2 E+12$ & $0.17 \%$ \\
\hline Plutonium-239 & 23,503 & $0.05 \%$ & $1.4 \mathrm{E}+3$ & $1.4 \mathrm{E}+15$ & $29.69 \%$ \\
\hline Totals & $44,669,077$ & $100 \%$ & 4,828 & $4.8 \mathrm{E}+15$ & $100 \%$ \\
\hline
\end{tabular}
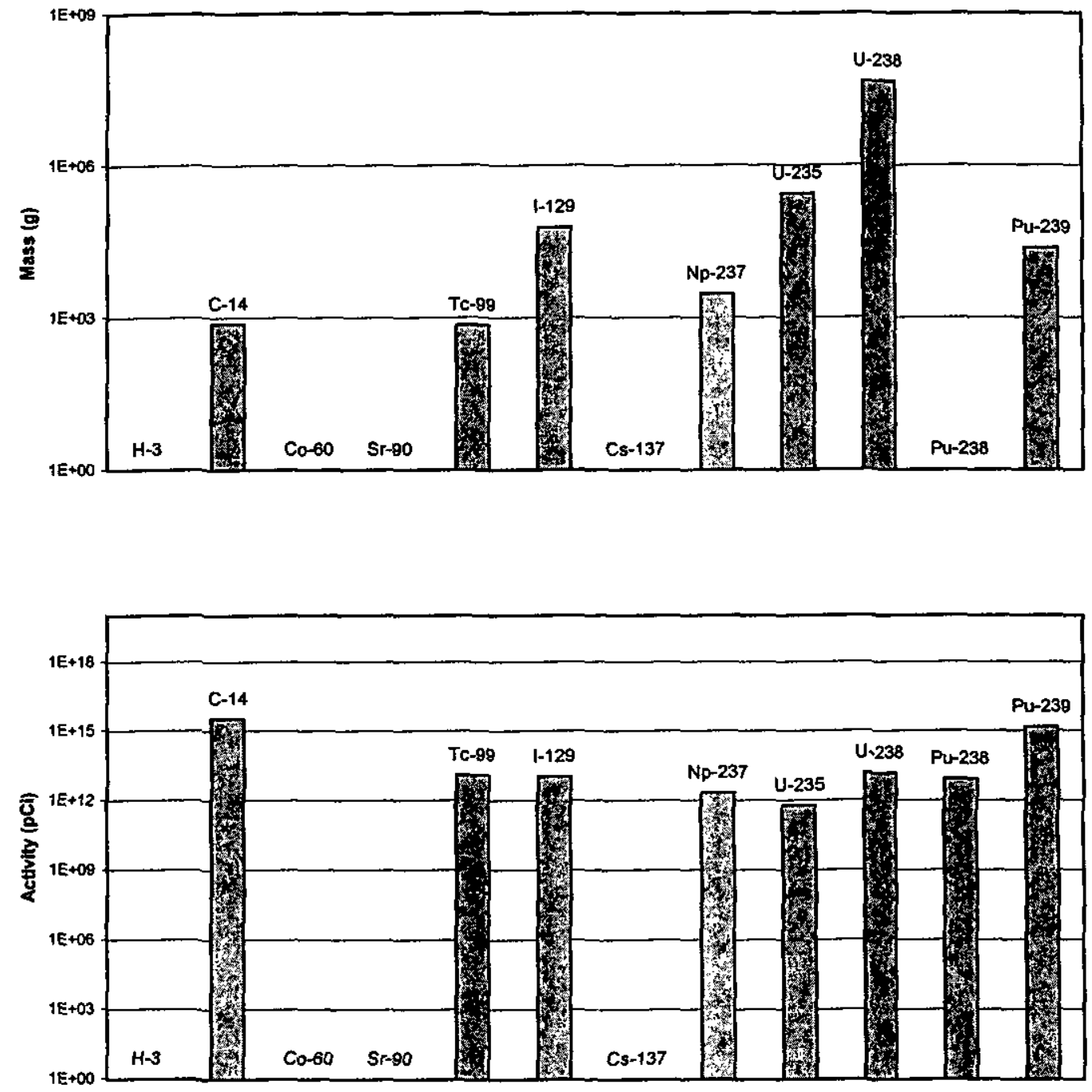

Figure 3-11. Summary of COBRA Inventory for Radioactive COIs at 1,000 Years After Burial 


\begin{tabular}{lrrrrr}
\hline \multicolumn{1}{c}{ Constituent of Interest } & Mass (g) & \% Total Mass & Activity (Ci) & Activity (pCi) & \% Total Activity \\
\hline Tritium & 0 & $0.00 \%$ & $000.0 \mathrm{E}+0$ & $000.0 \mathrm{E}+0$ & $0.00 \%$ \\
Carbon-14 & 461 & $0.00 \%$ & $2.1 \mathrm{E}+3$ & $2.1 \mathrm{E}+15$ & $60.97 \%$ \\
Cobalt-60 & 0 & $0.00 \%$ & $000.0 \mathrm{E}+0$ & $000.0 \mathrm{E}+0$ & $0.00 \%$ \\
Strontium-90 & 0 & $0.00 \%$ & $000.0 \mathrm{E}+0$ & $000.0 \mathrm{E}+0$ & $0.00 \%$ \\
Technetium-99 & 696 & $0.00 \%$ & $11.8 \mathrm{E}+0$ & $11.8 \mathrm{E}+12$ & $0.35 \%$ \\
Iodine-129 & 60,011 & $0.13 \%$ & $10.6 \mathrm{E}+0$ & $10.6 \mathrm{E}+12$ & $0.31 \%$ \\
Cesium-137 & 0 & $0.00 \%$ & $000.0 \mathrm{E}+0$ & $000.0 \mathrm{E}+0$ & $0.00 \%$ \\
Neptunium-237 & 2,986 & $0.01 \%$ & $2.1 \mathrm{E}+0$ & $2.1 \mathrm{E}+12$ & $0.06 \%$ \\
Uranium-235 & 269,767 & $0.60 \%$ & $580.0 \mathrm{E}-3$ & $580.0 \mathrm{E}+9$ & $0.02 \%$ \\
Uranium-238 & $44,311,377$ & $99.21 \%$ & $14.8 \mathrm{E}+0$ & $14.8 \mathrm{E}+12$ & $0.44 \%$ \\
Plutonium-238 & 0 & $0.00 \%$ & $000.0 \mathrm{E}+0$ & $000.0 \mathrm{E}+0$ & $0.00 \%$ \\
Plutonium-239 & 20,974 & $0.05 \%$ & $1.3 \mathrm{E}+3$ & $1.3 \mathrm{E}+15$ & $37.85 \%$ \\
\multicolumn{1}{c}{ Totals } & & & 3,380 & $3.4 \mathrm{E}+15$ & 15 \\
& $44,666,272$ & $100 \%$ & & \\
\hline
\end{tabular}
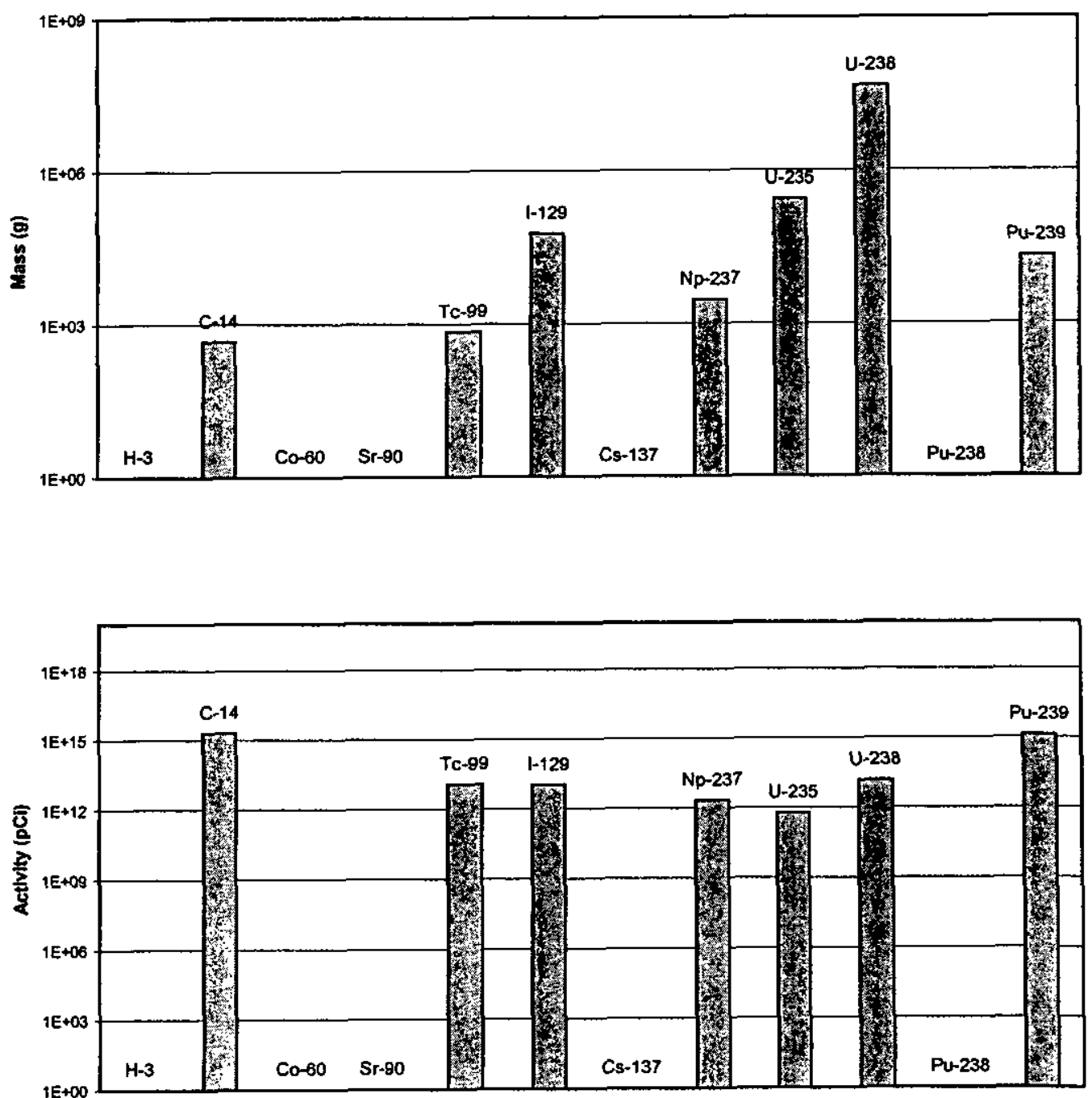

Figure 3-12. Summary of COBRA Inventory for Radioactive COIs at 5,000 Years After Burial 


\begin{tabular}{|c|c|c|c|c|c|}
\hline Constituent of Interest & Mass (g) & $\%$ Total Mass & Activity (Ci) & Activity (pCi) & $\%$ Total Activity \\
\hline Tritium & 0 & $0.00 \%$ & $000.0 \mathrm{E}+0$ & $000.0 \mathrm{E}+0$ & $0.00 \%$ \\
\hline Carbon-14 & 251 & $0.00 \%$ & $1.1 \mathrm{E}+3$ & $1.1 \mathrm{E}+15$ & $49.43 \%$ \\
\hline Cobalt- 60 & 0 & $0.00 \%$ & $000.0 \mathrm{E}+0$ & $000.0 \mathrm{E}+0$ & $0.00 \%$ \\
\hline Strontium-90 & 0 & $0.00 \%$ & $000.0 \mathrm{E}+0$ & $000.0 \mathrm{E}+0$ & $0.00 \%$ \\
\hline Technetium-99 & 685 & $0.00 \%$ & $11.6 \mathrm{E}+0$ & $11.6 \mathrm{E}+12$ & $0.51 \%$ \\
\hline Iodine-129 & 60,011 & $0.13 \%$ & $10.6 \mathrm{E}+0$ & $10.6 \mathrm{E}+12$ & $0.47 \%$ \\
\hline Cesium +137 & 0 & $0.00 \%$ & $000.0 \mathrm{E}+0$ & $000.0 \mathrm{E}+0$ & $0.00 \%$ \\
\hline Neptunium-237 & 2,986 & $0.01 \%$ & $2.1 \mathrm{E}+0$ & $2.1 \mathrm{E}+12$ & $0.09 \%$ \\
\hline Uranium-235 & 269,767 & $0.60 \%$ & $580.0 \mathrm{E}-3$ & $580.0 \mathrm{E}+9$ & $0.03 \%$ \\
\hline Uranium-238 & $44,311,377$ & $99.21 \%$ & $14.8 \mathrm{E}+0$ & $14.8 \mathrm{E}+12$ & $0.65 \%$ \\
\hline Plutonium-238 & $<1$ & $0.00 \%$ & $000.0 \mathrm{E}+0$ & $000.0 E+0$ & $0.00 \%$ \\
\hline Plutonium-239 & 18,193 & $0.04 \%$ & $1.1 \mathrm{E}+3$ & $1.1 \mathrm{E}+15$ & $48.82 \%$ \\
\hline Totals & $44,663,270$ & $100 \%$ & 2,273 & $2.3 E+15$ & $100 \%$ \\
\hline
\end{tabular}
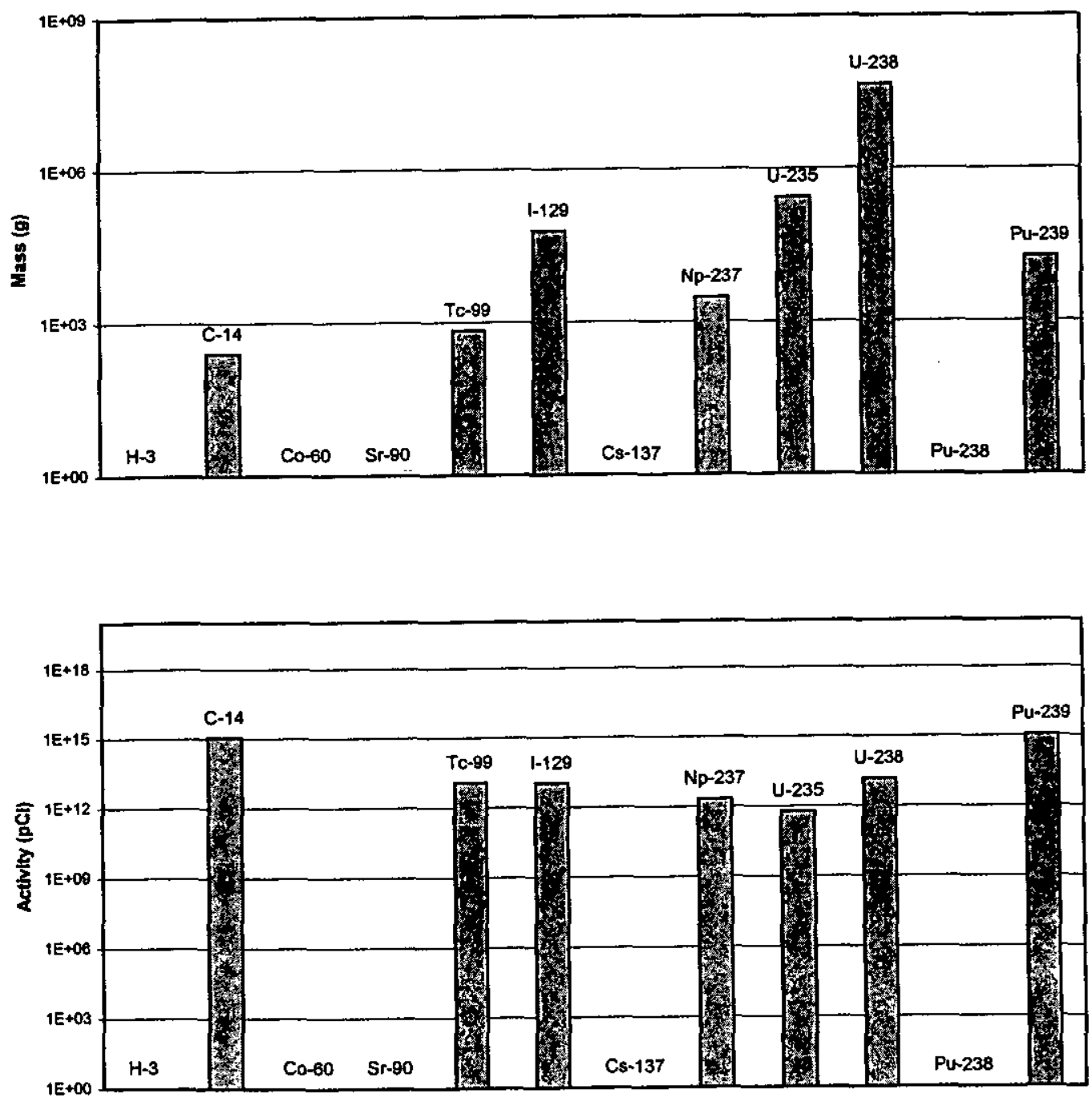

Figure 3-13. Summary of COBRA Inventory for Radioactive COIs at 10,000 Years After Burial 


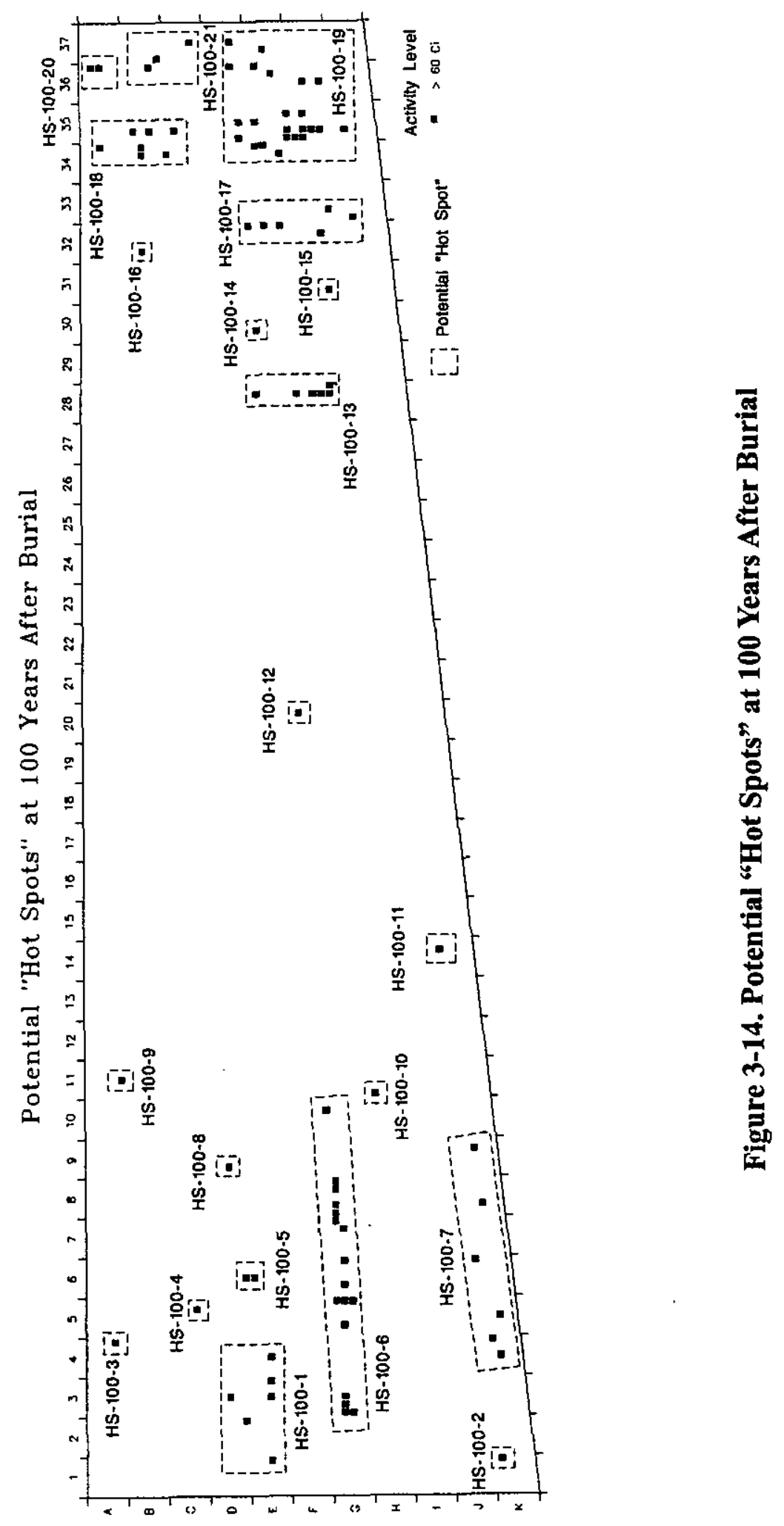




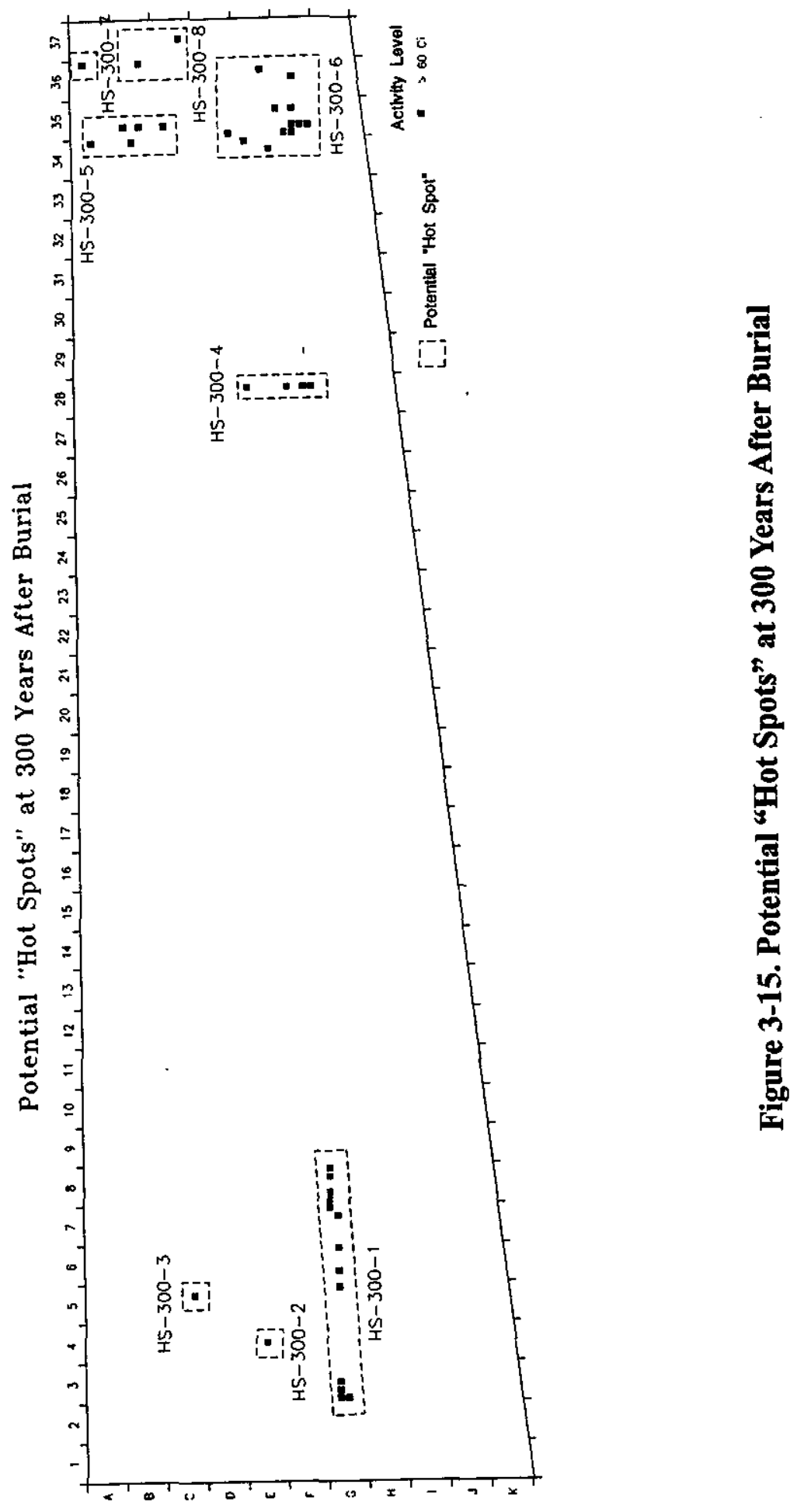




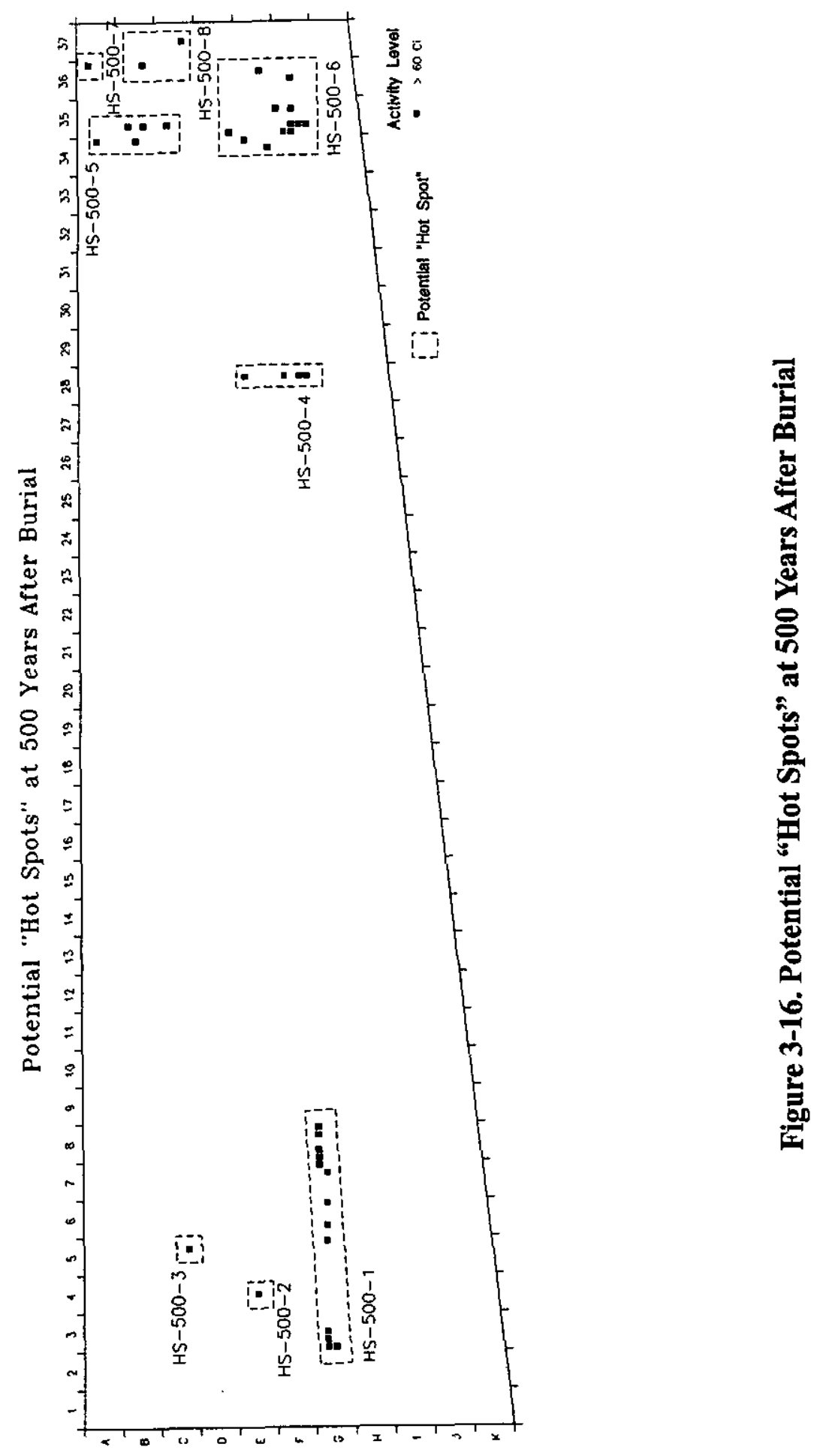


Table 3-1. Summary of COBRA Inventory Data for Nonradioactive COIs

\begin{tabular}{|c|c|c|c|c|c|c|c|}
\hline $\begin{array}{c}\begin{array}{c}\text { Constituent } \\
\text { of } \\
\text { Interest }\end{array} \\
\end{array}$ & $\begin{array}{c}\text { Estimated } \\
\text { OBG* }^{\star} \\
\text { Inventory }\end{array}$ & $\begin{array}{c}\text { Estimated } \\
\text { Total } \\
\text { Inventory } \\
\text { (WSRC,1997) } \\
\end{array}$ & $\begin{array}{c}\text { Applicable } \\
\text { COBRA Codes } \\
\text { and Search } \\
\text { Parameters } \\
\end{array}$ & $\begin{array}{c}\text { Total Number } \\
\text { of Applicable } \\
\text { COBRA } \\
\text { Records } \\
\end{array}$ & $\begin{array}{c}\text { Estimated } \\
\text { Inventory } \\
\text { from } \\
\text { from COBRA } \\
\end{array}$ & $\begin{array}{l}\text { No. of } \\
\text { Records } \\
\text { with } \\
\text { Locations } \\
\end{array}$ & $\begin{array}{l}\text { Percent of } \\
\text { Records } \\
\text { with } \\
\text { Locations } \\
\end{array}$ \\
\hline Cadmium (Cd) & 600 & $3,500 \quad l b$ & $\begin{array}{l}\text { Estimates based } \\
\text { on process } \\
\text { knowledge }\end{array}$ & 0 & - & - & - \\
\hline Lead $(\mathrm{Pb})$ & 40,000 & $100,000 \mathrm{lb}$ & $\begin{array}{l}\text { Estimates based } \\
\text { on process } \\
\text { knowledge }\end{array}$ & 0 & - & - & - \\
\hline Mercury (Hg) & 8,285 & $24,195 \mathrm{lb}$ & $\begin{array}{l}\text { Process } \\
\text { knowledge; } \\
\text { searches } \\
\text { included facility }\end{array}$ & 150 & $n / a^{l}$ & 136 & $91 \%$ \\
\hline \multicolumn{8}{|l|}{$\begin{array}{l}\text { Volatile Organic } \\
\text { Compounds (VOCs) }\end{array}$} \\
\hline VOC-OST Residue & & 7,539 gal & $\begin{array}{l}\text { Searched waste } \\
\text { type and } \\
\text { container type }\end{array}$ & $\mathrm{n} / \mathrm{a}$ & - & - & - \\
\hline VOC - Trenches & 6,480 & $26,200 \mathrm{~kg}$ & $\begin{array}{l}\text { Searched waste } \\
\text { type and } \\
\text { container type }\end{array}$ & 1889 & - & 1655 & $88 \%$ \\
\hline
\end{tabular}

Notes

1 COBRA records associated with mercury contained other waste; the exact quantity of mercury cannot be determined

*riginal Burial Ground 
Table 3-2. Summary of COBRA Inventory Data for Radioactive COIs

\begin{tabular}{|c|c|c|c|c|c|c|c|c|}
\hline Constituent of Interest & $\begin{array}{l}\text { Estimated } \\
\text { OBG* } \\
\text { Inventory }\end{array}$ & $\begin{array}{c}\text { Estimated } \\
\text { Total } \\
\text { Inventory }(\mathrm{Ci})^{!} \\
\end{array}$ & $\begin{array}{c}\text { Applicable COBRA } \\
\text { Codes and Search } \\
\text { Parameters }\end{array}$ & $\begin{array}{c}\text { Total Number of } \\
\text { Applicable COBRA } \\
\text { Records } \\
\end{array}$ & $\begin{array}{c}\text { No. of } \\
\text { Records with } \\
\text { Locations } \\
\end{array}$ & $\begin{array}{l}\text { Percent of } \\
\text { Records with } \\
\text { Locations } \\
\end{array}$ & $\begin{array}{l}\text { Located } \\
\text { Inventory } \\
\text { (Ci) } \\
\end{array}$ & $\begin{array}{c}\text { Located \% of } \\
\text { Best } \\
\text { Estimate } \\
\end{array}$ \\
\hline Tritium (H-3) & $881,224.00$ & $3,014,457.0$ & Variety code " $87 "$ & 3,579 & 3,307 & $92.4 \%$ & $2,023,601.4$ & $67.1 \%$ \\
\hline Carbon-14 (C-14) & $1,511.00$ & $3,778.0$ & $\begin{array}{l}\text { Searched keywords related } \\
\text { to deionizers }\end{array}$ & 147 & 141 & $95.9 \%$ & $3,603.4$ & $95.4 \%$ \\
\hline Cobalt-60 (CO-60) & $784,160.00$ & $1,960,400.0$ & $\begin{array}{l}\text { Searched for "induced } \\
\text { activity"; type code "3" }\end{array}$ & 4,449 & 4,133 & $92.9 \%$ & $824,910.6$ & $42.1 \%$ \\
\hline Strontium-90 (Sr-90) & $20,774.00$ & $58,657.0$ & Variety code "FP" & $24,165^{2}$ & $22,599^{2}$ & $93.5 \%$ & $17,471.0$ & $29.8 \%$ \\
\hline Technetium-99 (Tc-99) & 4.80 & 12.0 & Variety code "FP" & $24,165^{2}$ & 22,5992 & $93.5 \%$ & 5.8 & $48.7 \%$ \\
\hline Iodine-129 (I-129) & 4.20 & 10.6 & Process knowledge & $\mathrm{n} / \mathrm{a}$ & - & - & - & - \\
\hline Cesium-137 (Cs-137) & $20,774.00$ & $58,657.0$ & $\begin{array}{l}\text { Process knowledge; } \\
\text { searched variety "FP" }\end{array}$ & $24,165^{2}$ & $22,599^{2}$ & $93.5 \%$ & $18,621.7$ & $31.7 \%$ \\
\hline Neptunium-237 (Np-237) & $0.05^{3}$ & 1.99 & Variety codes "82" & 354 & 343 & $96.9 \%$ & 1.96 & $98.3 \%$ \\
\hline Uranium-235 (U-235) & 0.11 & 0.6 & Variety codes " 10 " and " $20^{n}$ & 394 & 368 & $93.4 \%$ & 0.3 & $54.3 \%$ \\
\hline Uranium-238 (U-238) & 2.40 & 14.8 & $\begin{array}{l}\text { Variety codes "10", "20", } \\
\text { and " } 81 "\end{array}$ & 4,199 & 4,016 & $95.6 \%$ & 12.8 & $86.6 \%$ \\
\hline Plutonium-238 (Pu-238) & $304.00^{3}$ & $20,514.0$ & Variety code "83" & 1,465 & 1,422 & $97.1 \%$ & $20,434.9$ & $99.6 \%$ \\
\hline Plutonium-239 (Pu-239) & 255.00 & $\underline{1,475.0}$ & Variety code " $50 "$ & 2,778 & 2,670 & $96.1 \%$ & $1,051.0$ & $71.3 \%$ \\
\hline Totals & $1,709,013.6$ & $5,117,978.0$ & & $41,530^{2}$ & 38,999 & $93.9 \%$ & $2,909,715.0$ & $56.9 \%$ \\
\hline
\end{tabular}

Notes:

${ }^{1}$ Estimated inventory in (WSRC, 1997)

${ }^{2}$ Source-term calculation for these COls used same records from COBRA

${ }^{3}$ Probably less than this quantity

* Original Burial Ground 
Table 3-3. Summary of Location Data in COBRA by Date of Burial Slip

\begin{tabular}{|c|c|c|c|c|}
\hline \multirow[b]{2}{*}{ Year } & \multicolumn{3}{|c|}{ Number of Burial Records } & \multirow[b]{2}{*}{ Significant Events } \\
\hline & Located & Total & $\%$ Located & \\
\hline $1952-55$ & 0 & 156 & $0 \%$ & OBG began receiving waste \\
\hline $1957-58$ & 0 & 98 & $0 \%$ & \\
\hline 1959 & 1 & 58 & $1.7 \%$ & \\
\hline 1960 & 0 & 49 & $0 \%$ & \\
\hline 1961 & 2452 & 4488 & $54.6 \%$ & COBRA started; expansion areas began receiving waste \\
\hline 1962 & 4989 & 5004 & $99.7 \%$ & \\
\hline 1963 & 4790 & 4807 & $99.6 \%$ & \\
\hline 1964 & 4895 & 5004 & $97.8 \%$ & \\
\hline 1965 & 3936 & 3952 & $99.6 \%$ & \\
\hline 1966 & 3797 & 3806 & $99.8 \%$ & \\
\hline 1967 & 3770 & 3790 & $99.5 \%$ & \\
\hline 1968 & 3579 & 3593 & $99.6 \%$ & \\
\hline 1969 & 3417 & 3431 & $99.6 \%$ & New Burial Ground (643-7E) began receiving waste \\
\hline 1970 & 2680 & 2718 & $98.6 \%$ & \\
\hline 1971 & 2896 & 2901 & $99.8 \%$ & \\
\hline 1972 & 375 & 390 & $96.2 \%$ & \\
\hline 1973 & 76 & 88 & $86.4 \%$ & ORWBG closed to routine burials \\
\hline
\end{tabular}

${ }^{1}$ from date recorded on burial slip 
Table 3-4. Summary of Estimated COI Inventories for the Original Burial Ground and Solvent Tanks S1-S22

\begin{tabular}{|c|c|c|c|}
\hline Constituent of Interest & $\begin{array}{c}\text { Amount Buried in Trenches } \\
\text { (Through 1960) }\end{array}$ & $\begin{array}{c}\text { Current Inventory in } \\
\text { OSTs (1997) } \\
\end{array}$ & Uncertainties \\
\hline \multicolumn{4}{|l|}{ Nonradioactive } \\
\hline Cadmium (Cd) & $600 \mathrm{lbs}$ & negligible & $\mathbf{a}$ \\
\hline $\operatorname{Lead}(\mathrm{Pb})$ & $40,000 \mathrm{lbs}$ & negligible & c \\
\hline Mercury $(\mathrm{Hg})$ & $8,285 \mathrm{lbs}$ & negligible & $a, c$ \\
\hline Volatile Organic & $2,840 \mathrm{~kg}$ toluene & $7,569 \mathrm{gal}$ & $a, e$ \\
\hline Compounds (VOCs) & $\begin{array}{r}2,840 \mathrm{~kg} \text { trimethylbenzene } \\
4,800 \mathrm{~kg} \text { xylene } \\
\text { unknown amount of waste oil }\end{array}$ & $\begin{array}{r}\text { (4,056 gal organic } \\
\text { phase and } 3,483 \text { gal } \\
\text { aqueous phase) }\end{array}$ & \\
\hline \multicolumn{4}{|l|}{ Radioactive } \\
\hline Tritium (H-3) & $881,224 \mathrm{Ci}$ & negligible & $\mathrm{a}, \mathrm{b}$ \\
\hline Cesium - $137(\mathrm{Cs}-137)$ & $20,774 \mathrm{Ci}$ & $1.30 \mathrm{Ci}$ & $\mathrm{b}$ \\
\hline Putonium-238 (Pu-238) & $<304 \mathrm{Ci}$ & $21.4 \mathrm{Ci}$ & $b, d, e, g$ \\
\hline Putonium - 239 (Pu-239) & $255 \mathrm{Ci}$ & $82.4 \mathrm{Ci}$ & $b, e, g$ \\
\hline Strontiurn-90 (Sr-90) & $20,774 \mathrm{Ci}$ & $1.28 \mathrm{Ci}$ & b \\
\hline Uranium-235 (U-235) & $0.113 \mathrm{Ci}$ & $0.11 \mathrm{Ci}$ & $b, e, f$ \\
\hline Uranium-238 (U-238) & $2.4 \mathrm{Ci}$ & $1.1 \mathrm{Ci}$ & $b, e, f$ \\
\hline Carbon-14 (C-14) & $1,511 \mathrm{Ci}$ & negligible & $a, g$ \\
\hline Cobalt-60 (Co-60) & $784,160 \mathrm{Ci}$ & negligible & a \\
\hline Technetium-99 (Tc-99) & $4.8 \mathrm{Ci}$ & negligible & $\mathrm{a}, \mathrm{f}$ \\
\hline Iodine-129 (I-129) & $4.2 \mathrm{Ci}$ & negligible & $a, f$ \\
\hline Neptune-237 (Np-237) & $<0.046 \mathrm{Ci}$ & negligible & $\mathrm{b}, \mathrm{d}, \mathrm{f}$ \\
\hline
\end{tabular}

Notes: Assumes all burials through 1960 occurred in the original burial ground, and that no burials occurred in the original burial ground after 1960.

a. Inventory is based on an average production/disposal rate, which is applied to the years 1953-1960 (inclusive).

b. Based on burial records, which are incomplete prior to 1961 .

c. Based on an unsubstantiated estimate.

d. Estimate includes some burials after 1960, which probably were in the eastern and/or western expansions.

e. Based on an estimated isotopic ratio.

f. Due to their long half-lives, the current inventories are assumed to be the same as the original amounts buried.

g. The current inventory assumes no radioactive decay prior to January 1, 1961. 
Table 3-5. Radioactive Decay of COIs to 10,000 Years After Burial

\begin{tabular}{|c|c|c|c|c|c|c|c|c|c|c|}
\hline \multirow[b]{2}{*}{$\mathrm{COI}$} & \multirow[b]{2}{*}{ Half Life (yr) } & \multicolumn{9}{|c|}{ Percent of Buried Inventory Remaining } \\
\hline & & Burial & $25 \mathrm{yr}$ & $50 \mathrm{yr}$ & $100 \mathrm{yr}$ & $300 \mathrm{yr}$ & $500 \mathrm{yr}$ & $1,000 \mathrm{yr}$ & $5,000 \mathrm{yr}$ & $10,000 \mathrm{yr}$ \\
\hline Tritium & 12.3 & $100 \%$ & $24.5 \%$ & $6.0 \%$ & $0.4 \%$ & $0 \%$ & $0 \%$ & $0 \%$ & $0 \%$ & $0 \%$ \\
\hline Carbon-14 & 5,715 & $100 \%$ & $99.70 \%$ & $99.40 \%$ & $98.79 \%$ & $96.43 \%$ & $94.12 \%$ & $88.58 \%$ & $54.54 \%$ & $29.74 \%$ \\
\hline Cobalt -60 & 5.27 & $100 \%$ & $3.73 \%$ & $0.14 \%$ & $0 \%$ & $0 \%$ & $0 \%$ & $0 \%$ & $0 \%$ & $0 \%$ \\
\hline Strontium-90 & 29.12 & $100 \%$ & $55.16 \%$ & $30.43 \%$ & $9.26 \%$ & $0.08 \%$ & $0 \%$ & $0 \%$ & $0 \%$ & $0 \%$ \\
\hline Technetium-99 & 213,000 & $100 \%$ & $99.99 \%$ & $99.98 \%$ & $99.97 \%$ & $99.90 \%$ & $99.84 \%$ & $99.68 \%$ & $98.39 \%$ & $96.80 \%$ \\
\hline Iodine-129 & $15,700,000$ & $100 \%$ & $100.00 \%$ & $100.00 \%$ & $100.00 \%$ & $100.00 \%$ & $100.00 \%$ & $100.00 \%$ & $99.98 \%$ & $99.98 \%$ \\
\hline Cesium-137 & 30 & $100 \%$ & $56.13 \%$ & $31.51 \%$ & $9.93 \%$ & $0.10 \%$ & $0 \%$ & $0 \%$ & $0 \%$ & $0 \%$ \\
\hline Neptunium-23 1 & $2,140,000$ & $100 \%$ & $100.23 \%$ & $100.45 \%$ & $100.86 \%$ & $102.21 \%$ & $103.19 \%$ & $104.62 \%$ & $105.78 \%$ & $105.78 \%$ \\
\hline Uranium-235 & $710,000,000$ & $100 \%$ & $100 \%$ & $100 \%$ & $100 \%$ & $100 \%$ & $100 \%$ & $100 \%$ & $100 \%$ & $100 \%$ \\
\hline Uranium-238 & $4,510,000,000$ & $100 \%$ & $100 \%$ & $100 \%$ & $100 \%$ & $100 \%$ & $100 \%$ & $100 \%$ & $100 \%$ & $100 \%$ \\
\hline Plutonium-238 & 87.4 & $100 \%$ & $82.02 \%$ & $67.27 \%$ & $45.25 \%$ & $9.27 \%$ & $1.90 \%$ & $0.04 \%$ & $0.00 \%$ & $0.00 \%$ \\
\hline Plutonium-239 & 24,360 & $100 \%$ & $99.93 \%$ & $99.86 \%$ & $99.72 \%$ & $99.15 \%$ & $98.59 \%$ & $97.20 \%$ & $86.74 \%$ & $75.24 \%$ \\
\hline
\end{tabular}

\section{Notes}

'Inventory of Np-237 includes in-growth from decay of Am-241 decayed from Pu-241 (WSRC,1997) 
Table 3-6. Decay Forecast for Inventory of Radioactive COIs in the Original Burial Ground

\begin{tabular}{|c|c|c|c|c|c|c|c|c|c|}
\hline \multirow[b]{2}{*}{$\mathrm{COI}$} & \multicolumn{9}{|c|}{ COI Activity (Ci) } \\
\hline & At Burial ${ }^{1}$ & $25 \mathrm{yr}$ & $50 \mathrm{yr}$ & $100 \mathrm{yr}$ & $300 \mathrm{yr}$ & $500 \mathrm{yr}$ & $1,000 \mathrm{yr}$ & $5,000 \mathrm{yr}$ & $10,000 \mathrm{yr}$ \\
\hline Tritium & 881,224 & 215,459 & 52,697 & 3,172 & 0 & 0 & 0 & 0 & 0 \\
\hline Carbon-14 & 1,511 & 1,506 & 1,502 & 1,493 & 1,457 & 1,422 & 1,338 & 824 & 449 \\
\hline Cobalt -60 & 784,160 & 29,249 & 1,098 & 0 & 0 & 0 & 0 & 0 & 0 \\
\hline Strontium-90 & 20,774 & 11,459 & 6,322 & 1,924 & 17 & 0 & 0 & 0 & 0 \\
\hline Technetium-99 & 4.8 & 4.8 & 4.8 & 4.8 & 4.8 & 4.8 & 4.8 & 4.7 & 4.6 \\
\hline lodine-129 & 4.2 & 4.2 & 4.2 & 4.2 & 4.2 & 4.2 & 4.2 & 4.2 & 4.2 \\
\hline Cesium-137 & 20,774 & 11,660 & 6,546 & 2,063 & 21 & 0 & 0 & 0 & 0 \\
\hline Neptunium-23 2 & 0.050 & 0.050 & 0.050 & 0.050 & 0.051 & 0.052 & 0.052 & 0.053 & 0.053 \\
\hline Uranium-235 & 0.11 & 0.11 & 0.11 & 0.11 & 0.11 & 0.11 & 0.11 & 0.11 & 0.11 \\
\hline Uranium-238 & 2.4 & 2.4 & 2.4 & 2.4 & 2.4 & 2.4 & 2.4 & 2.4 & 2.4 \\
\hline Plutonium-238 & 304 & 249 & 205 & 138 & 28 & 6 & 0 & 0 & 0 \\
\hline Plutonium-239 & 255 & 255 & 255 & 254 & 253 & 251 & 248 & 221 & 192 \\
\hline Totals & $1,709,014$ & 269,850 & 68,635 & 9,055 & 1,787 & 1,691 & 1,598 & 1,057 & 653 \\
\hline
\end{tabular}

Notes:

${ }^{1}$ Estimated inventory from Table 3-4 of this report

2 Decay Forecast for Np-237 includes in-growth from decay of Am-241 decayed from Pu-241 (WSRC,1997) 
Table 3-7. Summary of Distribution of Burial Locations for Mercury and VOCs

\begin{tabular}{|c|c|c|c|c|}
\hline \multirow{2}{*}{$\begin{array}{l}\text { No. of Burials } \\
\text { per Grid Cell }\end{array}$} & \multicolumn{2}{|c|}{ Mercury } & \multicolumn{2}{|c|}{ VOCs } \\
\hline & No. Cells & Total Burials & No. Cells & Total Burials \\
\hline 1 & 59 & 59 & 126 & 126 \\
\hline 2 & 19 & 38 & 36 & 72 \\
\hline 3 & 7 & 21 & 20 & 60 \\
\hline 4 & 1 & 4 & 11 & 44 \\
\hline 5 & 0 & 0 & 4 & 20 \\
\hline 6 & 0 & 0 & 2 & 12 \\
\hline 7 & 2 & 14 & 5 & 35 \\
\hline 8 & 0 & 0 & 4 & 32 \\
\hline 9 & 0 & 0 & 2 & 18 \\
\hline 10 & 0 & 0 & 1 & 10 \\
\hline 11 & 0 & 0 & 1 & 11 \\
\hline 12 & 0 & 0 & 1 & 12 \\
\hline 13 & 0 & 0 & 3 & 39 \\
\hline 14 & 0 & 0 & 1 & 14 \\
\hline 15 & 0 & 0 & 2 & 30 \\
\hline 16 & 0 & 0 & 1 & 16 \\
\hline 17 & 0 & 0 & 5 & 85 \\
\hline 18 & 0 & 0 & 3 & 54 \\
\hline 19 & 0 & 0 & 3 & 57 \\
\hline 20 & 0 & 0 & 1 & 20 \\
\hline 21 & 0 & 0 & 0 & 0 \\
\hline 22 & 0 & 0 & 1 & 22 \\
\hline 23 & 0 & 0 & 1 & 23 \\
\hline 24 & 0 & 0 & 1 & 24 \\
\hline 25 & 0 & 0 & 2 & 50 \\
\hline 26 & 0 & 0 & 0 & 0 \\
\hline 27 & 0 & 0 & 3 & 81 \\
\hline 28 & 0 & 0 & 1 & 28 \\
\hline 29 & 0 & 0 & 2 & 58 \\
\hline 30 & 0 & 0 & 3 & 90 \\
\hline $31-38$ & 0 & 0 & 0 & 0 \\
\hline 39 & 0 & 0 & 1 & 39 \\
\hline $40-41$ & 0 & 0 & 0 & 0 \\
\hline 42 & 0 & 0 & 2 & 84 \\
\hline 43 & 0 & 0 & 0 & 0 \\
\hline 44 & 0 & 0 & 1 & 44 \\
\hline 45 & 0 & 0 & 0 & 0 \\
\hline 46 & 0 & 0 & 1 & 46 \\
\hline $47-50$ & 0 & 0 & 0 & 0 \\
\hline 51 & 0 & 0 & 1 & 51 \\
\hline $52-74$ & 0 & 0 & 0 & 0 \\
\hline 75 & 0 & 0 & 1 & 75 \\
\hline $76-79$ & 0 & 0 & 0 & 0 \\
\hline 80 & 0 & 0 & 1 & 80 \\
\hline $81-92$ & 0 & 0 & 0 & 0 \\
\hline 93 & 0 & 0 & 1 & 93 \\
\hline Total Located Bur & & 136 & & 1655 \\
\hline
\end{tabular}


Table 3-8. Decay Forecast for Total Inventory of Radioactive COIs in the ORWBG

\begin{tabular}{|c|c|c|c|c|c|c|c|c|c|}
\hline \multirow[b]{2}{*}{$\mathrm{COI}$} & \multicolumn{9}{|c|}{ COI Activity (Ci) } \\
\hline & At Burial $^{1}$ & $25 \mathrm{yr}$ & $50 \mathrm{yr}$ & $100 \mathrm{yr}$ & $300 \mathrm{yr}$ & $500 \mathrm{yr}$ & $1,000 \mathrm{yr}$ & $5,000 \mathrm{yr}$ & $10,000 \mathrm{yr}$ \\
\hline Tritium & $3,014,457$ & 737,035 & 180,265 & 10,852 & 0 & 0 & 0 & 0 & 0 \\
\hline Carbon-14 & 3,778 & 3,767 & 3,755 & 3,732 & 3,643 & 3,556 & 3,347 & 2,061 & 1,124 \\
\hline Cobalt -60 & $1,960,400$ & 73,123 & 2,745 & 0 & 0 & 0 & 0 & 0 & 0 \\
\hline Strontium-90 & 58,657 & 32,355 & 17,849 & 5,432 & 47 & 0 & 0 & 0 & 0 \\
\hline Technetium-99 & 12.0 & 12.0 & 12.0 & 12.0 & 12.0 & 12.0 & 12.0 & 11.8 & 11.6 \\
\hline Iodine-129 & 10.6 & 10.6 & 10.6 & 10.6 & 10.6 & 10.6 & 10.6 & 10.6 & 10.6 \\
\hline Cesium-137 & 58,657 & 32,924 & 18,483 & 5,825 & 59 & 0 & 0 & 0 & 0 \\
\hline Neptunium-23 ${ }^{2}$ & 1.99 & 1.99 & 2.00 & 2.01 & 2.03 & 2.05 & 2.08 & 2.11 & 2.11 \\
\hline Uranium-235 & 0.58 & 0.58 & 0.58 & 0.58 & 0.58 & 0.58 & 0.58 & 0.58 & 0.58 \\
\hline Uranium-238 & 14.8 & 14.8 & 14.8 & 14.8 & 14.8 & 14.8 & 14.8 & 14.8 & 14.8 \\
\hline Plutonium-238 & 20,514 & 16,826 & 13,800 & 9,283 & 1,902 & 390 & 8 & 0 & 0 \\
\hline Plutonium-239 & 1,475 & 1,474 & 1,473 & 1,471 & 1,462 & 1,454 & 1,434 & 1,279 & 1,110 \\
\hline Totals & $5,117,978$ & 897,543 & 238,409 & 36,634 & 7,153 & 5,440 & 4,828 & 3,380 & 2,273 \\
\hline
\end{tabular}

Notes:

1 Estimated inventory from WSRC (1997)

2 Decay Forecast for $\mathrm{Np}-237$ includes in-growth from decay of Am-24l decayed from Pu-241 (WSRC,1997) 
Table 3-9. COI Activity in the ORWBG at 500 and 10,000 Years After Burial

500 Years

\begin{tabular}{cccc}
\hline & COI Activity & & \\
& at $500 \mathrm{yr}$ & $\%$ of Total & Cumulative \\
COI & $(\mathrm{Ci})^{1}$ & COI Activity & $\%$ \\
\hline
\end{tabular}

\section{Principal}

$\begin{array}{lrrr}\text { Carbon-14 } & 3,555.85 & 65.37 \% & 65.37 \% \\ \text { Plutonium-239 } & 1,454.20 & 26.73 \% & 92.10 \% \\ \text { Plutonium-238 } & 389.77 & 7.17 \% & 99.26 \%\end{array}$

\section{Subordinate}

$\begin{array}{lrrr}\text { Uranium-238 } & 14.80 & 0.27 \% & 99.54 \% \\ \text { Technetium-99 } & 11.98 & 0.22 \% & 99.76 \% \\ \text { Iodine-129 } & 10.60 & 0.19 \% & 99.95 \% \\ \text { Neptunium-237 } & 2.05 & 0.04 \% & 99.99 \% \\ \text { Uranium-235 } & 0.58 & 0.01 \% & 100.00 \% \\ \text { Cesium-137 } & 0.00 & 0 \% & - \\ \text { Strontium-90 } & 0.00 & 0 \% & - \\ \text { Tritium } & 0.00 & 0 \% & - \\ \text { Cobalt-60 } & 0.00 & 0 \% & \\ \text { Totals } & \mathbf{5 , 4 3 9 . 8 4} & \mathbf{1 0 0 \%} & \end{array}$

10,000 Years

\begin{tabular}{|c|c|c|c|}
\hline COI & $\begin{array}{c}\text { COI Activity } \\
\text { at } 10,000 \mathrm{yr} \\
(\mathrm{Ci})^{1} \\
\end{array}$ & $\begin{array}{c}\% \text { of Total } \\
\text { COI Activity }\end{array}$ & $\begin{array}{c}\text { Cumulative } \\
\% \\
\end{array}$ \\
\hline \multicolumn{4}{|l|}{ Principal } \\
\hline Carbon-14 & $1,123.58$ & $49.43 \%$ & $49.43 \%$ \\
\hline Plutonium-239 & $1,109.79$ & $48.82 \%$ & $98.25 \%$ \\
\hline Uranium-238 & 14.80 & $0.65 \%$ & $98.90 \%$ \\
\hline Technetium-99 & 11.62 & $0.51 \%$ & $99.42 \%$ \\
\hline \multicolumn{4}{|l|}{ Subordinate } \\
\hline Iodine-129 & 10.60 & $0.47 \%$ & $99.88 \%$ \\
\hline Neptunium-237 & 2.11 & $0.09 \%$ & $99.97 \%$ \\
\hline Uranium-235 & 0.58 & $0.03 \%$ & $100.00 \%$ \\
\hline Plutonium-238 & 0.00 & $0 \%$ & - \\
\hline Cesium-137 & 0.00 & $0 \%$ & - \\
\hline Strontium-90 & 0.00 & $0 \%$ & - \\
\hline Tritium & 0.00 & $0 \%$ & - \\
\hline Cobalt -60 & 0.00 & $0 \%$ & - \\
\hline Totals & $2,273.07$ & $100 \%$ & \\
\hline
\end{tabular}

Notes

1 Estimated inventory (WSRC, 1997) decayed per Table 3-5 of this report 
Table 3-10. Summary Statistics for COBRA Inventory of Potential "Hot Spot" HS-100-1

\begin{tabular}{|c|c|c|c|c|c|c|c|c|c|c|c|}
\hline \multirow[t]{2}{*}{$\frac{8}{\Sigma}$} & & & 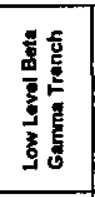 & 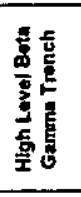 & 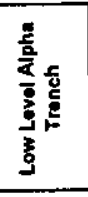 & 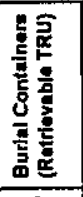 & 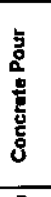 & 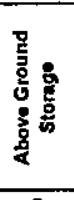 & $\frac{6}{\delta}$ & 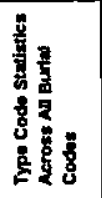 & 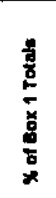 \\
\hline & & COBRA Burial Cods: & 1 & 2 & 3 & 4 & 5 & 6 & 7 & & \\
\hline \multirow{6}{*}{1} & \multirow{6}{*}{$\begin{array}{l}\text { Job Control Wastw, } \\
\text { including hous:- } \\
\text { keeping wast and } \\
\text { profective clothing }\end{array}$} & Number of Records & 2,485 & 0 & 233 & 217 & 0 & 0 & 0 & 2,935 & 94.7 \\
\hline & & Total Waste Volume (culit) & 318,983 & - & 23,122 & 1,773 & - & - & - & 343,878 & 95.9 \\
\hline & & Average Burial Volumo (culti) & 128 & - & 99 & 8 & - & - & - & 117 & nta \\
\hline & & Standard Deviation & 167 & - & 84 & 14 & - & - & $\therefore$ & 159 & $\mathrm{n} / \mathrm{e}$ \\
\hline & & Maximum Burial Voume (cumit) & 2,500 & - & 630 & 150 & - & - & - & 2500 & n/a \\
\hline & & Minimum Burtal Voume (avin) & 0 & - & 1 & 1 & $=$ & - & $=$ & 0 & no \\
\hline \multirow{6}{*}{2} & \multirow{6}{*}{ Oll } & Number of Records & 14 & 0 & 0 & 0 & 0 & 0 & 0 & 14 & 0.5 \\
\hline & & Total Waste Volume (cunt) & 635 & $=$ & - & - & - & - & $\therefore$ & 635 & 0.2 \\
\hline & & Average Burial Volume (cunn) & 45 & - & - & - & - & $\cdot$ & $=$ & 45 & Nha \\
\hline & & \begin{tabular}{|l} 
Standard Deviation \\
\end{tabular} & 50 & - & - & - & - & - & - & 50 & $\mathrm{ma}$ \\
\hline & & Maximum Burlal Volume (cunt) & 180 & - & - & - & $=$ & - & 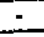 & 180 & $\mathrm{Ne}$ \\
\hline & & Minimum Burial Volumo (aunt) & 2 & - & - & $\therefore$ & - & - & - & 2 & n/a \\
\hline \multirow{6}{*}{3} & \multirow{6}{*}{$\begin{array}{l}\text { Irradiated Motal } \\
\text { Scrap }\end{array}$} & Number of Rocords & 6 & 39 & 0 & 0 & 0 & 0 & 0 & 45 & 1.5 \\
\hline & & Total Waste Volume (cunt) & 283 & 2.182 & 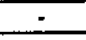 & - & - & - & 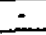 & 2,465 & 0.7 \\
\hline & & Average Aurial Volume (cunt) & 47 & 56 & - & - & - & - & $\therefore$ & 55 & $\mathrm{n} / \mathrm{a}$ \\
\hline & & Standard Deviation & 25 & 71 & - & - & - & - & - & 67 & no \\
\hline & & Maximum Burlal Volume (cumt) & 90 & 280 & + & - & - & $\therefore$ & - & 280 & no \\
\hline & & Minimum Burial Volume (aum) & 20 & 1 & - & - & $=$ & - & $\therefore$ & 1 & na \\
\hline \multirow{6}{*}{4} & \multirow{6}{*}{$\begin{array}{l}\text { Naturally } \\
\text { Radiosctive } \\
\text { Matorials }\end{array}$} & Number of Records & 75 & 0 & 0 & 0 & 0 & 0 & 0 & 75 & 2.4 \\
\hline & & Total Wasto Volume (curtt) & 9,475 & - & - & - & - & $\cdot$ & $\therefore$ & 9,475 & 2.6 \\
\hline & & Average Burlal Volume (cunt) & 126 & - & 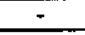 & - & - & $\therefore$ & $=$ & 126 & n/a \\
\hline & & Standard Devlation & 74 & $=$ & - & $\div$ & - & $\cdot$ & $\therefore$ & 74 & na \\
\hline & & Maxdmum Burial Volme (cult) & 250 & $\cdot$ & $\therefore$ & $\therefore$ & - & - & - & 250 & $\mathrm{nta}$ \\
\hline & & Minimum Burial Volume (cunt) & 2 & $\dot{-}$ & - & - & - & - & $\therefore$ & 2 & $\mathrm{Na}$ \\
\hline \multirow{6}{*}{5} & \multirow{6}{*}{$\begin{array}{c}\text { Capital Equipment, must } \\
\text { be accompanied by a } \\
\text { Plant Equipment } \\
\text { Transfor (PET) }\end{array}$} & Number of Records & 29 & 0 & 1 & 0 & 0 & 0 & 0 & 30 & 1.0 \\
\hline & & Total Woste Volume (curtt) & 2,053 & - & 75 & - & - & - & $\therefore$ & 2,128 & 0.6 \\
\hline & & Average Burtal Volume (cunt) & 71 & - & 75 & - & - & - & - & 71 & nia \\
\hline & & Standard Deviation & 97 & - & - & $\therefore$ & - & - & - & 95 & nea \\
\hline & & Maxdmum Burial Volume (cunt) & 450 & - & 75 & $\pi$ & - & - & $\therefore$ & 450 & nta \\
\hline & & Mirimum Burial Volume (cum) & 1 & - & 75 & - & $=$ & - & $=$ & 1 & nia \\
\hline \multirow{6}{*}{6} & \multirow{6}{*}{ Rosin } & Number of Reconds & 0 & 0 & 0 & 0 & 0 & 운 & 0 & 0 & $\cdot$ \\
\hline & & Total Weste Volume (culli) & $=$ & 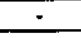 & - & - & - & - & $\therefore$ & $\div$ & $=$ \\
\hline & & Average Burial Volume (aunt) & - & $=$ & $\cdot$ & - & - & - & - & - & $\mathrm{n} / \mathrm{a}$ \\
\hline & & Standard Deviation & $\cdot$ & - & - & $\therefore$ & - & - & $\therefore$ & - & $\mathrm{Na}$ \\
\hline & & Maximum Eurial volume (aunt) & - & - & - & - & - & - & - & - & $n / a$ \\
\hline & & Minimum Burial Volume (curt) & - & - & - & - & - & $\therefore$ & $\therefore$ & - & nta \\
\hline \multirow{6}{*}{7} & \multirow{6}{*}{ Other } & Number of Recoros & 0 & 0 & 0 & 0 & 0 & 0 & 0 & 0 & $\therefore$ \\
\hline & & Total Wasto Voume (cum) & - & - & 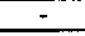 & - & - & - & - & - & $\therefore$ \\
\hline & & Average Burial Volume (aum) & $\cdot$ & - & - & - & - & - & - & - & n/a \\
\hline & & Standard Deviation & $\therefore$ & - & - & - & - & - & - & - & $n+a$ \\
\hline & & Maximum Burial Volume (autt) & 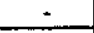 & $\div$ & - & - & - & - & + & - & noa \\
\hline & & Minimum Burlal Volume (cust) & 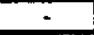 & - & - & - & $=$ & - & 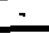 & - & ne \\
\hline \multirow{4}{*}{\multicolumn{2}{|c|}{ Totele Acrots All 7 Type Codes }} & Number of Records & 2,609 & 39 & 234 & 217 & 0 & 0 & 0 & 3.099 & \\
\hline & & $\%$ of Box 1 Totals & 84.2 & 1.3 & 7.6 & 7.0 & 0.0 & 0.0 & 0.0 & 100.0 & \\
\hline & & Total Waste Volumo (cultit) & 331.429 & 2,182 & 23,197 & 1.773 & 0 & 0 & 0 & 358,581 & \\
\hline & & $\%$ of Box 1 Totals & 92.4 & 0.6 & 6.5 & 0.5 & 0.0 & 0.0 & 0.0 & 100.0 & \\
\hline
\end{tabular}


Table 3-11. Decay Forecast for COBRA Inventory for Potential "Hot Spot" HS-100-1

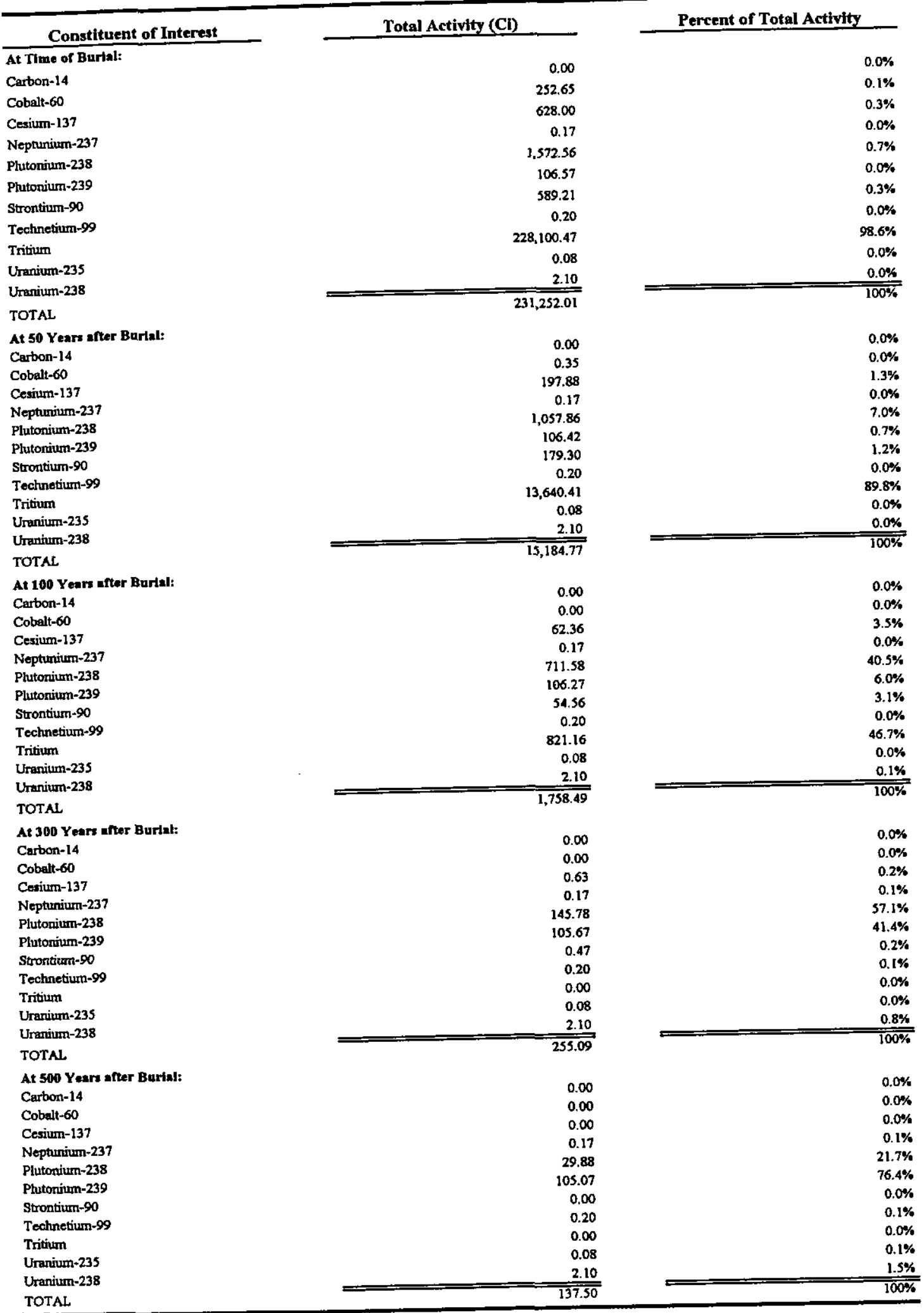


Table 3-11. Decay Forecast for COBRA Inventory for Potential "Hot Spot" HS-100-1 (Continued)

\begin{tabular}{|c|c|c|}
\hline Constituent of Interest & Total Activity (Cl) & Percent of Total Activity \\
\hline At 1,000 Years after Burial: & & \\
\hline Carbon-14 & 0.00 & $0.0 \%$ \\
\hline Cobalt- 60 & 0.00 & $0.0 \%$ \\
\hline Cexium-137 & 0.00 & $0.0 \%$ \\
\hline Nepturium-237 & 0.18 & $0.2 \%$ \\
\hline Phutonium-238 & 0.63 & $0.6 \%$ \\
\hline Plutonium-239 & 103.59 & $97.0 \%$ \\
\hline Strontium-90 & 0.00 & $0.0 \%$ \\
\hline Technetium-99 & 0.20 & $0.2 \%$ \\
\hline Tritum & 0.00 & $0.0 \%$ \\
\hline Utranium-235 & 0.08 & $0.1 \%$ \\
\hline Uranium-238 & 2.10 & $2.0 \%$ \\
\hline TOTAL & $\overline{106 . \overline{77}}$ & $\overrightarrow{100 \%}$ \\
\hline \multicolumn{3}{|l|}{ At 5,000 Years ofter Burlal: } \\
\hline Carbon-14 & 0.00 & $\begin{array}{l}0.0 \% \\
0.0 \%\end{array}$ \\
\hline Cobalt -60 & $\begin{array}{l}0.00 \\
0.00\end{array}$ & $0.0 \%$ \\
\hline Cesium-137 & $\begin{array}{l}0.00 \\
0.18\end{array}$ & $0.2 \%$ \\
\hline Neptunium-237 & 0.00 & $0.0 \%$ \\
\hline Pletonium-238 & 92.44 & $97.3 \%$ \\
\hline Phutoninum-239 & 0.00 & $0.0 \%$ \\
\hline Strontium-90 & 0.19 & $0.2 \%$ \\
\hline Technetium-99 & 0.00 & $0.0 \%$ \\
\hline Tritium & 0.08 & $0.1 \%$ \\
\hline Uranium-235 & 2.10 & $2.2 \%$ \\
\hline Urantum-238 & $\overline{94.99}$ & $100 \%$ \\
\hline TOTAL & & \\
\hline \multicolumn{3}{|l|}{ At 10,000 Yearn after Burlal: } \\
\hline Carbon-14 & $\begin{array}{l}0.00 \\
0.00\end{array}$ & $\begin{array}{l}0.0 \% \\
0.0 \%\end{array}$ \\
\hline Cobalt -60 & $\begin{array}{l}0.00 \\
0.00\end{array}$ & $0.0 \%$ \\
\hline Cesium-137 & $\begin{array}{l}0.00 \\
0.18\end{array}$ & $0.0 \%$ \\
\hline Neptunium-237 & 0.18 & $0.2 \%$ \\
\hline Phutonium-238 & 0.00 & $0.0 \%$ \\
\hline Plutonium-239 & 80.19 & $96.9 \%$ \\
\hline Strontium-90 & 0.00 & $0.0 \%$ \\
\hline Technetium-99 & 0.19 & $0.2 \%$ \\
\hline Tritium & 0.00 & $0.0 \%$ \\
\hline Uranium-235 & 0.08 & $0.1 \%$ \\
\hline Uranium-238 & 2.10 & $2.5 \%$ \\
\hline TOTAL & $\overline{82.74}$ & $100 \%$ \\
\hline
\end{tabular}


Table 3-12. Summary Statistics for COBRA Inventory of Potential "Hot Spot" HS-100-2

\begin{tabular}{|c|c|c|c|c|c|c|c|c|c|c|c|}
\hline \multirow[t]{2}{*}{$\begin{array}{l}\frac{8}{2} \\
\frac{8}{8} \\
\frac{8}{8}\end{array}$} & & & 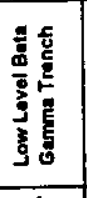 & 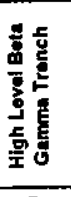 & 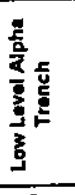 & 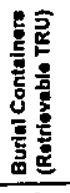 & 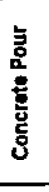 & 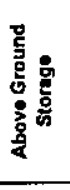 & $\frac{\bar{t}}{\delta}$ & 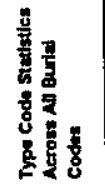 & 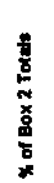 \\
\hline & & COBRA Burial Code: & 1 & 2 & 3 & 4 & 5 & 6 & 7 & & \\
\hline \multirow{5}{*}{1} & \multirow{6}{*}{$\begin{array}{l}\text { Job Control Waste, } \\
\text { including house- } \\
\text { keeping waste and } \\
\text { protective clothing }\end{array}$} & Number of Records & 281 & 0 & 15 & 0 & 0 & 0 & 0 & 296 & 93.4 \\
\hline & & Total Waste Volume (cu/n) & 39.150 & - & 1,092 & - & 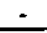 & - & - & 40,242 & 93.7 \\
\hline & & Average Burial Vohume (cu/t) & 139 & 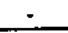 & 73 & - & 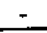 & - & - & 136 & $n / n$ \\
\hline & & Standard Devation & 211 & $\therefore$ & 46 & - & $=$ & - & 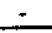 & 206 & $\mathrm{Na}$ \\
\hline & & Maxdrum Burial Volume (cumt) & 2.210 & $\therefore$ & 150 & - & - & - & - & 2210 & nes \\
\hline \multirow{6}{*}{2} & & Minimum Burial Votume (cumt) & 1 & - & 12 & - & - & - & - & 1 & na \\
\hline & \multirow{5}{*}{ oll } & Number of Reconds & 1 & 0 & 0 & 0 & 0 & 0 & 0 & 1 & 0.3 \\
\hline & & $\begin{array}{l}\text { Total Wasto Volume (cuft) } \\
\text { Average Burial Volume (cumti) }\end{array}$ & 20 & - & $=$ & + & $=$ & $=$ & - & 20 & 0.0 \\
\hline & & $\begin{array}{l}\text { Average Burial Volume (cumti) } \\
\text { Standard Deviation } \\
\end{array}$ & 20 & - & - & $=$ & - & - & - & 20 & nta \\
\hline & & $\begin{array}{l}\text { Standard Deviation } \\
\text { Maximum Burial Volume (cu/t) }\end{array}$ & - & - & 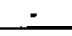 & - & - & $=$ & $=$ & - & nte \\
\hline & & $\begin{array}{l}\text { Maximum Burial Voume (cu/t) } \\
\text { Minimum Burial Volume (auft) }\end{array}$ & 20 & - & $=$ & 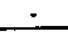 & - & - & $=$ & 20 & no \\
\hline \multirow{6}{*}{3} & \multirow{6}{*}{$\begin{array}{l}\text { Imratiated Motel } \\
\text { Scrap }\end{array}$} & $\begin{array}{l}\text { Minimum Burial Volume (au/t) } \\
\text { Nurnber of Records }\end{array}$ & 20 & - & - & $\therefore$ & - & - & - & 20 & $\mathrm{n} / \mathrm{a}$ \\
\hline & & \begin{tabular}{|l} 
Nurnber of Records \\
Total Waste Volume (auit) \\
\end{tabular} & 0 & 3 & 0 & 0 & 0 & 0 & 0 & 3 & 0.9 \\
\hline & & $\begin{array}{l}\text { Total Waste Volume (cu/t) } \\
\text { Average Burial Volume (cult) }\end{array}$ & $\dot{-}$ & 151 & $\therefore$ & - & - & $=$ & $=$ & 151 & 0.4 \\
\hline & & Standard Deviation & - & 50 & - & $\therefore$ & - & - & - & 50 & $\mathrm{n} / \mathrm{a}$ \\
\hline & & Maxdrum Burial Volume (culit) & - & 33 & $=$ & - & - & $\therefore$ & $\therefore$ & 33 & no \\
\hline & & Mirimum Burial Volume (curt) & - & $\frac{81}{16}$ & - & $\therefore$ & - & - & - & 81 & $\mathrm{~N} / \mathrm{a}$ \\
\hline \multirow{5}{*}{4} & \multirow{6}{*}{$\begin{array}{l}\text { Naturally } \\
\text { Redioactive } \\
\text { Materials }\end{array}$} & Number of Records & 16 & $\frac{16}{0}$ & - & - & - & $\therefore$ & - & 16 & $\mathrm{n} / \mathrm{a}$ \\
\hline & & Total Waste Volume (cu/tit) & 2,520 & 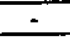 & $\begin{array}{l}0 \\
0 \\
-\end{array}$ & 0 & $\underline{0}$ & 0 & 0 & 16 & 5.0 \\
\hline & & Average Burial Volume (cum) & 158 & - & $\therefore$ & - & - & - & - & 2,520 & 5.9 \\
\hline & & Standard Deviation & 75 & - & - & - & - & - & $=$ & 158 & $n / \mathbf{a}$ \\
\hline & & Meximum Burial Volume (culn) & 250 & - & $\dot{-}$ & - & - & - & - & 75 & Na \\
\hline \multirow{6}{*}{$\mathbf{S}$} & & Mirimum Burlel Volume (aum) & 75 & - & $\dot{-}$ & $=$ & - & - & - & 250 & $\mathrm{n} / \mathrm{a}$ \\
\hline & \multirow{5}{*}{$\begin{array}{l}\text { Capital Equipment, must } \\
\text { be accompanied by a } \\
\text { Plant Equipment } \\
\text { Transfer (PET) }\end{array}$} & $\begin{array}{l}\text { Number of Records } \\
\text { Total Waste Volume (cu/t) } \\
\end{array}$ & 0 & 0 & $\frac{-}{1}$ & $=$ & - & ت & - & 75 & nta \\
\hline & & $\begin{array}{l}\text { Total Waste Voume (cuft) } \\
\text { Average Burial Volume (cum) } \\
\end{array}$ & - & - & 28 & 0 & 0 & 0 & 0 & 1 & 0.3 \\
\hline & & $\begin{array}{l}\text { Average Burial Volume (Cum) } \\
\text { Standard Deviation }\end{array}$ & - & $=$ & 28 & $=$ & - & - & - & 20 & 0.1 \\
\hline & & $\begin{array}{l}\text { Standard Devlation } \\
\text { Maximum Burial Volume (cum) } \\
\end{array}$ & - & - & - & - & $=$ & $=$ & - & 28 & $\mathrm{na}$ \\
\hline & & \begin{tabular}{|l|} 
Maximum Burial Volume (cunt) \\
Mirimum Burlal Volume (cu/t) \\
\end{tabular} & - & - & 28 & - & - & - & - & - & Na \\
\hline \multirow{5}{*}{6} & \multirow{6}{*}{ Resin } & $\begin{array}{l}\text { Mirimum Burlal Volume (cumt) } \\
\text { Number of Records }\end{array}$ & - & - & 28 & $\dot{\varphi}$ & - & - & - & 28 & no \\
\hline & & \begin{tabular}{|l|} 
Number of Records \\
Total Waste Volume (cunt) \\
\end{tabular} & 0 & 0 & 0 & $\frac{1}{0}$ & - & - & - & 28 & $\mathrm{nh}$ \\
\hline & & $\begin{array}{l}\text { Total Waste Volume (cu/n) } \\
\text { Average Burial Volume (cu/th) }\end{array}$ & $\therefore$ & $\therefore$ & - & 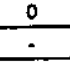 & $\frac{0}{2}$ & 0 & 0 & 0 & $=$ \\
\hline & & $\begin{array}{l}\text { Average Burial Volume (cu/ti) } \\
\text { Standard Devilation } \\
\end{array}$ & - & - & - & 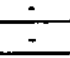 & $\dot{-}$ & $=$ & $\therefore$ & $=$ & - \\
\hline & & & - & - & - & 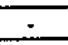 & $\dot{-}$ & 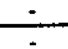 & - & - & $\mathrm{nde}$ \\
\hline \multirow{6}{*}{7} & & Mirimum Burlal Volume (cum) & - & - & - & $=$ & $\therefore$ & 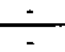 & - & - & nta \\
\hline & \multirow{5}{*}{ Other } & Number of Records & 0 & $\frac{-}{0}$ & $\therefore$ & - & - & - & 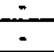 & - & $\mathrm{Na}$ \\
\hline & & Total Waste Vohme (cufti) & - & $\therefore$ & $\underline{0}$ & $\underline{0}$ & 0 & 0 & 0 & 0 & $\mathrm{n} / \mathrm{s}$ \\
\hline & & Averaga Burial Volume (cu/t) & - & - & - & - & - & - & $=$ & - & - \\
\hline & & Standard Deviation & - & - & $\dot{-}$ & - & - & $=$ & - & - & - \\
\hline & & Meximum Burial Voume (cunt) & - & - & 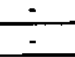 & $\therefore$ & - & - & - & - & $\mathrm{rat}$ \\
\hline \multirow{5}{*}{\multicolumn{2}{|c|}{ Totale Acroses All 7 Type Codes }} & Mirimum Burfal Volume (curt) & - & $\cdot$ & - & - & - & - & - & $\therefore$ & Na \\
\hline & & Number of Records & 298 & 3 & 16 & - & - & - & - & - & $\frac{\mathrm{nh}}{\mathrm{nda}}$ \\
\hline & & $\%$ of Box 2 Totals & 94.0 & 0.9 & 5.0 & 0 & 0 & 0 & 0 & 317 & \\
\hline & & $\begin{array}{l}\text { Total Waste Volume (cuint) } \\
\% \text { of Box } 2 \text { Totels }\end{array}$ & 41,690 & 151 & 1,120 & 0.0 & 0.0 & 0.0 & 0.0 & 100.0 & \\
\hline & & $\%$ of Box 2 Totels & 97.0 & 0.4 & 2.6 & $\frac{0}{0.0}$ & 0 & 0 & 0 & 42,961 & \\
\hline
\end{tabular}


Table 3-13. Decay Forecast for COBRA Inventory for Potential "Hot Spot" HS-100-2

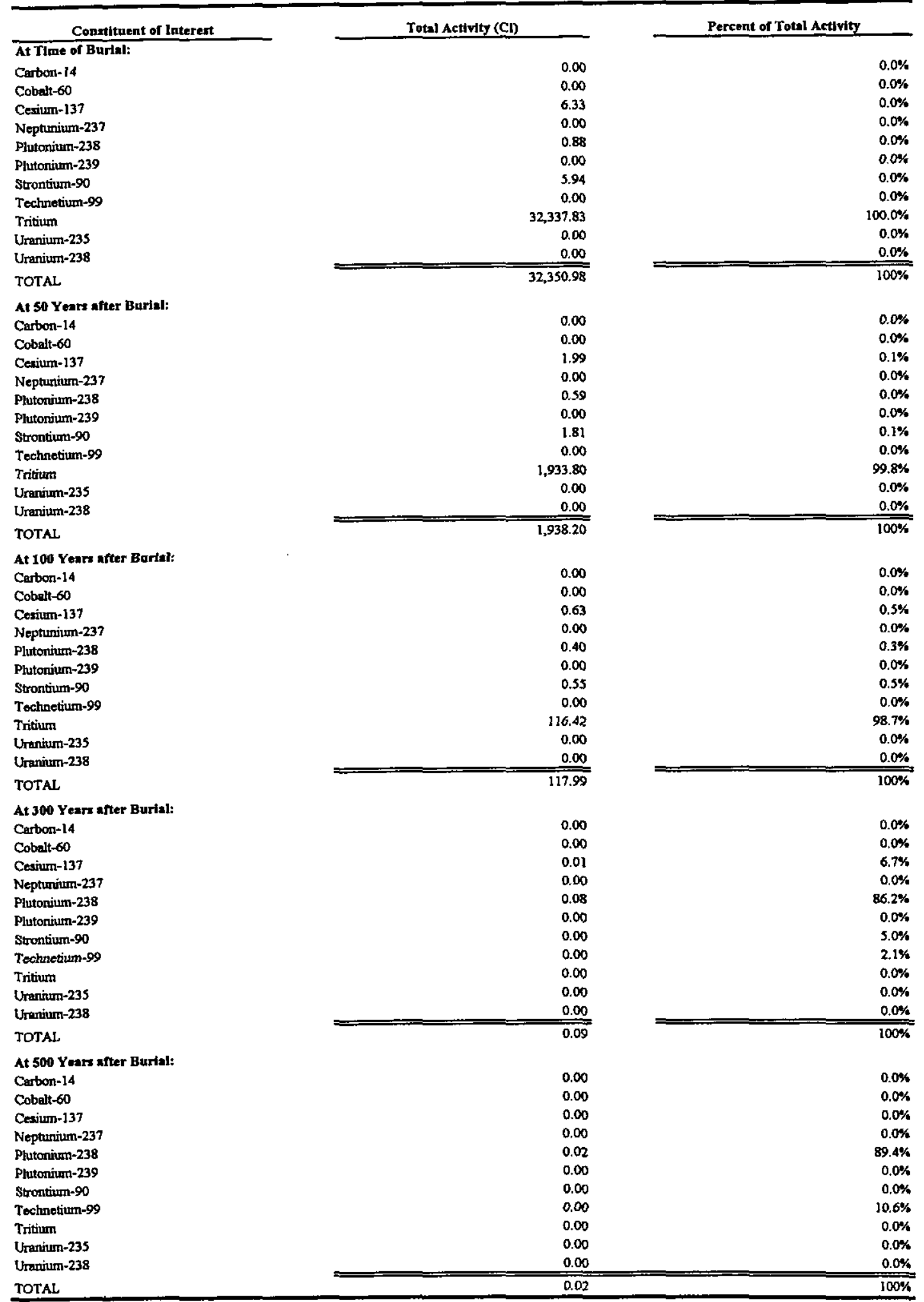


Table 3-13. Decay Forecast for COBRA Inventory for Potential "Hot Spot" HS-100-2 (Continued)

\begin{tabular}{|c|c|c|}
\hline Constituent of Interest & Total Activity (Ci) & Percent of Total Activity \\
\hline $\begin{array}{l}\text { At } 1,000 \text { Years after Burial: } \\
\text { Carbon-14 }\end{array}$ & & \\
\hline Carbon-14 & $\begin{array}{l}0.00 \\
0.00\end{array}$ & $\begin{array}{l}0.0 \% \\
0.0 \%\end{array}$ \\
\hline Cobalt-60 & $\begin{array}{l}0.00 \\
0.00\end{array}$ & $0.0 \%$ \\
\hline $\begin{array}{l}\text { Cesium-137 } \\
\text { Neptunium-237 }\end{array}$ & 0.00 & $0.0 \%$ \\
\hline $\begin{array}{l}\text { Neptunium-237 } \\
\text { Phutonium-238 }\end{array}$ & 0.00 & $15.0 \%$ \\
\hline $\begin{array}{l}\text { Phtonium-238 } \\
\text { Plutorium-239 }\end{array}$ & 0.00 & $0.0 \%$ \\
\hline $\begin{array}{l}\text { Plutomium-239 } \\
\text { Strontium-90 }\end{array}$ & $0 . \infty$ & $0.0 \%$ \\
\hline $\begin{array}{l}\text { Strontium-90 } \\
\text { Tochnetium-99 }\end{array}$ & 0.00 & $85.0 \%$ \\
\hline $\begin{array}{l}\text { Tochnetium-99 } \\
\text { Tritium }\end{array}$ & 0.00 & $0.0 \%$ \\
\hline $\begin{array}{l}\text { Tritium } \\
\text { Uranium-23s }\end{array}$ & 0.00 & $0.0 \%$ \\
\hline $\begin{array}{l}\text { Uranium-235 } \\
\text { Uranium-238 }\end{array}$ & $\underset{.000}{\longrightarrow}$ & $0.0 \%$ \\
\hline $\begin{array}{l}\text { Uranium-238 } \\
\text { TOTAL }\end{array}$ & 0.00 & $100 \%$ \\
\hline \multicolumn{3}{|l|}{ At 5,000 Yearz after Burlal: } \\
\hline Carbon-14 & 0.00 & $0.0 \%$ \\
\hline Cobalt- 60 & 0.00 & $0.0 \%$ \\
\hline Cosium-137 & 0.00 & $0.0 \%$ \\
\hline Neptunium-237 & 0.00 & $0.0 \%$ \\
\hline Phutonium-238 & 0.00 & $0.0 \%$ \\
\hline Plutonium-239 & 0.00 & $0.0 \%$ \\
\hline Strontium-90 & 0.00 & $0.0 \%$ \\
\hline Technetium-99 & 0.00 & $100.0 \%$ \\
\hline Tritium & 0.00 & $0.0 \%$ \\
\hline Uranium-235 & 0.00 & $0.0 \%$ \\
\hline Uranium-238 & $\underline{0.00}$ & $0.0 \%$ \\
\hline TOTAL & 0.00 & $100 \%$ \\
\hline \multicolumn{3}{|l|}{ At 10,000 Years after Burbal: } \\
\hline Carbon-14 & 0.00 & $0.0 \%$ \\
\hline Cobalt -60 & 0.00 & $0.0 \%$ \\
\hline Cexium-137 & 0.00 & $0.0 \%$ \\
\hline Neptumiura-237 & 0.00 & $0.0 \%$ \\
\hline Phutonium-238 & 0.00 & $0.0 \%$ \\
\hline Plutonium-239 & 0.00 & $0.0 \%$ \\
\hline Strontium-90 & 0.00 & $0.0 \%$ \\
\hline Technetium-99 & 0.00 & $100.0 \%$ \\
\hline Tritium & 0.00 & $0.0 \%$ \\
\hline Urarium-235 & 0.00 & $0.0 \%$ \\
\hline Uranium-238 & $\stackrel{0.00}{=}$ & $0.0 \%$ \\
\hline TOTAL & 0.00 & $100 \%$ \\
\hline
\end{tabular}


Table 3-14. Summary Statistics for COBRA Inventory of Potential "Hot Spot" HS-100-3

\begin{tabular}{|c|c|c|c|c|c|c|c|c|c|c|c|}
\hline \multirow{2}{*}{\multicolumn{2}{|c|}{$\begin{array}{l}\frac{8}{5} \\
\frac{5}{10} \\
8\end{array}$}} & & 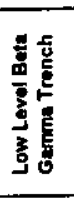 & 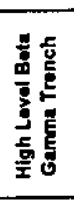 & 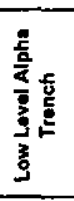 & 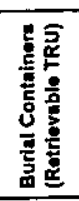 & 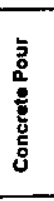 & 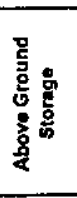 & 홓 & 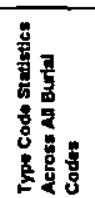 & 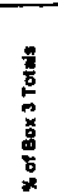 \\
\hline & & COBRA Burlat Code: & 1 & 2 & 3 & 4 & 5 & 6 & 7 & & \\
\hline \multirow{6}{*}{1} & \multirow{6}{*}{$\begin{array}{l}\text { Job Control Waste, } \\
\text { including house- } \\
\text { keoping waste and } \\
\text { protective elothing }\end{array}$} & Number of Records & 6 & 0 & 0 & 0 & 0 & 0 & 0 & 6 & 26.1 \\
\hline & & Totol Waste Volume (curt) & 382 & - & - & $=$ & - & - & - & 382 & 43.5 \\
\hline & & Average Burlal Volume (Cum) & 64 & - & $=$ & - & - & $=$ & - & 64 & na \\
\hline & & Standard Deviation & 30 & $=$ & - & - & - & - & - & 30 & n/a \\
\hline & & Maximum Buriei Voume (Cunt) & 90 & - & $=$ & - & - & $\because$ & - & 90 & no \\
\hline & & Mirimem Burlal Voume (cumt) & 22 & - & $=$ & - & - & - & $=$ & 22 & no \\
\hline \multirow{6}{*}{2} & \multirow{6}{*}{ OH } & Number of Records & 0 & 0 & 0 & 0 & 0 & 0 & 0 & 0 & $\therefore$ \\
\hline & & Total Waste Volume (curt) & - & + & $\therefore$ & $\therefore$ & $=$ & 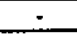 & - & - & - \\
\hline & & Averege Burlal Volume (curt) & - & - & $\therefore$ & - & $\therefore$ & - & - & 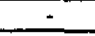 & $n / a$ \\
\hline & & Standard Deviation & - & - & $=$ & - & - & - & $\tau$ & 宓 & no \\
\hline & & Maxdmum Burial Volume (aun) & $\therefore$ & - & $\therefore$ & - & 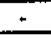 & - & $\therefore$ & $=$ & ria \\
\hline & & Minimum Burlal Volume (ault) & $\because$ & - & 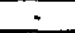 & - & - & - & - & - & nia \\
\hline \multirow{6}{*}{3} & \multirow{6}{*}{$\begin{array}{l}\text { Imradiated Moted } \\
\text { Scrap }\end{array}$} & $\begin{array}{l}\text { Number of Records } \\
\end{array}$ & 0 & 17 & 0 & 0 & 0 & 0 & 0 & 17 & 73.9 \\
\hline & & Total Waste Voume (cumt) & - & 497 & $\therefore$ & $=$ & - & - & - & 497 & 56.5 \\
\hline & & Average Burial Volume (cuit) & - & 29 & - & - & - & - & - & 29 & nia \\
\hline & & Standard Doviation & - & 12 & $=$ & - & - & 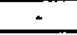 & $\therefore$ & 12 & $\mathrm{na}$ \\
\hline & & Maximum Burtel Volume (cunt) & - & 49 & $\therefore$ & - & - & $\therefore$ & - & 49 & $\mathrm{n} / \mathrm{a}$ \\
\hline & & Mirimum Burial Voume (aunt) & - & 10 & 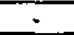 & - & - & - & - & 10 & n/a \\
\hline \multirow{6}{*}{4} & \multirow{6}{*}{$\begin{array}{c}\text { Naturally } \\
\text { Redioactive } \\
\text { Materials }\end{array}$} & Number of Records & 0 & 0 & 0 & 0 & 0 & 0 & 0 & 0 & - \\
\hline & & Total Waste Volume (cult) & - & - & $=$ & - & - & - & - & $\therefore$ & - \\
\hline & & Averago Burial Volume (cunt) & - & - & $\therefore$ & - & - & - & + & $=$ & $\mathrm{n} / \mathrm{s}$ \\
\hline & & Standard Deviation & - & $=$ & $\therefore$ & - & - & - & $=$ & - & na \\
\hline & & Maximum Burleal Voleme (cunt) & $\therefore$ & + & $=$ & - & $\cdot$ & - & - & - & $\mathrm{n} / \mathrm{a}$ \\
\hline & & Minimum Burial Voume (cunt) & - & $\cdot$ & - & - & - & $=$ & - & - & na \\
\hline \multirow{6}{*}{$\mathbf{5}$} & \multirow{6}{*}{$\begin{array}{l}\text { Capital Equipment, must } \\
\text { be accompaniod by a } \\
\text { Plant Equipment } \\
\text { Transfor (PET) }\end{array}$} & Number of Records & 0 & 0 & 0 & 0 & 0 & 0 & 0 & 0 & - \\
\hline & & Total Waste Volume (cult) & - & - & - & - & - & - & 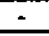 & $\therefore$ & - \\
\hline & & Average Burial Volume (culti) & - & 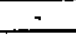 & - & - & $\therefore$ & - & - & $\therefore$ & na \\
\hline & & Standard Doviation & - & $=$ & - & $=$ & - & - & 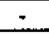 & - & na \\
\hline & & Maximum Burlal Volume (cuft) & - & $\cdot$ & - & - & - & $\dot{-}$ & $\therefore$ & - & na \\
\hline & & Minimum Burial Volume (cunt) & $\cdot$ & - & - & - & 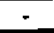 & $\cdot$ & - & $\therefore$ & na \\
\hline \multirow{6}{*}{6} & \multirow{6}{*}{ Resin } & Number of Reconds & 0 & 0 & 0 & 0 & 0 & 0 & 0 & 0 & - \\
\hline & & Total Waste Volume (ct/it) & - & - & - & - & - & - & - & - & $\dot{\tau}$ \\
\hline & & Average Burial Volume (cunt) & - & - & - & - & - & - & 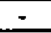 & $\therefore$ & nas \\
\hline & & Standard Deviation & - & 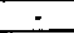 & - & - & - & - & $\therefore$ & - & $\mathrm{Na}$ \\
\hline & & Maximum Burlal Volume (avm) & - & - & $=$ & - & + & - & - & $=$ & ne \\
\hline & & Minimum Burlal Volume (curt) & - & - & - & - & - & - & - & - & Na \\
\hline \multirow{6}{*}{7} & \multirow{6}{*}{ Other } & Number of Records & 0 & 0 & 0 & 0 & 0 & 0 & 0 & D & $=$ \\
\hline & & Total Waste Vohme (avm) & - & - & - & - & - & - & - & - & - \\
\hline & & Averaga Burial Vokme (cum) & - & $=$ & - & - & - & - & $\therefore$ & $\therefore$ & n/a \\
\hline & & standard Deviation & - & $=$ & $\therefore$ & - & - & - & - & - & nis \\
\hline & & Maxímum Burial Voume (cunt) & - & $\therefore$ & $\therefore$ & $\therefore$ & $=$ & $\therefore$ & 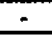 & $=$ & ne \\
\hline & & Minimum Burial Volume (cumt) & - & 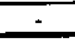 & - & - & - & - & - & - & na \\
\hline \multirow{4}{*}{\multicolumn{2}{|c|}{ Totale Acrose All 7 Type Codes }} & Number of Records & 6 & 17 & 0 & 0 & 0 & 0 & 0 & 23 & \\
\hline & & $x$ of Box 3 Totals & 26.1 & 73.9 & 0.0 & 0.0 & 0.0 & 0.0 & 0.0 & 100.0 & \\
\hline & & Total Weste Volume (cu/nt) & 382 & 497 & 0 & 0 & 0 & 0 & 0 & 879 & \\
\hline & & X of Box 3 Totals & 43.5 & 56.5 & 0.0 & 0.0 & 0.0 & 0.0 & 0.0 & 100.0 & \\
\hline
\end{tabular}


Table 3-15. Decay Forecast for COBRA Inventory for Potential "Hot Spot" HS-100-3

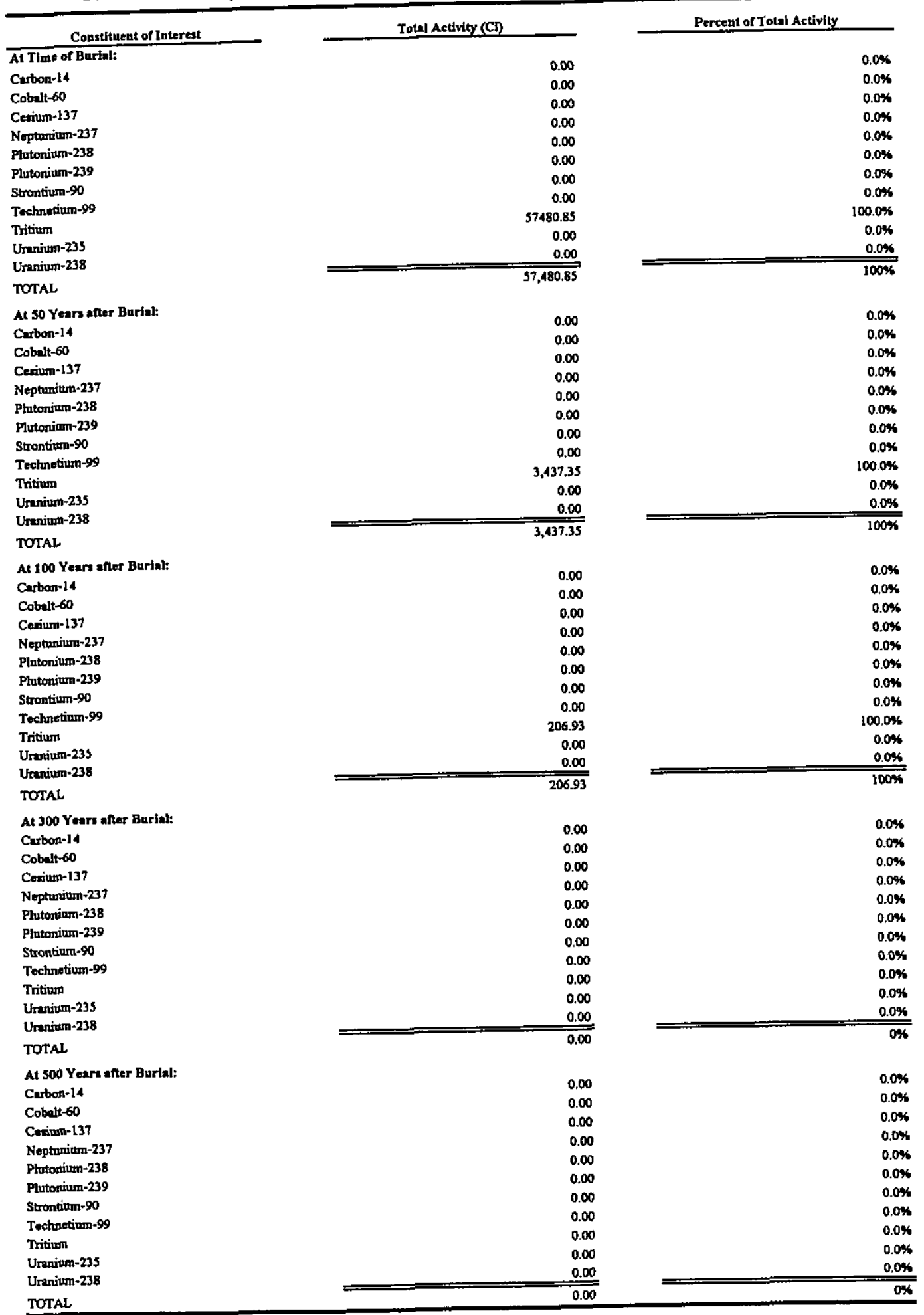


Table 3-15. Decay Forecast for COBRA Inventory for Potential "Hot Spot" HS-100-3 (Continued)

\begin{tabular}{|c|c|c|}
\hline Constituent or Interest & Total Activity (Ci) & Percent of Total Activity \\
\hline \multicolumn{3}{|l|}{ At 1,000 Years after Burial: } \\
\hline Curban-14 & 0.00 & $0.0 \%$ \\
\hline Cobalt -60 & 0.00 & $0.0 \%$ \\
\hline Cesinm-137 & 0.00 & $0.0 \%$ \\
\hline Neptuniurn-237 & 0.00 & $0.0 \%$ \\
\hline Plutonimm-238 & 0.00 & $0.0 \%$ \\
\hline Phutonium-239 & 0.00 & $0.0 \%$ \\
\hline Strontium-90 & 0.00 & 0.096 \\
\hline Technetinm-99 & 0.00 & $0.0 \%$ \\
\hline Tritium & 0.00 & $0.0 \%$ \\
\hline Uraxium-235 & 0.00 & $0.0 \%$ \\
\hline Uranium-238 & $\underline{0.00}$ & $0.0 \%$ \\
\hline TOTAL & 0.00 & ow \\
\hline \multicolumn{3}{|l|}{ At 5,000 Years anter Burtal: } \\
\hline Curbon-14 & 0.00 & $0.0 \%$ \\
\hline Cobalt -60 & 0.00 & $0.0 \%$ \\
\hline Cerium-137 & 0.00 & $0.0 \%$ \\
\hline Neptunium-237 & 0.00 & $0.0 \%$ \\
\hline Plutonium-238 & 0.00 & $0.0 \%$ \\
\hline Platonium-239 & 0.00 & $0.0 \%$ \\
\hline Strontium-90 & 0.00 & $0.0 \%$ \\
\hline Technetium-99 & 0.00 & $0.0 \%$ \\
\hline Tritium & 0.00 & $0.0 \%$ \\
\hline Unnium-235 & 0.00 & $0.0 \%$ \\
\hline Uranimum-238 & $\stackrel{0.00}{=}$ & $0.0 \%$ \\
\hline TOTAL & 0.00 & $0 \%$ \\
\hline \multicolumn{3}{|l|}{ At 10,000 Years after Burlal: } \\
\hline Carbon-14 & 0.00 & $0.0 \%$ \\
\hline Cobalt -60 & 0.00 & $0.0 \%$ \\
\hline Cecium-137 & 0.00 & $0.0 \%$ \\
\hline Neptanium-237 & 0.00 & $0.0 \%$ \\
\hline Platorium-238 & 0.00 & $0.0 \%$ \\
\hline Plutonixm-239 & 0.00 & $0.0 \%$ \\
\hline Strontium-90 & 0.00 & $0.0 \%$ \\
\hline Technetium-99 & 0.00 & $0.0 \%$ \\
\hline Tritium & 0.00 & $0.0 \%$ \\
\hline Uranium-235 & 0.00 & $0.0 \%$ \\
\hline Urunium-238 & $\stackrel{0.00}{=}$ & $0.0 \%$ \\
\hline TOTAL & 0.00 & $0 \%$ \\
\hline
\end{tabular}


Table 3-16. Summary Statistics for COBRA Inventory of Potential "Hot Spot" HS-100-4

\begin{tabular}{|c|c|c|c|c|c|c|c|c|c|c|c|}
\hline \multirow[t]{2}{*}{ 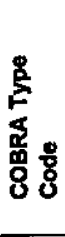 } & & & 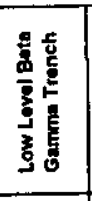 & 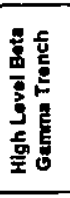 & 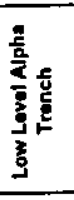 & 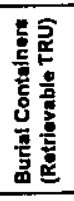 & 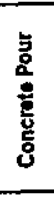 & 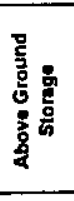 & $\frac{5}{5}$ & 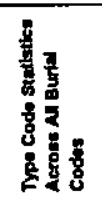 & 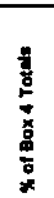 \\
\hline & & COBRA Burial Code: & 1 & 2 & 3 & 4 & 5 & 6 & 7 & & \\
\hline \multirow{5}{*}{1} & \multirow{6}{*}{$\begin{array}{l}\text { Job Control Wasto, } \\
\text { including houser } \\
\text { keeping waste ard } \\
\text { protective clothing }\end{array}$} & Number of Records & 191 & 0 & 32 & 0 & 0 & 0 & 0 & 223 & 94.1 \\
\hline & & Total Waste Volume (cum) & 28,323 & - & 2,861 & $=$ & - & - & - & 31,284 & 94.1 \\
\hline & & Average Burtal Volumo (cunt) & 148 & $\therefore$ & 93 & - & $=$ & - & - & 140 & $\mathrm{Na}$ \\
\hline & & Standard Deviation & 168 & - & 57 & - & - & - & $\therefore$ & 158 & n/a \\
\hline & & Maximum Burlal Volume (cuit) & 1.250 & $\therefore$ & 325 & $=$ & $=$ & - & 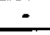 & 1250 & $\mathrm{Nh}$ \\
\hline \multirow{6}{*}{2} & & Mirkirum Burial Volume (curt) & 3 & - & 35 & - & - & - & - & 3 & $\mathrm{ma}$ \\
\hline & \multirow{5}{*}{ oil } & Number of Records & 2 & 0 & 0 & 0 & 0 & 0 & 0 & 2 & 0.8 \\
\hline & & Total Waste Volume (cu/t) & 224 & - & 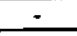 & - & - & - & - & 224 & 0.7 \\
\hline & & Average Burlai Volume (aunt) & 112 & - & $\dot{-}$ & $\therefore$ & - & - & - & 112 & $\mathrm{n} / \mathrm{e}$ \\
\hline & & \begin{tabular}{|l|} 
Standard Deviation \\
Maximum Burial Volume (cumt) \\
\end{tabular} & 11 & - & - & - & $=$ & $\therefore$ & - & 11 & $\mathrm{~N} / \mathrm{a}$ \\
\hline & & $\begin{array}{l}\text { Maximum Burial Vohme (cu/t) } \\
\text { Minimum Burtal Volume (cu/t) }\end{array}$ & 120 & $=$ & - & - & - & - & - & 120 & $\mathrm{~N} / \mathrm{s}$ \\
\hline \multirow{6}{*}{3} & \multirow{6}{*}{$\begin{array}{l}\text { Imodlated Motal } \\
\text { Scrap }\end{array}$} & $\begin{array}{l}\text { Mirimum Burtal Volume (cumit) } \\
\text { Number of Reconds }\end{array}$ & 104 & - & $\therefore$ & - & - & - & - & 104 & na \\
\hline & & \begin{tabular}{|l|} 
Number of Reconds \\
Total Waste Volume (cum) \\
\end{tabular} & 0 & 3 & 0 & 0 & 0 & 0 & 0 & 3 & 1.3 \\
\hline & & & $\therefore$ & 139 & - & - & - & - & $\therefore$ & 139 & 0.4 \\
\hline & & \begin{tabular}{|l} 
Average Burial Volume (Cumt) \\
Standard Deviation \\
\end{tabular} & - & 46 & $\therefore$ & $\therefore$ & - & $\therefore$ & - & 46 & nta \\
\hline & & \begin{tabular}{|l} 
Standard Deviation \\
Maximum Burial Volume (cuit) \\
\end{tabular} & - & 52 & $\therefore$ & $\therefore$ & - & $=$ & - & 52 & na \\
\hline & & $\begin{array}{l}\text { Maximum Burial Volume (curt) } \\
\text { Mirimum Burial Volume (cuift) } \\
\end{array}$ & $\dot{-}$ & 104 & $\therefore$ & - & $\cdot$ & - & $\therefore$ & 104 & n/a \\
\hline \multirow{6}{*}{4} & \multirow{6}{*}{$\begin{array}{l}\text { Naturally } \\
\text { Rediaectlve } \\
\text { Matertals }\end{array}$} & $\begin{array}{l}\text { Minimum Burlal Volume (cuntt) } \\
\text { Number of Records } \\
\end{array}$ & - & 3 & $\therefore$ & $\therefore$ & - & - & - & 3 & nto \\
\hline & & \begin{tabular}{|l} 
Number of Records \\
Total Waste Volume (cu/tit) \\
\end{tabular} & 6 & 0 & $\underline{0}$ & 0 & 0 & 0 & 0 & 6 & 2.5 \\
\hline & & \begin{tabular}{|l|} 
Total Waste Volume (cumt) \\
Average Burial Volume (cumit) \\
\end{tabular} & 1,201 & - & $=$ & - & - & - & - & 1,201 & 3.6 \\
\hline & & $\begin{array}{l}\text { Average Burial Volume (cum) } \\
\text { Standard Deviation }\end{array}$ & $\frac{200}{120}$ & - & - & - & $\therefore$ & - & - & 200 & nta \\
\hline & & Mexdmum Burial Voume (cum) & $\frac{120}{300}$ & $\therefore$ & - & - & 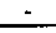 & - & - & 120 & no \\
\hline & & Minimum Burlal Volume (culti) & $\frac{300}{21}$ & $\therefore$ & - & - & - & - & - & 300 & $\mathrm{r} / \mathrm{e}$ \\
\hline \multirow{5}{*}{5} & \multirow{6}{*}{$\begin{array}{l}\text { Capled Equipment, must } \\
\text { be accompanied by a } \\
\text { Plant Equipment } \\
\text { Trensfor (PET) }\end{array}$} & Number of Records & $\frac{21}{3}$ & $\frac{1}{0}$ & $\therefore$ & $\therefore$ & - & $\therefore$ & $\therefore$ & 21 & nta \\
\hline & & Total Wasto Volume (curtt) & 408 & $\frac{0}{-}$ & 0 & 0 & 0 & 0 & 0 & 3 & 1.3 \\
\hline & & Average Burlal Volume (cunt) & 136 & - & - & - & - & - & $\therefore$ & 408 & 1.2 \\
\hline & & Standard Deviation & 167 & - & $\dot{-}$ & 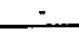 & $\therefore$ & - & - & 136 & Na \\
\hline & & Maximum Burial Volume (cuit) & 324 & $\dot{-}$ & $\frac{-}{-}$ & $\cdot$ & $\therefore$ & - & - & 167 & $\mathrm{na}$ \\
\hline \multirow{6}{*}{6} & & Minimum Burtal Volume (cultt) & 4 & - & 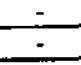 & - & - & $\therefore$ & - & 324 & nta \\
\hline & \multirow{5}{*}{ Rosin } & Number of Records & 0 & 0 & 0 & $\frac{-}{0}$ & - & - & $\therefore$ & 4 & Na \\
\hline & & Total Wasto Volume (cu/t) & $=$ & - & $=$ & $\frac{0}{-}$ & 0 & 0 & 0 & 0 & - \\
\hline & & Averege Burial Volurne (cumit) & - & - & - & - & - & - & - & - & - \\
\hline & & Standard Deviation & $=$ & - & + & $\dot{-}$ & $\therefore$ & - & $\cdot$ & - & No \\
\hline & & Maximum Burial Volume (cum) & - & - & - & $\dot{-}$ & - & - & 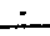 & - & nte \\
\hline \multirow{6}{*}{7} & \multirow{6}{*}{ Other } & Mintmum Burlal Votume (cu/tit) & - & - & - & $\begin{array}{ll}- \\
-\end{array}$ & - & $=$ & - & $\therefore$ & ne \\
\hline & & Number of Records & 0 & 0 & 0 & 0 & $\frac{1}{0}$ & $\frac{-}{0}$ & $\frac{-}{0}$ & $\frac{-}{0}$ & $\mathrm{na}$ \\
\hline & & Total Wasto Volume (CU/t) & - & $=$ & - & - & $\therefore$ & - & $\frac{0}{-}$ & - & $\cdot$ \\
\hline & & \begin{tabular}{|l} 
Average Burlal Volume (cunt) \\
Standard Deviation
\end{tabular} & $\stackrel{-}{-}$ & $\overline{-}$ & 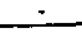 & $\therefore$ & - & - & & 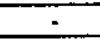 & - \\
\hline & & \begin{tabular}{|l|} 
Standard Deviation \\
Maximum Burial Volume (cuint) \\
\end{tabular} & $\dot{-}$ & - & - & - & - & - & - & $=$ & n/a \\
\hline & & \begin{tabular}{|l} 
Maximum Burial Volume (cu/t)) \\
Minimum Burial Volume (cu/tit) \\
\end{tabular} & - & + & $\dot{-}$ & - & - & $\therefore$ & - & - & Na \\
\hline \multirow{4}{*}{\multicolumn{2}{|c|}{ Totals Acroes All 7 Typo Codes }} & \begin{tabular}{|l|} 
Minimum Burial Volume (curt) \\
Number of Records \\
\end{tabular} & 202 & 3 & $\frac{-}{32}$ & - & - & - & - & - & Na \\
\hline & & \begin{tabular}{|l} 
Number of Records \\
of Box 4 Totals \\
\end{tabular} & 85.2 & 1.3 & $\frac{32}{13.5}$ & 0 & 0 & 0 & 0 & 237 & Na \\
\hline & & $\begin{array}{l}\text { * of Box } 4 \text { Totals } \\
\text { Total Waste Volume (cum) }\end{array}$ & 30,156 & 139 & $\frac{13.5}{2,961}$ & 0.0 & 0.0 & 0.0 & 0.0 & 100.0 & \\
\hline & & \begin{tabular}{|l} 
Total Waste Voume (cum) \\
\% of Box 4 Totals
\end{tabular} & 90.7 & 0.4 & $\frac{2,961}{8.9}$ & 0 & 0 & 0 & 0 & 33.256 & \\
\hline & & & & & 8.9 & 0.0 & 0.0 & 0.0 & 0.0 & 100.0 & \\
\hline
\end{tabular}


Table 3-17. Decay Forecast for COBRA Inventory for Potential "Hot Spot" HS-100-4

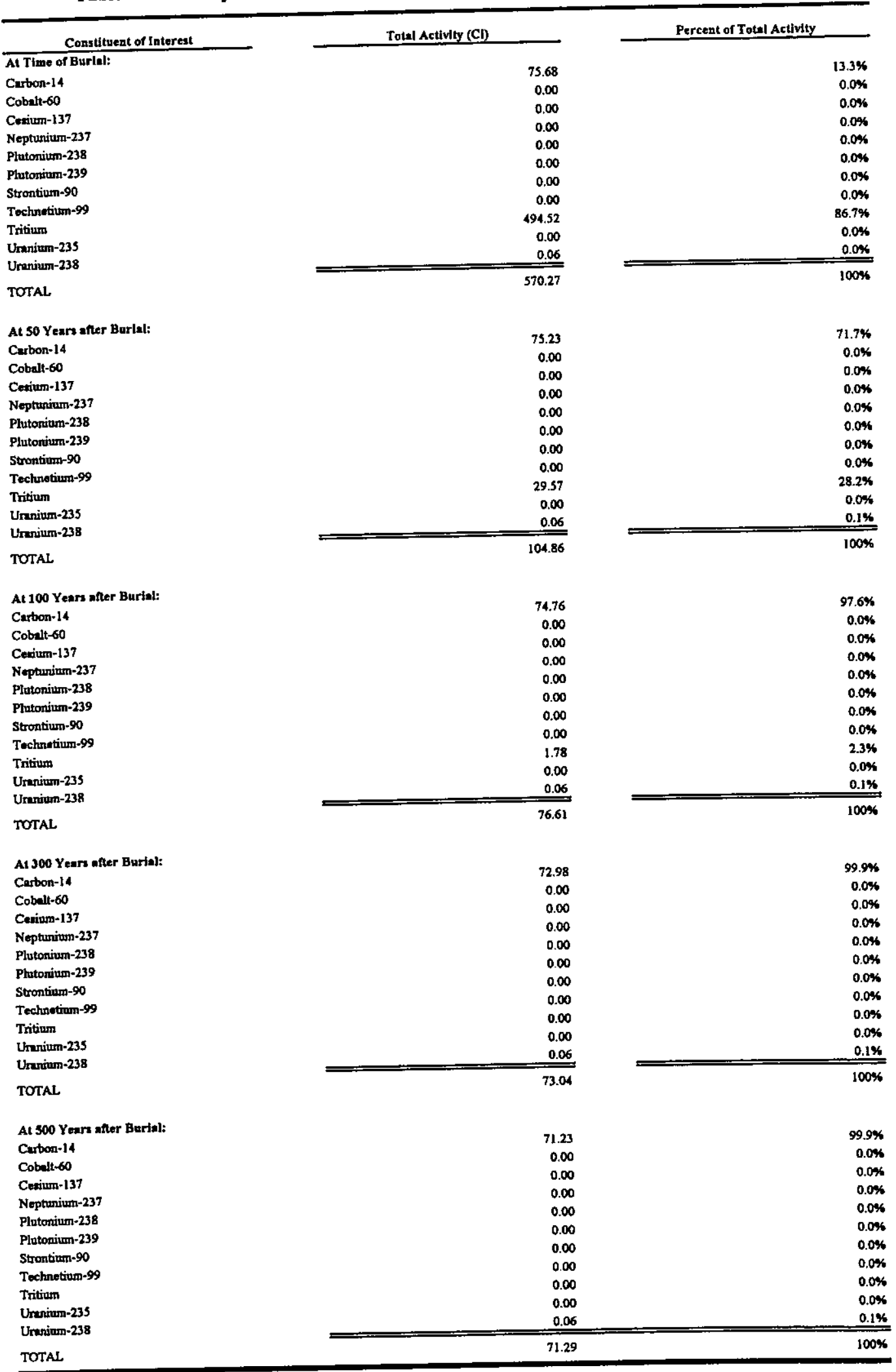


Table 3-17. Decay Forecast for COBRA Inventory for Potential "Hot Spot" HS-100-4 (Continued)

\begin{tabular}{|c|c|c|}
\hline Constituent of Interest & Total Activity (Ci) & Percent of Total Activity \\
\hline At 1,000 Years after Burial: & & \\
\hline Carbon-14 & 67.04 & $99.9 \%$ \\
\hline Cobalt -60 & 0.00 & $0.0 \%$ \\
\hline Cerium- 137 & 0.00 & $0.0 \%$ \\
\hline Nepturium-237 & 0.00 & $0.0 \%$ \\
\hline Plutonium-238 & 0.00 & $0.0 \%$ \\
\hline Plutonium-239 & 0.00 & $0.0 \%$ \\
\hline Strontium-90 & 0.00 & $0.0 \%$ \\
\hline Tuchnetium-99 & 0.00 & $0.0 \%$ \\
\hline Tritium & 0.00 & $0.0 \%$ \\
\hline Uranium-235 & 0.00 & $0.0 \%$ \\
\hline Uranium-238 & 0.06 & $0.1 \%$ \\
\hline TOTAL & 67.10 & $100 \%$ \\
\hline \multicolumn{3}{|l|}{ At 5,000 Years after Burial: } \\
\hline Carbon-14 & 41.28 & $99.8 \%$ \\
\hline Cobalt-60 & 0.00 & $0.0 \%$ \\
\hline Cenium-137 & 0.00 & $0.0 \%$ \\
\hline Nepturiom-237 & 0.00 & $0.0 \%$ \\
\hline Plutonium-238 & 0.00 & $0.0 \%$ \\
\hline Plutorium-239 & 0.00 & $0.0 \%$ \\
\hline Strontium-90 & 0.00 & $0.0 \%$ \\
\hline Technetinm-99 & 0.00 & $0.0 \%$ \\
\hline Tritiun & 0.00 & $0.0 \%$ \\
\hline Usanium-235 & 0.00 & $0.0 \%$ \\
\hline Unanium-238 & 0.06 & $0.2 \%$ \\
\hline TOTAL & 41.34 & $100 \%$ \\
\hline \multicolumn{3}{|l|}{ At 10,000 Years after Burial: } \\
\hline Carton-14 & 22.51 & $99.7 \%$ \\
\hline Cobalt -60 & 0.00 & $0.0 \%$ \\
\hline Cenium-137 & 0.00 & $0.0 \%$ \\
\hline Neptunium-237 & 0.00 & $0.0 \%$ \\
\hline Plutoninm-238 & 0.00 & $0.0 \%$ \\
\hline Platonium-239 & 0.00 & $0.0 \%$ \\
\hline Strontium-90 & 0.00 & $0.0 \%$ \\
\hline Twchnotivem-99 & 0.00 & $.0 .0 \%$ \\
\hline Tritum & 0.00 & $0.0 \%$ \\
\hline Uranium-235 & 0.00 & $0.0 \%$ \\
\hline Uranium-238 & $\stackrel{0.06}{\longrightarrow}$ & $0.3 \%$ \\
\hline TOTAL & 22.57 & $100 \%$ \\
\hline
\end{tabular}


Table 3-18. Summary Statistics for COBRA Inventory of Potential "Hot Spot" HS-100-5

\begin{tabular}{|c|c|c|c|c|c|c|c|c|c|c|c|}
\hline \multirow[t]{2}{*}{ 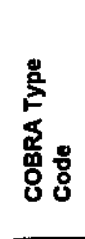 } & & & 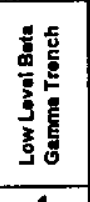 & 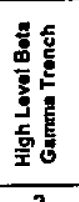 & 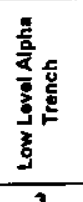 & 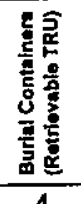 & 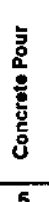 & 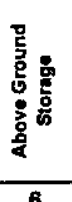 & ફ & 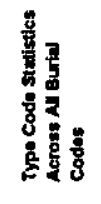 & 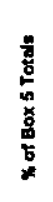 \\
\hline & & COBRA Burial Code: & 1 & 2 & 3 & 4 & 5 & 6 & 7 & & \\
\hline \multirow{6}{*}{1} & \multirow{6}{*}{$\begin{array}{l}\text { Job Control Waste, } \\
\text { including house- } \\
\text { keoping waste and } \\
\text { protective clothing }\end{array}$} & Number of Records & 259 & 0 & 22 & 1 & 0 & 0 & 0 & 282 & 94.6 \\
\hline & & Total Woste Voume (cumt) & 31,089 & $\cdot$ & 3,828 & 12 & $=$ & $\therefore$ & - & 34,929 & 97.4 \\
\hline & & Average Burlal Volume (cult) & 120 & $\therefore$ & 174 & 12 & - & - & - & 124 & $\mathrm{n} / \mathrm{a}$ \\
\hline & & Standard Deviation & 107 & - & 186 & $\tau$ & - & $\therefore$ & - & 116 & $\mathrm{n} / \mathrm{a}$ \\
\hline & & Maximum Burial Volume (cuft) & 820 & - & 800 & 12 & - & - & - & 820 & nta \\
\hline & & Minlmum Burial Volume (curt) & 3 & - & 15 & 12 & $=$ & - & $=$ & 3 & no \\
\hline \multirow{6}{*}{2} & \multirow{6}{*}{ on } & Number of Records & 2 & 0 & 0 & 0 & 0 & 0 & 0 & 2 & 0.7 \\
\hline & & Totad Waste Volumo (cunt) & 324 & - & - & - & - & $\cdot$ & $\therefore$ & 324 & 0.9 \\
\hline & & Average Burial Volume (cum) & 162 & - & - & - & + & - & - & 162 & n/o \\
\hline & & \begin{tabular}{|l} 
Standard Deviation \\
\end{tabular} & 195 & $=$ & 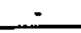 & - & - & $\therefore$ & 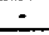 & 195 & na \\
\hline & & Maxdmum Burial Volume (cum) & 300 & $=$ & - & $=$ & - & $\therefore$ & + & 300 & $\mathrm{Na}$ \\
\hline & & Minimum Burlal Voume (aint) & 24 & - & - & - & - & - & - & 24 & $\mathrm{n} / \mathrm{a}$ \\
\hline \multirow{6}{*}{3} & \multirow{6}{*}{$\begin{array}{l}\text { Imadianed Metal } \\
\text { Scrap }\end{array}$} & Number of Records & 3 & 4 & 0 & 0 & 0 & 0 & 0 & 7 & 2.3 \\
\hline & & Total Waste Volume (cumt) & 55 & 244 & - & - & - & - & $\cdot$ & 299 & 0.8 \\
\hline & & Average Burial Volume (cuit) & 18 & 61 & - & - & - & - & $\therefore$ & 43 & nea \\
\hline & & Standard Deviation & 27 & 47 & - & - & - & - & $\therefore$ & 43 & Na \\
\hline & & Maximum Burial Volume (cum) & 49 & 128 & $\therefore$ & $\tau$ & $=$ & - & - & 128 & n/e \\
\hline & & Minimum Burial Voume (aunt) & 2 & 18 & - & $\therefore$ & $\therefore$ & - & - & 2 & na \\
\hline \multirow{5}{*}{4} & \multirow{5}{*}{$\begin{array}{l}\text { Naturally } \\
\text { Radloactlve } \\
\text { Materials }\end{array}$} & Number of Records & 3 & 0 & 0 & 0 & 0 & 0 & 0 & 3 & 1.0 \\
\hline & & Total Wasto Volume (curt) & 295 & $\therefore$ & - & - & $\therefore$ & $\therefore$ & - & 295 & 0.8 \\
\hline & & Averege Aurial Volume (cunti) & 98 & - & ست & - & $=$ & - & $\cdot$ & 98 & $\mathrm{Na}$ \\
\hline & & Standard Deviation & 24 & - & $\therefore$ & - & - & $\therefore$ & - & 24 & $n / a$ \\
\hline & & Maxdmum Burlal Volume (cu/t) & 125 & - & - & - & - & - & - & 125 & no \\
\hline \multirow{6}{*}{5} & \multirow{6}{*}{$\begin{array}{l}\text { Capital Equipment, must } \\
\text { be sccompanied by } \\
\text { Plant Equipment } \\
\text { Transfer (PET) }\end{array}$} & Mirimem Burial Volume (cunt) & 80 & - & - & $\therefore$ & - & - & $=$ & 80 & no \\
\hline & & $\begin{array}{l}\text { Number of Records } \\
\text { Total Waste volume (cuint) }\end{array}$ & 4 & 0 & 0 & 0 & 0 & 0 & 0 & 4 & 1.3 \\
\hline & & \begin{tabular}{|l|} 
Total Waste Voume (cunt) \\
Average Burial Volume (culnt) \\
\end{tabular} & $\frac{11}{3}$ & $=$ & - & - & - & ت & - & 11 & 0.0 \\
\hline & & \begin{tabular}{|l} 
Average Burial Volume (curt) \\
Standerd Doviation \\
\end{tabular} & $\frac{3}{2}$ & - & - & $\sim$ & - & $\therefore$ & - & 3 & no \\
\hline & & Maximum Burlal Vohme (cunt) & $\frac{2}{6}$ & 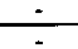 & $\therefore$ & - & - & - & $=$ & 2 & na \\
\hline & & Mtrimum Burial Volume (cumt) & 1 & $\frac{-}{-}$ & - & - & - & - & - & 6 & $\mathrm{ras}$ \\
\hline \multirow{6}{*}{6} & \multirow{6}{*}{ Resin } & Number of Records & 0 & $\frac{-}{0}$ & - & - & - & - & $\cdot$ & 1 & n/a \\
\hline & & Total Waste Volume (cuitt) & $=$ & $\stackrel{0}{-}$ & 0 & 0 & 0 & 0 & 0 & 0 & $=$ \\
\hline & & Average Burial Volume (cu/t) & - & 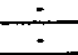 & $\dot{\tau}$ & 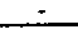 & N & مت & - & $\therefore$ & - \\
\hline & & Standand Deviation & - & $\dot{-}$ & - & - & - & - & $\dot{m}$ & - & nta \\
\hline & & Maximum Burial Volume (cwit) & - & - & - & - & $\therefore$ & - & $\therefore$ & $\therefore$ & n/a \\
\hline & & Minlmum Burial Volume (cust) & $\dot{-}$ & - & - & - & - & $=$ & - & - & na \\
\hline \multirow{6}{*}{7} & \multirow{6}{*}{ Other } & Number of Records & 0 & $\frac{1}{0}$ & $\dot{-}$ & - & $\therefore$ & - & - & - & no \\
\hline & & Total Wasta Voume (culti) & - & $\frac{0}{-}$ & 0 & 0 & 0 & 0 & $\mathbf{0}$ & 0 & - \\
\hline & & Average Burlal Volume (cutt) & - & $\therefore$ & $\therefore$ & $\div$ & $\therefore$ & - & - & - & - \\
\hline & & Standard Deviation & - & 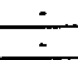 & - & - & $\therefore$ & - & $\dot{-}$ & $\therefore$ & No \\
\hline & & Maxmum Burial Vokume (curti) & - & - & - & - & - & - & - & - & No \\
\hline & & Misimum Burial Volume (cumt) & - & - & - & - & - & $\therefore$ & - & - & $\mathrm{Na}$ \\
\hline \multirow{4}{*}{\multicolumn{2}{|c|}{ Totale Across All 7 Type Codes }} & Number of Records & 271 & $=$ & $\therefore$ & $=$ & - & - & - & - & Na \\
\hline & & \% of Box 5 Totals & 90.9 & & 22 & 1 & 0 & 0 & 0 & 298 & \\
\hline & & Total Waste Volume (cult) & 31,774 & $\frac{1.3}{244}$ & 7.4 & 0.3 & 0.0 & 0.0 & 0.0 & 100.0 & \\
\hline & & $\%$ of Box 5 Totals & 88.6 & $\frac{244}{0.7}$ & 3,828 & 12 & 0 & 0 & $\underline{0}$ & 35,858 & \\
\hline & & & & & 10.7 & 0.0 & 0.0 & 0.0 & 0.0 & 100.0 & \\
\hline
\end{tabular}


Table 3-19. Decay Forecast for COBRA Inventory for Potential "Hot Spot" HS-100-5

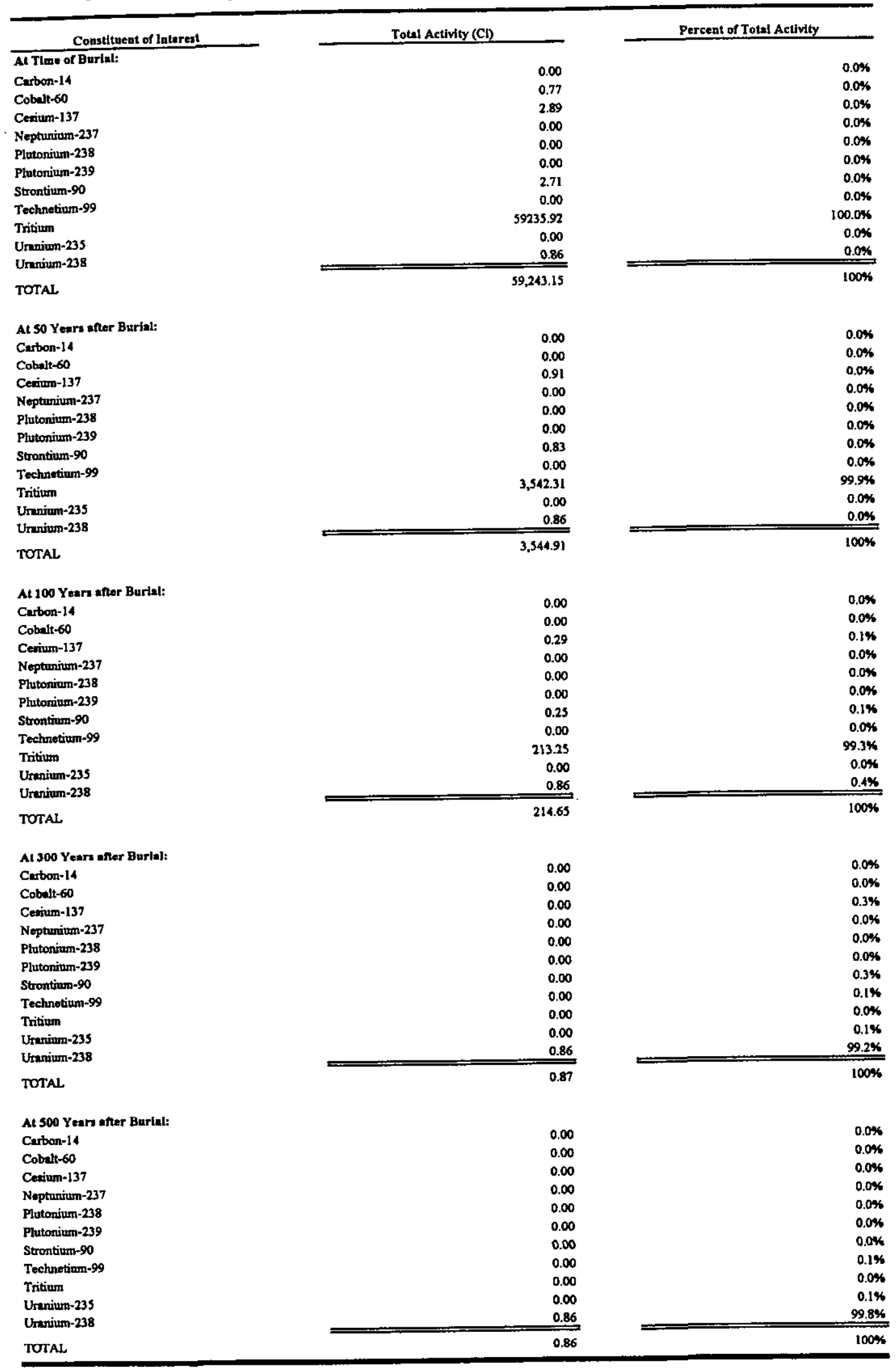


Table 3-19. Decay Forecast for COBRA Inventory for Potential "Hot Spot" HS-100-5 (Continued)

\begin{tabular}{|c|c|c|}
\hline Constituent of Interest & Total Activity (C) & Percent of Total Activity \\
\hline At 1,000 Years anter Burial: & & \\
\hline Carbon-14 & 0.00 & $0.0 \%$ \\
\hline Cobnalt 60 & 0.00 & $0.0 \%$ \\
\hline Cesium- 137 & 0.00 & $0.0 \% 6$ \\
\hline Neptunium-237 & 0.00 & $0.0 \%$ \\
\hline Plutonium-238 & 0.00 & $0.0 \%$ \\
\hline Plutonitum-239 & 0.00 & $0.0 \%$ \\
\hline Strontium-90 & 0.00 & $0.0 \%$ \\
\hline Technetium-99 & 0.00 & $0.1 \%$ \\
\hline Tritium & 0.00 & $0.0 \%$ \\
\hline Unanium-235 & 0.00 & $0.1 \%$ \\
\hline Uranium-238 & 0.86 & $99.8 \%$ \\
\hline TOTAL & 0.86 & $100 \%$ \\
\hline \multicolumn{3}{|l|}{ At 5,000 Yoars enter Burial: } \\
\hline Curbon-14 & 0.00 & $0.0 \%$ \\
\hline Cobalt -60 & 0.00 & $0.0 \%$ \\
\hline Conium-137 & 0.00 & $0.0 \%$ \\
\hline Nepturnium-237 & 0.00 & $0.0 \% 6$ \\
\hline Plutorvium-238 & 0.00 & 0.096 \\
\hline Plutonium-239 & 0.00 & $0.0 \%$ \\
\hline Strontiums -90 & 0.00 & $0.0 \%$ \\
\hline Technotium-99 & 0.00 & $0.1 \%$ \\
\hline Tritium & 0.00 & $0.0 \%$ \\
\hline Unanium-235 & 0.00 & $0.1 \%$ \\
\hline Unarium-238 & 0.86 & $99.8 \%$ \\
\hline TOTAL & 0.86 & $100 \%$ \\
\hline \multicolumn{3}{|l|}{ At 10,000 Years aner Burles: } \\
\hline Cutton-14 & 0.00 & $0.0 \%$ \\
\hline Cobalt-60 & 0.00 & $0.0 \%$ \\
\hline Cexium-137 & 0.00 & $0.0 \%$ \\
\hline Nepturium-237 & 0.00 & $0.0 \%$ \\
\hline Plutonimin-238 & 0.00 & $0.0 \%$ \\
\hline Plutonium-239 & 0.00 & $0.0 \%$ \\
\hline Strontium-90 & 0.00 & $0.0 \%$ \\
\hline Techunatium-99 & 0.00 & $0.1 \%$ \\
\hline Tritum & 0.00 & $0.0 \%$ \\
\hline Utanium-235 & 0.00 & $0.1 \%$ \\
\hline Uranium-238 & 0.86 & $99.8 \%$ \\
\hline TOTAL & 0.86 & $100 \%$ \\
\hline
\end{tabular}


Table 3-20. Summary Statistics for COBRA Inventory of Potential "Hot Spot" HS-100-6

\begin{tabular}{|c|c|c|c|c|c|c|c|c|c|c|c|}
\hline \multirow[t]{2}{*}{$\sum^{\frac{8}{2}}$} & & & 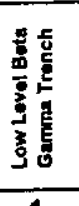 & 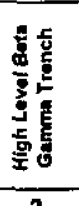 & 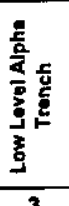 & 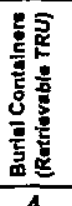 & 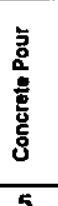 & 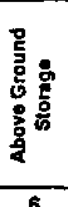 & $\frac{5}{5}$ & 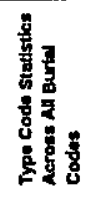 & 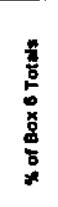 \\
\hline & & COBRA Burial Code: & 1 & 2 & 3 & 4 & 5 & 6 & 7 & & \\
\hline \multirow{6}{*}{1} & \multirow{6}{*}{$\begin{array}{l}\text { Jab Control Wastis, } \\
\text { including houser } \\
\text { keoping waste and } \\
\text { protective clothing }\end{array}$} & Number of Records & 7 & 0 & 17 & 724 & 5 & 0 & 0 & 753 & 98.8 \\
\hline & & Total Wasto Voume (cum) & 533 & - & 885 & 9,052 & 235 & - & - & 10,705 & 57.2 \\
\hline & & Average Burial Voume (cuitt) & 76 & - & 52 & 13 & 47 & 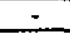 & - & 14 & Na \\
\hline & & Standard Deviation & 80 & - & 61 & 22 & 21 & $\therefore$ & - & 26 & $\mathrm{nta}$ \\
\hline & & Maximum Burial Volume (cunt) & 250 & $\dot{-}$ & 187 & 432 & 80 & $\therefore$ & - & 432 & na \\
\hline & & Minlmum Burlel Volumo (cunt) & 16 & $\cdot$ & 7 & 0 & 20 & - & $\cdot$ & 0 & ra \\
\hline \multirow{6}{*}{2} & \multirow{6}{*}{ oll } & Number of Records & 0 & 0 & 0 & 0 & 0 & 0 & 0 & 0 & - \\
\hline & & Total Waste Volume (cun) & - & $=$ & - & $=$ & $=$ & $\therefore$ & $\therefore$ & $\therefore$ & - \\
\hline & & Average Burial Volume (cum) & - & - & $=$ & $=$ & - & $\therefore$ & - & $=$ & no \\
\hline & & Standard Deviation & - & - & - & $=$ & - & - & - & - & n/a \\
\hline & & Maximum Burial Volume (cum) & - & - & - & . & - & + & - & + & $\mathrm{nta}$ \\
\hline & & Mirimum Burlel Voume (curt) & - & - & - & $=$ & - & $\therefore$ & - & ت & na \\
\hline \multirow{6}{*}{3} & \multirow{6}{*}{$\begin{array}{c}\text { Imadiated Mond } \\
\text { Scrap }\end{array}$} & Number of Records & 0 & 2 & 0 & 0 & 0 & 0 & 0 & 2 & 0.3 \\
\hline & & Total Wasto Volume (curtt) & $\therefore$ & 2,700 & - & $\therefore$ & - & - & - & 2.700 & 14.4 \\
\hline & & Average Burlal Volumo (cult) & - & 1,350 & - & $\therefore$ & - & $=$ & - & 1350 & na \\
\hline & & Standard Deviation & - & 0 & - & $=$ & - & $\therefore$ & - & 0 & na \\
\hline & & Maxirnum Burial volume (cum) & - & 1,350 & - & $=$ & - & - & - & 1350 & no \\
\hline & & Mirimum Burlal Volume (curtt) & - & 1,350 & - & $=$ & - & - & - & 1350 & $\mathrm{ma}$ \\
\hline \multirow{5}{*}{4} & \multirow{5}{*}{$\begin{array}{l}\text { Naturally } \\
\text { Redhoactive } \\
\text { Materials }\end{array}$} & Number of Records & 3 & 0 & 0 & 0 & 0 & 0 & 0 & 3 & 0.4 \\
\hline & & Total Wasto Volume (cu/ti) & 3 & - & - & - & - & - & - & 3 & 0.0 \\
\hline & & Average Burlal Voume (avn) & 1 & - & - & - & - & - & $\approx$ & 1 & no \\
\hline & & Standard Deviation & 0 & - & $\dot{-}$ & $\therefore$ & $\therefore$ & $\therefore$ & - & 0 & na \\
\hline & & Maxdmum Buriel Volume (cunt) & 1 & $\therefore$ & - & $=$ & - & - & - & 1 & nota \\
\hline \multirow{6}{*}{$\mathbf{5}$} & \multirow{6}{*}{$\begin{array}{l}\text { Capitul Equipment, must } \\
\text { bo accompanled by } \\
\text { Plant Equlpment } \\
\text { Transfer (PaT) }\end{array}$} & Minimum Burial Volume (Cu/ti) & 1 & - & - & 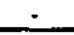 & - & - & - & 1 & nfa \\
\hline & & $\begin{array}{l}\text { Number of Records } \\
\text { Total Waste Volume (avit) }\end{array}$ & 4 & $\underline{0}$ & 0 & 0 & $\underline{0}$ & 0 & $\underline{0}$ & $\frac{4}{53 m}$ & 0.5 \\
\hline & & $\begin{array}{l}\text { Total Waste Volume (cu/t) } \\
\text { Average Buriel Volume (cu/t) }\end{array}$ & 5,300 & - & $\therefore$ & - & - & - & $\therefore$ & 5,300 & 28.3 \\
\hline & & $\begin{array}{l}\text { Average Burlel Volume (cumt) } \\
\text { Standard Deviation } \\
\end{array}$ & 1,325 & - & - & - & - & - & $\dot{-}$ & $\frac{1325}{350}$ & nte \\
\hline & & $\begin{array}{l}\text { Standard Deviation } \\
\text { Maximum Burlal Volume (aun) } \\
\end{array}$ & 350 & - & - & - & $=$ & $\therefore$ & - & $\frac{350}{1500}$ & Na \\
\hline & & \begin{tabular}{|l} 
Maximum Burlal Volume (avit) \\
Minimum Burial Volume (cunt) \\
\end{tabular} & 1,500 & $\therefore$ & - & - & - & - & - & 800 & no \\
\hline \multirow{6}{*}{6} & \multirow{6}{*}{ Resin } & \begin{tabular}{|l} 
Minimum Burlal Volumo (cu/t) \\
Number of Records \\
\end{tabular} & 800 & $\frac{-}{0}$ & $\frac{1}{0}$ & 0 & $\frac{-}{0}$ & 0 & 0 & 0 & nto \\
\hline & & \begin{tabular}{|l} 
Number of Records \\
Total Wasto Votume (cunt) \\
\end{tabular} & 0 & $\frac{0}{-}$ & - & 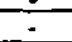 & - & - & - & - & - \\
\hline & & $\begin{array}{l}\text { Total Wasto Volume (cum) } \\
\text { Average Burtal Volume (cult) } \\
\end{array}$ & $\frac{-}{-}$ & $\div$ & - & $=$ & - & - & - & - & nhe \\
\hline & & Standard Deviation & + & - & + & - & - & - & - & - & na \\
\hline & & Maximum Burial Volume (cuit) & - & - & - & 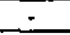 & - & - & - & - & nto \\
\hline & & \begin{tabular}{|c|} 
Minimum Burial Volume (curtt) \\
\end{tabular} & - & - & - & - & - & - & - & - & $n / a$ \\
\hline \multirow{6}{*}{7} & \multirow{6}{*}{ other } & Number of Records & 0 & 0 & 0 & 0 & 0 & $\underline{0}$ & 0 & 0 & - \\
\hline & & Total Waste Volume (cu/ti) & - & - & - & $\because$ & $\therefore$ & 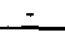 & - & - & - \\
\hline & & Average Burial Votume (ault) & - & - & - & - & - & $=$ & - & - & nta \\
\hline & & Standard Devilion & - & - & $\therefore$ & - & - & - & - & - & na \\
\hline & & Maximum Burial Volume (au/t) & - & - & - & - & $=$ & $\therefore$ & $\therefore$ & - & $\mathrm{Na}$ \\
\hline & & Minlmum Burial Volume (cu/tt) & - & - & - & $\cdot$ & - & $=$ & - & - & nas \\
\hline \multirow{4}{*}{\multicolumn{2}{|c|}{ Totals Across All 7 Type Codes }} & Number of Records & 14 & 2 & 17 & 724 & 5 & 0 & 0 & 762 & \\
\hline & & $\%$ of Box 6 Totots & 1.8 & 0.3 & 2.2 & 95.0 & 0.7 & $0 . \overline{0}$ & 0.0 & 100.0 & \\
\hline & & Total Waste Volumo (cunt) & 5,836 & 2,700 & 885 & 9,052 & 235 & 0 & 0 & 18,708 & \\
\hline & & $\%$ of Box 6 Totals & 31.2 & 14.4 & 4.7 & 48.4 & 1.3 & 0.0 & 0.0 & 100,0 & \\
\hline
\end{tabular}


Table 3-21. Decay Forecast for COBRA Inventory for Potential "Hot Spot" HS-100-6

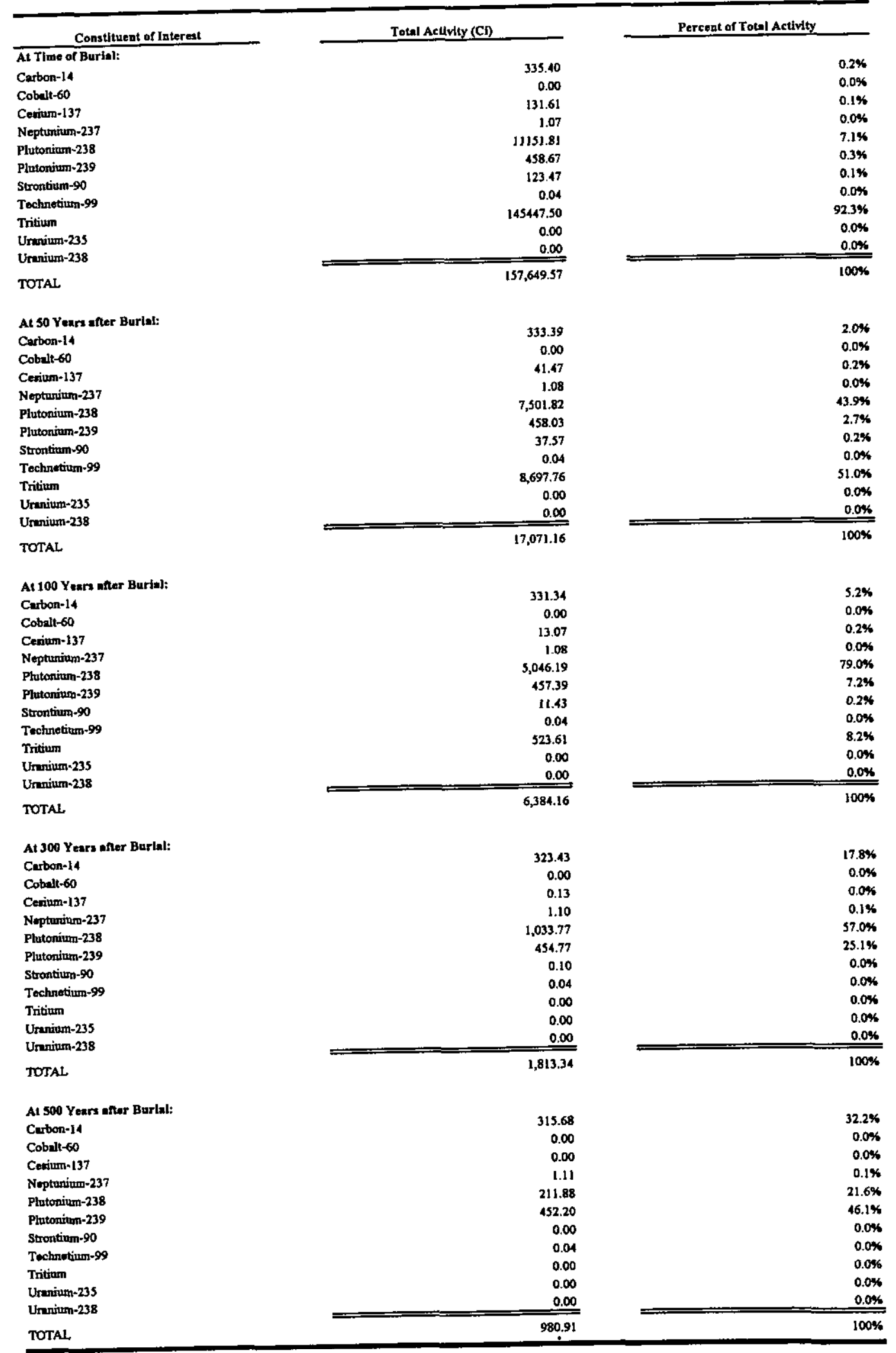


Table 3-21. Decay Forecast for COBRA Inventory for Potential "Hot Spot" HS-100-6 (Continued)

\begin{tabular}{|c|c|c|}
\hline Constituent of Interest & Total Activity (Ci) & Percent of Total Activity \\
\hline At 1,000 Years after Buris): & & \\
\hline Curbon-14 & $\begin{array}{r}297.10 \\
0.00\end{array}$ & $\begin{array}{r}39.7 \% \\
0.0 \%\end{array}$ \\
\hline Cobalt -60 & $\begin{array}{l}0.00 \\
0.00\end{array}$ & $\begin{array}{l}0.0 \% \\
0.0 \%\end{array}$ \\
\hline Cesium-137 & 1.12 & $0.1 \%$ \\
\hline $\begin{array}{l}\text { Nepturium-237 } \\
\text { Phutonium-238 }\end{array}$ & 4.46 & $0.6 \%$ \\
\hline $\begin{array}{l}\text { Phutonium-238 } \\
\text { Phutonium-239 }\end{array}$ & 445.83 & $59.6 \%$ \\
\hline $\begin{array}{l}\text { Phutonium-239 } \\
\text { Strontinm-90 }\end{array}$ & 0.00 & $0.0 \%$ \\
\hline $\begin{array}{l}\text { Strontium-90 } \\
\text { Technetium-99 }\end{array}$ & 0.04 & $0.0 \%$ \\
\hline $\begin{array}{l}\text { Tochnetium-99 } \\
\text { Tritium }\end{array}$ & 0.00 & $0.0 \%$ \\
\hline $\begin{array}{l}\text { Tritium } \\
\text { Unerium-235 }\end{array}$ & 0.00 & $0.0 \%$ \\
\hline $\begin{array}{l}\text { Unanium-235 } \\
\text { Unanium-238 }\end{array}$ & 0.00 & $0.0 \%$ \\
\hline Unnivm-238 & 748.55 & $100 \%$ \\
\hline TOTAL & & \\
\hline \multicolumn{3}{|l|}{ At 3,000 Yenrs after Burial: } \\
\hline Curbon-14 & $\begin{array}{r}182.93 \\
0.00\end{array}$ & $\begin{array}{r}31.46 \\
0.0 \% 6\end{array}$ \\
\hline Cobalt-60 & 0.00 & $0.0 \%$ \\
\hline Corium-137 & 1.13 & $0.2 \%$ \\
\hline $\begin{array}{l}\text { Nepturium-237 } \\
\text { Plntonium-238 }\end{array}$ & 0.00 & $0.0 \%$ \\
\hline $\begin{array}{l}\text { Plntonium-238 } \\
\text { Plutonium-239 }\end{array}$ & 397.85 & $68.4 \%$ \\
\hline $\begin{array}{l}\text { Plutonium-239 } \\
\text { Strontium-90 }\end{array}$ & 0.00 & $0.0 \%$ \\
\hline $\begin{array}{l}\text { Strontium-90 } \\
\text { Techrnatium-99 }\end{array}$ & 0.04 & $0.0 \%$ \\
\hline $\begin{array}{l}\text { Tochnotium-99 } \\
\text { Tritium }\end{array}$ & 0.00 & $0.0 \%$ \\
\hline $\begin{array}{l}\text { Tritium } \\
\text { Uranium-235 }\end{array}$ & 0.00 & $0.0 \%$ \\
\hline $\begin{array}{l}\text { Uranium-235 } \\
\text { Uranium-238 }\end{array}$ & 0.00 & $0.0 \%$ \\
\hline Uranium-238 & & \\
\hline TOTAL & 581.95 & $100 \%$ \\
\hline \multicolumn{3}{|l|}{ A1 10,000 Years after Burial: } \\
\hline Carbon-14 & 99.75 & $22.4 \%$ \\
\hline Cobalt- 60 & 0.00 & $0.0 \%$ \\
\hline Cesium-137 & 0.00 & $0.0 \%$ \\
\hline Nepturniom-237 & 1.13 & $0.3 \%$ \\
\hline Plutoniura-238 & 0.00 & $0.0 \%$ \\
\hline Plutonium-239 & 345.10 & $77.4 \%$ \\
\hline Strontium-90 & 0.00 & $0.0 \%$ \\
\hline Technetium-99 & 0.04 & $0.0 \%$ \\
\hline Tritium & 0.00 & $0.0 \%$ \\
\hline Uranium-235 & 0.00 & $0.0 \%$ \\
\hline Unarium-238 & 0.00 & $0.0 \%$ \\
\hline TOTAL & 446.03 & $100 \%$ \\
\hline
\end{tabular}


Table 3-22. Summary Statistics for COBRA Inventory of Potential "Hot Spot" HS-100-7

\begin{tabular}{|c|c|c|c|c|c|c|c|c|c|c|c|}
\hline \multirow[t]{2}{*}{$\begin{array}{l}\stackrel{8}{2} \\
\text { 蛋 } \\
0 \\
0\end{array}$} & & & 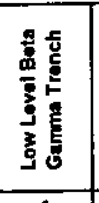 & 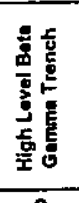 & 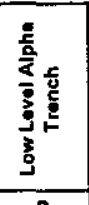 & 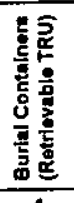 & 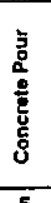 & 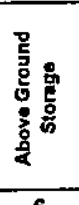 & 营 & 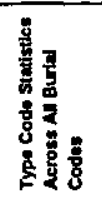 & 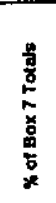 \\
\hline & & COBRA Burial Code: & 1 & 2 & 3 & 4 & 5 & 6 & 7 & & \\
\hline \multirow{6}{*}{1} & \multirow{6}{*}{$\begin{array}{l}\text { Job Control Waste, } \\
\text { inchuding house- } \\
\text { keeping waste and } \\
\text { protwetlve clothing }\end{array}$} & Number of Records & 1.943 & 0 & 124 & 1 & 0 & 0 & 0 & 2,068 & 94.7 \\
\hline & & Total Waste Volume (cumt) & 276.346 & - & 15,801 & 8 & - & - & + & 292,155 & 93.8 \\
\hline & & Average Burlal Volume (cunt) & 142 & $=$ & 127 & 8 & $\therefore$ & $\pi$ & $\therefore$ & 141 & No \\
\hline & & Standard Deviation & 940 & - & 149 & - & - & $=$ & - & 30 & nta \\
\hline & & Maximum Burial Volume (cunt) & 41.288 & - & 1,350 & 8 & - & - & $=$ & 41288 & na \\
\hline & & Mirimum Burleal Volume (aum) & 0 & $\cdot$ & 6 & 8 & - & - & $\therefore$ & 0 & Na \\
\hline \multirow{6}{*}{2} & \multirow{6}{*}{ Oll } & Number of Records & 40 & 0 & 0 & 0 & 0 & 0 & 0 & 10 & 0.5 \\
\hline & & Total Waste Volume (cum) & 522 & - & $=$ & - & - & - & - & 522 & 0.2 \\
\hline & & Average Burial Volume (cunt) & 52 & $=$ & - & - & - & - & - & 52 & $n \mathbf{a}$ \\
\hline & & Standard Deviation & 43 & $=$ & - & $=$ & $=$ & - & $=$ & & no \\
\hline & & Maxdmum Burtal Volume (cunt) & 140 & $\therefore$ & - & - & $\therefore$ & $\therefore$ & $\therefore$ & 140 & Na \\
\hline & & Minimum Burial Volumo (cum) & 3 & - & - & 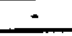 & - & - & - & 3 & $\mathrm{na}$ \\
\hline \multirow{6}{*}{3} & \multirow{6}{*}{$\begin{array}{l}\text { Imradiated Wotal } \\
\text { scrap }\end{array}$} & Number of Records & 0 & 24 & 0 & 0 & 0 & 0 & 0 & 24 & 1.1 \\
\hline & & Total Waste Volume (cu/t) & - & 8.629 & $\therefore$ & 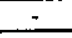 & - & - & - & 8,629 & 2.8 \\
\hline & & Average Eurial Volume (curt) & - & 360 & $\therefore$ & 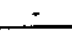 & - & - & - & 360 & na \\
\hline & & Standard Deviation & $\therefore$ & 1,421 & - & - & - & - & - & & nes \\
\hline & & Moximum Burial Volume (cunt) & $=$ & 7,000 & $\therefore$ & $=$ & - & - & $\therefore$ & 7000 & no \\
\hline & & Minlmum Burlel Volume (cunt) & - & 3 & - & - & - & - & - & 3 & Na \\
\hline \multirow{6}{*}{4} & \multirow{6}{*}{$\begin{array}{l}\text { Naturally } \\
\text { Redioactive } \\
\text { Materials }\end{array}$} & Nurnber of Records & 66 & 0 & 0 & 0 & 0 & 0 & 0 & 66 & 3.0 \\
\hline & & Total Waste Volume (cult) & 9,496 & - & - & 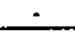 & 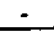 & - & - & 9,496 & 3.0 \\
\hline & & Average Buriel Vohmo (culit) & 144 & - & $\dot{-}$ & - & - & - & - & 144 & nta \\
\hline & & Standard Deviation. & 69 & - & - & $\dot{-}$ & - & - & - & & no \\
\hline & & Maximum Burial Volume (cuit) & 250 & $=$ & - & - & - & $\therefore$ & $\cdot$ & 250 & na \\
\hline & & Minimum Burtal Volume (cuft) & 5 & $\dot{-}$ & - & - & - & - & - & 5 & no \\
\hline \multirow{6}{*}{5} & \multirow{6}{*}{$\begin{array}{l}\text { Capital Equipment, must } \\
\text { be accompaniod by a } \\
\text { Plant Equipment } \\
\text { Transfer (PEI) }\end{array}$} & Number of Records & 14 & 0 & 1 & 0 & 0 & 0 & 0 & 15 & 0.7 \\
\hline & & Total Waste Volume (avin) & 561 & - & 1 & - & $\therefore$ & $\therefore$ & - & 562 & 0.2 \\
\hline & & Averege Burial Volume (cunt) & 40 & $\therefore$ & 1 & - & - & $\approx$ & - & 37 & na \\
\hline & & Standard Devilation & 51 & - & 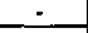 & - & - & - & $\therefore$ & & nia \\
\hline & & Moximum Burial Volume (cunt) & 175 & - & 1 & - & $=$ & 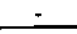 & $\therefore$ & 175 & nte \\
\hline & & Minimum Buriel Volumo (cunt) & 1 & - & 1 & - & - & - & - & 1 & n/a \\
\hline \multirow{6}{*}{6} & \multirow{6}{*}{ Resin } & Number of Records & 0 & 0 & 0 & $\underline{0}$ & 0 & 0 & 0 & 0 & - \\
\hline & & Total Waste Volume (Cu/t) & - & $\therefore$ & - & - & $=$ & - & - & 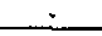 & - \\
\hline & & Average Burial Volume (cu/t) & - & 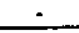 & - & - & - & - & $\therefore$ & $\therefore$ & n/a \\
\hline & & Standard Dentation & 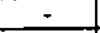 & - & - & - & - & - & $\therefore$ & & nia \\
\hline & & Maximum Burial Volume (cunt) & $\therefore$ & - & $\therefore$ & $\therefore$ & $=$ & - & $\therefore$ & $=$ & nta \\
\hline & & Mirimum Burlel Volume (cult) & - & - & - & - & - & - & - & $=$ & nas \\
\hline \multirow{6}{*}{7} & \multirow{6}{*}{ Other } & Number of Records & 0 & 0 & 0 & 0 & 0 & 0 & 0 & 0 & - \\
\hline & & Total Waste Volume (cum) & - & - & - & - & - & - & $\because$ & $\therefore$ & - \\
\hline & & Average Burtel Volume (cuntt) & - & - & - & $=$ & - & - & $\therefore$ & $=$ & no. \\
\hline & & Standard Deviation & $=$ & - & 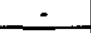 & $=$ & $\because$ & - & - & & nha \\
\hline & & Maximum Burial Volumo (cunti) & - & - & - & - & - & $\therefore$ & - & $\therefore$ & no \\
\hline & & Minimum Burlal Volume (aumt) & $\therefore$ & $\dot{-}$ & - & - & - & - & $=$ & - & nos \\
\hline \multirow{4}{*}{\multicolumn{2}{|c|}{ Totals Acrost All 7 Type Codes }} & Number of Records & 2.033 & 24 & 125 & 1 & 0 & 0 & 0 & 2.183 & \\
\hline & & X of Box 7 Totals & 93.1 & 1.1 & 5.7 & 0.0 & 0.0 & 0.0 & 0.0 & 100.0 & \\
\hline & & Total Waste Volume (cult) & 286.925 & 8,629 & 15.802 & $B$ & 0 & 0 & 0 & 311,364 & \\
\hline & & $\%$ of Box 7 Totals & 92.2 & 2.8 & 5.1 & 0.0 & 0.0 & 0.0 & 0.0 & 100.0 & \\
\hline
\end{tabular}


Table 3-23. Decay Forecast for COBRA Inventory for Potential "Hot Spot" HS-100-7

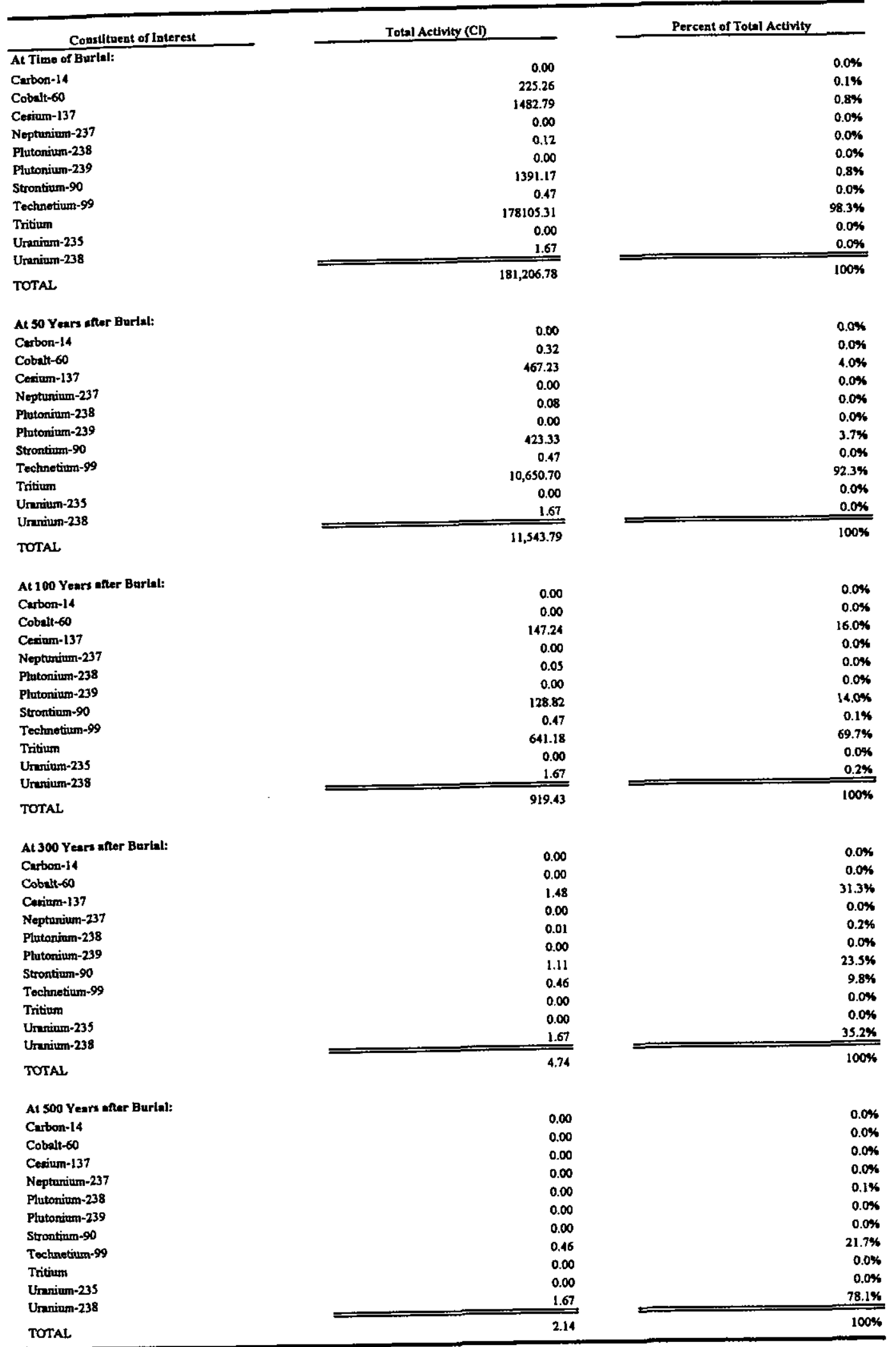


Table 3-23. Decay Forecast for COBRA Inventory for Potential "Hot Spot" HS-100-7 (Continued)

\begin{tabular}{|c|c|c|}
\hline Constituent of Interest & Total Activity (Ci) & Percent of Total Activity \\
\hline \multicolumn{3}{|l|}{ At 1,000 Years after Burial: } \\
\hline Curton-14 & 0.00 & $0.0 \%$ \\
\hline Cobelt -60 & 0.00 & $0.0 \%$ \\
\hline Cosium-137 & 0.00 & $0.0 \%$ \\
\hline Neptunium-237 & 0.00 & $0.0 \%$ \\
\hline Plutonium-238 & 0.00 & $0.0 \%$ \\
\hline Plutonium-239 & 0.00 & $0.0 \%$ \\
\hline Strontium-90 & 0.00 & $0.0 \%$ \\
\hline Technetium-99 & 0.46 & $21.7 \%$ \\
\hline Tritium & 0.00 & $0.0 \%$ \\
\hline Uranium-235 & 0.00 & $0.0 \%$ \\
\hline Uranium-238 & $\underline{1.67}$ & $78.2 \%$ \\
\hline TOTAL & 2.14 & $100 \%$ \\
\hline \multicolumn{3}{|l|}{ At 5,000 Years efter Burind: } \\
\hline Curbon-14 & 0.00 & $0.0 \%$ \\
\hline Cobalt -60 & 0.00 & $0,0 \%$ \\
\hline Cexiums-137 & 0.00 & $0.0 \%$ \\
\hline Neptunium-237 & 0.00 & $0.0 \%$ \\
\hline Plutonium-238 & 0.00 & $0.0 \%$ \\
\hline Plutonium-239 & 0.00 & $0.0 \%$ \\
\hline Strontium-90 & 0.00 & $0.0 \%$ \\
\hline Technetium -99 & 0.46 & $21.5 \%$ \\
\hline Tritium & 0.00 & $0.0 \%$ \\
\hline Uranium-235 & 0.00 & $0.0 \%$ \\
\hline Unerium-238 & 1.67 & $78.5 \%$ \\
\hline TOTAL. & 2.13 & $100 \%$ \\
\hline \multicolumn{3}{|l|}{ At 10,000 Years anter Burial: } \\
\hline Curbon-14 & 0.00 & $0.0 \%$ \\
\hline Cobalt-60 & 0.00 & $0.0 \%$ \\
\hline Cesium-137 & 0.00 & $0.0 \%$ \\
\hline Nepturium-237 & 0.00 & $0.0 \%$ \\
\hline Phutonium-238 & 0.00 & $0.0 \%$ \\
\hline Plutonium-239 & 0.00 & $0.0 \%$ \\
\hline Strontium-90 & 0.00 & $0.0 \%$ \\
\hline Technetium-99 & 0.45 & $21.2 \%$ \\
\hline Tritium & 0.00 & 0.066 \\
\hline Unanium-235 & 0.00 & $0.0 \%$ \\
\hline Uranim-238 & 1.67 & 78.7\% \\
\hline TOTAL & 2.12 & $100 \%$ \\
\hline
\end{tabular}


Table 3-24. Summary Statistics for COBRA Inventory of Potential "Hot Spot" HS-100-8

\begin{tabular}{|c|c|c|c|c|c|c|c|c|c|c|c|}
\hline \multirow[t]{2}{*}{$\frac{2}{\frac{5}{10}}$} & & & 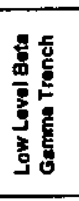 & 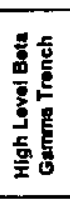 & 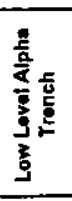 & 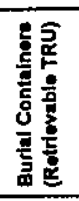 & 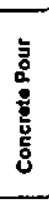 & 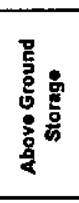 & $\frac{5}{\delta}$ & 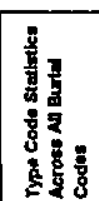 & 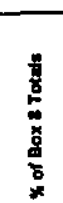 \\
\hline & & COBRA Burial Code: & 1 & 2 & 3 & 4 & 5 & 6 & 7 & & \\
\hline \multirow{6}{*}{1} & \multirow{6}{*}{$\begin{array}{l}\text { Job Control Waste, } \\
\text { inciluding house- } \\
\text { keeping waste and } \\
\text { protective ckothing }\end{array}$} & Number of Records & 35 & 0 & 0 & 0 & 0 & 0 & 0 & 35 & 100.0 \\
\hline & & Total Waste Volumo (autt) & 5,228 & - & $\cdot$ & - & $=$ & - & 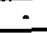 & 5,228 & 100.0 \\
\hline & & Averege Burial Volume (cuft) & 149 & - & - & $=$ & - & - & $=$ & 149 & na \\
\hline & & Stendard Deviation & 96 & - & - & - & $\therefore$ & - & $=$ & 96 & nata \\
\hline & & Maxdmum Buriel Volume (cult) & 350 & $\therefore$ & - & $\dot{*}$ & - & - & - & 350 & na \\
\hline & & Min'mum Burial Volume (cumt) & 25 & - & - & $\dot{-}$ & - & - & - & 25 & $\mathrm{Na}$ \\
\hline \multirow{5}{*}{2} & \multirow{5}{*}{ on } & Nimber of Rocords & 0 & 0 & 0 & 0 & 0 & 0 & $\mathbf{0}$ & 0 & $\therefore$ \\
\hline & & Total Waste Volume (cuitt) & - & - & - & - & 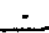 & - & $=$ & - & $\therefore$ \\
\hline & & Average Burlal Voume (aurt) & - & - & - & + & - & - & $=$ & - & nfo \\
\hline & & Standard Doviation & $\cdot$ & - & 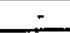 & - & $\because$ & - & - & - & no \\
\hline & & Moximum Burial Volumo (cuft) & $=$ & $=$ & $\cdot$ & $\therefore$ & $\cdot$ & - & - & - & $\mathrm{n} / \mathrm{a}$ \\
\hline \multirow{6}{*}{3} & \multirow{6}{*}{$\begin{array}{l}\text { Imedlated Motal } \\
\text { Scrap }\end{array}$} & Mirsirnem Burial Volume (avt) & - & $=$ & 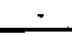 & - & - & - & - & - & na \\
\hline & & \begin{tabular}{|l} 
Number of Records \\
Total Waste Volume (cumt) \\
\end{tabular} & 0 & 0 & 0 & 0 & $\underline{0}$ & 0 & $\underline{0}$ & 0 & - \\
\hline & & $\begin{array}{l}\text { Total Waste Volume (cu/n) } \\
\text { Average Burlal Voume (cu/t) }\end{array}$ & - & - & - & - & $\cdot$ & - & 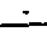 & - & - \\
\hline & & $\begin{array}{l}\text { Average Burlal Voume (cuint) } \\
\text { Standard Deviation } \\
\end{array}$ & $=$ & - & - & $\therefore$ & - & - & $=$ & - & n/e \\
\hline & & \begin{tabular}{|l} 
Standard Deviation \\
Maximum Burial Volume (cult) \\
\end{tabular} & - & - & $=$ & - & $\therefore$ & - & $\approx$ & - & n/e \\
\hline & & \begin{tabular}{|l|} 
Maximum Burial Volume (cunt) \\
Minimum Buriel Volume (avit) \\
\end{tabular} & - & $=$ & $\therefore$ & - & - & - & $=$ & - & n/a \\
\hline \multirow{5}{*}{4} & \multirow{5}{*}{$\begin{array}{l}\text { Naturally } \\
\text { Radioactive } \\
\text { Matestals }\end{array}$} & $\begin{array}{l}\text { Minimum Burlal Voume (au/t) } \\
\text { Nurnber of Records } \\
\end{array}$ & $=$ & - & - & - & - & - & $=$ & $\cdot$ & nea \\
\hline & & Average Burial Volume (cum) & $\frac{-}{-}$ & $\therefore$ & $=$ & - & $=$ & - & $=$ & - & $=$ \\
\hline & & Standard Deviation & $\dot{-}$ & - & - & - & - & - & $=$ & - & Na \\
\hline & & Maximum Burlal Vohume (cult) & - & - & - & - & - & - & $\therefore$ & $=$ & Na \\
\hline & & Minimum Burial Volume (cum) & - & $\frac{-}{-}$ & - & - & - & - & - & - & $\mathrm{n} / \mathrm{a}$ \\
\hline \multirow{6}{*}{5} & \multirow{6}{*}{$\begin{array}{l}\text { Capltal Equipment, must } \\
\text { bo sccompenied by a } \\
\text { Plant Equipment } \\
\text { Trensfor (PET) }\end{array}$} & Number of Records & 0 & $\frac{7}{0}$ & $=$ & - & - & - & - & - & ns \\
\hline & & Total Waste Volume (cumt) & - & - & D & 0 & 0 & - & 0 & $\frac{0}{-}$ & - \\
\hline & & Avertge Burlel Volume (oun) & - & $=$ & - & $\ddot{-}$ & - & - & $\ddot{-}$ & 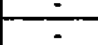 & $\therefore$ \\
\hline & & Standard Devation & $=$ & - & $\because$ & $\frac{-}{-}$ & $\because$ & $\frac{-}{5}$ & $=$ & - & no \\
\hline & & Maximum Burtal Volume (cuint) & - & - & - & $\dot{\tau}$ & - & - & - & - & Nhe \\
\hline & & Minlmum Burial Volume (aum) & - & - & - & - & - & - & . & - & $n / a$ \\
\hline \multirow{6}{*}{6} & \multirow{6}{*}{ Resin } & Number of Records & $\overline{0}$ & 0 & 0 & 0 & 0 & 0 & 0 & $\overline{0}$ & $\mathrm{n} / \mathrm{a}$ \\
\hline & & Total Waste Volume (cu/nt) & - & $=$ & - & - & $\because$ & $=$ & . & - & - \\
\hline & & Average Buntal Volums (cuint) & $\therefore$ & - & - & - & - & - & - & - & - \\
\hline & & Standard Deviation & - & - & - & - & $\cdot$ & - & - & 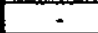 & $\frac{n}{n+a}$ \\
\hline & & Maximum Burlal Volume (OLnt) & - & - & - & - & - & - & $\sim$ & 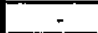 & $\frac{n+a}{n e s}$ \\
\hline & & Minimum Burial Volumo $(\mathrm{cu} / \mathrm{t})$ & $\cdot$ & - & - & - & - & - & - & - & $\frac{n / 2}{n / a}$ \\
\hline \multirow{6}{*}{7} & \multirow{6}{*}{ Other } & Number of Records & 0 & 0 & 0 & 0 & 0 & 0 & 0 & 0 & $\frac{\text { nota }}{-}$ \\
\hline & & Total Waste Volume (cum) & 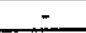 & - & - & - & - & - & - & - & 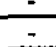 \\
\hline & & Average Burial Volume (curti) & - & - & - & $=$ & $=$ & $\therefore$ & - & 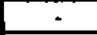 & $\mathrm{na}$ \\
\hline & & Standard Devtation & $=$ & - & - & 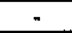 & $\therefore$ & - & - & $\dot{-}$ & no \\
\hline & & Maxtmum Burial Volume (cum) & - & $\therefore$ & - & $\cdot$ & 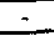 & - & - & - & $\mathrm{ns}$ \\
\hline & & Minimum Burlal Volume (cum) & - & - & - & - & - & - & $=$ & $=$ & $\mathrm{Na}$ \\
\hline \multirow{4}{*}{\multicolumn{2}{|c|}{ Totale Acrona All 7 Type Codes }} & Number of Records & 35 & 0 & 0 & 0 & 0 & 0 & 0 & 35 & \\
\hline & & $\%$ of Box 8 Totals & 100.0 & 0.0 & 0.0 & 0.0 & 0.0 & 0.0 & 0.0 & 100.0 & \\
\hline & & Total Woste Volume (ain) & 5.228 & 0 & 0 & 0 & 0 & 0 & 0 & 5.228 & \\
\hline & & $\%$ of Box 8 Totals & 100.0 & 0.0 & 0.0 & 0.0 & 0.0 & 0.0 & 0.0 & 100.0 & \\
\hline
\end{tabular}


Table 3-25. Decay Forecast for COBRA Inventory for Potential "Hot Spot" HS-100-8

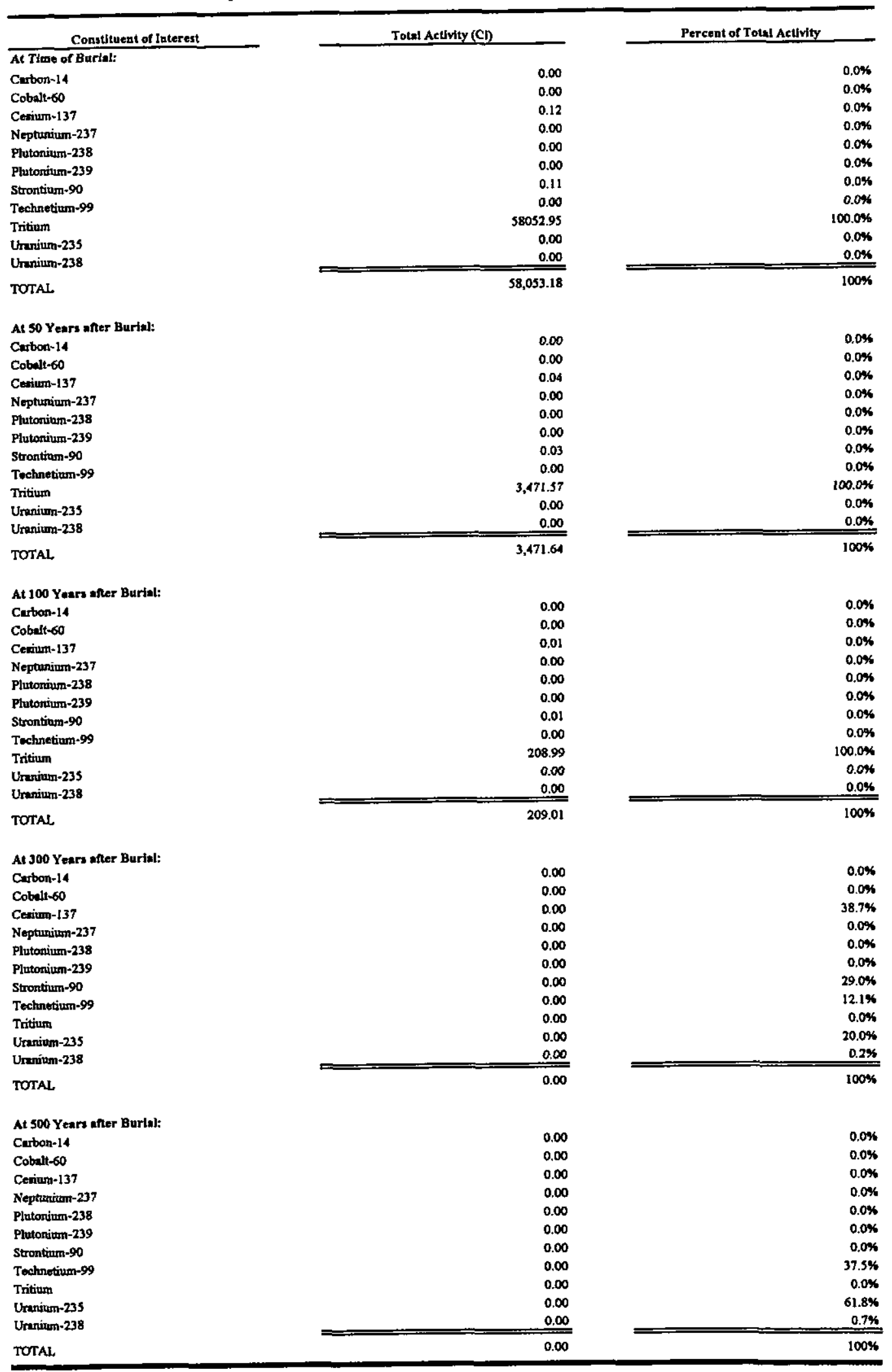


Table 3-25. Decay Forecast for COBRA Inventory for Potential "Hot Spot" HS-100-8 (Continued)

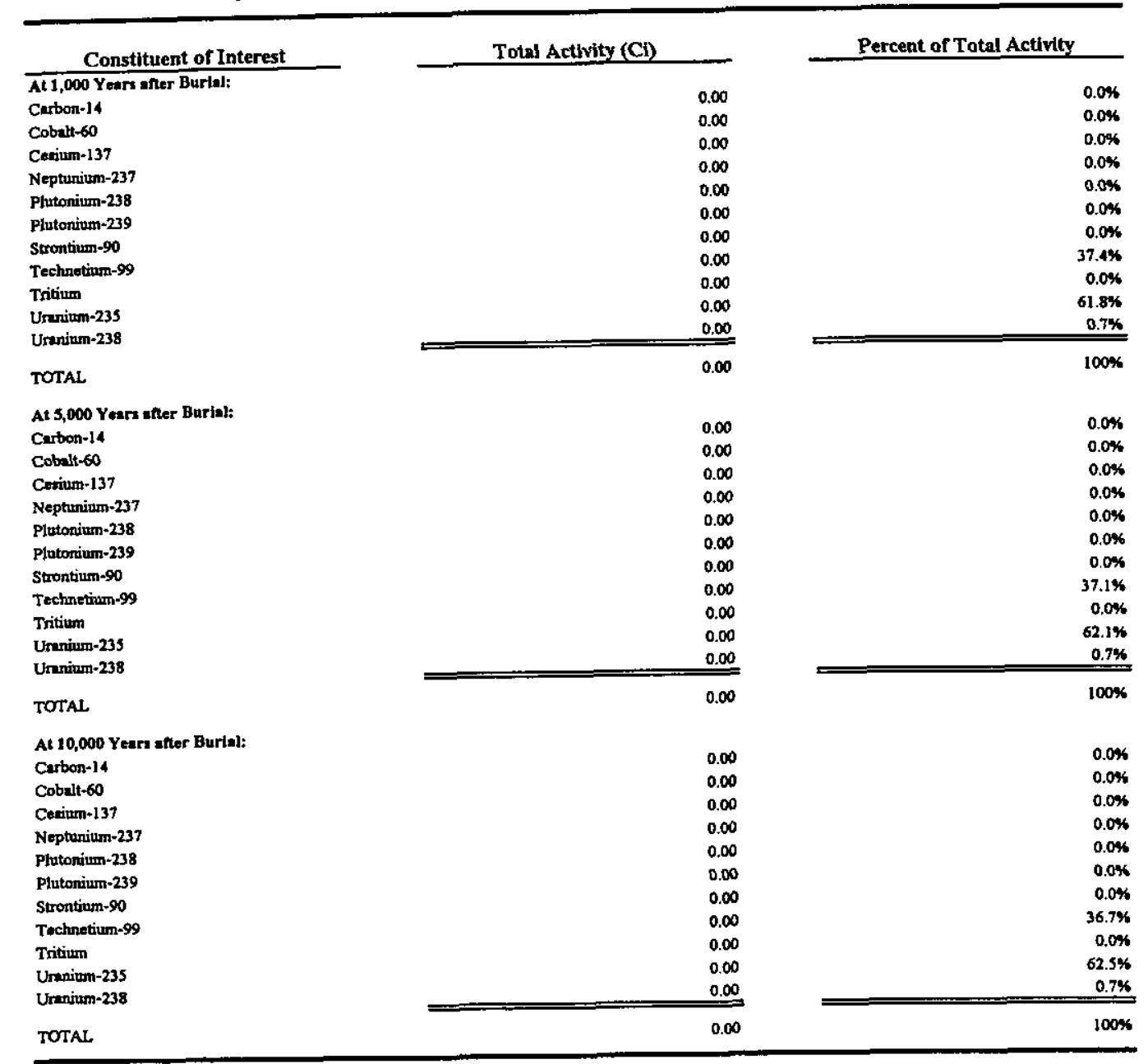


Table 3-26. Summary Statistics for COBRA Inventory of Potential "Hot Spot" HS-100-9

\begin{tabular}{|c|c|c|c|c|c|c|c|c|c|c|c|}
\hline \multirow{2}{*}{\multicolumn{2}{|c|}{ 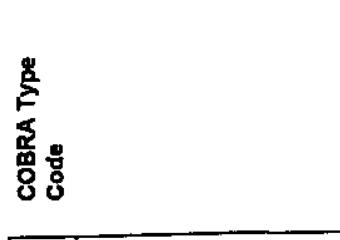 }} & & 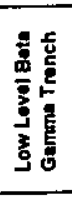 & 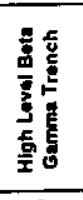 & 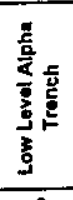 & 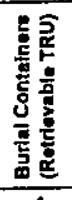 & 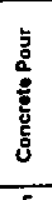 & 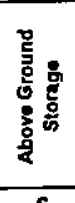 & $\frac{\bar{z}}{\delta}$ & 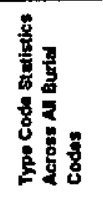 & 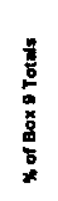 \\
\hline & & COBRA Burial Code: & 1 & 2 & 3 & 4 & 5 & 6 & 7 & & \\
\hline \multirow{6}{*}{1} & \multirow{6}{*}{$\begin{array}{l}\text { Job Control Wastes } \\
\text { including house. } \\
\text { koeping wrste and } \\
\text { protoctive clothing }\end{array}$} & Number of Records & 0 & 0 & 0 & 0 & 0 & 0 & 0 & 0 & $\therefore$ \\
\hline & & Total Wastie Voluma (curit) & - & - & $\therefore$ & - & - & $=$ & - & - & $\therefore$ \\
\hline & & Average Burral Volume (auit) & - & - & - & - & $\because$ & $\therefore$ & $\therefore$ & $=$ & Na \\
\hline & & Standard Deviation & $=$ & - & - & - & - & - & - & - & Nhen \\
\hline & & Maximum Burial Volumo (cam) & - & - & $\therefore$ & . & $=$ & - & - & - & no \\
\hline & & Mirrmum Burial Volume (cum) & $=$ & - & $\therefore$ & - & - & $\dot{-}$ & $\therefore$ & $\because$ & wa \\
\hline \multirow{5}{*}{2} & \multirow{5}{*}{ on } & \begin{tabular}{|l} 
Number of Records \\
\end{tabular} & 0 & 0 & 0 & 0 & 0 & o & 0 & 0 & - \\
\hline & & Total Waste Volume (carti) & $\because$ & $\therefore$ & $\therefore$ & - & $\therefore$ & - & 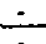 & $\therefore$ & $\frac{-}{n}$ \\
\hline & & \begin{tabular}{|l} 
Average Burlal Volume (CWI) \\
Standard Deviation \\
\end{tabular} & - & - & - & - & $\because$ & $\therefore$ & 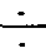 & $\dot{-}$ & $\frac{n / a}{n / a}$ \\
\hline & & Maximum Burlal Volumo (aunt) & - & - & $=$ & - & - & - & - & $\because$ & na \\
\hline & & Minimum Burial Voume (cum) & - & $\dot{-}$ & - & $=$ & - & - & - & - & No \\
\hline \multirow{5}{*}{$\mathbf{3}$} & \multirow{5}{*}{$\begin{array}{l}\text { Imadiatod Matal } \\
\text { Scrap }\end{array}$} & Number of Records & 0 & 0 & 0 & 0 & 0 & 0 & 0 & 0 & $=$ \\
\hline & & Total Waste Volume (cault) & - & - & $\therefore$ & $=$ & - & - & - & - & $\therefore$ \\
\hline & & \begin{tabular}{|l} 
Average Qurial Volume (cumt) \\
Standare Deviation \\
\end{tabular} & $=$ & 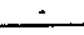 & $=$ & $\therefore$ & - & - & - & - & $\mathrm{Na}$ \\
\hline & & \begin{tabular}{|l|} 
Standard Deviabion \\
Maximum Burial Volmive (oumt)
\end{tabular} & - & $\therefore$ & $=$ & - & $\therefore$ & - & $\therefore$ & - & $\mathrm{Na}$ \\
\hline & & 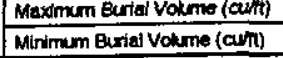 & - & $\because$ & $\div$ & $\therefore$ & $\therefore$ & $\therefore$ & - & - & $n / a$ \\
\hline \multirow{5}{*}{4} & \multirow{5}{*}{$\begin{array}{l}\text { Naturally } \\
\text { Redioaction } \\
\text { Matorrals }\end{array}$} & $\begin{array}{l}\text { Minimum Buxial Voume (avin) } \\
\text { Number of Records } \\
\end{array}$ & 0 & 0 & 0 & $\div$ & $\dot{0}$ & $\frac{-}{0}$ & - & $\div$ & $\frac{\text { nta }}{-}$ \\
\hline & & Total Waste Volume (cant) & - & - & - & $\therefore$ & - & - & - & - & - \\
\hline & & Average Burial Volume (cunt) & - & - & - & $\therefore$ & - & - & - & 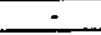 & $\mathrm{Non}$ \\
\hline & & Standard Deviation & - & $\therefore$ & - & $\therefore$ & - & $=$ & - & - & $\mathrm{nta}$ \\
\hline & & Maxmum Burtas Volume (cum) & - & $\therefore$ & - & $\dot{-}$ & - & $\therefore$ & - & - & No \\
\hline \multirow{4}{*}{$\mathbf{5}$} & \multirow{4}{*}{$\begin{array}{c}\text { Capital Equipment, must } \\
\text { be accompanied by a } \\
\text { Plant Equipment } \\
\text { Transfer (PET) }\end{array}$} & Minimum Burial Volmo (aum) & $\div$ & $\therefore$ & - & $\therefore$ & $\therefore$ & $\because$ & $\div$ & - & $\mathrm{n} / \mathrm{e}$ \\
\hline & & \begin{tabular}{|l} 
Average Buriel Volume (cufti) \\
Standard Devietson \\
\end{tabular} & $\ddot{-}$ & 3.880 & $\therefore$ & - & $\therefore$ & $\div$ & $\therefore$ & 3880 & nat \\
\hline & & 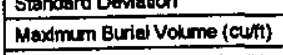 & - & 3,880 & - & $\dot{-}$ & $\dot{-}$ & $\because$ & $\because$ & 3880 & $\mathrm{mo}$ \\
\hline & & Minimum Burial Voume (cum) & $=$ & 3,880 & - & - & - & $\dot{1}$ & $=$ & 3880 & $\mathrm{Na}$ \\
\hline \multirow{3}{*}{6} & \multirow{3}{*}{ Resin } & \begin{tabular}{|l} 
Number of Records \\
\end{tabular} & 0 & 0 & 0 & 0 & 0 & 0 & 0 & 0 & $\because$ \\
\hline & & Total Waste Volume (aun) & $=$ & - & - & - & - & $\therefore$ & $\therefore$ & - & $\therefore$ \\
\hline & & Average Burlal Voume (anin) & - & $=$ & $=$ & $=$ & - & - & - & - & nota \\
\hline \multirow{5}{*}{7} & \multirow{5}{*}{ Other } & \begin{tabular}{|l} 
Minimum Buriel Voume (ciun) \\
Number of Records \\
\end{tabular} & 0 & 0 & 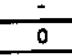 & $\div$ & $\div$ & $\div$ & $\frac{-}{0}$ & $\frac{1}{0}$ & $\frac{1}{-}$ \\
\hline & & $\begin{array}{l}\text { Totol Waste Volume (cumin) } \\
\end{array}$ & $\therefore$ & $\therefore$ & - & 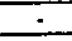 & - & - & $\therefore$ & $\because$ & - \\
\hline & & Average Burial Voume (cunt) & - & $\therefore$ & - & $\therefore$ & - & - & - & - & $\mathrm{nta}_{\mathrm{a}}$ \\
\hline & & Standard Doviation & $=$ & - & - & $\therefore$ & $=$ & - & $\therefore$ & - & $\mathrm{nm}$ \\
\hline & & Maxdrum Burial Volume (culti) & ت & - & $\therefore$ & - & $=$ & - & - & - & No \\
\hline \multirow{4}{*}{\multicolumn{2}{|c|}{ Totais Acroms All 7 Typo Codes }} & Mindmum Eurial Voume (cunt) & $\frac{1}{0}$ & $\frac{-}{1}$ & - & $\therefore$ & - & $\div$ & $\frac{-}{0}$ & $\frac{-}{1}$ & Na \\
\hline & & \begin{tabular}{|l|} 
Number of Records \\
$\%$ of Box 9 Yotals \\
\end{tabular} & 0.0 & 100.0 & $\frac{0}{0.0}$ & $\frac{0}{00}$ & 0.0 & 0.0 & 0.0 & $\frac{1}{100.0}$ & \\
\hline & & \begin{tabular}{|l|} 
\% of Box 9 Totals \\
Total Waste Volume (cuit) \\
\end{tabular} & 0 & 3.880 & $\frac{0.0}{0}$ & $\frac{0.0}{0}$ & 0 & 0 & 0 & 3,880 & \\
\hline & & \begin{tabular}{|l|} 
Total Waste Volume (cwit) \\
$\%$ of Box 9 Totals \\
\end{tabular} & 0.0 & 100.0 & $\frac{0}{0.0}$ & $\frac{0}{0.0}$ & 0.0 & 0.0 & 0.0 & 100.0 & \\
\hline
\end{tabular}


Table 3-27. Decay Forecast for COBRA Inventory for Potential "Hot Spot" HS-100-9

\begin{tabular}{|c|c|c|}
\hline Constitnent of Interest & Total Activity (C) & Percent of Total Activity \\
\hline At Time of Burial: & & \\
\hline Crrbon-14 & 0.00 & $0.0 \%$ \\
\hline Cobalt- 60 & 0.00 & $0.0 \%$ \\
\hline Cevium-137 & 922.50 & $51.6 \%$ \\
\hline Nepturium-237 & 0.00 & $0.0 \% 6$ \\
\hline Plutonium-238 & 0.00 & $0.0 \%$ \\
\hline Plutonitum-239 & 0.00 & $0.0 \%$ \\
\hline Strontium-90 & 865.50 & $48.4 \%$ \\
\hline Technetium-99 & 0.29 & $0.0 \%$ \\
\hline Tritium & 0.00 & $0.0 \%$ \\
\hline Unanium-235 & 0.00 & $0.0 \%$ \\
\hline Uranium-238 & $\stackrel{0.00}{=}$ & $0.0 \%$ \\
\hline TOTAL & $1,788.29$ & $100 \%$ \\
\hline \multicolumn{3}{|l|}{ At so Years afler Burial: } \\
\hline Carbon-14 & $\begin{array}{l}0.00 \\
0.00\end{array}$ & $0.0 \%$ \\
\hline Cobalt -60 & 290.68 & $52.4 \%$ \\
\hline Cerium-137 & 0.00 & $0.0 \%$ \\
\hline Nepturium-237 & 0.00 & $0.0 \%$ \\
\hline Plutoriem-238 & 0.00 & $0.0 \%$ \\
\hline Plutonium-239 & 263.37 & $47.5 \%$ \\
\hline Strontium-90 & 0.29 & $0.1 \%$ \\
\hline Technetium-99 & 0.00 & $0.0 \%$ \\
\hline Tritiun & 0.00 & $0.0 \%$ \\
\hline Unanium-235 & 0.00 & $0.0 \%$ \\
\hline Unnium-238 & 554.34 & \\
\hline TOTAL. & 394.34 & $100 \%$ \\
\hline \multicolumn{3}{|l|}{ At 100 Years after Burial: } \\
\hline Curton-14 & 0.00 & $0.0 \%$ \\
\hline Cobalt -60 & 0.00 & $0.0 \%$ \\
\hline Cesium-137 & 91.60 & $53.2 \%$ \\
\hline Neptunium-237 & 0.00 & $0.0 \%$ \\
\hline Platonium-238 & 0.00 & $0.0 \%$ \\
\hline Plutonium-239 & 0.00 & $0.0 \%$ \\
\hline Strontinem-90 & 80.15 & $46.6 \%$ \\
\hline Technetionn-99 & 0.29 & $0.2 \%$ \\
\hline Tritium & 0.00 & $0.0 \%$ \\
\hline Urerium-235 & 0.00 & $0.0 \%$ \\
\hline Uranium-238 & $\stackrel{0.00}{=}$ & $0.0 \%$ \\
\hline TOTAL & 172.04 & $100 \%$ \\
\hline \multicolumn{3}{|l|}{ At 380 Years atter Buristi } \\
\hline Carbon-14 & 0.00 & $0.0 \%$ \\
\hline Cobalt-60 & 0.00 & 0.096 \\
\hline Cercium-137 & 0.92 & $48.4 \%$ \\
\hline Neptunium-237 & 0.00 & $0.0 \%$ \\
\hline Plutonium-238 & 0.00 & $0.0 \%$ \\
\hline Plutonium-239 & 0.00 & $0.0 \%$ \\
\hline Strontium-90 & 0.69 & $36.4 \%$ \\
\hline Technetioun-99 & 0.29 & $15.2 \%$ \\
\hline Tritiom & 0.00 & $0.0 \%$ \\
\hline Uranium-235 & 0.00 & $0.0 \%$ \\
\hline Uranium-238 & $\stackrel{0.00}{=}$ & $0.0 \%$ \\
\hline TOTAL & 1.90 & $100 \%$ \\
\hline \multicolumn{3}{|l|}{ At 500 Years after Burial: } \\
\hline Carbots-14 & 0.00 & $0.0 \%$ \\
\hline Cobalt-60 & 0.00 & $0.0 \%$ \\
\hline Cenium-137 & 0.00 & $0.0 \%$ \\
\hline Neptuning -237 & 0.00 & $0.0 \%$ \\
\hline Plutonium-238 & 0.00 & $0.0 \%$ \\
\hline Plutonium-239 & 0.00 & $0.0 \%$ \\
\hline Strontium 90 & 0.00 & $0.0 \%$ \\
\hline Technetiun- 99 & 0.29 & $100.0 \%$ \\
\hline Tritium & 0.00 & $0.0 \%$ \\
\hline Uranium-235 & 0.00 & $0.0 \%$ \\
\hline Uranium-238 & 0.00 & $0.0 \%$ \\
\hline Tortal & 0.29 & $100 \%$ \\
\hline
\end{tabular}


Table 3-27. Decay Forecast for COBRA Inventory for Potential "Hot Spot" HS-100-9 (Continued)

\begin{tabular}{|c|c|c|}
\hline Constituent of Interest & Total Activity (Ci) & Percent of Total Activity \\
\hline \multicolumn{3}{|l|}{ At 1,000 Years after Burisl: } \\
\hline Carbon-14 & 0.00 & $0.0 \%$ \\
\hline Cobalt -60 & 0.00 & $0.0 \%$ \\
\hline Cexium-137 & 0.00 & $0.0 \%$ \\
\hline Nepturium-237 & 0.00 & $0.0 \%$ \\
\hline Plutonium-238 & 0.00 & $0.0 \%$ \\
\hline Plutonium-239 & 0.00 & $0.0 \%$ \\
\hline Strontium-90 & 0.00 & $0.0 \%$ \\
\hline Techretium-99 & 0.29 & $100.0 \%$ \\
\hline Tritiun & 0.00 & $0.0 \%$ \\
\hline Uranium-235 & 0.00 & $0.0 \%$ \\
\hline Uranium-238 & $\stackrel{0.00}{=}$ & $0.0 \%$ \\
\hline TOOTAL & 0.29 & $100 \%$ \\
\hline \multicolumn{3}{|l|}{ At 5,000 Years anter Barial: } \\
\hline Carbon-14 & 0.00 & $0.0 \%$ \\
\hline Cobalt 60 & 0.00 & $0.0 \%$ \\
\hline Cenium-137 & 0.00 & $0.0 \%$ \\
\hline Neptonium-237 & 0.00 & $0.0 \%$ \\
\hline Plutonium-238 & 0.00 & $0.0 \%$ \\
\hline Plutonium-239 & 0.00 & $0.0 \%$ \\
\hline Strontium-90 & 0.00 & $0.0 \%$ \\
\hline Tuchnetitum-99 & 0.28 & $100.0 \%$ \\
\hline Tritiun & 0.00 & $0.0 \%$ \\
\hline Uranium-235 & 0.00 & $0.0 \%$ \\
\hline Uranium-238 & 0.00 & $0.0 \%$ \\
\hline TOTAL. & 0.28 & $100 \%$ \\
\hline \multicolumn{3}{|l|}{ At 10,000 Years oner Burial: } \\
\hline Curbon-14 & 0.00 & $0.0 \%$ \\
\hline Cobalt -60 & 0.00 & $0.0 \%$ \\
\hline Cenium-137 & 0.00 & $0.0 \%$ \\
\hline Neptunium-237 & 0.00 & $0.0 \%$ \\
\hline Plutonium-238 & 0.00 & $0.0 \%$ \\
\hline Plutonivun-239 & 0.00 & $0.0 \%$ \\
\hline Strontium- 90 & 0.00 & $0.0 \%$ \\
\hline Technetium-99 & 0.28 & $100.0 \%$ \\
\hline Tritium & 0.00 & $0.0 \%$ \\
\hline Unnitom-235 & 0.00 & $0.0 \%$ \\
\hline Unerium-238 & 0.00 & $0.0 \%$ \\
\hline TOTAL. & 0.28 & $100 \%$ \\
\hline
\end{tabular}


Table 3-28. Summary Statistics for COBRA Inventory of Potential "Hot Spot" HS-100-10

\begin{tabular}{|c|c|c|c|c|c|c|c|c|c|c|c|}
\hline \multirow{2}{*}{\multicolumn{2}{|c|}{$\begin{array}{l}\frac{8}{2} \\
\frac{8}{5} \\
08 \\
0\end{array}$}} & & 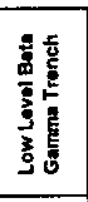 & 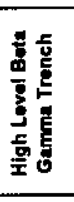 & 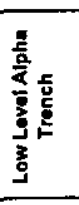 & 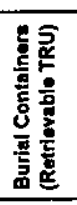 & 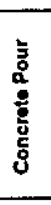 & 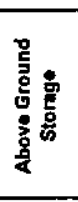 & 홓 & \multirow[t]{2}{*}{ 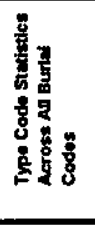 } & \multirow[t]{2}{*}{ 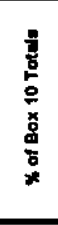 } \\
\hline & & COBRA Burial Code: & 1 & 2 & 3 & 4 & 5 & 6 & 7 & & \\
\hline \multirow{6}{*}{1} & \multirow{6}{*}{$\begin{array}{l}\text { Job Control Waste, } \\
\text { Inciuding house- } \\
\text { keeping waste and } \\
\text { protwetive clothing }\end{array}$} & Number of Records & 106 & 0 & 8 & 0 & 0 & 0 & 0 & 114 & 92.7 \\
\hline & & Total Waste Volume (curt) & 12,405 & - & 845 & - & - & - & $\therefore$ & 13,250 & 96.1 \\
\hline & & Average Burial Volume (aurt) & 117 & - & 106 & - & - & - & - & 116 & no \\
\hline & & Standard Deviation & 91 & - & 96 & - & - & - & - & 91 & na \\
\hline & & Maxinum Burial Volume (curtt) & 491 & - & 300 & - & $\therefore$ & $=$ & - & 491 & $\mathrm{ma}$ \\
\hline & & Minlmum Qurial Volume (cumt) & 2 & - & 35 & - & - & - & - & 2 & $\mathrm{n} / \mathrm{a}$ \\
\hline \multirow{6}{*}{2} & \multirow{6}{*}{ Oll } & Number of Records & 3 & 0 & 0 & 0 & 0 & 0 & 0 & 3 & 2.4 \\
\hline & & Total Waste Vokune (cumt) & 169 & - & - & - & - & $=$ & - & 169 & 1.2 \\
\hline & & Average Burial Volume (aunt) & 56 & - & - & - & - & $\therefore$ & - & 56 & na \\
\hline & & Standard Deviatton & 90 & - & - & $\tau$ & - & - & - & 90 & Nhe \\
\hline & & Maximum Burlal Volume (cu/t) & 160 & - & - & - & - & - & - & 160 & $\mathrm{Na}$ \\
\hline & & Minimum Burial Votume (cunti) & 1 & - & - & - & $\cdot$ & - & - & 1 & $\mathrm{n} / \mathrm{e}$ \\
\hline \multirow{6}{*}{3} & \multirow{6}{*}{$\begin{array}{l}\text { Irradiatud Motal } \\
\text { Scrap }\end{array}$} & Number of Records & $\overline{0}$ & 4 & 0 & 0 & 0 & 0 & 0 & 4 & 3.3 \\
\hline & & Total Waste Vourne (cu/tit) & + & 136 & - & - & - & - & - & 136 & 4.0 \\
\hline & & Average Burlal Volurne (cum) & - & 34 & - & - & $\cdot$ & - & - & 34 & nia \\
\hline & & Standard Deviation & $\cdot$ & 45 & - & - & - & $\cdot$ & - & 45 & na \\
\hline & & Maximum Burial Volume (cu/t) & - & 101 & - & - & - & - & $\cdot$ & 101 & na \\
\hline & & Minimum Burial Votme (curit) & - & 7 & - & - & - & - & - & 7 & n/a \\
\hline \multirow{6}{*}{4} & \multirow{6}{*}{$\begin{array}{l}\text { Naturally } \\
\text { Redioactive } \\
\text { Materials }\end{array}$} & Number of Records & 2 & 0 & 0 & 0 & 0 & 0 & 0 & 2 & 1.6 \\
\hline & & Total Waste Volume (cu/nt) & 231 & - & - & - & - & - & - & 231 & 1.7 \\
\hline & & Average Burlal Voume (cum) & 116 & - & - & - & - & - & $=$ & 116 & Ne \\
\hline & & Standard Doviation & 49 & - & 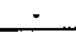 & - & - & - & - & 49 & $\mathrm{n} / \mathrm{s}$ \\
\hline & & Maximum Burial Volumo (cumt) & 150 & - & - & 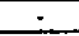 & - & - & 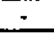 & 150 & Na \\
\hline & & Minlmum Burlal Volume (aumt) & 81 & $\therefore$ & - & - & - & - & - & 81 & nta \\
\hline \multirow{6}{*}{5} & \multirow{6}{*}{$\begin{array}{l}\text { Capital Equipment, must } \\
\text { be accompanted by a } \\
\text { Plent Equipment } \\
\text { Transfor (PEn) }\end{array}$} & Number of Records & 0 & 0 & 0 & 0 & 0 & 0 & 0 & 0 & - \\
\hline & & Total Waste volume (cu/t) & - & - & $\because$ & - & - & - & - & $=$ & - \\
\hline & & Average Burial Volume (cuint) & - & $=$ & - & - & - & - & - & - & $\mathrm{Nan}$ \\
\hline & & Standard Deviation & - & $=$ & - & - & - & - & - & - & nte \\
\hline & & Maximum Burial Volume (cultt) & $=$ & - & $=$ & - & - & - & - & - & na \\
\hline & & Mirxmum Burial Volume (cuftit) & - & - & $=$ & - & - & - & - & - & Na \\
\hline \multirow{6}{*}{6} & \multirow{6}{*}{ Resin } & Number of Records & 0 & 0 & 0 & 0 & 0 & 0 & 0 & 0 & - \\
\hline & & Total Waste Voume (cu/h) & - & - & - & - & - & - & - & - & - \\
\hline & & Average Burial Volume (cunt) & - & - & - & - & - & - & - & - & wa \\
\hline & & Standard Deviation & - & $=$ & - & - & - & - & - & - & $\mathrm{Na}$ \\
\hline & & Maximum Burtal Volume (culti) & - & - & - & - & - & - & - & - & $\mathrm{n} / \mathrm{a}$ \\
\hline & & Mirimum Burial volume (cunt) & - & - & - & - & - & - & - & $=$ & $\mathrm{Ne}$ \\
\hline \multirow{6}{*}{7} & \multirow{6}{*}{ Other } & Number of Records & 0 & 0 & 0 & 0 & 0 & 0 & 0 & 0 & $=$ \\
\hline & & Total Waste Vohme (CLIt) & - & - & - & $=$ & - & - & - & - & - \\
\hline & & Average Burial Volume (cunt) & $\cdot$ & - & $=$ & - & $=$ & - & - & س. & no \\
\hline & & Stendard Devintion & - & - & - & - & - & $\therefore$ & - & - & $\mathrm{Na}$ \\
\hline & & Maximum Burial Volumo (cunt) & - & - & - & - & - & - & - & - & nta \\
\hline & & Mirimum Burial Voume (cuint) & - & - & - & - & - & 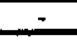 & - & - & n/a \\
\hline \multirow{4}{*}{\multicolumn{2}{|c|}{ Totals Acrose All 7 Type Codes }} & Number of Records & 111 & 4 & 8 & 0 & 0 & 0 & 0 & 123 & \\
\hline & & $\%$ of Box 10 Totals & 90.2 & 3.3 & 6.5 & 0.0 & 0.0 & 0.0 & 0.0 & 100.0 & \\
\hline & & Total Waste Volume (cu/t) & 12,805 & 136 & 845 & 0 & 0 & 0 & 0 & 13,786 & \\
\hline & & $\%$ of Box 10 Totals & 92.9 & 1.0 & 6.1 & 0.0 & 0.0 & 0.0 & 0.0 & 100.0 & \\
\hline
\end{tabular}


Table 3-29. Decay Forecast for COBRA Inventory for Potential "Hot Spot" HS-100-10

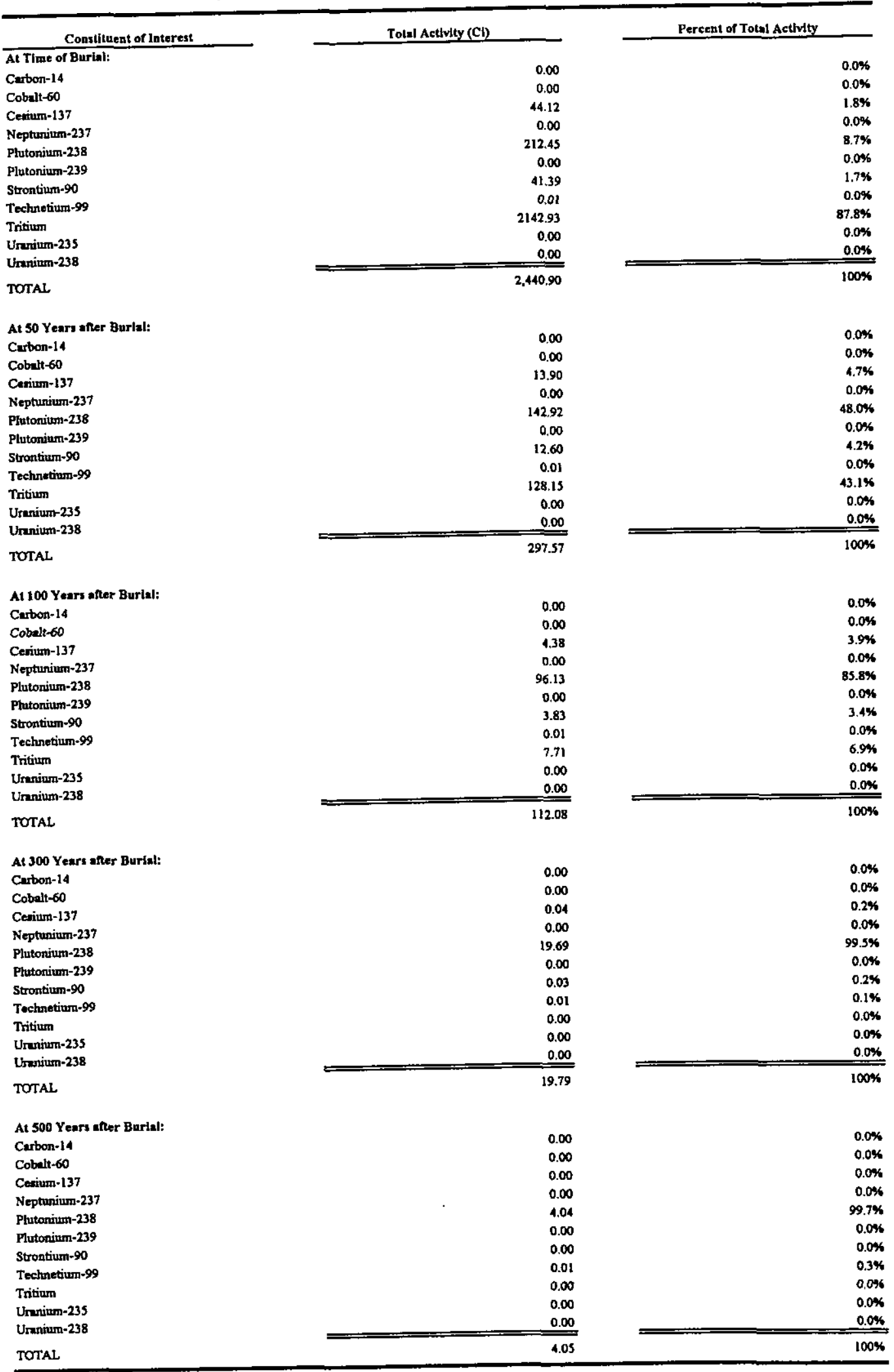


Table 3-29. Decay Forecast for COBRA Inventory for Potential "Hot Spot" HS-100-10 (Continued)

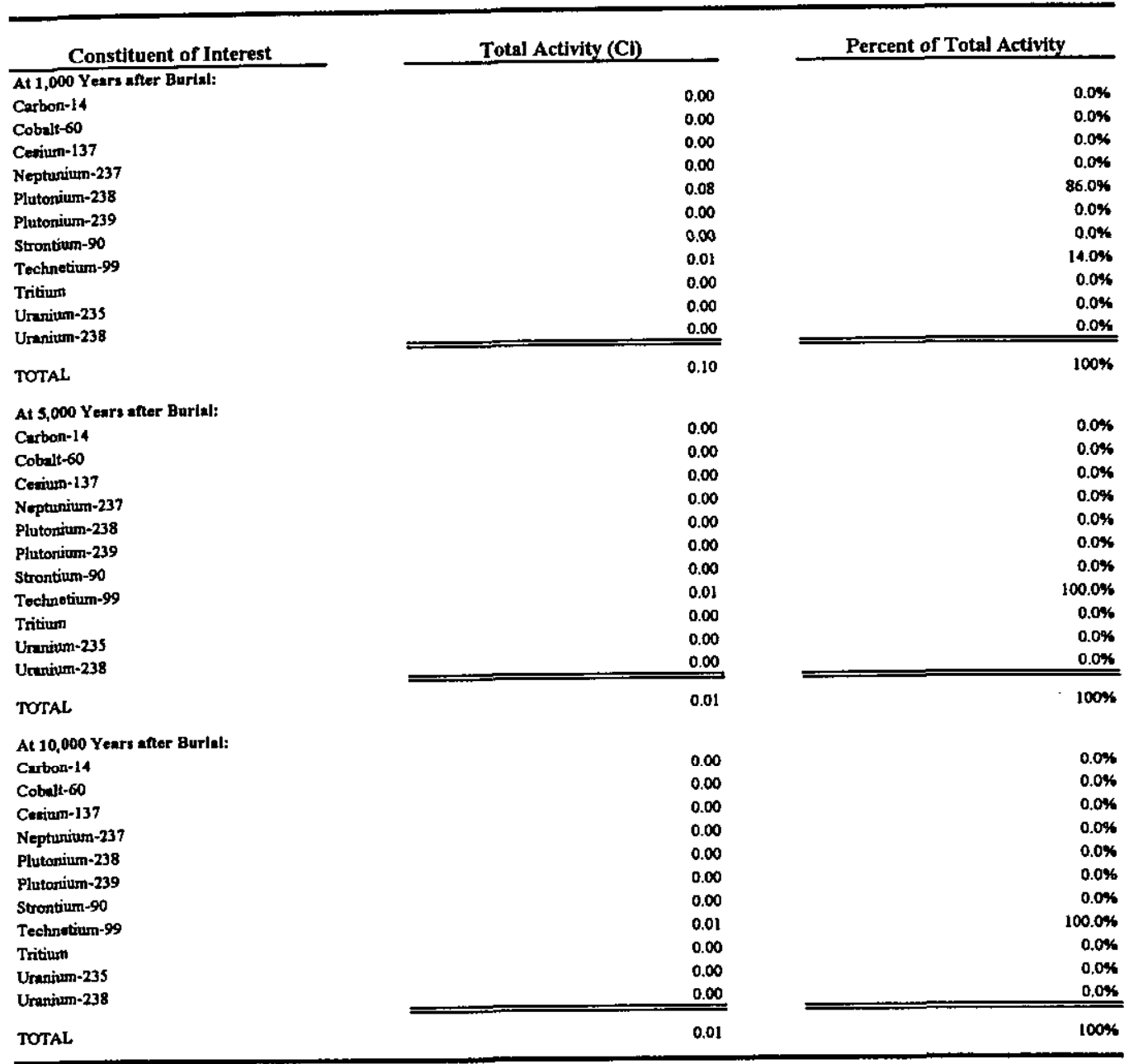


Table 3-30. Summary Statistics for COBRA Inventory of Potential "Hot Spot" HS-100-11

\begin{tabular}{|c|c|c|c|c|c|c|c|c|c|c|c|}
\hline \multirow{2}{*}{\multicolumn{2}{|c|}{ 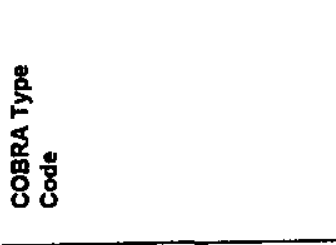 }} & & 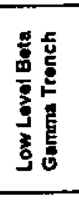 & 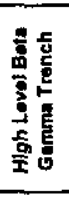 & 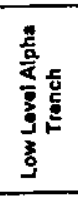 & 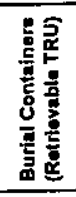 & 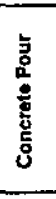 & 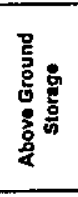 & 突 & \multirow[t]{2}{*}{ 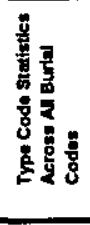 } & \multirow[t]{2}{*}{ 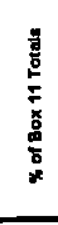 } \\
\hline & & COBRA Burial Code: & 1 & 2 & 3 & 4 & 5 & 6 & 7 & & \\
\hline \multirow{6}{*}{1} & \multirow{6}{*}{$\begin{array}{l}\text { Job Control Waste, } \\
\text { including house- } \\
\text { keeping waste and } \\
\text { protective clothing }\end{array}$} & Nimber of Records & 24 & 0 & 0 & 0 & 0 & 0 & 0 & 24 & 96.0 \\
\hline & & Total Waste Voume (cult) & 2,386 & - & - & - & - & $\therefore$ & - & 2,386 & 99.9 \\
\hline & & Average Burlal Volume (cunt) & 99 & $\therefore$ & - & - & $\therefore$ & - & $\dot{-}$ & 99 & Na \\
\hline & & Stanctard Deslation & 205 & - & $=$ & - & - & $\cdot$ & - & 205 & $\mathrm{n} / \mathrm{a}$ \\
\hline & & Maximum Burial Volume (cavit) & 77 & - & $=$ & - & - & $\therefore$ & - & 777 & Na \\
\hline & & Minimum Burial Volume (cum) & 2 & - & - & - & - & - & 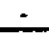 & 2 & no \\
\hline \multirow{6}{*}{2} & \multirow{6}{*}{ oll } & Number of Records & 0 & 0 & 0 & 0 & 0 & 0 & D & 0 & - \\
\hline & & Total Waste Volume (cu/t) & - & - & 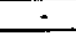 & $=$ & - & $\cdot$ & $\sim$ & - & $\therefore$ \\
\hline & & Average Burial Volume (cult) & $=$ & $\dot{-}$ & 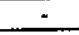 & - & - & - & - & $=$ & Na \\
\hline & & Standard Deviation & $=$ & $\therefore$ & - & $=$ & - & $=$ & - & $\dot{-}$ & $\mathrm{n} / \mathrm{a}$ \\
\hline & & Maximum Burisl Volume (cum) & $=$ & $\therefore$ & - & - & 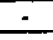 & - & - & - & n/a \\
\hline & & Minimum Burial Volume (ault) & $\div$ & - & - & $=$ & - & $\therefore$ & - & $\dot{+}$ & na \\
\hline \multirow{6}{*}{3} & \multirow{6}{*}{$\begin{array}{l}\text { Imadiated Motal } \\
\text { Serap }\end{array}$} & Number of Records & 0 & 1 & 0 & 0 & 0 & 0 & 0 & 1 & 4.0 \\
\hline & & Total Waste Volume (cunt) & - & 2 & - & - & - & - & - & 2 & 0.1 \\
\hline & & Average Burial Volume (cunt) & $\therefore$ & 2 & - & - & $=$ & - & $ت$ & 2 & n/a \\
\hline & & Standard Deviation & $\cdot$ & - & - & - & - & $\cdot$ & - & - & no \\
\hline & & Maximum Buntel Volume (cum) & $\therefore$ & 2 & - & 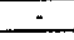 & - & - & - & 2 & n/a \\
\hline & & Minimum Burial Volume (cu/t) & - & 2 & $\cdot$ & - & - & - & 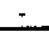 & 2 & nos \\
\hline \multirow{6}{*}{4} & \multirow{6}{*}{$\begin{array}{l}\text { Naturally } \\
\text { Radioactive } \\
\text { Materials }\end{array}$} & Nurrber of Records & 0 & 0 & 0 & 0 & 0 & 0 & 0 & 0 & - \\
\hline & & Total Waste Volume (culti) & $=$ & + & 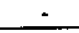 & $\therefore$ & $\therefore$ & - & $=$ & - & - \\
\hline & & Averege Burlel Voumo (cult) & $\therefore$ & $=$ & - & - & - & - & - & $\therefore$ & $\mathrm{Na}$ \\
\hline & & Standard Devilation & $=$ & $\therefore$ & 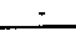 & - & - & - & - & - & nta \\
\hline & & Maxmum Qurial Volume (au/t) & - & $\therefore$ & - & - & - & $\cdot$ & - & $\cdot$ & no \\
\hline & & Minlmum Blrial Volume (cunt) & + & - & - & $\therefore$ & 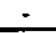 & $\dot{+}$ & $\therefore$ & - & $\mathrm{N} / \mathrm{a}$ \\
\hline \multirow{6}{*}{$\mathbf{5}$} & \multirow{6}{*}{$\begin{array}{l}\text { Capital Equipment, must } \\
\text { be accompanied by a } \\
\text { Plant Equipment } \\
\text { Transfer (PET) }\end{array}$} & Number of Records & 0 & 0 & 0 & 0 & 0 & 0 & 0 & 0 & - \\
\hline & & Total Waste Voume (cuit) & $=$ & - & $\therefore$ & - & - & $\cdot$ & - & $\therefore$ & $\therefore$ \\
\hline & & Average Burial Volume (cuit) & - & $\cdot$ & - & - & - & - & $\therefore$ & $\therefore$ & n/a \\
\hline & & Standard Deviation & - & - & $\cdot$ & - & - & - & $=$ & $\therefore$ & nia \\
\hline & & Maximum Burial Vokme (cuntt) & $\approx$ & - & - & - & 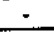 & - & - & $\cdot$ & Na \\
\hline & & Mlnimum Burial Volume (cunt) & - & $=$ & 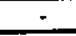 & $\therefore$ & - & - & $\therefore$ & + & $\mathrm{na}$ \\
\hline \multirow{6}{*}{6} & \multirow{6}{*}{ Rosin } & Number of Records & 0 & 0 & 0 & 0 & 0 & 0 & 0 & 0 & - \\
\hline & & Total Waste Volume (cu/t) & - & - & - & $\therefore$ & - & - & $\therefore$ & - & - \\
\hline & & Average Burlal Volume (cultit) & - & - & - & - & - & $=$ & ست & - & n/a \\
\hline & & Standard Devievion & - & - & - & - & - & $=$ & - & - & $\mathrm{Na}$ \\
\hline & & Maximum Burial Volume (cunt) & - & - & - & - & $=$ & $\therefore$ & - & - & $\mathrm{Na}$ \\
\hline & & Minimum Burial Vohme (curt) & - & - & - & - & - & 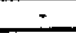 & - & $=$ & $\mathrm{n} / \mathrm{a}$ \\
\hline \multirow{6}{*}{7} & \multirow{6}{*}{ Other } & Number of Records & 0 & 0 & 0 & 0 & 0 & 0 & 0 & 0 & - \\
\hline & & Total Waste Volume (culit) & - & $\because$ & - & - & - & $=$ & - & $\therefore$ & - \\
\hline & & Average Burisl Voluma (cunt) & $\therefore$ & - & $\pi$ & - & - & - & - & - & $n / a$ \\
\hline & & Standard Deviation & - & - & - & $=$ & - & - & - & $\therefore$ & $\mathrm{nta}$ \\
\hline & & Maximum Burial Volume (cu/st) & - & 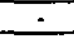 & $\because$ & 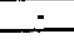 & متع & - & - & $=$ & nta \\
\hline & & Minimum Burial Vohme (curt) & - & - & $\cdot$ & $\therefore$ & 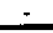 & $\tau$ & - & - & rea \\
\hline \multirow{4}{*}{\multicolumn{2}{|c|}{ Totale Acrose All 7 Type Codes }} & Number of Rocords & 24 & 1 & 0 & 0 & 0 & 0 & 0 & 25 & \\
\hline & & * of Box 11 Totals & 96.0 & 4.0 & 0.0 & 0.0 & 0.0 & 0.0 & 0.0 & 100.0 & \\
\hline & & Total Waste Volume (CL/t) & 2,386 & 2 & 0 & 0 & 0 & 0 & 0 & 2,388 & \\
\hline & & X of Box 11 Totals & 99.9 & 0.1 & 0.0 & 0.0 & 0.0 & 0.0 & 0.0 & 100.0 & \\
\hline
\end{tabular}


Table 3-31. Decay Forecast for COBRA Inventory for Potential "Hot Spot" HS-100-11

\begin{tabular}{|c|c|c|}
\hline Constituent of Interest & Total Activity (CA) & Percent of Total Activity \\
\hline \multicolumn{3}{|l|}{ At Time of Burfal: } \\
\hline Carbon-14 & 0.00 & $0.0 \%$ \\
\hline Coboltt 60 & 0.00 & $0.0 \%$ \\
\hline Cesrium-137 & 0.00 & $0.0 \%$ \\
\hline Neptonium-237 & 0.00 & $0.0 \%$ \\
\hline Plutonium-238 & 0.00 & $0.0 \%$ \\
\hline Plutoniun-239 & 0.00 & $0.0 \%$ \\
\hline Strontium-90 & 0.00 & $0.0 \%$ \\
\hline Tochnetium-99 & 0.00 & $0.0 \%$ \\
\hline Tritiun & $53,864.05$ & $100.0 \%$ \\
\hline Uraxium-235 & 0.00 & $0.0 \%$ \\
\hline Uranium -238 & 0.00 & $0.0 \%$ \\
\hline TOOTAL & $53,864.05$ & $100 \%$ \\
\hline \multicolumn{3}{|l|}{ At 50 Years after Bnrial: } \\
\hline Carbon-14 & 0.00 & $0.0 \%$ \\
\hline Cobalt 60 & 0.00 & $0.0 \%$ \\
\hline Cenium-137 & 0.00 & $0.0 \%$ \\
\hline Neptunium-237 & 0.00 & $0.0 \%$ \\
\hline Plutonium-238 & 0.00 & $0.0 \%$ \\
\hline Plutonium-239 & 0.00 & $0.0 \%$ \\
\hline Strontium-90 & 0.00 & $0.0 \%$ \\
\hline Tuchnetiusm-99 & $3,221.07$ & $100.0 \%$ \\
\hline Tritium & 0.00 & $0.0 \%$ \\
\hline Urenium-235 & $\stackrel{0.00}{=}$ & $0.0 \%$ \\
\hline Unnium-238 & $3,221.07$ & $100 \%$ \\
\hline TOTAL. & & \\
\hline \multicolumn{2}{|l|}{ At 100 Years ofter Burisl: } & $0.0 \%$ \\
\hline Carbon-14 & 0.00 & $0.0 \%$ \\
\hline Cobalt -60 & 0.00 & $0.0 \%$ \\
\hline Corium-137 & 0.00 & $0.0 \%$ \\
\hline $\begin{array}{l}\text { Neptunisum-237 } \\
\text { Plutonium-238 }\end{array}$ & 0.00 & $0.0 \%$ \\
\hline $\begin{array}{l}\text { Plutonium-238 } \\
\text { Plutonium-239 }\end{array}$ & 0.00 & $0.0 \%$ \\
\hline $\begin{array}{l}\text { Plutonium-239 } \\
\text { Strontium-90 }\end{array}$ & 0.00 & $0.0 \%$ \\
\hline $\begin{array}{l}\text { Strontium-90 } \\
\text { Tochnetiam-99 }\end{array}$ & 0.00 & $0.0 \%$ \\
\hline $\begin{array}{l}\text { Tochnetium-99 } \\
\text { Tritiom }\end{array}$ & 193.91 & $100.0 \%$ \\
\hline $\begin{array}{l}\text { Trition } \\
\text { Uranium-235 }\end{array}$ & 0.00 & $0.0 \%$ \\
\hline $\begin{array}{l}\text { Uranium-235 } \\
\text { Uranium-238 }\end{array}$ & 0.00 & $0.0 \%$ \\
\hline $\begin{array}{l}\text { Uronium-238 } \\
\text { TOTAL }\end{array}$ & 193.91 & $100 \%$ \\
\hline TOTAL & & \\
\hline \multicolumn{3}{|l|}{ At 300 Years ater Burial: } \\
\hline Curbon-14 & 0.00 & $0.0 \%$ \\
\hline $\begin{array}{l}\text { Cobalt-60 } \\
\text { Cerium-137 }\end{array}$ & 0.00 & $0.0 \%$ \\
\hline $\begin{array}{l}\text { Cerium-137 } \\
\text { Nepturiom-237 }\end{array}$ & 0.00 & $0.0 \%$ \\
\hline $\begin{array}{l}\text { Neptunivim-237 } \\
\text { Plutorium-238 }\end{array}$ & 0.00 & $0.0 \%$ \\
\hline $\begin{array}{l}\text { Plutorium-238 } \\
\text { Plutonium-239 }\end{array}$ & 0.00 & $0.0 \%$ \\
\hline $\begin{array}{l}\text { Plutonium-239 } \\
\text { Strontium-90 }\end{array}$ & 0.00 & $0.0 \%$ \\
\hline $\begin{array}{l}\text { Strontium-90 } \\
\text { Technetium-99 }\end{array}$ & $0 . \infty$ & $0.0 \%$ \\
\hline $\begin{array}{l}\text { Technetium-99 } \\
\text { Tritium }\end{array}$ & 0.00 & $0.0 \%$ \\
\hline $\begin{array}{l}\text { Tritium } \\
\text { Uranium-235 }\end{array}$ & 0.00 & 98.9\% \\
\hline $\begin{array}{l}\text { Uranium-235 } \\
\text { Uranium-238 }\end{array}$ & 0.00 & $1.1 \%$ \\
\hline $\begin{array}{l}\text { Unanium-238 } \\
\text { TOTAL }\end{array}$ & $\overline{0.00}$ & $100 \%$ \\
\hline TOTAL & & \\
\hline \multicolumn{2}{|l|}{ At 500 Years after Burial: } & $0.0 \%$ \\
\hline Cerbon-14 & 0.00 & $0.0 \%$ \\
\hline $\begin{array}{l}\text { Cobalt-60 } \\
\text { Cesium-137 }\end{array}$ & 0.00 & $0.0 \%$ \\
\hline $\begin{array}{l}\text { Cexium-137 } \\
\text { Neptunium-237 }\end{array}$ & 0.00 & 0.096 \\
\hline $\begin{array}{l}\text { Neptunium-237 } \\
\text { Phutonium-238 }\end{array}$ & 0.00 & $0.0 \%$ \\
\hline $\begin{array}{l}\text { Phatonium-238 } \\
\text { Plutonitum-239 }\end{array}$ & 0.00 & $0.0 \%$ \\
\hline $\begin{array}{l}\text { Plutonium-239 } \\
\text { Strontiom-90 }\end{array}$ & 0.00 & $0.0 \%$ \\
\hline $\begin{array}{l}\text { Strontium-90 } \\
\text { Tochnetimm-99 }\end{array}$ & 0.00 & $0.0 \%$ \\
\hline $\begin{array}{l}\text { Tochnetium-99 } \\
\text { Tritium }\end{array}$ & 0.00 & $0.0 \%$ \\
\hline $\begin{array}{l}\text { Tritium } \\
\text { Uravivin-235 }\end{array}$ & 0.00 & $98.9 \%$ \\
\hline $\begin{array}{l}\text { Uravivim-235 } \\
\text { Uranivam-238 }\end{array}$ & 0.00 & $1.1 \%$ \\
\hline TOTAL & 0.00 & $100 \%$ \\
\hline
\end{tabular}


Table 3-31. Decay Forecast for COBRA Inventory for Potential "Hot Spot" HS-100-11 (Continued)

\begin{tabular}{|c|c|c|}
\hline Constituent of Interest & Total Activity (Ci) & Percent of Total Activity \\
\hline \multicolumn{3}{|l|}{ At 1,000 Years ancer Burial: } \\
\hline Cerbon-14 & 0.00 & $0.0 \%$ \\
\hline Cobalt 60 & 0.00 & $0.0 \%$ \\
\hline Corium-137 & 0.00 & $0.0 \%$ \\
\hline Nepturium-237 & 0.00 & $0.0 \%$ \\
\hline Plutonium-238 & 0.00 & $0.0 \%$ \\
\hline Plutonium-239 & 0.00 & $0.0 \%$ \\
\hline Strontium- 90 & 0.00 & $0.0 \%$ \\
\hline Tecturetium-99 & 0.00 & $0.0 \%$ \\
\hline Tritium & 0.00 & $0.0 \%$ \\
\hline Unanium-235 & 0.00 & $98.9 \%$ \\
\hline Uranivem-238 & 0.00 & $1.1 \%$ \\
\hline TOTAL & 0.00 & $100 \%$ \\
\hline \multicolumn{3}{|l|}{ At 5,000 Years after Burial: } \\
\hline Carbon-14 & 0.00 & $0.0 \%$ \\
\hline Cobalt -60 & 0.00 & $0.0 \%$ \\
\hline Cesium-137 & 0.00 & $0.0 \%$ \\
\hline Nepturixm-237 & 0.00 & $0.0 \%$ \\
\hline Plutonium-238 & 0.00 & $0.0 \%$ \\
\hline Plutonium-2.39 & 0.00 & $0.0 \%$ \\
\hline Strontium-90 & 0.00 & $0.0 \%$ \\
\hline Technetium-99 & 0.00 & $0.0 \%$ \\
\hline Tritiom & 0.00 & $0.0 \%$ \\
\hline Uranium-235 & 0.00 & $98.9 \%$ \\
\hline Uraniumn-238 & $\stackrel{0.00}{=}$ & $1.1 \%$ \\
\hline TOTAL & 0.00 & $100 \%$ \\
\hline \multicolumn{3}{|l|}{ At 10,000 Years after Burtal: } \\
\hline Crrbon-14 & 0.00 & $0.0 \%$ \\
\hline Cobalt -60 & 0.00 & $0.0 \%$ \\
\hline Cerivtn-137 & 0.00 & $0.0 \%$ \\
\hline Nopturium-237 & 0.00 & $0.0 \%$ \\
\hline Plutorium-238 & 0.00 & $0.0 \%$ \\
\hline Plutonium-239 & 0.00 & $0.0 \%$ \\
\hline Strontium-90 & 0.00 & $0.0 \%$ \\
\hline Technetium-99 & 0.00 & $0.0 \%$ \\
\hline Tritium & 0.00 & $0.0 \%$ \\
\hline Unenium-235 & 0.00 & $98.9 \%$ \\
\hline Uranium-238 & 0.00 & 1.1\% \\
\hline TOTAL & 0.00 & $100 \%$ \\
\hline
\end{tabular}


Table 3-32. Summary Statistics for COBRA Inventory of Potential "Hot Spot" HS-100-12

\begin{tabular}{|c|c|c|c|c|c|c|c|c|c|c|c|}
\hline \multirow{2}{*}{\multicolumn{2}{|c|}{$\frac{5}{5}$}} & & 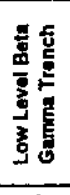 & 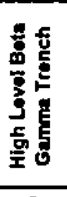 & 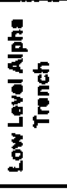 & 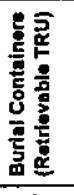 & 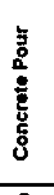 & 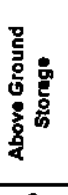 & t⿳亠口冋亍 & 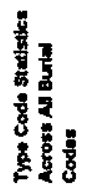 & 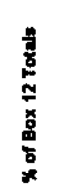 \\
\hline & & COBRA Burial Code: & 1 & 2 & 3 & 4 & 5 & 6 & 7 & & \\
\hline \multirow{6}{*}{1} & \multirow{6}{*}{$\begin{array}{l}\text { Jab Control Waste, } \\
\text { Including houss- } \\
\text { keoping waste and } \\
\text { protoctive clothing }\end{array}$} & Number of Records & 0 & 0 & 0 & 10 & 0 & 0 & 0 & 10 & 100.0 \\
\hline & & Toted Waste Volume (cu/t) & - & - & + & 104 & - & - & - & 104 & 100.0 \\
\hline & & Average Burlel Volume (cunt) & $\cdot$ & - & $=$ & 10 & $=$ & - & 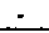 & 10 & nos \\
\hline & & Standard Devlation & - & - & - & 8 & - & - & - & 8 & Na \\
\hline & & Maximum Burial Volume (cumt) & - & - & - & 28 & - & - & - & 28 & $\mathrm{nh}$ \\
\hline & & Minitrum Burial Volurne (ant) & - & $\cdot$ & - & 2 & $\therefore$ & - & - & 2 & no \\
\hline \multirow{6}{*}{2} & \multirow{6}{*}{ oll } & Number of Rocords & 0 & 0 & 0 & 0 & 0 & 0 & 0 & 0 & - \\
\hline & & Total Waste Volume (cunt) & - & - & + & - & - & + & + & $\cdot$ & - \\
\hline & & Average Burial Volume (cunt) & - & - & $=$ & - & - & - & - & $\therefore$ & No \\
\hline & & Standard Deviation & - & - & - & - & - & - & - & - & Nhe \\
\hline & & Maximum Burtel Volume (cum) & $=$ & $\therefore$ & - & - & - & - & - & - & $\mathrm{n} / \mathrm{a}$ \\
\hline & & Minimum Burial volume (cu/t) & - & - & - & - & - & $=$ & - & - & na \\
\hline \multirow{6}{*}{3} & \multirow{6}{*}{$\begin{array}{l}\text { Irradiated Metal } \\
\text { Scrap }\end{array}$} & Number of Records & 0 & 0 & 0 & 0 & 0 & 0 & 0 & 0 & $\therefore$ \\
\hline & & Total Wasto Volume (cult) & - & - & - & - & - & - & - & - & - \\
\hline & & Average Burlal Volumo (ault) & - & - & - & - & $=$ & - & - & $=$ & Na \\
\hline & & Standard Deviation & - & - & - & - & - & 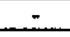 & - & $=$ & not \\
\hline & & Maxtmum Burial Volurne (cust) & $\therefore$ & - & - & - & - & $\therefore$ & - & - & no \\
\hline & & Minimem Burial Volume (cutt) & - & $\therefore$ & - & - & $\cdot$ & + & - & - & $\mathrm{Na}$ \\
\hline \multirow{6}{*}{4} & \multirow{6}{*}{$\begin{array}{l}\text { Naturally } \\
\text { Raclloactive } \\
\text { Materlals }\end{array}$} & Number of Records & 0 & 0 & 0 & 0 & $\underline{0}$ & 0 & 0 & 0 & - \\
\hline & & Totel Weste Voturne (cunt) & - & - & $=$ & - & - & - & - & - & - \\
\hline & & Average Burlal Volumo (cum) & $=$ & - & - & - & - & - & - & - & $\mathrm{n} / \mathbf{a}$ \\
\hline & & Standard Deviation & $\cdot$ & $\cdot$ & - & - & - & - & - & $=$ & $\mathrm{Na}$ \\
\hline & & Maximum Burial Volume (cun) & $=$ & - & - & - & - & - & - & - & $\mathrm{na}$ \\
\hline & & Minkrmamn Burial Volume (cu/t) & $=$ & 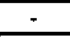 & - & - & - & - & $\pi$ & - & ma \\
\hline \multirow{6}{*}{5} & \multirow{6}{*}{$\begin{array}{c}\text { Capital Equipment, must } \\
\text { be accompanied by a } \\
\text { Plant Equipment } \\
\text { Transfer (PET) }\end{array}$} & Number of Records & 0 & 0 & 0 & 0 & 0 & 0 & 0 & 0 & - \\
\hline & & Total Waste Vohme (cuft) & - & $\therefore$ & - & - & - & - & + & - & $=$ \\
\hline & & Average Burlal Volume (cun) & - & - & - & - & $\therefore$ & $=$ & - & - & $\mathrm{No}$ \\
\hline & & Standard Devation & $\therefore$ & $\cdot$ & - & - & $\div$ & 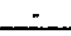 & $\therefore$ & - & $\mathrm{nta}$ \\
\hline & & Maximum Burlel Volme (cu/t) & - & - & $=$ & - & - & - & - & - & $\mathrm{n} / \mathrm{a}$ \\
\hline & & Minimum Burial Volkme (aut) & - & - & - & - & - & - & + & $\therefore$ & nat \\
\hline \multirow{6}{*}{6} & \multirow{6}{*}{ Resin } & Number of Records & 0 & 0 & 0 & 0 & 0 & 0 & 0 & 0 & - \\
\hline & & Total Waste Volume (cust) & $=$ & - & - & - & - & - & - & - & ست \\
\hline & & Average Burial Voume (cum) & - & 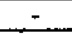 & - & - & - & - & - & - & nhe \\
\hline & & Standard Deviation & - & - & $=$ & $\dot{-}$ & - & - & - & $\cdot$ & no \\
\hline & & Maximum Burtal Volume (cum) & $\therefore$ & - & - & - & - & - & $\therefore$ & $=$ & No \\
\hline & & Minimum Burial Volume (cumt) & - & - & - & - & - & - & - & - & ne \\
\hline \multirow{6}{*}{7} & \multirow{6}{*}{ Other } & Number of Records & 0 & 0 & 0 & 0 & 0 & 0 & 0 & 0 & $\because$ \\
\hline & & Total Waste Volume (curtt) & $=$ & - & - & - & $=$ & $=$ & $=$ & - & - \\
\hline & & Averoge Burlal Volume (curt) & - & - & $\therefore$ & - & - & $\cdot$ & - & - & nia \\
\hline & & Standard Dovlation & - & $\therefore$ & - & - & - & - & - & - & note \\
\hline & & Maxmum Burial Volume (cun) & - & - & - & - & - & - & - & $=$ & n/a \\
\hline & & Minimum Burial Volume (cumt) & - & - & - & $=$ & - & - & - & - & Noa \\
\hline \multirow{4}{*}{\multicolumn{2}{|c|}{ Totalo Acroes All 7 Type Codes }} & Number of Records & 0 & 0 & 0 & 10 & 0 & 0 & 0 & 10 & \\
\hline & & $\%$ of Box 12 Totals & 0.0 & 0.0 & 0.0 & 100.0 & 0.0 & 0.0 & 0.0 & 100.0 & \\
\hline & & Total Waste Volume (cum) & 0 & 0 & 0 & 104 & 0 & 0 & 0 & 104 & \\
\hline & & \% of BoX 12 Totals & 0.0 & 0.0 & 0.0 & 100.0 & 0.0 & 0.0 & 0.0 & 100.0 & \\
\hline
\end{tabular}


Table 3-33. Decay Forecast for COBRA Inventory for Potential "Hot Spot" HS-100-12

\begin{tabular}{|c|c|c|}
\hline Constituent of Interest & Tolal Activity (Ci) & Percent of Total Activity \\
\hline \multicolumn{3}{|l|}{ At Time of Burial: } \\
\hline Carbon-14 & 0.00 & $0.0 \%$ \\
\hline Cobalt -60 & 0.00 & $0.0 \%$ \\
\hline Cerium-137 & 0.00 & $0.0 \%$ \\
\hline Nepturivm-237 & 0.04 & $0.0 \%$ \\
\hline Plutorium-238 & 148.38 & $96.6 \%$ \\
\hline Plutonium-239 & 5.19 & $3.4 \%$ \\
\hline Strontium-90 & 0.00 & $0.0 \%$ \\
\hline Technetiom-99 & 0.00 & $0.0 \%$ \\
\hline Tritium & 0.00 & $0.0 \%$ \\
\hline Unanium-235 & 0.00 & $0.0 \%$ \\
\hline Unanium-238 & $\underline{0.00}$ & $0.0 \%$ \\
\hline TOTAL & 153,61 & $100 \%$ \\
\hline \multicolumn{3}{|l|}{ At 50 Years after Burtal: } \\
\hline Curbon-14 & 0.00 & $0.0 \%$ \\
\hline Cobalt -60 & 0.00 & $0.0 \%$ \\
\hline Cesinm- 137 & 0.00 & $0.0 \%$ \\
\hline Neptunium-237 & 0.04 & $0.0 \%$ \\
\hline Plutonium-238 & 99.82 & $95.0 \%$ \\
\hline Plutonium-239 & 5.18 & $4.9 \%$ \\
\hline Strontinm-90 & 0.00 & $0.0 \%$ \\
\hline Twchnetium-99 & 0.00 & $0.0 \%$ \\
\hline Tritiun & 0.00 & $0.0 \%$ \\
\hline Uranium-235 & 0.00 & $0.0 \%$ \\
\hline Unarivorn-238 & 0.00 & $0.0 \%$ \\
\hline TOTAL & 105.04 & $100 \%$ \\
\hline \multicolumn{3}{|l|}{ At 100 Years anter Burial: } \\
\hline Carbon-14 & 0.00 & $0.0 \%$ \\
\hline Cobelt- 60 & 0.00 & $0.0 \%$ \\
\hline Cexium-137 & 0.00 & $0.0 \%$ \\
\hline Neptonium-237 & 0.04 & $0.1 \%$ \\
\hline Plutonium-238 & 67.14 & $92.8 \%$ \\
\hline Platonitum-239 & 5.18 & $7.2 \%$ \\
\hline Strontium- 90 & 0.00 & $0.0 \%$ \\
\hline Technetium-99 & 0.00 & $0.0 \%$ \\
\hline Tritium & 0.00 & $0.0 \%$ \\
\hline Uranium-235 & 0.00 & $0.0 \%$ \\
\hline Unaium-238 & 0.00 & $0.0 \%$ \\
\hline TOTAL & 72.36 & $100 \%$ \\
\hline \multicolumn{3}{|l|}{ At 300 Yeers sher Burial: } \\
\hline Carbon-14 & 0.00 & $0.0 \%$ \\
\hline Cobelt -60 & 0.00 & $0.0 \%$ \\
\hline Cetinm-137 & 0.00 & $0.0 \%$ \\
\hline Nepturuium-237 & 0.04 & $0.2 \%$ \\
\hline Platoniarn-238 & 13.75 & $72.6 \%$ \\
\hline Platonium-239 & 5.15 & $27.2 \%$ \\
\hline Strontium-90 & 0.00 & $0.0 \%$ \\
\hline Technetium-99 & 0.0 & $0.0 \%$ \\
\hline Tritium & 0.00 & $0.0 \%$ \\
\hline Utanimm-235 & 0.00 & $0.0 \%$ \\
\hline Uranium-238 & 0.00 & $0.0 \%$ \\
\hline TOTAL & 18.94 & $100 \%$ \\
\hline \multicolumn{3}{|l|}{ At 500 Years after Burial: } \\
\hline Carbon-14 & 0.00 & $0.0 \%$ \\
\hline Cobelt -60 & 0.00 & $0.0 \%$ \\
\hline Cesium-137 & 0.00 & $0.0 \%$ \\
\hline Neptunium-237 & 0.04 & $0.5 \%$ \\
\hline Plutonium-238 & 2.82 & $35.3 \%$ \\
\hline Plutonium-239 & 5.12 & $64.1 \%$ \\
\hline Strontium-90 & 0.00 & $0.0 \%$ \\
\hline Technetium-99 & 0.00 & $0.0 \%$ \\
\hline Trition & 0.00 & $0.0 \%$ \\
\hline Unaniurn-235 & 0.00 & $0.0 \%$ \\
\hline Unarium-238 & $\underline{0.00}$ & $0.0 \%$ \\
\hline TOTAL & 7.98 & $100 \%$ \\
\hline
\end{tabular}


Table 3-33. Decay Forecast for COBRA Inventory for Potential "Hot Spot" HS-100-12 (Continued)

\begin{tabular}{|c|c|c|}
\hline Constituent of Interest & Total Activity $(\mathrm{Ci})$ & Percent of Total Activity \\
\hline \multicolumn{3}{|l|}{ At 1,000 Years after Burial: } \\
\hline Custon-14 & 0.00 & $0.0 \%$ \\
\hline Cobult -60 & 0.00 & $0.0 \%$ \\
\hline Cenium-137 & 0.00 & $0.0 \%$ \\
\hline Nepturium-237 & 0.04 & $0.9 \%$ \\
\hline Plutoriem-238 & 0.06 & $1.2 \%$ \\
\hline Plutonium-239 & 5.04 & $98.0 \%$ \\
\hline Strontium-90 & 0.00 & $0.0 \%$ \\
\hline Tochnetiunn-99 & 0.00 & $0.0 \%$ \\
\hline Tritium & 0.00 & $0.0 \%$ \\
\hline Uranium-235 & 0.00 & $0.0 \%$ \\
\hline Unanium-238 & $\stackrel{0.00}{=}$ & $0.0 \%$ \\
\hline TOTAL & 5.15 & $100 \%$ \\
\hline \multicolumn{3}{|l|}{ At 5,000 Years afler Burial: } \\
\hline Carbon-14 & 0.00 & $0.0 \%$ \\
\hline Cobalt -60 & 0.00 & $0.0 \%$ \\
\hline Cesium-137 & 0.00 & $0.0 \%$ \\
\hline Neptunium-237 & 0.04 & $1.0 \%$ \\
\hline Plutonium-238 & 0.00 & $0.0 \%$ \\
\hline Plutonium-239 & 4.50 & $99.0 \%$ \\
\hline Strontium-90 & 0.00 & $0.0 \%$ \\
\hline Technetionn-99 & 0.00 & $0.0 \%$ \\
\hline Tritium & 0.00 & $0.0 \%$ \\
\hline Unariom-235 & 0.00 & $0.0 \%$ \\
\hline Uravitum-238 & $\underset{0.00}{\longrightarrow}$ & $0.0 \%$ \\
\hline TOTAL & 4.55 & $100 \%$ \\
\hline \multicolumn{3}{|l|}{ At 10,000 Years nfer Burial: } \\
\hline Cerbon-14 & 0.00 & $0.0 \%$ \\
\hline Cobellt -60 & 0.00 & $0.0 \%$ \\
\hline Cenium-137 & 0.00 & $0.0 \%$ \\
\hline Neptunitum-237 & 0.04 & $1.1 \%$ \\
\hline Plutonium-238 & 0.00 & $0.0 \%$ \\
\hline Plutonium-239 & 3.90 & $98.9 \%$ \\
\hline Strontium 990 & 0.00 & $0.0 \%$ \\
\hline Technetium-99 & 0.00 & $0.0 \%$ \\
\hline Tritium & 0.00 & $0.0 \%$ \\
\hline Uranium-235 & 0.00 & $0.0 \%$ \\
\hline Unnium-238 & 0.00 & $0.0 \%$ \\
\hline TOTAL & 3.95 & $100 \%$ \\
\hline
\end{tabular}


Table 3-34. Summary Statistics for COBRA Inventory of Potential "Hot Spot" HS-100-13

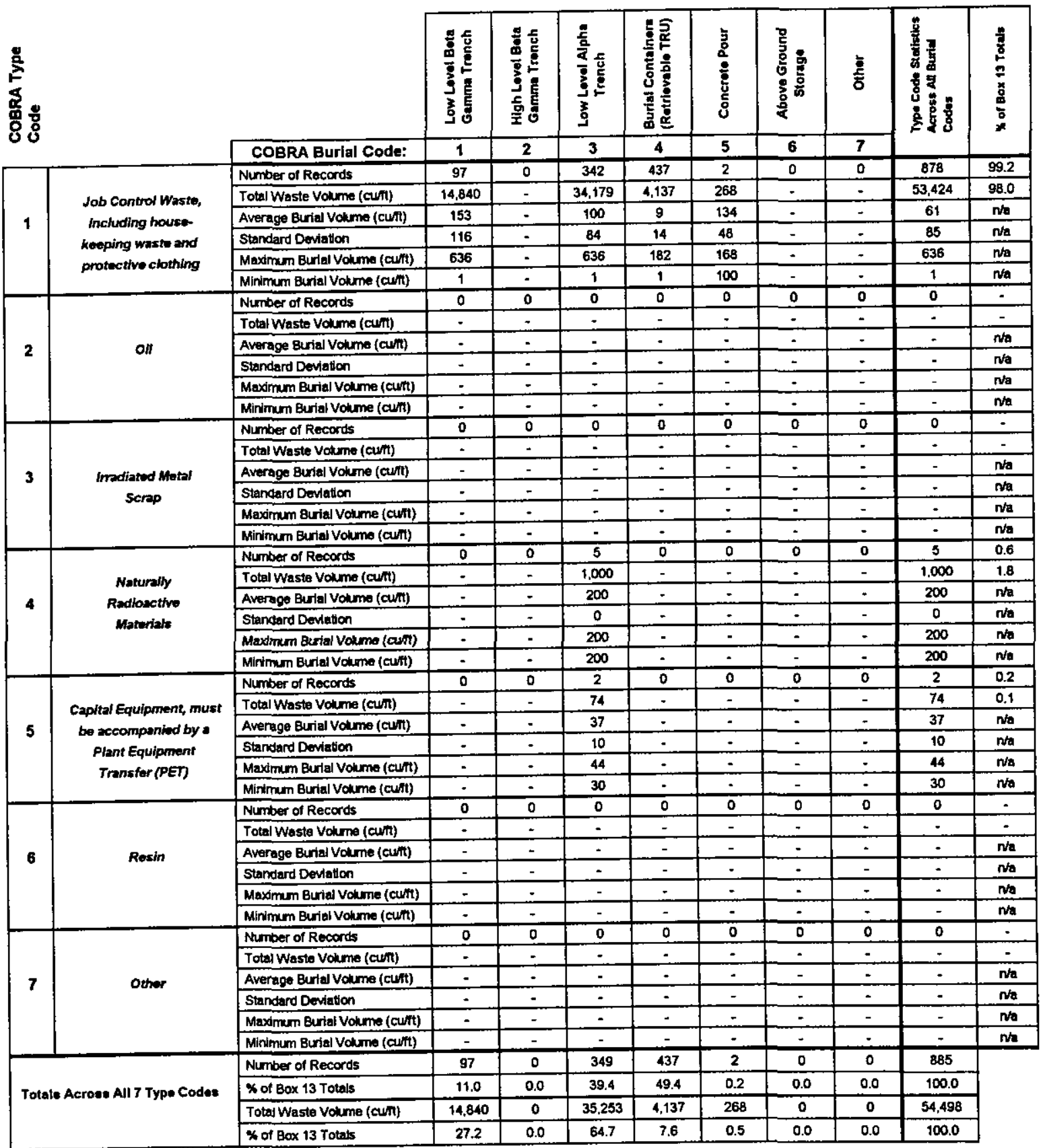


Table 3-35. Decay Forecast for COBRA Inventory for Potential "Hot Spot" HS-100-13

\begin{tabular}{|c|c|c|}
\hline Constituent of Interest & Total Activity (C) & Percent of Total Activity \\
\hline \multicolumn{3}{|l|}{ At Thme of Burlal: } \\
\hline Carbon-14 & 0.00 & $0.0 \%$ \\
\hline Cobalt -60 & 0.00 & $0.0 \%$ \\
\hline Cessium-137 & 98.64 & $1.7 \%$ \\
\hline Nepturnium-237 & 0.66 & $0.0 \%$ \\
\hline Plutonium-238 & $5,385.82$ & $90.4 \%$ \\
\hline Plutonium-239 & 379.45 & $6.4 \%$ \\
\hline Strontium-90 & 92.55 & $1.6 \%$ \\
\hline Techrotium-99 & 0.03 & $0.0 \%$ \\
\hline Tritium & 0.00 & $0.0 \%$ \\
\hline UTunim-235 & 0.00 & $0.0 \%$ \\
\hline Uranium-238 & $\stackrel{0.00}{=}$ & $0.0 \%$ \\
\hline TOTAL & $5,957.16$ & $100 \%$ \\
\hline \multicolumn{3}{|l|}{ At 50 Years a Rer Burial: } \\
\hline Carbon-14 & 0.00 & $0.0 \%$ \\
\hline Cobalt-60 & 0.00 & $\begin{array}{l}0.0 \% \\
0.8 \%\end{array}$ \\
\hline Cexium-137 & 31.08 & $0.8 \%$ \\
\hline Nepturium-237 & 0.67 & $0.0 \%$ \\
\hline Plutonium-238 & $3,623.04$ & $89.2 \%$ \\
\hline Plutonium-239 & 378.92 & $9.3 \%$ \\
\hline Strontium-90 & 28.16 & $0.7 \%$ \\
\hline Technetium-99 & 0.03 & $0.0 \%$ \\
\hline Tritium & 0.00 & $0.0 \%$ \\
\hline Unerium-235 & 0.00 & $0.0 \%$ \\
\hline Unnium-238 & 0.00 & $0.0 \%$ \\
\hline TOTAL & $\overline{4,061.90}$ & $100 \%$ \\
\hline \multicolumn{3}{|l|}{ At 100 Years atter Burial: } \\
\hline Curbon-14 & 0.00 & $0.0 \%$ \\
\hline Cobalt -60 & 0.00 & $0.0 \%$ \\
\hline Cerium-137 & 9.80 & $0.3 \%$ \\
\hline Neptuniurn-237 & 0.67 & $0.0 \%$ \\
\hline Plutonium-238 & $2,437.08$ & $86.0 \%$ \\
\hline Phutonium-239 & 378.39 & $13.3 \%$ \\
\hline Strontium-90 & 8.57 & $0.3 \%$ \\
\hline Tochnetium-99 & 0.03 & $0.0 \%$ \\
\hline Tritium & 0.00 & $0.0 \%$ \\
\hline Unarium-235 & 0.00 & $0.0 \%$ \\
\hline Uranium-238 & 0.00 & $0.0 \%$ \\
\hline TOTAL & $2,834.53$ & $100 \%$ \\
\hline \multicolumn{3}{|l|}{ At 300 Years after Burial: } \\
\hline Cerbon-14 & 0.00 & $0.0 \%$ \\
\hline Cobalt 60 & 0.00 & $0.0 \%$ \\
\hline Conium-137 & 0.10 & $0.0 \%$ \\
\hline Noptunium-237 & 0.68 & $0.1 \%$ \\
\hline Phutorium-238 & 499.27 & $57.0 \%$ \\
\hline Plutonium-239 & 376.22 & $42.9 \%$ \\
\hline Strontium-90 & 0.07 & $0.0 \%$ \\
\hline Techretiven-99 & 0.03 & $0.0 \%$ \\
\hline Tritium & 0.00 & $0.0 \%$ \\
\hline Uranium-235 & 0.00 & $0.0 \%$ \\
\hline Uranium-238 & 0.00 & $0.0 \%$ \\
\hline TOTAL & 876.37 & $100 \%$ \\
\hline \multicolumn{3}{|l|}{ At 500 Years aRer Burial: } \\
\hline Curbon-14 & 0.00 & $0.0 \%$ \\
\hline Cobalt -60 & 0.00 & $0.0 \%$ \\
\hline Cesium-137 & 0.00 & $0.0 \%$ \\
\hline Neptunium-237 & 0.68 & $0.1 \%$ \\
\hline Plutonitum-238 & 102.33 & $21.4 \%$ \\
\hline Plutonium-239 & 374.10 & $78.4 \%$ \\
\hline Strontium-90 & 0.00 & $0.0 \%$ \\
\hline Technotium-99 & 0.03 & $0.0 \%$ \\
\hline Tritium & 0.00 & $0.0 \%$ \\
\hline Urenimm-235 & 0.00 & $0.0 \%$ \\
\hline Uranium-238 & $\stackrel{0.00}{=}$ & $0.0 \%$ \\
\hline TOTAL & 477.14 & $100 \%$ \\
\hline
\end{tabular}


Table 3-35. Decay Forecast for COBRA Inventory for Potential "Hot Spot" HS-100-13 (Continued)

\begin{tabular}{|c|c|c|}
\hline Constituent of Interest & Total Activity (Ci) & Percent of Total Activity \\
\hline \multicolumn{3}{|l|}{ At 1,000 Years anter Burial: } \\
\hline Carbon-14 & 0.00 & $0.0 \%$ \\
\hline Cobalt-60 & 0.00 & $0.0 \%$ \\
\hline Cenium-137 & 0.00 & $0.0 \%$ \\
\hline Neptunium-239 & 0.69 & $0.2 \%$ \\
\hline Plutoniwm-238 & 2.15 & $0.6 \%$ \\
\hline Plutorcium-239 & 368.82 & $99.2 \%$ \\
\hline Strontium-90 & 0.00 & $0.0 \%$ \\
\hline Tochnetiurs-99 & 0.03 & $0.0 \%$ \\
\hline Tritium & 0.00 & $0.0 \%$ \\
\hline Unenium-235 & 0.00 & $0.0 \%$ \\
\hline Uranivom-238 & 0.00 & $0.0 \%$ \\
\hline TOTAL & 371.70 & $100 \%$ \\
\hline \multicolumn{3}{|l|}{ At 5,000 Years after Burial: } \\
\hline Carbon-14 & 0.00 & $0.0 \%$ \\
\hline Cobalt -60 & 0.00 & $0.0 \%$ \\
\hline Ceniurn-137 & 0.00 & $0.0 \%$ \\
\hline Neptaniourn-237 & 0.70 & $0.2 \%$ \\
\hline Plutonium-238 & 0.00 & $0.0 \%$ \\
\hline Plutonium-239 & 329.13 & $99.8 \%$ \\
\hline Strontiumn-90 & 0.00 & $0.0 \%$ \\
\hline Technetium-99 & 0.03 & $0.0 \%$ \\
\hline Tritium & 0.00 & $0.0 \%$ \\
\hline Untanium-235 & 0.00 & $0.0 \%$ \\
\hline Uranium-238 & 0.00 & $0.0 \%$ \\
\hline TOTAL & 329.87 & $100 \%$ \\
\hline \multicolumn{3}{|l|}{ At 30,000 Years netter Burial: } \\
\hline Carbon-14 & 0.00 & $0.0 \%$ \\
\hline Cobalt -60 & 0.00 & $0.0 \%$ \\
\hline Cerium-137 & 0.00 & $0.0 \%$ \\
\hline Nepturium-237 & 0.70 & $0.2 \%$ \\
\hline Plutonium-238 & 0.00 & $0.0 \%$ \\
\hline Plutonium-239 & 285.50 & $99.7 \%$ \\
\hline Strontium-90 & 0.00 & $0.0 \%$ \\
\hline Technotium-99 & 0.03 & $0.0 \%$ \\
\hline Tritium & 0.00 & $0.0 \%$ \\
\hline Unarium-235 & 0.00 & $0.0 \%$ \\
\hline Unanim-238 & 0.00 & $0.0 \%$ \\
\hline TOTAL & 286.23 & $100 \%$ \\
\hline
\end{tabular}


Table 3-36. Summary Statistics for COBRA Inventory of Potential "Hot Spot" HS-100-14

\begin{tabular}{|c|c|c|c|c|c|c|c|c|c|c|c|}
\hline \multirow[t]{2}{*}{ 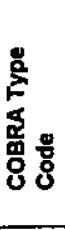 } & & & 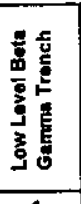 & 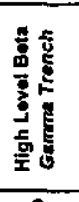 & 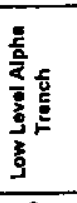 & 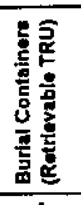 & 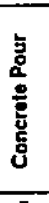 & 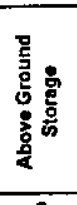 & $\frac{\hbar}{\delta}$ & 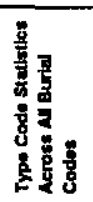 & 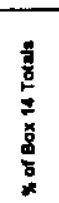 \\
\hline & & COBRA Burial Code: & 1 & 2 & 3 & 4 & 5 & 6 & 7 & & \\
\hline \multirow{6}{*}{1} & \multirow{6}{*}{$\begin{array}{l}\text { Job Control Waste, } \\
\text { inclunding house. } \\
\text { keepling wasto and } \\
\text { protective clothing }\end{array}$} & Number of Records & 35 & 0 & 12 & 0 & 0 & 0 & 0 & 47 & 74.6 \\
\hline & & Total Waste Votume (cu/t) & 3,518 & - & 1.132 & - & $\therefore$ & - & - & 4,650 & 60.8 \\
\hline & & Averege Burlal Volume (cuft) & 101 & $\approx$ & 94 & - & - & - & $\cdot$ & 99 & Nete \\
\hline & & Standard Deviation & 72 & $=$ & 52 & + & - & - & - & 67 & ne \\
\hline & & Maximum Burlal Volume (Cu/t) & 300 & $\therefore$ & 196 & - & - & $=$ & - & 300 & no \\
\hline & & Minimum Burial Volume (cuft) & 3 & - & 2 & - & - & - & - & 2 & Ne \\
\hline \multirow{6}{*}{2} & \multirow{6}{*}{ on } & Number of Records & 1. & $\underline{0}$ & $\underline{0}$ & 0 & $\underline{0}$ & 0 & 0 & 1 & 1.6 \\
\hline & & Totel Waste Volume (ault) & 54 & $\therefore$ & - & - & - & - & - & 54 & 0.7 \\
\hline & & Average Burial Volume (cumt) & 54 & - & - & + & - & - & - & 54 & n/a \\
\hline & & Standard Deviation & - & $=$ & - & $\sim$ & - & - & - & - & Nha \\
\hline & & Maxdmum Burtal Volume (cunt) & 54 & $\therefore$ & - & - & $\cdot$ & $\therefore$ & - & 54 & no \\
\hline & & Minimum Burlal Volume (cunt) & 54 & - & - & - & - & - & 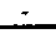 & 54 & na \\
\hline \multirow{6}{*}{3} & \multirow{6}{*}{$\begin{array}{l}\text { Irradiated Motal } \\
\text { Scrap }\end{array}$} & Number of Records & 0 & 0 & 0 & 0 & 0 & 0 & 0 & 0 & - \\
\hline & & Total Waste Vokme (cu/t) & - & $\therefore$ & $\therefore$ & - & - & $\therefore$ & - & - & - \\
\hline & & Average Burlal Volume (cunt) & - & - & $\therefore$ & - & $\therefore$ & - & - & - & $\mathrm{n} / \mathrm{a}$ \\
\hline & & Standard Deviation & - & - & - & - & - & - & - & - & no \\
\hline & & Maximum Burial Volume (aum) & - & $\therefore$ & - & - & - & - & - & - & No \\
\hline & & Minimum Burial Volume (curt) & - & - & - & - & - & - & - & - & ne \\
\hline \multirow{6}{*}{4} & \multirow{6}{*}{$\begin{array}{c}\text { Noturally } \\
\text { Rediasctive } \\
\text { Motorials }\end{array}$} & Number of Records & 16 & 0 & 0 & 0 & 0 & 0 & 0 & 15 & 23.8 \\
\hline & & Total Waste Volume (cunt) & 2,950 & - & $\therefore$ & $=$ & - & ت & 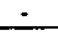 & 2,950 & 38.5 \\
\hline & & Average Burlal Volume (cumt) & 197 & $=$ & - & - & - & - & $\cdot$ & 197 & no \\
\hline & & Standard Deviation & 30 & $=$ & - & - & - & - & $\therefore$ & 30 & Na \\
\hline & & Maximum Burial Volume (cunt) & 250 & - & $\cdot$ & - & - & - & - & 250 & na \\
\hline & & Minimum Burial Volume (cult) & 100 & \pm & $\therefore$ & - & $\therefore$ & - & - & 100 & $\mathrm{Na}$ \\
\hline \multirow{6}{*}{5} & \multirow{6}{*}{$\begin{array}{l}\text { Capltal Equipment, must } \\
\text { be accompanied by a } \\
\text { Plant Equipment } \\
\text { Transfier (PET) }\end{array}$} & Number of Records & 0 & 0 & 0 & 0 & $\underline{0}$ & $\underline{0}$ & 0 & 0 & - \\
\hline & & Total Waste Volume (cu/t) & - & $\therefore$ & - & - & - & - & $=$ & - & - \\
\hline & & Average Buntal Volume (cu/n) & - & $=$ & - & - & - & - & - & - & na \\
\hline & & Standard Deviation & - & $\therefore$ & $\therefore$ & $=$ & - & - & - & - & No \\
\hline & & Maximum Burtal Volme (cu/n) & - & $\therefore$ & - & - & 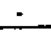 & - & - & - & $\mathrm{n} / \mathrm{a}$ \\
\hline & & Minimum Burial Volume (curt) & - & $=$ & - & - & - & - & - & $\therefore$ & nos \\
\hline \multirow{6}{*}{6} & \multirow{6}{*}{ Rosin } & Number of Records & 0 & 0 & 0 & 0 & 0 & 0 & 0 & 0 & 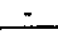 \\
\hline & & Total Waste Volume (curti) & - & $=$ & - & - & $\therefore$ & - & - & - & $=$ \\
\hline & & Average Burial Volume (cuntt) & - & $=$ & - & - & - & - & 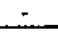 & - & nes \\
\hline & & Standard Deviation & - & $=$ & - & - & - & - & - & - & $\mathrm{n} / \mathrm{a}$ \\
\hline & & Maximum Burial Volume (cunt) & $\therefore$ & $=$ & - & - & - & - & - & - & nate \\
\hline & & Minimum Burial Volume (cuitt) & - & $=$ & - & - & - & - & - & - & ne \\
\hline \multirow{6}{*}{7} & \multirow{6}{*}{ Other } & Number of Records & 0 & 2 & 0 & 0 & 0 & 0 & 0 & 0 & $=$ \\
\hline & & Total Waste Volume (cumt) & - & - & $\therefore$ & - & $=$ & $=$ & - & - & $\therefore$ \\
\hline & & Average Burial Volume (cult) & - & - & - & - & $\cdot$ & - & $\therefore$ & - & $n / a$ \\
\hline & & Standard Deviation & - & $\therefore$ & - & - & - & $\therefore$ & - & - & nota \\
\hline & & Maximum Burial Volume (cumt) & - & $\therefore$ & - & - & - & - & $\therefore$ & - & na \\
\hline & & Minimum Burial Volume (cum) & - & - & $\therefore$ & - & - & - & - & - & nhe \\
\hline \multirow{4}{*}{\multicolumn{2}{|c|}{ Totale Acrose All 7 Type Codes }} & Number of Records & 51 & 0 & 12 & 0 & 0 & 0 & 0 & 63. & \\
\hline & & $\%$ of Box 14 Totals & 81.0 & 0.0 & 19.0 & 0.0 & 0.0 & 0.0 & 0.0 & 100.0 & \\
\hline & & Total Waste Volume (cuit) & 6,522 & 0 & 1.132 & 0 & 0 & 0 & 0 & 7,654 & \\
\hline & & $\%$ of Box 14 Totats & 85.2 & 0.0 & 14.8 & 0.0 & 0.0 & 0.0 & 0.0 & 100.0 & \\
\hline
\end{tabular}


Table 3-37. Decay Forecast for COBRA Inventory for Potential "Hot Spot" HS-100-14

\begin{tabular}{|c|c|c|}
\hline Constituent of lnterest & Total Activity (C) & Percent of Total Activity \\
\hline At Time of Burial: & & \\
\hline Carbon-14 & 0.00 & $0.0 \%$ \\
\hline Cobalt -60 & 0.00 & $0.0 \%$ \\
\hline Cenium-137 & 5.13 & $0.0 \%$ \\
\hline Neptunizm-237 & 0.00 & $0.0 \%$ \\
\hline Plutonium-238 & 0.00 & $0.0 \%$ \\
\hline Plutonium-239 & 0.14 & $0.0 \%$ \\
\hline Strontium-90 & 4.81 & $0.0 \%$ \\
\hline Technetium -99 & 0.00 & $0.0 \%$ \\
\hline Tritium & $46,863.18$ & $100.0 \%$ \\
\hline Urantium-235 & 0.00 & $0.0 \%$ \\
\hline Uranium-238 & $\stackrel{0.00}{=}$ & $\underline{0.0 \%}$ \\
\hline TOTAL & $46,873.26$ & $100 \%$ \\
\hline \multicolumn{3}{|l|}{ At 50 Years after Burtal: } \\
\hline Carbon-14 & 0.00 & $0.0 \%$ \\
\hline Cobalt -60 & 0.00 & $0.0 \%$ \\
\hline Cerium-137 & 1.62 & $0.1 \%$ \\
\hline Neptunium-237 & 0.00 & $0.0 \%$ \\
\hline Plutonium-238 & 0.00 & $0.0 \%$ \\
\hline Plutoniwn-239 & 0.14 & $0.0 \%$ \\
\hline Strontixum-90 & 1.46 & $0.1 \%$ \\
\hline Twchnetium-99 & 0.00 & $0.0 \%$ \\
\hline Tritium & $2,802.42$ & $99.9 \%$ \\
\hline Urenium-235 & 0.00 & $0.0 \%$ \\
\hline Urarium-238 & 0.00 & $0.0 \%$ \\
\hline TOTAL & $2,805.64$ & $100 \%$ \\
\hline \multicolumn{3}{|l|}{ At 100 Years nfter Burial: } \\
\hline Carbon-14 & 0.00 & $0.0 \%$ \\
\hline Cobalt-60 & 0.00 & $0.0 \%$ \\
\hline Cesium-137 & 0.51 & $0.3 \%$ \\
\hline Neptunimm-237 & 0.00 & $0.0 \%$ \\
\hline Plutonium-238 & 0.00 & $0.0 \%$ \\
\hline Plutonimm-239 & 0.14 & $0.1 \%$ \\
\hline Strontium-90 & 0.45 & $0.3 \%$ \\
\hline Technetium-99 & 0.00 & $0.0 \%$ \\
\hline Tritium & 168.71 & $99.4 \%$ \\
\hline Unanium-235 & 0.00 & $0.0 \%$ \\
\hline Unninm-238 & $\underline{0.00}$ & $0,0 \%$ \\
\hline TOTAL. & 169.80 & $100 \%$ \\
\hline \multicolumn{3}{|l|}{ At 300 Years after Burlaj: } \\
\hline Carton-14 & 0.00 & $0.0 \%$ \\
\hline Cobralt -60 & 0.00 & $0.0 \%$ \\
\hline Cesium-137 & 0.01 & $3.4 \%$ \\
\hline Nepturium-237 & 0.00 & $0.0 \%$ \\
\hline Plutonium-238 & 0.00 & $0.0 \%$ \\
\hline Plutonium-239 & 0.14 & $92.9 \%$ \\
\hline Strontium-90 & 0.00 & $2.6 \%$ \\
\hline Tochnotium-99 & 0.00 & $1.1 \%$ \\
\hline Tritium & 0.00 & $0.0 \%$ \\
\hline Unanium-235 & 0.00 & $0.0 \%$ \\
\hline Uranium-238 & 0.00 & $0.0 \%$ \\
\hline TOTAL & 0.15 & $100 \%$ \\
\hline \multicolumn{3}{|l|}{ At 500 Years after Burlal: } \\
\hline Curbon-14 & 0.00 & $0.0 \%$ \\
\hline Cobalt- 60 & 0.00 & $0.0 \%$ \\
\hline Cexium-137 & 0.00 & $0.0 \%$ \\
\hline Nepturium-237 & 0.00 & $0.0 \%$ \\
\hline Plutonium-238 & 0.00 & $0.0 \%$ \\
\hline Plutonium-239 & 0.14 & $98.8 \%$ \\
\hline Strontium-90 & 0.00 & $0.0 \%$ \\
\hline Techretium-99 & 0.00 & $1.2 \%$ \\
\hline Tritium & 0.00 & $0.0 \%$ \\
\hline Unarium-235 & 0.00 & $0.0 \%$ \\
\hline Unanim-238 & $\stackrel{0.00}{=}$ & $0.0 \%$ \\
\hline TOTAL & 0.14 & $100 \%$ \\
\hline
\end{tabular}


Table 3-37. Decay Forecast for COBRA Inventory for Potential "Hot Spot" HS-100-14 (Continued)

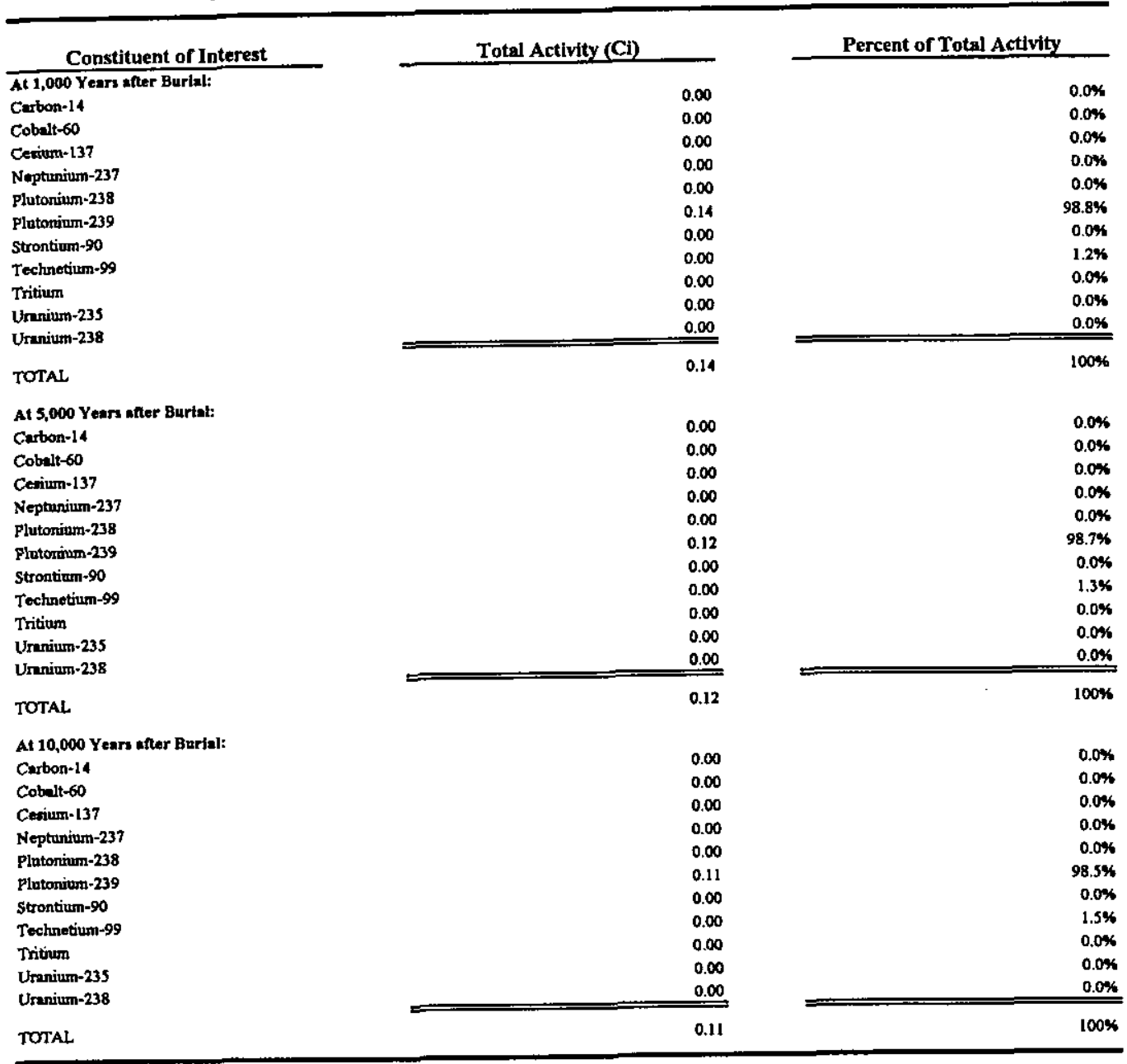


Table 3-38. Summary Statistics for COBRA Inventory of Potential "Hot Spot" HS-100-15

\begin{tabular}{|c|c|c|c|c|c|c|c|c|c|c|c|}
\hline \multirow[t]{2}{*}{$\begin{array}{l}\frac{8}{5} \\
\$ \\
\frac{5}{8} \\
8\end{array}$} & & & 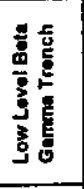 & 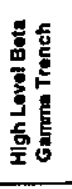 & 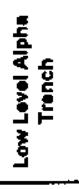 & 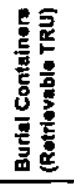 & 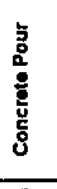 & 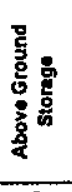 & $\begin{array}{l}\text { ț } \\
\text { ț }\end{array}$ & 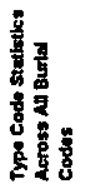 & 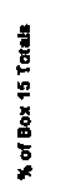 \\
\hline & & COBRA Burial Code: & 1 & 2 & 3 & 4 & 5 & 6 & 7 & & \\
\hline \multirow{6}{*}{1} & \multirow{6}{*}{$\begin{array}{l}\text { Job Control Waste, } \\
\text { including houser } \\
\text { keoping waste and } \\
\text { protective clothing }\end{array}$} & Number of Reconds & 98 & 0 & 37 & 1 & 0 & 0 & 0 & 136 & 92.5 \\
\hline & & Total Waste Volume (cu/t) & 13,101 & - & 3.698 & 7 & $\cdot$ & - & $\therefore$ & 16.806 & 93.0 \\
\hline & & Average Burlal Volume (cult) & 134 & - & 100 & 7 & - & - & - & 124 & ne \\
\hline & & Standard Deviation & 87 & - & 65 & - & - & $\therefore$ & $\cdot$ & 83 & $\mathrm{na}$ \\
\hline & & Maximum Burial Volume (culti) & 300 & - & 223 & 7 & - & - & - & 300 & $n / a$ \\
\hline & & Mlkimum Burial Vokme (cum) & 7 & - & 3 & 7 & - & - & - & 3 & ne \\
\hline \multirow{6}{*}{2} & \multirow{6}{*}{ Oll } & Number of Records & 4 & 0 & 0 & 0 & 0 & 0 & 0 & 4 & 2.7 \\
\hline & & Total Waste Volume (cu/t) & 127 & - & - & - & 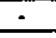 & $\therefore$ & - & 127 & 0.7 \\
\hline & & Average Burial Voume (avit) & 32 & - & - & - & - & - & $=$ & 32 & Na \\
\hline & & Standard Deviation & 41 & - & - & - & - & - & $=$ & 41 & Na \\
\hline & & Maximum Burlal Volume (cunt) & 90 & - & $=$ & - & - & - & - & 90 & nta \\
\hline & & Minimum Burlal Volume (aum) & 2 & - & - & - & - & - & - & 2 & $n / a$ \\
\hline \multirow{6}{*}{3} & \multirow{6}{*}{$\begin{array}{l}\text { Irradlated Motal } \\
\text { Scrap }\end{array}$} & Number of Reconds & 0 & 2 & 0 & 0 & 0 & $\underline{0}$ & 0 & 2 & 1.4 \\
\hline & & Total Waste Volume (cult) & - & 98 & - & 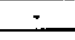 & - & - & - & 98 & 0.5 \\
\hline & & Averege Burial Volume (cumt) & - & 49 & - & - & - & - & - & 49 & No \\
\hline & & Standard Deviation & - & 1. & - & - & - & $=$ & $=$ & 1 & n/a \\
\hline & & Maximum Burial Volume (cum) & - & 50 & $\because$ & $=$ & - & - & - & 50 & $\mathrm{n} / \mathrm{a}$ \\
\hline & & Mirlirum Buriel Volume (au/t) & - & 48 & - & - & - & - & - & 48 & $\mathrm{n} / \mathrm{a}$ \\
\hline \multirow{6}{*}{4} & \multirow{6}{*}{$\begin{array}{l}\text { Narurally } \\
\text { Radlowctive } \\
\text { Materials }\end{array}$} & Number of Records & 4 & 0 & 0 & $\underline{0}$ & 0 & 0 & 0 & 4 & 2.7 \\
\hline & & Total Waste Volume (cu/t) & 1,000 & - & - & - & $\cdot$ & - & - & 1,000 & 5.5 \\
\hline & & Average Burlal Voume (cuitt) & 250 & - & - & - & - & - & - & 250 & No \\
\hline & & Standard Deviation & 0 & - & - & - & - & + & - & 0 & Na \\
\hline & & Maximum Burial Volume (culti) & 250 & - & - & - & - & - & - & 250 & na \\
\hline & & Mirimum Burial Volume (cuft) & 250 & $=$ & - & - & - & - & - & 250 & $\mathrm{na}$ \\
\hline \multirow{6}{*}{5} & \multirow{6}{*}{$\begin{array}{c}\text { Capital Equipment, must } \\
\text { be accompanied by a } \\
\text { Plent Equipment } \\
\text { Transfer (PET) }\end{array}$} & Number of Records & 1 & 0 & 0 & 0 & 0 & 0 & 0 & 1 & 0.7 \\
\hline & & Total Waste Volurse (cu/t) & 48 & - & - & - & - & - & - & 48 & 0.3 \\
\hline & & Average Burlel Volume (ault) & 48 & $\cdot$ & - & - & $=$ & - & - & 48 & $\mathrm{na}$ \\
\hline & & Standard Deviation & $\cdot$ & - & - & - & 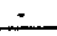 & - & - & - & nta \\
\hline & & Maximum Burial Volume (cum) & 48 & $\therefore$ & - & - & - & - & $\cdot$ & 48 & wa \\
\hline & & Minimum Burtal Voldene (aunt) & 48 & - & - & - & - & 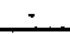 & - & 48 & $\mathrm{Na}$ \\
\hline \multirow{6}{*}{6} & \multirow{6}{*}{ Resin } & Number of Records & 0 & 0 & 0 & 0 & 0 & 0 & 0 & 0 & - \\
\hline & & Total Waste Volume (aunt) & - & - & - & $\therefore$ & - & $=$ & - & - & - \\
\hline & & Average Burlal Volurno (cu/t) & - & - & $\tau$ & - & - & - & $\therefore$ & $\cdot$ & Na \\
\hline & & Standard Deviation & - & - & - & - & - & - & - & - & no \\
\hline & & Maximum Burlal Volume (cuitit) & - & $=$ & - & - & - & - & $=$ & - & no \\
\hline & & Minimum Burial Volume (cunt) & - & - & $\therefore$ & - & - & $\cdot$ & - & - & na \\
\hline \multirow{6}{*}{7} & \multirow{6}{*}{ Other } & Number of Records & 0 & 0 & 0 & 0 & D & 0 & 0 & 0 & - \\
\hline & & Total Wasto Volume (cuit) & - & - & - & - & - & . & - & - & - \\
\hline & & Average Burial Volume (curt) & - & - & $=$ & - & - & - & $=$ & - & $\mathrm{Na}$ \\
\hline & & Standard Deviation & + & $=$ & - & - & - & - & - & $\therefore$ & no \\
\hline & & Maximum Burial Volume (cufti) & - & - & - & - & - & - & $=$ & - & $n$ \\
\hline & & Mirimum Burlal Volume (curtt) & - & $=$ & - & - & - & - & - & - & no \\
\hline \multirow{4}{*}{\multicolumn{2}{|c|}{ Totala Across All 7 Typo Codes }} & Number of Reconds & 107 & 2 & 37 & 1 & 0 & 0 & 0 & 147 & \\
\hline & & $\%$ of Box 15 Totals & 72.8 & 1.4 & 25.2 & 0.7 & 0.0 & 0.0 & 0.0 & 100.0 & \\
\hline & & Total Waste Vokune (cu/t) & 14,276 & 98 & 3,698 & 7 & 0 & 0 & 0 & 18.079 & \\
\hline & & \% of Box 15 Totals & 79.0 & 0.5 & 20.5 & 0.0 & 0.0 & 0.0 & 0.0 & 100.0 & \\
\hline
\end{tabular}


Table 3-39. Decay Forecast for COBRA Inventory for Potential "Hot Spot" HS-100-15

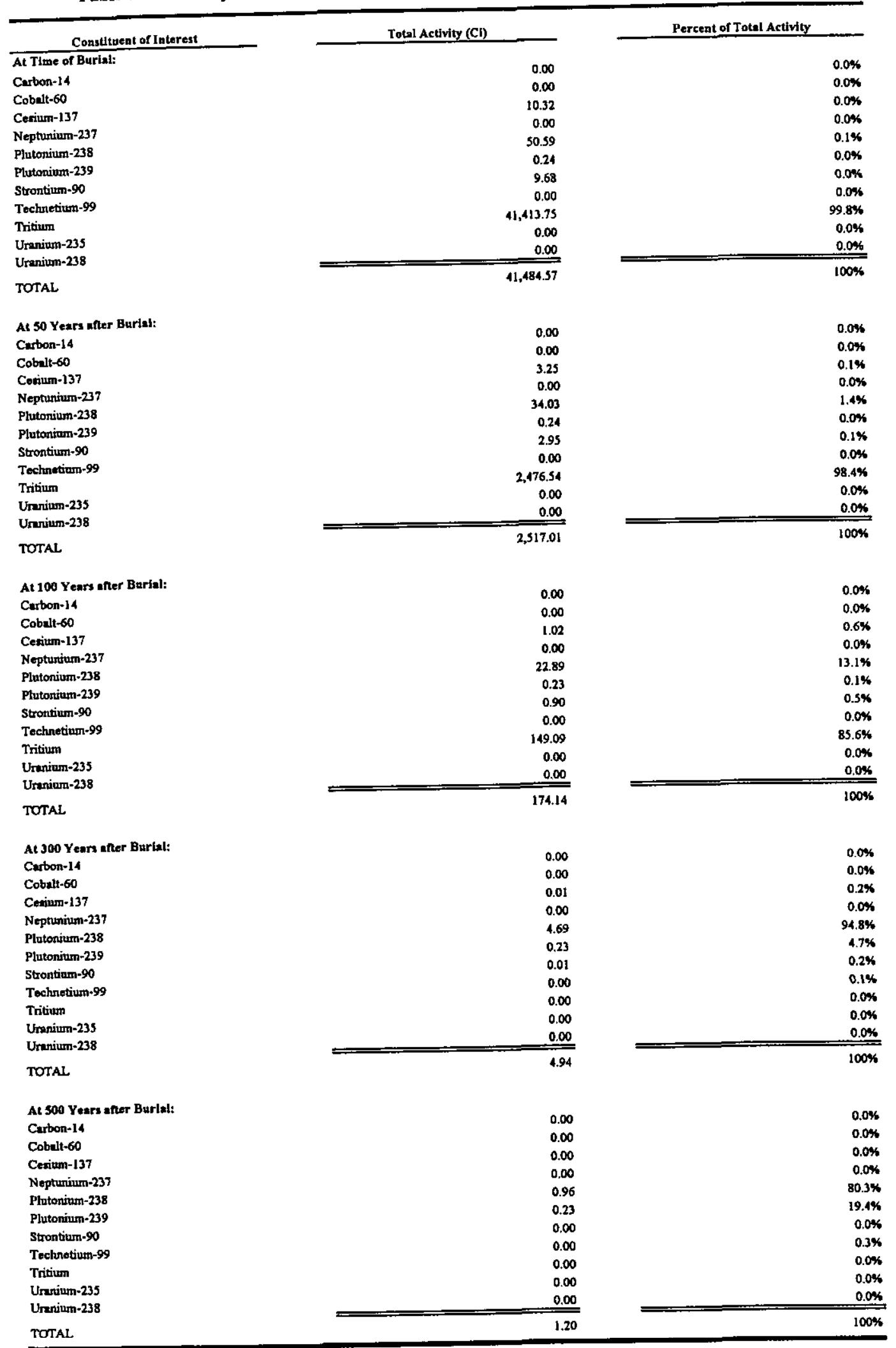


Table 3-39. Decay Forecast for COBRA Inventory for Potential "Hot Spot" HS-100-15 (Continued)

\begin{tabular}{|c|c|c|}
\hline Constituent of Interest & Total Activity (Ci) & Percent of Total Activity \\
\hline \multicolumn{3}{|l|}{ At 1,000 Years after Burfal: } \\
\hline Carbon-14 & 0.00 & $0.0 \%$ \\
\hline Cobult-60 & 0.00 & $0.0 \%$ \\
\hline Cesium-137 & 0.00 & $0.0 \%$ \\
\hline Neptunium-237 & 0.00 & $0.0 \%$ \\
\hline Plutonium-238 & 0.02 & $8.0 \%$ \\
\hline Plutonium-239 & 0.23 & $90.7 \%$ \\
\hline Strontium-90 & 0.00 & $0.0 \%$ \\
\hline Tochnetium-99 & 0.00 & $1.3 \%$ \\
\hline Tritiom & 0.00 & $0.0 \%$ \\
\hline Urarinm-235 & 0.00 & $0.0 \%$ \\
\hline Uratrium-238 & $\underline{0.00}$ & $0.0 \%$ \\
\hline TOTAL & 0.25 & $100 \%$ \\
\hline \multicolumn{3}{|l|}{ At 5,000 Years after Burial: } \\
\hline Curbon-14 & 0.00 & $0.0 \%$ \\
\hline Cobalt-60 & 0.00 & $0.0 \%$ \\
\hline Cesium-137 & 0.00 & $0.0 \%$ \\
\hline Nepturium-237 & 0.00 & $0.0 \%$ \\
\hline Plutoniwn-238 & 0.00 & $0.0 \%$ \\
\hline Plutonium-239 & 0.20 & $98.5 \%$ \\
\hline Strontioum-90 & 0.00 & $0.0 \%$ \\
\hline Technetium-99 & 0.00 & $1.5 \%$ \\
\hline Tritium & 0.00 & $0.0 \%$ \\
\hline Uranium-235 & 0.00 & $0.0 \%$ \\
\hline Unnium-238 & $\underline{0.00}$ & $0.0 \%$ \\
\hline TOTAL. & 0.21 & $100 \%$ \\
\hline \multicolumn{3}{|l|}{ At 10,000 Years after Burlat: } \\
\hline Carbon-14 & 0.00 & $0.0 \%$ \\
\hline Cobalt -60 & 0.00 & $0.0 \%$ \\
\hline Cesium-137 & 0.00 & $0.0 \%$ \\
\hline Nepturtium-237 & 0.00 & $0.0 \%$ \\
\hline Plutonium-238 & 0.00 & $0.0 \%$ \\
\hline Plutonium-239 & 0.18 & $98.3 \%$ \\
\hline Strontium-90 & 0.00 & $0.0 \%$ \\
\hline Tochnotium-99 & 0.00 & $1.7 \%$ \\
\hline Trition & 0.00 & $0.0 \%$ \\
\hline Uranium-235 & 0.00 & $0.0 \%$ \\
\hline Uranium-238 & 0.00 & $0.0 \%$ \\
\hline TOTAL & 0.18 & $100 \%$ \\
\hline
\end{tabular}


Table 3-40. Summary Statistics for COBRA Inventory of Potential "Hot Spot" HS-100-16

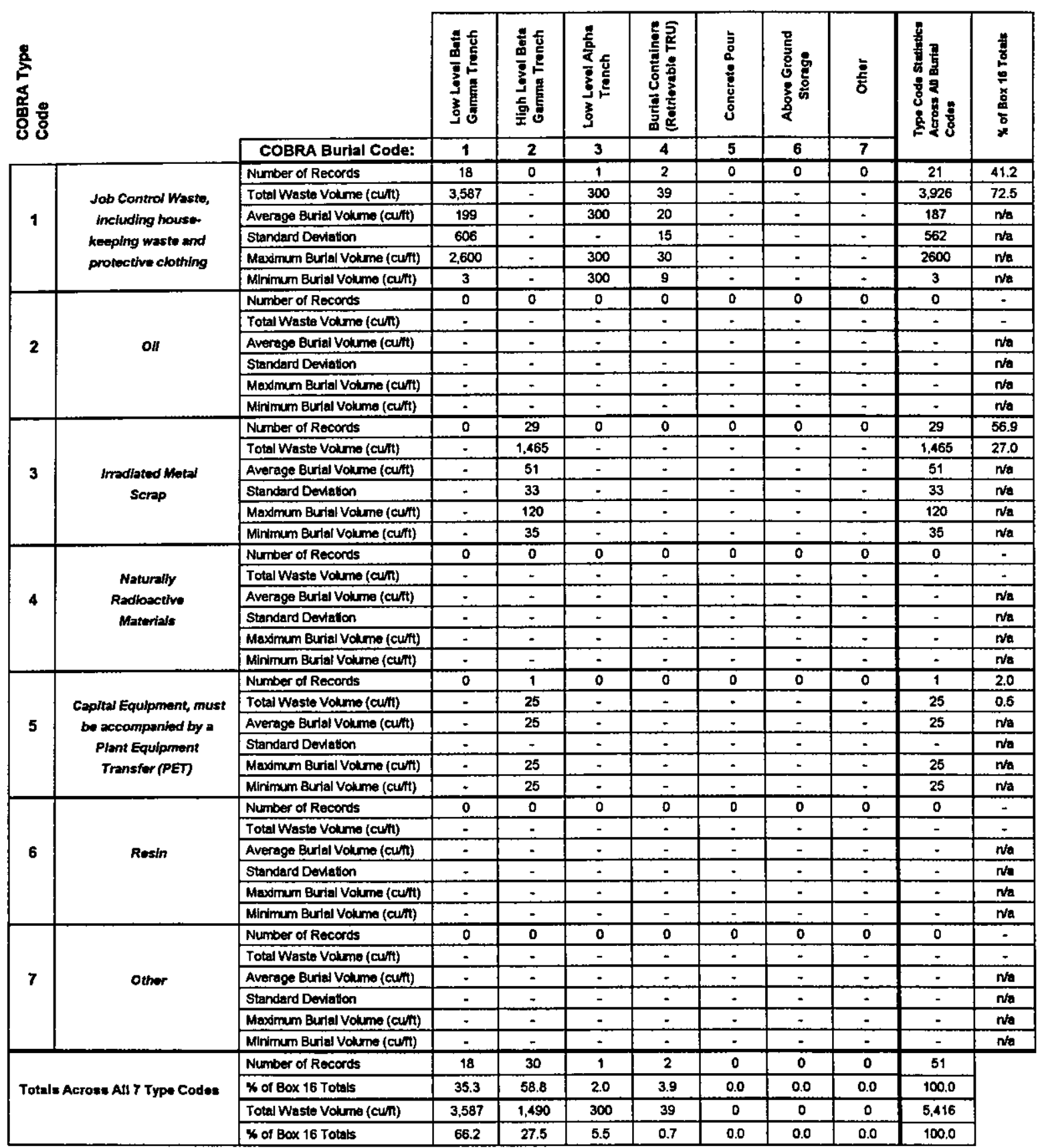


Table 3-41. Decay Forecast for COBRA Inventory for Potential "Hot Spot" HS-100-16

\begin{tabular}{|c|c|c|}
\hline Constituent of Interest & Total Activity (CD) & Percent of Tatal Activity \\
\hline \multicolumn{3}{|l|}{ A1 Time of Burial: } \\
\hline Carton-14 & 43.00 & $0.1 \%$ \\
\hline Cobalt -60 & 36818.60 & $95.6 \%$ \\
\hline Cesìum-137 & 136.99 & $0.4 \%$ \\
\hline Nepturium-237 & 0.00 & $0.0 \%$ \\
\hline Plutonitum-238 & 8.00 & $0.0 \%$ \\
\hline Plutonium-239 & 0.00 & $0.0 \%$ \\
\hline Strontium-90 & 128.52 & $0.3 \%$ \\
\hline Technetium-99 & 0.04 & $0.0 \%$ \\
\hline Tritium & 1386.60 & $3.6 \%$ \\
\hline Unanium-235 & 0.00 & $0.0 \%$ \\
\hline Unnium-238 & $\stackrel{0.00}{=}$ & $0.0 \%$ \\
\hline TOTAL & $38,521.75$ & $100 \%$ \\
\hline \multicolumn{3}{|l|}{ At 50 Years after Burfal: } \\
\hline Carton-14 & 42.74 & $16.1 \%$ \\
\hline Cobalt -60 & 51.55 & $19.5 \%$ \\
\hline Cestium-137 & 43.16 & $16.3 \%$ \\
\hline Neptanium-237 & 0.00 & $0.0 \%$ \\
\hline Plutonium-238 & 3.38 & $2.0 \%$ \\
\hline Plutonitur-239 & 0.00 & $0.0 \%$ \\
\hline Strontium-90 & 39.11 & $14.8 \%$ \\
\hline Technotium-99 & 0.04 & $0.0 \%$ \\
\hline Tritium & 82.92 & $31.3 \%$ \\
\hline Uranium-235 & 0.00 & $0.0 \%$ \\
\hline Uranium-238 & $\underline{0.00}$ & $\stackrel{0.0 \%}{=}$ \\
\hline TOTAL. & 264.90 & $100 \%$ \\
\hline \multicolumn{3}{|l|}{ At 100 Years after Burial: } \\
\hline Carbon-14 & 42.48 & $55.4 \%$ \\
\hline Cobalt-60 & 0.00 & $0.0 \%$ \\
\hline Cexium-137 & 13.60 & $17.7 \%$ \\
\hline Nepturium-237 & 0.00 & $0.0 \%$ \\
\hline Plutonium-238 & 3.62 & $4.7 \%$ \\
\hline Plutonium-239 & 0.00 & $0.0 \% 6$ \\
\hline Strontium-90 & 11.90 & $15.5 \%$ \\
\hline Techneting-99 & 0.04 & $0.1 \%$ \\
\hline Tritium & 4.99 & $6.5 \%$ \\
\hline Unarium-235 & 0.00 & $0.0 \%$ \\
\hline Uranium-238 & 0.00 & $0.0 \%$ \\
\hline TOTAL & 76.64 & $100 \%$ \\
\hline \multicolumn{3}{|l|}{ At 300 Yents efter Burial: } \\
\hline Curbon-14 & 41.46 & $97.6 \%$ \\
\hline Cobalt- 60 & 0.00 & $0.0 \%$ \\
\hline Cexium-137 & 0.14 & $0.3 \%$ \\
\hline Neptunium-237 & 0.00 & $0.0 \%$ \\
\hline Plutonium-238 & 0.74 & $1.7 \%$ \\
\hline Plutonium-239 & 0.00 & $0.0 \%$ \\
\hline Strontium-90 & 0.10 & $0.2 \%$ \\
\hline Technetium-99 & 0.04 & $0.1 \%$ \\
\hline Tritium & 0.00 & $0.0 \%$ \\
\hline Uraniwur-235 & 0.00 & $0.0 \%$ \\
\hline Unarium-238 & 0.00 & $0.0 \%$ \\
\hline TOTAL & 42.49 & $100 \%$ \\
\hline \multicolumn{3}{|l|}{ A1 500 Years after Buriel: } \\
\hline Carbon-14 & 40.47 & $99.5 \%$ \\
\hline Cobalt-60 & 0.00 & $0.0 \%$ \\
\hline Cenium-137 & 0.00 & $0.0 \%$ \\
\hline Nepturium-237 & 0.00 & $0.0 \%$ \\
\hline Phatonium-238 & 0.15 & $0.4 \%$ \\
\hline Plutoninm-239 & 0.00 & $0.0 \%$ \\
\hline Strontium-90 & 0.00 & $0.0 \%$ \\
\hline Teclunetium-99 & 0.04 & $0.1 \%$ \\
\hline Tritium & 0.00 & $0.0 \%$ \\
\hline Unanium-235 & 0.00 & $0.0 \%$ \\
\hline Uranium-238 & 0.00 & $0.0 \%$ \\
\hline TOTAL & 40.67 & $100 \%$ \\
\hline
\end{tabular}


Table 3-41. Decay Forecast for COBRA Inventory for Potential "Hot Spot" HS-100-16 (Continued)

\begin{tabular}{|c|c|c|}
\hline Constituent of Interest & Total Activity (Ci) & Percent of Total Activity \\
\hline At 1,000 Years atter Burial: & & \\
\hline Curbon-14 & 38.09 & $99.9 \%$ \\
\hline Cobalt -60 & 0.00 & $0.0 \%$ \\
\hline Cexiurn-137 & 0.00 & $0.0 \%$ \\
\hline Neptuniurn-237 & 0.00 & $0.0 \%$ \\
\hline Plutonium-238 & 0.00 & $0.0 \%$ \\
\hline Plutonium-239 & 0.00 & $0.0 \%$ \\
\hline Strontium-90 & 0.00 & $0.0 \%$ \\
\hline Techrretium-99 & 0.04 & $0.1 \%$ \\
\hline Tritium & 0.00 & $0.0 \%$ \\
\hline Uranivarn-235 & 0.00 & $0.0 \%$ \\
\hline Uranium-238 & 0.00 & $0.0 \%$ \\
\hline TOTAL & 38.14 & $100 \%$ \\
\hline \multicolumn{3}{|l|}{ At 5,000 Years efter Burlal: } \\
\hline Curbon-14 & 23.45 & $99.8 \%$ \\
\hline Cobalt- 60 & 0.00 & $0.0 \%$ \\
\hline Cexium -137 & 0.00 & $0.0 \%$ \\
\hline Nepturium-237 & 0.00 & $0.0 \%$ \\
\hline Platonium-238 & 0.00 & $0.0 \%$ \\
\hline Plutoriom-239 & 0.00 & $0.0 \%$ \\
\hline Strontium-90 & 0.00 & $0.0 \%$ \\
\hline Technetium-99 & 0.04 & $0.2 \%$ \\
\hline Tritium & 0.00 & $0.0 \%$ \\
\hline Unanium-235 & 0.00 & $0.0 \%$ \\
\hline Unavium-238 & 0.00 & $0.0 \%$ \\
\hline TOTAL & 23.49 & $100 \%$ \\
\hline \multicolumn{3}{|l|}{ Al 10,000 Years after Burial: } \\
\hline Carton-14 & 12.79 & $99.7 \%$ \\
\hline Cobalt -60 & 0.00 & $0.0 \%$ \\
\hline Cesium-137 & 0.00 & $0.0 \%$ \\
\hline Noptunium-237 & 0.00 & $0.0 \%$ \\
\hline Plutonium-238 & 0.00 & $0.0 \%$ \\
\hline Plutonium-239 & 0.00 & $0.0 \%$ \\
\hline Strontium-90 & 0.00 & $0.0 \%$ \\
\hline Tochnutium-99 & 0.04 & $0.3 \%$ \\
\hline Tritium & 0.00 & $0.0 \%$ \\
\hline Uranium-235 & 0.00 & $0.0 \%$ \\
\hline Unanium-238 & 0.00 & $0.0 \%$ \\
\hline TOTAL & 12.83 & $100 \%$ \\
\hline
\end{tabular}


Table 3-42. Summary Statistics for COBRA Inventory of Potential "Hot Spot" HS-100-17

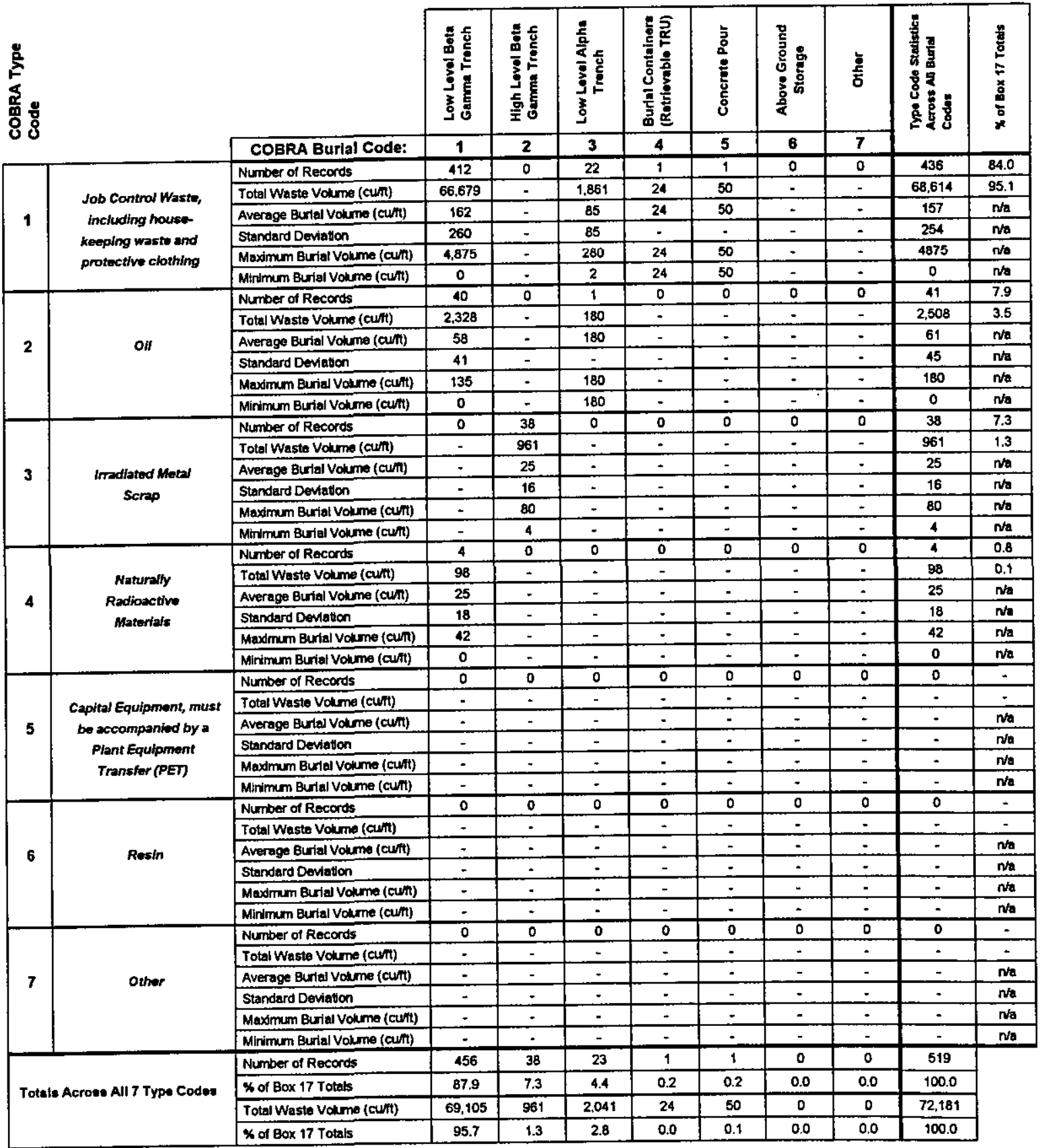


Table 3-43. Decay Forecast for COBRA Inventory for Potential "Hot Spot" HS-100-17

\begin{tabular}{|c|c|c|}
\hline Constituent of Interest & Totsl Activity (Cl) & Pereent of Total Activity \\
\hline \multicolumn{3}{|l|}{ At Time of Burial: } \\
\hline Carbon-14 & 0.00 & $0.0 \%$ \\
\hline Cobalt -60 & $1,667.77$ & $0.6 \%$ \\
\hline Cenium-137 & 210.74 & $0.1 \%$ \\
\hline Nepturtium-237 & 0.00 & $0.0 \%$ \\
\hline Plutonium-238 & 11.28 & $0.0 \%$ \\
\hline Plutonium-239 & 0.00 & $0.0 \%$ \\
\hline Strontium-90 & 197.72 & $0.1 \%$ \\
\hline Tochnetium-99 & 0.07 & $0.0 \%$ \\
\hline Tritium & $273,751.59$ & $99.2 \%$ \\
\hline Urenium-235 & 0.00 & $0.0 \%$ \\
\hline Uranium-238 & 0.00 & $0.0 \%$ \\
\hline TOTAL & $275,839.17$ & $100 \%$ \\
\hline \multicolumn{3}{|l|}{ At so Years efter Burial: } \\
\hline Carbon-14 & 0.00 & $0.0 \%$ \\
\hline Cobalt-60 & 2.33 & $0.0 \%$ \\
\hline Cenium- 137 & 66.41 & $0.4 \%$ \\
\hline Nepturium-237 & 0.00 & $0.0 \%$ \\
\hline Plutonium-238 & 7.59 & $0.0 \%$ \\
\hline Plutonium-239 & 0.00 & $0.0 \%$ \\
\hline Strontium-90 & 60.17 & $0.4 \%$ \\
\hline Technetium-99 & 0.07 & $0.0 \%$ \\
\hline Tritium & $16,370.34$ & $99.2 \%$ \\
\hline Unarium-23s & 0.00 & $0.0 \%$ \\
\hline Unnium-238 & $\stackrel{0.00}{\rightleftharpoons}$ & $0.0 \%$ \\
\hline TOTAL & $16,506.91$ & $100 \%$ \\
\hline \multicolumn{3}{|l|}{ At 100 Years anter Burial: } \\
\hline Carbon-14 & 0.00 & $0.0 \%$ \\
\hline Cobalt -60 & 0.00 & $0.0 \%$ \\
\hline Cexium-137 & 20.93 & $2.0 \%$ \\
\hline Neptrnium-237 & 0.00 & $0.0 \%$ \\
\hline Plutonium-238 & 5.11 & $0.5 \%$ \\
\hline Plutonium-239 & 0.00 & $0.0 \%$ \\
\hline Strontium-90 & 18.31 & $1.8 \%$ \\
\hline Tochnetium-99 & 0.07 & $0.0 \%$ \\
\hline Tritium & 985.51 & $95.7 \%$ \\
\hline Unanium-235 & 0.00 & $0.0 \%$ \\
\hline Unanium-238 & $\stackrel{0.00}{=}$ & $0.0 \%$ \\
\hline TOTAL & $1,029.91$ & $100 \%$ \\
\hline \multicolumn{3}{|l|}{ At 300 Yearn afer Burlal: } \\
\hline Carbon-14 & 0.00 & $0.0 \%$ \\
\hline Cobalt 60 & 0.00 & $0.0 \%$ \\
\hline Cesium-137 & 0.21 & $14.2 \%$ \\
\hline Neptunium-237 & 0.00 & $0.0 \%$ \\
\hline Plutonium-238 & 1.05 & $70.6 \%$ \\
\hline Plutaninu-239 & 0.00 & $0.0 \%$ \\
\hline Strontium-90 & 0.16 & $10.7 \%$ \\
\hline Technetium -99 & 0.07 & $4.5 \%$ \\
\hline Tritium & 0.00 & $0.0 \%$ \\
\hline Uranium-235 & 0.00 & $0.0 \%$ \\
\hline Unarixem-238 & 0.00 & $0.0 \%$ \\
\hline TOTAL & 1.48 & $100 \%$ \\
\hline \multicolumn{3}{|l|}{ At 500 Yoars after Burial: } \\
\hline Cerbon-14 & 0.00 & $0.0 \%$ \\
\hline Cobalt -60 & 0.00 & $0.0 \%$ \\
\hline Cenium-137 & 0.00 & $0.0 \%$ \\
\hline Neptoninum-237 & 0.00 & $0.0 \%$ \\
\hline Plutonium-238 & 0.21 & $76.4 \%$ \\
\hline Plutonicm-239 & 0.00 & $0.0 \%$ \\
\hline Strontium-90 & $0 . \infty$ & $0.0 \%$ \\
\hline Technotion-99 & 0.07 & $23.6 \%$ \\
\hline Tritium & 0.00 & $0.0 \%$ \\
\hline Uratium-23s & 0.00 & $0.0 \%$ \\
\hline Uranium-238 & 0.00 & $0.0 \%$ \\
\hline TOTAL & 0.28 & $100 x$ \\
\hline
\end{tabular}


Table 3-43. Decay Forecast for COBRA Inventory for Potential "Hot Spot" HS-100-17 (Continued)

\begin{tabular}{|c|c|c|}
\hline Constituent of Interest & Total Activity $(\mathrm{Cl})$ & Percent of Total Activity \\
\hline \multicolumn{3}{|l|}{ At 1,000 Years after Burial: } \\
\hline Curbon-14 & 0.00 & $0.0 \%$ \\
\hline Cobalt -60 & 0.00 & $0.0 \%$ \\
\hline Cerium-137 & 0.00 & $0.0 \%$ \\
\hline Nepturium-237 & 0.00 & $0.0 \%$ \\
\hline Plutonium-238 & 0.00 & $6.4 \%$ \\
\hline Plutonium-239 & 0.00 & $0.0 \%$ \\
\hline Strontivam-90 & 0.00 & $0.0 \%$ \\
\hline Technetium-99 & 0.07 & $93.6 \%$ \\
\hline Tritium & 0.00 & $0.0 \%$ \\
\hline Ununium-235 & 0.00 & $0.0 \%$ \\
\hline Unanium-238 & 0.00 & $0.0 \% 6$ \\
\hline TOTAL & 0.07 & $100 \%$ \\
\hline \multicolumn{3}{|l|}{ At 5,000 Years anter Burial: } \\
\hline Cerbon-14 & 0.00 & $0.0 \%$ \\
\hline Cobalt -60 & 0.00 & $0.0 \%$ \\
\hline Cetiom-137 & 0.00 & $0.0 \%$ \\
\hline Nepturium-237 & 0.00 & $0.0 \%$ \\
\hline Plutonium-238 & 0.00 & $0.0 \%$ \\
\hline Phutonium-239 & 0.00 & $0.0 \%$ \\
\hline Strontium-90 & 0.00 & $0.0 \%$ \\
\hline Technetium-99 & 0.07 & $100.0 \%$ \\
\hline Tritium & 0.00 & $0.0 \%$ \\
\hline Uranium-235 & 0.00 & $0.0 \%$ \\
\hline Uranium-238 & 0.00 & $0.0 \%$ \\
\hline TOTAL & 0.07 & $100 \%$ \\
\hline \multicolumn{3}{|l|}{ At 10,000 Yenrs after Buriat: } \\
\hline Carbon-14 & 0.00 & $0.0 \%$ \\
\hline Cobalt-60 & 0.00 & $0.0 \%$ \\
\hline Cetrium-137 & 0.00 & $0.0 \%$ \\
\hline Nepternium-237 & 0.00 & $0.0 \%$ \\
\hline Plutonium-238 & 0.00 & $0.0 \%$ \\
\hline Plutonium-239 & 0.00 & $0.0 \%$ \\
\hline Strontium-90 & 0.00 & $0.0 \%$ \\
\hline Technetium-99 & 0.06 & $100.0 \%$ \\
\hline Tritium & 0.00 & $0.0 \%$ \\
\hline Urenium-235 & 0.00 & $0.0 \%$ \\
\hline Unanium-238 & 0.00 & $0.0 \%$ \\
\hline TOTAL & 0.06 & $100 \%$ \\
\hline
\end{tabular}


Table 3-44. Summary Statistics for COBRA Inventory of Potential "Hot Spot" HS-100-18

\begin{tabular}{|c|c|c|c|c|c|c|c|c|c|c|c|}
\hline \multirow[t]{2}{*}{ 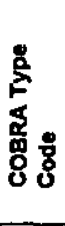 } & & & 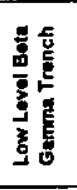 & 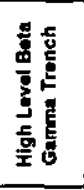 & 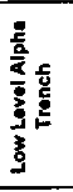 & 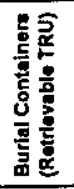 & 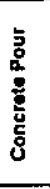 & 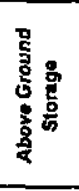 & $\frac{\mathbf{g}}{5}$ & 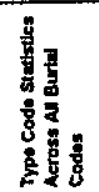 & 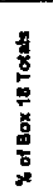 \\
\hline & & COBRA Burial Code: & 1 & 2 & 3 & 4 & 5 & 6 & 7 & & \\
\hline \multirow{6}{*}{1} & \multirow{6}{*}{$\begin{array}{l}\text { Job Control Waste, } \\
\text { including howst- } \\
\text { keeping wasto and } \\
\text { prorective clothing }\end{array}$} & Number of Records & 134 & 0 & 7 & 0 & 0 & 0 & 0 & 141 & 16.0 \\
\hline & & Total Wasto Volume (cunt) & 6.632 & - & 893 & - & - & - & - & 7,525 & 21.5 \\
\hline & & Average Burlal Volume (cumt) & 49 & 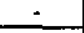 & 128 & - & - & - & - & 53 & na \\
\hline & & Standard Deviation & 152 & - & 120 & - & - & - & - & 151 & No. \\
\hline & & Maximum Burlal Volume (cu/t) & 1.500 & $=$ & 336 & $\therefore$ & - & - & - & 1500 & ne \\
\hline & & Minimum Burial Volume (cunt) & 1 & - & 14 & - & - & - & - & 1 & Na \\
\hline \multirow{6}{*}{2} & \multirow{6}{*}{ on } & Number of Records & 0 & 0 & 0 & 0 & 0 & 0 & 0 & 0 & $\cdot$ \\
\hline & & Total Waste Volume (cum) & $\cdot$ & - & - & - & - & - & - & - & - \\
\hline & & Averago Burlal Voume (cum) & - & 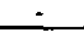 & - & $\therefore$ & - & - & + & $=$ & Na \\
\hline & & Standard Deviation & - & - & - & - & - & - & - & - & nhe \\
\hline & & Maximum Burlal Volume (culti) & - & $z$ & - & - & - & - & $\div$ & - & ne \\
\hline & & Minimum Burial Volume (cun) & - & $=$ & - & - & - & - & - & - & $\mathrm{Na}$ \\
\hline \multirow{6}{*}{3} & \multirow{6}{*}{$\begin{array}{l}\text { Irradiated Motal } \\
\text { Scrap }\end{array}$} & Number of Records & 0 & 730 & 0 & 0 & 0 & 0 & 0 & 730 & 82.9 \\
\hline & & Total Waste Volume (cu/t) & - & 26,123 & - & - & $\therefore$ & - & - & 26.123 & 74.5 \\
\hline & & Average Burlal Volume (avit) & - & 36 & - & + & - & - & $\therefore$ & 36 & nea \\
\hline & & Standard Deviation & - & 24 & - & $=$ & - & $\therefore$ & - & 24 & no \\
\hline & & Maximum Bural Vokne (cunt) & - & 240 & - & - & - & - & - & 240 & no \\
\hline & & Minimum Burial Volume (cum) & 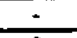 & 1 & $\therefore$ & $\therefore$ & - & - & - & 1 & n/a \\
\hline \multirow{6}{*}{4} & \multirow{6}{*}{$\begin{array}{l}\text { Naturalty } \\
\text { Ractlonctive } \\
\text { Matortals }\end{array}$} & Number of Records & 2 & 0 & 0 & 0 & 0 & 0 & 0 & 2 & 0.2 \\
\hline & & Total Wasto Volume (cu/t) & 300 & $\therefore$ & - & $\therefore$ & - & $\therefore$ & - & 300 & 0.9 \\
\hline & & Average Burlal Volume (cum) & 150 & $\therefore$ & ت & $\therefore$ & $=$ & $=$ & - & 150 & Non \\
\hline & & Standard Deviation & 0 & $\therefore$ & - & - & $\therefore$ & - & - & 0 & na \\
\hline & & Maximum Burlal Volume (cum) & 150 & $\therefore$ & $\therefore$ & - & $\therefore$ & - & + & 150 & no \\
\hline & & Minimum Burial Vokme (cunt) & 150 & $=$ & - & - & - & - & - & 150 & nia \\
\hline \multirow{6}{*}{5} & \multirow{6}{*}{$\begin{array}{l}\text { Capitel Equipment, must } \\
\text { be eccompanied by a } \\
\text { Plent Equipment } \\
\text { Transfur (PET) }\end{array}$} & Number of Reconds & 1 & 7 & 0 & 0 & 0 & 0 & 0 & 8 & 0.9 \\
\hline & & Total Waste Volume (cumt) & 960 & 146 & $\therefore$ & - & - & - & + & 1,106 & 3.2 \\
\hline & & Average Burlas Volume (aun) & 960 & 21 & - & - & - & - & - & 138 & Na \\
\hline & & Standard Deviation & - & 3 & - & - & - & - & - & 332 & ne \\
\hline & & Maximum Burlal Volume (culti) & 960 & 25 & - & + & - & - & - & 960 & na \\
\hline & & Minnimum Burtal Votume (cun) & 960 & 19 & $\sim$ & 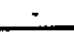 & - & - & - & 19 & $\mathrm{nas}$ \\
\hline \multirow{6}{*}{6} & \multirow{6}{*}{ Resin } & Number of Records & $\mathbf{0}$ & 0 & 0 & $\mathbf{0}$ & 0 & 0 & 0 & 0 & - \\
\hline & & Total Woste Volume (aum) & 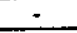 & $=$ & $\therefore$ & - & $\therefore$ & - & - & - & $\therefore$ \\
\hline & & Average Burlal Volume (cunt) & $\therefore$ & $=$ & $\therefore$ & - & - & $\cdot$ & $=$ & - & Nat \\
\hline & & Standard Deviatton & - & $=$ & - & - & $\therefore$ & + & - & - & now \\
\hline & & Maximum Burial Volume (cunt) & - & - & - & - & - & - & - & ت & $n / a$ \\
\hline & & Mirimum Burial Volume (culti) & - & - & - & - & - & - & - & - & Na \\
\hline \multirow{6}{*}{7} & \multirow{6}{*}{ Other } & Number of Rocords & 0 & 0 & 0 & 0 & 0 & 0 & 0 & 0 & - \\
\hline & & Total Waste Votume (cult) & - & $\therefore$ & - & - & $=$ & - & $=$ & - & - \\
\hline & & Average Burial Volume (cunti) & - & - & - & - & - & - & - & - & nhe \\
\hline & & Standard Devtation & - & - & - & - & - & - & - & - & no. \\
\hline & & Mwómum Burial Volume (aum) & $\therefore$ & - & - & - & - & - & - & - & $\mathrm{Na}$ \\
\hline & & Minimum Burial Volume (cunt) & - & $\therefore$ & - & - & - & - & - & - & na \\
\hline \multirow{4}{*}{\multicolumn{2}{|c|}{ Totals Across All 7 Type Codes }} & Number of Records & 137 & 737 & 7 & 0 & 0 & 0 & $\underline{0}$ & 881 & \\
\hline & & \% of Box 18 Totals & 15.6 & 83.7 & 0.8 & 0.0 & 0.0 & 0.0 & 0.0 & 100.0 & \\
\hline & & Total Waste Volume (cumt) & 7,892 & 26,269 & 893 & 0 & 0 & 0 & 0 & 35,054 & \\
\hline & & $\%$ of $B 0 \times 18$ Totals & 22.5 & 74.9 & 2.5 & 0.0 & 0.0 & 0.0 & 0.0 & 100.0 & \\
\hline
\end{tabular}


Table 3-45. Decay Forecast for COBRA Inventory for Potential "Hot Spot" HS-100-18

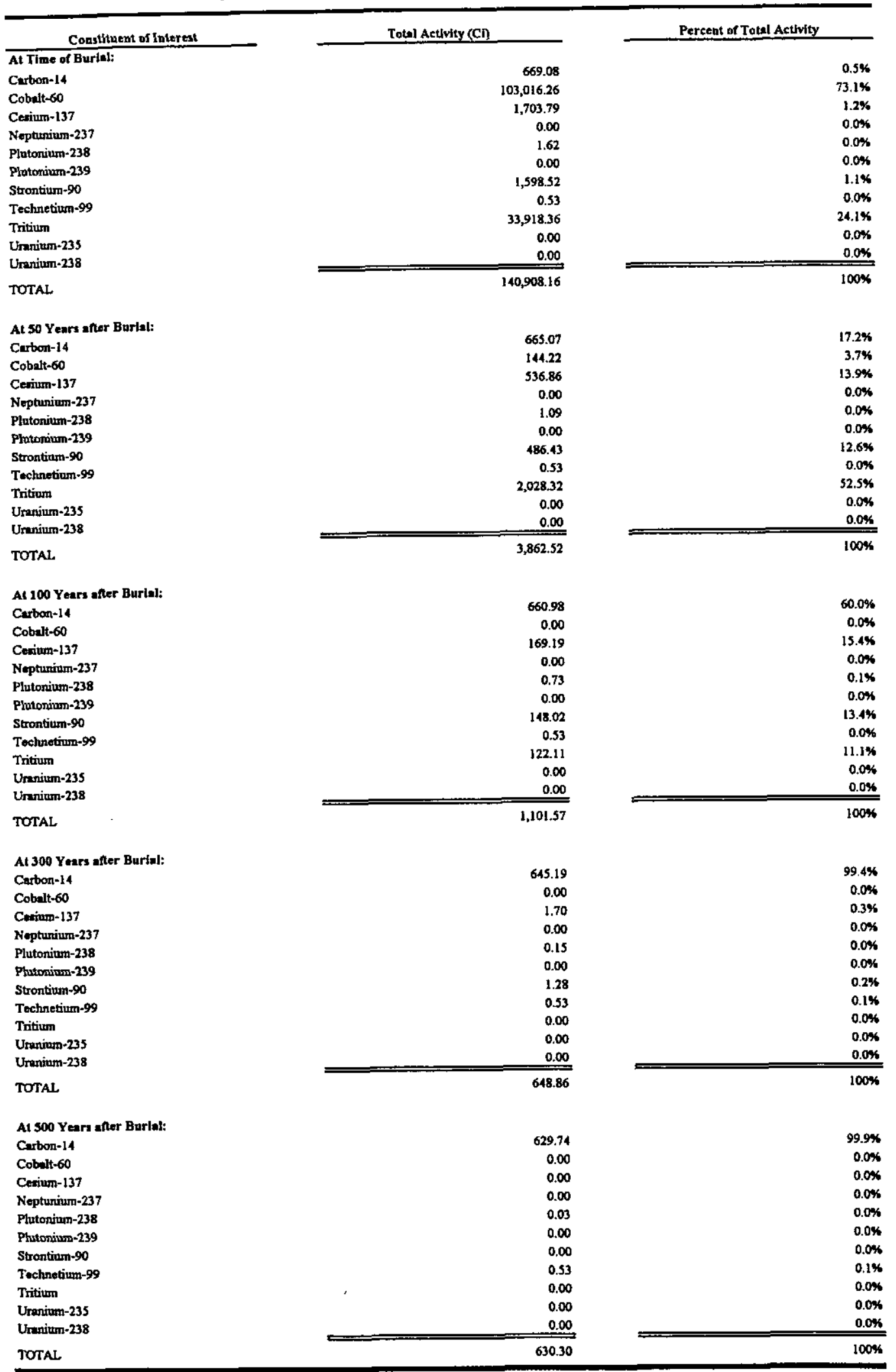


Table 3-45. Decay Forecast for COBRA Inventory for Potential "Hot Spot" HS-100-18 (Continued)

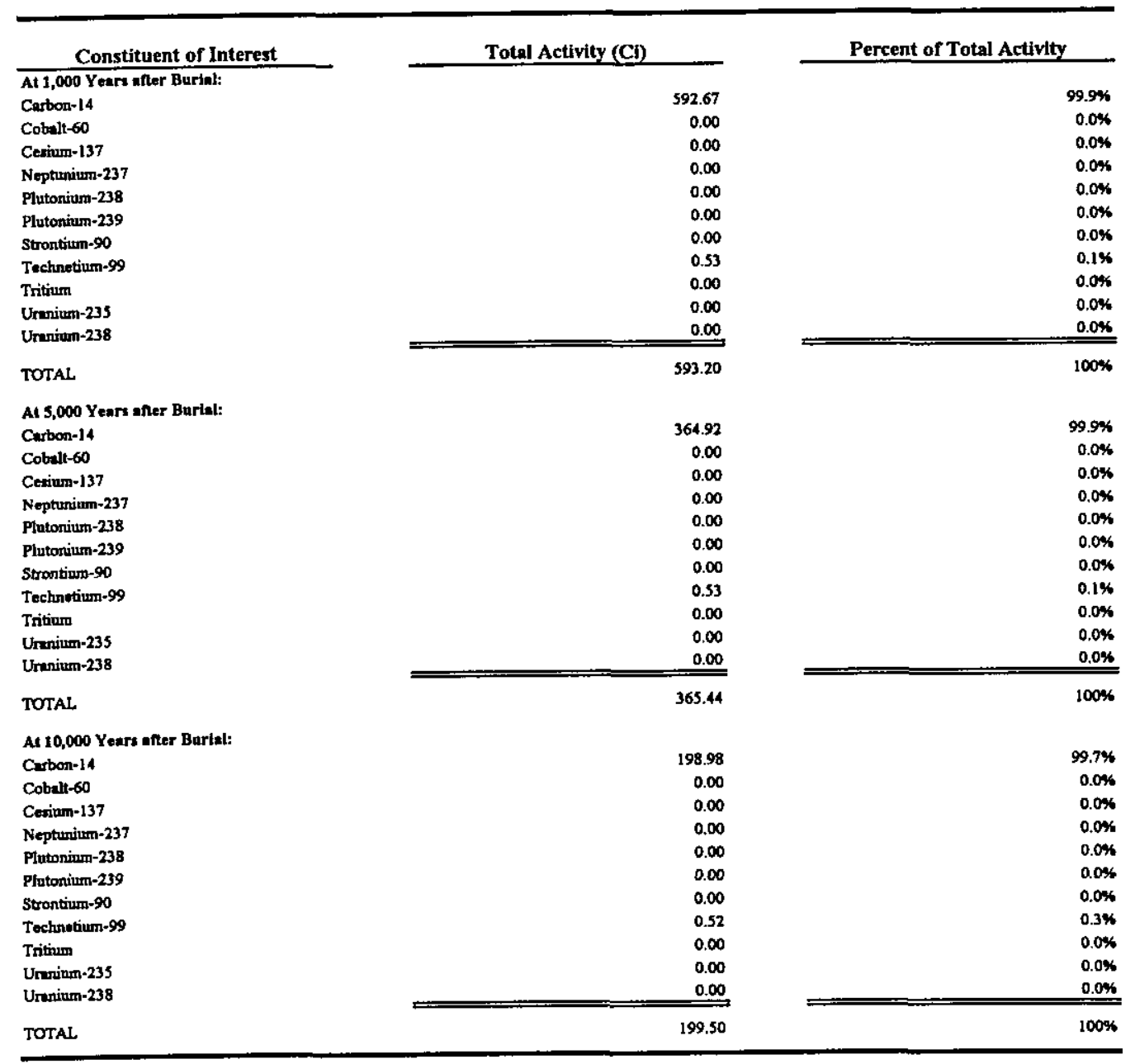


Table 3-46. Summary Statistics for COBRA Inventory of Potential "Hot Spot" HS-100-19

\begin{tabular}{|c|c|c|c|c|c|c|c|c|c|c|c|}
\hline \multirow{2}{*}{\multicolumn{2}{|c|}{$\frac{2}{2}$}} & & 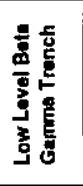 & 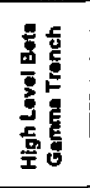 & 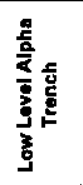 & 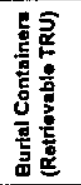 & 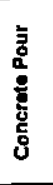 & 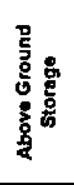 & $\frac{\mathbf{s}}{\delta}$ & 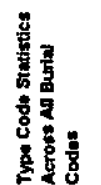 & 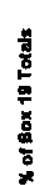 \\
\hline & & COBRA Burial Code: & 1 & 2 & 3 & 4 & 5 & 6 & 7 & & \\
\hline \multirow{6}{*}{1} & \multirow{6}{*}{$\begin{array}{l}\text { Job Control Waste, } \\
\text { including house- } \\
\text { keoping waste and } \\
\text { protective clothing }\end{array}$} & Number of Records & 712 & $t$ & 147 & 210 & 6 & 0 & 0 & 1.076 & 25.0 \\
\hline & & Total Waste Volume (cu/t) & 40.422 & 9 & 15,544 & 2,886 & 176 & - & - & 59,037 & 29.6 \\
\hline & & Averago Burial Volume (cuint) & 57 & 9 & 106 & 14 & 29 & - & - & 55 & n/a \\
\hline & & Standard Deviation & 109 & $\therefore$ & 186 & 7 & 25 & - & r & 115 & na \\
\hline & & Maximum Burial Volume (clutt) & 1,137 & 9 & 1,900 & 50 & 75 & $=$ & - & 1900 & no \\
\hline & & Minimum Burial Volume (cu/th) & 0 & 9 & 0 & 1 & 1 & - & - & 0 & nta \\
\hline \multirow{6}{*}{2} & \multirow{6}{*}{ Oll } & Number of Records & 5 & 0 & 0 & 0 & 0 & 0 & 0 & 5 & 0.1 \\
\hline & & Total Waste Volume (cultt) & 82 & $\therefore$ & - & - & + & - & $=$ & 82 & 0.0 \\
\hline & & Average Bunial Volume (culti) & 16 & - & - & - & - & - & $=$ & 16 & no \\
\hline & & Standard Deviation & 11 & $=$ & $\therefore$ & - & - & - & - & 11 & na \\
\hline & & Maxmum Burial Volume (cum) & 35 & - & - & $\therefore$ & - & - & - & 35 & no \\
\hline & & Minimun Burial Volumo (cuft) & 7 & - & - & $\therefore$ & $\therefore$ & - & - & 7 & rab \\
\hline \multirow{6}{*}{3} & \multirow{6}{*}{$\begin{array}{l}\text { Imadiated Whotal } \\
\text { Scrop }\end{array}$} & Number of Records & 0 & 3,107 & 1 & 2 & 0 & 0 & 0 & 3,110 & 72.3 \\
\hline & & Total Waste Volume (cunti) & $\therefore$ & 117,867 & 3 & 13 & - & - & - & 117,683 & 59.2 \\
\hline & & Average Burial Volume (culti) & - & 38 & 3 & 7 & - & - & 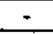 & 38 & no \\
\hline & & Standard Deviation & - & 57 & - & 8 & - & - & - & 57 & nta \\
\hline & & Maximum Burlel Volume (cult) & - & 1,200 & 3 & 12 & - & 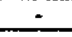 & - & 1200 & nta \\
\hline & & Minimum Burial Volume (cunn) & - & 0 & 3 & 1 & 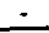 & - & - & 0 & na \\
\hline \multirow{6}{*}{4} & \multirow{6}{*}{$\begin{array}{l}\text { Naturalty } \\
\text { Radioactive } \\
\text { Marerials }\end{array}$} & Number of Records & 37 & 2 & 1 & 0 & $\underline{0}$ & 0 & 0 & 40 & 0.9 \\
\hline & & Total Waste Volume (cunt) & 3,855 & 9 & 150 & - & $=$ & - & - & 4,014 & 2.0 \\
\hline & & Average Burial Volume (ailli) & 104 & 5 & 150 & - & $=$ & $\approx$ & - & 100 & na \\
\hline & & Standard Deviation & 90 & 5 & - & + & $=$ & - & - & 90 & na \\
\hline & & Maximum Burial Volume (cint) & 250 & 8 & 150 & - & - & - & - & 250 & Na \\
\hline & & Minimum Burial Volume (cu/t) & 2 & 1 & 150 & - & - & 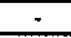 & - & 1 & $\mathrm{na}$ \\
\hline \multirow{6}{*}{5} & \multirow{6}{*}{$\begin{array}{l}\text { Capltal Equipment, must } \\
\text { bo accompaniled by a } \\
\text { Piam Equipment } \\
\text { Transfer (PEN) }\end{array}$} & Number of Records & 5 & 66 & 0 & 0 & 0 & 0 & 0 & 71 & 1.7 \\
\hline & & Total Waste Volume (curt) & 140 & 18.115 & - & $\therefore$ & - & - & $=$ & 18,255 & 9.2 \\
\hline & & Average Buriel Vohme (clin) & 28 & 274 & - & - & - & - & - & 257 & na \\
\hline & & Standard Deviation & 4 & 1,966 & - & - & $\therefore$ & - & - & 1895 & n/a \\
\hline & & Maximum Burial Volumo (avit) & 35 & 16,000 & - & - & + & - & - & 16000 & na \\
\hline & & Minimum Burial Volume (cuft) & 25 & 1 & - & $\cdot$ & $\therefore$ & $\therefore$ & - & 1 & $\mathrm{n} / \mathrm{a}$ \\
\hline \multirow{6}{*}{6} & \multirow{6}{*}{ Resin } & Number of Records & 0 & 0 & 0 & 0 & 0 & 0 & 0 & 0 & - \\
\hline & & Total Waste Volume (cult) & $=$ & $\therefore$ & - & $\therefore$ & $=$ & $=$ & $=$ & - & $\cdot$ \\
\hline & & Average Burtel Volume (cum) & - & - & - & - & $\div$ & $=$ & - & - & ne \\
\hline & & Standard Devation & - & 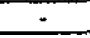 & - & 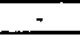 & - & - & - & $=$ & no \\
\hline & & Maximum Burial Volume (cuit) & - & $=$ & - & $=$ & 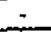 & 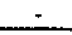 & $\therefore$ & - & no \\
\hline & & Minimum Burial Volumo (cunt) & - & - & - & - & - & - & - & - & no \\
\hline \multirow{6}{*}{7} & \multirow{6}{*}{ Other } & Number of Rocords & 0 & 0 & 0 & 0 & 0 & 0 & 0 & 0 & 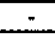 \\
\hline & & Total Waste Volume (CL/tt) & $\sim$ & - & - & $\therefore$ & - & - & - & $\therefore$ & $\therefore$ \\
\hline & & Average Burlal Volume (cu/t) & - & - & - & - & 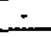 & $\therefore$ & - & $\therefore$ & $\mathrm{nta}$ \\
\hline & & Standard Deviation & - & - & - & $=$ & - & - & - & $\therefore$ & nia \\
\hline & & Maximum Burial Volume (cum) & $\therefore$ & $\therefore$ & - & - & $=$ & $=$ & - & - & $\mathbf{n a}$ \\
\hline & & Minimum Burial Volume (cu/t) & - & - & - & - & - & - & - & $=$ & na \\
\hline \multirow{4}{*}{\multicolumn{2}{|c|}{ Totals Acrosn All 7 Typa Coden }} & Number of Records & 759 & 3.176 & 149 & 212 & 6 & 0 & 0 & 4,302 & \\
\hline & & $\%$ of Box 19 Totals & 17.6 & 73.8 & 3.5 & 4.9 & 0.1 & 0.0 & 0.0 & 100.0 & \\
\hline & & Total Waste Volume (cult) & 44,499 & 136,000 & 15,697 & 2,899 & 176 & 0 & 0 & 199,271 & \\
\hline & & \% of Box 19 Totals & 22.3 & 68.2 & 7.9 & 1.5 & 0.1 & 0.0 & 0.0 & 100.0 & \\
\hline
\end{tabular}


Table 3-47. Decay Forecast for COBRA Inventory for Potential "Hot Spot" HS-100-19

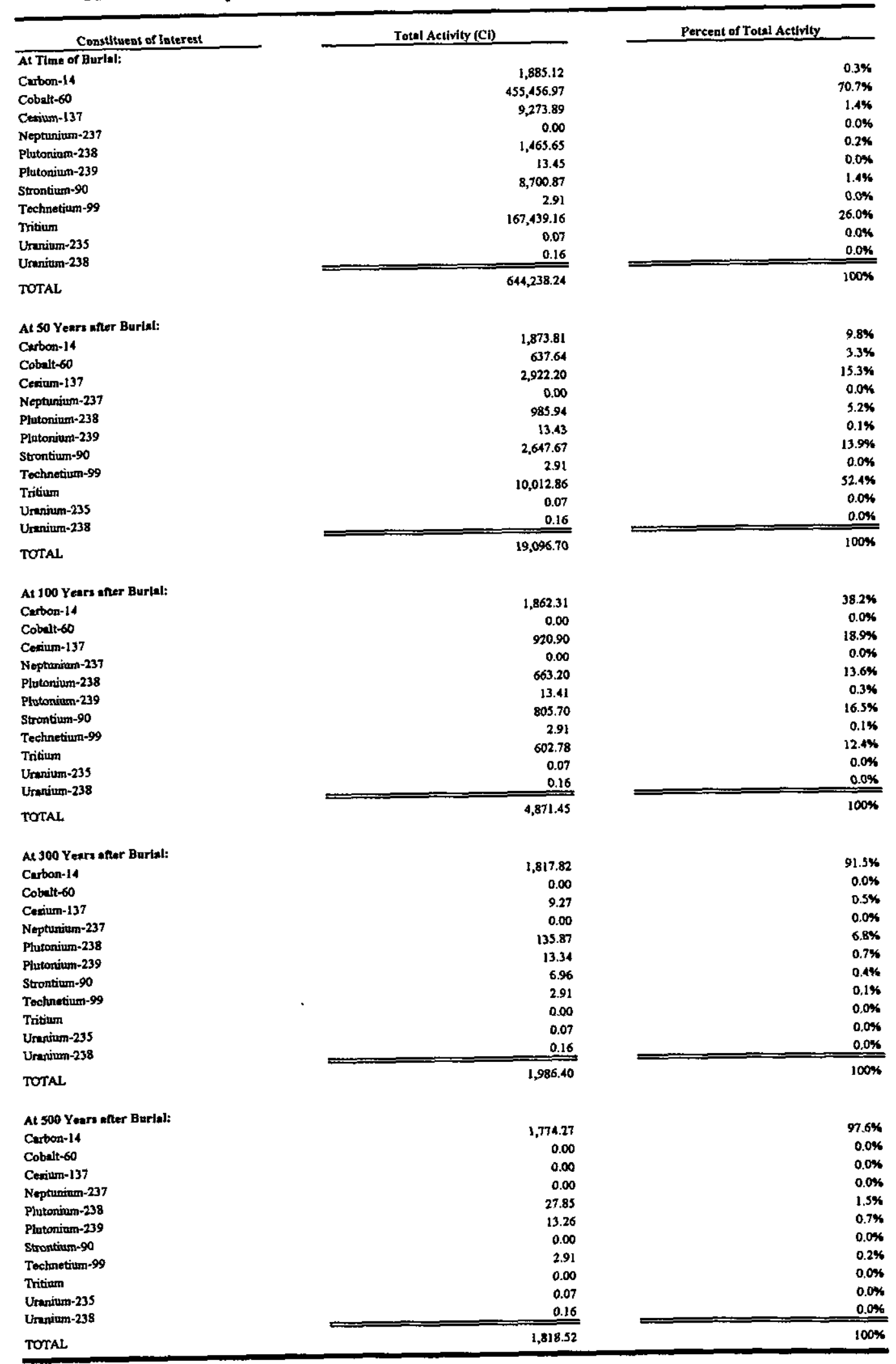


Table 3-47. Decay Forecast for COBRA Inventory for Potential "Hot Spot" HS-100-19 (Continued)

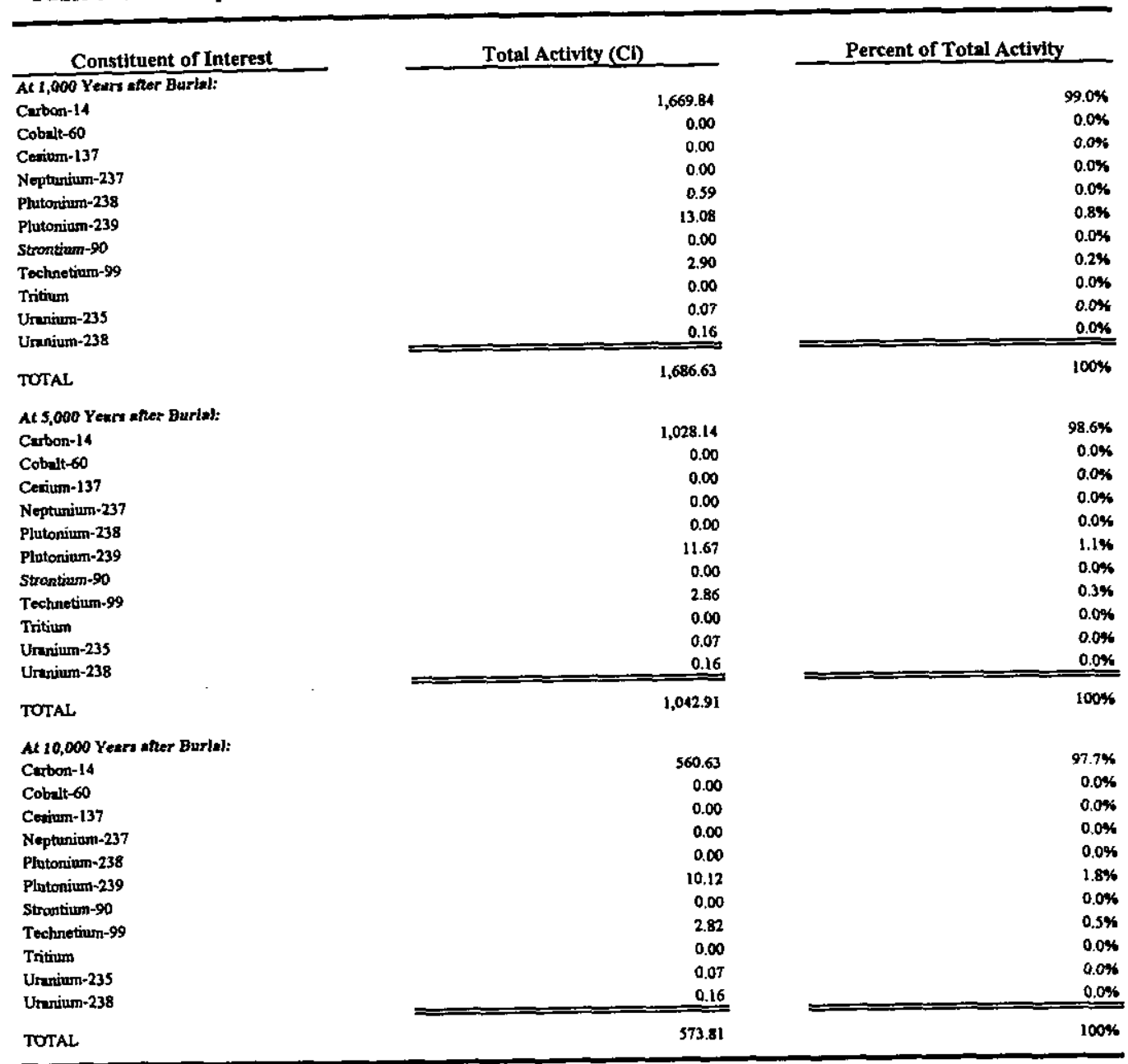


Table 3-48. Summary Statistics for COBRA Inventory of Potential "Hot Spot" HS-100-20

\begin{tabular}{|c|c|c|c|c|c|c|c|c|c|c|c|}
\hline \multirow[t]{2}{*}{ 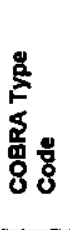 } & & & 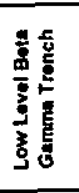 & 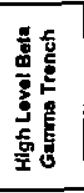 & 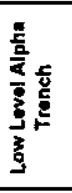 & 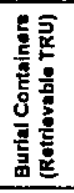 & 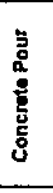 & 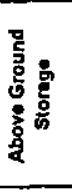 & $\frac{\bar{z}}{5}$ & 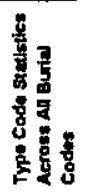 & 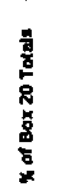 \\
\hline & & COBRA Burial Code: & 1 & 2 & 3 & 4 & 5 & 6 & 7 & & \\
\hline \multirow{6}{*}{1} & \multirow{6}{*}{$\begin{array}{l}\text { Job Control Waste, } \\
\text { including houss- } \\
\text { koeping wasto and } \\
\text { protective clothing }\end{array}$} & Number of Records & 60 & 0 & 0 & 0 & 0 & 0 & 0 & 60 & 9.7 \\
\hline & & Tatal Waste Votkrne (cum) & 2,700 & - & - & - & - & - & + & 2,700 & 15.8 \\
\hline & & Average Burial Volume (cumt) & 45 & - & - & - & $=$ & $\therefore$ & $\therefore$ & 45 & $\mathrm{nda}$ \\
\hline & & Standard Deviation & 96 & $\therefore$ & $=$ & $\therefore$ & $=$ & - & $\therefore$ & 96 & N/a \\
\hline & & Maximum Burial Volume (cunt) & 500 & $\therefore$ & $\therefore$ & - & - & $=$ & - & 500 & no \\
\hline & & Minimum Eurial Volume (cum) & 2 & $\cdot$ & $\therefore$ & - & $=$ & - & - & 2 & ne \\
\hline \multirow{6}{*}{2} & \multirow{6}{*}{ Oll } & Number of Reconds & 1 & 0 & 0 & 0 & 0 & 0 & 0 & 1 & 0.2 \\
\hline & & Total Waste Volume (cuit) & 19 & + & - & $\therefore$ & $\because$ & $\therefore$ & $=$ & 19 & 0.1 \\
\hline & & Average Burial Volume (cum) & 19 & - & - & - & - & - & $\therefore$ & 19 & $\mathrm{~N} / \mathrm{a}$ \\
\hline & & Standard Devation & $=$ & $\therefore$ & - & $\cdot$ & - & $=$ & $=$ & - & $\mathrm{Nat}$ \\
\hline & & Maximum Burial Volume (cu/t) & 19 & - & ست & - & - & $=$ & $\therefore$ & 19 & Na \\
\hline & & Minimum Burlal Volume (cum) & 19 & - & $\therefore$ & - & - & - & - & 19 & $\mathrm{na}$ \\
\hline \multirow{6}{*}{3} & \multirow{6}{*}{$\begin{array}{l}\text { Irradiatod Motal } \\
\text { scrap }\end{array}$} & Number of Records & D & 558 & 0 & 0 & 0 & 0 & 0 & 558 & 90.0 \\
\hline & & Total Waste Voumne (cum) & - & 14,361 & - & - & $=$ & - & $=$ & 14,361 & 840 \\
\hline & & Average Burtel Volume (aunt) & - & 26 & - & $\therefore$ & - & - & $\therefore$ & 26 & n/a \\
\hline & & Standard Deviation & - & 15 & - & $\therefore$ & $\therefore$ & $=$ & - & 15 & Na \\
\hline & & Maximum Burial Volume (cult) & $\dot{-}$ & 120 & - & $\therefore$ & - & $=$ & - & 120 & ne \\
\hline & & Mirimum Burial Volume (cultit) & - & 0 & - & - & - & - & - & 0 & nda \\
\hline \multirow{6}{*}{4} & \multirow{6}{*}{$\begin{array}{l}\text { Naturally } \\
\text { Radloactive } \\
\text { Matertals }\end{array}$} & Number of Records & 1 & 0 & 0 & 0 & 0 & 0 & $\underline{0}$ & 1 & 0.2 \\
\hline & & Total Waste Volume (cumt) & 9 & - & - & $\cdot$ & $\therefore$ & $=$ & $\therefore$ & 9 & 0.1 \\
\hline & & Average Burlal Volume (antt) & 9 & $\therefore$ & - & ت & - & - & $=$ & 9 & $\mathrm{na}$ \\
\hline & & Standard Deviation & - & - & $=$ & $\therefore$ & - & - & $=$ & - & núa \\
\hline & & Maximum Burial Vohme (autt) & 9 & - & $=$ & - & $\dot{-}$ & $=$ & - & 9 & $\mathrm{nh}$ \\
\hline & & Minimum Burial Voume (aunt) & 9 & $\therefore$ & - & - & - & - & - & 9 & $\mathrm{Na}$ \\
\hline \multirow{6}{*}{$\mathbf{5}$} & \multirow{6}{*}{$\begin{array}{l}\text { Capltal Equipment, must } \\
\text { bo accompanied by a } \\
\text { Plamt Equipment } \\
\text { Transfer (PET) }\end{array}$} & Number of Rocords & 0 & 0 & 0 & 0 & 0 & 0 & $\mathbf{0}$ & 0 & - \\
\hline & & Total Waste Volume (curt) & $\approx$ & 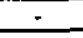 & - & - & - & $=$ & $=$ & - & - \\
\hline & & Averoge Burial Volume (cum) & - & $\therefore$ & - & - & - & $=$ & - & $\therefore$ & $\mathrm{na}$ \\
\hline & & Standard Deviation & 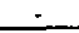 & - & $\therefore$ & $\therefore$ & $\therefore$ & $=$ & - & - & nta \\
\hline & & Maximum Burlal Volume (cunt) & $=$ & - & - & - & 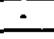 & ت & - & - & $\mathrm{Nha}$ \\
\hline & & Minimum Burial Volume (cunt) & - & - & - & - & - & $=$ & - & - & na \\
\hline \multirow{6}{*}{6} & \multirow{6}{*}{ Recin } & Number of Records & 0 & 0 & 0 & 0 & 0 & $\underline{0}$ & 0 & 0 & - \\
\hline & & Total Weste Volurne (curt) & - & - & - & $\therefore$ & - & - & - & $=$ & - \\
\hline & & Averege Burial Volume (cum) & $亡$ & $\dot{5}$ & $\therefore$ & - & $\therefore$ & - & $\therefore$ & $=$ & $\mathbf{n a}$ \\
\hline & & Standard Deviation & - & - & - & - & - & $=$ & $\therefore$ & $\therefore$ & $\mathrm{N} / \mathrm{a}$ \\
\hline & & Maximam Burlel Volume (curti) & $=$ & - & - & - & - & $=$ & - & $\therefore$ & no \\
\hline & & Minimum Burial Volume (curts) & - & 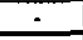 & - & 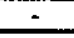 & - & - & - & - & $\mathbf{n h}$ \\
\hline \multirow{6}{*}{7} & \multirow{6}{*}{ other } & Number of Records & 0 & 0 & 0 & 0 & 0 & 0 & 0 & 0 & - \\
\hline & & Total Weste Volume (aum) & - & $=$ & - & - & - & $=$ & - & - & $=$ \\
\hline & & Average Burial Volume (cum) & $=$ & $=$ & + & - & - & $=$ & - & $\therefore$ & $\mathrm{n} / \mathrm{a}$ \\
\hline & & Standard Deviation & $=$ & - & $\therefore$ & $\div$ & - & $=$ & - & - & nta \\
\hline & & Moximum Buriel Vokme (autt) & $=$ & - & - & 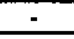 & + & $=$ & - & - & na \\
\hline & & Minimum Burial Volume (cult) & - & $=$ & - & - & - & - & $=$ & - & no \\
\hline \multirow{4}{*}{\multicolumn{2}{|c|}{ Totale Acrons All 7 Type Codon }} & Number of Records & 62 & 558 & 0 & 0 & 0 & 0 & 0 & 620 & \\
\hline & & $\%$ of Box 20 Totals & 10.0 & 90.0 & 0.0 & 0.0 & 0.0 & 0.0 & 0.0 & 100.0 & \\
\hline & & Total Waste Volume (aunt) & 2,728 & 14,361 & 0 & 0 & 0 & 0 & 0 & 17,089 & \\
\hline & & $\%$ of Box 20 Totals & 16.0 & 84.0 & 0.0 & 0.0 & 0.0 & 0.0 & 0.0 & 100.0 & \\
\hline
\end{tabular}


Table 3-49. Decay Forecast for COBRA Inventory for Potential "Hot Spot" HS-100-20

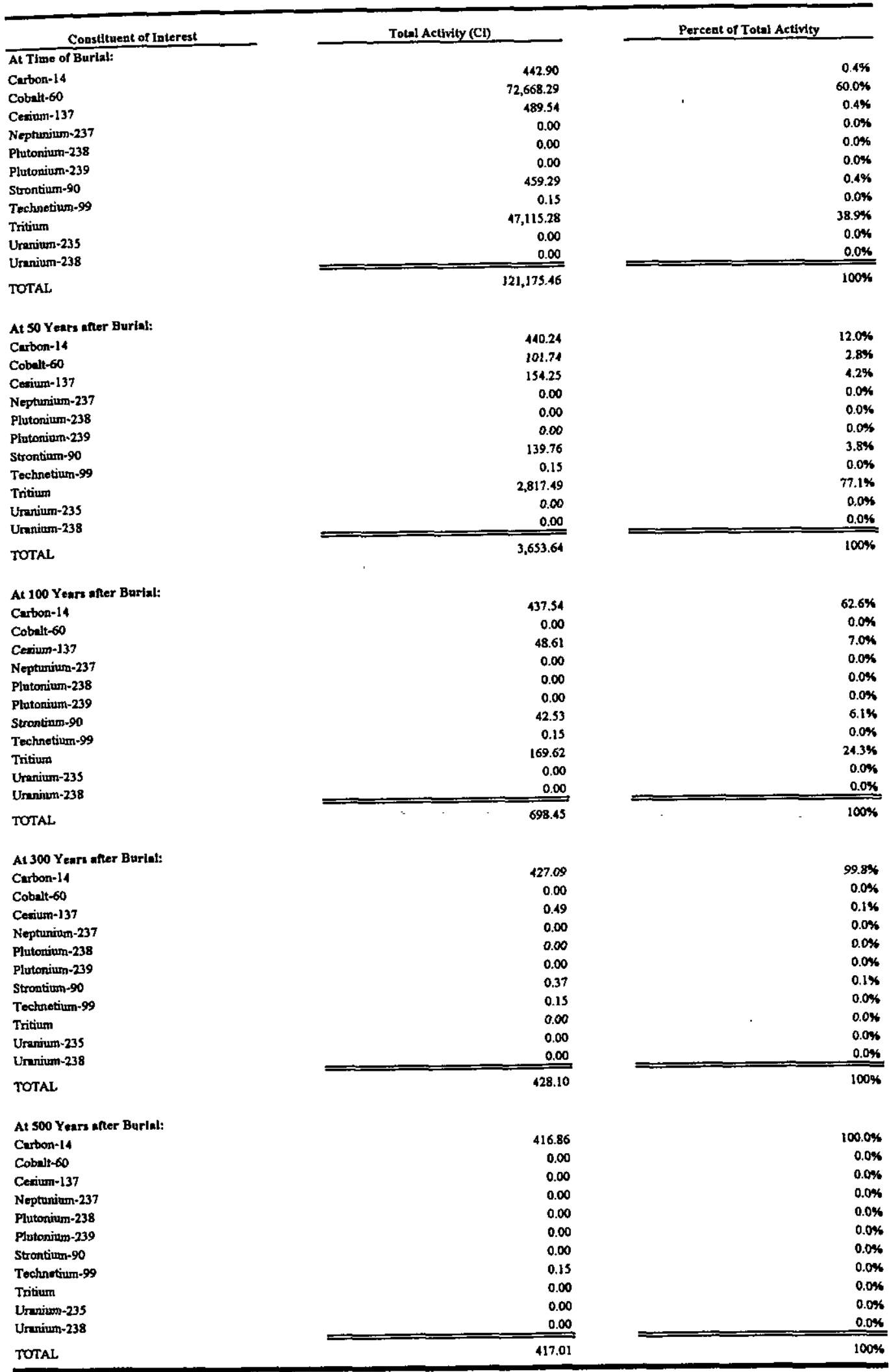


Table 3-49. Decay Forecast for COBRA Inventory for Potential "Hot Spot" HS-100-20 (Continued)

\begin{tabular}{|c|c|c|}
\hline Constituent of Interest & Total Activity (Ci) & Percent of Total Activity \\
\hline \multicolumn{3}{|l|}{ Al 1,000 Years after Burial: } \\
\hline Cerbon-14 & 392.32 & $100.0 \%$ \\
\hline Cobult- 60 & 0.00 & $0.0 \%$ \\
\hline Cenium-137 & 0.00 & $0.0 \%$ \\
\hline Nepturnium-237 & 0.00 & $0.0 \%$ \\
\hline Plutonium-238 & 0.00 & $0.0 \%$ \\
\hline Plutanium-239 & 0.00 & $0.0 \%$ \\
\hline Strontium-90 & 0.00 & $0.0 \%$ \\
\hline Technotium-99 & 0.15 & $0.0 \%$ \\
\hline Tritium & 0.00 & $0.0 \%$ \\
\hline Unanium-235 & 0.00 & $0.0 \%$ \\
\hline Uranium-238 & $\stackrel{0.00}{=}$ & $0.0 \%$ \\
\hline TOTAL & 392.47 & $100 \%$ \\
\hline \multicolumn{3}{|l|}{ At 5,000 Yearn after Burial: } \\
\hline Cerbon-14 & 241.36 & $99.9 \%$ \\
\hline Cobalt-60 & 0.00 & $0.0 \%$ \\
\hline Cesium-137 & 0.00 & $0.0 \%$ \\
\hline Nepturium-237 & 0.00 & $0.0 \%$ \\
\hline Plotonium-238 & 0.00 & $0.0 \%$ \\
\hline Ptutonium-239 & 0.00 & $0.0 \%$ \\
\hline Strontium-90 & 0.00 & $0.0 \%$ \\
\hline Technetion-99 & 0.15 & $0.1 \%$ \\
\hline Tritium & 0.00 & $0.0 \% 6$ \\
\hline Urarium-235 & 0.00 & $0.0 \%$ \\
\hline Unurium-238 & 0.00 & $0.0 \%$ \\
\hline TOTAL. & 241.71 & $100 \%$ \\
\hline \multicolumn{3}{|l|}{ At 10,000 Years after Burtal: } \\
\hline Carbon-14 & 131.72 & $99.9 \%$ \\
\hline Cobalt-60 & 0.00 & $0.0 \%$ \\
\hline Cenium-137 & 0.00 & $0.0 \%$ \\
\hline Neptuniurm-237 & 0.00 & $0.0 \%$ \\
\hline Plutoniurn-238 & 0.00 & $0.0 \% 6$ \\
\hline Plutonium-239 & 0.00 & $0.0 \%$ \\
\hline Strontium-90 & 0.00 & $0.0 \%$ \\
\hline Technetium-99 & 0.15 & $0.1 \%$ \\
\hline Tritium & 0.00 & $0.0 \%$ \\
\hline Unanium-235 & 0.00 & $0.0 \%$ \\
\hline Unarium-238 & $\stackrel{0.00}{=}$ & $0.0 \%$ \\
\hline TOTAL. & 131.87 & $100 \%$ \\
\hline
\end{tabular}


Table 3-50. Summary Statistics for COBRA Inventory of Potential "Hot Spot" HS-100-21

\begin{tabular}{|c|c|c|c|c|c|c|c|c|c|c|c|}
\hline \multirow[t]{2}{*}{$\begin{array}{l}8 \\
8 \\
8 \\
8\end{array}$} & & & 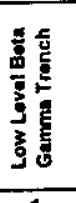 & 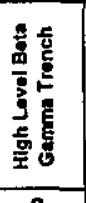 & 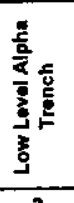 & 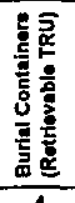 & 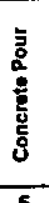 & $\begin{array}{l}\text { ㅁ } \\
5 \\
0 \\
0 \\
0 \\
8 \\
8 \\
8 \\
8\end{array}$ & $\frac{\hbar}{5}$ & 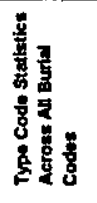 & 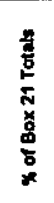 \\
\hline & & COBRA Burial Code: & 1 & 2 & 3 & 4 & 5 & 6 & 7 & & \\
\hline \multirow{6}{*}{1} & \multirow{6}{*}{$\begin{array}{l}\text { Jab Control Waste, } \\
\text { Including house- } \\
\text { keeping waste and } \\
\text { profective clothing }\end{array}$} & Number of Records & 54 & 0 & 5 & 0 & 0 & 0 & 0 & 59 & 7.7 \\
\hline & & Total Waste Volume (cu/t) & 1,926 & - & 116 & $\cdot$ & - & - & - & 2,042 & 9.5 \\
\hline & & Average Burial Volume (cult) & 36 & - & 23 & $=$ & + & - & - & 35 & $n / a$ \\
\hline & & Standard Devistion & 45 & - & 24 & - & $\therefore$ & - & - & 43 & na \\
\hline & & Maximum Burial Voume (cult) & 220 & - & 64 & - & - & - & - & 220 & na \\
\hline & & Minimum Burial Volume (cLfif) & 2 & - & 2 & $\dot{r}$ & - & - & $\therefore$ & 2 & N/a \\
\hline \multirow{6}{*}{2} & \multirow{6}{*}{ oll } & Number of Records & 1 & 0 & 0 & 0 & 0 & 0 & 0 & 1 & 0.1 \\
\hline & & Total Waste Volume (cum) & 34 & - & - & - & 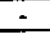 & - & - & 34 & 0.2 \\
\hline & & Averege Burlal Volume (cuft) & 34 & $=$ & - & - & - & - & - & 34 & $\mathrm{n} / \mathrm{a}$ \\
\hline & & Standerd Doviation & - & - & - & $=$ & - & 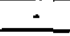 & - & $\therefore$ & No \\
\hline & & Maximum Burial Volume (cu/t) & 34 & - & - & - & - & - & $=$ & 34 & n/o \\
\hline & & Mirimum Burial Volume (curti) & 34 & - & - & - & - & - & - & 34 & $\mathrm{ne}$ \\
\hline \multirow{6}{*}{3} & \multirow{6}{*}{$\begin{array}{l}\text { Irradiated Mete! } \\
\text { Scrap }\end{array}$} & Number of Records & 0 & 706 & D & 0 & 0 & 0 & 0 & 706 & 92.0 \\
\hline & & Total Waste Votume (aim) & - & 19,295 & - & - & - & $=$ & $\therefore$ & 19,295 & 90.1 \\
\hline & & Average Burlal Volume (cunt) & $=$ & 27 & - & - & - & - & - & 27 & nia \\
\hline & & Standard Deviation & - & 17 & 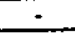 & - & $\therefore$ & $\therefore$ & $\therefore$ & 17 & ne \\
\hline & & Maximum Burlal Volume (cuin) & $=$ & 130 & - & - & - & $=$ & $=$ & 130 & $\mathrm{n} / \mathrm{e}$ \\
\hline & & Mintmum Burial Volume (cunt) & - & 0 & - & - & $=$ & $\therefore$ & 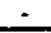 & 0 & no \\
\hline \multirow{6}{*}{4} & \multirow{6}{*}{$\begin{array}{l}\text { Naturally } \\
\text { Radiaactive } \\
\text { Maturials }\end{array}$} & Number of Records & 0 & 0 & 0 & 0 & 0 & $\underline{0}$ & 0 & o & - \\
\hline & & Total Waste Volume (cu/t) & - & - & 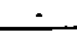 & $\therefore$ & - & - & ت & $=$ & $\cdot$ \\
\hline & & Average Burial Volume (cum) & - & - & - & $\therefore$ & - & $\therefore$ & - & $\therefore$ & nfa \\
\hline & & Standard Deviation & - & $\cdot$ & 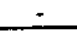 & - & $\cdot$ & $\therefore$ & $\therefore$ & $=$ & Na \\
\hline & & Maximum Burlal Volume (cum) & - & - & $\therefore$ & $=$ & $\therefore$ & - & $\therefore$ & $\approx$ & n/a \\
\hline & & Minimum Burial Volume (cu/n) & $\therefore$ & - & - & $=$ & $=$ & $\therefore$ & - & $=$ & na \\
\hline \multirow{6}{*}{5} & \multirow{6}{*}{$\begin{array}{l}\text { Capital Equipment, must } \\
\text { be accomponiod by a } \\
\text { Plant Equipment } \\
\text { Transfer (PET) }\end{array}$} & Number of Records & 0 & 1 & 0 & 0 & 0 & $\underline{0}$ & 0 & 1 & 0.1 \\
\hline & & Total Waste Volume (cu/t) & - & 35 & $\therefore$ & - & - & - & - & 35 & 0.2 \\
\hline & & Averege Burial Volume (cufit) & - & 35 & - & + & - & $\therefore$ & - & 35 & na \\
\hline & & Standard Deviation & - & - & - & $=$ & - & - & $\therefore$ & $=$ & $\mathrm{nta}$ \\
\hline & & Maxdmum Burial Volume (cunt) & - & 35 & $ت$ & $\therefore$ & - & $\therefore$ & $\cdot$ & 35 & no \\
\hline & & Minlmum Burlal Volume (cumt) & - & 35 & - & - & - & - & - & 35 & na \\
\hline \multirow{6}{*}{6} & \multirow{6}{*}{ Resh } & Number of Records & $\mathbf{0}$ & 0 & 0 & 0 & 0 & 0 & 0 & 0 & - \\
\hline & & Total Waste Volume (cwit) & - & - & $=$ & - & $\therefore$ & $=$ & - & $\therefore$ & $=$ \\
\hline & & Average Burial Volume (anm) & - & - & + & $\approx$ & $\cdot$ & $\therefore$ & - & $=$ & ne \\
\hline & & Standard Devlation & - & $=$ & - & $=$ & - & - & - & $=$ & na \\
\hline & & Maximum Burial Volume (cunt) & - & $\therefore$ & - & $=$ & $\therefore$ & $=$ & - & $\therefore$ & ros \\
\hline & & Minlmum Burial Volume (cum) & $\therefore$ & $=$ & - & $\approx$ & - & $=$ & $\cdot$ & $\therefore$ & na \\
\hline \multirow{6}{*}{7} & \multirow{6}{*}{ Other } & Number of Rocords & 0 & 0 & 0 & 0 & 0 & 0 & 0 & 0 & $\dot{5}$ \\
\hline & & Total Waste Vollme (curt) & - & 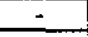 & - & - & 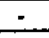 & $=$ & $=$ & $\therefore$ & - \\
\hline & & Averege Burial Volume (cum) & - & - & - & $=$ & - & - & - & - & no \\
\hline & & Stardard Deviation & - & $\therefore$ & - & $=$ & - & $=$ & - & - & Ne \\
\hline & & Maximum Burial Volume (cunt) & - & $=$ & $\therefore$ & - & $\cdot$ & $=$ & 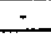 & $\therefore$ & $\mathrm{rat}$ \\
\hline & & Minlmum Burial Volumo (cum) & 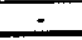 & $=$ & $\overline{-}$ & $=$ & - & $\therefore$ & - & $\therefore$ & $\mathrm{na}$ \\
\hline \multirow{4}{*}{\multicolumn{2}{|c|}{ Totale Acroes: All 7 Type Coden }} & Number of Records & 55 & 707 & 5 & 0 & 0 & 0 & 0 & 767 & \\
\hline & & $\%$ of Box 21 Totals & 7.2 & 92.2 & 0.7 & 0.0 & 0.0 & 0.0 & 0.0 & 100.0 & \\
\hline & & Total Waste Volume (cu/t) & 1,960 & 19.330 & 116 & 0 & 0 & 0 & 0 & 21.406 & \\
\hline & & \% of Box 21 Totals & 9.2 & 90.3 & 0.5 & 0.0 & 0.0 & 0.0 & 0.0 & 100.0 & \\
\hline
\end{tabular}


Table 3-51. Decay Forecast for COBRA Inventory for Potential "Hot Spot" HS-100-21

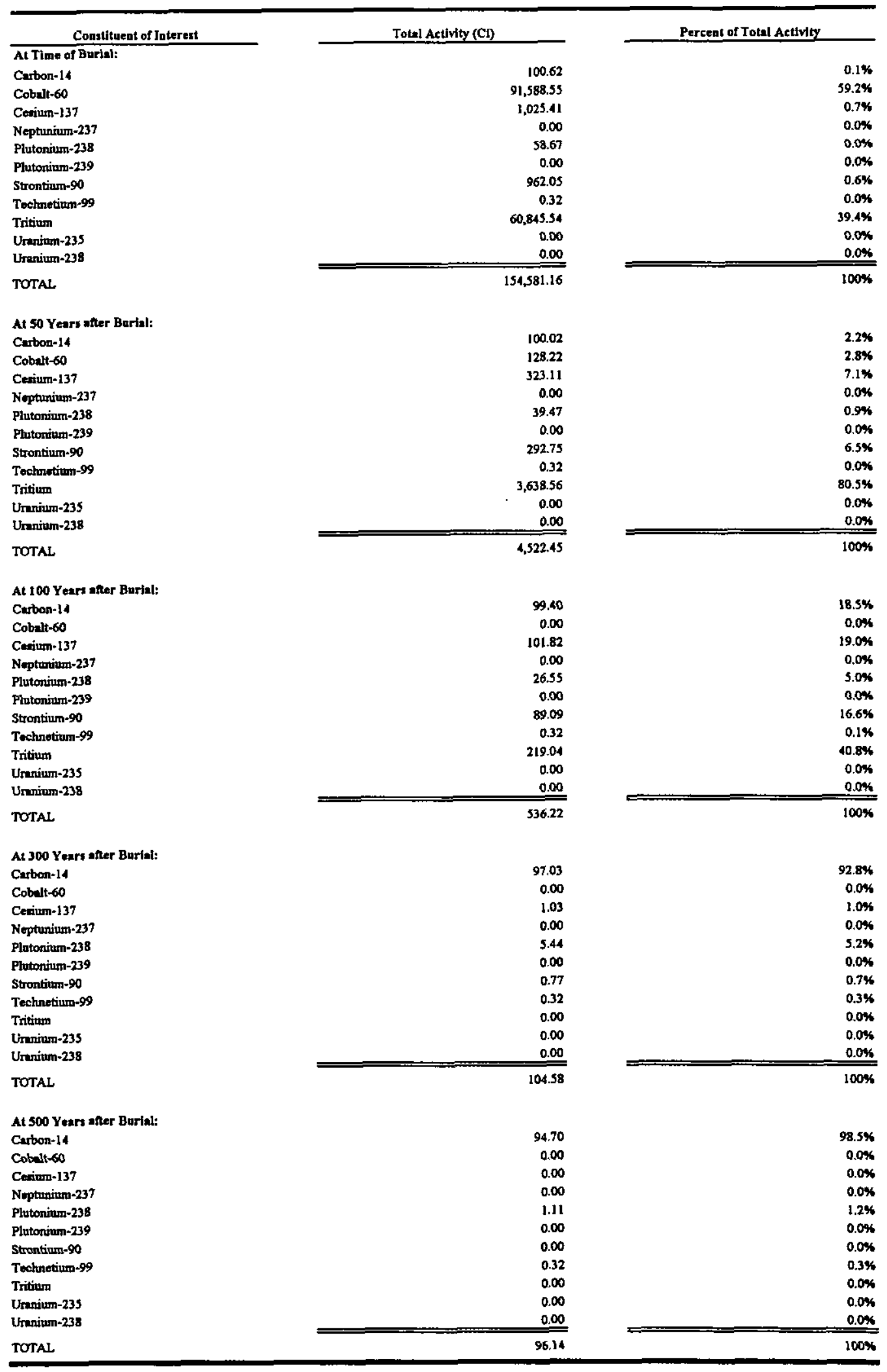


Table 3-51. Decay Forecast for COBRA Inventory for Potential "Hot Spot" HS-100-21 (Continued)

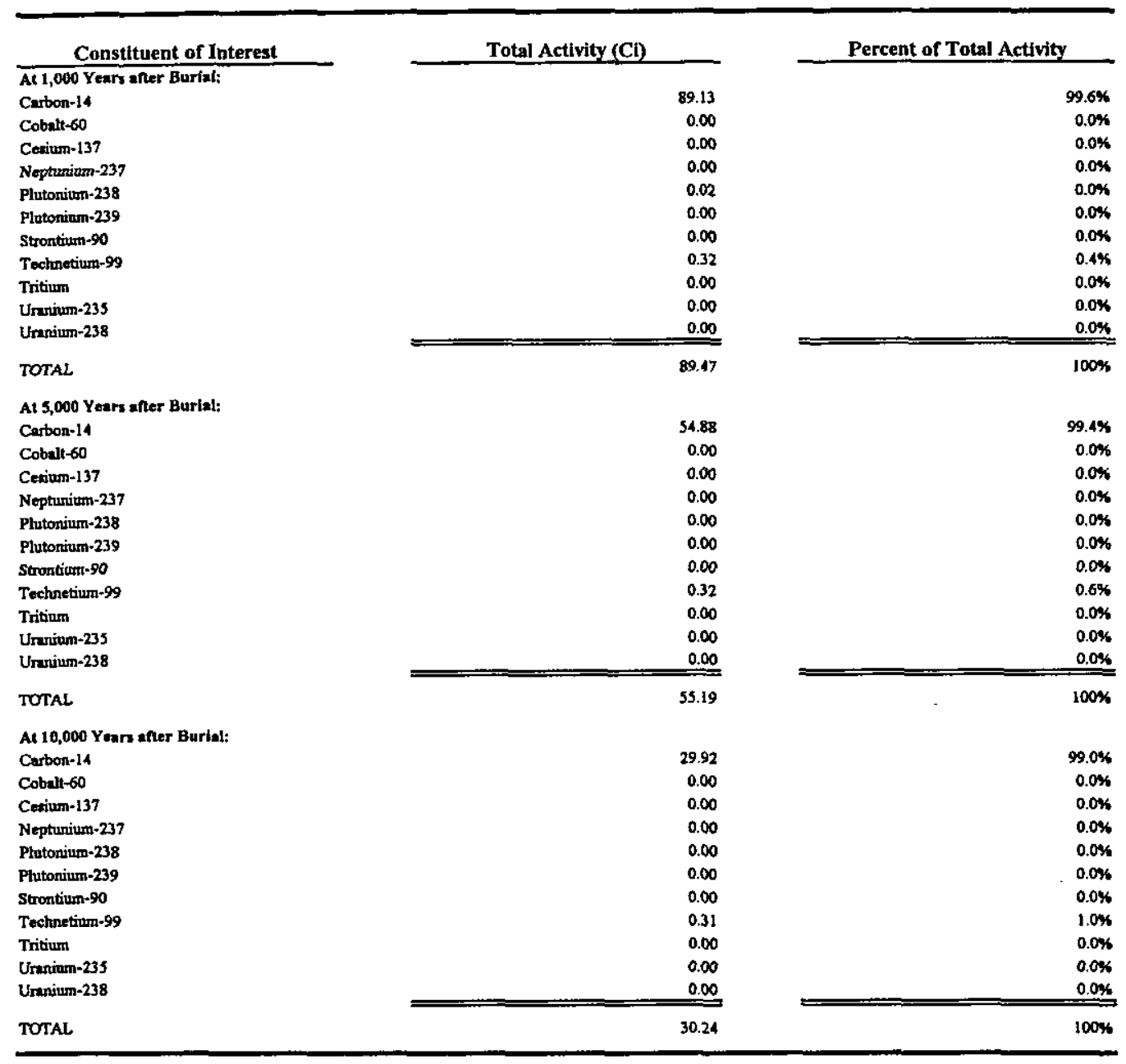


Table 3-52. Summary Statistics for COBRA Inventory of Potential "Hot Spots" HS-300-1

\begin{tabular}{|c|c|c|c|c|c|c|c|c|c|c|c|}
\hline \multirow{2}{*}{\multicolumn{2}{|c|}{$\begin{array}{l}\frac{8}{2} \\
\frac{1}{8} \\
8\end{array}$}} & & 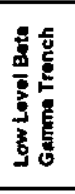 & 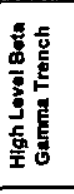 & 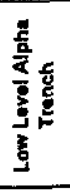 & 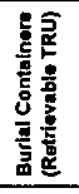 & 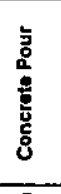 & 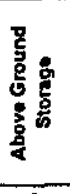 & 衰 & 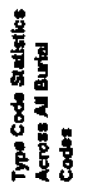 & 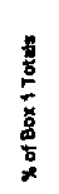 \\
\hline & & COBRA Burial Code: & 1 & 2 & 3 & 4 & 5 & 6 & 7 & & \\
\hline \multirow{6}{*}{1} & \multirow{6}{*}{$\begin{array}{l}\text { Job Control Waste, } \\
\text { Including house- } \\
\text { keeping waste and } \\
\text { protictive clothing }\end{array}$} & Number of Records & 7 & 0 & 8 & 724 & 5 & 0 & 0 & 744 & 98.7 \\
\hline & & Total Waste Volume (curt) & 511 & - & 513 & 9,052 & 235 & - & - & 10.311 & 56.2 \\
\hline & & Average Burlel Volume (culti) & 73 & 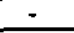 & 64 & 13 & 47 & - & - & 14 & nia \\
\hline & & Standard Doviation & 81 & $\because$ & 67 & 22 & 21 & $=$ & - & 25 & n/a \\
\hline & & Maximum Burlal Volume (cunti) & 250 & - & 187 & 432 & 80 & $\div$ & - & 432 & nia \\
\hline & & Minimum Burlal Volume (av/t) & 16 & $=$ & 9 & 0 & 20 & - & - & 0 & No \\
\hline \multirow{6}{*}{2} & \multirow{6}{*}{ Ont } & Number of Records & 0 & 0 & 0 & 0 & 0 & 0 & 0 & 0 & - \\
\hline & & \begin{tabular}{|l} 
Total Wasto Vohme (cu/n) \\
\end{tabular} & $\div$ & - & - & - & - & - & - & - & - \\
\hline & & Average Burial Volume (cult) & 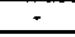 & - & - & - & $\therefore$ & - & - & - & n/a \\
\hline & & Standard Deviation & - & - & - & - & - & - & - & - & na \\
\hline & & Maximum Burial Volume (cumt) & - & - & - & $\tau$ & - & - & $\therefore$ & $\div$ & na \\
\hline & & Minumum Buial Volume (cum) & - & $\cdot$ & - & - & - & - & 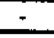 & - & nes \\
\hline \multirow{6}{*}{3} & \multirow{6}{*}{$\begin{array}{l}\text { Irradiatud Motel } \\
\text { Scrap }\end{array}$} & Number of Records & 0 & 3 & 0 & $D$ & 0 & 0 & 0 & 3 & 0.4 \\
\hline & & Total Waste Vokme (Cunt) & - & 2,725 & - & - & - & - & - & 2,725 & 14.9 \\
\hline & & Average Burial Volume (cumt) & - & 908 & $\div$ & مت: & - & - & - & 908 & $\mathrm{~N} / \mathrm{a}$ \\
\hline & & Standard Doviation & - & 765 & - & $\cdot$ & - & $=$ & - & 765 & $\mathrm{~N} / \mathrm{a}$ \\
\hline & & Maxdmum Burial Volume (curti) & - & 1,350 & - & - & $=$ & + & - & 1350 & n/a \\
\hline & & Minimum Eurial Voume (avit) & - & 25 & - & - & - & - & - & 25 & ne \\
\hline \multirow{6}{*}{4} & \multirow{6}{*}{$\begin{array}{l}\text { Naturally } \\
\text { Radioactive } \\
\text { Matoriale }\end{array}$} & Number of Recorts & 3 & 0 & 0 & 0 & 0 & 0 & 0 & 3 & 0.4 \\
\hline & & Totel Waste Volume (anit) & 3 & - & - & - & - & - & - & 3 & 0.0 \\
\hline & & Average Bural Vokme (aun) & 1 & $=$ & - & - & - & $\dot{-}$ & - & 1 & no \\
\hline & & Standard Deviatton & 0 & - & + & - & - & $\therefore$ & - & $\mathbf{0}$ & Na \\
\hline & & Maximum Butal Volume (cum) & 1 & - & - & - & - & - & - & 1 & $\mathrm{n} / \mathrm{s}$ \\
\hline & & Minimum Burial Vohme (cult) & 1 & - & - & - & - & - & $\tau$ & 1 & $n / 2$ \\
\hline \multirow{6}{*}{5} & \multirow{6}{*}{$\begin{array}{l}\text { Capital Equipment, must } \\
\text { be accompanind by } \\
\text { Plant Equipment } \\
\text { Transfor (PET) }\end{array}$} & Number of Records & 4 & 0 & 0 & 0 & 0 & 0 & 0 & 4 & 0.5 \\
\hline & & Total Waste Volume (cunt) & 5,300 & - & - & $=$ & 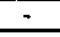 & $=$ & - & 5,300 & 28.9 \\
\hline & & Average Burial Volume (aunt) & 1,325 & - & - & $=$ & $=$ & $\therefore$ & - & 1325 & Na \\
\hline & & Standard Deviation & 350 & $\cdot$ & - & - & $=$ & - & - & 350 & na \\
\hline & & Maximum Burial Volume (cu/t) & 1,500 & - & - & - & $\therefore$ & - & $\therefore$ & 1500 & no \\
\hline & & Minimum Burial Volume (cuitit) & 800 & $\therefore$ & - & - & - & $\dot{-}$ & - & 800 & $\mathrm{n} / \mathrm{a}$ \\
\hline \multirow{6}{*}{6} & \multirow{6}{*}{ Rosin } & Number of Records & 0 & 0 & 0 & 0 & 0 & 0 & 0 & 0 & 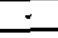 \\
\hline & & Total Wasto Voume (cunt) & - & $=$ & $\div$ & - & - & - & - & - & $\therefore$ \\
\hline & & Average Burlal Voume (avit) & - & - & - & - & - & - & - & - & n/a \\
\hline & & Standard Deviation & - & - & - & - & - & $=$ & - & $\cdot$ & Na \\
\hline & & Maximum Burial Volume (cu/li) & - & - & $=$ & - & $=$ & - & - & $\therefore$ & No \\
\hline & & Mirimum Burial Volume (cunti) & $\div$ & - & $\div$ & - & - & $=$ & - & - & na \\
\hline \multirow{6}{*}{7} & \multirow{6}{*}{ Other } & Number of Records & 0 & 0 & 0 & 0 & 0 & 0 & 0 & 0 & 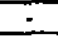 \\
\hline & & Total Waste Volume (Cu/tit) & - & - & - & 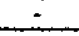 & - & - & - & $\therefore$ & $=$ \\
\hline & & Avernge Burlal Volme (cuit) & - & - & $\therefore$ & 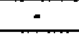 & - & - & - & $=$ & no \\
\hline & & Standard Deviation & - & - & - & - & - & $=$ & + & $=$ & nfa \\
\hline & & Maximum Burlal Volumo (cumit) & - & 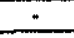 & - & - & - & $\therefore$ & - & - & na \\
\hline & & Mlrimum Burial Volume (cunt) & - & - & - & - & $=$ & - & - & - & na \\
\hline \multirow{4}{*}{\multicolumn{2}{|c|}{ Totals Across All 7 Type Coden }} & Number of Roconds & 14 & 3 & 8 & 724 & 5 & 0 & 0 & 754 & \\
\hline & & * of $80 \times 1$ Totals & 4.9 & 0.4 & 9.1 & 96.0 & 0.7 & 0.0 & 0.0 & 100.0 & \\
\hline & & Total Waste Volume (cult) & 5,814 & 2,725 & 513 & 9.052 & 235 & 0 & 0 & 18,339 & \\
\hline & & \% of Box 1 Totals & 31.7 & 14.9 & 2.8 & 49.4 & 1.3 & 0.0 & 0.0 & 100.0 & \\
\hline
\end{tabular}


Table 3-53. Decay Forecast for COI Inventory of Potential "Hot Spots"

HS-300-1 and HS-500-1

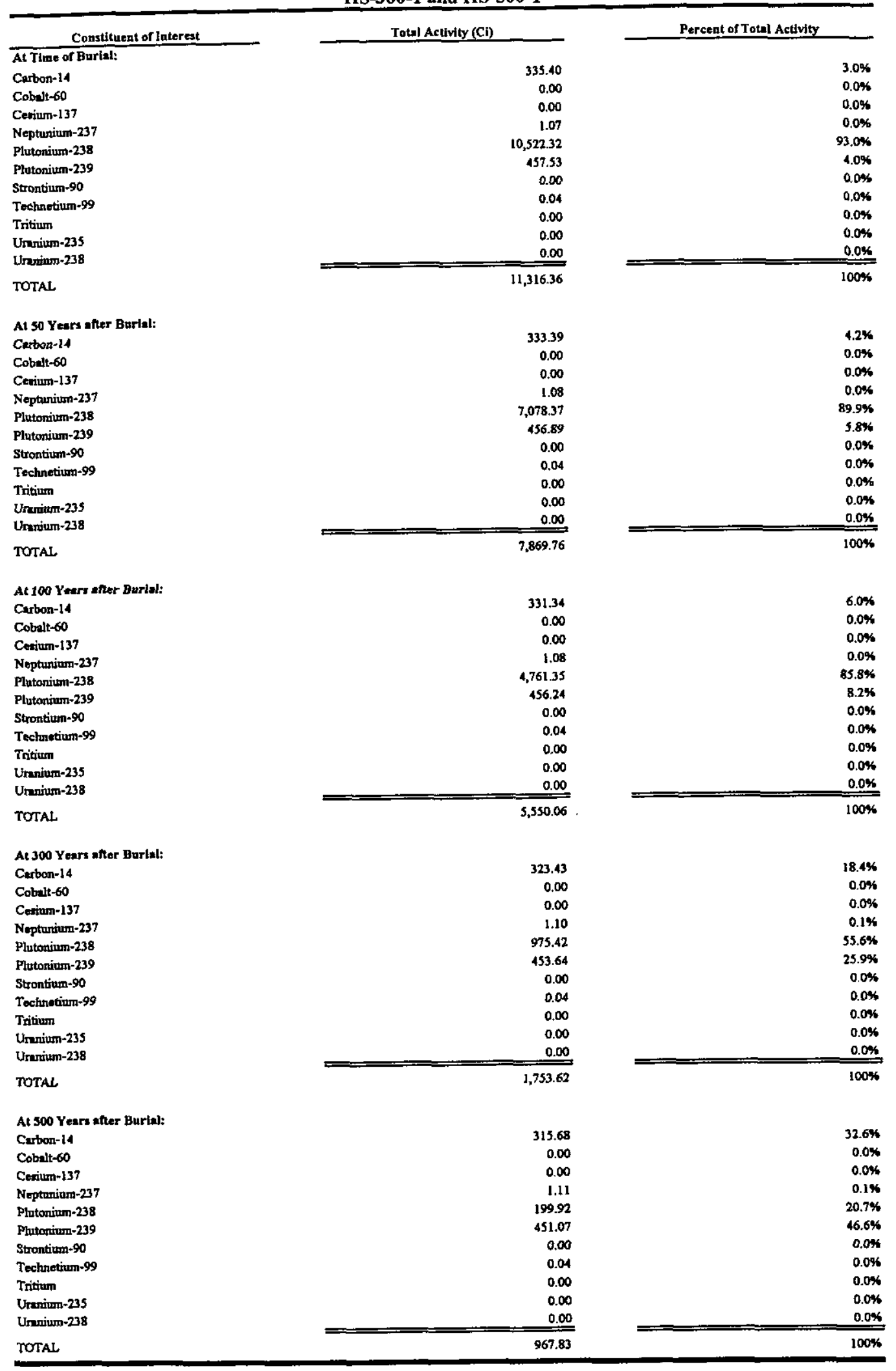


Table 3-53. Decay Forecast for COI Inventory of Potential "Hot Spots" HS-300-1 and HS-500-1 (Continued)

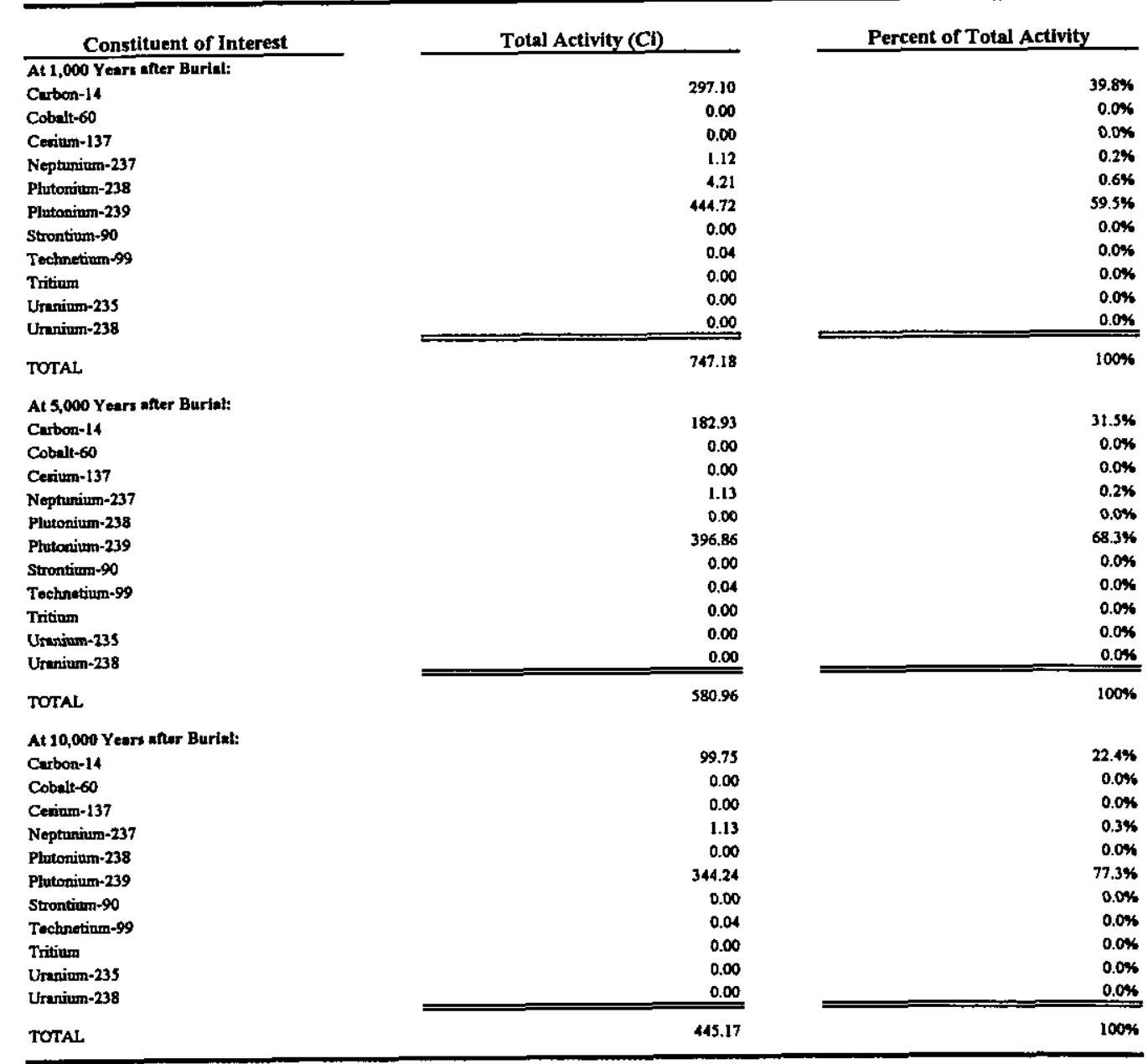


Table 3-54. Summary Statistics for COBRA Inventory of Potential "Hot Spots" HS-300-2 and HS-500-2

\begin{tabular}{|c|c|c|c|c|c|c|c|c|c|c|c|}
\hline \multirow{3}{*}{\multicolumn{2}{|c|}{ 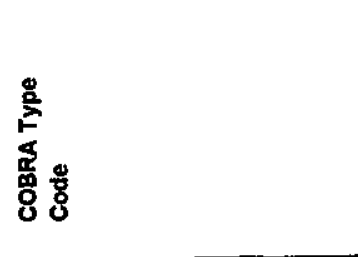 }} & & \\
\hline & & & 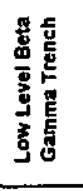 & 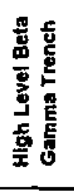 & 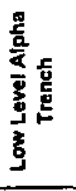 & 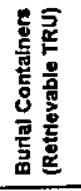 & 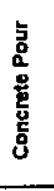 & 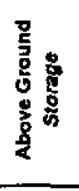 & 总 & 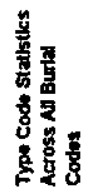 & 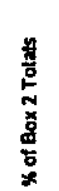 \\
\hline & & COBRA Burial Code: & 1 & 2 & 3 & 4 & 5 & 6 & 7 & & \\
\hline \multirow{6}{*}{1} & \multirow{6}{*}{$\begin{array}{l}\text { Job Control Waste, } \\
\text { including house- } \\
\text { keeping waste and } \\
\text { protective clothing }\end{array}$} & Number of Records & 357 & 0 & 49 & 215 & 0 & 0 & 0 & 621 & 96.3 \\
\hline & & Total Waste volume (cumt) & 42,075 & $\therefore$ & 5,052 & 1,621 & - & - & - & 48,748 & 90.0 \\
\hline & & Average Burtal Volume (cu/t) & 118 & $\therefore$ & 103 & 8 & $=$ & $\therefore$ & - & 78 & $n / a$ \\
\hline & & Standard Devtation & 134 & $\therefore$ & 93 & 10 & $\therefore$ & - & - & 117 & $n / 2$ \\
\hline & & Maximum Burtal Volume (cu/n) & 1,900 & $\therefore$ & 400 & 133 & - & - & - & 1900 & $n / a$ \\
\hline & & Minimum Burial Volume (cumt) & 5 & $=$ & 1 & 1 & - & $=$ & - & 1 & $n / a$ \\
\hline \multirow{6}{*}{2} & \multirow{6}{*}{ oll } & Number of Records & 4 & 0 & 0 & 0 & 0 & 0 & 0 & 4 & 0.6 \\
\hline & & Total Waste Volume (cu/tt) & 214 & - & - & - & $=$ & $\therefore$ & - & 214 & 0.4 \\
\hline & & Average Burfal Volume (cu/tt) & 54 & $\therefore$ & 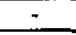 & - & - & $\therefore$ & - & 54 & $n / a$ \\
\hline & & Standard Deviation & 85 & $\therefore$ & $\cdot$ & - & - & $\therefore$ & - & 85 & $\mathrm{n} / \mathrm{a}$ \\
\hline & & Maxlmum Burlal Volume (cu/t) & 180 & $=$ & 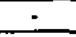 & - & - & - & - & 180 & $n / a$ \\
\hline & & MInimum Burial Volume (cu/th) & 2 & $=$ & - & $=$ & - & $\therefore$ & - & 2 & Na \\
\hline \multirow{6}{*}{3} & \multirow{6}{*}{$\begin{array}{l}\text { Irradlated Metal } \\
\text { Scrap }\end{array}$} & Number of Records & 5 & 6 & 0 & 0 & 0 & 0 & D & 11 & 1.7 \\
\hline & & Total Waste Volume (cu/th) & 193 & 62 & - & $\therefore$ & - & $\therefore$ & - & 255 & 0.5 \\
\hline & & Average Burbil volume (cumt) & 39 & 10 & - & $=$ & - & $=$ & $\cdot$ & 23 & $n / 2$ \\
\hline & & Standard Deviation & 15 & 14 & $\div$ & - & $\therefore$ & $=$ & - & 20 & $n / a$ \\
\hline & & Maximum Burial Volume (cu/tt) & 52 & 35 & - & $=$ & 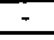 & $=$ & $=$ & 52 & $n / a$ \\
\hline & & MInimum Qurial Volume (cu/m) & 20 & 1 & - & - & $=$ & $=$ & 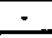 & 1 & $n / 2$ \\
\hline \multirow{6}{*}{4} & \multirow{6}{*}{$\begin{array}{l}\text { Noturally } \\
\text { Radlowetive } \\
\text { Materials }\end{array}$} & Number of Records & 4 & 0 & 0 & 0 & 0 & 0 & 0 & 4 & 0.6 \\
\hline & & Total Waste Volume (cum) & 206 & 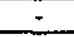 & $\cdot$ & - & - & $=$ & $\cdot$ & 206 & 0.4 \\
\hline & & Average Burial Volume (cu/n) & 52 & $=$ & - & - & - & $\therefore$ & - & 52 & $n / a$ \\
\hline & & Standard Deviation & 44. & - & $\therefore$ & - & $=$ & $\therefore$ & $\cdot$ & 44 & $n / \mathbf{a}$ \\
\hline & & Maximum Burtal Volume (cum) & 114 & - & - & $=$ & - & $\approx$ & $\dot{-}$ & 114 & $n / a$ \\
\hline & & Minimum Burlal Volume (cu/tt) & 20 & - & $\div$ & - & $\therefore$ & $\therefore$ & - & 20 & $n / a$ \\
\hline \multirow{6}{*}{5} & \multirow{6}{*}{$\begin{array}{l}\text { Copltal Equipment, must } \\
\text { be accompanied by a } \\
\text { Plant Equipment } \\
\text { Transfer (PEn) }\end{array}$} & Number of Records & 5 & 0 & 0 & 0 & 0 & 0 & 0 & 5 & 0.8 \\
\hline & & Total Waste Volume (cu/tt) & 320 & $\therefore$ & - & $\therefore$ & - & $\therefore$ & - & 320 & 0.6 \\
\hline & & Average Burlal Volumo (cu/tt) & 64 & $\therefore$ & - & - & - & $=$ & $\therefore$ & 64 & $n / a$ \\
\hline & & Standard Doviation & 62 & $\therefore$ & - & - & - & $=$ & - & 62 & Na \\
\hline & & Maximum Burlal Volume (cu/tt) & 160 & 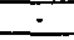 & - & - & - & $=$ & $\therefore$ & 160 & $n / a$ \\
\hline & & Minimum Burial Volume (cu/t) & 3 & $=$ & - & - & $\cdot$ & - & - & 3 & $n / a$ \\
\hline \multirow{6}{*}{6} & \multirow{6}{*}{ Resln } & Number of Records & 0 & 0 & 0 & 0 & 0 & 0 & 0 & 0 & - \\
\hline & & Total Waste Volume (cu/ti) & - & - & - & - & - & $=$ & - & - & - \\
\hline & & Averago Burial Volume (cu/t) & - & $=$ & - & $=$ & - & $=$ & - & - & $n / 2$ \\
\hline & & Standard Devation & - & $\dot{-}$ & $\cdot$ & - & - & $=$ & - & - & $n / a$ \\
\hline & & Maximum Burial Volume (cu/th) & - & 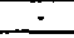 & 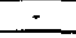 & - & - & $=$ & + & - & $n / a$ \\
\hline & & Minimum Burkal Volume (cu/nt) & 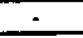 & - & - & - & - & - & - & - & Na \\
\hline \multirow{6}{*}{7} & \multirow{6}{*}{ Other } & Number of Records & D. & 0 & 0 & 0 & 0 & 0 & 0 & 0 & 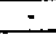 \\
\hline & & Total Waste Volume (cu/th) & - & - & - & - & - & $\div$ & - & - & $\cdot$ \\
\hline & & Average Burial Volume (cu/tit) & - & - & 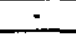 & 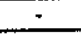 & - & $=$ & $\therefore$ & - & Na \\
\hline & & Standard Devation. & - & - & - & $\cdot$ & - & - & - & - & $n / 2$ \\
\hline & & Maximum Burial volume (cumt) & - & - & - & $=$ & - & - & - & - & $\mathrm{Na}$ \\
\hline & & Minimum Burtal Volume (cum) & - & - & $=$ & $\therefore$ & - & - & - & - & n/a \\
\hline \multirow{4}{*}{\multicolumn{2}{|c|}{ Totals Across Att 7 Type Codes }} & Number of Reconds & 375 & 6 & 49 & 215 & 0 & 0 & 0 & 645 & \\
\hline & & $\%$ of Box 2 Totals & 58.1 & 0.8 & 7.6 & 33.3 & 0.0 & 0.0 & 0.0 & 100.0 & \\
\hline & & Total Waste Volume (cumt) & 43,008 & 62 & 5.052 & 1.621 & 0 & 0 & 0 & 49,743 & \\
\hline & & $\%$ of Box 2 Totals & 86.5 & 0.1 & 10.2 & 3.3 & 0.0 & 0.0 & 0.0 & 100.0 & \\
\hline
\end{tabular}


Table 3-55. Decay Forecast for COI Inventory of Potential "Hot Spots"

HS-300-2 and HS-500-2

\begin{tabular}{|c|c|c|}
\hline Constituent of Interest & Total Axtivity (Ci) & Percent of Total Activity \\
\hline \multicolumn{3}{|l|}{ A! Time of Burial: } \\
\hline Carbon-14 & 0.00 & $0.0 \%$ \\
\hline Cobalt -60 & 0.01 & $0.0 \%$ \\
\hline Ceniurn-137 & 4.39 & $0.0 \%$ \\
\hline Nepturium-237 & 0.17 & $0.0 \%$ \\
\hline Plutorinum-238 & 1.57 & $0.0 \%$ \\
\hline Plutonium-239 & 106.57 & $0.7 \%$ \\
\hline Strontium-90 & 4.12 & $0.0 \%$ \\
\hline Tochretium-99 & 0.00 & $0.0 \%$ \\
\hline Tritiun & $15,892.56$ & $99.3 \%$ \\
\hline Uranium-235 & 0.00 & $0.0 \%$ \\
\hline Uraritum-238 & $\stackrel{0.67}{=}$ & $0.0 \%$ \\
\hline TOTAL & $16,010.06$ & $100 \%$ \\
\hline \multicolumn{3}{|l|}{ At so Years efter Burial: } \\
\hline Carbon-14 & 0.00 & $0.0 \%$ \\
\hline Cobalt -60 & 0.00 & $0.0 \%$ \\
\hline Cerium-137 & 1.38 & $0.1 \%$ \\
\hline Neptunium-237 & 0.17 & $0.0 \%$ \\
\hline Plutonitum-238 & 1.06 & $0.1 \%$ \\
\hline Phatonimm-239 & 106.42 & $10.0 \%$ \\
\hline Strontium-90 & 1.25 & $0.1 \%$ \\
\hline Technetium-99 & 0.00 & $0.0 \%$ \\
\hline Tritium & 950.38 & $89.5 \%$ \\
\hline Unaviestr-235 & 0.00 & $0.0 \%$ \\
\hline Uratum-238 & 0.67 & $0.1 \%$ \\
\hline TOTAL & $1,061.34$ & $100 \%$ \\
\hline \multicolumn{3}{|l|}{ At 100 Years after Burial: } \\
\hline Carbon-14 & 0.00 & $0.0 \%$ \\
\hline Cobalt -60 & 0.00 & $0.0 \%$ \\
\hline Сexium-137 & 0.44 & $0.3 \%$ \\
\hline Nepturium-237 & 0.17 & $0.1 \%$ \\
\hline Plutonium-238 & 0.71 & $0.4 \%$ \\
\hline Plutonium-239 & 106.27 & $64.1 \%$ \\
\hline Strantium- 90 & 0.38 & $0.2 \times$ \\
\hline Tochnetium-99 & 0.00 & $0.0 \%$ \\
\hline Tritium & 57.21 & $34.5 \%$ \\
\hline Unanimem-235 & 0.00 & $0.0 \%$ \\
\hline Unanium-238 & 0.67 & $0.4 \%$ \\
\hline TOTAL. & 165.86 & $100 \%$ \\
\hline \multicolumn{3}{|l|}{ At 300 Years aster Buriaf: } \\
\hline Curbon-14 & 0.00 & $0.0 \%$ \\
\hline Cobalt-60 & $0, \infty$ & $0.0 \%$ \\
\hline Cesium-137 & 0.00 & $0.0 \%$ \\
\hline Neptunium-237 & 0.17 & $0.2 \%$ \\
\hline Plutoniutr-238 & 0.15 & $0.1 \%$ \\
\hline Platonium-239 & 105.67 & $99.1 \%$ \\
\hline Strontium-90 & 0.00 & $0.0 \%$ \\
\hline Technotium-99 & 0.00 & $0.0 \%$ \\
\hline Trition & 0.00 & $0.0 \%$ \\
\hline Uneniumn-235 & 0.00 & $0.0 \%$ \\
\hline Uranian-238 & 0.67 & $0.6 \%$ \\
\hline TOTAL. & 106.67 & $100 \%$ \\
\hline \multicolumn{3}{|l|}{ At 500 Years efter Burlal: } \\
\hline Carbon-14 & 0.00 & $0.0 \%$ \\
\hline Cobalt -60 & 0.00 & $0.0 \%$ \\
\hline Cenium-137 & 0.00 & $0.0 \%$ \\
\hline Neptunizum-23? & 0.17 & $0.2 \%$ \\
\hline Plutonium-238 & 0.03 & $0.0 \%$ \\
\hline Platorimen-239 & 105.07 & $99.2 \%$ \\
\hline Strontium-90 & 0.00 & $0.0 \%$ \\
\hline Technotium-99 & 0.00 & $0.0 \%$ \\
\hline Tritium & 0.00 & $0.0 \%$ \\
\hline Uraniuen-235 & 0.00 & $0.0 \%$ \\
\hline Uneniumb-238 & 0.67 & $0.6 \%$ \\
\hline TOTAL & 105.95 & $100 \%$ \\
\hline
\end{tabular}


Table 3-55. Decay Forecast for COI Inventory of Potential "Hot Spots" HS-300-2 and HS-500-2 (Continued)

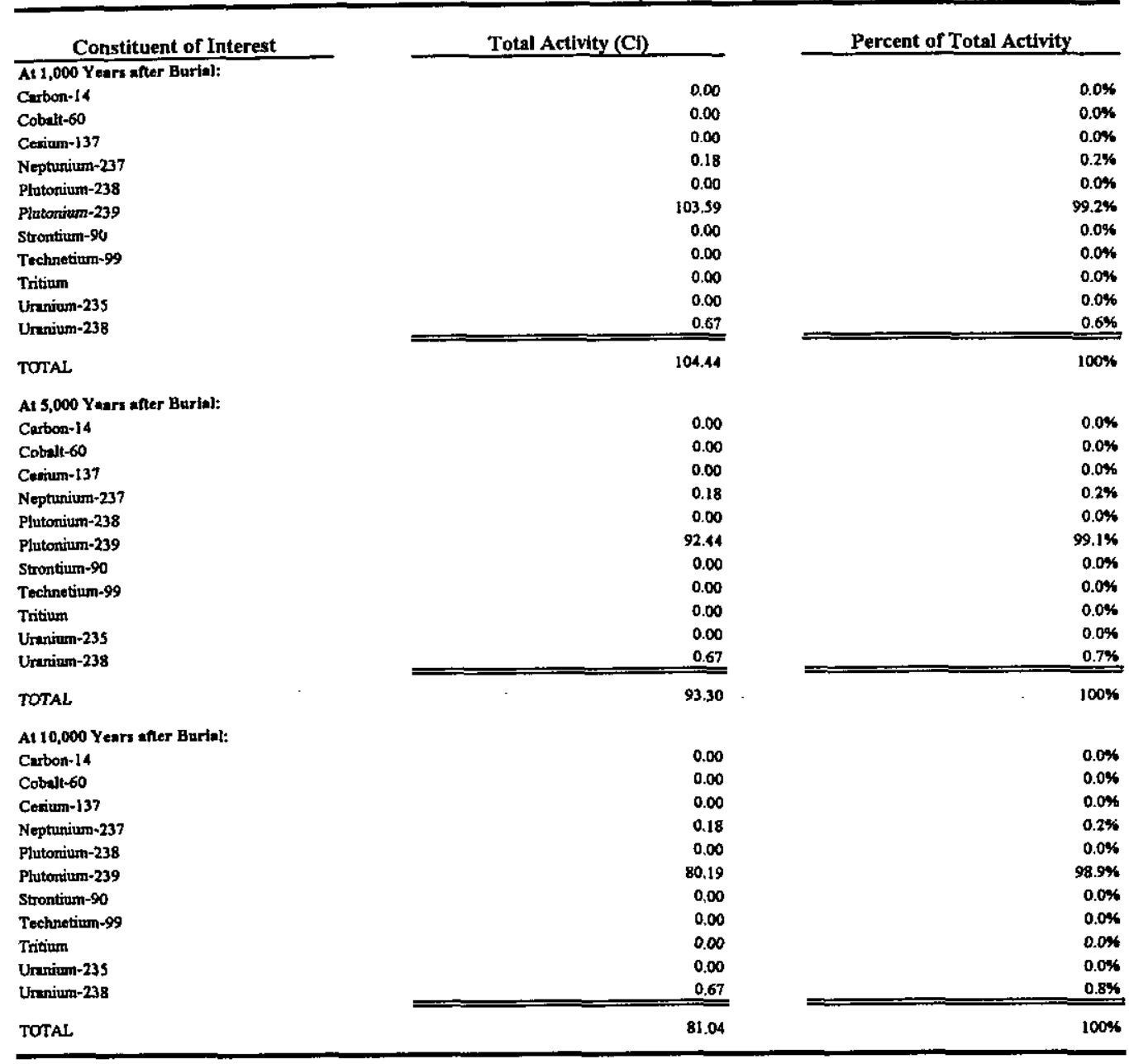


Table 3-56. Summary Statistics for COBRA Inventory of Potential "Hot Spots" HS-300-3 and HS-500-3

\begin{tabular}{|c|c|c|c|c|c|c|c|c|c|c|c|}
\hline \multirow{3}{*}{$\begin{array}{l}5 \\
5 \\
58 \\
8\end{array}$} & & & & \multirow{3}{*}{ 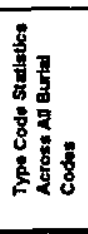 } & \multirow{3}{*}{ 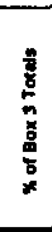 } \\
\hline & & & 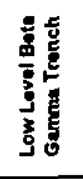 & 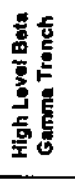 & 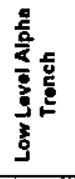 & 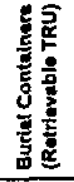 & 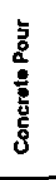 & 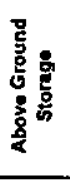 & $\frac{5}{5}$ & & \\
\hline & & COBRA Burlal Code: & 1 & 2 & 3 & 4 & 5 & 6 & 7 & & \\
\hline \multirow{6}{*}{1} & \multirow{6}{*}{$\begin{array}{l}\text { Job Control Waste, } \\
\text { including house. } \\
\text { keeping wastu and } \\
\text { protective clothing }\end{array}$} & Number of Records & 191 & 0 & 32 & 0 & 0 & 0 & 0 & 223 & 94.1 \\
\hline & & Total Waste Volume (cuft) & 28.323 & - & 2,961 & - & - & - & - & 31.284 & 94.1 \\
\hline & & Average Burial Volume (cunt) & 148 & $\because$ & 93 & - & - & - & 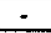 & 140 & $n / a$ \\
\hline & & Standard Deviation & 168 & - & 57 & 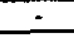 & - & $=$ & - & 158 & $\mathrm{Na}$ \\
\hline & & Maximum Burial Volume (aun). & 1,250 & - & 325 & 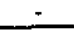 & $=$ & - & - & 1250 & na \\
\hline & & Mirimum Burital Volume (cunt) & 3 & 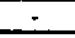 & 35 & $=$ & $\div$ & - & $\cdot$ & 3 & Na \\
\hline \multirow{6}{*}{2} & \multirow{6}{*}{ on } & Number of Reconds & 2 & 0 & 0 & 0 & 0 & 0 & 0 & 2 & 0.8 \\
\hline & & Total Waste Volume (curt) & 224 & - & - & - & - & $=$ & - & 224 & 0.7 \\
\hline & & Averago Burlal Voume (cum) & 112 & - & - & $=$ & - & $\therefore$ & - & 112 & $\mathrm{~N} / \mathrm{a}$ \\
\hline & & Standard Deviation & 11 & - & - & $=$ & - & - & - & 11 & Na \\
\hline & & Maximum Burial Volume (curt) & 120 & $\therefore$ & $\dot{-}$ & - & - & 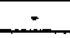 & - & 120 & $\mathrm{Na}$ \\
\hline & & Mirimum Burial Volume (cult) & 104 & $\therefore$ & - & - & - & $\therefore$ & - & 104 & na \\
\hline \multirow{6}{*}{3} & \multirow{6}{*}{$\begin{array}{l}\text { Imadiated Motal } \\
\text { Scrap }\end{array}$} & Number of Records & $\underline{0}$ & 3 & 0 & 0 & 0 & $\underline{0}$ & 0 & 3 & 1.3 \\
\hline & & Total Woste Volume (cunt) & $\therefore$ & 139 & $\cdot$ & $=$ & - & - & - & 139 & 0.4 \\
\hline & & Average Burtal Volume (aunit) & - & 46 & - & $=$ & - & - & $\cdot$ & 46 & $\mathrm{Na}$ \\
\hline & & Standard Devation & - & 52 & - & $\therefore$ & - & - & - & 52 & Na \\
\hline & & Maximum Burlal Voume (cumt) & - & 104 & $\therefore$ & - & - & - & - & 104 & Na \\
\hline & & Minimum Burial Volume (aum) & + & 3 & - & - & - & $\therefore$ & - & 3 & na \\
\hline \multirow{6}{*}{4} & \multirow{6}{*}{$\begin{array}{l}\text { Naturally } \\
\text { Recloactive } \\
\text { Materials }\end{array}$} & Number of Records & 6 & 0 & 0 & 0 & 0 & 0 & 0 & 6 & 2.5 \\
\hline & & Total Wasto Votume (cunt) & 1.201 & - & $\dot{-}$ & $=$ & $\therefore$ & - & - & 1,201 & 3.6 \\
\hline & & Average Burled Votume (civit) & 200 & - & - & - & - & - & $\therefore$ & 200 & $N / a$ \\
\hline & & Standare Devition & 120 & $=$ & $\therefore$ & $=$ & - & - & - & 120 & Na \\
\hline & & Maximum Burial Volume (cult) & 300 & $\dot{*}$ & $\therefore$ & - & + & - & - & 300 & $n / a$ \\
\hline & & Minimum Burial Voldme (cu/t) & 21 & $\therefore$ & - & - & - & - & - & 21 & $\mathrm{Na}$ \\
\hline \multirow{6}{*}{5} & \multirow{6}{*}{$\begin{array}{l}\text { Capital Equipment, must } \\
\text { be accompaniod by } \\
\text { Plant Equloment } \\
\text { Trenster (PET) }\end{array}$} & Number of Records & 3 & 0 & 0 & 0 & 0 & 0 & 0 & 3 & 1.3 \\
\hline & & Total Wasto Volume (cum) & 408 & - & - & $=$ & $\therefore$ & $\cdot$ & $=$ & 408 & 1.2 \\
\hline & & Averege Buriat Volume (aun) & 136 & - & - & $\therefore$ & - & - & $\therefore$ & 136 & Na \\
\hline & & Standard Deviation & 167 & - & - & $\therefore$ & $\therefore$ & - & $\therefore$ & 167 & na \\
\hline & & Maximum Burlal Volume (curt) & 324 & - & $\therefore$ & $=$ & - & - & $\therefore$ & 324 & na \\
\hline & & Minimum Burlal Volume (avn) & 4 & 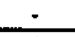 & $=$ & $\therefore$ & $\sim$ & - & - & 4 & ras \\
\hline \multirow{6}{*}{6} & \multirow{6}{*}{ Resin } & Number of Records & 0 & 0 & 0 & 2 & 0 & 0 & 0 & 0 & - \\
\hline & & Total Waste Volume (cult) & - & $\therefore$ & - & - & $=$ & $=$ & - & $=$ & - \\
\hline & & Average Burlal Volume (avt) & - & - & - & $=$ & ت & - & $=$ & 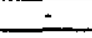 & N/n \\
\hline & & Standard Deviation & $=$ & - & - & : & $\therefore$ & - & $\therefore$ & $\therefore$ & no \\
\hline & & Maximum Burial Volume (cun) & - & - & $\therefore$ & $=$ & - & $\therefore$ & - & $=$ & The \\
\hline & & Minirrum Burlal Volume (as/n) & $\therefore$ & - & - & $\therefore$ & $=$ & - & - & - & nha \\
\hline \multirow{6}{*}{7} & \multirow{6}{*}{ Other } & Number of Records & 0 & 0 & 0 & 0 & 0 & 0 & 0 & 0 & - \\
\hline & & Total Waste Volume (cunt) & $\therefore$ & + & - & $=$ & - & - & $=$ & - & $\therefore$ \\
\hline & & Average Burlal Volume (aint) & $\therefore$ & - & + & $\therefore$ & - & - & - & $=$ & n/a \\
\hline & & Standard Deviation & - & 二 & $\therefore$ & 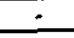 & $\sim$ & $\therefore$ & - & 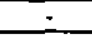 & Ne \\
\hline & & Maximum Burial Vokme (ant) & - & - & - & $=$ & - & - & $\therefore$ & $=$ & ne \\
\hline & & Minimum Burial Votume (avit) & $\therefore$ & - & - & 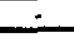 & - & - & - & - & na \\
\hline \multirow{4}{*}{\multicolumn{2}{|c|}{ Totals Acros: All 7 Typo Codo: }} & Number of Records & 202 & 3 & 32 & 0 & 0 & 0 & 0 & 237 & \\
\hline & & \% of Box 3 Totals & 85.2 & 1.3 & 13.5 & 0.0 & 0.0 & 0.0 & 0.0 & 100.0 & \\
\hline & & Total Waste Volume (cuitt) & 30,156 & 139 & 2,961 & 0 & 0 & 0 & 0 & 33,256 & \\
\hline & & $\%$ of Box 3 Totals & 90.7 & 0.4 & 8.9 & 0.0 & 0.0 & 0.0 & 0.0 & 100.0 & \\
\hline
\end{tabular}


Table 3-57. Decay Forecast for COI Inventory of Potential "Hot Spots" HS-300-3 and HS-500-3

\begin{tabular}{|c|c|c|}
\hline Constituent of Lpterest & Tot21 Aetivity (Ci) & Percent of Total Activity \\
\hline At Time of Burial: & & \\
\hline Carbon-14 & 75.68 & $13.3 \%$ \\
\hline Cobalt- 60 & 0.00 & $0.0 \%$ \\
\hline Cesium-137 & 0.00 & $0.0 \%$ \\
\hline Nepturium-237 & 0.00 & $0.0 \%$ \\
\hline Plutorium-238 & .0 .00 & $0.0 \%$ \\
\hline Plutonium-239 & 0.00 & $0.0 \%$ \\
\hline Strontium-90 & 0.00 & $0.0 \%$ \\
\hline Technetium-99 & 0.00 & $0.0 \%$ \\
\hline Tritium & 494.52 & $86.6 \%$ \\
\hline Unnium-235 & 0.00 & $0.0 \%$ \\
\hline Urunium-238 & 0.67 & $0.1 \%$ \\
\hline TOTAL & 570.87 & $100 \%$ \\
\hline \multicolumn{3}{|l|}{ Ac so Years after Burial: } \\
\hline Carton-14 & 75.23 & $71.3 \%$ \\
\hline Cobalt -60 & 0.00 & $0.0 \%$ \\
\hline Cerium-137 & 0.00 & $0.0 \%$ \\
\hline Nepturium-237 & 0.00 & $0.0 \%$ \\
\hline Plutorimm-238 & 0.00 & $0.0 \%$ \\
\hline Plutortium-239 & 0.00 & $0.0 \%$ \\
\hline Strontium-90 & 0.00 & $0.0 \%$ \\
\hline Technetium-99 & 0.00 & $0.0 \%$ \\
\hline Tritium & 29.57 & $28.0 \%$ \\
\hline Uranium-235 & 0.00 & $0.0 \%$ \\
\hline Urenium-238 & $\underline{0.67}$ & $0.6 \%$ \\
\hline TOTAL & 105.47 & $100 \%$ \\
\hline \multicolumn{3}{|l|}{ At 100 Yaurs after Burlal: } \\
\hline Carbon-14 & 74.76 & $96.8 \%$ \\
\hline Cobalt -60 & 0.00 & $0.0 \%$ \\
\hline Cesium-137 & 0.00 & $0.0 \%$ \\
\hline Neptunium-237 & 0.00 & $0.0 \%$ \\
\hline Plutonium-238 & 0.00 & $0.0 \%$ \\
\hline Plutonium-239 & 0.00 & $0.0 \%$ \\
\hline Strontium-90 & 0.00 & $0.0 \%$ \\
\hline Techretium-99 & 0.00 & $0.0 \%$ \\
\hline Tritium & 1.78 & $2.3 \%$ \\
\hline Uranium-235 & 0.00 & $0.0 \%$ \\
\hline Uranium-238 & $\underline{0.67}$ & $0.9 \%$ \\
\hline TOTAL & 77.22 & $100 \%$ \\
\hline \multicolumn{3}{|l|}{ At 300 Years efter Burial: } \\
\hline Curbon-14 & 72.98 & $99.1 \%$ \\
\hline Cobalt -60 & 0.00 & $0.0 \%$ \\
\hline Conium- 137 & 0.00 & $0.0 \%$ \\
\hline Neptonium-237 & 0.00 & $0.0 \%$ \\
\hline Plutonium-238 & 0.00 & $0.0 \%$ \\
\hline Plutonium-239 & 0.00 & $0.0 \%$ \\
\hline Strontium-90 & 0.00 & $0.0 \%$ \\
\hline Technetium-99 & 0.00 & $0.0 \%$ \\
\hline Tritium & 0.00 & $0.0 \%$ \\
\hline Unarium-235 & 0.00 & $0.0 \%$ \\
\hline Unerium-238 & 0.67 & $0.9 \%$ \\
\hline TOTAL & 73.65 & $100 \%$ \\
\hline \multicolumn{3}{|l|}{ At 500 Years after Burial: } \\
\hline Carbon-14 & 71.23 & $99.1 \%$ \\
\hline Cabalt -60 & 0.00 & $0.0 \%$ \\
\hline Cenium-137 & 0.00 & $0.0 \%$ \\
\hline Nepturium-237 & 0.00 & $0.0 \%$ \\
\hline Plutonium-238 & 0.00 & $0.0 \%$ \\
\hline Plutonium-239 & 0.00 & $0.0 \%$ \\
\hline Strontium-90 & 0.00 & $0.0 \%$ \\
\hline Tochnetiurn-99 & 0.00 & $0.0 \%$ \\
\hline Tritium & 0.00 & $0.0 \%$ \\
\hline Urenium-235 & 0.00 & 0.036 \\
\hline Utmivisn-238 & $\stackrel{0.67}{=}$ & $0.9 \%$ \\
\hline TOTAL & 71.90 & $100 \%$ \\
\hline
\end{tabular}


Table 3-57. Decay Forecast for COI Inventory of Potential "Hot Spots" HS-300-3 and HS-500-3 (Continued)

\begin{tabular}{|c|c|c|}
\hline Constituent of Interest & Total Activity (Ci) & Percent of Total Activity \\
\hline \multicolumn{3}{|l|}{ At 1,000 Years aner Burial: } \\
\hline Carbon-14 & 67.04 & $99.0 \%$ \\
\hline Cobalt -60 & 0.00 & $0.0 x$ \\
\hline Cexium-137 & 0.00 & $0.0 \%$ \\
\hline Neptunion-237 & 0.00 & $0.0 \%$ \\
\hline Plutonium-238 & 0.00 & $0.0 x$ \\
\hline Plutoniurn-239 & 0.00 & $0.0 \%$ \\
\hline Strontium -90 & 0.00 & $0.0 \%$ \\
\hline Technetium-99 & 0.00 & $0.0 x$ \\
\hline Tritium & 0.00 & $0.0 \%$ \\
\hline Unarvium-235 & 0.00 & $0.0 \%$ \\
\hline Uranium-238 & 0.67 & $1.0 \%$ \\
\hline TOTAL & 67.71 & $100 \%$ \\
\hline \multicolumn{3}{|l|}{ As 5,000 Years wher Burtat: } \\
\hline Curbon-14 & 11.28 & $98.4 \%$ \\
\hline Cobalt -60 & 0.00 & $0.0 \%$ \\
\hline Cexium-137 & 0.00 & 0.09 \\
\hline Nepturium-237 & 0.00 & $0.0 x$ \\
\hline Plutonium-238 & 0.00 & $0.0 \%$ \\
\hline Platonium-239 & 0.00 & $0.0 \times$ \\
\hline Strontium-90 & 0.00 & $0.0 \%$ \\
\hline Technetivm-99 & 0.00 & $0.0 x$ \\
\hline Tritiom & 0.00 & 0.09 \\
\hline Uranium-235 & 0.00 & $0.0 \%$ \\
\hline Unanium-238 & 0.67 & $1.6 \%$ \\
\hline TOTAL & 41.95 & $100 x$ \\
\hline \multicolumn{3}{|l|}{ At 10,000 Years after Burial: } \\
\hline Carbon-14 & 22.51 & $97.1 \%$ \\
\hline Cobalt-60 & 0.00 & $0.0 \%$ \\
\hline Cesium-137 & 0.00 & $0.0 \%$ \\
\hline Neptuniurn-237 & 0.00 & $0.0 x$ \\
\hline Plutonium-238 & 0.00 & 0.09 \\
\hline Plutonium-2.39 & 0.00 & $0.0 \%$ \\
\hline Strontium-90 & 0.00 & $0.0 x$ \\
\hline Teclunetium-99 & 0.00 & $0.0 x$ \\
\hline Tritium & 0.00 & $0.0 x$ \\
\hline Uranium-235 & 0.00 & $0.0 \%$ \\
\hline Unanium-238 & 0.67 & $2.9 \%$ \\
\hline TOTAL & 23.18 & $100 \%$ \\
\hline
\end{tabular}


Table 3-58. Summary Statistics for COBRA Inventory of Potential "Hot Spots" HS-300-4

\begin{tabular}{|c|c|c|c|c|c|c|c|c|c|c|c|}
\hline \multirow[t]{2}{*}{ 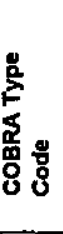 } & & & 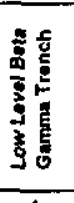 & 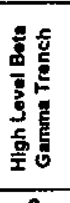 & 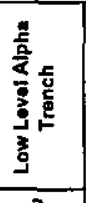 & 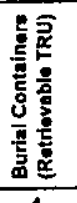 & 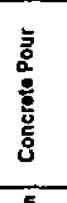 & 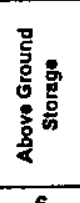 & $\frac{\bar{E}}{\delta}$ & 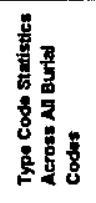 & 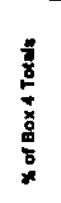 \\
\hline & & COBRA Burial Code: & 1 & 2 & 3 & 4 & 5 & 6 & 7 & & \\
\hline \multirow{6}{*}{1} & \multirow{6}{*}{$\begin{array}{l}\text { Job Control Waste, } \\
\text { Including house- } \\
\text { keeping wasto and } \\
\text { protective clothing }\end{array}$} & Number of Records & 58 & 0 & 210 & 410 & 1 & 0 & 0 & 679 & 99.1 \\
\hline & & Total Waste volume (curti) & 9,368 & - & 19,309 & 3,813 & 168 & - & - & 32,658 & 96.9 \\
\hline & & Average Burial Volumo (aunt) & 162 & $\therefore$ & 92 & 9 & 168 & + & - & 48 & na \\
\hline & & Standard Deviation & 131 & - & 82 & 14 & $=$ & 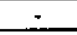 & - & 79 & n/a \\
\hline & & Maximum Burial Volume (cu/tit) & 636 & - & 636 & 182 & 168 & - & - & 636 & $\mathrm{Na}$ \\
\hline & & Minimum Burlel Volume (curit) & 1 & - & 1 & 1 & 168 & - & - & 1 & na \\
\hline \multirow{6}{*}{2} & \multirow{6}{*}{ oll } & Number of Records & 0 & 0 & 0 & 0 & $\underline{0}$ & 0 & 0 & 0 & - \\
\hline & & Totaf Waste volume (cutt) & - & 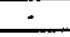 & $=$ & - & $=$ & - & - & - & $\therefore$ \\
\hline & & Average Burlal Volume (curtt) & - & - & $\therefore$ & + & $=$ & - & - & $=$ & na \\
\hline & & Standard Deviation & $\therefore$ & 正 & - & - & 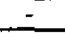 & - & - & - & $\mathrm{N} / \mathrm{a}$ \\
\hline & & Madmum Burlal Volume (cunt) & - & - & $=$ & - & $\therefore$ & - & - & $=$ & $\mathrm{n} / \mathrm{a}$ \\
\hline & & Mirtmum Burial Volume (cunt) & - & - & - & - & $=$ & - & - & - & no \\
\hline \multirow{6}{*}{3} & \multirow{6}{*}{$\begin{array}{l}\text { Irrediated Metal } \\
\text { Scrop }\end{array}$} & Number of Reconds & 0 & 0 & 0 & D & 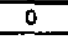 & 0 & 0 & 0 & $\therefore$ \\
\hline & & Total Waste Volume (cumt) & - & - & $=$ & - & - & - & - & - & 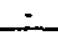 \\
\hline & & Average Burlal Volume (curt) & - & 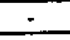 & $=$ & - & $=$ & - & - & - & na \\
\hline & & Standard Deviation & - & - & - & - & - & $\cdot$ & - & - & ne \\
\hline & & Maximum Burlal Volume (cum) & - & 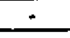 & - & - & $=$ & - & - & - & $\mathrm{Na}$ \\
\hline & & Minimum Burial Voume (cu/tit) & $=$ & - & - & - & $=$ & - & - & - & $\mathrm{n} / \mathrm{a}$ \\
\hline \multirow{6}{*}{4} & \multirow{6}{*}{$\begin{array}{l}\text { Noturally } \\
\text { Redioactive } \\
\text { Materials }\end{array}$} & Number of Records & 0 & 0 & 5 & 0 & 0 & 0 & $\underline{0}$ & 5 & 0.7 \\
\hline & & Total Waste Volurne (a)/tit) & - & - & 1,000 & - & - & - & - & 1,000 & 3.0 \\
\hline & & Average Burial Volume (cult) & - & - & 200 & - & $=$ & - & - & 200 & na \\
\hline & & Standard Deviation & - & $=$ & 0 & - & $=$ & - & - & 0 & na \\
\hline & & Maximum Burlal Volume (cunt) & - & - & 200 & $=$ & 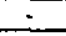 & $=$ & - & 200 & $\mathrm{n} / \mathrm{a}$ \\
\hline & & Mlnimum Burial Volume (cum) & - & - & 200 & - & $\therefore$ & - & $=$ & 200 & nta \\
\hline \multirow{6}{*}{5} & \multirow{6}{*}{$\begin{array}{l}\text { Capital Equipment, must } \\
\text { be accompanied by } \\
\text { Plant Equipment } \\
\text { Transfor (PET) }\end{array}$} & Number of Records & 0 & 0 & 1 & 0 & 0 & $\overline{0}$ & 0 & 1 & 0.1 \\
\hline & & Total Wasto Volume (curt) & - & $=$ & 44 & $\therefore$ & $=$ & 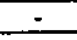 & - & 44 & 0.1 \\
\hline & & Average Burial Volumo (cult) & - & - & 44 & - & $\therefore$ & - & - & 44 & Na \\
\hline & & Standard Deviation & - & - & - & - & $=$ & - & - & - & $\mathrm{nat}$ \\
\hline & & Maximum Burital Volume (cumt) & - & - & 44 & - & $=$ & $=$ & $\therefore$ & 44 & $\mathrm{Na}$ \\
\hline & & Minimum Burial Volume (cuft) & - & - & 44 & - & $=$ & - & - & 44 & $\mathrm{Nat}$ \\
\hline \multirow{6}{*}{6} & \multirow{6}{*}{ Resin } & Number of Records & 0 & 0 & 0 & 0 & 0 & $\underline{0}$ & 0 & 0 & - \\
\hline & & Total Waste Voume (cunt) & - & - & - & - & $=$ & $\therefore$ & - & - & $\therefore$ \\
\hline & & Average Burial Volume (cum) & - & $\therefore$ & - & - & - & - & - & - & na \\
\hline & & Standard Deviation & - & - & - & - & - & - & \pm & - & ns \\
\hline & & Maximum Burial Vohme (cu/t) & - & 5 & 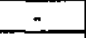 & - & $=$ & 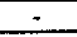 & - & - & $\mathrm{Nob}$ \\
\hline & & Minimum Burial Voume (curti) & - & - & - & - & - & - & 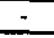 & - & ne \\
\hline \multirow{6}{*}{7} & \multirow{6}{*}{ Other } & Number of Records & 0 & 0 & 0 & 0 & 0 & 0 & $\underline{0}$ & 0 & E \\
\hline & & Total Waste Volume (cult) & - & - & - & - & - & - & - & - & 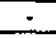 \\
\hline & & Average Burial Volume (cunt) & - & - & - & 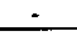 & - & - & $=$ & - & no \\
\hline & & Standard Deviation & - & 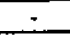 & - & $=$ & - & - & $=$ & - & $\mathrm{Na}$ \\
\hline & & Maximum Burtal Volume (cum) & - & - & $=$ & $\therefore$ & - & - & $\therefore$ & - & No \\
\hline & & Minimum Burial Volume (cu/t) & + & 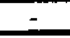 & - & - & - & - & $=$ & + & No \\
\hline \multirow{4}{*}{\multicolumn{2}{|c|}{ Totals Acroses All 7 Type Codas }} & Number of Records & 58 & 0 & 216 & 410 & 1 & $\underline{0}$ & 0 & 685 & \\
\hline & & $\%$ of Box 4 Totals & 8.5 & 0.0 & 31.5 & 59.9 & 0.1 & 0.0 & 0.0 & 100.0 & \\
\hline & & Total Wasto Volurre (cuntt) & 9,368 & 0 & 20,353 & 3,813 & 168 & 0 & $D$ & 33.702 & \\
\hline & & \% of Box 4 Totals & 27.8 & 0.0 & 60.4 & 11.3 & 0.5 & 0.0 & 0.0 & 100.0 & \\
\hline
\end{tabular}


Table 3-59. Decay Forecast for COI Inventory of Potential "Hot Spots" HS-300-4 and HS-500-4

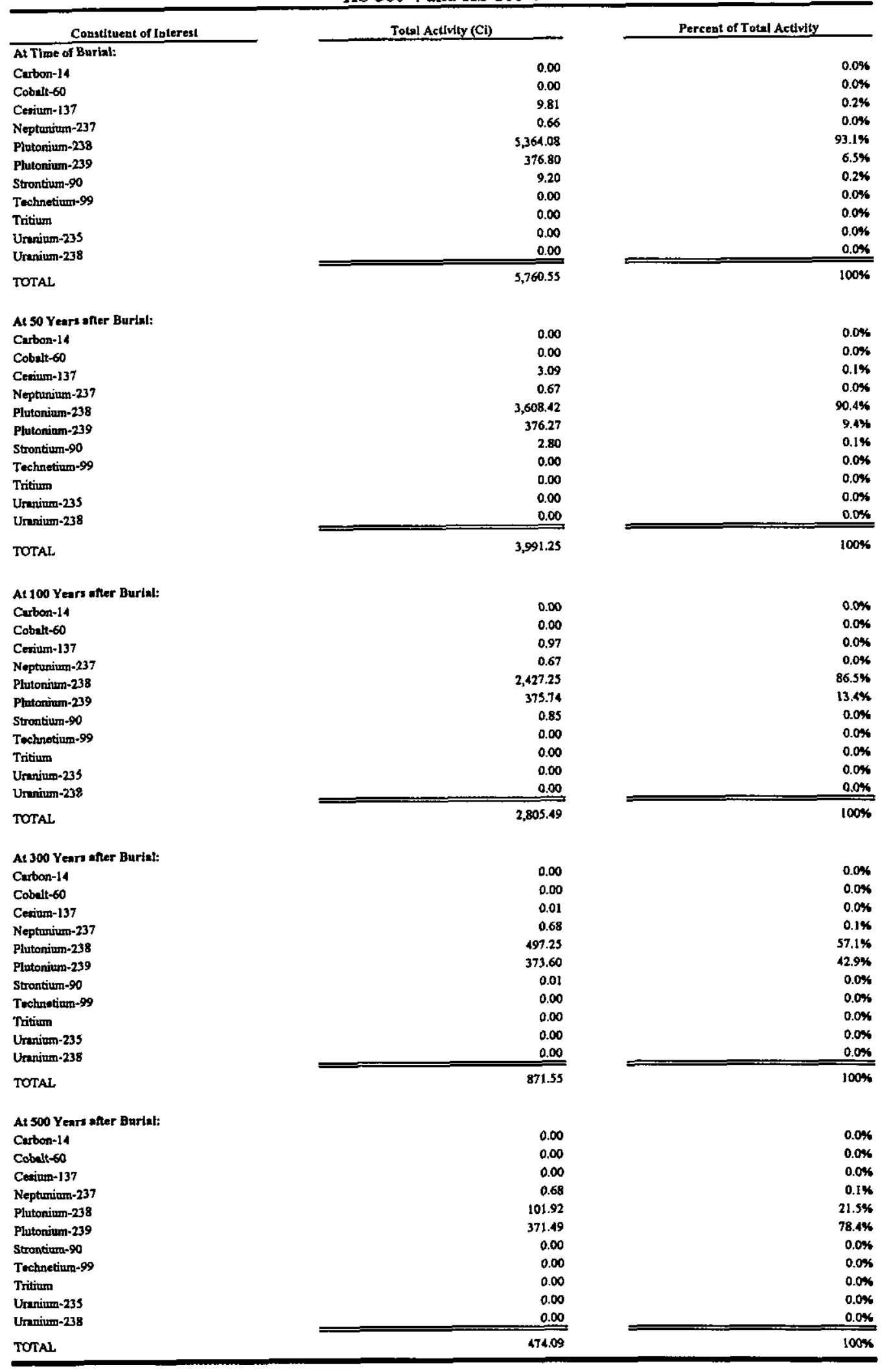


Table 3-59. Decay Forecast for COI Inventory of Potential "Hot Spots" HS-300-4 and HS-500-4 (Continued)

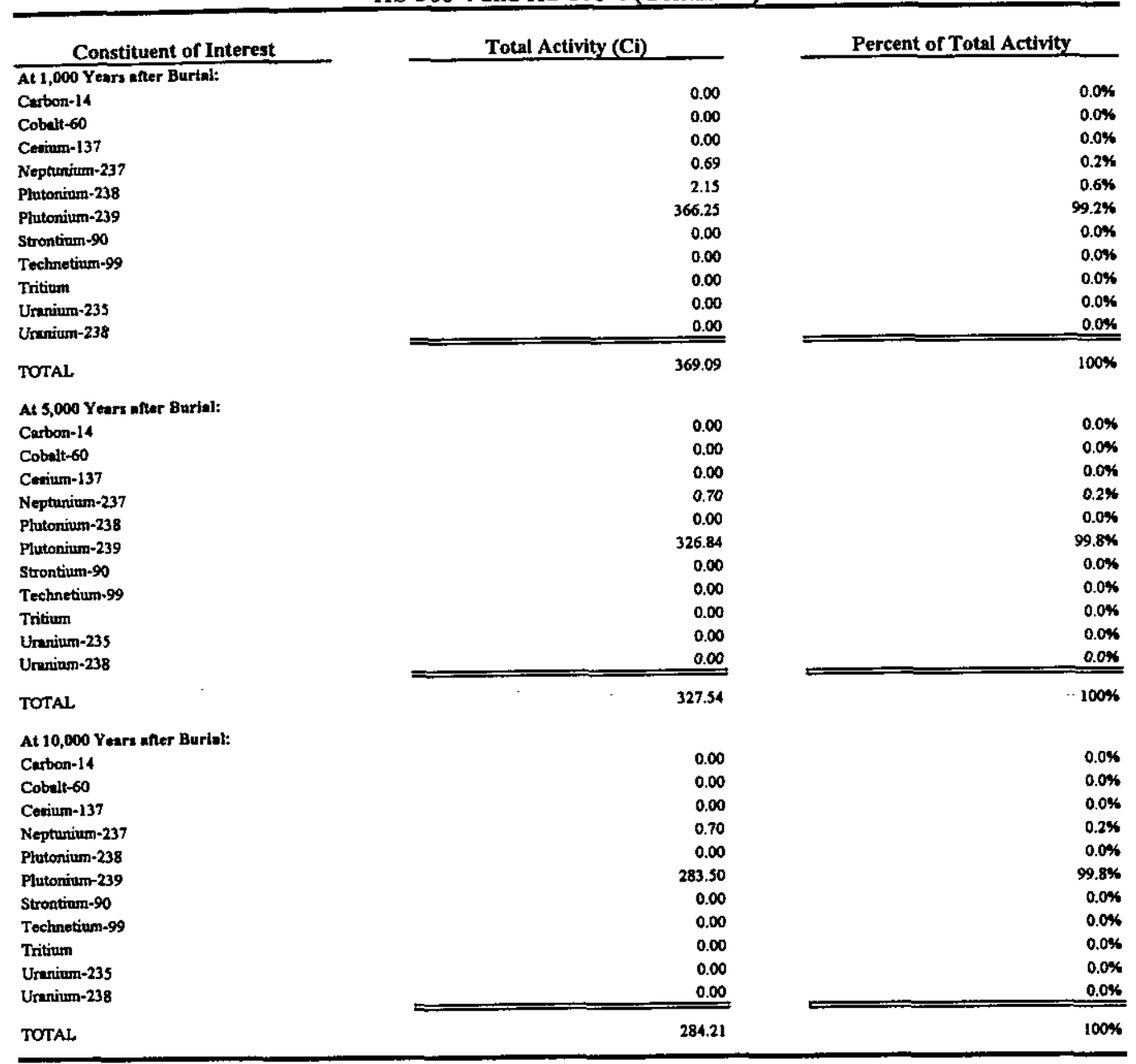


Table 3-60. Summary Statistics for COBRA Inventory of Potential "Hot Spots" HS-300-5

\begin{tabular}{|c|c|c|c|c|c|c|c|c|c|c|c|}
\hline \multirow[t]{2}{*}{ 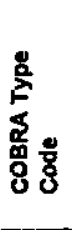 } & & & 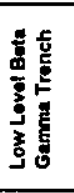 & 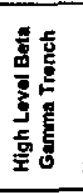 & 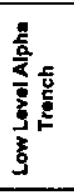 & 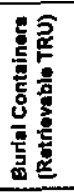 & $\begin{array}{l}5 \\
8 \\
8 \\
8 \\
\mathbf{8} \\
\mathbf{8}\end{array}$ & 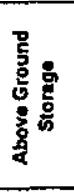 & ᄒ & 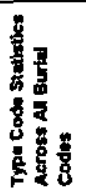 & 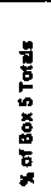 \\
\hline & & COBRA Burlal Code: & 1 & 2 & 3 & 4 & 5 & 6 & 7 & & \\
\hline \multirow{6}{*}{1} & \multirow{6}{*}{$\begin{array}{l}\text { Job Control Waste, } \\
\text { including house. } \\
\text { keoping waste and } \\
\text { protective chothing }\end{array}$} & Number of Records & 134 & 0 & 7 & $\underline{0}$ & $\underline{0}$ & 0 & 0 & 141 & 16.0 \\
\hline & & Total Waste Volumo (curt) & 6.632 & - & 893 & - & - & - & $\cdot$ & 7,525 & 21.5 \\
\hline & & Average Burial Volume (cult) & 49 & - & 128 & - & - & $=$ & $\therefore$ & 53 & Na \\
\hline & & Standerd Devtation & 152 & 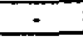 & 120 & $=$ & + & 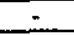 & - & 151 & $\mathrm{na}$ \\
\hline & & Maximum Burial Volume (curt) & 1,500 & $\cdot$ & 336 & - & - & $\therefore$ & - & 1500 & $\mathrm{n} / \mathrm{a}$ \\
\hline & & Minimum Burial Volume (cunt) & 1 & $\therefore$ & 14 & - & - & $\therefore$ & - & 1 & no \\
\hline \multirow{6}{*}{2} & \multirow{6}{*}{ oil } & Number of Records & 0 & 0 & 0 & 0 & 0 & 0 & 0 & 0 & - \\
\hline & & Total Waste Volume (culit) & - & - & - & 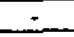 & $\therefore$ & - & - & - & - \\
\hline & & Average Burlal Volume (aunt) & $=$ & - & - & $\therefore$ & - & $=$ & $=$ & - & Na \\
\hline & & Standard Deviation & - & - & - & $=$ & - & $\tau$ & - & - & $\mathrm{na}$ \\
\hline & & Maxdmum Burlal Votume (cumt) & $\therefore$ & - & - & $=$ & $=$ & $=$ & - & $\therefore$ & $\mathrm{n} / \mathrm{a}$ \\
\hline & & Minimum Burlal Volume (cunt) & - & 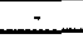 & - & $\therefore$ & $\therefore$ & - & - & - & n/a \\
\hline \multirow{6}{*}{3} & \multirow{6}{*}{$\begin{array}{l}\text { Imadiated Motal } \\
\text { Serap }\end{array}$} & Number of Records & 0 & 729 & 0 & $\underline{0}$ & 0 & 0 & 0 & 729 & 82.8 \\
\hline & & Total Waste Volume (cultt) & - & 26.088 & - & - & - & - & - & 26,088 & 74.5 \\
\hline & & Average Buriat Volumo (cumt) & - & 36 & - & - & - & $=$ & - & 36 & $\mathrm{~N} / \mathrm{a}$ \\
\hline & & Standard Deviation & - & 24 & - & $=$ & $=$ & $\therefore$ & - & 24 & nis \\
\hline & & Maximum Burlal Vohme (cunt) & - & 240 & - & - & $\therefore$ & 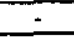 & - & 240 & $\mathrm{Na}$ \\
\hline & & Minimum Burlal Volumo (cunt) & $\therefore$ & 1 & - & - & - & - & $\cdot$ & 1 & nha \\
\hline \multirow{6}{*}{4} & \multirow{6}{*}{$\begin{array}{l}\text { Naturally } \\
\text { Ractionctive } \\
\text { Materials }\end{array}$} & Number of Rocords & 2 & 0 & 0 & 0 & 0 & 0 & 0 & 2 & 0.2 \\
\hline & & Totol Waste Volume (aum) & 300 & $=$ & - & - & - & - & - & 300 & 0.9 \\
\hline & & Average Burral Volume (cunt) & 150 & - & - & $=$ & $\therefore$ & - & - & 150 & nta \\
\hline & & Standand Deviation & 0 & - & $\therefore$ & $=$ & - & - & 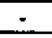 & 0 & n/a \\
\hline & & Maximum Burial Volume (cant) & 150 & - & - & - & - & $=$ & $\therefore$ & 150 & $\mathrm{ne}$ \\
\hline & & Mirumum Burial Volume (cum) & 150 & - & - & 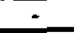 & + & $\therefore$ & - & 150 & $\mathrm{~N} / \mathrm{a}$ \\
\hline \multirow{6}{*}{5} & \multirow{6}{*}{$\begin{array}{l}\text { Capital Equipment, must } \\
\text { be accompanied by a } \\
\text { Plant Equipment } \\
\text { Transfor (PET) }\end{array}$} & Number of Records & 1 & 7 & 0 & 0 & 0 & 0 & 0 & 8 & 0.9 \\
\hline & & Total Waste Volume (aum) & 960 & 146 & - & $\therefore$ & $\cdot$ & - & - & 1,106 & 3.2 \\
\hline & & Average Burial Volume (cunt) & 960 & 21 & - & $=$ & - & $=$ & 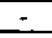 & 138 & $\mathrm{Nah}$ \\
\hline & & Standard Deviation & - & 3 & $=$ & $=$ & - & - & - & 332 & No \\
\hline & & Maxdmum Burial Vohme (cuint) & 960 & 25 & $=$ & $=$ & $\therefore$ & $=$ & $\therefore$ & 960 & $\mathrm{n} / \mathrm{a}$ \\
\hline & & Minimum Burial Volume (cun) & 960 & 19 & - & - & $\therefore$ & - & - & 19 & roa \\
\hline \multirow{6}{*}{6} & \multirow{6}{*}{ Resin } & Number of Records & 0 & 0 & 0 & 0 & 0 & 0 & 0 & 0 & $\cdot$ \\
\hline & & Total Waste Volume (cu/t) & - & $\therefore$ & - & - & - & - & - & - & - \\
\hline & & Average Burial Volume (cu/th) & - & - & - & - & - & 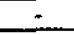 & - & $\therefore$ & $\mathrm{n} / \mathrm{a}$ \\
\hline & & Standard Deviation & - & - & - & - & - & $=$ & - & - & na \\
\hline & & Maxlmum Butal Volume (cumt) & $=$ & $\therefore$ & - & - & - & $=$ & - & - & nos \\
\hline & & Minimum Burial Volume (aum) & - & - & - & $=$ & - & - & 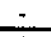 & - & n/a \\
\hline \multirow{6}{*}{7} & \multirow{6}{*}{ Other } & Number of Records & 0 & 0 & 0 & 0 & 0 & 0 & 0 & 0 & - \\
\hline & & Total Waste Volume (cun) & - & - & 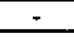 & $=$ & $\therefore$ & $=$ & - & $=$ & - \\
\hline & & Average Burfal Volume (ault) & $\approx$ & - & $=$ & - & $\therefore$ & - & $=$ & - & Na \\
\hline & & Standard Devilition & - & $\therefore$ & - & - & - & - & - & - & $\mathrm{n} / \mathrm{a}$ \\
\hline & & Maximum Burlal Volme (cult) & $=$ & $\therefore$ & - & - & 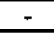 & . & $\therefore$ & - & $\mathrm{mat}$ \\
\hline & & Mirimum Burlal Volume (cuit) & - & - & - & - & - & $=$ & - & - & $\mathrm{na}$ \\
\hline \multirow{4}{*}{\multicolumn{2}{|c|}{ Totale Acroes All 7 Type Codes }} & Number of Records & 137 & 736 & 7 & 0 & 0 & 0 & 0 & 880 & \\
\hline & & $\%$ of Box 5 Totals & 15.6 & 83.6 & 0.8 & 0.0 & 0.0 & 0.0 & 0.0 & 100.0 & \\
\hline & & Total Waste Voume (cult) & 7,892 & 26,234 & 893 & 0 & 0 & 0 & 0 & 35,019 & \\
\hline & & $\%$ of Box 5 Totals & 22.5 & 74.9 & 2.6 & 0.0 & 0.0 & 0.0 & 0.0 & 100.0 & \\
\hline
\end{tabular}


Table 3-61. Decay Forecast for COI Inventory of Potential "Hot Spots"

HS-300-5 and HS-500-5

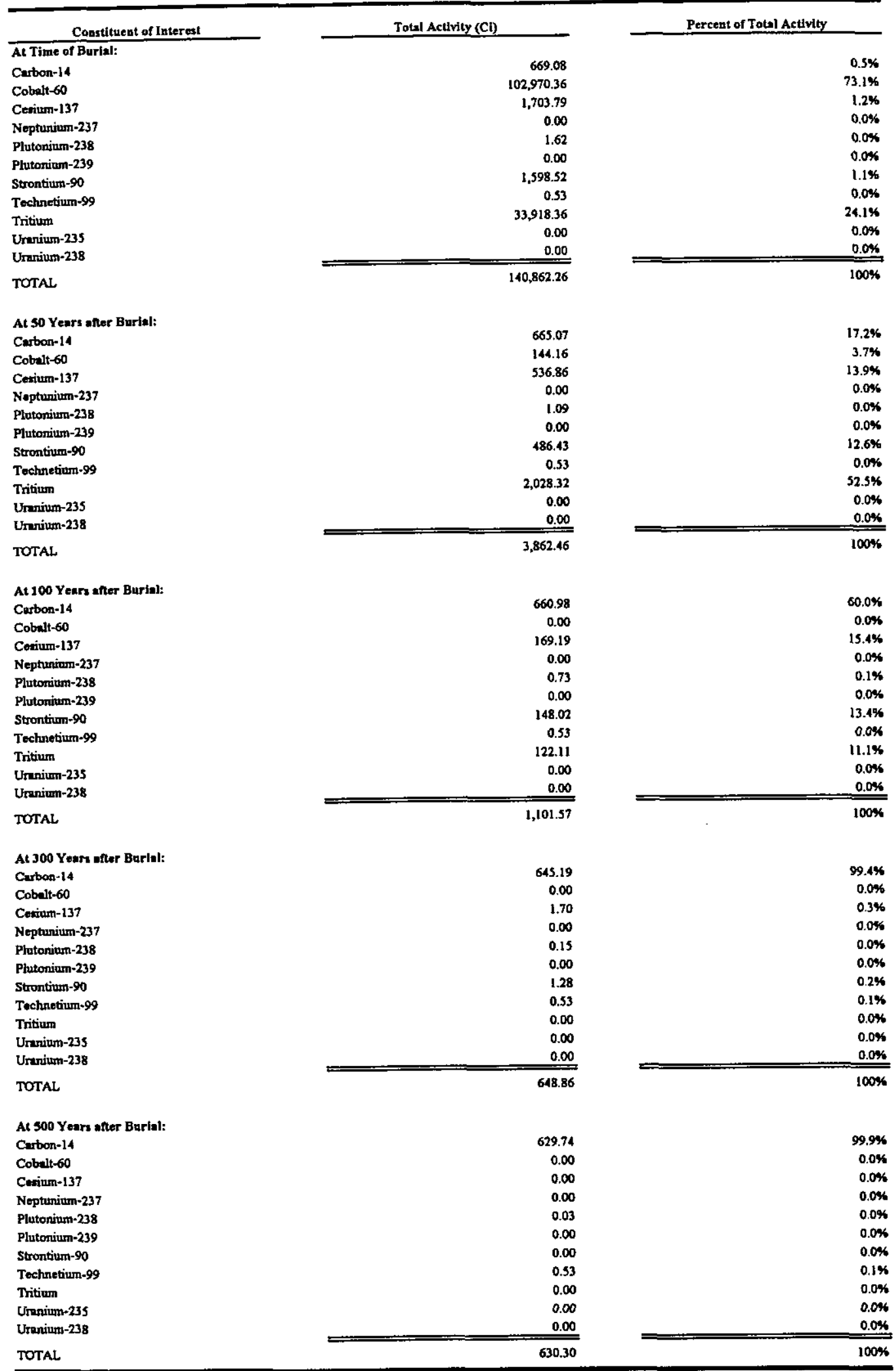


Table 3-61. Decay Forecast for COI Inventory of Potential "Hot Spots" HS-300-5 and HS-500-5 (Continued)

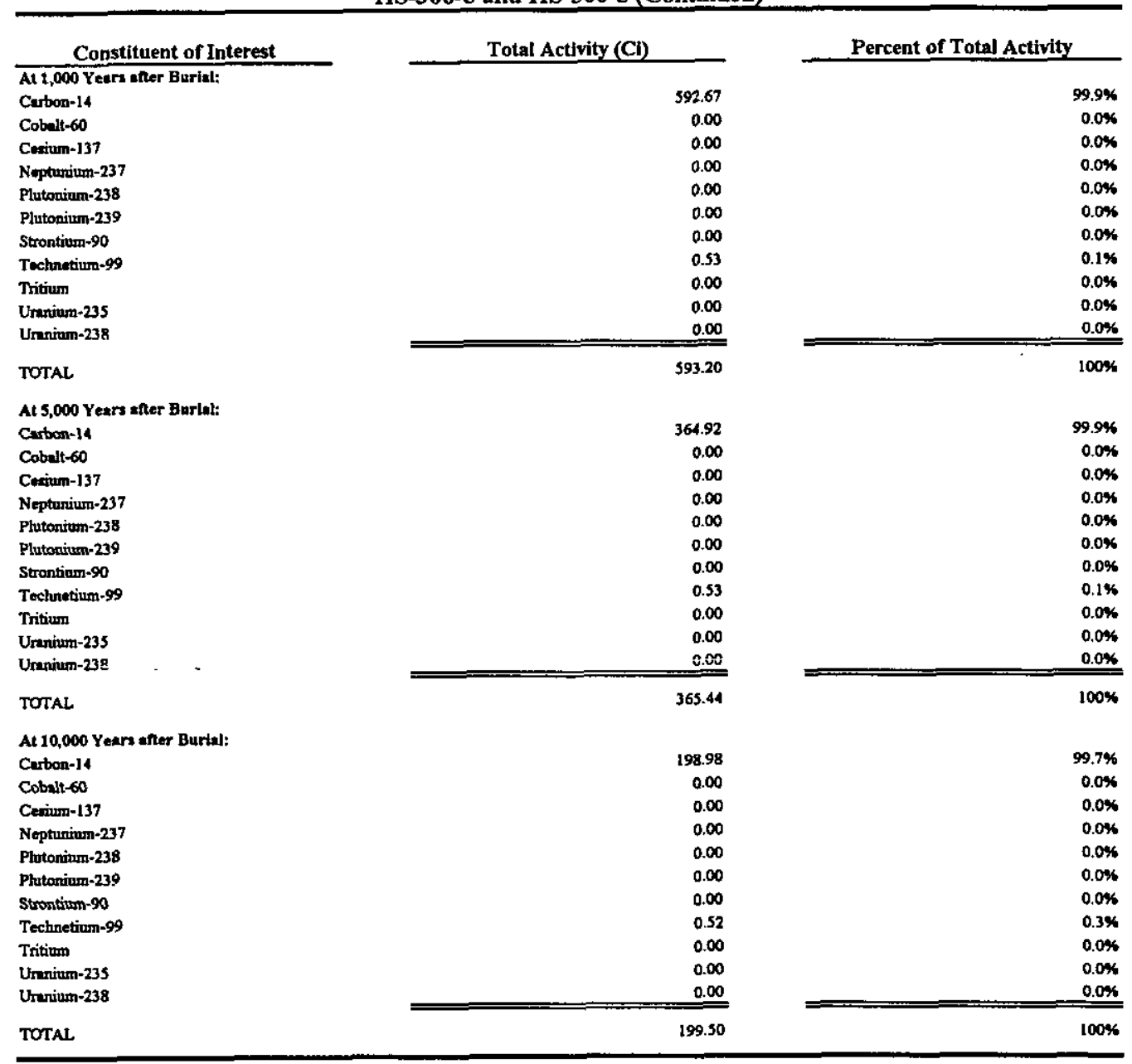


Table 3-62. Summary Statistics for COBRA Inventory of Potential "Hot Spots" HS-300-6

\begin{tabular}{|c|c|c|c|c|c|c|c|c|c|c|c|}
\hline \multirow[t]{2}{*}{ 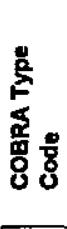 } & & & 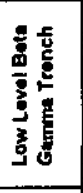 & 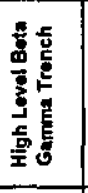 & 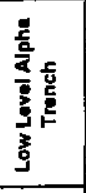 & 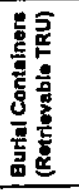 & 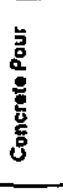 & 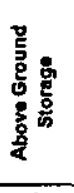 & 产 & 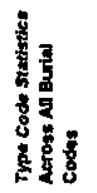 & 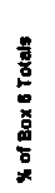 \\
\hline & & COBRA Burlal Code: & 1 & 2 & 3 & 4 & 5 & 6 & 7 & & \\
\hline \multirow{6}{*}{1} & \multirow{6}{*}{$\begin{array}{l}\text { Job Control Waste, } \\
\text { including houst. } \\
\text { keepling waste and } \\
\text { protectlve clothing }\end{array}$} & Number of Records & 631 & 1 & 217 & 204 & 6 & 0 & 0 & 1,059 & 29.2 \\
\hline & & Total Waste Volume (cu/t) & 47,474 & 9 & 28.222 & 2,831 & 176 & - & - & 78,712 & 40.1 \\
\hline & & Average Burlal Volume (cumt) & 75 & 9 & 130 & 14 & 29 & - & $\cdot$ & 74 & na \\
\hline & & Standard Deviation & 267 & $=$ & 176 & 7 & 25 & - & - & 224 & no \\
\hline & & Meximum Burial Volume (eutt) & 6.144 & 8 & 1,900 & 50 & 76 & - & - & 6144 & $n / m$ \\
\hline & & Misimum Burtal Voume (cunt) & 0 & 9 & 1 & 1 & 1 & - & - & 0 & $\mathrm{n} / \mathrm{a}$ \\
\hline \multirow{6}{*}{2} & \multirow{6}{*}{ Oll } & Number of Roconds & 4 & 0 & 0 & 0 & 0 & 0 & 0 & 4 & 0.1 \\
\hline & & Total Waste Volume (curt) & 47 & $=$ & - & - & - & - & 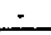 & 47 & 0.0 \\
\hline & & Average Burial Volume (cu/nt) & 12 & $\therefore$ & - & - & - & - & - & 12 & Na \\
\hline & & Starxtard Deviation & 5 & $\therefore$ & - & $\therefore$ & - & - & $=$ & 5 & Na \\
\hline & & Maximum Burial volume (cult) & 19 & $=$ & - & - & - & - & - & 19 & $\mathrm{Na}$ \\
\hline & & Minimum Burlal Volurne (cufti) & 7 & $=$ & - & - & - & - & - & 7 & na \\
\hline \multirow{6}{*}{3} & \multirow{6}{*}{$\begin{array}{l}\text { Irradiatod Hotwl } \\
\text { Scrap }\end{array}$} & Number of Records & 0 & 2.461 & 0 & 2 & 0 & 0 & 0 & 2,463 & 67.9 \\
\hline & & Total Waste Volume (cu/nt) & $\therefore$ & 96.659 & - & 13 & - & - & - & 96,672 & 49.3 \\
\hline & & Average Burlal Volume (cunt) & - & 39 & - & 7 & - & - & - & 39 & Na \\
\hline & & Standard Deviation & - & 59 & - & 8 & - & - & - & 59 & $\mathrm{~N} / \mathrm{a}$ \\
\hline & & Maximum Burlal Volume (curtt) & - & 1,200 & $=$ & 12 & - & - & - & 1200 & nra \\
\hline & & Minimum Burial Voume (cunt) & - & 0 & - & 1 & - & - & - & 0 & na \\
\hline \multirow{6}{*}{4} & \multirow{6}{*}{$\begin{array}{l}\text { Naturally } \\
\text { Radloactive } \\
\text { Materials }\end{array}$} & Number of Records & 28 & 2 & 1 & 0 & 0 & 0 & 0 & 31 & 0.9 \\
\hline & & Total Waste Volume (cu/n) & 2.401 & 9 & 150 & - & - & $=$ & - & 2,560 & 1.3 \\
\hline & & Average Burial Volume (aunt) & 86 & 5 & 150 & - & - & - & - & 63 & is \\
\hline & & Standard Deviayion & 82 & 5 & - & - & 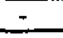 & - & $\cdot$ & 82 & Na \\
\hline & & Maximum Burial Volume (cu/n) & 250 & 8 & 150 & - & - & - & - & 250 & $\mathrm{n} / \mathrm{a}$ \\
\hline & & Minimum Burial Volume (curt) & 2 & 1 & 150 & - & $\approx$ & - & - & 1 & Ne \\
\hline \multirow{6}{*}{5} & \multirow{6}{*}{$\begin{array}{l}\text { Capltal Equipment, must } \\
\text { be accompanied by a } \\
\text { Plant Equipment } \\
\text { Transfor (PET) }\end{array}$} & Number of Records & 6 & 56 & 0 & 0 & 0 & 0 & $\underline{0}$ & 72 & 2.0 \\
\hline & & Total Waste Voume (cult) & 120 & 18.115 & - & - & $=$ & 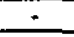 & - & 18.235 & 9.3 \\
\hline & & Average Burial Volume (cum) & 20 & 274 & - & - & $=$ & - & - & 253 & $\mathrm{na}$ \\
\hline & & Standard Devietion & 10 & 1,966 & - & - & - & - & - & 1882 & $\mathrm{Na}$ \\
\hline & & Maximum Burlal Voume (curt) & 30 & 16,000 & - & - & - & - & - & 16000 & no \\
\hline & & Minkmen Burtal Vokme (cun) & 6 & 1 & - & - & $\div$ & - & - & 1 & No \\
\hline \multirow{6}{*}{6} & \multirow{6}{*}{ Rosin } & Number of Records & 0 & 0 & D. & 0 & 0 & 0 & 0 & 0 & $\because$ \\
\hline & & Total Waste Voume (cult) & - & - & - & - & - & - & - & - & $=$ \\
\hline & & Average Burial Votume (curtt) & - & - & $\div$ & - & - & - & - & - & Na \\
\hline & & Standard Devation & - & - & $\therefore$ & - & - & $\dot{-}$ & $\therefore$ & - & $\mathrm{Na}$ \\
\hline & & Maximum Burial Vokme (curt) & - & - & - & + & - & - & - & - & $\mathrm{Na}$ \\
\hline & & Minirnum Burtal Volume (cu/ti) & $\cdot$ & - & $\therefore$ & $=$ & - & - & - & - & $\mathrm{Na}$ \\
\hline \multirow{6}{*}{7} & \multirow{6}{*}{ otfer } & Number of Records & 0 & 0 & 0 & 0 & 0 & 0 & 0 & 0 & $=$ \\
\hline & & Total Waste Volume (cu/t) & 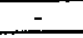 & 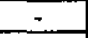 & - & $=$ & $\therefore$ & - & - & - & $=$ \\
\hline & & Average Burial Volume (cult) & - & - & 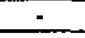 & - & - & - & - & - & Nio \\
\hline & & Standard Deviation & - & - & - & - & 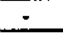 & - & - & 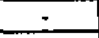 & $\mathrm{Nan}$ \\
\hline & & Maximem Burial Volume (cutt) & - & - & - & - & - & - & - & - & Na \\
\hline & & Minimum Burial Volume (cum) & - & 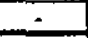 & - & - & - & - & - & $\cdot$ & Na \\
\hline \multirow{4}{*}{\multicolumn{2}{|c|}{ Totals Acroes All 7 Type Codos }} & Number of Records & 669 & 2,530 & 218 & 206 & 6 & 0 & 0 & 3.629 & \\
\hline & & $\%$ of Box 6 Totals & 18.4 & 69.7 & 6.0 & 5.7 & 0.2 & 0.0 & 0.0 & 100.0 & \\
\hline & & Total Waste Voume (curt) & 50,042 & 114,792 & 28,372 & 2,844 & 176 & 0 & 0 & 196,226 & \\
\hline & & $\%$ of Box 6 Totals & 25.5 & 58.5 & 14.5 & 1.4 & 0.1 & 0.0 & 0.0 & 100.0 & \\
\hline
\end{tabular}


Table 3-63. Decay Forecast for COI Inventory of Potential "Hot Spots"

$$
\text { HS-300-6 and HS-500-6 }
$$

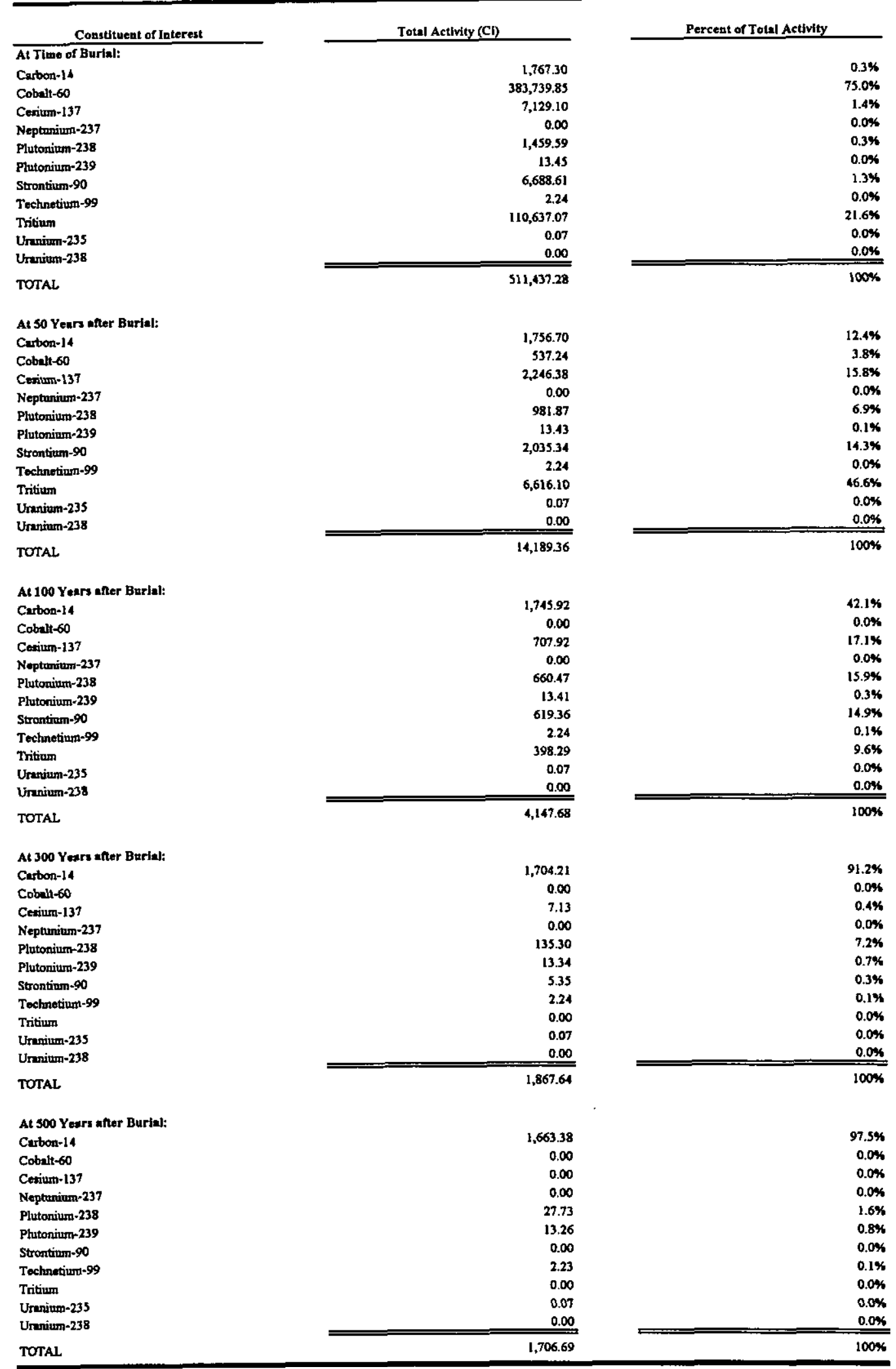


Table 3-63. Decay Forecast for COI Inventory of Potential "Hot Spots" HS-300-6 and HS-500-6 (Continued)

\begin{tabular}{|c|c|c|}
\hline Constituent of Interest & Total Activity (Ci) & Percent of Total Activity \\
\hline \multicolumn{3}{|l|}{ A1 1,000 Years eftor Burial: } \\
\hline Carbon-14 & $1,565.47$ & $99.0 \%$ \\
\hline Cobalt -60 & 0.00 & $0.0 \%$ \\
\hline Cesium-137 & 0.00 & $0.0 \%$ \\
\hline Nepturinum-237 & 0.00 & $0.0 \%$ \\
\hline Plutonium-238 & 0.58 & $0.0 \%$ \\
\hline Plutorium-239 & 13.08 & $0.8 \%$ \\
\hline Strontium-90 & 0.00 & $0.0 \%$ \\
\hline Technetium-99 & 2.23 & $0.1 \%$ \\
\hline Tritium & $0 . \infty$ & $0.0 \%$ \\
\hline Unenivm-235 & 0.07 & $0.0 \% 6$ \\
\hline Unuiven-238 & 0.00 & $0.0 \%$ \\
\hline TOTAL & $1,581.44$ & $100 \%$ \\
\hline \multicolumn{3}{|l|}{ At 5,000 Years after Burial: } \\
\hline Cerbon-14 & 963.89 & $98.6 \%$ \\
\hline Cobalt -60 & 0.00 & $0.0 \%$ \\
\hline Cexiun-137 & 0.00 & $0.0 \%$ \\
\hline Neptuniust-237 & 0.00 & $0.0 \%$ \\
\hline Phutonium-238 & 0.00 & $0.0 \%$ \\
\hline Plutonium-239 & 11.67 & $1.2 \%$ \\
\hline Strontium-90 & $0 . \infty$ & $0.0 \%$ \\
\hline Technetium-99 & 2.20 & $0.2 \%$ \\
\hline Tritium & 0.00 & $0.0 \%$ \\
\hline Uranium-235 & 0.07 & $0.0 \%$ \\
\hline Uranium-238 & $\stackrel{0 . \infty}{\underline{\underline{.}}}$ & $0.0 \%$ \\
\hline TOTAL & 977.83 & $100 \%$ \\
\hline \multicolumn{3}{|l|}{ At 10,000 Years after Burial: } \\
\hline Cubon-14 & 525.60 & $97.7 \%$ \\
\hline Cobralt-60 & 0.00 & $0.0 \%$ \\
\hline Cexinm-137 & 0.00 & $0.0 \%$ \\
\hline Neptunium-237 & 0.00 & 0.086 \\
\hline Plutonium-238 & 0.00 & $0.0 \%$ \\
\hline Plutoruium-239 & 10.12 & $1.9 \%$ \\
\hline Strontium-90 & 0.00 & $0.0 \%$ \\
\hline Twehnetium-99 & 2.17 & $0.4 \%$ \\
\hline Tritium & 0.00 & $0.0 \%$ \\
\hline Uranium-23s & 0.07 & $0.0 \%$ \\
\hline Uranium-238 & 0.00 & $0.0 \%$ \\
\hline TOTAL & 537.96 & $100 \%$ \\
\hline
\end{tabular}


Table 3-64. Summary Statistics for COBRA Inventory of Potential "Hot Spots" HS-300-7

\begin{tabular}{|c|c|c|c|c|c|c|c|c|c|c|c|}
\hline \multirow[t]{2}{*}{ 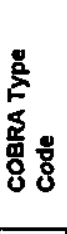 } & & & 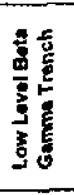 & 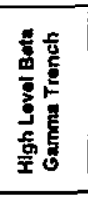 & 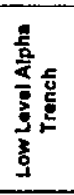 & 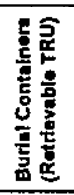 & 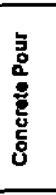 & 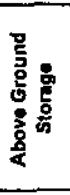 & $\frac{\grave{E}}{\mathbf{5}}$ & 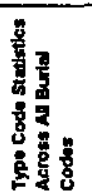 & 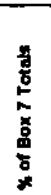 \\
\hline & & COBRA Burial Code: & 1 & 2 & 3 & 4 & 5 & 6 & 7 & & \\
\hline \multirow{6}{*}{1} & \multirow{6}{*}{$\begin{array}{l}\text { Jab Control Waste, } \\
\text { Including house- } \\
\text { keoping waste and } \\
\text { probective clothing }\end{array}$} & Number of Records & 52 & 0 & 0 & 0 & 0 & 0 & 0 & 52 & 10.1 \\
\hline & & Total Waste Volume (curt) & 2.656 & - & $\cdot$ & $\cdot$ & - & - & - & 2,656 & 18.7 \\
\hline & & Average Burial Volume (culn) & 51 & 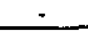 & - & - & - & $=$ & - & 51 & nth \\
\hline & & Standard Deviation & 102 & $=$ & - & - & - & $\therefore$ & - & 102 & no \\
\hline & & Maximum Burtal Voume (cunt) & 500 & $\therefore$ & 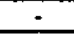 & - & $\therefore$ & 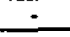 & $\therefore$ & 500 & $n_{n}$ \\
\hline & & Minimum Burial Volume (cunt) & 2 & - & - & - & - & - & - & 2 & nie \\
\hline \multirow{6}{*}{2} & \multirow{6}{*}{ oll } & Number of Records & D & 0 & 0 & 0 & 0 & 0 & 0 & 0 & - \\
\hline & & Total Waste Vokume (aum) & - & $=$ & - & - & - & $\therefore$ & - & - & - \\
\hline & & Average Burial Voume (cunt) & - & - & - & - & - & - & - & - & nte \\
\hline & & Standard Deviation & - & - & $=$ & $\therefore$ & - & $\therefore$ & - & - & $n / a$ \\
\hline & & Maxdmum Burlad Volume (curti) & - & - & $=$ & - & + & - & - & - & $\mathrm{n} / \mathrm{a}$ \\
\hline & & Minimum Burlal Volume (cun) & - & $\therefore$ & - & - & 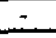 & - & - & - & na \\
\hline \multirow{6}{*}{3} & \multirow{6}{*}{$\begin{array}{l}\text { Imadiated Metel } \\
\text { Scrap }\end{array}$} & Number of Records & 0 & 463 & 0 & 0 & 0 & $\underline{0}$ & 0 & 463 & 89.7 \\
\hline & & Total Waste Volume (curtt) & - & 11,565 & - & - & - & $=$ & + & 11,565 & 81.3 \\
\hline & & Averege Burlai Volume (cuft) & - & 25 & $\therefore$ & - & 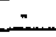 & 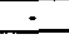 & - & 25 & na \\
\hline & & Standard Deviation & - & 15 & - & - & - & $=$ & - & 15 & Na \\
\hline & & Maximum Burlal Vohme (cum) & $\therefore$ & 120 & - & $\cdot$ & - & 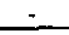 & 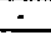 & 120 & $n / a$ \\
\hline & & Minimum Buial Vohme (cunn) & - & 0 & $=$ & $=$ & - & 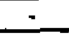 & - & 0 & $\mathrm{na}$ \\
\hline \multirow{6}{*}{4} & \multirow{6}{*}{$\begin{array}{l}\text { Noturally } \\
\text { Radionctivo } \\
\text { Matorials }\end{array}$} & Number of Records & 1 & 0 & 0 & 0 & 0 & $\underline{0}$ & 0 & 1 & 0.2 \\
\hline & & Total Waste Vohme (aunt) & 9 & - & $\therefore$ & - & - & 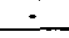 & - & 9 & 0.1 \\
\hline & & Average Burial Volume (cunit) & 9 & 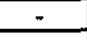 & - & - & - & $\therefore$ & $=$ & 9 & $\mathrm{n} / \mathrm{m}$ \\
\hline & & Standard Deviaton & - & $=$ & - & - & $=$ & - & $=$ & - & ne \\
\hline & & Maxdmum Burial Volume (cunt) & 9 & - & - & - & - & - & - & 9 & 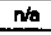 \\
\hline & & Minimum Burial Volume (cunit) & 9 & - & - & - & - & $\therefore$ & - & 9 & nes \\
\hline \multirow{6}{*}{5} & \multirow{6}{*}{$\begin{array}{l}\text { Caphad Equipment, must } \\
\text { be accompinied by a } \\
\text { Plant Equlpment } \\
\text { Transfer (PET) }\end{array}$} & Number of Records & 0 & 0 & $D$ & 0 & 0 & 0 & 0 & 0 & - \\
\hline & & Total Waste Volume (curt) & - & + & $=$ & - & - & $\therefore$ & - & - & - \\
\hline & & Average Burial Volume (caunt) & $\therefore$ & - & - & - & - & $\therefore$ & - & + & $\mathrm{Na}$ \\
\hline & & Standard Deviation & - & - & - & - & - & $\therefore$ & - & - & ne \\
\hline & & Maximum Burial Volume (cu/t) & - & - & - & - & $\therefore$ & $=$ & - & - & Na \\
\hline & & Minimum Burlal Volume (aun) & - & - & - & - & - & - & - & - & $\mathrm{n} / \mathrm{a}$ \\
\hline \multirow{6}{*}{6} & \multirow{6}{*}{ Rosin } & Number of Records & 0 & 0 & 0 & 0 & $\underline{0}$ & 0 & 0 & 0 & - \\
\hline & & Total Waste Volume (cu/t) & I & $\therefore$ & + & $\therefore$ & - & - & - & - & - \\
\hline & & Average Burlal volume (cult) & $=$ & - & - & $\cdot$ & - & - & $=$ & - & na \\
\hline & & Stenderd Deviation & $=$ & - & - & - & - & $=$ & - & - & $\mathrm{n} / \mathrm{e}$ \\
\hline & & Maximum Burial Volume (cultt) & $=$ & - & - & - & - & $=$ & - & - & nta \\
\hline & & Mirimum Burlal Volume (cu/ti) & - & - & - & $\cdot$ & - & 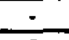 & - & - & $n$ no \\
\hline \multirow{6}{*}{7} & \multirow{6}{*}{ Other } & Number of Records & 0 & 0 & 0 & 0 & 0 & $\underline{0}$ & 0 & 0 & $\cdot$ \\
\hline & & Total Waste Volume (cum) & - & - & $\therefore$ & - & $\therefore$ & $\therefore$ & - & - & $\cdot$ \\
\hline & & Average Burlal Voume (cumt) & - & - & - & 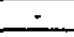 & $\therefore$ & 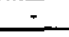 & - & - & $\mathrm{n} / \mathrm{a}$ \\
\hline & & Standard Deviation & - & - & 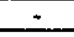 & - & - & $\therefore$ & - & $\therefore$ & $\mathrm{Na}$ \\
\hline & & Maximum Burlal Vohmo (cu/t) & $\therefore$ & - & $=$ & - & - & 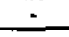 & - & - & $n$ \\
\hline & & Mirtmum Burlal Volume (cum) & - & $\therefore$ & $\therefore$ & - & - & - & - & - & $n / a$ \\
\hline \multirow{4}{*}{\multicolumn{2}{|c|}{ Totals Acrons All 7 Type Codes }} & Number of Records & 53 & 463 & 0 & 0 & 0 & 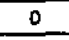 & 0 & 516 & \\
\hline & & * of Box 7 Totals & 10.3 & 89.7 & 0.0 & 0.0 & 0.0 & 0.0 & 0.0 & 100.0 & \\
\hline & & Total Wasto Vohme (Cumlt) & 2,665 & 11.565 & 0 & 0 & 0 & 0 & 0 & 14,230 & \\
\hline & & $x$ of Box 7 Totals & 18.7 & 81.3 & 0.0 & 0.0 & 0.0 & 0.0 & 0.0 & 100.0 & \\
\hline
\end{tabular}


Table 3-65. Decay Forecast for COI Inventory of Potential "Hot Spots" HS-300-7 and HS-500-7

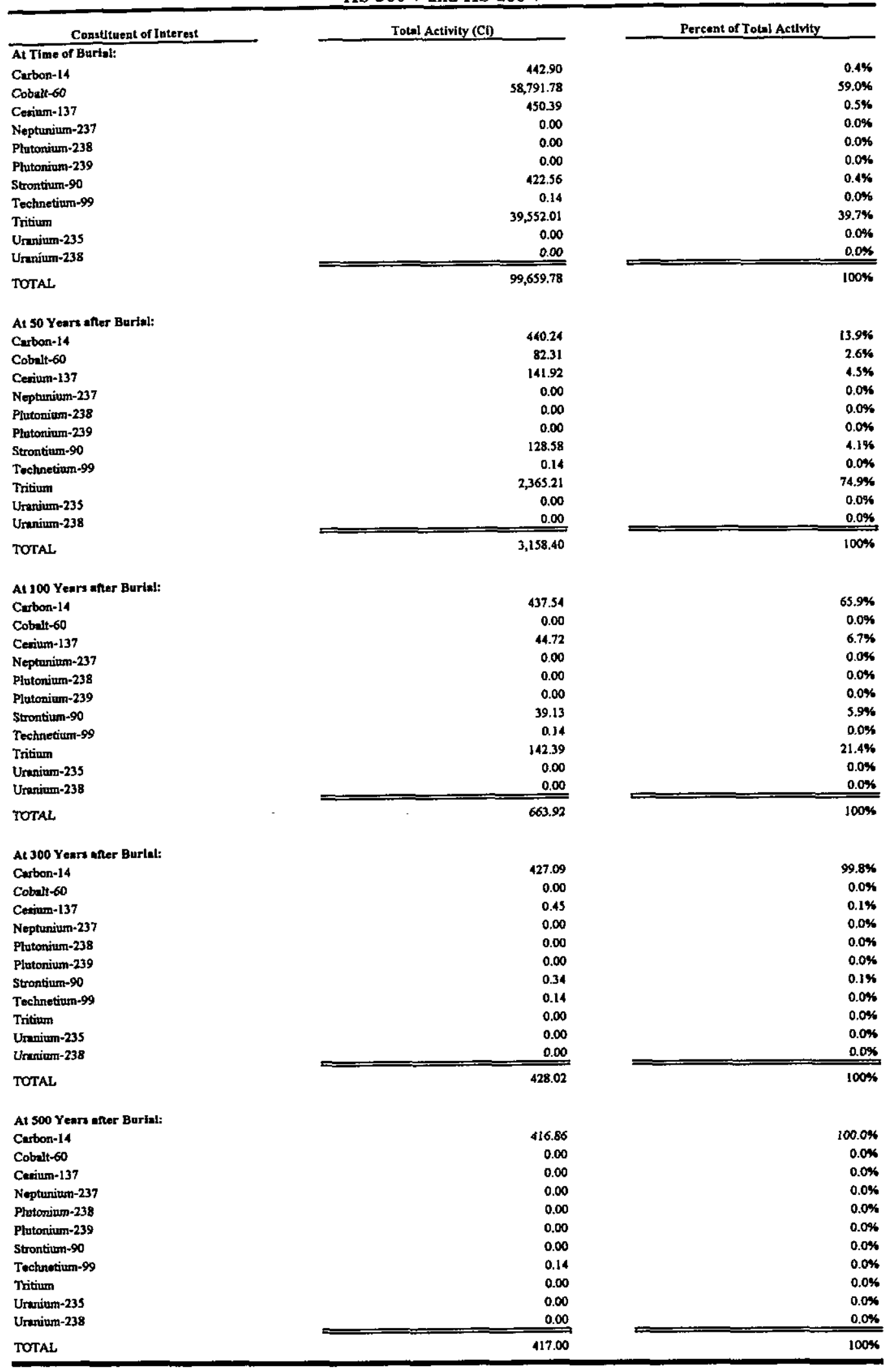


Table 3-65. Decay Forecast for COI Inventory of Potential "Hot Spots" HS-300-7 and HS-500-7 (Continued)

\begin{tabular}{|c|c|c|}
\hline Constituent of Interest & Total Activity (Ci) & Percent of Total Activity \\
\hline \multicolumn{3}{|l|}{ At 1,000 Years efter Burial: } \\
\hline Carbon-14 & 392.32 & $100.0 \%$ \\
\hline Cobalt- 60 & 0.00 & $0.0 \%$ \\
\hline Cexiuton-137 & 0.00 & $0.0 \%$ \\
\hline Neptunium-237 & 0.00 & $0.0 \%$ \\
\hline Plutonium-238 & 0.00 & $0.0 \%$ \\
\hline Plutonium-239 & 0.00 & $0.0 \%$ \\
\hline Strontium-90 & 0.00 & $0.0 \%$ \\
\hline Technetiun-99 & 0.14 & $0.0 \%$ \\
\hline Tritium & 0.00 & $0.0 \%$ \\
\hline Uaniuma-235 & 0.00 & $0.0 \%$ \\
\hline Untrium-238 & $\stackrel{0.00}{=}$ & $0.0 \%$ \\
\hline TOTAL & 392.46 & $100 \%$ \\
\hline \multicolumn{3}{|l|}{ At 5,000 Yearn meter Burial: } \\
\hline Curbon-14 & 241.56 & $99.9 \%$ \\
\hline Cobatt -60 & 0.00 & $0.0 \%$ \\
\hline Cexium-137 & 0.00 & $0.0 \%$ \\
\hline Neptanium-237 & 0.00 & $0.0 \%$ \\
\hline Plutonium-238 & 0.00 & $0.0 \%$ \\
\hline Plutonium-239 & 0.00 & $0.0 \%$ \\
\hline Strontium 90 & 0.00 & $0.0 \%$ \\
\hline Technetium-99 & 0.14 & $0.1 \%$ \\
\hline Tritium & 0.00 & $0.0 \%$ \\
\hline Uranium-235 & 0.00 & $0.0 \%$ \\
\hline Uranium-238 & 0.00 & $0.0 \%$ \\
\hline TOTAL & 241.70 & $100 \%$ \\
\hline \multicolumn{3}{|l|}{ At 10,000 Years ufter Burias: } \\
\hline Cutcon-14 & 131.72 & $99.9 \%$ \\
\hline Cobalt-60 & $0 . \infty$ & $0.0 \%$ \\
\hline Cesium-137 & 0.00 & $0.0 \%$ \\
\hline Neqpturium-237 & 0.00 & $0.0 \%$ \\
\hline Plutonium-238 & 0.00 & $0.0 \%$ \\
\hline Plutonium-239 & 0.00 & $0.0 \%$ \\
\hline Strontium-90 & 0.00 & $0.0 \%$ \\
\hline Tochretium-99 & 0.14 & $0.1 \%$ \\
\hline Tritium & 0.00 & $0.0 \%$ \\
\hline Urenium-235 & 0.00 & $0.0 \%$ \\
\hline Uranium-238 & $\stackrel{0.00}{=}$ & $0.0 \%$ \\
\hline TOTAL & 131.86 & $100 \%$ \\
\hline
\end{tabular}


Table 3-66. Summary Statistics for COBRA Inventory of Potential "Hot Spots" HS-300-8

\begin{tabular}{|c|c|c|c|c|c|c|c|c|c|c|c|}
\hline \multirow[t]{2}{*}{$\frac{8}{2}$} & & & 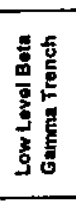 & 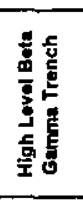 & 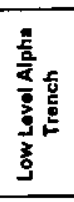 & 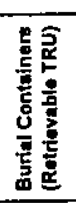 & 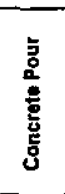 & 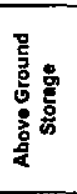 & $\frac{5}{\delta}$ & \multirow[t]{2}{*}{ 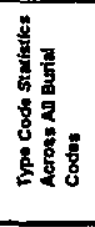 } & \multirow[t]{2}{*}{ 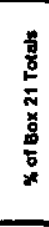 } \\
\hline & & COBRA Burial Code: & 1 & 2 & 3 & 4 & 5 & 6 & 7 & & \\
\hline \multirow{6}{*}{1} & \multirow{6}{*}{$\begin{array}{l}\text { Job Control Waste; } \\
\text { including house- } \\
\text { keeping waste and } \\
\text { protwetive clothing }\end{array}$} & Number of Records & 54 & 0 & 5 & 0 & 0 & 0 & D & 59 & 7.7 \\
\hline & & Total Waste Volume (cuift) & 1,926 & $\therefore$ & 116 & $=$ & - & - & - & 2,042 & 9.5 \\
\hline & & Average Burial Volume (aunt) & 36 & - & 23 & - & - & - & - & 35 & $\mathrm{n} / \mathrm{a}$ \\
\hline & & Stanctard Deviation & 45 & $\because$ & 24 & $\dot{-}$ & - & $\cdot$ & - & 43 & $n / a$ \\
\hline & & Maximum Burlal Vohume (cuntt) & 220 & $=$ & 64 & $=$ & - & - & 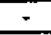 & 220 & $\mathrm{nata}$ \\
\hline & & Minimum Burial Volume (cumt) & 2 & - & 2 & 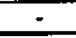 & $=$ & - & $\dot{-}$ & 2 & $\mathrm{n} / \mathrm{a}$ \\
\hline \multirow{6}{*}{2} & \multirow{6}{*}{ onl } & Number of Records & 1 & 0 & 0 & 0 & 0 & 0 & 0 & 1 & 0.1 \\
\hline & & Total Waste Vaumo (cum) & 34 & - & 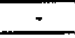 & $=$ & - & - & $=$ & 34 & 0.2 \\
\hline & & Average Burial Volume (cumt) & 34 & - & - & - & - & - & $\therefore$ & 34 & $\mathrm{na}$ \\
\hline & & Standard Devilution & 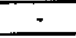 & - & - & - & - & - & - & $=$ & nos \\
\hline & & Maximum Burial Volume (cunt) & 34 & - & $\dot{-}$ & - & 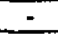 & - & 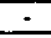 & 34 & $n / h$ \\
\hline & & Minimum Burlal Volusne (cum) & 34 & - & $\cdot$ & - & - & - & - & 34 & Noe \\
\hline \multirow{6}{*}{3} & \multirow{6}{*}{$\begin{array}{l}\text { Imadfated Motal } \\
\text { Scrap }\end{array}$} & Number of Records & 0 & 706 & 0 & 0 & 0 & 0 & 0 & 706 & 92.0 \\
\hline & & Total Waste Volume (cuilt) & $=$ & 19,295 & - & $=$ & $=$ & - & $=$ & 19,295 & 90.1 \\
\hline & & Average Burlal Volume (cultit) & 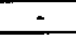 & 27 & - & - & - & - & - & 27 & $\mathrm{~N} / \mathrm{a}$ \\
\hline & & Standard Devistion & - & 17 & - & - & - & - & $=$ & 17 & $\mathrm{Na}$ \\
\hline & & Maximum Burial Volume (cult) & - & 130 & $\therefore$ & 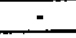 & $=$ & $=$ & - & 130 & $\mathrm{ne}$ \\
\hline & & Mindrum Burial Volume (curt) & 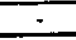 & 0 & - & - & + & $=$ & + & 0 & $\mathrm{ne}$ \\
\hline \multirow{6}{*}{4} & \multirow{6}{*}{$\begin{array}{c}\text { Naturally } \\
\text { Reciloactive } \\
\text { Matortals }\end{array}$} & Number of Records & 0 & 0 & 0 & 0 & 0 & 0 & 0 & 0 & - \\
\hline & & Total Waste Volume (cunt) & $\therefore$ & - & - & - & $=$ & $\because$ & $\dot{-}$ & - & - \\
\hline & & Average Burtal Volume (cunt) & $\div$ & - & $\cdot$ & - & - & $\therefore$ & - & - & $\mathrm{Na}$ \\
\hline & & Standard Deviation & - & + & - & - & - & $\therefore$ & - & $\dot{+}$ & $\mathrm{N} / \mathrm{a}$ \\
\hline & & Maximum Burial Volume (cult) & - & - & $=$ & $=$ & $=$ & - & - & - & $\mathrm{Na}$ \\
\hline & & Minimum Burlal Volume (cumt) & - & - & - & - & - & - & - & - & Na \\
\hline \multirow{6}{*}{$\mathbf{5}$} & \multirow{6}{*}{$\begin{array}{l}\text { Capital Equipment, must } \\
\text { be sccompanted by a } \\
\text { Plant Equipment } \\
\text { Trantfor (PET) }\end{array}$} & Number of Records & 0 & 1 & 0 & 0 & 0 & 0 & 0 & 1 & 0.1 \\
\hline & & Total Wasto Votume (calft) & - & 35 & - & - & - & $\therefore$ & $\therefore$ & 35 & 0.2 \\
\hline & & Average Burial Volume (cult) & - & 35 & - & - & - & - & $\cdot$ & 35 & nta \\
\hline & & Standard Devation & - & $\cdot$ & $\therefore$ & - & - & - & - & 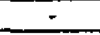 & $\mathrm{N} / \mathrm{a}$ \\
\hline & & Maximum Burial Volume (cult) & - & 35 & $\because$ & - & 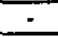 & 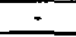 & $\therefore$ & 35 & $\mathrm{ne}$ \\
\hline & & Minimum Burled Volume (cum) & - & 35 & - & $\therefore$ & - & - & - & 35 & $\mathrm{~N} / \mathrm{a}$ \\
\hline \multirow{6}{*}{6} & & Number of Reconds & 0 & 0 & 0 & 0 & 0 & 0 & 0 & 0 & $\therefore$ \\
\hline & & Total Waste Volume (cunt) & - & - & - & 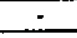 & $\therefore$ & $=$ & 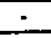 & - & $\therefore$ \\
\hline & Rasin & Average Burtal Volume (curt) & - & - & - & - & - & - & - & - & $\mathrm{ntan}$ \\
\hline & & Standard Deviation & + & - & - & - & - & 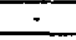 & - & - & no \\
\hline & & Maximum Burial volume (cult) & - & - & - & $=$ & - & - & - & - & no \\
\hline & & Mirimum Burial Volme (anti) & - & $\therefore$ & $=$ & - & $\cdot$ & $=$ & $\dot{-}$ & - & nia \\
\hline & & Number of Records & 0 & 0 & 0 & $\overline{0}$ & 0 & 0 & 0 & 0 & $\therefore$ \\
\hline & & Total Waste Volume (cun) & $\because$ & $\div$ & $\because$ & - & $\dot{-}$ & - & $\dot{-}$ & - & - \\
\hline 7 & other & Average Burfel Volume (cunt) & - & - & - & - & - & - & $=$ & - & $\mathrm{Ma}$ \\
\hline & & Standard Deviation & - & $\cdot$ & - & $\cdot$ & - & $=$ & 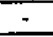 & - & $\mathrm{Na}$ \\
\hline & & Maximum Buntal Volume (cuntt) & - & - & - & - & $\therefore$ & $=$ & $=$ & 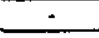 & No \\
\hline & & Minlmum Burlal Volume (cum) & - & $=$ & - & - & - & - & - & - & Na \\
\hline & & Number of Reconds & 55 & 707 & 5 & 0 & 0 & 0 & 0 & 767 & \\
\hline Tote & Across All 7 Type Codes & $\%$ of Box 21 Totals & 7.2 & 92.2 & 0.7 & 0.0 & 0.0 & 0.0 & 0.0 & 100.0 & \\
\hline & & Total Waste Volume (cuit) & 1,960 & 19,330 & 116 & 0 & 0 & 0 & 0 & 21,406 & \\
\hline & & $\%$ of Box 21 Totals & 9.2 & 90.3 & 0.5 & 0.0 & 0.0 & 0.0 & 0.0 & 100.0 & \\
\hline
\end{tabular}


Table 3-67. Decay Forecast for COI Inventory of Potential "Hot Spots" HS-300-8 and HS-500-8

\begin{tabular}{|c|c|c|}
\hline Constituent of Interest & Total Activity (CI) & Percent of Total Activity \\
\hline \multicolumn{3}{|l|}{ At Time of Burial: } \\
\hline Curbon-14 & 100.62 & $0.1 \%$ \\
\hline Cobalt- 60 & $91,588.55$ & $59.2 \%$ \\
\hline Cenium-137 & $1,025.41$ & $0.7 \%$ \\
\hline Neptunium-237 & 0.00 & $0.0 \%$ \\
\hline Phutonium-238 & 58.67 & $0.0 \%$ \\
\hline Plutonium-239 & 0.00 & $0.0 \%$ \\
\hline Strontium-90 & 962.05 & $0.6 \%$ \\
\hline Techretiun-99 & 0.32 & $0.0 \%$ \\
\hline Tritium & $60,845.54$ & $39.4 \%$ \\
\hline Unarium-235 & 0.00 & $0.0 \%$ \\
\hline Unanium-238 & $=$ & $0.0 \%$ \\
\hline TOTAL & $154,581.16$ & $100 \%$ \\
\hline \multicolumn{3}{|l|}{ At 50 Yoars after Burtal: } \\
\hline Carbon-14 & 100.02 & $2.2 \%$ \\
\hline Cobalt-60 & 128.22 & $2.8 \%$ \\
\hline Cenium-137 & 323.11 & $7.1 \%$ \\
\hline Neptorium-237 & 0.00 & $0.0 \%$ \\
\hline Plutonizm-238 & 39.47 & $0.9 \%$ \\
\hline Plutonium-239 & 0.00 & $0.0 \%$ \\
\hline Strontium-90 & 292.75 & $6.5 \%$ \\
\hline Technotium-99 & 0.32 & $0.0 \%$ \\
\hline Tritium & $3,638.56$ & $80.5 \%$ \\
\hline Unnium-235 & 0.00 & $0.0 \%$ \\
\hline Uranium-238 & 0.00 & $0.0 \%$ \\
\hline TOTAL & $4,522.45$ & $100 \%$ \\
\hline \multicolumn{3}{|l|}{ At 100 Years after Burlal: } \\
\hline Carbon-14 & 99.40 & $18.5 \%$ \\
\hline Cobalt -60 & 0.00 & $0.0 \%$ \\
\hline Cesium-137 & 101.82 & $19.0 \%$ \\
\hline Nopturium-237 & 0.00 & $0.0 \%$ \\
\hline Plutonium-238 & 26.55 & $5.0 \%$ \\
\hline Plotanium-239 & 0.00 & $0.0 \%$ \\
\hline Strontium-90 & 89.09 & $16.6 \%$ \\
\hline Tochnotiura-99 & 0.32 & $0.1 \%$ \\
\hline Tritium & 219.04 & $40,8 \%$ \\
\hline Unanium-235 & 0.00 & $0.0 \%$ \\
\hline Uranium-238 & 0.00 & $0.0 \%$ \\
\hline TOTAL & 536.22 & $100 \%$ \\
\hline \multicolumn{3}{|l|}{ As 300 Years enter Burtel: } \\
\hline Carbon-14 & 97.03 & $92.8 \%$ \\
\hline Cobalt -60 & 0.00 & $0.0 \%$ \\
\hline Caximom-137 & 1.03 & $1.0 \%$ \\
\hline Neptrnium-237 & 0.00 & $0.0 \%$ \\
\hline Plutonizum-238 & 5.44 & $5.2 \%$ \\
\hline Plutonium-239 & 0.00 & $0.0 \%$ \\
\hline Strontium-90 & 0.77 & $0.7 \%$ \\
\hline Technetium-99 & 0.32 & $0.3 \%$ \\
\hline Tritium & 0.00 & $0.0 \%$ \\
\hline Uranitum-235 & 0.00 & $0.0 \%$ \\
\hline Uranium-238 & 0.00 & $0.0 \%$ \\
\hline TOTAL & 104.58 & $100 \%$ \\
\hline \multicolumn{3}{|l|}{ A: 500 Years anter Burlal: } \\
\hline Curbon-14 & 94.70 & $98.5 \%$ \\
\hline Cobalt-60 & 0.00 & $0.0 \%$ \\
\hline Cexium-137 & 0.00 & $0.0 \%$ \\
\hline Neptunitum-237 & 0.00 & $0.0 \%$ \\
\hline Plutonium-238 & 1.11 & $1.2 \%$ \\
\hline Plutonium-239 & 0.00 & $0.0 \%$ \\
\hline Strontium-90 & 0.00 & $0.0 \%$ \\
\hline Tochnetium-99 & 0.32 & $0.3 \%$ \\
\hline Tritium & 0.00 & $0.0 \%$ \\
\hline Unanium-235 & 0.00 & $0.0 \%$ \\
\hline Unanium-238 & 0.00 & $0.0 \%$ \\
\hline TOTAL & 96.14 & $100 \%$ \\
\hline
\end{tabular}


Table 3-67. Decay Forecast for COI Inventory of Potential "Hot Spots" HS-300-8 and HS-500-8 (Continued)

\begin{tabular}{|c|c|c|}
\hline Constituent of Interest & Total Activity (Ci) & Percent of Total Activity \\
\hline \multicolumn{3}{|l|}{ A! 1,000 Years after Burlal: } \\
\hline Carbon-14 & 89.13 & $99.6 \%$ \\
\hline Cobalt -60 & $0 . \infty$ & $0.0 \%$ \\
\hline Cerium-137 & 0.00 & $0.0 \%$ \\
\hline Noptunium-237 & 0.00 & $0.0 \%$ \\
\hline Plutonium-238 & 0.02 & $0.0 \%$ \\
\hline Plutonium-239 & 0.00 & $0.0 \%$ \\
\hline Strontivem-90 & 0.00 & $0.0 \%$ \\
\hline Technetium-99 & 0.32 & $0.4 \%$ \\
\hline Tritium & 0.00 & $0.0 \%$ \\
\hline Uranium-235 & 0.00 & $0.0 \%$ \\
\hline Usanium-238 & 0.00 & $0.0 \%$ \\
\hline TOTAL & 89.47 & $100 \%$ \\
\hline \multicolumn{3}{|l|}{ At 5,000 Years after Burfal: } \\
\hline Carbon-14 & 54.88 & $99.4 \%$ \\
\hline Cobelt -60 & 0.00 & $0.0 \%$ \\
\hline Cexium- 137 & 0.00 & $0.0 \%$ \\
\hline Neptunium-237 & 0.00 & $0.0 \%$ \\
\hline Plutoninim-238 & 0.00 & $0.0 \%$ \\
\hline Plutonium-239 & 0.00 & $0.0 \%$ \\
\hline Strontium-90 & 0.00 & $0.0 \%$ \\
\hline Tochnetium-99 & 0.32 & $0.6 \%$ \\
\hline Tritium & 0.00 & $0.0 \%$ \\
\hline Uranium-235 & 0.00 & $0.0 \%$ \\
\hline Uranium-238 & $\stackrel{0.00}{=}$ & $0.0 \%$ \\
\hline TOTAL & 55.19 & $100 \%$ \\
\hline \multicolumn{3}{|l|}{ At 10,000 Years enter Burlal: } \\
\hline Carbon-14 & 29.92 & $99.0 \%$ \\
\hline Cobalt-60 & 0.00 & $0.0 \%$ \\
\hline Cexiutn- 137 & 0.00 & $0.0 \%$ \\
\hline Neptunium-237 & 0.00 & $0.0 \%$ \\
\hline Phutonium-2.38 & 0.00 & $0.0 \%$ \\
\hline Plutonizm-239 & 0.00 & $0.0 \%$ \\
\hline Strontium-90 & 0.00 & $0.0 \%$ \\
\hline Technetium-99 & 0.31 & $1.0 \%$ \\
\hline Tritium & 0.00 & $0.0 \%$ \\
\hline Uranium-235 & 0.00 & $0.0 \%$ \\
\hline$U_{\text {raniun-238 }}$ & $\underline{0.00}$ & $0.0 \%$ \\
\hline TOTAL & 30.24 & $100 \%$ \\
\hline
\end{tabular}




\subsection{CONCLUSIONS}

The original burial ground contains an unknown quantity of the COI inventory. Individual "hot spots" cannot be delineated because the locations of individual burials are not known. An estimated inventory of the original burial ground is summarized in Table 4-1. Standard decay constants were used to calculate the percentage of each COI which remains after certain periods of time. Tritium and cobalt-60 are the principal COIs in the original burial ground at the time of burial. The principal COIs at 300 years after burial are carbon-14 and plutonium239 (Table 3-6).

The Solvent Tanks (S1-S22) are defined as a potential "hot spot" because their inventory is relatively well documented and their locations are known (Figure 4-1). Their inventory is estimated at 7,539 gallons of VOCs (Table 4-1).

An analysis of the COI inventory recorded in COBRA indicates that tritium contributes the majority of the radioactivity during the first 100 years after burial. After that time, the principal COIs (in terms of total activity) are carbon-14, plutonium-238, and plutonium-239.

Spatial analysis of the burial locations and concentrations for the nonradioactive COIs indicates one potential "hot spot" containing an estimated 5,325 pounds of mercury (Figure 41, Table 4-1). Analysis of the COBRA database indicates 21 potential "hot spots" for the radioactive COIs after 100 years of burial which decrease to only eight potential "hot spots" at 300 years after burial (Figure 4-1). The configuration of potential "hot spots" at 500 years after burial is identical to those delineated at 300 years. The configuration of the potential "hot spots" delineated for 300 and 500 years is due to the persistence of carbon-14 associated with buried deionizers and plutonium-238 and plutonium-239 in TRU waste burials and encapsulated waste. The 300 and 500 year maps are virtually identical in appearance because of the very long half-lives of the principal COIs at these time intervals.

At the time of burial, COI-bearing waste contributed approximately 5.1 million curies of activity to the total COI inventory. Approximately $58 \%(3,014,457$ curies $)$ of the activity is attributed to tritium and $37 \%(1,960,400$ curies $)$ is attributed to cobalt- 60 . Both of these COIs are relatively short-lived isotopes. After 100 years, the total activity will decay to less than $1 \%(36,634$ curies) of the original level. After 500 years, the total activity will drop to $0.1 \%(5,440$ curies $)$ of the original level and be associated primarily with carbon-14 $(3,556$ curies), plutonium-238 (390 curies), and plutonium-239 (1,454 curies)(Table 3-8). Of the 
COI activity remaining after 500 years of decay, approximately $80 \%$ (4,370 curies) will be contained within eight radioactive "hot spots" (Figure 4-1).

The potential "hot spots" identified at 300 and 500 years for the radioactive COIs (Figure 4-1) should be considered the "principal" potential "hot spots" because of their persistence and high activity levels. Most of the waste which contains the plutonium-238, plutonium-239, and carbon-14 is buried in casks or encapsulated in concrete. The majority of the waste forms contributing this activity are not likely to release large quantities of the radionuclides. 


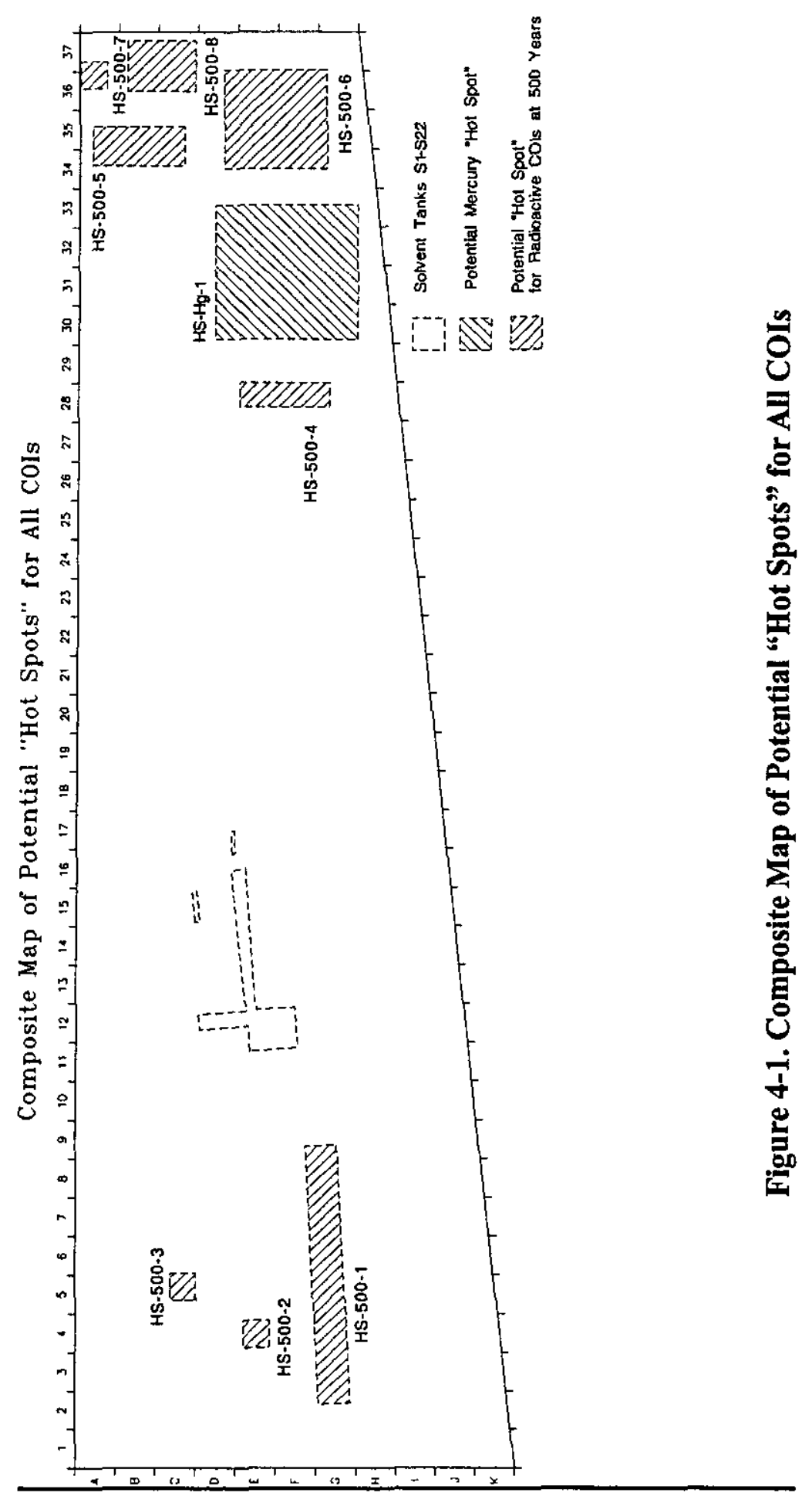


Table 4-1. Summary of Estimated COI Inventory for the Original Burial Ground, Solvent Tanks (S1-S22), and Potential "Hot Spots"

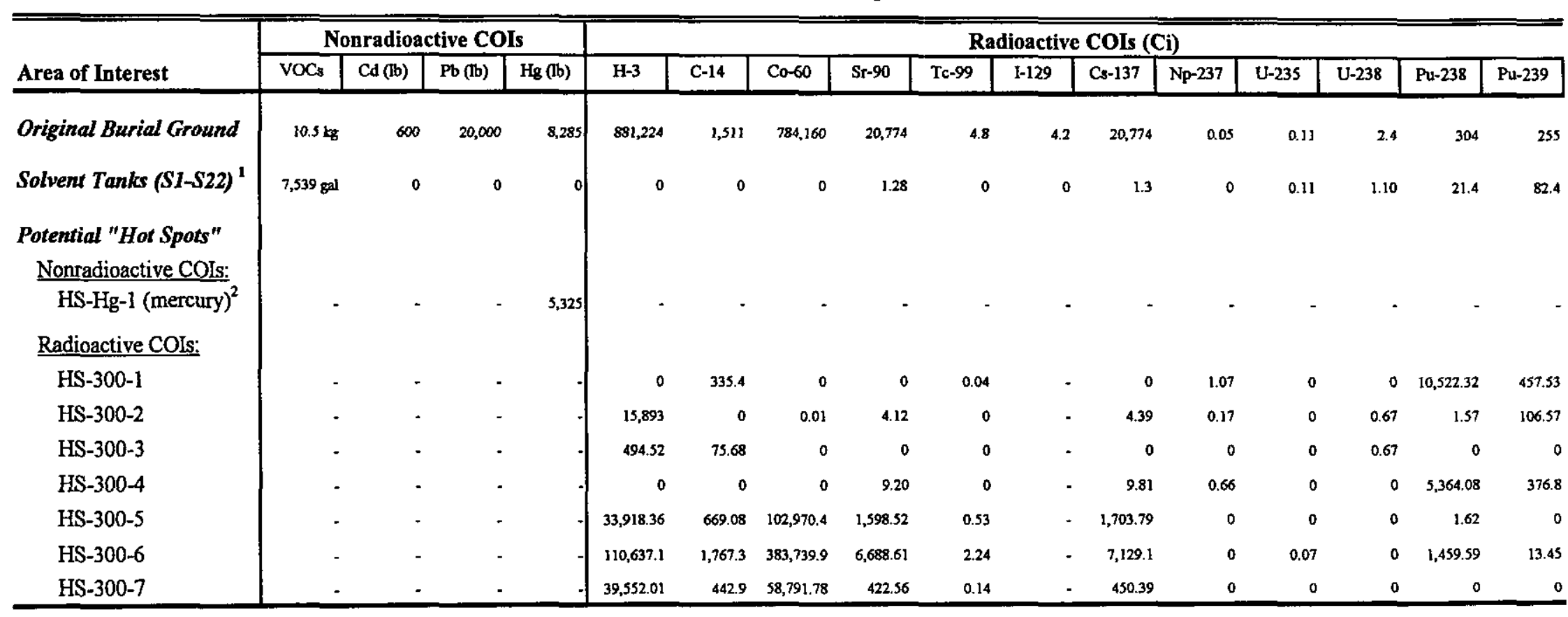

Notes

Estimates are quantity at time of burial except where noted

0 indicates inventory is negligible for this COI (WSCR, 1997)

- no data

1 estimate in current tank inventory (WSRC, 1996)

${ }^{2}$ estimate assumes 75 pounds of mercury per burial (Orebaugh and Hale, 1976) 


\subsection{REFERENCES}

Cook, 1987. Plan for Closure of the 643-G Burial Ground, DPSTD-87-2, August 1987.

Cook, J.R. and B.D. Helton, 1989. An Assessment of Buried Waste Containing Transuranium Isotopes in the Savannah River Site Radioactive Waste Burial Ground, memorandum to B.G. Kitchen, August 23, 1989.

Flach, G.P., S.Y Lee, and A.D. Yu, 1996. Old Burial Ground COC Transport Modeling Progress Report, Memorandum to R.W. Malanowski, E.K. Baradale, and C.M. Lewis, SRT-ESS-96-366, Westinghouse Savannah River Company, Savannah River Site, Aiken, $\mathrm{SC}$.

Oblath, S.B., 1985. Lead and Cadmium Measurements of Groundwater Beneath the LowLevel Waste Burial Ground, memorandum to H.F. Sturm, Jr., DPST-85-969, Technical Division, Savannah River Laboratory, Aiken, SC.

Orbaugh, E.G., and W.H. Hale, Jr., 1976. Dispersion Study of Buried Elemental Mercury, DP-140 UC-41, E.I. du Pont de Nemours \& Company, Savannah River Laboratory, Aiken, SC.

Ryan, J.P., 1983. Groundwater Monitoring in the Savannah River Plant Low Level Waste Burial Ground: A Summary and Interpretation of the Analytical Data, DPST-83-209, Savannah River Laboratory, Aiken, SC, February 20, 1983.

Tharin, D.W., Jr., 1965. Burning of Radioactive Process Solvent, AEC Research and Development Report, DP-942, E.I. du Pont De Nemours \& Company, Savannah River Laboratory, Aiken, SC, February 1965.

WSRC, 1994. RFI/RI Work Plan for the Burial Ground Complex, WSRC-RP-90-1140, Westinghouse Savannah River Company, Savannah River Site, Aiken, SC, December, 1994.

WSRC, 1996. Information Document on the Old Solvent Tanks S1-S22 in the Old Radioactive Waste Burial Ground 643-E (U), WSRC-RP-96-00144, Rev. 0, Westinghouse Savannah River Company, Savannah River Site, Aiken, SC, June 24, 1996. 


\subsection{REFERENCES (Continued)}

WSRC, 1997. Source Term for the Old Radioactive Waste Burial Ground (ORWBG), Savannah River Site (U), WSRC-97-0119, Rev. 0, Westinghouse Savannah River Company, Savannah River Site, Aiken, SC, September, 1997. 


\section{APPENDIX A}

\section{SUMMARY OF SOURCE TERM}


(This page intentionally left blank) 


\section{Appendix A. Summary of Source Term for COIs at the ORWBG}

\begin{tabular}{|c|c|c|c|c|c|}
\hline $\mathrm{COI}$ & INVENTORY & UNCERTAINTIES & FORM & ORIGIN & NOTES \\
\hline Cadmium & $\begin{array}{l}\text { best estimate buried } \\
\text { in trenches: } 3,500 \mathrm{lb} \text { : } \\
2,000 \mathrm{lb} \text { from control } \\
\text { rods } \\
+ \\
75 \mathrm{lb} / \text { year of } \mathrm{Cd} \text { sheet } \\
\text { consumed over } 20 \\
\text { years }(1,500 \mathrm{lb}) \\
\text { OSTs: negligible }\end{array}$ & $\begin{array}{l}\text { accuracy: } \pm 20 \% \text {. } \\
\text { Amount from } L \text { and } R \\
\text { Reactors is accurate } \\
\text { within } 10 \% \text {. } \\
\text { Cd sheet consumption } \\
\text { accurate within } 30 \% \text {. }\end{array}$ & $\begin{array}{l}\text { control rods } \\
\text { safety rods } \\
\text { Cd sheets }\end{array}$ & $\begin{array}{l}2 \text { large shipments of } \\
\text { control rods from } R \\
\text { (1964) and } L(1970) \\
\text { Reactors }(2,000 \mathrm{lb}) \text {. } \\
\text { Cd sheet }(1,000 \text { to } \\
2,000 \mathrm{lb}) \text {. }\end{array}$ & $\begin{array}{l}\text { Scrap metal and rods were put into disassembly } \\
\text { basins for decay of short-lived isotopes, then cut } \\
\text { into pieces and placed in casks. } \\
\text { Induced activity waste. } \\
\text { COBRA does not keep track of Cd, and no } \\
\text { records in COBRA could be identified as control } \\
\text { rods, safety rods, and neutron shielding sheets. } \\
\text { All estimates for the cadmium source term are } \\
\text { based on process knowledge. } \\
\text { The two large shipments of control rods were } \\
\text { buried in the areas of the burial ground that were } \\
\text { active in } 1964 \text { and } 1970 \text { (during the shutdowns } \\
\text { of R and L reactors). }\end{array}$ \\
\hline Lead & $\begin{array}{l}\text { best estimate buried } \\
\text { in trenches: } 50 \text { tons } \\
\text { Separations disposed } \\
1.5 \text { tons/year over } 20 \\
\text { years. } \\
\text { Also from reactors } \\
\text { and to shield offsite } \\
\text { waste. } \\
\text { OSTs: negligible }\end{array}$ & $\begin{array}{l}\text { accuracy: } \pm 30 \% \text {. } \\
\text { Amount from reactors and } \\
\text { to shield offsite waste is } \\
\text { unknown. }\end{array}$ & $\begin{array}{l}\text { shielding } \\
\text { equipment (e.g. } \\
\text { junior caves) } \\
\text { shot } \\
\text { bricks } \\
\text { sheets } \\
\text { in OSTs }\end{array}$ & $\begin{array}{l}\text { Mainly Separations. } \\
\text { Smaller amounts } \\
\text { from reactors and to } \\
\text { shield offsite waste. }\end{array}$ & $\begin{array}{l}\text { Buried either because it was contaminated and } \\
\text { required disposal or it was used to shield buried } \\
\text { rad waste. } \\
\text { COBRA has less than } 12 \text { references to Pb. } \\
\text { Because of the use of lead to shield certain high- } \\
\text { level waste burials, the primary location for } \\
\text { buried lead would be in the high-level waste } \\
\text { trenches. }\end{array}$ \\
\hline Mercury & $\begin{array}{l}\text { best estimate buried } \\
\text { in trenches: } \\
24,195 \mathrm{lb} \\
\text { OSTs: negligible }\end{array}$ & $\begin{array}{l}\text { accuracy: } \\
\quad+25 \% \text { to }-10 \% \\
\text { Possible mechanical } \\
\text { rupture of the containers. } \\
\text { Hg is also in ash of } \\
\text { burned solvent. }\end{array}$ & $\begin{array}{l}2 \text { or } 3 \text { one-liter } \\
\text { polyethylene bottles } \\
\text { wrapped in two PE } \\
\text { bags and placed in } \\
5 \text {-gallon steel lard } \\
\text { cans. } \\
\text { Over } 100 \text { shipments } \\
\text { of } 2 \text { cans each } \\
\end{array}$ & $\begin{array}{l}\text { Tritium facilities: } \\
232-\mathrm{H} \\
234-\mathrm{H} \\
232-\mathrm{F} \\
\text { Separations: } \\
221-\mathrm{H} \\
221-\mathrm{F}\end{array}$ & $\begin{array}{l}\text { Hg was stored after } 1968 \text { and not sent to } \\
\text { ORWBG. } \\
\text { Hg was tritiated. } \\
\text { Used as a sealant in pumps, as a catalyst for } \\
\text { dissolving Pu-Al in Separations operations, and } \\
\text { as a component of laboratory operations } \\
\text { COBRA shows burial locations of mercury. }\end{array}$ \\
\hline
\end{tabular}


Appendix A. Summary of Source Term for COIs at the ORWBG (Continued)

\begin{tabular}{|c|c|c|c|c|c|}
\hline \multirow{3}{*}{$\frac{\text { COI }}{\text { VOCs }}$} & INVENTORY & UNCERTAINTIES & FORM & ORIGIN & NOTES \\
\hline & $\begin{array}{l}\text { buried in trenches: } \\
7100 \mathrm{~kg} \text { toluene } \\
7100 \mathrm{~kg} \\
\text { trimethylbenzene } \\
12,000 \mathrm{~kg} \text { xylene }\end{array}$ & $\begin{array}{l}\text { Volatilization } \\
\text { Migration }\end{array}$ & $\begin{array}{l}\text { Scintillation solutions } \\
\text { and tritiated pump oils } \\
\text { are drummed. } \\
\text { Liquid scintillation } \\
\text { solution wastes are in } \\
\text { small polyethylene vials } \\
\text { which, from 1965, were } \\
\text { packed with oil-dry in } \\
\text { 55-gallon drums and } \\
\text { buried. } \\
\text { Waste oils were both } \\
\text { stored in the OSTs and } \\
\text { absorbed on an oil-dry } \\
\text { compound, placed in } \\
\text { drums, and buried as } \\
\text { solidified waste. }\end{array}$ & $\begin{array}{l}\text { Drummed scintillation } \\
\text { solutions } \\
\text { Waste oils in absorbent } \\
\text { materials (from reactor and } \\
\text { tritium facilities including } \\
\text { pump oils, cutting oils, and } \\
\text { die oils) } \\
\text { Residue from } \\
\text { decontamination operations } \\
\text { prior to waste burial }\end{array}$ & $\begin{array}{l}\text { Shipments of organics are not documented in } \\
\text { the COBRA database per se, though there } \\
\text { are some indirect references to possible VOC } \\
\text { sources. No quantity or specific VOC } \\
\text { constituent information is contained in any } \\
\text { COBRA record. } \\
\text { VOCs associated with liquid scintillation } \\
\text { solutions and waste oils are present in the } \\
\text { trenches of the ORWBG. } \\
\text { The OSTs not only contained waste PUREX } \\
\text { solvent but also contained contaminated } \\
\text { waste solvents of other sorts. }\end{array}$ \\
\hline & $\begin{array}{l}\text { Residue in the OSTs } \\
\text { (S-1 through S-22): } \\
4056 \text { gal organic } \\
\text { phase }+3483 \mathrm{gal} \\
\text { aqueous phase = } \\
7539 \text { gallons } \\
\text { Mason } 1996 \\
\text { provides analytical } \\
\text { data of vapor phase } \\
\text { (Table 2-5). }\end{array}$ & $\begin{array}{l}\text { OST tank dimensions } \\
\text { and inclinations }\end{array}$ & $\begin{array}{l}\text { VOCs in OSTs are in } \\
\text { residue of spent } \\
\text { PUREX solvent and } \\
\text { associated degradation } \\
\text { products. }\end{array}$ & $\begin{array}{l}\text { Spent PUREX solvent was } \\
\text { generated in Separations in a } \\
\text { chemical process for } \\
\text { removing plutonium and } \\
\text { uranium from spent rods. } \\
\text { Plant records show that from } \\
1956 \text { through } 1964,88 \% \text { of } \\
\text { the waste solvent receipts } \\
\text { were from F-Area. From } \\
1965 \text { to } 1972,86 \% \text { of the } \\
\text { waste solvent was generated } \\
\text { in H-Area. }\end{array}$ & $\begin{array}{l}\text { Most PUREX solvent was transferred to } 643- \\
7 G \text { around } 1980 \text {. The OSTs are empty except } \\
\text { for unpumpable heel, which contains some } \\
\text { VOCs in vapor, and organic phases. Minor } \\
\text { amounts of VOCs are present in the aqueous } \\
\text { phase. The amount of VOCs in the sludge } \\
\text { solids phases are negligible. }\end{array}$ \\
\hline
\end{tabular}


Appendix A. Summary of Source Term for COIs at the ORWBG (Continued)

\begin{tabular}{|c|c|c|c|c|c|}
\hline $\mathrm{COI}$ & INVENTORY & UNCERTAINTIES & FORM & ORIGIN & NOTES \\
\hline Tritium & $\begin{array}{l}\text { best estimate buried in } \\
\text { trenches: } 3,014,457 \mathrm{Ci} \\
\text { decayed to } 1997 \text { (in } \\
\text { trenches): } 467,889 \mathrm{Ci} \\
\text { OSTs: negligible }\end{array}$ & $\begin{array}{l}\text { Tritium content } \\
\text { estimates in waste } \\
\text { forms (assumed } \\
\text { constant quantities of } \\
\text { tritium in a given } \\
\text { waste form). } \\
\text { Migration (there is no } \\
\text { correction for such } \\
\text { unknown loss). }\end{array}$ & $\begin{array}{l}\text { Job control waste } \\
\text { Waste oils and } \mathrm{Hg} \\
\text { Used equipment \& } \\
\text { components } \\
\text { Spent melts } \\
\text { Reactive beds }\end{array}$ & $\begin{array}{l}232-\mathrm{H} \\
234-\mathrm{H} \\
238-\mathrm{H} \\
232-\mathrm{F} \\
\text { The buik of tritium was } \\
\text { processed in the three } \mathrm{H}- \\
\text { Area buildings; } 232-\mathrm{F} \\
\text { operated only briefly in the } \\
\text { late 1950s. }\end{array}$ & $\begin{array}{l}\text { Half-life: } 12.3 \text { years } \\
\text { COBRA provides both quantity } \\
\text { and location estimates. }\end{array}$ \\
\hline Cesium-137 & $\begin{array}{l}\text { best estimate buried in } \\
\text { trenches: } 58,657 \mathrm{Ci} \\
\text { decayed to } 1997 \text { (in } \\
\text { trenches): } 26,838 \mathrm{Ci} \\
\text { OSTs: } 1.30 \mathrm{Ci}\end{array}$ & $\begin{array}{l}\text { Original estimates of } \\
\text { fission products } \\
\text { amounts (based on } \\
\text { external dose rates). } \\
\text { Variations in isotopic } \\
\text { distributions. } \\
\text { Use of fixed ages in } \\
\text { decay calculations. }\end{array}$ & $\begin{array}{l}\text { This waste was buried in } \\
\text { cardboard boxes, plastic } \\
\text { bags, and metal containers. } \\
\text { The fission product-bearing } \\
\text { waste was buried in low- } \\
\text { level and high-level } \\
\text { trenches, depending on the } \\
\text { dose rate from the package. }\end{array}$ & $\begin{array}{l}\text { Byproduct of reactors } \\
\text { Fission products are a } \\
\text { component of job control } \\
\text { waste and other waste } \\
\text { streams from spent reactor } \\
\text { fuel and targets or high-level } \\
\text { liquid wastes. These include } \\
\text { reactors, Separations (F-and } \\
\text { H-Areas), and associated } \\
\text { tank farms, and process } \\
\text { control and experimental } \\
\text { laboratories. }\end{array}$ & $\begin{array}{l}\text { Half-life: } 30 \text { years } \\
\text { COBRA recorded "fission } \\
\text { products", not Cs-137 per se. } \\
<50 \mathrm{mR} / \mathrm{hr} \text { wastes were buried } \\
\text { in low activity beta-gamma } \\
\text { trenches. } \\
>50 \mathrm{mR} / \mathrm{hr} \text { wastes were buried } \\
\text { in intermediate level (aka high } \\
\text { level) trenches. }\end{array}$ \\
\hline
\end{tabular}


Appendix A. Summary of Source Term for COIs at the ORWBG (Continued)

\begin{tabular}{|c|c|c|c|c|c|}
\hline COI & INVENTORY & UNCERTAINTIES & FORM & ORIGIN & NOTES \\
\hline Plutonium-238 & $\begin{array}{l}\text { best estimate } \\
\text { buried in } \\
\text { trenches: } \\
1192.7 \text { grams } \\
(20,514 \mathrm{Ci}) \\
\text { decayed to } 1997 \\
\text { (in trenches): } \\
16,825 \mathrm{Ci} \\
\text { OSTs: } 1.24 \text { grams } \\
(21.4 \mathrm{Ci} \text { ) }\end{array}$ & $\begin{array}{l}\text { validity of COBRA } \\
\text { estimates }\end{array}$ & $\begin{array}{l}\text { Uncontainerized in plastic } \\
\text { bags and cardboard boxes } \\
\text { Concrete culverts } \\
\text { containing drummed or } \\
\text { boxed waste } \\
\text { Encapsulated waste }\end{array}$ & $\begin{array}{l}\text { Thermionic heat sources for } \\
\text { power generation } \\
\text { Separations, reactor areas, and } \\
\text { research facilities like SRTC }\end{array}$ & $\begin{array}{l}\text { Half-life: } 87.4 \text { years } \\
\text { Inventory estimate based on } \\
\text { COBRA, pre-COBRA burial } \\
\text { records and bumed solvent } \\
\text { residues. } \\
\text { COBRA shows burial locations } \\
\text { of plutonium- } 238 \text {. }\end{array}$ \\
\hline Plutonium-239 & $\begin{array}{l}\text { best estimate } \\
\text { buried in } \\
\text { trenches: } \\
24,188 \text { grams } \\
(1,475 \mathrm{Ci}) \\
\text { decayed to } 1997 \\
\text { (in trenches): } \\
1,474 \mathrm{Ci} \\
\text { OSTs: } 1351 \mathrm{~g} \\
(82.4 \mathrm{Ci})\end{array}$ & $\begin{array}{l}\text { validity of COBRA } \\
\text { estimates }\end{array}$ & $\begin{array}{l}\text { Uncontainerized in plastic } \\
\text { bags and cardboard boxes } \\
\text { Concrete culverts } \\
\text { containing drummed or } \\
\text { boxed waste } \\
\text { Encapsulated waste }\end{array}$ & $\begin{array}{l}\text { Special nuclear material } \\
\text { Separations, reactor areas, and } \\
\text { research facilities like SRTC }\end{array}$ & $\begin{array}{l}\text { Half-life: } 24,360 \text { years } \\
\text { Inventory estimate based on } \\
\text { COBRA database total, which } \\
\text { includes plutonium- } 239 \text { in } \\
\text { special burials, pre-COBRA } \\
\text { burial records, and burned } \\
\text { solvent residues. } \\
\text { Cobra shows burial locations of } \\
\text { plutonium- } 239 .\end{array}$ \\
\hline Strontium-90 & $\begin{array}{l}\text { best estimate } \\
\text { buried in } \\
\text { trenches: } 58,657 \\
\mathrm{Ci} \\
\text { best estimate: } \\
\text { decayed to } 1997 \\
\text { (in trenches): } \\
26,216 \mathrm{Ci} \\
\text { OSTs: } 1.28 \mathrm{Ci}\end{array}$ & $\begin{array}{l}\text { Original estimates of } \\
\text { fission products } \\
\text { amounts (based on } \\
\text { external dose rates } \\
\text { and assumed isotopic } \\
\text { distribution). } \\
\text { Use of fixed ages in } \\
\text { decay calculations. }\end{array}$ & $\begin{array}{l}\text { This waste was buried in } \\
\text { cardboard boxes, plastic } \\
\text { bags, and metal containers. } \\
\text { The fission product-bearing } \\
\text { waste was buried in low- } \\
\text { level and high-level } \\
\text { trenches, depending on the } \\
\text { dose rate from the package. }\end{array}$ & $\begin{array}{l}\text { Byproduct of reactors } \\
\text { Fission products are a component } \\
\text { of job control waste and other } \\
\text { waste streams from spent reactor } \\
\text { fuel and targets or high-level } \\
\text { liquid wastes. These include } \\
\text { reactors, Separations (F- and H- } \\
\text { Areas), and associated tank } \\
\text { farms, and process control and } \\
\text { experimental laboratories. }\end{array}$ & $\begin{array}{l}\text { Half-life: } 29.12 \text { years } \\
\text { COBRA recorded "fission } \\
\text { products", not Sr- } 90 \text { per se. } \\
<50 \mathrm{mR} / \mathrm{hr} \text { wastes were buried } \\
\text { in low activity beta-gamma } \\
\text { trenches. } \\
>50 \mathrm{mR} / \mathrm{hr} \text { wastes were buried } \\
\text { in intermediate level (aka high } \\
\text { level) trenches. }\end{array}$ \\
\hline
\end{tabular}


Appendix A. Summary of Source Term for COIs at the ORWBG (Continued)

\begin{tabular}{|c|c|c|c|c|c|}
\hline $\mathrm{COI}$ & INVENTORY & UNCERTAINTIES & FORM & ORIGIN & NOTES \\
\hline Uranium-235 & $\begin{array}{l}\text { best estimate } \\
\text { buried in } \\
\text { trenches: } 273,185 \\
\text { grams } \\
(0.6 \mathrm{Ci}) \\
\text { OSTs: } 0.11 \mathrm{Ci}\end{array}$ & $\begin{array}{l}\text { Variable isotopic } \\
\text { ratios of enriched U- } \\
235\end{array}$ & $\begin{array}{l}\text { Generally, U-235 bearing } \\
\text { wastes, primarily scrap } \\
\text { from fuel fabrication } \\
\text { operations, were buried in } \\
\text { alpha activity waste } \\
\text { trenches, without any } \\
\text { special containerization. } \\
\text { The waste would have been } \\
\text { buried in cardboard boxes, } \\
\text { plastic bags, and possibly } \\
\text { metal containers. }\end{array}$ & $\begin{array}{l}\text { According to the COBRA } \\
\text { database, U-235, as enriched } \\
\text { uranium, was sent to the OBG } \\
\text { from M-Area, A-Area, F-Area, } \\
\text { H-Area, and from offsite } \\
\text { facilities. Normal, or natural, } \\
\text { uranium was sent to the OBG } \\
\text { from M-Area, A-Area, H-Area, } \\
\text { and F-Area. }\end{array}$ & $\begin{array}{l}\text { Half-life: } 7.1 \times 10^{8} \text { years } \\
\text { natural U: } 0.72 \% \text { U- } 235 \\
\text { enriched U: } 93 \% \text { U-235 } \\
\text { COBRA shows the burial } \\
\text { locations of enriched and normal } \\
\text { uranium. } \\
\text { OSTs estimate is based on } \\
\text { assigning U- } 235 \text { an arbitrary } \\
\text { activity fraction of } 0.25 \text { percent } \\
\text { for tanks that had indicated } \\
\text { uranium content. }\end{array}$ \\
\hline Uranium-238 & $\begin{array}{l}\text { best estimate } \\
\text { buried in } \\
\text { trenches: } \\
44,233 \mathrm{~kg} \\
(14.8 \mathrm{Ci}) \\
\text { OSTs: } 1.1 \mathrm{Ci}\end{array}$ & $\begin{array}{l}\text { COBRA error of } \mathrm{Ci} \\
\text { units (should be } \mathrm{kg} \text { ). } \\
\text { OST value is } \\
\text { arbitrary, but based } \\
\text { on actual alpha } \\
\text { activity in the tanks }\end{array}$ & $\begin{array}{l}\text { It is likely that U-238 } \\
\text { bearing wastes were } \\
\text { disposed of in alpha } \\
\text { activity waste trenches, } \\
\text { without any special } \\
\text { containerization. The } \\
\text { waste would have been } \\
\text { buried in cardboard boxes, } \\
\text { plastic bags, and possibly } \\
\text { metal containers. }\end{array}$ & $\begin{array}{l}\text { According to the COBRA } \\
\text { database, U-238, as depleted } \\
\text { uranium, was sent to the OBG } \\
\text { from M-Area, A-Area, F-Area, } \\
\text { H-Area, G-Area and from off-site } \\
\text { facilities. } \\
\text { Normal, or natural, uranium was } \\
\text { sent to the OBG from M-Area, } \\
\text { A-Area, H-Area, and F-Area. } \\
\text { Enriched uranium was sent to the } \\
\text { OBG from M-Area, A-Area, F- } \\
\text { Area, H-Area, and from offsite } \\
\text { facilities. }\end{array}$ & $\begin{array}{l}\text { Half-life: } 4.51 \times 10^{9} \text { years } \\
\text { natural U: } 99.3 \% \text { U-238 } \\
\text { depleted U: } 100 \% \text { U-238 } \\
\text { enriched U: } 7 \% \text { U-238 } \\
\text { COBRA shows the burial } \\
\text { locations of enriched, normal, } \\
\text { and depleted uranium. } \\
\text { OSTs estimate is based on } \\
\text { assigning U-238 an arbitrary } \\
\text { activity fraction of } 2.5 \text { percent } \\
\text { for tanks that had indicated } \\
\text { uranium content. }\end{array}$ \\
\hline
\end{tabular}


Appendix A. Summary of Source Term for COIs at the ORWBG (Continued)

\begin{tabular}{|c|c|c|c|c|c|}
\hline $\mathrm{COI}$ & INVENTORY & UNCERTAINTIES & FORM & ORIGIN & NOTES \\
\hline Carbon-14 & $\begin{array}{l}\text { best estimate } \\
\text { buried in } \\
\text { trenches: } 3,778 \mathrm{Ci} \\
\\
\text { decayed to } 1997 \\
\text { (in trenches): } \\
3,767 \mathrm{Ci} \\
\text { OSTs: negligible }\end{array}$ & $\begin{array}{l}\text { Assumes: } \\
-15 \% \text { of the amount } \\
\text { of C-14 produced in } \\
\text { the reactor was lost to } \\
\text { the atmosphere. } \\
\text {-All other C-14 } \\
\text { remained in the } \\
\text { deionizer resin and no } \\
\text { other releases } \\
\text { occurred. } \\
\text { - The average } \\
\text { production/disposal } \\
\text { rate of C-14 from } \\
\text { start-up to } 1972 \text { and } \\
\text { from } 1972 \text { to } 1988 \\
\text { was the same. }\end{array}$ & $\begin{array}{l}\text { During the first ten years of } \\
\text { SRS operations, deionizer } \\
\text { resins were dumped in } \\
\text { slurry form directly into } \\
\text { ORWBG trenches. Later, } \\
\text { the resins were disposed of } \\
\text { in stainless steel vessels. }\end{array}$ & $\begin{array}{l}\text { Various reactions in the fuel, } \\
\text { moderator, and core construction } \\
\text { material in the five production } \\
\text { reactors. } \\
\text { Small quantities were produced } \\
\text { by the test reactors and neutron } \\
\text { activation analyses. }\end{array}$ & $\begin{array}{l}\text { Half-life: } 5,715 \text { years } \\
\text { COBRA burial records provide } \\
\text { the date, location, and volumes } \\
\text { of disposal of deionizer resin } \\
\text { waste packages. Most of the } \\
\text { source term in the ORWBG is } \\
\text { likely due to the bicarbonate } \\
\text { anion }\left(\mathrm{HC}^{14} \mathrm{O}_{3}\right) \text { that is sorbed on } \\
\text { mixed-bed ion exchange resin } \\
\text { used to purify the reactor } \\
\text { moderator. }\end{array}$ \\
\hline Cobalt-60 & 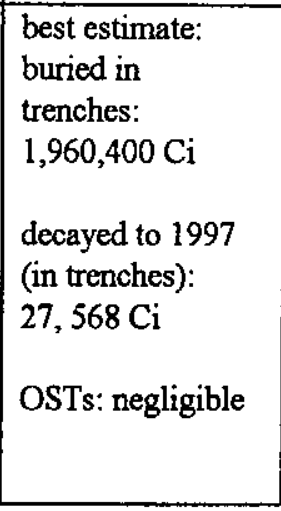 & $\begin{array}{l}\text { Annual disposal rates } \\
\text { The percentage of } \\
\text { induced activity } \\
\text { associated with } \\
\text { cobalt- } 60 \text { in reactor } \\
\text { scrap metal }\end{array}$ & $\begin{array}{l}\text { Scrap metal was placed } \\
\text { into casks and buried in the } \\
\text { ORWBG. }\end{array}$ & $\begin{array}{l}\text { Cobalt- } 60 \text { at the SRS was } \\
\text { produced primarily as a } \\
\text { byproduct of irradiating cobalt- } \\
\text { bearing stainless steel } \\
\text { components in SRS reactors. } \\
\text { The amount of cobalt- } 60 \\
\text { produced by other sources } \\
\text { (cobalt- } 59 \text { wafers, SREL, and } \\
\text { SRTC) and disposed in the } \\
\text { ORWBG is relatively small } \\
\text { compared to that from induced } \\
\text { activity. }\end{array}$ & $\begin{array}{l}\text { Half-life: } 5.27 \text { years } \\
\text { COBRA recorded "induced } \\
\text { activity" not cobalt- } 60 \text { per se. } \\
\text { Most of the cobalt- } 60 \text { in the } \\
\text { ORWBG is buried as stainless } \\
\text { steel scrap metal in casks. } \\
\text { Cobalt- } 60 \text { is not a fission } \\
\text { product, but small quantities } \\
\text { accompanied burials of fission } \\
\text { product waste in the ORWBG. }\end{array}$ \\
\hline
\end{tabular}


Appendix A. Summary of Source Term for COIs at the ORWBG (Continued)

\begin{tabular}{|c|c|c|c|c|c|}
\hline $\mathrm{COI}$ & INVENTORY & UNCERTAINTIES & FORM & ORIGIN & NOTES \\
\hline Technetium-99 & $\begin{array}{l}\text { best estimate } \\
\text { buried in } \\
\text { trenches: } \\
12 \mathrm{Ci} \\
\text { OSTs: negligible }\end{array}$ & $\begin{array}{l}\text { Five-year-old in-tank } \\
\text { waste contains } \\
5.53 \mathrm{E}-04 \text { curies of } \\
\text { technetium- } 99 \text { per } \\
\text { gallon, which } \\
\text { assumes an isotopic } \\
\text { distribution of fission } \\
\text { products. } \\
\end{array}$ & $\begin{array}{l}\text { Most of the technetium-99 } \\
\text { in the ORWBG is in } \\
\text { buriais of fission product } \\
\text { waste. } \\
\text { The most likely state of } \\
\text { technetiurn- } 99 \text { in SRS } \\
\text { waste streams and solid } \\
\text { waste is } \mathrm{TcO}_{4}^{-} \text {. }\end{array}$ & $\begin{array}{l}\text { Technetium- } 99 \text { is a fission } \\
\text { product produced by the fission } \\
\text { of uranium- } 235 \text { and plutonium- } \\
239 \text {. }\end{array}$ & $\begin{array}{l}\text { Half-life: } 213,000 \text { years } \\
\text { Shipments of technetium-99 are } \\
\text { not documented in the COBRA } \\
\text { database. Technetium- } 99 \text { is } \\
\text { assumed to have been disposed } \\
\text { with other fission product waste. }\end{array}$ \\
\hline Iodine -129 & $\begin{array}{l}\text { best estimate } \\
\text { buried in } \\
\text { trenches: } 10.6 \mathrm{Ci} \\
\text { OSTs: negligible }\end{array}$ & $\begin{array}{l}\text { Assumes: } \\
\text { - } 39 \text { Ci of iodine- } \\
129 \text { was } \\
\text { produced at SRS } \\
\text { from startup to } \\
1974 \\
\text { - } 30 \text { percent of this } \\
\text { amount was } \\
\text { buried in the } \\
\text { ORWBG. }\end{array}$ & $\begin{array}{l}\text { spent ceramic chips coated } \\
\text { with silver nitrate (Berl } \\
\text { saddles) }\end{array}$ & $\begin{array}{l}\text { Radioiodine is a fission product } \\
\text { at the SRS that originated } \\
\text { predominantly in the fuel and } \\
\text { target materials. } \\
\text { Berl saddles were used to sorb } \\
\text { radioiodine (principally I-129 and } \\
\text { I-131) during the dissolution of } \\
\text { fuel and targets in F and H Areas. }\end{array}$ & $\begin{array}{l}\text { Half-life: } 1.57 \times 10^{7} \text { years } \\
\text { In the COBRA database there } \\
\text { are no references to Berl } \\
\text { saddles, nor is there any specific } \\
\text { iodine- } 129 \text { constituent } \\
\text { information. } \\
\text { The number of spent charges in } \\
\text { the ORWBG, assuming a } \\
\text { constant disposal rate, is } \\
\text { estimated to be } 34 \text {. Each } \\
\text { container held approximately } 20 \\
\text { cu ft of Berl saddles. } \\
\text { Essentially all of the iodine- } 129 \\
\text { in the burial grounds from Berl } \\
\text { saddles used in the process air } \\
\text { filters. Other sources } \\
\text { contributed smaller amounts to } \\
\text { the inventory. }\end{array}$ \\
\hline
\end{tabular}


Appendix A. Summary of Source Term for COIs at the ORWBG (Continued)

\begin{tabular}{|c|c|c|c|c|c|}
\hline $\mathrm{COI}$ & INVENTORY & UNCERTAINTIES & FORM & ORIGIN & NOTES \\
\hline Neptunium-237 & $\begin{array}{l}\text { best estimate: } \\
1.99 \mathrm{Ci} \text { (originally } \\
\text { buried in the trenches) } \\
\text { The amount of } \\
\text { ingrown neptunium- } \\
237 \mathrm{is:} \\
0.004 \mathrm{Ci} \text { (in trenches) } \\
\text { OSTs: negligible }\end{array}$ & classified burials & $\begin{array}{l}\text { Uncontained in plastic } \\
\text { bags and cardboard boxes. } \\
\text { Concrete culverts } \\
\text { containing drummed or } \\
\text { boxed waste. } \\
\text { Encapsulated waste. } \\
\text { Waste potentially } \\
\text { contaminated with } \\
\text { neptunium-237 included } \\
\text { cabinet waste originating } \\
\text { from } 221-H B L, \text { laboratory } \\
\text { glove boxes and radio } \\
\text { benches, waste originating } \\
\text { from } 235-F, \text { waste } \\
\text { effluents from processing } \\
\text { in the Separation areas } \\
\text { and PUREX waste in } \\
\text { storage tanks (241-F and } \\
\text { H-Areas Tank Farms), } \\
\text { and in the OSTs in the } \\
\text { ORWBG. }\end{array}$ & $\begin{array}{l}\text { Neptunium-237 is produced } \\
\text { as a byproduct during the fuel } \\
\text { cycle. } \\
\text { It is produced by two primary } \\
\text { sources at SRS: } \\
\text { alpha decay of } \\
\text { americium- } 241 \text { that is } \\
\text { produced by the beta } \\
\text { decay of plutonium-241 } \\
\text { in weapons-grade } \\
\text { plutonium } \\
\text { via a side reaction during } \\
\text { the irradiation of } \\
\text { uranium-238 targets to } \\
\text { eventually produce } \\
\text { plutonium-239 } \\
\text { Neptunium-237 is also the } \\
\text { target material used to } \\
\text { produce plutonium-238 in } \\
\text { SRS reactors. }\end{array}$ & $\begin{array}{l}\text { Half-life: } 2.14 \times 10^{6} \text { years } \\
\text { The COBRA database provides } \\
\text { both quantity and location } \\
\text { estimates for neptunium- } 237 \\
\text { burials in the ORWBG. }\end{array}$ \\
\hline
\end{tabular}




\section{APPENDIX D}

Sampling and Analysis Plan for Old Solvent Tanks S1-S22 to Address Waste Acceptance Criteria, WSRC-RP-97-00770 
This page intentionally left blank.

i 


\title{
Sampling and Analysis Plan for Old Solvent Tanks S1-S22
} to Address Waste Acceptance Criteria (U)

\author{
P. E. Filpus-Luyckx
}

\author{
Unclassified
}

Does Not Contain Unclassified Controlled Nuclear Information (UCNI)

May 2000

Westinghouse Savannah River Company Savannah River Site Aiken, SC 29808

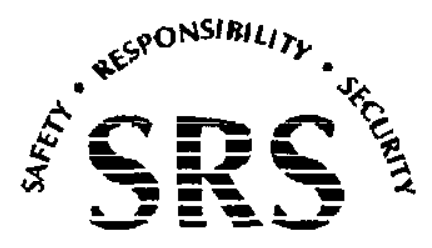




\section{DISCLAIMER}

This report was prepared by Westinghouse Savannah River Company (WSRC) for the United States Department of Energy under Contract No. DEAC09-89SR18035 and is an account of work performed under that contract. Neither the United States Department of Energy, nor WSRC, nor any of their employees makes any warranty, expressed or implied, or assumes any legal liability or responsibility for the accuracy, completeness, or usefulness, of any information, apparatus, or product or process disclosed herein or represents that its use will not infringe privately owned rights. Reference herein to any specified commercial product, process, or service by trademark, name, manufacturer or otherwise does not necessarily constitute or imply endorsement, recommendation, or favoring of same by WSRC or by the United States Government or any agency thereof. The views and opinions of the authors expressed herein do not necessarily state or reflect those of the United States Government or any agency thereof. 


\section{TABLE OF CONTENTS}

1.0. INTRODUCTION

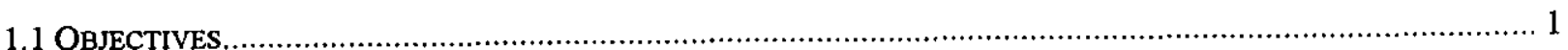

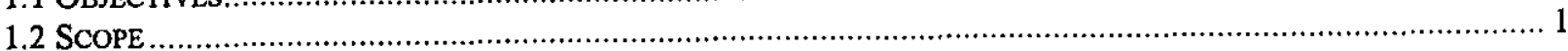

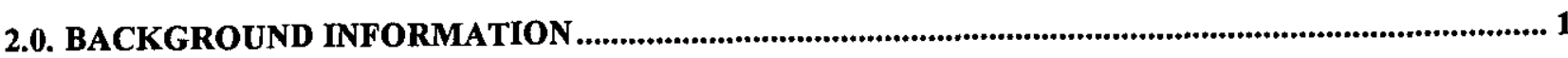

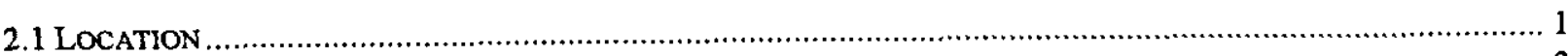

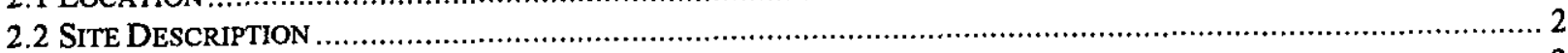

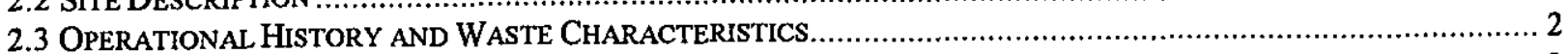

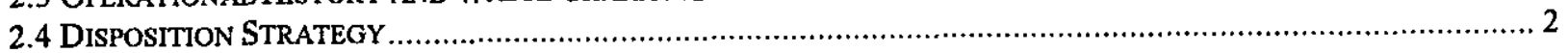

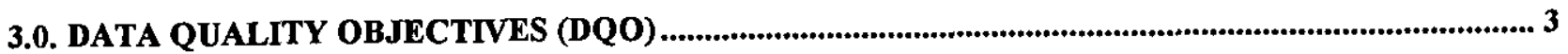

3.1 OLD SOlVENT TANKS S1-S22 IN THE OLD RADIOACTIVE WASTE BURIAL GROUND 643-E DQO

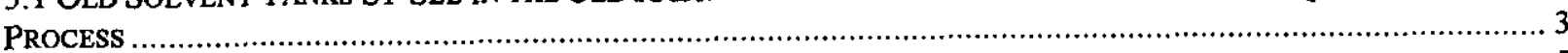

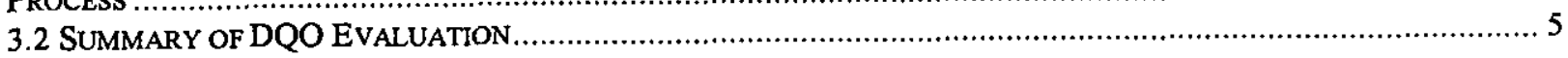

4.0. FIELD SAMPLING AND LABORATORY ANALYSIS PLAN ............................................................. 5

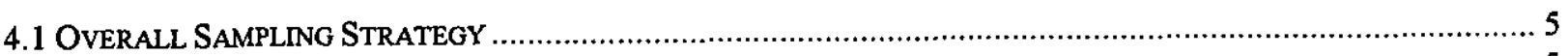

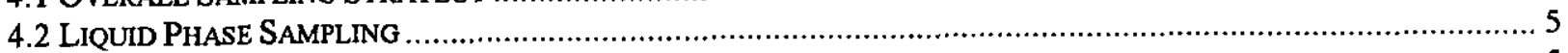

4.3 SLUDGE

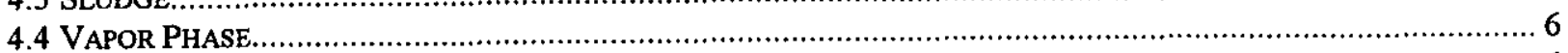

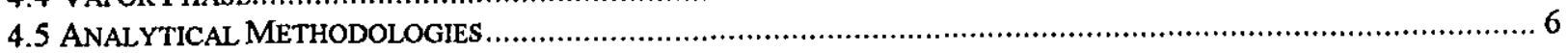

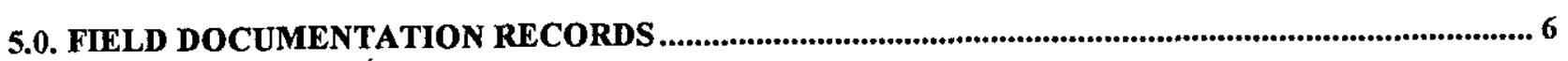

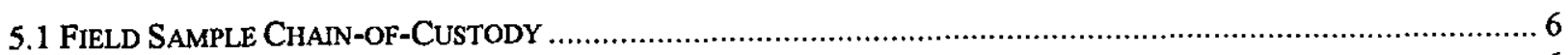

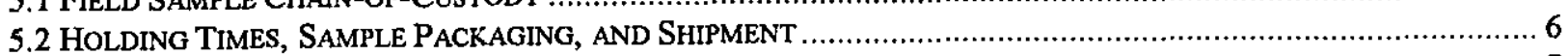

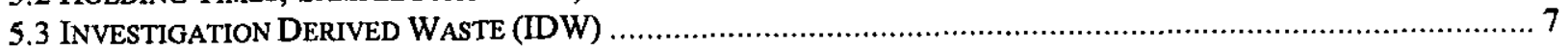

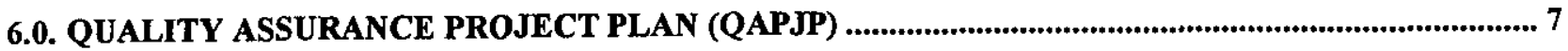

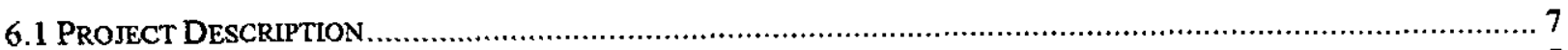

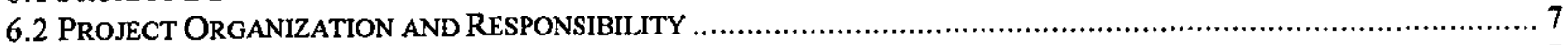

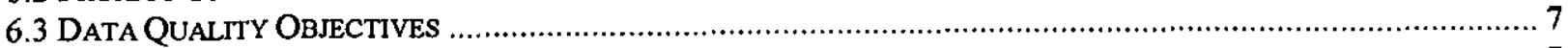

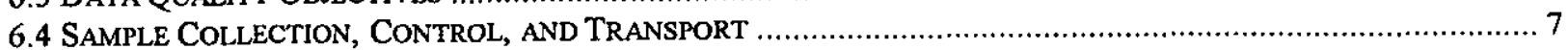

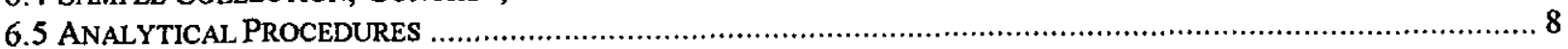

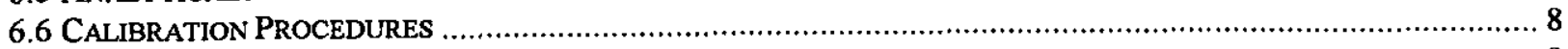

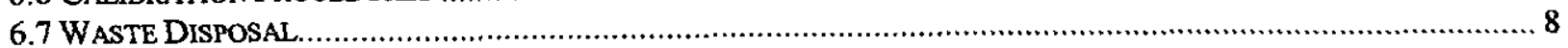

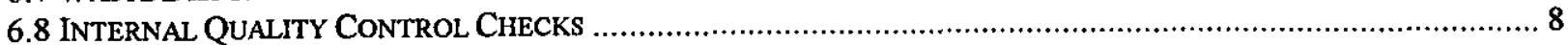

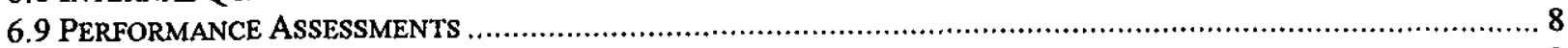

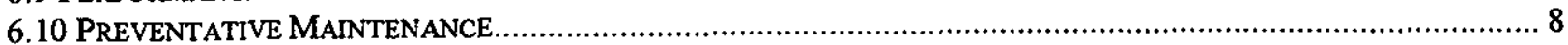

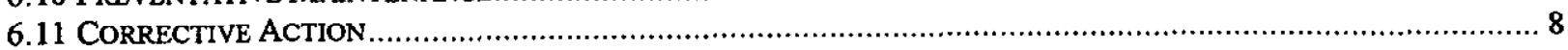

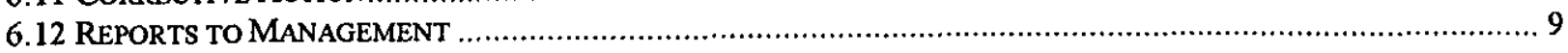

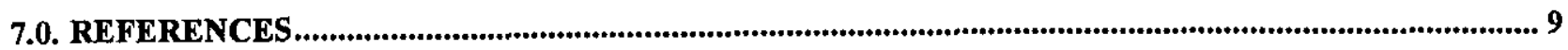

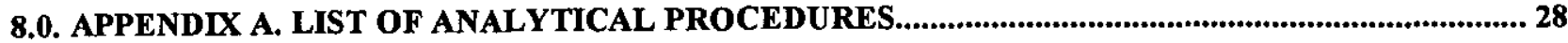




\section{LIST OF FIGURES}

1 Location of the ORWBG in relation to other E Areas

2 Location of Tanks S1-22 in Relation to the ORWBG

3 Relative locations of Tanks S1-22

12

4 Material Disposition Strategy

13

5 Field Chain-of-Custody Form

\section{LIST OF TABLES}

1 Analytical Constituents, Parameters, and Detection Limits 


\section{LIST OF ACRONYMS}

$\begin{array}{ll}\text { AAS } & \text { Atomic Absorption Spectrophotometry } \\ \text { ADS } & \text { Analytical Development Section } \\ \text { CIF } & \text { Consolidated Incineration Facility } \\ \text { COC } & \text { Chain-of-Custody } \\ \text { CVAA } & \text { Cold Vapor Atomic Absorption } \\ \text { DQO } & \text { Data Quality Objective } \\ \text { ERD } & \text { Environmental Restoration Department } \\ \text { EPA } & \text { United States Environmental Protection Agency } \\ \text { GC } & \text { Gas Chromatography } \\ \text { GC/MS } & \text { Gas Chromatography/Mass Spectrometry } \\ \text { HLWD } & \text { High Level Waste Division } \\ \text { IC } & \text { Ion Chromatography } \\ \text { ICP-ES } & \text { Inductively-Coupled Plasma-Emission Spectroscopy } \\ \text { ICP-MS } & \text { Inductively-Coupled Plasma-Mass Spectrometry } \\ \text { IDW } & \text { Investigation-Derived Waste } \\ \text { LEPS } & \text { Low Energy Photon Spectroscopy } \\ \text { LSC } & \text { Liquid Scintillation Counting } \\ \text { MWSF } & \text { Mixed Waste Storage Facilities } \\ \text { ORWBG } & \text { Old Radioactive Waste Burial Ground } \\ \text { PHA } & \text { Pulse Height Analysis } \\ \text { QA } & \text { Quality Assurance } \\ \text { QAPjP } & \text { Quality Assurance Project Plan } \\ \text { QC } & \text { Quality Control } \\ \text { SAP } & \text { Sampling and Analysis Plan } \\ \text { SRS } & \text { Savannah River Site } \\ \text { SRTC } & \text { Savannah River Technology Center } \\ \text { SST } & \text { Solvent Storage Tank Facility } \\ \text { SWD } & \text { Solid Waste Division } \\ \text { TCLP } & \text { Toxic Characteristic Leaching Procedure } \\ \text { TOC } & \text { Total Organic Carbon } \\ \text { TRU } & \text { Transuranic } \\ \text { WAC } & \text { Waste Acceptance Criteria } \\ \text { WSRC } & \text { Westinghouse Savannah River Company } \\ \text { XRD } & \text { X-ray Diffraction } \\ \text { XRS } & \text { X-ray Spectroscopy } \\ & \end{array}$


This page intentionally left blank. 


\subsection{INTRODUCTION}

The Environmental Restoration Department (ERD) assumed custody of the Old Solvent Tanks (Tanks S1-S22) in the Old Radioactive Waste Burial Ground (ORWBG, 643-E) from Waste Management in January 1991. The purpose of this Sampling and Analysis Plan (SAP) is to collect and analyze samples of the sludge solids, organic and aqueous phases to determine the level of radioactivity, the isotopic constituents, the specific gravity, and other physical parameters. These data must be obtained to evaluate the process safety of remediating the tanks, to determine the disposal path for the material in the tanks, and to determine the most viable closure technology for the tanks.

\subsection{Objectives}

Project objectives are:

- To update and supplement existing compositional information regarding the vapor phase, liquid phase(s), and solid phase(s) in each tank.

- To provide sufficient compositional information to develop the safety envelope for waste removal and tank closure in a way that will not unnecessarily constrain operations.

- To quantify the necessary constituents and physical parameters in the solvent and aqueous phases to meet the Waste Acceptance Criteria (WAC) at the Solvent Storage Facility ${ }^{1}$ (SST) operated by Solid Waste Division (SWD) and to meet the WAC for incineration at the Consolidated Incineration Facility ${ }^{2}$ (CIF).

- To quantify the necessary constituents and physical parameters in the sludge phase for acceptance at the 241-F/H Tank Farms ${ }^{3}$ operated by High Level Waste Division (HLWD).

- To quantify the necessary constituents and physical parameters in the solvent, aqueous and sludge phases to meet the Waste Acceptance Criteria (WAC) at the Mixed Waste Storage Facilities ${ }^{4}$ (MWSF) operated by SWD.

\subsection{Scope}

The scope of this SAP includes: collecting samples of the liquid phase(s), and Solid phase(s) (sludge) from specific tanks; analyzing the samples to determine compliance with the Waste Acceptance Criteria of potential accepting SRS Waste Treatment Facilities; collecting samples of the vapor phase from specific tanks; and analyzing the samples to provide the information required for environmental, safety and health considerations. ERD will develop criteria specifying which tanks will be sampled. This criteria will be based on actual tank conditions observed during previous video surveys.

\subsection{BACKGROUND INFORMATION}

\subsection{Location}

The ORWBG (Building Number 643-E) comprises approximately 76 acres located in the north-central portion of SRS, about five miles southeast of A-Area on the north side of Road E between F- and H-Areas (Separations). The ORWBG was a trench disposal area which received radioactive waste from 1952 until 1972. A map showing the ORWBG in relation to the locations of the major E-Area facilities is included in Figure 1. 


\section{$2.2 \quad$ Site Description}

The 22 Old Solvent Tanks are located in a "T"'-shaped block near the center of the ORWBG about 400 feet northeast of the Burial Ground Administration Building 724-7E and 500 feet north of Road E. A map showing the location of the Old Solvent Tanks S1-S22 in relation to the ORWBG is included in Figure 2. The relative location of each tank is shown in Figure 3.

\subsection{Operational History and Waste Characteristics}

The Old Solvent Tanks S I-S22 were single-wall steel tanks installed between 1955 and 1968 to receive spent PUREX solvent from Separations in F- and H-Areas. The tanks are all cylindrical, single-wall carbon steel tanks buried with the long axis horizontal. Each tank was installed with an approximate inclination of six inches.

In the PUREX process, targets and spent fuel rods were processed in Separations to recover activation products and to recover residual plutonium and uranium for recycling. The targets and rods were clipped into small pieces and placed in the nitric acid dissolver solution to dissolve the plutonium and uranium. The PUREX solvent, which consisted of tri-n-butyl phosphate dissolved in kerosene, was used to extract plutonium and uranium from the dissolver solution. Plutonium and uranium were recovered from the solvent and the solvent was recycled. After a number of cycles, the solvent became degraded and was neutralized with caustic compounds and stored in Tanks S1-S22 for aging. During the aging period, generally about six months, most of the short-lived, high-gamma fission products decayed and the heavy alpha emitters settled out of the solvent. The solvent separated into three phases: organic, aqueous, and sludge solids, consisting of alpha emitters in hydroxides and dibutyl phosphate complexes.

After aging, the sludge solids accumulated in the bottoms of Tanks S1-S22. The organic phase was drawn out of the tanks and burned in shallow pans placed in trenches in the Old Radioactive Waste Burial Ground. Approximately 382,750 gallons of spent solvent were burned between 1956 and 1972.

Tanks S1-S18 were pumped out to "unpumpable heel" in the solvent relocation program between March 1977 and May 1978. The solvent was placed in Tanks S19-S22. Tanks S19S22 were pumped out and the solvent was transferred to Tanks S23-S30 between November 1980 and January 1981. No additional waste was placed in Tanks S1-S22 after January 1981. The total volumes of the material remaining in Tanks S1-S22 is $\sim 8000$ gallons of liquid and up to $1250 \mathrm{Kg}$ solids. These values are being confirmed by remote camera surveillance.

Thus, one of the objectives of this SAP is to yield analytical results which can update and supplement existing compositional information regarding the vapor phase, liquid phase(s), and solid phase in each tank.

\subsection{Disposition Strategy}

The material disposition strategy that this Sampling and Analysis Plan supports is shown in Figure 4. 


\subsection{DATA QUALITY OBJECTIVES (DQO)}

According to the United States Environmental Protection Agency (EPA), "The DQO Process was developed to help EPA personnel collect data that are important to decision making". The process allows decision makers to define their data requirements and acceptable levels of decision errors while in the planning stage (before data are collected). Application of the DQO Process will result in the collection of data that yield results of appropriate quality for "defensible decision making". The DQO process is designed to ensure that the appropriate type, quality and quantity of environmental data match the intended applications.

The Data Quality Objectives (DQOs) for this project represent the level of analysis needed to quantify the contents adequately to allow evaluation of the process safety envelope and to evaluate transfer to SWD and/or HLW facilities.

\subsection{Old Solvent Tanks S1-S22 in the Old Radioactive Waste Burial Ground 643-E DQO Process}

Old Solvent Tanks S1-S22 in the Old Radioactive Waste Burial Ground 643-E are radioactively contaminated sites with the potential for commingled radiological and chemical contamination. The intended application of the Sampling and Analysis Plan is to collect data to support transfer to SWD and HLW Waste Treatment facilities. Meeting the WACs of these Waste Treatment facilities requires both radiological and chemical characterization.

\subsubsection{Problem}

Determine the appropriate sampling scheme necessary to characterize solvent and sludge phases of selected tanks to identify disposal options for the solvent and sludge.

\subsubsection{Key Decisions}

- Determine the composition of the vapor phase to provide design data and support environmental, safety and health considerations for the disposition of material in the tanks.

- Determine the chemical and radiological constituents in each liquid phase to determine compliance with the SST WAC, the CIF WAC, the TRU Pad WAC ${ }^{5}$ and/or the MWSF WAC.

- Determine the chemical and nuclide constituents in the sludge to evaluate the criticality safety envelope for waste removal and tank closure activities.

- Determine the chemical and radiological constituents in the sludge to determine compliance with the F/H Tank Farms WAC, the TRU Pad WAC and/or the MWSF WAC.

\subsubsection{Identify the Inputs to the Decisions}

- Definitive analytical data will be used to determine chemical and radiological constituents in the vapor phase.

- Definitive analytical data will be used to determine the chemical and radiological constituents in the liquid phase(s). 
- Definitive analytical data will be used to determine the chemical and radiological constituents in the sludge phase.

\subsubsection{Define the Boundaries of the Study}

The primary goals of this sampling plan are to quantify the nature of the material within Tanks S1 through S22 to support evaluation of the safety envelope and to compare to the SST, CIF, MWSF, F/H Tank Farms, TRU Pad and the MWSF WACs.

\subsubsection{Decision Rules}

- IF the tank has $<50$ gallons of solid phase, THEN no solid samples will be taken.

- IF the as-received sample has both a solid AND liquid phase(s), THEN the sample will be filtered by the Analytical Development Section (ADS) of the Savannah River Technology Center (SRTC) to segregate the solid sludge from the liquid.

- IF the liquid (or filtrate) shows both an organic AND an aqueous phase, THEN the two phases will be separated by ADS and analyzed separately.

- IF the solid material shows more than one phase, THEN the phases will be separated by ADS to the extent practicable and analyzed separately.

- IF the liquid phase(s) meet the SST and CIF WAC, THEN the liquids can be transferred to the SST facility. ELSE, the composition of the liquid phase(s) will be compared to the TRU limit. The TRU limit is defined as waste contaminated with alpha-emitting transuranic radionuclides with half-lives greater than 20 years in concentrations greater than $100 \mathrm{nCi} / \mathrm{g}$ of the waste matrix without regard to source or form. TRU radionuclides have an atomic number greater than 92 .

- IF the liquid phase(s) exceed the $100 \mathrm{nCi}$ TRU/g AND the TRU Pad WAC is met, THEN the liquids can be transferred to the TRU Pad. ELSE, the composition of the liquid phase(s) will be compared to the MWSF WAC.

- IF the liquid phase(s) meet the MWSF WAC, THEN the liquids can be transferred to the MWSF. ELSE, stabilization in place will be evaluated.

- IF the solid phase meets the F/H Tank Farm WAC, THEN the solids can be transferred to the F/H Tank Farm. ELSE, the composition of the solid phase will be compared to the TRU limit.

- IF the solid phase exceed the $100 \mathrm{nCi}$ TRU/g AND the TRU Pad WAC is met, THEN the solids can be transferred to the TRU Pad. ELSE, the composition of solid phase will be compared to the MWSF WAC.

- IF the solid phase meets the MWSF WAC, THEN the solids can be transferred to the MWSF. ELSE, stabilization in place will be evaluated.

- IF any WAC is not met, THEN the compositional data derived from this SAP will be used to support a deviation request or evaluation for in place stabilization of the materials. 


\subsubsection{Tolerance for Uncertainty}

The establishment of sampling protocol and use of definitive analyses will minimize potential errors introduced during field operations.

Given the nature, history, and inaccessibility of the material in the tanks, there exists the potential for the samples to be non-representative due to non-homogeneity of the tank contents. Any such additional uncertainties will likely cause the criticality safety controls to be more restrictive than otherwise, due to the conservative nature of such calculations.

\subsection{Summary of DQO Evaluation}

The solvent and sludge phases for each tank will need to be analyzed for all chemical and radiological constituents required by the respective WACs and to support evaluation of the safety envelope.

\subsection{FIELD SAMPLING AND LABORATORY ANALYSIS PLAN}

\subsection{Overall Sampling Strategy}

The overall field sampling strategy will, to the greatest extent possible, obtain samples from the tanks that will be representative of all phases present in the tank.

\subsection{Liquid Phase Sampling}

Organic phase and aqueous phase samples will be collected using a pumping system designed and fabricated by the Engineered Equipment \& Systems Section, SRTC. The sample will be obtained at the lowest end of the tank, directly below the tank riser pipe. Certain tanks with large quantities of liquids will be sampled at both ends of the tank. The sampling devices must limit sample volume to avoid risks of criticality when working with materials of unknown composition. Specific volume limits will be documented in a Nuclear Criticality Safety Evaluation to be provided before sampling begins. The entire sample will be sent to ADS. If the as-received sample has both a solid and liquid phase(s), then the sample will be filtered by ADS to segregate the solid sludge from the liquid. If the liquid (or filtrate) shows both an organic and an aqueous phase, the two phases will be separated by ADS and analyzed separately for the constituents and physical parameters shown in Table 1. The selected parameters are those specified in the SST, CIF and MWSF WACs.

\subsection{Sludge}

Sludge phase samples will be collected using a system designed and fabricated by the Engineered Equipment \& Systems Section, SRTC. The system will be designed to collect a core sample of the dried sludge. The sludge sample will be obtained at the lowest end of the tank, below the tank riser pipe. Certain tanks with large quantities of sludge will be sampled at both ends of the tank. The sampling devices must limit sample volume to avoid risks of criticality when working with materials of unknown composition. Specific volume limits will be documented in a Nuclear Criticality Safety Evaluation to be provided before sampling 
begins. The entire sample will be sent to ADS. The selected parameters are those specified in the F/H Tank Farm and the MWSF WACs.

\subsection{Vapor Phase}

Hydrogen samples will be collected by pumping $1 / 2$ liter of tank air into a Tedlar ${ }^{*}$. Three hydrogen samples at three different elevations will be obtained from each tank sampled.

The hydrogen samples will be taken at tank bottom (approximately 6" above liquid/sludge), at mid-tank and at the top of the tank. One volatile/semi-volatile organic compound sample will be collected by pumping 100 liters of the tank air through an activated charcoal cartridge, then a silica gel cartridge using a Constant Flow Air Sampler. This sample will be taken at midtank elevation. The Tedlar bags, activated charcoal cartridges, and silica gel cartridges will be sent to ADS and analyzed for the constituents shown in Table 1.

\subsection{Analytical Methodologies}

The analytical procedures that will be used by ADS are listed in Táble 2, corresponding to the list of the constituents and physical parameters shown in Table 1.

Appendix A lists the applicable ADS procedure titles from the Savannah River Technology Center ADS Analytical Operating Procedures, Manual L16.1.

\subsection{FIELD DOCUMENTATION RECORDS}

\subsection{Field Sample Chain-of-Custody}

Samples will be assigned unique numbers in the field that identify the specific tank and sample type for each sample.

A formal quality control process (COC) will be used to ensure the integrity of the samples from the point of origin through the sample analysis is implemented. This process will demonstrate that the samples obtained in the field have been securely transported, and have reached the analytical laboratory without alteration. The COC process has been established by SRS Environmental Compliance procedures ${ }^{6}$. An example COC form is shown in Figure 5. The COC within the ADS laboratories will be maintained in accordance with SRTC-ADS COC procedure?

\subsection{Holding Times, Sample Packaging, and Shipment}

The time required for shipping samples to the laboratory will be minimized to the extent possible. Sample holding times shall be commensurate with EPA Guidelines ${ }^{8}$. The shortest holding time for the samples that will be collected is 14 days for volatiles in aqueous samples. ADS will be responsible for ensuring that samples are analyzed within EPA specified holding times, as shown in Table 2. Samples will be packaged for shipment in accordance WSRC Transportation Procedures (Radioactive Material Packaging Certification and Authorization Requirements). Samples will be transported in accordance with WSRC Transportation Procedures (Radioactive Materials Transported In Excepted Packages). The WSRC 
Transportation Procedure demonstrates compliance with Department of Energy transportation safety standards.

\section{$5.3 \quad$ Investigation Derived Waste (IDW)}

Pending the results of laboratory analysis, the aqueous and non-aqueous IDW will be handled in accordance with SRS Management Plan (WSRC-RP-91227) Rev. $2^{9}$. The laboratory results will be compared to the limits set in the Management Plan to determine the final disposition of the wastes.

\subsection{QUALITY ASSURANCE PROJECT PLAN (QAPJP)}

WSRC Procedure Quality Assurance Plan (QAP) $21-1^{10}$ establishes quality assurance requirements and responsibilities for environmental data collection and evaluation activities. This Sampling and Analysis Plan (SAP) is designed to comply with QAP 21-1 guidelines. The elements for a Quality Assurance Project Plan (QAPjP) called for under this SRS site guidance are addressed below. If the element has been previously addressed elsewhere in this document the appropriate section is referenced.

\subsection{Project Description}

A brief description of the project and its objectives is provided in Section 1.

\subsection{Project Organization and Responsibility}

The Analytical Development Section (ADS) of the Savannah River Technology Center (SRTC) will be the point of contact and will have overall responsibility for implementation of this SAP.

Environmental Restoration is responsible for the field collection of the samples.

ADS will provide technical assistance as required, and will ensure that adequately qualified personnel and necessary equipment are available to complete the laboratory work in a timely manner.

ADS will be responsible for the technical review of the data, results, and Quality Control (QC) information obtained throughout the project.

\subsection{Data Quality Objectives}

Data Quality Objectives are described in Section 3.

\subsection{Sample Collection, Control, and Transport}

Sampling methodologies are provided in Section 4. Sampling details and radiological controls will be specified in the Solvent Tank Specific Sampling Procedure and Radiation Work Permit. 


\subsection{Analytical Procedures}

The applicable standard operating procedure for each measurement parameter is provided in Appendix A. ADS results would be Level 5 results, per WSRC Manual 1Q, Procedure 21-1.

\subsection{Calibration Procedures}

Calibration procedural steps are described within the applicable standard operating procedure for each measurement parameter as provided in Table 2.

\subsection{Waste Disposal}

The handling and disposal of waste materials resulting from field investigations is presented in Section 5.3. Waste resulting from laboratory operations will be in accordance with ADS procedures.

\subsection{Internal Quality Control Checks}

ADS has in place a Quality Assurance Program Plan that provides internal quality control checks on analytical work.

\subsection{Performance Assessments}

SRTC has in place a Quality Assurance internal assessment program that provides independent review. Non-compliance issues will be logged, documented, and controlled through assessment findings, which are attached to and become a part of the internal assessment report. These assessment findings will be directed to the appropriate supervisor for corrective action in a specified and timely manner.

\subsection{Preventative Maintenance}

Preventative maintenance procedural steps are described within the applicable standard operating procedure for each measurement parameter as provided in Table 2. Service to all equipment, instruments, tools, gauges, etc., will be performed only by qualified personnel. Non-conforming items will be managed in accordance with the Program Plan.

\subsection{Corrective Action}

When a significant condition adverse to quality is noted, the cause of the condition will be determined and corrective action will be taken to preclude repetition of the same condition. Condition identification and cause, documents affected, and corrective action will be documented and reported to ADS. Implementation of corrective action will be verified by documented follow-up action. All task personnel have the responsibility, as part of the normal work duties, to promptly identify and report conditions adverse to quality. Non-conforming items or services will be documented on an Nonconformance Report Form. 


\subsection{Reports to Management}

Field logbooks will be maintained for recording and reporting field activity. Analytical results will be compiled within ADS, including the QA status of measurement systems and data.

\subsection{REFERENCES}

1. Procedure WAC 3.16, Solvent Storage Tank Facility - Waste Acceptance Criteria, Rev. 0, WSRC Manual 1S, Savannah River Site, Aiken, SC 29808 (1997).

2. Procedure WAC 3.17, Low Level Radioactive Waste Acceptance Criteria, Rev. 1, WSRC Manual 1S, Savannah River Site, Aiken, SC 29808 (1997).

3. Brown, D. F. and Georgeton, G.K. Waste Acceptance Criteria for High Level Liquid Waste Transfers to the 241-F/H Tank Farms (U), X-SD-G-00001, Rev. 1, Savannah River Site, Aiken, SC 29808 (1995).

4. Procedure WAC 3.07, Mixed Waste Storage Facilities - Mixed Waste Acceptance Criteria, Rev. 3, WSRC Manual 1S, Savannah River Site, Aiken, SC 29808 (1997).

5. Procedure WAC 3.06, E-Area, TRU Pads Transuranic Waste Acceptance Criteria, Rev. 3, WSRC Manual 1S, Savannah River Site, Aiken, SC 29808 (1995).

6. Procedure 21.1, Sample Chain-of-Custody, Rev. 0, WSRC Manual 3Q, Savannah River Site, Aiken, SC 29808 (1995).

7. Procedure ADS-1006, Rev. 1, Chain-of-Custody, Savannah River Technology Center ADS Analytical Operating Procedures, Manual L16.1, Westinghouse Savannah River Company, Savannah River Site, Aiken, SC 29808 (1996).

8. USEPA, SW-846 Test Methods for Evaluating Solid Waste Physical/Chemical Methods, U. S. Environmental Protection Agency, Office of Solid Waste and the National Technical Information Service (NTIS), Springfield, VA 22161 (1996)

9. SRS, IDW Management Plan, WSRC-RP-91227, Rev. 2, Westinghouse Savannah River Company, Aiken, SC 29808 (1994).

10. Procedure 21-1, Quality Assurance Requirements for the Collection and Evaluation of Environmental Data, Rev. 0, WSRC Manual 1Q, Savannah River Site, Aiken, SC 29808 (1994).

11. Franson, M. A., Ed. Standard Methods for the Examination of Waste and Wastewater, 17th ed., pg. 2-71, American Public Health Association, Washington, DC (1989) 
Savannah River Site

WSRC-RP-97-00770

Sampling and Analysis Plan for Old Solvent Tanks S1-S22

Revision 1.0

to Address Waste Acceptance Criteria (U)

May 2000

Page 10

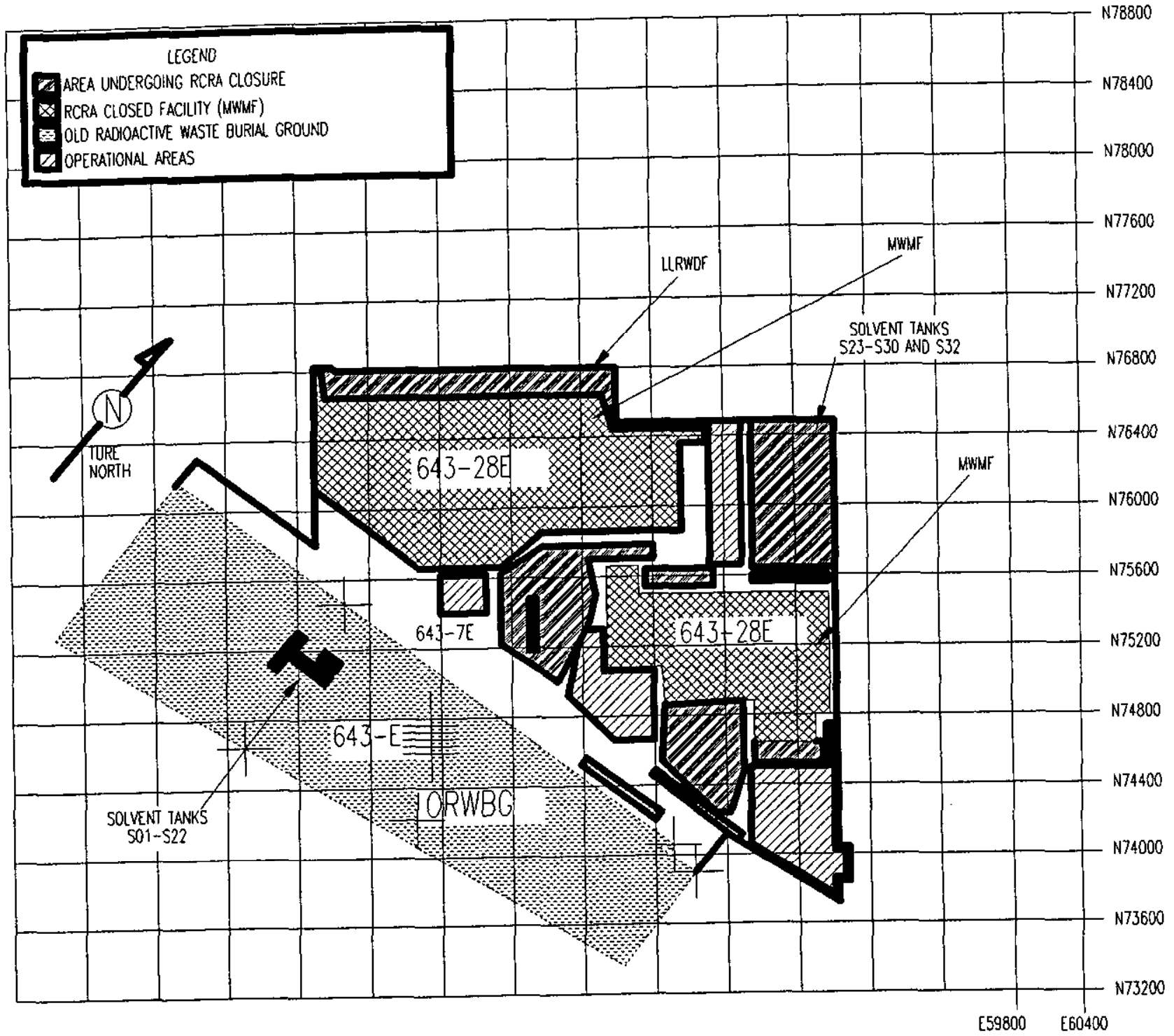

Figure 1. Location of the ORWBG in relation to other $\mathbf{E}$ Areas. 


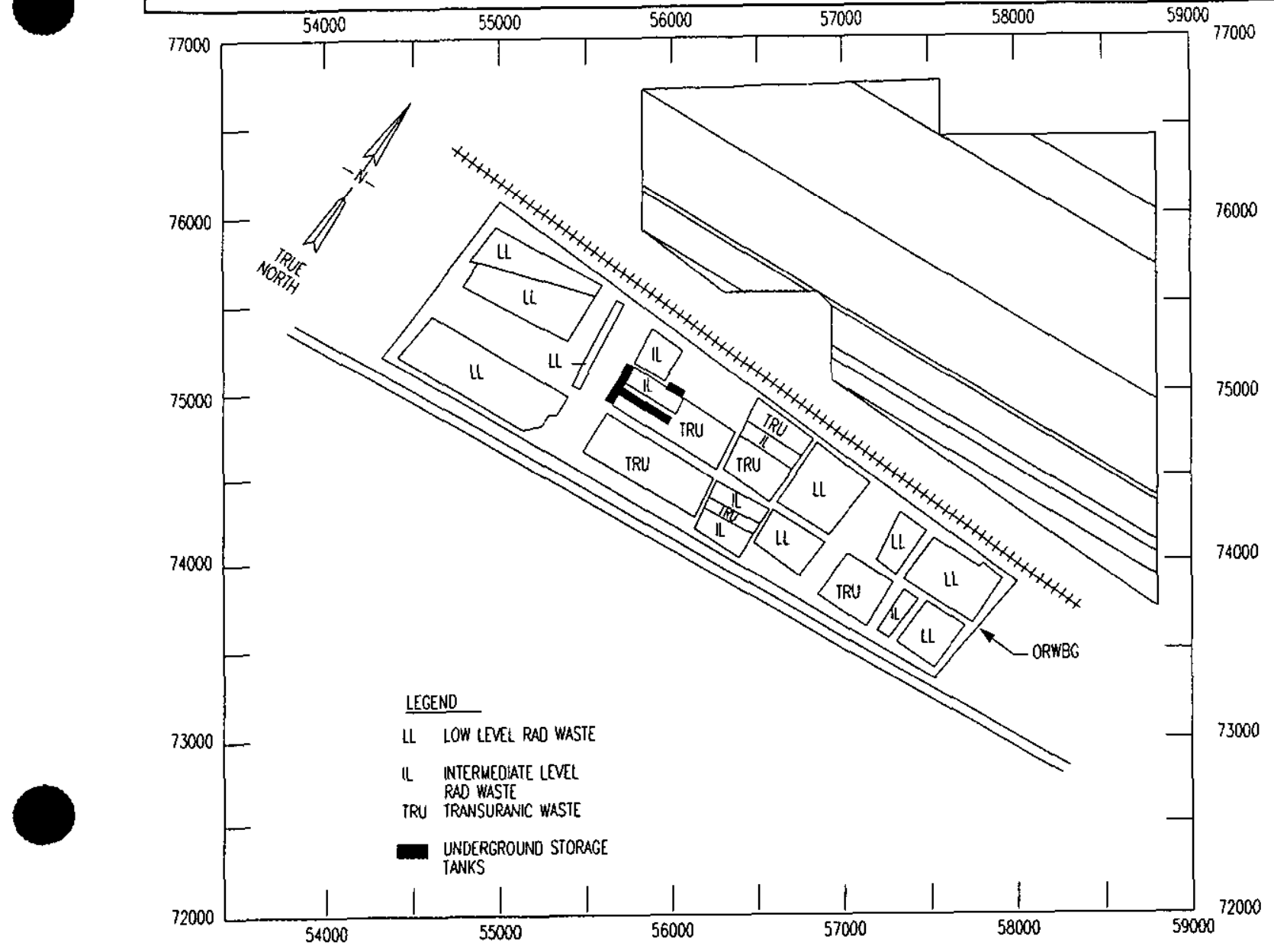

Page 11

Figure 2. Location of Tanks S1-22 in Relation to the ORWBG 


\section{OLD SOLVENT TANK 643-E LAYOUT}

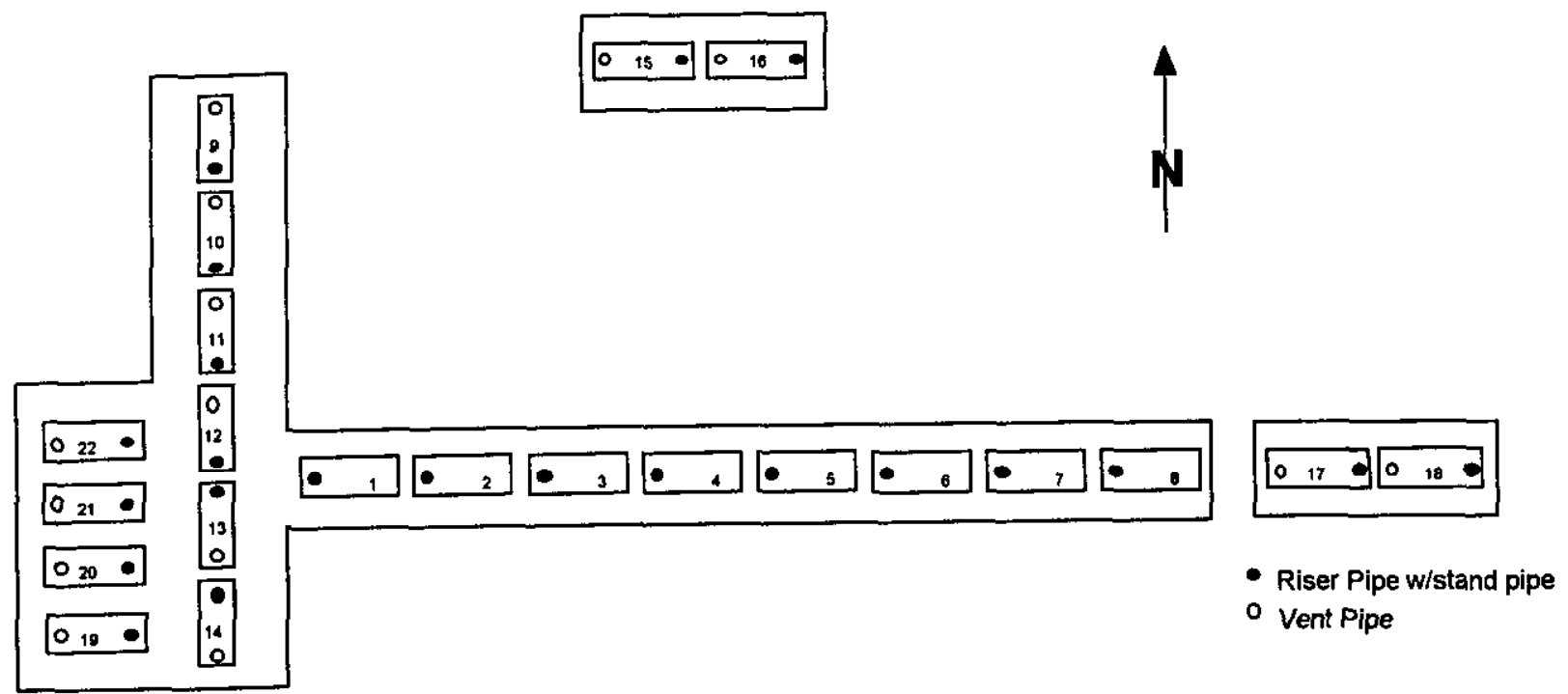

Figure 3. Relative locations of Tanks S1-22.

\begin{tabular}{|c|c|c|c|}
\hline Tank No. & Tank Dimension (ft.) & Tank Capacity (gallons) & Tank Volume (cu. ft.) \\
\hline $\mathrm{S} 1$ & $8.0 \times 26.75$ & 10,059 & 1344.6 \\
\hline $\mathrm{S} 2$ & $8.0 \times 26.75$ & 10,059 & 1344.6 \\
\hline $\mathrm{S} 3$ & $8.0 \times 26.75$ & 10,059 & 1344.6 \\
\hline $\mathrm{S} 4$ & $8.0 \times 14.0$ & 5265 & 703.7 \\
\hline $\mathrm{S} 5$ & $10.5 \times 38.5$ & 24,940 & 3333.7 \\
\hline $\mathrm{S} 6$ & $10.5 \times 38.5$ & 24,940 & 3333.7 \\
\hline $\mathrm{S} 7$ & $8.5 \times 18.0$ & 7641 & 1021.4 \\
\hline $\mathrm{S} 8$ & $8.5 \times 18.0$ & 7641 & 1021.4 \\
\hline $\mathrm{S} 9$ & $8.0 \times 20.0$ & 7521 & 1005.3 \\
\hline $\mathrm{S} 10$ & $8.0 \times 20.0$ & 7521 & 1005.3 \\
\hline $\mathrm{S} 11$ & $8.0 \times 20.0$ & 7521 & 1005.3 \\
\hline $\mathrm{S} 12$ & $8.0 \times 20.0$ & 7521 & 1005.3 \\
\hline $\mathrm{S} 13$ & $10.0 \times 23.0$ & 13,514 & 1806.4 \\
\hline $\mathrm{S} 14$ & $11.0 \times 38.0$ & 27,016 & 3611.3 \\
\hline $\mathrm{S} 15$ & $7.5 \times 32.0$ & 10,576 & 1413.7 \\
\hline $\mathrm{S} 16$ & $7.5 \times 32.0$ & 10,576 & 1413.7 \\
\hline $\mathrm{S} 17$ & $8.0 \times 18.0$ & 6769 & 904.8 \\
\hline $\mathrm{S} 18$ & $8.0 \times 18.0$ & 6769 & 904.8 \\
\hline $\mathrm{S} 19$ & $10.5 \times 38.5$ & 24,940 & 3333.7 \\
\hline $\mathrm{S} 20$ & $10.5 \times 38.5$ & 24,940 & 3333.7 \\
\hline $\mathrm{S} 21$ & $10.5 \times 38.5$ & 24,940 & 3333.7 \\
\hline $\mathrm{S} 22$ & $10.5 \times 38.5$ & 24,940 & 3333.7 \\
\hline
\end{tabular}

Figure 3A. Tank Dimensions, Capacity and Volumes 


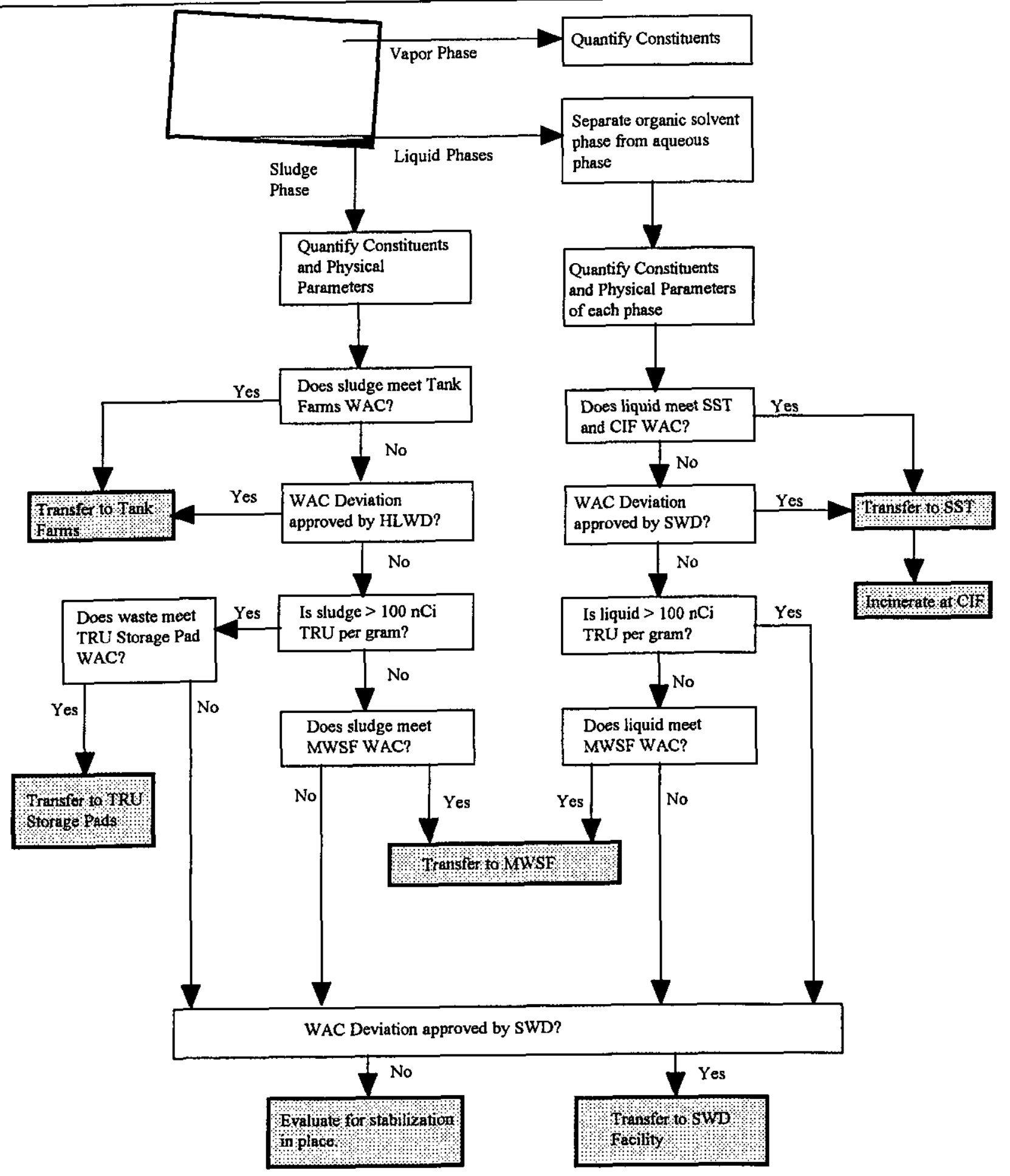

Figure 4. Material Disposition Strategy 

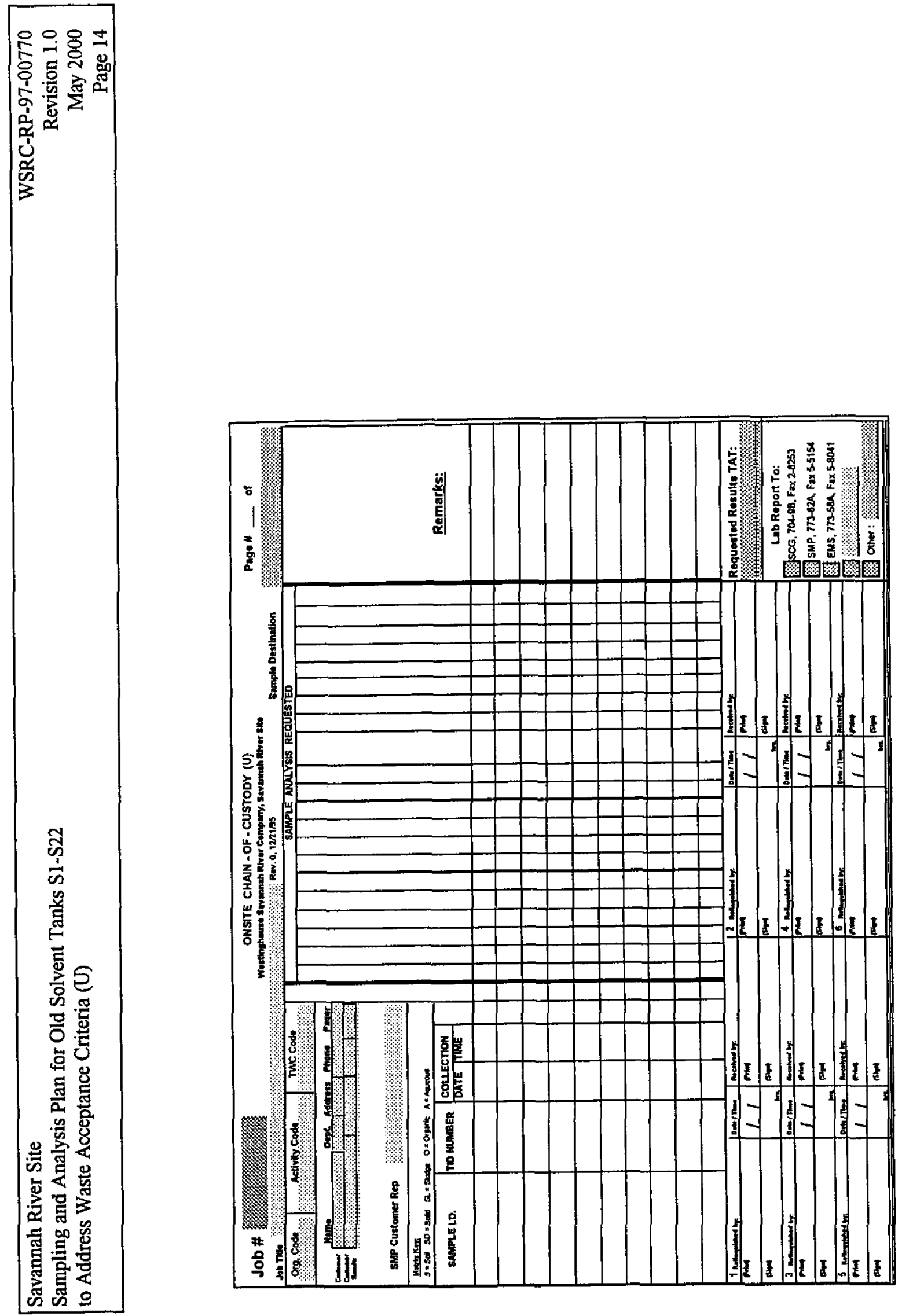

롱 
Table 1. Analytical Constituents, Parameters, and Detection Limits

\begin{tabular}{|c|c|c|c|c|c|c|c|c|}
\hline \multicolumn{2}{|c|}{ Constituent/Parameter } & \multirow{2}{*}{\begin{tabular}{|l} 
WAC(s) \\
F/H Tank Farms
\end{tabular}} & \multirow{2}{*}{\begin{tabular}{|l|} 
Vapor \\
\end{tabular}} & \multirow{2}{*}{\begin{tabular}{|l|} 
Organic \\
Liquid \\
\\
\end{tabular}} & \multirow{2}{*}{\begin{tabular}{|l|} 
Aqueous \\
Liquid
\end{tabular}} & \multirow{2}{*}{\begin{tabular}{|l|} 
Solid(s) \\
$\mathrm{X}$ \\
\end{tabular}} & \multirow[t]{2}{*}{$\begin{array}{l}\text { Required Analytical } \\
\text { Detection Limit (Note 1) }\end{array}$} & \multirow{2}{*}{$\begin{array}{l}\text { Typical Analytical } \\
\text { Detection Limit } \\
\text { (Note 2) } \\
\end{array}$} \\
\hline Aluminate & $\mathrm{AlO2}-$ & & & & & & & \\
\hline Aluminum & $\mathrm{Al}$ & $\begin{array}{l}\text { SST, CIF } \\
\text { SST, CIF } \\
\text { F/H Tank Farms }\end{array}$ & & $\mathrm{X}$ & $\mathbf{X}$ & $\mathrm{X}$ & & $\begin{array}{l}42 \mathrm{mg} / \mathrm{L} \\
0.083 \mathrm{mg} / \mathrm{L} \\
830 \mathrm{mg} / \mathrm{Kg} \\
\end{array}$ \\
\hline Ammonium & $\mathrm{NH} 4+$ & F/H Tank Farms & & & & $\mathbf{X}$ & $\leq 0.56 \mathrm{wt} \%$ in solution & \\
\hline Antimony & $\mathrm{Sb}$ & $\begin{array}{l}\text { SST, CIF } \\
\text { SST, CIF } \\
\text { F/H Tank Farms } \\
\end{array}$ & & $\mathrm{X}$ & X & $X$ & $\begin{array}{l}730 \mathrm{mg} / \mathrm{Kg} \\
730 \mathrm{mg} / \mathrm{Kg}\end{array}$ & $\begin{array}{l}100 \mathrm{mg} / \mathrm{L} \\
0.2 \mathrm{mg} / \mathrm{L} \\
2000 \mathrm{mg} / \mathrm{Kg}\end{array}$ \\
\hline Arsenic & As & \begin{tabular}{|l} 
SST, CIF \\
SST, CIF \\
F/H Tank Farms \\
\end{tabular} & & $\mathrm{X}$ & $X$ & $\mathrm{X}$ & $\begin{array}{l}50 \mathrm{mg} / \mathrm{Kg} \\
50 \mathrm{mg} / \mathrm{Kg}\end{array}$ & $\begin{array}{l}3 \mathrm{mg} / \mathrm{L} \\
0.005 \mathrm{mg} / \mathrm{L} \\
50 \mathrm{mg} / \mathrm{Kg}\end{array}$ \\
\hline Barium & $\mathrm{Ba}$ & $\begin{array}{l}\text { SST, CIF } \\
\text { SST, CIF } \\
\text { F/H Tank Farms }\end{array}$ & & $\mathrm{X}$ & $\mathrm{X}$ & $\underline{X}$ & $\begin{array}{l}100,000 \mathrm{mg} / \mathrm{Kg} \text { (CIF), } \\
\leq 1000 \mathrm{mg} / \mathrm{Kg} \text { (SST) } \\
100,000 \mathrm{mg} / \mathrm{Kg}(\mathrm{CIF}) \\
\leq 1000 \mathrm{mg} / \mathrm{Kg} \text { (SST) }\end{array}$ & $\begin{array}{l}2 \mathrm{mg} / \mathrm{L} \\
0.004 \mathrm{mg} / \mathrm{L} \\
40 \mathrm{mg} / \mathrm{Kg}\end{array}$ \\
\hline Beryllium & $\mathrm{Be}$ & $\begin{array}{l}\text { SST, CIF } \\
\text { SST, CIF } \\
\text { F/H Tank Farms }\end{array}$ & & $\mathrm{X}$ & $X$ & $\mathrm{X}$ & $\begin{array}{l}\text { Detectable } \\
\text { Detectable }\end{array}$ & $\begin{array}{l}2 \mathrm{mg} / \mathrm{L} \\
0.004 \mathrm{mg} / \mathrm{L} \\
40 \mathrm{mg} / \mathrm{Kg}\end{array}$ \\
\hline Boron & $\mathbf{B}$ & $\begin{array}{l}\text { SST, CIF } \\
\text { SST, CIF } \\
\text { F/H Tank Farms }\end{array}$ & & $\mathrm{X}$ & $X$ & $\mathrm{X}$ & & $\begin{array}{l}10 \mathrm{mg} / \mathrm{L} \\
0.02 \mathrm{mg} / \mathrm{L} \\
200 \mathrm{mg} / \mathrm{Kg}\end{array}$ \\
\hline Cadmium & $\mathrm{Cd}$ & $\begin{array}{l}\text { SST, CIF } \\
\text { SST, CIF } \\
\text { F/H Tank Farms }\end{array}$ & & $\mathrm{X}$ & $X$ & $\mathrm{X}$ & $\begin{array}{l}20 \mathrm{mg} / \mathrm{Kg} \\
20 \mathrm{mg} / \mathrm{Kg} \\
20 \mathrm{mg} / \mathrm{Kg} \text { (Note } 3)\end{array}$ & $\begin{array}{l}1 \mathrm{mg} / \mathrm{L} \\
0.002 \mathrm{mg} / \mathrm{L} \\
19 \mathrm{mg} / \mathrm{Kg}\end{array}$ \\
\hline
\end{tabular}


Table 1. Analytical Constituents, Parameters, and Detection Limits (cont.)

\begin{tabular}{|c|c|c|c|c|c|c|c|c|}
\hline \multicolumn{2}{|c|}{ Constituent/Parameter } & WAC(s) & Vapor & $\begin{array}{l}\text { Organic } \\
\text { Liquid } \\
\end{array}$ & $\begin{array}{l}\text { Aqueous } \\
\text { Liquid }\end{array}$ & Solid(s) & $\begin{array}{l}\text { Required Analytical } \\
\text { Detection Limit (Note 1) }\end{array}$ & $\begin{array}{l}\text { Typical } \\
\text { Analytical } \\
\text { Detection Limit } \\
\text { (Note 2) }\end{array}$ \\
\hline Carbonate & CO3- & F/H Tank Farms & & & & $\mathrm{X}$ & & \\
\hline Chloride & $\mathrm{Cl}-$ & $\begin{array}{l}\text { SST, CIF } \\
\text { SST, CIF } \\
\text { F/H Tank Farms } \\
\end{array}$ & & Note 4 & $\mathrm{X}$ & $\mathrm{X}$ & $\leq 0.11 \mathrm{M} \simeq 3.8 \mathrm{~g} / \mathrm{L}$ & $0.2 \mathrm{mg} / \mathrm{L}$ \\
\hline Chromium & $\mathrm{Cr}$ & $\begin{array}{l}\text { SST, CIF } \\
\text { SST, CIF } \\
\text { F/H Tank Farms }\end{array}$ & & $\mathrm{X}$ & $\mathrm{X}$ & $\mathrm{X}$ & $\begin{array}{l}2500 \mathrm{mg} / \mathrm{Kg} \\
2500 \mathrm{mg} / \mathrm{Kg}\end{array}$ & $\begin{array}{l}3 \mathrm{mg} / \mathrm{L} \\
0.006 \mathrm{mg} / \mathrm{L} \\
63 \mathrm{mg} / \mathrm{Kg}\end{array}$ \\
\hline Copper & $\mathrm{Cu}$ & $\begin{array}{l}\text { SST, CIF } \\
\text { SST, CIF } \\
\text { F/H Tank Farms }\end{array}$ & & $\mathrm{X}$ & $\mathrm{X}$ & $\mathbf{X}$ & & $\begin{array}{l}4 \mathrm{mg} / \mathrm{L} \\
0.009 \mathrm{mg} / \mathrm{L} \\
87 \mathrm{mg} / \mathrm{Kg}\end{array}$ \\
\hline Cyanide & $\mathrm{CN}-$ & $\begin{array}{l}\text { SST, CIF, MWSF } \\
\text { Tank Farms, MWSF }\end{array}$ & & & $\mathrm{X}$ & $\mathrm{x}$ & & \\
\hline Fluoride & F- & F/H Tank Farms & & & & $\mathrm{X}$ & $\leq 0.086 \mathrm{M} \simeq 1600 \mathrm{mg} / \mathrm{L}$ & $0.2 \mathrm{mg} / \mathrm{L}$ \\
\hline $\begin{array}{l}\text { Hydroxide, } \\
\text { Free }\end{array}$ & $\mathrm{OH}-$ & F/H Tank Farms & & & & $\mathrm{X}$ & & \\
\hline Iron & $\mathrm{Fe}$ & $\begin{array}{l}\text { SST, CIF } \\
\text { SST, CIF } \\
\text { F/H Tank Farms }\end{array}$ & & $\mathrm{X}$ & $\mathrm{X}$ & $\mathrm{X}$ & & $\begin{array}{l}3 \mathrm{mg} / \mathrm{L} \\
0.006 \mathrm{mg} / \mathrm{L} \\
64 \mathrm{mg} / \mathrm{Kg}\end{array}$ \\
\hline Lead & $\mathrm{Pb}$ & $\begin{array}{l}\text { SST, CIF } \\
\text { SST, CIF } \\
\text { F/H Tank Farms }\end{array}$ & & $\mathrm{X}$ & $\mathrm{X}$ & $\mathrm{X}$ & $\begin{array}{l}10,000 \mathrm{mg} / \mathrm{Kg} \\
10,000 \mathrm{mg} / \mathrm{Kg}\end{array}$ & $\begin{array}{l}26 \mathrm{mg} / \mathrm{L} \\
0.052 \mathrm{mg} / \mathrm{L} \\
520 \mathrm{mg} / \mathrm{Kg}\end{array}$ \\
\hline Manganese & $\mathrm{Mn}$ & $\begin{array}{l}\text { SST, CIF } \\
\text { SST, CIF } \\
\text { Criticality } \\
\end{array}$ & & $\mathrm{X}$ & $\mathrm{X}$ & $\mathrm{X}$ & & $\begin{array}{l}1 \mathrm{mg} / \mathrm{L} \\
0.001 \mathrm{mg} / \mathrm{L} \\
13 \mathrm{mg} / \mathrm{Kg} \\
\end{array}$ \\
\hline
\end{tabular}


Table 1. Analytical Constituents, Parameters, and Detection Limits (cont.)

\begin{tabular}{|c|c|c|c|c|c|c|c|c|}
\hline \multicolumn{2}{|c|}{ Constituent/Parameter } & WAC(s) & Vapor & $\begin{array}{l}\text { Organic } \\
\text { Liquid }\end{array}$ & $\begin{array}{l}\text { Aqueous } \\
\text { Liquid }\end{array}$ & Solid(s) & $\begin{array}{l}\text { Required Analytical } \\
\text { Detection Limit (Note 1) }\end{array}$ & $\begin{array}{l}\text { Typical } \\
\text { Analytical } \\
\text { Detection Limit } \\
\text { Note 2) }\end{array}$ \\
\hline Mercury & $\mathrm{Hg}$ & $\begin{array}{l}\text { SST, CIF } \\
\text { SST, CIF } \\
\text { F/H Tank Farms } \\
\end{array}$ & & $\mathrm{X}$ & $X$ & $\mathrm{X}$ & $\begin{array}{l}260 \mathrm{mg} / \mathrm{Kg} \\
260 \mathrm{mg} / \mathrm{Kg}\end{array}$ & $\begin{array}{l}100 \mathrm{mg} / \mathrm{L} \\
0.2 \mathrm{mg} / \mathrm{L} \\
2000 \mathrm{mg} / \mathrm{Kg}\end{array}$ \\
\hline Nickel & $\mathrm{Ni}$ & $\begin{array}{l}\text { SST, CIF } \\
\text { SST, CIF } \\
\text { Criticality }\end{array}$ & & $\mathrm{X}$ & $\mathrm{X}$ & $\mathrm{X}$ & $\begin{array}{l}600 \mathrm{mg} / \mathrm{L} \\
600 \mathrm{mg} / \mathrm{L}\end{array}$ & $\begin{array}{l}5 \mathrm{mg} / \mathrm{L} \\
0.01 \mathrm{mg} / \mathrm{L} \\
96 \mathrm{mg} / \mathrm{Kg}\end{array}$ \\
\hline Nitrate & $\mathrm{NO3-}$ & $\begin{array}{l}\text { SST, CIF } \\
\text { F/H Tank Farms }\end{array}$ & & & $\mathrm{X}$ & $\mathrm{X}$ & $\begin{array}{l}\leq 8.5 \mathrm{M} \simeq 535,000 \mathrm{mg} / \mathrm{L} \\
\text { Dependent on } \mathrm{OH} \text {-and } \mathrm{NO} 2- \\
\text { concentration. }\end{array}$ & $1 \mathrm{mg} / \mathrm{L}$ \\
\hline Nitrite & NO2- & F/H Tank Farms & & & & $\mathrm{X}$ & $\begin{array}{l}\text { Dependent on } \mathrm{OH}-\text { and } \\
\text { NO3-concentration. }\end{array}$ & $1 \mathrm{mg} / \mathrm{L}$ \\
\hline Oxalate & C2O4- & F/H Tank Farms & & & & $\mathrm{X}$ & & $1 \mathrm{mg} / \mathrm{L}$ \\
\hline Phosphate & (PO4) -3 & $\begin{array}{l}\text { SST, CIF } \\
\text { F/H Tank Farms }\end{array}$ & & & $\mathrm{X}$ & $\mathrm{X}$ & & $1 \mathrm{mg} / \mathrm{L}$ \\
\hline Potassium & $\mathrm{K}$ & F/H Tank Farms & & & & $\mathrm{X}$ & & $400 \mathrm{mg} / \mathrm{Kg}$ \\
\hline Selenium & $\mathrm{Se}$ & $\begin{array}{l}\text { SST, CIF } \\
\text { SST, CIF } \\
\text { F/H Tank Farms }\end{array}$ & & $\mathrm{X}$ & $\mathrm{X}$ & $\mathrm{X}$ & $\begin{array}{l}0.1 \mathrm{mg} / \mathrm{L} \\
0.1 \mathrm{mg} / \mathrm{L}\end{array}$ & $\begin{array}{l}3 \mathrm{mg} / \mathrm{L} \\
0.005 \mathrm{mg} / \mathrm{L} \\
50 \mathrm{mg} / \mathrm{Kg}\end{array}$ \\
\hline Silver & $\mathrm{Ag}$ & $\begin{array}{l}\text { SST, CIF } \\
\text { SST, CIF } \\
\text { F/H Tank Farms }\end{array}$ & & $\mathrm{X}$ & $\mathrm{X}$ & $\mathrm{X}$ & $\begin{array}{l}7,300 \mathrm{mg} / \mathrm{Kg} \\
7,300 \mathrm{mg} / \mathrm{Kg} \\
\text { None detectable }\end{array}$ & $\begin{array}{l}28 \mathrm{mg} / \mathrm{L} \\
0.055 \mathrm{mg} / \mathrm{L} \\
550 \mathrm{mg} / \mathrm{Kg}\end{array}$ \\
\hline Sodium & $\mathrm{Na}$ & $\mathrm{F} / \mathrm{H}$ Tank Farms & & & & $\mathrm{X}$ & & $700 \mathrm{mg} / \mathrm{Kg}$ \\
\hline Sulfate & (SO4) -2 & $\mathrm{F} / \mathrm{H}$ Tank Farms & & & & $\mathrm{X}$ & $\leq 0.18 \mathrm{M} \simeq 17,000 \mathrm{mg} / \mathrm{L}$ & $0.5 \mathrm{ppm}$ \\
\hline Thallium & $\mathrm{Tl}$ & $\begin{array}{l}\text { SST, CIF } \\
\text { SST, CIF } \\
\end{array}$ & & $\mathrm{X}$ & $\mathrm{X}$ & & $\begin{array}{l}730 \mathrm{mg} / \mathrm{Kg} \\
730 \mathrm{mg} / \mathrm{Kg}\end{array}$ & $\begin{array}{l}30 \mathrm{mg} / \mathrm{L} \\
0.06 \mathrm{mg} / \mathrm{L}\end{array}$ \\
\hline
\end{tabular}


Table 1. Analytical Constituents, Parameters, and Detection Limits (cont.)

\begin{tabular}{|c|c|c|c|c|c|c|c|c|}
\hline \multicolumn{2}{|c|}{ Constituent/Parameter } & WAC(s) & Vapor & $\begin{array}{l}\text { Organic } \\
\text { Liquid }\end{array}$ & $\begin{array}{l}\text { Aqueous } \\
\text { Liquid }\end{array}$ & Solid(s) & $\begin{array}{l}\text { Required Analytical } \\
\text { Detection Limit (Note 1) }\end{array}$ & $\begin{array}{l}\text { Typical } \\
\text { Analytical } \\
\text { Detection Limit } \\
(\text { Note 2) }\end{array}$ \\
\hline Titanium & $\mathrm{Ti}$ & F/H Tank Farms & & & & $\mathrm{X}$ & & $50 \mathrm{mg} / \mathrm{Kg}$ \\
\hline Uranium & $\mathrm{U}$ & $\begin{array}{l}\text { SST, CIF } \\
\text { SST, CIF }\end{array}$ & & $\mathrm{X}$ & $X$ & & & $\begin{array}{l}18 \mathrm{mg} / \mathrm{L} \\
0.036 \mathrm{mg} / \mathrm{L}\end{array}$ \\
\hline Zinc & $\overline{Z n}$ & $\begin{array}{l}\text { SST, CIF } \\
\text { SST, CIF } \\
\text { Criticality } \\
\end{array}$ & & $X$ & $x$ & $\mathrm{X}$ & & $\begin{array}{l}1 \mathrm{mg} / \mathrm{L} \\
0.002 \mathrm{mg} / \mathrm{L} \\
16 \mathrm{mg} / \mathrm{Kg}\end{array}$ \\
\hline \multicolumn{2}{|c|}{ Crystallography } & $\begin{array}{l}\text { None, to support grout } \\
\text { formulation }\end{array}$ & & & & $\mathrm{X}$ & & \\
\hline \multicolumn{2}{|l|}{ TCLP } & $\begin{array}{l}\text { None, to support grout } \\
\text { formulation }\end{array}$ & & & & $\mathrm{X}$ & & \\
\hline \multicolumn{2}{|c|}{ Gas Constituents } & $\begin{array}{l}\text { None, for environmental, } \\
\text { safety and health. }\end{array}$ & $\mathrm{X}$ & & & & & \\
\hline \multicolumn{2}{|c|}{$\begin{array}{l}\text { Any known volatiles }> \\
20 \mathrm{mg} / \mathrm{L}\end{array}$} & $\mathrm{F} / \mathrm{H}$ Tank Farms & & & & Note 5 & & \\
\hline \multicolumn{2}{|l|}{ n-Butanol } & F/H Tank Farms & & & & & & \\
\hline \multicolumn{2}{|c|}{$\begin{array}{l}\text { Phenol/phenoxide/nitroph } \\
\text { enols }\end{array}$} & \multicolumn{2}{|l|}{ SST, CIF, F/H Tank Farms } & Note 6 & Note 6 & Note 6 & & \\
\hline \multicolumn{2}{|c|}{ Semi-Volatile Organics } & SST, CIF & $\mathrm{X}$ & Note 7 & Note 7 & & & \\
\hline \multicolumn{2}{|c|}{ Total Organic Carbon } & SST, CIF, F/H Tank Farm & & $\mathrm{X}$ & $\mathrm{X}$ & $\mathrm{X}$ & & \\
\hline \multicolumn{2}{|c|}{ Volatile \% Organics } & F/H Tank Farms & & & & $\mathrm{X}$ & $<0.5 \mathrm{vol} \%$ & \\
\hline \multicolumn{2}{|c|}{ Volatile Organics } & SST, CIF & Note 5 & Note 5 & Note 5 & & & \\
\hline \multicolumn{2}{|l|}{ PCBs } & SST, CIF, MWSF & & $X$ & $\mathrm{X}$ & $\mathrm{X}$ & $<50 \mathrm{ppm}$ & \\
\hline \multicolumn{2}{|c|}{$\begin{array}{l}\text { Kepone, } \mathrm{p}- \\
\text { Nitrophenol }\end{array}$} & SST, CIF & & Note 7 & Note 7 & & Detectable (SST) & \\
\hline
\end{tabular}


Table 1. Analytical Constituents, Parameters, and Detection Limits (cont.)

\begin{tabular}{|c|c|c|c|c|c|c|c|}
\hline Constituent/Parameter & WAC(s) & Vapor & $\begin{array}{l}\text { Organic } \\
\text { Liquid }\end{array}$ & \begin{tabular}{|l|} 
Aqueous \\
Liquid
\end{tabular} & Solid(s) & $\begin{array}{l}\text { Required Analytical } \\
\text { Detection Limit (Note 1) }\end{array}$ & $\begin{array}{l}\text { Typical } \\
\text { Analytical } \\
\text { Detection Limit } \\
\text { (Note 2) }\end{array}$ \\
\hline Benzene & SST, CIF & & Note 5 & Note 5 & & & \\
\hline MEK, PCE & SST, CIF & & Note 5 & Note 5 & & & \\
\hline Acidity & SST, CIF & & & $\mathrm{X}$ & & & \\
\hline Boiling Point & SST, CIF & & $\mathrm{X}$ & $\mathrm{X}$ & & $\geq 135^{\circ} \mathrm{F}$ & \\
\hline $\mathrm{BTU} / \mathrm{lb}$ & SST, CIF & & $\mathrm{X}$ & $\mathrm{X}$ & & $\geq 5000$ & \\
\hline Flash Point & SST, CIF & & $\mathrm{X}$ & $\mathrm{X}$ & & $\geq 140^{\circ} \mathrm{F}$ & \\
\hline Freezing Point & SST, CIF & & $\mathrm{X}$ & $\mathrm{X}$ & & $\leq 40^{\circ} \mathrm{F}$ & \\
\hline Paint Filter Liquids Test & SST, CIF & & $\mathrm{X}$ & $\mathrm{X}$ & & & \\
\hline $\mathrm{pH}$ & \multicolumn{3}{|l|}{$\begin{array}{l}\text { SST, CIF, MWSF } \\
\text { F/H Tank Farms, MWSF }\end{array}$} & $\mathrm{X}$ & $\mathrm{X}$ & $\begin{array}{l}4 \leq \mathrm{pH} \leq 12.5 \\
\mathrm{pH}>9.5\end{array}$ & \\
\hline Specific Gravity & \multicolumn{2}{|l|}{ SST, CIF, F/H Tank Farms } & $\mathrm{X}$ & $\mathrm{X}$ & $\mathrm{X}$ & $\leq 1.15$ & \\
\hline Total Dissolved Solids & \multicolumn{2}{|l|}{$\begin{array}{l}\text { SST, CIF, F/H Tank Farms, } \\
\text { MWSF }\end{array}$} & $\mathrm{X}$ & $\mathrm{X}$ & $\mathrm{X}$ & & \\
\hline $\begin{array}{l}\text { Total } \\
\text { Insoluble/Suspended } \\
\text { Solids } \\
\end{array}$ & \multicolumn{2}{|l|}{$\begin{array}{l}\text { SST, CIF, F/H Tank Farms, } \\
\text { MWSF }\end{array}$} & $\mathrm{X}$ & $\mathrm{X}$ & $\mathrm{X}$ & $\begin{array}{l}\leq 10 \mathrm{wt} \% \text { Total Suspended } \\
\text { Solids }\end{array}$ & \\
\hline Viscosity & SST, CIF & & $\mathrm{X}$ & $\mathrm{X}$ & & $0.002-0.045$ Pas @ 25 $25^{\circ} \mathrm{C}$ & \\
\hline Water, wt\% & SST, CIF & & $\mathrm{X}$ & $\mathrm{X}$ & & & $0.002 \mathrm{wt} \%$ \\
\hline Am-241 & $\begin{array}{l}\text { ES\&H } \\
\text { SST, CIF, MWSF } \\
\text { MWSF }\end{array}$ & Note 8 & $\mathrm{X}$ & $\mathrm{X}$ & $\mathrm{X}$ & $\begin{array}{l}\text { None Specified } \\
1.00 \mathrm{E}-05 \mu \mathrm{Ci} / \mathrm{cc} \text { (Note 9) } \\
1.00 \mathrm{E}-05 \mu \mathrm{Ci} / \mathrm{g} \text { (Note 9) }\end{array}$ & $9 \mathrm{E}-6 \mu \mathrm{Ci} / \mathrm{mL}$ \\
\hline Am Series, Total & F/H Tank Farms & & & & Note 10 & & \\
\hline
\end{tabular}


Table 1. Analytical Constituents, Parameters, and Detection Limits (cont.)

\begin{tabular}{|c|c|c|c|c|c|c|c|}
\hline Constituent/Parameter & WAC(s) & Vapor & $\begin{array}{l}\text { Organic } \\
\text { Liquid }\end{array}$ & $\begin{array}{l}\text { Aqueous } \\
\text { Liquid }\end{array}$ & Solid(s) & $\begin{array}{l}\text { Required Analytical } \\
\text { Detection Limit (Note 1) }\end{array}$ & \begin{tabular}{|l} 
Typical \\
Analytical \\
Detection Limit \\
(Note 2) \\
\end{tabular} \\
\hline C-14 & $\begin{array}{l}\text { SST, CIF, MWSF } \\
\text { F/H Tank Farms, MWSF }\end{array}$ & & $\mathrm{x}$ & $\mathrm{X}$ & $\mathrm{X}$ & $\begin{array}{l}1.00 \mathrm{E}-05 \mu \mathrm{Ci} / \mathrm{cc} \text { (Note } 9) \\
1.00 \mathrm{E}-05 \mu \mathrm{Ci} / \mathrm{g} \text { (Note 9) }\end{array}$ & $1 \mathrm{E}-5 \mu \mathrm{Ci} / \mathrm{mL}$ \\
\hline Ce-144 & $\begin{array}{l}\text { ES\&H } \\
\text { SST, CIF, MWSF } \\
\text { F/H Tank Farms, MWSF }\end{array}$ & Note 8 & $\mathrm{x}$ & $\mathrm{X}$ & $\mathrm{X}$ & $\begin{array}{l}\text { None Specified } \\
<1 \% \text { Total Activity (Note } \\
11) \\
<1 \% \text { Total Activity (Note } \\
11 \text { ) }\end{array}$ & $1 \mathrm{E}-5 \mu \mathrm{Ci} / \mathrm{mL}$ \\
\hline Cm Series & F/H Tank Farms & & & & Note 12 & & $1 \mathrm{E}-5 \mu \mathrm{Ci} / \mathrm{mL}$ \\
\hline Co-60 & $\begin{array}{l}\text { ES\&H } \\
\text { SST, CIF, MWSF } \\
\text { F/H Tank Farms, MWSF }\end{array}$ & Note 8 & $\mathrm{X}$ & $\mathrm{X}$ & $\mathrm{x}$ & $\begin{array}{l}\text { None Specified } \\
1.00 \mathrm{E}-04 \mu \mathrm{Ci} / \mathrm{cc} \text { (Note 9) } \\
1.00 \mathrm{E}-04 \mu \mathrm{Ci} / \mathrm{g} \text { (Note 9) } \\
\end{array}$ & $3 \mathrm{E}-6 \mu \mathrm{Ci} / \mathrm{mL}$ \\
\hline Cs-134 & F/H Tank Farms & & & & $\mathrm{X}$ & & $2 \mathrm{E}-6 \mu \mathrm{Ci} / \mathrm{mL}$ \\
\hline Cs-137 & $\begin{array}{l}\text { ES\&H } \\
\text { SST, CIF, MWSF } \\
\text { F/H Tank Farms, MWSF }\end{array}$ & Note 8 & $\mathrm{X}$ & $\mathrm{X}$ & $\mathrm{x}$ & $\begin{array}{l}\text { None Specified } \\
1.00 \mathrm{E}-05 \mu \mathrm{Ci} / \mathrm{cc}(\text { Note } 9) \\
<3.48 \mathrm{E}+03 \mathrm{dpm} / \mathrm{ml}\end{array}$ & $4 \mathrm{E}-6 \mu \mathrm{Ci} / \mathrm{mL}$ \\
\hline Eu-154 & F/H Tank Farms & & & & $\mathrm{x}$ & & $3 \mathrm{E}-6 \mu \mathrm{Ci} / \mathrm{mL}$ \\
\hline Gross Alpha & $\begin{array}{l}\text { ES\&H } \\
\text { SST, CIF, MWSF } \\
\text { F/H Tank Farms, MWSF }\end{array}$ & $\mathrm{x}$ & $\mathrm{X}$ & $\mathrm{x}$ & $\mathrm{X}$ & $\begin{array}{l}\text { None Specified } \\
5 \mathrm{nCi} / \mathrm{g}=5 \mathrm{E}-3 \mu \mathrm{Ci} / \mathrm{g}\end{array}$ & $9 \mathrm{E}-6 \mu \mathrm{Ci} / \mathrm{mL}$ \\
\hline $\mathrm{H}-3$ & $\begin{array}{l}\text { ES\&H } \\
\text { SST, CIF, MWSF } \\
\text { F/H Tank Farms, MWSF }\end{array}$ & $\mathrm{X}$ & $\mathrm{X}$ & $\mathrm{x}$ & $\mathrm{x}$ & $\begin{array}{l}\text { None Specified } \\
1.00 \mathrm{E}-04 \mu \mathrm{Ci} / \mathrm{cc} \text { (Note 9) } \\
1.00 \mathrm{E}-04 \mu \mathrm{Ci} / \mathrm{g} \text { (Note 9) }\end{array}$ & $1 \mathrm{E}-4 \mu \mathrm{Ci} / \mathrm{mL}$ \\
\hline
\end{tabular}


Table 1. Analytical Constituents, Parameters, and Detection Limits (cont.)

\begin{tabular}{|c|c|c|c|c|c|c|c|}
\hline Constituent/Parameter & WAC(s) & Vapor & $\begin{array}{l}\text { Organic } \\
\text { Liquid }\end{array}$ & $\begin{array}{l}\text { Aqueous } \\
\text { Liquid }\end{array}$ & Solid(s) & $\begin{array}{l}\text { Required Analytical } \\
\text { Detection Limit (Note 1) }\end{array}$ & $\begin{array}{l}\text { Typical } \\
\text { Analytical } \\
\text { Detection Limit } \\
\text { (Note 2) } \\
\end{array}$ \\
\hline $1-129$ & \begin{tabular}{|l} 
SST, CIF, MWSF \\
F/H Tank Farms, MWSF
\end{tabular} & & $\mathrm{X}$ & $\bar{X}$ & $\mathrm{X}$ & $\begin{array}{l}1.00 \mathrm{E}-06 \mu \mathrm{Ci} / \mathrm{cc} \text { (Note 9) } \\
1.00 \mathrm{E}-06 \mu \mathrm{Ci} / \mathrm{g} \text { (Note 9) }\end{array}$ & $1 \mathrm{E}-6 \mu \mathrm{Ci} / \mathrm{mL}$ \\
\hline $\mathrm{Nb}-94$ & F/H Tank Farms & & & & $\mathrm{X}$ & & $3 \mathrm{E}-6 \mu \mathrm{Ci} / \mathrm{mL}$ \\
\hline Ni-59 & \begin{tabular}{|l|} 
SST, CIF, MWSF \\
F/H Tank Farms, MWSF
\end{tabular} & & $\mathrm{X}$ & $\mathrm{X}$ & $\mathrm{X}$ & $\begin{array}{l}1.00 \mathrm{E}-04 \mu \mathrm{Ci} / \mathrm{cc} \text { (Note } 9) \\
1.00 \mathrm{E}-04 \mu \mathrm{Ci} / \mathrm{g} \text { (Note 9) }\end{array}$ & $1 \mathrm{E}-4 \mu \mathrm{Ci} / \mathrm{mL}$ \\
\hline $\mathrm{Ni}-63$ & F/H Tank Farms & & & & $\mathrm{X}$ & & $1 \mathrm{E}-7 \mu \mathrm{Ci} / \mathrm{mL}$ \\
\hline Gross Beta & \begin{tabular}{|l|} 
ES\&H \\
SST, CIF, MWSF \\
F/H Tank Farms, MWSF \\
\end{tabular} & $\mathrm{X}$ & $\mathrm{X}$ & $\mathrm{X}$ & $\mathrm{X}$ & $\begin{array}{l}\text { None Specified } \\
2600 \mathrm{nCi} / \mathrm{g}=2.6 \mu \mathrm{Ci} / \mathrm{g}\end{array}$ & $9 \mathrm{E}-6 \mu \mathrm{Ci} / \mathrm{mL}$ \\
\hline Np-237 & \begin{tabular}{|l|} 
ES\&H \\
SST, CIF, MWSF \\
F/H Tank Farms, MWSF
\end{tabular} & Note 8 & $\mathrm{X}$ & $\mathrm{X}$ & $\mathrm{X}$ & $\begin{array}{l}\text { None Specified } \\
1.00 \mathrm{E}-06 \mu \mathrm{Ci} / \mathrm{cc} \text { (Note 9) } \\
1.00 \mathrm{E}-06 \mu \mathrm{Ci} / \mathrm{g} \text { (Note 9) }\end{array}$ & $5 \mathrm{E}-6 \mu \mathrm{Ci} / \mathrm{mL}$ \\
\hline Plutonium, Total & F/H Tank Farms & & & & Note 13 & & \\
\hline Plutonium-238 & \begin{tabular}{|l|} 
SST, CIF, MWSF \\
F/H Tank Farms, MWSF \\
\end{tabular} & & $\mathrm{X}$ & $\mathrm{X}$ & $\mathrm{X}$ & $\begin{array}{l}1.00 \mathrm{E}-06 \mu \mathrm{Ci} / \mathrm{cc} \text { (Note } 9) \\
1.00 \mathrm{E}-06 \mu \mathrm{Ci} / \mathrm{g} \text { (Note 9) }\end{array}$ & $1 \mathrm{E}-6 \mu \mathrm{Ci} / \mathrm{mL}$ \\
\hline Plutonium-239 & \begin{tabular}{|l|} 
SST, CIF, MWSF \\
F/H Tank Farms, MWSF
\end{tabular} & & $\mathrm{X}$ & $\mathrm{X}$ & $\mathrm{X}$ & $\begin{array}{l}1.00 \mathrm{E}-06 \mu \mathrm{Ci} / \mathrm{cc} \text { (Note 9) } \\
1.00 \mathrm{E}-06 \mu \mathrm{Ci} / \mathrm{g} \text { (Note 9) }\end{array}$ & $1 \mathrm{E}-6 \mu \mathrm{Ci} / \mathrm{mL}$ \\
\hline Plutonium-240 & $\begin{array}{l}\text { SST, CIF, MWSF } \\
\text { F/H Tank Farms, MWSF }\end{array}$ & & $\mathrm{X}$ & $\mathrm{X}$ & $\mathrm{X}$ & $\begin{array}{l}1.00 \mathrm{E}-06 \mu \mathrm{Ci} / \mathrm{cc} \text { (Note 9) } \\
1.00 \mathrm{E}-06 \mu \mathrm{Ci} / \mathrm{g} \text { (Note 9) }\end{array}$ & $1 \mathrm{E}-6 \mu \mathrm{Ci} / \mathrm{mL}$ \\
\hline Plutonium-241 & $\begin{array}{l}\text { SST, CIF, MWSF } \\
\text { F/H Tank Farms, MWSF }\end{array}$ & & $\mathrm{X}$ & $\mathrm{X}$ & $\mathrm{X}$ & $\begin{array}{l}1.00 \mathrm{E}-05 \mu \mathrm{Ci} / \mathrm{cc} \text { or } \\
1 \% \text { Total Activity (Note } 14) \\
1.00 \mathrm{E}-05 \mu \mathrm{Ci} / \mathrm{cc} \text { or } \\
1 \% \text { Total Activity (Note } 14)\end{array}$ & $1 \mathrm{E}-6 \mu \mathrm{Ci} / \mathrm{mL}$ \\
\hline
\end{tabular}




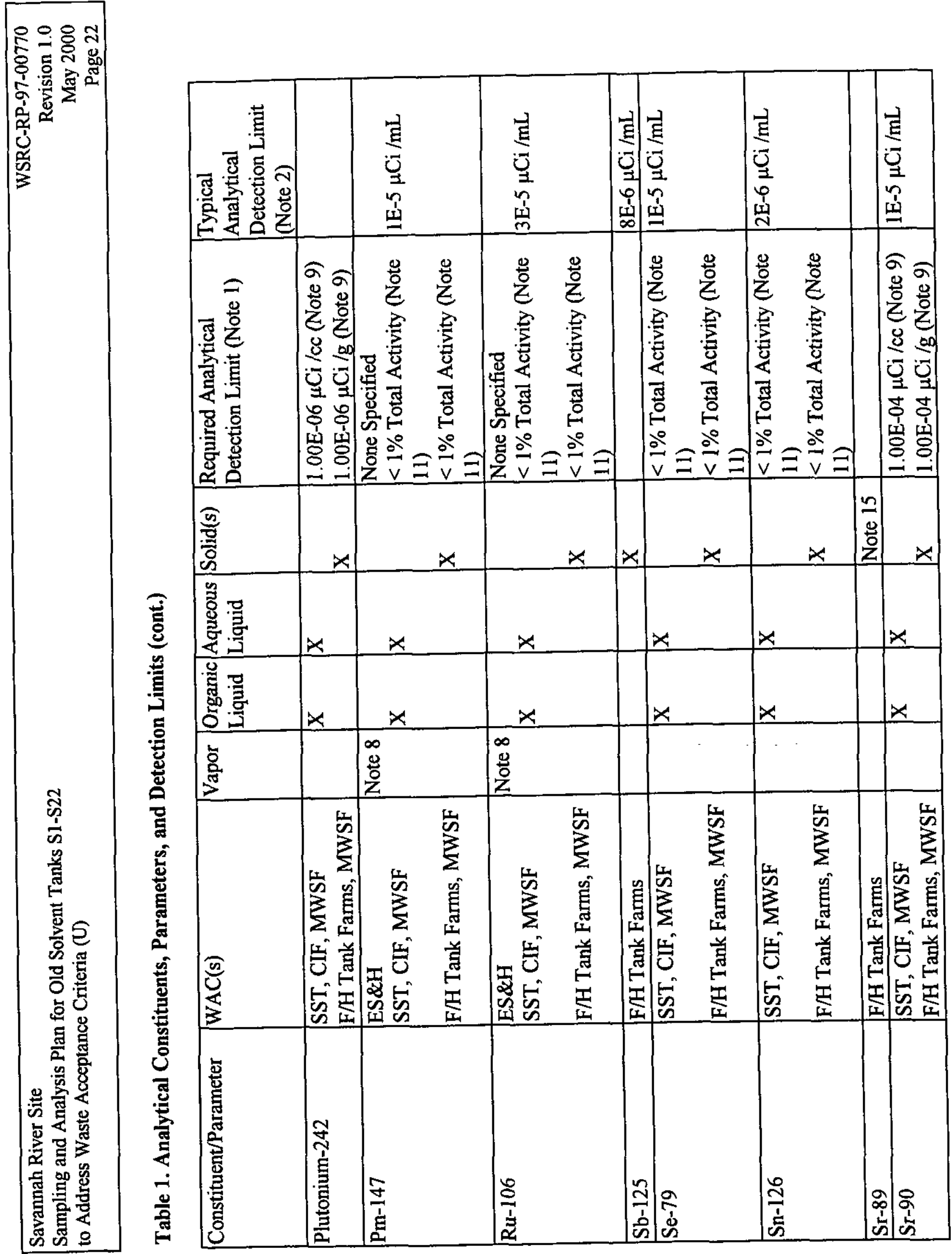


Table 1. Analytical Constituents, Parameters, and Detection Limits (cont.)

\begin{tabular}{|c|c|c|c|c|c|c|c|}
\hline Constituent/Parameter & WAC(s) & Vapor & $\begin{array}{l}\text { Organic } \\
\text { Liquid }\end{array}$ & $\begin{array}{l}\text { Aqueous } \\
\text { Liquid }\end{array}$ & Solid(s) & $\begin{array}{l}\text { Required Analytical } \\
\text { Detection Limit (Note 1) }\end{array}$ & $\begin{array}{l}\text { Typical } \\
\text { Analytical } \\
\text { Detection Limit } \\
\text { (Note 2) } \\
\end{array}$ \\
\hline Tc-99 & \begin{tabular}{|l|} 
SST, CIF, MWSF \\
F/H Tank Farms, MWSF \\
\end{tabular} & & $\mathrm{X}$ & $\mathrm{x}$ & $\mathrm{X}$ & $\begin{array}{l}1.00 \mathrm{E}-06 \mu \mathrm{Ci} / \mathrm{cc} \text { (Note 9) } \\
1.00 \mathrm{E}-06 \mu \mathrm{Ci} / \mathrm{g} \text { (Note 9) }\end{array}$ & $1 \mathrm{E}-6 \mu \mathrm{Ci} / \mathrm{mL}$ \\
\hline Uranium-233 & $\begin{array}{l}\text { SST, CIF, MWSF } \\
\text { F/H Tank Farms, MWSF }\end{array}$ & & $\mathrm{X}$ & $\mathrm{X}$ & $\mathrm{x}$ & $\begin{array}{l}1.00 \mathrm{E}-06 \mu \mathrm{Ci} / \mathrm{cc} \text { or } \\
1 \% \text { Total Activity (Note } 14) \\
1.00 \mathrm{E}-06 \mu \mathrm{Ci} / \mathrm{cc} \text { or } \\
1 \% \text { Total Activity (Note } 14)\end{array}$ & $1 \mathrm{E}-6 \mu \mathrm{Ci} / \mathrm{mL}$ \\
\hline Uranium-234 & \begin{tabular}{|l|} 
SST, CIF, MWSF \\
F/H Tank Farms, MWSF \\
\end{tabular} & & $\mathrm{X}$ & $\mathrm{X}$ & $X$ & $\begin{array}{l}1.00 \mathrm{E}-06 \mu \mathrm{Ci} / \mathrm{cc} \text { (Note 9) } \\
1.00 \mathrm{E}-06 \mu \mathrm{Ci} / \mathrm{g} \text { (Note 9) }\end{array}$ & $1 \mathrm{E}-6 \mu \mathrm{Ci} / \mathrm{mL}$ \\
\hline Uranium-235 & $\begin{array}{l}\text { SST, CIF, MWSF } \\
\text { F/H Tank Farms, MWSF }\end{array}$ & & $\mathrm{x}$ & $\mathrm{X}$ & $\mathrm{X}$ & $\begin{array}{l}1.00 \mathrm{E}-06 \mathrm{uCi} / \mathrm{cc} \text { or } \\
1 \% \text { Total Activity (Note } 14) \\
1.00 \mathrm{E}-06 \mathrm{uCi} / \mathrm{cc} \text { or } \\
1 \% \text { Total Activity (Note } 14)\end{array}$ & $1 \mathrm{E}-6 \mu \mathrm{Ci} / \mathrm{mL}$ \\
\hline Uranium-236 & $\begin{array}{l}\text { SST, CIF, MWSF } \\
\text { F/H Tank Farms, MWSF }\end{array}$ & & $\mathrm{X}$ & $\mathrm{X}$ & $\mathrm{X}$ & $\begin{array}{l}1.00 \mathrm{E}-06 \mu \mathrm{Ci} / \mathrm{cc} \text { or } \\
1 \% \text { Total Activity (Note } 14) \\
1.00 \mathrm{E}-06 \mu \mathrm{Ci} / \mathrm{cc} \text { or } \\
1 \% \text { Total Activity (Note } 14)\end{array}$ & $1 \mathrm{E}-6 \mu \mathrm{Ci} / \mathrm{mL}$ \\
\hline Uranium-238 & \begin{tabular}{|l|} 
SST, CIF, MWSF \\
F/H Tank Farms, MWSF
\end{tabular} & & $\mathrm{X}$ & $\mathrm{x}$ & $\mathrm{X}$ & $\begin{array}{l}1.00 \mathrm{E}-06 \mu \mathrm{Ci} / \mathrm{cc} \text { or } \\
1 \% \text { Total Activity (Note } 14) \\
1.00 \mathrm{E}-06 \mu \mathrm{Ci} / \mathrm{cc} \text { or } \\
1 \% \text { Total Activity (Note } 14)\end{array}$ & $1 \mathrm{E}-6 \mu \mathrm{Ci} / \mathrm{mL}$ \\
\hline
\end{tabular}

Table 1 Notes:

1. Required detection limits are from the respective WACs. 
2. Typical detection limits are listed for informational purposes, the actual detection limits obtained are sample-specific and may be higher or lower than those shown. The typical detection limits for the elemental analyses of the organic liquid assumed a $1 \mathrm{ml}$ sample digested and diluted to $50 \mathrm{~mL}$, with a 10fold dilution prior to the spectroscopic measurement. The typical detection limits for the elemental analyses of the solid assumed a $0.25 \mathrm{~g}$ sample digested and diluted to $250 \mathrm{~mL}$, with a 10 -fold dilution prior to the spectroscopic measurement.

3. The required detection limit for these RCRA metals in the solid sample is assumed to be 20 times the leachate limit from the TCLP. The planned analyses will be total metal digestions, not leachings, these values account for the 20-fold excess used in the TCLP.

4. Chlorine in the organic phase will be determined by summing the chlorinated hydrocarbons identified in the VOC and SVOC analyses.

5. The Volatile Organic Compound analysis addresses these specific WAC requirements: benzene, methyl ethyl ketone, perchloroethylene, n-butanol, any known volatiles $>20$ $\mathrm{mg} / \mathrm{L}$. It does not address methanol.

6. The addition of nitric acid to alkaline wastes may create nitrated organic compounds that did not originate in the sample.

7. The Semi-Volatile Organic Compound analysis addresses these specific WAC requirements: kepone and p-nitrophenol.

8. Gamma spectroscopy of the vapor phase cartridges will identify Cs-137 and other gamma emitting radionuclides in the vapor phase.

9. WAC 2.02 in the WSRC IS Manual requires documentation of the technical justification for exceeding these Maximum Allowable Lower Limit of Detection values.

10. Total americium will be the sum of any identified Am-241 and Am-243.

11. WAC 2.02 in the WSRC IS Manual defines a significance level of $1 \mathrm{Ci} \%$ for nuclides that do not have specific limits in WAC 3.17 .

12. Total curium will be the sum of $\mathrm{Cm}-244$ and any other $\mathrm{Cm}$ isotopes identified by alpha spectrometry.

13. Total plutonium will be the sum of all identified $\mathrm{Pu}$ isotopes.

14. The required detection limit is assumed to be the greater of $1 \mathrm{Ci} \%$ or the Maximum Allowable Lower Limit of Detection value.

15. Sr-89 will not be analyzed for due to the short half-life ( 50.5 days) and the age of the material in the tanks. 
Table 2. Analytical Methods and Hold Times

\begin{tabular}{|c|c|c|c|c|}
\hline \multicolumn{2}{|l|}{ Constituent/Parameter } & \multirow{2}{*}{\begin{tabular}{|l|} 
Technique \\
Titration
\end{tabular}} & \multirow{2}{*}{\begin{tabular}{|l|} 
L16.1 Procedure \\
ADS-2312 \\
\end{tabular}} & \multirow{2}{*}{$\begin{array}{l}\text { Hold Time (per SW- } \\
846^{8} \text { ) }\end{array}$} \\
\hline $\begin{array}{l}\text { Aluminate, Carbonate, } \\
\text { and Free Hydroxide }\end{array}$ & $\begin{array}{l}\mathrm{AlO}_{2}^{-}, \mathrm{CO}_{3}^{-}, \\
\mathrm{OH}^{-}\end{array}$ & & & \\
\hline \begin{tabular}{|l|} 
Aluminum, Antimony, \\
Barium, Beryllium, \\
Boron, Cadmium, \\
Chromium, Copper, \\
Iron, Lead, Manganese, \\
Nickel, Silver, Sodium, \\
Thallium, Titanium, \\
Uranium, Zinc \\
\end{tabular} & $\begin{array}{l}\mathrm{Al}, \mathrm{Sb}, \mathrm{Ba}, \mathrm{Be} \\
\mathrm{B}, \mathrm{Cd}, \mathrm{Cr}, \mathrm{Cu} \\
\mathrm{Fe}, \mathrm{Pb}, \mathrm{Mn}, \mathrm{Ni} \\
\mathrm{Ag}, \mathrm{Na}, \mathrm{Tl}, \mathrm{Ti} \\
\mathrm{U}, \mathrm{Zn}\end{array}$ & ICP-ES & ADS-1509 & 6 months \\
\hline $\begin{array}{l}\text { Ammonium, Chloride, } \\
\text { Fluoride, Nitrate, } \\
\text { Nitrite, Oxalate, } \\
\text { Phosphate, Sulfate } \\
\end{array}$ & $\begin{array}{l}\mathrm{NH}_{4}^{+}, \mathrm{Cl}^{-}, \mathrm{F}^{-} \\
\mathrm{NO}_{3}^{-}, \mathrm{NO}_{2}^{-} \\
\mathrm{C}_{2} \mathrm{O}_{4}^{-},\left(\mathrm{PO}_{4}^{-3}\right)^{-3} \\
\left(\mathrm{SO}_{4}\right)^{-2}\end{array}$ & IC & ADS-2306 & $\begin{array}{l}\text { Not specified in SW- } \\
846\end{array}$ \\
\hline Cyanide & $\mathrm{CN}^{-}$ & & ADS-2278 & \\
\hline Arsenic, Selenium & $\mathrm{As}, \mathrm{Se}$ & Hydride AAS & ADS-1557 & 6 months \\
\hline Mercury & $\mathrm{Hg}$ & CVAA & ADS-1556 & 28 days \\
\hline Potassium & $\mathrm{K}$ & Flame AAS & ADS-1549 & 6 months \\
\hline Crystallography & & $\mathrm{XRD}$ & ADS-1101 & \\
\hline TCLP & & Modified TCLP & ADS-2512 & \\
\hline Gas Constituents & & GC, GC/MS & ADS- 1600 & \\
\hline $\begin{array}{l}\text { Phenol/phenoxide/nitrop } \\
\text { henols }\end{array}$ & & HPLC & Task Technical Plan & $\begin{array}{l}\text { Extract within } 14 \\
\text { days, analyze within } \\
40 \text { days of extraction }\end{array}$ \\
\hline Semi-Volatile Organics & & GC/MS & ADS-2657 & $\begin{array}{l}\text { Extract within } 14 \\
\text { days, analyze within } \\
40 \text { days of extraction }\end{array}$ \\
\hline Total Organic Carbon & & TOC & ADS- 1200 & $\begin{array}{l}\text { Not specified in SW- } \\
846\end{array}$ \\
\hline Volatile \% Organics & & $\begin{array}{l}\text { Oil Content } \\
\text { Analyzer } \\
\end{array}$ & ADS-2213 & $\begin{array}{l}\text { Not specified in SW- } \\
846\end{array}$ \\
\hline Volatile Organics & & GC/MS & ADS-2656 & 14 days \\
\hline PCBs & & GC, GC/MS & ADS-2659 & $\begin{array}{l}\text { Extract within } 14 \\
\text { days, analyze within } \\
40 \text { days of extraction }\end{array}$ \\
\hline Acidity & & Titration & ADS-2301 & \\
\hline Boiling Point & & & ADS-2280 & \\
\hline BTU/lb & & & ADS-2277 & \\
\hline Flash Point & & & ADS-2250 & \\
\hline
\end{tabular}


Table 2 Analytical Methods and Hold Times (cont.)

\begin{tabular}{|c|c|c|c|}
\hline Constituent/Parameter & Technique & L16.1 Procedure & $\begin{array}{l}\text { Hold Time (per SW- } \\
846^{8} \text { ) }\end{array}$ \\
\hline Freezing Point & & ADS-2279 & \\
\hline Paint Filter Liquids Test & & ADS-2275 & $\begin{array}{l}\text { Not specified in SW- } \\
846\end{array}$ \\
\hline $\mathrm{pH}$ & & ADS-2309 & $\begin{array}{l}\text { Not specified in SW- } \\
846\end{array}$ \\
\hline \multicolumn{4}{|l|}{ Specific Gravity } \\
\hline $\begin{array}{l}\text { Total Dissolved, } \\
\text { Insoluble/Suspended } \\
\text { Solids }\end{array}$ & & $\begin{array}{l}\text { Standard Method } \\
2540^{11}\end{array}$ & \\
\hline Viscosity & & ADS-2276 & \\
\hline Water, wt $\%$ & Karl-Fischer & ADS-2210 & \\
\hline $\begin{array}{l}\text { Am-241, Ce-144, Co-60, Cs-134, Cs- } \\
137, \text { Eu-154, Nb-94, Np-237, Ru-106, } \\
\text { Sb-125, Sn-126 }\end{array}$ & Gamma PHA & ADS-2420 & \\
\hline Am Series, Total & $\begin{array}{l}\text { Gamma and } \\
\text { Alpha PHA } \\
\end{array}$ & $\begin{array}{l}\text { ADS-2420, ADS- } \\
2402\end{array}$ & \\
\hline$\overline{C-14}$ & \begin{tabular}{|l} 
Separation \& \\
LSC \\
\end{tabular} & & \\
\hline Cm Series & Alpha PHA & ADS-2402 & \\
\hline Gross Alpha & Gross Alpha & ADS-2405 & $\begin{array}{l}\text { Not specified in SW- } \\
846\end{array}$ \\
\hline $\mathrm{H}-3$ & \begin{tabular}{|l} 
Distillation \& \\
LSC \\
\end{tabular} & ADS-2444 & \\
\hline $1-129$ & $\begin{array}{l}\text { Separation \& } \\
\text { LEPS }\end{array}$ & & \\
\hline $\mathrm{Ni}-59$ & $\begin{array}{l}\text { Separation \& } \\
\text { XRS }\end{array}$ & ADS-2452 & \\
\hline Ni-63 & $\begin{array}{l}\text { Separation \& } \\
\text { LSC } \\
\end{array}$ & ADS-2452 & \\
\hline Gross Beta & LSC & ADS-2424 & $\begin{array}{l}\text { Not specified in SW- } \\
846\end{array}$ \\
\hline Plutonium, Total & Summation & & \\
\hline $\begin{array}{l}\text { Pu-238, Pu-239, Pu-240, Pu-242, U-233, } \\
\text { U-234, U-236, U-238 }\end{array}$ & $\begin{array}{l}\text { ICP-MS \& Alpha } \\
\text { PHA }\end{array}$ & $\begin{array}{l}\text { ADS-1551, ADS- } \\
2402\end{array}$ & \\
\hline Plutonium-241 & $\begin{array}{l}\text { Separation \& } \\
\text { LSC }\end{array}$ & & \\
\hline $\mathrm{Pm}-147$ & $\begin{array}{l}\text { Separation \& } \\
\text { LSC } \\
\end{array}$ & & \\
\hline Se-79 & $\begin{array}{l}\text { Separation \& } \\
\text { LSC }\end{array}$ & & \\
\hline
\end{tabular}


Savannah River Site

WSRC-RP-97-00770

Sampling and Analysis Plan for Old Solvent Tanks S1-S22

Revision 1.0

to Address Waste Acceptance Criteria (U)

May 2000

Page 27

Table 2 Analytical Methods and Hold Times (cont.)

\begin{tabular}{|l|l|l|l|}
\hline Constituent/Parameter & Technique & L16.1 Procedure & $\begin{array}{l}\text { Hold Time (per SW- } \\
\left.846^{8}\right)\end{array}$ \\
\hline Sr-90 & $\begin{array}{l}\text { Separation \& } \\
\text { SC }\end{array}$ & ADS-2447 & \\
\hline Tc-99 & $\begin{array}{l}\text { Separation \& } \\
\text { SC }\end{array}$ & ADS-2445 & \\
\hline Uranium-235 & $\begin{array}{l}\text { ICP-MS, Gamma } \\
\text { PHA, Alpha } \\
\text { SHA }\end{array}$ & $\begin{array}{l}\text { ADS-1551, ADS- } \\
2420, \text { ADS-2402 }\end{array}$ & \\
\hline
\end{tabular}




\section{APPENDIX A. LIST OF ANALYTICAL PROCEDURES}

\begin{tabular}{|c|c|c|c|}
\hline \begin{tabular}{|l|} 
L16.1 \\
Procedure
\end{tabular} & Revision & Title & Year \\
\hline ADS-1101 & $\operatorname{Rec} .3$ & Siemens D-500 Contained X-Ray Diffreaction System (U) & 1995 \\
\hline ADS-1509 & Rev. 3 & $\begin{array}{l}\text { Inductively Coupled Plasma Emission Spectrometer for Aqueous Liquid } \\
\text { Sample Analysis ARL 3580 (U) }\end{array}$ & 1996 \\
\hline$\overline{\text { ADS-1549 }}$ & Rev. 1 & $\begin{array}{l}\text { Procedure for Operating Varian SpectrAA-400 Atomic Absorption } \\
\text { Spectrophotometer }(\mathrm{U})\end{array}$ & 1997 \\
\hline ADS-1551 & Rev. 0 & $\begin{array}{l}\text { Inductively Coupled Plasma-Mass Spectrometry Elemental and Isotopic } \\
\text { Analysis for Aqueous Liquid Sample Fisons Plasmaquad I (U) }\end{array}$ & 1996 \\
\hline ADS-1556 & Rev. 0 & $\begin{array}{l}\text { Procedure for Cold Vapor Atomic Absorption Determination of } \\
\text { Mercury on the Varian SpectrAA-400 Atomic Absorption } \\
\text { Spectrophotometer (U) }\end{array}$ & 1996 \\
\hline ADS-1557 & Rev. 0 & Procedure for Hydride Generation/Atomic Absorption (U) & 1997 \\
\hline ADS-1600 & Rev. 4 & Procedure for Gas Chromatography (U) & 1996 \\
\hline $\mathrm{ADS}-2210$ & Rev. 6 & Water Determination with the Karl Fischer Reagent (U) & 1997 \\
\hline ADS-2213 & Rev. 4 & Measurement of Oil and Grease in Aqueous Suspensions (U) & 1996 \\
\hline ADS-2250 & Rev. 2 & $\begin{array}{l}\text { Flashpoint Determination Using Petrolab Mini-Flash Flashpoint Tester } \\
\text { (U) }\end{array}$ & 1996 \\
\hline ADS-2275 & Rev. 0 & EPA SW-846 Method 9095 Paint Filter Liquids Test(U) & 1997 \\
\hline ADS-2276 & Rev. 0 & $\begin{array}{l}\text { Measurement of Viscosity using Glass Capillary Kinematic Opaque } \\
\text { Viscosmeter }\end{array}$ & 1997 \\
\hline ADS-2277 & Rev. 0 & Measurement of Heat of Combustion of Liquids by Bomb Calorimetry & 1997 \\
\hline ADS-2278 & Rev. 0 & Measurement of Cyanide Ion in Aqueous Solutions & 1997 \\
\hline ADS-2279 & Rev. 0 & Freezing Point Determeination of Liquids & 1997 \\
\hline ADS-2280 & Rev. 0 & Boiling Point Determeination of Liquids & 1997 \\
\hline ADS-2276 & Rev. 0 & $\begin{array}{l}\text { Measurement of Viscosity using Glass Capillary Kinematic Opaque } \\
\text { Viscosmeter }\end{array}$ & 1997 \\
\hline ADS-2301 & Rev. 5 & Determination of Total Acid by Autotitration (U) & 1996 \\
\hline ADS-2306 & Rev. 6 & Analysis of Solutions by Ion Chromatography (U) & 1997 \\
\hline ADS-2309 & Rev. 4 & $\mathrm{pH}$ Determination of Aqueous Liquids $(\mathrm{U})$ & 1996 \\
\hline ADS-2312 & Rev. 5 & $\begin{array}{l}\text { Automatic Determination of Hydroxide, Aluminate and Carbonate in } \\
\text { Alkaline Solutions of Nuclear Waste (U) }\end{array}$ & 1996 \\
\hline $\mathrm{ADS}-2401$ & Rev. 2 & Beta Liquid Scintillation (U) & 1995 \\
\hline $\mathrm{ADS}-2402$ & Rev. 2 & Alpha Pulse Height Analysis (U) & 1994 \\
\hline ADS-2405 & Rev. 2 & Alpha and Beta Plate Making Direct Mount and Count (U) & 1995 \\
\hline ADS-2420 & Rev. 3 & Gamma Sample Preparation and Analysis (g-PHA) (U) & 1997 \\
\hline ADS-2424 & Rev. 4 & Gross Alpha/Beta Determination by Liquid Scintillation Counting (U) & 1996 \\
\hline ADS-2444 & Rev. 1 & Tritium in Environmental Samples - A Distillation Procedure & 1996 \\
\hline ADS-2445 & Rev. 1 & Technicium-99 Extraction and Chromatography & 1996 \\
\hline $\mathrm{ADS}-2447$ & Rev. 1 & Strontium- 90 in Environmental Samples & 1996 \\
\hline ADS-2452 & Rev. 0 & Ni-59,63 in Environmental and High Activity Samples & 1997 \\
\hline
\end{tabular}




\section{Appendix A (cont.)}

\begin{tabular}{|l|l|l|c|}
\hline $\begin{array}{l}\text { L16.1 } \\
\text { Procedure }\end{array}$ & Revision & Title & Year \\
\hline ADS-2512 & Rev. 2 & Modified Toxic Characteristic Leaching Procedure & 1996 \\
\hline ADS-2655 & Rev. 2 & High Performance Liquid Chromatography Operating Procedure (U) & 1996 \\
\hline ADS-2656 & Rev. 1 & $\begin{array}{l}\text { Gas Chromatography/Mass Spectrometry for Volatile Organics: } \\
\text { Contract Laboratory Program Methods (U) }\end{array}$ & 1996 \\
\hline ADS-2657 & Rev. 1 & $\begin{array}{l}\text { Gas Chromatography/Mass Spectrometry for Semi-Volatile Organics: } \\
\text { Contract Laboratory Program Methods (U) }\end{array}$ & 1997 \\
\hline ADS-2659 & Rev. 0 & $\begin{array}{l}\text { Gas Chromatography and Gas Chromatography/Mass Spectrometry for } \\
\text { Polychlorinated Biphenyls Analysis: Contract Laboratory Program } \\
\text { Methods (U) }\end{array}$ & 1995 \\
\hline
\end{tabular}


This page intentionally left blank. 


\section{APPENDIX E \\ Addendum to the \\ Workplan/RCRA Facility Investigation/ \\ Remedial Investigation Report for the Old Radioactive \\ Waste Burial Ground 643-E, S01-S22 (U)}


(This page intentionally left blank.) 
United States Department of Energy

Savannah River Site

\section{Addendum to the \\ Workplan/RCRA Facility Investigation/ \\ Remedial Investigation Report for the Old Radioactive \\ Waste Burial Ground 643-E, S01-S22}

\section{WSRC-RP-99-4023 \\ Revision 1.1 \\ August 2000}

Prepared by:

Westinghouse Savannah River Company

Savannah River Site

Aiken, S.C. 29808

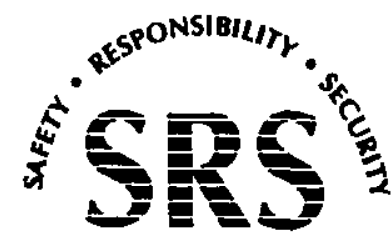

Prepared for the US Department of Energy Under

Contract No. DE-AC09-96SR18500 


\section{DISCLAIMER}

This report was prepared by Westinghouse Savannah River Company (WSRC) for the United States Department of Energy under Contract No. DE-AC09-96-SR18500 and is an account of work performed under that contract. Reference herein to any specific commercial product, process, or services by trademark, name, manufacturer, or otherwise does not necessarily constitute or imply endorsement, recommendation, or favoring of same by WSRC or by the United States Government or any agency thereof.

Printed in the United States of America

Prepared for

U. S. Department of Energy

and

Westinghouse Savannah River Company

Aiken, South Carolina 


\section{TABLE OF CONTENTS}

SECTION

PAGE

LIST OF FIGURES......................................................................................................................

LIST OF TABLES ...iv

LIST OF ATTACHMENTS. .iv

ACRONYMS $\ldots v$

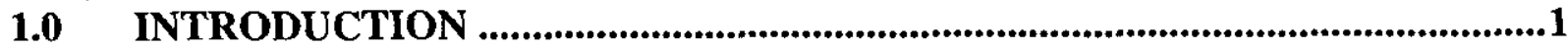

1.1 SUMMARY OF UNIT DESCRIPTION ......................................................................1

2.0 PREVIOUS CHARACTERIZATION HISTORY OF OLD SOLVENT TANK (S01 THROUGH S22) WASTES ........................................................................................3

$3.0 \quad 1997 / 98$ AND 1998/99 OST CHARACTERIZATION ACTIVITIES ......................4

3.1 SUMMARY OF 1997/98 VideO SURVEY OF SOLVENT TANKS S01 THROUGH S22. 5

3.2 SUMmaRY OF 1998/99 ChaRACTERIZATION OF SAMPLES FROM SOLVENT

TANKS S01 THROUGH S22 ........................................................................................6

3.3 Summary OF CRITICAlity Evaluation OF OLd SOlVENT STORAGE

TANKS S01 THROUGH S22 .................................................................................

4.0 UNCERTAINTIES ASSOCIATED WITH CHARACTERIZATION ACTIVITIES.....................................................................................................................8

4.1 UNCERTAINTY IN VIDEO SURVEY AND SAMPLING ..............................................

4.2 UNCERTAINTY IN SAMPLE ANALYSES...................................................................9

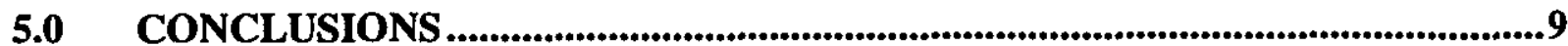

6.0 REFERENCES ..........................................................................................................11 


\section{LIST OF FIGURES}

Figure 1. Location of the Old Solvent Tanks (S01 through S22) in E Area 12

\section{LIST OF TABLES}

Table 1. Old Solvent Tank Specifications from Video Survey

Table 2. Detected Constituent Concentrations in Filtered Aqueous Phase of Old Solvent Tanks.

Table 3. Detected Constituent Concentrations in Filtered Solid (Aqueous) Phase of Old Solvent Tanks.

Table 4. Detected Constituent Concentrations in Sludge Phase of Old Solvent

Tanks

Table 5. Detected Constituent Concentrations in Filtered Organic Phase of Old Solvent Tanks.

Table 6. Maximum Constituent Concentrations in Old Solvent Tanks above the Method Detection Limit/Activity

\section{LIST OF ATTACHMENTS}

Attachment 1 Technical Report on the Old Solvent Tanks Video Survey Summary

Attachment 2 Characterization of Samples from Old Solvent Tanks S1 through S22

Attachment 3 Total Inventory of Selected Radionuclides in Old Solvent Tanks S1 through S22

Attachment 4 WSMS-CRT-00-0011 - Evaluation of Old Solvent Storage Tanks 122 (Rev. 1) and Supporting Documentation 


\section{ACRONYMS}

CERCLA Comprehensive Environmental Response, Compensation and Liability Act

$\mathrm{cm} \quad$ centimeter

DQO data quality objective

ft foot

HM H-Area modified

in. inch

m meter

ORWBG Old Radioactive Waste Burial Ground

OSTs Old Solvent Tanks (S01 through S22)

OU operable unit

PUREX plutonium and uranium extraction

RCRA Resource Conservation and Recovery Act

SCDHEC South Carolina Department of Health and Environmental Control

SRS Savannah River Site

SVOC semivolatile organic compound

TBP tri-n-butyl-phosphate

US EPA United States Environmental Protection Agency

UST underground storage tank

VOC volatile organic compound 
(This page intentionally left blank.) 


\subsection{INTRODUCTION}

A Workplan/RCRA Facility Investigation/Remedial Investigation Report for the Old Radioactive Waste Burial Ground 643-E, SO1-S22 (U) was submitted to the South Carolina Department of Health and Environmental Control (SCDHEC) and the United States Environmental Protection Agency (US EPA) in November 1998 (WSRC 1997a). That document summarizes the known or suspected inventory of primary source material, results of previous characterization investigations, and identification of potential "hot spots" that may require special feasibility assessment in the development of a final remedy for the Old Radioactive Waste Burial Ground (ORWBG). The data quality objectives (DQOs) and unit assessment evaluations concluded that a single data gap remained to complete the characterization of the ORWBG. That data gap was the sampling and analysis of the remaining contents of the Old Solvent Tanks S01 through S22 (OSTs).

This document is an addendum to the Workplan/RCRA Facility Investigation/Remedial Investigation Report for the Old Radioactive Waste Burial Ground 643-E, SO1-S22 (U) (WSRC 1997a) and presents the results of the old solvent tank investigations conducted in 1997, 1998, and 1999. A brief overview of the solvent tanks and previous waste disposal practices are provided below. The description and results of characterization activities are provided in Sections 2.0 and 3.0. Section 4.0 describes uncertainties associated with the characterization process. Conclusions are presented in Section 5.0, and references are given in Section 6.0. Attachments 1 and 2 contain detailed reports of the characterization activities. Attachment 3 provides an estimated inventory of Constituents of Interest. An evaluation of criticality concerns for waste material handling and tank closure is provided in Attachment 4..

\subsection{Summary of Unit Description}

The 22 OSTs are located in a "T-shaped" block near the center of the ORWBG, approximately $122 \mathrm{~m}(400 \mathrm{ft})$ northeast of the Burial Ground Administration Building (724-7E) and $152 \mathrm{~m}$ $(500 \mathrm{ft}$ ) north of Road E (Figure 1).

Solvent, consisting of tri-n-butyl phosphate (TBP) dissolved in kerosene, was used in the plutonium and uranium extraction (PUREX) process in the F-Area separations facility. The 
H-Area Modified (HM) process utilized TBP dissolved in Ultracene ${ }^{\mathrm{TM}}$ for uranium extraction. The PUREX and HM processes were chemical methods for removing residual plutonium and/or uranium from spent fuel rods and activation products from target rods. The solvent was reused in extraction processes until it became laden with organic and metallic contaminants (i.e., degraded). Nitric acid was recovered from the degraded solvent, which was then neutralized with caustic solutions (sodium hydroxide).

The OSTs were installed in the ORWBG between 1955 and 1970 to receive degraded solvents generated from the PUREX and HM processes, as well as smaller amounts of tritiated pump oil. The waste was "aged" in the solvent tanks, allowing the short-lived fission products to undergo decay and the suspended solids and precipitates to settle out of the solvent. The "aging" period ranged from six months to 12.4 years, with an average "aging" time of 4.6 years. During "aging", the solvent separated into three phases: organic, aqueous, and sludge solids. The organic phase likely consisted of TBP, naphthalene, toluene, trimethylbenzene, xylene, and n-paraffin hydrocarbons (i.e., kerosene). Degradation of the solvents and TBP also produced various organic compounds (WSRC 1997a). Once "aging" was complete, the organic phase was pumped to a surface holding tank. The organic phase then flowed via gravity through surface piping to open pans, located in nearby trenches, where it was incinerated. Open burning of the solvent was discontinued in 1972 under Executive Order 11507. Approximately 1.5 to 1.6 million liters ( 382,750 to 425,800 gallons) of spent solvent was burned between 1956 and 1972.

The first three solvent tanks (S01, S02, and S03), installed in July 1955, were previously used as fuel storage tanks during the construction of the Savannah River Plant. Solvent tanks S04 through S22 were installed between late 1955 and late 1970. Little information on the construction of the tanks is available; however, it is thought that all tanks were constructed of thin-walled (1.9 cm [0.75 inch]) milled steel (WSRC 1997a). All the tanks are cylindrical and were buried with the long axis slightly inclined from the horizontal. It is known that two coats of bitumastic were applied to tanks S10 through S22 during installation.

In the early 1970s, the Savannah River Site (SRS) discontinued use of solvent tanks S01 through S22. New solvent tanks S23 through S32 were installed in the Low Level Radioactive Waste Disposal Facility during the mid- to late 1970s to receive solvent remaining in the old tanks. From 1976 to 1978, the solvent in tanks S01 through S18 was pumped into tanks S19 through S22. The solvent in tanks S19 through S22 was later 
transferred in 1980 and 1981 to the new solvent tanks, S23 through S30. No additional wastes have been placed in solvent tanks S01 through S22 since that time. Only residual liquids and/or solids remain.

In 1987, solvent tanks S01 through S22, located in the ORWBG, were designated as underground storage tanks (USTs) under RCRA and reported on the SRS RCRA UST lists. The SRS Environmental Restoration Department assumed custody of the OSTs in January 1991. In August 1992, solvent tanks S01 through S22 were removed from the SRS RCRA UST list because they were determined to be inactive. The ORWBG, which includes the OSTs, has been identified as a RCRA/Comprehensive Environmental Response, Compensation and Liability Act (CERCLA) operable unit (OU). As such, remediation activities at this $\mathrm{OU}$ are being coordinated per the Federal Facility Agreement negotiated between the United States Department of Energy, SCDHEC, and US EPA.

\subsection{PREVIOUS CHARACTERIZATION HISTORY OF OLD SOLVENT TANK (S01 THROUGH S22) WASTES}

Prior to December 1994, solvent tanks S01 through S22 were open to the environment. Vapor phase samples were collected from the headspace in tanks S01 through S22 in December 1994 and March 1995. The vapor phase samples were analyzed for volatile organic compounds (VOCs), semivolatile organic compounds (SVOCs), and radionuclides. No VOCs were detected in the vapor phase samples from solvent tanks S01, S07, S08, and S11. VOCs detected in the vapor phase samples from other solvent tanks included alkyl hydrocarbons, acetone, benzene, xylenes, methyl ethyl ketone, methyl butyl ketone (2-hexanone), and tetrachloroethylene. No SVOCs or radionuclides were detected in any of the vapor phase samples (WSRC 1997a).

In 1996 and 1997, a detailed literature review and evaluation of ORWBG operations was integrated with available characterization data, aerial photographs, construction drawings, health physics burial maps, the computerized burial record analysis data base, and interviews with SRS staff (WSRC 1997b). The integrated data were used to estimate waste volume in the ORWBG and their sources; the location and time of disposal; waste type, form and potential leachability; disposal methods; and variety of contamination. 
The estimated potential contaminant inventory in the OSTs was discussed in the Source Term for the Old Radioactive Waste Burial Ground (ORWBG) Savannah River Site (WSRC 1997b) and the Workplan/RCRA Facility Investigation/Remedial Investigation Report for the Old Radioactive Waste Burial Ground 643-E, SO1-S22 (U) (WSRC 1997a). These documents identified VOCs and radionuclides (strontium-90, cesium-137, uranium-235, uranium-238, plutonium-238, and plutonium-239) as constituents of interest for solvent tanks S01 through S22. Total residual volumes of waste in the OSTs were estimated at 28,530 liters (7,539 gallons) - 15,349 liters (4,056 gallons) organic phase and 13,181 liters (3,483 gallons) aqueous phase. The OSTs were identified as a potential "hot spot" in the ORWBG because they contain liquid waste, their locations are precisely known, and potential remediation of waste in the solvent tanks may be substantially different from that of waste in the "landfill style" burials in the remainder of the ORWBG (WSRC 1997a).

The Workplan/RCRA Facility Investigation/Remedial Investigation Report for the Old Radioactive Waste Burial Ground 643-E, SO1-S22 (U) indicated that the characterization of the ORWBG was adequate for evaluation of risk (WSRC 1997a). However, additional data were required to assess remedial options for waste remaining in the OSTs. Additional characterization of the solvent tanks was conducted from late 1997 until early 1999.

\subsection{7/98 AND 1998/99 OST CHARACTERIZATION ACTIVITTES}

In the fall of 1997 , a strategy was developed to evaluate the most viable closure technology and process safety for remediating the solvent tanks and to determine disposal alternatives for the waste in the OSTs. Specific project DQOs included the following:

- Update and supplement existing compositional information regarding the waste phases (vapor, liquid, and solid)

- Provide sufficient compositional information to develop a "safety envelope" for waste removal and tank closure 
- Quantify the concentration of constituents and physical parameters to evaluate compliance with Waste Acceptance Criteria at SRS treatment, storage and disposal facilities

Once the DQOs were established, a sampling and analysis plan was designed to collect vapor phase samples from specific tanks; determine the condition of the tanks; collect samples of liquid and solid phases; and analyze the samples for appropriate parameters. The workplan was implemented in two stages: a remote video survey conducted concurrently with vapor phase analyses and subsequent sample analysis of solid and liquid phases present in the OSTs. Details of the characterization efforts can be found in Attachments 1 and 2 of this document. The following sections provide a summary of the characterization activities and results. An evaluation of nuclear criticality was conducted to address potential safety concerns associated with closure of the tanks. Results of the evaluation are summarized in Section 3.3 and provided in detail in Attachment 4 of this document.

\subsection{Summary of 1997/98 Video Survey of Solvent Tanks S01 through S22}

A video survey was conducted to determine the condition and inclination of the storage tanks and to estimate the volume and remaining contents of the solvent tanks. Attachment 1 is a survey report and includes photographs of the tank interiors.

Air monitoring was performed prior to the video survey to determine if combustible gases were present. The atmosphere in each tank was tested with a Mine Safety Appliance Model 261 Combustible Gas and Oxygen Indicator immediately before the video camera was inserted into the tank. All tanks (except tanks S12, S19, and S20) had combustible gases less than $10 \%$ of the Lower Explosion Limit. These tanks were surveyed and videotaped. Tanks S19 and S20 were visually inspected, and tank S12 was surveyed with a fiberscope and light source.

The video surveys of 19 tanks revealed the tanks had maintained their structural integrity and showed no signs of tank penetration. Heavy corrosion was apparent on the ceilings of most tanks. Because of their construction, tanks S15 and S16 are thought to have been old railroad tank cars. Several of the tanks contain unanticipated interior structures. 
Because the Lower Explosion Limit detected in the headspace of tanks S12, S19, and S20 exceeded acceptance criteria for camera insertion, these tanks were inspected by alternate means. A fiber scope and fiber optic cable were used to survey the interior of tank S12. Neither liquid nor sludge were identified in this tank. Tanks S19 and S20 were visually inspected at both ends through the riser pipes. Liquid was identified at the east end of tank S19. Only sludge was present at the west end of the tank. Liquid was identified at the east and west ends of tank S20.

Table 1 provides the tank specifications and volume estimates obtained from the video survey information. The total volume of all tank contents was estimated at 21,325 liters (5,635 gallons) liquid and 3,376 liters (892 gallons) sludge. The results of the video survey were used to design a tank-specific sampling plan.

\subsection{Summary of 1998/99 Characterization of Samples from Solvent Tanks S01 through $\mathbf{S 2 2}$}

The organic, aqueous, and sludge wastes in OSTs were sampled and analyzed to obtain sufficient data for assessing closure options. The parameters chosen to characterize the tank contents were based upon the waste acceptance criteria of potential SRS treatment, storage, and disposal facilities (WSRC 1997a). Tables 2 through 5 list the parameters and analytical techniques used to characterize the solvent tank waste. In some instances, sample quantities were very small. Only limited and/or qualitative analyses were performed on these samples.

Actual sampling of the tanks' contents was conducted in three parts: (1) 9 liquid samples obtained from 7 tanks; (2) 6 liquid samples obtained from 6 additional tanks; and (3) 14 sludge samples obtained from 12 tanks and an additional 2 liquid samples obtained from 2 tanks not previously sampled. A total of 17 liquid samples from 15 different tanks and 14 sludge samples from 12 different tanks were collected for analyses. Seven tanks were essentially dry, containing 38 liters (10 gallons) or less of liquid. Ten tanks were not sampled for sludge. Of these 10 tanks, nine had 114 liters ( 30 gallons) or less of sludge. Tank S05 was estimated to contain approximately 424 liters (112 gallons) of sludge, but internal structure of the tank, such as piping and bracing, prohibited sampling of this material. Organic phase samples were obtained from 2 tanks, S11 and S20. Tables 2 through 5 provide results for each analyzed parameter by tank and medium. Table 6 provides the maximum results for each analyzed 
parameter by medium. Attachment 2 is a detailed report on the characterization of the samples obtained from solvent tanks S01 through S22.

\subsection{Summary of Criticality Evaluation of Old Solvent Storage Tanks S01 through $\mathbf{S 2 2}$}

Fission occurs when a neutron strikes the nucleus of a heavy element (U-235, Pu-239 or U-233). The neutron is absorbed or captured by the nucleus, which then becomes unstable. The unstable nucleus then splits into two lighter parts, called fission products, and releases radiation (energy) and approximately 2.5 neutrons. The newly released neutrons (second generation) can become absorbed by other nuclei, which in turn can produce more fission products, radiation, and neutrons. When the number of fissions produced by these second-generation neutrons is equal to the fissions produced by the preceding generation neutrons, the system is called "critical".

To produce "criticality," several conditions must be present including sufficient mass and density. Mass relates to the total amount of fissionable material present. If there are relatively few atoms of fissionable material present in a given location, fewer reactions can occur. Because 2.5 neutrons are produced during each fission, $40 \%$ or more of these neutrons must also produce fissions or the reaction will stop. The density of the fissionable material determines the amount per unit volume. Enrichment increases the amount per unit volume (density) by removing other neutron-absorbing materials (i.e., U-238). Therefore, if the atoms of fissionable material are diluted with other materials (lowering the density of fissionable material), it is less likely that the released neutrons will strike fissionable nuclei.

The effective enrichments for combined U-235, Pu-239 and U-238 and calculated fissile mass of U-235 and Pu-239 were evaluated for the Old Solvent Tanks S1 through S22 (Attachment 4). Where analytical data were not available, very conservative calculations, based upon available sample data, were conducted to provide estimated quantities of radionuclides in unsampled tanks. The criticality evaluation indicates that several tanks approach or are at the ANS 8.1 limiting enrichment of 0.93 weight percent U-235. The limiting enrichment is not exceeded in any tank. The mass (grams) of U235 in each of these tanks is also significantly lower than the 8,000 grams that would cause a criticality concern at an enrichment level of less than 2.0 weight \% (per ANS 8.1 
criticality safety standards). Therefore, as long as the weight percent or effective enrichment of the fissionable material is not increased, the solvent tanks will not present a criticality concern. The only processes that would increase the weight percent or enrichment of the U-235 would be addition of U-235 to the solvent tanks or removal of nonfissile isotopes through the separations process, respectively. Since no remedial action for the tanks will involve these processes, criticality is not a concern for closure of the solvent tanks.

\subsection{UNCERTAINTIES ASSOCIATED WITH CHARACTERIZATION ACTIVITIES}

Uncertainties are anticipated during field characterization activities and laboratory sample analyses. A discussion of uncertainties associated with the characterization of the waste in the OSTs is provided below.

\subsection{Uncertainty in Video Survey and Sampling}

One purpose of conducting the video survey of the tank interiors was to determine the geometry of the waste body and location of sludge. The sludge typically rests on the floor of the tank under the liquid waste. The sludge thickness was estimated using the dimensions of objects, such as tapes, ropes and sample tubing, observed on the tank floor. Since the solid residue is usually beneath the liquid phase, a high degree of uncertainty exists in estimating the volume of this material. Where there is no liquid in the tank, the sludge volume was estimated by visual estimation of thickness multiplied by the known dimensions of the tank. The density of the sludge phase has not been measured. Based on the density of the burning pan residue and modeling of paraffinactinide complexes, a density of 2.0 gram/cubic centimeter was estimated. This density was found to be consistent with the measured density of similar waste at the Oak Ridge National Laboratory.

The total volume of waste (liquid and sludge) was estimated by scaling the width of the liquid at each end of the tank. Using the known diameter of the tank to provide scale on the video, accurate liquid measurements at each end of the tanks were achievable. Tank-specific computer models were produced using this data and the known diameter and length of the tank to establish the total volume of waste material. The total volume 
of liquid was estimated by subtracting the estimated sludge volume from the total volume. A high level of confidence exists with the total volume of waste estimates.

Given the nature and history of waste material in the OSTs, there exists the potential for non-homogeneity of the contents within each tank. Because criticality conditions were unknown, the waste material could not homogenized. In addition, limited sample volume was obtained from each phase due to inaccessibility of the material in the tanks. Therefore, uncertainty exists in the representativeness of samples obtained from the OSTs. Any such uncertainties will likely result in more conservative criticality safety controls and assessment of disposal options.

\subsection{Uncertainty in Sample Analyses}

When samples have complex matrices, as do those from the solvent tanks, the accuracy and precision of the analytical data are a matter of concern. To counter this problem, daily calibration check standards, blind standards, inter-laboratory comparisons, quality control charts, and spikes of known concentrations are routinely used to monitor the analytical laboratory methods. These activities are performed as part of the laboratory's quality assurance program.

Overall, analytical uncertainties associated with the solvent tank samples were estimated to range from 1 to $25 \%$, depending upon the analytical method. Greater uncertainties result when analytes are found at or near the method detection limits. For example, for low activity levels of a radionuclide, the statistical counting error will dominate the overall uncertainty. The precision of these measurements can be directly estimated by comparing data from multiple samples from the same phase in one tank if the phase is assumed to be homogeneous. Under this assumption, the samples can be treated as replicates.

\subsection{CONCLUSIONS}

Characterization of the residual contents in the OSTs was identified as a data gap for assessing remedial options for the ORWBG OU (WSRC 1997a). A strategy was then developed to evaluate the most viable closure technology and process safety for remediating the OSTs and for determining disposal alternatives for the waste in the 
OSTs. The subsequent characterization activities included a video survey of the interior of the OSTs and sampling and analysis of the vapor, liquid, and solid phases present in the OSTs. The video survey provides a means for more accurately estimating liquid and solid waste volumes and the condition of the tank interiors. The analysis of vapor, liquid, and solid phase samples obtained from the OSTs characterizes the waste streams and provides data for evaluating potential safety issues. These data are adequate for determining the appropriate disposition of the solvent waste and closure of the OSTs as part of the ORWBG remediation process. 


\subsection{REFERENCES}

WSRC 1997a. Workplan/RCRA Facility Investigation/Remedial Investigation Report for the Old Radioactive Waste Burial Ground 643-E, SOI-S22 (U). WSRC-RP-97-00127, Rev. 0. Westinghouse Savannah River Company, Savannah River Site, Aiken, SC.

WSRC 1997b. Source Term for the Old Radioactive Waste Burial Ground (ORWBG), Savannah River Site (U). WSRC-RP-97-0119, Rev. 0, Westinghouse Savannah River Company, Savannah River Site, Aiken, SC. 


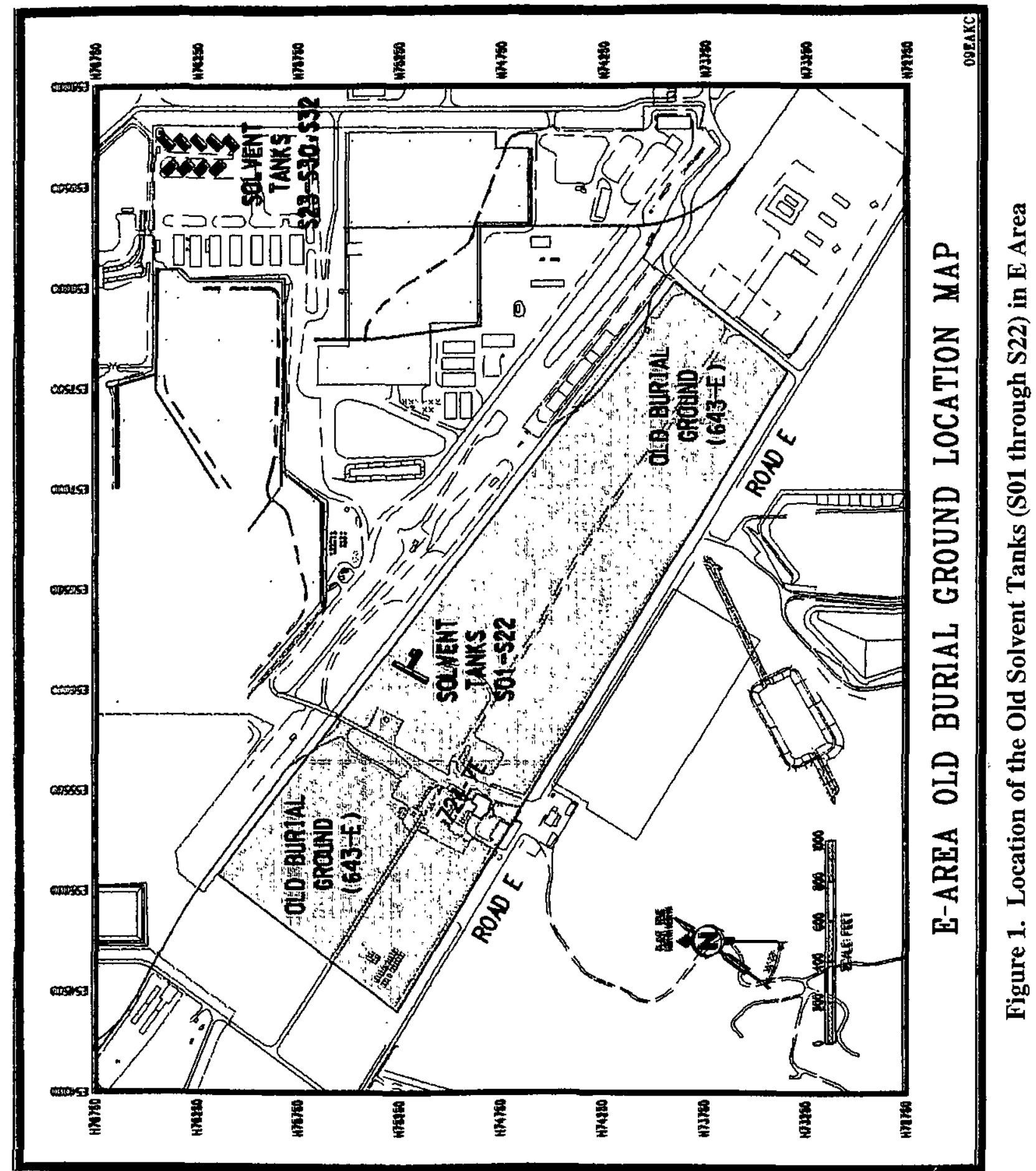


(This page intentionally left blank.) 
Table 1. Old Solvent Tank Specifications from Video Survey

\begin{tabular}{|c|c|c|c|c|c|c|c|c|c|}
\hline \multirow[b]{2}{*}{ Tank } & \multirow[b]{2}{*}{$\begin{array}{c}\text { Year } \\
\text { Installed }\end{array}$} & \multirow[b]{2}{*}{$\begin{array}{c}\text { Depth } \\
\text { to Top } \\
\text { of Tank }\end{array}$} & \multicolumn{2}{|c|}{ Dimensions ( $\mathrm{ft}$ ) } & \multirow[b]{2}{*}{$\begin{array}{l}\text { Capacity } \\
\text { (gal) }\end{array}$} & \multicolumn{2}{|c|}{ Liquids } & \multicolumn{2}{|c|}{ Solids } \\
\hline & & & Diameter & Length & & $\begin{array}{c}\text { Waste } \\
\text { Volume } \\
\text { (gal) }\end{array}$ & $\begin{array}{c}\% \text { of } \\
\text { Tank } \\
\text { Filled } \\
\end{array}$ & $\begin{array}{c}\text { Waste } \\
\text { Volume } \\
\text { (gal) }\end{array}$ & $\begin{array}{l}\text { \% of } \\
\text { Tank } \\
\text { Filled }\end{array}$ \\
\hline 1 & 1955 & 1'10' & 8.0 & 26.75 & 10,059 & 117 & 1.163 & 5 & 0.050 \\
\hline 2 & 1955 & 2'2" & 8.0 & 26.75 & 10,059 & 112 & 1.113 & 33 & 0.328 \\
\hline 3 & 1955 & 2'9" & 8.0 & 26.75 & 10,059 & 398 & 3.957 & 4 & 0.040 \\
\hline 4 & 1955 & 2'3" & 8.0 & 27.0 & 10,059 & 369 & 3.668 & 6 & 0.060 \\
\hline 5 & 1955 & 2'0" & 10.5 & 38.5 & 24,940 & 92 & 0.369 & 112 & 0.449 \\
\hline 6 & 1956 & 2'5" & 8.0 & 24.0 & 8,790 & 275 & 3.129 & 0 & 0 \\
\hline 7 & 1956 & $3^{\prime} 6^{\prime \prime}$ & 8.5 & 18.0 & 7,641 & 317 & 4.149 & 2 & 0.026 \\
\hline 8 & 1956 & 3'11' & 8.5 & 18.0 & 7,641 & 137 & 1.793 & 6 & 0.079 \\
\hline 9 & 1959 & 5'3" & 8.0 & 20.0 & 7,521 & 0 & 0 & 13 & 0.173 \\
\hline 10 & 1959 & 5'2" & 8.0 & 20.0 & 7,521 & 10 & 0.133 & 31 & 0.412 \\
\hline 11 & 1959 & $5,2 "$ & 8.0 & 20.0 & 7,521 & 14 & 0.186 & 13 & 0.173 \\
\hline 12 & 1959 & 3'3" & 8.0 & 20.0 & 7,521 & 5 & 0.066 & 5 & 0.066 \\
\hline 13 & 1960 & $5,5^{\prime \prime}$ & 23.0 & 23.0 & 13,514 & 218 & 1.613 & 43 & 0.318 \\
\hline 14 & 1960 & 4'9" & 11.0 & 38.0 & 27,016 & 367 & 1.358 & 118 & 0.437 \\
\hline 15 & 1961 & 7'4" & 7.5 & 32.0 & 10,576 & 0 & 0 & 145 & 1.371 \\
\hline 16 & 1961 & 5'0" & 7.5 & 32.0 & 10,576 & 0 & 0 & 273 & 2.581 \\
\hline 17 & 1962 & $0^{\prime} 6^{\prime \prime}$ & 8.0 & 18.0 & 6,769 & 0 & 0 & 7 & 0.103 \\
\hline 18 & 1962 & 0'9" & 8.0 & 18.0 & 6,769 & 5 & 0.074 & 2 & 0.030 \\
\hline 19 & 1968 & $50^{\prime \prime}$ & 10.5 & 38.5 & 24,940 & 573 & 2.298 & 27 & 0.108 \\
\hline 20 & 1968 & 5 '2" & 10.5 & 38.5 & 24,940 & 1,995 & 7.999 & 9. & 0.036 \\
\hline 21 & 1968 & 3'2" & 10.5 & 38.5 & 24,940 & 183 & 0.734 & 31 & 0.124 \\
\hline 22 & 1968 & $3,2 "$ & 10.5 & 38.5 & 24,940 & 448 & 1.796 & 7 & 0.028 \\
\hline $\begin{array}{c}\text { Total } \\
\text { Volumes }\end{array}$ & & & & & 294,308 & 5,635 & & 892 & \\
\hline
\end{tabular}


Addendum to the

WSRC-RP-99-4023, Rev. 1.1

Workplan/RFI/RI Report for the Old Radioactive

August 2000

Waste Burial Ground 643E, S01-S22
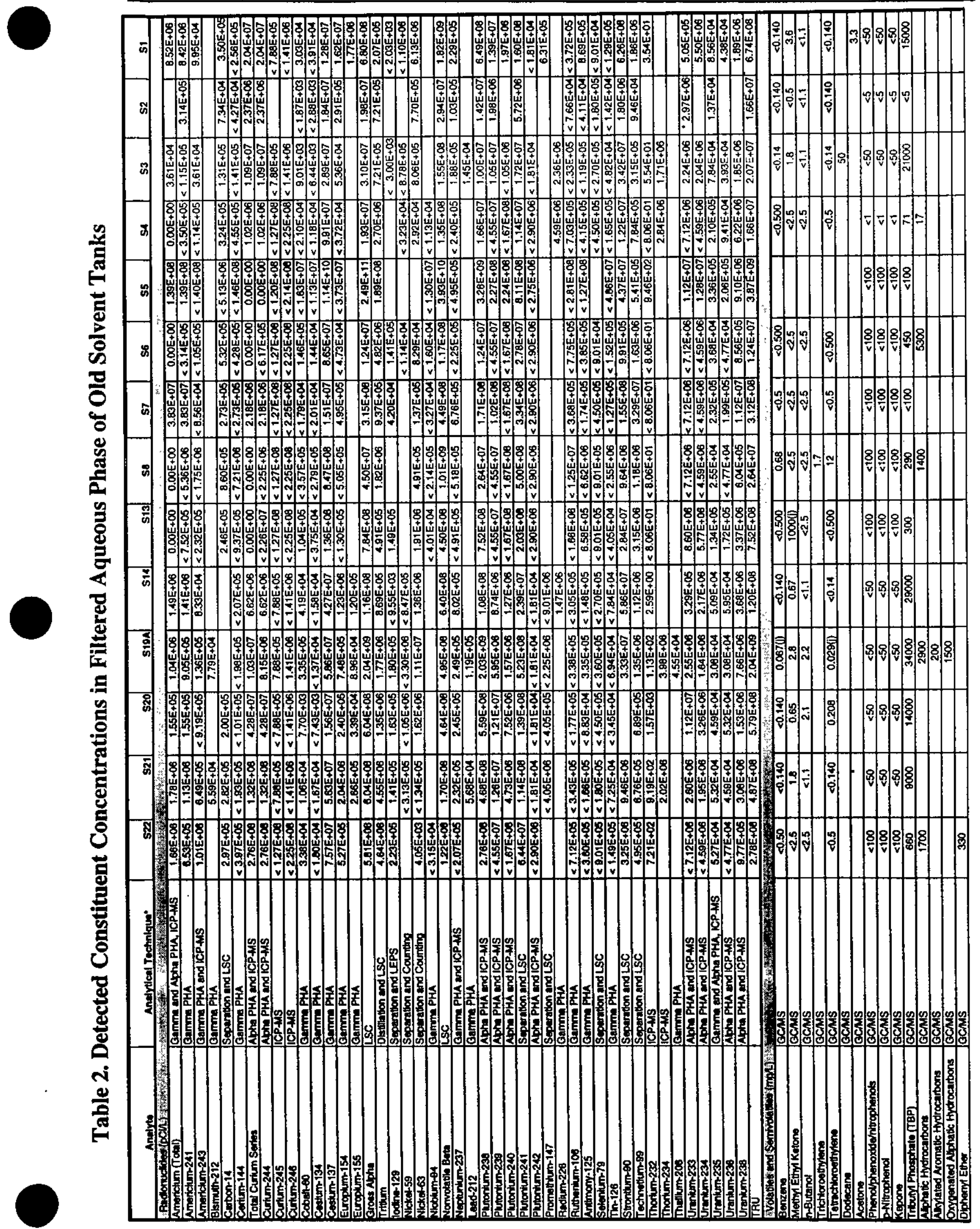

15

OSTADD.doc 
Waste Burial Ground 643E, S01-S22

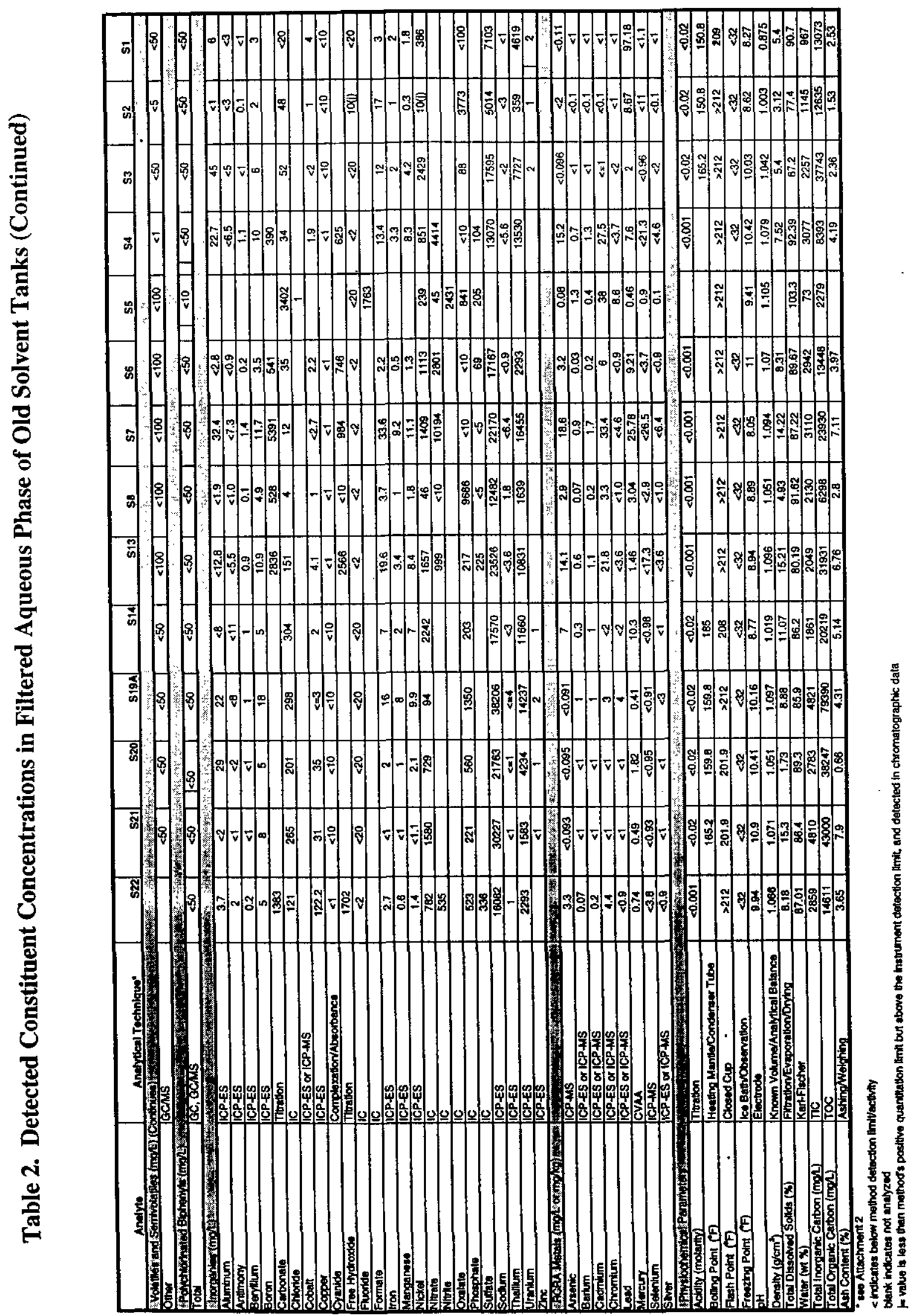


Addendum to the

WSRC-RP-99-4023, Rev. 1.1

Workplan/RFI/RI Report for the Old Radioactive August 2000

Waste Burial Ground 643E, S01-S22

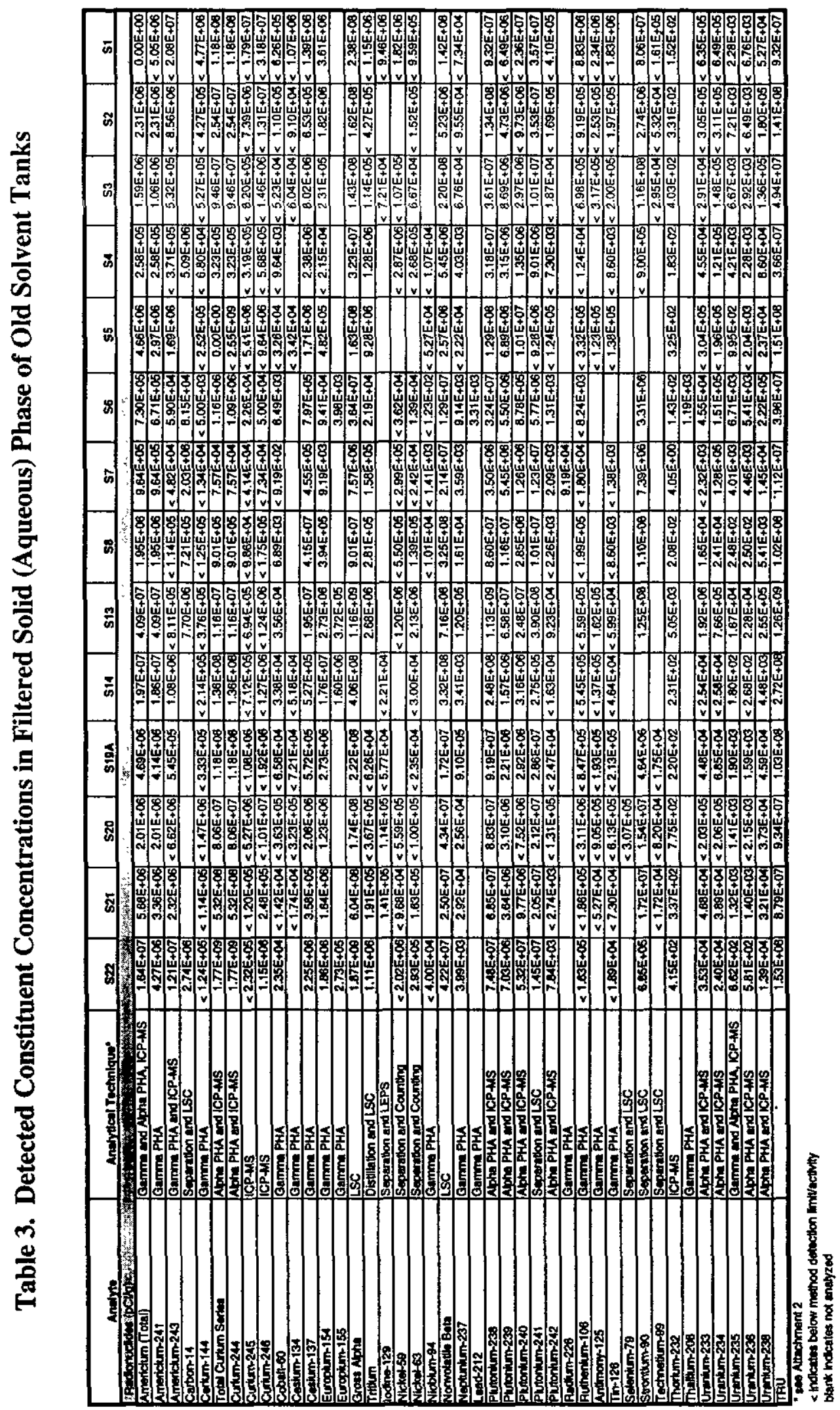


Addendum to the

WSRC-RP-99-4023, Rev. 1.1

Workplan/RFI/RI Report for the Old Radioactive

August 2000

Waste Burial Ground 643E, S01-S22

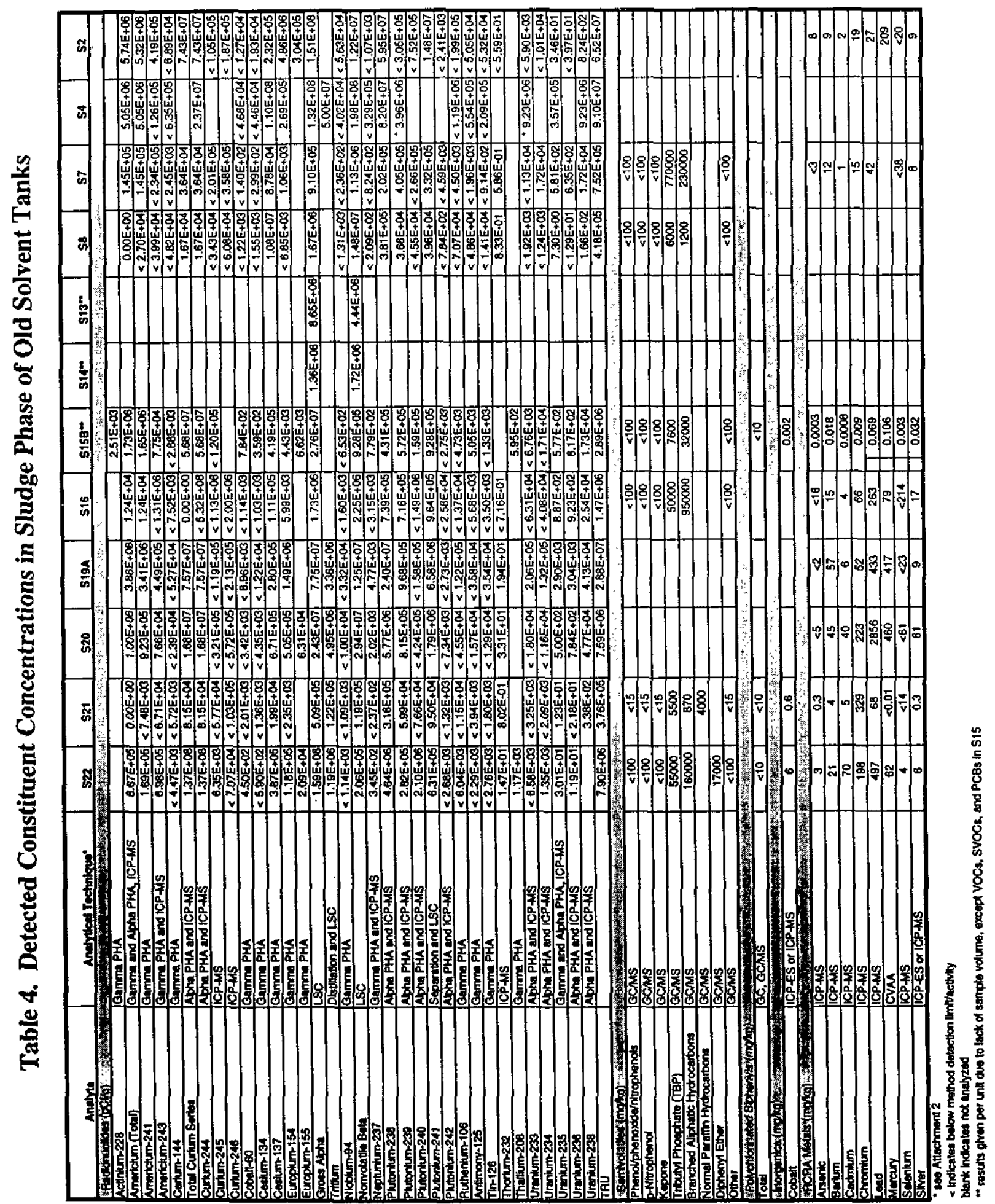

OSTADD.doc 


\section{Table 5. Detected Constituent Concentrations in Filtered Organic Phase of Old Solvent Tanks}

\begin{tabular}{|c|c|c|c|c|c|}
\hline Analyte & Analytical Technique: & $\begin{array}{l}\text { S20 (organic } \\
\text { liquid) }\end{array}$ & $\begin{array}{l}\text { S20 (filtered } \\
\text { solid) }\end{array}$ & $\begin{array}{l}\text { Si1 (organic } \\
\text { liquid) }\end{array}$ & $\begin{array}{l}\text { S11 (filtered } \\
\text { solid) } \\
\end{array}$ \\
\hline \multicolumn{6}{|l|}{ Radionuclides (pCl/L) } \\
\hline Americium (Total) & Gamma and Alpha PHA, ICP-MS & $6.40 E+05$ & $0.00 E+\infty 0$ & $0.00 E+00$ & $1.76 E+06$ \\
\hline Americium-241 & Gamma PHA & $5.77 \mathrm{E}+05$ & $<1.71 E+05$ & $<3.71 E+06$ & $1.59 E+06$ \\
\hline Americium-243 & Gamma PHA and ICP.MS & $6.26 \mathrm{E}+04$ & $<9.95 \mathrm{E}+05$ & $<1.45 \mathrm{E}+06$ & $1.74 \mathrm{E}+05$ \\
\hline Carbon-14 & Separation and LSC & $3.08 \mathrm{E}+05$ & & & \\
\hline Cerium-144 & Gamma PHA & $<2.62 \mathrm{E}+04$ & $<1.71 \mathrm{E}+05$ & $<5.77 \overline{\mathrm{E}}+06$ & \\
\hline Total Curium Series & Alpha PHA and ICP-MS & $1.07 \mathrm{E}+07$ & $1.26 \mathrm{E}+06$ & $5.30 E+09$ & $6.81 E+07$ \\
\hline Curium-244 & Alpha PHA and ICP-MS & $1.07 E+07$ & $1.26 \mathrm{E}+06$ & $5.09 E+09$ & $6.81 E+07$ \\
\hline Curtum-245 & ICP.MS & $<7.88 \mathrm{E}+05$ & $<8.49 \mathrm{E}+05$ & $<1.20 E+08$ & $<4.14 \mathrm{E}+05$ \\
\hline Curium-246 & ICP-MS & $<1.41 E+06$ & $<1.51 E+06$ & $2.14 \mathrm{E}+08$ & $<7.39 \mathrm{E}+05$ \\
\hline Cobalt-60 & Gamma PHA & $<4.45 E+03$ & $<4.85 E+04$ & $6.31 E+05$ & $<9.01 E+03$ \\
\hline Cesium-134 & Gamma PHA & $<5.86 E+03$ & $<3.20 \mathrm{E}+04$ & $<2.40 \mathrm{E}+05$ & $<1.43 \mathrm{E}+04$ \\
\hline Cesium-137 & Gamma PHA & $<7.93 E+03$ & $<6.93 \mathrm{E}+04$ & $9.82 E+08$ & $6.40 \mathrm{E}+06$ \\
\hline Europlum-154 & Gamma PHA & $4.77 E+05$ & $<6.74 \mathrm{E}+04$ & $1.08 E+06$ & $7.70 \mathrm{E}+05$ \\
\hline Europium +155 & Gamma PHA & $4.82 E+04$ & & & \\
\hline Gross Apha & LSC & $1.27 \mathrm{E}+07$ & $2.30 E+06$ & $1.02 E+10$ & $7.84 E+07$ \\
\hline Tritlum & Distillation and LSC & $1.89 E+08$ & $<4.94 \mathrm{E}+04$ & $6.12 E+06$ & $2.30 \mathrm{E}+07$ \\
\hline lodine-129 & Separation and LEPS & & $3.26 E+04$ & & \\
\hline Nickel-59 & Separation and Counting & & $<1.68 \mathrm{E}+03$ & & \\
\hline Nickel-63 & Separation and Counting & & $<1.60 \mathrm{E}+04$ & & \\
\hline Niobium-94 & Gamma PHA & & & $<2.44 E+05$ & $<2.84 \mathrm{E}+04$ \\
\hline Nomvolatile Beta & LSC & $1.02 E+08$ & $1.20 E+06$ & $1.50 E+11$ & $1.11 E+08$ \\
\hline Neptunium-237 & Gamma PHA and ICP-MS & $1.20 E+04$ & $<3.51 \varepsilon+03$ & $4.95 E+03$ & $<1.70 \mathrm{E}+03$ \\
\hline Plutonium-238 & Alpha PHA and ICP-MS & $1.41 \mathrm{E}+06$ & $8.63 E+05$ & $2.52 E+09$ & $2.45 \mathrm{E}+07$ \\
\hline Plutonium-239 & Alpha PHA and ICP-MS & $3.10 E+05$ & $<3.08 E+05$ & $4.34 E+07$ & $1.49 E+06$ \\
\hline Plutonium-240 & Alpha PHA and ICP-MS & $<1.05 E+06$ & $<1.13 \mathrm{E}+06$ & $1.59 \mathrm{E}+08$ & $8.06 \mathrm{E}+05$ \\
\hline Plutonium-241 & Separation and LSC & $4.77 \mathrm{E}+05$ & $1.66 \mathrm{E}+05$ & $1.14 \mathrm{E}+09$ & $9.46 \mathrm{E}+06$ \\
\hline Plutonium-242 & Alpha PHA and ICP-MS & $<1.81 \mathrm{E}+04$ & $<1.94 \mathrm{E}+04$ & $<2.75 \mathrm{E}+06$ & $<9.50 \mathrm{E}+03$ \\
\hline Promethium-147 & Separation and LSC & $<2.70 \mathrm{E}+06$ & & & \\
\hline Puthenium-106 & Gamma PHA & $<5.95 E+04$ & $<3.47 \dot{E}+05$ & $<9.91 E+06$ & $<2.08 \mathrm{E}+05$ \\
\hline Antimony-125 & Gamma PHA & $<1.61 E+04$ & $<9.17 E+04$ & $<5.14 E+06$ & $<9.37 E+04$ \\
\hline Selenlum -79 & Separation and LSC & $<1.80 \mathrm{E}+05$ & & & \\
\hline Tin-126 & Gamma PHA & $<1.72 \mathrm{E}+04$ & $<6.06 \mathrm{E}+04$ & $<1.82 E+06$ & $<8.29 \mathrm{E}+04$ \\
\hline Strontium-90 & Separation and LSC & $1.71 E+06$ & $6.27 \mathrm{E}+05$ & $1.81 E+07$ & \\
\hline Technetium-99 & Separation and LSC & $7.78 \mathrm{E}+05$ & $<6.12 \mathrm{E}+03$ & $2.93 E+06$ & \\
\hline Thorium-232 & ICP-MS & $<5.05 E-01$ & $3.03 E+00$ & $9.55 E+01$ & $4.41 E+02$ \\
\hline Uranlum-233 & Alpha PHA and ICP-MS & $1.62 \mathrm{E}+05$ & $<3.03 E+04$ & $<6.76 E+04$ & $<2.32 E+04$ \\
\hline Uranium-234 & Alpha PHA and ICP-MS & $1.13 E+05$ & $<3.08 E+04$ & $4.35 \mathrm{E}+04$ & $<1.50 \mathrm{E}+04$ \\
\hline Uranium-235 & Gamma and Alpha PHA, ICP-MS & $2.11 E_{+03}$ & $2.28 E+01$ & $2.02 E+03$ & $5.54 \mathrm{E}+01$ \\
\hline Uranium-236 & Apha PHA and ICP-MS & $2.15 \mathrm{E}+03$ & $<3.21 E+02$ & $4.55 \mathrm{E}+02$ & $<1.56 \mathrm{E}+02$ \\
\hline Uranium-238 & Atpha PHA and ICP-MS & $9.23 E+03$ & $6.05 E+02$ & $<4.86 \mathrm{E}+04$ & $1.50 \mathrm{E}+03$ \\
\hline TRU & & $2.37 \mathrm{E}+06$ & $8.63 E+05$ & $2.94 \mathrm{E}+09$ & $2.86 \mathrm{E}+07$ \\
\hline \multicolumn{6}{|c|}{ 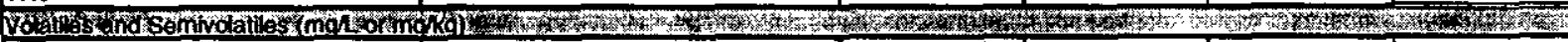 } \\
\hline Benzene & GCNMS & $0.37(1)$ & & & \\
\hline Methyl Ethy Ketone & GCIMS & 7.3 & & & \\
\hline n-Butanol & GCMS & $<1.1$ & & & \\
\hline Tetrachloroethyene & GCMS & $0.054(1)$ & & & \\
\hline Phenolh henoxide/nitrophenols & GCAMS & $<50$ & & $\leq 100$ & \\
\hline p-Nitrophend & GC/MS & $<50$ & & $<100$ & \\
\hline Kepone & GCMMS & $<50$ & & $<100$ & \\
\hline Tributy Phosphate (TBP) & GCMMS & $<900000$ & & 810000 & \\
\hline Branched Allphatlc Hydrocarbons & GCNMS & & & 40000 & \\
\hline Oxygenated Organles & GC/MS & & & 150000 & \\
\hline Paraffins & GCMMS & $<100000$ & & & $\check{-}$ \\
\hline Other & GC/MS & $<50$ & & & \\
\hline \multicolumn{6}{|c|}{ 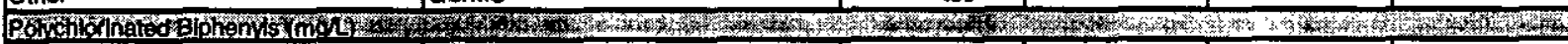 } \\
\hline Total & GC, GC/MS & $<50$ & & $<10$ & \\
\hline \multicolumn{6}{|c|}{ 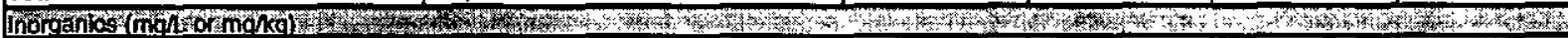 } \\
\hline Aluminum & ICP-ES & $<4$ & & & \\
\hline Antimony & ICP-ES & $<4$ & & & \\
\hline Berdllum & ICP-ES & $<1$ & & & \\
\hline Boron & ICP-ES & $<1$ & & & \\
\hline Chloride & IC & $\leq 2$ & & 149 & \\
\hline Cobalt & ICP-ES or ICP-MS & & & 2.50 & \\
\hline
\end{tabular}


Table 5. Detected Constituent Concentrations in Filtered Organic Phase of Old Solvent Tanks (Continued)

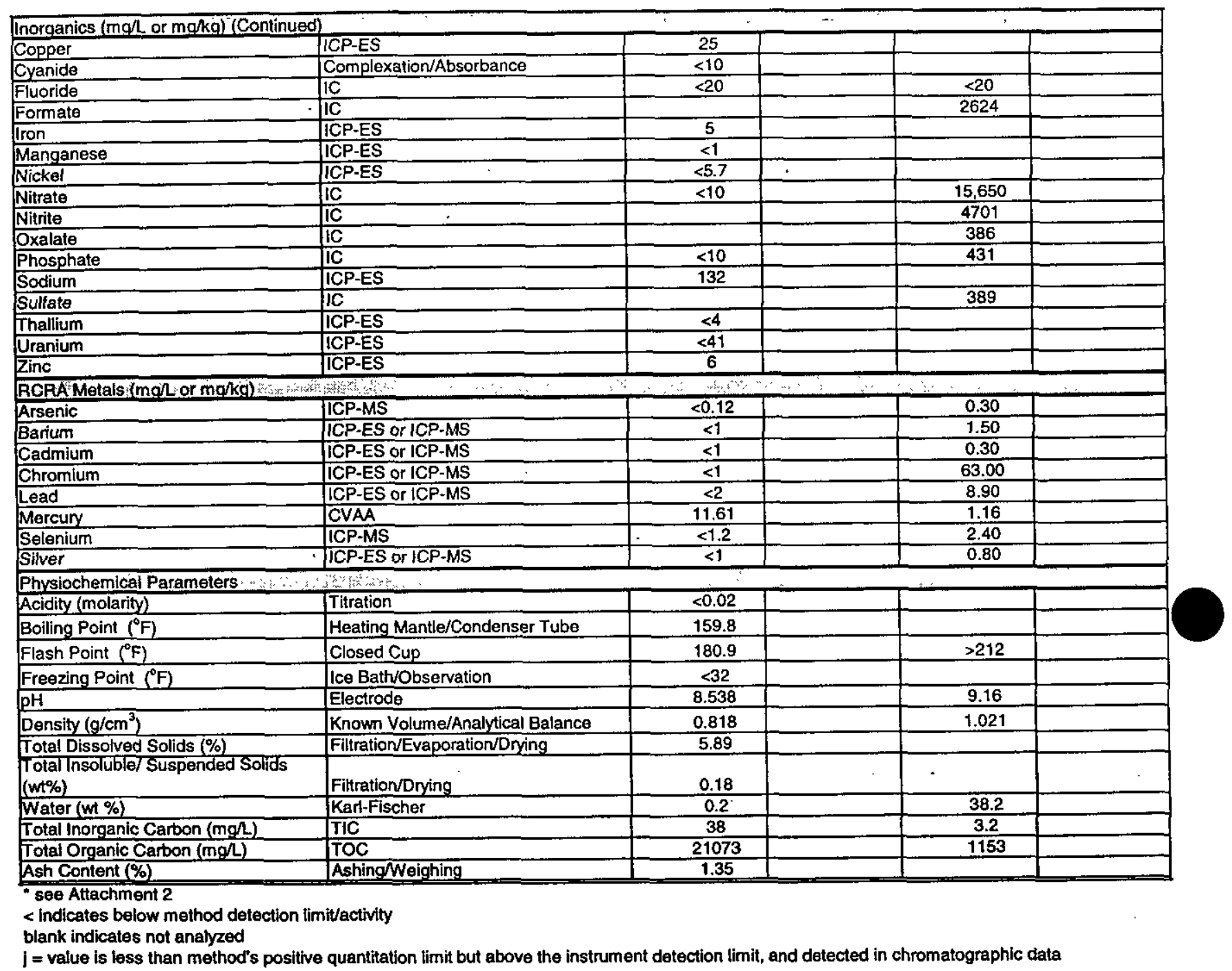


Table 6. Maximum Constituent Concentrations in OSTs above the Method Detection Limits/Activities

\begin{tabular}{|c|c|c|c|c|c|}
\hline Analyte & Aqueous & $\begin{array}{l}\text { Filtered } \\
\text { Solid } \\
\text { (Aqueous) }\end{array}$ & Sludge & $\begin{array}{c}\text { Organic } \\
\text { Liquid }\end{array}$ & $\begin{array}{c}\text { Filtered } \\
\text { Solid } \\
\text { (Organic) }\end{array}$ \\
\hline \multicolumn{6}{|c|}{ Radionuclides (pCi/L [liquid phase] or $\mathrm{pCi} / \mathrm{g}$ [solid phase]) } \\
\hline Actinium-228 & $\overline{N A}$ & $\overline{\mathrm{NA}}$ & $2.51 E+03$ & $\overline{\mathrm{NA}}$ & $\overline{\mathrm{NA}}$ \\
\hline Americium-241 & $1.39 E+08$ & $4.09 E+07$ & $5.32 E+06$ & $5.77 \mathrm{E}+05$ & $1.59 E+06$ \\
\hline Americium-243 & $1.01 \mathrm{E}+06$ & $1.21 E+07$ & $6.98 \mathrm{E}+05$ & $6.26 \mathrm{E}+04$ & $1.74 \mathrm{E}+05$ \\
\hline Bismuth-212 & $7.79 \mathrm{E}+04$ & $\mathrm{NA}$ & $\mathrm{NA}$ & NA & NA \\
\hline Carbon-14 & $8.60 \mathrm{E}+05$ & $7.70 \mathrm{E}+06$ & NA & $3.08 \mathrm{E}+05$ & NA \\
\hline Cerium-144 & $\angle M D L$ & $\angle M D L$ & $<M D L$ & $\angle M D L$ & $\angle M D L$ \\
\hline Curium-244 & $2.76 \mathrm{E}+08$ & $1.77 \mathrm{E}+09$ & $1.37 \mathrm{E}+08$ & $5.09 E+09$ & $6.81 E+07$ \\
\hline Curium-245 & $7.88 \mathrm{E}+05$ & $2.26 \mathrm{E}+04$ & $6.35 \mathrm{E}+03$ & $<\mathrm{MDL}$ & $<\mathrm{MDL}$ \\
\hline Curium-246 & $1.41 \mathrm{E}+06$ & $1.15 E+06$ & $<\mathrm{MDL}$ & $2.14 \mathrm{E}+08$ & $<M D L$ \\
\hline Cobalt-60 & $3.35 E+05$ & $3.56 \mathrm{E}+04$ & $7.84 \mathrm{E}+02$ & $6.31 E+05$ & $<M D L$ \\
\hline Cesium-134 & $1.44 \mathrm{E}+04$ & $<\mathrm{MDL}$ & $3.59 E+02$ & $<\mathrm{MDL}$ & $<\mathrm{MDL}$ \\
\hline Cesium-137 & $1.14 \mathrm{E}+10$ & $4.15 E+07$ & $1.10 \mathrm{E}+08$ & $9.82 E+08$ & $6.40 \mathrm{E}+06$ \\
\hline Europium-154 & $1.62 \mathrm{E}+07$ & $1.76 \mathrm{E}+07$ & $4.86 \mathrm{E}+06$ & $1.08 \mathrm{E}+06$ & $7.70 E+05$ \\
\hline Europium-155 & 1.77E+06 & $1.60 E+06$ & $3.04 E+05$ & $4.82 E+04$ & NA \\
\hline Gross Alpha & $2.49 \mathrm{E}+11$ & $1.87 E+09$ & $1.59 \mathrm{E}+08$ & $1.02 E+10$ & $7.84 \mathrm{E}+07$ \\
\hline Tritium & $4.82 \mathrm{E}+06$ & $9.28 \mathrm{E}+06$ & $5.00 \mathrm{E}+07$ & $1.89 \mathrm{E}+08$ & $2.30 E+07$ \\
\hline lodine-129 & $2.23 E+05$ & $1.41 E+05$ & NA & NA & $3.26 \mathrm{E}+04$ \\
\hline Nickel-59 & $<M D L$ & $\angle M D L$ & $\overline{N A}$ & NA & $\angle M D L$ \\
\hline Nickel-63 & $1.11 \mathrm{E}+07$ & $2.13 \mathrm{E}+06$ & NA & NA & $<M D L$ \\
\hline Niobium-94 & $<M D L$ & $<\mathrm{MDL}$ & $<\mathrm{MDL}$ & $<\mathrm{MDL}$ & $<\mathrm{MDL}$ \\
\hline Nonvolatile Beta & $3.93 \mathrm{E}+10$ & $7.16 \mathrm{E}+08$ & $1.98 \mathrm{E}+08$ & $1.50 \mathrm{E}+11$ & $1.11 \mathrm{E}+08$ \\
\hline Neptunium-237 & $8.02 E+05$ & $9.10 E+05$ & $4.77 E+03$ & $1.20 \mathrm{E}+04$ & $<M D L$ \\
\hline Lead-212 & $1.19 E+05$ & $3.31 E+03$ & $\mathrm{NA}$ & NA & NA \\
\hline Plutonium-238 & $3.28 \mathrm{E}+09$ & $1.13 E+09$ & $8.20 E+07$ & $2.52 E+09$ & $2.45 \mathrm{E}+07$ \\
\hline Plutonium-239 & $2.27 E+08$ & $6.58 E+07$ & $3.96 \mathrm{E}+06$ & $4.34 \mathrm{E}+07$ & $1.49 E+06$ \\
\hline Plutonium-240 & $2.24 \mathrm{E}+08$ & $5.32 E+07$ & $2.10 \mathrm{E}+06$ & $1.59 E+08$ & $8.06 E+05$ \\
\hline Plutonium-241 & $8.11 E+08$ & $3.90 \mathrm{E}+08$ & $1.48 \mathrm{E}+07$ & $1.14 \mathrm{E}+09$ & $9.46 E+06$ \\
\hline Plutonium-242 & $<M D L$ & $9.23 E+04$ & $<\mathrm{MDL}$ & $<M D L$ & $<M D L$ \\
\hline Promethium-147 & $6.31 E+05$ & NA & NA & $<\mathrm{MDL}$ & NA \\
\hline Radium-226 & $4.59 E+06$ & $9.19 E+04$ & NA & $\mathrm{NA}$ & NA \\
\hline Ruthenium-106 & $<\overline{M D L}$ & $\angle M D L$ & $<M D L$ & $<\mathrm{MDL}$ & $<\mathrm{MDL}$ \\
\hline Antimony-125 & $8.69 E+05$ & $1.62 \mathrm{E}+05$ & $5.05 E+03$ & $<M D L$ & $<\mathrm{MDL}$ \\
\hline Selenium-79 & $<\mathrm{MDL}$ & $<\mathrm{MDL}$ & $\mathrm{NA}$ & $<M D L$ & NA \\
\hline Tin-126 & $\angle \mathrm{MDL}$ & $1.83 \mathrm{E}+06$ & $<M D L$ & $<M D L$ & $<M D L$ \\
\hline Strontium-90 & $6.26 \mathrm{E}+08$ & $1.25 \mathrm{E}+08$ & NA & $1.81 \mathrm{E}+07$ & $6.27 E+05$ \\
\hline Technetium-99 & $3.29 E+07$ & $8.20 E+04$ & NA & $2.93 E+06$ & $<M D L$ \\
\hline Thorium-232 & $1.57 E+03$ & $5.05 E+03$ & $3.31 \mathrm{E}+01$ & $9.55 E+01$ & $4.41 \mathrm{E}+02$ \\
\hline Thorium-234 & $3.98 \mathrm{E}+06$ & NA & NA & NA & NA \\
\hline Thallium-208 & $4.55 \mathrm{E}+04$ & $1.19 E+03$ & $1.17 E+03$ & NA & NA \\
\hline Uranium-233 & $1.12 E+07$ & $1.92 E+06$ & $9.23 E+06$ & 1.62E+05 & $<M D L$ \\
\hline Uranium-234 & $1.28 E+07$ & $7.66 \mathrm{E}+05$ & $1.32 E+05$ & 1.13E+05 & $<\mathrm{MDL}$ \\
\hline Uranium-235 & $3.36 \mathrm{E}+05$ & $1.67 E+04$ & $3.57 \mathrm{E}+05$ & $2.11 E+03$ & $5.54 \mathrm{E}+01$ \\
\hline Uranium-236 & $2.06 E+05$ & $2.28 E+04$ & $3.04 \mathrm{E}+03$ & $2.15 E+03$ & $<M D L$ \\
\hline
\end{tabular}


Addendum to the

WSRC-RP-99-4023, Rev. 1.1

Workplan/RFI/RI Report for the Old Radioactive

Waste Burial Ground 643E, S01-S22

Table 6. Maximum Constituent Concentrations in OSTs above the Method Detection Limits/Activities (Continued)

Radionuclides (pCi/L [liquild phase] or pCi/g /solid phasel) (Continued)

Uranium-238

\begin{tabular}{|l|l|l|l|l|}
$1.12 \mathrm{E}+07$ & $2.55 \mathrm{E}+05$ & $9.23 \mathrm{E}+06$ & $9.23 \mathrm{E}+03$ & $1.50 \mathrm{E}+03$ \\
\hline
\end{tabular}

TRU

\begin{tabular}{l|c|c|c|c|}
\hline $3.87 \mathrm{E}+09$ & $1.26 \mathrm{E}+09$ & $9.10 \mathrm{E}+07$ & $2.94 \mathrm{E}+09$ & $2.86 \mathrm{E}+07$ \\
\hline
\end{tabular}

Volatiles and Semivolatiles (mg/ $\mathrm{L}$ or $\mathrm{mg} / \mathrm{kg}$ )

Benzene

Methyl Ethyl Ketone

n-Butanol

Trichloroethylene

Tetrachloroethylene

Dodecane

Acetone

Phenol/phenoxide/nitrophenols

p-Nitrophenol

Kepone

Tributyl Phosphate (TBP)

Aliphatic Hydrocarbons

Alkylated Aromatic Hydrocarbons

Oxygenated Aliphatic Hydrocarbons

Branched Aliphatic Hydrocarbons

Oxygenated Organics

Paraffins

Normal Paraffin Hydrocarbons

Diphenyl Ether

Other

0.68

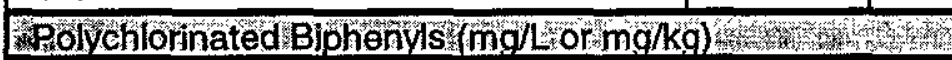

Total $<\mathrm{MDL}$

NA

NA 1 NA

\begin{tabular}{l|l}
\hline $\mathrm{MDL}$ & $\mathrm{NA}$ \\
\hline 7.3 & $\mathrm{NA}$ \\
\hline
\end{tabular}

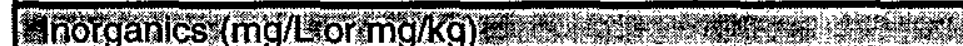

Aluminum

Antimony

Beryllium

Boron

Carbonate

Chloride

Cobalt

Copper

Cyanide

Fluoride

Formate

Free Hydroxide

Iron

Manganese

Nickel

Nitrate

Nitrite

\begin{tabular}{|c|}
\hline 45 \\
\hline 2 \\
\hline 1.4 \\
\hline 18 \\
\hline 5391 \\
\hline 3402 \\
\hline 1 \\
\hline 122.2 \\
\hline$<\mathrm{MDL}$ \\
\hline$<\mathrm{MDL}$ \\
\hline 1763 \\
\hline 2566 \\
\hline 33.6 \\
\hline 9.2 \\
\hline 11.1 \\
\hline 2429 \\
\hline 10194 \\
\hline
\end{tabular}

\begin{tabular}{l} 
NA \\
NA \\
NA \\
NA \\
NA \\
NA \\
NA \\
NA \\
\hline NA \\
NA \\
NA \\
NA \\
NA \\
NA \\
NA \\
NA \\
NA
\end{tabular}

\begin{tabular}{l|l}
\hline 7.3 & NA \\
\hline
\end{tabular}

\begin{tabular}{l|l|l|l} 
NA & NA & $<M D L$ & NA
\end{tabular}

\begin{tabular}{l|l|l|l} 
NA & NA & NA & NA \\
\hline
\end{tabular}

\begin{tabular}{l|l|l|l} 
NA & NA & $<M D L$ & NA
\end{tabular}

\begin{tabular}{l|l|l|l} 
NA & NA & NA & NA \\
\hline
\end{tabular}

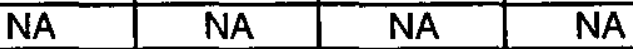

\begin{tabular}{l|l|l|l}
$\mathrm{NA}$ & $<\mathrm{MDL}$ & $<\mathrm{MDL}$ & $\mathrm{NA}$
\end{tabular}

\begin{tabular}{l|l|l|l}
$N A$ & $<M D L$ & $<M D L$ & $N A$
\end{tabular}

\begin{tabular}{l|l|l|l}
$\mathrm{NA}$ & $<\mathrm{MDL}$ & $<\mathrm{MDL}$ & $\mathrm{NA}$
\end{tabular}

\begin{tabular}{l|l|l|l} 
NA & 770000 & 810000 & NA
\end{tabular}

\begin{tabular}{l|l|l|l} 
NA & NA & NA & NA \\
\hline NA & NA & NA & NA
\end{tabular}

\begin{tabular}{l|l|l|l} 
NA & NA & NA & NA
\end{tabular}

\begin{tabular}{l|l|l|l} 
NA & NA & NA & NA
\end{tabular}

\begin{tabular}{l|l|l|l} 
NA & 950000 & 40000 & NA
\end{tabular}

\begin{tabular}{l|l|l|l} 
NA & NA & 150000 & NA
\end{tabular}

\begin{tabular}{l|l|l|l} 
NA & NA & $<M D L$ & NA
\end{tabular}

\begin{tabular}{l|l|l|l} 
NA & 4000 & NA & NA
\end{tabular}

\begin{tabular}{l|l|l|l} 
NA & 17000 & NA & NA
\end{tabular}

\begin{tabular}{l|l|l|l} 
NA & $<M D L$ & $<M D L$ & NA
\end{tabular}

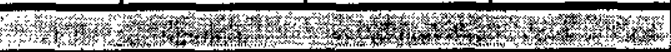

\begin{tabular}{l|l|l|}
$<\mathrm{MDL}$ & $<\mathrm{MDL}$ & $\mathrm{NA}$ \\
\hline
\end{tabular} 
Table 6. Maximum Constituent Concentrations in OSTs above the Method Detection Limits/Activities (Continued)

\begin{tabular}{|c|c|c|c|c|c|}
\hline \multicolumn{6}{|l|}{ Inorganics (mg/L or $\mathrm{mg} / \mathrm{kg}$ ) (Continued) } \\
\hline Oxalate & 2431 & NA & NA & 386 & NA \\
\hline Phosphate & 9686 & NA & NA & 436 & $\mathrm{NA}$ \\
\hline Sodium & 38206 & NA & NA & 132 & $\overline{N A}$ \\
\hline Sulfate & 336 & $\mathrm{NA}$ & NA & 389 & NA \\
\hline Thallium & 1.8 & NA & $\overline{\mathrm{NA}}$ & $<\mathrm{MDL}$ & NA \\
\hline Uranium & 16455 & NA & NA & $<\mathrm{MDL}$ & NA \\
\hline Zinc & 2 & NA & NA & 6 & NA \\
\hline \multicolumn{6}{|l|}{ RCRA Metals (mg/L or $\mathrm{mg} / \mathrm{kg}$ ) } \\
\hline Arsenic & 18.6 & $\mathrm{NA}$ & 8 & 0.3 & NA \\
\hline Barium & 1.3 & NA & 57 & 1.5 & NA \\
\hline Cadmium & 1.7 & NA & 70 & $<\mathrm{MDL}$ & NA \\
\hline Chromium & 38 & NA & 329 & 63 & NA \\
\hline Lead & 8.6 & NA & 2856 & 8.9 & NA \\
\hline Mercury & 97.18 & NA & 460 & 11.61 & $\mathrm{NA}$ \\
\hline Selenium & 0.9 & NA & 4 & 2.4 & NA \\
\hline Silver & 0.1 & NA & 61 & 0.8 & NA \\
\hline \multicolumn{6}{|l|}{ Physiochemical Parameters } \\
\hline Acidity (molarity) & $<\mathrm{MDL}$ & $\mathrm{NA}$ & $\mathrm{NA}$ & $\mathrm{NA}$ & $\mathrm{NA}$ \\
\hline Boiling Point $\left({ }^{\circ} \mathrm{F}\right)$ & 185 & NA & NA & 159.8 & NA \\
\hline Flash Point $\left({ }^{\circ} \mathrm{F}\right)$ & 209 & NA & NA & 180.9 & NA \\
\hline Freezing Point $\left({ }^{\circ} \mathrm{F}\right)$ & $<\mathrm{MDL}$ & NA & NA & $<M D L$ & NA \\
\hline $\mathrm{pH}$ & 11 & $\mathrm{NA}$ & $\mathrm{NA}$ & 9.16 & NA \\
\hline Specific Gravity $\left(\mathrm{g} / \mathrm{cm}^{3}\right)$ & 1.105 & NA & NA & 1.021 & $\overline{N A}$ \\
\hline Total Dissolved Solids (\%) & 15.3 & NA & NA & 5.89 & NA \\
\hline Total Insoluble/Suspended Solids (\%) & NA & NA & $\mathrm{NA}$ & 0.18 & NA \\
\hline Water (wt \%) & 103.3 & NA & NA & 38.2 & NA \\
\hline Total Inorganic Carbon $(\mathrm{mg} / \mathrm{L})$ & 4821 & NA & NA & 38 & NA \\
\hline Total Organic Carbon $(\mathrm{mg} / \mathrm{L})$ & 79390 & NA & NA & 21073 & NA \\
\hline Ash Content (\%) & 7.9 & NA & $\mathrm{NA}$ & 1.35 & NA \\
\hline
\end{tabular}

$<M D L$ indicates present below method detection limit/activity NA indicates not analyzed in any sample 


\section{ATTACHMENT 1}

Technical Report on the Old Solvent Tanks

Video Survey Summary 
(This page intentionally left blank.) 


\title{
Technical Report on the ORWBG Solvent Tanks, Video Survey Summary
}

by

\author{
A. S. Preston
}

Westinghouse Savannah River Company

Savannah River Site

Aiken, South Carolina 29808

This paper was prepared in connection with work done under the above contract number with the $U$. $S$.

Department of Energy. By acceptance of this paper, the publisher and/or recipient acknowledges the U. S. Government's right to retain a nonexclusive, royalty-free license in and to any copyright covering this paper, along with the right to reproduce and to authorize others to reproduce all or part of the copyrighted paper. 


\title{
TECHNICAL REPORT
}

\author{
on the
}

\author{
Old Solvent Tanks
}

\section{Video Survey Summary (U)}

December , 1998

Prepared by:

Cindur F, Fata

Andrew Preston

ERD Construction Engineering

Verified by

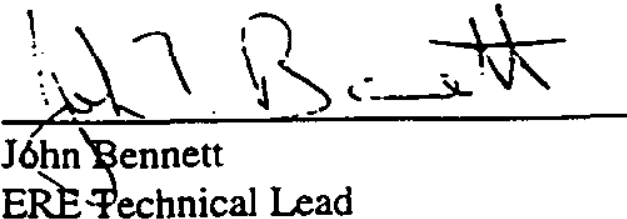

ERE Pechnical Lead

Approved by

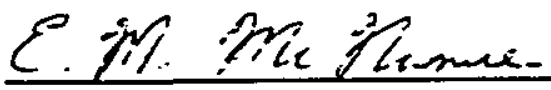

Ed Mcnamee

Project Manager
Date: $1 / 14 / 98$

Date: $1112 / 49$
UNCLASSIFIED

DOES NOT CONTAIN UNCLASSIFLED CONTROLLED NUCLEAR INFORMATION

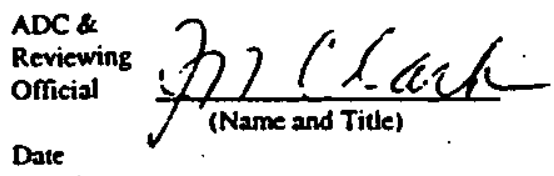




\section{TABLE OF CONTENTS}

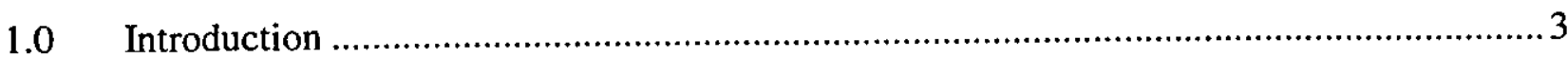

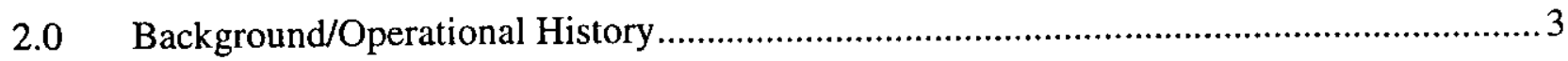

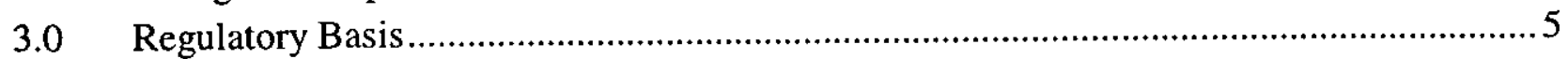

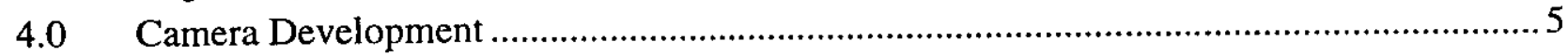

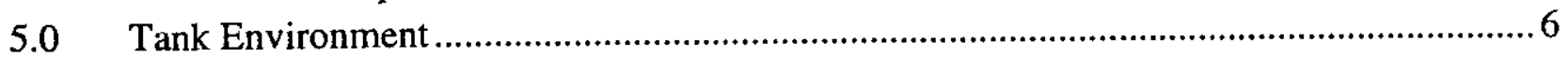

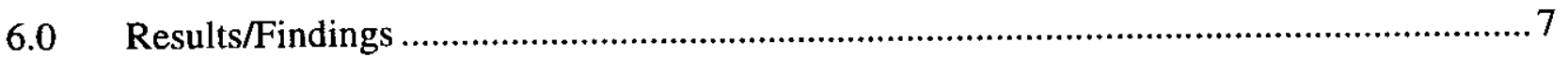

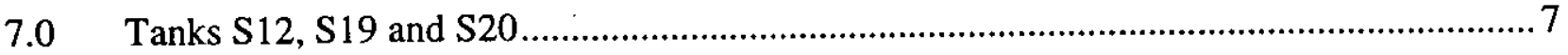

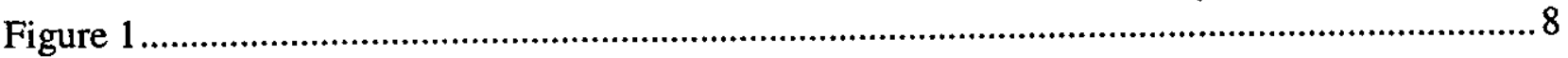

APPENDIX A

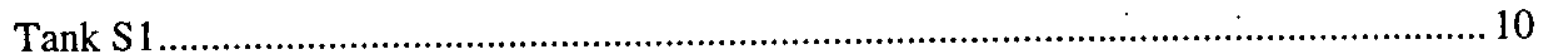

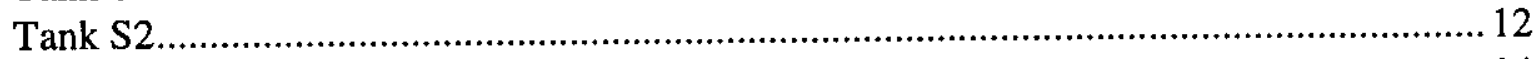

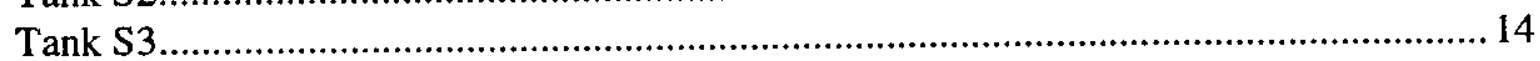

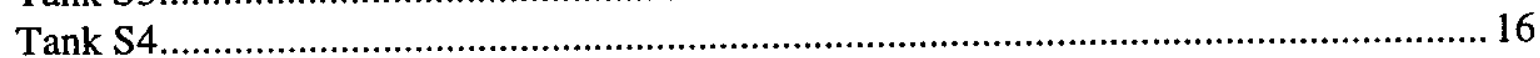

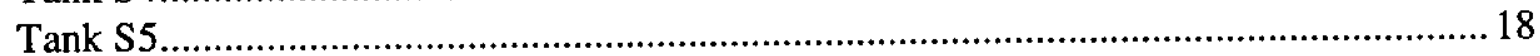

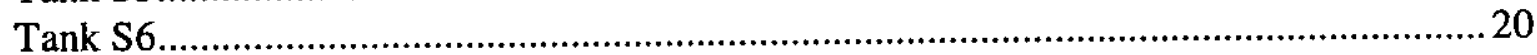

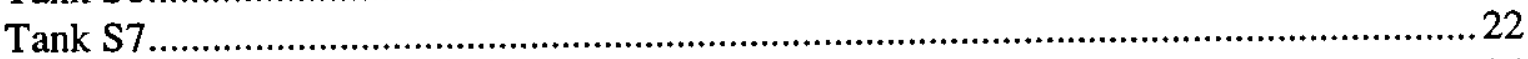

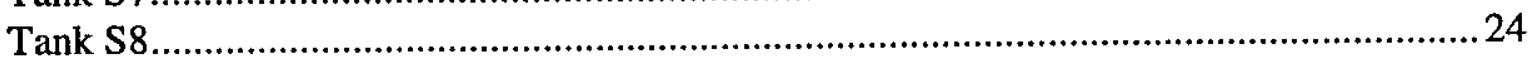

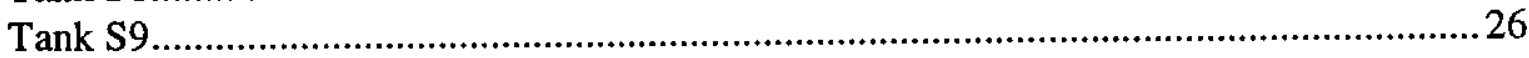

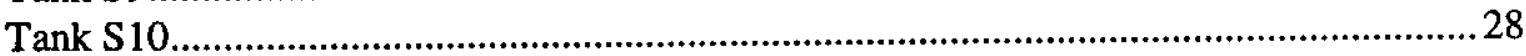

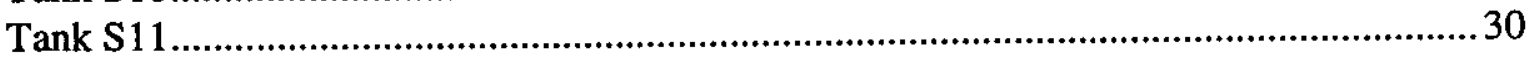

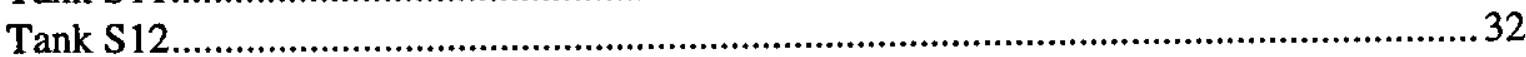

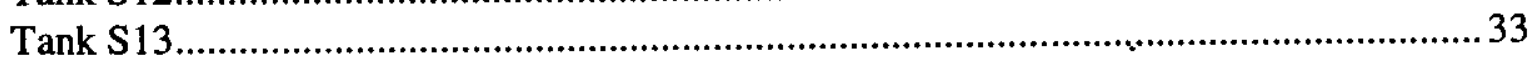

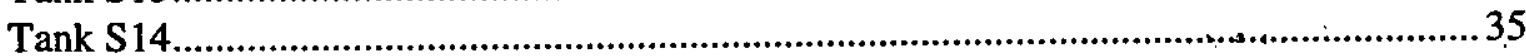

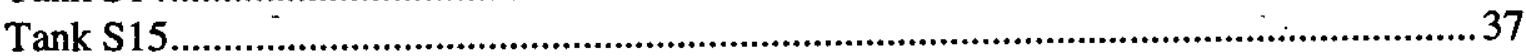

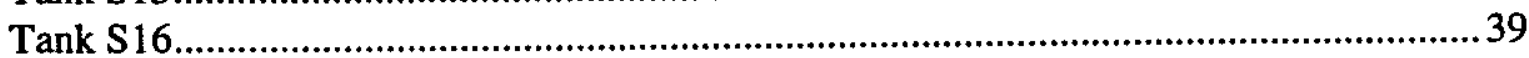

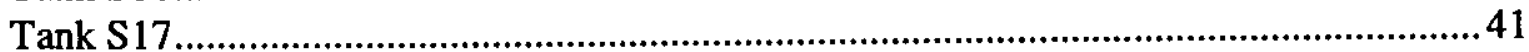

Tank S18

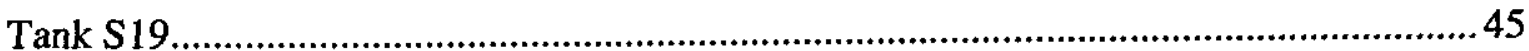

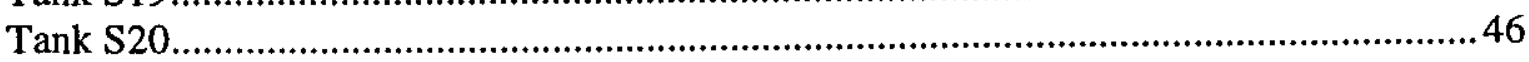

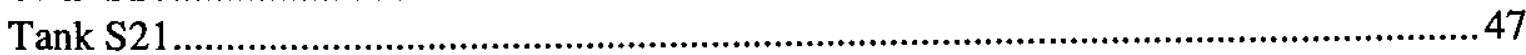

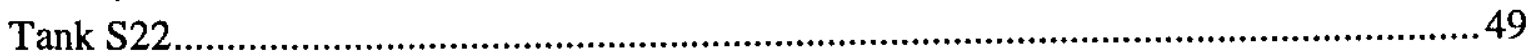




\subsection{INRODUCTION}

The WSRC Environmental Restoration Department (ERD) assumed custody of the Old Solvent Tanks (Tanks S1-S22) located in the Old Radioactive Waste Burial Ground (ORWBG) from Waste Management in January 1991. Little was known about the existing structural condition of these tanks, tank installation, the waste residue that remained and the radiological and chemical contaminates in the waste residue. In an effort to fill these information gaps and support the development of a characterization plan for the waste residue in the tanks, ERD developed a video survey program. The purpose of this program was to:

1. determine the presence of combustible gases,

2. establish the condition of the tanks,

3. determine tank inclination,

4. identify the quantity, type (i.e. liquid/sludge) and location of the waste material,

5. support the development of a tank specific sampling plan.

\subsection{BACKGROUND/OPERATIONAL HISTORY}

The following discussion of the operational history of Tanks S1-S22 is based on review of available historical internal memos, correspondence and procedures.

Five production reactors were operated at the SRS from 1953 until the last reactors were shut down for safety upgrades in 1988. Beginning in 1953, reactor-produced materials were processed in the F- and $\mathrm{H}$ Area chemical separations facilities. The process required the use of solvents to remove residual plutonium and uranium from spent fuel rods and activation products from target rods. After use, the solvent was introduced into a solvent recovery system where the solvent was washed alternately with sodium carbonate and dilute nitric acid. This system removed radioactivity and solvent degradation products, maintained acceptable quality, and returned the washed solvent to the extraction cycle. The solvent was reused until it became laden with organic and metallic contaminants. Nitric acid was recovered from the spent solvent and was then washed with caustic solutions (sodium hydroxide) to neutralize the spent solvent. The spent solvent and the aqueous phase (decontamination solution and process water) was then stored in waste holding tanks located within the F- and H-Area facilities. Solvent from F-Separations, consisted of $30 \%$ tri-n-butyl phosphate (TBP) dissolved in kerosene. Solvent from HSeparations contained 3.5 to $7.5 \%$ TBP dissolved in Ultracene ${ }^{\mathrm{TM}}$.

By July 1955 , the degraded solvent temporarily stored in the F- and H-Area facilities had reached a volume of 28,000 gallons and the Separations Department recognized the need for additional storage capacity and a viable disposal technology. The solution to the first need was underground storage of the spent solvent in small tanks inside a secured area with limited potential for direct exposure of personnel. The most feasible disposal technology was determined to be incineration, specifically burning the solvent in open pans. A site was selected in undisturbed soil near the center of the Old Radioactive Waste Burial Ground (ORWBG). The first three tanks were installed in July 1955. The first solvent was placed in these tanks in August 1955. Tanks S4 through S22 were installed between late 1955 and late 1970, bringing the total available storage capacity in Tanks S1-S22 to 305,667 gallons. Some of these tanks are known to 
have had a previous history as fuel storage tanks at SRS and other Federal sites. Tanks S1-S3 were surplus fuel storage tanks from the construction of the SRP, which began in 1951. Tanks S1-S22 are all believed to be conventional thin walled, mild steel tanks. The tanks are all cylindrical, buried with the long axis slightly inclined from the horizontal. Very little information on the installation of the tanks is available. Generally no documents are available which reported coatings, saddles and tiedowns, bedding, depth of burial, and compaction of backfill. Two coats of Bitumastic were applied to Tanks S19-S22 during installation. Appendix A summarizes tank specific installation dates, tank volumes and quantity of solvent stored. solvent comprised most (88\%) of the solvent placed in these tanks through 1964, After 1964, HM solvent was dominant (86\%).

Between August 1955 and the end of 1974, approximately 606,080 gallons of solvent was cycled through the solvent tanks. While the solvent was stored in Tanks S1-S22, the short- lived fission products underwent decay and suspended solids and precipitates settled out of the solvent. This decrease in activity during storage was referred to as "aging" the solvent. The aging period ranged from one year to 12.4 years, the average aging time was 4.6 years. After aging and settling, the solvent was periodically checked for activity level in preparation for incineration. In 1956 when solvent was first burned, an arbitrary limit of $100 \mathrm{c} / \mathrm{m} / \mathrm{ml}$ of gamma in the solvent was adopted. Initially, the solvent was processed through two large scale carbon bed units buried west of Tank $S 1$ to reduce the radiological concentrations before the solvent was burned. This process was discontinued by the end of 1956 due to a decline in performance of the units and was never resumed. As the program progressed, the limit of activity was relaxed and by 1957 , solvent having up to $10,000 \mathrm{c} / \mathrm{m} / \mathrm{ml}$ was burned. The solvent was pumped to a surface holding tank and gravit flowed through surface piping to open pans and other burning equipment in trenches, located east or Tanks S1-S22. Approximately 425,800 gallons of solvent were burned in open pans at the ORWBG between February 1956 and February 1972 when the practice was suspended under Executive Order 11507. ). There is no record of any solvent being placed in Tanks S1-S22 after 1974.

In 1974, Waste Management began formulating plans to discontinue use of Tanks S1-S22. Tanks S23-S28 and S29-S32 were installed in 1975 and 1979 respectively in the Low Level Radioactive Waste Disposal Facility (LLRWDF) to the north of the ORWBG. The purpose of Tanks S23-S30 was to relocate the solvent inventory from Tanks S1-S22 to the newer tanks and abandon Tank S1-S22 in place. Tanks S23S30 were also used for new receipts of solvent after 1974. Tank 31 never received waste and Tank 32 was used exclusively for tritiated oil. The solvent stored in Tanks S1-S18 was pumped into Tanks S19-S22 from early 1976 to May 1978 leaving unpumpable heels remaining in those 18 tanks. The solvent stored in Tanks S19-S22 was transferred to Tanks S23-S30 in late 1980 to early 1981 leaving unpumpable heels remaining in those four tanks. A total of approximately 173,753 gallons of solvent was transferred to Tanks S23-S30 leaving 6,527 gallons of solvent and sludge in Tanks S1-S22. Appendix A summarizes tank specific calculated quantities of solvent/sludge remaining. 


\subsection{REGULATORY BASIS}

The solvent tanks (S1-S22) in the ORWBG, were designated as underground storage tanks (USTs) under RCRA and reported to SCDHEC on SRS RCRA UST lists beginning in 1987. In August 1992, Tanks S1S22 were removed from the SRS RCRA UST list due to a determination that the tanks were inactive (since January 1981). Currently, Tanks S1-S22 are being addressed as part of the larger ORWBG facility under the Federal Facility Agreement.

\subsection{CAMERA DEVELOPMENT}

The WSRC Engineered Equipment and Systems Department, working in conjunction with ERD, developed an inspection system that could be deployed into the solvent tanks. This inspection system was developed with a color video camera with a zoom lens and a high intensity light. The camera was mounted in a housing which enabled it to be tilted up and down remotely by safety cables once inside the tank. The system was also designed to be panned by rotating a steering plate on top of the riser. The light demanded a special deployment due to the narrow access riser along with the need for the light to be parallel to the camera. The light was mounted to a springed door in the side of the system housing and secured with an electromagnet. Once the inspection system penetrated the inside of the tank, the electromagnet was released, allowing the springed light panel to rotate out of the camera housing and into position.

Insertion of the inspection system into several of the tanks was prevented due to obstructions in the riser pipes. The obstruction consisted of flat barstock made of stainless steel with a cross section of approximately 1-1/4 inch by $1 / 4$ inch. The flat barstock stood on the floor of the tank and projected up into the riser pipe. The top end of the barstock was several feet down in the riser. Multiple pieces of barstock were also found in the same riser. The barstock was previously used by Waste Management during the Tanks S1-S22 operational period and again during the mid 1980s to measure aqueous levels in the tanks. Inspection of the tanks with blocked risers could not continue without the development of a second, smaller system or removal of the barstock.

To accelerate the inspection process, a second system was developed with a black and white video camera with a wide-angle lens and a high intensity light. The camera was mounted in a smaller housing which would pass by the barstock and enter into the tank. The operation and capabilities of the second system was the same as the first.

WSRC procedures require that final acceptance inspection is made before new equipment is placed in service. Based on the final acceptance inspection of the cameras, both systems were classified by WSRC Industrial Hygiene (IH) and Safety Departments as being non-intrinsically safe. The cameras were approved for use but with safety controls in place. 


\subsection{TANK ENVIRONMENT}

Prior to December 1994, Tanks S1-S22 were open to the environment facilitating atmospheric exchange and the loss of volatiles from within the tanks. Vapor phase samples were collected from the headspace in Tanks S1-S22 in December 1994 and March 1995. The vapor phase samples were analyzed for Volatile Organic Compounds (VOCs), Semi-Volatile Organic Compounds (SVOCs) and radionuclides. Airborne SVOCs and radionuclides were not detected in any of the vapor phase samples. No VOCs were detected in the vapor phase samples taken from Tanks S1, S7, S8, and S1.1. The VOCs that were detected in the vapor phase samples from the remaining tanks is shown in the Table below with units in ppm.

\begin{tabular}{|l|l|l|l|l|l|l|l|}
\hline Tank No. & $\begin{array}{l}\text { alkyl } \\
\text { hydrocarbons }\end{array}$ & Acetone & Benzene & Xylenes & MEK & MBK & PCE \\
\hline S2 & 0.03 & & 0.2 & & 0.04 & & 0.007 \\
\hline S3 & 0.02 & & & & & & \\
\hline S4 & 0.009 & & & & & & \\
\hline S5 & & 0.007 & 0.009 & & & & 0.004 \\
\hline S6 & 0.03 & & & & & & \\
\hline S9 & & & & & 0.04 & & 0.004 \\
\hline S10 & & & 0.1 & & & & 0.007 \\
\hline S12 & & & & & & & 0.004 \\
\hline S13 & 0.02 & 0.14 & & & 0.01 & & 0.004 \\
\hline S14 & 0.03 & & & & & & 0.004 \\
\hline S15 & 0.48 & 1.1 & 0.004 & & & 0.14 & 0.004 \\
\hline S16 & 0.08 & & 0.02 & & & & 0.004 \\
\hline S17 & 0.01 & & 0.2 & & 0.03 & 0.007 & 0.007 \\
\hline S18 & 0.1 & & 0.08 & 0.01 & 0.05 & 0.007 & \\
\hline S19 & 0.47 & 1.5 & & & 2.1 & 0.47 & \\
\hline S20 & 0.23 & 0.05 & & & & & \\
\hline S21 & 0.05 & 0.06 & & & & & \\
\hline S22 & 0.14 & & & & 0.07 & & \\
\hline
\end{tabular}

Based upon review of this analytical data, Industrial Hygiene and Fire Protection Engineering determined that it is unlikely that any of the tanks had contained combustible atmospheres at the time of sampling.

Prior to sampling, glove bags with HEPA filters were placed over all riser pipes to prevent personnel exposure to potential airborne radiological releases during the sampling process. Upon completion of the sampling, ERD elected to leave plastic sleeves with HEPA filters over all riser pipes to prevent any future potential airborne radiological releases and the infiltration of precipitation into the tanks. These sleeves also prevented atmospheric exchange and the loss of volatiles. Since December 1994, all riser pipes have remained continually covered with the plastic sleeving. The sleeves are currently inspected on a monthly basis and replaced when required.

Based on the potential build-up of combustible gases in the tanks and the plan to insert non-intrinsically safe cameras into the tanks, a combustible gas testing program in conjunction with the camera survey program was developed. This program was developed by ERD, WSRC Industrial Hygiene and WSRC Fire Protection Engineering. The atmosphere in each tank was tested immediately prior to insertion of the camera into the tank using a Mine Safety Appliance (MSA) Model 261 Combustible Gas and Oxy 
Indicator. An MSA air sample hose was lowered into each tank, stopping at three foot intervals to test the atmosphere. Testing began at the top of the riser pipe and continued to within two feet of the bottom of the tank. The final two feet was not tested due to potential contact with the tank solvents and the MSA air sample hose. The atmosphere in all 22 tanks was successfully tested. The air sampling hose that was inserted into each tank was constructed to provide the ability to measure the tank from the top of the riser pipe to the floor of the tank. This measurement provided the means to verify tank burial depth. The results of the combustible gas testing and tank burial depths are shown in Appendix A.

IH established the acceptance criteria for placing the camera into a tank at $\leq 10 \%$ of the Lower Explosion Limit (LEL). All tanks with the exception of Tanks S12, S19 and S20 met this criteria and were successfully surveyed and videotaped. These 19 video tapes are currently controlled as records in ERD Document Control.

\subsection{RESULTS/ FINDINGS}

Review of the video tapes indicate that none of the 19 tanks surveyed have structurally failed. There was no visible signs of tank penetration on any of the tanks. Heavy corrosion was seen on the ceiling (above the liquid level lines) of most of the tanks. Another video finding is the nature of the tank construction. Tanks S15 and S16 are riveted construction and have a considerable amount of interior piping, bracing, and a large man way with a vertical ladder. Review of the video tapes of these two tanks with members of the SRS Railroad Department have determined the tanks are probably railroad tank cars. Several other tanks contain unexpected structural members which are described in Appendix A. The video also provided the direction of tank inclination. Tank inclination is shown on Figure 1 and Appendix A. All tanks contain some quantity of residue. The total estimated quantity of liquid \& sludge in each tank is shown in Appendix A.

\subsection{TANKS S12, S19, AND S20}

The Lower Explosion Limit detected in the headspace in Tanks S12, S19, and S20 was 20\%. This exceeded the acceptance criteria for camera insertion into these tanks. Tanks S19 and S20 were subsequently visually inspected, looking into the tanks at both ends through the riser pipes of each tank. Liquid was identified at the east end of Tank S19 and sludge only at the west end. Liquid was identified at the east and west end of Tank 20. An intrinsically safe camera (Fiber Scope) and light source (Fiber Optic Cable) were used to survey Tank 12. Both ends of Tank S12 were surveyed with no liquid or sludge identified. The fiber scope camera was not compatible with the video unit so the survey of Tank S12 was not video taped. The headspace in these three tanks was resampled in mid 1998 and analyzed for the same parameters as previously performed, but with the addition of total hydrogen. The VOC, SVOC and radionuclide analytical results were consistent with the results previously found. However, the hydrogen detected in the tank headspace samples taken from these three tanks was is the range of $0.3 \%$ to $0.5 \%$ by volume. This would explain the elevated LEL reading and may indicate radiolytic degradation of solid material in these three tanks. 
Technical Report on the ORWBG

Solvent Tanks

Video Survey Summary
WSRC-RP-98-04225

Revision No. 0

Page 8 of 50

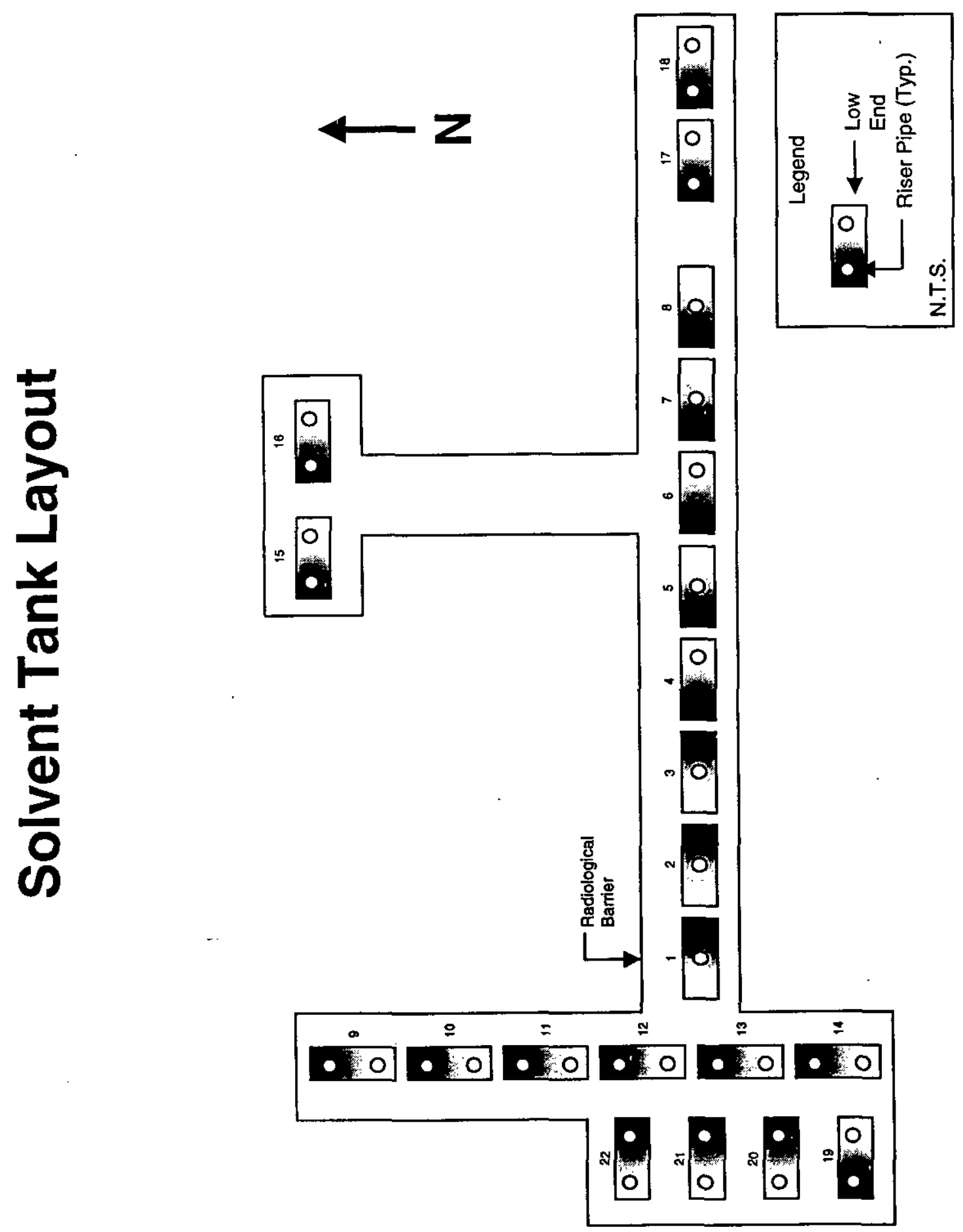

Figure 1. 


\section{APPENDIX A}

1. "Tank Installation Dates" were obtained from historical documentation related to Tanks S1-S22.

2. "Tank Sizes" were initially obtained from historical documentation related to Tanks S1-S22. Tank sizes were verified by Ground Penetrating Radar in 1993.

3. "Tank Capacity" was calculated using the tank dimensions.

4. "Lifetime Quantity of Solvent Stored" was obtained from historical documentation related to Tanks S1-S22.

5. "Estimated Total Volume of Waste Remaining" was estimated by approximating the width of the liquid pond (relative to the diameter) at each end of the tank as seen on the video tapes. Tank specific computer models were produced using this data to establish the total volume of waste material in each tank. The fiber scope camera survey performed in Tank S12 was inconclusive due to the limited visual range of the fiber scope and light source. The survey indicated that liquids and sludge were not present directly beneath the riser pipes, however, the lowest point in the tank was beyond range of the fiber scope. The total volume of waste material in this tank is based on the worst case scenario. It has been assumed that liquid and sludge exist in the lowest end of the tank just beyond the visible area. A computer model was produced using this assumption. The computer model produced for Tanks S19 was based on the visual inspection of the tank discussed in Section 7.0 and the liquid measurement performed in the east end of the tank in late 1995. The computer model for Tank 20 was based on the liquid measurement performed in the east end of the tank in late 1995 and the known inclination of the tank (shown in Appendix A).

6. "Estimated Liquid Currently Stored in Tank" was obtained by subtracting the estimated sludge from the total volume.

7. "Estimated Sludge Currently Stored in Tank" was estimated by the relative percentage of sludge material that was visible compared to the liquid phase. Since the solids reside beneath the liquid in most cases, a high degree of uncertainty exists with these estimates. Where there was no liquid in the tank, the sludge content was approximated by estimating the thickness of the dried residue from visual observations, and multiplying it by the estimated area.

8. "LEL Tank Survey Readings" have been documented by WSRC Industrial Hygiene. These documents are controlled as records and stored in the SRS Records Retention System.

9. "Tank Features" are based on review of the video tapes. All tanks had at least one measure rod (discussed in Section 4.0). All measure rods have been cut in half and laid on the tank floor. All tanks with the exception of S6 and S8 had one stand pipe. The stand pipe is a 2" diameter pipe that was used to add solvent to the tank and remove solvent from the tank during the tank's operational period. All stand pipes have been cut in half and laid on the floor of the tank.

10. "Elevation View" tank inclination is based on the tank specific computer models produced. Burial depth is based on historical documentation and confirmed by measurements (top of riser pipe to tank floor) obtained during the combustible gas testing program discussed in Section 5.

11. Photos have been taken from the video tapes for tanks $S 1$ to $S 22$, not including $S 12, S 19$, and $S 20$. These photos where selected to give a representative view of the tanks and the type of visual data that was gathered during the video survey. In general, the selected photos shown are designed to provide an indication of tank incline and the approximate quantity of waste remaining in the tanks. Some photos were selected that show unique features of some tanks. 


\section{TANK S1}

\begin{tabular}{|l|c|}
\hline Tank Installation Date & $7 / 55$ \\
\hline Tank Size (ft) & $8.0 \times 27.0$ \\
\hline Tank Capacity (gal) & 10,059 \\
\hline Lifetime Quantity of Solvent Stored (gal) & 35,851 \\
\hline Estimated Total Volume of Waste Remaining (gal) & 122 \\
\hline Estimated Liguid Currently Stored in Tank (gal) & 117 \\
\hline Estimated Sludge Currently Stored in Tank (gal) & 5 \\
\hline
\end{tabular}

\section{LEL TANK SURVEY READINGS}

\section{TESTING INTERVALS}

\begin{tabular}{|c|c|c|c|c|c|}
\hline $3^{\prime}-0^{\prime \prime}$ & $6^{\prime}-0^{\prime \prime}$ & $9^{\prime}-0^{\prime \prime}$ & $12^{\prime}-0^{\prime \prime}$ & $15^{\prime}-0^{\prime \prime}$ & $18^{\prime}-0^{\prime \prime}$ \\
\hline & & & & & \\
\hline $5 \%$ & $7 \%$ & $7 \%$ & $8 \%$ & N/A & N/A \\
\hline
\end{tabular}

Tank Features:

This tank has two capped drain plugs located at the base of the tank wall (one at each end of the tank).

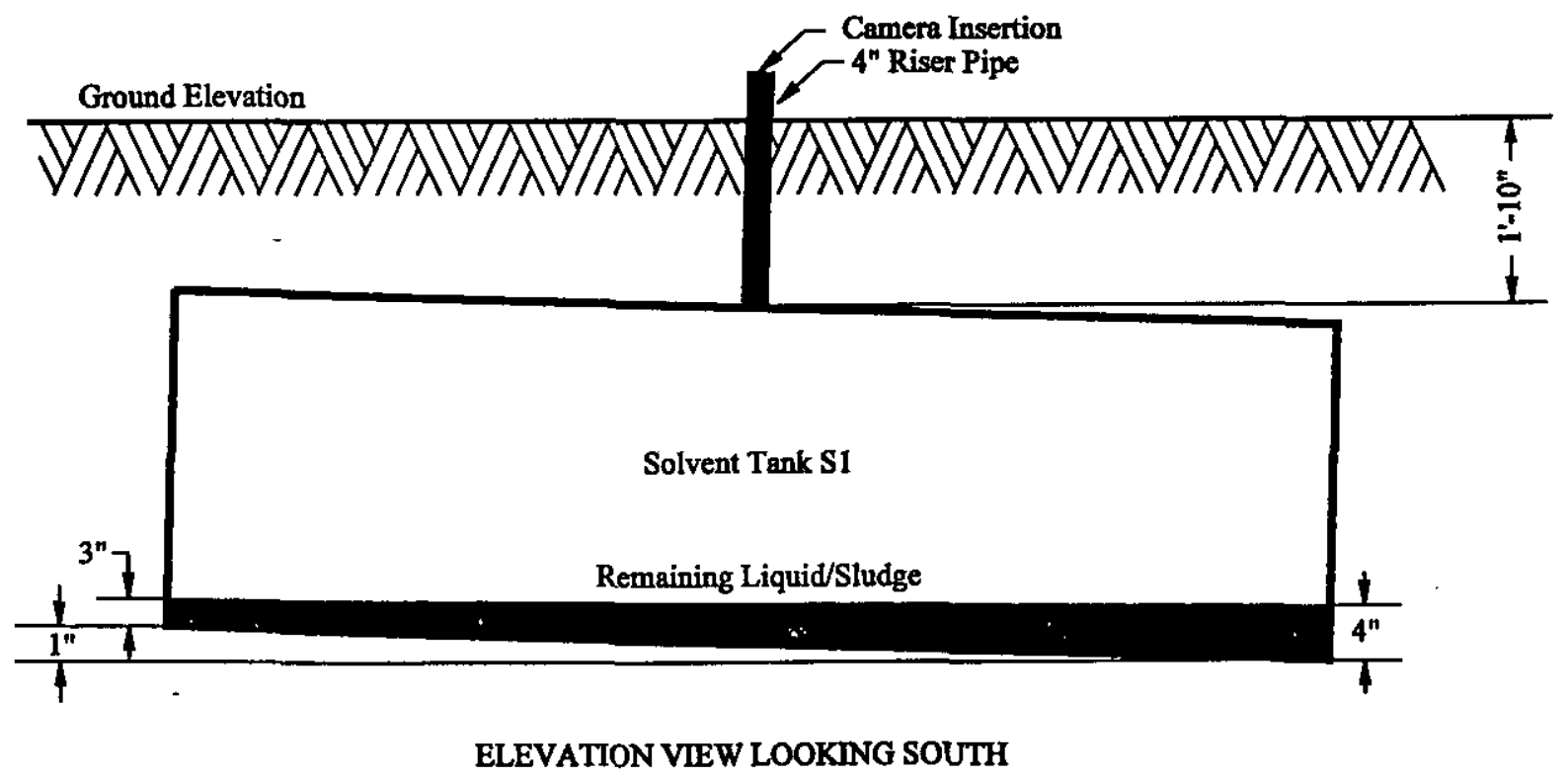


Technical Report on the ORWBG

Appendix A

\section{Tank S1}

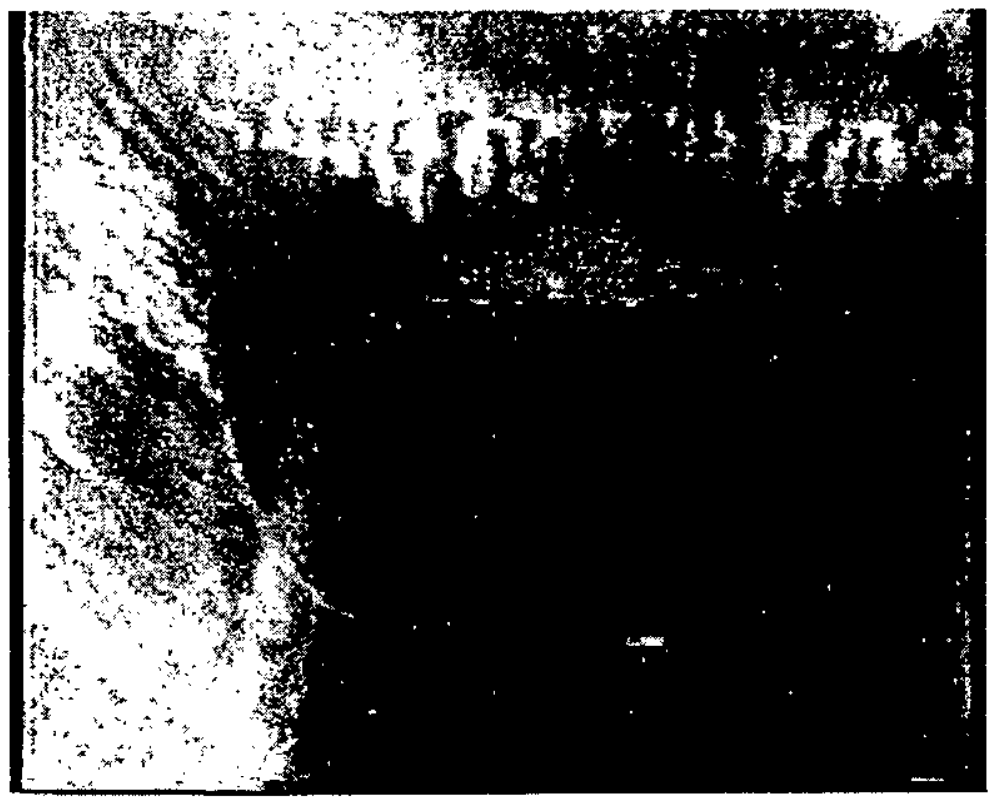

View of liquid waste at east end of tank

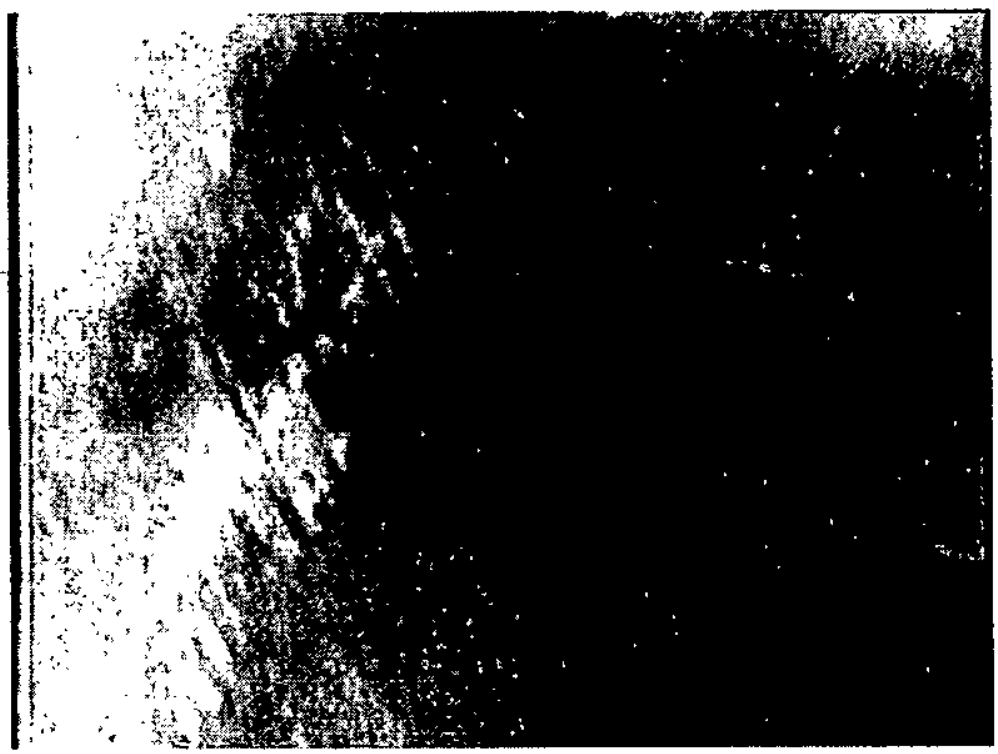

View of liquid waste at west end of tank 


\section{Appendix A}

\section{Tank S2}

\begin{tabular}{|l|c|}
\hline Tank Installation Date & $7 / 55$ \\
\hline Tank Size (ft) & $8.0 \times 27.0$ \\
\hline Tank Capacity (gal) & 10,059 \\
\hline Lifetime Quantity of Solvent Stored (gal) & 28,243 \\
\hline Estimated Total Volume of Waste Remaining (gal) & 145 \\
\hline Estimated Liquid Currently Stored in Tank (gal) & 112 \\
\hline Estimated Sludge Currently Stored in Tank (gal) & 33 \\
\hline
\end{tabular}

\section{LEL TANK SURVEY READINGS}

TESTING INTERVALS

\begin{tabular}{|c|c|c|c|c|c|}
\hline $3^{\prime}-0^{n}$ & $6^{\prime}-0^{\prime \prime}$ & $9^{\prime}-0^{\prime \prime}$ & $12^{\prime}-0^{n}$ & $15^{\prime}-0^{n}$ & $18^{\prime}-0^{n}$ \\
\hline & & & & & \\
\hline $0 \%$ & $0 \%$ & $0 \%$ & $0 \%$ & N/A & N/A \\
\hline
\end{tabular}

Tank Features:

This tank has two capped drain plugs located at the base of the tank wall (one at each end of the tank).

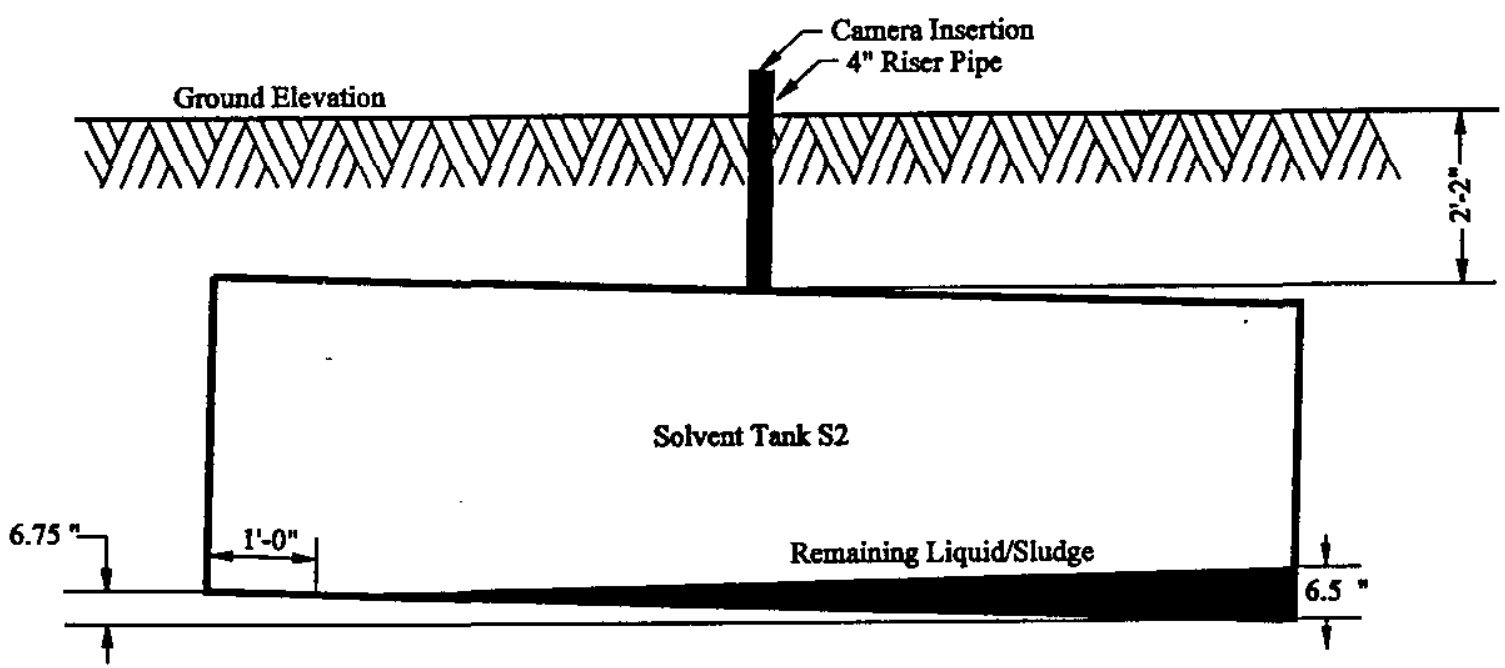

ELEVATION VIEW LOOKING SOUTH 
Technical Report on the ORWBG

WSRC-RP-98-04225

Solvent Tanks

Revision No. 0

Video Survey Summary

Page 13 of 50

Appendix A

\section{Tank S2}

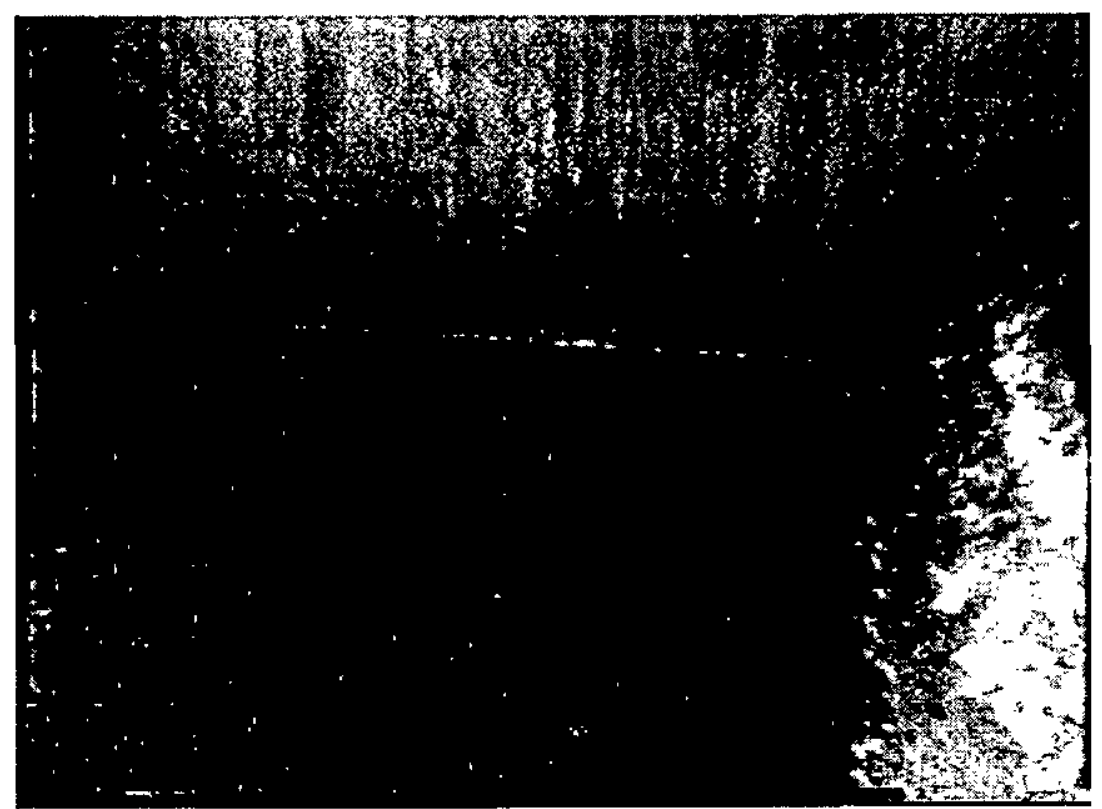

View of liquid waste at west end of tank

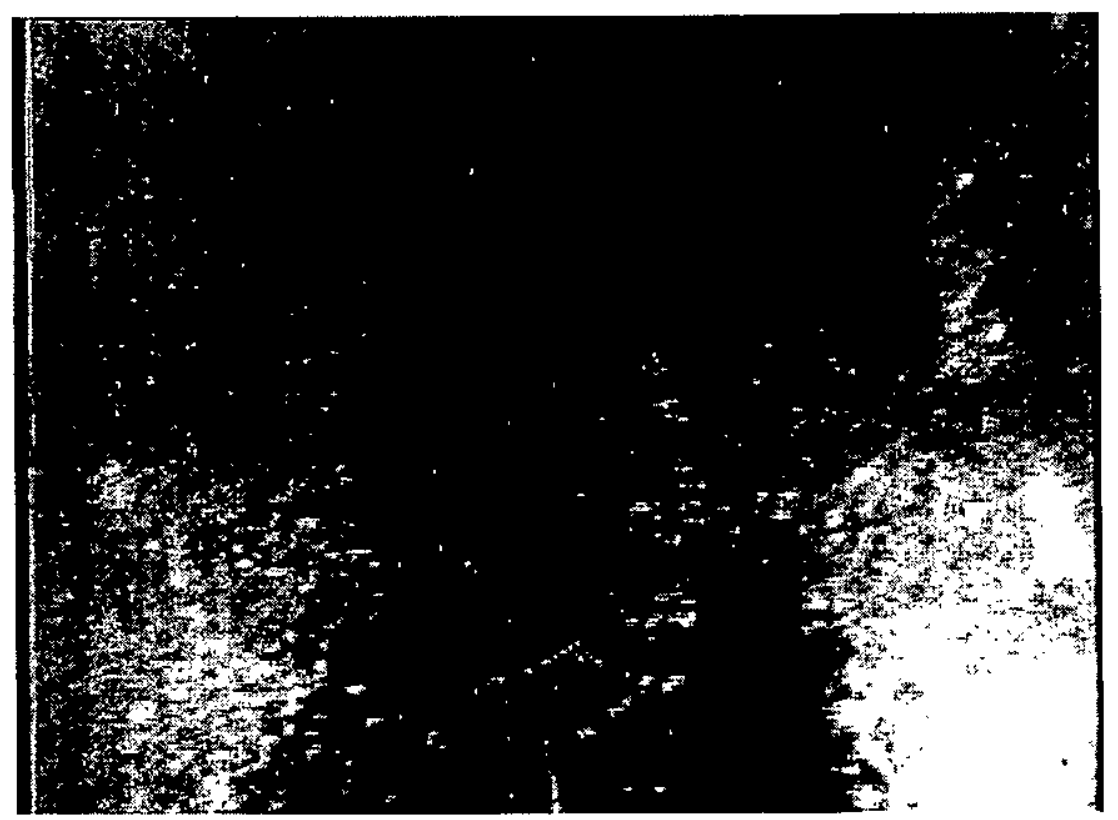

View of liquid \& sludge waste at east end of tank 


\section{TANK S3}

\begin{tabular}{|l|c|}
\hline Tank Installation Date & $7 / 55$ \\
\hline Tank Size (ft) & $8.0 \times 27.0$ \\
\hline Tank Capacity (gal) & 10,059 \\
\hline Lifetime Quantity of Solvent Stored (gal) & 29,528 \\
\hline Estimated Total Volume of Waste Remaining (gal) & 402 \\
\hline Estimated Liquid Currently Stored in Tank (gal) & 398 \\
\hline Estimated Sludge Currently Stored in Tank (gal) & 4 \\
\hline
\end{tabular}

\section{LEL TANK SURVEY READINGS}

\section{TESTING INTERVALS}

\begin{tabular}{|c|c|c|c|c|c|}
\hline $3^{\prime}-0^{\prime \prime}$ & $6^{\prime}-0^{\prime \prime}$ & $9^{\prime}-0^{n}$ & $12^{\prime}-0^{n}$ & $15^{\prime}-0^{\prime \prime}$ & $18^{\prime}-0^{\prime \prime}$ \\
\hline & & & & & \\
\hline $2 \%$ & $3 \%$ & $3 \%$ & $3 \%$ & N/A & N/A \\
\hline
\end{tabular}

Tank Features:

This tank has two capped drain plugs located at the base of the tank wall (one at each end of the tank).

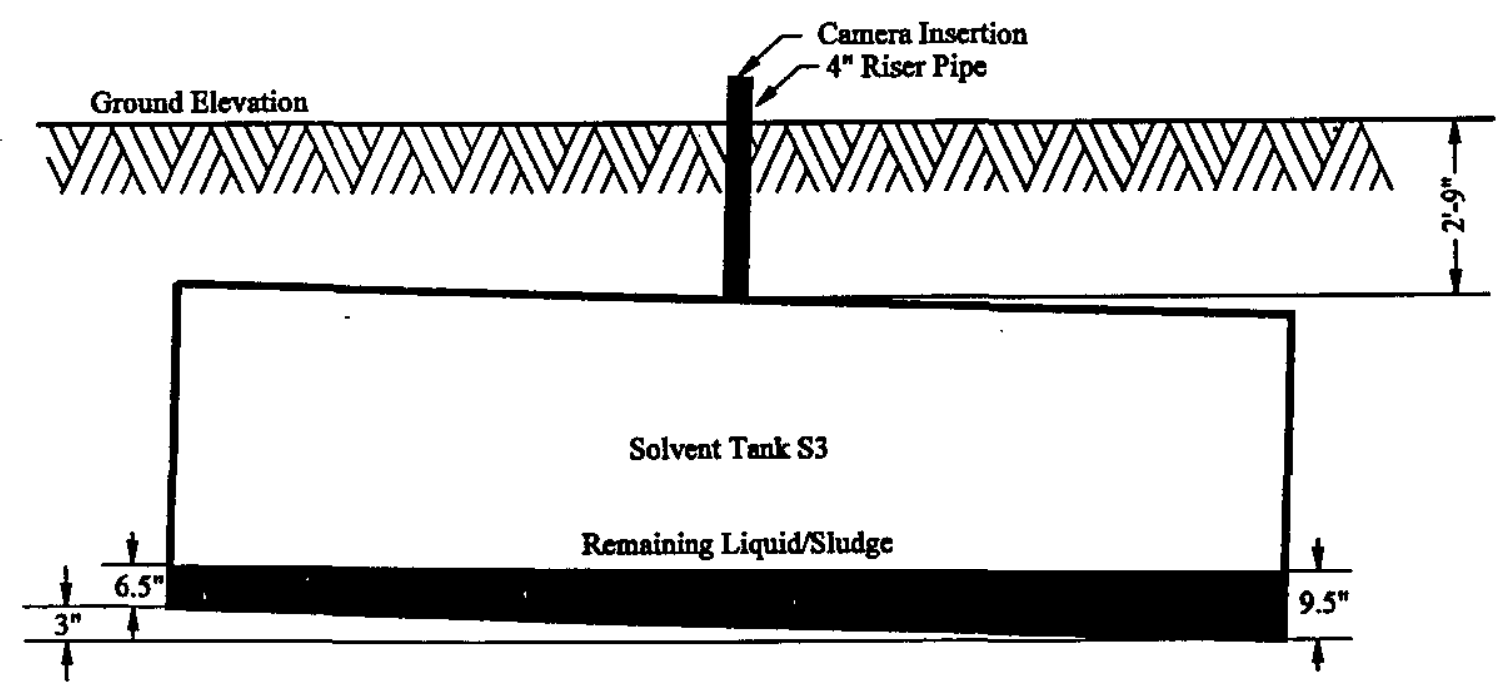

ELEVATION VIEW LOOKING SOUTH 
Technical Report on the ORWBG

Appendix A

\section{Tank S3}

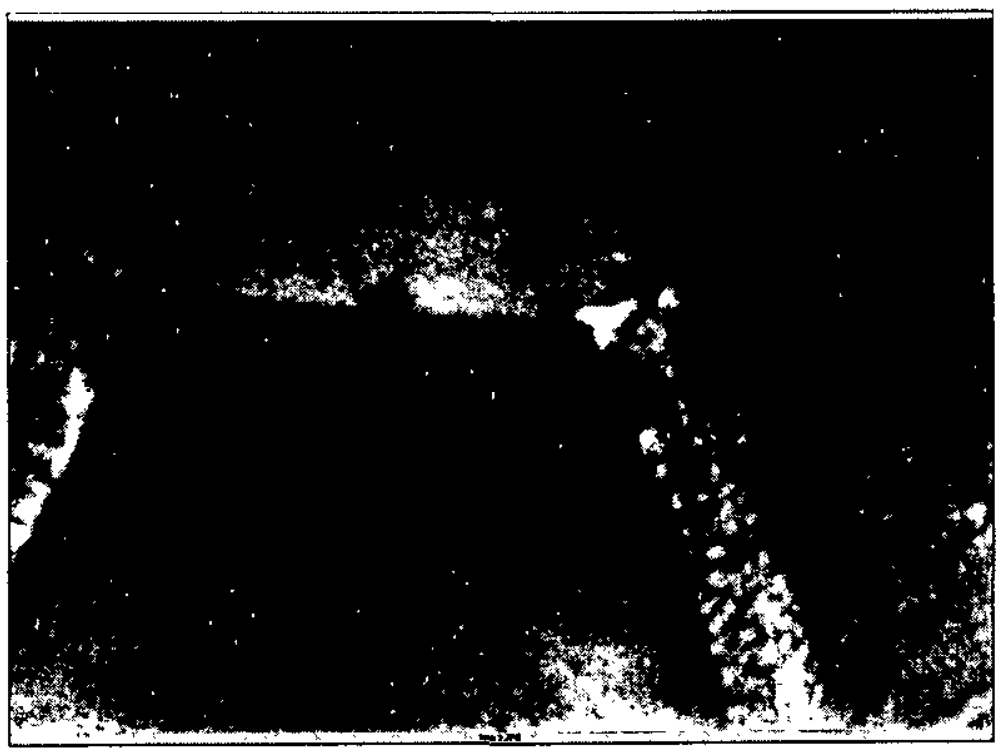

View of liquid and sludge waste at east end of tank

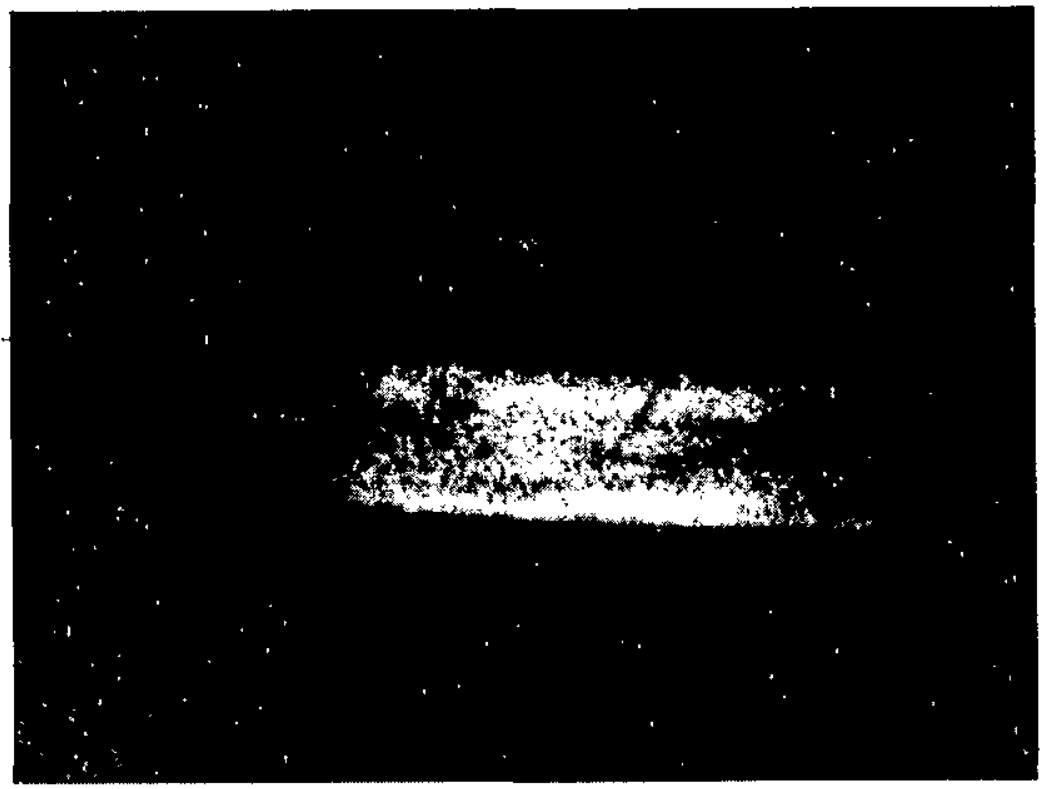

View of liquid waste at west end of tank Appendix A 


\section{TANK S4}

\begin{tabular}{|l|c|}
\hline Tank Installation Date & $8 / 55$ \\
\hline Tank Size (ft) & $8.0 \times 14.0$ \\
\hline Tank Capacity (gal) & 5,264 \\
\hline Lifetime Quantity of Solvent Stored (gal) & 10,237 \\
\hline Estimated Total Volume of Waste Remaining (gal) & 375 \\
\hline Estimated Liquid Currently Stored in Tank (gal) & 369 \\
\hline Estimated Sludge Currently Stored in Tank (gal) & 6 \\
\hline
\end{tabular}

\section{LEL TANK SURVEY READINGS}

TESTING INTERVALS

\begin{tabular}{|c|c|c|c|c|c|}
\hline $3^{\prime}-0^{\prime \prime}$ & $6^{\prime}-0^{\prime \prime}$ & $9^{\prime}-0^{\prime \prime}$ & $12^{\prime}-0^{\prime \prime}$ & $15^{\prime}-0^{\prime \prime}$ & $1^{\prime}-0^{\prime \prime}$ \\
\hline & & & & & \\
\hline $0 \%$ & $2 \%$ & $2 \%$ & $2 \%$ & N/A & N/A \\
\hline
\end{tabular}

Tank Features:

This tank has one 2" diameter pipe at the far end of the tank. This pipe stands vertically and spans between the floor and the ceiling of the tank. This pipe appears to be a structural support member.

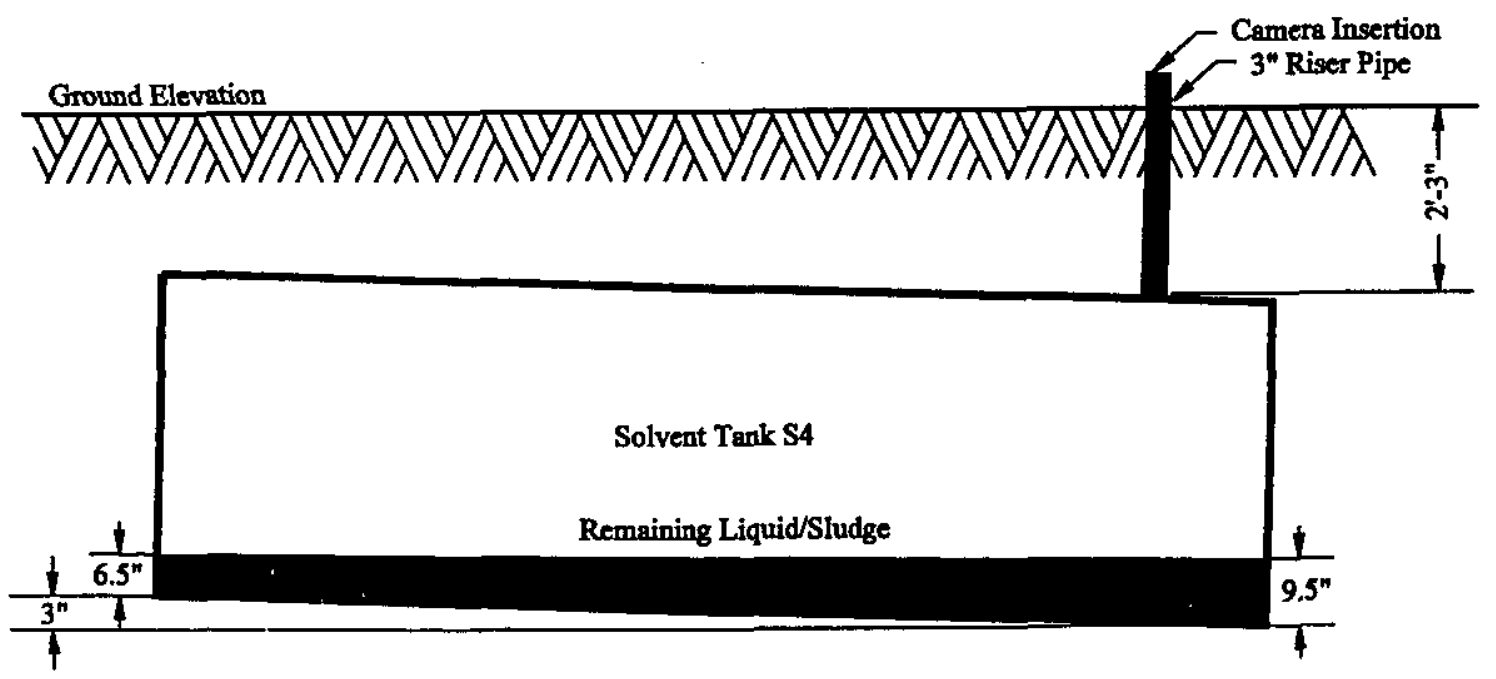

ELEVATION VIEW LOOKING SOUTH 
Technical Report on the ORWBG

Solvent Tanks

Video Survey Summary
WSRC-RP-98-04225

Revision No. 0

Page 17 of 50

Appendix A

\section{Tank S4}

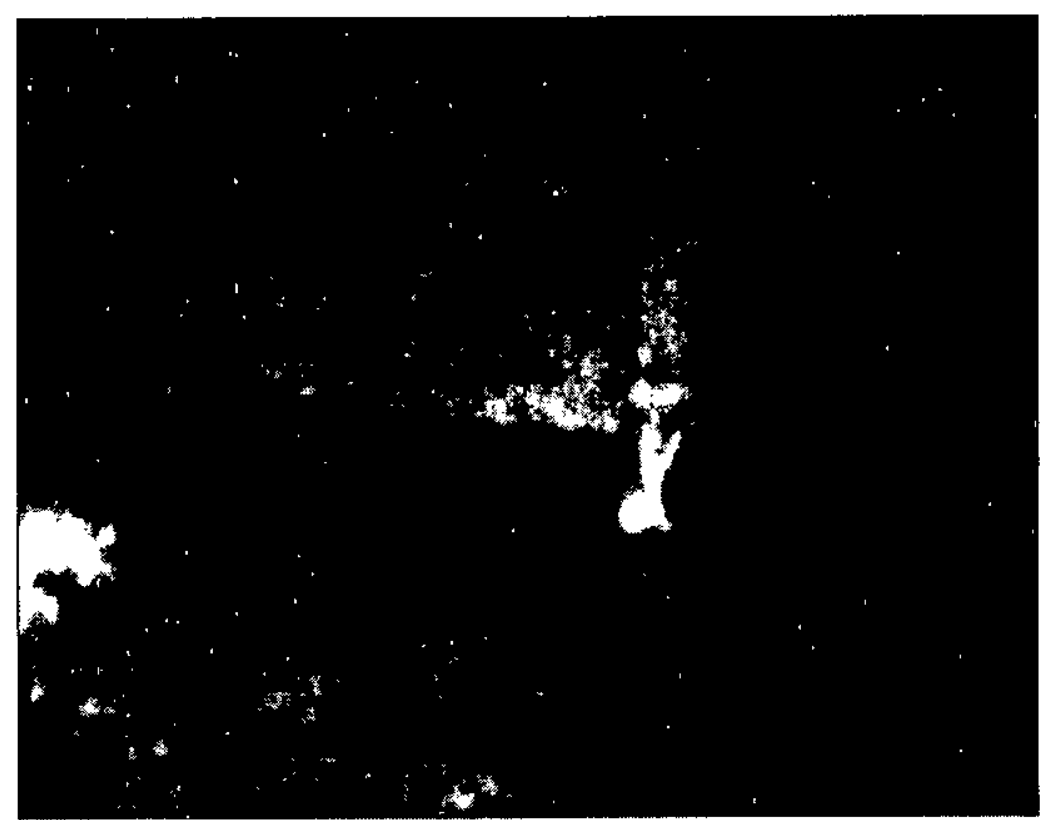

View of liquid waste \& 2" $\phi$ pipe at east end of tank

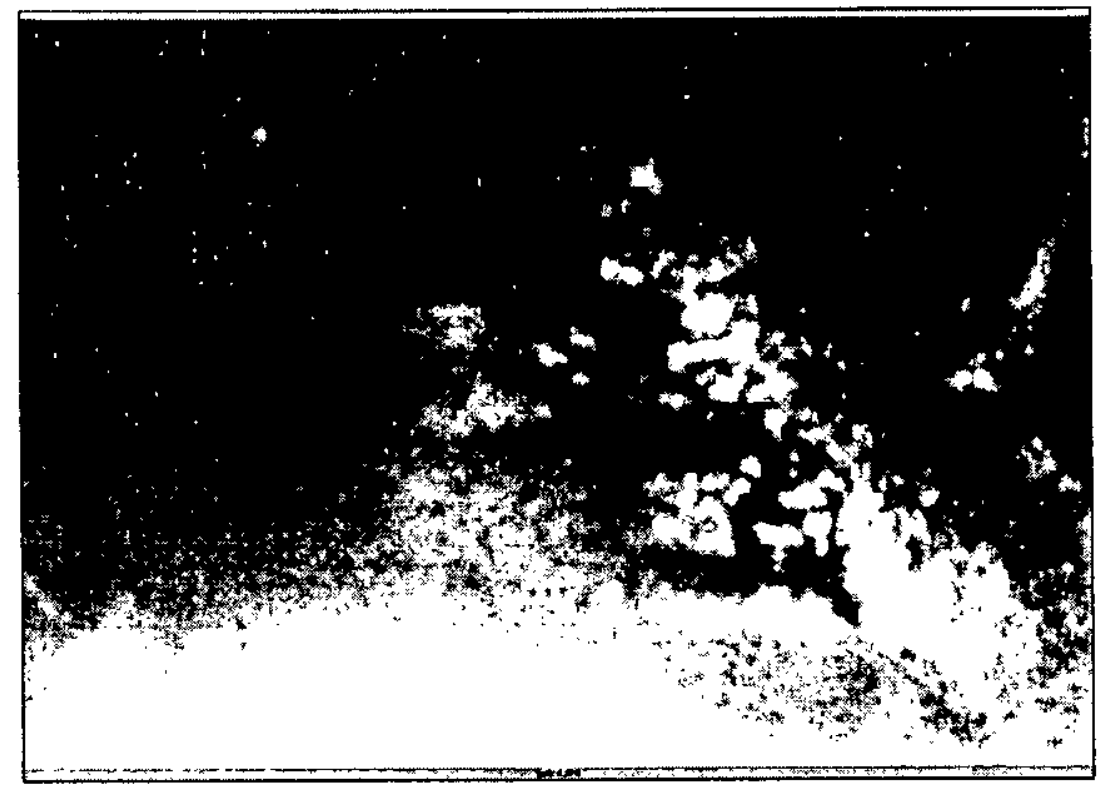

View of liquid and sludge waste at mid tank 


\section{APPENDIX A}

\section{TANK S5}

\begin{tabular}{|l|c|}
\hline Tank Installation Date & $9 / 55$ \\
\hline Tank Size (ft) & 10.5 X 38.5 \\
\hline Tank Capacity (gal) & 24,940 \\
\hline Lifetime Quantity of Solvent Stored (gal) & 96,230 \\
\hline Estimated Total Volume of Waste Remaining (gal) & 204 \\
\hline Estimated Liquid Currently Stored in Tank (gal) & 92 \\
\hline Estimated Sludge Currently Stored in Tank (gal) & 112 \\
\hline
\end{tabular}

\section{LEL TANK SURVEY READINGS}

\section{TESTING INTERVALS}

\begin{tabular}{|c|c|c|c|c|c|}
\hline $3^{\prime}-0^{\prime \prime}$ & $6^{\prime}-0^{\prime \prime}$ & $9^{\prime}-0^{\prime \prime}$ & $12^{\prime}-0^{n}$ & $15^{\prime}-0^{n}$ & $18^{\prime}-0^{\prime \prime}$ \\
\hline & & & & & \\
\hline $2 \%$ & $9 \%$ & $8 \%$ & $8 \%$ & $8 \%$ & N/A \\
\hline
\end{tabular}

\section{Tank Features:}

This tank contains several structural members, including a metal ladder. There are four horizontal structural members which appear to be 1' above the floor of the tank. One member appears to be a 6" wide structural beam which spans the length of the tank. The other three appear to be 4" diameter pipes that are perpendicular to the beam. There is one pipe located at each end of the tank and one at mid tank. The is one vertical 2" diameter pipe at mid tank that is attached to the top of the beam and stops approximately 1' from the ceiling of the tank. There are two, 2" diameter pipes (standing side by side) at one end of the tank that project into the tank approximately 3' through the ceiling of the tank.

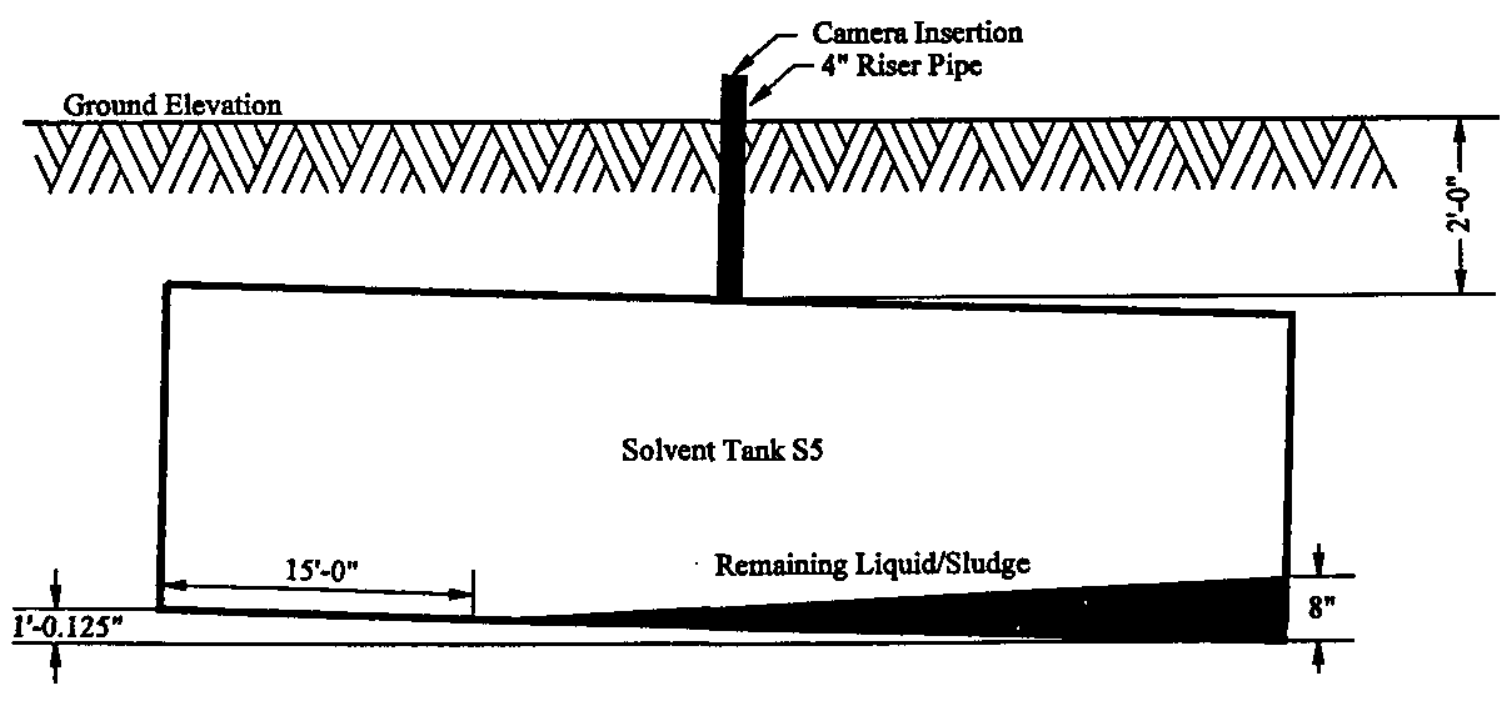

ELEVATION VIEW LOOKING NORTH

Appendix A 


\section{Tank S5}

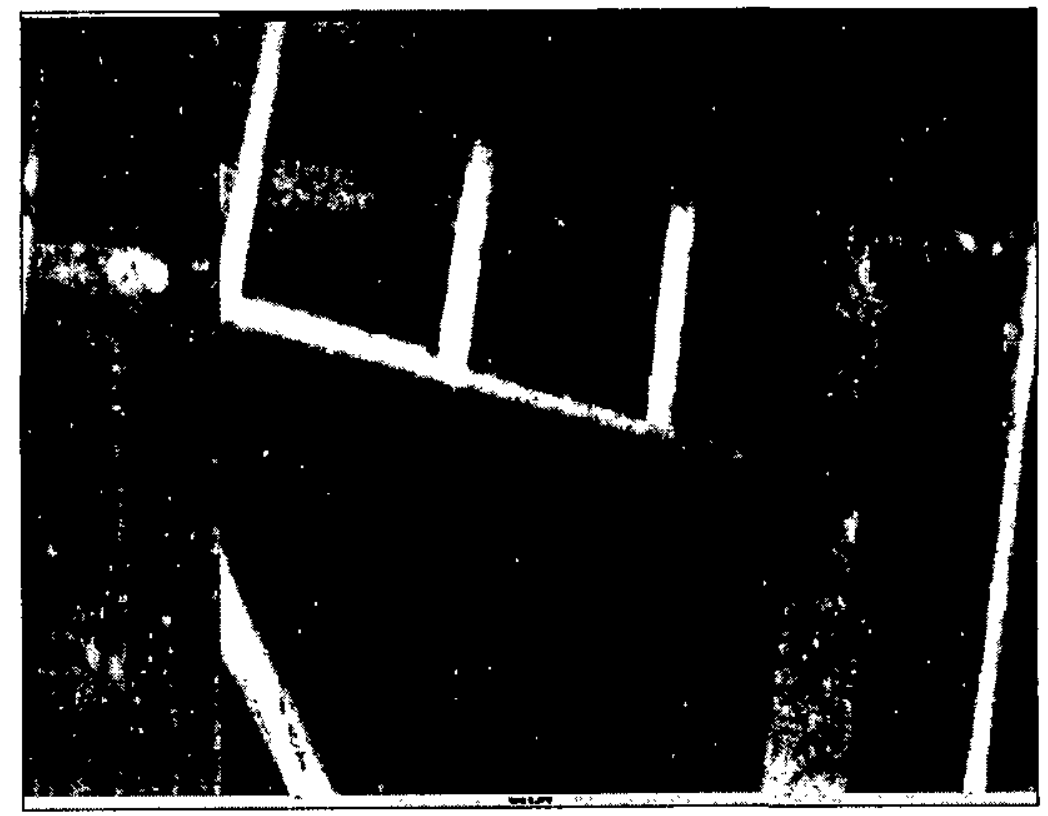

View of tank internal structural members at mid tank

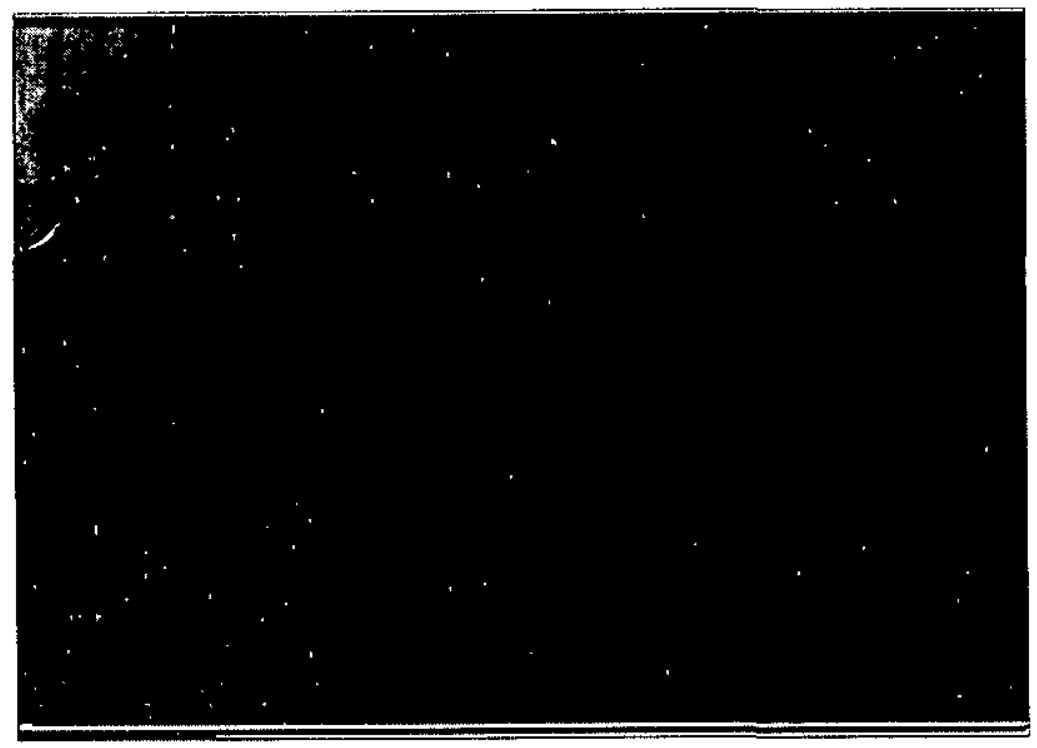

View of liquid waste at west end of tank 


\section{Appendix A}

\section{Tank S6}

\begin{tabular}{|l|c|}
\hline Tank Installation Date & $4 / 56$ \\
\hline Tank Size (ft) & $10.5 \times 38.5$ \\
\hline Tank Capacity (gal) & 24,940 \\
\hline Lifetime Quantity of Solvent Stored (gal) & 64,023 \\
\hline Estimated Total Volume of Waste Remaining (gal) & 275 \\
\hline Estimated Liquid Currently Stored in Tank (gal) & 275 \\
\hline Estimated Sludge Currently Stored in Tank (gal) & 0 \\
\hline
\end{tabular}

\section{LEL TANK SURVEY READINGS}

TESTING INTERVALS

\begin{tabular}{|c|c|c|c|c|c|}
\hline $3^{\prime}-0^{n}$ & $6^{\prime}-0^{\prime \prime}$ & $9^{\prime}-0^{\prime \prime}$ & $12^{\prime}-0^{n}$ & $15^{\prime}-0^{n}$ & $18^{\prime}-0^{n}$ \\
\hline & & & & & \\
\hline $2 \%$ & $2 \%$ & $2 \%$ & $2 \%$ & N/A & N/A \\
\hline
\end{tabular}

Tank Features:

None

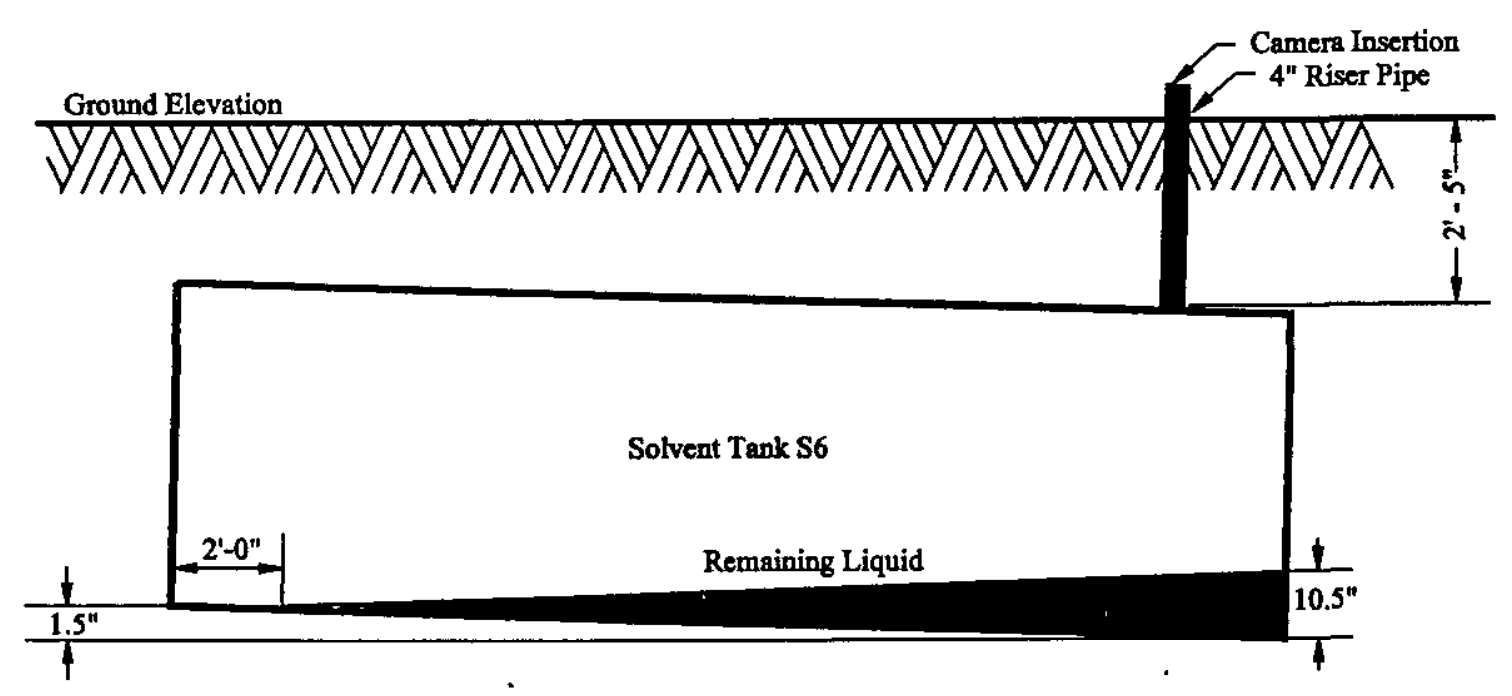

ELEVATION VIEW LOOKING NORTH 
Appendix A

\section{Tank S6}

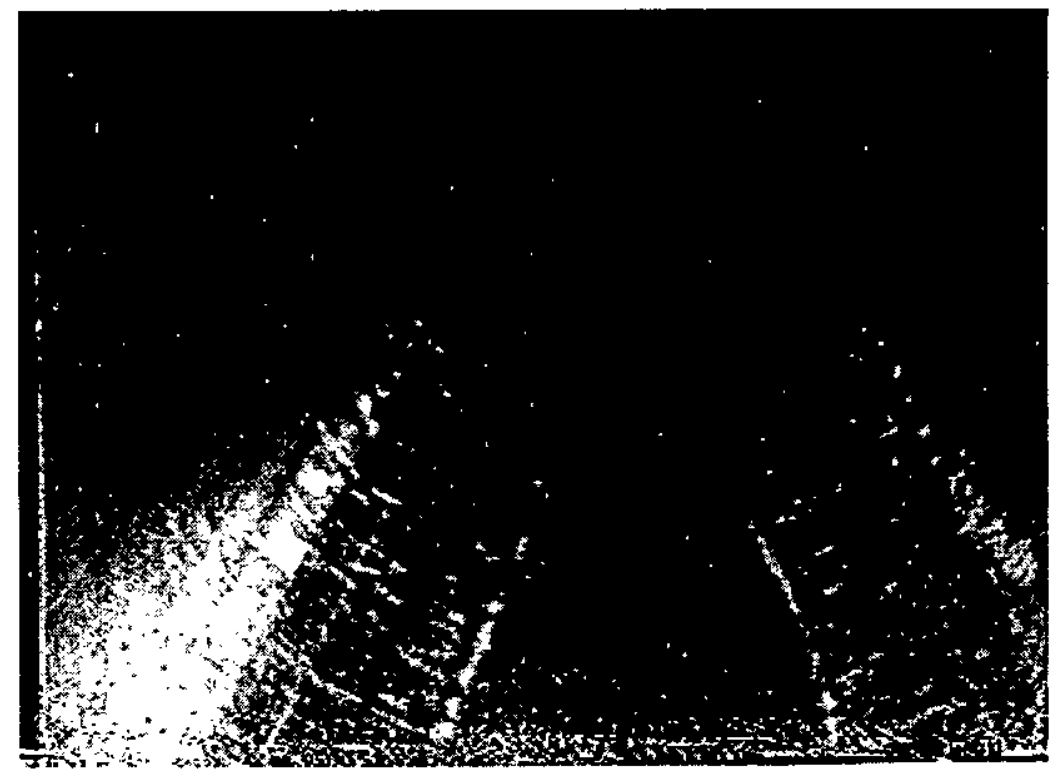

View of liquid waste at west end of tank

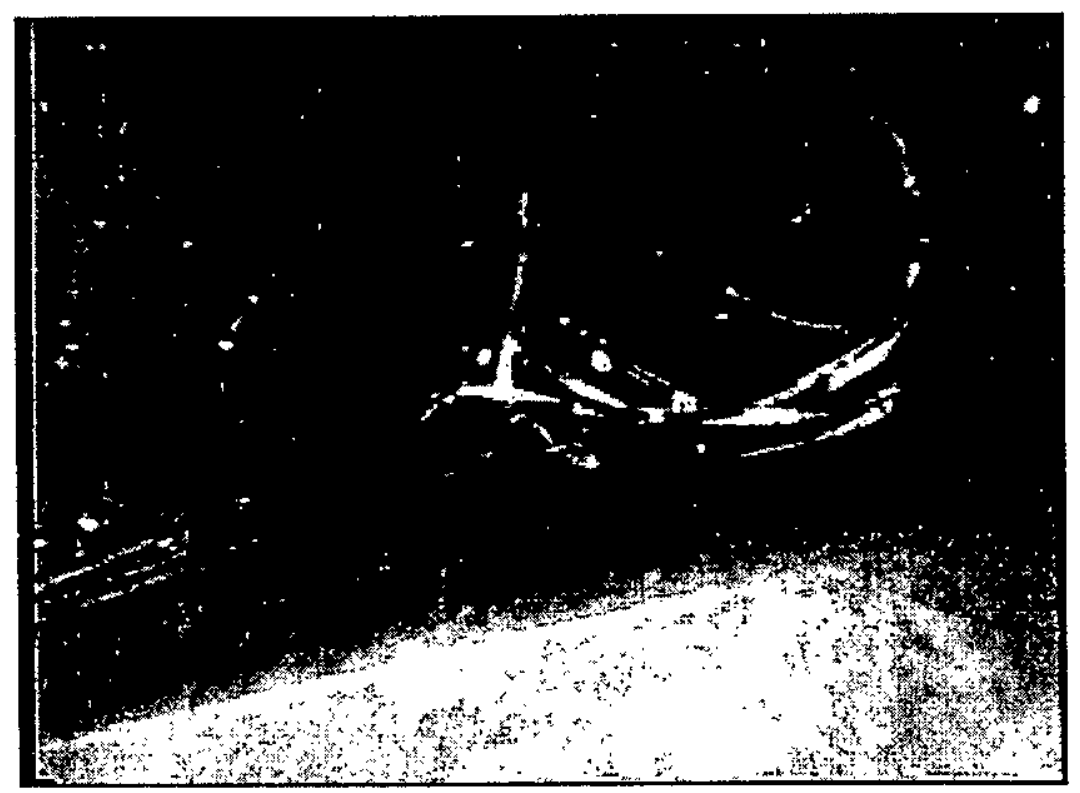

View of liquid waste and air sample hose at east end of tank 


\section{TANK S7}

\begin{tabular}{|l|c|}
\hline Tank Installation Date & $4 / 56$ \\
\hline Tank Size (ft) & $8.5 \times 18.0$ \\
\hline Tank Capacity (gal) & 7,641 \\
\hline Lifetime Quantity of Solvent Stored (gal) & 23,944 \\
\hline Estimated Total Volume of Waste Remaining (gal) & 319 \\
\hline Estimated Liquid Currently Stored in Tank (gal) & 317 \\
\hline Estimated Sludge Currently Stored in Tank (gal) & 2 \\
\hline
\end{tabular}

\section{LEL TANK SURVEY READINGS}

\section{TESTING INTERVALS}

\begin{tabular}{|c|c|c|c|c|c|}
\hline $3^{\prime}-0^{\prime \prime}$ & $6^{\prime}-0^{\prime \prime}$ & $9^{\prime}-0^{\prime \prime}$ & $12^{\prime}-0^{n}$ & $15^{\prime}-0^{\prime \prime}$ & $18^{\prime}-0^{\prime \prime}$ \\
\hline & & & & & \\
\hline $0 \%$ & $2 \%$ & $2 \%$ & $2 \%$ & N/A & N/A \\
\hline
\end{tabular}

Tank Features:

This tank contains one 2" diameter pipe at the far end of the tank. This pipe stands vertically and spans between the floor and the ceiling of the tank. This pipe appears to be a structural support member.

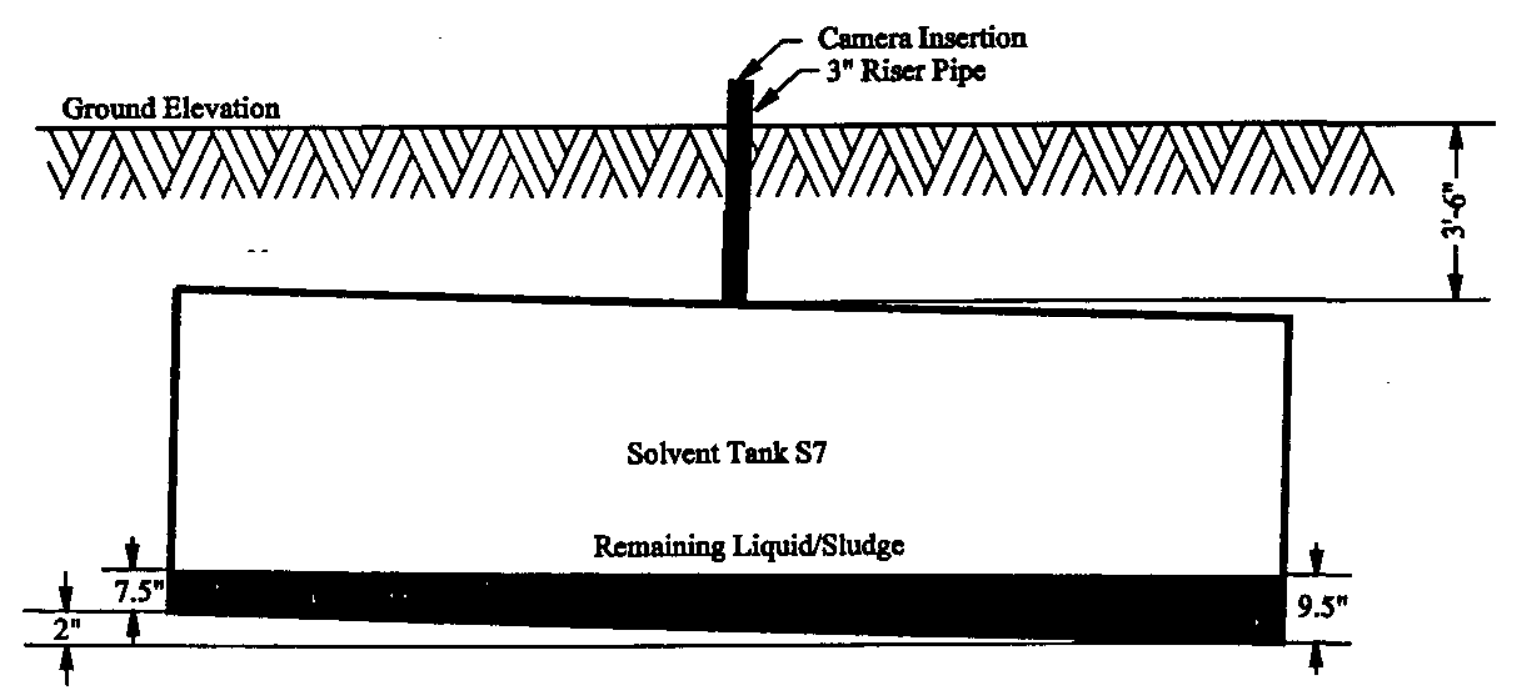

ELEVATION VIEW LOOKING NORTH 
Technical Report on the ORWBG

Appendix A

\section{Tank S7}

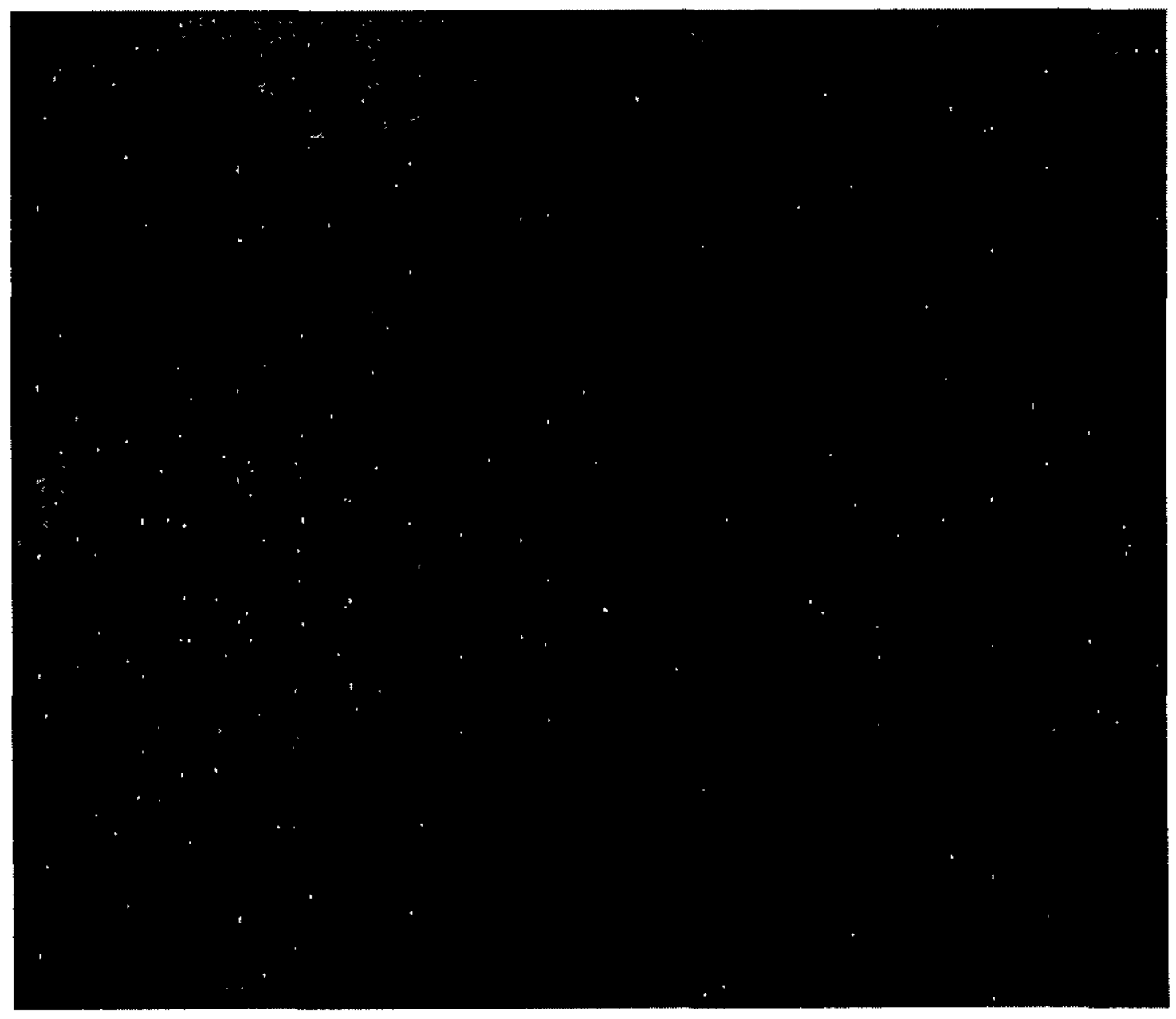

View of liquid waste \& 2 ' $\phi$ pipe at east end of tank 


\section{TANK S8}

\begin{tabular}{|l|c|}
\hline Tank Installation Date & $4 / 56$ \\
\hline Tank Size (ft) & $8.5 \times 18.0$ \\
\hline Tank Capacity (gal) & 7,641 \\
\hline Lifetime Quantity of Solvent Stored (gal) & 14,381 \\
\hline Estimated Total Volume of Waste Remaining (gal) & 143 \\
\hline Estimated Liquid Currently Stored in Tank (gal) & 137 \\
\hline Estimated Sludge Currently Stored in Tank (gal) & 6 \\
\hline
\end{tabular}

\section{LEL TANK SURVEY READINGS}

TESTING INTERVALS

\begin{tabular}{|c|c|c|c|c|c|}
\hline $3^{\prime}-0^{\prime \prime}$ & $6^{\prime}-0^{\prime \prime}$ & $9^{\prime}-0^{n}$ & $12^{\prime}-0^{n}$ & $15^{\prime}-0^{n}$ & $18^{\prime}-0^{n}$ \\
\hline & & & & & \\
\hline $0 \%$ & $0 \%$ & $0 \%$ & $0 \%$ & N/A & N/A \\
\hline
\end{tabular}

Tank Features:

This tank contains one 2" diameter pipe at the far end of the tank. This pipe stands vertically and spans between the floor and the ceiling of the tank. This pipe appears to be a structural support member.

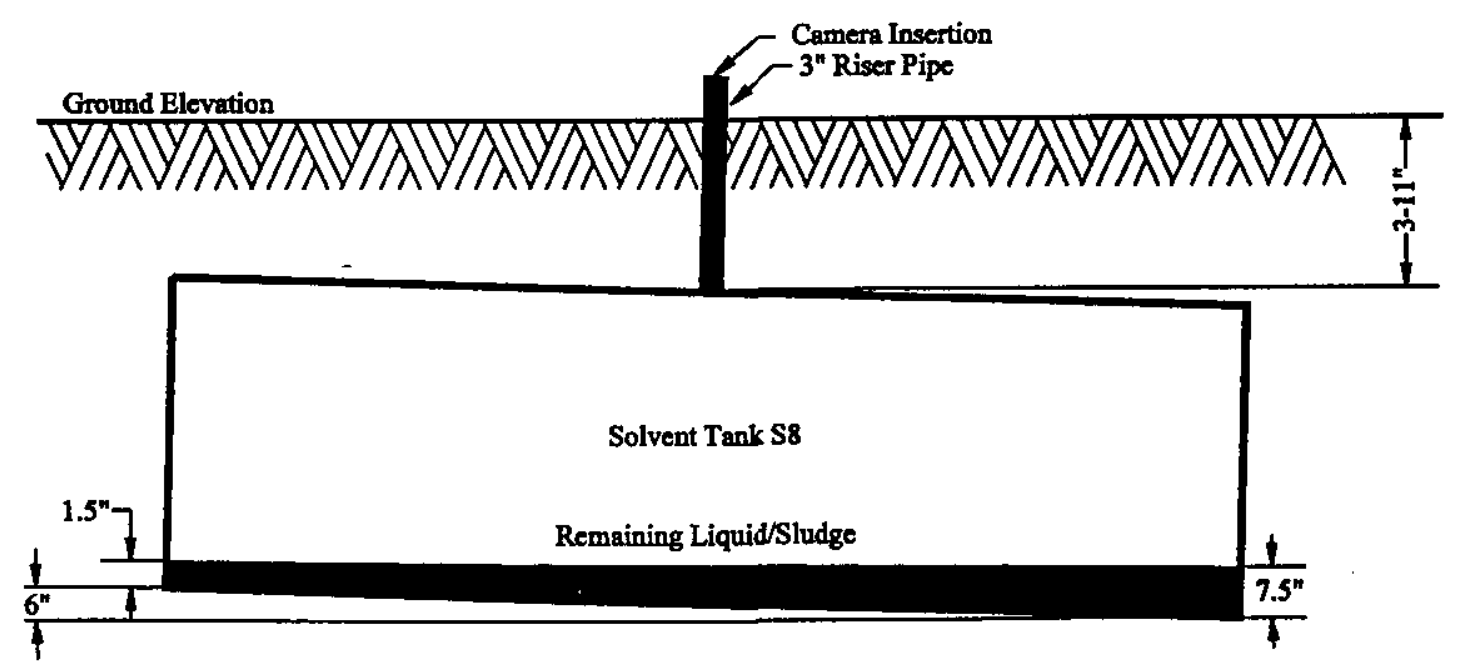

ELEVATION VIEW LOOKING NORTH 


\section{Appendix A}

\section{Tank S8}

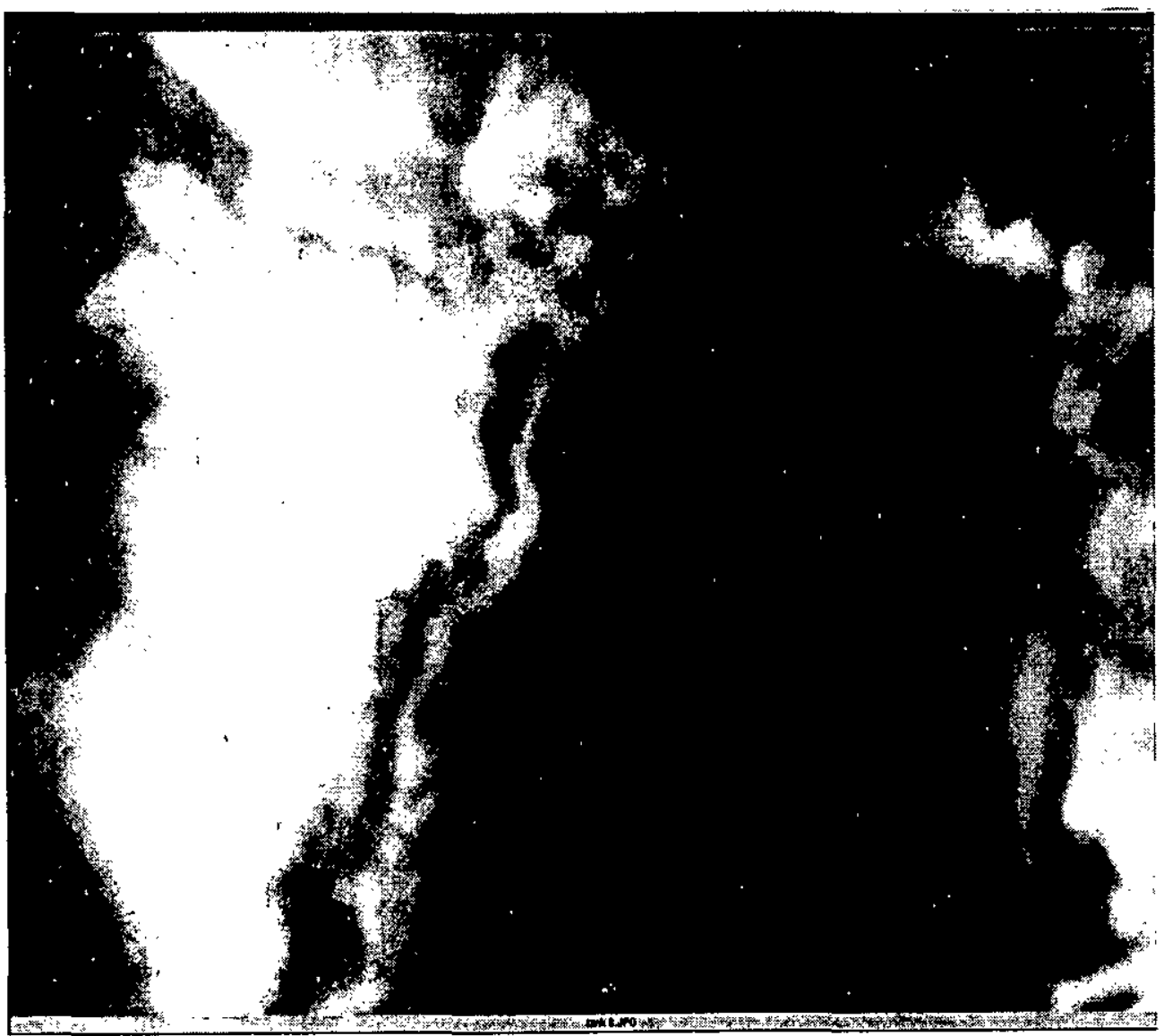

View of liquid and sludge waste at west end of tank 
Appendix A

\section{Tank S9}

\begin{tabular}{|l|c|}
\hline Tank Installation Date & $3 / 59$ \\
\hline Tank Size (ft) & $8.0 \times 20.0$ \\
\hline Tank Capacity (gal) & 7,521 \\
\hline Lifetime Quantity of Solvent Stored (gal) & 21,113 \\
\hline Estimated Total Volume of Waste Remaining (gal) & 13 \\
\hline Estimated Liquid Currently Stored in Tank (gal) & 0 \\
\hline Estimated Sludge Currently Stored in Tank (gal) & 13 \\
\hline
\end{tabular}

\section{LEL TANK SURVEY READINGS}

TESTING INTERVALS

\begin{tabular}{|c|c|c|c|c|c|}
\hline $3^{\prime}-0^{\prime \prime}$ & $6^{\prime}-0^{\prime \prime}$ & $9^{\prime}-0^{\prime \prime}$ & $12^{\prime}-0^{\prime \prime}$ & $15^{\prime}-0^{n}$ & $18^{\prime}-0^{n}$ \\
\hline & & & & & \\
\hline $0 \%$ & $0 \%$ & $0 \%$ & $0 \%$ & $0 \%$ & $0 \%$ \\
\hline
\end{tabular}

Tank Features:

This tank contains two capped man ways in the tank ceiling located at mid tank.

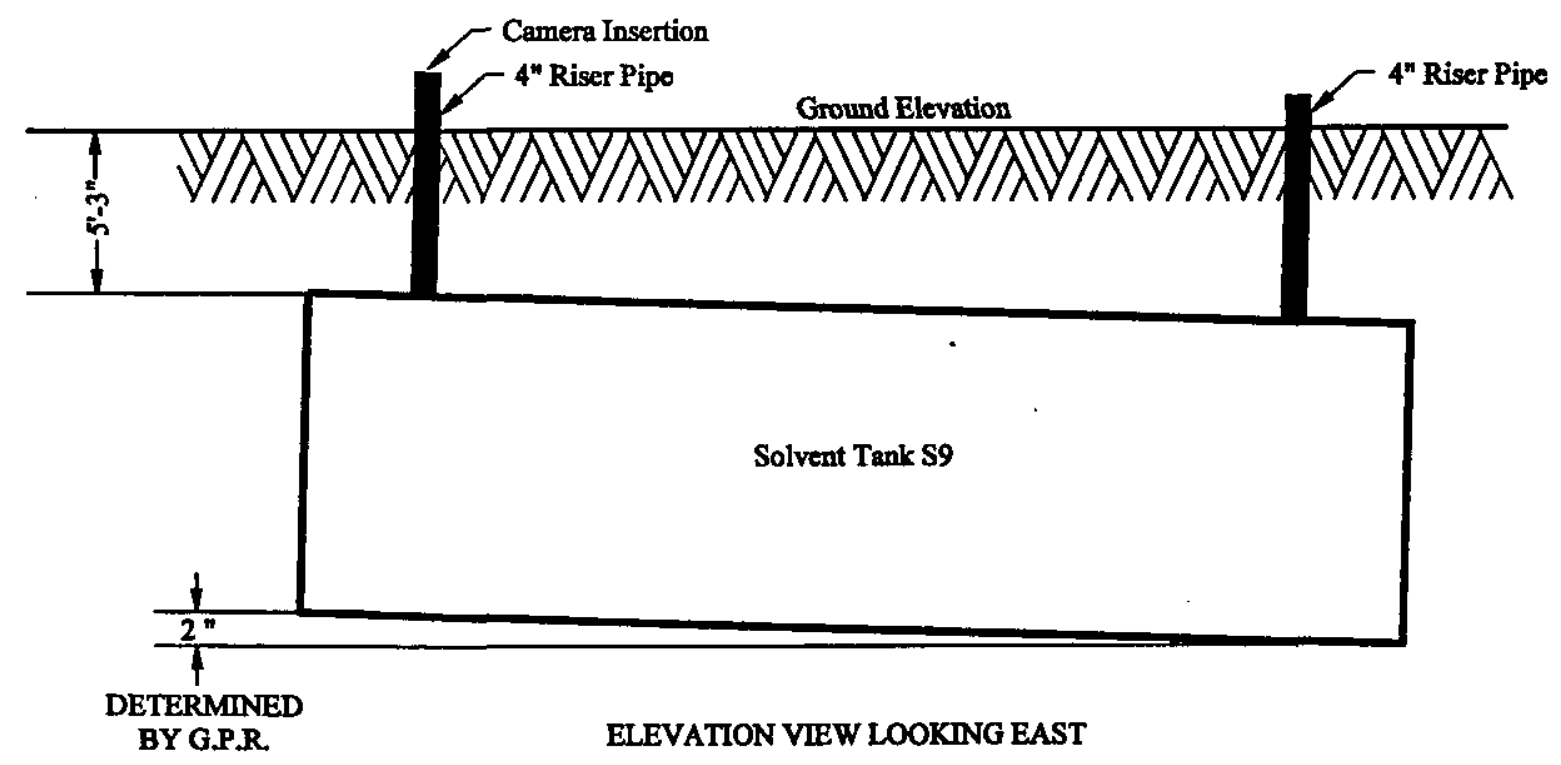


Technical Report on the ORWBG

Appendix A

\section{Tank S9}

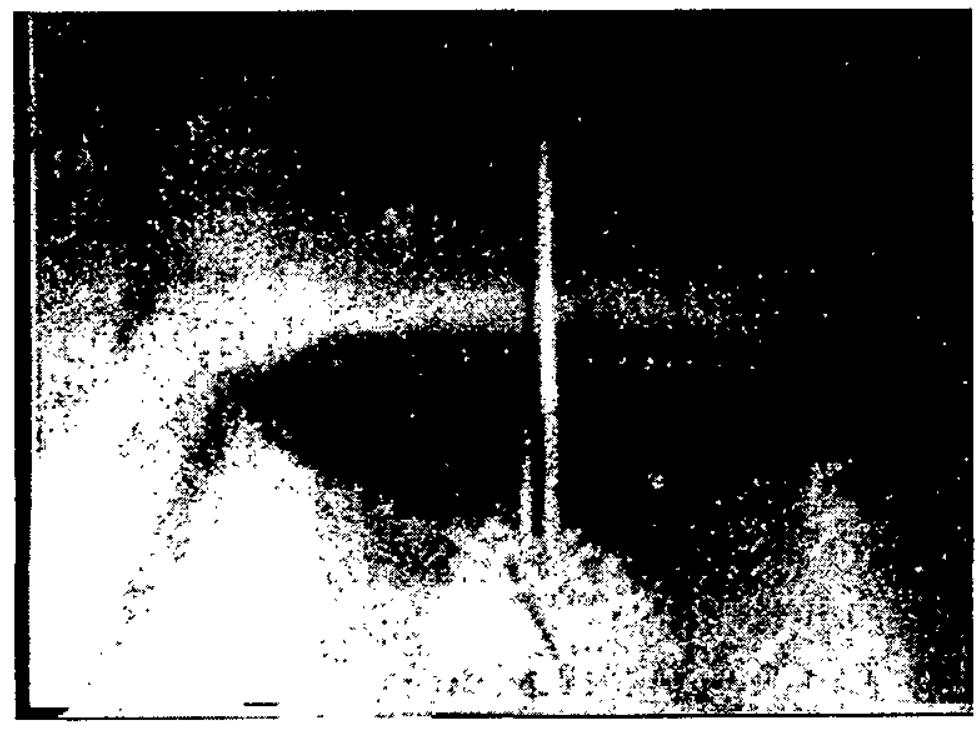

View of dried sludge at south end of tank

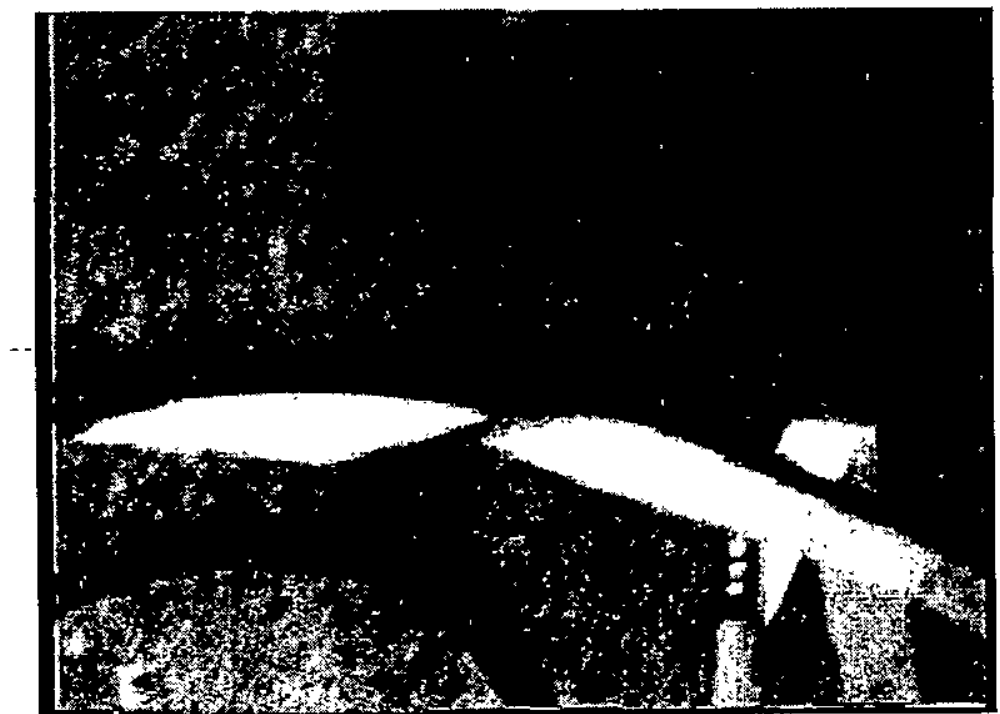

View of dried sludge \& air sample hose at north end of tank 
Appendix A

\section{Tank S10}

\begin{tabular}{|l|c|}
\hline Tank Installation Date & $3 / 59$ \\
\hline Tank Size (ft) & $8.0 \times 20.0$ \\
\hline Tank Capacity (gal) & 7,521 \\
\hline Lifetime Quantity of Solvent Stored (gal) & 17,553 \\
\hline Estimated Total Volume of Waste Remaining (gal) & 41 \\
\hline Estimated Liquid Currently Stored in Tank (gal) & 10 \\
\hline Estimated Sludge Currently Stored in Tank (gal) & 31 \\
\hline
\end{tabular}

\section{LEL TANK SURVEY READINGS}

\section{TESTING INTERVALS}

\begin{tabular}{|c|c|c|c|c|c|}
\hline $3^{\prime}-0^{n}$ & $6^{\prime}-0^{n}$ & $9^{\prime}-0^{n}$ & $12^{\prime}-0^{n}$ & $15^{\prime}-0^{n}$ & $18^{\prime}-0^{n}$ \\
\hline & & & & & \\
\hline $0 \%$ & $0 \%$ & $0 \%$ & $0 \%$ & $0 \%$ & $0 \%$ \\
\hline
\end{tabular}

Tank Features:

This tank contains one, 1 " diameter by approximately 10' long pipe laying on the tank floor. This pipe is lying loose and is not attached to the tank. There are also two capped man ways in the tank ceiling located at mid tank.

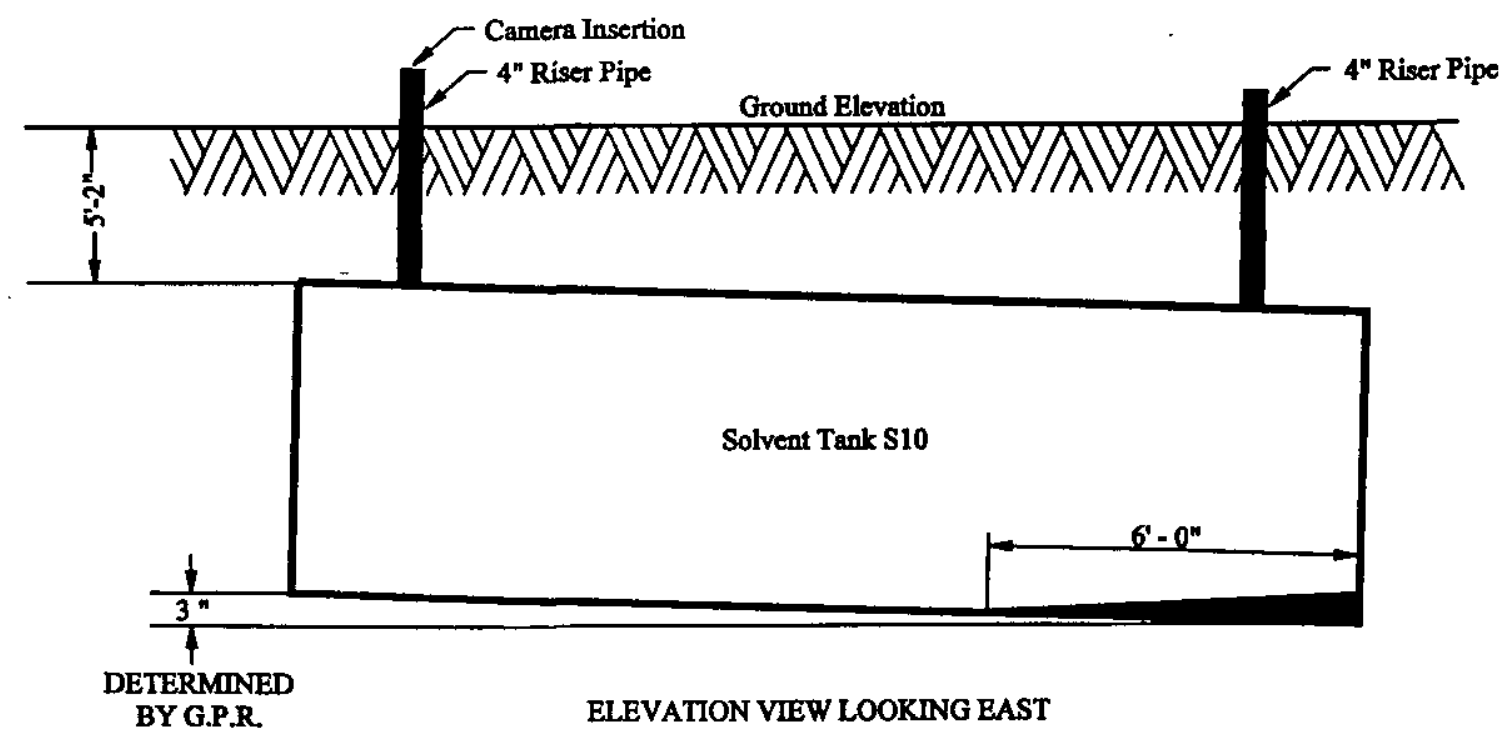


Technical Report on the ORWBG

Solvent Tanks

WSRC-RP-98-04225

Video Survey Summary

Revision No. 0

Page 29 of 50

Appendix A

\section{Tank S10}

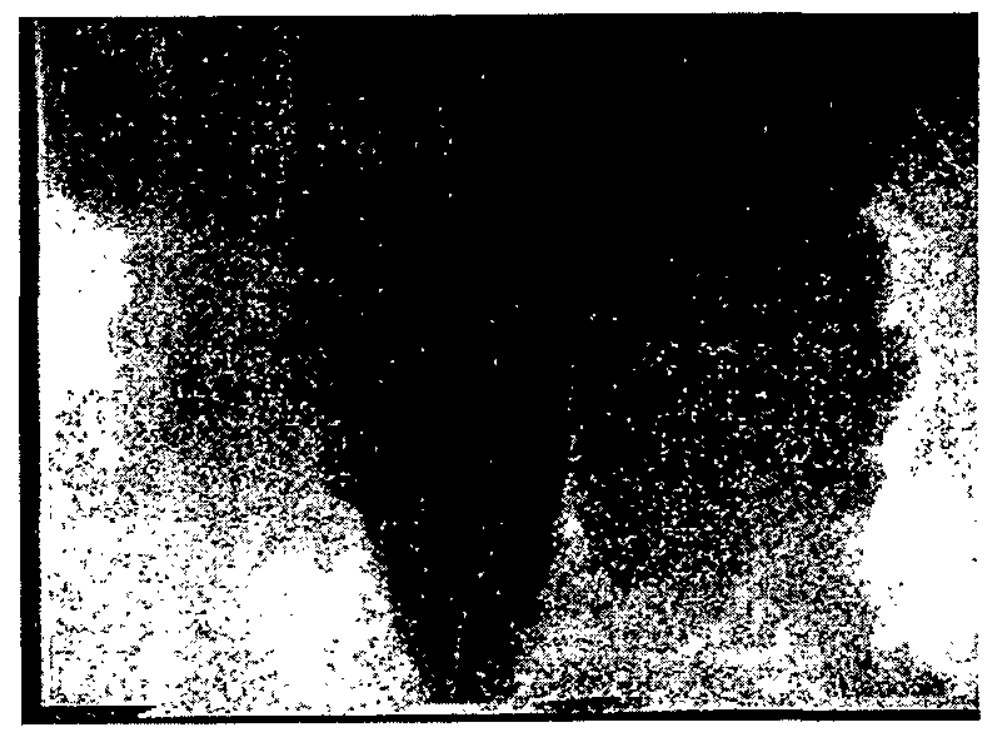

View of liquid waste at south end of tank 


\section{TANK S11}

\begin{tabular}{|l|c|}
\hline Tank Installation Date & $3 / 59$ \\
\hline Tank Size (ft) & $8.0 \times 20.0$ \\
\hline Tank Capacity (gal) & 7,521 \\
\hline Lifetime Quantity of Solvent Stored (gal) & 20,806 \\
\hline Estimated Total Volume of Waste Remaining (gal) & 27 \\
\hline Estimated Liquid Currently Stored in Tank (gal) & 14 \\
\hline Estimated Sludge Currently Stored in Tank (gal) & 13 \\
\hline
\end{tabular}

\section{LEL TANK SURVEY READINGS}

TESTING INTERVALS

\begin{tabular}{|c|c|c|c|c|c|}
\hline $3^{\prime}-0^{\prime \prime}$ & $6^{\prime}-0^{\prime \prime}$ & $9^{\prime}-0^{\prime \prime}$ & $12^{\prime}-0^{\prime \prime}$ & $15^{\prime}-0^{\prime \prime}$ & $18^{\prime}-0^{\prime \prime}$ \\
\hline & & & & & \\
\hline $0 \%$ & $0 \%$ & $0 \%$ & $0 \%$ & $0 \%$ & N/A \\
\hline
\end{tabular}

Tank Features:

This tank contains two capped man ways in the tank ceiling located at mid tank.

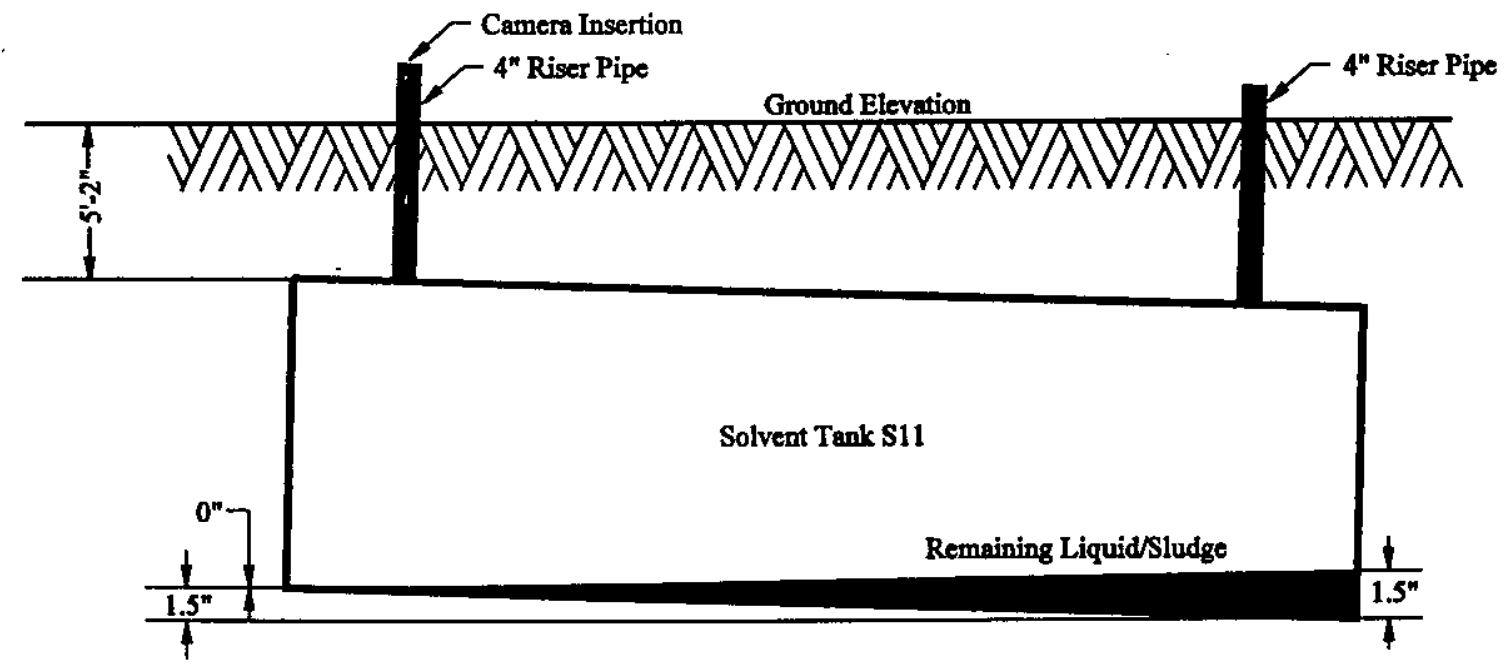


Appendix A

\section{Tank S11}

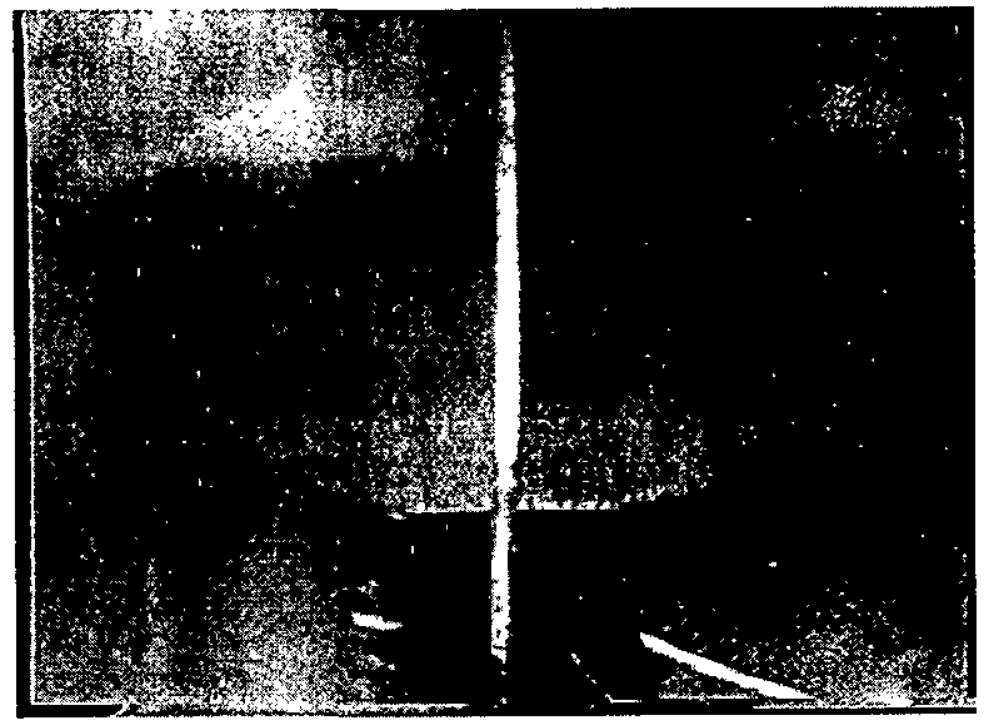

View of liquid waste at south end of tank 


\section{Appendix A}

\section{Tank S12}

\begin{tabular}{|l|c|l|}
\hline Tank Installation Date & $3 / 59$ & \\
\hline Tank Size (ft) & $8.0 \times 20.0$ & \\
\hline Tank Capacity (gal) & 7,521 & \\
\hline Lifetime Quantity of Solvent Stored (gal) & 19,206 & \\
\hline Estimated Total Volume of Waste Remaining (gal) & 10 & Based on conservative assumptions \\
\hline Estimated Liquid Currently Stored in Tank (gal) & 5 & Based on conservative assumptions \\
\hline Estimated Sludge Currently Stored in Tank (gal) & 5 & Based on conservative assumptions \\
\hline
\end{tabular}

\section{LEL TANK SURVEY READINGS}

TESTING INTERVALS

\begin{tabular}{|c|c|c|c|c|c|}
\hline $3^{\prime}-0^{\prime \prime}$ & $6^{\prime}-0^{\prime \prime}$ & $9^{\prime}-0^{\prime \prime}$ & $12^{\prime}-0^{\prime \prime}$ & $15^{\prime}-0^{\prime \prime}$ & $18^{\prime}-0^{\prime \prime}$ \\
\hline & & & & & \\
\hline $8 \%$ & $19 \%$ & $21 \%$ & $\mathrm{X}$ & $\mathrm{X}$ & $\mathrm{X}$ \\
\hline
\end{tabular}

$X=S T O P P E D$, EXCEEDING RADIOLOGICAL LIMITS

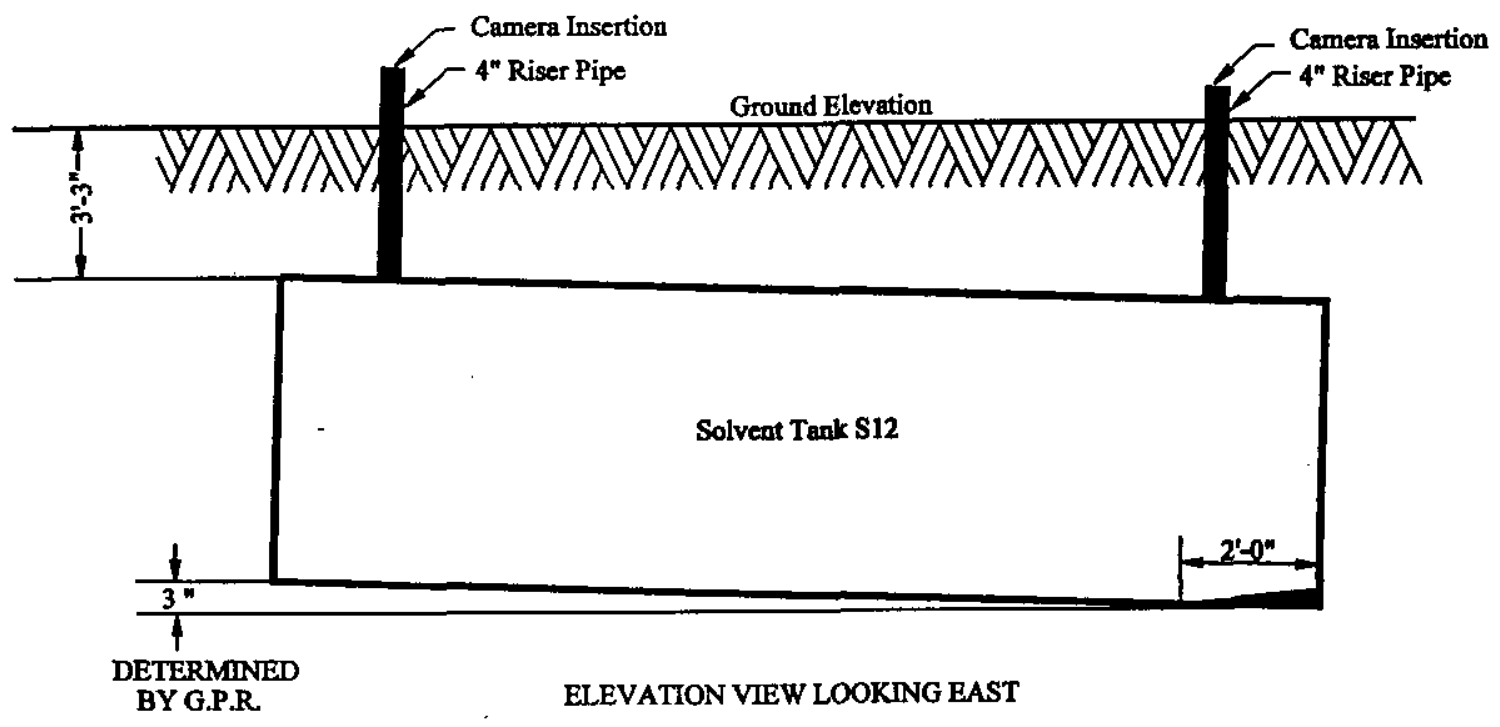


APPENDIX A

\section{TANK S13}

\begin{tabular}{|l|c|}
\hline Tank Installation Date & $8 / 60$ \\
\hline Tank Size (ft) & $10.0 \times 23.0$ \\
\hline Tank Capacity (gal) & 13,514 \\
\hline Lifetime Quantity of Solvent Stored (gal) & 21,389 \\
\hline Estimated Total Volume of Waste Remaining (gal) & 261 \\
\hline Estimated Liquid Currently Stored in Tank (gal) & 218 \\
\hline Estimated Sludge Currently Stored in Tank (gal) & 43 \\
\hline
\end{tabular}

\section{LEL TANK SURVEY READINGS}

\section{TESTING INTERVALS}

\begin{tabular}{|c|c|c|c|c|c|}
\hline $3^{\prime}-0^{n}$ & $6^{\prime}-0^{\prime \prime}$ & $9^{\prime}-0^{\prime \prime}$ & $12^{\prime}-0^{\prime \prime}$ & $15^{\prime}-0^{\prime \prime}$ & $1^{\prime}-0^{\prime \prime}$ \\
\hline & & & & & \\
\hline $8 \%$ & $8 \%$ & $8 \%$ & $8 \%$ & $4 \%$ & N/A \\
\hline
\end{tabular}

Tank Features:

This tank contains one capped man way in the tank ceiling located at mid tank.

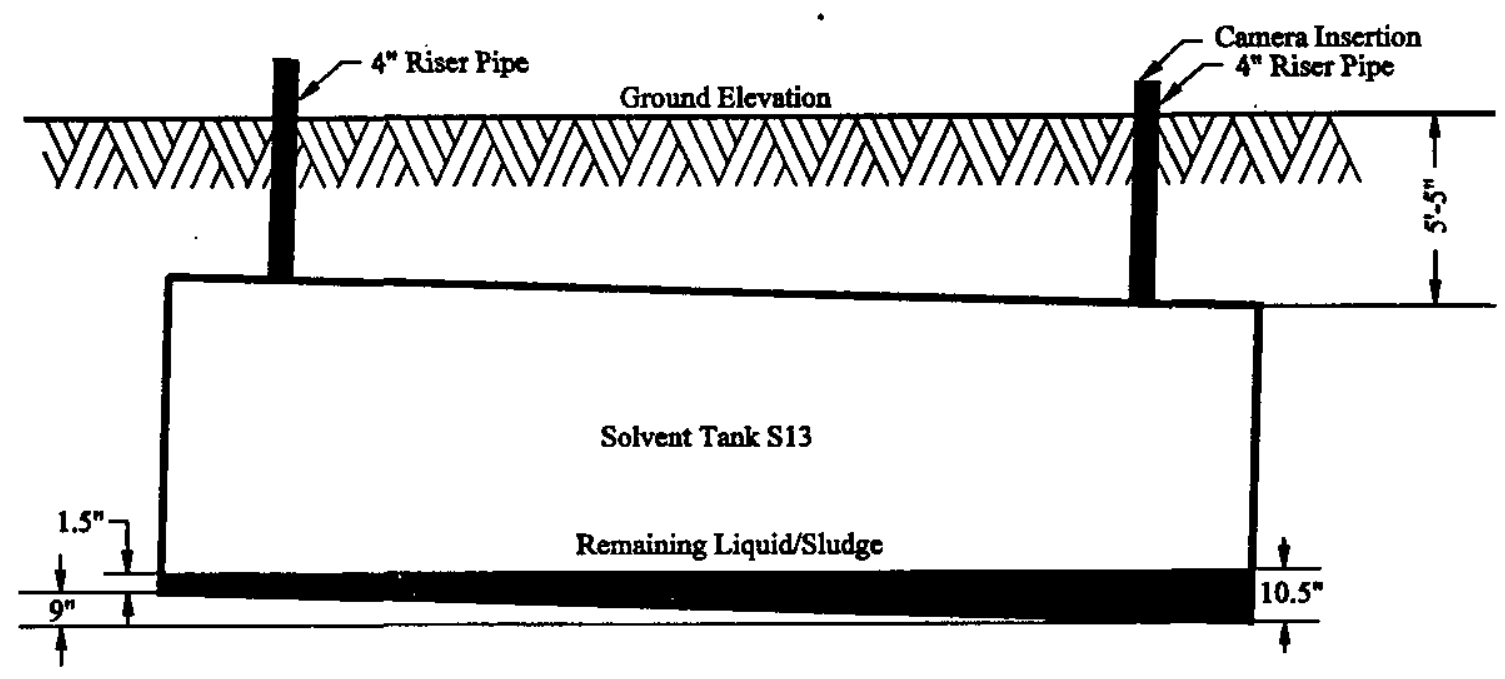

ELEVATION VIEW LOOKING EAST 
Appendix A

\section{Tank S13}

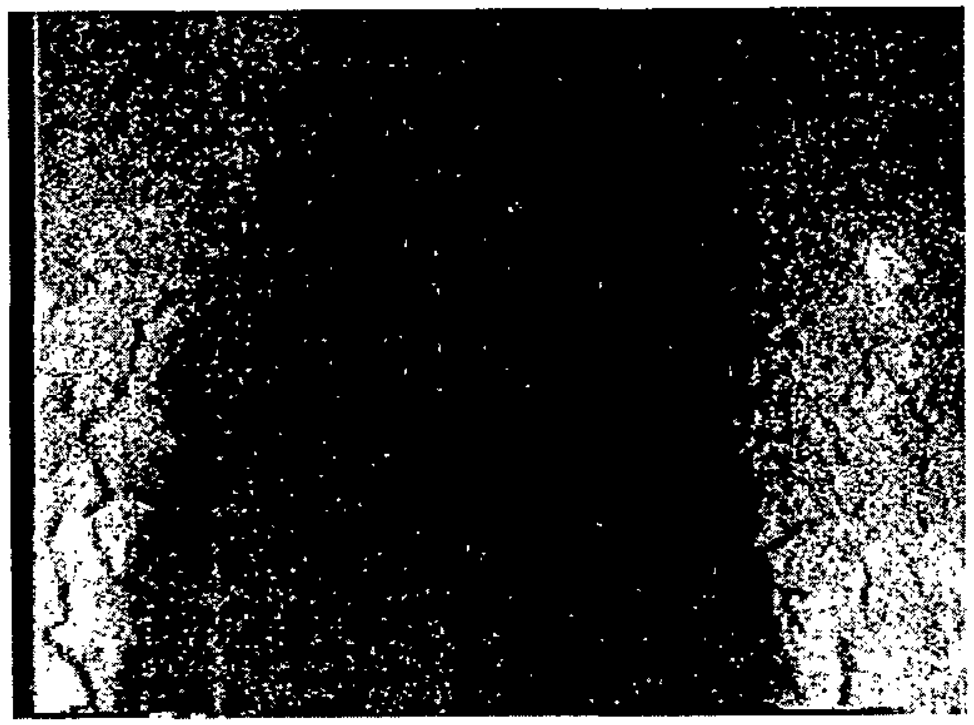

View of liquid and sludge waste at mid tank

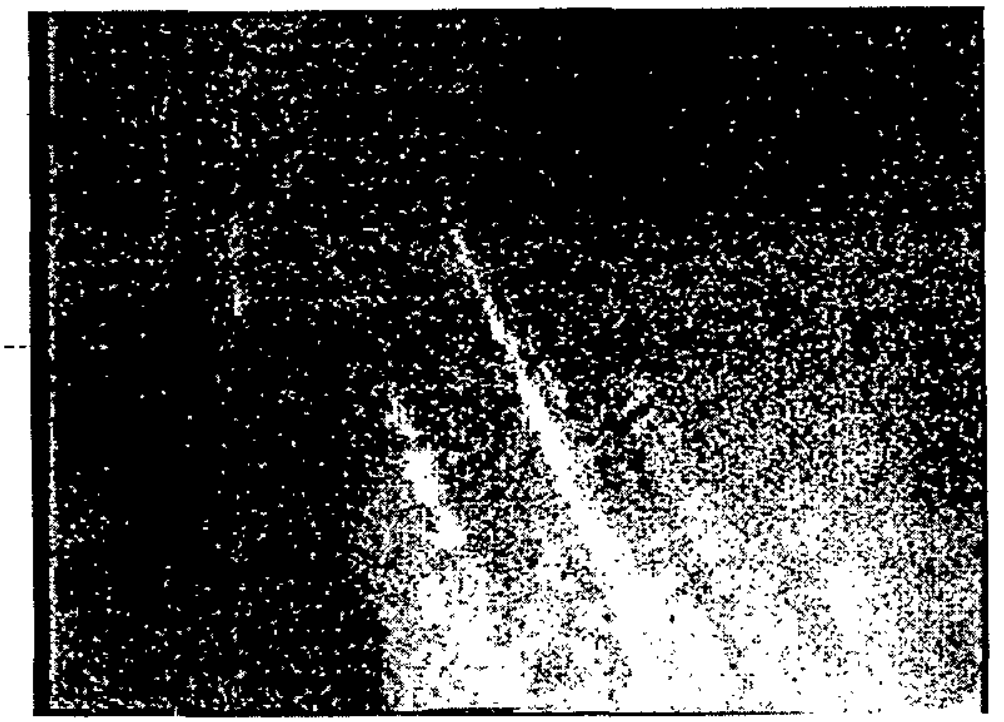

View of liquid and sludge waste at north end of tank 


\section{APPENDIX A}

\section{TANK S14}

\begin{tabular}{|l|c|}
\hline Tank Installation Date & $8 / 60$ \\
\hline Tank Size (ft) & $11.0 \times 38.0$ \\
\hline Tank Capacity (gai) & 27,016 \\
\hline Lifetime Quantity of Solvent Stored (gal) & 76,041 \\
\hline Estimated Total Volume of Waste Remaining (gal) & 485 \\
\hline Estimated Liquid Currently Stored in Tank (gal) & 367 \\
\hline Estimated Sludge Currently Stored in Tank (gal) & 118 \\
\hline
\end{tabular}

\section{LEL TANK SURVEY READINGS}

TESTING INTERVALS

\begin{tabular}{|c|c|c|c|c|c|}
\hline $3^{\prime}-0^{\prime \prime}$ & $6^{\prime}-0^{\prime \prime}$ & $9^{\prime}-0^{\prime \prime}$ & $12^{\prime}-0^{\prime \prime}$ & $15^{\prime}-0^{\prime \prime}$ & $18^{\prime}-0^{\prime \prime}$ \\
\hline & & & & & \\
\hline $0 \%$ & $0 \%$ & $8 \%$ & $8 \%$ & $6 \%$ & $6 \%$ \\
\hline
\end{tabular}

Tank Features:

This tank contains one, approximately 3 " diameter pipe projecting diagonally through the side of the tank. This pipe projects approximately 4" into the tank. The tank also contains four 2 " diameter by approximately 15 ' long pipes laying on the tank floor. These pipes are lying loose and not attached to the tank.

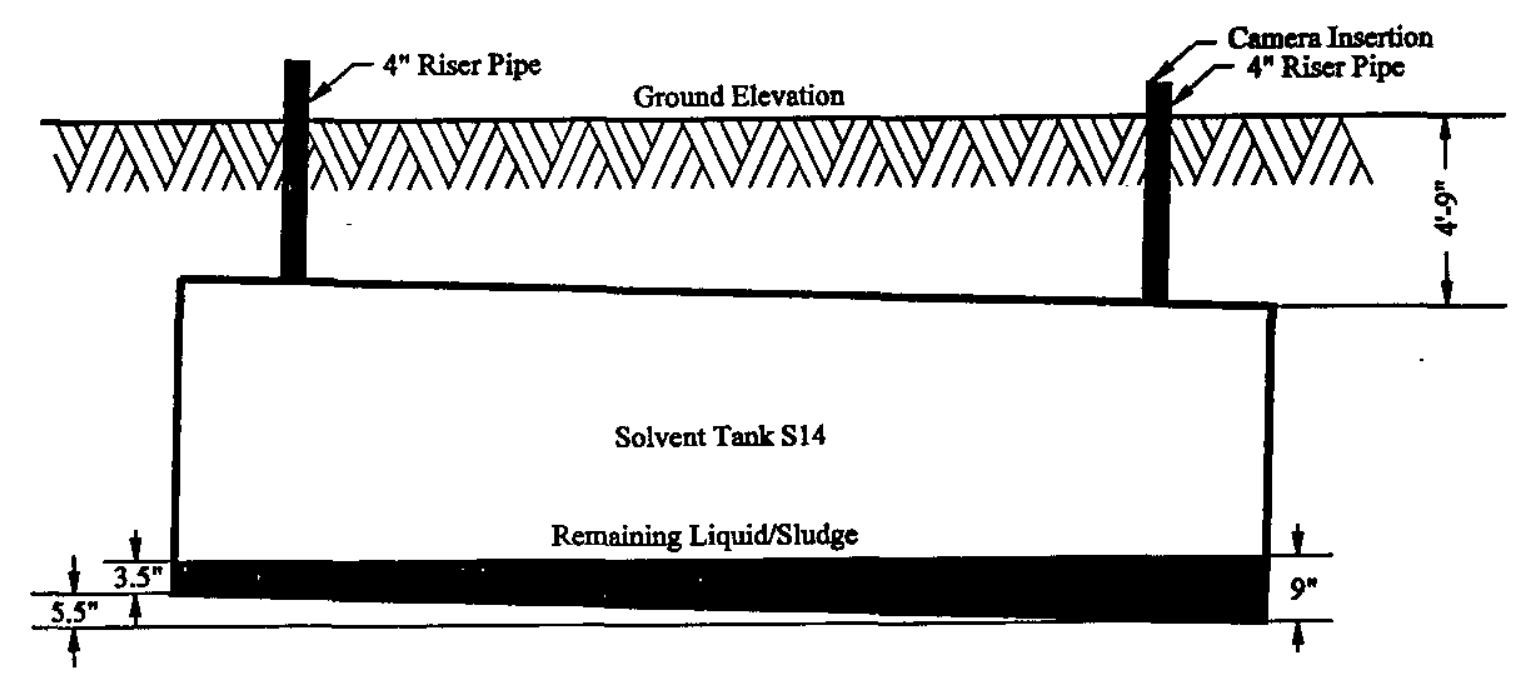

ELEVATION VIEW LOOKING EAST 
Appendix A

\section{Tank S14}

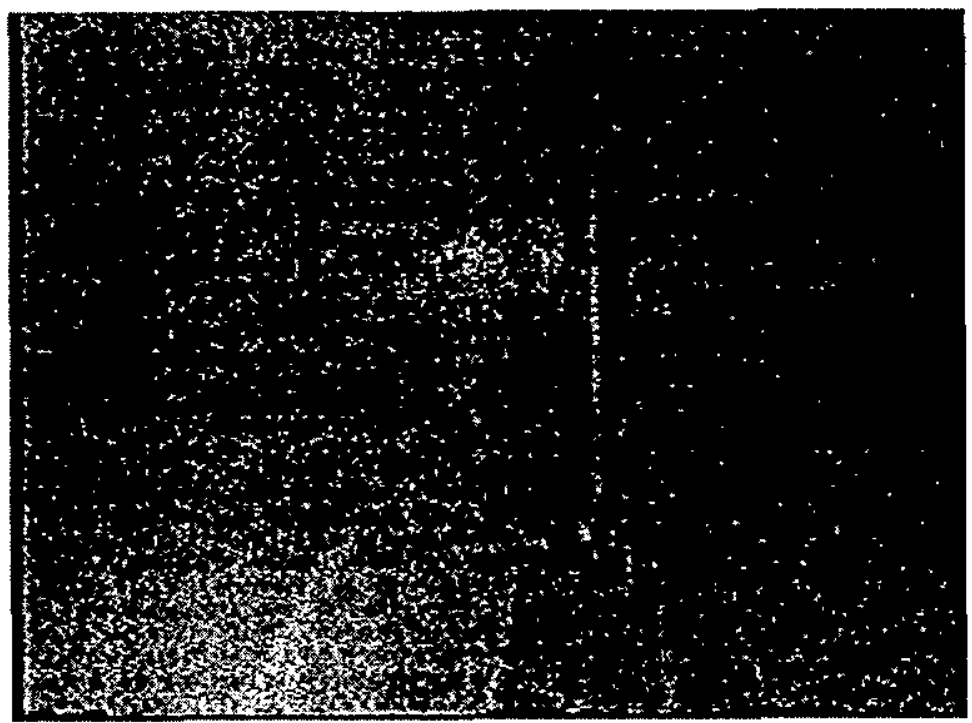

View of liquid waste and four 2" $\phi$ pipes at north end of tank

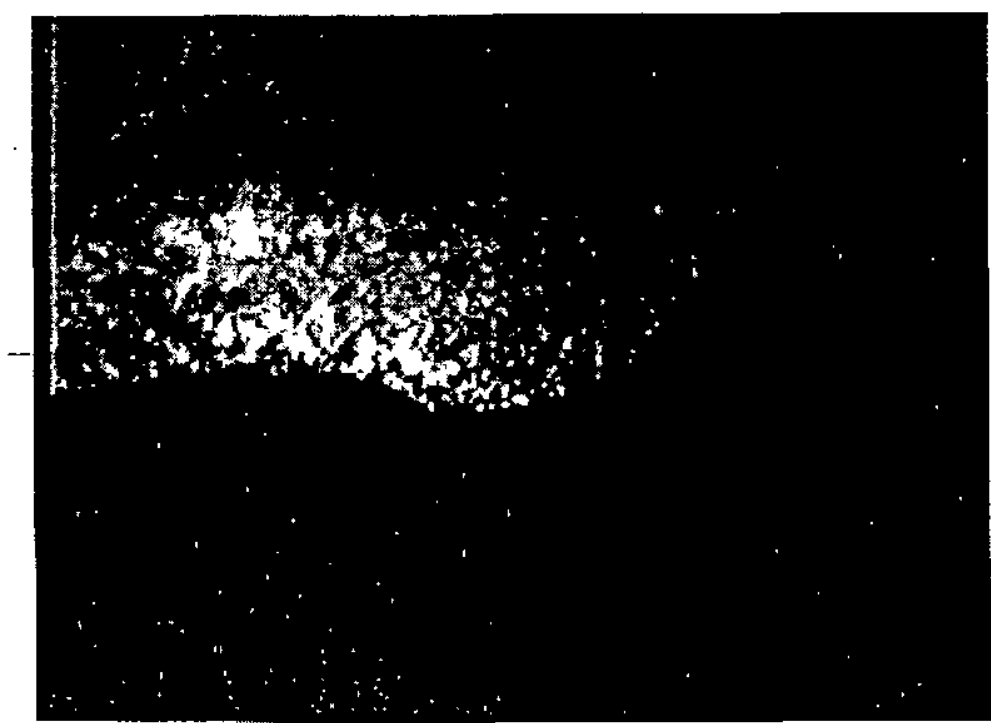

View of liquid and crystalline waste at south end of tank 


\section{TANK S15}

\begin{tabular}{|l|c|}
\hline Tank Installation Date & $1 / 61$ \\
\hline Tank Size (ft) & $7.5 \times 32.0$ \\
\hline Tank Capacity (gal) & 10,576 \\
\hline Lifetime Quantity of Solvent Stored (gal) & 22,431 \\
\hline Estimated Total Volume of Waste Remaining (gal) & 145 \\
\hline Estimated Liquid Currently Stored in Tank (gal) & 0 \\
\hline Estimated Sludge Currently Stored in Tank (gal) & 145 \\
\hline
\end{tabular}

\section{LEL TANK SURVEY READINGS}

\section{TESTING INTERVALS}

\begin{tabular}{|c|c|c|c|c|c|}
\hline $3^{\prime}-0^{\prime \prime}$ & $6^{\prime}-0^{\prime \prime}$ & $9^{\prime}-0^{\prime \prime}$ & $12^{\prime}-0^{\prime \prime}$ & $15^{\prime}-0^{\prime \prime}$ & $1^{\prime}-0^{\prime \prime}$ \\
\hline & & & & & \\
\hline $4 \%$ & $8 \%$ & $8 \%$ & $8 \%$ & $9 \%$ & $9 \%$ \\
\hline
\end{tabular}

Tank Features:

There are several, 2 " diameter pipes attached to the floor of the tank with steel braces. These four pipes travel the length of the tanks. It is unknown if these pipes penetrate through the walls of the tank. The tank also has a large man way with a vertical ladder that spans from the ceiling to the tank floor.

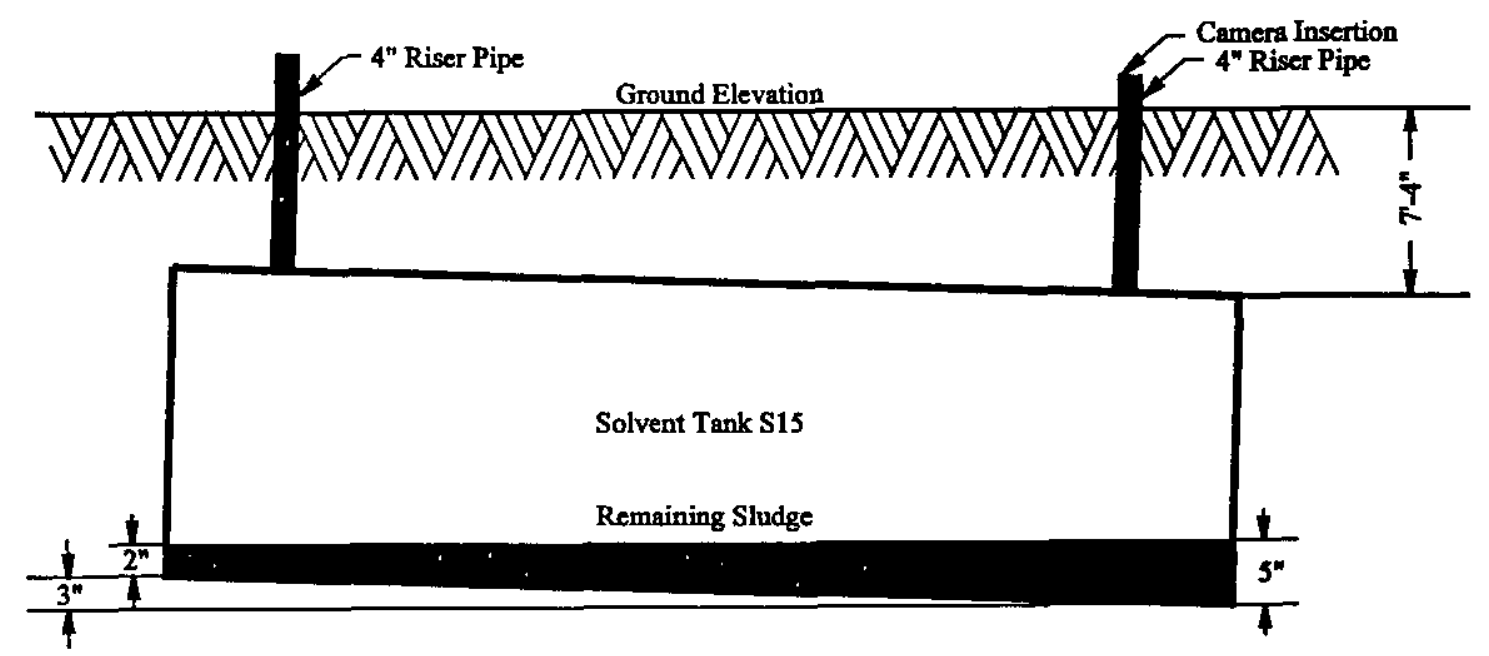

ELEVATION VIEW LOOKING NORTH 
Appendix A

\section{Tank S15}

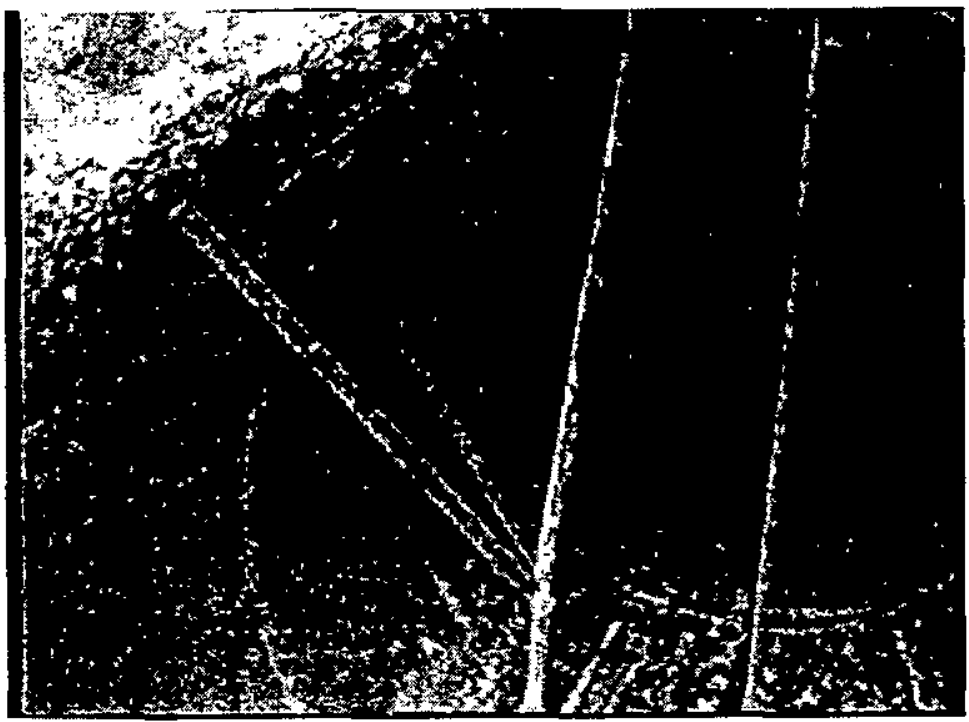

View of sludge waste, ladder and ladder supports at west end of tank

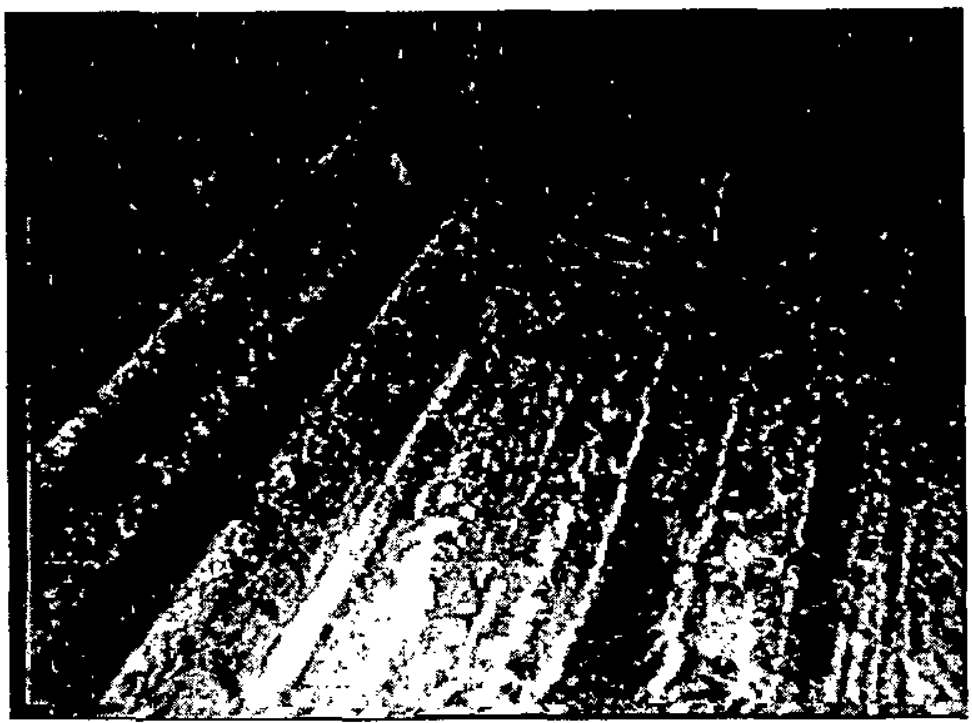

View of sludge waste, internal piping $\&$ piping supports on tank floor at mid tank 


\section{APPENDIX A}

\section{TANK S16}

\begin{tabular}{|l|c|}
\hline Tank Installation Date & $1 / 61$ \\
\hline Tank Size (ft) & $7.5 \times 32.0$ \\
\hline Tank Capacity (gal) & 10,576 \\
\hline Lifetime Quantity of Solvent Stored (gal) & 19,615 \\
\hline Estimated Total Volume of Waste Remaining (gal) & 273 \\
\hline Estimated Liquid Currently Stored in Tank (gal) & 0 \\
\hline Estimated Sludge Currently Stored in Tank (gal) & 273 \\
\hline
\end{tabular}

\section{LEL TANK SURVEY READINGS}

TESTING INTERVALS

\begin{tabular}{|c|c|c|c|c|c|}
\hline $3^{\prime}-0^{n}$ & $6^{\prime}-0^{n}$ & $9^{\prime}-0^{\prime \prime}$ & $12^{\prime}-0^{n}$ & $15^{\prime}-0^{\prime \prime}$ & $18^{\prime}-0^{n}$ \\
\hline $0 \%$ & & & & & \\
\hline $0 \%$ & $0 \%$ & $3 \%$ & $3 \%$ & $3 \%$ & N/A \\
\hline
\end{tabular}

Tank Features:

There are several, 2" diameter pipes attached to the floor of the tank with steel braces. These pipes travel the length of the tanks. It is unknown if these pipes penetrate through the walls of the tank. The tank also has a large man way with a vertical ladder that spans from the ceiling to the tank floor.

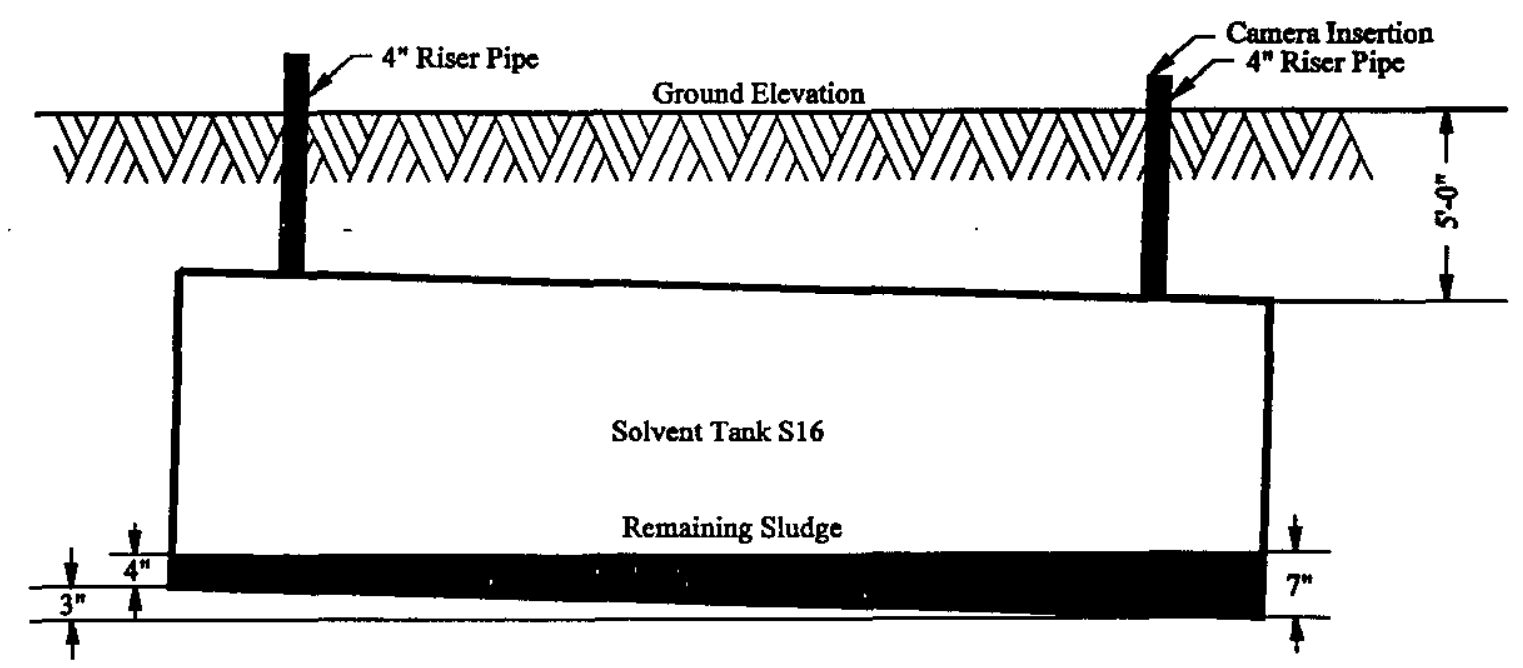

ELEVATION VIEW LOOKING NORTH 
Appendix A

\section{Tank S16}

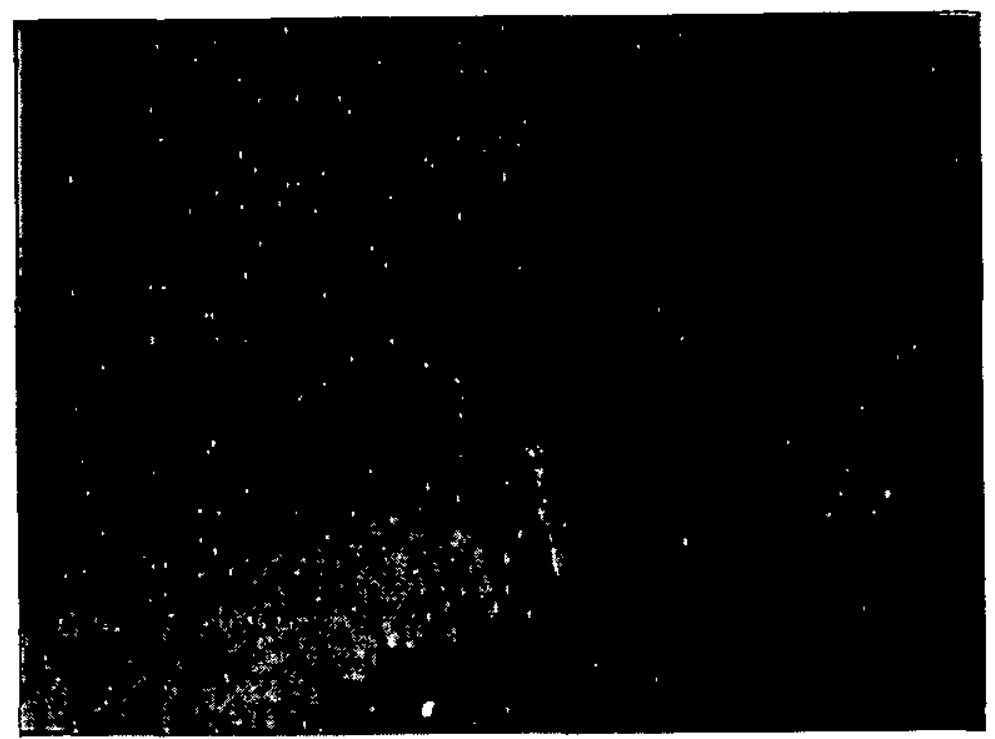

View of sludge waste, internal piping \& pipe supports on tank floor at east end of tank

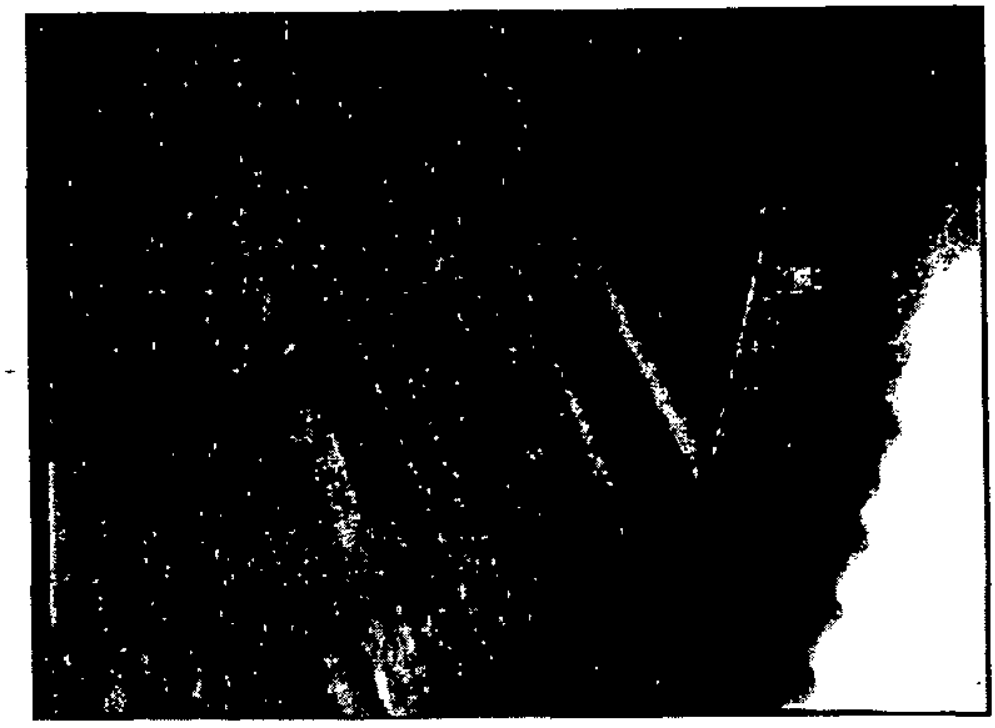

View of sludge waste and ladder at west end of tank 
APPENDIX A TANK S17

\begin{tabular}{|l|c|}
\hline Tank Installation Date & $7 / 62$ \\
\hline Tank Size (ft) & $8.0 \times 18.0$ \\
\hline Tank Capacity (gal) & 6,769 \\
\hline Lifetime Quantity of Solvent Stored (gal) & 5,700 \\
\hline Estimated Total Volume of Waste Remaining (gal) & 7 \\
\hline Estimated Liquid Currently Stored in Tank (gal) & 0 \\
\hline Estimated Sludge Currently Stored in Tank (gal) & 7 \\
\hline
\end{tabular}

\section{LEL TANK SURVEY READINGS}

\section{TESTING INTERVALS}

\begin{tabular}{|c|c|c|c|c|c|}
\hline $3^{\prime}-0^{\prime \prime}$ & $6^{\prime}-0^{\prime \prime}$ & $9^{\prime}-0^{\prime \prime}$ & $12^{\prime}-0^{\prime \prime}$ & $15^{\prime}-0^{\prime \prime}$ & $18^{\prime}-0^{\prime \prime}$ \\
\hline $0 \%$ & & & & & \\
\hline $0 \%$ & $0 \%$ & $0 \%$ & $0 \%$ & N/A & N/A \\
\hline
\end{tabular}

Tank Features:

This tank contains one capped man way and one capped penetration in the tank ceiling located at mid tank.

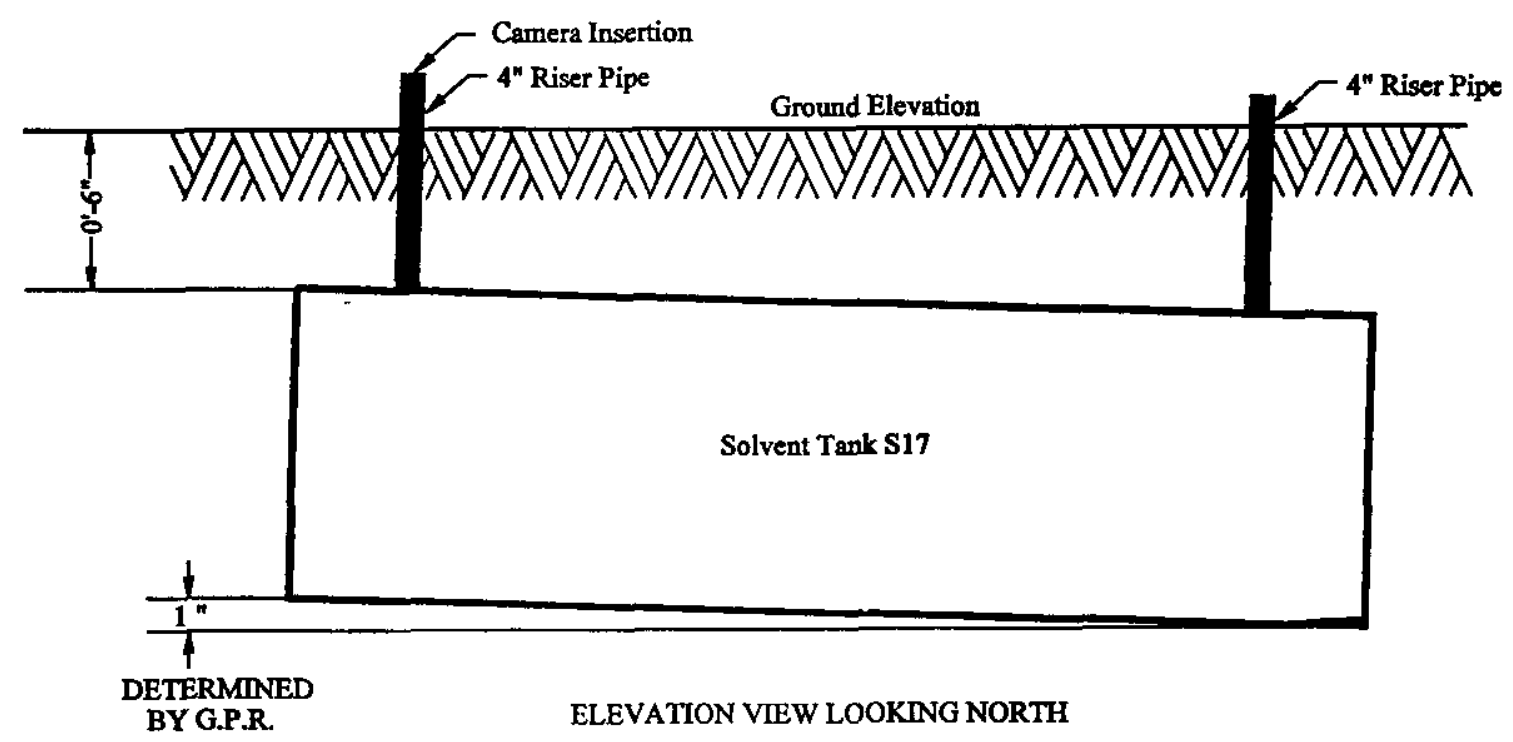


Technical Report on the ORWBG

Solvent Tanks

Video Survey Summary

Appendix A

\section{Tank S17}

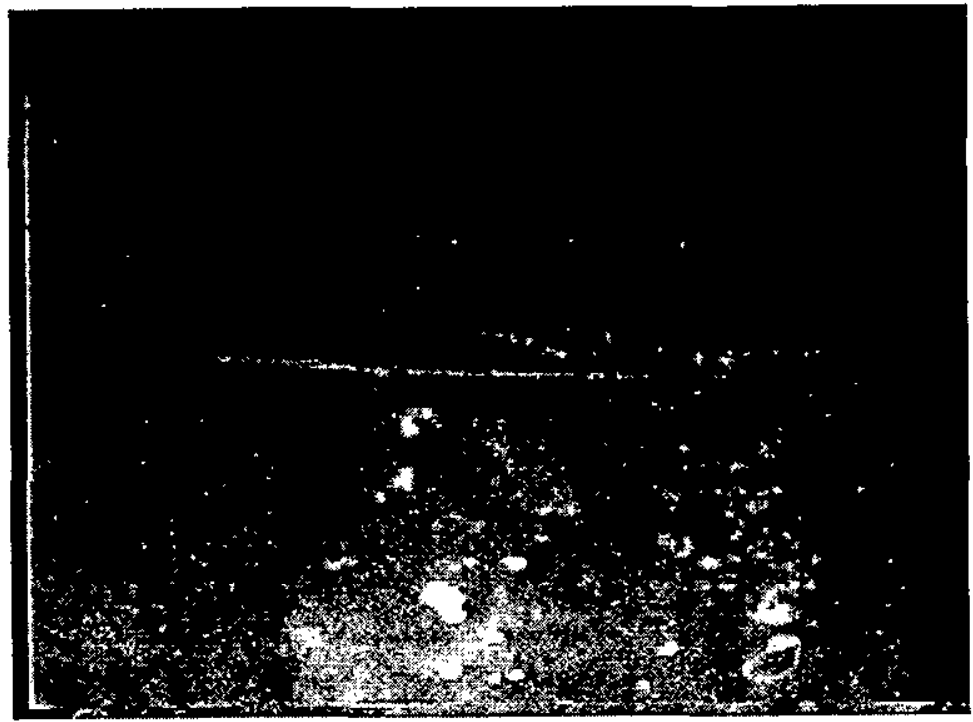

View of sludge material at east end of tank

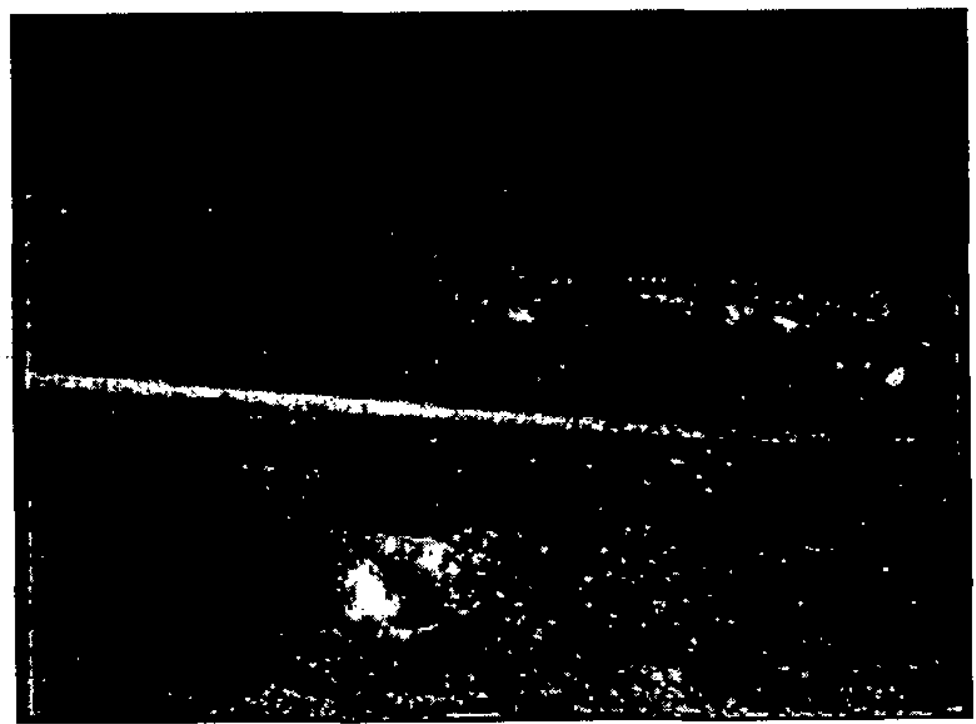

View of tank floor with measure rod \& chain at west end of tank
C-RP-98-04225

Revision $\mathrm{No}$

Page 42 of 50 
APPENDIX A

TANK S18

\begin{tabular}{|l|c|}
\hline Tank Installation Date & $7 / 62$ \\
\hline Tank Size (ft) & $8.0 \times 18.0$ \\
\hline Tank Capacity (gal) & 6,769 \\
\hline Lifetime Quantity of Solvent Stored (gal) & 6,760 \\
\hline Estimated Total Volume of Waste Remaining (gal) & 7 \\
\hline Estimated Liquid Currently Stored in Tank (gal) & 5 \\
\hline Estimated Sludge Currently Stored in Tank (gal) & 2 \\
\hline
\end{tabular}

\section{LEL TANK SURVEY READINGS}

\section{TESTING INTERVALS}

\begin{tabular}{|c|c|c|c|c|c|}
\hline $3^{\prime}-0^{\prime \prime}$ & $6^{\prime}-0^{\prime \prime}$ & $9^{\prime}-0^{\prime \prime}$ & $12^{\prime}-0^{\prime \prime}$ & $15^{\prime}-0^{\prime \prime}$ & $18^{\prime}-0^{\prime \prime}$ \\
\hline $0 \%$ & & & & & \\
\hline $0 \%$ & $0 \%$ & $0 \%$ & $0 \%$ & N/A & N/A \\
\hline
\end{tabular}

Tank Features:

This tank contains one capped man way in the tank ceiling located at mid tank.

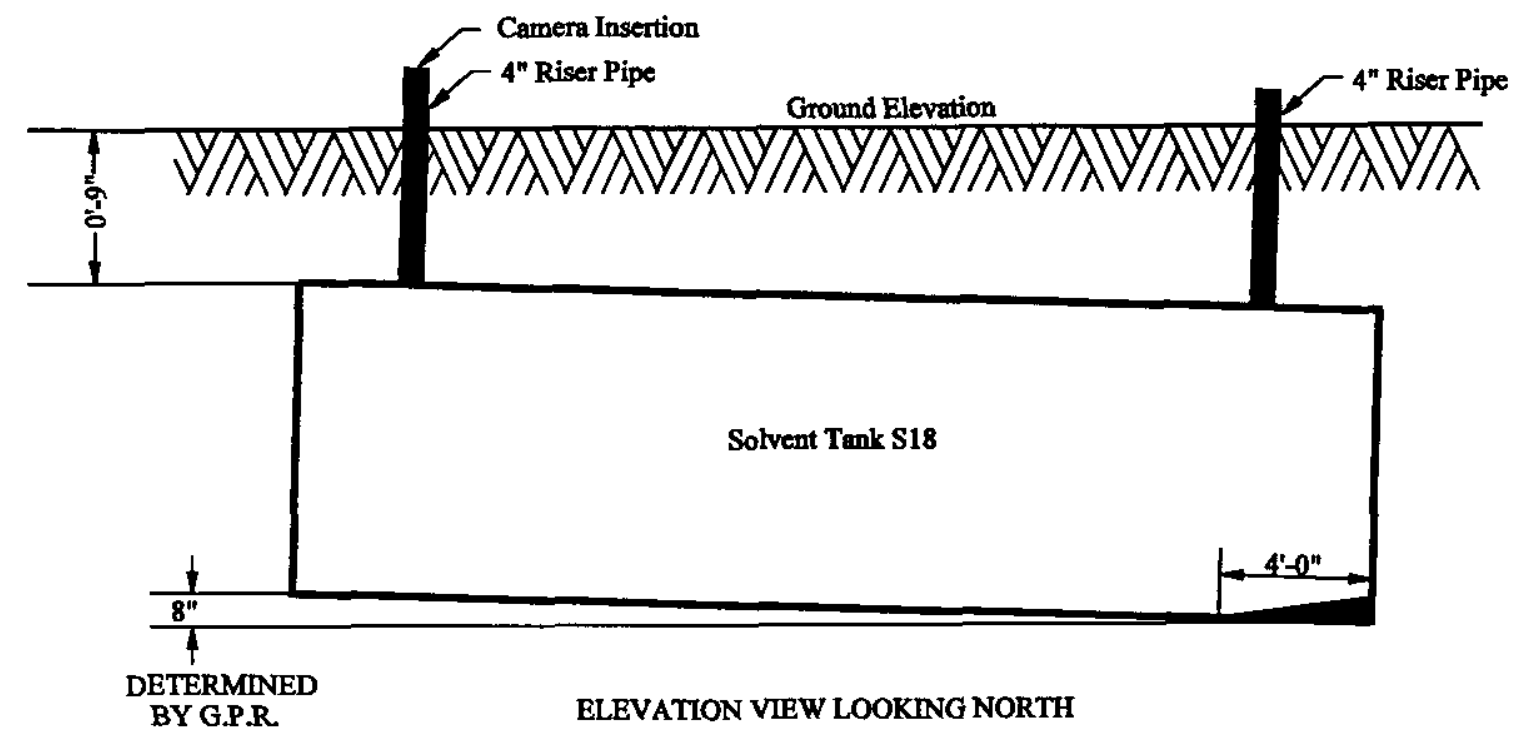


Appendix A

\section{Tank S18}

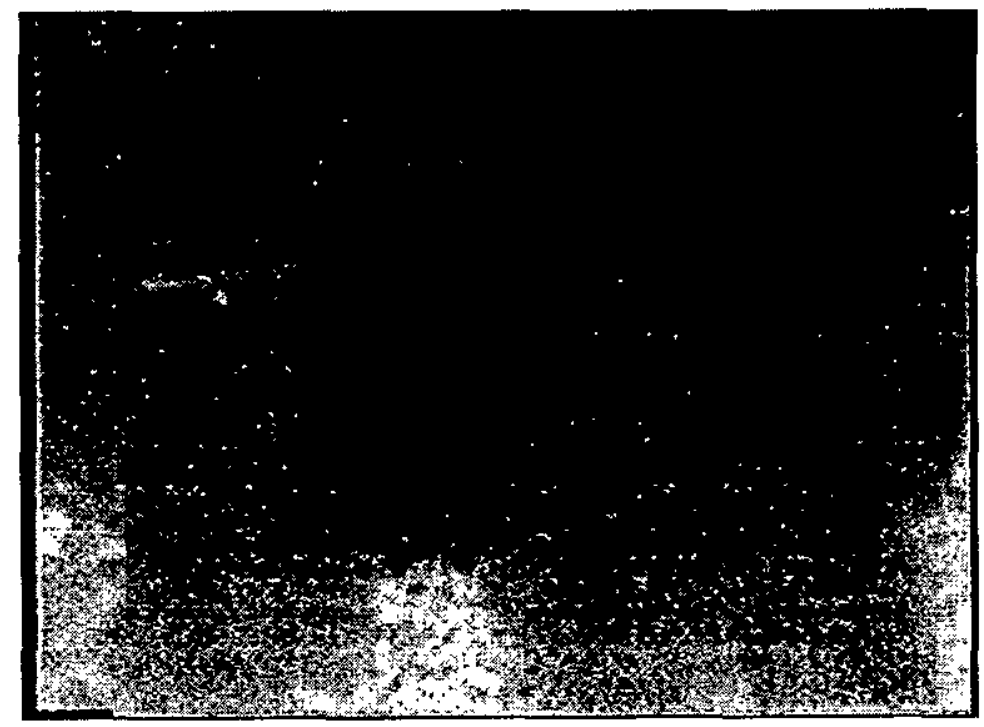

View of liquid waste and measure rod at east end of tank

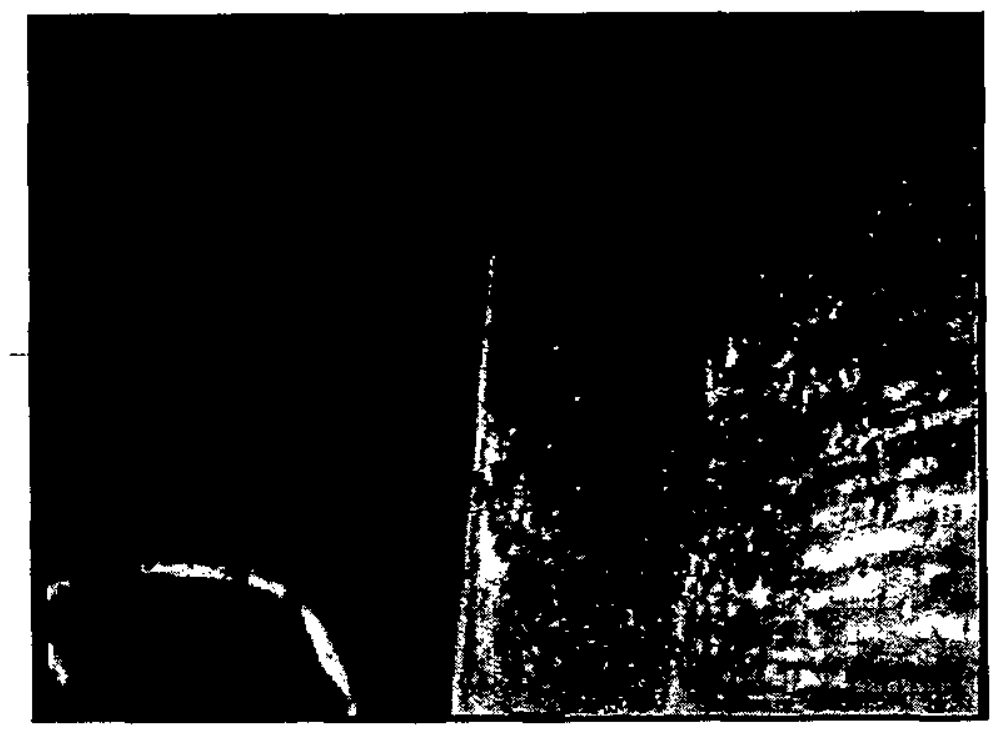

View of tank floor and support brace at west end of tank 


\section{Appendix A}

\section{TANK S19}

\begin{tabular}{|l|c|}
\hline Tank Installation Date & $11 / 69$ \\
\hline Tank Size (ft) & $10.5 \times 38.5$ \\
\hline Tank Capacity (gal) & 24,940 \\
\hline Lifetime Quantity of Solvent Stored (gal) & 37,357 \\
\hline Estimated Total Volume of Waste Remaining (gal) & 600 \\
\hline Estimated Liquid Currently Stored in Tank (gal) & 573 \\
\hline Estimated Sludge Currently Stored in Tank (gal) & 27 \\
\hline
\end{tabular}

\section{LEL TANK SURVEY READINGS}

TESTING INTERVALS

\begin{tabular}{|c|c|c|c|c|c|}
\hline $3^{\prime}-0^{\prime \prime}$ & $6^{\prime}-0^{\prime \prime}$ & $9^{\prime}-0^{\prime \prime}$ & $12^{\prime}-0^{\prime \prime}$ & $15^{\prime}-0^{\prime \prime}$ & $18^{\prime}-0^{\prime \prime}$ \\
\hline & & & & & \\
\hline $4 \%$ & $12 \%$ & $20 \%$ & $20 \%$ & $20 \%$ & $20 \%$ \\
\hline
\end{tabular}

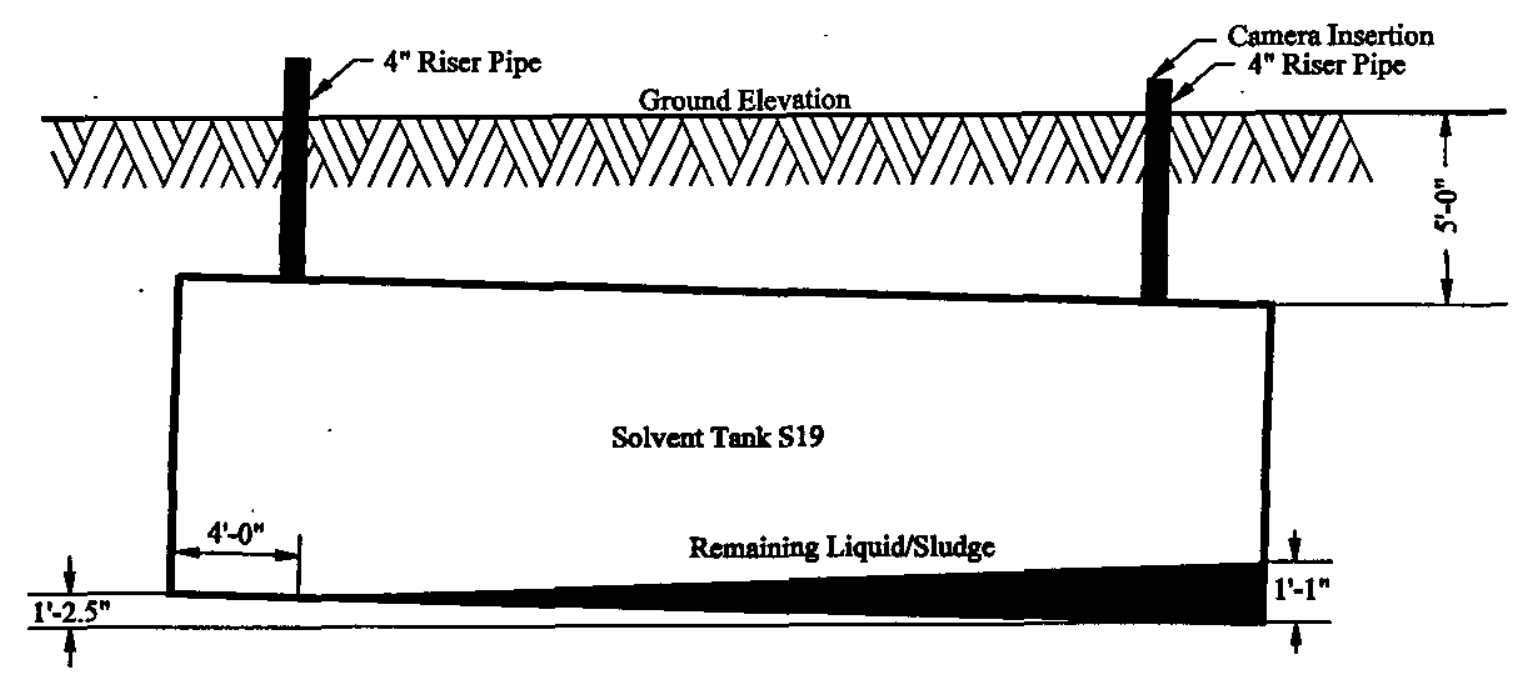

ELEVATION VIEW LOOKING NORTH 


\section{APPENDIX A}

\section{TANK S20}

\begin{tabular}{|l|c|}
\hline Tank Installation Date & $11 / 69$ \\
\hline Tank Size (ft) & 10.5 X 38.5 \\
\hline Tank Capacity (gal) & 24,940 \\
\hline Lifetime Quantity of Solvent Stored (gal) & 12,743 \\
\hline Estimated Total Volume of Waste Remaining (gal) & 2004 \\
\hline Estimated Liquid Currently Stored in Tank (gal) & 1995 \\
\hline Estimated Sludge Currently Stored in Tank (gal) & 9 \\
\hline
\end{tabular}

\section{LEL TANK SURVEY READINGS}

TESTING INTERVALS

\begin{tabular}{|c|c|c|c|c|c|}
\hline $3^{\prime}-0^{n}$ & $6^{\prime}-0^{\prime \prime}$ & $9^{\prime}-0^{\prime \prime}$ & $12^{\prime}-0^{\prime \prime}$ & $15^{\prime}-0^{\prime \prime}$ & $18^{\prime}-0^{\prime \prime}$ \\
\hline & & & & & \\
\hline $12 \%$ & $18 \%$ & $20 \%$ & $20 \%$ & $20 \%$ & N/A \\
\hline
\end{tabular}

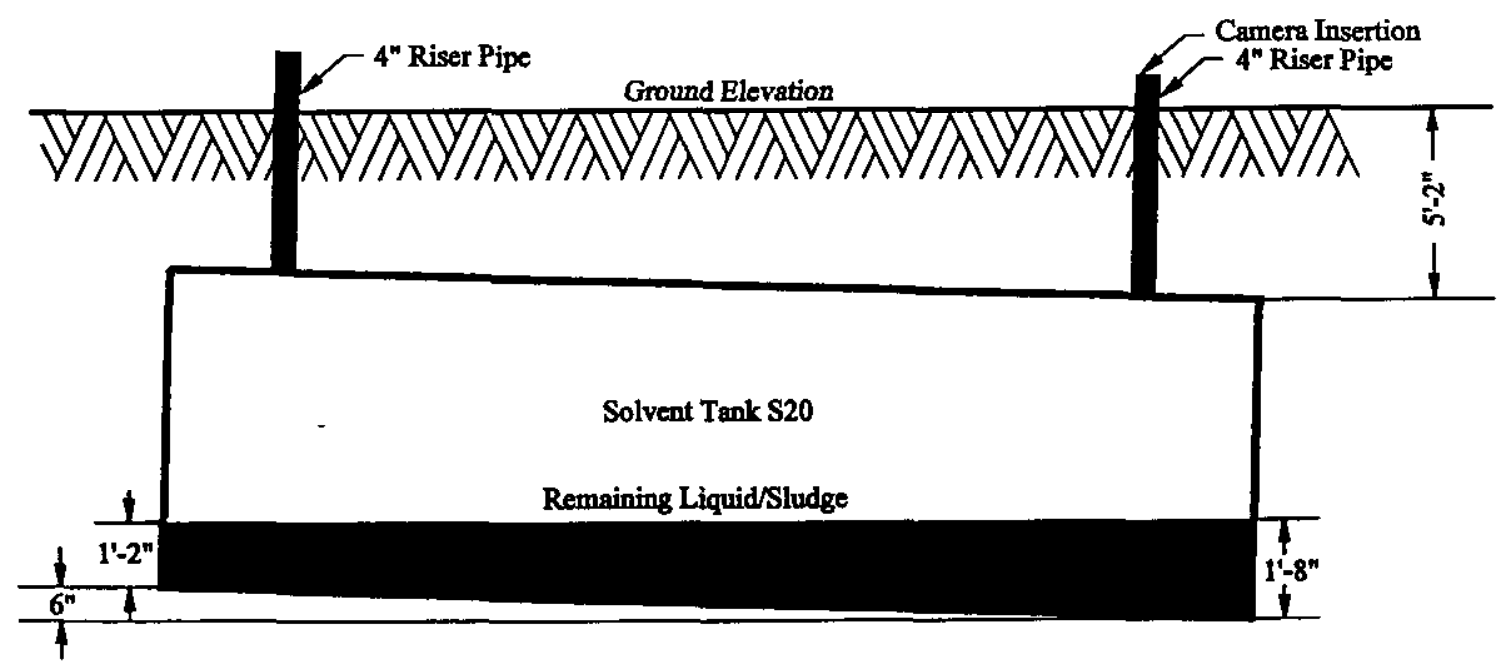

ELEVATTON VIEW LOOKING SOUTH 
APPENDIX A

TANK S21

\begin{tabular}{|l|c|}
\hline Tank Installation Date & $11 / 69$ \\
\hline Tank Size (ft) & $10.5 \times 38.5$ \\
\hline Tank Capacity (gal) & 24,940 \\
\hline Lifetime Quantity of Solvent Stored (gal) & 20,045 \\
\hline Estimated Total Volume of Waste Remaining (gal) & 214 \\
\hline Estimated Liquid Currently Stored in Tank (gal) & 183 \\
\hline Estimated Sludge Currently Stored in Tank (gal) & 31 \\
\hline
\end{tabular}

\section{LEL TANK SURVEY READINGS}

TESTING INTERVALS

\begin{tabular}{|c|c|c|c|c|c|}
\hline $3^{\prime}-0^{\prime \prime}$ & $6^{\prime}-0^{\prime \prime}$ & $9^{\prime}-0^{\prime \prime}$ & $12^{\prime}-0^{\prime \prime}$ & $15^{\prime}-0^{\prime \prime}$ & $18^{\prime}-0^{\prime \prime}$ \\
\hline & & & & & \\
\hline $4 \%$ & $4 \%$ & $4 \%$ & $4 \%$ & $4 \%$ & N/A \\
\hline
\end{tabular}

Tank Features:

This tank contains one capped man way in the tank ceiling located at west end of the tank.

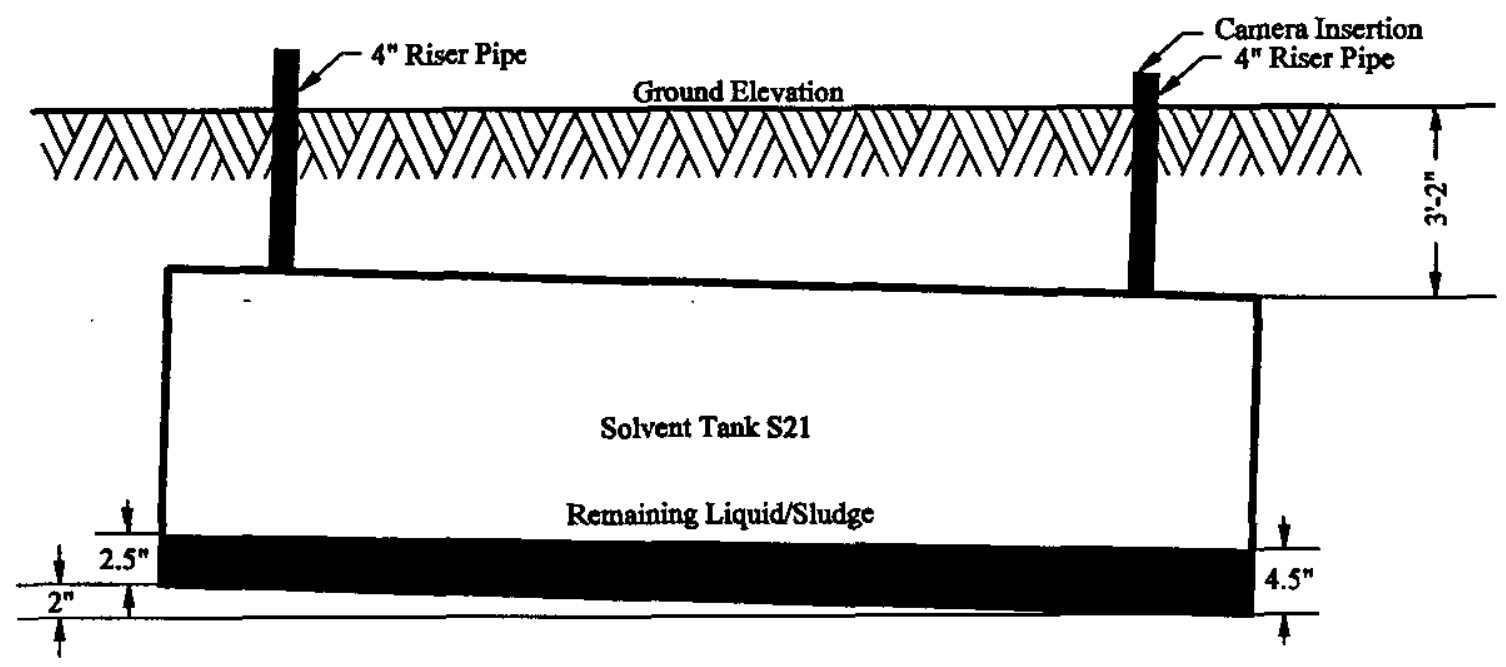

ELEVATION VIEW LOOKING SOUTH 
Appendix A

\section{Tank S21}

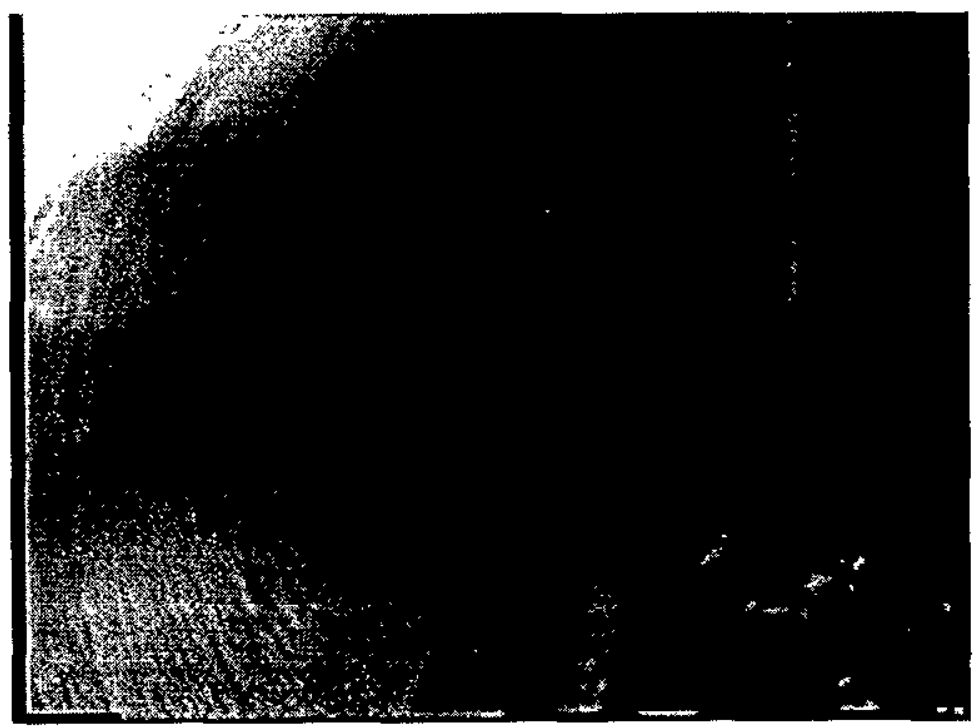

View of liquid and sludge waste at east end of tank

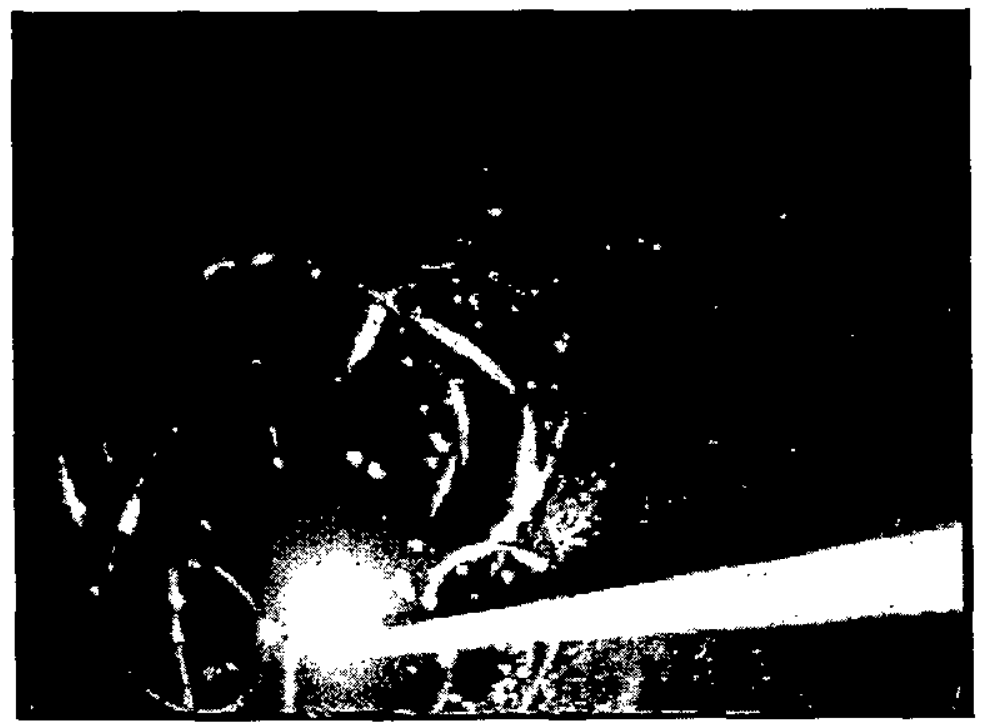

View of liquid \& sludge waste and air sample hose at west end of tank 


\section{APPENDIX A}

\section{TANK S22}

\begin{tabular}{|l|c|}
\hline Tank Installation Date & $11 / 69$ \\
\hline Tank Size (ft) & $10.5 \times 38.5$ \\
\hline Tank Capacity (gal) & 24,940 \\
\hline Lifetime Quantity of Solvent Stored (gal) & 2,884 \\
\hline Estimated Total Volume of Waste Remaining (gal) & 455 \\
\hline Estimated Liquid Currently Stored in Tank (gal) & 448 \\
\hline Estimated Sludge Currently Stored in Tank (gal) & 7 \\
\hline
\end{tabular}

\section{LEL TANK SURVEY READINGS}

TESTING INTERVALS

\begin{tabular}{|c|c|c|c|c|c|}
\hline $3^{\prime}-0^{\prime \prime}$ & $6^{\prime}-0^{\prime \prime}$ & $9^{\prime}-0^{\prime \prime}$ & $12^{\prime}-0^{\prime \prime}$ & $15^{\prime}-0^{\prime \prime}$ & $18^{\prime}-0^{\prime \prime}$ \\
\hline & & & & & \\
\hline $4 \%$ & $4 \%$ & $4 \%$ & $4 \%$ & $4 \%$ & $4 \%$ \\
\hline
\end{tabular}

Tank Features:

This tank contains what appears to be a galvanized steel trash can with lid. The trash can is approximately 30 gallon in size and is resting on the floor of the tank at the west end. Inert debris that was probably contained in the trash can is also seen on the tank floor.

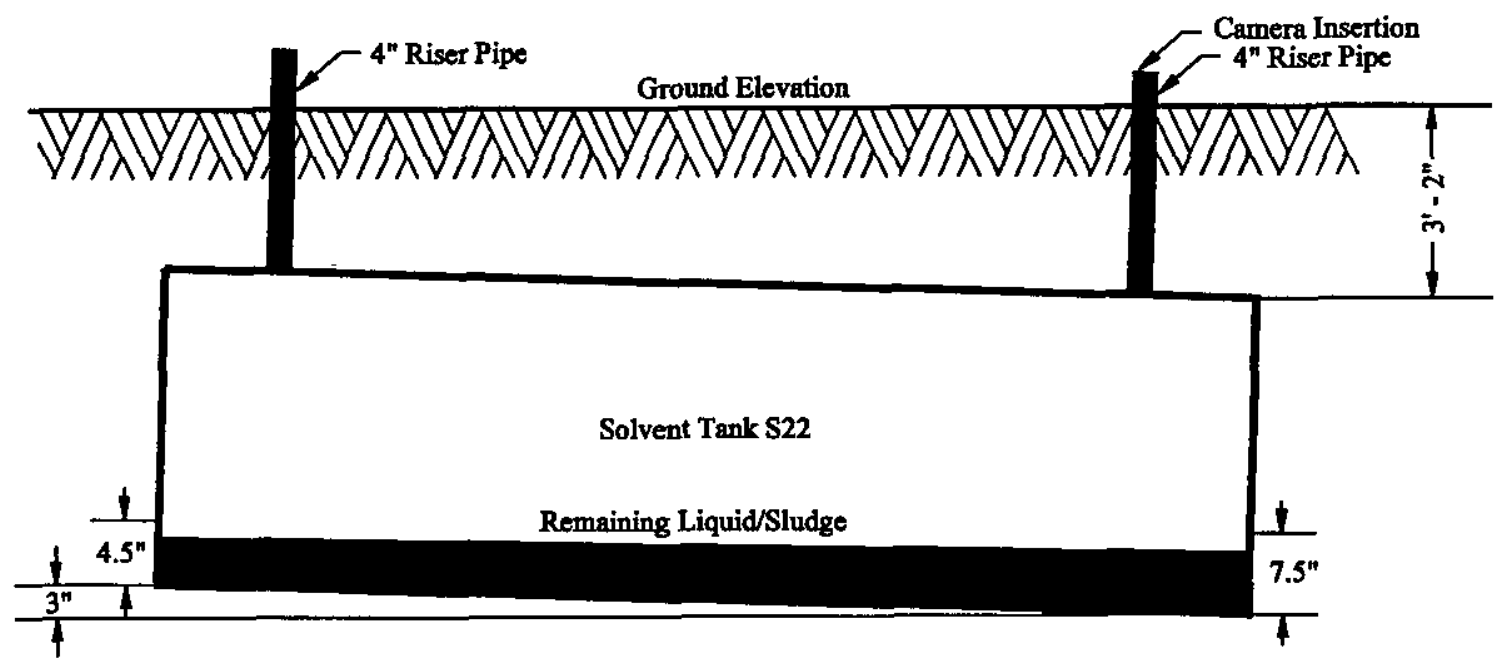

ELEVATION VIEW LOOKING SOUTH 
Appendix A

\section{Tank S22}

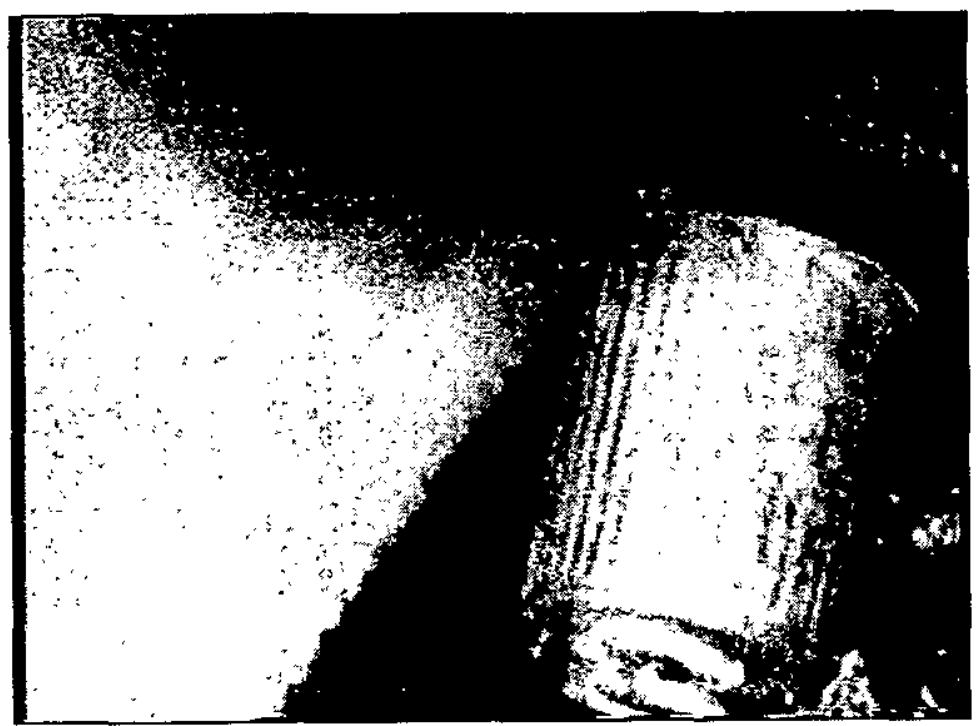

View of liquid waste and trash can at west end of tank

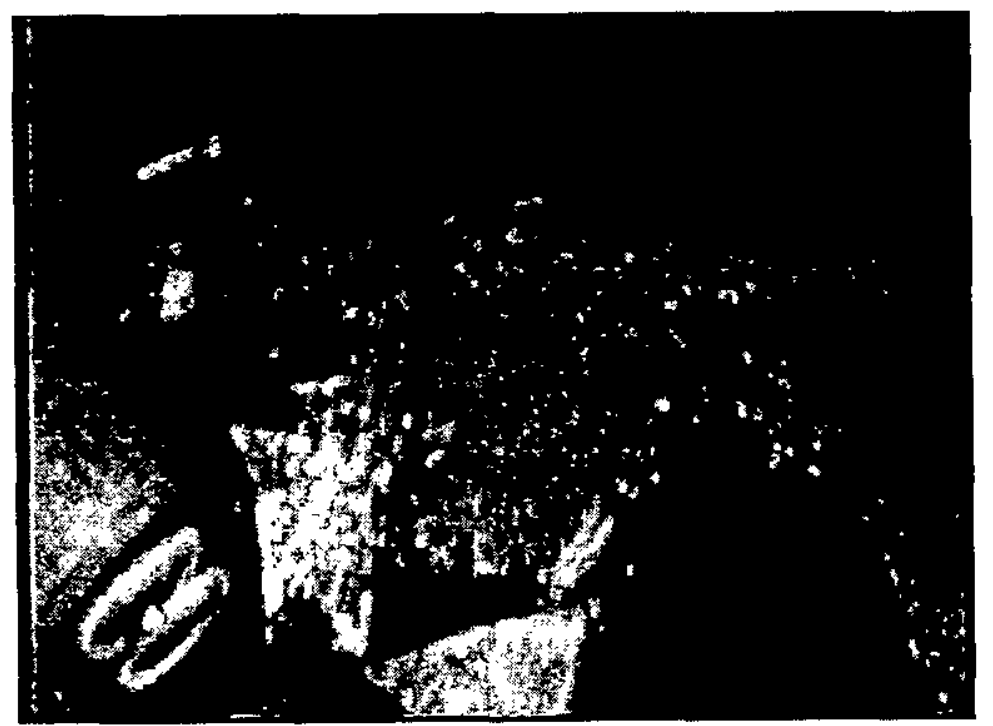

View of liquid waste, trash can and debris at west end of tank 


\section{ATTACHMENT 2}

Characterization of Samples from Old Solvent Tanks S1 through S22 
(This page intentionally left blank.) 
Westinghouse Savannah River Company

Savannah River Technology Center

WSRC-RP-98-01486, Rev. 2

Key Words:

Characterization

Radioactive

Solvent

Waste

CLASSIFICATION: U

Does not contain UCNI

$\frac{\text { C. W. Yenkins, ADC/RO }}{\text { C. }}$

\section{Characterization of Samples from Old Solvent Tanks}

S1 through $\mathbf{S 2 2}$

Prepared By: $\frac{\text { Joh-dideyba, SRTC/MTD/ADS }}{\text { Date }}$

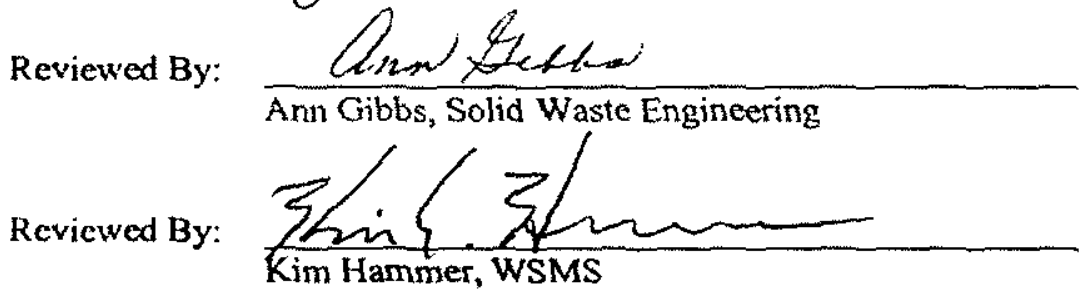

$\frac{6 / 20 / \infty}{\text { Date }}$

$8 / 28 / 00$

Revicwed By: Tindu fret

Approved By: Andrew Preston, Const. Engincering

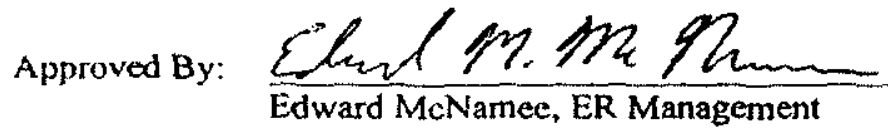

$\frac{8 / 28 / 00}{\text { Date }}$

$\frac{8 / 24100}{\text { Date }}$

$8 / 28 / 00$

Date 


\section{DISCLAIMER}

This report was prepared by Westinghouse Savannah River Company (WSRC) for the United States Department of Energy under Contract No. DE-AC09-96SR18500 and is an account of work performed under that contract. Neither the United States Department of Energy, nor WSRC, nor any of their employees makes any warranty, expressed or implied, or assumes any legal liability or responsibility for the accuracy, completeness, or usefulness, of any information, apparatus, or product, or process disclosed herein or represents that its use will not infringe on privately owned rights. Reference herein to any specified commercial product, process, or service by trademark, name, manufacturer or otherwise does not necessarily constitute or imply endorsement, recommendation, or favoring of same by WSRC or by the United States Government or

any agency thereof. The views and opinions of the authors expressed herein do not necessarily state or reflect those of the United States Government or any agency thereof. 


\section{TABLE OF CONTENTS}

1.0 INTRODUCTION................................................................................................................................1

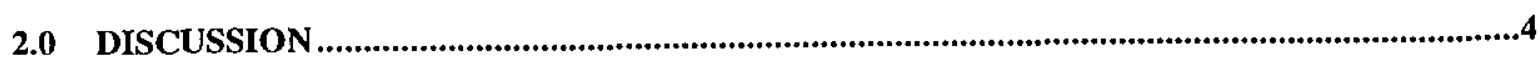

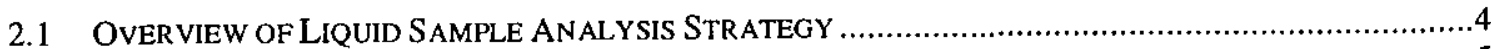

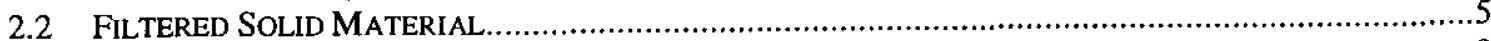

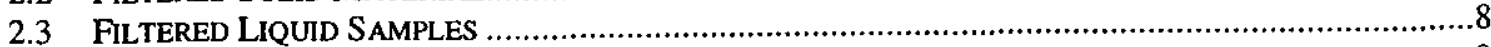

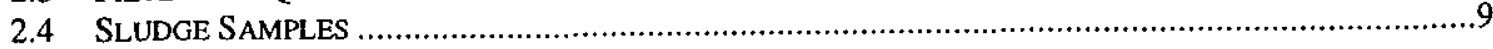

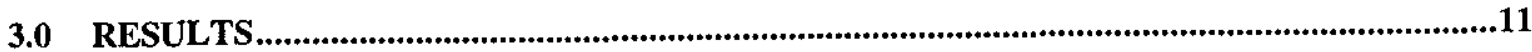

3.1 ANALYTICAL RESULTS OF OLD SOLVENT TANK SAMPLES ….................................................

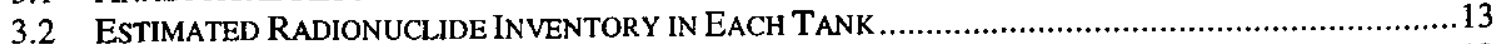

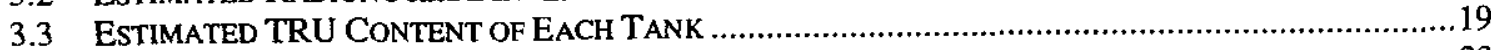

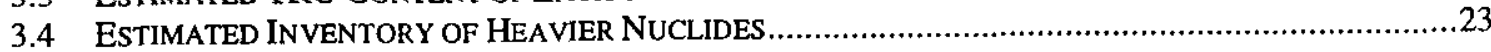

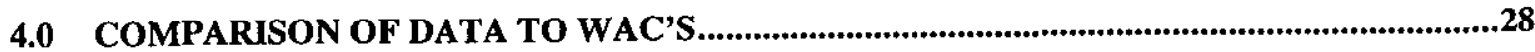

4.1 COMPARISON OF RAW LIQUID DATA TO CIF WAC

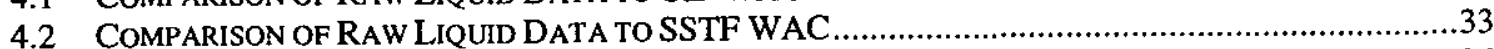

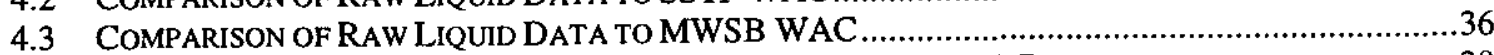

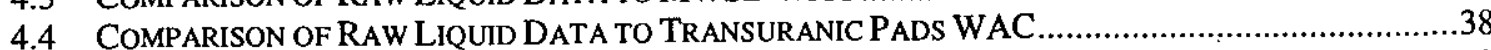

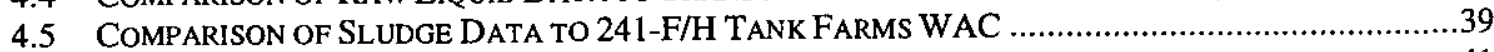

4.6 COMPARISON OF SLUDGE DATA TO TRANSURANIC PADS WAC ...................................................41

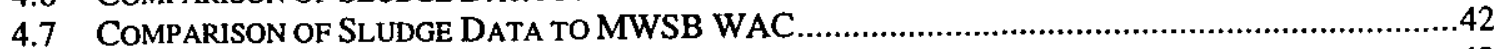

4.8 SUMMARY OF COMPARISONS TO THE VARIOUS WACS ...........................................................4

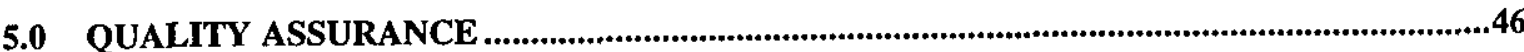

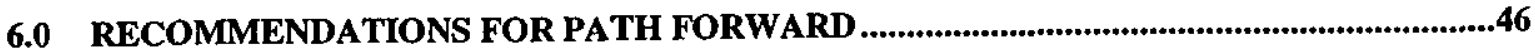

7.0 REFERENCES

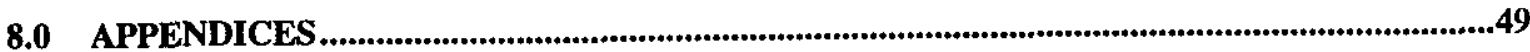

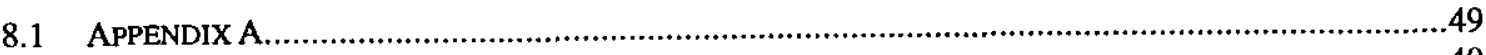

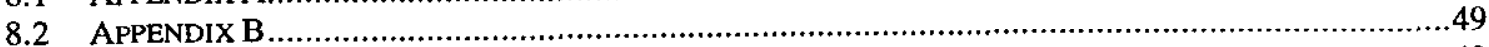

8.3 APPENDIX C

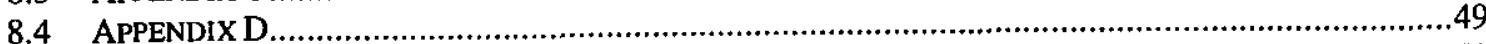

8.5 APPENDIXE

8.6 APPENDIX F ..

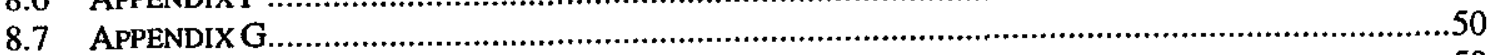

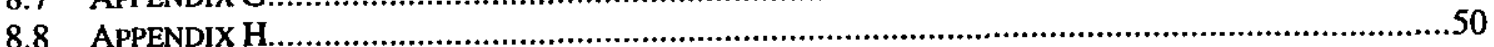

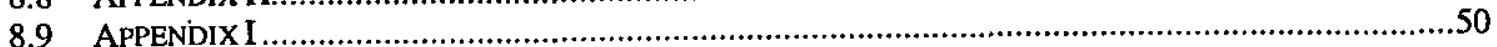

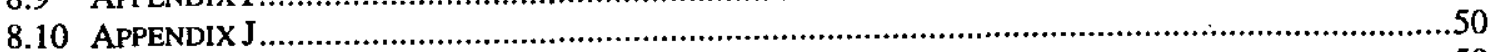

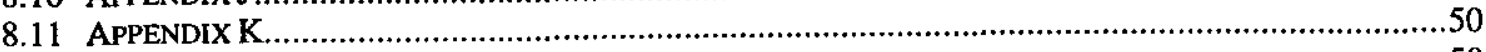

8.12 APPENDIX L...

8.13 APPENDIX M

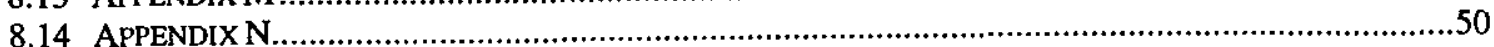

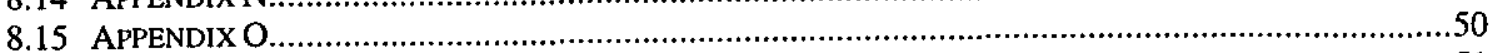

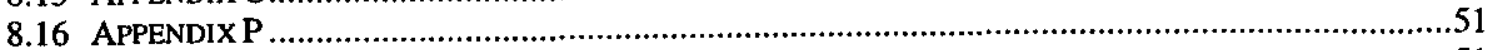

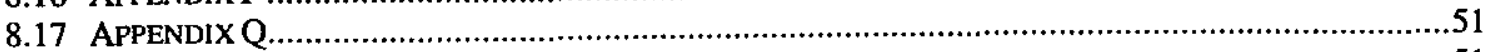

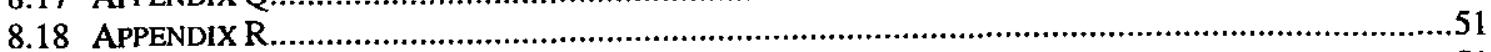

8.19 APPENDIX S

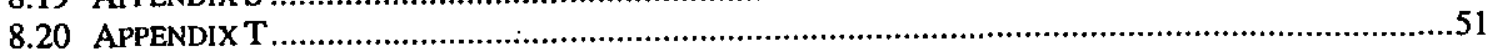

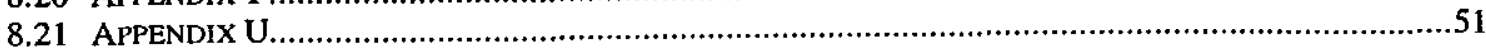




\section{LIST OF TABLES}

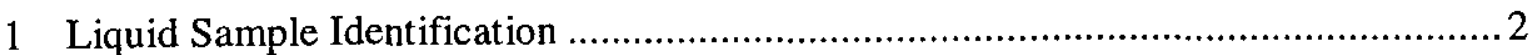

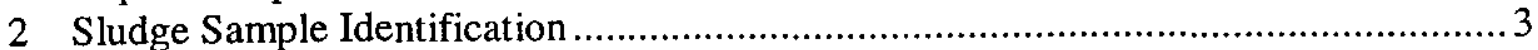

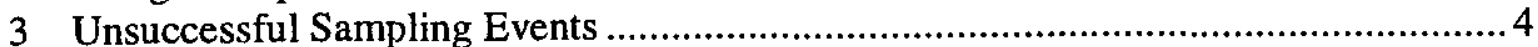

4 Filtered Sample Identification............................................................................

5 Mass of Suspended Solids Recovered from Original Samples...................................6

6 Target Analytes for Suspended Solids........................................................................

7 Additional Parameters for Filtered Liquids ........................................................ 9

8 Additional Parameters for Sludges ..................................................................... 10

9 XRD Data on Sludge Samples .......................................................................... 13

10 Estimated Liquid and Sludge Content of Tanks S1 - S22 ...................................... 14

11 Calculated Gross Activity Content of Raw Liquids in Solvent Tanks ......................... 16

12 Calculated Gross Activity Content of Sludges in Solvent Tanks ...............................17

13 Calculated Total Gross Activity Content of Sampled Solvent Tanks ....................... 18

14 Calculated TRU Concentrations of Filtered Liquid Phases and Filtered Solids......... 19

15 TRU Nuclides Measured in this Characterization.................................................2.20

16 Calculated Activity Fractions for Selected Actinide Nuclides ..................................2

17 Calculated TRU Concentrations of Sludges ............................................................22

18 Specific Activities and Equivalence Factors for U-235 FGE Calculations ................. 23

19 U-235, U-238, and Pu-239 Masses Contained in the Filtered Liquids........................25

20 U-235, U-238, and Pu-239 Masses Contained in the Suspended Solids .....................26

$21 \mathrm{U}-235$, U-238, and Pu-239 Masses Contained in the Sludges .................................. 27

22 Total U-235, U-238, and Pu-239 Content of Sampled Solvent Tanks ........................ 27

23 Metal Concentration Limits for CIF......................................................................30

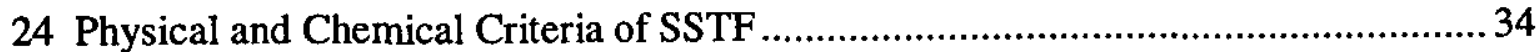

25 Organic Content of Sludge Samples....................................................................40

26 Sludge Phase Cs-137 Activity Concentration .............................................................40

27 RCRA Characteristics of Sludge Samples..............................................................4 41

28 Liquid Parameters Failing to Meet WAC Requirements............................................4 44

29 Sludge Parameters Failing to Meet WAC Requirements ...........................................45 


\section{LIST OF ACRONYMS}

$\begin{array}{ll}\text { ADS } & \text { Analytical Development Section } \\ \text { BTU } & \text { British Thermal Unit } \\ \text { CIF } & \text { Consolidated Incineration Facility } \\ \text { CMS/FMS } & \text { Corrective Measures Study/Feasibility Study } \\ \text { COC } & \text { Chain-of-Custody } \\ \text { CVAA } & \text { Cold Vapor Atomic Absorption } \\ \text { EML } & \text { Environmental Measurements Laboratory } \\ \text { FAA } & \text { Flame Atomic Absorption } \\ \text { FGE } & \text { Fissile Gram Equivalent } \\ \text { GC } & \text { Gas Chromatography } \\ \text { GC/MS } & \text { Gas Chromatography/Mass Spectrometry } \\ \text { HLWE } & \text { High Level Waste Engineering } \\ \text { IC } & \text { Ion Chromatography } \\ \text { ICP-ES } & \text { Inductively Coupled Plasma-Emission Spectroscopy } \\ \text { ICP-MS } & \text { Inductively Coupled Plasma- Mass Spectrometry } \\ \text { LEPS } & \text { Low Energy Photon Spectroscopy } \\ \text { LIMS } & \text { Laboratory Information Management System } \\ \text { LSC } & \text { Liquid Scintillation Counting } \\ \text { MAPEP } & \text { Mixed Analyte Performance Evaluation Program } \\ \text { MEK } & \text { Methyl Ethyl Ketone } \\ \text { MTD } & \text { Measurements Technology Department } \\ \text { MWSB } & \text { Mixed Waste Storage Building(s) } \\ \text { MWSF } & \text { Mixed Waste Storage Facilities } \\ \text { ORWBG } & \text { Old Radioactive Waste Burial Ground } \\ \text { PCB's } & \text { Polychlorinated Biphenyls } \\ \text { PCE } & \text { Perchloroethylene } \\ \text { PHA } & \text { Pulse Height Analysis } \\ \text { PUREX } & \text { Plutonium-Uranium Extraction } \\ \text { QAP } & \text { Quality Assessment Program } \\ \text { RESL } & \text { Radiological and Environmental Sciences Laboratory } \\ \text { SRS-ERD } & \text { Savannah River Site-Environmental Restoration Division } \\ \text { SRTC } & \text { Savannah River Technology Center } \\ \text { SSTF } & \text { Solvent Storage Tank Facility } \\ \text { SVOA } & \text { Semi-Volatile Organics Analysis } \\ \text { semi-VOC's } & \text { Semi-Volatile Organic Compounds } \\ \text { SWB } & \text { Standard Waste Box } \\ \text { SWD } & \text { Solid Waste Division } \\ \text { TCE } & \text { Trichloroethene } \\ \text { TCLP } & \text { Toxicity Characteristic Leaching Procedure } \\ \text { TOC } & \text { Total Organic Carbon } \\ \text { VRU } & \text { Transuranic } \\ \text { VOC's } & \text { Volatile Organic Compounds } \\ & \end{array}$


Savannah River Site

Characterization of Samples from Old Solvent Tanks

S1 Through S22

WSRC Westinghouse Savannah River Company

XRD

X-Ray Diffraction
WSRC-RP-98-01486

Revision 2 $6 / 8 / 00$

Page vi 


\section{LIST OF EPA/DHEC HAZARDOUS WASTE CODES}

Section 261.24 of the South Carolina Hazardous Waste Management Regulations (May $28,1993)$ defines "toxicity characteristic" as follows:

"a) A solid waste exhibits the characteristic of toxicity if, using the Toxicity Characteristic Leaching Procedure, test Method 1311 in Test Methods for Evaluating Solid Waste, Physical/Chemical Methods,'EPA Publication SW-846, as incorporated by reference in 260.11 , the extract from a representative sample of the waste contains any of the contaminants listed in table 1 at the concentration equal to or greater than the respective value given in that table. Where the waste contains less than 0.5 percent filterable solids, the waste itself, after filtering using the methodology outlined in Method 1311 , is considered to be the extract for the purpose of this section (revised 12/92;12/93; 12/94)

b) A solid waste that exhibits the characteristic of toxicity has the EPA Hazardous Waste Number specified in Table 1 which corresponds to the toxic contaminant causing it to be hazardous (revised 12/92)."

Table 1 is entitled, "Maximum Concentration of Contaminants for the Toxicity Characteristic (amended 11/90)." A section of Table 1, containing five entries is shown below.

$\begin{array}{clcc}\text { EPA HW No. } & \text { Contaminant } & \text { CAS NO. } & \begin{array}{c}\text { Regulatory Level } \\ (\mathrm{mg} / \mathrm{L})\end{array} \\ \text { D004 } & \text { Arsenic } & 7440-38-2 & 5.0 \\ \text { D006 } & \text { Cadmium } & 7440-43-9 & 1.0 \\ \text { D007 } & \text { Chromium } & 7440-47-3 & 5.0 \\ \text { D009 } & \text { Mercury } & 7439-97-6 & 0.2 \\ \text { D010 } & \text { Selenium } & 7782-49-2 & 1.0\end{array}$




\section{LIST OF HAZARDOUS WASTE CODES ACCEPTABLE AT THE HAZARDOUS/MIXED WASTE STORAGE FACILITIES}

Partial reproduction of Attachment 3, Table 5 from the Mixed Waste Storage Building Waste Acceptance Criteria with associated contaminant names ${ }^{15}$.

EPA HW No. Contaminant

$\begin{array}{ll}\text { D004 } & \text { Arsenic } \\ \text { D005 } & \text { Barium } \\ \text { D018 } & \text { Benzene } \\ \text { D006 } & \text { Cadmium } \\ \text { D019 } & \text { Carbon tetrachloride } \\ \text { D020 } & \text { Chlordane } \\ \text { D021 } & \text { Chlorobenzene } \\ \text { D022 } & \text { Chloroform } \\ \text { D007 } & \text { Chromium } \\ \text { D023 } & \text { o-Cresol } \\ \text { D024 } & \text { m-Cresol } \\ \text { D025 } & \text { p-Cresol } \\ \text { D026 } & \text { Cresol } \\ \text { D016 } & \text { 2,4-D } \\ \text { D027 } & \text { 1,4-Dichlorobenzene } \\ \text { D028 } & \text { 1,2-Dichloroethane } \\ \text { D029 } & \text { 1,1-Dichloroethylene } \\ \text { D030 } & \text { 2,4-Dinitrotoluene } \\ \text { D012 } & \text { Endrin } \\ \text { D031 } & \text { Heptachlor (and its epoxide) } \\ \text { D032 } & \text { Hexachlorobenzene } \\ \text { D033 } & \text { Hexachlorobutadiene } \\ \text { D034 } & \text { Hexachloroethane } \\ \text { D008 } & \text { Lead } \\ \text { D013 } & \text { Lindane } \\ \text { D009 } & \text { Mercury } \\ \text { D014 } & \text { Methoxychlor } \\ \text { D035 } & \text { Methyl ethyl ketone } \\ \text { D036 } & \text { Nitrobenzene } \\ \text { D037 } & \text { Pentrachlorophenol } \\ \text { D038 } & \text { Pyridine } \\ \text { D010 } & \text { Selenium } \\ \text { D011 } & \text { Silver } \\ \text { D039 } & \text { Tetrachloroethylene } \\ \text { D015 } & \text { Toxaphene } \\ \text { D040 } & \text { Trichloroethylene } \\ \text { D041 } & \text { 2,4,5-Trichlorophenol } \\ & \end{array}$


D042

D017

D043

F001

F002

F003

F004

F005

F006
2,4,6-Trichlorophenol

\section{2,4,5-TP (Silvex)}

Vinyl chloride

The following spent halogenated solvents used in degreasing:

Tetrachloroethylene, trichloroethylene, methylene chloride, 1,1,1trichloroethane, carbon tetrachloride, and chlorinated fluorocarbons; all spent solvent mixtures/blends used in degreasing containing, before use, a total of ten percent or more (by volume) of one or more of the above halogenated solvents or those solvents listed in F002, F004, and F005; and still bottoms from the recovery of these spent solvents and spent solvent mixtures.

The following spent halogenated solvents: Tetrachloroethylene, methylene chloride, trichloroethylene, 1,1,1-trichloroethane, chlorobenzene, 1,1,2-trichloro-1,2,2-trifluoroethane, ortho-dichlorobenzene, trichlorofluoromethane, and 1,1,2-trichloroethane; all spent solvent mixtures/blends containing, before use, a total often percent or more (by volume) of one or more of the above halogenated solvents or those listed in F001, F004, or F005; and still bottoms from the recovery of these spent solvents and spent solvent mixtures.

The following spent non-halogenated solvents: xylene, acetone, ethyl acetate, ethyl benzene, ethyl ether, methyl isobutyl ketone, n-butyl alcohol, cyclohexanone, and methanol; all spent solvent mixtures/blends containing, before use, only the above spent nonhalogenated solvents; and all spent solvent mixtures/blends containing, before use, one or more of the above non-halogenated solvents, and, a total of ten percent or more (by volume) of one or more of those solvents listed in F001, F002, F004, and F005; and still bottoms from the recovery of these spent solvents and spent solvent mixtures.

The following spent non-halogenated solvents: Cresols and cresylic acid, and nitrobenzene; all spent solvent mixtures/blends containing, before use, a total of ten percent or more (by volume) of one or more of the above non-halogenated solvents or those solvents listed in F001, F002, and F005; and still bottoms from the recovery of these spent solvents and spent solvent mixtures.

The following spent non-halogenated solvents: Toluene, methyl ethyl ketone, carbon disulfide, isobutanol, pyridine, benzene, 2ethoxyethanol, and 2-nitropropane; all spent solvent mixtures/blends containing, before use, a total of ten percent or more (by volume) of one or more of the above non-halogenated solvents or those solvents listed in F001, F002, or F004; and still bottoms from the recovery of these spent solvents and spent solvent mixtures.

Wastewater treatment sludges from electroplating operations except from the following processes: (1) Sulfuric acid anodizing of 
aluminum; (2) tin plating on carbon steel; (3) zinc plating (segregated basis) on carbon steel; (4) aluminum or zinc-aluminum plating on carbon steel; (5) cleaning/stripping associated with tin, zinc and aluminum plating on carbon steel; and (6) chemical etching and milling of aluminum.

Discarded unused formulations containing tri-, tetra-, or pentachlorophenol or discarded unused formulations containing compounds derived from these chlorophenols. (This listing does not include formulations containing Hexachlorophene synthesized from prepurified 2,4,5-trichlorophenol as the sole component).

P005

P009

$\mathrm{P} 010$

P011

$\mathrm{P} 012$

P015

P016

$\mathrm{P} 017$

P018

$\mathrm{P} 020$

$\mathrm{P} 022$

$\mathrm{P} 023$

$\mathrm{P} 024$

P028

$\mathrm{P} 030$

P037

P045

P048

P050

P051

P054

P059

P060

P063 Allyl alcohol, 2-Propen-1-ol Ammonium picrate (R), Phenol, 2,4,6-trinitro-, ammonium salt (R) Arsenic acid $\mathrm{H}_{3} \mathrm{AsO}_{4}$ Arsenic oxide $\mathrm{As}_{2} \mathrm{O}_{5}$, Arsenic pentoxide Arsenic oxide $\mathrm{As}_{2} \mathrm{O}_{3}$, Arsenic trioxide Beryllium powder Dichloromethyl ether, Methane, oxybis[chloro-]

Bromoacetone, 2-Propanone, 1-bromo-

Brucine, Strychnidin-10-one, 2,3- dimethoxy-

Dinoseb, Phenol, 2-(1-methylpropyl)4,6- dinitro-

Carbon disulfide

Acetaldehyde, chloro-, Chloroacetaldehyde

Benzenamine, 4-chloro-, p-Chloroaniline

Benzene, (chloromethyl), Benzyl chloride

Cyanides (soluble cyanide salts), not otherwise specified

Dieldrin, 2,7:3,6-Dimethanonaphth[2,3-b] oxirene, 3,4,5,6,9,9hexachloro-1a,2,2a,3,6,6a,7, 7a-octahydro-, (1 aalpha,2beta, 2aalpha,3beta, 6beta, 6aalpha,7beta,7aalpha)-

2-Butanone, 3,3-dimethyl-1- (methylthio)- O-[(methylamino)carbonyl]oxime, Thiofanox

2,4-Dinitrophenol, Phenol, 2,4-dinitro

Endosulfan, 6,9-Methano-2,4,3- benzodioxathiepin, 6,7, 8,9,10,10hexachloro-1,5, 5a,6,9,9a-hexahydro-, 3-oxide Endrin, \& metabolites, 2,7:3,6-Dimethanonaphth [2,3-b] oxirene, 3,4,5,6,9,9-hexachloro - 1a,2,2a,3,6,6a,7,7a-octahydro-, (1aalpha,2beta,2abeta,3alpha, 6alpha,6abeta,7beta, 7aalpha)-, \& metabolites

Aziridine, Ethyleneimine

Heptachlor, 4,7-Mẹthano-1H-indene, 1,4,5,6,7,8,8-heptachloro3a,4,7, 7a-tetrahydro-

Isodrin, 1,4,5,8-Dimethanonaphthalene, 1,2,3,4,10,10-hexa-chloro1,4,4a,5,8,8a-hexahydro, (1alpha,4alpha,4abeta, 5beta,8beta,8a beta)Hydrocyanic acid 
P064

P068

P069

P070

P071

P077

P089

P093

P095

P098

P102

P104

P105

P106

P108

P112

P115

P116

P119

P120

P123

P127

P128

P185

P188

P189

P190

P191

P192

P194

P196

P197

P198
Methane, isocyanato-, Methyl isocyanate

Hydrazine, methyl-, Methyl hydrazine

Propanenitrile, 2-hydroxy-2-methyl, 2-Methyllactonitrile

Aldicarb, Propanal, 2-methyl-2- (methylthio)-, O-[(methyl-

amino)carbonyl]oxime

Methyl parathion, Phosphorothioic acid, O,O,- dimethyl O-(4-

nitrophenyl) ester

p-Nitroaniline, Benzenamine, 4-nitro-

Parathion, Phosphorothioic acid, O,O- diethyl O-(4-nitrophenyl) (R)

Phenylthiourea, Thiourea, phenyl-

Phosgene, Carbonic dichloride

Potassium cyanide

Propargyl alcohol, 2-Propyn-1-ol

Silver cyanide

Sodium azide

Sodium cyanide

Strychnidin-10-one, \& salts

Methane, tetranitro- (R), Tetranitromethane (R)

Thallium(I) sulfate, Sulfuric acid, dithallium(1) salt

Thiosemicarbazide, Hydrazinecarbothioamide

Ammonium vanadate, Vanadic acid, ammonium salt

Vanadium pentoxide, Vanadium oxide $\mathrm{V}_{2} \mathrm{O}_{5}$

Toxaphene

Carbofuran, 7-Benzofuranol, 2,3-dihydro-2, 2-dimethyl-, methylcarbamate

Mexacarbate, Phenol, 4-(dimethylamino)-3,5- dimethyl-, methylcarbamate (ester)

Tirpate, 1,3-Dithiolane-2-carboxaldehyde, 2,4-dimethyl-, O-

[(methyl-amino)- carbonyl]oxime

Benzoic acid, 2-hydroxy-, compd. with (3aS-cis)-1,2,3,3a, 8,8a-

hexahydro-1,3a,8-trimethyl-pyrrolo[2,3-b]indol-5-yl

methylcarbamate ester (1:1), Physostigmine salicylate

Carbosulfan, Carbamic acid, [(dibutylamino)- thio]methyl-, 2,3-

dihydro-2, 2-dimethyl- 7-benzofuranyl ester

Carbamic acid, methyl-, 3-methylphenyl ester, Metolcarb

Dimetilan, Carbamic acid, dimethyl-, 1-[(dimethyl-amino)carbonyl]5-methyl-1H-pyrazol-3-yl ester.

Isolan, Carbamic acid, dimethyl-, 3- methyl-1- (1-methylethyl)-1Hpyrazol-5-yl ester

Oxamyl

Manganese, bis(dimethyl- carbamodithioato-S,S')-, Manganese

dimethyldithio- carbamate

Formparanate

Formetanate hydrochloride, Methanimidamide, N,N-dimethyl- N'[3-[[(methylamino)-carbonyl]oxy]phenyl]-, monohydrochloride 


\section{P199}

P201

P202

P203

P204

P205

U001

U002

U003

U004

U006

U007

U008

U009

U011

U012

U014

U017

U019

U021

U022

U023

U025

U027

U028

U031

U032

U034

U036

U037

U041

U043

U044

U045

U046

U047

U048

U050

U051
Phenol, (3,5-dimethyl-4- (methylthio)-, methylcarbamate, Methiocarb Phenol, 3-methyl-5-(1- methylethyl)-, methyl carbamate, Promecarb Phenol, 3-(1-methylethyl)-, methyl carbamate, 3-Isopropylphenyl Nmethyl- carbamate, m-Cumenyl methylcarbamate

Aldicarb sulfone, Propanal, 2-methyl-2-(methyl- sulfonyl)-, O[(methylamino) carbonyl] oxime

Physostigmine, Pyrrolo[2,3-b]indol-5-ol, 1,2,3,3a,8,8a-hexahydro1,3a,8-trimethyl-, methyl- carbamate (ester), (3aS-cis)-

Ziram

Ethanal (I), Acetaldehyde (I)

Acetone (I), 2-Propanone (I)

Acetonitrile (I,T)

Acetophenone, Ethanone, 1-phenyl-

Acetyl chloride (C,R,T)

Acrylamide, 2-Propenamide

2-Propenoic acid (I), Acrylic acid (I)

Acrylonitrile, 2-Propenenitrile

Amitrole, 1H-1,2,4-Triazol-3-amine, Benzenamine (I,T)

Aniline (I,T)

Benzenamine, 4,4'-carbonimidoylbis[N,N-dimethyl-, Auramine

Benzene, (dichloromethyl), Benzal chloride

Benzene (I,T)

[1,1'-Biphenyl]-4,4'-diamine, Benzidine

Benzo[a]pyrene

Benzene, (trichloromethyl)-, Benzotrichloride (C,R,T)

Dichloroethyl ether, Ethane, 1,1'-oxybis[2-chloro-

Dichloroisopropyl ether, Propane, 2,2'-oxybis[2-chloro-

1,2-Benzenedicarboxylic acid, bis(2-ethylhexyl) ester,

Diethylhexyl phthalate

1-Butanol (I), n-Butyl alcohol (I)

Calcium chromate, Chromic acid $\mathrm{H}_{2} \mathrm{CrO}_{4}$, calcium salt

Chloral, Acetaldehyde, trichloro-

4,7-Methano-1H-indene, 1, 2, 4, 5, 6, 7, 8, 8-octachloro-2, 3, 3a, 4,

$7,7 \mathrm{a}-$ hexahydro-, Chlordane, alpha \& gamma isomers

Benzene, chloro-, Chlorobenzene

Epichlorohydrin, Oxirane, (chloromethyl)-

Ethene, chloro-, Vinyl chloride

Chloroform, Methane, trichloro-

Methane, chloro-(I, T), Methyl chloride (I,T)

Methane, chloromethoxy-, Chloromethyl methyl ether

beta-Chloronaphthalene, Naphthalene, 2-chloro-

Phenol, 2-chloro-, o-Chlorophenol

Chrysene

Creosote 
U052

U053

U055

U056

U057

U060

U061

U063

U067

U068

U069

U070

U071

U072

U073

U074

U075

U076

U077

U078

U079

U080

U081

U082

U083

U084

U088

U091

U092

U095

U102

U103

U105

U106

U108

U109

U110

U112

U115

U116

U117

U121
Cresol (Cresylic acid), Phenol, methyl-

2-Butenal, Crotonaldehyde

Benzene, (1-methylethyl)-(I), Cumene (I)

Cyclohexane (I), Benzene, hexahydro-(I)

Cyclohexanone (I)

Benzene, 1,1'-(2,2-dichloroethylidene)bis[4-chloro-, DDD

Benzene, 1,1'-(2,2,2-trichloroethylidene)bis[4-chloro-, DDT

Dibenz[a,h]anthracene

Ethane, 1,2-dibromo-, Ethylene dibromide

Methane, dibromo-, Methylene bromide

1,2-Benzenedicarboxylic acid, dibutyl ester, Dibutyl phthalate

o-Dichlorobenzene, Benzene, 1,2-dichloro-

Benzene, 1,3-dichloro-, m-Dichlorobenzene

Benzene, 1,4-dichloro-, p-Dichlorobenzene

[1,1'-Biphenyl]-4,4'-diamine, 3,3'-dichloro-, 3,3'-

Dichlorobenzidine

2-Butene, 1,4-dichloro-(I,T), 1,4-Dichloro-2-butene (I,T)

Methane, dichlorodifluoro-, Dichlorodifluoromethane

Ethane, 1,1-dichloro-, Ethylidene dichloride

Ethane, 1,2-dichloro-, Ethylene dichloride

Ethene, 1,1-dichloro-, 1,1-Dichloroethylene

Ethene, 1,2-dichloro-, (E)-, 1,2-Dichloroethylene

Methane, dichloro-, Methylene chloride

2,4-Dichlorophenol, Phenol, 2,4-dichloro-

2,6-Dichlorophenol, Phenol, 2,6-dichloro-

Propane, 1,2-dichloro-, Propylene dichloride

1,3-Dichloropropene, 1-Propene, 1,3-dichloro-

1,2-Benzenedicarboxylic acid, diethyl ester, Diethyl phthalate

[1,1'-Biphenyl]-4,4'-diamine, 3,3'-dimethoxy-, 3,3'-

Dimethoxybenzidine

Methanamine, N-methyl-(I), Dimethylamine (I)

3,3'-Dimethylbenzidine, [1,1'-Biphenyl]-4,4'-diamine, 3,3'-

dimethyl-

Dimethyl phthalate, 1,2-Benzenedicarboxylic acid, dimethyl ester

Dimethyl sulfate, Sulfuric acid, dimethyl ester

2,4-Dinitrotoluene, Benzene, 1-methyl-2,4-dinitro-

Benzene, 2-methyl-1,3-dinitro-, 2,6-Dinitrotoluene

1,4-Diethyleneoxide, 1,4-Dioxane

Hydrazine, 1,2-diphenyl-, 1,2-Diphenylhydrazine

1-Propanamine, N-propyl-(I), Dipropylamine (I)

Ethyl acetate (I), Acetic acid ethyl ester (I)

Ethylene oxide (I,T), Oxirane (I,T)

2-Imidazolidinethione, Ethylenethiourea

Ethane, 1,1'-oxybis-(I), Ethyl ether (I)

Methane, trichlorofluoro-, Trichloromonofluoromethane 
U122

U123

$\mathrm{U} 124$

$\mathrm{U} 125$

U127

$\mathrm{U} 128$

U129

U130

U131

U132

U133

U134

U136

$\mathrm{U} 138$

U140

U142

U144

U146

U147

U151

U154

U157

U158

U159

U161

U162

U165

U166

U167

U169

U170

U171

U182

U183

U184

U185

U187

U188
Formaldehyde

Formic acid (C,T)

Furan (I), Furfuran (I)

2-Furancarboxaldehyde (I), Furfural (I)

Hexachlorobenzene, Benzene, hexachloro-

1,3-Butadiene, 1,1,2,3,4,4-hexachloro-, Hexachlorobutadiene

Cyclohexane, 1, 2, 3, 4, 5, 6-hexachloro-, (1alpha, 2alpha, 3beta, 4alpha, 5alpha, 6beta)-, Lindane

Hexachlorocyclopentadiene, 1,3-Cyclopentadiene, 1, 2, 3, 4, 5, 5hexachloro-

Hexachloroethane, Ethane, hexachloro-

Hexachlorophene, Phenol, 2,2'-methylenebis[3,4,6-trichloro-

Hydrazine (R,T)

Hydrofluoric acid $(C, T)$, Hydrogen fluoride $(C, T)$

Cacodylic acid, Arsinic acid, dimethyl-

Methane, iodo-, Methyl iodide

Isobutyl alcohol (I,T), 1-Propanol, 2-methyl-(I,T)

Kepone, 1,3,4-Metheno-2H-cyclobuta[cd] pentalen-2-one, 1, 1a, 3, 3a, 4, 5, 5, 5a, 5b, 6-decachlorooctahydro-

Lead acetate, Acetic acid, lead(2) salt

Lead, bis(acetato-O)tetrahydroxytri-, Lead subacetate

2,5-Furandione, Maleic anhydride

Mercury

Methanol (I), Methyl alcohol (I)

3-Methylcholanthrene, Benz[j]aceanthrylene, 1,2-dihydro-3-

methyl-

Benzenamine, 4,4'-methylenebis[2-chloro-, 4,4'-Methylenebis(2-

chloroaniline)

2-Butanone (I,T), Methyl ethyl ketone (MEK) (I,T)

4-Methyl-2-pentanone (I), Methyl isobutyl ketone (I), Pentanol, 4methyl-

2-Propenoic acid, 2-methyl-, methyl ester (I,T), Methyl

methacrylate (I,T)

Naphthalene

1,4-Naphthalenedione, 1,4-Naphthoquinone

1-Naphthalenamine, alpha-Naphthylamine

Benzene, nitro-, Nitrobenzene (I,T)

Phenol, 4-nitro-, p-Nitrophenol

2-Nitropropane (I,T), Propane, 2-nitro-(I,T)

1,3,5-Trioxane, 2,4,6-trimethyl-, Paraldehyde

Benzene, pentachloro-, Pentachlorobenzene

Ethane, pentachloro-, Pentachloroethane

Benzene, pentachloronitro-, Pentachloronitrobenzene (PCNB)

Acetamide, N-(4-ethoxyphenyl)-, Phenacetin

Phenol 
U190

U196

U197

U197

U201

U204

U207

U208

U209

$\mathrm{U} 210$

U21 1

U213

$\mathrm{U} 215$

U216

U218

U219

$\mathrm{U} 220$

U223

U225

U226

U227

U228

U234

U236

U239

U240

U247

U271

U278

U279

$\mathrm{U} 280$

U328

U359

U364

U367

U372

U373

U386
1,3-Isobenzofurandione, Phthalic anhydride

Pyridine

p-Benzoquinone

2,5-Cyclohexadiene-1,4-dione

1,3-Benzenediol, Resorcinol

Selenious acid, Selenium dioxide

Benzene, 1,2,4,5-tetrachloro-, 1,2,4,5-Tetrachlorobenzene

Ethane, 1,1,1,2-tetrachloro-, 1,1,1,2-Tetrachloroethane

Ethane, 1,1,2,2-tetrachloro-, 1,1,2,2-Tetrachloroethane

Ethene, tetrachloro-, Tetrachloroethylene

Carbon tetrachloride, Methane, tetrachloro-

Furan, tetrahydro-(I), Tetrahydrofuran (I)

Carbonic acid, dithallium(1) salt, Thallium(I) carbonate

Thallium chloride $\mathrm{TICl}$, Thallium(I) chloride

Ethanethioamide, Thioacetamide

Thiourea

Benzene, methyl-, Toluene

Benzene, 1,3-diisocyanatomethyl-(R,T), Toluene diisocyanate

$(\mathrm{R}, \mathrm{T})$

Bromoform, Methane, tribromo-

Methyl chloroform, Ethane, 1,1,1-trichloro-

1,1,2-Trichloroethane, Ethane, 1,1,2-trichloro-

Ethene, trichloro-, Trichloroethylene

Benzene, 1,3,5-trinitro-, 1,3,5-Trinitrobenzene (R,T)

2,7-Naphthalenedisulfonic acid, 3,3'-[(3,3'-dimethyl[1,1'-

biphenyl]-4,4'-diyl)bis(azo)bis[5-amino-4-hydroxy]-, tetrasodium

salt, Trypan blue

Benzene, dimethyl-(I,T), Xylene (I)

2,4-D, salts \& esters, Acetic acid, (2,4-dichlorophenoxy)-, salts \&

esters

Benzene, 1,1'-(2,2,2-trichloroethylidene) bis[4-methoxy-,

Methoxychlor

Carbamic acid, [1-[(butylamino)carbonyl]-1H-benzimidazol-2-yl]-, methyl ester, Benomyl.

1,3Benzodioxol4ol, 2,2dimethyl, methyl carbamate, Bendiocarb.

1-Naphthalenol, methylcarbamate, Carbaryl.

Carbamic acid, (3-chlorophenyl)-, 4-chloro-2-butynyl ester,

Barban.

Benzenamine, 2-methyl-, o-Toluidine

Ethanol, 2-ethoxy-, Ethylene glycol monoethyl ether

1,3Benzodioxol4ol, 2,2dimethyl, Bendiocarb phenol.

Carbofuran phenol, Benzofuranol, 2,3-dihydro2,2-dimethyl

Carbendazim, Carbamic acid, 1H-benzimidazol-2-yl, methyl ester.

Carbamic acid, phenyl-, 1-methylethyl ester, Propham.

Carbamothioic acid, cyclohexylethyl-, S-ethyl ester. 
Carbamothioic acid, dipropyl-, S-(phenylmethyl) ester, Prosulfocarb. propenyl) ester, Triallate. Carbamothioic acid, dipropyl-, S-ethyl ester. oxo-, methyl ester.

Ethanol, 2,2'-oxybis-, dicarbamate, Diethylene glycol, dicarbamate. dimethyl ester, Thiophanate-methyl. Ethanimidothioic acid, N,N'-[thiobis[(methylimino)carbonyloxy]] bis-, dimethyl ester, Thiodicarb.

U411 Phenol, 2-(1-methylethoxy)-, methylcarbamate, Propoxur. 
WSRC-RP-97.00127 Rev. 1.4 Vol. 2 PH. 4

Savannah River Site

WSRC-RP-98-01486

Revision 2

$6 / 8 / 00$

S1 Through $\$ 22$

\subsection{INTRODUCTION}

RECORDS ADMINISTRATION

Page 1 of 51

The Old Radioactive Waste Burial Ground (ORWBG, 643-E) contains 22 old solvent tanks (S1 - S22) which were used to receive and store spent PUREX solvent from F- and H-Canyons. The tanks are cylindrical, carbon-steel, single-wall vessels buried at varying depths. A detailed description of the tanks and their history can be found in Reference 1 .

A Sampling and Analysis Plan for the characterization of the material contained in the old solvent tanks was developed by the Analytical Development Section (ADS) in October of $1997^{2}$. The Sampling and Analysis Plan identified several potential disposal facilities for the organic and aqueous phases present in the old solvent tanks which included the Solvent Storage Tank Facility (SSTF), the Mixed Waste Storage Facilities (MWSF), Transuranic (TRU) Pads, and/or the Consolidated Incineration Facility (CIF). In addition, the 241-F/H Tank Farms, TRU Pads, and/or the MWSF were identified as potential disposal facilities for the sludge phases present in the tanks.

The purpose of this sampling and characterization was to obtain sufficient data on the material present in the old solvent tanks so that a viable path forward, based upon the data in this report, could be established for the closure of the tanks. Therefore, the parameters chosen for the characterization of the various materials present in the tanks were based upon the Waste Acceptance Criteria (WAC) of the SSTF ${ }^{3}$, TRU Pads ${ }^{4}$, $\mathrm{MWSF}^{5}, \mathrm{CIF}^{6}$, and/or 241-F/H Tank Farms ${ }^{7}$. Several of the WAC's have been revised, cancelled, or replaced by new procedures since October of 1997 and hence where required, the results of this characterization program were compared against the latest revision of the appropriate WAC.

It must be emphasized that this project was performed in order to characterize the contents of the Old Solvent Tanks. This study included determining the physical, chemical, and radiochemical characteristics of the contents of the Old Solvent Tanks. Criticality safety is not within the scope of this report. However, a criticality safety review has been performed ("Evaluation of Old Solvent Storage Tanks 1-22", WSMSCRT-99-0039) using the data from this characterization and is included as Attachment 4 to the "Addendum to the Workplan/RCRA Facility Investigation/Remedial Investigation Report of the Old Radioactive Waste Burial Ground 643-E, S01-S22." Please refer to WSMS-CRT-99-0039 for criticality safety issues regarding the Old Solvent Tanks, including the calculation of Fissile Gram Equivalent (FGE) quantities.

The sampling campaign was essentially divided into three parts. The first part consisted of nine liquid samples from seven tanks while the second part consisted of six liquid samples from six additional tanks. Finally, the third part focussed on sludge sampling and also attempted to obtain liquid samples from those tanks that contained liquid but were not previously sampled. Thus, ADS of the Measurement Technology Department (MTD) of the Savannah River Technology Center (SRTC) received 17 liquid samples (from 15 different tanks) and 14 sludge samples (from 12 different tanks) for 
characterization. In some cases, only very small sample quantities were obtained. In these cases, only limited and/or qualitative analyses were performed; hence, a significant deviation from the Sampling and Analysis Plan resulted. Qualitative analytical results refer to those data that provide information regarding what constituents are present. This is in contrast to quantitative analytical results, which not only identify what constituents are present but also how much of these constituents are present. This report discusses in detail the chemical and radiological characterization of all of the samples submitted to ADS for analyses.

Tables 1 and 2 list the identities of the liquid and sludge samples, respectively, submitted to ADS. These tables also have any general comments associated with the original samples.

Table 1. Liquid Sample Identification

\begin{tabular}{|c|c|c|l|}
\hline Sample ID & Tank \# & LIMS \# & \multicolumn{1}{|c|}{ Comments } \\
\hline $98018-1$ & S1 & 300103987 & N/A \\
\hline $98018-2$ & S2 & 300105060 & N/A \\
\hline $98018-3$ & S3 & 300104037 & N/A \\
\hline $98018-4$ & S4 & 300109222 & N/A \\
\hline $98018-5$ & S5 & 300119028 & N/A \\
\hline $98018-6$ & S6 & 300109223 & N/A \\
\hline $98018-7$ & S7 & 300109224 & N/A \\
\hline $98018-8$ & S & 300109225 & N/A \\
\hline $98018-11$ & S11 & 300118504 & N/A \\
\hline $98018-13$ & S13 & 300109226 & N/A \\
\hline $98018-14$ & S14 & 300103694 & N/A \\
\hline $98018-19-O$ & S19 & 300104695 & "Top" liquid layer, thought to be organic \\
\hline $98018-19-A$ & S19 & 300104696 & "Bottom" liquid layer, thought to be aqueous \\
\hline $98018-20-T$ & S20 & 300104694 & "Top" liquid layer, thought to be organic \\
\hline $98018-20-\mathrm{B}$ & S20 & 300104693 & "Bottom" liquid layer, thought to be aqueous \\
\hline $98018-21$ & S21 & 300104360 & N/A \\
\hline $98018-22$ & S22 & 300109227 & N/A \\
\hline
\end{tabular}

The sampling process was unsuccessful on multiple tanks. Tanks S10, S12, and S18 were not sampled for liquids due to the presence of only very minimal amounts of liquids in these tanks. Tanks $S 9$ and $S 17$ were not sampled for liquids because these tanks contained no liquids. For Tanks S15 and S16, initial sludge sampling indicated the potential presence of liquids in both tanks. However, upon re-sampling, only sludge was obtained.

Typically for the sludges, the unsuccessful sampling events were caused by the presence of only very minimal amounts of solid material (<1/16" thickness). Sludge sampling was attempted in Tanks S3, S5, S10, S11 (see Tables 2 and 3), and S12. However, due to the presence of only very minimal amounts of material in these tanks, sludge samples were 
not obtained. Even though attempts were made to obtain sludge samples, the Sampling and Analysis Plan did not require sludge sampling in Tanks S3, S10, S11, and S12 due to the presence of less than 50 gallons of solid phase ${ }^{2}$. No sludge sampling was attempted from Tanks S1, S9, S17, and S18. All four of these tanks contained small amounts of sludge (<50 gallons) and therefore sampling was not required per the Sampling and Analysis Plan ${ }^{2}$. Tanks S12, S13, S14, S15, and S16 were sampled twice due to unsuccessful sampling events. Even after two attempts, an acceptable sludge sample was not obtained from Tank S12; and the minimal amounts of sludge obtained from Tanks $\mathrm{S} 13, \mathrm{~S} 14$, and $\mathrm{S} 15$ resulted in qualitative analytical results only. Finally, an attempt was made to sample Tank S6 but the tank was found to contain no sludge. Table 3 summarizes the unsuccessful sampling events. Section 3.2 discusses the quantities of liquids and solids present in each tank in detail.

Table 2. Sludge Sample Identification

\begin{tabular}{|c|c|c|l|}
\hline Sample ID & Tank \# & LIMS \# & \multicolumn{1}{|c|}{ Comments } \\
\hline $98351-2$ & S2 & 300117917 & N/A \\
\hline $98351-4$ & S4 & 300117919 & Mostly liquid, limited analyses performed. \\
\hline $98351-7$ & S7 & 300117921 & N/A \\
\hline $98351-8$ & S8 & 300117922 & N/A \\
\hline $98351-11$ & S11 & 300117924 & Same as 98018-11, treated as a liquid sample. \\
\hline $98351-13$ & S13 & 300117927 & No significant sample, limited analyses performed. \\
\hline $98351-14$ & S14 & 300117928 & Sample looks like an insect, limited analyses performed. \\
\hline $98351-15$ & S15 & 300117705 & No significant sample, limited analyses performed. \\
\hline $98018-15 B$ & S15 & 300118522 & No significant sample, limited analyses performed. \\
\hline $98351-16 B$ & S16 & 300119031 & N/A \\
\hline $98351-19$ & S19 & 300117929 & N/A \\
\hline $98351-20$ & S20 & 300117930 & N/A \\
\hline $98351-21$ & S21 & 300117707 & N/A \\
\hline $98351-22$ & S22 & 300117708 & No significant sample, limited analyses performed. \\
\hline $98351-22 B$ & S22 & 300118217 & N/A \\
\hline
\end{tabular}

In summary, fifteen of the twenty-two Old Solvent Tanks were successfully sampled for liquids. Three tanks were not sampled for liquids due to the presence of only minimal quantities of liquids. Two tanks were not sampled because they contained no liquids and the final two tanks were found to contain no liquid when attempts were made to sample the contents. Successful sludge samples were obtained from nine of the twenty-two Old Solvent Tanks. In addition, limited samples were obtained from three other tanks. Nine of the ten remaining tanks contained less than 50 gallons of solid phase and thus the Sampling and Analysis Plan did not require that they be sampled ${ }^{2}$. Sampling was attempted on some of these tanks, however. Only one of the tanks (Tank S5) which was required to be sampled by the Sampling and Analysis Plan was not successfully sampled for sludge. 
Table 3. Unsuccessful Sampling Events

\begin{tabular}{|c|c|c|l|}
\hline Sample ID & Tank & Matrix & \multicolumn{1}{|c|}{ Comments } \\
\hline $98351-3$ & S3 & Sludge & Minimal solid present. \\
\hline $98351-5$ & S5 & Sludge & Minimal solid present. \\
\hline $98351-6$ & S6 & Sludge & Minimal solid present. \\
\hline $98351-10$ & S10 & Sludge & Minimal solid present. \\
\hline $98351-11$ & S11 & Sludge & Minimal solid present, liquid sample only obtained \\
\hline $98351-12 \mathrm{~N}$ & S12 & Sludge & Minimal solid present. \\
\hline $98351-12$ S & S12 & Sludge & Minimal solid present. \\
\hline $98351-13 \mathrm{~B}$ & S13 & Sludge & Minimal solid present. \\
\hline $98351-14 \mathrm{~B}$ & S14 & Sludge & Minimal solid present. \\
\hline $98018-15$ & S15 & Aqueous & No liquid sample obtained, solid material only. \\
\hline $98018-16$ & S16 & Aqueous & No liquid sample obtained, solid material only. \\
\hline $98351-16$ & S16 & Sludge & Minimal solid obtained. \\
\hline
\end{tabular}

\section{$2.0 \quad$ DISCUSSION}

\subsection{Overview of Liquid Sample Analysis Strategy}

Upon receipt by ADS, the original liquid samples were logged into ADS's Laboratory Information Management System (LIMS) and assigned unique identification numbers by the LIMS computer. LIMS is an online sample management and tracking system that utilizes a relational database to store information and analyses results of samples received and analyzed by ADS. Tables 1, 2 and 3 list the unique LIMS numbers assigned to the Old Solvent Tank samples. Throughout this characterization project, control of the samples was maintained by the ADS sample custodians in 773-A, B-150 and by the various $\mathrm{ADS}$ personnel assigned to analyze these samples.

After login, a 10-mL aliquot (if available) of each liquid sample was filtered using a $0.45 \mu \mathrm{m}$ membrane (Millipore Type HA mixed cellulose esters, 47 $\mathrm{mm}$ ) in order to separate the suspended solid material from the liquid phase. New LIMS numbers were subsequently assigned to each of the filtered liquid phases and the filtered solid material to facilitate tracking. These LIMS numbers are shown in Table 4. Only five milliliters of the original liquid sample from Tank S13 was filtered due to the limited amount of sample received by ADS. The original liquids from Tanks S5 and S11 had only very small amounts of suspended solid material; therefore the entire volume of both samples was filtered upon receipt by ADS. See the footnotes of Table 5 for more details on these samples. After filtration of the original liquid samples, the filtered liquid and solid materials were then independently characterized based upon the Sampling and Analysis Plan. 
Table 4. Filtered Sample Identification

\begin{tabular}{|c|c|c|c|c|}
\hline Sample ID & Tank \# & $\begin{array}{c}\text { Original } \\
\text { LIMS \# }\end{array}$ & $\begin{array}{c}\text { Filtered } \\
\text { Solid Material } \\
\text { LIMS \# }\end{array}$ & $\begin{array}{c}\text { Filtered } \\
\text { Liquid } \\
\text { LIMS \# }\end{array}$ \\
\hline $98018-1$ & S1 & 300103987 & 300104914 & 300104940 \\
\hline $98018-2$ & S2 & 300105060 & 300105061 & 300105063 \\
\hline $98018-3$ & S3 & 300104037 & 300104918 & 300104938 \\
\hline $98018-4$ & S4 & 300109222 & 300109278 & 300109291 \\
\hline $98018-5$ & S5 & 300119028 & 300119290 & 300119289 \\
\hline $98018-6$ & S6 & 300109223 & 300109279 & 300109292 \\
\hline $98018-7$ & S7 & 300109224 & 300109280 & 300109293 \\
\hline $98018-8$ & S8 & 300109225 & 300109281 & 300109294 \\
\hline $98018-11$ & S11 & 300118504 & 300118520 & 300118517 \\
\hline $98018-13$ & S13 & 300109226 & 300109282 & 300109295 \\
\hline $98018-14$ & S14 & 300103694 & 300103841 & 300104912 \\
\hline $98018-19-\mathrm{O}$ & S19 & 300104695 & 300104932 & 300104922 \\
\hline $98018-19-\mathrm{A}$ & S19 & 300104696 & 300104936 & 300104916 \\
\hline $98018-20-\mathrm{T}$ & $\mathrm{S} 20$ & 300104694 & 300104928 & 300104926 \\
\hline $98018-20-\mathrm{B}$ & $\mathrm{S} 20$ & 300104693 & 300104924 & 300104930 \\
\hline $98018-21$ & $\mathrm{~S} 21$ & 300104360 & 300104920 & 300104934 \\
\hline $98018-22$ & S22 & 300109227 & 300109283 & 300109296 \\
\hline
\end{tabular}

\subsection{Filtered Solid Material}

When the Sampling and Analysis Plan was conceived, it was anticipated that an adequate mass of sludge could be obtained in order to perform the desired analyses ${ }^{2}$. In practice; however, it was discovered that only very fine suspended solid particles could be obtained with the raw liquid samples. The extremely small mass of suspended solid material thus limited the number of analyses that could be performed on this phase of the material. Thus, only radiochemical characterization and ICP-MS were performed on the suspended solids. It was decided with the customer that this limited analytical data would be useful in answering potential TRU and fissile material concerns associated with the Old Solvent Tanks.

The recovered quantities of suspended solid material from each raw liquid sample are shown in Table 5. The remarkably limited quantities of suspended solids also significantly impacted the detection limits for the radiochemical and IPC-MS analyses. Thus, for radionuclides such as Cm245 and $\mathrm{Cm}-246$, the data is only of limited use because of the high detection limits. 
Table 5. Mass of Suspended Solids Recovered from Original Samples

\begin{tabular}{|c|c|c|}
\hline Sample \# & $\begin{array}{c}\text { Solid Material } \\
\text { LIMS \# }\end{array}$ & $\begin{array}{c}\text { Mass of Suspended } \\
\text { Solids Recovered per } \\
\text { 10 mL of Sample }\end{array}$ \\
\hline $98018-1$ & 300104914 & $0.0007 \mathrm{~g}$ \\
\hline $98018-2$ & 300105061 & $0.0017 \mathrm{~g}$ \\
\hline $98018-3$ & 300104918 & $0.0153 \mathrm{~g}$ \\
\hline $98018-4$ & 300109278 & $0.002 \mathrm{~g}$ \\
\hline $98018-5$ & 300119290 & $0.0017 \mathrm{~g}^{\mathrm{a}}$ \\
\hline $98018-6$ & 300109279 & $0.157 \mathrm{~g}$ \\
\hline $98018-7$ & 300109280 & $0.021 \mathrm{~g}$ \\
\hline $98018-8$ & 300109281 & $0.010 \mathrm{~g}$ \\
\hline $98018-11$ & 300118520 & $0.0074 \mathrm{~g}^{\mathrm{b}}$ \\
\hline $98018-13$ & 300109282 & $0.001 \mathrm{~g}^{\mathrm{c}}$ \\
\hline $98018-14$ & 300103841 & $0.0176 \mathrm{~g}^{\mathrm{d}}$ \\
\hline $98018-19-\mathrm{O}$ & 300104932 & $0.0132 \mathrm{~g}$ \\
\hline $98018-19-\mathrm{A}$ & 300104936 & $0.0116 \mathrm{~g}$ \\
\hline $98018-20-\mathrm{T}$ & 300104928 & $0.0176 \mathrm{~g}$ \\
\hline $98018-20-\mathrm{B}$ & 300104924 & $0.0022 \mathrm{~g}$ \\
\hline $98018-21$ & 300104920 & $0.1046 \mathrm{~g}$ \\
\hline $98018-22$ & 300109283 & $0.003 \mathrm{~g}$ \\
\hline
\end{tabular}

a- The volume of original liquid filtered from Tank S5 was approximately $120 \mathrm{~mL}$. This large volume was filtered due to the extremely low suspended solids content of the raw liquid.

b- The volume of original liquid filtered from Tank S11 was approximately $105 \mathrm{~mL}$. This large volume was filtered due to the extremely low suspended solids content of the raw liquid.

c- The volume of original liquid filtered from Tank S13 was $5 \mathrm{~mL}$ because of the limited amount of sample received.

d- The volume of original liquid filtered from Tank S14 was $100 \mathrm{~mL}$.

Prior to subsequent analyses on the suspended solid material, the solids were dissolved in $5 \mathrm{~mL}$ of concentrated nitric acid. A gamma pulse height analysis was then performed on an aliquot of the dissolved solid material followed by a myriad of radiochemical analyses. In addition, IPC-MS was employed for detection of many heavier actinides ranging from Th-232 to $\mathrm{Cm}-246$. The ICP-MS data also provided an independent analysis of nuclides such as U-235, U-238, Np-237, Am-243, and Cm-244 for comparison to the data obtained from traditional radiochemical techniques. Table 6 lists the analytes of interest for the suspended solid material as originally envisioned in the Sampling and Analysis Plan ${ }^{2}$. As mentioned before, significant deviations from this plan did occur due to the extremely 
limited sample size. When necessary, prioritization was established for the various radiochemical and ICP-MS analyses so that the critical analyses (such as TRU and fissile nuclides) could be performed first on the small quantity of available sample.

Table 6. Target Analytes for Suspended Solids

\begin{tabular}{|c|c|c|}
\hline Analyte & Technique & Procedure \\
\hline $\mathrm{Am}-241$ & Gamma PHA & ADS-2420 \\
\hline Ce-144 & Gamma PHA & $\mathrm{ADS}-2420$ \\
\hline Co-60 & Gamma PHA & ADS-2420 \\
\hline Cs-134 & Gamma PHA & ADS-2420 \\
\hline Cs-137 & Gamma PHA & ADS-2420 \\
\hline Eu-154 & Gamma PHA & ADS-2420 \\
\hline $\mathrm{Nb}-94$ & Gamma PHA & ADS-2420 \\
\hline Np-237 & Gamma PHA & ADS-2420 \\
\hline $\mathrm{Ru}-106$ & Gamma PHA & ADS -2420 \\
\hline Sb-125 & Gamma PHA & ADS-2420 \\
\hline Sn-126 & Gamma PHA & ADS-2420 \\
\hline $\mathrm{U}-235$ & Gamma PHA & ADS-2420 \\
\hline $\mathrm{Am}-243$ & Gamma PHA and ICP-MS & ADS-2420, ADS- 1551 \\
\hline Am Series, Total & Gamma and Alpha PHA, ICP-MS & $\begin{array}{l}\text { ADS-2420, ADS-2402, } \\
\text { ADS-1551 }\end{array}$ \\
\hline $\mathrm{C}-14$ & Separation and LSC & Special work instruction \\
\hline $\mathrm{Cm}-244$ & Alpha PHA and ICP-MS & ADS-2420, ADS-1551 \\
\hline $\mathrm{Cm}-245$ & ICP-MS & ADS-1551 \\
\hline $\mathrm{Cm}-246$ & ICP-MS & ADS-1551 \\
\hline Cm Series & Alpha PHA and ICP-MS & ADS-2402, ADS-1551 \\
\hline Gross Alpha and Beta & LSC & ADS-2424 \\
\hline $\mathrm{H}-3$ & Distillation and LSC & ADS-2444 \\
\hline I-129 & Separation and LEPS & Special work instruction \\
\hline $\mathrm{Ni}-59, \mathrm{Ni}-63$ & Separation and Counting & ADS-2452 \\
\hline Plutonium, Total & Summation & N/A \\
\hline $\begin{array}{l}\mathrm{Pu}-238, \mathrm{Pu}-239 \\
\mathrm{Pu}-240, \mathrm{Pu}-242\end{array}$ & Alpha PHA and ICP-MS & ADS-2402, ADS-1551 \\
\hline $\mathrm{Pu}-241$ & Separation and LSC & ADS-2453 (Modified) \\
\hline $\mathrm{Pm}-147$ & Separation and LSC & SRT-ADS-98-0399 \\
\hline Se-79 & \begin{tabular}{|l} 
Separation and LSC \\
\end{tabular} & SRT-ADS-98-0261 \\
\hline Sr-90 & \begin{tabular}{|l} 
Separation and LSC \\
\end{tabular} & ADS-2441 \\
\hline Tc-99 & \begin{tabular}{|l} 
Separation and LSC \\
\end{tabular} & ADS-2413 \\
\hline $\begin{array}{l}\text { U-233, U-234, U-236, } \\
\text { U-238 }\end{array}$ & Alpha PHA and ICP-MS & ADS-2402, ADS-1551 \\
\hline $\mathrm{U}-235$ & Gamma and Alpha PHA, ICP-MS & $\begin{array}{l}\text { ADS-2420, ADS-2402, } \\
\text { ADS-1551 }\end{array}$ \\
\hline
\end{tabular}




\subsection{Filtered Liquid Samples}

Since the volume of filtered liquid samples was typically not a limiting factor, these samples were more extensively characterized (per the Sampling and Analysis Plan) than the suspended solid material described in Section 2.2. The filtered liquid samples were analyzed for essentially all of the parameters listed in Table 6 and the parameters shown in Table $7^{2}$. As stated in Section 1.0, these parameters where chosen based upon potential disposal routes of the various phases present in the tanks.

The methodologies chosen were based solely on the analytes of interest listed in the various WAC's. No consideration was made for method requirements of the WAC's. The implication of this decision is discussed further in Section 4.2 in relation to the Solvent Storage Tanks WAC that has specific method requirements.

Any Volatile Organic Compounds (VOCs) present in the samples at concentrations above the Gas Chromatography/Mass Spectrometry (GC/MS) method detection limit were reported for this characterization. The Sampling and Analysis Plan specifically targeted benzene, methyl ethyl ketone (MEK), perchloroethylene (PCE), n-butanol and any known VOC's at concentrations greater than $20 \mathrm{mg} / \mathrm{L} .{ }^{2}$ Some of the other VOC's which were found by this characterization included acetone, trichloroethene (TCE) and dodecane.

Semi-Volatile Organic Compounds (semi-VOC's) present at concentrations above the Gas Chromatography/Mass Spectrometry (GC/MS) method detection limit were also reported for this characterization. In addition, the Sampling and Analysis specifically required that polychlorinated biphenyls (PCB's), kepone, and phenol/phenoxide/ nitrophenols (including pnitrophenol) be targeted ${ }^{2}$. Other semi-VOC's identified in various Old Solvent Tank samples included diphenyl ether, tributyl phosphate, and aliphatic hydrocarbons.

An instrument problem involving the ICP-ES occurred prior to the analysis of the liquid samples from Tanks S5 and S11. Due to this problem, these samples were analyzed for metals using ICP-MS. Several pieces of data from Tanks S5 and S11 were not previously reported and have therefore been included in this revision of the characterization report. 
Table 7 Additional Parameters for Filtered Liquids

\begin{tabular}{|c|c|c|}
\hline Analyte & Technique & $\begin{array}{c}\text { Procedure/ } \\
\text { Technical Reference }\end{array}$ \\
\hline $\begin{array}{l}\mathrm{Al}, \mathrm{Sb}, \mathrm{Ba}, \mathrm{Be}, \mathrm{B}, \mathrm{Cd}, \mathrm{Cr}, \\
\mathrm{Cu}, \mathrm{Fe}, \mathrm{Pb}, \mathrm{Mn}, \mathrm{Ni}, \mathrm{Ag}, \mathrm{Na} \text {, } \\
\text { Tl, U, Zn }\end{array}$ & ICP-ES & $\mathrm{ADS}-1509$ \\
\hline Chloride, Nitrate, Phosphate & $\mathrm{IC}$ & ADS-2306 \\
\hline $\begin{array}{ll}\text { Cyanide } \\
\end{array}$ & Complexation/Absorbance & ADS-2278 \\
\hline $\mathrm{As}, \mathrm{Se}$ & ICP-MS & ADS-1551 \\
\hline $\mathrm{Hg}$ & CVAA & ADS-1556 \\
\hline $\begin{array}{l}\text { Phenol/Phenoxide/ } \\
\text { Nitrophenols } \\
\end{array}$ & GC/MS & ADS-2657 \\
\hline Semi-Volatile Organics & GC/MS & ADS-2657 \\
\hline $\begin{array}{l}\text { Total Inorganic } \\
\text { Carbon/Total Organic } \\
\text { Carbon } \\
\end{array}$ & TIC/TOC & ADS-1200 \\
\hline Volatile Organics & GC/MS & ADS-2656 \\
\hline PCB's & $\mathrm{GC}, \mathrm{GC} / \mathrm{MS}$ & ADS-2659 \\
\hline Acidity & Titration & ADS-2301 \\
\hline Boiling Point & Heating Mantle/Condenser Tube & ADS-2280 \\
\hline $\mathrm{BTU} / \mathrm{lb}$ & Calculation & N/A \\
\hline Flash Point & Closed Cup & ADS-2250 \\
\hline Freezing Point & Ice Bath/Observation & ADS-2279 \\
\hline Paint Filter Liquids Test & EPA SW-846 Method 9095 & ADS-2275 \\
\hline $\mathrm{pH}$ & Electrode & ADS-2309 \\
\hline Density & Known Volume/Analytical Balance & ADS-2219 \\
\hline Total Dissolved Solids & Filtration/Evaporation/Drying & Standard Method $2540 \mathrm{C}$ \\
\hline $\begin{array}{l}\text { Total Insoluble/Suspended } \\
\text { Solids }\end{array}$ & Filtration/Drying & Standard Method 2540 D \\
\hline Ash Content & Modified ASTM Method D 482 & Special Work Instruction \\
\hline Water Weight Percent & Karl-Fischer & ADS-2210 \\
\hline
\end{tabular}

\subsection{Sludge Samples}

Upon receipt by ADS, the sludge samples were logged into the ADS LIMS and assigned unique identification numbers by the LIMS computer. Table 2 lists the unique LIMS numbers assigned to these samples. As with the liquid samples, control of the sludge samples was maintained by the ADS sample custodians in 773-A, B-150 and by the various ADS personnel assigned to analyze these samples. 
Table 8. Additional Parameters for Sludges

\begin{tabular}{|l|l|l|}
\hline \multicolumn{1}{|c|}{ Analyte } & \multicolumn{1}{|c|}{ Technique } & \multicolumn{1}{c|}{$\begin{array}{c}\text { Procedure/ } \\
\text { Technical Reference }\end{array}$} \\
\hline $\begin{array}{l}\text { Al, Sb, Ba, Be, B, Cd, Cr, } \\
\text { Cu, Fe, Pb, Mn, Ni, Ag, Na, } \\
\text { Ti, Tl, Zn }\end{array}$ & ICP-ES & ADS-1509 \\
\hline $\begin{array}{l}\text { Ammonium, Chloride, } \\
\text { Fluoride, Nitrate, Nitrite, } \\
\text { Oxalate, Phosphate, Sulfate }\end{array}$ & IC & ADS-2306 \\
\hline Cyanide & Complexation/Absorbance & ADS-2278 \\
\hline As, Se & ICP-MS & ADS-1551 \\
\hline Hg & CVAA & ADS-1556 \\
\hline K & FAA & ADS-1549 \\
\hline $\begin{array}{l}\text { Aluminate, Carbonate, Free } \\
\text { Hydroxide }\end{array}$ & Titration & ADS-2312 \\
\hline Crystallography & XRD & ADS-1101 \\
\hline TCLP & Modified TCLP & ADS-2512 \\
\hline $\begin{array}{l}\text { Phenol/Phenoxide/ } \\
\text { Nitrophenols (SVOA) }\end{array}$ & GC/MS & ADS-2657 \\
\hline Total Organic Carbon & TOC & ADS-1200 \\
\hline Volatile \% Organics & Oil Content Analyzer & ADS-2213 \\
\hline Volatile Organics & GC/MS & ADS-2656 \\
\hline PCB's & GC, GC/MS & ADS-2659 \\
\hline pH & Electrode & ADS-2309 \\
\hline Density & Known Volume/Analytical Balance & ADS-2219 \\
\hline Total Dissolved Solids & Filtration/Evaporation/Drying & Standard Method 2540C \\
\hline $\begin{array}{l}\text { Total Insoluble/Suspended } \\
\text { Solids }\end{array}$ & Filtration/Drying & Standard Method 2540 D \\
\hline
\end{tabular}

Prior to subsequent analyses of the sludges, a small amount of the solid material was removed for XRD if the amount of sample warranted it. The remaining sample or a portion of it was then dissolved in acid for subsequent analyses.

The amount of sludge sample ultimately dictated which analyses would be performed; thus in some cases a significant deviation from the Sampling and Analysis Plan occurred. Tables 6 and 8 list the complete set of target analytes specified in the Sampling and Analysis Plan for the sludge phases ${ }^{2}$. However, in order to deal with sample, time, and resource constraints on the sludge samples, the analytes listed in the Sampling and Analysis Plan were prioritized. Gross Alpha/Gross Beta, XRD (if the sample was a solid), Gamma PHA, ICP-MS (Ag, As, $\mathrm{Ba}, \mathrm{Cd}, \mathrm{Cr}, \mathrm{Pb}, \mathrm{Se}$, and heavy actinides), Pu Separation, Alpha PHA, GC-MS SVOA, GC/MS PCB's, and CVAA 
(Hg). Originally, ICP-ES was to be used for the RCRA metals but a last minute instrument problem prohibited this and ICP-MS was employed.

If sample size restricted the analyses further, prioritization was given to Gross Alpha/Gross Beta, Gamma PHA, ICP-MS, Pu Separation, and Alpha PHA. For the sludges from Tanks $S 13$ and S14, only a qualitative Gross Alpha/Gross Beta analysis was performed. Qualitative Gross Alpha/Gross Beta and Gamma PHA were performed on the first sludge sample from Tank S15. On the second sludge sample from Tank S15, quantitative GC/MS SVOA and GC/MS PCB analyses were performed while qualitative Gamma PHA, Gross Alpha/Gross Beta, Alpha PHA, Pu Separation, and ICP-MS analyses were performed.

\subsection{RESULTS}

\subsection{Analytical Results of Old Solvent Tank Samples}

The analytical results of all samples analyzed are presented by tank number in Appendices A through Q. In each appendix, the data are presented for the unfiltered, original sample (suspended solids data only); filtered liquid sample; suspended solid material, and sludge, respectively. As mentioned previously, specific tanks may not have been successfully sampled for a particular phase. Therefore, not all of the Appendices will contain data for each sample type (original liquid sample, filtered liquid, filtered solids, and sludge). All errors reported are at the $95.5 \%$ confidence level (2-sigma).

Results reported without any qualifiers are positive values above detection limits for that particular method. Values preceded by a " $<$ " are detection limits for the method under the conditions used for the measurement. Thus for these values, no signal above instrument background was seen. A "UL" listed after a radionuclide activity means the value is an upper limit only. Upper limits typically result when interfering nuclides prevent the quantification of another radionuclide. Radionuclide data followed by "MDA" are minimum detectable concentrations calculated using the methodology of Currie ${ }^{8}$. A "DL" following a radionuclide activity signifies a detection limit as reported by ICP-MS; hence, no positive signal above background was seen.

Typical detection limits for the methodologies employed in this characterization study are given in Table 1 of Reference 2 . For those methods requiring the dissolution of a solid sample, dilution factors for the sludges ranged from 12.5 to 675.7 while dilution factors for the suspended solids ranged from 31.8 to 7143 . Thus, detection limits for a given nuclide had large ranges because of the various dilution factors involved for the 
different sample types. The large dilution factors for some of the suspended solid samples significantly impacted the usefulness of the analytical data. Detection limits from these large dilution factor samples were extremely high.

Total americium, total curium, and total plutonium activities represent sums of all positively identified isotopes of these elements. No detection limit or minimum detectable concentration values were included in these totals. However, if activities were reported as upper limits, they were included in the total for conservatism.

When originally sampled, it was thought that the two liquid samples from Tank S19 (98018-O and 98018-A) were from two different phases. Based upon previous information regarding the contents of the tank, each sample was taken from a different depth within the tank. The analytical data from the two samples clearly shows that these two samples are both from the aqueous phase of the tank. Thus, these samples can be considered duplicates and can be used to check the precision of the analytical results.

The two samples taken from Tank S20 (98018-20-B and 98018-20-T) appear to be from two different phases based upon the analytical data. These two samples were also taken at different depths within the tank. Thus, it was concluded that this tank definitely contains an organic phase and an aqueous phase. The volume of each phase, however, is unknown. Finally, the liquid obtained from Tank S11 was also organic; hence, this tank may also have two different liquid phases. However, only a single liquid sample was obtained from this tank and the presence of an aqueous phase could not be confirmed.

The XRD data from ten sludge samples are given in Table 9. Major, minor, and trace constituents present are reported. XRD was not required by any of the WAC's but was performed for possible investigations into grout formulations if that route is chosen for treatment. These data are useful for determining the physical makeup of the sludge material within the tanks. The data clearly shows the variety of material present in the various tanks. 
Table 9. XRD Data on Sludge Samples

\begin{tabular}{|c|c|c|c|}
\hline Sample ID & Tank\# & LIMS \# & Description of Solid \\
\hline $98351-2$ & S2 & $3-117917$ & $\begin{array}{l}\text { Chernikovite, syn }-\mathrm{H}_{2}\left(\mathrm{UO}_{2}\right)_{2}\left(\mathrm{PO}_{4}\right)_{2} \bullet 8 \mathrm{H}_{2} \mathrm{O} \text { (Major) } \\
\text { Metavanuralite - } \mathrm{Al}\left(\mathrm{UO}_{2}\right)_{2} \mathrm{~V}_{2} \mathrm{O}_{8}(\mathrm{OH}) \bullet 8 \mathrm{H}_{2} \mathrm{O} \text { (Major) }\end{array}$ \\
\hline $98351-7$ & S7 & $3-117921$ & $\begin{array}{l}\text { Uranyl Oxonium Phosphate Hydrate }-\mathrm{H}_{3} \mathrm{OUO}_{2} \mathrm{PO}_{4} \bullet \\
\text { 3-xH } \mathrm{H}_{2} \mathrm{O} \text { (Major) } \\
\text { Silicon Oxide - } \mathrm{SiO}_{2} \text { (Major) }\end{array}$ \\
\hline 98351-8 & S8 & $3-117922$ & $\begin{array}{l}\text { Silicon Oxide }-\mathrm{SiO}_{2} \text { (Major) } \\
\text { Magnetite, syn }-\mathrm{Fe}_{3} \mathrm{O}_{4} \text { (Trace) } \\
\text { Hematite, syn }-\mathrm{Fe}_{2} \mathrm{O}_{3} \text { (Trace) } \\
\end{array}$ \\
\hline $98351-15$ & S15 & $3-117705$ & $\begin{array}{l}\text { Uranyl Oxonium Hydrogen Phosphate Hydrate - } \\
\mathrm{UO}_{2} \mathrm{H}_{\mathrm{x}} \mathrm{PO}_{4}\left(\mathrm{H}_{3} \mathrm{O}\right)_{1-\mathrm{x}} \mathrm{H}_{2} \mathrm{O} \text { (Major) } \\
\text { Sodium Uranium Oxide - } \mathrm{Na}_{2} \mathrm{U}_{2} \mathrm{O}_{7} \text { (Major) } \\
\text { Nickel Hydroxide - } \mathrm{Ni}(\mathrm{OH})_{2} \text { (Major) }\end{array}$ \\
\hline 98351-16B & S16 & $3-119031$ & $\begin{array}{l}\text { Sodium Uranium Oxide - } \mathrm{Na}_{6} \mathrm{U}_{7} \mathrm{O}_{24} \text { (Major) } \\
\text { Nickel Hydroxide - } \mathrm{Ni}(\mathrm{OH})_{2} \text { (Major) } \\
\text { Uranyl Oxonium Hydrogen Phosphate Hydrate - } \\
\mathrm{UO}_{2} \mathrm{H}_{\mathrm{x}} \mathrm{PO}_{4}\left(\mathrm{H}_{3} \mathrm{O}\right)_{1-x} \mathrm{H}_{2} \mathrm{O} \text { (Major) }\end{array}$ \\
\hline $98351-19$ & S19 & $3-117929$ & $\begin{array}{l}\text { Sodium Uranyl Carbonate - } \mathrm{Na}_{4}\left(\mathrm{UO}_{2}\right)\left(\mathrm{CO}_{3}\right)_{3} \text { (Major) } \\
\text { Sodium Uranium Oxide - } \mathrm{Na}_{6} \mathrm{U}_{7} \mathrm{O}_{24} \text { (Major) }\end{array}$ \\
\hline $98351-20$ & S20 & $3-117930$ & $\begin{array}{l}\text { Sodium Uranium Oxide }-\mathrm{Na}_{6} \mathrm{U}_{7} \mathrm{O}_{24} \text { (Major) } \\
\text { Gibbsite, syn - } \mathrm{Al}(\mathrm{OH})_{3} \text { (Major) } \\
\text { Halite, potassian, syn }-\mathrm{K}_{0.2} \mathrm{Na}_{0.8} \mathrm{Cl} \text { (Major) } \\
\end{array}$ \\
\hline $98351-21$ & $\mathbf{S 2 1}$ & $3-117707$ & $\begin{array}{l}\text { Gibbsite - } \mathrm{Al}(\mathrm{OH})_{3} \text { (Major) } \\
\text { Quartz, alpha, syn - } \mathrm{SiO}_{2} \text { (Major) } \\
\end{array}$ \\
\hline $98351-22$ & S22 & $3-117708$ & $\begin{array}{l}\text { Bayerite - } \mathrm{Al}(\mathrm{OH})_{3} \text { (Major) } \\
\text { Gibbsite - } \mathrm{Al}(\mathrm{OH})_{3} \text { (Major) } \\
\end{array}$ \\
\hline $98351-22 B$ & S22 & 3-118217 & $\begin{array}{l}\text { Quartz, alpha, syn - } \mathrm{SiO}_{2} \text { (Major) } \\
\text { Gibbsite - } \mathrm{Al}(\mathrm{OH})_{3} \text { (Minor) }\end{array}$ \\
\hline
\end{tabular}

\subsection{Estimated Radionuclide Inventory in Each Tank}

Table 10 lists the estimated quantities of liquid and sludge for each tank in terms of mass and volume $9,10,11$. These data are based upon video and physical surveillances of the tanks. As can be seen from the data in this table, Tanks S9, S15, S16, and S17 contain sludge but no liquid while Tank S6 contains liquid but no sludge. All of the remaining tanks appear to have both liquid and sludge. The estimated sludge in the tanks ranges from 0 to greater than $2000 \mathrm{~kg}$ with a total sludge content of approximately $6750 \mathrm{~kg}$. The estimated liquid ranges from 0 to over 7500 liters with a total liquid content in all of the tanks of approximately 21,300 liters. As mentioned previously, it should be noted that at least two of the tanks (S11 and S20) have organic liquid layers present. This was proven by the analytical results of this characterization study. 
Table 10. Estimated Liquid and Sludge Content of Tanks S1 - S22

\begin{tabular}{|c|c|c|c|c|c|c|}
\hline $\begin{array}{c}\text { Tank } \\
\#\end{array}$ & $\begin{array}{l}\text { Liquid } \\
\text { Volume } \\
\text { (liters) }\end{array}$ & $\begin{array}{l}\text { Liquid } \\
\text { Mass } \\
\text { (kg) }\end{array}$ & $\begin{array}{l}\text { Successfully } \\
\text { Sampled? }\end{array}$ & $\begin{array}{c}\text { Sludge } \\
\text { Volume } \\
\text { (liters) }^{\mathrm{f}}\end{array}$ & $\begin{array}{c}\text { Sludge } \\
\text { Mass } \\
\text { (kg) }\end{array}$ & $\begin{array}{l}\text { Successfully } \\
\text { Sampled? }\end{array}$ \\
\hline S1 & $4.43 E+02$ & $3.88 \mathrm{E}+02$ & Yes & $1.70 \mathrm{E}+01$ & $3.41 \mathrm{E}+01$ & Not sampled \\
\hline S2 & $4.23 \mathrm{E}+02$ & $4.24 \mathrm{E}+02$ & Yes & $1.26 \mathrm{E}+02$ & $2.51 \mathrm{E}+02$ & Yes \\
\hline S3 & $1.51 \mathrm{E}+03$ & $1.57 \mathrm{E}+03$ & Yes & $1.40 \mathrm{E}+01$ & $2.80 \mathrm{E}+01$ & No \\
\hline $\mathrm{S} 4$ & $1.40 \mathrm{E}+03$ & $1.51 \mathrm{E}+03$ & Yes & $2.20 \mathrm{E}+01$ & $4.39 \mathrm{E}+01$ & Yes \\
\hline S5 & $3.48 \mathrm{E}+02$ & $3.85 \mathrm{E}+02$ & Yes & $4.24 \mathrm{E}+02$ & $8.48 \mathrm{E}+02$ & No \\
\hline S6 & $1.04 \mathrm{E}+03$ & $1.12 \mathrm{E}+03$ & Yes & $0.00 \mathrm{E}+00$ & $0.00 \mathrm{E}+00$ & No sludge \\
\hline S7 & $1.20 \mathrm{E}+03$ & $1.31 \mathrm{E}+03$ & Yes & $5.68 \mathrm{E}+00$ & $1.14 \mathrm{E}+01$ & Yes \\
\hline S8 & $5.19 \mathrm{E}+02$ & $5.45 \mathrm{E}+02$ & Yes & $2.27 \mathrm{E}+01$ & $4.54 \mathrm{E}+01$ & Yes \\
\hline S9 & $0.00 \mathrm{E}+00$ & $0.00 \mathrm{E}+00$ & No liquid & $4.92 \mathrm{E}+01$ & $9.84 \mathrm{E}+01$ & Not sampled \\
\hline $\mathrm{S10}$ & $3.79 \mathrm{E}+01$ & $3.79 \mathrm{E}+01^{\mathrm{c}}$ & Not sampled & $1.17 \mathrm{E}+02$ & $2.35 \mathrm{E}+02$ & No \\
\hline S11 & $5.41 \mathrm{E}+01^{\mathrm{a}}$ & $5.53 \mathrm{E}+01$ & Yes & $4.81 \mathrm{E}+01$ & $9.61 \mathrm{E}+01$ & No \\
\hline S12 & $1.89 \mathrm{E}+01$ & $1.89 \mathrm{E}+01^{\mathrm{c}}$ & Not sampled & $1.89 \mathrm{E}+01$ & $3.79 \mathrm{E}+01$ & No \\
\hline $\mathrm{S} 13$ & $8.26 \mathrm{E}+02$ & $9.06 \mathrm{E}+02$ & Yes & $1.63 \mathrm{E}+02$ & $3.26 \mathrm{E}+02$ & Yes \\
\hline $\mathrm{S} 14$ & $1.39 \mathrm{E}+03$ & $1.41 \mathrm{E}+03$ & Yes & $4.48 \mathrm{E}+02$ & $8.96 \mathrm{E}+02$ & Yes \\
\hline S15 & $0.00 \mathrm{E}+00$ & $0.00 \mathrm{E}+00$ & No liquid & $5.49 \mathrm{E}+02$ & $1.10 \mathrm{E}+03$ & Yes \\
\hline S16 & $0.00 \mathrm{E}+00$ & $0.00 \mathrm{E}+00$ & No liquid & $1.03 \mathrm{E}+03$ & $2.07 \mathrm{E}+03$ & Yes \\
\hline S17 & $0.00 \mathrm{E}+00$ & $0.00 \mathrm{E}+00$ & No liquid & $2.65 \mathrm{E}+01$ & $5.30 \mathrm{E}+01$ & Not sampled \\
\hline S18 & $1.89 \mathrm{E}+01$ & $1.89 \mathrm{E}+01^{\mathrm{c}}$ & Not sampled & $7.57 \mathrm{E}+00$ & $1.51 \mathrm{E}+01$ & Not sampled \\
\hline S19 & $2.17 \mathrm{E}+03^{\mathrm{b}}$ & $2.37 \mathrm{E}+03^{\mathrm{d}}$ & Yes & $1.02 \mathrm{E}+02$ & $2.04 \mathrm{E}+02$ & Yes \\
\hline $\mathrm{S} 20$ & $7.55 \mathrm{E}+03^{\mathrm{b}}$ & $7.94 \mathrm{E}+03^{\mathrm{e}}$ & Yes & $3.41 \mathrm{E}+01$ & $6.81 \mathrm{E}+01$ & Yes \\
\hline S21 & $6.90 \mathrm{E}+02$ & $7.39 \mathrm{E}+02$ & Yes & $1.18 \mathrm{E}+02$ & $2.37 \mathrm{E}+02$ & Yes \\
\hline S22 & $1.69 \mathrm{E}+03$ & $1.81 \mathrm{E}+03$ & Yes & $2.84 \mathrm{E}+01$ & $5.68 \mathrm{E}+01$ & Yes \\
\hline Total & $2.13 \mathrm{E}+04$ & $2.26 \mathrm{E}+04$ & N/A & $3.38 \mathrm{E}+03$ & $6.75 E+03$ & N/A \\
\hline
\end{tabular}

a- This tank contains organic liquid. It is unknown whether any aqueous liquid in present in the tank.

b- The volumes listed for Tanks $S 19$ and $\mathbf{S} 20$ represent the total liquid volume contained in these tanks. Tank S20 definitely contains an organic phase, however; it is unknown whether Tank S19 has an organic phase. Two liquid samples were taken from Tank S19 and both of them were aqueous. For Tanks $\mathrm{S} 19$ and $\mathrm{S} 20$, the fraction of the liquid that is organic and the fraction that is aqueous are unknown.

c- The densities of these liquids were assumed to be $1.00 \mathrm{~g} / \mathrm{cm}^{3}$.

d- The density of sample 98018-19-O (see Table 1) was used to calculate the total mass of the liquid in Tank $S 19$.

e- Since this tank contains both an organic and aqueous layer, the density of the aqueous phase was used to calculate the total mass of the liquid in the tank for conservatism.

f- The sludge mass was determined based upon the estimated volume and an estimated density of $2.0 \mathrm{~g} / \mathrm{cm}^{3}$. 
For the various tanks, the total estimated inventory of each radionuclide identified in the filtered liquid was calculated based upon the estimated volumes of the liquid phases and the activity concentrations of the radionuclides. This data is presented in the final columns of the filtered liquid spreadsheets in Appendices $\mathrm{A}$ through $\mathrm{K}$ and $\mathrm{N}$ through $\mathrm{Q}$. Using Tank $S 1$ as an example, the total aqueous phase activity of Am-241 was calculated by simply multiplying the activity per unit volume of this nuclide $\left(8.42 \times 10^{-3} \mu \mathrm{Ci} / \mathrm{mL}\right)$ by the estimated volume $(443,000 \mathrm{~mL})$ to obtain $3.73 \times 10^{3} \mu \mathrm{Ci}$. Similarly, the total estimated inventory of each radionuclide identified in the filtered (suspended) solids was calculated based upon the estimated masses of the filtered solids and the activity concentrations of the radionuclides. This data is presented in the final columns of the filtered solids spreadsheets in Appendices A through $\mathrm{K}$ and $\mathrm{N}$ through $\mathrm{Q}$. It should be noted that this inventory does not include the radionuclides contained in the sludge phase of each tank. The total estimated inventory of each identified radionuclide in the sludge material of each tank was calculated from the estimated mass of sludge present and the activity concentrations. These inventories are presented in the sludge spreadsheets in Appendices B, $D, G, H, M, N, O, P$, and $Q$. There was insufficient sample to determine a mass on the sludges obtained from Tanks S13, S14, and S15; hence, total activities per nuclide and total tank inventories could not be calculated. However, the qualitative radionuclide data for these three tanks are given in the sludge spreadsheets of Appendices J, $\mathrm{K}$, and $\mathrm{L}$.

The gross activity contained in the raw liquid (liquid phase plus the suspended solid material contained in the liquid phase) of each tank was calculated based upon the sum of the gross alpha and gross beta activities of the filtered liquid and suspended solid phases. The gross activity information of the raw liquids is summarized in Table 11.

It should be noted that the gross beta activity contains the contribution from tritium. Only the total liquid volume present in Tank S20 has been estimated based upon the video and physical surveillances. The fraction of this volume that is organic and the fraction that is aqueous are not known. Thus in order to conservatively calculate the gross activity present in the tank, all of the liquid was assumed to be organic when calculating the gross raw liquid activity for sample 98018-20-T (organic liquid). Likewise, when calculating the gross raw liquid activity for sample 98018-20-B (aqueous liquid), all of the liquid in the tank was assumed to be aqueous. Hence, the gross raw liquid activities for these two tanks should be considered upper limits. No data are available on the liquids and suspended solids in Tanks $\mathrm{S} 10, \mathrm{S12}$, and S18. These tanks were not sampled for liquids due to the presence of only very minimal amounts of liquids. See Section 1.0 for a 
more detailed discussion of the sampling events involving the liquids from the Old Solvent Tanks. Also data are not available for Tanks S9, S15, S16, and $S 17$ because these tanks contained no liquids (and thus no suspended solids) ${ }^{9,10,11}$.

Table 11. Calculated Gross Activity Content of Raw Liquids in Solvent Tanks

\begin{tabular}{|c|c|}
\hline Tank \# & $\begin{array}{c}\text { Gross Raw Liquid } \\
\text { Activity } \\
\text { (Ci) }\end{array}$ \\
\hline S1 & $1.12 \mathrm{E}+00$ \\
\hline S2 & $3.50 \mathrm{E}-02$ \\
\hline S3 & $1.08 \mathrm{E}+00$ \\
\hline S4 & $2.27 \mathrm{E}-01$ \\
\hline S5 & $1.00 \mathrm{E}+02$ \\
\hline S6 & $9.49 \mathrm{E}-01$ \\
\hline S7 & $9.89 \mathrm{E}-01$ \\
\hline S8 & $7.51 \mathrm{E}-01$ \\
\hline S11 & $8.67 \mathrm{E}+00$ \\
\hline S13 & $1.36 \mathrm{E}+00$ \\
\hline S14 & $1.24 \mathrm{E}+00$ \\
\hline S19-O & $6.16 \mathrm{E}+00$ \\
\hline S19-A & $5.36 \mathrm{E}+00$ \\
\hline S20-T & $<9.05 \mathrm{E}-01^{\mathrm{a}}$ \\
\hline S20-B & $<8.41 \mathrm{E}+00$ \\
\hline S21 & $5.00 \mathrm{E}+00$ \\
\hline S22 & $2.23 \mathrm{E}+00$ \\
\hline
\end{tabular}

a- The gross alpha and gross beta activity concentrations of the suspended solids could not be determined due to the immeasurably small amount of mass that was obtained for analysis after filtering the raw liquid from the organic phase of Tank S20. The activity concentrations were therefore calculated based upon the activity contained on the filter, suspended solids data of the raw liquid, density of the liquid, and volume of liquid filtered.

The gross activity contained in the sludge of each analyzed tank was also calculated based upon the sum of the gross alpha and gross beta activities of the sludges. The gross activity information of the sludges is summarized in Table 12. Once again it should be noted that the gross beta activity contains the contribution from tritium.

Two sludge samples were taken from Tank S22 on two different dates. It is obvious from the gross activity data shown in Appendix $Q$ that the activity is not homogeneously distributed in this solid material. In addition, the 
XRD data given in Table 9 supports the conclusion that these two solids were two different types of material. Thus, the value given in Table 12 was based upon the sample with the higher activity concentration (98351-22B). Note that no information is available on the sludges in Tanks S1, S3, S5, S9, S10, S11, S12, S17, and S18. Adequate sludge samples were not obtained for these tanks due to unsuccessful sampling events and/or the presence of only very minimal amounts of sludge. See Section 1.0 for a more detailed discussion of the sampling events involving the sludges from the Old Solvent Tanks. Also no data are available for Tank S6 because this tank contained no sludge ${ }^{9,10,11}$. Finally, insufficient sludge samples were obtained from Tanks S13, S14, and S15 for quantitative analyses. Thus, for these tanks, only qualitative data were obtained.

Table 12. Calculated Gross Activity Content of Sludges in Solvent Tanks

\begin{tabular}{|c|c|}
\hline Tank \# & $\begin{array}{c}\text { Gross Sludge } \\
\text { Activity } \\
\text { (Ci) }\end{array}$ \\
\hline$S 2$ & $4.11 \mathrm{E}+01$ \\
\hline$S 4$ & $7.25 \mathrm{E}-03$ \\
\hline$S 7$ & $2.31 \mathrm{E}-02$ \\
\hline$S 8$ & $7.48 \mathrm{E}-01$ \\
\hline$S 13$ & unknown $^{\mathrm{a}}$ \\
\hline$S 14$ & unknown $^{\mathrm{a}}$ \\
\hline$S 15$ & unknown $^{\mathrm{a}}$ \\
\hline$S 16$ & $8.23 \mathrm{E}+00$ \\
\hline$S 19$ & $1.84 \mathrm{E}+01$ \\
\hline$S 20$ & $3.66 \mathrm{E}+00$ \\
\hline$S 21$ & $1.49 \mathrm{E}-01$ \\
\hline$S 22$ & $9.04 \mathrm{E}+00$ \\
\hline
\end{tabular}

a- The amount of sample obtained was insufficient to determine a mass, therefore activity concentrations and total activities could not be determined. Only relative activities are available for these tanks.

Table 13 shows the total activity in those tanks for which quantitative data was obtained for the raw liquid phase and/or the sludge phase. Note that according to the video and physical surveillances, Tank S6 has no sludge in it and Tanks S15 and S16 have no liquid in them ${ }^{9,10,11}$. Thus the activities listed for these phases in Table 13 are zero. The sludge phases from Tanks $\mathrm{S} 1$ and $\mathrm{S} 11$ were not sampled but the liquid phases from these tanks were sampled and analyzed. For the sludge phases in Tanks S3 and S5, the sludge phases were unsuccessfully sampled thus no analytical data were obtained for these phases. However, the liquids from both of these tanks were successfully sampled and analyzed. 
It should be noted that the raw liquid data for Tank S19 represents the average of the two aqueous samples that were taken from this tank. The agreement of the data between these two samples was quite good. As stated before for Tank S20, two phases are present and the volume of each phase is unknown. However, the total volume of liquid in this tank has been estimated. Thus when the total activity of each liquid phase was calculated, it was assumed that the volume of each phase equaled the total liquid volume present in the tank. The raw liquid activity was then calculated by summing the upper limits of the total activity of the organic and aqueous phases. Hence, the raw liquid value given in Table 13 represents an upper limit for the amount of activity in the two liquid phases of this tank. Since two sludge samples from Tank S22 were taken and the gross activities of these two samples differed significantly, the higher gross activity was used for the total activity calculation in this tank.

Table 13. Calculated Total Gross Activity Content of Sampled Solvent Tanks

\begin{tabular}{|c|c|c|c|}
\hline Tank \# & $\begin{array}{c}\text { Raw Liquid } \\
\text { Activity } \\
\text { Ci }\end{array}$ & $\begin{array}{c}\text { Sludge } \\
\text { Activity } \\
\text { Ci }\end{array}$ & $\begin{array}{c}\text { Total } \\
\text { Ci }\end{array}$ \\
\hline S1 & $1.12 \mathrm{E}+00$ & Not sampled & $\geq 1.12 \mathrm{E}+00$ \\
\hline S2 & $3.50 \mathrm{E}-02$ & $4.11 \mathrm{E}+01$ & $4.11 \mathrm{E}+01$ \\
\hline S3 & $1.08 \mathrm{E}+00$ & No sample obtained & $\geq 1.08 \mathrm{E}+00$ \\
\hline S4 & $2.27 \mathrm{E}-01$ & $7.25 \mathrm{E}-03$ & $2.34 \mathrm{E}-01$ \\
\hline S5 & $1.00 \mathrm{E}+02$ & No sample obtained & $\geq 1.00 \mathrm{E}+02$ \\
\hline S6 & $9.49 \mathrm{E}-01$ & $0.00 \mathrm{E}+00$ & $9.49 \mathrm{E}-01$ \\
\hline S7 & $9.89 \mathrm{E}-01$ & $2.31 \mathrm{E}-02$ & $1.01 \mathrm{E}+00$ \\
\hline S8 & $7.51 \mathrm{E}-01$ & $7.48 \mathrm{E}-01$ & $1.50 \mathrm{E}+00$ \\
\hline S11 & $8.67 \mathrm{E}+00$ & Not sampled & $\geq 8.67 \mathrm{E}+00$ \\
\hline S13 & $1.36 \mathrm{E}+00$ & Unknown $^{\mathrm{a}}$ & $\geq 1.36 \mathrm{E}+00$ \\
\hline S14 & $1.24 \mathrm{E}+00$ & Unknown & $\geq 1.24 \mathrm{E}+00$ \\
\hline S15 & $0.00 \mathrm{E}+00$ & Unknown $^{\mathrm{a}}$ & Unknown \\
\hline S16 & $0.00 \mathrm{E}+00$ & $8.23 \mathrm{E}+00$ & $8.23 \mathrm{E}+00$ \\
\hline S19 & $5.76 \mathrm{E}+00$ & $1.84 \mathrm{E}+01$ & $2.42 \mathrm{E}+01$ \\
\hline S20 & $<9.32 \mathrm{E}+00$ & $3.66 \mathrm{E}+00$ & $<1.30 \mathrm{E}+01$ \\
\hline S21 & $5.00 \mathrm{E}+00$ & $1.49 \mathrm{E}-01$ & $5.15 \mathrm{E}+00$ \\
\hline S22 & $2.23 \mathrm{E}+00$ & $9.04 \mathrm{E}+00$ & $1.13 \mathrm{E}+01$ \\
\hline
\end{tabular}

a- The amount of sample obtained was insufficient to determine a mass, therefore activity concentrations and total activities could not be determined. Only relative activities are available for these tanks. 


\subsection{Estimated TRU Content of Each Tank}

The TRU content of the filtered liquid phase, the filtered solids contained in the liquid phase, and the raw liquid of each tank were calculated based upon the data contained in Appendices A through $\mathrm{K}$ and $\mathrm{N}$ through Q. These TRU data are presented in Table 14. Only upper limit values and positively identified transuranic nuclides (i.e. no detection limits were used) were included in the TRU calculations. Table 15 lists the TRU nuclides that were measured and considered for this characterization study of the Old Solvent Tanks. It should be noted that detection limits were quite high for some TRU nuclides especially for the filtered solid material due to the analytical technique used and the small amount of material obtained. Thus, the detection limit data for these nuclides is only of limited value. For the liquid phases, activities per unit volume have been converted to activities per gram using the measured density of each liquid. It should be emphasized that this information does not include the TRU content of the sludge phase in each tank. As previously noted, no information is available on the liquids and suspended solids in Tanks S10, S12, and S18. These tanks were not sampled for liquids due to the presence of only very minimal amounts of liquids. See Section 1.0 for a more detailed discussion of the sampling events involving the liquids from the Old Solvent Tanks. Also data are not available for Tanks S9, S15, S16, and S17 because these tanks contained no liquids (and thus no suspended solids) ${ }^{9,10,11}$.

Table 14. Calculated TRU Concentrations of Filtered Liquid Phases and Filtered Solids

\begin{tabular}{|c|c|c|c|}
\hline Sample ID & $\begin{array}{c}\text { Filtered Liquid } \\
\text { TRU } \\
\text { Concentration } \\
\text { (nCi/g) }\end{array}$ & $\begin{array}{c}\text { Filtered Solids TRU } \\
\text { Concentration } \\
\text { (nCi/g) }\end{array}$ & $\begin{array}{c}\text { Raw } \\
\text { Liquid TRU } \\
\text { Concentration } \\
\text { (nCi/g) }\end{array}$ \\
\hline $98018-1$ & $7.70 \mathrm{E}+02$ & $9.32 \mathrm{E}+04$ & $7.80 \mathrm{E}+02$ \\
\hline $98018-2$ & $1.46 \mathrm{E}+01^{\mathbf{2}}$ & $1.41 \mathrm{E}+05$ & $4.47 \mathrm{E}+01$ \\
\hline $98018-3$ & $1.99 \mathrm{E}+01$ & $4.94 \mathrm{E}+04$ & $8.89 \mathrm{E}+01$ \\
\hline $98018-4$ & $1.54 \mathrm{E}+01$ & $3.66 \mathrm{E}+04$ & $2.27 \mathrm{E}+01$ \\
\hline $98018-5$ & $3.87 \mathrm{E}+03$ & $1.51 \mathrm{E}+05$ & $3.50 \mathrm{E}+03$ \\
\hline $98018-6$ & $1.16 \mathrm{E}+01$ & $3.96 \mathrm{E}+04$ & $5.89 \mathrm{E}+02$ \\
\hline $98018-7$ & $2.85 \mathrm{E}+02$ & $1.12 \mathrm{E}+04$ & $3.06 \mathrm{E}+02$ \\
\hline $98018-8$ & $2.51 \mathrm{E}+01$ & $1.02 \mathrm{E}+05$ & $1.17 \mathrm{E}+02$ \\
\hline $98018-11$ & $2.94 \mathrm{E}+03$ & $2.86 \mathrm{E}+04$ & $2.88 \mathrm{E}+03$ \\
\hline $98018-13$ & $6.86 \mathrm{E}+02$ & $1.26 \mathrm{E}+06$ & $9.38 \mathrm{E}+02$ \\
\hline $98018-14$ & $1.18 \mathrm{E}+02$ & $2.72 \mathrm{E}+05$ & $1.67 \mathrm{E}+02$ \\
\hline $98018-19-0$ & $1.86 \mathrm{E}+03$ & $1.03 \mathrm{E}+05$ & $1.98 \mathrm{E}+03$ \\
\hline $98018-19-\mathrm{A}$ & $1.86 \mathrm{E}+03$ & $2.46 \mathrm{E}+04$ & $1.89 \mathrm{E}+03$ \\
\hline $98018-20-\mathrm{T}$ & $2.90 \mathrm{E}+00$ & $8.63 \mathrm{E}+02$ & $4.44 \mathrm{E}+00$ \\
\hline $98018-20-\mathrm{B}$ & $5.51 \mathrm{E}+02$ & $9.34 \mathrm{E}+04$ & $5.70 \mathrm{E}+02$ \\
\hline $98018-21$ & $4.55 \mathrm{E}+02$ & $8.79 \mathrm{E}+04$ & $1.29 \mathrm{E}+03$ \\
\hline $98018-22$ & $2.61 \mathrm{E}+02$ & $1.53 \mathrm{E}+05$ & $3.07 \mathrm{E}+02$ \\
\hline
\end{tabular}


a- Limited analytical data available. This number should be considered a lower limit only.

b- The TRU activity concentration of the suspended solids could not be determined due to the immeasurably small amount of mass that was obtained for analysis after filtering the raw liquid from the organic phase of Tank S20. This value was therefore calculated based upon the activity contained on the filter, suspended solids data of the raw liquid, density of the liquid, and volume of liquid filtered.

Table 15. TRU Nuclides Measured in this Characterization

\begin{tabular}{|c|c|}
\hline Nuclide & $\begin{array}{c}\text { Half Life }^{\mathbf{1 2}} \\
\text { (yrs) }\end{array}$ \\
\hline $\mathrm{Np}-237$ & 2140000 \\
\hline $\mathrm{Am}-241$ & 432.2 \\
\hline $\mathrm{Am}-243$ & 7370 \\
\hline $\mathrm{Cm}-245$ & 8500 \\
\hline $\mathrm{Cm}-246$ & 4730 \\
\hline $\mathrm{Pu}-238$ & 87.7 \\
\hline $\mathrm{Pu}-239$ & 24110 \\
\hline $\mathrm{Pu}-240$ & 6563 \\
\hline $\mathrm{Pu}-242$ & 373300 \\
\hline
\end{tabular}

Based on these characterization data, the raw aqueous liquids contained in Tanks S1, S5, S6, S7, S8, S13, S14, S19, S20, S21, and S22 have specific TRU activities of $>100 \mathrm{nCi} / \mathrm{g}$. In addition, the raw organic liquid contained in Tank S11 also has a TRU activity concentration of $>100 \mathrm{nCi} / \mathrm{g}$. The TRU concentration of the suspended solids in the organic phase of Tank S20 had to be calculated in an alternate manner due to the immeasurably small mass of solids present after the suspended solids were filtered from the raw liquid. The activity calculations were based upon the relative amounts of activity detected on the filter used to separate the suspended solids from the raw liquid, the weight percent of total suspended solids in the raw liquid, the density of the liquid, and the volume of raw liquid filtered. The TRU activity concentration of the raw organic liquid of Tank S20 was calculated to be $4.44 \mathrm{nCi} / \mathrm{g}$. It should also be emphasized; however, that $\mathrm{Am}-242 \mathrm{~m}$, $\mathrm{Pu}-244, \mathrm{Cm}-243, \mathrm{Cm}-247, \mathrm{Bk}-247, \mathrm{Cm}-248, \mathrm{Cf}-249$, and Cf-251 were not measured in this characterization study. The nuclides measured are the most predominate TRU nuclides in the material and those that were not measured are expected to be less than $10 \%$ of those measured. Reference 13 provides the calculated actinide content, after 15 years of decay, for two frequently used SRS reactor assemblies. The calculated actinide content is based upon JOSHUA, a nuclear physics computer code used to calculate the production 
of nuclides for SRS reactor operations. Based upon the JOSHUA output, the curie fraction of various heavy actinides was calculated. These data are presented in Table 16.

The curie fraction for each nuclide was calculated by taking the normalized, isotopic content (in grams per assembly) from the JOSHUA output, multiplying by the specific activity for that nuclide (in $\mathrm{Ci} / \mathrm{g}$ ), and dividing that product by the total normalized actinide activity of the assembly. As can be seen in Table 16, the heavier actinides are only minor contributors to the total activity. Furthermore, if one considers only the TRU nuclides listed in Table 16 (i.e. Pu-241, Cm-242, Cm-244, Bk-249, Cf-250, and Cf252 are ignored), then approximately $96 \%$ of the activity from each type of assembly comes from $\mathrm{Pu}-238$ and approximately $2.5 \%$ comes from Am-241.

Table 16. Calculated Activity Fractions for Selected Actinide Nuclides

\begin{tabular}{|c|c|c|c|c|}
\hline Nuclide & $\begin{array}{c}\text { Normalized } \\
\text { Mark 16B } \\
\text { Activity } \\
\text { Content } \\
\text { Ci/assembly }\end{array}$ & $\begin{array}{c}\text { Mark 16 B } \\
\text { Activity } \\
\text { Curie } \\
\text { Fraction }\end{array}$ & $\begin{array}{c}\text { Normalized } \\
\text { Mark 22 } \\
\text { Activity } \\
\text { Content } \\
\text { Ci/assembly }\end{array}$ & $\begin{array}{c}\text { Mark 22 } \\
\text { Activity } \\
\text { Curie } \\
\text { Fraction }\end{array}$ \\
\hline Pu-238 & $7.09 \mathrm{E}+00$ & $5.59 \mathrm{E}-01$ & $6.95 \mathrm{E}+00$ & $5.43 \mathrm{E}-01$ \\
\hline $\mathrm{Pu}-239$ & $6.20 \mathrm{E}-02$ & $4.90 \mathrm{E}-03$ & $6.20 \mathrm{E}-02$ & $4.84 \mathrm{E}-03$ \\
\hline $\mathrm{Pu}-240$ & $4.56 \mathrm{E}-02$ & $3.60 \mathrm{E}-03$ & $4.11 \mathrm{E}-02$ & $3.21 \mathrm{E}-03$ \\
\hline $\mathrm{Pu}-241$ & $5.29 \mathrm{E}+00$ & $4.18 \mathrm{E}-01$ & $5.56 \mathrm{E}+00$ & $4.34 \mathrm{E}-01$ \\
\hline $\mathrm{Pu}-242$ & $6.32 \mathrm{E}-05$ & $4.99 \mathrm{E}-06$ & $6.16 \mathrm{E}-05$ & $4.81 \mathrm{E}-06$ \\
\hline $\mathrm{Am}-241$ & $1.81 \mathrm{E}-01$ & $1.43 \mathrm{E}-02$ & $1.90 \mathrm{E}-01$ & $1.48 \mathrm{E}-02$ \\
\hline $\mathrm{Am}-242 \mathrm{~m}$ & $9.77 \mathrm{E}-05$ & $7.71 \mathrm{E}-06$ & $1.11 \mathrm{E}-04$ & $8.67 \mathrm{E}-06$ \\
\hline $\mathrm{Am}-243$ & $1.06 \mathrm{E}-04$ & $8.37 \mathrm{E}-06$ & $1.17 \mathrm{E}-06$ & $9.12 \mathrm{E}-08$ \\
\hline $\mathrm{Cm}-242$ & $7.48 \mathrm{E}-05$ & $5.91 \mathrm{E}-06$ & $8.48 \mathrm{E}-05$ & $6.62 \mathrm{E}-06$ \\
\hline $\mathrm{Cm}-243$ & $4.00 \mathrm{E}-05$ & $3.16 \mathrm{E}-06$ & $4.51 \mathrm{E}-05$ & $3.52 \mathrm{E}-06$ \\
\hline $\mathrm{Cm}-244$ & $2.05 \mathrm{E}-03$ & $1.62 \mathrm{E}-04$ & $2.54 \mathrm{E}-05$ & $1.98 \mathrm{E}-06$ \\
\hline $\mathrm{Cm}-245$ & $1.22 \mathrm{E}-07$ & $9.62 \mathrm{E}-09$ & $1.84 \mathrm{E}-09$ & $1.43 \mathrm{E}-10$ \\
\hline $\mathrm{Cm}-246$ & $9.77 \mathrm{E}-09$ & $7.71 \mathrm{E}-10$ & $1.40 \mathrm{E}-10$ & $1.09 \mathrm{E}-11$ \\
\hline $\mathrm{Cm}-247$ & $1.19 \mathrm{E}-14$ & $9.37 \mathrm{E}-16$ & $2.04 \mathrm{E}-16$ & $1.59 \mathrm{E}-17$ \\
\hline $\mathrm{Cm}-248$ & $1.25 \mathrm{E}-14$ & $9.84 \mathrm{E}-16$ & $2.44 \mathrm{E}-16$ & $1.90 \mathrm{E}-17$ \\
\hline $\mathrm{Bk}-249$ & $1.66 \mathrm{E}-16$ & $1.31 \mathrm{E}-17$ & $2.02 \mathrm{E}-20$ & $1.57 \mathrm{E}-21$ \\
\hline $\mathrm{Cf}-249$ & $7.37 \mathrm{E}-14$ & $5.82 \mathrm{E}-15$ & $8.76 \mathrm{E}-18$ & $6.84 \mathrm{E}-19$ \\
\hline $\mathrm{Cf}-250$ & $1.72 \mathrm{E}-13$ & $1.35 \mathrm{E}-14$ & ---- & ---- \\
\hline $\mathrm{Cf}-251$ & $1.22 \mathrm{E}-15$ & $9.65 \mathrm{E}-17$ & ---- & --- \\
\hline $\mathrm{Cf}-252$ & $2.25 \mathrm{E}-15$ & $1.77 \mathrm{E}-16$ & --- & -- \\
\hline
\end{tabular}

The TRU content of the sludge phases present in the various tanks was also calculated based upon the data contained in Appendices B, D, G, H, M, N, $\mathrm{O}, \mathrm{P}$, and $\mathrm{Q}$. These TRU data are presented in Table 17. As mentioned 
earlier, only upper limit values and positively identified transuranic nuclides (i.e. no detection limits were used) were included in the TRU calculations. Once again, only those TRU nuclides listed in Table 15 were measured and considered for this characterization study of the Old Solvent Tanks. Due to the analytical techniques used and the dilution factors involved, detection limits were quite high for some TRU nuclides especially for the sludge material. Thus, the detection limit data for these nuclides is only of limited value. As stated before, no information is available on the sludges from Tanks S1, S3, S5, S9, S10, S11, S12, S17, and S18. Adequate sludge samples were not obtained for these tanks due to unsuccessful sampling events and/or the presence of only very minimal amounts of sludge. See Section 1.0 for a more detailed discussion of the sampling events involving the sludges from the Old Solvent Tanks. Also no data are available for Tank S6 because this tank contained no sludge ${ }^{9,10,11}$. Finally, insufficient sludge samples were obtained from Tanks S13, S14, and S15 for quantitative analyses. Thus, for these tanks, only qualitative data were obtained.

Table 17. Calculated TRU Concentrations of Sludges

\begin{tabular}{|c|c|}
\hline Sample ID & $\begin{array}{c}\text { Sludge } \\
\text { TRU } \\
\text { Concentration } \\
\text { (nCi/g) }\end{array}$ \\
\hline $98351-2$ & $6.52 \mathrm{E}+04$ \\
\hline $98351-4^{\mathrm{a}}$ & $4.55 \mathrm{E}+01$ \\
\hline $98351-7$ & $7.52 \mathrm{E}+02$ \\
\hline $98351-8$ & $4.18 \mathrm{E}+02$ \\
\hline $98351-13$ & Unknown $^{\mathrm{b}}$ \\
\hline $98351-14$ & Unknown $^{\mathrm{b}}$ \\
\hline $98351-15$ & Unknown $^{\mathrm{b}}$ \\
\hline $98351-15 \mathrm{~B}$ & Unknown $^{\mathrm{b}}$ \\
\hline $98351-16 \mathrm{~B}$ & $1.47 \mathrm{E}+03$ \\
\hline $98351-19$ & $2.88 \mathrm{E}+04$ \\
\hline $98351-20$ & $7.59 \mathrm{E}+03$ \\
\hline $98351-21$ & $3.76 \mathrm{E}+02$ \\
\hline $98351-22 \mathrm{~B}$ & $7.90 \mathrm{E}+03$ \\
\hline
\end{tabular}

a- Complete TRU data not available. This number should be considered a lower limit. TRU activity concentration was calculated from this liquid sample assuming a sludge density of $2.0 \mathrm{~g} / \mathrm{cm}^{3}$.

b- The amount of sample obtained was insufficient to determine a mass, therefore activity concentrations and total activities could not be determined. Only relative activities are available for these tanks. 


\subsection{Estimated Inventory of Heavier Nuclides}

The fissile material content of the various phases in the Old Solvent Tanks must be measured before any treatment and/or disposal options can be considered. In addition, FGE calculations are required by the WAC's of the potential disposal facilities for the material in the Old Solvent Tanks. It is important for criticality considerations to know the mass of various fissile nuclides present in the tanks. Total activities and masses were calculated from published specific activities and the activity concentrations of the various heavier nuclides determined in this characterization study ${ }^{14}$. The specific activities for the heavier radionuclides studied in this characterization are summarized in Table 18. As discussed previously, it should be emphasized that nuclides such as Am-242m, Cm-242, Cm-243, Cm-247, Bk-247, Cf-249, Cf-250, Cf-251, and Cf-252 were not measured in this study; however, these nuclides are not expected to be important contributors to the material in the Old Solvent Tanks ${ }^{13}$. The FGE calculations and criticality discussions for the Old Solvent Tanks are in "Evaluation of Old Solvent Storage Tanks 1-22" (WSMS-CRT-99-0039), which is included as Attachment 4 to the "Addendum to the Workplan/RCRA Facility Investigation/Remedial Investigation Report of the Old Radioactive Waste Burial Ground 643-E, S01-S22."

Table 18. Specific Activities for Mass Calculations

\begin{tabular}{|c|c|}
\hline Nuclide & $\begin{array}{c}\text { Specific Activity } \\
\text { (Ci/g) }\end{array}$ \\
\hline $\mathrm{U}-233$ & $9.64 \mathrm{E}-03$ \\
\hline $\mathrm{U}-234$ & $6.24 \mathrm{E}-03$ \\
\hline $\mathrm{U}-235$ & $2.16 \mathrm{E}-06$ \\
\hline $\mathrm{U}-236$ & $6.47 \mathrm{E}-05$ \\
\hline $\mathrm{U}-238$ & $3.36 \mathrm{E}-07$ \\
\hline $\mathrm{Np}-237$ & $7.05 \mathrm{E}-04$ \\
\hline $\mathrm{Pu}-238$ & $1.71 \mathrm{E}+01$ \\
\hline $\mathrm{Pu}-239$ & $6.21 \mathrm{E}-02$ \\
\hline $\mathrm{Pu}-240$ & $2.27 \mathrm{E}-01$ \\
\hline $\mathrm{Pu}-241$ & $1.03 \mathrm{E}+02$ \\
\hline $\mathrm{Pu}-242$ & $3.93 \mathrm{E}-03$ \\
\hline $\mathrm{Am}-241$ & $3.44 \mathrm{E}+00$ \\
\hline $\mathrm{Am}-243$ & $2.00 \mathrm{E}-01$ \\
\hline $\mathrm{Cm}-244$ & $8.10 \mathrm{E}+01$ \\
\hline $\mathrm{Cm}-245$ & $1.72 \mathrm{E}-01$ \\
\hline $\mathrm{Cm}-246$ & $3.04 \mathrm{E}-01$ \\
\hline
\end{tabular}

Conservatism was built into the total activity and mass calculations for the heavier radionuclides measured in this study in a twofold manner. The activity of a radionuclide known or suspected to be in the Old Solvent Tanks 
but not detected was assumed to be equal to the detection limit for that radionuclide for the measurement conditions used. And secondly, for those positively identified radionuclides, the 2-sigma measurement error was added to the activity before performing the total activity and mass calculations.

Table 19 summarizes the results of the U-235, U-238, and Pu-239 mass calculations for the filtered liquid samples. The details of these calculations are given in Appendix R. An example calculation using U-233 in the filtered liquid from Tank $\mathrm{S} 1$ is given below.

$\mathrm{U}-233$ activity in filtered liquid $=5.05 \times 10^{5} \pm 1.01 \times 10^{5} \mathrm{pCi} / \mathrm{L}$

Specific Activity of $\mathrm{U}-233=9.64 \times 10^{-3} \mathrm{Ci} / \mathrm{g}$

Volume of filtered liquid in the tank $=443.2717 \mathrm{~L}$

Total $\mathrm{U}-233$ in the tank including error $=\left(5.05 \times 10^{5}+1.01 \times 10^{5}\right) \times 443.2717=2.686 \times 10^{8} \mathrm{pCi}$

Total U - 233 in the tank including error $=2.686 \times 10^{8} \mathrm{pCi} \times \frac{1 \mathrm{Ci}}{1 \times 10^{12} \mathrm{pCi}} \approx 2.69 \times 10^{-4} \mathrm{Ci}$

$\mathrm{U}-233$ activity concentration including error $=\frac{2.686 \times 10^{-4} \mathrm{Ci}}{443.2717 \text { liters }}=6.06 \times 10^{-7} \mathrm{Ci} / \mathrm{L}$

Mass of $\mathrm{U}-233$ in the tank including error $=\frac{2.686 \times 10^{-4} \mathrm{Ci}}{9.64 \times 10^{-3} \mathrm{Ci} / \mathrm{g}}=2.787 \times 10^{-2} \approx 2.79 \times 10^{-2} \mathrm{~g}$

Mass of $U-233$ per liter of waste $=\frac{2.787 \times 10^{-2} \text { grams }}{443.2717 \text { liters }}=6.286 \times 10^{-5} \approx 6.29 \times 10^{-5} \mathrm{~g} / \mathrm{L}$

For Tank S19 as stated before, samples 98018-19-O and 98018-19-A were both aqueous and can be considered duplicates. The results from these two samples can be used as an indication of the precision of the analytical results and homogeneity of the liquid in this tank. Tank S20 is known to contain both organic and aqueous liquid phases. However, only the total volume is known and the volume of each of the two liquid phases is unknown. Therefore, the nuclide masses determined for samples 98018-20-T and 98018-20-B were calculated in a conservative manner. For sample 9801820-T (organic phase), it was assumed that the entire volume of liquid in Tank S20 was organic when calculating the nuclide masses for this phase. Then, for sample 98018-20-B (aqueous phase), it was assumed that the 
entire volume was aqueous when calculating the total masses for the aqueous phase. These two values can then be summed to give a conservative upper limit of the nuclide content of the filtered liquid phases in this tank. No information is available on the liquids (and suspended solids) in Tanks S10, S12, and S18. These tanks were not sampled for liquids due to the presence of only very minimal amounts of liquids. See Section 1.0 for more details of the sampling events involving the liquids from the Old Solvent Tanks. Also, U-235, U-238, and Pu-239 mass data are not available for Tanks S9, S15, S16, and S17 because these tanks contained no liquids (or suspended solids) ${ }^{9,10,11}$.

Table 19. U-235, U-238, and Pu-239 Masses Contained in the Filtered Liquids

\begin{tabular}{|c|c|c|c|}
\hline Tank \# & $\begin{array}{c}\text { U-235 } \\
(\mathbf{g})\end{array}$ & $\begin{array}{c}\mathbf{U}-238 \\
(\mathbf{g})\end{array}$ & $\begin{array}{c}\text { Pu-239 } \\
(\mathbf{g})\end{array}$ \\
\hline S1 & $2.11 \mathrm{E}+01$ & $2.99 \mathrm{E}+03$ & $1.49 \mathrm{E}-01$ \\
\hline S2 & $3.72 \mathrm{E}+00$ & $0.00 \mathrm{E}+00^{\mathrm{a}}$ & $<1.35 \mathrm{E}-02$ \\
\hline S3 & $6.56 \mathrm{E}+01$ & $9.95 \mathrm{E}+03$ & $3.82 \mathrm{E}-01$ \\
\hline S4 & $1.63 \mathrm{E}+02$ & $3.32 \mathrm{E}+04$ & $<1.02 \mathrm{E}+00$ \\
\hline S5 & $6.50 \mathrm{E}+01$ & $1.13 \mathrm{E}+04$ & $1.53 \mathrm{E}+00$ \\
\hline S6 & $2.13 \mathrm{E}+01$ & $3.19 \mathrm{E}+03$ & $<7.64 \mathrm{E}-01$ \\
\hline S7 & $2.24 \mathrm{E}+02$ & $4.80 \mathrm{E}+04$ & $2.76 \mathrm{E}+00$ \\
\hline S8 & $7.35 \mathrm{E}+00$ & $1.12 \mathrm{E}+03$ & $<3.80 \mathrm{E}-01$ \\
\hline S11 & $6.07 \mathrm{E}-02$ & $<7.83 \mathrm{E}+00$ & $4.54 \mathrm{E}-02$ \\
\hline S13 & $6.15 \mathrm{E}+01$ & $9.95 \mathrm{E}+03$ & $<6.05 \mathrm{E}-01$ \\
\hline S14 & $3.92 \mathrm{E}+01$ & $1.83 \mathrm{E}+04$ & $2.93 \mathrm{E}-01$ \\
\hline S19-O & $3.68 \mathrm{E}+01$ & $5.72 \mathrm{E}+04$ & $3.12 \mathrm{E}-01$ \\
\hline S19-A & $3.71 \mathrm{E}+01$ & $4.72 \mathrm{E}+04$ & $2.50 \mathrm{E}-01$ \\
\hline S20-T & $<8.85 \mathrm{E}+00$ & $<2.49 \mathrm{E}+02$ & $<5.65 \mathrm{E}-02$ \\
\hline S20-B & $<1.93 \mathrm{E}+02$ & $<4.12 \mathrm{E}+04$ & $<2.21 \mathrm{E}+00$ \\
\hline S21 & $2.04 \mathrm{E}+01$ & $7.68 \mathrm{E}+03$ & $2.10 \mathrm{E}-01$ \\
\hline S22 & $4.96 \mathrm{E}+01$ & $5.91 \mathrm{E}+03$ & $<1.24 \mathrm{E}+00$ \\
\hline
\end{tabular}

a- Value not measured.

The U-235 masses in the filtered liquids range from 0.0607 grams in Tank $\mathrm{S} 11$ to 224 grams in Tank S7. The U-238 masses range from $<7.83$ grams in Tank S11 to 57,200 grams in one of the two samples from Tanks S19. The Pu-239 mass range is from $<0.0135$ grams in Tank $\mathbf{S} 2$ to 2.76 grams in Tank S7.

Table 20 summarizes the results of the U-235, U-238, and Pu-239 mass calculations for the suspended solid samples. The details of these calculations are given in Appendix S. The U-235 masses range from 0.000117 grams in Tank S11 to 57.1 grams in Tank S6. The U-238 masses 
range from 0.0203 grams in Tank S1 1 to 12,600 grams in Tanks S6. The $\mathrm{Pu}-239$ mass range is from 0.000127 grams in Tank S11 to 1.75 grams in Tank S6.

The U-235, U-238, and Pu-239 mass calculation results for the sludges are shown in Table 21. The details of these calculations are given in Appendix T. The calculated U-235 mass values range from 0.184 grams in Tank S8 to 1020 grams in Tank S16. The U-238 mass values in the sludges range from 26.9 grams in Tank S8 to 187,000 grams in Tank S16. The Pu-239 mass values in the sludges range from $<0.00224$ grams in Tank S4 to 28.6 grams in Tank S16. As stated before, no quantitative information is available on the sludges in Tanks S1, S3, S5, S9, S10, S11, S12, S13, S14, S15, S17, and $\mathrm{S} 18$. Adequate sludge samples were not obtained for these tanks due to unsuccessful sampling events and/or the presence of only very minimal amounts of sludge. See Section 1.0 for a more detailed discussion of the sampling events involving the sludges from the Old Solvent Tanks. Also no U-235, U-238, and Pu-239 mass data are available for Tank S6 because this tank contained no sludge $e^{9,10,11}$.

Table 20. U-235, U-238, and Pu-239 Masses Contained in the Suspended Solids

\begin{tabular}{|c|c|c|c|}
\hline Tank \# & $\begin{array}{c}\text { U-235 } \\
(\mathrm{g})\end{array}$ & $\begin{array}{c}\text { U-238 } \\
(\mathrm{g})\end{array}$ & $\begin{array}{c}\text { Pu-239 } \\
(\mathrm{g})\end{array}$ \\
\hline S1 & $4.92 \mathrm{E}-02$ & $7.30 \mathrm{E}+00$ & $<4.05 \mathrm{E}-03$ \\
\hline S2 & $3.40 \mathrm{E}-01$ & $5.45 \mathrm{E}+01$ & $9.04 \mathrm{E}-03$ \\
\hline S3 & $8.14 \mathrm{E}+00$ & $1.07 \mathrm{E}+03$ & $3.69 \mathrm{E}-01$ \\
\hline S4 & $7.05 \mathrm{E}-01$ & $9.26 \mathrm{E}+01$ & $1.84 \mathrm{E}-02$ \\
\hline S5 & $1.92 \mathrm{E}-03$ & $2.95 \mathrm{E}-01$ & $4.63 \mathrm{E}-04$ \\
\hline S6 & $5.71 \mathrm{E}+01$ & $1.26 \mathrm{E}+04$ & $1.75 \mathrm{E}+00$ \\
\hline S7 & $5.56 \mathrm{E}+00$ & $1.29 \mathrm{E}+02$ & $2.63 \mathrm{E}-01$ \\
\hline S8 & $6.76 \mathrm{E}-02$ & $1.58 \mathrm{E}+01$ & $1.10 \mathrm{E}-01$ \\
\hline S11 & $1.17 \mathrm{E}-04$ & $2.03 \mathrm{E}-02$ & $1.27 \mathrm{E}-04$ \\
\hline S13 & $1.68 \mathrm{E}+00$ & $2.75 \mathrm{E}+02$ & $2.30 \mathrm{E}-01$ \\
\hline S14 & $2.54 \mathrm{E}-02$ & $4.07 \mathrm{E}+00$ & $7.72 \mathrm{E}-03$ \\
\hline S19-O & $3.01 \mathrm{E}+00$ & $4.67 \mathrm{E}+02$ & $1.22 \mathrm{E}-01$ \\
\hline S19-A & $1.54 \mathrm{E}+00$ & $2.47 \mathrm{E}+02$ & $4.10 \mathrm{E}-02$ \\
\hline S20-T & $<1.64 \mathrm{E}-01$ & $<2.40 \mathrm{E}+01$ & $<5.51 \mathrm{E}-02$ \\
\hline S20-B & $<1.24 \mathrm{E}+00$ & $<2.12 \mathrm{E}+02$ & $<1.11 \mathrm{E}-01$ \\
\hline S21 & $5.21 \mathrm{E}+00$ & $8.14 \mathrm{E}+02$ & $4.99 \mathrm{E}-01$ \\
\hline S22 & $1.99 \mathrm{E}-01$ & $<2.24 \mathrm{E}+01$ & $7.36 \mathrm{E}-02$ \\
\hline
\end{tabular}

Table 22 shows the total U-235, U-238, and Pu-239 mass values in those tanks for which quantitative data was obtained for the raw liquid phase and the sludge phase. Note that Tank S6 has no sludge in it and Tank S16 has no liquid in it. Data was not obtained for the sludges from Tanks S1, S3, 
S5, S11, S13, and S14. Thus, the results listed in Table 22 for these tanks represent lower limits since they contain the contributions from the filtered liquids and suspended solids only.

Table 21. U-235, U-238, and Pu-239 Masses Contained in the Sludges

\begin{tabular}{|c|c|c|c|}
\hline Tank \# & $\begin{array}{c}\text { U-235 } \\
(\mathbf{g})\end{array}$ & $\begin{array}{c}\text { U-238 } \\
(\mathbf{g})\end{array}$ & $\begin{array}{c}\text { Pu-239 } \\
(\mathbf{g})\end{array}$ \\
\hline S2 & $4.83 \mathrm{E}+00$ & $7.40 \mathrm{E}+02$ & $<1.23 \mathrm{E}+00$ \\
\hline S4 & $<3.63 \mathrm{E}+00$ & $9.65 \mathrm{E}+02$ & $<2.24 \mathrm{E}-03$ \\
\hline S7 & $3.66 \mathrm{E}+00$ & $6.98 \mathrm{E}+02$ & $8.89 \mathrm{E}-02$ \\
\hline S8 & $1.84 \mathrm{E}-01$ & $2.69 \mathrm{E}+01$ & $3.21 \mathrm{E}-02$ \\
\hline S16 & $1.02 \mathrm{E}+03$ & $1.87 \mathrm{E}+05$ & $2.86 \mathrm{E}+01$ \\
\hline S19 & $3.28 \mathrm{E}+02$ & $3.00 \mathrm{E}+04$ & $3.81 \mathrm{E}+00$ \\
\hline S20 & $1.89 \mathrm{E}+01$ & $1.16 \mathrm{E}+04$ & $1.07 \mathrm{E}+00$ \\
\hline S21 & $1.89 \mathrm{E}+00$ & $2.86 \mathrm{E}+02$ & $2.74 \mathrm{E}-01$ \\
\hline S22 & $9.50 \mathrm{E}-01$ & $0.00 \mathrm{E}+00^{\mathrm{b}}$ & $3.09 \mathrm{E}-01$ \\
\hline
\end{tabular}

a- U-235, U-238, and Pu-239 masses were calculated from this liquid sample assuming a sludge density of $2.0 \mathrm{~g} / \mathrm{cm}^{3}$ :

b- Value not measured.

Table 22. Total U-235, U-238, and Pu-239 Content of Sampled Solvent Tanks

\begin{tabular}{|c|c|c|c|}
\hline Tank \# & $\begin{array}{c}\text { U-235 } \\
\text { (g) }\end{array}$ & $\begin{array}{c}\text { U-238 } \\
(\mathrm{g})\end{array}$ & $\begin{array}{c}\text { Pu-239 } \\
\text { (g) }\end{array}$ \\
\hline$S 1^{\mathrm{a}}$ & $\geq 2.11 \mathrm{E}+01$ & $\geq 3.00 \mathrm{E}+03$ & $\geq 1.53 \mathrm{E}-01$ \\
\hline S2 & $8.89 \mathrm{E}+00$ & $7.95 \mathrm{E}+02^{\mathrm{c}}$ & $<1.25 \mathrm{E}+00$ \\
\hline $\mathrm{S3}^{\mathrm{a}}$ & $\geq 7.37 \mathrm{E}+01$ & $\geq 1.10 \mathrm{E}+04$ & $\geq 7.51 \mathrm{E}-01$ \\
\hline S4 & $<1.67 \mathrm{E}+02$ & $3.43 E+04$ & $<1.04 \mathrm{E}+00$ \\
\hline $\mathrm{S5}^{\mathrm{a}}$ & $\geq 6.50 \mathrm{E}+01$ & $\geq 1.13 \mathrm{E}+04$ & $\geq 1.53 \mathrm{E}+00$ \\
\hline S6 & $7.84 \mathrm{E}+01$ & $1.58 \mathrm{E}+04$ & $<2.51 \mathrm{E}+00$ \\
\hline S7 & $2.33 \mathrm{E}+02$ & $4.88 \mathrm{E}+04$ & $3.11 \mathrm{E}+00$ \\
\hline S8 & $7.60 \mathrm{E}+00$ & $1.16 \mathrm{E}+03$ & $<5.22 \mathrm{E}-01$ \\
\hline$S 11^{a}$ & $\geq 6.08 \mathrm{E}-02$ & $\geq 7.85 \mathrm{E}+00$ & $\geq 4.55 \mathrm{E}-02$ \\
\hline$S 13^{a}$ & $\geq 6.32 \mathrm{E}+01$ & $\geq 1.02 E+04$ & $\geq 8.35 \mathrm{E}-01$ \\
\hline $\mathrm{S} 14^{\mathrm{a}}$ & $\geq 3.92 \mathrm{E}+01$ & $\geq 1.83 \mathrm{E}+04$ & $\geq 3.01 \mathrm{E}-01$ \\
\hline S16 & $1.02 \mathrm{E}+03$ & $1.87 \mathrm{E}+05$ & $2.86 \mathrm{E}+01$ \\
\hline $\mathbf{S 1 9}$ & $3.67 \mathrm{E}+02^{\mathrm{b}}$ & $8.26 \mathrm{E}+04$ & $4.17 \mathrm{E}+00$ \\
\hline S20 & $<2.22 \mathrm{E}+02$ & $<5.33 E+04$ & $<3.50 \mathrm{E}+00$ \\
\hline S21 & $2.75 \mathrm{E}+01$ & $8.78 \mathrm{E}+03$ & $9.83 \mathrm{E}-01$ \\
\hline$\$ 22$ & $5.07 \mathrm{E}+01$ & $<5.93 \mathrm{E}+03^{\circ}$ & $<1.62 \mathrm{E}+00$ \\
\hline
\end{tabular}

a- Sludge data not available for this sample, see Section 1.0 for details.

b- This value was calculated using the average values of the two liquid and suspended solid samples. 
c- U-238 not measured on the filtered liquid sample.

d- U-238 not measured on the sludge sample.

As discussed previously, the raw liquid data for Tank S19 represents the average of two aqueous samples taken from this tank. The data for Tank S20 represents an upper limit only since there are two phases present in this tank and the volume of each phase is unknown. Thus when the various nuclide masses of each liquid phase were calculated, it was assumed that the volume of each phase equaled the total liquid volume present in the tank.

\subsection{COMPARISON OF DATA TO WAC'S}

Once the analyses were complete for the raw liquids, filtered liquids, suspended solids, and sludges, a detailed comparison relative to the appropriate WAC's was requested by ADS's customer, Savannah River Site-Environmental Restoration Division (SRS-ERD). Therefore, the extensive analytical data from the filtered liquids were compared to the requirements of the latest revisions of the WAC's from $\mathrm{CIF}^{15}, \mathrm{SSTF}^{16}, \mathrm{MWSB}^{15}$, and the TRU Pads ${ }^{17}$. For those tanks with sufficient data available for the sludges, a comparison to the latest revisions of the WAC's from the 241-F/H Tank Farms ${ }^{18}$, TRU Pads ${ }^{17}$, and MWSB $^{15}$ was performed. Since only a limited amount of radionuclide data were available for the suspended solids and sludges, only a limited comparison to the requirements of the WAC's could be performed. Specifically, this comparison focused primarily on the contribution of the suspended solids and sludges to the radionuclide inventory. The results of the comparisons of the raw liquids, filtered liquids, suspended solids, and sludges are given below. The intent of Section 4.0 of this report is to provide an initial screening only of the analytical results versus the various WAC's. The actual screening of the various remedial alternatives for the ORWBG Solvent Tanks was performed elsewhere and the results of the screening are documented in the Corrective Measures Study/Feasibility Study (CMS/FS).

\subsection{Comparison of Raw Liquid Data to CIF WAC}

The raw liquid, filtered liquid, and suspended solids data were first compared to the waste acceptance criteria of the Consolidated Incineration Facility ${ }^{15}$. Since the CIF cannot accept TRU waste, the first point of comparison was the activity concentration of the TRU components. For the aqueous raw liquids, Tanks S1, S5, S6, S7, S8, S13, S14, S19, S20, S21 and $S 22$ have TRU activity concentrations of $>100 \mathrm{nCi} / \mathrm{g}$. Thus the raw liquids in these tanks are transuranic waste and are prohibited from incineration in the CIF. In addition, the organic raw liquid from Tank S11 also has a TRU activity concentration of $>100 \mathrm{nCi} / \mathrm{g}$. Because of their TRU status, the raw liquids from these tanks will not be considered any further for candidate CIF waste and will not be compared against any other requirements of the CIF WAC's. Tanks S2, S3 and S4 have TRU activity concentrations of 44.7, 88.9 , and $22.7 \mathrm{nCi} / \mathrm{g}$ respectively; hence, they are not considered TRU 
waste. As stated previously in Section 3.3, the TRU activity concentration had to be calculated in an alternate manner for the suspended solids portion of the raw organic liquid in Tank S20. This calculation was necessary because not enough suspended solids were present to quantitatively measure the TRU activity concentration of the suspended solids. The activity calculations were based upon the relative amounts of activity detected on the filter used to separate the suspended solids from the raw liquid, the weight percent of total suspended solids in the raw liquid, the density of the liquid, and the volume of raw liquid filtered. Thus, the TRU activity concentration of the raw organic liquid of Tank S20 was calculated to be $4.44 \mathrm{nCi} / \mathrm{g}$.

If the suspended solids are separated from the liquids in Tanks S6 and S8, the resulting filtered solutions will have TRU activity concentrations of 11.6 and $25.1 \mathrm{nCi} / \mathrm{g}$, respectively (see Table 14). Thus, these two filtered solutions could also be considered for incineration at CIF.

Section A.1.d of the CIF WAC lists multiple properties that are prohibited in wastes that are acceptable to $C_{I F}{ }^{15}$. The filtered aqueous liquids contained in Tanks S2, S3, S4, S6, S8, and the filtered organic phase in Tank S20 do not have any of the prohibited properties according to best available information at the time of this report. The boiling points were not measured on the filtered liquid samples from Tanks S4, S6, and S8. However, since their composition is similar to the other aqueous filtered samples, they most likely have similar boiling points $\left(-160^{\circ} \mathrm{F}\right)$. If required, these boiling points can be determined at a later date. As mentioned previously in Section 2.1, the total suspended solids determinations were performed on the raw liquids whereas the boiling point, freezing point, sodium, and fluorine determinations were performed on the filtered liquids only. The PCB content of the filtered liquids contained in Tanks S2, S3, S4, S6, S8, and S20 (organic phase) is $<50 \mathrm{mg} / \mathrm{L}$ for all six liquids. This is within the acceptable limit specified in Reference 15 for the CIF.

For the raw liquids from Tanks S2, S3, S4, and the organic fraction of S20, it must be emphasized that filtering will not remove any waste characteristics because the liquid fraction, alone, exhibits the characteristic of toxicity. All four of these liquids have less than $0.5 \%$ filterable solids. See the definition entitled "List of EPA/DHEC Hazardous Waste Codes" on Page viii of this report for more details regarding toxicity characteristics. Hence, it is appropriate to compare the CIF WAC to the filtered liquid data. Because of the low TRU activity concentration of the raw liquids from Tanks S2, S3, S4, and the organic phase of S20, it would not be necessary, nor desirable, to separate the suspended solids from the liquid fraction. Filtration of the raw liquids from Tanks S6 and S8 would be required in order to obtain a non-TRU liquid fraction. Thus, filtration would not be used as a treatment method, but to pre-sort and segregate the non-TRU aqueous 
phase and the TRU suspended solids phase. In addition, the high suspended solids content $(1.48 \mathrm{wt} \%$ ) of the raw liquid in Tank S8 would dictate that the solids be filtered and treated as a separate matrix.

The previous CIF WAC ${ }^{6}$ prohibited waste streams with greater than 2000 $\mathrm{mg} / \mathrm{L}$ of Hexamethylene-1, 6-diisocyanate; p-Aminodiphenyl; Kepone; aNaphthylamine; b-Naphthylamine; Nitrogen Mustard; Nitrosodimethylamine; or p-Nitrosophenol. None of these compounds were detected in the filtered liquids from Tanks S2, S3, S4, S6, S8, or the organic phase of Tank S20 in the qualitative evaluation of the GC/MS data, meeting the CIF WAC requirements for levels below $2000 \mathrm{mg} / \mathrm{L}$. The limits for these organic compounds are not in the latest revision of the WAC $3.17^{15}$. The latest revision of WAC 3.18 requires CIF notification prior to shipping waste containers with greater than $2000 \mathrm{ppm}$ of these compounds ${ }^{15}$.

The CIF WAC requires antimony, arsenic, barium, beryllium, cadmium, chromium, cobalt, lead, manganese, mercury, nickel, selenium, silver, and thallium to be quantified if these metals are known or suspected to be present in the material ${ }^{15}$. Since the Sampling and Analysis Plan was written before Revision 1 of WAC 3.18 was issued, cobalt was not quantified in many of the Old Solvent Tank samples. The metal concentration limits for CIF are shown in Table $23^{15}$. Comparing the data for the filtered liquids given in Appendices B, C, D, F, H, and O with the data given in Table 23; one can clearly see that the filtered aqueous liquids in Tanks S2, S3, S4, S6, $S 8$, and the filtered organic liquid in Tank $S 20$ do not contain any of these metals above the CIF concentration limits.

Table 23. Metal Concentration Limits for CIF

\begin{tabular}{|c|c|}
\hline Metal & $\begin{array}{c}\text { Maximum Allowable } \\
\text { Concentration } \\
\text { mg/kg }\end{array}$ \\
\hline Antimony & 730 \\
\hline Arsenic & 50 \\
\hline Barium & 100,000 \\
\hline Beryllium & 20 \\
\hline Cadmium & 100 \\
\hline Chromium & 2,500 \\
\hline Lead & 10,000 \\
\hline Mercury & 260 \\
\hline Silver & 7,300 \\
\hline Thallium & 730 \\
\hline
\end{tabular}

WAC 3.18 requires (through the use of form OSR 29-47) BTU/lb, $\mathrm{pH}$, estimated viscosity, estimated specific gravity, total suspended solids, total dissolved solids, total organic carbon, weight percent water, ash content, and 
total halogens weight percent to be determined/calculated ${ }^{15}$. All of the above have been measured as specified by the Sampling and Analysis Plan ${ }^{2}$ except viscosity, BTU/lb, and total halogens weight percent. Per a request by the customer, viscosity measurements were not performed on the liquid samples. However, the viscosity can be estimated from the analytical data, and if necessary, an analytical measurement can be made. Total halogen weight percent was not specified by the Sampling and Analysis Plan (because it was not a requirement in the previous revision of the CIF WAC ${ }^{6}$ ) and therefore was not determined. If necessary, total halogen weight percent can be determined at a later date. The BTU/lb for the aqueous liquids contained in Tanks S2, S3, S4, S6, and S8 and the organic liquid in Tank $\mathrm{S} 20$ can be calculated based upon the available analytical data and published thermodynamic data if required. If necessary, it can be measured.

The CIF WAC prohibits items with nuclide activities that are greater than Class $\mathrm{C}$ requirements ${ }^{15}$. Specifically, C-14, Tc-99, and I-129 must be less than or equal to $8.02,3.00$, and $0.0802 \mu \mathrm{Ci} / \mathrm{mL}$, respectively. In addition, the alpha emitting TRU radionuclides with half-lives greater than 5 years, $\mathrm{Pu}-241$, and $\mathrm{Cm}-242$ must be less than or equal to 100,3500 , and 20,000 $\mathrm{nCi} / \mathrm{g}$, respectively. Curium-242 was not measured in any of the Old Solvent Tank samples. However, as was shown in Section $3.3, \mathrm{Cm}-242$ is expected to be a very minor contributor to the total activity present in the Old Solvent Tanks. For the raw liquid from Tank S2, the Tc-99, TRU content, and $\mathrm{Pu}-241$ do not exceed the Class $\mathrm{C}$ requirements. However, the C-14 content of the suspended solids and the I-129 content of the filtered liquid and suspended solids were not measured for this tank. For the raw liquid from Tank S3, the Tc-99, I-129, TRU content, and Pu-241 do not exceed the Class $\mathrm{C}$ requirements. The $\mathrm{C}-14$ content of the suspended solids from Tank S3 was not measured. For the raw liquid from Tank S4, the C14, TRU content, and $\mathrm{Pu}-241$ do not exceed the Class $\mathrm{C}$ requirements. For Tank S4, the Tc-99 content of the suspended solids and the I-129 content of the filtered liquid and suspended solids were not measured. For the filtered organic layer of Tank S20, the Tc-99, TRU content, and Pu-241 do not exceed the Class $\mathrm{C}$ requirements. However, the $\mathrm{C}-14$ content of the suspended solids and the I-129 content of the filtered liquid were not measured for this tank. With the exception of $\mathrm{Cm}-242$ (which was not measured), the filtered liquid from Tank $\$ 6$ does not exceed any of the Class $\mathrm{C}$ requirements. For the filtered liquid from Tank S8, the C-14, Tc-99, TRU content, and $\mathrm{Pu}-241$ do not exceed the Class $\mathrm{C}$ requirements. The I-129 and $\mathrm{Cm}-242$ levels were not measured in the filtered liquid from Tank S8. If this disposal path is identified as a critical route for the above mentioned liquids, the necessary activity parameters which have not yet been determined can be measured at a later time. 
Next the radiological control limits for the CIF had to be considered. For $>55$ gallons of liquid, CIF has a gross alpha limit of $5 \mathrm{nCi} / \mathrm{g}$. Tanks S2, S3, S4, S6, and S8 contain $>55$ gallons of liquid and have gross alpha activity concentrations of $52.1,230,24.3,11.6$, and $44.7 \mathrm{nCi} / \mathrm{g}$ respectively. Thus, all five of the tanks fail to meet the gross alpha criterion of the CIF WAC. For the calculations involving Tanks S6 and S8 it was assumed that the suspended solids would be removed from the liquid phase. Details of these calculations can be found in Appendix U. An example calculation using the gross alpha activity value in the liquid from Tank $\mathrm{S} 2$ is given below.

Gross alpha activity in filtered liquid $=8372.04 \mu \mathrm{Ci}$

Gross alpha activity in suspended solids $=13740.84 \mu \mathrm{Ci}$

Raw liquid gross alpha activity in the tank $=8372.04+13740.84=22112.88 \mu \mathrm{Ci}$

Filtered liquid mass $=424098.49 \mathrm{~g}$

Suspended solids mass $=84.82 \mathrm{~g}$

Raw liquid mass $=424098.49+84.82=424183.31 \mathrm{~g}$

Gross alpha specific activity $=\frac{22112.88 \mu \mathrm{Ci}}{424183.31 \mathrm{~g}}=5.213 \times 10^{-2} \approx 5.21 \times 10^{-2} \mu \mathrm{Ci} / \mathrm{g}$

Gross alpha specific activity $=5.213 \times 10^{-2} \mu \mathrm{Ci} / \mathrm{g} \times \frac{1 \times 10^{3} \mathrm{nCi}}{\mu \mathrm{Ci}}=5.213 \times 10^{1}=5.21 \times 10^{1} \mathrm{nCi} / \mathrm{g}$

The volume of the organic phase in Tank S20 is unknown; therefore, the more restrictive WAC gross alpha limit $(5 \mathrm{nCi} / \mathrm{g})$ was used for comparison. The calculated gross alpha activity concentration for the organic phase of Tank $\mathrm{S} 20$ is $19.6 \mathrm{nCi} / \mathrm{g}$. See Section 3.2 and Appendix $\mathrm{U}$ for details behind this calculation. Based upon the limited amount of data from the organic phase of Tank S20, it can be concluded that the gross alpha activity is above the CIF limit of $5 \mathrm{nCi} / \mathrm{g}$.

For $\mathrm{H}-3$ activity concentration, $\mathrm{CIF}$ has a limit of $1200 \mathrm{nCi} / \mathrm{g}$ for $>55$ gallons of liquid. As shown in Appendix U, Tanks S2, S3, S4, S6, and S8 have $\mathrm{H}-3$ activity concentrations of $<0.804,0.853,2.76,4.50$, and 1.73 $\mathrm{nCi} / \mathrm{g}$ respectively. The data for the organic liquid in Tank S20 $(231 \mathrm{nCi} / \mathrm{g})$ represents an upper limit only. As mentioned previously, the calculations 
involving Tanks S6 and S8 assume that the suspended solids would be removed from the liquid phase.

Taking the data from Appendix $\mathrm{U}$, the total activity concentrations (Gross Alpha + Gross Beta) are 82.5, 686, 150.3, 120.6, and $1003.8 \mathrm{nCi} / \mathrm{g}$ for Tanks S2, S3, S4, S6, and S8 respectively. For the organic phase of Tank $\mathrm{S} 20$ the total activity concentration is $146.6 \mathrm{nCi} / \mathrm{g}$. All six of these values are well below the CIF WAC limit of $2600 \mathrm{nCi} / \mathrm{g}$ for liquid wastes with volumes greater than 55 gallons.

As specified in the CIF WAC's, the U-235 FGE of the waste must be calculated and submitted to CIF prior to waste acceptance ${ }^{15}$. Currently, the nuclear safety limit for the CIF inventory of fissile nuclides is 700 FGE U235. FGE calculations and criticality discussions for the Old Solvent Tanks are given in "Evaluation of Old Solvent Storage Tanks 1-22" (WSMS-CRT99-0039, Attachment 4 to the "Addendum to the Workplan/RCRA Facility Investigation/Remedial Investigation Report of the Old Radioactive Waste Burial Ground 643-E, S01-S22).

\subsection{Comparison of Raw Liquid Data to SSTF WAC}

The Solvent Storage Tank Facility is similar to the Old Solvent Tanks. This facility consists of four 30,000-gallon carbon steel tanks located next to the CIF. The SSTF is prohibited from receiving TRU waste ${ }^{16}$. As stated before in Section 4.1, the aqueous raw liquids in tanks S1, S5, S6, S7, S8, S13, $\mathrm{S} 14, \mathrm{~S} 19, \mathrm{~S} 20, \mathrm{~S} 21$, and S22 have TRU activity concentrations of $>100$ $\mathrm{nCi} / \mathrm{g}$. In addition, the organic raw liquid in Tank $\mathrm{S} 11$ has a TRU activity concentration of $>100 \mathrm{nCi} / \mathrm{g}$. Because of the TRU activity concentrations in these tanks, the raw liquids will not be considered any further for storage in the SSTF and will not be compared against any other requirements of the SSTF WAC. The aqueous liquids contained in Tanks S2, S3, and S4 have TRU activity concentrations of $44.7,88.9$ and $22.7 \mathrm{nCi} / \mathrm{g}$ respectively, hence they are not considered TRU waste. In addition, as stated earlier, the TRU activity concentration had to be calculated in an alternate manner for the suspended solids portion of the raw organic liquid in Tank S20 (see Section 3.3). The TRU activity concentration of the raw organic liquid of Tank $S 20$ was calculated to be $4.44 \mathrm{nCi} / \mathrm{g}$.

As stated in Section 4.1, if the suspended solids are separated from the liquids in Tanks S6 and S8, the resulting filtered solutions will have TRU activity concentrations of 11.6 and $25.1 \mathrm{nCi} / \mathrm{g}$, respectively (see Table 14). Thus, these two filtered solutions could also be considered for candidate waste at the SSTF. For the raw liquids from Tanks S2, S3, S4, and the organic fraction of $\mathbf{S 2 0}$, filtering will not remove any waste characteristics because the liquid fraction, alone, exhibits the characteristic of toxicity. All 
four of these liquids have less than $0.5 \%$ filterable solids. See the definition entitled "List of EPA/DHEC Hazardous Waste Codes" on Page viii of this report for more details regarding toxicity characteristics. Hence, it is appropriate to compare the SSTF WAC to the filtered liquid data. Because of the low TRU activity concentration of the raw liquids from Tanks S2, S3, $\mathrm{S} 4$, and the organic phase of $\mathbf{2 0}$, it would not be necessary, nor desirable, to separate the suspended solids from the liquid fraction. Filtration of the raw liquids from Tanks S6 and S8 would be required in order to obtain a non-TRU liquid fraction. Thus, filtration would not be used as a treatment method, but to pre-sort and segregate the non-TRU aqueous phase and the TRU suspended solids phase. In addition, the high suspended solids content (1.48 wt \%) of the raw liquid in Tank S8 would dictate that the solids be filtered and treated as a separate matrix.

Section B.1 of the SSTF WAC lists several characteristics that are prohibited in waste that is acceptable to the $\operatorname{SSTF}^{16}$. The filtered aqueous liquids contained in Tanks S2, S3, S4, S6, S8, and the filtered organic phase in Tank S20 do not have any of the prohibited characteristics according to best available information at the time of this report with the exception of beryllium. The filtered liquids in Tanks S2, S4, S6, and S8 all have very low levels $(0.1,1.1,0.2$, and $0.1 \mathrm{mg} / \mathrm{kg}$ respectively) of beryllium.

Table 24. Physical and Chemical Criteria of SSTF

\begin{tabular}{|c|c|}
\hline Parameter/Analyte & Acceptable Values \\
\hline Freezing Point & $\leq 40^{\circ} \mathrm{F}$ \\
\hline Boiling Point & $\geq 135^{\circ} \mathrm{F}$ \\
\hline Total Suspended Solids & $\leq 10 \mathrm{wt} \%$ \\
\hline $\mathrm{pH}$ & $6 \leq \mathrm{pH} \leq 11$ \\
\hline Viscosity $^{\circ}$ & $<40 \mathrm{cps} @ 25^{\circ} \mathrm{C}$ \\
\hline Total Metals $^{\mathrm{a}}$ & Required \\
\hline
\end{tabular}

a- A total metals characterization is required if arsenic, cadmium, chromium, lead, mercury, nickel, or silver are known or suspected to be in a waste stream.

The physical and chemical criteria requirements are given in Section B.2 of the SSTF WAC ${ }^{16}$. These are summarized in Table 24. All of the parameters in Table 24 were measured as specified by the Sampling and Analysis $\operatorname{Plan}^{2}$ except boiling point (on filtered liquid samples from Tanks S4, S6, and S8), and viscosity. The analytical results for the filtered aqueous liquids in Tanks S2, S3, S4, S6, S8, and the filtered organic phase of Tank S20 are given in Appendices B, C, D, F, H, and O respectively. 
ADS's customer requested that viscosity measurements not be performed on the liquid samples. However, the viscosity can be estimated from the analytical data, and if necessary, an analytical measurement can be made.

WAC 3.16 requires (through the use of form OSR 29-47) BTU/lb, pH, estimated viscosity, estimated specific gravity, total suspended solids, total dissolved solids, total organic carbon, weight percent water, ash content, and total halogens weight percent to be determined/calculated ${ }^{16}$. All of the above have been measured as specified by the Sampling and Analysis Plan ${ }^{2}$ except viscosity, BTU/lb, and total halogens weight percent. Total halogen weight percent was not specified by the Sampling and Analysis Plan and therefore was not determined. If necessary, total halogen weight percent can be determined at a later date. The BTU/lb for the aqueous liquids contained in Tanks S2, S3, S4, S6, and S8 and the organic liquid in Tank S20 can be calculated based upon the available analytical data and published thermodynamic data if required. If necessary, it can be measured

As mentioned in Section 4.1, the boiling point was not measured on the filtered liquid sample from Tanks S4, S6, and S8. However, since their composition is similar to the other aqueous filtered samples, they most likely have similar boiling points $\left(-160^{\circ} \mathrm{F}\right)$. If required, these boiling points can be determined at a later date. The total suspended solids were measured on the raw liquids. For Tanks S2, S3, S4, S6, S8, and the organic phase of Tanks $\mathbf{S 2 0}$, none of the limits on the measured physical and chemical criteria listed in Table 24 were exceeded except for Be in Tanks S2,S4, S6, and S8. As stated earlier, a very small amount was detected in these four filtered aqueous liquids.

It must be emphasized that Section B. 2 of the SSTF WAC requires that an explicit set of analytical test methods be used when characterizing waste for specified physical and chemical criteria ${ }^{16}$. However, ADS of SRTC uses its own procedures/work instructions that may or may not be equivalent to the analytical test methods listed in Attachment 1 of the SSTF WAC. A comparison of the various methods may be needed prior to acceptance by SSTF if this route is chosen for some of the Old Solvent Tank material.

The SSTF WAC requires that "generators provide information regarding the radionuclides present in the waste and the number of curies of each radionuclide" 16 . The radionuclide data for the filtered liquids and suspended solid material for Tanks S2, S3, S4, S6, S8, and S20 are given in Appendices B, C, D, F, H, and $\mathrm{O}$ respectively.

As specified in the SSTF WAC, the U-235 FGE of the waste must not exceed the equivalence of 23 grams per 1000-gallon shipment. FGE calculations and criticality discussions for the Old Solvent Tanks are given 
in "Evaluation of Old Solvent Storage Tanks 1-22" (WSMS-CRT-99-0039, Attachment 4 to the "Addendum to the Workplan/RCRA Facility Investigation/Remedial Investigation Report of the Old Radioactive Waste Burial Ground 643-E, S01-S22).

\subsection{Comparison of Raw Liquid Data to MWSB WAC}

The MWSF include Mixed Waste Storage Buildings (MWSB) 643-29E, 643-43E, and 645-2N; and the mixed waste storage pads located in the Solid Waste Disposal Facility ${ }^{5,15}$. In addition, Buildings 315-4M and 316-M are operated in partnership with the Reactor Materials Division. These facilities have the capability of storing low-level mixed waste. TRU waste is prohibited in the MWSB per Section 1.C.2.a of WAC 3.18 ${ }^{15}$. Since the aqueous raw liquids in tanks S1, S5, S6, S7, S8, S13, S14, S19, S20, S21, and S22 have TRU activity concentrations of $>100 \mathrm{nCi} / \mathrm{g}$, these tanks will not be considered any further for storage in the MWSB. In addition, the organic raw liquid in Tank S11 is also TRU waste and will not be considered any further. As previously stated, the aqueous liquid in Tanks S2, S3, and S4 have TRU activity concentrations of 44.7, 88.9, and 22.7 $\mathrm{nCi} / \mathrm{g}$ respectively, hence they are not considered TRU waste. Also, as stated earlier, the TRU activity concentration had to be calculated for the suspended solids portion of the raw organic liquid in Tank \$20 (see Section 3.3). The TRU activity concentration of the raw organic liquid of Tank S20 was calculated to be $4.44 \mathrm{nCi} / \mathrm{g}$.

By separating the suspended solids from the liquids in Tanks S6 and S8, the resulting filtered solutions will have TRU activity concentrations of 11.6 and $25.1 \mathrm{nCi} / \mathrm{g}$, respectively (see Table 14). Thus, these two filtered solutions could also be considered for candidate waste at the MWSB. As previously discussed, for the raw liquids from Tanks S2, S3, S4, and the organic fraction of S20, filtering will not remove any waste characteristics because the liquid fraction, alone, exhibits the characteristic of toxicity. All four of these liquids have less than $0.5 \%$ filterable solids. See the definition entitled "List of EPA/DHEC Hazardous Waste Codes" on Page viii of this report for more details regarding toxicity characteristics. Therefore, it is appropriate to compare the SSTF WAC to the filtered liquid data. Because of the low TRU activity concentration of the raw liquids from Tanks S2, S3, $\mathrm{S} 4$, and the organic phase of $\mathbf{2 0}$, it would not be necessary, nor desirable, to separate the suspended solids from the liquid fraction. Filtration of the raw liquids from Tanks $\mathbf{S 6}$ and S8 would be required in order to obtain a non-TRU liquid fraction. Thus, filtration would not be used as a treatment method, but to pre-sort and segregate the non-TRU aqueous phase and the TRU suspended solids phase. In addition, the high suspended solids content (1.48 wt \%) of the raw liquid in Tank S8 would dictate that the solids be filtered and treated as a separate matrix. 
Section 1.C.1.a of the MWSB WAC lists multiple characteristics that are prohibited in waste that is acceptable to the MWSB ${ }^{15}$. Based upon the current analytical data, the filtered aqueous liquid contained in Tanks S2, S3, S4, S6, S8, and the filtered organic liquid in Tank S20 do not have any of the prohibited characteristics. Attachment 3, Table 5 (see pages viii through xvi of this report), lists the hazardous waste codes acceptable at the MWSB $^{15}$. Based upon the best available analytical data, the filtered aqueous liquid in Tank S2 will carry D009 and potentially D010 (See EPA/DHEC Hazardous Waste Code List on Page viii for definitions of these codes). The filtered aqueous liquid in Tank S3 will carry D009. The filtered aqueous liquid in Tank S4 will carry D004, D006, D007, D009, and potentially D010. The filtered aqueous liquid in Tank S6 will carry D007, D009, and potentially D010. The filtered aqueous liquid in Tank S8 will carry D009 and potentially D010. Finally, the organic liquid in Tank S20 will be assigned a D009 code and potentially D010. The aqueous liquids from Tank S2, S4, S6, and S8 and the organic liquid from Tank S20 have total Selenium levels of $<11,<21.3,<3.7,<2.9$, and $<1.2 \mathrm{mg} / \mathrm{L}$ respectively. However, the regulatory limit for Selenium is 1.0 . It cannot be proven with current analytical data that these three liquids have less than the regulatory limit. Thus their status relative to carrying a D010 code is in question. At the current time, it is unknown if the organic liquid in Tank S20 carries any additional waste codes. Note that total metal concentrations were determined for these samples, not TCLP.

The MWSB WAC prohibits items with nuclide activities that are greater than Class $C$ requirements ${ }^{15}$. Specifically, C-14, Tc-99, and I-129 must be less than or equal to $8.02,3.00$, and $0.0802 \mu \mathrm{Ci} / \mathrm{mL}$, respectively. In addition, the alpha emitting TRU radionuclides with half-lives greater than 5 years, Pu-241, and Cm-242 must be less than or equal to 100,3500 , and $20,000 \mathrm{nCi} / \mathrm{g}$, respectively. See Section 4.1 for the discussion regarding the Class $\mathrm{C}$ requirements.

The MWSB WAC requires that "generators will provide information regarding the radionuclide distribution present in the waste and the total number of curies contained in each package" 15 . The radionuclide data for the filtered liquids and suspended solid material for Tanks S2, S3, S4, S6, S8, and S20 (organic layer) are given in Appendices B, C, D, F, H, and O respectively. It should be noted that Appendices $\mathrm{B}, \mathrm{C}, \mathrm{D}, \mathrm{F}, \mathrm{H}$, and $\mathrm{O}$ do not contain information regarding daughter radionuclides such as $\mathrm{Y}-90$ and Ba-137m. However, these values can be easily calculated based upon radionuclide growth and decay equations.

WAC 3.18 requires that form OSR $29-47$ be submitted with the waste. This form requires several pieces of information regarding each waste stream. 
See Section 4.1 for a detailed discussion of the form OSR 29-47 requirements.

The Nuclear Safety Criterion specified in the MWSB WAC limits the U-235 FGE of the waste to 200 grams per 55-gallon drum. FGE calculations and criticality discussion for the Old Solvent Tanks are given in "Evaluation of Old Solvent Storage Tanks 1-22" (WSMS-CRT-99-0039, Attachment 4 to the "Addendum to the Workplan/RCRA Facility Investigation/Remedial Investigation Report of the Old Radioactive Waste Burial Ground 643-E, S01-S22).

\subsection{Comparison of Raw Liquid Data to Transuranic Pads WAC}

As discussed previously, the aqueous raw liquids in S1, S5, S6, S7, S8, S13, $\mathrm{S} 14, \mathrm{~S} 19, \mathrm{~S} 20, \mathrm{~S} 21$, and S22 have TRU activity concentrations of $>100$ $\mathrm{nCi} / \mathrm{g}$, thus these liquids cannot be considered low-level waste. In addition, the organic liquid in Tank S11 has a TRU activity concentration of $>100$ $\mathrm{nCi} / \mathrm{g}$. One possible disposal option for these TRU materials is the E-Area TRU Pads. The waste characteristics requirements for the TRU Pads are given in Section A of the TRU Pads Transuranic WAC ${ }^{17}$. Multiple chemical requirements are given in Section A.2. Only small quantities of liquid $(<2$ liters/55-gallon drum or $<8$ liters/SWB or $<1$ inch in any internal container) can be present in TRU waste. Thus in their current form, the aqueous raw liquids of S1, S5, S6, S7, S8, S13, S14, S19, S20, S21, and S22 and the organic raw liquid in Tank S11 would not be acceptable to the E-Area TRU Pads. The raw liquids would have to be treated in some manner to convert the liquid into a suitable solid.

It would be beneficial to separate the suspended solids from the liquids in Tanks S6 and S8. In both of these tanks the TRU content of the filtered liquid is $<100 \mathrm{nCi} / \mathrm{g}$ while the TRU content of the suspended solids is much greater than $100 \mathrm{nCi} / \mathrm{g}$. Without separation, the raw liquids from both of these tanks would be considered TRU waste. Separation of the suspended solids from the liquids would thus be an effective TRU volume reduction step.

The aqueous raw liquids in Tanks S2, S3, and S4 cannot be considered for disposal at the E-Area TRU Pads since these liquids are low level waste. In addition, since the TRU activity concentration of the organic raw liquid contained in Tank S20 was calculated to be $<100 \mathrm{nCi} / \mathrm{g}$, this liquid was not considered for disposal at the E-Area TRU Pads. However, separation of the organic liquid from the aqueous liquid in Tank $\$ 20$ would be needed in order to consider disposal of the aqueous phase at the E-Area TRU Pads. One technical challenge would thus be the identification of an efficient means to separate the organic and aqueous layers contained in this tank. 
The TRU Pads WAC requires heat load calculations based upon the nuclide content of the waste container. This calculation is automatically performed by form OSR 29-90 once the radionuclide information (in grams) has been entered in the form. The TRU Pads WAC also requires that the waste contain less than or equal to $195 \mathrm{FGE}$ of $\mathrm{Pu}-239$ per 55 -gallon drum ${ }^{17}$. As stated previously, criticality related discussions are contained in "Evaluation of Old Solvent Storage Tanks 1-22" (WSMS-CRT-99-0039, Attachment 4 to the "Addendum to the Workplan/RCRA Facility Investigation/Remedial Investigation Report of the Old Radioactive Waste Burial Ground 643-E, S01-S22). Some of the liquids contain trace amounts (ppm range) of beryllium and may require an approved deviation request prior to acceptance by the TRU Pads. SWD should be consulted on this matter.

\subsection{Comparison of Sludge Data to 241-F/H Tank Farms WAC}

As originally written, the Sampling and Analysis Plan considered four options for the sludge from the Old Solvent Tanks. These options were disposal at the 241-F/H Tank Farms, disposal at the E-Area TRU Pads, disposal at the MWSB, and in-place stabilization. Since it was technically very challenging to acquire adequate sludge samples, sludge was obtained from only twelve of the tanks (Tanks S2, S4, S7, S8, S13, S14, S15, S16, S19, S20, S21, and S22) for limited characterization. Of these twelve samples, three (Tanks S13, S14, and S15) had insufficient sample for quantitative radiological characterization. Sludge from Tanks S1, S3, S5, S6, S9, S10, S11, S12, S17, and S18 could not be obtained due to the absence of significant quantities of sludge or physical limitations of the tank geometries and riser pipes. Of the nine sludge samples for which a measurable mass was obtained, time restraints and limited sample quantities significantly impacted the number of analyses that could be performed. Hence, the comparison of the sludge data to the 241-F/H Tank Farms WAC will be of very limited scope.

The maximum organic concentration (assuming that the constituents contribute to the flammability limit of a High Level Liquid Waste Tank) as stated in Section 13.3.4 of the 241-F/H Tank Farms WAC must be less than $0.5 \mathrm{vol} \%$ organic/aqueous. The organic content (if measured) of the nine sludge samples quantitatively characterized is shown in Table $25^{18}$. The organic constituents of the sludge samples from Tanks S7, S8, S16, S21, and S22 can be found in Appendices G, H, M, P and Q. These five samples do not meet the organic content requirement of the 241-F/H Tank Farms WAC. Additional sampling and analyses would be required to determine the organic content of the sludges from Tanks S2, S4, S19, and S20. 
Section 13.5 .1 of the $241-\mathrm{F} / \mathrm{H}$ Tank Farms WAC lists a Cs-137 activity concentration limit of $3.48 \times 10^{8} \mathrm{dpm} / \mathrm{mL}$ for Type IV waste tanks ${ }^{18}$. Type IV waste tanks do not have secondary containment. Table 26 lists the Cs137 activity concentrations for the nine sludge samples quantitatively characterized in this study assuming a sludge density of $2.0 \mathrm{~g} / \mathrm{cm}^{3}$. All nine sludges contain Cs-137 at activity concentrations less than the 241-F/H Tank Farms limit.

Table 25. Organic Content of Sludge Samples

\begin{tabular}{|c|c|}
\hline Tank \# & Organic Content \\
\hline $2^{\mathrm{a}}$ & Unknown \\
\hline $4^{\mathrm{a}}$ & Unknown \\
\hline 7 & $100 \%$ \\
\hline 8 & $>0.72 \%$ \\
\hline 16 & $100 \%$ \\
\hline $19^{\mathrm{a}}$ & Unknown \\
\hline $20^{\mathrm{a}}$ & Unknown \\
\hline 21 & $>1 \%$ \\
\hline 22 & $>23 \%$ \\
\hline
\end{tabular}

a- Semi-Volatile Organics analysis by GC/MS not performed on this sample due to sample size restrictions.

Table 26. Sludge Phase Cs-137 Activity Concentration

\begin{tabular}{|c|c|c|}
\hline Tank \# & $\begin{array}{c}\text { Cs-137 Activity } \\
\mu \mathrm{Ci} / \mathrm{g}\end{array}$ & $\begin{array}{c}\text { Cs-137 Activity } \\
\mathbf{d p m} / \mathbf{m L}\end{array}$ \\
\hline 2 & $2.32 \mathrm{E}-01$ & $1.03 \mathrm{E}+06$ \\
\hline 4 & $1.10 \mathrm{E}-01$ & $4.88 \mathrm{E}+05$ \\
\hline 7 & $8.78 \mathrm{E}-02$ & $3.90 \mathrm{E}+05$ \\
\hline 8 & $1.08 \mathrm{E}+01$ & $4.80 \mathrm{E}+07$ \\
\hline 16 & $1.11 \mathrm{E}-01$ & $4.93 \mathrm{E}+05$ \\
\hline 19 & $2.80 \mathrm{E}-01$ & $1.24 \mathrm{E}+06$ \\
\hline 20 & $6.71 \mathrm{E}-01$ & $2.98 \mathrm{E}+06$ \\
\hline 21 & $1.99 \mathrm{E}-02$ & $8.84 \mathrm{E}+04$ \\
\hline 22 & $3.87 \mathrm{E}-01$ & $1.72 \mathrm{E}+06$ \\
\hline
\end{tabular}

Section 13.5.2 of the 241-F/H Tank Farms WAC states, "The composite (solids and liquids) dose potential concentration must be less than 2.3E9

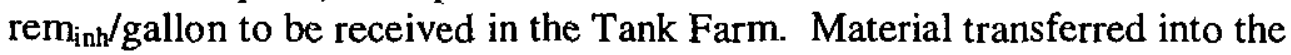
evaporator feed tanks (i.e. Tanks $43 \mathrm{H}$ and $26 \mathrm{~F}$ ) must not cause the evaporator RST of $1 \mathrm{E9} \mathrm{rem} / \mathrm{gallon}$ to be exceeded"18. The assessment of the sludges relative to the requirements stated in Section 13.5.2 of the Tank 
Farms WAC would need to be performed if this option becomes a critical disposal path for the sludges.

Section 13.6 of the $241-\mathrm{F} / \mathrm{H}$ Tank Farms WAC lists the regulatory requirements from a RCRA standpoint. It must be emphasized that TCLP analyses were not performed on these sludge samples. Instead, these samples were analyzed for total metals. Based upon the total metal results, several of the sludges fail to meet the 241-F/H Tank Farms RCRA requirements. Table 27 displays those parameters that fail to meet the RCRA requirements.

Table 27. RCRA Characteristics of Sludge Samples

\begin{tabular}{|c|l|}
\hline Tank \# & $\begin{array}{c}\text { RCRA Parameter Failing to Meet } \\
\text { Tank Farms WAC }\end{array}$ \\
\hline $2^{\mathrm{a}}$ & As, Cd, Se(?) \\
\hline $4^{\mathrm{b}}$ & Unknown \\
\hline $7^{\mathrm{a}}$ & $\mathrm{Cd}, \mathrm{Se}(?),($ Hg not measured) \\
\hline $8^{\mathrm{b}}$ & Unknown \\
\hline $16^{\mathrm{c}}$ & $\mathrm{As}(?), \mathrm{Cd}, \mathrm{Se}(?)$ \\
\hline $19^{\mathrm{a}}$ & $\mathrm{Cd}, \mathrm{Se}(?)$ \\
\hline $20^{\mathrm{a}}$ & $\mathrm{Cd}, \mathrm{Se}(?)$ \\
\hline $21^{\mathrm{a}}$ & $\mathrm{Cd}, \mathrm{Se}(?)$ \\
\hline 22 & $\mathrm{Cd}, \mathrm{Se}$ \\
\hline
\end{tabular}

a- Selenium detection limit above regulatory requirement for this sample.

b- Metals analysis not performed on this sample due to sample size restrictions.

c- Arsenic and selenium detection limits above regulatory requirement for this sample.

The sludges from Tanks S2, S7, S16, S19, S20, and S22 had $\geq 5 \mathrm{mg} / \mathrm{kg}$ of silver. The origin of the silver is unknown. Hence, the silver restriction as stated in Section 13.4 of the 241-F/H Tank Farms WAC might have an impact on the acceptability of the sludge from these six tanks.

Using the information provided in Section 3.4 of this report, additional criticality safety and Authorization Basis issues will need to be addressed if and when it is decided to pursue the disposal of the sludge to the $241-\mathrm{F} / \mathrm{H}$ Tank Farms.

\subsection{Comparison of Sludge Data to Transuranic Pads WAC}

The calculated TRU content of the nine quantitatively characterized sludge samples was given in Table 17 of Section 3.3. All of the sludges are considered TRU except the sludge from Tank S4. This material was liquid 
in nature and the TRU component was calculated assuming that the density of the material was $2.0 \mathrm{~g} / \mathrm{cm}^{3}$. Thus, only the sludges from Tanks S2, S7, S8, S16, S19, S20, S21, and S22 would meet the TRU requirements for disposal at the E-Area TRU Pads. The waste characteristics requirements for the TRU Pads are given in Section A of the TRU Pads Transuranic WAC ${ }^{17}$. Multiple chemical requirements are given in Section A.2. Due to the small sample quantities, only very limited analyses could be performed on these sludges. Thus, additional sampling and analyses may be required prior to further consideration of this disposal option. The TRU Pads WAC requires heat load calculations based upon the nuclide content of the waste container. This calculation is automatically performed by form OSR $29-90$ once the radionuclide information (in grams) has been entered in the form. The TRU Pads WAC also requires that the waste contain less than or equal to 195 FGE of Pu-239 per 55 gallon drum ${ }^{17}$. Please refer to "Evaluation of Old Solvent Storage Tanks 1-22" (WSMS-CRT-99-0039, Attachment 4 to the "Addendum to the Workplan/RCRA Facility Investigation/Remedial Investigation Report of the Old Radioactive Waste Burial Ground 643-E, S01-S22") for criticality discussions and FGE calculations. Additionally, due to the liquid restrictions of the TRU Pads WAC, a treatment and/or stabilization may be needed for the sludges prior to acceptance by the TRU Pads $^{17}$.

One very important consideration for disposal of the sludges at the TRU Pads is the need to remove the sludges from the tanks. As the sludge sampling events demonstrated, the removal of the sludges from the tanks will represent a formidable technical challenge.

\subsection{Comparison of Sludge Data to MWSB WAC}

As mentioned in Section 4.6, only one of the nine quantitatively characterized sludge samples was not TRU. Thus, the sludge from Tank S4 could potentially be sent to the MWSB. Section 1.C.1.a of the MWSB WAC lists multiple characteristics that are prohibited in waste that is acceptable to the MWSB ${ }^{15}$. Based upon the current analytical data, the sludge contained in Tank $\$ 4$ does not have any of the prohibited characteristics. Attachment 3, Table 5 of the MWSB WAC (see pages viii through xvi of this report), lists the hazardous waste codes acceptable at the MWSB $^{15}$. The hazardous waste code assignments to this sludge are unknown at this time. Due to the very limited amount of sample obtained, a metals analysis and GC/MS SVOA were not performed on this sample.

The MWSB WAC requires that "generators will provide information regarding the radionuclide distribution present in the waste and the total number of curies contained in each package"15. The radionuclide data for the sludge from Tank S4 are given in Appendix D. It should be noted that 
Appendix $\mathrm{D}$ does not contain information regarding daughter radionuclides such as $\mathrm{Y}-90$ and $\mathrm{Ba}-137 \mathrm{~m}$. However, these values can be easily calculated based upon radionuclide growth and decay equations.

WAC 3.18 requires (through the use of form OSR 29-47) the measurement/ determination of multiple parameters which include BTU/lb and ash content ${ }^{15}$. If this disposal path becomes a viable option for this sludge material, then these analyses will be needed.

The Nuclear Safety Criterion specified in the MWSB WAC limits the U-235 FGE of the waste to 200 grams per 55-gallon drum. FGE calculations and criticality discussion for the Old Solvent Tanks are given in "Evaluation of Old Solvent Storage Tanks 1-22" (WSMS-CRT-99-0039, Attachment 4 to the "Addendum to the Workplan/RCRA Facility Investigation/Remedial Investigation Report of the Old Radioactive Waste Burial Ground 643-E, S01-S22). The MWSB WAC prohibits items with nuclide activities that are greater than Class $\mathrm{C}$ requirements ${ }^{15}$. Specifically, limits are given for C-14, Tc-99, I-129, alpha emitting TRU radionuclides with half-lives greater than 5 years, $\mathrm{Pu}-241$, and $\mathrm{Cm}-242$. However, none of the these nuclides were measured in this characterization study. Thus, these nuclides, with the possible exception of $\mathrm{Cm}-242$ (see sections 5.1 and 3.3 for more details on why $\mathrm{Cm}-242$ would not necessarily need to be measured), would need to be measured if this disposal option is chosen for the sludge from Tank S4. It is obvious from the above discussion that a more extensive characterization may be required on this material if disposal of the material is going to be seriously considered at the MWSB. This will assume, of course, that it is physically possible to obtain a reasonably sized sample for characterization.

\subsection{Summary of Comparisons to the Various WACS}

Based upon the discussions of Section 4.1 through Section 4.4, a summary table (see Table 28) was constructed for the liquids from the Old Solvent Tanks. This table lists the parameters of each tank that fail to meet the criteria of the various WAC's. In their current form, the aqueous raw liquids of S1, S5, S6, S7, S8, S13, S14, S19, S20, S21, and S22 and the organic raw liquid in Tank $S 11$ would be acceptable to the E-Area TRU Pads once converted into a suitable solid.

Table 29 summarizes the available sludge data from Sections 4.5 through 4.7. It is apparent from looking at Table 29 that data are not available for many of the sludges. However, based upon the data that were obtained from the sludges in this characterization and the similar, but distinct processes (PUREX and H-Modified) which generated the solvents that were placed into these tanks and co-mingled, then the following can be concluded: all 
sludges would meet the TRU Pads WAC but fail to meet the WAC's from 241-F/H Tank Farms and the MWSB.

Table 28. Liquid Parameters Failing to Meet WAC Requirements

\begin{tabular}{|c|c|c|c|c|}
\hline Tank \# & $\begin{array}{c}\text { CIF } \\
\text { WAC }\end{array}$ & $\begin{array}{c}\text { SSTF } \\
\text { WAC }\end{array}$ & $\begin{array}{c}\text { MWSB } \\
\text { WAC }\end{array}$ & $\begin{array}{c}\text { TRU Pads } \\
\text { WAC }\end{array}$ \\
\hline 1 & TRU & TRU & TRU & None \\
\hline 2 & Gross Alpha & Beryllium & None & Non-TRU \\
\hline 3 & Gross Alpha & None & None & Non-TRU \\
\hline 4 & Gross Alpha & Beryllium & None & Non-TRU \\
\hline 5 & TRU & TRU & TRU & None \\
\hline $6^{\text {a }}$ & TRU & TRU & TRU & None \\
\hline 7 & TRU & TRU & TRU & None \\
\hline $8^{\text {a }}$ & TRU & TRU & TRU & None \\
\hline 9 & b & b & b & b \\
\hline 10 & c & c & c & c \\
\hline 11 & TRU & TRU & TRU & None \\
\hline 12 & c & c & c & c \\
\hline 13 & TRU & TRU & TRU & None \\
\hline 14 & TRU & TRU & TRU & None \\
\hline 15 & b & b & b & b \\
\hline 16 & b & b & b & b \\
\hline 17 & b & b & b & b \\
\hline 18 & c & c & c & c \\
\hline 19 & TRU & TRU & TRU & None \\
\hline $20-$ Organic & Gross Alpha & None & None & Non-TRU \\
\hline 20 -Aqueous & TRU & TRU & TRU & None \\
\hline 21 & TRU & TRU & TRU & None \\
\hline 22 & TRU & TRU & TRU & None \\
\hline
\end{tabular}

a- Separation of the suspended solids from the liquid results in the liquid being non-TRU, hence the liquid would potentially be acceptable at MWSB.

b- Tank contains no liquid.

c- Tank contains less than 10 gallons of liquid. 
Table 29. Sludge Parameters Failing to Meet WAC Requirements

\begin{tabular}{|c|c|c|c|}
\hline Tank \# & $\begin{array}{l}\text { 241-F/H Tank } \\
\text { Farms WAC }\end{array}$ & $\begin{array}{l}\text { TRU Pads } \\
\text { WAC }\end{array}$ & $\begin{array}{c}\text { MWSB } \\
\text { WAC }\end{array}$ \\
\hline 1 & $\mathrm{a}$ & a & $\mathrm{a}$ \\
\hline 2 & Arsenic, Cadmium $^{d}$ & None & TRU \\
\hline 3 & $\mathrm{a}$ & $\mathrm{a}$ & $\mathrm{a}$ \\
\hline 4 & $\mathrm{~g}$ & $\mathrm{~g}$ & $\mathrm{~g}$ \\
\hline 5 & $\mathrm{c}$ & c & $\mathrm{c}$ \\
\hline 6 & $\mathrm{~b}$ & b & $\mathrm{b}$ \\
\hline 7 & Organic Content, Cadmium ${ }^{\mathrm{d}, e}$ & None & TRU \\
\hline 8 & Organic Content & None & TRU \\
\hline 9 & $\mathbf{a}$ & $\mathrm{a}$ & $\mathrm{a}$ \\
\hline 10 & $\mathrm{c}$ & c & c \\
\hline 11 & $\mathbf{a}$ & a & a \\
\hline 12 & a & a & a \\
\hline 13 & $\bar{g}$ & $\mathrm{~g}$ & $\mathrm{~g}$ \\
\hline 14 & $\mathrm{~g}$ & $\mathrm{~g}$ & $\mathrm{~g}$ \\
\hline 15 & $\mathrm{~g}$ & $\mathrm{~g}$ & $\mathrm{~g}$ \\
\hline 16 & Organic Content, Cadmium $^{\mathrm{d} . \mathrm{f}}$ & None & TRU \\
\hline 17 & $\mathrm{a}$ & a & a \\
\hline 18 & $\mathrm{a}$ & a & $\mathrm{a}$ \\
\hline 19 & Cadmium $^{\mathrm{d}}$ & None & TRU \\
\hline 20 & Cadmium $^{\mathrm{d}}$ & None & TRU \\
\hline 21 & Organic Content, Cadmium ${ }^{\mathrm{d}}$ & None & TRU \\
\hline 22 & Organic Content, Cadmium, Selenium & None & TRU \\
\hline
\end{tabular}

a- This tank contains less than 15 gallons of sludge.

b- This tank contains no sludge.

c- Sludge contained in tank was not accessible to sampling.

d- The detection limit for selenium in this sample was higher than the regulatory limit, thus, this sample may or may not meet the RCRA requirements of the WAC.

e- Mercury was not measured on this sample, hence it may or may not meet the RCRA requirements of the WAC.

f- The detection limit for arsenic in this sample was higher than the regulatory limit, thus, this sample may or may not meet the RCRA requirements of the WAC.

g- Data limited due to insufficient sample quantity. Insufficient sample data to make a full comparison to WAC's. 


\subsection{QUALITY ASSURANCE}

The Analytical Development Section has an extensive quality assurance program in order to produce and disseminate data of the highest quality. ADS uses a graded approach for implementing DOE Order 5700.6C, 10CFR830-120, and ASME NQA-1 Quality Assurance Requirements for Nuclear Facilities ${ }^{19}$.

Measurement and Test Equipment such as balances and pipets are controlled using the WSRC 1Q, Quality Assurance Manual, Procedure 12-1 (Control of Measuring and Test Equipment). Analytical Measurement Systems (i.e. gamma detectors, GC's, etc.) are controlled using the WSRC 1Q, Quality Assurance Manual, Procedure 2-7 (Program Requirements for Analytical Measurement Systems) and Procedure ADS-0114 (Measurement Control Program) of Manual ADS L16.1 (Analytical Development Section Analytical Operating Procedures). In addition, ADS instrument procedures specifically define calibration procedures and quality control requirements. Quality control charts are compiled on a monthly basis for review. These data are issued in the monthly ADS Sample Management and Quality Control Report.

Accuracy and precision of the various analytical methods used by ADS are routinely checked by bench/check standards, blind standards, split samples, replicate measurements, external sources/laboratories, inter-laboratory comparison samples, quality control charts, and/or spikes of known concentrations. ADS currently participates in the DOE Radiological and Environmental Sciences Laboratory (RESL) Mixed Analyte Performance Evaluation Program (MAPEP) for laboratories performing radiological, inorganic, and/or organic analyses in support of DOE environmental monitoring activities. In the past, ADS has also participated in the DOE Environmental Measurements Laboratory (EML) Quality Assessment Program (QAP) for laboratories performing environmental radiological analyses for DOE environmental monitoring activities.

\subsection{RECOMMENDATIONS FOR PATH FORWARD}

At the request of SRS-ERD, ADS included this section as part of the Old Solvent Tank characterization report. The intent of this section is to provide recommendations of potential disposal options for the contents of the Old Solvent Tanks. This section is not intended to provide any remedial decisions regarding the Old Solvent Tanks.

The sampling and characterization of liquid and sludge samples from the Old Solvent Tanks has brought to light many important considerations. The most important of these considerations is the immense difficulty in obtaining/removing both liquid and sludge samples from the Old Solvent Tanks. In particular, it became very evident that the sludges contained in the tanks are extremely hard to remove. These lessons in conjunction with the physical condition of the tanks should heavily influence 
treatment/disposal options of the material within the Old Solvent Tanks. It must also be emphasized that bulk removal of the remaining liquids and solids in these tanks will present an even more stifling challenge. This is due to the relatively small volumes of material in the tanks compared to the volumes of the tanks themselves.

One major limiting factor for a majority of the liquids, suspended solids, and sludges characterized in this study is the TRU content of the material. The TRU nature of the majority of the raw liquids contained in the tanks excludes all of the facilities that can accept exclusively low level waste. Only the raw aqueous liquids in Tanks S2, S3, and S4 and the raw organic liquid in Tank S20 have TRU activity concentrations of less than $100 \mathrm{nCi} / \mathrm{g}$. None of the suspended solids have TRU activity concentrations of less than or equal to $100 \mathrm{nCi} / \mathrm{g}$ and only the filtered liquids in Tanks S2, S3, S4, S6, S8, and S20 (organic phase only) have TRU activity concentrations of less than $100 \mathrm{nCi} / \mathrm{g}$. Thus, one would gain nothing by filtering the suspended solids out of Tanks S2, S3, S4, and S20 (organic phase). In fact, it would be advantageous to leave the suspended solids in the liquids since these raw liquids are not considered TRU waste. It would appear advantageous, though, to filter the suspended solids out of the liquids from Tanks $S 6$ and S8. The much smaller volume of suspended solids could be treated as TRU waste while the filtered, low-level liquid could potentially be treated at a low-level waste facility such as CIF. Blending all of the tanks will not be of use either since there is not enough nonTRU liquid to combine with the TRU liquid to result in the mixture being less than or equal to $100 \mathrm{nCi} / \mathrm{g}$. It appears that such a blend would be over $600 \mathrm{nCi} / \mathrm{g}$, assuming no other liquid or solid material is added to the mixture.

The TRU Pads appear to be one potential disposal option for the raw aqueous liquids contained in Tanks in S1, S5, S6, S7, S8, S13, S14, S19, S20, S21, and S22, as well as the organic liquid in Tank S11. However, the liquids would not be acceptable in their liquid form since the current E-Area TRU Pads WAC prohibits any significant amount of liquids. Treatment options would thus have to be considered in which the liquid is converted into a suitable solid. Of course this treatment option would require an efficient pumping mechanism for the removal of the raw liquids from the tanks. Thus, facilities would have to be built that are external to the currently existing tanks resulting in the generation of additional waste.

The TRU Pads are also a potential disposal option for the sludges contained in Tanks S2, S7, S8, S16, S19, S20, S21, and S22. One major technical challenge is the removal of the sludge from the Old Solvent Tanks. The sampling events for this characterization study have shown that the sludge is not amenable to easy removal. Assuming one could remove the sludge in a reasonable manner, only small quantities of liquid could be present in order for the sludge to be acceptable to the E-Area TRU Pads (see Section 4.4 for further discussion). Hence, the removal technique could have a significant impact on the physical form of the sludge.

CIF remains a potentially viable choice for the raw aqueous liquids in Tanks S2, S3, and $\mathrm{S} 4$, and for the organic liquid in Tank 20 . A deviation request would have to be 
submitted for these liquids due to the high gross alpha content. Potentially, a minimum of $\sim 3330$ liters or approximately $16 \%$ of the total liquid volume contained in the Old Solvent Tanks could be disposed of in this manner. If the suspended solids are separated from the raw liquids from Tanks S6 and S8, potentially $\sim 1560$ additional liters could be disposed of at CIF bringing the total to $\sim 890$ liters or approximately $23 \%$ of the total liquid volume in the Old Solvent Tanks.

It is obvious from the outcome of this characterization that whatever options are chosen for the various liquids and solids contained in the Old Solvent Tanks, additional sampling and characterization work could be required. In conclusion, this extensive characterization project on the material contained in the Old Solvent Tanks now makes it possible to reasonably evaluate the risks and costs associated with the treatment options for the closure of these tanks.

\subsection{REFERENCES}

1. Information Document on the Old Solvent Tanks S1-S22 in the Old Radioactive Waste Burial Ground 643-E, WSRC-RP-96-00144, Rev. 0, Westinghouse Savannah River Company, Aiken, SC 29808 (1996).

2. Filpus-Luyckx, P., Sampling and Analysis Plan for Old Solvent Tanks S1-S22 to Address Waste Acceptance Criteria (U), WSRC-RP-97-00770, Rev. 0, Westinghouse Savannah River Company, Aiken, SC 29808 (1997).

3. Procedure WAC 3.16, Solvent Storage Tank Facility - Waste Acceptance Criteria, Rev. 0, WSRC 1S Manual, Westinghouse Savannah River Company, Aiken, SC 29808, (1997).

4. Procedure WAC 3.06, E-Area TRU Pads Transuranic Waste Acceptance Criteria, Rev. 5, WSRC 1S Manual, Westinghouse Savannah River Company, Aiken, SC 29808, (1998).

5. Procedure WAC 3.07, Mixed Waste Storage Facilities - Mixed Waste Acceptance Criteria, Rev. 3, WSRC 1S Manual, Westinghouse Savannah River Company, Aiken, SC 29808, (1997).

6. Procedure WAC 3.17, Low Level Radioactive Waste Acceptance Criteria, Interim, Rev. 1, WSRC Manual 1S, Westinghouse Savannah River Company, Aiken, SC 29808 (1997).

7. Brown, D. and Georgeton, G, Waste Acceptance Criteria for High Level Liquid Waste Transfers to the 241-F/H Tank Farms (U), X-SD-G-00001, Rev. 1, Westinghouse Savannah River Company, Aiken, SC 29808 (1995).

8. Currie, L., Limits for Qualitative Detection and Quantitative Determination, Analytical Chemistry 40, 5861968.

9. Mason, J., Estimation of Total Solids in Tanks S1-S22 Based on the Video Surveys, Interoffice Memorandum, April 22, 1998, Westinghouse Savannah River Company, Aiken, SC 29808 (1998). 
10. Preston, A., Solvent Tank Liquid and Sludge Quantities, Electronic Mail Private Communication, December 9, 1998, Westinghouse Savannah River Company, Aiken, SC 29808 (1998).

11. Preston, A., Private Communications, December 18, 1998 and January 5, 1999, Westinghouse Savannah River Company, Aiken, SC 29808 (1998, 1999).

12. Firestone, R., Table of Isotopes, Eighth Edition, Volume II, John Wiley \& Sons, Inc., New York (1996).

13. Gibbs, A., Production of Transplutonium Nuclides at SRS, SWD-SWE-99-00093, Westinghouse Savannah River Company, Aiken, SC 29808 (1999).

14. East, J., Specific Activities of 167 Common Accident Analysis Radionuclides (U), N-CLC-G-00040, Rev. 0, Westinghouse Savannah River Company, Aiken, SC 29808 (1996).

15. Procedure WAC 3.18, Hazardous, Mixed and Polychlorinated Biphenyl Waste Acceptance Criteria, Rev. 1, WSRC 1S Manual, Westinghouse Savannah River Company, Aiken, SC 29808, (1998).

16. Procedure WAC 3.16, Solvent Storage Tank Facility - Waste Acceptance Criteria, Rev. 1, WSRC 1S Manual, Westinghouse Savannah River Company, Aiken, SC 29808, (1999).

17. Procedure WAC 3.06, E-Area TRU Pads Transuranic Waste Acceptance Criteria, Rev. 6, WSRC 1S Manual, Westinghouse Savannah River Company, Aiken, SC 29808, (1999).

18. Aponte, C. I., Waste Acceptance Criteria for High Level Liquid Waste Transfers to the 241-F/H Tank Farms (U), X-SD-G-00001, Rev. 3, Westinghouse Savannah River Company, Aiken, SC 29808, (1998).

19. Polochko, M., ADS Analytical Services QA Requirements, 6/29/98 MAP, Westinghouse Savannah River Company, Aiken, SC 29808 (1998).

\subsection{APPENDICES}

\subsection{Appendix A}

See Pages A1-A5

\subsection{Appendix B}

See Pages B1-B6

\subsection{Appendix C}

See Pages C1-C5

\subsection{Appendix D}

See Pages D1-D6 


\subsection{Appendix E}

See Pages E1-E4

\subsection{Appendix F}

See Pages F1-F5

8.7 Appendix G

See Pages G1-G7

\subsection{Appendix $\mathrm{H}$}

See Pages H1-H7

\subsection{Appendix I}

See Pages I1-I4

\subsection{Appendix J}

See Pages J1-J7

\subsection{Appendix K}

See Pages K1-K6

\subsection{Appendix L}

See Pages L1-L3

\subsection{Appendix M}

See Pages M1-M2

\subsection{Appendix N}

See Pages N1-N13

\subsection{Appendix O}

See Pages 01-014 
Savannah River Site

Characterization of Samples from Old Solvent Tanks

S1 Through S22
WSRC-RP-98-01486

Revision 2

$6 / 8 / 00$

Page 51 of 51

\subsection{Appendix P}

See Pages P1-P8

\subsection{Appendix Q}

See Pages Q1-Q8

8.18 Appendix R

See Pages R1-R7

\subsection{Appendix $S$}

See Pages S1-S7

\subsection{Appendix T}

See Pages T1-T7

\subsection{Appendix U}

See Page UI 


\begin{tabular}{|c|l|l|l|l|l|}
\hline Tank S1 & & & & & \\
\hline Sample \# & $3-103987$ & & & & \\
\hline Customer ID & $98018-1$ & & & & \\
\hline Description & Original Aqueous Sample & & \\
\hline & & & & \\
\hline Analyte & Concent. & Units & & & \\
\hline Total Suspended Solids & 0.01 & wt \% & & & \\
\hline
\end{tabular}




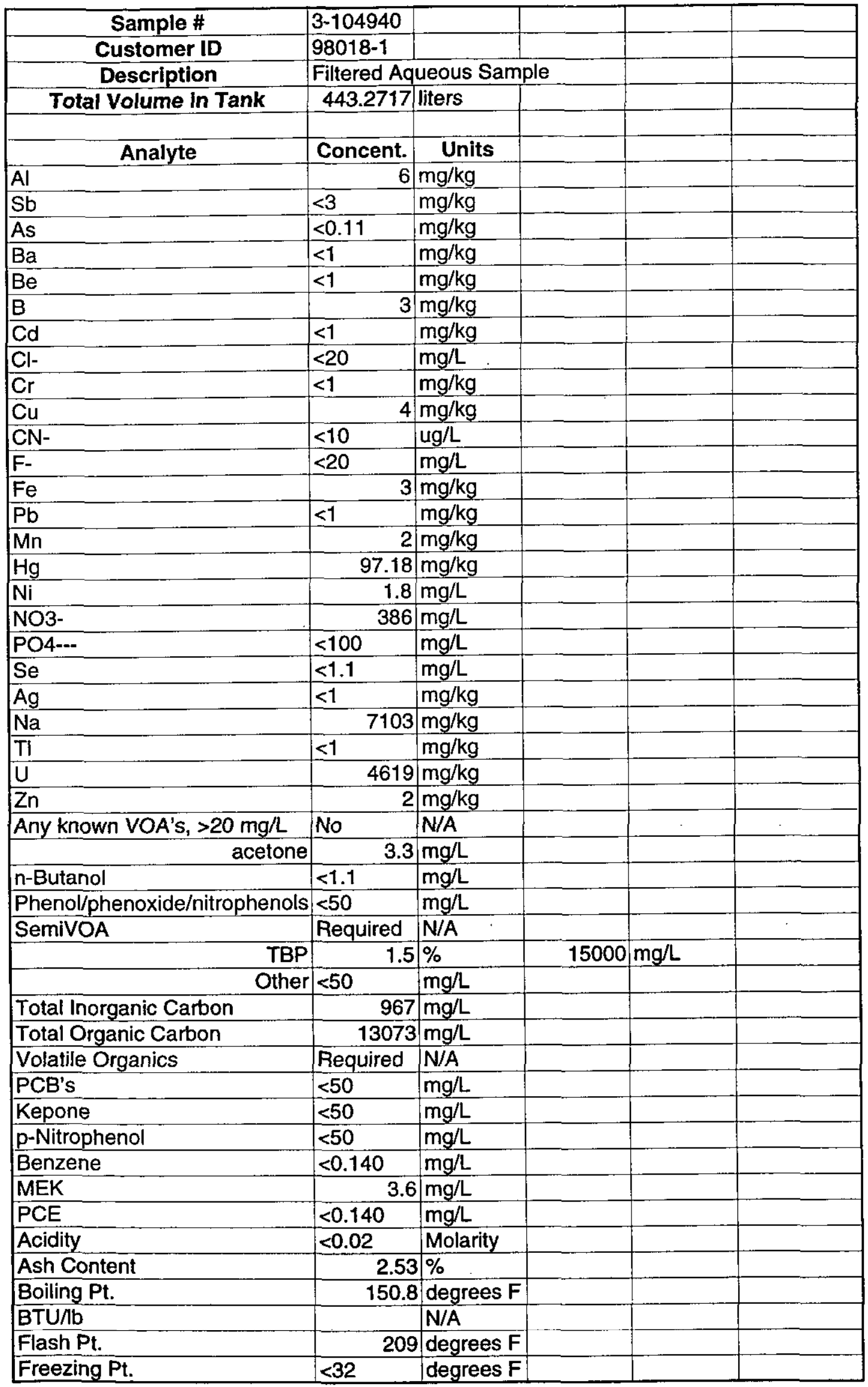

Appendix A

Page A2 


\begin{tabular}{|c|c|c|c|c|c|}
\hline Free Liquid? & Yes & $\mathrm{N} / \mathrm{A}$ & & & \\
\hline $\mathrm{pH}$ & 8.27 & $\mathrm{~N} / \mathrm{A}$ & & & \\
\hline Density & 0.875 & $\mathrm{~g} / \mathrm{cm} 3$ & & & \\
\hline TDS & $5 . \overline{40}$ & $\%$ & & & \\
\hline \multirow[t]{5}{*}{ Water, wt\% } & 90.7 & $\%$ & & & \\
\hline & & & & & Aqueous \\
\hline & & & & & Phase \\
\hline & & & & & Total \\
\hline & Activity & Error & Activity & Error & Activity \\
\hline Radionuclides & $\mathrm{uCi} / \mathrm{mL}$ & $\mathrm{uCi} / \mathrm{mL}$ & $\mathrm{pCi} / \mathrm{L}$ & $\mathrm{pCi} / \mathrm{L}$ & $\mathrm{uCi}$ \\
\hline Total Am & $8.52 E-03$ & UL & $8.52 E+06$ & UL & $3.78 \mathrm{E}+03$ \\
\hline Am-241 & 8.42E-03 & $4.36 \mathrm{E}-04$ & $8.42 E+06$ & $4.36 \mathrm{E}+05$ & $3.73 E+03$ \\
\hline Am-243 & $9.95 E-05$ & UL & $9.95 E+04$ & $\mathrm{UL}$ & $4.41 E+01$ \\
\hline C-14 & $3.50 \mathrm{E}-04$ & UL & $3.50 \mathrm{E}+05$ & UL & $1.55 \bar{E}+02$ \\
\hline $\mathrm{Ce}-144$ & $2.56 \mathrm{E}-04$ & MDA & $2.56 \mathrm{E}+05$ & MDA & $1.13 \mathrm{E}+02$ \\
\hline Total $\mathrm{Cm}$ & 2.04E-02 & 4.07E-02 & $2.04 \mathrm{E}+07$ & $4.07 E+07$ & $9.04 \mathrm{E}+03$ \\
\hline $\mathrm{Cm}-244$ & 2.04E-02 & 4.07E-02 & $2.04 \mathrm{E}+07$ & $4.07 \mathrm{E}+07$ & $9.04 \mathrm{E}+03$ \\
\hline $\mathrm{Cm}-245$ & $7.88 E-04$ & $\mathrm{DL}$ & $7.88 \mathrm{E}+05$ & $\mathrm{DL}$ & $3.49 E+02$ \\
\hline $\mathrm{Cm}-246$ & $1.41 \mathrm{E}-03$ & $\mathrm{DL}$ & 1.41E+06 & $\mathrm{DL}$ & $6.25 E+02$ \\
\hline Co-60 & 3.03E-05 & 9.17E-06 & $3.03 E+04$ & $9.17 \mathrm{E}+03$ & $1.34 E+01$ \\
\hline Cs-134 & 3.91E-05 & MDA & $3.91 E+04$ & MDA & $1.73 E+01$ \\
\hline Cs-137 & $1.28 \mathrm{E}-02$ & 4.47E-04 & $1.28 \mathrm{E}+07$ & $4.47 \mathrm{E}+05$ & $5.67 E+03$ \\
\hline Eu-154 & 1.62E-02 & 2.85E-04 & $1.62 \mathrm{E}+07$ & $2.85 \mathrm{E}+05$ & $7.18 \mathrm{E}+03$ \\
\hline Eu-155 & $1.77 \mathrm{E}-03$ & $8.13 E-05$ & 1.77E+06 & $8.13 \mathrm{E}+04$ & $7.85 \mathrm{E}+02$ \\
\hline $\mathrm{GA}$ & $6.80 \mathrm{E}-01$ & 0.136 & $6.80 E+08$ & $1.36 \mathrm{E}+08$ & $3.01 E+05$ \\
\hline $\mathrm{H}-3$ & 2.07E-04 & 2.07E-05 & $2.07 E+05$ & $2.07 E+04$ & $9.18 \mathrm{E}+01$ \\
\hline $1-129$ & $2.03 E-06$ & MDA & $2.03 E+03$ & MDA & $9.00 \mathrm{E}-01$ \\
\hline Ni-59 & $1.10 \mathrm{E}-03$ & MDA & $1.10 \mathrm{E}+06$ & MDA & $4.88 \mathrm{E}+02$ \\
\hline $\mathrm{Ni}-63$ & $6.13 \mathrm{E}-03$ & UL & $6.13 E+06$ & UL & $2.72 E+03$ \\
\hline$\overline{G B}$ & $1.82 \mathrm{E}+00$ & $7.30 \mathrm{E}-01$ & $1.82 \mathrm{E}+09$ & $7.30 \mathrm{E}+08$ & $8.07 E+05$ \\
\hline Np-237 & $2.29 E-04$ & $1.15 \mathrm{E}-04$ & $2.29 E+05$ & $1.15 \mathrm{E}+05$ & $1.02 E+02$ \\
\hline Total $\mathrm{Pu}$ & 8.25E-01 & $8.11 \mathrm{E}-02$ & $8.25 E+08$ & $8.11 \mathrm{E}+07$ & $3.66 \mathrm{E}+05$ \\
\hline Pu-238 & $6.49 \mathrm{E}-01$ & $6.49 \mathrm{E}-02$ & $6.49 E+08$ & $6.49 \mathrm{E}+07$ & $2.88 E+05$ \\
\hline Pu-239 & $1.39 E-02$ & $6.94 \mathrm{E}-03$ & $1.39 E+07$ & $6.94 \mathrm{E}+06$ & $6.16 \mathrm{E}+03$ \\
\hline Pu-240 & $1.97 \mathrm{E}-03$ & $9.86 \mathrm{E}-04$ & $1.97 \mathrm{E}+06$ & $9.86 \mathrm{E}+05$ & $8.73 E+02$ \\
\hline Pu-241 & $1.60 \mathrm{E}-01$ & $4.81 E-02$ & $1.60 \mathrm{E}+08$ & $4.81 E+07$ & $7.09 E+04$ \\
\hline Pu-242 & $1.81 \mathrm{E}-05$ & $\mathrm{DL}$ & $1.81 E+04$ & $\mathrm{DL}$ & $8.02 E+00$ \\
\hline Pm-147 & 6.31E-04 & $4.50 \mathrm{E}-04$ & $6.31 E+05$ & $4.50 \mathrm{E}+05$ & $2.80 E+02$ \\
\hline Ru-106 & 3.72E-04 & MDA & $3.72 E+05$ & MDA & $1.65 \mathrm{E}+02$ \\
\hline Sb-125 & 8.69E-04 & $6.78 \mathrm{E}-05$ & $8.69 E+05$ & $6.78 \mathrm{E}+04$ & $3.85 E+02$ \\
\hline Se-79 & $9.01 E-05$ & MDA & $9.01 E+04$ & MDA & $3.99 E+01$ \\
\hline Sn-126 & $1.29 \mathrm{E}-04$ & MDA & $1.29 \mathrm{E}+05$ & MDA & $5.72 E+01$ \\
\hline Sr-90 & $6.26 \mathrm{E}-01$ & $6.31 \mathrm{E}-02$ & $6.26 \mathrm{E}+08$ & $6.31 E+07$ & $2.77 E+05$ \\
\hline TC-99 & $1.86 \mathrm{E}-03$ & $3.86 \mathrm{E}-04$ & $1.86 \mathrm{E}+06$ & $3.86 E+05$ & $8.24 E+02$ \\
\hline Th-232 & $3.54 \mathrm{E}-08$ & $7.08 \mathrm{E}-09$ & $3.54 \mathrm{E}+01$ & $7.08 \mathrm{E}+00$ & 1.57E-02 \\
\hline $\mathrm{U}-233$ & $5.05 E-04$ & 1.01E-04 & $5.05 E+05$ & $1.01 \mathrm{E}+05$ & $2.24 \mathrm{E}+02$ \\
\hline U-234 & $5.50 \mathrm{E}-03$ & 1.10E-03 & $5.50 \mathrm{E}+06$ & $1.10 \mathrm{E}+06$ & $2.44 E+03$ \\
\hline U-235 & $8.56 \mathrm{E}-05$ & $1.71 \mathrm{E}-05$ & $8.56 \mathrm{E}+04$ & $1.71 E+04$ & $3.79 E+01$ \\
\hline U-236 & $4.38 E-05$ & $8.77 \mathrm{E}-06$ & $4.38 E+04$ & $8.77 E+03$ & $1.94 E+01$ \\
\hline U-238 & $1.89 \mathrm{E}-03$ & $3.77 \mathrm{E}-04$ & $1.89 \mathrm{E}+06$ & $3.77 E+05$ & $8.38 E+02$ \\
\hline TRU & $6.74 \mathrm{E}-01$ & & $6.74 \mathrm{E}+08$ & & $2.99 \mathrm{E}+05$ \\
\hline & & & & & \\
\hline
\end{tabular}

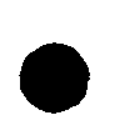


$\mathrm{DL}=$ Detection Limit

UL = Upper Limit

TBP = Tributyl Phosphate
$6 / 8 / 00$

Appendix A

Page A4 


\begin{tabular}{|c|c|c|c|c|c|}
\hline Sample \# & $3-104914$ & & & & \\
\hline Customer ID & 98018-1 & & & & \\
\hline Description & \multicolumn{2}{|c|}{ Filtered Solids } & & & \\
\hline \multirow[t]{9}{*}{ Estimated Solids } & \multicolumn{2}{|c|}{$38.79 \mathrm{~g}$} & \multicolumn{3}{|c|}{ (based upon TSS, volume and } \\
\hline & & & \multicolumn{3}{|c|}{ density of liquid phase) } \\
\hline & & & & & \\
\hline & & & & & \\
\hline & & & & & \\
\hline & & & & & Suspended \\
\hline & & & & & Solids \\
\hline & & & & & Total \\
\hline & Activity & Error & Activity & Error & Activity \\
\hline Analyte & $\mathrm{uCi} / \mathrm{g}$ & $\mathrm{uCi} / \mathrm{g}$ & $\mathrm{pCi} / \mathrm{g}$ & $\mathrm{pCi} / \mathrm{g}$ & $\mathrm{uCi}$ \\
\hline Total Am & $0.00 \mathrm{E}+00$ & $0.00 \mathrm{E}+00$ & $0.00 \mathrm{E}+00$ & $0.00 \mathrm{E}+00$ & $0.00 \mathrm{E}+00$ \\
\hline $\mathrm{Am}-241$ & $5.05 E+00$ & MDA & $5.05 E+06$ & MDA & $1.96 E+02$ \\
\hline$A m-243$ & $2.08 \mathrm{E}+01$ & $\mathrm{DL}$ & $2.08 E+07$ & $\mathrm{DL}$ & $8.07 E+02$ \\
\hline Ce-144 & $4.77 \mathrm{E}+00$ & MDA & $4.77 \mathrm{E}+06$ & MDA & $1.85 \mathrm{E}+02$ \\
\hline Total $\mathrm{Cm}$ & $1.18 \mathrm{E}+02$ & $2.17 E+01$ & $1.18 \mathrm{E}+08$ & $2.17 E+07$ & $4.58 \mathrm{E}+03$ \\
\hline $\mathrm{Cm}-244$ & $1.18 \mathrm{E}+02$ & 2.17E+01 & $1.18 \mathrm{E}+08$ & 2.17E+07 & $4.58 \mathrm{E}+03$ \\
\hline $\mathrm{Cm}-245$ & $1.79 \mathrm{E}+01$ & $\mathrm{DL}$ & $1.79 E+07$ & $\mathrm{DL}$ & $6.94 \mathrm{E}+02$ \\
\hline $\mathrm{Cm}-246$ & $3.18 \mathrm{E}+01$ & $D L$ & $3.18 \mathrm{E}+07$ & $D$ & $1.23 E+03$ \\
\hline Co-60 & $6.26 \mathrm{E}-01$ & MDA & $6.26 \mathrm{E}+05$ & MDA & $2.43 \mathrm{E}+01$ \\
\hline Cs-134 & $1.07 \mathrm{E}+00$ & $\mathrm{MDA}$ & $1.07 \mathrm{E}+06$ & $\overline{\mathrm{MDA}}$ & $4.15 \mathrm{E}+01$ \\
\hline Cs-137 & $1.39 \mathrm{E}+00$ & MDA & $1.39 E+06$ & MDA & $5.39 E+01$ \\
\hline Eu-154 & $3.61 \mathrm{E}+00$ & $3.19 E+00$ & $3.61 \mathrm{E}+06$ & $3.19 \mathrm{E}+06$ & $1.40 \mathrm{E}+02$ \\
\hline $\mathrm{GA}$ & $2.38 \mathrm{E}+02$ & $2.38 \mathrm{E}+01$ & $2.38 \mathrm{E}+08$ & $2.38 E+07$ & $9.23 \mathrm{E}+03$ \\
\hline $\mathrm{H}-3$ & $1.15 \mathrm{E}+00$ & MDA & $1.15 \mathrm{E}+06$ & MDA & $4.46 \mathrm{E}+01$ \\
\hline $1-129$ & $9.46 \mathrm{E}+00$ & MDA & $9.46 \mathrm{E}+06$ & MDA & $3.67 \mathrm{E}+02$ \\
\hline $\mathrm{Ni}-59$ & $1.82 \mathrm{E}+00$ & MDA & $1.82 E+06$ & MDA & $7.06 \mathrm{E}+01$ \\
\hline $\mathrm{Ni}-63$ & $9.59 \mathrm{E}-01$ & MDA & $9.59 \mathrm{E}+05$ & MDA & $3.72 E+01$ \\
\hline $\mathrm{GB}$ & $1.42 \mathrm{E}+02$ & $5.69 \mathrm{E}+01$ & $1.42 E+08$ & $5.69 \mathrm{E}+07$ & $5.51 E+03$ \\
\hline Np-237 & $7.34 \mathrm{E}-02$ & $\mathrm{DL}$ & $7.34 \mathrm{E}+04$ & $\mathrm{DL}$ & $2.85 E+00$ \\
\hline Total Pu & $1.29 E+02$ & $4.70 \mathrm{E}+01$ & $1.29 E+08$ & $4.70 \mathrm{E}+07$ & $5.00 \mathrm{E}+03$ \\
\hline Pu-238 & $9.32 E+01$ & $2.80 \mathrm{E}+01$ & $9.32 \mathrm{E}+07$ & $2.80 \mathrm{E}+07$ & $3.62 E+03$ \\
\hline Pu-239 & $6.49 \mathrm{E}+00$ & $\mathrm{DL}$ & $6.49 \mathrm{E}+06$ & $\mathrm{DL}$ & $2.52 \mathrm{E}+02$ \\
\hline Pu-240 & $2.36 \mathrm{E}+01$ & DL & $2.36 \mathrm{E}+07$ & $\overline{D L}$ & $9.15 E+02$ \\
\hline Pu-241 & $3.57 E+01$ & $3.78 \mathrm{E}+01$ & $3.57 \mathrm{E}+07$ & $3.78 E+07$ & $1.38 E+03$ \\
\hline Pu-242 & $4.10 \mathrm{E}-01$ & $\mathrm{DL}$ & $4.10 E+05$ & $\mathrm{DL}$ & $1.59 \mathrm{E}+01$ \\
\hline Ru-106 & $8.83 E+00$ & MDA & $8.83 E+06$ & MDA & $3.43 E+02$ \\
\hline Sb-125 & $2.34 \mathrm{E}+00$ & MDA & $2.34 \mathrm{E}+06$ & MDA & $9.08 \mathrm{E}+01$ \\
\hline Sn-126 & $1.83 E+00$ & MDA & $1.83 E+06$ & MDA & $7.10 \mathrm{E}+01$ \\
\hline Sr-90 & $8.06 \mathrm{E}+01$ & $1.94 E+01$ & $8.06 \mathrm{E}+07$ & $1.94 \mathrm{E}+07$ & $3.13 E+03$ \\
\hline Tc-99 & $1.61 \mathrm{E}-01$ & MDA & $1.61 E+05$ & MDA & $6.25 E+00$ \\
\hline Th-232 & $1.52 \mathrm{E}-04$ & 3.05E-05 & $1.52 E+02$ & $3.05 \mathrm{E}+01$ & $5.90 \mathrm{E}-03$ \\
\hline U-233 & $6.35 \mathrm{E}-01$ & DL & $6.35 \mathrm{E}+05$ & $\overline{D L}$ & $2.46 E+01$ \\
\hline U-234 & $6.49 \mathrm{E}-01$ & $\mathrm{DL}$ & $6.49 \mathrm{E}+05$ & $\mathrm{DL}$ & $2.52 \mathrm{E}+01$ \\
\hline U-235 & $2.28 \mathrm{E}-03$ & $4.57 \mathrm{E}-04$ & $2.28 E+03$ & $4.57 \mathrm{E}+02$ & $8.84 E-02$ \\
\hline$U-236$ & $6.76 \mathrm{E}-03$ & DL & $6.76 \mathrm{E}+03$ & $\mathrm{DL}$ & 2.62E-01 \\
\hline U-238 & 5.27E-02 & 1.05E-02 & $5.27 E+04$ & $1.05 \mathrm{E}+04$ & $2.04 \mathrm{E}+00$ \\
\hline TRU & $9.32 \mathrm{E}+01$ & & $9.32 E+07$ & & $3.62 E+03$ \\
\hline $1 \mathrm{~A}$ & ity fo & ו & used & & \\
\hline $\mathrm{DL}=$ Detection Limit & & & & & \\
\hline
\end{tabular}




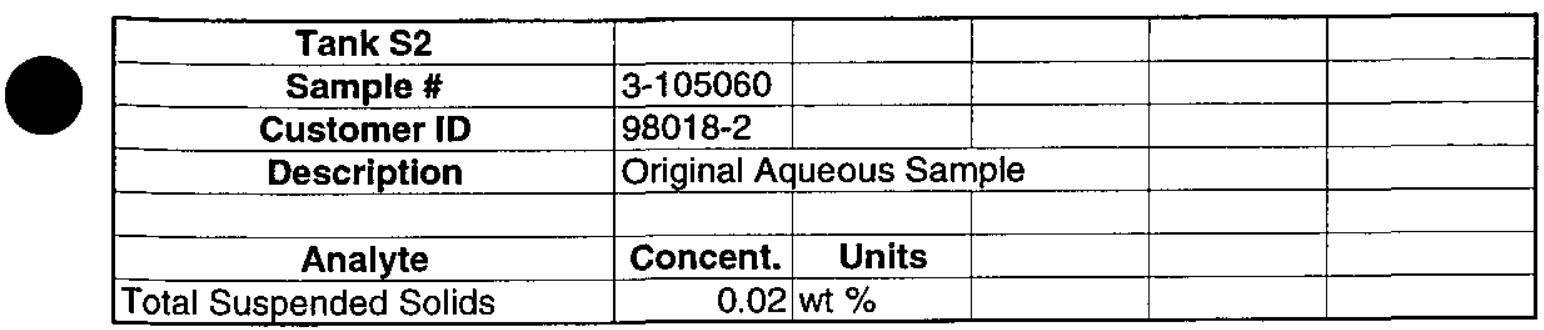




\begin{tabular}{|c|c|c|c|c|}
\hline Sample \# & 3-105063 & & & \\
\hline Customer ID & 98018-2 & & & \\
\hline Description & Filtered AqI & queous Samp & & \\
\hline Total Volume in Tank & 422.8305 & liters & & \\
\hline Analyte & Concent. & Units & & \\
\hline $\mathrm{Al}$ & $<1$ & $\mathrm{mg} / \mathrm{kg}$ & & \\
\hline $\mathrm{Sb}$ & $<3$ & $\mathrm{mg} / \mathrm{kg}$ & & \\
\hline As & $<2$ & $\mathrm{mg} / \mathrm{kg}$ & & \\
\hline $\mathrm{Ba}$ & $<0.1$ & $\mathrm{mg} / \mathrm{kg}$ & & \\
\hline $\mathrm{Be}$ & 0.1 & $\mathrm{mg} / \mathrm{kg}$ & & \\
\hline B & 2 & $\mathrm{mg} / \mathrm{kg}$ & & \\
\hline $\mathrm{Cd}$ & $<0.1$ & $\mathrm{mg} / \mathrm{kg}$ & & \\
\hline $\mathrm{Cl}-$ & 48 & $\mathrm{mg} / \mathrm{L}$ & & \\
\hline $\mathrm{Cr}$ & $<0.1$ & $\mathrm{mg} / \mathrm{kg}$ & & \\
\hline $\mathrm{Cu}$ & 1 & $\mathrm{mg} / \mathrm{kg}$ & & \\
\hline $\mathrm{CN}-$ & $<10$ & ug/L & & \\
\hline F. & $10(a)$ & $\mathrm{mg} / \mathrm{L}$ & & \\
\hline $\mathrm{Fe}$ & 17 & $\mathrm{mg} / \mathrm{kg}$ & & \\
\hline $\mathrm{Pb}$ & $<1$ & $\mathrm{mg} / \mathrm{kg}$ & & \\
\hline $\mathrm{Mn}$ & 1 & $\mathrm{mg} / \mathrm{kg}$ & & \\
\hline $\mathrm{Hg}$ & 8.67 & $\mathrm{mg} / \mathrm{kg}$ & & \\
\hline $\mathrm{Ni}$ & 0.3 & $\mathrm{mg} / \mathrm{L}$ & & \\
\hline NO3- & $10(a)$ & $\mathrm{mg} / \mathrm{L}$ & & \\
\hline PO4--- & 3773 & $\mathrm{mg} / \mathrm{L}$ & & \\
\hline Se & $<11$ & $\mathrm{mg} / \mathrm{L}$ & & \\
\hline $\mathrm{Ag}$ & $<0.1$ & $\mathrm{mg} / \mathrm{kg}$ & & \\
\hline $\mathrm{Na}$ & 5014 & $\mathrm{mg} / \mathrm{kg}$ & & \\
\hline $\mathrm{Tl}$ & $<3$ & $\mathrm{mg} / \mathrm{kg}$ & & \\
\hline $\bar{U}$ & 359 & $\mathrm{mg} / \mathrm{kg}$ & & \\
\hline $\mathrm{Zn}$ & 1 & $\mathrm{mg} / \mathrm{kg}$ & & \\
\hline Any known VOA's, $>20 \mathrm{mg} / \mathrm{L}$ & No & N/A & & \\
\hline n-Butanol & $<1.1$ & $\mathrm{mg} / \mathrm{L}$ & & \\
\hline Phenol/phenoxide/nitrophenols & $<5$ & $\mathrm{mg} / \mathrm{L}$ & & \\
\hline SemiVOA & Required & N/A & & \\
\hline TBP & $<5$ & $\mathrm{mg} / \mathrm{L}$ & & \\
\hline Other & $<5$ & $\mathrm{mg} / \mathrm{L}$ & & \\
\hline Total Inorganic Carbon & 1145 & $\mathrm{mg} / \mathrm{L}$ & & \\
\hline Total Organic Carbon & 12635 & mghl & & \\
\hline Volatile Organics & Required & N/A & & \\
\hline PCB's & $<50$ & $\mathrm{mg} / \mathrm{L}$ & & \\
\hline Kepone & $<5$ & $\mathrm{mg} / \mathrm{L}$ & & \\
\hline p-Nitrophenol & $<5$ & $\mathrm{mg} / \mathrm{L}$ & & \\
\hline Benzene & $<0.140$ & $\mathrm{mg} / \mathrm{L}$ & & \\
\hline MEK & $<0.5$ & $\mathrm{mg} / \mathrm{L}$ & & \\
\hline$\overline{P C E}$ & $<0.140$ & $\mathrm{mg} / \mathrm{L}$ & & \\
\hline Acidity & $<0.02$ & Molarity & & \\
\hline Ash Content & 1.53 & $3 \%$ & & \\
\hline Boiling Pt. & 150.8 & degrees $F$ & & \\
\hline Flash Pt. & $>212$ & degrees $\mathrm{F}$ & & \\
\hline Freezing $\mathrm{Pt}$. & $<32$ & degrees $\mathrm{F}$ & & \\
\hline
\end{tabular}




\begin{tabular}{|c|c|c|c|c|c|}
\hline Free Liquid? & Yes & N/A & & & \\
\hline $\mathrm{pH}$ & 8.62 & N/A & & & \\
\hline Density & 1.003 & $\mathrm{~g} / \mathrm{cm} 3$ & & & \\
\hline TDS & 3.12 & $\%$ & & & \\
\hline \multirow[t]{2}{*}{ Water, wt\% } & 77.4 & $\%$ & & & \\
\hline & & & & & Aqueous \\
\hline \multirow{4}{*}{-} & & & & & Phase \\
\hline & & & & & Total \\
\hline & Activity & Error & Activity & Error & Activity \\
\hline & $\mathrm{uCl} / \mathrm{mL}$ & $\mathrm{uCi} / \mathrm{mL}$ & pCi/L & $\mathrm{pCi} / \mathrm{L}$ & uCi \\
\hline$\overline{A m-241}$ & $3.14 E-04$ & 2.29E-05 & $3.14 E+05$ & $2.29 E+04$ & $1.33 E+02$ \\
\hline C-14 & $7.34 \mathrm{E}-05$ & UL & $7.34 \mathrm{E}+04$ & UL & $3.10 E+01$ \\
\hline $\mathrm{Ce}-144$ & 4.27E-05 & MDA & $4.27 E+04$ & MDA & $1.81 E+01$ \\
\hline Total $\mathrm{Cm}$ & 2.37E-03 & $4.75 \mathrm{E}-04$ & $2.37 E+06$ & $4.75 \mathrm{E}+05$ & $1.00 \mathrm{E}+03$ \\
\hline $\mathrm{Cm}-244$ & 2.37E-03 & $4.75 E-04$ & $2.37 E+06$ & $4.75 \mathrm{E}+05$ & $1.00 \mathrm{E}+03$ \\
\hline Co-60 & 1.87E-06 & MDA & $1.87 E+03$ & MDA & $7.91 \mathrm{E}-01$ \\
\hline Cs-134 & $2.88 \mathrm{E}-06$ & MDA & $2.88 E+03$ & MDA & $1.22 E+00$ \\
\hline Cs-137 & $1.84 \mathrm{E}-02$ & $6.30 \mathrm{E}-04$ & $1.84 \mathrm{E}+07$ & $6.30 \mathrm{E}+05$ & $7.78 E+03$ \\
\hline Eu-154 & $2.91 \mathrm{E}-04$ & $7.81 E-06$ & $2.91 E+05$ & $7.81 E+03$ & $1.23 E+02$ \\
\hline $\mathrm{GA}$ & $1.98 \mathrm{E}-02$ & 3.95E-03 & $1.98 E+07$ & $3.95 \mathrm{E}+06$ & $8.37 E+03$ \\
\hline $\mathrm{H}-3$ & $7.21 \mathrm{E}-04$ & 7.21E-05 & $7.21 E+05$ & $7.21 \mathrm{E}+04$ & $3.05 E+02$ \\
\hline $\mathrm{Ni}-63$ & 7.70 E-04 & $3.08 \mathrm{E}-04$ & $7.70 \mathrm{E}+05$ & $3.08 \mathrm{E}+05$ & $3.26 E+02$ \\
\hline GB & $2.94 \mathrm{E}-02$ & $1.18 \mathrm{E}-02$ & $2.94 \mathrm{E}+07$ & $1.18 \mathrm{E}+07$ & $1.24 E+04$ \\
\hline Np-237 & 1.03E-04 & $2.62 E-05$ & $1.03 E+05$ & $2.62 \mathrm{E}+04$ & 4.36E+01 \\
\hline Pu-238 & $1.42 \mathrm{E}-02$ & $2.84 \mathrm{E}-03$ & $1.42 \mathrm{E}+07$ & $2.84 \mathrm{E}+06$ & $6.00 \mathrm{E}+03$ \\
\hline $\mathrm{Pu}-239 / 240$ & $1.98 \mathrm{E}-03$ & UL & $1.98 E+06$ & UL & $8.37 E+02$ \\
\hline $\mathrm{Pu}-241$ & $5.72 \mathrm{E}-03$ & $2.52 E-03$ & $5.72 E+06$ & $2.52 E+06$ & $2.42 E+03$ \\
\hline Ru-106 & $7.66 \mathrm{E}-05$ & MDA & $7.66 \mathrm{E}+04$ & MDA & $3.24 E+01$ \\
\hline$S b-125$ & $4.11 \mathrm{E}-05$ & MDA & $4.11 E+04$ & MDA & $1.74 \mathrm{E}+01$ \\
\hline Se-79 & $1.80 \mathrm{E}-04$ & MDA & $1.80 E+05$ & MDA & $7.61 \mathrm{E}+01$ \\
\hline Sn-126 & $1.42 E-05$ & MDA & $1.42 \mathrm{E}+04$ & MDA & $6.00 \mathrm{E}+00$ \\
\hline Sr-90 & $1.80 \mathrm{E}-03$ & $9.01 \mathrm{E}-04$ & $1.80 E+06$ & $9.01 \mathrm{E}+05$ & $7.61 E+02$ \\
\hline TC-99 & $9.46 \mathrm{E}-05$ & $5.41 \mathrm{E}-05$ & $9.46 \mathrm{E}+04$ & $5.41 \mathrm{E}+04$ & $4.00 \mathrm{E}+01$ \\
\hline U-233/234 & 2.97E-03 & $1.78 \mathrm{E}-03$ & $2.97 \mathrm{E}+06$ & $1.78 \mathrm{E}+06$ & $1.26 \mathrm{E}+03$ \\
\hline U-235 & 1.37E-05 & $5.31 E-06$ & $1.37 E+04$ & $5.31 \mathrm{E}+03$ & $5.79 \mathrm{E}+00$ \\
\hline TRU & $1.66 \mathrm{E}-02$ & & $1.66 \mathrm{E}+07$ & & $7.02 \mathrm{E}+03$ \\
\hline \multicolumn{6}{|c|}{ MDA $=$ Minimum Detectable Activity for the conditions used } \\
\hline \multicolumn{6}{|l|}{$\mathrm{DL}=$ Detection Limit } \\
\hline \multicolumn{6}{|l|}{$\mathrm{UL}=$ Upper Limit } \\
\hline \multicolumn{6}{|c|}{$\mathrm{a}=$ compound present but below quantitation limit } \\
\hline TBP = Tributyl Pho & & & & & \\
\hline
\end{tabular}

Pu- 


\begin{tabular}{|c|c|c|c|c|c|}
\hline Sample \# & 3-105061 & & & & \\
\hline Customer ID & 98018-2 & & & & \\
\hline Description & \multicolumn{2}{|c|}{ Filtered Solids } & & & \\
\hline \multirow[t]{8}{*}{ Estimated Solids } & 84.82 & $\mathrm{~g}$ & \multicolumn{3}{|c|}{ (based upon TSS, volume and } \\
\hline & & & \multicolumn{3}{|c|}{ density of liquid phase) } \\
\hline & & & & & \\
\hline & & & & & \\
\hline & & & & & Suspended \\
\hline & & & & & Solids \\
\hline & & & & & Total \\
\hline & Activity & Error & Activity & Error & Activity \\
\hline Analyte & $\mathrm{uCi} / \mathrm{g}$ & $\mathbf{u C i} / \mathrm{g}$ & $\mathrm{pCi} / \mathrm{g}$ & $\mathrm{pCi} / \mathrm{g}$ & $\mathbf{u C i}$ \\
\hline Total Am & $2.31 E+00$ & $3.95 \mathrm{E}-01$ & $2.31 E+06$ & $3.95 E+05$ & $1.96 \mathrm{E}+02$ \\
\hline $\mathrm{Am}-241$ & $2.31 \mathrm{E}+00$ & 3.95E-01 & $2.31 \mathrm{E}+06$ & $3.95 \mathrm{E}+05$ & $1.96 \mathrm{E}+02$ \\
\hline Am-243 & $8.56 E+00$ & $\mathrm{DL}$ & $8.56 E+06$ & $O L$ & $7.26 E+02$ \\
\hline $\mathrm{Ce}-144$ & $4.27 \mathrm{E}-01$ & MDA & $4.27 E+05$ & $\overline{M D A}$ & $3.62 E+01$ \\
\hline Total Cm & $2.54 \mathrm{E}+01$ & $5.07 E+00$ & $2.54 \mathrm{E}+07$ & $5.07 \mathrm{E}+06$ & $2.15 E+03$ \\
\hline $\mathrm{Cm}-244$ & $2.54 \mathrm{E}+01$ & $5.07 \mathrm{E}+00$ & $2.54 \mathrm{E}+07$ & $5.07 \mathrm{E}+06$ & $2.15 \mathrm{E}+03$ \\
\hline $\mathrm{Cm}-245$ & $7.39 E+00$ & $D L$ & $7.39 E+06$ & $D L$ & $6.27 \mathrm{E}+02$ \\
\hline $\mathrm{Cm}-246$ & $1.31 \mathrm{E}+01$ & $\mathrm{DL}$ & $1.31 E+07$ & $\mathrm{DL}$ & $1.11 \mathrm{E}+03$ \\
\hline $\mathrm{Co}-60$ & $1.10 \mathrm{E}-01$ & MDA & $1.10 \mathrm{E}+05$ & $\overline{M D A}$ & $9.33 \mathrm{E}+00$ \\
\hline Cs-134 & $9.10 \mathrm{E}-02$ & MDA & $9.10 \mathrm{E}+04$ & $\mathrm{MDA}$ & $7.72 \mathrm{E}+00$ \\
\hline Cs-137 & $6.53 \mathrm{E}-01$ & 9.43E-02 & $6.53 E+05$ & $9.43 E+04$ & $5.54 \mathrm{E}+01$ \\
\hline Eu-154 & $1.82 E+00$ & $1.09 \mathrm{E}-01$ & $1.82 E+06$ & $1.09 \mathrm{E}+05$ & $1.54 \mathrm{E}+02$ \\
\hline $\mathrm{GA}$ & $1.62 E+02$ & $1.62 E+01$ & $1.62 E+08$ & $1.62 \mathrm{E}+07$ & 1.37E+04 \\
\hline $\mathrm{H}-3$ & 4.27E-01 & MDA & $4.27 \mathrm{E}+05$ & MDA & $3.62 \mathrm{E}+01$ \\
\hline $\mathrm{Ni}-63$ & $1.52 \mathrm{E}-01$ & MDA & $1.52 E+05$ & $M D A$ & $1.29 E+01$ \\
\hline GB & $5.23 \mathrm{E}+00$ & $5.43 \mathrm{E}+00$ & $5.23 \mathrm{E}+06$ & $5.43 \mathrm{E}+06$ & $4.44 \mathrm{E}+02$ \\
\hline $\mathrm{Np}-237$ & $9.55 \mathrm{E}-02$ & $\mathrm{DL}$ & $9.55 \mathrm{E}+04$ & $\mathrm{DL}$ & $8.10 \mathrm{E}+00$ \\
\hline Total Pu & $1.74 \mathrm{E}+02$ & UL & $1.74 \mathrm{E}+08$ & UL & $1.48 \mathrm{E}+04$ \\
\hline Pu-238 & $1.34 \mathrm{E}+02$ & $1.36 \mathrm{E}+01$ & $1.34 \mathrm{E}+08$ & $1.36 E+07$ & $1.14 \mathrm{E}+04$ \\
\hline Pu-239 & $4.73 E+00$ & $1.89 E+00$ & $4.73 \mathrm{E}+06$ & $1.89 E+06$ & $4.01 E+02$ \\
\hline Pu-240 & $9.73 E+00$ & $\mathrm{DL}$ & $9.73 \mathrm{E}+06$ & $\mathrm{DL}$ & $8.25 E+02$ \\
\hline Pu-241 & $3.53 \mathrm{E}+01$ & UL & $3.53 \mathrm{E}+07$ & UL & $2.99 \mathrm{E}+03$ \\
\hline $\mathrm{Pu}-242$ & 1.69E-01 & DL & $1.69 E+05$ & $\overline{D L}$ & $1.43 E+01$ \\
\hline Ru-106 & $9.19 \mathrm{E}-01$ & MDA & $9.19 \mathrm{E}+05$ & MDA & $7.79 \mathrm{E}+01$ \\
\hline Sb-125 & 2.53E-01 & MDA & $2.53 E+05$ & MDA & $2.15 \mathrm{E}+01$ \\
\hline$S n-126$ & 1.97E-01 & MDA & 1.97E+05 & MDA & $1.67 E+01$ \\
\hline Sr-90 & $2.74 \mathrm{E}+00$ & 5.32E-01 & $2.74 \mathrm{E}+06$ & $5.32 \mathrm{E}+05$ & $2.32 \mathrm{E}+02$ \\
\hline Tc-99 & 5.32E-02 & MDA & $5.32 \mathrm{E}+04$ & MDA & $4.51 \mathrm{E}+00$ \\
\hline Th-232 & $3.31 E-04$ & $6.61 E-05$ & $3.31 \mathrm{E}+02$ & $6.61 \mathrm{E}+01$ & 2.81E-02 \\
\hline$U-233$ & 3.05E-01 & $\mathrm{DL}$ & $3.05 \mathrm{E}+05$ & $\mathrm{DL}$ & $2.59 \mathrm{E}+01$ \\
\hline U-234 & $3.11 \mathrm{E}-01$ & $D L$ & $3.11 E+05$ & $\mathrm{DL}$ & $2.64 \mathrm{E}+01$ \\
\hline U-235 & $7.21 \mathrm{E}-03$ & 1.44E-03 & $7.21 \mathrm{E}+03$ & $1,44 \mathrm{E}+03$ & 6.12E-01 \\
\hline U-236 & $6.49 \mathrm{E}-03$ & $\mathrm{DL}$ & $6.49 \mathrm{E}+03$ & $\mathrm{DL}$ & $5.50 \mathrm{E}-01$ \\
\hline $\mathrm{U}-238$ & $1.80 \mathrm{E}-01$ & $3.60 \mathrm{E}-02$ & $1.80 E+05$ & $3.60 \mathrm{E}+04$ & $1.53 \mathrm{E}+01$ \\
\hline TRU & $1.41 E+02$ & & $1.41 \mathrm{E}+08$ & & $1.20 \mathrm{E}+04$ \\
\hline & & 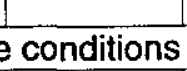 & 1580 & & \\
\hline $\mathrm{DL}=\mathrm{D}$ & & & & & \\
\hline
\end{tabular}




\begin{tabular}{|c|c|c|c|c|c|}
\hline Sample \# & 3-117917 & & & & \\
\hline Customer ID & $98351-2$ & & & & \\
\hline Description & Sludge & & & & \\
\hline Total Mass In Tank & 251351.3 & grams & & & \\
\hline & & & & & \\
\hline Analyte & Concent. & Units & & & \\
\hline As & 8 & $\mathrm{mg} / \mathrm{kg}$ & & & \\
\hline $\mathrm{Ba}$ & 9 & $\mathrm{mg} / \mathrm{kg}$ & & & \\
\hline $\mathrm{Cd}$ & 2 & $\mathrm{mg} / \mathrm{kg}$ & & & \\
\hline $\mathrm{Cr}$ & 19 & $\mathrm{mg} / \mathrm{kg}$ & & & \\
\hline $\mathrm{Pb}$ & 27 & $\mathrm{mg} / \mathrm{kg}$ & & & \\
\hline $\mathrm{Hg}$ & 209 & $\mathrm{mg} / \mathrm{kg}$ & & & \\
\hline Se & $<20$ & $\mathrm{mg} / \mathrm{kg}$ & & & \\
\hline $\mathrm{Ag}$ & 9 & $\mathrm{mg} / \mathrm{kg}$ & & & \\
\hline & & & & & Sludge \\
\hline & & & & & Phase \\
\hline & & & & & Total \\
\hline & Activity & Error & Activity & Error & Activity \\
\hline & $\mathrm{uCi} / \mathrm{g}$ & $\mathrm{uCV} / \mathrm{g}$ & $\mathrm{pCi} / \mathrm{g}$ & $\mathrm{pCi} / \mathrm{g}$ & uCi \\
\hline Total Am & $5.74 \mathrm{E}+00$ & 2.83E-01 & $5.74 \mathrm{E}+06$ & $2.83 E+05$ & $1.44 E+06$ \\
\hline$A m-241$ & $5.32 \mathrm{E}+00$ & 2.82E-01 & $5.32 E+06$ & $2.82 E+05$ & $1.34 \mathrm{E}+06$ \\
\hline$A m-243$ & 4.19E-01 & 2.09E-02 & 4.19E+05 & $2.09 E+04$ & $1.05 \mathrm{E}+05$ \\
\hline $\mathrm{Ce}-144$ & $6.89 E-02$ & $\mathrm{MDA}$ & $6.89 E+04$ & MDA & $1.73 \mathrm{E}+04$ \\
\hline Total $\mathrm{Cm}$ & $7.43 \mathrm{E}+01$ & $1.49 \mathrm{E}+01$ & $7.43 E+07$ & $1.49 \mathrm{E}+07$ & $1.87 \mathrm{E}+07$ \\
\hline $\mathrm{Cm}-244$ & $7.43 \mathrm{E}+01$ & $1.49 \mathrm{E}+01$ & $7.43 E+07$ & $1.49 E+07$ & $1.87 E+07$ \\
\hline Cm-245 & $1.05 \mathrm{E}-01$ & $\mathrm{DL}$ & $1.05 E+05$ & $\mathrm{DL}$ & $2.64 \mathrm{E}+04$ \\
\hline $\mathrm{Cm}-246$ & $1.87 E-01$ & $\overline{D L}$ & $1.87 E+05$ & $\mathrm{DL}$ & $4.70 \mathrm{E}+04$ \\
\hline Co-60 & $1.27 \mathrm{E}-02$ & MDA & 1.27E+04 & MDA & $3.19 E+03$ \\
\hline Cs-134 & 1.93E-02 & MDA & $1.93 E+04$ & MDA & $4.85 E+03$ \\
\hline Cs-137 & 2.32E-01 & $2.21 \mathrm{E}-02$ & $2.32 E+05$ & $2.21 E+04$ & $5.83 E+04$ \\
\hline Eu-154 & $4.86 \mathrm{E}+00$ & 1.02E-01 & $4.86 \mathrm{E}+06$ & $1.02 E+05$ & $1.22 \mathrm{E}+06$ \\
\hline Eu-155 & $3.04 \mathrm{E}-01$ & 5.72E-02 & $3.04 E+05$ & $5.72 \mathrm{E}+04$ & $7.64 \mathrm{E}+04$ \\
\hline $\mathrm{GA}$ & $1.51 \mathrm{E}+02$ & $3.03 E+01$ & $1.51 E+08$ & $3.03 E+07$ & $3.80 E+07$ \\
\hline $\mathrm{Nb}-94$ & $5.63 \mathrm{E}-02$ & MDA & $5.63 E+04$ & MDA & $1.42 E+04$ \\
\hline GB & $1.22 \mathrm{E}+01$ & $2.44 \mathrm{E}+00$ & $1.22 E+07$ & $2.44 \mathrm{E}+06$ & $3.07 E+06$ \\
\hline $\mathrm{Np}-237$ & $1.07 \mathrm{E}-03$ & $\mathrm{DL}$ & $1.07 \mathrm{E}+03$ & $\mathrm{DL}$ & $2.69 E+02$ \\
\hline Total Pu & $7.43 \mathrm{E}+01$ & $2.45 \mathrm{E}+01$ & $7.43 E+07$ & $2.45 \mathrm{E}+07$ & 1.87E+07 \\
\hline Pu-238 & $5.95 E+01$ & $2.38 \mathrm{E}+01$ & $5.95 E+07$ & $2.38 \mathrm{E}+07$ & $1.50 \mathrm{E}+07$ \\
\hline Pu-239 & 3.05E-01 & $\mathrm{DL}$ & $3.05 E+05$ & $D L$ & $7.67 E+04$ \\
\hline Pu-240 & $7.52 \mathrm{E}-01$ & $\mathrm{DL}$ & $7.52 \mathrm{E}+05$ & $\mathrm{DL}$ & $1.89 E+05$ \\
\hline Pu-241 & $1.48 E+01$ & $5.91 E+00$ & $1.48 \mathrm{E}+07$ & $5.91 E+06$ & $3.72 E+06$ \\
\hline Pu-242 & $2.41 \mathrm{E}-03$ & $\mathrm{DL}$ & $2.41 E+03$ & $\mathrm{DL}$ & $6.06 \mathrm{E}+02$ \\
\hline Ru-106 & 1.99E-01 & MDA & $1.99 E+05$ & MDA & $5.00 E+04$ \\
\hline $\mathrm{Sb}-125$ & $5.05 \mathrm{E}-02$ & MDA & $5.05 \mathrm{E}+04$ & MDA & $1.27 E+04$ \\
\hline $5 n-126$ & 5.32E-02 & MDA & $5.32 E+04$ & MDA & $1.34 \mathrm{E}+04$ \\
\hline Th-232 & 5.59E-05 & $D L$ & $5.59 \mathrm{E}+01$ & $D L$ & $1.41 \mathrm{E}+01$ \\
\hline U-233 & $5.90 \mathrm{E}-03$ & $\mathrm{DL}$ & $5.90 \mathrm{E}+03$ & $\mathrm{DL}$ & $1.48 \mathrm{E}+03$ \\
\hline $\mathrm{U}-234$ & 1.01E-02 & $\mathrm{DL}$ & $1.01 E+04$ & $\mathrm{DL}$ & $2.54 \mathrm{E}+03$ \\
\hline U-235 & 3.46E-05 & $6.92 \mathrm{E}-06$ & $3.46 \mathrm{E}+01$ & $6.92 \mathrm{E}+00$ & $8.70 \mathrm{E}+00$ \\
\hline U-236 & 3.97E-05 & $\mathrm{DL}$ & $3.97 E+01$ & $D L$ & $9.98 \mathrm{E}+00$ \\
\hline U-238 & $8.24 \mathrm{E}-04$ & $\begin{array}{r}1.65 E-04 \\
\end{array}$ & $8.24 \mathrm{E}+02$ & $1.65 \mathrm{E}+02$ & $2.07 E+02$ \\
\hline
\end{tabular}




\begin{tabular}{|c|c|c|c|}
\hline TRU & $6.52 \mathrm{E}+01$ & $6.52 \mathrm{E}+07$ & $1.64 \mathrm{E}+07$ \\
\hline \multicolumn{4}{|c|}{ MDA = Minimum Detectable Activity for the conditions used } \\
\hline $\mathrm{DL}=$ Detection Limit & & & \\
\hline $\mathrm{UL}=$ Upper Limit & & & \\
\hline
\end{tabular}

Appendix B

Page B6

= Detection

$\mathrm{UL}=$ Upper Limit 
Revision 2

$6 / 8 / 00$

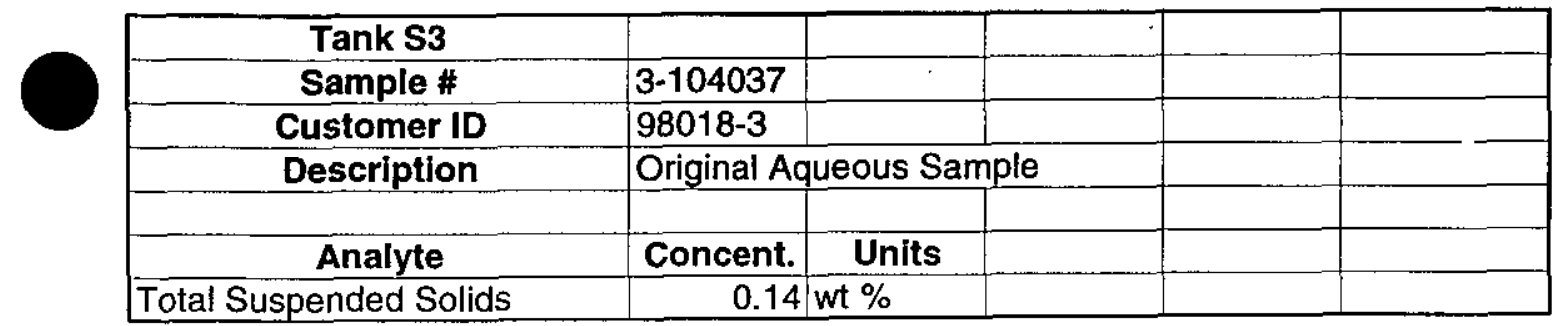

Appendix C

Page C1 


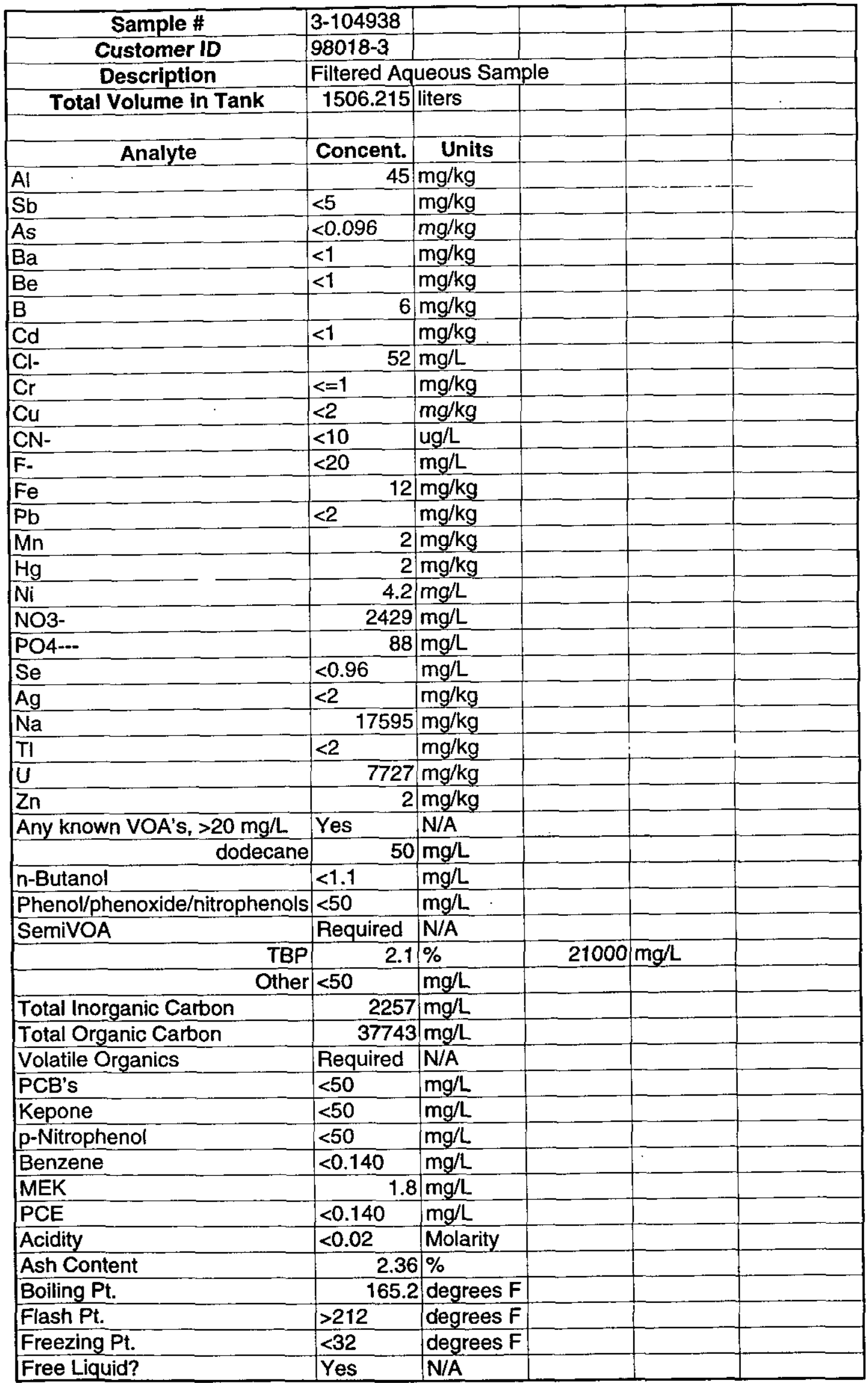




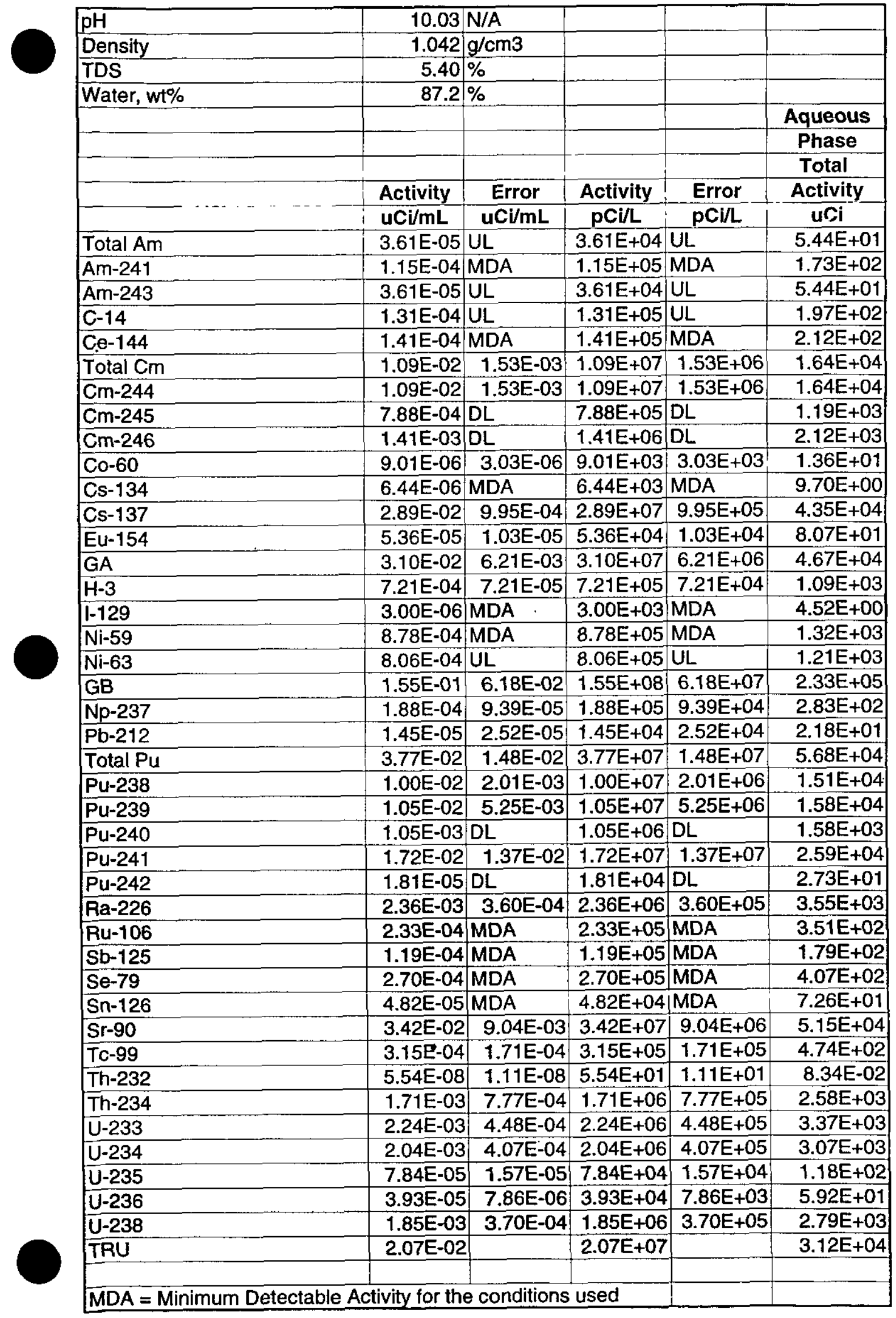

Appendix $\mathrm{C}$

Page C3 
$\mathrm{DL}=$ Detection Limit

UL $=$ Upper Limit

Appendix $\mathrm{C}$

$a=$ compound present but below quantitation limit

Page C4

TBP = Tributyl Phosphate 


\begin{tabular}{|c|c|c|c|c|c|}
\hline Sample \# & 3-104918 & & & & \\
\hline Customer ID & 98018-3 & & & & \\
\hline Description & \multicolumn{2}{|c|}{ Filtered Solids } & & & \\
\hline \multirow[t]{9}{*}{ Estimated Solids } & 2197.27 & $g$ & \multicolumn{3}{|c|}{ (based upon TSS, volume and } \\
\hline & & & \multicolumn{3}{|c|}{ density of liquid phase) } \\
\hline & & & & & \\
\hline & & & & & \\
\hline & & & & & \\
\hline & & & & & Suspended \\
\hline & & & & & Solids \\
\hline & & & & & Total \\
\hline & Activity & Error & Activity & Error & Activity \\
\hline Analyte & $\mathrm{uCl} / \mathrm{g}$ & $\mathrm{uCVg}$ & $\mathrm{pCi} / \mathrm{g}$ & $\mathrm{pCi} / \mathrm{g}$ & uCi \\
\hline Total Am & $1.59 \mathrm{E}+00$ & 2.82E-01 & $1.59 \mathrm{E}+06$ & $2.82 E+05$ & $3.50 \mathrm{E}+03$ \\
\hline Am-241 & $1.06 \mathrm{E}+00$ & $2.71 \mathrm{E}-01$ & $1.06 \mathrm{E}+06$ & $2.71 E+05$ & $2.33 \mathrm{E}+03$ \\
\hline $\mathrm{Am}-243$ & 5.32E-01 & 7.91E-02 & $5.32 \mathrm{E}+05$ & $7.91 E+04$ & $1.17 \mathrm{E}+03$ \\
\hline $\mathrm{Ce}-144$ & 5.27E-01 & MDA & $5.27 E+05$ & $\overline{M D A}$ & $1.16 E+03$ \\
\hline Total $\mathrm{Cm}$ & $9.46 E+01$ & $9.46 \mathrm{E}+00$ & $9.46 \mathrm{E}+07$ & $9.46 \mathrm{E}+06$ & $2.08 \mathrm{E}+05$ \\
\hline $\mathrm{Cm}-244$ & $9.46 \mathrm{E}+01$ & $9.46 \mathrm{E}+00$ & $9.46 \mathrm{E}+07$ & $9.46 \mathrm{E}+06$ & $2.08 \mathrm{E}+05$ \\
\hline $\mathrm{Cm}-245$ & $8.20 \mathrm{E}-01$ & $\mathrm{DL}$ & $8.20 E+05$ & $\overline{D L}$ & $1.80 \mathrm{E}+03$ \\
\hline $\mathrm{Cm}-246$ & $1.46 E+00[$ & $\mathrm{DL}$ & $1.46 \mathrm{E}+06$ & $\mathrm{DL}^{-}$ & $3.21 \mathrm{E}+03$ \\
\hline Co-60 & $5.23 \mathrm{E}-02$ & MDA & $5.23 \mathrm{E}+04$ & $\mathrm{MDA}$ & $1.15 \mathrm{E}+02$ \\
\hline Cs-134 & \begin{tabular}{ll|}
$6.04 E-02$ & 1
\end{tabular} & MDA & $6.04 \mathrm{E}+04$ & MDA & $1.33 E+02$ \\
\hline Cs-137 & $8.02 E+00$ & $4.04 \mathrm{E}-01$ & $8.02 E+06$ & $4.04 \mathrm{E}+05$ & $1.76 \mathrm{E}+04$ \\
\hline Eu-154 & $2.31 \mathrm{E}-01$ & $8.68 \mathrm{E}-02$ & $2.31 E+05$ & $8.68 \mathrm{E}+04$ & $5.08 \mathrm{E}+02$ \\
\hline GA & $1.43 \mathrm{E}+02$ & $1.43 E+01$ & $1.43 E+08$ & $1.43 E+07$ & $3.14 \mathrm{E}+05$ \\
\hline $\mathrm{H}-3$ & $1.14 \mathrm{E}-01$ & $4.58 \mathrm{E}-02$ & $1.14 \mathrm{E}+05$ & $4.58 \mathrm{E}+04$ & $2.50 \mathrm{E}+02$ \\
\hline $1-129$ & $7.21 \mathrm{E}-02$ & MDA & $7.21 \mathrm{E}+04$ & MDA & $1.58 \mathrm{E}+02$ \\
\hline $\mathrm{Ni}-59$ & 1.07E-01 & MDA & $1.07 E+05$ & MDA & $2.35 E+02$ \\
\hline $\mathrm{Ni}-63$ & $6.67 \mathrm{E}-02$ & 4.00E-02 & $6.67 \mathrm{E}+04$ & $4.00 \mathrm{E}+04$ & $1.47 E+02$ \\
\hline GB & $2.20 E+02$ & $8.79 E+01$ & $2.20 \mathrm{E}+08$ & $8.79 E+07$ & $4.83 E+05$ \\
\hline $\mathrm{Np}-237$ & $6.76 \mathrm{E}-02$ & 1.35E-02 & $6.76 \mathrm{E}+04$ & $1.35 E+04$ & $1.49 E+02$ \\
\hline Total $\mathrm{Pu}$ & $5.79 \mathrm{E}+01$ & $5.49 E+00$ & $5.79 \mathrm{E}+07$ & $5.49 \mathrm{E}+06$ & $1.27 E+05$ \\
\hline Pu-238 & $3.61 \mathrm{E}+01$ & $4.33 E+00$ & $3.61 \mathrm{E}+07$ & $4.33 E+06$ & $7.93 \mathrm{E}+04$ \\
\hline $\mathrm{Pu}-239$ & $8.69 \mathrm{E}+00$ & $1.74 \mathrm{E}+00$ & $8.69 \mathrm{E}+06$ & $1.74 E+06$ & $1.91 E+04$ \\
\hline Pu-240 & $2.97 \mathrm{E}+00$ & $5.94 \mathrm{E}-01$ & $2.97 E+06$ & $5.94 \mathrm{E}+05$ & $6.53 E+03$ \\
\hline $\mathrm{Pu}-241$ & $1.01 E+01$ & $2.84 E+00$ & $1.01 E+07$ & $2.84 \mathrm{E}+06$ & $2.22 E+04$ \\
\hline Pu-242 & $1.87 \mathrm{E}-02$ & $\mathrm{DL}$ & $1.87 E+04$ & $D L$ & $4.11 \mathrm{E}+01$ \\
\hline$R u-106$ & $6.98 \mathrm{E}-01$ & $\overline{M D A}$ & $6.98 \mathrm{E}+05$ & MDA & $1.53 E+03$ \\
\hline$S b-125$ & $3.17 \mathrm{E}-01$ & MDA & $3.17 E+05$ & MDA & $6.97 E+02$ \\
\hline Sn-126 & $2.00 \mathrm{E}-01$ & MDA & $2.00 E+05$ & MDA & $4.39 E+02$ \\
\hline Sr-90 & $1.16 \mathrm{E}+02$ & $1.46 \mathrm{E}+01$ & $1.16 \mathrm{E}+08$ & $1.46 \mathrm{E}+07$ & $2.55 \mathrm{E}+05$ \\
\hline Tc-99 & $2.95 \mathrm{E}-02$ & MDA & $2.95 E+04$ & $\mathrm{MDA}$ & $6.48 E+01$ \\
\hline Th-232 & $4.03 E-04$ & $8.06 \mathrm{E}-05$ & $4.03 E+02$ & $8.06 E+01$ & $8.85 E-01$ \\
\hline U-233 & $2.91 E-02$ & DL & $2.91 E+04$ & $\mathrm{DL}$ & $6.39 \mathrm{E}+01$ \\
\hline U-234 & $1.48 \mathrm{E}-01$ & $2.96 \mathrm{E}-02$ & $1.48 \mathrm{E}+05$ & $2.96 \mathrm{E}+04$ & $3.25 E+02$ \\
\hline $\mathrm{U}-235$ & $6.67 \mathrm{E}-03$ & $1.33 E-03$ & $6.67 E+03$ & $1.33 E+03$ & $1.47 E+01$ \\
\hline U-236 & $2.92 \mathrm{E}-03$ & $5.84 E-04$ & $2.92 E+03$ & $5.84 E+02$ & $6.42 E+00$ \\
\hline U-238 & $1.36 \mathrm{E}-01$ & $2.73 E-02$ & $1.36 \mathrm{E}+05$ & $2.73 E+04$ & $2.99 E+02$ \\
\hline TRU & $4.94 \mathrm{E}+01$ & & $4.94 E+07$ & & $1.09 E+05$ \\
\hline |NLA $=\mathrm{N}$ & Ity tor to & 00 & used & & \\
\hline$\overline{D L}=$ Detection Limit & & & & & \\
\hline
\end{tabular}

Appendix C Page C5

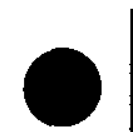




\begin{tabular}{|c|c|c|c|c|}
\hline Tank S4 & & & & \\
\hline Sample \# & $3-109222$ & & & \\
\hline Customer ID & $98018-4$ & & & \\
\hline Description & Original Aqueous Sample & & \\
\hline & & & & \\
\hline Analyte & Concent. & Units & & \\
\hline Total Suspended Solids & 0.02 & wt $\%$ & & \\
\hline
\end{tabular}




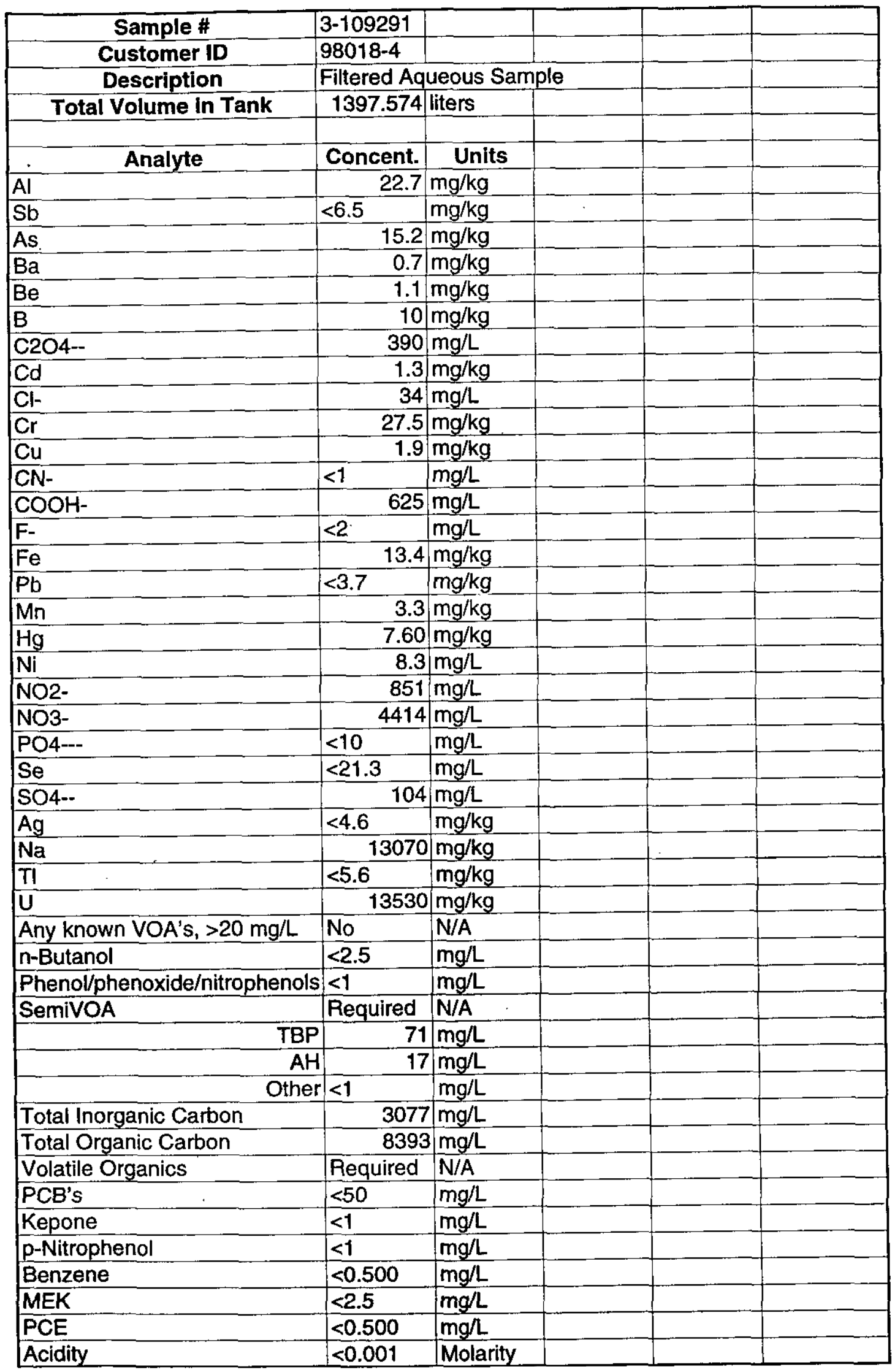




\begin{tabular}{|c|c|c|c|c|c|}
\hline Ash Content & 4.19 & & & & \\
\hline Flash Pt. & $>212$ & degrees $\mathrm{F}$ & & & \\
\hline Freezing Pt. & $<32$ & degrees $\mathrm{F}$ & & & \\
\hline Free Liquid? & Yes & N/A & & & \\
\hline$\overline{\mathrm{pH}}$ & 10.42 & N/A & & & \\
\hline Density & 1.079 & $\mathrm{~g} / \mathrm{cm3}$ & & & \\
\hline TDS & 7.52 & $\%$ & & & \\
\hline \multirow[t]{6}{*}{ Water, wt $\%$} & 92.39 & $\%$ & & & \\
\hline & & & & & Aqueous \\
\hline & & & & & Phase \\
\hline & & & & & Total \\
\hline & Activity & Error & Activity & Error & Activity \\
\hline & $\mathrm{uCi} / \mathrm{mL}$ & $\mathrm{uCU} / \mathrm{mL}$ & pCi/L & $\mathrm{pCi} / \mathrm{L}$ & $\mathrm{uCi}$ \\
\hline Total Am & $0.00 \mathrm{E}+00$ & $0.00 \mathrm{E}+00$ & $0.00 \mathrm{E}+00$ & $0.00 E+00$ & $0.00 \mathrm{E}+00$ \\
\hline Am-241 & 3.50E-04 & MDA & $3.50 \mathrm{E}+05$ & MDA & $4.89 E+02$ \\
\hline $\mathrm{Am}-243$ & $1.14 \mathrm{E}-04$ & MDA & $1.14 \mathrm{E}+05$ & MDA & $1.59 E+02$ \\
\hline C-14 & $3.24 E-04$ & UL. & $3.24 E+05$ & UL & $4.53 E+02$ \\
\hline $\mathrm{Ce}-144$ & $4.55 \mathrm{E}-04$ & MDA & $4.55 E+05$ & MDA & $6.36 \mathrm{E}+02$ \\
\hline Total Cm & $1.02 E-03$ & $2.05 \mathrm{E}-03$ & $1.02 \mathrm{E}+06$ & $2.05 \mathrm{E}+06$ & $1.43 E+03$ \\
\hline $\mathrm{Cm}-244$ & $1.02 E-03$ & 2.05E-03 & $1.02 E+06$ & $2.05 \mathrm{E}+06$ & $1.43 E+03$ \\
\hline $\mathrm{Cm}-245$ & $1.27 \mathrm{E}-01$ & $\mathrm{DL}$ & $1.27 E+08$ & $\mathrm{DL}$ & 1.77E+05 \\
\hline $\mathrm{Cm}-246$ & $2.25 \mathrm{E}-01$ & $\mathrm{DL}$ & $2.25 E+08$ & $\mathrm{DL}$ & $3.14 E+05$ \\
\hline Co-60 & $2.10 \mathrm{E}-05$ & MDA & $2.10 \mathrm{E}+04$ & MDA & $2.93 E+01$ \\
\hline Cs-134 & $1.18 \mathrm{E}-05$ & MDA & $1.18 E+04$ & MDA & $1.65 E+01$ \\
\hline Cs-137 & 9.91E-02 & 3.41E-03 & $9.91 E+07$ & $3.41 E+06$ & $1.38 E+05$ \\
\hline Eu-154 & 3.72E-05 & MDA & $3.72 E+04$ & MDA & $5.20 E+01$ \\
\hline GA & $1.93 \mathrm{E}-02$ & $3.86 \mathrm{E}-03$ & $1.93 \mathrm{E}+07$ & $3.86 \mathrm{E}+06$ & $2.70 E+04$ \\
\hline $\mathrm{H}-3$ & 2.70E-03 & 2.70E-04 & $2.70 E+06$ & $2.70 \mathrm{E}+05$ & 3.77E+03 \\
\hline $\mathrm{Nb}-94$ & $1.13 \mathrm{E}-05$ & MDA & $1.13 E+04$ & MDA & $1.58 \mathrm{E}+01$ \\
\hline $\mathrm{Ni}-59$ & $3.23 E-05$ & MDA & $3.23 E+04$ & MDA & $4.51 \mathrm{E}+01$ \\
\hline $\mathrm{Ni}-63$ & $2.92 E-05$ & UL & $2.92 E+04$ & UL & $4.08 E+01$ \\
\hline $\mathrm{GB}$ & $1.35 \mathrm{E}-01$ & 5.39E-02 & $1.35 E+08$ & $5.39 \mathrm{E}+07$ & $1.89 E+05$ \\
\hline $\mathrm{Np}-237$ & $2.40 \mathrm{E}-04$ & MDA & $2.40 E+05$ & MDA & $3.35 E+02$ \\
\hline Total $\mathrm{Pu}$ & 2.80E-02 & UL & $2.80 E+07$ & $\mathrm{UL}$ & $3.91 E+04$ \\
\hline Pu-238 & $1.66 \mathrm{E}-02$ & 6.63E-03 & $1.66 \mathrm{E}+07$ & $6.63 E+06$ & $2.32 E+04$ \\
\hline Pu-239 & $4.55 \mathrm{E}-02$ & $D L$ & $4.55 E+07$ & $D L$ & $6.36 \mathrm{E}+04$ \\
\hline Pu-240 & 1.67E-01 & $D L$ & $1.67 E+08$ & $\mathrm{DL}$ & $2.33 \mathrm{E}+05$ \\
\hline Pu-241 & $1.14 \mathrm{E}-02$ & $\mathrm{UL}$ & $1.14 E+07$ & UL & $1.59 E+04$ \\
\hline Pu-242 & $2.90 \mathrm{E}-03$ & $\mathrm{DL}$ & $2.90 E+06$ & $D L$ & $4.05 E+03$ \\
\hline $\mathrm{Ra}-226$ & $4.59 \mathrm{E}-03$ & UL & $4.59 E+06$ & UL & $6.41 E+03$ \\
\hline$R u-106$ & 7.03E-04 & MDA & $7.03 \mathrm{E}+05$ & MDA & $9.82 \mathrm{E}+02$ \\
\hline $\mathrm{Sb}-125$ & $4.15 \mathrm{E}-04$ & MDA & $4.15 E+05$ & MDA & $5.80 E+02$ \\
\hline Se-79 & $4.50 \mathrm{E}-04$ & MDA & $4.50 E+05$ & MDA & $6.29 E+02$ \\
\hline $5 n-126$ & $1.65 \mathrm{E}-04$ & MDA & $1.65 \mathrm{E}+05$ & MDA & $2.31 E+02$ \\
\hline $5 r-90$ & $1.22 E-02$ & 4.50 E-03 & $1.22 E+07$ & $4.50 E+06$ & $1.71 E+04$ \\
\hline Tc-99 & 7.84E-04 & $9.88 \mathrm{E}-05$ & $7.84 \mathrm{E}+05$ & $9.88 E+04$ & $1.10 E+03$ \\
\hline Th-232 & $8.06 \mathrm{E}-08$ & $\mathrm{DL}$ & $8.06 E+01$ & $\mathrm{DL}$ & 1.13E-01 \\
\hline Th-234 & 2.84E-03 & 1.77E-03 & $2.84 \mathrm{E}+06$ & 1.77E+06 & $3.97 \mathrm{E}+03$ \\
\hline U-233 & $7.12 E-03$ & $\mathrm{DL}$ & $7.12 \mathrm{E}+06$ & $D L$ & $9.95 \mathrm{E}+03$ \\
\hline $\mathrm{U}-234$ & 4.59E-03 & $\overline{D L}$ & $4.59 E+06$ & $\mathrm{DL}$ & $6.41 \mathrm{E}+03$ \\
\hline U-235 & $2.10 \mathrm{E}-04$ & $4.20 \mathrm{E}-05$ & $2.10 \mathrm{E}+05$ & $4.20 \mathrm{E}+04$ & $2.93 \mathrm{E}+02$ \\
\hline
\end{tabular}




\begin{tabular}{|l|l|l|l|l|l|}
\hline $\mathrm{U}-236$ & $9.41 \mathrm{E}-05$ & $1.88 \mathrm{E}-05$ & $9.41 \mathrm{E}+04$ & $1.88 \mathrm{E}+04$ & $1.32 \mathrm{E}+02$ \\
\hline $\mathrm{U}-238$ & $6.22 \mathrm{E}-03$ & $1.77 \mathrm{E}-03$ & $6.22 \mathrm{E}+06$ & $1.77 \mathrm{E}+06$ & $8.69 \mathrm{E}+03$ \\
\hline $\mathrm{TRU}$ & $1.66 \mathrm{E}-02$ & & $1.66 \mathrm{E}+07$ & & $2.32 \mathrm{E}+04$ \\
\hline & & & & & \\
\hline MDA = Minimum Detectable Activity for the conditions used & & \\
\hline $\mathrm{DL}=$ Detection Limit & & & & & \\
\hline $\mathrm{UL}=$ Upper Limit & & & & & \\
\hline $\mathrm{TBP}=$ Tributyl Phosphate & & & & & \\
\hline $\mathrm{AH}=$ Aliphatic Hydrocarbons & & & & & \\
\hline
\end{tabular}




\begin{tabular}{|c|c|c|c|c|c|}
\hline Sample \# & 3-109278 & & & & \\
\hline Customer ID & $98018-4$ & & & & \\
\hline Description & \multicolumn{2}{|c|}{ Filtered Solids } & & & \\
\hline Estimated Solids & \multicolumn{2}{|c|}{$301.60 \mathrm{~g}$} & \multicolumn{3}{|c|}{ (based upon TSS, volume and } \\
\hline & & & \multicolumn{3}{|c|}{ density of liquid phase) } \\
\hline & & & & & \\
\hline & & & & & \\
\hline & & & & & \\
\hline & & & & & Suspended \\
\hline & & & & & Solids \\
\hline & & & & & Total \\
\hline & Activity & Error & Activity & Error & Activity \\
\hline Analyte & $\mathrm{uCi} / \mathrm{g}$ & $\mathrm{uCi} / \mathrm{g}$ & $\mathrm{pCi} / \mathrm{g}$ & $\mathrm{pCi} / \mathrm{g}$ & $\mathbf{u C i}$ \\
\hline Total Am & $2.58 \mathrm{E}-01$ & $4.44 \mathrm{E}-02$ & $2.58 \mathrm{E}+05$ & $4.44 E+04$ & $7.78 \mathrm{E}+01$ \\
\hline Am-241 & $2.58 \mathrm{E}-01$ & 4.44E-02 & $2.58 \mathrm{E}+05$ & $4.44 \mathrm{E}+04$ & $7.78 \mathrm{E}+01$ \\
\hline Am-243 & 3.71E-01 & $\mathrm{DL}$ & $3.71 E+05$ & $\mathrm{DL}$ & $1.12 E+02$ \\
\hline C-14 & $5.09 \mathrm{E}+00$ & UL & $5.09 E+06$ & UL & $1.54 \mathrm{E}+03$ \\
\hline $\mathrm{Ce}-144$ & $6.80 \mathrm{E}-02$ & MDA & $6.80 \mathrm{E}+04$ & MDA & $2.05 E+01$ \\
\hline Total $\mathrm{Cm}$ & $3.23 E-01$ & 1.94E-01 & $3.23 E+05$ & $1.94 \mathrm{E}+05$ & $9.74 E+01$ \\
\hline $\mathrm{Cm}-244$ & $3.23 \mathrm{E}-01$ & $1.94 \mathrm{E}-01$ & $3.23 E+05$ & $1.94 E+05$ & $9.74 \mathrm{E}+01$ \\
\hline $\mathrm{Cm}-245$ & $3.19 \mathrm{E}-01$ & $\mathrm{DL}$ & $3.19 \mathrm{E}+05$ & $\mathrm{DL}$ & $9.62 \mathrm{E}+01$ \\
\hline $\mathrm{Cm}-246$ & $5.68 \mathrm{E}-01$ & DL & $5.68 \mathrm{E}+05$ & $D L$ & $1.71 E+02$ \\
\hline Co-60 & $9.64 \mathrm{E}-03$ & MDA & $9.64 \mathrm{E}+03$ & MDA & $2.91 E+00$ \\
\hline Cs-137 & $2.38 E+00$ & 9.94E-02 & $2.38 E+06$ & $9.94 \mathrm{E}+04$ & $7.18 \mathrm{E}+02$ \\
\hline Eu-154 & $2.15 E-02$ & MDA & $2.15 E+04$ & MDA & $6.48 \mathrm{E}+00$ \\
\hline $\mathrm{GA}$ & $3.23 E+01$ & $6.47 E+00$ & $3.23 \mathrm{E}+07$ & $6.47 E+06$ & $9.74 \mathrm{E}+03$ \\
\hline $\mathrm{H}-3$ & $1.28 \mathrm{E}+00$ & $4.10 \mathrm{E}-01$ & $1.28 \mathrm{E}+06$ & $4.10 \mathrm{E}+05$ & $3.86 \mathrm{E}+02$ \\
\hline $\mathrm{Nb}-94$ & 1.07E-02 & MDA & $1.07 \mathrm{E}+04$ & MDA & $3.23 E+00$ \\
\hline Ni-59 & $2.87 E+00$ & MDA & $2.87 E+06$ & MDA & $8.66 E+02$ \\
\hline Ni-63 & $2.68 \mathrm{E}-01$ & $\mathrm{MDA}$ & $2.68 \mathrm{E}+05$ & MDA & $8.08 E+01$ \\
\hline GB & $5.45 \mathrm{E}+00$ & $2.18 \mathrm{E}+00$ & $5.45 E+06$ & $2.18 \mathrm{E}+06$ & $1.64 \mathrm{E}+03$ \\
\hline Np-237 & $4.03 E-03$ & 8.05E-04 & $4.03 E+03$ & $8.05 E+02$ & $1.22 E+00$ \\
\hline Total Pu & $4.53 \mathrm{E}+01$ & $7.34 E+00$ & $4.53 E+07$ & $7.34 \mathrm{E}+06$ & $1.37 E+04$ \\
\hline Pu-238 & $3.18 \mathrm{E}+01$ & $6.36 \mathrm{E}+00$ & $3.18 E+07$ & $6.36 \mathrm{E}+06$ & $9.59 E+03$ \\
\hline Pu-239 & $3.15 \mathrm{E}+00$ & $6.31 \mathrm{E}-01$ & $3.15 E+06$ & $6.31 E+05$ & $9.50 \mathrm{E}+02$ \\
\hline Pu-240 & $1.35 E+00$ & $2.69 \mathrm{E}-01$ & $1.35 \mathrm{E}+06$ & $2.69 E+05$ & $4.07 E+02$ \\
\hline Pu-241 & $9.01 \mathrm{E}+00$ & $3.60 E+00$ & $9.01 \mathrm{E}+06$ & $3.60 \mathrm{E}+06$ & $2.72 E+03$ \\
\hline Pu-242 & $7.30 \mathrm{E}-03$ & $\mathrm{DL}$ & $7.30 \mathrm{E}+03$ & $D L$ & $2.20 E+00$ \\
\hline Ru-106 & 1.24E-02 & MDA & $1.24 \mathrm{E}+04$ & MDA & $3.74 E+00$ \\
\hline Sn-126 & $8.60 \mathrm{E}-03$ & MDA & $8.60 E+03$ & MDA & $2.59 E+00$ \\
\hline Sr-90 & $9.01 \mathrm{E}-01$ & MDA & $9.01 E+05$ & MDA & $2.72 E+02$ \\
\hline Th-232 & $1.83 E-04$ & 3.66E-05 & $1.83 \mathrm{E}+02$ & $3.66 \mathrm{E}+01$ & $5.52 \mathrm{E}-02$ \\
\hline $\mathrm{U}-233$ & $4.55 \mathrm{E}-02$ & $9.10 \mathrm{E}-03$ & $4.55 E+04$ & $9.10 \mathrm{E}+03$ & $1.37 E+01$ \\
\hline U-234 & 1.21E-01 & $2.42 E-02$ & $1.21 E+05$ & $2.42 E+04$ & $3.65 \mathrm{E}+01$ \\
\hline U-235 & $4.21 E-03$ & $8.42 E-04$ & $4.21 E+03$ & $8.42 \mathrm{E}+02$ & $1.27 E+00$ \\
\hline U-236 & $2.28 \mathrm{E}-03$ & $4.57 \mathrm{E}-04$ & $2.28 E+03$ & $4.57 \mathrm{E}+02$ & 6.88E-01 \\
\hline U-238 & $8.60 \mathrm{E}-02$ & $1.72 \mathrm{E}-02$ & $8.60 E+04$ & $1.72 E+04$ & $2.59 E+01$ \\
\hline TRU & $3.66 \mathrm{E}+01$ & & $3.66 \mathrm{E}+07$ & & $1.10 E+04$ \\
\hline & vity & conditions & used & & \\
\hline $\mathrm{DL}=$ Detection Limit & & & & & \\
\hline
\end{tabular}

\section{Sample \#}

Description

Estimated Solids

Am-241

Am-243

C-14

Ce-144

$\mathrm{Cm}-244$

$\mathrm{Cm}-245$

$\mathrm{Cm}-246$

Co-60

Eu-154

$\mathrm{H}-3$

$\mathrm{Nb}-94$

$\mathrm{Ni}-63$

GB

Total Pu

Pu-238

Pu-239

Pu-240

Pu-241

Pu-242

Ru-106

Sn-126

Sr-90

Th-232

U-233

U-234

U-235

U-236

U-238

$\widehat{M D A}=$ Minimum Detectable Activity for the conditions used

$\overline{D L}=$ Detection Limit (based upon TSS, volume and density of liquid phase)
Suspended Solids Activity

$7.78 \mathrm{E}+01$

$1.12 \mathrm{E}+02$

$1.54 \mathrm{E}+03$

$74 \bar{E}+0$

$74 \mathrm{E}+01$

$1.71 \mathrm{E}+02$

$7.18 \mathrm{E}+02$

$6.48 \mathrm{E}+00$

$9.74 \mathrm{E}+03$

$3.23 \mathrm{E}+00$

$8.66 \mathrm{E}+02$

$8.08 \mathrm{E}+01$

1.64E+03

$1.22 \mathrm{E}+00$

1.37E+04

$9.59 E+03$

4.07E+02

$2.72 E+03$

$2.59 E+00$

1.37E+01

$3.65 \mathrm{E}+01$

$E+00$ $2.59 \mathrm{E}+01$ $1.10 E+04$ 


\begin{tabular}{|c|c|c|c|c|c|}
\hline Sample \# & 3-117919 & & & & \\
\hline Customer ID & $98351-4$ & & & & \\
\hline Description & Sludge & \multicolumn{2}{|c|}{ (Sample was a liquid) } & & \\
\hline \multirow[t]{8}{*}{ Total Volume in Tank } & 21.95539 & liters & & & \\
\hline & & & & & \\
\hline & & & & & \\
\hline & & & & & Aqueous \\
\hline & & & & & Phase \\
\hline & & & & & Total \\
\hline & Activity & Error & Activity & Error & Activity \\
\hline & $\mathrm{uCi} / \mathrm{mL}$ & $\mathrm{uCi} / \mathrm{mL}$ & $\mathrm{pCi} / \mathrm{L}$ & $\mathrm{pCi} / \mathrm{L}$ & $\mathrm{uCi}$ \\
\hline Total Am & $5.05 \mathrm{E}-03$ & $5.80 \mathrm{E}-04$ & $5.05 E+06$ & $5.80 \mathrm{E}+05$ & $1.11 E+02$ \\
\hline Am-241 & $5.05 \mathrm{E}-03$ & $5.80 \mathrm{E}-04$ & $5.05 E+06$ & $5.80 \mathrm{E}+05$ & $1.11 \mathrm{E}+02$ \\
\hline Am-243 & $1.26 E-04$ & MDA & $1.26 \mathrm{E}+05$ & MDA & $2.77 E+00$ \\
\hline $\mathrm{Ce}-144$ & $6.35 \mathrm{E}-04$ & MDA & $6.35 E+05$ & MDA & $1.39 E+01$ \\
\hline $\mathrm{Cm}-244$ & 2.37E-02 & $9.50 \mathrm{E}-03$ & $2.37 E+07$ & $9.50 \mathrm{E}+06$ & $5.20 \mathrm{E}+02$ \\
\hline Co-60 & $4.68 \mathrm{E}-05$ & MDA & $4.68 \mathrm{E}+04$ & MDA & $1.03 E+00$ \\
\hline Cs-134 & $4.46 \mathrm{E}-05$ & MDA & $4.46 E+04$ & MDA & 9.79E-01 \\
\hline Cs-137 & $1.10 \mathrm{E}-01$ & $3.78 \mathrm{E}-03$ & $1.10 \mathrm{E}+08$ & $3.78 \mathrm{E}+06$ & $2.42 \mathrm{E}+03$ \\
\hline Eu-154 & $2.69 E-04$ & $5.68 \mathrm{E}-05$ & $2.69 E+05$ & $5.68 \mathrm{E}+04$ & $5.91 \mathrm{E}+00$ \\
\hline GA & $1.32 \mathrm{E}-01$ & $2.64 \mathrm{E}-02$ & $1.32 E+08$ & $2.64 E+07$ & $2.90 E+03$ \\
\hline $\mathrm{H}-3$ & $5.00 \mathrm{E}-02$ & UL & $5.00 E+07$ & UL & $1.10 \mathrm{E}+03$ \\
\hline $\mathrm{Nb}-94$ & $4.02 E-05$ & MDA & $4.02 E+04$ & $\overline{\mathrm{MDA}}$ & 8.83E-01 \\
\hline $\mathrm{GB}$ & $1.98 \mathrm{E}-01$ & $3.96 \mathrm{E}-02$ & $1.98 \mathrm{E}+08$ & $3.96 \mathrm{E}+07$ & $4.35 E+03$ \\
\hline $\mathrm{Np}-237$ & $3.29 E-04$ & MDA & $3.29 E+05$ & MDA & $7.22 \mathrm{E}+00$ \\
\hline Pu-238 & $8.20 \mathrm{E}-02$ & $3.48 \mathrm{E}-02$ & $8.20 \mathrm{E}+07$ & $3.48 \mathrm{E}+07$ & $1.80 E+03$ \\
\hline $\mathrm{Pu}-239 / 240$ & $3.96 \mathrm{E}-03$ & $2.38 \mathrm{E}-03$ & $3.96 E+06$ & $2.38 E+06$ & $8.69 \mathrm{E}+01$ \\
\hline Ru-106 & $1.19 E-03$ & MDA & $1.19 \mathrm{E}+06$ & MDA & $2.61 E+01$ \\
\hline Sb-125 & $5.54 E-04$ & MDA & $5.54 \mathrm{E}+05$ & MDA & $1.22 \mathrm{E}+01$ \\
\hline Sn-126 & $2.09 \mathrm{E}-04$ & MDA & $2.09 E+05$ & MDA & $4.59 \mathrm{E}+00$ \\
\hline$U-233 / 234$ & $9.23 E-03$ & 5.54E-03 & $9.23 E+06$ & $5.54 \mathrm{E}+06$ & $2.03 E+02$ \\
\hline U-235 & $3.57 \mathrm{E}-04$ & UL & $3.57 \mathrm{E}+05$ & UL & $7.84 \mathrm{E}+00$ \\
\hline U-238 & $9.23 \mathrm{E}-03$ & $5.54 \mathrm{E}-03$ & $9.23 \mathrm{E}+06$ & $5.54 \mathrm{E}+06$ & $2.03 E+02$ \\
\hline TRU & 9.10 E-02 & & $9.10 \mathrm{E}+07$ & & $2.00 E+03$ \\
\hline \multicolumn{6}{|c|}{ MDA $=$ Minimum Detectable Activity for the conditions used } \\
\hline DL = Detection Limit & & & & & \\
\hline $\mathrm{UL}=$ Upper Limit & & & & & \\
\hline
\end{tabular}




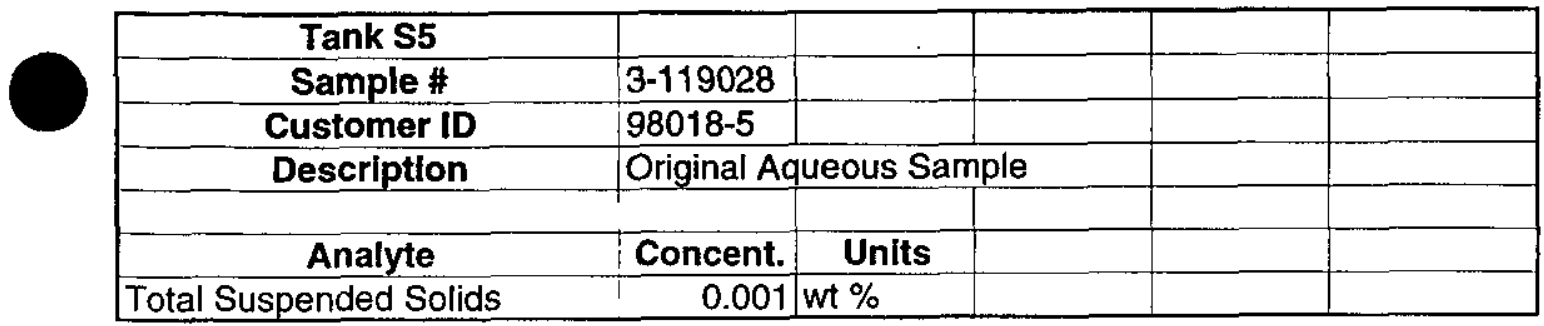

Appendix $\mathrm{E}$

Page E1 


\begin{tabular}{|c|c|c|c|c|c|}
\hline Sample \# & 3-119289 & & & & \\
\hline Customer ID & $98018-5$ & & & & \\
\hline Description & \multicolumn{3}{|c|}{ Filtered Aqueous Sample } & & \\
\hline Total Volume in Tank & 348.2579 & liters & & & \\
\hline & & & & & \\
\hline Analyte & Concent. & Units & & & \\
\hline As & 0.08 & $\mathrm{mg} / \mathrm{L}$ & & & \\
\hline $\mathrm{Ba}$ & 1.3 & $\mathrm{mg} / \mathrm{L}$ & & & \\
\hline C2O4-- & 2431 & $\mathrm{mg} / \mathrm{L}$ & & & \\
\hline $\mathrm{Cd}$ & $0 . \overline{4}$ & $\mathrm{mg} / \mathrm{L}$ & & & \\
\hline $\mathrm{Cl}-$ & 3402 & $\mathrm{mg} / \mathrm{L}$ & & & \\
\hline Co & 1 & $\mathrm{mg} / \mathrm{L}$ & & & \\
\hline $\mathrm{COOH}-$ & 1763 & $\mathrm{mg} / \mathrm{L}$ & & & \\
\hline $\mathrm{Cr}$ & 38 & $\mathrm{mg} / \mathrm{L}$ & & & \\
\hline F- & $<20$ & $\mathrm{mg} / \mathrm{L}$ & & & \\
\hline $\mathrm{Pb}$ & 8.6 & $\mathrm{mg} / \mathrm{L}$ & & & \\
\hline $\mathrm{Hg}$ & 0.46 & $\mathrm{mg} / \mathrm{L}$ & & & \\
\hline NO2- & 45 & $\mathrm{mg} / \mathrm{L}$ & & & \\
\hline NO3- & 239 & $\mathrm{mg} / \mathrm{L}$ & & & \\
\hline PO4--: & 841 & $m g / L$ & & & \\
\hline $\mathrm{Se}$ & 0.9 & $\mathrm{mg} / \mathrm{L}$ & & & \\
\hline SO4-- & 205 & $\mathrm{mg} / \mathrm{L}$ & & & \\
\hline $\mathrm{Ag}$ & 0.1 & $\mathrm{mg} / \mathrm{L}$ & & & \\
\hline Phenol/phenoxide/nitrophenols & $<100$ & $\mathrm{mg} / \mathrm{L}$ & & & \\
\hline SemivOA & Required & N/A & & & \\
\hline TBP & $<0.01$ & $\%$ & $<100$ & $\mathrm{mg} / \mathrm{L}$ & \\
\hline Other & $<100$ & $\mathrm{mg} / \mathrm{L}$ & & & \\
\hline Total Inorganic Carbon & 73 & $\mathrm{mg} / \mathrm{L}$ & & & \\
\hline Total Organic Carbon & 2279 & $\mathrm{mg} / \mathrm{L}$ & & & \\
\hline PCB's & $<10$ & $\mathrm{mg} / \mathrm{L}$ & & & \\
\hline Kepone & $<100$ & $\mathrm{mg} / \mathrm{L}$ & & & \\
\hline p-Nitrophenol & $<100$ & $\mathrm{mg} / \mathrm{L}$ & & & \\
\hline Acidity & N/A & $\mathrm{pH}>7$ & & & \\
\hline Flash Pt. & $>212$ & degrees $\mathrm{F}$ & & & \\
\hline $\mathrm{pH}$ & 9.41 & N/A & & & \\
\hline Density & 1.105 & $\mathrm{~g} / \mathrm{cm} 3$ & & & \\
\hline Water, wt\% & 103.3 & $3 \%$ & & & \\
\hline & & & & & Aqueous \\
\hline & & & & & Phase \\
\hline & & & & & Total \\
\hline & Activity & Error & Activity & Error & Activity \\
\hline & $\mathrm{uCi} / \mathrm{mL}$ & $\mathrm{uCi} / \mathrm{mL}$ & $\mathrm{pCi} / \mathrm{L}$ & $\mathrm{pCi} / \mathrm{L}$ & $\mathrm{uCi}$ \\
\hline Total Am & $1.39 \mathrm{E}-01$ & $5.60 \mathrm{E}-02$ & $1.39 E+08$ & $5.60 \mathrm{E}+07$ & $4.84 \mathrm{E}+04$ \\
\hline Am-241 & $1.39 \mathrm{E}-01$ & $5.60 \mathrm{E}-02$ & $1.39 \mathrm{E}+08$ & $5.60 \mathrm{E}+07$ & $4.84 E+04$ \\
\hline$A m-243$ & $1.40 \mathrm{E}-01$ & $D L$ & $1.40 E+08$ & $D L$ & $4.88 E+04$ \\
\hline C-14 & $1.37 \mathrm{E}-03$ & MDA & $1.37 \mathrm{E}+06$ & MDA & $4.77 E+02$ \\
\hline $\mathrm{Ce}-144$ & $1.46 \mathrm{E}-01$ & MDA & $1.46 E+08$ & MDA & $5.08 \mathrm{E}+04$ \\
\hline $\mathrm{Cm}-245$ & $1.20 \mathrm{E}-01$ & $\mathrm{DL}$ & $1.20 \mathrm{E}+08$ & $\mathrm{DL}$ & $4.18 \mathrm{E}+04$ \\
\hline $\mathrm{Cm}-246$ & $2.14 E-01$ & $\mathrm{DL}$ & $2.14 E+08$ & $\mathrm{DL}$ & $7.45 E+04$ \\
\hline Co-60 & $1.63 \mathrm{E}-02$ & MDA & $1.63 E+07$ & MDA & $5.68 \mathrm{E}+03$ \\
\hline Cs-134 & $1.13 \mathrm{E}-02$ & MDA & $1.13 E+07$ & MDA & $3.94 E+03$ \\
\hline
\end{tabular}




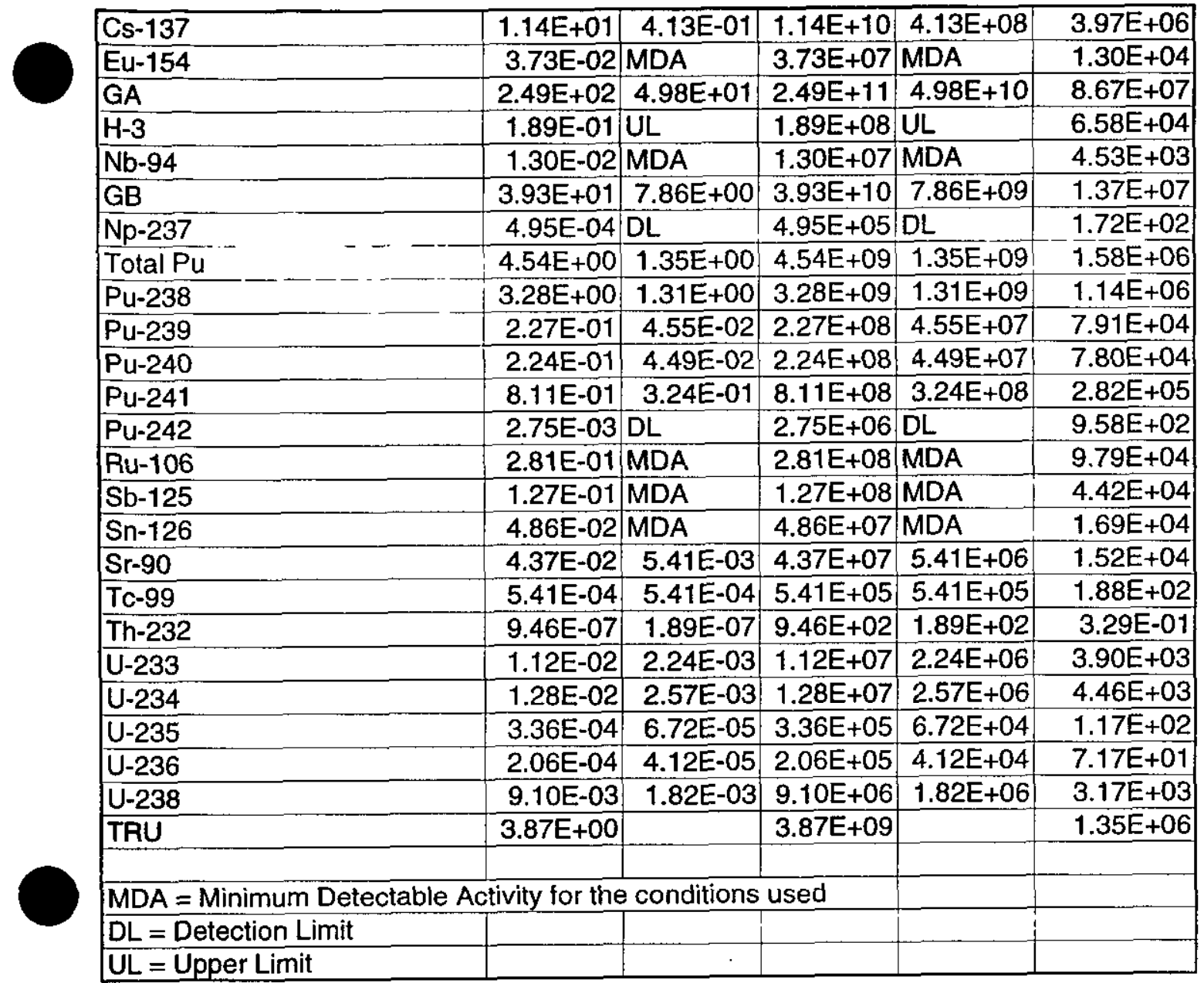




\begin{tabular}{|c|c|c|c|c|c|}
\hline Sample \# & 3-119290 & & & & \\
\hline Customer ID & 98018-5 & & & & \\
\hline Description & \multicolumn{2}{|c|}{ Filtered Solids } & & & \\
\hline \multirow[t]{9}{*}{ Estimated Solids } & 3.48 & $g$ & \multicolumn{3}{|c|}{ (based upon TSS, volume and } \\
\hline & & & \multicolumn{3}{|c|}{ density of liquid phase) } \\
\hline & & & \multicolumn{3}{|c|}{ (Assumes density $=1.00 \mathrm{~g} / \mathrm{cm} 3$ ) } \\
\hline & & & & & \\
\hline & & & & & \\
\hline & & & & & Suspended \\
\hline & & & & & Solids \\
\hline & & & & & Total \\
\hline & Activity & Error & Activity & Error & Activity \\
\hline Analyte & $\mathrm{uCi} / \mathrm{g}$ & $\mathbf{u C i / g}$ & $\mathrm{pCi/g}$ & $\mathrm{pCi} / \mathrm{g}$ & uCi \\
\hline Total Am & $4.66 \mathrm{E}+00$ & 0.322889 & $4.66 \mathrm{E}+06$ & $3.23 E+05$ & $1.62 E+01$ \\
\hline Am-241 & $2.97 E+00$ & 2.96E-01 & $2.97 \mathrm{E}+06$ & $2.96 \mathrm{E}+05$ & $1.03 E+01$ \\
\hline Am-243 & $1.69 \mathrm{E}+00$ & $1.29 \mathrm{E}-01$ & $1.69 E+06$ & $1.29 \mathrm{E}+05$ & $5.88 \mathrm{E}+00$ \\
\hline Ce-144 & $2.52 E-01$ & MDA & $2.52 E+05$ & $\overline{M D A}$ & 8.77E-01 \\
\hline Total Cm & $0.00 \mathrm{E}+00$ & $0.00 \mathrm{E}+00$ & $0.00 \mathrm{E}+00$ & $0.00 \mathrm{E}+00$ & $0.00 \mathrm{E}+00$ \\
\hline $\mathrm{Cm}-244$ & $2.55 \mathrm{E}+03$ & $\overline{D L}$ & $2.55 \mathrm{E}+09$ & $\mathrm{DL}$ & $8.87 E+03$ \\
\hline $\mathrm{Cm}-245$ & $5.41 E+00$ & $\mathrm{DL}$ & $5.41 \mathrm{E}+06$ & $\mathrm{DL}$ & $1.88 \mathrm{E}+01$ \\
\hline $\mathrm{Cm}-246$ & $9.64 \mathrm{E}+00$ & $\mathrm{DL}$ & $9.64 \mathrm{E}+06$ & $\mathrm{DL}$ & $3.35 \mathrm{E}+01$ \\
\hline Co-60 & $3.26 \mathrm{E}-02$ & MDA & $3.26 \mathrm{E}+04$ & MDA & 1.13E-01 \\
\hline Cs-134 & $3.42 \mathrm{E}-02$ & MDA & $3.42 E+04$ & $\mathrm{MDA}$ & $1.19 \mathrm{E}-01$ \\
\hline Cs-137 & $1.71 \mathrm{E}+00$ & 1.11E-01 & $1.71 E+06$ & $1.11 \mathrm{E}+05$ & $5.95 \mathrm{E}+00$ \\
\hline Eu-154 & $4.82 E-01$ & $5.56 \mathrm{E}-02$ & $4.82 E+05$ & $5.56 \mathrm{E}+04$ & $1.68 \mathrm{E}+00$ \\
\hline$\overline{\mathrm{GA}}$ & $1.63 \mathrm{E}+02$ & $3.26 \mathrm{E}+01$ & $1.63 \mathrm{E}+08$ & $3.26 \mathrm{E}+07$ & $5.67 \mathrm{E}+02$ \\
\hline $\mathrm{H}-3$ & $9.28 \mathrm{E}+00$ & $\mathrm{UL}$ & $9.28 \mathrm{E}+06$ & UL & $3.23 E+01$ \\
\hline Nb-94 & $5.27 \mathrm{E}-02$ & MDA & $5.27 \bar{E}+04$ & $\overline{\mathrm{MDA}}$ & $1.83 \mathrm{E}-01$ \\
\hline GB & $2.57 E+00$ & $1.54 \mathrm{E}+00$ & $2.57 E+06$ & $1.54 \mathrm{E}+06$ & $8.94 \mathrm{E}+00$ \\
\hline $\mathrm{Np}-237$ & 2.22E-02 & $\mathrm{DL}$ & $2.22 E+04$ & DL & $7.73 \mathrm{E}-02$ \\
\hline Total Pu & $1.55 \mathrm{E}+02$ & $5.16 \mathrm{E}+01$ & $1.55 E+08$ & $5.16 \mathrm{E}+07$ & $5.40 \mathrm{E}+02$ \\
\hline Pu-238 & $1.29 E+02$ & $5.15 \mathrm{E}+01$ & $1.29 \mathrm{E}+08$ & $5.15 \mathrm{E}+07$ & $4.49 \mathrm{E}+02$ \\
\hline Pu-239 & $6.89 \mathrm{E}+00$ & $1.38 \mathrm{E}+00$ & $6.89 E+06$ & $1.38 \mathrm{E}+06$ & $2.40 E+01$ \\
\hline Pu-240 & $1.01 \mathrm{E}+01$ & $2.02 E+00$ & $1.01 E+07$ & $2.02 E+06$ & $3.51 \mathrm{E}+01$ \\
\hline Pu-241 & $9.28 \mathrm{E}+00$ & UL & $9.28 \mathrm{E}+06$ & UL & $3.23 E+01$ \\
\hline $\mathrm{Pu}-242$ & 1.24E-0r & $\mathrm{DL}$ & $1.24 \mathrm{E}+05$ & $D L$ & $4.32 E-01$ \\
\hline Ru-106 & 3.32E-01 & MDA & $3.32 E+05$ & MDA & $1.16 E+00$ \\
\hline Sb-125 & 1.23E-01 & MDA & $1.23 \mathrm{E}+05$ & MDA & $4.28 \mathrm{E}-01$ \\
\hline $5 n-126$ & $1.38 \mathrm{E}-01$ & MDA & $1.38 \mathrm{E}+05$ & MDA & $4.80 E-01$ \\
\hline Th-232 & $3.25 E-04$ & $6.50 \mathrm{E}-05$ & $3.25 E+02$ & $6.50 \mathrm{E}+01$ & $1.13 \mathrm{E}-03$ \\
\hline U-233 & $3.04 \mathrm{E}-01$ & $\mathrm{DL}$ & $3.04 \mathrm{E}+05$ & $\mathrm{DL}$ & $1.06 \mathrm{E}+00$ \\
\hline U-234 & $1.96 \mathrm{E}-01$ & $D L$ & $1.96 E+05$ & $D L$ & $6.82 E-01$ \\
\hline $\mathrm{U}-235$ & $9.95 E-04$ & $1.99 \mathrm{E}-04$ & $9.95 \mathrm{E}+02$ & $1.99 \mathrm{E}+02$ & $3.46 \mathrm{E}-03$ \\
\hline $\mathrm{U}-236$ & $2.04 \mathrm{E}-03$ & $\overline{D L}$ & $2.04 \mathrm{E}+03$ & $D L$ & $7.10 \mathrm{E}-03$ \\
\hline $\mathrm{U}-238$ & $2.37 E-02$ & $4.74 \mathrm{E}-03$ & $2.37 E+04$ & $4.74 \mathrm{E}+03$ & $8.25 \mathrm{E}-02$ \\
\hline TRU & $1.51 E+02$ & & $1.51 \mathrm{E}+08$ & & $5.24 \mathrm{E}+02$ \\
\hline \multicolumn{6}{|c|}{ ctivity for the conditions used } \\
\hline $\mathrm{DL}=$ Detection Limit & & & & & \\
\hline UL = Upper Limit & & & & & \\
\hline
\end{tabular}

Appendix E 
Tank S6

Sample \#

Customer ID

Description

Analyte

Total Suspended Solids
3-109223

98018-6

Original Aqueous Sample

Concent. Units

1.48 wt \%

Appendix F

Page F1 


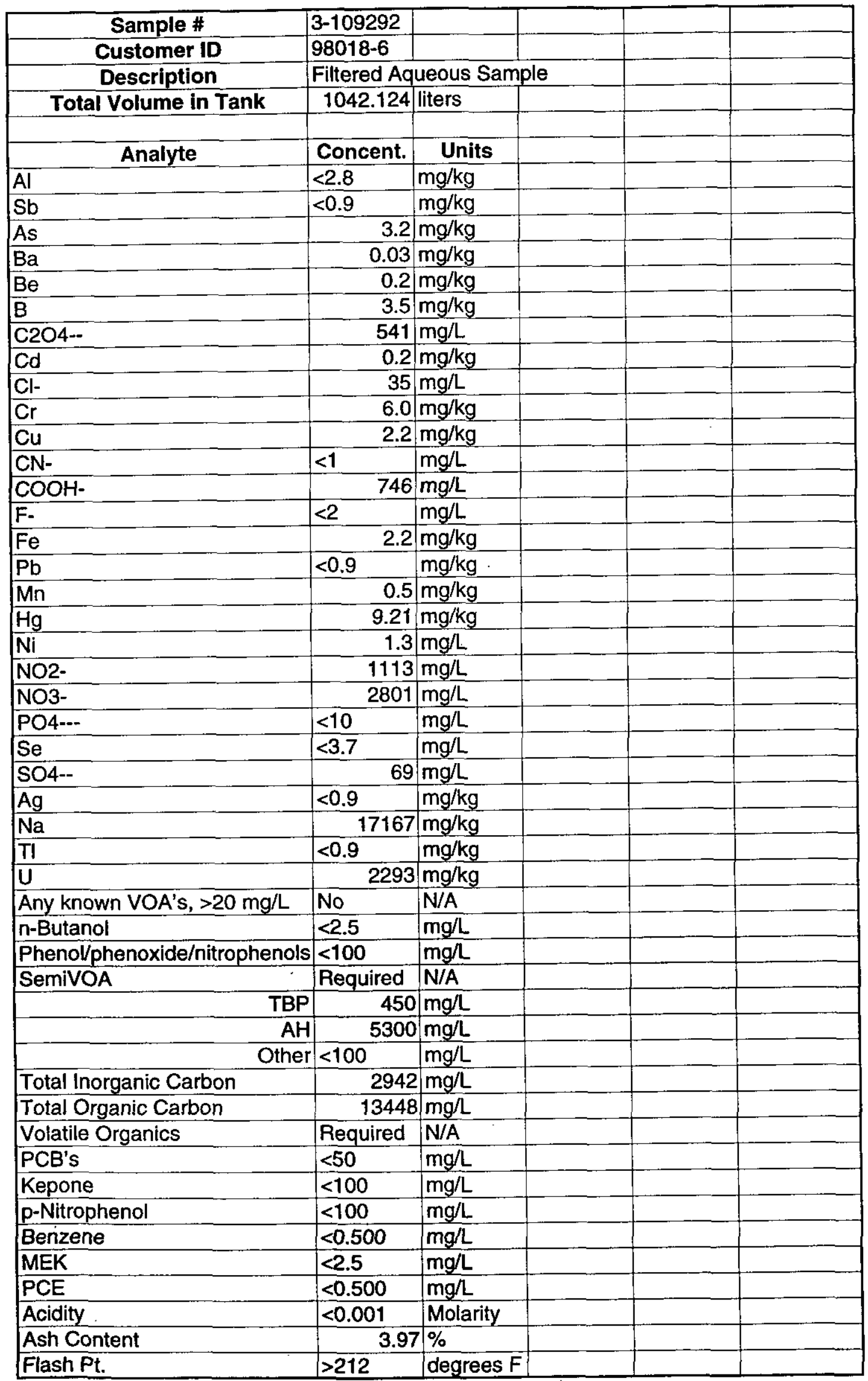


Freezing $\mathrm{Pt}$.

Free Liquid?

pH

Density

TDS

Water, wt\%

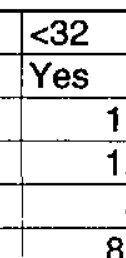

degrees $F$

$11.00 \mathrm{~N} / \mathrm{A}$

$1.070 \mathrm{~g} / \mathrm{cm} 3$

$8.31 \%$

$89.67 \%$

\begin{tabular}{|l|}
\hline \\
\hline \\
\hline \\
\hline
\end{tabular}

Total Am

Am-241

Am-243

C-14

Ce-144

Total $\mathrm{Cm}$

Cm-244

$\mathrm{Cm}-245$

$\mathrm{Cm}-246$

Co-60

Cs-134

Cs-137

Eu-154

GA

$\mathrm{H}-3$

$1-129$

Nb-94

$\mathrm{Ni}-59$

$\mathrm{Ni}-63$

GB

Np-237

Total Pu

Pu-238

Pu-239

Pu-240

Pu-241

Pu-242

Ru-106

Sb-125

Se-79

Sn-126

Sr-90

TC-99

Th-232

U-233

U-234

$\mathrm{U}-235$

$\mathrm{U}-236$

U-238

TRU

\begin{tabular}{|l|l|}
$89.67 \%$ \\
\hline
\end{tabular}

\section{Activity} $\mathrm{uCi} / \mathrm{mL}$

$0.00 \mathrm{E}+00 \quad 0.00 \mathrm{E}+00$ 3.14E-04 MDA

1.05E-04 MDA

5.32E-04 UL

4.28E-04 MDA $0.00 \mathrm{E}+00 \quad 0.00 \mathrm{E}+00$

6.17E-04 MDA

1.27E-01 DL

2.25E-01 DL

1.46E-04 1.57E-05

1.44E-05 2.98E-03

8.65E-02 $2.98 \mathrm{E}-03$

4.73E-05 MDA

1.24E-02

4.82E-03

$2.48 \mathrm{E}-03$

4.82E-04

1.41E-04 2.19E-05

1.60E-05 MDA

1.14E-05 MDA

8.29E-05 UL

1.17E-01 4.68E-02

2.25E-04 MDA

4.02E-02 $1.71 \mathrm{E}-02$

1.24E-02 3.72E-03

4.55E-02 DL

1.67E-01 DL

2.78E-02 1.67E-02

2.90E-03 DL

7.75E-04 MDA

3.85E-04 MDA

9.01E-05 MDA

1.52E-04 MDA

9.91E-04 6.34E-05

$1.63 \mathrm{E}-03$ 1.60E-04

8.06E-08 DL

7.12E-03 DL

$4.59 \mathrm{E}-03 \mathrm{DL}$

3.68E-05 7.37E-06

4.77E-05 DL

\begin{tabular}{l|l}
\hline $8.56 \mathrm{E}-04$ & $1.71 \mathrm{E}-04$
\end{tabular}

1.24E-02

\begin{tabular}{|l|l|}
\hline$F$ & \\
\hline & \\
\hline
\end{tabular}

Appendix $F$

Page F3

MDA $=$ Minimum Detectable Activity for the conditions used 
$\mathrm{DL}=$ Detection Limit

UL = Upper Limit

TBP = Tributyl Phosphate

AH = Aliphatic Hydrocarbons

Appendix F

Page F4 


\begin{tabular}{|c|c|c|c|c|c|}
\hline Sample \# & $3-109279$ & & & & \\
\hline Customer ID & $98018-6$ & & & & \\
\hline Description & \multicolumn{2}{|c|}{ Filtered Solids } & & & \\
\hline \multirow[t]{9}{*}{ Estimated Solids } & 16503.08 & $\mathrm{~g}$ & \multicolumn{3}{|c|}{ (based upon TSS, volume and } \\
\hline & & & \multicolumn{3}{|c|}{ density of liquid phase) } \\
\hline & & & & & \\
\hline & & & & & \\
\hline & & & & & \\
\hline & & & & & Suspended \\
\hline & & & & & Solids \\
\hline & & & & & Total \\
\hline & Activity & Error & Activity & Error & Activity \\
\hline Analyte & $\mathrm{uCl} / \mathrm{g}$ & $\mathrm{uCl} / \mathrm{g}$ & $\mathrm{pCl} / \mathrm{g}$ & $\mathrm{pCi} / \mathrm{g}$ & $\mathbf{u C i}$ \\
\hline Total Am & 7.30E-01 & $4.22 \mathrm{E}-02$ & $7.30 \mathrm{E}+05$ & $4.22 E+04$ & $1.20 \mathrm{E}+04$ \\
\hline $\mathrm{Am}-241$ & $6.71 E-01$ & 4.05E-02 & $6.71 E+05$ & $4.05 E+04$ & $1.11 \mathrm{E}+04$ \\
\hline $\mathrm{Am}-243$ & $5.90 \mathrm{E}-02$ & $1.18 \mathrm{E}-02$ & $5.90 E+04$ & $1.18 E+04$ & $9.74 \mathrm{E}+02$ \\
\hline $\mathrm{C}-14$ & $8.15 \mathrm{E}-02$ & UL & $8.15 E+04$ & UL & $1.35 \mathrm{E}+03$ \\
\hline $\mathrm{Ce}-144$ & $5.00 \mathrm{E}-03$ & MDA & $5.00 \mathrm{E}+03$ & MDA & $8.25 E+01$ \\
\hline Total $\mathrm{Cm}$ & $1.16 E+00$ & $2.18 \mathrm{E}-01$ & $1.16 \mathrm{E}+06$ & $2.18 \mathrm{E}+05$ & $1.92 E+04$ \\
\hline $\mathrm{Cm}-244$ & $1.09 \mathrm{E}+00$ & $2.18 \mathrm{E}-01$ & $1.09 E+06$ & $2.18 \mathrm{E}+05$ & $1.80 \mathrm{E}+04$ \\
\hline $\mathrm{Cm}-245$ & $2.26 \mathrm{E}-02$ & $4.51 \mathrm{E}-03$ & $2.26 E+04$ & $4.51 E+03$ & $3.73 E+02$ \\
\hline $\mathrm{Cm}-246$ & $5.00 \mathrm{E}-02$ & $1.00 \mathrm{E}-02$ & $5.00 \mathrm{E}+04$ & $1.00 \mathrm{E}+04$ & $8.25 E+02$ \\
\hline Co-60 & $6.49 \mathrm{E}-03$ & $3.31 \mathrm{E}-04$ & $6.49 \mathrm{E}+03$ & $3.31 \mathrm{E}+02$ & $1.07 E+02$ \\
\hline Cs-137 & 7.97E-01 & $2.74 \mathrm{E}-02$ & $7.97 \mathrm{E}+05$ & $2.74 \mathrm{E}+04$ & $1.32 \mathrm{E}+04$ \\
\hline Eu-154 & $9.41 E-02$ & $2.15 E-03$ & $9.41 E+04$ & $2.15 \mathrm{E}+03$ & $1.55 E+03$ \\
\hline Eu-155 & $3.98 \mathrm{E}-03$ & $3.23 E-03$ & $3.98 \mathrm{E}+03$ & $3.23 E+03$ & $6.57 E+01$ \\
\hline $\mathrm{GA}$ & $3.64 \mathrm{E}+01$ & $7.27 \mathrm{E}+00$ & $3.64 \mathrm{E}+07$ & $7.27 \mathrm{E}+06$ & $6.01 E+05$ \\
\hline $\mathrm{H}-3$ & $2.19 \mathrm{E}-02$ & $6.13 \mathrm{E}-03$ & $2.19 E+04$ & $6.13 \mathrm{E}+03$ & $3.61 E+02$ \\
\hline $\mathrm{Nb}-94$ & $1.23 \mathrm{E}-04$ & MDA & $1.23 \mathrm{E}+02$ & MDA & $2.03 E+00$ \\
\hline $\mathrm{Ni}-59$ & $3.62 \mathrm{E}-02$ & MDA & $3.62 \mathrm{E}+04$ & MDA & $5.97 E+02$ \\
\hline $\mathrm{Ni}-63$ & 1.39E-02 & $\mathrm{UL}$ & $1.39 E+04$ & UL & $2.29 E+02$ \\
\hline GB & $1.29 E+01$ & $5.17 \mathrm{E}+00$ & $1.29 E+07$ & $5.17 E+06$ & $2.13 E+05$ \\
\hline $\mathrm{Np}-237$ & $9.14 \mathrm{E}-03$ & $1.83 \mathrm{E}-03$ & $9.14 \mathrm{E}+03$ & $1.83 \mathrm{E}+03$ & $1.51 E+02$ \\
\hline Pb-212 & 3.31E-03 & $1.11 \mathrm{E}-03$ & $3.31 E+03$ & $1.11 E+03$ & $5.46 \mathrm{E}+01$ \\
\hline Total Pu & $4.45 E+01$ & $1.01 E+01$ & $4.45 \mathrm{E}+07$ & $1.01 E+07$ & $7.35 E+05$ \\
\hline Pu-238 & $3.24 E+01$ & $9.73 E+00$ & $3.24 \mathrm{E}+07$ & $9.73 E+06$ & $5.35 E+05$ \\
\hline Pu-239 & $5.50 \mathrm{E}+00$ & $1.10 \mathrm{E}+00$ & $5.50 \mathrm{E}+06$ & $1.10 \mathrm{E}+06$ & $9.08 \mathrm{E}+04$ \\
\hline Pu-240 & 8.78E-01 & $1.76 \mathrm{E}-01$ & $8.78 \mathrm{E}+05$ & $1.76 \mathrm{E}+05$ & $1.45 E+04$ \\
\hline Pu-241 & $5.77 \mathrm{E}+00$ & $2.65 E+00$ & $5.77 E+06$ & $2.65 E+06$ & $9.52 E+04$ \\
\hline $\mathrm{Pu}-242$ & $1.31 E-03$ & $2.62 \mathrm{E}-04$ & $1.31 E+03$ & $2.62 \mathrm{E}+02$ & $2.16 E+01$ \\
\hline Ru-106 & $8.24 \mathrm{E}-03$ & MDA & $8.24 \mathrm{E}+03$ & MDA & $1.36 \mathrm{E}+02$ \\
\hline Sr-90 & $3.31 E+00$ & $3.84 \mathrm{E}-01$ & $3.31 E+06$ & $3.84 \mathrm{E}+05$ & $5.46 \mathrm{E}+04$ \\
\hline Th-232 & $1.43 \mathrm{E}-04$ & $2.86 \mathrm{E}-05$ & $1.43 E+02$ & $2.86 E+01$ & $2.36 \mathrm{E}+00$ \\
\hline TI-208 & $1.19 \mathrm{E}-03$ & $2.96 \mathrm{E}-04$ & $1.19 E+03$ & $2.96 E+02$ & $1.96 \mathrm{E}+01$ \\
\hline U-233 & $4.55 \mathrm{E}-02$ & $9.10 \mathrm{E}-03$ & $4.55 \mathrm{E}+04$ & $9.10 \mathrm{E}+03$ & $7.51 E+02$ \\
\hline U-234 & $1.51 \mathrm{E}-01$ & 3.03E-02 & $1.51 E+05$ & $3.03 E+04$ & $2.49 E+03$ \\
\hline U-2.35 & $6.71 \mathrm{E}-03$ & $7.68 \mathrm{E}-04$ & $6.71 E+03$ & $7.68 \mathrm{E}+02$ & $1.11 \mathrm{E}+02$ \\
\hline U-236 & $5.41 E-03$ & $1.08 \mathrm{E}-03$ & $5.41 E+03$ & $1.08 E+03$ & $8.93 E+01$ \\
\hline$U-238$ & $2.22 \mathrm{E}-01$ & 3.42E-02 & $2.22 \mathrm{E}+05$ & $3.42 E+04$ & $3.66 E+03$ \\
\hline TRU & $3.96 \mathrm{E}+01$ & & $3.96 \mathrm{E}+07$ & & $6.53 E+05$ \\
\hline & $\sigma$ & cons & used & & \\
\hline $\mathrm{DL}=$ Detection Limit & & & & & \\
\hline
\end{tabular}

Description Filtered Solids

C-14

Ce-144

$\mathrm{Cm}-244$

\begin{tabular}{ll|l|l|l}
$1.16 \mathrm{E}+00$ & $2.18 \mathrm{E}-01$ & $1.16 \mathrm{E}+06$ & $2.18 \mathrm{E}+05$
\end{tabular}

Suspended

Solids

$\mathrm{Cm}-245$

\section{2.}

Co-60

$6.49 \mathrm{E}-03$

7.97E-01

9.41E-02

$3.98 \mathrm{E}-03$

$3.64 \mathrm{E}+01$

\begin{tabular}{l|l|l|}
$2.19 E-02$ & $6.13 \mathrm{E}-03$ \\
\hline
\end{tabular}

1.23E-04 MDA

3.62E-02 MDA

$1.39 \mathrm{E}-02$ UL

\begin{tabular}{l|l|l|l|}
$1.29 \mathrm{E}+01$ & $5.17 \mathrm{E}+00$ & $1.29 \mathrm{E}+07$ & $5.17 \mathrm{E}+06$ \\
\hline $0.14 \mathrm{E}-03$ & $1.83 \mathrm{E}-03$ & $9.14 \mathrm{E}+03$ & $1.83 \mathrm{E}+03$
\end{tabular} \begin{tabular}{ll|l|l|l}
$3.31 \mathrm{E}-03$ & $1.11 \mathrm{E}-03$ & $3.31 \mathrm{E}+03$ & $1.11 \mathrm{E}+03$
\end{tabular}

$1.51 E+02$

$5.46 \mathrm{E}+01$

\begin{tabular}{ll|l|l|l|l}
\hline $4.45 E+01$ & $1.01 E+01$ & $4.45 E+07$ & $1.01 E+07$
\end{tabular}

$5.35 \mathrm{E}+05$

\begin{tabular}{ll|l|l|l|}
$3.24 \mathrm{E}+01$ & $9.73 \mathrm{E}+00$ & $3.24 \mathrm{E}+07$ & $9.73 \mathrm{E}+06$
\end{tabular}

$9.08 \mathrm{E}+04$

\begin{tabular}{ll|l|l}
$5.50 \mathrm{E}+00$ & $1.10 \mathrm{E}+00$ & $5.50 \mathrm{E}+06$ & $1.10 \mathrm{E}+06$
\end{tabular}

\begin{tabular}{r|r|r|r|r|}
$8.78 \mathrm{E}-01$ & $1.76 \mathrm{E}-01$ & $8.78 \mathrm{E}+05$ & $1.76 \mathrm{E}+05$ & $1.45 \mathrm{E}+04$ \\
\hline $5.77 \mathrm{E}+00$ & $2.65 \mathrm{E}+00$ & $5.77 \mathrm{E}+06$ & $2.65 \mathrm{E}+06$ & $9.52 \mathrm{E}+04$ \\
\hline
\end{tabular}

\begin{tabular}{lllll}
$1.31 E-03$ & $2.62 \mathrm{E}-04$ & $1.31 \mathrm{E}+03$ & $2.62 \mathrm{E}+02$ \\
\hline
\end{tabular}

$2.16 \mathrm{E}+01$

$1.36 \mathrm{E}+02$

$5.46 \mathrm{E}+04$

$2.36 \mathrm{E}+00$

\begin{tabular}{ll|l|l|l|l}
$1.43 \mathrm{E}-04$ & $2.86 \mathrm{E}-05$ & $1.43 \mathrm{E}+02$ & $2.86 \mathrm{E}+01$
\end{tabular}

$1.96 \mathrm{E}+01$

\begin{tabular}{llllll}
\hline $4.55 \mathrm{E}-02$ & $9.10 \mathrm{E}-03$ & $4.55 \mathrm{E}+04$ & $9.10 \mathrm{E}+03$
\end{tabular}

7.51E+02

$2.49 \mathrm{E}+03$

\begin{tabular}{|c|c|c|c|c|}
\hline $6.71 \mathrm{E}-03$ & $7.68 \mathrm{E}-04$ & $6.71 \mathrm{E}+03$ & $7.68 \mathrm{E}+02$ & $1.11 \mathrm{E}+02$ \\
\hline
\end{tabular}

\begin{tabular}{|l|l|l|l|l|}
\hline $5.41 \mathrm{E}-03$ & $1.08 \mathrm{E}-03$ & $5.41 \mathrm{E}+03$ & $1.08 \mathrm{E}+03$ & $8.93 \mathrm{E}+01$ \\
\hline
\end{tabular} 


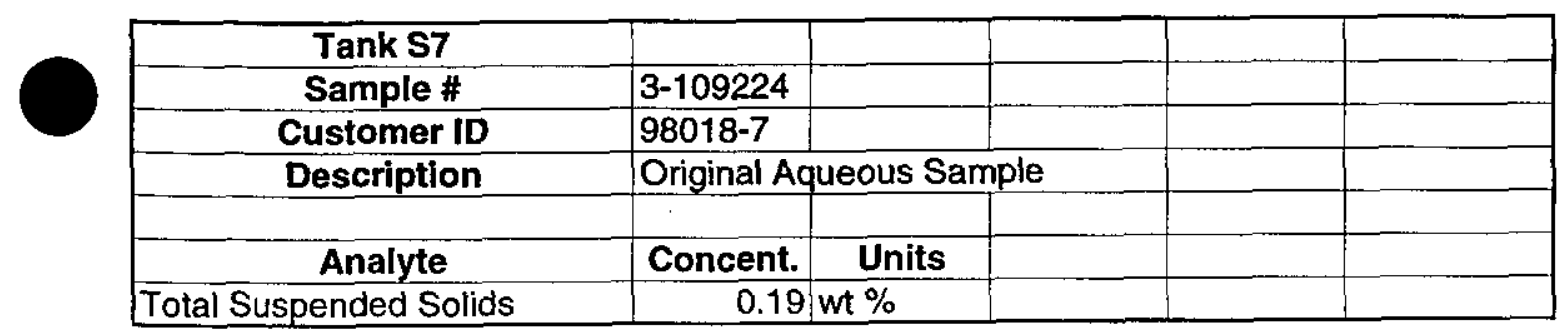




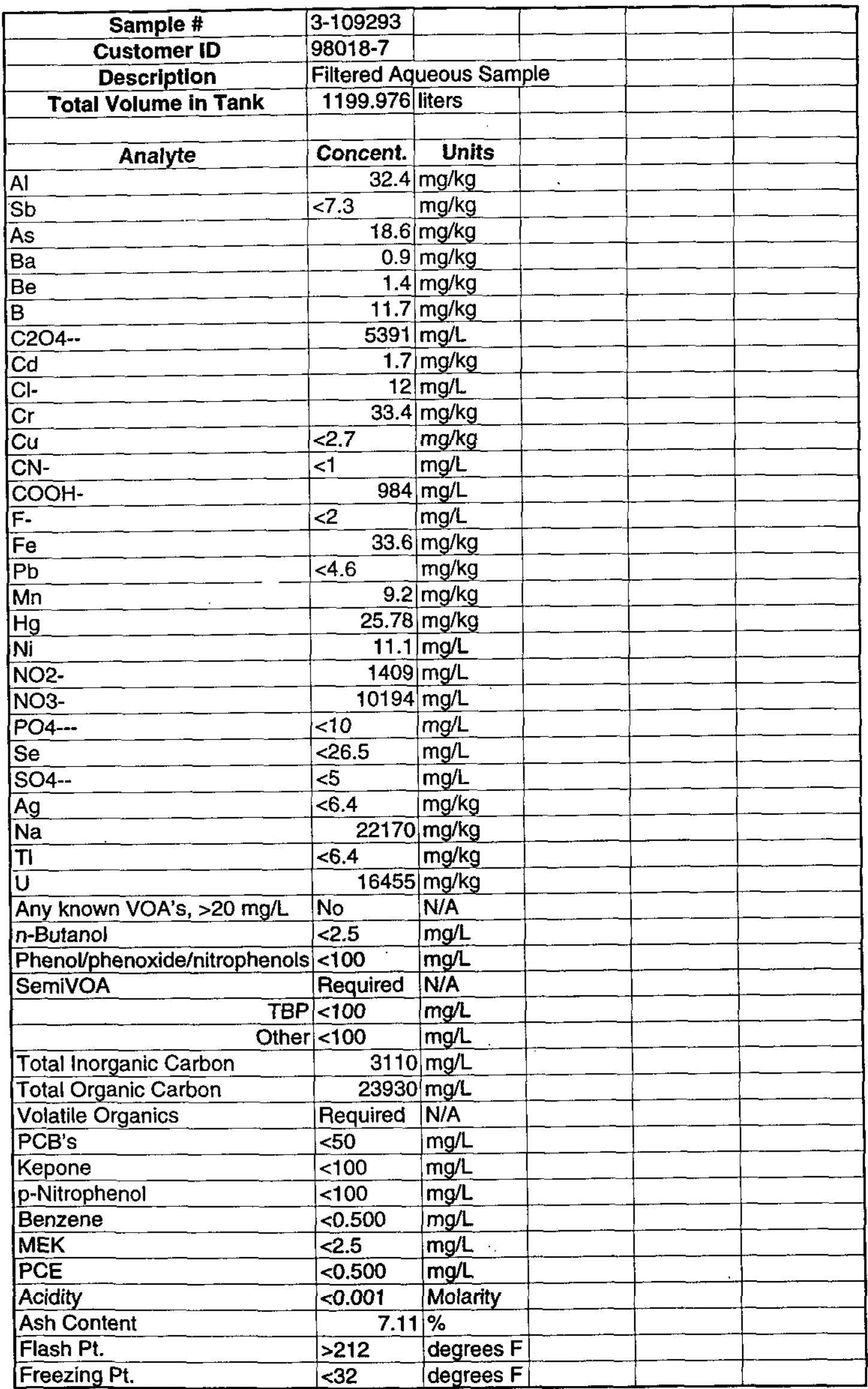




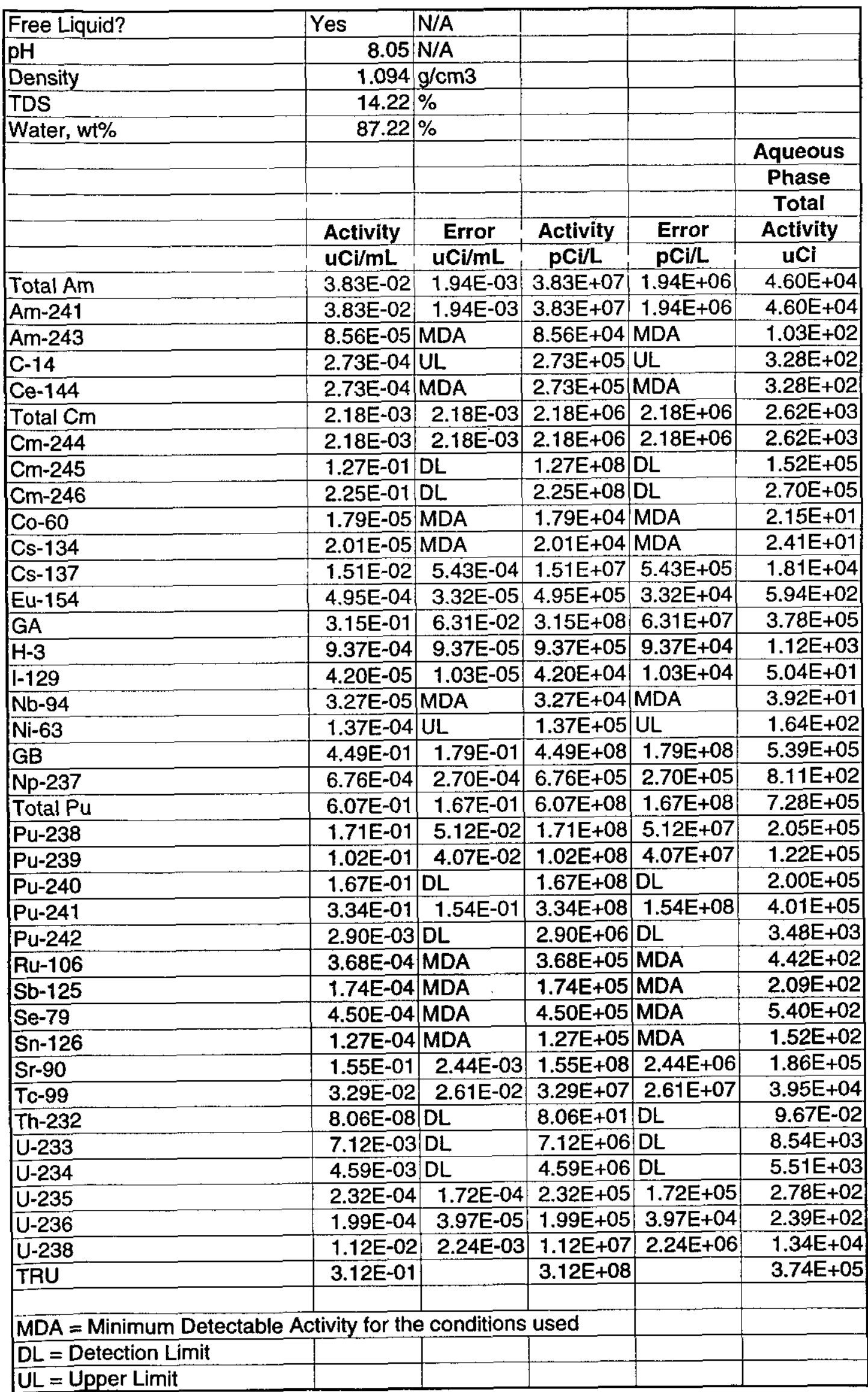

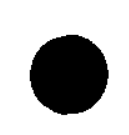




\begin{tabular}{|c|c|c|c|c|c|}
\hline Sample \# & 3-109280 & & & & \\
\hline Customer ID & 98018-7 & & & & \\
\hline Description & \multicolumn{2}{|c|}{ Filtered Solids } & & & \\
\hline Estimated Solids & 2494.27 & $g$ & \multicolumn{3}{|c|}{ (based upon TSS, volume and } \\
\hline & & & \multicolumn{3}{|c|}{ density of liquid phase) } \\
\hline & & & & & \\
\hline & & & & & \\
\hline & & & & & \\
\hline & & & & & Suspended \\
\hline & & & & & Solids \\
\hline & & & & & Total \\
\hline & Activity & Error & Activity & Error & Activity \\
\hline Analyte & $\mathrm{uCi} / \mathrm{g}$ & uCi/g & pCig & $\mathrm{pCl} / \mathrm{g}$ & $\mathbf{u C i}$ \\
\hline Total Am & $9.64 \mathrm{E}-01$ & $5.21 E-02$ & $9.64 E+05$ & $5.21 E+04$ & $2.40 E+03$ \\
\hline $\mathrm{Am}-241$ & 9.64E-01 & $5.21 \mathrm{E}-02$ & $9.64 \mathrm{E}+05$ & $5.21 E+04$ & $2.40 \mathrm{E}+03$ \\
\hline $\mathrm{Am}-243$ & 4.82E-02 & $\mathrm{DL}$ & $4.82 E+04$ & DL & $1.20 \mathrm{E}+02$ \\
\hline C-14 & $2.03 E+00$ & UL & $2.03 E+06$ & UL & $5.06 E+03$ \\
\hline $\mathrm{Ce}-144$ & $1.34 \mathrm{E}-02$ & MDA & $1.34 \mathrm{E}+04$ & MDA & $3.34 \mathrm{E}+01$ \\
\hline Total $\mathrm{Cm}$ & 7.57E-02 & $\mathrm{UL}$ & $7.57 \mathrm{E}+04$ & UL & $1.89 E+02$ \\
\hline $\mathrm{Cm}-244$ & 7.57E-02 & UL & $7.57 \mathrm{E}+04$ & UL & $1.89 E+02$ \\
\hline $\mathrm{Cm}-245$ & 4.14E-02 & $\mathrm{DL}$ & $4.14 E+04$ & $\mathrm{DL}$ & $1.03 E+02$ \\
\hline Cm-246 & $7.34 \mathrm{E}-02$ & $\mathrm{DL}$ & $7.34 \mathrm{E}+04$ & $D L$ & $1.83 E+02$ \\
\hline Co-60 & $9.19 \mathrm{E}-04$ & MDA & $9.19 \mathrm{E}+02$ & MDA & $2.29 E+00$ \\
\hline Cs-137 & 4.55E-01 & $1.74 \mathrm{E}-02$ & $4.55 \mathrm{E}+05$ & $1.74 E+04$ & $1.13 E+03$ \\
\hline Eu-154 & $9.19 \mathrm{E}-03$ & $1.52 E-03$ & $9.19 \mathrm{E}+03$ & $1.52 E+03$ & $2.29 \mathrm{E}+01$ \\
\hline $\mathrm{GA}$ & $7.57 \mathrm{E}+00$ & $1.51 \mathrm{E}+00$ & $7.57 \mathrm{E}+06$ & $1.51 \mathrm{E}+06$ & $1.89 \mathrm{E}+04$ \\
\hline $\mathrm{H}-3$ & $1.58 \mathrm{E}-01$ & $4.42 E-02$ & $1.58 E+05$ & $4.42 E+04$ & $3.94 \mathrm{E}+02$ \\
\hline $\mathrm{Nb}-94$ & $1.41 \mathrm{E}-03$ & MDA & $1.41 \mathrm{E}+03$ & MDA & $3.52 E+00$ \\
\hline Ni-59 & 2.99E-01 & MDA & $2.99 \mathrm{E}+05$ & MDA & $7.46 \mathrm{E}+02$ \\
\hline $\mathrm{Ni}-63$ & $2.42 \mathrm{E}-02$ & MDA & $2.42 E+04$ & MDA & $6.04 \mathrm{E}+01$ \\
\hline GB & $2.14 \mathrm{E}+01$ & $8.58 \mathrm{E}+00$ & $2.14 \mathrm{E}+07$ & $8.58 E+06$ & $5.34 \mathrm{E}+04$ \\
\hline $\mathrm{Np}-237$ & $3.59 \mathrm{E}-03$ & $7.18 \mathrm{E}-04$ & $3.59 E+03$ & $7.18 E+02$ & $8.95 E+00$ \\
\hline Total Pu & $2.25 E+01$ & $5.70 E+00$ & $2.25 E+07$ & $5.70 \mathrm{E}+06$ & $5.62 E+04$ \\
\hline Pu-238 & $3.50 \mathrm{E}+00$ & $2.66 \mathrm{E}+00$ & $3.50 E+06$ & $2.66 \mathrm{E}+06$ & $8.73 E+03$ \\
\hline Pu-239 & $5.45 \mathrm{E}+00$ & $1.09 \mathrm{E}+00$ & $5.45 \mathrm{E}+06$ & $1.09 E+06$ & $1.36 \mathrm{E}+04$ \\
\hline Pu-240 & $1.26 \mathrm{E}+00$ & $2.51 \mathrm{E}-01$ & $1.26 \mathrm{E}+06$ & $2.51 \mathrm{E}+05$ & $3.14 E+03$ \\
\hline Pu-241 & $1.23 \mathrm{E}+01$ & $4.92 \mathrm{E}+00$ & $1.23 E+07$ & $4.92 E+06$ & $3.07 E+04$ \\
\hline Pu-242 & $2.09 E-03$ & $4.19 \mathrm{E}-04$ & $2.09 E+03$ & $4.19 E+02$ & $5.21 \mathrm{E}+00$ \\
\hline Ra-226 & $9.19 \mathrm{E}-02$ & UL & $9.19 \mathrm{E}+04$ & UL & $2.29 \mathrm{E}+02$ \\
\hline Ru-106 & $1.80 E-02$ & MDA & $1.80 \mathrm{E}+04$ & MDA & $4.49 E+01$ \\
\hline Sn-126 & $1.38 \mathrm{E}-03$ & MDA & $1.38 \mathrm{E}+03$ & MDA & $3.44 \mathrm{E}+00$ \\
\hline Sr-90 & $7.39 \mathrm{E}+00$ & 8.57E-01 & $7.39 \mathrm{E}+06$ & $8.57 E+05$ & $1.84 \mathrm{E}+04$ \\
\hline Th-232 & $4.05 \mathrm{E}-06$ & $8.09 \mathrm{E}-07$ & $4.05 \mathrm{E}+00$ & $8.09 \mathrm{E}-01$ & 1.01E-02 \\
\hline$U-233$ & $2.32 \mathrm{E}-03$ & $\mathrm{DL}$ & $2.32 E+03$ & $\mathrm{DL}$ & $5.79 \mathrm{E}+00$ \\
\hline U-234 & $1.28 \mathrm{E}-01$ & $2.56 \mathrm{E}-02$ & $1.28 \mathrm{E}+05$ & $2.56 \mathrm{E}+04$ & $3.19 \mathrm{E}+02$ \\
\hline $\mathrm{U}-235$ & 4.01E-03 & 8.02E-04 & $4.01 E+03$ & $8.02 E+02$ & $1.00 \mathrm{E}+01$ \\
\hline $\mathrm{U}-236$ & $4.46 \mathrm{E}-03$ & $8.92 E-04$ & $4.46 \mathrm{E}+03$ & $8.92 E+02$ & $1.11 \mathrm{E}+01$ \\
\hline U-238 & $1.45 \mathrm{E}-02$ & $2.90 \mathrm{E}-03$ & $1.45 E+04$ & $2.90 E+03$ & $3.62 E+01$ \\
\hline TRU & $1.12 \mathrm{E}+01$ & & $1.12 \mathrm{E}+07$ & & $2.79 E+04$ \\
\hline MDA $=$ Minimum Detec & ivity & & & & \\
\hline $\begin{array}{l}\overline{M D A}=\text { Minimum Detec } \\
\overline{D L}=\text { Detection Limit }\end{array}$ & ivity for $t$ & cor & & & \\
\hline
\end{tabular}

Appendix $G$

Page G5 


\begin{tabular}{|c|c|c|c|c|c|}
\hline Sample \# & 3-117921 & & & & \\
\hline Customer ID & $98351-7$ & & & & \\
\hline Description & Sludge & & & & \\
\hline Total Mass in Tank & 11356.24 & grams & & & \\
\hline Analvte & Concent & Units & & & \\
\hline As & $<3$ & $\mathrm{mg} / \mathrm{kg}$ & & & \\
\hline $\mathrm{Ba}$ & 12 & $\mathrm{mg} / \mathrm{kg}$ & & & \\
\hline Cd & 1. & $\mathrm{mg} / \mathrm{kg}$ & & & \\
\hline $\mathrm{Cr}$ & 15 & $\mathrm{mg} / \mathrm{kg}$ & & & \\
\hline $\mathrm{Pb}$ & 42 & $\mathrm{mg} / \mathrm{kg}$ & & & \\
\hline Se & $<38$ & $\mathrm{mg} / \mathrm{kg}$ & & & \\
\hline $\mathrm{Ag}$ & 8 & $\mathrm{mg} / \mathrm{kg}$ & & & \\
\hline Phenol/phenoxide/nitrophenols & $<100$ & $\mathrm{mg} / \mathrm{kg}$ & & & \\
\hline SemiVOA & Required & N/A & & & \\
\hline TBP & 77] & $\%$ & 770000 & $\mathrm{mg} / \mathrm{kg}$ & \\
\hline BAH & 23 & $\%$ & 230000 & $\mathrm{mg} / \mathrm{kg}$ & \\
\hline Other & $<100$ & $\mathrm{mg} / \mathrm{kg}$ & & & \\
\hline Kepone & $<100$ & $\mathrm{mg} / \mathrm{kg}$ & & & \\
\hline p-Nitrophenol & $<100$ & $\mathrm{mg} / \mathrm{kg}$ & & & \\
\hline & & & & & Sludge \\
\hline & & & & & Phase \\
\hline & & & & & Total \\
\hline & Activity & Error & Activity & Error & Activity \\
\hline & $\mathrm{uCl} / \mathrm{g}$ & $\mathrm{uCl} / \mathrm{g}$ & $\mathrm{pCi} / \mathrm{g}$ & $\mathrm{pCi} / \mathrm{g}$ & $\mathbf{u C i}$ \\
\hline Total Am & $1.45 \mathrm{E}-01$ & $8.79 \mathrm{E}-03$ & $1.45 E+05$ & $8.79 E+03$ & $1.65 E+03$ \\
\hline Am-241 & $1.45 \mathrm{E}-01$ & 8.79E-03 & $1.45 E+05$ & $8.79 \mathrm{E}+03$ & $1.65 \mathrm{E}+03$ \\
\hline$A m-243$ & $2.34 \mathrm{E}-01$ & $\mathrm{DL}$ & $2.34 \mathrm{E}+05$ & $\mathrm{DL}$ & $2.66 \mathrm{E}+03$ \\
\hline Ce-144 & $2.45 E-03$ & MDA & $2.45 \mathrm{E}+03$ & MDA & $2.78 \mathrm{E}+01$ \\
\hline Total $\mathrm{Cm}$ & $3.64 E-02$ & $1.46 \mathrm{E}-02$ & $3.64 E+04$ & $1.46 \mathrm{E}+04$ & $4.13 E+02$ \\
\hline $\mathrm{Cm}-244$ & $3.64 \mathrm{E}-02$ & $1.46 \mathrm{E}-02$ & $3.64 E+04$ & $1.46 E+04$ & $4.13 E+02$ \\
\hline $\mathrm{Cm}-245$ & $2.01 E-01$ & $\mathrm{DL}$ & $2.01 E+05$ & $\overline{D L}$ & $2.28 \mathrm{E}+03$ \\
\hline $\mathrm{Cm}-246$ & $3.58 \mathrm{E}-01$ & DL & $3.58 \mathrm{E}+05$ & $\mathrm{DL}$ & $4.07 E+03$ \\
\hline Co-60 & $1.40 \mathrm{E}-04$ & MDA & $1.40 E+02$ & MDA & $1.59 \mathrm{E}+00$ \\
\hline Cs-134 & $2.99 \mathrm{E}-04$ & MDA & $2.99 E+02$ & MDA & $3.40 \mathrm{E}+00$ \\
\hline Cs-137 & $8.78 \mathrm{E}-02$ & $3.64 E-03$ & $8.78 E+04$ & $3.64 \mathrm{E}+03$ & $9.97 E+02$ \\
\hline Eu-154 & $1.06 \mathrm{E}-03$ & 3.81E-04 & $1.06 E+03$ & $3.81 E+02$ & $1.20 \mathrm{E}+01$ \\
\hline GA & $9.10 \mathrm{E}-01$ & $1.82 \mathrm{E}-01$ & $9.10 \mathrm{E}+05$ & $1.82 E+05$ & $1.03 E+04$ \\
\hline Nb-94 & $2.36 \mathrm{E}-04$ & MDA & $2,36 \mathrm{E}+02$ & MDA & $2.68 \mathrm{E}+00$ \\
\hline GB & $1.13 E+00$ & $2.26 \mathrm{E}-01$ & $1.13 E+06$ & $2.26 \mathrm{E}+05$ & $1.28 E+04$ \\
\hline $\mathrm{Np}-237$ & $8.24 E-04$ & $D L$ & $8.24 E+02$ & $D L$ & $9.36 \mathrm{E}+00$ \\
\hline Total Pu & $9.39 E-01$ & $1.75 \mathrm{E}-01$ & $9.39 E+05$ & $1.75 E+05$ & $1.07 E+04$ \\
\hline Pu-238 & $2.02 \mathrm{E}-01$ & $8.07 \mathrm{E}-02$ & $2.02 E+05$ & $8.07 E+04$ & $2.29 E+03$ \\
\hline Pu-239 & $4.05 \mathrm{E}-01$ & $8.09 \mathrm{E}-02$ & $4.05 E+05$ & $8.09 \mathrm{E}+04$ & $4.60 \mathrm{E}+03$ \\
\hline Pu-240 & $2.66 \mathrm{E}-01$ & $\overline{D L}$ & $2.66 E+05$ & $D L$ & $3.02 E+03$ \\
\hline Pu-241 & $3.32 E-01$ & $1.33 \mathrm{E}-01$ & $3.32 E+05$ & $1.33 E+05$ & $3.77 \mathrm{E}+03$ \\
\hline Pu-242 & $4.59 \mathrm{E}-03$ & $\mathrm{DL}$ & $4.59 E+03$ & $\mathrm{DL}$ & $5.21 E+01$ \\
\hline$R u-106$ & $4.50 \mathrm{E}-03$ & MDA & $4.50 \mathrm{E}+03$ & MDA & $5.11 \mathrm{E}+01$ \\
\hline Sb-125 & $1.96 \mathrm{E}-03$ & MDA & $1.96 \mathrm{E}+03$ & MDA & $2.23 E+01$ \\
\hline$S n-126$ & $9.14 \mathrm{E}-04$ & MDA & $9.14 \mathrm{E}+02$ & MDA & $1.04 E+01$ \\
\hline Th-232 & $5.86 \mathrm{E}-07$ & 1.17E-07 & $5.86 \mathrm{E}-01$ & 1.17E-01 & 6.65E-03 \\
\hline $\mathrm{U}-233$ & 1.13E-02 & $D L$ & $1.13 \mathrm{E}+04$ & $D L$ & $1.28 E+02$ \\
\hline$U-234$ & $1.72 \mathrm{E}-02$ & $3.43 E-03$ & $1.72 E+04$ & $3.43 E+03$ & $1.95 E+02$ \\
\hline
\end{tabular}

Appendix $G$ 


\begin{tabular}{|l|l|l|l|l|l|}
\hline U-235 & $5.81 \mathrm{E}-04$ & $1.16 \mathrm{E}-04$ & $5.81 \mathrm{E}+02$ & $1.16 \mathrm{E}+02$ & $6.60 \mathrm{E}+00$ \\
\hline $\mathrm{U}-236$ & $6.35 \mathrm{E}-04$ & $1.27 \mathrm{E}-04$ & $6.35 \mathrm{E}+02$ & $1.27 \mathrm{E}+02$ & $7.21 \mathrm{E}+00$ \\
\hline $\mathrm{U}-238$ & $1.72 \mathrm{E}-02$ & $3.44 \mathrm{E}-03$ & $1.72 \mathrm{E}+04$ & $3.44 \mathrm{E}+03$ & $1.95 \mathrm{E}+02$ \\
\hline TRU & $7.52 \mathrm{E}-01$ & & $7.52 \mathrm{E}+05$ & & $8.54 \mathrm{E}+03$ \\
\hline & & & & & \\
\hline $\mathrm{MDA}=$ Minimum Detectable Activity for the conditions used & & \\
\hline $\mathrm{DL}=$ Detection Limit & & & & & \\
\hline $\mathrm{UL}=$ Upper Limit & & & & \\
\hline TBP = Tributyl Phosphate & & & & \\
\hline BAH = Branched Aliphatic Hydrocarbons & & & & \\
\hline
\end{tabular}

\section{Appendix $\mathbf{G}$}

Page G7 
Tank S8

Sample \#

Customer ID Description

3-109225

98018-8

Original Aqueous Sample

\section{Analyte Concent. Units}

Total Suspended Solids

0.09 iwt \%

Appendix $\mathrm{H}$

Page $\mathrm{H} 1$ 


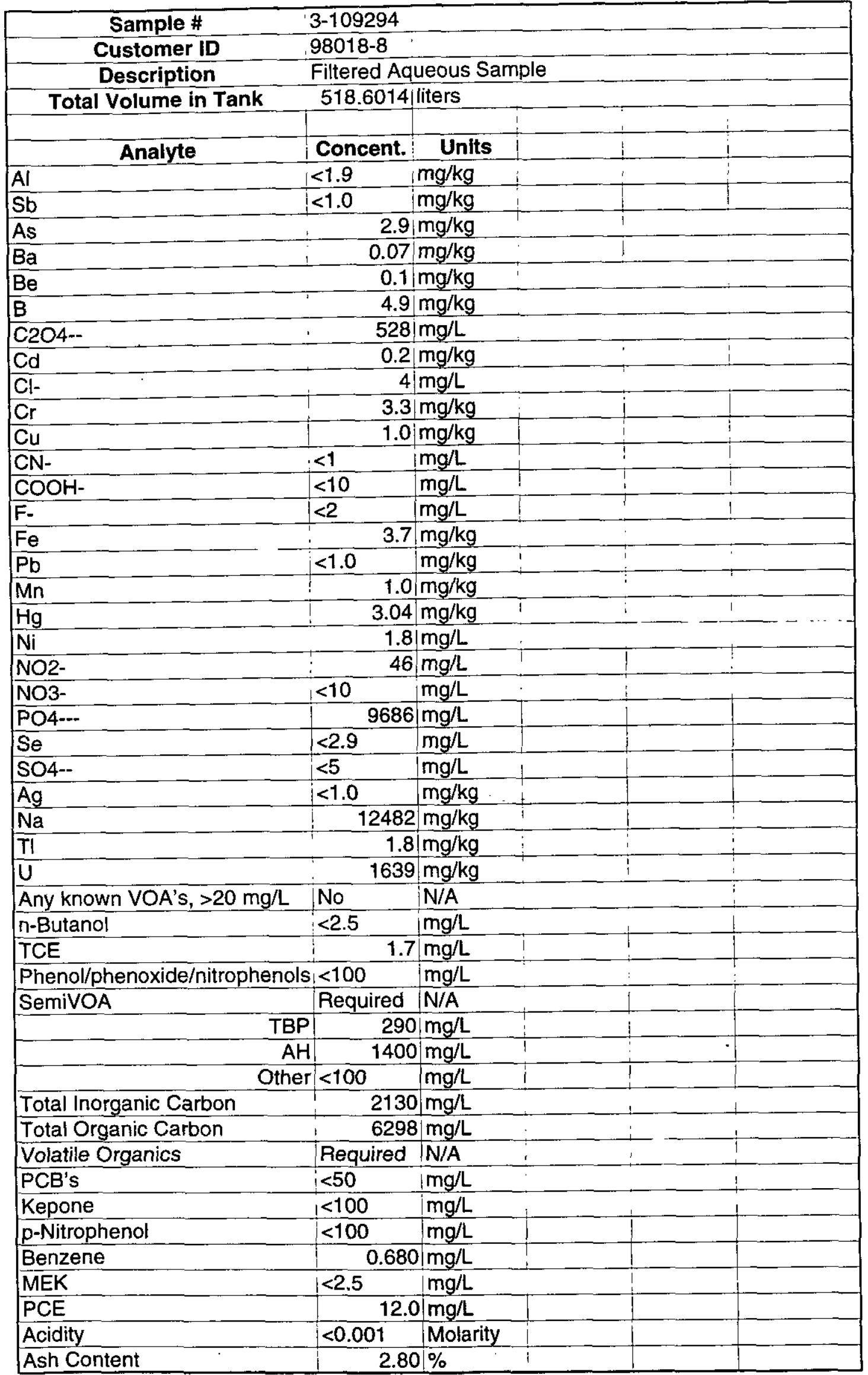




\begin{tabular}{|c|c|c|c|}
\hline Flash Pt. & degrees $F$ & & \\
\hline Freezing Pt. & degrees $F$ & & \\
\hline Free Liquid? & Yes & & \\
\hline $\mathrm{pH}$ & $8.89, \mathrm{~N} / \mathrm{A}$ & & \\
\hline Density & $1.051, \mathrm{~g} / \mathrm{cm} 3$ & & \\
\hline TDS & $4.93 \%$ & & \\
\hline Water, wt\% & $91.62 \%$ & & \\
\hline & & & Aqueous \\
\hline & & & Phase \\
\hline & & & Total \\
\hline & Activity & Activity & Activity \\
\hline & $\mathrm{uCi} / \mathrm{mL}$ & $\mathrm{pCi} / \mathrm{L}$ & $\mathrm{uCi}$ \\
\hline Total Am & $0.00 \mathrm{E}+0010.00 \mathrm{E}+00$ & $0.00 \mathrm{E}+00,0.00 \mathrm{E}+00$ & $0.00 \mathrm{E}+0 \mathrm{C}$ \\
\hline Am-241 & $5.36 \mathrm{E}-031 \mathrm{MDA}$ & $5.36 \mathrm{E}+06 \mathrm{MDA}$ & $2.78 \mathrm{E}+03$ \\
\hline$A m-243$ & 1.75E-03!MDA & $1.75 \mathrm{E}+06 \mathrm{iMDA}$ & $9.08 \overline{\mathrm{E}}+02$ \\
\hline $\mathrm{C}-14$ & $8.60 \mathrm{E}-041 \mathrm{UL}$ & $8.60 \mathrm{E}+05$ & $4.46 \mathrm{E}+02$ \\
\hline $\mathrm{Ce}-144$ & 7.21E-03MDA & $7.21 \mathrm{E}+06, \mathrm{MDA}$ & $3.74 \mathrm{E}+03$ \\
\hline Total $\mathrm{Cm}$ & $0.00 \mathrm{E}+00 \mid 0.00 \mathrm{E}+00$ & $0.00 \mathrm{E}+00: 0.00 \mathrm{E}+00$ & $0.00 \mathrm{E}+00$ \\
\hline $\mathrm{Cm}-244$ & $2.25 \mathrm{E}-03 / \mathrm{MDA}$ & $2.25 \mathrm{E}+06 \mathrm{MDA}$ & $1.17 \mathrm{E}+03$ \\
\hline $\mathrm{Cm}-245$ & $1.27 \mathrm{E}-01 \mathrm{DL}$ & $1.27 \mathrm{E}+08 \mid \mathrm{DL}$ & $6.59 \mathrm{E}+04$ \\
\hline $\mathrm{Cm}-246$ & $2.25 \mathrm{E}-01 \| \mathrm{DL}$ & $2.25 \mathrm{E}+08 \mid \mathrm{DL}$ & $1.17 E+05$ \\
\hline Co-60 & 3.57E-04|MDA & $3.57 \mathrm{E}+05 \mathrm{MDA}$ & $1.85 E+02$ \\
\hline Cs-134 & $2.79 \mathrm{E}-04 \mathrm{MDA}$ & $2.79 \mathrm{E}+05 \mid \mathrm{MDA}$ & $1.45 \mathrm{E}+02$ \\
\hline Cs-137 & $8.47 \mathrm{E}-01 \quad 2.96 \mathrm{E}-02$ & $8.47 \mathrm{E}+08,2.96 \mathrm{E}+07$ & $4.39 \mathrm{E}+05$ \\
\hline Eu-154 & 5.05E-04|MDA & $5.05 \mathrm{E}+05 \mathrm{MDA}$ & $2.62 \mathrm{E}+02$ \\
\hline GA & 4.50E-02 $9.00 \mathrm{E}-03$ & $4.50 \mathrm{E}+07 \quad 9.00 \mathrm{E}+06$ & $2.33 E+04$ \\
\hline $\mathrm{H}-3$ & $1.82 \mathrm{E}-03,1.82 \mathrm{E}-04$ & $1.82 E+06,1.82 E+05$ & $9.44 \mathrm{E}+02$ \\
\hline $\mathrm{Nb}-94$ & $2.14 \mathrm{E}-04 \mathrm{MDA}$ & $2.14 \mathrm{E}+05 \mathrm{MDA}$ & $1.11 \bar{E}+02$ \\
\hline $\mathrm{Ni}-63$ & 4.91E-04,UL & $4.91 E+05 \mathrm{UL}$ & $2.55 \mathrm{E}+02$ \\
\hline GB & $1.01 \mathrm{E}+00 \quad 4.04 \mathrm{E}-01$ & $1.01 E+09 \mid 4.04 E+08$ & $5.24 \mathrm{E}+05$ \\
\hline $\mathrm{Np}-237$ & $5.18 \mathrm{E}-04 \mathrm{DL}$ & $5.18 \mathrm{E}+05 \mid \mathrm{DL}$ & $2.69 \mathrm{E}+02$ \\
\hline Total Pu & 5.26E-01: $7.80 \mathrm{E}-01$ & $5.26 \mathrm{E}+087.80 \mathrm{E}+08$ & $2.73 E+05$ \\
\hline Pu-238 & $2.64 \mathrm{E}-02 \quad 7.92 \mathrm{E}-03$ & $2.64 \mathrm{E}+07 \quad 7.92 \mathrm{E}+06$ & $1.37 E+04$ \\
\hline Pu-239 & $4.55 \mathrm{E}-02 \mathrm{DL}$ & $4.55 \mathrm{E}+07 \mid \mathrm{DL}$ & $2.36 \mathrm{E}+04$ \\
\hline Pu-240 & $1.67 \mathrm{E}-01 \mathrm{DL}$ & $1.67 E+08 / D L$ & $8.66 E+04$ \\
\hline Pu-241 & $5.00 \mathrm{E}-01 \quad 7.80 \mathrm{E}-01$ & $5.00 \mathrm{E}+08 \quad 7.80 \mathrm{E}+08$ & $2.59 E+05$ \\
\hline $\mathrm{Pu}-242$ & $2.90 \mathrm{E}-03, \mathrm{DL}$ & $2.90 \mathrm{E}+06, \mathrm{DL}$ & $1.50 E+03$ \\
\hline Ru-106 & 1.25E-02 MDA & 1.25E+07 MDA & $6.48 \bar{E}+03$ \\
\hline$\overline{S b}-125$ & 6.62E-03 MDA & $6.62 \mathrm{E}+06 \mathrm{MDA}$ & $3.43 E+03$ \\
\hline Se-79 & 9.01E-04 MDA & $9.01 \mathrm{E}+05 \mid \mathrm{MDA}$ & 4.67E+02 \\
\hline Sn-126 & 2.55E-03 MDA & $2.55 \mathrm{E}+06 \mid \mathrm{MDA}$ & $1.32 \mathrm{E}+03$ \\
\hline $\mathrm{Sr}-90$ & \begin{tabular}{|l|l|}
$9.64 \mathrm{E}-03$ & $1.77 \mathrm{E}-03$ \\
\end{tabular} & \begin{tabular}{|l|l|}
$9.64 E+06$ & $1.77 E+06$ \\
\end{tabular} & $5.00 \mathrm{E}+03$ \\
\hline TC-99 & $1.18 \mathrm{E}-03 \mathrm{1}$ & $1.18 E+06 \quad 1.72 E+05$ & $6.12 E+02$ \\
\hline Th-232 & $8.06 \mathrm{E}-08 \mid \mathrm{DL}$ & $8 . \overline{06} \overline{E+01 i D L}$ & 4.18E-02 \\
\hline $\mathrm{U}-233$ & 7.12E-03 $\mathrm{DL}$ & $7.12 \mathrm{E}+06 \mid \mathrm{DL}$ & $3.69 E+03$ \\
\hline U-234 & 4.59E-03|DL & $4.59 \mathrm{E}+06 \mid \mathrm{DL}$ & $2.38 E+03$ \\
\hline $\mathrm{U}-235$ & $2.55 \mathrm{E}-05,5.11 \mathrm{E}-06$ & $2.55 E+04,5.11 E+03$ & $1.32 E+01$ \\
\hline U-236 & 4.77E-05/DL & $4.77 \mathrm{E}+04 \mid \mathrm{DL}$ & 2.47E+01 \\
\hline U-238 & $6.04 \mathrm{E}-04 \quad 1.21 \mathrm{E}-04$ & $6.04 \mathrm{E}+05 \quad 1.21 \mathrm{E}+05$ & $3.13 E+02$ \\
\hline TRU & $2.64 \mathrm{E}-02$ & $2.64 E+07$ & $1.37 E+04$ \\
\hline
\end{tabular}

Appendix $\mathrm{H}$

Page $\mathrm{H} 3$

. 


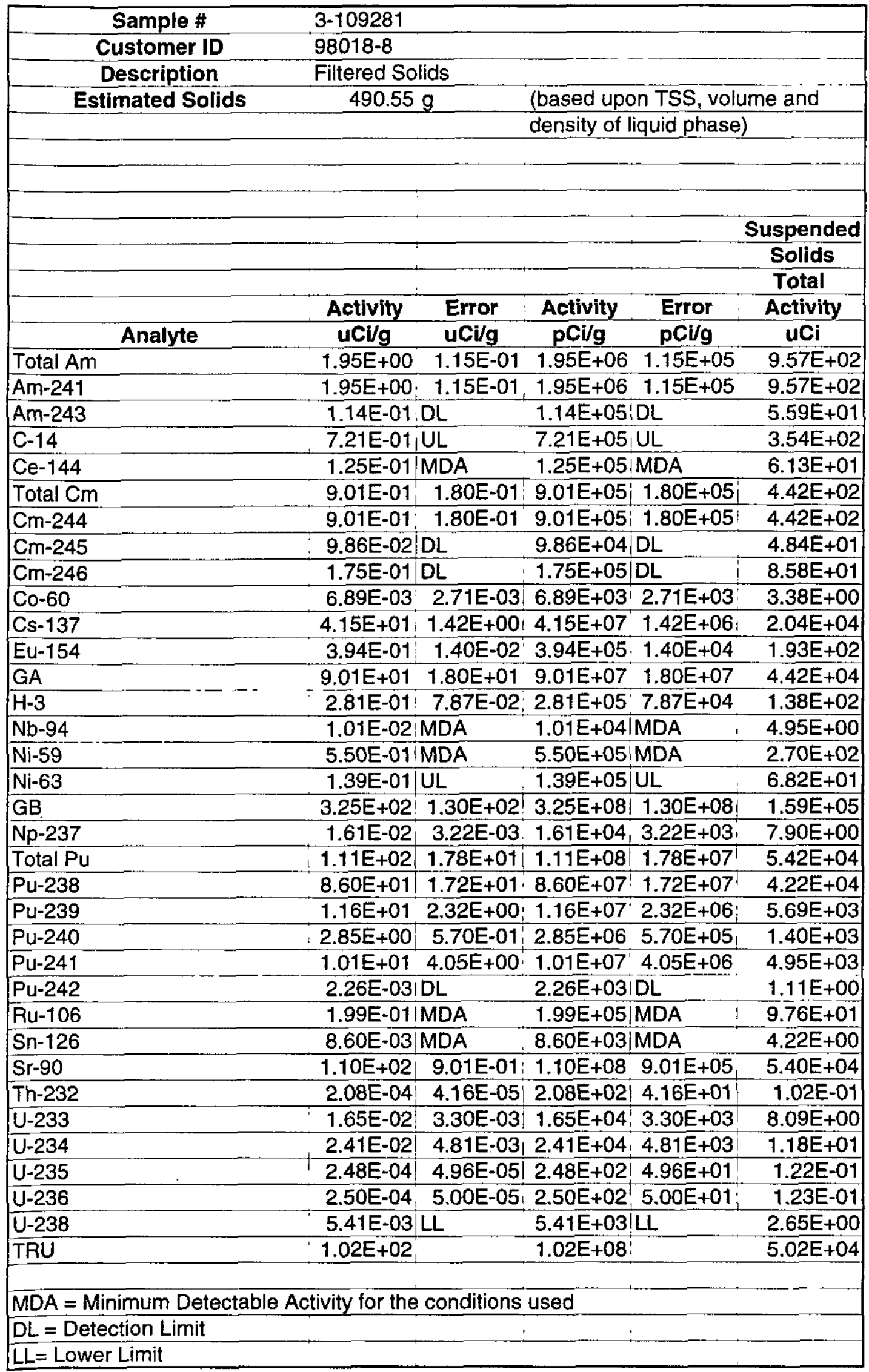

Appendix $\mathrm{H}$

Page $\mathrm{H} 5$ 


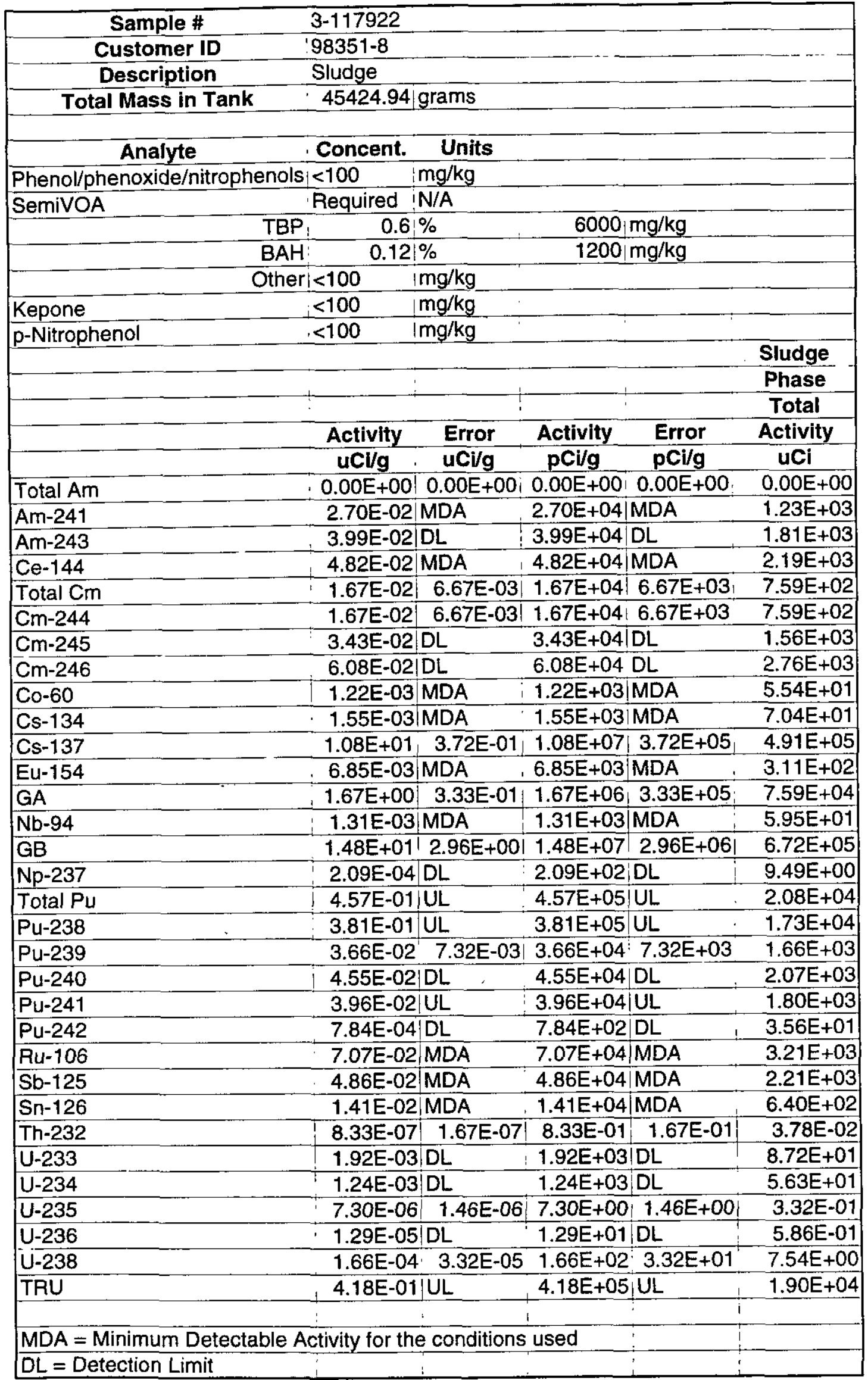

Appendix $\mathrm{H}$ 


\begin{tabular}{|cc|}
\hline Tank S11 & \\
\hline Sample \# & $3-118504$ \\
\hline Customer ID & $98018-11$ \\
\hline Description & Original Aqueous Sample \\
\hline & \\
\hline Analyte & Concent. Units \\
\hline Total Suspended Solids & 0.007 wt \% \\
\hline
\end{tabular}

Appendix 1

Page 11 


\begin{tabular}{|c|c|c|c|c|c|}
\hline Sample \# & $3-118517$ & & & & \\
\hline Customer ID & $98018-11$ & & & & \\
\hline Description & Filtered Org & ganic Samp & ple & & \\
\hline Total Volume in Tank & 54.13139 & liters & & & \\
\hline Analyte & Concent. & Units & $i$ & 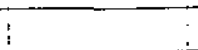 & \\
\hline As & 0.3 & Img/L & & & \\
\hline $\mathrm{Ba}$ & 1.5 & $\mathrm{mg} / \mathrm{L}$ & 1 & & \\
\hline C2O4-- & 386 & $\mathrm{mg} / \mathrm{L}$ & & & \\
\hline $\mathrm{Cd}$ & 0.3 & $\mathrm{mg} / \mathrm{L}$ & & & \\
\hline $\mathrm{Cl}-$ & 149 & $\mathrm{mg} / \mathrm{L}$ & & & \\
\hline Co & 2.5 & $\mathrm{mg} / \mathrm{L}$ & $i$ & & \\
\hline $\mathrm{COOH}-$ & 26241 & $\mathrm{mg} / \mathrm{L}$ & & & \\
\hline $\mathrm{Cr}$ & 63 & $\mathrm{mg} / \mathrm{L}$ & & & \\
\hline F. & $1<20$ & $\mathrm{mg} / \mathrm{L}$ & 1 & & \\
\hline$\overline{\mathrm{Pb}}$ & 8.9 & $\mathrm{mg} / \mathrm{L}$ & 7 & & \\
\hline $\mathrm{Hg}$ & $1.1 \overline{1}$ & $\mathrm{mg} / \mathrm{L}$ & & & \\
\hline NO2- & 4701 & $\mathrm{mg} / \mathrm{L}$ & & & \\
\hline NO3- & 15650 & $\mathrm{mg} / \mathrm{L}$ & & 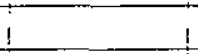 & \\
\hline PO4--: & 431 & $\mathrm{mg} / \mathrm{L}$ & & 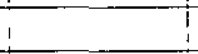 & \\
\hline Se & 2.4 & $\mathrm{mg} / \mathrm{L}$ & & 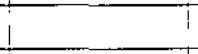 & \\
\hline SO4-- & 389 & $\mathrm{mg} / \mathrm{L}$ & & i & \\
\hline$\overline{\mathrm{Ag}}$ & 0.8 & $\mathrm{mg} / \mathrm{kg}$ & & & \\
\hline Phenol/phenoxide/nitrophenols & $<100$ & $\mathrm{mg} / \mathrm{L}$ & & 1 & \\
\hline SemiVOA & Required & $\mathrm{N} / \mathrm{A}$ & & 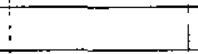 & \\
\hline TBP & 81 & $\%$ & 810000 & $\mathrm{mg} / \mathrm{L}$ & \\
\hline Branched Aliph. Hydrocarbons & 4.0 & $\%$ & 40000 & $\mathrm{mg} / \mathrm{L}$ & \\
\hline Oxygenated Organics & 15 & $\%$ & 150000 & $\mathrm{mg} / \mathrm{L}$ & \\
\hline Total Inorganic Carbon & 3.2 & $\mathrm{mg} / \mathrm{L}$ & & & \\
\hline Total Organic Carbon & 1153 & $\mathrm{mg} / \mathrm{L}$ & & & \\
\hline PCB's & $<10$ & $\mathrm{mg} / \mathrm{L}$ & & & \\
\hline Kepone & $<100$ & $\mathrm{mg} / \mathrm{L}$ & & 1 & \\
\hline p-Nitrophenol & $<100$ & $\mathrm{mg} / \mathrm{L}$ & & $i$ & \\
\hline Acidity & N/A & $\mathrm{pH}>7$ & & & \\
\hline Flash Pt. & $>212$ & degrees $\mathrm{F}$ & & & \\
\hline $\mathrm{pH}$ & 9.16 & $N / A$ & & & \\
\hline Density & 1.021 & $\mathrm{~g} / \mathrm{cm} 3$ & & 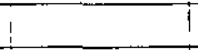 & \\
\hline Water, wt\% & 38.2 & $\%$ & & $i$ & \\
\hline & & & & & Organic \\
\hline & & & & ! & Phase \\
\hline & & & 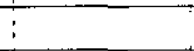 & & Total \\
\hline & Activity & Error & Activity & Error & Activity \\
\hline & $\mathrm{uCi} / \mathrm{mL}$ & $\mathrm{uCl} / \mathrm{mL}$ & pCi/L & pCill & uCi \\
\hline Total Am & $0.00 E+00$ & $0.00 \mathrm{E}+00$ & $0.00 E+00$ & $0.00 \mathrm{E}+00$ & $0.00 E+00$ \\
\hline Am-241 & $3.71 \mathrm{E}-03$ & MDA & $3.71 \bar{E}+06$ & IMDA & $2.01 E+02$ \\
\hline Am-243 & $1.45 E-03$ & MDA & $1.45 \mathrm{E}+06$ & MDA & $7.85 E+01$ \\
\hline $\mathrm{Ce}-144$ & $5.77 E-03$ & MDA & $5.77 E+06$ & $\overline{M D A}$ & $3.12 E+02$ \\
\hline Total Cm & $5.30 E+00$ & $1.02 E+00$ & $5.30 \bar{E}+09$ & $1.02 E+09$ & $2.87 E+05$ \\
\hline Cm-244 & $5.09 E+00$ & $1.02 E+00$ & $5.09 \mathrm{E}+09$ & $1.02 E+09$ & $2.76 \mathrm{E}+05$ \\
\hline Cm-245 & $1.20 \mathrm{E}-01$ & $\mathrm{DL}$ & $1.20 \bar{E}+08$ & $\overline{D L}$ & $6.50 E+03$ \\
\hline $\mathrm{Cm}-246$ & $2.14 \mathrm{E}-01$ & $4.28 \mathrm{E}-02$ & $2.14 E+08$ & $4.28 \mathrm{E}+07$ & $1.16 \mathrm{E}+04$ \\
\hline
\end{tabular}

Appendix I

Page 12 


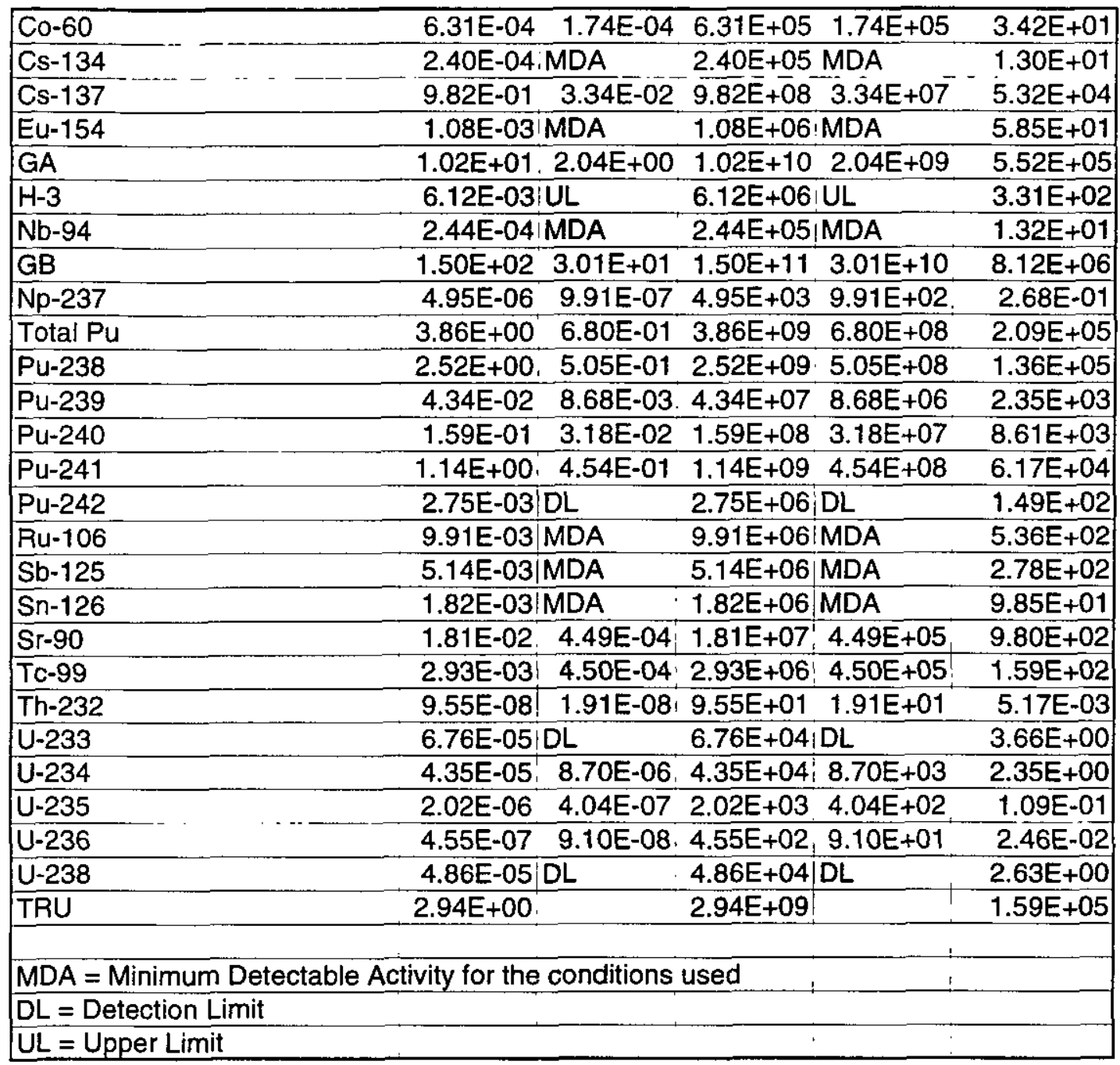

Appendix 1

Page I3 


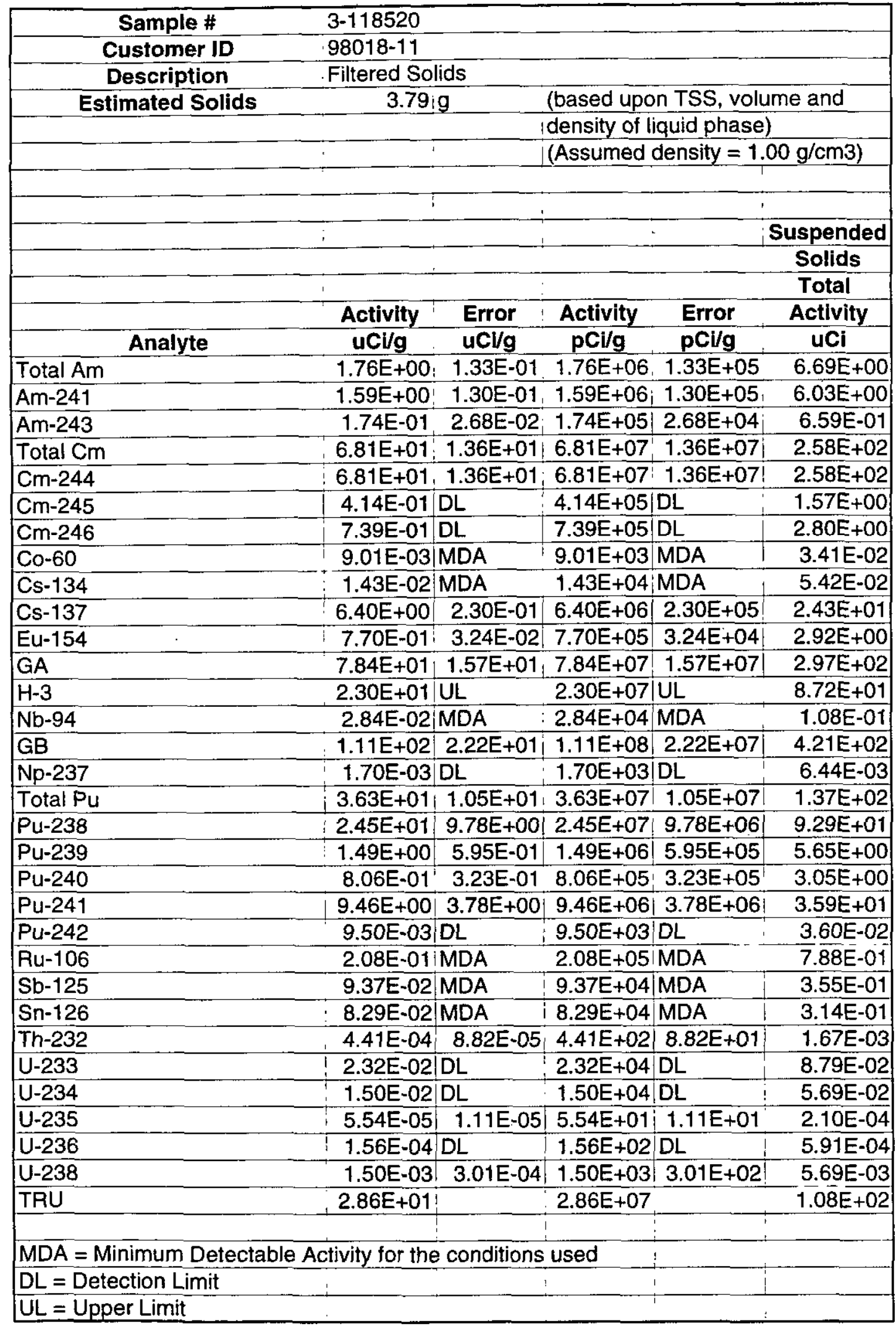

Appendix I

(based upon TSS, volume and density of liquid phase

(Assumed density $=1.00 \mathrm{~g} / \mathrm{cm} 3$ )

spended

Solids

Total

$\begin{array}{lllll}1.76 \mathrm{E}+00: & 1.33 \mathrm{E}-01 & 1.76 \mathrm{E}+06 & 1.33 \mathrm{E}+05 & 6.69 \mathrm{E}+00\end{array}$

$1.59 \mathrm{E}+00,1.30 \mathrm{E}-01,1.59 \mathrm{E}+06 ; 1.30 \mathrm{E}+05,6.03 \mathrm{E}+00$

\begin{tabular}{ll|l|l|l|}
$1.74 \mathrm{E}-01$ & $2.68 \mathrm{E}-02$ & $1.74 \mathrm{E}+05$ & $2.68 \mathrm{E}+04$ & $6.59 \mathrm{E}-01$ \\
\hline
\end{tabular}

$6.81 \mathrm{E}+01,1.36 \mathrm{E}+01 ; 6.81 \mathrm{E}+07,1.36 \mathrm{E}+07$ ! $2.58 \mathrm{E}+02$

4.14E-01 DL

$4.14 \mathrm{E}+05 \mid \mathrm{DL}$

$1.57 \mathrm{E}+00$

$3.41 \mathrm{E}-02$

\begin{tabular}{|l|l|l|l|l|}
\hline $6.40 \mathrm{E}+00$ & $2.30 \mathrm{E}-01$ & $6.40 \mathrm{E}+06$ & $2.30 \mathrm{E}+05$ & $2.43 \mathrm{E}+01$ \\
\hline
\end{tabular}

\begin{tabular}{|l|l|l|l|l|}
$7.70 \mathrm{E}-01$ & $3.24 \mathrm{E}-02$ & $7.70 \mathrm{E}+05$ & $3.24 \mathrm{E}+04$ & $2.92 \mathrm{E}+00$ \\
\hline
\end{tabular}

$2.30 \mathrm{E}+01|\mathrm{UL} \quad 2.30 \mathrm{E}+07| \mathrm{UL} \quad 8.72 \mathrm{E}+01$

\begin{tabular}{|l|l|l|l|l|}
\hline $1.11 E+02$ & $2.22 \mathrm{E}+01$ & $1.11 \mathrm{E}+08$ & $2.22 \mathrm{E}+07$ & $4.21 \mathrm{E}+02$ \\
\hline
\end{tabular}

$1.70 \mathrm{E}-03|\mathrm{DL} \quad 1.70 \mathrm{E}+03| \mathrm{DL}$

\begin{tabular}{|l|l|l|l|l|}
\hline $.63 E+01$ & $1.05 E+01,3.63 E+07$ & $1.05 E+07$ & $1.37 E+02$ \\
\hline
\end{tabular}

\begin{tabular}{|l|l|l|l|l|l|}
\hline $2.45 E+01$ & $9.78 E+00$ & $2.45 E+07$ & $9.78 E+06$ & $9.29 E+01$ \\
\hline
\end{tabular}

\begin{tabular}{lll|l|l|l|l|}
$8.06 \mathrm{E}-01$ & $3.23 \mathrm{E}-01$ & $8.06 \mathrm{E}+05$ & $3.23 \mathrm{E}+05$ & $3.05 \mathrm{E}+00$ \\
\hline
\end{tabular}

\begin{tabular}{ll|l|l|l|}
$9.46 \mathrm{E}+00$ & $3.78 \mathrm{E}+00$ & $9.46 \mathrm{E}+06$ & $3.78 \mathrm{E}+06$ & $3.59 \mathrm{E}+01$ \\
\hline
\end{tabular}

\begin{tabular}{l|l|l|}
$9.50 \mathrm{E}-03 / \mathrm{DL}$ & $9.50 \mathrm{E}+03 \mid \mathrm{DL}$ & $3.60 \mathrm{E}-02$ \\
\hline
\end{tabular}

2.08E-01 IMDA $\quad 2.08 \mathrm{E}+05 \mid \mathrm{MDA} \quad 7.88 \mathrm{E}-01$

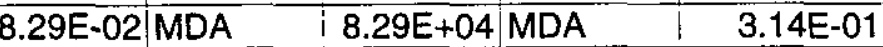

\begin{tabular}{ll|l|l|l|} 
& \\
\hline
\end{tabular}

$2.32 \mathrm{E}+04 \mathrm{DL}$

\begin{tabular}{l|l|l|l|l|}
$5.54 \mathrm{E}-05$ & $1.11 \mathrm{E}-05$ & $5.54 \mathrm{E}+01$ & $1.11 \mathrm{E}+01$ & $2.10 \mathrm{E}-04$ \\
\hline
\end{tabular}

\begin{tabular}{l|l|l|l|l|l|}
$1.56 \mathrm{E}-04 \mathrm{DL}$ & $1.56 \mathrm{E}+02 \mathrm{DL}$
\end{tabular}

\begin{tabular}{ll|l|l|l|l|l|l|l|}
$1.50 \mathrm{E}-03$ & $3.01 \mathrm{E}-04$ & $1.50 \mathrm{E}+03$ & $3.01 \mathrm{E}+02$ & $5.69 \mathrm{E}-03$ \\
\hline
\end{tabular}

$2.86 \mathrm{E}+01 \quad 2.86 \mathrm{E}+07$

$1.08 \mathrm{E}+02$ 


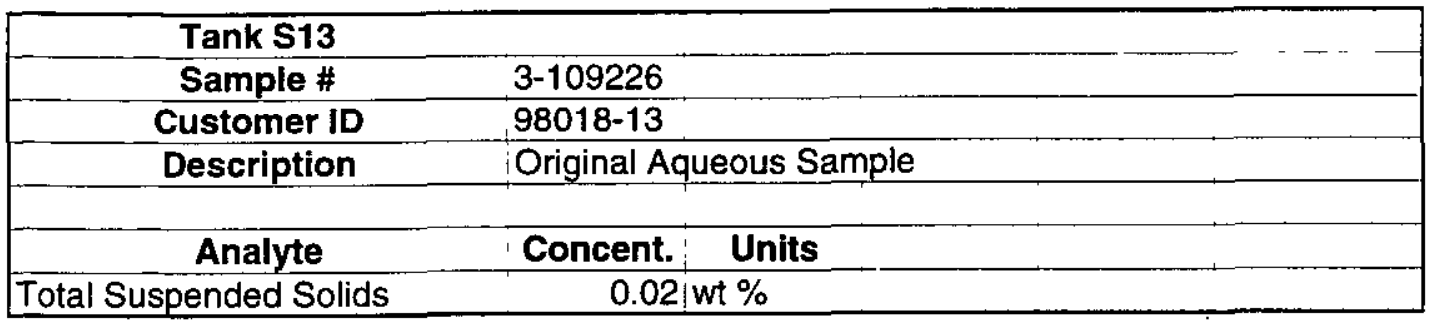

Appendix $\mathrm{J}$

Page J1 


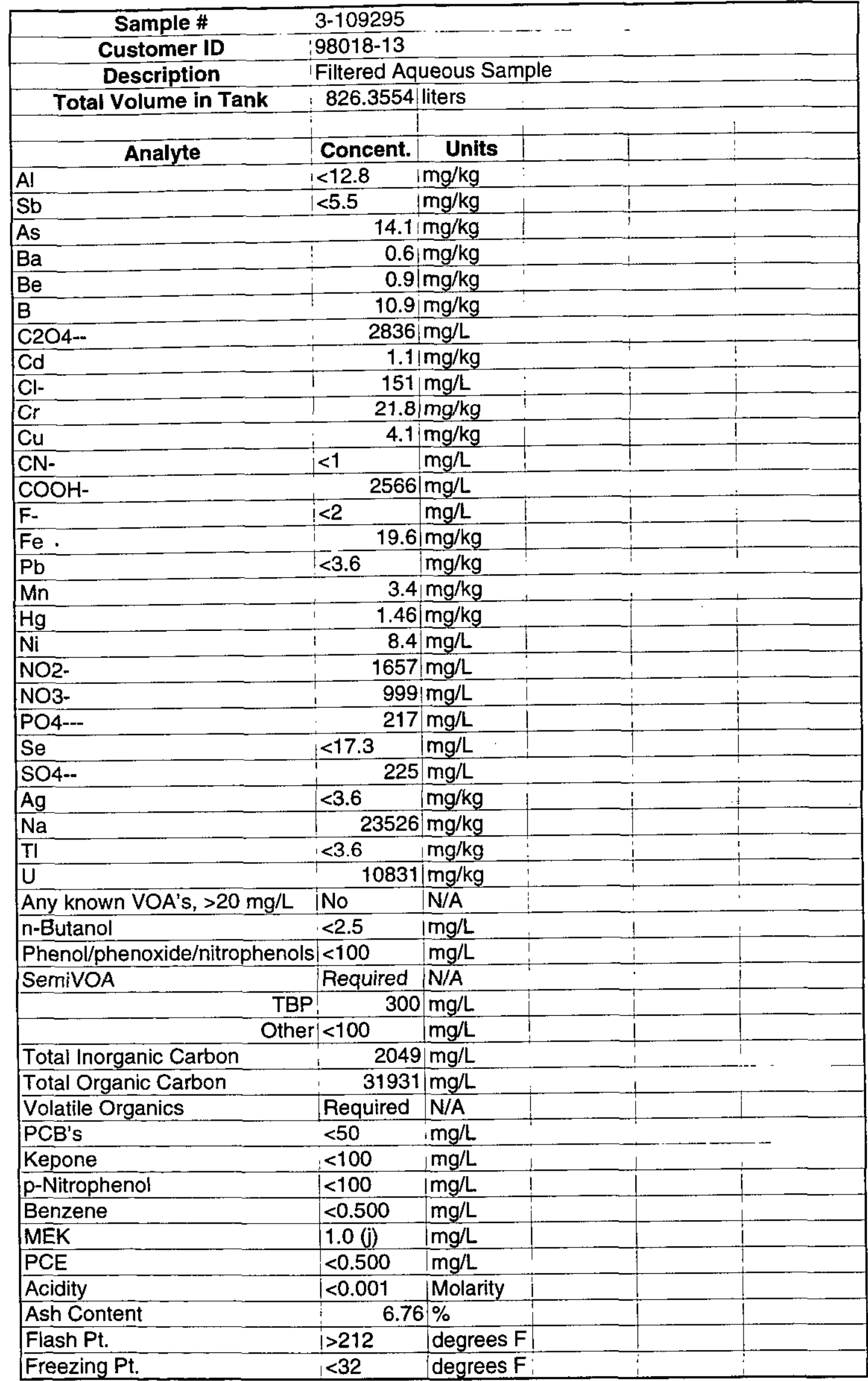




\begin{tabular}{|c|c|c|c|}
\hline Free Liquid? & Yes & & \\
\hline $\mathrm{pH}$ & $8.94 \mid \mathrm{N} / \mathrm{A}$ & & \\
\hline Density & $1.096 \mathrm{~g} / \mathrm{cm} 3$ & & \\
\hline TDS & $15.21^{\prime} \%$ & & \\
\hline Water, wt\% & $80.19 \%$ & & \\
\hline & & & Aqueous \\
\hline & & & Phase \\
\hline & & & Total \\
\hline & Activity & Activity & Activity \\
\hline & $\mathrm{uCi} / \mathbf{m L}$ & pCill & $\mathbf{u C i}$ \\
\hline Total Am & $0.00 \mathrm{E}+00 \mid 0.00 \mathrm{E}+00$ & $0.00 \mathrm{E}+00,0.00 \mathrm{E}+00$ & $0.00 \mathrm{E}+00$ \\
\hline$A m-241$ & 7.52E-04/MDA & $7.52 \mathrm{E}+05 \mid \mathrm{MDA}$ & $6.21 E+02$ \\
\hline $\mathrm{Am}-243$ & 2.32E-04|MDA & $2.32 \mathrm{E}+05 \mathrm{MDA}$ & $1.92 E+02$ \\
\hline C-14 & $2.46 \mathrm{E}-04 \mid \mathrm{UL}$ & $2.46 \mathrm{E}+05 \mid \mathrm{UL}$ & $2.03 E+02$ \\
\hline Ce-144 & 9.37E-04!MDA & $9.37 \mathrm{E}+05 \mathrm{MDA}$ & $7.74 E+02$ \\
\hline Total Cm & \begin{tabular}{ll|l}
$0.00 \mathrm{E}+00$ & $0.00 \mathrm{E}+00$ \\
\end{tabular} & \begin{tabular}{l|l}
$0.00 \mathrm{E}+00$ & $0.00 \mathrm{E}+00$ \\
\end{tabular} & $0.00 E+00$ \\
\hline$\overline{C m}-244$ & $2.26 \mathrm{E}-02$ MDA & $2.26 \mathrm{E}+07 \mid \mathrm{MDA}$ & $1.87 E+04$ \\
\hline $\mathrm{Cm}-245$ & $1.27 \mathrm{E}-01 / \mathrm{DL}$ & 1.27E+08|DL & $1.05 E+05$ \\
\hline $\mathrm{Cm}-246$ & 2.25E-01|DL & $2.25 \mathrm{E}+08 \mathrm{DL}$ & $1.86 E+05$ \\
\hline Co-60 & 1.04E-04, 2.49E-05 & $1.04 \mathrm{E}+05 \quad 2.49 \mathrm{E}+04$ & $8.59 E+01$ \\
\hline Cs-134 & 3.75E-05/MDA & $3.75 \mathrm{E}+04 \mid \mathrm{MDA}$ & $3.10 E+01$ \\
\hline Cs-137 & $1.36 \mathrm{E}-01,4.71 \mathrm{E}-03$ & $1.36 \mathrm{E}+08 ! 4.71 \mathrm{E}+06$ & $1.12 \mathrm{E}+05$ \\
\hline Eu-154 & 1.30E-04 MDA & $1.30 \mathrm{E}+05 \mathrm{MDA}$ & $1.07 E+02$ \\
\hline GA & 7.84E-01 1.57E-01 & $7.84 E+08 \quad 1.57 E+08$ & $6.48 \mathrm{E}+05$ \\
\hline $\mathrm{H}-3$ & 4.91E-04 4.91E-05 & $4.91 E+054.91 E+04$ & $4.06 E+02$ \\
\hline $1-129$ & 1.49E-04 3.30E-05 & 1.49E+05 $3.30 \mathrm{E}+04$ & $1.23 E+02$ \\
\hline $\mathrm{Nb}-94$ & 4.01E-05 MDA & $4.01 \mathrm{E}+04 \mid \mathrm{MDA}$ & $3.31 E+01$ \\
\hline $\mathrm{Ni}-63$ & $1.91 \mathrm{E}-03 \mathrm{UL}$ & $1.91 \mathrm{E}+06 \mid \mathrm{UL}$ & $1.58 \mathrm{E}+03$ \\
\hline GB & 4.50E-01 $1.80 \mathrm{E}-01$ & $4.50 \mathrm{E}+08,1.80 \mathrm{E}+08$ & $3.72 E+05$ \\
\hline Np-237 & $4.91 \mathrm{E}-04 \mid \mathrm{MDA}$ & $4.91 \mathrm{E}+05 \mathrm{MDA}$ & $4.06 E+02$ \\
\hline Total Pu & $9.55 \mathrm{E}-011 \quad 1.71 \mathrm{E}-01_{\mathrm{i}}$ & $9.55 E+08+1.71 E+08$ & $7.89 E+05$ \\
\hline Pu-238 & 7.52E-01 1.50E-01 & $7.52 \mathrm{E}+08+1.50 \mathrm{E}+08$ & $6.21 E+05$ \\
\hline Pu-239 & \begin{tabular}{l|l|}
$4.55 E-02$ & $\mathrm{DL}$ \\
\end{tabular} & 4.55E+07/DL & $3.76 E+04$ \\
\hline Pu-240 & $1.67 \mathrm{E}-01 \mathrm{DL}$ & $1.67 E+08 \mid \mathrm{DL}$ & $1.38 E+05$ \\
\hline Pu-241 & $2.03 \mathrm{E}-01 \quad 8.13 \mathrm{E}-02$ & $2.03 E+0818.13 E+07$ & $1.68 E+05$ \\
\hline Pu-242 & $2.90 \mathrm{E}-03 / \mathrm{DL}$ & $2.90 \mathrm{E}+06 \mid \mathrm{DL}$ & $2.40 \mathrm{E}+03$ \\
\hline Ru-106 & 1.66E-03|MDA & $1.66 \mathrm{E}+06 \mathrm{MDA}$ & $1.37 \bar{E}+03$ \\
\hline$S b-125$ & $6.58 \mathrm{E}-04 \quad 4.33 \mathrm{E}-04$ & $6.58 \mathrm{E}+05 \quad 4.33 \mathrm{E}+05$ & $5.44 \mathrm{E}+02$ \\
\hline Se-79 & 9.01E-04|MDA & $9.01 \mathrm{E}+05 \mathrm{MDA}$ & $7.45 \mathrm{E}+02$ \\
\hline Sn-126 & 4.05E-05IMDA & $4.05 \mathrm{E}+04 \mathrm{MDA}$ & $3.35 E+01$ \\
\hline Sr-90 & 2.84E-02 7.95E-04 & $2.84 E+07 \quad 7.95 E+05$ & $2.35 E+04$ \\
\hline Tc-99 & \begin{tabular}{|l|l|}
$3.15 \mathrm{E}-03$ & $9.02 \mathrm{E}-04$ \\
\end{tabular} & $3.15 E+06,9.02 E+05$ & $2.60 E+03$ \\
\hline Th-232 & $8.06 \mathrm{E}-08 \mid \mathrm{DL}$ & $8.06 \mathrm{E}+01 \mathrm{DL}$ & $6.66 \mathrm{E}-02$ \\
\hline U-233 & $8.60 \mathrm{E}-03 \mid 1.72 \mathrm{E}-03$ & $8.60 E+06: 1.72 E+06$ & $7.11 E+03$ \\
\hline U-234 & \begin{tabular}{|l|l|}
$5.77 \mathrm{E}-03$ & $1.15 \mathrm{E}-03$ \\
\end{tabular} & $5.77 \mathrm{E}+06,1.15 \mathrm{E}+06$ & 4.77E+03 \\
\hline U-235 & \begin{tabular}{|c|c|}
$1.34 \mathrm{E}-04$ & $2.68 \mathrm{E}-05$ \\
\end{tabular} & \begin{tabular}{ll|}
$1.34 E+05$ & $2.68 E+04$ \\
\end{tabular} & $1.11 E+02$ \\
\hline U-236 & $1.72 \mathrm{E}-04 ; 3.43 \mathrm{E}-05_{1}$ & $1.72 E+05 \quad 3.43 E+04$ & $1.42 E+02$ \\
\hline U-238 & \begin{tabular}{|l|l|}
$3.37 E-03$ & $6.75 E-04$ \\
\end{tabular} & 3.37E+06 $6.75 E+05 \mid$ & $2.78 E+03$ \\
\hline TRU & $7.52 E-011$ & $7.52 \mathrm{E}+08$ & $6.21 \mathrm{E}+05$ \\
\hline \multicolumn{4}{|c|}{ MDA = Minimum Detectable Activity for the conditions useo } \\
\hline \multicolumn{4}{|c|}{$\overline{D L}=$ Detection Limit } \\
\hline
\end{tabular}

Appendix $\mathrm{J}$ Page J3 
$\mathrm{j}=$ value is less than the method's PQL for this dilution but above the $6 / 8 / 00$

IDL, and detected in the chromatographic data

Appendix $\mathrm{J}$

Page $\mathrm{J} 4$

TBP $=$ Tributyl Phosphate 


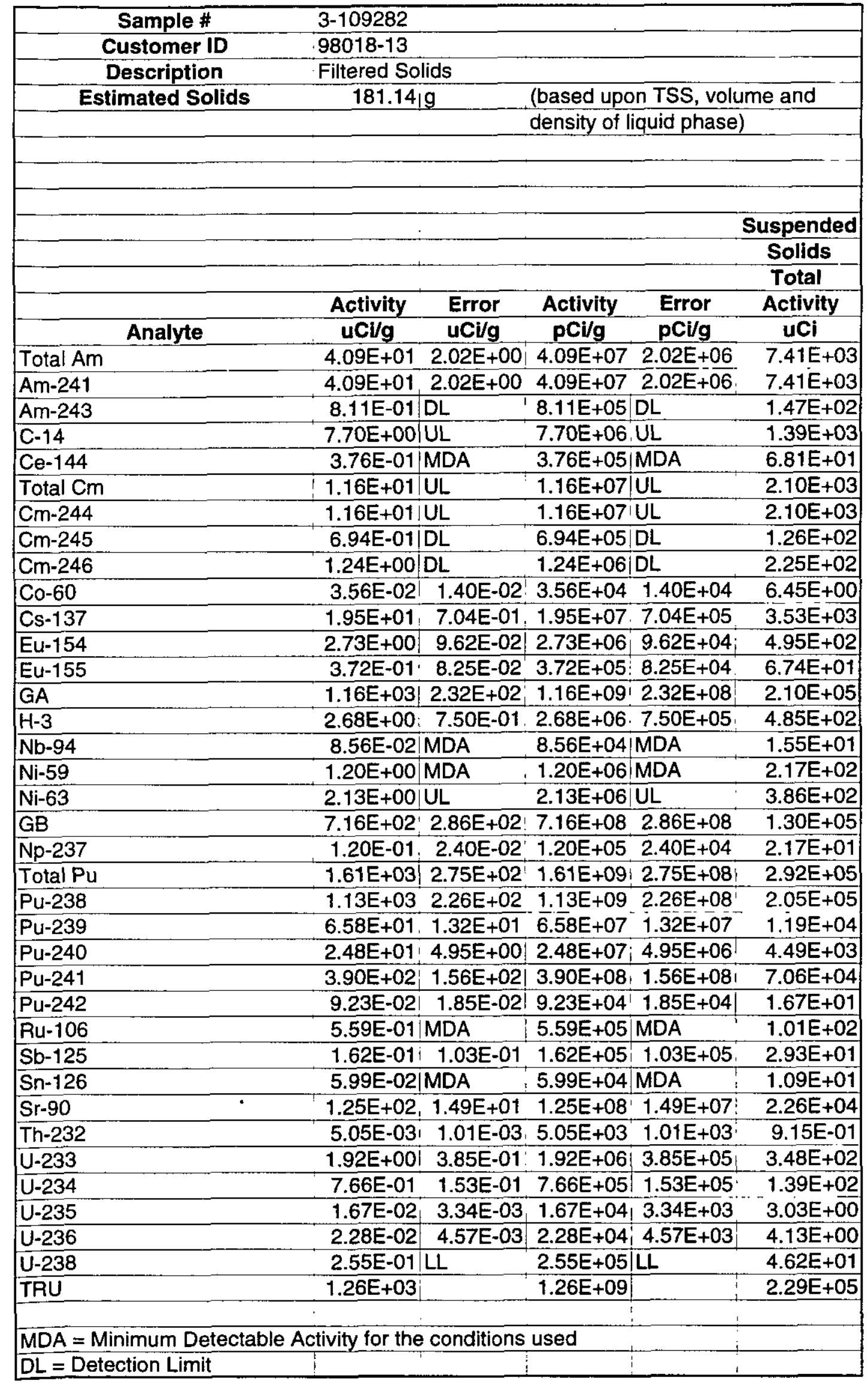

Appendix $\mathrm{J}$

Page J5 

$6 / 8 / 00$

Appendix $\mathrm{J}$

Page J6 


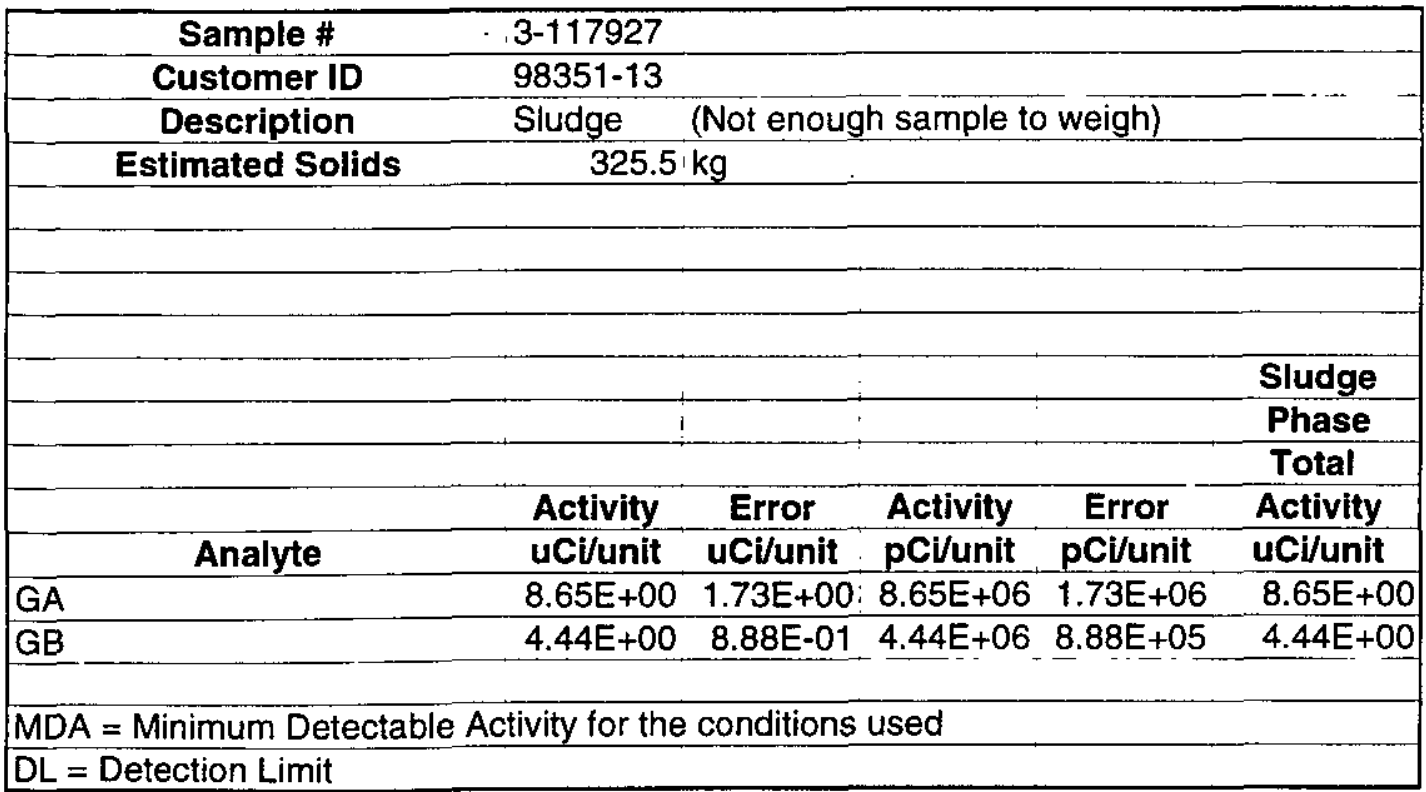

Appendix J

Page J7

$\mathrm{DL}=$ Detection Limit 


\begin{tabular}{|c|c|c|c|c|c|}
\hline Tank S14 & & & & \\
\hline Sample \# & $3-103694$ & & & & \\
\hline Customer ID & $98018-14$ & & & & \\
\hline Description & Original Aqueous Sample & & \\
\hline & & & & & \\
\hline Analyte & Concent. & Units & & & \\
\hline Total Suspended Solids & 0.018 & wt \% & & & \\
\hline
\end{tabular}

Appendix $\mathrm{K}$

Page K1 
$6 / 8 / 00$

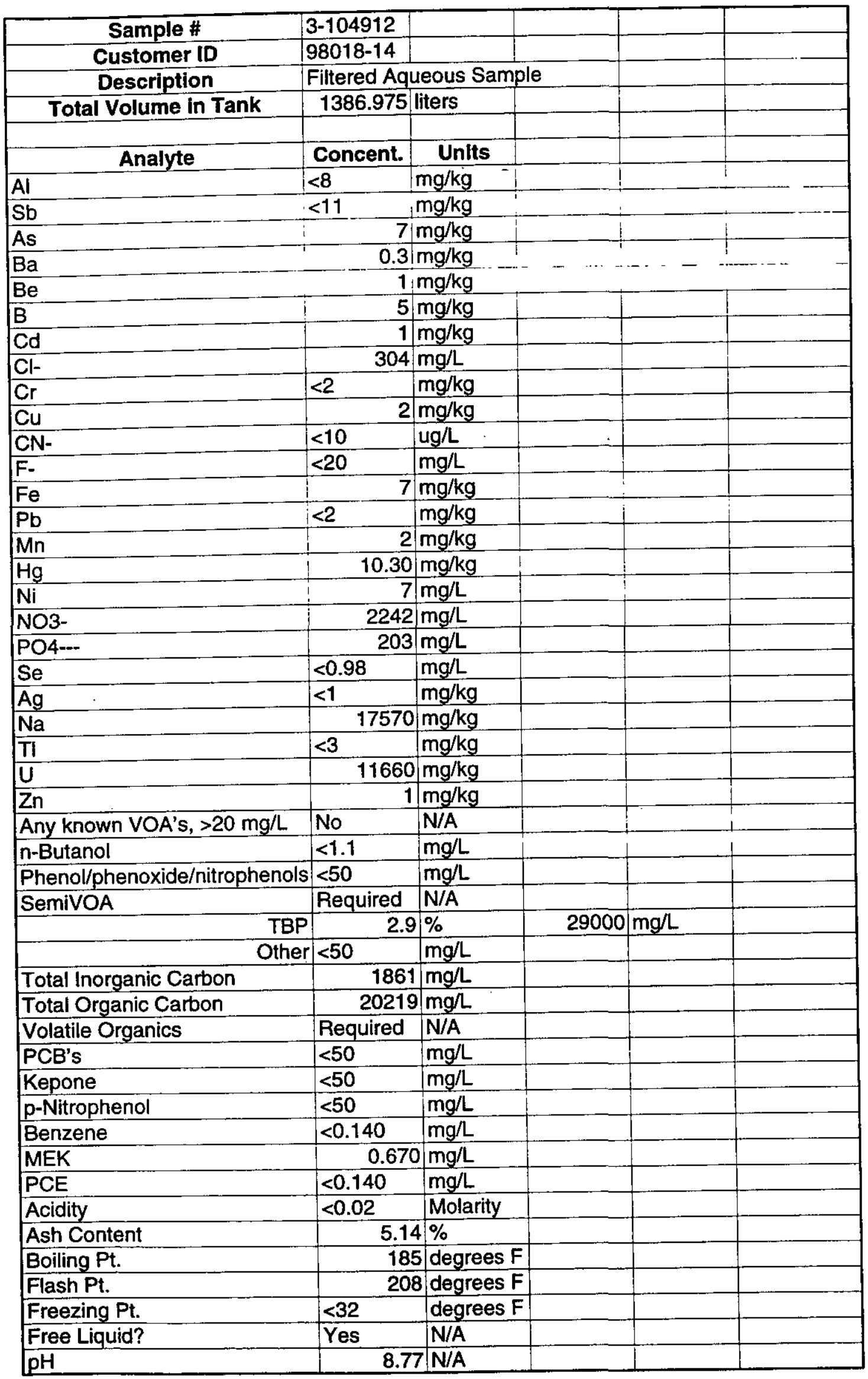




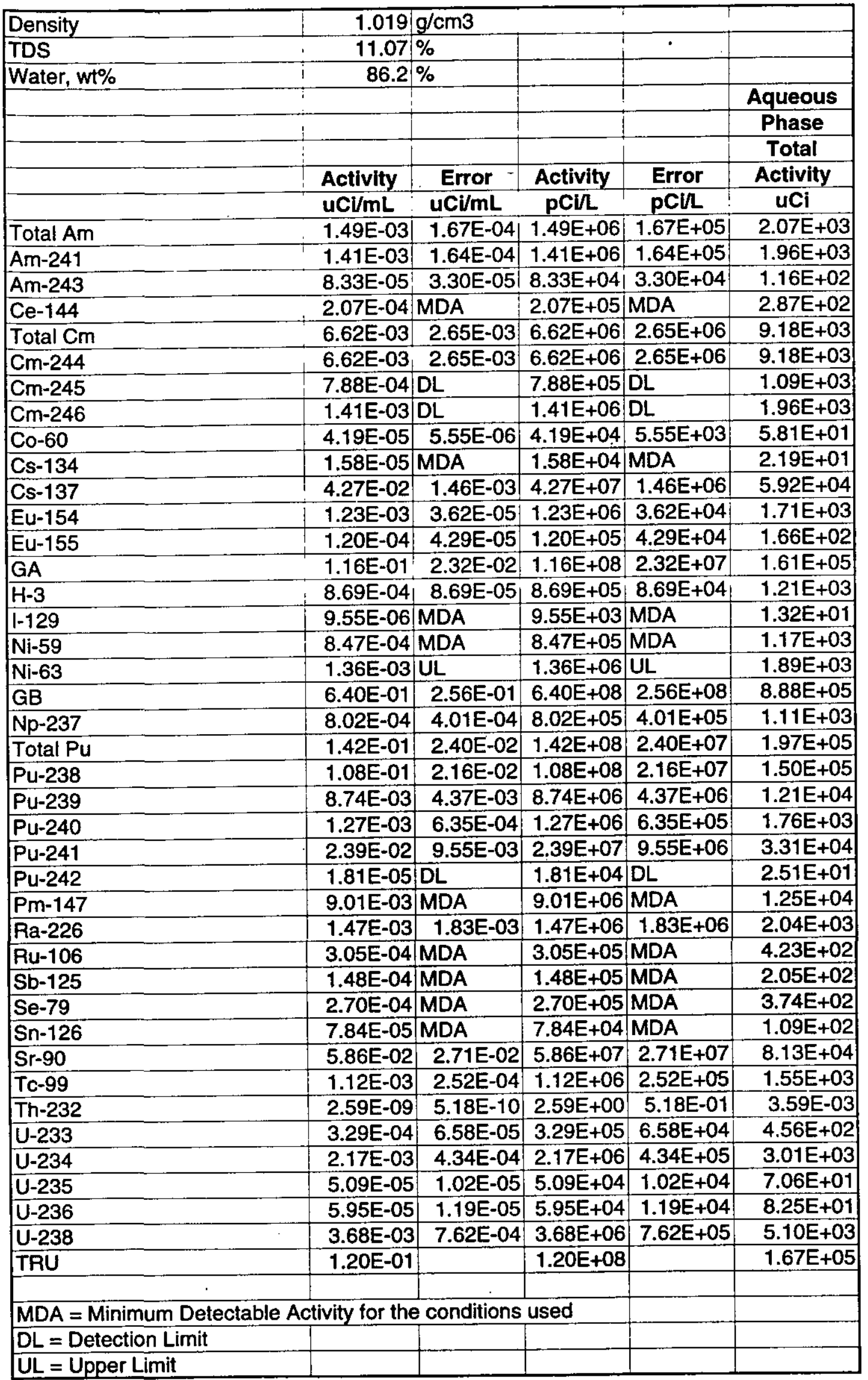

TDS $1.07 \%$

Water, wt\%

$\mathrm{uCl} / \mathrm{mL} \mathrm{uCi} / \mathrm{mL} \quad \mathrm{pCi}$ p pCiL

Aqueous

Phase

Activity

\begin{tabular}{l|c|c|c|c|c|}
$1.49 \mathrm{E}-03$ & $1.67 \mathrm{E}-04$ & $1.49 \mathrm{E}+06$ & $1.67 \mathrm{E}+05$ & $2.07 \mathrm{E}+03$ \\
\hline
\end{tabular}

\begin{tabular}{l|l|l|l|l|}
$1.41 \mathrm{E}-03$ & $1.64 \mathrm{E}-04$ & $1.41 \mathrm{E}+06$ & $1.64 \mathrm{E}+05$ & $1.96 \mathrm{E}+03$ \\
\hline
\end{tabular}

$1.16 \mathrm{E}+02$

2.07E-04 MDA

$2.87 E+02$

\begin{tabular}{|l|l|l|l|l|}
$6.62 \mathrm{E}-03$ & $2.65 \mathrm{E}-03$ & $6.62 \mathrm{E}+06$ & $2.65 \mathrm{E}+06$ & $9.18 \mathrm{E}+03$ \\
\hline
\end{tabular}

$7.88 \mathrm{E}-04 \mid \mathrm{DL}$

$7.88 \mathrm{E}+05 \mathrm{DL}$

$1.09 \mathrm{E}+03$

\begin{tabular}{l|l|l|l|l|}
\hline $4.19 \mathrm{E}-05$ & $5.55 \mathrm{E}-06$ & $4.19 \mathrm{E}+04$ & $5.55 \mathrm{E}+03$ & $5.81 \mathrm{E}+01$ \\
\hline
\end{tabular}

\begin{tabular}{ll|l|l|l|l|}
\hline $4.27 \mathrm{E}-02$ & $1.46 \mathrm{E}-03$ & $4.27 \mathrm{E}+07$ & $1.46 \mathrm{E}+06$ & $5.92 \mathrm{E}+04$ \\
\hline
\end{tabular}

\begin{tabular}{ll|l|l|l|l|}
$1.23 \mathrm{E}-03$ & $3.62 \mathrm{E}-05$ & $1.23 \mathrm{E}+06$ & $3.62 \mathrm{E}+04$ & $1.71 \mathrm{E}+03$ \\
\hline
\end{tabular}

\begin{tabular}{|l|l|l|l|l|}
$1.20 \mathrm{E}-04$ & $4.29 \mathrm{E}-05$ & $1.20 \mathrm{E}+05$ & $4.29 \mathrm{E}+04$ & $1.66 \mathrm{E}+02$ \\
\hline
\end{tabular}

\begin{tabular}{|l|l|l|l|l|}
\hline $1.16 \mathrm{E}-01$ & $2.32 \mathrm{E}-02$ & $1.16 \mathrm{E}+08$ & $2.32 \mathrm{E}+07$ & $1.61 \mathrm{E}+05$ \\
\hline
\end{tabular}

\begin{tabular}{ll|l|l|l|l|l|}
\hline $8.69 \mathrm{E}-04$ & $8.69 \mathrm{E}-05$ & $8.69 \mathrm{E}+05$ & $8.69 \mathrm{E}+04$ & $1.21 \mathrm{E}+03$ \\
\hline
\end{tabular}

\begin{tabular}{l|l|l|l|}
$9.55 \mathrm{E}-06$ & $\mathrm{MDA}$ & $9.55 \mathrm{E}+03 \mathrm{MDA}$
\end{tabular}

\begin{tabular}{l|l|l|l|}
$8.47 E-04$ & $M D A$ & $8.47 E+05$ & $M D A$
\end{tabular}

$1.17 \mathrm{E}+03$

$1.36 \mathrm{E}-03 \mathrm{UL} \quad 1.36 \mathrm{E}+06 \mathrm{UL}$

\begin{tabular}{l|l|l|l|l}
$6.40 \mathrm{E}-01$ & $2.56 \mathrm{E}-01$ & $6.40 \mathrm{E}+08$ & $2.56 \mathrm{E}+08$ \\
\hline
\end{tabular}

$8.88 \mathrm{E}+05$

\begin{tabular}{|l|l|l|l|l|}
\hline $8.02 \mathrm{E}-04$ & $4.01 \mathrm{E}-04$ & $8.02 \mathrm{E}+05$ & $4.01 \mathrm{E}+05$ & $1.11 \mathrm{E}+03$ \\
\hline
\end{tabular}

\begin{tabular}{l|l|l|l|l|}
$1.42 \mathrm{E}-01$ & $2.40 \mathrm{E}-02$ & $1.42 \mathrm{E}+08$ & $2.40 \mathrm{E}+07$ & $1.97 \mathrm{E}+05$ \\
\hline
\end{tabular}

\begin{tabular}{l|l|l|l|l|}
$1.08 \mathrm{E}-01$ & $2.16 \mathrm{E}-02$ & $1.08 \mathrm{E}+08$ & $2.16 \mathrm{E}+07$ & $1.50 \mathrm{E}+05$ \\
\hline
\end{tabular}

\begin{tabular}{|l|l|l|l|l|}
\hline $8.74 \mathrm{E}-03$ & $4.37 \mathrm{E}-03$ & $8.74 \mathrm{E}+06$ & $4.37 \mathrm{E}+06$ & $1.21 \mathrm{E}+04$ \\
\hline
\end{tabular}

\begin{tabular}{|l|l|l|l|l|}
\hline $1.27 \mathrm{E}-03$ & $6.35 \mathrm{E}-04$ & $1.27 \mathrm{E}+06$ & $6.35 \mathrm{E}+05$ & $1.76 \mathrm{E}+03$ \\
\hline
\end{tabular}

\begin{tabular}{l|l|l|l|}
\hline $.39 \mathrm{E}-02$ & $9.55 \mathrm{E}-03$ & $2.39 \mathrm{E}+07$ & $9.55 \mathrm{E}+06$
\end{tabular}

3.31E+04

$1.81 \mathrm{E}-05 \mathrm{DL}$

$1.81 \mathrm{E}+04 \mathrm{DL}$

9.01E-03 MDA $9.01 E+06$ MDA

$1.25 \mathrm{E}+04$

\begin{tabular}{ll|l|l|l|}
\hline $1.47 E-03$ & $1.83 E-03$ & $1.47 E+06$ & $1.83 E+06$ & $2.04 E+03$ \\
\hline
\end{tabular}

\begin{tabular}{|l|l|l|l|}
\hline 3.05E-04 & MDA & $3.05 \mathrm{E}+05$ & $\mathrm{MDA}$ \\
\hline
\end{tabular}

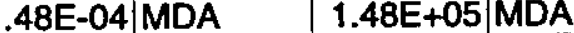

$2.05 E+02$

7.70E-04 MDA

$1.09 E+02$

\begin{tabular}{|l|l|l|l|l|}
\hline $5.86 \mathrm{E}-02$ & $2.71 \mathrm{E}-02$ & $5.86 \mathrm{E}+07$ & $2.71 \mathrm{E}+07$ & $8.13 \mathrm{E}+04$ \\
\hline
\end{tabular}

\begin{tabular}{l|l|l|l|l|}
$1.12 \mathrm{E}-03$ & $2.52 \mathrm{E}-04$ & $1.12 \mathrm{E}+06$ & $2.52 \mathrm{E}+05$ & $1.55 \mathrm{E}+03$ \\
\hline
\end{tabular}

\begin{tabular}{l|l|l|l|l|}
\hline $2.59 \mathrm{E}-09$ & $5.18 \mathrm{E}-10$ & $2.59 \mathrm{E}+00$ & $5.18 \mathrm{E}-01$ & $3.59 \mathrm{E}-03$ \\
\hline
\end{tabular}

\begin{tabular}{|l|l|l|l|l|}
$3.29 \mathrm{E}-04$ & $6.58 \mathrm{E}-05$ & $3.29 \mathrm{E}+05$ & $6.58 \mathrm{E}+04$ & $4.56 \mathrm{E}+02$ \\
\hline
\end{tabular}

\begin{tabular}{|l|l|l|l|l|}
\hline $2.17 \mathrm{E}-03$ & $4.34 \mathrm{E}-04$ & $2.17 \mathrm{E}+06$ & $4.34 \mathrm{E}+05$ & $3.01 \mathrm{E}+03$ \\
\hline
\end{tabular}

\begin{tabular}{|l|l|l|l|l|}
\hline $5.09 \mathrm{E}-05$ & $1.02 \mathrm{E}-05$ & $5.09 \mathrm{E}+04$ & $1.02 \mathrm{E}+04$ & $7.06 \mathrm{E}+01$ \\
\hline
\end{tabular}

\begin{tabular}{|l|l|l|l|l|l|}
\hline $5.95 \mathrm{E}-05$ & $1.19 \mathrm{E}-05$ & $5.95 \mathrm{E}+04$ & $1.19 \mathrm{E}+04$ & $8.25 \mathrm{E}+01$ \\
\hline
\end{tabular}

\begin{tabular}{|l|l|l|l|l|}
\hline $3.68 \mathrm{E}-03$ & $7.62 \mathrm{E}-04$ & $3.68 \mathrm{E}+06$ & $7.62 \mathrm{E}+05$ & $5.10 \mathrm{E}+03$ \\
\hline
\end{tabular}

$1.67 \mathrm{E}+05$ 


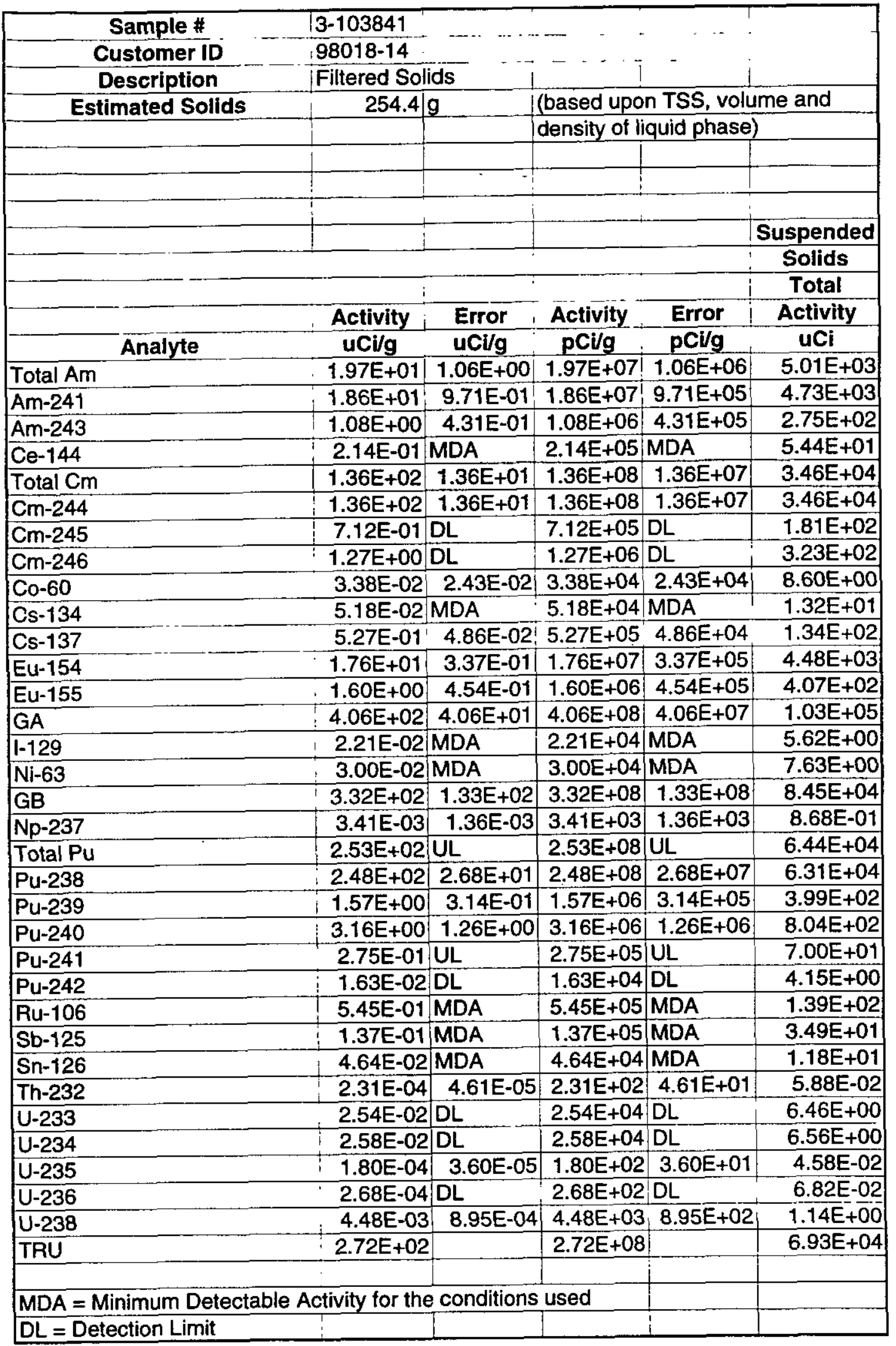




\begin{tabular}{|c|c|c|c|c|c|}
\hline Sample \# & $3-117928$ & & & & \\
\hline Customer ID & $98351-14$ & & & & \\
\hline Description & Sludge & (Not enoug & h sample to & weigh) & \\
\hline Estimated Solids & 896.4 & $\mathrm{~kg}$ & 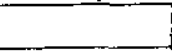 & $\tau$ & \\
\hline & & & & & \\
\hline & & & 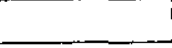 & 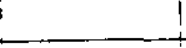 & \\
\hline & & & & & \\
\hline & 1 & & t & 1 & \\
\hline & & & & & Sludge \\
\hline & $!$ & & & & Phase \\
\hline & & & & & Total \\
\hline & Activity & Error & Activity & Error & Activity \\
\hline Analyte & uCi/unit & uCi/unit & $\mathrm{pCl}$ /unit & pCi/unit & uCi/unit \\
\hline$\overline{\mathrm{GA}}$ & $1.36 \mathrm{E}+00$ & 2.73E-01 & $1.36 \mathrm{E}+06$ & $2.73 E+05$ & $1.36 \mathrm{E}+00$ \\
\hline $\mathrm{GB}$ & $1.72 E+00$ & 3.44E-01 & $1.72 \mathrm{E}+06$ & $3.44 \mathrm{E}+05$ & $1.72 E+00$ \\
\hline $\mathrm{DL}=$ Detection Limit & & & & & \\
\hline
\end{tabular}

Appendix $K$

Page K6 


\begin{tabular}{|c|c|c|c|c|c|}
\hline \multicolumn{6}{|l|}{ Tank S15 } \\
\hline Sample \# & 3-118522 & & & & \\
\hline Customer ID & \multicolumn{2}{|l|}{ 98018-15B } & \multicolumn{2}{|c|}{ (98018-15-Sludge) } & \\
\hline \multirow{2}{*}{$\begin{array}{c}\text { Description } \\
\text { Total Mass in Tank }\end{array}$} & Sludge & & & & \\
\hline & 1098527 & grams & \multicolumn{3}{|c|}{ (Not enough sample to weigh) } \\
\hline & & & & & \\
\hline Analyte & Concent. & Units & & & \\
\hline As & 0.3 & $\mu \mathrm{g} / \mathrm{unit}$ & & & \\
\hline $\mathrm{Ba}$ & 18 & $\mu \mathrm{g} /$ /unit & & & \\
\hline$\overline{\mathrm{Cd}}$ & 0.8 & $\mu \mathrm{g} / \mathrm{unit}$ & & & \\
\hline Co & 21 & $\mu g$ /unit & & & \\
\hline $\mathrm{Cr}$ & 9 & $\mu g$ /unit & & & \\
\hline $\mathrm{Pb}$ & 69 & $\mu \mathrm{g} / \mathrm{unit}$ & & & \\
\hline $\mathrm{Hg}$ & 106 & $\mu g /$ unit & & & \\
\hline $\mathrm{Se}$ & 3 & $\mu \mathrm{g} / \mathrm{unit}$ & & & \\
\hline $\mathrm{Ag}$ & 32 & $\mu \mathrm{g} /$ /unit & & & \\
\hline Phenol/phenoxide/nitrophenols & $<100$ & $\mathrm{mg} / \mathrm{kg}$ & & & \\
\hline SemivOA & Required & N/A & & & \\
\hline TBP & 0.76 & $\%$ & 7600 & $\mathrm{mg} / \mathrm{kg}$ & \\
\hline $\mathrm{BAH}$ & 3.2 & $\%$ & 32000 & $\mathrm{mg} / \mathrm{kg}$ & \\
\hline Other & $<100$ & $\mathrm{mg} / \mathrm{kg}$ & & & \\
\hline PCB's & $<10$ & $\mathrm{mg} / \mathrm{kg}$ & & & \\
\hline Kepone & $<100$ & $\mathrm{mg} / \mathrm{kg}$ & & & \\
\hline p-Nitrophenol & $<100$ & $\mathrm{mg} / \mathrm{kg}$ & & & \\
\hline & & & & & Sludge \\
\hline & & & & & Phase \\
\hline & & & & & Total \\
\hline & Activity & Error & Activity & Error & Activity \\
\hline & uCi/unit & uCi/unit & pCi/unit & pCi/unit & uCi/unit \\
\hline Ac-228 & $2.51 E-03$ & $9.68 \mathrm{E}-04$ & $2.51 \mathrm{E}+03$ & $9.68 \mathrm{E}+02$ & 2.51E-03 \\
\hline Total Am & $1.73 E+00$ & 7.94E-02 & $1.73 E+06$ & $7.94 \mathrm{E}+04$ & $1.73 E+00$ \\
\hline Am-241 & $1.65 E+00$ & $7.91 \mathrm{E}-02$ & $1.65 E+06$ & $7.91 \mathrm{E}+04$ & $1.65 \mathrm{E}+00$ \\
\hline Am-243 & $7.75 \mathrm{E}-02$ & $6.35 \mathrm{E}-03$ & $7.75 E+04$ & $6.35 \mathrm{E}+03$ & $7.75 \mathrm{E}-02$ \\
\hline $\mathrm{Ce}-144$ & $2.88 \mathrm{E}-03$ & MDA & $2.88 \mathrm{E}+03$ & MDA & $2.88 \mathrm{E}-03$ \\
\hline Total $\mathrm{Cm}$ & $5.68 \mathrm{E}+01$ & 1.14E+01 & $5.68 \mathrm{E}+07$ & $1.14 \mathrm{E}+07$ & $5.68 \mathrm{E}+01$ \\
\hline $\mathrm{Cm}-244$ & $5.68 \mathrm{E}+01$ & $1.14 E+01$ & $5.68 \mathrm{E}+07$ & $1.14 \mathrm{E}+07$ & $5.68 \mathrm{E}+01$ \\
\hline $\mathrm{Cm}-245$ & $1.20 \mathrm{E}-01$ & $\mathrm{DL}$ & $1.20 \mathrm{E}+05$ & $\mathrm{DL}$ & $1.20 \mathrm{E}-01$ \\
\hline Co-60 & $7.84 \mathrm{E}-04$ & 1.18E-04 & $7.84 E+02$ & $1.18 \mathrm{E}+02$ & 7.84E-04 \\
\hline Cs-134 & 3.59E-04 & MDA & $3.59 E+02$ & MDA & 3.59E-04 \\
\hline Cs-137 & $4.19 \mathrm{E}-01$ & 1.43E-02 & $4.19 \mathrm{E}+05$ & $1.43 \mathrm{E}+04$ & 4.19E-01 \\
\hline Eu-154 & 4.43E-03 & $1.15 \mathrm{E}-03$ & $4.43 E+03$ & $1.15 E+03$ & $4.43 \mathrm{E}-03$ \\
\hline Eu-155 & $6.62 \mathrm{E}-03$ & $8.21 \mathrm{E}-04$ & $6.62 \mathrm{E}+03$ & $8.21 \mathrm{E}+02$ & $6.62 E-03$ \\
\hline GA & $2.76 \mathrm{E}+01$ & $5.51 E+00$ & $2.76 \mathrm{E}+07$ & $5.51 \mathrm{E}+06$ & $2.76 \mathrm{E}+01$ \\
\hline $\mathrm{Nb}-94$ & $6.53 \mathrm{E}-04$ & MDA & $6.53 E+02$ & MDA & $6.53 \mathrm{E}-04$ \\
\hline $\mathrm{GB}$ & $9.28 \mathrm{E}-01$ & UL & $9.28 \mathrm{E}+05$ & UL & $9.28 \mathrm{E}-01$ \\
\hline Np-237 & $7.79 \mathrm{E}-04$ & $1.56 \mathrm{E}-04$ & $7.79 E+02$ & $1.56 \mathrm{E}+02$ & $7.79 \mathrm{E}-04$ \\
\hline Total Pu & $2.09 \mathrm{E}+00$ & $\mathrm{UL}$ & $2.09 \mathrm{E}+06$ & UL & $2.09 \mathrm{E}+00$ \\
\hline Pu-238 & 4.31E-01 & 4.31E-01 & $4.31 E+05$ & $4.31 E+05$ & 4.31E-01 \\
\hline Pu-239 & 5.72E-01 & 1.14E-01 & $5.72 E+05$ & $1.14 \mathrm{E}+05$ & $5.72 E-01$ \\
\hline Pu-240 & $1.59 E-01$ & $3.18 E-02$ & $1.59 E+05$ & $3.18 E+04$ & $1.59 \mathrm{E}-01$ \\
\hline
\end{tabular}




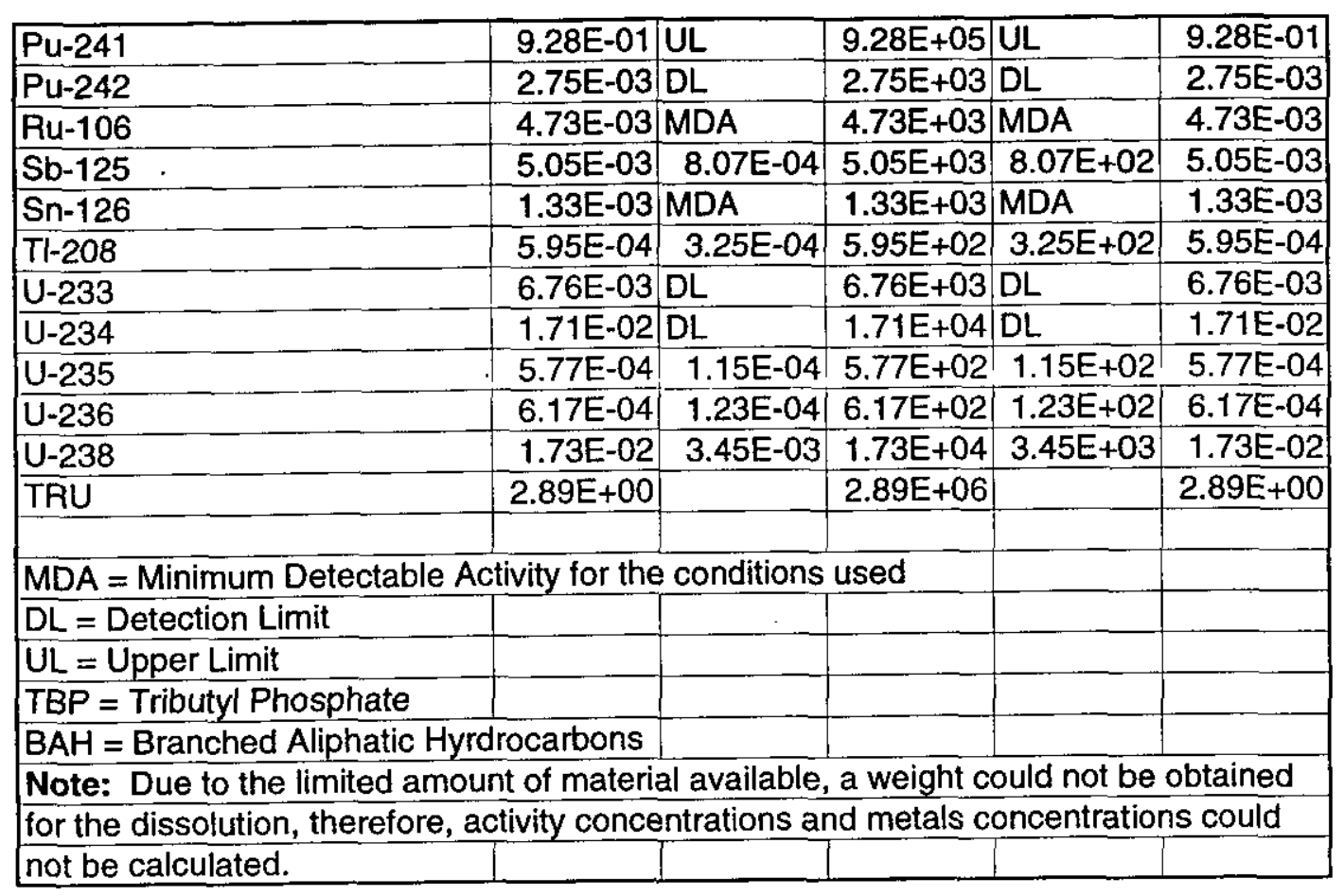




\begin{tabular}{|c|c|c|c|c|c|}
\hline Sample \# & 3-117705 & & \multirow[b]{2}{*}{ 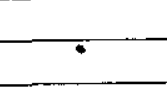 } & & \\
\hline Customer ID & $98351-15$ & & & & \\
\hline Description & Sludge & & & & \\
\hline Total Mass in Tank & 1098527 & \multirow[t]{2}{*}{ grams } & \multicolumn{3}{|c|}{ (Not enough sample to weigh) } \\
\hline & & & & & \\
\hline & & & & & \\
\hline & & & & & $\ldots$ \\
\hline & & & & & \\
\hline & & & & & Sludge \\
\hline & & & & & Phase \\
\hline & & & & & Total \\
\hline & Activity & Error & Activity & Error & Activity \\
\hline Analyte & uCi/unit & uCi/unit & $\mathrm{pCi} /$ unit & pCi/unit & uCi/unit \\
\hline Total Am & $1.02 E-01$ & 6.17E-03 & $1.02 E+05$ & $6.17 \mathrm{E}+03$ & $1.02 \mathrm{E}-01$ \\
\hline Am-241 & $9.77 \mathrm{E}-02$ & $6.14 \mathrm{E}-03$ & 9.77E+04 & $6.14 \mathrm{E}+03$ & 9.77E-02 \\
\hline Am-243 & $4.18 \mathrm{E}-03$ & 6.04E-04 & $4.18 \mathrm{E}+03$ & $6.04 \mathrm{E}+02$ & $4.18 \mathrm{E}-03$ \\
\hline Cs-137 & $9.64 \mathrm{E}-02$ & 4.07E-03 & $9.64 \mathrm{E}+04$ & $4.07 E+03$ & $9.64 \mathrm{E}-02$ \\
\hline Eu-154 & 1.07E-03 & 3.54E-04 & 1.07E+03 & $3.54 \mathrm{E}+02$ & $1.07 \mathrm{E}-03$ \\
\hline $\mathrm{GA}$ & $1.31 \mathrm{E}+00$ & $2.62 \mathrm{E}-01$ & $1.31 E+06$ & $2.62 E+05$ & $1.31 \mathrm{E}+00$ \\
\hline GB & $2.88 \mathrm{E}-01$ & 5.77E-02 & $2.88 \mathrm{E}+05$ & $5.77 \mathrm{E}+04$ & $2.88 \mathrm{E}-01$ \\
\hline & & & & & \\
\hline MDA = Minimum Dete & vity for the & conditions & used & & \\
\hline$\overline{\mathrm{DL}}=$ Detection Limit & & & & & \\
\hline
\end{tabular}




\begin{tabular}{|c|c|c|c|c|c|}
\hline Tank S16 & & & & & \\
\hline Sample \# & 3-119031 & & & & \\
\hline Customer ID & $98351-16 \mathrm{~B}$ & & & & \\
\hline Description & Sludge & & & & \\
\hline Total Mass in Tank & 2066835 & grams & & & \\
\hline & & & & & \\
\hline Analyte & Concent. & Units & & & \\
\hline As & $<16$ & $\mathrm{mg} / \mathrm{kg}$ & & & \\
\hline $\mathrm{Ba}$ & 15 & $\mathrm{mg} / \mathrm{kg}$ & & & \\
\hline $\mathrm{Cd}$ & 4 & $\mathrm{mg} / \mathrm{kg}$ & & & \\
\hline $\mathrm{Cr}$ & 66 & $\mathrm{mg} / \mathrm{kg}$ & & & \\
\hline $\mathrm{Pb}$ & 263 & $\mathrm{mg} / \mathrm{kg}$ & & & \\
\hline $\mathrm{Hg}$ & 79 & $\mathrm{mg} / \mathrm{kg}$ & & & \\
\hline $\mathrm{Se}$ & $<214$ & $\mathrm{mg} / \mathrm{kg}$ & & & \\
\hline $\mathrm{Ag}$ & 17 & $\mathrm{mg} / \mathrm{kg}$ & & & \\
\hline Phenol/phenoxide/nitrophenols & $<100$ & $\mathrm{mg} / \mathrm{kg}$ & & & \\
\hline SemiVOA & Required & N/A & & & \\
\hline TBP & 5.0 & $\%$ & 50000 & $\mathrm{mg} / \mathrm{kg}$ & \\
\hline $\mathrm{BAH}$ & 95 & $\%$ & 950000 & $\mathrm{mg} / \mathrm{kg}$ & \\
\hline Other & $<100$ & $\mathrm{mg} / \mathrm{kg}$ & & & \\
\hline Kepone & $<100$ & $\mathrm{mg} / \mathrm{kg}$ & & & \\
\hline p-Nitrophenol & $<100$ & $\mathrm{mg} / \mathrm{kg}$ & & & \\
\hline & & & & & Sludge \\
\hline & & & & & Phase \\
\hline & & & & & Total \\
\hline & Activity & Error & Activity & Error & Activity \\
\hline & $\mathrm{uCl} / \mathrm{g}$ & uCi/g & $\mathrm{pCl} / \mathrm{g}$ & $\mathrm{pCl} / \mathrm{g}$ & $\mathrm{uCl}$ \\
\hline Total Am & $1.24 \mathrm{E}-02$ & $6.99 E-04$ & $1.24 \mathrm{E}+04$ & $6.99 \mathrm{E}+02$ & $2.56 \mathrm{E}+04$ \\
\hline Am-241 & 1.24E-02 & $6.99 \mathrm{E}-04$ & $1.24 \mathrm{E}+04$ & $6.99 \mathrm{E}+02$ & $2.56 E+04$ \\
\hline$A m-243$ & $1.31 E+00$ & $\mathrm{DL}$ & $1.31 E+06$ & $D L$ & $2.71 \mathrm{E}+06$ \\
\hline $\mathrm{Ce}-144$ & $7.52 \mathrm{E}-03$ & MDA & $7.52 \mathrm{E}+03$ & MDA & $1.55 \mathrm{E}+04$ \\
\hline Total $\mathrm{Cm}$ & $0.00 \mathrm{E}+00$ & $0.00 \mathrm{E}+00$ & $0.00 \mathrm{E}+00$ & $0.00 \mathrm{E}+00$ & $0.00 \mathrm{E}+00$ \\
\hline $\mathrm{Cm}-244$ & $5.32 E+02$ & $\mathrm{DL}$ & $5.32 E+08$ & $\mathrm{DL}$ & $1.10 \mathrm{E}+09$ \\
\hline Cm-245 & $1.13 E+00$ & DL & $1.13 E+06$ & $\overline{D L}$ & $2.34 \mathrm{E}+06$ \\
\hline $\mathrm{Cm}-246$ & $2.00 \mathrm{E}+00$ & $\mathrm{DL}$ & $2.00 E+06$ & DL & $4.13 E+06$ \\
\hline Co-60 & $1.14 \mathrm{E}-03$ & MDA & $1.14 \mathrm{E}+03$ & MDA & $2.36 E+03$ \\
\hline Cs-134 & $1.03 \mathrm{E}-03$ & MDA & $1.03 E+03$ & MDA & $2.13 E+03$ \\
\hline Cs-137 & 1.11E-01 & 6.67E-03 & $1.11 E+05$ & $6.67 E+03$ & 2.29E+05 \\
\hline Eu-154 & $5.99 E-03$ & $1.44 \mathrm{E}-03$ & $5.99 E+03$ & $1.44 \mathrm{E}+03$ & $1.24 \mathrm{E}+04$ \\
\hline GA & $1.73 E+00$ & $3.47 \mathrm{E}-01$ & $1.73 E+06$ & $3.47 \mathrm{E}+05$ & $3.58 E+06$ \\
\hline $\mathrm{Nb}-94$ & $1.60 \mathrm{E}-03$ & MDA & $1.60 \mathrm{E}+03$ & MDA & $3.31 \mathrm{E}+03$ \\
\hline GB & $2.25 E+00$ & $4.50 \mathrm{E}-01$ & $2.25 E+06$ & $4.50 \mathrm{E}+05$ & $4.65 E+06$ \\
\hline Np-237 & $3.15 \mathrm{E}-03$ & MDA & $3.15 \mathrm{E}+03$ & MDA & $6.51 E+03$ \\
\hline Total $\mathrm{Pu}$ & $2.42 E+00$ & UL & $2.42 \mathrm{E}+06$ & UL & $5.00 \mathrm{E}+06$ \\
\hline Pu-238 & $7.39 \mathrm{E}-01$ & $2.95 E-01$ & $7.39 \mathrm{E}+05$ & $2.95 E+05$ & $1.53 E+06$ \\
\hline Pu-239 & $7.16 \mathrm{E}-01$ & $1.43 E-01$ & $7.16 \mathrm{E}+05$ & $1.43 E+05$ & $1.48 \mathrm{E}+06$ \\
\hline Pu-240 & $1.49 E+00$ & $\mathrm{DL}$ & $1.49 E+06$ & $\mathrm{DL}$ & $3.08 \mathrm{E}+06$ \\
\hline $\mathrm{Pu}-241$ & 9.64E-01 & $\mathrm{UL}$ & $9.64 \mathrm{E}+05$ & $\mathrm{UL}$ & $1.99 E+06$ \\
\hline $\mathrm{Pu}-242$ & $2.58 \mathrm{E}-02$ & $\mathrm{DL}$ & $2.58 \mathrm{E}+04$ & $\overline{D L}$ & $5.33 E+04$ \\
\hline$R u-106$ & 1.37E-02 & MDA & $1.37 E+04$ & MDA & $2.83 E+04$ \\
\hline Sb-125 & $5.68 \mathrm{E}-03$ & MDA & $5.68 \mathrm{E}+03$ & MDA & 1.17E+04 \\
\hline
\end{tabular}




\begin{tabular}{|l|l|l|l|l|l|}
\hline $\mathrm{Sn}-126$ & $3.50 \mathrm{E}-03$ & $\mathrm{MDA}$ & $3.50 \mathrm{E}+03$ & $\mathrm{MDA}$ & $7.23 \mathrm{E}+03$ \\
\hline $\mathrm{Th}-232$ & $7.16 \mathrm{E}-07$ & $\mathrm{DL}$ & $7.16 \mathrm{E}-01$ & $\mathrm{DL}$ & $1.48 \mathrm{E}+00$ \\
\hline $\mathrm{U}-233$ & $6.31 \mathrm{E}-02$ & $\mathrm{DL}$ & $6.31 \mathrm{E}+04$ & $\mathrm{DL}$ & $1.30 \mathrm{E}+05$ \\
\hline $\mathrm{U}-234$ & $4.08 \mathrm{E}-02$ & $\mathrm{DL}$ & $4.08 \mathrm{E}+04$ & $\mathrm{DL}$ & $8.43 \mathrm{E}+04$ \\
\hline $\mathrm{U}-235$ & $8.87 \mathrm{E}-04$ & $1.77 \mathrm{E}-04$ & $8.87 \mathrm{E}+02$ & $1.77 \mathrm{E}+02$ & $1.83 \mathrm{E}+03$ \\
\hline $\mathrm{U}-236$ & $9.23 \mathrm{E}-04$ & $1.85 \mathrm{E}-04$ & $9.23 \mathrm{E}+02$ & $1.85 \mathrm{E}+02$ & $1.91 \mathrm{E}+03$ \\
\hline $\mathrm{U}-238$ & $2.54 \mathrm{E}-02$ & $5.08 \mathrm{E}-03$ & $2.54 \mathrm{E}+04$ & $5.08 \mathrm{E}+03$ & $5.25 \mathrm{E}+04$ \\
\hline $\mathrm{TRU}$ & $1.47 \mathrm{E}+00$ & & $1.47 \mathrm{E}+06$ & & $3.03 \mathrm{E}+06$ \\
\hline & & & & & \\
\hline $\mathrm{MDA}=$ Minimum Detectable Activity for the conditions used & & \\
\hline $\mathrm{DL}=$ Detection Limit & & & & & \\
\hline $\mathrm{UL}=$ Upper Limit & & & & & \\
\hline TBP $=$ Tributyl Phosphate & & & & & \\
\hline BAH = Branched Aliphatic Hyrdrocarbons & & & & \\
\hline
\end{tabular}

Appendix $\mathrm{M}$

Page M2 
Revision 2

$6 / 8 / 00$

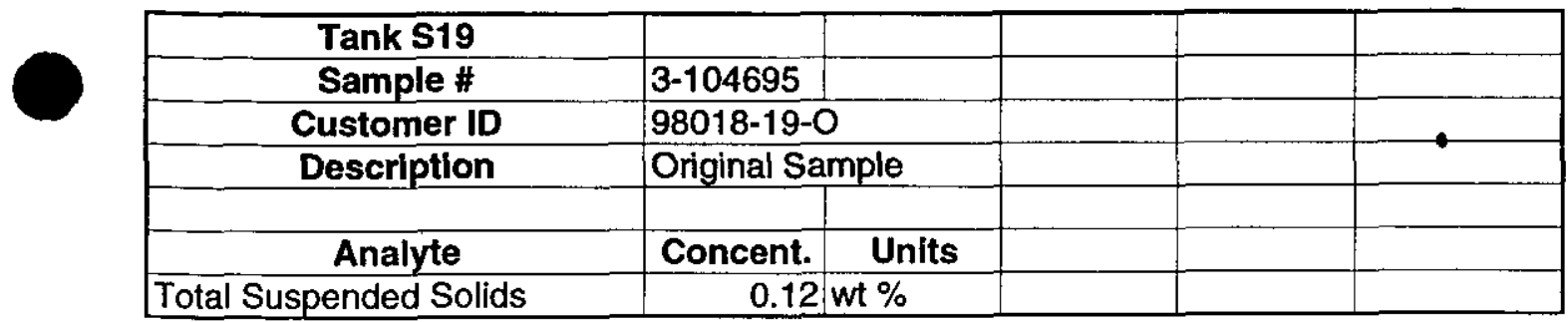




\begin{tabular}{|c|c|c|c|c|c|}
\hline Sample \# & 3-104922 & & & & \\
\hline Customer ID & 98018-19-0 & & & & \\
\hline Description & Filtered Top & p Sample & & & \\
\hline Total Volume in Tank & 2170.555 & liters & (Assumes a & all liquic & aqueous) \\
\hline Analyte & Concent. & Units & & & \\
\hline $\mathrm{Al}$ & 22 & $\mathrm{mg} / \mathrm{kg}$ & & & \\
\hline $\mathrm{Sb}$ & $<8$ & $\mathrm{mg} / \mathrm{kg}$ & & & \\
\hline As & $<0.091$ & $\mathrm{mg} / \mathrm{kg}$ & & & \\
\hline $\mathrm{Ba}$ & 11 & $\mathrm{mg} / \mathrm{kg}$ & & & \\
\hline $\mathrm{Be}$ & 11 & $\mathrm{mg} / \mathrm{kg}$ & & & \\
\hline$B$ & 18 i & $\mathrm{mg} / \mathrm{kg}$ & & & \\
\hline $\mathrm{Cd}$ & 1 & $\mathrm{mg} / \mathrm{kg}$ & & & \\
\hline $\mathrm{Cl}-$ & 298 & $\mathrm{mg} / \mathrm{L}$ & & & \\
\hline $\mathrm{Cr}$ & 3 & $\mathrm{mg} / \mathrm{kg}$ & & & \\
\hline $\mathrm{Cu}$ & $<=3$ & $\mathrm{mg} / \mathrm{kg}$ & & & \\
\hline $\mathrm{CN}-$ & $<10$ & ug/L & & & \\
\hline F- & $<20$ & $\mathrm{mg} / \mathrm{L}$ & & & \\
\hline $\mathrm{Fe}$ & 16 & $\mathrm{mg} / \mathrm{kg}$ & & & \\
\hline $\mathrm{Pb}$ & 4 & $\mathrm{mg} / \mathrm{kg}$ & & & \\
\hline $\mathrm{Mn}$ & 8 & $\mathrm{mg} / \mathrm{kg}$ & & & \\
\hline $\mathrm{Hg}$ & 0.24 & $\mathrm{mg} / \mathrm{kg}$ & & & \\
\hline $\mathrm{Ni}$ & 9.8 & $\mathrm{mg} / \mathrm{L}$ & & & \\
\hline NO3- & 94 & $\mathrm{mg} / \mathrm{L}$ & & & \\
\hline PO4--. & 1350 & $\mathrm{mg} / \mathrm{L}$ & & & \\
\hline $\mathrm{Se}$ & $<0.91$ & $\mathrm{mg} / \mathrm{L}$ & & & \\
\hline $\mathrm{Ag}$ & $<3$ & $\mathrm{mg} / \mathrm{kg}$ & & & \\
\hline $\mathrm{Na}$ & 38206 & $\mathrm{mg} / \mathrm{kg}$ & & & \\
\hline TI & $<=4$ & $\mathrm{mg} / \mathrm{kg}$ & & & \\
\hline $\mathrm{U}$ & 14237 & $\mathrm{mg} / \mathrm{kg}$ & & & \\
\hline$\overline{Z n}$ & 2 & $\mathrm{mg} / \mathrm{kg}$ & & & \\
\hline Any known VOA's, $>20 \mathrm{mg} / \mathrm{L}$ & No & N/A & & & \\
\hline n-Butanol & $<1.1$ & $\mathrm{mg} / \mathrm{L}$ & & & \\
\hline Phenol/phenoxide/nitrophenols & $<50$ & $\mathrm{mg} / \mathrm{L}$ & & & \\
\hline SemiVOA & Required & N/A & & & \\
\hline TBP & 3.4 & $\%$ & 34000 & $\mathrm{mg} / \mathrm{L}$ & \\
\hline Other & $<50$ & $\mathrm{mg} / \mathrm{L}$ & & & \\
\hline Total Inorganic Carbon & 4460 & $\mathrm{mg} / \mathrm{L}$ & & & \\
\hline Total Organic Carbon & 79390 & $\mathrm{mg} / \mathrm{L}$ & & & \\
\hline Volatile Organics & Required & N/A & & & \\
\hline PCB's & $<50$ & $\mathrm{mg} / \mathrm{L}$ & & & \\
\hline Kepone & $<50$ & $\mathrm{mg} / \mathrm{L}$ & & & \\
\hline p-Nitrophenol & $<50$ & $\mathrm{mg} / \mathrm{L}$ & & & \\
\hline Benzene & $0.067(j)$ & $\mathrm{mg} / \mathrm{L}$ & & & \\
\hline MEK & 2.4 & $\mathrm{mg} / \mathrm{L}$ & & & \\
\hline PCE & $<0.140$ & $\overrightarrow{m g} / \mathrm{L}$ & & & \\
\hline Acidity & $<0.02$ & Molarity & & & \\
\hline Ash Content & 4.06 & $\%$ & & & \\
\hline Boiling Pt. & 159.8 & degrees $F$ & & & \\
\hline Flash Pt. & 198 & degrees $F$ & & & \\
\hline Freezing Pt. & $<32$ & degrees $F$ & & & \\
\hline Free Liquid? & Yes & N/A & & & \\
\hline $\mathrm{pH}$ & 10.02 & N/A & & & \\
\hline
\end{tabular}




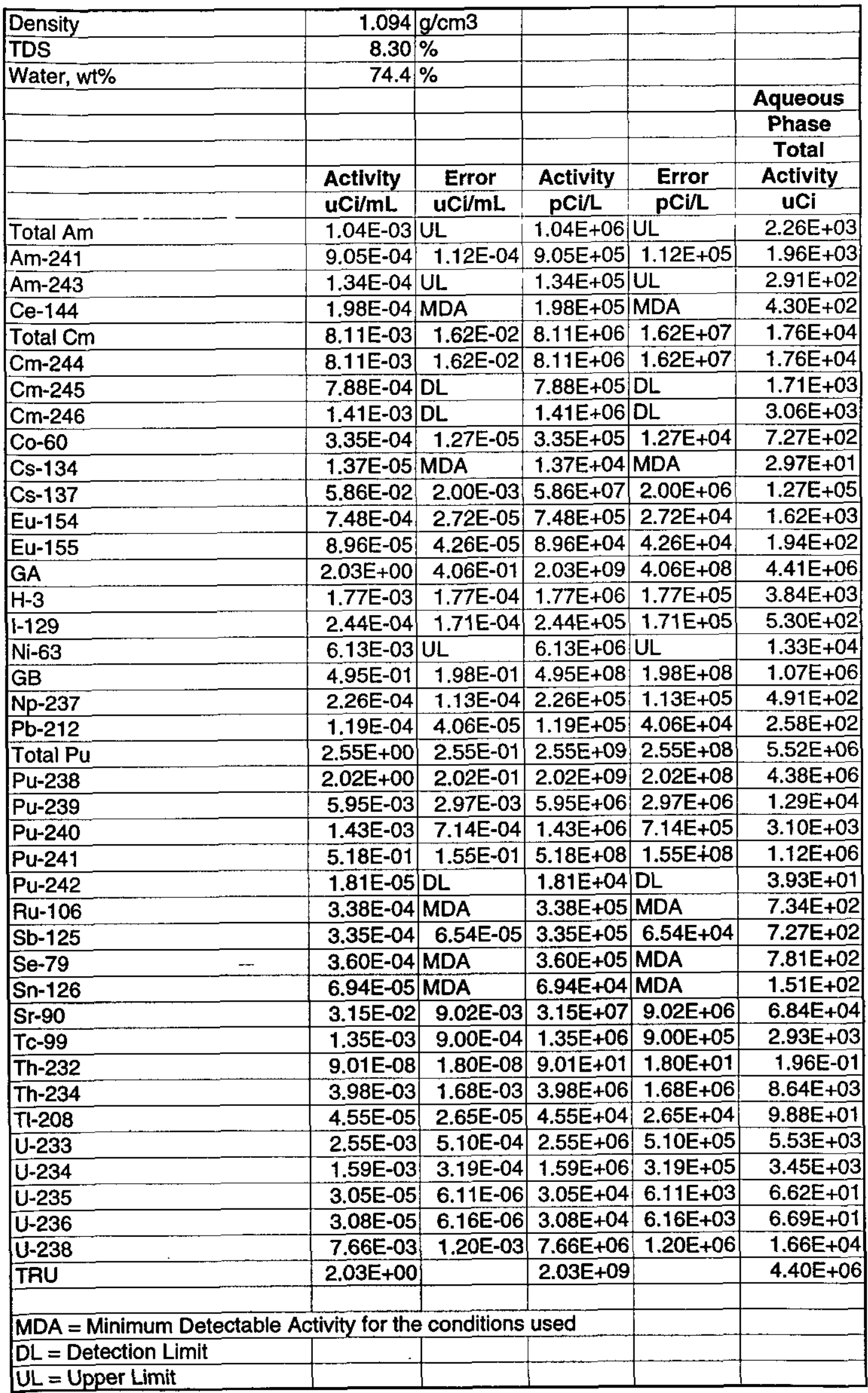

TDS $8.30 \%$

Water, wt\% 
$6 / 8 / 00$

$a=$ compound present but below quantitation limit Appendix $\mathrm{N}$

$\mathrm{j}=$ value is less than the method's PQL for this dilution but above the

Page N4

IDL, and detected in the chromatographic data

TBP $=$ Tributyl Phosphate 


\begin{tabular}{|c|c|c|c|c|c|}
\hline Sample \# & 3-104932 & & & & \\
\hline Customer ID & 98018-19-0 & & & & \\
\hline Description & Filtered Soli & lids & & & \\
\hline \multirow[t]{9}{*}{ Estimated Solids } & \multicolumn{2}{|c|}{$2849.5 \mathrm{~g}$} & \multicolumn{3}{|c|}{ (based upon TSS, volume and } \\
\hline & & & \multicolumn{3}{|c|}{ density of liquid phase) } \\
\hline & & & & & \\
\hline & & & & & \\
\hline & & & & & \\
\hline & & & & & Suspended \\
\hline & & & & & Solids \\
\hline & & & & & Total \\
\hline & Activity & Error & Activity & Error & Activity \\
\hline Analyte & uCi/g & $\mathrm{uCi} / \mathrm{g}$ & $\mathrm{pCi} / \mathrm{g}$ & $\mathrm{pCi} / \mathrm{g}$ & $\mathrm{uCi}$ \\
\hline Total Am & $4.69 \mathrm{E}+00$ & $4.55 \mathrm{E}-01$ & $4.69 E+06$ & $4.55 E+05$ & $1.33 E+04$ \\
\hline Am-241 & $4.14 \mathrm{E}+00$ & $4.43 E-01$ & $4.14 \mathrm{E}+06$ & $4.43 E+05$ & $1.18 E+04$ \\
\hline Am-243 & $5.45 \mathrm{E}-01$ & $1.05 \mathrm{E}-01$ & $5.45 \mathrm{E}+05$ & $1.05 \mathrm{E}+05$ & $1.55 E+03$ \\
\hline $\mathrm{Ce}-144$ & 3.33E-01 & MDA & $3.33 \mathrm{E}+05$ & MDA & $9.49 \mathrm{E}+02$ \\
\hline Total Cm & $1.18 \mathrm{E}+02$ & $1.18 \mathrm{E}+01$ & $1.18 \mathrm{E}+08$ & $1.18 \mathrm{E}+07$ & $3.36 \mathrm{E}+05$ \\
\hline $\mathrm{Cm}-244$ & $1.18 \mathrm{E}+02$ & $1.18 \mathrm{E}+01$ & $1.18 \mathrm{E}+08$ & $1.18 \mathrm{E}+07$ & $3.36 E+05$ \\
\hline Cm-245 & $9.50 \mathrm{E}-01$ & DL & $9.50 \mathrm{E}+05$ & $D L$ & $2.71 E+03$ \\
\hline Cm-246 & $1.69 \mathrm{E}+00$ & $\mathrm{DL}$ & $1.69 \mathrm{E}+06$ & $\mathrm{DL}$ & $4.82 E+03$ \\
\hline Co-60 & $6.58 \mathrm{E}-02$ & MDA & $6.58 \mathrm{E}+04$ & MDA & $1.87 E+02$ \\
\hline Cs-134 & $7.21 \mathrm{E}-02$ & MDA & $7.21 E+04$ & MDA & $2.05 E+02$ \\
\hline Cs-137 & $5.72 \mathrm{E}-01$ & $9.60 \mathrm{E}-02$ & $5.72 E+05$ & $9.60 E+04$ & $1.63 E+03$ \\
\hline Eu-154 & $2.73 \mathrm{E}+00$ & $2.53 E-01$ & $2.73 E+06$ & $2.53 E+05$ & $7.78 E+03$ \\
\hline GA & $2.22 E+02$ & $2.22 E+01$ & $2.22 E+08$ & $2.22 \mathrm{E}+07$ & $6.33 E+05$ \\
\hline $\mathrm{H}-3$ & $5.81 \mathrm{E}-02$ & MDA & $5.81 \mathrm{E}+04$ & MDA & $1.66 \mathrm{E}+02$ \\
\hline $1-129$ & $2.98 \mathrm{E}-02$ & MDA & $2.98 \mathrm{E}+04$ & MDA & $8.49 E+01$ \\
\hline $\mathrm{Ni}-59$ & $9.14 \mathrm{E}-02$ & MDA & $9.14 \mathrm{E}+04$ & MDA & $2.60 E+02$ \\
\hline $\mathrm{Ni}-63$ & $1.77 \mathrm{E}-01$ & UL & $1.77 E+05$ & UL & $5.04 \mathrm{E}+02$ \\
\hline GB & $1.72 \mathrm{E}+01$ & $6.86 \mathrm{E}+00$ & $1.72 E+07$ & $6.86 \mathrm{E}+06$ & $4.90 E+04$ \\
\hline Np-237 & $9.10 \mathrm{E}-01$ & 3.42E-01 & $9.10 \mathrm{E}+05$ & $3.42 \mathrm{E}+05$ & $2.59 E+03$ \\
\hline Total $\mathrm{Pu}$ & $1.26 \mathrm{E}+02$ & $1.30 \mathrm{E}+01$ & $1.26 \mathrm{E}+08$ & $1.30 \mathrm{E}+07$ & $3.58 \mathrm{E}+05$ \\
\hline $\mathrm{Pu}-238$ & $9.19 \mathrm{E}+01$ & $9.19 \mathrm{E}+00$ & $9.19 \mathrm{E}+07$ & $9.19 \mathrm{E}+06$ & $2.62 \mathrm{E}+05$ \\
\hline Pu-239 & $2.21 E+00$ & $4.41 \mathrm{E}-01$ & $2.21 \mathrm{E}+06$ & $4.41 \mathrm{E}+05$ & $6.30 E+03$ \\
\hline $\mathrm{Pu}-240$ & $2.92 \mathrm{E}+00$ & 5.85E-01 & $2.92 \mathrm{E}+06$ & $5.85 \mathrm{E}+05$ & $8.32 E+03$ \\
\hline $\mathrm{Pu}-241$ & $2.86 \mathrm{E}+01$ & $9.15 \mathrm{E}+00$ & $2.86 E+07$ & $9.15 \mathrm{E}+06$ & $8.15 E+04$ \\
\hline $\mathrm{Pu}-242$ & $2.18 E-02$ & $\mathrm{DL}$ & $2.18 \mathrm{E}+04$ & $\mathrm{DL}$ & $6.21 \mathrm{E}+01$ \\
\hline Ru-106 & 8.47E-01 & MDA & $8.47 E+05$ & MDA & $2.41 E+03$ \\
\hline$S b-125$ & $1.93 E-01$ & MDA & $1.93 E+05$ & MDA & $5.50 \mathrm{E}+02$ \\
\hline Se-79 & $5.14 \mathrm{E}-02$ & MDA & $5.14 \mathrm{E}+04$ & MDA & $1.46 E+02$ \\
\hline Sn-126 & $2.13 \mathrm{E}-01$ & MDA & $2.13 E+05$ & MDA & $6.07 E+02$ \\
\hline Sr-90 & $1.73 E+01$ & $2.73 E+00$ & $1.73 E+07$ & $2.73 E+06$ & $4.93 E+04$ \\
\hline Tc-99 & $1.19 \mathrm{E}-01$ & MDA & $1.19 E+05$ & MDA & $3.39 E+02$ \\
\hline Th-232 & $2.20 \mathrm{E}-04$ & $4.41 \mathrm{E}-05$ & $2.20 \mathrm{E}+02$ & $4.41 E+01$ & 6.27E-01 \\
\hline U-233 & $3.93 \mathrm{E}-02$ & 1.57E-02 & $3.93 E+04$ & $1.57 E+04$ & $1.12 \mathrm{E}+02$ \\
\hline U-234 & $6.85 \mathrm{E}-02$ & 1.37E-02 & $6.85 \mathrm{E}+04$ & $1.37 E+04$ & $1.95 \mathrm{E}+02$ \\
\hline U-235 & $1.90 \mathrm{E}-03$ & 3.79E-04 & $1.90 \mathrm{E}+03$ & $3.79 \mathrm{E}+02$ & $5.41 E+00$ \\
\hline U-236 & $1.59 \mathrm{E}-03$ & 3.19E-04 & $1.59 E+03$ & $3.19 E+02$ & $4.53 E+00$ \\
\hline U-238 & 4.59E-02 & $9.19 \mathrm{E}-03$ & $4.59 E+04$ & $9.19 \mathrm{E}+03$ & $1.31 E+02$ \\
\hline TRU & $1.03 E+02$ & & $1.03 E+08$ & & $2.92 E+05$ \\
\hline Im Detect & ity for the & conditions & used & & \\
\hline
\end{tabular}


Revision 2

\begin{tabular}{|c|l|l|l|l|}
\hline Sample \# & $3-104696$ & & & \\
\hline Customer ID & $98018-19-\mathrm{A}$ & & & \\
\hline Description & Original Aqueous Sample & & \\
\hline & & & & \\
\hline Analyte & Concent. Units & & & \\
\hline Total Suspended Solids & $0.11 \mathrm{wt} \%$ & & & \\
\hline
\end{tabular}

$6 / 8 / 00$

Appendix $N$

Page N7 


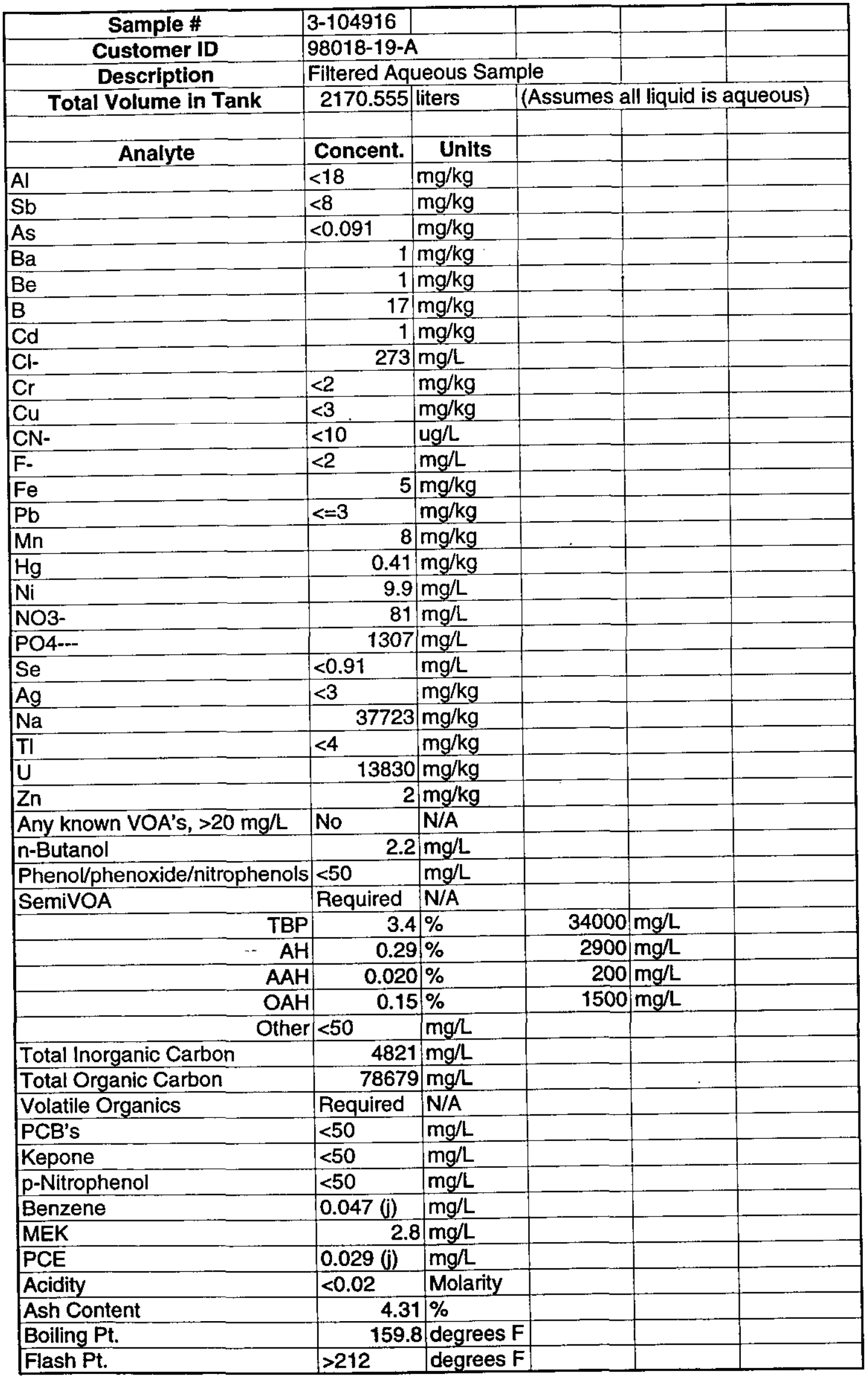




\begin{tabular}{|c|c|c|c|c|c|}
\hline Freezing $\mathrm{Pt}$. & $<32$ & degrees F & & & \\
\hline Free Liquid? & Yes & N/A & & & \\
\hline $\mathrm{pH}$ & 10.16 & N/A & & & \\
\hline Density & 1.097 & $\mathrm{~g} / \mathrm{cm3}$ & & & \\
\hline TDS & 8.88 & $\%$ & & & \\
\hline \multirow[t]{6}{*}{ Water, wt\% } & 85.9 & $\%$ & & & \\
\hline & & & & & Aqueous \\
\hline & & & & & Phase \\
\hline & & & & & Total \\
\hline & Activity & Error & Activity & Error & Activity \\
\hline & $\mathrm{uCi} / \mathrm{mL}$ & $\mathrm{uCi} / \mathrm{mL}$ & $\mathrm{pCi} / \mathrm{L}$ & pCi/L & $\mathbf{u C i}$ \\
\hline Total Am & $1.04 \mathrm{E}-03$ & UL & $1.04 \mathrm{E}+06$ & UL & $2.26 \mathrm{E}+03$ \\
\hline Am-241 & $9.05 \mathrm{E}-04$ & $1.08 \mathrm{E}-04$ & $9.05 E+05$ & $1.08 E+05$ & $1.96 E+03$ \\
\hline$A m-243$ & 1.36E-04 & UL & $1.36 E+05$ & UL & $2.95 E+02$ \\
\hline Bi-212 & $7.79 \mathrm{E}-05$ & 6.41E-05 & $7.79 \mathrm{E}+04$ & $6.41 E+04$ & $1.69 \mathrm{E}+02$ \\
\hline $\mathrm{Ce}-144$ & $1.96 \mathrm{E}-04$ & MDA & $1.96 \mathrm{E}+05$ & MDA & $4.25 E+02$ \\
\hline Total $\mathrm{Cm}$ & $8.15 \mathrm{E}-03$ & $1.63 \mathrm{E}-02$ & $8.15 E+06$ & $1.63 E+07$ & $1.77 E+04$ \\
\hline $\mathrm{Cm}-244$ & 8.15E-03 & 1.63E-02 & $8.15 E+06$ & $1.63 \mathrm{E}+07$ & 1.77E+04 \\
\hline $\mathrm{Cm}-245$ & $7.88 E-04$ & $\mathrm{DL}$ & $7.88 E+05$ & $\overline{D L}$ & $1.71 E+03$ \\
\hline $\mathrm{Cm}-246$ & $1.41 \mathrm{E}-03$ & $\mathrm{DL}$ & $1.41 \mathrm{E}+06$ & $\mathrm{DL}$ & $3.06 \mathrm{E}+03$ \\
\hline Co-60 & $3.20 \mathrm{E}-04$ & 1.23E-05 & $3.20 E+05$ & $1.23 E+04$ & $6.95 E+02$ \\
\hline Cs-134 & 1.33E-05 & MDA & $1.33 E+04$ & MDA & $2.89 E+01$ \\
\hline Cs-137 & 5.81E-02 & $1.99 \mathrm{E}-03$ & $5.81 \mathrm{E}+07$ & $1.99 \mathrm{E}+06$ & $1.26 \mathrm{E}+05$ \\
\hline Eu-154 & $7.16 \mathrm{E}-04$ & $2.76 \mathrm{E}-05$ & $7.16 \mathrm{E}+05$ & $2.76 \mathrm{E}+04$ & $1.55 E+03$ \\
\hline Eu-155 & $6.76 \mathrm{E}-05$ & $4.55 \mathrm{E}-05$ & $6.76 \mathrm{E}+04$ & $4.55 \mathrm{E}+04$ & $1.47 \mathrm{E}+02$ \\
\hline $\mathrm{GA}$ & $2.04 \mathrm{E}+00$ & $4.08 \mathrm{E}-01$ & $2.04 E+09$ & $4.08 E+08$ & $4.43 E+06$ \\
\hline $\mathrm{H}-3$ & 1.47E-03 & 1.47E-04 & $1.47 \mathrm{E}+06$ & $1.47 \mathrm{E}+05$ & $3.19 E+03$ \\
\hline $\mid-129$ & $1.80 \mathrm{E}-04$ & UL & $1.80 \mathrm{E}+05$ & UL & $3.91 E+02$ \\
\hline Ni-59 & $3.30 \mathrm{E}-03$ & MDA & $3.30 \mathrm{E}+06$ & MDA & $7.16 \mathrm{E}+03$ \\
\hline $\mathrm{Ni}-63$ & $1.11 \mathrm{E}-02$ & UL & $1.11 E+07$ & UL & $2.41 \mathrm{E}+04$ \\
\hline GB & $3.50 \mathrm{E}-01$ & 1.40E-01 & $3.50 \mathrm{E}+08$ & $1.40 \mathrm{E}+08$ & $7.60 \mathrm{E}+05$ \\
\hline Np-237 & $2.49 E-04$ & $1.24 \mathrm{E}-04$ & $2.49 E+05$ & $1.24 \mathrm{E}+05$ & $5.40 E+02$ \\
\hline $\mathrm{Pb}-212$ & $6.98 \mathrm{E}-05$ & 3.69E-05 & $6.98 \mathrm{E}+04$ & $3.69 E+04$ & $1.52 E+02$ \\
\hline Total Pu & $2.56 \mathrm{E}+00$ & $2.57 \mathrm{E}-01$ & $2.56 \mathrm{E}+09$ & $2.57 \mathrm{E}+08$ & $5.56 \mathrm{E}+06$ \\
\hline Pu-238 & $2.03 E+00$ & 2.03E-01 & $2.03 E+09$ & $2.03 E+08$ & $4.41 \mathrm{E}+06$ \\
\hline Pu-239 & 4.77E-03 & $2.39 \mathrm{E}-03$ & 4.77் +06 & $2.39 E+06$ & $1.04 E+04$ \\
\hline Pu-240 & $1.57 \mathrm{E}-03$ & $7.84 \mathrm{E}-04$ & $1.57 \mathrm{E}+06$ & $7.84 \mathrm{E}+05$ & $3.41 E+03$ \\
\hline Pu-241 & $5.23 \mathrm{E}-01$ & 1.57E-01 & $5.23 E+08$ & $1.57 E+08$ & $1.14 \mathrm{E}+06$ \\
\hline $\mathrm{Pu}-242$ & $1.81 E-05$ & $\mathrm{DL}$ & $1.81 E+04$ & $\overline{\mathrm{DL}}$ & $3.93 E+01$ \\
\hline $\mathrm{Pm}-147$ & 2.25E-03 & MDA & $2.25 \mathrm{E}+06$ & MDA & $4.88 E+03$ \\
\hline$R u-106$ & $3.32 E-04$ & MDA & $3.32 E+05$ & MDA & $7.21 \mathrm{E}+02$ \\
\hline Sb-125 & $2.94 \mathrm{E}-04$ & 6.45E-05 & $2.94 \mathrm{E}+05$ & $6.45 E+04$ & $6.38 \mathrm{E}+02$ \\
\hline Se-79 & $2.70 \mathrm{E}-04$ & MDA & $2.70 \mathrm{E}+05$ & MDA & $5.86 E+02$ \\
\hline $5 n-126$ & $6.94 \mathrm{E}-05$ & MDA & $6.94 \mathrm{E}+04$ & MDA & $1.51 E+02$ \\
\hline Sr-90 & $3.33 \mathrm{E}-02$ & $3.60 \mathrm{E}-03$ & $3.33 E+07$ & $3.60 \mathrm{E}+06$ & $7.23 E+04$ \\
\hline Tc-99 & $4.68 \mathrm{E}-04$ & $9.93 E-05$ & $4.68 \mathrm{E}+05$ & $9.93 \mathrm{E}+04$ & $1.02 E+03$ \\
\hline Th-232 & $1.13 \mathrm{E}-07$ & $2.26 \mathrm{E}-08$ & $1.13 \mathrm{E}+02$ & $2.26 \mathrm{E}+01$ & $2.45 \mathrm{E}-01$ \\
\hline Th-234 & $4.18 E-03$ & $1.75 \mathrm{E}-03$ & $4.18 E+06$ & $1.75 E+06$ & $9.07 E+03$ \\
\hline TI-208 & 3.87E-05 & 2.23E-05 & $3.87 E+04$ & $2.23 E+04$ & $8.40 E+01$ \\
\hline U-233 & $2.33 \mathrm{E}-03$ & $4.66 E-04$ & $2.33 E+06$ & $4.66 \mathrm{E}+05$ & $5.06 E+03$ \\
\hline U-234 & $1.64 \mathrm{E}-03$ & $3.28 \mathrm{E}-04$ & $1.64 E+06$ & $3.28 E+05$ & $3.56 E+03$ \\
\hline U-235 & $3.08 \mathrm{E}-05$ & $6.15 \mathrm{E}-06$ & $3.08 E+04$ & $6.15 \mathrm{E}+03$ & $6.69 \mathrm{E}+01$ \\
\hline U-236 & 2.97E-05 & 5.94E-06 & $2.97 E+04$ & $5.94 \mathrm{E}+03$ & $6.45 E+01$ \\
\hline
\end{tabular}


$6 / 8 / 00$

\begin{tabular}{|c|c|c|c|c|c|}
\hline U-238 & $6.26 \mathrm{E}-03$ & 1.05E-03 & $6.26 \mathrm{E}+06$ & $1.05 E+06$ & $1.36 \mathrm{E}+04$ \\
\hline TRU & $2.04 E+00$ & & $2.04 \mathrm{E}+09$ & & $4.42 \mathrm{E}+06$ \\
\hline \multicolumn{6}{|c|}{ MDA = Minimum Detectable Activity for the conditions used } \\
\hline \multicolumn{6}{|l|}{$\mathrm{DL}=$ Detection Limit } \\
\hline \multicolumn{6}{|l|}{$\mathrm{UL}=$ Upper Limit } \\
\hline \multicolumn{6}{|c|}{$a=$ compound present but below quantitation limit } \\
\hline \multicolumn{6}{|c|}{$\mathrm{j}=$ value is less than the method's PQL for this dilution but above the } \\
\hline TBP = Tributyl Phosphate & & & & & \\
\hline \multicolumn{6}{|c|}{ IDL, and detected in the chromatographic data } \\
\hline $\mathrm{AH}=$ Aliphatic Hyrdocarbons & & & & & \\
\hline \multicolumn{6}{|c|}{ AAH = Alkylated Aromatic hydrocarbons } \\
\hline $\mathrm{OAH}=$ Oxygenated Aliphatic & drocarbons & & & & \\
\hline
\end{tabular}

Appendix $\mathrm{N}$

Page N10 $\mathrm{OAH}=\mathrm{Oxygenated}$ Aliphatic Hydrocarbons 


\begin{tabular}{|c|c|c|c|c|c|}
\hline Sample \# & $3-104936$ & & & & \\
\hline Customer ID & \multicolumn{2}{|l|}{ 98018-19-A } & & & \\
\hline Description & \multicolumn{2}{|c|}{ Filtered Solids } & & & \\
\hline \multirow[t]{2}{*}{ Estimated Solids } & \multicolumn{2}{|c|}{$2619.21 \mathrm{~g}$} & \multicolumn{3}{|c|}{ (based upon TSS, volume and } \\
\hline & & & \multicolumn{3}{|c|}{ density of liquid phase) } \\
\hline & & & & & \\
\hline & & & & & \\
\hline & & & & & \\
\hline & & & & & Suspended \\
\hline & & & & & Solids \\
\hline & & & & & Total \\
\hline & Activity & Error & Activity & Error & Activity \\
\hline Analyte & $\mathrm{uCi} / \mathrm{g}$ & $\mathrm{uCl} / \mathrm{g}$ & $\mathrm{pCi} / \mathrm{g}$ & $\mathrm{pCi} / \mathrm{g}$ & $\mathbf{u C i}$ \\
\hline Total Am & $1.01 \mathrm{E}+00$ & 2.22E-01 & $1.01 E+06$ & $2.22 \mathrm{E}+05$ & $2.65 \mathrm{E}+03$ \\
\hline Am-241 & $1.01 \mathrm{E}+00$ & 2.22E-01 & $1.01 E+06$ & $2.22 \mathrm{E}+05$ & $2.65 \mathrm{E}+03$ \\
\hline Am-243 & $1.26 \mathrm{E}+00$ & $\mathrm{DL}$ & $1.26 E+06$ & $\mathrm{DL}$ & $3.30 \mathrm{E}+03$ \\
\hline $\mathrm{Ce}-144$ & $2.83 E-01$ & MDA & $2.83 E+05$ & MDA & $7.41 E+02$ \\
\hline Total $\mathrm{Cm}$ & $3.03 E+01$ & $3.03 E+00$ & $3.03 E+07$ & $3.03 \mathrm{E}+06$ & $7.94 \mathrm{E}+04$ \\
\hline $\mathrm{Cm}-244$ & $3.03 \mathrm{E}+01$ & $3.03 E+00$ & $3.03 E+07$ & $3.03 E+06$ & 7.94E+04 \\
\hline $\mathrm{Cm}-245$ & $1.08 \mathrm{E}+00$ & $D L$ & $1.08 E+06$ & $D L$ & $2.83 \mathrm{E}+03$ \\
\hline $\mathrm{Cm}-246$ & $1.92 E+00$ & DL & $1.92 E+06$ & $\mathrm{DL}$ & $5.03 E+03$ \\
\hline Co-60 & $6.17 \mathrm{E}-02$ & MDA & $6.17 \mathrm{E}+04$ & MDA & $1.62 E+02$ \\
\hline Cs-134 & $6.44 \mathrm{E}-02$ & MDA & $6.44 E+04$ & MDA & $1.69 \mathrm{E}+02$ \\
\hline Cs-137 & 2.57E-01 & 7.13E-02 & $2.57 E+05$ & $7.13 E+04$ & $6.73 E+02$ \\
\hline Eu-154 & $5.90 \mathrm{E}-01$ & $1.50 \mathrm{E}-01$ & $5.90 \mathrm{E}+05$ & $1.50 E+05$ & $1.55 \mathrm{E}+03$ \\
\hline GA & $5.63 E+01$ & $5.63 \mathrm{E}+00$ & $5.63 \mathrm{E}+07$ & $5.63 \mathrm{E}+06$ & $1.47 \mathrm{E}+05$ \\
\hline $\mathrm{H}-3$ & $6.26 \mathrm{E}-02$ & MDA & $6.26 E+04$ & MDA & $1.64 \mathrm{E}+02$ \\
\hline $1-129$ & $5.77 \mathrm{E}-02$ & MDA & $5.77 E+04$ & MDA & $1.51 \mathrm{E}+02$ \\
\hline $\mathrm{Ni}-63$ & $2.35 E-02$ & MDA & $2.35 E+04$ & MDA & $6.16 \mathrm{E}+01$ \\
\hline GB & $1.01 \mathrm{E}+01$ & $4.04 \mathrm{E}+00$ & $1.01 E+07$ & $4.04 \mathrm{E}+06$ & $2.65 E+04$ \\
\hline $\mathrm{Np}-237$ & $1.40 \mathrm{E}-02$ & $2.79 \mathrm{E}-03$ & $1.40 \mathrm{E}+04$ & $2.79 \mathrm{E}+03$ & $3.67 E+01$ \\
\hline Total Pu & $3.72 E+01$ & $6.67 \mathrm{E}+00$ & $3.72 E+07$ & $6.67 \mathrm{E}+06$ & $9.74 \mathrm{E}+04$ \\
\hline Pu-238 & $2.29 \mathrm{E}+01$ & $2.29 \mathrm{E}+00$ & $2.29 \mathrm{E}+07$ & $2.29 \mathrm{E}+06$ & $6.00 \mathrm{E}+04$ \\
\hline Pu-239 & 6.94E-01 & 2.77E-01 & $6.94 E+05$ & $2.77 E+05$ & $1.82 E+03$ \\
\hline Pu-240 & $1.43 E+00$ & $\mathrm{DL}$ & $1.43 \mathrm{E}+06$ & $\overline{D L}$ & $3.75 E+03$ \\
\hline Pu-241 & $1.36 \mathrm{E}+01$ & $6.26 \mathrm{E}+00$ & $1.36 E+07$ & $6.26 \mathrm{E}+06$ & $3.56 \mathrm{E}+04$ \\
\hline Pu-242 & 2.47E-02 & $D L$ & $2.47 E+04$ & $\mathrm{DL}$ & $6.47 E+01$ \\
\hline Ru-106 & 5.09E-01 & MDA & $5.09 E+05$ & MDA & $1.33 \mathrm{E}+03$ \\
\hline Sb-125 & 1.68E-01 & MDA & $1.68 E+05$ & MDA & $4.40 \mathrm{E}+02$ \\
\hline Sn-126 & $1.18 \mathrm{E}-01$ & MDA & $1.18 E+05$ & MDA & $3.09 E+02$ \\
\hline Sr-90 & $4.64 \mathrm{E}+00$ & 2.32E-01 & 4.64E+06 & $2.32 E+05$ & $1.22 \mathrm{E}+04$ \\
\hline TC- 99 & $1.75 \mathrm{E}-02$ & MDA & $1.75 E+04$ & MDA & $4.58 \mathrm{E}+01$ \\
\hline Th-232 & 4.86E-05 & 9.73E-06 & $4.86 \mathrm{E}+01$ & $9.73 \mathrm{E}+00$ & $1.27 \mathrm{E}-01$ \\
\hline $\mathrm{U}-233$ & $4.48 \mathrm{E}-02$ & $1.79 \mathrm{E}-02$ & $4.48 E+04$ & $1.79 E+04$ & $1.17 E+02$ \\
\hline $\mathrm{U}-234$ & $4.55 \mathrm{E}-02$ & 1.82E-02 & $4.55 \mathrm{E}+04$ & $1.82 E+04$ & $1.19 E+02$ \\
\hline $\mathrm{U}-235$ & $1.06 \mathrm{E}-03$ & $2.12 E-04$ & $1.06 \mathrm{E}+03$ & $2.12 \mathrm{E}+02$ & $2.78 \mathrm{E}+00$ \\
\hline $\mathrm{U}-236$ & $9.50 E-04$ & $1.90 \mathrm{E}-04$ & $9.50 E+02$ & $1.90 \mathrm{E}+02$ & $2.49 \mathrm{E}+00$ \\
\hline U-238 & 2.64E-02 & $5.28 E-03$ & $2.64 E+04$ & $5.28 \mathrm{E}+03$ & $6.91 E+01$ \\
\hline TRU & $2.46 \mathrm{E}+01$ & & $2.46 \mathrm{E}+07$ & & $6.45 E+04$ \\
\hline & the & conditions & used & & \\
\hline $\mathrm{DL}=$ Detection Limit & & & & & \\
\hline
\end{tabular}




\begin{tabular}{|c|c|c|c|c|c|}
\hline Sample \# & 3-117929 & & & & \\
\hline Customer ID & $98351-19$ & & & & \\
\hline Description & Sludge & & & & \\
\hline Total Mass in Tank & 203655.2 & grams & & & \\
\hline & & & & & \\
\hline Analyte & Concent. & Units & & & \\
\hline As & $<2$ & $\mathrm{mg} / \mathrm{kg}$ & & & \\
\hline$\overline{\mathrm{Ba}}$ & 57 & $\mathrm{mg} / \mathrm{kg}$ & & & \\
\hline Cd & 6 & $\mathrm{mg} / \mathrm{kg}$ & & & \\
\hline $\mathrm{Cr}$ & 52 & $\mathrm{mg} / \mathrm{kg}$ & & & \\
\hline$\overline{\mathrm{Pb}}$ & 433 & $\mathrm{mg} / \mathrm{kg}$ & & & \\
\hline $\mathrm{Hg}$ & 417 & $\mathrm{mg} / \mathrm{kg}$ & & & \\
\hline $\mathrm{Se}$ & $<23$ & $\mathrm{mg} / \mathrm{kg}$ & & & \\
\hline $\mathrm{Ag}$ & 91 & $\mathrm{mg} / \mathrm{kg}$ & & & \\
\hline & & & & & Sludge \\
\hline & & & & & Phase \\
\hline & & & & & Total \\
\hline & Activity & Error & Activity & Error & Activity \\
\hline & $\mathrm{uCl} / \mathrm{g}$ & uCi/g & $\mathrm{pC} / \mathrm{g}$ & $\mathrm{pCi} / \mathrm{g}$ & $\mathbf{u C i}$ \\
\hline Total Am & $3.86 \mathrm{E}+00$ & $6.89 \mathrm{E}-01$ & $3.86 E+06$ & $6.89 E+05$ & $7.86 E+05$ \\
\hline Am-241 & $3.41 \mathrm{E}+00$ & $6.83 \mathrm{E}-01$ & $3.41 E+06$ & $6.83 E+05$ & $6.94 \mathrm{E}+05$ \\
\hline Am-243 & 4.49E-01 & 8.97E-02 & $4.49 \mathrm{E}+05$ & $8.97 E+04$ & $9.14 \mathrm{E}+04$ \\
\hline $\mathrm{Ce}-144$ & $5.27 \mathrm{E}-02$ & $\mathrm{MDA}$ & $5.27 E+04$ & $\overline{\mathrm{MDA}}$ & $1.07 E+04$ \\
\hline Total $\mathrm{Cm}$ & 7.57E+01 & $1.51 E+01$ & $7.57 \bar{E}+07$ & $1.51 \mathrm{E}+07$ & $1.54 \mathrm{E}+07$ \\
\hline $\mathrm{Cm}-244$ & $7.57 \mathrm{E}+01$ & $1.51 E+01$ & $7.57 \mathrm{E}+07$ & $1.51 E+07$ & $1.54 \mathrm{E}+07$ \\
\hline $\mathrm{Cm}-245$ & 1.19E-01 & $D L$ & $1.19 E+05$ & $\overline{D L}$ & $2.42 E+04$ \\
\hline $\mathrm{Cm}-246$ & 2.13E-01 & $\overline{\mathrm{DL}}$ & $2.13 E+05$ & $\mathrm{DL}$ & $4.34 \mathrm{E}+04$ \\
\hline $\mathrm{Co}-60$ & 8.96E-03 & MDA & $8.96 \mathrm{E}+03$ & MDA & $1.82 E+03$ \\
\hline Cs-134 & $1.22 \mathrm{E}-02$ & MDA & $1.22 E+04$ & MDA & $2.48 \mathrm{E}+03$ \\
\hline Cs-137 & $2.80 \mathrm{E}-01$ & 2.07E-02 & $2.80 \mathrm{E}+05$ & $2.07 \mathrm{E}+04$ & $5.70 \mathrm{E}+04$ \\
\hline Eu-154 & $1.49 \mathrm{E}+00$ & 4.17E-02 & $1.49 E+06$ & $4.17 \mathrm{E}+04$ & $3.03 E+05$ \\
\hline GA & $7.75 \mathrm{E}+01$ & $1.55 E+01$ & $7.75 \mathrm{E}+07$ & $1.55 \mathrm{E}+07$ & $1.58 \mathrm{E}+07$ \\
\hline $\mathrm{H}-3$ & $3.36 \mathrm{E}+00$ & UL & $3.36 \mathrm{E}+06$ & UL & $6.84 \mathrm{E}+05$ \\
\hline $\mathrm{Nb}-94$ & $3.32 E-02$ & MDA & $3.32 E+04$ & MDA & $6.76 \mathrm{E}+03$ \\
\hline GB & $1.25 \mathrm{E}+01$ & $2.50 \mathrm{E}+00$ & $1.25 \mathrm{E}+07$ & $2.50 \mathrm{E}+06$ & $2.55 E+06$ \\
\hline $\mathrm{Np}-237$ & 4.77E-03 & $9.55 E-04$ & $4.77 E+03$ & $9.55 \mathrm{E}+02$ & $9.71 E+02$ \\
\hline Total Pu & $3.15 E+01$ & $9.96 \mathrm{E}+00$ & $3.15 \mathrm{E}+07$ & $9.96 \mathrm{E}+06$ & $6.42 E+06$ \\
\hline $\mathrm{Pu}-238$ & $2.40 \mathrm{E}+01$ & $9.60 \mathrm{E}+00$ & $2.40 \mathrm{E}+07$ & $9.60 \mathrm{E}+06$ & $4.89 \mathrm{E}+06$ \\
\hline Pu-239 & $9.68 \mathrm{E}-01$ & $1.94 E-01$ & $9.68 \mathrm{E}+05$ & $1.94 \mathrm{E}+05$ & $1.97 \mathrm{E}+05$ \\
\hline $\mathrm{Pu}-240$ & $1.58 \mathrm{E}-01$ & $\mathrm{DL}$ & $1.58 \mathrm{E}+05$ & DL & $3.22 E+04$ \\
\hline Pu-241 & $6.58 \mathrm{E}+00$ & $2.63 \mathrm{E}+00$ & $6.58 E+06$ & $2.63 \mathrm{E}+06$ & $1.34 \mathrm{E}+06$ \\
\hline Pu-242 & $2.73 E-03$ & $\mathrm{DL}$ & $2.73 E+03$ & $\mathrm{DL}$ & $5.56 \mathrm{E}+02$ \\
\hline Ru-106 & $1.22 E-01$ & MDA & $1.22 \mathrm{E}+05$ & MDA & $2.48 E+04$ \\
\hline Sb-125 & $3.58 \mathrm{E}-02$ & MDA & $3.58 \mathrm{E}+04$ & MDA & $7.29 \mathrm{E}+03$ \\
\hline Sn-126 & 3.54E-02 & MDA & $3.54 \mathrm{E}+04$ & MDA & $7.21 E+03$ \\
\hline Th-232 & $1.94 \mathrm{E}-05$ & $3.88 \mathrm{E}-06$ & $1.94 \mathrm{E}+01$ & $3.88 \mathrm{E}+00$ & $3.95 \mathrm{E}+00$ \\
\hline $\mathrm{U}-233$ & 2.06E-01 & 4.12E-02 & $2.06 \mathrm{E}+05$ & $4.12 E+04$ & $4.20 E+04$ \\
\hline U-234 & $1.32 E-01$ & $2.63 \mathrm{E}-02$ & $1.32 E+05$ & $2.63 E+04$ & $2.69 E+04$ \\
\hline $\mathrm{U}-235$ & $2.90 \mathrm{E}-03$ & 5.80E-04 & $2.90 \mathrm{E}+03$ & $5.80 \mathrm{E}+02$ & $5.91 E+02$ \\
\hline $\mathrm{U}-236$ & $3.04 \mathrm{E}-03$ & $6.08 E-04$ & $3.04 E+03$ & $6.08 \mathrm{E}+02$ & $6.19 \mathrm{E}+02$ \\
\hline $\mathrm{U}-238$ & 4.13E-02 & $8.25 E-03$ & $4.13 E+04$ & $8.25 \mathrm{E}+03$ & $8.41 E+03$ \\
\hline TRU & $2.88 E+01$ & & $2.88 \mathrm{E}+07$ & & $5.87 \mathrm{E}+06$ \\
\hline & & & & & \\
\hline
\end{tabular}


Revision 2 $6 / 8 / 00$

MDA = Minimum Detectable Activity for the conditions used Appendix $\mathrm{N}$

$D L=$ Detection Limit

Page N13 UL = Upper Limit 
Tank S20

WSRC-RP-98-01486

\section{Tank 820}

Tank $\$ 20$

Sample \#

Customer ID

Description

Analyte

Total Suspended Solids

Revision 2

$6 / 8 / 00$

Appendix 0

Page 01
3-104694

Original Organic Sample

Concent. Units

0.18 wt \% 


\begin{tabular}{|c|c|c|c|c|c|}
\hline Sample \# & 3-104926 & & & & \\
\hline Customer ID & 98018-20-T & & & & \\
\hline Description & Filtered Top & p Sample (C & Organic) & & \\
\hline Total Volume in Tank & 7551.897 & liters & (Assumes & all liquid is & rganic) \\
\hline Analyte & Concent. & Units & & & \\
\hline $\mathrm{Al}$ & $<4$ & $\mathrm{mg} / \mathrm{kg}$ & & & \\
\hline $\mathrm{Sb}$ & $<4$ & $\mathrm{mg} / \mathrm{kg}$ & & & \\
\hline As & $<0.12$ & $\mathrm{mg} / \mathrm{kg}$ & & & \\
\hline $\mathrm{Ba}$ & $<1$ & $\mathrm{mg} / \mathrm{kg}$ & & & \\
\hline $\mathrm{Be}$ & $<1$ & $\mathrm{mg} / \mathrm{kg}$ & & & \\
\hline B & $<1$ & $\mathrm{mg} / \mathrm{kg}$ & & & \\
\hline $\mathrm{Cd}$ & $<1$ & $\mathrm{mg} / \mathrm{kg}$ & & & \\
\hline $\mathrm{Cl}-$ & $<2$ & $\mathrm{mg} / \mathrm{L}$ & & & \\
\hline $\mathrm{Cr}$ & $<1$ & $\mathrm{mg} / \mathrm{kg}$ & & & \\
\hline $\mathrm{Cu}$ & 25 & $\mathrm{mg} / \mathrm{kg}$ & & & \\
\hline $\mathrm{CN}-$ & $<10$ & ug/L & & & \\
\hline F- & $<20$ & $\mathrm{mg} / \mathrm{L}$ & & & \\
\hline $\mathrm{Fe}$ & 5 & $\mathrm{mg} / \mathrm{kg}$ & & & \\
\hline $\mathrm{Pb}$ & $<2$ & $\mathrm{mg} / \mathrm{kg}$ & & & \\
\hline $\mathrm{Mn}$ & $<1$ & $\mathrm{mg} / \mathrm{kg}$ & & & \\
\hline $\mathrm{Hg}$ & 11.61 & $\mathrm{mg} / \mathrm{kg}$ & & & \\
\hline $\mathrm{Ni}$ & $<5.7$ & $\mathrm{mg} / \mathrm{L}$ & & & \\
\hline NO3- & $<10$ & $\mathrm{mg} / \mathrm{L}$ & & & \\
\hline PO4-:- & $<10$ & $\mathrm{mg} / \mathrm{L}$ & & & \\
\hline Se & $<1.2$ & $\mathrm{mg} / \mathrm{L}$ & & & \\
\hline $\mathrm{Ag}$ & $<1$ & $\mathrm{mg} / \mathrm{kg}$ & & & \\
\hline $\mathrm{Na}$ & 132 & $\mathrm{mg} / \mathrm{kg}$ & & & \\
\hline $\mathrm{TI}$ & $<4$ & $\mathrm{mg} / \mathrm{kg}$ & & & \\
\hline $\mathrm{U}$ & $<41$ & $\mathrm{mg} / \mathrm{kg}$ & $\cdot$ & & \\
\hline$\overline{\mathrm{Zn}}$ & 6. & $\mathrm{mg} / \mathrm{kg}$ & & & \\
\hline Any known VOA's, $>20 \mathrm{mg} / \mathrm{L}$ & No & N/A & & & \\
\hline n-Butanol & $<1.1$ & $\mathrm{mg} / \mathrm{L}$ & & $\cdot$ & \\
\hline Phenol/phenoxide/nitrophenols & $8<50$ & $\mathrm{mg} / \mathrm{L}$ & & & \\
\hline SemiVOA & Required & N/A & & & \\
\hline TBP & $>90$ & $\%$ & $>900000$ & $\mathrm{mg} / \mathrm{L}$ & \\
\hline Paraffins & $<<10$ & $\%$ & $<100000$ & $\mathrm{mg} / \mathrm{L}$ & \\
\hline Other & $r<50$ & $\mathrm{mg} / \mathrm{L}$ & & & \\
\hline Total Inorganic Carbon & 38 & $\mathrm{mg} / \mathrm{h}$ & & & \\
\hline Total Organic Carbon & 21073 & $\mathrm{mg} / \mathrm{L}$ & & & \\
\hline Volatile Organics & Required & N/A & & & \\
\hline PCB's & $<50$ & $\mathrm{mg} / \mathrm{L}$ & & & \\
\hline Kepone & $<50$ & $\mathrm{mg} / \mathrm{L}$ & & & \\
\hline p-Nitrophenol & $<50$ & $\mathrm{mg} / \mathrm{L}$ & & & \\
\hline Benzene & $0.370(j)$ & $\mathrm{mg} / \mathrm{L}$ & & & \\
\hline MEK & 7.3 & $\mathrm{mg} / \mathrm{L}$ & & & \\
\hline PCE & $0.054(j)$ & $\mathrm{mg} / \mathrm{L}$ & & & \\
\hline Acidity & $<0.02$ & Molarity & & & \\
\hline Ash Content & 1.35 & $\%$ & & & \\
\hline Boiling Pt. & 159.8 & degrees F & & & \\
\hline Flash Pt. & 180.9 & degrees F & & & \\
\hline Freezing Pt. & $<32$ & degrees $\mathrm{F}$ & & & \\
\hline Free Liquid? & Yes & N/A & & & \\
\hline
\end{tabular}




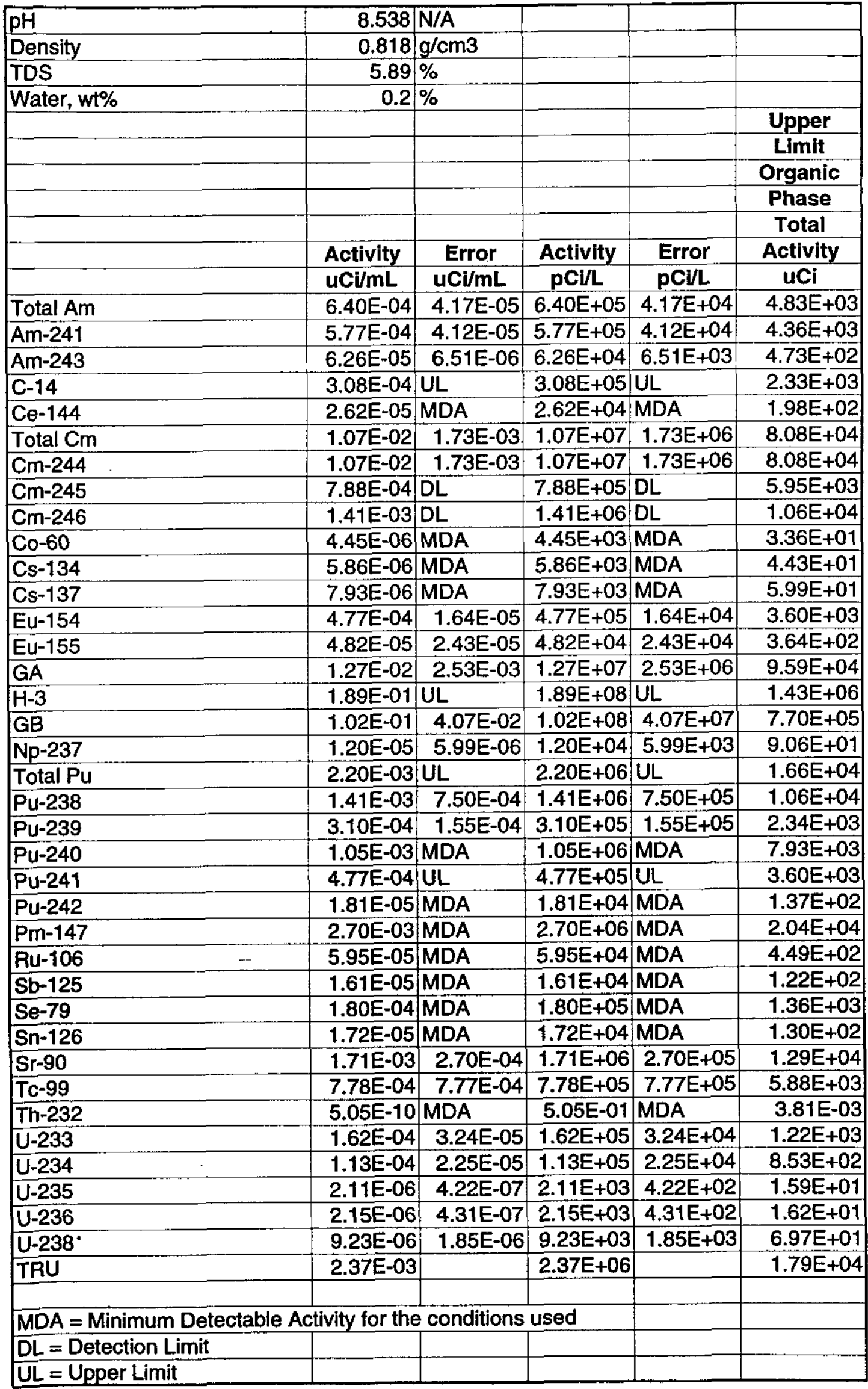

Appendix $\mathrm{O}$ Page $\mathrm{O} 3$

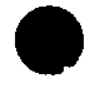


$a=$ compound present but below quantitation limit

Appendix $\mathrm{O}$

$\mathrm{j}=$ value is less than the method's PQL for this dilution but above the

Page 04

IDL, and detected in the chromatographic data

TBP $=$ Tributyl Phosphate

+_.

\begin{tabular}{l|l}
\hline & \\
\hline &
\end{tabular}




\begin{tabular}{|c|c|c|c|c|c|}
\hline \multirow{2}{*}{$\begin{array}{c}\text { Sample \# } \\
\text { Customer ID }\end{array}$} & \multicolumn{4}{|c|}{\begin{tabular}{|l|l|} 
3-104928 & Alternative Calculation \\
\end{tabular}} & \\
\hline & \multicolumn{2}{|l|}{ 98018-20-T } & & & \\
\hline Description & \multicolumn{2}{|c|}{ Filtered Solids } & & & \\
\hline Estimated Solids & \multicolumn{2}{|c|}{$11119.41 / \mathrm{g}$} & \multicolumn{3}{|c|}{ (based upon TSS, volume and } \\
\hline \multirow[t]{2}{*}{ Est. Solids on Filter } & \multirow[t]{2}{*}{$1.472 \mathrm{E}-02$} & g & \multicolumn{2}{|c|}{ density of liquid phase) } & \\
\hline & & & & & \\
\hline & & & & & Suspended \\
\hline & & & & & Solids \\
\hline & & & & & Upper \\
\hline & & & & & Limit \\
\hline & & & & & Total \\
\hline & Activity & Error & Activity & Error & Activity \\
\hline Analyte & uCi/filter & uCi/filter & $\mathrm{pCi} / \mathrm{g}$ & $\mathrm{pCi} / \mathrm{g}$ & uCi (1) \\
\hline Total Am & $0.00 E+00$ & $0.00 E+00$ & $0.00 \mathrm{E}+00$ & $0.00 \mathrm{E}+00$ & $0.00 \mathrm{E}+00$ \\
\hline Am-241 & $2.52 E-03$ & MDA & $1.71 E+05$ & MDA & $1.90 \mathrm{E}+03$ \\
\hline $\mathrm{Am}-243$ & $1.46 \mathrm{E}-02$ & $\mathrm{DL}$ & $9.92 E+05$ & $\mathrm{DL}$ & $1.10 \mathrm{E}+04$ \\
\hline $\mathrm{Ce}-144$ & 2.52E-03 & MDA & 1.71E+05 & MDA & $1.90 \mathrm{E}+03$ \\
\hline Total $\mathrm{Cm}$ & $1.85 E-02$ & 1.85E-03 & $1.26 \mathrm{E}+06$ & $1.26 E+05$ & $1.40 \mathrm{E}+04$ \\
\hline $\mathrm{Cm}-244$ & $1.85 \mathrm{E}-02$ & $1.85 \mathrm{E}-03$ & $1.26 \mathrm{E}+06$ & $1.26 E+05$ & $1.40 E+04$ \\
\hline $\mathrm{Cm}-245$ & $1.25 \mathrm{E}-02$ & $\mathrm{DL}$ & $8.49 E+05$ & $\mathrm{DL}$ & $9.44 E+03$ \\
\hline $\mathrm{Cm}-246$ & $2.23 \mathrm{E}-02$ & $\mathrm{DL}$ & $1.51 E+06$ & $\mathrm{DL}$ & $1.68 E+04$ \\
\hline Co- 60 & $7.14 \mathrm{E}-04$ & MDA & $4.85 E+04$ & MDA & $5.39 E+02$ \\
\hline Cs-134 & $4.71 \mathrm{E}-04$ & MDA & $3.20 E+04$ & MDA & $3.56 \mathrm{E}+02$ \\
\hline Cs-137 & $1.02 \mathrm{E}-03$ & MDA & $6.93 E+04$ & MDA & $7.71 E+02$ \\
\hline Eu-154 & $1.00 \mathrm{E}-03$ & MDA & $6.79 E+04$ & MDA & $7.55 \mathrm{E}+02$ \\
\hline $\mathrm{GA}$ & $3.38 \mathrm{E}-02$ & $3.38 \mathrm{E}-03$ & $2.30 E+06$ & $2.30 \mathrm{E}+05$ & $2.55 \mathrm{E}+04$ \\
\hline $\mathrm{H}-3$ & 7.27E-04 & MDA & $4.94 \mathrm{E}+04$ & MDA & $5.49 \mathrm{E}+02$ \\
\hline $1-129$ & $4.80 E-04$ & 4.27E-05 & $3.26 E+04$ & $2.90 \mathrm{E}+03$ & $3.63 E+02$ \\
\hline $\mathrm{Ni}-59$ & $2.48 \mathrm{E}-05$ & MDA & $1.68 \mathrm{E}+03$ & MDA & $1.87 E+01$ \\
\hline $\mathrm{Ni}-63$ & $2.36 \mathrm{E}-04$ & MDA & 1.60E+04 & MDA & $1.78 E+02$ \\
\hline GB & $1.76 \mathrm{E}-02$ & $7.05 \mathrm{E}-03$ & $1.20 E+06$ & $4.79 E+05$ & $1.33 \mathrm{E}+04$ \\
\hline $\mathrm{Np}-237$ & 5.16E-05 & $D L$ & $3.51 E+03$ & $\mathrm{DL}$ & $3.90 \mathrm{E}+01$ \\
\hline Total Pu & $1.52 E-02$ & $8.03 \mathrm{E}-03$ & $1.03 E+06$ & $5.46 \mathrm{E}+05$ & $1.14 \mathrm{E}+04$ \\
\hline Pu-238 & $1.27 \mathrm{E}-02$ & $6.36 \mathrm{E}-03$ & $8.63 E+05$ & $4.32 E+05$ & $9.59 \mathrm{E}+03$ \\
\hline $\mathrm{Pu}-239$ & $4.53 E-03$ & $D L$ & $3.08 \mathrm{E}+05$ & $D L$ & $3.42 E+03$ \\
\hline $\mathrm{Pu}-240$ & $1.66 \mathrm{E}-02$ & $\mathrm{DL}$ & $1.13 E+06$ & $\mathrm{DL}$ & $1.25 E+04$ \\
\hline $\mathrm{Pu}-241$ & $2.45 E-03$ & $4.91 \mathrm{E}-03$ & $1.66 \mathrm{E}+05$ & $3.34 E+05$ & $1.85 E+03$ \\
\hline Pu-242 & $2.86 E-04$ & $D L$ & $1.94 E+04$ & $D L$ & $2.16 E+02$ \\
\hline Ru-106 & $5.11 \mathrm{E}-03$ & MDA & $3.47 E+05$ & $\overline{M D A}$ & $3.86 E+03$ \\
\hline $\mathrm{Sb}-125$ & $1.35 E-03$ & $\mathrm{MDA}$ & $9.17 E+04$ & MDA & $1.02 E+03$ \\
\hline Sn-126 & $8.92 E-04$ & MDA & $6.06 E+04$ & MDA & $6.74 \mathrm{E}+02$ \\
\hline Sr-90 & $9.23 E-03$ & $4.51 E-04$ & $6.27 E+05$ & $3.06 E+04$ & $6.97 E+03$ \\
\hline Tc-99 & $9.01 E-05$ & MDA & $6.12 E+03$ & MDA & $6.81 \mathrm{E}+01$ \\
\hline Th-232 & 4.86E-08 & $9.73 E-09$ & 3.30E+00 & $6.61 E-01$ & $3.67 \mathrm{E}-02$ \\
\hline U-233 & $4.46 \mathrm{E}-04$ & $\mathrm{DL}$ & $3.03 E+04$ & $\mathrm{DL}$ & $3.37 E+02$ \\
\hline U-234 & $4.53 E-04$ & $D L$ & $3.08 E+04$ & $\mathrm{DL}$ & $3.42 E+02$ \\
\hline U-235 & 3.36E-07 & 1.34E-07 & $2.28 \mathrm{E}+01$ & $9.10 E+00$ & $2.54 \mathrm{E}-01$ \\
\hline U-236 & $4.73 E-06$ & $D L$ & $3.21 E+02$ & $\mathrm{DL}$ & $3.57 E+00$ \\
\hline U-238 & $8.90 \mathrm{E}-06$ & $1.78 \mathrm{E}-06$ & $6.05 E+02$ & $1.21 E+02$ & $6.72 \mathrm{E}+00$ \\
\hline TRU & 1.27E-02 & & $8.63 E+05$ & & $9.59 \mathrm{E}+03$ \\
\hline & 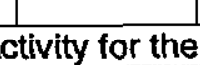 & condi & used & & \\
\hline $\mathrm{DL}=$ Detect & & & & & \\
\hline
\end{tabular}

Appendix 0

Page 05 
No measureable mass was present on the filter, therefore the $6 / 8 / 00$ activity is reported in units of activity/filter. Appendix 0 (1) The total activity calculation is based upon a filtered volume of $10 \mathrm{~mL}$, a density of $0.818 \mathrm{~g} / \mathrm{mL}$, and $0.18 \mathrm{wt} \%$ TSS. 


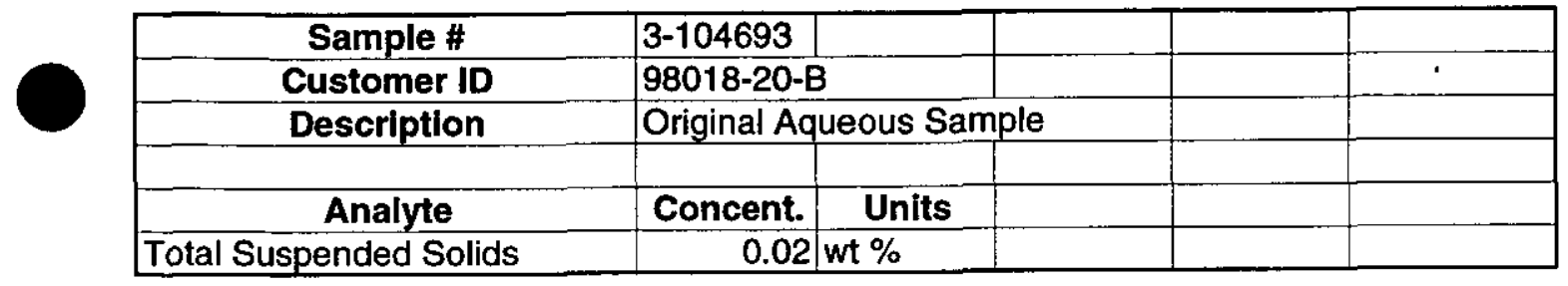




\begin{tabular}{|c|c|c|c|c|c|}
\hline Sample \# & $3-104930$ & & & & \\
\hline Customer ID & \multicolumn{2}{|l|}{$98018-20-B$} & & & \\
\hline Description & \multicolumn{3}{|c|}{ Filtered Aqueous Sample } & & \\
\hline Total Volume in Tank & 7551.897 & liters & Assumes a & all liquic & aqueous) \\
\hline Analyte & Concent. & Units & & & \\
\hline $\mathrm{Al}$ & 29 & $\mathrm{mg} / \mathrm{kg}$ & & & \\
\hline $\mathrm{Sb}$ & $<2$ & $\mathrm{mg} / \mathrm{kg}$ & & & \\
\hline As & $<0.095$ & $\mathrm{mg} / \mathrm{kg}$ & & & \\
\hline $\mathrm{Ba}$ & $<1$ & $\mathrm{mg} / \mathrm{kg}$ & & & \\
\hline $\mathrm{Be}$ & $<1$ & $\mathrm{mg} / \mathrm{kg}$ & & & \\
\hline $\mathrm{B}$ & 5 & $\mathrm{mg} / \mathrm{kg}$ & & & \\
\hline $\mathrm{Cd}$ & $<1$ & $\mathrm{mg} / \mathrm{kg}$ & & & \\
\hline Cl- & 201 & $\mathrm{mg} / \mathrm{L}$ & & & \\
\hline $\mathrm{Cr}$ & $<1$ & $\mathrm{mg} / \mathrm{kg}$ & & & \\
\hline $\mathrm{Cu}$ & 35 & $\mathrm{mg} / \mathrm{kg}$ & & & \\
\hline CN- & $<10$ & $u g / L$ & & & \\
\hline F- & $<20$ & $\mathrm{mg} / \mathrm{L}$ & & & \\
\hline $\mathrm{Fe}$ & 2 & $\mathrm{mg} / \mathrm{kg}$ & & & \\
\hline $\mathrm{Pb}$ & $<1$ & $\mathrm{mg} / \mathrm{kg}$ & & & \\
\hline $\mathrm{Mn}$ & 1. & $\mathrm{mg} / \mathrm{kg}$ & & & \\
\hline $\mathrm{Hg}$ & 1.82 & $\mathrm{mg} / \mathrm{kg}$ & & & \\
\hline $\mathrm{Ni}$ & 2.1 & $\mathrm{mg} / \mathrm{L}$ & & & \\
\hline NO3- & 729 & $\mathrm{mg} / \mathrm{L}$ & & & \\
\hline PO4--- & 560 & $\mathrm{mg} / \mathrm{L}$ & & & \\
\hline Se & $<0.95$ & $\mathrm{mg} / \mathrm{L}$ & & & \\
\hline $\mathrm{Ag}$ & $<1$ & $\mathrm{mg} / \mathrm{kg}$ & & & \\
\hline $\mathrm{Na}$ & 21763 & $\mathrm{mg} / \mathrm{kg}$ & & & \\
\hline $\mathrm{TI}$ & $<=1$ & $\mathrm{mg} / \mathrm{kg}$ & & & \\
\hline $\mathrm{U}$ & 4234 & $\mathrm{mg} / \mathrm{kg}$ & & & \\
\hline $\mathrm{Zn}$ & 1 & $\mathrm{mg} / \mathrm{kg}$ & & & \\
\hline Any known VOA's, $>20 \mathrm{mg} / \mathrm{L}$ & No & N/A & & & \\
\hline n-Butanol & 2.1 & $\mathrm{mg} / \mathrm{L}$ & & & \\
\hline Phenol/phenoxide/nitrophenols & $<50$ & $\mathrm{mg} / \mathrm{L}$ & & & \\
\hline SemiVOA & Required & N/A & & & \\
\hline TBP & 1.4 & $\%$ & 14000 & $\mathrm{mg} / \mathrm{L}$ & \\
\hline Other & $<50$ & $\mathrm{mg} / \mathrm{L}$ & & & \\
\hline Total Inorganic Carbon & 2783 & $\mathrm{mg} / \mathrm{L}$ & & & \\
\hline Total Organic Carbon & 38247 & $m g / l$ & & & \\
\hline Volatile Organics & Required & N/A & & & \\
\hline PCB's & $<50$ & $\mathrm{mg} / \mathrm{L}$ & & & \\
\hline Kepone & $<50$ & $\mathrm{mg} / \mathrm{L}$ & & & \\
\hline p-Nitrophenol & $<50$ & $\mathrm{mg} / \mathrm{L}$ & & & \\
\hline Benzene & $<0.140$ & $\mathrm{mg} / \mathrm{L}$ & & & \\
\hline MEK & 0.650 & $\mathrm{mg} / \mathrm{L}$ & & & \\
\hline PCE & 0.208 & $\mathrm{mg} / \mathrm{L}$ & & & \\
\hline Acidity & $<0.02$ & Molarity & & & \\
\hline
\end{tabular}




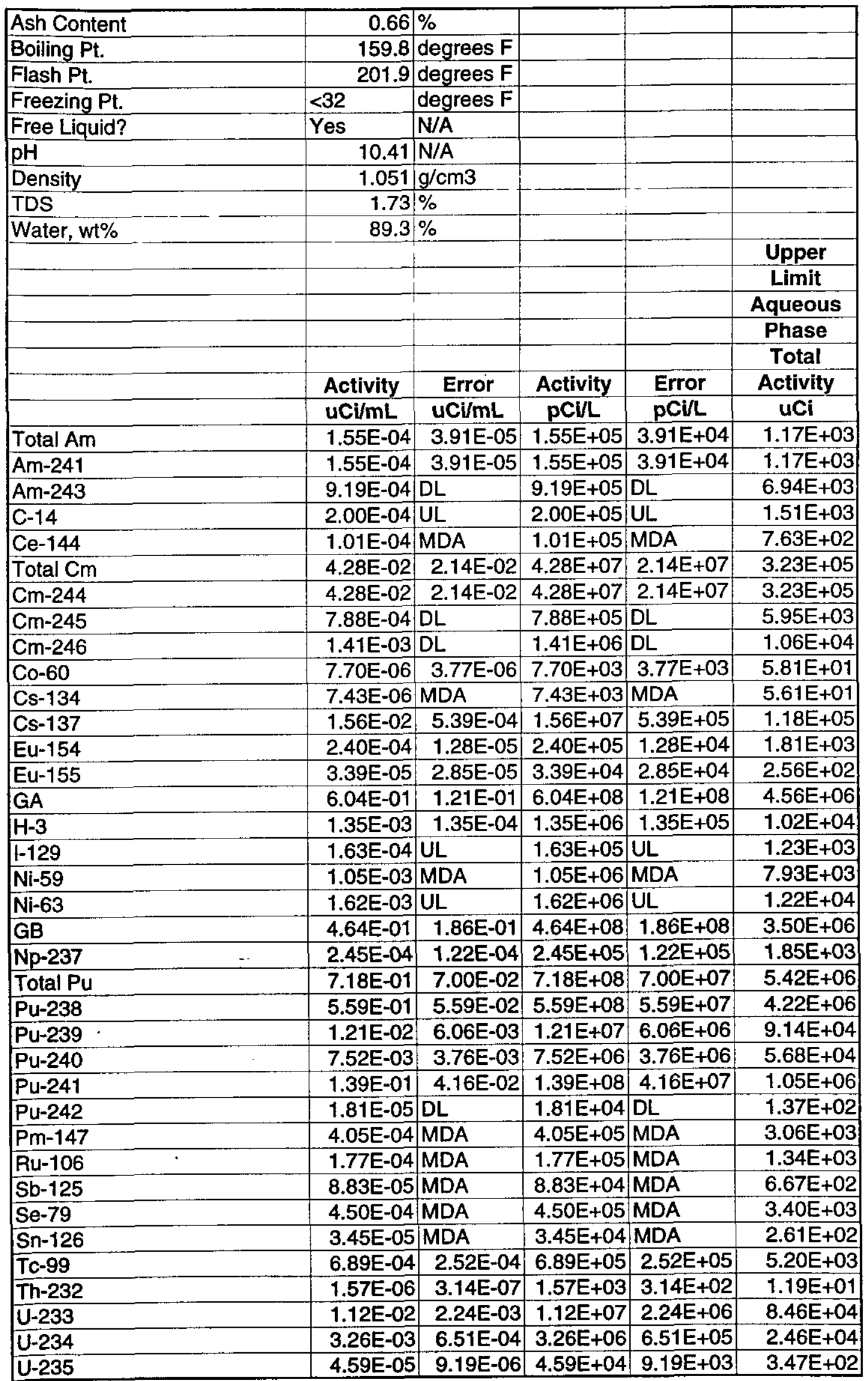




\begin{tabular}{|l|r|r|r|r|r|}
\hline $\mathrm{U}-236$ & $5.32 \mathrm{E}-05$ & $1.06 \mathrm{E}-05$ & $5.32 \mathrm{E}+04$ & $1.06 \mathrm{E}+04$ & $4.02 \mathrm{E}+02$ \\
\hline $\mathrm{U}-238$ & $1.53 \mathrm{E}-03$ & $3.05 \mathrm{E}-04$ & $1.53 \mathrm{E}+06$ & $3.05 \mathrm{E}+05$ & $1.16 \mathrm{E}+04$ \\
\hline TRU & $5.79 \mathrm{E}-01$ & & $5.79 \mathrm{E}+08$ & & $4.37 \mathrm{E}+06$ \\
\hline & & & & & \\
\hline $\mathrm{MDA}=$ Minimum Detectable Activity for the conditions used & & \\
\hline $\mathrm{DL}=$ Detection Limit & & & & & \\
\hline $\mathrm{UL}=$ Upper Limit & & & & \\
\hline $\mathrm{a}=$ compound present by below quantitation limit & & & \\
\hline TBP = Tributyl Phosphate & & & & \\
\hline
\end{tabular}




\begin{tabular}{|c|c|c|c|c|c|}
\hline Sample \# & 3-104924 & & & & \\
\hline Customer ID & 98018-20-B & & & & \\
\hline Description & Filtered Soli & lids & & & \\
\hline Estimated Solids & 1587.41 & & \multicolumn{3}{|c|}{ (based upon TSS, volume and } \\
\hline & & & \multicolumn{3}{|c|}{ density of liquid phase) } \\
\hline & & & & & \\
\hline & & & & & Suspended \\
\hline & & & & & Solids \\
\hline & & & & & Upper \\
\hline & & & & & Limit \\
\hline & & & & & Total \\
\hline & Activity & Error & Activity & Error & Activity \\
\hline Analyte & $\mathbf{u C i} / \mathrm{g}$ & $\mathbf{u C l} / \mathrm{g}$ & $\mathrm{pCl} / \mathrm{g}$ & $\mathrm{pCi} / \mathrm{g}$ & uCi \\
\hline Total Am & $2.01 E+00$ & 8.52E-01 & $2.01 E+06$ & $8.52 E+05$ & $3.19 E+03$ \\
\hline $\mathrm{Am}-241$ & $2.01 \mathrm{E}+00$ & 8.52E-01 & $2.01 \mathrm{E}+06$ & $8.52 E+05$ & $3.19 E+03$ \\
\hline $\mathrm{Am}-243$ & $6.62 \mathrm{E}+00$ & DL : & $6.62 \mathrm{E}+06$ & $\mathrm{DL}$ & $1.05 \mathrm{E}+04$ \\
\hline Ce-144 & $1.47 E+00$ & MDA & 1.47E+06 & MDA & $2.33 \mathrm{E}+03$ \\
\hline Total $\mathrm{Cm}$ & $8.06 \mathrm{E}+01$ & $8.06 E+00$ & $8.06 \mathrm{E}+07$ & $8.06 E+06$ & $1.28 \mathrm{E}+05$ \\
\hline $\mathrm{Cm}-244$ & $8.06 \mathrm{E}+01$ & $8.06 E+00$ & $8.06 \mathrm{E}+07$ & $8.06 \mathrm{E}+06$ & $1.28 \mathrm{E}+05$ \\
\hline $\mathrm{Cm}-245$ & $5.27 \mathrm{E}+00$ & $\mathrm{DL}$ & $5.27 \mathrm{E}+06$ & $\mathrm{DL}$ & $8.37 \mathrm{E}+03$ \\
\hline $\mathrm{Cm}-246$ & $1.01 E+01$ & $\mathrm{DL}$ & $1.01 E+07$ & $\mathrm{DL}$ & $1.60 \mathrm{E}+04$ \\
\hline Co-60 & $3.63 E-01$ & MDA & $3.63 E+05$ & MDA & $5.76 \mathrm{E}+02$ \\
\hline Cs-134 & 3.23E-01 & MDA & $3.23 E+05$ & MDA & $.13 \mathrm{E}+02$ \\
\hline Cs-137 & $2.08 \mathrm{E}+00$ & 4.46E-01 & $2.08 \mathrm{E}+06$ & $4.46 \mathrm{E}+05$ & $30 \mathrm{E}+03$ \\
\hline Eu-154 & $1.23 \mathrm{E}+00$ & $3.16 \mathrm{E}-01$ & $1.23 E+06$ & $3.16 \mathrm{E}+05$ & $1.95 \mathrm{E}+03$ \\
\hline $\mathrm{GA}$ & $1.74 \mathrm{E}+02$ & $1.74 \mathrm{E}+01$ & $1.74 \mathrm{E}+08$ & $1.74 \mathrm{E}+07$ & $2.76 \mathrm{E}+05$ \\
\hline $\mathrm{H}-3$ & 3.67E-01 & MDA & $3.67 \mathrm{E}+05$ & MDA & $5.83 E+02$ \\
\hline $1-129$ & $1.14 \mathrm{E}-01$ & UL & $1.14 \mathrm{E}+05$ & UL & $1.81 \mathrm{E}+02$ \\
\hline $\mathrm{Ni}-59$ & $5.59 \mathrm{E}-01$ & MDA & $5.59 \mathrm{E}+05$ & MDA & $8.87 \mathrm{E}+02$ \\
\hline $\mathrm{Ni}-63$ & $1.00 \mathrm{E}-01$ & MDA & $1.00 \mathrm{E}+05$ & MDA & $1.59 \mathrm{E}+02$ \\
\hline $\mathrm{GB}$ & $4.34 \mathrm{E}+01$ & $1.74 \mathrm{E}+01$ & $4.34 \mathrm{E}+07$ & $1.74 \mathrm{E}+07$ & $6.89 E+04$ \\
\hline Np-237 & $2.56 E-02$ & $1.03 \mathrm{E}-02$ & $2.56 E+04$ & $1.03 E+04$ & $4.06 \mathrm{E}+01$ \\
\hline Total Pu & $1.13 E+02$ & $1.05 E+01$ & $1.13 E+08$ & $1.05 \mathrm{E}+07$ & $1.79 \mathrm{E}+05$ \\
\hline Pu-238 & $8.83 E+01$ & $8.83 E+00$ & $8.83 E+07$ & $8.83 E+06$ & $1.40 \mathrm{E}+05$ \\
\hline Pu-239 & $3.10 \mathrm{E}+00$ & $1.24 E+00$ & $3.10 E+06$ & $1.24 \mathrm{E}+06$ & $4.92 \mathrm{E}+03$ \\
\hline Pu-240 & $7.52 \mathrm{E}+00$ & $\mathrm{DL}$ & $7.52 E+06$ & $D L$ & $1.19 \mathrm{E}+04$ \\
\hline Pu-241 & $2.12 \mathrm{E}+01$ & $5.52 \mathrm{E}+00$ & $2.12 E+07$ & $5.52 E+06$ & 3.37E+04 \\
\hline Pu-242 & $1.31 \mathrm{E}-01$ & $\mathrm{DL}$ & $1.31 E+05$ & $\mathrm{DL}$ & $2.08 \mathrm{E}+02$ \\
\hline Ru-106 & $3.11 E+00$ & MDA & $3.11 \mathrm{E}+06$ & MDA & $4.94 \mathrm{E}+03$ \\
\hline Sb-125 & $9.05 E-01$ & MDA & $9.05 E+05$ & MDA & $1.44 \mathrm{E}+03$ \\
\hline Se-79 & 3.07E-01 & MDA & $3.07 \mathrm{E}+05$ & MDA & $4.87 \mathrm{E}+02$ \\
\hline $5 n-126$ & $6.13 \mathrm{E}-01$ & MDA & $6.13 E+05$ & MDA & $9.73 E+02$ \\
\hline Sr-90 & $1.54 \mathrm{E}+01$ & $2.05 \mathrm{E}+00$ & $1.54 \mathrm{E}+07$ & $2.05 E+06$ & $2.44 \mathrm{E}+04$ \\
\hline TC-99 & $8.20 \mathrm{E}-02$ & MDA & $8.20 E+04$ & MDA & $1.30 \mathrm{E}+02$ \\
\hline Th-232 & 7.75E-04 & $1.55 \mathrm{E}-04$ & $7.75 \mathrm{E}+02$ & $1.55 \mathrm{E}+02$ & $1.23 \mathrm{E}+00$ \\
\hline U-233 & 2.03E-01 & $\mathrm{DL}$ & $2.03 E+05$ & $\mathrm{DL}$ & $3.22 E+02$ \\
\hline U-234 & $2.06 \mathrm{E}-01$ & $\mathrm{DL}$ & $2.06 \mathrm{E}+05$ & DL & $3.27 E+02$ \\
\hline U-235 & 1.41E-03 & 2.81E-04 & $1.41 E+03$ & $2.81 \mathrm{E}+02$ & $2.24 \mathrm{E}+00$ \\
\hline $\mathrm{U}-236$ & $2.15 \mathrm{E}-03$ & $\mathrm{DL}$ & $2.15 E+03$ & $\mathrm{DL}$ & $3.41 E+00$ \\
\hline U-238 & $3.73 \mathrm{E}-02$ & 7.47E-03 & $3.73 E+04$ & $7.47 \mathrm{E}+03$ & $5.92 \mathrm{E}+01$ \\
\hline TRU & $9.34 \mathrm{E}+01$ & & $9.34 E+07$ & & $1.48 E+05$ \\
\hline & & & & & \\
\hline
\end{tabular}

Appendix $\mathrm{O}$

Page 011 


\begin{tabular}{|c|c|c|c|c|c|}
\hline Sample \# & $3-117930$ & & & & \\
\hline Customer ID & $98351-20$ & & & & \\
\hline Description & Sludge & & & & \\
\hline Total Mass in Tank & 68137.41 & grams & & & \\
\hline & & & & & \\
\hline Analyte & Concent. & Units & & & \\
\hline As & $<5$ & $\mathrm{mg} / \mathrm{kg}$ & & & \\
\hline Ba & 45 & $\mathrm{mg} / \mathrm{kg}$ & & - & \\
\hline$\overline{C d}$ & 40 & $\mathrm{mg} / \mathrm{kg}$ & & & \\
\hline $\mathrm{Cr}$ & 223 & $\mathrm{mg} / \mathrm{kg}$ & & & \\
\hline $\mathrm{Pb}$ & 2856 & $\mathrm{mg} / \mathrm{kg}$ & & & \\
\hline $\mathrm{Hg}$ & 460 & $\mathrm{mg} / \mathrm{kg}$ & & & \\
\hline Se & $<61$ & $\mathrm{mg} / \mathrm{kg}$ & & & \\
\hline $\mathrm{Ag}$ & 61 & $\mathrm{mg} / \mathrm{kg}$ & & & \\
\hline & & & & & Sludge \\
\hline & & & & & Phase \\
\hline & & & & & Total \\
\hline & Activity & Error & Activity & Error & Activity \\
\hline & $\mathrm{uCi} / \mathrm{g}$ & $\mathrm{uCi} / \mathrm{g}$ & $\mathrm{pCi} / \mathrm{g}$ & $\mathrm{pCi} / \mathrm{g}$ & uCi \\
\hline Total Am & $1.00 \mathrm{E}+00$ & $5.22 \mathrm{E}-02$ & $1.00 E+06$ & $5.22 E+04$ & $6.81 E+04$ \\
\hline Am-241 & $9.23 \mathrm{E}-01$ & $5.17 \mathrm{E}-02$ & $9.23 \mathrm{E}+05$ & $5.17 \mathrm{E}+04$ & $6.29 \mathrm{E}+04$ \\
\hline Am-243 & $7.66 \mathrm{E}-02$ & $7.35 \mathrm{E}-03$ & $7.66 \mathrm{E}+04$ & $7.35 \mathrm{E}+03$ & $5.22 E+03$ \\
\hline $\mathrm{Ce}-144$ & $2.39 E-02$ & MDA & $2.39 \mathrm{E}+04$ & MDA & $1.63 \mathrm{E}+03$ \\
\hline Total $\mathrm{Cm}$ & $1.68 \mathrm{E}+01$ & $3.36 \mathrm{E}+00$ & $1.68 \mathrm{E}+07$ & $3.36 \mathrm{E}+06$ & $1.14 E+06$ \\
\hline $\mathrm{Cm}-244$ & $1.68 E+01$ & $3.36 \mathrm{E}+00$ & $1.68 \mathrm{E}+07$ & $3.36 \mathrm{E}+06$ & $1.14 \mathrm{E}+06$ \\
\hline $\mathrm{Cm}-245$ & 3.21E-01 & $\mathrm{DL}$ & $3.21 E+05$ & $\mathrm{DL}$ & $2.19 E+04$ \\
\hline $\mathrm{Cm}-246$ & 5.72E-01 & $\mathrm{DL}$ & $5.72 E+05$ & $\mathrm{DL}$ & $3.90 E+04$ \\
\hline Co-60 & $3.42 \mathrm{E}-03$ & MDA & $3.42 E+03$ & MDA & $2.33 E+02$ \\
\hline Cs-134 & $4.35 \mathrm{E}-03$ & MDA & $4.35 \mathrm{E}+03$ & MDA & $2.96 \mathrm{E}+02$ \\
\hline Cs-137 & $6.71 \mathrm{E}-01$ & 2.68E-02 & $6.71 \mathrm{E}+05$ & $2.68 E+04$ & $4.57 E+04$ \\
\hline Eu-154 & 5.05E-01 & 1.41E-02 & $5.05 E+05$ & $1.41 E+04$ & $3.44 \mathrm{E}+04$ \\
\hline Eu-155 & $6.31 E-02$ & $7.82 \mathrm{E}-03$ & $6.31 \mathrm{E}+04$ & $7.82 \mathrm{E}+03$ & $4.30 \mathrm{E}+03$ \\
\hline GA & $2.43 E+01$ & $4.86 \mathrm{E}+00$ & $2.43 E+07$ & $4.86 \mathrm{E}+06$ & $1.66 E+06$ \\
\hline $\mathrm{H}-3$ & $4.95 E+00$ & $\mathrm{UL}$ & $4.95 E+06$ & UL & $3.37 E+05$ \\
\hline $\mathrm{Nb}-94$ & 1.00 E-02 & MDA & $1.00 \mathrm{E}+04$ & MDA & $6.81 E+02$ \\
\hline GB & $2.94 \mathrm{E}+01$ & $5.88 \mathrm{E}+00$ & $2.94 \mathrm{E}+07$ & $5.88 \mathrm{E}+06$ & $2.00 \mathrm{E}+06$ \\
\hline $\mathrm{Np}-237$ & $2.02 E-03$ & 4.04E-04 & $2.02 E+03$ & $4.04 E+02$ & $1.38 \mathrm{E}+02$ \\
\hline Total Pu & $8.38 E+00$ & $2.42 E+00$ & $8.38 E+06$ & $2.42 E+06$ & $5.71 E+05$ \\
\hline Pu-238 & $5.77 \mathrm{E}+00$ & $2.31 E+00$ & $5.77 E+06$ & $2.31 E+06$ & $3.93 E+05$ \\
\hline Pu-239 & $8.15 \mathrm{E}-01$ & 1.63E-01 & $8.15 E+05$ & $1.63 E+05$ & $5.55 E+04$ \\
\hline Pu-240 & $4.24 E-01$ & $\mathrm{DL}$ & $4.24 E+05$ & $D L$ & $2.89 E+04$ \\
\hline $\mathrm{Pu}-241$ & $1.79 \mathrm{E}+00$ & $7.15 \mathrm{E}-01$ & $1.79 E+06$ & $7.15 E+05$ & $1.22 \mathrm{E}+05$ \\
\hline Pu-242 & 7.34E-03 & $\mathrm{DL}$ & $7.34 \mathrm{E}+03$ & $\mathrm{DL}$ & $5.00 E+02$ \\
\hline Ru-106 & $4.55 \mathrm{E}-02$ & MDA & $4.55 \mathrm{E}+04$ & MDA & $3.10 \mathrm{E}+03$ \\
\hline $\mathrm{sb}-125$ & 1.57E-02 & MDA & $1.57 E+04$ & MDA & $1.07 E+03$ \\
\hline Sn-126 & $1.29 \mathrm{E}-02$ & MDA & $1.29 E+04$ & MDA & $8.79 E+02$ \\
\hline Th-232 & 3.31E-05 & 6.61E-06 & $3.31 \mathrm{E}+01$ & $6.61 \mathrm{E}+00$ & $2.26 \mathrm{E}+00$ \\
\hline $\mathrm{U}-233$ & $1.80 \mathrm{E}-02$ & DL & $1.80 E+04$ & $\mathrm{DL}$ & $1.23 E+03$ \\
\hline U-234 & $1.16 E-02$ & $\mathrm{DL}$ & $1.16 \mathrm{E}+04$ & $D L$ & $7.90 \mathrm{E}+02$ \\
\hline U-235 & $5.00 \mathrm{E}-04$ & $1.00 \mathrm{E}-04$ & $5.00 \mathrm{E}+02$ & $1.00 \mathrm{E}+02$ & $3.41 E+01$ \\
\hline U-236 & $7.84 E-04$ & 1.57E-04 & $7.84 E+02$ & $1.57 \mathrm{E}+02$ & $5.34 \mathrm{E}+01$ \\
\hline U-238 & 4.77E-02 & $9.55 \mathrm{E}-03$ & $4.77 \mathrm{E}+04$ & $9.55 \mathrm{E}+03$ & $3.25 E+03$ \\
\hline TRU & $7.59 \mathrm{E}+00$ & & $7.59 \mathrm{E}+06$ & & $5.17 \mathrm{E}+05$ \\
\hline
\end{tabular}


$\overline{M D A}=$ Minimum Detectable Activity for the conditions used Appendix $\mathrm{O}$

$\mathrm{DL}=$ Detection Limit

Page 014

UL = Upper Limit 
Revision 2

$6 / 8 / 00$

\begin{tabular}{|c|r|l|l|l|l|}
\hline Tank S21 & & & & & \\
\hline Sample \# & $3-104360$ & & & & \\
\hline Customer ID & $98018-21$ & & & & \\
\hline Description & Original Aqueous Sample & & \\
\hline & & & & & \\
\hline Analyte & Concent. & Units & & & \\
\hline Total Suspended Solids & 0.96 & wt \% & & & \\
\hline
\end{tabular}

Appendix $P$

Page P1 


\begin{tabular}{|c|c|c|c|c|c|}
\hline Sample \# & 3-104934 & & & & \\
\hline Customer ID & $98018-21$ & & & & \\
\hline Description & Filtered Aq & ueous Samp & ple & & \\
\hline Total Volume in Tank & 690.4591 & liters & & & \\
\hline & & & & & \\
\hline Analyte & Concent. & Units & & & \\
\hline $\mathrm{Al}$ & $<2$ & $\mathrm{mg} / \mathrm{kg}$ & & & \\
\hline $\mathrm{Sb}$ & $<1$ & $\mathrm{mg} / \mathrm{kg}$ & & & \\
\hline As & $<0.093$ & $\mathrm{mg} / \mathrm{kg}$ & & & \\
\hline $\mathrm{Ba}$ & $<1$ & $\mathrm{mg} / \mathrm{kg}$ & & & \\
\hline $\mathrm{Be}$ & $<1$ & $\mathrm{mg} / \mathrm{kg}$ & & & \\
\hline$B$ & 8 & $\mathrm{mg} / \mathrm{kg}$ & & & \\
\hline $\mathrm{Cd}$ & $<1$ & $\mathrm{mg} / \mathrm{kg}$ & & & \\
\hline $\mathrm{Cl}-$ & 265 & $\mathrm{mg} / \mathrm{L}$ & & & \\
\hline $\mathrm{Cr}$ & $<1$ & $\mathrm{mg} / \mathrm{kg}$ & & & \\
\hline $\mathrm{Cu}$ & 31 & $\mathrm{mg} / \mathrm{kg}$ & & & \\
\hline $\mathrm{CN}-$ & $<10$ & $\mathrm{ug} / \mathrm{L}$ & & & \\
\hline F- & $<20$ & $\mathrm{mg} / \mathrm{L}$ & & & \\
\hline $\mathrm{Fe}$ & $<1$ & $\mathrm{mg} / \mathrm{kg}$ & & & \\
\hline $\mathrm{Pb}$ & $<1$ & $\mathrm{mg} / \mathrm{kg}$ & & & \\
\hline $\mathrm{Mn}$ & $<1$ & $\mathrm{mg} / \mathrm{kg}$ & & & \\
\hline $\mathrm{Hg}$ & 0.49 & $\mathrm{mg} / \mathrm{kg}$ & & & \\
\hline $\mathrm{Ni}$ & $<1.1$ & $\mathrm{mg} / \mathrm{L}$ & & & \\
\hline NO3- & 1580 & $\mathrm{mg} / \mathrm{L}$ & & & \\
\hline PO4--. & 221 & $\mathrm{mg} / \mathrm{L}$ & & & \\
\hline Se & $<0.93$ & $\mathrm{mg} / \mathrm{L}$ & & & \\
\hline $\mathrm{Ag}$ & $<1$ & $\mathrm{mg} / \mathrm{kg}$ & & & \\
\hline $\mathrm{Na}$ & 30227 & $\mathrm{mg} / \mathrm{kg}$ & & & \\
\hline $\mathrm{TI}$ & $<1$ & $\mathrm{mg} / \mathrm{kg}$ & & & \\
\hline $\mathrm{U}$ & 1583 & $\mathrm{mg} / \mathrm{kg}$ & & & \\
\hline $\mathrm{Zn}$ & $<1$ & $\mathrm{mg} / \mathrm{kg}$ & & & \\
\hline Any known VOA's, $>20 \mathrm{mg} / \mathrm{L}$ & No & N/A & & & \\
\hline n-Butanol & $<1.1$ & $\mathrm{mg} / \mathrm{L}$ & & & \\
\hline Phenol/phenoxide/nitrophenols & $5<50$ & $\mathrm{mg} / \mathrm{L}$ & 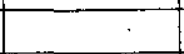 & & \\
\hline SemiVOA & Required & N/A & & & \\
\hline TBP & 0.9 & $\%$ & 9000 & $\mathrm{mg} / \mathrm{L}$ & \\
\hline - Other & $r<50$ & $\mathrm{mg} / \mathrm{L}$ & & & \\
\hline Total Inorganic Carbon & 4810 & $\mathrm{mg} / \mathrm{L}$ & & & \\
\hline Total Organic Carbon & 43000 & $\mathrm{mg} / \mathrm{L}$ & & & \\
\hline Volatile Organics & Required & N/A & & & \\
\hline PCB's & $<50$ & $\mathrm{mg} / \mathrm{L}$ & & & \\
\hline Kepone & $<50$ & $\mathrm{mg} / \mathrm{L}$ & & & \\
\hline p-Nitrophenol & $<50$ & $\mathrm{mg} / \mathrm{L}$ & & & \\
\hline Benzene & $<0.140$ & $\mathrm{mg} / \mathrm{L}$ & & & \\
\hline MEK & 1.8 & $\mathrm{mg} / \mathrm{L}$ & & & \\
\hline PCE & $<0.140$ & $\mathrm{mg} / \mathrm{L}$ & & & \\
\hline Acidity & $<0.02$ & Molarity & & & \\
\hline Ash Content & 7.90 & $\%$ & & & \\
\hline Boiling Pt. & 165.2 & degrees F & & & \\
\hline Flash Pt. & 201.9 & degrees $\mathrm{F}$ & & & \\
\hline Freezing Pt. & $<32$ & degrees $\mathrm{F}$ & & & \\
\hline
\end{tabular}




\begin{tabular}{|c|c|c|c|c|c|}
\hline Free Liquid? & Yes & $\mathrm{N} / \mathrm{A}$ & & & \\
\hline $\mathrm{pH}$ & 10.90 & N/A & & & \\
\hline Density & 1.071 & $\mathrm{~g} / \mathrm{cm} 3$ & & & \\
\hline TDS & 15.3 & $\%$ & & & \\
\hline Water, wt\% & 86.4 & $\%$ & & & \\
\hline & & & & & Aqueous \\
\hline & & & & & Phase \\
\hline & & & & & Total \\
\hline & Activity & Error & Activity & Error & Activity \\
\hline & $\mathrm{uCi} / \mathrm{mL}$ & $\mathrm{uCl} / \mathrm{mL}$ & $\mathrm{pCi} / \mathrm{L}$ & pCi/L & uCi \\
\hline Total Am & $1.78 \mathrm{E}-03$ & $\mathrm{UL}$ & $1.78 \mathrm{E}+06$ & UL & $1.23 E+03$ \\
\hline Am-241 & $1.13 \mathrm{E}-03$ & $1.61 E-04$ & $1.13 E+06$ & $1.61 E+05$ & $7.80 E+02$ \\
\hline Am-243 & $6.49 E-04$ & UL & $6.49 \mathrm{E}+05$ & UL & $4.48 \mathrm{E}+02$ \\
\hline Bi-212 & $5.59 \mathrm{E}-05$ & 5.08E-05 & $5.59 \mathrm{E}+04$ & $5.08 \mathrm{E}+04$ & $3.86 \mathrm{E}+01$ \\
\hline$C-14$ & $2.82 \mathrm{E}-04$ & UL & $2.82 E+05$ & UL & $1.95 E+02$ \\
\hline $\mathrm{Ce}-144$ & 1.93E-04 & MDA & $1.93 E+05$ & MDA & $1.33 E+02$ \\
\hline Total $\mathrm{Cm}$ & $1.32 \mathrm{E}-01$ & 3.97E-02 & $1.32 E+08$ & $3.97 \mathrm{E}+07$ & $9.11 \mathrm{E}+04$ \\
\hline $\mathrm{Cm}-244$ & 1.32E-01 & 3.97E-02 & $1.32 \mathrm{E}+08$ & $3.97 \mathrm{E}+07$ & $9.11 E+04$ \\
\hline Cm-245 & $7.88 \mathrm{E}-04$ & $D L$ & $7.88 \mathrm{E}+05$ & DL & $5.44 \mathrm{E}+02$ \\
\hline Cm-246 & 1.41E-03 & $\mathrm{DL}$ & $1.41 E+06$ & $\overline{D L}$ & $9.74 \mathrm{E}+02$ \\
\hline Co-60 & $1.06 \mathrm{E}-05$ & $6.70 \mathrm{E}-06$ & $1.06 \mathrm{E}+04$ & $6.70 \mathrm{E}+03$ & $7.32 \mathrm{E}+00$ \\
\hline Cs-134 & 1.67E-05 & MDA & 1.67E+04 & MDA & $1.15 E+01$ \\
\hline Cs-137 & $5.63 \mathrm{E}-02$ & $1.93 \mathrm{E}-03$ & $5.63 \mathrm{E}+07$ & $1.93 E+06$ & $3.89 \mathrm{E}+04$ \\
\hline Eu-154 & $2.04 \mathrm{E}-03$ & 5.43E-05 & $2.04 \mathrm{E}+06$ & $5.43 \mathrm{E}+04$ & $1.41 \mathrm{E}+03$ \\
\hline Eu-155 & $2.66 \mathrm{E}-04$ & 4.81E-05 & $2.66 \mathrm{E}+05$ & $4.81 E+04$ & $1.84 \mathrm{E}+02$ \\
\hline $\mathrm{GA}$ & $6.04 E-01$ & 1.21E-01 & $6.04 \mathrm{E}+08$ & $1.21 \mathrm{E}+08$ & 4.17E+05 \\
\hline $\mathrm{H}-3$ & $4.55 \mathrm{E}-03$ & 4.55E-04 & $4.55 \mathrm{E}+06$ & $4.55 \mathrm{E}+05$ & $3.14 \mathrm{E}+03$ \\
\hline $1-129$ & $1.41 E-04$ & UL & $1.41 E+05$ & UL & $9.74 \mathrm{E}+01$ \\
\hline $\begin{array}{l}\mathrm{Ni}-59 \\
\end{array}$ & $3.13 \mathrm{E}-04$ & MDA & $3.13 \mathrm{E}+05$ & MDA & $2.16 \mathrm{E}+02$ \\
\hline $\mathrm{Ni}-63$ & $1.34 \mathrm{E}-04$ & MDA & $1.34 E+05$ & MDA & $9.25 E+01$ \\
\hline GB & $1.70 \mathrm{E}-01$ & $6.81 E-02$ & $1.70 \mathrm{E}+08$ & $6.81 E+07$ & $1.17 E+05$ \\
\hline Np-237 & 2.32E-04 & 1.16E-04 & $2.32 E+05$ & $1.16 E+05$ & $1.60 \mathrm{E}+02$ \\
\hline $\mathrm{Pb}-212$ & $5.68 \mathrm{E}-05$ & $3.28 E-05$ & $5.68 \mathrm{E}+04$ & $3.28 \mathrm{E}+04$ & $3.92 E+01$ \\
\hline Total Pu & $5.99 \mathrm{E}-01$ & $1.49 \mathrm{E}-01$ & $5.99 E+08$ & $1.49 E+08$ & $4.14 \mathrm{E}+05$ \\
\hline $\mathrm{Pu}-238$ & $4.68 \mathrm{E}-01$ & 1.41E-01 & $4.68 \mathrm{E}+08$ & $1.41 \mathrm{E}+08$ & $3.23 E+05$ \\
\hline Pu-239 & $1.26 \mathrm{E}-02$ & $6.28 \mathrm{E}-03$ & $1.26 \mathrm{E}+07$ & $6.28 E+06$ & $8.70 \mathrm{E}+03$ \\
\hline$\overline{\text { Pu-240 }}$ & $4.73 \mathrm{E}-03$ & $2.36 \mathrm{E}-03$ & $4.73 E+06$ & $2.36 \mathrm{E}+06$ & $3.27 E+03$ \\
\hline Pu-241 & 1.14E-01 & 4.77E-02 & $1.14 \mathrm{E}+08$ & $4.77 \mathrm{E}+07$ & $7.87 E+04$ \\
\hline Pu-242 & $1.81 \mathrm{E}-05$ & $\mathrm{DL}$ & $1.81 E+04$ & DL & $1.25 \mathrm{E}+01$ \\
\hline $\mathrm{Pm}-147$ & $4.05 E-03$ & MDA & $4.05 E+06$ & MDA & $2.80 E+03$ \\
\hline Ru-106 & 3.43E-04 & MDA & $3.43 E+05$ & MDA & $2.37 E+02$ \\
\hline $\mathrm{Sb}-125$ & $1.66 \mathrm{E}-04$ & MDA & $1.66 \mathrm{E}+05$ & MDA & $1.15 E+02$ \\
\hline Se-79 & $1.80 \mathrm{E}-04$ & MDA & $1.80 E+05$ & MDA & $1.24 \mathrm{E}+02$ \\
\hline Sn-126 & $7.25 E-05$ & MDA & $7.25 \mathrm{E}+04$ & MDA & $5.01 E+01$ \\
\hline Sr-90 & $9.46 \mathrm{E}-03$ & $9.08 \mathrm{E}-04$ & $9.46 E+06$ & $9.08 \mathrm{E}+05$ & $6.53 \mathrm{E}+03$ \\
\hline Tc-99 & $6.76 \mathrm{E}-04$ & $4.50 E-04$ & $6.76 \mathrm{E}+05$ & $4.50 \mathrm{E}+05$ & $4.67 \mathrm{E}+02$ \\
\hline Th-232 & 9.19E-07 & 1.84E-07 & $9.19 \mathrm{E}+02$ & $1.84 E+02$ & 6.35E-01 \\
\hline Th-234 & 2.02E-03 & 1.02E-03 & $2.02 E+06$ & $1.02 E+06$ & $1.39 E+03$ \\
\hline$U-233$ & $2.60 \mathrm{E}-03$ & 5.21E-04 & $2.60 \mathrm{E}+06$ & $5.21 E+05$ & $1.80 E+03$ \\
\hline U-234 & $1.95 E-03$ & 3.90E-04 & $1.95 E+06$ & $3.90 \mathrm{E}+05$ & $1.35 \mathrm{E}+03$ \\
\hline $\bar{U}$ & 5.32E-05 & $1.06 \mathrm{E}-05$ & $5.32 E+04$ & $1.06 E+04$ & $3.67 E+01$ \\
\hline
\end{tabular}




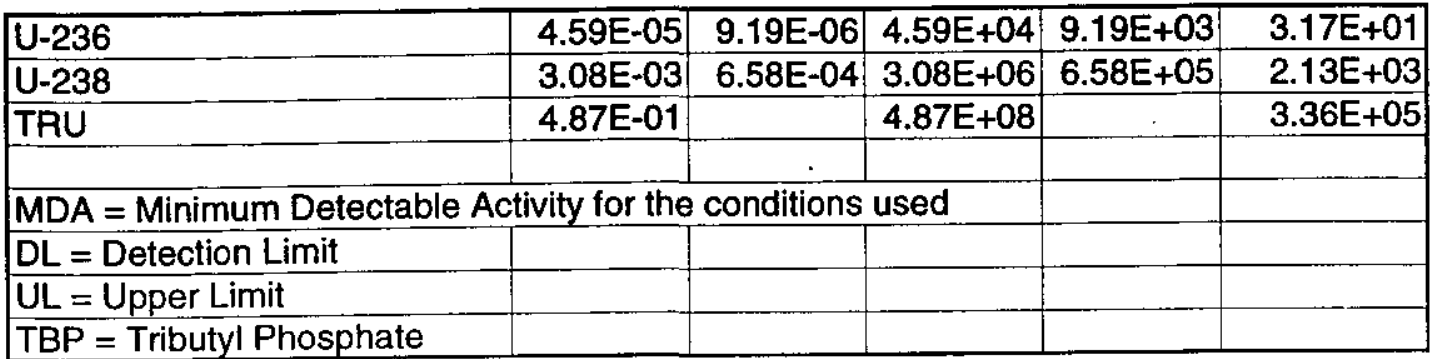




\begin{tabular}{|c|c|c|c|c|c|}
\hline Sample \# & $3-104920$ & & & & \\
\hline Customer ID & $98018-21$ & & & & \\
\hline Description & \multicolumn{2}{|c|}{ Filtered Solids } & & & \\
\hline \multirow[t]{2}{*}{ Estimated Solids } & 7099.02 & $g$ & \multicolumn{3}{|c|}{ (based upon TSS, volume and } \\
\hline & & & \multicolumn{3}{|c|}{ density of liquid phase) } \\
\hline & & & & & \\
\hline \multirow{2}{*}{\multicolumn{6}{|c|}{ 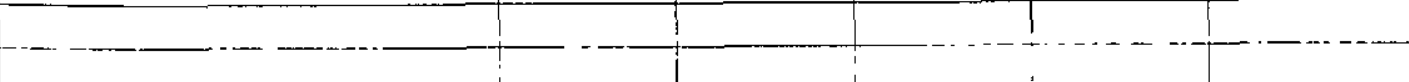 }} \\
\hline & & & & & \\
\hline & & & & & Suspended \\
\hline & & & & & Solids \\
\hline & & & & & Total \\
\hline & Activity & Error & Activity & Error & Activity \\
\hline Analyte & $\mathrm{uCi} / \mathrm{g}$ & uCi/g & $\mathrm{pCi} / \mathrm{g}$ & $\mathrm{pCV} / \mathrm{g}$ & $\mathrm{uCi}$ \\
\hline Total Am & $5.68 E+00$ & 5.10E-01 & $5.68 \mathrm{E}+06$ & $5.10 \mathrm{E}+05$ & $4.03 E+04$ \\
\hline $\mathrm{Am}-241$ & $3.36 \mathrm{E}+00$ & 2.11E-01 & $3.36 \mathrm{E}+06$ & $2.11 E+05$ & $2.39 E+04$ \\
\hline Am-243 & $2.32 E+00$ & 4.64E-01 & $2.32 E+06$ & $4.64 \mathrm{E}+05$ & $1.65 E+04$ \\
\hline $\mathrm{Ce}-144$ & $1.14 \mathrm{E}-01$ & MDA & $1.14 E+05$ & MDA & $8.09 E+02$ \\
\hline Total $\mathrm{Cm}$ & $5.32 E+02$ & $1.06 \mathrm{E}+02$ & $5.32 E+08$ & $1.06 \mathrm{E}+08$ & $3.78 \mathrm{E}+06$ \\
\hline $\mathrm{Cm}-244$ & $5.32 E+02$ & $1.06 \mathrm{E}+02$ & $5.32 E+08$ & $1.06 \mathrm{E}+08$ & $3.78 E+06$ \\
\hline $\mathrm{Cm}-245$ & $1.20 \mathrm{E}-01$ & $\mathrm{DL}$ & $1.20 \mathrm{E}+05$ & $\mathrm{DL}$ & $8.52 E+02$ \\
\hline $\mathrm{Cm}-246$ & $2.48 \mathrm{E}-01$ & $9.93 \mathrm{E}-02$ & $2.48 \mathrm{E}+05$ & $9.93 \mathrm{E}+04$ & $1.76 E+03$ \\
\hline Co-60 & 1.42E-02 & MDA & $1.42 E+04$ & MDA & $1.01 \mathrm{E}+02$ \\
\hline Cs-134 & 1.74E-02 & MDA & $1.74 \mathrm{E}+04$ & MDA & $1.24 \mathrm{E}+02$ \\
\hline Cs-137 & $3.58 \mathrm{E}-01$ & $2.99 \mathrm{E}-02$ & $3.58 E+05$ & $2.99 \mathrm{E}+04$ & $2.54 E+03$ \\
\hline Eu-154 & $1.64 E+00$ & $6.03 \mathrm{E}-02$ & $1.64 E+06$ & $6.03 E+04$ & $1.16 \mathrm{E}+04$ \\
\hline GA & $6.04 \mathrm{E}+02$ & $6.04 \mathrm{E}+01$ & $6.04 E+08$ & $6.04 \mathrm{E}+07$ & $4.29 E+06$ \\
\hline $\mathrm{H}-3$ & 1.91E-01 & $7.66 \mathrm{E}-02$ & $1.91 E+05$ & $7.66 \mathrm{E}+04$ & $1.36 E+03$ \\
\hline $1-129$ & 1.41E-01 & UL & $1.41 E+05$ & UL & $1.00 E+03$ \\
\hline Ni-59 & $9.68 \mathrm{E}-02$ & MDA & $9.68 \mathrm{E}+04$ & MDA & $6.87 E+02$ \\
\hline $\mathrm{Ni}-63$ & 1.63E-01 & UL & $1.63 E+05$ & UL & $1.16 \mathrm{E}+03$ \\
\hline GB & $2.50 \mathrm{E}+01$ & $2.50 \mathrm{E}+01$ & $2.50 \mathrm{E}+07$ & $2.50 \mathrm{E}+07$ & $1.77 E+05$ \\
\hline $\mathrm{Np}-237$ & 2.92E-02 & $5.85 \mathrm{E}-03$ & $2.92 E+04$ & $5.85 E+03$ & $2.07 E+02$ \\
\hline Total $\mathrm{Pu}$ & $1.02 E+02$ & $1.94 \mathrm{E}+01$ & $1.02 E+08$ & $1.94 \mathrm{E}+07$ & $7.27 E+05$ \\
\hline Pu-238 & $6.85 \mathrm{E}+01$ & $1.78 \mathrm{E}+01$ & $6.85 \mathrm{E}+07$ & $1.78 E+07$ & $4.86 \mathrm{E}+05$ \\
\hline Pu-239 & $3.64 \mathrm{E}+00$ & $7.28 \mathrm{E}-01$ & $3.64 \mathrm{E}+06$ & $7.28 E+05$ & $2.58 E+04$ \\
\hline Pu-240 & $9.77 E+00$ & $1.95 \mathrm{E}+00$ & $9.77 E+06$ & $1.95 \mathrm{E}+06$ & $6.94 E+04$ \\
\hline Pu-241 & $2.05 E+01$ & $7.38 E+00$ & $2.05 E+07$ & $7.38 E+06$ & $1.46 E+05$ \\
\hline Pu-242 & $2.74 E-03$ & $\mathrm{DL}$ & $2.74 E+03$ & $D L$ & $1.95 \mathrm{E}+01$ \\
\hline$R u-106$ & $1.86 \mathrm{E}-01$ & MDA & $1.86 E+05$ & MDA & $1.32 E+03$ \\
\hline $\mathrm{Sb}-125$ & $5.27 \mathrm{E}-02$ & MDA & $5.27 \mathrm{E}+04$ & MDA & $3.74 \mathrm{E}+02$ \\
\hline Sn-126 & $7.30 \mathrm{E}-02$ & MDA & $7.30 \mathrm{E}+04$ & MDA & $5.18 E+02$ \\
\hline Sr-90 & $1.72 E+01$ & $8.60 \mathrm{E}+00$ & $1.72 E+07$ & $8.60 E+06$ & $1.22 \mathrm{E}+05$ \\
\hline Tc-99 & $1.72 \mathrm{E}-02$ & MDA & $1.72 E+04$ & MDA & $1.22 E+02$ \\
\hline Th-232 & 3.37E-04 & 6.74E-05 & $3.37 E+02$ & $6.74 \mathrm{E}+01$ & $2.39 E+00$ \\
\hline U-233 & $4.68 \mathrm{E}-02$ & 9.37E-03 & $4.68 \mathrm{E}+04$ & $9.37 E+03$ & $3.32 E+02$ \\
\hline U-234 & $389 \mathrm{E}-02$ & $7.78 \mathrm{E}-03$ & $3.89 E+04$ & $7.78 \mathrm{E}+03$ & $2.76 \mathrm{E}+02$ \\
\hline U-235 & $1.32 E-03$ & 2.64E-04 & $1.32 E+03$ & $2.64 \mathrm{E}+02$ & 9.37E+00 \\
\hline U-236 & $1.40 E-03$ & $2.79 \mathrm{E}-04$ & $1.40 E+03$ & $2.79 \bar{E}+02$ & $9.94 E+00$ \\
\hline U-238 & $3.21 E-02$ & $6.41 E-03$ & $3.21 E+04$ & $6.41 \mathrm{E}+03$ & $2.28 E+02$ \\
\hline TRU & $8.79 E+01$ & & $8.79 E+07$ & & $6.24 E+05$ \\
\hline & & & & & \\
\hline
\end{tabular}


Revision 2

$6 / 8 / 00$

MDA = Minimum Detectable Activity for the conditions used

Appendix $P$

$\mathrm{DL}=$ Detection Limit

Page P6 


\begin{tabular}{|c|c|c|c|c|c|}
\hline Sample \# & 3-117707 & & & & \\
\hline Customer ID & $98351-21$ & & & & \\
\hline Description & Sludge & & & & \\
\hline Total Mass In Tank & 236966.8 & grams & & & \\
\hline & & & & & \\
\hline Analyte & Concent. & Units & & & \\
\hline As & 0.3 & $\mathrm{mg} / \mathrm{kg}$ & & & \\
\hline $\mathrm{Ba}$ & 4 & $\mathrm{mg} / \mathrm{kg}$ & & & \\
\hline $\mathrm{Cd}$ & 5 & $\mathrm{mg} / \mathrm{kg}$ & & & \\
\hline Co & 0.6 & $\mathrm{mg} / \mathrm{kg}$ & & & \\
\hline $\mathrm{Cr}$ & 329 & $\mathrm{mg} / \mathrm{kg}$ & & & \\
\hline$\overline{\mathrm{Pb}}$ & 68 & $\mathrm{mg} / \mathrm{kg}$ & & & \\
\hline $\mathrm{Hg}$ & $<0.01$ & $\mathrm{mg} / \mathrm{kg}$ & & & \\
\hline $\mathrm{Se}$ & $<14$ & $\mathrm{mg} / \mathrm{kg}$ & & & \\
\hline $\mathrm{Ag}$ & 0.3 & $\mathrm{mg} / \mathrm{kg}$ & & & \\
\hline Phenol/phenoxide/nitrophenols & $<15$ & $\mathrm{mg} / \mathrm{kg}$ & & & \\
\hline SemiVOA & Required & N/A & & & \\
\hline TBP & 0.55 & $\%$ & 5500 & $\mathrm{mg} / \mathrm{kg}$ & \\
\hline $\mathrm{NPH}$ & 0.40 & $\%$ & 4000 & $\mathrm{mg} / \mathrm{kg}$ & \\
\hline $\mathrm{BAH}$ & 0.087 & $\%$ & 870 & $\mathrm{mg} / \mathrm{kg}$ & \\
\hline Other & $<15$ & $\mathrm{mg} / \mathrm{kg}$ & & & \\
\hline PCB's & $<10$ & $\mathrm{mg} / \mathrm{kg}$ & & & \\
\hline Kepone & $<15$ & $\mathrm{mg} / \mathrm{kg}$ & & & \\
\hline p-Nitrophenol & $<15$ & $\mathrm{mg} / \mathrm{kg}$ & & & \\
\hline & & & & & Sludge \\
\hline & & & & & Phase \\
\hline & & & & & Total \\
\hline & Activity & Error & Activity & Error & Activity \\
\hline & $\mathrm{uCl} / \mathrm{g}$ & $\mathrm{uCi} / \mathrm{g}$ & $\mathrm{pCi} / \mathrm{g}$ & $\mathrm{pCl} / \mathrm{g}$ & $\mathrm{uCi}$ \\
\hline Total Am & $0.00 E+00$ & $0.00 E+00$ & $0.00 E+00$ & $0.00 \mathrm{E}+00$ & $0.00 \mathrm{E}+00$ \\
\hline$A m-241$ & $7.48 E-03$ & MDA & $7.48 E+03$ & MDA & $1.77 \mathrm{E}+03$ \\
\hline Am-243 & $6.71 E-02$ & MDA & $6.71 E+04$ & MDA & $1.59 \mathrm{E}+04$ \\
\hline $\mathrm{Ce}-144$ & $5.72 E-03$ & MDA & $5.72 E+03$ & MDA & $1.36 \mathrm{E}+03$ \\
\hline Total $\mathrm{Cm}$ & $8.15 \mathrm{E}-02$ & 1.63E-02 & $8.15 E+04$ & $1.63 \mathrm{E}+04$ & $1.93 \mathrm{E}+04$ \\
\hline $\mathrm{Cm}-244$ & $8.15 E-02$ & 1.63E-02 & $8.15 E+04$ & $1.63 E+04$ & $1.93 E+04$ \\
\hline $\mathrm{Cm}-245$ & 5.77E-02 & $\mathrm{DL}$ & $5.77 \mathrm{E}+04$ & $\mathrm{DL}$ & $1.37 E+04$ \\
\hline $\mathrm{Cm}-246$ & $1.03 \mathrm{E}-01$ & $\mathrm{DL}$ & $1.03 E+05$ & $\mathrm{DL}$ & $2.44 \mathrm{E}+04$ \\
\hline Co-60 & $2.01 E-03$ & MDA & $2.01 E+03$ & $\mathrm{MDA}$ & $4.76 \mathrm{E}+02$ \\
\hline Cs-134 & $1.36 \mathrm{E}-03$ & MDA & $1.36 \mathrm{E}+03$ & MDA & $3.22 \mathrm{E}+02$ \\
\hline Cs-137 & 1.99E-02 & $3.08 \mathrm{E}-03$ & $1.99 E+04$ & $3.08 \mathrm{E}+03$ & $4.72 \mathrm{E}+03$ \\
\hline Eu-154 & 2.35E-03 & MDA & $2.35 E+03$ & MDA & $5.57 E+02$ \\
\hline GA & $5.09 E-01$ & 1.02E-01 & $5.09 E+05$ & $1.02 E+05$ & $1.21 \mathrm{E}+05$ \\
\hline $\mathrm{H}-3$ & $1.22 \mathrm{E}-01$ & UL & $1.22 E+05$ & UL & $2.89 E+04$ \\
\hline $\mathrm{Nb}-94$ & $1.09 \mathrm{E}-03$ & MDA & $1.09 E+03$ & MDA & $2.58 \mathrm{E}+02$ \\
\hline GB & $1.19 \mathrm{E}-01$ & 2.38E-02 & $1.19 E+05$ & $2.38 \mathrm{E}+04$ & $2.82 E+04$ \\
\hline $\mathrm{Np}-237$ & 2.37E-04 & $\mathrm{DL}$ & $2.37 E+02$ & $\mathrm{DL}$ & $5.62 \mathrm{E}+01$ \\
\hline Total Pu & $4.71 E-01$ & 3.35E-01 & $4.71 E+05$ & $3.35 E+05$ & $1.12 E+05$ \\
\hline Pu-238 & $3.16 E-01$ & $1.26 \mathrm{E}-01$ & $3.16 E+05$ & $1.26 \mathrm{E}+05$ & $7.49 E+04$ \\
\hline Pu-239 & 5.99E-02 & 1.20E-02 & $5.99 E+04$ & $1.20 E+04$ & $1.42 E+04$ \\
\hline Pu-240 & 7.66 E-02 & $\mathrm{DL}$ & $7.66 E+04$ & $D L$ & $1.82 E+04$ \\
\hline Pu-241 & $9.50 \mathrm{E}-02$ & $3.80 \mathrm{E}-02$ & $9.50 \mathrm{E}+04$ & $3.80 \mathrm{E}+04$ & $2.25 E+04$ \\
\hline
\end{tabular}




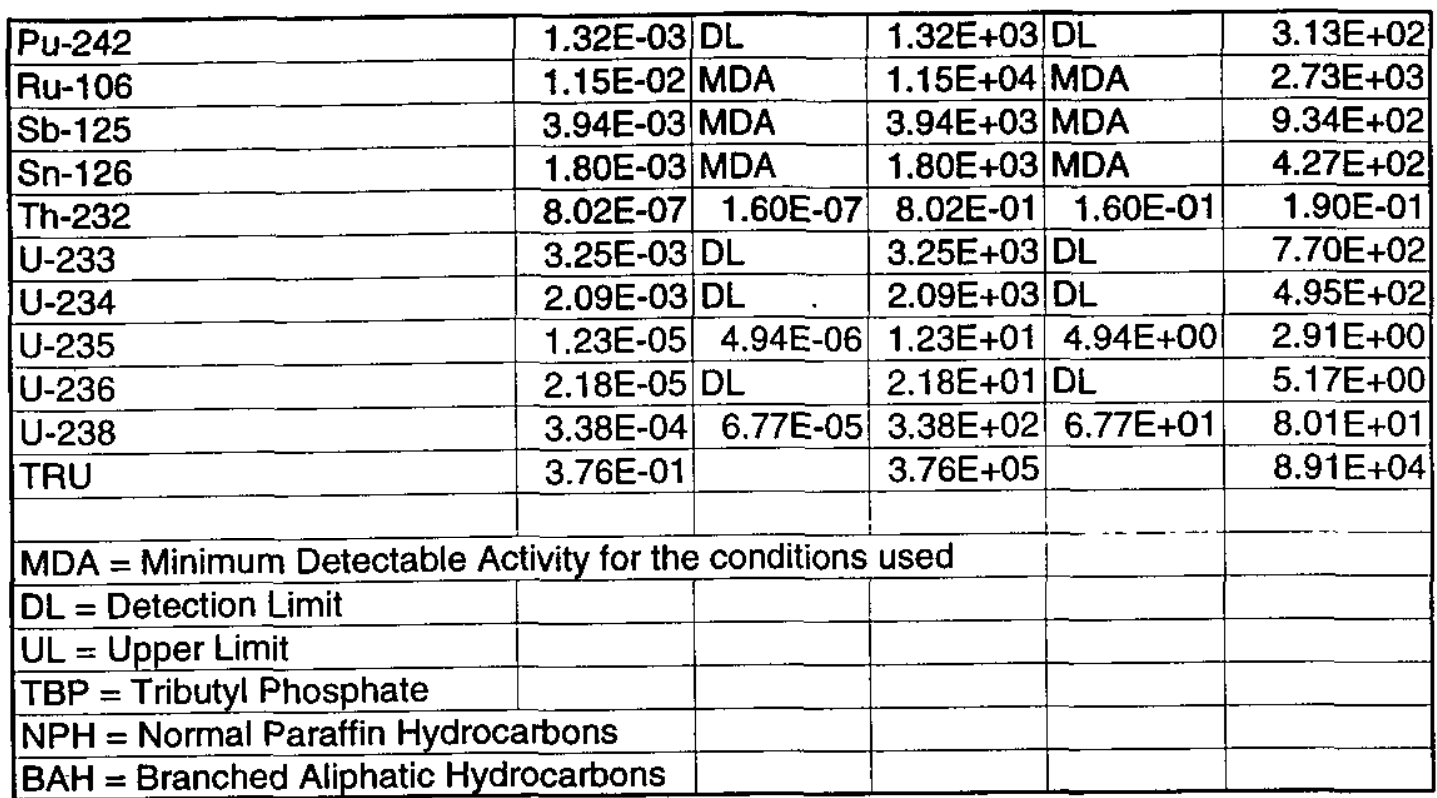




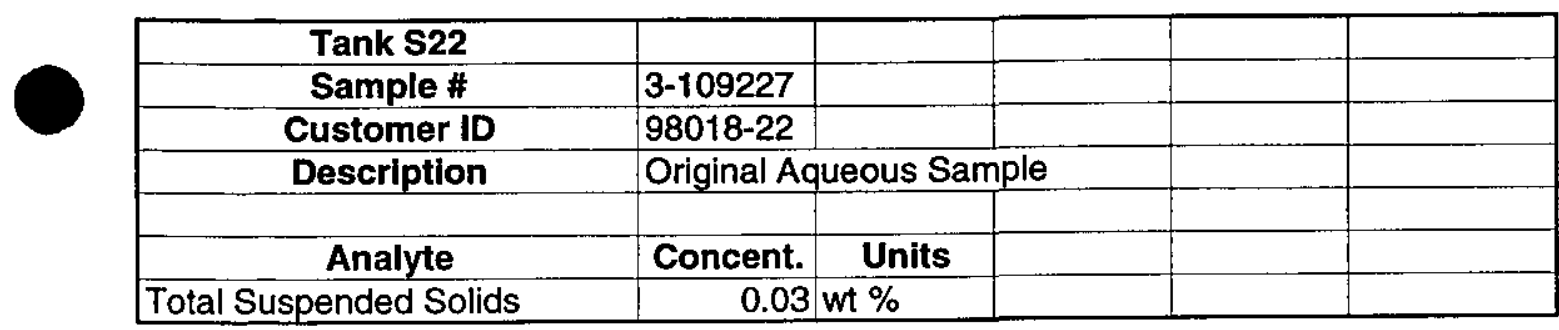

Appendix $Q$

Page Q1 


\begin{tabular}{|c|c|c|c|c|}
\hline Sample \# & 3-109296 & & & \\
\hline Customer ID & $98018-22$ &. & & \\
\hline Description & Filtered Aqu & queous Sam & & \\
\hline Total Volume in Tank & 1694.35 & liters & & \\
\hline Analyte & Concent. & Units & & \\
\hline $\mathrm{Al}$ & 3.7 & $\mathrm{mg} / \mathrm{kg}$ & & \\
\hline$\overline{S b}$ & 2.0 & $\mathrm{mg} / \mathrm{kg}$ & & \\
\hline As & 3.3 & $\mathrm{mg} / \mathrm{kg}$ & & \\
\hline $\mathrm{Ba}$ & 0.07 & $\mathrm{mg} / \mathrm{kg}$ & & \\
\hline $\mathrm{Be}$ & 0.2 & $\mathrm{mg} / \mathrm{kg}$ & & \\
\hline$B$ & 5.0 & $\mathrm{mg} / \mathrm{kg}$ & & \\
\hline C2O4-- & 1383 & $\mathrm{mg} / \mathrm{L}$ & & \\
\hline $\mathrm{Cd}$ & 0.21 & $\mathrm{mg} / \mathrm{kg}$ & & \\
\hline $\mathrm{Cl}-$ & 121 & $\mathrm{mg} / \mathrm{L}$ & & \\
\hline$\overline{\mathrm{Cr}}$ & 4.4 & $\mathrm{mg} / \mathrm{kg}$ & & \\
\hline $\mathrm{Cu}$ & 122.2 & $\mathrm{mg} / \mathrm{kg}$ & & \\
\hline $\mathrm{CN}-$ & $<1$ & $\mathrm{mg} / \mathrm{L}$ & & \\
\hline $\mathrm{COOH}-$ & 1702 & $\mathrm{mg} / \mathrm{L}$ & & \\
\hline F- & $<2$ & $\mathrm{mg} / \mathrm{L}$ & & \\
\hline $\mathrm{Fe}$ & 2.7 & $\mathrm{mg} / \mathrm{kg}$ & & \\
\hline $\mathrm{Pb}$ & $<0.9$ & $\mathrm{mg} / \mathrm{kg}$ & & \\
\hline $\mathrm{Mn}$ & 0.6 & $\mathrm{mg} / \mathrm{kg}$ & & \\
\hline $\mathrm{Hg}$ & 0.74 & $\mathrm{mg} / \mathrm{kg}$ & & \\
\hline $\mathrm{Ni}$ & 1.4 & $\mathrm{mg} / \mathrm{L}$ & & \\
\hline NO2- & 782 & $\mathrm{mg} / \mathrm{L}$ & & \\
\hline NO3- & 535 & $\mathrm{mg} / \mathrm{L}$ & & \\
\hline PO4--- & 523 & $\mathrm{mg} / \mathrm{L}$ & & \\
\hline Se & $<3.8$ & $\mathrm{mg} / \mathrm{L}$ & & \\
\hline SO4-- & 336 & $\mathrm{mg} / \mathrm{L}$ & & \\
\hline $\mathrm{Ag}$ & $<0.9$ & $\mathrm{mg} / \mathrm{kg}$ & & \\
\hline $\mathrm{Na}$ & 16082 & $\mathrm{mg} / \mathrm{kg}$ & & \\
\hline $\mathrm{TI}$ & 1.0 & $\mathrm{mg} / \mathrm{kg}$ & & \\
\hline $\mathrm{U}$ & 2293 & $\mathrm{mg} / \mathrm{kg}$ & & \\
\hline Any known VOA's, $>20 \mathrm{mg} / \mathrm{L}$ & No & N/A & & \\
\hline n-Butanol & $<2.5$ & $\mathrm{mg} / \mathrm{L}$ & & \\
\hline Phenol/phenoxide/nitrophenols & $<100$ & $\mathrm{mg} / \mathrm{L}$ & & \\
\hline SemiVOA & Required & N/A & & \\
\hline TBP & 660 & $\mathrm{mg} / \mathrm{L}$ & & \\
\hline $\mathrm{AH}$ & 1700 & $\mathrm{mg} / \mathrm{L}$ & & \\
\hline $\mathrm{DE}$ & 330 & $\mathrm{mg} / \mathrm{L}$ & & \\
\hline Total Inorganic Carbon & 2859 & $\mathrm{mg} / \mathrm{L}$ & & \\
\hline Total Organic Carbon & 14611 & $\mathrm{mg} / \mathrm{L}$ & & \\
\hline Volatile Organics & Required & N/A & & \\
\hline PCB's & $<50$ & $\mathrm{mg} / \mathrm{L}$ & & \\
\hline Kepone & $<100$ & $\mathrm{mg} / \mathrm{L}$ & & \\
\hline p-Nitrophenol & $<100$ & $\mathrm{mg} / \mathrm{L}$ & & \\
\hline Benzene & $<0.500$ & $\mathrm{mg} / \mathrm{L}$ & & \\
\hline MEK & $<2.5$ & $\mathrm{mg} / \mathrm{L}$ & & \\
\hline PCE & $<0.500$ & $\mathrm{mg} / \mathrm{L}$ & & \\
\hline Acidity & $<0.001$ & Molarity & & \\
\hline Ash Content & 3.65 & $\%$ & & \\
\hline Flash Pt. & $>212$ & degrees $\mathrm{F}$ & & \\
\hline
\end{tabular}




\begin{tabular}{|c|c|c|c|c|c|}
\hline Freezing Pt. & $<32$ & degrees F & & & \\
\hline Free Liquid? & Yes & N/A & & & \\
\hline $\mathrm{pH}$ & 9.94 & N/A & & & \\
\hline Density & 1.066 & $\mathrm{~g} / \mathrm{cm} 3$ & & & \\
\hline TDS & 8.18 & $\%$ & & & \\
\hline \multirow[t]{6}{*}{ Water, wt\% } & 87.01 & $\%$ & & & \\
\hline & & & & & Aqueous \\
\hline & & & & & Phase \\
\hline & & & & & Total \\
\hline & Activity & Error & Activity & Error & Activity \\
\hline & uCi/mL. & $\mathrm{uCi} / \mathrm{mL}$ & $\mathrm{pCi} / \mathrm{L}$ & $\mathrm{pCl} / \mathrm{L}$ & $\mathbf{u C i}$ \\
\hline Total Am & $1.66 \mathrm{E}-03$ & $2.06 \mathrm{E}-04$ & $1.66 E+06$ & $2.06 \mathrm{E}+05$ & $2.82 E+03$ \\
\hline $\mathrm{Am}-241$ & $6.53 \mathrm{E}-04$ & $1.96 \mathrm{E}-04$ & $6.53 \mathrm{E}+05$ & $1.96 \mathrm{E}+05$ & $1.11 \mathrm{E}+03$ \\
\hline Am-243 & 1.01E-03 & 6.24E:05 & $1.01 \mathrm{E}+06$ & $6.24 \mathrm{E}+04$ & $1.71 \mathrm{E}+03$ \\
\hline C-14 & 2.97E-04 & UL & $2.97 \mathrm{E}+05$ & \begin{tabular}{|l|l} 
UL \\
\end{tabular} & $5.03 E+02$ \\
\hline $\mathrm{Ce}-144$ & 3.97E-04 & MDA & $3.97 \mathrm{E}+05$ & MDA & $6.73 \mathrm{E}+02$ \\
\hline Total Cm & $2.76 \mathrm{E}-01$ & 5.51E-02 & $2.76 \mathrm{E}+08$ & $5.51 \mathrm{E}+07$ & $4.68 \mathrm{E}+05$ \\
\hline Cm-244 & $2.76 \mathrm{E}-01$ & $5.51 \mathrm{E}-02$ & $2.76 \mathrm{E}+08$ & $5.51 E+07$ & $4.68 \mathrm{E}+05$ \\
\hline Cm-245 & 1.27E-01 & DL & $1.27 \mathrm{E}+08$ & DL & $2.15 \mathrm{E}+05$ \\
\hline $\mathrm{Cm}-246$ & $2.25 \mathrm{E}-01$ & $\overline{D L}$ & $2.25 \mathrm{E}+08$ & $D L$ & $3.81 \mathrm{E}+05$ \\
\hline Co-60 & $3.38 \mathrm{E}-05$ & $1.22 \mathrm{E}-05$ & $3.38 \mathrm{E}+04$ & $1.22 E+04$ & $5.73 \mathrm{E}+01$ \\
\hline Cs-134 & $1.80 \mathrm{E}-05$ & MDA & $1.80 \mathrm{E}+04$ & MDA & $3.05 \mathrm{E}+01$ \\
\hline Cs-137 & 7.57E-02 & $2.60 \mathrm{E}-03$ & 7.57E+07 & $2.60 \mathrm{E}+06$ & $1.28 \mathrm{E}+05$ \\
\hline Eu-154 & 5.27E-04 & $4.36 \mathrm{E}-05$ & $5.27 \mathrm{E}+05$ & $4.36 \mathrm{E}+04$ & $8.93 \mathrm{E}+02$ \\
\hline $\mathrm{GA}$ & 5.81E-01 & $1.16 \mathrm{E}-01$ & $5.81 \mathrm{E}+08$ & $1.16 \mathrm{E}+08$ & $9.84 \mathrm{E}+05$ \\
\hline $\mathrm{H}-3$ & 4.64E-03 & $4.64 \mathrm{E}-04$ & $4.64 \mathrm{E}+06$ & $4.64 \mathrm{E}+05$ & $7.86 \mathrm{E}+03$ \\
\hline $1-129$ & $2.23 E-04$ & $3.27 \mathrm{E}-05$ & $2.23 \mathrm{E}+05$ & $3.27 E+04$ & $3.78 \mathrm{E}+02$ \\
\hline $\mathrm{Nb}-94$ & $3.15 \mathrm{E}-05$ & MDA & $3.15 E+04$ & MDA & $5.34 \mathrm{E}+01$ \\
\hline $\mathrm{Ni}-63$ & $4.05 E-06$ & UL & $4.05 \mathrm{E}+03$ & $\mathrm{UL}$ & $6.86 \mathrm{E}+00$ \\
\hline GB & $1.22 E-01$ & $4.88 \mathrm{E}-02$ & $1.22 \mathrm{E}+08$ & $4.88 \mathrm{E}+07$ & $2.07 \mathrm{E}+05$ \\
\hline $\mathrm{Np}-237$ & 2.07E-04 & MDA & $2.07 \mathrm{E}+05$ & MDA & $3.51 \mathrm{E}+02$ \\
\hline Total Pu & $3.40 \mathrm{E}-01$ & $6.08 \mathrm{E}-02$ & $3.40 \mathrm{E}+08$ & $6.08 E+07$ & $5.77 \mathrm{E}+05$ \\
\hline Pu-238 & $2.76 \mathrm{E}-01$ & $5.51 \mathrm{E}-02$ & $2.76 \mathrm{E}+08$ & $5.51 \mathrm{E}+07$ & $4.68 \mathrm{E}+05$ \\
\hline Pu-239 & $4.55 \mathrm{E}-02$ & $\mathrm{DL}$ & $4.55 \mathrm{E}+07$ & $\mathrm{DL}$ & $7.71 \mathrm{E}+04$ \\
\hline Pu-240 & 1.67E-01 & $\mathrm{DL}$ & $1.67 E+08$ & $D L$ & 2.83E+05 \\
\hline Pu-241 & 6.44E-02 & $2.58 \mathrm{E}-02$ & $6.44 E+07$ & $2.58 \mathrm{E}+07$ & $1.09 E+05$ \\
\hline Pu-242 & $2.90 \mathrm{E}-03$ & $\mathrm{DL}$ & $2.90 \mathrm{E}+06$ & $\mathrm{DL}$ & $4.91 E+03$ \\
\hline Ru-106 & $7.12 E-04$ & MDA & $7.12 E+05$ & MDA & $1.21 \mathrm{E}+03$ \\
\hline Sb-125 & $3.60 \mathrm{E}-04$ & MDA & $3.60 \mathrm{E}+05$ & MDA & $6.10 \mathrm{E}+02$ \\
\hline Se-79 & $9.01 \mathrm{E}-04$ & $M D A$ & $9.01 \mathrm{E}+05$ & MDA & $1.53 E+03$ \\
\hline $5 n-126$ & 1.49E-04 & MDA & $1.49 \mathrm{E}+05$ & MDA & $2.52 \mathrm{E}+02$ \\
\hline Sr-90 & 3.25E-03 & $4.56 \mathrm{E}-04$ & $3.25 \mathrm{E}+06$ & $4.56 \mathrm{E}+05$ & $5.51 \mathrm{E}+03$ \\
\hline Tc-99 & $4.95 \mathrm{E}-04$ & $1.80 \mathrm{E}-04$ & $4.95 \mathrm{E}+05$ & $1.80 \mathrm{E}+05$ & $8.39 E+02$ \\
\hline Th-232 & $7.21 \mathrm{E}-07$ & 1.44E-07 & $7.21 \mathrm{E}+02$ & $1.44 \mathrm{E}+02$ & $1.22 \mathrm{E}+00$ \\
\hline U-233 & $7.12 \mathrm{E}-03$ & $\mathrm{DL}$ & $7.12 E+06$ & $\mathrm{DL}$ & $1.21 \mathrm{E}+04$ \\
\hline U-234 & $4.59 E-03$ & $\mathrm{DL}$ & $4.59 \mathrm{E}+06$ & $\mathrm{DL}$ & $7.78 \mathrm{E}+03$ \\
\hline$U-235$ & 5.27E-05 & $1.05 \mathrm{E}-05$ & $5.27 E+04$ & $1.05 E+04$ & $8.93 E+01$ \\
\hline U-236 & 4.77E-05 & $D L$ & $4.77 \mathrm{E}+04$ & $\mathrm{DL}$ & $8.08 E+01$ \\
\hline U-238 & 9.77E-04 & 1.95E-04 & $9.77 E+05$ & $1.95 \mathrm{E}+05$ & $1.66 \mathrm{E}+03$ \\
\hline TRU & $2.78 \mathrm{E}-01$ & & $2.78 \mathrm{E}+08$ & & $4.70 E+05$ \\
\hline & & & & & \\
\hline & 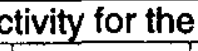 & e condition & sed & & \\
\hline $\mathrm{DL}=\mathrm{D}$ & & & & & \\
\hline
\end{tabular}


UL = Upper Limit

TBP = Tributyl Phosphate

$\mathrm{AH}=$ Aliphatic Hydrocarbons

$\mathrm{DE}=$ Diphenyl Ether
$6 / 8 / 00$

Appendix Q

Page Q4 


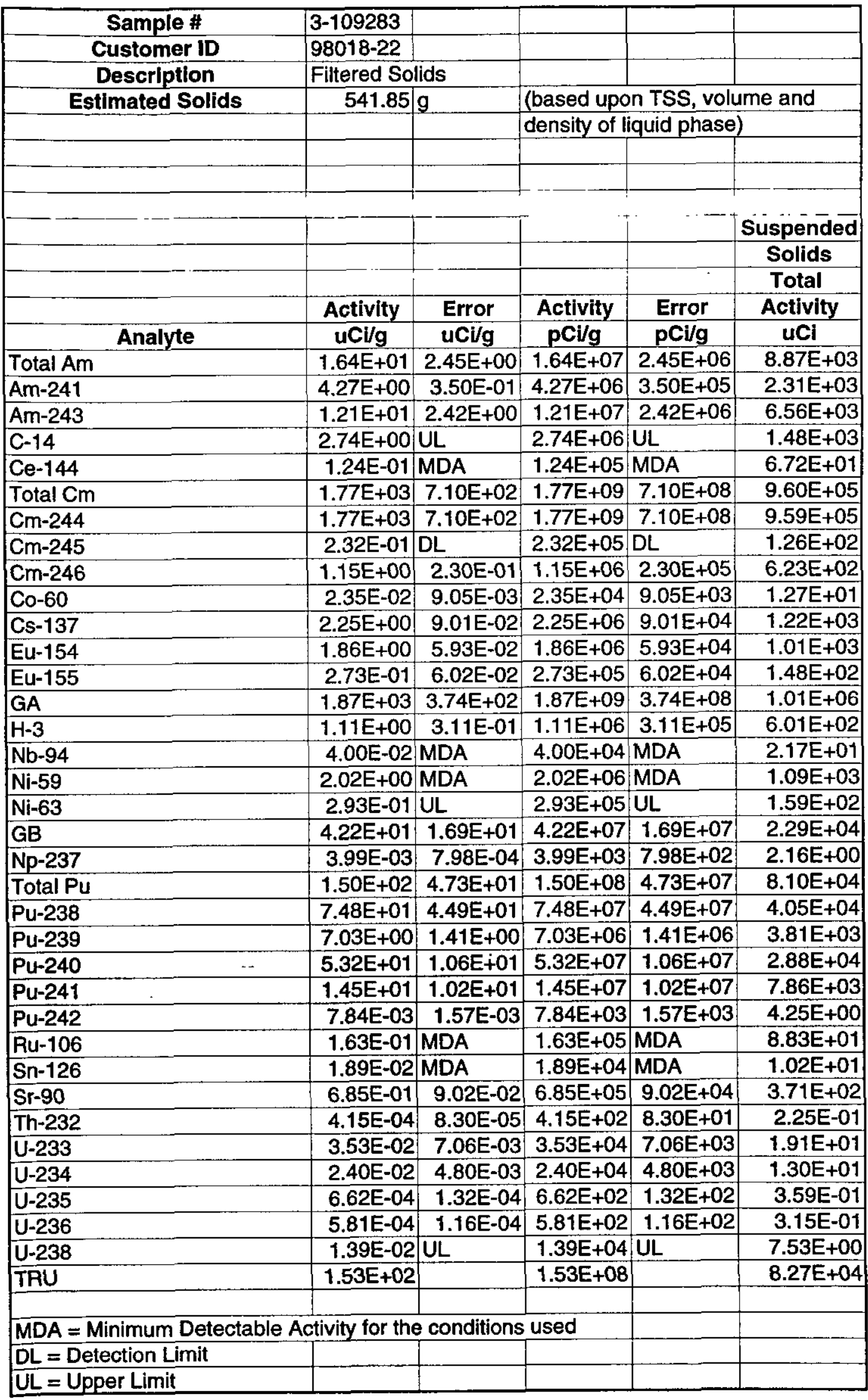




\begin{tabular}{|c|c|c|c|c|c|}
\hline Sample \# & $3-118217$ & & & & \\
\hline Customer ID & $98351-22 B$ & & & & \\
\hline Description & Sludge & & & & \\
\hline Total Mass In Tank & 56781.18 & grams & & & \\
\hline & & & & & \\
\hline Analyte & Concent. & Units & & & \\
\hline As & 3 & $\mathrm{mg} / \mathrm{kg}$ & & & \\
\hline $\mathrm{Ba}$ & 21 & $\mathrm{mg} / \mathrm{kg}$ & & & \\
\hline Cd & 70 & $\mathrm{mg} / \mathrm{kg}$ & & & \\
\hline Co & 6 & $\mathrm{mg} / \mathrm{kg}$ & & & \\
\hline $\mathrm{Cr}$ & 198 & $\mathrm{mg} / \mathrm{kg}$ & & & \\
\hline $\mathrm{Pb}$ & 497 & $\mathrm{mg} / \mathrm{kg}$ & & & \\
\hline $\mathrm{Hg}$ & 62 & $\mathrm{mg} / \mathrm{kg}$ & & & \\
\hline $\mathrm{Se}$ & 4 & $\mathrm{mg} / \mathrm{kg}$ & & & \\
\hline$\overline{\mathrm{Ag}}$ & 6 & $\mathrm{mg} / \mathrm{kg}$ & & & \\
\hline Phenol/phenoxide/nitrophenols & $<100$ & $\mathrm{mg} / \mathrm{kg}$ & & & \\
\hline SemiVOA & Required & $\mathrm{N} / \mathrm{A}$ & & & \\
\hline TBP & 5.5 & $\%$ & 55000 & $\mathrm{mg} / \mathrm{kg}$ & \\
\hline $\mathrm{BAH}$ & 16 & $\%$ & 160000 & $\mathrm{mg} / \mathrm{kg}$ & \\
\hline $\mathrm{DE}$ & 1.7 & $\%$ & 17000 & $\mathrm{mg} / \mathrm{kg}$ & \\
\hline Other & $<100$ & $\mathrm{mg} / \mathrm{kg}$ & & & \\
\hline PCB's & $<10$ & $\mathrm{mg} / \mathrm{kg}$ & & & \\
\hline Kepone & $<100$ & $\mathrm{mg} / \mathrm{kg}$ & & & \\
\hline p-Nitrophenol & $<100$ & $\mathrm{mg} / \mathrm{kg}$ & & & \\
\hline & & & & & Sludge \\
\hline & & & & & Phase \\
\hline & & & & & Total \\
\hline & Activity & Error & Activity & Error & Activity \\
\hline & $\mathrm{uCi} / \mathrm{g}$ & $\mathrm{uCi} / \mathrm{g}$ & $\mathrm{pCi} / \mathrm{g}$ & $\mathrm{pCi} / \mathrm{g}$ & uCi \\
\hline Total Am & 8.67E-01 & UL & $8.67 E+05$ & UL & $4.92 E+04$ \\
\hline Am-241 & $1.69 \mathrm{E}-01$ & $1.35 \mathrm{E}-02$ & $1.69 \mathrm{E}+05$ & $1.35 E+04$ & $9.60 \mathrm{E}+03$ \\
\hline Am-243 & $6.98 \mathrm{E}-01$ & UL & $6.98 \mathrm{E}+05$ & UL & $3.96 E+04$ \\
\hline $\mathrm{Ce}-144$ & 4.47E-03 & MDA & $4.47 \mathrm{E}+03$ & MDA & $2.54 \mathrm{E}+02$ \\
\hline Total $\mathrm{Cm}$ & $1.37 E+02$ & $2.74 \mathrm{E}+01$ & $1.37 E+08$ & $2.74 E+07$ & $7.78 \mathrm{E}+06$ \\
\hline $\mathrm{Cm}-244$ & $1.37 E+02$ & $2.74 E+01$ & $1.37 \mathrm{E}+08$ & $2.74 \mathrm{E}+07$ & $7.78 E+06$ \\
\hline $\mathrm{Cm}-245$ & $6.35 \mathrm{E}-03$ & $2.92 \mathrm{E}-03$ & $6.35 E+03$ & $2.92 E+03$ & $3.61 E+02$ \\
\hline $\mathrm{Cm}-246$ & 7.07E-02 & $\mathrm{DL}$ & $7.07 E+04$ & $\mathrm{DL}$ & $4.01 E+03$ \\
\hline Co-60 & $4.50 \mathrm{E}-04$ & $1.62 E-04$ & $4.50 E+02$ & $1.62 E+02$ & $2.56 E+01$ \\
\hline Cs-134 & $5.90 E-04$ & MDA & $5.90 \mathrm{E}+02$ & MDA & $3.35 E+01$ \\
\hline Cs-137 & 3.87E-01 & $1.55 \mathrm{E}-02$ & $3.87 E+05$ & $1.55 E+04$ & $2.20 E+04$ \\
\hline Eu-154 & $1.18 \mathrm{E}-01$ & $2.36 \mathrm{E}-03$ & $1.18 E+05$ & $2.36 \mathrm{E}+03$ & $6.70 \mathrm{E}+03$ \\
\hline Eu-155 & $2.09 \mathrm{E}-02$ & $2.09 \mathrm{E}-03$ & $2.09 E+04$ & $2.09 \mathrm{E}+03$ & $1.19 E+03$ \\
\hline GA & $1.59 \mathrm{E}+02$ & $3.18 E+01$ & $1.59 \mathrm{E}+08$ & $3.18 \mathrm{E}+07$ & $9.03 E+06$ \\
\hline $\mathrm{H}-3$ & $1.19 \mathrm{E}+00$ & UL & $1.19 \mathrm{E}+06$ & UL & $6.76 \mathrm{E}+04$ \\
\hline $\mathrm{Nb}-94$ & $1.14 \mathrm{E}-03$ & MDA & $1.14 E+03$ & MDA & $6.47 E+01$ \\
\hline $\mathrm{GB}$ & $2.06 \mathrm{E}-01$ & $4.12 \mathrm{E}-02$ & $2.06 E+05$ & $4.12 E+04$ & 1.17E+04 \\
\hline $\mathrm{Np}-237$ & 3.45E-04 & $6.90 \mathrm{E}-05$ & $3.45 \mathrm{E}+02$ & $6.90 \mathrm{E}+01$ & $1.96 \mathrm{E}+01$ \\
\hline Total Pu & $7.65 \mathrm{E}+00$ & 1.051242 & $7.65 \mathrm{E}+06$ & $1.05 \mathrm{E}+06$ & 4.35E+05 \\
\hline Pu-238 & $4.64 \mathrm{E}+00$ & $9.28 \mathrm{E}-01$ & $4.64 \mathrm{E}+06$ & $9.28 \mathrm{E}+05$ & $2.63 E+05$ \\
\hline Pu-239 & 2.82E-01 & $5.64 \mathrm{E}-02$ & $2.82 E+05$ & $5.64 E+04$ & $1.60 E+04$ \\
\hline Pu-240 & $2.10 E+00$ & $4.21 E-01$ & $2.10 \mathrm{E}+06$ & $4.21 E+05$ & $1.19 E+05$ \\
\hline Pu-241 & $6.31 E-01$ & 2.52E-01 & $6.31 E+05$ & $2.52 E+05$ & $3.58 E+04$ \\
\hline Pu-242 & $2.68 E-03$ & $\mathrm{DL}$ & $2.68 E+03$ & $\mathrm{DL}$ & $1.52 E+02$ \\
\hline
\end{tabular}




\begin{tabular}{|l|r|l|l|l|r|}
\hline Ru-106 & $6.04 \mathrm{E}-03$ & $\mathrm{MDA}$ & $6.04 \mathrm{E}+03$ & $\mathrm{MDA}$ & $3.43 \mathrm{E}+02$ \\
\hline $\mathrm{Sb}-125$ & $2.29 \mathrm{E}-03$ & $\mathrm{MDA}$ & $2.29 \mathrm{E}+03$ & $\mathrm{MDA}$ & $1.30 \mathrm{E}+02$ \\
\hline Sn-126 & $2.76 \mathrm{E}-03$ & $\mathrm{MDA}$ & $2.76 \mathrm{E}+03$ & $\mathrm{MDA}$ & $1.57 \mathrm{E}+02$ \\
\hline Th-232 & $1.47 \mathrm{E}-05$ & $2.95 \mathrm{E}-06$ & $1.47 \mathrm{E}+01$ & $2.95 \mathrm{E}+00$ & $8.35 \mathrm{E}-01$ \\
\hline $\mathrm{TI}-208$ & $1.17 \mathrm{E}-03$ & $3.97 \mathrm{E}-04$ & $1.17 \mathrm{E}+03$ & $3.97 \mathrm{E}+02$ & $6.64 \mathrm{E}+01$ \\
\hline $\mathrm{U}-233$ & $6.58 \mathrm{E}-03$ & $\mathrm{DL}$ & $6.58 \mathrm{E}+03$ & $\mathrm{DL}$ & $3.74 \mathrm{E}+02$ \\
\hline $\mathrm{U}-234$ & $1.35 \mathrm{E}-03$ & $2.70 \mathrm{E}-04$ & $1.35 \mathrm{E}+03$ & $2.70 \mathrm{E}+02$ & $7.67 \mathrm{E}+01$ \\
\hline $\mathrm{U}-235$ & $3.01 \mathrm{E}-05$ & $6.03 \mathrm{E}-06$ & $3.01 \mathrm{E}+01$ & $6.03 \mathrm{E}+00$ & $1.71 \mathrm{E}+00$ \\
\hline $\mathrm{U}-236$ & $1.19 \mathrm{E}-05$ & $2.38 \mathrm{E}-06$ & $1.19 \mathrm{E}+01$ & $2.38 \mathrm{E}+00$ & $6.76 \mathrm{E}-01$ \\
\hline TRU & $7.90 \mathrm{E}+00$ & & $7.90 \mathrm{E}+06$ & & $4.48 \mathrm{E}+05$ \\
\hline & & & & & \\
\hline MDA = Minimum Detectable Activity for the conditions used & & \\
\hline DL = Detection Limit & & & & & \\
\hline UL = Upper Limit & & & & & \\
\hline TBP = Tributyl Phosphate & & & & & \\
\hline BAH = Branched Aliphatic Hydrocarbons & & & & \\
\hline DE $=$ Diphenyl Ether & & & & & \\
\hline
\end{tabular}

Appendix Q

Page Q7 


\begin{tabular}{|c|c|c|c|c|c|}
\hline Sample \# & 3-117708 & & & & \\
\hline Customer ID & $98351-22$ & & & & \\
\hline Description & Sludge & & & & \\
\hline \multirow{2}{*}{\multicolumn{6}{|c|}{ Estimated Solids }} \\
\hline & & & & & \\
\hline & & & & & \\
\hline & & & & & \\
\hline & & & & & \\
\hline & & & & & Sludge \\
\hline & & & & & Phase \\
\hline & & & & & Total \\
\hline & Activity & Error & Activity & Error & Activity \\
\hline Analyte & $\mathrm{uCVg}$ & $\mathrm{uCi} / \mathrm{g}$ & $\mathrm{pCl} / \mathrm{g}$ & $\mathrm{pCi} / \mathrm{g}$ & $\overline{\mathrm{uCi}}$ \\
\hline $\mathrm{GA}$ & $8.56 \mathrm{E}-01$ & $1.71 \mathrm{E}-01$ & $8.56 \mathrm{E}+05$ & $1.71 \mathrm{E}+05$ & $4.86 \mathrm{E}+04$ \\
\hline $\mathrm{H}-3$ & 1.67E-01 & $\mathrm{UL}$ & 1.67E+05 & $\mathrm{UL}$ & $9.48 E+03$ \\
\hline GB & $1.80 \mathrm{E}-01$ & $3.60 \mathrm{E}-02$ & $1.80 \mathrm{E}+05$ & $3.60 \mathrm{E}+04$ & $1.02 E+04$ \\
\hline$\overline{\mathrm{MDA}}=$ Minimum Detect & ivity for the & conditions & used & & \\
\hline $\mathrm{DL}=$ Detection Limit & & & & & \\
\hline UL = Upper Limit & & & & & \\
\hline
\end{tabular}




\begin{tabular}{|c|c|c|c|c|c|c|c|c|c|c|c|c|c|c|c|c|}
\hline \multicolumn{17}{|c|}{ Solvent Tank Nuclide Inventory Calculations - Filtered Llquids } \\
\hline & & & & & & & & & & & & & & & & \\
\hline & $\mathrm{CVg}$ & & $\mathrm{CV} / \mathrm{g}$ & & $\mathrm{Cl}_{\mathrm{g}}$ & & Ci/g & & $\mathrm{Cl} / \mathrm{g}$ & & C/g & & $\mathrm{CV} / \mathrm{g}$ & & $\mathrm{Cl} / \mathrm{g}$ & \\
\hline \multirow[t]{2}{*}{ SPCAT } & $9.64 E-03$ & & $6.24 E-03$ & & $2.16 E-06$ & & 6.47E-05 & & $3.36 \mathrm{E}-07$ & & $7.05 E-04$ & & $1.71 \mathrm{E}+01$ & & $6.21 \mathrm{E}-02$ & \\
\hline & & & & & & Error & U-236 & Error & U-238 & Error & Np-237 & Error & Pu-238 & Error & Pu-239 & Error \\
\hline Tank \# & $\frac{0-20 s}{p c h}$ & pcrl & $\mathrm{pCI}$ & pCin & $\mathrm{pCln}$ & $\mathrm{pCl}$ & $\mathrm{pCI} / \mathrm{L}$ & $\mathrm{pCl}$ & $\mathrm{pCi}$ & $\mathrm{pCi/2}$ & pcil & PClR & PCil & $\mathrm{pCl/L}$ & $\mathrm{pCl/2}$ & pCin \\
\hline s1 & $5.05 E+05$ & $1.01 E+05$ & $5.50 \mathrm{E}+06$ & $1.10 E+06$ & $8.56 \mathrm{E}+04$ & $1.71 E+04$ & $4.38 E+04$ & $8.77 \mathrm{E}+03$ & $1.89 \mathrm{E}+06$ & $3.77 \mathrm{E}+05$ & $2.29 E+05$ & $1.15 E+05$ & $6.49 \mathrm{E}+08$ & $6.49 \mathrm{E}+07$ & $1.39 \mathrm{E}+07$ & $6.94 E+06$ \\
\hline S2 & $0.00 E+00$ & $0.00 \mathrm{E}+00$ & $2.97 E+06$ & $1.78 E+06$ & $1.37 E+04$ & $5.31 E+03$ & $0.00 \mathrm{E}+00$ & \begin{tabular}{|c|}
$0.00 \mathrm{E}+00$ \\
\end{tabular} & $0.00 \mathrm{E}+00$ & $0.00 \mathrm{E}+00$ & $1.03 E+05$ & $2.62 \mathrm{E}+04$ & $1.42 E+07$ & $2.84 E+06$ & $1.98 E+06$ & $0.00 E+00$ \\
\hline S3 & $2.24 E+06$ & $4.48 E+05$ & $2.04 \mathrm{E}+06$ & $4.07 \mathrm{E}+05$ & $7.84 E+04$ & $1.57 \mathrm{E}+04$ & $3.93 E+04$ & \begin{tabular}{|l|}
$7.86 \mathrm{E}+03$ \\
\end{tabular} & $1.85 \mathrm{E}+06$ & $3.70 \mathrm{E}+05$ & $1.88 E+05$ & $9.39 E+04$ & $1.00 \mathrm{E}+07$ & $2.01 E+06$ & $1.05 \mathrm{E}+07$ & $5.25 \mathrm{E}+06$ \\
\hline S4 & \begin{tabular}{|l|}
$7.12 E+06$ \\
\end{tabular} & $0.00 \mathrm{E}+00$ & $4.59 E+06$ & $0.00 E+00$ & $2.10 E+05$ & $4.20 E+04$ & $9.41 E+04$ & \begin{tabular}{|c|}
$1.88 E+04$ \\
\end{tabular} & $6.22 E+06$ & $1.77 E+06$ & $2.40 E+05$ & $0.00 E+00$ & $1.66 \mathrm{E}+07$ & $6.63 E+06$ & \begin{tabular}{|l}
$4.55 E+07$ \\
\end{tabular} & $0.00 E+00$ \\
\hline 55 & $1.12 E+07$ & $2.24 E+06$ & $1.28 E+07$ & $2.57 \mathrm{E}+06$ & $3.36 \mathrm{E}+05$ & $6.72 E+04$ & $2.06 \mathrm{E}+05$ & \begin{tabular}{|c|}
$4.12 E+04$ \\
\end{tabular} & $9.10 E+06$ & $1.82 E+06$ & $4.95 E+05$ & $0.00 E+00$ & $3.28 \mathrm{E}+09$ & $1.31 E+09$ & \begin{tabular}{|l|}
$2.27 \mathrm{E}+08$ \\
\end{tabular} & $4.55 E+07$ \\
\hline S6 & $7.12 E+06$ & $0.00 E+00$ & $4.59 E+06$ & $0.00 E+00$ & $3.68 \mathrm{E}+04$ & $7.37 \mathrm{E}+03$ & $4.77 E+04$ & $0.00 \mathrm{E}+00$ & $8.56 \mathrm{E}+05$ & $1.71 E+05$ & $2.25 E+05$ & $0.00 E+00$ & $1.24 E+07$ & $3.72 E+06$ & \begin{tabular}{|l|}
$4.55 E+07$ \\
\end{tabular} & $0.00 E+00$ \\
\hline S7 & $7.12 E+06$ & $0.00 E+00$ & $4.59 E+06$ & $0.00 E+00$ & $2.32 \mathrm{E}+05$ & $1.72 E+05$ & $1.99 E+05$ & $3.97 E+04$ & $1.12 E+07$ & $2.24 E+06$ & $6.76 E+05$ & $2.70 E+05$ & $1.71 E+08$ & $5.12 E+07$ & $1.02 E+08$ & $4.07 E+07$ \\
\hline So & $7.12 E+06$ & $0.00 E+00$ & $4.59 E+06$ & $0.00 E+00$ & $2.55 E+04$ & $5.11 \mathrm{E}+03$ & $4.77 E+04$ & $0.00 E+00$ & $6.04 E+05$ & $1.21 \mathrm{E}+05$ & $5.18 E+05$ & $0.00 E+00$ & $2.64 \mathrm{E}+07$ & $7.92 E+06$ & $4.55 E+07$ & $0.00 E+00$ \\
\hline S11 & $6.76 E+04$ & $0.00 E+00$ & $4.35 E+04$ & $8.70 E+03$ & $2.02 E+03$ & $4.04 \mathrm{E}+02$ & $4.55 \mathrm{E}+02$ & $9.10 E+01$ & $4.86 E+04$ & $0.00 \mathrm{E}+00$ & $4.95 \mathrm{E}+03$ & $9.91 \mathrm{E}+02$ & $2.52 E+09$ & $5.05 E+08$ & $4.34 E+07$ & $8.68 \mathrm{E}+06$ \\
\hline$S 13$ & $8.60 \mathrm{E}+06$ & $1.72 \mathrm{E}+06$ & $5.77 E+06$ & $1.15 \mathrm{E}+06$ & $1.34 \mathrm{E}+05$ & $2.68 E+04$ & $1.72 \mathrm{E}+05$ & \begin{tabular}{|l|}
$3.43 E+04$ \\
\end{tabular} & $3.37 \mathrm{E}+06$ & $6.75 E+05$ & $4.91 E+05$ & $0.00 E+00$ & $7.52 E+08$ & $1.50 \mathrm{E}+08$ & $4.55 E+07$ & $0.00 E+00$ \\
\hline$\$ 14$ & $3.29 \mathrm{E}+05$ & $6.58 \mathrm{E}+04$ & $2.17 E+06$ & $4.34 E+05$ & $5.09 \mathrm{E}+04$ & $1.02 E+04$ & $5.95 \mathrm{E}+04$ & \begin{tabular}{|c|}
$1.19 \mathrm{E}+04$ \\
\end{tabular} & $3.68 \mathrm{E}+06$ & $7.62 E+05$ & $8.02 E+05$ & $4.01 \mathrm{E}+05$ & $1.08 \mathrm{E}+08$ & $2.16 E+07$ & \begin{tabular}{|l|}
$8.74 \mathrm{E}+06$ \\
\end{tabular} & $4.37 E+06$ \\
\hline S19-0 & \begin{tabular}{|l|}
$2.55 E+06$ \\
\end{tabular} & $5.10 E+05$ & $1.59 \mathrm{E}+06$ & $3.19 E+05$ & $3.05 E+04$ & $6.11 E+03$ & $3.08 \mathrm{E}+04$ & $6.16 \mathrm{E}+03$ & $7.66 \bar{E}+06$ & $1.20 \mathrm{E}+06$ & $2.26 \mathrm{E}+05$ & $1.13 \mathrm{E}+05$ & $2.02 \mathrm{E}+09$ & $2.02 E+08$ & $5.95 \mathrm{E}+06$ & $2.97 E+06$ \\
\hline S19-A & $2.33 E+06$ & \begin{tabular}{|c|}
$4.66 \mathrm{E}+05$ \\
\end{tabular} & $1.64 \mathrm{E}+06$ & $3.28 E+05$ & $3.08 E+04$ & $6.15 E+03$ & $2.97 \mathrm{E}+04$ & $5.94 \mathrm{E}+03$ & \begin{tabular}{|l|}
$6.26 \mathrm{E}+06$ \\
\end{tabular} & $1.05 \mathrm{E}+06$ & $2.49 \mathrm{E}+05$ & $1.24 \mathrm{E}+05$ & \begin{tabular}{|c|}
$2.03 \mathrm{E}+09$ \\
\end{tabular} & $2.03 E+08$ & $4.77 \mathrm{E}+06$ & $2.39 E+06$ \\
\hline S2O-T & $1.62 E+05$ & \begin{tabular}{|c|}
$3.24 E+04$ \\
\end{tabular} & $1.13 E+05$ & $2.25 \mathrm{E}+04$ & $2.11 E+03$ & $4.22 E+02$ & $2.15 \mathrm{E}+03$ & $4.31 \mathrm{E}+02$ & $9.23 \mathrm{E}+03$ & $1.85 E+03$ & $1.20 \mathrm{E}+04$ & $5.99 \mathrm{E}+03$ & $1.41 \mathrm{E}+06$ & $7.50 E+05$ & $3.10 \mathrm{E}+05$ & $1.55 \mathrm{E}+05$ \\
\hline S20-B & $1.12 E+07$ & $2.24 \mathrm{E}+06$ & $3.26 \mathrm{E}+06$ & $6.51 E+05$ & $4.59 E+04$ & $9.19 \mathrm{E}+03$ & $5.32 \mathrm{E}+04$ & $1.06 E+04$ & $1.53 E+06$ & $3.05 E+05$ & $2.45 \mathrm{E}+05$ & $1.22 \mathrm{E}+05$ & $5.59 \mathrm{E}+08$ & $5.59 \mathrm{E}+07$ & $1.21 E+07$ & $6.06 \mathrm{E}+06$ \\
\hline S21 & $2.60 E+06$ & $5.21 E+05$ & $1.95 E+06$ & $3.90 E+05$ & $5.32 E+04$ & $1.06 \mathrm{E}+04$ & $4.59 \mathrm{E}+04$ & $9.19 E+03$ & $3.08 \mathrm{E}+06$ & $6.58 \mathrm{E}+05$ & $2.32 \mathrm{E}+05$ & $1.16 E+05$ & $4.68 \mathrm{E}+08$ & $1.41 E+08$ & $1.26 E+07$ & $6.28 \mathrm{E}+06$ \\
\hline \multirow[t]{3}{*}{ S22 } & $7.12 E+06$ & \begin{tabular}{|l|}
$0.00 E+00$ \\
\end{tabular} & $4.59 E+06$ & $0.00 E+00$ & $5.27 \mathrm{E}+04$ & $1.05 E+04$ & \begin{tabular}{|l|}
$4.77 E+04$ \\
\end{tabular} & $0.00 E+00$ & $9.77 \mathrm{E}+05$ & $1.95 \mathrm{E}+05$ & $2.07 E+05$ & $0.00 \mathrm{E}+00$ & $2.76 \mathrm{E}+08$ & $5.51 E+07$ & \begin{tabular}{|l|}
$4.55 E+07$ \\
\end{tabular} & $0.00 E+00$ \\
\hline & & & & & & & & & & & & & & & & \\
\hline & & & & & & & & & & & & & & & & \\
\hline \multirow{2}{*}{\multicolumn{17}{|c|}{$\begin{array}{l}\text { Values listed in Bold Italles print are detection limits or upper limits } \\
\text { Tank S2 U-233 included in U-234 activity, Pu-240 included in PU-23 }\end{array}$}} \\
\hline & & & & & & & & & & & & & & & & \\
\hline \multirow{2}{*}{\multicolumn{7}{|c|}{$\begin{array}{l}\text { Tank S5 Cm-244 upper limit value estimated from Gross Alpha activity. } \\
\text { The values calculated for samples S20-T and S20-B are upper Ilimilis. }\end{array}$}} & & & & & & & & & & \\
\hline & & & & & & & & & & & & & & & & \\
\hline
\end{tabular}




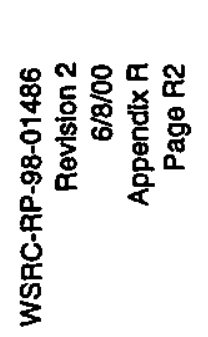

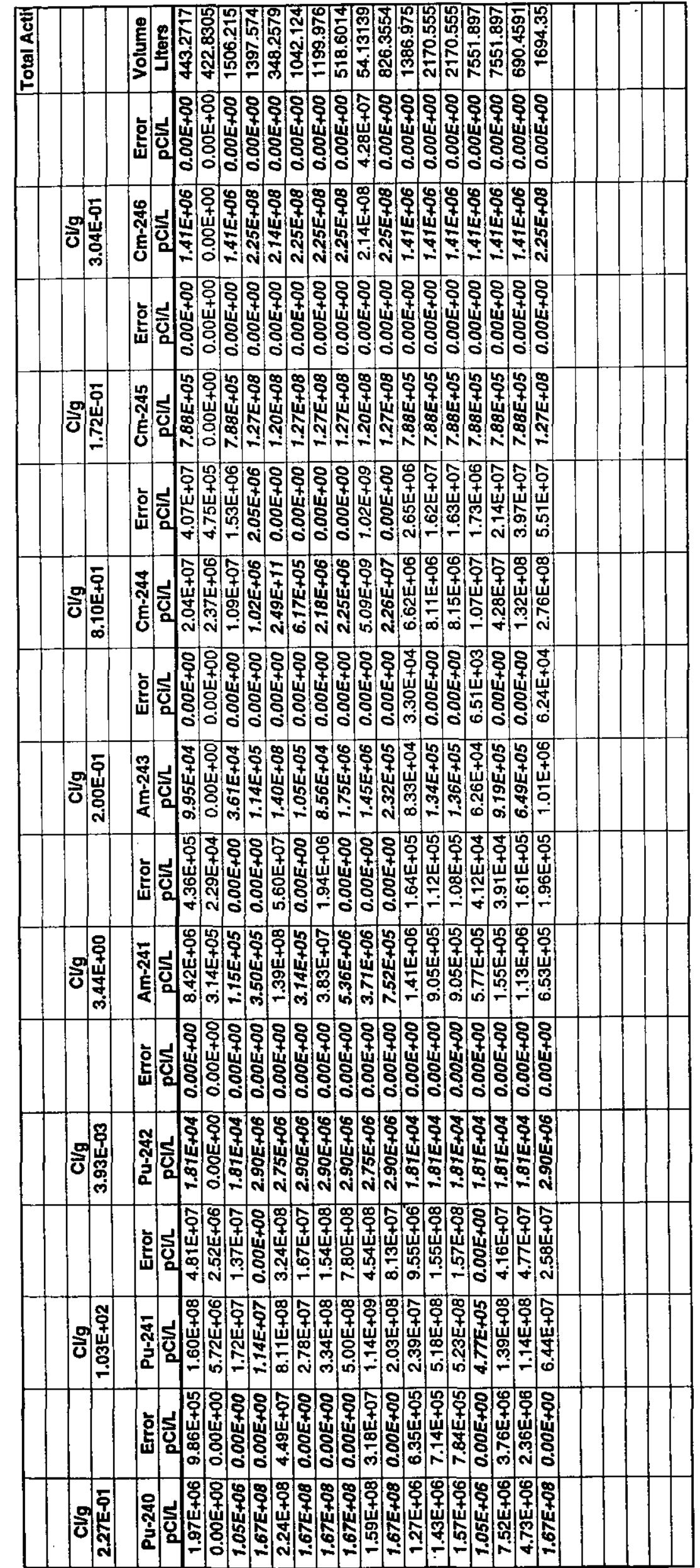




\begin{tabular}{|c|c|c|c|c|c|c|c|c|c|c|c|c|c|c|c|}
\hline \multicolumn{16}{|c|}{ Ity Inciuding Error } \\
\hline & & & & & & & & & & & & & & & \\
\hline & & & & & & & & & & & & & & & \\
\hline & & & & & & & & & & & & & & & \\
\hline$U-233$ & U-234 & U-235 & U-236 & U-238 & Np-237 & Pu-238 & $P u-239$ & Pu-240 & Pu-241 & Pu-242 & Am-241 & Am-243 & $\mathrm{Cm}-244$ & Cm-245 & $\mathrm{Cm}-246$ \\
\hline Cl & $\mathbf{C l}$ & $\mathrm{Cl}$ & $\mathrm{Cl}$ & $\mathrm{Cl}$ & Cl & $\mathrm{Cl}$ & $\mathrm{Cl}$ & $\mathrm{Cl}$ & $\mathrm{Ci}$ & $\mathrm{CI}$ & $\mathrm{Cl}$ & $\mathrm{Cl}$ & $\mathrm{CI}$ & $\mathrm{Cl}$ & $\mathrm{Cl}$ \\
\hline $2.69 E-04$ & 2.93E-03 & $4.55 \mathrm{E}-05$ & $2.33 E-05$ & $1.00 \mathrm{E}-03$ & 1.52E-04 & $3.16 \mathrm{E}-01$ & $9.24 \mathrm{E}-03$ & 1.31E-03 & 9.22E-02 & $8.02 E-06$ & 3.93E-03 & $4.41 E-05$ & $2.71 \mathrm{E}-02$ & $3.49 E-04$ & $6.25 E-04$ \\
\hline $0.00 E+00$ & $2.01 E-03$ & 8.04E-06 & $0.00 \mathrm{E}+00$ & $0.00 E+00$ & 5.46E-05 & $7.21 \mathrm{E}-03$ & $8.37 E-04$ & $0.00 E+00$ & $3.48 \mathrm{E}-03$ & $0.00 \mathrm{E}+00$ & $1.42 E-04$ & $0.00 E+00$ & $1.20 \mathrm{E}-03$ & $0.00 \mathrm{E}+00$ & $0.00 E+00$ \\
\hline $4.05 E-03$ & $3.69 E-03$ & $1.42 E-04$ & $7.10 \mathrm{E}-05$ & $3.34 \mathrm{E}-03$ & 4.25E-04 & $1.81 E-02$ & $2.37 \mathrm{E}-02$ & $1.58 E-03$ & $4.65 \mathrm{E}-02$ & $2.73 E-05$ & $1.73 E-04$ & $5.44 E-05$ & $1.87 \mathrm{E}-02$ & $1.19 E-03$ & $2.12 E-03$ \\
\hline $9.95 E-03$ & $6.41 E-03$ & $3.52 E-04$ & $1.58 E-04$ & $1.12 \mathrm{E}-02$ & $3.35 E-04$ & $3.25 \mathrm{E}-02$ & $6.36 E-02$ & $2.33 E-01$ & $1.59 E-02$ & $4.05 E-03$ & $4.89 E-04$ & $1.59 E-04$ & $4.29 E-03$ & $1.77 E-01$ & $3.14 E-01$ \\
\hline $4.68 E-03$ & $5.35 E-03$ & $1.40 \mathrm{E}-04$ & 8.61E-05 & $3.80 \mathrm{E}-03$ & $1.72 E-04$ & $1.60 \mathrm{E}+00$ & $9.49 \mathrm{E}-02$ & $9.36 \mathrm{E}-02$ & $3.95 \mathrm{E}-01$ & $9.58 E-04$ & 6.79E-02 & $4.88 E-02$ & $8.67 E+01$ & $4.18 E-02$ & $7.45 E-02$ \\
\hline $7.42 E-03$ & $4.78 E-03$ & $4.60 \mathrm{E}-05$ & $4.97 E-05$ & $1.07 \mathrm{E}-03$ & $2.34 E-04$ & $1.68 \mathrm{E}-02$ & $4.74 E-02$ & $1.74 E-01$ & $4.64 \mathrm{E}-02$ & $3.02 E-03$ & $3.27 E-04$ & $1.09 E-04$ & $6.43 E-04$ & $1.32 E-01$ & $2.34 E-01$ \\
\hline $8.54 E-03$ & $5.51 E-03$ & $4.85 E-04$ & $2.86 \mathrm{E}-04$ & $1.61 \mathrm{E}-02$ & $1.14 E-03$ & $2.67 E-01$ & $1.71 E-01$ & $2.00 E-01$ & $5.86 \mathrm{E}-01$ & $3.48 E-03$ & $4.83 E-02$ & $1.03 E-04$ & $2.62 E-03$ & $1.52 E-01$ & $2.70 E-01$ \\
\hline $3.69 E-03$ & $2.38 E-03$ & $1.59 E-05$ & $2.47 E-05$ & $3.76 \mathrm{E}-04$ & $2.69 E-04$ & $1.78 \mathrm{E}-02$ & $2.36 E-02$ & $8.66 E-02$ & $6.64 \mathrm{E}-01$ & $1.50 E-03$ & $2.78 E-03$ & $9.08 E-04$ & $1.17 E-03$ & $6.59 E-02$ & $1.17 E-01$ \\
\hline $3.66 E-06$ & $2.83 E-06$ & $1.31 \mathrm{E}-07$ & $2.96 E-08$ & $2.63 E-06$ & $3.22 E-07$ & 1.64E-01 & $2.82 \mathrm{E}-03$ & 1.03E-02 & $8.63 \mathrm{E}-02$ & $1.49 E-04$ & $2.01 E-04$ & $7.85 E-05$ & $3.31 \mathrm{E}-01$ & $6.50 E-03$ & 1.39E-02 \\
\hline $8.53 E-03$ & $5.72 E-03$ & $1.33 E-04$ & $1.70 \mathrm{E}-04$ & $3.34 E-03$ & $4.06 E-04$ & 7.45E-01 & $3.76 E-02$ & $1.38 E-01$ & 2.35E-01 & $2.40 E-03$ & 6.21E-04 & $1.92 E-04$ & $1.87 E-02$ & $1.05 E-01$ & $1.86 E-01$ \\
\hline $5.48 E-04$ & $3.61 E-03$ & 8.47E-05 & $9.90 \mathrm{E}-05$ & $6.16 \mathrm{E}-03$ & $1.67 \mathrm{E}-03$ & 1.80E-01 & $1.82 E-02$ & $2.64 \mathrm{E}-03$ & $4.64 \mathrm{E}-02$ & $2.51 E-05$ & $2.18 E-03$ & $1.61 E-04$ & $1.29 \mathrm{E}-02$ & $1.09 E-03$ & $1.96 E-03$ \\
\hline $6.64 E-03$ & $4.14 E-03$ & $7.95 \mathrm{E}-05$ & $8.02 E-05$ & $1.92 E-02$ & $7.36 \mathrm{E}-04$ & $4.82 \mathrm{E}+00$ & $1.94 \mathrm{E}-02$ & $4.65 \mathrm{E}-03$ & $1.46 \mathrm{E}+00$ & $3.93 E-05$ & $2.21 E-03$ & $2.91 E-04$ & $5.28 \mathrm{E}-02$ & $1.71 E-03$ & $3.06 E-03$ \\
\hline $6.07 \mathrm{E}-03$ & $4.27 \mathrm{E}-03$ & 8.02E-05 & $7.74 \mathrm{E}-05$ & $1.59 \mathrm{E}-02$ & $8.10 \varepsilon-04$ & $4.85 E+00$ & $1.55 \mathrm{E}-02$ & 5.11E-03 & $1.48 \mathrm{E}+00$ & $3.93 E-05$ & $2.20 \mathrm{E}-03$ & $2.95 E-04$ & 5.31E-02 & $1.71 E-03$ & $3.06 E-03$ \\
\hline $1.47 \mathrm{E}-03$ & $1.02 E-03$ & 1.91E-05 & $1.95 E-05$ & $8.37 E-05$ & $1.36 \mathrm{E}-04$ & $1.63 \mathrm{E}-02$ & $3.51 E-03$ & $7.93 E-03$ & $3.60 E-03$ & $1.37 E-04$ & $4.67 \mathrm{E}-03$ & $5.22 \mathrm{E}-04$ & $9.39 E-02$ & $5.95 E-03$ & $1.06 E-02$ \\
\hline $1.01 \mathrm{E}-01$ & $2.95 E-02$ & $4.16 E-04$ & $4.82 E-04$ & $1.39 E-02$ & $2.77 \mathrm{E}-03$ & $4.64 \mathrm{E}+00$ & $1.37 \mathrm{E}-01$ & $8.52 \mathrm{E}-02$ & $1.36 \mathrm{E}+00$ & $1.37 E-04$ & $1.47 \mathrm{E}-03$ & $6.94 E-03$ & $4.85 E-01$ & $5.95 E-03$ & $1.06 E-02$ \\
\hline $2.15 \mathrm{E}-03$ & $1.62 E-03$ & 4.41E-05 & $3.80 \mathrm{E}-05$ & $2.58 \mathrm{E}-03$ & $2,40 E-04$ & $4.20 \mathrm{E}-01$ & $1.30 \mathrm{E}-02$ & $4.90 \mathrm{E}-03$ & $1.12 E-01$ & $1.25 E-05$ & $8.91 E-04$ & $4.48 E-04$ & $1.19 \mathrm{E}-01$ & $5.44 E-04$ & $9.74 E-04$ \\
\hline $1.21 E-02$ & $7.78 E-03$ & $1.07 \mathrm{E}-04$ & $8.08 E-05$ & $1.99 \mathrm{E}-03$ & $3.51 E-04$ & $5.61 E-01$ & 7.71E-02 & $2.83 E-01$ & $1.53 \mathrm{E}-01$ & $4.91 E-03$ & $1.44 \mathrm{E}-03$ & $1.82 \mathrm{E}-03$ & 5.61E-01 & $2.15 E-01$ & $3.81 E-01$ \\
\hline & & & & & & & & & & & & & & & \\
\hline & & & & & & & & & & & & & & & \\
\hline & & & & & & & & & & & & & & & \\
\hline & & & & & & & & & & & & & & & \\
\hline & & & & & & & & & & & & & & & \\
\hline & & & & & & & & & & & & & & & \\
\hline
\end{tabular}


WSRC-RP-98-01486

Revision 2

$6 / 8 / 00$

Appendlx A

Page R4

\begin{tabular}{|c|c|c|c|c|c|c|c|c|c|c|c|c|c|c|c|c|}
\hline \multicolumn{17}{|c|}{ Actlvity Concentration Including Error } \\
\hline & & & & & & & & & & & & & & & & \\
\hline & & & & & & & & & & & & & & & & \\
\hline & & & & & & & & & & & & & & & & \\
\hline & & & & & & & & & & & & & & & & \\
\hline & U-233 & U-234 & U-235 & U-236 & U-238 & Np-237 & Pu-238 & Pu-239 & Pu-240 & Pu-241 & Pu-242 & Am-241 & Am-243 & $\mathrm{Cm}-244$ & $\mathrm{Cm}-245$ & $\mathrm{Cm}-246$ \\
\hline Tank : & $\mathrm{Cl} / \mathrm{L}$ & $\mathrm{CVL}$ & $\mathrm{Ci} / \mathrm{L}$ & $\mathrm{Cin}$ & Ch & Cll & cin & $\mathrm{Ci} / \mathrm{L}$ & Cin & $\mathrm{Cl} / \mathrm{L}$ & $\mathrm{Cl}$ & $\mathrm{Cl}$ L & $\mathrm{CI} / \mathrm{L}$ & $\mathrm{Ci} / \mathrm{L}$ & $\mathrm{Cl} /$ & Cin \\
\hline S1 & 6.06E-07 & $6.60 \mathrm{E}-06$ & $1.03 \mathrm{E}-07$ & 5.26E-08 & \begin{tabular}{|l|}
$2.27 E-06$ \\
\end{tabular} & 3.44E-07 & 7.14E-04 & $2.08 \mathrm{E}-05$ & 2.96E-06 & $2.08 \mathrm{E}-04$ & \begin{tabular}{|l|}
$1.81 E-08$ \\
\end{tabular} & 8.86E-06 & 9.95E-08 & $6.11 \mathrm{E}-05$ & $7.88 E-07$ & $1.41 E-06$ \\
\hline S2 & $0.00 E+00$ & 4.75E-06 & $1.90 E-08$ & $0.00 \mathrm{E}+00$ & $0.00 \mathrm{E}+00$ & $1.29 \mathrm{E}-07$ & $1.70 E-05$ & $1.98 E-06$ & $0.00 \mathrm{E}+00$ & $8.24 \mathrm{E}-06$ & $0.00 \mathrm{E}+00$ & 3.37E-07 & $0.00 \mathrm{E}+00$ & 2.85E-06 & $0.00 \mathrm{E}+00$ & $0.00 \mathrm{E}+00$ \\
\hline $\mathrm{S3}$ & $2.69 \mathrm{E}-06$ & 2.45E-06 & 9.41E-08 & $4.72 E-08$ & 2.22E-06 & 2.82E-07 & $1.20 \mathrm{E}-05$ & $1.58 \mathrm{E}-05$ & $1.05 E-06$ & $3.09 \mathrm{E}-05$ & \begin{tabular}{|l|l|}
$1.81 E-08$ \\
\end{tabular} & $1.15 E-07$ & $3.61 E-08$ & 1.24E-05 & $7.88 E-07$ & 1.41E-06 \\
\hline 54 & $7.12 E-06$ & $4.59 E-06$ & 2.52E-07 & 1.13E-07 & $7.99 \mathrm{E}-06$ & $2,40 E-07$ & $2.32 \mathrm{E}-05$ & $4.55 E-05$ & $1.67 E-04$ & $1.14 E-05$ & 2.90E-06 & $3.50 E-07$ & $1.14 E-07$ & $3.07 E-06$ & 1.27E-04 & $2.25 E-04$ \\
\hline S5 & $1.34 E-05$ & $1.54 \mathrm{E}-05$ & 4.03E-07 & $2.47 \mathrm{E}-07$ & $1.09 \mathrm{E}-05$ & $4.95 E-07$ & $4.59 \mathrm{E}-03$ & $2.73 E-04$ & 2.69E-04 & $1.14 \mathrm{E}-03$ & $2.75 E-06$ & 1.95E-04 & $1,40 E-04$ & $2,49 E-01$ & $1.20 E-04$ & $2.14 E-04$ \\
\hline S6 & $7.12 E-06$ & 4.59E-06 & $4.42 E-08$ & $4.77 E-08$ & $1.03 \mathrm{E}-06$ & 2.25E-07 & \begin{tabular}{|l|}
$1.61 E-05$ \\
\end{tabular} & $4.55 E-05$ & $1.67 E-04$ & 4.45E-05 & 2.90E-06 & 3.14E-07 & $1.05 E-07$ & $6.17 E-07$ & 1.27E-04 & 2.25E-04 \\
\hline S7 & $7.12 E-06$ & $4.59 E-06$ & 4.04E-07 & $2.39 \mathrm{E}-07$ & $1.34 \mathrm{E}-05$ & $9.46 \mathrm{E}-07$ & 2.22E-04 & 1.43E-04 & \begin{tabular}{|l|}
$1.67 E-04$ \\
\end{tabular} & $4.88 \mathrm{E}-04$ & $2.90 E-06$ & 4.02E-05 & $8.56 E-08$ & $2.18 E-06$ & $1.27 E-04$ & 2.25E-04 \\
\hline 58 & $7.12 E-06$ & $4.59 E-06$ & $3.06 E-08$ & $4.77 E-08$ & 7.25E-07 & $5.18 E-07$ & $3.43 E-05$ & 4.55E-05 & $1.67 E-04$ & $1.28 \mathrm{E}-03$ & $2.90 \mathrm{E}-06$ & $5.36 E-06$ & $1.75 E-06$ & $2.25 E-06$ & $1.27 E-04$ & $2.25 E-04$ \\
\hline S11 & $6.76 E-08$ & $5.22 E-08$ & 2.42E-09 & $5.46 \mathrm{E}-10$ & $4.86 E-08$ & 5.94E-09 & $3.03 \mathrm{E}-03$ & 5.21E-05 & $1.91 \mathrm{E}-04$ & 1.59E-03 & \begin{tabular}{|l|}
$2.75 E-06$ \\
\end{tabular} & 3.71E-06 & $1.45 E-06$ & 6.11E-03 & $1.20 E-04$ & 2.57E-04 \\
\hline $\mathbf{S 1 3}$ & 1.03E-05 & 6.92E-06 & 1.61E-07 & $2.06 \mathrm{E}-07$ & $4.05 E-06$ & $4.91 E-07$ & 9.02E-04 & $4.55 \mathrm{E}-05$ & $1.67 E-04$ & $2.84 \mathrm{E}-04$ & $2.90 E-06$ & $7.52 E-07$ & 2.32E-07 & $2.26 E-05$ & $1.27 E-04$ & $2.25 E-04$ \\
\hline$S 14$ & 3.95E-07 & $2.60 \mathrm{E}-06$ & $6.11 \mathrm{E}-08$ & $7.14 \mathrm{E}-08$ & 4.44E-06 & $1.20 \mathrm{E}-06$ & $1.30 \mathrm{E}-04$ & 1.31E-05 & $1.91 \mathrm{E}-06$ & $3.35 \mathrm{E}-05$ & 1.81E-08 & $1.57 \mathrm{E}-06$ & $1.16 \mathrm{E}-07$ & $9.27 \mathrm{E}-06$ & $7.88 E-07$ & $1.41 E-06$ \\
\hline S19-0 & $3.06 \mathrm{E}-06$ & 1.91E-06 & $3.66 \mathrm{E}-08$ & $3.70 E-08$ & $8.86 \mathrm{E}-06$ & 3.39E-07 & 2.22E-03 & 8.92E-06 & $2.14 E-06$ & $6.73 E-04$ & $1.81 E-08$ & $1.02 \mathrm{E}-06$ & 1.34E-07 & $2.43 \mathrm{E}-05$ & $7.88 E-07$ & $1.41 E-06$ \\
\hline S19-A & 2.80E-06 & 1.97E-06 & $3.70 \mathrm{E}-08$ & $3.56 \mathrm{E}-08$ & 7.31E-06 & $3.73 \mathrm{E}-07$ & $2.23 \mathrm{E}-03$ & $7.16 \mathrm{E}-06$ & 2.35E-06 & $6.80 \mathrm{E}-04$ & $1.81 E-08$ & 1.01E-06 & $1.36 \mathrm{E}-07$ & 2.45E-05 & $7.88 E-07$ & $1.41 E-06$ \\
\hline S2O-T & $1.94 \mathrm{E}-07$ & $1.36 \mathrm{E}-07$ & 2.53E-09 & $2.58 \mathrm{E}-09$ & 1.11E-08 & $1.80 \mathrm{E}-08$ & 2.16E-06 & 4.65E-07 & $1.05 E-06$ & $4.77 E-07$ & $1.81 E-08$ & 6.18E-07 & $6.91 \mathrm{E}-0 \mathrm{~B}$ & $1.24 \mathrm{E}-05$ & $7.88 E-07$ & 1.41E-06 \\
\hline S20-B & $1.34 \mathrm{E}-05$ & $3.91 \mathrm{E}-06$ & 5.51E-08 & $6.38 E-08$ & \begin{tabular}{|l|}
$1.84 E-06$ \\
\end{tabular} & 3.67E-07 & \begin{tabular}{|c|}
$6.15 \mathrm{E}-04$ \\
\end{tabular} & 1.82E-05 & $1.13 \mathrm{E}-05$ & 1.81E-04 & $1.81 E-08$ & \begin{tabular}{|c|}
$1.94 \mathrm{E}-07$ \\
\end{tabular} & 9.19E-07 & $6.42 \mathrm{E}-05$ & $7.88 E .07$ & $1.41 E-06$ \\
\hline S21 & 3.12E-06 & 2.34E-06 & 6.38E-08 & $5.51 \mathrm{E}-08$ & 3.74E-06 & $3.48 \mathrm{E}-07$ & \begin{tabular}{|l|}
$6.09 E-04$ \\
\end{tabular} & $1.89 \mathrm{E}-05$ & $7.09 \mathrm{E}-06$ & $1.62 \mathrm{E}-04$ & 1.81E-08 & 1.29E-06 & $6.49 E-07$ & $1.72 \mathrm{E}-04$ & \begin{tabular}{|l|}
$7.88 E-07$ \\
\end{tabular} & $1.41 E-06$ \\
\hline 522 & $7.12 E-06$ & 4.59E-06 & $6.32 \mathrm{E}-08$ & $4.77 E-08$ & 1.17E-06 & 2.07E-07 & 3.31E-04 & \begin{tabular}{|l|}
$45 E-05$ \\
\end{tabular} & $1.67 E-04$ & 9.02E-05 & $2.90 E-06$ & 8.49E-07 & 1.07E-06 & $3.31 \mathrm{E}-04$ & $1.27 E-04$ & $2.25 E-04$ \\
\hline & & & & & & & & & & & & & & & & \\
\hline & & & & & & & & & & & & & & & & \\
\hline & & & & & & & & & & & & & & & & \\
\hline & & & & & & & & & & & & & & & & \\
\hline & & & & & & & & & & & & & & & & \\
\hline & & & & & & & & & & & & & & & & \\
\hline
\end{tabular}




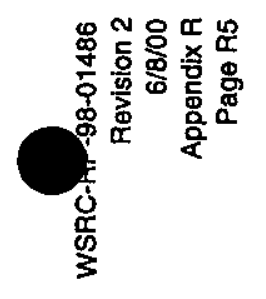

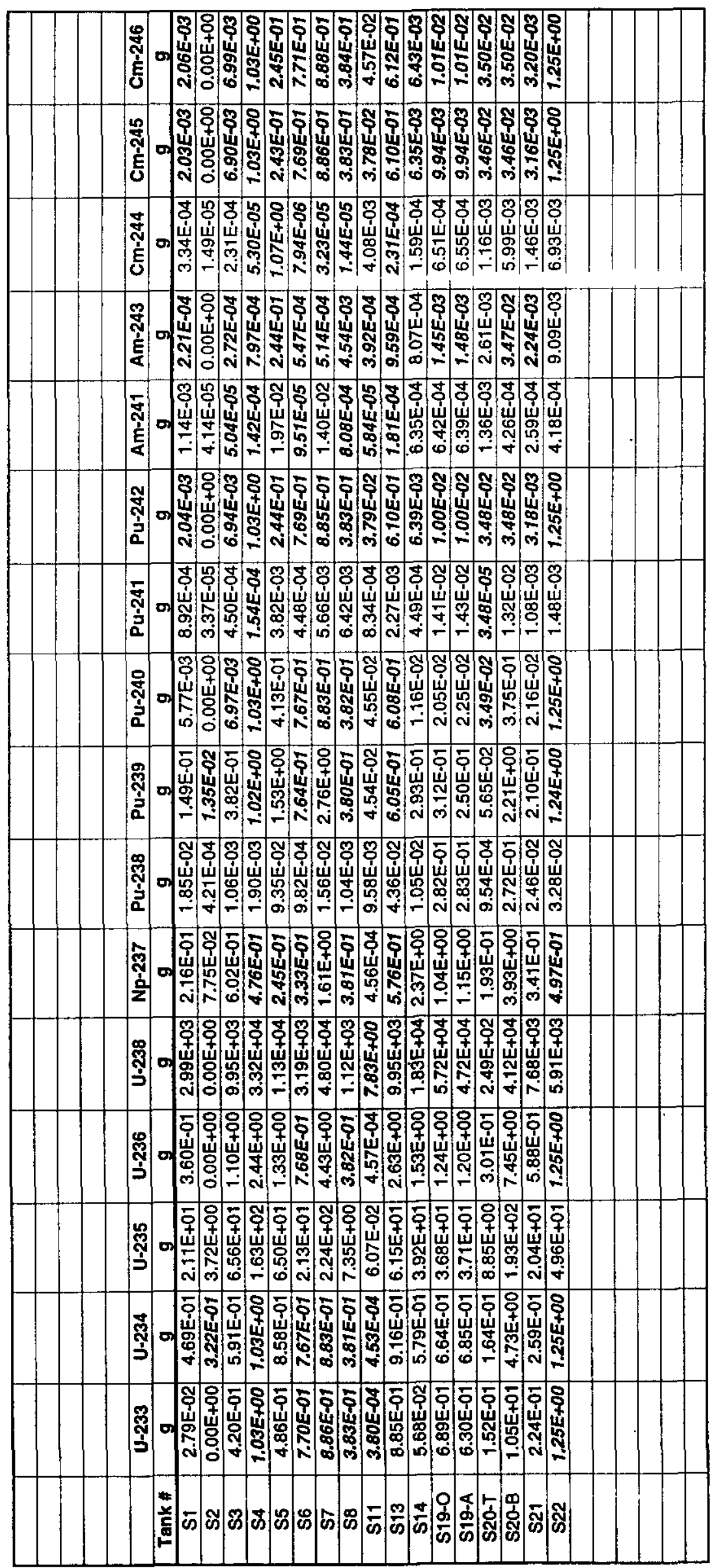




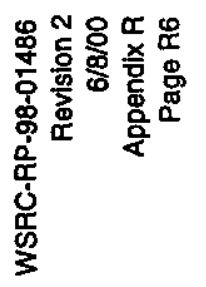

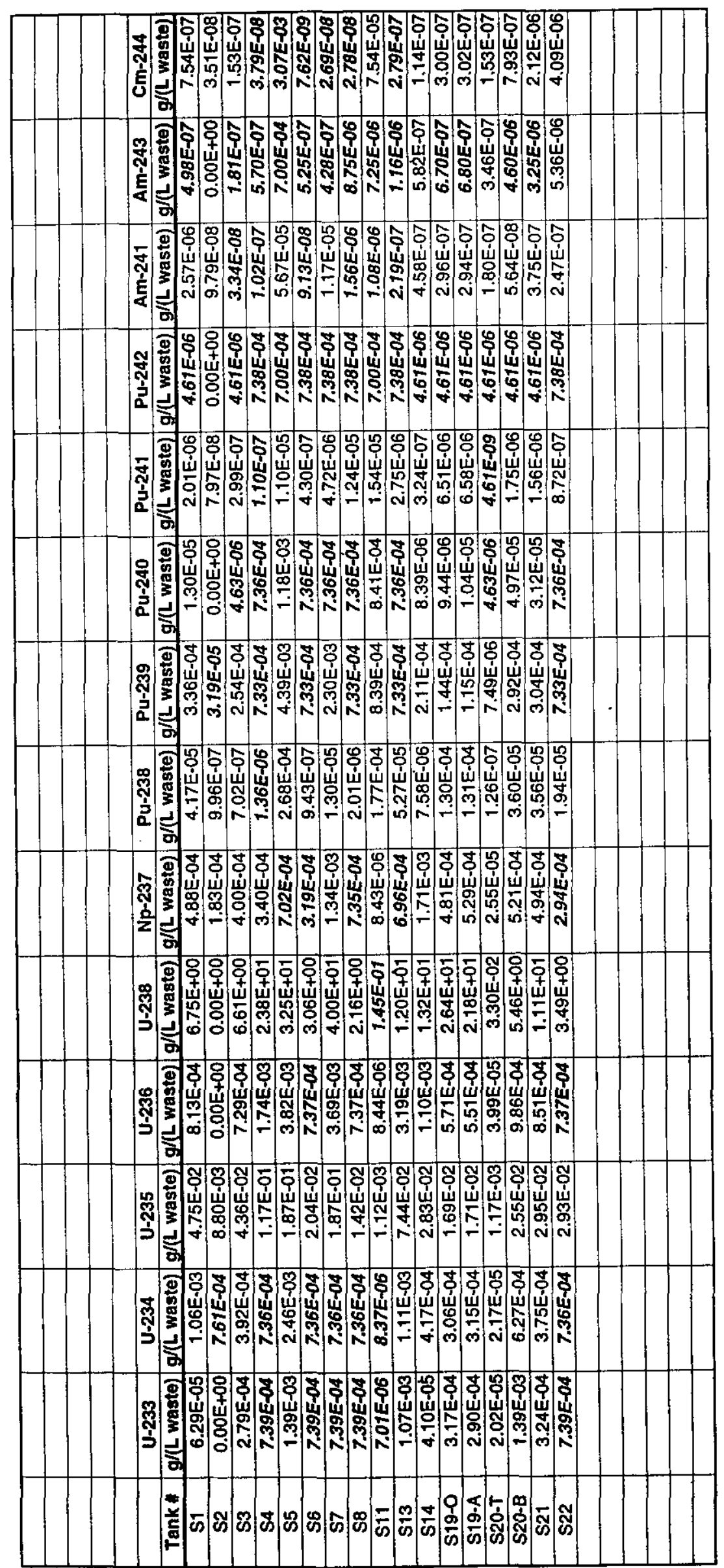




\begin{tabular}{|c|c|c|}
\hline & & \\
\hline & & \\
\hline & & \\
\hline & & \\
\hline & $\mathrm{Cm}-245$ & Cm-246 \\
\hline Tank * & $g /(L$ waste $)$ & $g /($ L waste $)$ \\
\hline $\mathrm{s} 1$ & $4.58 \mathrm{E}-06$ & $4.64 E-06$ \\
\hline s2 & $0.00 \mathrm{E}+00$ & $0.00 \mathrm{E}+00$ \\
\hline 53 & $4.58 E-06$ & $4.64 E-06$ \\
\hline 54 & $7.38 E-04$ & $7.40 E-04$ \\
\hline S5 & $6.98 E-04$ & $7.04 E-04$ \\
\hline 56 & $7.38 E-04$ & $7.40 E-04$ \\
\hline 57 & $7.38 E-04$ & $7.40 E-04$ \\
\hline 58 & $7.38 E-04$ & $7.40 E-04$ \\
\hline$S 11$ & $6.98 E-04$ & $8.45 \mathrm{E}-04$ \\
\hline s13 & $7.38 E-04$ & $7.40 E-04$ \\
\hline S14 & $4.58 E-06$ & $4.64 E-06$ \\
\hline S19-0 & $4.58 E-06$ & $4.64 E-06$ \\
\hline S19-A & $4.58 E-06$ & $4.64 E-06$ \\
\hline S20-T & $4.58 E-06$ & $4.64 E-06$ \\
\hline$S 20-B$ & $4.58 E-06$ & $4.64 E-06$ \\
\hline$\$ 21$ & $4.58 E-06$ & $4.64 E-06$ \\
\hline 522 & $7.38 E-04$ & $7.40 E-04$ \\
\hline & & \\
\hline & & \\
\hline & & \\
\hline & & \\
\hline & & \\
\hline
\end{tabular}



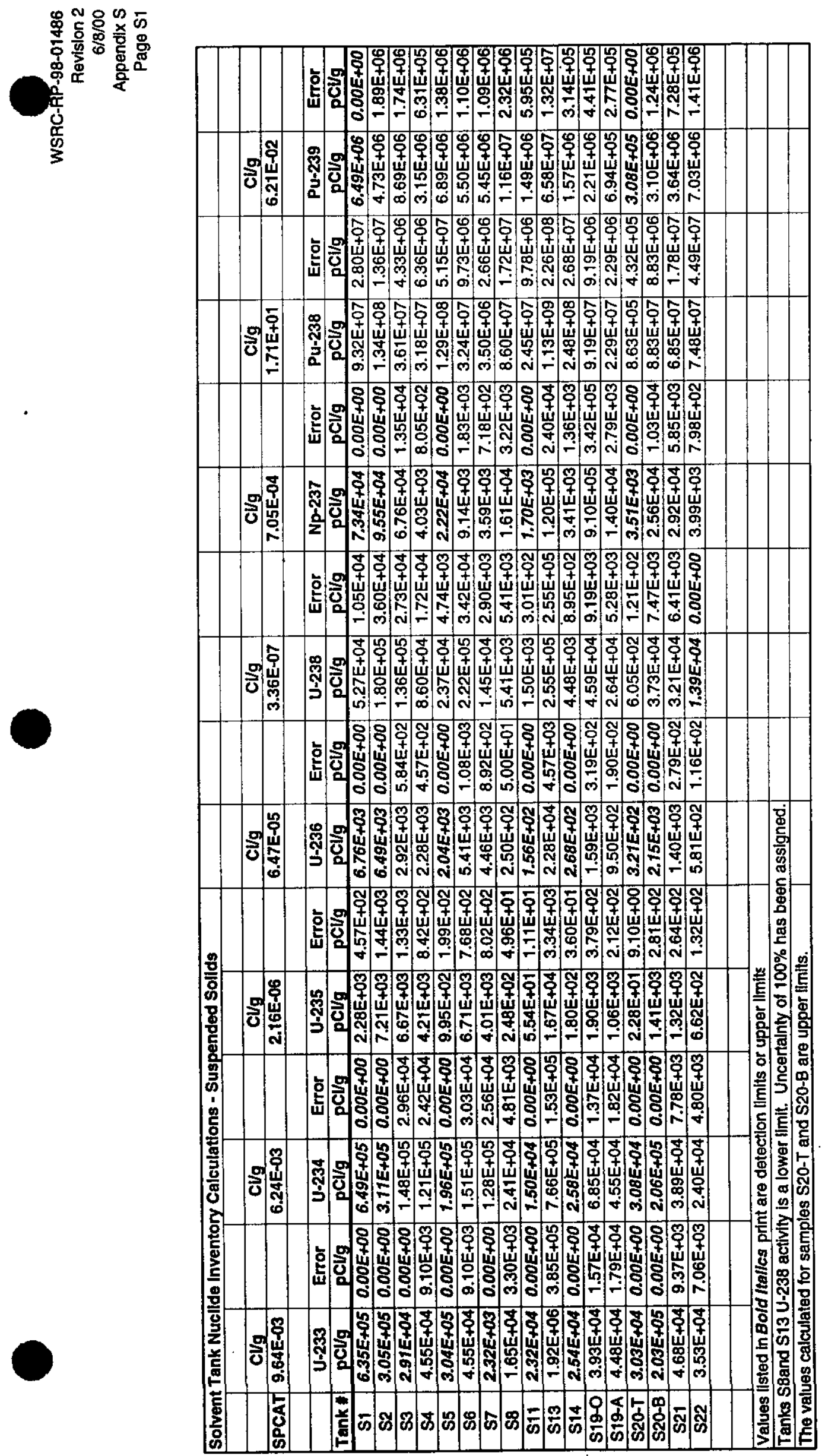


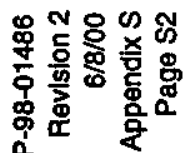

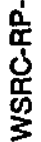

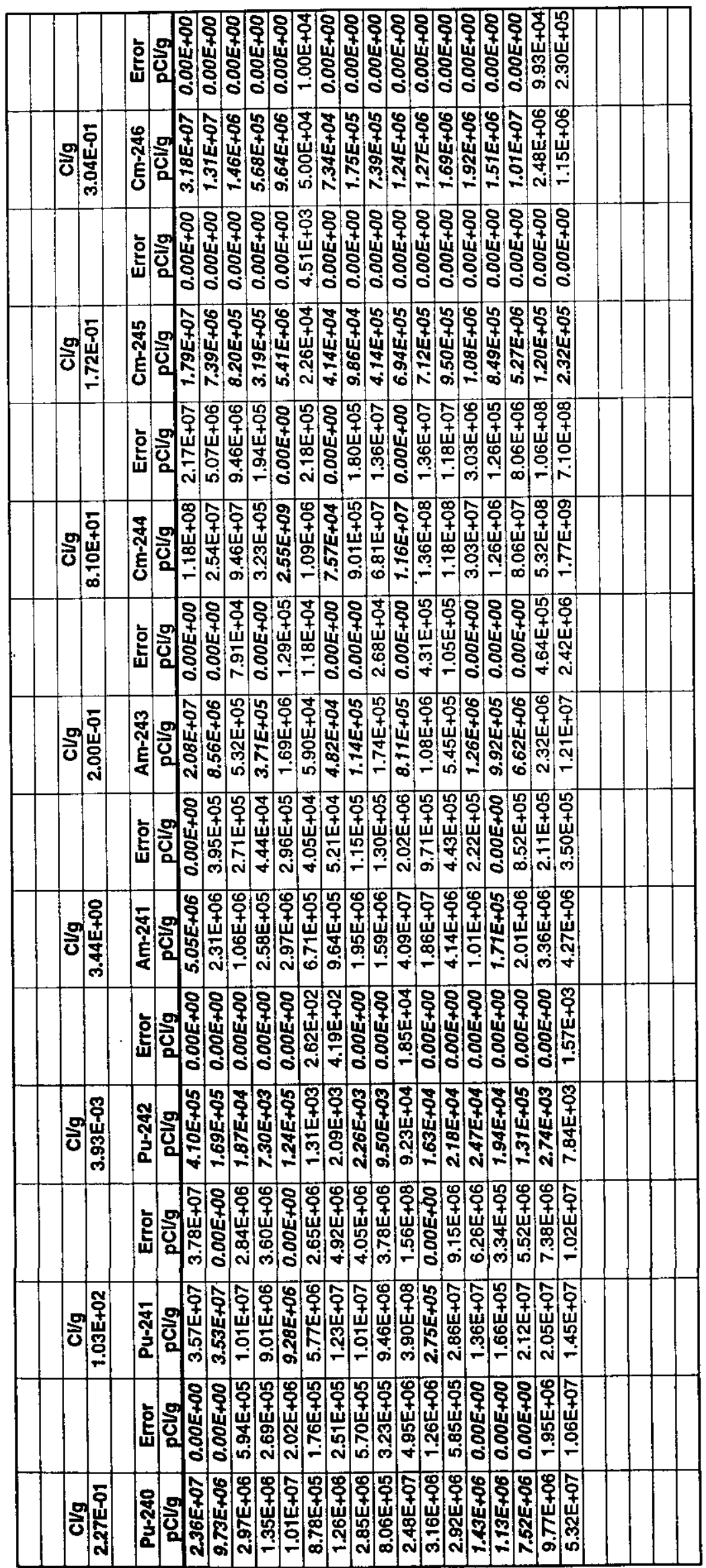



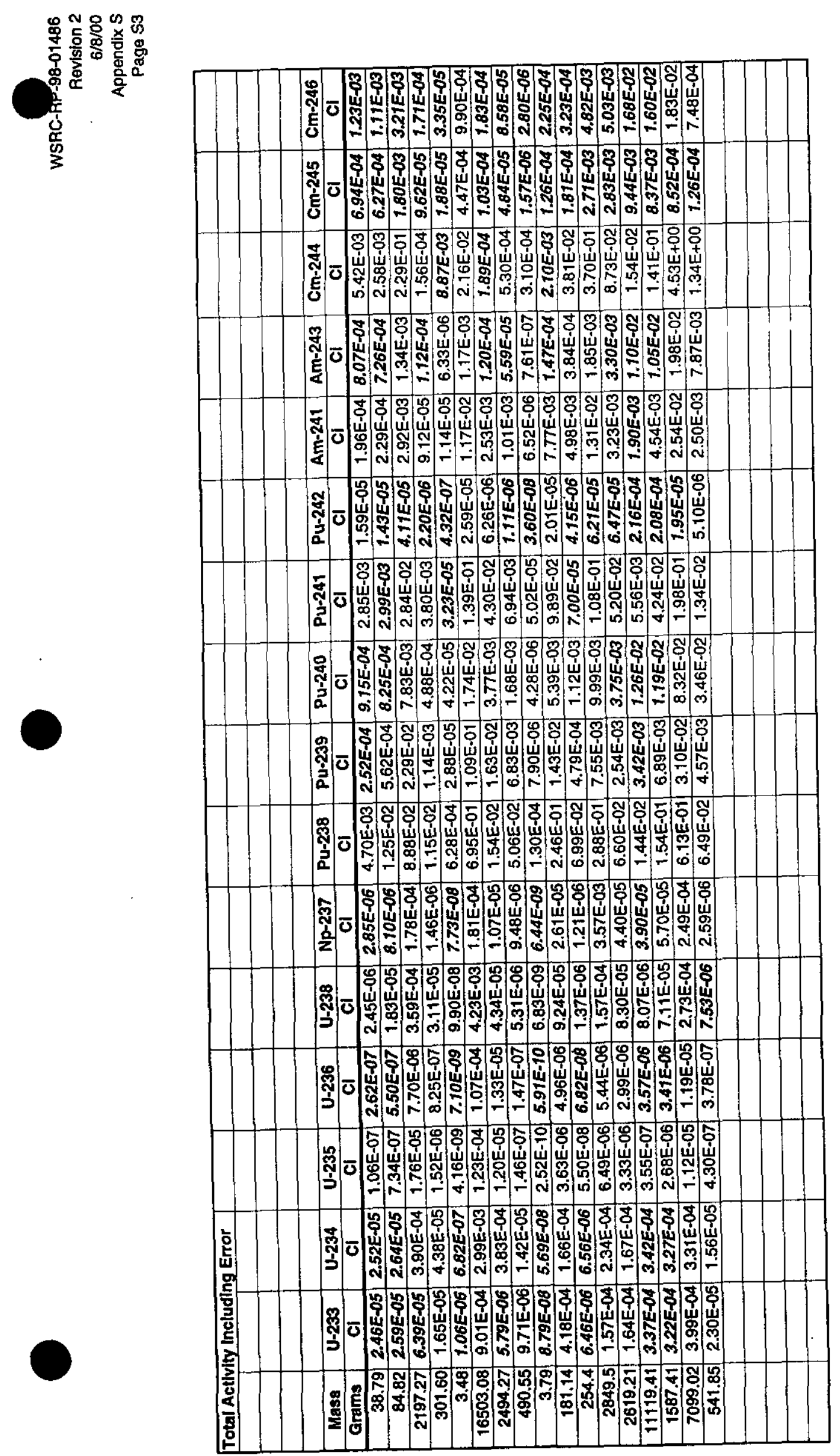


\begin{tabular}{|c|c|c|c|c|c|c|c|c|c|c|c|c|c|c|c|c|}
\hline \multicolumn{17}{|c|}{ Activity Concentration Including Error } \\
\hline & & & & & & & & & & & & & & & & \\
\hline & & & & & & & & & & & & & & & & \\
\hline & & & & & & & & & & & & & & & & \\
\hline & & & & & & & & & & & & & & & & \\
\hline & U.233 & U-234 & $\mathrm{U}-235$ & U-236 & $\mathrm{U}-238$ & Np-237 & Pu-238 & Pu-239 & Pu-240 & Pu-241 & Pu-242 & Am-241 & Am-243 & $\mathrm{Cm}-244$ & $\mathrm{Cm}-245$ & $\mathrm{Cm}-246$ \\
\hline Tank * & $\mathrm{CV} / \mathrm{g}$ & $\mathrm{C} / \mathrm{g}$ & $\mathrm{CUg}$ & $\mathrm{Cl/g}$ & $\mathrm{CV} / \mathrm{g}$ & $\mathrm{CV} / \mathrm{g}$ & $\mathrm{Cl} / \mathrm{g}$ & $\mathrm{Cl} / \mathrm{g}$ & $\mathrm{Cl} / \mathrm{g}$ & $\mathrm{Cl} / \mathrm{g}$ & $\mathrm{CV} / \mathrm{g}$ & $\mathrm{Cl} / \mathrm{g}$ & $\mathrm{Cl} / \mathrm{g}$ & $\mathrm{Cl} / \mathrm{g}$ & $\mathrm{Cl} / \mathrm{g}$ & $\mathrm{Cl} / \mathrm{g}$ \\
\hline$\overline{\text { S1 }}$ & $6.35 E-07$ & $6.49 E-07$ & 2.74E-09 & $6.76 E-09$ & $6.32 E-08$ & $7.34 E-08$ & 1.21E-04 & 6.49E-06 & $2.36 E-05$ & $7.35 \mathrm{E}-05$ & 4.10E-07 & 5.05E-06 & $2.08 E-05$ & $1.40 \mathrm{E}-04$ & $1.79 E-05$ & $3.18 E-05$ \\
\hline S2 & $3.05 E-07$ & $3.11 E-07$ & $8.65 E-09$ & $6.49 E-09$ & $2.16 \mathrm{E}-07$ & 9.55E-08 & $1.48 \mathrm{E}-04$ & $6.62 \mathrm{E}-06$ & $9.73 E-06$ & $3.53 E-05$ & $1.69 E-07$ & $2.71 \mathrm{E}-06$ & $8.56 E-06$ & $3.05 E-05$ & $7.39 E-06$ & $1.31 E-05$ \\
\hline S3 & $2.91 E-08$ & $1.78 \mathrm{E}-07$ & $8.00 E-09$ & $3.50 \mathrm{E}-09$ & $1.63 \mathrm{E}-07$ & 8.11E-08 & $4.04 \mathrm{E}-05$ & $1.04 \mathrm{E}-05$ & $3.56 \mathrm{E}-06$ & $1.29 \mathrm{E}-05$ & $1.87 E-08$ & $1.33 \mathrm{E}-06$ & $6.11 \mathrm{E}-07$ & $1.04 \mathrm{E}-04$ & $8.20 E-07$ & $1.46 E-06$ \\
\hline S4 & \begin{tabular}{|c|}
$5.46 \mathrm{E}-08$ \\
\end{tabular} & $1.45 \mathrm{E}-07$ & 5.05E-09 & \begin{tabular}{|l|}
$2.74 E-09$ \\
\end{tabular} & $1.03 E-07$ & $4.84 \mathrm{E}-09$ & 3.82E-05 & $3.78 \mathrm{E}-06$ & $1.62 \mathrm{E}-06$ & $1.26 \mathrm{E}-05$ & $7.30 E-09$ & $3.02 \mathrm{E}-07$ & $3.71 E-07$ & 5.17E-07 & $3.19 E-07$ & $5.68 E-07$ \\
\hline S5 & $3.04 E-07$ & $1.96 E-07$ & $1.19 \mathrm{E}-09$ & $2.04 E-09$ & $2.84 \mathrm{E}-08$ & $2.22 E-08$ & $1.81 E-04$ & 8.27E-06 & $1.21 \mathrm{E}-05$ & $9.28 E-06$ & $1.24 E-07$ & $3.27 \mathrm{E}-06$ & $1.82 \mathrm{E}-06$ & $2.55 E-03$ & 5.41E-06 & $9.64 E-06$ \\
\hline 56 & $5.46 \mathrm{E}=08$ & $1.81 E-07$ & $7.48 E-09$ & \begin{tabular}{|c|}
$6.49 \mathrm{E}-09$ \\
\end{tabular} & $2.56 \mathrm{E}-07$ & $1.10 \mathrm{E}-08$ & 4.21E-05 & $6.60 \mathrm{E}-06$ & 1.05E-06 & 8.42E-06 & 1.57E-09 & $7.12 \mathrm{E}-07$ & $7.08 \mathrm{E}-08$ & 1.31E-06 & $2.71 E-08$ & 6.00 E-08 \\
\hline 57 & $2.32 E-09$ & $1.54 \mathrm{E}-07$ & $4.81 \mathrm{E}-09$ & \begin{tabular}{|l|}
$5.35 \mathrm{E}-09$ \\
\end{tabular} & $1.74 \mathrm{E}-08$ & 4.31E-09 & 6.16E-06 & $6.54 \mathrm{E}-06$ & $1.51 \mathrm{E}-06$ & $1.72 E-05$ & 2.51E-09 & \begin{tabular}{|l|}
$1.02 E-06$ \\
\end{tabular} & $4.82 E-08$ & 7.57E-08 & $4.14 E-08$ & $7.34 E-08$ \\
\hline 58 & \begin{tabular}{|c|}
$1.98 E-08$ \\
\end{tabular} & $2.89 \mathrm{E}-08$ & $2.98 E-10$ & $3.00 E-10$ & 1.08E-0B & \begin{tabular}{|c|}
$1.93 E-08$ \\
\end{tabular} & $1.03 E-04$ & 1.39E-05 & $3.42 \mathrm{E}-06$ & 1.42E-05 & 2.26E-09 & $2.07 \mathrm{E}-06$ & $1.14 E-07$ & $1.08 \mathrm{E}-06$ & $9.86 E-08$ & $1.75 E-07$ \\
\hline S11 & $2.32 E-08$ & $1.50 E-08$ & \begin{tabular}{|c|}
$6.65 \mathrm{E}-11$ \\
\end{tabular} & $1.56 \mathrm{E}-10$ & 1.80E-09 & $1.70 E-09$ & $3.43 \mathrm{E}-05$ & $2.09 E-06$ & $1.13 \mathrm{E}-06$ & $1.32 \mathrm{E}-05$ & $9.50 E-09$ & $1.72 \mathrm{E}-06$ & 2.01E-07 & $8.17 E-05$ & $4.14 E-07$ & 7.39E-07 \\
\hline$\$ 13$ & \begin{tabular}{|l|}
$2.31 E-06$ \\
\end{tabular} & $9.19 E-07$ & $2.00 E-08$ & $2.74 \mathrm{E}-08$ & 5.10E-07 & $1.44 E-07$ & $1.36 \mathrm{E}-03$ & 7.90 E-05 & $2.98 \mathrm{E}-05$ & $5.46 \mathrm{E}-04$ & 1.11E-07 & 4.29E-05 & 8.11E-07 & $1.16 E-05$ & $6.94 E-07$ & $1.24 E-06$ \\
\hline 514 & \begin{tabular}{|l|}
$2.54 E-08$ \\
\end{tabular} & $2.58 E-08$ & $2.16 \mathrm{E}-10$ & $2.68 E_{\cdots 10}$ & $\begin{array}{l}5.38 \mathrm{E}-09 \\
\end{array}$ & 4.77E-09 & $2.75 E-04$ & $1.88 \mathrm{E}-06$ & 4.42E-06 & $2.75 E-07$ & $1.63 E-08$ & $1.96 \mathrm{E}-05$ & \begin{tabular}{|l|}
$1.51 E-06$ \\
\end{tabular} & $1.50 \mathrm{E}-04$ & $7.12 E-07$ & 1.27E- 06 \\
\hline$\$ 19-0$ & \begin{tabular}{|l|}
$5.50 \mathrm{E}-08$ \\
\end{tabular} & 8.22E-08 & $2.28 \mathrm{E}-09$ & 1.91E-09 & $5.51 E-08$ & $1.25 \mathrm{E}-06$ & 1.01E-04 & 2.65E-06 & $3.51 E-06$ & $3.78 \mathrm{E}-05$ & $2.18 E-08$ & 4.58E-06 & $6.50 \mathrm{E}-07$ & 1.30E-04 & 9.50E-07 & $1.69 E-06$ \\
\hline S19-A & $6.27 \mathrm{E}-08$ & $6.37 E-08$ & \begin{tabular}{|c|}
$1.27 \mathrm{E}-09$ \\
\end{tabular} & $1.14 E-09$ & $3.17 E-08$ & $1.68 \mathrm{E}-08$ & $2.52 E-05$ & $9.71 \mathrm{E}-07$ & $1.43 E-06$ & $1.99 \mathrm{E}-05$ & $2.47 E-08$ & \begin{tabular}{|l|}
$1.23 E-06$ \\
\end{tabular} & $1.26 E-06$ & 3.33E-05 & $1.08 E-06$ & $1.92 E-06$ \\
\hline S2O-T & \begin{tabular}{|l|}
$3.03 E-08$ \\
\end{tabular} & $3.08 E-08$ & $3.19 E-11$ & \begin{tabular}{|l|}
$3.21 E-10$ \\
\end{tabular} & $7.26 \mathrm{E}-10$ & 3.51E-09 & $1.30 \mathrm{E}-06$ & $3.08 E-07$ & $1.13 E-06$ & $5.00 \mathrm{E}-07$ & $1.94 E-08$ & $1.71 E-07$ & 9.92E-07 & 1.39E-06 & $8.49 E-07$ & $1.51 E-06$ \\
\hline $520-B$ & $2.03 E-07$ & $2.06 E-07$ & 1.69E-09 & \begin{tabular}{|l|}
$2.15 E-09$ \\
\end{tabular} & \begin{tabular}{|l|}
$4.48 E-08$ \\
\end{tabular} & $3.59 \mathrm{E}-08$ & $9.71 E-05$ & 4.34E-06 & $7.52 E-06$ & 2.67E-05 & 1.31E-07 & \begin{tabular}{|c|}
$2.86 \mathrm{E}-06$ \\
\end{tabular} & $6.62 E-06$ & 8.87E-05 & $5.27 E-06$ & $1.01 E-05$ \\
\hline 521 & $5.62 \mathrm{E}-08$ & 4.67E-08 & $1.58 \mathrm{E}-09$ & \begin{tabular}{|c|}
$1.68 \mathrm{E}-09$ \\
\end{tabular} & $3.85 \mathrm{E}-08$ & $3.51 E-08$ & 8.63E-05 & \begin{tabular}{|l|}
$4.37 E-06$ \\
\end{tabular} & 1.17E-05 & $2.79 E-05$ & $2.74 E-09$ & \begin{tabular}{|l|}
$3.57 \mathrm{E}-06$ \\
\end{tabular} & $2.78 \mathrm{E}-06$ & $6.38 \mathrm{E}-04$ & $1.20 E-07$ & $2.58 \mathrm{E}-06$ \\
\hline S22 & $4.24 E-08$ & $2.88 E-08$ & $7.94 \mathrm{E}-10$ & \begin{tabular}{|c|}
$6.97 \mathrm{E}-10$ \\
\end{tabular} & $1.39 E-08$ & 4.79E-09 & $1.20 \mathrm{E}-04$ & $8.44 \mathrm{E}-06$ & $6.38 \mathrm{E}-05$ & $2.47 E-05$ & $9.41 \mathrm{E}-09$ & 4.62E-06 & $1.45 \mathrm{E}-05$ & $2.48 \mathrm{E}-03$ & $2.32 E-07$ & 1.38E-06 \\
\hline & & & & & & & & & & & & & & & & \\
\hline & & & & & & & & & & & & & & & & \\
\hline & & & & & & & & & & & & & & & & \\
\hline & & & & & & & & & & & & & & & & \\
\hline & & & & & & & & & & & & & & & & \\
\hline
\end{tabular}




\begin{tabular}{|c|c|c|c|c|c|c|c|c|c|c|c|c|c|c|c|c|}
\hline & & & & & & & & & & & & & & & & \\
\hline & & & & & & & & & & & & & & & & \\
\hline & & & & & & & & & & & & & & & & \\
\hline & & & & & & & & & & & & & & & & \\
\hline & U-233 & U-234 & U-235 & U-236 & $U-238$ & Np-237 & Pu-238 & Pu-239 & PU-240 & Pu-241 & Pu-242 & Am-241 & Am-243 & $\mathrm{Cm}-244$ & $C_{m-245}$ & Cm-246 \\
\hline Tank : & 9 & g & $g$ & g & $g$ & $\mathrm{~g}$ & g & g & g & g & 9 & $g$ & $g$ & $g$ & 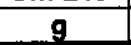 & 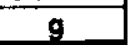 \\
\hline S1 & $2.56 E-03$ & $4.03 E-03$ & $4.92 \mathrm{E}-02$ & $4.05 E-03$ & $7.30 E+00$ & $4.04 E-03$ & $2.75 E-04$ & $4.05 E-03$ & $4.03 E-03$ & $2.76 \mathrm{E}-05$ & $4.05 \mathrm{E}-03$ & $5.69 \mathrm{E}-05$ & $4.03 E-03$ & $6.69 \mathrm{E}-05$ & $4.04 E-03$ & $4.06 E-03$ \\
\hline S2 & $2.68 E-03$ & $4.23 E-03$ & $3.40 E-01$ & $8.51 E-03$ & $5.45 \mathrm{E}+01$ & $1.15 E-02$ & $7.32 \mathrm{E}-04$ & $9.04 \mathrm{E}-03$ & $3.64 E-03$ & $2.90 E-05$ & $3.65 E-03$ & $6.67 E-05$ & $3.63 E-03$ & $3.19 \mathrm{E}-05$ & $3.64 E-03$ & $3.66 E-03$ \\
\hline S3 & $6.63 E-03$ & $6.25 \mathrm{E}-02$ & $8.14 \mathrm{E}+00$ & $1.19 \mathrm{E}-01$ & $1.07 E+03$ & $2.53 E-01$ & $5.20 \mathrm{E}-03$ & $3.69 \mathrm{E}-01$ & $3.45 \mathrm{E}-02$ & $2.75 E-04$ & $1.05 E-02$ & $8.50 E-04$ & $6.71 \mathrm{E}-03$ & $2.82 E-03$ & $1.05 E-02$ & $1.06 E-02$ \\
\hline S4 & $1.71 E-03$ & $7.02 E-03$ & $7.05 \mathrm{E}-01$ & $1.28 \mathrm{E}-02$ & $9.26 \mathrm{E}+01$ & $2.07 \mathrm{E}-03$ & $6.73 \mathrm{E}-04$ & $1.84 \mathrm{E}-02$ & $2.15 \mathrm{E}-03$ & $3.68 \mathrm{E}-05$ & $5.60 E-04$ & $2.65 \mathrm{E}-05$ & $5.59 E-04$ & $1.93 \mathrm{E}-06$ & $5.59 E-04$ & 5.64E-04 \\
\hline S5 & $1.10 E-04$ & $1.09 E-04$ & $1.92 \mathrm{E}-03$ & $1.10 E-04$ & 2.95E-01 & $1.10 E-04$ & $3.67 \mathrm{E}-05$ & 4.63E-04 & $1.86 \mathrm{E}-04$ & $3.12 E-07$ & $1.10 E-04$ & $3.30 \mathrm{E}-06$ & 3.17E-05 & $1.10 E-04$ & $1.09 E-04$ & $1.10 E-04$ \\
\hline 56 & $9.35 \mathrm{E}-02$ & $4.79 \mathrm{E}-01$ & $5.71 E+01$ & $1.66 \mathrm{E}+00$ & $1.26 \mathrm{E}+04$ & 2.57E-01 & 4.07E-02 & $1.75 E+00$ & $7.66 \mathrm{E}-02$ & \begin{tabular}{|c|}
$1.34 E-03$ \\
\end{tabular} & $6.60 \mathrm{E}-03$ & $3.41 \mathrm{E}-03$ & $5.84 \mathrm{E}-03$ & $2.66 \mathrm{E}-04$ & $2.60 \mathrm{E}-03$ & $3.26 \mathrm{E} \cdot 03$ \\
\hline \$7 & $6.00 E-04$ & $6.14 \mathrm{E}-02$ & $5.56 \mathrm{E}+00$ & $2.06 E-01$ & $1.29 \mathrm{E}+02$ & 1.52E-02 & $8.99 \mathrm{E}-04$ & $2.63 \mathrm{E}-01$ & $1.66 \mathrm{E}-02$ & $4.15 E-04$ & $1.59 \mathrm{E}-03$ & $7.37 \mathrm{E}-04$ & $6.01 E-04$ & $2.33 E-06$ & $6.00 E-04$ & $6.02 E-04$ \\
\hline 58 & $1.01 \mathrm{E}-03$ & $2.27 \mathrm{E}-03$ & $6.76 \mathrm{E}-02$ & $2.27 \mathrm{E}-03$ & $1.58 E+01$ & $1.34 \mathrm{E}-02$ & $2.96 \mathrm{E}-03$ & $1.10 \mathrm{E}-01$ & $7.39 \mathrm{E}-03$ & $6.71 \mathrm{E}-05$ & $2.82 E-04$ & $2.94 \mathrm{E}-04$ & $2.80 E-04$ & $6.55 \mathrm{E}-06$ & $2.81 E-04$ & $2.82 E-04$ \\
\hline S11 & $9.12 E-06$ & $9.11 E-06$ & $1.17 E-04$ & $9.14 E-06$ & $2.03 \mathrm{E}-02$ & $9.14 E-06$ & $7.60 \mathrm{E}-06$ & $1.27 \mathrm{E}-04$ & $1.88 \mathrm{E}-05$ & 4.85E-07 & $9.16 E-06$ & $1.90 E-06$ & $3.81 \mathrm{E}-06$ & $3.82 \mathrm{E}-06$ & $9.12 E-06$ & $9.21 E-06$ \\
\hline S13 & $4.33 \mathrm{E}-02$ & $2.67 \mathrm{E}-02$ & $1.68 \mathrm{E}+00$ & $7.66 \mathrm{E}-02$ & $2.75 E+02$ & $3.70 \mathrm{E}-02$ & $1.44 \mathrm{E}-02$ & $2.30 \mathrm{E}-01$ & $2.37 \mathrm{E}-02$ & $9.57 \mathrm{E}-04$ & $5.11 \mathrm{E}-03$ & $2.26 \mathrm{E}-03$ & $7.35 E-04$ & 2.59E-05 & $7.31 E-04$ & $7.39 E-04$ \\
\hline S14 & $6.70 E-04$ & $1.05 E-03$ & $2.54 \mathrm{E}-02$ & $1.05 \mathrm{E}-03$ & $4.07 E+00$ & $1.72 \mathrm{E}-03$ & $4.09 \mathrm{E}-03$ & $7.72 \mathrm{E}-03$ & $4.95 \mathrm{E}-03$ & $6.77 E-07$ & $1.06 E-03$ & $1.45 \mathrm{E}-03$ & $1.92 \mathrm{E}-03$ & $4.70 \mathrm{E}-04$ & $1.05 E-03$ & $1.06 E-03$ \\
\hline s19-0 & $1.63 \mathrm{E}-02$ & $3.75 \mathrm{E}-02$ & $3.01 E+00$ & $8.41 \mathrm{E}-02$ & $4.67 E+02$ & $5.06 \mathrm{E}+00$ & $1.68 \mathrm{E}-02$ & $1.22 \mathrm{E}-01$ & $4.40 \mathrm{E}-02$ & $1.04 \mathrm{E}-03$ & $1.58 E-02$ & $3.80 \mathrm{E}-03$ & $9.26 \mathrm{E}-03$ & $4.57 \mathrm{E}-03$ & $1.57 E-02$ & $1.58 E-02$ \\
\hline S19-A & $1.70 \mathrm{E}-02$ & $2.67 \mathrm{E}-02$ & $1.54 E+00$ & $4.61 \mathrm{E}-02$ & $2.47 E+02$ & $6.24 \mathrm{E}-02$ & $3.86 \mathrm{E}-03$ & $4.10 \mathrm{E}-02$ & $1.65 E-02$ & $5.03 \mathrm{E}-04$ & $1.65 E-02$ & $9.38 \mathrm{E}-04$ & $1.65 E-02$ & $1.08 \mathrm{E}-03$ & $1.64 E-02$ & $1.65 E-02$ \\
\hline S20-T & $3.50 E-02$ & $5.49 E-02$ & $1.64 \mathrm{E}-01$ & $5.52 E-02$ & $2.40 E+01$ & $5.54 E-02$ & $8.42 \mathrm{E}-04$ & $5.51 E-02$ & $5.54 E-02$ & $5.38 \mathrm{E}-05$ & $5.49 E-02$ & $5.53 E-04$ & $5.52 E-02$ & $1.90 \mathrm{E}-04$ & $5.49 E-02$ & $5.52 E-02$ \\
\hline S20-B & $3.34 E-02$ & $5.24 E-02$ & $1.24 \mathrm{E}+00$ & $5.28 E-02$ & $2.12 E+02$ & $8.08 \mathrm{E}-02$ & $9.02 \mathrm{E}-03$ & $1.11 \mathrm{E}-01$ & $5.26 E-02$ & $4.10 \mathrm{E}-04$ & $5.29 E-02$ & $1.32 \mathrm{E}-03$ & $5.25 E-02$ & $1.74 \mathrm{E}-03$ & $4.86 E-02$ & $5.27 E-02$ \\
\hline S21 & $4.14 \mathrm{E}-02$ & $5.31 \mathrm{E}-02$ & $5.21 E+00$ & $1.84 \mathrm{E}-01$ & $8.14 E+02$ & $3.53 E-01$ & $3.58 \mathrm{E}-02$ & $4.99 \mathrm{E}-01$ & $3.67 \mathrm{E}-01$ & $1.91 \mathrm{E}-03$ & $4.95 E-03$ & $7.37 \mathrm{E}-03$ & $9.88 \mathrm{E}-02$ & $5.59 \mathrm{E}-02$ & $4.95 E-03$ & $6.02 \mathrm{E}-02$ \\
\hline 522 & $2.38 E-03$ & $2.50 \mathrm{E}-03$ & $1.99 \mathrm{E}-01$ & $5.84 E-03$ & $2.24 E+01$ & $3.68 \mathrm{E}-03$ & $3.79 \mathrm{E}-03$ & $7.36 \mathrm{E}-02$ & $1.52 \mathrm{E}-01$ & $1.29 E-04$ & $1.30 \mathrm{E}-03$ & $7.28 \mathrm{E}-04$ & $3.93 \mathrm{E}-02$ & $1.66 \mathrm{E}-02$ & 7.31E-04 & $2.46 \mathrm{E}-03$ \\
\hline & & & & & & & & & & & & & & & & \\
\hline & & & & & & & & & & & & & & & & \\
\hline & & & & & & & & & & & & & & & & \\
\hline & & & & & & & & & & & & & & & & \\
\hline
\end{tabular}


III $^{n}$

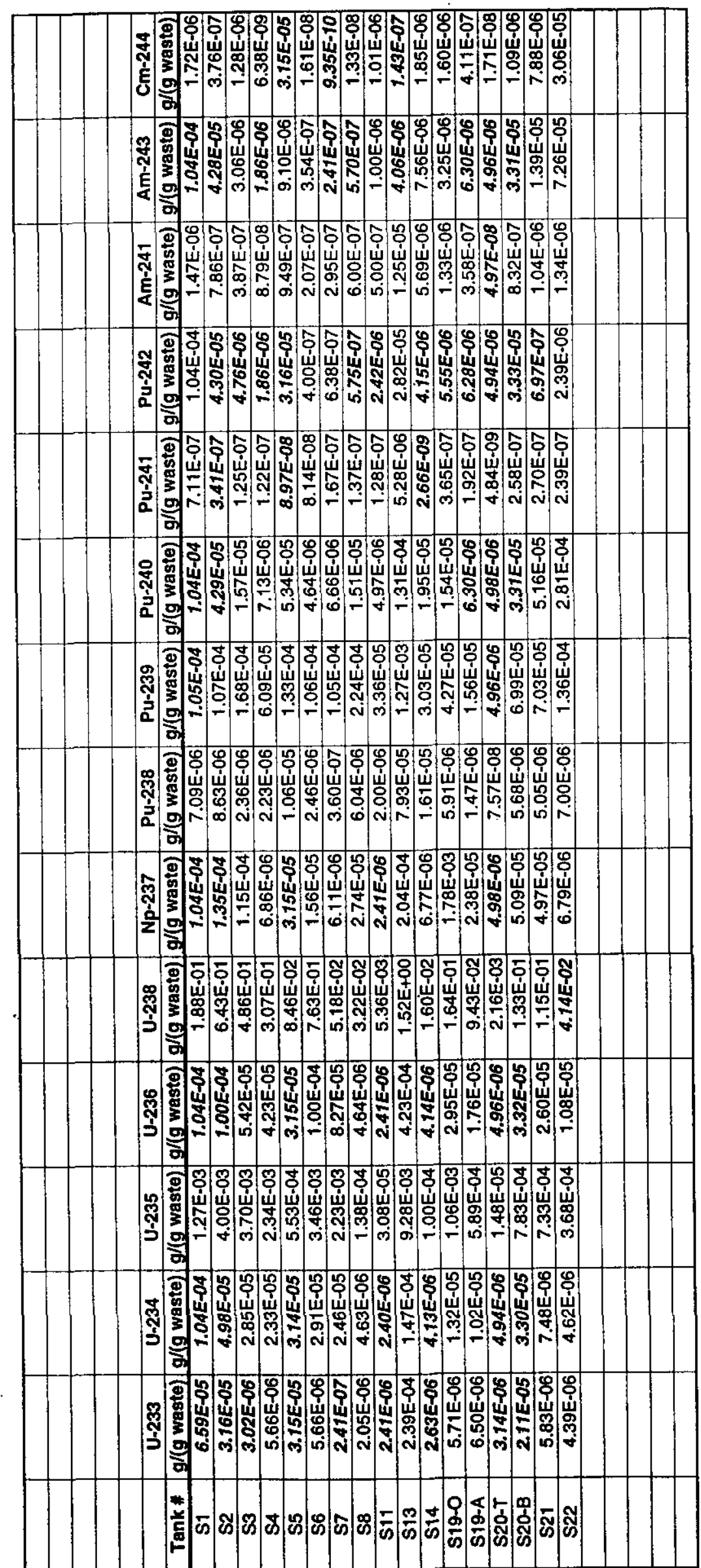


$\sqrt{\text { J"m }}$

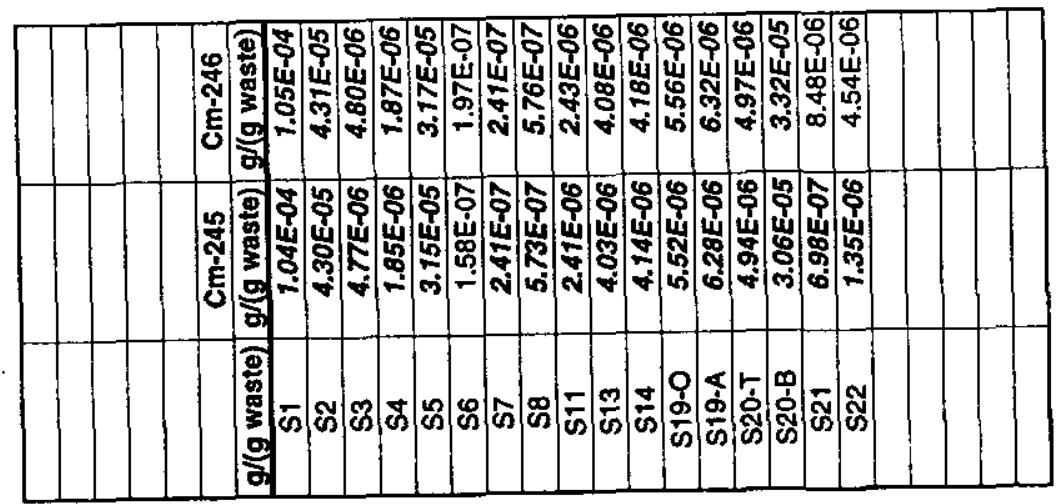



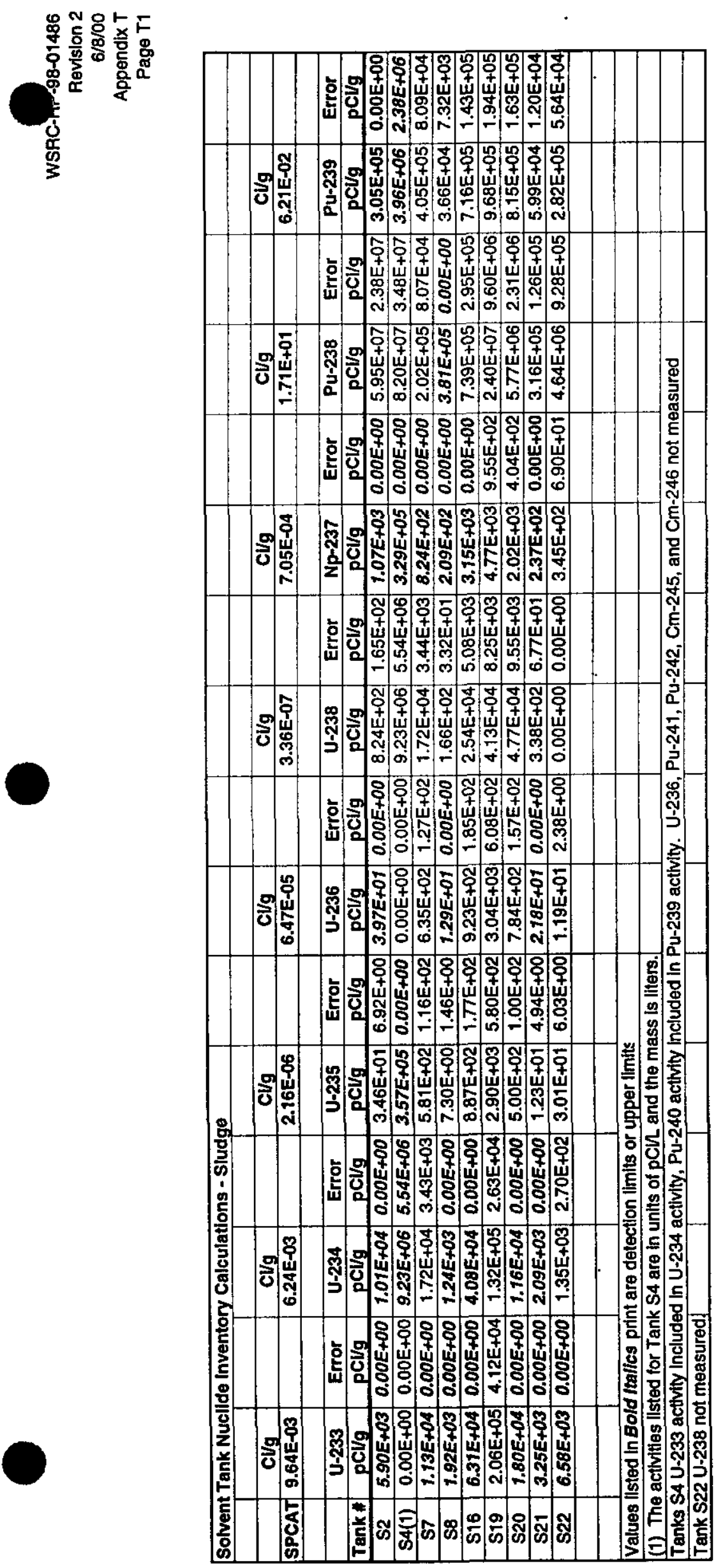


\begin{tabular}{|c|c|c|c|c|c|c|c|c|c|c|c|c|c|c|c|}
\hline & & & & & & & & & & & & & & & \\
\hline & & & & & & & & & & & & & & & \\
\hline $\mathrm{CV}_{\mathrm{g}}$ & & $\mathrm{Cl} / \mathrm{g}$ & & $\mathrm{Cl} / \mathrm{g}$ & & $\mathrm{CVg}$ & & $\mathrm{Cl} / \mathrm{g}$ & & $\mathrm{CV} / \mathrm{g}$ & & $\mathrm{CV} / \mathrm{g}$ & & $\mathrm{Ci} / \mathrm{g}$ & \\
\hline 2.27E-01 & & $1.03 E+02$ & & 3.93E-03 & & $3.44 \mathrm{E}+00$ & & $2.00 \mathrm{E}-01$ & & $8.10 \mathrm{E}+01$ & & $1.72 E-01$ & & $3.04 \mathrm{E}-01$ & \\
\hline & & & & & & & & & & & & & & & \\
\hline Pu-240 & Error & Pu-241 & Error & Pu-242 & Error & Am-241 & Error & Am-243 & Error & Cm-244 & Error & Cm-245 & Error & $\mathrm{Cm}-246$ & Error \\
\hline $\mathrm{pCV} / \mathrm{g}$ & $\mathrm{pCl} / \mathrm{g}$ & $\mathrm{pCl} / \mathrm{g}$ & $\mathrm{pCl} / \mathrm{g}$ & $\mathrm{pCl} / \mathrm{g}$ & $\mathrm{pCl/g}$ & $\mathrm{pCl} / \mathrm{g}$ & $\mathrm{pCl} / \mathrm{g}$ & $\mathrm{pCl} / \mathrm{g}$ & $\mathrm{pCi} / \mathrm{g}$ & $\mathrm{pCi} / \mathrm{g}$ & $\mathrm{pCi} / \mathrm{g}$ & $\mathrm{pCl} / \mathrm{g}$ & $\mathrm{pCl} / \mathrm{g}$ & $\mathrm{pCl} / \mathrm{g}$ & $\mathrm{pCl} / \mathrm{g}$ \\
\hline $7.52 E+05$ & $0.00 E+00$ & $1.48 E+07$ & $5.91 \mathrm{E}+06$ & $2.41 E+03$ & $0.00 E+00$ & $5.32 E+06$ & $2.82 E+05$ & $4.19 E+05$ & $2.09 E+04$ & $7.43 E+07$ & $1.49 \mathrm{E}+07$ & $1.05 E+05$ & $0.00 E+00$ & $1.87 E+05$ & $0.00 E+00$ \\
\hline $0.00 E+00$ & $0.00 \mathrm{E}+00$ & $0.00 \mathrm{E}+00$ & $0.00 E+00$ & $0.00 \mathrm{E}+00$ & $0.00 E+00$ & $5.05 \mathrm{E}+06$ & $5.80 \mathrm{E}+05$ & $1.26 E+05$ & $0.00 E+00$ & $2.37 E+07$ & $9.50 E+06$ & $0.00 E+00$ & $0.00 E+00$ & $0.00 E+00$ & $0.00 E+00$ \\
\hline $2.66 E+05$ & $0.00 E+00$ & $3.32 E+05$ & $1.33 \mathrm{E}+05$ & $4.59 E+03$ & $0.00 E+00$ & $1.45 E+05$ & $8.79 E+03$ & $2.34 E+05$ & $0.00 E+00$ & $3.64 E+04$ & $1.46 \mathrm{E}+04$ & $2.01 E+05$ & $0.00 E+00$ & $3.58 E+05$ & $0.00 E+00$ \\
\hline $4.55 E+04$ & $0.00 E+00$ & $3.96 E+04$ & $0.00 E+00$ & $7.84 E+02$ & $0.00 E+00$ & $2.70 E+04$ & $0.00 E+00$ & $3.99 E+04$ & $0.00 E+00$ & $1.67 \mathrm{E}+04$ & $6.67 E+03$ & $3.43 E+04$ & $0.00 E+00$ & $6.08 E+04$ & $0.00 E+00$ \\
\hline $1.49 E+06$ & $0.00 E+00$ & $9.64 E+05$ & $0.00 E+00$ & $2.58 E+04$ & $0.00 E+00$ & $1.24 E+04$ & $6.99 E+02$ & $1.31 E+06$ & $0.00 E+00$ & $5.32 E+08$ & $0.00 E+00$ & $1.13 E+06$ & $0.00 E+00$ & $2.00 E+06$ & $0.00 E+00$ \\
\hline $1.58 E+05$ & $0.00 E+00$ & $6.58 E+06$ & $2.63 E+06$ & $2.73 E+03$ & $0.00 E+00$ & $3.41 E+06$ & $6.83 E+05$ & $4.49 \mathrm{E}+05$ & $8.97 \mathrm{E}+04$ & $7.57 \mathrm{E}+07$ & $1.51 \mathrm{E}+07$ & $1.19 E+05$ & $0.00 E+00$ & $2.13 E+05$ & $0.00 E+00$ \\
\hline $4.24 E+05$ & $0.00 E+00$ & $1.79 \mathrm{E}+06$ & $7.15 E+05$ & $7.34 E+03$ & $0.00 E+00$ & $9.23 E+05$ & $5.17 \mathrm{E}+04$ & $7.66 E+04$ & $7.35 E+03$ & $1.68 \mathrm{E}+07$ & $3.36 \mathrm{E}+06$ & $3.21 E+05$ & $0.00 E+00$ & $5.72 E+05$ & $0.00 E+00$ \\
\hline $7.66 E+04$ & $0.00 E+00$ & $9.50 \mathrm{E}+04$ & $3.80 \mathrm{E}+04$ & $1.32 E+03$ & $0.00 E+00$ & $7.48 E+03$ & $0.00 E+00$ & $6.71 E+04$ & $0.00 E+00$ & $8.15 E+04$ & $1.63 E+04$ & $5.77 E+04$ & $0.00 E+00$ & $1.03 E+05$ & $0.00 E+00$ \\
\hline $2.10 E+06$ & $4.21 E+05$ & $6.31 E+05$ & $2.52 \mathrm{E}+05$ & $2.68 E+03$ & $0.00 E+00$ & $1.69 E+05$ & $1.35 E+04$ & $6.98 E+05$ & $0.00 E+00$ & $1.37 E+08$ & $2.7 \overline{4 E}+07$ & $6.35 E+03$ & $2.92 E+03$ & $7.07 E+04$ & $0.00 E+00$ \\
\hline & & & & & & & & & & & & & & & \\
\hline & & & & & & & & & & & & & & & \\
\hline & & & & & & & & & & & & & & & \\
\hline & & & & & & & & & & & & & & & \\
\hline & & & & & & & & & & & & & & & \\
\hline & & & & & & & & & & & & & & & \\
\hline
\end{tabular}




\begin{tabular}{|c|c|c|c|c|c|c|c|c|c|c|c|c|c|c|c|c|}
\hline \multirow{2}{*}{\multicolumn{17}{|c|}{ Total Activity Including Error }} \\
\hline & & & & & & & & & & & & & & & & \\
\hline & & & & & & & & & & & & & & & & \\
\hline & & & & & & & & & & & & & & & & \\
\hline & & & & & & & & & & & & & & & & \\
\hline Mass & $\mathrm{U}-233$ & U-234 & U-235 & U-236 & U-238 & $\mathrm{Np}-237$ & Pu-238 & Pu-239 & Pu-240 & Pu-241 & Pu-242 & Am-241 & $A m-243$ & $\mathrm{Cm}-244$ & $\mathrm{Cm}-245$ & $\mathrm{Cm}-246$ \\
\hline Grams & $\mathbf{C l}$ & CI & $\mathrm{Cl}$ & Cl & $\mathrm{Cl}$ & $\mathrm{Cl}$ & $\mathbf{C l}$ & $\mathbf{C l}$ & $\mathbf{C i}$ & $\mathrm{Cl}$ & Cl & $\mathbf{C I}$ & $\mathbf{C l}$ & $\mathbf{C l}$ & $\mathbf{C l}$ & $\mathrm{Cl}$ \\
\hline 251351.3 & $1.48 E-03$ & $2.54 E-03$ & $1.04 \mathrm{E}-05$ & 9.98E-06 & 2.49E-04 & $2.69 E-04$ & $2.09 E+01$ & 7.67E-02 & $1.89 E-01$ & $5.21 E+00$ & $6.06 E-04$ & $1.41 \mathrm{E}+00$ & 1.11E-01 & $2.24 \mathrm{E}+01$ & $2.64 E-02$ & $4.70 E-02$ \\
\hline 21.95539 & $0.00 E+00$ & $3.24 E-04$ & $7.84 E-06$ & $0.00 \mathrm{E}+00$ & $3.24 E-04$ & $7.22 E-06$ & $2.56 \mathrm{E} \cdot 03$ & $1.39 E-04$ & $0.00 \mathrm{E}+00$ & $0.00 \mathrm{E}+00$ & $0.00 E+00$ & 1.24E-04 & $2.77 E-06$ & $7.29 \mathrm{E}-04$ & $0.00 E+00$ & $0.00 \mathrm{E}+00$ \\
\hline 11356.24 & $1.28 E-04$ & 2.34E-04 & $7.92 E-06$ & 8.65E-06 & 2.34E-04 & $9.36 E-06$ & $3.21 \mathrm{E}-03$ & $5.52 \mathrm{E}-03$ & $3.02 E-03$ & $5.28 \mathrm{E}-03$ & 5.21E-05 & $1.75 \mathrm{E}-03$ & $2.66 E-03$ & $5.79 \mathrm{E}-04$ & $2.28 E-03$ & 4.07E-03 \\
\hline 45424.94 & 8.72E-05 & $5.63 E-05$ & 3.98E-07 & $5.86 E-07$ & $9.05 \mathrm{E}-06$ & 9.49E-06 & $1.73 E-02$ & $2.00 \mathrm{E}-03$ & $2.07 E-03$ & $1.80 E-03$ & $3.56 E-05$ & $1.23 E-03$ & $1.81 E-03$ & $1.06 \mathrm{E}-03$ & $1.56 E-03$ & $2.76 E-03$ \\
\hline 2066835 & $1.30 E-01$ & $8.43 E-02$ & $2.20 \mathrm{E}-03$ & 2.29E-03 & $6.30 \mathrm{E}-02$ & $6.51 E-03$ & $2.14 E+00$ & $1.78 \mathrm{E}+00$ & $3.08 E+00$ & $1.99 E+00$ & $5.33 E-02$ & $2.71 \mathrm{E}-02$ & $2.71 E+00$ & $1.10 E+03$ & $2.34 E+00$ & $4.13 E+00$ \\
\hline 203655.2 & $5.03 E-02$ & $3.22 E-02$ & $7.09 \mathrm{E}-04$ & $7.43 E-04$ & $1.01 \mathrm{E}-02$ & $1.17 \mathrm{E}-03$ & $6.84 \mathrm{E}+00$ & 2.37E-01 & $3.22 E-02$ & $1.88 E+00$ & $5.56 E-04$ & 8.34E-01 & $1.10 \mathrm{E}-01$ & $1.85 \mathrm{E}+01$ & $2.42 E-02$ & 4.34E-02 \\
\hline 68137.41 & $1.23 E-03$ & $7.90 E-04$ & 4.09E-05 & 6.41E-05 & $3.90 \mathrm{E}-03$ & $1.65 \mathrm{E}-04$ & 5.51E-01 & $6.66 \mathrm{E}-02$ & $2.89 E-02$ & 1.71E-01 & $5.00 E-04$ & $6.64 \mathrm{E}-02$ & $5.72 \mathrm{E}-03$ & 1.37E+00 & $2.19 E-02$ & $3.90 E-02$ \\
\hline 236966.8 & $7.70 E-04$ & $4.95 E-04$ & 4.09E-06 & 5.17E-06 & 9.61E-05 & $5.62 E-05$ & $1.05 \mathrm{E}-01$ & $1.70 \mathrm{E}-02$ & $1.82 E-02$ & $3.15 E-02$ & 3.13E-04 & $1.77 E-03$ & $1.59 E-02$ & $2.32 E-02$ & $1.37 E-02$ & $2.44 E-02$ \\
\hline 56781.18 & $3.74 E-04$ & $9.20 \mathrm{E}-05$ & $2.05 E-06$ & $8.11 E-07$ & $0.00 \mathrm{E}+00$ & 2.35E-05 & $3.16 E-01$ & 1.92E-02 & $1.43 \mathrm{E}-01$ & 5.01E-02 & 1.52E-04 & $1.04 \mathrm{E}-02$ & $3.96 E-02$ & $9.33 E+00$ & 5.26E-04 & $4.01 E-03$ \\
\hline & & & & & & & & & & & & & & & & \\
\hline & & & & & & & & & & & & & & & & \\
\hline & & & & & & & & & & & & & & & & \\
\hline & & & & & & & & & & & & & & & & \\
\hline & & & & & & & & & & & & & & & & \\
\hline & & & & & & & & & & & & & & & & \\
\hline
\end{tabular}




\begin{tabular}{|c|c|c|c|c|c|c|c|c|c|c|c|c|c|c|c|c|}
\hline \multicolumn{17}{|c|}{ Activity Concentratlon Including Error } \\
\hline & & & & & & & & & & & & & & & & \\
\hline & & & & & & & & & & & & & & & & \\
\hline & & & & & & & & & & & & & & & & \\
\hline & & & & & & & & & & & & & & & & \\
\hline & U-233 & $\mathrm{U}-234$ & U-235 & U-236 & U-238 & Np-237 & Pu-238 & Pu-239 & Pu-240 & Pu-241 & Pu-242 & Am-241 & Am-243 & $\mathrm{Cm}-244$ & Cm-245 & $\mathrm{Cm}-246$ \\
\hline Tank : & $\mathrm{CV} / \mathrm{g}$ & $\mathrm{Cl} / \mathrm{g}$ & $\mathrm{Cl} / \mathrm{g}$ & $\mathrm{Cl} / \mathrm{g}$ & $\mathrm{Cl} / \mathrm{g}$ & $\mathrm{Cl} / \mathrm{g}$ & $\mathrm{Cl} / \mathrm{g}$ & $\mathrm{Cl} / \mathrm{g}$ & $\mathrm{Cl} / \mathrm{g}$ & $\mathrm{Cl} / \mathrm{g}$ & $\mathrm{Ci} / \mathrm{g}$ & $\mathrm{Cl} / \mathrm{g}$ & $\mathrm{CV} / \mathrm{g}$ & $\mathrm{Ci} / \mathrm{g}$ & $\mathrm{Cl} / \mathrm{g}$ & $\mathrm{CVg}$ \\
\hline $\mathbf{S 2}$ & $5.90 E-09$ & $1.01 E-08$ & $4.15 \mathrm{E}-11$ & $3.97 E-11$ & $9.89 \mathrm{E}-10$ & 1.07E-09 & $8.33 \mathrm{E}-05$ & $3.05 E-07$ & $7.52 E-07$ & 2.07E-05 & 2.41E-09 & $5.60 \mathrm{E}-06$ & $4.40 \mathrm{E}-07$ & 8.92E-05 & $1,05 E-07$ & $1.87 E-07$ \\
\hline S4(1) & $0.00 E+00$ & $1.48 E-05$ & $3.57 E-07$ & $0.00 E+00$ & 1.48E-05 & $3.29 E-07$ & 1.17E-04 & $6.34 E-06$ & $0.00 \mathrm{E}+00$ & $0.00 E+00$ & $0.00 \mathrm{E}+00$ & $5.63 \mathrm{E}-06$ & $1.26 E-07$ & 3.32E-05 & $0.00 E+00$ & $0.00 E+00$ \\
\hline$\$ 7$ & $1.13 E-08$ & $2.06 E-08$ & $6.97 \mathrm{E}-10$ & $7.62 E-10$ & $2.06 \mathrm{E}-08$ & $8.24 E-10$ & 2.83E-07 & $4.86 \mathrm{E}-07$ & $2.66 E-07$ & 4.65E-07 & $4.59 E-09$ & 1.54E-07 & $2.34 E-07$ & 5.10E-08 & 2.01E-07 & $3.58 E-07$ \\
\hline S8 & $1.92 E-09$ & $1.24 E-09$ & $8.76 E-12$ & $1.29 E-11$ & $1.99 \mathrm{E}-10$ & $2.09 E-10$ & $3.81 E-07$ & $4.39 \mathrm{E}-08$ & $4.55 E-08$ & $3.96 E-08$ & $7.84 E-10$ & $2.70 E-08$ & $3.99 E-08$ & $2.34 \mathrm{E}-08$ & $3.43 E-08$ & $6.08 E-08$ \\
\hline S16 & $6.31 E-08$ & $4.08 E-08$ & $1.06 E-09$ & 1.11E-09 & $3.05 E-08$ & $3.15 E-09$ & $1.03 \mathrm{E}-06$ & $8.59 \mathrm{E}-07$ & $1.49 E-06$ & $9.64 E-07$ & $2.58 E-08$ & 1.31E-08 & $1.31 E-06$ & 5.32E-04 & $1.13 E-06$ & $2.00 E-06$ \\
\hline 518 & $2.47 \mathrm{E}-07$ & $1.58 \mathrm{E}-07$ & $3.48 E-09$ & $3.65 \mathrm{E}-09$ & $4.96 \mathrm{E}-08$ & 5.73E-09 & $3.36 \mathrm{E}-05$ & $1.16 E-06$ & $1.58 E-07$ & $9.21 \mathrm{E}-06$ & $2.73 E-09$ & 4.09E-06 & 5.39E-07 & $9.08 \mathrm{E}-05$ & $1.19 E-07$ & $2.13 E-07$ \\
\hline 520 & $1.80 E-08$ & $1.16 E-08$ & $6.00 E-10$ & $9.41 E-10$ & 5.73E-08 & 2.42E-09 & 8.08E-06 & $9.78 \mathrm{E}-07$ & $4.24 E-07$ & $2.51 E-06$ & $7.34 E-09$ & 9.75E-07 & $8.40 \mathrm{E}-08$ & 2.02E-05 & $3.21 E-07$ & $5.72 E-07$ \\
\hline 521 & $3.25 E-09$ & 2.09E-09 & $1.72 \mathrm{E}-11$ & $2.18 E-11$ & $4.06 \mathrm{E}-10$ & $2.37 E-10$ & 4.42E-07 & $7.19 E-08$ & $7.66 E-08$ & $1.33 \mathrm{E}-07$ & $1.32 E-09$ & $7.48 E-09$ & 6.71E-08 & $9.78 \mathrm{E}-08$ & 5.77E-08 & $1.03 E-07$ \\
\hline 522 & 6.58E-09 & 1.62E-09 & $3.61 \mathrm{E}-11$ & $1.43 E-11$ & $0.00 \mathrm{E}+00$ & $4.14 \mathrm{E}-10$ & 5.57E-06 & 3.38E-07 & 2.52E-06 & 8.83E-07 & $2.68 E-09$ & 1.83E-07 & $6.98 E-07$ & $1.64 \mathrm{E}-04$ & 9.27E-09 & $7.07 E-08$ \\
\hline & & & & & & & & & & & & & & & & \\
\hline & & & & & & & & & & & & & & & & \\
\hline & & & & & & & & & & & & & & & & \\
\hline & & & & & & & & & & & & & & & & \\
\hline & & & & & & & & & & & & & & & & \\
\hline & & & & & & & & & & & & & & & & \\
\hline
\end{tabular}




\begin{tabular}{|c|c|c|c|c|c|c|c|c|c|c|c|c|c|c|c|c|}
\hline & & & & & & & & & & & & & & & & \\
\hline & & & & & & & & & & & & & & & & \\
\hline & & & & & & & & & & & & & & & & \\
\hline & & & & & & & & & & & & & & & & \\
\hline & U-233 & $\mathrm{U}-234$ & U-235 & U-236 & U-238 & Np-237 & Pu-238 & Pu-239 & Pu-240 & Pu-241 & Pu-242 & Am-241 & Am-243 & $\mathrm{Cm}-244$ & Cm-245 & $\mathrm{Cm}-246$ \\
\hline Tank: & 9 & $g$ & $g$ & g & 9 & 9 & $g$ & $g$ & g & $g$ & 9 & 9 & 9 & $g$ & 9 & 9 \\
\hline S2 & $1.54 E-01$ & $4.07 E-01$ & $4.83 \mathrm{E}+00$ & $1.54 E-01$ & $7.40 \mathrm{E}+02$ & $3.81 E-01$ & $1.22 E+00$ & $1.23 E+00$ & $8.33 E-01$ & $5.03 E-02$ & $1.54 E-01$ & $4.09 \mathrm{E}-01$ & $5.53 \mathrm{E}-01$ & $2.77 \mathrm{E}-01$ & $1.53 E-01$ & $1.55 E-01$ \\
\hline$\$ 4(1)$ & $0.00 E+00$ & $5.20 E-02$ & $3.63 E+00$ & $0.00 \mathrm{E}+00$ & $9.65 \mathrm{E}+02$ & $1.02 E-02$ & $1.50 \mathrm{E}-04$ & $2.24 E-03$ & $0.00 \mathrm{E}+00$ & $0.00 E+00$ & $0.00 \mathrm{E}+00$ & $3.59 \mathrm{E}-05$ & $1.38 E-05$ & $9.00 \mathrm{E}-06$ & $0.00 \mathrm{E}+00$ & $0.00 \mathrm{E}+00$ \\
\hline S7 & $1.33 E-02$ & $3.75 E-02$ & $3.66 \mathrm{E}+00$ & $1.34 \mathrm{E}-01$ & $6.98 E+02$ & $1.33 E-02$ & $1.88 \mathrm{E}-04$ & $8.89 \mathrm{E}-02$ & $1.33 E-02$ & $5.11 E-05$ & $1.33 E-02$ & $5.08 \mathrm{E}-04$ & $1.33 E-02$ & $7.15 \mathrm{E}-06$ & $1,33 E-02$ & $1.34 E-02$ \\
\hline 58 & $9.05 E-03$ & $9.03 E-03$ & $1.84 \mathrm{E}-01$ & $9.06 E-03$ & $2.69 \mathrm{E}+01$ & 1.35E-02 & $1.01 E-03$ & $3.21 \mathrm{E}-02$ & $9.10 E-03$ & $1.74 E-05$ & $9.06 E-03$ & $3.57 E-04$ & $9.06 E-03$ & $1.31 \mathrm{E}-05$ & $9.06 E-03$ & $9.08 E-03$ \\
\hline 516 & $1.35 E+01$ & $1.35 E+01$ & $1.02 E+03$ & $3.54 \mathrm{E}+01$ & $1.87 \mathrm{E}+05$ & $9.23 E+00$ & $1.25 \mathrm{E}-01$ & $2.86 E+01$ & $1.36 E+01$ & \begin{tabular}{|c|}
$1.93 E-02$ \\
\end{tabular} & $1.36 E+01$ & $7.87 \mathrm{E}-03$ & $1.35 E+01$ & $1.36 E+01$ & $1.36 E+01$ & $1.36 E+01$ \\
\hline S19 & $5.22 \mathrm{E}+00$ & $5.17 E+00$ & $3.28 \mathrm{E}+02$ & $1.15 E+01$ & $3.00 E+04$ & $1.65 \mathrm{E}+00$ & $4.00 \mathrm{E}-01$ & $3.81 \mathrm{E}+00$ & 1.42E-01 & $1.81 \mathrm{E}-02$ & $1.41 E-01$ & $2.42 \mathrm{E}-01$ & $5.49 \mathrm{E}-01$ & $2.28 \mathrm{E}-01$ & 1.41E-01 & 1.43E-01 \\
\hline $\mathbf{S 2 0}$ & $1.27 E-01$ & $1.27 E-01$ & $1.89 \mathrm{E}+01$ & $9.91 \mathrm{E}-01$ & $1.16 E+04$ & $2.34 E-01$ & $3.22 \mathrm{E}-02$ & $1.07 \mathrm{E}+00$ & 1.27E-01 & $1.65 \mathrm{E}-03$ & $1.27 E-01$ & $1.93 \mathrm{E}-02$ & $2.86 \mathrm{E}-02$ & $1.70 \mathrm{E}-02$ & $1.27 E-01$ & $1.28 E-01$ \\
\hline $\mathbf{S 2 1}$ & $7.99 E-02$ & $7.94 E-02$ & $1.89 \mathrm{E}+00$ & $7.98 E-02$ & $2.86 E+02$ & $7.97 E-02$ & $6.13 \mathrm{E}-03$ & $2.74 \mathrm{E}-01$ & B.00E-02 & $3.05 \mathrm{E}-04$ & $7.96 E-02$ & $5.15 E-04$ & $7.95 E-02$ & $2.86 \mathrm{E}-04$ & $7.95 E-02$ & $8.03 E-02$ \\
\hline S22 & $3.88 E-02$ & $1.47 \mathrm{E}-02$ & $\begin{array}{l}9.50 \mathrm{E}-01 \\
\end{array}$ & $1.25 \mathrm{E}-02$ & $0.00 E+00$ & $3.33 E-02$ & 1.85E-02 & $3.09 \mathrm{E}-01$ & $6.31 \mathrm{E}-01$ & $4.85 \mathrm{E}-04$ & $3.87 E-02$ & $3.01 \mathrm{E}-03$ & $1.98 \mathrm{E}-01$ & $\begin{array}{l}1.15 \mathrm{E}-01 \\
\end{array}$ & $3.06 \mathrm{E}-03$ & $1.32 E-02$ \\
\hline & & & & & & & & & & & & & & & & \\
\hline & & & & & & & & & & & & & & & & \\
\hline & & & & & & & & & & & & & & & & \\
\hline & & & & & & & & & & & & & & & & \\
\hline & & & & & & & & & & & & & & & & \\
\hline & & & & & & & & & & & & & & & & \\
\hline
\end{tabular}



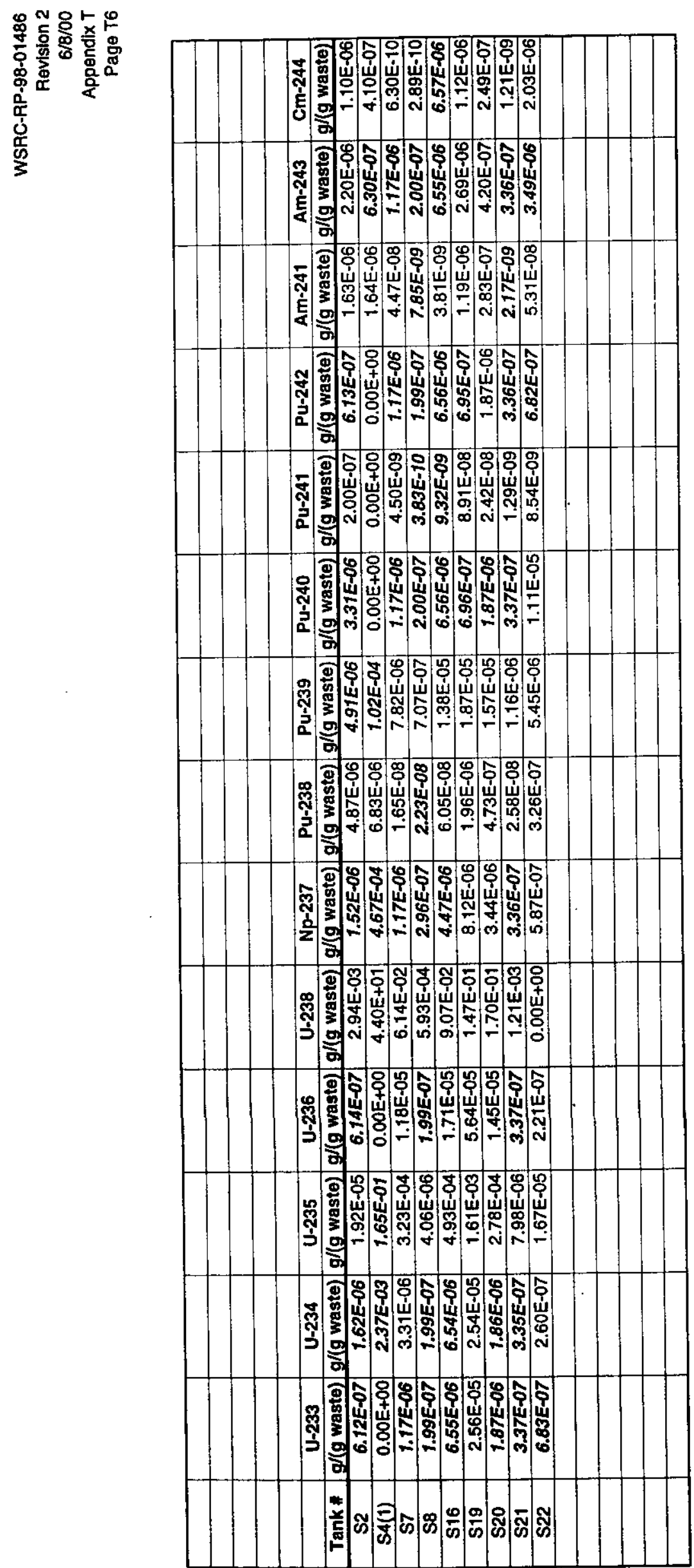


$$
\overbrace{}^{\frac{1}{\mid l y e}}
$$

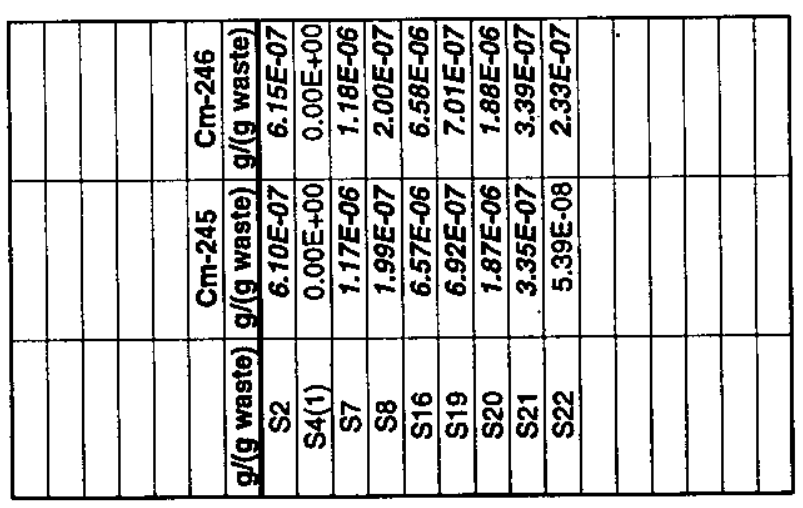


WSRC-RP-98-01486

Revision 2

$6 / 8 / 00$

Appendix U

Page U1

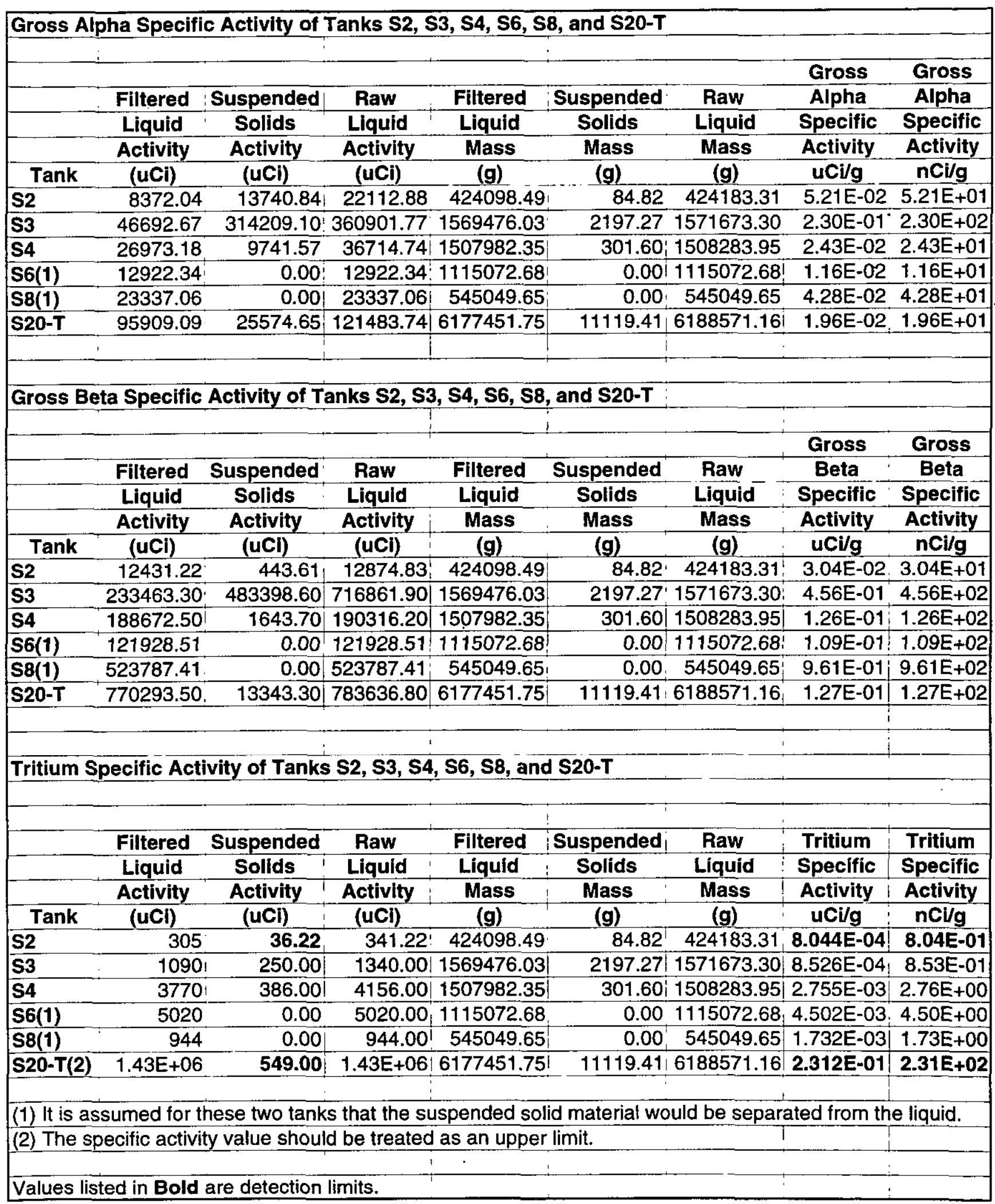




\section{ATTACHMENT 3}

Total Inventory of Selected Radionuclides in Old Solvent Tanks S1 through S22 
(This page intentionally left blank.) 
WSRC-TR-2000-00011

Revision 0

\title{
TOTAL INVENTORY OF SELECTED RADIONUCLIDES IN OLD SOLVENT TANKS S1 THROUGH S22 (U)
}

\author{
John D. Leyba
}

Unclassified

Does Not Contain Unclassified Controlled Nuclear Information (UCNI)

January 21,2000

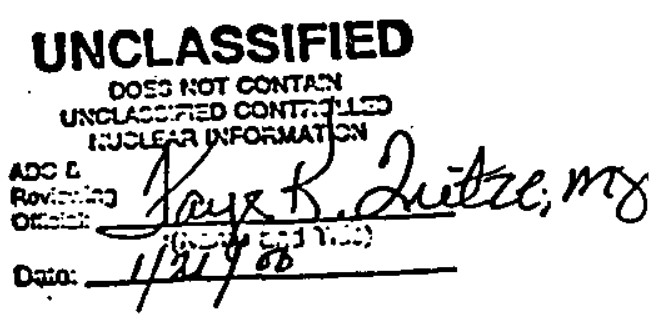

Westinghouse Savannah River Company

Savannah River Site

Aiken, SC 29808

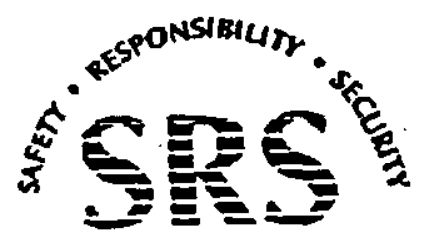


WSRC-TR-2000-00011

Revision 0

Keywords: Characterization

Radioactive

Solvent

Waste

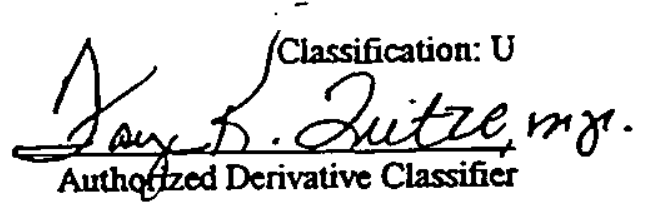

\section{TOTAL INVENTORY OF SELECTED RADIONUCLIDES IN OLD SOLVENT}

TANKS S1 THROUGH S22 (U)

\section{J. D. Leyba}

Publication Date: January 21, 2000

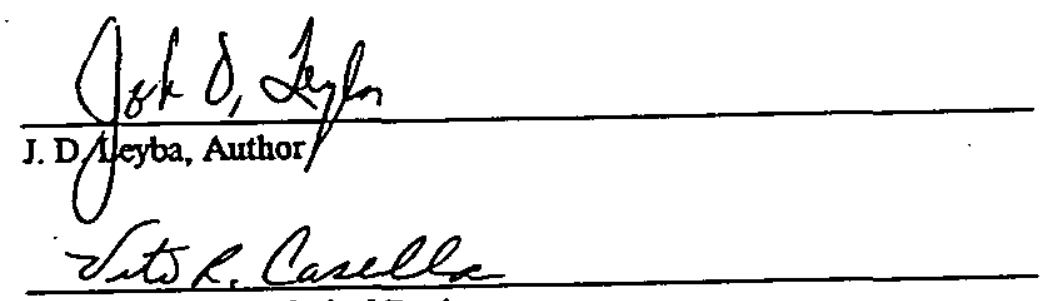

V. R Casella, Technical Reviewer

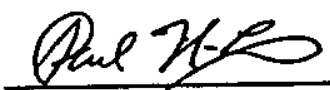

P. E. Filpus-Luryckx, ADS L4 Manager

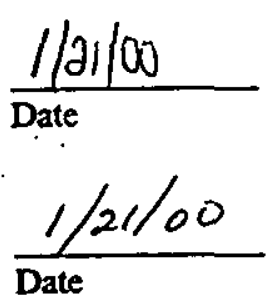

$\frac{1 / 21 / 00}{\text { Date }}$

Westinghouse Savannah River Company

Savannah River Site

Aiken, SC 29808

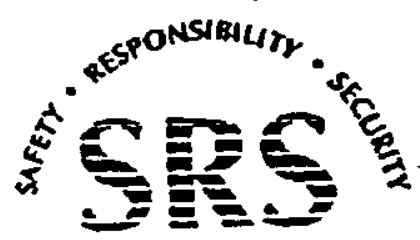




\section{DISCLAIMER}

This report was prepared by Westinghouse Savannah River Company (WSRC) for the United States Department of Energy under Contract No. DE-AC09-96SR18500 and is an account of work performed under that contract. Neither the United States Department of Energy, nor WSRC, nor any of their employees makes any warranty, expressed or implied, or assumes any legal liability or responsibility for the accuracy, completeness, or usefulness, of any information, apparatus, or product or process disclosed herein or represents that its use will not infringe privately owned rights. Reference herein to any specified commercial product, process, or service by trademark, name, manufacturer or otherwise does not necessarily constitute or imply endorsement, recommendation, or favoring of same by WSRC or by the United States Government or any agency thereof. The views and opinions of the authors expressed herein do not necessarily state or reflect those of the United States Government or any agency thereof. 


\section{ABSTRACT}

The total inventory of fourteen radionuclides, three metals, and volatile organic compounds (VOCs) has been calculated for the twenty-two Old Solvent Tanks (OSTs). The inventory calculations are based upon extensive characterization data of the multiple liquid and sludge samples taken from the OSTs. In addition, the total inventory of sixteen actinides (including error) has been calculated. The actinide inventory will be useful for criticality safety considerations. 
This page intentionally left blank. 


\section{TABLE OF CONTENTS}

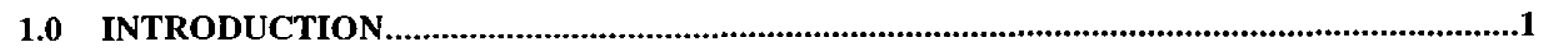

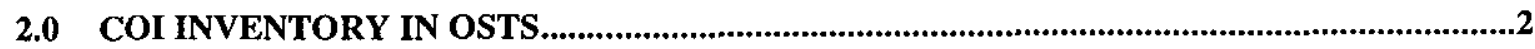

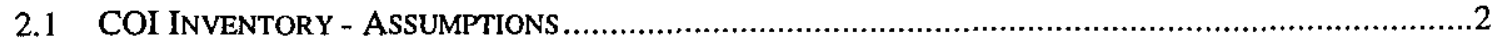

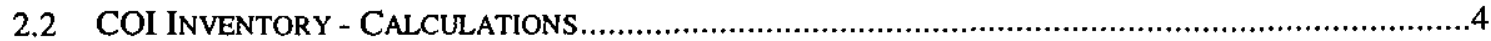

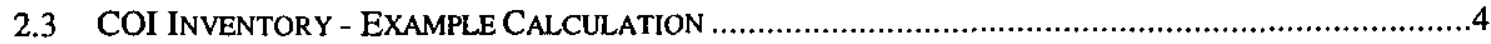

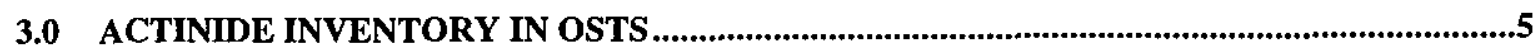

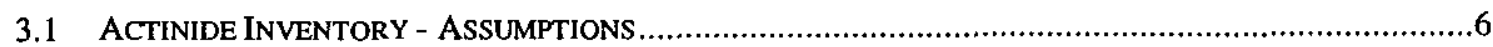

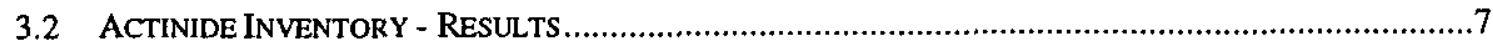

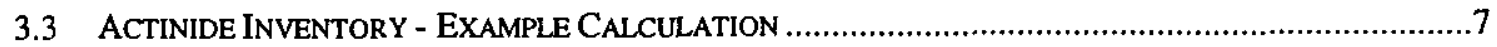

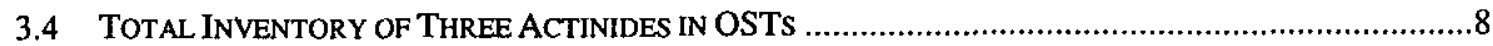

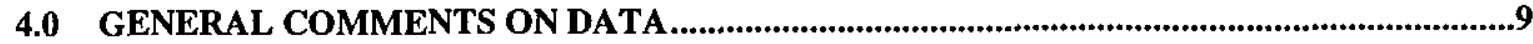

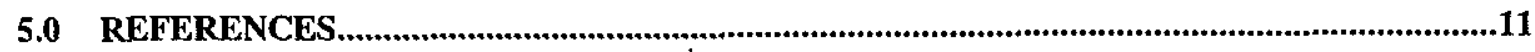

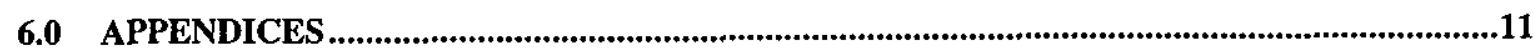

6.1 APPENDIX 1. COI TOTAL INVENTORY OF OSTS S1 THROUGH S22 ….....................................12

6.2 APPENDIX 2. SOLVENT TANK NUCLIDE INVENTORY - FILTERED LIQUIDS ..................................26

6.3 APPENDIX 3. SOLVENT TANK NUCLIDE INVENTORY - SUSPENDED SOLIDS ....................................3

6.4 APPENDIX 4. SOLVENT TANK NUCLIDE INVENTORY - SLUDGES ................................................40

\section{LIST OF TABLES}

Table 1. Total Estimated U-235, U-238, and Pu-239 Content of Old Solvent Tanks S1 through S22..............................................................9

Table 2. Comparison of Activity Levels in Suspended Solids and Sludge .................10 


\section{LIST OF ACRONYMS USED}

$\begin{array}{ll}\text { ADS } & \text { Analytical Development Section } \\ \text { COI } & \text { Contaminant of Interest } \\ \text { ORWBG } & \text { Old Radioactive Waste Burial Ground } \\ \text { OSTs } & \text { Old Solvent Tanks } \\ \text { PUREX } & \text { Plutonium-Uranium Extraction } \\ \text { SRS-ERD } & \text { Savannah River Site-Environmental Restoration Division } \\ \text { SRTC } & \text { Savannah River Technology Center } \\ \text { VOCs } & \text { Volatile Organic Compounds }\end{array}$




\title{
TOTAL INVENTORY OF SELECTED RADIONUCLIDES IN OLD SOLVENT TANKS S1 THROUGH S22 (U)
}

\author{
J. D. Leyba \\ Westinghouse Savannah River Company \\ Savannah River Site \\ Aiken, SC 29808
}

\subsection{INTRODUCTION}

The Old Radioactive Waste Burial Ground (ORWBG, 643-E) contains twenty-two buried old solvent tanks. These tanks, consisting of cylindrical, carbon-steel, single-wall vessels were used to store spent Plutonium-Uranium Extraction (PUREX) process solvent.

Reference 1 provides a detailed description of the tanks and their associated history. The Analytical Development Section (ADS) of the Savannah River Technology Center (SRTC) developed a Sampling and Analysis Plan for the characterization of the material contained in the twenty-two tanks [2]. The purpose of this characterization was to obtain a sufficient database so that a viable path forward could be established for the closure of the tanks. Reference 3 contains the analytical results of the OST characterization study.

Due to various reasons, not all of the phases present in all of the tanks were sampled. As discussed in Reference 3, liquid samples were successfully obtained from fifteen out of twenty-two tanks. Of the remaining seven tanks, three were not sampled because of the presence of only very minimal amounts of liquid and four tanks contained no liquid phase. For the sludges, nine out of twenty-two tanks were successfully sampled while only very limited sludge samples were obtained from three other tanks. The Sampling and Analysis Plan did not require sampling in nine of the ten remaining tanks because they contained less than 50 gallons each of solid phase. Unsuccessful attempts were made; however, to sample the sludge in some of these remaining tanks. Thus, only one tank (Tank S5), which was required to be sampled by the Sampling and Analysis Plan, was not sampled.

The Savannah River Site-Environmental Restoration Division (SRS-ERD) has subsequently requested an estimate of the total inventory of eighteen Contaminants of Interest (COIs) for all twenty-two tanks. Included in the COI list are H-3, C-14, I-129, Cs-137, Pu-238, Pu-239, Pu-241, Sr-90, U-235, U-238, Co-60, Tc-99, Np-237, Cm-244, $\mathrm{Cd}, \mathrm{Pb}, \mathrm{Hg}$, and total VOCs. Also, an estimate of the total inventory of sixteen actinides, including seven COIs, was calculated. The actinide list includes U-233, U-234, U-235, 
U-236, U-238, Np-237, Pu-238, Pu-239, Pu-240, Pu-241, Pu-242, Am-241, Am-243, $\mathrm{Cm}-244, \mathrm{Cm}-245$, and $\mathrm{Cm}-246$. The sixteen actinides are important for criticality considerations.

\subsection{COI Inventory in OSTs}

In order to accurately estimate the total inventory of the eighteen COIs contained in the OSTs, one must systematically categorize the contents of each tank. Based upon previous video and physical surveillances of the tanks, an estimated sludge mass and liquid volume was determined for each tank [4][5][6]. Once liquid samples were obtained and submitted to ADS for characterization, they were filtered to obtain separate fractions of liquid and suspended solids material. Each fraction was subsequently analyzed for the various COIs. Sludge samples were also independently analyzed by ADS. Analytical data was thus obtained, by phase, for many of the OSTs.

A methodology was therefore developed to accurately estimate the inventory of those tank phases that were not sampled. This methodology uses as its starting point the latest analytical data of the various phases present (e.g. aqueous liquid, suspended solids, and sludge) in each tank. For a specific phase (filtered liquid, filtered solid, or sludge), the methodology assumes that the concentration of a given COI in those tanks that were not sampled is equal to the average concentration of the COI in the tanks that were sampled and analyzed. Three general cases were identified and are delineated below:

1) COI detected in more than three samples of a given phase - the analytical data were averaged and the COI concentration in those tanks which were not sampled was assumed to be equal to this calculated average COI concentration.

2) COI detected in less than or equal to three samples of a given phase - the COI concentration in those tanks which were not sampled was assumed to be equal to the higher of the average detected COI concentration or the average detection limit value.

3) COI not detected in any samples of a given phase - the COI concentration in those tanks not sampled was assumed to be equal to the average detection limit value or average upper limit value of those tanks that were sampled.

Once the average COI concentrations were assigned, the total inventories could easily be calculated by taking the product of the activity concentration and the volume or mass of phase present in a given tank.

\subsection{COI Inventory - Assumptions}

The characterization of the material in the OSTs showed that at least two of the tanks (Tanks S11 and S20) contained an organic liquid phase [3]. In addition, Tank S20 
contained both organic and aqueous liquid layers. For the purposes of these calculations, it was assumed that Tanks S1-S8, S10, S12-S14, S18, S19, S21 and S22 contained an aqueous liquid phase and no organic liquid phase. Furthermore, it was assumed that Tank S11 contained an organic liquid phase and no aqueous liquid phase. Finally, it was assumed that Tank S20 contained both an aqueous liquid phase and an organic liquid phase. It should be noted that only the total liquid volume in Tank S20 was estimated, thus the fraction that is aqueous and the fraction that is organic were not known. For the sake of conservatism, when performing the inventory calculations, it was assumed that the entire liquid volume was aqueous when performing the aqueous liquid calculations and subsequently it was assumed that the entire liquid volume was organic when performing the organic liquid calculations. It should be noted that several tanks in addition to Tanks S11 and S20 might also contain an organic liquid phase. This is discussed in detail in Reference 1. The assumptions used for the calculations in this present document regarding the aqueous/organic nature of the various liquids in the OSTs are based upon the analytical results (which are documented in Reference 3) of the latest samples obtained.

Two liquid samples were obtained from Tank S19 and both were analyzed. The analytical results indicated that both samples were aqueous; hence, the samples can be treated as duplicates. See Reference 3 for more details regarding this issue. Therefore, when averaging the aqueous liquid phases and associated suspended solids, only sample S19-O (taken at the higher depth) was included in the calculations.

The organic liquids contained in Tanks S11 and S20 were not included when calculating the average concentrations of the various COIs in the filtered aqueous liquids. Similarly, the suspended solids from the organic liquids in Tanks S11 and S20 were not included when calculating the average concentrations of the various COIs in the suspended solids from aqueous liquids. The sludge obtained from Tank S4 was not included when determining the average concentrations of the eighteen COIs due to the fact that it displayed the characteristics of a liquid rather than sludge.

The liquids contained in Tanks S10, S12, and S18 were not sampled. However, the total suspended solids content had to be estimated so that the COI content of the suspended solids could be calculated. The weight percent of total suspended solids for these three tanks was assumed to be equal to the average weight percent of total suspended solids for the aqueous phases of the other tanks. When performing these suspended solids calculations, the density of the filtered liquids in Tanks S10, S12, and S18 was assumed to be equal to $1.0 \mathrm{~g} / \mathrm{cm}^{3}$.

Certain radionuclides were not detected; hence, the average concentration of these nuclides had to be calculated based upon detection limit or upper limit values. These radionuclides are listed below:

1) The average $\mathrm{H}-3$ activity concentration in sludge is based upon upper limit values. 
2) The average Co-60 activity concentration in sludge is based upon detection limit values.

3) The average C-14 activity concentration in the filtered liquids is based upon upper limit values.

4) The average C-14 activity concentration in the suspended solids is based upon upper limit values.

5) The average I-129 activity concentration in the suspended solids is based upon upper limit values.

6) The average Tc-99 activity concentration in the suspended solids is based upon detection limit values.

The C-14, I-129, Sr-90, and Tc-99 average concentrations in the sludge are based upon data obtained from the suspended solids: The implications of this assumption are discussed further in Section 4.0.

Since quantitative metals data were not obtained on the suspended solids, fifty times the average concentrations of $\mathrm{Cd}, \mathrm{Pb}$, and $\mathrm{Hg}$ in the sludge were used to calculate the content of these metals in the suspended solids. This issue is also discussed further in Section 4.0.

The VOC content of both the suspended solids material and sludge was based upon the filtered liquid data and corrected for the expected difference in density between the materials. For these calculations, it was assumed that the VOC average mass per unit volume for the suspended solids and sludge was equal to that of the filtered liquids. It was also assumed that the density of the sludge and suspended solids was $2 \mathrm{~g} / \mathrm{cm}^{3}$. The average density of the filtered liquids was approximately $1 \mathrm{~g} / \mathrm{cm}^{3}$.

\subsection{COI Inventory - Calculations}

The results of the COI inventory calculations are shown in Appendix 1. Results are listed by phase for each tank for the eighteen COIs. Values shown in bold black print are detection limit values. Values shown in bold red are explained in the notes of Appendix 1 and represent calculated upper limit values. Values shown in bold blue represent calculated values (using the methodology explained in Sections 2.0 and 2.1) for those phases that were not analyzed. The total activities for the radionuclides and total mass for the other COIs are shown on pages 13 and 16 respectively of Appendix 1.

\subsection{COI Inventory - Example Calculation}

The calculated H-3 activity in the Tank S1 filtered liquid will be used as an example.

The average aqueous $\mathrm{H}-3$ concentration was calculated from the analytical results of Tanks S1, S2, S3, S4, S6, S7, S8, S13, S14, S19-O, S20-B, S21, and S22. The average $\mathrm{H}-3$ concentration was determined to be $1.97 \times 10^{-3} \mu \mathrm{Ci} / \mathrm{mL}$. The estimated aqueous liquid volume in Tank S12 was determined to be $1.890 \times 10^{4} \mathrm{~mL}$, thus, 


\section{$1.97 \times 10^{-3} \mu \mathrm{Ci} / \mathrm{mL} \times 1.890 \times 10^{4} \mathrm{~mL}=3.72 \times 10^{1} \mu \mathrm{Ci}$.}

\subsection{Actinide Inventory in OSTs}

The existing analytical data (for those tank phases that were analyzed) were used as a starting point for the actinide inventory calculations. For each specific phase (filtered liquid, filtered solid, or sludge), the calculation methodology assumes that the concentration of a given actinide in those tanks that were not sampled is equal to the average concentration of the actinide in the tanks that were sampled. As with the eighteen COIs, three general cases for the actinide calculations were identified and are listed below:

1) Radionuclide detected in more than three samples of a given phase - the analytical data were averaged and the radionuclide concentration in those tanks that were not sampled was assumed to be equal to this calculated average radionuclide concentration.

2) Radionuclide detected in less than or equal to three samples of a given phase - the radionuclide concentration in those tanks which were not sampled was assumed to be equal to the higher of either the average detected radionuclide concentration or the average detection limit value.

3) Radionuclide not detected in any samples of a given phase - the radionuclide concentration in those tanks not sampled was assumed to be equal to the average detection limit value or average upper limit value of those tanks that were sampled.

The error associated with the calculated average activity for each radionuclide was assigned as twice the standard deviation of the respective average. When detection limits were averaged, no errors were assigned since these numbers represent $\sim 95 \%$ confidence limits.

Since the actinide inventory will be used for criticality safety calculations, conservatism was built into the calculation methodology. Firstly, for a radionuclide known or suspected to be in the OSTs but not detected in a sample, the activity was assumed to be equal to the detection limit or upper limit for that radionuclide for the measurement conditions used. Secondly, for those nuclides that were positively identified, the 2-sigma measurement error was added to the activity before performing the total activity and mass calculations. For those tanks in which a radionuclide was not measured for a given phase and an average radionuclide concentration was assigned, the calculated error (see previous paragraph) was added to the calculated radionuclide activity concentration prior to performing the total activity and mass calculations. 


\subsection{Actinide Inventory - Assumptions}

The assumptions for the actinide inventory calculations are similar to those used for the eighteen COIs described in Section 2.1. The characterization of the material in the OSTs showed that at least two of the tanks (Tanks S11 and S20) contained an organic liquid phase [3]. In addition, Tank $\$ 20$ contained both organic and aqueous liquid layers. For the purposes of these calculations, it was assumed that Tanks S1-S8, S10, S12-S14, S18, $\mathrm{S} 19, \mathrm{~S} 21$ and S22 contained an aqueous liquid phase and no organic liquid phase. Furthermore, it was assumed that Tank S11 contained an organic liquid phase and no aqueous liquid phase. Finally, it was assumed that Tank $S 20$ contained both an aqueous liquid phase and an organic liquid phase. It should be noted that only the total liquid volume in Tank S20 was estimated, thus the fraction that is aqueous and the fraction that is organic were not known. For the sake of conservatism, when performing the inventory calculations, it was assumed that the entire liquid volume was aqueous when performing the aqueous liquid calculations and subsequently it was assumed that the entire liquid volume was organic when performing the organic liquid calculations. It should be noted that several tanks in addition to Tanks S11 and S20 might also contain an organic liquid phase. This is discussed in detail in Reference 1. The assumptions used for the calculations in this present document regarding the aqueous/organic nature of the various liquids in the OSTs are based upon the analytical results (which are documented in Reference 3) of the latest samples obtained.

Two liquid samples were obtained from Tank S19 and both were analyzed. The analytical results indicated that both samples were aqueous; hence, the samples can be treated as duplicates. See Reference 3 for more details regarding this issue. Therefore, when averaging the aqueous liquid phases and associated suspended solids, only sample S19-O (taken at the higher depth) was included in the calculations.

The organic liquids contained in Tanks S11 and S20 were not included when calculating the average concentrations of the various actinides in the filtered aqueous liquids. Similarly, the suspended solids from the organic liquids in Tanks S11 and S20 were not included when calculating the average concentrations of the various actinides in the suspended solids from aqueous liquids. The sludge obtained from Tank S4 was not included when determining the average concentrations of the sixteen actinides due to the fact that it displayed the characteristics of a liquid rather than sludge.

The liquids contained in Tanks S10, S12, and S18 were not sampled. However, the total suspended solids content had to be estimated so that the actinide content of the suspended solids could be calculated. The weight percent of total suspended solids for these three tanks was assumed to be equal to the average weight percent of total suspended solids for the aqueous phases of the other tanks. When performing these suspended solids calculations, the density of the filtered liquids in Tanks S10, S12, and S18 was assumed to be equal to $1.0 \mathrm{~g} / \mathrm{cm}^{3}$. 
Certain radionuclides were not detected; hence, the average concentration of these nuclides had to be calculated based upon detection limit or upper limit values. These radionuclides are listed below:

1) The average $\mathrm{Pu}-242$ activity concentration in sludge is based upon detection limit values.

2) The average Am-243 activity concentration in sludge is based upon detection limit values and one upper limit value, even though this nuclide was detected in three sludges. However, based upon rule 2 of Section 3.0, the higher average detection limit/upper limit value was used.

3) The average Cm-245 activity concentration in sludge is based upon detection limit values even though this nuclide was detected in one sludge. However, based upon rule 2 of Section 3.0, the higher average detection limit value was used.

4) The average $\mathrm{Cm}-246$ activity concentration in the sludge is based upon detection limit values.

5) The average $\mathrm{Pu}-242$ activity concentration in the filtered liquids is based upon detection limit values.

6) The average $\mathrm{Cm}-245$ activity concentration in the filtered liquids is based upon detection limit values.

7) The average $\mathrm{Cm}-246$ activity concentration in the filtered liquids is based upon detection limit values.

8) The average $\mathrm{Cm}-245$ activity concentration in the suspended solids is based upon detection limit values even though this nuclide was detected in one suspended solids sample. However, based upon rule 2 of Section 3.0, the higher average detection limit value was used.

9) The average $\mathrm{Cm}-246$ activity concentration in the suspended solids is based upon detection limit values even though this nuclide was detected in three suspended solids samples. However, based upon rule 2 of Section 3.0, the higher average detection limit value was used.

\subsection{Actinide Inventory - Results}

The results of the actinide inventory calculations are shown in Appendices 2 through 4. Results are listed by phase for each tank for the sixteen actinides. Values shown in bold black print are detection limit values. Values shown in bold blue represent calculated values (using the methodology explained in Sections 3.0 and 3.1) for those phases that were not analyzed.

\subsection{Actinide Inventory - Example Calculation}

The calculated U-234 activity and error in the Tank S1 sludge will be used as an example. The average U-234 concentration was calculated from the analytical results of Tanks S7, $\mathrm{S} 19$ and $\mathrm{S} 22$. The average U-234 concentration was determined to be $5.02 \times 10^{4} \mathrm{pCi} / \mathrm{g}$ (see page 40 of Appendix 4). The error was calculated to be $1.43 \times 10^{5} \mathrm{pCi} / \mathrm{g}$. Since 
U-234 was found in only three of the sludge samples, the average U-234 detection limit in the other analyzed sludge samples was also calculated (see Section 3.0). Thus, the average U-234 detection limit calculated from Tanks S2, S8, S16, S20, and S21 was determined to be $1.32 \times 10^{4} \mathrm{pCi} / \mathrm{g}$. Therefore, for the purposes of these calculations, the higher calculated activity concentration $\left(5.02 \times 10^{4} \mathrm{pCi} / \mathrm{g}\right)$ was used.

Continuing on with the example calculation using U-234 in the sludge from Tank S1 we get:

$\mathrm{U}-234$ activity in sludge $=5.02 \times 10^{4} \pm 1.43 \times 10^{5} \mathrm{pCi} / \mathrm{g}$

Specific Activity of $\mathrm{U}-234=6.24 \times 10^{-3} \mathrm{Ci} / \mathrm{g}$

Mass of sludge in the tank $=34068.71$ grams

Total U-234 in the tank including error $=\left(5.02 \times 10^{4}+1.43 \times 10^{5}\right) \times 34068.71=6.582 \times 10^{9} \mathrm{pCi}$

Total U-234 in the tank including error $=6.582 \times 10^{9} \mathrm{pCi} \times \frac{1 \mathrm{Ci}}{1 \times 10^{12} \mathrm{pCi}} \approx 6.58 \times 10^{-3} \mathrm{Ci}$

$\mathrm{U}-234$ activity concentration including error $=\frac{6.582 \times 10^{-3} \mathrm{Ci}}{34068.71 \mathrm{grams}}=1.93 \times 10^{-7} \mathrm{Ci} / \mathrm{g}$

Mass of U-234 in the tank including error $=\frac{6.582 \times 10^{-3} \mathrm{Ci}}{6.24 \times 10^{-3} \mathrm{Ci} / \mathrm{g}}=1.055 \times 10^{0} \approx 1.06 \times 10^{0} \mathrm{~g}$

Mass of U-234 per gram of waste $=\frac{1.055 \times 10^{0} \text { grams }}{34068.71 \text { grams }}=3.097 \times 10^{-5} \approx 3.10 \times 10^{-5} \mathrm{~g} / \mathrm{g}$ (waste)

\subsection{Total Inventory of Three Actinides in OSTs}

Table 1 summarizes the results of the U-235, U-238, and Pu-239 mass calculations for the twenty-two OSTs. For each of these nuclides in a given tank, the contributions from the 
filtered liquid phase(s), suspended solids phase(s), and sludge phase have been summed to obtain the total.

Table 1. Total Estimated U-235, U-238, and Pu-239 Content of Old Solvent Tanks S1 through S22

\begin{tabular}{|c|c|c|c|}
\hline Tank \# & $\begin{array}{c}\text { U-235 } \\
(\mathbf{g})\end{array}$ & $\begin{array}{c}\text { U-238 } \\
(\mathbf{g})\end{array}$ & $\begin{array}{c}\text { Pu-239 } \\
(\mathbf{g})\end{array}$ \\
\hline S1 & $6.18 \mathrm{E}+01$ & $8.98 \mathrm{E}+03$ & $<8.16 \mathrm{E}-01$ \\
\hline S2 & $8.89 \mathrm{E}+00$ & $1.45 \mathrm{E}+04$ & $<1.25 \mathrm{E}+00$ \\
\hline S3 & $1.07 \mathrm{E}+02$ & $1.59 \mathrm{E}+04$ & $1.30 \mathrm{E}+00$ \\
\hline S4 & $<1.67 \mathrm{E}+02$ & $3.43 \mathrm{E}+04$ & $<1.04 \mathrm{E}+00$ \\
\hline S5 & $1.08 \mathrm{E}+03$ & $1.60 \mathrm{E}+05$ & $1.80 \mathrm{E}+01$ \\
\hline S6 & $7.84 \mathrm{E}+01$ & $1.58 \mathrm{E}+04$ & $<2.51 \mathrm{E}+00$ \\
\hline S7 & $2.33 \mathrm{E}+02$ & $4.88 \mathrm{E}+04$ & $3.11 \mathrm{E}+00$ \\
\hline S8 & $7.60 \mathrm{E}+00$ & $1.16 \mathrm{E}+03$ & $<5.22 \mathrm{E}-01$ \\
\hline S9 & $1.18 \mathrm{E}+02$ & $1.73 \mathrm{E}+04$ & $1.92 \mathrm{E}+00$ \\
\hline S10 & $2.86 \mathrm{E}+02$ & $4.25 \mathrm{E}+04$ & $4.76 \mathrm{E}+00$ \\
\hline S11 & $1.15 \mathrm{E}+02$ & $<1.69 \mathrm{E}+04$ & $1.92 \mathrm{E}+00$ \\
\hline S12 & $4.80 \mathrm{E}+01$ & $7.30 \mathrm{E}+03$ & $8.30 \mathrm{E}-01$ \\
\hline S13 & $4.52 \mathrm{E}+02$ & $6.74 \mathrm{E}+04$ & $<7.18 \mathrm{E}+00$ \\
\hline S14 & $1.11 \mathrm{E}+03$ & $1.75 \mathrm{E}+05$ & $1.78 \mathrm{E}+01$ \\
\hline S15 & $1.31 \mathrm{E}+03$ & $1.93 \mathrm{E}+05$ & $2.14 \mathrm{E}+01$ \\
\hline S16 & $1.02 \mathrm{E}+03$ & $1.87 \mathrm{E}+05$ & $2.86 \mathrm{E}+01$ \\
\hline S17 & $6.33 \mathrm{E}+01$ & $9.31 \mathrm{E}+03$ & $1.03 \mathrm{E}+00$ \\
\hline S18 & $2.09 \mathrm{E}+01$ & $3.31 \mathrm{E}+03$ & $3.88 \mathrm{E}-01$ \\
\hline S19 & $3.68 \mathrm{E}+02^{\mathrm{a}}$ & $8.77 \mathrm{E}+04^{\mathrm{a}}$ & $4.24 \mathrm{E}+00^{\mathrm{a}}$ \\
\hline S20 & $<2.22 \mathrm{E}+02$ & $<5.33 \mathrm{E}+04$ & $<3.50 \mathrm{E}+00$ \\
\hline S21 & $2.75 \mathrm{E}+01$ & $8.78 \mathrm{E}+03$ & $9.83 \mathrm{E}-01$ \\
\hline S22 & $5.07 \mathrm{E}+01$ & $<1.59 \mathrm{E}+04$ & $<1.62 \mathrm{E}+00$ \\
\hline
\end{tabular}

a- This value was calculated using the results from sample 19-O.

\subsection{GENERAL COMMENTS ON DATA}

The various samples from the OSTs presented ADS with a unique analytical challenge. It is extremely difficult to determine the quantities of trace radionuclides in the presence of gross amounts of other radionuclides. This is especially pertinent to constituents such as $\mathrm{C}-14, \mathrm{I}-129, \mathrm{Ni}-59$, and $\mathrm{Ni}-63$. For example, the gross beta activity level in the Tanks $\mathrm{S} 1$ filtered liquid was determined to be $1.82 \mu \mathrm{Ci} / \mathrm{mL}$ [3]. The $\mathrm{C}-14$ upper limit value in this liquid was determined to be $3.50 \times 10^{-4} \mu \mathrm{Ci} / \mathrm{mL}$, which represents less than $0.02 \%$ of the total activity. It should also be emphasized that the finite sample size available for analysis hindered the achievement of lower detection limit numbers. 
Carbon-14 was not actually detected in any of the OST samples that were analyzed for this constituent. In all cases but one, the C-14 analytical data had to be qualified as upper limit values due to the presence of alpha activity in the separated $\mathrm{C}-14$ fractions. In the sole case where the data was not qualified as an upper limit, no C-14 was detected and a detection limit value was assigned. The average $\mathrm{C}-14$ values calculated for the filtered liquid and suspended solids samples were based upon detection limit and upper limit numbers. Therefore, these data should be viewed as conservative upper limits only.

Extremely limited quantities of sludge samples severely restricted the analyses that could be performed on the samples. Because of the limited analytical data available on the sludges, C-14, I-129, Sr-90, and Tc-99 activity levels had to be based upon average activity concentrations of these radionuclides in the suspended solids. This assumption is most likely very conservative, since the activity per gram of these radionuclides is probably much higher in the suspended solids than in the sludge. The net result of this assumption is therefore most likely a gross overestimation of the inventories of these four radionuclides in the sludge phases. This assumption is supported by the data shown in Table 2 which compares the average activity concentrations of several radionuclides present in both the suspended solids and the sludge.

Table 2. Comparison of Activity Levels in Suspended Solids and Sludge

\begin{tabular}{|c|c|c|c|}
\hline COI & $\begin{array}{c}\text { Suspended Solids } \\
\mu \mathrm{Ci} / \mathrm{g}\end{array}$ & $\begin{array}{c}\text { Sludge } \\
\mu \mathrm{Ci} / \mathrm{g}\end{array}$ & $\begin{array}{c}\text { Ratio of } \\
\text { Susp Solids/Sludge }\end{array}$ \\
\hline $\mathrm{H}-3$ & $7.29 \mathrm{E}-01$ & $2.41 \mathrm{E}+00$ & $3.02 \mathrm{E}-01$ \\
\hline $\mathrm{Cs}-137$ & $6.22 \mathrm{E}+00$ & $1.57 \mathrm{E}+00$ & $3.96 \mathrm{E}+00$ \\
\hline $\mathrm{Pu}-238$ & $1.61 \mathrm{E}+02$ & $1.36 \mathrm{E}+01$ & $1.18 \mathrm{E}+01$ \\
\hline $\mathrm{Pu}-239$ & $9.95 \mathrm{E}+00$ & $4.69 \mathrm{E}-01$ & $2.12 \mathrm{E}+01$ \\
\hline $\mathrm{Pu}-241$ & $5.07 \mathrm{E}+01$ & $4.04 \mathrm{E}+00$ & $1.25 \mathrm{E}+01$ \\
\hline $\mathrm{U}-235$ & $3.89 \mathrm{E}-03$ & $6.19 \mathrm{E}-04$ & $6.28 \mathrm{E}+00$ \\
\hline $\mathrm{U}-238$ & $7.92 \mathrm{E}-02$ & $1.90 \mathrm{E}-02$ & $4.17 \mathrm{E}+00$ \\
\hline $\mathrm{Co}-60$ & $2.13 \mathrm{E}-02$ & $4.50 \mathrm{E}-04^{\mathrm{a}}$ & $4.73 \mathrm{E}+01$ \\
\hline $\mathrm{Np}-237$ & $1.08 \mathrm{E}-01$ & $2.38 \mathrm{E}-03$ & $4.54 \mathrm{E}+01$ \\
\hline $\mathrm{Cm}-244$ & $2.62 \mathrm{E}+02$ & $4.34 \mathrm{E}+01$ & $6.04 \mathrm{E}+00$ \\
\hline
\end{tabular}

a- This value is based upon one data point only. Co-60 was not detected in any of the other sludge samples analyzed for this constituent.

Since no data exists for the metals $(\mathrm{Cd}, \mathrm{Pb}$, and $\mathrm{Hg}$ ) content of the suspended solids material, their concentration can only be suggested from Table 2 . Based upon the data in Table 2, the ratios of Suspended Solids to Sludge ranged from 0.302 to 47.3 . The average of this ratio for the COIs listed in Table 2, excluding tritium, was 17.6 \pm 17.2. Tritium was omitted because it is believed to be entrenched in the sludge, and is therefore, not representative of $\mathrm{Pb}, \mathrm{Hg}$, and $\mathrm{Cd}$. Thus, in order to be conservative, the $\mathrm{Pb}, \mathrm{Hg}$, and $\mathrm{Cd}$ concentrations in the suspended solids were assumed to be 50 times the concentrations of these respective metals in the sludge. 
The VOC content of both the suspended solids material and sludge was based upon the filtered liquid data and corrected for the expected difference in density between the materials (e.g. sludge and suspended solids density was assumed $2 \mathrm{~g} / \mathrm{cm}^{3}$ while the liquid density was approximately $1 \mathrm{~g} / \mathrm{cm}^{3}$ ). It was also assumed that the average VOC mass per unit volume was the same for the sludge, suspended solids, and filtered liquids. It is unknown whether these assumptions are conservative or not.

\subsection{REFERENCES}

1. Information Document on the Old Solvent Tanks S1-S22 in the Old Radioactive Waste Burial Ground 643-E, WSRC-RP-96-00144, Rev. 0, Westinghouse Savannah River Company, Aiken, SC 29808 (1996).

2. Filpus-Luyckx, P., Sampling and Analysis Plan for Old Solvent Tanks S1-S22 to Address Waste Acceptance Criteria (U), WSRC-RP-97-00770, Rev. 0, Westinghouse Savannah River Company, Aiken, SC 29808 (1997).

3. Leyba, J. D. Characterization of Samples from Old Solvent Tanks S1 through S22, WSRC-RP-98-01486, Rev. 1, Westinghouse Savannah River Company, Aiken, SC 29808 (1999).

4. Mason, J., Estimation of Total Solids in Tanks S1-S22 Based on the Video Surveys, Interoffice Memorandum, April 22, 1998, Westinghouse Savannah River Company, Aiken, SC 29808 (1998).

5. Preston, A., Solvent Tank Liquid and Sludge Quantities, Electronic Mail Private Communication, December 9, 1998, Westinghouse Savannah River Company, Aiken, SC 29808 (1998).

6. Preston, A., Private Communications, December 18, 1998 and January 5, 1999, Westinghouse Savannah River Company, Aiken, SC 29808 (1998, 1999).

\subsection{APPENDICES}

\subsection{Appendix 1. COI Total Inventory of OSTs S1 through S22}

\subsection{Appendix 2. Solvent Tank Nuclide Inventory - Filtered Liquids}

6.3 Appendix 3. Solvent Tank Nuclide Inventory - Suspended Solids

\subsection{Appendix 4. Solvent Tank Nuclide Inventory - Sludges}




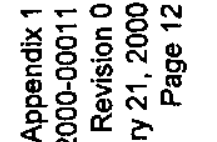

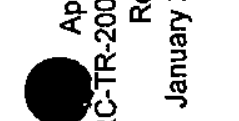

Ұ \%m:

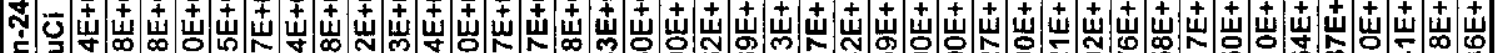

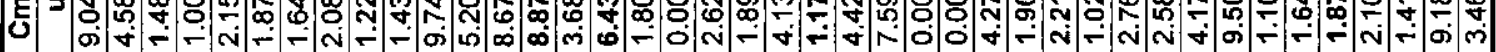

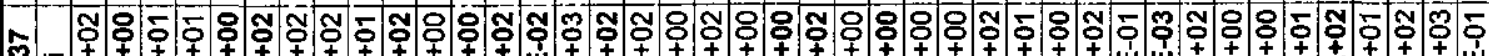

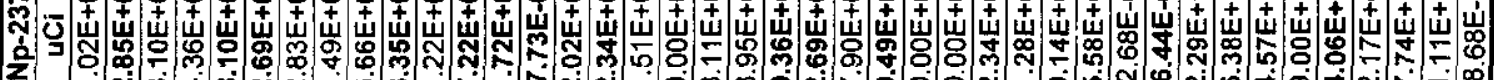
2 -

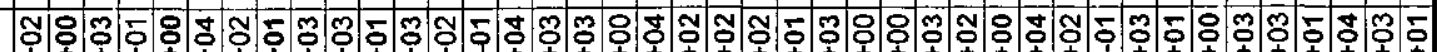
\%

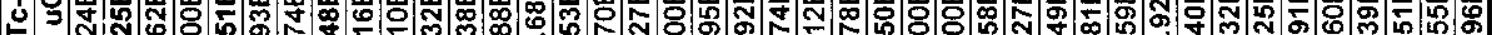

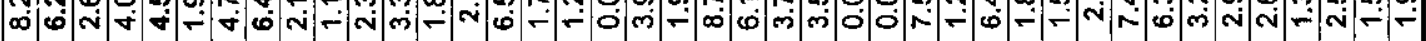

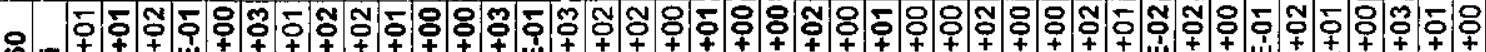

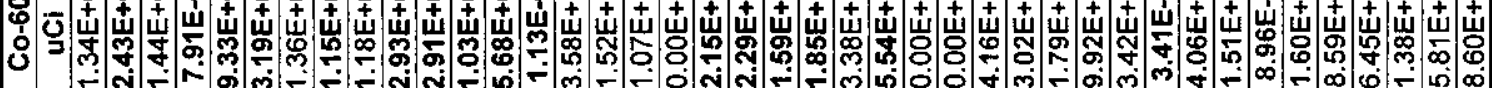

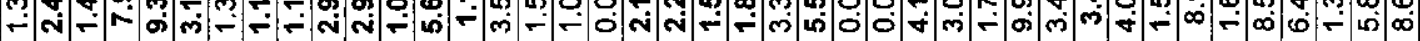

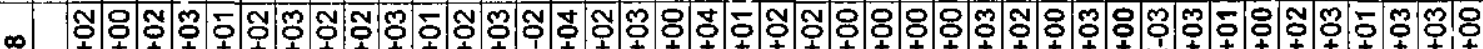

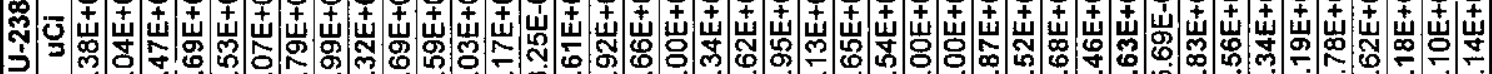

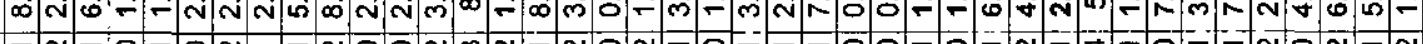

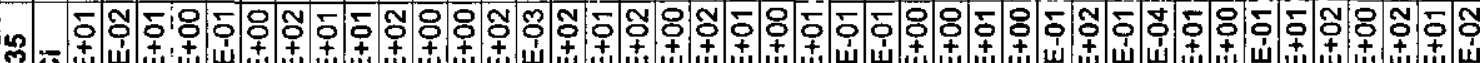

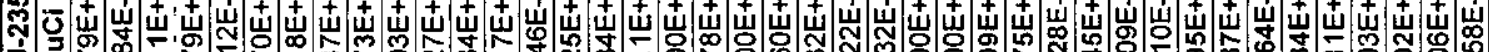

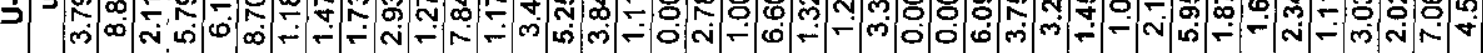

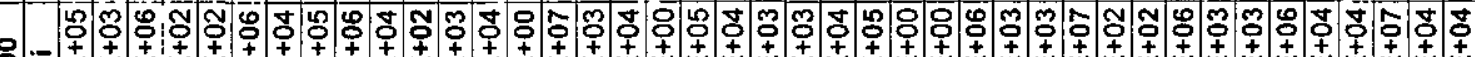

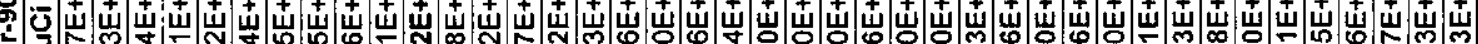
क Nm

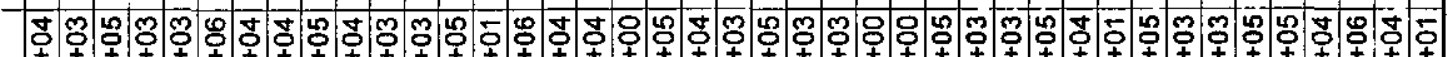

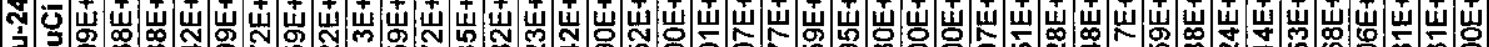
3 Э

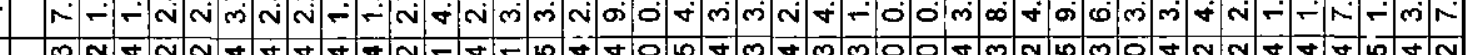
9 ج̛ a Э \%

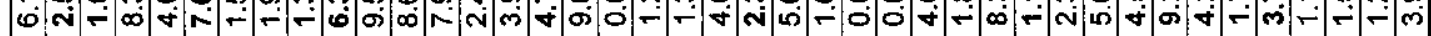

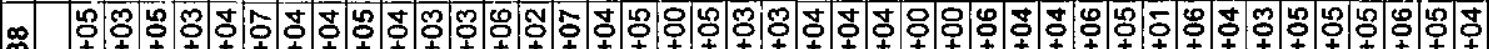
งิ aे

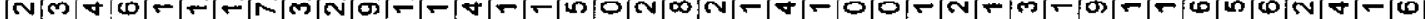

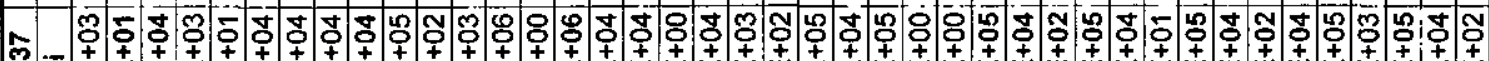

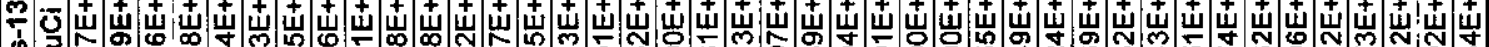

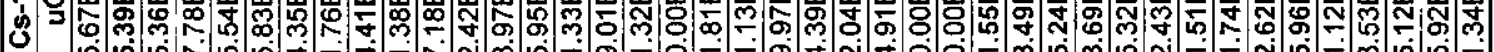

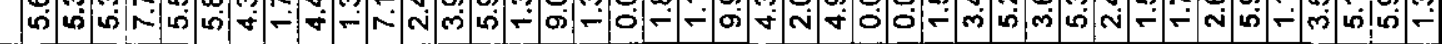

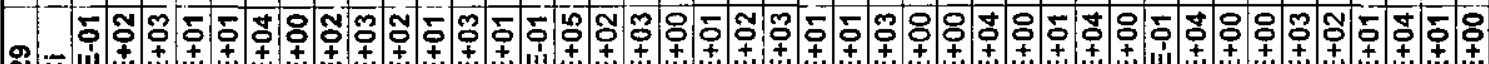

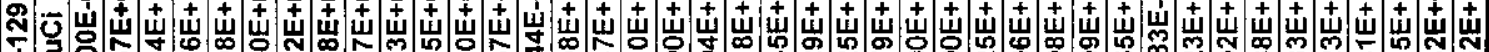

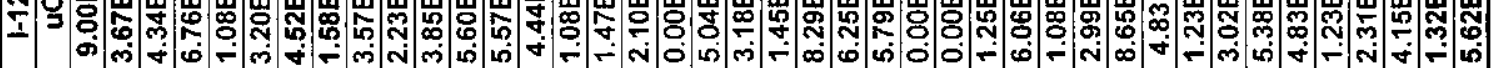

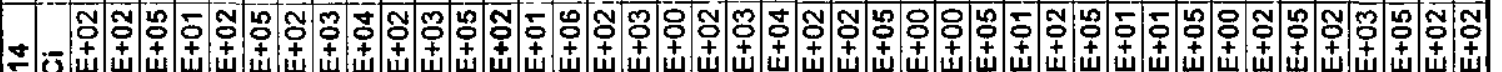

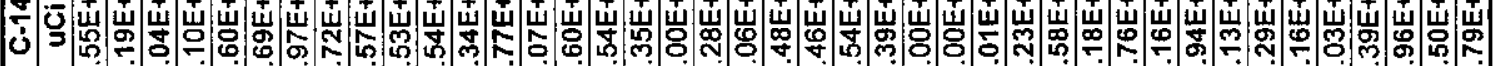

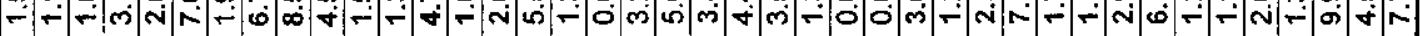

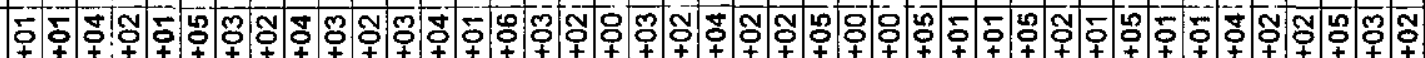

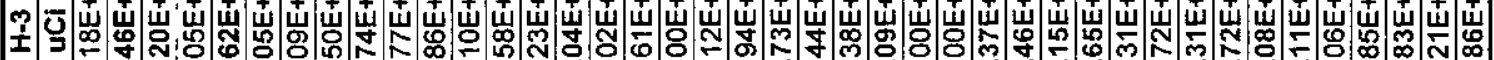

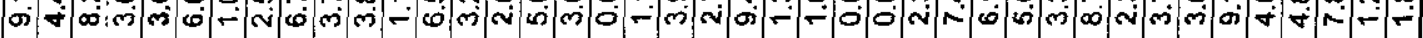

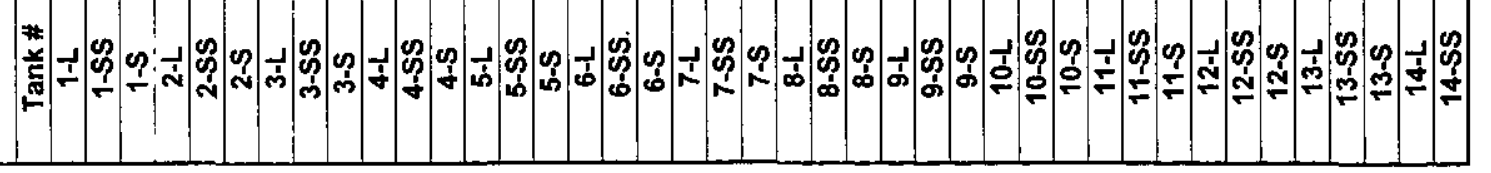




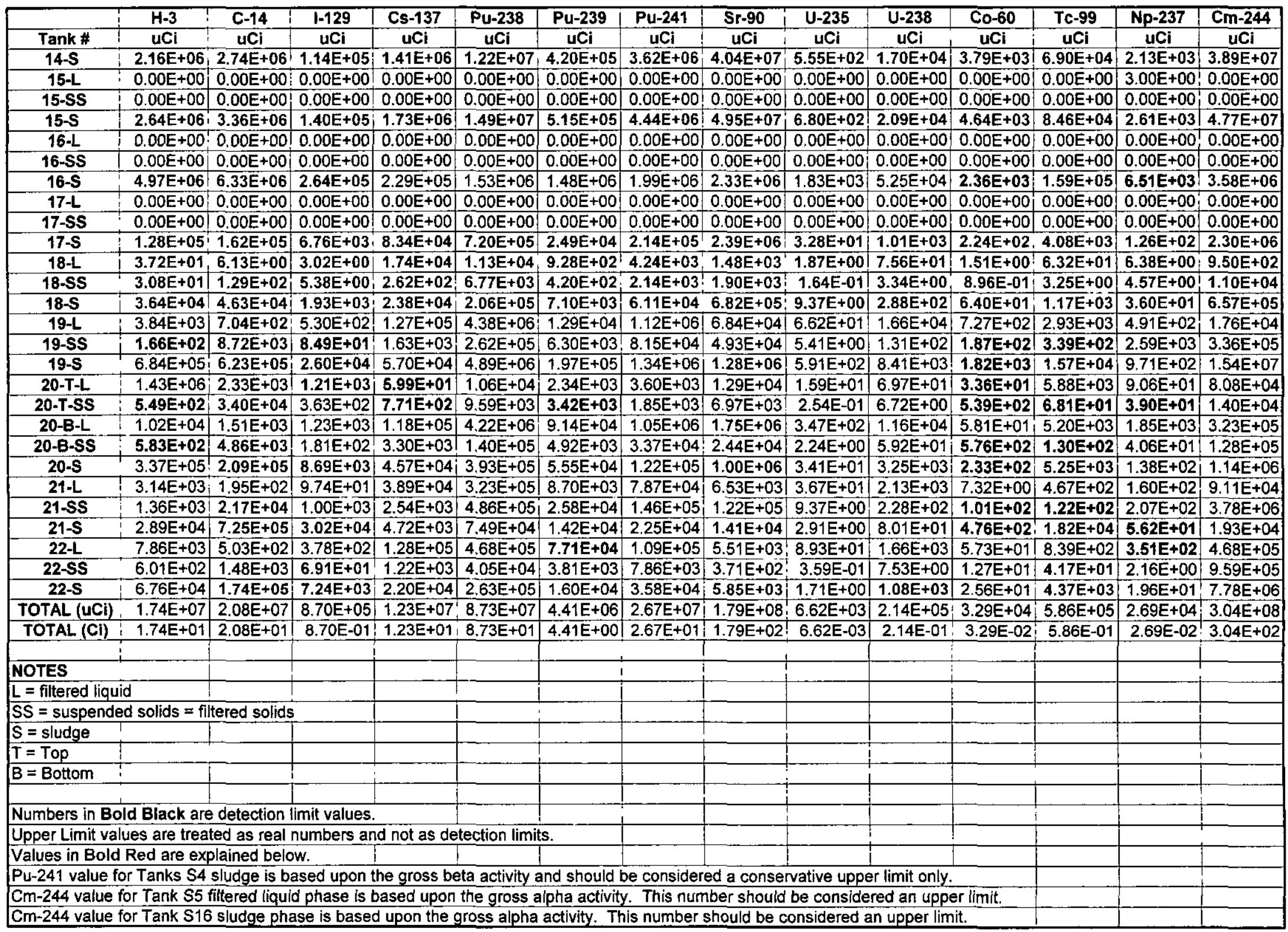


Sr-90 values for Tanks S2, S4, S7, S8, S16, S19, S20, S21, and S22 sludges are based upon the gross beta activities and should be considered conservative ULs only. $\mathrm{Sr}-90$ values for Tanks $\mathrm{S5}, \mathrm{S11}$, and $\mathrm{S} 14$ filtered solids are based upon the gross beta activities and should be considered conservative upper limits only. Sr-90 value for Tank S20-B filtered liquid is based upon the gross beta activity and should be considered a conservative upper limit only. Values in Bold Blue are explained below.

Most Bold Blue values were calculated using the average activity concentrations for each phase times the mass in that phase.

(Ex: $\mathrm{H}-3$ for Tank $10-\mathrm{L}$ was calc'd by using the ave $\mathrm{H}-3$ activity concentration for all of the liquids for which $\mathrm{H}-3$ was measured times the volume of the Tank $\mathrm{S} 10$ liquid.)

C-14, I-129, Sr-90, and TC-99 values for the sludiges are based upon the suspended solids data.

VOC for sludges and suspended solids is based upon filtered liquid data and corrected for estimated density of $2 \mathrm{~g} / \mathrm{cm} 3$.

$\mathrm{Cd}, \mathrm{Pb}$, and $\mathrm{Hg}$ values for the suspended solids are based upon the sludge data (no metals or VOC data were taken for the suspended solids)

$\mathrm{C}-14$ and $\mathrm{I}-129$ values for Tank $11-\mathrm{L}$ (organic liquid) are based upon average aqueous liquid data.

1-129 value for Tank 20-T-L (organic liquid) is based upon average aqueous liquid data.

C-14, $1-129$, and Tc-99 values for Tank 11-SS (suspended solids in organic liquid) are based upon average suspended solids in aqueous liquid data.

C-14 value for Tank 20-T-SS (suspended solids in organic liquid) is based upon average suspended solids in aqueous liquid data.

Page 14

C-14 data are based upon upper limits only. 


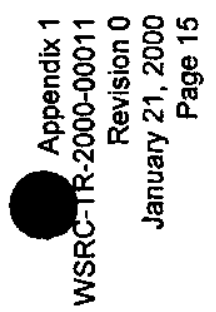

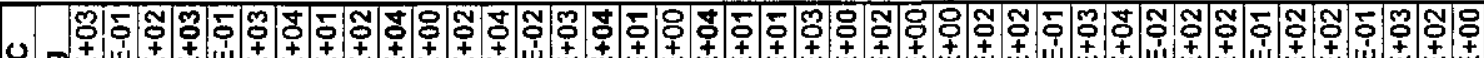

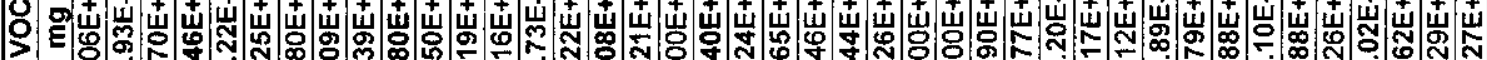

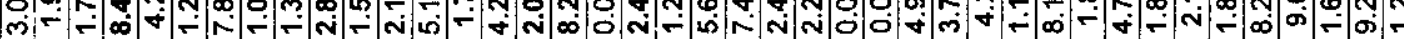
বृत्

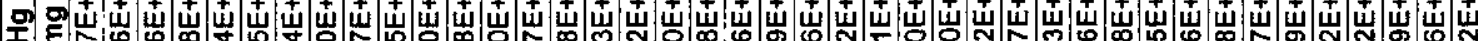
N

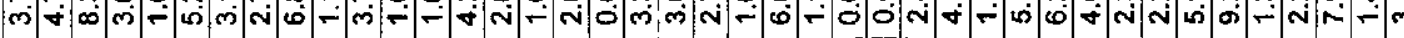

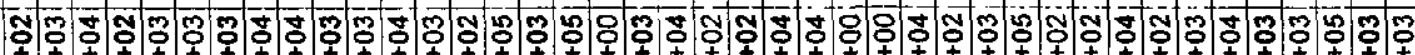

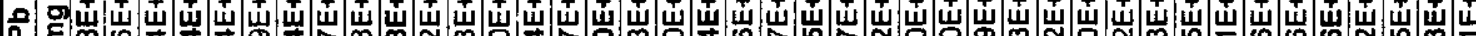

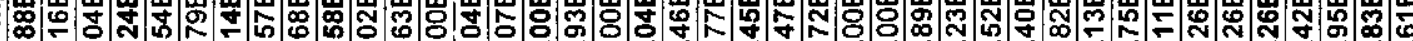

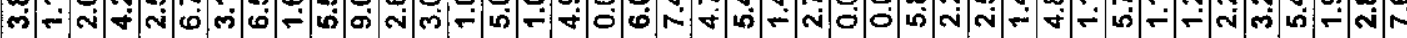

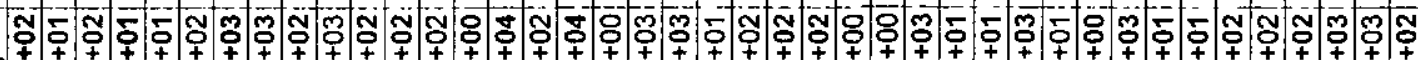

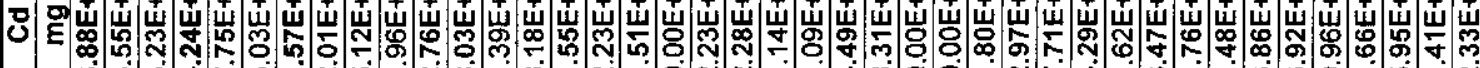

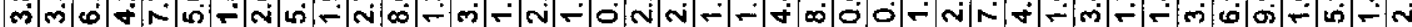

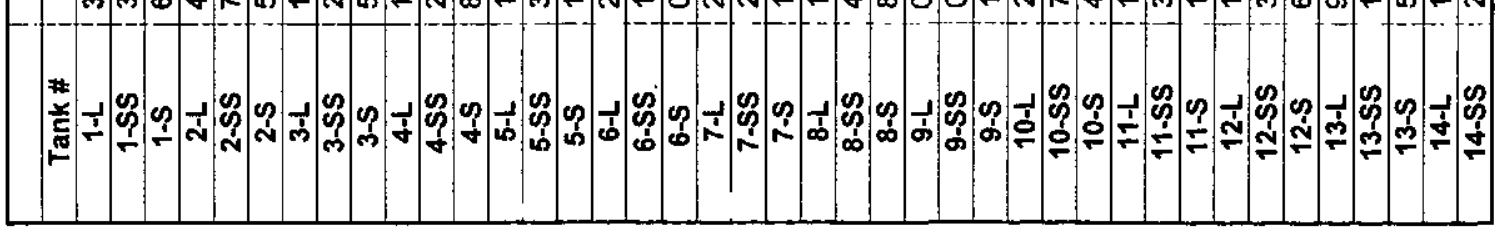



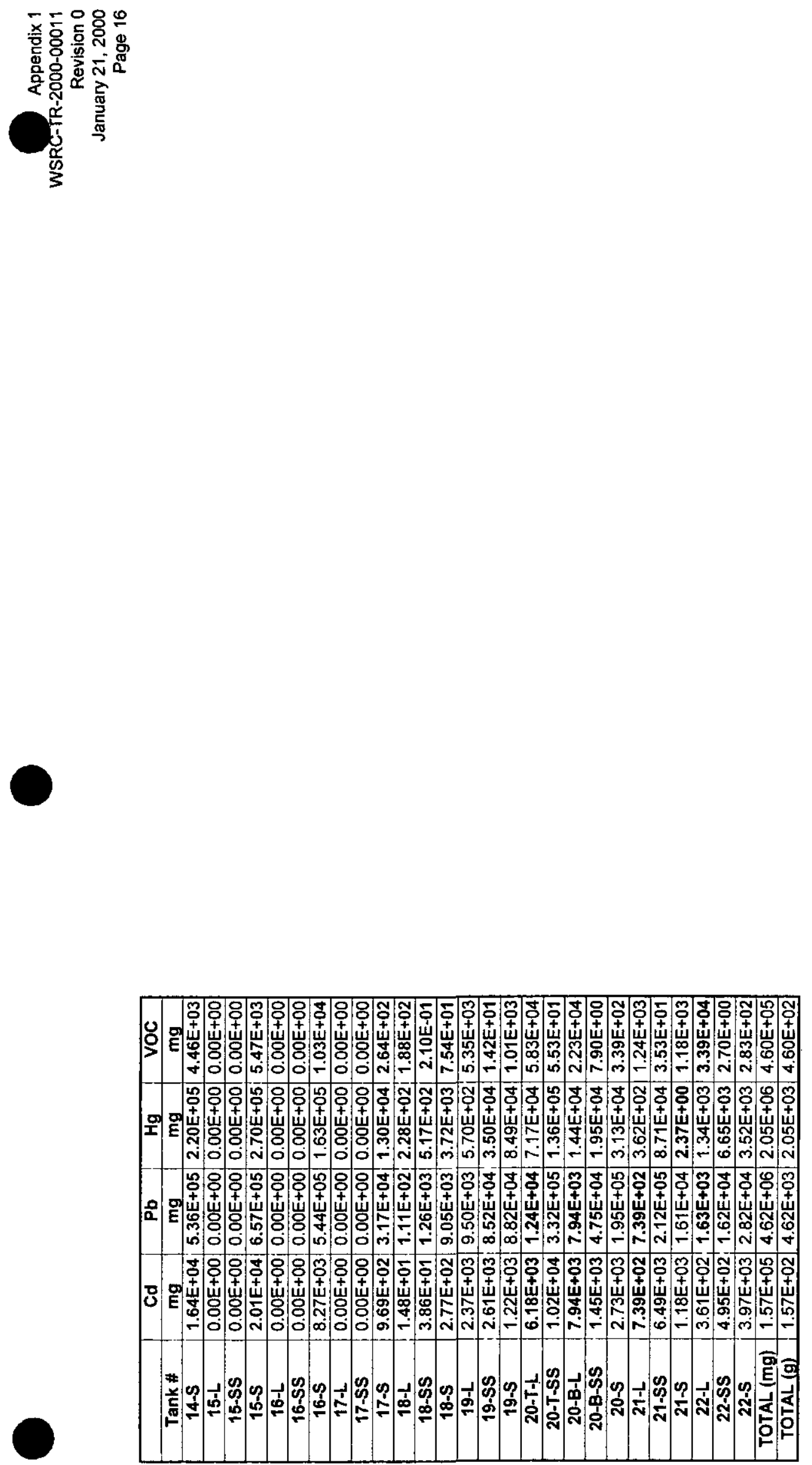


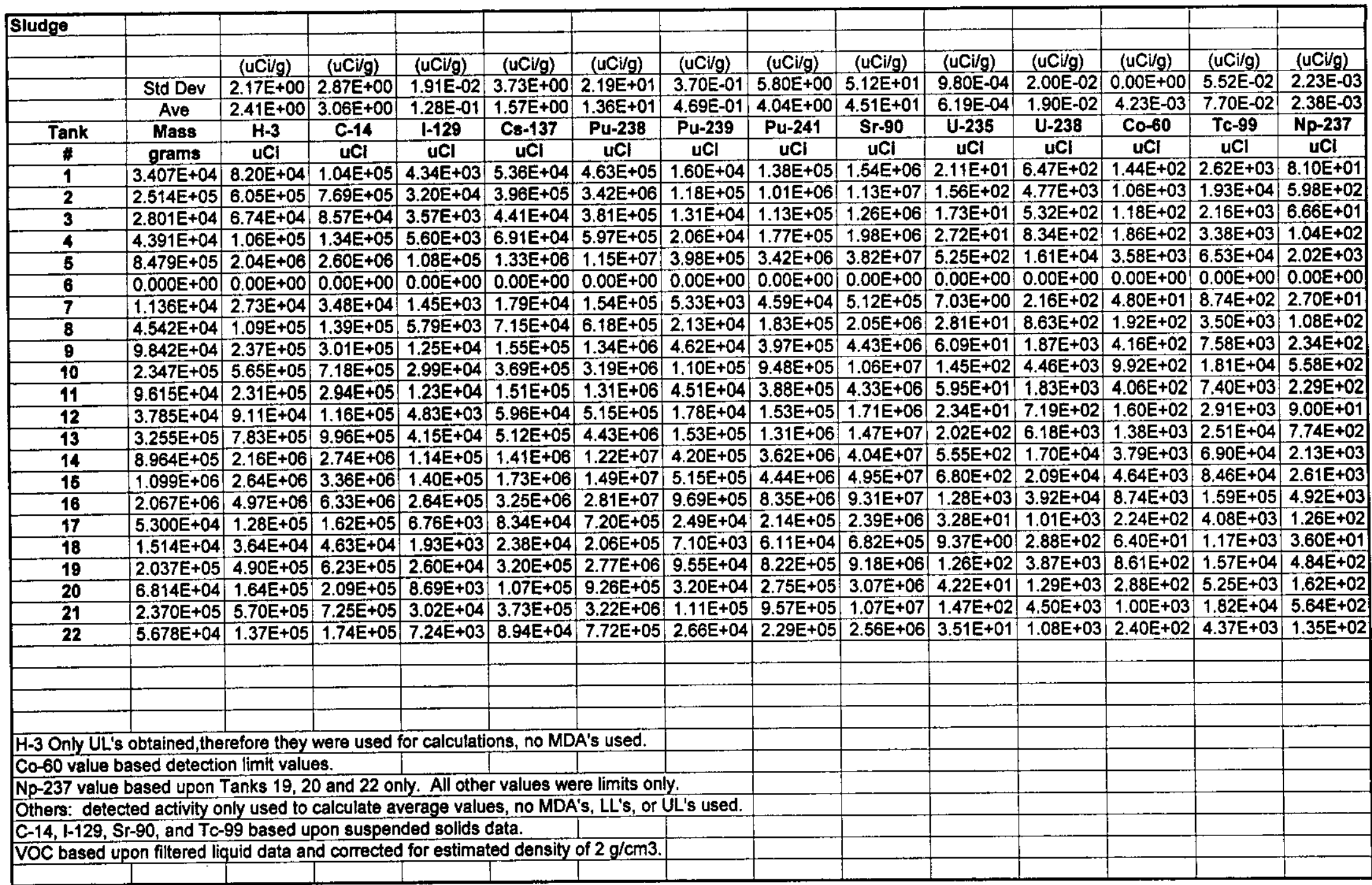




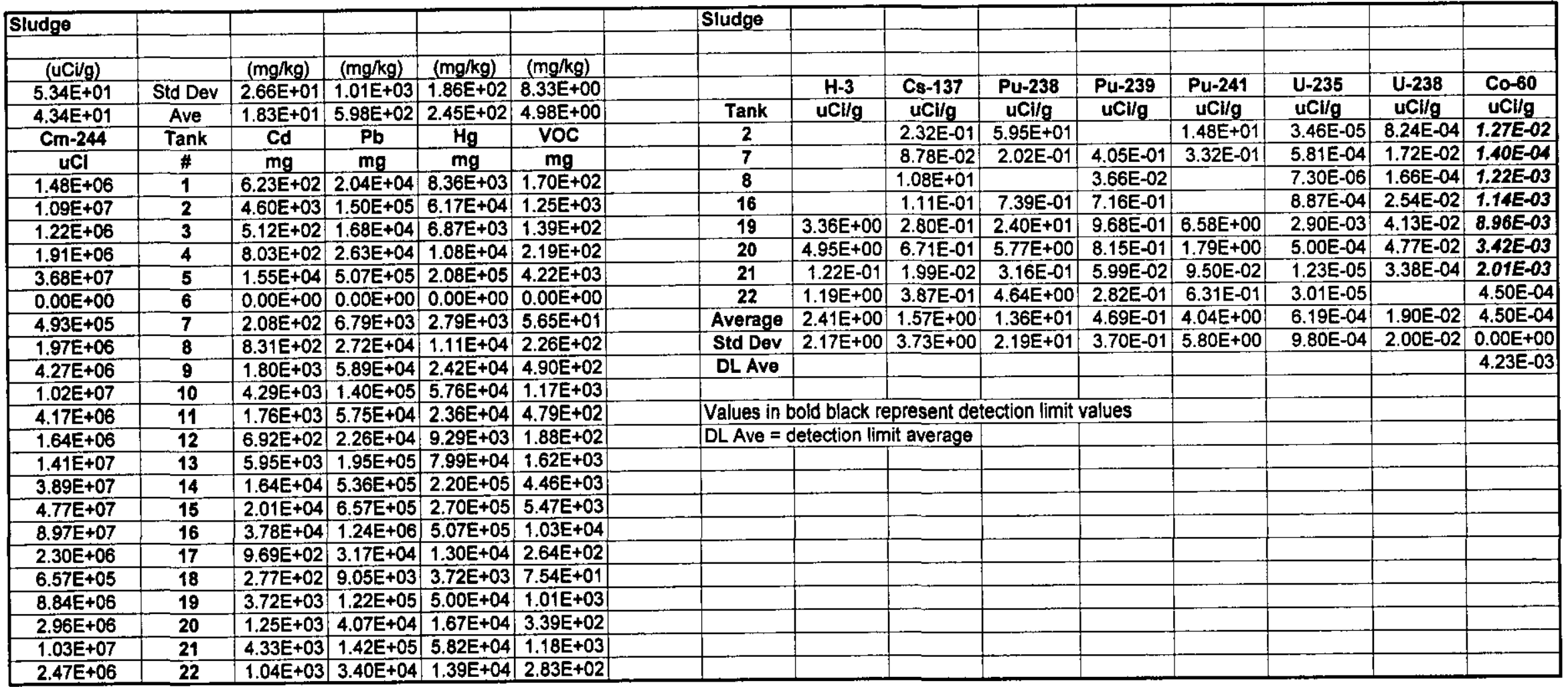



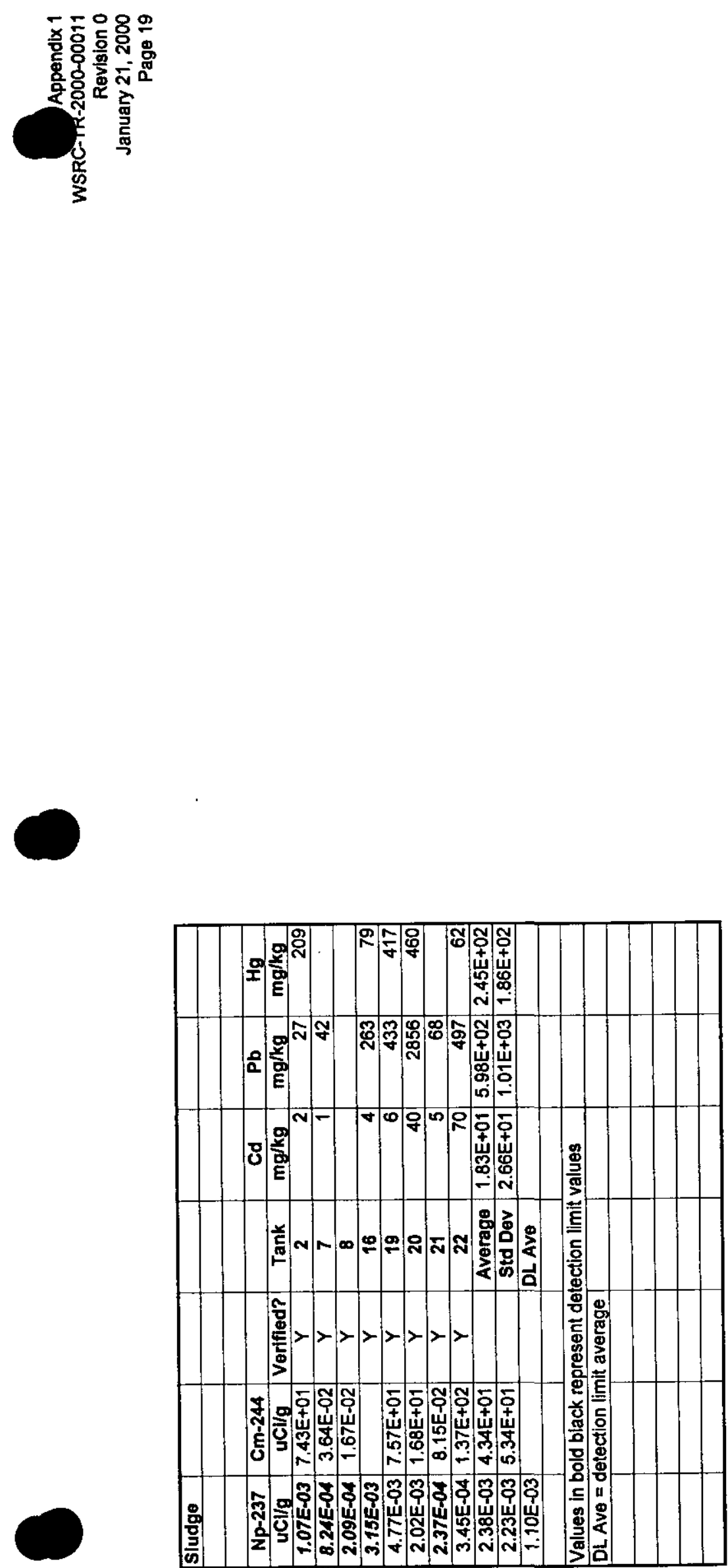


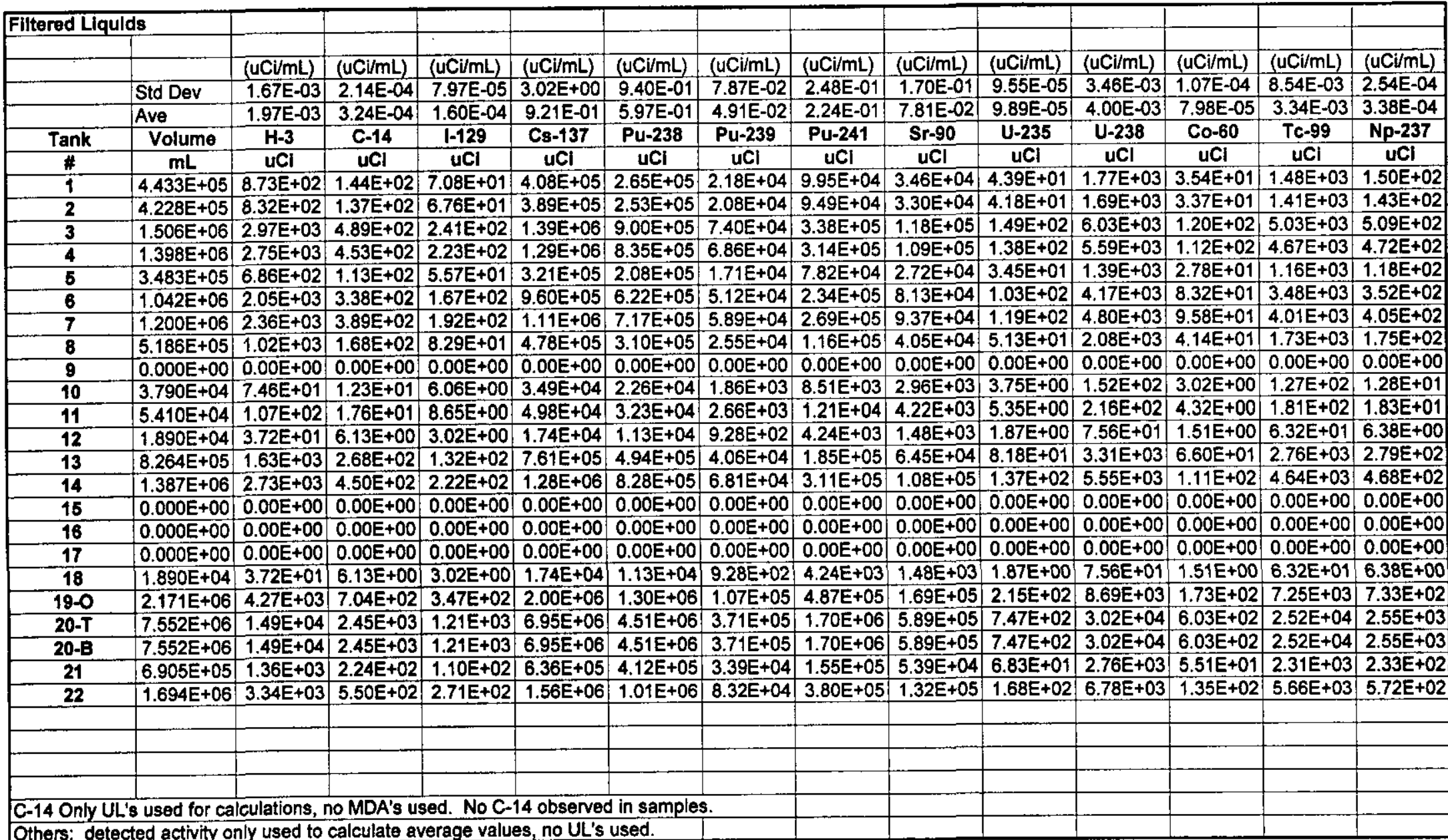




\begin{tabular}{|c|c|c|c|c|c|c|c|c|c|c|c|c|c|c|c|}
\hline \multicolumn{2}{|c|}{ Flitered Liquids } & & & & & & \multicolumn{2}{|c|}{ Filtered Liquids } & & & & & & & \\
\hline & & & & & & & & & & & & & & & \\
\hline$\frac{(\mathrm{uCi} / \mathrm{mL})}{8.87 \mathrm{E}-02}$ & & $(\mathrm{mg} / \mathrm{kg})$ & $(\mathrm{mg} / \mathrm{kg})$ & $\begin{array}{c}(\mathrm{mg} / \mathrm{kg}) \\
5 \mathrm{~F}^{2}+01\end{array}$ & $\frac{(\mathrm{mg} / \mathrm{kg})}{167 \mathrm{~F}+01}$ & & & H-3 & C-14 & |-129 & Cs-137 & Pu-238 & Pu-239 & Pu-24t & Sr-90 \\
\hline$\frac{8.87 \mathrm{E}-02}{5.02 \mathrm{E}-02}$ & $\frac{\text { Std Dev }}{\text { Ave }}$ & $\begin{array}{l}5.59 \mathrm{E}-01 \\
7.84 \mathrm{E}-01\end{array}$ & $\frac{2.67 \mathrm{E}+00}{5.89 \mathrm{E}+00}$ & $\frac{2.54 E+01}{1.21 E+01}$ & $9.95 \mathrm{E}+00$ & & Tank & $\mathrm{uCi} / \mathrm{mL}$ & $\mathrm{uCi} / \mathrm{mL}$ & $\mathrm{uCl} / \mathrm{mL}$ & $\mathrm{uCl} / \mathrm{mL}$ & $\mathrm{uCl} / \mathrm{mL}$ & $\mathrm{uCl} / \mathrm{mL}$ & $4 \mathrm{Cl} / \mathrm{mL}$ & $\mathrm{uCi} / \mathbf{m L}$ \\
\hline $\mathrm{Cm}-244$ & Tank & Cd & $\mathbf{P b}$ & $\mathrm{Hg}$ & VOC & Density & 1 & 2.07E-04 & $3.50 \mathrm{E}-04$ & & $1.28 \mathrm{E}-02$ & $6.49 \mathrm{E}-01$ & $1.39 \mathrm{E}-02$ & $1.60 \mathrm{E}-01$ & $6.26 \mathrm{E}-01$ \\
\hline $\mathrm{uCl}$ & $\#$ & $\mathrm{mg}$ & $\mathrm{mg}$ & $\mathrm{mg}$. & $\mathrm{mg}$ & $\mathrm{g} / \mathrm{cm}^{3}$ & 2 & $7.21 E-04$ & $7.34 E-05$ & & $1.84 \mathrm{E}-02$ & $1.42 \mathrm{E}-02$ & & $5.72 E-03$ & $1.80 \mathrm{E}-03$ \\
\hline $2.23 E+04$ & 1 & $3.04 E+02$ & $2.28 \mathrm{E}+03$ & $4.68 \mathrm{E}+03$ & $3.86 \mathrm{E}+03$ & 0.875 & 3 & $7.21 \mathrm{E}-04$ & $1.31 \mathrm{E}-04$ & & $2.89 \mathrm{E}-02$ & $1.00 \mathrm{E}-02$ & $1.05 \mathrm{E}-02$ & $1.72 E-02$ & $3.42 E-02$ \\
\hline $2.12 E+04$ & 2 & $3.33 \mathrm{E}+02$ & $2.50 E+03$ & $5.12 E+03$ & $4.22 \mathrm{E}+03$ & 1.003 & 4 & 2.70E-03 & $3.24 \mathrm{E}-04$ & & $9.91 E-02$ & $1.66 \mathrm{E}-02$ & & & 1.22E-02 \\
\hline $7.57 \mathrm{E}+04$ & 3 & $1.23 E+03$ & $9.24 E+03$ & $1.89 E+04$ & $1.56 \mathrm{E}+04$ & 1.042 & 5 & & & & $1.14 E+01$ & $3.28 \mathrm{E}+00$ & 2.27E-01 & $8.11 E-01$ & $4.37 E-02$ \\
\hline $7.02 E+04$ & 4 & $1.18 E+03$ & $8.88 E+03$ & $1.82 \mathrm{E}+04$ & $1.50 \mathrm{E}+04$ & 1.079 & 6 & $4.82 \mathrm{E}-03$ & 5.32E-04 & $1.41 \mathrm{E}-04$ & $8.65 E-02$ & $1.24 \mathrm{E}-02$ & & $2.78 \mathrm{E}-02$ & $9.91 E-04$ \\
\hline $1.75 E+04$ & 5 & $3.02 \mathrm{E}+02$ & $2.27 \mathrm{E}+03$ & $4.64 E+03$ & $3.83 E+03$ & 1.105 & 7 & 9.37E-04 & $2.73 E-04$ & 4.20E-05 & $1.51 \mathrm{E}-02$ & $1.71 \mathrm{E}-01$ & 1.02E-01 & $3.34 E-01$ & 1.55E-01 \\
\hline $5.24 E+04$ & 6 & $8.75 E+02$ & $6.57 E+03$ & $1.35 \mathrm{E}+04$ & $1.11 E+04$ & 1.070 & 8 & $1.82 \mathrm{E}-03$ & $8.60 E-04$ & & 8.47E-01 & 2.64E-02 & & $5.00 \mathrm{E}-01$ & $9.64 \mathrm{E}-03$ \\
\hline $6.03 E+04$ & 7 & $1.03 E+03$ & $7.73 E+03$ & $1.58 \mathrm{E}+04$ & $1.31 E+04$ & 1.094 & 13 & 4.91E-04 & $2.46 \mathrm{E}-04$ & 1.49E-04 & $1.36 \mathrm{E}-01$ & 7.52E-01 & & 2.03E-01 & $2.84 \mathrm{E}-02$ \\
\hline $2.61 \mathrm{E}+04$ & 8 & $4.28 \mathrm{E}+02$ & $3.21 E+03$ & $6.58 \mathrm{E}+03$ & $5.43 \mathrm{E}+03$ & 1.051 & 14 & $8.69 \mathrm{E}-04$ & & & $4.27 \mathrm{E}-02$ & $1.08 \mathrm{E}-01$ & $8.74 \mathrm{E}-03$ & $2.39 \mathrm{E}-02$ & $5.86 \mathrm{E}-02$ \\
\hline $0.00 \mathrm{E}+00$ & 9 & $0.00 \mathrm{E}+00$ & $0.00 \mathrm{E}+00$ & $0.00 \mathrm{E}+00$ & $0.00 \mathrm{E}+00$ & 0.000 & $19-0$ & $1.77 \mathrm{E}-03$ & & 2.44E-04 & $5.86 \mathrm{E}-02$ & $2.02 \mathrm{E}+00$ & $5.95 \mathrm{E}-03$ & $5.18 \mathrm{E}-01$ & $3.15 E-02$ \\
\hline $1.90 \mathrm{E}+03$ & 10 & $2.97 \mathrm{E}+01$ & $2.23 \mathrm{E}+02$ & $4.57 \mathrm{E}+02$ & $3.77 \mathrm{E}+02$ & 1.000 & 20-B & $1.35 \mathrm{E}-03$ & 2.00E-04 & & $1.56 \mathrm{E}-02$ & $5.59 \mathrm{E}-01$ & $1.21 \mathrm{E}-02$ & $1.39 \mathrm{E}-01$ & \\
\hline $2.72 E+03$ & 11 & $4.33 \mathrm{E}+01$ & $3.25 E+02$ & $6.67 \mathrm{E}+02$ & $5.50 \mathrm{E}+02$ & 1.021 & 21 & $4.55 E-03$ & 2.82E-04 & & $5.63 \mathrm{E}-02$ & 4.68E-01 & $1.26 \mathrm{E}-02$ & $1.14 \mathrm{E}-01$ & 9.46E-03 \\
\hline $9.50 \mathrm{E}+02$ & 12 & $1.48 \mathrm{E}+01$ & $1.11 E+02$ & $2.28 \mathrm{E}+02$ & $1.88 \mathrm{E}+02$ & 1.000 & 22 & 4.64E-03 & 2.97E-04 & 2.23E-04 & $7.57 \mathrm{E}-02$ & $2.76 \mathrm{E}-01$ & & $6.44 \mathrm{E}-02$ & $3.25 \mathrm{E}-03$ \\
\hline $4.15 E+04$ & 13 & $7.10 \mathrm{E}+02$ & $5.33 E+03$ & $1.09 E+04$ & $9.02 E+03$ & 1.096 & Averago & $1.97 \mathrm{E}-03$ & $3.24 \mathrm{E}-04$ & $1.60 \mathrm{E}-04$ & $9.21 \mathrm{E}-01$ & $5.97 \mathrm{E}-01$ & $4.91 \mathrm{E}-02$ & $2.24 E-01$ & $7.81 \mathrm{E}-02$ \\
\hline $6.97 E+04$ & 14 & 1.11E+03 & $8.32 \mathrm{E}+03$ & $1.71 \mathrm{E}+04$ & $1.41 E+04$ & 1.019 & Std Dev & 1.67E-03 & 2.14E-04 & 7.97E-05 & $3.02 E+00$ & $9.40 \mathrm{E}-01$ & 7.87E-02 & $2.48 \mathrm{E}-01$ & 1.70E-01 \\
\hline $0.00 \mathrm{E}+00$ & 15 & $0.00 \mathrm{E}+00$ & $0.00 \mathrm{E}+00$ & $0.00 E+00$ & $0.00 E+00$ & 0.000 & & & & & & & & & \\
\hline $0.00 \mathrm{E}+00$ & 16 & $0.00 \mathrm{E}+00$ & $0.00 \mathrm{E}+00$ & $0.00 \mathrm{E}+00$ & $0.00 \mathrm{E}+00$ & 0.000 & & & & & & & & & \\
\hline $0.00 \mathrm{E}+00$ & 17 & $0.00 \mathrm{E}+00$ & $0.00 \mathrm{E}+00$ & $0.00 \mathrm{E}+00$ & $0.00 \mathrm{E}+00$ & 0.000 & & & & & & & & & \\
\hline $9.50 \mathrm{E}+02$ & 18 & $1.48 \mathrm{E}+01$ & $1.11 E+02$ & $2.28 \mathrm{E}+02$ & $1.88 \mathrm{E}+02$ & 1.000 & & & & & & & & & \\
\hline $1.09 E+05$ & $19-0$ & $1.86 \mathrm{E}+03$ & $1.40 \mathrm{E}+04$ & $2.87 E+04$ & $2.36 \mathrm{E}+04$ & 1.094 & & & & & & & & & \\
\hline $3.79 \mathrm{E}+05$ & 20-T & $4.85 \mathrm{E}+03$ & $3.64 E+04$ & $7.45 \mathrm{E}+04$ & $6.15 E+04$ & 0.818 & & & & & & & & & \\
\hline $3.79 E+05$ & $20-B$ & $6.23 \mathrm{E}+03$ & $4.67 E+04$ & $9.58 \mathrm{E}+04$ & $7.90 \mathrm{E}+04$ & 1.051 & & & & & & & & & \\
\hline $3.47 E+04$ & 21 & $5.80 \mathrm{E}+02$ & $4.36 E+03$ & $8.92 E+03$ & $7.36 \mathrm{E}+03$ & 1.071 & & & & & & & & & \\
\hline $8.51 E+04$ & 22 & $1.42 \mathrm{E}+03$ & $1.06 E+04$ & $2.18 \mathrm{E}+04$ & $1.80 \mathrm{E}+04$ & 1.066 & & & & & & & & & \\
\hline & & & & & & & & & & & & & & & \\
\hline
\end{tabular}



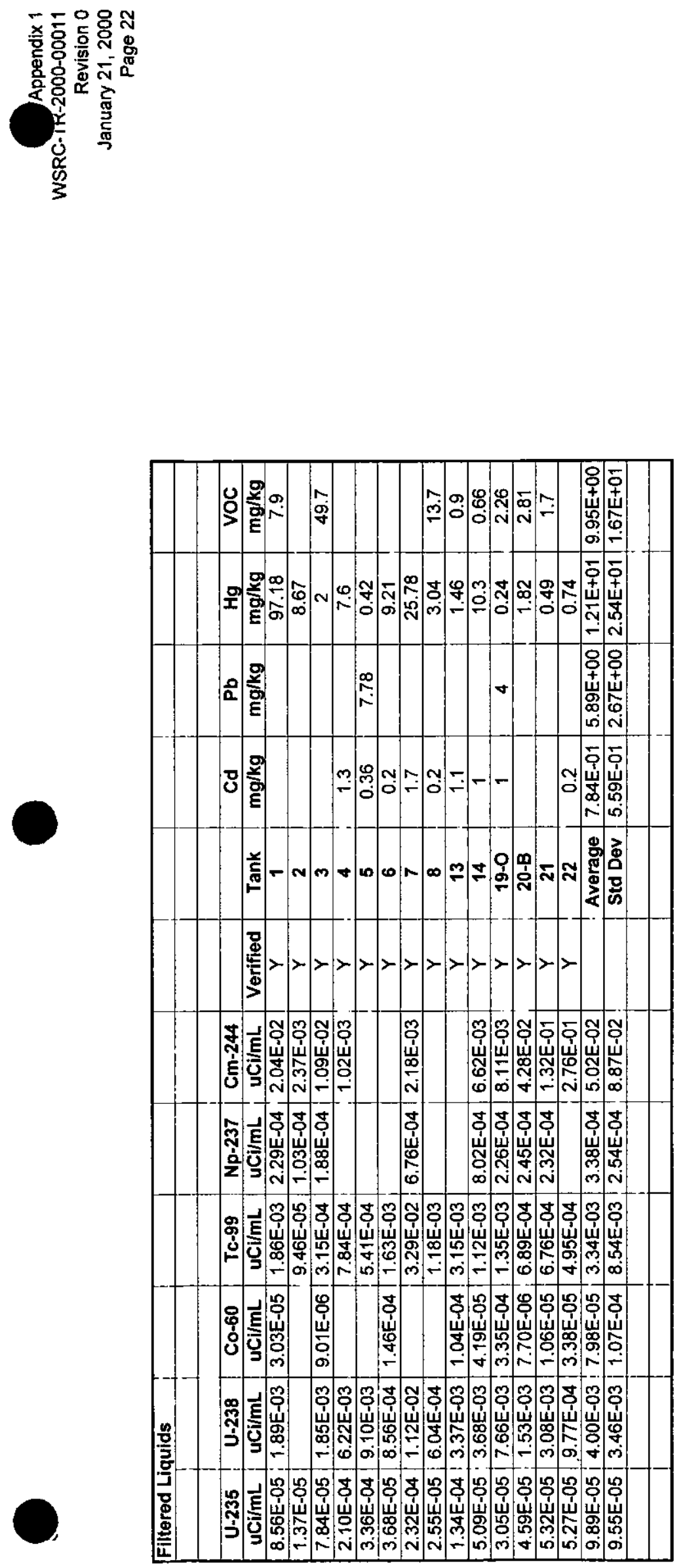

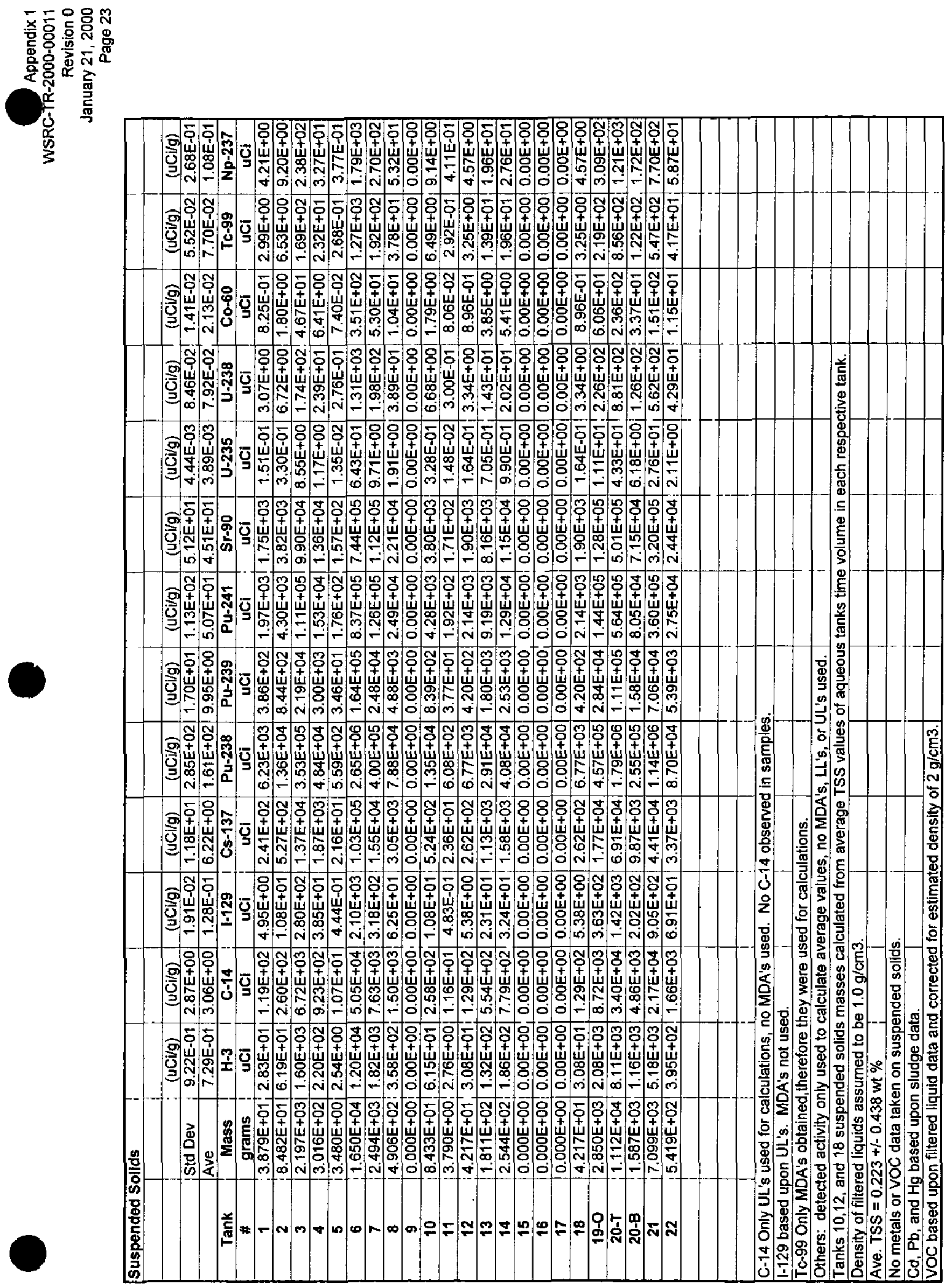


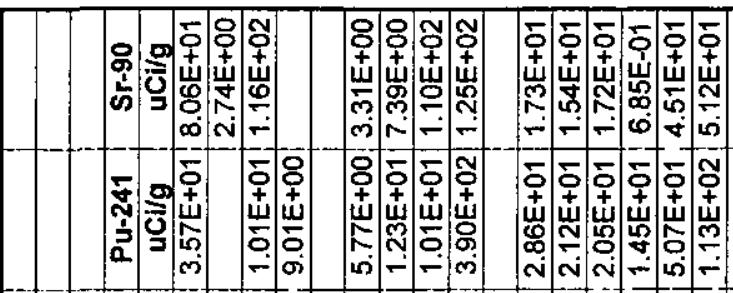

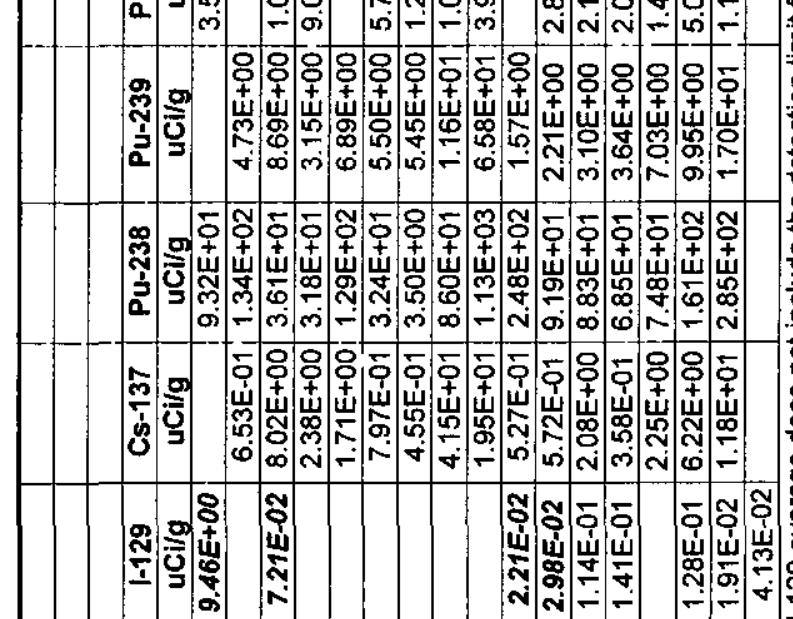
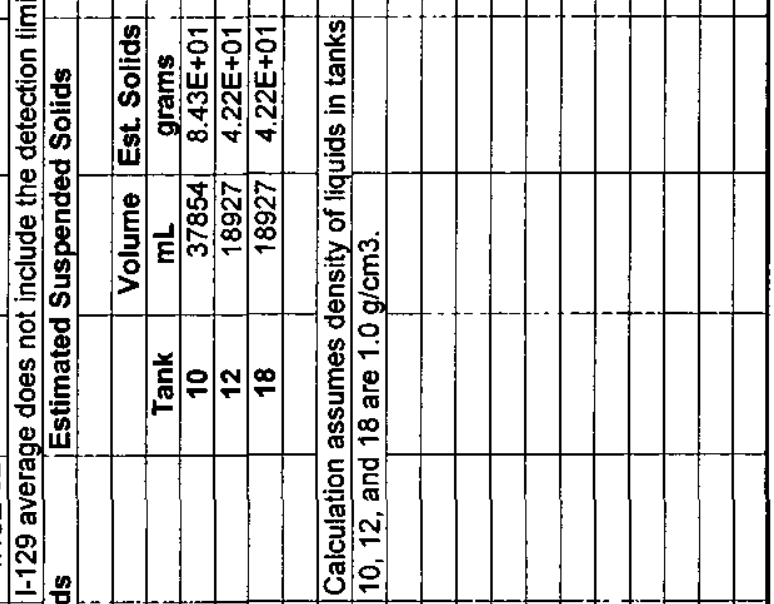

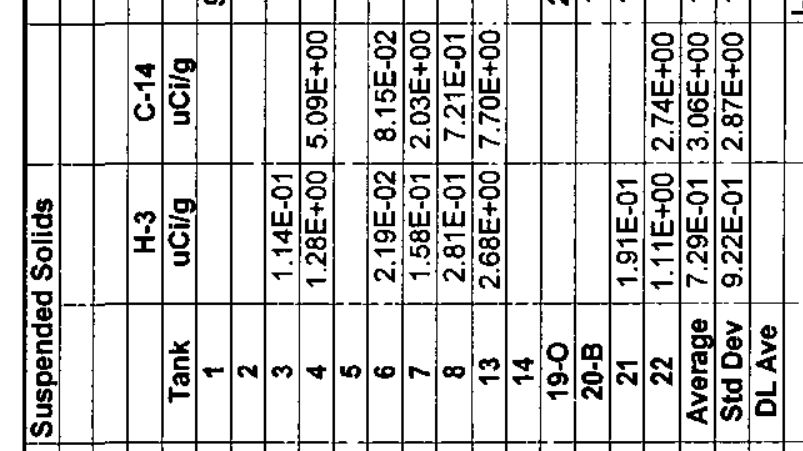

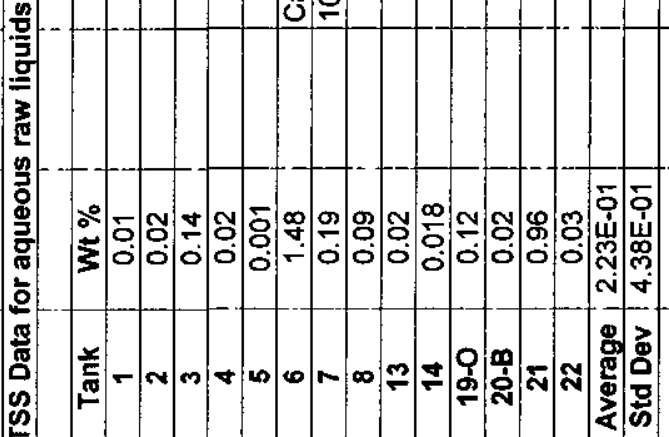

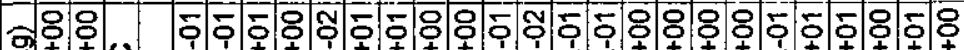

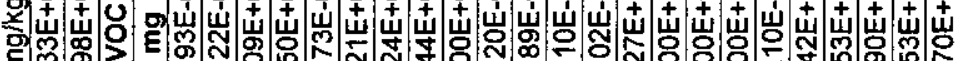

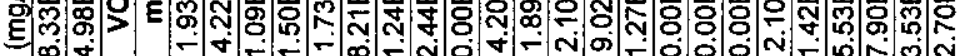

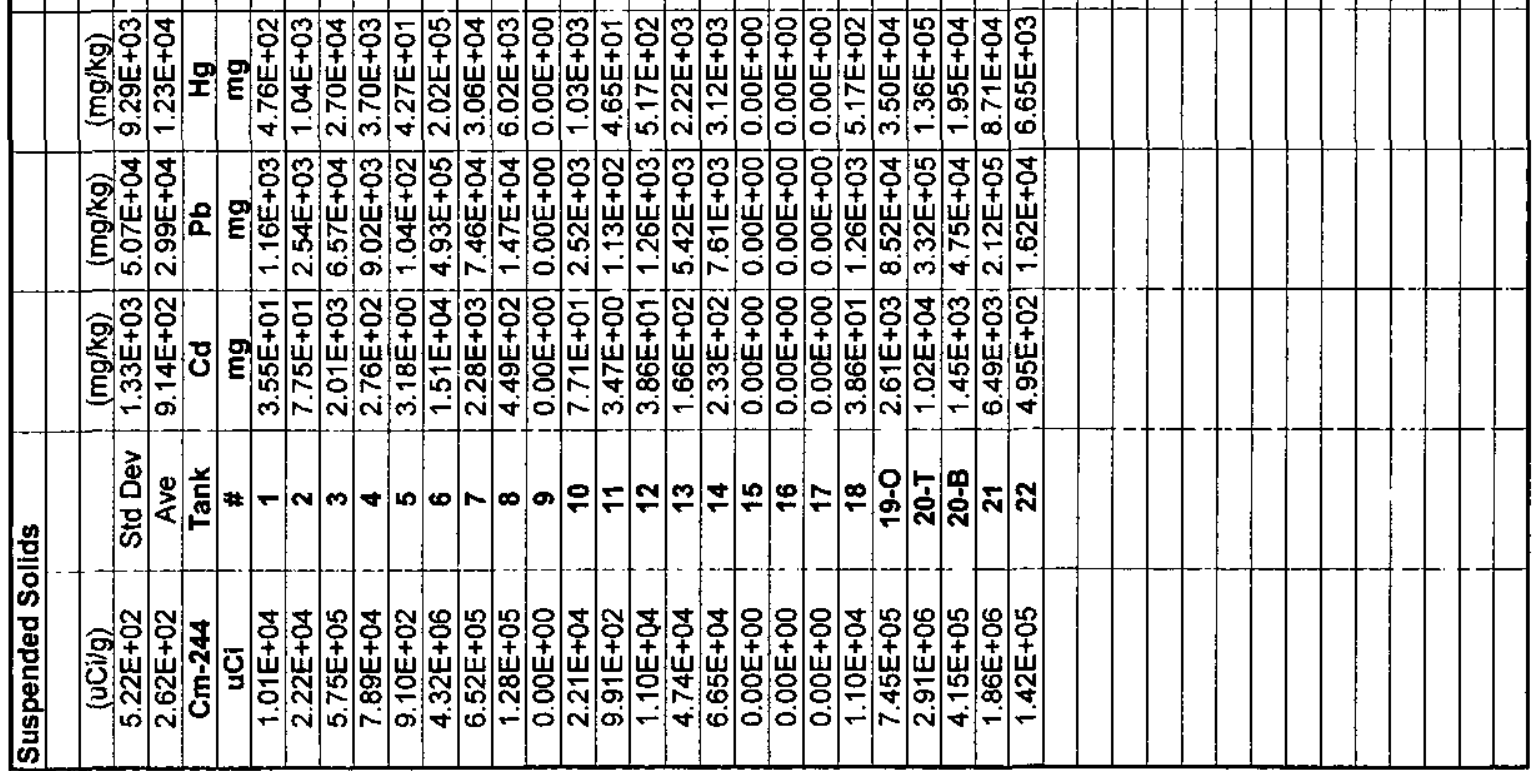




\section{$\sqrt{1 m^{2}}$}

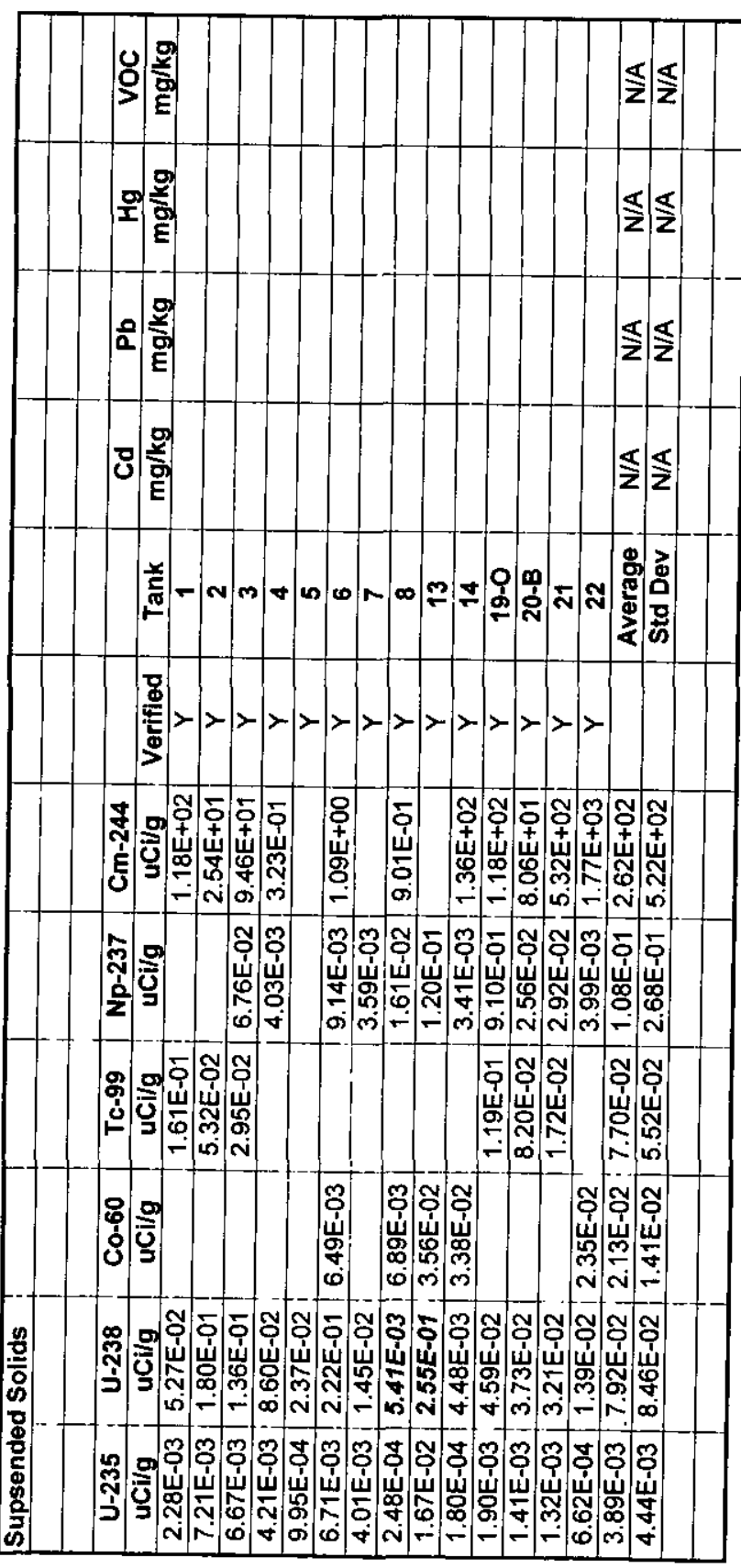




\begin{tabular}{|c|c|c|c|c|c|c|c|c|c|c|c|c|c|c|c|c|}
\hline \multicolumn{17}{|c|}{ Solvent Tank Nuclide Inventory Calculations - Filtered Liquids } \\
\hline \multicolumn{6}{|l|}{1} & & & & & & & & & & & \\
\hline & $\mathrm{Ci} / \mathrm{g}$ & & $\mathrm{Ci} / \mathrm{g}$ & & $\mathrm{Ci} / \mathrm{g}$ & & $\mathrm{Ci} / \mathrm{g}$ & & $\mathrm{Ci} / \mathrm{g}$ & & $\mathrm{Ci} / \mathrm{g}$ & & $\mathrm{Ci} / \mathrm{g}$ & & $\mathrm{Ci} / \mathrm{g}$ & \\
\hline \multirow[t]{3}{*}{ SPCAT } & 9.64E-03 & & $6.24 E-03$ & & $2.16 E-06$ & & 6.47E-05 & & $3.36 \mathrm{E}-07$ & & $7.05 E-04$ & & $1.71 \mathrm{E}+01$ & & $6.21 \mathrm{E}-02$ & \\
\hline & & & & & & & & & & & & & & & & \\
\hline & U-233 & Error & U-234 & Error & U-235 & Error & U-236 & Error & $\mathbf{U - 2 3 8}$ & Error & Np-237 & Error & Pu-238 & Error & Pu-239 & Error \\
\hline Tank \# & $\mathrm{pCi} / \mathrm{L}$ & $\mathrm{pCl} / \mathrm{L}$ & $\mathrm{pCi} / \mathrm{L}$ & $\mathrm{pCl} / \mathrm{L}$ & $\mathrm{pCi} / \mathrm{L}$ & $\mathrm{pCi} / \mathrm{L}$ & $\mathrm{pCi} / \mathrm{L}$ & pCi/L & $\mathrm{pCi} / \mathrm{L}$ & $\mathrm{pCi} / \mathrm{L}$ & $\mathrm{pCi} / \mathrm{L}$ & $\mathrm{pCi} / \mathrm{L}$ & $\mathrm{pCi} / \mathrm{L}$ & $\mathrm{pCi} / \mathrm{L}$ & $\mathrm{pCi} / \mathrm{L}$ & $\mathrm{pCi} / \mathrm{L}$ \\
\hline \multirow{2}{*}{$\begin{array}{l}\text { S1 } \\
\text { S2 }\end{array}$} & $5.05 E+05$ & $1.01 E+05$ & $5.50 E+06$ & $1.10 E+06$ & $8.56 E+04$ & $1.71 E+04$ & $4.38 \mathrm{E}+04$ & $8.77 \mathrm{E}+03$ & $1.89 E+06$ & $3.77 \mathrm{E}+05$ & $2.29 \mathrm{E}+05$ & $1.15 E+05$ & $6.49 E+08$ & $6.49 \mathrm{E}+07$ & $1.39 \mathrm{E}+07$ & $6.94 \mathrm{E}+06$ \\
\hline & $0.00 \mathrm{E}+00$ & $0.00 \mathrm{E}+00$ & $2.97 E+06$ & $1.78 E+06$ & $1.37 E+04$ & $5.31 \mathrm{E}+03$ & $9.44 E+04$ & $1.40 \mathrm{E}+05$ & $4.00 \mathrm{E}+06$ & $6.92 E+06$ & $1.03 \mathrm{E}+05$ & $2.62 \mathrm{E}+04$ & $1.42 E+07$ & $2.84 \mathrm{E}+06$ & $1.98 E+06$ & $0.00 E+00$ \\
\hline \multirow{2}{*}{$\begin{array}{l}\text { S3 } \\
\text { S4 }\end{array}$} & $2.24 \mathrm{E}+06$ & $4.48 E+05$ & $2.04 E+06$ & $4.07 \mathrm{E}+05$ & $7.84 E+04$ & $1.57 \mathrm{E}+04$ & $3.93 E+04$ & $7.86 \mathrm{E}+03$ & 1.85E+06 & $3.70 E+05$ & $1.88 \mathrm{E}+05$ & $9.39 E+04$ & $1.00 \mathrm{E}+07$ & $2.01 \mathrm{E}+06$ & $1.05 E+07$ & $5.25 \mathrm{E}+06$ \\
\hline & $7.12 E+06$ & $0.00 E+00$ & $4.59 E+06$ & $0.00 E+00$ & $2.10 E+05$ & $4.20 \mathrm{E}+04$ & $9.41 \mathrm{E}+04$ & $1.88 \mathrm{E}+04$ & $6.22 \mathrm{E}+06$ & $1.77 \mathrm{E}+06$ & $2.40 E+05$ & $0.00 E+00$ & $1.66 \mathrm{E}+07$ & $6.63 \mathrm{E}+06$ & $4.55 E+07$ & $0.00 E+00$ \\
\hline S5 & $1.12 E+07$ & $2.24 E+06$ & $1.28 \mathrm{E}+07$ & $2.57 \mathrm{E}+06$ & $3.36 \mathrm{E}+05$ & $6.72 \mathrm{E}+04$ & $2.06 \mathrm{E}+05$ & $4.12 E+04$ & $9.10 \mathrm{E}+06$ & $1.82 E+06$ & $4.95 E+05$ & $0.00 E+00$ & $3.28 \mathrm{E}+09$ & $1.31 \mathrm{E}+09$ & $2.27 E+08$ & $4.55 \mathrm{E}+07$ \\
\hline \multirow{2}{*}{$\begin{array}{l}\text { S6 } \\
\text { S7 }\end{array}$} & $7.12 E+06$ & $0.00 E+00$ & $4.59 E+06$ & $0.00 E+00$ & $3.68 E+04$ & $7.37 E+03$ & $4.77 E+04$ & $0.00 E+00$ & $8.56 \mathrm{E}+05$ & $1.71 \mathrm{E}+05$ & $2.25 E+05$ & $0.00 E+00$ & $1.24 \mathrm{E}+07$ & $3.72 \mathrm{E}+06$ & $4.55 E+07$ & $0.00 E+00$ \\
\hline & $7.12 E+06$ & $0.00 E+00$ & $4.59 E+06$ & $0.00 E+00$ & $2.32 E+05$ & $1.72 E+05$ & $1.99 \mathrm{E}+05$ & $3.97 \mathrm{E}+04$ & 1. $12 \mathrm{E}+07$ & $2.24 E+06$ & $6.76 \mathrm{E}+05$ & $2.70 \mathrm{E}+05$ & $1.71 \mathrm{E}+08$ & $5.12 E+07$ & $1.02 \mathrm{E}+08$ & $4.07 E+07$ \\
\hline 58 & $7.12 E+06$ & $0.00 E+00$ & $4.59 E+06$ & $0.00 E+00$ & $2.55 E+04$ & $5.11 \mathrm{E}+03$ & $4.77 E+04$ & $0.00 E+00$ & $6.04 E+05$ & $1.21 E+05$ & $5.18 E+05$ & $0.00 E+00$ & $2.64 E+07$ & $7.92 E+06$ & $4.55 E+07$ & $0.00 E+00$ \\
\hline \multirow{2}{*}{$\begin{array}{l}\text { S9 } \\
S 10\end{array}$} & $4.90 \mathrm{E}+06$ & $9.30 E+06$ & $4.39 \mathrm{E}+06$ & $7.54 E+06$ & $9.89 \mathrm{E}+04$ & $1.91 E+05$ & $9.44 E+04$ & $1.40 \mathrm{E}+05$ & $4.00 E+06$ & $6.92 E+06$ & $3.38 E+05$ & $5.08 \mathrm{E}+05$ & $5.97 E+08$ & $1.88 E+09$ & $4.91 E+07$ & $1.57 E+08$ \\
\hline & $4.90 \mathrm{E}+06$ & $9.30 \mathrm{E}+06$ & $4.39 E+06$ & $7.54 \mathrm{E}+06$ & $9.89 \mathrm{E}+04$ & $1.91 \mathrm{E}+05$ & $9.44 E+04$ & $1.40 \mathrm{E}+05$ & $4.00 \mathrm{E}+06$ & $6.92 \mathrm{E}+06$ & $3.38 \mathrm{E}+05$ & $5.08 \mathrm{E}+05$ & $5.97 E+08$ & $1.88 E+09$ & $4.91 E+07$ & $1.57 E+08$ \\
\hline$S 11$ & $6.76 E+04$ & $0.00 E+00$ & $4.35 E+04$ & $8.70 E+03$ & $2.02 E+03$ & $4.04 E+02$ & $4.55 E+02$ & $9.10 E+01$ & $4.86 E+04$ & $0.00 E+00$ & $4.95 \mathrm{E}+03$ & $9.91 \mathrm{E}+02$ & $2.52 \mathrm{E}+09$ & $5.05 \mathrm{E}+08$ & $4.34 \mathrm{E}+07$ & $8.68 E+06$ \\
\hline \multirow{2}{*}{$\begin{array}{l}\mathrm{S} 12 \\
\mathrm{~S} 13\end{array}$} & $4.90 \mathrm{E}+06$ & $9.30 E+06$ & $4.39 \mathrm{E}+06$ & $7.54 \mathrm{E}+06$ & $9.89 E+04$ & $1.91 \mathrm{E}+05$ & $9.44 \mathrm{E}+04$ & $1.40 \mathrm{E}+05$ & $4.00 E+06$ & $6.92 \mathrm{E}+06$ & $3.38 \mathrm{E}+05$ & $5.08 \mathrm{E}+05$ & $5.97 \mathrm{E}+08$ & $1.88 \mathrm{E}+09$ & $4.91 \mathrm{E}+07$ & $1.57 \mathrm{E}+08$ \\
\hline & $8.60 \mathrm{E}+06$ & $1.72 \mathrm{E}+06$ & $5.77 \mathrm{E}+06$ & $1.15 \mathrm{E}+06$ & $1.34 \mathrm{E}+05$ & $2.68 E+04$ & $1.72 \mathrm{E}+05$ & $3.43 \mathrm{E}+04$ & $3.37 \mathrm{E}+06$ & $6.75 \mathrm{E}+05$ & $4.91 E+05$ & $0.00 E+00$ & $7.52 \mathrm{E}+08$ & $1.50 \mathrm{E}+08$ & $4.55 E+07$ & $0.00 E+00$ \\
\hline$\$ 14$ & $3.29 \mathrm{E}+05$ & $6.58 \mathrm{E}+04$ & $2.17 \mathrm{E}+06$ & $4.34 \mathrm{E}+05$ & $5.09 \mathrm{E}+04$ & $1.02 E+04$ & $5.95 E+04$ & $1.19 \mathrm{E}+04$ & $3.68 \mathrm{E}+06$ & $7.62 \mathrm{E}+05$ & $8.02 E+05$ & $4.01 \mathrm{E}+05$ & $1.08 \mathrm{E}+08$ & $2.16 \mathrm{E}+07$ & $8.74 \mathrm{E}+06$ & $4.37 E+06$ \\
\hline S15 & $4.90 \mathrm{E}+06$ & $9.30 \mathrm{E}+06$ & $4.39 E+06$ & $7.54 \mathrm{E}+06$ & $9.89 E+04$ & $1.91 \mathrm{E}+05$ & $9.44 E+04$ & $1.40 \mathrm{E}+05$ & $4.00 \mathrm{E}+06$ & $6.92 E+06$ & $3.38 \mathrm{E}+05$ & $5.08 \mathrm{E}+05$ & $5.97 E+08$ & $1.88 \mathrm{E}+09$ & $4.91 E+07$ & $1.57 \mathrm{E}+08$ \\
\hline 516 & $4.90 \mathrm{E}+06$ & $9.30 \mathrm{E}+06$ & $4.39 E+06$ & $7.54 \mathrm{E}+06$ & $9.89 E+04$ & $1.91 \mathrm{E}+05$ & $9.44 E+04$ & $1.40 \mathrm{E}+05$ & $4.00 \mathrm{E}+06$ & $6.92 \mathrm{E}+06$ & $3.38 \mathrm{E}+05$ & $5.08 \mathrm{E}+05$ & $5.97 E+08$ & $1.88 \mathrm{E}+09$ & $4.91 E+07$ & $1.57 E+08$ \\
\hline S17. & $4.90 \mathrm{E}+06$ & $9.30 \mathrm{E}+06$ & $4.39 \mathrm{E}+06$ & $7.54 \mathrm{E}+06$ & $9.89 E+04$ & $1.91 E+05$ & $9.44 E+04$ & $1.40 \mathrm{E}+05$ & $4.00 \mathrm{E}+06$ & $6.92 \mathrm{E}+06$ & $3.38 \mathrm{E}+05$ & $5.08 \mathrm{E}+05$ & $5.97 \mathrm{E}+08$ & $1.88 \mathrm{E}+09$ & $4.91 E+07$ & $1.57 E+08$ \\
\hline \multirow{2}{*}{$\frac{\mathrm{S} 18}{\mathrm{~S} 19-0}$} & $4.90 E+06$ & $9.30 E+06$ & $4.39 \mathrm{E}+06$ & $7.54 \mathrm{E}+06$ & $9.89 E+04$ & $1.91 E+05$ & $9.44 E+04$ & $1.40 E+05$ & $4.00 \bar{E}+06$ & $6.92 \mathrm{E}+06$ & $3.38 \mathrm{E}+05$ & $5.08 \mathrm{E}+05$ & $5.97 \mathrm{E}+08$ & $1.88 E+09$ & $4.91 \mathrm{E}+07$ & $1.57 \mathrm{E}+08$ \\
\hline & $2.55 \mathrm{E}+06$ & $5.10 \mathrm{E}+05$ & $1.59 \mathrm{E}+06$ & $3.19 \mathrm{E}+05$ & $3.05 E+04$ & $6.11 E+03$ & $3.08 \mathrm{E}+04$ & $6.16 \mathrm{E}+03$ & $7.66 \mathrm{E}+06$ & $1.20 \mathrm{E}+06$ & $2.26 \mathrm{E}+05$ & $1.13 E+05$ & $2.02 \mathrm{E}+09$ & $2.02 \mathrm{E}+08$ & $5.95 E+06$ & $2.97 \mathrm{E}+06$ \\
\hline $\mid$\begin{tabular}{|c|} 
S19-O-A \\
\end{tabular} & $2.33 E+06$ & $4.66 \mathrm{E}+05$ & $1.64 \mathrm{E}+06$ & $3.28 \mathrm{E}+05$ & $3.08 \mathrm{E}+04$ & $6.15 E+03$ & $2.97 \mathrm{E}+04$ & $5.94 \mathrm{E}+03$ & $6.26 \mathrm{E}+06$ & $1.05 E+06$ & $2.49 \mathrm{E}+05$ & $1.24 E+05$ & $2.03 E+09$ & $2.03 \mathrm{E}+08$ & $4.77 \mathrm{E}+06$ & $2.39 \mathrm{E}+06$ \\
\hline \multirow{2}{*}{$\begin{array}{l}\text { S20-T } \\
\text { S20-B }\end{array}$} & $1.62 E+05$ & $3.24 E+04$ & $1.13 E+05$ & $2.25 \mathrm{E}+04$ & $2.11 \mathrm{E}+03$ & $4.22 \mathrm{E}+02$ & $2.15 E+03$ & $4.31 \mathrm{E}+02$ & $9.23 \mathrm{E}+03$ & $1.85 E+03$ & $1.20 \mathrm{E}+04$ & $5.99 \mathrm{E}+03$ & $1.41 \mathrm{E}+06$ & $7.50 \mathrm{E}+05$ & $3.10 E+05$ & $1.55 \mathrm{E}+05$ \\
\hline & $1.12 \mathrm{E}+07$ & $2.24 E+06$ & $3.26 \mathrm{E}+06$ & $6.51 \mathrm{E}+05$ & $4.59 \mathrm{E}+04$ & $9.19 E+03$ & $5.32 E+04$ & $1.06 \mathrm{E}+04$ & $1.53 \mathrm{E}+06$ & $3.05 E+05$ & $2.45 E+05$ & $1.22 \mathrm{E}+05$ & $5.59 \mathrm{E}+08$ & $5.59 \mathrm{E}+07$ & $1.21 \mathrm{E}+07$ & $6.06 \mathrm{E}+06$ \\
\hline $\mathrm{S} 21$ & $2.60 \mathrm{E}+06$ & $5.21 \mathrm{E}+05$ & $1.95 E+06$ & $3.90 \mathrm{E}+05$ & $5.32 \mathrm{E}+04$ & $1.06 \mathrm{E}+04$ & $4.59 \mathrm{E}+\overline{04}$ & $9.19 \mathrm{E}+03$ & $3.08 \mathrm{E}+06$ & $6.58 \mathrm{E}+05$ & $2.32 E+05$ & $1.16 \mathrm{E}+05$ & $4.68 E+08$ & $1.41 \mathrm{E}+08$ & $1.26 \mathrm{E}+07$ & $6.28 E+06$ \\
\hline $\mathrm{S} 22$ & $7.12 E+06$ & $0.00 E+00$ & $4.59 E+06$ & $0.00 E+00$ & $5.27 \mathrm{E}+04$ & $1.05 \mathrm{E}+04$ & $4.77 E+04$ & $0.00 \mathrm{E}+00$ & $9.77 E+05$ & $1.95 E+05$ & $2.07 E+05$ & $0.00 E+00$ & $2.76 E+08$ & $5.51 \mathrm{E}+07$ & $4.55 E+07$ & $0.00 E+00$ \\
\hline & & & & & & & & & & & & & & & & \\
\hline Values I & isted in Bla & Dorata & os & 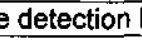 & . & . & & & & & & & & & & \\
\hline Tank S2 & U-233 incl & & & & & & 230 & 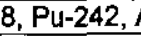 & $2+$ & 8 & $\pi$ & & & & & \\
\hline Tank S5 & $\mathrm{Cm}-244$ up & per limit val & ue estimate & from Gros & s Alpha acti & & & & & & & & & & & \\
\hline The valu & Ies caiculate & d for sampl & es $S 20-T$ ar & Id $\mathrm{S} 20-\mathrm{B}$ ar & upper limit & & & & & & & & & & & \\
\hline & & & & & & & & & & & & & & & & \\
\hline The orge & anic liquids & n Tank S11 & and S20 (2 & D-T) were no & t used to ce & Hate ave & rage activi & Noit & (1) & & & & & & & \\
\hline $\cos _{1}$ & $19-0$ and $s$ & -A repres & nt duplicate & innos & nly \$19-0 & & the avera & activity $\mathrm{ca}$ & lat & & & & & & & \\
\hline Average & $\mathrm{Pu}-242, \mathrm{Cr}$ & 245 , and & m-246 valu & s calculate & d from de & ion limit $n$ & umbers. & & & & & & & & & \\
\hline irors a & ssociated & average & activities W & & & & & & & & & & & & & \\
\hline
\end{tabular}




\begin{tabular}{|c|c|c|c|c|c|c|c|c|c|c|c|c|c|c|c|}
\hline & & & & & & & & & & & & & & & \\
\hline & & & & & & & & & & & & & & & \\
\hline $\mathrm{Ci} / \mathrm{g}$ & & $\mathrm{Ci} / \mathrm{g}$ & & $\mathrm{Ci} / \mathrm{g}$ & & $\mathrm{Ci} / \mathrm{g}$ & & $\mathrm{Ci} / \mathrm{g}$ & & $\mathrm{Ci} / \mathrm{g}$ & & $\mathrm{Ci} / \mathrm{g}$ & & $\mathrm{Ci} / \mathrm{g}$ & \\
\hline 2.27E-01 & & $1.03 E+02$ & & 3.93E-03 & & $3.44 E+00$ & & $2.00 \mathrm{E}-01$ & & $8.10 E+01$ & & 1.72E-01 & & $3.04 E-01$ & \\
\hline & & & & & & & & & & & & & & & \\
\hline Pu-240 & Error & Pu-241 & Error & Pu-242 & Error & Am-241 & Error & $A m-243$ & Error & Cm-244 & Error & $\mathrm{Cm}-245$ & Error & $\mathrm{Cm}-246$ & Error \\
\hline $\mathrm{pCi} / \mathrm{L}$ & pCi/L & $\mathrm{pCi} / \mathrm{L}$ & $\mathrm{pCi} / \mathrm{L}$ & $\mathrm{pCi} / \mathrm{L}$ & $\mathrm{pCi} / \mathrm{L}$ & $\mathrm{pCi} / \mathrm{L}$ & $\mathrm{pCi} / \mathrm{L}$ & $\mathrm{pCi} / \mathrm{L}$ & $\mathrm{pCi} / \mathrm{L}$ & $\mathrm{pCi} / \mathrm{L}$ & $\mathrm{pCl} / \mathrm{L}$ & $\mathrm{pCi} / \mathrm{L}$ & $\mathrm{pCi} / \mathrm{L}$ & $\mathrm{pCl} / \mathrm{L}$ & $\mathrm{pCi} / \mathrm{L}$ \\
\hline $1.97 \mathrm{E}+06$ & $9.86 \mathrm{E}+05$ & $1.60 \mathrm{E}+08$ & $4.81 \mathrm{E}+07$ & $1.81 E+04$ & $0.00 E+00$ & $8.42 E+06$ & $4.36 \mathrm{E}+05$ & $9.95 E+04$ & $0.00 E+00$ & $2.04 \mathrm{E}+07$ & $4.07 \mathrm{E}+07$ & $7.88 E+05$ & $0.00 E+00$ & $1.41 E+06$ & $0.00 E+00$ \\
\hline $0.00 \mathrm{E}+00$ & $0.00 \mathrm{E}+00$ & $5.72 E+06$ & $2.52 \mathrm{E}+06$ & $1.56 \mathrm{E}+06$ & $0.00 \mathrm{E}+00$ & $3.14 \mathrm{E}+05$ & $2.29 \mathrm{E}+04$ & $1.31 \mathrm{E}+07$ & $0.00 \mathrm{E}+00$ & $2.37 \mathrm{E}+06$ & $4.75 E+05$ & $6.82 \mathrm{E}+07$ & $0.00 \mathrm{E}+00$ & $1.21 E+08$ & $0.00 \mathrm{E}+00$ \\
\hline $1.05 \overline{E+06}$ & $0.00 E+00$ & $1.72 \mathrm{E}+07$ & $1.37 \mathrm{E}+07$ & $1.81 E+04$ & $0.00 E+00$ & $1.15 E+05$ & $0.00 E+00$ & $3.61 \overline{1 E+04}$ & $0.00 E+00$ & $1.09 \mathrm{E}+07$ & $1.53 E+06$ & $7.88 E+05$ & $0.00 E+00$ & $1.41 E+06$ & $0.00 E+00$ \\
\hline $1.67 E+08$ & $0.00 E+00$ & $1.14 E+07$ & $0.00 E+00$ & $2.90 E+06$ & $0.00 E+00$ & $3.50 E+05$ & $0.00 E+00$ & $1.14 E+05$ & $0.00 E+00$ & $1.02 E+06$ & $2.05 E+06$ & $1.27 E+08$ & $0.00 E+00$ & $2.25 E+08$ & $0.00 E+00$ \\
\hline $2.24 \mathrm{E}+08$ & $4.49 \mathrm{E}+07$ & $8.11 \mathrm{E}+08$ & $3.24 E+08$ & $2.75 E+06$ & $0.00 \mathrm{E}+00$ & $1.39 \mathrm{E}+08$ & $5.60 \mathrm{E}+07$ & $1.40 E+08$ & $0.00 E+00$ & $2.49 E+11$ & $0.00 E+00$ & $1.20 E+08$ & $0.00 E+00$ & $2.14 E+08$ & $0.00 E+00$ \\
\hline $1.67 E+08$ & $0.00 E+00$ & $2.78 \mathrm{E}+07$ & $1.67 \mathrm{E}+07$ & $2.90 E+06$ & $0.00 E+00$ & $3.14 E+05$ & $0.00 E+00$ & $1.05 E+05$ & $0.00 \mathrm{E}+00$ & $6.17 E+05$ & $0.00 \mathrm{E}+00$ & $1.27 E+08$ & $0.00 E+00$ & $2.25 E+08$ & $0.00 E+00$ \\
\hline $1.67 E+08$ & $0.00 E+00$ & $3.34 \mathrm{E}+08$ & $1.54 \mathrm{E}+08$ & $2.90 E+06$ & $0.00 E+00$ & $3.83 \mathrm{E}+07$ & $1.94 \mathrm{E}+06$ & $8.56 E+04$ & $0.00 E+00$ & $2.18 E+06$ & $0.00 E+00$ & $1.27 E+08$ & $0.00 E+00$ & $2.25 E+08$ & $0.00 E+00$ \\
\hline $1.67 E+08$ & $0.00 E+00$ & $5.00 \mathrm{E}+08$ & $7.80 E+08$ & $2.90 E+06$ & $0.00 E+00$ & $5.36 E+06$ & $0.00 E+00$ & $1.75 E+06$ & $0.00 E+00$ & $2.25 E+06$ & $0.00 E+00$ & $1.27 E+08$ & $0.00 E+00$ & $2.25 E+08$ & $0.00 E+00$ \\
\hline $4.02 E+07$ & $1.80 \mathrm{E}+08$ & $2.24 E+08$ & $4.96 \mathrm{E}+08$ & $1.56 \mathrm{E}+06$ & $0.00 \mathrm{E}+00$ & $2.11 \mathrm{E}+07$ & $9.18 \mathrm{E}+07 \mathrm{I}$ & $1.31 \mathrm{E}+07$ & $0.00 \mathrm{E}+00$ & $5.56 \mathrm{E}+07$ & $1.85 E+08$ & $6.82 \mathrm{E}+07$ & $0.00 \mathrm{E}+00$ & $1.21 \mathrm{E}+08$ & $0.00 \mathrm{E}+00$ \\
\hline $4.02 E+07$ & $1.80 \mathrm{E}+08$ & $2.24 \mathrm{E}+08$ & $4.96 \mathrm{E}+08$ & $1.56 \mathrm{E}+06$ & $0.00 \mathrm{E}+00$ & 2.11E+07 & $9.18 \mathrm{E}+07$ & $1.31 E+07$ & $0.00 \mathrm{E}+00$ & $5.56 \mathrm{E}+07$ & $1.85 \mathrm{E}+08$ & $6.82 \mathrm{E}+07$ & $0.00 \mathrm{E}+00$ & $1.21 \mathrm{E}+08$ & $0.00 \mathrm{E}+00$ \\
\hline $1.59 E+08$ & $3.18 \mathrm{E}+07$ & $1.14 \mathrm{E}+09$ & $4.54 \mathrm{E}+08$ & $2.75 E+06$ & $0.00 E+00$ & $3.71 E+06$ & $0.00 \mathrm{E}+00$ & $1.45 E+06$ & $0.00 E+00$ & $5.09 E+09$ & $1.02 E+09$ & $1.20 E+08$ & $0.00 E+00$ & $2.14 \mathrm{E}+08$ & $4.28 \mathrm{E}+07$ \\
\hline $4.02 \mathrm{E}+07$ & $1.80 \mathrm{E}+08$ & $2.24 \mathrm{E}+08$ & $4.96 \mathrm{E}+08$ & $1.56 \mathrm{E}+06$ & $0.00 \mathrm{E}+00$ & $2.11 E+07$ & $9.18 \mathrm{E}+07$ & $1.31 \mathrm{E}+07$ & $0.00 \mathrm{E}+00$ & $5.56 \mathrm{E}+07$ & $1.85 E+08$ & $6.82 \mathrm{E}+07$ & $0.00 \mathrm{E}+00$ & $1.21 \mathrm{E}+08$ & $0.00 E+00$ \\
\hline $1.67 E+08$ & $0.00 E+00$ & $2.03 E+08$ & $8.13 \mathrm{E}+07$ & $2.90 E+06$ & $0.00 E+00$ & $7.52 E+05$ & $0.00 E+00$ & $2.32 E+05$ & $0.00 E+00$ & $2.26 E+07$ & $0.00 E+00$ & $1.27 E+08$ & $0.00 E+00$ & $2.25 E+08$ & $0.00 E+00$ \\
\hline $1.27 E+06$ & $6.35 \mathrm{E}+05$ & $2.39 E+07$ & $9.55 \mathrm{E}+06$ & $1.81 E+04$ & $0.00 E+00$ & $1.41 \mathrm{E}+06$ & $1.64 \mathrm{E}+05$ & $8.33 \mathrm{E}+04$ & $3.30 \mathrm{E}+04$ & $6.62 \mathrm{E}+06$ & $2.65 E+06$ & $7.88 E+05$ & $0.00 E+00$ & $1.41 E+06$ & $0.00 E+00$ \\
\hline $4.02 E+07$ & $1.80 \mathrm{E}+08$ & $2.24 E+08$ & $4.96 \mathrm{E}+08$ & $1.56 \mathrm{E}+06$ & $0.00 \mathrm{E}+00$ & $2.11 E+07$ & $9.18 \mathrm{E}+07$ & $1.31 \mathrm{E}+07$ & $0.00 \mathrm{E}+00$ & $5.56 \mathrm{E}+07$ & $1.85 \mathrm{E}+08$ & $6.82 E+07$ & $0.00 \mathrm{E}+00$ & $1.21 \mathrm{E}+08$ & $0.00 \mathrm{E}+00$ \\
\hline $4.02 \mathrm{E}+07$ & $1.80 E+08$ & $2.24 \mathrm{E}+08$ & $4.96 \mathrm{E}+08$ & $1.56 \mathrm{E}+06$ & $0.00 \mathrm{E}+00$ & 2.11E+07 & $9.18 \mathrm{E}+07$ & $1.31 \mathrm{E}+07$ & $0.00 \mathrm{E}+00$ & $5.56 \mathrm{E}+07$ & $1.85 \mathrm{E}+08$ & $6.82 E+07$ & $0.00 \mathrm{E}+00$ & $1.21 E+08$ & $0.00 \mathrm{E}+00$ \\
\hline $4.02 E+07$ & $1.80 \mathrm{E}+08$ & $2.24 \mathrm{E}+08$ & $4.96 \mathrm{E}+08$ & $1.56 \mathrm{E}+06$ & $0.00 \mathrm{E}+00$ & $2.11 \mathrm{E}+07$ & $9.18 \mathrm{E}+07$ & 1.31E+07 & $0.00 \mathrm{E}+00$ & $5.56 E+07$ & $1.85 \mathrm{E}+08$ & $6.82 \mathrm{E}+07$ & $0.00 \mathrm{E}+00$ & $1.21 \mathrm{E}+08$ & $0.00 E+00$ \\
\hline $4.02 \mathrm{E}+07$ & $1.80 \mathrm{E}+08$ & $2.24 E+08$ & $4.96 \mathrm{E}+08$ & $1.56 \mathrm{E}+06$ & $0.00 E+00$ & $2.11 \mathrm{E}+07$ & $9.18 \mathrm{E}+07$ & $1.31 E+07$ & $0.00 \mathrm{E}+00$ & $5.56 \mathrm{E}+07$ & $1.85 E+08$ & $6.82 E+07$ & $0.00 \mathrm{E}+00$ & $1.21 \mathrm{E}+08$ & $0.00 \mathrm{E}+00$ \\
\hline $1.43 E+06$ & $7.14 E+05$ & $5.18 \mathrm{E}+08$ & $1.55 \mathrm{E}+08$ & $1.81 E+04$ & $0.00 \mathrm{E}+00$ & $9.05 E+05$ & $1.12 \mathrm{E}+05$ & $1.34 E+05$ & $0.00 E+00$ & $8.11 \mathrm{E}+06$ & $1.62 E+07$ & $7.88 E+05$ & $0.00 E+00$ & $1.41 E+06$ & $0.00 E+00$ \\
\hline $1.57 \mathrm{E}+06$ & $7.84 \mathrm{E}+05$ & $5.23 E+08$ & $1.57 \mathrm{E}+08$ & $1.81 E+04$ & $0.00 E+00$ & $9.05 E+05$ & $1.08 E+05$ & $1.36 E+05$ & $0.00 E+00$ & $8.15 E+06$ & $1.63 \mathrm{E}+07$ & $7.88 E+05$ & $0.00 E+00$ & $1.41 E+06$ & $0.00 E+00$ \\
\hline $1.05 E+06$ & $0.00 E+00$ & $4.77 E+05$ & $0.00 E+00$ & $1.81 E+04$ & $0.00 E+00$ & $5.77 \mathrm{E}+05$ & $4.12 \mathrm{E}+04$ & $6.26 \mathrm{E}+04$ & $6.51 \mathrm{E}+03$ & $1.07 \mathrm{E}+07$ & $1.73 \mathrm{E}+06$ & $7.88 E+05$ & $0.00 E+00$ & $1.41 E+06$ & $0.00 E+00$ \\
\hline $7.52 \mathrm{E}+06$ & $3.76 \mathrm{E}+06$ & $1.39 E+08$ & $4.16 E+07$ & $1.81 E+04$ & $0.00 E+00$ & $1.55 \mathrm{E}+05$ & $3.91 E+04$ & $9.19 E+05$ & $0.00 E+00$ & $4.28 \mathrm{E}+07$ & $2.14 E+07$ & $7.88 E+05$ & $0.00 E+00$ & $1.41 E+06$ & $0.00 E+00$ \\
\hline $4.73 \mathrm{E}+06$ & $2.36 E+06$ & $1.14 \mathrm{E}+08$ & $4.77 E+07$ & $1.81 E+04$ & $0.00 E+00$ & $1.13 E+06$ & $1.61 \mathrm{E}+05$ & $6.49 E+05$ & $0.00 E+00$ & $1.32 \mathrm{E}+08$ & $3.97 \mathrm{E}+07$ & $7.88 E+05$ & $0.00 E+00$ & $1.41 E+06$ & $0.00 E+00$ \\
\hline $1.67 E+08$ & $0.00 E+00$ & $6.44 \mathrm{E}+07$ & $2.58 \mathrm{E}+07$ & $2.90 E+06$ & $0.00 E+00$ & $6.53 \mathrm{E}+05$ & $1.96 \mathrm{E}+05$ & $1.01 \mathrm{E}+06$ & $6.24 \mathrm{E}+04$ & $2.76 \mathrm{E}+08$ & $5.51 \mathrm{E}+07$ & $1.27 E+08$ & $0.00 E+00$ & $2.25 E+08$ & $0.00 E+00$ \\
\hline & & & & & & & & & & & & & & & \\
\hline & & & & & & & & & & & & & & & \\
\hline & & & & & & & & & & & & & & & \\
\hline & & & & & & & & & & & & & & & \\
\hline & & & & & & & & & & & & & & & \\
\hline & & & & & & & & & & & & & & & \\
\hline & & & & & & & & & & & & & & & \\
\hline & & & & & & & & & & & & & & & \\
\hline & & & & & & & & & & & & & & & \\
\hline & & & & & & & & & & & & & & & \\
\hline
\end{tabular}


7 -

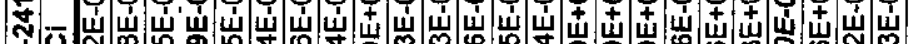

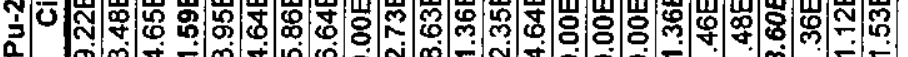

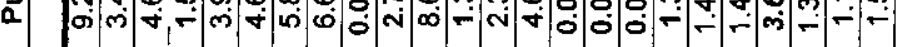

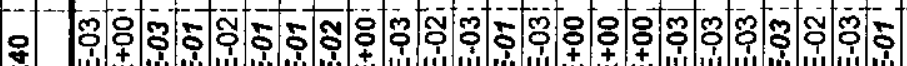

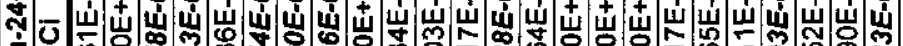

a.

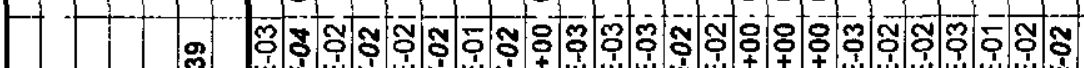

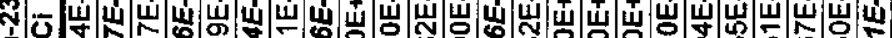
a

$\infty$ ס̄ ஸि ৩

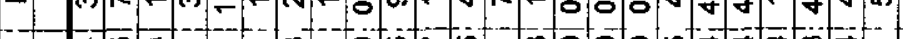

- 1 o \%ั

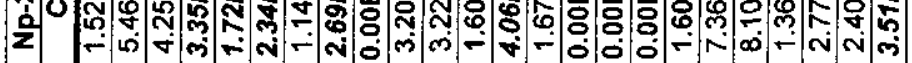

-

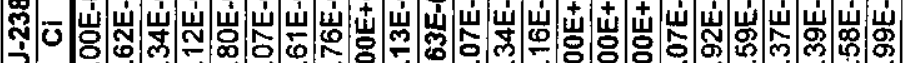

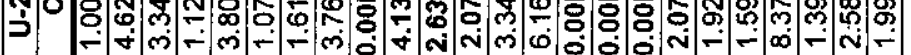

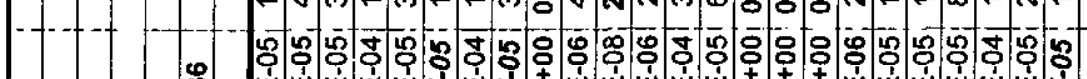

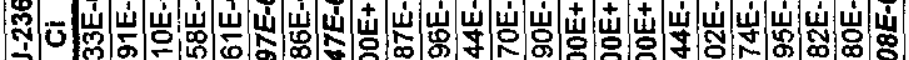

3 N

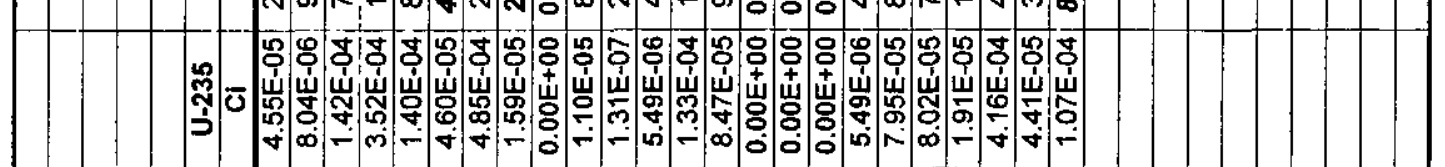

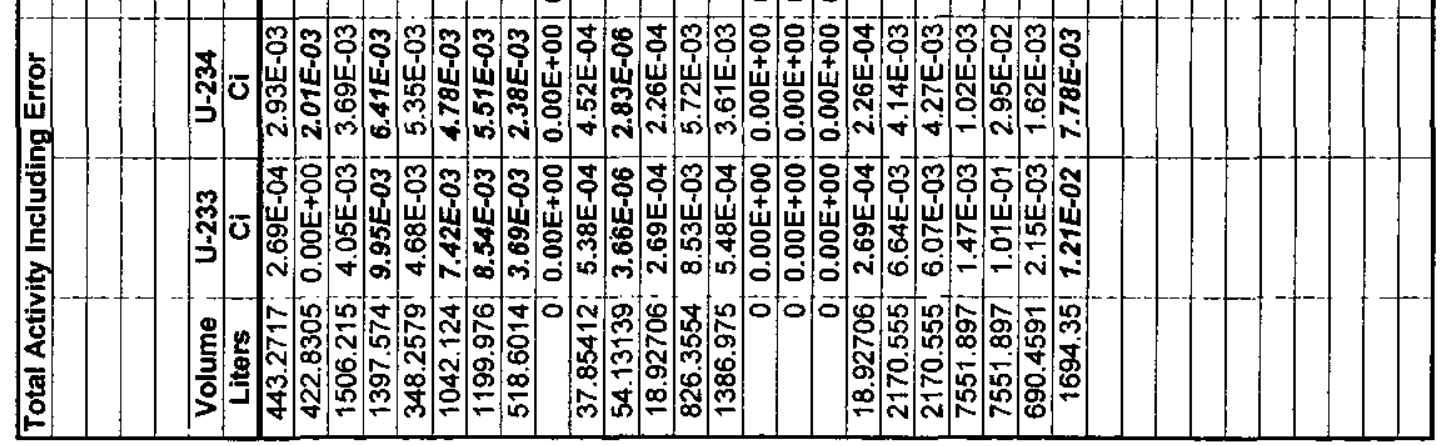




\begin{tabular}{|c|c|c|c|c|c|c|c|c|c|c|c|c|c|c|c|c|}
\hline \multicolumn{17}{|c|}{ Activity Concentration Including Error } \\
\hline & & & & & & & & & & & & & & & & \\
\hline \multicolumn{17}{|c|}{ T } \\
\hline \multirow{2}{*}{\multicolumn{17}{|c|}{$:$}} \\
\hline & & & & & & & & & & & & & & & & \\
\hline & U-233 & U-234 & U-235 & U-236 & U-238 & Np-237 & Pu-238 & Pu-239 & Pu-240 & Pu-241 & Pu-242 & Am-241 & Am-243 & $\mathrm{Cm-244}$ & $\mathrm{Cm}-245$ & $\mathrm{Cm}-246$ \\
\hline Tank \# & $\mathrm{Ci} / \mathrm{L}$ & $\mathrm{Ci} / \mathrm{L}$ & $\mathrm{Ci} / \mathrm{L}$ & $\mathrm{Ci} / \mathrm{L}$ & $\mathrm{Ci} / \mathrm{L}$ & $\mathrm{Ci} / \mathrm{L}$ & $\mathrm{Ci} / \mathrm{L}$ & $\mathrm{Ci} / \mathrm{L}$ & $\mathrm{Ci} / \mathrm{L}$ & $\mathrm{Ci} / \mathrm{L}$ & $\mathrm{Ci} / \mathrm{L}$ & $\mathrm{Ci} / \mathrm{L}$ & $\mathrm{Ci} / \mathrm{L}$ & $\mathrm{Ci} / \mathrm{L}$ & $\mathrm{Cl} / \mathrm{L}$ & $\mathrm{Ci} / \mathrm{L}$ \\
\hline S1 & $6.06 \mathrm{E}-07$ & $6.60 \mathrm{E}-06$ & $1.03 E-07$ & 5.26E-08 & 2.27E-06 & $3.44 E-07$ & $7.14 E-04$ & $2.08 E-05$ & 2.96E-06 & $2.08 \mathrm{E}-04$ & $1.81 E-08$ & 8.86E-06 & 9.95E-08 & $6.11 E-05$ & $7.88 E-07$ & 1.41E-06 \\
\hline \$2 & $0.00 E+00$ & 4.75E-06 & 1.90E-08 & $2.34 E-07$ & 1.09E-05 & 1.29E-07 & $1.70 \mathrm{E}-05$ & 1.98 E-06 & $0.00 \mathrm{E}+00$ & $8.24 \mathrm{E}-06$ & $1.56 \mathrm{E}-06$ & 3.37E-07 & $1.31 \mathrm{E}-05$ & $2.85 \mathrm{E}-06$ & $6.82 \mathrm{E}-05$ & $1.21 \mathrm{E}-04$ \\
\hline 53 & 2.69E-06 & $2.45 E-06$ & 9.41E-08 & $4.72 \mathrm{E}-08$ & $2.22 \mathrm{E}-06$ & $2.82 \mathrm{E}-07$ & $1.20 \mathrm{E}-05$ & $1.58 \mathrm{E}-05$ & $1.05 E-06$ & $3.09 \mathrm{E}-05$ & $1.81 E-08$ & $1.15 E-07$ & $3.61 E-08$ & $1.24 \mathrm{E}-05$ & $7.88 \mathrm{E}-07$ & $1.41 E-06$ \\
\hline 54 & 7.12E-06 & $4.59 E-06$ & 2.52E-07 & 1.13E-07 & $7.99 \mathrm{E}-06$ & $2.40 E-07$ & 2.32E-05 & 4.55E-05 & $1.67 E-04$ & 1.14E-05 & $2.90 E-06$ & $3.50 E-07$ & $1.14 E-07$ & $3.07 E-06$ & $1.27 E-04$ & 2.25E-04 \\
\hline$\$ 5$ & 1.34E-05 & $1.54 \mathrm{E}-05$ & 4.03E-07 & 2.47E-07 & $1.09 \mathrm{E}-05$ & 4.95E-07 & 4.59E-03 & $2.73 \mathrm{E}-04$ & $2.69 \mathrm{E}-04$ & $1.14 \mathrm{E}-03$ & $2.75 E-06$ & $1.95 \mathrm{E}-04$ & $1.40 E-04$ & $2.49 E=01$ & $1.20 E-04$ & $2.14 E-04$ \\
\hline S6 & $7.12 E-06$ & 4.59E-06 & $4.42 \mathrm{E}-08$ & 4.77E-08 & 1.03E-06 & 2.25E-07 & $1.61 \mathrm{E} .05$ & $4.55 E-05$ & $1.67 E-04$ & $4.45 \mathrm{E}-05$ & $2.90 \mathrm{E}-06$ & $3.14 E-07$ & $1.05 E-07$ & $6.17 E-07$ & $1.27 E-04$ & $2.25 E-04$ \\
\hline 57 & $7.12 E-06$ & $4.59 E-06$ & $4.04 \mathrm{E}-07$ & $2.39 \mathrm{E}-07$ & $1.34 \mathrm{E}-05$ & $9.46 \mathrm{E}-07$ & $2.22 \mathrm{E}-04$ & $1.43 \mathrm{E}-04$ & $1.67 E-04$ & $4.88 \mathrm{E}-04$ & $2.90 E-06$ & 4.02E-05 & $8.56 E-08$ & $2.18 E-06$ & 1.27E-04 & 2.25E-04 \\
\hline 58 & 7.12E-06 & $4.59 E-06$ & $3.06 \mathrm{E}-08$ & 4.77E-08 & $7.25 \mathrm{E}-07$ & 5.18E-07 & 3.43E-05 & $4.55 \mathrm{E}-05$ & $1.67 E-04$ & $1.28 \mathrm{E}-03$ & $2.90 E .06$ & $5.36 E-06$ & $1.75 E-06$ & $2.25 E-06$ & $1.27 E-04$ & $2.25 E-04$ \\
\hline 59 & $0.00 \mathrm{E}+00$ & $0.00 \mathrm{E}+\overline{00}$ & $0.00 \mathrm{E}+00$ & $0.00 \mathrm{E}+00$ & $0.00 \mathrm{E}+00$ & $0.00 \mathrm{E}+00$ & $0.00 \mathrm{E}+00$ & $0.00 \mathrm{E}+00$ & $0.00 \mathrm{E}+00$ & $0.00 \mathrm{E}+00$ & $0.00 \mathrm{E}+00$ & $0.00 \mathrm{E}+00$ & $0.00 \mathrm{E}+00$ & $0.00 \mathrm{E}+00$ & $0.00 \mathrm{E}+00$ & $0.00 \mathrm{E}+00$ \\
\hline$\$ 10$ & 1.42E-05 & 1.19E-05 & 2.90E-07 & $2.34 \mathrm{E}-07$ & $1.09 \mathrm{E}-05$ & $8.46 \mathrm{E}-07$ & $2.48 \mathrm{E}-03$ & $2.06 \mathrm{E}-04$ & $2.20 \mathrm{E}-04$ & $7.20 \mathrm{E}-04$ & 1.56E-06 & 1.13E-04 & $1.31 \mathrm{E}-05$ & $2.41 \mathrm{E}-04$ & 6.82E-05 & 1.21E-04 \\
\hline S11 & $6.76 E=08$ & 5.22E-08 & 2.42E-09 & $5.46 \mathrm{E}-10$ & $4.86 E-08$ & 5.94E-09 & 3.03E-03 & 5.21E-05 & $1.91 \mathrm{E}-04$ & 1.59E-03 & $2.75 E-06$ & $3.71 E-06$ & $1.45 E-06$ & 6.11E-03 & $1.20 \mathrm{E}-04$ & $2.57 \mathrm{E}-04$ \\
\hline 512 & $1.42 \mathrm{E}-05$ & 1.19E-05 & $2.90 \mathrm{E}-07$ & $2.34 \mathrm{E}-07$ & $1.09 \mathrm{E}-05$ & $8.46 \mathrm{E}-07$ & $2.48 \mathrm{E}-03$ & $2.06 \mathrm{E}-04$ & $2.20 \mathrm{E}-04$ & $7.20 \mathrm{E}-04$ & $1.56 \mathrm{E}-06$ & $1.13 \mathrm{E}-04$ & 1.31E-05 & 2.41E-04 & $6.82 \mathrm{E}-05$ & 1.21E-04 \\
\hline$\$ 13$ & $1.03 \mathrm{E}-05$ & $6.92 \mathrm{E}-06$ & $1.61 \mathrm{E}-07$ & $2.06 \mathrm{E}-07$ & $4.05 \mathrm{E}-06$ & $4.91 E-07$ & $9.02 E-04$ & $4.55 E-05$ & 1.67E-04 & $2.84 \mathrm{E}-04$ & $2.90 \bar{E}-06$ & $7.52 E-07$ & $2.32 E-07$ & 2.26E-05 & $1.27 E-04$ & $2.25 E-04$ \\
\hline$S 14$ & 3.95E-07 & $2.60 \mathrm{E}-06$ & $6.11 \mathrm{E}-08$ & $7.14 \mathrm{E}-08$ & 4.44E-06 & $1.20 \mathrm{E}-06$ & $1.30 \mathrm{E}-04$ & $1.31 \mathrm{E}-05$ & $1.91 \mathrm{E}-06$ & $3.35 \mathrm{E}-05$ & $1.81 E-08$ & $1.57 \mathrm{E}-06$ & $1.16 \mathrm{E}-07$ & $9.27 \mathrm{E}-06$ & $7.88 \mathrm{E}-07$ & $1.41 E-06$ \\
\hline$\$ 15$ & $0.00 \mathrm{E}+00$ & $0.00 E+00$ & $0.00 E+00$ & $0.00 E+00$ & $0.00 \mathrm{E}+00$ & $0.00 \mathrm{E}+00$ & $0.00 E+00$ & $0.00 E+00$ & $0.00 \mathrm{E}+00$ & $0.00 E+00$ & $0.00 \mathrm{E}+00$ & $0.00 \mathrm{E}+00$ & $0.00 \mathrm{E}+00$ & $0.00 \mathrm{E}+\overline{00}$ & $0.00 \mathrm{E}+00$ & $0.00 \mathrm{E}+00$ \\
\hline$\$ 16$ & $0.00 \mathrm{E}+00$ & $0.00 \mathrm{E}+00$ & $0.00 \mathrm{E}+00$ & $0.00 \mathrm{E}+00$ & $0.00 \mathrm{E}+00$ & $0.00 \mathrm{E}+00$ & $0.00 \mathrm{E}+00$ & $0.00 E+00$ & $0.00 \mathrm{E}+00$ & $0.00 \mathrm{E}+00$ & $0.00 E+00$ & $0.00 \mathrm{E}+00$ & $0.00 \mathrm{E}+00$ & $0.00 \mathrm{E}+00$ & $0.00 \mathrm{E}+00$ & $0.00 \mathrm{E}+00$ \\
\hline$S 17$ & $0.00 \mathrm{E}+00$ & $0.00 E+00$ & $0.00 \mathrm{E}+00$ & $0.00 \mathrm{E}+00$ & $0.00 \mathrm{E}+00$ & $0.00 \mathrm{E}+00$ & $0.00 E+00$ & $0.00 E+00$ & $0.00 \mathrm{E}+00$ & $0.00 \mathrm{E}+00$ & $0.00 \mathrm{E}+00$ & $0.00 E+00$ & $0.00 \mathrm{E}+00$ & $0.00 \mathrm{E}+00$ & $0.00 \mathrm{E}+00$ & $0.00 E+00$ \\
\hline$\$ 18$ & 1.42E-05 & 1.19E-05 & $2.90 \mathrm{E}-07$ & $2.34 E-07$ & 1.09E-05 & $8.46 \mathrm{E}-07$ & $2.48 \mathrm{E}-03$ & $2.06 \mathrm{E}-04$ & $2.20 \mathrm{E}-04$ & $7.20 \mathrm{E}-04$ & $1.56 \mathrm{E}-06$ & $1.13 \mathrm{E}-04$ & 1.31E-05 & 2.41E-04 & 6.82E-05 & $1.21 E-04$ \\
\hline S19-0 & $3.06 \mathrm{E}-06$ & 1.91E-06 & 3.66E-08 & 3.70E-08 & $8.86 \mathrm{E}-06$ & 3.39E-07 & 2.22E-03 & $8.92 \mathrm{E}-06$ & $2.14 \mathrm{E}-06$ & $6.73 \mathrm{E}-04$ & 1.81E-08 & $1.02 \mathrm{E}-06$ & $1.34 E-07$ & $2.43 E-05$ & $7.88 E-07$ & 1.41E-06 \\
\hline S19-A & $2.80 \mathrm{E}-06$ & 1.97E-06 & $3.70 \mathrm{E}-08$ & $3.56 \mathrm{E}-08$ & 7.31E-06 & 3.73E-07 & 2.23E-03 & $7.16 \mathrm{E}-06$ & $2.35 \mathrm{E}-06$ & $6.80 \mathrm{E}-04$ & $1.81 E-08$ & 1.01E-06 & $1.36 E-07$ & $2.45 E-05$ & $7.88 E-07$ & $1.41 E-06$ \\
\hline S20-T & $1.94 \mathrm{E}-07$ & 1.36E-07 & 2.53E-09 & $2.58 \mathrm{E}-09$ & 1.11E-08 & $1.80 \mathrm{E}-08$ & $2.16 \mathrm{E}-06$ & 4.65E-07 & $1.05 E-06$ & $4.77 E-07$ & $1.81 E-08$ & 6.18E-07 & $6.91 \overline{E-08}$ & $1.24 E-05$ & $7.88 E-07$ & $1.41 E-06$ \\
\hline S20-B & $1.34 \mathrm{E}-05$ & $3.91 \mathrm{E}-06$ & $5.51 \mathrm{E}-08$ & $6.38 \mathrm{E}-08$ & $1.84 \mathrm{E}-06$ & $3.67 \mathrm{E}-07$ & $6.15 \mathrm{E}-04$ & 1.82E-05 & 1.13E-05 & $1.81 \mathrm{E}-04$ & $1.81 E-08$ & 1.94E-07 & 9.19E-07 & $6.42 \mathrm{E}-05$ & $7.88 E-07$ & 1.41E-06 \\
\hline$\$ 21$ & $3.12 E-06$ & 2.34E-06 & $6.38 \mathrm{E}-08$ & $5.51 \mathrm{E}-08$ & 3.74E-06 & $3.48 \mathrm{E}-07$ & $6.09 \mathrm{E}-04$ & $1.89 \mathrm{E}-05$ & $7.09 \mathrm{E}-06$ & $1.62 \mathrm{E}-04$ & $1.81 E-08$ & 1.29E-06 & $6.49 E-07$ & 1.72E-04 & $7.88 E-07$ & $1.41 E .06$ \\
\hline \multirow[t]{2}{*}{$\$ 22$} & 7.12E-06 & $4.59 E-06$ & $6.32 \mathrm{E}-08$ & 4.77E-08 & 1.17E-06 & 2.07E-07 & $3.31 \mathrm{E}-04$ & $4.55 E .05$ & $1.67 E-04$ & $9.02 \mathrm{E}-05$ & $2.90 E-06$ & $8.49 \mathrm{E}-07$ & 1.07E-06 & $3.31 \mathrm{E}-04$ & $1.27 E-04$ & $2.25 E-04$ \\
\hline & & & & & & & & & & & & & & & & \\
\hline \\
\hline \\
\hline & & & & & & & & & & & & & & & & \\
\hline \multicolumn{17}{|l|}{ - } \\
\hline \multirow{2}{*}{\multicolumn{17}{|c|}{ 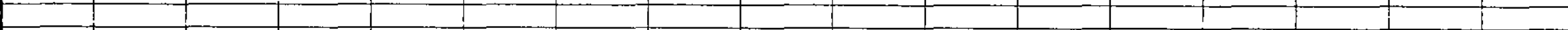 }} \\
\hline & & & & & & & & & & & & & & & & \\
\hline \multirow{2}{*}{\multicolumn{17}{|c|}{ 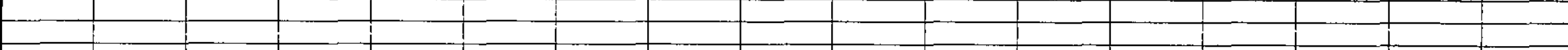 }} \\
\hline & & & & & & & & & & & & & & & & \\
\hline & & & & & & & & & & & & & & & & \\
\hline
\end{tabular}




\begin{tabular}{|c|c|c|c|c|c|c|c|c|c|c|c|c|c|c|c|c|}
\hline & & & & & & & & & & & & & & & & \\
\hline & & & & & & & & & & & & & & & & \\
\hline & U-233 & U-234 & U-235 & U-236 & U-238 & Np-237 & Pu-238 & Pu-239 & Pu-240 & Pu-241 & Pu-242 & $\mathrm{Am-241}$ & $A m-243$ & $\mathrm{Cm}$ & $m-245$ & $\mathrm{Cm}-$ \\
\hline Tank \# & $\mathbf{g}$ & g & g & 9 & $\mathbf{g}$ & g & $g$ & $\mathbf{g}$ & g & $\mathrm{g}$ & $\mathrm{g}$ & $g$ & $\mathbf{g}$ & $\mathrm{g}$ & $g$ & $=$ \\
\hline S1 & $2.79 E-02$ & $4.69 \mathrm{E}-01$ & $2.11 \mathrm{E}+01$ & $3.60 \mathrm{E}-01$ & $2.99 \mathrm{E}+03$ & $2.16 \mathrm{E}-01$ & $1.85 E-02$ & $1.49 \mathrm{E}-01$ & 5.77E-03 & $8.92 E-04$ & $2.04 E-03$ & $1.14 \mathrm{E}-03$ & $2.21 E-04$ & $3.34 \mathrm{E}-04$ & $2.03 E-03$ & $2.06 E-03$ \\
\hline S2 & $0.00 E+00$ & 3.22E $=01$ & $3.72 \mathrm{E}+00$ & $1.53 \mathrm{E}+00$ & $1.37 \mathrm{E}+04$ & $7.75 E-02$ & $4.21 \mathrm{E}-04$ & $1.35 E-02$ & $0.00 \mathrm{E}+00$ & $3.37 \mathrm{E}-05$ & $1.68 \mathrm{E}-01$ & 4.14E-05 & 2.77E-02 & $1.49 E-05$ & $1.68 \mathrm{E}-01$ & $1.68 \mathrm{E}-0$ \\
\hline 53 & 4.20E-01 & $5.91 \mathrm{E}-01$ & $6.56 \mathrm{E}+01$ & $1.10 \mathrm{E}+00$ & $9.95 \mathrm{E}+03$ & $6.02 \bar{E}-01$ & 1.06E-03 & 3.82E-01 & $6.97 E-03$ & 4.50E-04 & $6.94 E-03$ & $5.04 E-05$ & $2.72 E-04$ & 2.31E-04 & $6.90 E-03$ & $6.99 E-03$ \\
\hline S4 & $1.03 E+00$ & $1.03 E+00$ & $1.63 E+02$ & $2.44 \mathrm{E}+00$ & $3.32 \mathrm{E}+04$ & $4.76 E-01$ & $1.90 \mathrm{E}-03$ & $1.02 E+00$ & $1.03 E+00$ & $1.54 E-04$ & $1.03 E+00$ & $1.42 E-04$ & $7.97 E-04$ & $5.30 E-05$ & $1.03 E+00$ & $1.03 E+00$ \\
\hline S5 & 4.86E-01 & 8.58E-01 & $6.50 \mathrm{E}+01$ & $1.33 \mathrm{E}+00$ & $1.13 \mathrm{E}+04$ & $2.45 E-01$ & $9.35 \mathrm{E}-02$ & $1.53 \mathrm{E}+00$ & 4.13E-01 & $3.82 E-03$ & $2.44 E-01$ & 1.97E-02 & 2.44E-01 & $1.07 E+00$ & $2.43 E-01$ & $2.45 E-01$ \\
\hline S6 & $7.70 E-01$ & $\overline{7} .67 E-01$ & $2.13 E+01$ & $7.68 E-01$ & $3.19 \mathrm{E}+03$ & 3.33E-01 & $9.82 E-04$ & $7.64 E-01$ & $7.67 E-01$ & $4.48 \mathrm{E}-04$ & $7.69 E-01$ & $9.51 E-05$ & $5,47 E-04$ & $7.94 E-06$ & $7.69 E-01$ & $7.71 E-01$ \\
\hline S7 & $8.86 E-01$ & $8.83 E-01$ & $2.24 \mathrm{E}+02$ & $4.43 \mathrm{E}+00$ & $4.80 \mathrm{E}+04$ & $1.61 \mathrm{E}+00$ & $1.56 \mathrm{E}-02$ & $2.76 \mathrm{E}+00$ & $8.83 E-01$ & $5.66 \mathrm{E}-03$ & $8.85 E-01$ & $1.40 \mathrm{E}-02$ & $5.14 E-04$ & $3.23 E-05$ & $8.86 E-01$ & $8.88 E-01$ \\
\hline S8 & $3.83 E-01$ & $3.81 E-01$ & $7.35 E+00$ & $3.82 E-01$ & $1.12 \mathrm{E}+03$ & $3.81 E-01$ & $1.04 \mathrm{E}-03$ & $3.80 E-01$ & $3.82 E-01$ & $6.42 \mathrm{E}-03$ & $3.83 E-01$ & $8.08 E-04$ & $4.54 E-03$ & $1.44 E-05$ & $3.83 E-01$ & $3.84 E-01$ \\
\hline S9 & $0.00 \mathrm{E}+00$ & 0.00 & $0.00 \mathrm{E}+00$ & $0.00 \mathrm{E}+00$ & $0.00 E+00$ & $0.00 \mathrm{E}+00$ & $0.00 \mathrm{E}+00$ & $E+001$ & $0.00 \mathrm{E}+00$ & $0.00 \mathrm{E}+00$ & $E+00$ & $0.00 \mathrm{E}+00$ & $0.00 \mathrm{E}+00$ & $0.00 \mathrm{E}+00$ & $0.00 \mathrm{E}+00$ & $E+00$ \\
\hline$\$ 10$ & $5.58 \mathrm{E}-02$ & -02 & +00 & -01 & $1.23 E+03$ & 4.5 & $=03$ & $E-01^{+}$ & E-02 & $E-04$ & $E-02$ & & E-03 & & E-02 & $=-02$ \\
\hline S11 & $3.80 E-04$ & $4.53 E-04$ & $6.07 \mathrm{E}-02$ & 4.57E-04 & $7.83 E+00$ & 4.5 & $=-03$ & $4.54 \mathrm{E}-02$ & $=-02$ & $E-04$ & $3.79 E-02$ & 5.8 & -04 & -03 & -02 & $E-02$ \\
\hline S12 & 2.79E-02 & 3.62E-02 & $2.54 \mathrm{E}+00$ & $6.86 \mathrm{E}-02$ & $6.15 \mathrm{E}+02$ & 2.27E-02 & $2.74 \mathrm{E}-03$ & $6.28 \mathrm{E}-02$ & 1.84E-02 & $1.32 \mathrm{E}-04$ & $7.51 \mathrm{E}-03$ & E-04 & E-03 & $E-05$ & E-03 & $\mathrm{E}-03$ \\
\hline$\$ 13$ & 8.85E-01 & -01 & $6.15 \mathrm{E}+01$ & $2.63 \mathrm{E}+00$ & $9.95 \mathrm{E}+03$ & $5.76 E-01$ & $4.36 \mathrm{E}-02$ & $6.05 E-01$ & $=\overline{01}$ & 2.27E-03 & $6.10 E-01$ & $E-04$ & $9.59 E-04$ & $E-04$ & E-01 & $E-01$ \\
\hline S14 & $5.68 \mathrm{E}-02$ & 5.79E-01 & $3.92 E+01$ & $1.53 \mathrm{E}+00$ & $1.83 \mathrm{E}+04$ & 2.37 & $1.05 \mathrm{E}-02$ & $2.93 \mathrm{E}-01$ & $1.16 \mathrm{E}-02$ & 4.49E-04 & $6.39 E-03$ & $E-04$ & $E-04$ & E-04 & $E-03$ & $E-03$ \\
\hline S15 & $0.00 \mathrm{E}+00$ & $0.00 \mathrm{E}+00$ & $0.00 \mathrm{E}+00$ & $0.00 \mathrm{E}+00$ & $0.00 \mathrm{E}+00$ & $0.00 \mathrm{E}+00$ & $0.00 \mathrm{E}+00$ & $0.00 \mathrm{E}+00$ & $0.00 \mathrm{E}+00$ & $0.00 \mathrm{E}+00$ & $0.00 \mathrm{E}+00$ & $=00$ & $=+00$ & $E+00$ & $=00$ & +00 \\
\hline S16 & $0.00 \mathrm{E}+00$ & $0.00 E+00$ & $0.00 \mathrm{E}+00$ & $0.00 E+00$ & $0.00 E+00$ & $0.00 \mathrm{E}+00$ & $0.00 E+00$ & $0.00 \mathrm{E}+00$ & $0.00 \mathrm{E}+00$ & $0.00 E+00$ & $0.00 E+00$ & +00 & $=+00$ & +00 & $E+00$ & 0. \\
\hline S17 & $0.00 \mathrm{E}+00$ & $0.00 \mathrm{E}+00$ & $0.00 \mathrm{E}+00$ & $0.00 \mathrm{E}+00$ & $0.00 \mathrm{E}+00$ & $0.00 \mathrm{E}+00$ & $0.00 E+00$ & $0.00 \mathrm{E}+00$ & $0.00 E+00$ & $0.00 \mathrm{E}+00$ & $0.00 \mathrm{E}+00$ & +00 & \pm 00 & $E+00$ & $E+00$ & +00 \\
\hline S18 & $2.79 E-02$ & $3.62 \mathrm{E}-02$ & $2.54 \mathrm{E}+00$ & $6.86 \mathrm{E}-02$ & $6.15 \mathrm{E}+02$ & 2.27E -02 & $2.74 \mathrm{E}-03$ & $6.28 \mathrm{E}-02$ & 1.84E-02 & 1.32E-04 & $7.51 \mathrm{E}-03$ & $=-04$ & $E-03$ & $E-05$ & $E-03$ & $E-03$ \\
\hline S19-0 & $6.89 \mathrm{E}-01$ & $6.64 \mathrm{E}-01$ & $3.68 \mathrm{E}+01$ & $1.24 \mathrm{E}+00$ & $5.72 \mathrm{E}+04$ & $1.04 \mathrm{E}+00$ & 2.82E-01 & $3.12 \mathrm{E}-01$ & $2.05 \mathrm{E}-02$ & 1.41E-02 & $1.00 E-02$ & -04 & $E-03$ & $=-04$ & $E-03$ & $E-02$ \\
\hline S19-A & 6.30E-01 & $6.85 \mathrm{E}-01$ & $3.71 \mathrm{E}+01$ & $1.20 \mathrm{E}+00$ & $4.72 E+04$ & $1.15 E+00$ & 2.83E-01 & $2.50 \mathrm{E}-01$ & $2.25 \mathrm{E}-02$ & $1.43 E-02$ & $1.00 E-02$ & -04 & $E-03$ & $E-04$ & $E-03$ & $E-02$ \\
\hline S20-T & $1.52 \mathrm{E}-01$ & $1.64 \mathrm{E}-01$ & $8.85 \mathrm{E}+00$ & $3.01 E-01$ & $2.49 \mathrm{E}+02$ & $1.93 \mathrm{E}-01$ & $9.54 \mathrm{E}-04$ & $5.65 \mathrm{E}-02$ & $3.49 E-02$ & $3.48 E-05$ & $3.48 E-02$ & $E-03$ & $E-03$ & $E-03$ & $3.46 E-02$ & $E-02$ \\
\hline S20-B & $1.05 \mathrm{E}+01$ & $4.73 E+00$ & $1.93 E+02$ & $7.45 E+00$ & $4.12 E+04$ & $3.93 E+00$ & $2.72 \mathrm{E}-01$ & $2.21 \mathrm{E}+00$ & $3.75 \mathrm{E}-01$ & $1.32 \mathrm{E}-02$ & $3.48 E-02$ & $4.26 \mathrm{E}-04$ & $E-02$ & E-03 & $3.46 E-02$ & $E-02$ \\
\hline S21 & 2.24E-01 & 2.59E-01 & $2.04 E+01$ & $5.88 \mathrm{E}-01$ & $7.68 E+03$ & $3.41 \mathrm{E}-01$ & $2.46 \mathrm{E}-02$ & $2.10 \mathrm{E}-01$ & $2.16 \mathrm{E}-02$ & $1.08 E-03$ & $E-03$ & E-04 & $2.24 E-03$ & $\mathrm{E}-03$ & $G E-03$ & $3.20 E-03$ \\
\hline \multirow[t]{3}{*}{$\mathbf{S 2 2}$} & $1.25 E+00$ & $1.25 E+00$ & $4.96 \mathrm{E}+01$ & $1.25 E+00$ & $5.91 E+03$ & $4.97 E-01$ & $3.28 E-02$ & $1.24 E+00$ & $1.25 E+00$ & $1.48 \mathrm{E}-03$ & $1.25 E+00$ & 4.18E-04 & 9.09E-03 & $3 E-03$ & $1.25 E+00$ & $1.25 E+00$ \\
\hline & & & & & & & & & & & & & & & & \\
\hline & & & & & & & & & & & & & & & & \\
\hline
\end{tabular}



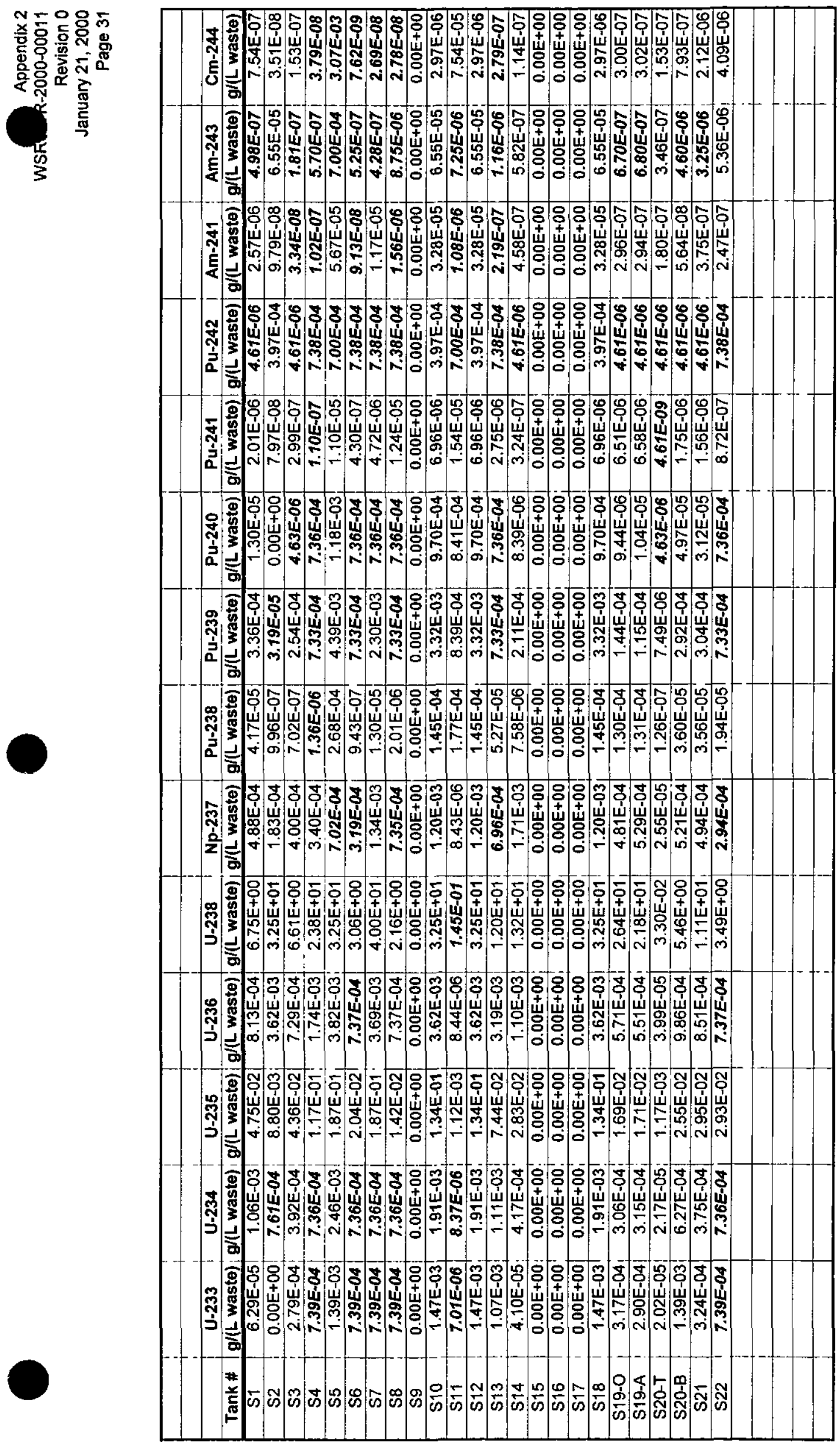

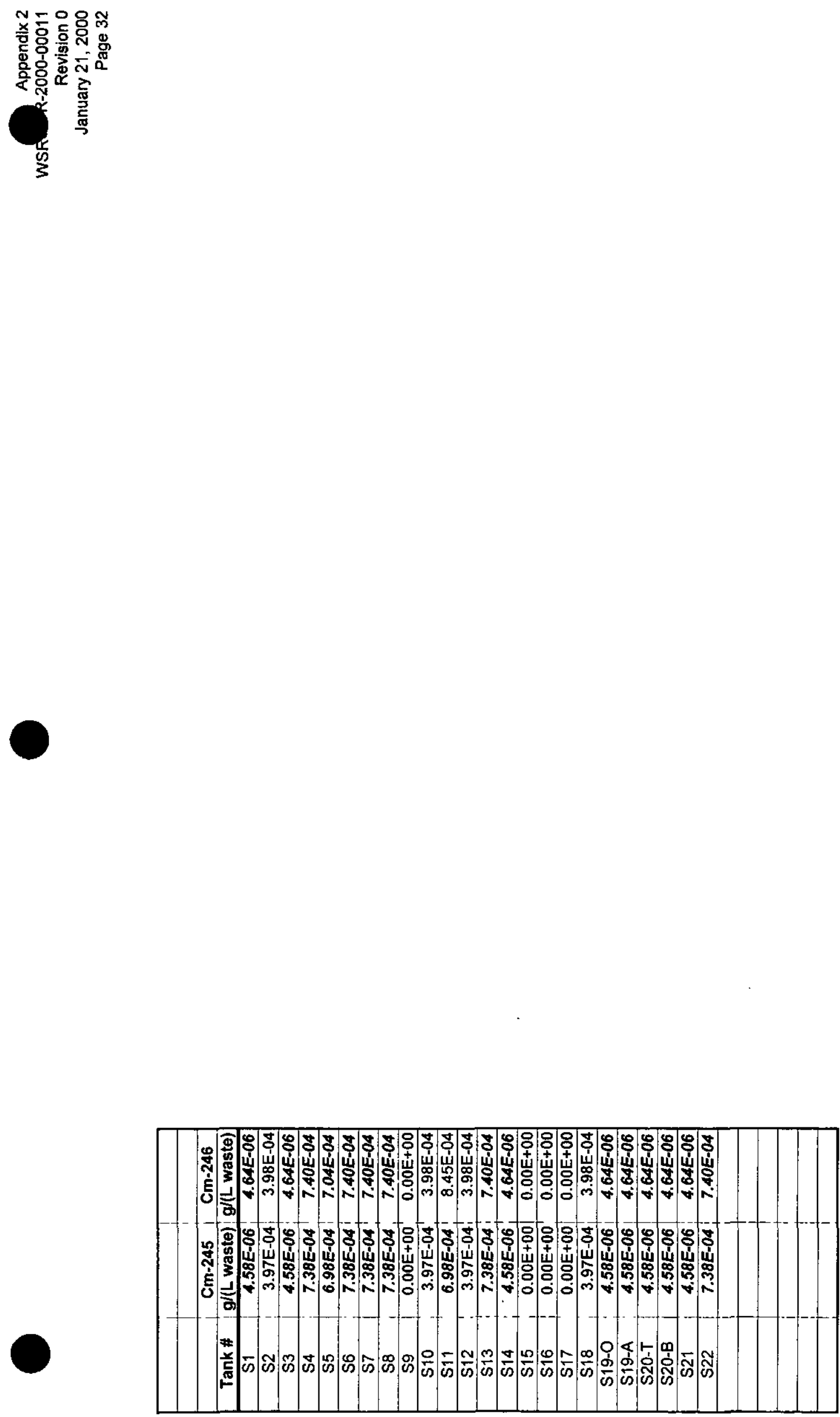


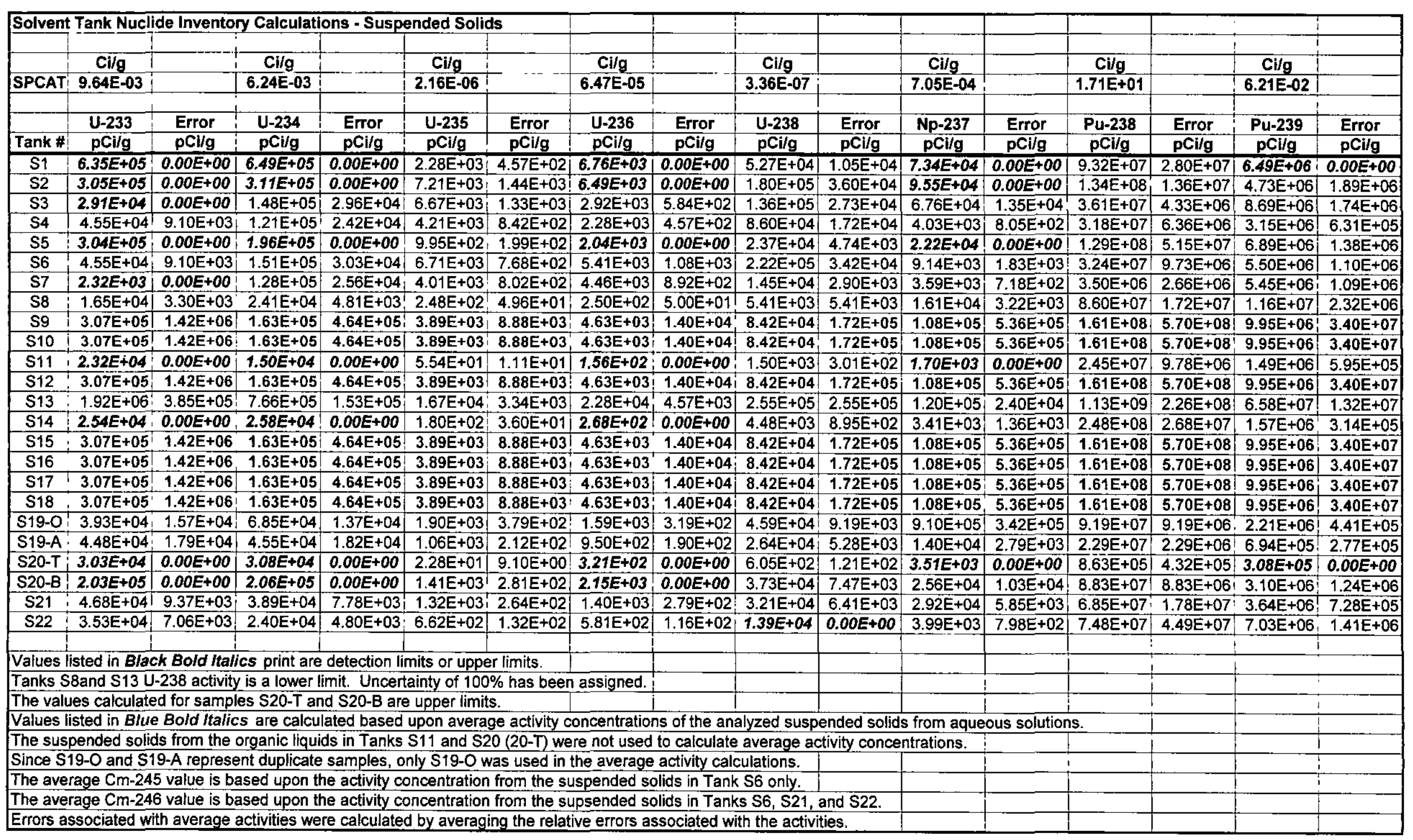




\begin{tabular}{|c|c|c|c|c|c|c|c|c|c|c|c|c|c|c|c|}
\hline & & & & & & & & & & & & & $T$ & & \\
\hline & & & & & & & & & & & & & & & \\
\hline $\mathrm{Ci} / \mathrm{g}$ & & $\mathrm{Ci} / \mathrm{g}$ & & $\mathrm{Cilg}$ & & $\mathrm{Ci} / \mathrm{g}$ & & $\mathrm{Ci} / \mathrm{g}$ & & $\mathrm{Ci} / \mathrm{g}$ & & $\mathrm{Ci} / \mathrm{g}$ & & $\mathrm{Ci} / \mathrm{g}$ & \\
\hline 2.27E-01 & & $1.03 \mathrm{E}+02$ & & $3.93 \mathrm{E}-03$ & & $3.44 E+00$ & & $2.00 \mathrm{E}-01$ & & $8.10 E+01$ & & $1.72 \mathrm{E}-01$ & & 3.04E-01 & \\
\hline Pu-240 & Error & Pu-241 & Error & Pu-242 & Error & Am-241 & Error & $\mathrm{Am}-243$ & Error & $\mathrm{Cm}-244$ & Error & $\mathrm{Cm}-245$ & Error & $\mathrm{Cm}-246$ & Etror \\
\hline pCi/g & $\mathrm{pCi} / \mathrm{g}$ & $\mathrm{pCi} / \mathrm{g}$ & $\mathrm{pCl} / \mathrm{g}$ & $\mathrm{pCi} / \mathrm{g}$ & $\mathrm{pCi} / \mathrm{g}$ & $\mathrm{pCi} / \mathrm{g}$ & $\mathrm{pCi} / \mathrm{g}$ & $\mathrm{pCi} / \mathrm{g}$ & $\mathrm{pCi} / \mathrm{g}$ & $\mathrm{pCi} / \mathrm{g}$ & $\mathrm{pCi} / \mathrm{g}$ & $\mathrm{pCl} / \mathrm{g}$ & $\mathrm{pCi} / \mathrm{g}$ & $\mathrm{pCi} / \mathrm{g}$ & $\mathrm{pCi} / \mathrm{g}$ \\
\hline $2.36 E+07$ & $0.00 E+00$ & $3.57 E+07$ & $3.78 \mathrm{E}+07$ & $4.10 E+05$ & $0.00 E+00$ & $5.05 E+06$ & $0.00 E+00$ & $2.08 E+07$ & $0.00 E+00$ & $1.18 \mathrm{E}+08$ & $2.17 E+07$ & $1.79 E+07$ & $0.00 E+00$ & $3.18 E+07$ & $0.00 E+00$ \\
\hline $9.73 E+06$ & $0.00 E+00$ & $3.53 E+07$ & $0.00 E+00$ & $1.69 E+05$ & $0.00 E+00$ & $2.31 \mathrm{E}+06$ & $3.95 \mathrm{E}+05$ & $8.56 E+06$ & $0.00 E+00$ & $2.54 \mathrm{E}+07$ & $5.07 \mathrm{E}+06$ & $7.39 E+06$ & $0.00 E+00$ & $1.31 E+07$ & $0.00 E+00$ \\
\hline $2.97 \mathrm{E}+06$ & $5.94 \mathrm{E}+05$ & $1.01 \mathrm{E}+07$ & $2.84 E+06$ & $1.87 E+04$ & $0.00 E+00$ & $1.06 \mathrm{E}+06$ & $2.71 E+05$ & $5.32 \mathrm{E}+05$ & $7.91 \mathrm{E}+04$ & $9.46 \mathrm{E}+07$ & $9.46 \mathrm{E}+06$ & $8.20 E+05$ & $0.00 E+00$ & $1.46 E+06$ & $0.00 E+00$ \\
\hline $1.35 \mathrm{E}+06$ & $2.69 \mathrm{E}+05$ & $9.01 \mathrm{E}+06$ & $3.60 \mathrm{E}+06$ & $7.30 E+03$ & $0.00 E+00$ & $2.58 \mathrm{E}+05$ & $4.44 E+04$ & $3.71 E+05$ & $0.00 E+00$ & $3.23 \mathrm{E}+05$ & $1.94 \mathrm{E}+05$ & $3.19 E+05$ & $0.00 E+00$ & $5.68 E+05$ & $0.00 E+00$ \\
\hline $1.01 \mathrm{E}+07$ & $2.02 E+06$ & $9.28 E+06$ & $0.00 E+00$ & $1.24 E+05$ & $0.00 E+00$ & $2.97 \mathrm{E}+06$ & $2.96 E+05$ & $1.69 \mathrm{E}+06$ & $1.29 \mathrm{E}+05$ & $2.55 E+09$ & $0.00 E+00$ & $5.41 E+06$ & $0.00 E+00$ & $9.64 E+06$ & $0.00 E+00$ \\
\hline $8.78 \mathrm{E}+05$ & $1.76 \mathrm{E}+05$ & $5.77 \mathrm{E}+06$ & $2.65 \mathrm{E}+06$ & $1.31 \mathrm{E}+03$ & $2.62 \mathrm{E}+02$ & $6.71 \mathrm{E}+05$ & $4.05 \mathrm{E}+04$ & $5.90 \mathrm{E}+04$ & $1.18 \mathrm{E}+04$ & $1.09 E+06$ & $2.18 \mathrm{E}+05$ & $2.26 \mathrm{E}+04$ & $4.51 E+03$ & $5.00 \mathrm{E}+04$ & $1.00 E+04$ \\
\hline $1.26 \mathrm{E}+06$ & $2.51 \mathrm{E}+05$ & $1.23 E+07$ & $4.92 E+06$ & $2.09 \mathrm{E}+03$ & $4.19 \mathrm{E}+02$ & $9.64 \mathrm{E}+05$ & $5.21 \mathrm{E}+04$ & $4.82 E+04$ & $0.00 E+00$ & $7.57 E+04$ & $0.00 E+00$ & $4.14 E+04$ & $0.00 E+00$ & $7.34 E+04$ & $0.00 E+00$ \\
\hline $2.85 E+06$ & $5.70 E+05$ & $1.01 \mathrm{E}+07$ & $4.05 E+06$ & $2.26 E+03$ & $0.00 E+00$ & $1.95 E+06$ & $1.15 \mathrm{E}+05$ & $1.14 E+05$ & $0.00 E+00$ & $9.01 \mathrm{E}+05$ & $1.80 \mathrm{E}+05$ & $9.86 E+04$ & $0.00 E+00$ & $1.75 E+05$ & $0.00 E+00$ \\
\hline $1.03 E+07$ & $3.18 \mathrm{E}+07$ & $5.07 E+07$ & $2.26 E+08$ & $2.59 \mathrm{E}+04$ & $8.88 \mathrm{E}+04$ & $6.42 \mathrm{E}+06$ & $2.28 \mathrm{E}+07$ & $2.62 \mathrm{E}+06$ & $8.50 \mathrm{E}+06$ & $2.62 \mathrm{E}+08$ & $1.04 E+09$ & $3.07 \mathrm{E}+06$ & $0.00 \mathrm{E}+00$ & $6.47 E+06$ & $0.00 \mathrm{E}+00$ \\
\hline $1.03 E+07$ & $3.18 E+07$ & $5.07 \mathrm{E}+07$ & $2.26 \mathrm{E}+08$ & $2.59 \mathrm{E}+04$ & $8.88 E+04$ & $6.42 \mathrm{E}+06$ & $2.28 \mathrm{E}+07$ & $2.62 \mathrm{E}+06$ & $8.50 \mathrm{E}+06$ & $2.62 \mathrm{E}+08$ & $1.04 \mathrm{E}+09$ & $3.07 E+06$ & $0.00 \mathrm{E}+00$ & $6.47 E+06$ & $0.00 E+00$ \\
\hline $8.06 E+05$ & $3.23 E+05$ & $9.46 \mathrm{E}+06$ & $3.78 \mathrm{E}+06$ & $9.50 E+03$ & $0.00 E+00$ & $1.59 \mathrm{E}+06$ & $1.30 \mathrm{E}+05$ & $1.74 \mathrm{E}+05$ & $2.68 E+04$ & $6.81 \mathrm{E}+07$ & $1.36 \mathrm{E}+07$ & $4.14 E+05$ & $0.00 E+00$ & $7.39 E+05$ & $0.00 E+00$ \\
\hline $1.03 E+07$ & $3.18 E+07$ & $5.07 \mathrm{E}+07$ & $2.26 \mathrm{E}+08$ & $2.59 \mathrm{E}+04$ & $8.88 \mathrm{E}+04$ & $6.42 \mathrm{E}+06$ & $2.28 \mathrm{E}+07$ & $2.62 \mathrm{E}+06$ & $8.50 \mathrm{E}+06$ & $2.62 \mathrm{E}+08$ & $1.04 E+09$ & $3.07 E+06$ & $0.00 \mathrm{E}+00$ & $6.47 \mathrm{E}+06$ & $0.00 E+00$ \\
\hline $2.48 \mathrm{E}+07$ & $4.95 E+06$ & $3.90 \mathrm{E}+08$ & $1.56 \mathrm{E}+08$ & $9.23 E+04$ & $1.85 E+04$ & $4.09 E+07$ & $2.02 E+06$ & $8.11 E+05$ & $0.00 E+00$ & $1.16 E+07$ & $0.00 E+00$ & $6.94 E+05$ & $0.00 E+00$ & $1.24 E+06$ & $0.00 E+00$ \\
\hline $3.16 E+06$ & $1.26 \mathrm{E}+06$ & $2.75 E+05$ & $0.00 E+00$ & $1.63 E+04$ & $0.00 E+00$ & $1.86 E+07$ & $9.71 \mathrm{E}+05$ & $1.08 \mathrm{E}+06$ & $4.31 E+05$ & $1.36 \mathrm{E}+08$ & $1.36 \mathrm{E}+07$ & $7.12 E+05$ & $0.00 E+00$ & $1.27 E+06$ & $0.00 E+00$ \\
\hline $1.03 E+07$ & $3.18 \mathrm{E}+07$ & $5.07 \mathrm{E}+07$ & $2.26 \mathrm{E}+08$ & $2.59 \mathrm{E}+04$ & $8.88 \mathrm{E}+04$ & $6.42 \mathrm{E}+06$ & $2.28 \mathrm{E}+07$ & $2.62 \mathrm{E}+06$ & $8.50 E+06$ & $2.62 E+08$ & $1.04 E+09$ & $3.07 E+06$ & $0.00 E+00$ & $6.47 \mathrm{E}+06$ & $0.00 E+00$ \\
\hline $1.03 E+07$ & $3.18 E+07$ & $5.07 \mathrm{E}+07$ & $2.26 \mathrm{E}+08$ & $2.59 \mathrm{E}+04$ & $8.88 \mathrm{E}+04$ & $6.42 \mathrm{E}+06$ & $2.28 \mathrm{E}+07$ & $2.62 \mathrm{E}+06$ & $8.50 \mathrm{E}+06$ & $2.62 \mathrm{E}+08$ & $1.04 \mathrm{E}+09$ & $3.07 E+06$ & $0.00 \mathrm{E}+00$ & $6.47 E+06$ & $0.00 \mathrm{E}+00$ \\
\hline $1.03 \mathrm{E}+07$ & $3.18 E+07$ & 5.07E+07 & $2.26 \mathrm{E}+08$ & $2.59 E+04$ & $8.88 \mathrm{E}+04$ & $6.42 E+06$ & $2.28 \mathrm{E}+07$ & $2.62 \mathrm{E}+06$ & $8.50 \mathrm{E}+06$ & $2.62 E+08$ & $1.04 \mathrm{E}+09$ & $3.07 \mathrm{E}+06$ & $0.00 \mathrm{E}+00$ & $6.47 \mathrm{E}+06$ & $0.00 \mathrm{E}+00$ \\
\hline $1.03 E+07$ & $3.18 E+07$ & 5.07E+07 & $2.26 \mathrm{E}+08$ & $2.59 E+04$ & $8.88 \mathrm{E}+04$ & $6.42 \mathrm{E}+06$ & $2.28 \mathrm{E}+07$ & $2.62 E+06$ & $8.50 \mathrm{E}+06$ & $2.62 E+08$ & $1.04 E+09$ & $3.07 \mathrm{E}+06$ & $0.00 \mathrm{E}+00$ & $6.47 \mathrm{E}+06$ & $0.00 E+00$ \\
\hline $2.92 \mathrm{E}+06$ & $5.85 \mathrm{E}+05$ & $2.86 \mathrm{E}+07$ & $9.15 \mathrm{E}+06$ & $2.18 E+04$ & $0.00 E+00$ & $4.14 \mathrm{E}+06$ & $4.43 E+05$ & $5.45 \mathrm{E}+05$ & $1.05 \mathrm{E}+05$ & $1.18 \mathrm{E}+08$ & $1.18 E+07$ & $9.50 E+05$ & $0.00 E+00$ & $1.69 E+06$ & $0.00 E+00$ \\
\hline $1.43 E+06$ & $0.00 E+00$ & $1.36 \mathrm{E}+07$ & $6.26 \mathrm{E}+06$ & $2.47 E+04$ & $0.00 E+00$ & $1.01 \mathrm{E}+06$ & $2.22 \mathrm{E}+05$ & $1.26 E+06$ & $0.00 E+00$ & $3.03 E+07$ & $3.03 E+06$ & $1.08 E+06$ & $0.00 E+00$ & $1.92 E+06$ & $0.00 E+00$ \\
\hline $1.13 E+06$ & $0.00 E+00$ & $1.66 \mathrm{E}+05$ & $3.34 \mathrm{E}+05$ & $1.94 E+04$ & $0.00 E+00$ & $1.71 E+05$ & $0.00 E+00$ & $9.92 E+05$ & $0.00 E+00$ & $1.26 \mathrm{E}+06$ & $1.26 E+05$ & $8.49 E+05$ & $0.00 E+00$ & $1.51 E+06$ & $0.00 E+00$ \\
\hline $7.52 E+06$ & $0.00 E+00$ & $2.12 \mathrm{E}+07$ & $5.52 E+06$ & $1.31 E+05$ & $0.00 E+00$ & $2.01 \mathrm{E}+06$ & $8.52 E+05$ & $6.62 E+06$ & $0.00 E+00$ & $8.06 E+07$ & $8.06 E+06$ & $5.27 E+06$ & $0.00 E+00$ & $1.01 E+07$ & $0.00 E+00$ \\
\hline $9.77 E+06$ & $1.95 E+06$ & $2.05 \mathrm{E}+07$ & $7.38 \mathrm{E}+06$ & $2.74 E+03$ & $0.00 E+00$ & $3.36 \mathrm{E}+06$ & $2.11 \mathrm{E}+05$ & $2.32 \mathrm{E}+06$ & $4.64 E+05$ & $5.32 E+08$ & $1.06 \mathrm{E}+08$ & $1.20 E+05$ & $0.00 E+00$ & $2.48 E+06$ & $9.93 E+04$ \\
\hline $5.32 \mathrm{E}+07$ & $1.06 \mathrm{E}+07$ & $1.45 \mathrm{E}+07$ & $1.02 E+07$ & $7.84 \mathrm{E}+03$ & 1.57E+03 & $4.27 \mathrm{E}+06$ & $3.50 \mathrm{E}+05$ & $1.21 \mathrm{E}+07$ & $2.42 \mathrm{E}+06$ & $1.77 \mathrm{E}+09$ & $7.10 E+08$ & $2.32 E+05$ & $0.00 E+00$ & $1,15 E+06$ & $2.30 \mathrm{E}+05$ \\
\hline & & & & & & & & & & & & & & & \\
\hline & & & & & & & & & & & & & & & \\
\hline & & & & & & & & & & & & & & & \\
\hline & & & & & & & & & & & & & & & \\
\hline i & & & & & & & & & & & & & & & \\
\hline T & & & & & & & & & & & & & & & \\
\hline 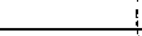 & & i & & & & & & & & & & & & & \\
\hline 4 & & 1 & & & & & & & & & & & & & \\
\hline & & & & & & & & & & & & & & & \\
\hline & & & & & & & & & & & & & & & \\
\hline
\end{tabular}


- 1 m ปิ

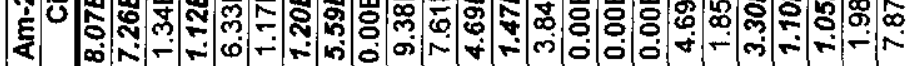

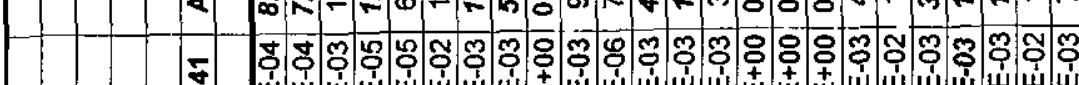

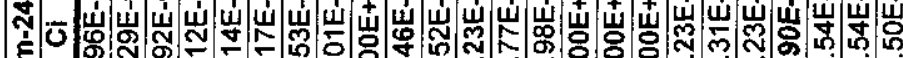
主 ₹-

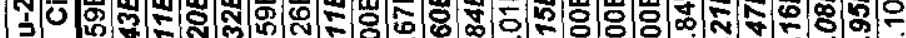
a F N N స̄ a N N Nंm

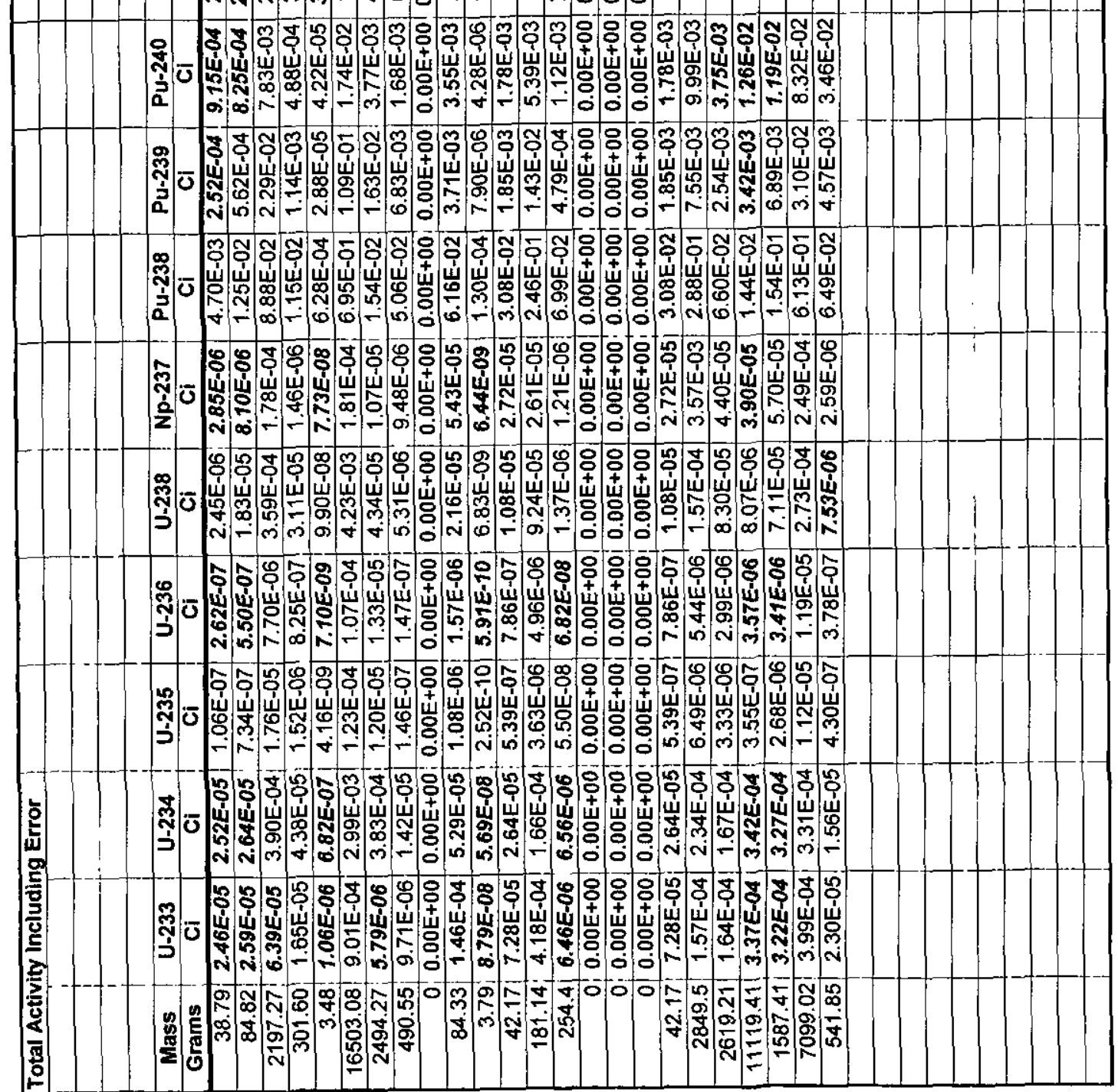




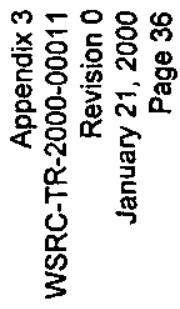

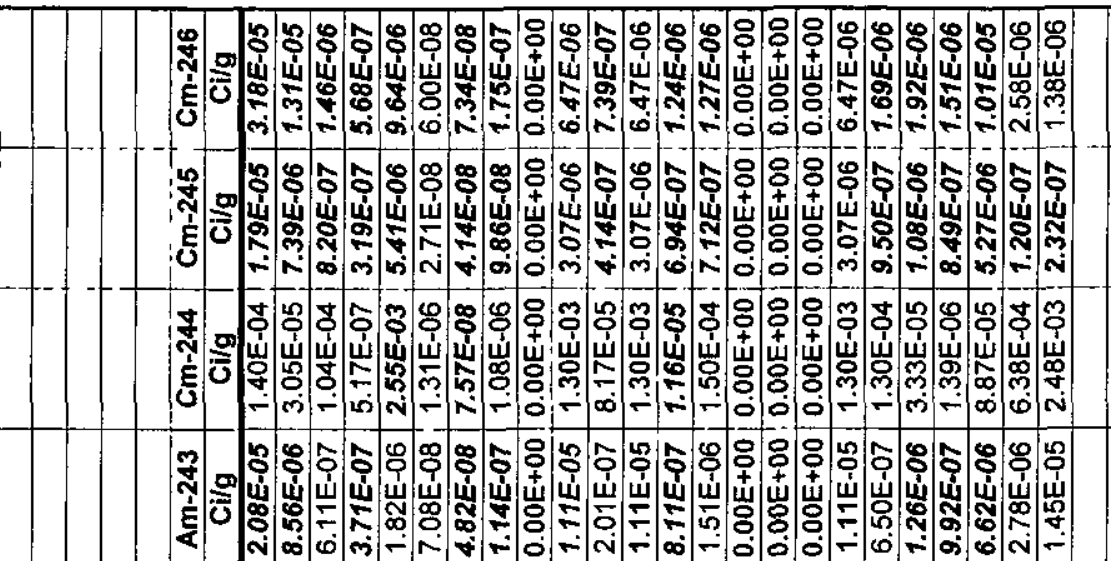

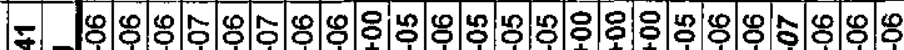

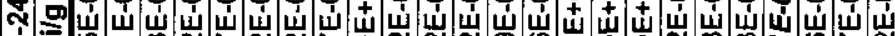

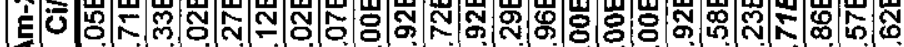

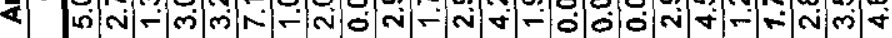

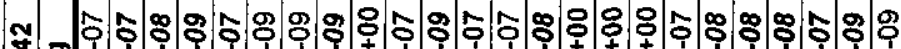

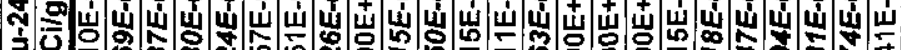

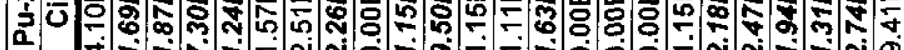

에

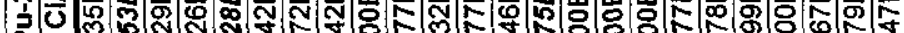

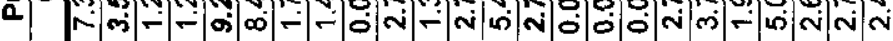

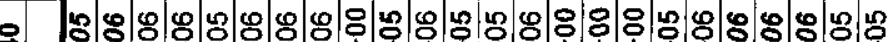

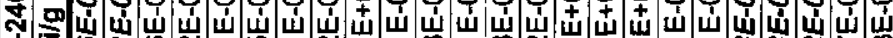
సै

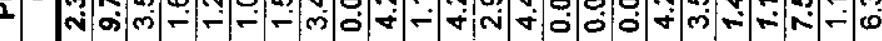

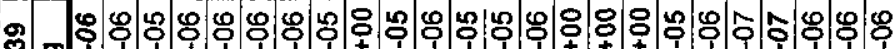

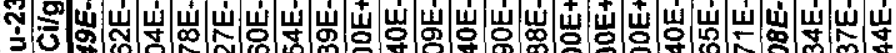
(1)

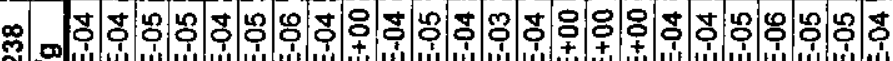

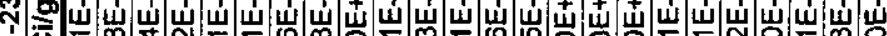
ju

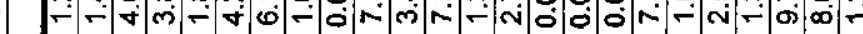

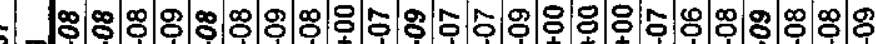
กิ

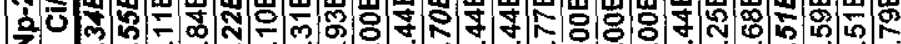

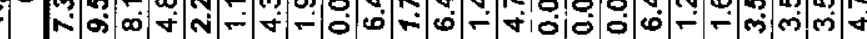

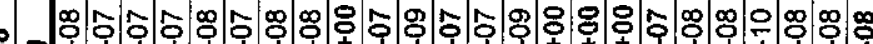

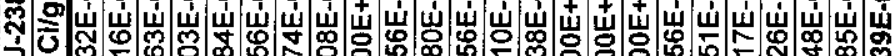

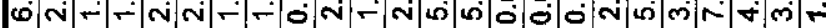

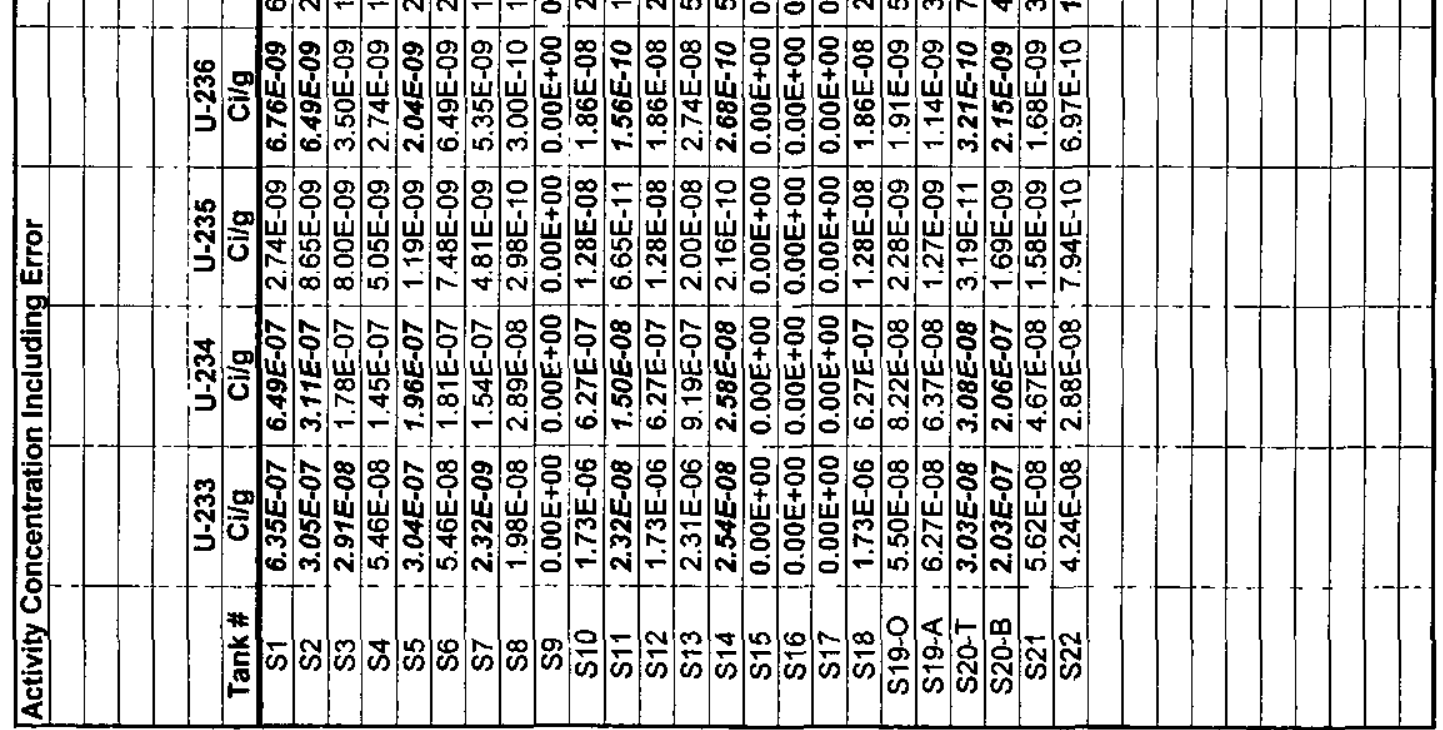




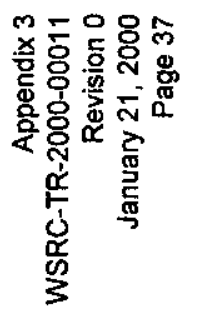

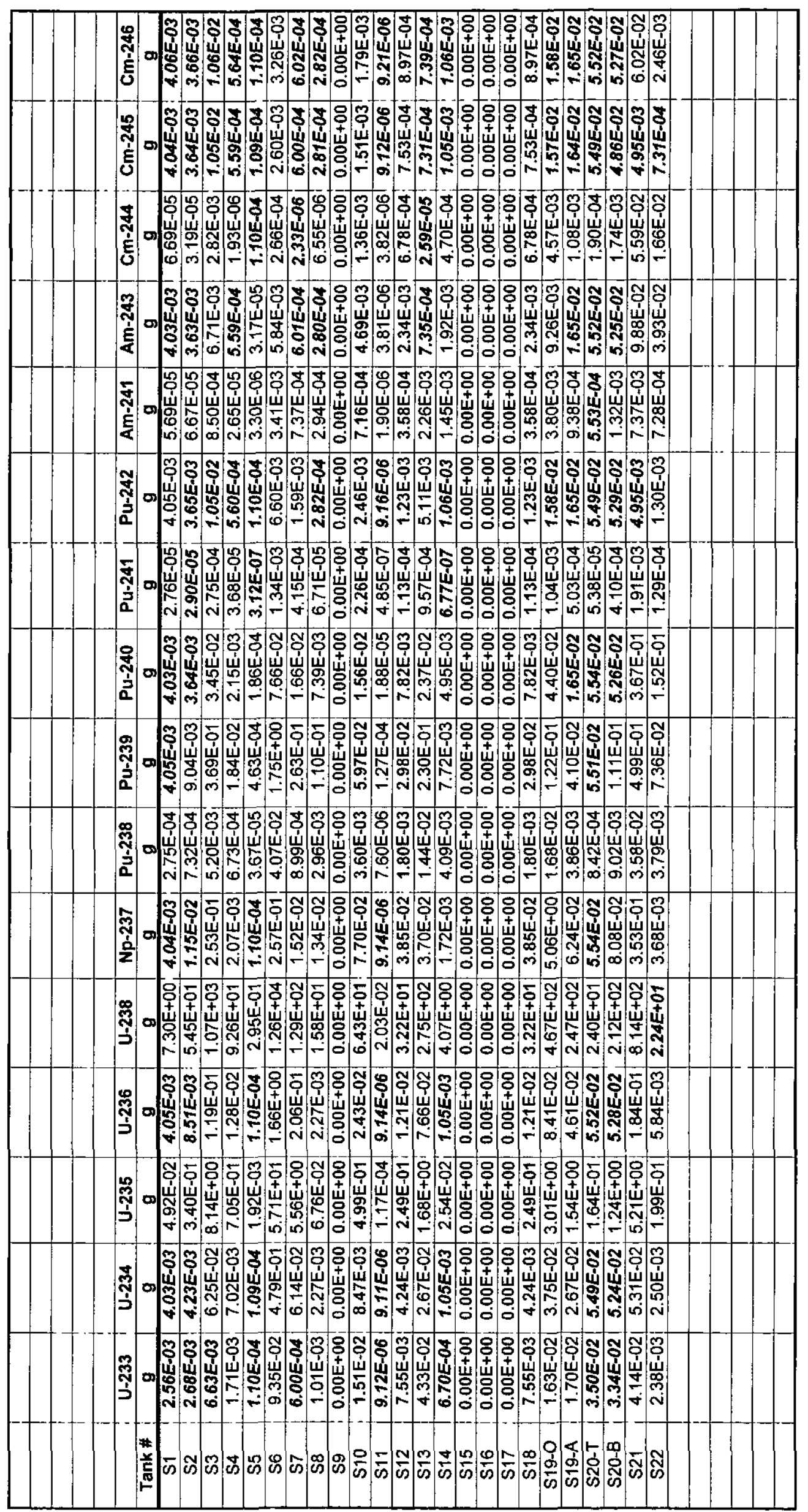




\begin{tabular}{|c|c|c|c|c|c|c|c|c|c|c|c|c|c|c|}
\hline & & & & & & & & & & & & & & \\
\hline & & & & & & & & & & & & & & \\
\hline & $U-233$ & U-234 & U-235 & $U-236$ & U-238 & Np-237 & Pu-238 & Pu-239 & Pu-240 & Pu-241 & Pu-242 & Am-241 & Am-243 & $\mathrm{Cm}-244$ \\
\hline Tank \# & $\mathrm{g} /$ (g waste) & g/(g waste) & g/(g waste) & g/(g waste) & g/(g waste) & g/(g waste) & g/(g waste) & g/(g waste) & $g /(g$ wast $\theta)$ & g/(g wast $\theta)$ & gl(g waste $)$ & g/(g waste $)$ & g/(g waste $)$ & $g /(g$ waste $)$ \\
\hline S1 & $6.59 E-05$ & 1.04E-04 & $1.27 \mathrm{E}-03$ & $1.04 E-04$ & $1.88 \mathrm{E}-01$ & $1.04 E-04$ & 7.09E-06 & $1.05 E-04$ & 1.04E-04 & 7.11E-07 & $1.04 E-04$ & $1.47 E-06$ & $1.04 E-04$ & $1.72 \mathrm{E}-06$ \\
\hline S2 & $3.16 E-05$ & $4.98 E-05$ & $4.00 \mathrm{E}-03$ & $1.00 \mathrm{E}-04$ & $6.43 \mathrm{E}-01$ & $1.35 E-04$ & $8.63 \mathrm{E}-06$ & $1.07 \mathrm{E}-04$ & $4.29 E-05$ & $3.41 E-07$ & $4.30 E-05$ & $7.86 \mathrm{E}-07$ & $4.28 E-05$ & $3.76 \mathrm{E}-07$ \\
\hline S3 & $3.02 E-06$ & $2.85 \mathrm{E}-05$ & $3.70 \mathrm{E}-03$ & $5.42 \mathrm{E}-05$ & $4.86 \mathrm{E}-01$ & $1.15 \mathrm{E}-04$ & $2.36 \mathrm{E}-06$ & $1.68 \mathrm{E}-04$ & $1.57 \mathrm{E}-05$ & 1.25E-07 & $4.76 E-06$ & $3.87 \mathrm{E}-07$ & $3.06 \mathrm{E}-06$ & $1.28 E-06$ \\
\hline S4 & $5.66 \mathrm{E}-06$ & $2.33 \mathrm{E}-05$ & $2.34 \mathrm{E}-03$ & $4.23 \mathrm{E}-05$ & $3.07 \mathrm{E}-01$ & $6.86 \mathrm{E}-06$ & $2.23 \mathrm{E}-06$ & $6.09 \mathrm{E}-05$ & $7.13 \mathrm{E}-06$ & 1.22E-07 & $1.86 \mathrm{E}-06$ & $8.79 \mathrm{E}-08$ & $1.86 \mathrm{E}-06$ & $6.38 \mathrm{E}-09$ \\
\hline S5 & $3.15 E-05$ & $3.14 E-05$ & $5.53 \mathrm{E}-04$ & $3.15 E=05$ & $8.46 \mathrm{E}-02$ & $3.15 E-05$ & $1.06 \mathrm{E}-05$ & $1.33 \mathrm{E}-04$ & $5.34 \mathrm{E}-05$ & $8.97 E-08$ & $3.16 E-05$ & $9.49 \mathrm{E}-07$ & $9.10 \mathrm{E}-06$ & $3.15 E-05$ \\
\hline S6 & $5.66 \mathrm{E}-06$ & $2.91 \mathrm{E}-05$ & $3.46 \mathrm{E}-03$ & $1.00 \mathrm{E}-04$ & $7.63 \mathrm{E}-01$ & 1.56E-05 & $2.46 \mathrm{E}-06$ & $1.06 \mathrm{E}-04$ & $4.64 \mathrm{E}-06$ & $8.14 \mathrm{E}-08$ & $4.00 \mathrm{E}-07$ & 2.07E-07 & $3.54 \mathrm{E}-07$ & $1.61 \mathrm{E}-08$ \\
\hline S7 & 2.41E-07 & $2.46 \mathrm{E}-05$ & $2.23 E-03$ & $8.27 \mathrm{E}-05$ & $5.18 \mathrm{E}-02$ & $6.11 \mathrm{E}-06$ & $3.60 \mathrm{E}-07$ & $1.05 \mathrm{E}-04$ & $6.66 \mathrm{E}-06$ & $1.67 \mathrm{E}-07$ & $6.38 \mathrm{E}-07$ & $2.95 \mathrm{E}-07$ & 2.41E-07 & $9.35 E-10$ \\
\hline S8 & $2.05 \mathrm{E}-06$ & $4.63 \mathrm{E}-06$ & $1.38 \mathrm{E}-04$ & $4.64 \mathrm{E}-06$ & $3.22 \mathrm{E}-02$ & $2.74 \mathrm{E}-05$ & $6.04 \mathrm{E}-06$ & $2.24 \mathrm{E}-04$ & 1.51E-05 & 1.37E-07 & 5.75E-07 & $6.00 \mathrm{E}-07$ & $5.70 E-07$ & $1.33 \mathrm{E}-08$ \\
\hline s9 & $0.00 E+00$ & $0.00 \mathrm{E}+00$ & $0.00 \mathrm{E}+00$ & $0.00 \mathrm{E}+00$ & $0.00 \mathrm{E}+00$ & $0.00 \mathrm{E}+00$ & $0.00 \mathrm{E}+00$ & $0.00 \mathrm{E}+00$ & $0.00 \mathrm{E}+00$ & $0.00 E+00$ & $0.00 E+00$ & $0.00 \mathrm{E}+00$ & $0.00 \mathrm{E}+00$ & $0.00 \mathrm{E}+00$ \\
\hline S10 & $1.79 \mathrm{E}-04$ & $1.00 \mathrm{E}-04$ & $5.91 \mathrm{E}-03$ & $2.88 \mathrm{E}-04$ & 7.63E-01 & $9.13 \mathrm{E}-04$ & 4.27E-05 & $7.08 \mathrm{E}-04$ & $1.85 E-04$ & $2.68 \mathrm{E}-06$ & 2.92E-05 & $8.49 \mathrm{E}-06$ & $5.56 \mathrm{E}-05$ & 1.61E-05 \\
\hline S11 & 2.41E-06 & $2.40 E-06$ & $3.08 \mathrm{E}-05$ & 2.41E-06 & $5.36 \mathrm{E}-03$ & 2.41E-06 & $2.00 \mathrm{E}-06$ & $3.36 \mathrm{E}-05$ & 4.97E-06 & $1.28 \mathrm{E}-07$ & $2.42 E-06$ & $5.00 \mathrm{E}-07$ & $1.00 \mathrm{E}-06$ & $1.01 E-06$ \\
\hline $\mathrm{S} 12$ & $1.79 E-04$ & $1.00 \mathrm{E}-04$ & 5.91E-03 & 2.88E-04 & $7.63 \mathrm{E}-\overline{01}$ & $9.13 E-04$ & $4.27 \mathrm{E}-05$ & $7.08 E-04$ & $1.85 \bar{E}-04$ & $2.68 \mathrm{E}-06$ & $2.92 \mathrm{E}-05$ & $8.49 E-06$ & $5.56 \mathrm{E}-05$ & $1.61 \mathrm{E}-05$ \\
\hline 513 & $2.39 \mathrm{E}-04$ & $1.47 \mathrm{E}-04$ & $9.28 \mathrm{E}-03$ & $4.23 \mathrm{E}-04$ & $1.52 \mathrm{E}+00$ & 2.04E-04 & $7.93 \mathrm{E}-05$ & $1.27 \mathrm{E}-03$ & 1.31E-04 & $5.28 \mathrm{E}-06$ & $2.82 \mathrm{E}-05$ & $1.25 \mathrm{E}-05$ & $4.06 E-06$ & $1.43 E-07$ \\
\hline S14 & $2.63 E-06$ & 4.13E-06 & $1.00 \mathrm{E}-04$ & 4.14E-06 & $1.60 \mathrm{E}-02$ & $6.77 \mathrm{E}-06$ & 1.61E-05 & $3.03 \mathrm{E}-05$ & $1.95 \mathrm{E}-05$ & $2.66 E-09$ & 4.15E-06 & $5.69 \mathrm{E}-06$ & $7.56 \mathrm{E}-06$ & $1.85 \mathrm{E}-06$ \\
\hline S15 & $0.00 E+00$ & $0.00 \mathrm{E}+00$ & $0.00 \mathrm{E}+00$ & $0.00 E+00$ & $0.00 E+00$ & $0.00 \mathrm{E}+00$ & $0.00 \mathrm{E}+00$ & $0.00 E+00$ & $0.00 \mathrm{E}+00$ & $0.00 \mathrm{E}+00$ & $0.00 \mathrm{E}+00$ & $0.00 \mathrm{E}+00$ & $0.00 \mathrm{E}+00$ & $0.00 \mathrm{E}+00$ \\
\hline S16 & $0.00 E+00$ & $0.00 \mathrm{E}+00$ & $0.00 \mathrm{E}+00$ & $0.00 E+00$ & $0.00 \mathrm{E}+00$ & $0.00 \mathrm{E}+00$ & $0.00 \mathrm{E}+00$ & $0.00 E+00$ & $0.00 \mathrm{E}+00$ & $0.00 \mathrm{E}+00$ & $0.00 \mathrm{E}+00$ & $0.00 E+00$ & $0.00 E+00$ & $0.00 E+00$ \\
\hline S17 & $0.00 E+00$ & $0.00 E+00$ & $0.00 \mathrm{E}+00$ & $0.00 \mathrm{E}+00$ & $0.00 \mathrm{E}+00$ & $0.00 \mathrm{E}+00$ & $0.00 \mathrm{E}+00$ & $0.00 E+00$ & $0.00 \mathrm{E}+00$ & $0.00 \mathrm{E}+00$ & $0.00 E+00$ & $0.00 E+00$ & $0.00 \mathrm{E}+00$ & $0.00 E+00$ \\
\hline S18 & $1.79 \mathrm{E}-04$ & $1.00 \mathrm{E}-04$ & $5.91 \mathrm{E}-03$ & $2.88 \mathrm{E}-04$ & $7.63 \mathrm{E}-01$ & $9.13 \mathrm{E}-04$ & 4.27E-05 & $7.08 \mathrm{E}-04$ & $1.85 \mathrm{E}-04$ & $2.68 \mathrm{E}-06$ & $2.92 \mathrm{E}-05$ & 8.49E-06 & $5.56 \mathrm{E}-05$ & 1.61E-05 \\
\hline S19-0 & 5.71E-06 & $1.32 \mathrm{E}-05$ & $1.06 \mathrm{E}-03$ & $2.95 \mathrm{E}-05$ & $1.64 E-01$ & $1.78 \mathrm{E}-03$ & 5.91E-06 & $4.27 \mathrm{E}-05$ & $1.54 \mathrm{E}-05$ & $3.65 \mathrm{E}-07$ & 5.55E-06 & $1.33 \mathrm{E}-06$ & $3.25 \mathrm{E}-06$ & $1.60 \mathrm{E}-06$ \\
\hline S19-A & $6.50 \mathrm{E}-06$ & $1.02 E-05$ & $5.89 \mathrm{E}-04$ & 1.76E-05 & $9.43 E-02$ & $2.38 \mathrm{E}-05$ & $1.47 \mathrm{E}-06$ & $1.56 \mathrm{E}-05$ & $6.30 \mathrm{E}-06$ & $1.92 \mathrm{E}-07$ & $6.28 E-06$ & $3.58 \mathrm{E}-07$ & $6.30 E-06$ & $4.11 \mathrm{E}-07$ \\
\hline S20-T & $3.14 E-06$ & $4.94 E-06$ & $1.48 \mathrm{E}-05$ & $4.96 E-06$ & $2.16 \mathrm{E}-03$ & $4.98 E-06$ & 7.57E-08 & 4.96E-06 & $4.98 E-06$ & 4.84E-09 & $4.94 E-06$ & 4.97E-08 & $4.96 E-06$ & $1.71 \mathrm{E}-08$ \\
\hline S20-B & 2.11E-05 & $3.30 E-05$ & $7.83 E-04$ & $3.32 E-05$ & 1.33E-01 & 5.09E-05 & $5.68 \mathrm{E}-06$ & $6.99 E-05$ & $3.31 E-05$ & $2.58 \mathrm{E}-07$ & $3.33 E-05$ & 8.32E-07 & $3.31 E-05$ & $1.09 \mathrm{E}-06$ \\
\hline$S 21$ & $5.83 E-06$ & $7.48 \mathrm{E}-06$ & $7.33 E-04$ & $2.60 \mathrm{E}-05$ & 1.15E-01 & 4.97E-05 & $5.05 \mathrm{E}-06$ & $7.03 E-05$ & 5.16E-05 & $2.70 \mathrm{E}-07$ & $6.97 E-07$ & 1.04E-06 & $1.39 E-05$ & $7.88 \mathrm{E}-06$ \\
\hline \multirow[t]{11}{*}{$\$ 22$} & 4.39E-06 & $4.62 \mathrm{E}-06$ & $3.68 \mathrm{E}-04$ & $1.08 \mathrm{E}-05$ & $4.14 E-02$ & $6.79 \mathrm{E}-06$ & $7.00 \mathrm{E}-06$ & $1.36 E-04$ & 2.81E-04 & 2.39E-07 & 2.39E-06 & $1.34 E-0 \overline{6}$ & $7.26 \mathrm{E}-05$ & 3.06E-05 \\
\hline & & & & & & & & & & & & & & \\
\hline & & & & & & & & & & & & & & \\
\hline & & & & & & & & & & & & & & \\
\hline & & & & & & & & & & & & & & \\
\hline & & & it & & & & & & & & & & & \\
\hline & & & & & & & & & & & & & & \\
\hline & & & & & & & & & & & & & & \\
\hline & & & & & & & & & & & & & & 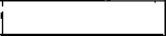 \\
\hline & & & & & & & & & & & & & & \\
\hline & & & & & & & & & & & & & & \\
\hline
\end{tabular}




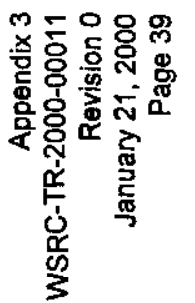

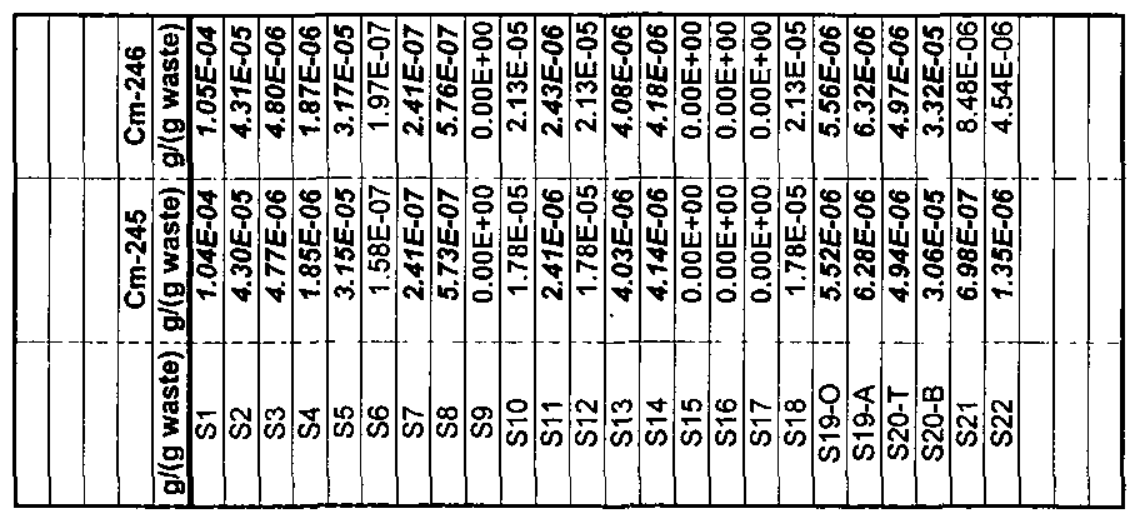




\begin{tabular}{|c|c|c|c|c|c|c|c|c|c|c|c|c|c|c|c|c|}
\hline \multicolumn{17}{|c|}{ Solvent Tank Nuclide Inventory Calculations - Sludge } \\
\hline & & & & & & & & & & & & & & & i & \\
\hline & $\mathrm{Ci} / \mathrm{g}$ & & $\mathrm{Ci} / \mathrm{g}$ & & $\mathrm{Ci} / \mathrm{g}$ & & $\mathrm{Ci} / \mathrm{g}$ & & $\mathrm{Ci} / \mathrm{g}$ & & $\mathrm{Ci} / \mathrm{g}$ & & $\mathrm{Ci} / \mathrm{g}$ & & $\mathrm{Ci} / \mathrm{g}$ & \\
\hline \multirow[t]{3}{*}{ SPCAT } & $9.64 E-03$ & & $6.24 E-03$ & & 2.16E-06 & & $6.47 \mathrm{E}-05$ & & $3.36 E-07$ & & 7.05E-04 & & $1.71 E+01$ & & $6.21 E-02$ & \\
\hline & & & & & & & & & & & & & & & & \\
\hline & U-233 & Error & U-234 & Error & U-235 & Error & U-236 & Error & U-238 & Error & Np-237 & Error & Pu-238 & Error & Pu-239 & Error \\
\hline Tank\#! & $\mathrm{pCi} / \mathrm{g}$ & pCi/g & $\mathrm{pCi} / \mathrm{g}$ & $\mathrm{pCi} / \mathrm{g}$ & $\mathrm{pCi} / \mathrm{g}$ & $\mathrm{pCi} / \mathrm{g}$ & $\mathrm{pCi} / \mathrm{g}$ & pCilg & $\mathrm{pCi} / \mathrm{g}$ & $\mathrm{pCi} / \mathrm{g}$ & $\mathrm{pCl} / \mathrm{g}$ & $\mathrm{pCi} / \mathrm{g}$ & $\mathrm{pCi} / \mathrm{g}$ & $\mathrm{pCi} / \mathrm{g}$ & $\mathrm{pCi} / \mathrm{g}$ & $\mathrm{pCi} / \mathrm{g}$ \\
\hline$\overline{S 1}$ & $2.06 \mathrm{E}+05$ & $4.12 E+04$ & $5.02 E+04$ & $1.43 E+05$ & $6.19 \mathrm{E}+02$ & $1.96 \mathrm{E}+03$ & $1.08 E+03$ & $2.30 \mathrm{E}+03$ & \multicolumn{2}{|c|}{$1.90 \mathrm{E}+0414.00 \mathrm{E}+04$} & $2.38 E+03$ & $4.46 E+03$ & $1.36 \mathrm{E}+07$ & $4.38 E+07$ & $4.69 E+05$ & $7.40 E+05$ \\
\hline S2 & $5.90 E+03$ & $0.00 E+00$ & $1.01 E+04$ & $0.00 E+00$ & $3.46 \mathrm{E}+01$ & $6.92 \mathrm{E}+00$ & $3.97 E+01$ & $0.00 E+00$ & $8.24 E+02$ & $1.65 \mathrm{E}+02$ & $1.07 E+03$ & $0.00 E+00$ & $5.95 E+07$ & $2.38 \mathrm{E}+07$ & $3.05 E+05$ & \multirow{2}{*}{$\begin{array}{l}0.00 \mathrm{E}+00 \\
7.40 \mathrm{E}+05\end{array}$} \\
\hline s3 & $2.06 \mathrm{E}+05$ & $4.12 E+04$ & $5.02 \mathrm{E}+04$ & $1.43 \mathrm{E}+05$ & $6.19 \mathrm{E}+02$ & $1.96 \mathrm{E}+03$ & $1.08 \mathrm{E}+03$ & $2.30 \mathrm{E}+03$ & $1.90 \mathrm{E}+04$ & $4.00 E+04$ & $2.38 \mathrm{E}+03$ & $4.46 \mathrm{E}+03$ & $1.36 \mathrm{E}+07$ & $4.38 E+07$ & $4.69 \mathrm{E}+05$ & \\
\hline S4(1) & $0.00 E+00$ & $0.00 \mathrm{E}+00$ & $9.23 E+06$ & $5.54 E+06$ & $3.57 E+05$ & $0.00 E+00$ & $1.08 E+03$ & $2.30 \mathrm{E}+03$ & $9.23 E+06$ & $5.54 \mathrm{E}+06$ & $3.29 E+05$ & $0.00 E+00$ & $8.20 E+07$ & $3.48 E+07$ & $3.96 E+06$ & $2.38 E+06$ \\
\hline s5 & $2.06 \mathrm{E}+05$ & $4.12 \mathrm{E}+04$ & $5.02 \mathrm{E}+04$ & $1.43 \mathrm{E}+05$ & $6.19 \mathrm{E}+02$ & $1.96 \mathrm{E}+03$ & $1.08 \mathrm{E}+03$ & $2.30 \mathrm{E}+03$ & $1.90 E+04$ & $4.00 \mathrm{E}+04$ & $2.38 E+03$ & $4.46 E+03$ & $1.36 \mathrm{E}+07$ & $4.38 E+07$ & $4.69 \mathrm{E}+05$ & \multirow{2}{*}{$\begin{array}{l}7.40 E+05 \\
7.40 E+05\end{array}$} \\
\hline S6 & $2.06 \mathrm{E}+05$ & $4.12 \mathrm{E}+04$ & $5.02 \mathrm{E}+04$ & $1.43 E+05$ & $6.19 E+02$ & $1.96 \mathrm{E}+03$ & $1.08 E+03$ & $2.30 \mathrm{E}+03$ & $1.90 E+04$ & $4.00 \mathrm{E}+04$ & $2.38 \mathrm{E}+03$ & $4.46 \mathrm{E}+03$ & $1.36 \mathrm{E}+07$ & $4.38 E+07$ & $4.69 E+05$ & \\
\hline S7 & $1.13 E+04$ & $0.00 E+00$ & $1.72 \mathrm{E}+04$ & $3.43 E+03$ & $5.81 E+02$ & $1.16 \mathrm{E}+02$ & $6.35 E+02$ & $1.27 \mathrm{E}+02$ & $1.72 \mathrm{E}+04 !$ & $3.44 \mathrm{E}+03$ & $8.24 E+02$ & $0.00 E+00$ & $2.02 E+05$ & $8.07 E+04$ & $4.05 E+05$ & $8.09 E+04$ \\
\hline 58 & $1.92 E+03$ & $0.00 E+00$ & $1.24 E+03$ & $0.00 E+00$ & $7.30 \mathrm{E}+00$ & $1.46 \mathrm{E}+00$ & $1.29 E+01$ & $0.00 E+00$ & $1.66 \mathrm{E}+02$ & $3.32 \mathrm{E}+01$ & $2.09 E+02$ & $0.00 E+00$ & $3.81 E+05$ & $0.00 E+00$ & $3.66 \mathrm{E}+04$ & $47.32 E+03$ \\
\hline S9 & $2.06 \mathrm{E}+05$ & $4.12 E+04$ & $5.02 E+04$ & $1.43 E+05$ & $6.19 \mathrm{E}+02$ & $1.96 E+03$ & $1.08 E+03$ & $2.30 \mathrm{E}+03$ & $1.90 E+04$ & $4.00 \mathrm{E}+04$ & $2.38 E+03$ & $4.46 E+03$ & $1.36 \mathrm{E}+07$ & $4.38 \mathrm{E}+07$ & $4.69 \mathrm{E}+05$ & $7.40 E+05$ \\
\hline S10 & $2.06 \mathrm{E}+05$ & $4.12 \mathrm{E}+04$ & $5.02 \mathrm{E}+04$ & $1.43 E+05$ & $6.19 E+02$ & $1.96 \mathrm{E}+03$ & $1.08 \mathrm{E}+03$ & $2.30 \mathrm{E}+03$ & $1.90 E+04$ & $4.00 \mathrm{E}+04$ & $2.38 E+03$ & $4.46 \mathrm{E}+03$ & $1.36 \mathrm{E}+07$ & $4.38 \mathrm{E}+07$ & $4.69 \mathrm{E}+05$ & $7.40 \mathrm{E}+05$ \\
\hline S11 & $2.06 E+05$ & $4.12 \mathrm{E}+04$ & $5.02 \mathrm{E}+04$ & $1.43 E+05$ & $6.19 \mathrm{E}+02$ & $1.96 \mathrm{E}+03$ & $1.08 \mathrm{E}+03$ & $2.30 \mathrm{E}+03$ & $1.90 \mathrm{E}+04$ & $4.00 E+04$ & $2.38 \mathrm{E}+03$ & $4.46 \mathrm{E}+03$ & $1.36 \mathrm{E}+07$ & $4.38 E+07$ & $4.69 E+05$ & \begin{tabular}{l|l}
5 & $7.40 \mathrm{E}+05$
\end{tabular} \\
\hline $\mathrm{S} 12$ & $2.06 \mathrm{E}+05$ & $4.12 \mathrm{E}+04$ & $5.02 E+04$ & $1.43 E+05$ & $6.19 E+02$ & $1.96 \mathrm{E}+03$ & $1.08 E+03$ & $2.30 \mathrm{E}+03$ & $1.90 \mathrm{E}+04$ & $4.00 E+04$ & $2.38 \mathrm{E}+03$ & $4.46 \mathrm{E}+03$ & $1.36 \mathrm{E}+07$ & $4.38 \mathrm{E}+07$ & $4.69 \mathrm{E}+05$ & \multirow{2}{*}{$\frac{7.40 E+05}{7.40 E+05}$} \\
\hline S13 & $2.06 \mathrm{E}+05$ & $4.12 \mathrm{E}+04$ & $5.02 E+04$ & $1.43 \vec{E}+05$ & $6.19 \mathrm{E}+02$ & $1.96 \mathrm{E}+03$ & $1.08 E+03$ & $2.30 \mathrm{E}+03$ & $1.90 \mathrm{E}+04$ & $4.00 E+04$ & $2.38 E+03$ & $4.46 \mathrm{E}+03$ & $1.36 \mathrm{E}+07$ & $4.38 E+07$ & $4.69 \mathrm{E}+05$ & \\
\hline S14 & $2.06 \mathrm{E}+05$ & $4.12 E+04$ & $5.02 E+04$ & $1.43 \mathrm{E}+05$ & $6.19 E+02$ & $1.96 \mathrm{E}+03$ & $1.08 \mathrm{E}+03$ & $2.30 \mathrm{E}+03$ & $1.90 E+04$ & $4.00 E+04$ & $2.38 E+03$ & $4.46 \mathrm{E}+03$ & $1.36 \mathrm{E}+07$ & $4.38 \mathrm{E}+07$ & $4.69 E+05$ & \begin{tabular}{|ll}
5 & $7.40 E+05$ \\
\end{tabular} \\
\hline S15 & $2.06 E+05$ & $4.12 E+04$ & $5.02 \mathrm{E}+04$ & $1.43 \mathrm{E}+05$ & $6.19 E+02$ & $1.96 \mathrm{E}+03$ & $1.08 \mathrm{E}+03$ & $2.30 \mathrm{E}+03$ & $1.90 E+04$ & $4.00 E+04$ & $2.38 \mathrm{E}+03$ & $4.46 E+03$ & $1.36 \mathrm{E}+07$ & $4.38 E+07$ & $4.69 \mathrm{E}+05$ & $7.40 \mathrm{E}+05$ \\
\hline S16 & $6.31 E+04$ & $0.00 E+00$ & $4.08 E+04$ & $0.00 E+00$ & $8.87 E+02$ & $1.77 \mathrm{E}+02$ & $9.23 E+02$ & $1.85 E+02$ & $2.54 \mathrm{E}+04$ & $5.08 \mathrm{E}+03$ & $3.15 E+03$ & $0.00 E+00$ & $7.39 E+05$ & $2.95 E+05$ & $7.16 \mathrm{E}+05$ & \multirow{2}{*}{\begin{tabular}{|l|l}
5 & $1.43 E+05$ \\
5 & $7.40 E+05$
\end{tabular}} \\
\hline S17 & $2.06 \mathrm{E}+05$ & $4.12 \mathrm{E}+04$ & $5.02 E+04$ & $1.43 \mathrm{E}+05$ & $6.19 E+02$ & $1.96 \mathrm{E}+03$ & $1.08 \mathrm{E}+03$ & $2.30 \mathrm{E}+03$ & $1.90 \mathrm{E}+04$ & $4.00 \mathrm{E}+04$ & $2.38 \mathrm{E}+03$ & $4.46 \mathrm{E}+03$ & $1.36 \mathrm{E}+07$ & $4.38 \mathrm{E}+07$ & $4.69 \mathrm{E}+05$ & \\
\hline S18 & $2.06 \mathrm{E}+05$ & $4.12 \mathrm{E}+04$ & $5.02 E+04$ & $1.43 E+05$ & $6.19 \mathrm{E}+02$ & $1.96 \mathrm{E}+03$ & $1.08 E+03$ & $2.30 \mathrm{E}+03$ & $1.90 \mathrm{E}+04$ & $4.00 \mathrm{E}+04$ & $2.38 \mathrm{E}+03$ & $4.46 \mathrm{E}+03$ & $1.36 \mathrm{E}+07$ & $4.38 E+07$ & $4.69 \mathrm{E}+05$ & $7.40 \mathrm{E}+05$ \\
\hline $\mathbf{S 1 9}$ & $2.06 E+05$ & $4.12 E+04$ & $1.32 \mathrm{E}+05$ & $2.63 \mathrm{E}+04$ & $2.90 \mathrm{E}+03$ & $5.80 \mathrm{E}+02$ & $3.04 \mathrm{E}+03$ & $6.08 E+02$ & $4.13 E+04$ & $8.25 \mathrm{E}+03$ & $4.77 E+03$ & $9.55 \mathrm{E}+02$ & $2.40 E+07$ & $9.60 \mathrm{E}+06$ & $9.68 \mathrm{E}+05$ & $1.94 \mathrm{E}+05$ \\
\hline $\mathrm{S} 20$ & $1.80 E+04$ & $0.00 E+00$ & $1.16 E+04$ & $0.00 E+00$ & $5.00 \mathrm{E}+02$ & $1.00 \mathrm{E}+02$ & $7.84 E+02$ & $1.57 \mathrm{E}+02$ & $4.77 E+04$ & $9.55 \mathrm{E}+03$ & $2.02 \mathrm{E}+03$ & $4.04 \mathrm{E}+02$ & $5.77 \mathrm{E}+06$ & $2.31 E+06$ & $8.15 E+05$ & $1.63 E+05$ \\
\hline S21 & $3.25 E+03$ & $0.00 E+00$ & $2.09 E+03$ & $0.00 E+00$ & $1.23 \mathrm{E}+01$ & $4.94 \mathrm{E}+00$ & $2.18 E+01$ & $0.00 \mathrm{E}+00$ & $3.38 E+02$ & $6.77 \mathrm{E}+01$ & $2.37 E+02$ & $0.00 \mathrm{E}+00$ & $3.16 \mathrm{E}+05$ & $1.26 E+05$ & $5.99 E+04$ & $4 \quad 1.20 \mathrm{E}+04$ \\
\hline$\$ 22$ & $6.58 E+03$ & $0.00 E+00$ & $1.35 \mathrm{E}+03$ & $2.70 \mathrm{E}+02$ & $3.01 \mathrm{E}+01$ & $6.03 E+00$ & $1.19 \mathrm{E}+01$ & $2.38 E+00$ & $1.90 E+04$ & $4.00 E+04$ & $3.45 E+02$ & $6.90 \mathrm{E}+01$ & $4.64 E+06$ & $9.28 E+05$ & $2.82 \mathrm{E}+05$ & $5.64 E+04$ \\
\hline & & & & & & & & & & & & & & & & \\
\hline Values & isted in Blac & k Bold /tali & cs print are & detection li & mits or uppe & er limits. & & & & & & & & & & \\
\hline (1) $\mathrm{Th}$ & activities lis & ted for Tank & S4 are in $u$ & nits of $\mathrm{pCi} / \mathrm{L}$ & and the ma & ass is liters. & & & & & & & & & & \\
\hline & & & $\mathrm{J}-234$ & tivity, $\mathrm{Pu}$ & ctivity & & 然 & o & $=$ & 40 & & & & & & \\
\hline and are & based upon & the calculat & ted average & activity con & centrations & of these nuc & clides in the & other analy & zed sludge & & & & & & & \\
\hline Tank S2 & $2 \mathrm{U}-238 \mathrm{not}$ & measured. & Calculated & activity ba & ed upon ave & erage activ & concen & ons of th & - & & & & & & & \\
\hline S. & ed in $B /$ & Bold /tal & s are & A th & & & & & & & & & & & & \\
\hline & 5 & Tank S & is & alculat & avera & ivity $\mathrm{C}$ & tion: & & $a_{1}$ & iavic & & & & & & \\
\hline The ave & rage U-233 & activity conc & centration is & based upor & the sludge & in Tank S1 & 9 only. & & & & & & & & & \\
\hline The calc & Sulated Pu-2 & 40 activity $\mathrm{c}$ & oncentratio & $\mathrm{i}$ is based $u$ & pon the sluc & ge in Tank & S22 only. & & & & & & & & & \\
\hline & ge Pu-24 & $2, \mathrm{Cm}-245$, & and $\mathrm{Cm}-246$ & activi & entration & IcL & ated from & & & & & & & & & \\
\hline$x_{2}+2$ & ociated & 7 average & activities $\mathrm{V}$ & calcula & & & & & & & & & & & & \\
\hline
\end{tabular}




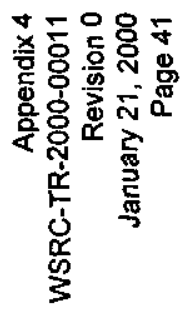

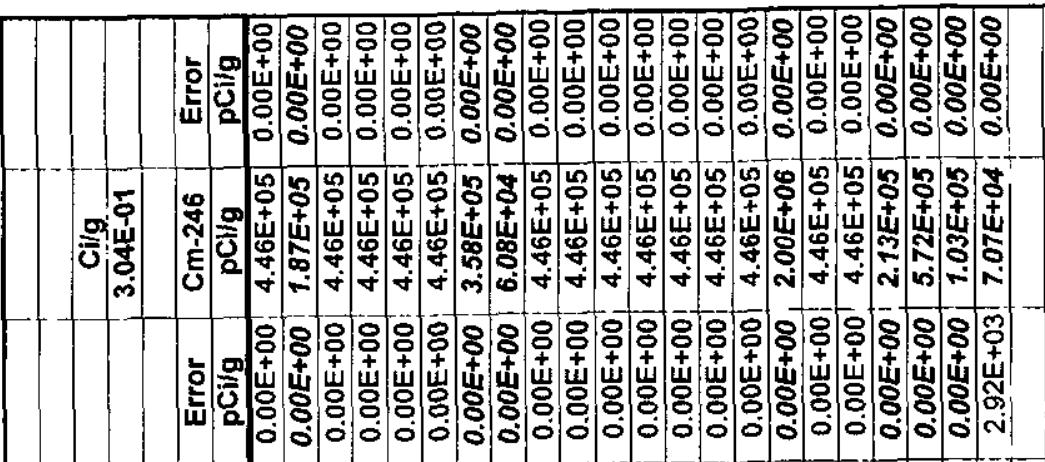

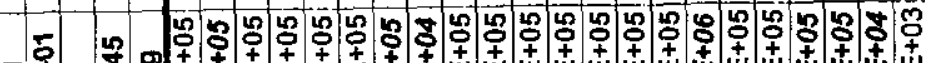

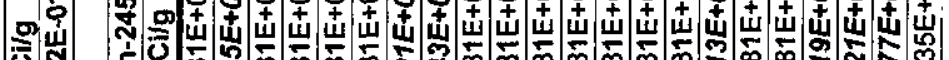

0 స్

:

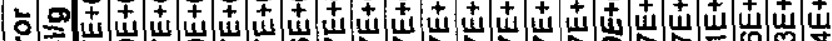

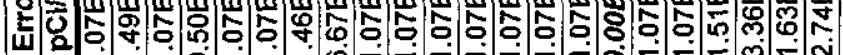

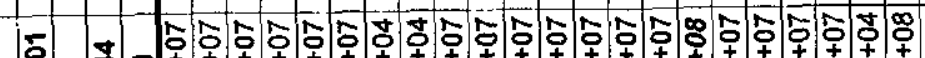

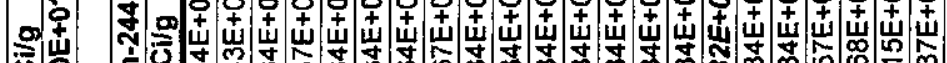

ô

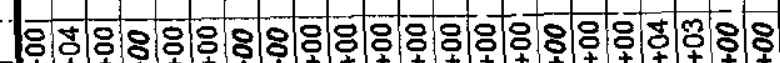

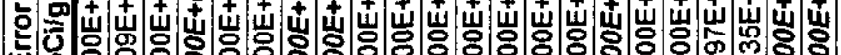

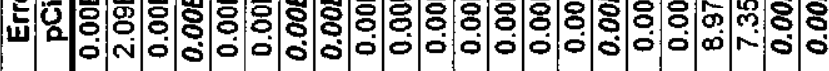

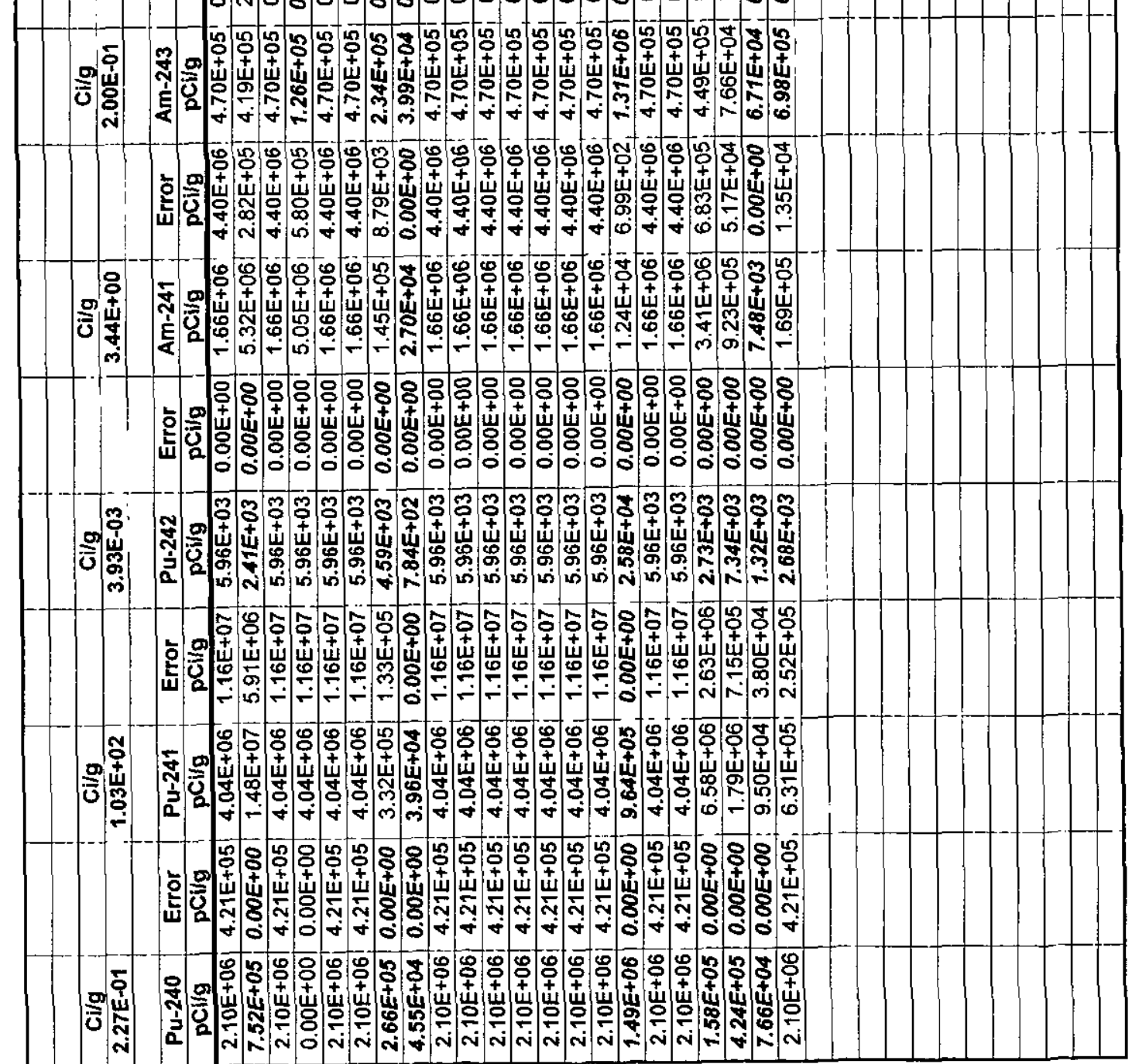




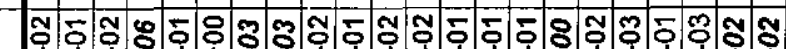

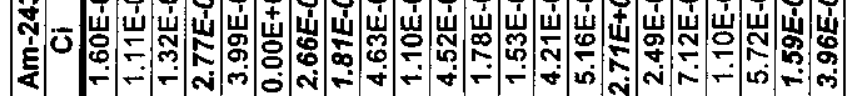

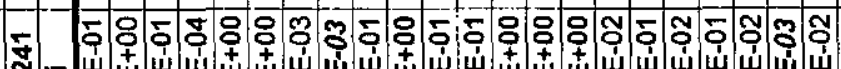

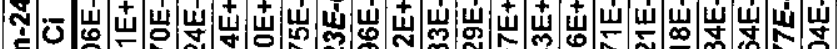
定

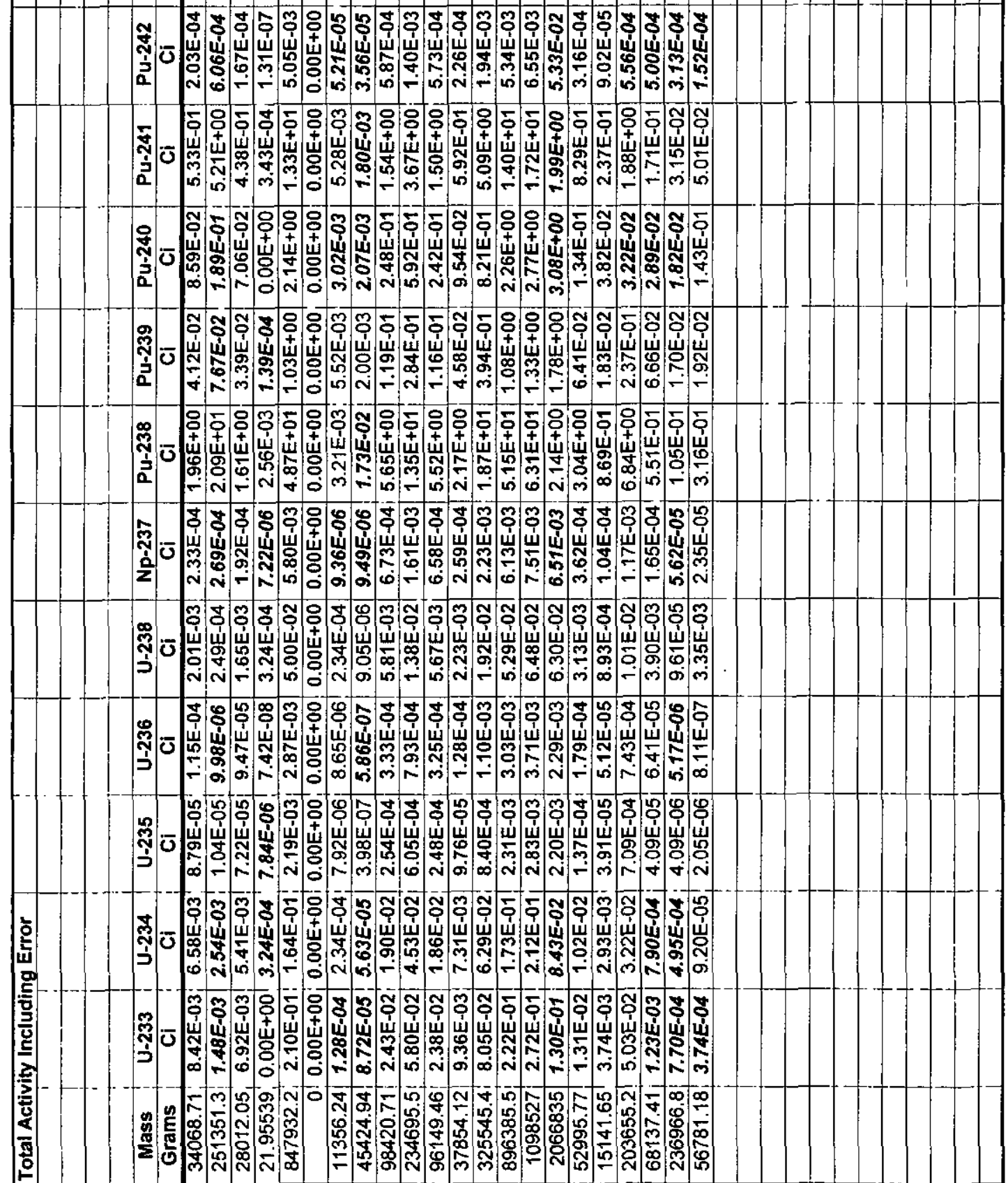




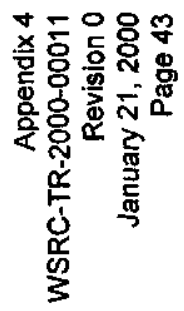

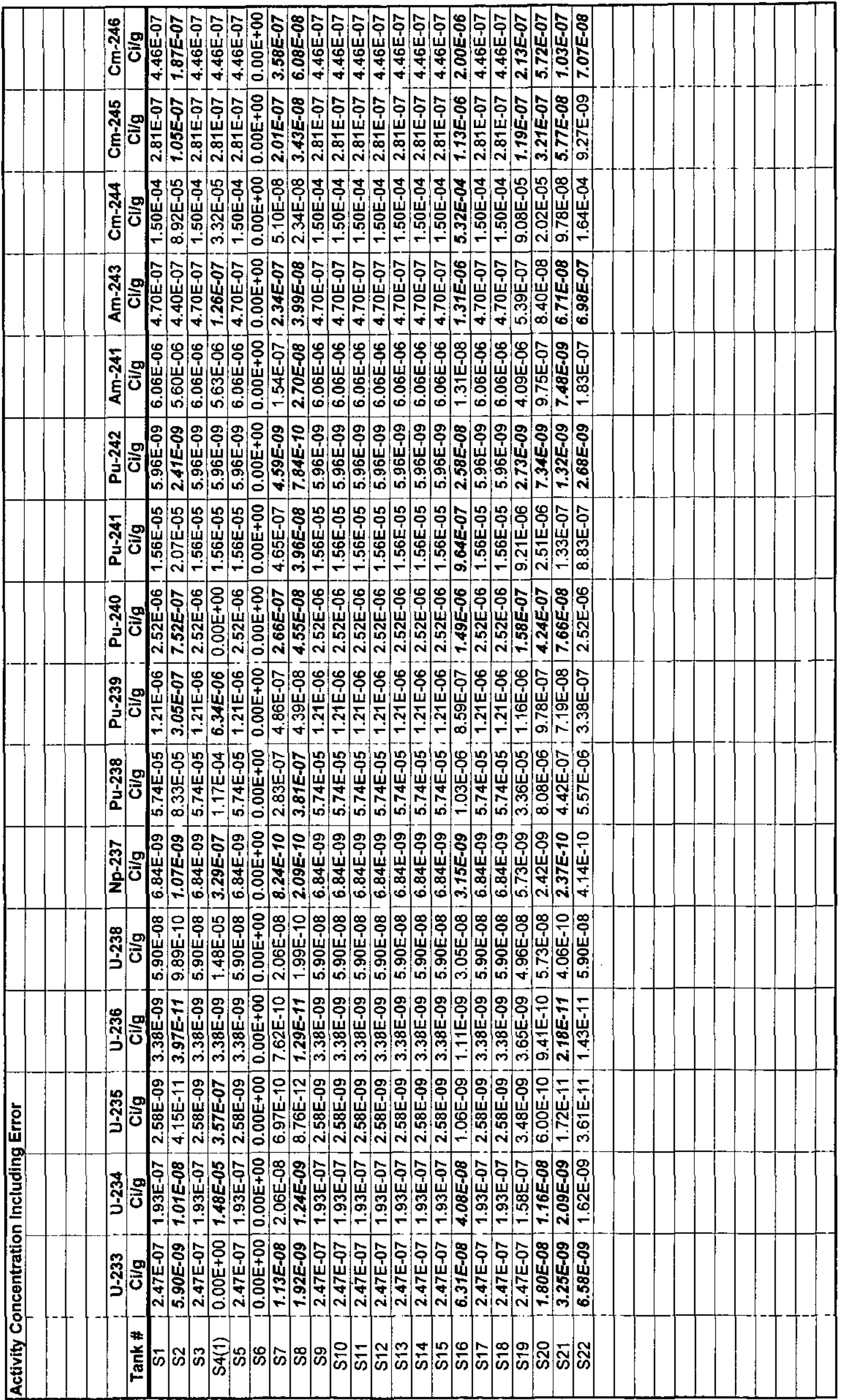




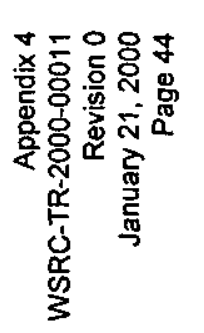

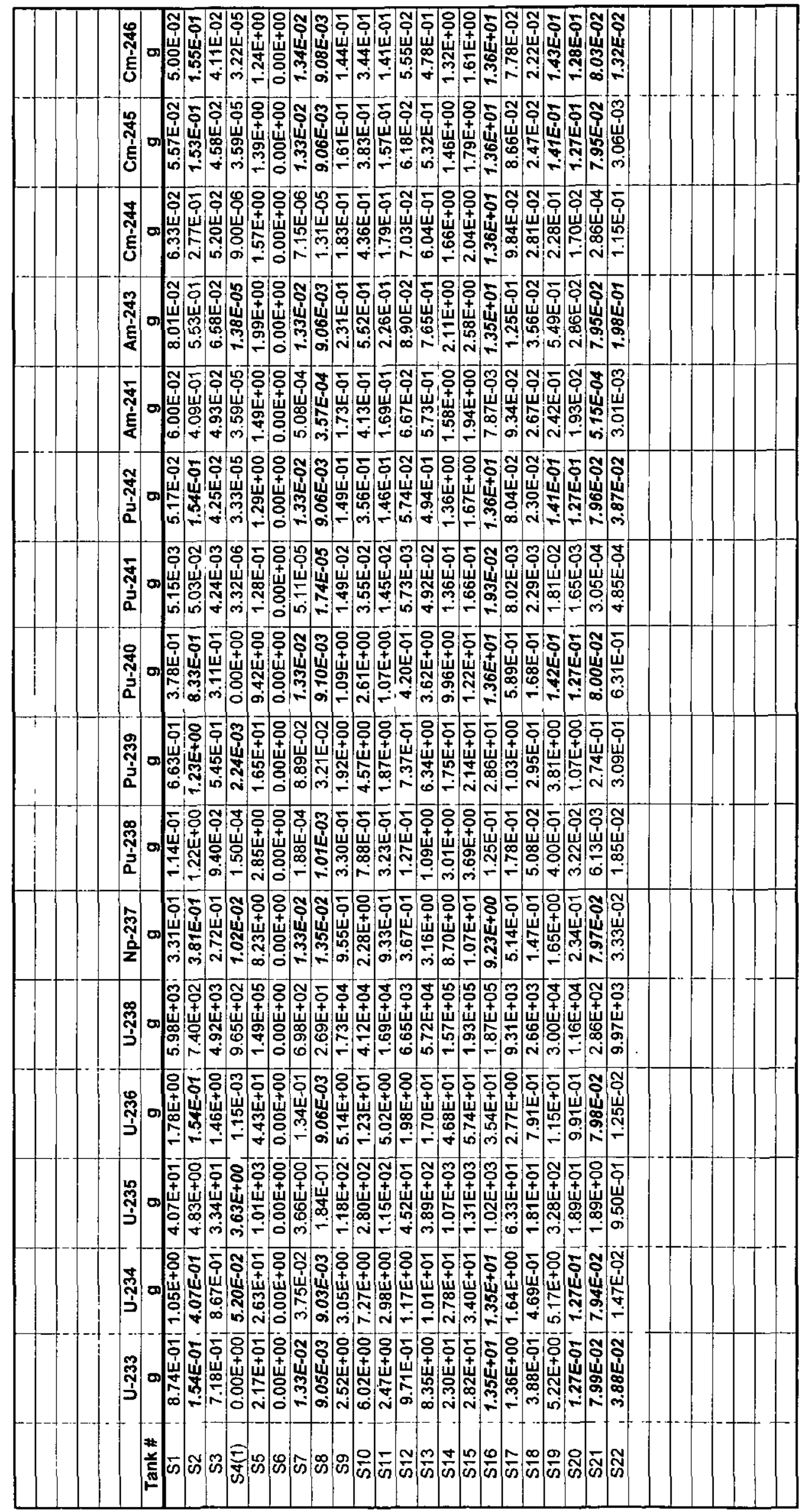




\begin{tabular}{|c|c|c|c|c|c|c|c|c|c|c|c|c|c|c|}
\hline & & & & & & & & & & & & & & \\
\hline & & & & & & & & & & & & & & \\
\hline & & & & & & & & & & & & & & \\
\hline & † & & & & & & & & & & & & & \\
\hline & & & & & & & & & & & & & & \\
\hline & U-233 & U-234 & U-235 & U-236 & $\mathrm{U}-238$ & $\mathrm{Np-237}$ & Pu-238 & Pu-239 & $\mathrm{Pu}-240$ & Pu-241 & Pu-242 & Am-241 & $A m-243$ & $\mathrm{Cm}-244$ \\
\hline Tank\# & g/(g waste) & $g /(g$ wast $\theta)$ & g/(g waste) & $g /(g$ waste $)$ & g/(g waste $)$ & $g /(g$ waste $)$ & g/(g waste) & g/(g waste $)$ & g/(g waste $)$ & g/(g waste) & g/(g waste $)$ & $g /(g$ waste $)$ & g/(g waste) & $g /($ g waste $)$ \\
\hline$\overline{\mathrm{S1}}$ & $2.56 \mathrm{E}-05$ & $3.10 \mathrm{E}-05$ & $1.19 \mathrm{E}-03$ & $5.22 \mathrm{E}-05$ & $1.76 \mathrm{E}-01$ & $9.70 \mathrm{E}-06$ & $3.36 \mathrm{E}-06$ & 1.95E-05 & 1.11E-05 & 1.51E-07 & 1.52E-06 & $1.76 \mathrm{E}-06$ & $2.35 E-06$ & 1.86E-06 \\
\hline S2 & 6.12E-07 & $1,62 E-06$ & 1.92E-05 & $6.14 E-07$ & $2.94 E-03$ & $1.52 E-06$ & $4.87 \mathrm{E}-06$ & 4.91E-06 & $3.31 E-06$ & 2.00E-07 & $6.13 E-07$ & $1.63 E-06$ & $2.20 \mathrm{E}-06$ & 1.10E-06 \\
\hline S3 & 2.56 E-05 & $3.10 \mathrm{E}-05$ & $1.19 E-03$ & 5.22E-05 & $1.76 E-01$ & 9.70 E- 06 & $3.36 \mathrm{E}-06$ & 1.95E-05 & $1.11 \mathrm{E}-05$ & 1.51E-07 & $1.52 \mathrm{E}-06$ & $1.76 \mathrm{E}-06$ & $2.35 E-06$ & 1.86 E-06 \\
\hline S4(1) & $0.00 E+00$ & $2.37 E-03$ & $1.65 E-01$ & 5.22E-05 & $4.40 \mathrm{E}+01$ & $4.67 E-04$ & $6.83 \mathrm{E}-06$ & $1.02 E-04$ & $0.00 \mathrm{E}+00$ & $1.51 \mathrm{E}-07$ & 1.52E-06 & $1.64 \mathrm{E}-06$ & $6.30 E-07$ & $4.10 \mathrm{E}-07$ \\
\hline S5 & 2.56E-05 & $3.10 E-05$ & $1.19 \mathrm{E}-03$ & 5.22E-05 & 1.76E-01 & 9.70E-06 & $3.36 \mathrm{E}-06$ & $1.95 \mathrm{E}-05$ & 1.11E-05 & 1.51E-07 & 1.52E-06 & $1.76 \mathrm{E}-06$ & $2.35 \mathrm{E}-06 \mathrm{i}$ & 1.86E-06 \\
\hline S6 & $0.00 \mathrm{E}+00$ & $0.00 \mathrm{E}+00$ & $0.00 \mathrm{E}+00$ & $0.00 \mathrm{E}+00$ & $0.00 \mathrm{E}+00$ & $0.00 \mathrm{E}+00$ & $0.00 \mathrm{E}+00$ & $0.00 \mathrm{E}+00$ & $0.00 \mathrm{E}+00$ & $0.00 \mathrm{E}+00$ & $0.00 \mathrm{E}+00$ & $0.00 \bar{E}+00$ & $0.00 \mathrm{E}+00$ & $0.00 \mathrm{E}+00$ \\
\hline S7 & 1.17E-06 & $3.31 \mathrm{E}-06$ & $3.23 \mathrm{E}-04$ & $1.18 \mathrm{E}-05$ & $6.14 \mathrm{E}-02$ & $1.17 \mathrm{E}-06$ & $1.65 E-08$ & $7.82 \mathrm{E}-06$ & 1.17E-06 & $4.50 \mathrm{E}-09$ & $1.17 E-06$ & $4.47 \mathrm{E}-08$ & $1.17 E-06$ & $6.30 \mathrm{E}-10$ \\
\hline S8 & $1.99 E-07$ & $1.99 E-07$ & 4.06E-06 & $1.99 E-07$ & $5.93 \mathrm{E}-04$ & $2.96 E-07$ & $2.23 E-08$ & $7.07 \mathrm{E}-07$ & $2.00 \mathrm{E}-07$ & $3.83 E-10$ & $1.99 E-07$ & $7.85 E-09$ & $2.00 E-07$ & $2.89 \mathrm{E}-10$ \\
\hline 59 & 2.56E-05 & $3.10 \mathrm{E}-05$ & $1.19 \mathrm{E}-03$ & $5.22 \mathrm{E}-05$ & $1.76 \mathrm{E}-01$ & $9.70 \mathrm{E}-06$ & $3.36 \mathrm{E}-06$ & $1.95 E-05$ & 1.11E-05 & 1.51E-07 & $1.52 E-06$ & $1.76 \mathrm{E}-06$ & $2.35 \mathrm{E}-06$ & $1.86 \mathrm{E}-06$ \\
\hline S10 & $2.56 \mathrm{E}-05$ & $3.10 \mathrm{E}-05$ & $1.19 \mathrm{E}-03$ & 5.22E-05 & $1.76 \mathrm{E}-01$ & $9.70 \mathrm{E}-06$ & $3.36 \mathrm{E}-06$ & 1.95E-05 & 1.11E-05 & 1.51E-07 & $1.52 \mathrm{E}-06$ & $1.76 E-06$ & $2.35 \mathrm{E}-06$ & $1.86 \mathrm{E}-06$ \\
\hline S11 & $2.56 \mathrm{E}-05$ & $3.10 \mathrm{E}-05$ & $1.19 \mathrm{E}-03$ & 5.22E-05 & $1.76 \mathrm{E}-011$ & $9.70 \mathrm{E}-06$ & $3.36 \mathrm{E}-06$ & $1.95 \mathrm{E}-05$ & $1.11 \mathrm{E}-05$ & 1.51E-07 & $1.52 \mathrm{E}-06$ & $1.76 E-06$ & 2.35E-06 & $1.86 E-06$ \\
\hline $\mathrm{S} 12$ & $2.56 \mathrm{E}-05$ & $3.10 \mathrm{E}-05$ & 1.19E-03 & $5.22 \mathrm{E}-05$ & $1.76 \mathrm{E}-01$ & $9.70 \mathrm{E}-06$ & $3.36 \mathrm{E}-06$ & $1.95 \mathrm{E}-05$ & $1.11 \mathrm{E}-05$ & $1.51 \mathrm{E}-07$ & $1.52 \mathrm{E}-06$ & $1.76 \mathrm{E}-06$ & $2.35 \mathrm{E}-06$ & $1.86 \mathrm{E}-06$ \\
\hline$\$ 13$ & 2.56E-05 & $3.10 \mathrm{E}-05$ & 1.19E-03 & $5.22 \mathrm{E}-05$ & $1.76 \mathrm{E}-01$ & $9.70 \mathrm{E}-06$ & $3.36 \mathrm{E}-06$ & $1.95 \mathrm{E}-05$ & $1.11 \mathrm{E}-05$ & 1.51E-07 & $1.52 \mathrm{E}-06$ & $1.76 \mathrm{E}-06$ & 2.35E-06 & $1.86 \mathrm{E}-06$ \\
\hline S14 & 2.56E-05 & $3.10 \mathrm{E}-05$ & 1.19E-03 & $5.22 \mathrm{E}-05$ & $1.76 \mathrm{E}-01$ & $9.70 \mathrm{E}-06$ & $3.36 E-06$ & $1.95 \mathrm{E}-05$ & 1.11E-05 & $1.51 \mathrm{E}-07$ & $1.52 \mathrm{E}-06$ & $1.76 \mathrm{E}-06$ & 2.35E-06 & $1.86 \mathrm{E}-06$ \\
\hline S15 & 2.56E-05 & $3.10 \mathrm{E}-05$ & $1.19 \mathrm{E}-03$ & $5.22 \mathrm{E}-05$ & $1.76 \mathrm{E}-01$ & $9.70 \mathrm{E}-06$ & $3.36 \mathrm{E}-06$ & $1.95 \mathrm{E}-05$ & $1.11 \mathrm{E}-05$ & $1.51 \mathrm{E}-07$ & $1.52 \mathrm{E}-06$ & $1.76 \mathrm{E}-06$ & 2.35E-06 & $1.86 \mathrm{E}-06$ \\
\hline $\mathrm{S} 16$ & $6.55 E=06$ & $6.54 E-06$ & $4.93 \mathrm{E}-04$ & $1.71 \mathrm{E}-05$ & 9.07E-02 & $4.47 E-06$ & $6.05 \mathrm{E}-08$ & $1.38 \mathrm{E}-05$ & $6.56 E-06$ & $9.32 E-09$ & $6.56 E-06$ & 3.81 E-09 & $6.55 E-06$ & $6.57 E-06$ \\
\hline S17 & 2.56E-05 & $3.10 \mathrm{E}-05$ & $1.19 E-03$ & $5.22 \mathrm{E}-05$ & $1.76 \mathrm{E}-01$ & $9.70 \mathrm{E}-06$ & $3.36 \mathrm{E}-06$ & $1.95 \mathrm{E}-05$ & $1.11 \mathrm{E}-05$ & 1.51 E-07 & $1.52 \mathrm{E}-06$ & $1.76 \mathrm{E}-06$ & $2.35 \mathrm{E}-06$ & 1.86E-06 \\
\hline S18 & $2.56 \mathrm{E}-05$ & $3.10 \mathrm{E}-05$ & $1.19 \mathrm{E}-03$ & $5.22 \mathrm{E}-05^{\prime}$ & $1.76 \mathrm{E}-01$ & $9.70 E-06$ & $3.36 \mathrm{E}-06$ & $1.95 E-05$ & $1.11 E-05$ & 1.51E-07 & $1.52 \mathrm{E}-06$ & $1.76 \mathrm{E}-06$ & 2.35E-06 & $1.86 E-06$ \\
\hline S19 & $2.56 \mathrm{E}-05$ & $2.54 \mathrm{E}-05$ & $1.61 \mathrm{E}-03$ & $5.64 \mathrm{E}-05$ & 1.47E-01 & $8.12 E-06$ & $1.96 \mathrm{E}-06$ & 1.87E-05 & $6.96 E-07$ & 8.91E-08 & $6.95 E-07$ & $1.19 \mathrm{E}-06$ & 2.69E-06 & $1.12 E-06$ \\
\hline $\mathrm{S} 20$ & $1.87 E-06$ & $1.86 E-06$ & $2.78 \mathrm{E}-04$ & $1.45 \mathrm{E}-05$ & 1.70E-01 & $3.44 \mathrm{E}-06$ & 4.73E-07 & 1.57E-05 & $1.87 E-06$ & 2.42E-08 & 1.87E-06 & $2.83 \mathrm{E}-07$ & $4.20 \mathrm{E}-07$ & 2.49E-07 \\
\hline S21 & 3.37E-07 & $3.35 E-07$ & $7.98 \mathrm{E}-06$ & $3.37 E-07$ & $1.21 \mathrm{E}-03$ & $3.36 E-07$ & $2.58 \mathrm{E}-08$ & 1.16E-06 & 3.37E-07 & $1.29 \mathrm{E}-09$ & $3.36 E \cdot 07$ & $2.17 E-09$ & $3.36 E-07$ & 1.21E-09 \\
\hline \$22 & $6.83 E-07$ & $2.60 \mathrm{E}-07$ & 1.67E-05 & 2.21E-07 & $1.76 \mathrm{E}-01$ & $5.87 \mathrm{E}-07$ & $3.26 \mathrm{E}-07$ & $5.45 \mathrm{E}-06$ & 1.11E-05 & $8.54 \mathrm{E}-09$ & $6.82 E-07$ & $5.31 \mathrm{E}-08$ & $3.49 E-06$ & 2.03E-06 \\
\hline & i & & & & & & & & & & & & & \\
\hline & 7 & & & & & & & & & & & & & \\
\hline & & & & & & & & & & & & & & \\
\hline & & & & & & & & & & & & & & \\
\hline & & & & & & & & & & & & & 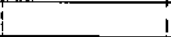 & \\
\hline & & & & & & & & & & & & & & \\
\hline & 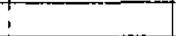 & & & & & & & & & & & & & \\
\hline & 1 & & & & & & & & & & & & & \\
\hline & & & & & & & & & & & & & & \\
\hline & & & & & & & & & & & & & & \\
\hline & ? & & & & & & & & & & & & & \\
\hline & i & 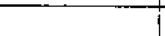 & & & & & & & & & & & 1 & \\
\hline
\end{tabular}




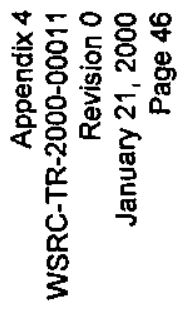

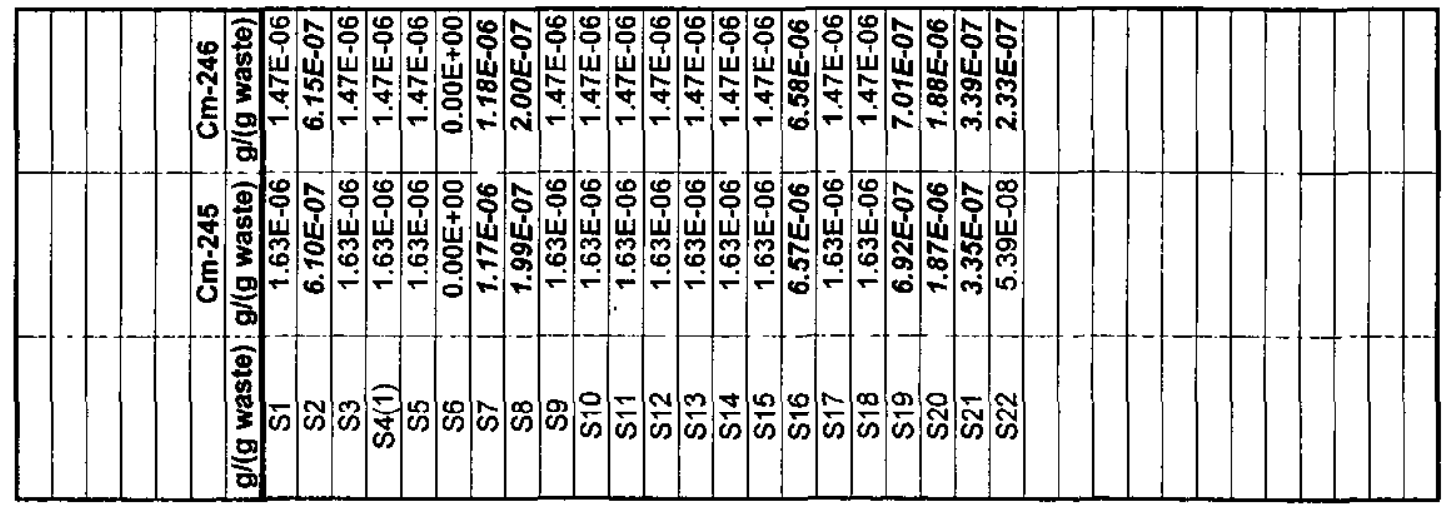




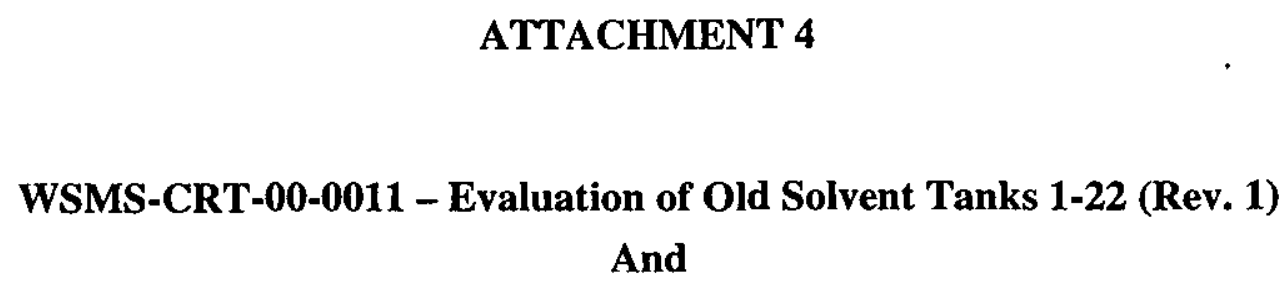

Supporting Documentation 
(This page intentionally left blank.) 
WSMS-CRT-00-0011

Page 1 of 3

006636

\section{DISCLAIMER}

This document was prepared by Westinghouse Safery Management Solutions LLC (WSMS) under contract with Westinghouse Savannah River Company (WSRC), subject to the warranty
contract with the United States Department of Energy (DOE).

Release to and Use by Third Partics. As it pertains to releases of this document to thitd parties, and the use of or reference to this document by such third parties in whole or in part, neither WSMS, WSRC, DOE, nor their respective officers. directors, employees. agents, consultants or personal services contractors (i) make any wartanty, expressed or implied. (ii) assume any legal liability or responsibility for the accuracy, completeness, or usefulness, of any information. apparatus. product or process disclosed herein or (iii) represent that use of the same will not infringe privately owned rights. Reference herein to any specific commercial product, process, or service by trademark, name, manufacture or otherwise, does not necessarily constitute or imply endorsement, recommendation, or favoring of the same by WSMS, WSRC, DOE or their respective officers, directors, employees, agents, consultants or personal services contractors. The views and opinions of the authors expressed herein do not necessarily state or reflect those of the. United States Government or any agency thereof. 


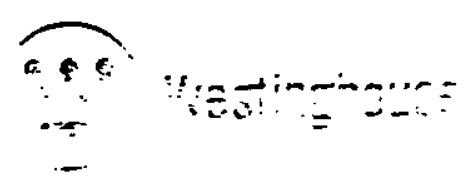

Government Services Group
WESTNGHOUSE SAFETY MANAGEMENT SOLU

co sox 538 E

AIKEN SOUTH CAROLINA $29804538 \mathrm{C}$ 1993 SOUTH CENTENNIAL AVENUE SE

AIKEN SOUTH CAAOLINA 29803

PHONE (BO3: 502.9767

FAX (1003) 502.9999

WSMS-CRT-00-0011

Page 2 of 3

February 8,2000

TO:

M. R. Welty, 730-2B

FROM:

K. E. Hammer, CCC-3/321

Technical Review:

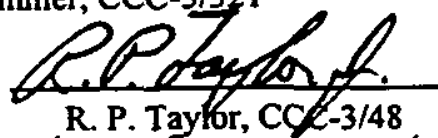

Approved By:

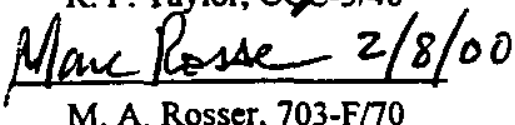

\section{EVALUATION OF OLD SOLVENT STORAGE TANKS 1-22 (Rev. 1)}

This report is a revision of a previous report (Ref. 1) that documents the evaluation of the sampled contents of the Old Solvent Storage Tanks against ANSI Standards (Ref. 2) for criticality safety. Evaluations in the previous report were limited to those tanks for which sampling was performed. Improved methodologies for determining tank contents, both sampled and non-sampled, have resulted in improved estimates of tank fissile material contents (Ref. $3,4,5$ ). This report improves the previous evaluations for the sampled tanks and provides the equivalent evaluations for the non-sampled tanks.

\section{INTRODUCTION AND SUMMARY}

As part of the project to close the Old Solvent Storage Tanks 1-22, it is necessary to perform an evaluation of criticality concerns associated with this effort. The purpose of this report is to document the results of the evaluation.

Criticality concerns for waste material handling and tank closure of Old Solvent Storage Tanks 1-22 was evaluated based on enrichment and fissile mass. Tank isotopic contents were determined in a previous analysis (Ref. 3; 4, 5). Effective enrichments were deternined based on combined U-235, Pu-239 and U238 using the Rule of Fractions. Calculations indicate that there is insufficient fissile mass for criticality, as long as the U-238 is not separated from the other waste constituents and the effective enrichment of the material is not increased.

\section{EVALUATION OF ENRICHMENT}

The evaluation is based on previous nuclear criticality safety evaluations that use the Rule of Fractions to determine enrichment of mixed U-235/Pu-239 systems (Ref. 6). Results of determining effective enrichment of fissile material remaining in the Old Solvent Storage Tanks 1-22 is listed in Table 1. 
TABLE 1 - Fissile Material Content and Enrichment of Old Solvent Storage Tanks.

\begin{tabular}{|c|c|c|c|c|c|c|c|}
\hline Tank & $\begin{array}{c}u-235 \\
(g)\end{array}$ & $\begin{array}{c}U-238 \\
(g)\end{array}$ & $\begin{array}{c}\text { Pu-239 } \\
(g)\end{array}$ & $\begin{array}{c}\text { Pu-239 U-235 } \\
\text { FGE }\end{array}$ & $\begin{array}{l}\text { Total U- } \\
235 \mathrm{FGE}\end{array}$ & Total U & $\begin{array}{c}\text { Effective } \\
\text { Enfichment }\end{array}$ \\
\hline 51 & $7.60 \mathrm{E}+01$ & $8.98 \mathrm{E}+03$ & $8.16 E-01$ & $2.27 E+00$ & $7.73 E+0:$ & $\subseteq .06 E+03$ & C.BE \\
\hline 52 & $8.89 E+00$ & $1.45 E+04$ & $1.25 E+00$ & $1.94 E+00$ & $1.08 E+01$ & $1.45 E+04$ & C. $0^{-}$ \\
\hline 53 & $1.19 \mathrm{E}+02$ & $1.59 E+04$ & $1.30 \mathrm{E}+00$ & $2.02 E+00$ & $1.21 E+02$ & $1.60 \mathrm{E}+04$ & C. 76 \\
\hline 54 & $1.67 E+02$ & $3.43 E+04$ & $1.04 E+00$ & $1.62 \mathrm{E}+00$ & $1.69 \mathrm{E}+02$ & $3.45 E+04$ & 0.49 \\
\hline 55 & $1.44 E+03$ & $1.60 E+05$ & $1.80 E+01$ & $2.80 E+01$ & $1.47 E+03$ & $1.61 \mathrm{E}+05$ & 0.91 \\
\hline 56 & $7.84 E+01$ & $1.58 \mathrm{E}+04$ & $2.51 E+00$ & $3.90 \mathrm{E}+00$ & $8.23 E+01$ & $3.59 E+04$ & 0.52 \\
\hline 57 & $2.33 E+02$ & $4.88 E+04$ & $3.11 E+00$ & $4.84 E+00$ & $2.38 \mathrm{E}+02$ & $4.90 E+04$ & 0.49 \\
\hline 58 & $7.60 E+00$ & $1.16 \mathrm{E}+03$ & $5.22 \mathrm{E}-01$ & $8.12 \mathrm{E}-01$ & $8.41 E+00$ & $1.17 E+03$ & 0.72 \\
\hline 59 & $1.59 \mathrm{E}+02$ & $1.73 E+04$ & $1.92 \mathrm{E}+00$ & $2.99 E+00$ & $1.62 \mathrm{E}+02$ & $1.75 E+04$ & 0.93 \\
\hline 510 & $3.84 E+02$ & $4.25 E+04$ & $4.76 E+00$ & $7.40 \mathrm{E}+00$ & $3.91 E+02$ & $4.29 E+04$ & 0.91 \\
\hline 511 & $1.55 \mathrm{E}+02$ & $1.69 \mathrm{E}+04$ & $1.92 \mathrm{E}+00$ & $2.99 \mathrm{E}+00$ & $1.58 \mathrm{E}+02$ & $1.71 E+04$ & 0.93 \\
\hline 512 & $6.38 E+01$ & $7.30 \mathrm{E}+03$ & $8.30 \mathrm{E}-01$ & $1.29 \mathrm{E}+00$ & $6.51 E+01$ & $7.37 E+03$ & 0.88 \\
\hline 513 & $5.87 \mathrm{E}+02$ & $6.74 E+04$ & $7.18 E+00$ & $1.12 \mathrm{E}+01$ & $5.98 \mathrm{E}+02$ & $6.80 E+04$ & 0.88 \\
\hline 514 & $1.48 E+03$ & $1.75 E+05$ & $1.78 \mathrm{E}+01$ & $2.77 \mathrm{E}+01$ & $1.51 E+03$ & $1.77 \varepsilon+05$ & 0.85 \\
\hline 515 & $1.77 E+03$ & $1.93 E+05$ & $2.14 E+01$ & $3.33 \mathrm{E}+01$ & $1.80 E+03$ & $1.95 \mathrm{E}+05$ & 0.93 \\
\hline 516 & $1.02 \mathrm{E}+03$ & $1.87 \mathrm{E}+05$ & $2.86 E+01$ & $4.45 E+01$ & $1.06 \mathrm{E}+03$ & $1.88 E+05$ & 0.57 \\
\hline 517 & $8.54 \mathrm{E}+01$ & $9.31 E+03$ & $1.03 \mathrm{E}+00$ & $1.60 E+00$ & $8.70 \mathrm{E}+01$ & $9.40 \mathrm{E}+03$ & 0.93 \\
\hline S18 & $2.72 \mathrm{E}+01$ & $3.31 \mathrm{E}+03$ & $3.88 \mathrm{E}-01$ & $6.04 E-01$ & $2.78 E+01$ & $3.34 E+03$ & 0.83 \\
\hline S19 & $3.68 \mathrm{E}+02$ & $8.77 \mathrm{E}+04$ & $4.24 E+00$ & $6.60 \mathrm{E}+00$ & $3.75 \mathrm{E}+02$ & $8.81 E+04$ & 0.43 \\
\hline $\mathrm{S} 20$ & $2.22 E+02$ & $5.33 E+04$ & $3.50 \mathrm{E}+00$ & $5.44 \mathrm{E}+00$ & $2.27 E+02$ & $5.35 E+04$ & 0.42 \\
\hline 521 & $2.75 E+01$ & $8.78 \mathrm{E}+03$ & $9.83 \mathrm{E}-01$ & $1.53 \mathrm{E}+00$ & $2.90 E+01$ & $8.61 E+03$ & 0.33 \\
\hline 522 & $5.07 E+01$ & $1.59 \mathrm{E}+04$ & $1.62 E+00$ & $2.52 E+00$ & $5.32 E+01$ & $1.60 \mathrm{E}+04$ & 0.33 \\
\hline
\end{tabular}

U-235, U-238 and Pu-239 masses were obtained from reference 5. The fissile gram equivalence of Pu-239 to $\mathrm{U}-235$ was determined by rule of fractions (U-235 FGE $=$ Pu-239 $\mathrm{g} *(700 \mathrm{~g} \mathrm{U}-235 / 450 \mathrm{~g} \mathrm{Pu}-239)$ ). Total U-235 FGE is the sum of U-235 and Pu-239 U-235 FGE. Total $U$ was determined by the sum of Total U-235 FGE and U-238. Effective Enrichment was determined by the ratio of Total U-235 FGE and Total U.

Comparing tank effective enrichments to the ANS 8.1 limiting enrichment for criticality concerns $(0.93$ weight percent U-235, Ref. 2 ) shows all 22 Tanks are within the limit.

\section{COMPARISON TO ANSI CRITICALITY SAFETY STANDARDS}

ANSI Standards for criticality safety provide guidelines for criticality safety for low enrichments (Ref. 2). The standard states that naturally enriched uranium is not a criticality concern. Guidelines for sub-critical masses for uniform aqueous low enrichment systems are found in Table 6 of the ANSI standard.

\section{CONCLUSION}

This report concludes that the Old Solvent Storage Tanks S1 through S22 have critically safe invertories of fissile materials. The tanks will remain critically safe during future operations/closure provided no action is taken that would cause an increase in enrichment above the ANS 8.1 limiting enrichment of 0.93 weight percent U-235.

\section{REFERENCES}

1. "Evaluation of Old Solvent Storage Tanks 1-22", WSMS-CRT-99-0039, Rev 0, 23 June 1999.

2. "American National Standard for Nuclear Criticality Safety in Operations with Fissionable Materials Outside Reactors", ANSI/ANS-8.1-1983.

3. "Total Inventory of Selected Radionuclides in Old Solvent Tanks S1 through S22 (U)", WSRCRP-2000-00011, Rev. 0, 21 January 2000.

4. "Concerns Regarding OSTs Total Inventory", SRT-ADS-00-0057, 3 February 2000.

5. "Addressing Concerns Regarding OSTs Total Inventory", SRT-ADS-00-0059, 4 February 2000.

6. "Storage and Handling Limits for Sludge and Mark 31 Corrosion Products in L Basin (U)", NNCS-L-00006, Rev 0, 12 June 1997. 
(This page intentionally left blank.) 
WSMS-CRT-99-0039

Page 1 of 3

\section{DISCLAIMER}

This document was prepared by Westinghouse Safety Management Solutioos LLC (WSMS) under contract with Westinghouse Savannah River Company (WSRC), subject to the warranty and other obligations of that contract and in furcherance of WSRC's coatract with the United States Department of Energy (DOE).

Release to and Use by Thind Parties. As it pertains to releases of this documeot to third parties. and the use of or reference to this document by such third parties in whole or in part, neither WSMS, WSRC, DOE, nor their respective officers, directors, employees. agents. consultants or personal services contractors (i) make any warranty, expressed or implied, (ii) assume any kgal liability or responsibility for the accuracy, completeness, or usefulness, of any information, apparatus, product or process disclosed herein or (iii) represent that use of the same will not infriage privately owned rights. Reference herein to any specific commercial product, process, or service by trademark. name, manufacture or otherwise, does not vecessarily constitute or imply endorsement, recommendation, or favoring of the alme by WSMS, WSRC, DOE or their respective officers, directors, employees, agents, consultants or personal services contractors. The views and opinions of the authors expressed berein do not necessarily state or reflect those of the United States Government or any agency thereof. 
TO: $\quad$ M. R. Welty, 730-2B

FROM: K. E. Hammer, CCC-3/321

Technical Review:

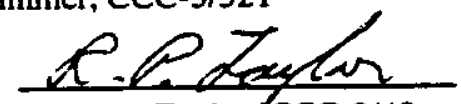

R. P. Taylor, $\mathrm{CCC}-3 / 48$

Approved By:

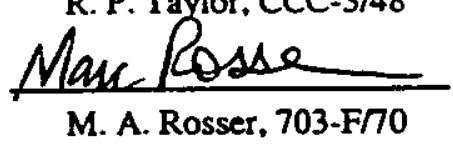

\section{EVALUATION OF OLD SOLVENT STORAGE TANKS 1-22}

\section{INTRODUCTION AND SUMMARY}

As part of the project to close the Old Solvent Storage Tanks 1-22, it is necessary to perform an evaluation of criticality concems associated with this effort. The purpose of this report is to document the results of the evaluation.

Criticality concerns for waste material handling and tank closure of Old Solvent Storage Tanks 1-22 were evaluated based on enrichment and fissile mass. Tank isotopic contents were determined in a previous analysis (Ref. 2). Effective enrichments were determined based on combined U-235, Pu-239 and U-238 using the Rule of Fractions. Calculations indicate that there is insufficient fissile mass for criticality, as long as the U-238 is not separated from the other waste constituents and the effective enrichment of the material is not increased.

\section{EVALUATION OF ENRICHMENT}

The evaluation is based on previous nuclear criticality safety evaluations that use the Rule of Fractions to determine enrichment of mixed U-235/Pu-239 systems (Ref. 1). Results of determining effective enrichment of fissile material remaining in the Old Solvent Storage Tanks 1-22 are listed in Table 1.

TABLE 1 - Fissile Material Content and Enrichment of Old Solvent Storage Tanks.

\begin{tabular}{|c|c|c|c|c|c|c|c|}
\hline Tank & $\begin{array}{c}0-235 \\
(0)\end{array}$ & $\begin{array}{c}\nabla-238 \\
(g)\end{array}$ & $\begin{array}{c}\text { Pu-239 } \\
\text { (g) }\end{array}$ & $\begin{array}{c}P u-2390-235 \\
\text { FCE }\end{array}$ & $\begin{array}{l}\text { rotal } 0- \\
235 \text { ros }\end{array}$ & Total 0 & $\begin{array}{l}\text { Efeective } \\
\text { torlehnent }\end{array}$ \\
\hline s1 & $2.11 E+01$ & $3.00 \mathrm{E}+03$ & $2.53 \mathrm{E}-01$ & $2: 38 E-01$ & $2.13 E+01$ & $3.02 E+03$ & 0.71 \\
\hline s2 & $8.89 \mathrm{E}-00$ & $7.95 \mathrm{E}+02$ & $1.25 \mathrm{E}-00$ & $1.94 \mathrm{E}-00$ & $1.08 \mathrm{E}+01$ & $8.06 E+02$ & 2.34 \\
\hline 53 & $7.37 \mathrm{E}+01$ & $1.10 \mathrm{E}+04$ & $7.51 \mathrm{E}-01$ & $1.17 E-00$ & $7.49 E+01$ & $1.11 \mathrm{E}+04$ & 0.68 \\
\hline S4 & $1.67 \mathrm{E}+02$ & $3.43 E+04$ & $1.04 E-00$ & $1.62 \mathrm{E}-00$ & $1.69 E+02$ & $3.45 E+04$ & 0.49 \\
\hline s5 & $6.50 \mathrm{E}+01$ & $2.13 E+04$ & $1.53 \mathrm{E}-00$ & $2.38 E-00$ & $6.76 E+01$ & $1.14 E+04$ & 0.59 \\
\hline 56 & $7.84 E+01$ & $1.58 E+04$ & $2.51 E-00$ & $3.90 \mathrm{E}-00$ & $8.23 \mathrm{E}+01$ & $1.59 \mathrm{E}+04$ & 0.52 \\
\hline 57 & $2.33 \mathrm{E}+02$ & $4.88 E+04$ & $3.11 \mathrm{E}-00$ & $4.84 E-00$ & $2.38 \mathrm{E}+02$ & $4.90 \mathrm{E}+04$ & 0.49 \\
\hline 88 & $7.60 \mathrm{E}-00$ & $1.16 \mathrm{E}+03$ & $5.22 E-01$ & $8.12 \mathrm{E}-01$ & $8.41 E-00$ & $1.17 \mathrm{E}+03$ & 0.72 \\
\hline s11 & $6.08 E-02$ & $7.85 \mathrm{E}-00$ & $4.55 \mathrm{E}-02$ & $7.08 \mathrm{E}-02$ & $1.32 \mathrm{E}-01$ & $7.98 \mathrm{E}-00$ & 1.65 \\
\hline 513 & $6.32 \mathrm{E}+01$ & $1.02 E+04$ & $8.35 \mathrm{E}-01$ & $1.30 \mathrm{E}-00$ & $6.45 \mathrm{E}+01$ & $1.03 E+04$ & 0.63 \\
\hline 514 & $3.92 \mathrm{E}+01$ & $1.83 E+04$ & $3.01 E-01$ & $4.68 \mathrm{E}-01$ & $3.97 E+01$ & $1.83 \mathrm{E}+04$ & 0.22 \\
\hline 516 & $1.02 \mathrm{E}+03$ & $1.87 E+05$ & $2.86 \mathrm{E}+01$ & $4.45 E+01$ & $1.06 E+03$ & $1.88 E+05$ & 0.57 \\
\hline S19 & $3.67 E+02$ & $8.26 E+04$ & $4.17 E-00$ & $6.49 \mathrm{E}-00$ & $3.73 \mathrm{E}+02$ & $8.30 \mathrm{E}+04$ & 0.45 \\
\hline 520 & $2.22 E+02$ & $5.33 E+04$ & $3.50 \mathrm{E}-00$ & $5.44 E-00$ & $2.27 E+02$ & $5.35 E+04$ & 0.42 \\
\hline$\$ 21$ & $2.75 E+01$ & $8.78 E+03$ & $9.83 \mathrm{E}-01$ & $1.53 \mathrm{E}-00$ & $2.90 \mathrm{E}+01$ & $8.82 \mathrm{E}+03$ & 0.33 \\
\hline $\mathbf{S 2 2}$ & $5.07 E+01$ & $5.93 E+03$ & $1.62 \mathrm{E}-00$ & $2.52 \mathrm{E}-00$ & $5.32 \mathrm{E}+01$ & $5.98 \mathrm{E}+03$ & 0.89 \\
\hline
\end{tabular}


U-235, U-238 and Pu-239 were determined by sampling of all the tanks. Fissile material was not found in Tanks S9, S10, S12, S15, S17 and S18. The fissile gram equivalence of Pu-239 to U-235 was determined by rule of fractions (U-235 FGE $=$ Pu-239 $\mathrm{g} *(700 \mathrm{~g} \mathrm{U}-235 / 450 \mathrm{~g}$ Pu-239)). Total U-235 FGE is the sum of U-235 and Pu-239 U-235 FGE. Total U was determined by the sum of Total U-235 FGE and U-238. Effective Enrichment was determined by the ratio of Total U-235 FGE and Total U.

Comparing tank effective enrichments to the ANS 8.1 limiting enrichment for criticality concerns $(0.93$ weight percent U-235, Ref. 3) shows Tanks S2 and S11 exceed this limit. The other tanks are less than the ANS 8.1 limit and are not a criticality concern unless enrichments are changed.

Tank S2 has an effective enrichment of $1.34 \%$ and a total U-235 FGE of 10.8 grams. Tank S11 has an effective enrichment of $1.65 \%$ and a total U-235 FGE of 0.123 grams.

\section{COMPARISON TO ANSI CRITICALITY SAFETY STANDARDS}

ANSI Standards for criticality safety provide guidelines for criticality safety for low enrichments (Ref. 3). The standard states that naturally enriched uranium is not a criticality concern. Guidelines for sub-critical masses for uniform aqueous low enrichment systems are found in Table 6 of the ANSI standard. Relevant enrichments and their associated mass limits have been included in Table 2 of this document. UO2F2 systems were used for reference because these were the most restrictive limits.

TABLE 2 - Sub-Critical Mass Limits for Uniform Aqueous Low Enrichment Systems.

\begin{tabular}{|c|c|}
\hline Enrichment, wt $\times 0-235$ & Mans, $\mathrm{Kg}$ V-235 [002F2] \\
\hline 4.0 & 2.98 \\
\hline 3.0 & 2.75 \\
\hline 2.0 & 8.00 \\
\hline
\end{tabular}

The trend in Table 2 indicates that more than $8 \mathrm{Kg}$ of U-235 is needed to exceed the critical safe mass limit for enrichments less than $2.0 \mathrm{wt} \%$. Tanks $S 2$ and $S 11$ have significantly less than $8 \mathrm{Kg} \mathrm{U}-235$ FGE. In fact, the calculations for this evaluation indicate that there is less than $2520 \mathrm{~g} \mathrm{U}-235 \mathrm{FGE}$ in all 22 tanks put together. This comparison of tank inventories to ANSI standards has shown these tanks in their current configuration do not represent a criticality safety concern. This determination of criticality safety is valid provided U-238 is not separated from the waste and the existing effective enrichments are not improved.

\section{CONCLUSION}

This report concludes that the Old Solvent Storage Tanks S1 through S22 have critically safe inventories of fissile materials and will remain critically safe during future operations/closure provided no action is taken that would cause an increase in enrichment above the values listed in Table 2.

\section{REFERENCES}

1. "Storage and Handling Limits for Sludge and Mark 31 Corrosion Products in L Basin (U)", NNCS-L-00006, Rev 0, 12 June 1997.

2. "Characterization of Samples from Old Solvent Tanks S1 through S22", WSRC-RP-98-01486, Rev. 0, 13 January 1999.

3. "American National Standard for Nuclear Criticality Safety in Operations with Fissionable Materials Outside Reactors", ANSVANS-8.1-1983. 


\section{WESTINGHOUSE SAVANNAH RIVER COMPANY INTEROFFICE MEMORANDUM}
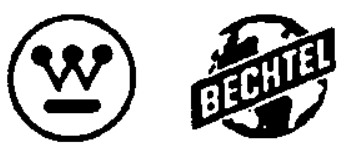

SRT-ADS-00-0057

February 3, 2000

To: John Bennett, 730-2B

Karen Conner, 730-2B

Andy Preston, 730-2B

Kim Hammer, WSMS

From: John D. Leyba, 773-41A. JDL

\section{Concerns Regarding OSTs Total Inventory}

An issue has been raised regarding the total inventory of various contaminants contained in the Old Solvent Tanks (OSTs). In a previous technical report (WSRC-TR-2000-00011, "Total Inventory of Selected Radionuclides in Old Solvent Tanks S1 through S22"), I calculated the estimated total inventory of various contaminants in those tanks which were not sampled based upon the average concentrations of the contaminants in the tanks which were sampled and analyzed. The data for these calculations was taken from WSRC-RP-98-01486, Rev. 1 ("Characterization of Samples from Old Solvent Tanks S1 through S22"). A question has been asked which states, "By not having samples from the specific tanks, have we missed a period of operation when the waste stream characteristics would have been different significantly from the characteristics of the waste streams that filled the measured tanks?" I discussed this issue with Ann Gibbs and we have come to the conclusion that the methodology currently used in WSRC-TR-2000-00011 to estimate the total inventory of contaminants in the OSTs is conservative from a criticality perspective. This conclusion is based upon an examination of the calculated U-235/U-238 and Pu-238/Pu-239 ratios. These ratios were calculated for each phase from the average concentrations of these nuclides in the OSTs. The table below contains the average elemental ratios calculated from the characterization data of OST samples for the various phases present in the tanks.

\begin{tabular}{|c|c|c|}
\hline Phase & $\begin{array}{c}\text { U-235/U-238 Ratio } \\
\text { (g/g) }\end{array}$ & $\begin{array}{c}\text { Pu-238/Pu-239 Ratio } \\
\text { (g/g) }\end{array}$ \\
\hline Sludge & $6.8 \mathrm{E}-03$ & $1.7 \mathrm{E}-01$ \\
\hline Aqueous Liquid & $4.1 \mathrm{E}-03$ & $4.4 \mathrm{E}-02$ \\
\hline Organic Liquid & $3.6 \mathrm{E}-02^{2}$ & $1.1 \mathrm{E}-01^{\circ}$ \\
\hline Suspended Solids - Aq. Phase & $7.8 \mathrm{E}-03$ & $6.0 \mathrm{E}-02$ \\
\hline Suspended Solids - Org. Phase & $6.3 \mathrm{E}-03^{\mathrm{b}}$ & $6.0 \mathrm{E}-02^{\iota}$ \\
\hline
\end{tabular}

a - Based on data from Tank S20 organic phase only.

b - Based on data from Tanks S11 and S20 organic phases.

c - Based on data from Tank S11 organic phase only. 
On average, it appears that the tanks contain F-Area Solvent. The ratios agree reasonably well with the F-Area products of weapons grade plutonium and depleted uranium. H-Area materials contain higher quantities of $\mathrm{Pu}-238$ and $\mathrm{U}-235$. Since these two elemental ratios are in agreement with material from F-Area, the tanks that were not sampled should not have a significantly higher weapons grade plutonium content. In fact, if any $\mathrm{H}$-Area material is present, the Pu- 239 content will be lower. It should be noted that the U-235/U-238 ratio in the organic liquid and the $\mathrm{Pu}-238 / \mathrm{Pu}-239$ ratio in the suspended solids phase of the organic liquid are each based upon one data point. Only two of the liquid samples obtained in the OST characterization study were organic liquids. Liquid samples were not obtained from seven of the tanks. Of these seven tanks, four tanks had no liquid in them and the other three tanks (Tanks S10, $\mathrm{S} 12$ and $\mathrm{S} 18$ ) contained ten gallons or less.

The feed material of irradiated uranium, however, is one area of concern. If the insampled solvent tanks were to contain H-Area solvent, they could contain a higher quantity of U-235. Thus, Ann Gibbs recommends that WSMS examine the U-235/U238 ratios for each of the sampled tanks and determine which tank has the highest U-235/U-238 ratio. The U-235 concentration in the tank with the highest U235/U-238 ratio should then be used to calculate the bounding concentrations in the unsampled tanks.

CC Ann Gibbs, 724-21E ADS Files 
SRT-ADS-00-0059

February 4, 2000

To: John Bennett, 730-2B

Karen Conner, 730-2B

Andy Preston, 730-2B

Kim Hammer, WSMS

From: John D. Leyba, 773-41A JSL

\section{Addressing Concerns Regarding OSTs Total Inventory}

The issue regarding the potential of having a significantly different waste stream in the uncharacterized Old Solvent Tanks (OSTs) was addressed in SRT-ADS-00-0057 ("Concerns Regarding OSTs Total Inventory"). In SRT-ADS-00-0057 it is stated, "Thus, Ann Gibbs recommends that WSMS examine the U-235/U238 ratios for each of the sampled tanks and determine which tank has the highest U-235/U-238. ratio. The U-235 concentration in the tank with the highest U-235/U-238 ratio should then be used to calculate the bounding concentrations in the unsampled tanks."

This present memo explores Ann Gibbs' recommendation. For the various phases (liquid, suspended solids, sludge) present in the tanks which were sampled and analyzed, the U-235/U-238 mass ratio was determined. These ratios are given in Table 1. The data in blue represent calculated values based upon the assumptions given in WSRC-TR-2000-00011 ("Total Inventory of Selected Radionuclides in Old Solvent Tanks S1 Through S22"). These blue numbers are based upon the average measured concentrations of the analyte of interest (U-235 or U-238) plus two times the standard deviation of the average concentration. The "less than value" indicates that only an upper limit was established for U235 in the sludge sample from Tank S4. Two ratios (Tank S11 filtered liquid and Tank S22 suspended solids) are listed as "greater than values" because U-238 was not detected in these samples. The highest measured U-235/U-238 mass ratio for sludge, filtered liquid, and suspended solids phases are Tank S19, S20-T (organic phase of Tank S20), and S7 respectively.

Table 2 compares the U-235 activity concentration plus error to the calculated average activity concentration plus two standard deviations (as calculated in WSRC-TR-2000-00011) for the sludge from Tank S19, the filtered liquid from Tank S20-T, and the suspended solids from Tank S7. Table 2 shows that the calculated average plus two standard deviations for the sludges is lower than the sum of the measured Tank S19 sludge activity and the 2-sigma error. The calculated average plus two standard deviations for the filtered liquid is higher by over a factor of a hundred than the sum of the measured Tank S20-T filtered liquid activity and the 2-sigma error. The calculated average plus two standard deviations for the suspended solids is higher than the Tank S7 suspended solids activity value plus the 2sigma error. Thus, taking the recommendation of Ann Gibbs, the Tank S19 measured U-235 sludge 
activity plus the 2-sigma error should be used instead of the calculated average plus two standard deviations value to calculate the estimated total mass of U-235 in the sludge phase of the unsampled itanks. For the filtered liquids and suspended solids, the sum of the calculated average plus two standard deviations should be used in estimating the total U-235 in these two phases of the unsampled tanks since these values give a more conservative approach than the methodology proposed by Ann Gibbs.

Table 1 Calculated U-235/U-238 Mass Ratios

\begin{tabular}{|c|c|c|c|}
\hline Tank \# & $\begin{array}{c}\text { Shudge } \\
\text { Uranium } \\
235 / 238 \\
\text { Ratio }\end{array}$ & $\begin{array}{c}\text { Fitered } \\
\text { Liquid } \\
\text { Uranium } \\
\mathbf{2 3 5 / 2 3 8} \\
\text { Ratio }\end{array}$ & $\begin{array}{c}\text { Suspended } \\
\text { Solids } \\
\text { Uranium } \\
\mathbf{2 3 5 / 2 3 8} \\
\text { Ratio }\end{array}$ \\
\hline S1 & $6.81 \mathrm{E}-03$ & $7.06 \mathrm{E}-03$ & $6.74 \mathrm{E}-03$ \\
\hline S2 & $6.53 \mathrm{E}-03$ & $2.72 \mathrm{E}-04$ & $6.24 \mathrm{E}-03$ \\
\hline S3 & $6.79 \mathrm{E}-03$ & $6.59 \mathrm{E}-03$ & $7.61 \mathrm{E}-03$ \\
\hline S4 & $63.76 \mathrm{E}-03$ & $4.91 \mathrm{E}-03$ & $7.61 \mathrm{E}-03$ \\
\hline S5 & $6.78 \mathrm{E}-03$ & $5.75 \mathrm{E}-03$ & $6.51 \mathrm{E}-03$ \\
\hline S6 & N/A & $6.68 \mathrm{E}-03$ & $4.53 \mathrm{E}-03$ \\
\hline S7 & $5.24 \mathrm{E}-03$ & $4.67 \mathrm{E}-03$ & $4.31 \mathrm{E}-02$ \\
\hline S8 & $6.84 \mathrm{E}-03$ & $6.56 \mathrm{E}-03$ & $4.28 \mathrm{E}-03$ \\
\hline S9 & $6.82 \mathrm{E}-03$ & N/A & N/A \\
\hline S10 & $6.80 \mathrm{E}-03$ & $4.13 \mathrm{E}-03$ & $7.76 \mathrm{E}-03$ \\
\hline S11 & $6.80 \mathrm{E}-03$ & $>7.75 \mathrm{E}-03$ & $5.76 \mathrm{E}-03$ \\
\hline S12 & $6.80 \mathrm{E}-03$ & $4.13 \mathrm{E}-03$ & $7.73 \mathrm{E}-03$ \\
\hline S13 & $6.80 \mathrm{E}-03$ & $6.18 \mathrm{E}-03$ & $6.11 \mathrm{E}-03$ \\
\hline S14 & $6.82 \mathrm{E}-03$ & $2.14 \mathrm{E}-03$ & $6.24 \mathrm{E}-03$ \\
\hline S15 & $6.79 \mathrm{E}-03$ & N/A & N/A \\
\hline S16 & $5.45 \mathrm{E}-03$ & N/A & N/A \\
\hline S17 & $6.80 \mathrm{E}-03$ & N/A & N/A \\
\hline S18 & $6.80 \mathrm{E}-03$ & $4.13 \mathrm{E}-03$ & $7.73 \mathrm{E}-03$ \\
\hline S19 & $1.09 \mathrm{E}-02$ & $6.43 \mathrm{E}-04$ & $6.45 \mathrm{E}-03$ \\
\hline S20-T & $1.63 \mathrm{E}-03$ & $3.55 \mathrm{E}-02$ & $6.83 \mathrm{E}-03$ \\
\hline S20-B & N/A & $4.68 \mathrm{E}-03$ & $5.85 \mathrm{E}-03$ \\
\hline S21 & $6.61 \mathrm{E}-03$ & $2.66 \mathrm{E}-03$ & $6.40 \mathrm{E}-03$ \\
\hline S22 & $9.53 \mathrm{E}-05$ & $8.39 \mathrm{E}-03$ & $>8.88 \mathrm{E}-03$ \\
\hline & & & \\
\hline
\end{tabular}

Table 2 Comparison of Eighest Measured U-235 Activity Concentration Plus 2-Sigma Error and Calculated Avernge Value Plus 2 Standard Deviations

\begin{tabular}{|c|c|c|}
\hline Method & Activity \pm Error & Total \\
\hline Tank 19 Stodge & $2.90 \mathrm{E}+03 \pm 5.80 \mathrm{E}+02 \mathrm{pCi} / \mathrm{g}$ & $3.48 \mathrm{E}+03 \mathrm{pCi} / \mathrm{g}$ \\
\hline Calculated Slodge Average & $6.19 \mathrm{E}+02 \pm 1.96 \mathrm{E}+03 \mathrm{pCi} / \mathrm{g}$ & $2.58 \mathrm{E}+03 \mathrm{pCi} / \mathrm{g}$ \\
\hline Tank 20-T Fititered Liqud & $2.11 \mathrm{E}+03 \pm 4.22 \mathrm{E}+02 \mathrm{pCi} / \mathrm{L}$ & $2.53 \mathrm{E}+03 \cdot \mathrm{pCi} / \mathrm{L}$ \\
\hline Filtered Liquid Average & $9.89 \mathrm{E}+04 \pm 1.91 \mathrm{E}+05 \mathrm{pCi} / \mathrm{L}$ & $2.90 \mathrm{E}+05 \mathrm{pCi} / \mathrm{L}$ \\
\hline Tank 7 Suspendled Solids & $4.01 \mathrm{E}+03 \pm 8.02 \mathrm{E}+02 \mathrm{pCi} / \mathrm{g}$ & $4.81 \mathrm{E}+03 \mathrm{pCi} / \mathrm{g}$ \\
\hline Suspended Solids Average & $3.80 \mathrm{E}+03 \pm 8.88 \mathrm{E}+03 \mathrm{pCi} / \mathrm{g}$ & $1.28 \mathrm{E}+04 \mathrm{pCi} / \mathrm{g}$ \\
\hline
\end{tabular}


Table 3 lists the total estimated U-235, U-238, and Pu-239 content of the OSTs based upon the calculational methodology given in WSRC-TR-2000-00011 and on the recommendation of Ann Gibbs given in SRT-ADS-00-0057. Note that the U-235 mass values in Table 3 below are greater than the corresponding values of Table 1 of WSRC-TR-2000-00011 by approximately $30 \%$. I recommend that the new U-235 mass values given in Table 3 below be used when performing the criticality safety calculations.

Table 3 Total Estimated U-235, U-238, and Pu-239 Content of Old Solvent Tanks S1 through S22

\begin{tabular}{|c|c|c|c|}
\hline Tank \# & $\begin{array}{c}\text { U-235 } \\
(\mathbf{g})\end{array}$ & $\begin{array}{c}\text { U-238 } \\
(\mathbf{g})\end{array}$ & $\begin{array}{c}\text { Pu-239 } \\
(\mathbf{g})\end{array}$ \\
\hline S1 & $7.60 \mathrm{E}+01$ & $8.98 \mathrm{E}+03$ & $<8.16 \mathrm{E}-01$ \\
\hline S2 & $8.89 \mathrm{E}+00$ & $1.45 \mathrm{E}+04$ & $<1.25 \mathrm{E}+00$ \\
\hline S3 & $1.19 \mathrm{E}+02$ & $1.59 \mathrm{E}+04$ & $1.30 \mathrm{E}+00$ \\
\hline S4 & $<1.67 \mathrm{E}+02$ & $3.43 \mathrm{E}+04$ & $<1.04 \mathrm{E}+00$ \\
\hline S5 & $1.44 \mathrm{E}+03$ & $1.60 \mathrm{E}+05$ & $1.80 \mathrm{E}+01$ \\
\hline S6 & $7.84 \mathrm{E}+01$ & $1.58 \mathrm{E}+04$ & $<2.51 \mathrm{E}+00$ \\
\hline S7 & $2.33 \mathrm{E}+02$ & $4.88 \mathrm{E}+04$ & $3.11 \mathrm{E}+00$ \\
\hline S8 & $7.60 \mathrm{E}+00$ & $1.16 \mathrm{E}+03$ & $<5.22 \mathrm{E}-01$ \\
\hline S9 & $1.59 \mathrm{E}+02$ & $1.73 \mathrm{E}+04$ & $1.92 \mathrm{E}+00$ \\
\hline S10 & $3.84 \mathrm{E}+02$ & $4.25 \mathrm{E}+04$ & $4.76 \mathrm{E}+00$ \\
\hline S11 & $1.55 \mathrm{E}+02$ & $<1.69 \mathrm{E}+04$ & $1.92 \mathrm{E}+00$ \\
\hline S12 & $6.38 \mathrm{E}+01$ & $7.30 \mathrm{E}+03$ & $8.30 \mathrm{E}-01$ \\
\hline S13. & $5.87 \mathrm{E}+02$ & $6.74 \mathrm{E}+04$ & $<7.18 \mathrm{E}+00$ \\
\hline S14 & $1.48 \mathrm{E}+03$ & $1.75 \mathrm{E}+05$ & $1.78 \mathrm{E}+01$ \\
\hline S15 & $1.77 \mathrm{E}+03$ & $1.93 \mathrm{E}+05$ & $2.14 \mathrm{E}+01$ \\
\hline S16 & $1.02 \mathrm{E}+03$ & $1.87 \mathrm{E}+05$ & $2.86 \mathrm{E}+01$ \\
\hline S17 & $8.54 \mathrm{E}+01$ & $9.31 \mathrm{E}+03$ & $1.03 \mathrm{E}+00$ \\
\hline S18 & $2.72 \mathrm{E}+01$ & $3.31 \mathrm{E}+03$ & $3.88 \mathrm{E}-01$ \\
\hline S19 & $3.68 \mathrm{E}+02^{2}$ & $8.77 \mathrm{E}+04$ & $4.24 \mathrm{E}+00^{2}$ \\
\hline S20 & $<2.22 \mathrm{E}+02$ & $<5.33 \mathrm{E}+04$ & $<3.50 \mathrm{E}+00$ \\
\hline S21 & $2.75 \mathrm{E}+01$ & $8.78 \mathrm{E}+03$ & $9.83 \mathrm{E}-01$ \\
\hline S22 & $5.07 \mathrm{E}+01$ & $<1.59 \mathrm{E}+04$ & $<1.62 \mathrm{E}+00$ \\
\hline
\end{tabular}

a- This value was calculated using the results from sample 19-0.

This new methodology proposed by Ann Gibbs has also been review by Vito Casella and he is in agreement with the method.

CC Ann Gibbs, 724-21E

Vito Casella, 773-41A

ADS Files 